\title{
THE
}

\section{RUFFED GROUSE}

IIFE MISTORY * PROPAGATION \& MANAGEMENT

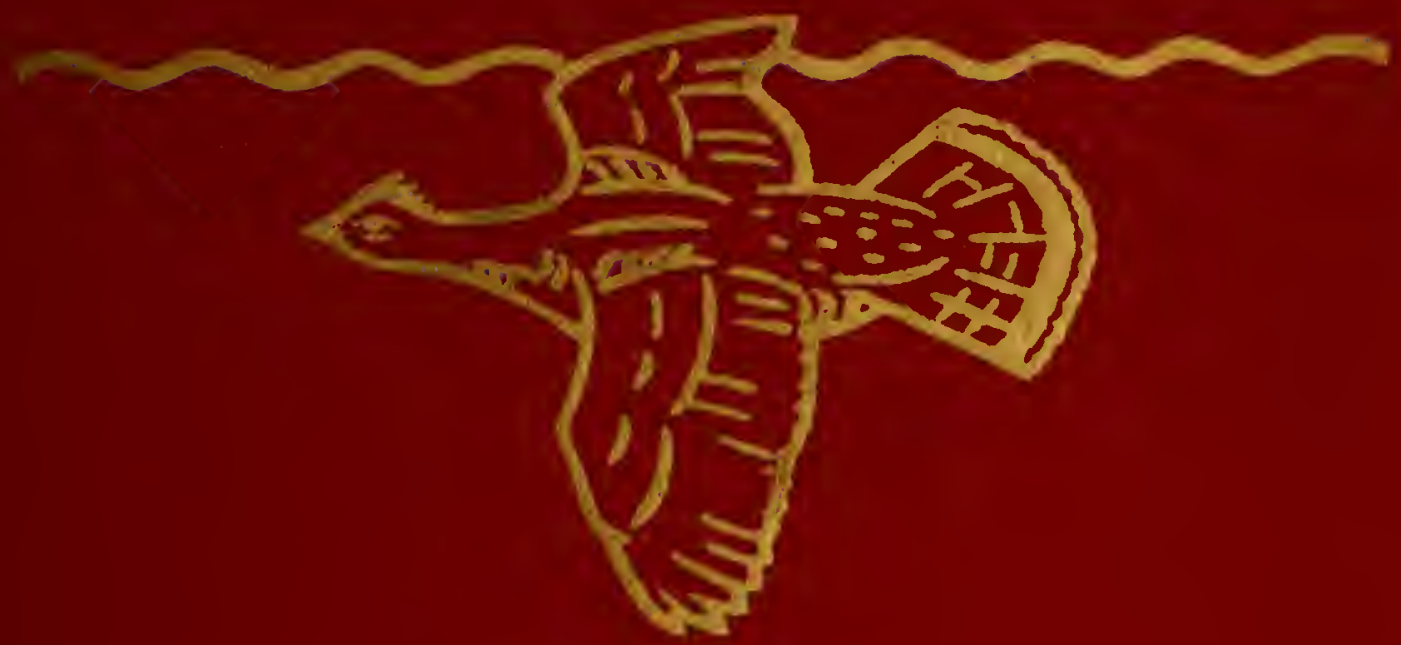

CARBINER BUMP BOBERT W. DARROW FRANK C. EOMINSTER WALTER F. CRISSEY 


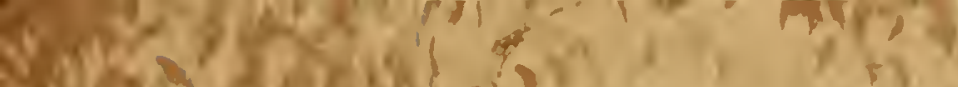

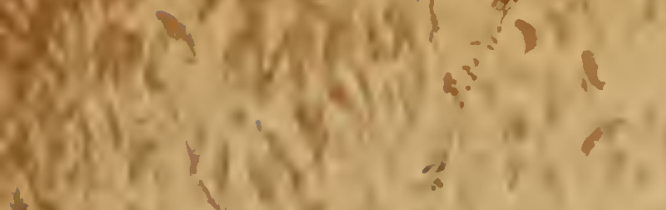

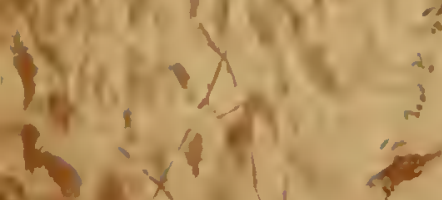

$\sqrt{3}$

(n)

iterotis

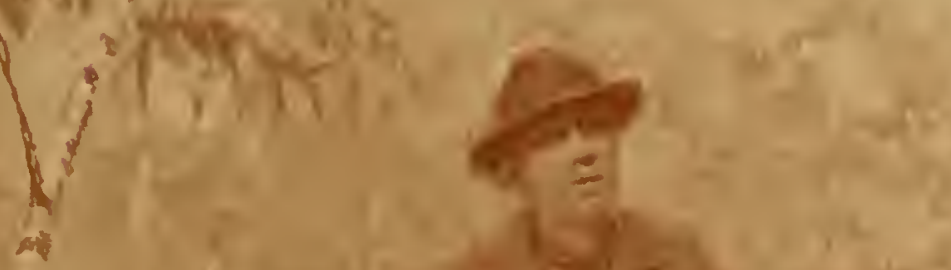

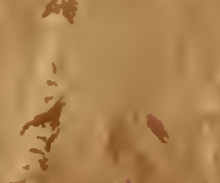

$x_{4}$

intolis

(2) 2

$74-6)^{2}+2$

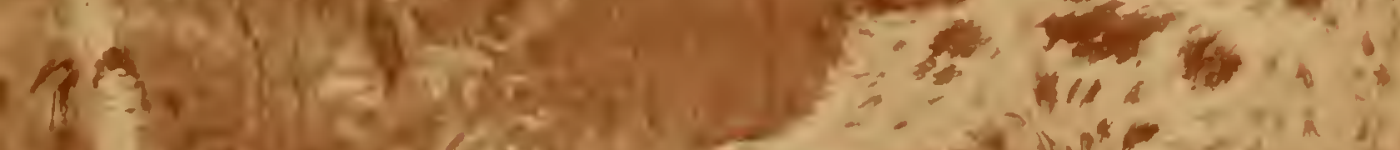

(1)

(3)

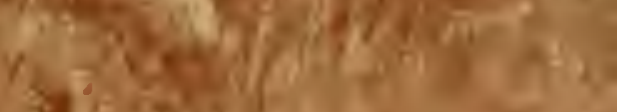

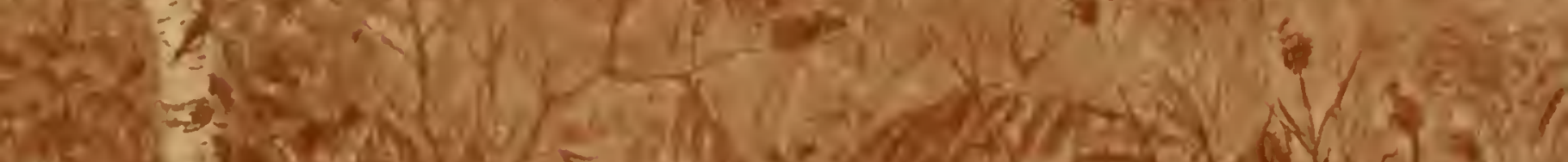

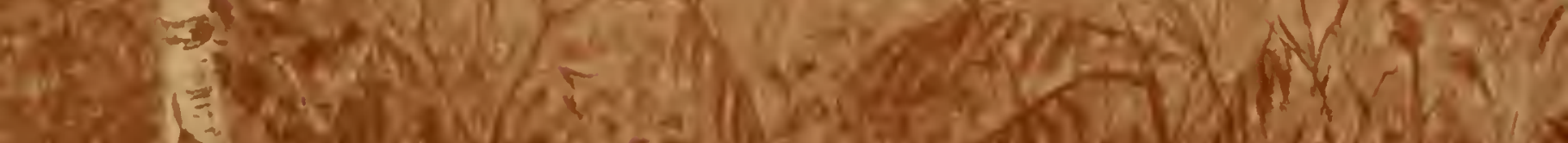

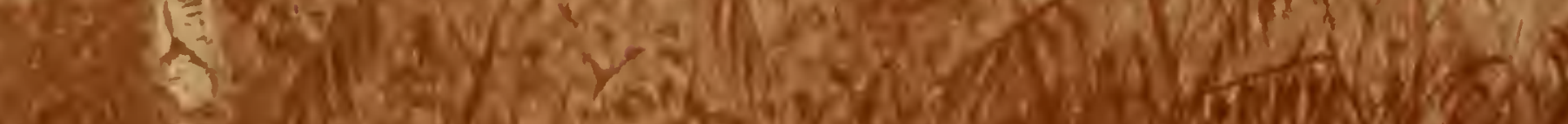

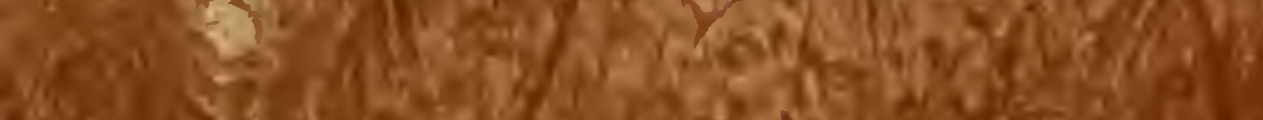
mes Mf $x=20$ 


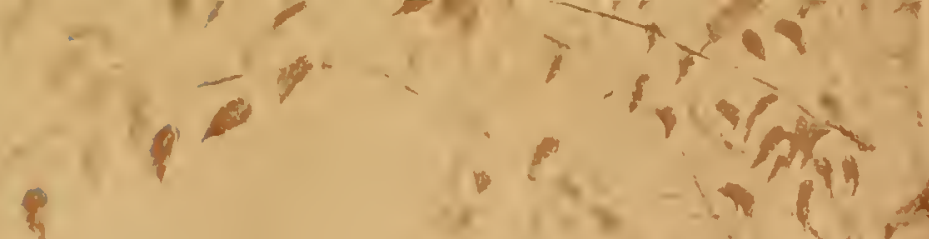




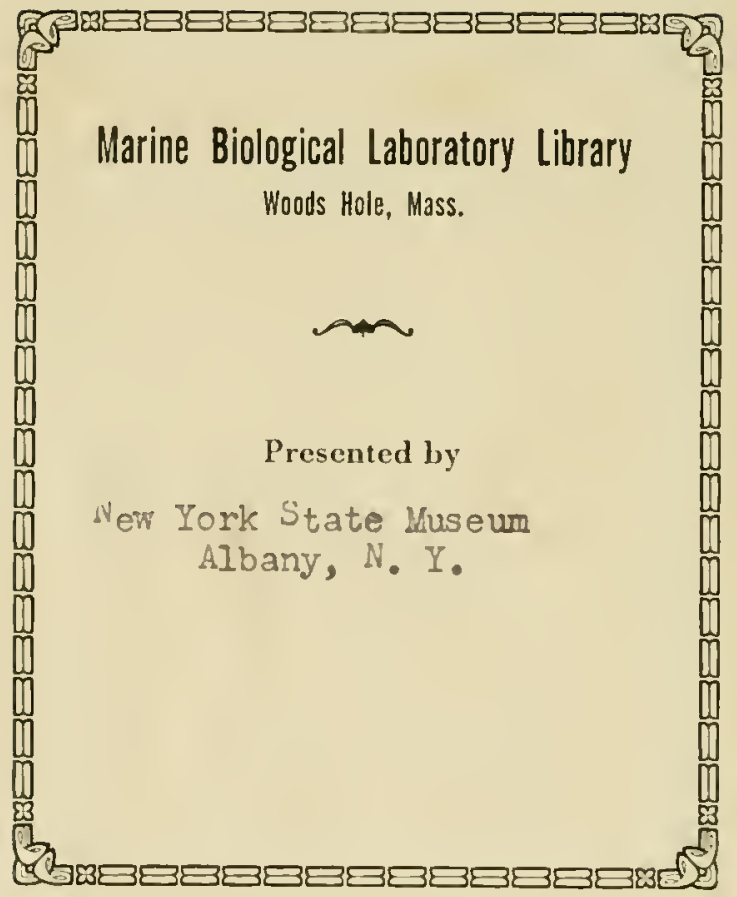




\section{THE RUFFED GROUSE}

Life Histury - I'mpagantion • Maningentent 


\section{Copyright 1947}

by

State of New lork

Conservation Department

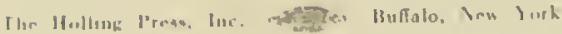



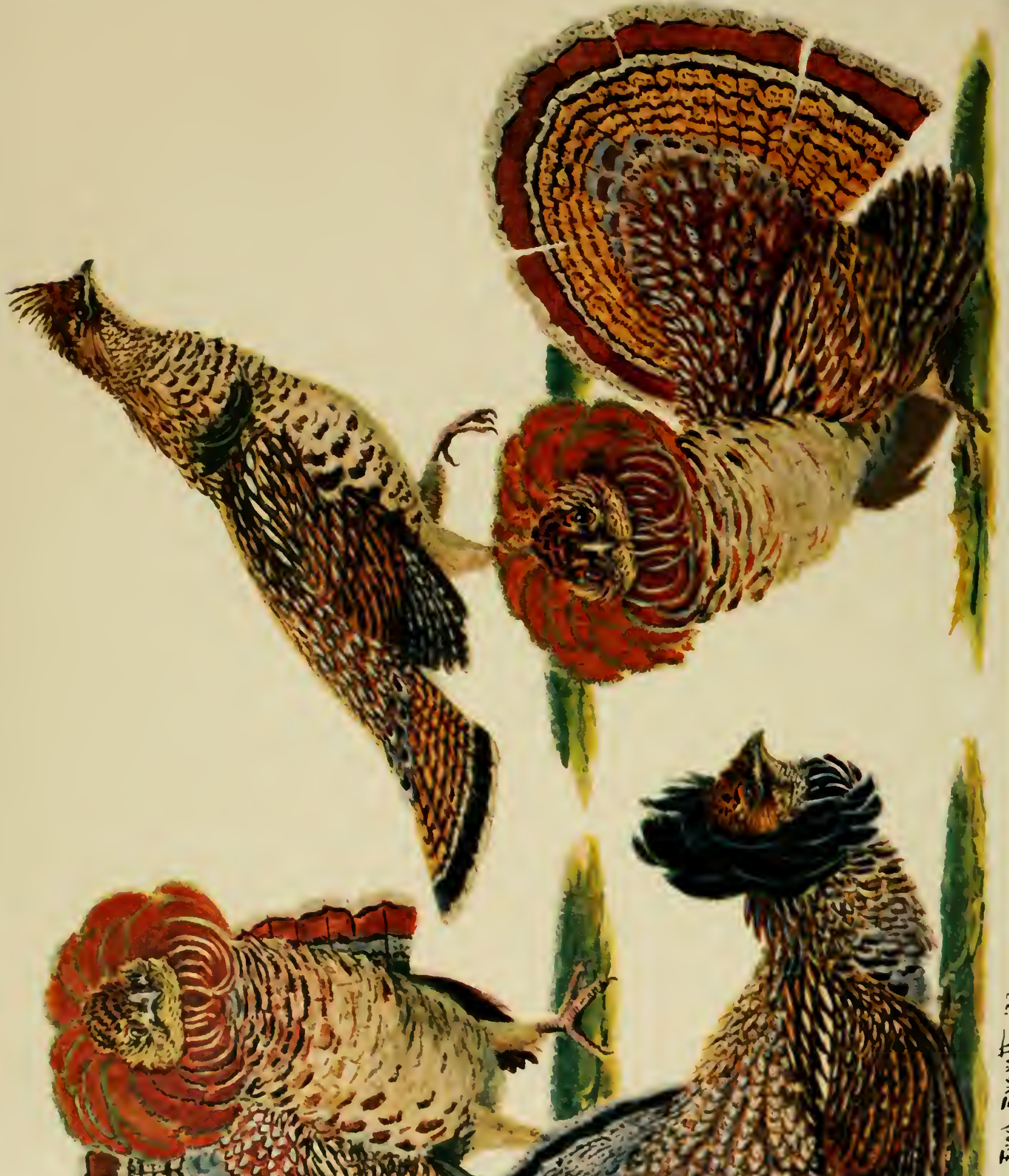

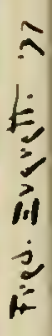

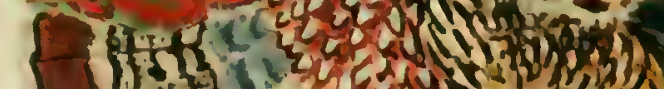

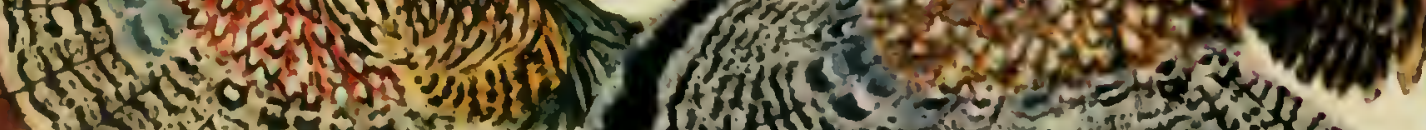
(i)

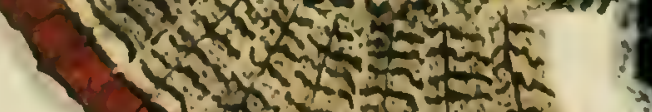

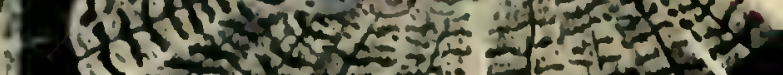


NEW YORK STATE CONSERVATION IDEPARTMENT

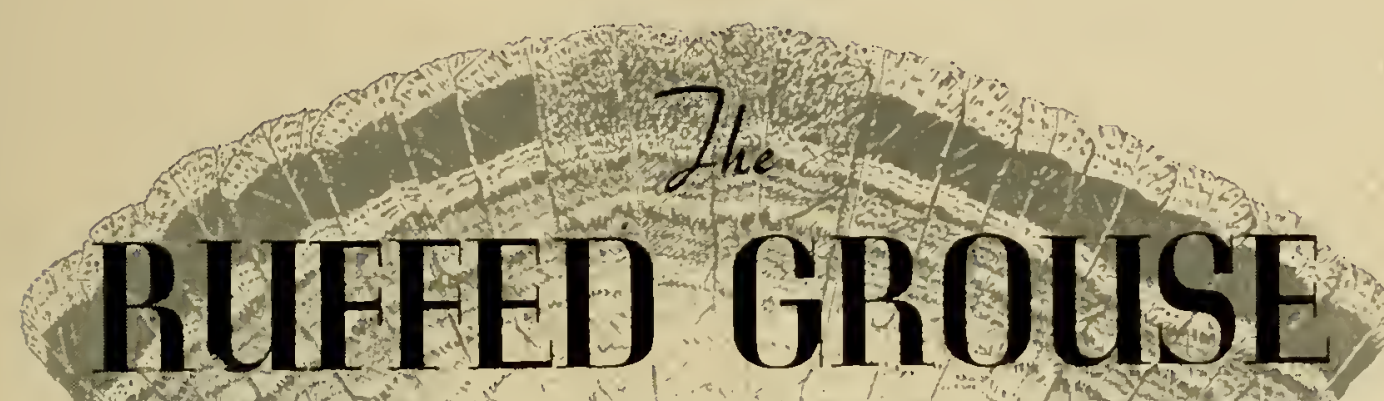

LIFE HISTOHY $*$ PROPAGATION $*$ MANAGEMENT

\section{Sy}

GA R II INE R B II M P

RO II ERT W. IIA R ROW

FHANKIC. EDMINSTER

WALTER F. C;RISSEY

\section{as}

Wilh Four P'aintingos in Full linlor hy FREI). EVERETT and 127 Shrotedrs IIV CLAYTON B. SEAGEAHS (III) FRED. EVERETT
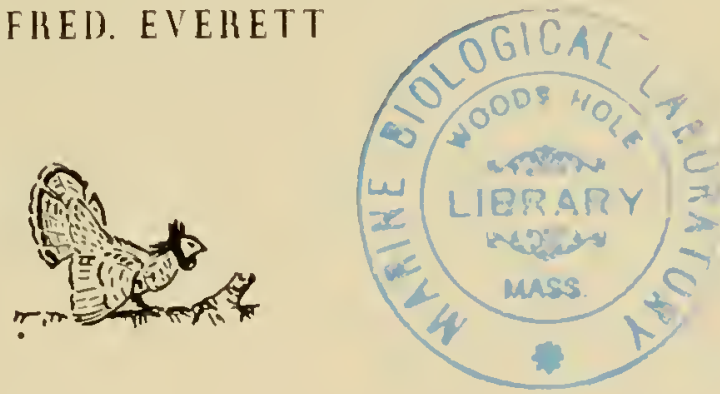

PURIISHED BY AUTHIRITY OF THE NEW YORK STATE LEGISLATURE 1947 



\section{FOREWORD}

This story of the ruffed grouse in New Yurk. lased primarily on the Ruffed Grouse lnvestigation, will, I believe, make a permanent and important niche for itself in the nation: wildlife literature.

The Investigation was a unique undertaking in wildlife research. When it was initiated 16 years ago, in 1930, wildlife research was in its infancy-even as today it is still in its youth. It started with a handful of young workers struggling with untested techniques to uncover some of Nature's secrets, and grew into a highly developed group of specialized scientists. In miniature, it portrays the rapid changes which have taken place in this important field in sur time.

The Investigation is noteworthy in a number of respects. It represents the most sustained and comprehensive effort ever made to study any une form of American wildlife. It follows that it required the largest investment ever made in the imrestigation of a single species.

In addition to providing a myriad of facts and fignres relative to the ruffel grouse, which the reader will find pleasant to explore for hinself, the luvestigation has had a number of valuable by-products. These include the development of wildlife techniques. practices and policies from the application of which the State has already heen a sulstantial beneficiary. Probably one of the most valuable hy-produets has come from the employment of the Investigation as a training ground for young wildlife workers. Inmumerable students at Cornell and a number of employees of the Department cut their teeth on wm or more of the many phases of this sturly. In the ensuing years, many of these young men have grown up to take over positions of high responsibility in our own Department. in the Conservation Department: of other states and in the Federal conservation agencies.

When 1 took office, the laboratory and field work upou which this hook is based had largely been concluded for some time. Although publication difficulties arising during the war still continue. I feel that the sportsmen of the State. Who have contributed a large sum from their Conservation Fund to finance this lnvestigation over the years. are entitled to a direct and long averdue return on their investment in the form of this book. Likewise. 1 feel that New York has a moral obligation to hundreds of other wildlife workers scattered throughout the country to make available to them the findings which had been so long accumulating. Consequently. I deemed it my duty to take the necessary steps to provide this publication without further delay.

Every effort has been made to make the hook as factual. sound and useful as possihle--to all who have an interest in the ruffed grouse. I take this oceasion to eongratulate the authors of the look, and the numerous unidentified workers who have assisted them. hoth in the Invesligation and in the preparation of the manuscript. 


\section{FOREWORD}

On hehalf of the four commissioners who preceded me in office while the study was in progress, and speaking for myself, I take great pleasure in presenting this book to all sportsmen. wildlife workers, and conservationists who, I know, will he very much inierested in it and who, I confidently believe, will derive a great deal from it.

Perry B. Duryea

Conservation Commissioner

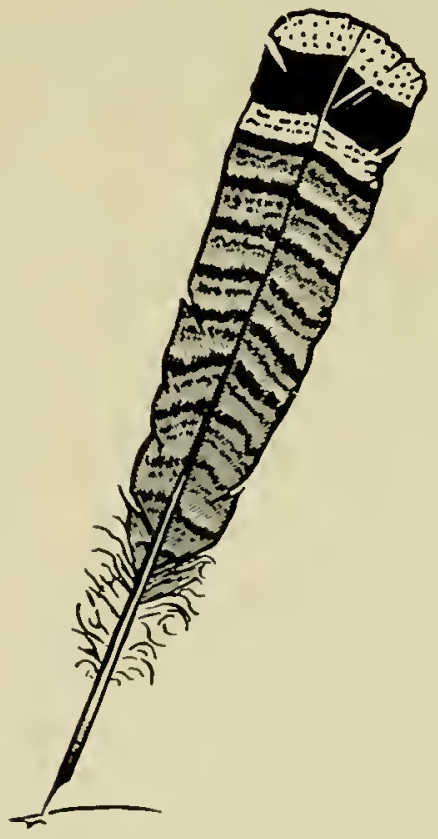




\section{CON TENT S}

FOREWORD ly Perry B. Duryea, Conservation Commissioner

Page

vii

PREFACE by Gardiner Bump

$\mathrm{xxxi}$

ACKNOWLEDGMENTS

xxxvi

PART I. THE RUFFED GROUSE - ITS BACKGROUND. BASIC BIOLOGY AND ECONOMIC IMPORTANCE

\section{Chapter}

I The Ruffeu Grouse in tile Marci of Time by Gardiner Bump

II The Species: its Taxonony, Range, Biology, and Econonic Importance by

Robert W. Darrow and Gardiner Bump. with individual sections by Fred

Everett, David E. Davis, John E. Trainer. William H. Long, A. L. Roman-

off, Earl R. Holm, and Walter F. Crissey

\section{I'ART II. THE FACTORS THAT AFFECT ABUNDANCE}

III Cover Characteristics and Shelter Requinements by Gardiner Bump

IV Foon Habits and Requirements by Gardiner Bump and John C. Jones

V General Habits by Roheri W. Darrow

VI INFLUEce of Weather ly Waher F. Crissey

VIl Predation by Robert W. Darrow

VIII Reproductive Capacity of The Species by Frank C. Eilminster and Walter F.

$$
\text { Crissey }
$$

IX Influence or Man by Frank C. Edminster, with a section by J. Victor Skiff

I Parasimism ano Distase: by Philip P. Levine and Frans C. Goble

XI Artificial Propagation by Gardiner Bump

XII Productivity of Grouse I'opulations by Rohert IV. Darrow

Xill Fluctuations in Grouse Abundance by Rohert W. Darrow

\section{PART III. MANAGING TIHE GROUSE CROP}

Grouse Management by Gardiner Bump

XIV Managing Grouse Areas by Gardiner Bump

XV Designing Grouse Coverts and Setting Up Management l'lans by Gardiner

Bump

XVI Improving and Mantaining Grouse Coverts by Gardiner Bump and Frank C. Edminster

XVil The Maintenance of a Grouse Crop ly Gardiner Bump. Robert IV. Darrow and Frank C. Eduinster

XVill Coorninating Grouse Production Witil Other Primari Land Uses by Frank C. Edminster 


\section{I'ART IV. APPENDIX}

Methons ano Techilques by Walter F. Crissey

'The Avatomy of the Ruffed Grouse by David E. Davis

Tine Pterylography of the Ruffed Grouse by John E. Trainer

Pingsiolocical Studes of the Ruffed Grouse by William H. Long

A vallable Insect Food for Grouse Cuncks, condensed from a report by M. E.

Phillips

Forest Stano Improvement Work for Woodaxos in Which a Conbixation of Forest and Gane Crops Is Desiren by Gardiner Bump

Tables RelatiNg to:

Shelter Requiremexts by Gardiner Bump and W. Mason Lawrence

Predatiox by Robert W. Darrow.

Artificial Propagation hy Gardiner Bump and S. C. Fordham

Propagation of Foon or Shelter Producixo, Species by Frank C. Edminster 


\section{LIST OF ILLUSTRATIONS \\ COLOR PLATES}

Color Pijases of Ruffed Grousf

Frontispiece

Visual Diffelences Between Sexes of Ruffed Grouse

Ciiallenge or love Call. the Morning Roll

Of a Drumming Grouse Awakes One's Soll..

Breaking Day, Morning Dew,

Old Rail Fence, Woods Edge: Too,

Young Grolise Chicks. Watchifu. Hex.

Junetime's Come to Partridge Glex

\section{BLACK AND WHITE PLATES}

Snares Confiscated by the New Yonk State Conservation Deiphtment

Dr. A. A. Allfin, Dean of Ameirican Grouse Blifepers, With Some of His Havo. RAISEN BIRDS

Partial Alaino Ruffed Grouse Taken \eall fort Kext, Me.

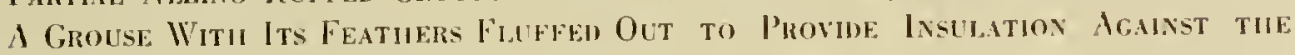
Col.1)

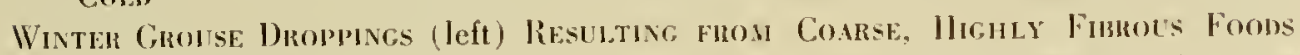

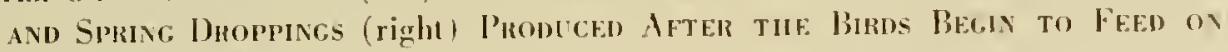
Fresh Gliekn Materin.

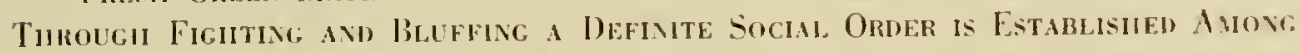

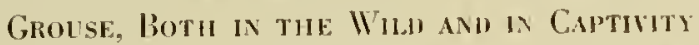

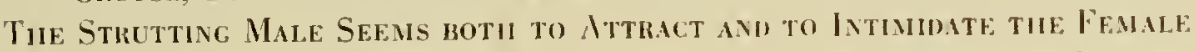

During The "Gentle l'hase" botu Sexfs are Qulet and Subdifo in Actios

While in the Figiting l'hase. Tue Male Exhunts Coxsiderable l'ugnaciolsness in

DeEense, of His Territom

RoMEO AND JULiET

A Group of Typical Grouse lisgs

Thuef. Grousl Chicks Six llonis NFtek Hatchisi,

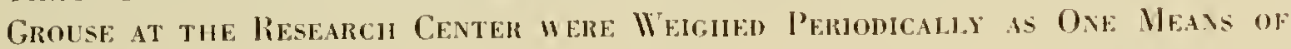
CombatTing DISEAsE

Grolse arf. SElnon Abundant Where the Forests are Extensite and Unbrokex

Tile Ambondack Region Consists of Mlountans and Wide Lowlands. Foresten Cimefly With Spruce, Batsam. Pine, Burci, and Maple. In the Valleys ahe Scattemen Ponds, Swamps and Clearings

Tine Catskill Region is a land of Narrow, Fanmed Valleys With Pastures Extending up tilf Slopes to Meet Extensive forests Composed Maingy of Beecil, Birch, Majle, Hemlock axd Pine

The Rest of State Region is Cuaracterized by Fertile Valdeys axd Pooris Farmed Uplanis. Here tile Mosalc of Abandoned Fields, Old Pastures and WoOnLots lorms May a l'Ron ctire Covent

Grouse Covel is Coxstantly Cinanging as Fields Seed in, Woods Grow up Perhajs to Fall Again Before tie Lumberdian's Axe 
The Stares of Succession Tumogen lluich Cover Passes Mal be Duved Into

Cover Trpes Bastil on tile Composition axo the Use Grovse Make of it

Oprix Laxi) (Type A)

Overghowx Laid-Popple (Type B)

Overcrowx Laxi-Alokr Beds (Type B)

Oyergrown Land-Pure Bircu Staxd (Type B)

Oyergrown land Fulling in to Berries. Shrlbs axi Smal, Trees, bet Preioni-

natey Hakd wood in Character (Type C)

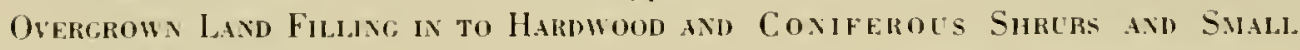

Trees (Type D)

Sacond-Growth HaRmwoods (Type E)

Second-Growth Hardwods and Conifers (Type EH)

Mature Hardwoods (Tyje Fi

Hature Hardwoods and Conifers (Tyje FH)

Spot-lunberad) Area (Type G)

Conifers-Mature SPruce (Type H)

Conifers-Mature Henlock and Pine. (Type H)

Conifers -Hemlock Ciump (Type H)

A Young Siasing Largely in the Herb, Berry and Young Sprout Stare (Type I)

Ax Oliner Slashing with Sprout Hardwoons Gradualy Crowding Out the Herbs AND Briers (Type J)

Nearly Half of the Grolse Nests in New York State are to be Folnd in Second-

Growtil Hardwoons (Type E)

Many a Nrst is Placed Against a Stump

Tue Site Most Conmoxly Chosen is at the Base of a Tree

A Very Unusual location is in the Hollow of a Stual

129

A Nest is Occasionalis Situated ily a Pile of Logs

A Fear Birus Place Their Nests Under Locs.....

A Loose Tangle of Brusij Offelss a Likel. Spot for a Nest

But Few Nests are Piacen Where the lmanhate Cover is Dense

An Old Woods Road is Attractive Alikf to the Man in Searcil of Relasation and

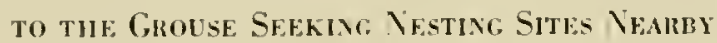

The Favorite Haunt of Grofse: Broods Thuroughout the Sumar is the Orekcrown Field, Especially if But Few Confers ale Present (Type C)

Alder Runs are Particularly Attractive to Broome in the Anmondacks

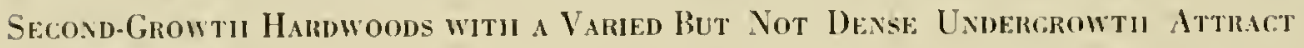

MATY likoods

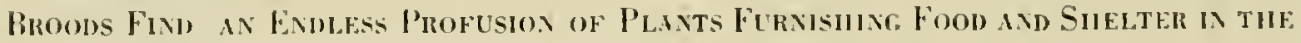

SIASIIINES

Fan.y Broon Cover is xot Always lunvisied by the Vecetitiox

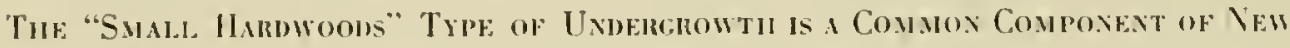

YORK WOODIANIS

WINTER Sileltei

SPRINC, BuFEMM: Guounds

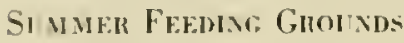


While Preferring the Ground, Grouse take Readily to Trees when Necessari

Grouse Often "Sit Tight" When Threatened by Danger

Grouse Thrive where there is a Rich Diversity of Trpes. Herf. Opex Fields.

Overgrowx Laid, Secoxd-Growti Hardwoods axd Mixed Hardwoods and Coxi-

fers Combine to Make a Problctive Covert

The Luther Preserve is Reforfated with Blocks of Conifers which Oftex AdJoin Natural WoOdiands

GOOD "EnCE" COVER

Sinall Siasinigs are Atrractive to Broous and dollts Alike

Tue Amount ani Variety of Food Found in the Crop of a Grolse is Often Sur. PRISING

Spring Grouse Foods

Summer Grouse. Foods

Fall Grouse Foods

Winter Grouse Foons

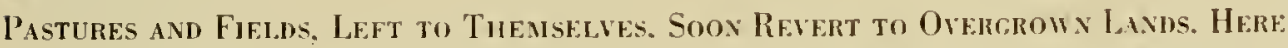

Species l'rovidixg Excellent Grouse Fond and Some Sineltek aie $\lambda$ pt to be: Plentiful

Scrur Apples and Hawtuornes, Cattle. Seeded in Old Pastires, are Iriae FavorITES WITII TIIE GROUSE

From Junf: Through Sertember no Covel 'Type is so Ricil in Grouse food Plants as are Cut-Over Lands

Track of Ruffed Grouse in Snow

Wing-Tip I IPRessions Left in Swow where Grouse had Takex OfF

"Billy" (sce Text) Silowing, Rieaction to Runving Motor of Tractor

252

253

26.3

Pile of Winter Droppings Showing where Grolse il ud Roosted ox the Grouvd FOR SEVRiR, HOURS

Trpical, Grouse Dust Batil Besine Stump

A Drummine, Grouse

Rear, Front and Side Views of Coch Grolse dirive Drunumg Priformance. Each Sequence Starts at Top

Where a Grouse Dremane in the Srow on a Grante Ledge iv Februar

A Typical Gronse Drummag Iog

A Strutting Grouse

Tue Nest of a Ruffed Grouse is Merely a Cup-Shaped Depressiox Amoxg tile Leaves of the Forest Fl.ook

Grouse which Continuen to Sit on Nest in Spite of Woon-Cutting Operation DIRECTII BESIDE IT

Grouse Negt Containing Six Pheasant Eggs

Grouse Egg Silelis Found in Vicinity of Brokex-lp Nest Giving, Euinexce of having been Eaten by a Fo\. Sileils were Actualy Left Much More Widely Scattered thax Shown in l'hoto

Site of Broken-up Grouse Nest Showing Feathers of Female wilch was Probably Killed by a Great Horned Owl ayd Several Egg Shells Giving Evidexce of Having Been Eaten by a Raccoon 


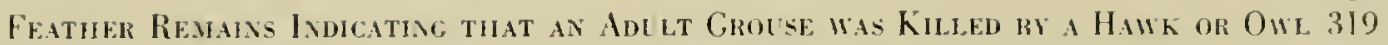

Fox Dropping Containing Grouse. Feather Remains

Phllet of Great HorNen Owl Showixg Grouse Remaixs axd Susceptibility to

Disistecrating of Pellets Composed of this Sort of Materiar.

A Tipical Clutch of Grouse Eggs

A Vest Fuli, of Grouse Cuicks Just Hatciled (several shells removed hy photographer)

Explayatory Posters and Report Cards were Tested as a Metmod of Securixg

Ilunter Kill Records

INFestatiox of the Gizzard WoRy (Cheilospirura spinosa) Uxder Gizzaro lisho-

a Relathely Hariless Parasite of Crovse

A Normal. Proventriculus (right) Compared witu Oxe Infected with the Stomach

Woru (Dispharynx spiralis) - a Relativer Harmful Parasite of Grolise

Three External. Parasites of the Ruffed Grouse and the Solibug. Iateriedite

Host of the Stonaci Wory (Dispharynx)

Some lnternal. Parasites of the Ruffen Grouse

Bird Ticks (Haemaphysalis chordeilis) Attached to Hean avi Neck of Anelt Grotse 431

lesions of Aspergillosis ix LuNg AND KidNey of Adult Grolise

Field Station IN the Western Catskile Molntains where the lniestigatioxs

First Tests of Rearixg Grouse Under Semi-naturil Conditions. as welt as in

Brooneks, Were Carried Oet

Ix this Kettle, Ixcubaten Grouse Eggs, Burien Betwegx Liyers of Cotton. \ere

Carried Successfuldy Over Distances up to 200 Mliles

The Ixterion of a Pex Used to Raise Grouse by the Semi-xatukal Methon it tile

Catskill. Station

Eakli Ferstian Incubatol

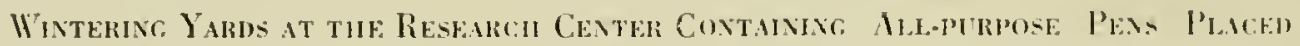

END to ENI

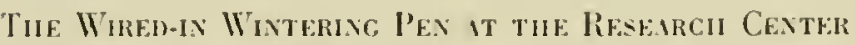

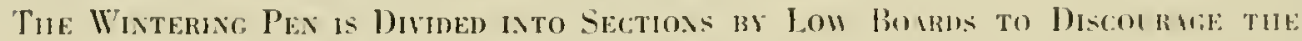

Biros frov Chasing One Awotuel

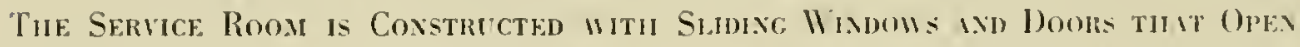

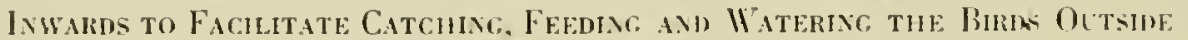

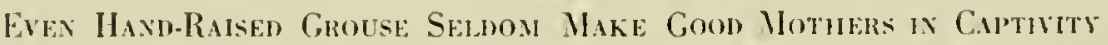

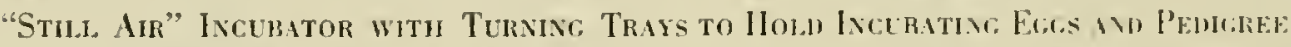

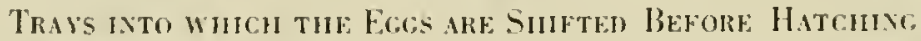

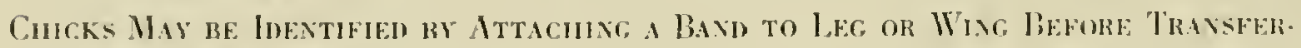

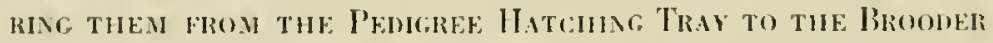

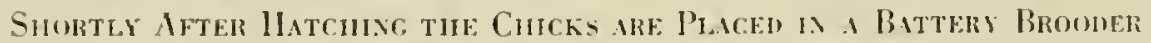

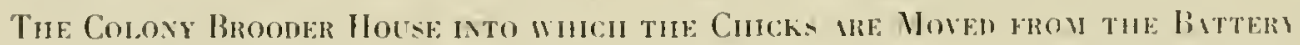

BroONERS WHEX FroM TEN hO TWELE MAS OLd

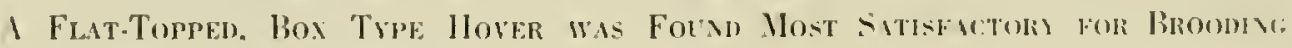

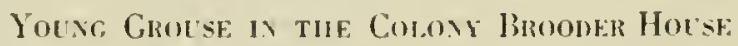

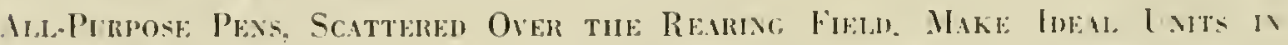

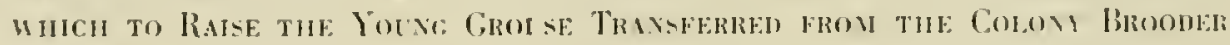
InISE: 
Birds May be Kept in the All.Purpose Pexs in the Rearisg Field Lxtil Mell. INTO TIE FALL

White or Orange-Colored Chickes Featilers, Mired Fast to the Tall Feathers of time Grouse Berore Liberatjos. Aid in Checking ox Slbseqlent Movemexts 505 Liberated Grouse Soon Adapt Themselves to Wild Covitiovs Altholgh Some Never Regain thejr Fear of Min so Characteristic of Their Wijd Cousins

An Excellent Covert in wijicif Mixed Woods are Edged With Overorowy Fields and Broken, Here and Tuere, by Siall Slashings and Abandoned Lands. Sucil a Covert May Proyide. Large Crops of Botu Grouse and Tinibr. If Skil.t. FULLY MAINTAINED

Typjcal Abaxdoned Upland

An Ideal Edge Suciu as tils is of More Vale for Wililife tian as a Site ox Which to PJant Evercheens

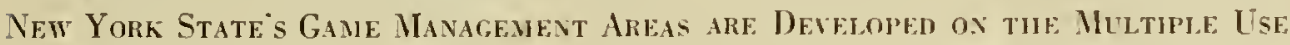
Principis.

An Occasional, Small Siashing, Makes Extensive WoOdland More AtTrictive to GROUSE.

Winter Feening, Statioxs Attract Onhy al Occasional. Bird

In Back Pastures, Mavy a "Croesy Nook" is Mhataixed by Moderate Grazino,

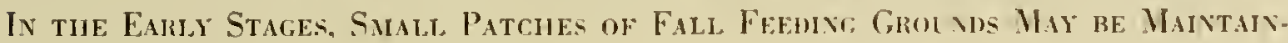
ed Rather Fasily

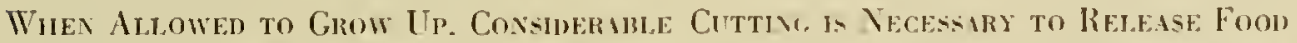
Species fron tul: Competitjox of Tueir Tallek Nighroks. Witholt this Hecp, Aprefe axi Sumacil (indicated hy arrows) Wh.l. Soon In. Cuoken Ort

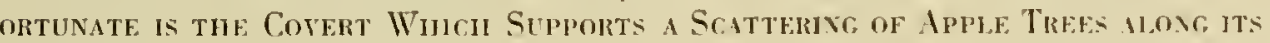
Enges

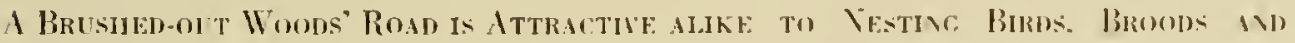
ADUi.Ts

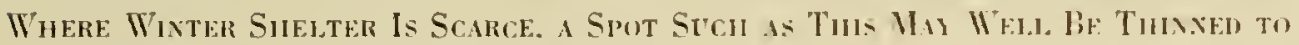
ENcourage tije EV ERgreans Beneatil

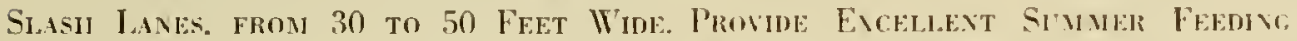
Grounds for Broods and Fald. Fehoinc Areas for ADuts

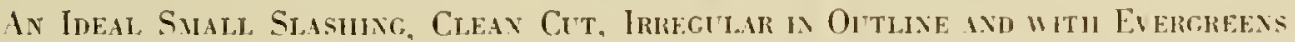
NEARBY

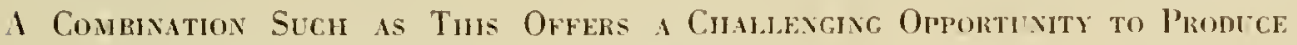
Large Crops of Botij Crolse and Timber

Heavif Prunen Plantations and Grouse Are jot Compatible

Where the Proper Segn Trees Are Preseyt Nature May Oftey Bf, Depexine

UpON to Re-establisi Satisfactory IT OOnY Coler

Planting Spruce by the Center Hole. Techimue

Most Harnwonn Trees and Shrubs Respond Best When Playten Directuy Ixto

Newly Plowed Fi riows

White Pine, Interplanted in an Openisg ix Second-Growth Hirdwonds. Heli:

Provides Much Needed Tinter Silelter for Grouse

Where tile Crowy Coner Is Fairly Opex ax Underplantix, of Shade-Tolfratt Spricf. May Also Furnish Winter Sileat ter 
Ax Excellent, Planten Surub Bornek

Tius Shrur Border Resulted from Cuttigf a Bano 20 Feet Wide Along the Enge OF TIIE WOODS

There Is a Sharp Coxtrast in Undergrowtil Dexsity axd Diversity Between Heav. ily Pastured Woodand and Those fron Which Cattle Have Beex Excluded 66.5 Grouse Survey Field Crew Lined up Ready to Enter a Covert on thif Connecticut HIL, AREA

Trpical Speciness of Grouse Egc Shell Remains as Left by Various Nest P'renaTORS

Remaixs of ADelit Grouse Killen by an Accepithixe: Hawh (probably Cooper's) Showrig, Hean Still attached to Carcass, Fener Picked Cleax But Not Firactutred. and Gizzard Uneates

Winter Grouse Trapping, Setup Silowing (upper) Silelter with Bare Ground Beneath aNo (lower) Wire Cagf. Trap With Captured Bird

Grouse Trapped at Nest and Marked With Colored Chicken Feithers Wired to ITS TAIL

Rear Portiox of Bony Cavity of a Bird of the lear (left) Showing Bursa as ConPARE.) Witil TIIAT OF AN OldPER BiRd 


\section{LIST OF FIGURES}

Number

Tille

1 Range of the Ruffed Grouse

2 Distribution of Recent Records of Ruffed Grolse Over Its Former Raxge in tile Nortif-Central and Mid-Western States

3 Relative Abundance of the Ruffed Grouse Throughout Its Presext Range

4. Structure of the Fresh ani of the Developing Grolse Egg

5 Annual Cianges in Sinel. Thickness of Grouse Egcs Collected from the ITHACA, New YoRK, Reglov-1936.1940

6 Annual Changes in the Whigut without the Yolk Sic of lewly Hatched

Grouse Collectei) rrow tie Ithaca, New York. RegroN-1936-19.17

7 Grouse Developaent from Hatching to Adultiood

8 Progrfasion of Wing Feather Developiest in Yolyg Grous:

9 Relative Deverophent at WeEkl.y Intervals of INing Feathers of lolwo, Crouse

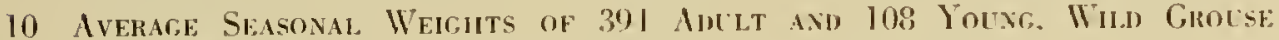
FROM \EW YORK

11 Seasonal Weicht-Healti Relatonshro of Anclat Grol :

12 Grousl Curck Calls

13 Parts of New York State Most Typical of the Tulez Majom Grolse. Habi-

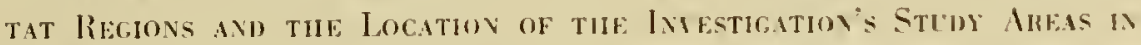
Eacil

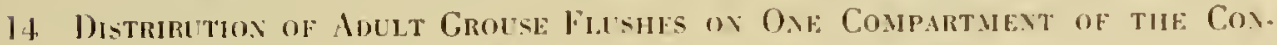

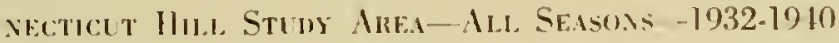

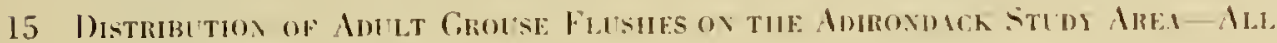
SEAsom-1932-1911

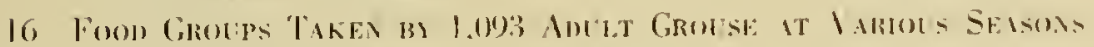

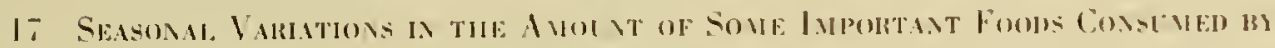
1.093 Anelt Grocse IN \eW lork

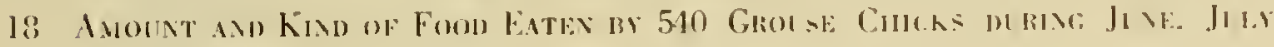
(N) $\Delta+1 ; 1=T$

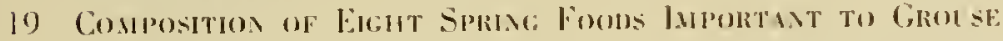

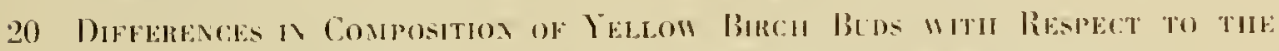

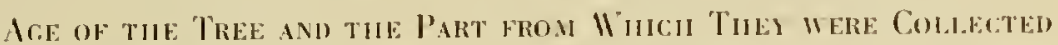

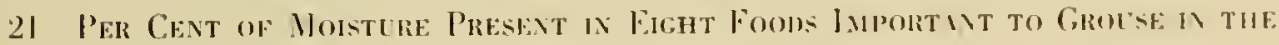
SPRIN,

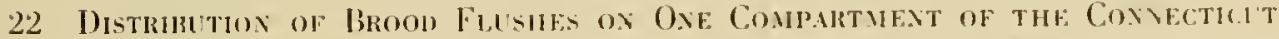

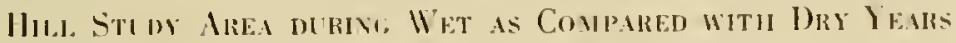

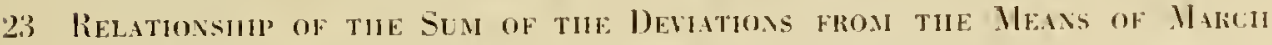

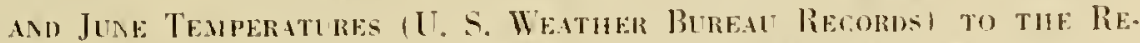

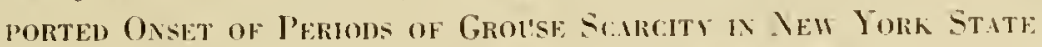

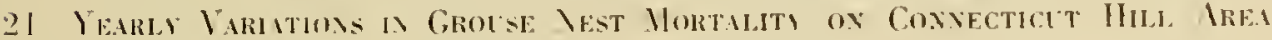
As Compafed witi Exthe STATE-] 931-19.1!

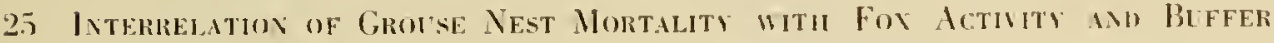
Ablanance Connecticht Hill AREA 1931.1911 
26 Average Progression of Grolse Broon Mortality on Connecticut Hill axi Adronmck Areas as Comparei with Tilat of Chicks IJ atched from Irul Egos at tue Researcil Cexter

27 Relationsinp of Numrer of Adut Grouse lost to Precening Fall Population Level on Connecticut Hill and Admondack Aleas-1930-1942

28 Relatoxship of Inchence of Grouse Remains in Great Horned OWl Pellets to Grousf Adult Mortality and to Buffer Abuvdance-ConvectiCLT Hill AreA-1930-31 to 1941.42

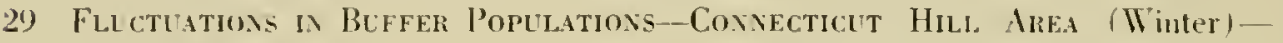
$193.1-1941$

30 Comparisox of Fluctuations in Buffer Abundance and Fox Activity - CoxNecticut Hill AREA (Winter)-1934-1941

31 Trifal Ifife Crcle of Pakasite Ixvolixg Indrect Mode of Transmissiox-.. Stomacu IIORM (Dispharynx spiralis)

32 Distribltow of Townships from Winch Grolse Harboring the Stomacil WORM (Dispharynx) Have BeEx Collectel)

33 Detalls of tile Wintering Pey Bullt Around a Service Room

31 Form Used at the Researcu Center for Keeping Pedigree Recoris

35 Foru Used for Keeping Reconds of Ixdindul. Male Birds

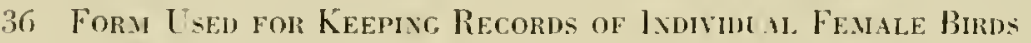

37 All-Purpose l'ess (Right) l'rovide Slitabi.f Ourters for Breedro. Rearinc and Oyer-winterin; Grouse. To the Left ake Multiple-unit Bread)ING. PENS

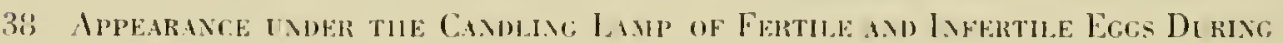
IXCI BATION

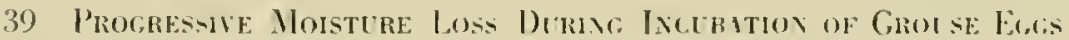

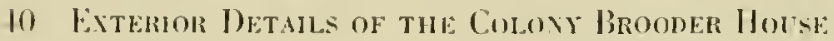

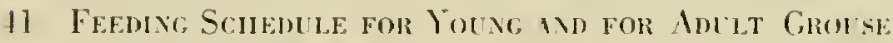

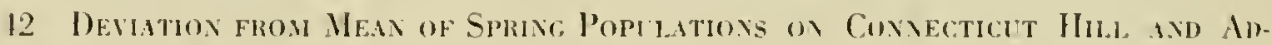
IRONHACK AREAS-1930-1912

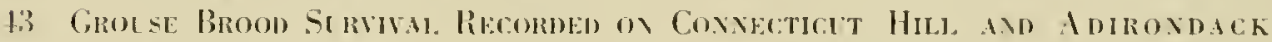
IRFAS -1930.1942

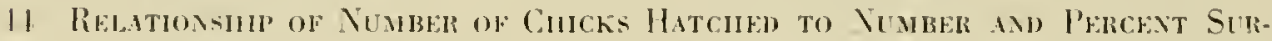

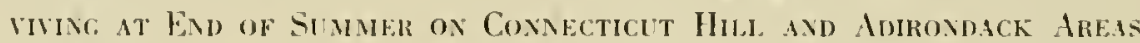
1930-19.12

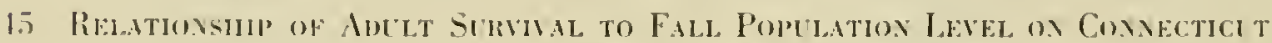

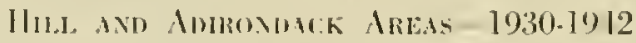

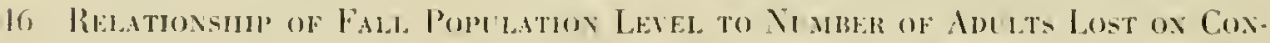

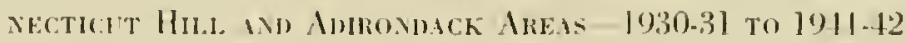

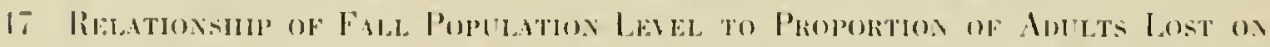

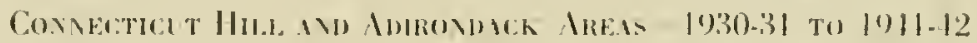

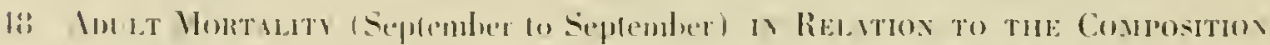

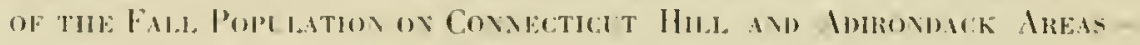
1930.31 (I) (1) $11-12$ 
49 Relative: Survival among Adult Grouse Adjusted to the Mean Size and Age Composition of tile fall Population on Coxnecticut Hill and AdronDACK AREAS-1930-31 TO 1941-42

50 Seasonal. Distribution of Dead Grouse founi ox Connecticut Hill Area1930-1942

51 Grouse Population fluctuations Recorded from Year to Year dering the lnvestigation on the Connecticut Hill and Adirondack Studi Areas1930-1942

52 Average life Equation of Increasing Grouse: Population

53 Average life Equatiox of Stable Grouse Population

51. Average life Equation of Grouse Population Decreasixg Primarily as a Result of High Over-winter Mortaliti

5.5 Average life Equation of Grouse Population Dforkasico, P'rianalla as a Result of Higil Nest Mortality

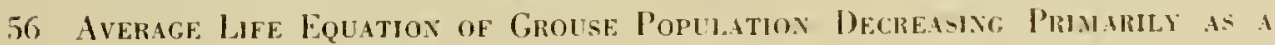
Result of High Brood Mortalaty

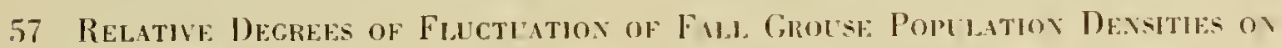
Connecticut Hil. and Adrovidack Areas - 1930-1912

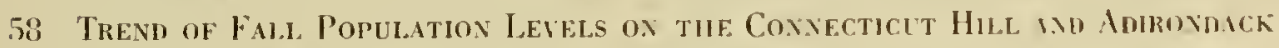
ARHAS WITI SNOOTHED VALER SLPERIMPOSEH

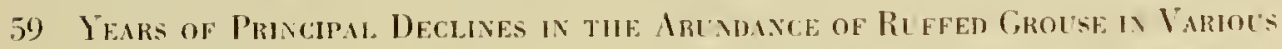

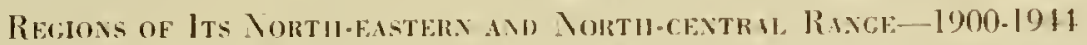

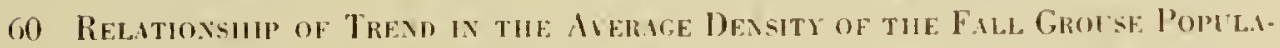

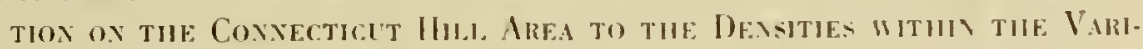

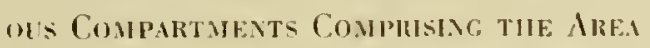

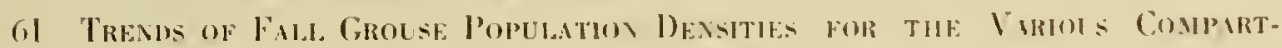
MLATS OF THE CONNECTCIT HILI. ARE 19:30.1912

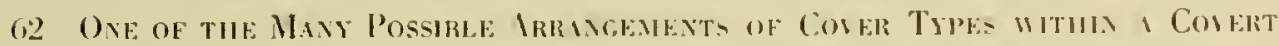

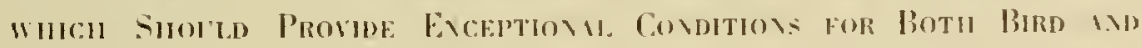
IITNER

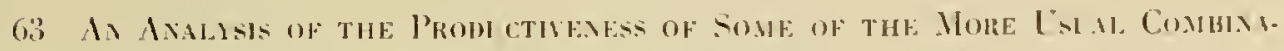

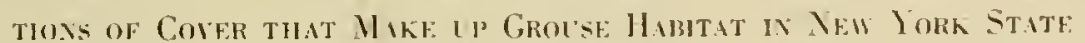

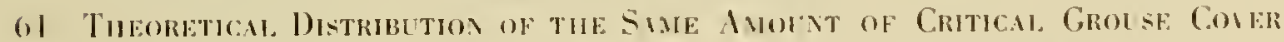

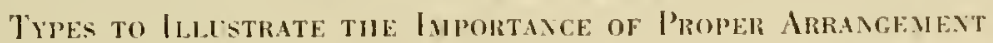

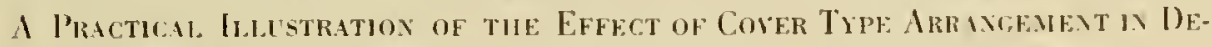

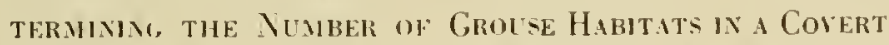

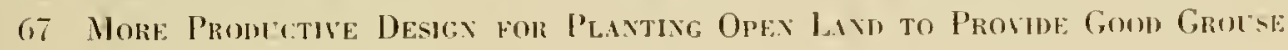
Covisk

6 Grover llabitat Develophext ox Subuarginal Lind

69 Organization of a Conert fok Both Grolse ind Tiurer Production

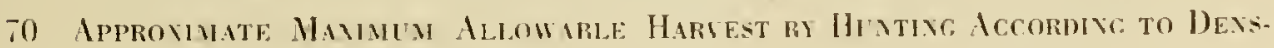
ity of Fil. Popelatio.

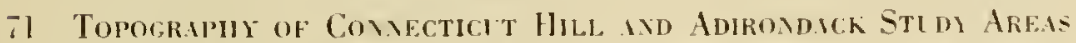

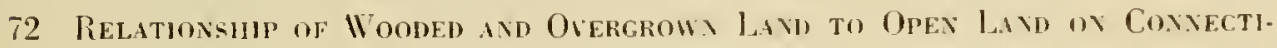
CET HILL. 


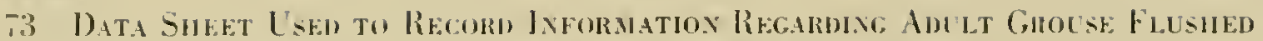

7. Data Silete [sed to Ricolio Grouse Nest Informatiox

7.5 Data Sheet (ised to Ri:corn Grouse Brood Informatiox

76 Data Sheet Used to Recomd Ixformatox Regaring Dead Grouse Found

77 Majoh COMPONENTS OF GROUSF SKELETON

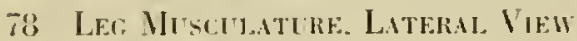

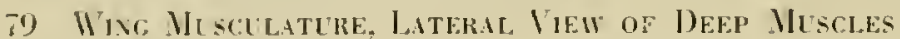

30 Digestive SYste:M

738

8) LONGITIDINA. SECTION OF LARGE lNTESTINE

82 Frather Tracts and Spaces of the Rlffen Grouse

83 Ditran. Trexis ix Rectal. Traperature of Two Groups of Adulj Grolse, Group A of Which Was Exposed to ax Ambtional Hour of IllimixaTION IT Night

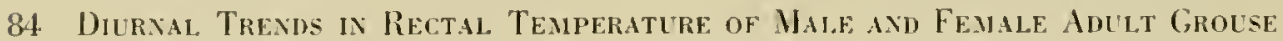

85 Effect of Excitemext on Rectal. Temperaterf and Respiration Rate of ADelt Grouse:

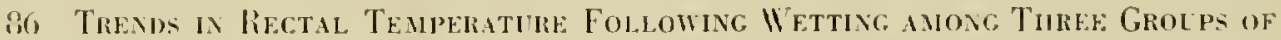
Adult Grolse Exposed to Differext Condtions of Air Temperitire Avi HuvInIT

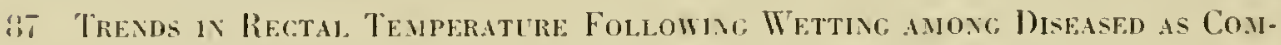
ParED "ITI HEALTHY ADLLT GROLSE

88 P'H SIOHoge Reactions of Two Grouse to Rrpost:

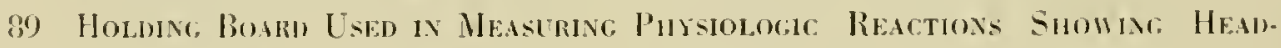

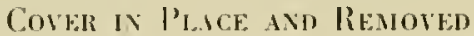

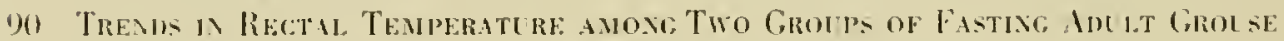
JHLI AT DHFERENT AIR TEMPERATURFS

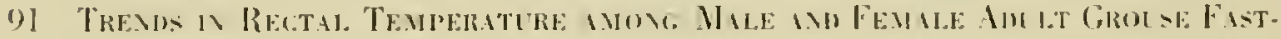
IN, WITHOT T DRISKH, IIATER

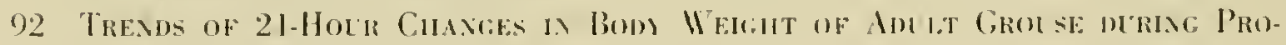

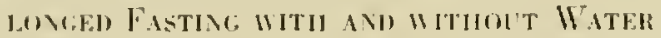

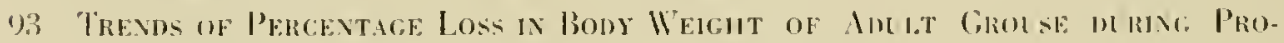
LONGED FASTIN; WITH ANI "ITHOCT II ATEL

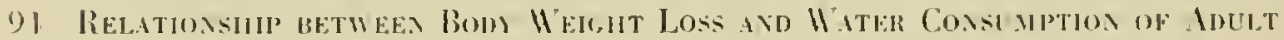

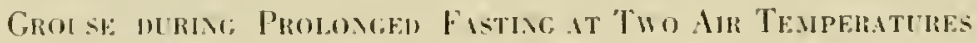

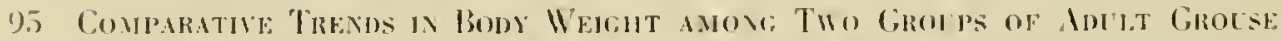

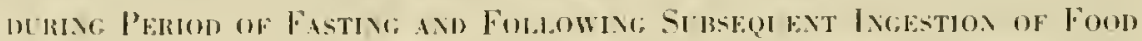

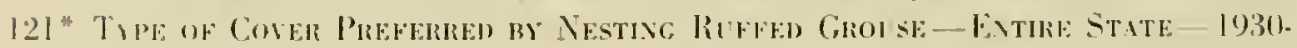
1930

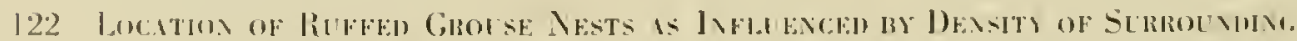

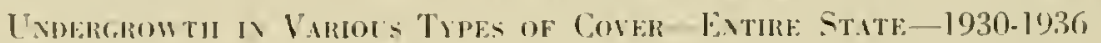

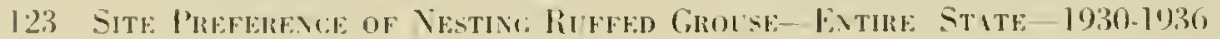

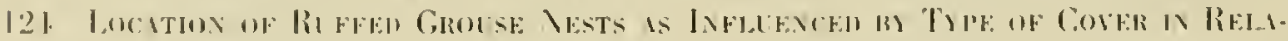

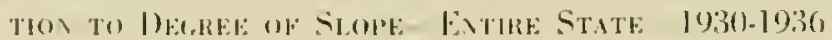

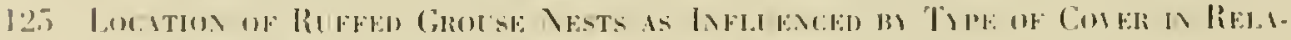

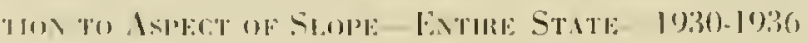


126 Location of Ruffed Grouse Nests as INILUEAced b Distance from Nearest Conifers-Entire State-1930-1936

127 Location of Ruffed Grouse Nests in Relation to Distance frow an OpesING-Entire State-1930-1936

I28 Location of Ruffed Grouse Nests as Influkicen by Type of Corer in Rela. tion to Distance fron the Mearest Slasimg; ENtire State-1930-1936

129 Location of Ruffed Grouse Nests as Influenced by Type of Opexing, in ReLation to Distaxce fron an Openisg-Entire State-1930-1936

130 Fate of Grouse Nests Accordng to the Trpe of Crows Cover ix Which Found a ; lnfluencell BI Reriox-ENtire State-1930-1936

131 Fate of Ruffen Grouse Nests as Inflelicein by the Lidergrowtil Dexsit in Variols Types of Crowy Cover-Entine STATE-1930-1936

132 Fate of RufFen Grouse Nests as INfluencen bi the DeNstT of Cover at tile Nest Site--EntiRe State-1930-1936

133 Fate of Riffed Grouse Nests as Infle facen b their Distance frou a Roau. Trail, or Other Opening ax the Varhohs Types of Crown Cover-Extire STATE-1930.1936

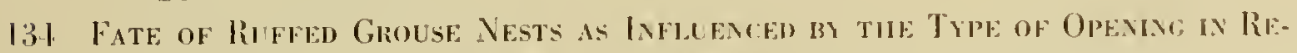

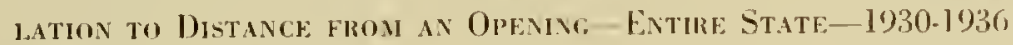

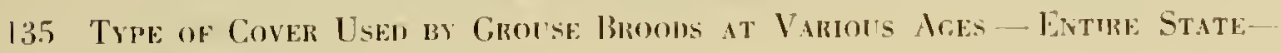
] $930-1930$

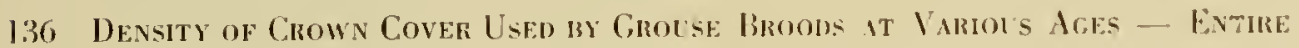
State - 1930.1936

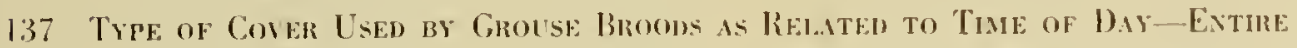
STATE-1930.1936

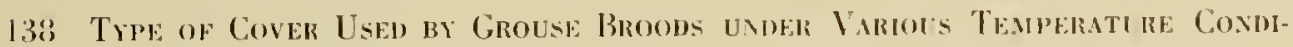
Tions- Entire: State-1930-1936

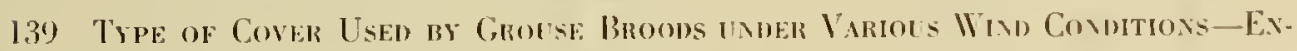
TIKE STATE-1930-1936

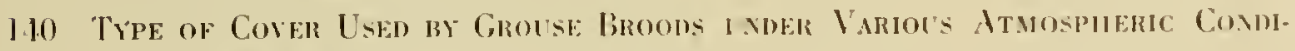
TIONS ENTIRE STATE-193(1)-19336

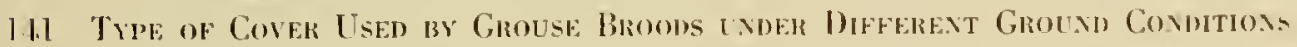
- Entire State-1930-1936

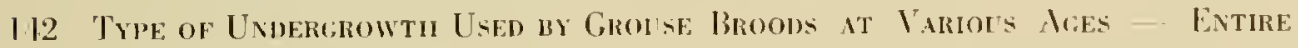
STATE-1930-1936

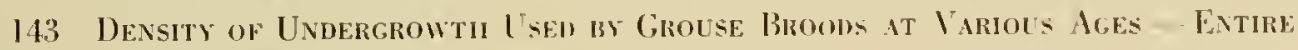
STATE 1930.1936

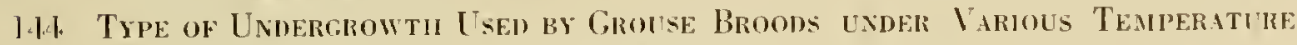
Condrons-Entire State-1930-1936

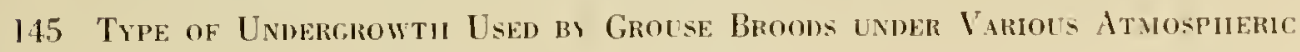
Condtions-EntiRe STATE- 1930-1936

116 Trpe of Undergrowth Usen by Grouse Broong ivner Variols Wind CompiTIONS-ENTIRE STATE-1930-1936

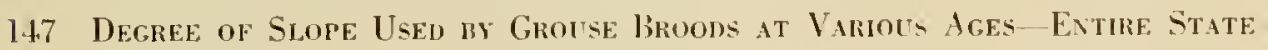
1930.]936 
Number

Tille

l'age

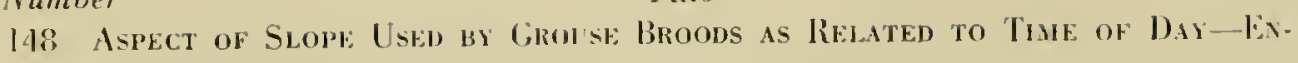
TIRE STATR-1930-1936

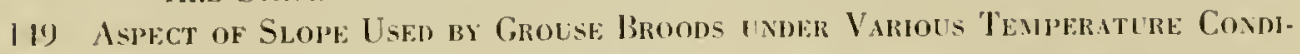
TIONS-ENTIRE STATk-1930-1936,

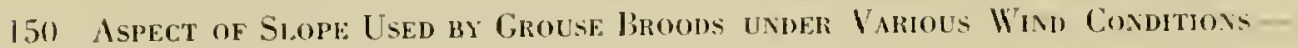
ENTJR: STATE-1930-1936

(i)

151 Aspect of Slope Used by Grouse Broods under Variols Atmospieric CondTIONS ENTIRE STATE-1930-1936 ...

152 Locations Used by Grolse Broons as Related To Interspersion of Crow Cover Trues-Entire State-1930-1936

I53 Type of Cover USed by Mnult Grouse by Seasons - Convecticut Hill Area $-1930-1936$

151. Type of Cover Used by Adult Grouse by Montis-Connecticut Hill Area $-1930-1936$

155 Type of Cover Used by Adult Grouse in Winter as Related to Time of Day - Connecticut Hill Area-1930-1936

156 Type of Cover Used by Adult Grouse in Siring as Related to Time of Day - Connecticut Hill Area-1930-1936

157 Type of Cover Used by Adult Grouse in Summer as Relateb to Time of Day -Connecticut Hill Area-1930-1936

158 Type of Cover Used by Adult Grouse in Fali. as Relaten to Time of Day-

Connecticut Hill Area-1930-1936

159 Trpe of Cover Used by Adult Grouse in Octorfir and November as líkitate to Time of DAY-ENTHE Statk-1930-1936

160 Type of Cover Used by Adult Grouse under Various Temperature CondTIONS-ConNeCTICUT 11ILL. AREA - 1930-1936

16] Tripe of Cover Used by Adult Grouse under Varrous Mixi Conditions - ConNeCTICUT Hil, AREA-1930-1936

162 Trpe of Cover Useb by Adurt Grouse under Varous Atmospueric Coniftlons-Connecticut Hili. Area-1930-1936

I63 Trpe of Coner Usen by Anuto Grouse under Various Groc vil ConitionsConinecticht llul. Area 1930-1936

161. Seasonal. Preferface of Anult Grouse for Ground on Ther-Four Areas1930-1936

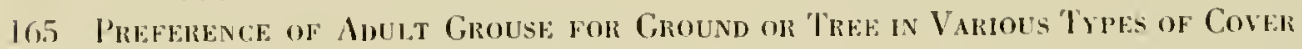
Folr Arras-1930-1936

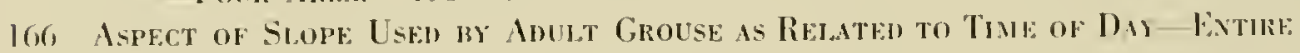
STATE-1930-1936

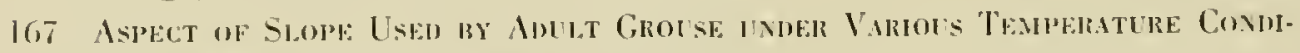
TJONS-ENTIR: STATE-1930-1936

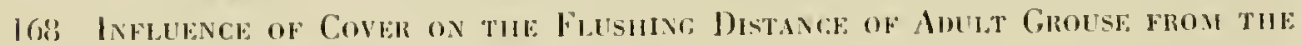
OLservier Four Arbas-1930-1936

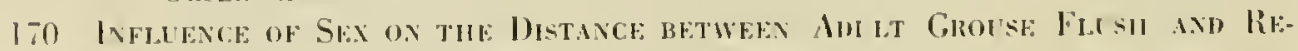
FISH-FNTHR: STATE: 193(1.1936

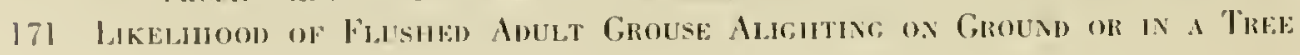

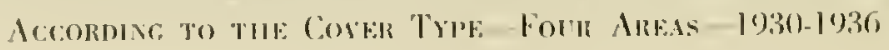




\section{LIST OF TABLES}

Number

Tille

I A Curonology of local or General Caises of Grouse Scarcity as Listed by

Two or More Authors

2 Recorns and Results of Grouse Liberations hinown to tile Investigation

3 Known attempts to Rear Ruffed Grolse iv Captivity fron Egge Collected IN TIIE IVILD-1879-1942

4. Known Attempts to Rear Ruffed Grouse in Captivity from Eggs Securen FROM HAND-RAISEI BIRDS-I875-1942

5 Recent Ruffed Grouse Investications

7 A Generalized Breeding Behavion Pattern Corering dullt Male Rílffed Grouse in Captivity Conplled from a Stum of 78 Indindal. l'atteris

: Physico-Chemical Properties of Groise Egcs Collecten frou tile lthaci. NEW YORK, REGION-1936-19.10

9 Chemical Composition of 189 ) Nenly Hatched Grouse Cincks Collected FROM tIE, ITHACA, NEW YORK, REgION-1936-1940

10 Average Monthly Welghts of 391. Anllt and jo Yol:ag Gohse CollectED IN NEW YORK STATE--1931-1941

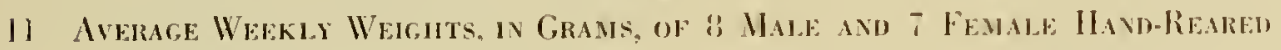
Grouse Chicks

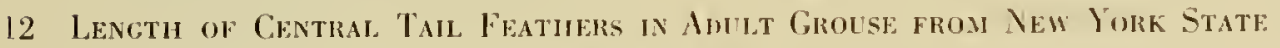

13 Explanation of the Cover Tress and Srmbols Usen av the RefFen Grouse INVESTIGATION

14. Type of Cover Used by Grouse Broods-Convecticit Hill Are.1-1930-1936

1.10

15 Types of Cover Used by Adult Gronse-Coxnecticut Hill Area - 1930-I936

I6 Relationship of the Frequency with Whici boges Occur to the Average level of Spring Populations on 12 Sectiose of the Conneticit Hil. AREA-1930-1942

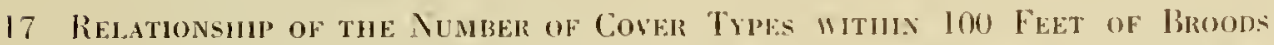
Contacted to the l'robability of Contact as Deterninen ry Rando.i SAMPLing-Connecticut Ilili. Area-1930-1912

18 Relation of Grouse Flishes to Enges ix Planted Coniferols l'laxtation ani) in Naturar. Woonlands-Lutjek Preserve-1933-1931

19 Major Stumes of the foon Habits of Ruffen Grouse:

20 Seasonal and Reglonal Distribution of tilf: 1.093 Adult Grolse: anil 510 Chicks, Collected and Analyzed for Food Habits Studes Extire STATE-- I93I-1941

21 Average Volumes, in Cubic Centimeters, of the Crop and Gizzard Contents of 1,093 Adult Grouse, by Season and Relation-New Jork

22 Seasonal. Variation in the Number of Foon ltems Per Indundul, Crop and Gizzard Taken by Grolse iN DeU York

23 Volumetric Percentage of Grave1, in the Gizzard of 1.093 Anult and 540 Cuick Grolse, for Variols Selsons of the Year and Reglons of the STATE

21 Properties of Some Polsonolis Plants Faten by Grouse 
2.5 Sources of Plant and Ammal foods that bulked Lakgket in the Diet of

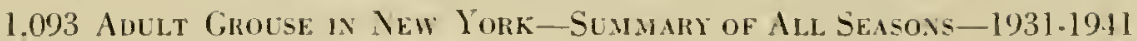

26 Q(antities of Becchuts Consumei) BI 1,093 Anlut Grolse IN \eW lokk 1931.1941

27 The Ten Grolps of l'lant foods Most Comaosly Eatex by Grouse ix NeW York duning Each Season, Silowing the Volumetric Percentaces, Mportant Species and Parts Eaten

28 Regional Variation in the Tex Most Impontant Plant foods of Adult Grousf, for Each Season-New York

29 Yearly Variations in Percentage Bulk of luportant Fuod Plants of Adllt Grouse in New York in Cojparison Witil the ll-year Aierage

30 A Comparison of the Volumetric Percentages of Fall Foons Chosen by Adult Grouse in New York with that Reported frow Other Parts of ITS RaNge

31 Monthly Variations in tie Inpoktant Plant and Animal foods of 510 New York Grouse Chicks

32 Cinaracteristics of Some lmortant Food Plants Commonily Utilized by Grouse IN NEW Jork

33 Distance betweex Successive Nests of Ixdvidual Markeb Female Grolse

34 Relation of Drumming Logs to Nests-Connecticut Hill-1930-1942

35 Grouse Nest Mortality Recorded in New York State and Proportion

RESULTING FROM P'REDATION-1930-19.12

36 Grouse Nest Mortality Recorded in Adrondack Recion-1931-1912

37 Brood Mortality Reconded ox Connecticut Hill ay Adrondack Study AREAS-1930-1942

38 Auult Mortality Recorded on Connecticut Hili, and Adrondack Stum AREAS - 1930.1941

39 Incioence of Grouse Remaixs in fos Droppines-Connecticlt Hib. Area $-1930-1941$

10 Proportion of Broken-lp Grouse Nests Atturuted to Varioly Preuators IN Different Regions of NEW YORK-1929-1942

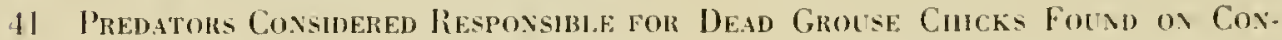
Necticut Hili. AND ADIRoxnick STIDY AREAs-1930-1912

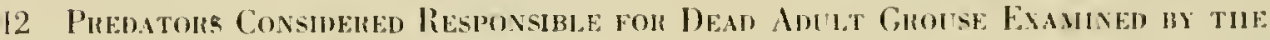
INVESTIGATIOA 1930-19.12

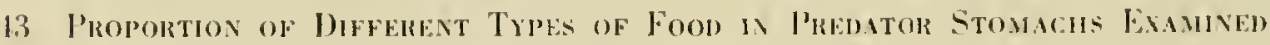
BЗ THE INVESTIGATION 1930.1912

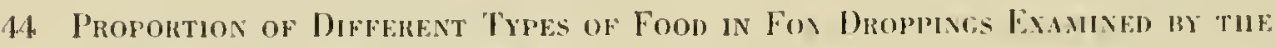
INVETIGATION-1930.191:2

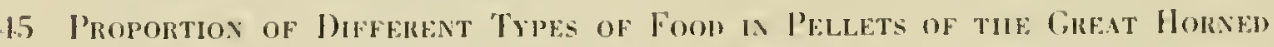

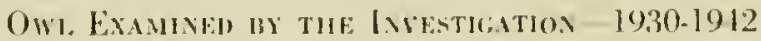

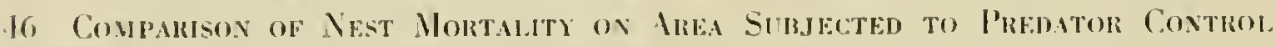
AND ox CuEck AIEA - Convecticit Hill-1931-1935

17 Compakison of Broon Moktality on Akea Subjectei) to Phematok Control.

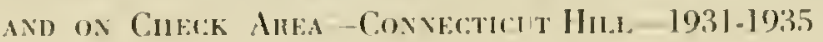




\section{LIST OF TABLES}

Number

Tille

Page

19 Comparison of Adllt Mortaliti on Area Subjected to Predator Control AND on Check Area-Conxecticut Hill-1931-1935

49 Relationship of Density of Grouse Breeners to that of Chicks at Hatciling axd to that of Total Population ix Fall os Controlled and Check Areas during Prenator Control Experiments on Connecticut Hill 1931-1935

50 Average Mumber of Egrs in First Nests--Entire State-1931-1941

51 Greatest Variation in Average Annlai. Clutch Size (in egge)

52 Average Number of Eggs in Renests- Eytire State-1931-1911

53 Infertiliti Rates in First Nests am liknests-Entire Stath-1931-1911

54 Embryo Mortality in First Nests and in liexests-Extire State-1931-194l

55 Reported Kill of Grouse avd Averacf. Seasonal. Bac per licensen Hixter likportin, IN NEW YONK-1923-1939

56 Grolse: Killed iby Hunters on HuNting CHeck Areas - 1930-1931

57 Analysis of Hunting Season Losses of Grolse IN \EW YoRK-1930, 1931 A.XD 1930

58 Cripling lose on Population Control Exiperiment- Conneticit ilil.

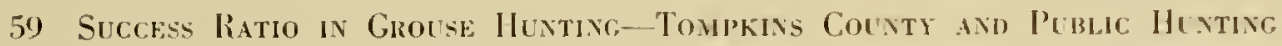
Ground Hunter-Cueck Mreas

60 Reported Take of Certais Predatory Fuk Beanens IX New York-1926-I939

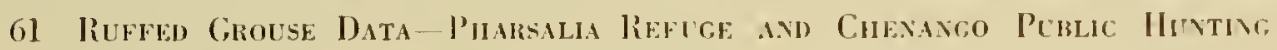

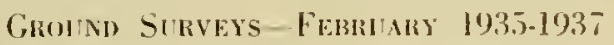

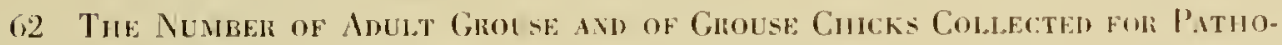
logicar. Examination bi Years and Rrgions

63 Tile Anima Parasites of the Riffed Grolse and their likported Misthibi. TION

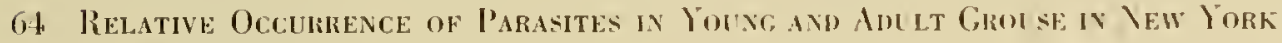
$-1931-1911$

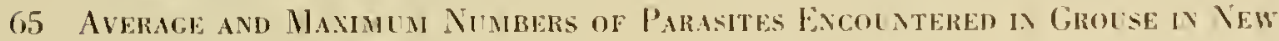
YokK-1931.19.11

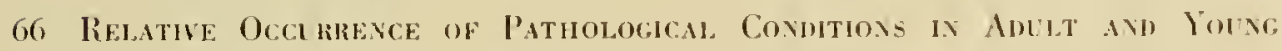
Grouse IN NEW YokK 1931.1941

67 Inchence of the Common Parasites of Grousfo IN NeW Jolk B Age Ciases $-1931-1941$

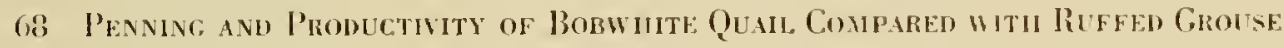
in Captivity

69 Average Weights in Grams of Hand-Rearen Grolse at the Researcil Centek DURing Clitian P'erions

70 Sugcested Conditions for the Incibatiox of Grouse Eggs

72 Summer Sex Ratios of Adult Grouse as Impicated by Popilation Estimates Connecticut Hill Area-Algust 31, 1930-1942

73 Sumuer Sex Ratios of Adllt Grouse as lndicated by Popilation Estimates -Adrondack Area-Auritst 31. $1932-1912$ 
7. Sax Ratios of Grouse Collecteo during Naraly Complete limisation of l'opulation on Tract Adjacent to Connecticut Hill-Octorer-Marcil, 1934.1936

75 Sex Ratios of hamatule: Grousk- Statewhr. Collections - August 1 Througil Drcenbel 31, 193\%-194I

76 Number of Females per 100 Acies in Spring Grouse Population on Consec.

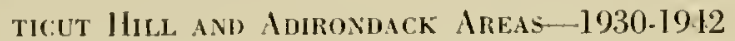

77 Nusibll of Grouse Broods per 100 A cres ox Connecticut Hill and AdroxDACK AREAS - 1930-1942

7i Number of Adult Grouse per 100 Acres on Connecticut Hill ani AidroxDACK AREAS - I930-1912

79 Relative Skcurity of Fall Grouse Populations on Connecticut Hill and ADIRONDACK AREAS-1930-1941

(3) Proportion of Broken-up Grouse Nests Observed during tile lNestigatiox ATtributed to Various Causes-I930-1942

il Brood Survival Recorded on Connecticut Hill and Anrosdack Study Arfas $-1930-1942$

;2 Relationship of Density of Grouse Cuicks at Hatcinng Tine to Survival, during Brood Period ox Connecticut Hill and Adirondack Stidi Areas $-1930.1942$

83. Relationship of Density of Breeding Populations to Survital during the: Brood Period on Connecticut Hili. and Adirondack Stuny Areas-1930. 1942

¿t Anult Survival Recorden ox Connecticut Hih. ano Adroxpack Studi Areas $-1930.1941$

¿45 Proportion of Dead Grouse Found ox Various Stum Arfas attributed to Varlous CaUsFis-1930-1942

¿36 Relationship of Density of Fall Grolse Populations to Subskelent Suria. yal ox Connecticut Hill ano Adroxdack Study Areas-1930-1942

ii l'ronuction Ratio of Grouse Brekding Populations on Connecticlt Hil. and ADIRONDACK STUDY AREAS as of SEPTEMBER 1. 1930-1942

88 Reiationshli of Density of Brefolicg l'opulations to Pronuction Ratio os

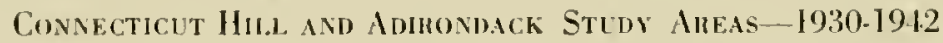

8) loss of Potential, P'ronectivity purixg Brefong, anb Nesting, Seasox Con-

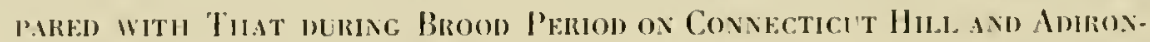
DACK STUDY AREAS-1930-]912

g) EfFect al Breeding Population Rroucorox ox Phopuctivity as of Septramben I Connecticut Hil, - - 1935-1937

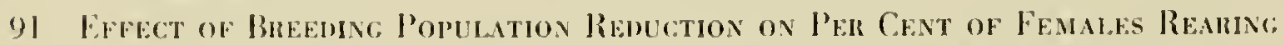

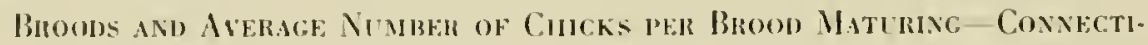
cuT 111.1.-1935-19.37

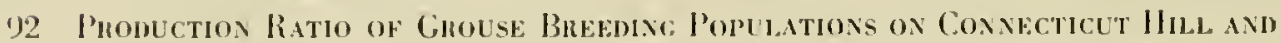

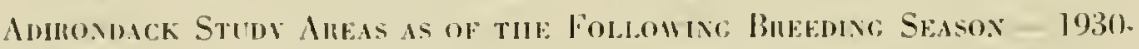
1912

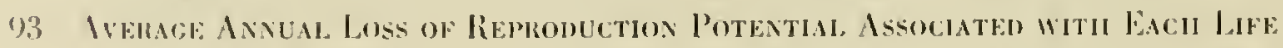

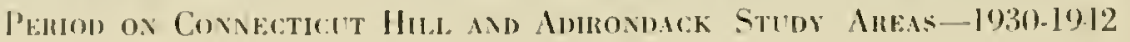


94 Extent to Whicil Certain Cover Types Found in the Northeast Fulfill Important Grouse Requirements and Furnish Cover for Otjer Activities

95 Relative Susceptibility of Various Trees and Shrubs to Poisoning with Sodium Arsenite

96 Approximate Cost of Establishing and Mantaning Clear-cut Units by Varjous Methods under New York Conditions

97 Uses of Trees, Shrubs and Vines for Plantations and Tieir Site RequireMENTS

98 Comparison of the "Averaging Percentages" and "Averagino Volume" Methods of Summarlzivg; Grouse Foods

99 Average Skeletal Measureulexts of 16 Adult Grouse

100 Average Measurenents of Digestive Tract of 16 Adult Grouse:

10] Number of Featilers Counted on an Indvidual Ruffed Grolse:

102 Average Rectal Temperature and Respiration Rate of Adult Grouse

103 Effect of Inactivity on the Body Temperatire, Heart Rate ard Respiration of Botil Feeding and Fasting Grouse

104 Heart Rates of Adult Grovse Living at Two Aik Teuperatlres witi Residect to Different Degrees of Activity

105 Average Standard Quiet Heart Rate of Inactive Adult Grolise lou Holks AFter Witjidrainal of FoOd

106 Calchlation of Amount of Depfondence ibetheex Pilsiological. Reactiovs of Feeding Adult Grouse:

107 Calculation of Amount of Dependence ibetween Ply siological Reactiovs of Fasting Adult Grouse.

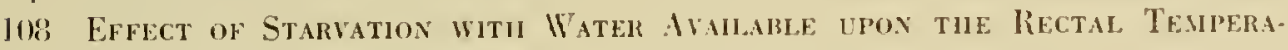
TURE OF ADULT Grouse

109 Efrect of Starvation upox Respiration Rate or Anult Grouse

110 Effect of Stakytion witholy Water upon the Rectal Temperitire and Respiration Rate of Adult Grouse

111 Comparison of Bod Temperature of Feening Grouse witi Timat of Grolse AFter Fasting 84 llouks Both WITI AND WITHOLt Water

112 Loss in Weight anong Anult Grouse diring Starvation under Different ConDITIONS

113 Rate of Digestion of Anult Grouse Feebin: Uninterrlptedix at Differest Air Temperatures

114. Rate of Digestion of Adilit Grolese after Fasting at Different air TemperATURES

115 Relationship between Envlongental. Temiperatire ani Digestine Activity

116 Dally Calonic Intake in Relation to Weight Chajee of Abult Groise at Two Air Temperatures

17 Dally Caloric Intake in Relation to Weight Cinage of Adllt Grouse aftek J'ROLONGED FASTINi;

118 Calculated Daly Caloric Intake of Food Needed by Adult Grouse to Main. TAIN WEIGHT AND VIGOR

119 Nunters of Insects and Allied Groups, by Orders, Collected fron 3-Foot axd 10-Font plots on the Connecticut Hill Area betweex June 2 - 


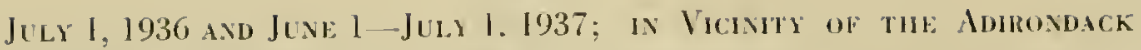
AREA BETWEEX JUNE 9 -JULY I I. 1936

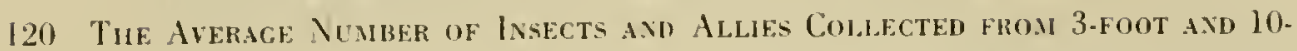
foot l'lots in Differeat Types of Cover on the Connecticut Hill drea BETWEEN JUNE 2-JULY 1, 1936; IN Vicinity OF THE ADIRONDACK AREA BETWEEN JuNE: 9-JULX 14, 1936

121 Type of Cover Preferred bi Destix. Ruffed Grouse-Entire State-1930. 1936

122 Location of Ruffed Grolse Nests as Influenced bi Dexisty of Surroundic. Undergrowtu in Various Types of Cover-Entire State-1930-1936

123 Site Preference of Nestixg Ruffed Grouse-Fitire State-1930-1936

12. Location of Ruffed Grovse Nests as Influencen by Type of Coyer ix Relation to Degree of Slope-EntiRe STATE-1930-1936

125 Jocatiox of Ruffed Grouse Nests as Influenced by Type of Covfr in RelaTION to Aspect of SLOPE-ENTiRE STATE-1930-1936

126 location of Rufred Grouse Nests as Influenced by Distance fron Nearest Conifers-Entire State-1930-1936

127 Location of Ruffed Grodse Nests ix Relation to Distance rrou ax OpexING-ENTIRE STATE-1930.1936

120 Location of Reffed Grouse Nests as lnfluenced by Type of Coyer in Relation to Distance from the Nearest Slasining-Entire State-1930.1936

129 Location of Ruffed Grouse Nests as Influenced by Type of Opening in ReLation to Distance from an Opening-Fntire State-1930-1936

130 Fate of Grouse Nests According to the Trpe of Crowx Coner ix Which Found as Influenced by Region-EntiRe Statr-1930-1936

131 Fate of Ruffed Grouse Nests as Ixfluenced by thr. Undergrowtu Dexsity in Various Trpes of Crown Cover-Entire, State-1930-1930

132 Fate of Ruffen Grorse Nests as Influencen by tuf Density of Cofer at tul.

Nest Sith:- ENTIRE: STate-1930-1936

133 Fate of Ruffed Grouse Nests as Influenced bi them Distancf from a Road, Trail or Other Opesinc in the Variol's Trpes of Crown Cover-Extirf. STATE-1930-1936

131 Fate of Ruffed Grouse Nests as Influenced by tile Type of Opening in RelatION to Distance frod an Opening-Fntme State-1930-1936

135 Type of Cover Useu by Grovse Broons at Various Agre - Fatire State 1930-1936

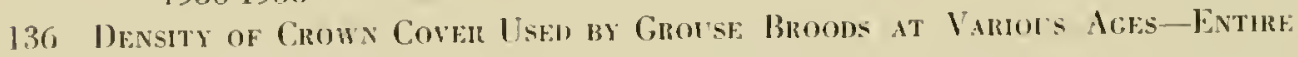
STATE-1930-1936

137 Trpe of Coler Lisen by Grovse Broons as lielatro to Trae of Day-Extike. STATE- $1930-1936$

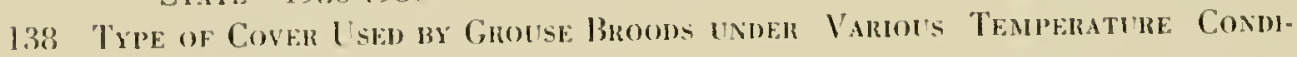
TIONS-liNTHR: STATF-1930-1936

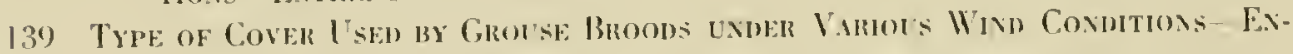
TIRE STATE-1930-1930

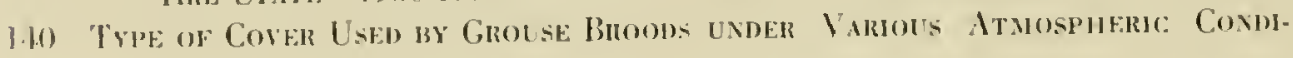
TIONS-Fonthe STate- 19:30-1936 
141 Trpe of Coler Used by Grouse Broons under Different Ground Conditons -Entire State-1930-1936

1.12 Trpe of Undergrowti Used by Grouse Broods at Various Ages - Entire STATE-1930-1936

143 Density of Undergrowth Used by Grouse Broods at Various Ages Entire STATE-1930-1936

144. Tipe of Undergrowtil Usen bi Grouse Broods under Various Temperature Conditjons-EntiRe State-1930-1936

145 Type of Undergrowtil USED BY Grolse Broons under VAriols AtMosplieric

CONDITIONS-FNTIRE. STATE-1930-1936

146 Type of Undergrowth Used ry Grouse Broobs under Variols Wind CovilTIONS-ENTIRE STATE-1930-1936

147 Degre of Slope Usen by Grouse Bromes at Varous Ages - Entrase State1930.1936

148 Aspect of Slope Usen by Grolse Broons as Related to Timp of DiY ExTIRE STATE-1930-1930

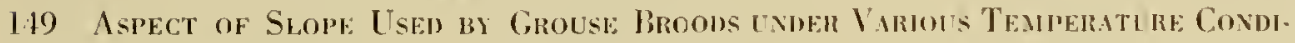
TJONS-Fitire STATE-1930-1936

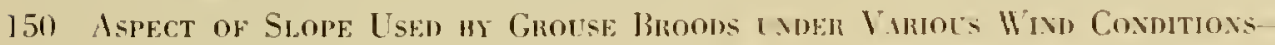
ENTIRE STATE-1930.1936

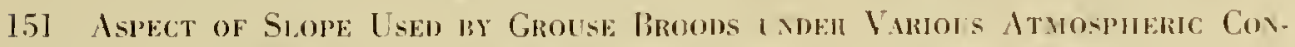
DITIONS ENTIRE STATE 1930-1936.

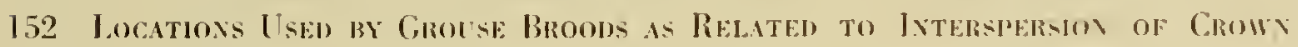
Cover TYPEs-FNTHE STATF-1930-1936

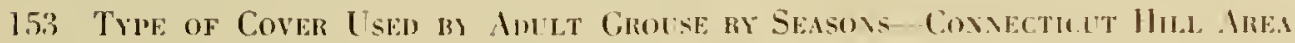
$-1930-1936$

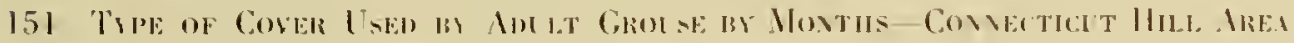
$-1930-1930$

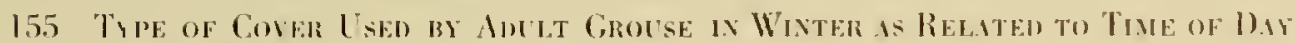
- Convectecete Hil. Area 1930-1936

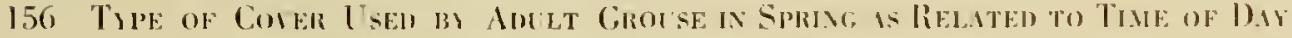
- Conmeticit 111.. Area 1930-1936

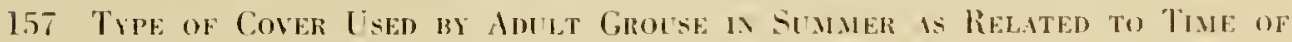

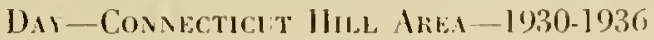

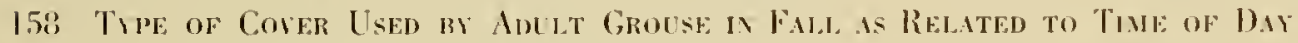
-Connecticit Hil. Are.i-1930-1936

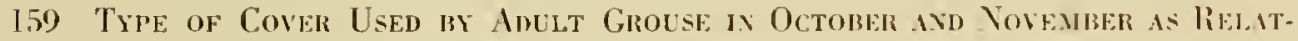
ED Tu TINE OF DA1 - ENTIRE State 1930-1930

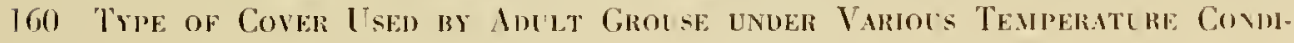
TiONS-CONnecticet Hill AREA-1930-J936

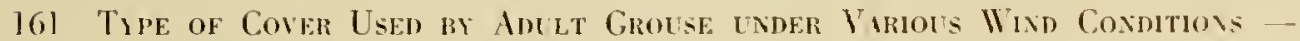
Convecticht Hill dira 1930.1936

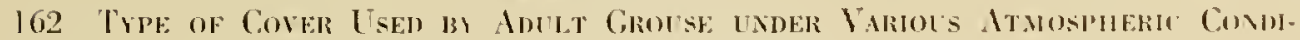
TIONS-CONNECTICIT HILL, AREL-1930-1936

163 Type of Coyer Used br Antit Grof CONNECTIClT Hill, AREA-19301-1936 
164 Shasonal Prefereice of Anllt Grouse fol Ground or Tree-Fon Areas$1930-1936$

165 Prefereyce of Adult Grouse for Grouxd or Tree ix Various Types of Coyer - Four Areas-1930-1936

166 Aspect of Slope Used $m$ Adult Grouse as Related to Tine of Day-Extire STATE- $-1930-1936$

838

167 Aspect of Slope Usen by Auult Grouse under Variols Temperature ConmTIO.NS-ENTIRE STATE-1930-1936

$16 \%$ Ixeluence of Cover on the Flushing Distaxce of Adut Grouse rrom the OBSFRVER-FOLR AREAS-1930-1936

169 Type of Cover Usen by Adult Grolse before and after Being Flusied FoUR AREAS-1930-1936

170 lnfluence of Sex on the Distance betweex Auurt Grouse Flisil axp ReFlusil-Entili: State-1930-1936

마3

171 Likelinood of Flushen Adult Grouse Alightixg ox Grouxd or ix a Tree According to tile Cover Type-Four Areas-1930-1930

172 Chemical, Composition of Some: Fonos Commoxly Eatex by Rifffed Grocse IN NEW YoRK

173 Srstevatic List of Foods Fousd ix Crops and Gizzards of 1.093 Ade lt Ruffed Grouse and 540 Chucks, Showing the Volumetric Jercentaces and the Number of Birds ix Whicil Fouxd-Fitire: State-1931-191]

174. SEAsoxal, Mistribltiox of Predator Stomach Specinexs Examised

175 Nimers of Various Prenators Takes diting, Controi. Experialests on CoxvFCTICUT HILL AREA-1930-1936

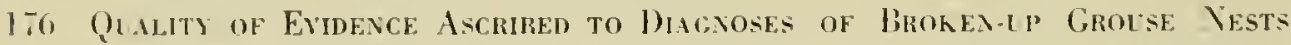

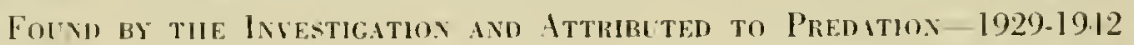

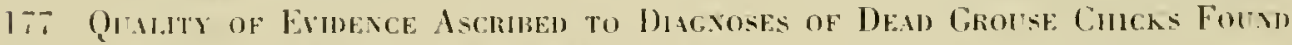

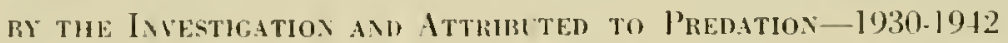

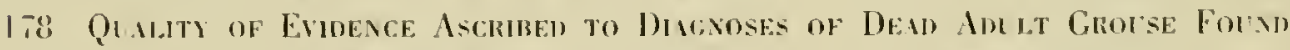

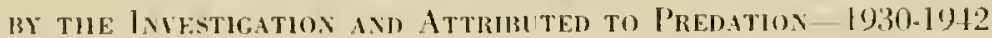

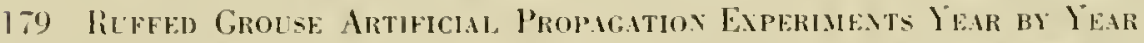

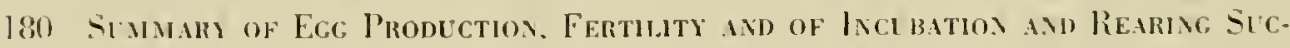

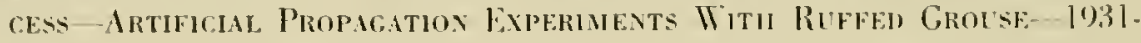
19.12

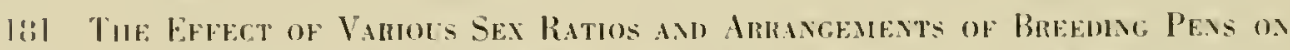

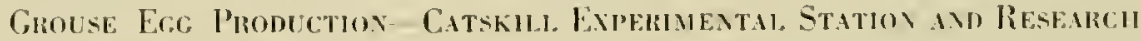
Centrik 1931-1912

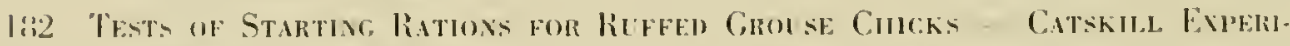

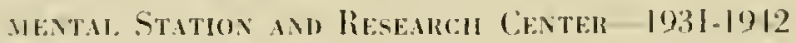

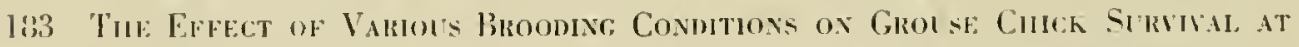

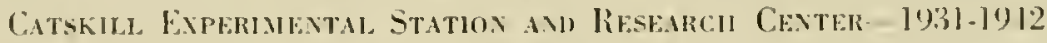

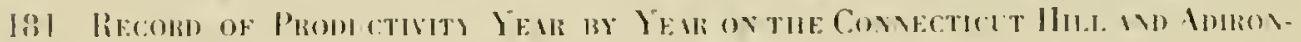
IICK STLW AREL 1930-1912

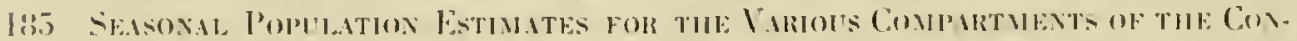

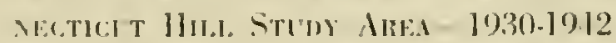

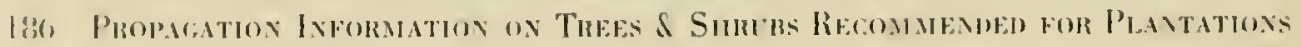




\section{PREFACE}

\section{"To know the grouse is to love it \\ And loving it, to wish it seell."}

In a scientific report such as this, there is little room for personalities or individual feel. ings. Only in the preface can one give expression to thoughts quite unscientific but undeniably human.

When those we love are in trouble we do our best to help. So it is with the ruffed grouse. Two and a quarter centuries have passed since the first law protecting grouse was enacted in the Colony of New York. Since then a million men. crun in hand, heart in the highlands and the swish of leaves in their faces, have roamed woods roads and forest glades, hunting partridge and finding zest in life.

That all who know the grouse come to have an affertion for this unpredictable thunderbolt of the uplands, is axiomatic. Its rolling drum and roariug fush add a persunality to the woods which nothing can replace. Its uncamy skill in foiling the sportsman has cudeared it to all who prize a wortly opponent.

The partridge asks no favors. It has never leen on relief. an with pheasants and quail in a northern winter. Yet, that it. 100, has trouble was realized years ago. The mysterious way in which. from abundance it suddeuly locomes scaree. then gradually grows plentiful again. has long causel genuine conceru. Iu fact. these violent periodic fluctuations in grousc mp. ulation have made many fear for the futmre of this remarkable bird.

More than a few endeavored to do something alwut it: Hodge. Torrey. Stodelart, Forbush. Walcott. Burnlıam, Nllen and a host of others: thus the honor roll rums.

As far back as 1907 the New lork State Conservition Department realized the need for an investigation of thesc so-called epidemies. Accordingly, it employed E. Seymour W'oodruff to send out questionnaires to oluain the opinion of sportsmen and game protectors throughout the State as to the cause. A. M. Stoddan. Rod and Gum editor of the New York Sun, made a similar study for the Department covering the 1917 scarcity. For over ten years it cooperated with Professor $A$. A. Allen of Cornell Tniversity by sending him, through its game protectors, the viscera of grousc from all over the State to facilitate his study uf grouse discases and by encouraging his pioneer researches into the artifucial raising of this: species.

Though plenty had always followed scarcity. by 1928 grouse were at such a low ehl, in New York that a closed season was invoked and retained through 1929. In August of that ycar, a group of carnest. worried sportsmen. led by George Lawyer of Watertown. met with Conservation Commissioner Alcxander MacDonald to see what might he done to save the hest shot-dodger of the woods. Out of the conference came the decision of the Conscrva- 
lion Defartment 10 inaugurate a five-year study of the bird, more thorough and complete than any made before. Unlike many surveys, conceived in the necessity of the moment, this one cut its tecth. waxed strong and matured, with the sympathetic lacking of sportsmen. into a full-fledged Investigation.

Its organization and administration have been the direct responsibility of the senior author of this Report since its incejtion although, for the most part. malters of procedure and policy have been recirled in consultation with the other authors. who likewise were directly responsible for research into varions phases of the broad problem. Thus this report is the result of the combined efforts of a grouj, of research workers, at first small in number, later enlarged to include many specialists in jarticular fields.

As lime went on, the scope of the Investigation widened. New horizons were brought to biew and unsuspecterl fields discovered which had to he cullivaterl hefore a harvest of facts could be reaped. The original five-year plan stretched to thirteen years. Though a stopping point has been reached, the end to productive fact finding is not yet in sight.

No reasonable amount of time or effort has been spared to make this study comprehen. sive. The work was planned to secure comparable pictures of field conditions throughout the periods of increasing, of maximum. of decreasing and of nimimum grouse abundance. Field olservations were supplemented hy laboratory experiments and examinations wherever necessary and possible. In fact. the States Mildlife Research Center near Allany was one direct outerowth of the Grouse Investigation.

To allow for regional variations, comparable life history studies covering four widely separated areas in the State were inaugurated in 1931 and carried on. for the most part. to date.

The problems to be considered were early divided by the Investigation into ten factors, each possessing the possibility of markedly infuencing grouse abundance. Attention was first focused on olutaining hasic life history facts covering food and shelter requirements. reproductive capacity. weather relationships and the part played by predators. diseases and parasites. and ly man. Ceneral halits of the grouse were thoroughly sturlied. as were the factors limiting the sncessful artificial propagation of the hirds. Only recently there has leen added an important study of gruuse phỵsiolog!.

All data, no matter how ajparently insignificant. were carefully noted. recorded and analyzed. Modern statistical methods and machines have heen called into play and. through vears of roustant work. more than a million records have been coded. punched on statistical rards and run through statistical counting and solting machines to complete the desired correlations. To awid possible pitfalls, each of the 186 tahles here presenterl has heen checked carcfully ly the lates biological statistical methods.

To carry on the luvestigation has been our pleasure as well as our work. IInw efficiently w" have dour it. only time can prove. To each generation the efforts of those preceding uffen alpurar incffertual and misquided. Wildlife research workers and sportsmen in the: fulure, with their more advanced viewpoints and resources. made possible by past sucresus and failures. may view our efforts in the same light. Indred. it should he so. All growth is based on going further-with heing discontented will presint results.

Thounh. in part, the rescarch has bon tedinus in dotail. as a whole it has beren interesting and fruitful and often surprising in results. Certainly it has given us a new ronception uf some of the fuwreful forese which are sereretly workines under the surface of lature. It ha- 
also brought us to realize how impotent we have been and still are to recugnize and control all those forces affecting the ahundance of any wildlife species with the knowledge and means at hand.

From its inception in 1930 to the date of publication of this report, one idea has been uppermost - to find ways and means of assuring the future of the ruffed grouse. Far from proving an end in itself. the Investigation has, in reality, opened a gate upon vast and fertile fields for future research. It is fortunate that there is always a challenge in the plowing of new furrows and the reseeding of the old.

Our thirteen years of intensive expluration have indeed led us far afield. for many of the management principles promulgated for improving grouse coverts are likewise applicahle in handling other game species. In fact these principles have become an integral part of the wildlife management prattices which are helping the Empire State to maintain good hunting of several species for some half a million outdonr-mimled men.

In presenting this volume the anthors have attempted. in the first chapter. to correlate and preserve the saga of the ruffer grouse. Leavened with droll notes, for the most part left ln! the venerable describers of another das. it will be found to furnish man! a pleasant source for eomjecture. In the rest of the volume. the summarizing of the fondings. and particularly the interpretation of them in semi-technical terms in the form of management sugges-

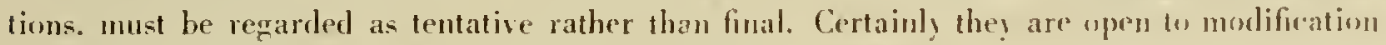
by whatever light may be sherl upon them hy future research.

If the biologists find. herein, a few new farts rearly presented; if the nature losers are reminded of pleasant days afold: if the sportsmen diewre some practical answrs to man! puzzling questions and the wildlife managers a few helpful suegestions-our own game lagg will not hang slack nor will those who hase denonstrated an abiling faith in the solution of the grouse problem go unrewarded.

Nay 27. 1912

GRRDTER BC.MP.

senior furhou
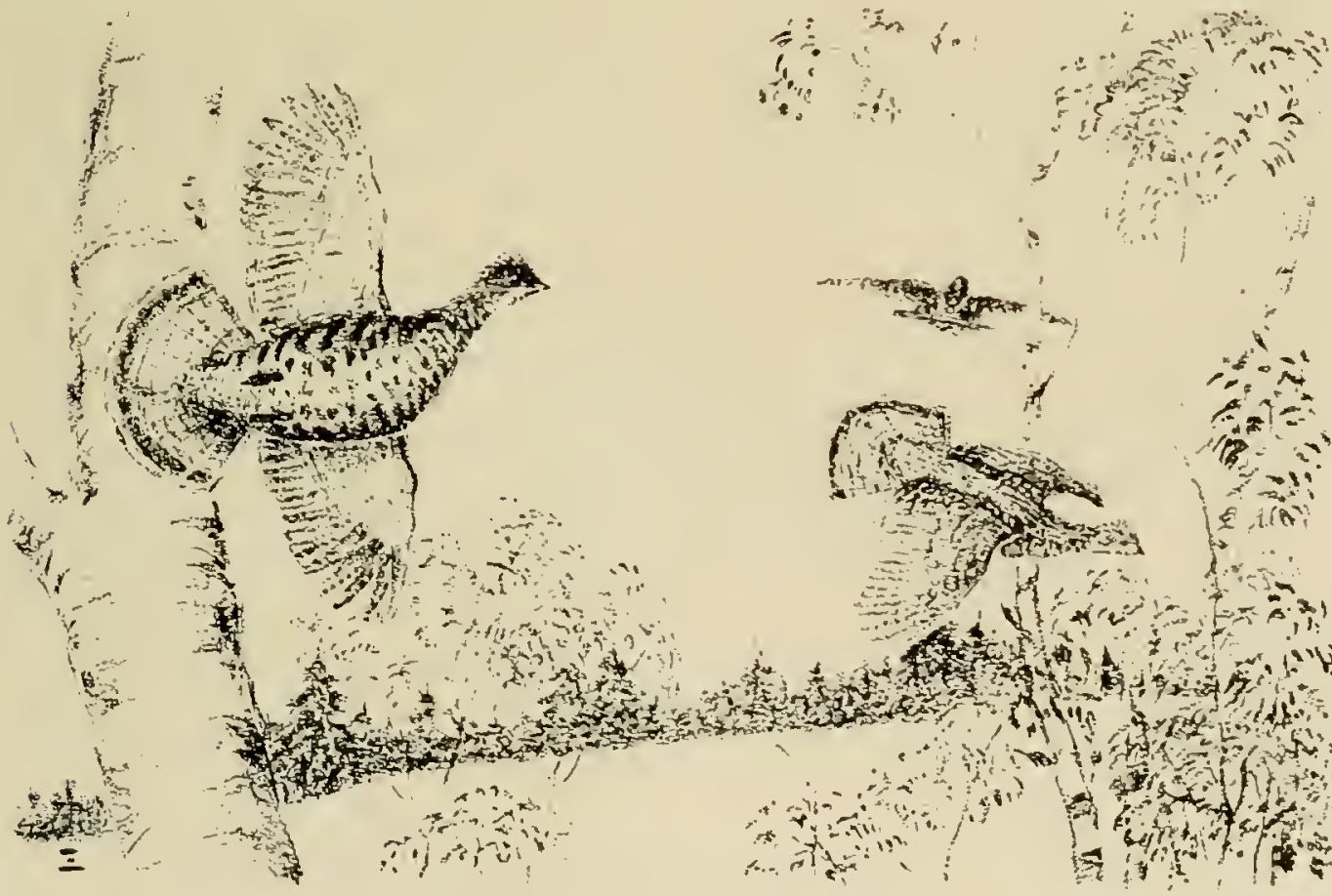



\section{ACKNOWLEDGMENTS}

"Acknowledgment" is a poor word to fully convey the authors" feeling of deht to the many. individuals and organizations who have given freety of their time and knowledge, as well as furnishing material aid. in helping to make this book possible. To each and every one we extend our sincere thanks for the understanding and generous cooperation which has been so vital to the progress and completion of this Report. May this public recognition, therefore, represent the gratitude we owe them. We regret that cach cannot be cited individually. Yet we trust that they will find a real measure of reward in the knowledge of har. ing shared in the undertaking.

Preeminent anong those to whom wo are indebted are those who initiated the lnvestigation and have been its cooperative hacklone ever since. We refer to the sportsmen and to our associates in the Conservation Department of New York State. Without George $A$. Lawyer and his committee of sportsmen, who met at the Bepartment offices one hlistering August day in 1929 to find ways and means of helping the "partridge" stage a comclack. the Investigation might never have been initiated. Without the help of a legion of understanding friends both within and without the varions sportsmens organizations. the study could never hate heen carried to maturity.

The Investigation was a Conservation Bepartment project. But since individuals constitute the Department, the degree of suress attained by the project is inded a measure of the exceptional cooperation which each and every one of our associates gave the authors through. out the entire course wf their work. To the otlicers of the Department, through the years. headed hy Commissioners Mexander Machonall. Henry Morgenthau. Lithgow Oshorme. John A. White, and Perry B. Duryea, we are rspecially grateful for that inspiration and leadership so essential to success. The encouragement and sympathetic interest in the work given us by the Direetor. William C. Adams. of the Division of Fish and Game. has heen unfailing.

Throughout the Department cooperation has been complete and whole-hearted. Particular eredit is due Depuly Commissioners Victor Skiff. John T. Gibhs. Herbert E. Gaston and Carl E. Ladd. Secretary John 1. Halpin. William G. Howard. Director of the Division of Lands and Forests. Jouis J. Flanigan, Chief Finance Officer. and their respective staffs. worked overtime to furnish us with the solution to many a knotty problem. John T. McCormick. Llewellyn Legge and Morris $\mathbb{W}$. Brackett. as well as Superintendent of Law Enforcement Henry A. Teal. joined with their force of game protectors in gathering invaluable field data. Without their assistance progress would have been halting at best.

The real "hewers of wood and earriers of water" hase heen our assuciates in the Bureat of Game who, through long hours of hard work and loyal assistance have patiently assisted in gathering and compiling the hasic data without which the Report could not have been written. Theirs was not a spectarular jol. Yet the whole weh of contimity depended upon its 
heing well done. To them the authors owe a deep personal deht of gratitude. We have not met their equal in many a day.

larticular appreriation is due to Mary $\mathrm{K}$. 'Thornton who carried on most of the immense lask of examining the literature as a hasis for compiling the hibliography. hut who unfortunately met with a fatal accident hefore the work was completed. In this comnection we wish w) thank the stalf of the New York State Library. as well as those of the libraries of New York City. Curnell University and the American Museum of Natural History for their (n"peration in locating references.

Few wildlife species have been subject to more study than has the ruffed grouse. We feel deeply ohligated to those who have gone before us for their exploration and delineation of the problem. Outstanding. perhaps, was the Anerican Game Protective Association. which has fostered grouse research since its organization in 1912.

Beyond these, a mumber of individuals have contrihuted generously from their experience: have been instrumental in providing facilities for speeial projects: or have given substantial help in conncetion with the preparation of the manuscript. Among these may be mentioned J. B. Burnham. F. C. Walcott. C. E. Ladd. A. O. Gross, W. L. MeAtee. Aldo Leopold. J. C. Ihillips. K. T. Frederiek. C. N]. Allen. E. L. Brmett. E. K. Burckmyer. Clarence Cottam and Ario lardee.

Likewise. holpful anlvice and data have been furnished by the Conservation Departments of Massachuselts. Michigan. Minnesota, Pennsylvania and Wisconsin. by Cornell University. the Massachusetts Fish and Game Protective Association. U. S. Fish and Wildlife Service and the U. S. Burean of Animal Indusiry.

Material aid, largely in the form of labor and materials, Las been contrihuted by the Civiljan Conservation Corps. Works Progress Administration and State Temporary Emergency Reliof Administration.

For special aid with techuical problens. the authors are also indebted to the following:

For identification and interpretation of foud habits material: II. G. Barber. l'aul Bartsch. H. J. Chamberlain. Adrian Fox, A. B. Gurnes. II. J. Hamilnu Jr.. Carl Heinrich. F. J. IIermann. H. D. House. J. V. Norrison and W. C. Muenscher. as well ats the entire staff "If the Food llabits Sertion of the Fish and Wildlife Service.

For identification of parasites: J. C. Bequart, E. B. Cram, M. C. Junes. Robert Matheson. R. R. Parker and l\%. F. Wehr.

For datal innerning the range of the species: Rudolph Bemith. B. W. Carwrigh, C. II. I). Clarke. R. T. King. I1. F. lewis. J. A. Munro. D. I. Rasmussen. Willian Rowan. J. I). soper and 1. L. Suyder, as well as the many representatives of state. provincial and tore riturial game administrations thronghout the recrion involved.

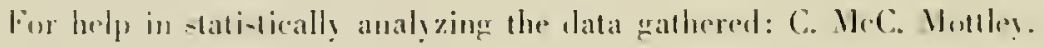

Finally. the authors wish ho pa! tribute to one who. more than any other. has served as (omesellur throughont the Investignation-1)r. A. A. Allen of Cornell University. Deeply in= terested in grouse himself. he has heen associated will every important study of the species in the Northeast during the past guarter-eentury. His pioneer attempts to rear grouse in captivity hase earned him the appellation "dean of grouse breeders." From such a hack.

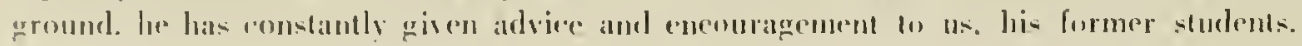




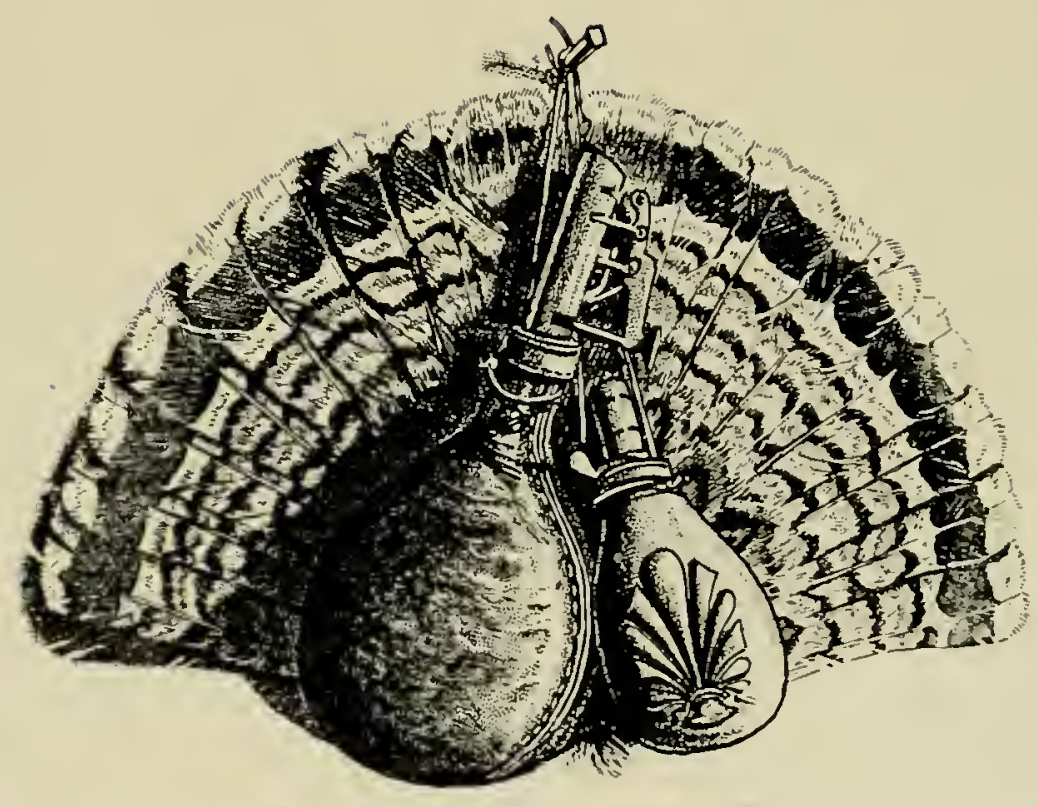




\section{PART I}

The Rufred Grouse--Its Backghound, Basic

Bology and Econovic: Mnentayce 



\section{CHAPTER I}

\section{THE RUFFED GROUSE IN THE MARCH OF TIME \\ By GaRDinfir Brup}

SONE: RIECORIS OF EARI,Y ORSEFVERS

FIRST DRECRIPTIOS

\AMES BY IHHCH IT IS KVOW'

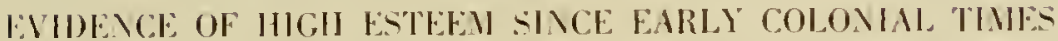

IXCREASE IX VUMBERS NEAR SETTLERS CIEARWCS

REIUCTION IN NUMBERS \EMR CENTERS OF POIULATHON

THE: ERA OF ENP.OITATION - MARKET HI \TIV;

GROLSE BOU YTES

RECOGNTION OF PLRIOIS OF SCARCITY

A CHRONOLOGY OF SIGGF'TEL CALEE

ATTLMIPTEM REMLUIES

RISE IX IMIORTA ICE AS A STORTIAG BIRI)

EAlRY EFFORTS AT ARTHEIII, PROPAGATION

THE PERIOI) OF CORRELATED RFSEARCH

MITITTOS OF" THE PRESET MVETICNTOS

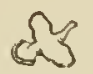

Whatever contributes to make our life more attractise usually funds a place in history. So it is that. furmishing bolh food and sport. the ruffed grouse has reserved for itself a fascinating niche in man's annals of the past. The larger part of the story is. of course, lurked away in menories. hut an astonishing amount has heen more permanently preserved in written form.

The curtain rises amid the rugged walls of the Frankstum Cave in central Pemsylvania. $A$ group of naturalists led hy Alexander Wetmore are huddled around their light expertly sepa- 
rating. from the layered dehris. the bones of animals long extinct. One, small and character. istically light. is identifued as a part of the cranium of a ruffed grouse. Another is a complete tibio-tarsus, a bone from the leg of the same speciss. With these are uncovered parts from the skeleton of a turke?.

The scene shifts to the Cumberland Case, broken into while making a railroad cut near Corriganville, Maryland. Here are found the remains of a crocodilian, an extinct eland and three species of giant peccaries, as well as a variety of other forms. Among them is a single lird bone which proves to be a fragment of the humerus of a grouse.

Across the continent. in Potter Creek Cave, California, searchers discovered other bones helonging to the same species. Taken collectively. these discoveries. associated as they were with the skeletons of animals characteristic of the l'leistocene period. place the ruffed grouse as a resident in the New World more than 25.000 years ago. Nany of its contemporaries have vanished but not this adaptable bird.

Records and writings about the grouse through the march of time, are engrossing and sometimes surprisingly revealing of facts litsle realized from today's casual association with this regal bird. They furnish invaluable assistance in understanding present conditions for they represent a background against which to evaluate present concepts and to formulat future plans. Lacking such perspective, thought and action. all to often, become dully repetitious even though progress be our goal.

To save a part of this material from obscurity, to make a large portion readily available and to stimulate interest in and thoughtful consideration of it, the more informative record. have been collected for this chapter. Many of the quaint colloquialisms and the naive expresions found in early writings have been here reproduced by way of piquing the curiosity and seasoning the Report.

\section{SOME RECORDS OF EALLY OBSERVELS}

Hahit and size decreed for the ruffed grouse a place of importance anong our native birds. History has, accordingly, been generous with her records.

One surmises, from the hroken grouse hones that are accasionally excavated from their camping grounds, that Indians found the hirds to their liking. But it is with the white man that the story really begins.

In 1531, to his royal household in Kent. King Henry VIll issued a decree controlling the shooting of "grows". The name. perhaps anglicized from the old French griesch. meaning spotted, had been applied. not only to the introduced blackcock for which the decree was issued. but also to its much more common cousin. the red grouse.

Arriving in the New World, French and English colonists, carrying with them impressions of Old World rrouse, promptl! named the spotted hird which hanted these woodlands. fromse or partridge. Farther south, it hecame the monntain phessant. a name hy which it is still known among the back country folk of today.
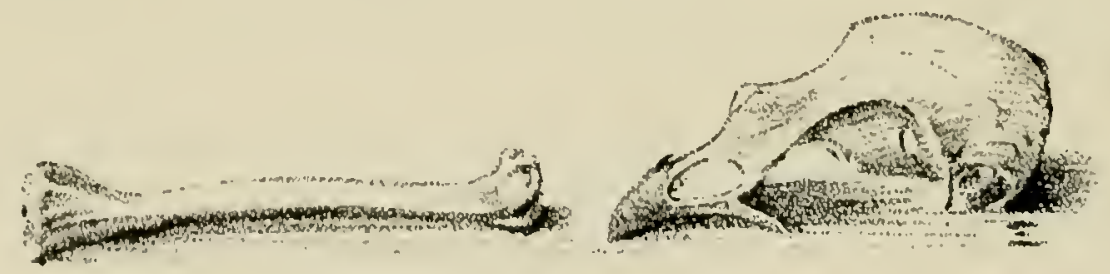
As early as 1632, Thomas Mortmo:" early adventurer and Indian trader. records seeing 40 grouse in a single tree, an indication of their abundance at that time. Later Nicholas Denys $\mathrm{s}^{\mathrm{m}}$, French representative in Nova Scotia, in 1672. reports their tails were used as fans in France. He tried twice to transport the birds there. "lout wher approaching France. they die; which has made me believe that our air must be contrary to their good." Despite the tendency for early observers to confuse the spruce grouse with our ruffed grouse, it seens fairly certain that Baron de Lahontan"15 was referring to the latter when in 1703, in his "Some New Voyages to America", he comments on the ahundance and stupidity of what he called the woods heul. "for they sat upon the trees in flocks and were killed one after another without offering to stir", writes the Baron. who added that this phenomenon was the most comical thing he had seen in America.

Less sure are we that Abbott" was not confusing this species with the eastern heath hen, when he indicated that, in the clnsing years of the eighteenth century "these birds used to congregate by the thousands" in the swamps of central New Jersey. Here it was common sport to surround them and either show or net them in huge numbers.

That the grouse unwittingly played still other parts in the lives of the early settlers is gathered from many a record. One unusual instance will suflice. Rumor had carly linked deposits of desirable metak-lead and iron-with New York's Adirundack Mountains ${ }^{343}$. Mis ressel becalmed one warm day near Red Rocks on Lake Champlain. skipper A. M. Martin crooked his arm around his gun and sallied forth in quest of partridges and a change of diet. Following a lird that had llushed, he tried to pull himself up over a small ledge hy grabhing a small bush. When this pulled loose. it mocoscred a dark. interesting-lonking stone. Sticking it into his pocket, he hurried on. later he sent it to Ticonderoga. there to be recognized as high-grade iron ore. Thus were the l'enfield iron depusits discovered.

\section{HIRST IOESCRIPTION}

Explorers and the colonists that followed them ware, for the most part. men of action and of the land. Few among them were interested in the natural sciences. It is not surprising. therefore, In find that the grouse. in common with many another hird, did not receive taxonesmic recognition until a century and a quarter had passed. John Bartram. an enthusiastir traveler, sent a letter to England. in 1750. recounting some habits of the hird. This was accompanied by a specimen which was described h! Edwards. a Britisl naturalist ${ }^{11}$. This: eventually hecame the type specimen lrecause on the hasis of this account. bimaeus ineluded the species in lis Systema Naturae which has since heen designated as the foundation of modern nomenclature.

\section{NAMES BY WHICH IT IS KIOWN}

What's in a name? That which we call a rose

By any other name would smell as sweet.

Shakespeare

So it is with our native ruffed grouse. This bird carries such a myriad of names so diverse in meaning that a casual glance at a list of them might create the impression it represented several species. rather than one. The unwary "fool hen" of wilderness areas is the alert "king of game hirds" where heavily hunted. The "pine hen" of the west. the "hirch partridge" of the Northeast and the "spruce-woods ruftled grouse" of our northern climate are one and

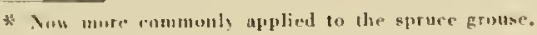


the sature with the "pats" of Mirhigan and the "mountain coek" or "pheasant" of the South.

The diversity of these picturesque charaterizations is so great and their contrast, in many cases, so striking. that it may he of interest to loek into the manner in which they probably originated. Indians picturesquely referred to it as "carpenter hird" because it "pounded on a $\log ^{* 143}$. Limnaeus, in first describing it, assigned it to the genus Tetrao with the liuropean grousc and speeifically temed it umbellus because of the umbrella-like ruff which. when erect. framed the head. This also accounted for the most eommonly used name, "ruffed grouse". Later. however. the generie name Bonasu (Lat. honasus-bison) was used. likening the drumming of the grouse to the bellowing of a bull. Thus. scientifically. the ruffed grouse became Bonasu umbellus. The word "armuse" scems to have been derised from the Freneh terns greoche, greiche and griais, meaning spotted bird. and in the form "urous" was used in England hefore being applied to New Wurld species.

Among the Indians and Eskimos, its names were as many as the dialeets of the varying tribes which frequented the range of the bird. No record remains of most of these. Then came the white man: Spaniard. Frenchman, Englishman. Seandinavian. German and the rest. As settlement proceeded. these various races tended to colonize in different seetions. It was quite natural for them to apply to the new birds they encountered, the same names used in thein homeland for species of similar appearance. Memories of the blackcock, the Sentch grouse and of the ancestors of our adopted ringneck pheasant. gave rise among the English to snch term: as "moor-fowl", "ruffled heathcoek", and "mountain pheasant." Similarly in French Canada, the ruffed grouse became "La Grosse, Gelinote de Canada" and "Con de Bruyere" a Fraise", while the Penmshania Dutch likened it to the German "fesond."

In addition to names derived from the racial haekground of the early settlers. many others have had their origin in distinetive characteristics or hahits of the bird. Those mentioned abose do not need further explanation hut a few more will round out the discussion. The nature of the meat suggested the designation "whiteflesher". White its unique drumming earned the name "drummer" in man! localities. Thoughont the Northeas, where birches were a favorite food, it is commonly kunw as the "hirch partridge". At the other end of its range, howcver. Ozark momtaineers "all it "woods pheasant" as distinguished from the bohwhite quail which is still kmown as "partridge" in the South.

Remembering that the ruffed grouse has adapted itself to half a continemt, it is not surpris. ingr that so many dissinilar and localized names appear in the literature. Doubtess there are many nure than listed here which are koally common but of which no record has been found.

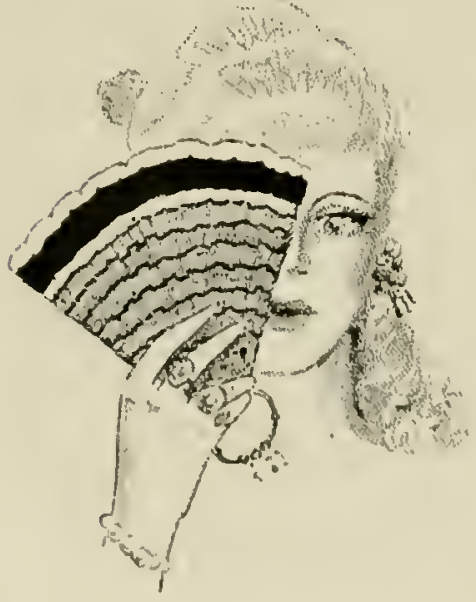


Names Used in the Literature in Referring to the Ruffed Grouse

By non-English speaking races

bi-ne (grouse in general)

carpenter hird

ka-xit'l-se

kh-tuk (Eskimo)

kwi-ut -- pah-uta

pupuskee

wen gi-da-bi-ne (Chippewa)

French

gelinotte

greoche

griais
Indian names

juskee

griesche

French-Canadian

attagen Pennsylianiae

coq de bruyere a fraise

grosse gelinotte du Canada

la gelinot hupee de Pensilvania

la grosse gelimotte de Canada

la perdix ordinaire

perdrix franc

\section{German}

fesund

haselhuhn

Scandinavian

hjerpe

By Einglish-spealing raees

\section{Eilglish}

grous

moor fowl

more-heı

ruffled heathrock

\section{Canalian}

hirch partridge (Br. Provinces)

Canada ruffed grouse

Canadian ruffed grouse

Fremch hens (Iabrador and Queher)

patridge (Maritime Provinces)

shoulder-krot grouse

white-flesher

white-meated grouse

willow gronse $(\mathrm{Br}$. Col.)

\section{Northeastern Lniled States}

American jartridge

birch partridge (Maine)

common partridge

drumming grouse (New lork)

eastern ruffed grouse (common)

partridge (common)

patridge (common)

ruffed grouse (rommon)

wood-pile quawker (Long Istand)
Southern Lnited States

monre fowl (Son. Carolina)

mountain cock (Carolinas)

mountain grous (Carolinas)

momutain partridge (Virginia)

mountain pheasant (Virginias and Carulinas)

pheasant (common)

ruffed grouse (common)

IT'estern L'mifed States

fool hen I Rorky Mts.)

Oregen grouses

pats M Michigran and ten Engrland

pine hen I Wasateh Mts. I

Sabime" gromse

western ruffed grouse

wood pheasant

woods pheasant (Ozarks Missouri) 
Based on sub-species according to:

Color

brown ruffed grouse

ropper ruffed grouse

gray mountain grouse

gray ruffed grouse

gray ruffled grouse

gray-tail

red-ruffed grouse

red-tail

silver-tail

Based on structure

ruffer

ruffed grouse

tipuet grouse

\section{Distribution}

Arctic ruffed grouse

bush pheasant

Canadian ruffed grouse

eastern ruffed grouse

northern ruffed grouse

Oregon grouse

western ruffed grouse

Based on habits

drummer

frumming grouse

drumming partridge

drumming pheasant

fool hen

ruffled grouse

\section{EVIDENCE OF HIGH ESTEEM SINCE EARLY COLONIAI, TIMES}

That the "fool hen" tharacteristic of the bird in the early days did uot affect the high esteem in which it was held as a piece de resistance for the table. is clear in all of the early: writings. A letter from John Bartram. sent to England about 1752 and quoted by Edwards. states. "thejr flesh is white and goud". Audubon opines that the grouse "far surpass. as an article of food, every other land hird except the wild turkey". while Billings". writing at the same time, reaches a similar conclusion.

Larger than the quail and more abundant than the turkey throughout the northeast. half a contury ago. one might bave found grouse competing with ducks in pepularity in the markets of the larger rities and definitely more common in rural kitchens. That today it can rarely les shot on the ground wer much of its range. has. of eourse. matle grouse a less

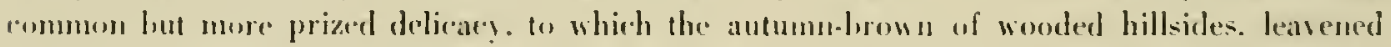
with falliner leaves and tired muscles. often ades a piquant flawor. With more hunters than ever afeeld. turning their altention in increasing mumbers from pheasant to grouse. the enthu. -iasm for the sport vies with its thrills in putting the ruffed grouse in a class by itself. For. to be a good grouse humler. with dog and gun or a camera. is 6 place onses self in a rather sclect circle of outdoor deroteres.

Thus time has served to shift the emphasis from proune as an article of fond to a place of high favor as one of the most sporting hides that enriehes our coverts.

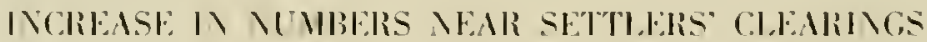

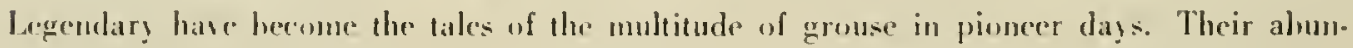
dance was mot uniform hut rather concentrated about openings in the forest cover, most of which were man-made. This is indieated ly several of the earl! anthors. although they did

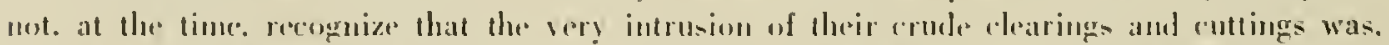
in a larere measure. the rause of this concentration. Swainsul and Richardson state that grouse "frequents the lorse-paths and charings about the forts". While Alexander Wilson" recorrls that he rould alwats suppl! himsolf with plent! of hirds " without leaving the path". 
Today the effect of woods edges on the ahundance of many a wild-life species is well recognized. Perhaps more woods-wise hut certainly less analytical, the early settlers utilized this source of fresh meat close at hand. They seldom questioned (if we may believe the records) but that the woodland heyond the ring of their axes likewise held countless thousands of birds. For then, unlike now, the hunter apparently rarely inquired as to the cause of such concentrations. They preferred rather to harvest the crop and. when the number of grouse in their coverts periodically shrank to a fraction of their former abundance. to hope for better days.

Thus the axe. where not followed too closely by fire and the plow. served to break up the forest cover and. as with deer, to inerease its carrying capacity for game. Partridge thrived accordingly.

\section{REDUCTION II NUMBERS NEAR CFNTERS OF POPLLATION}

The difference between optimum and poor grouse habitat is often a matter of the degree to which forest cutting and clearing are carried. Men were eager to turn the forest duff into fertile fields. It was. of course. inevitable that. around the larger centers of population. where this activity was greatest. fond and shelter for grouse became progressively less and hunters more numerous. This led to a gradual reduction of the species in such areas. Bartram ${ }^{m}$. about 1752, noted the disappearance of the gronse in the lower settlements of Pennsylvania. Sixt! years later. Alexander $W$ ilson" saw the same trend and wrote: "formerly they were numerous in the immediate virinty of Philadelphia hut. as the woods were cleared and the population increased. they retreated to the intorior".

Some of this range. in the Eas. has been taken wer ly the pheasant and the bobwhite quail. All (on much of it. particularly where it is heavily pastured has been left harren of any game hid. salve possibly the woudeock. ly the retreating feet of the partridere.

Influences generally little recognized. in the form of the machine and of soientific agricul. ture have recently made farming unprofitable in so much of the hill land and hack country that once was grouse habitat. that the trend has been reversed again. Wondlots are going brushy. and wouds edges are growing 11 t to a varief! of plant species furnishiug both food and shelter for the grouse. In Xen York alone, upwards of 6.000 .0000 aeres of oncefarmed fields are now in proess of abandomment. Fiven the lands of mediun quality are apt to be worked less intensively. The woods are aceordingly. growing back toward the enters of population, hringing the grouse in their train.

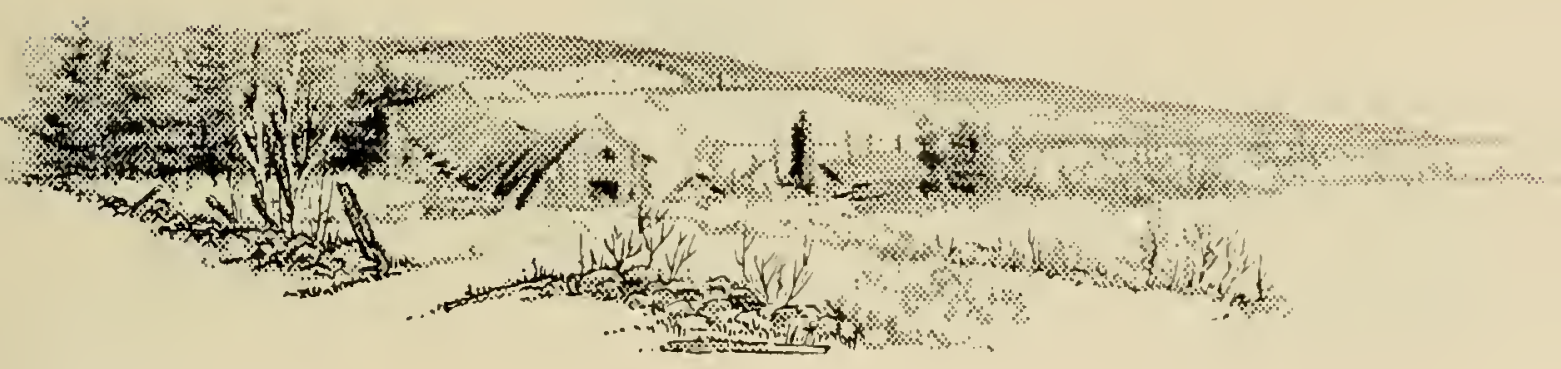




\section{THE ERA OF EXPLOITATION MARKET HU\TING}

The use of the grouse as a source in fond for the bome table hy the rarly settlers wa: followed naturally by the exploitation of the species for the market as commercial facilities developed. The price which these birds brought in Boston. New York. and Philadelphia. where most of them were shipped, ranged from 121\%.2 cents to $\$ 2.00$ apiece. depending upon the abundance and proximity of the supply to the place of sale. The all-time high is a recent record in 1918 of $\$ 7.00$ a pair in Washington. A few of the more interesting records are as follows:

Place

New lork

I'hiladelphia

Boston

Boston

Cincinnati

Eastern Cities

Pittsburgh

Kingston. \. Y.

Maine

lew Yurk

Maine

New York

Chicago

Jew York City

Dew York City Jrice List

St. Stephens, X. B. (Canarla)

lew York

Michigan

II ashiugtun. D. C.
Dale

1763

Around 1812

1820

1820

Late $1820^{\circ}$

Alout 1825

$187 \%$

$13 \% 6$

1890

Alout 1891

1899

1902

19012

1908

1908

1910

1911

191:
Warket I'rice

.21 each

.75 .1 .00 each

$.121 \%$ each

.50 each

$.12^{1} \cong \mathrm{each}$

.75- 1.00 each

$.121 \%$ each

.40 hrace

.0: earli

1.50. 2.010 earch

1.00. 2.00 pair

2.00 pair

10.00 doz.

1.25 each

1.00 each

$.00 \mathrm{each}$

1.75. 2.00 earh

1.00 eachl

7.110 pais

Market hunting was a profitable oreupation throughout muclo of the grouse range. largel! lecause of the ease with which the hird. when occurring in sulfuent numbers. conld be secured. Methouls of hagrging them for market were as varied as the ingenuity of the hunters. Snares. lures traps and guns all prosed effertive. Two of the more unigue means

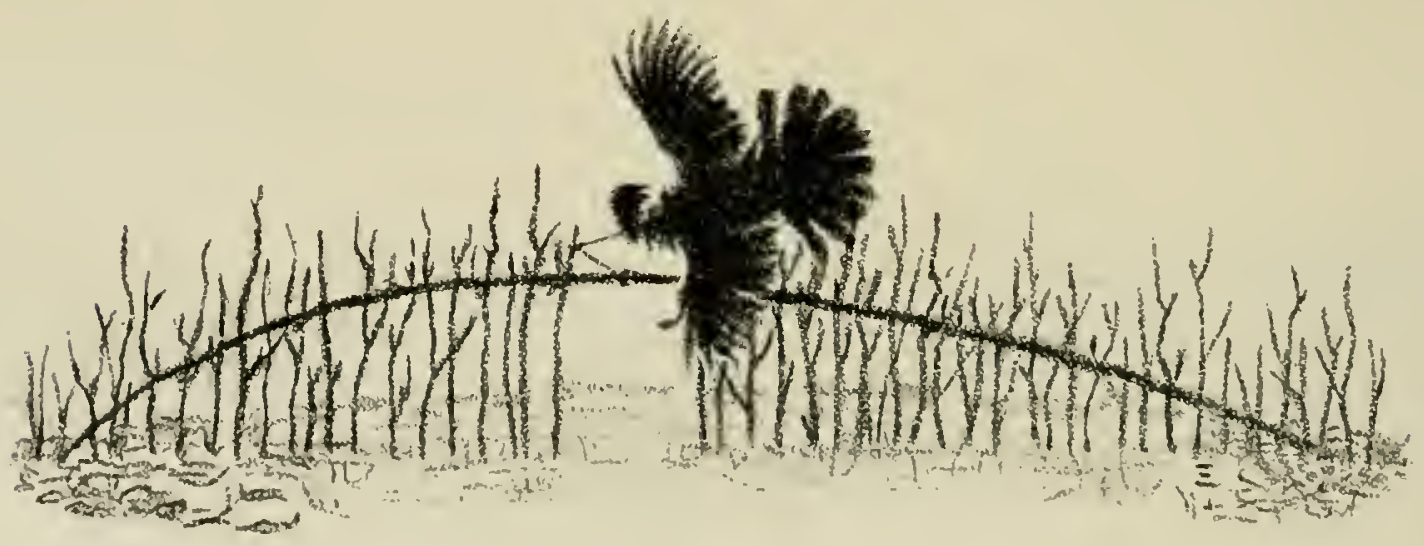


are described by Nuttall". One is the imitation of drumming to lure "jealous males" within shooting distance by striking upon an inflated hladder. Another is the smoking to death of the birds "in the same manner as the wild pigeons in the western country."

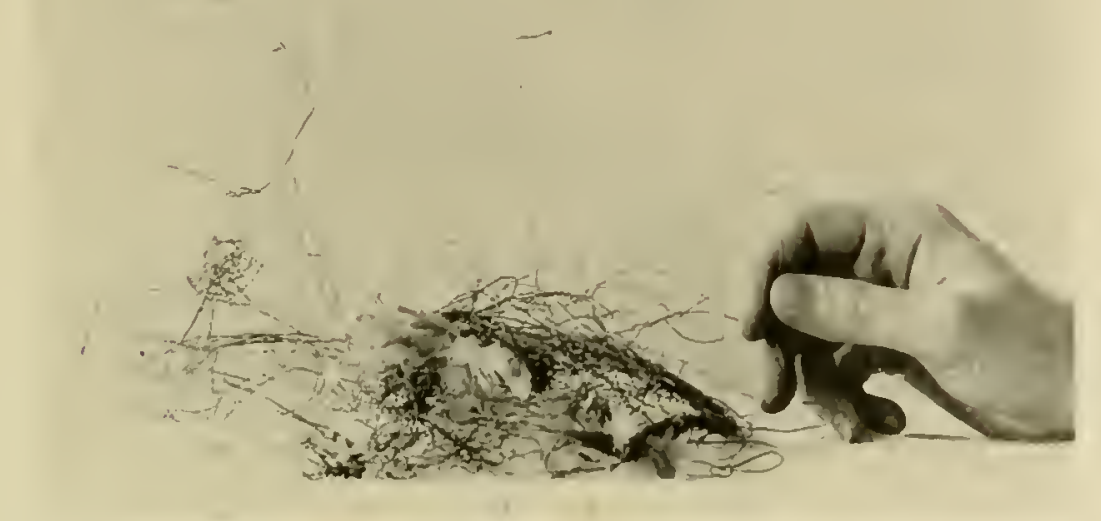

SNARES CONFISCATED BY THE XEW IORK STATE CONSERVATION DEPARTMENT

A very amusing and interesting story on trapping. illustrative of the general practices of the limes, is given by Whitehead when writing in Mayer"s= "Sport with Rol and Gun." as follows:

"This hird is the friend of the country boy. It has many a time made him jump as it burst out of the wayside bushes, and lird and boy perpetually match their wits ayaiust each other - the one in trapping and the other in avoiding being trapped. Master Barefoot finds a drumming log, and at once whips on bis jack-knife and, bending down a neighboring lickory sapling, sets a twitch-np. with a slip-nonse at the end. nade of a string pulled out of one of his capacious pockets. The twitch-up being well watched, is sure to catch the hird or drive it away. As Barefoot grows older, he learns to set ruming snares of horsehair or silk in the paths in the woods. and he will walk miles to attend them when he is too sick to go half a mile to school. At length. he grows to be a young man. "some farmer. some poacher". making a precarious living by sclling game he has trapped or shot in season and out. and killing more hirds than all the minks, owls. and foxes in the countryside."

A method, formerly common and still practiced illegally in remote parts of New York State, is to construct one or more low hrush fences running through a cover frequented by grouse. At intervals. openings are left in these fenees, the ground in the immediate vicinity heing eleared of leaves and other debris to attract the attention of the hirds. At each break. a wire snare is so set as 10 be sprung by a grouse walking throngh it. Once released. a springy: stick promptly jerks the unfortunate hird by the neck. several feet off the ground. Grouse are prone to do more walking than is generally realized. A brush fence. therefore. is an effectire means of guiding them to the opcnings in which the snares are set. 
One can come closer to wiping out these birds. in a patch of woodland, with snares than ly any other means. Edward Howe Forbush" for many years state ornithologist for Massachusetts. reported "two men in the vicinity of Westfield, Massachusetts, took one hundred and twenty of these birds from snares in one day". Five men of Foxborough snared grouse prior to 1888 and averaged about a hundred hirds a week. The most successful snarers probably never published their records, for obvious reasons, though one finds, in an 1878 issue of "Forest and Stream", a notation that 1.189 grouse were snared in 54 days, an average of hetter than 22 a day.

We have seen somewhat similar arrangements designed to catch grouse by the feet at their dusting places. Fox traps set at the edge of spring-holes in winter still take a surprising toll of feathered game. a method doubtless also employed by some marketeers during the off-season for other trapping operations.

But shooting remained the most popular method wherever large numbers had to be secured at definite intervals. Unlike today, around every center of population there was always plenty of back country into which but few of those interested in grouse, save the market hunter, penetrated. There grouse were undisturbed and so were comparatively unafraid of man. Forbush"10 quotes E. F. Staples of Taunton, Mass, who writes, "This gentleman said that, in the early 1230 "s. about a thousand hirds were killed in a season on 20,000 acres that he ranged." It was not unusual, in a good year. for one hunter to kill from 30 to 50 hirds in a day. Careful inquiry. however, indicates that the average was suhstantially lower than this. Mershon ${ }^{\text {mn }}$, when a boy. found ten to twelve hirds a day to be a fair average under Michigan conditions. Also, Maymard in $1870^{110}$. states that market hunters from Worcester, Mass., killed ten to fifteen hirds a day. While the year's best hunts, then as now, were long remembered, personal contact with several of the fast vanishing market hunters in the Northeast indicates the average daily bag in this region to have been much higher.

Most hirds were shot on the ground, an item seldom appreciated when one compares the take of yesteryear with today's much smaller legal limits. Roads, trails and woods edges were fasorite places. for there the eover was open and the birds more apt to be concentrated, particularly in the summer and fall. When spring shooling was permitted. drumming logs often provided an mexpected rendezons with deatl.

So highly commercialized were these activities that individual hotels, in many a large city, employed their own hunters. One trapper in Chenango County" reported selling over 3,500 grouse to one New York hotel. Some 2.500 birds were shipped to the New York City markets from the Ponghkeepsie railroad station alone in 1875\%. Nr. George Ilowes killed and mar. keted 398 birds in one slooting season while Haight ${ }^{2 i d}$ relates the fact of two men taking 998 grouse from September 15 to January 31, one season in the late 1800 s.

Down from the timbered hills to the markets came the grouse by the hundreds of thousands -in harrels, in boxes, in hags, by horse or train-until the turn of the present century.

Almost from the beginning. a few men had deeried the practice. Nuttall ${ }^{\text {sn }}$, though primarily a botanist, was also a keen olserver of animal life. As early as 1832. it was his opinion that this indiscriminate killing had greatly thimed the numbers of grouse throughout the more populous parts of the Union. Toward the close of the last entury. these complaints lecame more widespread but it was the shortage of the grouse crop in 1897. followed by a more severe decrease in 1903-04, that lent sulstantial impetus to the drive to outlaw all mar. ket hunting. Hunters were increasing and grouse was prized game. The idea of a periodic disappearanee was, as yet. unborn, and so, when the decrease came, market hunting received 
more than its share of attention as one of the major causes.

Thus ended, by popular demand, a most colorful and profitable period. Almost immedi. atcly, another era began, for the invention of the automobile and the airplane so lengthened man's legs as to make most back country but a few short steps from the firesides of an army of hunters that grew phenomenally with the years.

\section{GROUSE BOUNTIES}

To some it is a new thought that game can become so abundant in favorable hahitats as to be inimical to man's interests. The deer, in many parts of its range, is a striking example. Among the most paradoxical developments in all grouse history was its classification as "vermin".

Beginning about the middle of the nineteenth century, the development of apple orchards in New England, many of which were in close proximity to grouse coverts, offered the birds a new and highly acceptahle source of winter food-the apple buds. So thoroughly did these natural pruners set to work, that bounties of 25 cents each were placed on their heads in certain Massachusetts townships ${ }^{203}$.

But, for those prophets who painted the grouse as a rapidly diminishing species, New Hampshire has reserved the crowning incongruity. In the year ending June 30, 1921 claims of grouse damage primarily to apple orchards in this State were paid totaling some $\$ 26,800.72$, a sum nearly one-quarter of the entire revente received from the combined hunting and Irap. ping licenses".

The changing emplasis on grouse hunting as sport, and the waning importance of the apple industry. led to the abolition of bounties but not of damage. Within the past ten years, the State of Massachusetts has paid such claims on orchards ludded by grouse. In other New England states, and in New York as well, letters still find their way to game authorities during periods of grouse abundaner, asking that something be donc about it.

\section{RECOGNITION OF PERIODS OF SCARCITY}

Bartram, in one of his several letters to Edwards ${ }^{10}$. written in 1754. gives the first account of local grouse scarcity, when he says. "They have been common in Pennsylvania, but now most of them are destroyed in the lower settlements though the hack Indian inhabitants still bring them to market." To the orthodox protectionist it may well he a shock to discover that the first indication of general scarcity was noted by Nuttall ${ }^{2 m}$ in 1832 , who wrote that in November, 1831. while traveling nearly to the extremity of New Hampshire, "not a single bird of the species was now to be scen". Falling into a common and much discussed error, he continued, "They have no doult migrated southward with the first threatening and untimely snow." That this scarcity was of sudden occurrence is indicated when he says that they were "indeed

\footnotetext{
* Carpenter, R. C. personal letter tu the authors, Decrmber 26, 1911.
} 
so unusually abundant previnus to that period as to sell in the markets of Boston for as low as 12 1 cents each". Of more than coincidental significance, therefore. is an editorial carried by the Rochester (N.Y.) Daily Advertiser of April 11, 1832, begiming. "We have regretted the destruction of this hird by the hard winter of 1830-31, hecause his note was necessary to the (horus of the field and the forest - the only chorus that we ever admired", and urging its further protection. The significance of this evidence of scarcity during the same year from sources 600 miles apart, was to remain unrealized, however, for most of the next hundred years.

But not so with the records of scarcity. A letter from a market hunter of the old school, Mr. IV. E. Hookway of Syracuse, N. Y., to the authors, states that a companion of his father:s. engaged by the old Saratoga Hotel, killed only one grouse in five months during 1867. As though to corroborate this observation for other counties of the State, a few years after the Civil War, Judge John W. Spoare, a locally famous grouse shot of Columbia County (N.Y.), is reputed to have sold his only bunting dog because "the partridge are all gone". That coming events sometimes cast their shadows before, is indicated by Norris ${ }^{203}$, who records grouse as common in Massachusetts but scarce in Vermont in 1866. "The Fluctuating Grouse Supply" is the litle of an article published in Field and Stream in 1883. According to the author. in southwestem Ontario, grouse were reportedly scarce, in sharp contrast to their abundance two years previous.

Apparently reliable though fragmentary reports indicate a periol of scarcity in 1896 or 1897. In substantiation of this. Dillin ${ }^{103}$ records that. in two weeks. he flushed two birds and his companion but three. in southern Pennsyania in 1897, whereas they had averaged 14 per day in 1889 , on the same area.

With the turn of the century. interest grew ajace. The first comprehensive altempt to outline the prohlem followed the excedingly severe winter of 1903-04. when Edward Howe Forbush" sent a questionnaire 10 some 400 interested naturalists, game wardens and sportsmen throughout Massachusetts. inquiring as to its effects on bird life. Grouse. as well as other wild birks, were reported excedingly scarce. On the winter rested most of thr blame.

The searcity of 1906.07 was unique in that it was so generally recognized by observers. Writers recorded that the species fell to rock bottom and it was frankly predicted that the end of the grouse was at hand. The New York Forest. Fish and Game Commission hecame so alarmed that an extensive survey hy questionnaire was conducted to "bring out" the situation (Toodruff ${ }^{\text {ind }}$ ).

Attention by now was aroused to the rather regular recurrence of these periods. When the next "die-off" uccurred. Stoddart". then Rod and Gun editor on the New York Times, was accordingly chagaged hy the Now York Commission lo circulate an even more extensive ques. tionnaire. particularly amoug hunters and game protectors, to determine supposed causes of the lean years of 1915-16 and 17. Now, too. He Ameriean Game Protective Association. formed in 1912. Was becoming intensely interested. not only in altempting to proparate grouse artificially. hut also in the causes of their scarcity. An off-cycle decrease in 192. throughout much of the grouse range. was suffeiently intense to cause the formation of the Crouse Investigation Committee at the American Came Conference that year. Less than twrlve monthe later. throughout the North and Niddle West, competent olververs. Leopold ${ }^{2}$ : reported ruffed grouse to be at the numerically low point of another cycle. Throughout the East the tide of scarcity reversed itself. surging upward for wo short years, then shrank to the wrll rememhered low of $1927-28$. 
By now everyone was cycle-conscious. The present Investigation was born of this scarcity in 1930. Following its inception, the birds were reported as having practically disappeared in the Northwest and far North in 1935. As though to make the work more difficult and challenging, an anticipated seareity, in 1937, throughout the East, did not materialize though the numbers of birds were not up to par in 1936 in New York State.

\section{A CHRONOLOGY OF SUGGESTED CAUSES}

From the earliest records, the reasons for each period of scarcity has been conjectured hy its historians. Some, usually interpreting limited experience, have uffered a single, simple solution. Others, of a more imaginative turn of mind, have submitted numbers of potential explanations. The more important of these are listed here in table 1.

Bartram $^{30}$, perhaps comes closer to the truth than many when he attributes the disappearance of grouse in the "lower settlements of Pennsylvania", to the eneroachment of civilization. From that early date most of the recorded canses, though legion, may easily be catalogued under one or more of the four "principal changes" supposed to beset grousc. In addition to hunting, already mentioned, there were predators, bad weather and disease. Thus hunting did not remain the unly recorded cause for long for a seant six years later. a Mr. Bronhe of Maryland, in a letter to Edwards", complained that "the great number and variety of hawks in Maryland feeding on them (grouse) prevents them from increasing fast". "This emphasis on the effect of possible predators has held the stage as a favorite cause of decimation ever since.

Nuttall took an easy "ont" in explaining their disappearance in New Hampshire, in 1831, hy deciding that they must have migrated. It is probahle that. leing somewhat of a cataloguer, he was influenced by Audubon's carlier reference to migration.

Already referred to is the newsy comment in the Rochester Daily Adertiser ascribing the shorlage in the partridge crop to the severe winter of 1830.31 .

Local explanations were, of course, rife after each disappearance. Jillin ${ }^{103}$ arlds a new note, attributing their disappearance in Penns lvania. in 1897, to forest fires. The circumstances surrounding the issuing of Forhush's questionnaire into the effect of the severe winter of 1903-01, may have strongly influenced the verdict against the extreme weather. the effect of which was under investigation.

With the phenomenon now better recognized, logical explanations became more difficult. Individual opinions were less well received and questionnaires, therefore, eane into their own as a method of hringing the collective judgment of mon of wide experience in the out-of. doors to bear on the problem. Thus, when 1904's lean year. in certain regions. followed by a partial recovery in 1905. was in tum climaxed by a die-off of even greater proportions in 1906-07. New York's Forest, Fish and Game Commission employed E. Seymour Woodruff "ut to

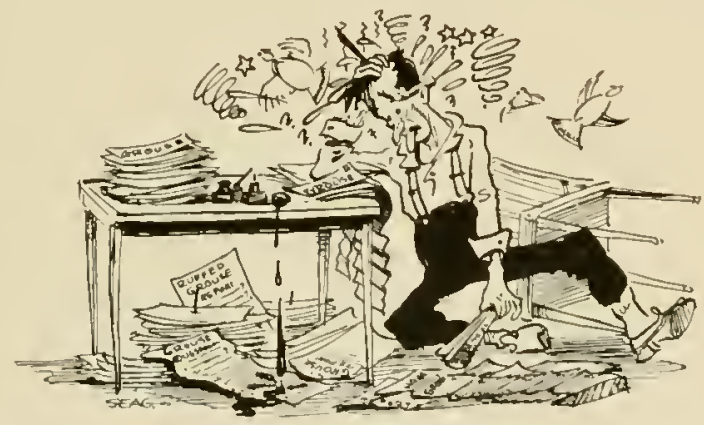




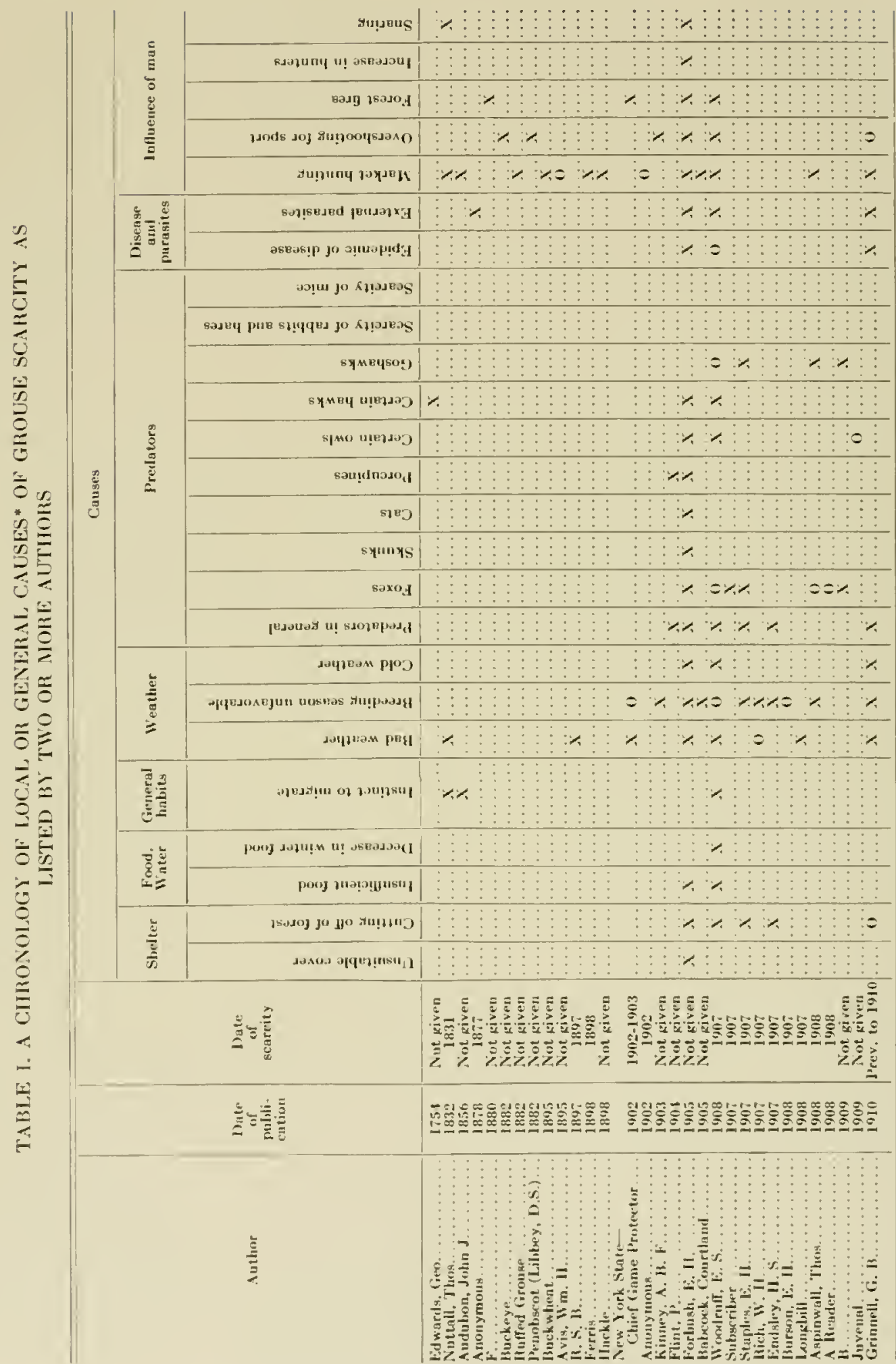




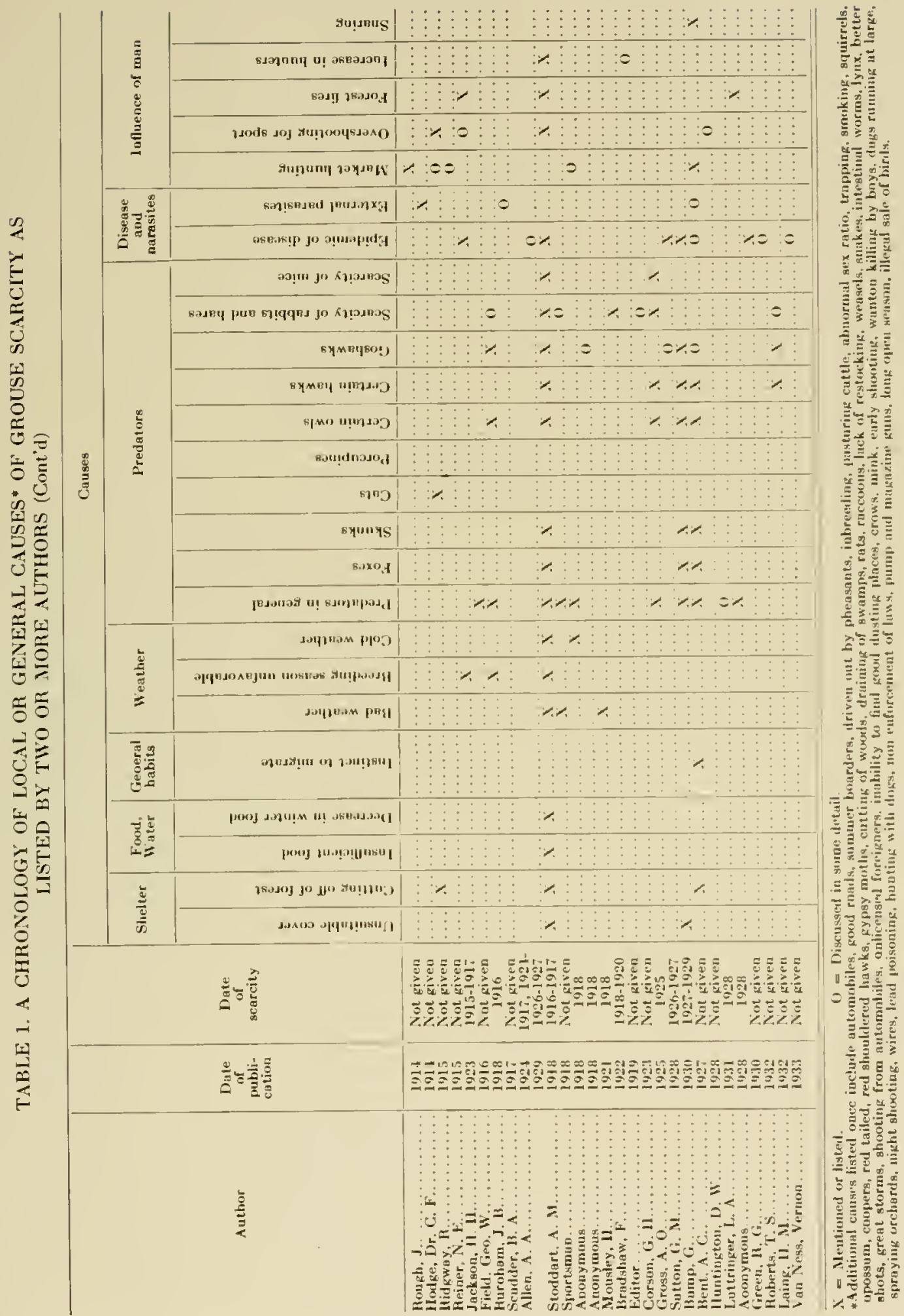


conduct a survey, by questionnaire, of the probable causes. The answers ran the gamut of possille influences, with the following nine theories predominating:

I. The serere winter of 1906.07

2. Unusual ahundance of foxes and goshawks

3. The cold wet spring of 1907

4. The extreme dryness of the following July and Angust

5. A disease epiclenic

6. Internal parasites

7. An infestation of parasitic ticks

8. Pot hunting in the closed season

9. Resumption of migratory instincts

With conmendable inclusiveness he coneluded the best het to he an unhappy combination of the cold wet spring, the unusual abundance of predators, and an epidemic of some disease or parasite.

By now, interest was general and the outdoor magazines of the day were filled with causative speculations. Biologists, loo. were sharing in this interest. Thus George Bird Grinnell ${ }^{105}$, in 1910, lists six of Woodrulf's nine factors as suggestions but places the most emphasis on the cutting off of the forest, with over-shooting as a close second in importance. He was also the first to publicize the periodicity of the scarcity phenomenon.

In the meantime, striking progress was being made in raising and kecping grouse in captiv. ity. P'oison had brought an end to one of Dr. Hodge's pioneer attempts at Worcester, Mass. as described later. Encouraged by the newly formed American Game Protective Association. Torrey, Dimmick and Fields, in Massachusetts and Walcott and Mac Vickers. in Connecticut, each watched and described the psychology, the food habits and the general reactions of the bird in captivity. In 1915, John Burnham arranged for George Jeffries ${ }^{314}$ to pen grouse under natural conditions. feed them natural foods and raise a few young grouse to maturity, in an attempt to discover causes for their fluctuating numbers.

All this contributerl to an understanding of the bird but did not sulve the prohlem. lnterest remained intense. but, with magnificent disdain for the efforts of the investigators, the grouse calmly proceded to disappear again in 1916-17. The distractions of war notwithstanding. New York's Conservation Commission promptly organized a survey under the direction of $\mathrm{A}$. M. Stoddart which was more far-flung than any yet attempted. Game protectors were ordered to submit weckly reports covering their field olservations of grouse ahund. ance and habits. The presenee of some birds, dead in the field. was nuted. lut surmise was still substituted for the more certain results of scientific examination to determine the cause of death.

The methods, hasie to good wildlife research, were as yet largely nurecognized. While attempting to get at the facts through the directed obeervation of many individuals, Stoddart was, accordingly. Forced to fall hack wn the most extensive guestionnare yet devised to furnish the broadest possible background for his explorations. His report. as fually brought togeth. er. leans strongly toward predators as most likely to le responsible for periodic scarcities. These are listed in the following order: hawks, owls. weasels. foxes and the common eat. 'To this lint were added: disease. the rigors of winter, slaughter ly man. and had nesting seasons 
-none of which were new to the picture. An all-time high was reached when he listed thirtysix additional possibilities. A few of the most choice ones are mentioned here for the reader's delectation: driven out by pheasants, shooting from autos, summer boarders. foreigners with. out licenses, and too long a rabbit season.

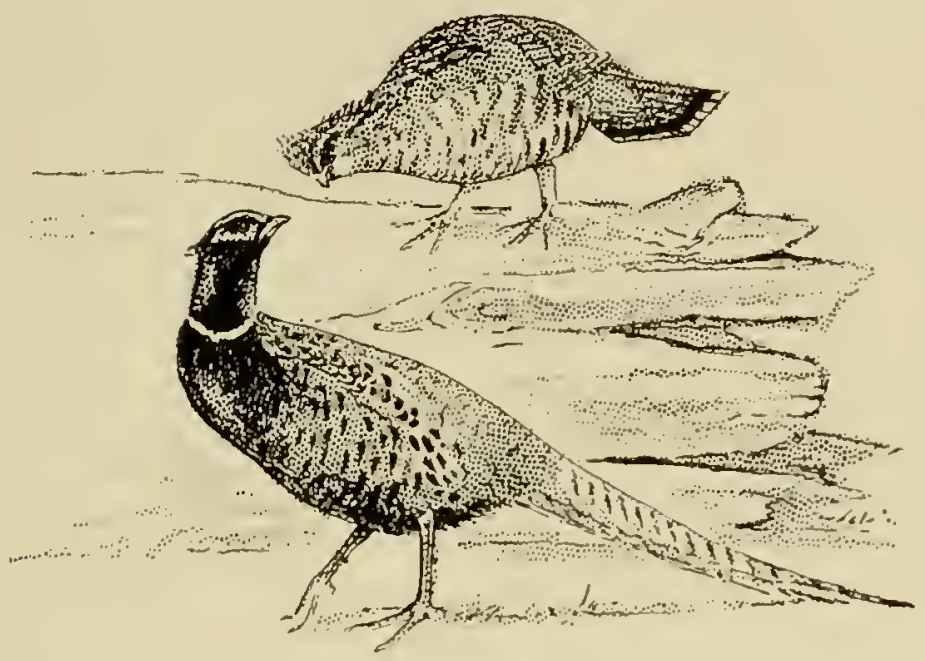

Another of Stoddart's list of causes, entitled "new stock needed". is the hrst indieation of the suggestion, common in the late 1920s, that the lugaboo of inbrerding might lee at the root of the troulhle. Thus was completed such an excellent joh of cam asciner miscellaneous opinions that no further inspirations have come to light. at least until the period of mudern investigation.

\section{ATTEMPTED REMEDIES}

Conjecture as 10 the factors possibly responsible for decimating the grotine was and still remains a very pupular occupation. To translate even a fer of these supposed anses into preventative practices proved to he quite another matter.

Of course, the first remedy tried was to control the hunting of grousc. It is surprising to note how early this was applied, for a closed season on ruffed grouse, heath hen, quail and wild turkey, was first promulgated in the Prosince of New York in $1708^{211}$. This was soon followed, in 1721. in Quclece, by an "ordinance to prevent the destruction of Partridge" The American Revolution brought home rule-and problems, including game ones - for in 1791, the lumting of partridges from April 1 to Octoher 5 was prohihited in three counties now a part of New York City. Thus the crils of spring and summer shooting were first controlled over 150 years ago. The temptation to shoot partridges for sale in the closed season was so strong that, in 1837. a law prohihiting their purchase or sale in four counties, was passed. The application of this law was extended to the rest of New York State in 1862. Again. in 1839 , a closed season was voted to include the whole State ${ }^{\text {non }}$. Other states, too. resorted to similar measures as the best way, then known, to bring the grouse back. as is evidenced by Massachusclis' action in 1818, and Ohio's in 1857.

Other eontrols followed in time. In 1903, spring shooting was abolished in New York and market hunting was legally oullawed. Many other northeastern states look similar action at 
about the same time. Shorter open seasons were firmly established and made effective through proper protection, backed up by hunter cooperation. Few further changes have been made since, except to vary the length of the closed season, as in 1928-29 in New York State. when no open season at all was permitted.

While the protection thus granted certainly helped, it did not solve the problem of periodic disappearances. Interested sportsmen. therefore, tried other methods. Grouse were imported and released on Staten Island (N. Y.) about 1880, to give the few hirds left there the added impetus of numbers. Outram Bangs reported a small shipment of hirds from northern New Hampshire to have been liherated by him near Wareham. Massachusetts, in the latter 80 's ${ }^{200}$. Bureau of Biological Survey records indicate a shipment of 56 Canadian birds was

TARLE 2. RECORDS AND IRESULTS OF GROUSE LIRERATIONS KNOWN TO TIIE INVESTIGATION

\begin{tabular}{|c|c|c|c|c|c|c|c|}
\hline Date & $\begin{array}{l}\text { Number } \\
\text { liberated }\end{array}$ & Sourie & $\begin{array}{l}\text { Wild } \\
\text { or reared } \\
\text { stork }\end{array}$ & $\begin{array}{l}\text { Where } \\
\text { liherated }\end{array}$ & 13y n liom & $\begin{array}{l}\text { Banded } \\
\text { or } \\
\text { marked }\end{array}$ & Results \\
\hline 1880 & $30 \pm$ & $\ldots \ldots \ldots \ldots \ldots$ & Wild & Staten Is., V Y. & $\ldots \ldots \ldots \ldots \ldots \ldots$ & $\ldots \ldots \ldots$ & $\ldots \ldots \ldots \ldots \ldots \ldots \ldots$ \\
\hline $\begin{array}{l}\text { Fall } \\
1880\end{array}$ & $\begin{array}{l}\text { Simall } \\
\text { shipment }\end{array}$ & $\begin{array}{l}\text { No. New } \\
\text { tlampshire }\end{array}$ & Wild & $\begin{array}{c}\text { Wareluau. } \\
\text { Mass. }\end{array}$ & Outram Baugs & $\ldots \ldots \ldots$ & $\ldots \ldots \ldots \ldots$ \\
\hline $1907-1908$ & 56 & Canada & Wild & Green 13ay, Wis. & William Jarnhard & - & $\cdots$ \\
\hline 1911 & 38 or 39 & Nova Scotia & Wild & $\begin{array}{l}\text { Anticosti } \\
\text { Island }\end{array}$ & $\ldots \ldots \ldots$ & & $\begin{array}{l}19 \text { anrived the frat } \\
\text { winter; bred and apread }\end{array}$ \\
\hline $\left.\begin{array}{l}1921 \\
1922\end{array}\right\}$ & 400 & Alberta & Wild & $\begin{array}{l}\text { Wratuhester } \\
\text { Co.. N. Y. }\end{array}$ & $\begin{array}{l}\text { So. N. Y. Fish } \\
\text { N liame Ass'n }\end{array}$ & Marked & $\ldots \ldots \ldots \ldots \ldots$ \\
\hline 1923 & $\begin{array}{c}8 \text { of } 30 \\
\text { purcliased }\end{array}$ & Alberta & Will & Connecticut & Sturgis \& Tnintor & $\ldots \ldots \ldots \ldots$ & $\cdots \cdots$ \\
\hline 1923 & ? & Alberta & Wild & $\begin{array}{l}\text { lsland in } \\
\text { Puget Sound }\end{array}$ & - & . & $\cdots \ldots \ldots \ldots \ldots \ldots \ldots$ \\
\hline 1923 & 72 & Alberts & Wild & $\begin{array}{l}\text { Westchester } \\
\text { Co.. N. Y. }\end{array}$ & $\begin{array}{l}\text { Si) N. Y. Fish } \\
\text { Ninme Ass'u }\end{array}$ & Marked & $\ldots \ldots \ldots \ldots \ldots \ldots \ldots \ldots$ \\
\hline 1921 & $\begin{array}{l}115 \text { of } 126 \\
\text { purcluased }\end{array}$ & Albertis & Wrild & Connecticut & Sturgis \& Tuintor & $\cdots \ldots \ldots$ & $\cdots \cdots \cdots$ \\
\hline 1921 & 72 & Alberta & Wild & $\begin{array}{l}\text { Wistehesturs } \\
\text { Co.. N. Y. }\end{array}$ & $\begin{array}{l}\text { So, N. Y. Fish } \\
\text { A liame Ass'n }\end{array}$ & Marked & $\cdots \ldots \ldots \ldots \ldots \ldots \ldots$ \\
\hline 1021 & $\Lambda$ few & Alberta & W'ild & $\cdot$ & $\begin{array}{l}\text { Pa. Game } \\
\text { Comminision }\end{array}$ & $\ldots \ldots \ldots$ & $\ldots \ldots \ldots \ldots \ldots \ldots \ldots$ \\
\hline $1924-1925$ & A fin & & $\ldots \ldots \ldots$ & Maryluod & $\ldots \ldots \ldots \ldots$ & $\cdots \cdots$ & $\ldots \ldots \ldots \ldots \ldots \ldots$ \\
\hline 1925 & 100 & Alberta & Wilal & $\begin{array}{l}\text { Wrestehesti'r } \\
\text { Co.. N. Y. }\end{array}$ & $\begin{array}{l}\text { Sos. N. Y Fish } \\
\text { N Gune Ass'n }\end{array}$ & Marhed & $\ldots \ldots \ldots \ldots \ldots \ldots \ldots$ \\
\hline 1925 & 100 & Alberta & Wild & Putnam Co.. N. V. & Noble & $\cdot$ & $\cdots \cdots$ \\
\hline 1927 & A few & Saskatcluwau & Hild & $\begin{array}{l}\text { Cypress dills, } \\
\text { Sushntehewan }\end{array}$ & & - & $\ldots \ldots \ldots \ldots$ \\
\hline $1930(?)$ & - & Alburta & Wilit & $\begin{array}{l}\text { Marthais } \\
\text { lintyurd }\end{array}$ & $\begin{array}{l}\text { Mass. Fisli } \\
\text { N Gums: Div }\end{array}$ & $\begin{array}{l}\text { J'robatily } \\
\text { butideal }\end{array}$ & l)isapjwarml \\
\hline $\begin{array}{l}F(1) \\
1931\end{array}$ & $\begin{array}{c}11 \text { of } 31 \\
\text { purclatasid }\end{array}$ & Alberlu & Wild & Cimn. 1lill & I. I.S. & Hotl. & 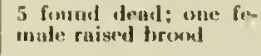 \\
\hline $\begin{array}{l}\text { Felo. } \\
1031\end{array}$ & $\begin{array}{l}5 \text { of }: 31 \\
\text { purcliased }\end{array}$ & Allueraz & Wild & Phursulia & N. I. S. & liolli & $\begin{array}{l}\text { 2 frumd dearl: } 3 \text { sur- } \\
\text { vived at least until July }\end{array}$ \\
\hline $\begin{array}{l}\text { 1) Pre. } \\
\text { 1131 }\end{array}$ & 5 & $\begin{array}{c}\text { N. Y. S. Ithacy } \\
\text { Crame Farm! }\end{array}$ & Ilourenl & Coma. Ilill & N. Y.S. & Hoth & $\begin{array}{l}\text { killed loy predators; } \\
\text { survived }\end{array}$ \\
\hline $\begin{array}{l}\text { Dec. } \\
1931\end{array}$ & 15 & Alberta & Wiild & $\begin{array}{l}\text { Cajut. I list. } \\
\text { fiame Hof. }\end{array}$ & N. i.s. & Bmmled & $\ldots \ldots \ldots \ldots \ldots \ldots$ \\
\hline $\begin{array}{c}\text { Nov.-1)ec. } \\
1931\end{array}$ & 15 & Alberta & Wild & $\begin{array}{l}\text { l'hursalia } \\
\text { fame } 11+r \text {. }\end{array}$ & $>Y . S$. & Handent & $\ldots \ldots \ldots \ldots \ldots \ldots \ldots$ \\
\hline $\begin{array}{l}10 e c . \\
1931\end{array}$ & 29 & Altwerta & Wild & Comu. Ilill & N. Y.s. & Hoth & 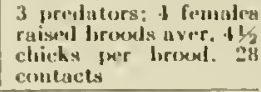 \\
\hline
\end{tabular}


TABLE 2. RECORDS AND RESULTS OF GROUSE LIBERATIONS

KNOWN TO THE INVESTIGATION (cont'd)

\begin{tabular}{|c|c|c|c|c|c|c|c|}
\hline Date & $\begin{array}{l}\text { Number } \\
\text { liberated }\end{array}$ & Source & $\begin{array}{l}\text { Wild } \\
\text { or reared } \\
\text { stock }\end{array}$ & $\begin{array}{l}\text { Where } \\
\text { liberated }\end{array}$ & By whom & $\begin{array}{l}\text { Banded } \\
\text { or } \\
\text { marked }\end{array}$ & Results \\
\hline $\begin{array}{l}\text { Nov, } \\
1933\end{array}$ & 75 & Alberta & Wild & $\begin{array}{l}\text { Delaware } \\
\text { Co., N.Y. } \\
\text { Delawure } \\
\text { Co.. N. Y. }\end{array}$ & Robert Gerry & Veitlarr & $\begin{array}{l}\text { See heluw-1936 by } \\
\text { fierry } \\
\text { See Jnelow-1936 by } \\
\text { fierry }\end{array}$ \\
\hline 1934 & 56 & Albertis & Will & $\begin{array}{l}\text { Franklin } \\
\text { Co.. N.Y. }\end{array}$ & Robert Lehotan & Neitlin't & $\ldots \ldots \ldots \ldots$ \\
\hline $\begin{array}{l}\text { Spring } \\
1934\end{array}$ & 13 & N. Y. S. & lieared & Coun. IJill & N. Y.s. & $\|\}_{1} H_{1}$ & $\begin{array}{l}\text { (Bily } 3 \text { recorded dead } \\
\text { by Sepit. }\end{array}$ \\
\hline $\begin{array}{l}\text { Spring } \\
1931\end{array}$ & 12 & $\begin{array}{c}\text { N. Y. S. } \\
\text { Resenrcli Conter }\end{array}$ & Heared & Ilyde l'ark & N. Y.S. & |kandial & $\begin{array}{l}\text { (Dif contacterl } 6 \text { miles } \\
\text { uway }\end{array}$ \\
\hline $\begin{array}{l}\text { Ang. } \\
1935\end{array}$ & 23 & fiorry's Fiarm & Heared & $\begin{array}{l}\text { Delaware } \\
\text { Co.. N. Y. }\end{array}$ & Ilobert Gerry & Hatuled & $\begin{array}{l}2 \text { linnere killend. No } \\
\text { nore seven }\end{array}$ \\
\hline $\begin{array}{l}\text { Jan. } \\
1936\end{array}$ & 23 & Alferta & Wiled & $\begin{array}{l}\text { Delaware } \\
\text { Co.. N.Y. }\end{array}$ & Hobert Gerry & & $\begin{array}{l}15 \text { dead or hilled. liec- } \\
\text { ord may inchidle some } \\
\text { from sbove. ledentity } \\
\text { hased ouly on colur }\end{array}$ \\
\hline $\begin{array}{l}\text { Apr. } \\
1938\end{array}$ & 12 & N. Y.s. & Heared & Cumn. Ilill & N. Y.S. & $\ln ,||_{1}$ & $\begin{array}{l}\text { One foumd deud. } \\
\text { Several contacts }\end{array}$ \\
\hline $\begin{array}{c}\text { Apr.-May } \\
1938\end{array}$ & 8.1 & $\begin{array}{l}\text { N. Y'. S. } \\
\text { Ireseareli Center }\end{array}$ & lleared & I'tursalia & N. Y.S. & $\mid\}_{i},||$ & $\begin{array}{l}\text { 17 found dead: } 1 \text { fp- } \\
\text { male foomal witl bromd; } \\
\text { to contucts, one } 3 \mathrm{~L}_{2}\end{array}$ \\
\hline $\begin{array}{l}\text { Aug. } \\
1939\end{array}$ & 17 & Wushingtim & J6rarted & I'rutection Is. & $\begin{array}{l}\text { Uregun "Threp- } \\
\text { way Conol. Unit }\end{array}$ & Dritlere & $\begin{array}{l}1 \text { browel in } 1910 . \text { Vo } \\
\text { mests fundid. } 1 \text { remaia. } \\
\text { ing in fall of } 1912\end{array}$ \\
\hline $\begin{array}{l}\text { Uct. } \\
1939\end{array}$ & 6 & $\begin{array}{c}\text { N. Y. S. } \\
\text { Researchi Center }\end{array}$ & Houred & Westclusster Co. & N. Y.s. & Kusuded & Nosul sexpuent contacts \\
\hline $\begin{array}{l}\text { Winter } \\
1939-40\end{array}$ & 216 & Altuertis & Wild & $\begin{array}{l}\text { S. 1. phart } \\
\text { of State }\end{array}$ & $\begin{array}{l}\text { Mhio Cinse. } \\
\text { Devet. }\end{array}$ & $\cdots$ & $\ldots \ldots \ldots \ldots$ \\
\hline $\begin{array}{l}\text { Winter } \\
1939-40\end{array}$ & 26 & Wisconsin & Wild & $\begin{array}{l}\text { Inting Truil } \\
\text { Ifofupe" }\end{array}$ & $\begin{array}{l}\text { Ma. Corns. } \\
\text { Cusum. }\end{array}$ & $\begin{array}{l}\text { l'robubly } \\
\text { loumedecl }\end{array}$ & Wour lieard frons \\
\hline $\begin{array}{l}\text { Wister } \\
\text { 1940-41 }\end{array}$ & 38 & Altuertin & Wild & 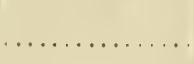 & $\begin{array}{l}\text { Mhic Cintis. } \\
\text { Dept. }\end{array}$ & $\cdots \ldots$ & $\ldots \ldots \ldots \ldots \ldots \ldots$ \\
\hline $\begin{array}{l}\text { Wiuter } \\
19.10-41\end{array}$ & 86 & Wisconsin & Wild & & $\begin{array}{l}\text { Ohin Cons. } \\
\text { Deryt. }\end{array}$ & 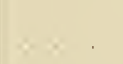 & $\ldots \ldots \ldots \ldots \ldots$ \\
\hline $\begin{array}{l}\text { Winter } \\
19.40-11\end{array}$ & 6 & Wisconsin & Wilu & $\begin{array}{l}\text { Deer Ilun } \\
\text { liefoge }\end{array}$ & $\begin{array}{l}\text { Mo. Cinns. } \\
\text { Commrn. }\end{array}$ & $\begin{array}{l}\text { Probutaly } \\
\text { lyandiod }\end{array}$ & 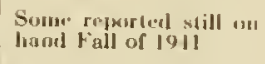 \\
\hline $\begin{array}{l}\text { Winter } \\
19.10-41\end{array}$ & 25 & Wiseonsin & lleured & $\begin{array}{l}\text { Neur } \\
\text { Clarr, Micls. }\end{array}$ & R. livlle'tt & - & $\begin{array}{l}\text { Magy still uromshol } \\
(19.12)\end{array}$ \\
\hline A $_{19.11}$ & 12 & N. Y. Si. & Ilestred & Cuyuga Co. & N. Y.s. & 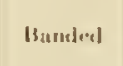 & Nosulisepuent centacts \\
\hline 1941 & 6 & $\begin{array}{l}\text { N. Y. S. } \\
\text { Iesearch Cenitur }\end{array}$ & lietrred & Westchester Co. & 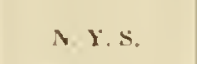 & $\mid$ |nIulvel & $\begin{array}{l}\text { Four survived at least } \\
\text { one month }\end{array}$ \\
\hline $\begin{array}{l}\text { Jreci } \\
\text { 194I }\end{array}$ & 50 & Wiscoasin & Wild & $\begin{array}{l}\text { Deer lloun } \\
\text { licfoge: }\end{array}$ & $\begin{array}{l}\text { Mo. Coas. } \\
\text { Comm. }\end{array}$ & $\begin{array}{l}\text { |'robulily } \\
\text { tunntiol }\end{array}$ & $\ldots \ldots \ldots \ldots \ldots$ \\
\hline $\mathrm{A}_{19.11}$ & 18 & Nescarch Senter & licared & d'urtriclue ltur & N. I.S. & Heth & No sulseyoent coutacts \\
\hline $\mathrm{A}_{19.11}$ & 19) & N. I. S. & linared & l'harsuliu & N. I. S. & ffanded & $\begin{array}{l}\text { Sumn safen for several } \\
\text { numths in vicinity of } \\
\text { puint of liberotion }\end{array}$ \\
\hline A 19.410 & 10 & $\begin{array}{c}\text { N. I. S. } \\
\text { Researcli Cienter }\end{array}$ & lioured & Milmar & N. I. S. & Itusaded & $\begin{array}{l}\text { Some seen for several } \\
\text { months in vicinity }\end{array}$ \\
\hline $\begin{array}{l}\text { Winter } \\
1941-12\end{array}$ & $\frac{223 \text { of }}{381}$ & Albertu & wild & & $\begin{array}{l}\text { Ohio Cons. } \\
\text { Deve. }\end{array}$ & & $\ldots \ldots$ \\
\hline $\begin{array}{l}\text { Winter } \\
19.61-12\end{array}$ & 106 & Wiseonsin & Wild & & $\begin{array}{l}\text { Uhio Cons. } \\
\text { Dept. }\end{array}$ & & $\cdots \ldots \ldots \ldots \ldots \ldots$ \\
\hline $\begin{array}{l}\text { Winter } \\
19 \$ 1-42\end{array}$ & 36 & Hisconsin & lieured & $\begin{array}{l}\text { Maniton } \\
\text { Is. (Wis.) }\end{array}$ & IR. Hollett & $\cdots$ & Disappeared \\
\hline$\underset{1942}{\text { Sprimg }}$ & 40 & Wisconsin & Heared & $\begin{array}{c}\text { Near } \\
\text { Clare, Mich. }\end{array}$ & H. Follett & & \\
\hline
\end{tabular}


liberated by William Baruhard, a deputy game warden in Wiscousin, on Washington Island at the entrance to Green Bay in 1907-08. About 1911, 39 wild grouse were liberated on the lsland of Anticosti in the Gulf of St. Lawrence, where previously they had been unknown. Al. though but 19 are said to have survived the first winter, they apparently bred and spread, for these birds are now fairly common over the Island*. While the demand always greatly exceeded the supply, no doubt many more birds were shipped, particularly during the 1920s. A record of those attenpts, known to the Investigation, is given in table 2. Apparently, few permanent records were kept, for, if we may judge by present day experiences, scarcely a year goes by but that two or three such importations cone to light. For instance, Robert Gerry liberated 50 grouse on his estate near Delhi, N. Y., in 1933. and 75 the following year. the birds coming from Alberta. Most recent records of importation are of 261 from Alberta, in 1940-42, by the Ohio Division of Conservation, for liberation in the southeastern part of that State.

Not all the interest in grouse liberations is in the East. In August 1939 Arthur S. Einarsen, in charge of the Oregon Three-Way Cooperative Unit, liberated 17 hand-raised grouse on Protection Island. Subsequent survival was carefully checked; one brood of five was seen the following fall. In 1942, however, there was apparently but a single survivor of the liberation resident on the Island.

Another practice, the establisbment of refuges, also became popular. These were organized largely for bird protection in general rather than for grouse alone. Where fear was particularly strong that grouse might vanish entirely; such areas were selected primarily to preserve this species.

The refuges served as breeding and nesting places so that grouse might be undisturbed by man. Occasionally the habitat was improved ly planting open areas to food or cover-producing species. In some instances, also, the axe did its part in creating breaks in the forest cover. Thus opened up. the all-too-barren forest floor, in the Northeast. at least, usually gave way to a profusion of herbs, berries and second-growth sprouts. This proved to he a particu. larly attractive combination 10 birds, both old and young alike.

Considered as protective oases in the vast expanse of huntable grouse cover. these refuges could have had only the most local of possible effects on the abundance of the species as a whole. History records no startling examples of immediate and satisfying increases following their establishment. l'erlaps it is because man is, after all, but one of the major factors controlling the abmulance of this great game hird.

\section{RISE IN IMPORTANCE AS A SPORTING BIRD}

No game hird in America has heen more completely investigated than has the ruffed yrouse. It was widely dispersed wer the country. Its periods of abundance. followed ly sudden disappearances. were disconcertingly mysterions. Its ability to maintain itself in close proximity to man and to make him aware of its presence lyy its slightly unreal but intrigu. ing drumming, created for most country folk, living within its range. many pleasant and memorable experiences. That it ws sumght after as food and was easily salable in the markets also contributed to the interest which made these investigations possible.

But it was the sportsmen to whom the skill and daring of the hird most appealed. Pur. sued by the oecasional market lunter. it remained surprisingly tane. Once partridge hunting became popular however. the birl became wary and alert. It seldom proved possible to 
shoot the last bird out of a covert. so adept did it become at dodging and screening its flight behind a convenient tree. Practice truly gave it more perfection until hunters came to have a very real respect for the hird and a genuine concern for its continued welfare. The men who had seeured their living hunting partridges gave way to those who made it their recreation.

Quick transportation made it possible for still larger numbers to enjoy the sport. The suceessful introduction of the ringneeked pheasant throughout portions of the grouse range. at a time when real sportsmen everywhere were particularly eoneerned about the ability of the ruffed grouse to survive, caused some to shift their hunting to the newcomer. With each periodic recovery of the upland favorite, however, devotees flocked back to it in ever inereasing numbers. On the average these later hunters may not compare with the old grouse gunner in sheer deadliness, for they are neither such good shots nor do they spend so mueh time in pursuit of the grouse. but they are amnig the hest class of sportsmen afield.

But what has really appealed to the sportsmen as potentially the most practical measure of all, were the attempts to raise grouse artificially.

\section{EARLY EFFORTS AT ARTIFICIAL PROPAGATION}

It is as true with grouse as with other game that, next to protection as a methorl of in. creasing abundance. man puts his faith in artificial propagation. Indisturbed. gronse are probably the tamest game hirds we have. Harried suffieiently, they cumpare favorably with the wildest. But their nests, while hard to find, are not uncommon. Often they are uneovered by accident. Once found, the resistless human tendeney to "see what will happen" has been the cause for literally hundreds of attempts to hatch out a chutch or two under a barnyard hen and to raise the resulting brood. (tables 3 and 4 ).

These efforts began carly. In a letter from John Bartram to George Eilwards. dated July $15,1750^{110}$, that keen ohserver wrote. "Many have attempted to raise the young ones and to tame them, but to no purpose. When hatehed under a hen they escape into the woods after they are hatched. where they either fund means (o) subsist or perish." While such empirical experiments were unquestionahly repeated hundreds of times. it was unt until 125 years later that the results found their way widely into print.

In the fall of 1874. near Dansville. Maine. M. IT. Clark trapperl four wild partridge overwintering them in a small cage. The following spring, he built an enchusure in the form of a cirele, 10 feet in diameter, with walls five feet high. to protect the hirds and prevent their escape. The top was eovered over with a conieal tent. To make the grouse feel at home, he planted little pines and firs in elose elumps, between which were scattered dry forest leaves. Even wild ruffed grouse may be tamed rather quickly in raptivity and these proved no exception, for one soon made a nest in which were depusited 18 eggs.

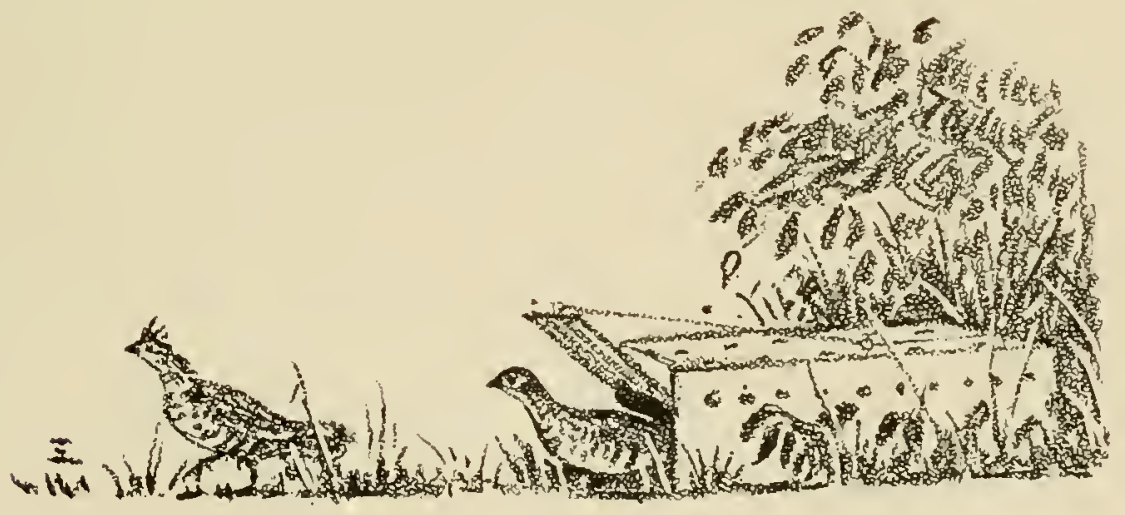


Clark tells us that the two females quarreled over the privilege of sitting on the eggs, a situation which more recent experimentors have seldom noted. Most likely both laid in the same nest. At all events, the egrs were subsequently set under two bantam hens, one of which, unfortunately, was killed shortly by some predator. The other hatched four young grouse. Put in a snall coop, she is reported to have developed a deep affection for them for which they made a poor return. Clark indicates they took little note of her anxious calls and that frequently at night he had to place one or two "lost" chicks under her. Almost prophetically, they all died, but Clark. little dismayed, carried on similar experiments for six long years before concluding that his failures were attributable to a lack of proper food.

TABLE 3. KNOWN ATTEMPTS TO REAR RUEFED GROUSE IN CAPTIVITY FHOM EGGS COLLECTED IN THE WILD-1879-1912

\begin{tabular}{|c|c|c|c|c|c|c|c|c|c|c|c|}
\hline Year & Experinentator & Statu & $\begin{array}{l}\text { EgRes } \\
\text { set }\end{array}$ & $\begin{array}{c}\text { Eggs } \\
\text { halched }\end{array}$ & $\begin{array}{l}\text { Birds } \\
\text { rnist'd }\end{array}$ & Year & Exprerimentator & Slate: & $\begin{array}{l}\text { ligks } \\
\text { set }\end{array}$ & $\left|\begin{array}{c}\text { Egges } \\
\text { hatchied }\end{array}\right|$ & $\begin{array}{l}\text { Birds } \\
\text { raistad }\end{array}$ \\
\hline $\begin{array}{l}1879 \\
1880\end{array}$ & Clnok, M. H. & Maint" & 10 & ? & ? & 1913 & Jol, $11 . \mathrm{k}$. & Conn. & $13 ?$ & 13 & 6 \\
\hline 1886 & "l'f"uri" & $?$ & 12 & ? & 0 & $\begin{array}{l}1911 \\
1915\end{array}$ & $\begin{array}{l}\text { Mrlean, Sen. Gi, I. } \\
\text { George, A. E } \\
\text { Graham, Ci. II. }\end{array}$ & Conn. & 30 & 27 & $?$ \\
\hline 1890 & $0.0 . \mathrm{s}$ & 3 & 11 & 9 & 0 & 1011 & & N. Y. & 7 & 6 & 5 \\
\hline 1897 & Newrone, $A$. & 3 & 40 & 34 & :11 & 1915 & & 1. & $\dot{j}$ & 3 & pi \\
\hline $\begin{array}{l}100.3 \\
1901\end{array}$ & 1)r. C. F. Ilerl phe & Mass. & $\begin{array}{l}20 \\
12\end{array}$ & 12 & $\begin{array}{l}0 \\
6\end{array}$ & 1916 & $\begin{array}{c}\text { Wolcott, Sen. } \\
\text { F. C. nnd }\end{array}$ & Cons. & 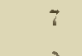 & 7 & 4 \\
\hline $\begin{array}{l}1905 \\
1906\end{array}$ & & & 12 & $\begin{array}{l}15 \\
10\end{array}$ & $\begin{array}{l}0 \\
0\end{array}$ & 1917 & Vaclicar, I). & & 3 & 34 & 8 \\
\hline 1007 & & & 54 & 34 & 10 & 1916 & Gierry, II. L. \& & N. Y'. & 1.3 & 12 & 10 \\
\hline 1908 & & & 12 & I1) & 3 & $101 \%$ & Jarshall, Win. & & 11 & ? & 8 \\
\hline 1401 & Manruss, F. N. & Conn. & H & $\|$ & 5 & 1928 & Gierry, Il, 1. \& & N. Y. & 10 & ) & 0 \\
\hline 1905 & & & 3 & s & s & $\begin{array}{l}1030 \\
1933\end{array}$ & 13ae, $\mathrm{T}$. & & $\begin{array}{r}30 \\
3\end{array}$ & 3 & $\begin{array}{l}0 \\
3\end{array}$ \\
\hline 190.1 & Pawson, C. I. & $?$ & ? & ? & 2 & 1931 & & & 1.5 & 32 & 6 \\
\hline 1905 & Mass. I't. of Cons. & Mass. & & $\$$ & & 1935 & & & 57 & 12 & 33 \\
\hline $\begin{array}{l}1906 \\
1907\end{array}$ & Merrill, $\mathrm{A}$. & & $\begin{array}{l}82 \\
56\end{array}$ & $\begin{array}{l}70 \\
50\end{array}$ & $\begin{array}{l}3 \\
4\end{array}$ & $\begin{array}{l}1919 \\
1920\end{array}$ & An Gatue l'ros. A'u' & N. Y. & 5.5 & 19 & 1 \\
\hline 1008 & & & 150 & 122 & 2 & & & & 37 & $2 H$ & 1 \\
\hline 1909 & & & 20 & 16 & 11 & 1921 & Alen, А. А. & N. Y & 66 & 57 & 0 \\
\hline 1910 & & & 1.3 & 13 & 0 & 1922 & & & 3 & 3 & 3 \\
\hline 1925 & & & 8 & 0 & 0 & 1923 & & & 53 & $5 i 5$ & 0 \\
\hline 1926 & & & 10 & 10 & 6 & 1925 & & & 35 & 31 & ! \\
\hline 1928 & & & 9 & 3 & 3 & 1926 & & & 15 & II & i \\
\hline 1929 & & & 11 & 11 & 0 & 1927 & & & 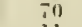 & 67 & 1 \\
\hline 1930 & & & 13 & 13 & 6 & 1928 & & & 11 & ? & 3 \\
\hline 1931 & & & 12 & 16 & 0 & $\begin{array}{l}1924 \\
19.30\end{array}$ & & & $\begin{array}{l}52 \\
.12\end{array}$ & 12 & ! \\
\hline 1912 & An, Gonte I'rot, A'n & Misss. & 40 & 16 & 8 & $19: 31$ & & & 13月 & 125 & 57 \\
\hline 1913 & Tisirey. II. A. & & 40 & $?$ & 11 & $\begin{array}{l}19,32 \\
1933\end{array}$ & & & 711 & 51 & 17: \\
\hline 1911 & Mnss, 1)'t of Cons. & Vinse. & 1.36 & 9 & 18 & & & & & & \\
\hline $\begin{array}{l}1915 \\
1916\end{array}$ & Torrey, II. $\Lambda$. & & $\begin{array}{r}123 \\
12\end{array}$ & $\begin{array}{r}19 \\
?\end{array}$ & $\begin{array}{c}190 \\
?\end{array}$ & 1917 & MeVienr, A. d. & 3 & 210 & $\$ 1$ & 1 \\
\hline 1920 & & & 8 & j & 1 & 1929 & Iloughton, W. II & N. Y. & $1: 3$ & 13 & 0 \\
\hline 1021 & & & 11 & 0 & i) & 19.30 & & & ii & 11 & ") \\
\hline $\begin{array}{l}1922 \\
19021\end{array}$ & & & 8 & s & 0 & 19.31 & & & $: 36$ & $i$ & 0 \\
\hline 1925 & & & $\begin{array}{r}13 \\
8\end{array}$ & $\begin{array}{l}0 \\
8\end{array}$ & $\begin{array}{l}0 \\
0\end{array}$ & 1029 & Sines. II. J. & l'il. & 11 & 11 & " \\
\hline $\begin{array}{l}1926 \\
1024\end{array}$ & & & 10 & 6 & 2 & 11730 & & & 10 & 35 & 0 \\
\hline $\begin{array}{l}1924 \\
1929\end{array}$ & & & $\stackrel{9}{11}$ & 11 & $\begin{array}{l}3 \\
0\end{array}$ & 1920 & 'lurrill, I). & I"I. & () & ) & \\
\hline 1931 & & & 13 & $\begin{array}{l}11 \\
13\end{array}$ & 8 & 1930 & & & bis & $3 i$ & i \\
\hline 193:3 & & & 20 & 15 & 11 & 10332 & & & 12 & 32 & 4 \\
\hline 1931 & & & 20 & 19) & 11 & & & & & & \\
\hline $193 \$ 6$ & VInss. 1)'t. of rents. & 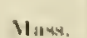 & 31 & 29 & 1 & $\begin{array}{l}10,30 \\
10,31\end{array}$ & Y Y. Cons lege. & Y. Y & 3.21 & 180 & $\ddot{10}$ \\
\hline $19: 37$ & Hackus, li. li. & & 19 & -7 & 0 & $19: 2$ & Bump, r. and J & & 365 & 2415 & 111 \\
\hline $19: 36$ & Mra4, b't of Cons & Yugg & 51 & 30 & 2 & 1933.3 & Hump, i, and I, & & 6111 & b12 & 120 \\
\hline $19: 17$ & Silorman, 1. 11. & & 13 & 13 & $\tilde{0}$ & $\begin{array}{l}19.314 \\
1935\end{array}$ & llolm, li. & & $10: 3 \mathrm{I}$ & $110: 3$ & 154 \\
\hline & & & & & & $\begin{array}{l}19.35 \\
1936\end{array}$ & 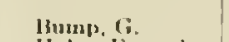 & & 37 & $\begin{array}{l}301 \\
\$ 118\end{array}$ & 127 \\
\hline $19: 36$ & Muxs. 1)'2. of Cents. & Mass. & 20 & 12 & 0 & $19: 1 \%$ & IIolin, It.., nusel & & 237 & 211 & 51 \\
\hline & Torrey, J. A. & & & & & $\begin{array}{l}19: 28 \\
1930\end{array}$ & Forillom, si. & & 157 & $\begin{array}{l}1.13 \\
1.35\end{array}$ & $\begin{array}{l}16 \\
\text { (1) }\end{array}$ \\
\hline 19.30 & Whs. I)'t of (ions. & M & 67 & 18 & ? & 1910 & & & 108 & 102 & 58 \\
\hline $19: 37$ & Wourl, F, W. & & 11 & 2 & 0 & 1111 & & & $\because 1$ & 75 & (1) \\
\hline $\begin{array}{l}19.34 \\
19.30\end{array}$ & & & $\begin{array}{l}10 \\
36\end{array}$ & $\begin{array}{l}10 \\
34\end{array}$ & $\begin{array}{l}6 * \\
15^{*}\end{array}$ & 1012 & & & 37 & $3: 1$ & 13 \\
\hline & & & & & & 1930 & Coleman & Iu. & 13 & 1:3 & 5 \\
\hline 1900 & Gollits, MI. II. & Миงч. & 12 & 12 & 0 & 19,31 & & & 58 & 11 & 10 \\
\hline 1911 & Ililey, l'hil. M. & $s$ & $\boldsymbol{B}$ & 8 & 5 & 19,30 & Melamplay, A. r: & $P^{\prime}$ & 86 & .10 & 17 \\
\hline
\end{tabular}


TABLE 3. KNOWN ATTEMPTS TO REAR RUFFED GROLSE IN CAPTIVITY FROM EGGS COLLECTED IN THE WIID -18:9-1912 (Cont'd)

\begin{tabular}{|c|c|c|c|c|c|c|c|c|c|c|c|}
\hline Year & lixperimentator & State & $\begin{array}{l}\text { Eiges } \\
\text { set }\end{array}$ & $\begin{array}{l}\text { ligugs } \\
\text { hatehod }\end{array}$ & $\begin{array}{l}\text { lBirds } \\
\text { raised }\end{array}$ & Year & Expreimentator & State: & $\begin{array}{l}\text { Egars } \\
\operatorname{set}\end{array}$ & $\begin{array}{l}\text { Eigks } \\
\text { hatched }\end{array}$ & $\begin{array}{l}\text { Mirds } \\
\text { raised }\end{array}$ \\
\hline 1931 & Hridges, 11. 1'. & IV. Ia. & $?$ & 3 & 0 & 1933 & I ermont Fish and & Vit. & 48 & $?$ & 0 \\
\hline $\begin{array}{l}1931 \\
1932\end{array}$ & ()te, F. & N. C. & $\frac{32}{26}$ & $\begin{array}{l}19 \\
17\end{array}$ & 5 & & Ishaw. It. II. & & & & \\
\hline 1933 & & & 50 & 511 & 7 & $\begin{array}{l}19.31 \\
1935\end{array}$ & $\begin{array}{l}\text { Maryld Cons. D't. } \\
\text { IfCompte, E. I. }\end{array}$ & Md. & 12 & $1 !$ & $\begin{array}{l}0 \\
1\end{array}$ \\
\hline 1931 & Mcrarthy, D. F. & Pa. & $?$ & ? & 0 & 1931 & Banta, I. & Uass. & $?$ & ? & 1 \\
\hline $\begin{array}{l}1932 \\
1933\end{array}$ & Kelrher, C. $M$. & $\mathbf{P a}$. & $\begin{array}{l}30 \\
29\end{array}$ & $\frac{21}{28}$ & $\begin{array}{r}18 \\
3\end{array}$ & 19.35 & & & 152 & 118 & 5 \\
\hline 1933 & Ohio Cons. Drpt. & Ohis & 3.5 & 24 & 11 & 1935 & IIart, D. & & 10 & 10 & 8 \\
\hline 19.3 .5 & Trautman. .1. 1 . & पाl० & 3.) & -9 & 11 & 19.35 & & Mich. & 9 & \% & 0 \\
\hline 1933 & $\begin{array}{l}\text { Conn. State Bul. of } \\
\text { Fisheries and Ciame } \\
\text { lseck, T. }\end{array}$ & Conn. & 16 & 11 & 0 & 1036 & $\begin{array}{l}\text { Ruhl, II. D. E. } \\
\text { I'rippetisce, 11. L. }\end{array}$ & Mass. & 28 & 26 & 1 \\
\hline 1933 & MeNamara, L. C. & N. J. & 22 & 16 & 11 & $\begin{array}{l}1039 \\
1020 \\
1011\end{array}$ & Follete, Il. & Mich. & $\begin{array}{r}90 \\
313 \\
110\end{array}$ & $\begin{array}{r}8.3 \\
8 ! \\
?\end{array}$ & $\begin{array}{l}61 \\
52 \\
71\end{array}$ \\
\hline 1933 & Jees-MeRae Coll. & N. C. & 50 & 50 & 10 & ? & lingers, II T. & N.Y.S & & & \\
\hline 1933 & $\begin{array}{l}\text { N. J. Ihl. of Fish } \\
\text { and Gitme Comm. } \\
\text { Roth. Fd. }\end{array}$ & N. J. & 15 & 15 & 10 & ? & Hendick. I). II. & Man.t & & & \\
\hline 1933 & Nirkerson, F... Jr. & Comm. & 10 & 7 & 7 & ? & $\begin{array}{l}\text { Brackele, Comm. } \\
\text { Jiatelle, J. B. }\end{array}$ & $\begin{array}{l}\text { Mass. } \\
\text { ()tuios }\end{array}$ & & & \\
\hline 1933 & Smith. 11. r. & Conn. & 3 & 6 & $\therefore$ & $?$ & kiner, A. II. & V.J.s & & & \\
\hline
\end{tabular}

* Fesults of both wild and hand-reared eges.

slaised some birds.

tSome raiged in large, open pens and suld.

tSome eress hatebed; none reared.

fone hroud started.

Encludes will chicks rescued and raised.

fWeek-old chicks cankht in the will.

But then, as now, it was easier to try out the raising of grouse than to read of others' experiences-and infunitely more fun. "Penn" in 1886. "O. O. S." in 1891, and Commissioner Brackett ${ }^{247}$ in Massachusetts. ahout 1895. all started grouse under bantam hens with. out bothering to leave more than passing records of their methods or their difficulties. Perhaps the most cucouraging record was made by Newconb. who, in 1897 . collected 40 egrs. hatched 34 under heus and raised 31 chicks leyond four weeks of age.

By the turn of the century it was generally estallished that grouse could he hatched from eggs gathered in the wild. Folks were not so sure, however. that the resulting hirds could le raised to maturity, kept over winter and encouraged to produce fertile egge the following spring. Long arguments around cracker barrels failed to settle the subject, lut helped might. ily to make the jol, the more worth doing. It became a challenge to ability as well as an opportunity to contribute to science. With this in mind, Dr. Clifton F. Hodge ${ }^{103}$, head of the Department of Biology of Clark University, weighed earefully, in the fall of 1902. the problem of raising grouse on a large scale, and found it worth doing, "if merely to prove its practicability from the standpoint of science". So Massachusetts, long a pionecr in grouse rearing work, issued Dr. Hodge a permit to collect the necessary eggs from wild nests. A student, fired with the doctor's enthusiasm, placed the eggs in his hat and, putting it gingerly on his head, brought them to the Hodge home, there to he turned over to a broody hantam. This care was rewarded when six young partridges were hatched. None survived, however, beyond the first two weeks.

Undiscouraged by the chorus of "I told you so" that arose, the spring of 1904 saw six birds raised from a clutch of 12 eggs. But, with these almost a year old and victory in his 
TABLE 1. WNOW ATTEMPTS TO REAR RIFFED GROUSE IY CAPTIVTY FROM EGGS SIECURED FIROM IIAND-RAISED IBIRDS-1875-19t2

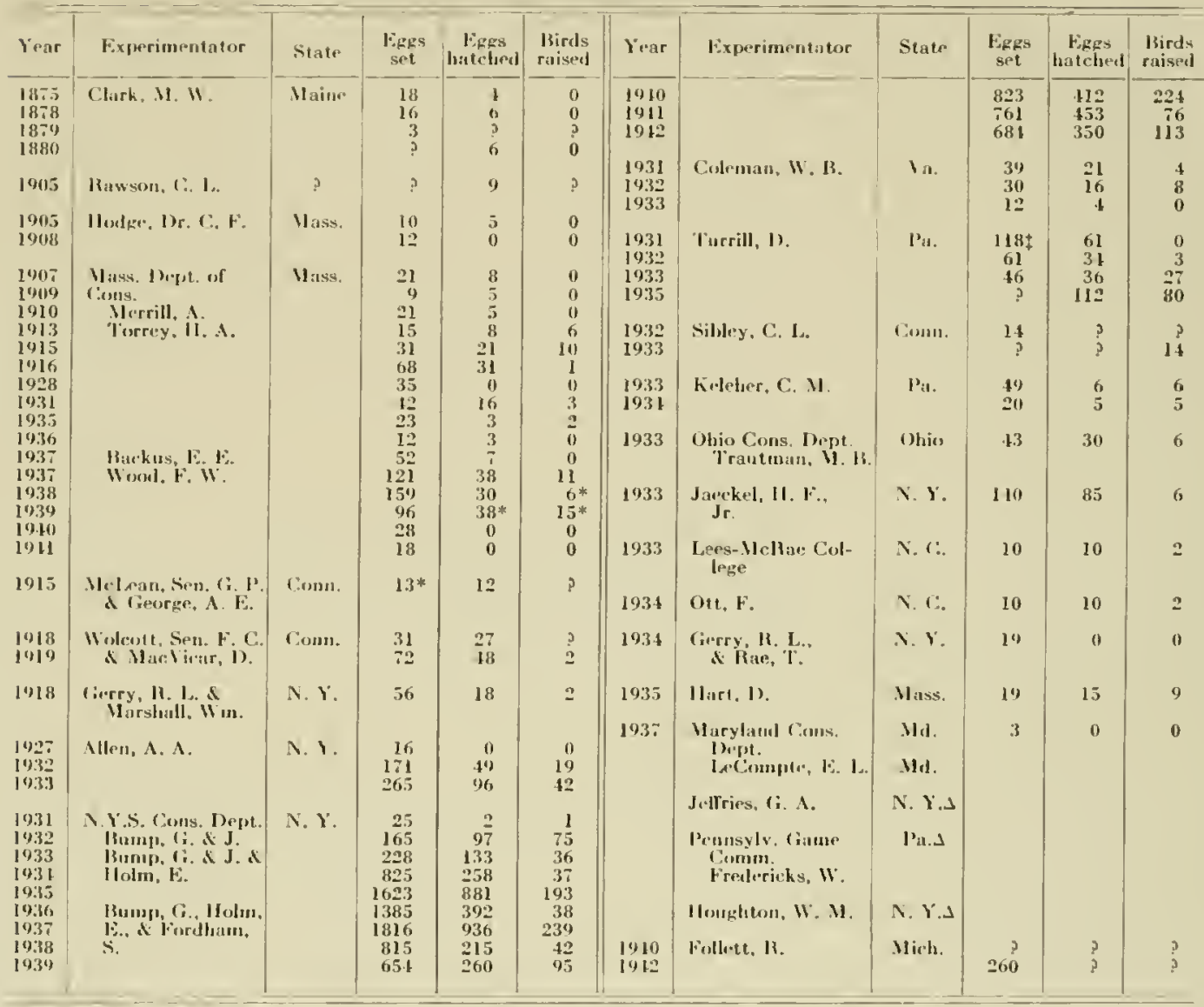

* Hesults from eqes secured fron the wild and from hand-raised birds.

3 llaisud some groust.

¥Twelve of this 20 birds producing these eggs were from wild-trapued stock.

grasp, fate played the persistent doctor the first of a series of strange and discouraging tricks. A cat appropriated all but wo for a midnight lumeh although the grouse were carefully penned.

Undannted, the following vear he collected a larger number of eggs. The two survivors of the presious year were. fortunalely, a pair. One can imagine the excilement and satisfaction engentered when ten eggs were laid and five chicks emerged from them. By this time, too, cats hal learnel to give Pine Hill, where the Hodge family lived, a wide berth. This edu. cation was not an altogether painless process, however, for an assistant. Dr. Dellinger, was haled before the Worester police court, charged with cruelty to animals for having killed 
one of the feline predators. The court held that the eat was a wild animal and therefore not entitled to protection by law exeept when treated in an inhumane manner. The doctor was released. Historians add that, thereafter, eats passed through Pine Hill. "only on the run".

But not so with the indignant neighbors. some of whom, by now, were convinced that the only good grouse was a dead one. Feeling that the birds desired natural surroundings. a spruce tree on the Hodge lawn, 30 feet tall, was completely enclosed with wire and the seven survivors of the rearing season just passed were placed therein. With October's falling leaves eame frosty nights, during one of which some acorns, filled with poison. were mysteriously tossed in the enclosure. After eating them. all the birds promptly died. The papers came out with articles about poison-fiends, hut the eats were avenged and science suffered accord. ingly.

Still determined and undeterred. Dr. Hodge continued his experiments for three more years. In keeping with all attempts made hefore or after, success always lay "just around the corner". In 1907. his perseverance and good judgment in handling the experiments secured from the Carnegie Institute of Washington a grant of $\$ 500$ to further the work. That year, too. convinced that hantam hens were temperanentally unreliable and likely earriers of disease as well, he took a long step forward by raising a small group of birds under the prinitive brooders of that day.

The following year. grouse nests were extremely hard to find. Only one was collected. Though ten youngsters were hatcherl, seven were killed while feediug on striped hugs. From the adults of the preceding year, one hen laid 12 excoss all of which proved to be infertile. Though he must have had some misgivings. as late as June, 1909. Dr. Hodge was still attempting to secure ergs from as wide a territory as possible "to learn to what extent geographieal eonditions enter into the life of the bird". No eggs were fortheoming, luwever. and he was forced, regretfulh. to turn to other fields.

It is significant to note that. at the end of seven years of eareful experimentation. he felt fully equipped, both as regards experience and teehniques. to breed and raise partridge suc. cessfully in captivity. Food. both for young and old birds, seemed to be one of the liniting factors. The number of exgs produed hy hand-raised hids. as well as their fertility. lue believed. were depondent upon it. How often thereafter. careful experimentors reached the same threshold of success. only to find it eluding their grasp!

Contemporary with Hodge was the work of Arthur Merrill ${ }^{2 w}$. carried on in the cramper quarters of a small trout hatchery in Sutton. Superintendent Merrill was forced to divide his time hetween the regular work of the hatchery and attempts to rear pheasants. quail. ducks, geese. black grouse. capereailzie, heath hen and European gray partridge. in addi. tion to ruffed grouse. Though published records are hlank. Merrill tells us* that at least one elutch of grouse was raised in 1904 or 1905. Work commeneed in earnest in 1906. when 87 eggs were brought in from wild nests. Part of these were placed under the unreliable

\footnotetext{
* Merrill, A. personal letter to the authors.
} 
bantam: part in an incubator whose tendencies were eharacteristically unpredictable. Once hatched. these birds were then placed under the primitive edition of the now highly developed artificial brooder. The brooder promptly hurnel and so did the chicks. Some of those entruster to hens died of disease, diagnosed as blackhead, and others from a series of accidents which characteristically befall grouse in captivity. Only three survived the winter.

By now: Hodge and Merrill were well known to each other. The former secured his bantam hens in Sutton, as well as a supply of food. Merrill. profiting by these contacts. placed each of his two hand-raised females on the ground in a separate pen, $8 \times 60$ feet. The cock grouse alternated between the pens. However, the birds proved adamant. One hen laid several fertile eggs but alsandoned her nest when they were only partly inculated. The second hen laid 14, which were promptly removed to encourage her to lay a second cluteh hut to no avail. Though most of these eggs were fertile, the chicks died during incubation or shortly thereafter, as did most of the 50 which cmerged from 56 wild-gathered eggs. Only four of these hirds survived the winter.

At Sutton, in 1908, a larger number of eggs than usual was brought in. perhaps 150 in all. However, details of the progress of the work are lacking. There is an indication of a heavy loss at the age of seven weeks. However, a fairly large number was still on hand at the beginning of winter, during which they were aqain reduced to four. These proved to be a cock and three hens, wo of which were killed during the breeding season. The remaining onc nested and laid five eggs which failed to hatch. Better luck followed some 20 wild eggs that were collected, in that 11 hirds were raised to maturity. Once again, winter losses reduced the flock to four.

There is a period, sometimes a recurring one in the life of male grouse in captivity, during which they are extremely vicious. Apparently Merrill encountered this in 1910. for he states. "This year a cock was so vicious that it was unwise to mate in small pens. and a new experiment was tried. The four birds were wing-clipped and lumed loose in a 2 -acre enclosure. Two nests were found. one with 12 infertile eggs, the other with nine eggs, of which five were fortile and were hatched by a hen. Her last chick was lost ly drowning when three weeks old."

Then came one of those strokes of rare luck. Two wild nests were found and brought in. One was quickly Inst. Lut, of the other, every one of the eggs hatched and the 13 chicks were grown in an artificial brooder to the age of six weeks without a single loss. Then, as though to prevent over-eonfidence on the part of their kerpers. all promptly dicd of an infection.

A change of administration in Massachusetts terminated the work at Sutton. But other hands were ready to take it up. The American Game Protective and Propagation Association had just been formed am Harry $A$. Torre was engaged to take over the work of propagating grouse at their farm in South Carver. By 19I2. they were ready and a start was made ly locating four wild nests. From these. cight young birds reached maturity in 1913. Ahout the same ummber of eggs was collected and enough more birk were reared to make a total of 19 on hand at the end of that year.

Here. sienificantly. werurs the first record of wo grouse brouglut to the sceond generation in raptivity. The lirds wre raised. for the most part, on the ground and with bantans in much the same manuer an has been previonsly described. In spite of this early suecess. the farm was closed in January, 19]4, and the 19 hand-rearcd grouse dropped from sight.

1)r. George W. Fiekl. chairman of the Massadhustt. Game Comnission. was not at all 
diseouraged. Torrey, therefore, was placed in charge of the East Sandwich Game Farm and instructed to trap a wild brood stock of grouse. About a dozen were finally secured but did not breed well in captivity. so that the main dependence was again on wild eggs. During this and the succeding year. at least 150 of these were obtained from one source or an. other, mostly by the game wardens. Sensing a long and difficult time ahead. however, the "powers that be" overuled Dr. Field and officially terminated the experiments in the spring of 1916. Without so much as a hand being placed on them to help determine future survival, the birds raised that summer were liberated.

However, Torrey's heart was with the grouse to the last. Thereafter he never lost a chance in pick up a clutch or two of ergs and to rear as many as possible of the chicks. usually with bantams. In 1933, nine of the lirds, which Torrey raised personally, were graciously contributed to swell the propagation experiments already underway by this Investigation. The following year Charles Dimnick. Iong-time grouse enthusiast. returned from a fishing Irip in Vermont with two clutches of eggs. All in all, he carried these well over 300 miles. At his request Torrey set these under two hroody hantams, one nest in ritlee side of an orange crate. Eleven of the hirds that hatched grew to maturity cared for hy their foster mothers, only to fall prey to great horned owls which decapitated them while they vainly. tried to fly through the wire of their pen. A decade earlier, Dr. Arthur A. Allen had demon. strated conclusively that poultry could usually be depended upon to carry diseases fatal to gronse. That these birds were raised at all, therefore, was a tribute indeed to the care and perseverance with which Torrey carried on his work.

Two athers among a host of experimentors stand out during this early period-John Burnham, long-time president of the American Game Protective Association. and U. S. Senator Frederic C. Walcott of Connecticut. one of its most enthusiastic backers. Both were dissatisfied with the cessation of Torrey's South Carver experiments. To each came the opportunity to further the cause.

With the establishment of the U. S. Biological Survey's experimental fur farm in northern New York, George Jeffries was appointed its operating head in 1915. liacked by Burnhan s enthusiasm, Jeffries secured a few clutches. in 1915. from which he over-wintered six or seven hirds. This experiment was repeated the second year. with like suecess. Thongh. at the time, few folk worried about ground-horne diseases, the fact that Jeffries selected land on which no poultry had run for over 20 years, unpuestionably was one secet of his sue. ress. The World War. in 1917. removed Jeffries to other fields and terminated the experiment.

Meanwhile. in western Connecticut. on the Childs and Waleott preserve. a Scotch game.

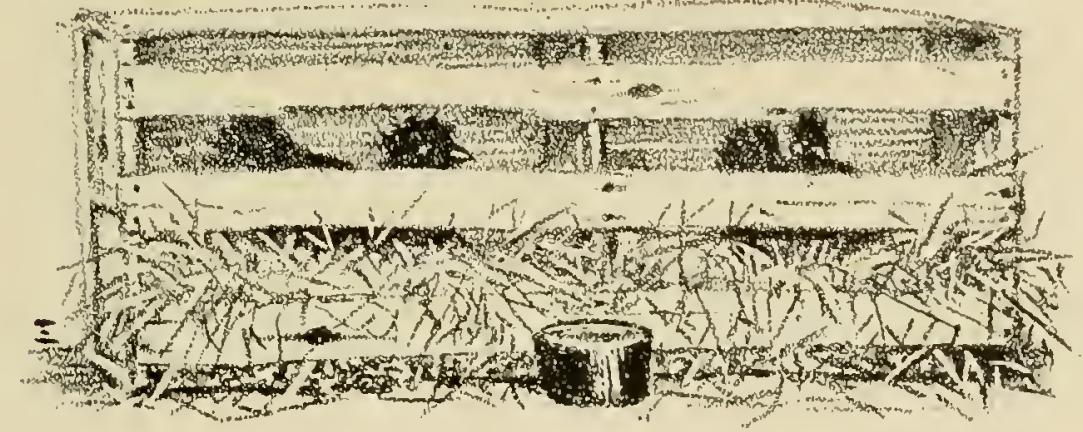


keeper of the old school. Donald MacVicar, under the appraising eye of Walcott. abandoned small coops and enclosures in favor of wide ranges to raise four grouse out of seven hatched in 1916. The foster mother, a game bantan. was wild and exvitalle. and the birds required constant wathing. It is interesting to funl that a chipmunk is credited with killing two youngsters. three weeks uld. In addition to the insects and. later. the seeds and herries which the chicks picked up. the usual feed of hard-boiled ergr yulks and fure game meal or cracker crumbs was provided. Given their freedom. one bird was killed in the kemels and the other three disappeared carly in September at the beginning of the "crazy llionth" period. Only one ever returned.

MacVicar's whole emphasis seems to have leen on the maintenance of natural conditions. The following year. three elutches of eggs were placed under hantans in coops 50 yards apart. The hillside was dotted with cvergreens, birches. ferms. wild grasses and huckleberry bushes-an ideal natural grouse habitat. Because the weather was wet and inserts not too plentiful. ant eggrs and cottage cheese were adderl to the diet of the broods. As with pheasants. when a couple of days ald. the birds were liberated from the conps in which the foster mother was still confined. All went well, when difficulties. characterized by diarthea, resulted in the death of most of the hirds. MacVicar attributed this to stale fond left in the vicinity hy a new ascistant. though later experimentors have encountered the same tronble under a variety of conditions.

The eight birds that pulled through were placed in a special jen covering about threequarters of an acre. One bird escaped and another was killed by flying into the wire. Of the six hirds left, one of the three males hegan strutting in September. Sn savagely did he dominate the enclosure that the other two males had to be fed sejarately and eventually were killed by him. The thrce hens nested and laid 31 aggs, from which 27 chicks were hatehed. Thus again were the polygamous and often domineering tendeneies of the hird, in captivity. demonstrated.

There are man others who might also he mentioned. particularly Manross of Connecticut, Herhert K. Joh. and Harry Rogrers. Inilder of New York's pioneer Sherburne State Game Farm. All of the experiments, however. followed more of les the same pattern. Foster mothers or primitive inculation and brooding equipment were tsed. the eggos heing largely collected from wild nests. and the birds. when hatched. being allowed to run on the ground in small enclosures comtaining more or less natural cover. Discase was only sporadically rec. ognized as a cause of loss. particularly among the young chicks, and then it was traced back to its prolable source. the hen. Enphasis was placed largely upon providing the birds with as nearly natural surroundings as possible and. partienlarly. with natural foods. Egrg were usually removed from the nests when incubation was already well along and. therefore. most "f them hatehed well. Usually the hirds started to die almost immediately. howerer, and the hosses continued at a heary rate until they were three or four weeks old. After that. a few loirds might be lost from disease or the whole group wiped out ly an epizootic. So primitive were the eonditions under which the grouse were raised and so consuming of time and attention were the terhniques required. that most experimentors ascribed their losses to preventalle causes of one kind or another. thus encouraging futher trials.

Nuw. lowever. the pirture clianges.

Poultry seience was making rapid strides. not only in perfecting immation and brooding chutpment. but also in the ficld of nutrition. Pathologists. likewise. learned how to recoge nize and prevent many serious avian diseases. The stage was set for somente to lift these 
empirical experiments out of the realm of chance and to make of them a careful series of planned projects. That man was Dr. A. A. Allen, l'rofessor of Ornithology at Cornell.

Emphasis in the conservation picture was rapidly shifting from protection to the raising and liberation of game birds as an assurance of better shooting days ahead-the result largely of unprecedented successes in rearing and stocking pheasants.

The American Game Protective Association attempted to further this movement throngh establishing an experimental game farm at Cornell University with Dr. A. A. Allen in charge of the research program. It was Dr. Allen's thought to contribute to the success of this venture by developing a technique for the artificial propagation of ruffed grouse.

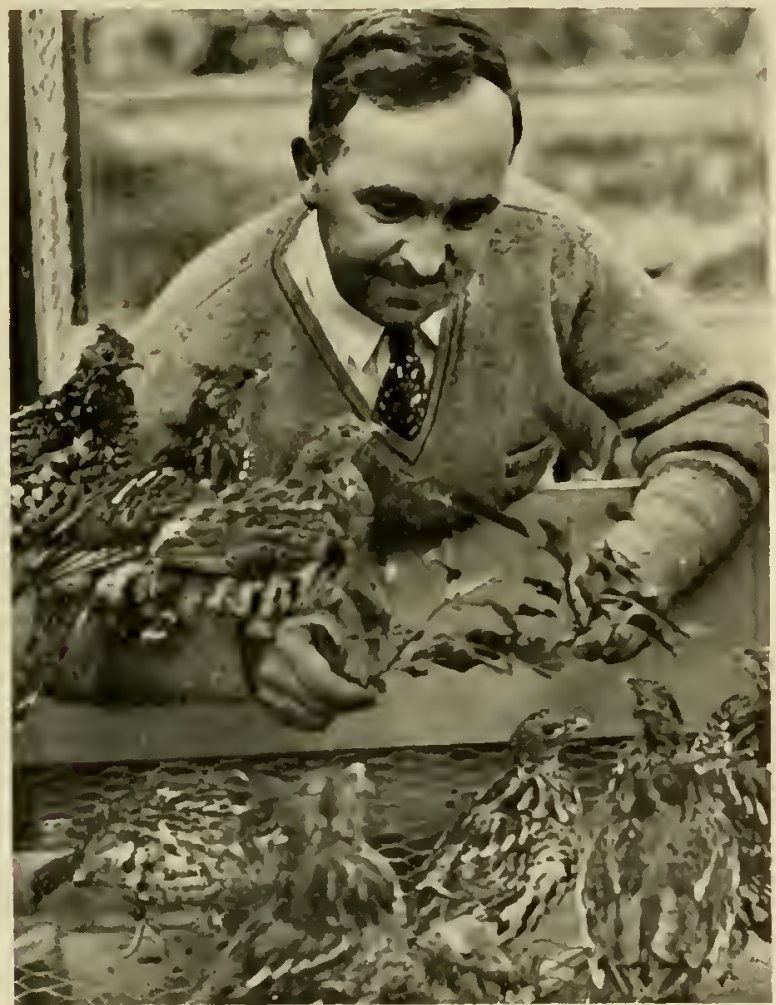

DR. A. A. ALLEN, DEAN OF AMERICAN GROUSE

BREEDERS. WITII SOME OF HIS HA.VD.RAISED BIRDS

When the farm was taken over two ycars later ly New York State as a pheasant propagation unit. Allen, "in full ignorance of the real problem. spurred on hy the partial success of others..." continued for a full 13 years a series of most significant and productive experiments. The lulk of these are well described in a paper entitled "Ten Years Experiments in the Rearing of huffed Grinse in Captivity ${ }^{914}$ presented hefore the Sixteenth American Game Conference in 1929. It was he who first successfully controlled many of the diseases, which had plagned earlier breeders. by rearing and holding his birds on wire. Likewise, his experiments led to the development of feeding formulas which furnished a sound basis for propagation experiments subsequently carried on by the lnvestigation. The colony breeding 


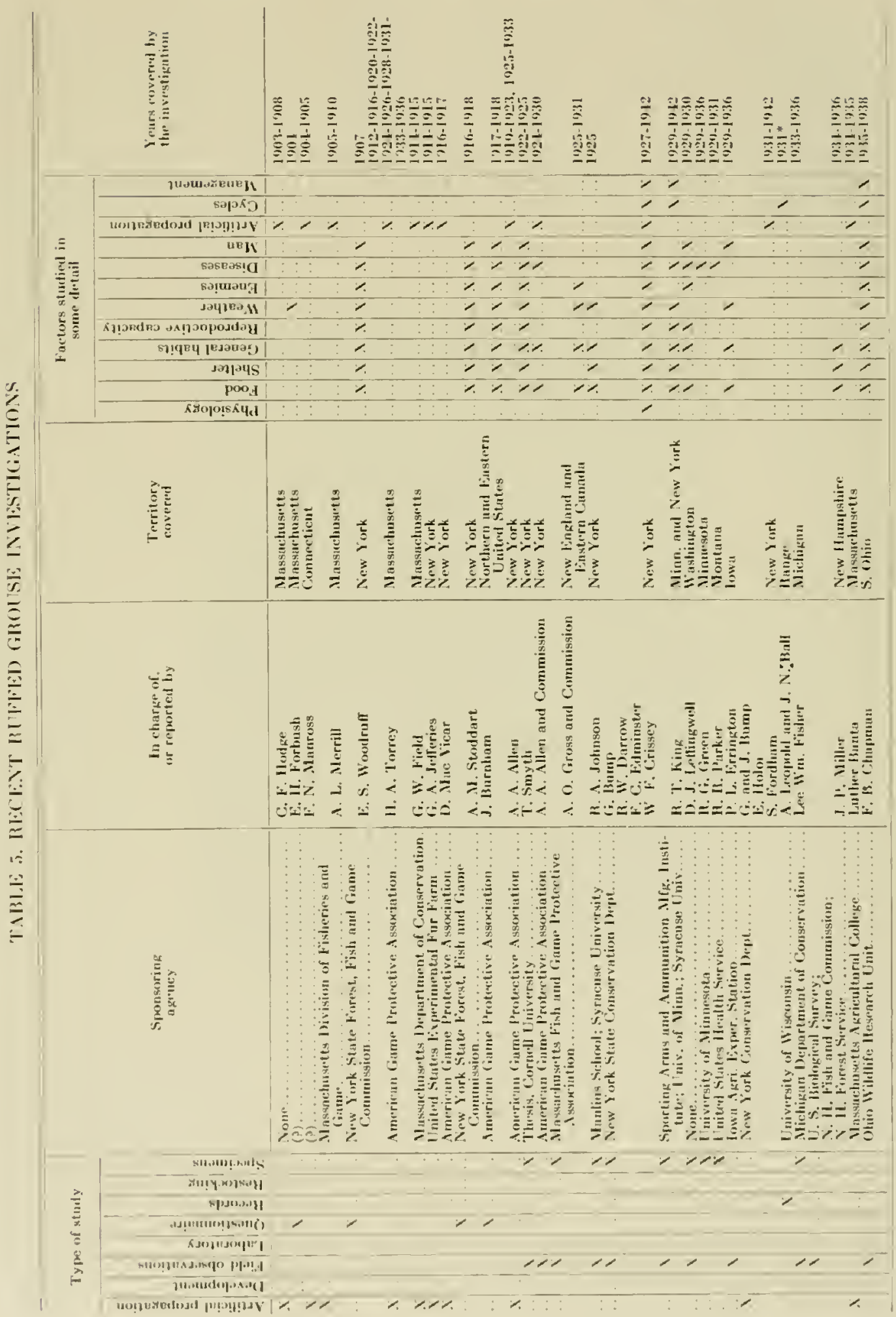




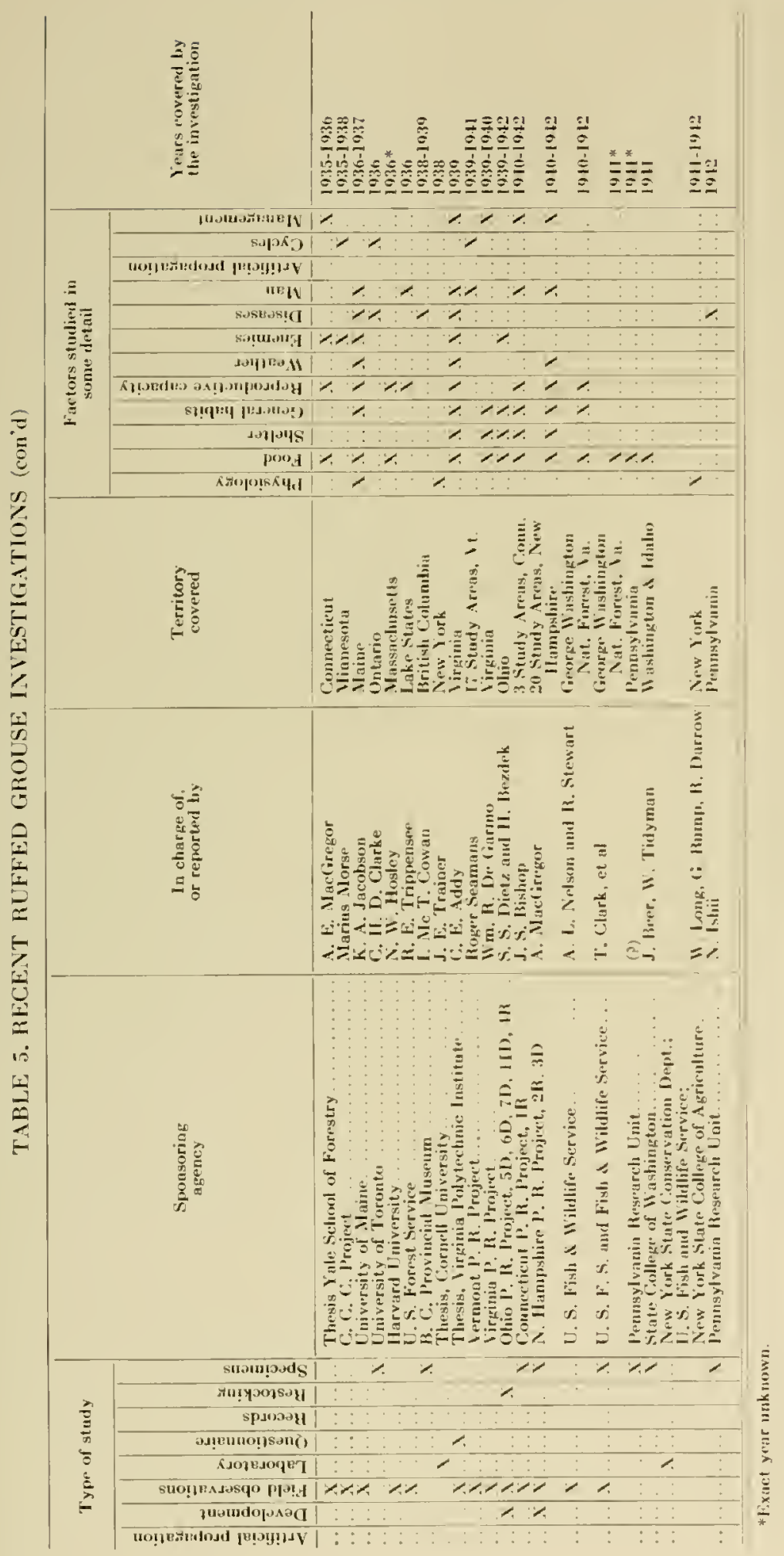


pens in which his birds were successfully maintained to the second and third generation opened fresh possibilities. His studies of hreeding behavior. completed in $1933^{25}$, for the first time pointed the way to the successful handling of grouse breeders, a problem heretofore little understood. In fact, it was these experiments that first served to focus the attention of other scientists on the field of grouse propagation and to encourage the present Investigation to include large-scale attempts to raise grouse artificially among its projects.

The successes - and the failures-of these more modern attempts to raise grouse. are so inextricably interwoven with present-day propagation methods as to make it more logical to refer to them in some detail in the forthcoming chapter on artificial propagation. One cannot leave the old order for the new, however, without a strong realization of the important part all of these patient pioneers played in unraveling many strands of the life thread of this grand bird.

\section{THE PERIOD OF CORRELATED RESEARCH}

So long as grouse increased in popularity, it was inevitable that modern scientific methods of analysis should some day he invoked to evaluate the problem of increasing grouse abun. dance and to seek a solution. A bird's-eye view of the attention this species has received may he gained from a glance at table 5. Forbush' 1904 questionnaire was the foreruner of this, quite in keeping with the advanced thoughts of his day. Woodruff and Stoddart, in collaboration with the American Came Protective Association, one nay remember, carried this sampling of public opinion to its productive limit, for there is a point beyond which additional observations, even without bias, become increasingly unproductive. The existence and extent of a condition may often he determined by a questionnaire but the causes of changes in grouse abundance were too diverse and interrelated in their results to yield to productive analysis by a mere canvass of observers.

Likewise, the early attempts to rear grouse artificially contributed much to our understanding of grouse hahits. Allen, in particular. not content to limit his studies, took full advantage of all opportunities to hecome familiar with the various diseases and parasites to which grouse are subject. either in captivity or in the wild. Through the cooperation of the New York State Conservation Department in the fall of 1922, he received 65 viscera of grousc from ten different parts of the State. Fourteen of these were fomd to be infected with the stomach worm (Dispharynx spiralis). The following year grouse were reported as ahormally scarce in the areas from which the infected specimens were secured. This was purely circumstantial evi. dence, lut it was closely in line with his experience with the local birds about Ithaca, New York, and with his lirds which had died in captivity. Thus he felt justified in concluding that he had discovered "one of the causes, if not the main cause, for the periodie disappearance of the species". and in reporting his findings to the American Game Conference. at their 1923 session.

There was alumdant opportunity to harvest grouse in 1923. A year later in many parts of the Northeast only a fraction of them remained. Their disappearance, certainly not caused hy man. was a prime topic of conversation as the report, just mentioned, was read. Upon the recommendation of Senator F.C. Wolcott who was Chairman of the Conference, a Grouse Committer was formed to plan possible remedial measures. The late Juhn Burnham, President of the American Came Protective Association, was appointed chairman with C. C. Adams, A. A. Allen. William B. Mershon and F. C. Wolcott as the other members.

At the next Gime Conference, this Committer called for an intensive study of the "grouse 
disease", over a three year period. Selected because of their previous work, Dr. Allen and Alfred 0 . Gross of Boudoin were placed in charge. A research project was thus started that was to continue and enlarge, during the next six years, eventually to be superceded by the present Investigation.

In 1925, C. C. Adams resigned from the Committee and Dr. A. O. Gross and John C. Phillips were appointed. They, in the meantime, had organized a New England Gronse Investigation Committee under the personal direction of Dr. Gross to delve into conditions in this region.

At the 13th Game Conference in 1926, Allen and Gross presented their combined findings of the previous seasons. This was based on an examination of nearly a thousand grouse which had been shipped to them from varions parts of the Northeast. Included were some specimens from as far west as $\mathbb{W}$ isconsin and Minnesota. Over twenty different parasites and diseases were identified, any one of which, they felt, might prove important in some locality, under certain conditions. This study was made in cluse cooperation with the Game Depart. ments of many of the northern states. The Michigan Conservation Department ordered each of its wardens in counties inhabited by grouse, to send one each week throughum the year to Dr. Allen. A good many interested sportsmen likewise sent in specimens so that it hecame necessary to rall on specialists in various fields for help.

Dr. E. E. Tyzzer, of the Department of Pathology of the Harvard Medical School touk rharge of the diagnosis of diseased hirels from New England and 1)r. L. L. Brunett. of the New York State Veterinary College at Cornell University, rendered similar service for the General Committee. Dr. Eloise Cram, of the Bureau of Animal lndustry. identitied many of the parasites and, later, while associated with and funanced by the New Engrland liuffed Grouse Investigation, was successful in working ont the intermediate host of the stomach worm, a problem upon which Mrs. E. K. Burckmyer did some preliminary work. Mr. Charles C. Sperry of the U. S. Biological Survey idlentified the food contents of the crops and stomachs of the New England hirds and two of 1)r. Allen's graduate students. Thomas Smyth and the late Dana Leffingwell, also rendered similar service for the General Committee. Smyth had just completed a 3 year study of the hird in central New York and written a doctur's thesis on the life history of the grouse. In it he answered many a moot question ahout the environment and habits of the bird. An earlier paper ly Smylh" on the food of the grouse. still stands as a first-class list of the fall food habits of the hird, particularly in lew lork. Leffugwell moved to the State College of Washington where he initiated a western division of the grouse investigation but did not live to get it more than well started.

By 1928. over two thousand speeimens had been sent in to the New England Committee by local sportsmen and by others from Nova Scotia and Quebec. While the Ceneral Committee had received as many more from other parts of the conntry from Virerinia to Minnesota. Thus a fairly accurate picture of the fall foods and of the degree of parasitic infestation was obtained. However, no disease or parasite discovered in the wild hirds was thought to be of greater significance than the stomach worm. (Dispharynx spiralis). This was found to occur in large numbers only in New York and New England. Unfortunately, too few hirds were received from the same area over a period of several yars to make it possible to chart changes in the local incidence of the more important diseases. But the picture of their distribution and effect upon the individual birds sent in represented an invaluable contribution. In addition. birds were weighed and abont 25 standard measurements taken of each. Plumage and moult studies were also made and later served as the hasis for a manuscript by James L. 
Peters ${ }^{300}$ on the races of the ruffed grouse. At Brunswick. Mainc, extensive field observations. some all day and night, were made on every detail of their nesting life from the time the nest was made until the young left it so that a fairly complete picture of nesting behavior was oltained.

Thus was gathered a large amount of data on the gencral hahits. fall food, and the incidence and distribution of diseases of the ruffed grouse. When in 1927, agitation arose for a comprehensive study of all the factors affecting grouse abundance, the work of both commitlees provided an invaluable background.

\section{INITIATION OF THE PRESENT INVESTIGATION}

One of the faults of many studies is that others working in the same field are not kept abreast of the results. It is small wonder. therefore, that a group of worried sportsmen, under the guidance of George A. Lawyer of Watertown, following the closed seasons of 1927.28 in New York State, met in Albany the following year to "do something" ahout the disappearing grouse. Called in to advise, Dr. Allen outlined the results of his studies and pointed ont that progress must, of necessity, he slow. Discussion disclosed the need for inclusive research on most of the factors on which the abundance of grouse depends, and on a scale larger and better integrated than ever before.

It was then recommended that a research program be inaugurated on Connecticut Hill. a tract of submarginal hilltop land recently acquired by the State for a grouse refuge, and that Gardiner Bump, who, as one of Dr. Allen's graduate students, had recently mapped the game habitats, studied the requirements of the bird and set up a suggested management plan for the area, be clarged with organizing and directing an intensive and inclusive investigation. At the request of the orranized sportsmen and backed ly Alexander MacDonald, then Conservation Commissioner of New York State, the 1929 Legislature appropriated $\$ 10,000$ to initiate this work.

Thus came into lieing the present Investigation, of whose subsequent activities spread over a period of 13 ycars, this is a report.
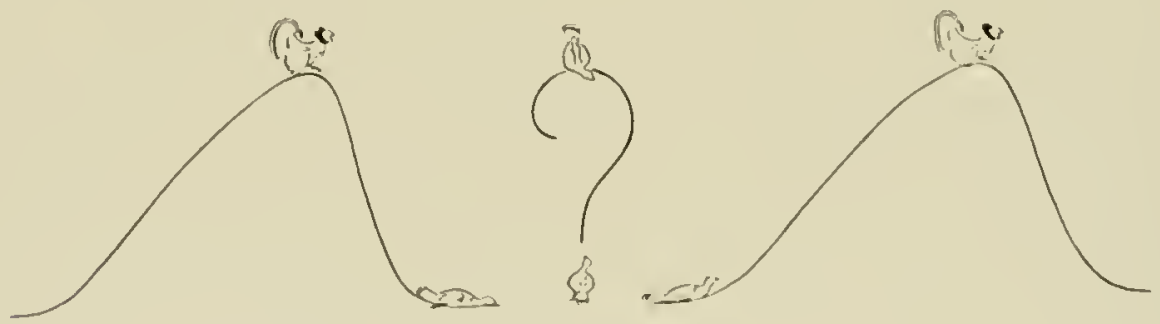


\section{CHAPTER II}

\section{THE SPECIES}

\section{ITS TAXONOMY, RANGE, BIOLOGY, AND ECONOMIC IMPOR'TANCE}

by Rorert IV. Darrow, Gardiner Bump and Others

\section{TAXONOMY}

Description - How to Rzcognize SEX - The First Things to Look For-- General Appearance - Other Visual Differences - Differences in Action - Cussification Recognition of Sub-specifs

\section{RANGE}

DISTRIBUTION AND RELATIVE ABUNDANCE

Entme Rance - New York State

POLYCHROMA'TSM

ANATOMY

PTERYLOGRAI'HY

PHYSIOLOGY

I'SYCHOLOGY AND BEHAVIOR

Sochal Order - Mating, Behavior - Strutting Phase-Gentle Phase-Fighting Phase EGGS

\section{EMBRYOLOGY}

Preview of Problems - Hatchihility - Livahility - Developanent of Grouse Eggs - Structure of the Eggs - l’uysico-cilemical Properties of tile Egg - Axinual. Changes in Egg Quality-Development of tile Eirbyo- Exibryonic Mortality - Cinemical Composition of Newly Hatchen Grovie

\section{GROWTH AND DEVELOPMENT}

Sequence of Moult and Featier Succession - Natal Plumage - Juvenile Plumage - Adult Plumage - Age Identification Based on Featier Developient - One Week-Two Weeks - Three Weeks - Four Weeks - Five Weeks - Six Weeks Seven Weeks - Eight Weeks - Nine Weeks - Ten Weeks - Eleven Weeks - Twelve Weeks - Thirteen Weeks - Fourteen to Seventeen Weeks 


\section{WEICHT}

Seasonal Trend - Differences Between the Sexes - Age Differiacles - Regrovat. aNd Yearly Differexces - ENtremes of Grouse Weicht - Weight as an linicator of HeALTH

\section{MEASUREMENTS}

$1 \mathrm{OICE}$

\section{ECONOMIC IMPORTANCE}

Groust: as a Food - The Importance of Food Preferences - Budding of Frutt Trees - Grolse As a Game Crop - Sale of Rreeding Stock

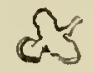

\section{SUIIMARY}

The ruffed grouse is a hrown fowl-like woodland bird about the size of a bantam hen. possessing a dark, partially coneealed ruff on each side of the neek. and a fan-slaped tail having a broad dark subterminal hand. (1). 38).

While exceptions are frequent, males usually have tails over six inches in length, females less: the subterminal tail band is normally unbroken in the male, but interrupted on the central tail feathers in the female; the light spots on the lower hack and rump feathers tend to be arrow-shaped in the male, less distinct in the female. (p. 4.5$)$.

Remains of ruffed grouse indistinguishable from the modern form have been found in deposits at least 25,000 years old in caves in l'ennsylvania, Maryland, Temessee and California. (j. 46$)$.

Although known to the Indian from time immemorial and to the white man from the early: sixteenth century, the first puhlished description of the speries was in Edwards" "Gleanings of Natural History" (London 1758), based on a specimen from eastern Pennsyl. vania. (p. 46).

Its range is greater than that of any other non-migratury North Ameriean game bird, extending from coast to coast aeross Canada and into Alaska. as well as south in the mountains to central Utals and northern Goorgia. (p. 48).

In New York it is universally distributed with minor exceptions such as metropolitan areas and certain Adirondack mountain tops. It is most abundant in the alsandoned farm areas south of the Mohawk and Ontario Plain. as well as in various localities cas of the Hutson and ahout the periphery of the Adirondack forest. (p.56).

Throughout the sperien Iwo color phases-red and gray-are found irrespective of age or scx. (j. 57).

On one hird over four thousand feathers were counted, exclusive of down and hair-feathers. (p) 601 )

lu a warm-lilooded animal the vital processes. especially production of lowly hoat. heart action and respiration. must constantly arljust themelves to changes in envirommental conditions if the animal is 10 mantaitu its vitality. (p. (1) ). 
In grouse, body temperature was found to average $107^{\circ} \mathrm{F}$. heart rate 342 beats per minute and breathing 63 respirations per minute. (p. 62).

A daily consumption of food equivalent 1078 calories was necessary for adult grouse to maintain weight at a moderate environmental temperature. (p. 63).

Among any group of grouse there soon develops a definite order of dominance from the strongest to the weakest individuals. (p. 64).

Mating is the culmination of a hasic hehavior cycle in the two sexes each spring. (p. 65).

Grouse eggs are ovate in form and vary in color from milky white to cinnamon buff, often spotted with reddish or drab. (p. 71$)$.

In grouse the amount of unahsorled yolk at hathing is much smaller in proportion to the body weight than in man! domesticated hirds. indicating they can survive only a relatively short time without food. (1). 76).

Feather growth and replacement follow an orderly and regular sequence. (p. 78 ).

The degree of development among the flight feathers furni-hes a convenient index to the age of young grouse from hatching 10 maturity at 18 to 20 weeks. Similarly the character of the first two primaries affords a means of distinguishing birds of the year from older birds in the fall. (1.81).

Weight is affected loy the physiological comdition of the hird as well as hy environmental influcnces such as shelter, food and weather which vary between regions, years and seasons. $1 \% .90)$.

Average fall weights for grouse in New York State num ahout 1 H. 7 oz. for males, and 1 ll. 5 oz. for females. (p. 91$).$

A rough yardstick of health, fall wrights below alout a pound for males and 11 onnces for females nsually indieate a (ritical condition. (p. 97).

Adult hirds average about 17 inches in length and haw a wing-spread of some 23 inches. (p. 98).

Gronse fecling halits are laggely neutral from an cconomic standpoint. but their ludding of fruit trees has, in some sections. been serious cmough to result in bounties in at least two states. (p. 102).

As a game species the grouse is an important economic asset, both funcially and recrealionally. (p. 103).

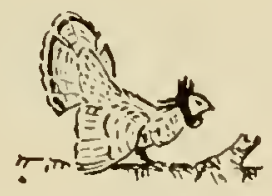

Inherently endowed with a "hump of curiosity". the human animal has heen interested in other forme of life about him since long before the dawn of history. As one expression of this interest, primitive man drew pictures of familiar species. or carved imagres of them, to decorate his caves. lodges and implements.

Crude at first, his skill constantly developed and. with it. a desire for more than mere reproduction of the form of the creatures he encountered. Conscquently, students have carefully described their appearance and probed their anatomy, plotted their occurrence over the 
earth's surface and pondered their evolutionary relationships. More recently, preliminary excursions have been made into the vast fields of animal behavior and experimental physiology as they apply to wildlife species.

Unknown to the white man until after the discovery of North America, the ruffed grouse has since received considerable attention, especially becanse of its cconomic importance. The resultant information has, however, been widely scattered in the literature. It is the purpose of this chapter, therefore, to bring together the more important of these data as well as what new material has been lrought to light by the present Investigation. A logical starting point is the bird's taxonomy.

\section{TAXONOMY}

A major step in the development of man's knowledge of the universe has heen the cataloguing of other forms of life. Largely haphazard at first. there has gradually evolved a definite system for classifying any animal or plant according to its evolutionary relationships to other species.

While anatomical features are the fundamental hasis for such classification, a deseription of the external appearance of a species is a basic preliminary, and is also important to the general wildlife student.

\section{DESCRIPTION}

The ruffed grouse is a brown. fowl-like, woodland bird alout the size of a bantam hen. possessing a dark. partially concealed ruff on each side of the neck and a fan-shaped tail having a broad, dark subterminal band.

Although referring primarily to the type form Bonasa umbellus ambellus (Linnaens)" the following detailed account ${ }^{4}$ applies in general to the species as a whole, the differences between subspecies being largely a matter of degree. ${ }^{\dagger}$

"Allult male: Top of head with many narrow hars or spots of rusty lrown, black and sometimes whitish; rest of upper plumage mottled and variegated rusty brown and whitish or buffy, witl some llack marks; inner secondaries and wing-eoverts commonly edgerl or tipped buffy-whitish, often spotterl with hack; primaries dark hrownisl-gray. marked and spotted with buffy or whitish on narrow outer wobs: back and rump with numerous oblong or lance-shaped pale, black-edged shaft-spots; neck ruffs nsually black with green and purplish reflections, in some cases reddish-brown: tail bright reddishbrown to gray, harred regularly with from 6 to 11 narrow blackish bars and one broad subterminal black bar; chin and throat buff. lower and lateral feathers often tipped dusky; wing linings and axillars browniah-gray and white; rest of lower plumage whitish, grayish-white or buffy-white. usually tinged buffy on lower neek and breast. with many bars of deep buff, brown or black. all darkest on siles and flanks, often fading and obseure on breast and belly; buff and white predominate on under tail-coverts: bill dark brown; iris hazel; feet dark horn.

"Alult female: Similar but duller, with somewhat lewer ruffe and shorter tail: iris, hill and feet as in male."

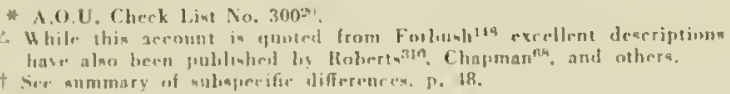




\section{How to Recorvize SEx*}

How to tell male from female has always been a matter of interest among sportsmen. From the stag and wild hoar of the mediaeval sons of Diana to the grouse and pheasant of contemporary scattergun enthusiasts, there has heen a tendenry to prize male specimens more highly. But, while the males of many game species have distinctive adornments or plumage, in others Nature has been much less lavish. Among the latter is the ruffed grouse.

Positive determination of sex must, of course. depend on examination of the gonads ${ }^{\Delta}$. In birds, this is often difficult, especially for the untrained observer. since the organs are internal and very small, except during the breeding season. Therefore, a knowledge of any features of coloration, external anatomy or actions, which tend to distinguish the sexes, is desirable.

The Investigation has had unusual opportunities for observing such differences in gronse. particularly with respect to artificially propagated stock at the Research Center. Constant association with birds at this unit, as well as in the field, has led to the recognition of certain characteristics as indicative of male or female ${ }^{\dagger}$. Activities such as drumming and nesting are, of course, quite definite criteria of sex, but features of feather marking and bodily proportions are much less distinct. The latter will be considered first.

Before discussing these differences in appearance. it should be pointed out that no one characteristic, or even a comhination, is infallihle. In general, they represent extremes of variations which exhibit all degrees of intergradation. Thus it would he a very musual hird which would possess all of them as described for its sex, yet most specimens will have a majority.

One must also realize that the characters are larcely relative and. unless one has a suitable basis for comparison (either a series of other specimens or wide persunal experience). judgment is difficult. Furthermore, the features astoriated with bodily propurtions apply primarily to living grouse, although many of them ran. with care. be used for freshly killed birds.

The accompanying illustrations will be helpful in visualizing most of the differences discussed. In studying hoth paintingst and marginal sketches, one should keep in mind that the extremes have been pictured in order to emphasize the varions characteristics.

\section{The First Things to Look For}

Perhaps the most diagnostic external feature is the tail. Birds having the broad, dark, subterminal band unjform over all tail feathers are almost invariably cocks, only one exception having come to the authors' attention. But, if this band is loroken on the two middle feathers, the bird may be either male or female. In such cases, the length of the tail should be determined. In males, this appendage tends to be over six inches long: in females, it is shorter. Exceptions are not umsual, however, and a more applicable rule would be to consider only those of six and a quarter inches or over as male, and five and three-quarters inches or less as female. When the tail band is broken, the mottled design in this area is apt to be coarser among the cocks. Moreover, a closeup view of the tail will show a tendency in

\footnotetext{
* This aecount has ben written by Fred. Everett, ulan, while studving the birds at the Researcls Centur and painting the colored

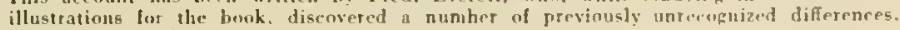

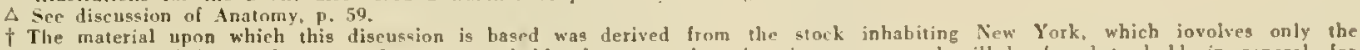
subspecies umbellus and togata. It seems prohable, however, that thr characters noted will be founl to hold, in general. for the other races.

sce color plate facing p. 40.
} 
喜 


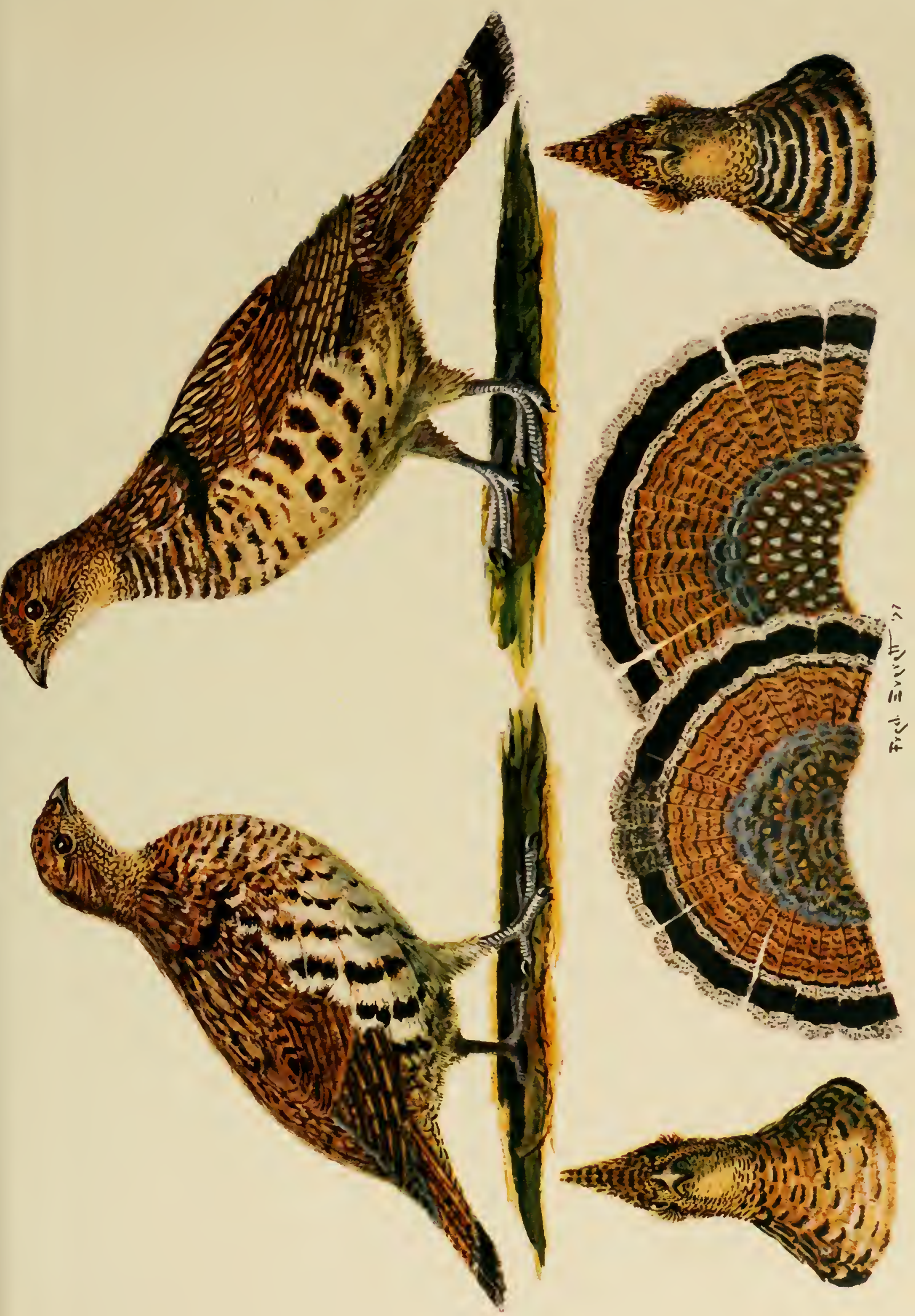



this sex for the narrower dark stripes to be pronounced, often bounded by very light bands which help to set them off, while in females, these markings are not so regular or prominent.

Another indication may be found by spreading the tail until it occupies a full 180 degrees. If this separates the feathers so that they cease to overlap, the bird is probably a female. Otherwise it may be either sex.

Next, one should examine the feathers of the neck region. The male tends to have what is known as a "necklace" - a clearly defined series of light and dark hands of color ringing the front half of the neck, mostly black, white, and buff. These feathers are at the same level as the ruff and are raised with it so that, on such occasions, their white tips are conspicuous under the chin between the dark collar on either side. In the female, the darks are broken up into spots with very little white showing on a pale, chestnut-colored background.

With respect to the ruff itself, in the male, the ends of the feathers usually extend beyond the hackles, as iridescent lines, lying well past the bend of the folded wing. The hen's shorter ruff is not often visible and rarely reaches as far as the wings. Also, the number of ruff feathers is greater in the male.

The hackles, 10o, in the cock, are longer and have a greater number of partial dark bars.

Another important consideration with respert to the general appearance of the bird is the nature of the color pattern. Among males, the markings are much more bold and elearly defined, while in their mates, except for those of the flank feathers, as noted later, they tend to be diffused and blended with the backgrouml color.

Beyond these differences, a number of other features have been reeognized which, when averaged, will aid materially in judging the sex of grouse.

\section{General Appearance}

First may be mentioned certain aspects of the bodily proportions of the hirds as illustrated in the accompanying illustrations. Males tend to look more rugged. heavier and more solidly built than females. Actually. they do average two to six ounces heavier, depending on the season (New York State records) *. But heyond this, they grow longer feathers with more sharply defined markings. These longer frathers produce heavier looking masses. causing the cock to appear relatively larger than he really is.

The head of the male is larger, having more forehead. or depth fron crown to chin, while that of the female is smaller and daintier. Althongh the eycs are usually the same size, they appear larger in the female hecause the head is smaller in comparison.

The male's neck appears more massive, the neck line leing built out ly thicker, longer feathers so that it joins the throat directly unler the eye and tapers out toward the breast. In the hen, it appears much thinner, the neck line joining the throat well behind the eye, as well as meeting the hody higher up and at more of an angle, thus giving a fuller, more rounded shape to her breast.

A similar relationship applies to the rump, where long loody feathers, together with long tail feathers, give the cock a tapered appearance. while the shorter foathers of the female tend to give her more of a rounded, "butterball" shape.

Because of structural differences of the aldomen, particularly during the mating season, the legs of the cock appear longer than those of the hen.

* Average fall weight for New York grouse is $1 \mathrm{lb} .7 \mathrm{oz}$. for males and $1 \mathrm{lb}$. 5 oz. for lemalcs. Fee discussion of licight, r. 9 l. 


\section{Other V'isual Differences}

Turning to the markings of the feathers themselves, the tail has already been described. Associated with it are the markings of the rump feathers and upper tail eoverts. On the former the light spots (ealled arrowheads, ocelots. or eyes) have fine black outlines, coming to a point in male hirds and usually are regularly and thickly arranged. In females. these spots are less distinct. not so pointed or regular in shape, fewer in number and irregularly scattered, often blending with patches of gray and black on the lrownish background tone.

Examination of the upper tail coverts will show well defined black "eves" clearly outlined by light, rich gray in cocks. while, in their mates. the "eyes" are not as black or as regularly shaped-sometimes being a very dark gray or even absent altogether. Neither are the gray outlines so distinct in the latter, the entire feather being dark in tone.

Another important character is the position of the wing-tips. when folded at rest, in relation to the rump feathers. In the female, they usually reach the ends of the rump feathers, while in the male, the rump feathers extend considerahly beyond the wing tips.

Contrary to the general color pattern, the barring of the flank feathers tends. in the female. to be arranged in continuous hands of solid black on a white hackground. In the male. on the other hand, these dark markings are more irregular in distribution and often more lirownish than black.

The black and white or light buff scapular markings-like chevrons are well defined in both sexes but the blacks are richer and the lights cleaner cut in the male.

Finally, among males, the hare spot over the upper eyelid is more pronounced and may he a bright reddish-orange. especially in the breeding season. It is much duller in the female. often with harlly a trace of color.

The foregoing is intended primarily as an aid in sexing dead birks or those under close observation in captivity. It is hased on the study of several hundred birds of known sex in captivity over a number of years. supplemented by the examination of wild birds collected from time to time. But, while utilization of these characters will enable one to sex grouse with reasunable accuracy. it must he emphasized again that no single feature is a suitable criterion. Judgment must be hased on the average of all possible indices and. even then, one may at times make mistakes. In fact, men with long experience on the game farm many times have placed in the breeding pen. "cock" hirds which have proceeded to lay eggs. Gradual recognition of the differenees describerl. however, has resulted in a virtual elimination of such errors in pairing the breeding stock at the New York State Resarch Center.

\section{Differences of Action}

This account would not be complete without mentioning certain distinctive activities* of the two sexps. They are most useful with respect to wild birds and, when one is able to olserse them, are, in most cases, quite diagnostic.

Primarily they are asocociated with the hreeding season. Only males drum and. with rare exceptions, strutting is also confuned to this sex. When a female does strut. the performance is usually short and rather ineomplete, lacking pronounced feather display. On the other hand. hirds found on nests or with a brood are almost invariahly females. likewise. hirds which feign injury or "squeal" are hens.

Another way in which the sex of wild grouse may sonetimes be judged relates to their * see uluo Chnpers $v$. 
manner of rising from the ground when flushed. On such occasions males tend to climb steeply for ten or a dozen feet before leveling off, while females more often fly off low, at least for a short distance. One must bear in mind, however, that this distinction is most applicable on level ground without obstacles which must be surmounted in the immediate path of flight.

Table 6 correlates the sex differences in a condensed form.

TABLE 6. COMPARISON OF VISUAL SEX DIFFERENCES IN RUFFED GIROUSE

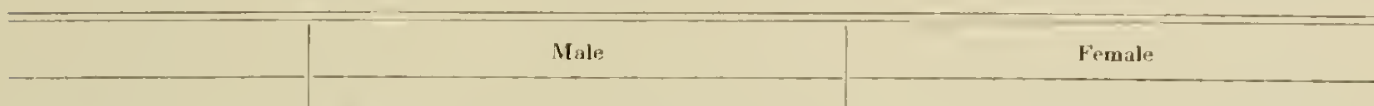

General appearance.

Head.

Neck.

\section{Ruff fentliers.}

Rump fenthers.

Tail.

Upper tail coverts.

flank feathers.

Seapulars.

Legs.

Distinctive attions.

Flight.
More ruggted, heavier*, contour tapering loth ways to form an elongated Joily; color markings more definite.

Decener from crown to chin; bare skin over upper eyelid bright orange, especially in breeding season; sere appeariug smaller.

Thicker, tavering from Jranst to throat. front neck line joining throut under aye; a nocklace of light and dark lounds rimping front laalf; lackles longer with several partial dark lars.

Number grentor: longer, reacluing back over folded wing witl exlges visible bryond lackles.

Ionger, reaching well beyond wingtips; definitely marked with regular, elcarly dofinod arrowheads.

Over $61 / 4$ inclues long; sulı erminal band solid sor liroken on two middle feathers, in broken bands mottling coarser: stripes sharply defined.

Exhilit delinite, llack "eyes."

Brokon l,ack or lorown lands.

Distinet "cherrons" of black, and white or light bull.

Appear longer.

Drums, struts; Ioes not take part in nesting or care of chicks.

Tenrl to rise sleeply when flushod.
Dainfier, contour less tapering, body more "Iutterlaall" sliaped; color markings more blended.

Deptl! less; lare skin over upper eyelid pale to colorless; eye appearing larger.

More slender, meeting bouly hipher and st more of an angle, front neck line joining throat woll bethind eye; front of neck marked with hroken spots of dirker colors; luckles shorter with seldom more than one dark marking on either sade of sluaft.

Number fewier. slorfor, barely reaching wings, edges raraly visible.

Shorter, not reaching leyond wing-tips: coloration soft, well blended with arrowlieads neither strongly defined nor ImInerous.

Inder $5 \%$ inches long; sulterminal hand broken on two middle fenthers, in liroken loands mottling finer; stripes less clear.

"lyes" not so definite, if present at all.

Definite black bands against white.

"Chevrons" less distinet, of ten a darker lsult.

Appear slorter.

Does not Irum, rarely struts; when nesting or witl chicks, often feigns injury. "siucals."

T'end to fly off low 10 ground.

* Average fall wrighte for mules is $1 \mathrm{lb}, 7$ us; for females 1 th., 5 on

$\Delta \mathrm{A}$ solid band almost invariably indicates a male, ouly ous fomule so marked baving come to our attention.

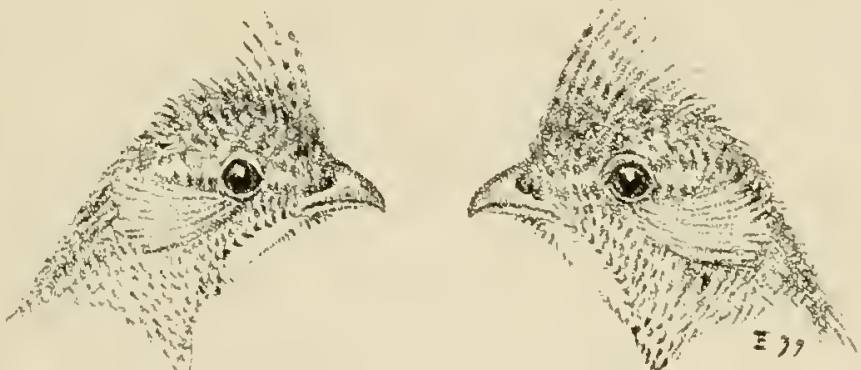




\section{Ciassification*}

Among the birds of the world, the ruffed grouse belongs to the order Galliformes or fowllike hirds which includes, anong others, the domestic chicken, peacock, pheasant, quail and lurkey. Within this group it is a member of the family Tetraonidae or grouse-like birds along with such forms as the ptarmigan, sage hen, Scotch grouse and black cock. It is the sole living representative of the grenus Bonasa and has been broken down into several subspeeies.

Among the characters used in its classifieation ${ }^{\triangle}$ may be mentioned the following. First. the ruffed grouse possesses these features in common with other members of the Tetraonidae: a completely feathered head, except a naked strip of skin over the eye; external nasal opening feathered; tarsi feathered nearly to the toes on the upper side; spurs absent: sexes similar. But it differs in having a dark umbrella-like ruff on either side of the neck with no obvious bare space; soft, rounded tail; lower surface of tarsi bare.

Known to the red man from time immemorial, remains, in no way distinguishable from the modern form, have been found among Pleistocene deposits from caves in Pennsylvania, Maryland, Tennessee and California ${ }^{394}$. Moreover Wetmore, in the same publication, suggests that Bonasa ceres of Shufeldt ${ }^{31}$, from the fissure beds of Arkansas of the same geologic age: may possibly be a synonym.

But it will remain forever a riddle who was the first "paleface" to sce a ruffed grouse. It is possible one or anolher of the early navigators may have seen one before 1500. Certainly Cartier encountered these birds in the St. Lawrence country in 1535. Very likely Hudson or some of his crew observed them in what is now New York State in 1609. In any event, they soon hecame familiar to the settlers, explorers, missionaries and couriers de bois who penetrated their range from the sixteenth century on.

Nevertheless, it was not until the middle of the eighteenth eentury that the bird was aecorded formal scientifie recognition. In 1750 John Bartram, a settler in Pennsylrania, sent a specimen to Peter Colinson F.R.S. in England together with a letter telling something of its habits. This material found its way into the hands of George Edwards who incorporated an account of the bird, together with a colored plate under the name Ruffed Heath-eock or Grous, in his "Gleanings of Natural History" which was published in London in 1758 ". As a result of his account ${ }^{\ddagger}$, Linnacus included the species in the 1760 edition of his "Systema Naturae" assigning it the hinomial name Tetrao Umbellus (referring to its umbrella-like ruff) which has since been alopted as the starting point in its systematic elassification. Thus this specimen, from somewhere in eastern Pennsylvania, became the type of the species.

On the basis of his limited material, limnaeus placed the species in his genus Tetrao in which he also included the spruce grouse, sharp-tailed grouse, heath hen and bobwhite quail, as well as many Ohl World species. But as knowledge inereased, differences were recognized and, in 1819, Stephens ${ }^{322}$ proposed the genus Bonasa ${ }^{\S}$ for the rufforl gronse and the heath hen. He failed, however, to selcet either as the type. It thus remained for Gray ${ }^{130}$ in 1840 to designate the former $\bullet$ Similarly, each of the wher North Ameriean members of Limaeus' Tetrao has heen placed in a separate genus, although they remain within the family Tetraonidae. except for the quail which have been removed to the family Perdicidae.

\footnotetext{
- By Robert Ni. Darrow.

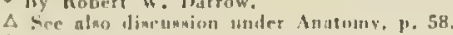

$\uparrow$ The Pleistocene age of grologic time cnded about 25,000 years age, and is entimated to have covered a peried al approximately a million yeara.

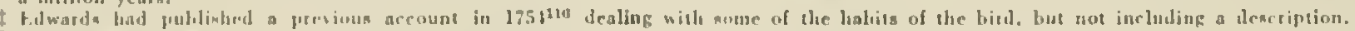

\$ I as, bonosus, a wihl trull.

- The heath hern has been ansigned to the gerun $T$ mpanuchus.
} 
In 1760, however, Brisson ${ }^{56}$ had published an account of "La grosse Gelinotte de Canada": designating it Bonasia major Canadensis. His material presumably came from the lower St. Lawrence valley. This was also included by Limnaeus under the name Tetrao togatus, but has since been recognized as a subspecies of Bonasa umbellus.

\section{Recognition of Subspecies}

As the "Path of Empire" moved westward, so also did faunal explorations. Ruffed grouse were found to occur from the Atlantic to the Pacific and from the mountains of Georgia and Colorado to the lower Yukon Valley, and the shores of Hudson Bay and Lalirador. Specimens were collected and sent to various museums where subsequent examination revealed differences in the representatives of certain sections. Thus a number of subspecies gradually became recognized.

The form of which the specinen described by Edwards was representative of conrse, became the typical subspecies Bonasa umbellus umbellus (Linnaens)".

Early in the nineteenth century Duuglas, a British traveler in the Pacific Northwest, recognized the grouse he encountered in certain parts of what is nw Washington, British Columbia and Alberta, as somewhat different from those he had seen in the East. Therefore in $1829^{\text {ros }}$ he described two new species, namely, certain pale hirds, found about the sources of the Peace River, for which he suggested the name Tetrao Umbelloides, and the birds inhabiting the humid forests of the west slope of the coast ranges, which he called $T$. Sabini. The furmer was reduced to the rank of sulspecies by Baird in $1858^{\prime 2}$, and the latter by Coues in $1872^{\circ}$. loecom$\operatorname{ing} B . u$. umbelloides (Douglas) ${ }^{\Delta}$ and $B . u$. sabimi (Donglas) ${ }^{\dagger}$ respectively. Of interest is the fact, pointed out by Coues Clark in 1805-06 and named Tetrao fusca by Ond in Guthries Geography ${ }^{20}$ in 1815. Due to the indefiniteness of the description, however, its identity was not recognized until after Donglas" name had become establisherl.

In 1885 Ridgway $^{313}$ called attention to the fact that linnaeus' $T$. logalus should be $B$. $u$. logala (Limnaeus) $\ddagger$.

Then in 1912 Bangs: differentiated the birds of Nova Scotia as distinct from B. u. logala and described B. u. thayeri Bangs $\$$.

A short time later (1916) Grimell ${ }^{\text {ton }}$, upon examining a series of specimens collected by C. L. Hall at Fortymile. Yukon Territory, described a sixth subspecies. B. u. yutionensis Grinnell•.

These are the subspecies of the ruffed grouse as recognized in the 1931 edition of the American Ornithologists' Union's "Check-List of North American Birds" "

\footnotetext{
* Type locality, easteru Pennsylvania.

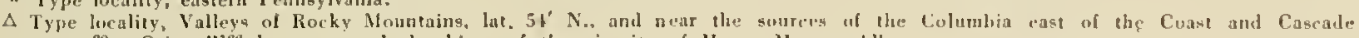
ranges ${ }^{20}$. Grinnelliou has proposed the birus of the vicinity of Henry llouse, Alberta, as topolypes.

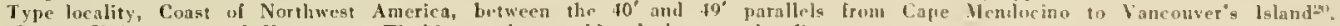
Conover ${ }^{78}$ has proposed bancouver, Washington be considered the type lacality.

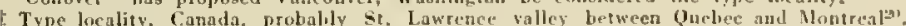

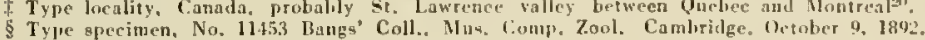
Type locality, Digby, Nova Beotia.

Type specimen. No, 4515, Mus, Vert, Zoul., Calif., Noumher 5, 1890.

Type locality, Fortymile, Yukon Territory (C. L. Hallı.
} 
Briefly, their comparative characters" may be set forth as follows:

B. u. umbellus - a red frown bird; the dark markings on the lower surface much reduced so that the breast appears very light, under tail eoverts whiter.

B. u. logatu - a gray lrown bird: markings on lower surface abundant. dark, and broad, the cross bars beine predominant in the coloration of this area; under tail coverts with more brown.

B. u. thayeri-simitar to togata but general color of upper parts darker, more dusky or sooty, less grayish: the whole underparts (except throat) heavily and regularly banded with dusky, the tark bands blacker and much more boldly contrasted against the ground colorless blended.

B. u. umbelloides - similar to togata but paler; the breast and underparts usually more rufous or buffy; the barring a lighter brown.

B. u. yulionensis -a decidedly gray bird, heavily and uniformly barred below with dusky gray; paler and ashier than umbelloides.

B. u. sabini - a deep rufous bird.

Thronghout all these races, dichromatism-the oceurrence in the same brood of individuals of both color phases, gray and rufous-is well markeds. In general, however, the preponderance of the lird in northern areas or at high altitudes tend to be grayish. and vice versa.

Beyond this, Uttal ${ }^{\text {wo }}$ has reported a tendency for the degree of tarsal fcathering as well as the length of the "snowshoes" to be greater among the more northern subspecies.

More recently, additional subspecies have been proposedt. Working with the birds of the l'acific coast, Conover ${ }^{78}$ descrilied certain differences in the grouse of Vancouver lsland and named B. u. brunnescens as distinct from the mainland form B. u. sabini. In the East, Bailey ${ }^{* 0}$ deseribed a race from Long lsland (N. I.), calting it B. $u$. helmei. Finally, Todd in $1940^{500}$ and $A$ drich and Friedman in 19.13 ${ }^{10}$ have presented extensive revisions of the subspecies of this grouse. These are mentioned here for completeness but it is outside the province of this report to discuss their respective taxonomic merits.

\section{RANGE $\ddagger$}

Occurring through thirty-four degrees of latitnde and from the Atlantic to the Pacific, the ruffed grouse is found wver a greater area than any other non-migratory North American game lird. The accompanying map (figure I) illustrates this range graphically for both present and primitive conditions.

Primarily a hird of the Tramsition and Boreal forent, it extends from coast to coast across southem Canada, strethes northwestward into the Machenzie basin and through the "Liard Gap" into the Yukon valley of Alaska, and reaches twin arms sonthward in the Appalachians and Rorkies.

Arid and trecless, the Great Pains represent conditions which exchde it from a large arra lying east of the Rockies and extenting northward into sonthern Alberta and Saskatch"wan. Similarty. it is not found in the arid Hanne! Basin of central Orecon, the interior of Ilashington, ur the Snake River Plains of sonthern ldaho.

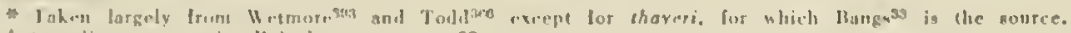

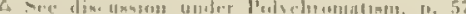

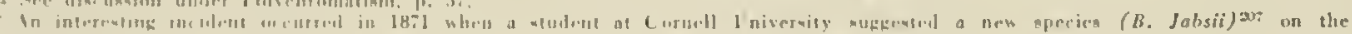

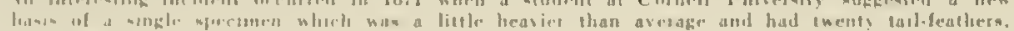

\$H Roliere II. Darrow. 


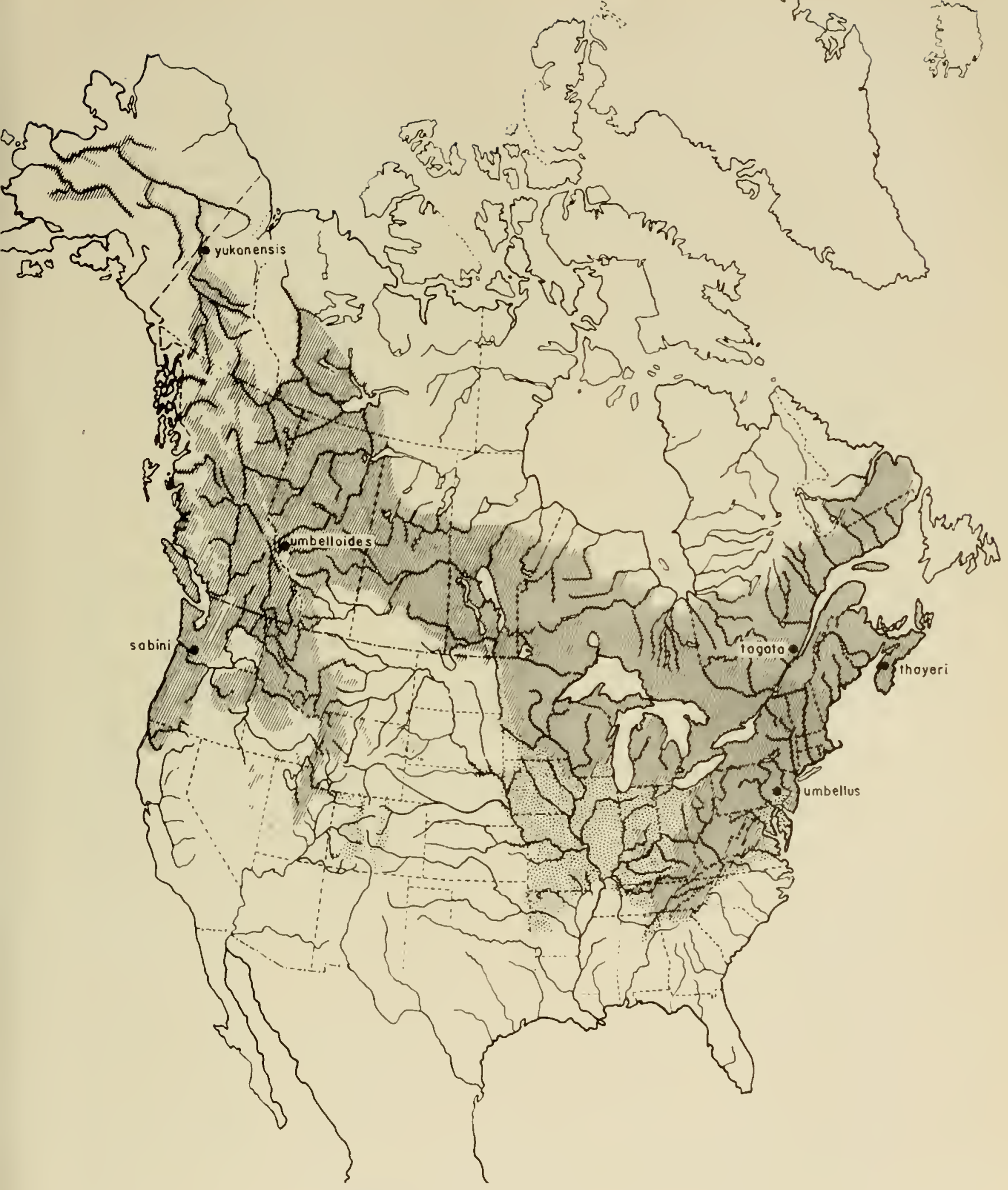


On the other hand, limited populations are found in certain quite isolated tracts of cover associated chielly witl outliers of the Rocky Mountain systen, such as the Black Hills of IIyoming and South Dakota, the Big Horn Mountains of Wyoming and Montana, the Sweetgrass Hills of northwestern Montana, and the White Pine, and Ruby Mountains of northern Nevada. It was also reported in $1921^{2 x p}$ from the Lone Pine Hills of southeastern Montana.

Furthermore, the species exhibits an interesting island distribution. In most cases, where islands having suitable cover have been unoccupied, the reason scems to lie in the flight limits of the bird which apparently are restricted to between ten and 15 miles. Thus the species was abscnt from Newfoundland, 45 miles from St. Pauls Island, and Anticosti", 20 miles from the Mingans ${ }^{30 t}$. Neither does it seem to have reached 1sle Royal, 15 miles from shore in Lake Superior. But it did establish itself on Prince Edward Island, requiring a flight of only ten iniles, and on Grand Manan Island only slightly less distant from shore, as well as Nantucket and Marthas Vineyard. Similarly, it reached Vancouver Island off the coast of British Columbia. At present, lowever, grouse have disappeared from Nantucket and Marthas Vineyard and are found on Grand Manan only as the result of successful restocking in 1925.

Under primitive conditions, a few grouse managed to eke out an existence in the brushy cover which penetrated the edge of the plains region along the streams of eastern Kansas, Nebraska and the Dakotas as well as along the eastern base of the Rockies.

Similarly, a scattered population existed throughout the irregular checkerboard of cover which was found over much of the prairie country bordering the Great Plains and extending eastward to Ohio and Kentucky. Here, timber grew along the streams as well as in groves over the rolling uplands. Wooded swamps were frequent while considerable areas of open grassland were also interspersed throughout the region. On the other hand, in the Ozark and Ouachita Mountains of Missouri and Arkansas, the timber was more extensive and grouse range accordingly more uniform. Yet, apparently they were never recorded from the Cypress Hills of southwestern Saskatchewan although they have recently been introduced there.

It has been in this region of more or less marginal enviromment that the greatest shrinkage in grouse range lias occurred. Although highly adaptable, the birds have not been able to withstand the exteusive land clearing, burning and grazing which accompanied settlement and agricultural development. The changes wrought by these operations were largely complete by 1900 lut a scaltered population of gronse continued to linger on for many years, chiefly in swamps and the more inaccessible hill sections (figure 2). In the Ozarks, a number of records were reported by Bennitt and Nagel" in 1931 and at the present time a few scat. tered birds are believed to persist ${ }^{\triangle}$. The situation in lowa is similar. In lllinois, grouse have in general heen unreported for over a decade hut in $1937^{\dagger}$ a lone olservation was recorded in Pope County just across the river from Kentucky. In south central lndiana they still persist in a small area and are said to be extending their range. In Kentucky, also, a

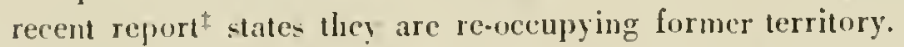

Elsewhere there has been comparatively little reduction. In the Ruckics. grumse populations have always been sparse. Many of the carly expeditions to this region failed to record a single specimen. Fet they apparently occurred in small numbers over a considerable area. The gencral situation seems to have undergone scant change. but in Colorado no records since that of Sclater ${ }^{832}$ in 1899 have come to light and it appears that the species is no longer

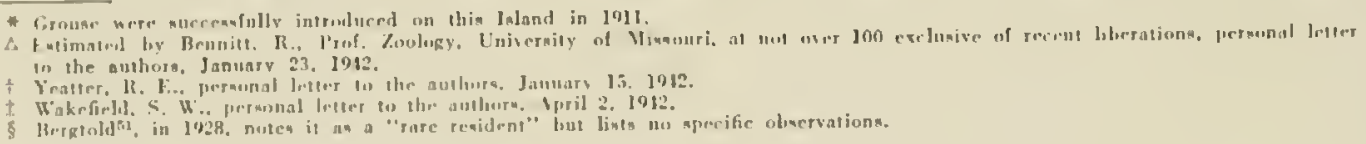




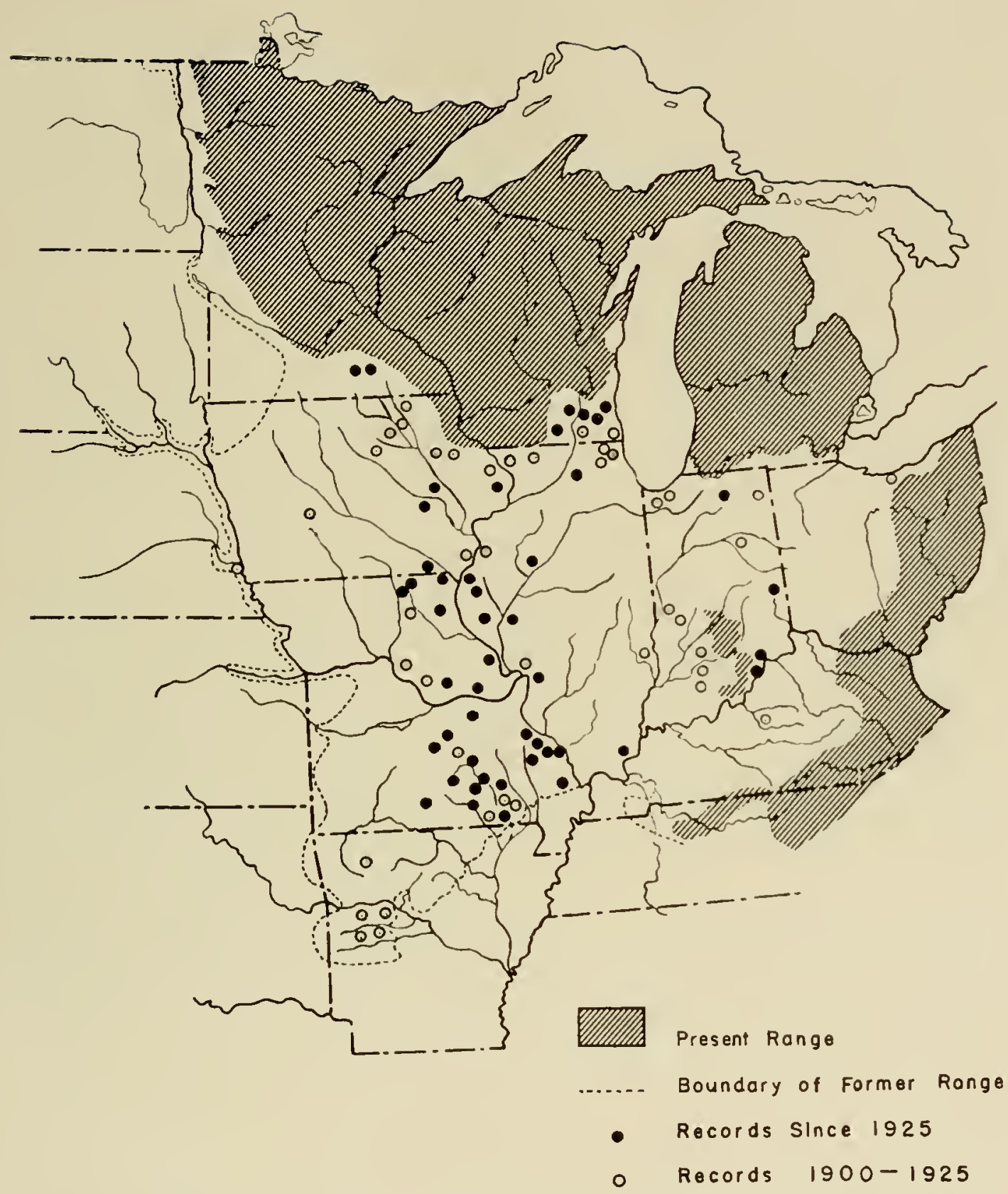

FIGURE 2. DISTRIBUTIOX OF RECENT RECORDS OF RLFFED GROLSE OVER ITS FORMER RANGE IX THE NORTH-CENTRAL AND MID-WESTERN STATES

present. In the East, various of man's land use operations have forced the lirds to retreat somewhat to the higher mountains in Virginia and the southern Appalachians. In the North there is no reason to believe its distribution has undergone any inportant change. Since it is a species of sub-climax associations and is not intolerant of man's activities, so long as suit- 
able cover remains. it is probable that its present range will remain esscntially stable for some time to come.

Of interest is the inclusion of two states, Nevada and Oklahoma. in which the presence of grouse has hitherto been unrecognized. With respect to the former, although substantiating specinens are not at hand, liassmussen has recently reported* the scattered occurrence of the species in the White l'inc Mountains, the Ruby Mountains and another small area in the northern part of the state. For Oklahoma, no records are available, but the former existence of the bird in the Ouachita Mountains to the western limits of Arkansas clearly indicates that it must have occurred at one time along the eastem margin of the state.

In compiling the data upon which figures 1 and 2 are based every effort has been exerted to assemble the available material on the subject. In addition, the game departments, as well as other recognized authorities of the 52 states, provinces and territories in which the species at one tinse or another las been reported were canvassed by letter during the winter of 194142. The replies received have been invaluahle in supplementing published accounts. Nevertheless, errors are inevitable where definite records are scarce or lacking and one must rely on judgment. This is particularly true in northern Canada and much of the Rocky Mountain area. The authors helicve, however, that such discrepancies will prove to be minor.

Beyond this, certain statements which warrant comment are to be found in the literature. In 1831, Audubon ${ }^{25}$ indicated the occurrence of gronse south of Tennessee along the Mississippi, stating "but as you approach the city of Natchez they disappear". This seems to have been the basis for the inclusion of Mississippi in the range of the bird as given lyy Baird, Brewer and Ridgway ${ }^{31}$. No specific records were given by either author and, since subsequent confirmation is lacking, this section has not been included. At the same time Auduhon also ascribed the species to Texas hut gave no particulars. Ilere too there is considerable doubt. The only other reference to its occurrence in this state is a note in Forest and Stream for $1878^{\text {ma }}$ concerning its reported presence in the "Brown Sand Hills almost in the center of the Staked Plains west of Cedar Lake". It seems quite probable that this was a case of mistaken identity since Cooke states definitely that the species did not reach this state.

On the west coast, sabini was stated by Cooper ${ }^{23}$ to occur as far south as N. lat. $34^{\circ} 30^{\prime}$, and northward, Macoun ${ }^{21}$ credited it to the entire coast of British Columbia as well as the Qucen Charlotte Islands. Since these records now appear to have been based on misinformation, they are not included. One possible source of error was a specimen of this subspecies collected by Bishoft and cited hy Nelson ${ }^{25}$ which was labeled Sitka, Alaska. but which, it has since been determined ${ }^{\text {sus }}$, was undoubtedly taken elsewhere.

Another aspect of this subject is the sporadic uccurrence of lone individuals outside the normal range of the species. In the North, as dis-ussed elsewhere ${ }^{\Delta}$ there appears to he a considerable area where stragegler may not be uncommon although observers are so few that data acrumulate slowly. Thus Russesecorded the species about 1860, at La Pierre Honse near the mouth of the Peel River in the Mackenzie Delta region where it probahly: wandered from the valley of the Porempine. In 1878. Bell"s reported it from York Factory at the montly of the Nelson River on Iludwon Bay. Nore rerently. Clarke ${ }^{\text {75 }}$ took a specimen at Fort Reliance at the eastern end of Great Slave lake where natives recarded it as quite rare. Similarly, Wayne rites a recoral for Canden. Sunth Carolina in 1901. It is possible. too, that Audulon's experience in Missisuppi may have involud observations of this kind.

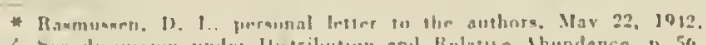

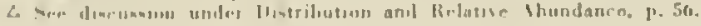


As stated previously, it is not within the scope of this report to undertake a detailed discussion of subspecific relationships. Therefore, only a very generalized picture is presented. For each race, the type locality* is marked in figure 1. It is probable that the area of former range throughout the Mississippi watershed, east of the Great Plains was largely occupied by umbellus, while in Colorado. umbelloides was the predominant form. An important aspect of the distribution of these races is that between no two does a clear cut line of demarcation exist. Rather, one finds zones of intergradation where individuals of one subspecies occur side by side with those of another and where birds of intermediate coloration are also common.

The subspecies involved in such zones of intergradation are. in general. those whose basic ranges are adjacent. In the case of logata. however, certain interesting variations exist. In the East, it invades the area oceupied by umbellus in the form of a long anm reaching down the Appalachian Mountains where Transition or Canadian conditions occur. In the Ifest, it extends along the eastern margin of the Rockies through Montana and Wyominc. and in British Columbia, it crosses the momtains. intergrading witl sabini in the lower Fraser Valley and with umbelloides northward. at least to the Caribun djstricl. This suggests the possibility that, from the standpoint of evolution. logata may represent the original race while the others are more recent modifications.

\section{MISTRIBLTION AND RELATIVE ABUND IVCE}

The ability to occupy such an extensive range illustratce a highly important element in grouse ecology, namely, that the species is typical of -ub-elimax forest regetation-shrubs. second growth and forest edges. Accordingly, it finds suitable conditions associated with the developmental stages of several climax types lhiomes) rather than heing restricted hy the limits of any particular nnet. From Alaska and northern Canarla. Where it frequents the spruce timber side by side with the spruce grouse. it seems equally at home in the redwoml forests of the Pacific Coast. the aspen groves of the prairie country. and the mixed wonds of the Northeast. Furthermore. early recorrts indicate cumideralble populations to have inhahited the hardwond swamps of Iudiana and Ohin. and Audulon even states he encountered these birds in the canchrakes of the Mississippi.

At the same time its distribution within this trritory is far from uniform. Such a range of necessity includes a host of local areas unsuitable to grouse hut impossible to indicate on a small seale map such as figure 1. Furthermore. the habitats in which the hird is found run the gamut from good to poor. resulting in wide variations in relative alundance irrespective of fluctuations assoriated with ryclic hehavior. The following discussion of these features is divided into two parts dealing with the range of the species in general and with New Yonk State respectively.

\section{ENTIRE Ravere}

Conditions approaching the optimum for grouse are found mainly across southern Canada. northern Minnesota, northern Wisconsin. northern Nichigan and south through New England. New York. northern Pemsylvania and portions of the Alleganies (figure 3). Even here. however, are nany areas unfavorable to grouse. British Columbia and western Alberta. in particular. present a complex interspersion of timbered valleys and alpine peaks the one supporting grouse. the other not. Alng the edge of the prairies in southern Alberta and

\footnotetext{
* See discussion under Taxonomy, p. 17.

$\triangle$ By Robert W. Darrow.

Sie alan Pitelka 300 .

* See Chapter 111. P. 110. and 1V. P. 229.
} 
Saskatchewan (and formerly over much of the area now within the states of Ohio, Indiana, Illinois and Kentucky, which would have been included in the region under primitive conditions) tracts of treeless grassland are found in the midst of good grouse cover and vice rersa. Many other minor exceptions also exist, such as the sand dunes of Michigan and the alpine mountain tops of the Adirondacks and White Mountains.

Grouse have. in general, always been most plentiful within this portion of their range, but, though the average is relatively high, some sections are more productive than others. Thus, well watered areas are more productive than dry; moderate slopes are preferred to steep; and cover containing an appreciable admixture of evergreens is better than pure hardwood. Areas intensively occupied by man support relatively fewer grouse than those where the habitat has been less altered.

Beyond this grouse find their needs most adequately supplied in coverts comprising an irregular pattem of types and having a more or less open crown but eonsiderable undergrowth. They prosper bes in habitats associated with sub-climax forest types. The greatest primitive populations were probably produced along the water courses of the region of mixed coniferous and deciduous forest, about the swamps in the hardwood sections, and in portions of the prairie border of the middle-west and the southern prairie provinees. Burns and windslashes, however, also hroke up the uniformity of the cover and produced highly farorable conditions. Conversely. extensive tracts of uniform type seldom have been conducire to high densities of population. Thus grouse ahundance increased materially in the second growth following settlement and lumbering. although, of course, they disappeared where land clearing was intensive. Some of the most highly productive coverts today are found among the hill farms of New England and southern New York, especially where many of the clearings are beginning to revert to overgrown-land as a result of abandonment.

Elsewhere grouse populations are more sparse and. in many sections, the distribution of favorahle cover more scattered. Through its southward extension in the Appalachian system. its numbers are relatively low. While they formerly may have heen more abundant locally. especially where Canadian conditions existed, the effects of hmbering. huming. land clearing and grazing, through eliminating the evergreens, destroying the undergrowth. and drying up the streams. have resulted in their now being relatisely scarce. A recent report * from Kentueky, however, states that grouse are re-oecupving many areas following hetter coutrol of l)urning.

Throughont their range in the western states, wrouse have never been numerous. Reports indicate that, on the Pacific Coast. they are most plentiful on Vancourer Island. The distrilution of the scattered lirds in Utah and Nevada is very irregular and changes continually although the general extent of their range remains the same. Here they are found chiefly where aspen and willow groves occur in canyon bottons at moderate elevations. In the southern Rocky Mountain region the area occupied by grouse lies as a band along the moun. tain slopes, its lower level heing roughly defuned by the occurrenee of evergreen timber. its upper limits falling somewhat below timberline. In its former range in Colorado. this band lay roughly betwen 6000 feet and 8000 feet. To the northward it gradually fowers until. in the murthern states and Canada. the valleys comprise the grouse range and more and more of the mountains project above timber-line. Throughout this region. especially in northem British Columbia. Yuhon Territory and Alaska. local areas unsuited to grouse (indicated onl! approximately on the map) are frequent. To the north. alpine conditions are chiefly responsible; to the south, arid intrusions of the Sonoran Zone in the river valleys are also involved.

"Wakofiets, S. W., persunal Inter t" the authors, April 2. 1912. 


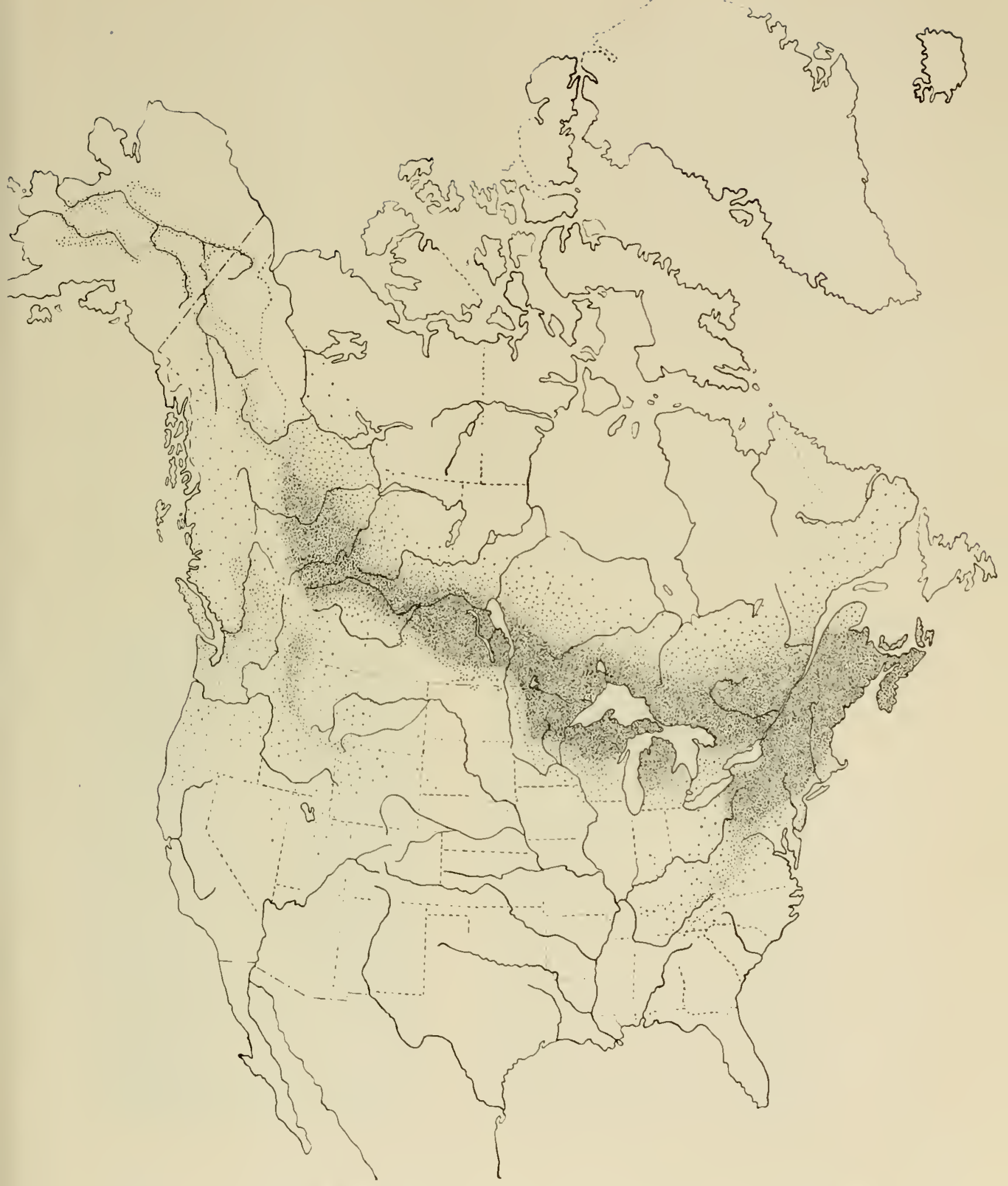

FIGLRE 3. RELATIVE ABUNDAXCE OF THE RUFFED GROUSE THROLGHOLT ITS PRESENT RAXGE 
Along the northern horder of its range in western Canada, the forest cover is found primarily close to the margins of the streams and lakes, reaching like tentacles into the tundra and leaving expanses of nearly treeless moor between. South of the area leeween lork Factory at the mouth of the Delon liver and the east end of Athabasca Lake. gronse are regularly found in small numbers alung these projections. liut northward, the relationship between grouse range and the tree-line dininishes rapidly. In this section. the line shown on the maps represents the boundary of the area within which grouse are fairly constant in their occurrence, although their numbers are low and many local areas, from which they are absent. exist. Nevertheless, grouse occur sporadically beyond this boundary. often to considerable distances. Clarke* even suggests that the Mackenzie Mountains should be included in the area throughout which stragglers may he found. This region has been so little explored ornithologically: however. that defunte statements are impossible. Especially noteworthy records are those at Fort Reliance at the eastern end of Great Slave Lake, and La Pierre House near the mouth of the Peel River.

A similar situation, although the zone of termination is prohably narrower, exists along the southern edge of the great platean of Labrador and northern Queber. Here. hwwever. the extensions of suitable hahitat project up the streams where they have cut valleys in the southern cnastal escarpment, rather than downstream as in the case of the rivers flowing northward into the tundra. On this plateau there appears to he even less relationship between the extent of grouse distribution and the limit of treegrowth. The reason for this is that the tree line ${ }^{155}$ is considered to include a vast area supporting only a scattered and stunted growth of black spruce. halsam fir. birch and jack pine, interspersed with tamarack swamps and large expanses of hare Precambrian rock. Nevertheless, most of the region is still unexplored ornithologieally and our concept of grouse distribution in it may have to be considerably revised as further data are secured.

But below this northern border zone lies a broad belt stretching from Labrador to the Canadian Rockies and into the Yukon valley where conditions are such that grouse may occur most anywhere, lut where, although generally distributed. they seldom become numerous.

\section{New York State}

With the exreption of certain Adirondack mountain tops which rise to timber-line or above. and the coastal marshes of Long Island. the entire area of this State originally constituted suitalle ruffed grouse hahitat. varying. of course. in productivity. Today. after three cen. turies of settlement. one may still encounter this speries in every county, with the exception of the Bronx. New York, Kings. Queens and Rirhmond. all of which lie within the area of New York City. In fact. it is probable that densities of population now attained in many localities coniderably surpass those of primitive times.

Althougl the species often manages to persist in small numbers under marginal condi. tions, it naturally thrives best where it finds an ahundaure of its esomtial needs. In this eategory, in addition to an adequate area of fores or woodland cover. are an admixture of pergrecus and sufficient undergrnwtl. Furthermore, as discussed elsewhere ${ }^{\Delta}$. cover composed of a variety of types well interspersed is preforable to extemsive tracts of uniform type.

Therefore. grouse are to be found most abundantly in those localities where settlement has openod up the forest and where mixed ener is found hut where agriculure or other utilization ly man has mot heen intensive. Throughout the Southern Tier and much of the Catskills,

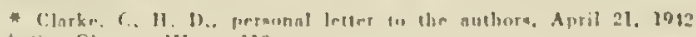

La sue rinapier III, B. 112. 
particularly where farms have been abandoned and are reverting. are found some of the finest grouse coverts in the State. Similar conditions exist in many sections east of the Hudson Valley, and highly productive coverts also occur about the periphery of the Adirondack forest area.

On the other hand in the more intensively farmed valley areas, grouse populations are usually low and often quite scattered. Illustrative of this are the lower Hudson Valley and the lowlands of the Moliawk, Susquehanna, Chemung, and Genesee rivers. Largely due to a lack of conifers, these birds are very scarce over the Ontario lake plain except in various swamps of which Bergen, in Genesee County, is an example. Likewise, in the extensive forests of the Adirondacks and certain portions of the Catskills. the species, although generally distributed, is seldom numerous. And in areas of heavy occupation by man, such as much of Westchester County and Long Island, it occurs in only moderate numbers.

\section{POLYCHROMATISM}

Throughout all subspecies of the ruffed grouse, the occurrence of dichromatism is an outstanding characteristie. Just as gray as well as black squirrels are found in the same litter, and red as well as gray screcch owls in the same nest. so also do gray phase and red phase grouse occur in the same brond. The differences are not apparent. however. until the bird acquires adult plumage. since it is the tail and ruff feathers which are most affected.

The most conspicuous feature is the tail which, on the one hand, may display a hright rufous color, on the other, a clear gray. Furthermore the subterminal hand, although alnost invariably black in gray-tailed birds, may in red-phase individuals, vary from hlack to a rich chocolate. Likewise the ruffs, while usually hlack, are sometimes chocolate in red hirds.
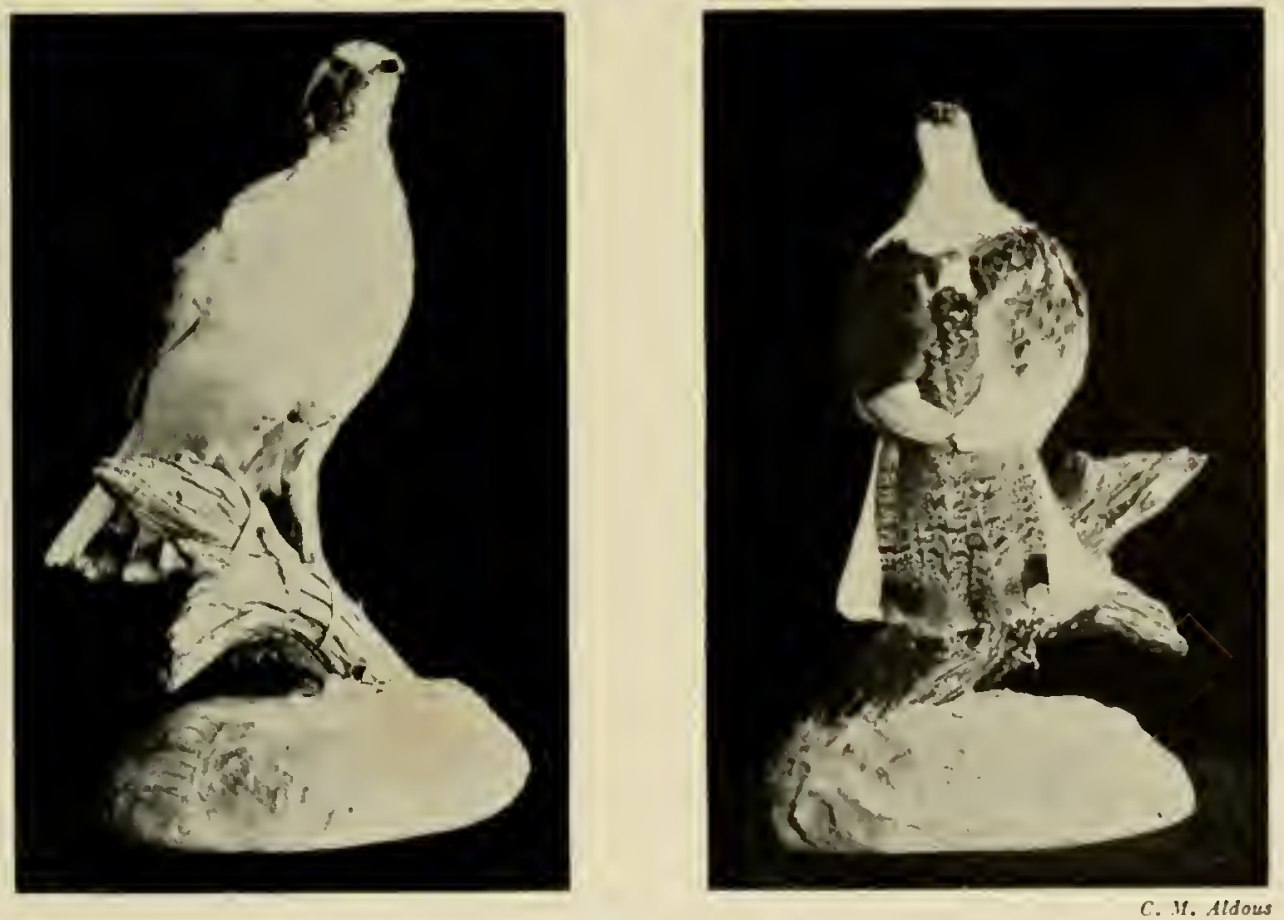

PARTIAL ALBINO RUFFED GROUSE TAKEN NEAR FORT KENT. ME. 
But, while these represent the extremes of the sariation. there are all manner of intergradations. The matter is further complicated by the intermating of members of different sul. species in areas where both are found. Thus one often encounters hirds which, although basically gray, exhibit a suffusion of buffy or pale rufous. Similarly. the tails of red-phase birds range from pale straw-color to a bright rufous. The degree of fine transverse barring in the tail-feathers also varies. being least prominent in decidedly rufous specimens.

That the color phase exhibited hy a hird may not always he constant was discovered at the Research Center when several hirds, which had tended toward the red type to hegin with. came to more nearly resemble the gray type following subsequent moults.

The occurrence of albinism has been reeorded but it is rare. In this connection. it may he noted that artificially propagated hirds sometimes produce white feathers as a result of mutritional disturbances.

So far as is known, melanism has not been observed. In 1928. howrer, Allen ${ }^{13}$ reported that. after moulting. the feathers of certain diseased birds exhihited an increased amount of hlack pigment.

\section{ANATOMY*}

Existing species of animal life have gradually developed. through inmumerable eons of time, from much more primitive forms. Structure is the primary hasis for tracing these lines of evolution. as well as for determining the relationships of contemporary groups.

In the Appendix ${ }^{\Delta}$ is included a comprehensive account of the anatomy of the ruffed grouse. of which the following is a lirief syopsis.

In common with other fowl-like hirds this species has a generalized structure. as shown by the presence of two carotid arteries and a gall bladder. and the absence of a penis. The intestines are looped in a primitive manner within the body cavity.

A notable specialization is a cutaneous muscle lying leneath cach tract of ruff feathers. the contraction of which causes these feathers to rise away from the neck.

In its skeleton, the grouse is essentially similar to the baruyard fowl hut smaller through. out. In comparison with other members of the Tetranondae, it is the lightest huilt. Most of the differences, however. are merely of degree. Perlaps the most promounced is its higher pelvis. Of interest is the fact that there is greater variation between the genera with respect to the pelvis and the vertebral column than the homs of the extremities.

Likewise, the arrangement of the muscles appears to he quite similar to that of other members of the family as well as the ehicken and quail. Present knowledge of this sulject. however. is very limited regarding most of the other species in the group.

The syrinx or "voice box" (which is highly developed among the singingr lirds) is of the primitive tracheo-bronchial type and is adapted to only rudimentary motest.

Respiration is carried on ly means of lungs as in mammals. In addition. and eonnerted to them by bronchial tubes. is a system of membranous bladders or air sacs (five in all) which serve to increase the huoyany of the hird's hody. Also associated with this arrangement are the hollow interiors of the larger bones of the hody:

Primarily a vegetarian, the gronse possesses a muscular gizzard capahle of grinding lunds

* By David E. Devto.

4 sen Aprenilar. p. 721

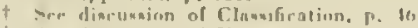

\pm Sirer diaruanion of boire, P. 9 R. 
and hard-coated seeds. Branching from the oesophagus, between the mouth and the gizzard, is the crop which serves chiefly as a storage pouch for freshly eaten material. At the junction of the small and large intestines are attached two blind ducts or caeca several inches in length.

As with birds in general, the two testes of the male are oval bodies lying on either side of the backbone and against the forward portion of the kidneys on their lower surface. During the breeding season these organs become greatly enlarged but at other times of the year may be so small as to be difficult for an untrained observer to identify. In the female. the ovary, resembling a bunch of grapes. occupies the same position as the testis. Normally, however, only the left ovary develops in hirds. It. too, becomes much enlarged during the breeding season.

Abnormalities of the sex organs are not infrequent. Thus, under certain conditions, the ovary may wither on the left and the rudinentary organ on the right develop into a testis. The effect on the plumage and other secondary sex characters is often remarkable.

\section{PTER YLOGRAPHY*}

The presence of feathers is one of the major distinctions of birds as a group. Among the various species of the earth. widl modifications from the primitive type have developed. Such differences, chiefly involving arrangement and types present, are used extensively in studying evolutionary relationships.

In the Appendix ${ }^{\Delta}$ is included a detailed account of the pterylography of the ruffed grouse, of which the following is a brief resume.

Although protecting practically the entire hody, the feathers of a grouse. like those of most other birds, grow in well defined areas called tracts rather than indiscriminately over the surface. These tracts are bilaterally symmetrical and in them the feathers are usually arranged in two series of rows, one at an angle to the other. This pattern can be casily seen in a plucked bird. The intervening areas of barc skin are termed spaces and are covered by feathers situated in adjacent tracts. The development of such spaces in birds. as well as the restriction of the feathers in tracta, undoultedly facilitates hetter hodily efficiency through allowing greater concentration of hlood vesscls. The brood spot is principally a space although some contour feathers are plucked hy the hen along its onter edges.

Of the many types of feathers found among hirds. the grouse possesses neossoptiles. mesoptiles, teleoptiles, and filoplumes. Certain teleoptiles appear down and are referred to as semiplumes, but truc down feathers, nr plumulae, are absent. Also. the neossoptiles which nake up the downy coat of the newly hatched chick are usually attached to the cuds of the following juvenile plumage. or mesoptilcs. The teleoptiles are the typical feathers of the adult.

An outstanding characteristic of the feathers of the grouse is the aftershaft-a second shaft hearing most of the typical feather parts and attacherl near the base of the main shaft. It is best observed among the contour feathers.

* By John E. Trainer.

$\triangle$ S.e Appendix, p. 741.
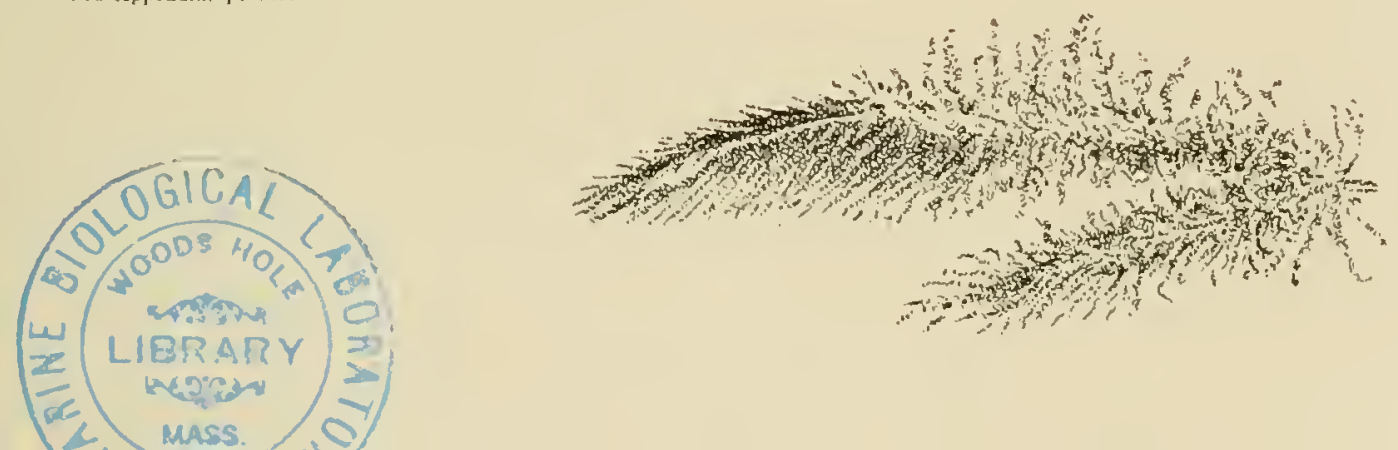
The feathers of a female grouse (teleoptiles and semiplumes) were counted as they were plucked and found to number $4.312^{*}$. In this species there are ten primaries and about 15 secondaries. The tail is normally composed of 18 but from 16 to 20 have been recorded.

Each year grouse grow a series of rod-like appendages as a fringe along the sides of the toes in the fall and shed them the following spring. The bird is thus provided with "snowshoes" for the winter. These rods are derived from the skin and are thus closely allied to the feathers.
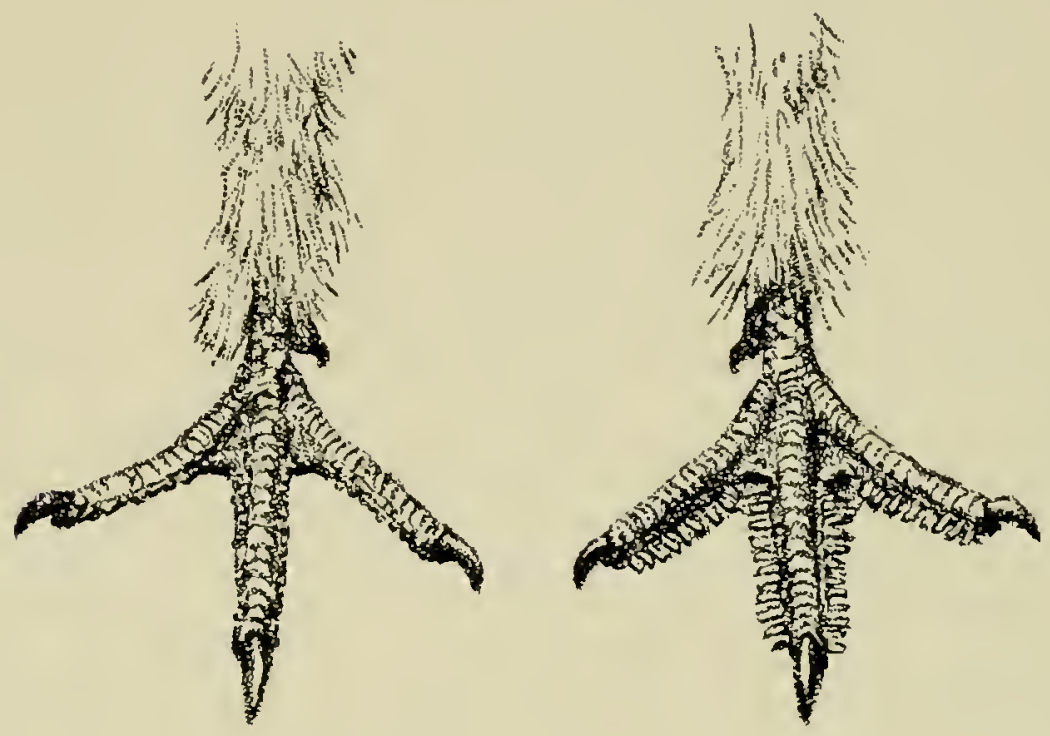

PHYSIOLOGY`

When winter comes man puts on heavier clothing and lights a fire in his furnace. Many northern mammals grow a thicker coat of hair or go into hibernation. Grouse seek shelter in thick evergreen elumps and fluff out their feathers to provide insulating air spaces. Maintenance of body temperature is of paramomt importance to the well-being of all warm-blomled animals.

Yet means of regulating heat los represent onl wne side of the picture. The manufacture of heat through the hurning of food materials in the hody must also be carried on. Unless the two are suitably coordinated an animal cannot survive long.

One shonld realize tom that wild species. unlike civilized man, do not hawe access to arti. ficial heat nor cau they put on extra clothing at will. This is particularly tme of birds which do not even grow a heavier coat of feathers. They must. therefore. rely to a much greater degree on producing within their uwn bodies the added warmth necessary in cold weather.

P'roduction of lody heat is dependent upon the proper functioning of the various internal urgans-in other works. the animal's plyysolog! - as well as upon adequate shelter and food. These vital processes are not static. Rather they undergo constant adjustuent to changes in the activity of the animal and the environment in which it lives. as well as in the amount and quality of food eaten. the presence of disease and other influenees.

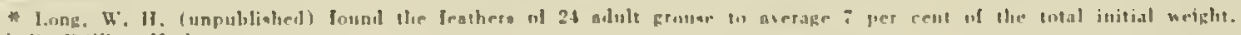

A Hi. Willian li. long. 
There are, however, limits to the adjustment which an animal can make. When environmental conditions become more severe than it can coje with, death results.

But even though survival is not endangered, changes in the conditions to which an animal is subjected affect its vigor and behavior. The varying cumulative effect of such forces at different places undoubtedly is a major factor in determining the extent of the distribution of a species. Similarly, at different points within its range these relationships govern to a considerable degree scasonal need for various lypes of food and shelter. Again, severe conditions during one year may so lower an animal's vitality that it is unable to recuperate in time to survive the next.

Therefore, a knowledge of the principal environmental influences involved and of how they affect the species in which one is interested will aid both layman and technician in recognizing habitat deficiencies. Likewise the game manager will be better ahle to devise effeclive developnient measures.

Only recently, however, have detailed studies of these relationships been undertaken dealing with game species. The data presented herewith are the first pertaining in the ruffed grouse* .

With respect to this species the hasic envirommental forces affecting it physiologically are air temperature, air movement, radiation of heat, evaporation, humidity and light. Factors such as shelter and food merely modify a bird's response to the other more fundamental influences.

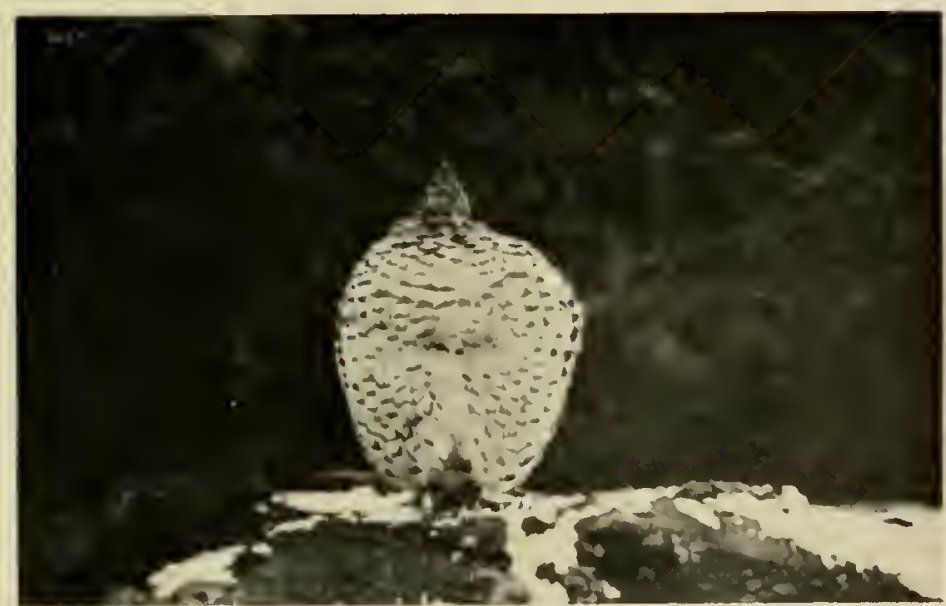

A GROUSE WITH ITS FEATHERS FLUFFED OUT TO PROVIDE INSULATION AGAINST THE COLD

In measuring the effect on the bird of such conditions or combinations, the primary indices, in addition to survival itself, are hody temperature, respiration rate and heart rate. But before significant variations can be recognized one must know what the normal is. Initial experiments were planned accordingly. Then, following these, others were conducted to determine the effect of various envirommental changes. In connection with the data secured. however, one must bear in mind that the birds used were from hand-raised stock and may not be entirely representative of wild grouse. They were also all adult.

* A more detailed account of these experiments is included in the Appendix, $\mathrm{p}$. 779 . 
It was found that the average body temperature of the birds used was just over $107^{\circ} \mathrm{F}$. and that it varied slightly with the air temperature and with activity. The data also demonstrated a regular fluctuation each 24 hours, in which the temperature of the birds was highest between $2: 30 \mathrm{p} . \mathrm{m}$. and 5:30 p. m. and lowest between $11: 30 \mathrm{p} . \mathrm{m}$. and 2:30 a. m. Wetting the birds with a water spray in simulation of rainfall caused their body temperalure to decrease sharply. The colder the water as well as the surrounding air, the greater the degree of drop and the slower the rate of recovery. The effect was also much more severe on three specimens aflicted with an intestinal disorder.

The average rate of breathing anong inactive grouse was nearly 63 respirations per minute. This rate increased with the activity of the bird, as well as with the body temperature. It appears, however. to be a less significant indication of relative vitality than either body temperature or heart rate.

The average heart rate of inactive grouse was found to be about 342 beats per minute. Like respiration rate it varied with the hird's temperature, but there was a tendency for it to become more rapid as the environment became colder. When the birds becane excitcd a pronounced and almost instantaneous increasc occurred.

To study the effect of starvation on the bird, 12 grouse were held for nine days without food. While this did not markedly affect the general level of body temperature until the last day, it did cause a drop in the low point of the 24-hour cycle each night. Since these birds were held at a constant air temperature this drop would be greater under natural conditions where the air becomes colder at this time of night. Thus hirds without adequate food would have greater difficulty than well-fed ones in preventing excessive reduction of body heat. Furthermore, the fact that these birds did maintain their body temperature. especiali? when living at low air temperatures, demonstrates that such conditions force birds to draw on their reserve in order to compensate.

In addition to the above. six grouse were allowed neither food nor water. After the 48 th hour under these conditions their temperature-regulating mechanism broke down and in several cases death resulted. A definite daily need for water is thus apparent.
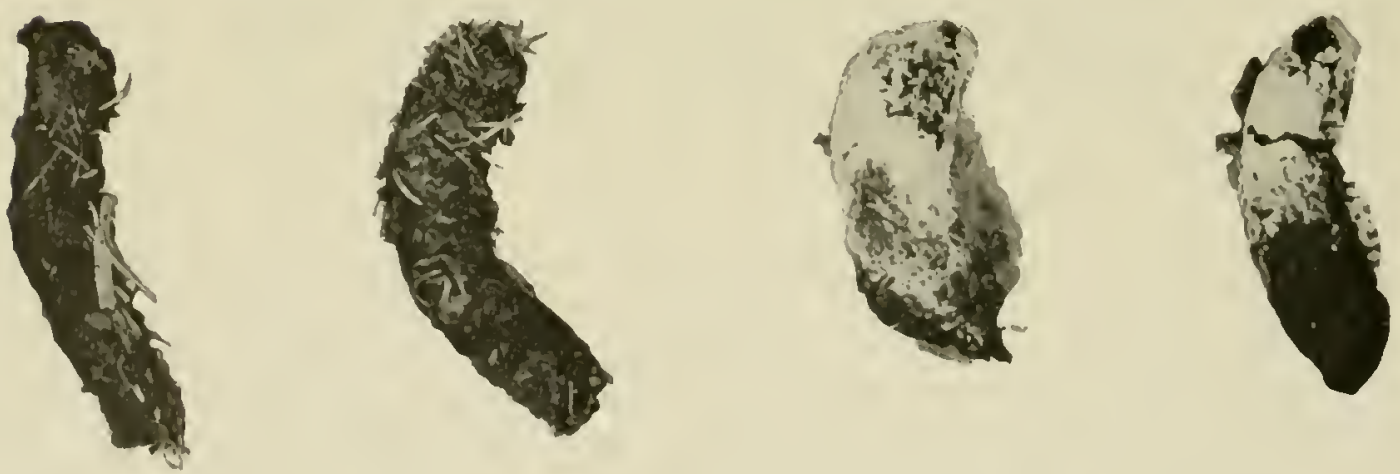

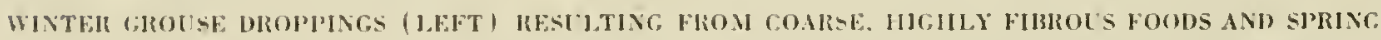
DIOPPINGS (RIGHT) PROHUCEI) AFTEX THE HHUS HEGIN TO FEEI) ON FIESI GREEN MATERIAI. 
Under starvation conditions birds which were heavier at the start maintained their weight better than did lighter individuals. Wejght loss was greater for all birds at night than during the day time.

Under normal conditions food was found to pass more slowly through the alimentary tract as the envirommental temperature dropped.

Finally an effort was made to determine the amount of food needed by an adult grouse to maintain its weight under average living conditions. Since differences in composition between various foods cause their fuel values to differ, a standard unit of measurement, the calorie, was used for comparison. It was found that, for the birds studied in this experiment, a food consumption having a value of 78 calories per day should result in their neither gaining nor losing weight at an environmental temperature of $65^{\mathrm{c}} \mathrm{F}$. when not subjected to exertion.

\section{PSYCIIOLOGY AND BEHAVIOR*}

Each activity of a living organism is a component of its behavior. Reactions are largely the result of an animal's physiological and psychological makeup in response to external stimulation coming from the hahitat in which it lives. Therefore, a wildife manager must understand and take into consideration as many of the patterns of hehavior as he can if he is to take full advantage of the possibilitics of increasing wildlife abundance through devel. oping and managing its environment. Yet. with nut game species, grouse included, very little is known about these basic relationships.

The huvestigation has had an abundant opportunity to note grouse behavior in the wild and in captivity. Consideration of the pertinent obervations gathered therefrom falls logically into two categories. Either one mily describe the actions of the lirds under various circumstances primarily from the standpoint of a disinterested spectator, as in Clapter $V$, or one may go beyond that and attempt to understand such liehavior in terms of its significance in the life of the bird. The psychological aspeet of the latter approach seems sufficiently distinct to warrant special attention here.

Two such hehavior patterns have beconc clearly enough defned to merit description. The first is the social order; the second, that of mating behavior.

It should be recognized at the intset that it is difficult and oflimes misleading to attempt an analysis of animal psychology, based (n) hehavior, because of the inevitable tendency to interpret reactions in terms of their human countcrparts. Likewise, pitfalls beset one in trying to evaluate observations made of captive individuals, which of necessity have been the luasis of much of this discussion with respect to grouse. Realizing this, no suggestion as to their degree of applicability to birds in the wild is contemplated here for. in doing so, one may be guilty of ascribing to such birds responses possibly induced in their hand-raised cousins to some extent hy the artificial conditions under which they are held. On the other hand, the reactions here described are basic and alnost certainly are to be found among wild birds as well as anong those held in captivity. Let us then depict them here.

\section{The Social Order}

The ruffed grouse may not normally be considered a gregarious or social bird. Yet from the time the chicks are first liatched until well into the fall. numbers of individuals are found together either in the loose association of the brood or, very oceasionally, in so-called

* Hy Gardiner Bump. 
"packs", the latter probably representing several broods or groups of individuals gathered together at a particularly favorable feeding site. Likewise, throughout the late fall and winter more than one bird may resort to as small an area as a clump of conifers for night roosting, thus bringing it into relatively cluse contact with others of its kind. But it is to captivity, where the birds are grouped in pens, that one must turn for examples of the social order which, were we more skilled in making observations, might be recognized as also existing whenever grouse congregate.

At the end of each brooding season at the Research Center, the birds of the year, along with the breeders, are placed in wintering pens where they remain as groups until the beginning of the following breeding season. Here, as has been described with poultry ${ }^{12}$ there is soon established a rigid and demanding social hierarchy. In ruffed grouse, where the sexes are relatively similar in appearance. the basis of this social hierarchy apparently lies, not primarily in the age, sex or weight of the individual birds, but rather in the vigor of the individual and the degree to which it is ahle to dominate its penmates. Success in fighting, in bluff and, to a lesser extent, in display, such as strutting, rapidly establishes a definite social order in which each, save for the bottom hird, exercises a dominance over its less fortunate penmates. Except for the ranking bird, each is in turn dominated by its physiologically and psychologically stronger companions.

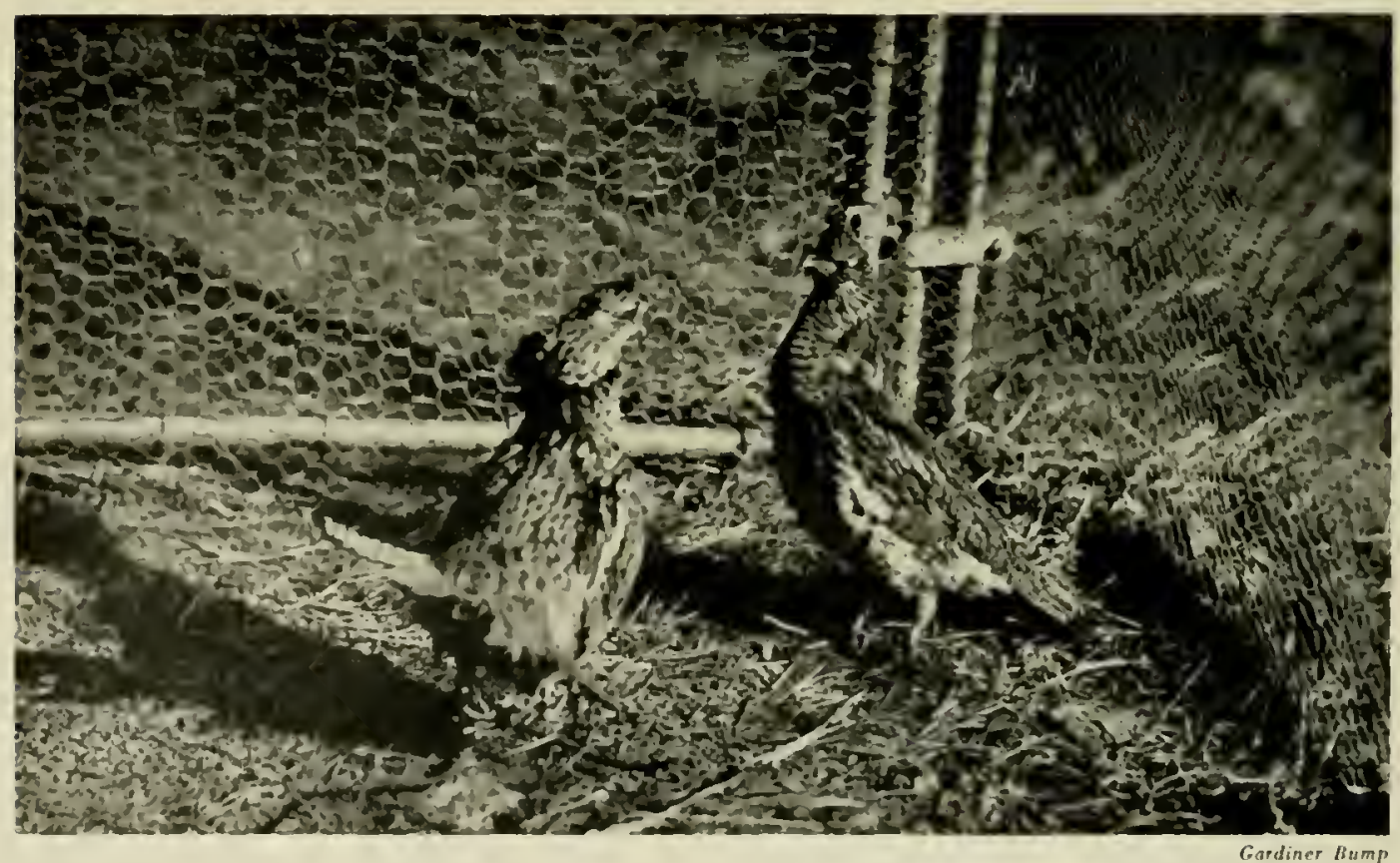

TIIROUGII FIGITING AND ILUFFING A DEFINITE SOCIA, ORDER IS ESTAIISIIEI AMOAG GROLSF.

BOTII IN TIE WILD AND IN CAPTIVITY

In captivity, scrions consequences may often follow this process of estahlishing such social rank. A hird, defeated in one or another of the frequent combats that take place, is occasionally pursued by the vietor into a comer of the pen and there pecked on the head until the skull, in extreme cascs, is laid hare. Once completely subjugated and without the licnefit of self-eonfirlence. if it does not die of mechanical injury or starvation, it soon becomes 
the object of attack by most other birds in the enclosure. If, on the other hand, the combat ends in the weaker bird edging away without being pursued, meanwhile recognizing the victor as the dominant individual, it may in turn be successful in combats with others, thus establishing its own position without serious harm to itself.

Although the order is not directly determined by sex or age, the fact that the heavier and larger birds are principally males over one year old usually results in a larger proportion of these birds occupying high ranking positions of dominance when groups comprising all ages and sexes are penned together. Since those low in the scale must keep out of the way of their stronger companions, the practice of segregating males from females and, occasionally, adults from birds of the year, has grown up. Even in such groups, however, a dominance order soon develops.

It is interesting to note that, should a dominant bird in one pen be placed in another, it must establish its rank among its new companions by the same method as heretofore described. In this case, however, the new arrival is at an added disadvantage in that the resident birds have also established a feeling of ownership of the territory represented by the pen. Apparently the newcomer recognizes this and is, therefore, placed at a psychological disadvantage at the start. It is for much the same reason that a bird once removed from an enclosure and later retumed thereto, does not always reestablish its old position in the social scale. Also, if a vigorous bird, high in the social order, is weakened by disease or some other factor, it will be forced by its companions to assume a lower position in the hierarchy. It is such considerations as these that have given rise to the practice of shifting a bird in captivity from one pen to another when it becomes so strongly dominant as to upset the social balance of the pen.

Translated in terms of relationships among wild grouse, it is possible that the existence of a strong dominance complex, partiularly among the males, represents one of the important factors limiting the numbers which will occupy a given habitat. One likewise finds here a possible explanation for the lreakup of a lorond in the fall for, at least in captivity, the young birds, as early as the first half of September, begin the conflicts that lead to the establishment of a social order.

\section{Mating Behavior}

Aside from dominance, the only other behavior pattern which is sufliciently distinctive to warrant special consideration outside of the chapter on General Habits, occurs during the mating period in response to the marked physiological and psychological changes associated with the reproductive cycle. Here, too. one must turn largely to observations on captive grouse for a knowledge of reactions and an interpretation of their meaning.

Watching grouse activities throughout the spring and early summer, one is impressed by the number and variety of reactions to be observed. With close study, however, they will be found to fall logically into three phases as here described.

\section{Strulting Phase}

In the pens at the Research Center, where males and females are by necessity placed together most of the year, the males show signs of aggressiveness towards their penmates of either sex as early as the first of Narch. Though they may have heen strutting* on warm days throughout the winter, they now display more frequently and with greater vigor, even in the 
absence of the female. Apparently they feel the need of making themselves appear conspicnous and formidable, possibly as an aid in maintaining their dominance complex. In fact, Allen" has termed this the "intimidation display".

As the scason progresses and excitation mounts, a locomotive-like hissing and violent head shaking are added to the strutting performance with increasing frequency. Occasionally, they may select a high point and drum. These, it would seem, are the first steps in their spring lireeding pattern.

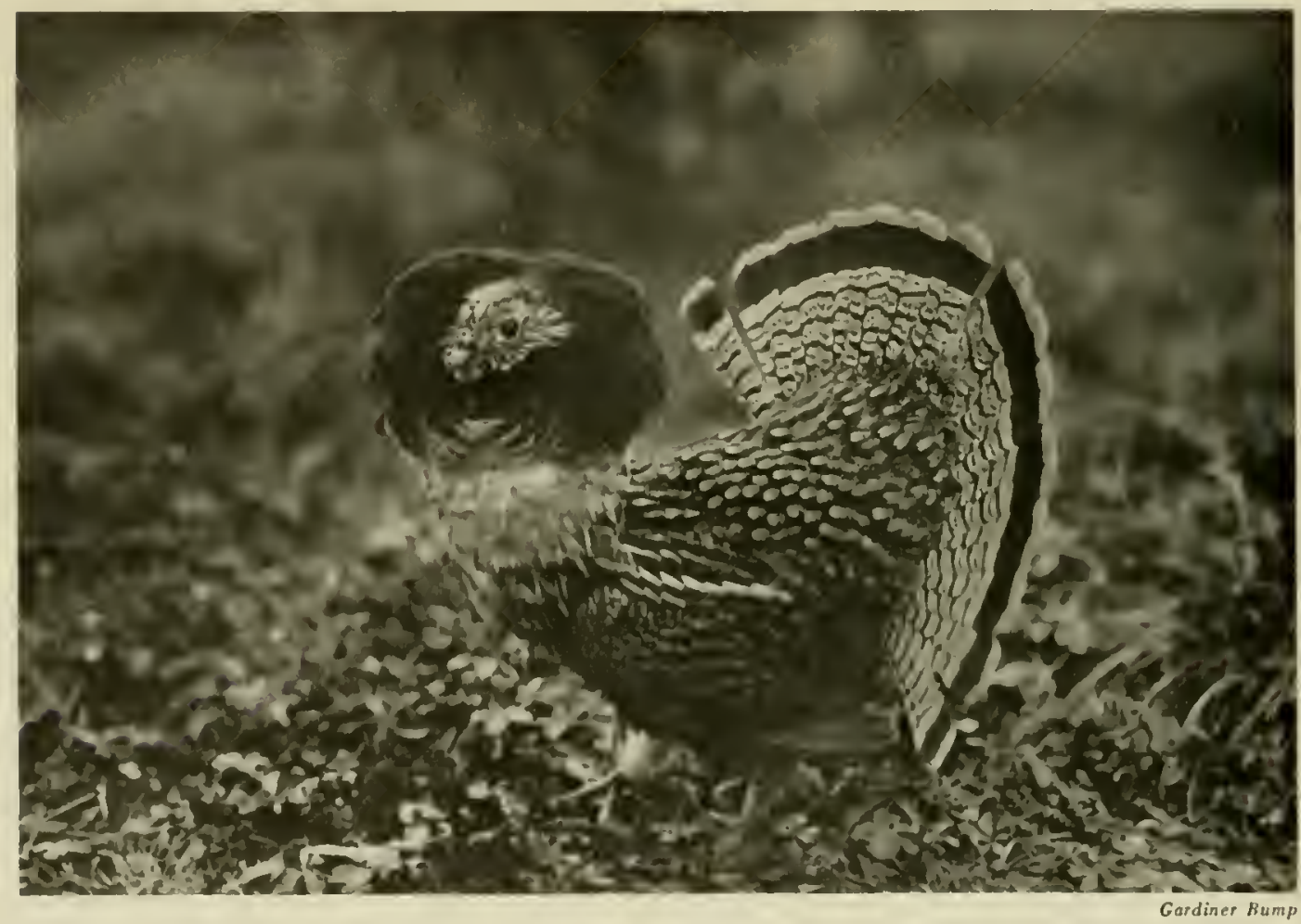

TIIE STRUTTING MALE, SEEMS BOTH TO ATTRACT AND TO INTIMIDATE THE, FEMALE

At the height of this first phase, so strong is the physiological stimulus that, in captivity, full display may often be inspired by the presence of man or of many other objects not familiarly associated with the enclosure. In fact, almost any change in the immediate environment at this time will result in a display. In securing recordings of grouse calls. for instance, the male would frequently respond in this manner to the placement of the microphone in the pen.

Throughout this phase, the mate seems preoccupied with establishing and maintaining his torritory, as well as with display. At first he accepts the enforced presence of the female; later he is increasingly stimulated by her. She, in turn, evidences little apparent interest in his reactions except for a lesire to keep out of his way. If display becomes too vigorous. she may spend considerable time hiding or on a pereh in an altempt to cseape his over-zealous attentions. Though in the latter part of this phase, the male may he physiologically ready to mate. the majority of the females have not as yet reached this stage. 


\section{Gentle Phase}

It is the second, or gentle, phase of the mating cycle that, in the male, is most distinct and easiest to recognize. At its height he seems to abandon for a lew days all interest in territory and in striking display. He is subdued and relatively inactive, preferring to sit still or to

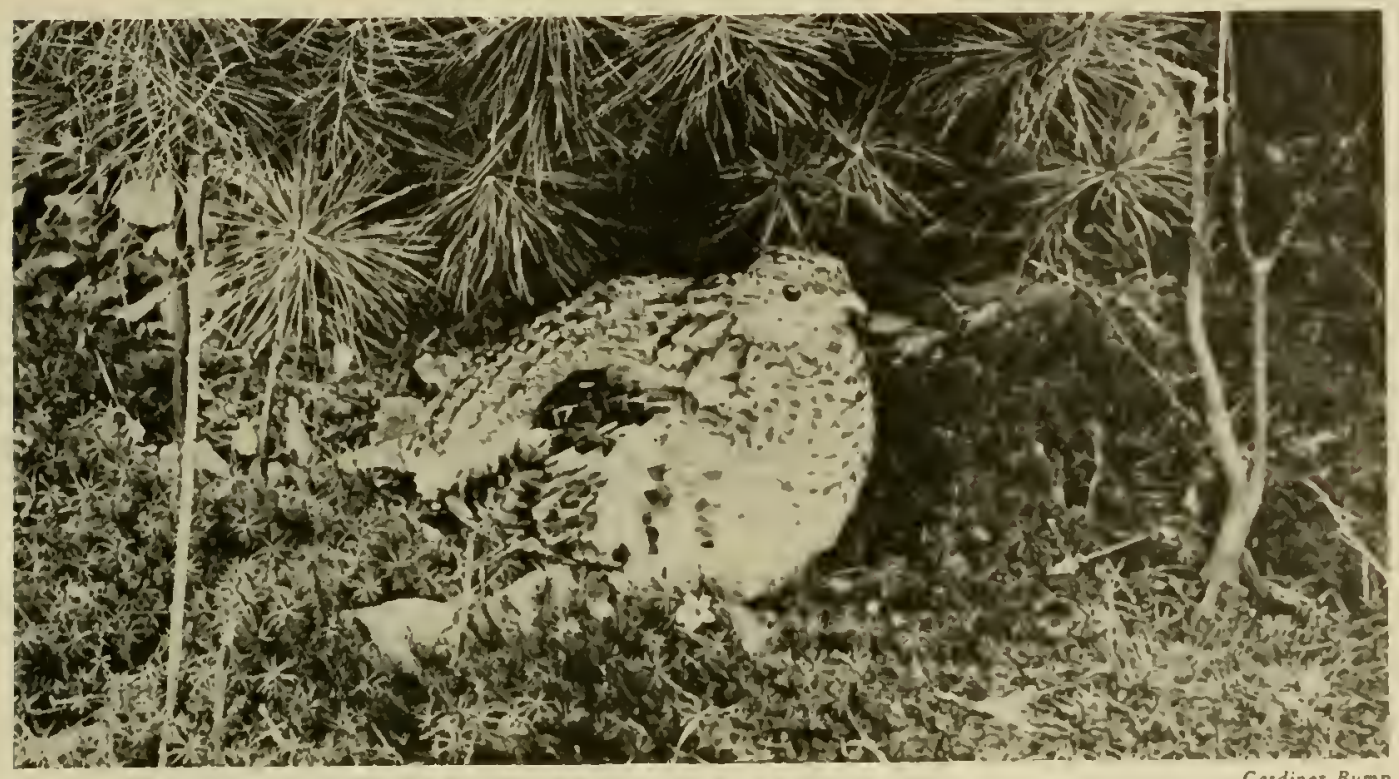

DURING TIIE "GENTLE PIIASE" BOTII SENES ARE QLIET AND SL'BDUED IX ACTION

follow the female at a slow, careful walk, meanwhile twitehing his head and neck slightly. Oceasionally he repeats a call somewhat similar to that of a female singing on the nest. His whole attitude is the epitome of gentleness. Often he follows close after the female and. when she pauses, lightly places one foot on her tail or back. meanwhile pecking her suftly. When she moves away he follows slowly, almost as though in a trance.

For her part, the femate perhaps recognizes that her mate, abandoning his pugnaciousness for the moment, is in a gentle mood. If she is in the period of sexual desire or oestrus, she may squat and assume the mating posture*, whereupon mating may take place. But, because this second phase seldom lasts, in captivity at least. more than a week, coition has been more frequently observed at the Center during the last part of the preceding pliase, and the first part of the phase to follow. More often, she is inclined to lead him here and there about the pen. oftimes singing and occupying her nest box, interested in his altentions lut not yet ready t" yield. It is almost as though, for a brief time, she recognized some bond of mutual under. standing.

\section{Fighting Phase}

Transition to the third or fighting phase may come swiftly. In it, for a time, the male may return to the strutting display characleristic of the first period, perhaps by way of finding an outlet for the intense energy and stimulation so evident in him at this time. Gradually, however, as interest in the female wanes, he develops a strong pugnaciousuess in defense of his

* See Chapter V, p. 267. 
pen against all comers save only those of whom he is mortally afraid. Assuming a characteristic fighting attitude with head low, he will follow the altcndant, as the latter moves around the pen, and try determinedly to get out and at him. Should the pen be entered, the lird will fight with surprising vigor and viciousncss. The same holds if another male is introduced. Even when a strutting hird is approached at this period, the change to fighting pose is commonly accomplished in from five to 15 seconds. Following the disappearance of the intruder, the bird may resume his strutting or carry on various pen activities, meanwhile keeping a sharp lookout for the next visitor. As spring merges into summer the male gradually abandons strutting altogether and not long thereafter may become incapable of being stimulated to the point where mating can take place. The fact that he exhibits the fighting reaction rather than strutting is, however, by no means a good indication that he is not physiologi. cally able to mate.

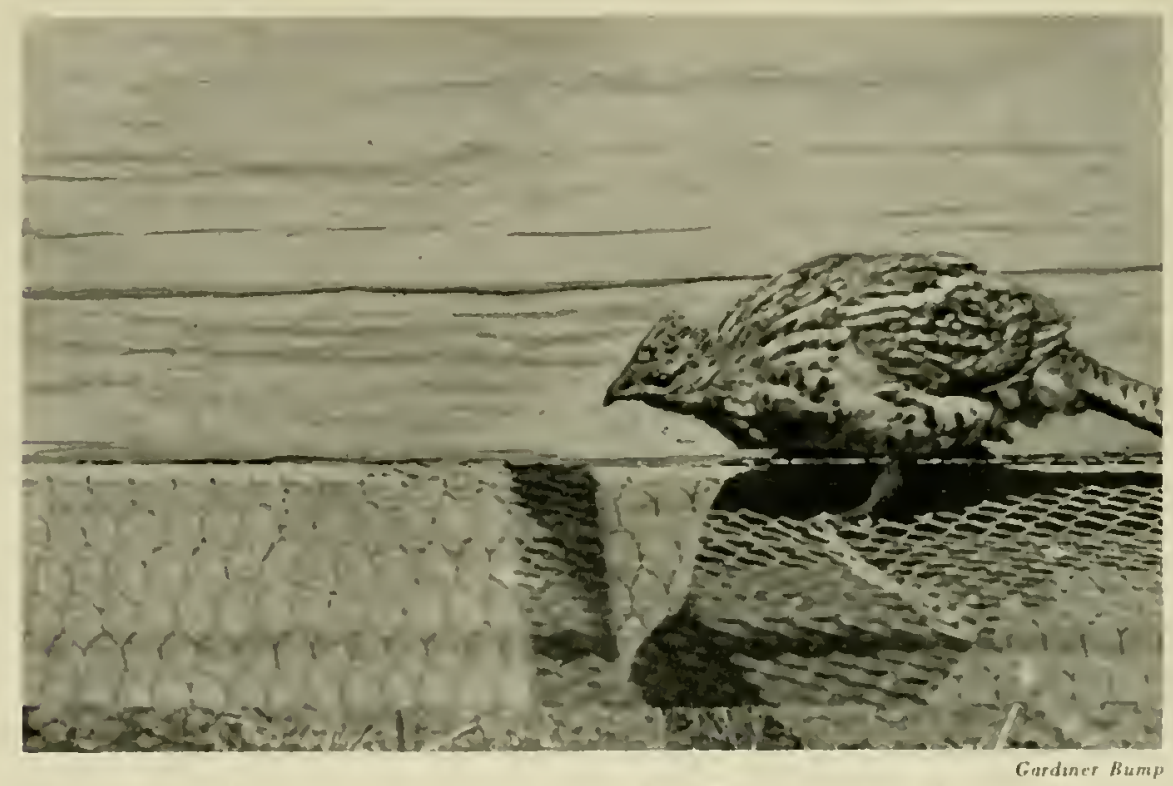

W III.E IN THE FICHTING PHASE TIE MALF EXHIBITS CONSIOERAULE PLGNACIOUSNESS IN DEFFNSF OF IIS TI:IIRITORY

For her part, the female, during her third phase, exhibits little interest in the male except to keep out of his way. This is her period of egg production and considerable time is accordingly spent on and ahout the nest. Allen ${ }^{10}$ has given an excellent description of her behavior at this time.

Beyond the third phase the reactions of the male are characterized by a complete lack of interest in his matc except as an individual to be dominated if occasion demands. For her part, she reciprocates in kind by going about the business of incubating her eggs and raising her brood. Her actions throughont this perind are described in the chapter on General Ilabits.

In interpreting certain of the reactions on which recognition of the three phases here described is hased, one experienecs real difficulty. In studying hreeding behavior, Allen concluded that grouse did not recognize sex and described in the male a recurring mating rhythm involving physiological and psychological readiness to mate. The present anthors, in the 
course of experiments, have many times observed the reactions on which Allen's conclusions were based. Complete records taken twice a day of the occurrence of each phase in all the breeding grouse at the Research Center over a period of two spring seasons have also been kept (table 7). Analyzing these, a different interpretation is here suggested.

Let us consider for a moment the matter of sex recognition. Unquestionably male grouse may display to a bird of either sex or even to unfamiliar objects, as previously mentioned, during the height of their display phase. At other times the presence of a female seems more likely to stimulate this response by the male. Likewise, place loth a female and a male with a displaying cock for a few minutes and, providing one bird is not too over-dominant, the latter will often intensify its strutting in the direction of the female and exhibit a desire to fight the male. Two cocks do not commonly display to each other. Nevertheless. as suggested, one function of strutting may be intimidation.

No evidence has been noted of a recurrent sex rhythm in the male. True, as described by Allen, there are times during all of the three phases when most male grouse will mate with another bird if it be posturing and other days when such hirds will not mate at all. In the first place, strulting. to which. at the height of excitation. the hissing and headshaking reactions are added, is predominant. The second phase, characterized by gentleness and head-twitching, follows in turn, to be superseded in a short time by the strutting and chasing characteristic

TABLE 7. A GENERALIZED BREEDING BEIIAVIOR PATTEIV COVIRING ADIJTT MAIE RUFFED GROUSE IN CAPTIVITY COVIPIIED FROUI A STEID) OF 78 INDIVIDUAL, MTTERYS

\begin{tabular}{|c|c|c|c|c|c|c|c|c|c|c|c|c|c|c|c|c|c|c|c|c|c|}
\hline \multirow{2}{*}{ Illour } & \multicolumn{21}{|c|}{ April } \\
\hline & 10 & 11 & 12 & 13 & 14 & 15 & 16 & 17 & 18 & 19 & 20 & 21 & 22 & $2: 3$ & 21 & 25 & 26 & 27 & 28 & 29 & 30 \\
\hline 8 A.M.......... & $\mathbf{S}$ & $\mathrm{S}$ & 8 & S & 11 & $\mathbf{s}$ & $\mathbf{S}$ & II & S & II & 11 & 11 & $s$ & II & $s$ & $S$ & 11 & $s$ & $S$ & C, & 11 \\
\hline $51 . M \ldots \ldots \ldots$ & $\mathrm{S}$ & $\mathbf{N}$ & $S$ & s & $\mathrm{S}$ & S & II & S & S & II & 4 & 11 & 11 & H & C. & 11 & $S$ & C & $s$ & $s$ & $s$ \\
\hline
\end{tabular}

\begin{tabular}{|c|c|c|c|c|c|c|c|c|c|c|c|c|c|c|c|c|c|c|c|c|c|c|c|c|c|c|c|c|c|c|c|}
\hline \multirow{2}{*}{ IIsur } & \multicolumn{31}{|c|}{ Muy } \\
\hline & 1 & 2 & 3 & 4 & 5 & 6 & 7 & 8 & 4 & 10 & 11 & 12 & 13 & 11 & 15 & 16 & 17 & 18 & 19 & 20 & $2 \mathrm{~L}$ & 22 & 23 & 21 & 25 & 20 & 27 & 28 & 29 & 30 & 31 \\
\hline $8 \wedge . M \ldots \ldots$ & $\overrightarrow{\mathrm{C}}$ & $s$ & $\bar{c}$ & $\mathrm{~s}$ & 5 & $\mathrm{~s}$ & $\mathrm{~s}$ & C & 11 & $s$ & $s$ & C & C & C & C & C & 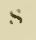 & i: & C: & $\lambda$ & C: & C & (: & C: & $\mathbf{N}$ & C & C & $N$ & C & C & $X$ \\
\hline 5 I'. M. & $\mathrm{s}$ & $\mathrm{C}$ & C. & $s$ & C: & S & C. & C & $\mathrm{S}$ & C. & C. & C: & S & C. & C & G & i: & i: & $S$ & C: & $r$ & C & 1 & 1 & C & C & 1 & C & C & $\mathrm{N}$ & 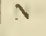 \\
\hline
\end{tabular}

of the third phase. If one charts for all the males the occurrence of each phase based on characteristic hehavior. there appears to he little tendency to pass throngh these more than once in a single season.

A bird, of course. loes not change from one phase to another overnight. Huring the interval. which may last for a week or more, one finds the liehavior characteristic of both phases exhilited many times. Once the bird is well into a phase. lowever. except for strutting, one does not commonly observe the behavior characleristic of the next stage until it is approached.

Perhaps the situation, as it seems to the authors, can be clarified by considering that male grouse in captivity normally are in a state of physiological readiness to mate during the latter part of the first phase, throughout the second and the first part of the third plase. The act is not nomally carried to completion, however, mless the male is externally stimulated above a point one might call the threshold of mating. 
Light, heat, air movement, food, mood of the female, are some of the factors varying from hour to hour which may serve to stimulate a grouse psychologically to a point above this threshold. Properly stimulated. he may attempt coition in the morning; elange the external conditions and he may avoid the art in the afternoon.

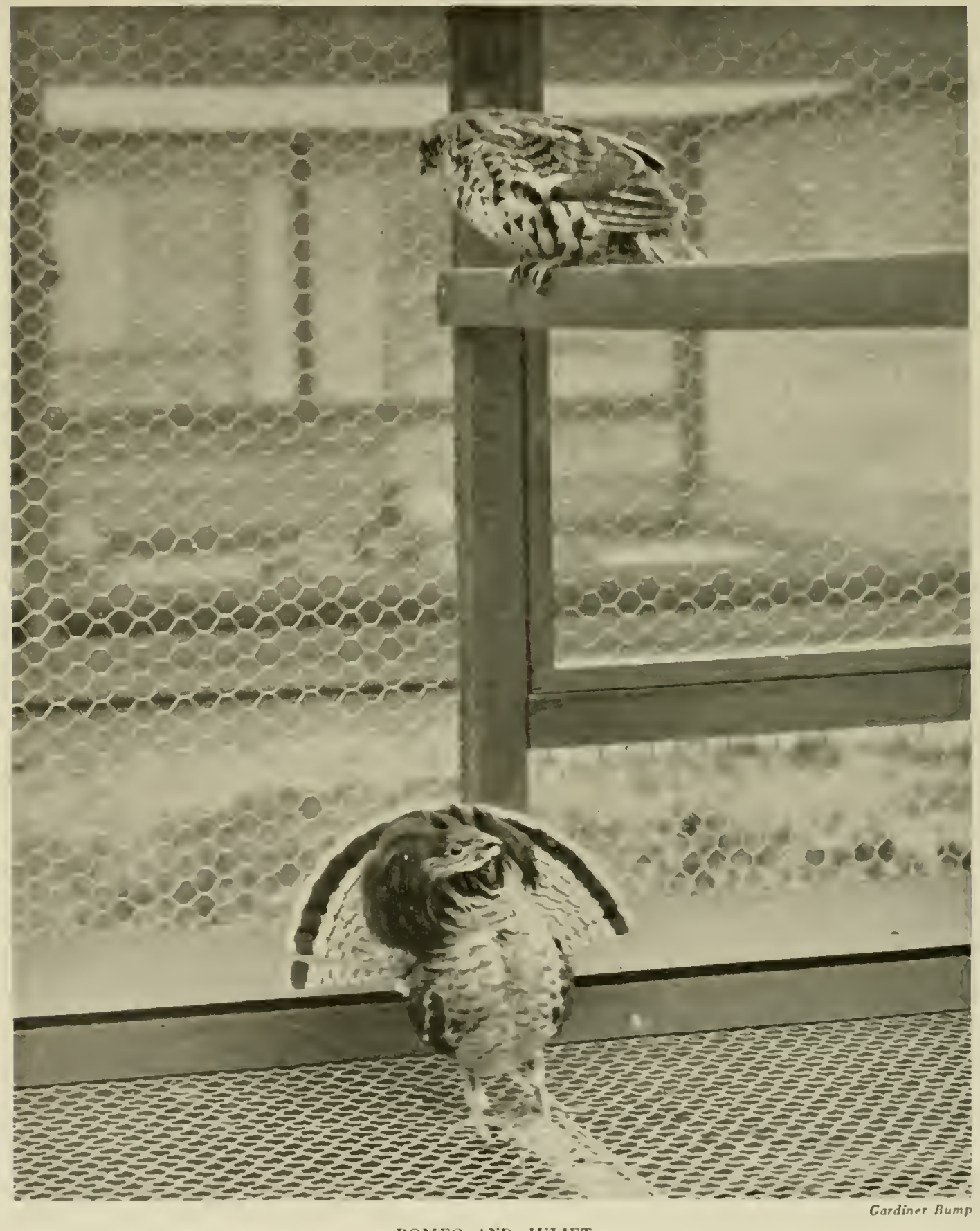

ROMEO AND JULIET 
To prove that he is physiologically ready, however, in several such cases the birds. under manual stimulations, have ejected sperm. Females not previously bred. artificially insem. inated with this, have in turn produced fertile eggs. Also, given the right conditions. males have been successfully mated with three different females in the course of one day. Perhaps then changes in external stimuli, rather than a recurring sex rhythm, cause a male grouse to he ready to mate at irregular intervals throughout the breeding period and to refuse coition in the meantime.

\section{EGGS}

The ruffed grouse most frequently lays from nine to $14 \mathrm{eggs,}$ although both larger and smaller numbers are not uncommon*, the latter usually indicating a rcnesting hird.

The eggs are ovate in form. In color. they vary from milky white to cinnamon buff. usually plain but often spotted with reddish or drab. The shell is smooth with a slight gloss. As incubation progresses, they often become considerahly stained with dirty hrownish blotches.

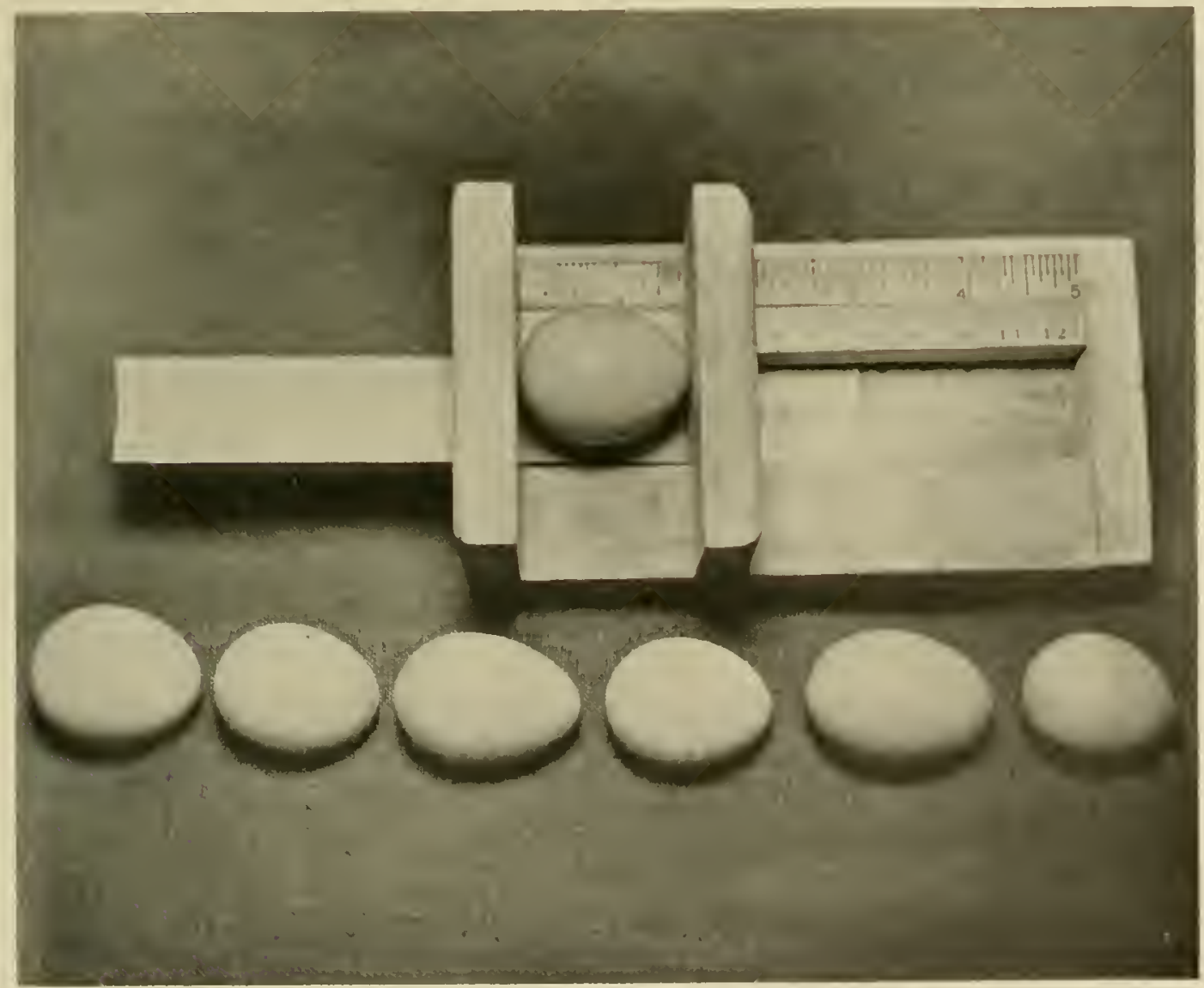

A GROUP OF TYPICAL GROL'SE EGGS 
During the seasons of 1937 and 1938, measurements were recorded for 366 grouse eggs in 30 nests on the Connecticut Hill arca. The average of this group was $39 \times 29$ millimeters. The largest egg measured $49 \times 33$, although the next largest were $42 \times 31$ and $39 \times 32$ millimeters respectively. The smallest was $36 \times 28$ millimeters.

Regarding size, Bendire ${ }^{4 z}$ states:

"The average measurement of forty-four specimens (of B. u. umbellus) in the United States National Museum collection is 38.5 by 30 millimeters, the largest egg of the series measuring 40 by 32 . the smallest 33 by 25 millimeters."

The type clutch of this group was secured near Harper's Ferry; West Virginia, but no locality for the others is given.

Bent $^{50}$ records the average of seventy-three eggs as 38.9 by 29.6 millimeters. This group seems to have included that reported by Bendire since the extremes are identical except for maximum length which in the latter was 42.7 millimeters.

In Maine, a clutch of twelve eggs measured by Knight $^{215}$ averaged $37.8 \times 29.4$ milli. meters*. while a series of nine from Maryland ${ }^{140}$ (apparently not from the same clutch) averaged $41.4 \times 29.7$ millimeters*".

Occasionally abnormally small eggs are encountered and the Investigation has recorded one double yolked egg.

According to Bent ${ }^{80}$ the eggs of the various subspecies are indistinguishable, although those of sabini show a possible tendency to be "slightly darker in color and somewhat more often spotted."

\section{EMBRYOLOGY ${ }^{\Delta}$}

The question of which came first, the grouse or the egg, may not be pertinent, but to what degree the egg controls the future destiny of the grouse is certainly of utmost importance. An investigation of the embryonic stage, therefore, was one of the first natural steps in trying to discover the underlying factors which cause the fluctuations in abundance of this unpredictable hird.

\section{Preview of the Problems}

With grouse, however, the saying "Don't count your chickens before they hatch" slould include "and live". Both the hatchability of the ergs and the livability of the chicks are vital to maintaining population lcrels. Furthermore, they are closely related. In studying the eggs with respect to their hearing on these factors, many other prohlems had to he taken into consideration also and attempts made to solve them, either in whole or in part.

Among these was the quality of the eggs and whether or not it varied between years or even during the samc season. Also involved were the influence of climatic or solar changes, the function of essential food ingredients and variations in their supply and the effects of differences in egg conformation on hoth the growth of the cmbryo and the mortality of the chicks.

\section{Halchability}

Will the erge hatch? If it has becn fertilized. it may. But there is no way to find out

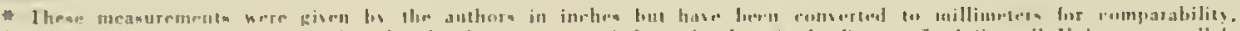

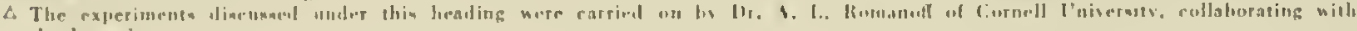
the Investigation. 
except by incubating it and awaiting developments in the embryo. Among eggs from wild grouse the proportion hatching successfully has been consistently high and variations apparently have had little relationship to fluctuations in the number of hirds. Among those from captive grouse the proportion has been somewhat less but the difference las been slight.

\section{Livability}

Will the chick live? This is a more difficult problem. The high mortality rate of the young birds even after a successful hatch has been a primary factor in regulating the size of fall populations. Yet what causes it cannot be determined from field data alone. Both the quality of the egg and the environment into which the chick is born, play major roles. Laboratory and field research must be coordinated in order to find out what those roles are.

Realizing this, the Investigation undertook a five-year study; from 1936 through 1940, to determine, as far as possible, how much the inherent qualities of the egg influenced the growth of the embryro and the viahility of the chick. In all. 398 wild ruffed grouse egrs from 44 clutches, collected near Ithaca, N. Y., and 189 newly hatched chicks were analyz. ed.

The study included the general development and structure of the eggs, their physicn.rhemical properties, annual changes in quality, development of the enbryn and embryonic membranes, and embryonic mortality. It also included the chemical composition of hatched chicks and its anmual changes.

To date, the Investigation has not carricd on extcnsive enough studies of the rest of the prob. lems to report findings. The influence, if any, of elimatic or solar changes on concentration of essential food ingredients, as minerals and vitamins in plants and even insects. the effects of food supply on egg development. how weather reacts on the quality of the egrgs, and the possibility that variations in egc conformation may retard growth of the entryo and help determine livability, are still problems for the future.

\section{Devflopdent of Grouse Eggs}

Grouse eggs in their development resemble in many respects those of other gallinareous birds. such as pheasant and quail. The inculation period is normally about 23.5 days. It is only a few hours shorter than that of pheasants and about one day longer than that of quail ${ }^{\text {sh }}$. From the weight of eggs and birds at hatching, it is also cvident that the growth rate of the grouse embryo is somewhere between the growth rates of pheasant and quail embryos ${ }^{310}$.

\section{Structure of tilf: Ege}

In structure the fresh grouse egg is, in general, similar to the eggs of other hirds. It consists of yolk, albumen. shell and blastoderm (figure 1). The stratification of yellow and white yolk corresponds to the day and night growth of the yolk in the ovary. The four layers of albumen, with two cord.like attachments at the opposite poles of the yolk. occupy nearly two-thirds of the entire egg. except for a small space at the large end known as the air-sac. The inner surface of the egg is lined with two parchment-like membranes. The blastoderm, appearing like a small whitish speck on the upper surface of the yolk. is the seat of the future embryo.

]'hysico-chenical Properties of the Egg

Table 8 gives the average total weight, shape. breaking strength. weight and thickness of 
eggshell, and the thickness of shell membrane. All these, including the total ash and calcium content of the eggshell, facilitate the functioning of the specific characteristic propertics of the eqg of this species and are called its values. They are noticeably different in many respects from those of the eggs of pheasant, quail and other domesticated birds ${ }^{320}$.

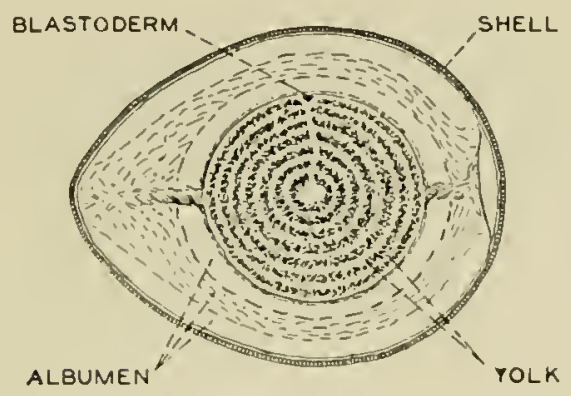

FRESH EGG

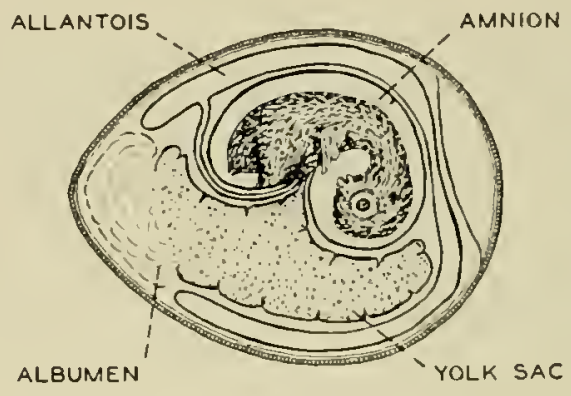

ELEVEN DAY EMBRYO

FIGURE 4. STRUCTURE OF THE FRESH AND OF THE DEVELOPING GROUSE EGG

On the other hand, some of these values, when corrected for the size of the egg. show striking similarities. The chemical composition of eggshell and possibly of egg contents, on a percentage basis, are much the same as in the eggs of other species, especially of pheasant and quail. The variation in relative values among individual egrs of the same species is frequently greater than the variation between the averages for different species.

There was little difference in physical properics and chemical composition between grouse eggs from birds in the wild and from those in confinement. The eggs of wild birds had somewhat stronger and thicker shells. with greater content of total ash and calcium. It would seem from this that artificial environment and possilly the lack of natural foods have modified the shell structure. There was a teudency for the cags of captive birds to become progressively smaller. more elongated. and to have thinner. lighter. and more easily broken shells. the later in the season they were laid.

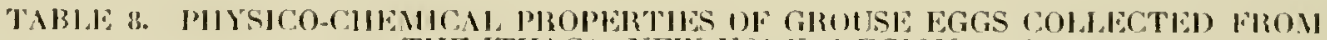
TIE ITIACA. NEW YOIK, REGION 1936-1910

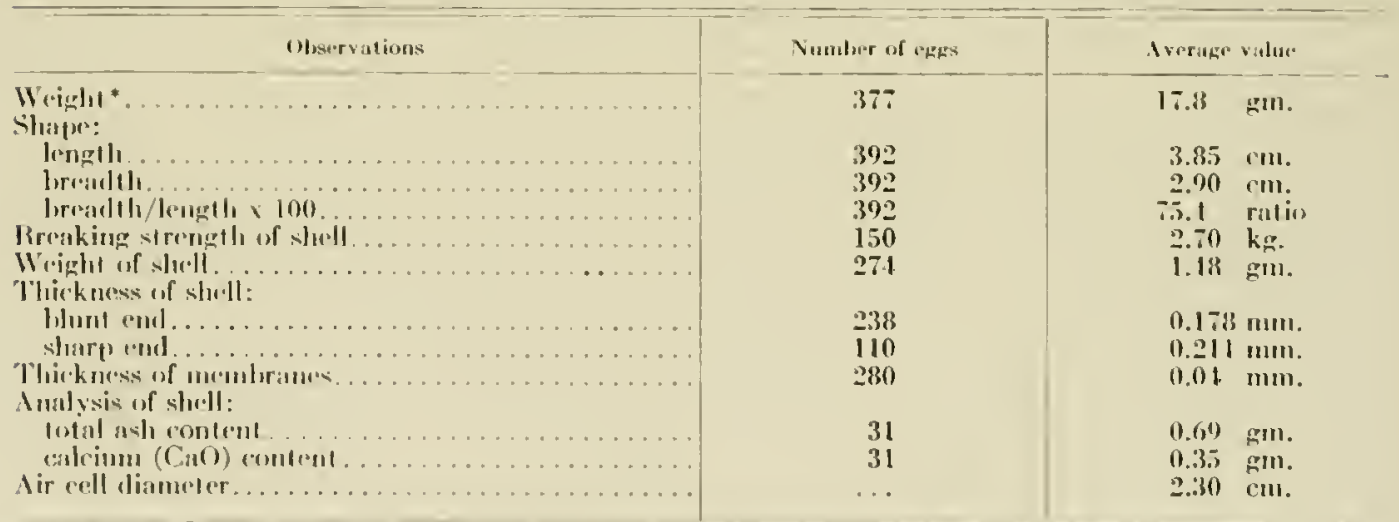

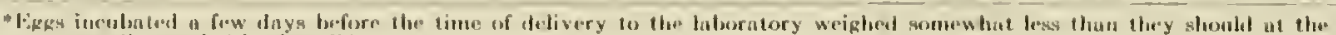
enerresponding porienl it the wild. 


\section{Annual Cifanges in Egg Quality}

So far, only the changes in various physical and chemical properties of the eggshell have been determined. Data for the composition of the egg contents are not sufficient to warrant reporting.

It was established that there are differences in shell quality, year by year and. during any one season, between clutches and even bctween eggs in a clutch. For example, figure 5 shows annual variations in egrshell thickness for the fivc-year period of the study. the yearly averages for each clutch and the different thickness of each eggshell. The average thickness during 1936 and 1940 was higher than for the intervening years. Yel earh year had some clutches with high and others with low averages. while indiviclual egrga varied greatly.

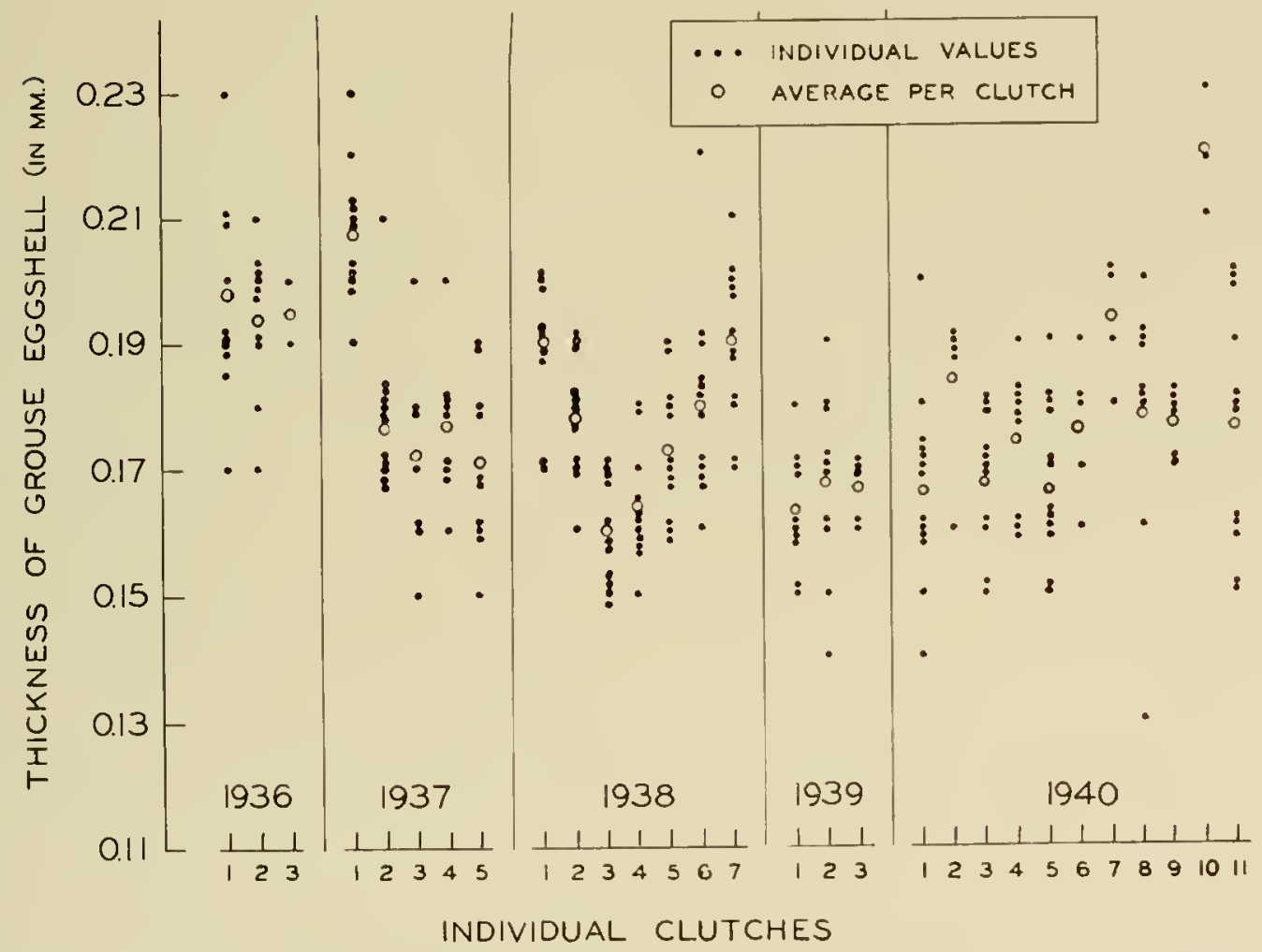

FIGURE 5. ANNAL CHANGES IN MIFLL THICKNESS OF GROLSE EGIS COLLETED FROM THE ITIICA, NEW IORK, REGHA-1936-1910

Since hatchability is consistently high, a change in eggshell thichness seems of little significance. However, future study of thickness and compusition of the shells of eggs which had hatched. as compared with those in the clutch which did not. mas give some new evidence as to how these qualities influence hatching. Thein effert on livability may also he determined by checking them against the subsequent mortalit of the chicks. Nore time and greater numbers than have heen availahle for this study are required to make the data conclusive. 


\section{DEVELOPMENT OF TIJ: EMBRYO}

The development of the grouse embryo is essentially identical with the development of that in other lirels ${ }^{31 \%}$, The structural complexity has a direct relationship to the environmental conditions under which birds' egrs develop. Provision is made in the structure of the exrof for the protection of the embryo, for its nutrition, respiration and excretion. To scrve these important functional activities of the embryo there are present scveral secondary embryonic structures termed "fetal memlianes." Among the most important of these are the yolk sac, allantois and amnion (figure 4). These organs appear early in the life of the em. bryo and persist until the time of hatching.

The yolk sac, consisting of the yolk mass itself, is a chief source of fond material for embryonic growth. Shortly hefore hatching, an unused portion of it slips through the navel into the body cavity and is absorbed during the first few days after hatching. The allantois ultimately underlies the entire shell and serves as the functional "lung" of the embron. The allantuic cavity serves as a reservoir for the excreta of the embryonic kidneys. The ammion surrounds the embryo and. hy its fluid. protects the embryo against all mechanical shorks and jars.

Study of the development of yolk sac and allantois-locause of the limited supply of eggs availahle-was too incomplete to show any changes associated with grouse abundance. It had been anticipated. in analogy with the other forms, that the allantois and yolk sac might. in some cases. he undeveloped. causing the general symptoms of ancmia of the embryo which may result from a deficiency of vitamin E. Ordinarily the ecrog yolk is the carrier of this vita. min. Similarly it was expected that a deficiency in vitamin D might he responsible for slow rolcification of the emlryo. Evidently this was not the case. as will he shown later from the analyses for calcium of newly hatched grouse.

\section{EMBRYONic MoRTALity}

The average embryonie mortality of all wild grouse eqgos. incubated at the Laboratory. var. ind from year to year. The highest was 32 per cent in 1937. The reasons for this are not known at present.

\section{Chevich Composithox of Vewh Hatchen Grol:s:}

The average values for the chemical composition of newly hat hed gromse in terms of dry weight. and total ash and calrium content. are shom in table 9. These values. in proportion

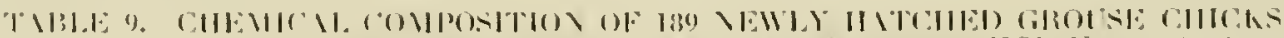

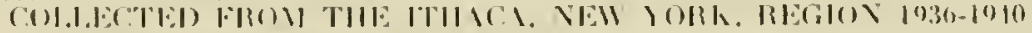

\begin{tabular}{|c|c|}
\hline (H)Wrations & 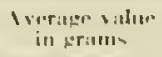 \\
\hline liso weizht. & 13.0 \\
\hline Wrighe wirhoul yolk. & 11.1 \\
\hline II right of yolk site with romlents & $1.5 \%$ \\
\hline I)ry wright. . . . . . , . . & 2.92 \\
\hline Tolal asli rontent . . . . . & 0.21 \\
\hline Cailrinm (Ca()) rontent & $0.0 \div 3$ \\
\hline
\end{tabular}

to the bul! weight. are comparable to those of wher yame birds. especially pheasants and prail. On the other hand. the propertion of mabsorherl yolk to the lond! weight at hateh. 
ing. while quite similar for the three species of game is, however. much smaller than in some domesticated birds. such as poultry. This means that grouse, after hatching, can survive only a relatively short time without food.

The chemical analysis of newly hatched grouse showed some annual changes during the five-year period. However. the occurrence of a few highly variable values frequently interfered with the analysis of these chemicals. For example, in most of the clutches the weight of a chick without the yolk was the lowest in the year 1937 (figure 6). but the arerage total weight was nearly the same as in the other years.

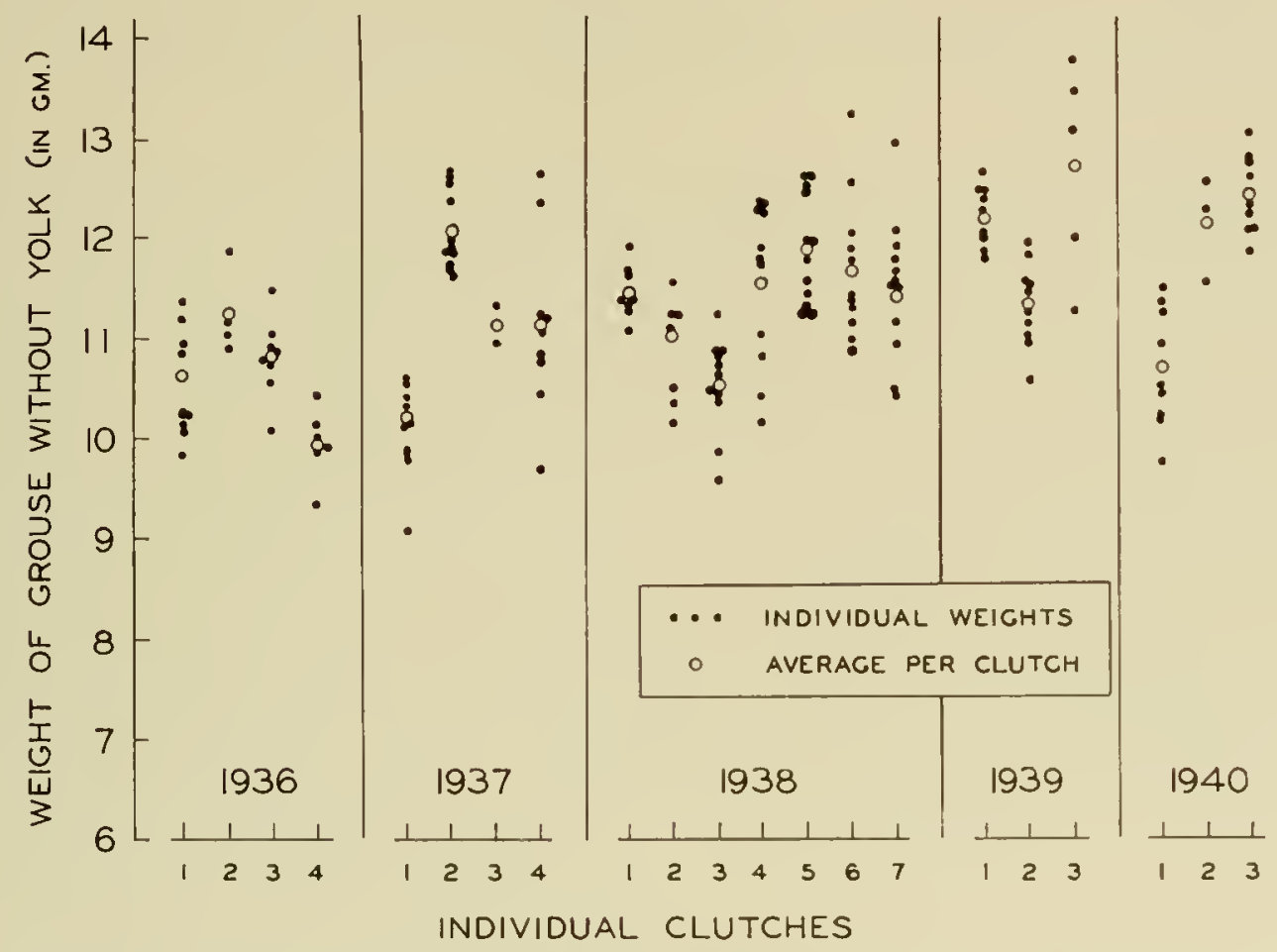

FIGURE 6. ANNUAL CHANGES IN THE WEIGHT. WITHOIT YOLK SAC. OF NEWLY HATCIEI GROUSE COLLECTEU FROM THE ITIIACA. NEW YORK. REGION- 1936-19.10

Besides these viriations, it is also possible that the selected measurentents were not signifi. ('ant. Nore delicate measurements of physical and chemical phenomena of cmbryonic development may. however, disclose greater annual differences in embryonic melabolic activity.

It is a question whether deviation in such activily could have been responsible for the lower viability and early death of certain embryos, and thereby he one of the causes of low grouse abuntance.

\section{GROWTH AND DEVELOP'MENT*}

The phenomenon of changing the protective coat coincident with growth of animals is accomplished in many interesting ways. Fishes, for instance, retain the covering in which they are horn but the scales increase in size and afford complete protection throughout life as

is By Earl R. Holm. 
may be noted from their anumal growth rings. In certain reptiles the complete shin is shed at intervals during the period of growth. Among birds, a series of regular feather monlts maintains the necessary protection to the body not only by compensating for growth hut also by: adeguately covering the surface to a greater or lesser degree in accordance with seasonal rhanges in temperature.

Apparently the primary function of feathering is protection. This coat is not only a temperature regulating device offselting the effects of the elements, lut also affords protection from natural enemies. Prohably everyone who has liunted grouse has had the experience of picking up a bird, only to have it make its escape leaving but a handful of feathers. The shedding of featluers in this way seems to be controlled by soluntary muscular action and is undoubtedly utilized in escaping from predators. The replacement of feathers lost in this way or by other accidents probably explains many of the variations in the normal pattern of the moult.

Much has already been written on the moult aud sequence of plumage among birds. Dwight ${ }^{\text {too }}$ was one of the first to disuel many of the old theories which persisted even into the present century. His studies of the passerines as well as certain of the gallinaceous species represented a major advance in our knowledge of this subject. Considerable work, too, has been done on domestic fowl. Warren and Gordon ${ }^{\text {ano }}$ carefully noted the number of days required for the replacement of the flight feathers in certain breeds of poultry. Other studies were conducted by Radi and $\mathbb{W}^{\mathrm{arren}}{ }^{311}$ and by Marble ${ }^{243}$. ${ }^{2+3}$ specifically to determine the relation. ship between feathering and growth as well as egg production. More reently Host ${ }^{\text {mon }}$, working with a close relative of our native grouse, found light to be the main factor controlling the develupment of spring and summer plumages in ptamigan. Many other researcher: have done equally important work on other phases of the subject. In view of the foregoing, the emphasis in this discussion is placed on the sequence of the moult in the ruffed gronse as an aid in age identifieation*.

Students as well as research agencies working with immature gallinaceous game hirds have often been at a loss 10 estimate even approximately the age of specimens with which they were dealing. Sportsmen, too, wonld like to be able to differentiate between birds of the year and mature specimens a full year old or older. Such knowledge ofttines might be quite convenient for when the game is divided at the end of the day one could generously give the older heavie lirds to his companion and retain the younger more tender ones for himself. Farh would be well satisfied since both would feel sure that they bested in the deal. By studying the frather patterns and sequence of the monlt. particularly in the flight feathers, it appears that age can be determined within relatively narrow limits when dealing with average birds.

Since the feather patterns are discussed in detail in the Appendix under the Pterylography of the Ruffed Grouse, it will suffice to say here that the arrangement of the feathers as well as their replacement during the nuoult follows an orderly and regular sequence. This is con. trary to the once popular cunception that the fealluers are shed like the leaves from a tree and replacerl all at once like luds bursting in the spring.

\section{Shotence of Mohlt and Featuer Succession}

The sequence of the moult may be divided into linee creneral phmage classifications. natal. jurenile and adult. It should be horme in mimb. however, that there is no definite line of

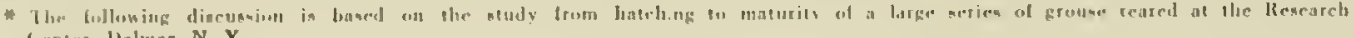
r.nenter, Itrlenar, N. Y.
} 
demarkation between one and the other since the moult is in constant progress until the bird reaches maturity. Even while the chick is in its natal down* the flight feathers or remiges are developing. In like manner when the juvenile plumage covers most of the body, the natal down is still present in certain feather tracts while the mature plumage is developing in others. In certain instances the natal down is replaced directly by feathers identical in pattern and structure to those of the mature plumage. Thus the intermediate juvenile feather does not occur in this sequence.

\section{Natal Plumage}

At the time of hatching, the body of the grouse chick is almost completely covered with feathers that are popularly called down.* All of the spaces, i.e., areas between the regular featloc tracts, are bare although they are obseured by the fluffy down. The most conspic-

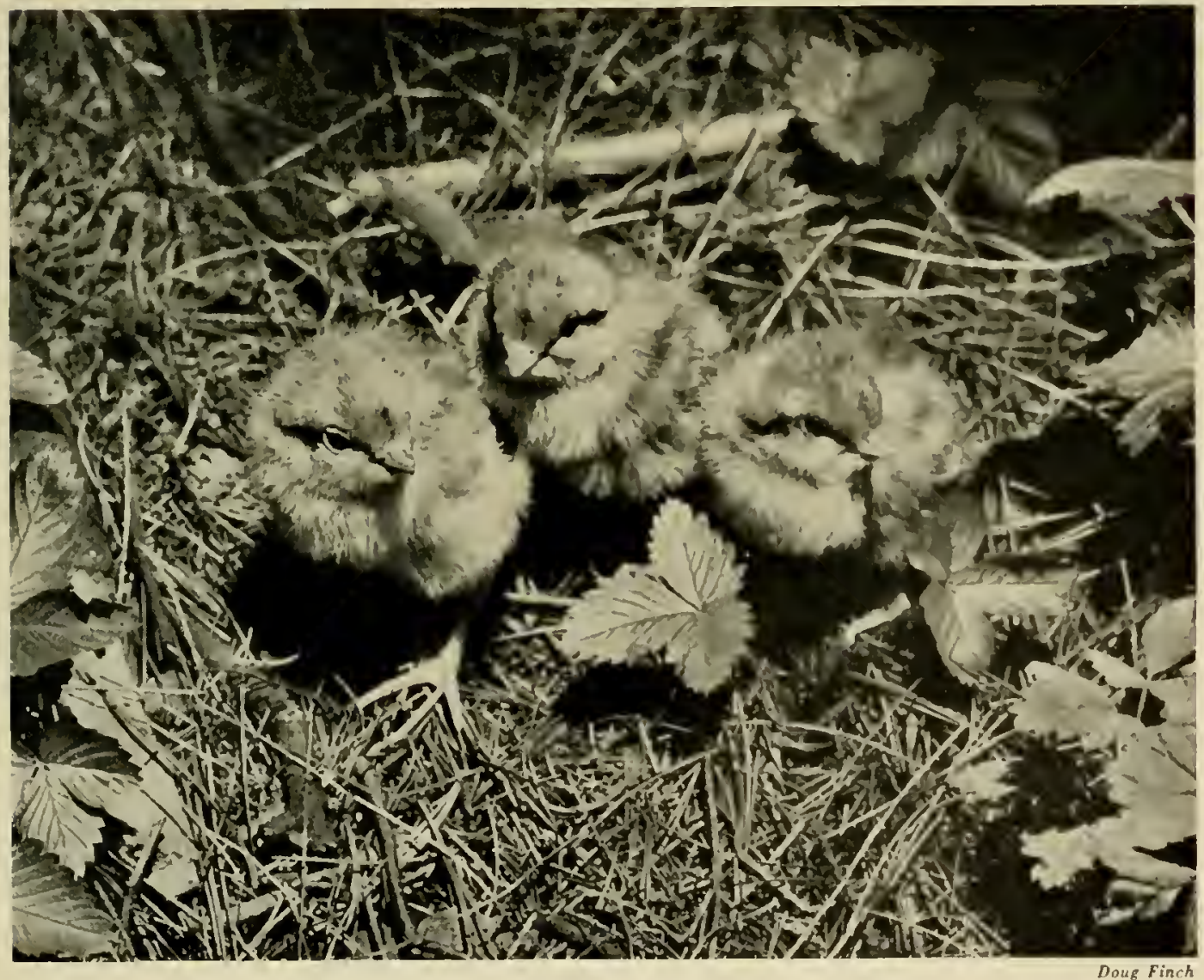

THREE GROUSE CHICKS SIX IIOURS AFTER HATCIING

uous of these are the arcas over the lungs (which are directly bencath the folded wings). the web of the wings and also the sides of the abdomen. The down as well as some of the flight feathers begins its dcvelopment during the carly slages of ineuhation of the egg and growth apparently is uninterrupted by hatching. 
After the chick has dried off and takes its first furtive peek at the world from under the wing of the mother, seven primaries may be counted. The longest of these usually has approximately one-lalf inch exposed and a few will have about one-eighth inch of the feather (ip protruding from the sheath. None of the other three which make up the complement are visible. While the average number of secondaries is 15 , only nine are visible in the day. old chick. Mlost of these have the downy tuft appended. The tail is represented by fuzz in the form of longer drooping feathers.

\section{Juvenile Plumage}

The juvenile feathers begin to appear immediately after hatching led by two or three scapulars which may be noted at four days of age. The flight feathers which are present at hatch. ing, however, are functionally juvenile.

When it occurs, the intermediate plumage represents a transition stage wherein the size and number of the feathers are adapted to and conform with the progressive increase in size of the bird. The feather which replaces the down develops in the same folliele and as it emerges the latter is forced alsead of it. The downy tuft remains appended to the tip of the sheath of the new feather. Unless it is broken off it remains attached until the sheath opens exposing the tip of the developing feather. Thus the down with its elongated shaft and the new juvenile supplement each other to afford the necessary protective covering for the body.

$\mathrm{I}$ is evident, from studying feather succession, that the replacement follows a definite pattern designed to afford the chick the greatest protection compatible with its habits at a given age. Hence, the lungs, which are probably the most vulnerable organs of the young chick, are protected by the flight feathers, wings and rapid development of the scapulars (figure 7 ). The latter merge with the back feathers and close over the back of the bird at about three weeks of age. This coincides with the time it is being weaned from brooding by the mother. Coincident with this growth, the feathers on the sides appear although these are obscured in the early stages by the dense down. It is apparent that when the chick snuggles into the breast feath. ers of the mother for warmilh, the naked area over the lungs may he exposed to the maximum heat from her body.

While there are certain exceptions, the pattern of succession in general is such that the first feathers which appear cover and protect the base of those subsequently developing. In line with this, the emergence of the scapulars progresses toward the rear from a point oppusite the bend of the folded wing. These feathers also develop laterally to merge with those of the lack at the hase of the nape. Those of the sicles develop from front to rear and downward to cover the bases of the flank and upper belly feathers respectivaly. The feathers in the upper rump region appear first, followed by those toward the rear which cover the tail coverts. Similarly the tail coverts attain sufficiont length to cover the base of the tail hefore the pin feathers in the latter apjear. The flank feathers come in before those of the thigh, while the appearance of the latter commences at the upper end of the leg. progressing downward along the tibia and tarsus. These are feathered on the rear and front and finally hecome closed in at the sides. On the lielly, the succession has a tendency to spread in all directions. A hird at three weeks of age has a triangle of down extending backward from the forward point of the keel, with its apex alout midway to the pelvis. This triangle is lounded laterally by a fringe of juveniles. At the forward part of the belly this fringe consiats of only one feather on each sicle. Following (o) the rear on each side a pair apprar. then three rows and finally fonr rows where the two sides join at the midpoint on the keel. Fight rows of feathers extend from here to the rear point of the keel. In the belly area the 
feathering progresses up toward the sides and flanks and down toward the median line of the keel. Feathering on the breast begins at the upper forward parts and progresses downward toward the belly. On the neck it progresses from the crown toward the back and from the chin to the breast, the front centerline of the throat being the last to close in. The wing coverts are fully developed in advance of the flight and the body feathers. the upper corerts being completed before the lower.

The head region is the last to be completed. While two or three pinfeathers may be observed in the crown at two weeks of age, down remains in the auricular region and chin until the bird has completed the change to the juvenal plumage over the rest of the body. The first to appear on the head are the elongated crest feathers. The succession progresses frum front to back on top of the crown then down loward the eye. The forehead and upper auricular region are filled in simultaneously with all feathers appearing at about the same time.

As a general rule, it may be said that the succession of feathering progresses in the direction in which the feathers lie. It is well to remember, however, that development begins almost simultaneously in each of the topographical regions as outlined in the foregoing. By the time the chick is two weeks of age, pinfeathers of the juvenal plumage appear in all of these regions.

The replacement of jusenile by adult plumage as well as the annal renewal of feathers in mature birds is followed in the same relative order. While there may loe some variation among the individual birds, it follows in general the pattern and succession as that from natal to juvenile.

\section{Adult Plumage}

This is the plumage attained ly the mature birds in the fall. If a line or division can be drawn between the cul of the juvenile and the heginning of the adult plumage. it might well be established at seven weeks of age, for by this time the tail has attained it growth and the feathering on the head is complete. While down is still present in certain regions notably on the upper thigh, lower sides of the rump, forward of the scapulars and portions of the upper breast, mature plumage is in evidence over most of the body. At this age many pinfeathers can be seen protruding from the skin with the juvenile feathers appended to the tip of the sheath. These pinfeathers may be recognized as the adult plumage by their pigmentation; some being white, others nfous or gray. It was noted that the juveniles remained appended in the same manner as the natal down was appended to then. This was observed in all regions except in the flight feathers and the tail.

The adult plumage, however, does not approach completion until the bird attains the age of 18 to 20 weeks, although this is subject to some variation. At the Research Center most of the birds had acquired their mature plumage by October first.

But even in the fall the plumage cannot be considered as fully complete since new feathers continue to grow as the season progresses. and probably do so well into mid-winter. As the temperature decreases during the winter months it may be noted that the feathers are much tighter and more closely interlocked than during the fall. At this time all of the spaces are concealed by a thick mat of feathers.

By the time spring arrives a slight change in coloration is evident. particularly in the head region, due not to moutt but to feather wear. As the season advances. however, certain feathers are moulted about the body. It may be noted that such feathers are dropped from areas adjacent to the spaces and a slight thinning of feathers occurs all over the body in general. It 


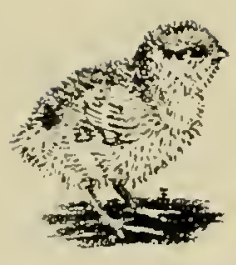

$1 d a y$

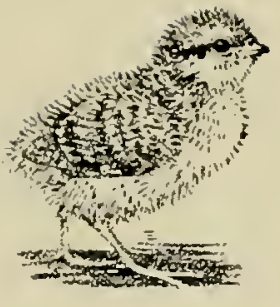

1 week

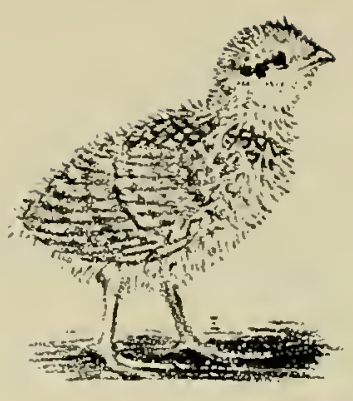

2 ueetis
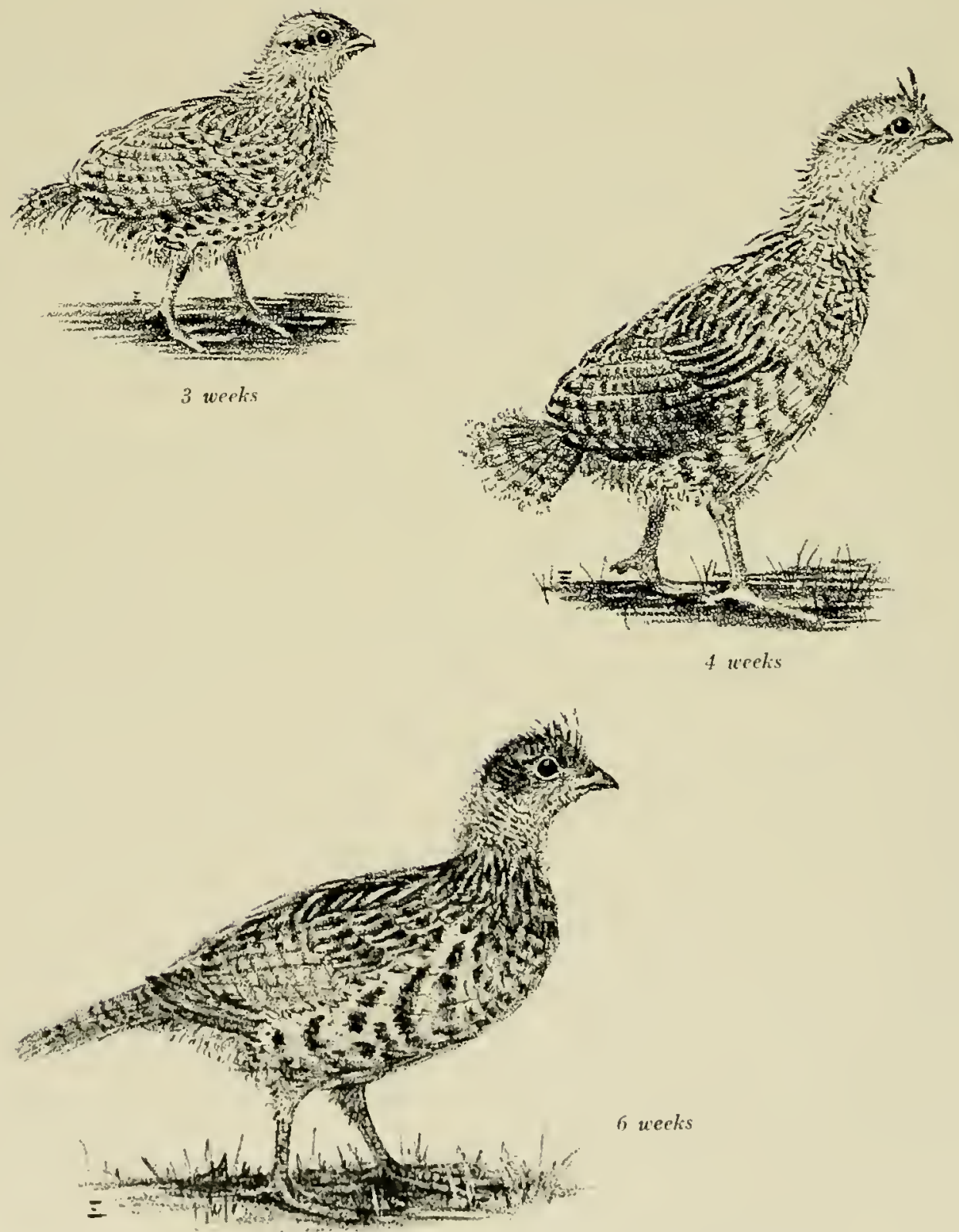

FIGLRF, 7. CROLSF, DELELOPVEXT FROM HATCHIN, TO MULTHOOH 
appears that this is the only period during the course of the year when an actual moult occurs which is not followed immediately by feather replacenont. Dwight"' refers to this as the post-nuptial moult.

Most feathers which drop at this time are not renewed until fall. It seems logical to assume that such sloughing of feathers adjacent to the spaces serves to assist in regulating lody temperature, since grouse as well as other birds lack the ability to perspire. Penned hirds are commonly obsersed during the warm summer month panting much like a dog. with wings and body feathers distented. making it pussible for air to circulate more freely over the body.

The reverse may be equally true during the winter months, whon the feathers alout these areas are more alundant and are held more tightly together to insulate the body and conserve heat.

\section{Age ldentification Based on Feather Denelopanent}

Many are the times researchers and sprortsmen alike have desired to know within reasonable limits the age of young hirds collected or found dead in the field. Oftlimes. too. the question arises whether the hird is one hatched during the present year or is over a year old.

Regarding the latter, there are (wo well known methods of determining whether a specimen is a bird of the year or older. The first of these. which requires dissection. is hased on the presence or absence of the bursa Fabricii* and therefore is outside of the province of this study. The other and more readily available method (although less positive) is based on examination of the first wo primaries or flight feathers.

As will be shown later, these two feathers develop in the form of juveniles and are not moulted until the year following hatching. The other primaries in the adult phumage luave rounded tips while the tips of the two mentioned are pointed. conforming in character to the other juvenile remiges previously moulted.
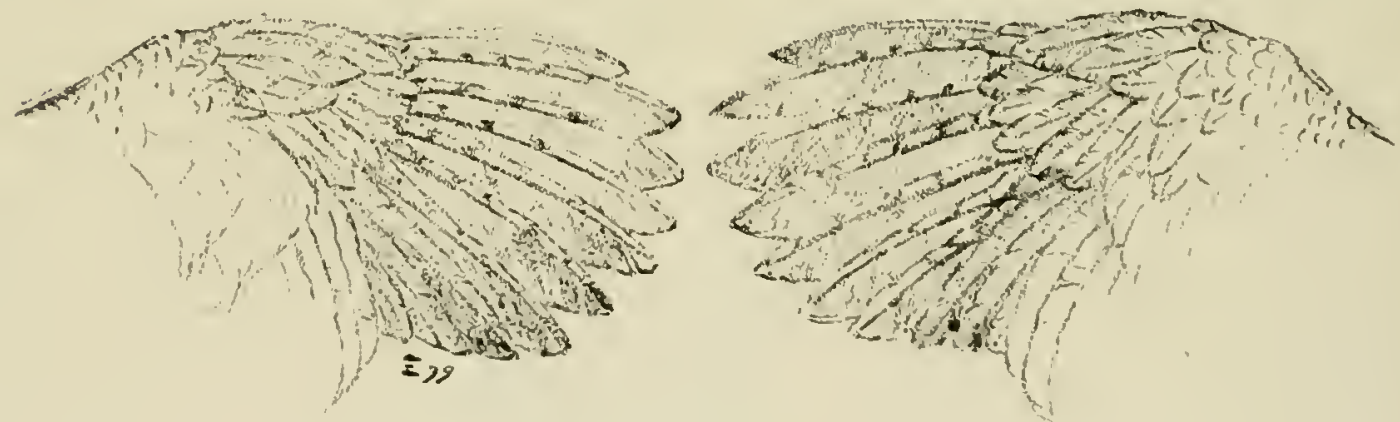

With respect to the relationship of phunare development to the ane of the ehick durine the brond period, an attempt has been made to deserihe the prineipal features to le lowked for carh wrek from hatehing until the hird nil! be considered adult. Figures 8 and 9 correspond to the aqe intervals recognized and show graphically the development of the flimht feather which. owing to their regularity of rephacencent. furnish the mos conventent index for this purpose. 
It may be seen that at hatching only seven primaries and nine secondaries are present, although the full complement comprises 10 and 15 respectively. For the purpose of this discussion the primaries are numbered with the first at the outermost portion of the wing and the tenth closest the body. Among the secondaries. the short axial feather adjacent to the tenth primary is designated as 1 and the others numbered consecutively toward the body. This order of mumbering is most generally followerl in ornithological literature although a different system is frequently followed in discussions lealing with domestic fowl. Among the primaries, development progresses in a regular order from number 10 toward number 1. while among the secondaries the pattern is not as regular. The succession here seems to rum in the following order: from 3 to 15 consecutively with number 2 appearing simultaneously with number 5 and 1 appearing simultaneously with number 6 .

\section{One Week}

By the end of the first week considerable growth may loe ohserved in the flight feathers. In addition to the seven visible at the time of hatching. numbers 1 and 2 are usually just protruding from the skin. The longest primary of the folded wing extends lack to the tail fuzz. In addition, three or four scapulars are present on eath side where the wing joins lhe body.

\section{Two Weeks}

By this time growth of the junnile primaries number 10,9. and 8 has heen completed as evidenced by the alsence of blood in the hase of the quill where it enters the skin*. The first primary is slightly longer than the overlying greater cosert. The axial ur number 1 secondary is half grown. While numbers 2 to 11 are from two-thirds to onespuarter developed and number 12 is in the pin stacer.

Ten or more scapulars are now apparent on each shunlder and feathers are visible on the sides. Pinfeathers with the downy tufts of the natil plumage still appended are present in the region of the lower naje. lack. rump. tail. belly, and flank. Two or three pinfeathers. which later develop into the crest. may be discemed on the crown. The lower wing curret: are still obsecured by duwn.

\section{Three $\mathbb{T}$ eeiks}

The juvenile primaries number 10 and 9 have already dropped out and are heing replaced by adult feathers. The tip of number $10 \mathrm{is}$ expused and slightly longer than the base of the quill. Number 9 either may be missing or the tip harely showing through the skin. Of the juvenile flight feathers still present. growth is complete in primaries number 8,7 and 6 , as is also true of secondaries number 3 and 4 .

The greater wing coverts are fully developed and the upper surface of the wing is well corered except in the area of the wel. This latter region is sparsely covered with down with no pin feathers in evidence. The edge of the web. however. is covered with three rows of feathers. growth in the first row being complete.

The upper part of the head is completely covered wilh pinfeathers from the base of the mandible back to the nape. That portion helow the eves and under the chin is still in down. Juwenile feathers have appeared on the hack of the neck merging with the scapulars. The complete bridge of feathers across the hack has been acquired at this age. The feathers on the sides have attained sufficient length to cover a portion of the belly. This latter re- 

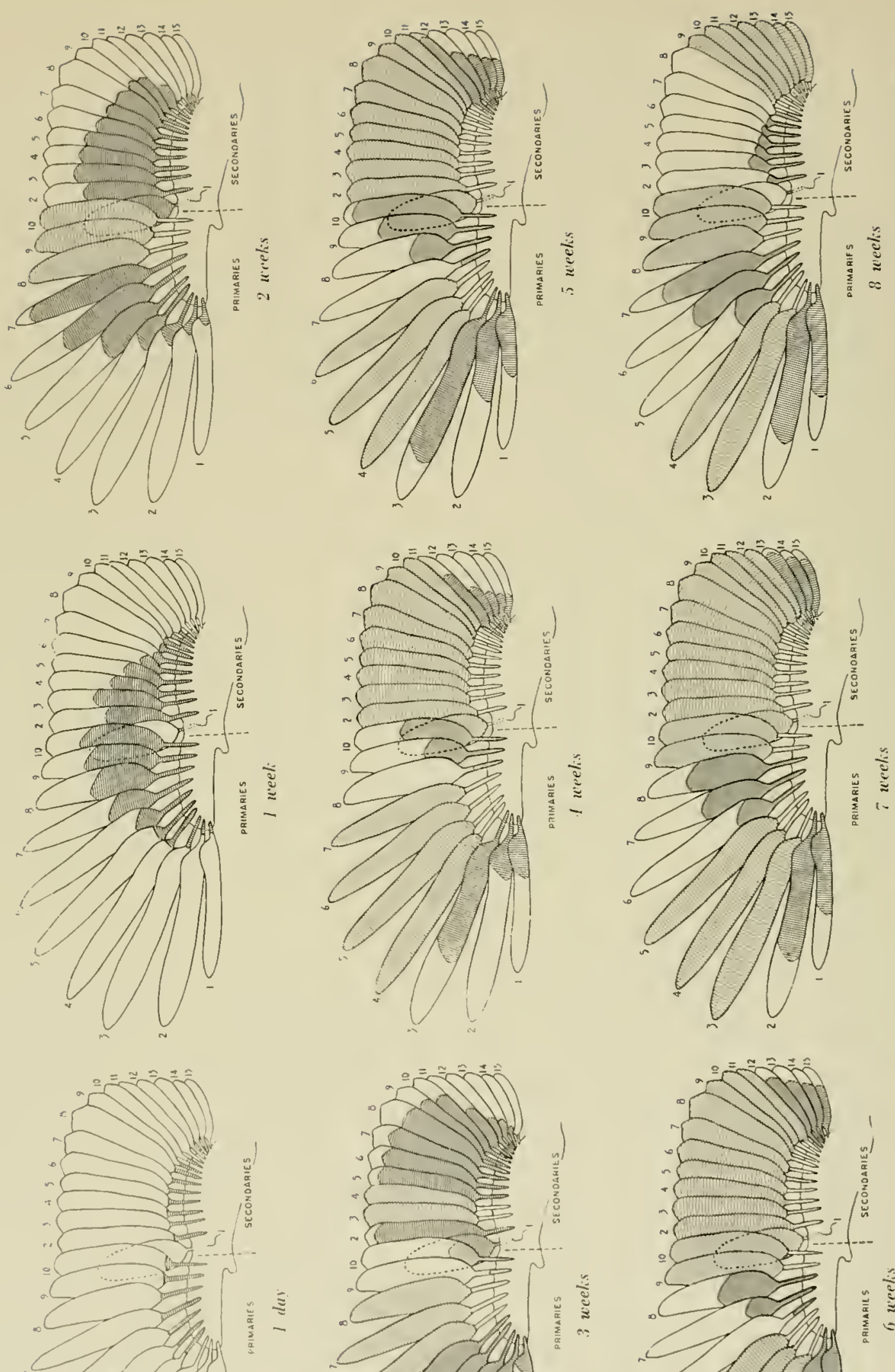

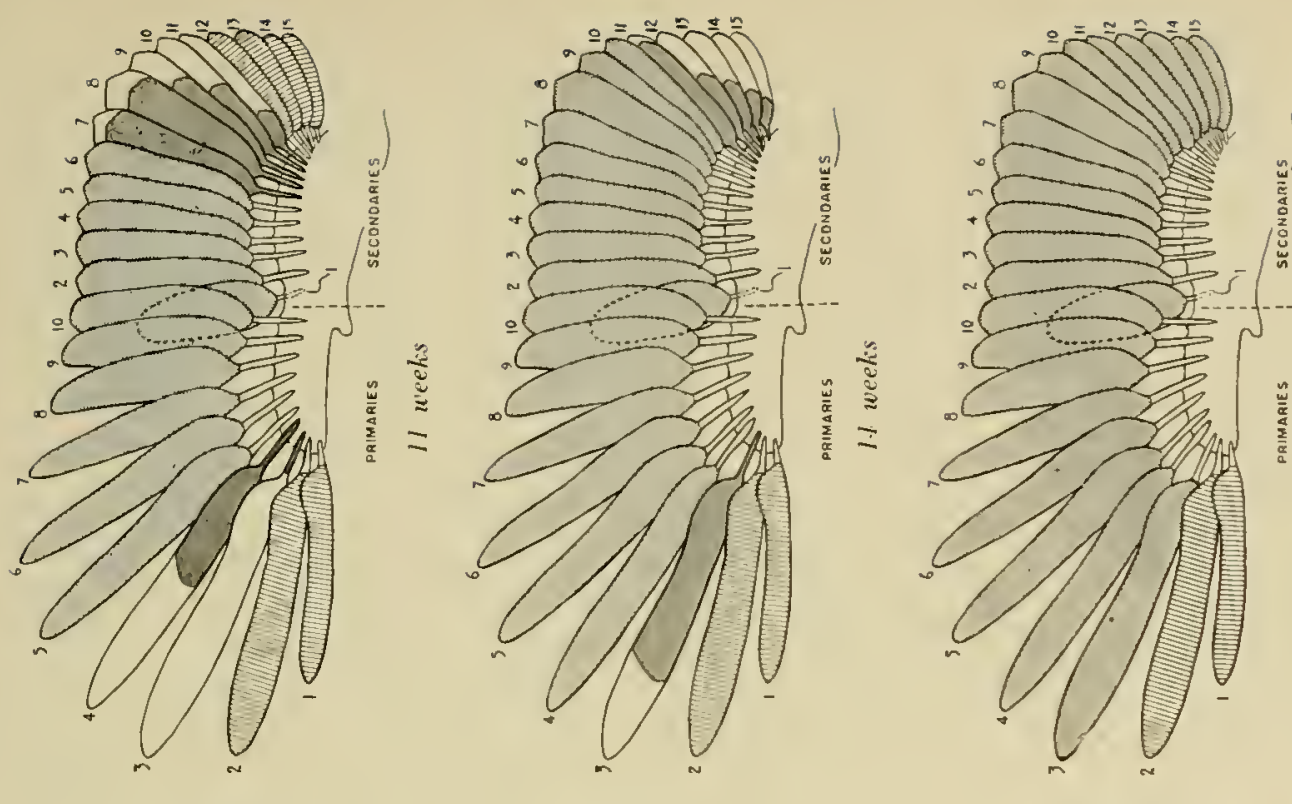

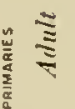
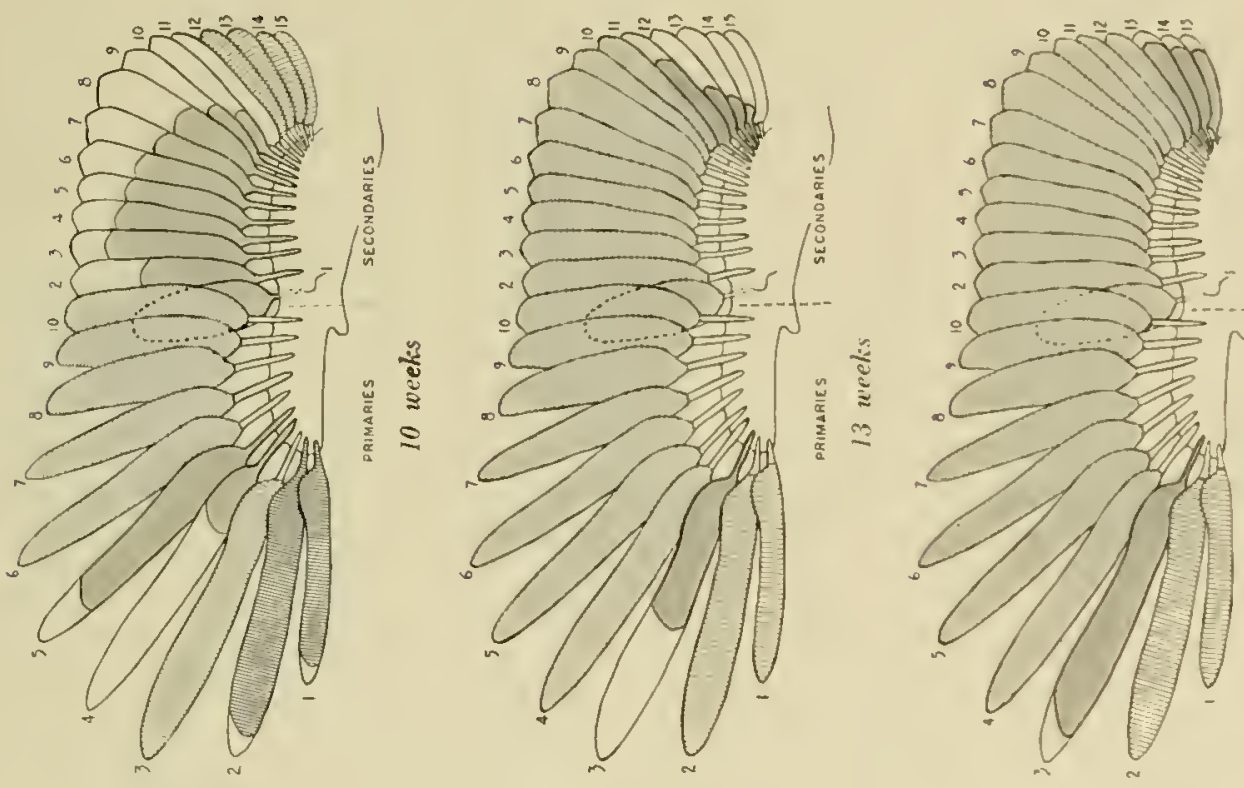

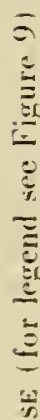

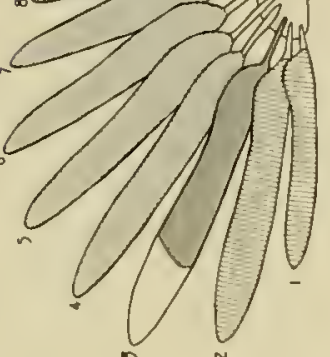

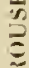

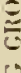

3

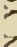

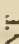

产
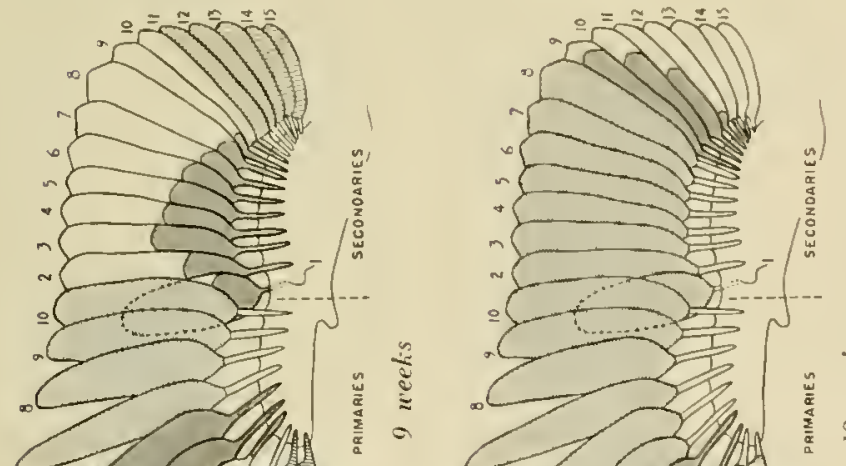

I
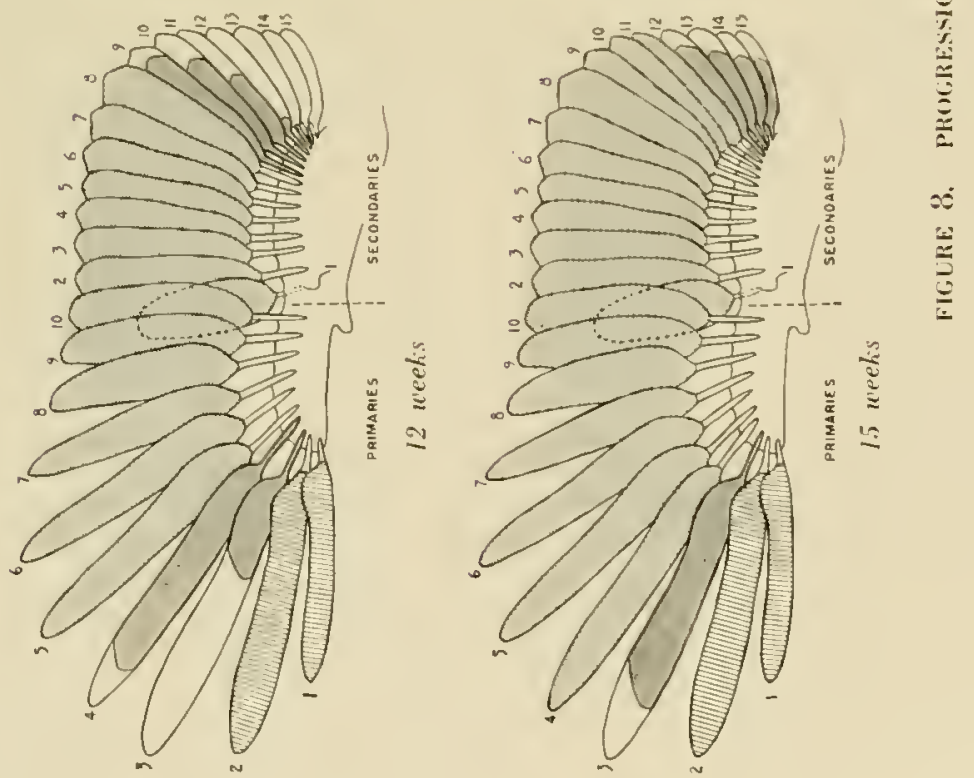
gion is still mosly obseured by down and no pinfeathers appear on the median line of the kcel. Pinfeathers with downy lufts attached cover the back and rump from the neck to the oil gland. These feathers have attained sufficient growth so that they are partially visible through the downy fuzz. On the rump the lips of a few feathers are showing beyond their sheaths. While the outer tail feathers are still in the pin stage. the central ones have emerged from their sheathes.

Four Weeks

At this age adult primary number 10 is about half grown, number 9 is about one-third developed and number 8 is in the pin stage. Growth is complete in juveniles $7,6.5$ and 4. Among the secondaries the axial as well as numbers 2 to 10 inclusive are fully developed while number 15 is well out of its sheath.

The body of the hird in general appears well feathered in juvenile plumage. The side of the head still appears downy. The pinfeathers on the chin also are obscured by down. The juvenile feathers on the sides of the neck cover the downy area of the front median line of the lisroat. The same is true of the feathers which cover the downy median line of the belly. Numerous feathers are noted on the legs with those on the upper tarsus having downy tufts appended.

\section{Five $W$ eeks}

During the fifth week. although none complete their development, growth progresses rapid. ly among the adult primary feathers numbered 10.9 and 8 . Number 10 is now approxi. mately the same length as the number 2 juvenile secondary. Juvenile primary number $T_{\text {: }}$ how. ever. has been dropped and the tip of the adult feather is exposed.

The hird now has a sleek appearance. having lost the fuzziness due to the many appendant downy tufts which were prevalent during previous stages of development. Growth is complete in many of the body feathers. The tail, however. is still growing.

\section{Six Weeks}

Anong the flight feathers adult primaries number 10 and 9 have completed their growth and number 6 has appeared as a pinfeather. Juvniles 5. I ant 3 have also become completely developed. Among the juvenile secondaries. number 11 has completed its growth. It should be noted particularly that two of the adult primaries have completed their develop. ment before the juvenile primaries numbered 1 and 2 are half grown.

The juvenile tail has completed its growth.

\section{Seren IFecks}

Though the flight feathers eontinue their regular growth. the only significant change in feather replacement is the jusenile secondary number 12 which has completed its growth by the end of the seventh week. Over the body in general the juvenile plumage is now complete. with most of the feathers very lonesly held in the follicles and released readily when the bird is handled.

Fvidence of the adult body plumage hegins to appear in the furm of pinfeathers according to the regular succession outlined in the discussion of juvenile plumage. Some spaces and areas adjacent to them are still comparatively bare with down remaining in most cases. 


\section{Eight Weeks}

Among the adult primaries in addition to number 10 and 9.8 is now fully developed. Numbers 7. 6 and 5 continue their growth. Growth is complete in jurenile secondaries from number 9 to 15 and the adult feathers from number 1 to 8 are developing. numbers 1 and 8 being still in the pin stage.

The back and rump are completely covered with pinfeathers of the adult plumage. In practically all cases the juvenile feathers are appended to the tips of the shealhs. This arrangement causes the old juvenile feathers to be lengthened and thereby protects the new feathers coming in under them.

The natal down which is still present in areas previously described is being forced out ly adult pinfeathers. In these cases the intermediate or jusenile plumage is onitted. The downy tuft is appended to the tip of the adult pinfeather.

\section{Nine Wreeks}

Juvenile primary number 4 has been dropped and is heing replaced ly the adult primary. In like manner numbers 9 and 10 in the juvenile secondaries have heen dropped and are heing replaced by adult feathers.

The adult body plumage continues its growlh at approximately the same rate as the juvenile developed previonsly. The general pattern followed relosely parallet the succession of feathering from the thind to the eighth week.

\section{Ten Weeks}

Growth of the adult flight feathers continues with only the number 11 jusenile second. ary being replaced by the adult fealher. The growth of the number 6 adult primary has been completed. Numbers 1 and 2 primaries have nearly completed their development.

Juvenile tail feathers drop out between the ninth and tenth week and are replaced almost immediately by pinfeathers of the adult plumage.

\section{Eleven ITecks}

From the tenth week to maturity, there is little of significane in the pattern of feathering to identify age other than the flight feathers. Therefore, only the derchpment of the latter is discusscel. The growth of the adult flight feallers is complete in mumbers 10 to 5 in the primaries and numbers 1 to 6 in the serondaries. Coincident with this. the deselopment is completed in primaries numbers 1 and 2 which, as pointed out previously. are the first feathers to appear subsequent to hatehing. The juvenile number 3 primary is dropped and is being replaced by the adult feather.

\section{Tuelve Weeks}

All adult primaries have completed their growh except numbers 3 and 4. while the aduh secondaries from numbers 9 to 15 are developing.

\section{Thirteen W'}

Growth is completed in the fourth adult primary and the tenth adult secondary in addition to those mentioned under the previous week. 


\section{Fourteen to Seventeen IT eeks}

The growth of the adult flight feathers during this period is completed at the following intervals: number 11 sccondary - 14 to 15 weeks; number 12 secondary-16 weeks; num. ber 3 primary-17 weeks. The number 13 secondary has also completed its growth by the seventeenth week and this is followed within one or two days by completion of the numbers 14 and 15 secondaries.

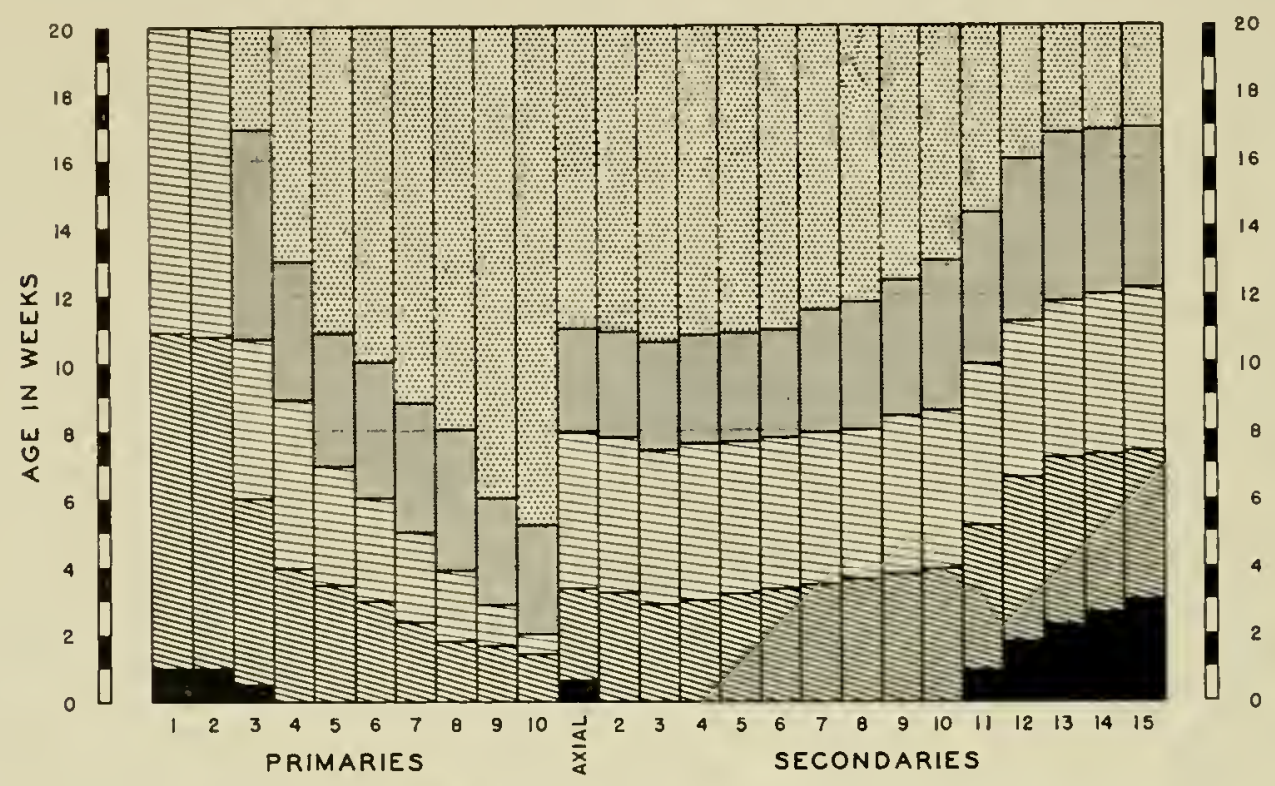

Feather not yet visible
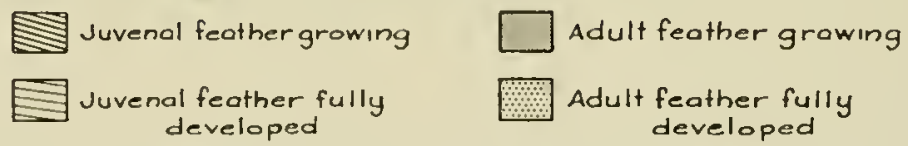

FGIRE, 9. RELATIE DEVELOPWNT IT WEEKLY INTERVALS OF WIX, FEATHERS OF IOLNC; GROLSE.

Beyond this point no important rhanges in the adult plumage alke place until the follow. ing spring. As has heen deseribed. however, hirds of the year ma! be distinguished from older individuals ly the presence of the bursa Faluricii and the character of the first two primaries.

\section{WEIGHT *}

Grouse weights are interenting as a species characteristic and important as one of the major vardsticks ly which the health of the individual birds may le judged. Factors af. fectinc weight run the gamut from envirommental influences. such as shelter. food and weather. to those of a pathological or physological rature. Aetivities requiring the expendiure of umusual amomis of encrgy. notahly courtship and ege laying. as well as physiological elanges associaled with age differenem and monlting. are important eatses of weight loss. Also. re. 
stricted feeding opportunity, attendant upon limited movenent during periods of incubation and brooding, may serve to further reduce weight in grouse. Sex, too, introduces an important differentiation.

Interpretation of the effect of each of these influences is dependent upon the availability of records extensive enough to enable analysis on a seasonal and yearly basis for each region to be studied. Attention must also be given to a number of small but important items which are often overlooked, such as the interval elapsing between collecting and weighing the bird, and the conditions under which it has been kept during this period. It is even pertinent to point out that the accuracy of the scales used should be checked. In lable 10, normal variations in the weight of New York grouse, birds heavily parasitized or evidently diseased have heen excluded, as have those which died from other causes of an abnormal nature.

TABLE 10. AVERARE WONTILY WEIGHTS OF 391 ADUIT AND 108 YOUNG GROUSE COLLECTED IN NEW IORK STATE-1931-1911

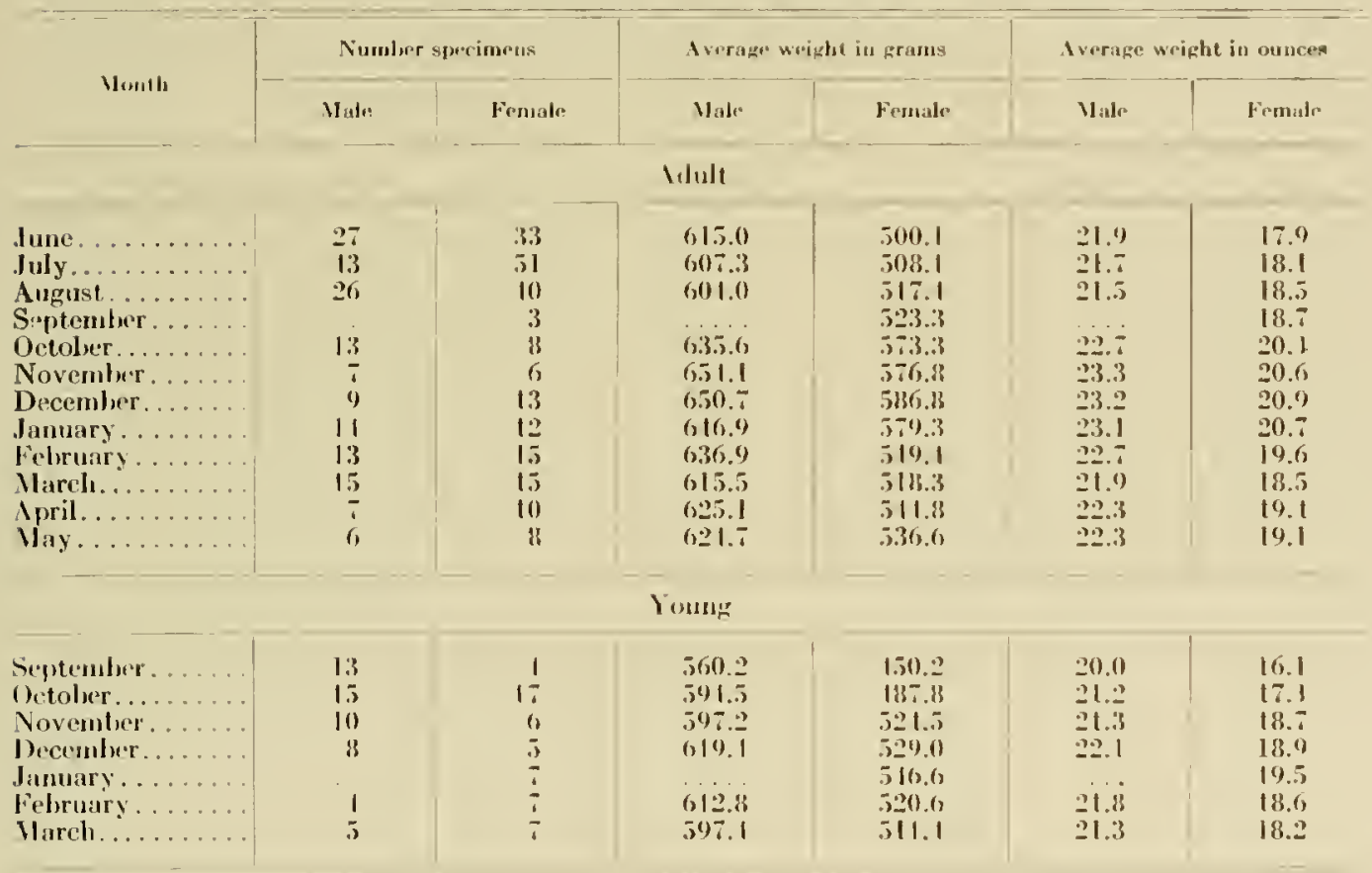

\section{SEASONAL 'TREND}

An analysis of weight trends and differentiations as here illustrated (figure 10) raises many an interesting question of influence and relationship. In distinct contrast with the Scoteh grouse of Great Britain, ruffed grouse of all ages and sexes in general seem to follow much the same trend at approximately the same time. They reach their highest weight of the year in November or December following a period of fall plenty. The average weight of New York grouse at this season is about $1 \mathrm{ll}$. $7 \mathrm{oz}$. (65l grams) for adult males and $1 \mathrm{lb} .5 \mathrm{oz}$. (587 grams) for adult females. With the onset of real winter. certainly by the middle of January in New York, a loss in weight sets in, gradual at first but more rapid as the winter progresses. This culminates about the middle of March with an average loss of from $1^{1} \frac{1}{4}$ to $21 \%$ oz. (35 to 69 grams). 
Over the mext month. the birds regain some $3 / 10 \%$ 19 to 27 grams) of the weight they have lost. I'ussibly the melting snows ly then have uncosered foods of greater mutritive value or. perhaps with spring"s warmer weather. the energ! ontgo is less than that provided ly the food taken in. At all events. the increase is short-lived for, through the aetive days of May and June, more weight is lost. The low point of the year. for females, is about June 15. for males about August 15. When they average about 1 lb. 2 oz. (500 grams) and $1 \mathrm{lb} .6 \mathrm{oz} .1604$ grams) respectively. The demanding responsibilities of courtship, of starting a family, and of moulting ahout over. their weight rises. slowly at first, then more rapidly throughout the early fall to its November peak.

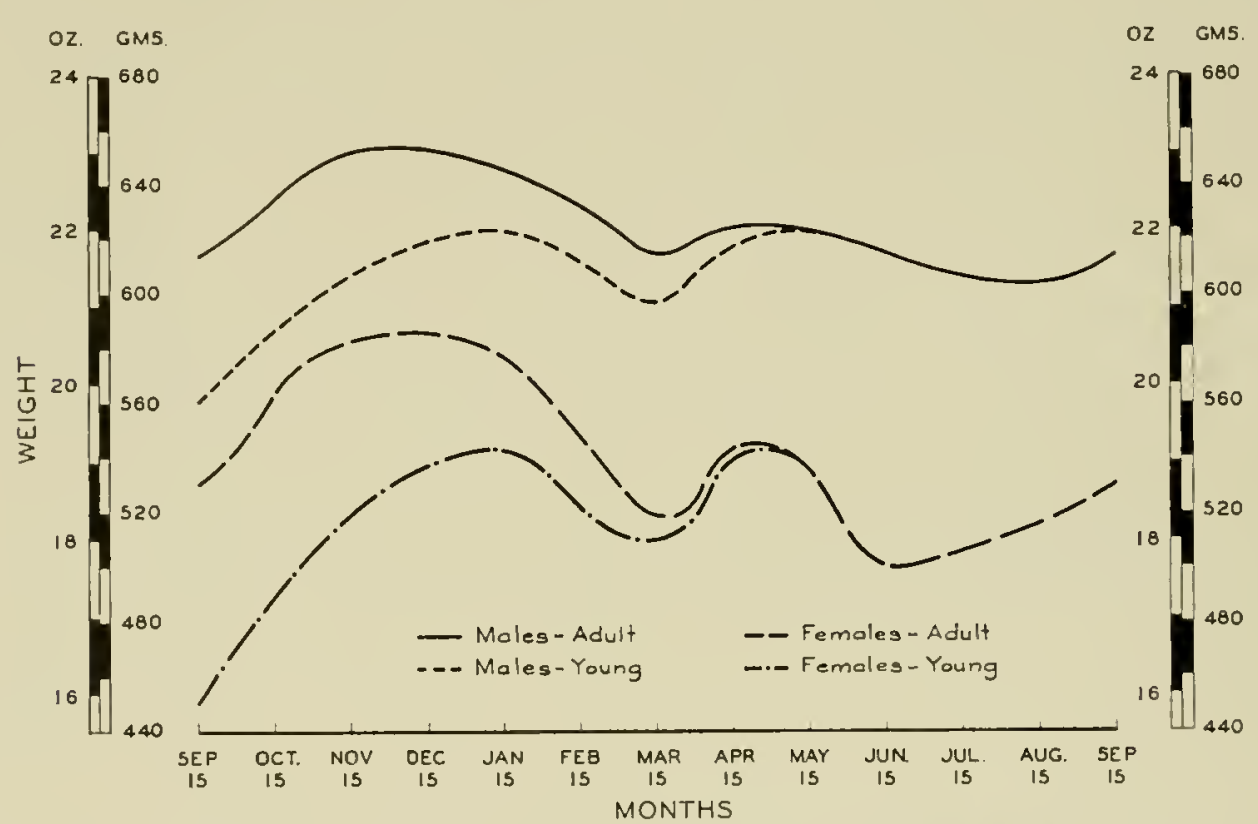

FIGURE 10. AVEIRGE SEASONAL WEIGHTS OF 394 ADULT AND 108 IOIN, WLU GROUSE FROM NEW YOKK

\section{DFferhaces between the Sexes}

Many a hiolonist, in attempting to identify the sex of grouse in the field. has been puzaled by the over-lapping of indicative characteristiss". Among the hest of these is the lenerth of the lail. for in males it will average nearly three-quarters of an inch longer. By stulying the weight graph. one also finds that the rule-of-thumb judgment of many hunters by which the heavier grouse are ronsidered to be males. holds good in general. During the hunting season. the male adult will usually aserage abent $2.36 \%$ (7) gramsi heavior than its mate. Even a male of the year. while averaging alout $20 \% 15$ grams) lighter than one of the precediun year. is. uevertheless. apt to be some $3 ;$ oz. $(20$ grams) heavier than an adult fomale.

Weight must, of course, he acepted merely as a gencral indication of sex. for many hirds of each group are killed which are above or below the levels here given. I'sually. however. a heavy, longr-bodied birt is a male: a plump. fairly light hird. a female. On the average. an arlult fomale is still $2: 3 \mathrm{w} \%$ (17 grams) lighter. even at her Deember peak. than is the 
male at his lowest weight in August.

It is at year's end that the weights of the two sexes most nearly match, for the birds are then only about $2^{1 / 4}$ oz. (6t grams) apart. Curiously enough, the weight difference is greatest early in June shortly after the strain of egg laying and subsequent incubation is passed. The female loses rajidly during the nesting period. reaching the low point, about 4 oz. (115 grams) below that of her more carefree mate, shortly after the chicks are hatched.

It is not always easy to ascribe reasons for the variations in the weight pattern of either sex. The influence of good food and of freedom from reproductive activities offer likely ex. planations for the rapid gain of weight in the fall. Through the winter, the female apparently loses weight more rapidly than the male but, like the Scotch grouse, with the coming of spring, some is regained. Losses during ecc laying (mainly mid-April to early May in New York) are not large. But the subsequent confmement of incubation brings on a swift and deep decline in female weights, possibly in response to restriction of her opportunity to feed freely. At the liw point, the average female will weigh hut 1 ll. 2 oz. 1500 grams). This is probably dangerously low, for then it is. in raising grouse in captisity, that thes are most likely to die from chronic discases.

Throughout late June and July. the male is moulting and slowly losing weight. Yet the female, though likewise renewing her feathers, gains steadily. Grouse are able to call rather quickly on their chemical reserve once their metalolic reserve has heen exhausted. It is prob. able that the hen approaches this condition early in June. the result of having abready lost almost one-sixth of her becember weight and that from this time on a slow recovery takes place.

This may contrilute to the ability of the female to put on weight even though moulting and caring for ber broul. During the latter half of September or early Octuber. she gains almost $2 \mathrm{oz}$. (about 50 grams) to put her unce more in good flesl.

The male neither varies $s$ greatly in his weight througlout the year. nor are the changes as rapid. His drumming and strutting so prevalent in early spring, do not prevent him from gaining slightly as winter wanes. though the increase is not as pronounced as with the female. By early June. though his breeding display is now largely an actibity of the past and he las scarcely begun to moult. his weight. curioush enough. is still dropping. This continues slowly throughout the period of featler replacement and well into duycust. In the fall. he apparently requires some three months to put on the same amount of flesh that the female arrouires in one.

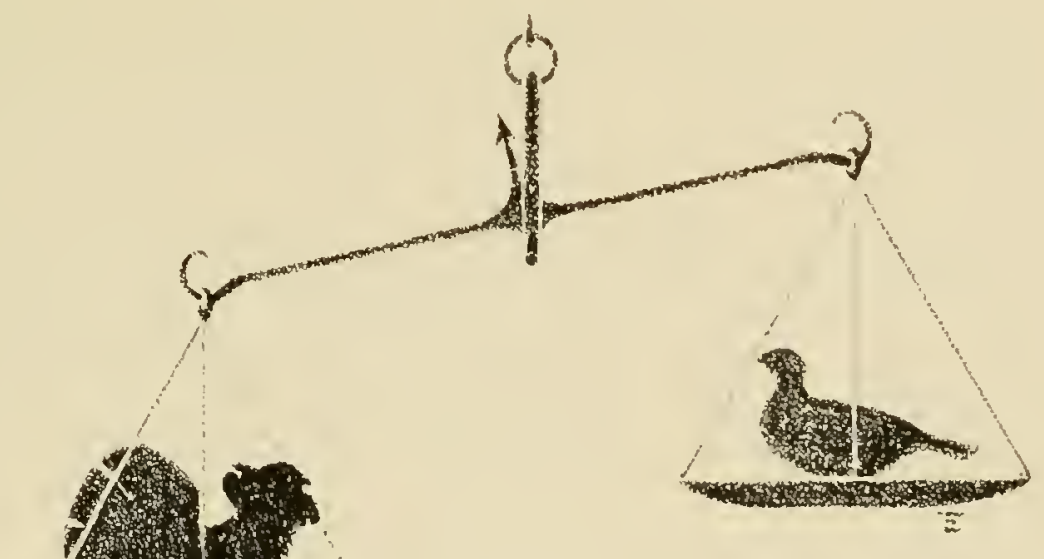




\section{ArE: DIFFERENCES}

Nonually, a grouse chick at birth weighs nearly $1 / 20 \%$ (1) to 13 grams), though this varies slightly from year to year. Because of the difficulties involved, few youngsters have been banded and subsequently recaptured and weighed in the wild. Weekly weights of birds raised in captivity, however, have been kept (table 11). Comparing these data with those in figure 10 it will be noted that while the pen-reared females attained somewhat higher weights by early fall than the average for birds collected in the field, the reverse was true among the males.

From September's frosty nights, the birds of the year seem to follow much the same weight pattern as do their elders (figure 10). Although they are then some $2 \frac{1}{6} \mathrm{oz}$. (60 to 70 grams) lighter on the average, they are probably even more active foragers, for they rapidly narrow the gap. Too, the gain is continued later, for apparently they do not reach their peak until sometime in January, although they still average upwards of $1 \mathrm{oz}$. (20 to $30 \mathrm{grams}$ ) less at this time. Also, birds of the year seem to lose a little less throughout the rest of the winter, though they are still some 8 to 16 grams lighter as late as the first of March, the greater difference being recorded among the males. Beyond this time they usually become indistinguishable from older birds, due to the disappearance of the bursa and the moulting of their two juvenile outer primaries.

TABLE II. AVERAGE WEEKLY WEIGITS, IN GHANS, OF 8 MALE AND ? FEMAL IIAND-REARED GHOUSE CHICKS

\begin{tabular}{|c|c|c|c|c|c|c|c|c|c|c|c|c|c|c|c|c|c|c|c|c|c|}
\hline \multirow{2}{*}{ Sex } & \multirow{2}{*}{$\begin{array}{c}\text { Weight } \\
\text { at } \\
\text { hatehing }\end{array}$} & \multicolumn{20}{|c|}{ Weight at weekly intervals aftur hatching } \\
\hline & & 1 & 2 & 3 & 1 & j & 6 & 7 & 8 & 9 & 10 & 11 & $1 \%$ & 1.3 & $1+$ & 15 & 16 & 17 & 18 & 19 & 20 \\
\hline Hide... & 12 & 21 & 39 & 61 & 45 & 1.32 & 180 & 237 & 295 & 350 & 100 & 112 & 179 & 503 & 525 & 510 & 550 & 5.59 & 567 & 571 & $5 i^{\prime \prime}$ \\
\hline Finat & 11 & 20 & 32 & 53 & 81 & 119 & 163 & 213 & 260 & $30^{4}$ & 352 & 341 & 128 & 152 & 470 & 481 & 498 & 5012 & 508 & 510 & 511 \\
\hline
\end{tabular}

By the middle of Septemler, the weight difference hetween the sexes anong these younger birds has apparently reached its maximum, for the female is nearly $\&$ oz. (110 grams) the lighter of the two, the average being $1 \mathrm{lb}$. ( 450 grams) and $1 \mathrm{lb}$. $40 \%$ (560 grams) respectively. Even at their January preak there is a difference of close to $3 \mathrm{oz}$. (75 grams) between them, a spread, however, not much greater than that between their elders at this point.

Differences in weights of grouse shot during the hunting season may often he ascribed to age differentials for even then the birds of the year average 2 oz. less in weight than do old hirds of the same sex.

\section{legional and Yearly Differences}

To secure an accurate picture of regional and yearly differences, it is necessary to analyze the weights of an adequate number of individuals collected from each region each year. Unfortunately, full grown birds eollected prior to 1939 were not separated into adults and lirds of the year. At that time the reasonally accurate means of identifying the latter by the presence of the hursa of Fabricii or an examination of the tips of the two outer primaries. had not been reengnized. A careful analysis of the resultant weight data for each age group for 1939.4l reveals no signifieant differenees eilher letween the three major regions of the 
state or between years for the state as a whole during this period.

From 1936 through 1940, Dr. A. L. Romanoff conducted for the Investigation a detailed study of annual variations in the development of the embryo*. Slight weight differences year by year among the eggs and among the chicks upon hatching were recorded. Their significance, however, is not yet clear.

It is to an expansion of this study of the causes of these less obvious changes in grouse weights year by year as well as to other physiological research that one must look for indicalions of the part played by food and, indirectly, by weather, in influencing periodic decreases in grouse abundance. Many more eggs and birds will have to be collected over a much wider area, and better techuiques for their physical and chemical examination worked out, before the indications that surely exist here of the relationships of these environmental factors to cycles can be adequately outlined or understood.

\section{Extremes of Grouse Weicht}

Few subjects provoke better arguments among gruuse hunters than does the weight of the largest grouse ever shot. Nearly every year, birds are killed weighingr over $1_{3.4}^{3}$ lb. I'ublished records on this subject are numerous. "Sus Q. Hannah"sss, who handled many grouse for the markets, claims that the weight "varies from year to year according to circumstances, food, weather, etc." In 1930, there passed through his hands a cock grouse that is said to have weighed $30 \mathrm{oz}$, even though no unusual amount of food was in its crop. Writing in "Forest and Stream", in 1880, Fellows ${ }^{134}$ cites a bird killed near Itornellsville, N. I., which weighed $32 \frac{1}{2} \mathrm{oz}$. A still larger bird which "wcighed thirty-three vunces on tested scales" has been reported $^{319}$ as having been killed many years ago in Rutland, Mlass. But what seems to be the heaviest bird reliably recorded was weighed by John Burulam ${ }^{334}$. Shot in Essex County, $\mathrm{N}$. Y., in the Adirondacks, it tipped the scales at $2 \mathrm{lb} .4 \mathrm{oz}$. The luvestigation has not weighed one which has approached this Goliatl. Males usually weigh more than females and birds two to three years of age more than birds of the year. Probably therefore, all the above records are of old males.

In the other direction, adults may be reduced to skin and bones and stitl cling to the breath of life. One female, found in December 1910 in Chenango County, N. Y., and suffering from chronic stomach worm infection, weighed hut $10 \frac{1}{2}$ oz. (292 grams). Altogether too weak to $f_{y}$, it was easily caught by hand and died soon after.

\section{Weight as aN Indicator of Health}

Weight is still the best easily available measure of grouse health. Its fluctuations are enough, however, to be confusing. Weight, as an index of condition. must, therefore. he compared with the normal variation encountered anong healthy individuals month by month. This differs seasonally as well as among individual hirds during one season. But in general, there is a zone of good health (figure 11) extending ahove and below the average within which variations in the weights of most healthy individuals may be expected to fall. Below this is a danger zone. Weights falling here are apt to indicate envirommental difficulties or the presence of serious disease. Beyond this danger zone is a critical or lethal zone. Birds whose weights fall within this may seldom be expected to live for long.

It is recognized, however, that there exists a point above the weight at death below which. due to metabolic and chemical exhaustion, the system will not recover even though the bird 
OZ. GMS.

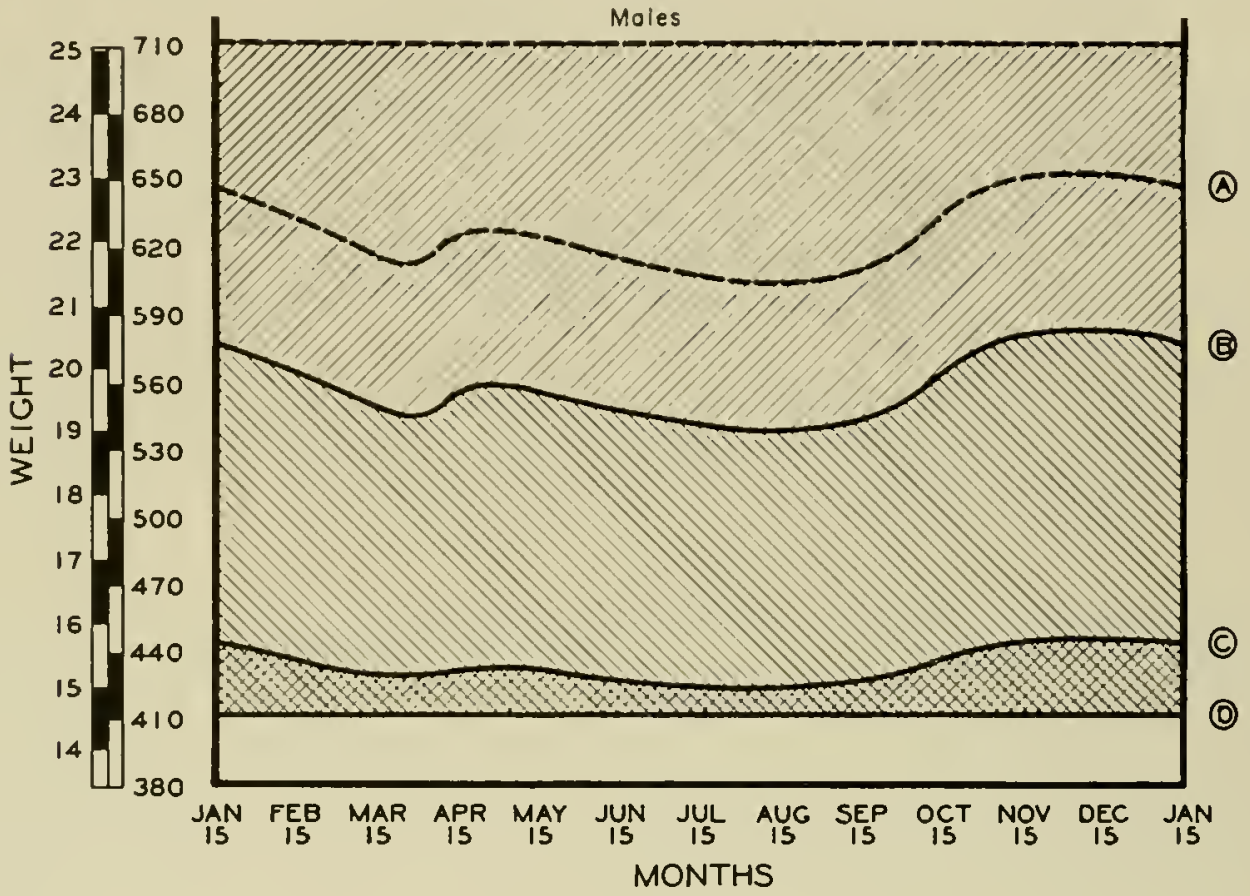

OZ. GMS.

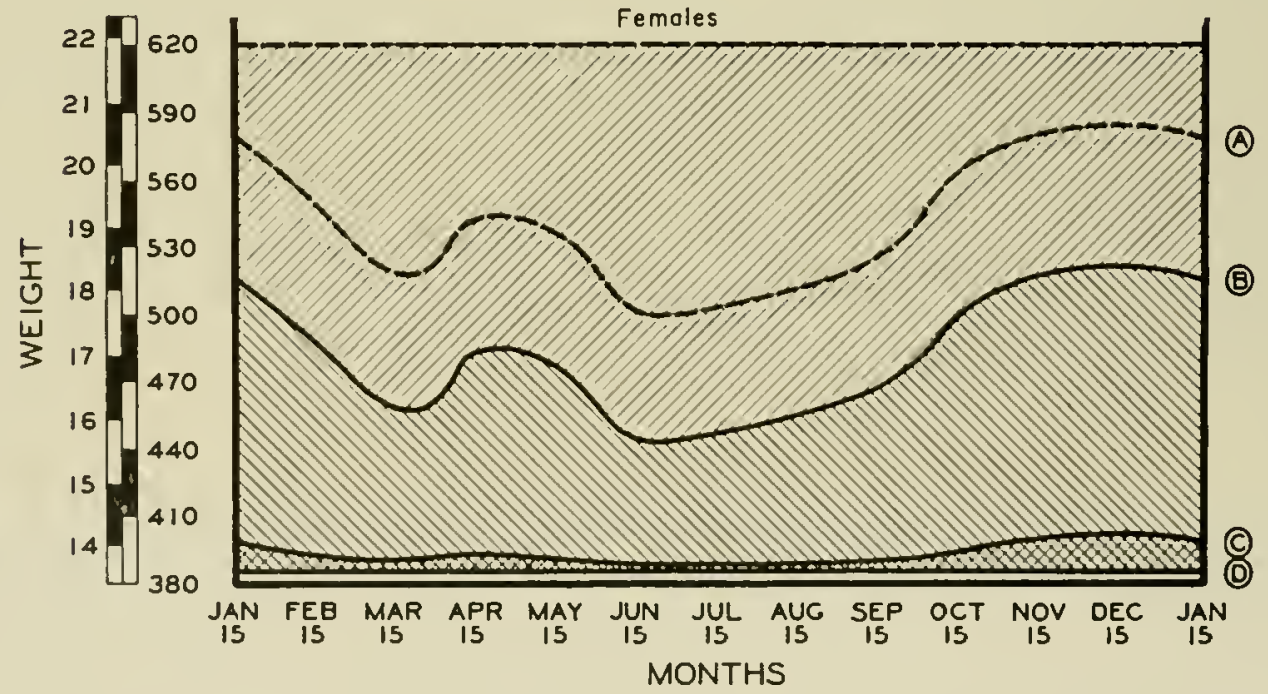

(A) AVERAGe WEIGHT BY MONTHS.

ZONE OF GOOO HEALTH

DANGER ZONE

(B) APPROXIMATE LOWEST WEIGHT FOR GOOD HEALTH.

(C) APPROXIMATE CRITICAL WEIGHT.

CRITICAL ZONE

(D) AVERAGe weight at DEATH.

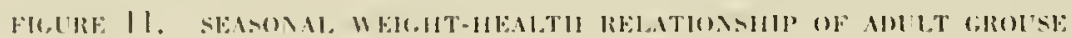


may still live for days or weeks. Naturally, this critical point may he expected to vary somewhat with the environment and the individual. Though known for the ring-necked pheasant in captivity. no exact measurement, covering a sufficient number of specimens. has ever been made to secure a reliable average for grouse. Long*. however. has worked out for the Investigation an approximation for adult hand-raised birds at the peak of their weight cycle. Roughly the line falls between about $16 \mathrm{oz} .(460$ grams) and $1+\mathrm{oz} .1390$ grams $)$ in the case of males and for females it lies between about $14 \mathrm{oz}$. 1400 grams 1 and $12 \mathrm{oz}$. (350 grams). It represents about a 30 per cent loss from original weight among both sexes.

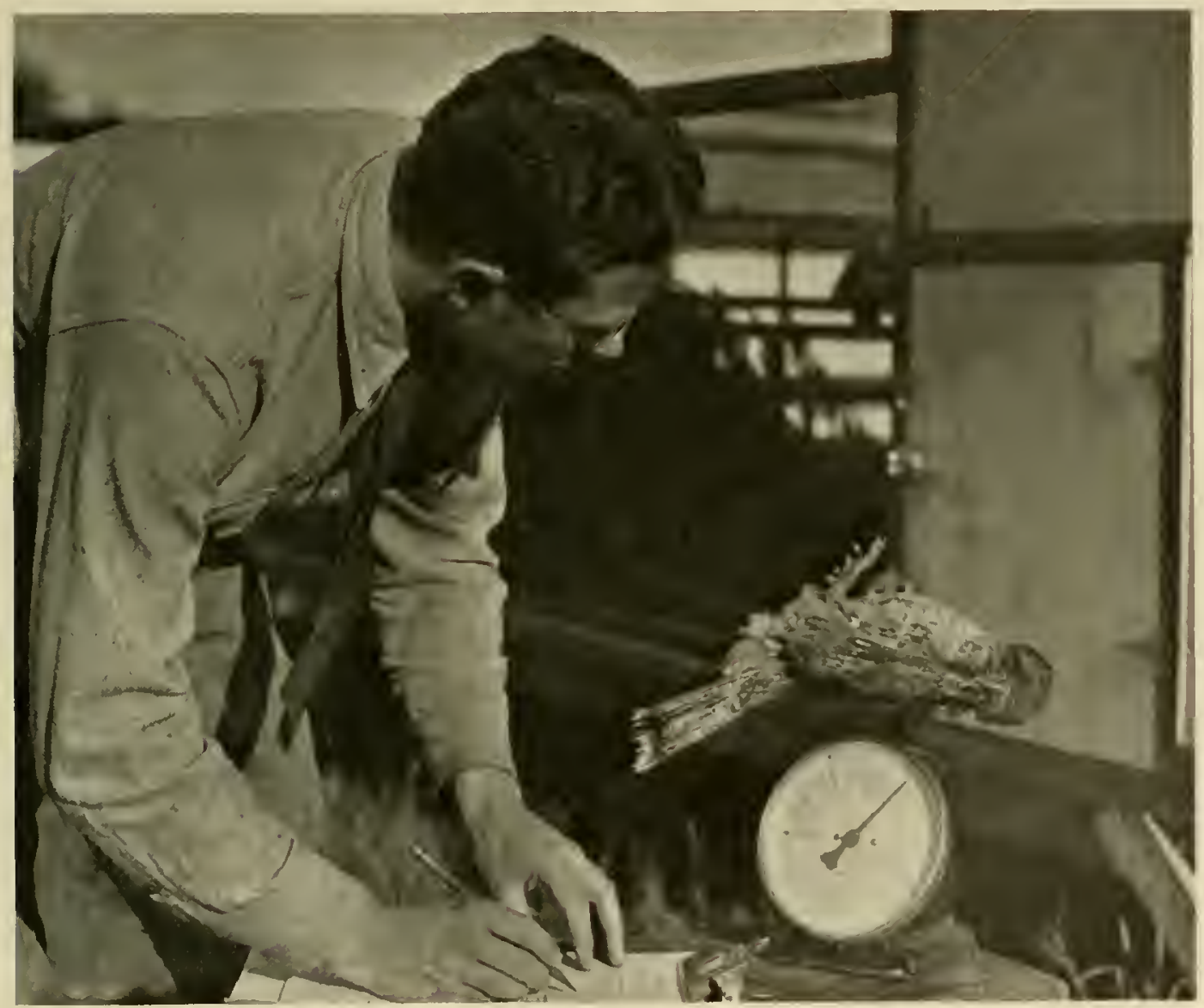

GROUSE AT THE RESFARCH CENTER WERE IIEIGHED PERIODHCAI.) AS ONE MEANS OF COMBAT-

TING IDISEASE;

Further light on what constitutes the danger zone and the critical weight is gained by analyzing weight losses under various conditions, such as extremes of temperature lack of food, intense activity and moulting. One indication of the threshold of the danger zone is the point at which birds are likely to fall prey to chronic diseases. At its lower limit are the weights under which a bird cannot drop and live for long. This has been roughly deter. mined for New York grouse ly a study of the final weight decline of birds which have died of chronic ailments. Nevertheless. this conclusion must be interpreted as only an estimate, 
carefully based on the meagrer fact availablc.

Perhaps the clearest idea of the weight-health relationship may be gained by studying figure 11. By comparing the weight of the birds collected or picked up dead at any period of the year, with the average here presented, a fair diagnosis of their relative state of health may be made.

Of course, one may also utilize his own judgment of the condition of the bird, but unless one is thoroughly skilled in such matters, rule-of-thumb methods, such as the mere hefting of a bird shot in the field or estimating its condition by the relative sharpuss of the breastbone, are notoriously unreliable. Many times grouse have been shot and sent to the Laboratory, as serionsly diseased, simply because a few of the long roundworms (Ascaridia), found upon cleaning, have predisposed a hunter to judge that the bird was poor in flesh. Actual weight comparisons with those given in the table, while of course in no way absolute, will provide, in most cases, the best method of appraising in New York, and probably throughout the Northeast, the general health of grouse.

\section{MEASUREMENTS}

In general, adult grouse do not vary greatly in size, especially with respect to their skeletal structure, although males tend to be slightly larger than females. Unfortumately, time has not permitted detailed measurement of the majority of the specimens which the Investigation has taken.

With respect to the eastern races of the species, the following as recorded by Forhush ${ }^{\text {ist }}$, is representative.

"Length 15.50 to $19.00 \mathrm{in}$; spread 22.00 to 25.00 ; folled wing 6.90 to 7.50 : tail 5.50 to 7.00 ; bill from nostril .50 to .53 ; tarsus 1.50 to $1.60 . "$

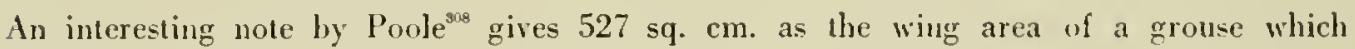
weighed 516.5 grams, or a relationship of $1.02 \mathrm{sq}$. cm. per gram.

In a series of adult birds collected in New York State hetween January and April. however. a record was kept of the length of the middle tail feathers. the results of which follow.

TABLE 12. LENGTI OF CENTRAL TAL FEATHERS OF ADULT GROUSE FROH NEW lORK STATE

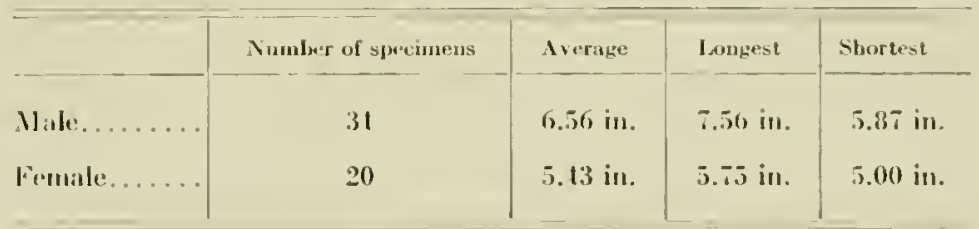

It should be noted that, while not found in this series, overlapping in length between the two sexes does occur". Smyth ${ }^{3 * 0}$ also measured a series of specimens in which the tails of the males averaged 1.17 inches longer athough there was only seven mu. difference hetween those of the shortent malc and the longest female.

\section{VOICE ${ }^{\triangle}$}

Although their vocal organs are of a primitive type, grousc can produce a wide variety of sounds. 'To many whose expericnce has been limited to the wild, this may secm an over-

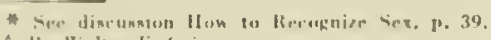

A iv. Waller f. C.risacy. 
statement. Yet association with captive stock cannot help but impress une with the conversational ability of a group of these birds. Here, at all seasons, "talking" seems to be enjoyed in much the same manner as among a group of women around a bridge table.

At the Research Center, the pens are seldom quiet during daylight hours. Accustomed to the presence of man, the birds freely express their thoughts about the world in general and their neighbors in particular. In fact, the regular attendants feel that, to some extent at least, they begin to comprehend "grouse language."

Observation under these conditions has revealed that the normal talking of undisturbed lirds in the main involves but a few basic sounds which are subjected to wide variations as to pitch and inflection. In this way, however, they seem to be able to run the gamut of emotional expression from satisfaction at having laid an ego to noisy indignation orer real or fancied mistreatment.

The majority of these calls probably are much the same as those used by grrotise in the wild under similar cireumstances. But observation of the latter in this respect is practically impossible since one can rarely approach the birds close enough without alarming them. Now and then, however, while driving along some old woods road in the fall or winter, small companies have been found conversing contentedly as they fed along amongst the underbrush. At the same time, it is probalsle that grouse in captivity indulge their abilities to a much greater extent than do their wild cousins which are not particularly gregarious. In fact, solitary individuals may utter few sounds.

On the other hand, a number of vocal expressions have been encountered among wild birds which are rarely heard at the Center. chiefly because the necessary circumstances are not present. Perhaps the most noticeable and spectacular is that of the female when disturbed at hatching time or while her lrood is very young. On such occasions she enits a loud and drawn-out nasal "squeal", apparently to distract the intruder's attentiun. If not satisfied with the effect, she may also rush hin, at the same time lissing angrily.

In quieting the occasional peeping of chicks in hiding. the hen resorts to a "scolding" call resembling that of a catbird but with a downward inflection. In quality it is more like a gentle but firm reminder than a command. To collect her brood after danger is past. she uses a low, humming call, something like covo-coo-coo-coo.

Among adults in general, in addition to the startled, "pete-pete-pete-pete--pete" of a bird just before flushing, is an expression of "curiosity" which is not so frequently heard. Many a "sit-on-a-stump-and-wait" deer hunter, however, has seen a grouse jump up on a log, and chirp, as if to say "what's all this about?", giving its partly spread tail a downward flirt at the same time. This call closely resembles a common note of the red squirrel and may be likened to "perrrck" given with a rising inflection.

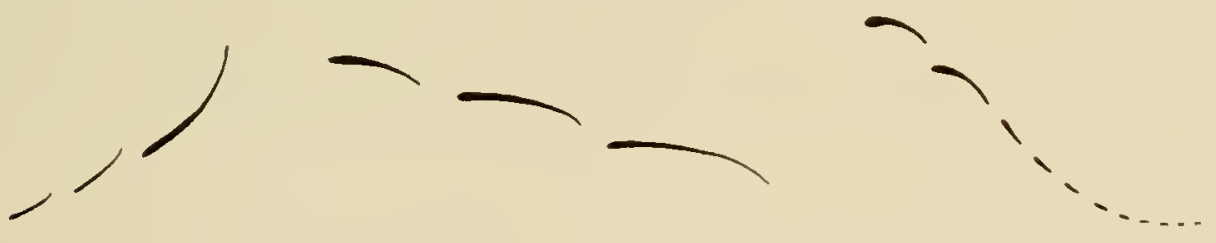

Inquiry

Distress

Warning

FIGURE 12. GROUSE CHICK CALLS 
Grouse chicks have four principal calls. For two or three weeks after hatehing, they usually voice several loud "peeps" of alam upon being disturbed. During this same time. as well as througlent most the brood period, the! are scldom able to remain silent long after being flushed. On such occasions, their first expression is an inquiring series of two or three peeps in an ascending seale with an upward inflection at the end, as if to say, "Here I am, where are you. what is the situation?" Often closely following the latter is a plaintive call composed of two or three peeps in a descending scale, each having a downward inflection, and sceming to say: "l'm lost, l'm scared, where is everyone?" Older chicks also seem to use a defunte warning signal of several notes in a descending pattern. the first two rather sharp, the rest progressively diminishing in intensity and length. But as summer wanes, the young birds rapidly acquire an adult vocabulary.

\section{ECONONIC IMPORTANCE*}

As some forgotten sage has put it, "One man's meat is another man's poison". Whatever he may have had in mind at the time, his maxim is likewise applicalle to wildlife in its relations to man. Human interests are so varied it would be well nigh impossible for a species of any consequence to be equally valued by all. The ruffed grouse is no exception.

In considering the economic niche best fitting this bird, it is at once apparent that cireumstances differ widely between regions. A sporting bird of the first water, the grouse in certain areas may he so scarce that no open season is feasible. while in other parts of its range sportsmen are so rare that its best use is to supplement the grub hag of the occasional trapper. Yet those most concerned with this phase of the bird's ecology are interested in regions where a wider variely of relationships are involved.

Standards of merit. however, are divers. To the frontiersman, food value was paramount. In the early days of economic ornithology. the relation of hirds to agriculture was a major criterion. Understandalsly. therefore, authors have ascribed great importance to the numbers of moxious insects consumed by the lirds which they have studied. Tu this tendency grouse liographers have by no means been immune. Characterizations of the grouse as the farmers" friend. leerase of its feeding habits, appeared as early as 1832 and have gained many adlerents in the literature as well as elacwlere. Less complimentary and more velument has been the controversy letwren sportsman and orehardist as to the damage grouse may do by loudding fruit trees. Another major consideration pertains to the one time extensive finan. rial interests of the market hunter which have given way to the even more productive maintenance of grouse as a game crop, the harvesting of which, the country over. draws afield wer half a million men and women cach year. And then there are those who regard the hird from a purely aesthetic point of view. These, and others in less degree, will give some indica. tion of the place the ruffed grouse occupies in man's economic and recreational domain.

But to grive the reader a mure complete picture of the situation, it seems advisalide to dis. cuss further the more important aspects of the problem. Considering them in more or less chromological order. the earliest use made of the grouse by man undoubtedly was as an article of food.

\section{Grol's: As a Foon}

The white, tender llesh of the hirel is hioghly palatalle when properly cooked. That the

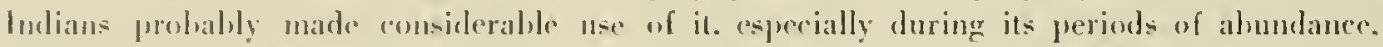
was indicated hy Baron de lathonten" who reported in 1703 that they "shot them with ar- 
rows, for they were not worth a charge of powder". From a quaint tract entitled "\ew England's Plantations" played a major part in the daily dinners of the earliest settlers.

Utilized at first for personal use only. as time went on grouse became increasingly popular as a commercial food. Two score years ago it required hundreds of thousands of grouse an. nually to satisfy the hungry markets in the larger cities. Prices. Where birds were scarce. ran as high as $\$ 5.00$ or even $\$ 7.00$ a pair. though during periods of abundance they oftumes sold for 50 cents apjece.*

With the prohibition of its sale. grousc have come to he looked upm more as an excusc for a keen day's sport than merely as an article of food. esen though today they remain one of the greatest delicaries of the hunt. The best figures avajlalıle indieate that upwards of two million grousc may he shot amnally throughout its range during periods of normal abundance. The average bird will weigh about a pound and a half in the field. P'ruperly prepared, the annual harvest may furnish upwards to four million meals.

\section{Tue Importance of Food Preferences}

Though grouse are highly insectivorus as youngsters and later great sced-eaters. they cannot compare with either the ring-necked pheasant or the lobwhite quail to say nothing of many of the smaller hirds in their consumption of items detrimental to agriculture. This is only natural. since good grousc coverts are never highly cultivated. Their foud consist- largely of woodland fruits, berries, buds. serds and leases. with minor emphasis on insects in the summer. For the most part. their feeding habits neither conflict with. nor cuntribute du. man's interest.

True, some seeds are not digested and many wildlife food plants are therely more widely dispersed. But it is mainly among the insects that the grouse makes its relatively small comtribution. The list of species picked up. largely by the chicks. includen. arcurding to Vedtee

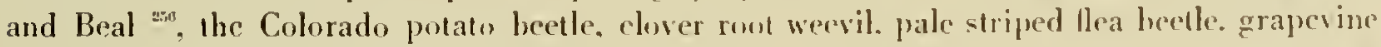
leaf beetle, red humped apple caterpillar. grasshoppers, cottomoms. army worms. cutworms. sawfly larvae and May beetles. To this group our own studies have adderl adult sawflies. the strawherry weevil, black vine weevil, poplar horer. cucumber loetle. clu leaf heetle. mapletree worm. canker worm. and various plant hugs and leaf hopprers.

Though ants, hectles, and caterpillars are taken primarily amoug this gronp. the great ahundance of insects in general ${ }^{\Delta}$. as well as of other fords. and the relatively large territory available to each brood. nakes it doulnful if grouse alone. even where the! are plentiful. make much of an impression on the numbers of larmful spureses. Vevertheless they do, of course. contrihute a share to the aggregate heneficial effect of hirds in holding in cherk the hexapod hordes.

* See Chaptur J. IP, B. average of over 300.000 indiviluals per acte in qood grouse cuver faumuer leetiag ground).

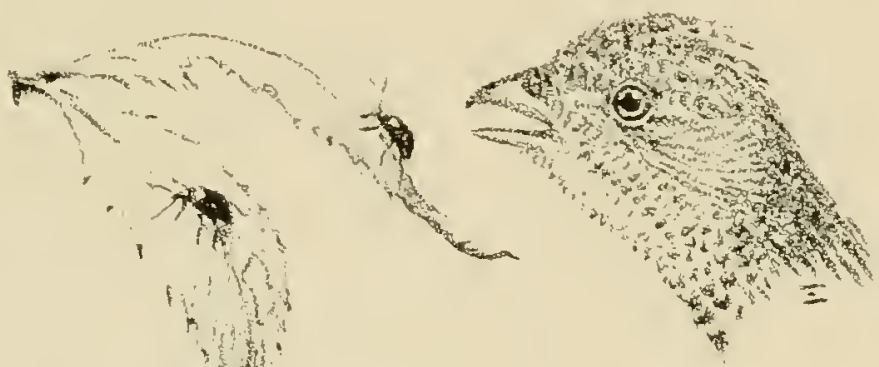




\section{Budding of Fruit Trees}

At first thought, it seems rather incongruous to present-day observers that the grouse may at times be an economic liability. Nevertheless, as early as 1870 , certain Massachusetts towns instituted a lounty of 25 cents on this specjes because of its alleged damage to apple orchards and fruit trees in general through eating the buds during the winter and early spring. In Kentucky also, according to Forbush" ${ }^{110}$ they early acquired a reputation blacker than that of the crow, nol only for their apple budding propensities, hut also because they were said to pick uj sown grain from the open fields-a supposition not reported in any other part of their range.

Apparently, however, New England grouse are the chief offenders, for among these rugged hills apple trees have been planted invitingly close to good grouse coverts. Usually but three or four hirds are involved at any one place, but there is one report ${ }^{110}$ of eighteen hirds simus. taneously working on one tree. Though food equally altractive to most grouse he abundant elose hy, a few birds thus concentrating on an orchard may easily strip many a limb almost bare of buds. Maynard ${ }^{253}$ mentions a grouse he shot about ten o'clock in the morning from whose crop he extracted 180 apple buds, although the average number laken is apparently much smaller.

Opinions as to the effects of such depredations vary with the interest of the individual and the severity of the pruning experienced. Complaints usually are limited to periods of grouse abundance and are handled in New York State by giving the harried landowner permission to shoot the culprits. But other more strenuous neasures, such as the Massachusetts bounty, have occasionally been resorted to elsewhere.

Probably the most paradoxical situation is to be found in the record of the State of New Hampshire, where a statute was passed in 1915 requiring the state "to pay for any damage to 'annual crops or fruit trees hy game birds or game quadrupeds protected by law' ", such payments to be made "ont of fish and game funds, which accrue entirely from license fees. fines and forfeitures" ${ }^{35}$. Under it, claims at first were few, largely because the law was little known and grouse were going through the periodic scarcity of 1917-18. Then the abundance of birds surged upwards and. with it, damage claims. It is even said that the Farm Bureau Federation and the State Horticultural Society started membership campaigns. using as a lever the assistance they might offer in settling complaints. By 1923. the situation had become so widespread that over 100 such claims were presented for adjustment. Since July 1. 1922. New Hampshire has paid approximately $\$ 70,000^{*}$ for damage hy grouse in spite of an investigation being made in each case. The outstanding years (fiscal). by far, were those ending June 30, 1924 and June 30, 1927, when $\$ 26.800 .72$ and $\$ 13.989 .50$ were paid respectively, the former amounting to almost one-guarter of the total income of the Fish and Game Department. But even in the years $1927-23$ and 1928.29 when. In many observers. the future of the grouse over mucli of the Northeast seemed in danger, payments of \$1.152.21 and \$1.017.00 respectively. were made. In 1911, over $\$ 1,000$ was paid.

But, eren as the controversy raged, many individuals were of the opinion that grouse bud. ding results in no appreciahle damage to the tree. As a rule. the hirds confme their aetivities In the top and center potions. Thus it often happens that trees. which have been quite heavily ludded, produce on their sids and lower loranches fruit of a locter size and quality than those which have not hern so pruned.

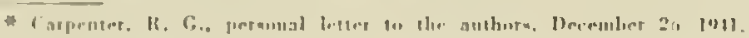

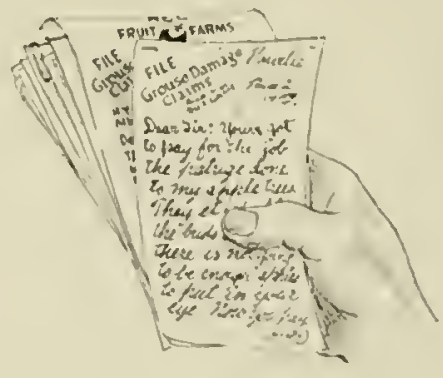


Whether this be an advantage to the orchardist or not depends upon conditions. Thus $\mathrm{Judd}^{2 t a}$ cites one case of an apple tree pruned severely two years in succession, yet producing "barrels of apples, all nearly perfect and fair, just the result of a vigorous trimming." On the other hand, Bartlett ${ }^{35}$, described an orchard planted on fertile land and well cared for throughout, one side of which adjoined inhabited grouse cover. The production record for both portions was about the same until the birds discovered the apple buds in the block closest to their covert. The result is described in these words:

"In the spring the broken ends of limbs and white spots where buds had been taken were so numerous that the trees looked white as you approached this section of the orchard. As you came nearer casual observation would almost make you believe that no fruit would set, and that very few leaves would appear. At blosson time. flowers were few and scattered. At fruit picking time. these trees had apples of very good quality, but not 50 per cent of the amount of fruit in bushels borne by the other sections of the orchard which had not heen hudded. The owner set the shortage of fruit at 200 barrels."

One must bear in mind, however, that the latter represents the exception rather than the mle, considering grouse range in general. And today, throughout the Northeast. one finds abandoned many farms from which damage complaints once originated. Then. too. hunters in increasing numbers, dissatisfied with the slower ring-necked pheasant. are again turning their attention to gronse. One has but to advertise a concentration of hirds snfficient to cause damage. to interest local sportsmen in assisting in their control.

\section{Grouse as a Game Crop}

With the outlawing of market hunting, the shooting of grouse became a sport to he indulged in primarily for recreation. Furthermore. the harvesting of the crop each year has contributed in many ways to the revenue of many states and the income of their citizens.

It has been estimated that the justly famous red grouse monos of Scotland and England bronght in about $1,300,000$ pounds $(\$ 6,500.000)$ in gross rent per year before World War II. In Scotland the "glorious 12 th" ( $\Lambda$ ugust) which commences the shooting season is a sporting and social event of the first rink. The railroads run special "grouse trains" and the day is celebrated in song and story. On these moors was provided shooting of a kind largely unknown in this country, since it was not musual for a relatively few shooters to kill in excess of 6000 hirds in a gond year on a single properly managed moor. Over here, ducks, pheasants. and Hungarian partridges occasionally reach concentrations which might permit hags of sinilar size, though largely on private shonting preserves. But the ruffed grouse is not particularly gregarious and though it has heen known to reach fall concentrations as high as one bird per two and a half acres. in individual coverts, efforts to maintain such abundance have not heen successful. Yet. for its sporting attributes. the hird is particularly esteemed among a large group of sportsmen who glory in the difficulties of the hunt. It is widely distributed and necupies for the most part land on which no lunting restrictions have been placed. Thesc factors combine in New York alone to put tenfold more nimrods in the field in its pursuit than take gun to humt the red gronse throughout the entire British Isles.

No figures as to the number of grouse actually killed in any one of the several states are available today nor is the number of hunters seking the species accurately known. In fact, but twelve slates lave even set up the machinery to gather aught save the most general of estinates on their game take. Even' in New York. where the law requires such records of every licensee and all are tabulated each year, the actual number of grouse taken is substantially in excess of that reported. In a normal year, when sportsmen's license returns indicate 
the take to be almout 170.000 birds. it is safe to say that the actual number shot would approximate 300.000 . Field studies conducted by the Investigation in certain Southern Tier N. Y.I counties over two successive years, indicate that about 17 per cent of the fall population of adult grouse in that region are killed by hunters in a season of average abundance. A lake of 300,000 birds. then. would indicate a population of approximately a million and three-quarters in New York alone. From an inspection of license records. onc finds thrce to he the number of grouse reported most frequently taken hy individual New York State hunter. Yet the number is undouhtelly lower in actuality. for most grouse here are so hard hunted and wary that some grouse hunters are entirely unsuccessful and thus make no report. But. if onc accepts three as the average kill it follows that there are upwards of 100.000 gronse hunters in this State alone.

Over its entire range. based on a canvas of existing records and estimates. a reasonable ap. proximation of the annual kill during a year of average grouse abmndance, would amount to at least 1.900 .000 lirds. If, by way of a very rough inference, one were to apply New York's kil] ratio to this. an estimated total population of $12,600.000$ would result.

Yet it is well known that these birds are tamer and, therefore, easier to kill in many parts. of their range than they are in the Northeast. To compensate for this the hunting pressure is probably less. Thus. should grouse hunters over the whole area occupied by the species average four birds sach per season. one might conjecture that there are perhaps 500.000 sportsmen who make grouse hunting their hobby:

Those who know New York grouse will agree that the estimates presented for that section well reflect conditions as they exist. I perhaps six or eight other states the figures covering the annual kill of grouse are equally indieative. For the rest it has heen necessary to fall hack on the ofttimes unreliable method of "best estimates". But. in spite of the obvious inaccuracies which beset such efforts. the picture is significant. The ruffed grouse. unlike its Scotch consin. represents a crop. the size of which is still controlled largely by the whims of nature. Yet it furnishes recreation to perhaps half a million hunters instead of the comparatively few who are able to enjoy this sport in the British Jsles. Furthermore. the actual revente derived from haresting the crop is apprecialle. An expenditure ly each grouse hunter of only alont \$16.00 a year for guns, ammunition. hunting cluthes. Iravel and loolging would roughly equal Great Britain's revenue from the rental of its grousc moors.

\section{SaIf, of Brfanic, Stock}

Grouse for restocking depleted coverts have hrought prices well above those paid for most native game hirds for many sears. Though current prices (1912) for wild trapped hirds are

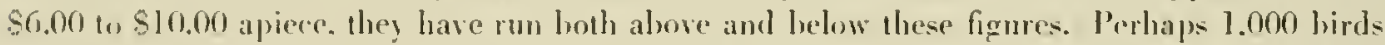
have been trapped, mostly in Canada, transported and released to restock depleted coverts and bring in new blood-an idea widely, thumgh probably erroneonsly. accepted as necesary.

Ifaurl-raised hirds, ton, are at a premium. for there are hut one ur two places where brecters hase suceceded in establishing a strain that will do more than reproduce itself in captivity without frequent additions of hirds or eggs from the wild. Such hand-raised hirds have lerought prices of from $\$ 10.0010 \$ 50.00$ a pair. with but few hirds for sale. Artificial grouse propagation. at least in its experimental stages, is costly and the present supply of handraised breeders is. therefore. Jargely encentrated in the hands of a few public ageneies, notably New York State. 


\section{PART II}

The Factors That Affect Abexdance 



\title{
CHAPTER III
}

\section{COVER CHARACTERISTICS AND SHELTER REQUIREMENTS}

\author{
By Gardiner Bump
}

\section{CHARACTERISTICS OF PRODUCTIVE GROUSF COVER}

In General-Covert Size and Shape-Type Size and Shape-Type Composition-Interspersion of Types-Br Regroxs in New YORK STATE - The Adirondack Region-The Catskill Region-Rest of State.

\section{THE ROLE OF SUCCESSION}

\section{COVER TYPES RECOGNIZED}

\section{COVER REQUIREMENTS OF THE GROUSE}

Nesting, Cover-Types of Cover Chosen-Density of Undergrowth at Nest Site-Sites Preferred as Nest Locations-Nest Location in Relation 10 Degree of Slope-Nest Location in Relation to Aspect of Slope-Influence of Conifers on Nest Location-Effect of Openings on Nest Location-Effect of Slashings on Nest Location-Influcnce of Other Types of Openings on Nest Location-Effect of Crown Corer on Nest Survival-Effect of Undergrowth Density on Nest Survival-Thickets versus Open Cover as Nest Locations -Effect of Distance from an Opcning on Nesting Success.

Brood Cover and lielated Influences-Types of Coser ITsed by Grouse BroodsChange in Cover Use as the Broods Develop-Effect of Cruwn Cover Density on Brood Choice Types of Cover Used by Gronse Broods at Various Times of Day-Choice of Crown Cover as Affected by Climatic and Ground Conditions-temperature-uind -atmospheric conditions-ground conditions-Some Relationships of Undergrowth to Grouse Broods-Types of Undergrowth Chosen ly Gruuse Broods at Various AgesEffect of Density of Undergrowth on Brood Cover Choice-Effect of Miscellaneous Conditions on the Types of Undergrowth Chosen by the Brood-Use of Different Degrees of Slope at Varions Ages-Slopes Used by Gronse Broods at Different Times of Day-Some Relationships of Temperature, Wind and Atmospheric Condilions to Slope Use.

Adult Grouse Cover and Reiaten Influences-Types of Cover Used by Adult Grouse -Scasonal and Monthly Cover Preferences-Types of Cover U'sed by Adulı Grouse at Various Times of Day-winter-spring-summer-fall-Effect of Various Weather Conditions on the Choice of Cover by Adult Grouse-temperature-uind atmospheric conditions-Effect of Various Ground Conditions on the Choice of Cover by Adult GrousePreference of Adult Grouse for Ground Over Tree-Influence of Slope on Adult Grousc Distribution-Influences Affecting the Distance Grouse Flush from an Observer. 
REFLusies - Cover chosen in which to alight - Distance between Flush and Reflush

Effect of Sex on Flight Distance - Tendency to Alight in a Tree.

\section{THE ROLE OF COVER CONIPOSITION AND ARRANGEMENT}

\section{THE VALUE OF EDGES}

Effect on Adult Grouse. Distribution-Effect on Brood Distribution-Relation of Edges to Nest Location-Variation in Importaice of Edges.

THE VAIUE OF CLEAR-CUT AREAS

$$
\S
$$

\section{SUMMIARY}

No factor is more important than cover in determining grouse distribution and in influencing the productivity of grouse populations. (p. 109 ).

Because of the sedentary nature of the birds, a gond grouse hahitat must meet all food and shelter requirements of the speeies within a relatively small area. (p. 110).

Grouse cover is constantly changing as one type grows into the next more advanced stage. (p. 118 ).

The outstanding grouse requirements which must be met by cover are for spring nesting grounds. summer feeding areas. fall feeding grounds and winter shelter. (p. 111).

Grouse cover is as much a reflection of the various farm and forest uses to which the land has been put as the result of varying clinatic. physiographic and biotie influences. (p. 114-118).

The extent to which such crops as forage or wood products are harvested maly affect the productivity of a woodland for grouse quite as much as does its natural composition. (p. 118).

The partridge funds its year-round requirements met neither in the first stages of plant succession associated with grasslands nor in the last or climax types of dense unbroken forest. (p. 118).

Some of the most productive grouse habitats in the State are to be found where woodlands are broken up by farm clearings which have been abandoned and are beginning to revert. (p. 116).

Nesting cover and site exhihit certain characteristics as follows:

Woodland types are strongly favored as nesting cover. (p. 128).

Of these. nests are most likely to be found in second-rgrowth hardwonds; least likely to he placed among conifers. (p. 128).

Wust hirds are reluctant to nest where the undergrowth is dense. (p. 128).

Grouse prefer to nest at the hase of a tree. (1. 130).

Slupe, degree or aspert. does not materially influence the choice of a resting site. (1. 130).

The desirahility of a nesting site varies inversely with its distance from an opening. (p. 131). 
Nests in woodland types are commonly located within 100 feet of a woods road. Irail or an open field. (p. 135).

Nests are most likely to be broken up by predators when in coniferous cover; least likely. if in spot-lumbered areas. (p. 135).

Abont the same number of nests are destroyed by predators irrespective of the density of the undergrowth in the cover type in which they are located. (p. 135).

A nest within a thicket is no safer from predators than is one located in a more open spot. (p. 136).

Nests located within ten feet of an opening (including woods' roads) are no more likely to be broken up by predators than are those at greater distances. (p. 136).

Grouse broods exhibit certain cover preferences as follows:

The outstanding characteristics of brood cover are its diversity and its youth. (p. 139).

Most used by broods are overgrown lands deficient in conifers. second-growth hardwoods, patches of popple, hirch or alder and the more recently cut-over areas. (p. 140).

The presence of conifers contributes little to brood cover. (p. 140).

Cover use changes, but not markedly, with the age of the brood. (p. 141).

Broods prefer types in which the crown cover is sparse. (p. 11]).

No type of cover is shunned by broods at any time of day. Woodlands are preferred for night roosting. early in the morning and in late afternoon. Overgroun lands and slashings are generally patronized during mid-morning. The former are also partieularly attractive during the mid-day and early afternoon periods. In late afternoon many birds seek out the alder rums and the young slashings. (p. 142).

Broods tend to prefer the more open hardwoods when the weather is colder than normal and the types containing some conifers when it is warmer than usual. (p. 142).

Wind but little affects brood cover choice. (p. 142).

Woodland types are more used in rainy weather. overgrown lands and cut-oser areas when it is clear. (p. 144).

Ground conditions (wet or dry) seem not to affect materially lorood cover choice. (p. 144).

The more complex the undergrowth. the more attractive it is to hroods. Small hardwoods. shrubs and berry bushes and a "combination of types" are most frequented. (p. 146).

Undergrowth density does not seriously affect brood cover choice. Sparse undergronth is more frequented by the very young birds; medium and dense, as they grow older. (p. 147).

Steep slopes are markedly less used by broods than are level lands or moderate inclines. (р. 148).

No aspect of slope is shumed at any time of day. although minor differences in use have been observed. (p. 149).

Adult grouse behavior in relation to cover and related influences may be summarized as follows:-

Adults spend most of their time in woodland cover types. (p. 152 ). 
In winter the birds frequent the more heavily wooded areas particularly if conifers are present. (p. 153).

In spring the birds are still partial to woodland types. Excursions into cut-orer patches and overgrown lands become frequent. (p. 153).

In summer the birds revel among the overgrown lands, cut-over areas and in the spot. lumbered woods. At this season, types containing many conifers are seldom frequented. (p. 153).

In early fall hedgerows and brushy patches, particularly if they border on conifers, draw birds like a magnet although all other types, save open land and mature hardwoods, may also be frequented. As the weather becones colder, overgrown lands and cut-over areas are less used: woodland types containjug conifers are more commonly patronized. (p. 153).

While few, if any, cover types are completely avoided even for a single month, the degree of use varies considerably. (p. 156).

Conifers represent the most used type for eight months out of the year but are avoided in summer. (p. 157).

The number of grouse found in any one cover type at any particular time of day varies considerably with the seasons. (p. 159).

Sunup is the best time to hunt the brushy pastures, woods' edges and cut-over areas in the fall. (p. 161).

Weather does not usually exercise a strong effect on corer use. (p. 161).

Birds tend to move into mixed second-growth hardwoods and conifers or to heavy evergreen cover when temperatures are colder than normal. Conversely on warmer than normal days birds move to the more open cover types deficient in conifers. (p. 161).

Heavy conifers and alder patches (when the leaves are present) comprise the must sought out refuges on windy days. (p. 162).

In suowy weather, birds seek eoniferous cover. (p. 162).

Rain bothers the birds but little. The more open woodlands are then preferred. (p. 162).

When snow eovers the ground the birds are most apt to be found among the conifers while the mature hardwood type is preferred for snow-roosting. (p. 163).

Grouse spend most of their time on the ground at all seasons of the year, though they frequently use trees for budding in the winter. (p. 163).

Slope, degree or aspect, as such, seems to influence grouse cover choice but little. (p. 16.1).

Most grouse flush within 50 feet of a person. Much-hunted birds generally flush wild as they do also on windy days. Females, generally, may he more elosely approached before flushing than males. (p. 165).

Flushed hirds normally alight in the same type of cover from which they were originally started except when it is not extensive or is quite open. (p.166).

Providing they do not remain in the same type of cover. when flushed, they tend to choose certain other types in which to alight, depending on the type of cover from which they were originally fushed. (p. 166). 
Upon being flushed, birds normally fly only a short distance before alighting. Males do not usually fly a greater distance than females upon flushing. (p. 167).

Two-thirds of all the birds flushed may be expected to alight in trees. (p. 168).

The quality of a luabitat is roughly proportional to the variety in the composition and arrangement of its component cover types. (p. 168).

The poorer the covert, the greater the need for "edges." (p. 173).

In highly productive coverts, such a relationship is less evident possibly because the varied composition within many types creates a diversification of cover. (p. 173).

Solid blocks of coniferous reforestation are used but little by grouse except along the edges. (p. 174).

Selective lumbering improves most grouse covers unless the conifers are thereby largely eliminated. (p. 176).

Where forest cover is dense and extensive, the clear-cutting of small areas may profitably he used to provide summer and fall feeding grounds. (p. 178).

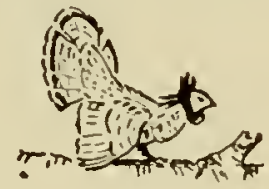

To every hunter of grouse, fall brings a recurring puzzle-in what cover will one find the most birds? The answer is by no means casy, for grousc are hardy individualists, and experience does not always point the way. But, with study, patience and careful correlation of such items as the type of cover, season, slope, time of day, wind and weather, certain preference patterus can be recognized and catalogued. Many a bird-wise sportsman has consciously done this for his favorite hunting coverts. using such general terms as woods' cdges, overgrown land, open land and evergreen thickets.

In the more exact terminology of the investigator these cover groupings become vegetative cover types. It is bis job to recognize and evaluate the nultitude of natural climatic. physio. graphic and biotic factors and, through repeated observation. to uncover gradually the often complex part each plays in influencing the survival of the bird.

The effect on grouse of each of these groups has becn studied in some detail. The hirds are tolcrant of a wide variation of clinatic factors-atmosphere, temperaturc and light. With a few exceptions, neither rain nor wind, snow nor drought, cold nor warmth, seem seriously to influence their survival. Physiographic features-slope aspect and degree-seem likewise of minor direct importance. Birds may be found in goodly numbers on steep slopes or flat lands irrespective of the compass direction the slope may face, providing the proper cover is present. Indirectly, of course. these factors usually play a commanding part with soil in determining the character of the third group. the biotic or plant and animal associations present. It is this group that largely decides whether grouse survive, become abundant or dis. appear.

Let us carry this a step further. As between plants and animals, it is the former that are by all means more important in maintaining high grouse populations. Good cover means fewer losses from predators and probably from discase as well. In other words its "carry. ing capacity" is higher. One must, therefore, learn to recognize the important components 
which make up good grouse cover as the first step to intelligent management.

$\mathrm{It}$ is. then, the purpose of this and the succecding chapter to describe cover characteristics and to explore and define. in some detail, the shelter and food requirements of the grouse.

While classified as woodland game, these birds find cover conditions to their liking only where a diversity of vegetation fulfills their food and shelter needs throughout each season of the year. The fact that the grouse is a sedentary species with a normal cruising radius of less than a mile and a minimum territory requirement of perhaps ten acres, suggests either very simple requirements or a fairly high degree of dependence on the occurrence of suitable habitat conditions within small areas. The latter surmise is more nearly the case for in large measure, it is the quality rather than the quantity of the cover that determines the number of hirds a given woodland can support.

Quality is seldum easy to recognize. One can determine the characteristics of grouse cover only by locating the various cover associations which support grouse and by finding just what part each plays in the life history of the hird. By studying the use grouse make of the trees. shrubs, grasses and herbs. individually and as a community. that comprise a cover type, one may gradually build a picture of food habits and shelter requirements.

Man has, as yet, few ways of perceiving bird needs except by the roundabout method of charting actions and, from them, attempting to recognize the compelling reason. The interpretation is, of necessity, slow, for we have only our own experience as a guide and imagination is required 10 put ourselses in the place of a grouse in attempting to explain its reactions. Because the probability of error in such observations is so great. a truly staggering number of these must be recorded covering each individual place and activity. The number must be large cnough to rule out the chance that, when analyzed. the result sccured may represent but an incidental reaction to a situation rather than a characteristic habit of the species.

liuffed grouse range extends from Georgia to Hudson Bay and Alaska. from the Atlantic to the Pacific, from Long Island's low-lying plains to the stunted forests atop the higher Adirondacks. Throughout all of it the broad factors that govern grouse productivity are the same. But the specific combinations of conditions prevailing in different localities vary widely. This is particularly true of the plant and animal associations. Thus a study of the relationships of the species in New York can reveal its shelter nceds as a whole but evaluation of the part each cover type plays in fulfilling them can he attempted only for the situa. tions actually ohserved.

\section{CHARACTIRISTICS OF PRODUCTIVE GROUSE, COYER}

For practical purposes, one may divide grouse cover into natural groups such as open land. wergruwn land. woodlands and slashings or cutower areas. Most of these, in turn. may be further sublivided into subgroups called cover types. Woodlands. for instance. may le compused of lilocks of second-growth hardwoods. mature hardwoods. conifers or a mixture of hardwools and conifers ${ }^{\Delta}$.

Lach large plant commmity and cover type carres within it al special set of eonditions. Though grouse are adaphble hirds. they have by necessity hecume more or less specialized for living within a fairly hroad range of cover conditions. The extent to which they (an find the hasic life needs met within a given cover type is a measure of that t! pes importance and use.

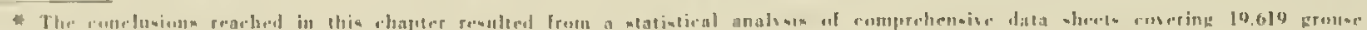

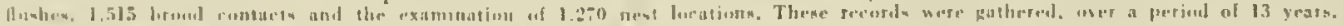

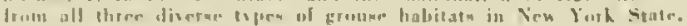

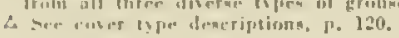


fulness to the bird. What, then, are the characteristics of productive grouse cover?

\section{In General}

Food and shelter are the two prime requisites of life. The largely wooded habitat in which grouse live, must provide these conveniently and in abundance throughout the entire life cycle from egg to adult if the birds are to prosper.

Each type of grouse cover normally produces some of both, hut in widely varying amounts. Few, if any, cover types contain within their borders amounts adequate to supply grouse needs for a month or a week or. with some types, even for a day. Furthermore these needs vary with the kind of day, the season and the particular activities lhat are heing carried on.

For instance. in the winter, cover furnishing favorable shelter is a prerequisite. for the danger from predators and unfavorahle weather is then at its heiglit. Food. on the other hand, is not a critical item for much wooded cover is sufficiently varied as regards composition so as to provide the necessary buds and fruits. In spring the prime need is for types providing adequate breeding and nesting cover. In summer, feeding grounds for the broods are important. Fall brings on the harvest moon for man and bird, with covers that support fattening foods receiving the lion's slare of attention.

These seem to be the outstanding seasunal requirements, though of course there are others of lesser importance. To meet these, good grouse cover must pussess certain characteristics.

\section{Covert Size and Shape}

The smallest unit of fairly isolated hahitat in which grouse have nested. raised brools and maintained themselves the year around. to be surveyed ly the Investigation. was about 10 acres in extent. Though completely surrounded by large open fields. hirds ucasionally traveled between it and other woodlands in the vicinity, thus making it impossille to state with certainty that, as a unit, it could have been self-maintaining. The same may he said of two other coverts, similarly situated. containing slightly less than 25 acres each.

Providing the proper cover ypes are present and productively intersperect. there seems to he no upper limit to the size of a goud grouse covert.

The shape of a covert. though often of interest to the hunter. seems not to be two important to the grouse. Long, narrow strips seldom provide for the proper interspersion of cover types. Rectangular-shaped coverts provide more "outside edges". in which food is often abundant. than do areas that are more nearly square in outline. This is especially true where the coverts are disconnected and apt to be small as in many farming communities.

\section{Type Size and Shape}

The reverse of the situation just described is often true as regards the size of the varioutypes that make up a covert. Ninimum dimensions are usually unimportant. A few clumps of a dozen conifers each may provide adequate winter shelter for several grouse. The culting of a few "wolf" trees. with wide-spreading, dominant crowns, in a woodlot may let in light sufficient to encourage small patches of briers furnishing summer food for a brood. The important thing is that the type be large enough to create an "edge" and to allow for the development of the regetation characteristic of that type within its borders.

But maximum size is another story. The amount of "edge" is inversely proportional to type size. Furthernore large blocks of a single type seldom encourage maximum popula- 
tions, since use, too, is often inversely proportional to the distance from the type edge. For instance, a study of the use made of blocks of coniferous reforestation " indicated that birds scldom penetrated much beyond 200 fect inside the block. Likewise, large, overgrown ficlds are seldom patronized much by grouse except where an edge adjoins wooded cover.

One cannot, however, carry this idea to extremes. Each type fulfills a function in providing certain necessities. In general those that provide food (overgrown lands and cut-over areas) may well be small and scattered. Those furnishing shelter at critical periods (particularly in winter and during the spring breeding season) meet grouse requirements better if they are somewhat more extensive.

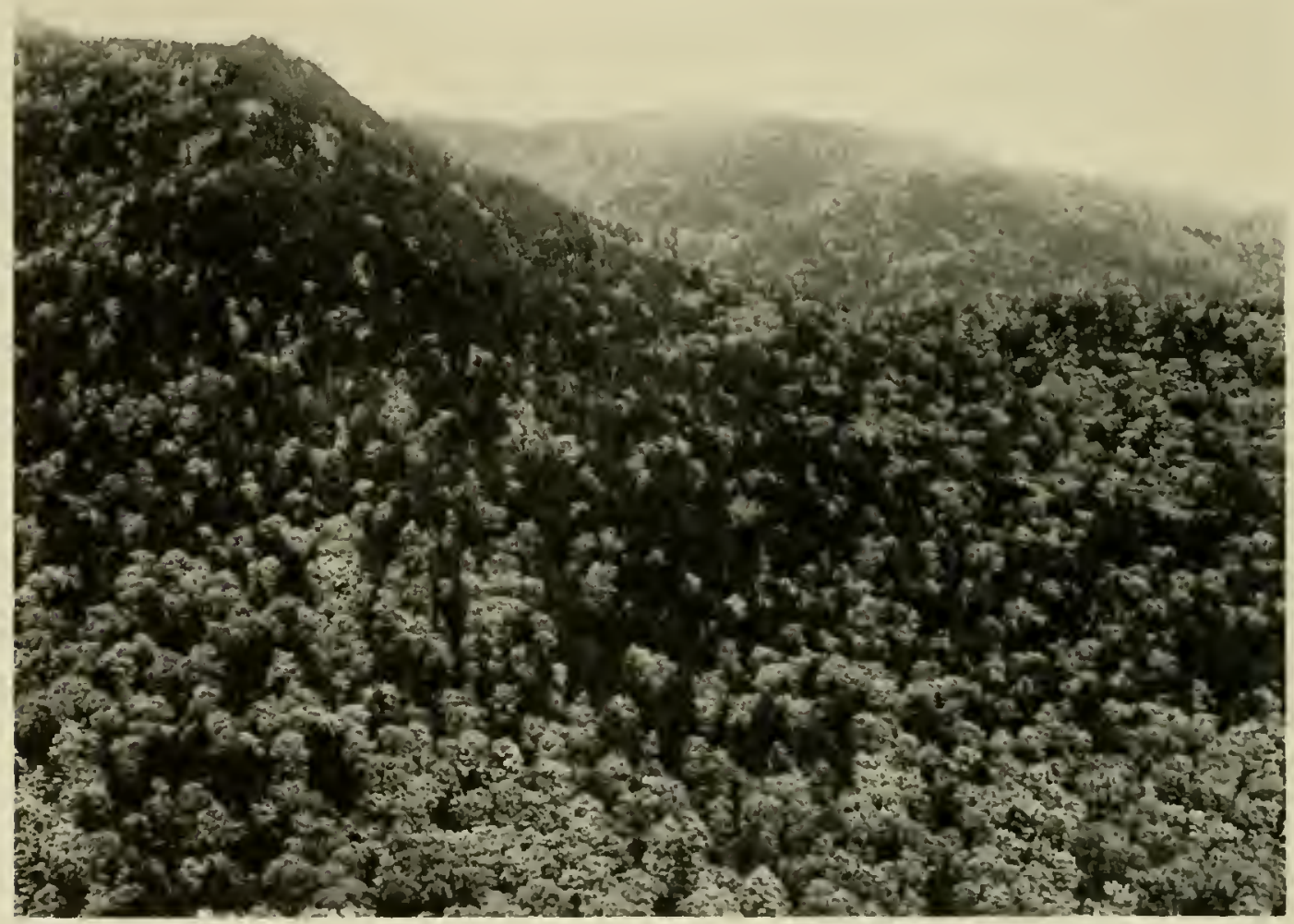

GROUSE ARE SELDOM ABUNDANT WIERE THE FORFSTS ARE EXTENSIVE AND UNBROKEN

Much of the foregoing discussion is also equally applieable in considering the shape of a type. In gencral, the larger the "cdge" the more productive the type, for the opportunity for grouse to make use of it is thereby increased. Irregularly shaped pieces are both desirable and the rule, though extremes may result in lowered use $e^{\Delta}$.

\section{Type Composition}

The vegetative makeup of a type is determined by climate, soil, slope, accidents such as fire, by the life within it and by man's activities. Grouse cover needs are hest met hy vegetation characteristic of the intermediate stages in plant succession from open land to climax forest.

- Described on P. 174.

\& See Chapt. Xil. "Hesigning Grouse Habitato" for sugceated upe pattern. 
Nature, often aided by axe and plow, produces the type; man distinguishes and classifies it according to its composition to meet his needs*. So also does the grouse. Though the makeup of a type may vary considerably, its essential vegetative characteristics are sufficiently constant so as to meet more or less completely certain requirements of the bird. Just how completely depends upon composition.

A type reaches its best development for grouse when a large variety of species distinctive of it and useful to the birds are present. An uneven distribution of species and of plant density within the type is usually a sign that it will adequately fill its niche by providing certain necessities of life for the grouse.

Likewise the more luxurious the growth (though not the density) of the various species, the better the net result is likely to be.

A more detailed discussion of type composition will be found later in this chapter for composition is one hallmark of quality in grouse cover.

\section{Interspersion of Types}

The same principles that make plant variety and interspersion so desirable within a type, apply with equal force as regards the arrangement of types within a covert. Two of these, furnishing essentially similar services, such as fall feeding grounds, adjoining each other, are less likely to be used than as though they were separated by types furnishing acceptable shelter and resting opportunities. On the other hand, should birds have to travel far from food to shelter over open land, for example, they would be more sulject to predation than as though the types were adjacent.

There is, then, a rather definite pattern of type arrangement which must exist if a covert is to be productive of grouse. The types that provide for the critical necessities, winter shelter, spring breeding grounds and summer and fall feeding grounds must lie within the territory ${ }^{\Delta}$ of, and be available to each grouse without necessitating the taking of undue risks or effort to reach them. The greater the distance any one is from all the others, the larger the territory occupied by an individual or a group of lirds must be and the smaller the number of grouse the covert will support.

The territory requirement of an individual grouse varies considerably. Psychologically a bird may be satisfied to maintain ten to fifteen acres as its especial domain, though at various seasons it may be shared with other grouse. But the cover quality and interspersion is often so poor that its food and shelter needs cannot be met without including 50 to 75 acres in its estate.

A major objective in cover management, then, is to encourage the development of a type pattern in which these cover requirements are met within a relatively small area. No matter how productive an individual type may be, grouse will not use it to the fullest extent unless it is properly located with respect to other types. The order of arrangement seemingly matters but little; it is the fact that all necessary types are to be fomnd within the normal cruising radius or territory, that is important.

\section{By Regions iN New York State}

On the basis of grouse habitats three major regions may be recognized in New York. In figure 13 the portions of the State most typically representative of these are shown. While

\footnotetext{
* See description of types recognized, p. 120.
}

$\Delta$ See discussion of grouse territories, p. 257. 
the fundamental character of each is distinct. there are wide belts around and between them where they merge with and overlap one ansther. Also included in many parts of this interme. diate zone, particularly along the Ontario-St. Lawrence plain and in the Mlobawk-Hudson Valley. are areas of intensively farmed agricultural land where grouse coverts are few and of low quality.

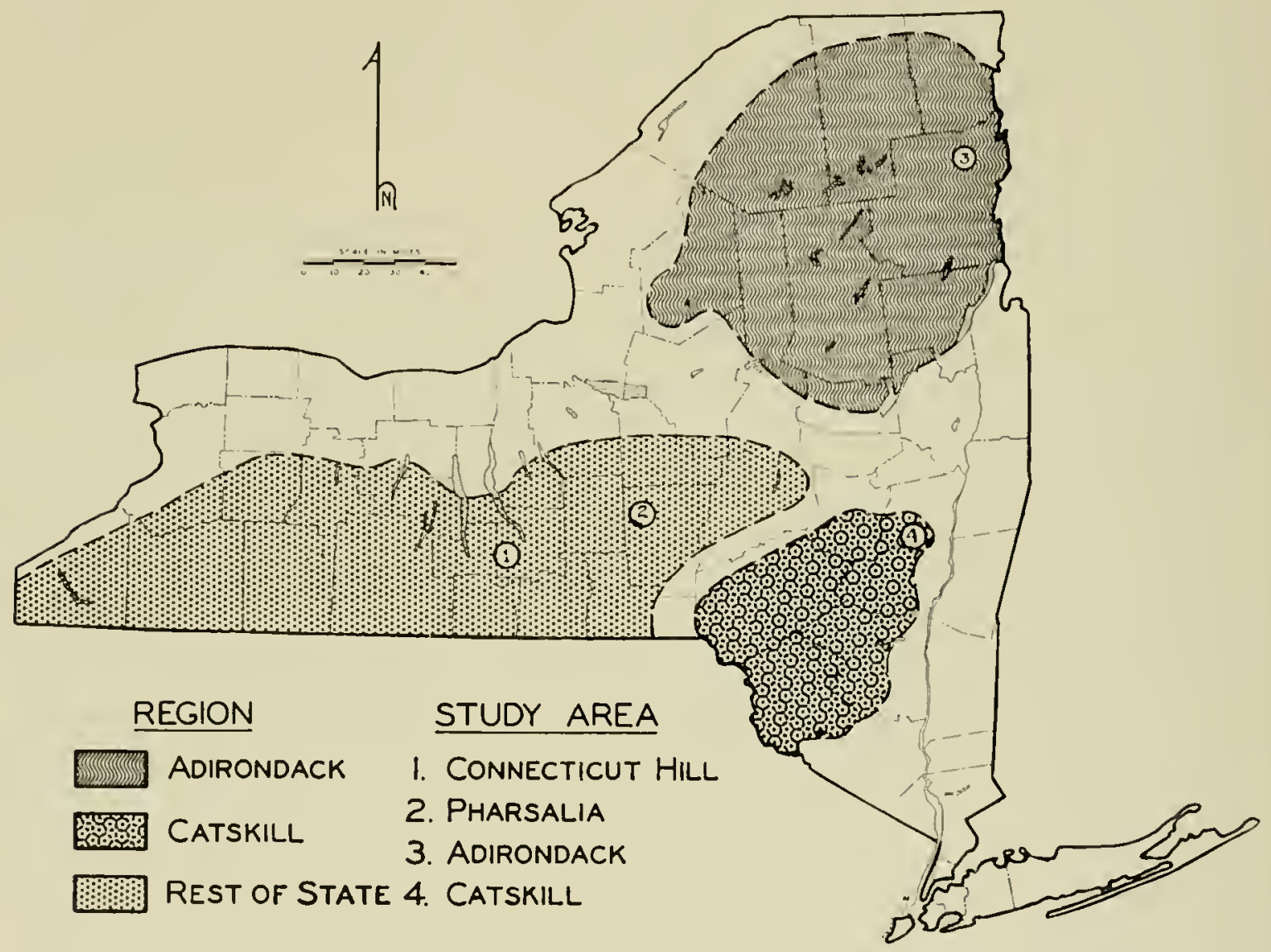

FICIRE, 13. PARTS OF NEW YORK STATE, MOST TYPICAI, OF THF, THREF, MAJOR CROUSF: HABITAT RFG;ONS AND THE LOCATIONS OF THE INVESTIGATIONS STUDY AREAS IN FACH

The basic factors controlling grouse ahundance. such as shelter. food. predation and disease have heen studied in some detail in each region". The conclusions thus reached are there directly applicable. Nevertheless most of them are probahly valid, in the main, for other sections of the Northeast where similar grouse labitats prevail. A lorief deseription of the conditions in each may, therefore. be of more than local interest.

\section{The Adiromlacti Region}

'lhe granite rocks and sands that make up the Adirondacks are among the oldest to be found on the North American continent. The suil is shallow, sandy and poor. 'The region is

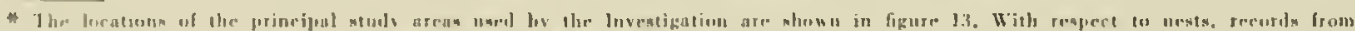

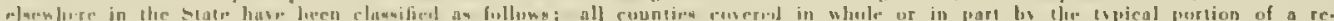

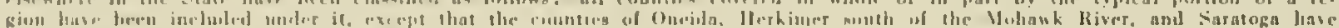

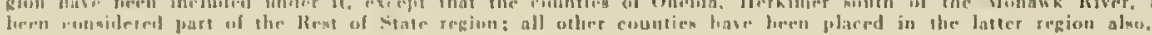


characterized by large tracts of forest. unbroken. except where rock outcroppings or wind. falls provide occasional small openings. Interspersed among these areas one finds beaver meadows, lake shores, alder beds. cranberry bogs, hurns and. about the settlements. clearings.

Mountain slopes and swamps were originally clothed with spruce, balsam, pine or hemlock mixed with hardwoods. notably beech, birch and maple. Although some virgin timber still exists, chiefly on State land, most of the region has been cut over. The larger conifers and some hardwoods have been taken for timber, the smaller ones floated to the paper mills for pulp. The few roads traversing the area have made lumbering costly except on an extensive scale, thousands of acres occasionally being involved in a single operation. On the higher ground the succeeding second-growth is predominantly hardwood with spruce or pine while in the lowlands and swamps, spruce, balsam and larch are often abundant. Here the whitetailed deer have repeatedly hrowsed off the smaller hardwoods and the halsam. Largely as an aftermath of logging, a number of severe burns have occurred. particularly in 1903 and 1908 , creating barrens into which such pioneer species as pin cherry and aspen are gradually seeding.

In terms of providing for the cover requirements of grousc, most of the Adirondack forrst leaves consideralote to he desired. Both second-growth and cutover land are apt to occur in large blocks. thus affording litule of the interspersion of types conmonly found in the other regions of the State. Conifers affording winter shelter are ahundant. hut the herls. berries and fruits furnishing good summer and fall food commonly occur in numbers only in the alder runs, along the edges of the hurns, in the recently cut-over lands and in the small. often grassy, openings resulting from windfalls or from one or another of man's activitics. In such places grouse tend to coneentrate: elsewhere they are nsually quite scattered. Nhout the periphery of the region, however. the soils are more fertile and. as the forest cover becomes more and more interspersed with farm land. one finds hahitats of much letter quality.

\section{The Catskill Region}

Although similar in many respects to the Adirondacks. the Catskils have a forest corel more varied and less continuous. Mostly a region of sedimentary rocks. it - forests are of birch, beech. maple, pine and hemlock, with spruce at higher elevations. particularly on the nurthern slopes. In type ther are more clusely associated with the Alleghenies to the south and the lower New England mountains to the east. Pastures thrust long fingers up from the farms scattered along the valleys. The region has been extensively cut over. mostly in rela. tively small blocks, the conifers for lumber and the hardwoods for cordwood and for saw logs. In the western part, where acid wood distillation was once a thriving industry. the slopes are largely grown up to second-growth hardwoods interspersed with hemlock. Much of the wondland is grazed though seldom with sufficient intensity to encourage much grass. There are many overgrown pastures.

The soil is more fertile than in the Adirondacks, thus producing a greater variety of species and density of cover. Where the crown eanopy of the woods is not too thick. undergrowth and ferns, including mountain laurel and rhododendron in the southern half. occur over large areas. Openings and cut-over lands commonly support a profusion of herbs and berries. They also seed in fairly rapidly to hardwoods and. occasionally: to hemlock and pine as well. Abandoned farms are not uncommon.

As might be anticipated under such conditions. woodland. cut-over areas and brushy pas- 
tures often combine to furnish much high quality grouse habitat, although, along the ridges and at the higher elevations, the continuous forest cover seems to meet less satisfactorily the varied needs of the birds.

\section{Rest of State}

The regions just discussed contained much land too steep, too stony or too difficult of access to attract many settlers but, in their broad periphery and across the south-central and south. western part of the State (locally known as the Southern Tier). conditions were more favoralle. On the hilltops farmers moved in, cleared or sold off much of the pine and hemlock,

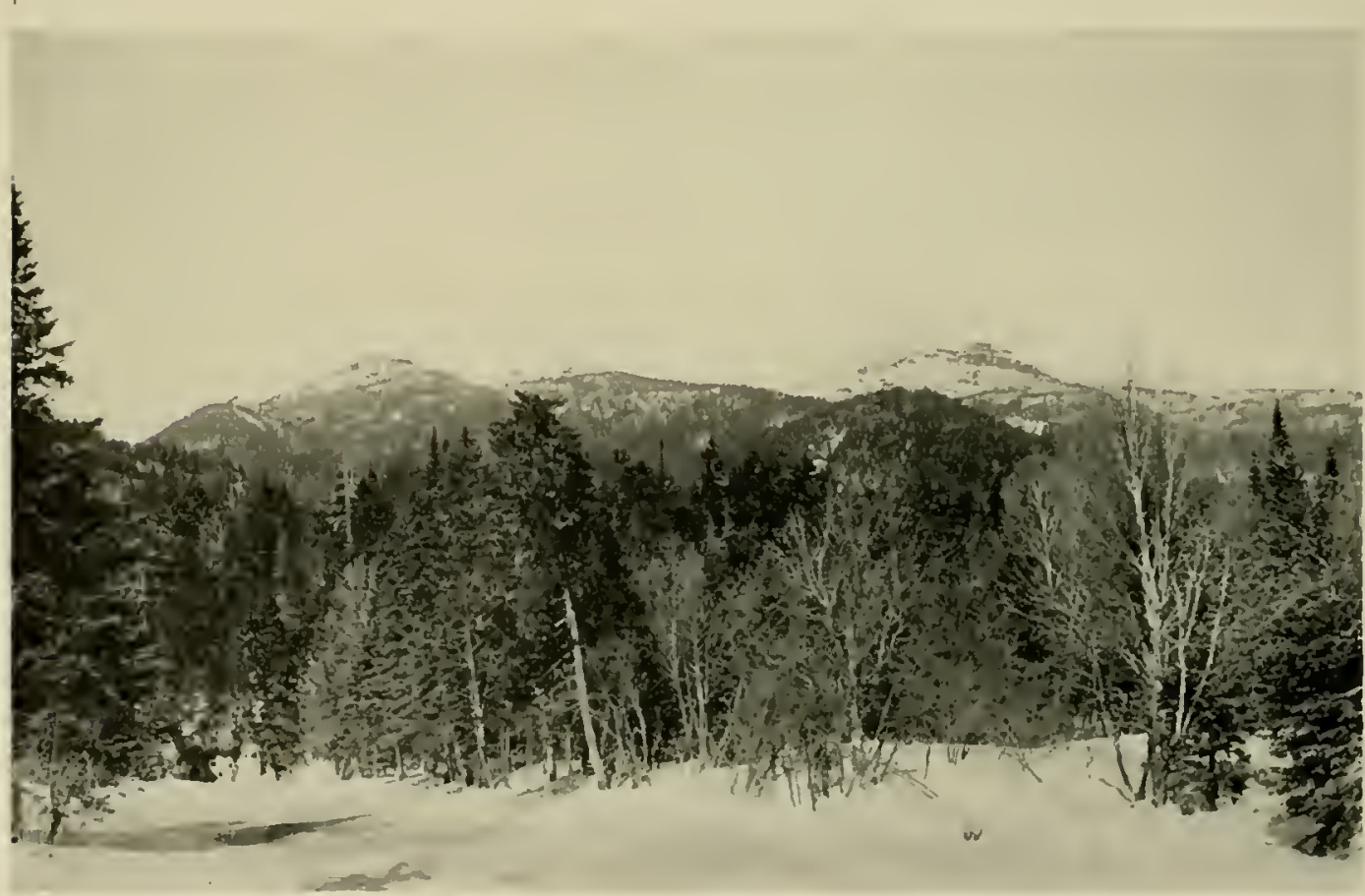

TIIE ADIRONDACK REGION CONSISTS OF MOUNTAIS AND WIDE LOWLANDS. FORESTED CHIEFLY WITI SPRLCE. BALSAM, PINE. BIRCII ANO MAPLE. IN THE VALLEYS ARE SCATTERED PONDS. SWAMPS AND CLEARIXGS

mined the shallow top soil of sidehill and upland and stripped the woods of everything worth selling and moved ont a century later.

In the deeper valleys and occasional fertile upland pocket, however, farming has prospered. Here wondlands have shrunk to woodlots. held as a source of lumber, posts and cordwood needed about the farm. Where these are sufficiently large and not too heavity pastured, some grouse usually find acceptable, if limited, coverts.

But in the poorer uplands, where the farmer has given up or is at hest making scant progress in combatting the shrubs and trees which seem, in a few short years, to take possession of his unworked fielels or his poorly grazed pasture, grouse habitats, as productive as any in the Northeast, are commonly to be found. Here Allegheny and Northern hardwood types meet. Oak and maple, beech and birch, pine and hembock vie with each other in endless profusion. The partly abandoned farmands and pastures are constantly heing overrun by fall 


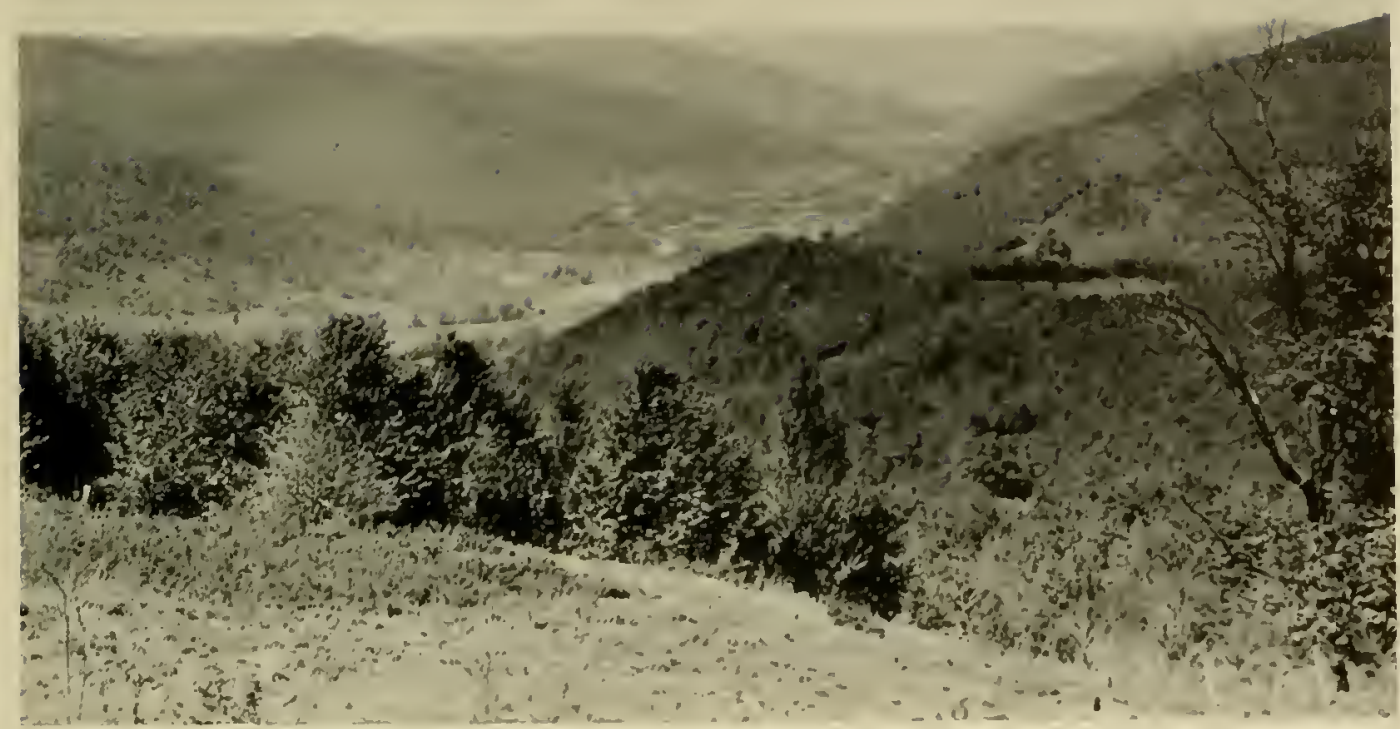

TIE CATSKILL REgION IS A LANI OF NARROW. FARMED VALLEYS WITI PASTURES EXTENDING UP THE SLOPES TO MEFT EXTENSIVE FORESTS COMPOSED MAINIY OF BEECII, BIRCH, MAPLE, IEMLOCK AND IINE

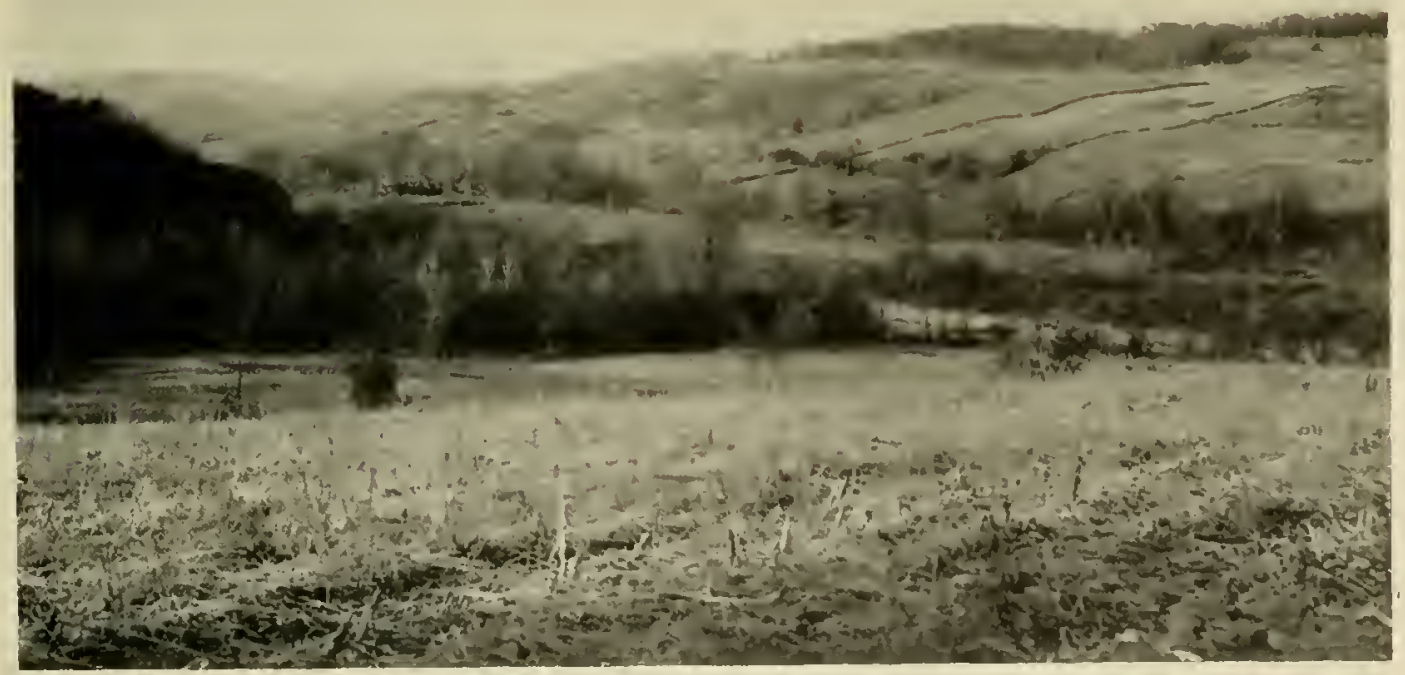

THE REST OF STATE REGION IS CHARACTERIZED BY FERTILE VALLEYS AND POORLY FARMED UPLANDS. HERE THE MOSAIC OF ABANDONED FIELDS, OLD PASTURES AND WOODLOTS FORMS MANY A PRODUCTIVE COVERT 
grrouse food species such as pin cherry: aspen. thornapple. wild apple, sumac. dogwoods and viburnums. These commonly occur adjacent to woodlands in which hardwoods and conjfers furnish winter shelter and spring hreeding grounds. Woodculting operations still make available a profusion of herbs. berries and insects for the summer use of the broods. The extent of any one covert is seldom large. thus providing a characteristically high interspersion of cover types and a wealth of desirable grouse habitats.

This is but a vignette of New York State grouse coverts. It is the setting in which the Investigation carried on its work.

Detailed descriptions of the physiographic features and plant associations of each region have been purposely omitted since a chapter would be necessary to describe each in detail.

\section{THE ROLE OF SUCCESSION}

In outlining the makcup of grouse coverts in each of these regions emphasis was intentionally placed on the forest uses. past and present. The extent to which such crops as forage or wood products are harvested may affect the productivity of a woodland for grouse quite as much as does its natural composition. Most of these practices tend to arrest or throw back its normal development to an earlier stage. This may exert a strong influence on the grouse. for each stage varies considerahly in its ability to produce the required food and shelter. Likewise grouse need change with the seasons as well as with the age and the sex of the birds. The partridge has justly been called a transition type species in that it finds its year-round requirements largely met neither in the first stages associated with grasslands nor in the last or climax types of dense unbroken forest. The productive coverts are those in between.

The progression by which one stage takes over and grows into the next higher association of plants has been termed succession. But. since in grouse habitats considerable lime is involved in making the change. many hunters fail to recognize in this a likely reason why there may not be as many birds in their favorite coverts as they once remember.

Grouse cover is constantly changing. Insects and disease, fire. the axe. cow and plow alter the normal succession. There the climax type is forest. meadows. if left alone, seed in sooner or later to rank herbs and brush. The lime and kind depend on mant things. Among these are site, seed supply, weather and the aetivities of birds and mammals, particularly mice. Quick-growing species that seldom do well under shade usually thrive here. furnishing a shelter under which the more permanent species find growth conditions farorable. Many of the larger fruiting trees and shrubs. such as sumach. cherry. apple. thornapple and grape. require considerable sun if they are to bear abundantly and. accordingly. reach their hest development on such overgrown lands.

On the degree to which this development has progressed depends the use grouse make of such wererown lands. As long as the regetation remains open and luxuriant in character. an abundance of inserts. seeds. [ruits and desirahle leafy material rharacteristic of such cover attract grouse and adults throughout both the summer and fall. Once the trees take over. slututing out the sunlight, most of these plants gradually disappear. It importance to grouse changes ascordingrly.

Left alunc. overgrown fields eventually hecome second-rercowth woodlands with a more or less dense undergrowth or a ground cover of herbs. sedges aud grasses. depending on soil fertility. muisture and the existing plant association. Cradually. the quick-growing. sun-loving speries of the previous stages are shaded out b! the taller oaks. beeches. hirches. maples and 


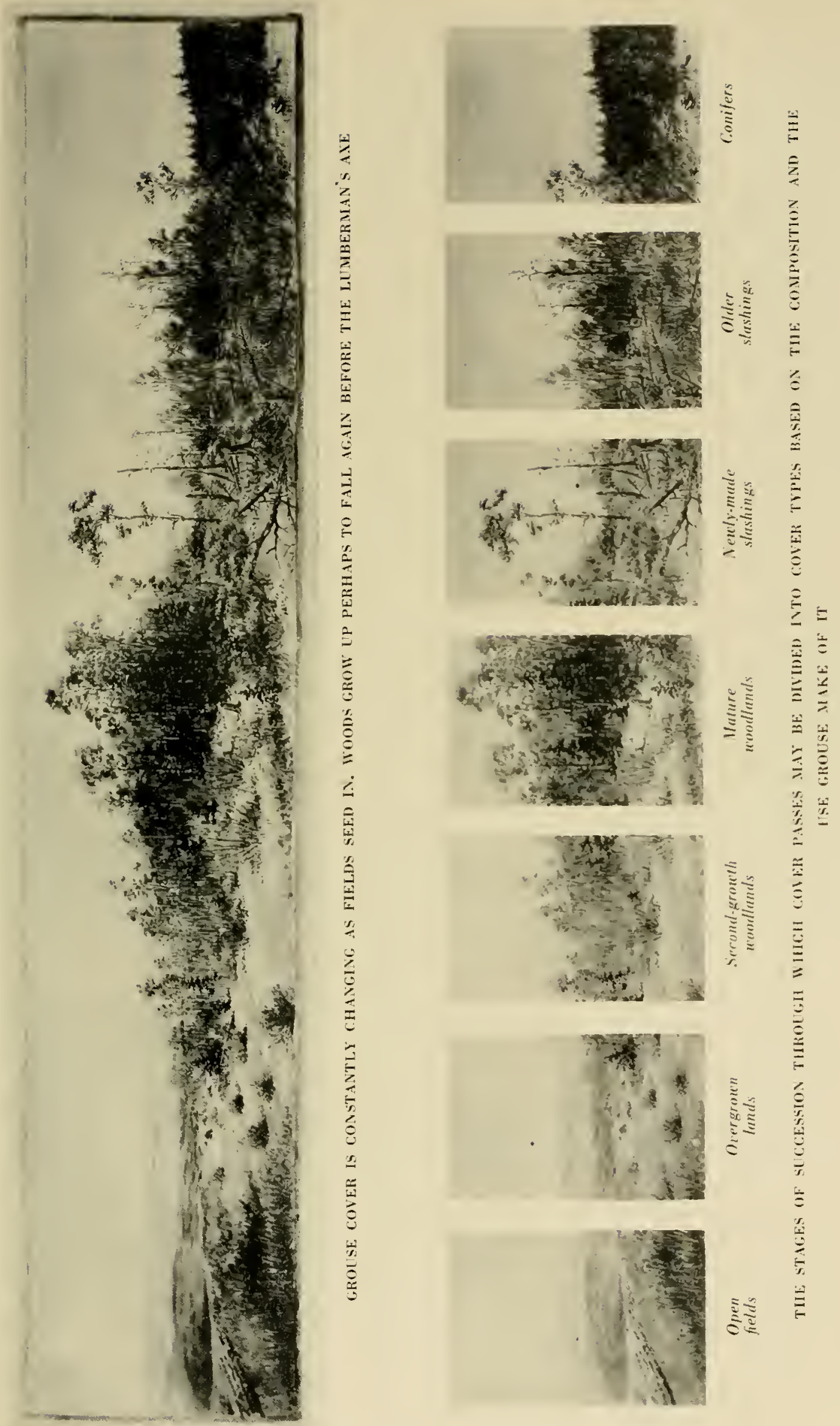


conifers that replace them.

Where the crown cover is sufficiently dense to maintain fairly open conditions beneath, such woods are often chosen as spring nesting grounds; where they are more open and the herbs and ferns thicker, they furnish considerable summer feed. With the addition of clumps of shade-loving conifers, snch as hemlock, spruce or of the more light-demanding pines and halsams (the latter usually started while the land was not yet heavily wooded), the require. ments of the grouse for shelter. especially in winter, may also be met.

As the forest matures and closes in. harring action by Nature or man to create openings. most summer and fall feed gradually disappears. The hirds are then forced to seek a more congenial hahitat along the edges. Let a wind storm create openings hy uprooting the less securely anchored trees, or a lumbering operation open up the cover, and the succession is set back accordingly. In the openings thus created herbs, briers and herries quickly spring up thus again providing abundant feed for old and young alike.

Then the birds move in again.

Thus goes on the pageant of succession. By it, the grouse are pushed hither and yon, ever seeking the places where winter shelter, spring breeding grounds and summer and fall feed lie close together. On these they must depend to a greater extent than is generally realized, for the essentials of their existence. In these they find varying degrees of protection from their scveral enemies whose success depends largely on finding the lirds in the poorer cover.

\section{COVER TYPES RECOGNIZED}

Botanists and foresters divide the various stages of succession through which a woodland may pass into cover types. The hunter, perhaps unconsciously, long ago applied the same technique as an aid in finding his birds in the fall. The basis of recognition, in one case, is largely what grows there; in the other, the use the birds make of the plants. Thus a scattering of thomapples, cherries and dogwoods along a wood's edge hecomes known as likely fall feeding grounds for the grouse. The emphasis is here clearly and rightly placed on use.

But the intricacies of cover are such that no clear picture of use ran he ohtained from chance observations alone. Neither is it practical to classify cover into innumerahle small subdivisions, for the number of records needed to determine to what cxtent each fulfills grouse cover requirements is ton great in the face of the varied habits of the bird. Based on experi. rnce, the Investigation gradually came to recognize the following twelve major cover types, representing four major stages of succession. (Tahle 13 ).

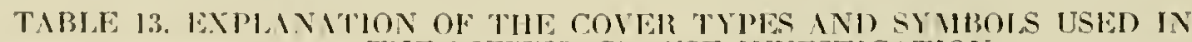
TIIE RUTFED GIROISE INVESTIGATION.

\begin{tabular}{|c|c|c|}
\hline $\begin{array}{l}\text { Sitnkess of } \\
\text { simeressiont }\end{array}$ & Typre uf emvit & $\begin{array}{l}\text { Type } \\
\text { codie }\end{array}$ \\
\hline 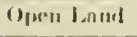 & 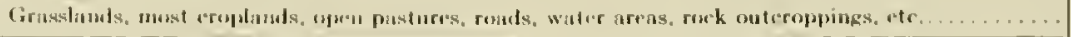 & A \\
\hline 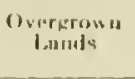 & 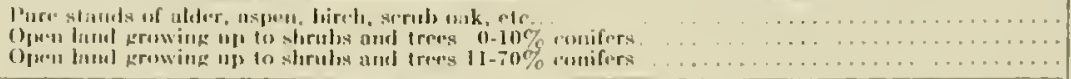 & $\stackrel{\text { Bi }}{\text { i) }}$ \\
\hline Wimsllaurls & 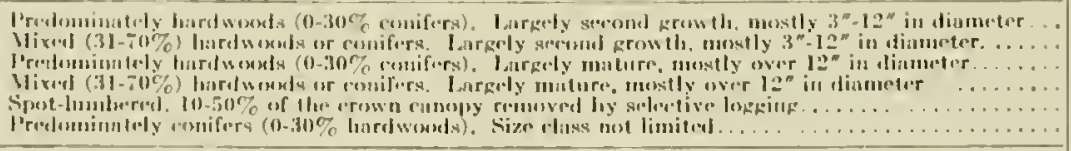 & $\begin{array}{l}\text { litis } \\
\text { ii } \\
\text { ii }\end{array}$ \\
\hline Slambings & 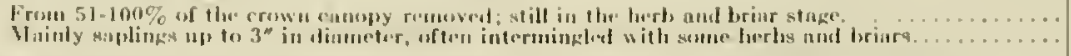 & J \\
\hline
\end{tabular}


This type selection obviously is not orthodox by such standards as foresters have proposed. A botanist may shake his head doubtfully, though the choice may make better sense to plant ecologists. Perhaps only the grouse-wise will recognize the importance of emphasizing, as the essential difference, the character rather than the kinds or species of plants as the basis of type differentiation best suited to the purpose at hand. Any one of the conifers or the broadleaved evergreens, such as mountain laurel, may represent, for a grouse, potential shelter from predators; a hundred different plants that grow in slashings may furnish it with food. In other words, the types here selected are largely representative of the different stages of forest succession or regression which function to fulfill some niche in the broad panoply of grouse cover needs.

In following such a line of reasoning, it is easy to lean over backwards. One cannot simply ignore all species of trees or shubs in evaluating the whole, for some are more productive of food and shelter than are others. The grouse is, however; so adaptable that no one or two species are indispensable to its welfare. Rather it is the groups of plants more or less characteristic of each type, which, in whole or in part. serve to fulfill one or more of the bird"s principal needs.

The degree to which these are met is regulated by the composition of the group and the proportion of the whole which it occupies. This, in part. explains why grouse are likely to be found more frequently in certain parts of a type than in others. Other equally important reasons, notably cover arrangement, are mentioned latcr.

The properties in each cover type that determine its value to the grouse may be spread throughout or localized here and there. Examples of the uniform situations which may occur are pure coniferous stands resulting from artificial plantings or an alder thicket so dense as to preclude the intrusion of other light-demanding species. Conversely. in brushy pastures. the best food conditions for grouse are usually to be found at some distance from the gate.

Though the details may differ, counterparts for most of the situations here described are prohably to be found throughout the range of the ruffed grouse. for though the species may differ, the pattern of woodland succession is much the same. Nevertieless, the usefulness of these particular type groupings in stulying the shelter requisites of the bird or in fact. of adapting many of the conclusions here drawn to other regions is depentent upon the extent to which conditions are similar to those pictured for New York and upon the success with which the influence of any differences can be evaluated.

\section{COVER REQUIREMENTS OF THE GROUSE}

Wherever grouse hunters gather, discussions are bound to arise. Where are the birds most likely to be found on warm Octoher days or in a November snow squall? Is it worthwhile hunting stecp slopes? How far will the hirds wander from shelter in search of food? Thus the questions go.

Occasionally the thought is expressed that, if the answers were definitely known. it might help an interested landowner or a state game department to manage some woodlands so as to produce more grouse. The only way to settle such matters is to turn to the hirds themselves for the answer.

It was with this thought in mind that the Investigation early started an intensive study of grouse cover requirements. Beginning in 1930 two primary study areas were estahlished in the Rest of State region and one each in the Adirondacks and the Catskills*. Secondary units

* The principal oures wete the Conneclicut Hill, Pharsalia. Adirondack and Catskill survey areas. 

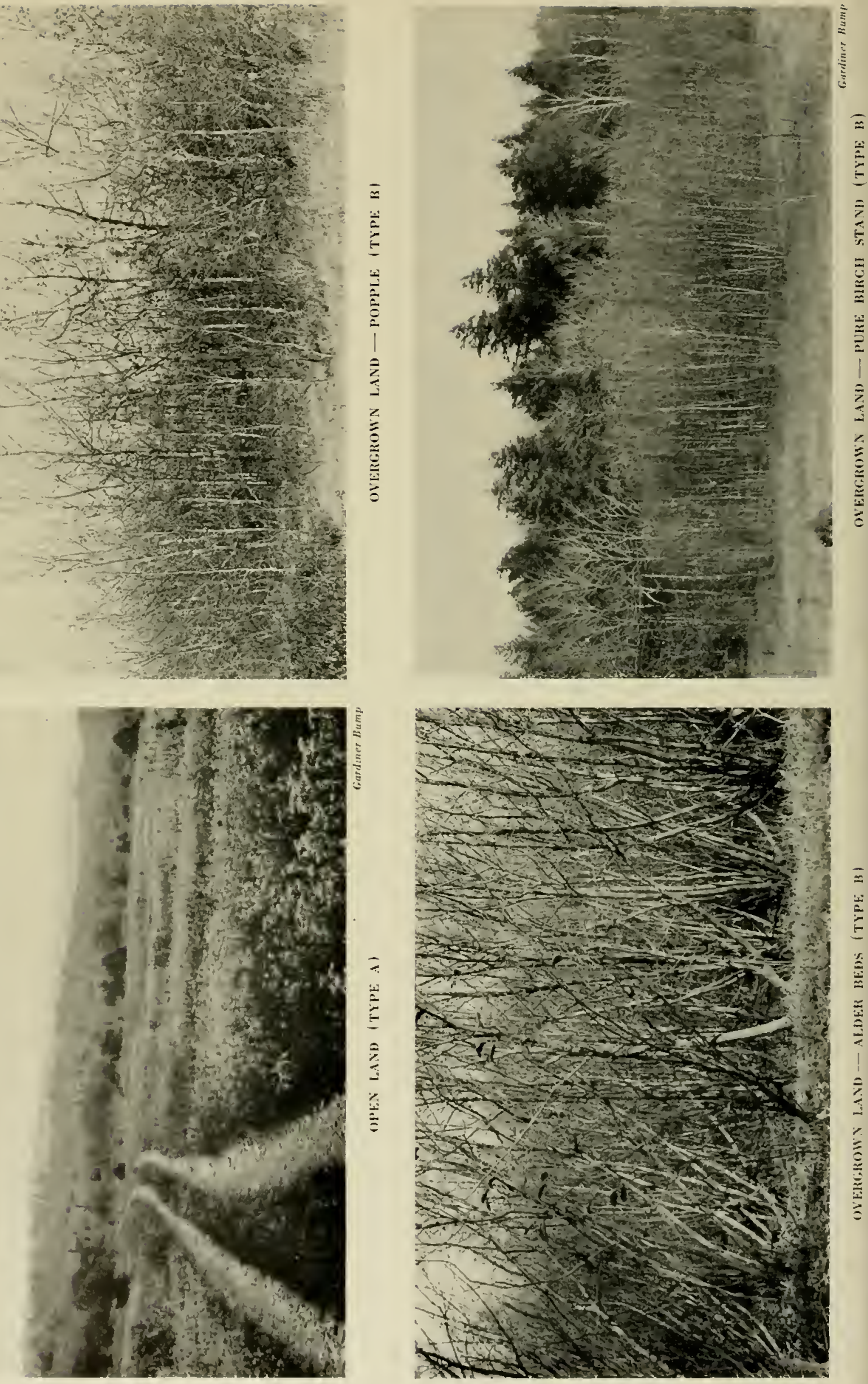
W

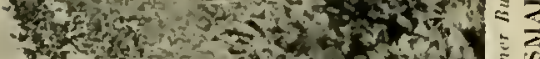

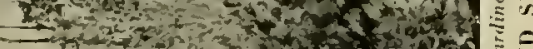

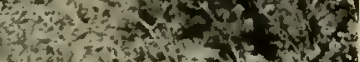

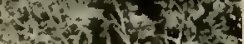

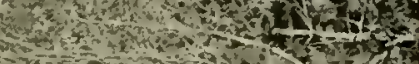
2.

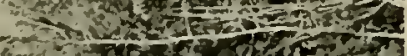

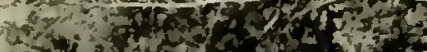

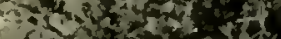

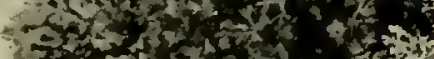

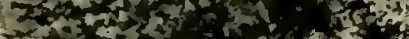

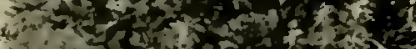
$4 x^{2}+2 x+2+2$

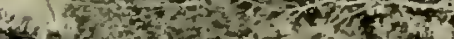

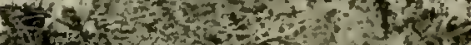

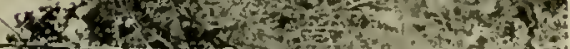

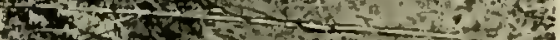

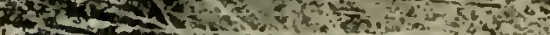

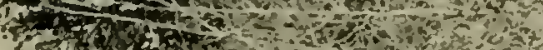

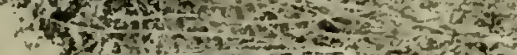

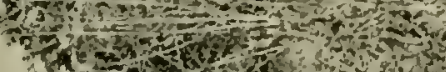

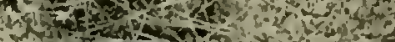

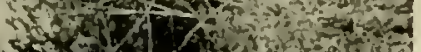

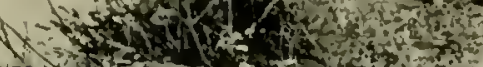

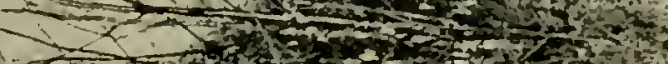

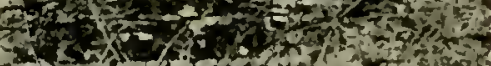

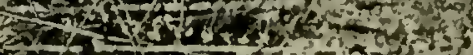

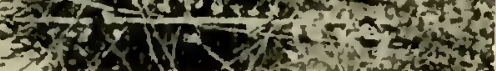

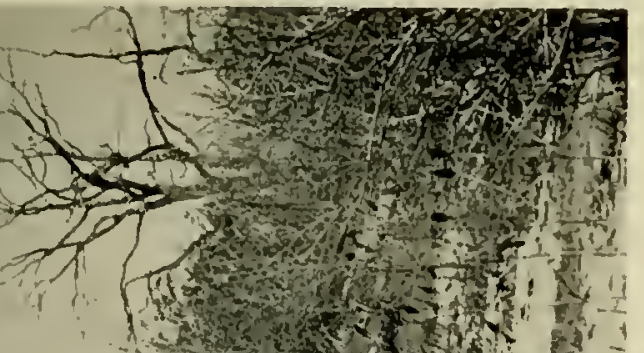

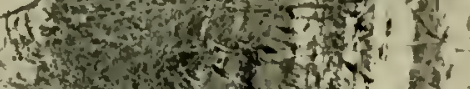

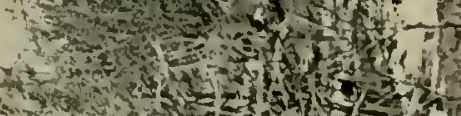

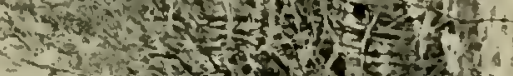

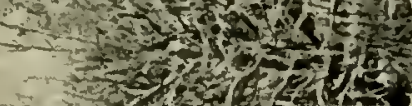

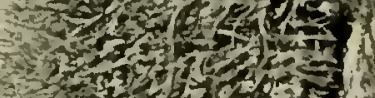

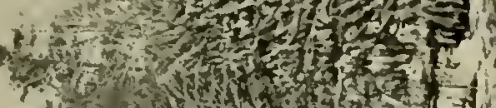

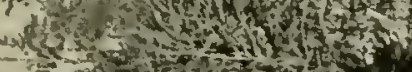

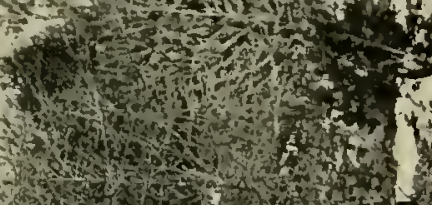

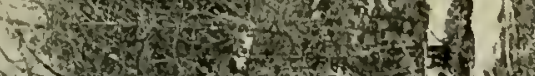

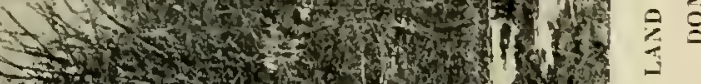

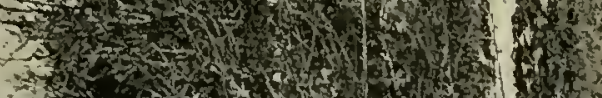

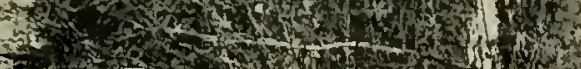

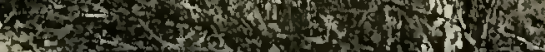

4iv (1)

$2+x+3 y-2$

Hy $x$.

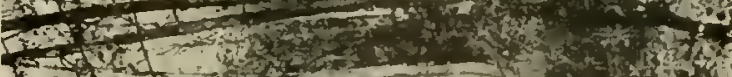

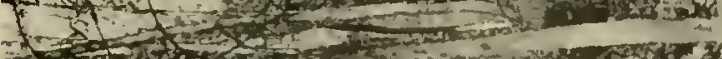

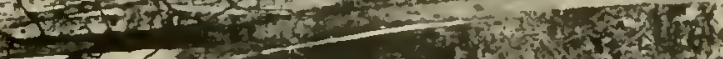

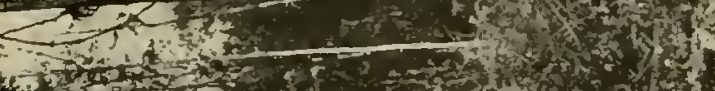

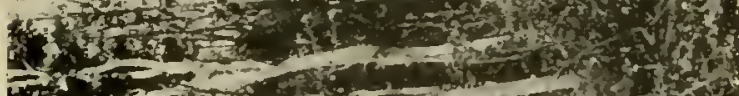
$-x=0-10$ -

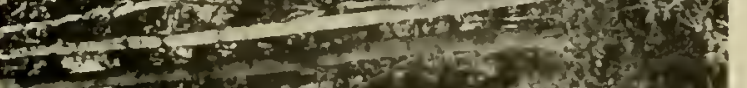

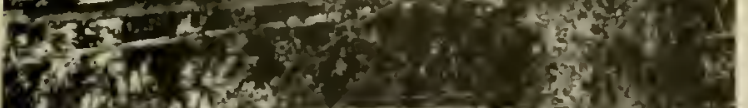

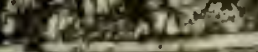

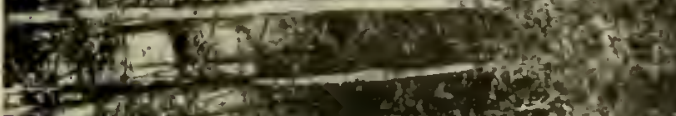

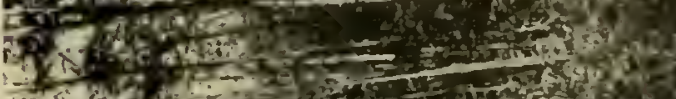

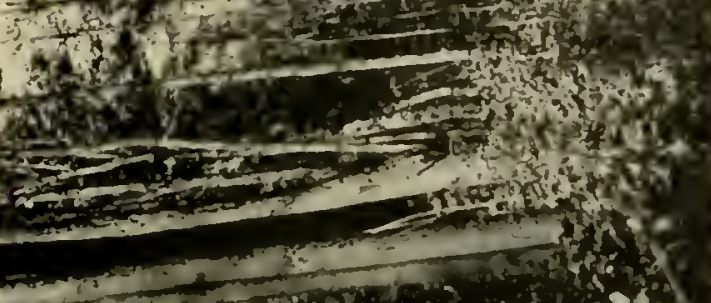

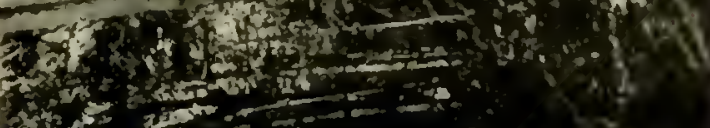

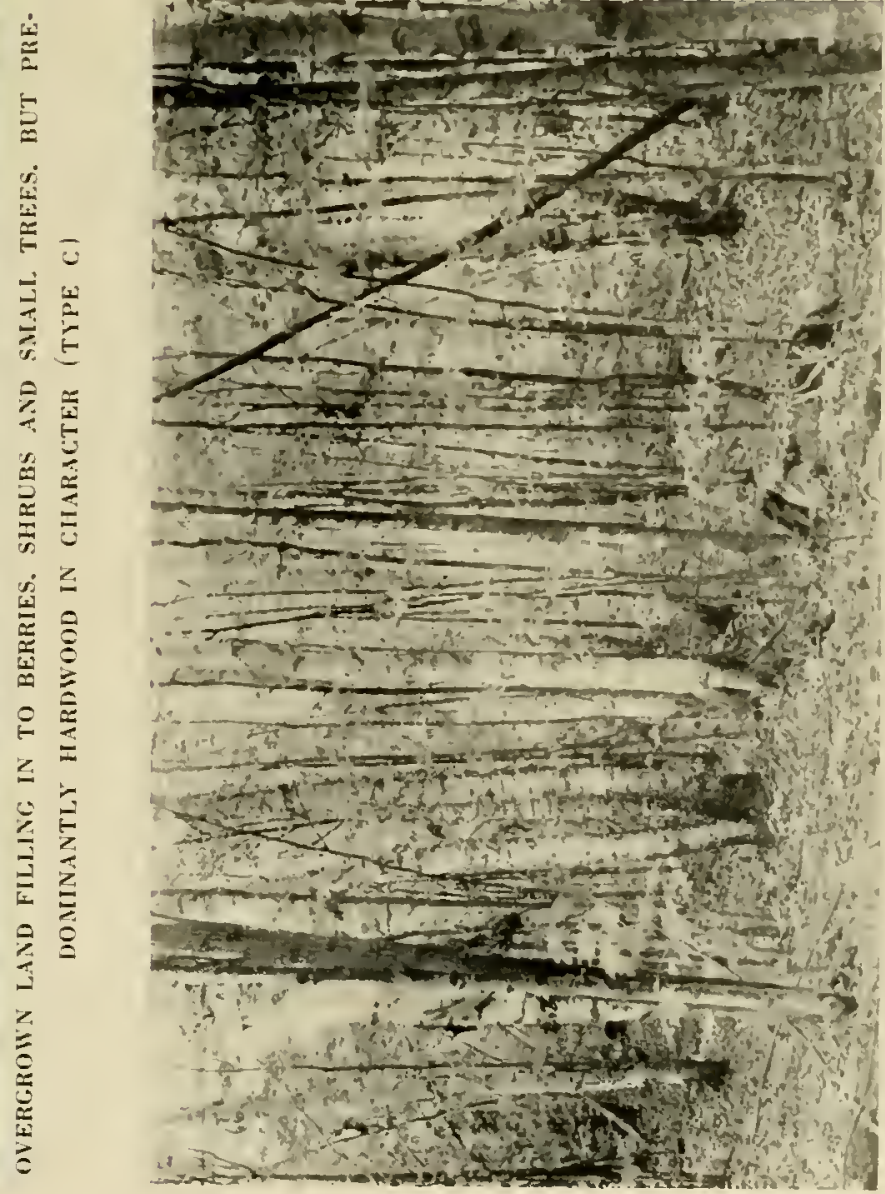


M.2.

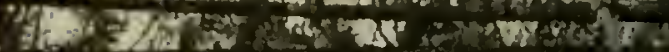
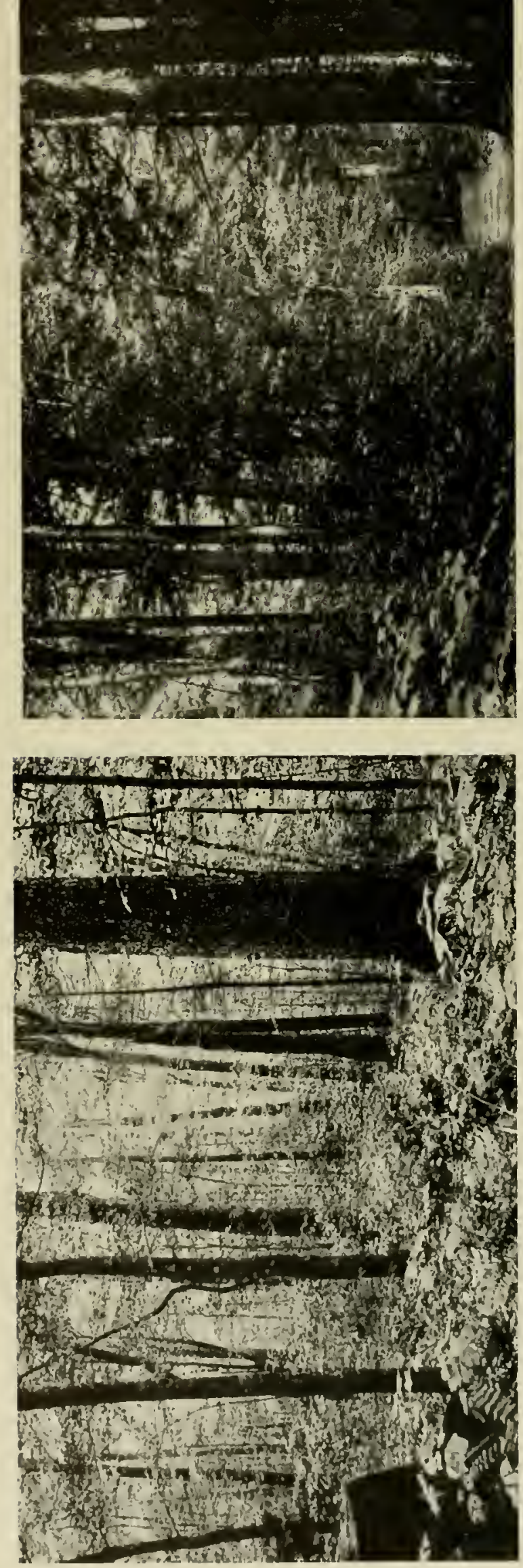

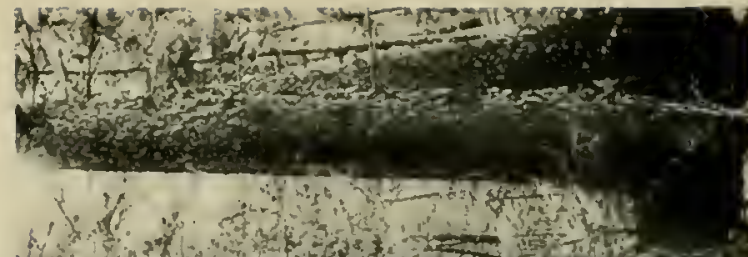

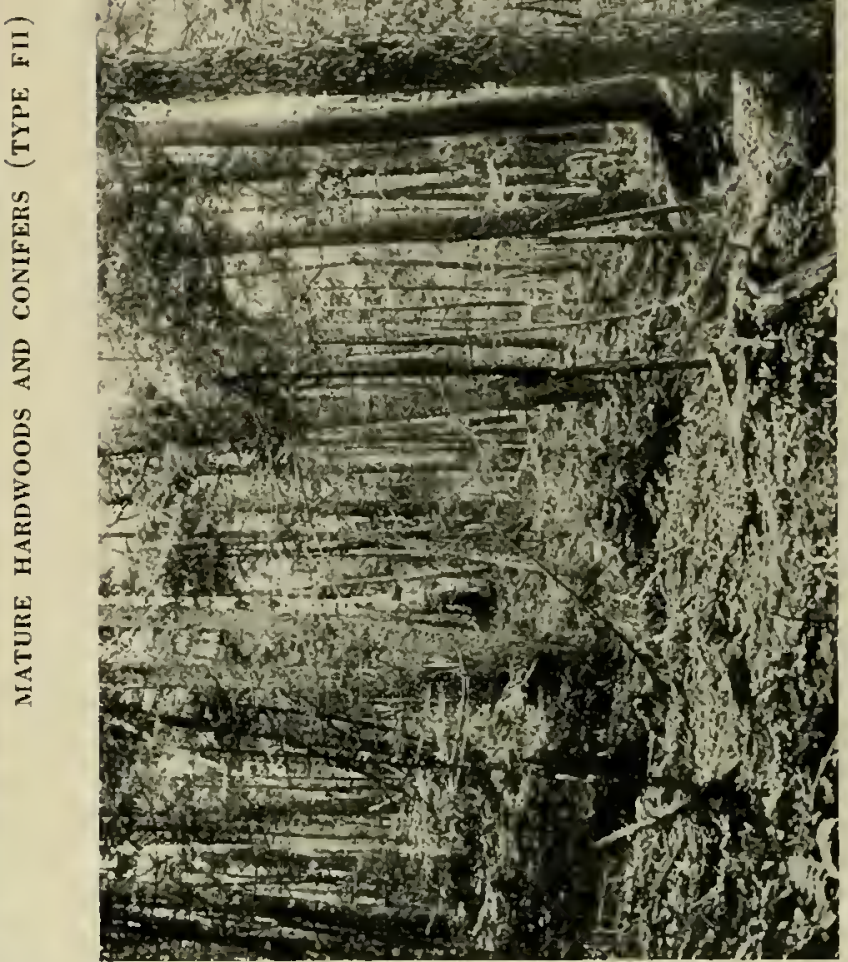

5
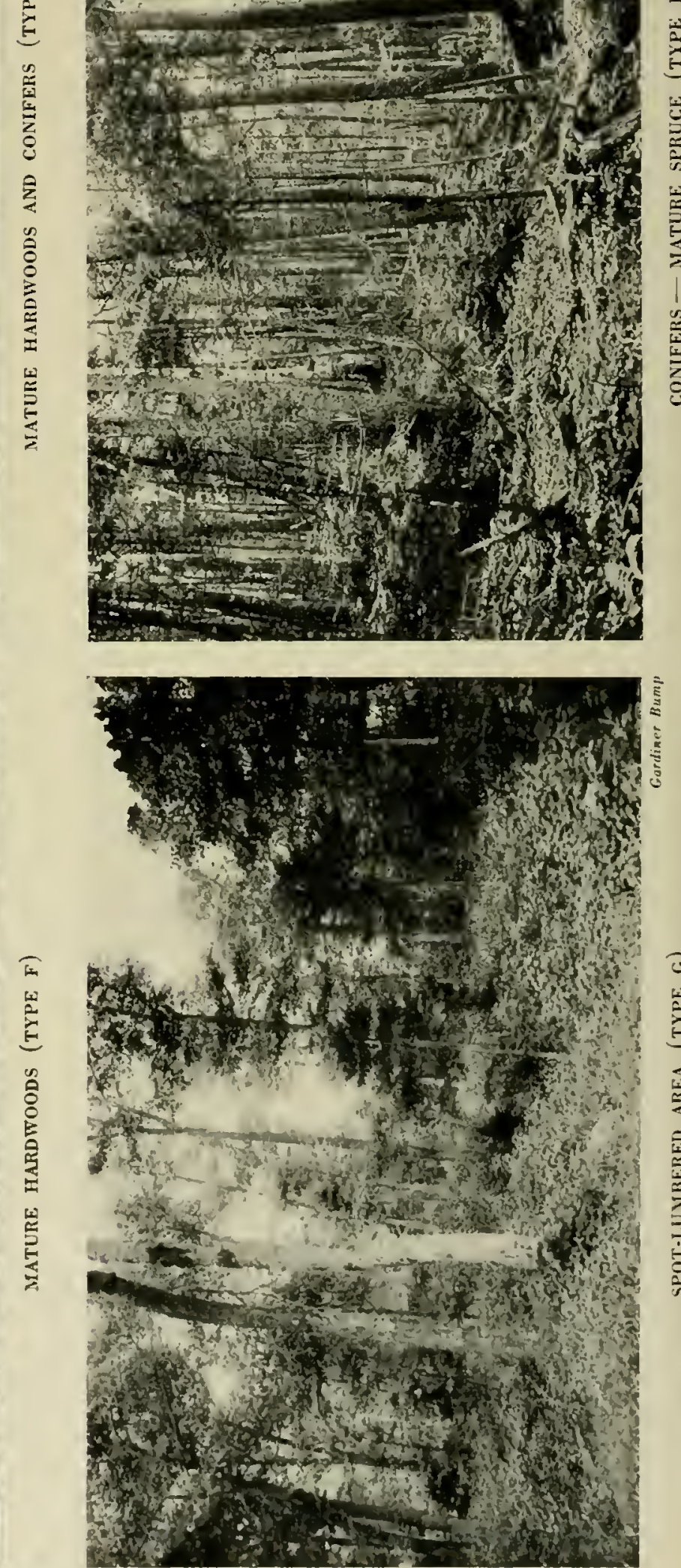

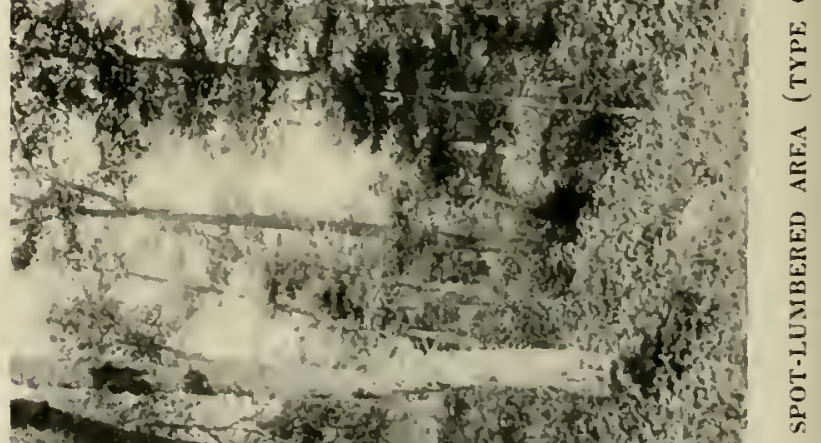



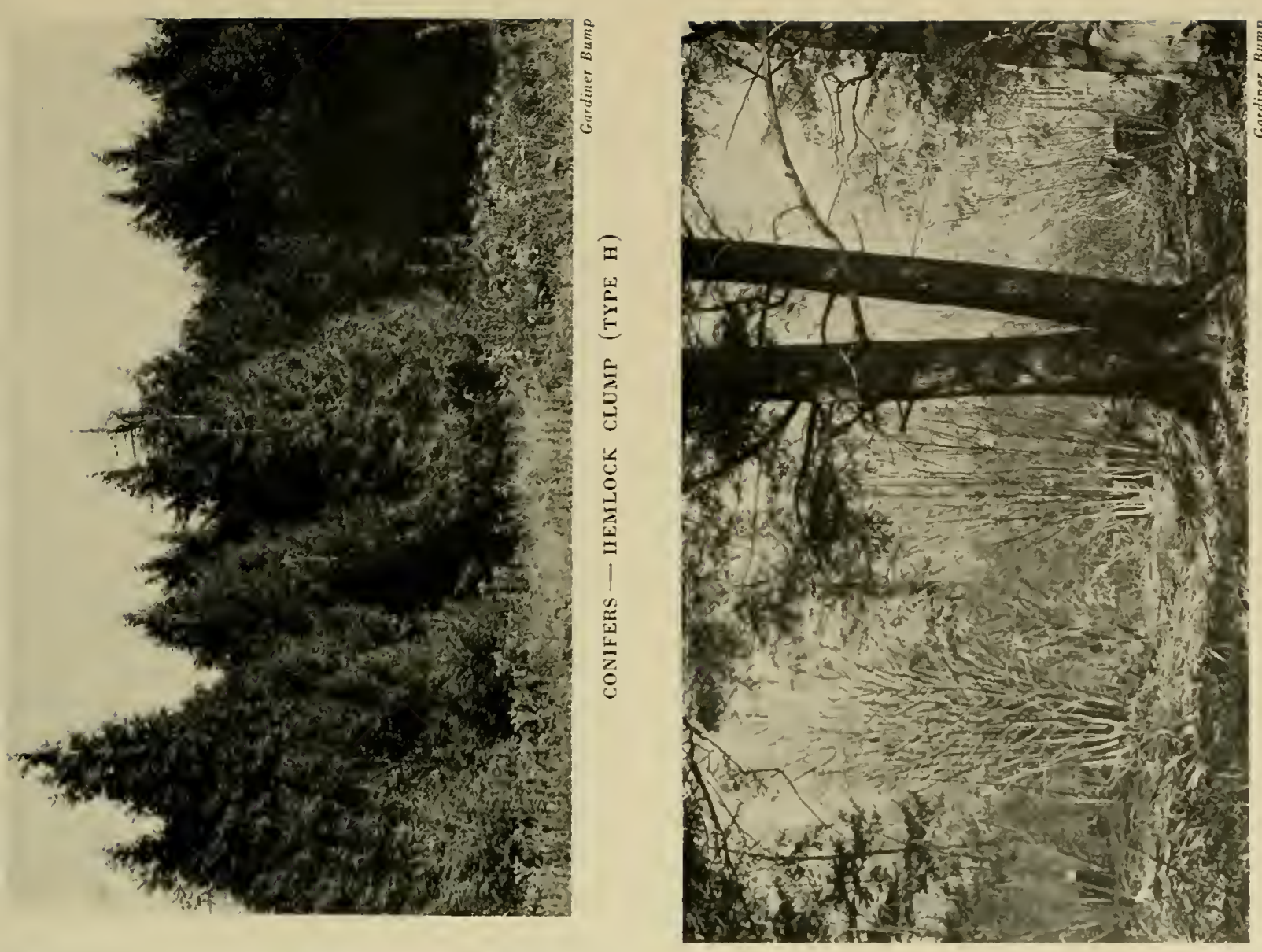

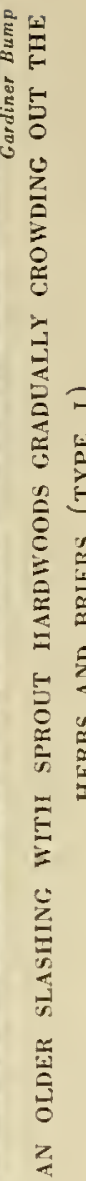
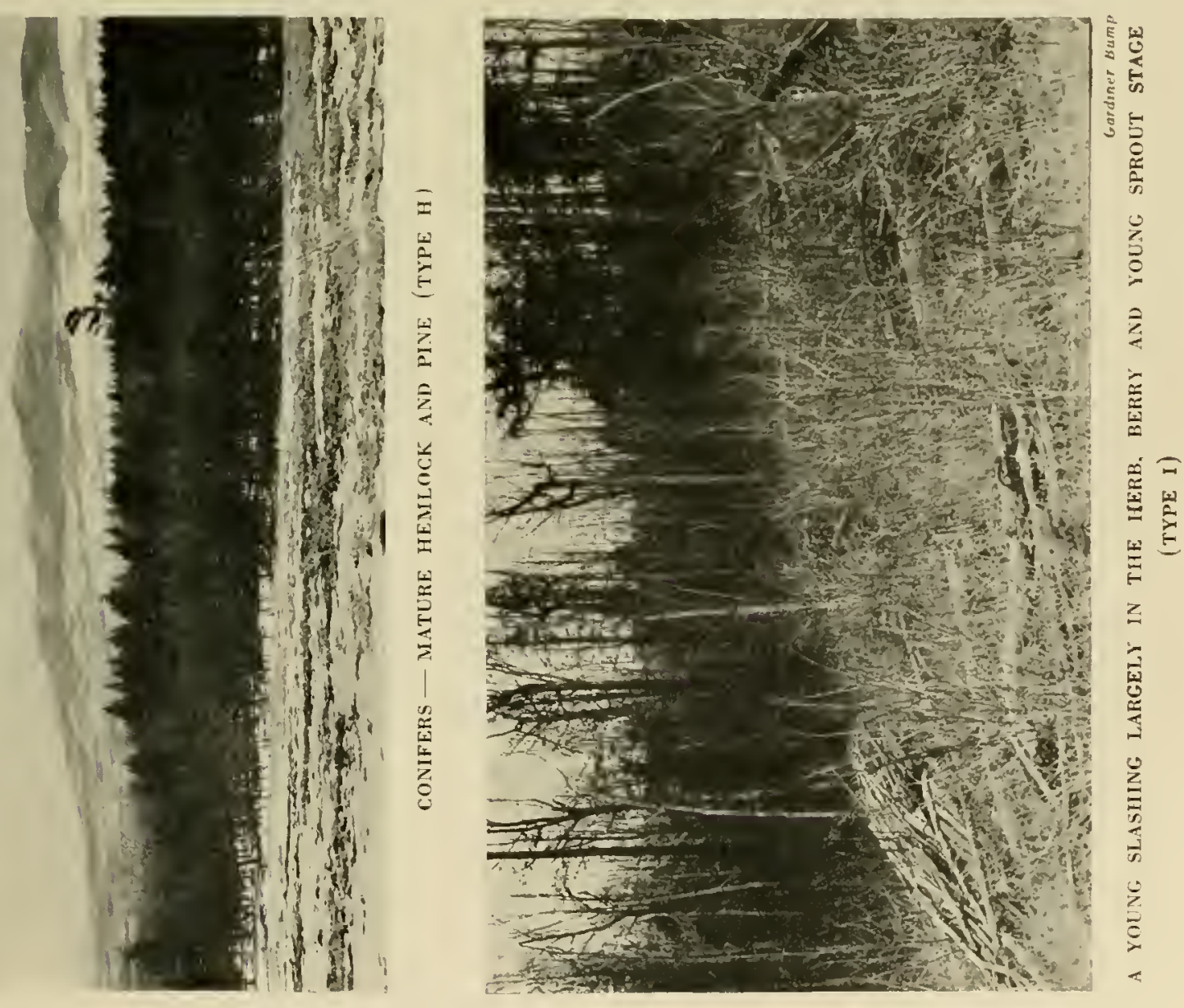
were set up as needed for special project study. On the primary areas, surveys were in process for from six to twelve months over a 33-year period. Over 16,000 man days were spent gathcring data on the conditions surrounding the 19.619 grouse flushes. 1.515 grouse loroods and 1.270 nests, which are here analyzed. The nesting studies were extended to cover those located by cooperators in most of the counties of the State where the grouse are common.

Not being certain as to just what details might be of value, the poliey of recording every item, which might conceivally be of interest, was adopted. In furtherance of this. each time a grouse was flushed it was found desirable to record data covering 36 separate items on a specially devised form sheet". Similar notes were made for nests, broods and dead birds encountered. By 1937, the mass of data thus gathered had become sufficient fover 700,000 records 10 warrant its tabulation ${ }^{\Delta}$ as a hasis for analyzing the shetter and other requirements of the grouse in New York State.

At the beginning. the authors little realized the complications involved in seeuring records representative of true conditions and sufficiently numerous to remove. in large measure, the probability of error. Though the hest statistical advice possible was early secured, the application of hiometries to such an ecological prohlem was still in its infancy. Full advantage has been taken, however. of the tremendous advance in the past decade in setting up and evaluating the tabular material from which most of the conclusions later described, have been drawn.

The problem of securing records representative of the actual situation was attacked by attempting to secure a sampling of actual conditions sufficiently large to reduce the probability or error to a minimum. Technically. representativeness can only be accomplished, as Dr. Mottley aptl! fut it. by "giving each and every grouse nest, brood and adult, in every type of grouse habitat, in each year and under each condition. an equal and independent chance of heing ohserved." Ohviously, this is not practical in a species like the grouse although it was approached in studying the cover relationships of grouse hroods and adults by following the birds on most of the study areas, throughout all four seasons year after year. with about the same degree of intensity. In arriving at the conclusions here presented. wherever praetical, the corrections necessary to account for such items as variations in the amount of each cuser type arailable to the grouse. have been made. This is necessary before one can secure a true pirture of grouse coser use.

In studying grouse nest locations, it is assumed, on the basis of experience. that each bird will rhose the coner type and nest site most nearly fulfilling its requirements. Man! instances has been olserved where females have traveled considerable distances presumahl! to secure conditions favrable to the lneation of the nest. Execpt for this special situation, it is believed that grouse floworls and adults) to a considerable extent must make the best of conditions within their territories as they foul them. Thus the results here presented eannot he considcred to be absolutely representative of what a grouse would sclect if given an mulimited choire or if all habitats represented optimum conditions.

The large number of records analyzed. however, is believed sufficient to present a picture of "average elusee" under New York conditions.

\section{Nestrixg Coveh}

Thengle grouse are not particularly adept at hiding their nest. their concealing coloration.

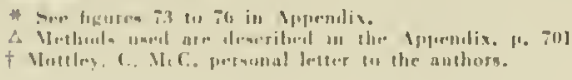


coupled with the hahit of "sitting close" when approached. makes the finding of one an event to he remembered. Thus it is not surprising to find no extensive studies and but few opinions expressed as to what constitutes gond nesting cover. Are thickets or open spots preferred? Do the birds avoid steep slopes as nest sites? Of some 39 per cent annually destroyed* are those located in any one cover Iy pe or other situation most likely to be broken up?

Such problems can seldom be solved with finality and. at hest. only for the regions studied. The answers here suggested are based on a study of 1.270 nest situations, yet it is certain that, with constant improsement in technique and witl more intensive study, others will add much to the picture. They may even prove sone of our interpretations wide of the mark. Therein lies the fascination of wildlife research.

It is sometimes easy to dictate results by the way in which one carries on an investigation. Of the nests here reported on, almost half were found while making the spring surveys on the various study areas. On these all cover types are searched for nests with equal thoroughness ${ }^{\Delta}$. Must of the remainder of the nests were reported by cooperators or other individuals who happened to stumble on then during the day"s work. "Building fence" and "going after the cows" were the most productive occupations in this respect.

Let us then look at some of the outstanding preferences rclating to nesting corer.

\section{Types of Cover Chosen}

The distribution of nests, acrording to the frequency with which each cover type is used. is presented in tahle 121\%. By studying it. one finds some interesting correlations.

\footnotetext{
* Ser Clbupler III, J, 311.

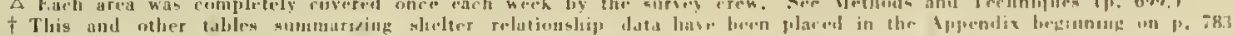

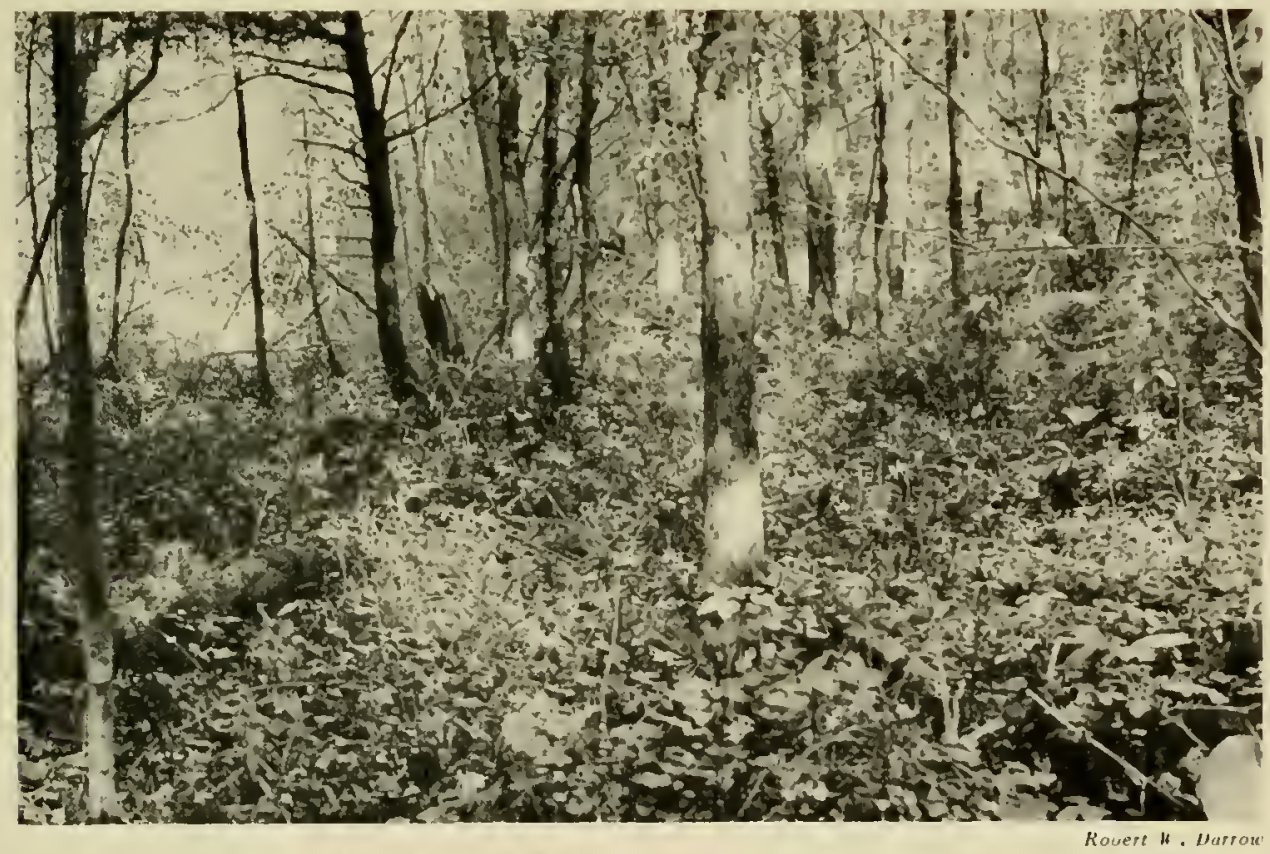

NEARLY HALF OF TIE GROLSE NESTS IN NEW YORK STATE ARE TO BE FOLND IN SECONI-CROWTH HARDWOODS (TYPE E) 
While some nests have been found in cach type, meadowlands (type $A$ ) supporting occasional trees or shrubs, and coniferous cover (type $\mathrm{H}$ ) are least utilized for this purpose.

Woodland types are strongly favored as nesting cover, 899 out of 1,270 nests being found therein.

Of all the woodland types, nests are most likely to be found in second-growilh woodlands (types $\mathrm{E}$ and $\mathrm{EH}$ ), for 565 (48.4 per cent) were located there. They are least likely to be placed among conifers in which but 52 (4.4 per cent) were discovered.

Only about one-third as many birds are likely to place their nest in mature woodlands as in second-growth cover.

Except for mature woodlands, which are apt to be fairly clear of much undergrowth or ground cover, all of the most likely cover types chosen are characterized by providing considerable summer food for broods. This is especially noticeable with respect to spot-lumbered areas (type G), which, although small in extent ly comparison with other types. attracted 105 birds $(9.0$ per cent).

There is a tendency for the nests to be located in types deficient in conifers. Thus three times as many birds nested in overgrown fields deficient in evergreens (type C) as located their nests in overgrown fields where a substantial number of conifers (type D) were present. A somewhat lower ratio is evidenced between second-growth hardwoods (type E), as contrasted with a mixture of hardwoods and conifers (type EH). As the stand approaches maturity, this difference tends to become less and less.

One finds second-growth hardwoods predominantly used as spring nesting grounds. The primary reason for this is still to be determined. The presence of considerable summer food and the more open eliaracter of nndergrowth and ground cover in this type, in contrast with that existing in most overgrown lands and slashings may furnish a clue.

\section{Density of Undergrowth at Nest Sile}

It is interesting to note from table $122^{*}$ that most hirds apparently are reluctant to place their nests where the undergrowth is dense. Thus we find 40.4 per cent of the nests situated where the undergrowth is sparse and 46.4 per cent where it is medium, whereas but 13.0 per cent of the nests are located in dense clumps of mudergrowth.

The table suggests an interesting but not always consistent correlation between the density of undergrowth surrounding the nest site and the characteristics of the woodland in which the nest is found. In types where the undergrowth is normally rather dense, such as overgrown land, second-growth woodland. cut-over areas and spot-lumbered woodlands, a large preponderance of nests occupies the more open spots. Conversely, where the crown cover is heary and the undergrowth normally sparse (such as in mature hardwood or coniferous wood. lands) the oreasional more dense undergrowth clumps are rather often chosen. thongh the majority of nests are still focated in comparatively open situations.

There is a certain. though. when recognized, not serious crror. which is elearly brought out by the abose comparisons. Whereas density in all types should have heen compared (1) a single rigid standard. in reality there was a tendency to depart somewhat from this liy considering the normal undergrowli for any type as medium. This may help to explain why. in cover types characterized hy heary undererowth, grouse were more apt to nest in the more open situations with the reverse being true in the types comparatively hare of undergrowth. 


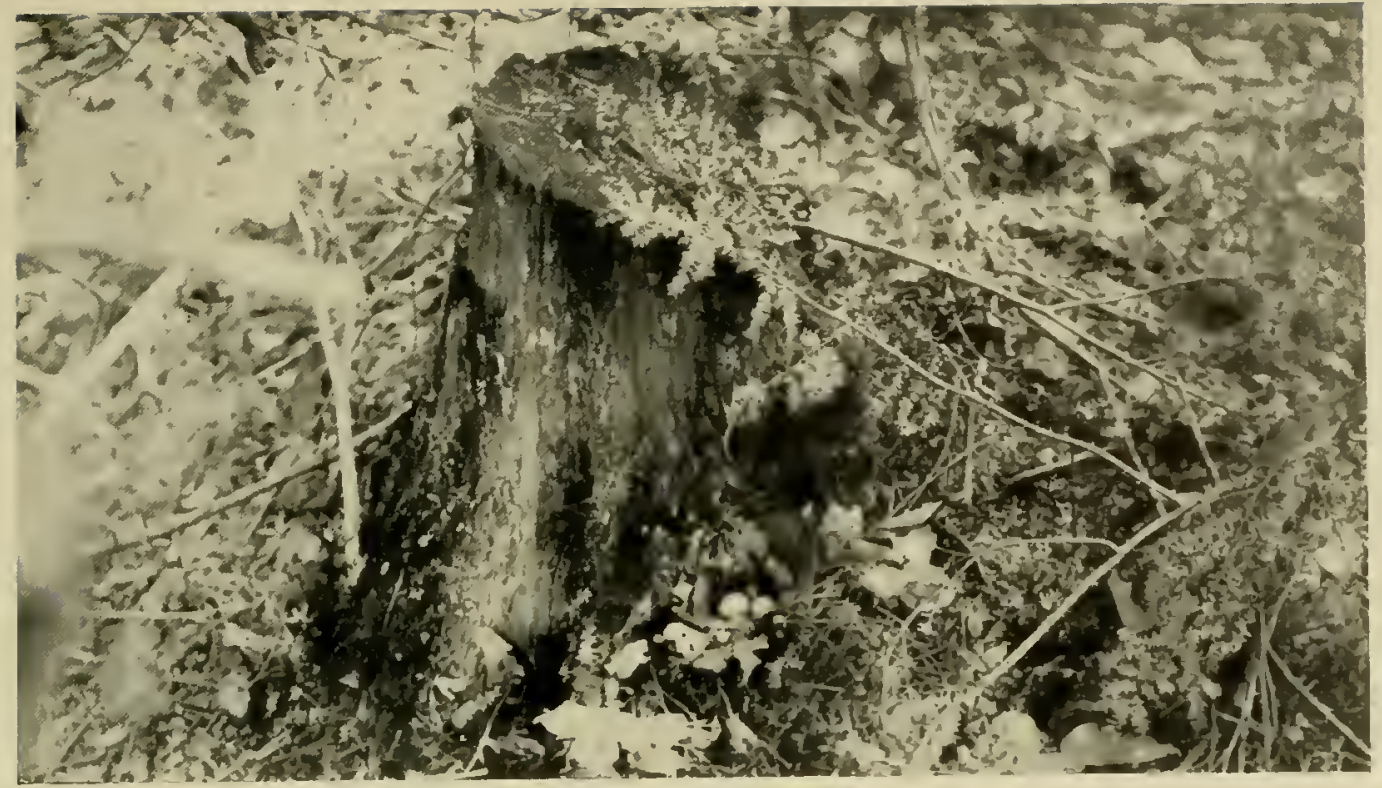

MIANY A NEST IS PLACED AGAINST A STUMP

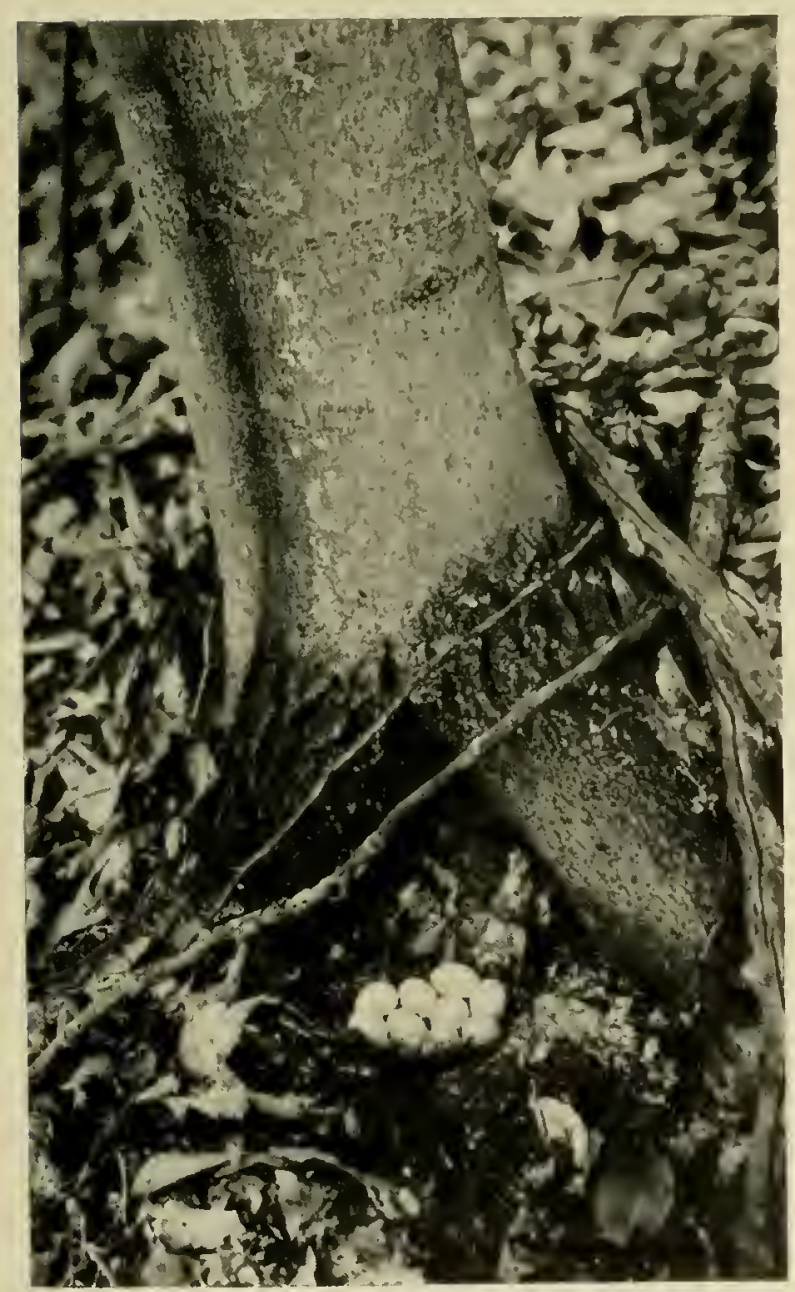

THE SITE MOST COMMONLY CHOSEN IS AT THE BASE

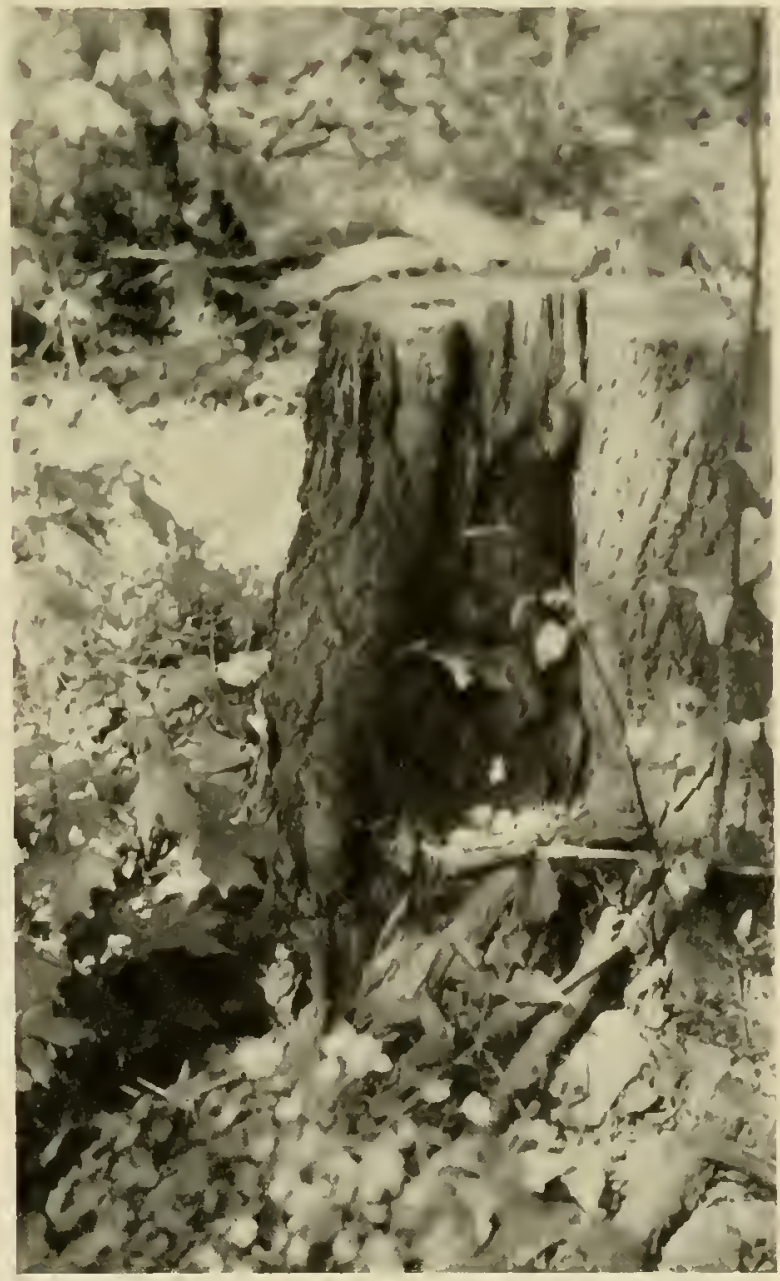

A VERY UNUSUAL, LOCATION IS IN THE HOLLOW OF 
It atl serves to strengthen the idea that crouse prefer a rather open cover in which to nest. The word preference is used adisedly for here there seems to be a clear example of the exercise of choice by the birds. Certainly the undergrowth densities selected were not those most commonly found either in overgrown lands, in slashings or in mature woodlands.

\section{Sites Preferred as N'est Locations}

The opinion generally held that grouse are more likely to nest at the hase of a tree or stump is borne out hy an inspection of table $123^{*}$. Of the two sites, the lase of a tree was chosen b! $599(51.7$ per cent). Whereas the next most attractive location. the base of a stump. was chosen by but 175 (15.1 per cent). Nearly as many, $15 \%$ (13.6 per cent). located their nests under a pile or tangle of dead brusl. The only other site commonly utilized was beside or under a log. where 120 nests $(10.4$ per cent) were found.

Neither rock ledges nor clumps of bushes were particularly popular although both were utilized. Interestingly enough. seven nests were found in conities in stumps or in semi-roofedover depressions on steep banks. Three were even borated in open fields with only such small shruls as low-bush blueberry for protection.

A study of the sites chosen again bears out the conclusion that dense cover around the nest is seldom desired. Because of the concealing coloration and hahits of the bird previously resferred to. attention was called to most nests only when the female flushed.

No difference was observed in the readiness with which a bird would flush from nests found in densc cover as comprared with nests located in the open.

\section{Nest Location in Relation to Degree of Stope}

Since an entire gronse covert may, upon occasion, lie largely on but one slope, there does not always exist an opportunity for hirds to choose a particular degree of slope. The same applies with regard to the direction it faces, technically called aspect. For this reason. in analyzing table $124^{\Delta}$ any comparison of the number nesting on Bat, gentle or steep slopes is subject to reservations. It was not possible to correct the figures in accordance with the proportion of each slope available. Therefore it is best mercly to indicate that. if occasion demands. birds will nest not only on flat or grentle slopes. but on stcep hanks as well. Since 281 nests 124.9 per cent) were found on flat land as compared with 149 (13.2 per cent) on steep slopes. One might conchde that it is the asailability of the slope within the habitat. rather than its steepness. which largely influences the mumber of nests found in each categrory.

Where gentle slopes are as ailable. they are much utilized as is evidenced by the funding of 702 nests thereon. The predominant shope on most of the areas studied. however. lice in this classification.

Nest Location in Relation to Aspeet of Stope

The same ohjection raised with the presions table is egually valid with table $125^{\dagger}$ describing the location of grouse nests as influenced by type of cover in relation to direction a slope may face. In addition, the difference in the number of nests found on a morth or an east slope compared with a south or a west slope is sol small as to dictate the conclusion that no slope is shunned. Whatever advantage there may be is apparently in favor of west slopes which were utilized somewhat more freguently for nesting than was an! other aspect.

None of the four slopes were utilized as frequently for nesting as was flat land.

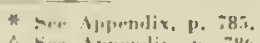

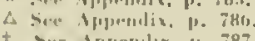

t Mir tpprmlux. 11. 787 


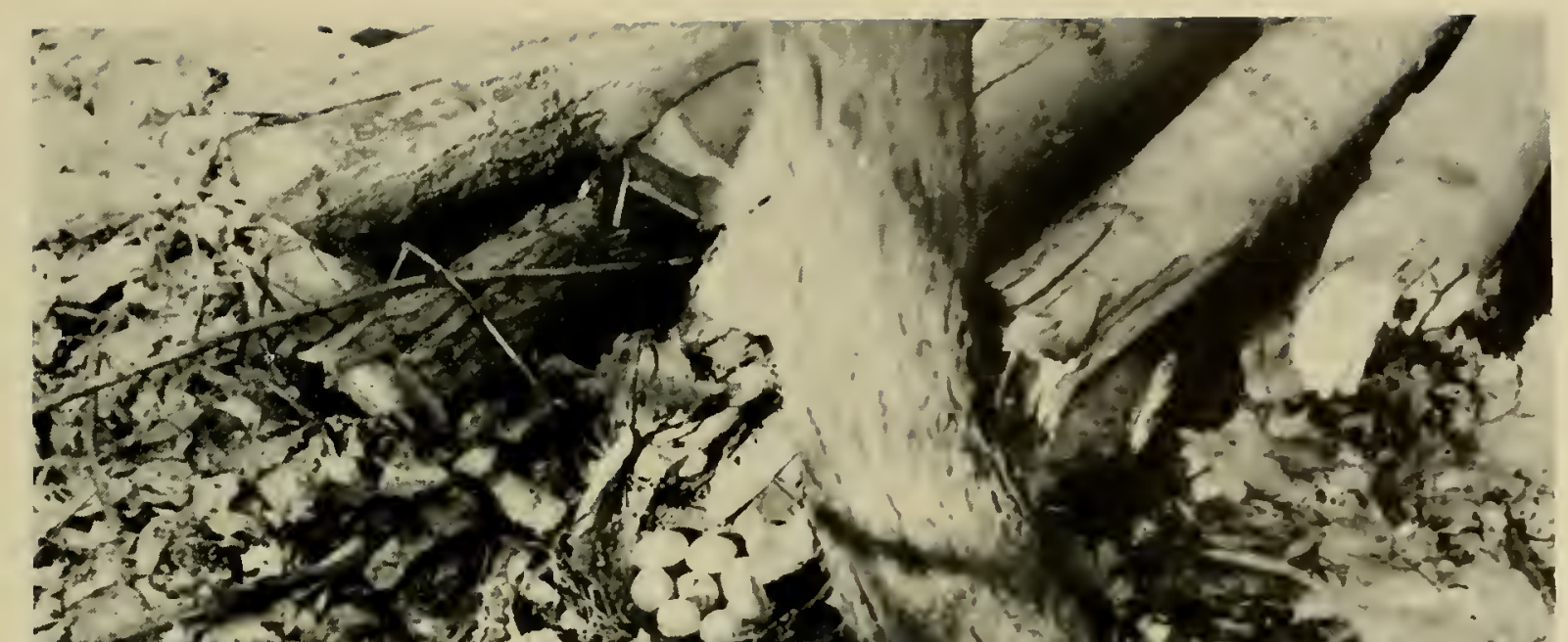

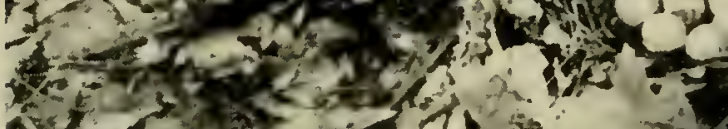

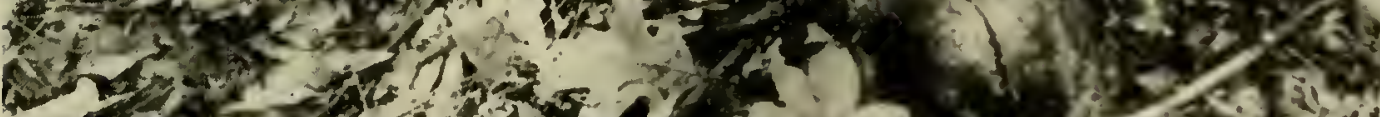

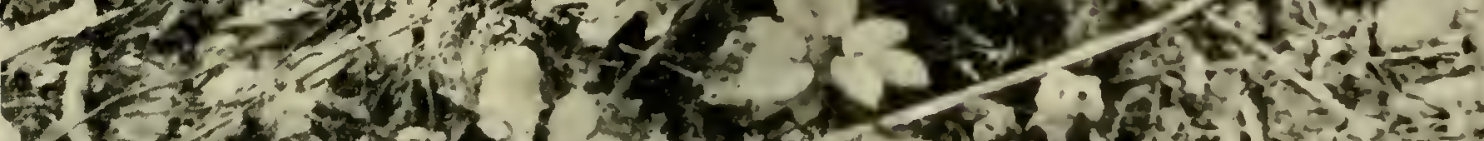

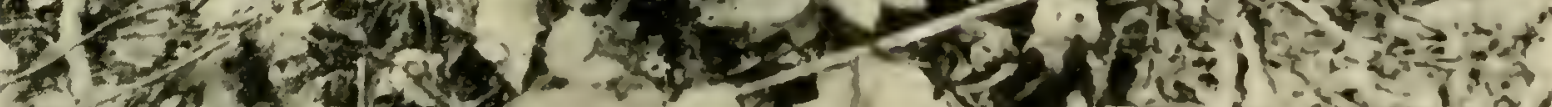

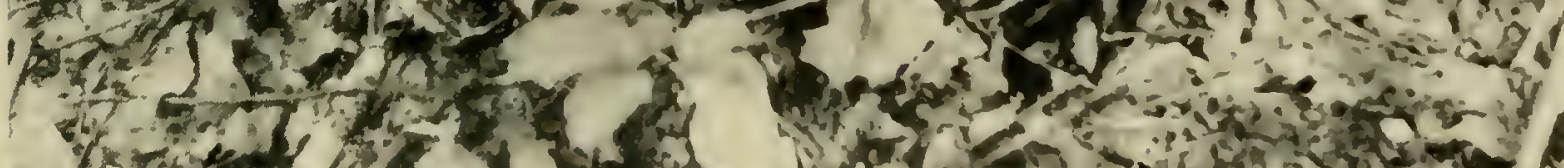

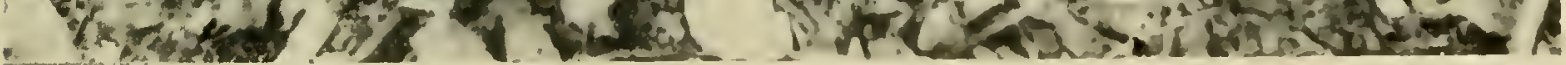

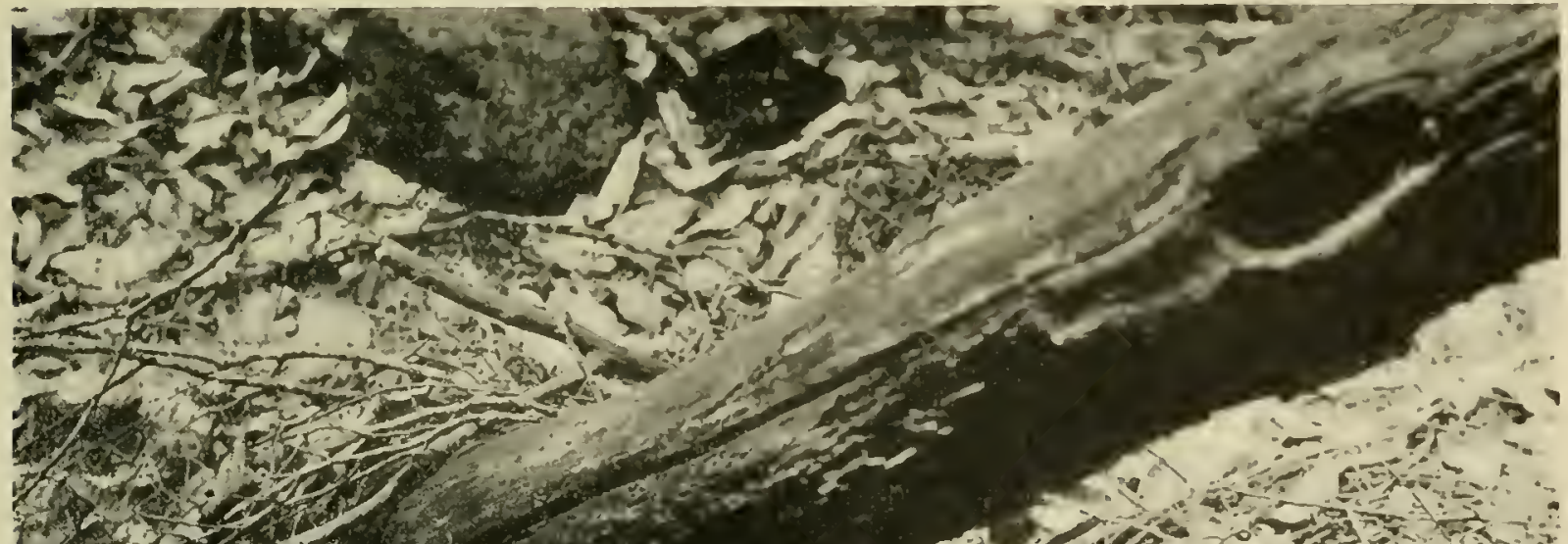
- 4. 51 (I)

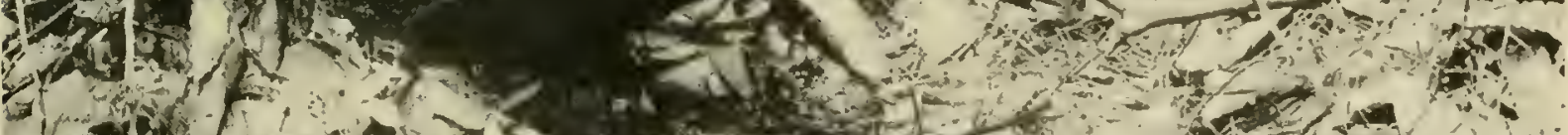

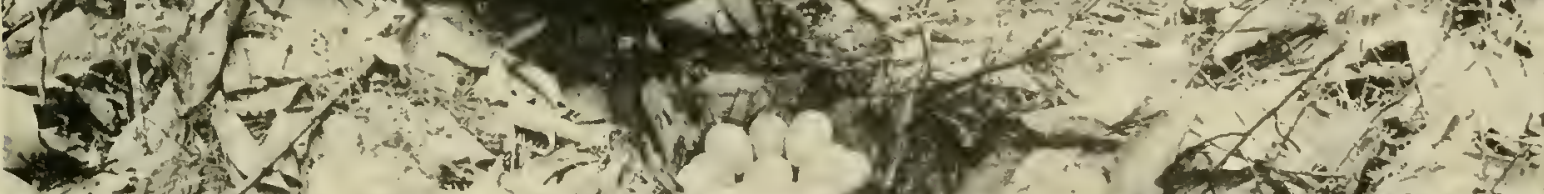

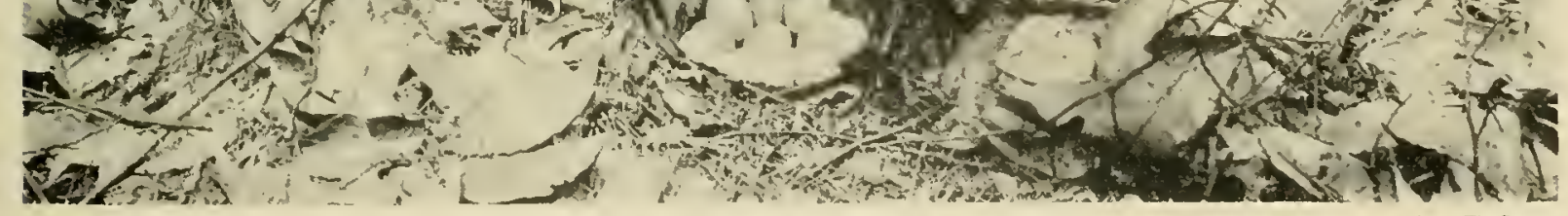


It is interesting to note that no one cover type seems to be substantially more attractive than another when associated with any given aspect. No justification can here be found for the thought occasionally expressed that warm southern slopes are most likely to attract nesting birds. Conversely, the more mature woodland types, offering greater shelter, are not pre. ferred on sumy slopes, nor are the more open types on northern exposures. In this connee. tion. one sometimes forgets that grouse establish their nests before the leaves are out and that. except where conifers are present. there might. therefore. apparently be no great difference hetween types in their sheltering effect on the nest.

Undoubtedly some preferences do exist. Perhaps 1,270 nests are too few to bring these out, particularly when many grouse find no more than one or two aspects of slope available within their normal territory.

Perhaps, also. were it possible to eonduct a study of grouse nest locations in a region where each aspect supported a different climax type, a valid difference in use night be obtained hased not so much on exposure as on the differences in cover type occupying each aspect. For instance there is a tendency in southern New York for southern slopes to support a larger proportion of the oak and hickory type in contrast with beech, birch, maple and hemlock on the colder northern aspects. On the other hand, if all aspects contained the same climax types, then it might be possible to determine the effect of exposure on cover choice. Witl bofls factors known, the data could be more accurately correlated to find the relation of each to nest location.

\section{The Influence of Conifers on Nest Location}

It has already been noted that only a few grouse nests were found in predominantly coniferous cover types. Where hardwood types prevail, in the region studied, it is normal to find a considerable mumber of individual or of small clumps of evergreens scattered through the woodlands. Analyzing the records to determine whether these trees are particularly songht out as nest sites (table 126) * one finds but 181 out of 1.088 nests, located at the base of conifers. An additional 197 were found from one to ten feet away from a eonifer, although often at the liase of some other tree.

The average distance of a nest from an evergreen was 136 feet. The fact that 228 nests were located more than 500 feet from any evergreen, again indieates that conifers do not represent a necessary element of nesting cover.

\section{Efject of Opcnings on Nest Locations}

Openings in the cover play a much larger part in determining the location of grouse nests than is generally realized (table 127$)^{\Delta}$. One may spend many an interesting hour in the woods looking for nests but seldom funding them. The fact that 18.6 per cent of those located were in an opening while 56.0 per cent were within 100 feet of an opening of some description may lielp io explain one's lack of success while coursing the decper woods. The word opening. however, must be interpreted broally. It includes not only meadows and fields hordering on woodlands lint also overgrown lands (types B. C and D) and recently cut-over areas which are still largely in the herb and herry stage (type I). Old wonds' roads and trails make an often unnoticed break in the crown cover but provide a better chance for a somewhat greater variety of herbs and sometimes herries to thrive than is found in the surrounding cover. $A$ hordering secund-growth of hardwoods (type E) represents favorite nesting cover.

- Sier Appendix, p. 789.

$\triangle$ Srr Appendix, p. 790. 


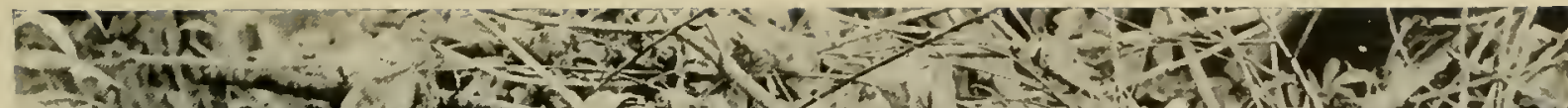

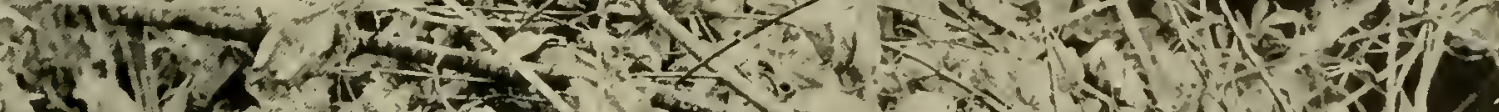

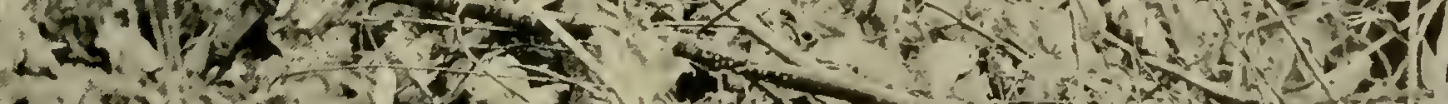

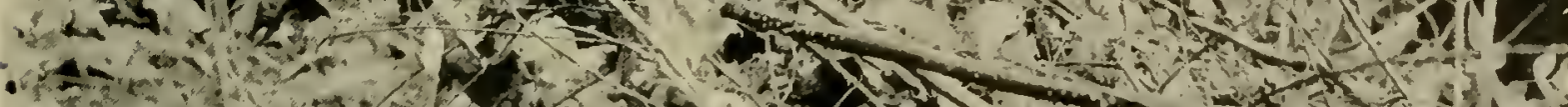

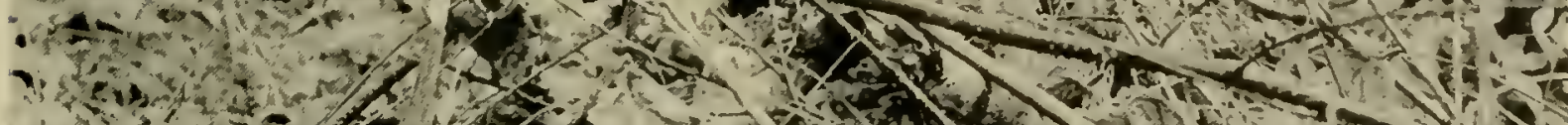

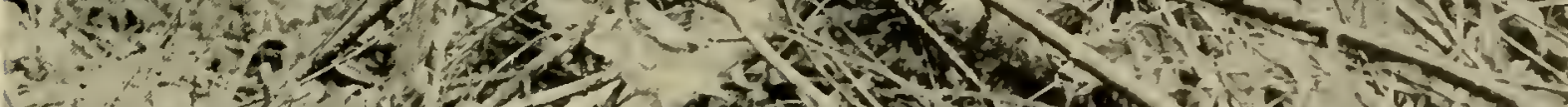

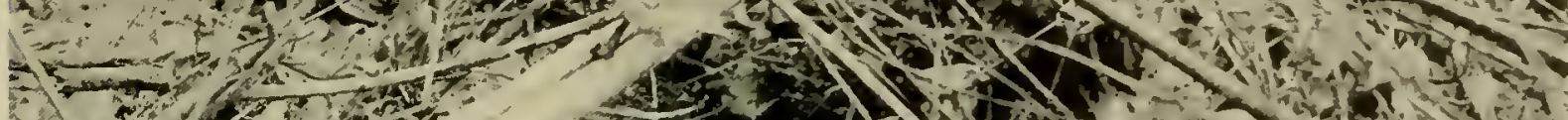

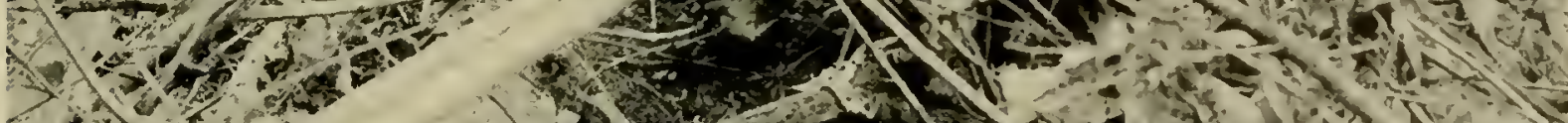

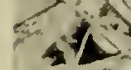

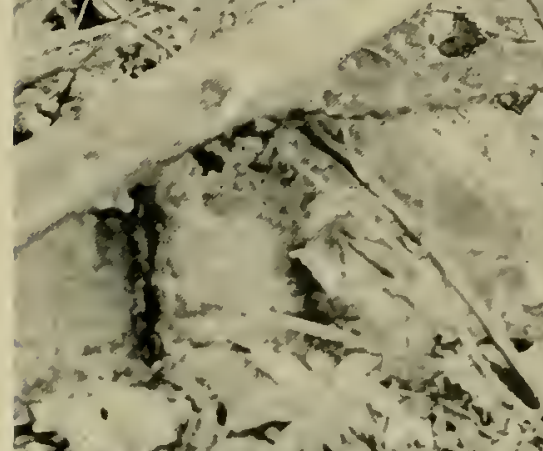

25.-1,

A LOOSF: TANGLE OF BRUSII OFFERS A L.IKELY SPOT FOR A NEST

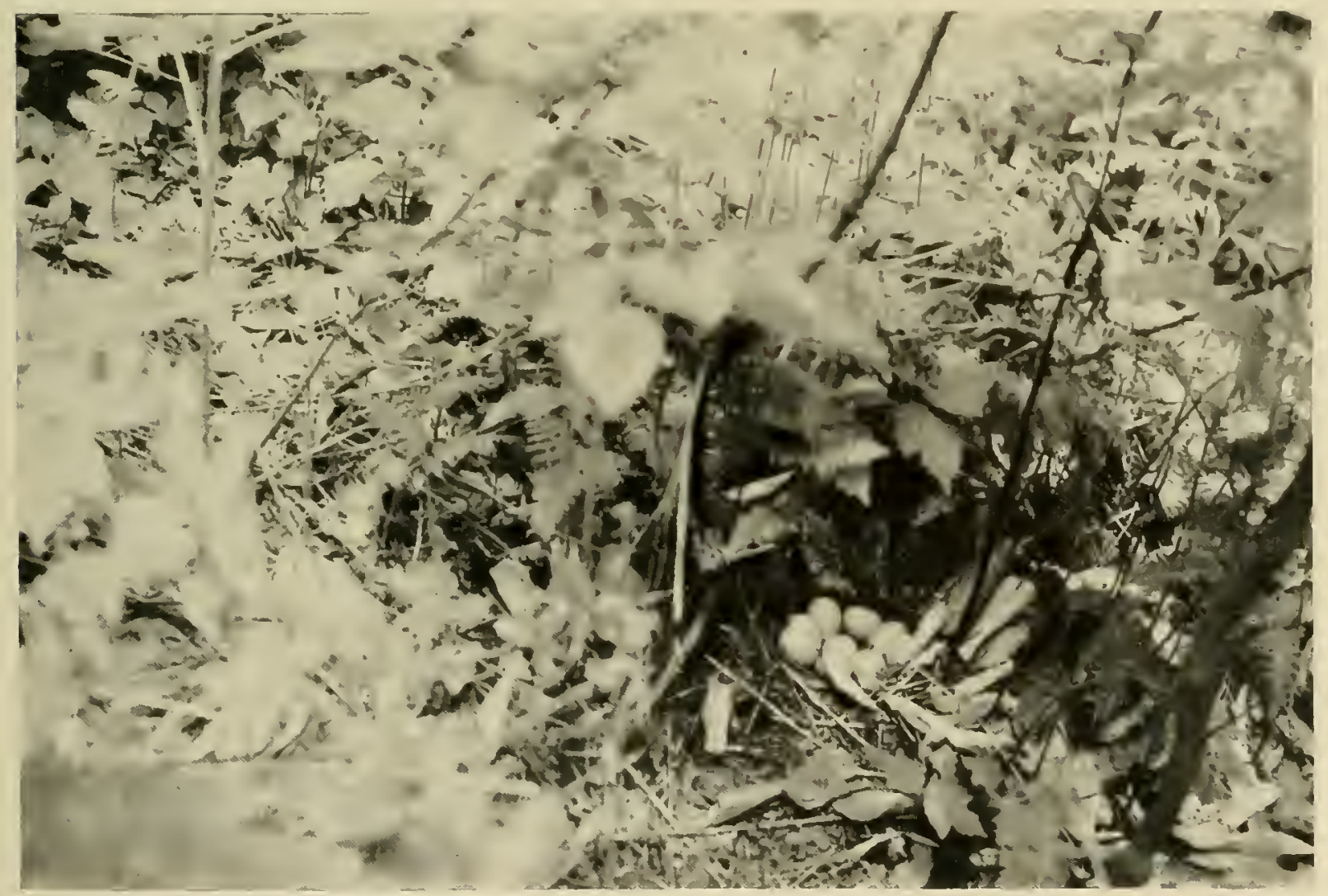


The general principle may be stated thus:-other factor being equal, the desirability of a nesting site varies inversely with its distance from an opening. This rule usually holds good irrespective of the t!pe of cover in which the nest is located. In all types. the decrease in the number of nests as the distance from an opening increases seems to occur at approximately. the same rate. Thus for 929 nests on which this point was sperifically olserved and which were not situated in an opening 19 ; $(21.2$ per cent) were found within ten feet of open eover and 261 (28.1 per cent) in the next 40 feet. Out of the whole group. in only 143 in. stances (15.4 per cent). was a nest more than 200 feet from an opening.

The prohability that many nests will actually be located in some of these openings has already been mentioned.

It is astonishing to see how close some birds will place their nest to well-traveled roads. Two instances. in particular. come to mind. One was on the southern flank of the Catskills. where a bird placed her nest on the overgrown hank of a steep cut through which a concrete highway passed. In the other case. the nest was found under a small slurul a scant six feet from a macadam highway in the northern Adirondacks.

The application of this principle of proximity to an opening in designing productive grouse habitat is covered in some detail in the chapters on Management.

\section{The Effect of Slashings on Nest Location}

Of all the openings. no one type normally contains as much summer food for grouse broods as do recently clear-cut areas. For this reason. special note was made of the rarious distances from a slashing at which nests were located in the different t! pes of cover trable 128)"

The data indicate elearly that nests are more likely to be lucated within the first ten-foot strip of nesting cover surrounding a slashing than in the sceond. the third or any more distant strip.

In comparison with openings in general. however. (table 127$)^{\mathrm{A}}$. the immediate vicinity of a slashing does not secm to he substantiall! mose attractive. One finds no greater tendency for the nests lowated near these units to be chacr thereto lhan were nests localed near other lypes of opening:.

It must not he forgotten that young grouse are precocial hirds, that is. they lahe rare of themselses to a large extent from the time they are hatched. This includes finding practi. cally all of their uwn food and. if it appears desirable. traveling relatively long distances soon after hatehing. This was evideneed ly one loroul. loanded all the nest and rontacted 21 hours later more than a half mile from that point. Other breods. not disturbed. have moved lesser distances or been contacted. for seseral da!s after hatching. in the immediate vicinit! of the nest site. Some grouse locate their nests elose to another opening even thouglo a slashing may be in the immerliate virinity.

To sum up, a slashing serems to lwe a desibahle lut ly no means necessary adjunct to good nesting cover. This t! pre really comes into its own as a probluer of summer and. to a leser extent. fall foods for ! ounte and adult alike.

\section{Influence of Other Types of Openings on Vest Lacation}

Openings are like matreds of different strength wheh serve to drab nesting gronse close

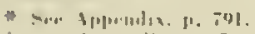

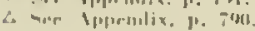


or into them. To this conception. table $129^{*}$ lends considerable weight.

When this table was analyzed. it was a distinct surprise to find more than a third (41.6 per cent) of all nests, that were not actually in an opening. Jocated within 100 feet of a road or trail.

This figure seems high unless one remembers that two of the three regions of the State are. to a considerable degree, farmed. Most woodlands adjacent to farms have several more or less used woods' roads or trails within their borders. The 100 per cent coverage given each study area hy the survey crew, howcver, precluded any chance that the cover along woods' roads might receive more than its share of attention in looking for nests.

Of the other types of openings, grouse are most likely to place their nests not far from open land. In total numbers of nests, this situation outranks both slashings and overgrown lands. Young slashings seem to furnish more attractive conditions alongside which to locate nests than do overgrown lands.

As previously mentioned, the attrartion of a road. trail or young slashing apparently diminishes rapidly as the distance therefrom increases. This tendency is much less marked with open lands. The nests are almost as likely to be placed at any distance up to 100 feet from an open field as within the first ten feet.

\section{Effect of Crown Cover on Nest Survival}

Having seen the effect cover may exert on nest location. let us examine the difference it may make on the success of nests placed therein. As will be seen in table $1300^{3}+3.5$ per cent $^{\dagger}$ of all the nests located were broken up. Any relationship between rover and the like. lihood of nest destruction may, therefore, prose important.

As indicated in the lable. cover seems to bear little relation to the fate of the nest except in a few cases. Nests placed in stands largely composed of conifers (tyje 11 ) are most likely to be broken up. Conversely, those located in selectively logged woodlands (G), with its scattering of lnsh herls and undergrowth where, here and there, a tree has heen cut. are least likely to be found by predators.

It is probable that this difference holds in all regions of the State though this cannot be inferred from the table, for the numbers. thus divided. are too few to show significant dif. ferences except for the Rest of State region. Here the trends follow those already descrilied although there is possibly a greater likelihood of nests in a mixture of mature hardwoods and conifers also being left alone.

\section{Effect of Undergrowth Density on Nest Survival}

As with crown cover, it is remarkable how little real difference the density of the under. growth seems to make on the fate of the nest (table 131) . Of 268 nests found in sparse undergrowth 60.4 per cent hatched: in medium density. of 300 nests. 59.0 per cent hatched, whereas of 95 nests found in dense undergrowth 55.8 per cent were successful.

When the fate of grouse nests is correlated with undergrowth density in the various types of crown cover, no significant tendencies are likewise to he found. There is a slight indication

\footnotetext{
* See Appendix, p. 792.

$\Delta$ sce Appendix.

$\ddagger$ This figure differs slightly from the averages indicated in Chapters III anl $1 / 1$ since is is based on records prior so 1937 while the latter include the period throngh 1942, and also because shelter data were included for cettain brnken.mp nests found while collecting eggs for proplagation.

See Appendix. 1. 796 .
} 
that nests are safer in sparse undergrowth in second-growth hardwoods (type $\mathrm{E}$ ). The same appears likely in the open undergrowth heneath mature hardwoods and conifers (FH). But the inference is not strong and is further weakened when the companion types (EH and F), upon examination, are found to show this tendency in reverse.

\section{Thicket versus Open Cover as Nest Locations}

As has been seen, grouse prefer to locate their nests where the undergrowth is neither particularly dense nor open. Referred to above, however. is the character of the undergrowth in the general vicinity of the nest rather than that actually at the nest site. Table 132* was accordingly prepared to answer the occasionally raised question, "Is a grouse nest, without benefit of immediately surrounding cover vegetation, more likely to be liroken up than one located in a thicket?"

The answer seems to be that it is not. Of 630 nests with but little sheltering cover, 362 (57.5 per cent) hatched, whereas of 208 thicket nests, $110(52.9$ per cent $)$ were not disturbed. Since most of the nests destroyed are broken up by predators it is evident that the concealing coloration of the bird and its habit of sitting close at the approach of danger are much more effective shields against danger than the thiekness of the cover immediately surrounding the nest. This is further borne out in the previous table.

\section{The Effect of Distance from an Opening on Nesting Success}

Investigation field men. early noticing a tendency of some predators. particularly fox. to follow along the edge of openings and woods' roads. considered the possibility that nests located close thereto might be more subjeet to predation than were those located at greater distances.

Table $133^{\Delta}$ illustrates the results of this study. "The percentage of nests hatching within ten feet of an opening was 53.6 per cent in comparison with 60.8 per cent for those located over 200 feet distant. Though hoth totals are based on a substantial number of nests. the difference is not large enough to represent with certainty a valid trend though. in this situation. such a one would seem logical.

In further subdividing the number of nests hatched at various distances into the cover types in which they were loeated, the numbers lecame too small to permit trends to be eval. uated except by combining similar types. This done, there still scems to be no substantial indication that nest mortality; at various distances from openings. varies markedly with the type of coser.

Since nearly half of all nests are located along woods" roads or trails. a special study of such situations was made to determine whether or not nests are more likely to be broken up when located along such trails than in the vicinity of other types of openings. As indicated in table 131\%. of 359 nests along a woods" road or trail. 210 (58.5 per cent) were not molested while of 572 near all other types of openings $313 \quad 151.7$ per cent $)$ hatched.

\footnotetext{
* Sue Appondir. jo. $79 \%$

A sire Apriondix, p. 398

Apendix, P. Bmo
}

A. (O.D WOOBS ROAI BS ATTR ICTIVF ALIKE TO THE MAN IX SEARCH OF RELAMTIOX ANI TO THE CROLSF SEKKINC, NFTING SITES NEARBO 
It is encouraging to find no important difference herc. for woods' roads represent an in. tegral part of most wondlands which it is wise to maintain in the interests of providing nure favrable nesting cover.

The surprising thing about grouse nests is that so few cover influences scem to strongly affect them, cither as regards location or fatc. As pointed out elsewhere, the ruffed grouse has survived over a period of at least 25.000 years. Ample opportunity has thus been provided for the species, either to develop highly specialized habits and requirements or to become so adaptable as to fit into many different situation- with reasonable success. Here is evidence that the latter is the case.

\section{Brood Cover and Related Influences}

Turning from nests to hroods, an even greater variety of questions arise. What types of cover most nearly meet their needs? How does this ehange with age. sex. seasons, weather, and with the time of day? What undergrowth conditions are to their liking? Are they partial to particular slope situations? These are but a few in need of answers.

As long as one is discussing nesting cover, the problem of recognizing grouse needs in terms of usage is not particularly complicated. It has been assumed, hased on the collective experience and judgment of the authors, that most types of cover were usually available to the female in which to nost if she chose and that the best liked one was selected. Thus use hecame directly interpretable into choice.

With broods and adults. the picture is scarcely as clear cut. Their requirements change with age, sex and the seasons. So also does the ability of the cover to satisfy them. A newly hatched chick, feeding largely on insects and unable as yet $t o$ fly; is naturally interested in a different food and shelter combination than is a ten-week-old hird sulsisting on leafy material and fruits and quite able to take care of itself. An werorown field may offer satisfactory refuge in summer yet fail completely to afford adequate shelter against winter weather.

Other complicating factors exist. The quantity, quality and arrangement of cover are dif. ferent in each individual covert. This means that broods and adults may not he ahle to exercise a free choice of cover types, undergrowth conditions and slope hecause such are not equally available to all at the same time.

Furthermore hoth quality and quantity of cover type vary with the scasons and over the years. The latter may often pass by the unwary investigatur unrecorded with the result that he. also. may not be ahle to exercise a free choice of cover type data.

As a hird matures it gradually cstahlishes its own territory. into which it. at times, resents intrusion by other grouse of the same sex. The best habitats may be fully oceupied. thus forcing some birds to cotablish their territories in the less desirable parts of a covert, though not from choice.

To make interpretation doubly diffenlt. the probability of observed hrood or adult reaetions not heing typical is directly proportional to the disturluaner of the normal response caused hy the investigator in the course of his work.

One cannot dengon and earry out a comprehensise study of the grouse and still fully com. prensate for the effets of all these complications. Their influence. however. may he minimized by securing a large number of recurds cowering a number of rears from each of the representative grouse halitats over the State. From these the signifieant tremds nsually ean he determined. This was the procedure followed in ascertaning such itents as cover preferences 
and the related effect of undergrowth type and density, weather conditions and slope on grouse.

Individuals addicted to making snap judgments may fail to see the connection between a knowledge of hrood preferences and an increase in the grouse crop. But those whose job it is to assist Nature in producing that crop, know better. As but one concrete example, grouse broods, in New York, at least, do not like steep slopes. A breeding area develuped there is. then, going to be less productive than one developed on a gentle grade or where the land is relatively level. Many similar preferences, each snall in itself but collectively important. must be ferreted out and catalogued if one is to go about the job of producing hetter grouse cover in an efficient, businesslike way.

What, then. are the characteristics of good brood cover?

\section{Types of Cover Used by Grouse Broods}

The outstanding characteristics of brood cover are its diversity and its youth. It is the early stages of woodland succession. with their profusion of fresh herhaceous growth. that are attractive. (See tahle 135)*. The ahandoned pastures. the overgrown fields. the fresh, not ton

* Sier Aprondix. \%, 801 .

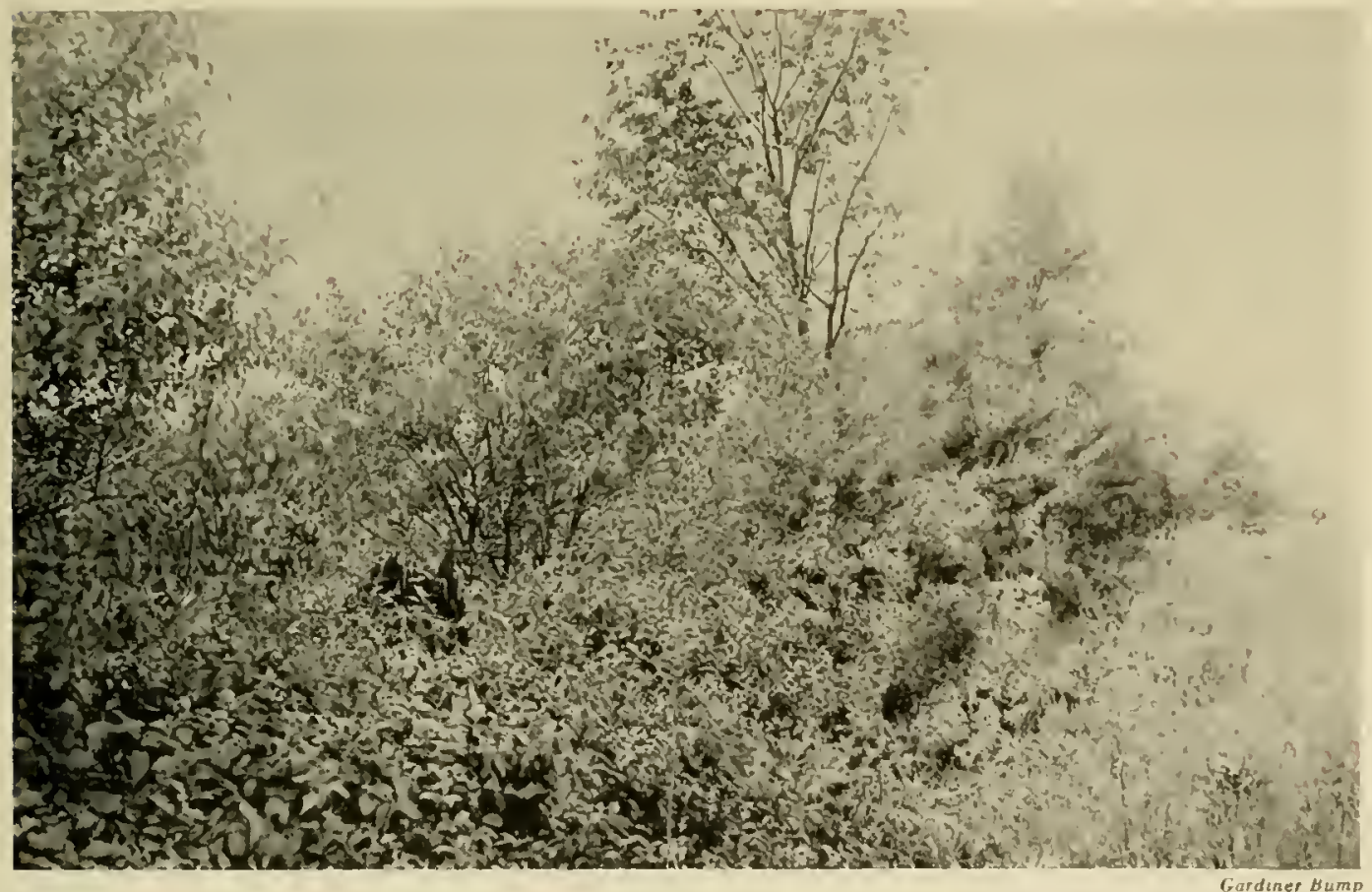

THE FAVORITE HAUNT OF GROLSE BROODS THROLGHOLT THE SL MUER IS THE OVERGROWX FIELD ESPECHALL IF BUT FEW CONIFERS ARE PRESENT (TYPE C) 
dense tangles that follow by a few years the cutting of the winter's fuel supply in the farmer"s woodlot-these are the truly happy hunting grounds for grouse chicks. Of all the woodland types only second-growth hardwoods (type E) with its often abundant understory, and spotlumbered areas $(G)$ scem worth a second visit until the brood is well on the road to maturity. Where summer slopes are dry, as in our Adirondacks, the moister alder beds (B) are prime favorites.

Least used are the types where grass predominates (A), where the ground cover is rela. tively deficient, as in the shade of older woodlands (F. FH) or under a dense stand of conifers (H). In fact, in New York, the presence of conifers, so dear to the hearts of grouse in the late fall and winter. is now almost ignored.

Yet it is not easy to state definitely just which are the most used types of brood cover. There appears to be a rather strong relationship between the amount of cover and use. To be strictly accurate. one must reduce l,rood contacts to a "per acre" basis. It was not feasible to do this for all of the study areas from which the records collectively contributed to table $135^{*}$. Therefore. the amount of each type of cover down to one-tenth of an acre on the principal study area. Connecticut Hill. was determined and the number of broods recorded was adjusted accordingly as a hasis for table 14 .

TABLE 1 1 . TYPES OF COVER USED BY' GROUSE BROODSCONNECTICUT HIL, NREA-1930-1936.

\begin{tabular}{|c|c|c|c|c|c|c|}
\hline $\begin{array}{l}\text { Type } \\
\text { of } \\
\text { eover }\end{array}$ & $\begin{array}{l}\text { Type } \\
\text { roule }\end{array}$ & 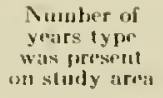 & $\begin{array}{l}\text { Areraze } \\
\text { arreage of } \\
\text { eich tyin }\end{array}$ & $\begin{array}{l}\text { Number of } \\
\text { hrexels } \\
\text { foumel in } \\
\text { ciach [yfe }\end{array}$ & $\begin{array}{l}\text { Adjusled } \\
\text { mumber of } \\
\text { hroweds } \\
\text { * }\end{array}$ & 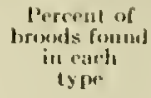 \\
\hline Open lasat & A & 6.2 & 220.7 & 14 & $s$ & $\ldots$ \\
\hline Overeroun lamd & $\left\{\begin{array}{l}1 \\
\vdots \\
\vdots \\
11\end{array}\right)$ & $\begin{array}{l}5.2 \\
5.6 \\
5.7\end{array}$ & $\begin{array}{l}111.2 \\
110.2 \\
111.1\end{array}$ & $\begin{array}{r}78 \\
1.18 \\
65\end{array}$ & $\begin{array}{r}83 \\
1.14 \\
58\end{array}$ & $\begin{array}{r}13.9 \\
24.1 \\
9.7\end{array}$ \\
\hline Wocnllam! & $\left(\begin{array}{ll}1 \\
1 \\
1 \\
1 \\
1 \\
11\end{array}\right.$ & $\begin{array}{l}6.2 \\
5.6 \\
2.2 \\
3.0 \\
3.11 \\
6.2\end{array}$ & $\begin{array}{r}415.8 \\
16.9 .5 \\
1.39 .0 \\
16.7 \\
58.3 \\
131.6\end{array}$ & $\begin{array}{r}110 \\
28 \\
5 \\
3 \\
31 \\
32\end{array}$ & $\begin{array}{c}31 \\
3 \\
3 \\
3 \\
63 \\
23\end{array}$ & $\begin{array}{r}15.2 \\
\ldots \ldots \\
\ldots \ldots \\
10.5 \\
1.7\end{array}$ \\
\hline Slanhing & I & $\frac{2.8}{3 .}$ & $\begin{array}{r}63.9 \\
136.5\end{array}$ & $\begin{array}{l}34 \\
65\end{array}$ & $\begin{array}{l}73 \\
61\end{array}$ & 10.2 \\
\hline Totat & & 58.3 & 2127.7 & 618 & 508 & 100.0 \\
\hline
\end{tabular}

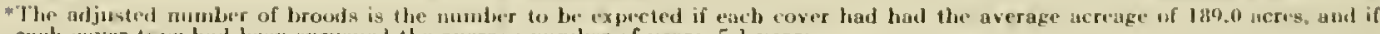

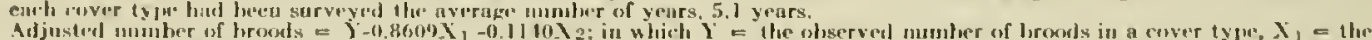

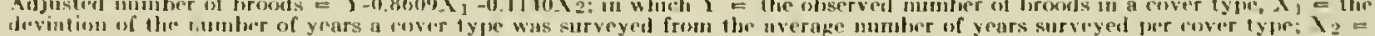

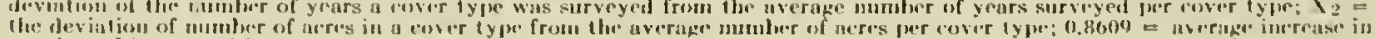

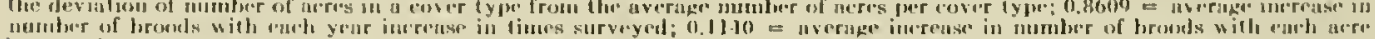

slinerense in cover tyme.

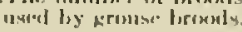

Outstandinur among the differences noted is the climination of second-growth hardwoods and conifers (Ell) as an important brond type and the increase in rating of spot-lumbered hard-

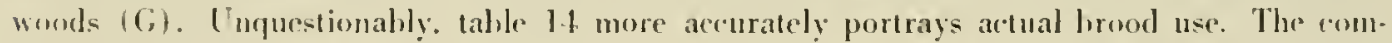
parison still further serves to emphasize the desirability of overgrown lands. !oung hardwoods and slaslings as the types predominantly chusen by grouse brouds.

That seend-growh hardwoods and conifers are nevertheless quite aceptable wo hroods has loen evident on the Alirondack area where they are a more predominant element of the halitat. In this reqion. toc. alder runs have had a marked attraction for grousc broods.

* Ser lipendix, fo. 801. 
The following comparison of these two tables is interesting in that when the acreage of each cover type is taken into consideration certain of them appear to be considerably more important than when acreage is disregarded.

In the first column are given, in order of importance, the preferences of the broods for the various cover types without regard for the amount of each (from table 135) while in the second column these choices are shown as indicated by use per acre (from table 14).

1. Overgrown land without conilers (C)

2. Second-growth hardwoods $(\mathrm{E})$

3. Relatively pure stands of popple. birch or alder (B)

4. Second-growth hardwoods and conifers (EH)

5. Older slashings $(\mathrm{J})$

6. Overgrown land with conifers

7. Younger slashings (I)
1. Overgrown land without conifers (C)

2. Second-growth hardwoods (E)

3. Relatively pure stands of popple, birch or alder (B)

4. Younger slashings (I)

5. Spot-lumbered hardwoods (G)

6. Older slashings (J)

7. Overorown land with conifers (D)

Changes in Cover Use as the Brood Develops

There are a number of intercsting. though relatively small differenees in cover use relater to the age of the brood. For instance. one finds a tendency for a small number of linods to seek out coniferous cover shortly after hatching but to shun it thereafter until they are over six weeks of age. Brushlots, small hardwoods and slashings are particularly attrative during the first wo weeks. The former remain consistently used throughout the season. but the cut-over areas secm to be less attractive during the perind in which the lrood is trying out its wings (two to four wecks). In general, however. there is less shifting in brood cover choice, as the birds mature, than might he anticipated.

\section{Effect of Crown Cover Density on Brood Choice}

The density of the forest canopy and the amount of herbs and grasses to be found heneath are closely related. Rememhering the preference of grouse chicks for luxurious vegetation where insects. leaves and fruits are abundant and easily picked up. it is not surprising that broods are most likely to be found in areas where the crown cover is sparse and are least likely to inhabit dense woods. Talule 136 illustrating this point. will he found in the Appendix, p. 802. Nor, as the broods maturc, does there seem to be any substantial change in choice due to the density of the crown cover. It is fortunate that the broods are so adaptable. for otherwise the wildlife manager would need to encourage one type of cover for young broods, another as they grow up.

To be really accurate, as with cover type choice, one mnst consider the amount of sparse. of medium and of dense crown cover available. The comparison for the Connecticut Hill study area is given below:--

$\begin{array}{ccc}\text { Density of cover } & \text { Relative amount of cover } & \text { Relative use } \\ \text { Spare } & 3 & 5 \\ \text { Mledium } & 51 / 2 & 31 / 2 \\ \text { Dense } & 1 \frac{1}{2} & 11 / 2\end{array}$


On the basis of use, when compared with the relative amount of each density present. the tendency for grouse broods to prefer types in which the crown cover is sparse is even more strongly emphasized.

\section{Types of Cover Used by Grouse Broods at T'arious Times of Day}

Grouse. even at an early age, are comparatively adaptable birds. As might he expected. therefore, in analyzing table $137^{*}$ one finds that no ype of cover is strongly shunned by the broods at any time of day. Apparently. however, most hirds prefer to spend the night in the shelter provided by woodlands rather than in the more open overgrown lands or slashings for there is a tendency for broods to he found most commonly in the former cover early in the morning and late in the afternoon. Curiously enough. open fields (type A), though not strongly patronized at any time, are again most likely to be used early and late. While, as previously noted, the presence of conifers usually makes but little difference to grouse broods, some types containing evergreens also show increased use at this time of day.

By mid-morning many of the groups have returned to overgrown lands (B, C and D) or recent slashings (I) where food is nomally most easily obtainable. The latter, also, seems to he more attractive again later on in the day.

Brush patches (C) continue to be particularly patronized throughout mid-day and the early afternoon. The table also indicates alder rums (B) to be rather attractive in the late afternoon.

It would be interesting to speculate on the reason for these trends, hut since one has avail. able only the limitations of human experience with which to interpret such reactions, no real hasis of fact can he established for such conjectures.

\section{Choice of Crown Cover as Affected by Climatic and Ground Conditions}

Temperature. wind and atmospheric conditions might logically be expected to affect brood cover choice. It is, therefore, desirable to check on this point and thus to determine whether or not any are sufficiently important to be taken into consideration in designing grouse habitats.

Temperature. The first of these to be considered is temperature (table 138 ) $\triangle$. White the number of hroods flushed in the varions types of cover did not show a strong relationship to temperature conditions, there is a tendency for grouse hroods to seck the more open cover of hardwood types during cold periods and of types where coniferous shelter is avail. able during warm weather. Thus overgrown land (ype C) and second-growth hardwoods (E) were found to be most frequented when temperature conditions were colder than normal. whereas young hardwoods and conifers (EII) and conifers alone (II) were patronized more on excessively warm days. Some inconsistencies in this general situation are apparent if one studies the table carefully hut these may he atributed to an insufficient number of records. At all events, the tendency above described is strong cnough in warrant the inclusion of some coniferous areas in developing hrood cover.

II'ind. Mature grouse are inclined to be ill at ease on windy days. Youngsters, too. normally move around less on such days. But in comparing eover type choices m windy versus still days. no strong tendency to take to heavy cower is apparent ftable 1391t. Here again. even though the reactions of 1.515 hroods have heen analyzed, the differences, which at first

\footnotetext{
* Ser Appendix. P. 803.

$\triangle$ sece Alperndix, 1, gol.

$t$ sire Aprendir. He. 805
} 


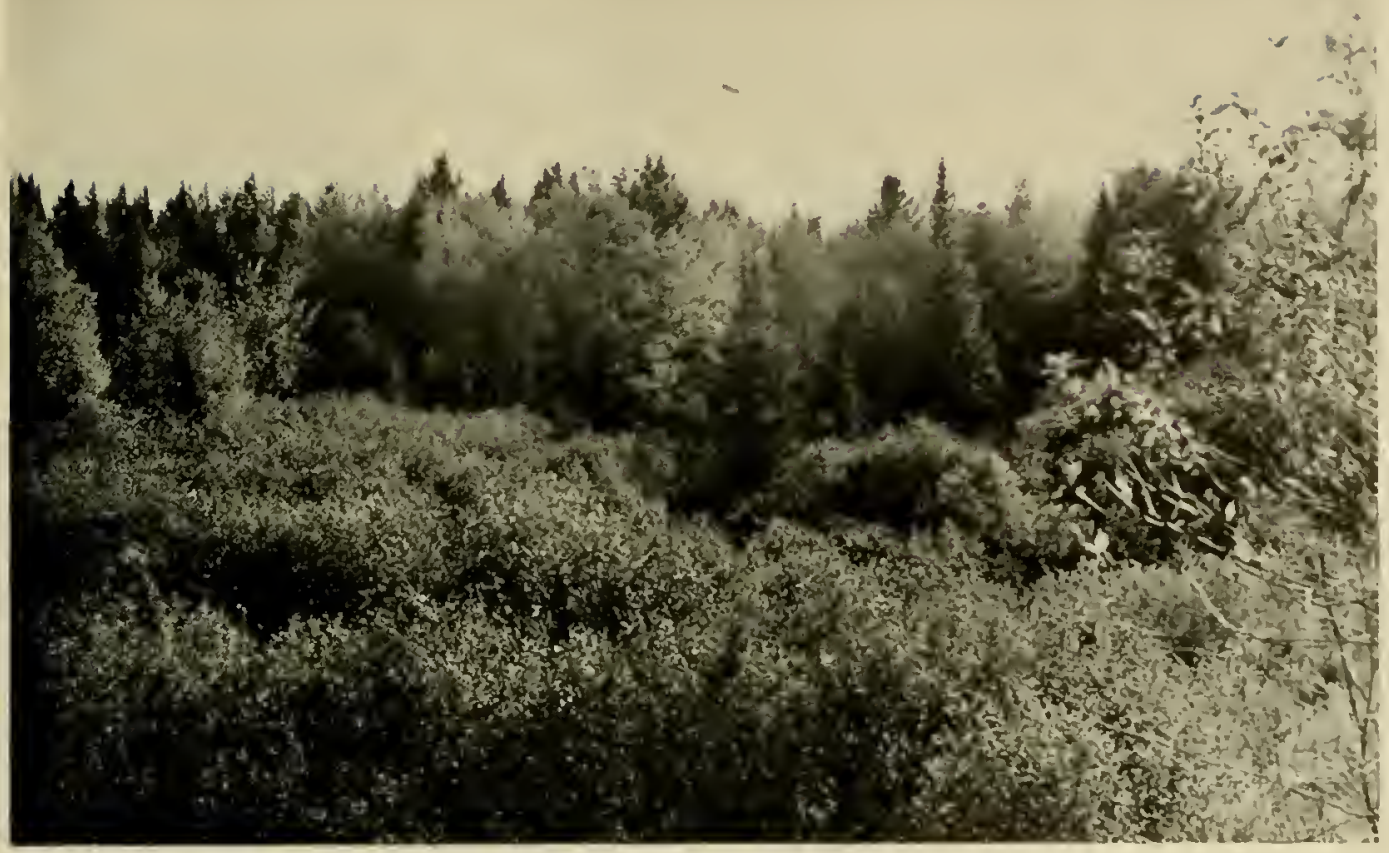

ALDER RUNS ARE PARTICULARLY ATTRACTIVE TO BROODS IN TIIE MDIRONIACKS

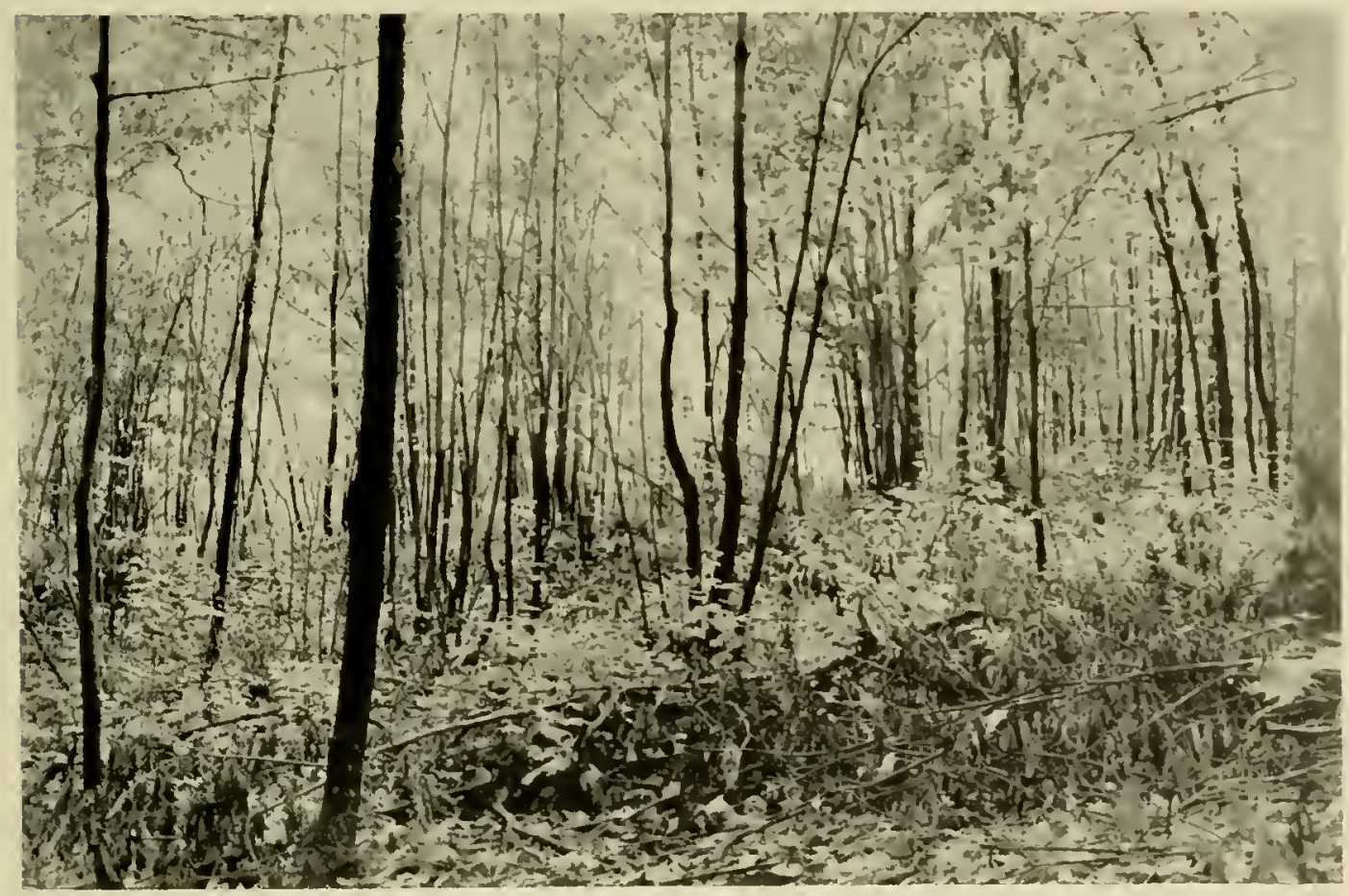

SECOND-GROWTII HARDWOODS WITH A VARIED BUT NOT DENSE

UNDERGROWTH ATTRACT MANY BROODS 
glance appear to be significant, are probably accidental rather than valid. for a closer inspection discloses no consistent tendencies. Most days. particularly in summer. are apt to be gusty or with moderate wind conditions and the number of broods contacted under either still or strong wind conditions are, therefore. comparatively small.

Atmospheric Conditions. In comparing cover choice in sunny, cloudy and rainy weather, a rather interesting reversal of trends evidenced under conditions warmer or colder than normal. is olservable (table 140)*. Apparently. woodland types (E. EH, F and $\mathrm{H}$ ) furnish rainy weather shelter, whereas the more open overgrown and slashing types are less well patronized at this time. Conversely. in sunny weather. the latter groups as well as the more open second-growth hardwoods. prove to he more attractive. Yet it is these same groups that are most sought out during colder weather. whereas, in warmer than normal weather, greater use is made of conifers, as has heen previously mentioned. As in sunny weather. the open land types are apt also to be favored in cloudy weather.

Ground Conditions. In attempting to phot brood cover choice under wet conditions. in contrast with dry ground, the results are complicated by the fact that, as soon as the youngsters can fly. they may seek shelter under conifers or in trees within the type. Thus, while the herbaceous cover may appear wet to the field man, the immediate situation where the birds are resting may be quite dry. One is prepared. therefore, to find from table $141^{\Delta}$ that grouse broods do not vary their eboice of cover depending on whether the ground is wet or dry. The table indieates no strong tendency in this direction. Nor are the records consistent in this regard. Apparently, wet cover is no deterrent to the birds secking food and rest in such open types as overgrown lands or slashings. Alder heds (type B) may then be used somewhat less, possibly hecause they are naturally a wit land type. Even here, the hirds have heen observed many times with their "feet almost in the water." for. especially in a dry season, some of the best food is there to be found.

In retrospect, one cannot escape the conclusion that few weather influences seem to be sufficiently strong in themselves to govern the Jrood rhoice of cover types.

\section{Some Relationships of l'ndererouth to Crouse Broods}

When the need arises, it is natural for most of $n$ s to classify a forested area according to the size and character of the tree growth. Only when the undergrowth contributes to the reproduction of the forest stand or is difficult to penetrate is it usually considered worthy of sperial mention. but grouse use different standards, for, to them. both undergrowth and ground cover may play a sulstantial part in meeting their individual food and shelter requirements. Just how important that part is. has never been determined. The Investigation. therefore. considered it worthwhile to look into a few of the less complex influences of un. dergrowth on grouse distribution.

The undergrowth on the various study areas wat divided into the following six types:-

1. Large loris:

2. Shrulis and herry Jushes

3. Hardwoods

4. Hardwouls and conifors

5. Conifers

6. Combination of types

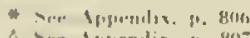

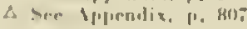




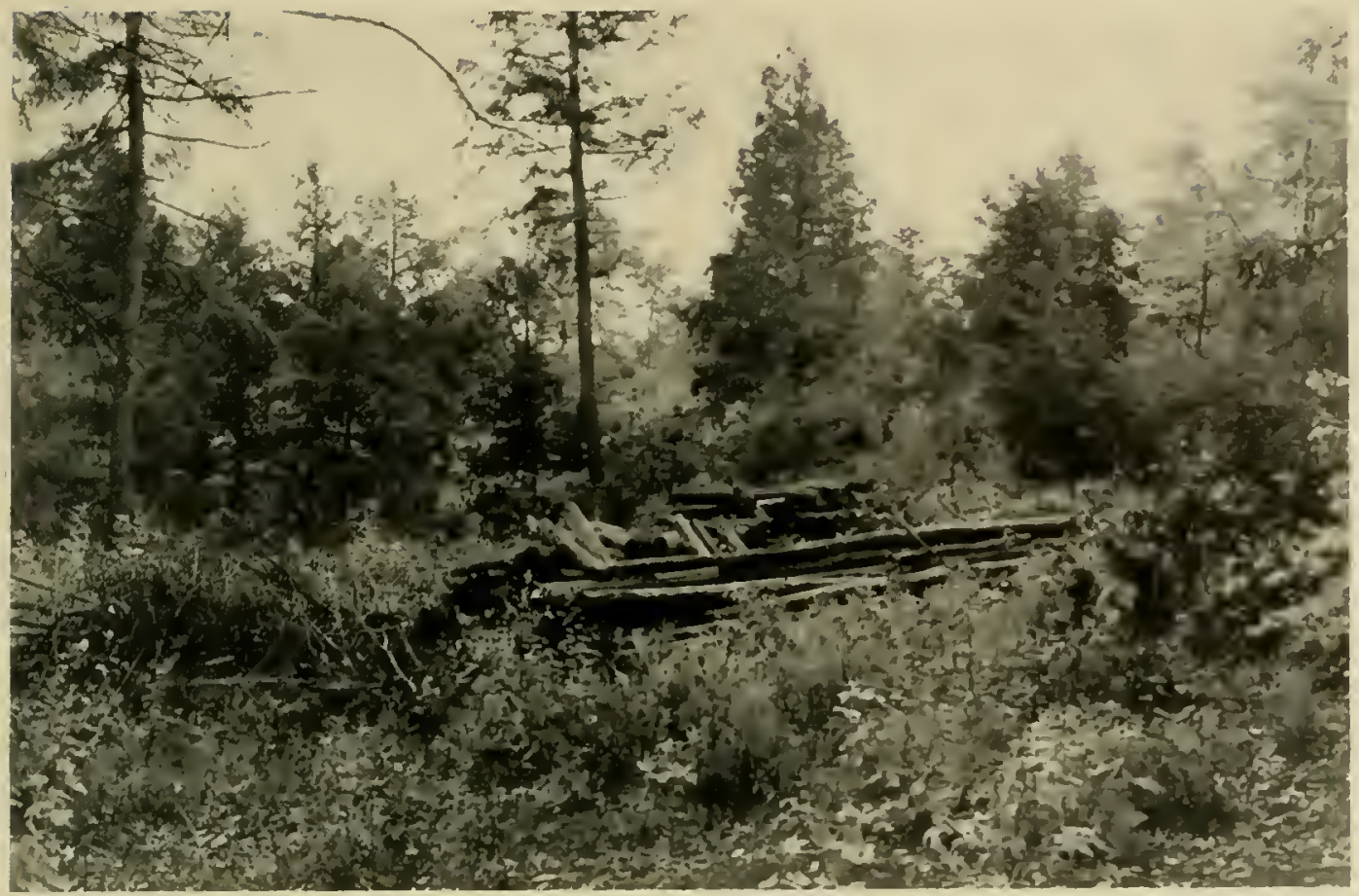

BROODS FIND AN ENDJESS PROFLSION OF PIANTS F[RNISIII, FOOI) A.TD

SHEJTER IX TIE, SI.ASHISC:

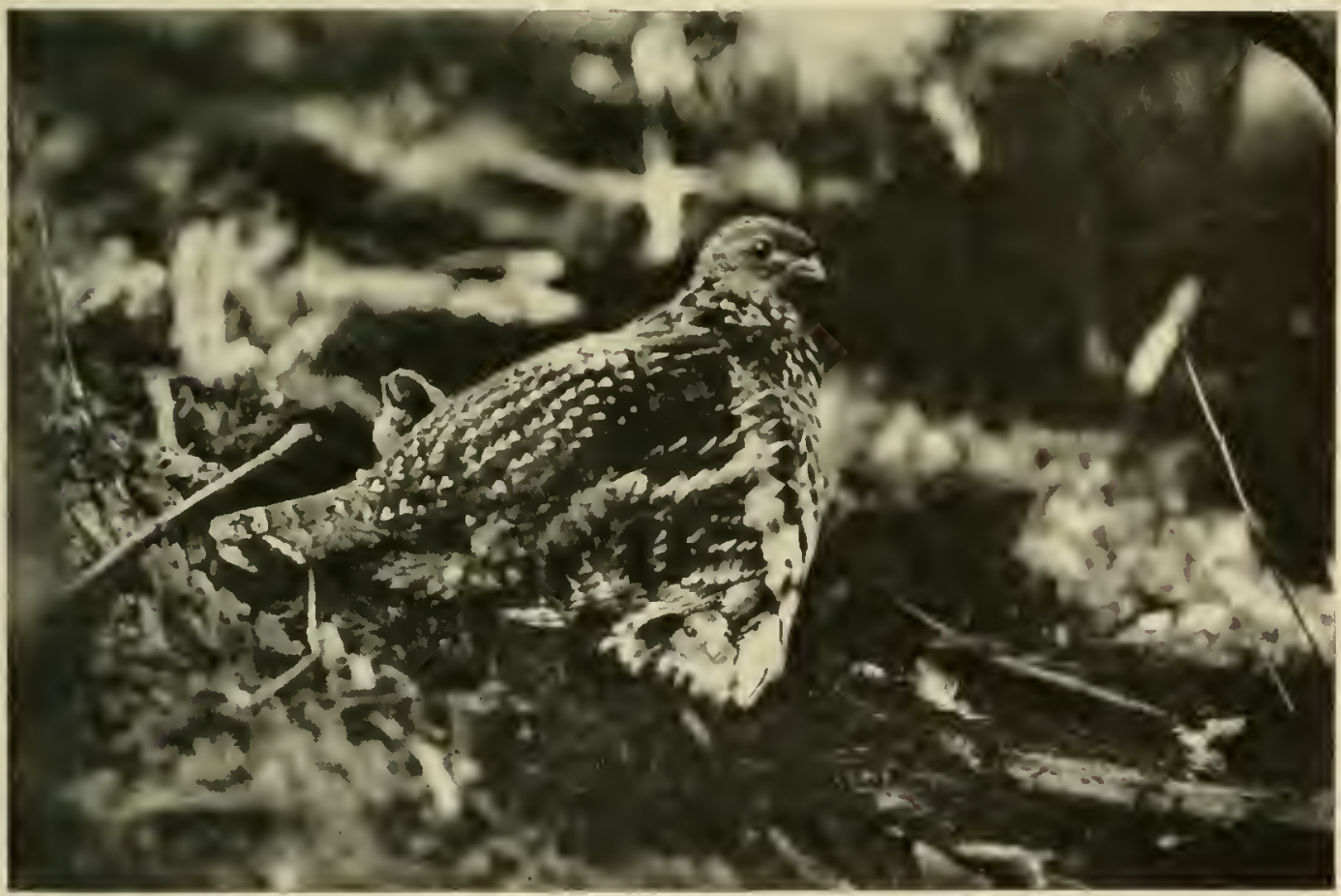

EARLY BROOD COVER IS NOT ALWAYS FURNISHED BI THE VEGETATION 
Records were kept on the number of broods found in each type. They have been tabulated in tables 142 and $144-146$ in the appendix.

\section{Types of Undergrowth Chosen by Grouse Broods at Various Ages}

Gencrally speaking, grouse broods seem to choose their habitat more because of the type of crown cover than of the type of undergrowth. As a rule, undergrowth types are accepted more or less in proportion to their extent and occurrence. Thus. in examining table $142^{*}$. one finds that the "small hardwoods" undergrowth type in New York is used more than all others combined. probably because it is the most common type.

There is, however. an interesting tendency to avoid those undergrowth types which run strongly to conifers when other types are also available. For instance. in such groups as "hardwoods and conifers" and "conifers," fewer broods were contacted than might be expected in proportion to the extent of the cover.

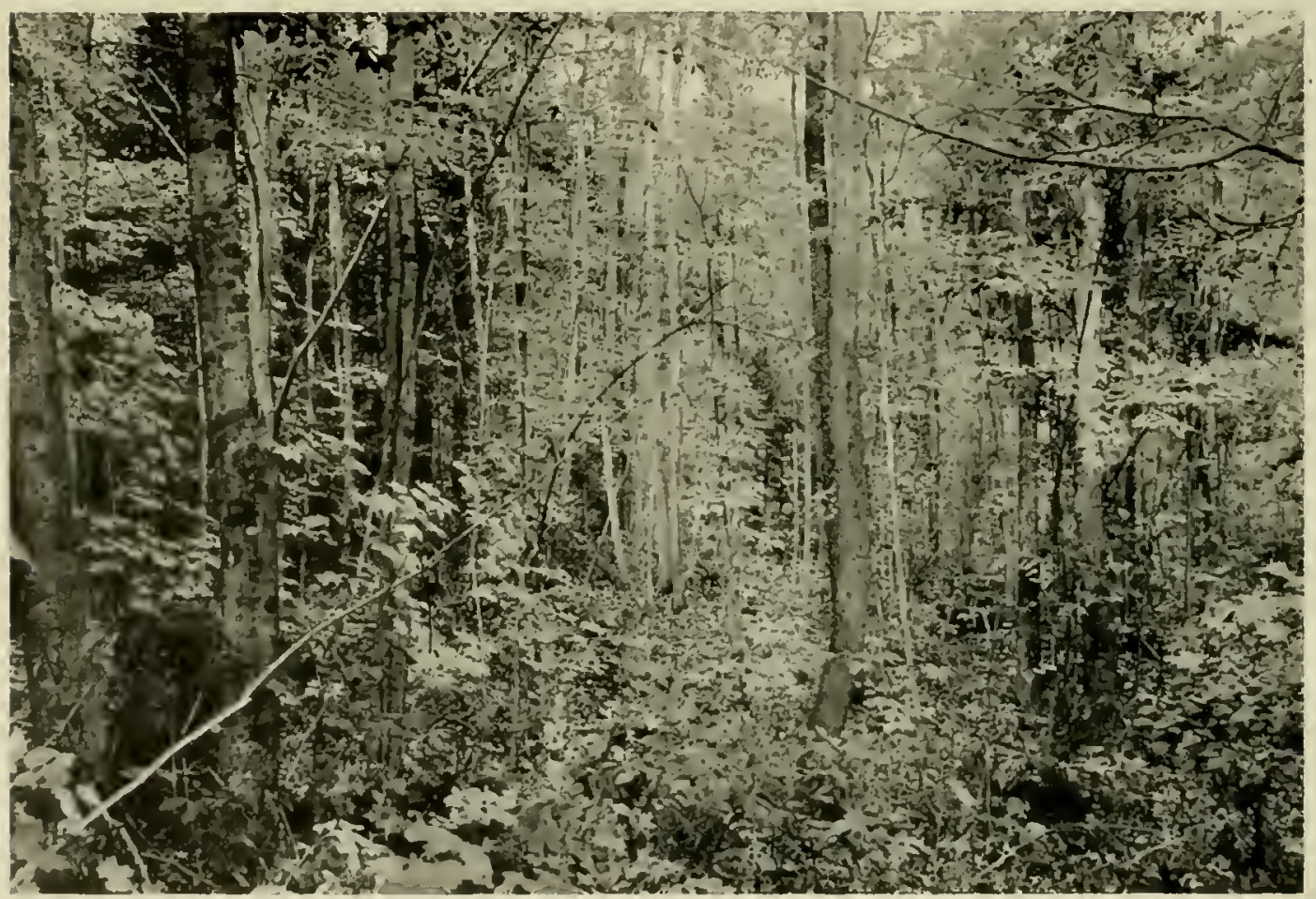

THE "SMALL HARDWOODS" TYPE OF UNDERGROWTH IS A COMMON COMPONENT OF NEW YORK WOODLANDS

The undergrowth types predominantly used are made up of "small hardwoods." "shruls and berry bushes" and a "combination of types." It seems likely, therefore. that the more com. plex the undergrowth. the more grouse broods will be found therein.

The desirability of having a varied arrangement of species making up the undergrowth is more apparent as the broods grow older, for the "eombination" type then shows a consistent rise in use. During the same period, there is an inclination to use "small hardwoods" less and 
less, although they still are frequented more than any other type even when the birds are nearly full grown. It is as though with grouse, as with humans, "variety is the spice of life."

As will be seen in the next chapter. even the young birds are omniverous in their choice of food. No one has, as yet, been able to determine whether the birds choose the more complex types of undergrowth because of the better food and shelter provided there or whether the variety of their bill of fare is the result of their preference for such a habitat. Such conjectures, while interesting, are never open to exact proof. Even in favorable locations. it is seldom possible to find any one type of undergrowth so completely dominant as not to be broken up by small patches of other types in which the birds might find food and slielter as desired. Other conditions being favorable. the combination of young hardwoods with shrubs and berry bushes seens to represent an undergrowth rondition quite acceptable to most young grrouse.

\section{Effect of Density of Undergrowth on Brood Cover Choice}

Remembering that young grouse are variety seekers in their choice of undergrowth types, one might anticipate the existence of a strong preference for those areas where the cover is both luxuriuns and dense. In actuality. whether the undergrowth is sparse or dense lunt otherwise attractive, it appears to be about equally well patronized. The larger number of broods found in undergrowth of medium density may be explained by the larger amount of this classification to be found on the areas studied. Likewise, areas of sparse undergrowth were more extensive than were the denser thickets or tangles so characteristic of some clear-cut woodlots. This being so, in analyzing table $143^{*}$ one detects a tendency to prefer cover types where the undergrowth is at least fairly dense.

Perhaps the age of the brood, too, may influence this choice somewhat for areas where the cover is sparse appear more attractive to the younger age groups. whereas the denser tangles are more likely to contain broods as they mature.

But the tendency is not so strongr as to warant much time and effort heincr spent on creating such coverts, should areas of dense undergrowtl he lacking. The table clearly indicates that broods, irrespective of age. will make use of any of the three categories.

\section{The Effect of II eather on the Type of Untergrowth Chosen by the Brood}

Weather exerts its effect on all cover types. irrespective of acreage. This reduces somewhat the probability of error in determining the brood use-undergrowth type relations under varying conditions of temperature, atmospheric conditions and wind.

Analyzing the first of these factors. one notes (table 14t) $\triangle$ an inclination for the hroods to frequent open fields. characterized hy large herhs. most commonly on warm days. Conversely, in colder than normal weather they seem nore likely to seek the shelter of the larger hardwoods. and occasionally those admixed with conifers. At such times the "combination type." characterized hy a variety of vegetation. scens distinctly less attractive to birds than on normal or warm days.

No really signifieant change in use is noted in the "shrub and berry bushes" type so characteristic of slashings. as a result of temperature changes, nor is there more than a very slight tendency to use "conifers" more on warm days than on cold days as was found to be the case when the crown cover was made up largely of evergreen species.

* See Appendix, p. 809.
$\Delta$ see Appendix. p. 810. 
Whether the weather be sumy, eloudy or rainy secus not to affect materially the type of undergrowth chosen by hroods (table 145)". Open land and edge types, such as "large herts" and the "combination type" are a little more likely to be used during sunny weather. There may also be a small tendency for coniferous underow row to be more frequented during cloudy and rainy days. Otherwise, the figures seem to vary so slightly as to rejresent a normal variation in the number of broods present rather than any definite inclination towards the use of one or another of the types as a result of the atmospheric conditions.

As has been mentioned, grouse are apt to be more nervous on windy days. It is not surprising, therefore, to find lroods then deserting the open land types characterized by "large herbs" (table 1.16) $\Delta$ in favor of the other undergrowth types: all of which furnish more shelter under such conditions. Though no test of wind velocity in the shelter of these types in comparisun with that existing in more open situations has ever been made, it is likely that the protection from wind there afforded is sufficient to keep the broods more comfortable. At least no one of these seems to be particularly preferred in comparison with another primarily hecause of strong air movement.

\section{Use of Differeut Degrees of Slope at V'arious Ages}

Grouse lanls. like the bird itself, are usually rough, often rugged. The energetic pioneers cleared the more arable parts for farms and the partridge took what was left and still thrived. Thus one would scarcely expect to find steep slopes and rough ravines, as well as the flat lands, without their quota of birds. Here the plow and the axe were wont to wrestle less successfully with the varied woodland vegetation; the changes. thus wrought. more likely to break up but not to destroy the habitat.

Remembering these things, it still must be recognized that, were the cover equally good. grouse might thrive letter on one slope than on another. Let us look first at what differences the steejmess of the slope may make. Here, again. the type of cover. rather than the ruggedness of the terrain, seems to he the most important factor. Even young broods are found on steep slopes occasionally (table 147$)^{\dagger}$ but level Jands and those that rise gently are preferred. On the Comnecticut Hill area, where a special study of the slope existence-lorood use ratio was made, a strong tendency for the young hirds to favor flat lands and moderate slopes rather than steep hillsisles was revealed.

lecause the hrood records from this area alone number lout 861 . table 147 was made up from all the broods contacted on all the study areas rather than from this one alone. On the other three units the exact proportion of each slope was not determined, for such a project would be tow time-consuming. From an intimate knowledge of each area supplemented by a study of arailable topographic maps it seems that ahout 15 per cent of the land surface is flat. some 6.5 per cent stopes more or less gently and 20 per eent lies on sterp hillsides. Compariug this with hrood occurrence, we fund the following:

$$
\begin{array}{r}
\text { Degree of slope } \quad \text { Proporlion of cach } \\
\text { (in per cenl) }
\end{array}
$$

Flat

Gentle

Steep

* Pare Inindir. [1. 811.

$\Delta$ sere logrenlix. 11. B1:.

tare Mpromativ, p. BI3.
Occurrence of broods

thereon (in per cenl)

27

6.1 
As on the Connecticut Hill area. from this it would appear that steep slopes are markedly less attractive to broods than are level lands or moderate inclines.

It will he remembered that few nests were found on abrupt hillsides. Perlaps the reason for this is that fewer grouse live there. Be that as it may, both observations point to the desirability of including as much good grouse cover on the less rugged slopes as possible in any lands on which a large partridge crop is to be encouraged. That few sportsmen are hardy enough to hunt there, and the likelihood of encouraging severe soil erosion should one attempt to improve the existing cover ly judicious cutting, should also not be overlooked.

There are a few minor variations in the choice of shopes at various ages to be found in the table. A majority of the broods at all ages (63.9 per (ent) are found on gentle slopes. Steep hillsides are used very occasionally either hy the very young birds (probalsly recently hatched) or by the broods as they approach maturity. In the Adirondacks flat alder beds are used to a pronounced degree throughout the brood period, although less during the latter part of August than earlier.

\section{Slopes Used by Grouse Broods at Different Times of Day}

After considering so many of the forces which unight, but seem not to. strongly affect brood cover choice, it is reassuring to find the chicks actually exhibiting. in table 1.18*. apparently valid preferences for certain slopes at certain times uf day.

The number of hroods found on a certain slope during any particular hour may at first glance be misleading for the records are so few as to vary comsiderably. By glancing at the graph*, however, the eye can pick up trends which are interesting thongh difficult to explain.

No slopes are really shunned at any particular priod. There is a trend for more grouse lroods to frequent the cooler north slopes in the mornitg rather than in the afternoon.

Likewise the east slopes, open to the morning sum, appear to be more attractive early in the day and again in the aftemoon rather than through the late moming lours or at midday. It is then that the warmer south slopes attract more broods.

No parlicular preference for western exposures at any special time of day is observed. Curents withont slope. that is flat lands, are likewise about equally well patronized throughout the day.

As with many another link in the chain of life-histury facts about the grouse, it is far easier to chart the trends than to offer logical explanations for the underlying reasons therefor. It seems evident, however. that to exposure is so uncomfortable at any certain time of day as to cause broods definitely to avoid it.

\section{Some Relationships of Temperature. If'ind and Amospheric Conditions to Slope I'se}

It is often productive o explore even the seemingly incunsequential relationships between a willlife species and the habitat which nurtures it. Like a complicated puzale. each piece of information that can be fitted into its proper njehe helps to interpret the whole even though individually it may be of hut little immediate moment.

The differences in use grouse bronds make of cover facing north. east. south or west under varying conditions of temperature. wind velocity and moisture conditions, are apt cases to point. For instance, if the hirds were disinclined to make use of otherwise satisfactory cover hecause it was located on a slope facing strong prevailing winds. such situations might be

* Sre Appendix. I. 811 . 
among the less desirable for inclusion or development in a grouse management area. The only sure way to answer such questions is to check carefully each such situation by way of finding out just how important it may really be.

In considering the effect, complieated as it is. of these inlluences upon grouse, one must remember that such items as the way a slope faces and the temperature conditions found thereon. certainly are responsible in some measure for the vegetation which occurs. For instance, in many parts of New York the colder north slopes run to the beech, birch. maple, hemlock type. The warmer south slopes are often covered with types such as oak and cherry which are common farther south.

One generally thinks of animals as seeking south slojes for warmth during cold weather and

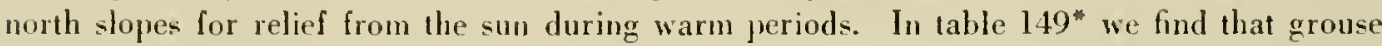
bronds seem to react in a reverse manner. The use of north, east and west slopes is apparently least on warm, greatest on cold days. Conversely, south slopes and hat lands are occupied least on cold din's, though the difference is admittedly not great.

Thus, while this table does show interesting brood choice trends under various temperature conditions, it is probable that cover types found on the slopes, rather than the exposure of the slope itself, may be largely responsible therefor. l'roduce the proper admixture of cover. and slope aspeet may not he important. To do this where it does not exist. may be a costly procedure. It is well to remember that, in New York, tracts containing large areas lying all on one slope nay be less easily made into high producing grouse units than those in which a natural variation in topography may assist materially in producing naturally the variety of cover grouse like.

Wind, too. may have its effect on the degree to which grouse broods frequent various slopes. While none is shunned by broods primarily because of wind conditions (table 150) ${ }^{4}$ there is an indieation that the hirds keep away from north and west slopes on windy days. This is logical when one remembers that prevailing winds over much of New York are from the west, and to a lesser extent from the north. Further developing this impression. the tahle indicates that east slopes and flat lands may be somewhat more attractive to grouse broods when strong winds are prevalent. Unfortmately. no record of wind direction on the particular days on which the data were reorded was kept. and. therefore, only the hroadest generalities are noted.

If grouse reacted like human heings. one would expect to find more hroods occupying south slopes on clear lays and seeking out the denser sheter of north slope cover in rainy weather. Hpon reference to table $151^{\dagger}$ we find no slopes shunned by grouse hroods. either in fair or foul weather though there is an inchination for them to use morth slopes more commonly on rainy days.

To sum up. grouse broods prefer to spend most of their time in the slashings. overgrown lands and second.urowth hardwoods which are characterized hy a diversity of vegetation. Thick woods and conifers are less attractive. Undergrowth types most used hy broods are shrulis and herry hushes, young hardwoods and a "combination of types." Dense tangles are less popular unless they are broken up by trails and other small openings. Cover use varies with the time of day. though no tyje is completely shumned at any time. Weather and slope influence brood distribution depending on the makeup of the crown cover and undergrowth but the effeet is seldom strong. Broods tend to avoid steep slopes.

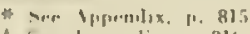

A ser trpendir, p. B16.

$t$ see Vplentix. p. 817 


\section{Adult Grouse Cover and Related Influences}

It is a pleasant part of every day's hunt to talk over in retrospect the experience of the chase. Here a grouse was found feeding on frosted fruit under a wild thornapple tree. There two birds flushed unexpectedly from a thicket of alder or hirch. Conifers screened a third that got safely away. Where were the rest of the partridge, and why were they, too, not found? To the old-timer cach new day's adventures. mellowed by experience. furnish fresh evidence to substantiate impressions as to the probable behavior of the bird under a wide variety of conditions. In a practical sort of way he becomes his own "expert" in predicting where they are most likely to be found and where they will fly to when flushed. His judgment may not always be vindicated, for each grouse is an individualist in its own right, but there is nevertheless much of truth in what he may say on the subject.

Wildlife managers, listening in. may perhaps be confuser by the variety of often conflicting opinions thus expressed. But to date there are few places. save for their own limited experience, to which they ean turn for more exact impressions. As we have seen. in attempting to ehart brood preferences for certain kinds of cover, slope, weather and wind eonditions. it is no easy job to interpret correctly grouse hehavior. The background of environmental influences is so varied as to require the most careful examination of thousands of records hefore one can even recognize a possibly valid tendency for the bird to art in a given mamer under a certain set of conditions. Yet there is no other way, known at the prosent time to analyze grouse eover requirements with sufficient arcuracy to justify the expenditure of hard cash in improving the hahitat to produce a larger grouse crop. In no other way ean we surt out the ideas and determine which of the old-timers' theories have real suhstance in fact.

Let us then look at the record written by the hirds themselves. To establish a pattern in which we can place confidence, individual variation has been largely compensated for hy analyzing 19,619 records of adult flushes from the three main regions of the State. To leaven out any radical differences which might be apparent in any one sear all flushes from 1930 through 1936 were tahulated. To insure representation from each region. four study areat totaling 10.000 aeres were set up. one cach in the Adirondacks and the Catskills and two in the Southern Tier counties. Ndult grouse contacts un these areas alone totaled 16.963 during these years.

In charting grouse reactions $t 1$ smme items such as cover types and slope still further refinements were necessary. The amount of each type and shope had to be determined and the record of birds found in each situation adjusted aceordingly. If, on a study area. one type of cover occupied much more of the land surface than another. yet both were equally attractive. hirds might he expected to lo found thereon in proportion to the size of each area. This would result in a seeming prepmenderance of hirds heing fonnd in the more extensive types mless such an adjustment wore nade. One fund this difference evident in comparing tables 15 and $153^{*}$.

To correct this situation the number of flushes in each type of cover had to be expressed on a "per acre" hasis. In making up some tables it was even found necessary to consider the ehanges in the extent of each cover type taking place while the Investigation was in prog. ress. Some of these were surprisingly large as abandoned meadows grew up to brush or small slashings were cut only to fill in to sprouts and berries in a few years.

To keep track of such items on all the study areas was a lask beyond the resources at 
hand. The Connecticut Hill area was therefore selected as the one on which these changes could best be noted. Thus the following tables from which the pattern of adult grouse behavior here described, is drawn, may represent one area, all four, or records from the entire State depending upon the complexity of the situation to be analyzed.

No exact way of taking into accoun differences in the arrangement or interspersion of cover types was found. Realizing the importance of having each type well scattered over an area selected for study. only units supporting a good aduixturc of cover were chosen. To the extent to which each varied in this respect (and others such as the quantity and quality of the vegetation making up a cover type) inaccuracies may have crept into the tables to influence the trends here presented. In sampling the effect of the environment on a species snch as grouse, no way of compensating for these has been discovered. Fortunately they are probahly not too large in most instances to obseure seriously the more pronounced trends.

With this understood. let us see what evidences of grouse reartions to cover have been found.

\section{Types of Cover Used by Adult Grouse}

Grouse broods love the lush confusion of slashing and brushlot. As the birds mature and the broods disperse. the approaching winter poses new problems of finding food and shelter. The overgrown lands and brier patehes no longer provide the same luxuriant protection once the leaves have fallen. Only the conifers and the broad-leaved evergreens maintain their promise of sanctuary against winter winds and winged predators alike. Tangles of vines too dense to be attractive while the leaves were on. now, with a mantle of snow. furnish places to doze in fair security. As winter gives way to spring. and spring to summer, cover use reflects the vegetative changes in the face of field and woodlot that accompany the seasons. The habits of adults are modified aceordingly.

Remembering the lrood cover preferences. one ma! be surprised to fund indieated in table

T'ABLE 15. TYPES OF COVER USED BY ADULT GROUSL: CONNEC:THCUT HHLL NREA-1930-1036.

\begin{tabular}{|c|c|c|c|c|c|c|}
\hline $\begin{array}{l}\text { Tyin" } \\
\text { of } \\
\text { atower }\end{array}$ & $\begin{array}{l}\text { Pyin } \\
\text { cuid }\end{array}$ & $\begin{array}{l}\text { Number of } \\
\text { yours lyone } \\
\text { wus present } \\
\text { oll studly arisu }\end{array}$ & $\begin{array}{l}\text { Avrrager } \\
\text { acreage" of } \\
\text { mach typo" }\end{array}$ & 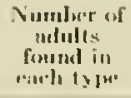 & $\begin{array}{c}\text { Adjusian } \\
\text { sumburer of } \\
\text { iudiulis } \\
*\end{array}$ & $\begin{array}{l}\text { Jorcent of } \\
\text { udults foumul } \\
\text { in ench } \\
\text { 1yfu. }\end{array}$ \\
\hline 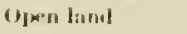 & $A$ & 6.3 & 2021. & 108 & $د$ & \\
\hline Ovirgirown land & II & $\begin{array}{l}5.2 \\
5.4 \\
5.4\end{array}$ & $\begin{array}{l}1111.2 \\
1111.2 \\
111.1\end{array}$ & $\begin{array}{l}710 \\
9113 \\
-11\end{array}$ & $\begin{array}{l}131.3 \\
830 \\
6.30\end{array}$ & $\begin{array}{l}7.2 \\
1.9\end{array}$ \\
\hline Wemilnum] & $\left\{\begin{array}{l}1: \\
1: 11 \\
1 \\
1011 \\
1 \\
11\end{array}\right.$ & $\begin{array}{l}6.2 \\
5.7 \\
2.2 \\
3.6 \\
3.0 \\
6.2\end{array}$ & $\begin{array}{r}155.8 \\
169 . .5 \\
159.0 \\
16 . . \\
58.7 \\
131.4\end{array}$ & 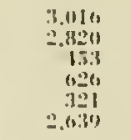 & $\begin{array}{l}1.126 \\
1.187 \\
1,1.13 \\
1.5110 \\
1.286 \\
2.1117\end{array}$ & $\begin{array}{r}10.0 \\
9.0 \\
8.6 \\
11.7 \\
9.7 \\
18.7\end{array}$ \\
\hline Sluahien: & $\left\{\begin{array}{l}\mathbf{I} \\
\mathrm{J}\end{array}\right.$ & $\frac{2.8}{3.7}$ & $\begin{array}{r}193.9 \\
136.7\end{array}$ & $\frac{2.60}{6.5 .5}$ & 1.213 & 0.1 \\
\hline Sul-total & & $\$ 8.1$ & 2.127. & 13.112 & $1: 1,211$ & 160.0 \\
\hline Not spuerifind & & $\ldots$ & $\ldots$ & 111 & & $\ldots$ \\
\hline Tutal & & 58.1 & $2,12: \ldots$ & $13,5.3 .3$ & 13,211 & $\ldots$ \\
\hline
\end{tabular}

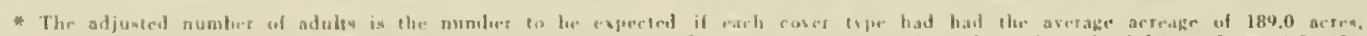

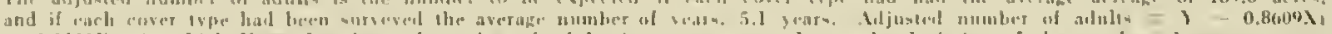

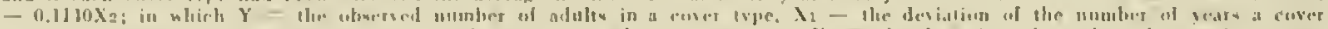

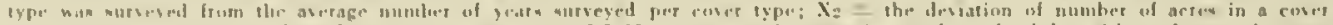

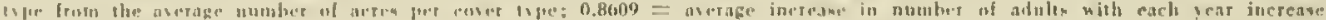

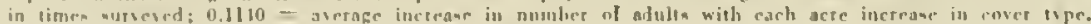

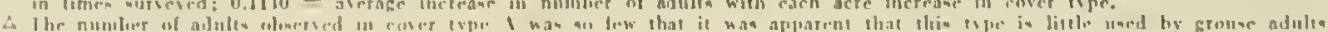


15 a generally lessened interest on the part of the adult in overgrown lands and in slashings* though many a bird still seeks the abundance of food to be found there, particularly during the summer and fall months. Second-growth woodlands. though usually well patronized, are also less important, unless they contain at least a scattering of evergreens. Conversely, the adults seem to find the more open ranks of the mature hardwoods and conifers. as well as the denser stands of evergreens, much more to their liking than did the broods.

In reducing grouse flushes to a "per acre" basis, one source of error has been avoided, but another encountered. The scarce types, even though moderately used, have been made to appear more important than would actually be the case, were they, in fact. more extensive.

In other words, use is not proportionate to size. In using a "per acre" analysis. types large in area are made to appear less important whereas types represented ly but few acres appear to support a larger use than is actually the case. This situation should be kept in mind when interpreting the cover preferences by month on page 157 . as well as in other tahles showing "birds per acre."

To be of much use the general cover pieture must be broken down ly seasons and montlu. Let us then take a look at where the adults are then to lie found.

\section{Seasonal and Monthly Cover Preferences}

Among the questions frequently asked ly sportsmen during the course of the lnvestigation bas been, "Where can I find the most grouse?" It is usually motivated hy the desire to har. vest a share of the crop, as well as liy a natural interest in the habits of the hird and its welfare.

Beginning with table $153^{\triangle}$ one will find described many a trend that will help to answer this perplexing problem.

A resume of gronse cover choice hy seasons in New York runs something like this. In the winter the hirds frequent the more heavily wooled areas particularly if conifers are present. Occasional forays into hrushlots seeding in to evergreens and hardwoods, or to the older slashings. especially if bordered with pines or hemlocks. are rarried out. possihly with an eye to sampling the greater variety of food to be found there.

In spring the birds are still partial to the woods, both second-growth and mature. They are also conifer-consejous thongh 10 a much smaller degree than in winter. Lxrursions into rut-over patches and overgrown lands become more frequent.

By snmmer the trend has hecome a habit as they revel among herry hriers and woods' edges. Though the hardwoods are by no means deserted during the warmer months. ever. greens are but little used if not actually avoided. Spot-lumbered areas also are popular.

The fall brings to maturity new crops both of grouse and of the fruits on which they fatten. Forgotten apple trees in fence corners. pasture-seeded thornapples. dogwood chmps and cherries in the hedgerows act like magnets drawing the hirds to fields long ahandoned. In beechmut years the hardwoods, loo, merit their share of attention. though they are otherwise least attractive at this season of the year. The presence of evergreens among mature hardwoods is, for gronse, again a woolland sign of welcome.

Wildlife managers partial to the partridge will fund much food for thought in table 153

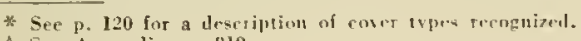

$\triangle$ See Appendix. p. 810. 


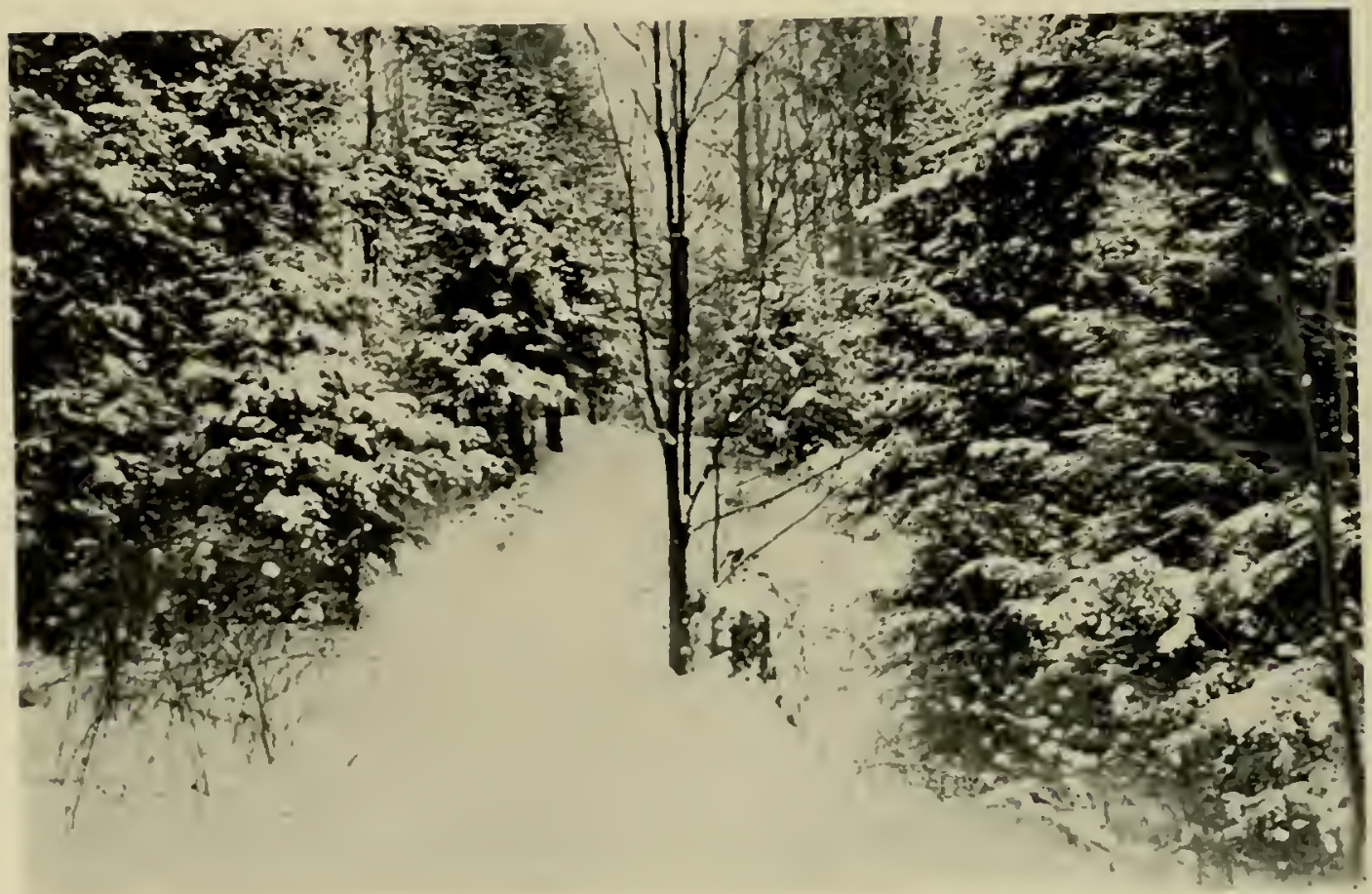

WINTER SIIELTER

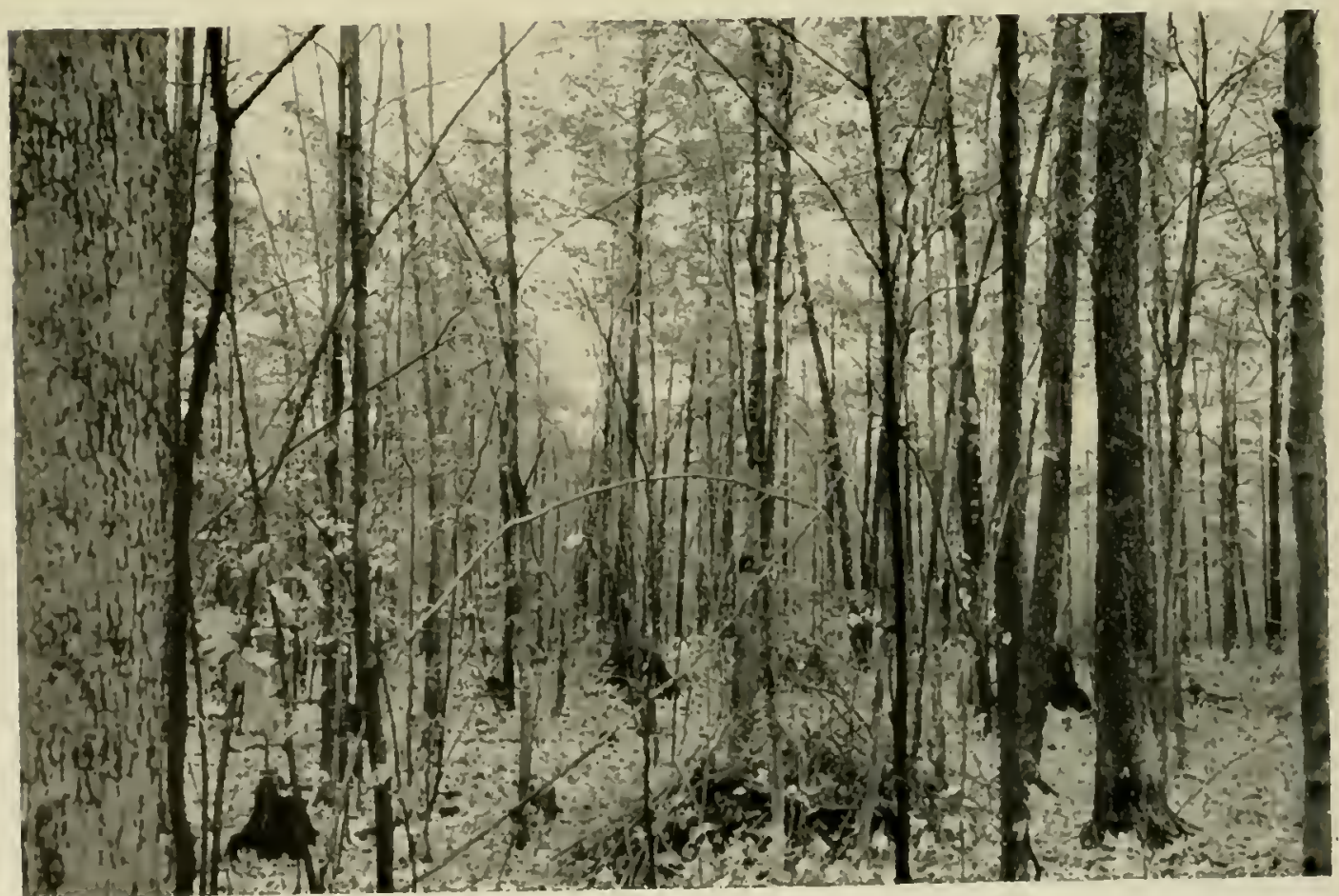




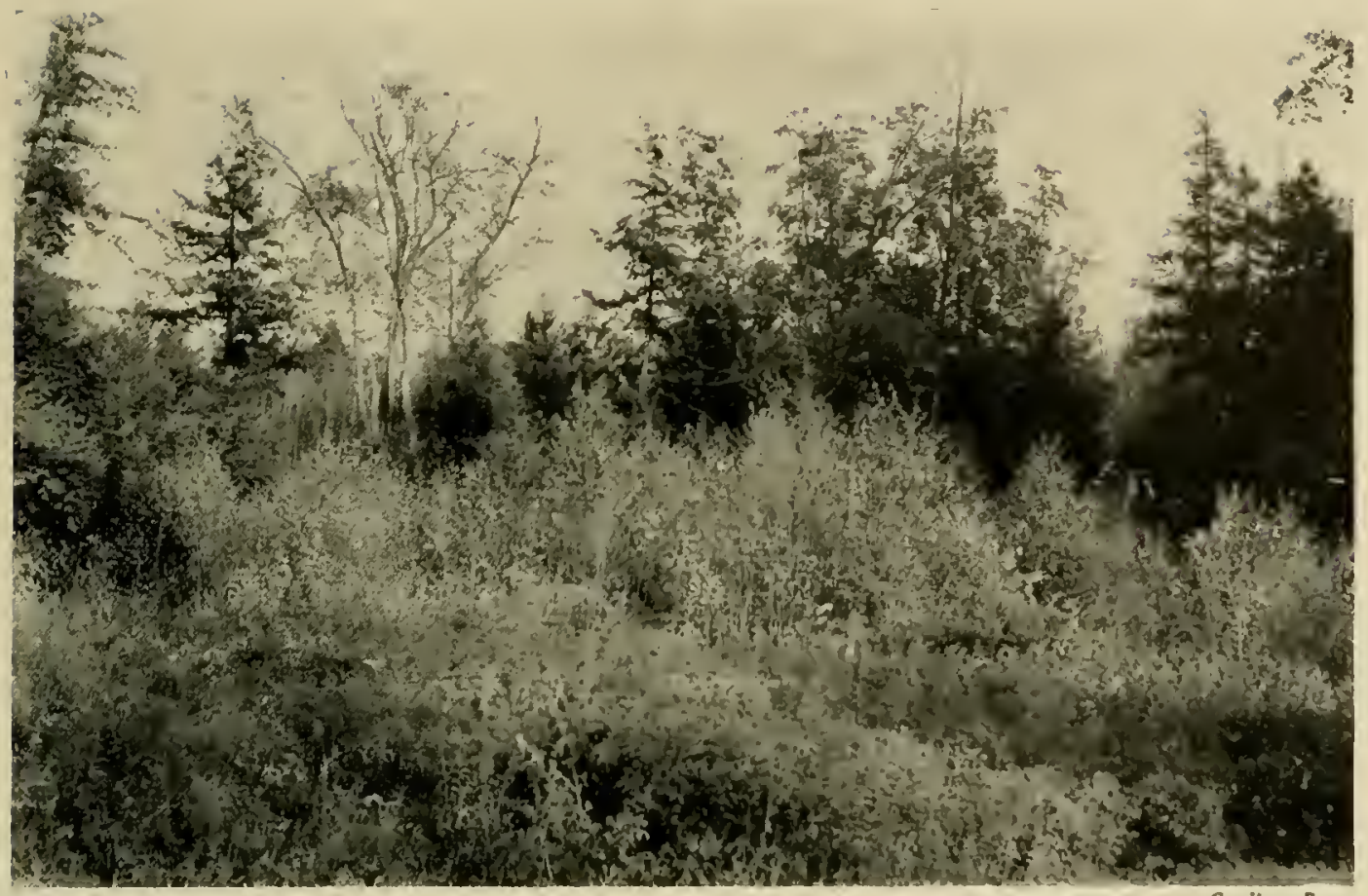

SUMMER FFEDING GROUNDS

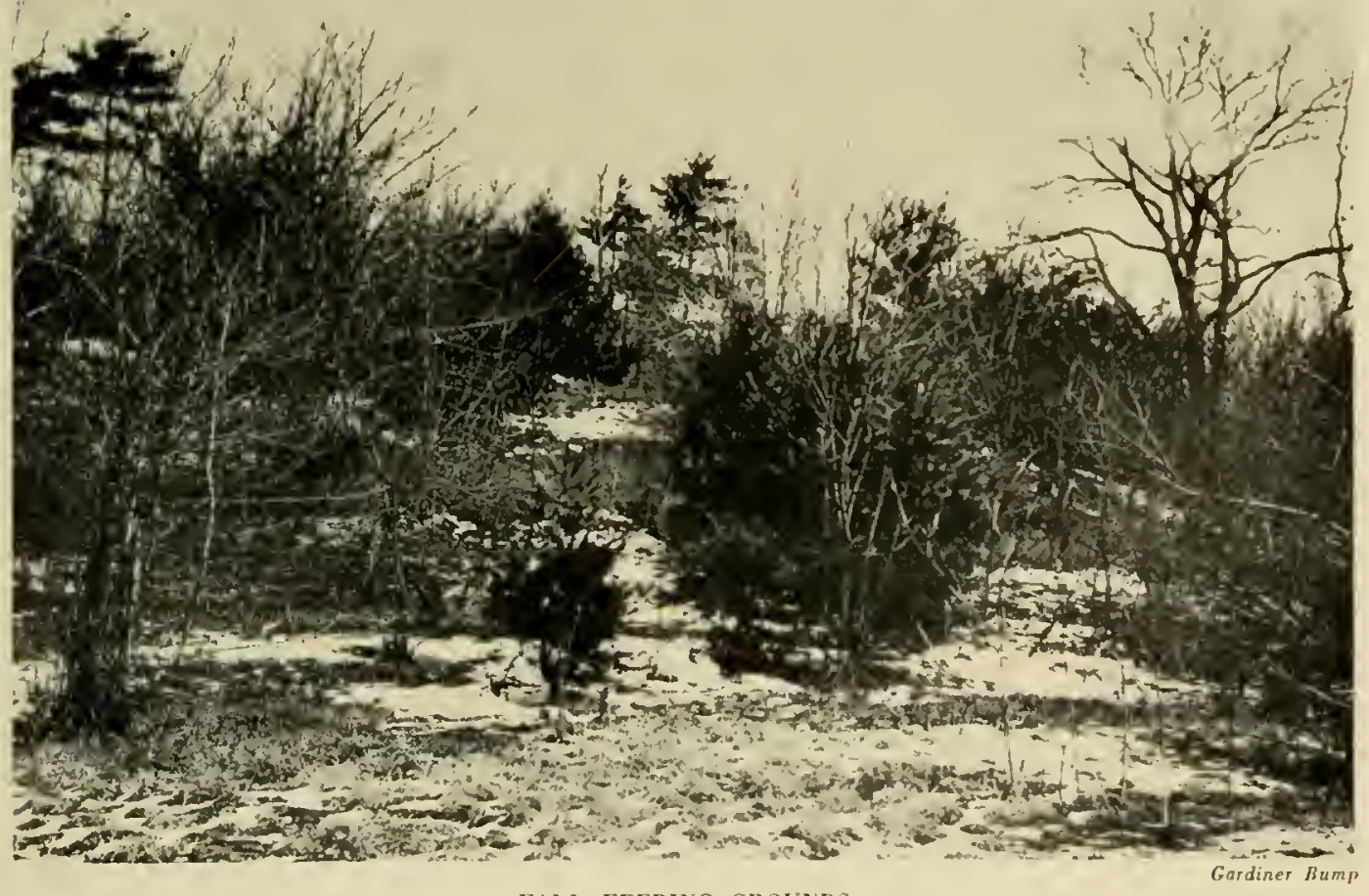

FAIL, FEEDING GROUNDS 
and in the accompanying detailed analysis of seasonal trends. Lest repecition dull perception. let us leave it there for refermce and pass on to a further detailing of there temlencies ly. types and months.

By referring to table $151^{\text {" }}$ one discovers no cover type that is completely avoided even for a single month ${ }^{A}$. Even the meadows (type A). in which the presence of a grown partridge is something of a rarity throughout most of the year. are occasionally frequented in the fall and early winter.

Overgrown lands (types B, C and D) but little sought out in midwinter (February), gradually increase in attractiveness throughout the succeding spring and summer to a peak in September and Octuber, then taper off rapidly in use through December and January. Alder beds and popple thickets (type B) deviate from the general picture by building up to their maximum use in June and again in October and November. Brushlots and wergrown pastures deficient in conifers (type C) are most used from Junc through October. Where evergreens have seeded in among the bushes and young hardwoods (type D) grouse usually frequent the area more in early spring than in May or June. Though conifers in brushy and wooded cover scem not to interest grouse throughout the warmer months, the birds hegin to seck them out in late summer, the trend becoming pronounced. as ohservant hunters know. by September and October.

Woodlands are of course the backbone of grouse habitats, although less important in the summer and early fall months. In Fehruary, 75.3 per cent of the birds were flushed therein. Threc-quarters of these were found in close association with varying amounts of conifcrous cover. Contrast this with August, when but 50.3 per cent of the adults were flushed from wooded areas largely composed of hardwoods. This hrings into sharp relief the inability of any one group of cover types adequately to meet the varying needs of the birds at all seasons of the year.

The component types that collectively constitute grouse cover may be divided up into second-growth woods. mature wook, spot-lumbered areas and coniferous cover. Considering these in order we find that sccond-growth hardwoods (type E) are particularly attractive in January and again in May. June and Septemher. Much less attention is paid to them in the fall and early winter. The presence of evergreens in this coser (type EH) tends to decrease its use sharply during the summer, and to increase its desirability in the fall and winter.

Turning to the older woodlands, after finding that the liroods made but little use of mature hardwood eoser (type $F$ ), it is surprising to note their elders seeking this type out esen more than second-growth hardwoods from late winter through mid-summer. Both types are alike in being little used in the fall and early winter. though mature hardwoods are also avoided into January. Add a sprinkling of conifers (type FIJ). hwwever. and the pieture changes radically for such coser is then more used throughout late winter. is much less attractive in summer, and is strongly preferred from Oetoler through Decenber. Except for thick conifer: (type II), a combination of mature hardwoods and conifers clearly vics with wergrown lands for popularity in Octoher, and is certinnly much proferred to the latter over the next two months. In fact. in December, 22.4 per cent of all the grouse Hushed were found in this: ine type of rover.

The effect, on woodland cover choiec of conifers as a type (II) or scattered throughout

- Appendis. p. 821.

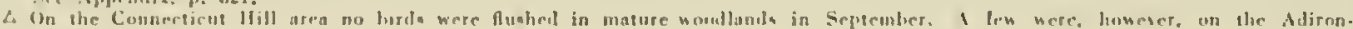
Aluk atuily area. 
wher types, is one of the outstanding impressions to bc gained from a close study of table 154. In winter, in New York, coniferous cover attracts grouse like a magnet. In spring, though still much used, it becomes of decreasing importance. This continues deep into the summer. Fall brings a strong resurgence of interest in this type on the part of the grouse.

The last forest type, spot-lumbered wondlands (type G) is strongly patronized during the summer months and is still attractive during the fall. It is of minor importance in winter. Remembering the profusion of small vegetation which often comes up in the miniature slashings produced by this operation, it is probable that the birds here find a weleome variety in comparison with the limited food choice available in most of the other wouded areas.

Turning to clear-cut areas, there seems to be considerable variation in the use grouse make of them, depending upon the length of time which has elapsed since cutting. Young slashings (type I) are patronized only intermittently by the birds from December until March, for the food availalle there is then largely covered by snow. With the coming of warmer weather interest in these areas increases gradually, until in July hettcr than nine per cent of the adults were found in such situations. The older slashings (type J) are patronized more consistently throughout the year. From June through August more adults are found here than in any other type. In the fall the birds are more likely to be found in old" rather than the young slashings except during the month of Novemler. when there seems to he a sharp return of interest in the latter areas.

A study of figure $154^{\Delta}$. where these relationships are graphed hy months. will prove well worthwhile.

The following analysis of the most used typest by mouths will also serve to hring the sit. uation more elearly to mind:-

Month

January

February

April

\section{Types most frequently used}

Conifers (type H)

Second-growth hardwoods (E)

Second-growth hardwoods and conifers (kil)

Overgrown lands with conifers (D)

Conifers $(\mathrm{H}$ )

Vature hardwoods and conifers (FH)

Mature harelwoods (F)

Second-growth hardwoods (E)

Conifers $(\mathbf{H})$

Mature hardwoods (F)

Mature hardwoods and conifers (FH)

Seeond-growth hardwoods (E)

Conifers (H)

Nature hardwoods (F)

Nature hardwoods and eonifers (FH)

Second-growth hardwoods and conifers (EH)

Seeond-growth hardwoods (E)

* On the areas slutleed a slashing passed its primo for grouse from eight in turlwe vears after iutting.

$\triangle$ See Appendix, r. 154 .

$f$ Adjusted for differenres in tvie acreage. 


\section{Homll}

Nay

June

July

August

September

Ortoluer

Novemlies
Types most frequently used (conid)

Nature hardwoods and conifers (FII)

Conifers $(\mathrm{H})$

Mature hardwoods (F)

Second-growth hardwoods(E)

Older slashings $(\mathrm{J})$

Older slashings $(\mathrm{J})$

Seeond-growth hardwoods (E)

Spot-lumbered areas (G)

Mature hardwoods (F)

Overgrown lands without conifers (C)

Relatively pure stands of popple, birch or alder (B)

Older slashings $(\mathrm{J})$

Spot-lumbered areas $(\mathrm{G})$

Mature hardwoods (F)

Overgrown lands without conifers (C)

Young slashings (I)

Second-growth hardwoods (E)

Otder slashings $(\mathrm{J})$

Spot-lumbered areas (G)

Second-growth hardwoods (E)

Mature hardwoods (F)

Overgrown lands without conifers (C)

Conifers $(\mathrm{H})$

Overgrown lands without conifers (C)

Overgrown lands with conifers (D)

Older slashings $(\mathrm{J})$

Second-growth hardwoods (E)

Spot-lumbered areas (G)

Conifers (H)

Overgrown lands without conifers (C)

Malure hardwoods with conifers (lil)

Spot-lumbered areas $(\mathrm{G})$

Older slashings (J)

Overgrown lands with conifers (1))

Conifers $(\mathrm{H})$

Mature hardwoods and conifers (FII)

Spot-lumbered areas (G)

Relatively pure stands of popple. birch or alder (B)

Younger slashings (I) 
Nonlh

December
Types most frequenly used (contid)

Conifers $(\mathrm{H})$

Mature hardwoods and conifers (FH)

Second-growth hardwoods and conifers (EH)

Older slashings $(\mathrm{J})$

From the above, one might well gather that grunse in New York State cannot exist where conifers are absent. Such is not the case. True, they are an outstanding part of most of our productive coverts. But when they are absent, other types, such as spot-lumbered areas (G) and older slashings, may furnish brushy tangles which serve the same purpose in providing escape cover and shelter. In general, however, the more severe the weather, the more conifers, properly interspersed, contribute to the desirability of any grouse halitat.

The above "design of living quarters" for adult grouse month by month is of course made up from the olserved preferences of the hirds under New York conditions. By and large. proh. ably it represents a fair cross-section of grouse cover choice throughout the Northeast.

\section{Types of Cover Used by Alult Grouse at Various Times of Day}

In tables 155 to $158^{*}$, one has, in effect, put a time clock on grouse movements from cover to cover throughout the day. Hunters, hird lovers and research workers alike are interested in finding out how these birds budget their time.

This is no casy task, for a quick glance at the tables leaves one puzzled by the complexities of the use pattern to be unraveled. In Iruth much of it eannot be assembled, for few strong trends stand out even when the records are broken down, scason ly season. In other words, there is no outstanding concentration of birds in any one type at any particular time of day. But there are some interesting scisonal use differences to be noted.

$\mathbb{W}$ inter. The necessity of finding food and shelter secms to be the controlling influence on grouse movements throughout the winter day (table 155). In the early morning, in general, the lirds are most likely to be found among the conifers (type H) or the second-growth hard. woods (E). The latter type often combines good budding opportunities with a chance to catch the morning sum. While overgrown lands and slashings are used least of all in winter. one finds a few carly feeding hirds in the former covers at this time.

The most unexpected thing about early moming use is a tendency to awoid second-growth hardwoods admixed with conifers (EH). The table clearly indicates that hirds do not move into this type in numbers until later in the day.

By mid-morning less birds are to be found in second-growth hardwoods alone: more in a mixture of these with conifers. Little change is noted in the attractiveness of overgrown land and coniferous patches.

At mid-day mixed hardwoods and conifers reach their maximum use. Birds now tend to forsake the alders, popples or birch thickets (B) and to be somewhat more prevalent in the older cut-over areas $(\mathrm{J})$. Many still stick to the conifers though possibly in less number than is the case earlier in the day.

Towards late afternoon more hirds may be found feeding in the overgrown lands. Second-growth hardwoods and conifers (EH) likewise are attractive but relatively pure stands

\footnotetext{
* See Appendix, p. 823 to 829 .
} 
of conifers (H) are likely to have less hirds among them than at any other time.

Spring. The daily cover use pattern in spring is markedly different from that of the winter (table 156)". As one would expect, nesting cover (types E, EH) is now important. Here one is apt to find about the same percentage of birds throughout the day. Conifers $(\mathrm{H})$, while less used now than in winter, are still frequented from daylight to dark.

In early morning a relatively large number of adults are to be found in the more open overgrown lands $(\mathrm{B}$ and $\mathrm{C}$ exccpt where young conifers predominate (D). Possibly they are in search of variety in their diet. Interestingly enough this tendency does not extend to rut-over areas ( $\mathrm{I}$ and $\mathrm{J}$ ). however. since these are but little used until later in the day.

By mid-morning this situation is apt to be reversed. The more open "edge" types $(A, B$ and C) appear to be utilized less, except for overgrown lands dotted with small conifers (type 1)), which for some reason. now gain markedly in popularity. Some birds also seek out the older slashings $(\mathrm{J})$.

From midday through late afternoon this pattern changes but little. As in winter, alder, popple and hirch cover (B) are progressively less used: brushy areas (C) more. Possih]y a few more birds may he found among the conifers, but the shifts are, at best, minor.

Summer. Two differences from other seasons stand out in summer cover use (table 157) ${ }^{\Delta}$. Thick, coniferous covers are but little frequented. Even mixed second-growth hardwoods and conifers (type EH) are much less popular than is hardwood cover alone (E). There is also a strong tendency to make greater use of shrubly and herhaceous areas such as brushy pastures, spot-Jumbered areas and slashings (B, C, D. G, I and J). Here hirds find summer feed in unending variety and abundance.

Early on a summer morning hirds are apt to be found in the overgrown fields (types B, $C$ and D) or in the second-growth hardwoods (type E). In fact the latter type is popular throughout the day.

Around midday the older slashings (J) seem to be particularly attractive, though the cover just mentioned is also frequented.

Late afternoon finds the birds more widely distrihuted though possibly with a tendency to work back into second-growth hardwoods (E).

fall. In some respects good fall grouse eover is not as different from that used by the birds in summer as one might think (table 158) As every grouse hunter knows. hirds are to be found in the overgrown lands (types B, C and D) in considerable numbers. Hedgerows and brushy patches, not too far from wooded areas, are favorite gunning spots in early fall. But unless it is a "leechnut year" one has only about half as much chance of finding hirds among the second-errowth hardwoods (E) ats in the summer. To add a fair sprinkling of conifers. anong the young hardwoods (EII), however, is to increase the popularity of this type considerably. Small patches of conifers (H) are three times as likely to be used in alu. tumn as during the warmer weather. Even so the birds are apt to he surprisingly well dis. tributed orcr most types. the notable exceptions being open land $(\lambda)$ and mature hardwoods (F). Apparently too, cut-over areas ( $I$ and $J)$ serve as summer and early fall feeding grounds for later they attraet somewhat less hirds, except in the early morning. Curiously enough. on the Connecticul Ifill area, young sashings (1) were also much frequented in Norember.

* See Apriendix. 1. 83:5.

A See Apprnitix. p. $82:$. 
Sunup is the time to hunt the brushy spots and overgrown pastures particularly where there is a dearth of small evergreens (C). Birds are apt to be found also in mixed second-growth hardwoods and conifers (type EH) and in clumps of conifers (H). A considerable propor. tion pay an early morning visit to the older cut-over areas $(\mathrm{J})$.

By mid-morning there is a tendency for birds to move back into the wooded areas, either into the two woodland types mentioned above or to second-growth hardwoods ( $E$ ).

Midday is apt to bring on a snall increase in birds among the popples, birches or alders (B) and in mature hardwoods with (FH) or without conifers (F). There are also likely to be fewer birds among the conifers $(H)$ even though they be in mixture with second. growth liardwoods (EH).

No significant changes from this pattern are indicated throughout mid-afternoon except that conifers (łl) are still less popular. This is apparently the best time of lay to hunt the spot-lumbered patches $(G)$ especially if they are not too extensive. The older slashings also show a small increase in use at this time.

It is interesting to find no great increase in the numbers of grouse frequenting overgrown lands (B, C and $\mathrm{D})$ ) and hut few birds in (ut-ower types ( $I$ and $J$ ) in the late afternoon in spite of the widcly accepted belief that such cwerts are much used for fecding at this time. Woodland coverts containing a mixture of ronifers (EII and H). however, exlibit in. creased use.

Thinking that the cover preferences of grouse during the hunting scason (October. No. vember) might differ significantly from the overall fall picture. flush records gathered from all parts of the State for these months, were assembled in table 159*. An analysis of these. however, reveals no great difference between the cover preferences of the birds in Septemler when compared with that of the later atumn months except that. as the days grow colder. less use is likely to be made of cut-over areas ( $I, J)$ in the rarly morning.

\section{Effect of Various $W$ eather Conditions on the Choice of Cover by Adult Crouse}

The reaction of grouse to different weather conditions is naturally of interes to the hunter. Such relationships may atso be important to the game manager in preparing development plans. Accordingly, the temperature. wind and atmospheric conditions prevailing at the time each grouse was flushed, were noted throughout the lnestigation ${ }^{\star}$.

As a general conctusion it appears that grouse may be found in any coser type under any of the weather conditions recorded. However, the types predominanty utilized at any on season tend to outrank the others regardless of the weather. But an analysis of tables 160 . 162 does reveal interesting differences of cover use under various weather conditions.

Temperature. Considering temperature first. the data have been summarized in table 160 . At a glance, an inclination for the birds to move into mixed second-growth hardwoods and conifers (EH) or to thick conifers (H) on colder than normal days is apparent. This secms, however, not to extend to mature mixed hardwoods $(\mathrm{FH})$ or to the more open overgrown lands with an interspersion of evergreens (D). This suggests that the higher shelter value of the denser woodland yypes may he the deciding factor. Thus conifers may serve the adults as protection from cold in winter hut not from heat in summer.

Conversely, on warmer than normal days, grouse tend to move to some of the more open

\footnotetext{
* See Appendix, 1. 830.

$\triangle$ Sce figures 73 to 76 , $17,702$.

$\dagger$ see Appendix, T. 831 io p. 833 .
} 
wer types defucient in conifers. Among these are alders. popple or birch patches (B), ser. ond-growth hardwoods (E), mature hardwoods (F) and young slaslings (1). This relationship does not hold true, however. for overgrown fields. with (C) or without (1)) an admixture of conifers. No good reason for this secming contradiction is apparent.

In considering the above, one should bear in mind that the designations warm. normal and cold refer to the relative temperatures at the time a flush was recorded as compared with the arerage for that time of year rather than to the actual temperature in degrees.

Wind. It is generally helieved that, on windy days, grouse often exhibit a tendency to "flush wild." Certainly: in windy wcather, they are more alert and nervous than at other times. One might expect to find, and be surprised at not finding. upon examining lable 161* . the birds concentrating largely in shclter types at this time. True, coniferous clumps (H) are then more likely to be used but mixed hardwoods and coniferous cover (D, EH and FH) exhibit no such tendency.

The only other covers, more attractive in windy weather, are the alder runs or stands of popple or birch (B). Particularly in the ease of alder runs, this seems related to the generally protected locations in which they usually occur. Possibly there is also a tendency for similarly situated portions of other types to he preferred at such times hut it has not been feasible to record the data covering this point in such great detail.

The table also indicates that more birds frequent second-growth hardwoods (E) on wind. less days than at other times, though the reason is not clear. Thick coniferous cover (H) appears less likely to be frequented. Other types show no significant differences in use in windy versus still weather. all of which leads one to surmise that wind nomally exerts a rather minor influence in grouse cover choice. There is. of course. the possibility that had the data been broken down according to the scason of the year, greater differences might have been found.

Atmospheric Conditions. In general, sunshine, rain or snow seem not to exert any pronounced influence on the general pattern of grouse cover choice (table l62) ${ }^{\Delta}$ except when shelter is needed. During snowstorms the birds, as expected, are most likely to seek out heavy coniferous cover (11). though, as with wind. this tendency does not extend to mixed hardwood and coniferous cover (D, EH and FH). Likewise the more open enver, even though sume conifers are present. shows a decline in use at this time. Rather curiously none is completely shumned even in snowy weather.

Rain apparently lothers grouse less than snow. Thus one finds at this time fewer birds resorting to the more adequate protection afforded by thick coniferous stands (II): more hirds preferring the mixed second-growth hardwools and coniferous cover (EII). There is also a curious tendency for open fields $(A)$ to he frequented more on rainy days. While worth noting, this is of no real importance since little use is made of this type at any time.

Several of the more open types are uscd more in sumny weather than at any other linse. This is true of wergrown ficlds, lacking in conifers (C), spot-lumbered arras (C), mature hardwoods (F) and the older slashings (J). Conversely, heavy coniferous stands (H) are then least attractive.

Effect of Various Cround Conditions on the Choice of Cover by Alult Crouse

Ground conditions exercise a greater effect on grouse eover choice than is generally realized

* Sere Appendix, 1, 832.

$\triangle$ Tee Ajpendix, p. 833 
for there is considerable variation in type use depending on whether the ground is dry, wet or snow-covered (table 163)*. For instance. we have already noted that conifers are most attraftive in winter. This is particularly apparent when snow covers the ground, for 40 per cent of all adults sought this type $(\mathrm{H})$ when the snow was moderately deep. Conversely. the more open types in which no, or hut few. conifers are present are less used at this time.

An interesting sidelight is the tendency for some birds to abandon conifers for relatively open, mature hardwouds $(F)$ when deep snow encourages snow roosting.

Cover use trends are less predictable when the ground is dry, damp or wet. Overgrown lands deficient in conifers (C) and the older slashings $(\mathrm{J})$ seem to he most attractive during dry or damp periods. with the lirds showing increased interest in coniferous stands as the ground becomes wet. Second.growth hardwoods (E) and mixed liardwood and coniferous cover, irrespective of age (D. EH and FH) are. however. frequented to about the same degree, irrespective of these eonditions, thus raising the question as to how much these differences really matter.

\section{Preference of Adult Cronse for Cround Over Trees}

Like other gallinacenus species, the grouse spends mont of its time on the ground at all seasons of the year. as shown in table $161^{\circ}$. Nevertheless it often resorts to trees. especially conifers. for roosting. or when disturbed by a predator or some other intruder. Budding in

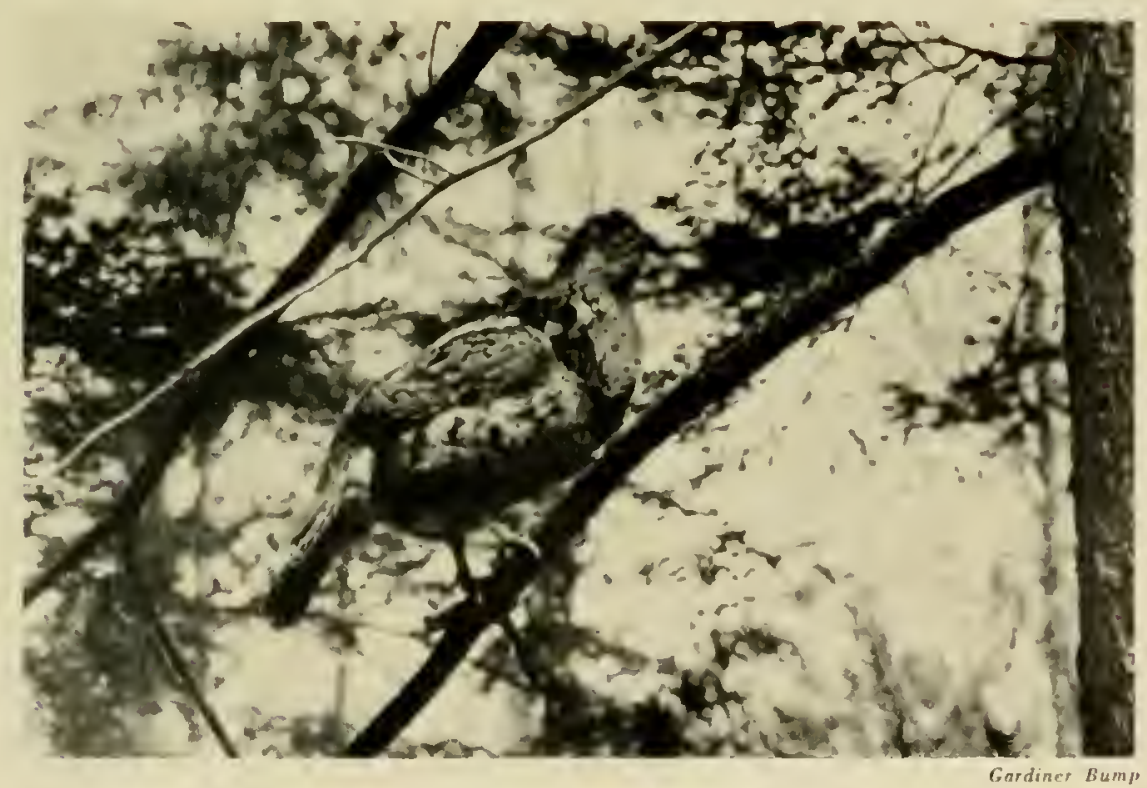

WHILE PREFERRING THE GR UUND. GROUSE TAKE READILY

TO TREES WHEN NECESSARY

trees is common during the colder months. Tree roosting has been most frequent during the winter and spring. with only an occasional bird to he found therein during the other seasons. Strong winds further discourage this practice. 
Table 165* was prepared to determine if this preference for the ground varied according to the type of cover. It is evident that this habit has held true in all types. When tree roosting has been resorted to, coniferous stands (type $H$ ) and mixed hardwoods and conifers (EH and $\mathrm{FH}$ ) have been most frequented because evergreen trees are usually preferred for this purpose.

Considering the few trees normally present in open lands (A), overgrown fields (B. C and D) and in slashings ( $I$ and $J$ ) it is surprising to find that from 4.7 to 10.8 per cent of the hirds found therein were flushed from trees. Perhaps this is a reflection of the tendency for some trees thus situated to fruit abundantly and for the birds to seek these out in the fall.

\section{Influence of Slope on Adult Grouse Distribution}

Had it been shown ly a study of table $166^{\Delta}$ that gronse are more likely to frequent one slope than another at any particular time of day. birds might be more easily located. With but one exception no such inclination is found. At midday a quarter more hirds were flushed from north slopes than at any other time. It is at this period that many birds prefer to rest quietly in some sheltered spot. North slopes in general are rather more likely to support conifers, in the area studied, than are other aspects. Evergreens furnish acceptable shelter. Herein, possibly. lies an explanation.

A question also arises as to whether or not temperature exercises an appreciable effect on the number of birds frequenting any particular slope. Table $167^{\dagger}$ indicates that nn aspect of slope is avoided whether the temperature is warmer than usual. normal or coller.

Though the trend is not pronounced. there is an inclination to use west slopes more and east less, on days which are warmer than normal. Likewise north and south slopes are less used when the weather is colder than normal. At this time fat lands seem to be most attraetive. The prevailing winds are from the west on the areas studied.

The underlying reasons for such apparent preferences are not always easy to fathom. Yet all these olservations are statistically significant. In other words the chances are at least 19 to 1 that these conclusions have a sound basis in fact. Thus the greater use of east slopes and flat lands in colder than normal weather points to the desirahility of encouraging winter shelter cover in such situalioms, insofar as is practical. when drawing up plans for improving grouse coverts.

Summing up. good adult cover is characterized by a variety of composition and a high interspersion of cover types. Woodlands, particularly if they contain some conifers. are the backlone of the covert. Overerrown lands and slashings furnish important summer and fall feeding opportunities.

Though no types of cover are completely shumned at an! season. month. "Ir time of day. there exists a fairly definite time-11se pattern.

Temperature, wind and atmospheric conditims exest a modifying influener on cover ehuser. In most instances. the differences thus caused are not pronounced. Ground conditions. partic. ularly snow, alsu are responsible for some shifts in eover use. Slope exerts a minor influence.

By studying the details of the points leere presenterl. there amerges a generalized "design uf lising quarters," whieb. when properly put togethert should fulfill all grouse courer re.

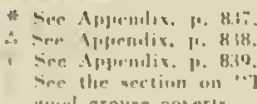

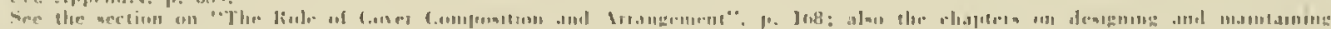
sainl gromier comerts. 
quirements.

Before turning to another phase of shelter, it is informative to note a few observations on the effect of cover on the distance grouse flush from an observer and on the habits of the bird when reflushed.

\section{Influences Affecting the Distance Grouse Flush from the Observer}

That grouse are apt to be "tight sitters" when approached, is generally recognized. Their reaction in this respect varies according to the sex. seasnn. weather, age and experience of the bird, type of cover and activity.

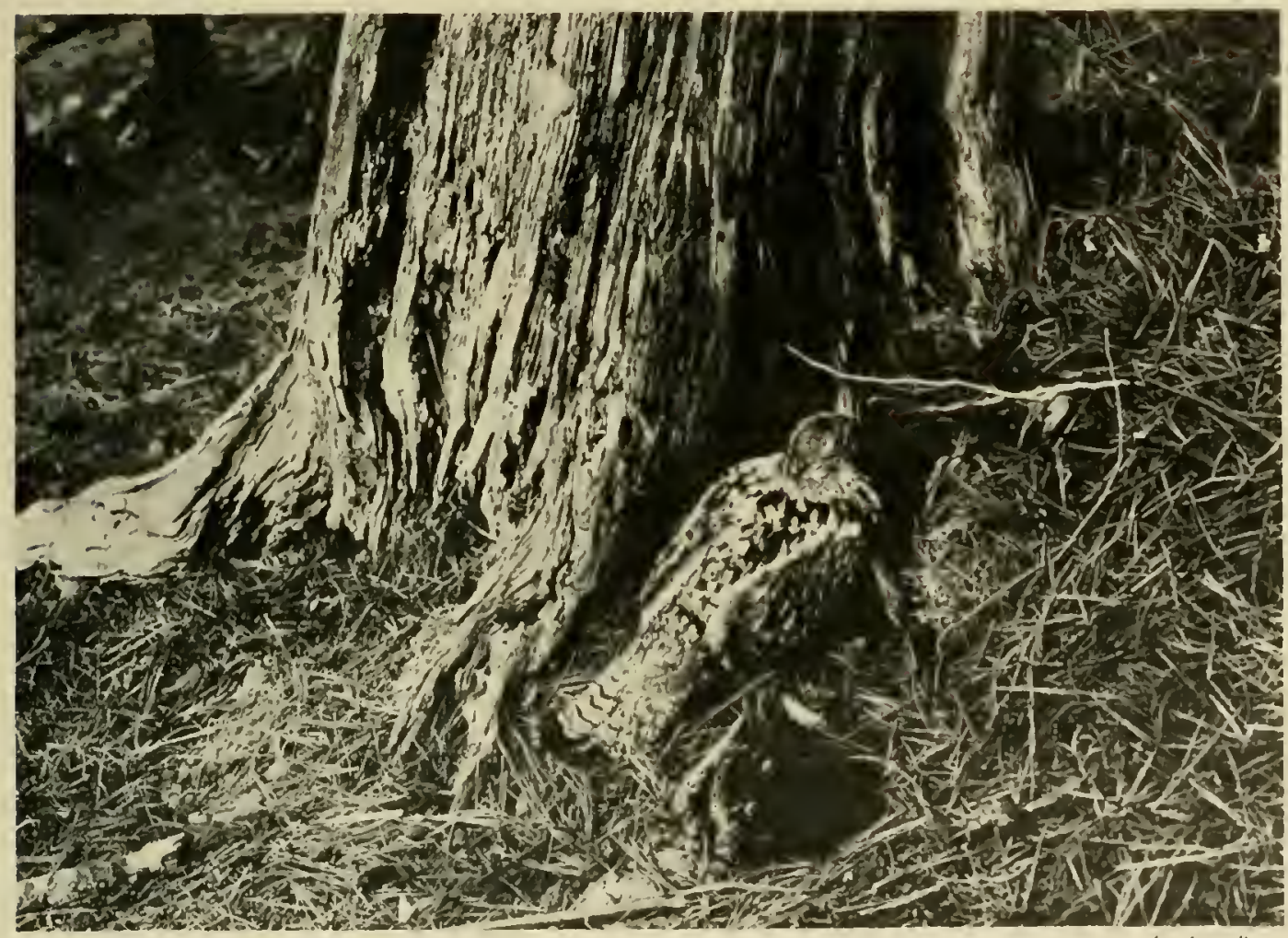

CROISE OFTEN "SIT TIGHT" WHEN THLFATENED BY DANGFR

Much-hunted grouse generally flush wild. So also do birds when the leaves are falling. Nesting grouse may often be approached to within a few feet as mas also loe the case when one surprises a female with a roung brond. Windy weather makes most hirds more wary especially if they are roosting in a tree-a habit which is not pronounced mnder such circumstances.

Sex, too, makes a difference. Nomall, most females are apt to flush within 30 feet of a person: males commonly rise at greater distances, though there are many exreptions.

Throughont the late fall and winter. when trees are hare. hirds are more wary unless they arc snow roosting. Taking the seasons as a whole, however, 791,2 per cent of all birds flushed by the Investigation were within 50 feet of the observer (tahle 168)*. Adults are most likely tw

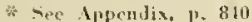


wait until a person is 10 to 30 feet away heforc taking to the air; young hirds usually may be more closely approached.

When surprised in the open. the largest number of birds have flushed from 11 to 20 feet away. In overgrown lands (lypes B, C and D) or in cut-over areas (I and J), especially if the cover consists of shrubs and small hardwoods (C) or a recontly cut slashing (I), birds are most likcly to wait until one is within 20 fect before seeking escape in flight. This inelination 10 "sit close" may be accentuated ly the presenee of luxuriant regetation usually associated with such covers.

In woodlands, cren where hardwoods and conifers are intermixed, birds normally flush at somewhat greater distances though usually within 50 feet. Birds in open, second-growth hardwoods (E) or in mature hardwoods and conifers (FH) are least likely to wait for a person to approach within 10 feet; most likely to flush at distanees of $11-30$ fect. Curiously cnough. those in eoniferous clumps $(\mathrm{H})$ are most difficult of all to approach closely. Except within the ten-foot zone. however, the presence of conifers in any cover type does not. in general. exert any marked influence on the flushing distance.

\section{ReFlushes}

Once a grouse is flushed the question naturally arises as to where it will go, how far it will fly, and the probahility of its alighting on the ground or in a tree. Seasoned hunters. alert to the probability of a reflush. often follow in the line of flight, quietly expectant. Game managers. faced with the responsibility of providing shooting opportunities, are likewise interested in answering these questions.

Cover chosen in which to alight.

Birds, when flushed, tend to scttle down in the same type of cover from which they were originally raised except when it is not extensive or is quitc open. These exceptions nccur in "pen lands (type A). newly (ut slashings $(1)$ and. to a lesser extent, overgrown fields deficient in conifers (C). This may be due in part to the faet that these types usually occur in small patches or are marginal in woodlands into which the flushed hirds usually fly and in part to their lack of coniferous shelter. It may well indicate the desiralility of keeping the width of any of these types small on an area managed for grousc.

Birds flushing from mived seeond-growth hardwoods with (Ell) wr without (F) eonifers or from coniferons cover $(\mathrm{H})$ are most likely to remain in these types. Possihly this is hecause conifers furnishing shelter are there reatily available.

These are the outstanding trends one finds in studying table 169*. P'roviding birds. when flusherl. do not remain in the same tyje of cower. however. one also finds other preferemes. less pronouncel. hut reengnizalile. These are listed below:

1. For lirds flushed in the open $(A)$ to go to overgrown lands defieient in conifers (C). to second-rrowth hardwoods (F) or to conifers (II).

2. For birds flusled in alders. birehes or popple (B) to go to overganow fields with an admixture of conifers (D)).

3. For hirds llushed from wergrown lands deficient in conifers (C) to go to second. growth hardwoods (E) or to conifers (H).

4. For birds fushed in overgrown ficlds with an admixture of conifers (D) to fy to a patch

* Emr Aprendix, p. 8s?. 
of coniferous woodland $(\mathrm{H})$ if it is close by.

5. Birds disturbed in second-growth hardwoods (E) are likely to go to mixed secondgrowth hardwoods and conifers $(\mathbf{E H})$ or to conifers $(\mathbf{H})$.

6. Birds found in mixed second-growth $(\mathrm{EH})$ are most likely to fly to second-growth hardwoods $(\mathrm{E})$ or to conifers $(\mathrm{H})$.

7. Birds flushed in mature hardwoods with (FH) or without (F) conifers usually go to any other woodland cover type except spot-lumbered areas (G).

8. For birds flushed in spot-lumbered areas (G) to go to mixed second-growth hardwoods and conifers $(\mathrm{EH})$.

9. Birds fushed from coniferous cover $(\mathrm{H})$ show no strong tendency to seek out any onc other type, going, as they do, to other woodland cover or even to overgrown lands.

10. For hirds flushed in young slashings (I) to go to serond-growth hardwoods either with $(\mathbf{E H})$ or without $(\mathrm{E})$ conifers.

11. For birds disturbed in older slashings $(\mathrm{J})$ to fly to mixed sccund-growth hardwoods and conifers (EH), to spot-lumbered areas (G) or to conifers (11).

It nust be recognized, in considering the above inclinations, that certain types of rover will normally be found adjacent to certain other types fsuch as overgrown lands ly ing levtween open fields and woodlands). This fact, unquestionahly. influences to a considerable extent the type of cover into which the hirds go when llushed. and therefore makes the natural cover choicc of birds less obvious.

\section{Distance between fush and refush}

How far, once flushed, may grouse he expected to lly before alighting? Obvinusly lhidepends on several factors. the most important of which is probably cover. But the 1.19.1 reflushes recorded by the Investigation were too few to satisfacturily answer this interesting point. Some indication of what to expeet in general may howerer. he gained hy glaneing at tahle $170^{*}$.

Very occasimally young birds, early in the fall, ma! alight within 50 feet of their starting point. Flights of from 150 to 300 feet are the rule - which is astonishingly short - unless the bird has been hard hunted. Then distances up to 500 feet or farther are not infrequently: recorded. These are likely 10 be less when leaves arc present or when the bird is in thick cover. Flights of me-quarter mile or more are not uncommon when they are startled while feeding under a thornapple or along a hedgerow at some distance from the woods. As previously mentioned a "crazy flight" may carry a bird scveral miles hefore alighting.

In this table we have then an indication that about 300 feet is a normal radius within whirh suitable shelter should be availahle at all times. in coserts one is trying to make more congenial for grouse.

\section{Effect of sex on flight distance.}

Males have a habit of hurting upwards in a conves curve towards the treetops. when llushcd in wooded cover. Females are more likely to rise in a much morc gradual. often conrave arc. Remcmhering this. records cosering the distance between flush and reflush werc kept on 969 grouse on which the sex was determinable with reasonable accuracy flahle 1701 . 
In spite of the variance in rising. no especial difference in the space covered liefore alighting was noted as between the sexes.

\section{Tendency to alight in tree}

While the great majority of grouse contacted have flushed from the ground. nearly twothirds of them chose a tree in which to alight (table 171)*. Presumably. hirds disturbed on the ground feel safer in a tree from which vantage point they can watch the progress of terrestrial enenies. This tendency is more pronounced in open types where there is a scattering of trees than in woodland cover.

\section{THE ROLE OF COVER COMPOSITION AND ARRANGEMENT}

A house on a hilltop may serve poorly the needs of the man who must work in the valley. With wildlife, the situation is even more pronounced for if food and shelter are far apart the birds are always exposed to their enemies in traversing the intervening distance. The thickest stand of conifers is but seldom occupied for long unless food is to be found close by.

Partridges are able to find some food in almost every lorushlot or woodland. Yet the fact that the birds frequent certain types of cover at certain seasons is evidence that conditions there. at such times. more adequately meet their needs. In part this may be due to the seasonal presence of preferred foods but the prime reason for this choice scems. in many cases. to be that these foods are found in combination with adequate shelter.

Thus cover composition and type arrangement hecome major influences which help to determine where grouse are 10 he found and in what numbers. If there is one key more important than another to the maintenance of a good crop, it is here. Like the instruments of a great symphony in which each plays a definite hut. to the layman's ear ofttimes indistinguishable part. so the divers items, from history to hunting. from biology to breeding. ocrupy niches of rarying importance in coordinating the forces, the sum of whose interactions determines grouse abundauce. The instruments that carry the theme. and they are not always the same for each part. cannot he out of order without losing the effectiveness of the whole composition.

So it is with cover. Shelter and food are the theme song around which grouse production is built. On the adequary of cover. more than one realizes. depends the success of the hirds in protecting themselves from their encmies, in rising alowe hat weather. in avoiding accidents. disease and starratiun. and in providing goot huntiug.

The needs of the hirds change with agc. sex and with the seasons. Their chosec of cover varies aceordingly. To the extent to which their hahitat is not adequate to meet all their varicd requirements. productivity suffers.

It is no supprise, then, to fund that gond grouse cover is characterized ly a varied composition and arrangement of types. This is simply another way of saying that the rovert vegetation is so arranged as to provide an infuite variety of food amel shelter. of suming and dusting spots. of drumming and nesting sites. This principle holds within each individual cover type as well as for the covert as a whole.

Following the same fundamental idea the more compesite the regetation is in each individual type, the less important is a high denree of interspersion of types. Thus. stands composed of hut one or two species selelom support the profusion of undergrowth and ground 
cover to be found under a more varied crown canopy. This is one of the reasons why large blocks of coniferous reforestation are apt to be productive of grouse largely along their edges".

The age of the trees or shrubs that make up a type also exerts an influence on the cover. Uneven-aged stands create breaks in the crown eanop!. These let more sunlight filter through thus encouraging a more abundant variety of shrubs and herbs beneath. The effect of removing a few trees here and there in a woodland. known as selective cutting. has been noted consistently in terms of increased use of the remaining cover (type $G$ in the foregoing tables) by both broods and adults.

The physical condition of the soil also has its effect. Fewer species are likely to thrive (n) lands from which the fertility has been exhausted. Consersely, the presence of a diversity of soils running from acid to alkaline. from wet to dry. and from gravel to loam, provides encouragement for a greater variety of plants. many of which are adapted only to particular situations. Such conditions. though seemingly small. should be taken into consideration by an individual or state interester in purchasing or developing areas for grouse.

On previous pages. the impression may have locen created that, as long as grouse cover contains an abundance of the various types which grouse frequent. it will proluce a high population of birds. Such is certainly not always the case. Patehes of almost pure conifers. dense hardwood sprouts. hawthorn thickets and second-growth maples. lying chose lyy une another. still would not provide acceptable winter shelter, spring hreeding grounds and summer and fall feeding areas to support man! gronse. To he really productive there must be present not only a good arrangement of coser types lut akn a variety of vegetation within each.

Of the two ideas, the former is. in principle, the better understood. One thinks of a ladly laid out farm as a poor produring unit. In like manner grouse correr that meets the food and shelter requirements of the birks for only a part of the scar cannot produce a good crop of partridges. The individual cover types. like the separate farm ficlds. may partially fulfill the need of hird or farmer as the case mal he. yet the whole he so organized as to spell failure of the year's crop.

The analogy hat heen used purposely. though man! sportsmen as set do not realize that their shooting in the fall is largely dependent upon the corcr being so put together as io satisfy the hirds. Fortunately. in \ew lork State. the axe and the economic conditions creating much little used or aliandoned farmbands lave acciolentally produced many fune coverts with a high carrying rapacity for grouse. They are the mes to which the hunter returns year after year, always to find some hirds. But there are others. and they are in the majorit! which are less frequently hunted simply herause the size of the bird crop is less predictahle. The most likels cause of this is poor arrangement of types. Vo winter woml has been cut there for some years: no cows have tranped down and thus kept the brushy pastures semiopen. Almost impereeptibly the trees are closing in and growing taller. The light-demanding vegetation is beine gradually choked out. Here year ly year individual grouse territories are becoming larger and hirds fewer as second-growth and mature cover types extend their loundaries and the edges retreat farther and farther from their centers.

Realizing this. wildlife managers responsiłle for developing better grouse coverts are planning their plantings of trees and shrubs in abandoned fields to produce the maximum of edges compatible with fulfiling other uses. Large lurk- of conifers are giving way to strip

\footnotetext{
th sec talie 18, I. 171.
} 
plantings interspersed with hardwoods. Where practical, a greater variety of species is being used. The rich regetation characteristic of many field edges and hedgerows is encouraged. Cuttings in existing woodlands arc so planned as to break up large areas of continuous forest cover.

All these are moves in the right direction, but their influence is, unfortunately, not as immediate or widespread as one might visualize. A year may produce a few oak leaves on a seedling planted in a recently abandoned field, but at least a generation of oaks is required to restore to the impoverished soil a fertility sufficient to support the woods' sedges and ferns, the wintergreen, partridge-berry, and the profusion of other herbs on which grouse feed at one time or another during the year. True, the pines may furnish shelter before they are head. high, the cherries and apples some food soon thereafter, but a rich profusion of woodland undergrowth and ground cover takes time to establish. Thus it becomes increasingly important on such lands that one encourages a diversification of vegetation by planting the proper

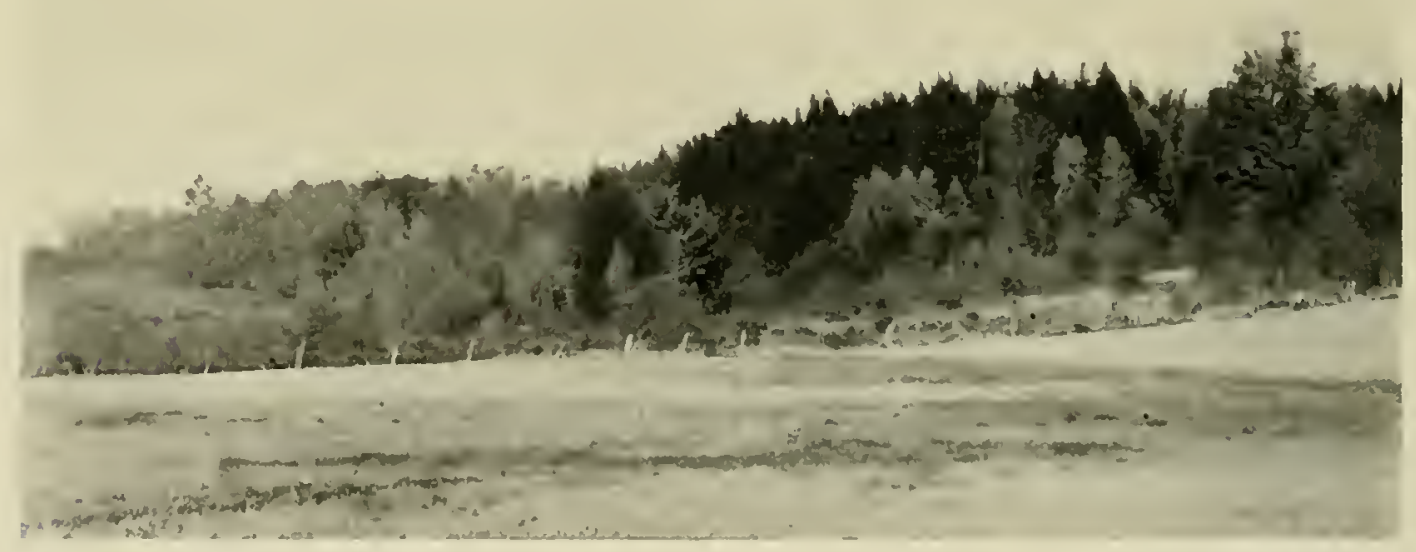

CROUSE TIIRIV WHERE THERE IS A RICII DIVERSITY OF TYPES. HERE OPEX FIELDS, OVERGROW. LAND. SECOND-GROWTH HARDWOODS AND MIXEN HARDWOODS AND CONIFEIS CONBINE TO MAKE. I PRODLCTIVE COVERT

species in the proper relationship, one to the other. Likcwise one should encourage those farming opcrations and wood-cutting activities that tend to maintain a rich diversity of types. Suggestions covering this are to be found in the succeeding chapters on food and on managrement.

\section{THE VALUE OF EOGES}

In discussing the makeup of cover for grouse we are venturing into a field long traversed by woodsmen but little known to scicnce. When this study first started, the catchy idea that to plant a blork of trees was to increase eover for wildlife. was still in the sales mamal of many a forester. It didut matter much what kind of trees were set out. how far apart they were, or where they were put. Il was leopold who first pointed out in 1936 that "the potential density of game of low cruising radius (such as the ruffed grouse) is. within ordinary limits, proportional to the sum of the type edges." Today the need for diverse makeup and interspersion of types is hotter understood by boll forester and game manager. 


\section{Effect of Edges on Adult Grouse Distribution}

In the old pastures and farm woodlots which characterized three of the four study areas, the axe and the plow had been quite successful in breaking down the original forest into an infinite variety of cover. Faced with the problem of classifying the vegetative groups, the Investigation recognized 12 major types as hesetofore described. To determine the "edge effect" of each type on grouse distribution, the location of each adult, brood and nest found over the 13 years of the study was plotted as accurately as possible on large scale maps.

A copy of a single section, chosen at random but representing adult flushes for all seasons of the year, is bere reproduced (figure 14). No strong tendency for the birds to be found along cover type edges is to be observed on many of these maps.

FIGURE 14. DISTRIBUTION OF ADULT GROUSE FLUSIIES ON ONE COMPARTMENT OF THE CONNECTICUT HLL. STUDY AREA - ALl. SEASONS, 19321940. EACH DOT ON THE MAP REPRESENTS THREE FLUSHES

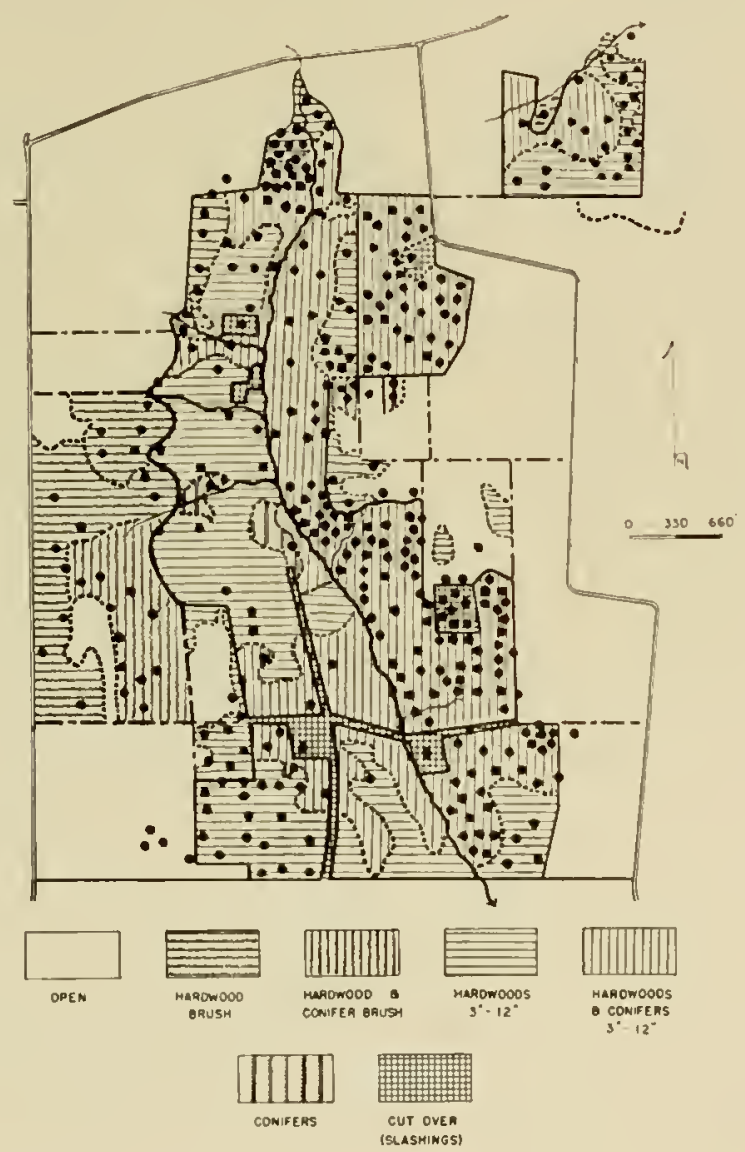

A further test was then employed. On the covej type maps of 12 sections of the Connecticut Hill study area, a series of 20 random lines* were run. From the number of type edges crossed by each line an index of edge frequency for each section was ohtained. These. tabulated with the corresponding average spring population densities for the period 1930 . 1942, are indicated in tahle 16. Studying this, one finds that, in general, the larger the number of edges, the higher the average population of grouse the areas will support.

\footnotetext{
* The position and direction of each line was established by otatistically valid random sampling methuds.
} 
TAULE T6. RELATIONSHIP OF THE RHEQUENGY WITH WHCH EDGES OCCUR TU THE AVERACE IISVL OF SIIING POPULATIONS ON 12 SECTIOYS OF THE CONNECTICIT HILI, AREA-1930-1912

\begin{tabular}{|c|c|c|}
\hline Section & $\begin{array}{l}\text { Lidese fretgetency } \\
\text { index }\end{array}$ & $\begin{array}{c}\text { Averape density of spring } \\
\text { jejpulations per lo0 acres } \\
\text { of cover }\end{array}$ \\
\hline $\begin{array}{l}15 \\
11 \\
5 \\
31 \\
1 \\
2 \\
0 \\
1 \\
34 \\
11 \\
8\end{array}$ & $\begin{array}{l}1.7 \\
3.0 \\
2.1 \\
2.2 \\
2.2 \\
2.3 \\
2.1 \\
2.6 \\
2.7 \\
3.0 \\
3.1 \\
3.3\end{array}$ & $\begin{array}{r}6.5 \\
6.1 \\
1.4 \\
9.2 \\
5.3 \\
7.3 \\
10.8 \\
8.7 \\
7.8 \\
8.7 \\
8.6\end{array}$ \\
\hline
\end{tabular}

\section{EFFect of Edges on Brood Distribution}

It has been the general impression that broods, like adults, are inclined to seek out the more varied edge vegetation. Table $152^{*}$ indicates the number of broods of different ages contacted on the Connecticul Hill area within 100 feet of the edge of one type of eover or a combination of two, three or four type edges. From it one gathers the impression that, irrespective of age, the broods do not particularly frequent the immediate vicinity of screral type borders. Realizing that the chance of finding the birds near where two types border one another is considerably greater than where one lype corners on two or three others. the relative degree of probability for each of the four siluations was determined by sclecting from this area 100 points at random ${ }^{\Delta}$ and listing the number of types to he found within 100 feet of each position. The results are shown in table 17 .

TABIS 17. RLIATIONSHIP UF TIE NUMBER OF COVER TIPES WITHIN 100 FELT OF BROODS CONTACTED TO THE PROB IBLLITY OF CONTACT AS

DETER MINED BI RANDOM SAMUJIXG CONNECTICIT HIILARLA-1930-1912

\begin{tabular}{|c|c|c|}
\hline 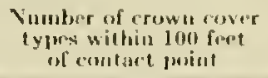 & $\begin{array}{l}\text { Porcent of } \\
\text { randem juints } \\
\text { in each proulp }\end{array}$ & 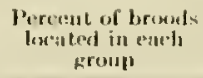 \\
\hline 1 & 1:3 & 51 \\
\hline 2 & 12 & .388 \\
\hline 3 & 12 & ") \\
\hline I & 3 & 2 \\
\hline
\end{tabular}

The percentages here given for cach group are so close as to lend further weight to the conchusions that broods do not particularly seek out situations where three or four type edges are to be found.

\section{ReLation OF Linges to Nest bocation}

Other factors beingr eøual. the desirability of a nesting site varies inversely with its distance from an openingt. A woods' ruarl. trail, slashing. overgrown land or an open field all serve in this rapacity. The first two are so tenuous as (1) represent merely an edge between two

* Aree Aprezuliv. 12. 818.

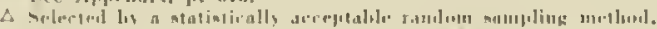

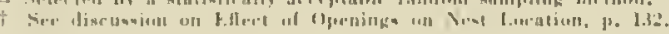


blocks of forest cover; the rest represent "open" cover types usually of considerable size. These of course also support edge vegetation and may in a sense be looked upon merely as more extensive edges.

On the other luand, type boundaries not apt to be characterized by edge vegetation such as those between hardwoods and conifers, appear to influence the location of the nest little if at all.

\section{Variation in IMPORTance of Edges}

The attractiveness of an edge is dependent not alune upon its particular composition. but also on the makeup of the abutting types. This principle may be stated thus: the attractiveness of an edge is inversely proportional to the extent to which the composition of the types that border it approach the edge in composition characteristics.

This idea is aptly illustrated ly the nest studies just mentioned.

Further evidence to indicate that the richness and variety of the regetation within a type may exert a strong influence on the use of the surrounding edges by both brooxds and adults is clearly shown in plotting grouse contacts on the Adirondack study area (figure 1.5).

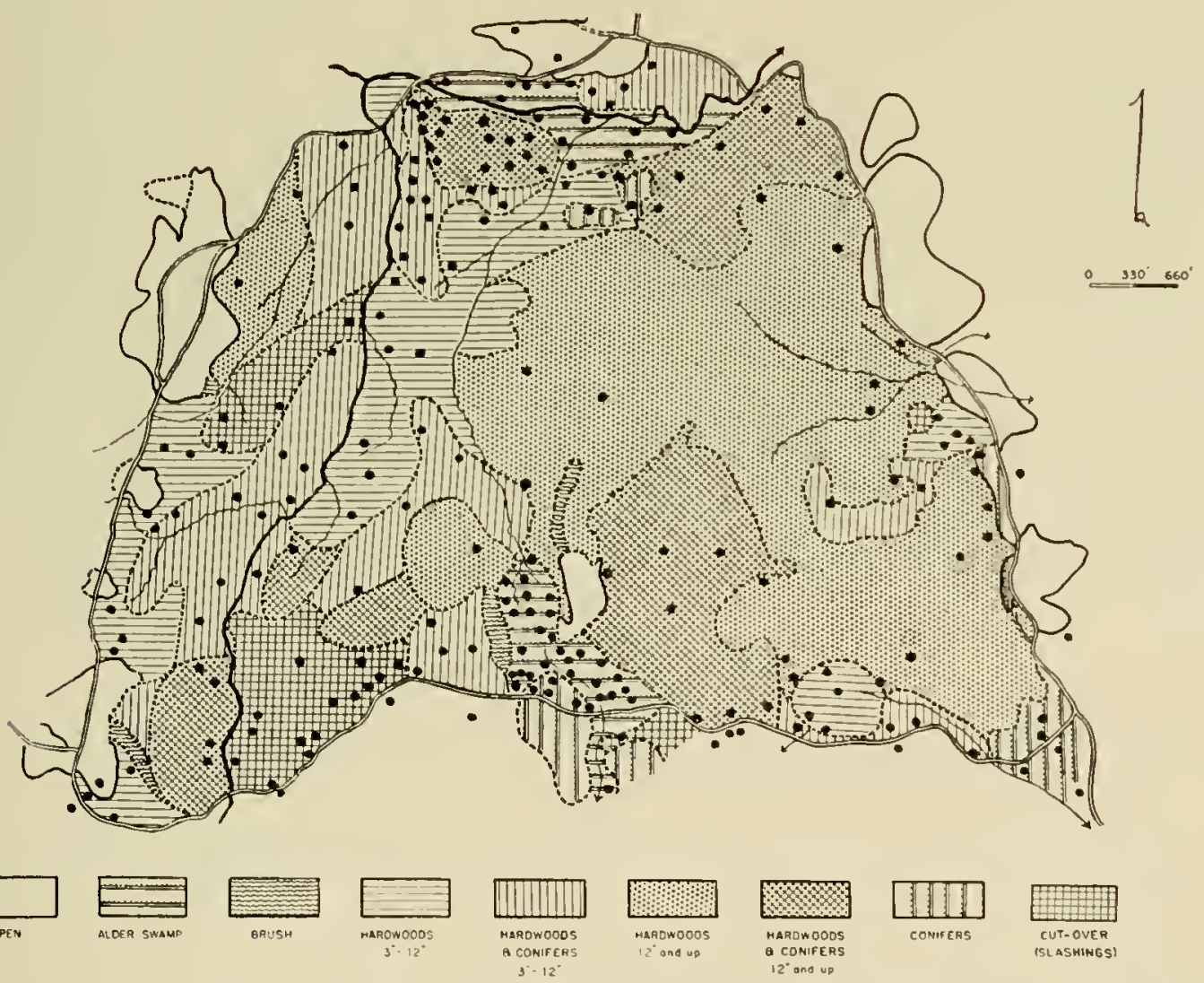

FIGURE 15. DISTRIBUTION OF ADULT GROLSE FLLSHES ON THE ADIRONDACK STLDY AREA - ALL SEASONS. 1932-1941. EACII DOT REPRESENTS TIIREE FLUSIIES 
Located in a mountainous regrion, the suil of the castern half is sandy and of low fertility. Undergrowth and ground cover are neither widely varied as to species, nor luxurious as to growth. Slopes are steeper and the larger, mature hardwoods and conifers, which form an often sparse crown cover, attract hut few grouse. By contrast, the western half is flatter and more fertile with a fair interspersion of cover types characterized by a much greater abundance and varicty of vegetation, particularly undergrowth. A glance at the figure will show that, in the poorer, eastern half, the birds are few in number and are much more likely to be found close to an edge than they are in the western half of the area.

The apparent liking of the birds for cover adjacent to roads in the eastern section fits into the general picture. Early settlers laid these out where the grade was easier and where the soil was apt to be better than on the steeper slopes. Here the soil is more fertile, the cover more varied and the hirds find conditions more to their liking. The correlation between lowproducing cover types and the use of edges by grouse, is clearly evident.

One further study, while not in all respects directly applicable here, should be mentioned. It involved the use made by adult grouse and other game of areas reforested with conifers. The Luther Preserve* was selected for this study. This area is composed of some 6500 acres of land reforested with conifers of various species, interspersed with natural woodlands and with open or overgrown fields. The plantations, on the part studied, were arranged in large blocks with the individual pine and spruce planted six feet apart. The average survival of planted trees was about 85 per cent. The stand was from 20 to 25 years of age and had never been thinned.

The purpose of the study was to determine the use made by game of such coniferous plantations in comparison with adjacent natural woodlands. The results as summarized in table 18 indicate that, both in winter and in summer, grouse were much more widely spread throughout the natural woods than in the coniferous plantation. In the latter twice as many grouse were to be found within 200 feet of an edge as were flushed in the entire interior of the plantation. The reverse was the case in the adjacent natural woodlands.

TABLE: 18. RELATION OF GROUSE FLUSHES TO EDGES IN PLANTED CONIFEHOUS 'JANTATION AND IN NATURAL. WOODIANDSLUTIIER PRESEITVE-1933-193:t

\begin{tabular}{|c|c|c|c|c|}
\hline \multirow{3}{*}{ Srinson } & \multicolumn{4}{|c|}{ l'ercentage of thushes per 100 acres of cover lype } \\
\hline & \multicolumn{2}{|c|}{ In natural noodlands } & \multicolumn{2}{|c|}{ In plunted conifers } \\
\hline & $\begin{array}{l}0 \text {-200 feet } \\
\text { from ty pa } \\
\text { odge }\end{array}$ & 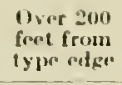 & $\begin{array}{c}0-200 \text { feret } \\
\text { from lype } \\
\text { orlge }\end{array}$ & $\begin{array}{l}\text { Over } 200 \\
\text { fred from } \\
\text { type edpot }\end{array}$ \\
\hline Sunumer & 11 & 71 & 56 & 27 \\
\hline Wituter ........... & 31 & 62 & 66 & 38 \\
\hline
\end{tabular}

One must remember that the grouse distribution here indicated represents not alone the attractiveness of the edge lint also that of the adjacent type.

On areas reforested to conifers, edges are of prime importance to grouse since they must provide the ariety of vegetation lacking in the plantations themselves. This situation has not. as yet, been widely grasped either by foresters or by wildlife managers, who still think largely 
in terms of gross composition rather than the mosaic of regetation which may be produced by cultural operations.

Reviewing the whole, the picture takes shape. Where the soil and the other site conditions are poor, both the variety and interspersion of plants suffer accordingly. Here edges are important in that they add diversity to the cover. Where the soil is good, the land not too dry and the environment has not been heavily impoverished by man or by natural agencies such as fire, Nature encourages a wide variety of plant species. In such situations the individual types usually provide within their borders the conditions that strongly attract grouse thereto. Thus there is less inclination to frequent the edges. When fresh desire or seasonal changes draw them to another type. good grouse habitats are usually so well broken up that the birds find no particular reason to stop at the edges. This, probably, explains the presence of many birds scattered throughout. rather than along, the edges of a type on the three study areas characterized by a favorable and frequent interspersion of cover.

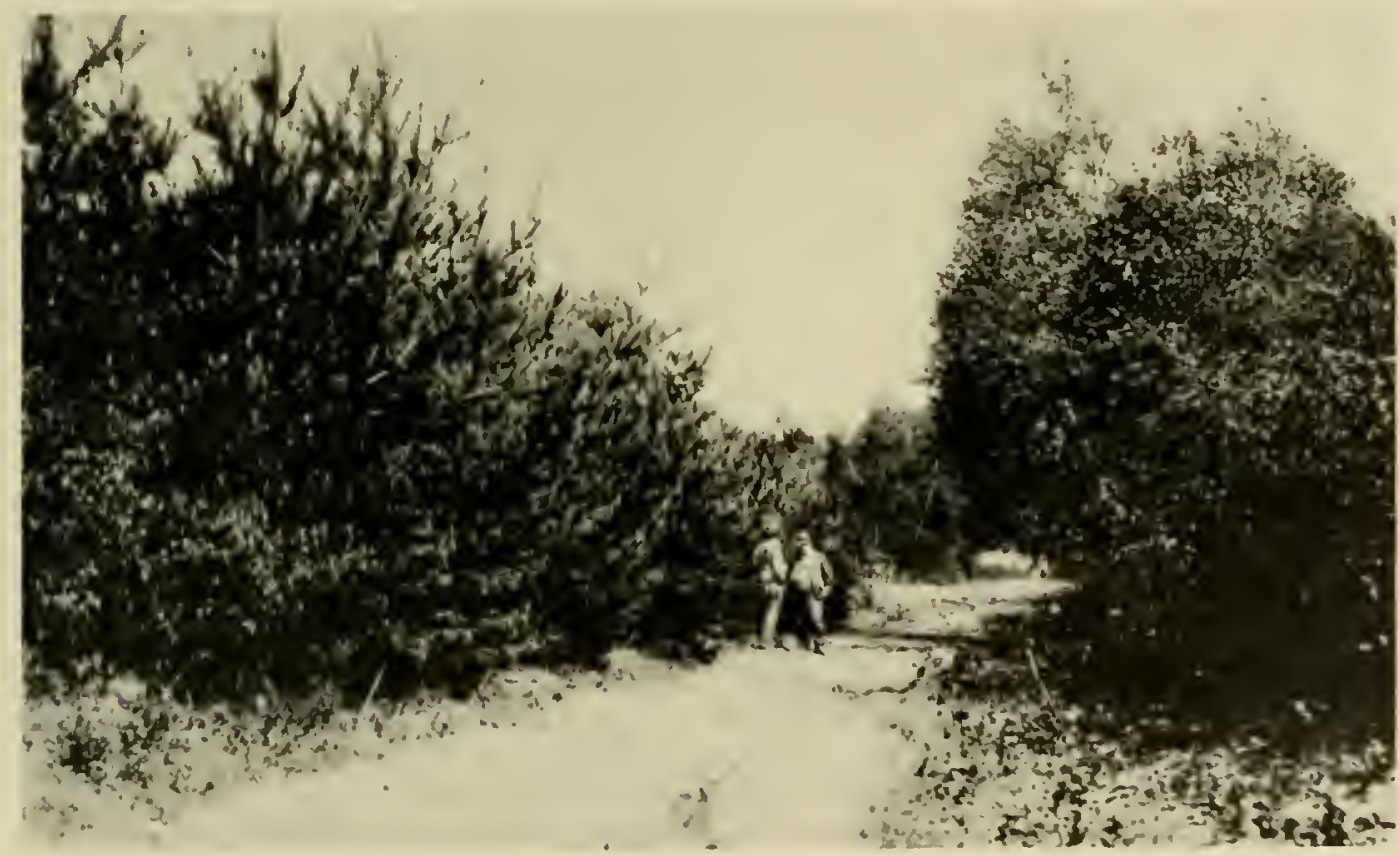

THE T.UTHER PRESERVE IS REFORESTED WITH BLOCKS OF CONIFERS WHICII OFTEN AU.JOIN NATURAL WOOLLANDS

Throughout this discussion we have used the word "edges" advisedly. Plotted on the cover maps are all the major vegetative groups occupying more than a tenth of an acre which are sufficienly distinct to make recognition of edges practical. Within these are found subdivisions in infinite variety. Here, in a wet spot, a patch of jewelweed has established itself; there, where the winds have lipped over a widespreading beech, letting in a shaft of sunlight, a patch of briers is springing up. Such spots cannot be mapped and measured as one does the cover types. Yet each potentially may fulfill some grouse need. Each has an edge which may be meaningful to a grouse even though too small to map. The more varied the patchwork, the greater the chance for the cover to fulfill the wants of the bird. 
We have mentioned size and composition of the edges but not their shape. The late Harry Rogers, dean of game breeders in this country, long ago pointed out that half a dozen rows of corn along a swale would not be as intensively used by pheasants as though the feed patch was 15 to 20 rows wide. A narrow fringe of shrubs between woodland and brushland is. as we have seen. less likely to be used by grouse than are either of the adjacent types. Thus it appears that width may also influence edge use.

To such an idea. one can think of exceptions. In classifying these one fonds that they are largely valid only when either one or both of the abutting lypes are markedly poorer in food and shelter quality than is the edge cover.

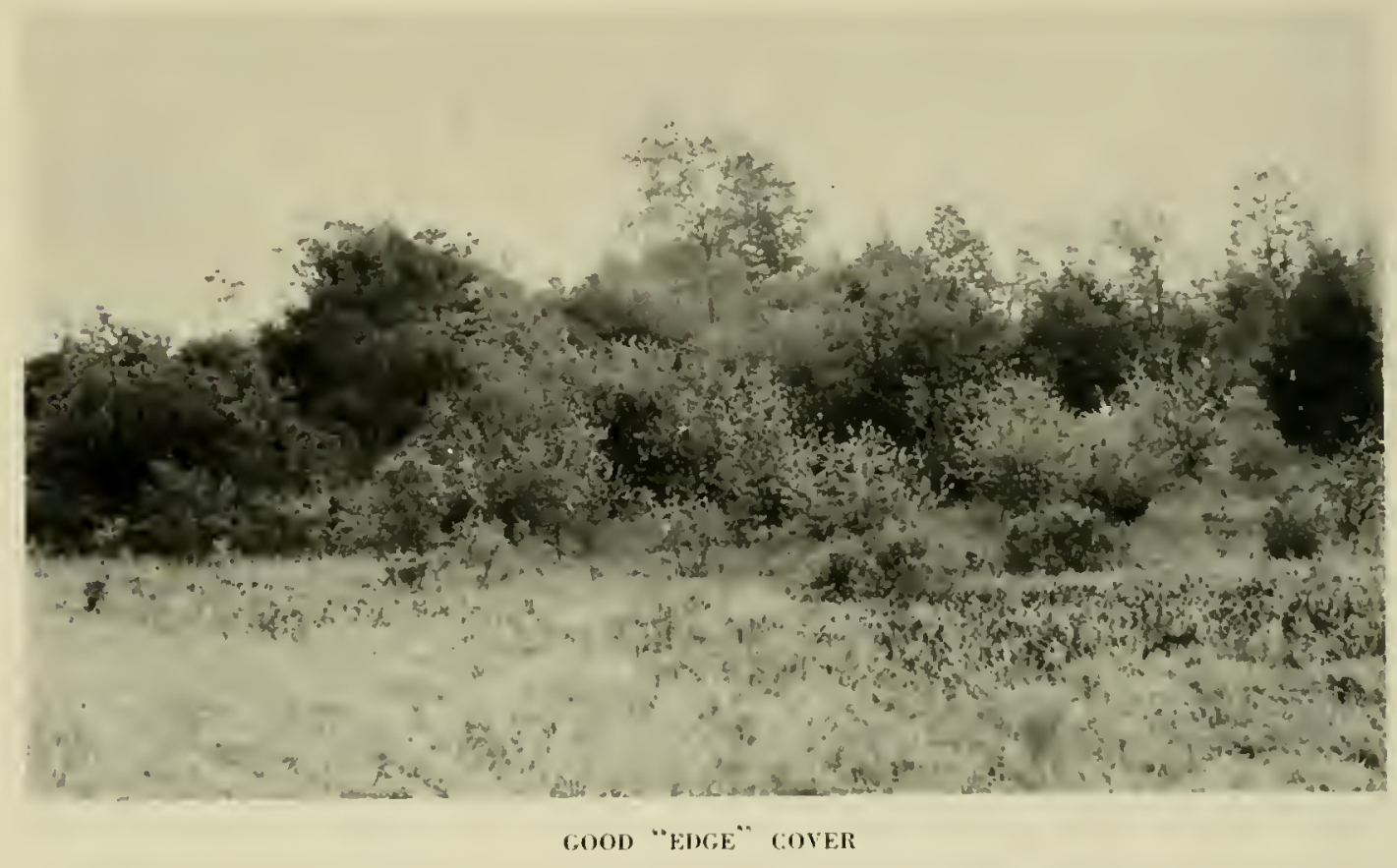

To sum up. grouse cover productivity seems to be more nearly proportional to the variety of the composition within each type making up the covert. than to the amount of type periphery, unless the cover is so poor that the edges furnish markedly greater food and shetter ralues than are to be found within one or both of the adjacent cover groups.

\section{VALUE OF CILAR-CUT AREAS*}

In the foregoing discussion of grouse cover requirements during each of the three main life periods of the birds. it has been shown that cut-over areas or stashings are anong the more important types which may enter into the composition of an adequate habitat. Their primary function seems to lo that of serving as summer and early fall feeding grouncts for broods and adults. They also represent upenings which act to break up extensive tracts of woodland. Furthermore. their influence becomes effection within a short lime after they are created. whereas plantings require many years.

Cut-over areas, therefore. offer the game manager a tuol promising relatisely quick results

"Written by Robert Larrow due to the atuennce of the serior anther in military arroire. 
where existing woodlands need to be broken up or where adequate summer feeding grounds are lacking. To study their role in creating and maintaining cover farorable to grouse, a number were cut on the Connecticut Hill area although nowhere was this area seriously inadequate in this respect.

During the winter of $1932-33$ a series of 2 -acre blocks were clear-eut in the woodlands

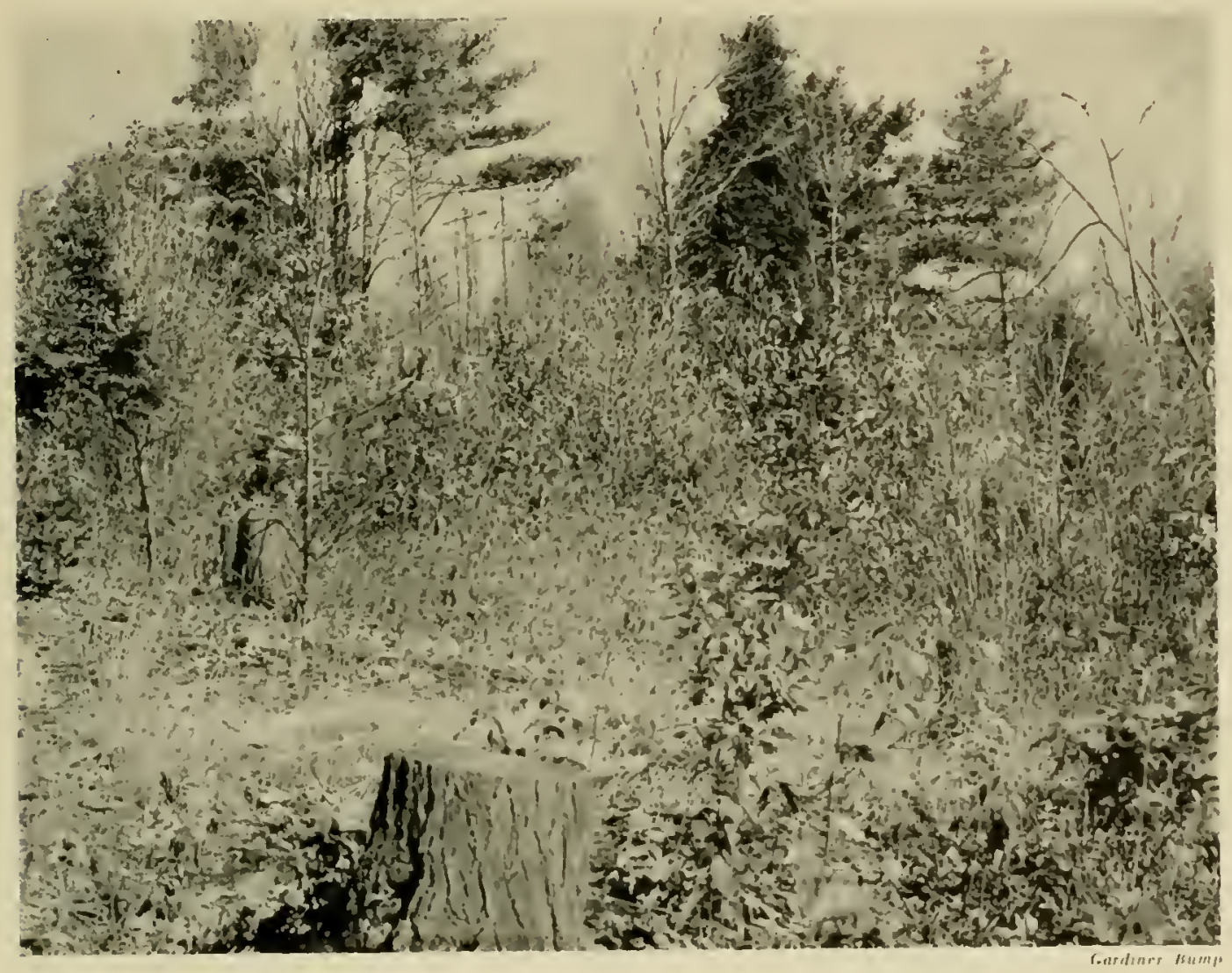

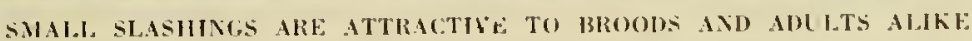

(n) a group of compartments adjoining the area. Most of these slashings were located at points over 300 feet from recognized existing openings. The following winter a number of slash lanes, from 30 to 50 feet wide and of varying lengths. were created. All were then left to follow the natural course of forest snccession.

The elimax flora of the Connecticut Hill area is northern hardwood with beech, maple and hemlock predominant. After clear-cutting on such a site the duff of the forest floor dries out. killing most of the shade-tolerant herbs and shallow-ronted seedlings. At the same time the increased amount of sunshine reaching the ground stimulates the stored seed of many specie.: such as raspleerries and cherries. The conditions thus created, especially when the brush has heen burned. also enable the wind-borne seeds of such pioneers as aspen and birch to become established. Beyond this an abundance of spronts from the newly-cut stumps soon springs up. As time goes on the temporary growth is gradually replaced by the more per- 
manent trees and shrubs of the climax type as outlined in the discussion of succession (p. 118).

During the first growing season a winter-cut slashing is little more than a bare opening in the woods. Although a few herbs usually fourish and some stump suckers spring up, the briers, shrubs and scedlings have not yet had time to take hold. By the second summer, however, the new growth has attained an appreciable density affording both food and shel. ter during this season. This density, and the variety of plants as well. increase until about the sixth year and are accompanied by the occurrence of a high abundance of insects, espe. cially in the low undergrowth zone*. After that, development becomes largely a matter of added height and the filling in of the overhead canopy. This results in a gradual shading out of any intolerant low-growing forms. Thus by about the twelfth to fifteenth year the cover, in most cases, consists predominantly of a thick stand of saplings, characterized by sparse undergrowth and little or no ground cover. If not recut it will rapidly pass into second-growth woodland.

Aside from the fact that they created openings in tracts of woodland where such features previously were lacking, these slashings seemed to exert little influence the first year. During the second, and more particularly the third growing seasons, however, they were frequented to a noticeable degree by both broods and adults during the summer and early fall. They remained highly attractive through the eighth or ninth year after cutting, then gradually diminished. Their use during the spring has been less marked although greater than during the late fall and winter.

In spite of the fact that these slashings have proven attractive to many grouse, both broods and adults, their development did not result in any pronounced shift in the distribution of the birds in the compartments involved. True, in many instances broods, in order to visit a slashing, extended their territories through portions of the woodlands where they probably would not otherwise have gone. But they also continued to occupy those portions of their habitat which had been most used previously. In other instances, slashings were apparently placed where the original interspersion of cover types had been satisfactory so that, even though broods were found consistently in their vicinity, records reveal that the same situations had also been occupied in the preceding years. Neither was survival among the chicks of the broods frequenting these cut-over plots consistently better than anong those elsewhere on the area.

Although this trial did not result in increased productivity one should not conclude that this management technique is not sound. Rather it seems evident that, in general, the diversification of the tracts of woodland on this area was sufficient, withont ereating additional clear-cut areas, to satisfy the summer territorial requirements of the birds which survived the winter and nested successfully from year to year. There seems little doubt that, on areas supporting low quality cover, the creation of small slashings in the interior of extensive tracts of woodland would result in raising the carrying eapacity. In many cases, however. it might also be necessary to improve the winter cover present in order to realize this benefit, since cut. over units of this kint function prinarily in fulfilling the birds summer and early fall re. quirements. On the other hand, such cuttings, although furnishing little winter shelter in themselves, might, if placed within overly-extensive tracts of the latter. enable them to winter a larger number of birds.

* See Appendix, p. iro. 
A further highly important use of slashing operations is to balance, within the covert, the constant tendency for open and overgrown lands to revert to woodland. As has been pointed out, a productive grouse habitat must include openings of one sort or another. Left to themselves, even the, at present, highly productive coverts, occurring where farming has recently been abandoned, would eventually grow into a continuous woodland of relatively low productivity for grouse. In maintaining the interspersion of cover in such areas necessary to encourage grouse ahundance clear-cutting is one of the game manager's most useful tools.

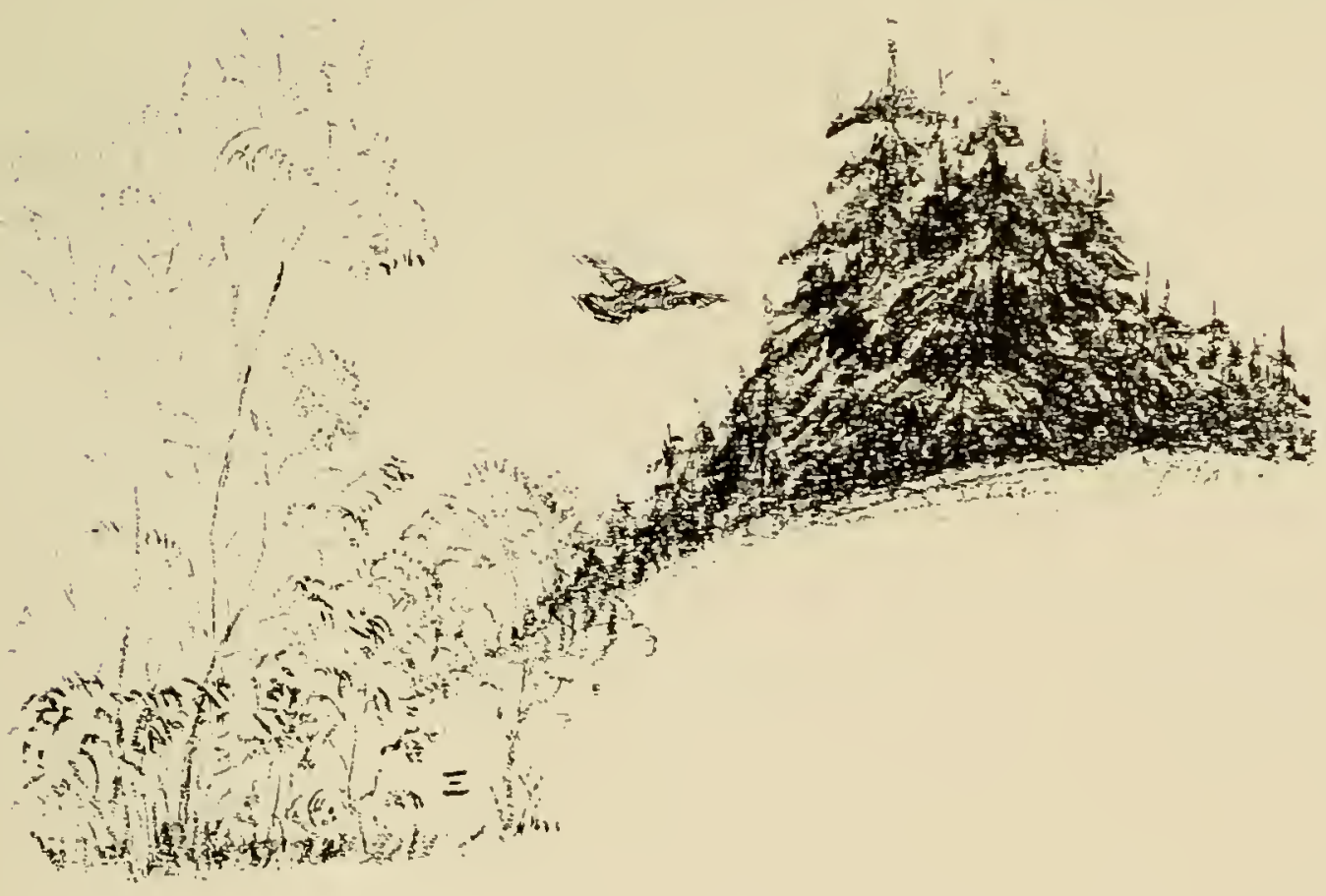




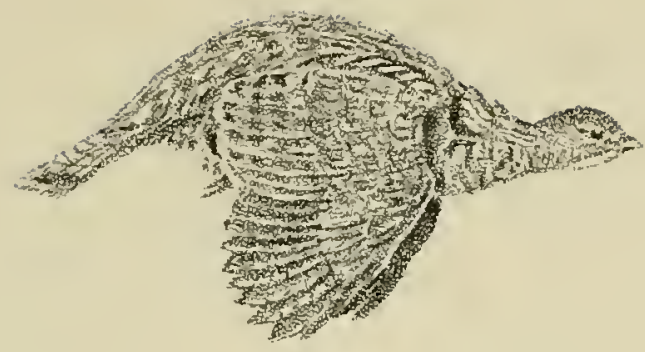




\section{CHAPTER IV}

\section{FOOD HABITS AND REQUIREMENTS}

By Gardiner Bump and Jojin C. Joses

\section{STUDIES OF GROUSE FOODS}

FEEDING HAIBITS

Feeding Periods-Feeding Peculiarities-Caltion a Acceptixi, Iew JoonsAnount of Food baten-Variety of Chole - Gravel Consumpto-Foons Oftex Considered In.Jurjous-EFFect of Certiv I'olsovol's Chenicil.s.

DIET

Foods Eaten and Familues Riviresented - Plant Foods-Families-rose-birch-uillow-beech-heah-sumach-sedge-honeysuchle-maple-composite doguood-fern -buckwheat - saxifrage-grape-grass-buttercup madder legume jeuel-ueed-Animal Foods-Seasoval Differences in Food Habits Reglonal. Vamations ix Foods Eaten- Yeariy Variatioss in Cossumption of Food ltems-Variations a Diet

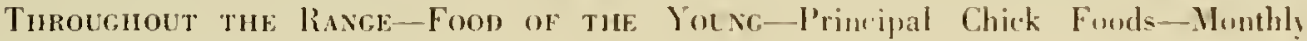
Variations in Summer Chick Foods.

IMSTRIBUTION AND HABITAT REOUHEMENTS OF GROUSE FOOI) PIATTS FOOD AVAILABHLIT AND SHORTAGES

EFFECT OF FOOI) ON GROUSE IOISTRIBUTIOX

COMPETITION IITH OTHER SPECILS FOlR fOOOI)

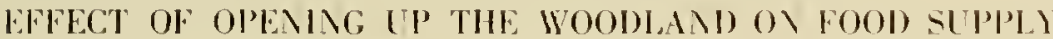

vatural. Openings Man-ahade Openisgs.

FOOD AND FLAVOR

FOOD AND ITS LELATION TO HEALTH

Chemical Compositjon of Some Grovse Foods-Crude Protein Fals-Nitrogen-free Extract-Crude Fiher-Ash-Vitamns-Differences in Chemical Compositiox-Relation of food to Wejgit - Relation of Food to Crcles.

II ATER REOUIREMENTS

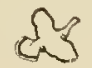




\section{SUMMARY}

Food shortages severe enough to cause stariation. pronounced weight losses and death apparently do not occur. (p. 229).

The ruffed grouse is omnivorous. (p. 184).

It is primarily a plant-eater. its known consumption including representatives of 65 families and over 334 species. (p. 197, 850).

Many of these species are widely distributed: they are normally to be fonnd, often in abundance. in good grouse coverts. (p. 198).

For the most part these are pioneer and temporary (transition) type species. (p. 199 ). Trecs and shrubs furnish the bulk of the food. (p. 198).

Few of the commonly eaten food species are found in dense woodlands. (p. 225, 231). The maximum number of these plants is present three to five years after heavy lum. bering. (p. 231).

Animal food. mainly insects. is predominantly taken only during the first two weeks after hatching. (p. 212).

With adults animal foor makes up but one-twenty-fifth of the summer diet: during other seasons it is much less. (p. 197, 212).

Available insects during the critical period following hatching may reach 330.000 per acre in areas recently lumbered. (p. 214. 776).

Insects most frequently taken are ants. beetles and caterpillars. (p. 213).

Over an 1l-year period the foods most commonly taken hy New York grouse came from aspens. herries. hirches. raspherries and blackberries. hop-hornbeams and thornapples. (p. 2151.

The diet varies year by year and season by season. Some of these variations. but not all. may be explained on the hasis of the relative abundance of the foods. (p. 214. 218).

Great differences in diet exist between various parts of the grouse range. The young differ widely from their parents in food eaten at first but acquire adult tastes by the end of Augusl. (p. 220, 225).

To obtain an accurate conception of food consumption over a large area, such as New lork, a mininum of 50 grouse should be examined each scason during each of at least five years. However, a fairly large list of foods taken can he compiled from the results of a single year's study. (p. 181).

The distribution of grouse is influenced to mo small extent by the feeding grounds in summer and fall. (p. 229).

Cormally grouse find satisfactory amounts of water regardless of the specific halitat they orrupy. (p. 245 ).

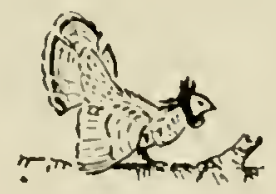


Food is one of the cardinal factors that determine the abundance of any wildlife species. Food shortages have long been considered a paramount eause of wildlife scarcity. Corrective measures, for the most part, have been quite inadequate. although usually dramatic enough to appeal to nature lover and sportsman alike.

As a result, studies of grouse food habits. ranging all the way from the penknife examination of a bird killed in the field to the most careful laboratory analysis, have furnished an informative but haphazard picture of what grouse eat at various periods and over many parts of their range.

\section{STUDIES OF GROUSE FOODS}

The first extensive survey of grouse fond habits was Sylvester D. Judd's analysis of 208 crops and stomachs gathered from widely separated parts of the bird's range. Fall food habits of New England grouse have leen admirably descrilsed by Gross ${ }^{173}$. Nelson. Clarke and Bailey ${ }^{2 n}$ have published the results of a small but thorough sampling of adults collected in November and December in the George Washington National Forest. largely in Virginia. Under the direction of Dr. A. A. Allen. Thomas Smyth ${ }^{311}$ prepared an excellent thesis on the food habits of the ruffed grouse (mostly fall and winter adults) with special emphasis on the region ahout thaca. N. Y. Local reports have been produced ly MacGregor for for New Hampshire. Kuhn"11 for Pennsylvania. and Chaddock ${ }^{67}$ for Wisconsin. Unfortunately most investigators have been largely dependent for specimens on birds shot during the hunting season; thus there is a dearth of information for other periods of the year. The food of grouse chicks has received little attention exrept by the current study.

The situation may best be visualized ly glancing through tahle 19 identifying the more comprehensive grouse food investigations.

TABLE 19. WAJOR STUDIES OF THE FOOI) IIIBITS OF RIFFED GROLSE

\begin{tabular}{|c|c|c|c|c|c|c|c|}
\hline Investigittor & $\begin{array}{l}\text { Nomblar } \\
\text { "xuminesal }\end{array}$ & $\begin{array}{l}\text { Apre of } \\
\text { hirds }\end{array}$ & $\begin{array}{l}\text { Srunsons } \\
\text { stmitiod }\end{array}$ & $\begin{array}{l}\text { Collution } \\
\text { ners }\end{array}$ & $\begin{array}{l}\text { Years } \\
\text { cenverend }\end{array}$ & $\begin{array}{l}\text { Diata on } \\
\text { moverroner }\end{array}$ & $\begin{array}{l}\text { Dista on } \\
\text { volume }\end{array}$ \\
\hline Judd, S. I ,......... & $\begin{array}{r}208 \\
8\end{array}$ & $\begin{array}{l}\text { Arbles } \\
\text { Clives }\end{array}$ & 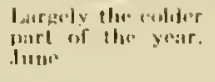 & $\begin{array}{l}\text { Watly llw" Vurthe } \\
\text { wist. }\end{array}$ & Vot given & $x$ & .. \\
\hline Sinyth, T.......... & 331 & $\begin{array}{l}\text { Midults } \\
\text { Chivks }\end{array}$ & $\begin{array}{l}\text { Whisly fall num } \\
\text { wintur. }\end{array}$ & 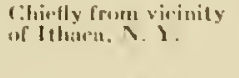 & $\begin{array}{l}11, x+1 y \\
1022-23\end{array}$ & $x$ & $\begin{array}{l}\cdots \\
\cdots\end{array}$ \\
\hline Firiss, $A .(0 \ldots \ldots \ldots$ & $1,0,50$ & Ariults & $(0,-1-1)+2$. & 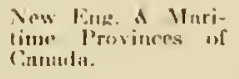 & $1926-32$ & $x$ & $\ldots$ \\
\hline 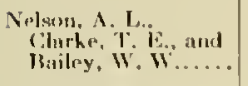 & 185 & Arlults & Vin.-1) & 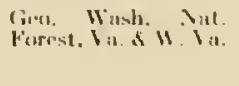 & $19: 3.5-30$ & $x$ & $x$ \\
\hline Kutho, 'I', II. ....... & 230 & Arlults & Fall. & P'a. & $\begin{array}{l}110 \mathrm{os} 11 y \\
19331\end{array}$ & r & $i$ \\
\hline 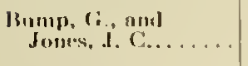 & $\begin{array}{r}1,000,3 \\
510\end{array}$ & $\begin{array}{l}\text { Ardults } \\
\text { Chichs }\end{array}$ & $\begin{array}{l}12 \text { montlis. } \\
\text { Jum-11\%. }\end{array}$ & $\begin{array}{l}\text { Vew York } \\
\text { Jew York }\end{array}$ & $\begin{array}{l}1931-11 \\
1931-11\end{array}$ & $x$ & i \\
\hline$K \cdot I s\{, 1, I I$ & $1110^{*}$ & $\begin{array}{l}\text { Adults } \\
\text { Aifults }\end{array}$ & 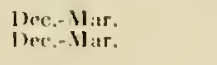 & $\begin{array}{l}\text { Jow Yerk } \\
\text { Norllinoust }\end{array}$ & $1931-31$ & $\cdots$ & i \\
\hline $\begin{array}{l}\text { Hackiregor, A. E.. } \\
\text { et al ........... }\end{array}$ & 102 & $\begin{array}{l}\text { Adults } \\
\text { A Chicks }\end{array}$ & June- tov. & Sin. X. 11 & 1110 & 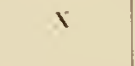 & $x$ \\
\hline Chadilurk. T. T. & 236 & Adults & $\begin{array}{l}\text { Mostly Sinut.. Ort. } \\
\text { \& Nive. }\end{array}$ & It iseonsin & $1938-34$ & Y & $x$ \\
\hline 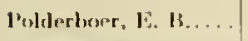 & 1763 & ITnknowm & 12 months & low: & 19:38-10 & $y$ & $\cdots$ \\
\hline
\end{tabular}

* Collected by the X. Y. S. Ifutfed Cirmse Investigation and erantined for it by the U. S. Fish aud Wildlif. Service. They are arcordingly utilized in enmpiling the results of the livestigation's food habits work. $\Delta$ Droppings only examined. 
Adequate support has allowed the Investigation to look into the food hahits of grouse in New York un a comprehensive scale. Experience indicates that these habits may change materially from year to year and from season to season. The habitat from which a bird is collected. as well as its age (whether adult or chick) may often be surmised from the character of the food. Another factor is the variation in the distribution and abundance of grouse foods, not only as between such extremes of range as Alaska and Alabama, but also to a surprisingly marked degree within the single State of New York.

To determine the differences between food habits for regions and hahitat, years and seasons, adults and chicks. it has thus been necessary to collect specimens over a period of 12 years and from three more or less differentiated regions of the State. To indicate reliably changes in the food taken. a goal was set for each year of at least 75 adult birds to be examined from each region during each of the four seasons. Similarly. at least 50 ehicks were collected representing each region for each of the months of June. July and Angust. (See table 20).

TABLE 20. SEASONAI, AND RGGIONA, DISTHIBUTION OF THL I,093 ADUIT GHOUSE. AND 510 CHICKS, COLLECTED AND ANALFED FOR FOOD IABITS STIDIE- ENTIRE STATE-1931-1911

\begin{tabular}{|c|c|c|c|c|c|c|c|c|c|}
\hline \multirow{3}{*}{ Heqion } & \multicolumn{5}{|c|}{ Arults } & \multicolumn{4}{|c|}{ Chicks } \\
\hline & \multicolumn{5}{|c|}{ Seasofi } & \multicolumn{4}{|c|}{ Month } \\
\hline & Spring & Sumper & Fall & Winter & Tutal & June & July & August & Tolal \\
\hline Arlirondacks.... & 82 & is & 80 & 92 & $3: 13$ & 52 & 53 & 51 & 159 \\
\hline Catskills... & 60 & 75 & 81 & 83 & 302 & 56 & 52 & 46 & 15.3 \\
\hline Hust of Sitale... & 86 & 81 & 141 & 117 & 158 & yt & 80 & 53 & 228 \\
\hline Tutnl.......... & 228 & $2: 35$ & 308 & 322 & 1.09 .3 & 202 & 185 & 153 & 510 \\
\hline
\end{tabular}

In gathering these. each year from 1931.41 was represented. although of course to varying extents.

The work involved in collecting this material is worthy of special mention. Cooperative game protectors and specially employed grouse colletors sent in grouse month after month and year after year from localities chosen in advanee. The difficulties these men surmounted in assuring adequacy of the collection would surprise the average sportsman used to the actions of birds in favorite fall coverts. The specimens when received at the State's Witdlife Research Center at Dehmar were examined externally and internally for evidence of discases and parasites. The contents of the crop and the stomach or gizard were rarefully separated and presersed for future identification.

Crouse are remarkably omnivorous. With abuut a thousanel plants or animals contributing to their diet. the analysis of stomach contents is a time-consuming procedure. So numerous may he the foud items that sorting and identifying them from only two or three sperimens often represents a good day"s work.

The Food Habit: Section of the U. S. Fish and Wildlife Service assisted materially by making 462 of the earlier examinations and prosided supervision for subsequent analyses mate in their laboratory. With the establishment of a Food llabits lahoratory at the Wildlife liesearch Center most of the later examinutions were mate there.

It is perhaps an excusable fallacy to eonsider that food research may well stop when the 
details of stomach analyses are in hand. This impression is heightened when one finds that food shortages apparently are not directly limiting influences on populations of the ruffed grouse. In fact, the Investigation has yet to examine its first bird. the death of which could be attributed to starvation. Upon deeper analysis, however, less apparent food relationships are revealed which, in the long run, may affect grouse welfare much more than does an occasional empty stomach. As with wildlife in general. even the simpler interrelationships of food with shelter, with predators, with diseases. with cycles and with the ability of the species to reproduce, have heretofore been little recognized nor much investigated. Not enough thought has been given to these less familiar effects in connection with the study of fond habits and requirements. Hence the Investigation has not limited its work to a determination of what grouse eat nor of how much of each foor item is consumed.

Some of the correlations referred to are so complex and little understood as to baffle understanding. That the composition of sunlight may differ from year to year is a recognized fact. But to prove. with present knowledge and equipment, that such variation is, or is not, a basic cause of periodic changes in ahundance, as suggested by 1)eLury and King, is an undertaking, challenging indeed, lut probably beyond today"s scientific resources.

A start, however, has been made by measuring the chemical composition of some of the more commonly eaten grouse foods. These, together with pertinent data already pub. lished, are presented later. ${ }^{*}$

Some attempt has also heen made to determine the nutritive requirement of grouse in captivity. Thus in 1931 and 1935 1)r. L. C. Vorris. wurking for the Investigation, fonnd that young grouse thrived best on a stanting diet of $27-30$ per cent protein which could be safely reduced to a 20 per cent level at ejght wecks. For the first time light has heen cast on the extent in which common grouse fords satisfy protein and other needs by a study of their effects on the metabolic rate of captive hirds. In this way sonte idea of the nutritive value of the more important foods has heen gained.

Empirical knowledge of this sort. while lasic. must be translated intu action in order to realize its potential value. Thus. when the typical diet hecame known. the next step was to chart the distribution and approximate abundance of these foods lluroughout the State and the habitats in which they most commonly uccur.

Nature is a generous provider. Nan has partially learned the trick of using her bounty for his ends. Thus some time was spent in learuing how to produce the most desirable foods in quantity and to make them grow where they will do the most good in creating more productive grouse habitat.

\section{FEEDING IIAIBITS $\triangle$}

One cannot loug watch either an adult grouse feeding or a brood fanned out in advance of their mother and on the alert for food without sensing that these hirds have absorbed something of the dignity and quiet of the woods in which they live. While quick and wideawake. the birds show little of the nervous activity so characteristic of the bolwhite. Feed. ing is for the most part a leisurely pastime, for food is plentifut and seldom difficult to ohtain.

* See discussion of Chemical Composition of Somr Giruser Foods. P. 237

$\Delta$ The actions of groubr, buth aulults and soung. while feeding, are described in Chapter $\mathrm{V}$ 


\section{FeEmivg Perions}

Many novices at hunting grouse are sure that the birds feed at the beginning and end of the day. Oldtimers are more reticent about committing themselves. Fach can likely re. member seeing a chuster of lirds about a thornapple tree in late afternoon, or birds budding an apple tree at woods edge well into the evening when the moon was bright. But the oldimer also remembers grouse feeding at high noon on beechuts shucked ont over the snow on a January day. The truth seems to be that where particularly attractive foods are to be found, there is a tendency for the birds to feed early and late: but the exceptions are legion. In general there is so much food available in most New York grouse habitats during all seasons of the year that the birds can feed at any time they choose.

Where favorite foods abound the birds must occasionally spend hours filling their crops with unbelievable amounts of luds. leaves. catkins or fruits. Thus one bird collected in winter was found to have eaten 1.300 buds of (rembling aspen (Populus tremuloides), while another had taken some 1.400 huds of cherry (Prunus) as well as smaller amounts of three other kinds of buds. Since hop-hornheam (Ostrya virginiana) catkins are by no means as common as the buds. the grouse that ate 820 of them must have spent a substantial portion of a day or night aloft in the quest. The same may be said of the hird in whose crop 1.069 hairy fruits of staghorn sumach (Rhus typhina) were found. Nor is this filling-up tendeney limited to winter. for the erop of a bird collected in spring in the Catskills contained nearly. a half pint of mountain laurel (Kalmia latijolia) leaves. A crop obtained in the same region in summer held 20 fruits and more than 6.000 seeds of strawbery (Fragaria). A favorite trick of both chicks and adults is to combine the lazy huxury of a summer dust lath with the picking up of insects, particularly ants. that may venture their way.

In summer. though, food seems to be so abundant that the birds can get all they want at any time, for the crops are not so well filled, on the average. as at other seasons. (Sce table 21 ).

TABLE 21. AVERAGE VOLUNES, IN CUBW CENTIUETERS, OF THE CROP AND

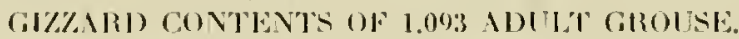

BY SEASON AND REGION NEII YORK

\begin{tabular}{|c|c|c|c|c|c|c|c|c|}
\hline \multirow{2}{*}{ Regrion } & \multicolumn{2}{|c|}{ Spring } & \multicolumn{2}{|c|}{ Sumburer } & \multicolumn{2}{|c|}{ Fall } & \multicolumn{2}{|c|}{ Winter } \\
\hline & Crospr & Gizzard & Cropr & Girghrel & Crop & Gizzard & Crop & Gizzard \\
\hline Adiroudasks.... & 17.5 & 9.8 & 5.0 & 6.5 & 15.3 & $7 . .1$ & 36.4 & 10.9 \\
\hline Catskills........ & $21 . \overline{1}$ & 10.3 & 3.6 & 5.11 & 13.9 & 8.1 & 21.0 & 9.7 \\
\hline Hust of Situlto... & 18.0 & 8.9 & 0.1 & i. & 10.5 & 6.4 & 16.2 & 9.2 \\
\hline Averuget* . . . . . . & 20.1 & 1, (1 & 1.9 & 11.- & 13.9 & $\therefore 1$ & 21.7 & 0.8 \\
\hline
\end{tabular}

"Average for ul] years, all seaseons: crepp, 1.3.9; kizzard, 8.1.

Of alt the elements, only wind secms commonly in affect the ruffed erouse sufficiently to change their feeding schedules. They are likely to he more alert and nervous on windy days. hut they mose around less. Aetivity is alow reduced during the colder days of winter. Fowd then may lie of less conern lhan shelter. for a bird may not emeroe from a snow renst mutil midaftermon.

Broods, while more actisc. usually are delightfully casual in their feeding habits. Such a eroup may start ont an hour or su after smm-np. Lut before the dew has left the grass. Earli little excursion is likel to be precipitated ly one or two especially artive or hungry chicks 
who venture forth, leaving the rest of the brood still hovered by the mother. Becoming anxious, she rises, oftlimes shaking out a chick or two from under her wing, and takes a few steps. The remaining chicks, even though they be only a few days old, lose no time in fanning out in a feeding formation, sometimes ten or 15 feet across. It seldom seems to take more than ten to 15 minutes for the chicks to satisfy their hunger. after which they are brooded again. On cooler days they are apt to seek the comforting body heat of the hen at even more frequent intervals. Thus at this early age life is much a matter of food and warmth and exploration, in frequent alternation.

That even young chicks can go without food for a considerable time was evidenced by a brood which, confined for observation in a half-acre pen built in a natural grouse habitat. re. mained in the same spot without moving or feeding to any extent for four or five hours at a time. As the youngsters grow older it is difficult to recognize any definite tendeney for them to feed at one time rather than another during the day. Records of the Investigation reveal that broods may be found in such choice feeding grounds as a brier patch, or among the tangled vegetation of a slashing, enjoying their fill at any lime of day.

\section{Feeding, Peculiarities}

It is usual for a gallinaceous bird to subsist on seeds, fruits and sueculent herbage, together with insects. But the grouse, occupying the greatest latitudinal range of all, could never have survived in the north were it not for its ability to utilize buds and esen the tips of twigs much as do deer. This browsing capacity banishes the danger of starvation which threatens certain other game birds at the northern linits of their ranges. That upon occasion a grousc may be a browser of the first order is shown by the one-lime adoption by certain lowns in llas. sachusets of a grouse hounty of 25 cents a hird, hecause of ton heary feeding upon apple buds. Practically every crop collected between October and April has contained luds. In fact, hey are found in greater abundance in the food, than is generally supposed, throughout every month of the year save only June and July. In volume the areragc grouse may he expected to eat approximately 13 pints of buds a year. With a large-hudded specics such as aspen this represents some 125.000 huds a year; with the smaller cherry, hirch or hornbeam bud the number might be twice as large. Thus huds and twigs are among its bulkiest, if not its most nutritious foods.

Although it has been suggested that grouse are color-wise. preferring hlue. little evidence of this is to be found in the color of the foods taken. All of the primary and secondary col. ors. as well as lolack and white, have been noted among fruits ealen in quantity. Likewise with grit all arailable colors are represented, although white quartz pelbles predominate, even in regions where other gravels are much more numerous.

It is possible that contrast may le more important than color. This interesting thought is the result of watching the feeding actions of several thousand grouse in captivity. Field ol). servations bearing on the subject. though few, lent some support to the idea. Grouse chicks when first hatehed may have to be taught to eat. Dr. A. A. Allen deseloped the practice of spattering curded milk on a shingle, thus enticing the newly-hatched chicks to pick at the spots. For several years finely ground charcoal was added to the starting diet for day-old chicks at the Research Center because the black spots proved to be attractive. Dry mash scattered over paper tuwels failed to interest these chicks. but the same mash moistened and seattered in small lumps on the same paper was eagerly picked up. Chicks from the day 
they are hatehed will pick at the black eyes, the faintl! pink toenails, the brownish beaks, and the vents of their companions. By reducing the light or changing it to red the picking is materially curtailed. for contrast both in tone and color is largely eliminated.

But it is among the adult birds that the most striking examples of the lure of the conspicuous occur. One of the surest ways of attracting penned birds is to hold a bright object in one's fingers. A galvanized nail head, a small watch, or, best of all, a ring, be it plain or set with stones, may usually be depended upon to bring one or more grouse close to pick at the bright object. Once when a visitor from another state. who was feeding the hand. raised birds at the Research Center, smiled appreciatively, a venturesume male, much to everyone's amusement, did his hest to snatch a couple of front teeth. Finrernails stuck through the wire mas prove equally tempting and in addition lead to the discovery that grouse can lite.

Motion is also attractive, at least to young grouse, providing they are not afraid of the moving object. Nealworms and fly larvae are favorite foods of grouse in captivity, the shortest shrift being given to the wigglers. The great activity of ants may he one reason why so many of these insects are taken by young chicks. A crawling, hopping or flying insect may be depended upon to create much more excitement in a group of chicks a few days old than would the same insect motionless.

Texture also may influence food selection; certainly grouse in captivity prefer to eat mash in the form of hard pellets; even mash moistened only enough to stick together in lumps is better than the mealy mash, though grouse can be taught to eat the latter perfectly well. In captivity young grouse seem to like tough apple leaves more than succulcnt lettuce.

It is difficult to draw conclusions on these points from food utilization in the wild. Soft larvae. hard bettles. juicy crickets, all fall prey and the rotten fruit of a March apple, the firm flesh of thornapple and the unyielding beechnuts and cherry seeds seem equally welcome.

Similarly a wide variety of sizes is acceptable. Seeds of sedge, so small that they must be gleaned by stripping the heads, may be found in the same crop with whole leaves of poplar or white oak acorns. Chestnuts, in the old days before the blight, were a popular food item in the fall, as are still the whole fruits of thomapple. These are often the width of a good-sized thumbnail. Stories of grouse swallowing young mice have been rereived but not verified by the lnvestigation, though l'olderboer after examining fowa grouse droppings, reported one or two collected in summer to contain bones and hair of deer mice (Peromyscus). Judd"s found a grcen sllake 17 inches long in one grouse rrop. indicating that the hirds are detersed by meither shape nor length once an item has been marked as food.

In computing the bulk contents of the crops and gizzards by scasons. as indicated in table 21. a curious situation was brought to light. There seems tu be little signifieant difference in the amount of food found either in the crop or in the gizzard of enrouse during the spring. fall or winter mouth. In smmmer. however. it is so much lower as to indicate a marked reduction in food consumption and in the time spent in feeding. The greater digestibility of summer foods, such as softolodied insects and fleshy fruits is another contributing factor.

\section{CaItuox an Accepting New Foons}

With precocial birds like grouse which leave the nest within a few hours after hatching. the ask of determining what is colible secms to fall larewely upon the younc. In captivity at least, the nother. unlike the harnyard hen, sems to spend relatively little time and effort 
in teaching them what to eat. Perhaps Nature has accordingly provided the chicks with the "pick-up" habit. It would seem all grouse exhibit it more or less throughout life.

Chicks seem at first to pick at items which move or are small and contrast with their surroundings. Whether they have a "feel" for those which have food possibilities, whether the mother, in a way too subtle for detection by human eyes or ears, instructs the chicks as to which items, among those picked up, are to be eaten, or whether they learn purely by trial and error, can only be guessed. Certain it is that the chicks are constantly picking up small articles, only a fraction of which are actually eaten.

By the time grouse are half grown this early caution in accepting foods has developed into a habit. An instance comes readily to mind. In trapping grouse, a comparatively simple pro. cedure in the deep woods where they are tame, it was found that birds come readily to feeding stations established before the ground becomes snowbund. However. once snow forced them to seek their food largely anong the treetops, many grouse exhibited a surprising unwillingness to return to a diet of fern leaves, thornapple fruits and other presumed delicacies previously eaten. Likewise illustrative is the difficulty experienced in getting captive hirds. long used to eating grain and pelleted mash, to take foods that are staple for their wild hrethren. Hand-raised grouse may starve rather than change to a diet of the buds so ap. petizing to free-living birds. Five bushels of beechnuts contributed to the Investigation re. mained largely untouched because of the difficulty of convincing some 200 grouse that they were good to eat.

There is something deeper than mere caution involved here, however, for the birds. Inoth in captivity and at feeding stations. increase markedly their consumption of corn as the weather becomes colder. Normally little of this grain is taken. hut as the temperature ap. proaches zero this tendency is reversed. Here is a prohlem for the hird physiologist land psychologist) to answer.

\section{AMOUNT of Foon Fatris}

The daily and seasonal consumption of food ly wild grouse is not susceptille of accurase measurenent, but conclusions from the record. pieceneal though it is. are not without in. terest and proballe value.

The daily intake varies with the as alability and character of the food. the age of the bird, the weather, and a host of other factors. A chick will take unbelievahle amounts of easily digested insects and surculent vegetation in the course of a single day"s feeding. In captivity it requires from six to ten mealworms each an inch long to satisfy a week-old bird. These may be fed at half hour intervals. Two 7 -week-oll hirds raised under semi-wild conditions. each proved equal to consuming 30 blueberries. several rasplicrries and from six to ten medium-sized grasshoppers at a meal. Leaves and luds in surprising quantities were alon much relished. The same birds three weeks later were ach consuming a head of lettuce as large as themselves cach day. The astonishing total of 4.350 strawerry seerls. perhaps representing 50 fruits. was found in the crop and gizzard of one gluttonous young hird collected in August in the Adirondacks. More than one day's food intake, however. was probably here represented. From an August adult in the same region were taken 20 whole strawberries and more than 6.000 seeds.

The largest crop examined. containing $153 \mathrm{cc}$. was that of a bird shot in spring in the Catskills. Nearly two-thirds of the contents consisted of leaves of mountain laurel (Kalmia latifolia), though there were 288 huds of aspen (Populus tremuloides) also present as well 
as eight other itcms in smaller amounts. Together. this crop's contents would constitute a good-sized handful. It is not unusual to find birds stuffing themselves on relished fonds at any season of the year save summer. Leaves are favorites during spring. fruits in early fall and louds and catkins in winter.

It was at first surprising. but on second thought logical. to find no crops containing more than 19 ce. of food in summer. The diet then is mainly insects. juicy berries and tender

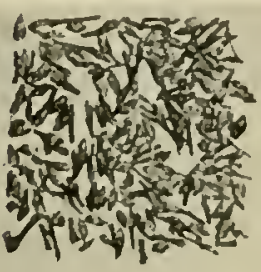

1
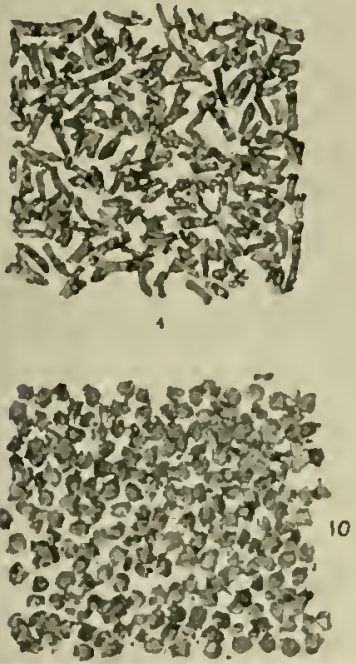
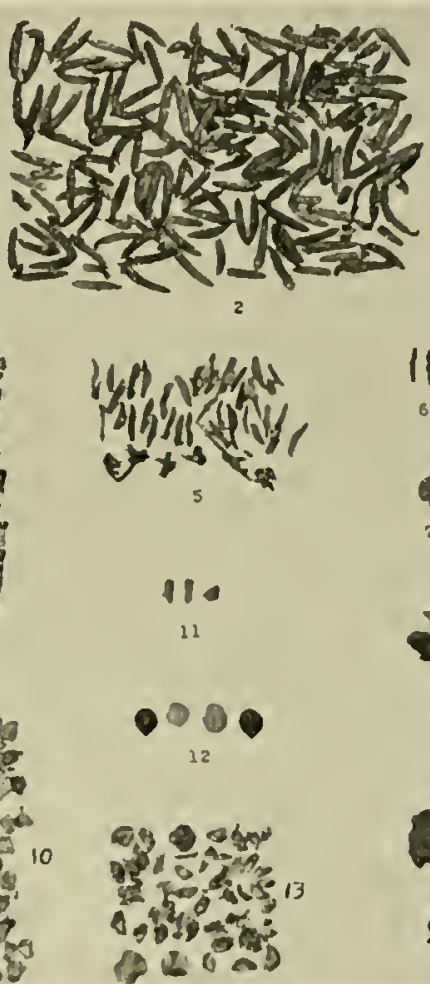
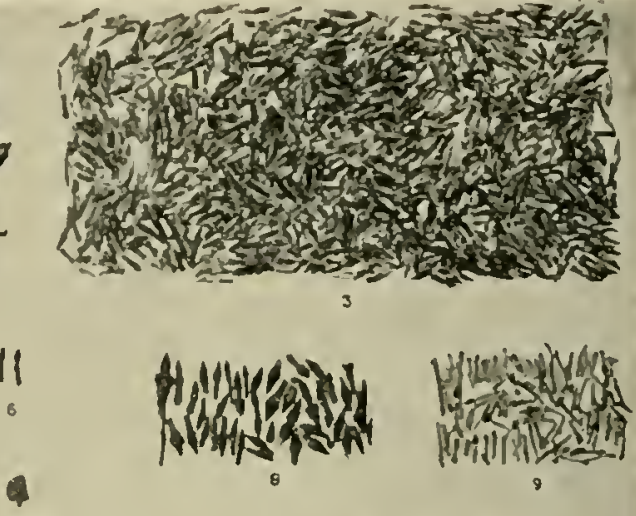

THE AMOUNT AND VARIETY OF FOOU FOUND IN TIIE CROP OF A GROLSE IS OFTEN SURPRISINE. PICTLIRE IS THE: CONTEXTS OF ONE WIICH CONTAINEH:

\begin{tabular}{|c|c|}
\hline 1. 188 buds. hop-hormbenm & 2. Ior cathins, hop-liornbe'am \\
\hline 1. 1.13 buds, hauthorne & 3. $38 \mathrm{huds}$, witch hasel \\
\hline 7. ane bud, scarlet ouk & 8. 1.3 buds. sugur maple \\
\hline 0. 22.3 fruits, stugharn sumarh & 11. 3 seeds, hawthorne \\
\hline 13. 37 fruits. seeds, bittersueet & 11. leares haulineded \\
\hline 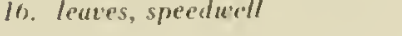 & 17. Icaves, strawberry \\
\hline
\end{tabular}

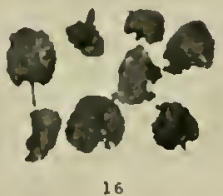

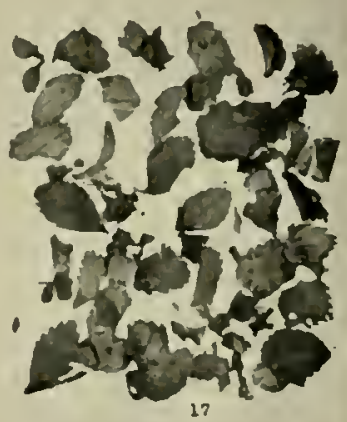
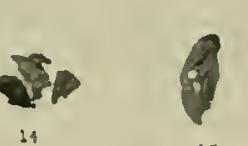

14
3. 096 buds. serviceberry
6. 2 buds, red cherry
9. 86 buls, low-bush blucberry
12. 1 fruits, seeds. mapte-leaved viburnum
1.5. Leaf, rummon speeduell

leaves which digest rapidly. In the midst of plenty. it is also possible that the hirds may feed more frequently and take less at at time.

In contrast to the crop. the erizaird holds a much smaller amomit of food. The largest observed to date was that of a winter lird from the Catskills. It contained 20 cc. 


\section{VARIETY OF ChOICE}

Perhaps the "pick-up" habit has something to do with the bewildering variety one finds in analyzing grouse crops and gizzards. Certainly this species is one of our most omnivorous game birds, for no fewer than 580 animal and 414 plant items have been identified from New York State grouse alone. From one summer bird. 45 separate items were determined. Although the average bird feeds upon a more varied diet during the summer than at any other time of year, there seems to be no period in which a considerable choice is not avail. ahle. Even in the teeth of a hard Adirondack winter, one grouse found 16 different items. However, the average for 90 birds collected in this region in winter over a period of years was only 4.6 items each. The seasonal and regional variation in number of food items is indicated in table 22.

TABLE 22. SEASONAL VARIATION IN TIIE NUMBER OF FOOD ITEVIS PER IVDINIDUAL, CROP AND GIZZARD TAKEV BY GROUSE IN VEW IORK

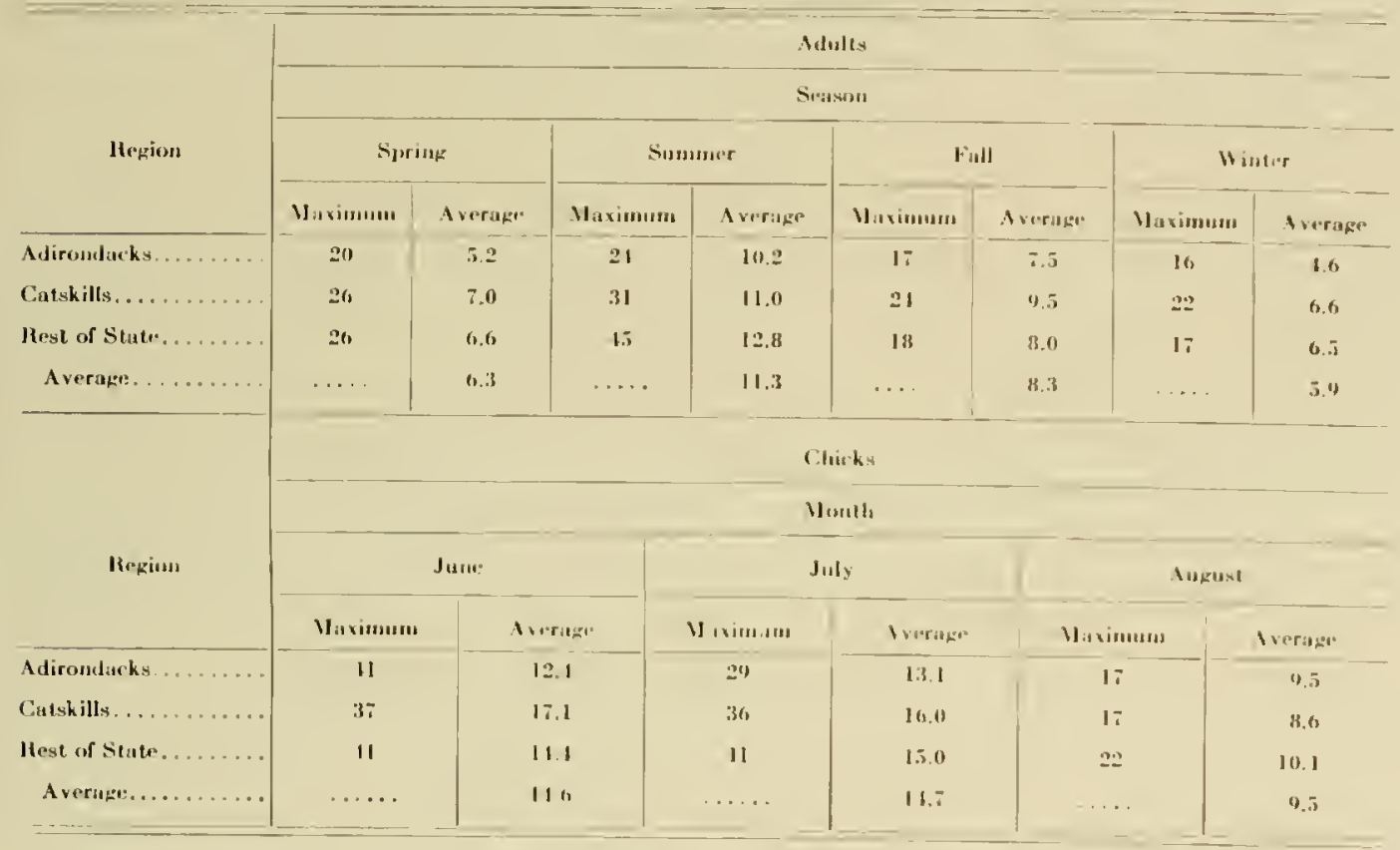

In spring Nature sets a more varied talle for the chicks. One active youngster in June. succeeded in catching 34 different insects and feeding on seven different plants. Fewer in. sects are taken in July and by Angust the menu of the young approximates that of the brood leader, the mother, in lessened variet! if not as yet in increased lulk.

As the ohservant hunter knows, grouse take a toll of many things in its enviromment. Buds, twigs, fruits, leeries. seeds. grains (particularly buckwheat). flowers. leaves, stems and even roots. are all eaten as fancy dictates. It is proper to call these hirds budders. browsers, lerry-pickers. seed eaters. leaf-clippers and even grain-gleaners. and they may be all six on many a feeding day. Nor do they find a smaller array of food items among the animals, for eggs. larvae. cocoons. pupae. nymphs and adult insects. as well as insect allies, such as spiders, all are fair game to the hungry grouse.

Under stress of circumstances. some unusual items may he taken. There are at least five 
published records of the birds eating snakes. The 17 .inch green snake mentioned by Judd is an example. A slightly smaller garter snake was found in a grouse crop by the Investigation. A number of scales from the same species were likewise identified in two other birds.

Four other vertebrates also have been recorded. Bones from a small unidentified bird were found in a grouse shot May 23, 1933 in the Adirondacks and feather remains in that of a Catskill bird. Even more mystifying were the cottontail hairs found in two other gizzards. It is more easily explained but equally interesting that another individual had fed to a slight extent upon small finger-nail clams (Sphaerium), and that wice mussels hase heen recognized. These mollusks are more or less common along the marshy shorelines of certain Adirondack lakes. Snails also were taken by 75 birds. mostly chicks.

There are a few plants in which the grouse exhibits a little-suspected interest. The leaves of pondweed (Potamogeton), stalks of sedge (Cyperus), seeds of spikerush (Eleocharis). bits of moss and traces of fungi and of mushrooms, have all been identified once or iwice.

There are in addition miscellaneons items among which might he mentioned: long-dead leaves, birch curls, bits of grlass and an inch-long roofing nail the latter puncturing the gizzard and killing the bird). Lead shot seems rarely to be picked up. though one case of what appeared to be lead poisoning was investigated.

\section{Gravel Cossumption}

Seed-eating hirds in general pick up hits of gravel and other hard particles to aid in grinding their food in their unusually strong muscular stomach called the gizzard. It is the function of this organ to pulverize the food before passing it on for digestion in the intestines. As a mechanical aid in this process the grouse, like its near relatives. usually keeps a small supply of gravel or other hard objects in its gizzard.

The mumber of these gizzard stones in a grouse is usually greater than one would suspect. In New York hirds. they are present in amounts rarying from a trace to nearly one-half the total bulk. the average being about 12 per cent, or one-ninth of the contents. It is possible that gravel is necessary to efficient gizzard action, hut its alssence for short periods at least scems to make little difference. With buds, twigs and heary-coated seeds the hreaking down action may be quite suecessful even in the alsence of gravel. In such cases it is not uncommon to fund a number of hard seeds which. it has been suggested. may act in somewhat the same capacity as grit. If such action does take place, it is of short duration in the ruffed grouse. for seeds in the gizzard seldom slow much evidence of long-continued wear. l'eblles, on the other hand, even the resistant granite. ma! le retained until they are smooth as though hand-polished.

The presence of grit in the gizard, hoth in frequency of occurrence and in anount, seems to he inlluenced more or less ly the weather. ly the habitat and ly the food which the grouse happens to be eating. Most hirds want grit at all seasons of the year. This is noticealule at winter freding stations. hoth for grouse and for pheasants where grit, as well as food. is taken. Whenever winter blankets the covests with snow. gravel is bard to oltain and grouse ma! retain the fall-secured supply. This may explain why gravel makes up only about nime per cent of the gizzard contcols at that time of the year. There is also a difference in relative volume of grit according to the type of food eaten. In winter the food items (mainly buds and twigs) hulk large. whereas the more compact foods of summer take up comparatively small space: in the former period the gravel oreupies a rather smaller proportion and in the latter period a larger proportion of the total stomach con- 
tents. Season to season, however, the actual amount of grit among New York grouse varies but little.

There is another difference attributable to food. Although exceptions are legion, there is a tendency for gravel to be associated with food items which in themselves are not hard. Conversely. less gravel is apt to be found mixed with such strongly protected seeds as cherry, sumach and thornapple. The amount of gravel in the gizzard depends also upon what is available to the birds. In the rugged Adirondacks where the soils are predominantly sandy and gravelly, grouse at all seasons of the year are likely to maintain in their gizzards nearly twice as much gravel as do birds from the sedimentary clay or loam soils of the Catskills or the Southern Tier (table 23). This difference is almost equally pronounced among the grouse chicks whose first grinding material is picked up almost as soon as the first insect.

TABJE 23. VOLA IITRIC PERCLNTAGE OF GRAVII, IN THE GIZZARDS OF 1,093 ADULT AND 510 CHICK GHOTSE, FOR VARJOUS SEASONS OF THIE IEAR

AND REGJONS OF TIL: STATE

\begin{tabular}{|c|c|c|c|c|c|c|c|}
\hline \multirow{2}{*}{ Region } & \multicolumn{4}{|c|}{ Adults } & \multicolumn{3}{|c|}{ Chicks } \\
\hline & Spring & Siunumer & Full & Winter & Jun & July & August \\
\hline Adlirondacks............. & 15.8 & 21.9 & 1.3 .3 & 12.4 & 17.1 & 11.1 & 11.6 \\
\hline Culskills........... & 9. 1 & 11.5 & 7.3 & 9.1 & 1.7 & $\therefore 1$ & 6.0 \\
\hline Rest of Stute....... & 7.6 & 17.4 & 9.0 & 6,2 & 116 & $\because 1$ & 8.6 \\
\hline Average* ........ & 11.1 & 18.3 & 10.1 & 9.1 & 11.2 & 9.2 & 10.0 \\
\hline
\end{tabular}

* A veruge for all seasons, autults: 12.2 per cent.

The size of the gravel sclected varies from half an inch in diameter down to fine particles, the average being about one-eighth of an inch in thickness. Though all available colors are chosen, white quartz pebbles seem to be picked up more often than would he accounted for by random taking. Shape seems to be of little moment, as does also texture, for hard granites and soft shales are taken without apparent discrimination.

\section{Foods Often Considereil Ixjurjous}

The grouse diet includes items which are known to be distasteful or actually poisonous to many animal species. Judd ${ }^{212}$ early noted this, obscring that, "The taste for rose hips, seedy. and husky as they are, and often beset with fine bristles which irritate the human skin and would seem really dangerous to internal tissues, is one of the singnlar freaks of bird feed. ing." It seems probable that spines and bristles must he wet and softened in the crop and gromnd up in the gizzard, else the hard conical style-bases of avens (Geum) and fruits of agrimony (Agrimonia) and the stiff spines of wild carrot (Daucus carota) and burdock (Arctium) might prove difficult to handle. At times these are taken extensively, a case in point lueing a grouse from British Columbia, killed in Octoleer, in which Judd found 500 ap. parently dead husks of Geum seeds.

The ability of a bird to withstand the toxic effects of generally injurious plants can well become an important factor in the survival of the species. Most of the poisonous species utilized by grouse supply food in small amounts, but occasionally mountain laurel (Kalmia latifolia) is eaten in quantity. The harmful substance loere involved is andromedotoxin, a bitter glucosid which acts as a narcotic to many animals. Found in the leaves and in the nectaries of the flowers, it is highly toxic to domestic livestock. Several fatalities from the honey of this plant are on reeord. 
The flesh of animals which have been sick or poisoned by laurel is supposedly unfit for consumption ${ }^{13}$. As a result hirds guilty of this laurel-eating habit in some instances. have heen pronounced unpalatahle, or even poisonous, to humans. Judd reported knowing of several instances in which persons were poisoned by eating grouse that had fed extensively. on laurel. Wilson "'in also referred to such poisoning, but attributed the ill-effects to failure to draw the birds immediately. and stated that after taking a handful of laurel from a "pheas. ant" he had eaten freely of the meat without any unpleasant consequences. Grouse were once lanned from the markets of P'hiladelphia through fear of laurel poisoning.

Nention has already heen made of one grouse consuming a half-pint of mountain laurel leaves at one feeding without any indication of discomfort. Among the birds examined. such leaves were eaten by 23 , comprising over half the contents in four. Twigs and buds were present in 11, but usually in small quantities.

In an effort to cast additional light on the subject, six adult hand-raised grouse were provided with their normal daily ration supplemented with a continuous supply of fresh laurel leaves. At the end of one week four were autopsied without finding any indication of injury that could be ascribed to laurel. The two remaining birds were continued on the same schedule for three more weeks without visible harmful results. They were then put on a diet of pure laurel. Death resulted. Upon autopsy, it was altributed directly to malnutrition.

Two additional grouse were fed on laurel only. Both showed consistent weight loss and died after seven days. Death from mahnutrition again was indicated.

Remains from six of the grouse, five from the first lot and one from the second, were fed to mice and kittens, none of which showed indications of discomfiture. The other two were eaten by the senior author. who reported no ill effects, though the lasle of the flesh was dislinctive.

Though these tests are admittedly not extensive, one finds here no indication that laurel is poisonous to gronse. or through them to bumans. When eaten alone it apparently has liule sustaining value. Grouse will eat large quantities of laurel leaves when deprived of other food and freely supplement their diet with laurel even when provided with an abundance of their normal rations.

That the grouse like many other birds can eat the berries of poison ivy (Rhus toxicodendron) will apparent impunity is another interesting fact. Sm!ll" quotes Forbes as finding 280 of these berries in a bird collected in Becember in Illinois. 1)r. A. K. Fisher counted 160 which were in the crop of an Adirondack gronse shot in Oelober. Nine of the adults and one chick collected for the present Investigation had been feeding on poison iry fruits or seets. That even in the stomach they may retain properties poisonous to man was indicated hy Judd. who cited the case of an investigator who was poisoned while examining the gimards of rows that had fed on poison ing berries.

A number of oher plants contain substances prisonous or higluly unpalatalle to man. Some of these are useful grouse food plants, while others are conspicuous hy their absence in the normal diet. The herries of yew (Taxus canadensis) and fruits of hittersweet (Celastrus scomdens) contain toxir alkaloids. but that did not deter 20) hirets from eating the former and five the latter. Secels of the smartweeds (l'olygomum) may rause poisoning when fed in grain or ground feeds despite the fart that they are widely used by many forms of wildlife. In all, 82 grouse, 48 adults and 34 chicks. ate smartweed seeds. Fruits of the hittersweet nightshade (Solanum Dulcamara). caten hy nine birds. are oreasionally poisonous to man. 
Some of the better known toxic plants, their poisonous properties and their use by grouse, are shown in table 24 .

TABLE 21. PROPERTIES OF SOME POISONOUS PLINTS EITEN BY GROUSE

\begin{tabular}{|c|c|c|c|c|c|}
\hline \multirow{2}{*}{ P'laut } & \multirow{2}{*}{$\begin{array}{l}\text { Purts } \\
\text { poisonous }\end{array}$} & \multicolumn{3}{|c|}{ P'oison } & \multirow{2}{*}{$\begin{array}{l}\text { Number of hirds } \\
\text { in which } \\
\text { found }\end{array}$} \\
\hline & & Nanne & Tyре & $\begin{array}{c}\text { Physiologicisl } \\
\text { artion }\end{array}$ & \\
\hline Horsetail . . . . . . . . . & stalks & aconitse acief, & alkalvied & ururotic & 3 \\
\hline Yew. & tipedles, serds & tixine & silkulonial & lifart depressint & 20 \\
\hline Poison ivy.... & whole plant & urushiual & volatil. oil & irritant & 10 \\
\hline Bittersweet. . . . . . . & leaves, fruits & eurnymin & alkaloid & purgative & 5 \\
\hline I aurel ........ & leaves & sudrouedotoxitu & alkaloidal plucosid. & meuro-muscular & 30 \\
\hline Ground ivy... & leaves & & volatile ril & irrilunt & $\overline{-}$ \\
\hline Jlitursweet nightshadr & leaves, fruits & solanine & alkuloidal gluroside. & ururotic, fastric & 9 \\
\hline
\end{tabular}

Interesting to note is the presence of salicylic acid. the active ingredient of aspirin. in aspen leaves. In spite of the bitler flavor thus imparted to these leaves. they rank among the important sources of summer foods. However. willow leaves. with a slightly higher concentration of salieylic acid, are rarely touched. Leaves of sheep sorrel (Rumex acelosella) and wood sorrel (Oxalis), sometimes eaten in large quantitics. contain oxalic acid. bust since calcium oxalate is highly insoluble it is doubtul if tothal quantities of the arid are released during digestion.

The deadly hydrocyanic acid is one of the decomposition products of cherry leaves. formed by the action of enzymes upon the glucoside. amygdalin. While wilted lears are the most dangerous, the vigorous succulent leaves from young shoots are far more poisonous than foliage from a mature or stunted tree. Perhaps, then. there is some significance in the fact that not once was the presence of cherry leaves detected in the course of the analyses. On the other hand, the fruits and the huds and twigs of cherries are anong the most popular grouse foods in New York, so there is ample opportmity for grouse to sample then. Other types of foliage are browsed, often extensively, hut that the hirds liere draw the line is an evident but mexplained mystery of bird psyehology. Anygdalin is likewise present in the kernels of the cherry pits. which are often broken open in the muscular gizard. Either the quantity of hydrocyanic acid produced is too small or conditions are not satisfactory for its lihera. tion, for the birds scem to experience no ill effects from digesting them.

Two other common plants in New York are ignored by grouse- the conspicuous briglit blue fruits of cohosh (Cuuloplyllum thalictroides) and the well-known mandrake. or May-apple (Podophyllum prltatum). The former contains the alkaloid methyleytisine. and the latter podophyllin. Both are purgatives and overdoses may prove fatal. Ripe fruits of the latter are edible, althongh a severe dermatitis may be produced from handling the rootstocks.

Animals. too. may contain unpalatahle substances. Ants are often spoken of as "protected" inseets duc to the presence of formic acid. liut more grouse feed on ants than on any one other kind of insect. Caterpillars armed with poisonous spines, and stinkbugs, are often eaten.

\section{Effect of Certaix Poisonous Chemicals}

Grouse are surprisingly resistant to the chemical poisons which are employed against noxious insects, predators. rodents and weeds. Probably the only ones possibly injurious to grouse 
are those used by orehardists and foresters involving sprays. in which lead arsenate and nico. tine sulfate are commonly the basic ingredients. The birds then run the double risk of eating either the poisoned insects or the plant parts covered with spray.

Whitehead ${ }^{3 n s}$ found that neither poisoned grasshoppers nor the lran-poisoned bait which killed them are apt to be consumed in sufficient quantities to cause many deaths among avian populations, either domestic or wild. Nor is there much danger of humans being poisoned from eating chickens that have eaten poisoned grasshoppers. Piper ${ }^{3 n}$, however, reported that a large number of magpies and blackbirds fell victims to poisoned grain scattered ahout in efforts to combat a Nevada nouse plague, where strychnine was the poison used.

To gain some insight into the effect on grouse of some of these poisons, three birds at the Center were offered their regular daily ration to which had been added powdered lead arsenate equivalent to 0.6 gallons of spray solution at the ratio of one pound arsenate to 40 gallons of water. Within three days the birds showed the effects of poisoning-loss of appetite and droopy appearance. Autopsy revealed bile-stained gizzard lining similar to that found in ducks suffering from lead poisoning. This might be taken to indicate that the lead in the compound is the lethal factor. These birds consumed the equivalent of better than a halfpint of solution each before suceumbing on the sixth day of the experiment. It would take many more sprayed fruits. buds and leaves than grouse might be expected to consume in the wild to equal the amount of poison administered.

To determine the repellent effects of spray solutions of lead arsenate. Iwo food trays. one containing untreated rations and the other sprayed with the solution were placed in a pen with four grouse. No tray preference was exhibited. The proximity of a bird to one tray or the other seemed to be the only factor in deternining from which it wonld eat.

Since nicotine sulfate is also commonly used as a commercial spray; the above experiment was repeated using a standard solution of two level teasponfuls to one gallon of water. None of these birds showed ill effects.

Grouse were also found to he surprisingly resistant to powdered stryclinine. The minimum lethal dose of most humans is 0.5 of a milligram per kilogram of body weightı. Three hirds were fed respectively 92.108 and 126 milligrams per kilogram of hody weight. All survived. The amount of strychnine consumed was respectively equal to 184.216 and 252 tines the lethal dose for humans.

Although the birds were found to be tolerant of powdered strychnine. 80 milligrams of the same chemical in solution ransed death within a few minutes. Strychnine does not mix readily with water so that solutions such as here tested are seldom used.

\section{DIET}

In considering the food of erouse it is common to ascribe 100 mucls importance to the species most commonly eaten. It is generally helieved that the hirds exereise a choice of food items based on need. Were this the stery. food hathis research would be tremendousty: simplified, for one would lave only to determine the relative consumption of varinus foods by seasons, regions and years for adults and chicks. Kunwing the volume of each food eaten. one could then easily compile a list of plant and animal speries to bre concouraged.

It is not as simple as that. for there are reasums to heliese that the grouse is not able to make equally gond use of each of the fonds which it devours. Thornapple and sumach sreds

- One kilogram equale approximately 2.2 mounda. 
are commonly picked up, but often prove too resistant for the gizzard to rrack. Yet throughout the colder portions of the year the stony seeds of staghorn sumach, with their thin hairy covering, are a favorite with New York grouse. Likewise the composition and nutrients present in various grouse foods vary widely, as is indicated by the section on "Food and It Relation to Health" (p. 235). Lastly, there is little indication of the presence anong grouse of an ability to pick and choose only or primarily those foods from which they can secure a balanced diet.

Considering the 4.14 plant and 580 animal items that grouse are known to eat in New York. one finds such factors as distribution and availability exercising a marked influence on the diet. In Michigan and Wisconsin, where clover grows commonly along the woods-roads. it is much eaten. hut in New York, clover, in such situations, is scarce. and the grouse accordingly turn to a variety of other plants. In the far North. Nelson indicates that the gray ruffed grouse (Bonasa umbellus umbelloides)* may browse extensively on spruce luods. whereas Loomis" ${ }^{225}$. writing of South Carolina "pheasants" reports that the hirds feed freely on mulberries. Though loeally present, neither of these fouts are to be noted in abundance thruout all New York's grouse range. In examining 1,633 sperimens. few traces of rither of them were found.

In individual cases large meals were made by New York hirds from uo fewer than 5. species of plants. Scarcely more than a dozen. however. were found to have been raten commonly in large quantities. In other words. within wide limits. the grouse is apt to make a meal on any one of numerous locally available plants that may suit the fancy of the hour.

Despite such peculiarities, the speries seems to thrive perfectly well on its varied diet. and one, therefore, feck quite justified in attaching considerable importance to the foods that are most frequently taken.

\section{Fond Eatex and liamife Represexten}

Basically the grouse is a vegetarian. although for the first few week of its existence it may live largely on insects. The adults, in summer take a fairly large variety of animal items, though, these for the most part, are small insects. In bulk they represent lut 3.9 per cent of the total food. The rate of consumption drops $t_{1}$ only 0.6 per cent in the fall, and to much smaller amounts in winter and spring. so that in the course of a year only 1.1 per cent of animal material is taken to 98.9 per cent regetalse.

l'resentations of food habits data often result in impressing the reader mainly with the detailed nature of the studies carried out. It is easy to lose oneself in a maze of facts and figures. To facilitate understanding of an admitterly complicated subject. the foods most important in New York, both plant and animal. are bore first summorized and discussed as a whole. Then the parts are analyzed lest the summary itself he misinterpreted. Accordingly seasonal variations are discussed separately. as are also the differences hetween the feeding habits in the three major regions of the State-Adirondacks. Catskills. and the remainder of the State.

Foods differ by years also, as do those taken by the young, in contrast to the mature birds. These, loo, are separately considered.

To understand the whole before picking it apart, judging only from the amount taken, the most important plant and animal foods of adult grouse are incorporated in table 25.

This list may contain various surprises for the average grouse hunter skilled largely in noting the numbers of heerhnuts and herries year by year in relation to the aloundance of 
grouse in his favorite coverts. Tet this is the food pattern by which grouse live each year over a wide range. As such it is well worth considering in some delail. Most of the plants and animals here listed are well known sources of food, but the part which these play in pro. viding grouse food is often not appreciated. For the sake of clarity the two groups are discussed separately.

\section{Plant Foods.}

It would he difficult in the Northeast to walk far through an over-grown or wooded area without seeing plants on which grouse feed. The 4.14 different species so far identified are distributed among 65 families. although the bulk of the food is taken from aboul 20 of these. They include: one fanily of ferns, one each of grasses and sedges. six largely herbs, five mainly shrubs, one family of vines and five of lrees. Cerlain of these, for example, the rose family, have representatives among each of the four groups-trees, shrubs. herbs, and vines.

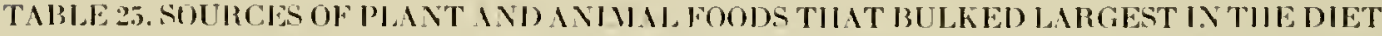

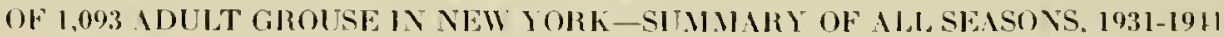

\begin{tabular}{|c|c|c|}
\hline Foods & $\begin{array}{l}\text { Yolumetric } \\
\text { imercentage }\end{array}$ & $\begin{array}{l}\text { Nomber of hirds } \\
\text { in which fousud * }\end{array}$ \\
\hline PIANTs (98.9 porecont) & & \\
\hline 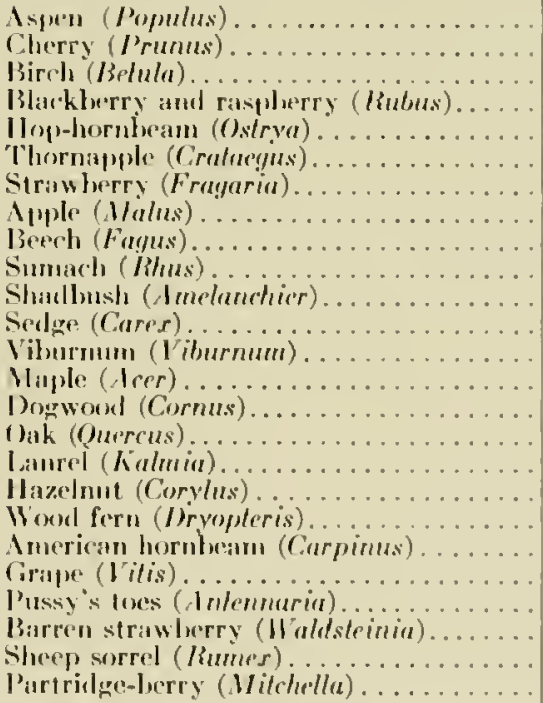 & $\begin{array}{r}12.1 \\
10.6 \\
9.2 \\
8.8 \\
5.6 \\
1.5 \\
3.8 \\
3.8 \\
3.3 \\
2.7 \\
2.5 \\
2.3 \\
2.0 \\
2.0 \\
1.6 \\
1.6 \\
1.5 \\
1.1 \\
1.2 \\
1.0 \\
1.0 \\
1.0 \\
.9 \\
.8 \\
.6\end{array}$ & $\begin{array}{r}211 \\
118 \\
232 \\
282 \\
112 \\
311 \\
107 \\
81 \\
101 \\
251 \\
101 \\
26.5 \\
717 \\
172 \\
179 \\
61 \\
30 \\
63 \\
75 \\
87 \\
83 \\
16 \\
26 \\
16 \\
213\end{array}$ \\
\hline ANIUIIS (I.I fwernl) & & \\
\hline 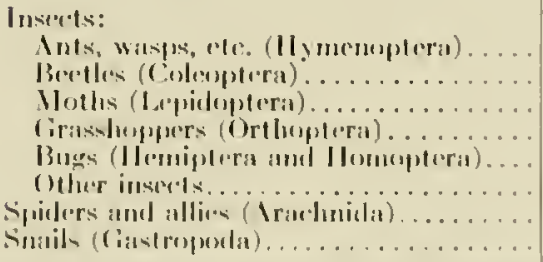 & 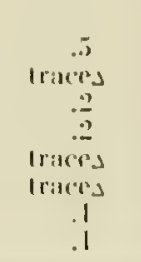 & $\begin{array}{r}312 \\
226 \\
13 \\
79 \\
71 \\
68 \\
123 \\
13\end{array}$ \\
\hline
\end{tabular}

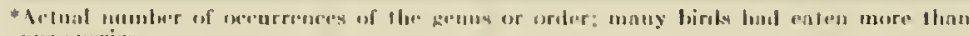

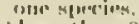

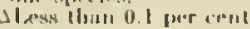


These families contain many of the pioneer species which fill in old meadows, pastures, or slashings. Several of the species contributing to grouse food as the blackberry, cherry, sumach, viburnum and aspen, are among the most common and widespread of northeastern woody plants. Within each family are from one to a dozen species which. under the right condilions of time and place, may furnish large quantities of buds. leaves. fruits or seeds on which many of the grouse examined have fed. Let us then look into these families a bit.

The Rose Family. One of the most common and important of these fanilies is the rose group (Rosaceae). During warm weather, strawberries. raspberrjes, sedges and aspen are the most commonly sought after fond species. Of these, the first two belong to this family. In the late spring and early summer. leaves and fruits of strawherry (Fragaria) are prime foods for both young and adults in all parts of the State. A chick collected in the Southern Tier in July contained 1,650 seeds; in another from the Adirondacks. shot during the same month, were found 2.100 seeds. Adults likewise relish strawberries. as is evidenced by a Catskill hird which had eaten fruits sufficient to provide the more than 6.000 seeds that were found in its crop and gizzard.

By the time the strawherry moon wanes, the rasplierry and blackberry (Rubus) season is approaching and the birds take full advantage of it. These plants are also members of the family Rosaceae. It is not uncommon to fund in excess of 2.000 seeds. representing sonc 30 fruits in a summer crop (and gizzard) of either chick or adult. One youngster collected in July in the Catskills contained 3.160 seeds. What their appetites may he when they grow up is indicated by the meal of a summer bird from Tompkins County in which more than 8.000 seeds (120 fruits) in the gizzard and 25 fruits in the crop were counted. In captivity. 108 red raspberries were consumed within half an hour by one jndividual less than three months old. Occasionally dried fruits. as well as leaves and buds. are laken thoughout the fall and winter months until April.

Products of cherrics (Prunus), probalily are the most consistently sought of all those of the rose family. The hard seeds are picked up throughout the year. As suon as the light red fruits of pin cherry and the darker drupes of choke and of wild hack cherries become available the grouse seeks them ont: in one Cetober hird 180 of the fir-maned were found. In September the wine-red juice of the wild black cherry may impart its color to the entire crop contents. Later the buds are very attractive. 1.100 being recorded from a February hird collected in St. Lawrence Comnty (N.Y.). The leares. however. are entirely neglected.

Although not so widespread in grouse covers. as some of the native plants, the apple (Malus) is utilized the year around. Young birds raised in eaptivity at the lieseareh Center seemed to prefer apple leaves to any others offered them. Acrording (1) stomarh analyses.

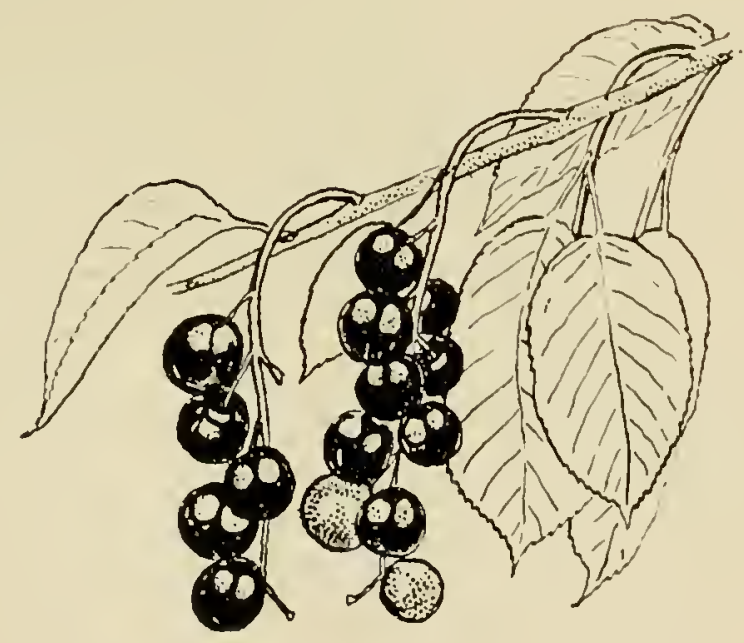


these leaves are not much taken in the wild though one bird collected from Jefferson County in late October had fed exclusively upon them. They stay green in the face of fall frosts and this may attract grouse to the trees though they feed largely on the buds and decaying fruit. That heavy pruning of apple buds may result is indicated by the meal of a Catskill bird which had eaten 566 of them in November.

In the late summer and fall, the birds have a tendency to gorge themselves on thornapple (Cralaegus) fruits. From the crop of one full fed grouse, collected Octoher 16, near Ithaca (N.Y.), were extracted 125 of these bulky fruits and seeds along with 11 other kinds of foud. In fact. throughout the State more fall birds were found to have fed exclusively on redhaws than on any other item. Buds of thornapples, however, do not seem to be much relished and only three birds had eaten the leaves.

Shadbush (Amelanchier) is also much patronized both for its early fruits and for buds. One winter-bound bird in the Adirondacks gathered 846 of the latter and another in the Calskills picked more than 1,300 .

One of the largest crops examined was filled with almost half a pint of leaves of the barren strawberry (Waldsteinia); this bird was collected on December 2.

Though avens (Geum) seeds, also of the rose group: were not taken in sufficient quantities to rank among the more common summer and fall foods, one bird taken October 22 in Albany County made most of its meal of them, taking more than 2,000 .

Occasionally some species with apparently desirable fruits are neglected. This scems to be the case with the chokeberries (Aronia). the buds of which were eaten by only 12 of the grouse examined. seeds and fruits by three adults and one chick: and leaves by one adult. With one exception, all of these were represented by small amounts.

The Birch Family. Second in importance, though little patronized in summer. is the birch family (Betulaceae). Chief among the group are the birches (Betula) themselves. among which the birds are so frequently found as to give rise to the appelation of birch partridge. The speds, though common travelers over the March snow, are seldom touched. but both cathins and buds are well liked. These are taken from all species: those of yellow birch ( $B$. lurea).

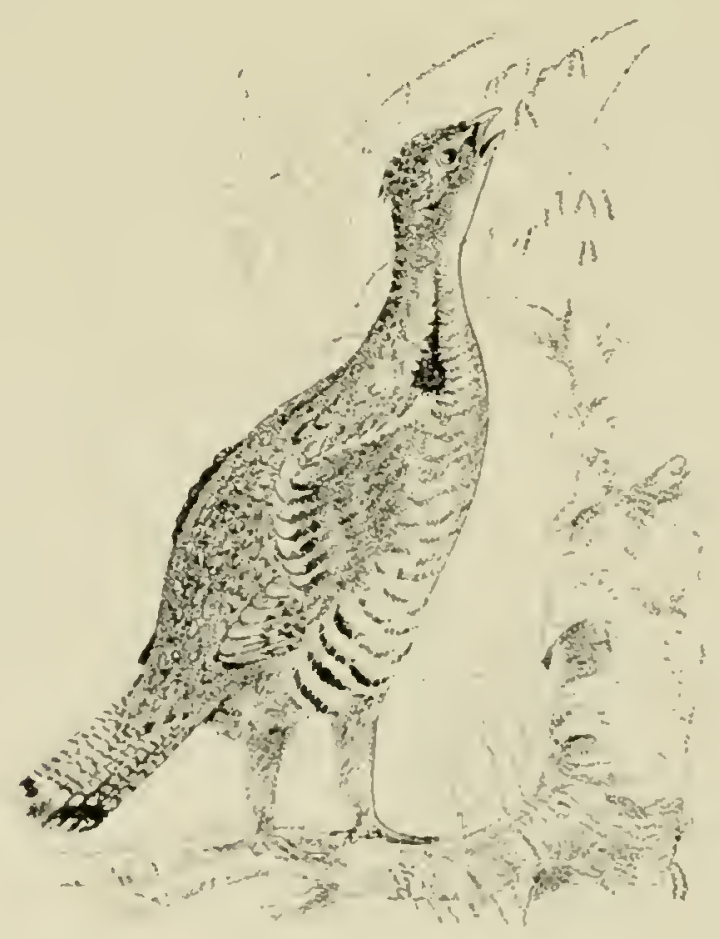


black birch (B. lenta), and paper birch (B. papyrifera) in largest quantities. Two birds collected from the Adirondacks, one in winter, the other in early spring, had consumed 728 and 1.150 buds and twig tips respectively. Even in the presence of an abundance of other appetizing foods, hirch buds are taken as early as September 18 and as late as May 11.

To a forester, the hornbeams or ironwoods are weed trees. but every grouse knows they have a place in its favorite covert. The leaves of the hop-hornbeam or hardhack (Ostrya virgini. ana) are but seldom eaten and the early maturing fruits are utilized less than might be expected. The smooth brown huds and particularly the flat-clustered staminate catkins furn. ish a wealth of food which bulks large in many a grouse crop from October through April. $\mathrm{U}_{p}$ to 523 of the former and 820 of the latter have been identified from separate birds. The smaller blue beech or hornbeam (Carpinus caroliniana) is browsed less commonly; perhaps because of its more slender branches.

One shrub, the hazelnut (Corylus). also a member of the birch family, is sometimes visited by grouse in search of buds or of the staminate anents borne at the end of last year's twigs. More adventurous birds may even assay to swallow the large slightly-flattened fruits.

The Willow Family. Among the trees and shrubs no family is more widely distributed than are the willows and poplars (Salicaceae). It is, then. fortunate that grouse browse upon them. The large buds. long catkins. and tough leaves set on the stout twigs of the aspens (Populus) are particular favorites even when other food is abundant. Bendire" notes, "The Canadian ruffed grouse, according to Mr. Hardy. feeds not alone on the poplar buds hut also on the hard old leaves. He wites me, "I have killed one with his crop filled with such leaves on the 20th of August, and they eat them eontinuously until the leaves have fallen in late October." Green leaves. too. are not nverlooked. for they had heen commonly taken by the birds studied from April 21 until late Novemler. Leaf-browsing thus nverlaps the bud. ding period at both ends. In the Adirondacks, aspen budding begins as early as September 18 and continues at least until May 17. On Jantary 6, one lird made a full meal of 1,300 trembling aspen ( $P$. tremuloides) buds and twigs. Its larger-leaved cousin ( $P$. grandiden. tata) is equally attractive.

The willows (Salix). though seldom important as a souree of food are not entirely passed by. Of this group, grouse, in common with children. may prefer the pussy willow (Salix (iscolor). judging from the 636 buds picked off by one lird collected on December 13.

The Beech Family. Were it not that alundant cops of hechnuts and acorns are produced only once in three or four years, the beech family (Fagacene) would be nutstanding as a producer of fall and winter grouse food (table 26). In the Northeast, coineident with the falling of the leaves, grouse-wise hunters often head for the beech ridges if it he a mast year. There the birds may have been feeding among the beeches (Fagus grandifolia) since early September. For the next two months, beechnuts. elose-lnoused in their lurrs or shueked out on the snow, are seldom overlooked. But it is the previous fall's crop revealed by March and April's shrinking snows that are really appreciated. Following a beechnut year, they rank sixth in the list of spring foods.

Occasionally these nuts are eaten in numbers. Bendire "mentions "finding 76 in one bird's crop and 60 in another". These were Canadian birds. Beech is a common tree in New York but no such heavy utilization has been found by the Investigation, though Smyth ${ }^{\text {stu }}$ records finding one crop collected December 8 . that contained 78 nuts. Thile occasionally found as the sole crop contents. heechnuts are commonly eaten along with other items. One bird col. lected near Elmira on November 5 had gathered 20 fruits of highbush cranlerry (Viburnum 
opulus), 42 fruits of arrowwood (I'irburnum dentatum) and ten other items. including 25 beechnuts.

TABLE 26. QINTTTIES OF BEECINUTS CONSITED BY 1,093 ADILT GHOUSE IN NEW YORK-1931-1911

\begin{tabular}{|c|c|c|c|c|}
\hline \multirow{2}{*}{ Iear } & \multirow{2}{*}{$\begin{array}{l}\text { Number } \\
\text { of birds } \\
\text { examined }\end{array}$} & \multicolumn{3}{|c|}{ Occurrence of beechnuts } \\
\hline & & $\begin{array}{l}\text { Yumber of birds } \\
\text { in which foumd }\end{array}$ & $\begin{array}{l}\text { Percent of } \\
\text { oceurrence }\end{array}$ & $\begin{array}{l}\text { Volumetric } \\
\text { ipercentage }\end{array}$ \\
\hline 1931 & 23 & 1 & 4.4 & 0.1 \\
\hline 1932 & 30 & 2 & 6.. & $0 . \overline{1}$ \\
\hline 19.33 & 91 & 1 & 4.3 & 0.1 \\
\hline 1931 & 164 & 36 & 21.3 & 8.3 \\
\hline 1935 & 302 & 31 & 10.3 & 1.9 \\
\hline 1936 & 1.11 & $i$ & 0.7 & 0.2 \\
\hline 1937 & 78 & 11 & 14.1 & 8.5 \\
\hline 1938 & 19 & 0 & 0.0 & 0.0 \\
\hline 1939 & 88 & 1 & 4.5 & 3.2 \\
\hline 1910 & 97 & 9 & 9.3 & 2.5 \\
\hline 1911 & 57 & 2 & 3.5 & 1.0 \\
\hline
\end{tabular}

In years of beech mast scarcity grouse of course turn to other foods. The long spiked beech huds, too, are occasionally eaten. though seldom in quantities and then probably incidental to feeding on the nuts. for they are usually more common in early spring and fall crops. One bird collected in October in the Catskills, however, contained 601 of these stick. like buds. Beech leaves also are taken oceasionally.

Now that the chestnut has all but vanished. the other great group of mast producers upon which wildlife must depend is the oaks (Quercus). Not such a factor in grouse economy in the Northeast as are beechnuts. acorns may nevertheless be taken in sizeable quantities. One bird killed October 15 had eaten ten of these large nuts. Acorns from the white oak group, particularly those from the white oak (Q. alba) and the bur oak (Q. macrocarpa) scem to le preferred to those of the hlack oak:* lhough the bitter acons of the black oak (Q. velu(ina), as well as of the searlet (Q. coccina). pin (Q. palustris) and particularly the scruh. (Q. ilicifolia) oaks are taken in increasing amounts towards the southern part of the grouse range. ${ }^{1=3}, 2=$. The red nak ( $Q$. borealis) acorn is so large that it is seldom swallowed whole. The Investigation has two records of the meat minus the shell heing eaten.

Grouse apparently enjoy eating tough leaves wecasionally such as those of oak for three of the hirds examined had included these in their diet. One collected July 2.I made almost its entire meal on the leaves of the lour oak (Q. macrocarpa). even though insects and rasplerrics were abundant.

One wonders how the grouse manage to break off the stublyg tight-lwigged oak buds. but they were found sparingly in the crops of eight hirds from April 3 to June 5.

The Ileall Family. Wherever acid snils abouml within the grouse range. plants of the heath family (Ericaceae) play an important part in the life of the grouse. In the Northeast. lreginning in July, Wueberries (Vaccinium) and later huckleberries (Gaylussacia) are much relished hy old and young alike. Judd found 300 herries of $r$. pennsylanicum in the crop "f a Septemher lird from Chateangay. X. I. Farther south they continue to he sought even in late fall as a Blackshurg. Va.. lird killed l)ecember 2. had made the bulk of its last meal of 295 fruits and an additional 99 seeds of hlueherries. Frequently large mumbers of the small comprart buds are taken. particularly in winter. for loluelerries are widely distrilunted in elearings and as an understory in the more upen woodlands. Buels. leaves or fruits of

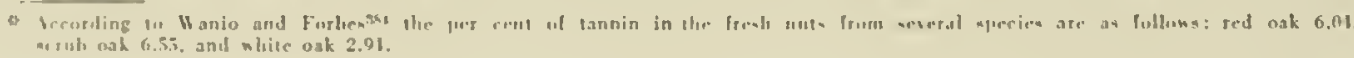


these two genera were eaten by no fewer than 80 of the birds collected by the Investigation.

From southern New York southward, the mountain laurel (Kalmia latifolia) supplies food. and even nore importantly, shelter. The fullest crop examined, which was collected March 15, 1936, near Middletown. N. Y., was stuffed with laurel leaves, buds and twigs. Again. tough leaves seemed to be attractive.

Weed and Dearborn ${ }^{349}$ found 12 leaves of sheep laurel (Kalmia angustifolia) in a January-killed bird. The buds of a cousin, the azalea (Rhododendron nudiflorum) are sometimes eaten in fair quantities.

Another evergreen which, because of its small size is often covered by snow, is the aro. matic wintergreen (Gaultheria procumbens), whose chewy leaves and solid-fleshed fruit are favorites with grouse. Collected near Blacksburg. Va., on November 25, one bird was found by Smyth ${ }^{34+}$ to have eaten enough fruits of this specics to furnish 2,499 seeds. But so small were they as to represent but 10 per cent of the gizzard contents. Ofttimes associated with wintergreen is the shinleaf (Pyrola), whose flat-clustered, basal leaves are picked up possibly because they also are evergreen.

Evergreen winter browse is furnished largely by conifers, ferns and heathers. Where arail. able, the last group is usually patronized more commonly than either of the others.

The Sumach Family.-In New York, the fruits of sumachs (Anacardiaceae) are well up in the list of favored foods. Yet difficulties experienced in cracking their hard-shelled sceds which lie just beneath the well known red coat of most of them pose a question not easy to answer. Beer and Tidyman" have suggested that such resistant seeds are taken in place of grit, a possibility discussed elsewhere in this chapter. In these days of vitamin-conscionsness one wonders if some nutritive nced may not be locked up in the hirsute and acid outer covering of the sumach seeds. It is difficult to believe that these thin-pulped fruits would he taken merely for stuffing with so many easily ohtained and nutritions substitutes usually at hand. It is a fact, however, that sumach fruits are often eaten in large quantities when an abundant supply of other foods is avalahle. For instance, one bird collected near Ithaca. N. Y.. on November 13, had swallowed 1.025 of the fuzzy fruits of staghorn sumach (Rhus typhina) along with small amounts of several other foods. In winter, one occasionally fuds an astonishing anount of these sizeable seeds in a erop: one contained 1.069 seeds.

Whatever the reason for their patronage, few of the sumachs are overlooked save possibly in summer. Even the poison ivy (R. tovicodendron) berry had heen eaten by ten of the birds examined. Sumach buds were found but once.

The Sedge Fanily. In the order of importance as producers of grouse food. the next most patronized group is the sedge family (Cyperaceac). They receive greatest attention in

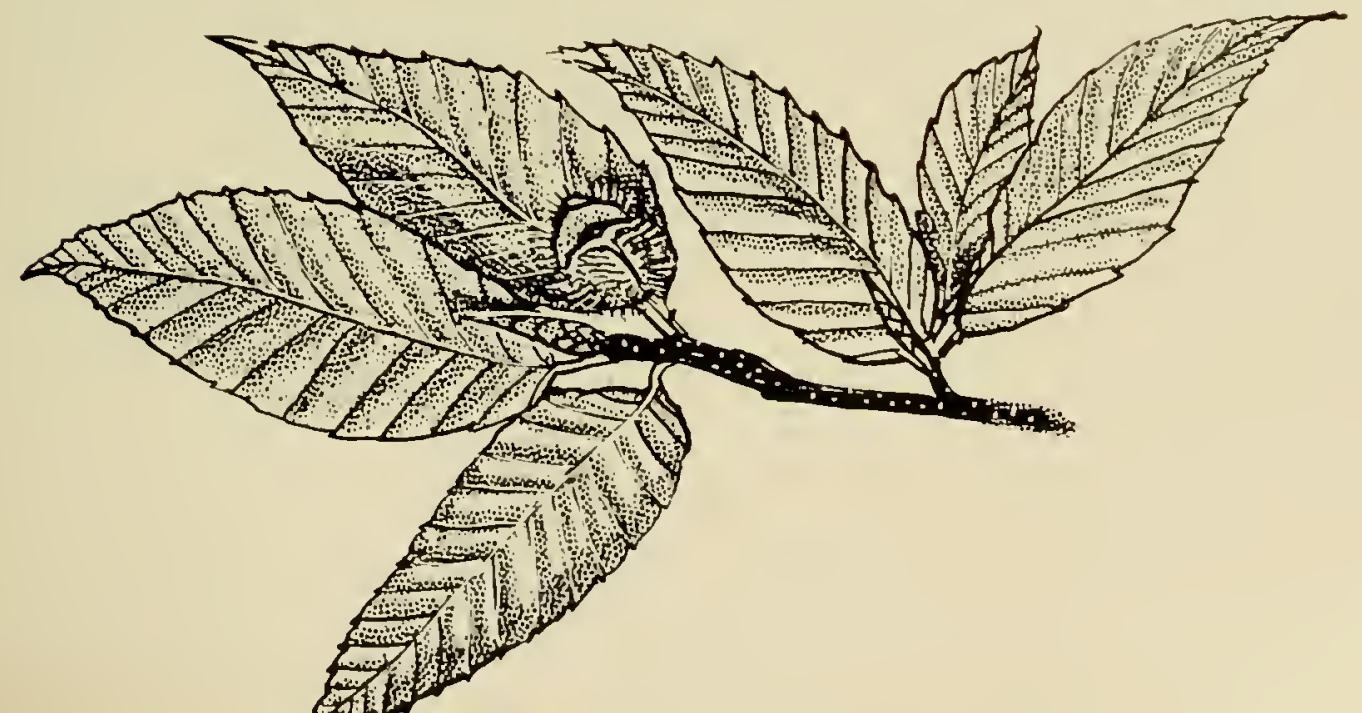


the summer, especially from the young birds. Many seeds of one genus, Carex, have been reported eater by individual birds. Apparently the broods during dry seasons often frequent the moister spots where the vegetation remains luxurious. Here too are found many of the sedges. As carly as June 16, a chick collected in the Catskills had eaten 269 seeds representing six species. July records include those of crops from the Adirondacks filled with 1,800 seeds, from the Southern Tier with 1.515, and from the Catskills with 2.200. One atdult taken in the middle of July had stripped some 4,200 sceds from Carex crimita as well as a few from three other species. The large-seeded bladder sedge ( $C$. intumescens), eaten by 101 birds, is also worthy of mention, as is the slender-stalked sedge (C. debilis, var. rulgei), fed upon by 119 grouse.

The Honeysuchle Family. Some may be surprised that the widely-scattered viburnums and dogwouds do not have a more prominent place among grouse fouds. The former plants belong to the honeysuckle family (Capriofoliaceae) along with the little-touched snowheries (Symphoricarpos) and the elderberries (Sambucus). Both the early fruiting, red-herried elder ( $S$. racemosa) that loves the woods edges, and its more open-growing cousin, the common clderberry ( $S$. canadensis) however, have fruit that is well off the ground at a time when other food is abundant and for both reasons may he little attractive to grouse. Compared with other hirds, the grouse, thongh favoring the red-berried elder, does not eat as much of the fruit of either species as might be expected.

It is the viburnums that are the real source of grouse food in this fanily. Annong fall fruits they rank seventh in importance, just three steps ahead of the dogwoods. The fruits of all native species are taken, though usually in small amounts. The maple-leaved viburnum (V'iburnum acerifolium), a woodland species, provided 74 fruits and seeds for one bird collected in Schoharie County (N.Y.) on October 5. The fruits of moisture-loving riburnums also are not overlooked, as is evidenced by a bird collected on December 28 from the Red River. a wilderness area in Hamilton County (N.Y.) which had swallowed 221 fruits of the withe-rod or buckbrush ( $V$. cassinoiles) The hrilliant red fruits of the highbush cranberry ( $V^{\prime}$.opulus) are but slightly less attractive to grouse. Two Adirondack birds, one killed October 29, the other a month later. had swallowed 57 and 83 of these fruits, respectively. A really ambitious bird, found near Elmira (N.Y.) on November 5, had managed to collect 20 red fruits of highbush cranberry, 42 blus fruits of arrow-wood ( $V$. dentatum), 25 brown beechnuts and nine other items.

The Maple Family. It is surprising "1" find the maple family (Aceraceae) important as a source of food largely in the summer. Then two of the smaller maples, mountain (Acer spicatum) and striped (A. pconsyleanicum). frequenters of the understory of the open woods. are sought for their fibrous-winged fruits. Those of the larger red maple (A. rubrum) are smmetimes eaten, but more often this species serses as a source of huds, a substantial numler of which are occasionally picked up. Buds of the well-known sugar maple (A. saccha. rum) rank well ahead of those of the other memlers of the family as a souree of food during the colder portions of the year.

The Composite Family. The largest family of flowering plants is the aster, or composite (Compositae). It is entirely logieal then that some members of this grouy should form an integral part of the grouse diet. From late fall to early spring the hirds find them a convenient source of leafy food, the most satisfactury heing the hawkerds (Ilieracium) and the pussy's.toes (Antennaria). Oceasionally a dried. long-dead leaf of goldenrod (Solidago) or aster (Aster) may he picked up. The fuzzy pappus-covered seeds characteristic of most 


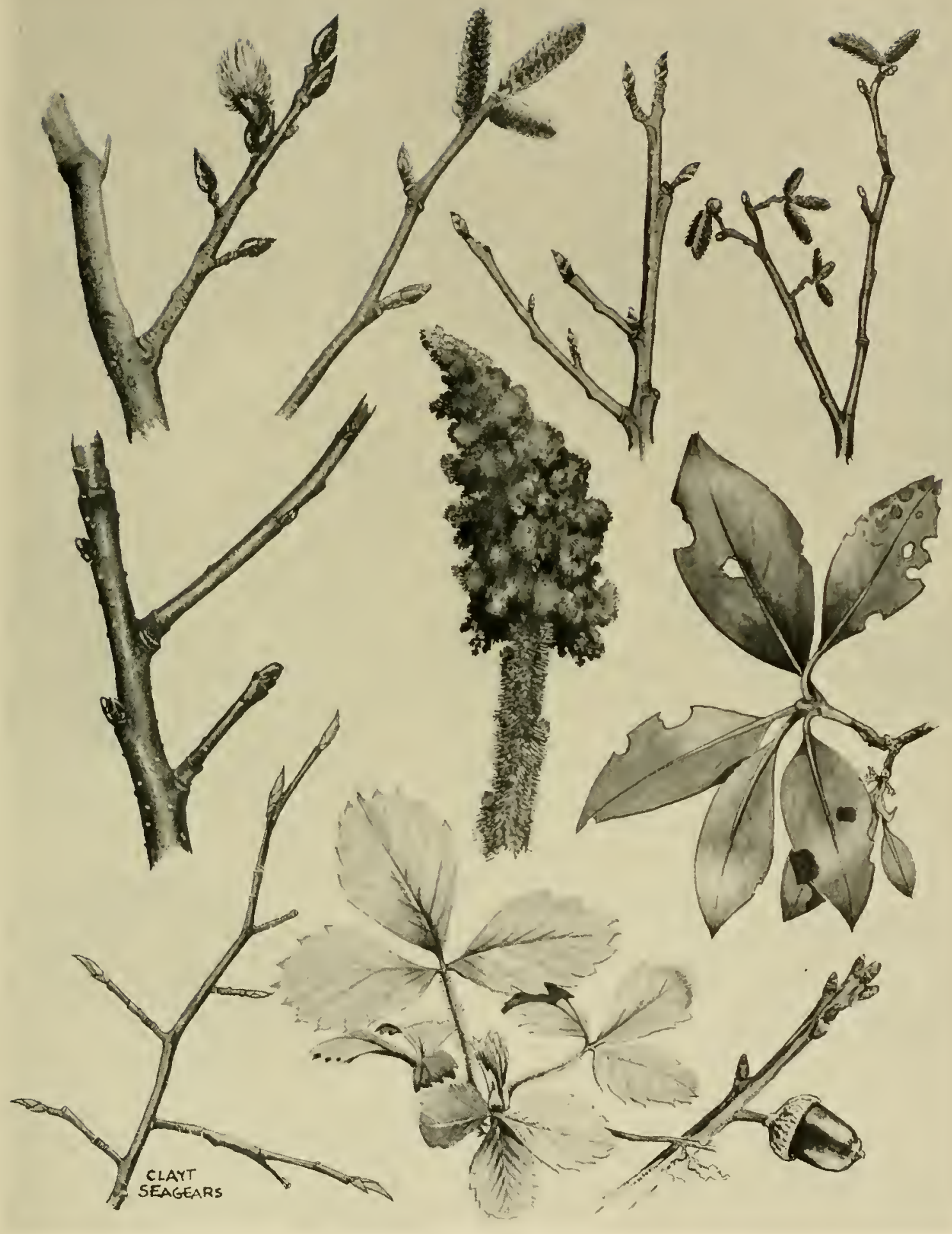

SPRING GROUSE FOODS
Trembling aspen Apple
Vellow birch
II ild black cherr Shodbush Staghorn sumach
Hop-hornbeam Laurel Red ook 
of the species of this fanily are rarely taken. The larger; more meaty seeds of ragweed (Ambrosia artemisiifolia), an cxcellent pheasant food in New York, provided an entire meal for one grouse, 1,525 being counted.

The Doguood Family. The dogwood family (Cornaceae) supplies fall foods chiefly, although leaves and buds from species belonging to it are taken on occasion at other times of the year. Fruits of this group furnisl the tenth ranking fall food, being taken consistently lut ustally in small amounts. Like the viburnums, dogwoods are largely pioneer shrubs. most common in bedgerows and forest edges, although some are to be found in the more open second-growth woodlands. The fruits of one of these, the bunchberry or dwarf cornel (Cornus canadensis) is readily taken. Throughout the State fruits of the panicled dogwood (C. paniculata) are the next most commonly sought food in the late fall and early winter. Unlike most dogwoods which drop their fruits early, thickets of this species oftlimes yield some seeds into March.

Only two records stand out with respect to quantity consumed. One is of an Adirondack bird which had picked up 182 fruits of that small conifer associate, the bunchlerry; the other is of a grouse from Delaware County, (N. Y.), which, on December 20, had eaten 226 of the light blue fruits of the much larger round-leaved dogwood (C. rugosa).

Though our New York records do not indicate it to be widely distributed or much taken. Weed and Dearborn ${ }^{338}$ believe that whencver the sour gum (Nyssa sylvalica), is common, its blue-black acid fruits are relished by grouse.

The Fern Family. Fern fiddleheads are among the signs of spring. Many of the species of the fern family (Polypodiaceae), in addition, stay green all winter. The grouse, seemingly always on the lookout for leafy items, manifest a peculiar liking for the late fronds of such species as the evergreen wood fems (Dryopteris spinulosa and D. marginalis). Such tough. leaved species as the Christmas fern (Polystichum acrostichoides) and the polypody (Polypodium virginianum) are also occasionally sampled. Only when matted down and covered up ly snow, do the grouse cease feeding on these, to return again as the evergreen fronds are revealed by winter thaws. As spring brings out the fern fiddles they, too, receive a share of attention. In fact, the wood ferns rate thirteenth in bulk among the foods of spring. fifteenth in fall, and thirteenth again in winter, a position of importance hitherto apparently unrealized.

The Buchwheal Family. 'Tasty leaves are supplied by the sheep sorrel (Rumex acetosella), a member of the buckwheat family (Polygonaceac). Though taken thronghont the year, they are of greatest importance in the spring, at which time they rank fourtecuth among the foods of that season. Unlike olher members of the family, the seeds are rarely touched.

The knotweeds (Polygonum), to the contrary, provide sects only. there heing no record of their leaves having been eaten. Taken usually in small amounts, remains of one or more seeds were found in 83 grouse.

The Saxifrage Family. To the list of early spring food sources should be added the members of the saxifrage fanily (Saxifragaceae). The foumfower (Tiarella cordifolia). the trim Bishop's cap (Mitella diphylla). and the saxifrages (Saxifraga) all contribute leafy louk to the diet. Few grouse stooped to the arduons task of picking the tiny sceds.

The Grape Family. In marked coutrast to the taste for grapes (Vitaceac) exhibited by grouse in some parts of their range. in New York they are taken in smaller quantitics than one might expect. Iargely because one species, the frost grape (Ititis vulpina) clings to the 


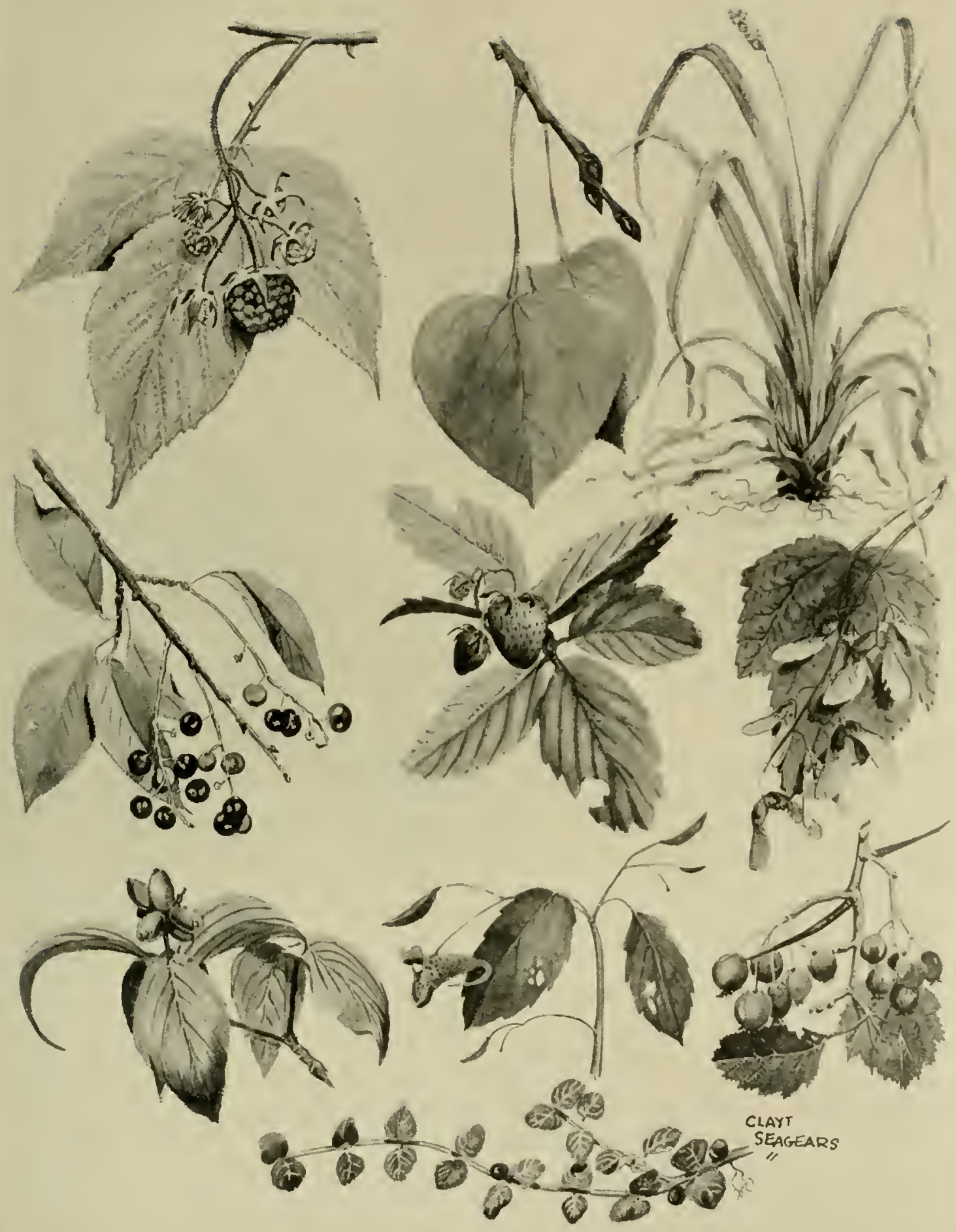

SUMMER GROLSE FOODS

Raspberr

Choke cherr

Dogwood
Trembling aspen

Strawberry

Jewel-weed

partridge-berry
Sedge

Yountain mavle

Thornapple 
vine long after fruits of other species have vanished, the family ranks eleventh on the list of inportant fall food producers. Only two birds consumed large amounts. One, shot October 18, had eaten $6+$ fruits of the frost grape along with 58 seeds of witeh-hazel (Hamamelis virginiana). Another, colleeted near Canandaigua in the dead of winter had a real feast. Counted in its erop and gizzard were 135 frost grapes, as well as seven other plants and four wasps.

Little attention is usually paid to the Virginia creeper (Parthenocissus quinquefolia) which may drop its smaller hlue berries from October till February.

The Grass Family. The seeds, and occasionally the blades, of grasses (Gramineae) are not overlooked. They supply nourishment largely during the summer months. Best liked are the manna grasses (Glyceria). Seeds of $G$. striala numbering 4,050 were found in the crop of one bird collected July 28. The reed canary grass (Phalaris arundinacea) also supplies seeds that are well received, as do the blue grasses (Poa). Blades of the latter are occasion. ally taken. In fact, grass blades furnish a sinall but constant source of food throughout the year.

The Butlercup Family. Much earlier in the season, perhaps in late spring or early summer, some of the better known spring flowers, belonging to the buttereup family (Ranunculaceae), come in for their share of attention, especially from the chicks. Seeds of the buttereups (Ramunculus) are prime favorites, while the leaves, flowers and sometimes the seeds of the liverleaf (Hepatica) and the dainty anemones (Anemone) are taken. In the swamps, under the hemlocks and along old stumps they find the goldthread (Coptis irifolia) and sample its seeds.

The Madder Family. There is one plant that has been so closely associated with the grouse as to be named after it - the partridge-berry (Milchella repens). It belongs to the madder family (Rubiaceae), of which the only other members known to he patronized are the bedstraws (Galium). The small evergreen leaves and pert twin berries certainly must he attractive, for one out of every five of the "patridges" examined had been feeding on the plant named after them, most frequently on the fruits. However, only small quantities seem to be taken at a time, and they fail to rank high as a source of food at any season except sum. mer. But in the minds of most old hunters partridge-herries and partridge woods are so closely associated as to halitat that the question of how much of the plant itself is really sought out is, after all, not of major inportance.

The Legume Family. Members of the legume fanily (Leguminosae) furnish some of our best bird feel. Where abundant, as on Michigan woods roads, white clover (Trifolium repens) is relished in the fall. The birds also take red clover ( $T$. pratense) when it occurs in their eoverts $^{325}$. Best liked of all the clovers $i n$ Wisconsin is the widely naturalized alsike $(T$. hy. bridum) which, according to Chaddock makes up 38 per cent of the fall food. The grouse, however, do not care much for the tick trefoils (Desmodium), the fruits of which often stick in the hunter's elothing. Likewise, the hard-shelled black locust (Robinia pseudo-acacia) seeds appear to be lut seldom eaten.

The Jerel-W'eed Family. Seeds, and rarely the leaves, of the touch-ne-not (Impatiens biflora) are the fourth most fawored August chick fool and rank eighth with the summer adults. They are members of the jewel-weed fanily (Balsaminaceae). found commonly on central and senthern New York's moist, shaly soils.

These, then, are the 20 most patronized plant families. But there are a number of others which under the right conditions may supply food more frequently than those of some higher 


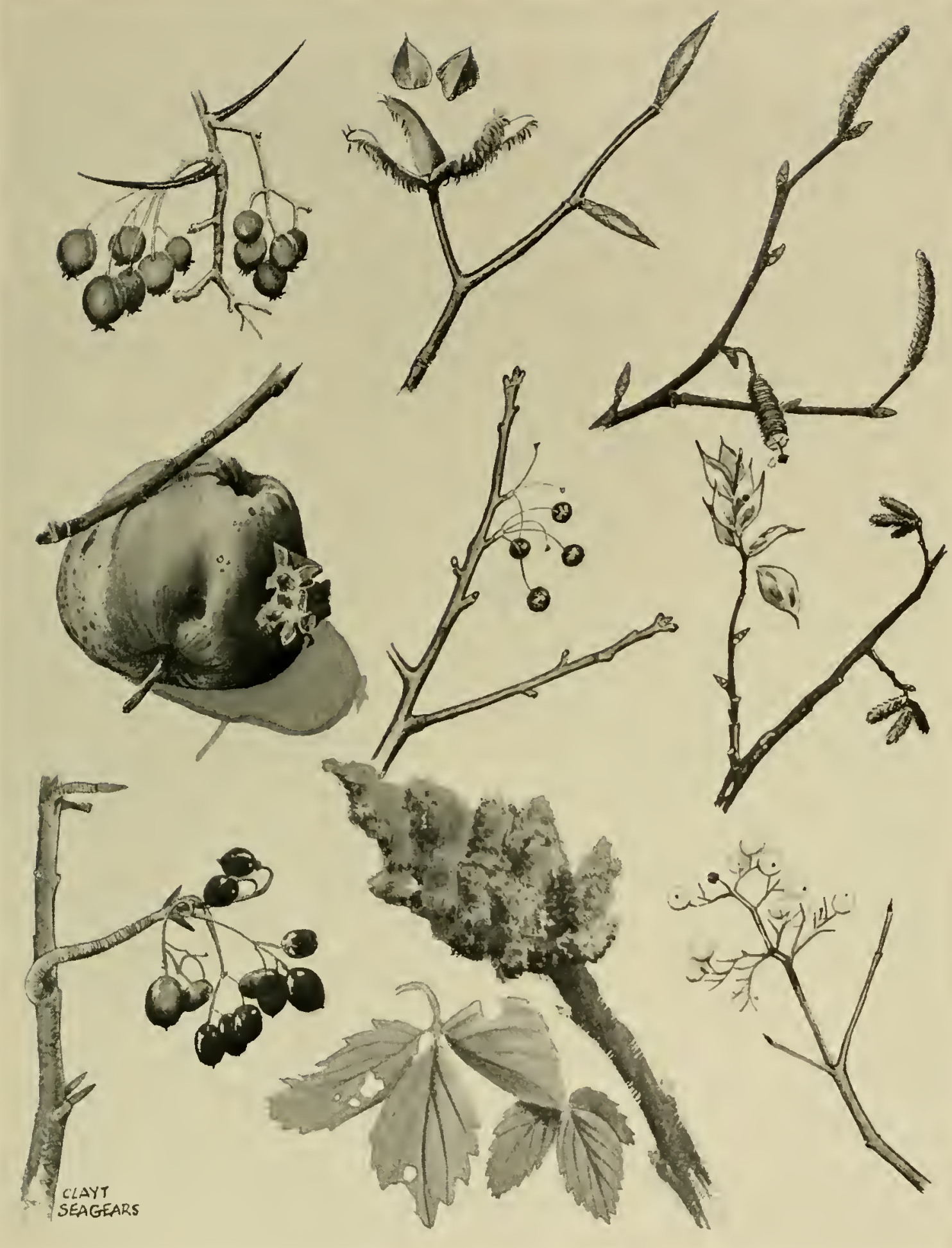

FALL GROUSE FOODS

Thornapple
Apple

l'iburnum
Beech

Pin cherry

Staghorn sumach
Yellow birch

Ilop-hornbeam

Dogwood 
in average rank. For example, leases. and to a lisser extent the small sreds, of wood sorrel (Oxalis), are taken throughout the year.

l'articularly favored hideaways of the grouse are bencath low-sweeping evergreen branches or well up in the crowns of pines, hemlocks or spruces. Here, particularly in winter, they pick an occasional needle or eren a bud or two. Now and then they may take a cropful, as did one Greene County (N. Y.) birl, which divided its attention on a late January day hetween white pine (l'inus Strobus) needles and thumapples. The needles are eaten consistently but in small quantities by grouse in captivity, either as a substitute for other greens or to furnish roughage. Curiously enough, pine seeds, though palatable to many birds and available in quantity every two or three years, are largely ignored.

Hemlock (Tsuga canadensis) needles likewise are eaten, though the seeds may he hetter liked, jutging from several records. One bird taken in the western Catskills, early in March laborivusly picked up 3,200 seeds and 138 needles. With little else to do from December to March, four other birds had each consumed on the day they were collected more than 1,000 seeds. the highest record heing 3,500 which still made up less than one-fourth of the erop contents. lneluded also were 241 huds of shadbush. as well as 566 buds and a large quan. lit) of the leaves of the laurel. In the Northwest, the gray ruffed grouse (B. u. umbelloides), though occasionally making a meal of spruce buds ${ }^{ \pm n}$, never feeds ujon them so extensively as does its near relative the spruce grouse (Canachites canadensis).

Perhaps because certain members are so generally distributed throughout the grouse woods of the Northeast, the lily family (Liliaceae) is worthy of mention. Certainly the 145 adults and 16 chicks that fed on the berries of the two-leaved Solomon's seal (Maianthemum canadense) found them useful. Farther south the fruits and the partly persistent leaves of greenbriers (Smilax) are sometimes important fall and winter foods ${ }^{2 \pi 6}$.

The seed-filled capsules of violets (Violaceac) are commonly taken by chicks, though the? are toro small to bulk large in the adult diet. The tender stalks of beechdrops (Epifagus virginiuna) are taken by adults in late summer and in the fall. They belong to the broomrape fanily (Orohanchaceae).

One hird started the New Year ly swallowing 18 of the thick-fleshed fruits of the skunk cabbage (Symplocarpus foetidus), an carly spring favorite of grouse and pheasants alike in low swampy gronuds. Allen found mulberies (Norus) to be much relished by young grouse rained in captivity. Mong with a host of other hirds, wild grouse also enjoy this fruit, particularly in the South. Loomis". writing of South Carolina "pheasants" says, "At this season (June) the mulberry trees are in fruit, and are much resorted to. Two of thesc Irees at the foot of Mt. Pinnacle were visited daily by pheasints during my stay."

Fruits of the bittersweet nightshade (Solanum Dulcamara) hang on well into the winter in many game coverts and are much liked hy pheasants. Dine mature grouse amd one chich samphed them. To one December hird from Oswego County (N.Y.) they must hase been really attrartive. for it had eaten in exress of 300 , as represented hy more than 3.000 rects in its giz. zard. Another red berry. hess noticed by grouse than one might expect. is the swamp-loving winterberry (llex verticillala). Though it is widely distributed and its searlet fruits persist until spring. only cight grousc hat sampled it, all in small quantities.

little mention has ben made of the various athivated grains. for grouse survive competently without them. In captivity litle difficulty is ancountered in teaching these hircts to eat rereats, including corn. wheat. oats and buckwheat. bxcept in cold weather when corn is a 


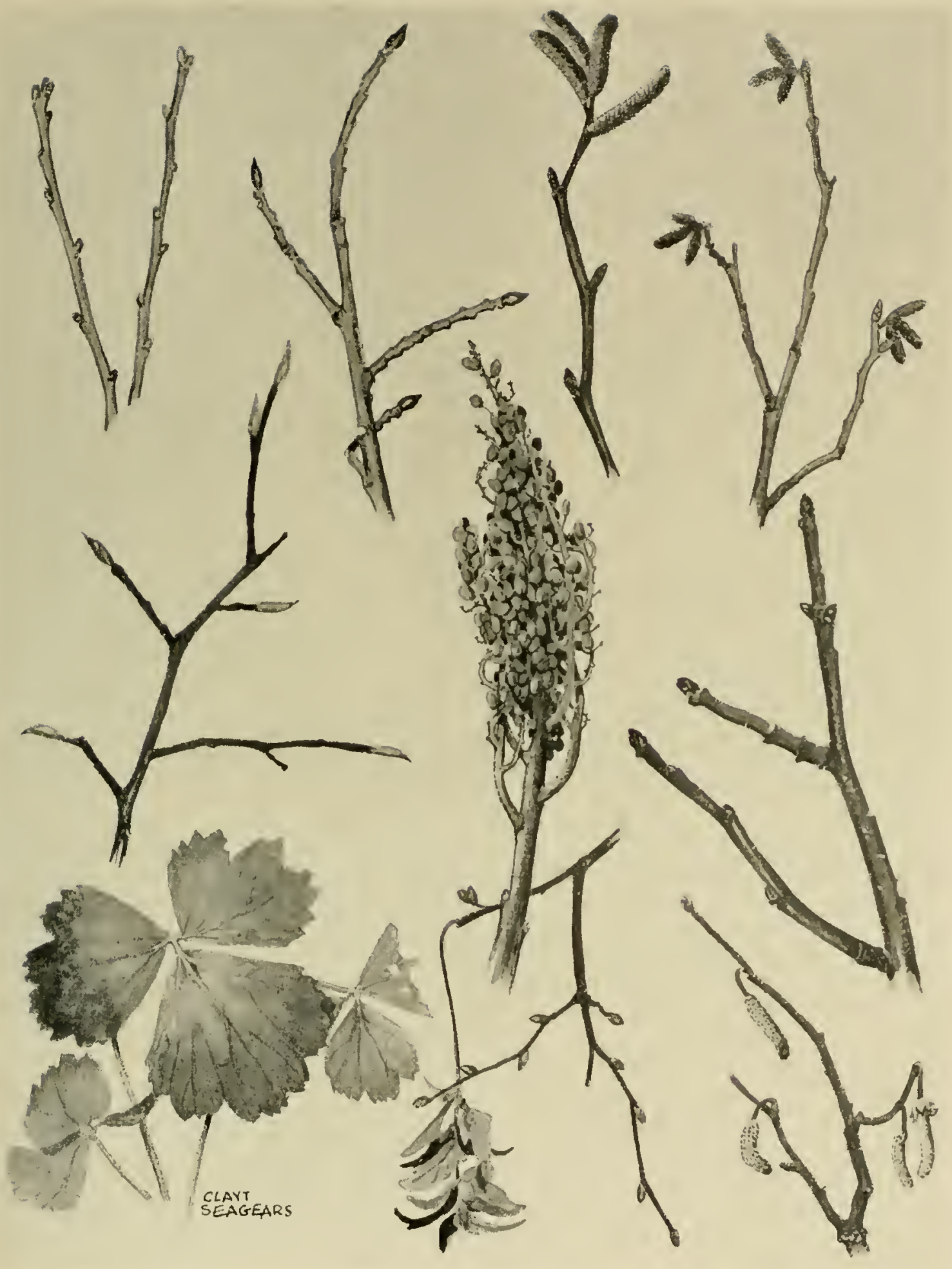

WINTER CROUSE FOOW

Cholie cherry

Shadbush

Barren strawberry
Trembling aspen Yellow birch

Smooth sumach

Hornberm
Ilop)-hormberm Apple
Ilazelnut 
favorite, burkwheat and wheat are generally best accepted, although individual grouse differ markedly in this respect. Oceasionally birds in the wild may pick up one or another of the cultivated grains. One lird consumed 123 kernels of corn, though from the location it is likely that the grain had been scattered as emergency feed for ring-necked pheasants. Eight other hirds each sampled a few kernels. Grinnell" mentions a "vivid recullection of a partridge which one winter could be started three times a day at the head of a small pond where corn had been scattered to attract hlack ducks". In the Wisconsin study of fall grouse foods. Chaddnck found corm. like clover. to be important.

Among the items. upon which, to our surprise. none of the 1,633 grouse examined had fed. are seeds of the ashes (Fraxinus). common trees of many northeastern habitats, and buds and fruits of sassafras (Sassafras variifolium), another locally abundant plant. The elms (Ulmus). among the producers of early flowers and fruits of spring, were generally disregarded, though one chick did sample a seed and a single adult the swelling buds. Alders (Alnus), also present in many grouse coverts, were largely ignored by the hirds. Only six grouse took sinall quantities of the seeds and wo others ate a few huds. That the hirds here draw a line is evident. but the reason therefor is not yet apparent.

\section{Animal Foods}

So far as bulk is concerned, animals supply a relatively small proportion of the normal grouse diet, outranking plants only in the first few weeks of the birds' existence. Consisting largely of insects and their relatives. they represent an amazing number of forms, seemingly limited largely by availability. Altogether 580 different identifications of animal fonds were obtained. Due to the mangled condition in which they were found in stomachs. many could not be determined as to species or even to genus. More than half again as many kinds of animals were noted as plants. hut despite numerical superiority they formed only 1.1 per cent of the diet (table 25). Distributed among 165 families, they represented 11 distinet classes. Few were of sufficient importance or taken with enough regularity; however. to warrant separate discussion.

Grouse undoubtedly render some service to man in the destruction of insect pests. Control of insect damage in grouse habitat is so difficult and costly that it is seldom attempted hy man. Hence, the frequent appearance of harmful species in the grouse diet, even though in small numbers, is worthy of mention. Such serious pests as saw-flies, weevils (such as strawherry weevils. the black vine weevil and the popular horer). leaf heetles (including the Colorado potato beetle, the curumber beetle and the elm leaf beetle), caterpillars (like the notorious cut-worms. maple-tree worms. canker-worms and apple-tree worms). and grasshoppers are all devoured. I'lant hugs and leaf-hoppers are also taken on orcasion**

Not only did the hirds as a whole take a wide variety of insects. lut individuals, particularly juveniles, often had picked up 20 or more different kinds in a single feeding period. One adult made a veritahle hiological survey of its habitat in Tompkins County (N.Y.) on June 21, in consuming 27 different animals and 17 species of plants. As is true with plants, a single species of animal may provide food in different forms; the immature as well as the adult stages of insects being taken. The egg sacs of spiders apparently are devoured when. ever discovered.

Ants, wasps. saw-flies and their relatives (Hymenopteral are among the best sources of animal food for gronse. Altogether $8 \mathrm{t}$ representatives of this group were identified, 
many, however, but once or twice during the lnvestigation.

Ants (Formicidae) were noted more frequently than any other kind of animal food. The large black carpenter ant (Camponotus herculeanus) was eaten by 327 chicks and 168 adults, the highest incidence for any one animal. These ants were equally popular throughout the State. although the number taken was not large. A bird from Delaware County (N.Y.) ate 19 and several others selected above 15, but fewer were usually taken. The little brown wood ants of the genus Myrmica were often eaten in great numbers. A chick, on July 15, picked up 208 at a single feeding. It, together with three others. all members of the same brood, accounted for 493 myrmicas. Ants of the genus Formica and the little brownish cornfield ant (Lasius niger) were also relished.

Saw-flies (Tenthredinidae) were the second hest-liked group of Hymenoptera, these woodland pests being taken by 139 chicks and 28 mature grouse. Both adults and larvae were avidly eaten, as many as 24 of the former being found in the last meal of a young bird from Sullivan County (N.Y.). Ichneumon-flies (Ichneumonidae) also are commonly eaten.

Beetles (Coleoptera) represented the most diversified food group, 228 different kinds being noted. Usually adults, hut ocrasionally larvae. and even eggs. are ingested. The stomach of one bird contained 300 heelle eggs. Ground inhabiting larvac, as wirc-worms (Elateridae) and May bectles (Ply.llophaga) are occasionally turned up and devoured. Adult beetles are usually taken one or two at a time. but some active chicks managed to corral as many as 15 or more of the same species. One from Jefferson County (N.Y.) had caten 18 strawberry weevils (Brachyrhimus rugifrons) and one from Allany County (N.Y.) 15 weevils of a (losely allied genus. Weevils (Curculionidae) are a usual source of ford to young and old alike. those of a single genus having been taken by 159 chicks. Grount beetles (Carabidae) and leaf beetles (Chrysomelidae) also were relished. Members of the genus Galerucella. American counterparts of the destructive European elm leaf heetle long estal,lished in this country. were frequently taken, as many as IJ heing found in a single stomach.

Moths and rarely butterflies (Lepidoptera), are eaten ly the grouse during their periods of availability. Larvac are preferred. Lut egros, cocoons and arlults are occasionally taken. The stomach of a very young bird collected on June 10 not far from lthaca contained 38 larvar. In a bird from Delaware County (N.Y.) 153 moth eggs were counted.

Grasshoppers and crickets (Orthoptera), alundant in late summer, provide a good source of bulk food. Judd ${ }^{212}$ reported grouse from New Hampshire, in September. 1898, as feeding extensively on grasshoppers. The remains of 15 red-legged grasshoppers (Melanoplus femur. rubrum) were present in the gizzard of a hird from the Sonthern Tier (N.Y.). This was one of 12 chicks collected there the first threc days of July which together had consumed 39 grasshoppers. As a group these 12 birds ate 243 insects of a number of different species in addition to 15,150 sceds. If that fairly represents one meal for a brood. the total food consumed during the entire summer must he stupendous. Ficld crickets (Gryllus assimilis) also apparently are fair game for the grouse. as many as 20 being found in a single hird.

Spiders and daddy long-legs (Arachnida) are eaten regularly, but rarely in quantity, evi. dently being taken in haphazard feeding rather than by persistent search. That they were found in almost two-thirds of all chick stomachs. however, testifies as to their acceptability. Stink-lugs of the genns (Euschistus) are more frequently taken than other true bugs (Hemiptera), and the scale insects and plant lice (Homoptera) also received some attention.

Snails are an occasional food. sometimes taken in large numbers. Almost the entire crop 
contents of a bird from Lewis County (N.I.) was supplied by 87 pond snails (Lymnaea col. umella). Most of the records, however, are of the common land forms found under dead leaves, in rotting logs and among other debris.

It is apparent from field observation that there exists at the time when most needed a wide variety in the seemingly unlimited supply of insect food. They are apparently most abundant in the cover types most commonly frequented by grouse in the late spring and summer. An intensive study of insect population by the sample plot method in each cover type represented on the Adirondack and the Connecticut Hill study areas was carried on in 1936. The investigation was repeated on the latter area the following year. In June 1936 the average number of insects available to grouse chicks was estimated at 326,000 per acre in the Adirondack study unit and 280,000 on Connecticut Hill. On the latter area at least 334.000 to the acre were believed to he present the following year. The increase was ascribed to a wetter sea. son. A more complete synopsis of the report on insect foods arailahle to grouse chicks is given in the Appendix (p. 775 ).

\section{Seasoval Differexces in Food Habits}

While seasonal differences in grouse food are sometimes marked, upon analysis they rarely have fundamental significance. Plant foods are dominant throughout the year if figure 16$)$. The

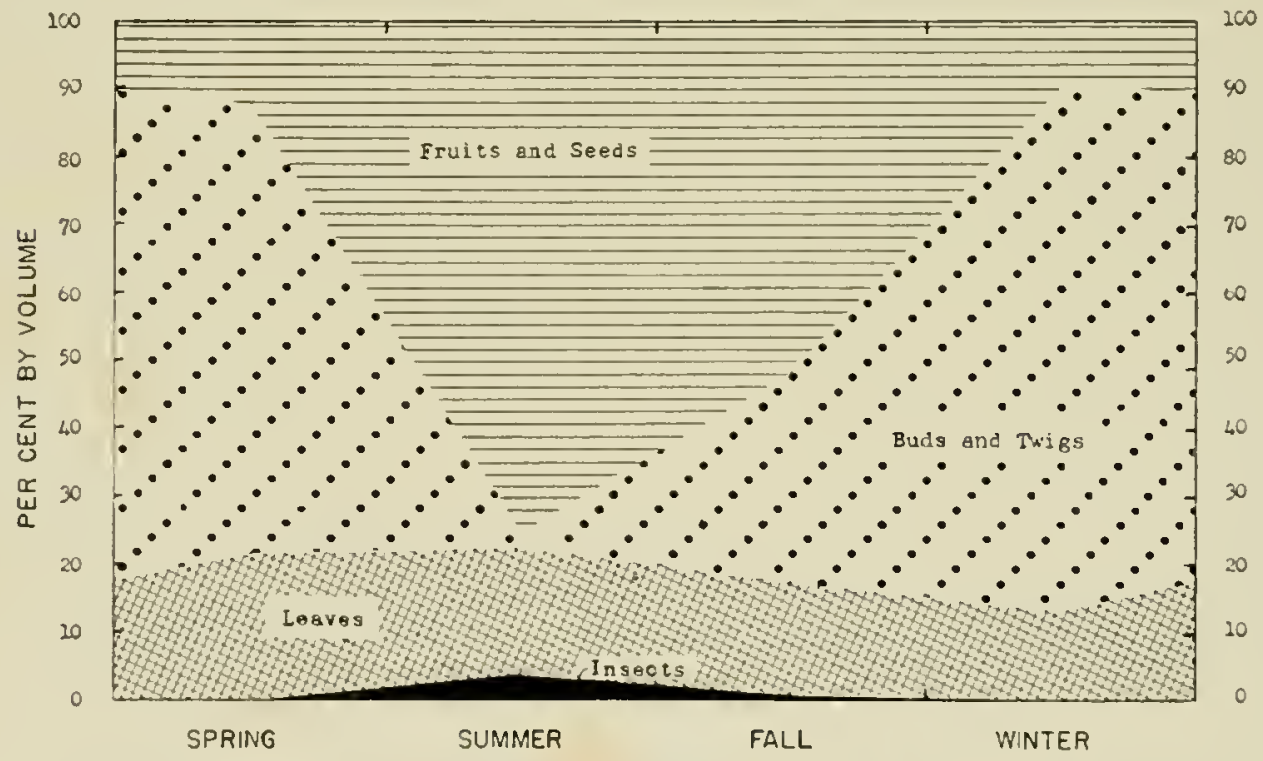

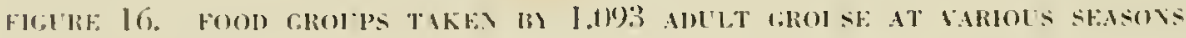

great lulk is produced. seawn by season. hy a lozen or so groups. such as the cherries, the aspens and the lowphornheam. One or another of the cherry species supply huds in the spring, fruits and seeds in the summer and fall. and buds again in the winter. From the hop. hornhean is laken an aloumlant supph of huds. I wiers and catkins throughout fall. winter and

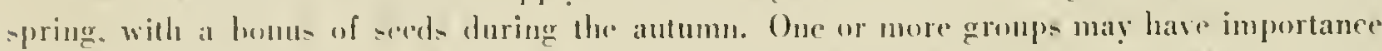
for a single s'asou. as the rasplerries in summer and the thornapples in the fall. No one. how rver, secms to ocrupt such a commanding position at any season that it elimination from the average rovert would reate a serionts food shorlige. 
The greatest variety of plant species is represented in the spring. Herbs, like insects, are taken largely in the summer. The pulpy fruits must be eaten in fall, as only a few of them hang on through the winter. Parts of broad-leaved evergreens are preferred to conifers in the late fall, winter and early spring, even though the birds are more apt to be feeding in the treetops. Buds are taken at all seasons of the year, though sparingly in summer.

It is reassuring to find a wide adaplability to various habitats among the foods most commonly chosen whatever the season may be. Except in deep shade and perhaps in heavily pastured or cultivated areas, a variety of habitually utilized species is usually to be found.

A seasonal listing of the ten most used groups of grouse foods is shown in table 27.

It is interesting to note in this list that only the cherries appear in all four seasons. Little attention is paid to the aspens in the fall or to the birches. hop-hornbeams, apples and sumachs in the summer. Strawberries are not usually accessible in New York in winter. No other groups appear among the first ten during more than two seasons out of the year.

Nevertheless, there are certain characteristics peculiar to each season which are worth noting. In spring the birds get their food largely from the woody species. As the snow melts they turn to last year's acorns and heechnuts that are exposed and to the large rar. iety of spring wildflowers that hecome avialahle. Fven in the presence of this fresh food

TABLE 27. THE TEN GROUPS OF PIANT FOODS MOST COMMONIA FATEY I3Y GIROISE:

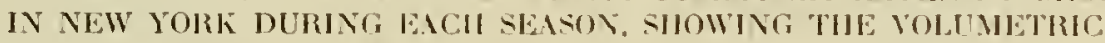
PERCENTAGES, IMPORTANT SPECIEN AND PARTS IATTEY

\begin{tabular}{|c|c|c|c|c|c|c|c|c|c|c|c|}
\hline \multicolumn{3}{|c|}{ Spring } & \multicolumn{3}{|c|}{ Summar } & \multicolumn{3}{|l|}{ Fnil } & \multicolumn{3}{|c|}{ Winter } \\
\hline Pant & $\begin{array}{l}\text { Volimire } \\
\text { fererent }\end{array}$ & $\begin{array}{l}\text { l'arts } \\
\text { eateil }\end{array}$ & Hiant & $\begin{array}{l}\text { Ioliame } \\
\text { pwer centit }\end{array}$ & $\begin{array}{l}\text { Piorts } \\
\text { ratent }\end{array}$ & ['lant & $\begin{array}{l}\text { Volumene } \\
\text { pherent }\end{array}$ & $\begin{array}{l}\text { l'arts } \\
\text { natenu }\end{array}$ & Plant & $\begin{array}{l}\text { Volumis } \\
\text { per cront }\end{array}$ & $\begin{array}{l}\text { Parte } \\
\text { eaten }\end{array}$ \\
\hline $\begin{array}{l}\text { Aspen* ...... } \\
\text { trembling } \\
\text { large-tonthed } \\
\text { J3ireh }\end{array}$ & 14.7 & $\ln u d x$ & $\begin{array}{l}\text { Blachlwrry aud } \\
\text { rospherrys. } \\
\text { Aspen........ } \\
\text { trembiliag }\end{array}$ & $\begin{array}{l}211.1 \\
11.1\end{array}$ & $\begin{array}{l}\text { fruits } \\
\text { Ienves }\end{array}$ & $\begin{array}{l}\text { Thurnapple. } \\
\text { Iberch.... } \\
\text { Birch. }\end{array}$ & $\begin{array}{r}11.8 \\
8.8 \\
-.8\end{array}$ & $\begin{array}{l}\text { Iruits } \\
\text { seends } \\
\text { burds }\end{array}$ & $\begin{array}{l}\text { Clierry.... } \\
\text { pin } \\
\text { black } \\
\text { clioke. }\end{array}$ & 17.6 & bust: \\
\hline $\begin{array}{l}\text { yellow } \\
\text { black } \\
\text { laper }\end{array}$ & III.. & catkius & $\begin{array}{l}\text { large-towiliod } \\
\text { Sindge" } \\
\text { gracefini }\end{array}$ & 8.6 & heods & 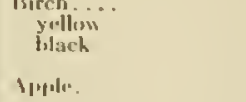 & 6. ${ }^{4}$ & busts & $\begin{array}{l}\text { Ispen } \\
\text { trembing } \\
\text { largre-trotlied }\end{array}$ & 16.1 & lurels \\
\hline $\begin{array}{l}\text { Cherry ....... } \\
\text { pin } \\
\text { hlack } \\
\text { choke. }\end{array}$ & 11.7 & busts & $\begin{array}{l}\text { stender-stalked } \\
\text { bladder } \\
\text { sichle } \\
\text { bristlo-stalked }\end{array}$ & & & Cherry. & 6.h & $\begin{array}{l}\text { fruits } \\
\text { fruit:. } \\
\text { hutls }\end{array}$ & $\begin{array}{l}\text { Ibirch....... } \\
\text { byllow } \\
\text { iblack }\end{array}$ & 13.7 & $\begin{array}{l}\text { luwl: } \\
\text { catkins }\end{array}$ \\
\hline Hop-horalneam & .3 .3 & $\begin{array}{l}\text { luds. } \\
\text { ratkins }\end{array}$ & $\begin{array}{l}\text { Lualo } \\
\text { Cherry.... }\end{array}$ & 8.2 & fruils & $\begin{array}{l}\text { inlach } \\
\text { chook. }\end{array}$ & & & [Iop-hormberaru & 11.2 & $\begin{array}{l}\text { Indky } \\
\text { catkins }\end{array}$ \\
\hline Ajphlis... & 3.4 & londs & bin & & & Ilop-liornlx'inus & 6.11 & $\begin{array}{l}\text { ludes } \\
\text { rilkins }\end{array}$ & Shodhuslis... & 3.8 & \\
\hline $\begin{array}{l}\text { Ainmach ... } \\
\text { staghurii } \\
\text { smenth } \\
\text { llwarl }\end{array}$ & 3.1 & fruits & $\begin{array}{l}\text { Strawlinery } \\
\text { Miple }\end{array}$ & $\begin{array}{l}7.6 \\
3.6\end{array}$ & $\begin{array}{l}\text { fruits } \\
\text { siseds }\end{array}$ & $\begin{array}{l}\text { I iburnum. . . . . . } \\
\text { highbusli cranterry } \\
\text { maple-leaverl } \\
\text { withe-rod }\end{array}$ & i.i. & iruits & $\begin{array}{l}\text { Simach.... } \\
\text { staghorn } \\
\text { smooth } \\
\text { dwarf }\end{array}$ & 3.6 & fruits \\
\hline $\begin{array}{l}\text { lanurel . . . . . } \\
\text { nountain }\end{array}$ & 31 & $\begin{array}{l}\text { leivers, } \\
\text { huds }\end{array}$ & $\begin{array}{l}\text { striped } \\
\text { mountain } \\
\text { red }\end{array}$ & & - & $\begin{array}{l}\text { Sitruwberty . . } \\
\text { Sinmoh. . . . . . }\end{array}$ & 3.5 & $\begin{array}{l}\text { lieaves } \\
\text { fruits }\end{array}$ & $\begin{array}{l}\text { Inple.......... } \\
\text { Bitrren slrawluerrs }\end{array}$ & $\begin{array}{l}3.3 \\
2.6\end{array}$ & $\begin{array}{l}\text { lumle } \\
\text { leaves }\end{array}$ \\
\hline $\begin{array}{l}\text { Shadibusha. } \\
\text { Strawherry . }\end{array}$ & $\begin{array}{l}3.6 \\
2.8\end{array}$ & $\begin{array}{l}\text { buats } \\
\text { loivices }\end{array}$ & $\begin{array}{l}\text { Dogwond ... } \\
\text { bunchberry } \\
\text { panicloed }\end{array}$ & $2 . .5$ & lenils & $\begin{array}{l}\text { Sumireh......... } \\
\text { staghinia } \\
\text { smorth }\end{array}$ & 3.3 & & $\begin{array}{l}\text { Jornheam } \\
\text { Arueriean }\end{array}$ & 2.3 & $\begin{array}{l}\text { seceds. } \\
\text { buids }\end{array}$ \\
\hline $\begin{array}{l}\text { ()ak } \\
\text { red } \\
\text { Jilach }\end{array}$ & 2.86 & $\begin{array}{l}\text { acorns, } \\
\text { tundis }\end{array}$ & 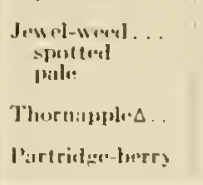 & $\begin{array}{l}2.2 \\
1.1\end{array}$ & $\begin{array}{l}\text { werels } \\
\text { fruits } \\
\text { fruits }\end{array}$ & $\begin{array}{l}\text { Dogwronl } \\
\text { bunchlorers } \\
\text { panicled } \\
\text { silky } \\
\text { rod omines }\end{array}$ & 3.0 & fruit, & $\begin{array}{c}\text { 11:uelnut } \\
\text { lreahod } \\
\text { Imerisoll }\end{array}$ & $2: 2$ & $\begin{array}{l}\text { busls. } \\
\text { catbias }\end{array}$ \\
\hline
\end{tabular}

* Stientific names will be found in tablo 173 in the Appendir. Aspecirs not ideutified. 


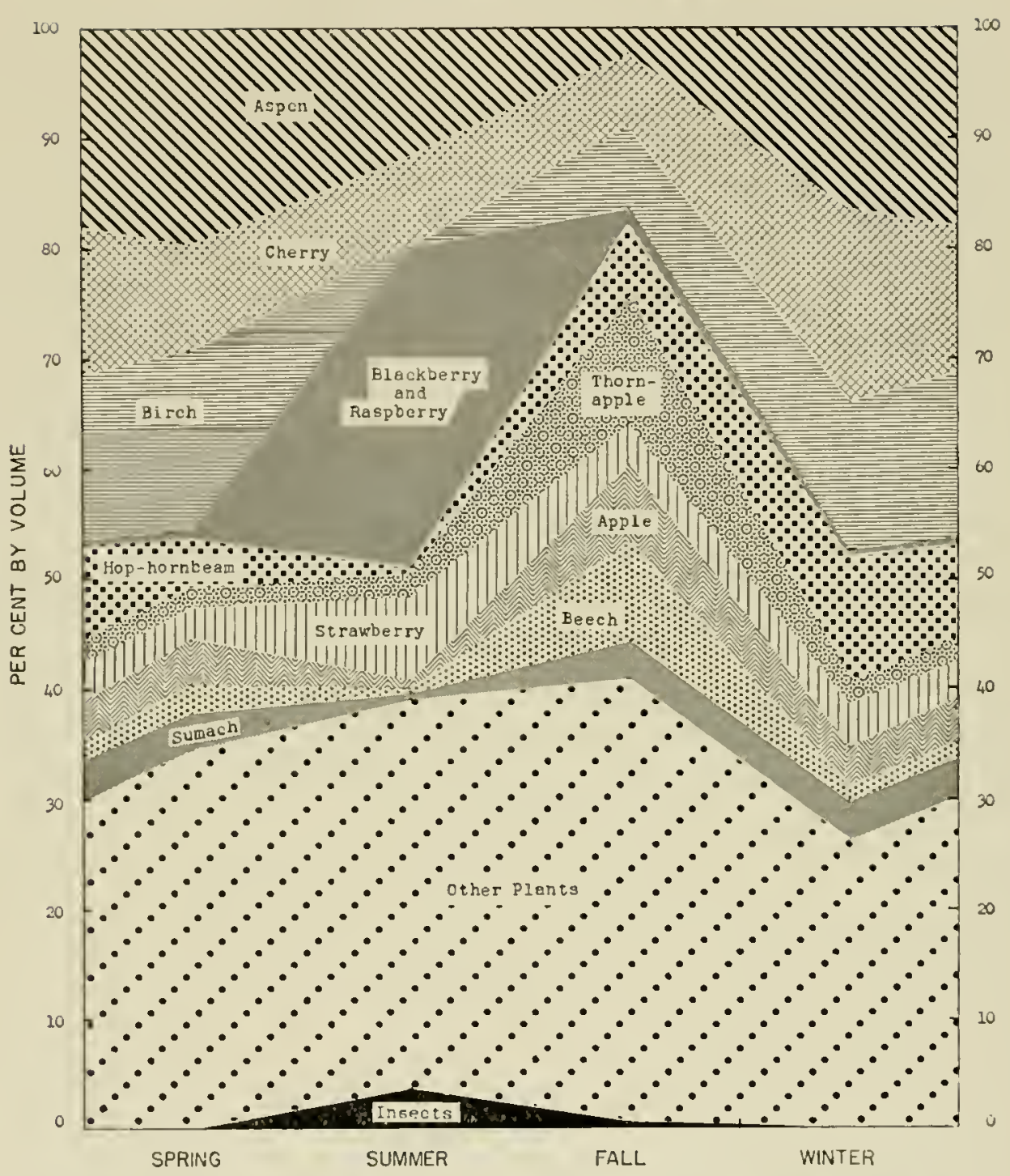

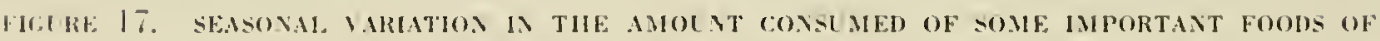
1.093 ADLT GROLE IY NEW YORK

-upply. bud and ratkins of wooly plants are still important ikems of food ifigure 17 .

The summer diet is one of great profusiun in which leaves and fruits predominate. In. sects at this season are everywhere available hut they do mot bulk large except in the food of the young rhick.

The fall is a time of fruit harest for the grouse with thormapples making the outstand. ine contribution. In autumu, too. mast is of real importanee. even though not regularly an ailahle every sear.

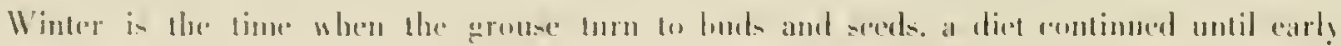
-pring. 


\section{Regional Variations in Foods Eaten}

A grouse, could it traverse all the wild lands of New York State, would find a great rar. iety of habitats. The partly sandy, partly granitic Adirondack Mountain region contains coverts in many essentials representative of much ruffed grouse range in the Northeast. The high-domed, sedimentary-rocked Catskill Nountains in the warmer southeastern part present an equally distinct set of conditions, in many respects comparable to those of portions of the Appalachians. The surrounding regions, together with the Allegheny Plateau. stretching westward across the southern and southwestern part of the State, represent a third type of habitat distinct from the others in important respeets".

The variations (table 28 ) between the plant foods that the grouse take in these three regions, even at the same season of the year. are rather surprising. Differences in weather and in plant distribution. of course. play their part. but it is not always easy to ascribe all the shifts in preference to these faetors alone.

However, the grouse show a distinct tendency to concentrate their feeding on certain favorites at each season. These are largely the same throughout the State, except in the Catskilts. This difference is puzzling. for the most-used groups, the poplars. hirches. thorn. apples and hop-hombeams, are weli distributed throughout all three regions. A partial explanation for a dietary difference in the Adirondacks may lie in the fact that deep snow covers most of the low-growing fond throughout the winter and well into the spring. The birds are accordingly forced to concentrate on the huds of a comparatively few species. The same situation holds to a lesser extent throughout the State. though this influence is offset in most regions by an parlier spring.

In the Adirondacks 89.7 per cent of the fourt in winter, and 86.7 per cent in spring. is provided by the ten most-used gronpss of plants whereas in the Catskils but 60.7 per cent uf the winter foost and 78.6 per cent of that of spring comes from these same sources.

The prevalence of a food species in a habitat is not always an indication of its use ing grouse. For instance, in the Catskills in winter. the bop-hornbeam is the most sought after species. with the aspens rating a poor eighth. But in the spring that follows. the situation is essentially reversed, with the poplars first in importance and the hop-hornbeams fifth. Contrast this with the record from the rest of the State, where in both winter and spring poplar luds seen to he chosen in preference to hop-hornhean huds and calkins. Both species are common. Fach rates among the first four chosen at some period of the year in each region. Many such inconsistencies of choice are funnd hetween the regions. but by no means are all of these explainable on the basis of food arailability. Perhajs a larger number of hirds needs to be examined.

In general, the products of poplars. birches and thomapples are unisersally preferred. Cherries, though equally well distributed. are apparently budded mostly in the spring in the Adirondacks. Here snow may remain until ver! late. Likewise its disappearance in the Catskills and wer the rest of the State. early in the season may account for the comparative importance of strawberr! leaves there.

Sumachs are not so widely distributerl in the Adirondacks, but in the Catskills and throughout the rest of the state there seems to exist an interesting relation between them and the beeches. for when heeches butk high as a source of food. sumachs do not and vice versa. Even so the rhoice is not always predictable. In the Catskills sumach is one of the important 
spring foods. ranking sixth while beech is twenty-seventh. whereas over the rest of the State luring the same season heerh is third and sumach a poor eleventh.

Broad-leaved evergreens are supplied largely by the wood fern except in the Catskills where mountain laurel is frequently taken. In the Adirondacks, partridge-berry, hawkweed and wood sorrel also are used to some extent.

There are few significant differences hetween animal items taken in the three regions at any season of the year.

TABLE 28. REGIONAI, VATIATION IN TIIE TEN MOST IMPORTANT PLANT FOODS OF ADUIT GROUSE FOR EACH SEASON-NEW YORK

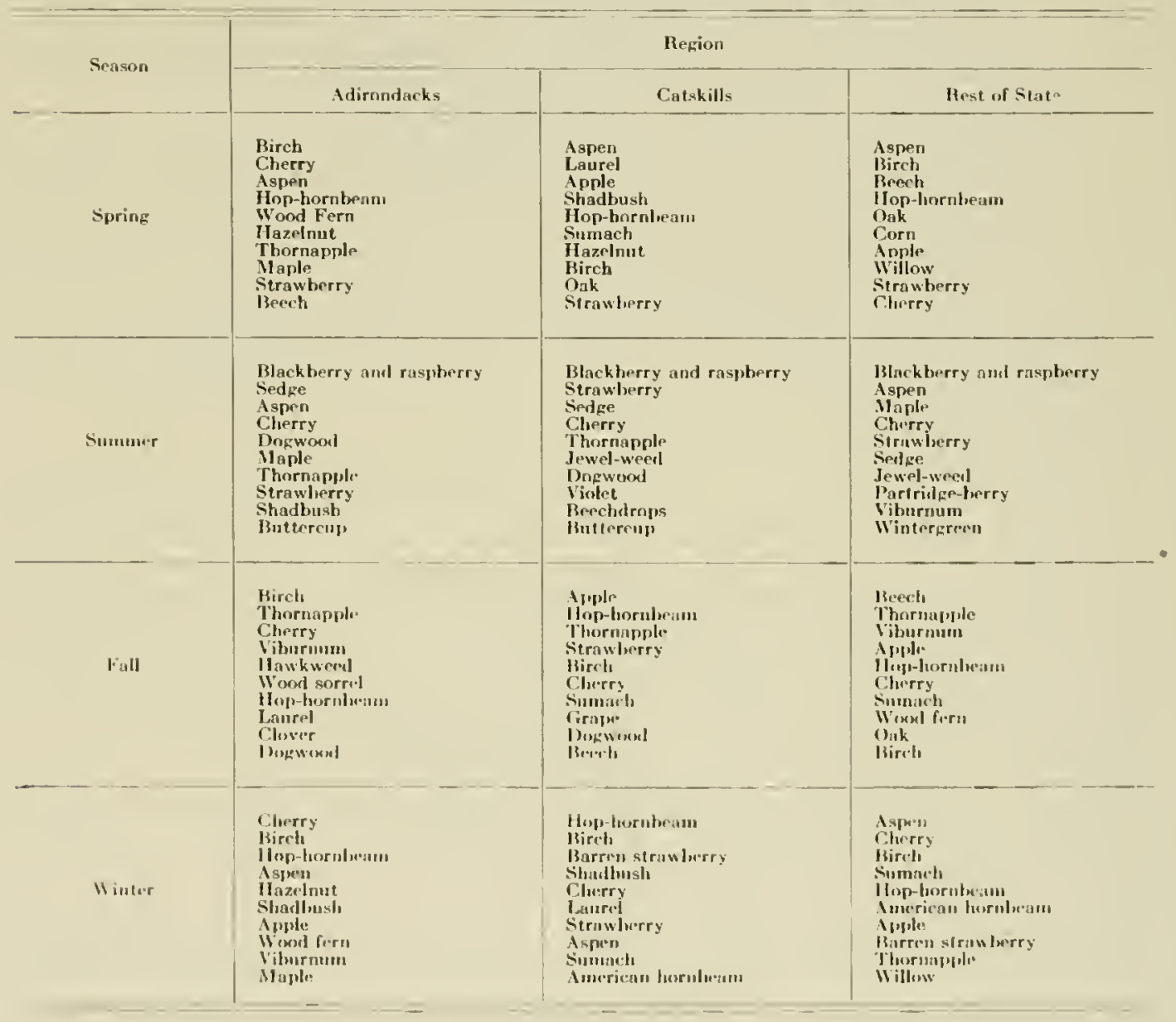

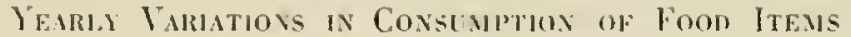

I comparion of the foods taken ly grouse over an Il-year perion brings lo light some interesting inconsistencies (table 29). In glancing ower this table, one might conclude that the birds exhibit little continuity of taste year h! yar. This is especially puzzling when the parts eaten are largely lud- or eatkins. as in the aspens and the hop-hornbeam, the quantities of which, availahle year ly year, apparntly are much the same. Another group iu 
which buds and catkins are also the chief parts eaten is utilized fairly consistently. In this are found the birches and maples. Then there is a third group, largely fruit-producers, such as cherries, sumachs, strawberries, sedges and blackberries, which exhibit inconsistent and substantial fluctuations in use by grouse over the 11 years.

TABIE 29. YEARLY VARIATIONS IN PERCENTAGL BULK OF IMPORTANT FOUD PLANTS OF ADULT GROUSE IN NEW IORK IN COMPARISON IVITH TIE 11 Y'EAR AVERAGE

\begin{tabular}{|c|c|c|c|c|c|c|c|c|c|c|}
\hline \multirow{2}{*}{ Fouds } & \multicolumn{10}{|c|}{ lears } \\
\hline & $\begin{array}{c}\text { Average } \\
1931-1911 \\
\end{array}$ & $1931-32 *$ & 1933 & 1931 & 1935 & 1936 & $1937-38 *$ & 1939 & 1910 & 19.11 \\
\hline Aspen.......... . & 12.1 & 1.6 & 15.3 & 13.0 & 17.3 & 83.5 & 6.7 & 6.5 & 22.4 & 25.9 \\
\hline Cherry........... & 10.6 & $\pi 1$ & 10.0 & 0.6 & 17.7 & 12.1 & 6.88 & 6.1 & 20.1 & 8.7 \\
\hline Birch............. & 9.2 & 11.9 & 11.6 & 10.8 & $11, .5$ & 13.6 & 17.8 & 11.7 & 9.1 & 111.3 \\
\hline Raspberry, etc. & 8.4 & 1.5 & 3.9 & 2.8 & 1.6 & 3.5 & 1.1 & 13.1 & 19 & 8.8 \\
\hline Ilop-bornbeun & 5.7 & 12.7 & 7.6 & 9.2 & 1.7 & 10.1 & 10.0 & 6.3 & 10.7 & 7.0 \\
\hline Thoroapple. & 1.5 & 9.9 & 3.1 & 2.8 & 1.1 & 3.11 & 5.2 & 4.9 & 1.2 & 1.2 \\
\hline Strawberry.... & 3.8 & $3 . i$ & 2.9 & 1.0 & 3.3 & 2.5 & 2.8 & i. 1 & 2.1 & $0 . \bar{\imath}$ \\
\hline Apple......... & 3.6 & 1.2 & $\because .9$ & $1 . .8$ & 6.5 & 3.1 & 0.6 & 2.3 & 0.9 & 0.2 \\
\hline iseech........ & 3.1 & 0.8 & 0.1 & 8.3 & 1.9 & 0.2 & 8.5 & 3.2 & 2.5 & 1.0 \\
\hline Sumach. & 2.7 & 2.1 & 3.3 & 11.7 & 1.3 & 1.0 & 2.6 & 3.8 & 2.1 & 2.2 \\
\hline Shadbush & 2.5 & $\ldots$. & 1 & 2.0 & $(.1)$ & 11 & 1.3 & 1.11 & 2.1 & 3.1 \\
\hline Sedge.... & 2.3 & 0.2 & 11.7 & 11.2 & 0.1 & 0.3 & 0.8 & 1.2 & 31 & 1.9 \\
\hline Viburoum & 2.11 & 0.9 & 0.2 & 2.0 & 2.1 & 0.1 & 5.2 & 11.2 & 2.3 & 01.5 \\
\hline Maple.... . & 2.11 & 1.1 & 1.1 & 1.1 & $0 .$. & 0.7 & 0.5 & 0.7 & 3.6 & 3,0 \\
\hline Dugwood... & 1.0 & 2.13 & 2.2 & 1.0 & 1.2 & 0.1 & 1.6 & 0.8 & 0.6 & 3.8 \\
\hline All other foids... & $\geq 1.8$ & 336.6 & .31 .5 & 31.2 & 22.1 & 33.0 & 28.5 & 2.2 .2 & $\because 9$ & 21.1 \\
\hline No. birds examined. & 1,043 & 31 & c) 1 & 101 & $30=3$ & 111 & $9 i$ & 88 & $\pi$ & 57 \\
\hline
\end{tabular}

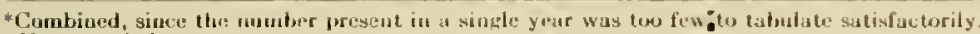
1 Not recorded.

Reasons for these variations are interesting but certainly still conjectural. I'recipitation and temperature conditions are probably basically responsible for fluctuations in the abun. dance of many fruits. A shift in the carbon-nitrogen relationship is said to control a cyele of approximately three years in the occurrence of beech mast. In years of plenty, the nuts are eaten in large quantities, their very size being conducive to their bulking large in the birds' diet. In non-beechnut years, however, the grouse fall back on other sources of food, notably sumach, thornapple, cherry and aspen. In each of the years studied, the bulk supplied by all four of these groups together was very similar. In 1934 the consmmption of hechnuts was about three times that of the subsequent two years, and products of the other three species were eaten correspondingly less that year.

As yet there is no satisfactory explanation for the yearly changes in consumption of the always available buds. Though the study should be continued over a much longer period before all conelusions can be stated with eertainty, it seems clear that ehanges in utilization are many times dictated not by availability, but rather by some other factor not yet apparent.

One has but to compare the 11-year average with that for any one of the individual years to raise the question as to the degree of importance to be assigned to studies covering short periods. The bulk of many of the foods taken in any of the 11 years here compared shows wide variations from the 11 -year average. Deviations too large to be ignored are likely to be obtained by drawing conclusions on the volumes taken over short periods, unless one is in. terested primarily in obtaining a mere list of foods and a rough indication of the extent to which they are utilized. The degree of reliance that one may place on such generalities is indi. cated by the fact that, of the five genera taken in greatest volume over an 11-year period, in only four years were the same five at the head of the list, and even then the order was shifted in each case. In 1934, 1935 and again in 1939 but three of the group were among the first five. 
The variety of choice also differs markedly. On an average. the 15 most used foods supplied a little over three-fourths of the volume of all food eaten. From 1931 through 1934 they dropped to less than two-thirds. while in 1940 they provided the astonishing amount of 92 per cent of the bulk for that year. Food from the birches was found most consistently. while the volume of aspen taken varied all the way from 1.6 to 25.9 per cent.

\section{Variations ix Diet Tirovghout the Raxee}

No matter how carefully food habits research may be carried on in one region. much can be learned ly comparing the results with those oltained elsewhere. This is not always possille, however. for records are occasionally gathered without reference to age of the birds or sea-

\section{TABLE 30. A COMPARISON OF TIE VOLUMETRIC PERCENTAGES OF FILL HOODS CIHOSEN BY ADULT GROUSE IN NEW YORK WITI THAT REPORTED FROM OTIER PARTS OF ITS RANGE*}

\begin{tabular}{|c|c|c|c|c|c|}
\hline \multirow[b]{2}{*}{ Foods } & \multicolumn{5}{|c|}{ Hegions } \\
\hline & $\begin{array}{c}\text { New YorkJ } \\
\text { (Bumy d Jones) }\end{array}$ & $\begin{array}{c}\text { New Iinglaus } \\
\text { (Iiroks) }\end{array}$ & $\begin{array}{c}\text { Pennosylvania } \\
\text { (Kuftu) }\end{array}$ & $\begin{array}{c}\text { Virginiat } \\
\text { (Aelsut et al) }\end{array}$ & $\begin{array}{l}\text { Wisconsin } \\
\text { (Chudlluck) }\end{array}$ \\
\hline 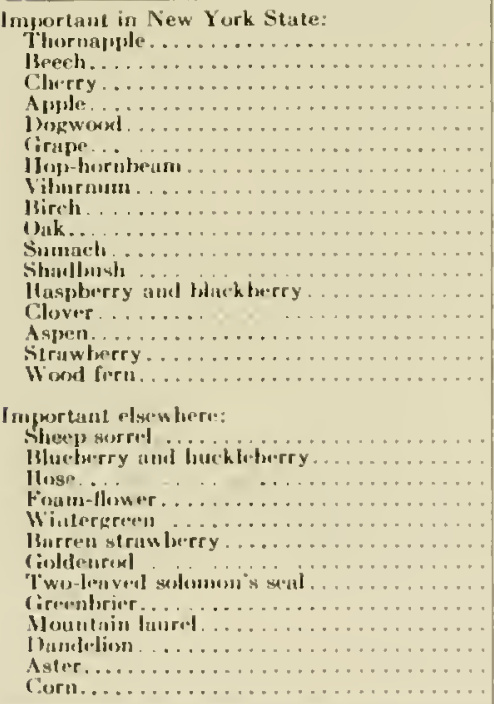 & $\begin{array}{l}15.9 \\
10.3 \\
6.1 \\
1.6 \\
4.5 \\
1.2 \\
3.4 \\
3.8 \\
3.3 \\
3.1 \\
3.1 \\
2.1 \\
2.3 \\
1.0 \\
1.8 \\
1.7 \\
1.2\end{array}$ & $\begin{array}{l}7.3 \\
0.9 \\
3.7 \\
5.3 \\
1.7 \\
5.7 \\
0.6 \\
2.5 \\
2.2 \\
11.6 \\
2.8 \\
1.0 \\
1.4 \\
2.4 \\
3.11 \\
0.8 \\
0.6\end{array}$ & $\begin{array}{c}\text { tracet } \\
31.6 \\
11.8 \\
2.0 \\
4.1 \\
3.2 \\
0.5 \\
7.1 \\
4.0 \\
1.5 \\
1.0 \\
2.3 \\
0.0 \\
0.1 \\
1.1 \\
1.4\end{array}$ & 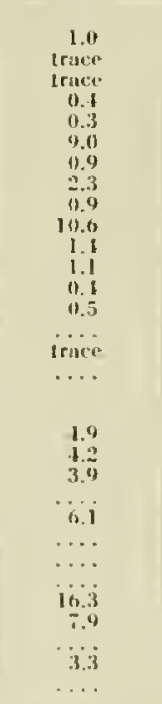 & $\begin{array}{l}2.1 \\
0.3 \\
0.5 \\
\ldots \ldots \\
\cdots \\
0.5 \\
1.5 \\
0.6 \\
\ldots \\
13.1 \\
\cdots \\
\ldots .2\end{array}$ \\
\hline
\end{tabular}

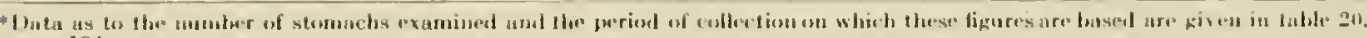

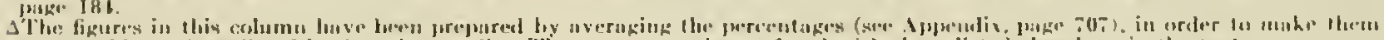

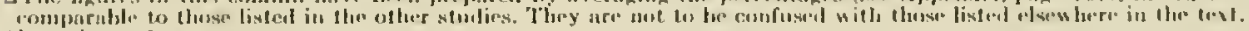
IAss than 0.1 in.t rent.

+Not reverderl.

sonal differences. No stamlard method of presenting the results has becn andopted. Studies of speeimens sufficient in number to warrent comparisons hase been made in other parts of the grouse range for only the fall months. To facilitate analysis. talse 30 lists the most important (by loulk) fall foods of New York gronse. together with those most outstanding in four other regions.

As one studies this table the farts derivel therefrom are reassuring. Foods much sought in one part are likely to he taken by grouse in other parts of the range. Variations in ineidenes and in lulk consumed are su wide. however, even between adjoining regions. as to make it inpractical to apply strictly fo other regions contusions valid in any one section. The reason 
for this may possibly be found in the variation in abundance and availability of foods or in the presence or absence of highly desirable substitutes. Thus one finds that thornapples, inportant in New England and New York, apparently are not much taken according to Pennsylvania reports. Conversely, in the states to the soutl of New York, where oak (particularly serub) is more ahundant. acorns are commonly preferred to beechmuts, which with us are a much more important food. Even such stand-bys as the cherries lose their significance in Virginia and Wisconsin and are replaced by greenbrier and elover, botls of which while pre. sent are taken to only a limited degree in New York.

There is real significance in the number of widely distributed plants, which for one reason or another rank high as grouse foods in various regions. Ihysiologically and psychologically. the grouse seems well able to adapt itself to a wide varicty of foods.

\section{FOOD OF THE YOUAG}

Variations in the food of chicks over the summer months is purtrayed in figure 18 . N1. though, when adult. the grouse is primarily a plant eater, a striking characteristic of its food habits is the reliance of the chicks upon inserts during the first week or ten days of their existence. Analysis of the food of 540 specimens, representing the brood period, indicates that 70 per cent of the food of the first two weeks is insects. in contrast to 30 per cent during the third and fourth weeks. By August the proportion has drupped to only 5 per cent.

Possibly attracted by movenent. the ehick mas take an ant or a spider a- its first morsel of food. These are likely to be picked "u within three to six burs after hatching. Ants remain the most common insect foud for several months.

As the rhieks mature, their utilization of plant foods increases markedly. until ly the end of August it approaches that of adults.

During the summer it is normal lor crops to be filled with a mixture of plant and animal material. Only nine birds were collected. all before the 15 th of June. Which had fed exclusively on insects. In contrast. seven had fed on plant material alone and 6.5 others contained only a trace of animal matter. None of these vegetarians were collected before the middle of June, and more than one-half were taken during dugust.

As the chicks turn their attention to plants, a tendency to sample man! kinds hut to concentrate on a few hecomes apparent. Sedge seeds together with strawberries make up 26.5 per cent of the June plant foods and with hlackherries 58.5 per cent of the July fare. In August dependence on staples is still more pronounced. blackberries and cherries constituting 65 per cent of all plant food. At this time of year they pay more altention to herbs, such as violets, and to smaller seeds, as those of sedges, than do the adults. but even young chicks will occasionally take items more characteristic of the food of their parents. Thus, a chick taken July 6, had eaten four whole oak buds and the remains of several others were in its stomach. Chicks like the adults sometimes take a considerable variety. as indicated by a late July lird from Essex County which had eaten 1.500 sedge seeds. 4 capsules and 637 seeds of violets. eight fruits of pin cherry. five of viburnum and a few seeds of 11 wher speries of plants. as well as a snail and 11 different kinds of insects.

\section{Principal Chick Foods}

Among the plants the really important sources of food for young grouse are sedges, raspherries and blackberries, strawherries and cherries. Apparently patronage of these four 
groups rises in direct proportion to the dechinc in insect food taken. Throughout the entire summer and orer the whole State, only three other food-producers (buttercups, violets and shadbush) contribute more than 3.0 per cent for any one month, though locally others nay be farored.

Based on the species which could he recognized, seeds of at least 36 kinds of sedges were picked up ly chicks. Some of these occurred but once or twice, but several appeared rath. er regularly. Achenes of the slender-stalked sedge (Carex debilis var. rudgei) were identified from 81 stomachs. This species is common in woods, thickets and moist openings, particularly in the Adirondack region. The seeds of the bladder sedge ( $C$. intumescens) were picked up by 35 chicks. These are the largest seeds of the New York sedges, being about the same size as those of pin cherries. Perhajs because of this, rarely more than ten to 20 were taken at a meal. The small triangular seeds of the green sedge ( $C$. viridula) were found in 26 stomachs and the flat lenticular grains of the graceful sedge $(C$. gracillima) in 26. Those of the former were rarely taken in large quantities, but 1,200 seeds of the latter, along with 400 seeds of the slender-stalked sedge, were identified from one Adirondack chick collected July 16.

Remains of raspberries and blackberries were found in 395 of the 540 chick stomachs examined. Not only were they taken frequently but often in large quantities. With one exception, where a few leaves were sampled only, the fruit was eaten.

Strawberry plants are sought as long as they are fruiting, but the leaves are seldom eaten. Evidences of strawherries were found in 212 chick stomachs, occasionally in great quantity. A Chenango County (N.Y.) bird collected on July 2, had eaten two whole fruits and enough more to furnish 1,825 seeds.

Other plant products to which the young tum their attention are those of buttercups and the partridge-berries in June, fruits of shadbush and red-berried elder and maple keys in July: and later the seeds of jewel-weeds and smartweeds and the fruits of dogwoods. Red berries of the American yew, thornapples, blueberries and seeds of witch-hazcl may hocome locally important. Bluelerries are popularly considered very acceptable to gronse, but according to the fundings they do not constitute more than 1.4 per cent of the bulk of the food of either chicks or adults during any month. They are taken rather frequently but rarely in quantity, for though caten by one ont of every ten chicks in August, neither pulp nor seeds were prominent either in the crops or the gizzards.

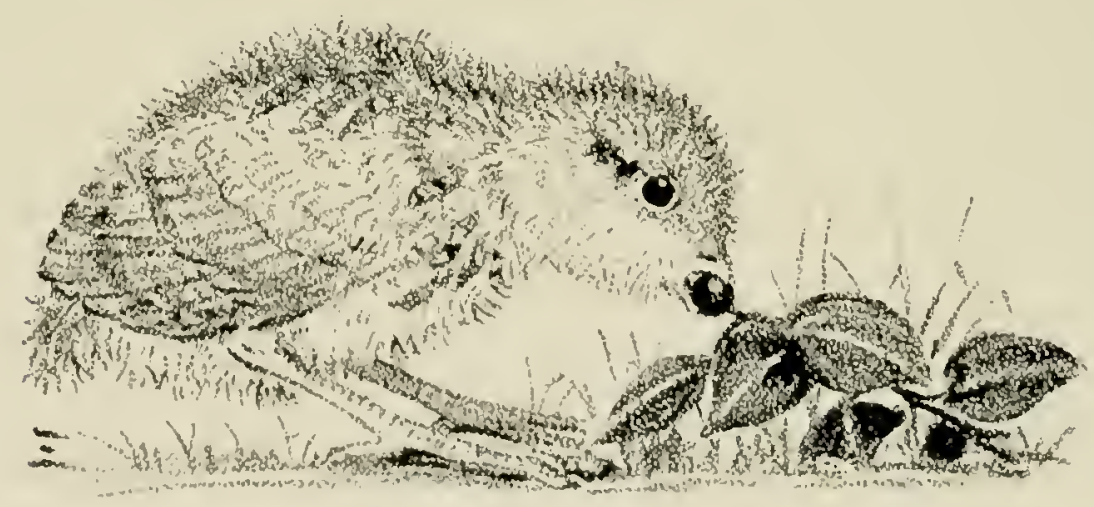




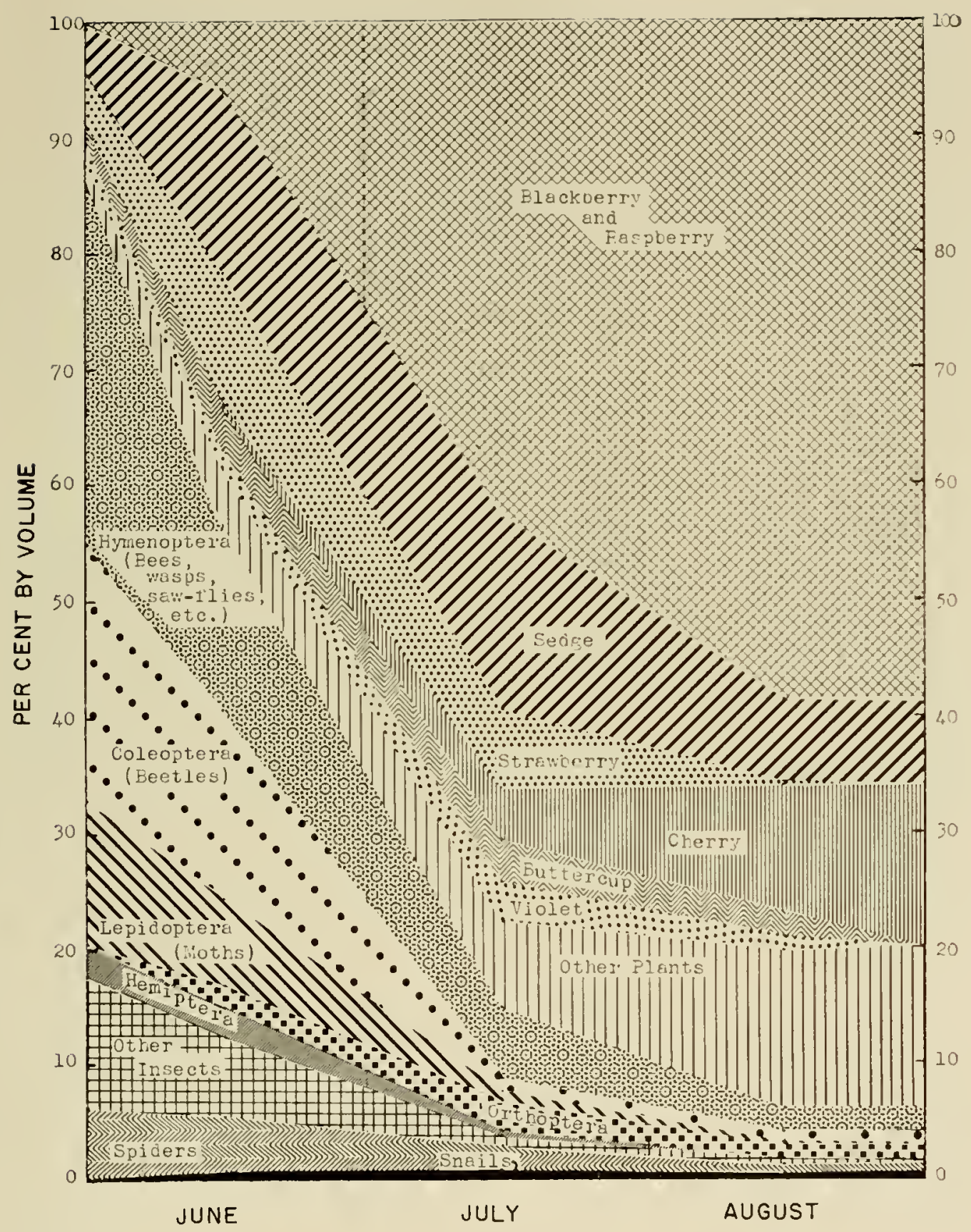

FIGURE 18. AMOUNT AND KIND OF FOOD EATEN BY 510 GROUSE CHICKS DURING JUNE, JULY AND AUG'ST 
Though in captivity the chicks feed freely on apple leaves. in the wild only a single individ. ual of all those examined had sampled them.

Animals bulk largest in the June foods of chicks; constituting 56.6 per cent: drop sharply in July to 13.0 per cent and in August to 5.0 per cent. At this time the diet approximates that of the adults. It is douhtful if ehicks search much for insects after they are several week: old. for they seem to concentrate on finding suitable plants. picking up animals only incidentally. Running back and forth in a most haphazard manner, pausing now and then to probe beneath a leaf, it is no wonder that the chicks uncover such a variety of insect life. No bug seems too bitter nor caterpillar too ugly to be tried at least once. In the 540 chicks examined, 475 different animal foods were identified. Many ate 20 or more kinds and several upwards of 30. Protective devices are $n$ ) certain deterrent, for the formidable lo moth larva, one of the fiercest-looking of all caterpillars and armed with poisonous spines. fell prey to one chick and stink-bugs seem to he taken with relish.

TALLE 31. MONTILY VARIATONS IN TIE IMPOITANT PLANT AND ANIMAL FOODS OF 5 t0 NEW YOIK GIROUSE CIIICKS

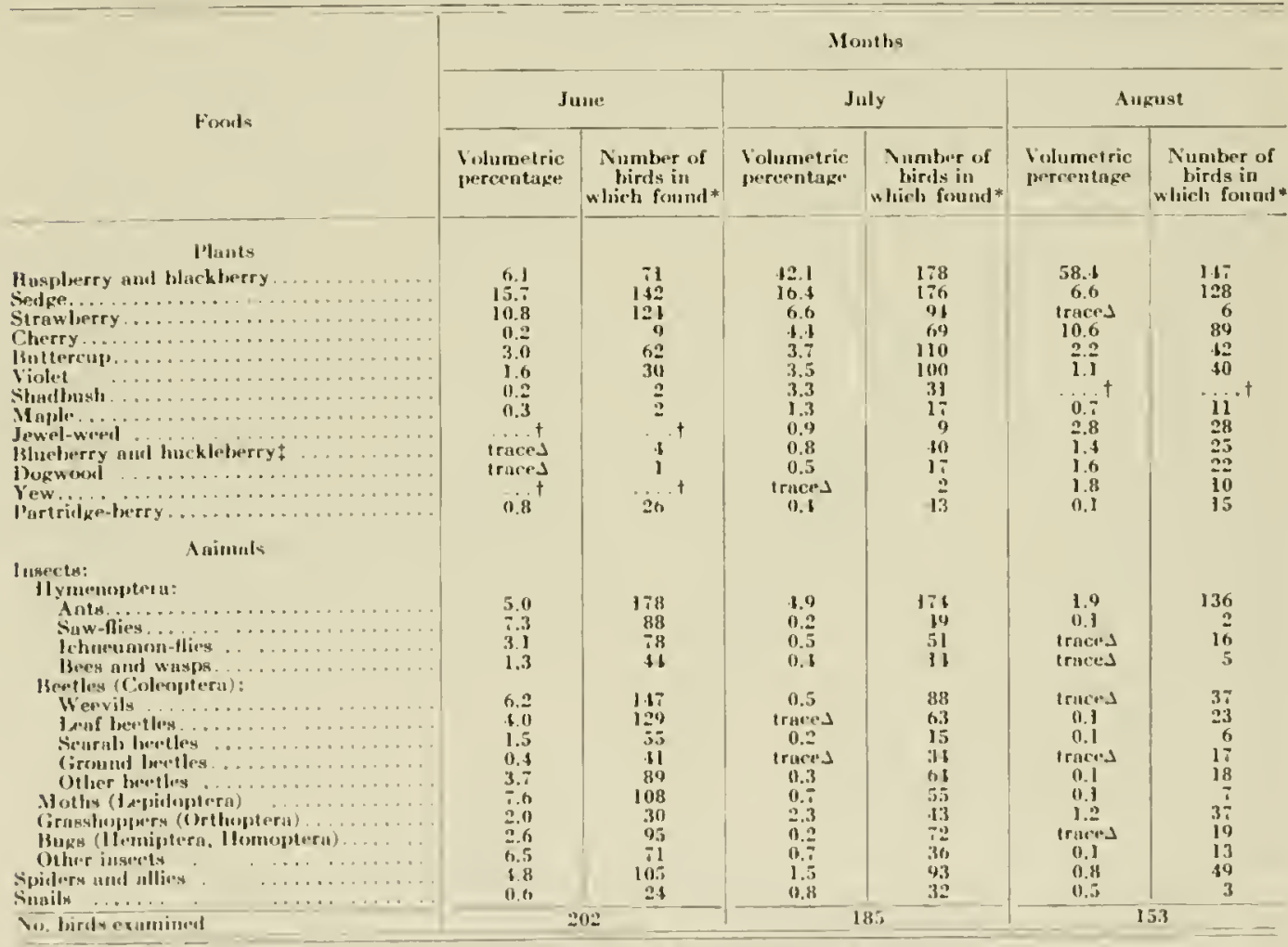

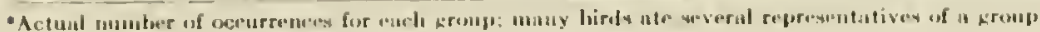

STrucu, or legs Ilua 0.1 per cent.

Not taken.

Tracludies (I arrinium) und (Gervlussurin).

Ants, often considered as "protectell" insects, are the most perpular food. 188 stomachs of the 5.10 tabulated comtaining one or more of them. Larvae and adults of saw-llies and the adults of ichnemon-flies are also well liked, 139 young hirds eating the former and 1.15 the latter. Beetles. largely weevils, leaf beetles and ground leeetles. along with caterpillars, spiders and grasshoppers. supplied the hulk of the remaining animal food. 


\section{Momhly Variations in Summer Chick Foods}

From June through August there is a progressive change from an animal to a vegetable diet. At first the plant foods are few in number and consist for the most part of the smaller seeds and bits of easily reached plants. Feeding acivity during the first ten days after hatching consists largely of catching ants and beetles and occasionally capturing a juicy caterpillar, interspersed with the diligent stripping of sedge seeds and sampling of strawberries.

By July animals make up only a tenth of the fond and the birds are patronizing a wide variety of plants, even including some fruit-bearing trees. The consumption of blackberries. the bushes of which provide hoth food and shelter. rose rapidly and amounted to 42.1 per cent of the total for the month. This gain was largely at the expense of animal foods. Which dropped from 56.6 per cent in June to 13.0 per cent in July. The foraging heconses still farther diversified in August and in later summer the young tend progressively to take about the same foods as do the adults.

The monthly variations of the most important plant and animal foods of chicks are indicated in table 31 .

\section{DISTRIBUTION AND HABITAT REOUIREMLATS OF GROLSE FOOH PLANTS}

Plants furnishing food for grouse at one ur more seasms of the year are to be found, often in ahundance and variety in most wergrown fields and woollands throughout the Northeast. Some, such as various species of wild cherries, aspens. hlackberries, raspherries. birches, sumachs and thornapples, which together supply 18 per cent of all grouse food. occur in every region of the State. They thrive on almost all types of soil. from sand to clay. from rich to poor, from wet to dry. For most of them, the one common recuirement appears to be an alsence of strong competition for crowing space. for many characteristically occur in the earlier stages of plant succession, as on cutover or overgrown lands.

Pin cherries, aspens, gray and hlack birches and smmachs are short-lived plants intolerant to shade. They build up a ground cover and prepare the way for the more shade tolerant and longer-lived species such as black eherry, ash. yellow birch. beech and maple, which follow them and ultimately shade them out. Other grouse food plants of overgrown lands as apple, thomapple, shadlush and hop-hombeam are perhaps more resistant to shading and therefore may persist for a longer time under the closing forest canopy. Only a few such as the mountain and the striped maples, are typically understory shrubs which thrive in relatively dense shade.

Of the many plants eaten in large quantities ly grouse. lout few are limited as to dis. tribution in New York by soil or climatic factors. Of the birches. neither black nor gray is found widely in the Adirondacks, nor is the latter conspicuous far west of the Hudson Valley. Hop-hornbeam is most abundant in central New York: less so in the mountains and on Long Island. Huckleberry, bheherry, bunchberry and wintergreen thrive on moderately to strongly acid soils. l'artridge-berry and evergreen woud ferms reach their best development in the duff of the forest floor.

In table 32 are recorded some of the habitat preferences and other characteristics of ruffed zrouse food plants.

Though many of the species may be widely distributed. most are restricted more or less to certain stages in plant succession.

Grouse habitats are made up of plant associations. For convenience in identification we 
divide these into cover types. These may he classified as open land; overgrown land; hardwood, softwood and mixed forest: slashings; and hurus.

In New lork, by far the largest part of the open land cover type, in the territory where grouse are conmon, is composed of poor hill pasture, together with a little meadow and cropland. Farming here is a precarious husiness at best and abandoned farms are becoming inereasingly common. When this occurs open areas revert to "poverty grass," weeds and moss.

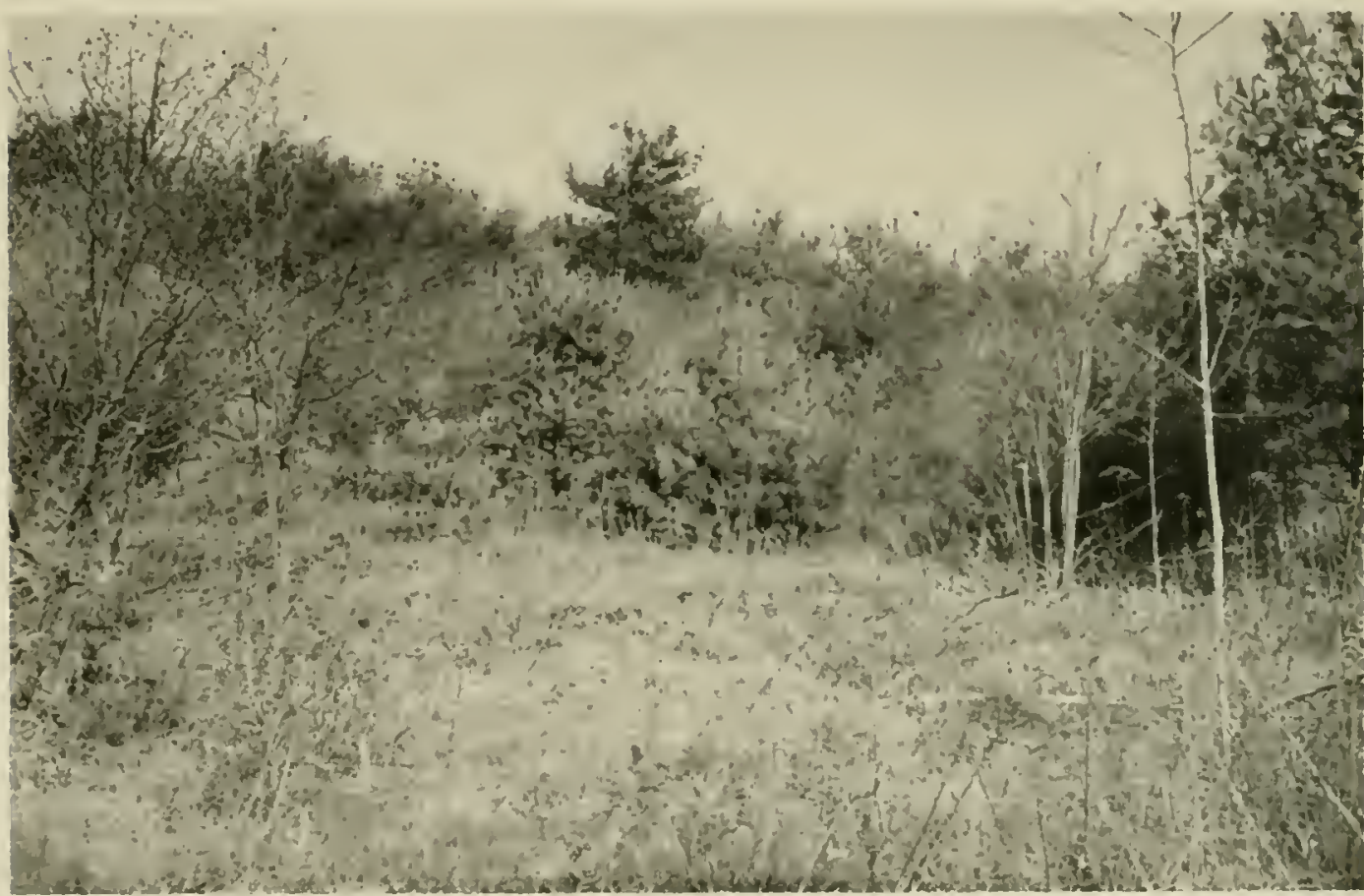

PASTIRFS AND IIELAS, LEFT TO TIIEMSELVES, SOON REVERT TO OVERGROWN LANDS. HERE SIE. CIES PROVIDIXg E.TCELENT GROUSE FOOD AND SOME SIELTER ARE APT TO BE PLENTIFUL

The character and composition varies with the last farm use and the degree of soil depletion. Fispecially on old meadows and in better pastures, an abundance of strawberries and of sedges, both seasonally important to grouse, may be produced. Areas that have been denuded by fire also may grow sedges, but seldom produce an abmdance of strawherries.

Fven before abandonment, ill-kept pastures and fields may be invaded by brush species such as sumachs, briers, scrub apples and thornapples. Because of unpalatability, thorms or sheer toughness. these plants are able to endure moderate browsing by stock. With this pressure removed there develops a typical overgroun land association of the above mentioned species together with pin and choke cherries, aspens. hirches and other trees. These establish themselves first in the protection of stone piles, stumps and old walls. From here they spread in ever-iucreasing numbers.

As the density of the stand and the consequent competition for growing space increase, the tree species are able to overtop the shrubs and reduce them to a subordinate position, ercntually to he crowded out entirely. As these trees form woods, they shade out the grasses and prepare the ground for the seedlings of the longer-lived speeies. Important among the latter are beech, 


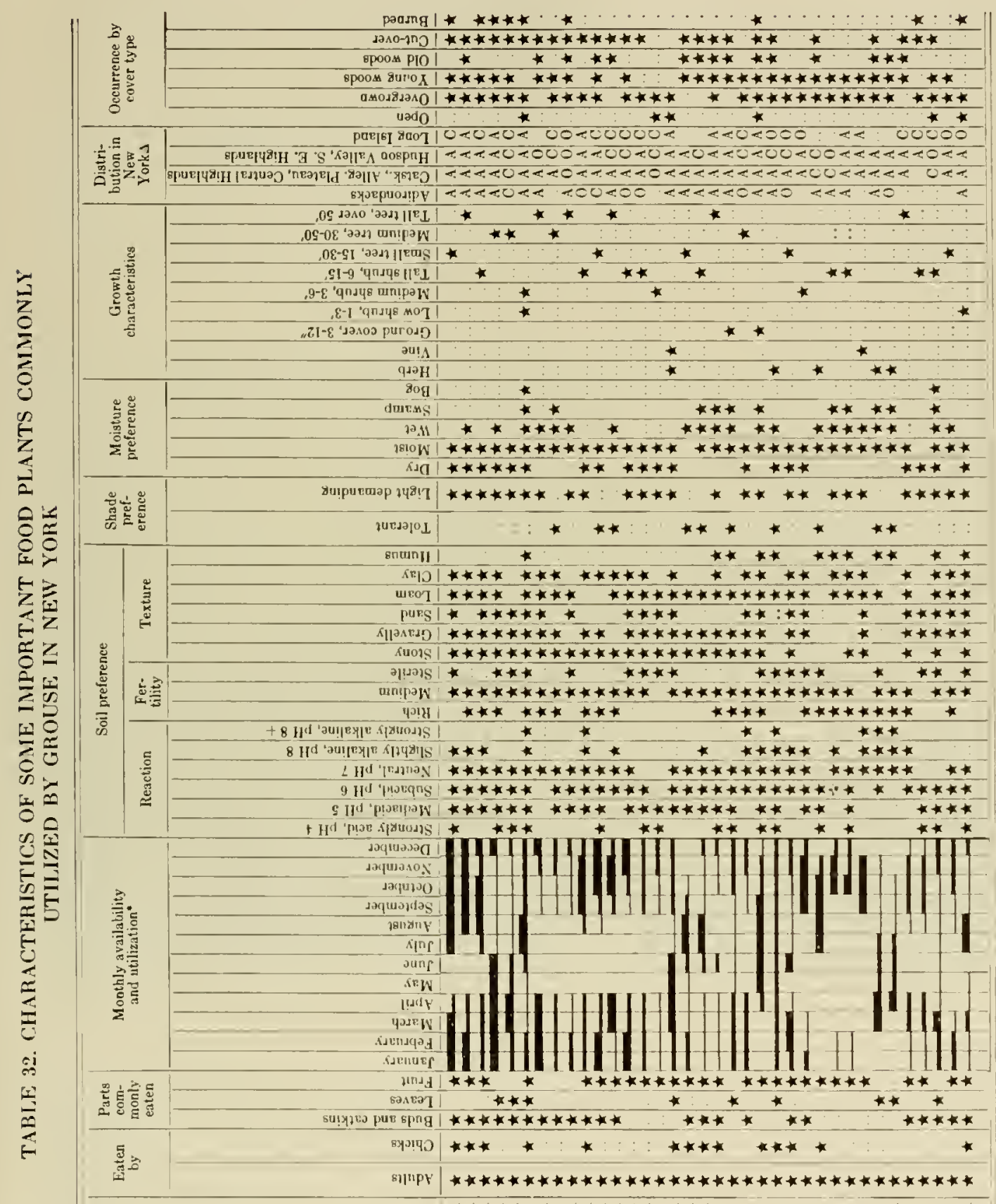


aak, black cherry and sugar maple. As such a stand develops toward maturity. the forest becomes progressively less productive of grouse food plants.

On wooded areas that have heen cul over. whether for forest products or especially to benefit wildlife. the character and ralue of the succeeding growth will depend upon how heavily the stand has been cut. whether or not the brush has been lourned and on the individual site conditions. If the stand has been lightly eut and the products skidded out on the snow, the change may be chiefly in age classes. with relatively slight alteration in species composition. With heavier cuts and especially when the brush is burned and when the forest floor is torn up by skidding on dry ground. the plant surcession is set back sharply bringing in more of the pioneer speries. such as hriers. pin cherry and aspens.

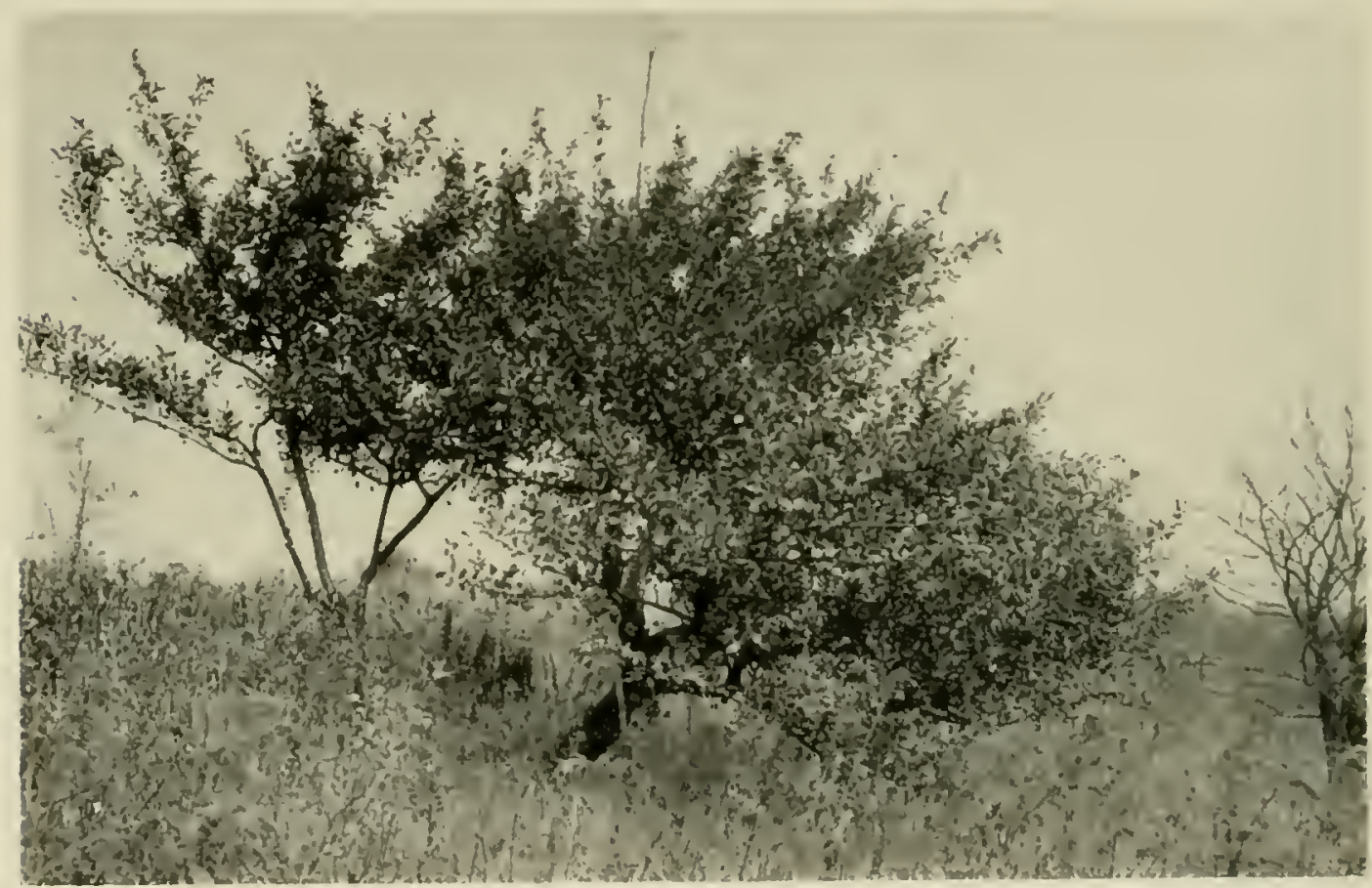

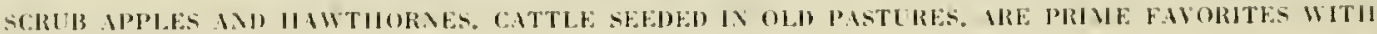

THE: GROLSE

None of the important forest types of tew York is resistant to fire. light surface hurns that run through the dry leaves may appear to do no harm. get thes not onty scoreh the trees but may also climinate many of the small and tender plants of the forest floor. suel as ferns and partridge-berries. A light surface fire once in a decate may he enemerts to exolude softwood sorellings completely. esperially lhose of the hemlock which are so useful to wildife. Mor severe hurns may seriously weaken or kill the whole forest. reverting the plant sucesesiun tu an early stage. This over areas of a few acres ma! be desirable. Repeated hums. huwever. deplete both soil and forest and ultimately reduce the plant cover to scrub. In some sections of the Adironlack where the soit was thin. fire has so completely decteored the fores that restoration will repulere a rentury al least.

Although fire is a useful tool at the right time and in the right place. it is an excedingls 
dangerous one and should be used with caution and then only by experienced operators. This item is considered in detail in Chapter XVI.

\section{FOOD AVAILABILITY AND SHORTAGES}

As has been noted, the list of plants patronized by grouse in New York alone includes 994 items. So widely distributed and commonly found over much of the State are many of these that there are few grouse habitats without a comparatively large native supply of foodproducing plants.

Because a plant is present. it does not always mean it is producing grouse food. for some do not fruit or seed except under favorable conditions. Mlost of the food plants are primarily: pioneer or transition species which do hest in the sunlight along woods edges, in overgrown lands, in cut-over areas or in blow-downs. Insects also are most abundant in well-lighted places where the vegetation is varied and lush. Grouse might not starve if they were confined exclusively to heavy woodlands. but they would not find there a majority of the foods they like best.

So long as the territory of an individual grouse includes openings, whether made by man or Nature, that foster the pioneer and transitional food species, these may usually be depended upon to produce a sequence of foods which meat the hirds' needs throughout the year unless grazing or cultivation intervenes. Of course lack of handy and sufficient shelter may make the food largely unavailable, for both cover and food must he present and adequately inter. spersed to make a grouse habitat productive.

There is no evidence that grouse have ever starved to death in the Northeast. The weights of adults collected in numbers throughout every month of the year show relatively slight variations. These can be explained in part on the hasis of seasonal activity, in part by the less adequate nutritional character of their winter and carly spring dict. Even the heaviest sleet storm does not armor buds and twigs long enongh to produce a serious fond shortage. Grouse held without food fail much more rapidly than do pheasants or quail. A period of from three to four foodless days under winter conditions produced an average loss of 22 per cent in the weight of birds kept in captivity. They had eaten only natural foods during the preceding weeks. Experiments* indicate that grouse have very little metabolic or chemieal reserves from which to endure much longer periods without food.

Whether they suffer from shortages of eertain nutrients one camot say. Relatively littl' is known as to the chemical composition of grouse diet and nothing as to the degree of physi. ological availability of the nutrients in their foods. Scientific studies of game hird nutrition. as yet in their infancy. must await the production of a large number of gronse in captivity. as well as improvement in techniques for handling them. In the meantime. in summary food items known to be taken by grouse in large quantities are available in large amounts throughout the year in every inhabited grouse cover known to the Investigation. No starved birds have ever been found. No sharp weight losses have heen recorded even in adverse weather. Food shortages in the generally accepted sense are believed. therefore, not to necur.

A few of the more abstract relationships of food to health are pointed nut later in the chapter.

\section{EFFECT OF FOOI) ON GROUSE DISTRIBUTION}

At some seasons grouse exhilit a marked preference for coverts where certain foods art easily obtained. Curiously enough this is most evident in the summer and fall when fond is

* See Apuenslis. I. iul. 
most abundant. The drawing power of a beech ridge in a good nut year is well known to many grouse hunters. The Investigation has records of grouse being flushed from thornapple clumps well over half a mile from their usual coverts. Hedgerows with choke cherries and frost grapes oftimes furnish the incentive for a bird or a brood to feed at a considerable dis. tance from its normal haunts. Spiller ${ }^{500}$ records concentrations of birds in fall feeding areas in groups too large to have been drawn from the immediate locality. So far as one can judge, these excursions may represent a temporary letting down of territorial bars for the old birds; birds of the year of course have not as yet established territories.

From the first of November, or earlier, especially if there is a blanket of snow, the birds no. ally forsake such exposed feeding places in favor of those closer to adequate shelter.

Not as pronounced, hut still definite, is the tendency to frequent cut-over areas, woods edges or overgrown pastures where the vegetation is varied and luxuriant. Here are found ample amounts of easily obtainable food combined with adequate shelter. The Investigation found these areas especially attractive in summer, when they were utilized by 26 per cent of the birds in contrast with 13.9, 8.5 and 13.6 per cent for fall, winter and spring respectively (table 152 , p. 818).

Broods in particular are to be found in the slashings during the warmer months (table $135, \mathrm{p} .801$ ). Though these may occasionally form a dense tangle, the spots most frequented may be rather open with food and cover interspersed. In fact there is a tendency to shun dense cover when not associated with a variety of other vegetation. especially in the summer and fall. This applies also to evergreen plantations.

Observations do not indicate that adults need to travel far beyond the boundary of their established territories for food at any season of the year. The usual territory of a grouse includes winter shelter, spring breeding grounds and summer and fall feeding coverts. If all of these are not present within easy flying radius. say one-half mile, it is not likely many grouse will set up housekeeping there until Nature or inan provides the missing requirements.

\section{COMPETITION WITH OTHER SPECIES FOR FOOD}

Few species are less affected $h$ competition for food, especially in winter than is the ruffed grouse. Adequate quantities of buds are always available. It is therefore no hardship to share the various berries, fruits and seeds, even in hard winters, with other birds and mammals. Grouse are quite independent of grains such as buckwheat and corn.

A possible relationship between adverse growing seasons, resulting in a lowering of the nutritive value of grouse foods, and the health of the birds the following spring has al. ready been mentioned. If this hypothesis is ever verified, one might wish that the grouse were more keenly interested in the more nutritious cereals and herries in addition to buds. However. fundamental grouse feeding habits are not easily changed as was demonstrated on the Connecticut Hill area in the fall of 1932, when 210 shocks of luckwheat were placed in well occupied cover. Only one lird was found to have utilized the grain for food. Similar results have been noted in attempts to entice grouse to return to such favored fall foods as beechuts and thornapples made arailable at fecling stations after winter snows had forced them to adopt a diet eonsisting mainly of buds.

All this tends to indicate that grouse are not hard-pushed for foud even in winter and that other speries of wildlife do not compete serionsly with it in this respeet even at that season. 


\section{THE EFFECT OF OPENING UP THE ITOODLAND ON FOOD SUPPLY}

Left to her own devices, Nature eventually produces a type of regetation termed the climax, which, generation after generation, succeeds itself. In New York, physical conditions run the gamut from seashore sands through cover of every age and density to Mt. Marcy's treeless top. Climax condilions show a correspondingly wide rariation.

In woodland hahitats such as are occupied by grouse, the forest climax is most often represented hy a mixture of large conifers and hardwoods, with interlocking crowns shading out all but a sparse vegetation beneath. In such situations food and shelter for wildlife living above ground but largely beneath the crown canopy are often scarce indeed.

However, natural forces tend constanlly to break up the continuity of this forest cover. Diseases such as the chestnut blight: insects such as lark beetles and the defoliating caterpillars; weather, particularly late frosts, drought and wind; fire and man's axe often cause the forest to revert to earlier stages of plant succession. Carried far enough. brush takes the place of woodland, grass takes the place of lirush and the plow furrows under the grass. Left alone, Nature then begins a slow process of environmental rehabilitation which, if not disturbed. ultimately will rezult in the reestablishment of the climax type.

The ruffed grouse finds its food and shelter needs best combined in certain of the intermediate types. Few individuals are found in cultivated areas because of the paucity of acceptable foods and shelter. Neadows are likewise aroided except where they adjoin woorllands or brush areas, even though they support such choice food plants as sedges, buttercups, clovers and strawherries. and a host of acceptahle insects. Where the shrubhy vanguards of the woods are invarling grasslands. however. greater concentrations of grouse foods usually occur. It $\mathrm{is}$ in this zonod intermingling of field and forest that wild apples and thomapples fund thenselves most at home. Stout-stemmed blackberrics form prickly tan. gles and there are clumps of dogwood and viburnum, largely hird-planted. along the field bor. ders. Though blueberries and the larger-fruited huckleberries may be spreading, if the soit is acid, they have not as yet crowded out the strawherrics, wrasses and sedges which grouse patronize. Pioneering trees. such as aspen, cherry, and birch. whose huds or fruit the grouse relish, may also he seerling in as a prelude of forests to cume. Furthermore, the number and variety of insects in this type of cover is cnormous.

In time, of conrse. the more permanent tree species take over, closing in the crown cover and eliminating the light-demanding shruhs, aspens and cherries. The forest has reestahlished itself.

Hahitat, dissimilar in appearance, but rich in gromse foods, may he created by heary forest cutting. Here, a great variety of seeds has lain dormant in the duff ready to spring to life at the coming of light in all the verdant comfusion characteristic of a cul-over area. Many brushland species, as well as a host of herbs, shrubs and trees will thrive in such slashings. Judging from the number of grouse. and especially those with broods, which frequent such spots from June to November. food and shelter conditions here must be nearly at their lest.

But again as cut-over areas grow up into woods. it is inevitable that many of the plants furnishing food for grouse give way to the climax species. Under them such shade-tolerant plants as the evergreen wood fern, partridge-berry dwarf comel and witch hobble, all good grouse foods. gradually fill in a small part of the gap left by the shading out of the luxuriant, light-loving regetation of the slashing. 
Such is the story in New York and throughout many parts of the Northeast. Elsewhere within the range of the grouse, the plant species characteristic of each stage in the succession may differ from those here named, but the results in terms of productive grouse habitat seem to he much the samc.

It is well recognized that good grouse coverts must include some of these openings which seasonally produce an abundance of food and shelter. A brief consideration of how these naturally occur, or may he made ly man is, therefore, not aniss.

\section{Natural. Openings}

These are largely the result of fire. weather, insects or diseases. Except in the case of severe fires the succession is seldom set back to bare ground. When the hurn is deep or repeated, however, the natural productivity of the site is usually so impaired as to make the re-establishment of desirable food and rover a matter of many vears, although such species as the pin cherry, aspens and blueberries may soon seed in. Ruffed grouse, unlike the sharp-tailed grouse which habitually frequent burns, are seldom found here except along the edges, near shelter. Light hurns. if continued, may have the effect of decreasing grouse food supply through encouraging the spread of grasses and weedy ground cover. Reduction of the more desirahle food plants, logether with the gradual elimination of small shelter-producing shrubs and conifers by fires, is likely so to change the habitat as to lower materially or wipe out its carrying capacity for grouse. This is particularly true within the woodland itself.

But fire is not always detrimental. Ocrasionally in a grown-up slashing a light burn may set the succession back perhaps ten to fifteen years, thus allowing man! desirahle species which otherwise would he shaded out, to re-establish themselves. In fact, even a severe burn, could it be limited to a few acres. might be useful in the same way. The ntilization of fire as a toul in wildlife management is discussed in somewhat greater detail in Chapter XVI. However, it is at hest a dangerous servant.

The effect of weather in ereating or maintaining openings is more wide-spread, though probably less well defined thin is that of fire. Many an ahandoned field in New York does not grow up rapidly to shrub or tree species, primarily because the alternate freezing and thawing to which it is subjected anses heaving that destroys seedlings. In wood. lands the effect of unseasonable frosts is ofttimes strikingly evident. In 1936, in the Adi. rondacks. late frosts pruned the early spring growth of beech, thus temporarily letting in more sunlight to the forest floor. Occasionally, also, extremely severe winter weather may kill less resistant species. thus creating small openings which increase feeding opportunilies for game.

Much more violent are the offects of wind. varying all the way from breaking off or up. rooting individual trees to opening up thousands of acres of closed canopy woodlands. The destruetise hurricane of 1938 that swept through Lomg lsland and Vew lingland is an example. Less clearly reongnized is the effect of sun and air mosement so drying out the soil in a fresh-made slashing at le climinate man! of the less adaptahle trees and shruhs left after lumbering. The result is to create ur maintain small patehes of light-loving plants which are fanerel hy, or ean adjust themselves to the new conditions.

An effect in many ways -inilar is somedines brought about by large-scale attacks of in. sects such as the lawh sawfly or of tree discases, as the chestnut blight. Throughout the Cats. kills in the late 1930's the forest tent eaterpillar defoliated sugar maples for several years so 
completely as to cause the death of thousands of trees. Where maple was the dominant speries and the undergrowth was not too dense. this resulted in many small openings. which were quickly orcupied by a host of herbs. hriers. sprouts and insects. The result was a rapid increase in grouse food. Thus natural forces may create many breaks in forest cover.

\section{MaN-Made Openings}

Spurred on by economic necessity. man ma! cause openings in woodlands of a variely of forms. Earh of these may differently affect the grouse food supply. The most severe of these is of course, wholesale clearing and subsequent cultivation. Crops such as buckwheat, corn, clover, together with accompaning weeds and inseets. unless located immediately adjacent to adequate shelter are seldom of much value to grouse. as these birds rarets venture far into the open for their foorl. Allowed to revert. however. as is occurring in many parts of the Northeast. cullivaled fields ma! be taken over by a productive combination of trees and shrubs. both evergreen and hardwourl. intererrown with grasses. straw. berries. elovers and other much songht after herbs.

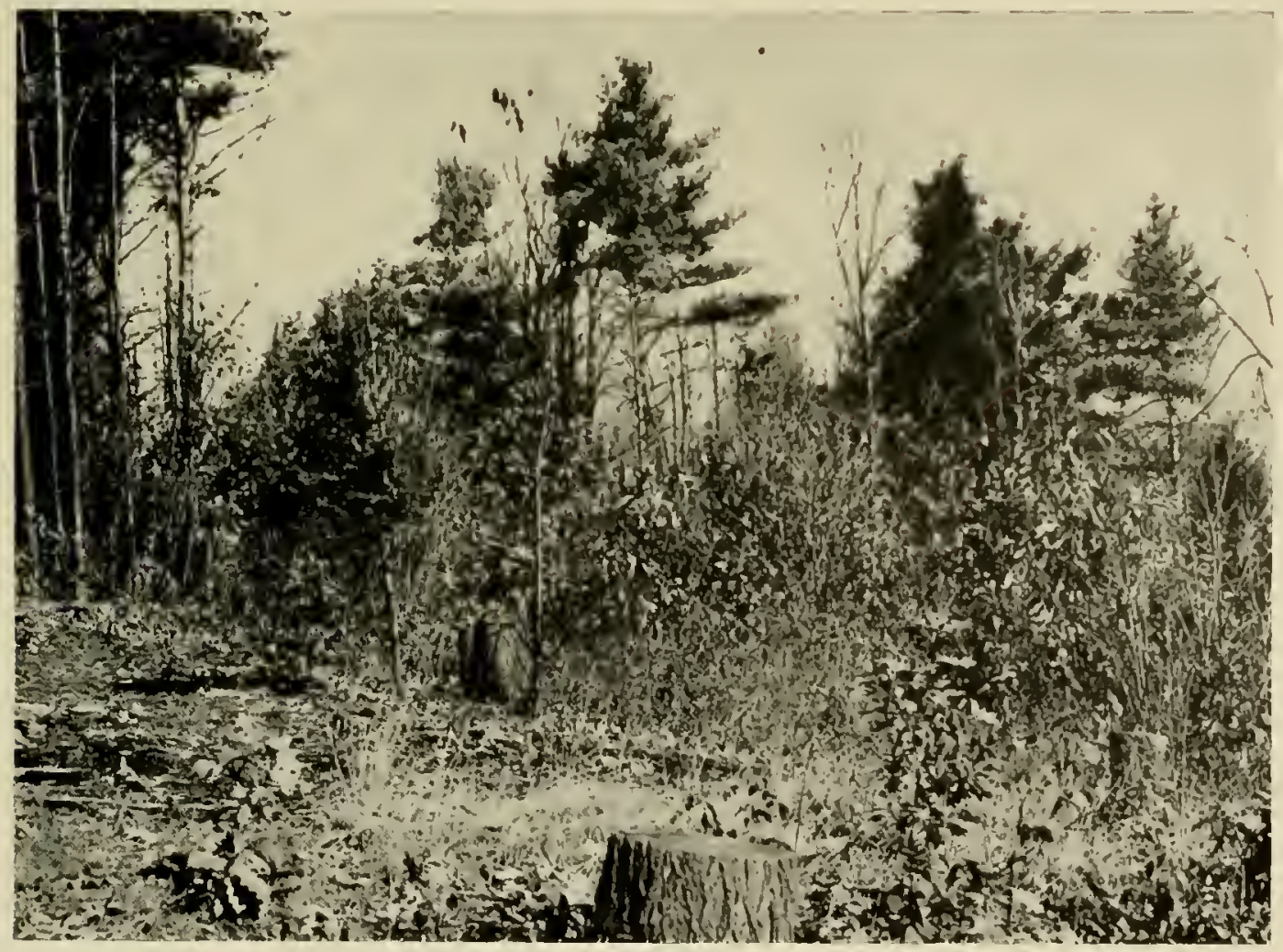

FROM JUNE TIROLGH SEPTEMBER NO COVER TYPE IS SO RICH IN GROLSE FOOD PILATS AS ARE, CUT-OVER LANIS

Grazing, particularly if heary. tends to eliminate woodland undergrowth and to encourage replacement of the normal flora of the forest floor with grass. Light grazing may be beneficial, however, where the undergrowth is dense and in need of being opened up. Many 
lightly pastured woodlands in New York produce good crops of grouse. Cattle help also to maintain cdges and to keep the woodland from encroaching too rapidly on the open ground. Here also occasional cattle-sown wild apples spring up. Thornapples and certain of the dogwoods and vilurnums, together with a sprinkling of conifers which the eattle do not like. furnish much-frequented feeding spots along the line where pasture and forest meet. Many of our finest summer and fall grouse feeding grounds in New York have been es. tallished in this way. The compacted earth of the cow paths is slow to change, but the hrushy areas, with their interspersion of conifers. and open spots may provide almost perfect feeding grounds for broods and adults from June to early November. Occasionally the grouse also choose such locations for their nests.

But of all man's tools, no single one has wrought such far-reaching changes in grouse habitat as has the axe. By lreaking up the forest canopy it las altered the enviromment so as to release light-loving trees, shrubs and herbs. In the openings thus created are to be found the greatest variety of grouse foods, hoth plant and animal, for lumbering not only lets in the sunlight but usually disturhs the soil as well. Thus is produced, often in the space of a few acres, the whole series of environmental conditions from hare ground to woodland.

The effect is depentent in large measure upon the site, the age and composition of the forest before cutting. the severity of the cut and the length of time since it was done. The hetter the site, the more raried the forest make-up, and the more severe the cult, the greater is the chance that the eutting operation will produce a profusion of grouse foods.

To understand the effects of patches of cut-over woodlands upon grouse production knowledge is required of conditions preceding as well as following the cutting operations. It was, therefore, necessary to make a study of slashings under controlled conditions. This began in 1932. when a series of openings varying in character and in location were estahlished. Subsequently 311 clear-cuttings were completed as test plots in 8 of the State's widely scattered wildlife management areas. Conditions preceding rutting and at regular intervals subsequently have been noted. In most plots detailed measurement of site changes have been carried out as discussed in the preceding rhapter on Shelter.

Analysis of results reveals that diversification of the regetation may stant within a month after cutting. In terms of grouse food production this tendency reaches its height in from three to five ycars. As the cut-over area continues 10 grow up. many light-loving grouse foods are gradually crowder out, until in from ten to fifteen years after cutting most of the grouse foods brought in by the operation will have been overshaduwed, if not entirely killed out.

The importance of openings as grouse food-producers is further emphasized by the substantial increase in fruit production b! the plants pioneering in them in comparism with that of the same speries under shade.

In the final analysis light is the prine cause of the vegetative changes that result in a large increase in available foul as the furest amopy is opened up. It is the amount rather than the method by which the light is let in that is important. Histurbance of the soil. surh as uccurs in humbering operations. also encourages the maximum variety of food plants.

On mote of caution. howesrr. Brushlands, be they overgrown pastures or slashings. selelom contain adequate amounts of species furnishing winter shelter for grouse. There- 
fore, when too extensive, they are not nsually conducive to maintaining large grouse populations. Many small slashings widely scattered and of different age classes are to be preferred to a few areas occupying many acres.

\section{FOOD AND FLAVOR}

One of the few points of general agreement among those who hunt the grouse is that its flesh is exceedingly palalable when properly cooked. Many an early author has ascribed this to a particular liking which the bird is supposed to exhibil for leaves and twigs of a pungent flavor. Eaton" list: "wintergreen, mint, sorrel, birch and various kinds of berries which impart a peculiar ganey flasor to its flesh". Maine birds, according to Mathews", "are particularly fond of the buds of the black birch which give their flesh a peeuliar and very agreeable flavor". That this is not a new thought is proved hy Alexander Wilson's", statement in 1812 that, "The "pheasant" is in hest order for the table in September and October. In this season they feed chiefly on whortleberries and the little red aromatic partridge-berries, the last of which gives llicir flesh a peculiar delicate flavour".

Additional backing for the food flavoring flesh idlea, though with a different meaning, comes from Elliott", who indicated that "its flesh, as is well known, is light and tender, lout in late fall and winter lecomes bilter because of the bird having fed on the leaves of the alder and to many persuns is then quite proisonuus".

ln speaking of Sabine's ruffed grouse (B. u. sabini), he continues, "The flesh is white and palatable save in winter, when it is often bitter, eccasionall! flasored with turpentine from eating the buds of the fir trees". In speaking of the gray ruffed gronse in the lukon Territory, he adds that it sulsists on spruce buds which give a disagreealble flator to the flesh. In this he is eloruently lorme out hy Sandys favorite food is the louds of the spruce which impart to the flesh a flaror which might appeal to the palate of an eastern spruce gum-chewer, but which signally fails 10 hold the appreciative allention of an epicure unless he also happens to le a lust prospector keen for a "grubstake" ".

The presumably poisonous properties imparted to the flesh of hirds that feed on laurel has already been discussed.

The present authors are duly appreciative of this background of testimony, but being neither spruce gun-chewers nor epicures they hase failed to mote presonally the peculiar flavors deseribed by these observers. The grouse. shot in season and properly prepared, is in New York invariably a delicacy of the first order.

\section{FOOD AND ITS RELATION TO IIEALTH}

The ability of the grouse to survive the rigors of a hiting winter on little more substantial foods than buds is but one of the interesting sitnations confronting those who would study its food habits. Pheasants and quail would starve miserably on a diet of cherry aspen and bireh

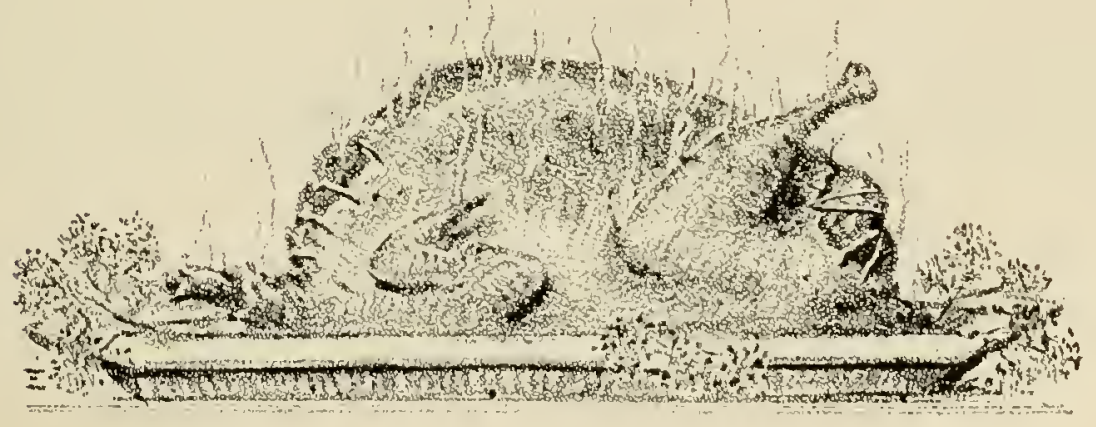


luds, all of which are staples for the ruffed grouse in New York from Sovember until April. True. they eat much more in proportion to their size. for the normal contents of a grouse crop in winter is almost as large in volume as is that of a pheasant. though the latter is usually twice as heavy. The albility to utilize buds for food is one reason why the grouse can survive from Alalıama to Alaska.

There are other ways in which fool alfects the existence of the species which are much less easy to illentify, for there is much more to the study of fool labits than the mere recornition of the amount of each kind which is eaten. True, in analyzing the relation of food to health. this is the first step. This done, the question uaturally arises as to the mutritive value of each food to the hird. One ean not logically assume that an item commonly eaten. by that token. must provide suhstantial nourishment. The next step, therefore, is to determine the amount of each nutritive constituent-proteins, fats, carbohydrates and minerals-that are present in the foods that constitute the normal diel. This can be accomplished by rather involved chem. ieal analyses.

But all birds are not alike in their ability to break down these chemical constituents. To complete the picture it is necessary. therefore. 10 conduct physiological tests. or "hiological assays" as they are known. by which the degree t" which grouse can utilize each important food item can be determined.

This chapter on foods deals largely. with the first step in this sequence. Some progress, as described shortly, has also been made on the second phase. wherein the chemical composition of a number of grouse fooks has been determined. But the third phase. without which no clear picture of the value of any individual food for grouse can be olutaned. is more difficult to study. With most mammals it is time-consuming. but otherwise not foo difficult. to measure more or less accurately the amount of each nutrient which can be absorbed from an! griven food. With hirds. on the other hand. the carrying out of such detailed hiological as. says. by chemically analyzing the feces. is complicated by the fact that the excretory prod. ucts of the kidneys and the intertines empty intes a common chamber. the cloaca. This makes it impossihle to separate the highly nitrogenous urates and anmonia from the rest of the feces. In the delieate tests required these items can not be analsocd logether. thus making it virtually impossible to attack the prollem ly this means.

Because of the importance of this stop. attempts have been made to secore an index of speries digestilsility ly other less accurate methods. Variations in lise weight of grouse in relation to the amount consumed of a single food item or of a combination of seseral kinds have been determined experimentally with hand-raised hirds at the Research Center. A start has also been made at testing the results of feedinger cerouse over a considerable period of time on one food loy aherking progressise changes in their plysiologieal reactions.

The lirst of these mothods yields results which are at hest only indieative. while the second involves such highly sperialized enuipnent and ted hniques as to make the completion of tests by it at best extremely diffieuh. Verertheless. the picture can not be completed withont sueh analyses. Greater attention therefore. must be concentrated on this phase of the problem.

There are atso other questions which have a more or less direct hearing on the relation of grouse fouds to health. In the light of what is known. how does foed affect weight. reproduction and resistance to discase? Is food ene of the auses of periodic fluctuations in grouse populations? Such indieations of the answers as are avalable are here presented. hut the many grapo that remain point to this ficld as a particularly froitful one for future research. 


\section{Chemical Conposition of Sone Grouse Foods}

The various elements. compounds and organic substances that form the structure of a plant or animal are the items that make up its nutritive character. To determine the amount of each present a standard procedure is followed. First fresh samples of the fond item to be analyzed are gathered. From it the moisture present is extracted by drying. Then the oven-dried sample is chemically analyzed to measure the quantities of proteins, fats, fiber and ash or mineral matter. All these are expressed in terms of weight per 100 grams of the sample. The sum of these is subtracted from 100 and the remainder. designated as "nitrogen-free extract". is used to represent the more digestible carbohydrates, in contrast with the crude filer, which is largely indigestible carbohydrates.

Such an analysis may be in itself extremely accurate. Because of the work involved. however, it is seldom completed in sufficient detail to present a full picture of food conposition.

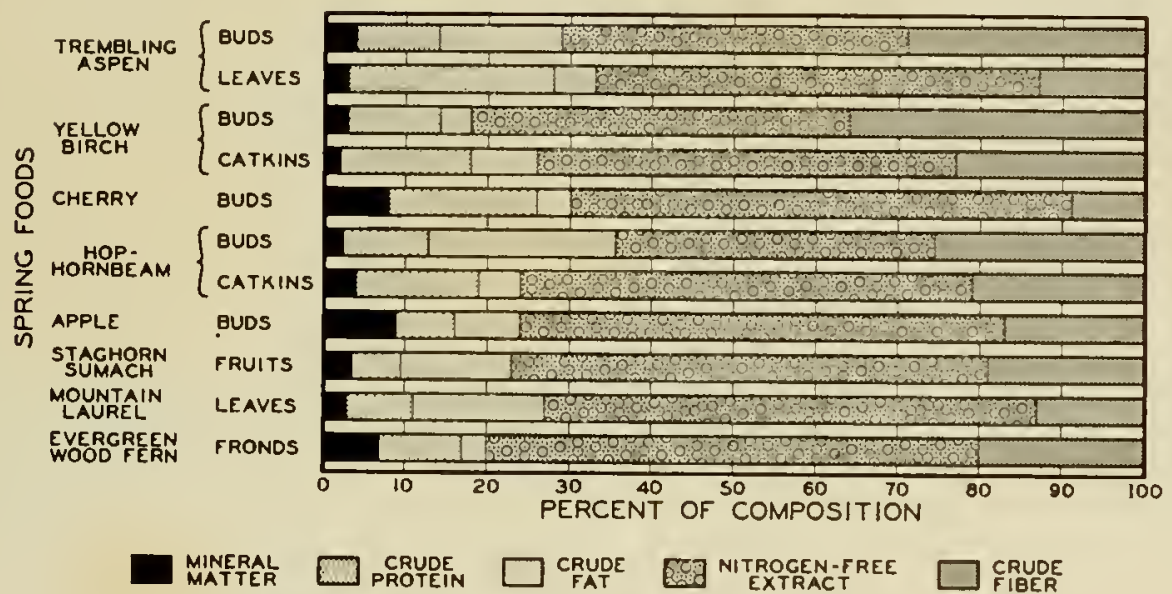

FIGURE 19. COMPOSITION OF EIGIIT SPRIXG FOODS IMIPORTANT TO CROLSE

Nevertheless, it serves as a rough measure for establishing the amounts of these substances present in each food. Accordingly. the chemical composition of a number of grouse foods have been analyzed by the Investigation. The results are presented in table 172 in the Appendix. For the sake of completeness and comparison additional examinations selected from published records but more or less applicable to New York ronditions aro also included. The proportions of these constituents present in eight foods commonly eaten ly grouse in spring are shown in figure 19.

One of these constitnents, moisture, usually forms a larger part of a plant's structure than does any other item. It may he defined as the amount of free water not incorporated in other compounds. Its relation to health is discussed later in some details.

\section{Crude Protein}

This is the chemical compound most concerned with body building and feather development. However. proteins differ markedly in their ability to meet the varied wants of the body due to their fundamental differences in molecular structure. Dr. L. C. Norris of Cornell University, working with the Investigation from 1932 to 1935. found indications that grouse chicks may thrive best on a starting diet containing from 27 to 30 per cent protein. This 
is considerably more than the 21 per cent level considered satislactory for domestic ehicks. but compares favorably with the 27 and 30 per cent that Norris found were best suited to the needs of young pheasant and quail respectively.

The comparatively large protein requirements of grouse chicks decreases materially with age. Those reared at the Research Center are now fed a ration containing 30 per cent protein, which is dropped to 20 per cent for adults*.

It is suggested that the need for protein by chicks parallels closely the proportion of insects found in the diet of wild birds. It has already been noted that inseets make up about 70 per cent of the total bulk of chick foods for the first two weeks following hatching. This tendency rapidly falls off until by the end of August the food of young and adult are alike. Most insects are relatively high in protein content. Carpenter ants, one of the most commonly eaten species, contain 30 per cent.

Adults and older juveniles depend largely upon plant foods for their sustenance. Is regards protein content, the leaves of aspens, dandelions and clovers, and the buds of eherries may stand them in good stead, for all are high in this respeet as compared with most other grouse lood plants, though low by comparison with most insects. It should be remembered, however, that digestibility varies with the kind of protein involved. As previously explained, biological assays are necessary to determine the ability of the grouse to utilize the protein present in any given food.

Fats

These are considered so valuable a source of food that in delermining the nutritive ratio they are given a value two and a quarter times that of carbohydrates. The crude fat, or ether extraet, given in chemical analyses represents the more or less digestible fats and oils as well as the less easily broken down resius and waxes, ehlorophyll and other substances soluble in ether.

Not all of the material here represented can he used by grouse. The crude fat content of the ration led to the hircls at the Research Cenler is 5 per rent for juveniles and slightly less for adults. Even allowing for the indigestible fraction, a number of grouse foods contain well ahove the ration standard. The buds of hop-hornheam stand out in this respeet as do leaves of mountain laurel. Surprisingly enough, hemlock needles and twigs, usually considered of little value as food, contain a large quantity of fat. allhough much of it is probably in the form of resin. Sumach fruits are also high in fat content.

\section{Nitrogen-free Extract}

The term nitrogen-free extract is used to designate the more digestible carbohydratessugars, starches and other saceharides. Since these figures represent the remainder from the other analyses rather than a separate analysis in themselves. small quantities of non-carbohydrates, such as tamnin. are unaroidably included.

It is significant that the foods most commonly eaten hy grouse are all well-supplied with these fat-produeing and cnergy-releasing substances. The artificial ration fed to young hirds contains 40 per eent, which is raised to 53 per cent for the adults. Spring foods, with the exception of hop-hornbeam buls, together with all of the smmmer foods thus far analyzed compare favorably with this standard. The high proportion of such earbohydrates in the 
spring diet is shown in figure 19. Unexpected is the high yield of the sumach fruits, considered by many to be "starvation food". The leaves of some wood ferms contain even higher amounts.

\section{Crude fiber}

Under this heading are placed the indigestible carbohydrates, such as cellulose. lignin and chitin, as well as the resins and tars that are not soluble in ether. As such they probably are the least useful items in the picture. Unfortunately it is not known to just what extent grouse can digest this material. Most mammals can obtain little of value as food from it. although ruminents, such as cattle and deer, are able to extract therefrom some nourishment with the aid of certain bacteria.

As might be expected, such winter and spring foods az huds, twigs and evergreen leaves all contain large quantities of crude fiber. A notable exception to this is the buds of cherry, which interestingly enough are taken more extensivcly in New York than is any other win. ter food. Apple buds and sumach fruits are also fairly low in fiber content. Here is a problem much in need of further study.

Ash

Under the heading ash is included the total measurable mineral matter that these plants contain. Since animal life is ultimately dependent upon vegetation for the majority of the inorganic portion of its make-up, the ash constituents, which provide the calcium. phosphorus, manganese and other body needs, become highly important. Buds of apples, hades of certain grasses and fronds of wood ferns, all commonly taken spring foods, are exceptionally high in mineral content. This is in fact characteristic of most grouse foods taken in late winter and early spring. The need for two of these minerals is indicated in that the calcium requirement for domestic chicks is 0.7 per ecul; that of phosphorus 0.5 per cent; for laying hens it is 2 per cent and 0.8 per cent, respectively. Assuming grouse needs to be somewhat comparable. those requirements are probably satisfactorily met at least in the spring diet.

An element less prominent but extremely inportant is manganese. Norris experiments showed it to play a large part in the prevention of perosis or slipped tendon ${ }^{30 x}$. This was formerly a common ailment of game hirds raised in captivity, as well as in domestic fowl. It is deseribed in somewhat greater detail in the chapter on Parasitism and Disease.

The character of the soil strongly influences the mineral content of a plant. INide variations in the ash constituents of a species in different portions of its range are therefore to be expected. Aspen buds gathered near Ithaca, N. Y.. contained half again as much mineral matters as did those analyzed by Hellmers ${ }^{198}$, taken a little over a hundred miles south, in Pennsyliania.

\section{Vitamins}

In any discussion of nutrition the role of vitamins must play an important part. The artificial rations fed to captivity-raised grouse at the Center are, of course, fortified to insure the presence of these elusive substances in suflicient quantity, but their status in the normal diet is at present little understood. Nor is there much known of the basic amounts required for proper growth and reproduction. The curing of a paralysis in grouse on experimental feeds by the use of vitamin B exlract may mean that the chicks have an unusually high vitamin B requirement. Studies by Norris indicated the need of young pheasants for vitamin D) 
and for certain factors of the vitamin B complex to he greater than that required by domestic fowl. Their vitamin G requirement, likewise, was found to be from two to two and onehalf times greater than that of white leghorn chicks. That such is the case for grouse doe: not necessarily follow, but a pussibility is here indicated that awaits further investigation. Such is the general picture derived from the chemical analyses of a food item.

\section{Differences in Chemical Composition}

There are other equally important questions that might well be raised. One of them concerns the individuat variation in these chemical components within the plant species that supply the food. As has already been pointed out. the character of the soil on which they grow plays an important part in determining the inorganic content of a plant.
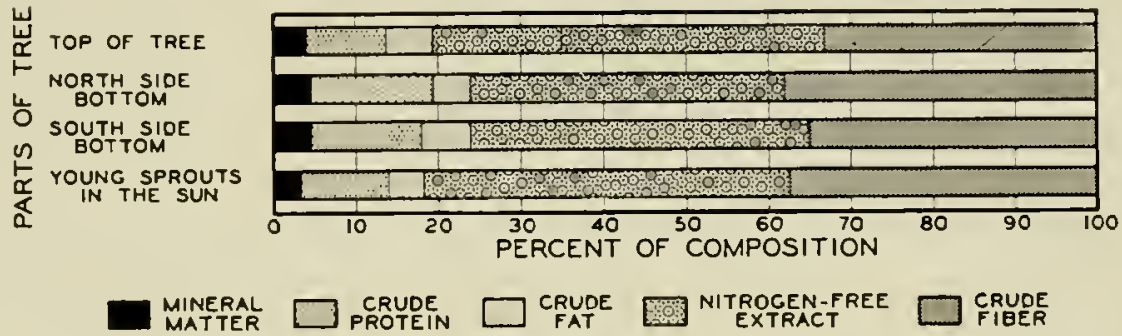

FHCLRE: 20. DIFFEREYCES IN COMPOSITION OF YELIOW BIRCH BLDS WITH RESPECT TO THE ACE OF TIE TREE ANI THE PART FROM WHICH THEY WERE COLLECTEN

Likewise there are substantial differences in composition hetween buds gathered from the shady as compared with the sunlit parts of the tree. Results of the analyses of yellow birch budstaken from the top. the bottom on the north and on the south sides (all on the same tree) and from young sprouts of the same species grathered close hy. are shown in figure 20. These exaninations were made from material collected on April 6. 1942.

Gronse are in great need of untritive constituents in their fond that produce heat and energy during the colder parts of the year. It is fascinating. then. to find that the highly digestihle (arbohydrates that make up the nitrogen-free eatract are sumewhat greater in buds collected from sum than from sharly locations. Investigations by Gauman have shown conchsively that this condition presails thronghout the year in the Furopean beed (Fagus sylvatica). Twig tips and terminal buds contain higher anounts of carbohydrates than do the branches and axial huds nearer the trunk. Thase on the top of the tree hase the highest enncentration of all. Here may he a likel! reason why grouse and deer feed on the huds from the top of the tree when analable rather than from the shaded side branches.

Fast growing sprouts. lou. may differ from their sower growing companions as indicated in table 172. Great variations are also apparent in the amount of erude protein, the buds from the bettem of the tree on both sides containing considerably more than these from the top or from soung sprouts. Seasonal differences. tou. have been noted. All such factors must. of contse. he consichered. in interpreting the results of "hemical analyses of grouse frods.

This. then, is a hroad omtline of the pieture that is just beginning to take shape. A large

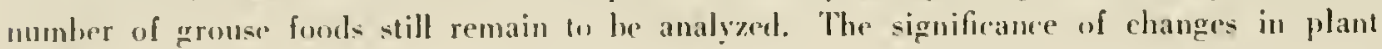


composition should be determined. To answer some of the problems a far more complete analyses than the "crude" determination of basic nutrients is required. The present studies must be continued for a long time to cone before many relationships can he even reasonably well understood. Finally, the limitations of the data provided by chemical anlyses alone must not be overlooked. Knowledge of the nutritive constituents is largely academic until the ability of grouse to use them is determined by biological assays.

\section{RELATION of FoOd to Weigit}

One of the less exact yardsticks by which the relation of the diet to the health of grouse may be measured is the ability of a fond to sustain weight and condition. That the hirds are able to survive from year to year on their normal diet would seem in itself indirect proof of its adequacy. But. as has been indicated, such an assumption toes not present the entire picture. The physiological experiments reported elsewhere* indicate that grouse have a remarkably high rate of metabolism. The amount of energy they expend. esen in a simple flight. is tremendous. Even the varied diet enjoyed by grouse in lew lork is not always sufficient to meet completely the normal demands of the hody when the energy output is high. Weight records of eollected specimens hear this ont. The females show an almost constant weight loss from January mutil the end of the breding season in June. and the makes until after the moult. When these period- are completed. the birds then gain steadily. building up reserves against the advent of cold weather. until a peak is reached an the beginning of the following winter.

With the coming of snow and low temperatures greater energy is required to move alout and to combat the loss of heat from the body. Then, too, the hirds are foreed off the ground to feed in the trees. It is indeed fortunate that they are then eapable of existing upon browse. for an enfored migration in search of food might well prove disastrous.

Yet there is no indication that the diet in wholly inalequate. for in no case was the weight recorded in a healthy bird dangerously low, nor has the lnestigation ever found a grouse in its natural habitat that died from stanation. The normal weighthealth relationship of New York grouse, adults and birds of the year, is indicated in figure 11. 1.96.

It is interesting to find that the wrights of raptive hirch at the Rrosarch Center likewise drop during the winter, despite the fact that they receive an artificial ration calculated to best suit their needs. Noteworthy. (oo, is the faet that in winter and spring the quantities of food eaten by wild grouse is considerahly greater than is taken in summer.

\section{Relatiox of FoOd to Crcles}

The possilility has been suggested that food. through eyclic qualitative changes in its nutritive components. may have a bearing upon the periodic fluctuations in grouse populations. It has been clearly established that the composition of plants. on which the grouse must depend for food, may vary somewhat with weather conditions. Criddle ${ }^{m a}$ has reported on fluctu. ations in the abundance of grouse and other species of wildlife in Canada. DeLury has connected these wherved variations with a close correlation hetween sunspot cycles and some weather phemomena.

All this is interesting but not even circumstantially conclusive for. as indicated in Chapter VI, weather ma! have a host of other direct as well as indirect effects on grouse abundance. The weather changes most likely to influence grouse food composition are precipitation, tem-

\footnotetext{
* See Apprulis. D. 719.
} 
perature, and the intensity, duration and composition of sunlight.

Weather records of local stations, however, fail to exhibit such a cyclic trend in most of these factors. In New York, wide differences in the amount of precipitation as between individual sections of the State over the same year normally occur. No substantial relationship was found when an attempt was made to link precipitation with subsequent grouse abundance from State records covering the past 40 years. Several records of high populations of grouse produced during ahmormally wet as well as in dry years were found. But no studies of food composition on wet is. dry years were made.

Temperature also affects plant composition, but the extremes are more likely to be felt than the average. Many plants are capable of growing under wide variations, therefore a trend differing only a few degrees from year to year in the average temperature would be unlikely to have an appreciable influence. The most noticeable effect of temperature, to date, is connected directly with grouse mortality rather than indirectly through food.

The third factor to consider is the relation of the intensity, duration and composition of sunlight to food. The first of these, changes in the intensity of sunlight, is closely tied up with sunspot activity and is, therefore, cyclic in nature. The possibility that light intensity affects plant composition, however, is largely offset by the phenomenon known as solarization. This arrests the action of chlorophyll as the intensity approaches a certain degree that is reached on all but the cloudiest of days.

Duration of sunlight, on the other hand, although extremely important to plant growth, bears no relation to sunspot activity, for the length of daylight is normally much the same year by year.

Sunspots control or affect still another physical condition, that of the quality of sunlight. Little is known of their effect on plant composition, though changes in the amounts of ultraviolet and infra-red light have been observed. The presence of vitamin $\mathrm{D}$ is depcudent upon the former, but it is doubtful if quantitative changes in plant foods, thus brought about, are great enough to seriously affect the health of grouse. Fxperiments with poultry" have shown that a relatively small quantity of sunlight will offset the absence of this vitamin from the diet. It is noteworthy that the Investigation has never found a grouse, either in the wild or in captivity, suffering from rickets.

In considering the broad picture it should not be forgotten that 994 separate food items have lieen idcntified from New York grouse ahone. Then, too, their food is the product of at least two growing seasons. Buds and leaves are formed from the energy of past years. whereas fruits are more largely the result of the prescnt year's activity. Such considerations tend to discount the probahle effeets of cyclic changes in plant composition on grouse abundance, even if such do occur.

The diet, too, can infuence population by affecting directly their resistance to the various decimating influences in their environment. A gronse in poor condition is more susceptible to disease or predators than one in good health. It is possible that such a condition could be bronght about by a generally inalequate diet. Iowerer, in view of the foregoing discus. sion, no eyclic tendency in grouse abundance, due to diet, is indicated.

Likewisc dietary deficiencies could disrupt reproduction. Here again. there is no evidence to verify a cyelic relationship. It is noteworthy that the number of egers laid by New York grouse renained almost constant over the 13 years of the lnvestigation". 
All this points to the conclusion that weather cycles are not likely to exert a strong indi. rect influence on grouse abundance by producing periodical changes in the composition of their food. But the subject is still too little understood to justify aught save an open mind as to the possibilities.

\section{WATER REQUIREMENTS}

Water is of prime importance to the living body, for it is vital to every physiolngical action as well as being an important constituent of the individual cells.

Grouse may obtain water from three main sources: drinking water (from puddles, streams and ponds, and also snow). dew, and succulence (water taken from plant or animal foods high in moisture content). The extent to which the (wo latter sources can supplement or take the place of the former determines the dependence of the birds upon a steady supply of drinking water.

The basic requirements of the species for water are not as yet definitely established. Iong. in carrying out physiological experiments", however. found that a defieiency soon made it. self felt. Six adults were held without access to either food or water. After a period of only $3 \frac{1}{2}$ days half of them had died. On the other hand, 12 lirds supplied with water, but no food, were able to maintain normal body temperatures for nine days and easily survived the experiment.

Birds reared at the Research Center are provided with drinking water from the time they are hatched. Inasmuch as their artificial ration is low in moisture content it is not surprising to find them drinking frcely. When the rearing of grouse was still in the experimental stage the chicks wore fol moist foods such as clablor and ny larvae. Drinking water, though available, was then only occasionally resorted to. Adults penned in large enclosures also managed without frequent recourse to drinking water. dew and succulence apparently satisfying their needs.

Small puddles formed ly rain may be utilized by wild grouse. Bradbury ${ }^{\Delta}$ witnessed such use but despite thousands of olservations the Investigation has never actually seen a wild adult grouse drinking from open water. Lehmamn similarly reported that prairie chickens rarely drink from surface water. but Girard ${ }^{15}$ states that sage grouse drink from two to three times daily, preferring running water to that from puddles.

The sources from which water is available, may vary with the different seasons. In the spring melting snows and heavy rains make surfaec water everywhere ahundant. A little later the succulent foods, to which the birds turn their attention after a winter-long diet of browse, are high in moisture content. Aspen leaves and fern fronds are well over two-thirds water. In contrast, buds and catkins generally contain less than 50 per cent moisture. The amount present in 8 conmon spring foods all freshly gathered. is shown in figure 21.

Summer foods are made up largely of frnits and insects for the jureniles, fruits and leaves for the adults. All are high in moisture content. Raspherries and blackberries, the most commonly eaten summer food, are four-fifths water. Dandelion leaves run as high as 89 per cent.

The moisture content of many common fall foods such as beechnuts, hard seeds and buds is somewhat less. For example, sumach fruits, taken commonly at this period. are less than 10

* See Appendix. P. ios.

$\triangle$ Bradbury, H. M.. personal letter to the autiors. 
per cent water. Both in summer and in fall the birds depend to some extent upon dew to help meet the lody needs.

Snow may take the place of dew to supplement the winter diet. which is also reduced in water content.

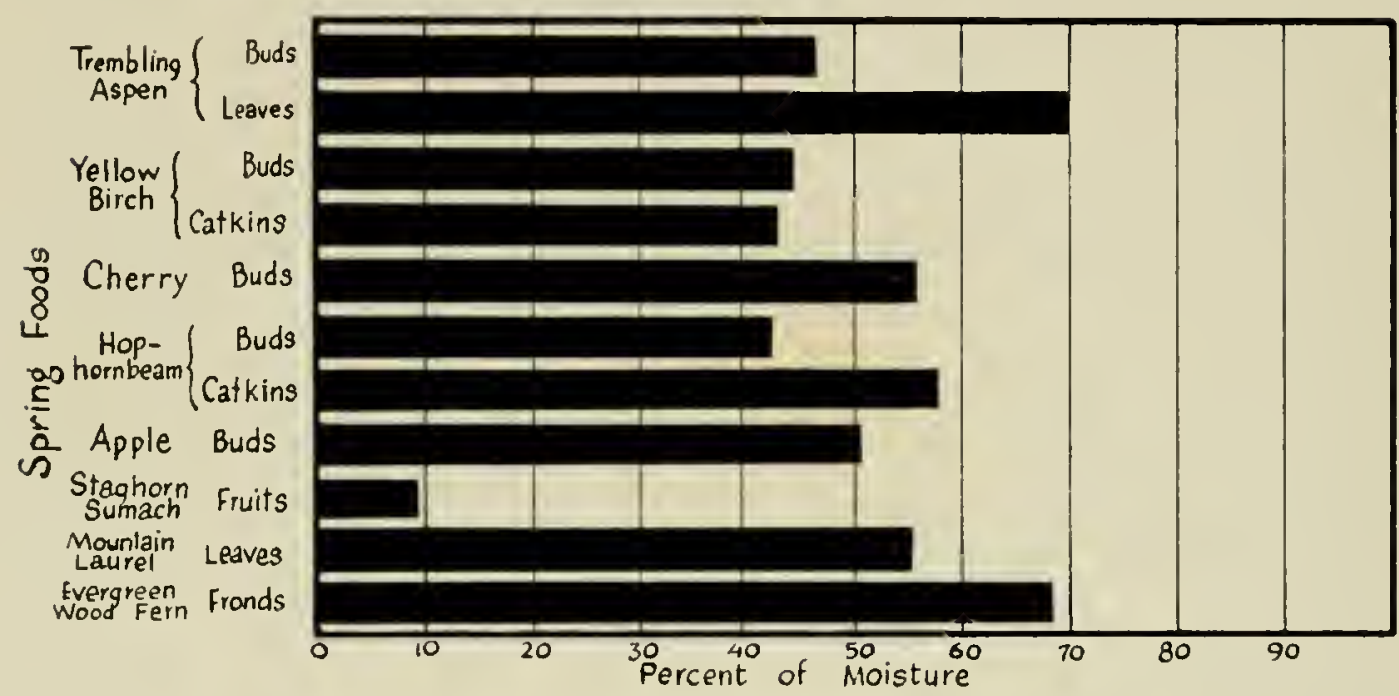

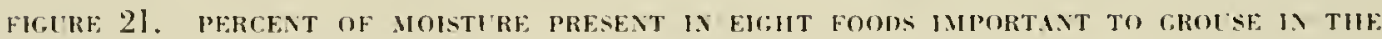
SPRING

The possible value of water as a source of minerals should not be overlooked. Not only do spring and surface waters often contain a high quantity of inorganic salts. but Heller has found that rainwater, usually considered pure in content. ma! contain mineral matter.

The question of the effect on brood distribution of analahle free water is a hit confused. Kingent. in Minnesota. stated that the distribution of grouse hrouds during the summer perind was controlled by the presence of water. At first glance. records of brood distribution from the Adirondack study unit in Vew York would seem to bear this out. since the great majority of the brood contacts were made in the seseral alder swamps which are scattered wer the area. On the Connecticut Hill and Pharsilia areas. howeser. hrouds rewularly live through the entire summer from a quarter to a half mile from rither a stream or swamp. Extremely Iry summers hate heen experiened when even dew was latking for considerable periods. and. althongh moist areas existed within the momal erusing range of the hroods. little or no use was marle of them. The distribution of brod llushes in gears of alwove arerage preripitation and in lis years are slown in figure 22.

The Connecticut Ilill and Pharsalia areas are composed of disconneded woodlots surrounded hy brush and open ficlds. On the other hand King's area in Minnesota. and the Adirndack unit are made up of more or less continuously forested land. Many of the brushy areas here occur along the streans or in the swamps. Since these are the type of ever most utilized by New York aroms during the summer period, it seems possible that their distribution at least in the Nortluast is unet affected by water supply as much as ly the associa. tion of plants that are often found in moist areas.

There seems to be little difference loetween broods and adults in this respeet. Likewise dur. 
ing the winter period there was no substantial correlation between the distribution of adults and streams or swamps even on the Adirondack area.

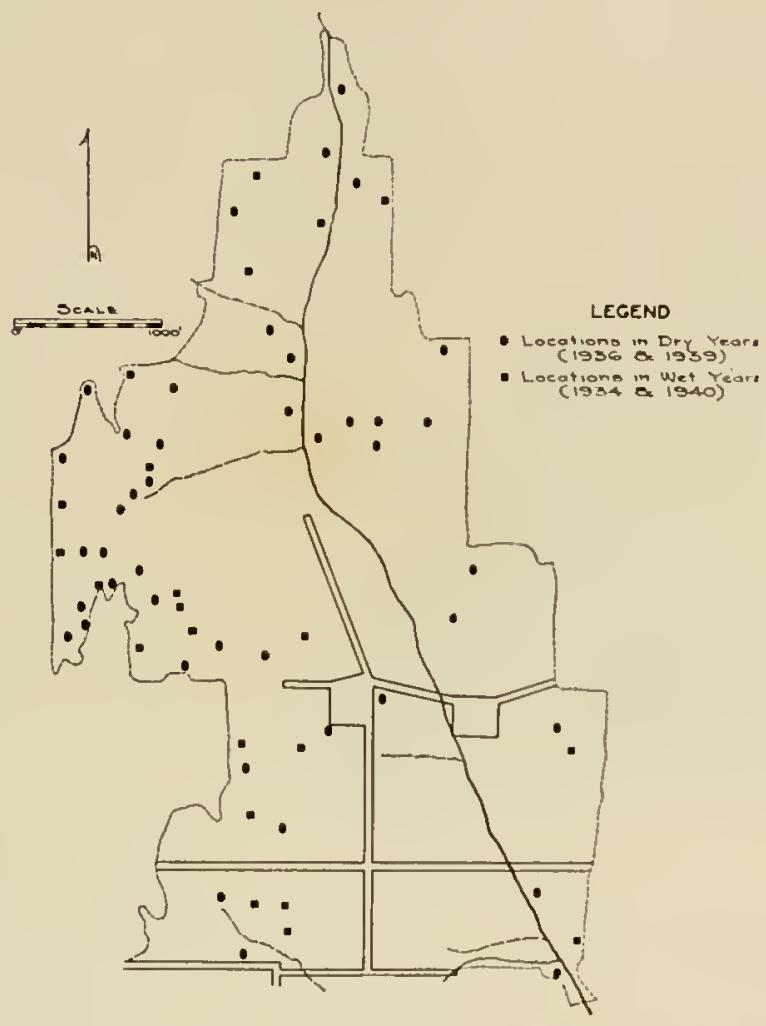

FIGURE 22. TIE DISTRIBLTION OF BROONS FLLSHEN ON ONF COMPARTMENT OF THF CONEGTICUT HIL. STUDY AREA DIRING WFT AS COMPARED WITH DRY YEARS

Generally speaking it may be said that shelter and food exert a greater influence than water upon grouse distribution in New York. Occasiunally drinking water may be utilized. but dew and sueculence probably supply the bulk of the moisture necessary for metaholic functions during the wamer months. Normally the hirds are capable of finding satisfactory amounts of water from one sonre or another regardless of the specific halitats they occupy. 



\section{CHAPTER V \\ GENERAL HABITS}

By Rorert W. Darkow

\section{SEASONAL PATTERN}

\section{COMMON TO BOTH SEXES}

Moвılity - Walking - Swimming - Flying - Flight Speed - Migration - Fall Dispersion (Crazy Flighl) - Spring Shuffle - TeknıtonY - Breeding Territory — Year Around Territory - size - when chosen - relation to cover quality - seasonal shifts Gregariousness - Warinfss - Primitive Tameness - The Transition - Present Caution - Strategems - Tame Grouse - Febdixg Ilabits - Artions - Time of Day Mating, Habits - Interbrelding, - Fichtix, - Roostix, - Sinw Roosting Dust Batuing - Idaptarility to Cilanoivo. Exvirosifest - Tolforance. of Other SPECIES

\section{CHARACTERISTIC OF THE MAIE,}

Drumang - The Drumming Performance - The Sound - how produced - Purpose - The Drumming Season - The Drumming Lor - number of logs used - Courrsur - Srrutring - Head-Twitching - Relation to tue Nest - Reiation to the Brood

\section{CHARACTERISTIC OF THE FEMAI.E.}

Nesting Dates - Structure of the Nest - Habits Dering Laying and Incubation - Nesting Tolerance - Desertion - Renesting - Lack of Second Broods - RelaTION to Brond - Defense of Chicks - Daily Artivities - Control of Chicks - Double Broods - Guidance

\section{CHARACTERISTIC OF THE BROOD}

Area Tranersei - Hidne, - Roostixg - Fefing, Habits - Dust Batilixg - GreGARIOUSNESS.

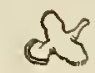

\section{SLTHMARY}

Grouse exhibit a definite hehavior pattern throughout the year in response to the environment and to the physiological changes which take place in the bird. (p. 250).

Although the grouse is a sedentary hird and its flight limits usnally short, it is capable of cov. ering over a mile withont stopping. (p. 253). 
Speeds approaching 50 miles per hour have been recorded, although the average of birds flushed in the woods is about 40 miles per hour. (p. 254).

It is not migratory although young birds may travel several miles during crazy flight or spring shuffle. (p. 254).

"Crazy flight" is a fall phenomenon. It is primarily a trait of first year birds and seems to be Nature's way of dispersing them before they choose a territory and settle down. (p. 255).

In general, adult grouse, year in and year out, tend to live in a relatively small area, referred to as their "territory". usually in the vicinity of and including the covert in which they spent their first breeding season. (p. 257).

Adults rarely form flocks, although loose groups often occupy the same patch of winter shelter. (p. 259).

Originally surprisingly tame, the partridge has developed traits of caution and wariness which now rank it as one of our most prized game species. (p. 260).

Although primarily a ground feeder. it readily perches in shrubs and trees when seeking fruits and buds. (p. 264).

While polygamy is the usual mating relationship, they are not averse to promiscuity if the occasion demands. (p. 267). Hybrids are very rare. (p. 268).

Grouse of all ages are subject to pronounced superiority and inferiority complexes. (p. 268).

Fighting is most common but not entirely confuned to the breeding season and to the fall shuffle of the young birds. (p. 269).

During periods of low temperature, grouse frequently dive or burrow into the snow for protection if it is soft and sufficiently deep. (p. 270).

Drumming is an attribute of the males only. It is primarily associated with courtship but has heen heard during every month of the year. The sonnd is produced by the hird's wings beating against the air. (p. 274).

The male neither assists in incubation nor aids in rearing the brood. (p. 284).

A ground nester, the female incubates her nsual clutch of about 11 egrgs for between 23 and 24. days, the normal hatching date in New lork State heing ahout June 1. (p. 285, 288).

Individual fentales do not rear more than one lrood during any one season, hut a hird whose first nest is destroyed frequently lays a second clutch. (p. 291).

The femalc exhibits remarkable courage in striving to safeguard her brood from danger, especially during its early life. (p. 291).

Grouse chicks are precocial and leave the nest under the gnidance of the hen within a few hours after hatching. From then until the hrood breaks up, heginning in mid-September, they range as a unit, generally remaining within an area of 40 to 100 acres. (p. 294).

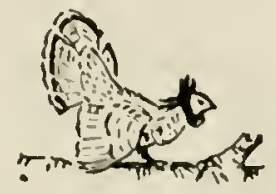


"Scare up partridges feeding about the green springy places under the edge of hills. See them skim or scale away for forty rods along and upward to the woods ... hear [their] distant drumming ... as if the earth's pulse now beats audi. bly ... meet a partridge with her brood in the woods... they still are sure to thrive like true natives of the soil, whatever revolutions occur."

Henry D. Thoreau

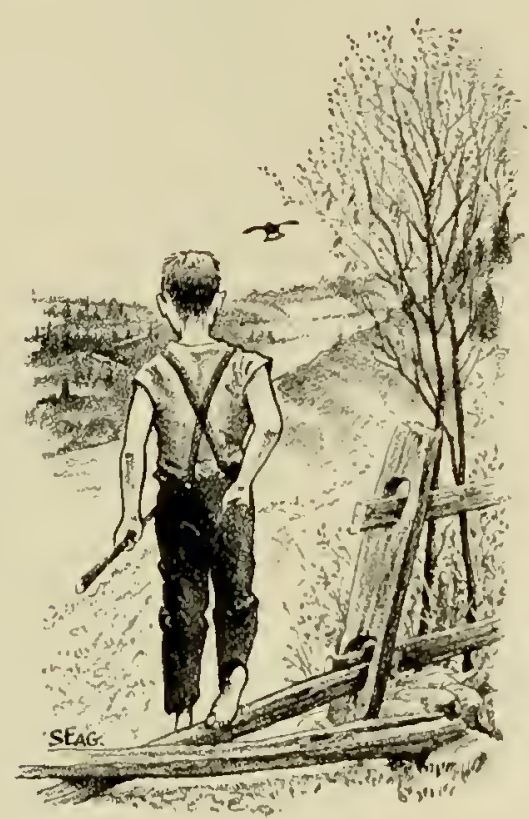

So wrote the naturalist-philosopher uearly a century ago. Yet. it is still such incidents of grouse life, together with the startling roar of the intrepid warrior as he bursts upward through Autumn's flaming foliage, which attract most of us. We can still recall vividly being scared half out of our wits when. as a bare-footed youngster getting the cows or following a trout stream, a "partridge" burst like a thunderbolt from beneath our feet. And, in the twilight, the roll of the "muffled drum" seems to symbolize Nature's immutable mystery.

The primary purpose of this Investigation, however, has hecn to study those factors of grouse ecology which control its abundance in New York State. Therefore, no special attcution has been given to the general habits of the species except as they have had a definite bearing on productivity. Nevertheless, a great deal of life history data have been accumulated incidental to carrying on specific studies. These observations are discussed in this chapter. Also, under certain headings, such as drumming, attention has been given to assembling the story of past thought on the subject since the writings of the early explorers.

For the sake of easy reading, then. the stories, old and new. and the facts, insofar as we have been able to decipher them, have been organized under separate descriptive headings. Since certain habits are not common to hoth sexes or to both adults and chicks, these discussions have been further grouped in four parts comprising those characteristic of both sexes, of the male, of the female, and of the brood respectively. Since, however. the various topics are more or less dissociated, it has appealed to the authors as desirable at the beginning to summarize the principal activities of a typical group of grouse as they are indulged in season by season. 


\section{SEASONAL PATTERN}

The reactions of grouse, as of other birds, exhibit a definite pattern throughout the year in response to the environment and to the physiological changes which take place in the bird. This is particularly true during the reproductive period. Yet male and female, adult and youngster, respond differently to such stimulations.

It is not within the scope of this Report to go deeply into an analysis of grouse behavior*, though naturally advantage has been taken of the many opportunities to observe it. both in the wild and in captivity. But, through frequent recurrence of such accasions, many reactions have become associated in the minds of the observers with certain stages or phases of the bird's annual existence. A brief resume of these relationships should be of interest to the sportsman who, in his days afield, often encounters many of the reactions involved. Like. wise, hoth wildlife manager and game hreeder will here fund correlations, an understanding of which will aid in developing methods and techniques for managing grouse both in the wild and in captivity.

For the adult male and the female as well, once the limiting requirements of raising hel brood are at an end. the fall is a period of recuperation fron the excitement of the reproductive season and from the physiological strain of the moult. Vigilance in defense of territory ${ }^{\Delta}$, which was constantly in the mind of the male throughout the breeding season, has long since become of minor importance. Similarly, his mate exhilits little intolerance of other adults. Birds of the year. however, that have not yet established any home grounds of their own. may occasionally intrude and need to be driven out. In general, the season is one of lazy enjoyment of life. of feeding wherever the forage is most attractive in preparation for the coming winter and of ronsting at night wherever darkness niertakes them.

For the young birds, it is a period of approaching maturity and of change in the pluysiral conditions ahout them. They appear to be restless. nervons and increasingly unsure of their status, for the society of the lrood now breaks up and each hird. apparently. must slift for itself. This situation finds expression in the fall shufle or "erazy flight". as later described.

After the falling of the leaves. the intensity of these reactions anong the hirds of the year seems definitcly on the wane. Thereafter, they, together with the older birds, prefer the sereurity that lies in coverts where good shelter is to be found adjacent to an abundance of food. Largely abandoned are the long trips afield in search of such delicacies as nannyberries and thornapples. As colder weather approaches. gregarionsness increases and throughout the winter several hirds often share particularly attractive patches of food and shelter.

From December to late February. the nsual daily trips in seareh of food are customarily short. The hirds. if undisturled. apparently walk as often as they fly from their nightly roosts. Occasionally, groups of two or three travel together. Ofttimes. their wanderings are so circumscriber as not to encompass more than two to half a dozen acres during the daylight lours, though occasional excursions may be made to more distant portions of their territory. At day's end. they commonly return to join with others in oceupying one of several favorite roosting spots. If the weather is severe and conditions suitable. the night may he spent in a snow-roost.

One cannot set the time when the first break in the winter routine will appear. Days, warm and smmy for mich-winter. may hring a recognizalle ehange in the helavior of the mate as corly as the middle of February. The first notiealbe sign may well be footprints in the

\footnotetext{
* sore Chupter 11, 1". 63.

$\triangle$ bee discusaion of Territory, p. 257.
} 
snow, often so close together that they almost tread upon one another, flanked by deep-cut parallel marks. Produced by the drooping wings of the strutting cock, these are truly a harbinger of spring, for they usher in the breeding season which lasts well into early summer.

Much of the early spring pattern, described by Howard ${ }^{109}$ for certain British birds, finds its counterpart in the actions of the male ruffed grouse at this time. He occupies a conspicuous position - the drumming log, drums rather than sings and becomes aggressive in defense of that portion of his territory encompassing his drumming sites. True, males may be heard drumming to some extent every month of the year, but the frequency now is increased until, by mid-April in New York, upwards to half of the day and night may often be spent on or in the immediate vicinity of such logs. Gone are the winter roosting concentrations, thongh there may still be many lapses back to the former routine. particularly if the weather be cold and stormy.

The female, also, is affected by the change in the physical world about her. Though she minds her own business without seeming to take too much notice of the male, she will he found with increasing frequency in the vieinity of drumming logs. Perhaps her actions may best be characterized as an independent awareness of the presence of the male. One may even postulate that she enjoys the excitation in the latter which her proximity evidently pro. duces. Yet she is quiet about it all, exhiliting little outward sign of her emotions.

From the above, but not substantiated by actual ubservation, one may conjecture that mat. ing takes place on one of these visits at a time when the reproductive rhythms of the two birds are synchronized. In eaptivity, at least, one mating commonly serves to fertilize a clutch, perhaps explaining why the female appears to lose interest rapidly after the act. Thereafter she spends but little time in the immediatc vicinity of the drumming territory.

The male continues to display and drum. possibly in hope of attracting the same or other females. By the middle of May or the first of June, however, his reaction is definitely on the wane and an increasing amount of time is spent in other parts of his territory. In early morning and late afternoon. he may make it a point to visit one or another of his ctrumming sites. Occasionally, throughout the day also, as he finds himself in the vicinity, he may strut or drum. But these instanees become less and less frequent until, hy mid-June, most of his time is occupied by a summer routine of feeding, dusting, sunning and slecping.

No such leisurely existence can be cnjoyed by the female, however, who must incubate her eggs and raise her brood. Once her clutch is complete, she pays but little attention to the male. After the chicks have hatched. she guides her brood wherever fancy or necessity dictates, frequently passing through the territories of other grouse in her wanderings. Her reactions apparently revolve around fulfilling the requirements of the brood until she is relieved of that responsibility following the fall dispersal period.

During late summer, both adults must renew their feathers through moulting. Although they at no time become flightless, the hirds, at this season. tend to be much more secluded in their hahits. The young hirds also hegin to acquire their mature plumage at this time although it is not completed until somewhat later.

\section{COMMON TO BOTH SEXES}

With the general pattern of activity in mind, the principal component habits and charac. teristics of the birds may be individually discussed in greater detail. Considering first those common to hoth sexes, a logical starting point is mobility. 


\section{MoBiLity}

Since time inmemorial, the flight of birds has captured man's imagination. The grouse is no exception. The characteristic explosive flight of this feathered "bombshell" is familiar to all who travel our northern woodlands.

\section{Walking}

Nevertheless, the grouse, when undisturled, does a considerable amount of walking about over the forest floor. During the warmer months, the greater part of its feeding is done in this manner, especially that of the female and her brood. But, even in winter. it is common to find their tracks in the snow, frequently extending for several hundred feet. In this con-

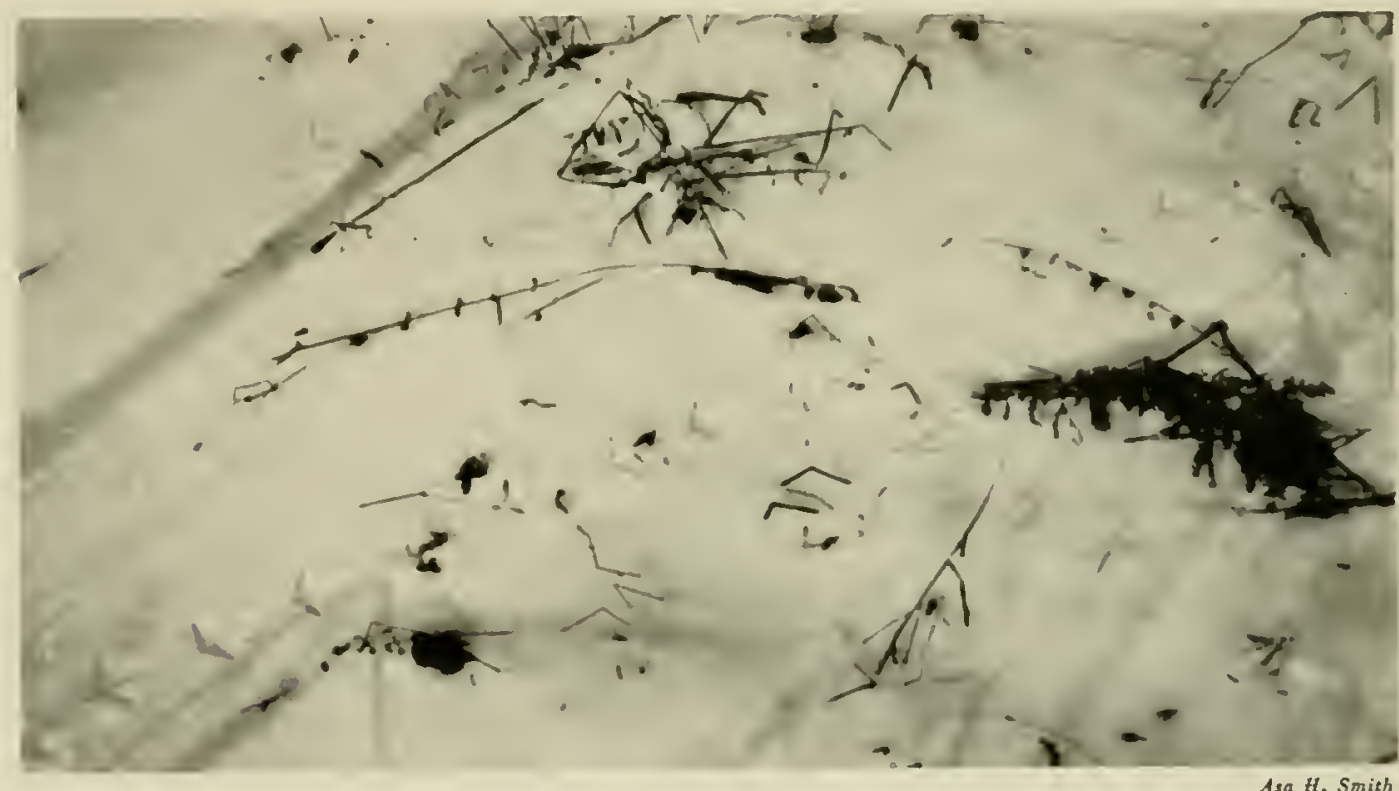

TRACK OF RUFFED GROUSE IN SNOW

nection, a comment of the editor of Forest and Strean ${ }^{134}$ is interesting":

"One reason why the ruffed grouse are increasing . . . is because they are not snared as much as they were in former years. Four years ago every piece of 'scrub oak', and every swamp or alder thicket had its 'hedgerows' ruming through it. During the fall and winter, the ruffed grouse travel from one picce of woods to anuther; if a hedgerow' runs across an entire wood, every grouse will be caught $j_{n}$ one of its snares while passing."

\section{Suimming}

That grousc also can swim when necessary is reported hy several observers including For. bush $^{209}$. One of these ${ }^{272}$ estimated the progress of a hird in the water to be nearly as rapid as that of a duck.

Flying

While it often springs directly from the ground into the air, or mounts a stump or other

- The term "hodgerow" in the following quotation was applied to the bruab borricrs at openings in which the anses wero placed. 
elevation for its take-off, it more commonly takes a few running steps before launching into flight. The gradual nature of its take-off is well illustrated when a light snow is present by a series of four or five wing-tip impressions which successively lessen in distinctness.

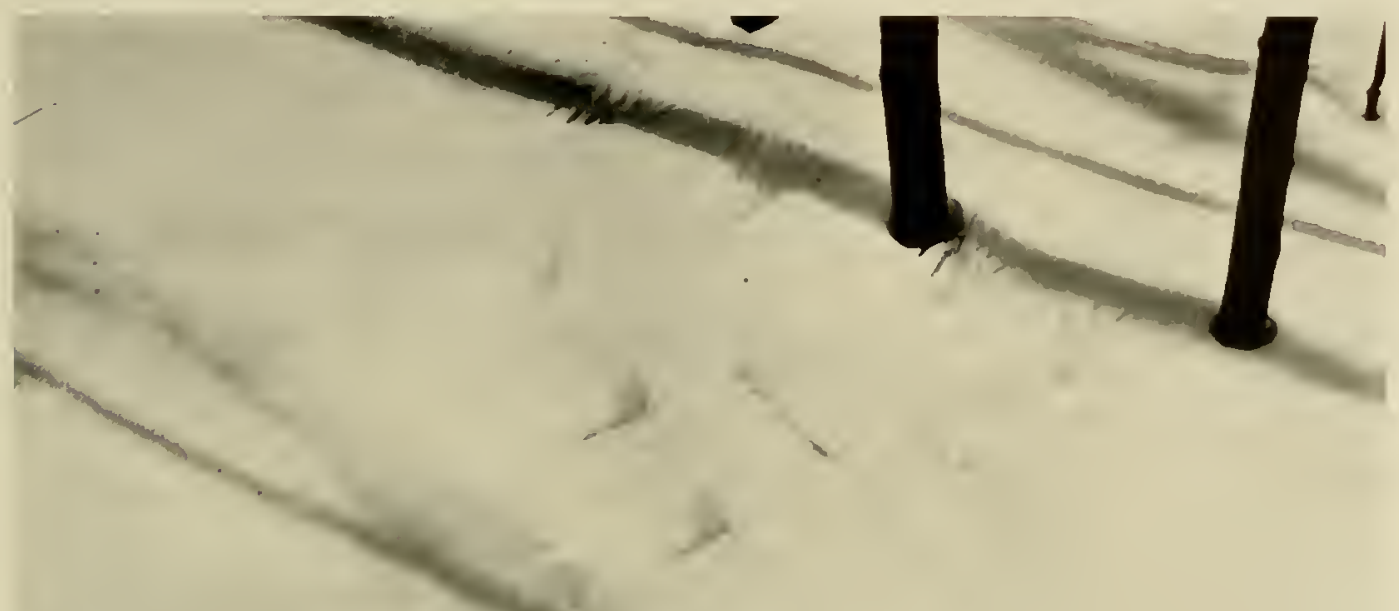

WING-TIP IMPRESSIONS LEFT IN SNOW WUERE GROUSE HAD TAKEN OFF

A fact not so well known, however, is that, when not alarmed, the grouse may lly very silently. Audubon recognized this, but later writcrs have more often left it ummentioned. During the present Investigation there have been many opportunities to olserve the flight of undisturhed grouse. These birds have invariably made almost no sound. Occasionally, birds. even though disturbed, will endeavor to "sneak" away in this manner, especially if they believe they are unobserved.

The grouse is primarily sedentary and its usual flights are short. That it is capable, however, of covering cousiderable distances has frequently hecn demonstrated by birds observed flying across open areas. In the woods, it almost invariahly flies out of sight, making an exact record of distance difficult. On many occasions. however, birds flushed at the edge of a piece of cover have flown across the open to another covert. Such observations show that distances of a quarter mile are traversed with ease.

Others, however, have recorded considerably greater powers of flight. For instance, grouse have been noted flying from out over a lake into the woods along its margin when the opposite shore was at least a half-mile away. Sutton ${ }^{239}$ cites Van Cleve as having ohserved grouse flying as much as three-quarters of a mile from one ridge to another, although he states that they appeared to be somewhat exhausted upon alighting. Rutledge ${ }^{324}$ refers to its ability to make flights of more than a mile. The fire lookout on Pocotello Mt. in New York State observed a grouse which flew past his station and disappeared in the distance, having covered at least half a mile.

Again, many instances of the so-called "crazy flight" indicate that considerable distances were covered, but specific data are lacking. Typical of many similar records is that of a 
grouse which flew into the showroom of the Briggs Motor Car Company in the business district of Binghanton, N. Y.- a point over a mile from any grouse cover, although, of course, this bird may have alighted several times along the way.

Thus it seems certain that, under sufficient stimulus, most gronse are capable of sustained flights of well over a mile.

On the other hand, the island distribution of the species* offers circumstantial evidence that, at some time, considerably greater distances have been negotiated. Thus native populations were present on Prince Edward, Grand Manan and Vancouver lslands, all within ten miles of the mainland. But it was absent from Isle Royal, 15 miles from shore in Lahe Superior, as well as from Anticosti and Newfoundland, 20 miles and 45 miles at sea. respectively. In this connection, a noteworthy contribution is made by Millais ${ }^{31}$ who states that the Scoteh grouse of Europe has been observed flying from Thurso, on the north coast of Scotland, to Hoy, an island 11 miles off shore.

\section{Flight Speed}

Because they are extremely difficult to secure, accurate records of the flight speed of grouse are scarcc. White ${ }^{\mathrm{n} 5}$ noted a speed of 22 miles per hour, apparently rejuresenting one observa. tion from an automobile. To augment this information. the Investigation went so far as to hold a stop watch on a number of individuals. The observer released the instrument the moment a bird flushed and checked it as the bird passed some defnite landmark in its course. Of a large number of such trials, only four proved worthy of record, one of which was rated as excellent with respect to accuracy. In this case, the bird flushed from the ground at the edge of a field, flew 251 feet across open land, and was checked as it entered the woods on the opposite side. The course was slightly downhill. The lird covered the distance in $33 / 4$ seconds, or at a speed of 47.2 miles per hour.

The other three records were secured in cover, two in slashings and one in second-growth hardwoods. Because of the difficulties involved in determining just when the lird passed the "marker", their accuracy can only be rated as fair. In two cases, the distance was 125 feet and in the other 175 feet. The recorded speed of llight ranged from 32.7 miles per hour to 48.4 miles per hour. Two further qualifications should he noted; namely, that these records inchude the time required for the bird to "get under way" and that they rejresent the reactions of birds under an impulse to escape.

Apparently, then, in the open, grouse are capalite of attaining a speed of close to 50 miles per hour, while in the wouds, with ohstacles to dodge. this rate averages somewhat less. On the other hand, when not alarmed, their usual flight is much slower.

Indicative of the speed with which a frightened grouse often makes off. is the following incident related by Girand"s:

"In the antumn of 1839. while two of my friends were in pursuit of the American Partridge (Quail). their dog put up a Rulted Gronse. Both wentlemen fired at the same instant-and seeing the bird lodge in a tree, hoth elaimed the prize each supposing that his slot had taken offeret. On arriving at the spot, they found the hird impaled on a small dry hranch, without having received a single pellet."

\section{Migration}

Observations during the present Investigation have revealed nothing to indicate that the ruffed grouse is other than thoroughly sedentary in its habits. While young lirds may wan- 
der considerably prior to their first breeding season, adults which have established themselves, seldom move far. Once settled, both their daily and seasonal ranges are usually small*, al. though in some of the more mountainous districts, particularly in the West, there has been reported $^{284}$, ${ }^{148}$ a movement of grouse from the higher elevations to lowland areas in the fall and vice versa in the spring. Nost references to migration in this species, however, either pertain to the so-called "crazy flight" or, more often, are erroneous interpretations of the occurrence of periodic scarcity.

On the other hand, certain records of some of the older naturalists are worth citing. Audubon" attributes to them habits akin to migration: "The Ruffed Grouse performs partial sorties at the approach of autumn", when they may be observed crossing such rivers as the Ohio and Susquehanna, "in parties of eight or ten, now and then of twelve or fifteen". He refers particularly to stich movements from Ohio, Illinois and Indiana into Kentucky. He further states that, with the approach of spring, "the males, as if leading the way, proceed singly towards the country from which they had retreated. The females follow in small parties of three or four". While he speaks as though this were not an uncommon occurrence, subsequent observers have not noted it. Whatever the actual facts may have been, therefore, this trait is not now important.

Other observers have, now and then. reportcl the occurrence of flocks or packs of gronse in the fall which seemed to be traveling as a group from one locality to another. For instance, Brewster $^{\text {tw }}$ relates finding a flock of one lundred and fifty to two hundred. in September, 1870. at the Forks of the Kennebec in northern Maine. On another occasion. he followed a flock of about 15 grouse over a mile through open farming country near Lake Umbagog, (Me.) luefore he lost track of it still going in the same direetion. More recently, Spiller ${ }^{3.9}$ writes of three similar olservations, one of which involved a pack of $40-50$ individuals which he witnessed personally.

Having encountered nothing of this nature during the present study, it is difficult to interpret these experiences. All have occurred in the fall. Auduhon suggested a quest for food as a motivating factor; Brewster a restigal tendency to migrate. Spiller reported an otherwise general scarcity of hirds at the lime of his experience. Without more definte and hetter correlated data, however, one might speculate endlessly on these and other equally intrigu. ing possibilities. In any case, such group movenents are rare.

That local conditions may sometimes be responsille for apparently migratory movements of grouse is illustrated by the following account from Smyth with $^{315}$ respect to the vicinity of Ithaca, N. Y., in the fall of 1921:

"Early in the fall, mast was very abundant and the grouse were widely scattered through the woods. appearing to he relatively scarce. Toward the elose of the hunting season, however, hunters reported the birds as having hecome alundant. this being due to the gathering of the grouse to more favored feeding places as the picking from the woods jn general became poor."

\section{Fall Dispersal (Crazy Flight)}

The so-called "crazy flight" among grouse has long becn the sulject of much discussion. In the fall of the year, lirds are often picked up which have flown blindly against buildings or through windows, frequently killing themselves. Others are found in unusual places far from their customary haunts. as in the business districts of large cities or about bouses and harn. yards. Their mad recklessness at sucl, times may be judged from the fact that they have been 
known to crash through plate glass windows a quarter-inch thick. Forbush ${ }^{144}$ states that they have even flown into locomotive headlights.

The impulse underlying this behavior is not clearly understood. Several theories have been advanced, at different limes, to explain it. An anonymous writer in the Rural New Yorker, in 1875 , attributed to an "old hunter" the opinion that the birds were frightened by the falling leaves. A writer in Forest and Stream, in $1878^{233}$, states it is a provision of nature against detrimental inbreeding. Forbush ${ }^{1+8}$ suggests the possibility of an inherited instinct of migration occurring sporadically among the birds. The same author credits Seton with the observation that "it is a trait of the young birds, which they exhibit during the first season and sometimes in the second, but never afterward". On the other hand, Gross ${ }^{30-}$ and Allen ${ }^{13}$, finding infestations of the stomach worm (Dispharynx) in grouse picked up dead under similar circumstances, suggested the possibility of disease as the cause.

While definite experimental data are lacking, it seems probable that this phenomenon is largely a characteristic of young birds seeking a territory in which to "paddle their own canoe". Of 15 specimens with this history which have been examined during this Investi. gation ${ }^{*}$, all were birds of the year. The time of usual oceurrence in the fall coincides with the period immediately following the breaking up of most of the broods. Apparently, it represents Nature's way of dispersing the surplus among the current season's crop.

During this period, some stimulus, we do not know what, spurs the young birds to leave the family group in which they have traveled all summer and to strike out for themselves. At this time they become noticeably wilder. In corroboration of this, it is significant that, each fall, in late September or early October, the hand-reared birds in wire pens at the Research Center almost overnight became markedly more nervous and jumpy. This condition often lasts until Thanksgiving time. While such environmental changes as the falling of the leaves may have some minor influence, it seems certain that the controlling factor is inherent in the lird itself.

Although the records are too seattered to be indicative, the incidence of "crazy flight" probably tends to vary directly with the fall abundance of gronse. Furthermore, it has been demonstrated that populations in excess of the saturation point decrease through dispersion at this season.

Of problematical significance is the record of a bird marked by tying a bell to its wing, which was found dead sometime later. having broken its neck flying into a tree. This sug. gests the possibility that irritation resulting from injury or perhaps diseasc. may sometimes produce, in individual birds, reactions snperficially resembling crazy flight.

\section{Spring Shufle}

As noted above, the territory in which they pass their first lireeding season becomes the permanent home of most grouse. The majority make this choice during the preceding fall. Some, however, either are laggards or bccome dissatisfied with the covert in which they spent the winter. The result is a "spring shuffle" in which such individuals wander about until they hecome settled. This movement. which takes place in late Mareh and early April, is on a much smaller scale than that of the fall and the hirds seldom exhibit the wild recklessness of the crazy flight season.

During the spring. hirds are often picked up dead after having flow into some obstacle. Such instances bave leen thought, by many, to represent a recurrence of the crazy flight im.

* Since the bura ol Fabricus ba heen employed as an index ol ace. 
pulse. In most cases, however, such specimens have been found in or close to normal grouse coverts rather than being in some definitely "foreign" situation, such as a large city. Usually they have collided with a fence, telephone wires or even a tree trunk. It seems more logical, therefore, to consider them merely as accidents associated with the spring shuffle.

\section{TERRITORY}

During recent years, students of bird behavior have, to a large degree, restricted the use of the term "territory" to denote that area which the males of certain species establish and defend just before and during the mating period ${ }^{107}$, ${ }^{905}$. This concept is most evident among various migratory species whose breeding range is distinct from their winter range. But it may likewise be noted in non-migratory forms, although here it is often obscured by the fact that the same range is occupied the year around. On the other hand, especially among sed. entary species, the term may also be used to represcnt the area necessary to satisfy the hahitat requirements of individual birds throughout the year and within which is included whatever specialized breeding territory the species may have. The former of these two concepts will be discussed first.

\section{Breeding Territory}

With respect to territory in this sense, Leopold" suggests that "the ruffed grouse practices polygamy of Wight's "crowing ground' type", in which the crowing ground of the cock tends to include the nesting territories of the hens which are more or less defended ly him. Observations in the case of the grouse, however. have failed to reveal any definite relationship he. tween the nest and the drumming $\log$ or evidence of defense by the male of the area in which the nest is located. This is in keeping with the fact that he has little to do with either the nesting female or the subsequent brood while, with the pheasant, there is considerable asso. ciation of this type. Rather, mating may take place anywhere within the cock's territory and it seems to be the responsibility of the female to seek out the male at such times, which results in such activity being most often associated with the vicinity of a drumming log * While the latter may be defended, on occasion, against other males, the establishment of distinct breeding territories has been but slightly developed in this species.

\section{Year Around Territory}

In its broader sense, the territory of an adult grouse is that area within which the bird finds those envirommental conditions it requires for a normal existence and within which it tends to remain permanently. As a non-migratory species, it seeks to satisfy those requirements in a relatively small area. While other features are necessary, in varying degrees, it is obvious that the primary qualities which such an area must supply are adequate shelter and satisfactory food at all seasons and in suitable relation to one another.

It is normal, then, for each grouse to establish its own territory. The areas occupied by individual birds, lowever, are extremely difficult to define. In the absence of conspicuously marked birds, the most significant records indicating territorial limits are those of birds which, when flushed, fly back past the observer. Unfortunately, however, instances of this type, in addition to being infrequent, most often occur at the edge of an open field, which is a recognized boundary anyway. For this reason, it has been necessary to rely mainly on successive re-flushes of the same bird and on repeated contacts with what is judged to be the same bird over a period of several weeks ${ }^{\Delta}$. Analysis of such plotted data demonstrates that,

* See discussion under Mating Habits, p. 266.

$\Delta$ See discussion of Methods and Techniques, p. 714. 
while individual birds probably have their own "stamping ground", the territories of several usually overlap one another to some degree. This is especially true with respect to patches of conifers to which groujs of birds resort for winter shelter. For this reason, any attempt to discuss the characteristics of grouse territory of this type must pertain to general areas used by several birds.

Size. Elsewhere in the book* the requirements for suitable grouse habitats are discussed in detail. The size of areas (i.e. territories) within which groups of birds have loen able to find conditions suitable for year around existence, has been observed to vary considerably: A major factor in this variability is the degree of interspersion of types. A separated unit, comprising 23 acres of diversified grouse cover on Connecticut Hill. has evidenced, throughout the period of the Investigation, a carrying capacity of one pair of birds and. in addition, has usually produced a brood. Although this unit is not sufficiently removed from nearby coverts to prevent some trading back and forth, it is the belief of the authors that, if completely isolated, it could still support at least two grouse. From this, the size of these composite territories, as near as it has been possible to estimate them, has ranged through all gradations to areas of from 100 to 150 acres oceupied by from three to 13 birds. It must be remembered, however, that a direct computation of the number of acres per bird over such an area rarely represents the size of the territory occupied by the individual members of the group. For example, although a population of 18 hirds was estimated on some 90 acres of the Connecticut Hill study area in the spring of 1935 , each bird, because of overlapping territories, actually occupied a much greater area than five acres.

The number of hirds utilizing individual areas varies, in general, with the cover types present and their degree of interspersion. Of course, it also varies with the general population level. The figures noted above represent spring densities which are the best measure of carrying caparity. In most cases, however, larger groups of lirds were present during the carly winter lout lecame reduced through losses and through the spring shuffle.

When Chosen. Final choice of territory by a grouse seems to be made prior to the hird's first brceding season. The locality chosen may be close to where the hird was reared or a considerable distance away. It is likely that this distance varies in general with the local population density. Similarly, it is probable that the so-called "crazy llight" is a by-product "f such movements ${ }^{A}$. An interesting fact in this connection is that adult hirds, brought in and liberated on an area new to them, often "light out" and travel considerable distances. But once settled, the torritory usually becomes the permanent home of the hird. This cons. rlusion is supported ly an interesting series of data from female grouse trapped and banded at their nests on the Commeticut Hill area as illustrated in table 33.

Another female. banted at her nest in 1932, was found deal in the spring of 1931 at a point 1,500 feet distant.

Three other retords of marked grouse have leen recorled ly Lloyd $\mathrm{d}^{\text {sa }}$. These hirds were banded at Muscow, Saskatchewan. in March. 1925. During the following Octoler, they were shot at distances of a quarter-mile. a lialf-mile and a mile, respectively. from the banding station. The third rase may represent cither an exception or a first-year bird which had not become fually lorated when banded.

* Ser Chajierga III, 11, and Xil.

$\Delta$ see diacuesion under Molility. 1. 255. 
TABLE 33. DISTANCE IBETWEEN SUCCESSIVE NESTS OF INDIVIDUAI. MARKED FEMALE GROUSE:

\begin{tabular}{|c|c|c|}
\hline $\begin{array}{l}\text { Year } \\
\text { banded }\end{array}$ & $\begin{array}{l}\text { Year } \\
\text { retaken }\end{array}$ & $\begin{array}{c}\text { Distance } \\
\text { between } \\
\text { nests }\end{array}$ \\
\hline $\begin{array}{l}1931 \\
1931 \\
1931 \\
1931 \\
1932 \\
1936^{*} \\
1938\end{array}$ & $\begin{array}{l}1932 \\
1932 \\
1932 \\
1932 \\
1933 \\
1937 \\
1910 \\
1939\end{array}$ & $\begin{array}{r}200 \mathrm{ft} \text {. } \\
300 \mathrm{ft} \text {. } \\
1.300 \mathrm{ft} \text {. } \\
2.000 \mathrm{ft} \text {. } \\
400 \mathrm{ft} \text {. } \\
660 \mathrm{ft} \text {. } \\
250 \mathrm{ft} \text {. } \\
1.150 \mathrm{ft}\end{array}$ \\
\hline
\end{tabular}

* Although this hisd was not rutaken in 1938 or 1939. the pres nece of broods Irom unkaown nots in the immriate vicinity indicate she uccupied the same territory.

Relation to Cover Quality. It may he stated from the data at hand that tracts of as low as 25 acres of good cover* may afford a suitahle annual range or territory for a pair of grouse but that. as the cover hecomes poorer, the hirds must travel over larger areas in order to find the envirommental requirements which they mut have to survive. It is seldom. however. that the territories of individual birds exeed 1.50 acres or an area. rutughly, one-half mile in diameter. Therefore, the number of possihle grouse territories in any tract varies with the quality of the cover - a relationship which is important in controlling carrying capacity ${ }^{\Delta}$.

As might be experted, when a covert is not stocked to capacity, only the hetter territories in it tend to be occupied. For this reason. hirds will be found in certain portions of an area, year after year, if they are to be found at all. while, elsewhere, one will cucuunter them only now and then except when high populations are present.

Furthermore, the nature of individual units of this kind is constantly changing as the cover itself ehanges in the process of succession. Corresponling shifts in utilization by the hirds also take place.

Seasonal Shifts. Within grouse territories. there are seasonal shifts. In winter, the birds tend to concentrate in the vicinity of coniferous shelter while, in the spring, they spread ont over the seconl-growth hardwood and overgrown brush areas. Likewise. in the late summer, the utilization of slashings increases and. in the fall, any portions of their domain offering fruits, such as hawthorns, wild apples and grapes, are favored.

\section{Gregariousness}

In 1812, Alexander Wilson" wrote "the manners of the pheasant [grouse] are solitary: they" are seldom found in coveys of more than four or five together. and more usually in pairs or singly". While Wilson seems to have had little experience with gronse during our northern winters, his statement is very applicable to the hahits of adults in the Northeast during most of the year. Although exceptions occur at all seasons. there is, in general, little evidence of sociability, except among the loose groups which occupy the same patches of shelter during the late fall and winter. Even these break up as the breeding season draws near.

Illustrative of this situation is the record for the Connecticut Hill area comparing the fall and winter period of 1934-35 with the following spring. From October through March. a total of 1,678 grouse flushes were recorded, of which 379 or 22.6 per cent, comprising 76 contaets,

* See Chapter IIf. H. 110.

$\Delta$ See Chapter Xil. p. 522 
were found to be in groups of four or more. These groups were as follows: 36 of four birds each; 23 of five each; 8 of six; 4 of seven; 3 of eight and one each of nine and 11 birds. During April and May, on the other hand, out of 1,327 hirds, only one such group was encountered, this being of four birds in April. During the summer, it is very rare to find even two adults together.

Several other observers, both hefore and since Wilson, have noted much greater degrees of gregariousness. Thus Morton in 1632, ${ }^{200}$ stated he saw 40 grouse in one tree. Forbush ${ }^{169}$ men. tions the report* of C.C.Abbot that, at one time, thousands congregated in the swamps of New Jersey. Again Lahontan", in speaking of this bird to which he referred as "fool hen", says, "they sat in the trees in flocks and were killed one after another". More recently, Brewster ${ }^{55}$ and Spiller ${ }^{\text {sa }} \Delta$ have reported large flocks in the fall.

In view of the usual reactions of this species today, such records are striking by contrast. Undoubtedly, some degree of change in its habits has taken place, although it is very unlikely that large flocks were ever of more than infrequent occurrence. Furthermore, it is probable that many of the early records applied to broods.

A common belief is stated by Billings $\mathrm{s}^{\mathrm{s}}$, "The males form small parties and continue sepa. rated from the females until the approach of winter, when the males, females and young mingle together". The Investigation has secured no evidence of social groups of this kind among male birds at any season. Likewise, the supposition of Maynard ${ }^{2 \pi x}$ that wintering groups represent broods which have not broken up, appears to be of rare oecurrence. Rather, such groups merely represent birds whose territories include the same patch of winter shelter.

\section{WARINESS}

One of the most important quatities which places the grouse of today in the first rank among game birds is its customary wariness wherever hunted to any extent.

\section{Primitive Tameness}

But this has not always been so. Descriptive of its original habits was the name of "fool hen" by which it, as well as its cousin the spruce gronse, was known in colonial day's. The Indians hunted it with the club and with blunt arrows ${ }^{20}$.

Many early writers referred to it as stupid and stated it was considered fit game for small boys who most often secured the birds, not by means of firearms but by knocking them off their perches with sticks and stones, or by snaring them in a noose at the end of a pole. Another method is described by Nuttall" :They are even smoked to death. in the same man. ner as the wild pigcons in the western country, while sleeping harmlessly and unsuspectingly in their leafy roosts". Other accounts tell of groups of birds which allowed themselves to be shot, one after the other, without flying ${ }^{a s}, 00$

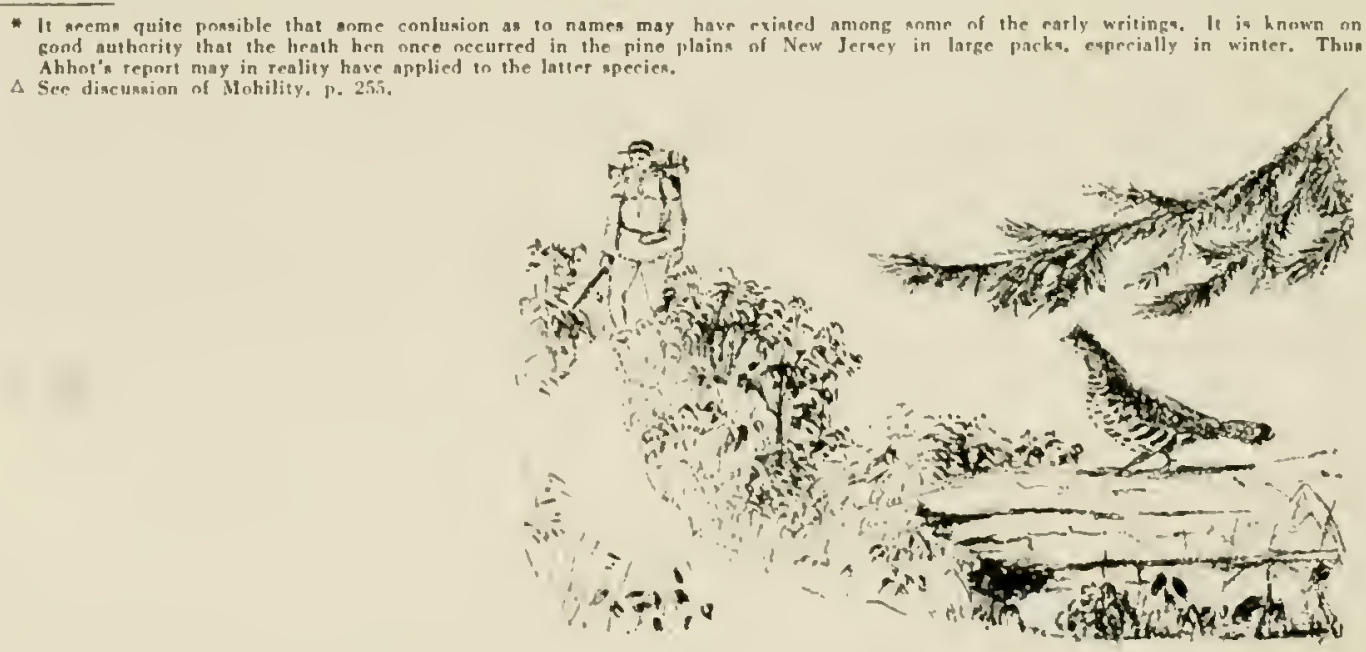


The following account by Brewster ${ }^{55}$, concerning the habits of ruffed grouse in Maine, is interesting:

"When l began to indulge in it [partridge shooting] about Lake Umbago in the early 70 's the birds were exceedingly tame, even close to the settlements . . My good dog found and pointed them readily, but was evidently not a little puzzled to comprehend why they should stand conspicuously upright in open ground, or on mossy logs, regarding him with seeming indifference from a distance of only a few yards . . . For instead of rising promptly on wing as I wished, and expected them to do, they would . . . start off at a slow walk with crests erect and perhaps also widespread tails, shaking their heads and necks, and twitching their expanded ruffs at each deliberate step, and continuing increasingly to utter their derisive and unseemly snickering . . Even when I forced them to take wing by running after them, they rarely went more than a few yards before alighting in a tree, or dropping again to the ground over which they might continue to hasten, if much alarmed, until it was useless to follow them farther."

In this connection, Elliot ${ }^{20}$ suggests that this extreme tameness is a characteristic of the Canadian subspecies (B. u. togata).

\section{The Transition}

It is a far cry from the birds which prompted such accounts to the grouse with which most present-day hunters are familiar. But even today, in remote forest areas, one often meets with individuals which are comparatively unafraid. In the Adirondacks and other similarly forested regions, it is not unusual to find hirds, either on the ground or perched in trees, which will allow approach to within ten yards or less. Similarly, one comes upon birds which merely run out of the way instead of flushing. Deer hunters frequently sccure such birds with a rifle. It is also said that, in certain areas which have been set aside as sanctuaries, the birds tend to lose their wariness.

But, in localities where hunting pressure has been appreciable, the species has undergone a process of education by which its memhers have acquired an instinct of caution. Beginning with the first pursuit of the birds by man, this process is gradual and continuous. Records do not tell us when the transition took place in most sections lut. in his notes on the Lake Umbagog region of Maine, Brewster ${ }^{6 s}$ states that, in that locality, it "began to be noticeable about 1889 or 1890 ", and that by 1900 the birds about the settlenient had hecome "almost as wary and otherwise sophisticated as those found in eastern Massachusetts".

Yet hunting cannot be held entirely responsible for this change. There seems little doubt but that the harassment of the birds by man's everyday activities is much greater in settled districts. Likewise, a similar relationship with respect to predators seems to exist in disconnected coverts as compared with extensive forest areas.

\section{Present Caution}

In most coverts, today, these birds are thoroughly alert and wary. They usually rise well ahead and make off rapidly in a more or less zig-zag course which soon puts a tree or other obstruction between them and the observer. Again one will wait until it has almost been passed by and then flush in the opposite direction. Occasionally, they become confused and run directly at one before flushing. Like many other species of wildlife, they may often be approached quite closely in an antomobile but flush immediately if one tries to get out of the car. After being flushed, they commonly alight in trees, particularly conifers.

The female, while incubating or during the brood period, is, of course, an exception. When on the nest, she sits very close, probably depending on her protective coloration and immo- 
bility, but when with the brood, especially during the first few weeks following hatching, she is often remarkably bold and aggressive.

Throughout the present Investigation, the majority of the grouse contacted have flushed within 50 feet of the observer. Over the fall. winter and spring period, 72.0 per cent of the flushes recorded have been in this zone, while during the summer, this proportion has increased to 87.4 per cent. Grouse generally flush much wilder in windy weather, however.

\section{Stratagems}

When trying to avoid detection, the grouse resorts to a variety of stratagems. The one practiced most commonly, perhaps, is to "freeze". If the intruder does not approach too close and continues on his way, the hird "sits tight"; otherwise, especially if one pauses in the near vicinity, it usually flushes. Sometimes, it will wait until passed by and then flush in the opposite direction, or again one will endeavor to sneak off by running. In hunting with a dog one frequently finds that a bird, upon becoming aware of the intruder, has run to the opposite side of some screening shrub or other obstacle before flushing. The apparent tendency for birds to dodge behind a tree or hush immediately after heing jumped seems. in reality. to be most often accomplished in this way.

An anonymous writer in Forest and Stream ${ }^{322}$ found one hiding in a hollow stump and a wounded bird was found by one of the authors to have taken refuge in a woodehuck hole. On another occasion, J. V. Skiff, Deputy Commissioner of this Department, witnessed a grousc being pursued in the open by a goshawk. The hird flew directly into a thick pine tree successfully evading the hawk. hut seemed to fall to the ground stunued. Yet a few moments later it was found unhurt. The ultimate seems to he represented by a wounded hird which submerged jtself in shallow water until only its head remained above the surface. Forbush ${ }^{169}$ has reported a similar case. Another device is for a bird. roosting in a trec. usually close to the trunk, to draw itself up very straight and stiff with its neek upstretched and to remain motionless in this position. Brewster's ${ }^{65}$ description of this trait is especially graphic:

"Standing stiffly erect with raised crests. grotesquely elongated necks and tighthly-eompressed body-plumage. they were easily mistaken for stout. stubbr prongs where upwardgrowing limls had broken off, or for thick clusters of Usnea moss. or perhaps for loose scales of rough bark."

A particularly curious reaction. reported by a number of observers. is that of "treeing". Attributed entirely to the less wary hirds of the hackwoods. it is said that. when fushed lyy a dog. especially one which harks considerably. they often merely fly into a tree and sometimes remain there until the hunter can come up.

\section{Tame Grouse}

In contrast with the usual temperament of this bird. the funding. now and then. of a so.ralled tame grouse. gives a Dr. Jekyll and Mr. Ifyde touch. One spring, as an observer drove up a little-used woolsroad near one of the Investigation's field stations, a grouse suddruly emerged from the wooks and ran beside the car. Upon coming to a stop. it was found that the bird would remain so long as the motor was kept running but flew when it was shut off. This bird performed in mueh the same manner on several sulsequent visits to the same spot. In another instance. a bird. apparently also attracted by the automolile motor. repeatedly ran alongside passing cars until caught one day in a trout landing net. Then. there was the cawe of "Billy. and the Steel Mule"" "This hird wis first eneountered when it undertook to display. one spring. before a farm iractor. The latter. however. had to be ruming to he effertive. There- 
after, the performance was repeated many times and Billy often actually allowed himself to be pieked up and taken for a ride.

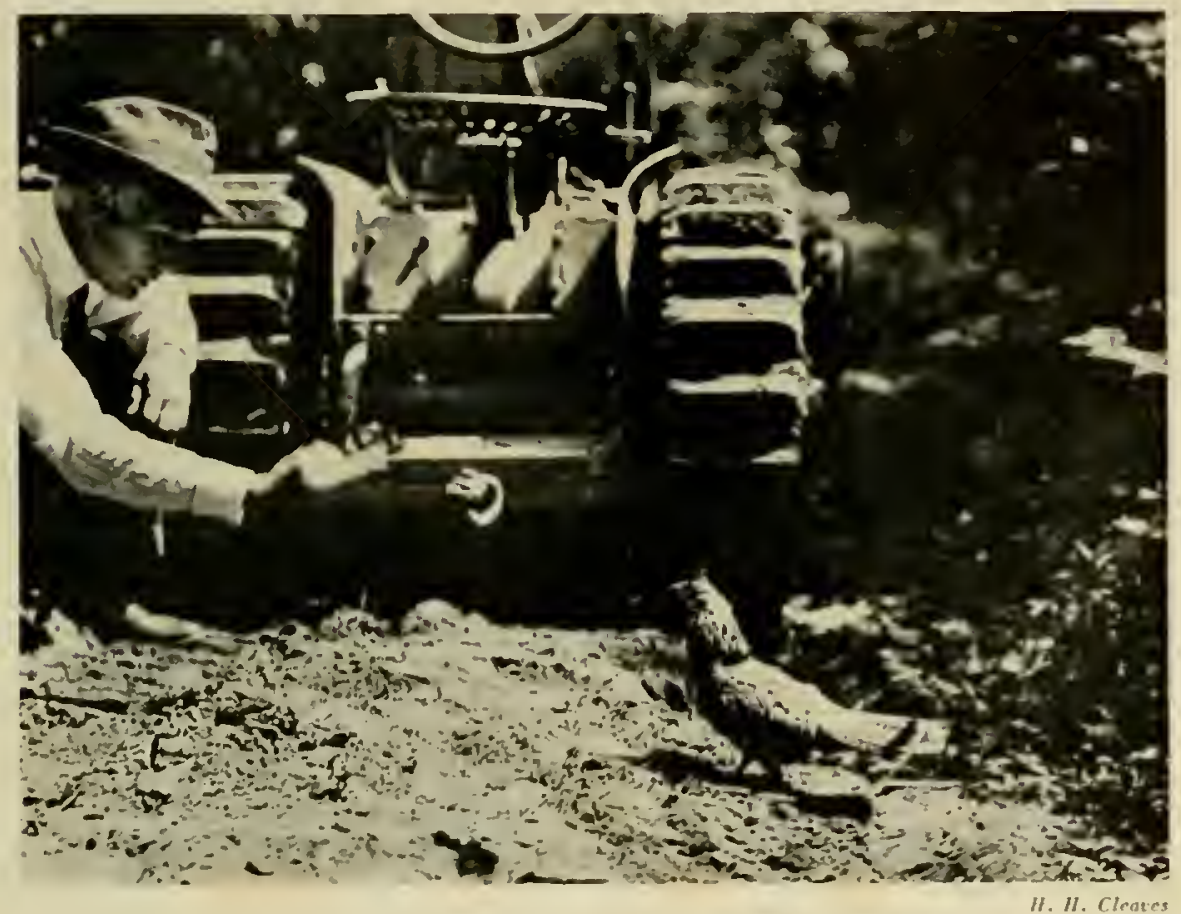

"BILLY" (SEE TEXT) SHOUING REACTION TO RLXNING MOTOR OF TRACTOR

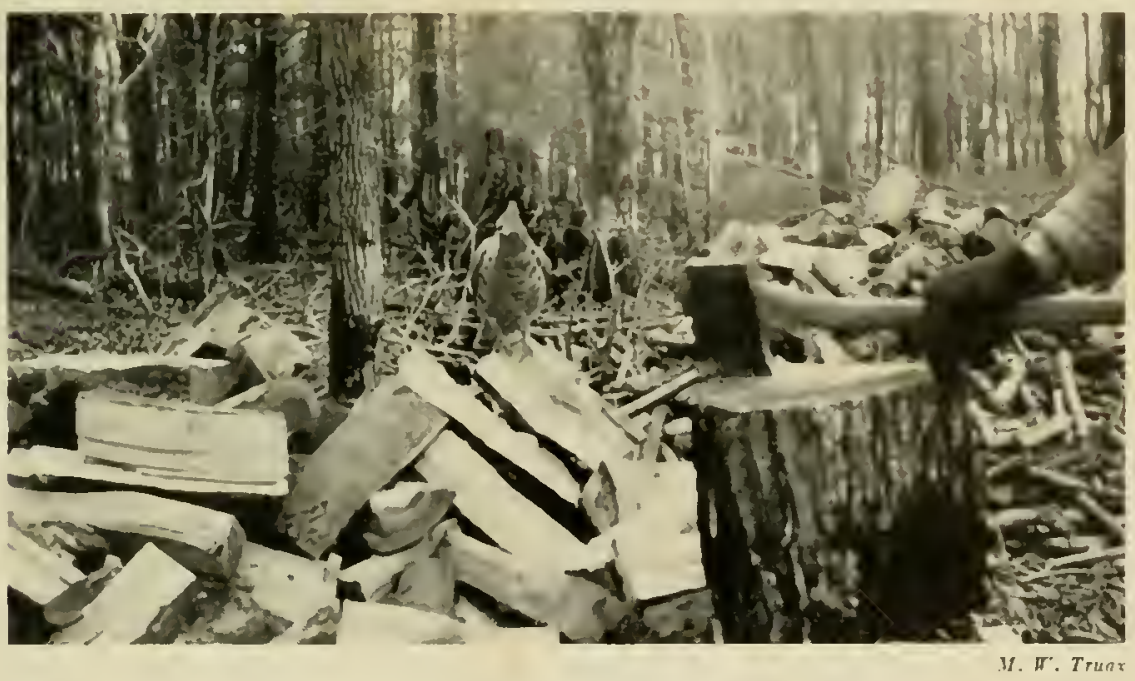

GROLSE ATTRACTED BY WOOD CHOPPINC

Nearly every year, reports are received of similar experiences. Some tell of hirds frequenting the vicinity of harniards or farmhouses and, in some instances, allowing themselves to he 
fed by hand. One of the most common relates to the attraction of a wood-cutter's chopping for certain birds. One winter. while thinning a stand of young cedars near Essex, N. Y., Mr. J. B. Burnham noticed a grouse nearby which seemed completely undisturbed. either by his pres. ence or by the sound of the chopping. Thereafter, for several weeks, this bird would appear each morning shortly after he had begun to chop and remain in the vicinity all day, often hopping up on the log leside him while he ate lunch. And when he left at night, the hird would follow hin to the car and then fty alongside for a short distance down the road.

A quite similar experience is related in the story of "Biddy" of Delaware County (N.Y.) ${ }^{3}$. After having made friens with a group of woulchoppers during the winter, this bird could be called throughout the spring and summer by simply "striking two sticks tngether" and, on one occasion. is said to have joincd a family picnic in the woods and eaten a dish of raspherries ${ }^{\star}$.

Just what the psychological motivation of such reactions may he. one can only guess. Undoubtedly, the sound of an automolile or tractor motor suggests the drumming of a rival hut what associations are inspired by the staccato ring of an axe, remains a mystery.

\section{Feeding Habits}

The grouse is primarily a ground bird and its food throughout the greater portion of the year is largely ohtained either from the forest floor itself or from the lower stratum of shrubs and bushes. Nevertheless. the birds are not averse to feeding at higher levels to secure the fruits of many trees and larger shrubs, when available. Furthermore, when hudding during the winter. they commonly frequent the tops of large forest trees. So wide a variety of both vegetahle and animal foods are taken that the species may he said to be to a considerable extent omnivorous.*

\section{Actions}

In general, grouse are constantly on the move while feeding although, when ludding in the winter or feeding on fruits in the fall, they may remain for some time in one tree or shruh. In securing food from amongst the ground litter. these hirds prefer to pick out what items they can as they mowe along without resorting to scratching as chickens and pheasants commonly do. In this connetion, no evidence has been found to support the statement of Grin. nell' that "when the snow is not too derp, they scratch for food overlooked in autumn". "r that of Forbush" that the old hirds are "persistent scratchers". When feeding on insects in the early summer alongr womls edges. traik and roads. or later on berries in the slashes and burns, they frequently jump from the ground will neck outstretched and often aided by a stroke or two of the wings in order to secure jtems slightly out of easy reach. Another halit is to pick up ants which often abound in the material chosen for dust baths.

An excellent acrount of their actions while hodding in an apple tree is given by Brewster ${ }^{n s}$. whirh is quoted in part:

"I comuled no lese than nine seattered all oret the tree. a few heing low down on stout limbs close to its main trunk and hene ineonspienoms. but the greater number near the rnds of its longer upper lianches. where thev could be plainly secn. while one or two were perehed on the very topmost twigs. boldly oudlined against the grey skv and looking as big as hen-lawks. They were husily engaged in budding ... At times, however, they would all stand erert and motionless for a fow moments. ovidently looking and listening intently. Thuse feeding mar the ends of long and slender branches had some diffeulty in 
keeping their foothold and were constantly obliged to jerk up their tails and flutter theit wings in order to preserve their balance... They picked off and swallowed the buds in rapid succession. with much the same quick, bobbing motion of the head as that of a domestic fowt feasting on corn."

\section{Time of Day}

With respect to the periods of the day favored for feeding during different seasons, representative data are difficult to secure. It is traditional for the limes preferred by game species to be early morning and late afternom or early evening. With respect to the ruffed grouse. however, experience indieates that this concept is not wholly correct although. during the falt and winter, it may hold to a considerable degree. A comparison of the proportion of birds flushed at various times of the day in those cover types primarily offering foorl as against that in the primarily shetter types fails to show such a relationship during most of the year. This 'ondition may be interpreted in one of two ways: either the birds have no regular feeding time or they find food and shelter sufficiently intersperserl to render such a tabulation meaningless. While the former. undoultedly, applics to some extent. particularly in spring. summer and early fall. the latter is probably the more signifieant.

Similarly. observation of traeks in the snow indicates that in winter they often feed during the middle of the day. At this season, ahout as many birds are flushed at all hours from roost: as are flushed while feeding. During this period in particular, weather is an important factor. stoms in general but wind especially causing gronse to restrict their feeding perions.

On the other hand. there is considerable evidence to indiente that. When visiting a certain spot for the express purpose of feeding on some particular item availahle there. these bird: utilize the early and late hours 10 a greater extent. This labit is particularly prevalent in the fall, a fact well-known to grouse hunters who lurn it to their adsantage. frain, one winter. a group of four grouse was noted each cvening. just bofore dusk. to fly into a certain large yellow birch to feed on the louds. This continued regularly for several weeks during feloruary and March. Grinnell ${ }^{\text {ns }}$ and Brewster ${ }^{\text {sin }}$ reeord the same habit. Similar obersations with respect to apple trees and thornapples hase been moted, chiefly during the fall. But whether such olservations represent the whole of a given feeding period or morel! one sol) in a period of much longer duration is not known. In any case it seems probahle that this ty pe of relationship oceurs primarily during fall and winter.

VATIN. HABITS

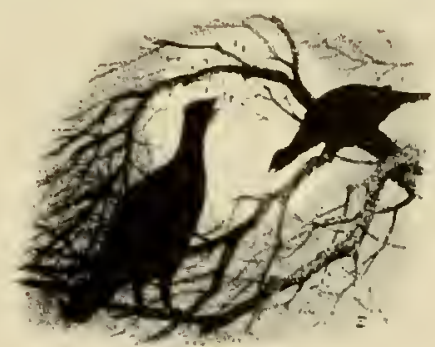

In New York the hreeding season for ruffed grouse commences in late March. Alhough drumming may be noted occasionally at any season, it is now heard frequently in all grouse coverts. Data indieate that the majority of nesting females lay their first egg sometime shortly after the middle of April. The period during which mating is at its beight extends from mid-April through early Vay. althongh recurrences occur in the case of many birds whose first rlutch is destroyed. 
In spite of the faet that a voluminous amount has leen written relative to the courtship of the ruffed grouse, particularly with respect to the drumming of the male. few data have been published concerning the actual relationships of the sexes in the wild during the mating period. Leopold suggests that it is probably often promiscuous hut states that the usual situation seems to be a polygamy of a similar nature to the "erowing ground" type deseribed by $\mathbb{W i g h t}^{307}$ in connection with pheasants, in which each male has his own separate group of hens.

But the analogy holds only partially for, although the males estahlish drumming areas "staked out" by their drumming logs, there seems to be no recognizahle relationship between these and the nesting sites of the females. The 481 nests. for whieh data are availahle from 1930 to 1942. were loeated with respect to distanee from the nearest known drumning log. (See table 3 h). From this it seems that, if anything, the female selects a nesting site at a considerable

TABIE 31. RELATION OF DRUMIING IOGS TO NESTS CONNECTICIT IIII. 1930-1912

\begin{tabular}{|c|c|c|c|c|c|}
\hline Drumming Logs & 0 to 50 fret & 51 to 100 feet & 101 to 200 freet & 201 to 100 feet & Mure 100 fient \\
\hline Number. & 12 & 36 & 7 & 135 & 225 \\
\hline leet cant & 2.5 & 7.t & 15.3 & 28.3 & 16.5 \\
\hline
\end{tabular}

distance from a drumming log. One year in the Catskills. however. a nest was but 10 feet from a used log.

It appears most likely that, when in the mood for mating, the hen visits the cock in the vicinity of his drumming log rather than the cock going to the hen as in the case of phea. sants."

Supporting this conclusinn, a number of obserations may be cited. In a number of instances where drumming logs have been under ohservation. another lird (presumably female) has frequently leen found roosting in a nearby tree. while the male occuried his log. Once the male and another hird were found roosting together directly above the log on several different nights and another time a second bird was olserved on the drumming log with the male. On numerous other occasions. birds judged to be females have been flushed relatively close to drumming logs while the male was drumming. It does not follow, however, that actual courtship and mating necessirily take place close to the drumming log.

There is no gunestion hut that more than one female often visits the same male, though no direct evidence has heen secured as to the number which may mate with a single cock under natural conditions. On several oceasions. however, fwo or more nests have heen found under circumstances strongly indicating that the females insolved mated with the same male. For example. in a croup estimated to comprise seven males and aleron females. all of the latter nested. And even under an equal sex ratio. sereral hens may dhose the same male. 
At the Research Center, it has been demonstrated that, under game farm conditions, one male will readily mate with up to five females in a single pen*. But to just what extent the reactions of such birds reflect conditions outside captivity, it is difficult to say. Stoddard ${ }^{253}$ found that polygamy could be freely induced in captive quail but that monogamy was the rule in the wild.

Unfortunately, it has not been possible to olserve these relationships directly among wild grouse. Undoubtedly, however, cocks tend to mate with as many hens as visit their territories, providing both birds are in the proper stage of the reproductive cycle. The usual evenness of the sex ratio at this season and the fact that the birds are generally well scattered would imply that this number is normally small. Similarly, it is unlikely that competition is often sufficient to force a hen to associate with more than one male. In fact, the result may, in many cases, amount to an enforced monogamy. On the other hand. there is considerable in. dication that grouse are not averse to promiscuity if the occasion demands.

It was long thought that male grouse are in constant readiness for mating throughout the breeding season. Then, after considerable study, Allen ${ }^{10}$ came to the conclusion that this condition is not continuous, but that it is recurrent in what he termed "sex rhythm". Recent experience with propragated birds at the Research Center, however, has shown that, while the degree of readiness does fluctuate ${ }^{\Delta}$, the right stimulus will induce mating even during low periods in the rhythm. In general, males have been found to be ahle to breed successfully over a period of three to four weeks. At the height of his cycle, one hird mated four times in one day. Nevertheless, there is considerable individual variation. In fact, some birds apparently never reach this stage during certain years. lts presence is indicated by the willingness of a cock to attempt copulation with another bird which is in a posturing attitude, although a lack of interest in one bird is no sign that another might not produce a positive reaction.

In the female, oestrus, the physiological condition which corresponds to heat in mammals, has been observed at the Research Center to commence from three to seven days prior to the laying of the first egg. The shorter period is more frequent. Its onsel is ahrupt. a hird often reacting negatively one day and the opposite the next morning. If the hen is mated pronptly, it ceases almost immediately but otherwise may last for three to five days . Indoubtelly additional matings often take place, particularly among renesting birds. Posturing, on the part of a female, indicates she is in a receptive state.

The exact manner by which the hirds determine whether they are suitably matched is still obscure. Nevertheless, it scems probable that the fenale, when in oestrus. seeks out the male in his territory, probably most often in the vicinity of one of his drumming logs and that the courtship performances which take place serve this purpose. If they are hoth in the proper stage, mating takes place. If not, the hen retires, to return later or to move on to another drumming male.

The courthip performances of the male are discussed elsewhere in this rhapter. Posturing, as the characteristic behavior of the female in oestrus has been termed. is described by Allen ${ }^{10}$ as follows: "The posture assumed by the receptive female is that of a stiffened. de. pressed body with wings slightly spread and tail slightly raised". Among hirds in captivity, females in this condition will posture before an attendant, particularly if he extends his hand over them.

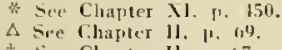

+ sie Chapter 11, 11. 67. 


\section{ITTRKRREDIN:}

Only one authenticated instance of the interbreeding of a grouse with another species has rome to our attention. In 1930. a grouse was killed in western New York whose tail feathers showed definite characters of both the grouse and the pheasant. The skin of this hirc has been examined and shows every indication of heing a genuine lybrid.

Other instances. from New York State. of crusses with the pheasant have been reported to the Investigation. but the proof is lacking. Also. a writer in Forest and Stream" reported one of his hens hatehed a brond whose heads and necks resembled grouse.

\section{Fighting}

Fighting anong wild grouse is very rarely observed and the circumstances surrounding its necurrence under natural conditions are accordingly ohscure. Nevertheless. observation of hand-reared birks has revealed many points in the behavior pattern associated with it. It has demonstrated that grouse of all ages are subject to very pronounced superiority and inferiority complexes and that vigorous birds, regardless of sex, feel constantly impelled to dominate weaker individuals. Among hirds artificially reared at the Research Center. fighting has been noted at all ages from chicks searcely a week okl on. Furthermore. it may take place at any time. although it is most prevalent during the breeding season and among the young birds in the fall of the year. Its purpose. therefore. seems to be two-fold. First. it represents one means of establishing and maintaining a bird: rank in the social scale of its group (i.e. social order) "and. second, it serses in settling disputes between individuals.

Display, however. has no definite relationship to it. Individuals will fight "at the drop of a hat", with no preliminaries. And a bird. which happens to be displaying when a fight is forced upon it, has been seen (n) drop its feathers. engage the assailant and then. if victorious, resume the display.

The attitude usually assumed ly a fighting bird is one in which the feathers are held close to the body, the tail is folded and dropped. and the neck and head are lowered and outstretched. It has been aptly likened to the profile of a dimosaur. By approaching its oppousnt in this manner, it apparently tries to get under the wher"s guard. If the rhallenged hird "picks up the gauntlet". it. too. assumes a similar attitude and both birds as they come into close quarters, circle arnund. sparring with their heats and enteavoring (n) peck one another. As the battle progresses. they often raise up wntil. with upstretched necks. the! stand "toe-tuun" or continue to circke, pecking with their beaks and buffeting each other with their wings. Oceasionally the foet are used in such combats.

An attacked bird may either attempt to elude its persecutor hy rumning or hying. or stand its ground and firht hatk. In the latter circumstance injury is soldom inflieted if the birds are evenly matched and the bout end shortly bu onc of the participants ruming or hy a termination of agegression on both sides. If. howerer, one lird capitulates. the other follows up its advantage by perking it alout the bead and further suhjugating it. In conlinement, such al hird hecomes the viotim of attack hy all the other birds present which rank alowe it in the social seale of the group. At the same time, it may stith retain its dominanere orer indisiduals ranking below it.

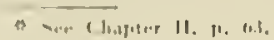


A badly vanquished hird may suffer severe wounds, chiefly about the head and. unless separated, may continue to be the victim of attack until it finally succumbs. Instances have occurred, however, in which a hird died, not from physical injury hut, apparently, from a form of nervous shock brought on by its lack of ability to resist its stronger associates.

In the wild, complete subjugation seldom occurs hecause there are always retreats to which a vanquished bird can fly and regain its composure. Moreover, the usual low densities of population provide a minimum of provocation for resorting to fighting. Aside from the breeding scason. such combats take place most frequently among youngsters beginning to "feel their oats" in the late summer and fall. During the breeding season, fighting most often involves males occupying adjacent drumming logs or in some way infringing on each other's "alleged rights". The males of this species do not indulge in contests for the possession of the female as an individual.

Instances in which fighting has been wherved anong wild grouse have been fow and usually incomplete. On one occasion, in Octoher. one of the authors was sitting quietly on a stump when wo birds, one chasing the other. came ruming toward him. The pursued hird soon flew, however, so no actual fighting took place. Again. early one fall. Sumner M. Cowden. Superintendent of Fish Culture of this Department, witnessed a clash inwolving three birds. two of which were engaged in a united effort against the other, which finally gave way and flew. This fracas lasted at least five minutes but, after the third hird flew. the remaining two seemed to lic perfectly amicalle.

An unnsual situation is reported liy an anonymous writer in forest and Strean"'." who describes a combat between two gronse on the same drmmming log in which the birds repeatedly: rushed at each other from a distance of a foot or two. After several "rounds". one bird retreated, jumped off the log and disappeared. following which the other drummed once and then also watked off.

\section{Roosting}

White typically a nocturnal habit. grouse often roust during the day time. In winter, especially, they are fond of resorting to some protected spot where they can bask in the sun or sit out a storm. High wind, in particular, causes the hirds to seek shelter at any time. In summer. however, they roost to a mueh less degree during the day. although dusting may serve to satisfy any desire for a siesta.

Grouse roost both on the ground and in trees. the grreatest use of the latter being made in cold stormy weather. As discussed elsewhere* snow-roosting is commonly indulged in when conditions are suitable but even during the winter they frequently spend the night heneath a small conifer whose thick low-hanging branches form a surt of tepee. The shelter of a stump or log may also he utilized. For a tree roost. a thick-topped conifer is almost invariably chosen and birds have often been flushed from such perches as high as 50 feet from the ground. Their ability to take advantage of circumstances is indicated by Forbush ${ }^{119}$ who found several hirds in a cave in the rocks. and $S_{m}$ thi" who reports a bird roosting beneath an old drain pipe.

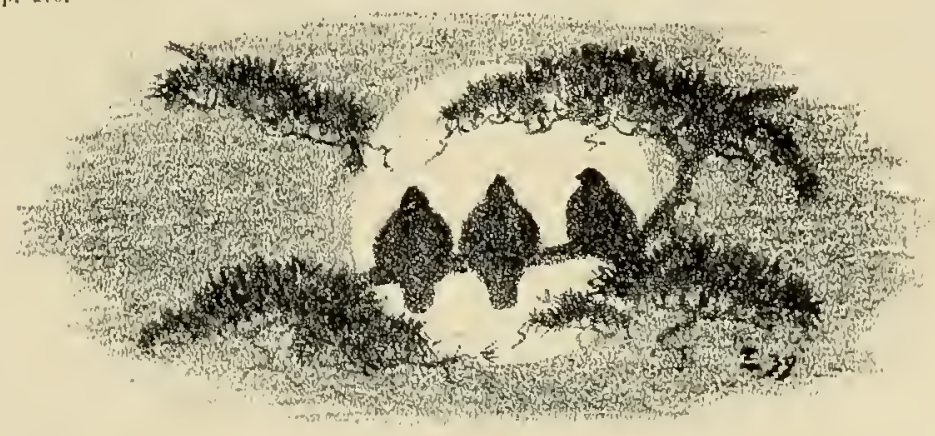




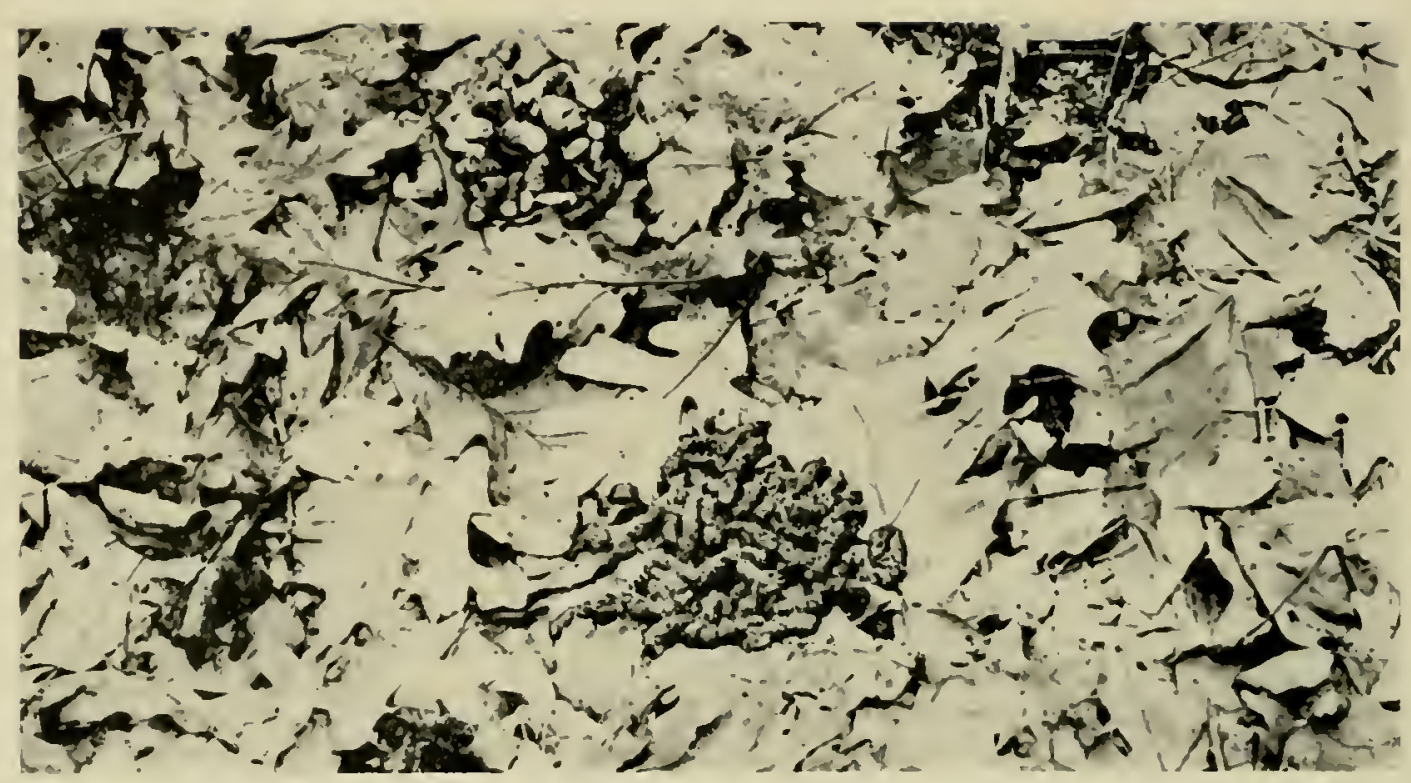

PILE OF WINTER DROPJINGS SHOWING WHERE GROUSE HAD ROOSTED ON TIE GROLNI FOR SEVERAL JIOURS

Although groups of several adults often roost in the same elump of cover, no tendency to form packs or coveys has lieen noled. While more than one bird may oceupy the same tree, each is an independent individual.

\section{SNow Roostinc}

Like the Eskimo in his igloo, the grouse may seck shelter during severe weather by hurrowing into the snow. The impulse to do this seems largely correlated with marked drops in temperature or with high wind. although the presence of light. soft snow of sufficient depth is, of "ourse. necessary. Forbush" also states that ground-roosting birds are at times eompletely covered by sum during a storm, thus creating the impression that they had burrowed into it. The habit has been observed throughout the range of the bird wherever heary snowfall uccurs. It is more prevalent northward only because the necessary conditions are present more often.

In New York, this habit is frequently employed at night during the winter. lout the birds come out in the morning unless the weather is very severe. Individuals may. however, remain in such a shelter several days, as evideneed by the number of droppings found in some burrows. During the daytinc. they soldom resort to the practice unless the weather is very harp and windly.

When conditions are right, errouse most often dise from an overhead branch or. sometimes. even directly from fiwht. Such a plunge is made at an whlique angle and carries the bird below the surface where as small spare is hellowed out. often a foot or wow from the entrance. if the white mantle is derp and soft. At other times. particularly if the suow depth is insuffieient to permit diving, the bird ma! walk lo the chosen spot and lourrow under the surface. lionsts

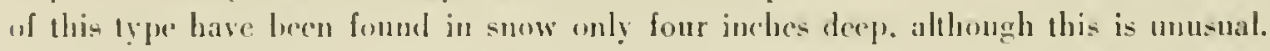

Fhe chanber formed ly the lired is sightly larger than its hody and is seldom more than

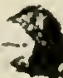


an inch or two below the surface. In fact, one sometimes finds a "breather-hole" through the roof, and birds have been observed with only their heads projecting like a periscope. The occupant of such a roost continues to face the same direction as it did on entering. For this reason, the pile of droppings normally present is on the side toward the entrance. When the snow is loose, it usually fills in behind the bird but it is sometimes possible to see directly into the cavity. Exit is from the opposite side. If disturbed, the bird bursts immediately into flight, scattering snow in all directions; otherwise, it may emerge through an inclined tunnel and walk away. One often comes upon such deserted shelters looking like railroad underpasses.

When diving into the snow, it is probable that the lird holds its head in such a manner that its breast strikes first.

It has been stated many times that grouse occasionally die as a result of heing imprisoned in a snow roost by a crust forming over them, or that they kill themselves in attempting to dive into snow heavily crusted over. While holl these ronditions ma! occur. no direct evidence las been secured in the present work.

Snow-roosting grouse, however, are sometimes quite vulnerable to predation. This was denonstrated clearly during the winter of 1935-36 on the Connecticut Hill study area. Conditions conducive to this habit were much more prevalcnt than usual and the hirds reacted arcordingly. Field observation soon revealed that grouse, roosting in this manner, were frequently being caught in their burrows, particularly by foxes. 'That winged predators may also take advantage of this characteristic has been shown in several instances where horned owls have been successful in capturing such individuals.

In this connection, the following experience is interesting. On a day of moderate tempera. Iure but with a strong wind blowing, it was olserved that a large proportion of the grouse were in snow roosts. As the snow was only six inches deep, it had leen necessary for the birds to alight first before forming their burrows and thus these roosts could be located before the birds flushed. By using extreme caution in stalking, a field man was able to capture in his hands two hirds out of three attempts. It was fouml. however. that if one so much as allowed his shadow to fall across the lird's location, it would flush.

\section{Dust Bathing}

Grouse indulge in the practice of wallowing in "baths" of dust, fine dirt, rotten wood and similar materials in the same way as the ordinary barnyard fowl. The summer season is the time when this habit is most in evidence. It was noted on the Connecticut Hill area, however, during the mild winter of 1932-33, that grouse occasionally dusted during Jamuary, utilizing rotten wood in well-sheltered spots where the sun had dried it out. The purpose of this habit is generally accepted to be that of helping the birds to rid thenselves of lice and other external parasites. It also aids in keeping feathers in good condition, functioning in much the same way as brushing and combing one's hair.

These baths may be located either in the woods, in slashings, in small openings or along the edge of larger openings such as clearings, fields. roads or streams-in fact. any spot offering suitable material and receiving the sm's rays during some portion of the day. The hath may he recognized as a rounded depression of about the size of the bird's ludy. It often contains several contour feathers and sometimes may show evidence of scratching. Another characteristic, particularly of earth baths, is a fine coating of dust covering the adjacent vegetation.

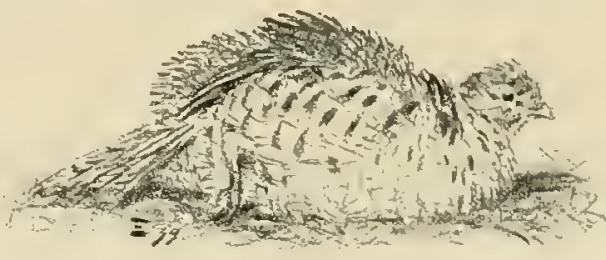


The material utilized for this purpuse is varied, the primang requisite being looseness and dryness. The dry. rollon wool of ald stumps and logs seems to be most frequently used with

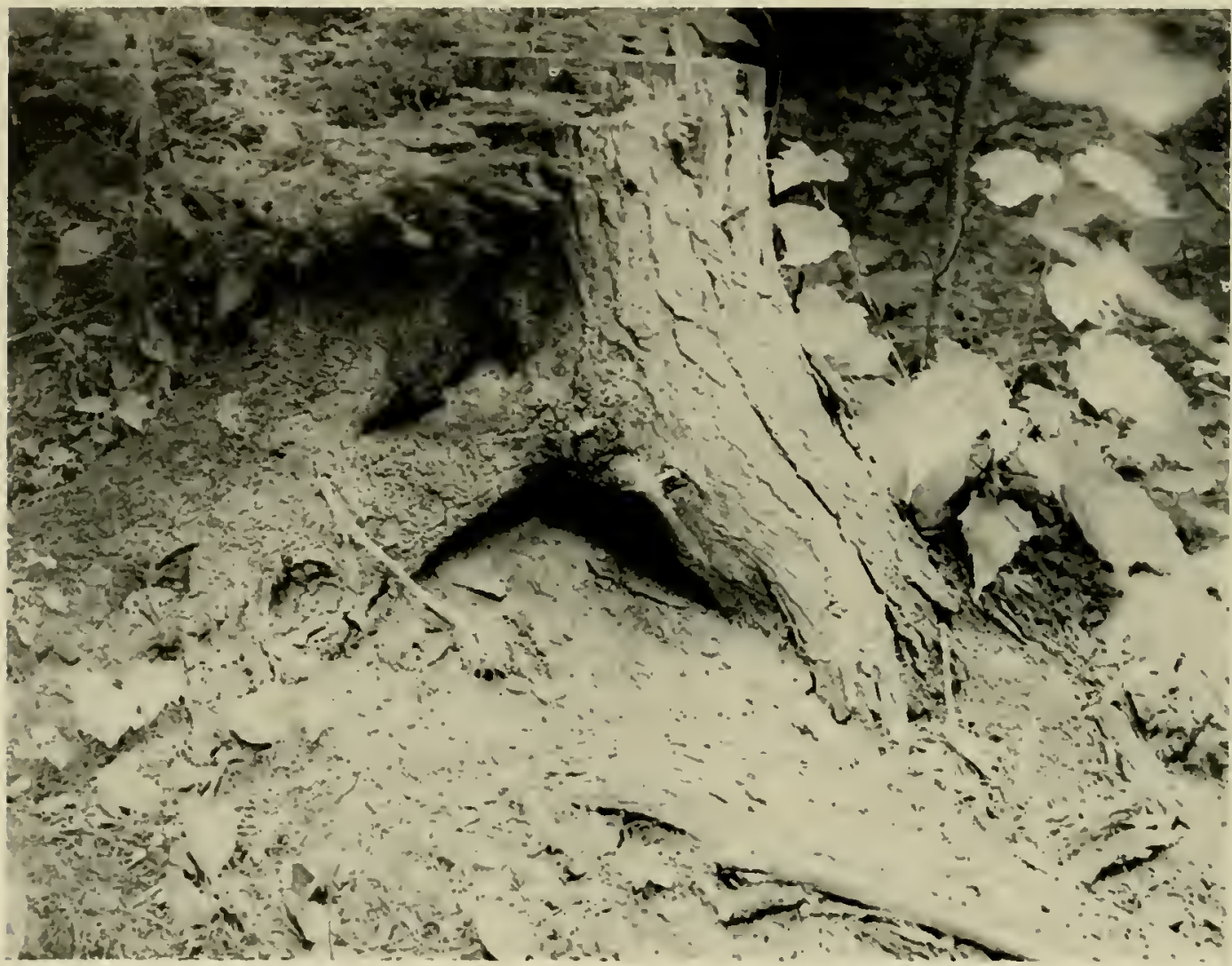

TYPCAI, (EROISE DIST BITI BFSHE, STLMP

fine, dry earth a close second. Another favorite situation is the dry duff in a slashing whieh had previously been oncupied ln conferous timber. Ant hills are very often selected as sites for dust baths. ats are also the entrances to abandoned woudeluuck boles and fox dens. In the menthern part of the State, fune sam is commonly favored. Leaf mold is very seldom used as it is cuarse and usually damp. exeept in slashings. Similarly. sawdust piles are rarely satisfar.tury.

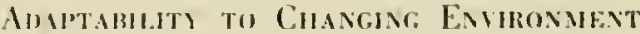

lissil hunters hat fouml hones of the ruffed grouse amone material of the l'leistocene are" from cales in l'ennsilvania. California, Maryland and Tennessere as well as remains probaloly referable to this speries from Arkansas ${ }^{3 a n}$. That it eould survive suel a period of time as well as oreups so extensive a range. hoth past and presents. imlicales a high dowree of adaptabilits.

Certain furbler wharbations are, howerer. worth eiting. Bering a hird of the woods edges.

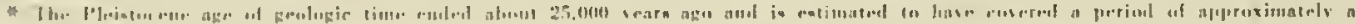
millswin ware. 
the opening up of the virgin forests by early land-clearing "peratims. lumbering. and even fire when not overly severe, ereated conditions decidedly more favorable for its existence. When extensive areas of open land were produced, however, the grouse was. of course, excluded. But where even small tracts of suitable cover were left. it continued to exist even within short distances of cities and the larger towns. Today it is found as a hreeding bird within 151/2 miles of New York City.

Extensive tracts of cover are not required. As noted under the discussion of Territory, farm woodlots as small as 25 acres of suitably diversified cover will support grouse throughout the year. Any activity, however, such as grazing. which seriously reduces the amount of undergrowth, tends to eliminate grouse whether the area is large or small.

In the oil fields of southwestern New York and the adjoining portion of l'ennsylvania. grouse are quite common over areas where wells. pumping stations, moving cables. and pipe lines are scattered throughout the woods and are continually being tended ly workmen. One year, a nest was discovered immediately under a cable line which had been in use several hours a day throughout the season and which produced a loud creaking noise at each stroke.

Perlaps the most significant recent evidence of adaptability is the manner in which the species has reacted to hunting ly mats. A stupid "fool hen" where little songht after". it has. over much of its range. developed a wariness which places it. corlas. among the most highly prized game hirds of the continent.

\section{Tolerance of Other Species}

Confliet between grouse and other native lirds in New York Statr for the ocrupation of a given unit of environment, is negligible. In lact, it is very donbtful if such a condition ever existed to a signifieant degree. In any event, the species. which at one time might have offered competition, are now either absent or of very restricted distribution in the State. The wild turkey is no longer present. the sprure grouse las been reduced to the rerge of extinction and the quail is confined largely to the extreme southe astern portion. Competition with other native woodland birds has not been important.

Neither, so far as it has been possible to determine. is there any indieation that the natural. ized pheasant competes for the right to occupy individual coverts or for the necessities of life. such as food. Essentially, the halitats chosen by the two species are distinet hut. where swamps and woodlots are associated with the agricultural land use and mild climate required by the pheasant, both may often be found in the same coverts throughout the area where their ranges overlap. Nevertheless, no direct confliet between individuals has been noted.

On the other hand. under suel circumstances. the parasitic propensity of the pheasant of laying its eggs in grouse nests ${ }^{\Delta}$ may he an important reason for the scarrity of gronse in many coverts of seemingly high quality adjacent to lowland farms.

Others have found that. where several species having similar habits do occupy the same habitat, there is a tendency for the limit to their combined increase to be reached at about the same level that any one might attain individually." Experience in 1931-32 and 1933-31, with the Reeve's pheasant (liberated in grouse coverts) corroborates this conclusion.

\footnotetext{
* See discussion of II ariness, p. 260.
}

A. See Chapier VII, I. 331. 


\section{CHARACTERISTIC OF THE MALE}

Beyond the foregoing, there are certain important habits peculiar to the male. 'They are primarily associated with breeding and that of drumming is perhaps of greatest general interest.

\section{1)RUMMING}

Wild hees hum through the forest vines

Where the bullets of England hummed,

And the partridge drums in the ringing pines

Where the drummers of England drummed.

Robert W. Chambers.

No phase of grouse life has been the subject of as much description or occasioned more speculation than has the drumming of the male. Called the "carpenter bird" hy certain Indian tribes ${ }^{103}$. the bird has since heen aptly dubbed "the kettledrum of Nature"s orchestra" In one of the earliest accounts of the habits of this species, Lahontan", referring to "their flapping", termed the performance "one of the greatest curiosities in the world". In a letter accompanying the first specimen of this species sent to England from Pennsylvania about 1750 by John Bartram (in Edwards ${ }^{310}$ ) attention is called to the "remarkalle manner" in which "Hhey thump". The same author quotes a letter dated 1752 from a Mr. Brooke of Maryland referring to the "leating of the Pheasant".

Alhough Labontan and others had likened the sound to that of a drum, Audubon ${ }^{2 *}$ seems to have heen the first to use this term directly o designate the performance. That this characterization was appropriate is attested by the fact lhat subsequent authors have used it almost without exception. With the rise in popularity of a number of sporting periodicals about the middle of the nincteenth century, notably Forest and Stream and American Field, discussions of grouse drumming lecame mumerous and many an ohserver, both seientist and woodsman, undertosk to explain the manner in which it is produced."

\section{The Drumming Performance}

In executing this enrious invilation to love or war, the male grouse. usually from some slightly elevated perch, such as a log. stump or boukler, proceeds to beat the air with his wings, producing a hollow, ventriloquistic somml which commences as a series of distinct "thumps" followed by a pause, continues with the strokes coming "so elose together that the sound of each merges wilh the next to produce the whirring of the "muffled drum" "330, and finally concludes with a single, weak beat. The cadence of the ordinary drum, expressed in sixtecnths of a seend between thumps, has been represented graphically by Allen (in Bent ${ }^{50}$ ) at follows: 5-6-3-8-6-5-5-4-1-3-3-3-2.2-1-2-1-1-1-1-1-1-0000000000000000000000-1. The time required has leen fetermined hy the same author as "almost exactly eight seronds".

Alubongh members of the Investigation have observed and photographed innumerahle drummings, it seens superluous to add another description of the performance to those already in the literature. Brewster ${ }^{25}$, for example, has painted a particularly graphic picture of Ilyr preliminary stages an follows:

"Suddronly lir stretcherl up his neck . . and ctanced keenly around ... Then he circled four or five timess around a space no more than a fout in dianeter. . and facing at a right angre with the log sated himself an it in the allitude of a l'enguin . . As he sat thus... his tarsi and lail wrere pressed closely for their entire length on . . . the log. A moment later the hirel leegan to drum."

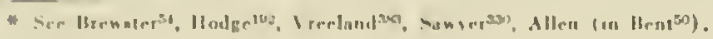




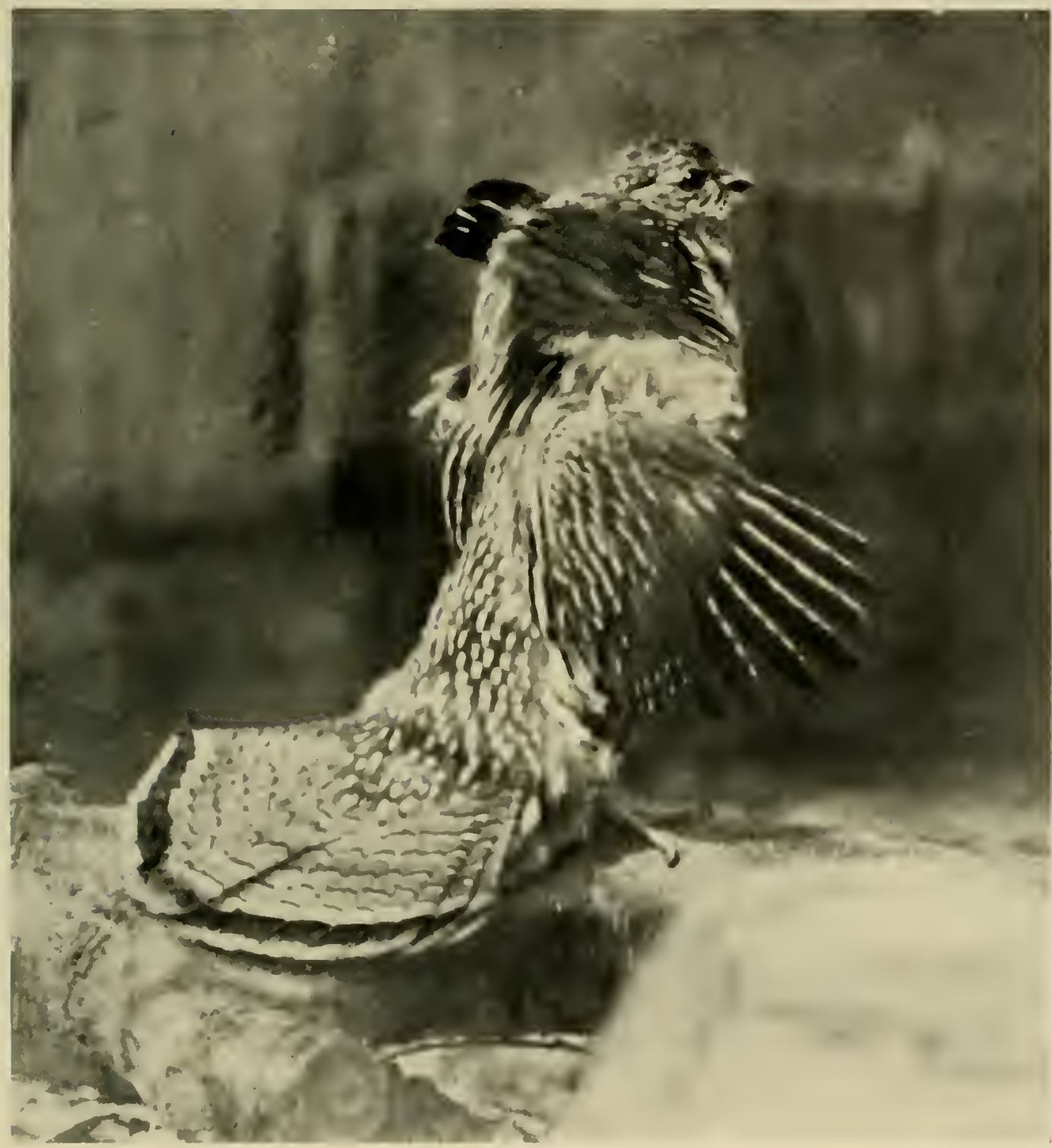

A BRUMMUNG, CROISE.

The balance of the performance is described by the same author ${ }^{\text {st }}$ as follows:

"a quick stroke [was] given forward; the wings immediately recovered and another stroke, a trifle quicker than the first. was succeeded ly another still quirker, until the wings vilhrated too fast to lie followed ly the eye..."

Regarding the initial thumps. Allen (in Bent ${ }^{50}$ ) says:

"he appears to throw his 'shoulders' back. This might give the impression that the wings were struck behind the back. berause the forward stroke of the wing follows so instantancously that the eye scarcely perceives it. and it is given with such foree and the wings come hack to the nommal position so quickly that the entire action registers on only one frame of the motion-picture film having an exposure of approximately one-fiftieth of a second." 
The drumming performance unavoidably advertises the hird's whereabouts to enemies at well as to others. It is significant, therefore, that a bird can stop in mid-action at any lime except during the height of the "roll". Individuals have been seen to "freeze" in this manner at the approach of a dog or upon spotting a hawk overhead. Even the faint click of a wellmuffled movie camera will cause this reaction. Nevertheless, many hirds are killed rach year on their drumming logss.

\section{The Sound}

Hany times during the Investigation, field men have mistaken the sound of a distant gasoline "ngine or tractor for a drumming grouse. Over the years, besides likening it to "the rapid rolling of a distant drum "..., a variety of other similes have been used by different ubservers. Thus, Lahontan" speaks of it as a "humming noise", and Edwards". quoting Bartram, reported "they sound like thunder at a distance"- a comparison which has since been made by innumerable authors. Its resemblance to the booming of a far-off gun has also been suggested.

Ventriloquistic to a high degree, the sound is deceptive with respect to loth the direction of the drummer and his distance away. Oser the hilly, broken terrain of most grouse covests in the Northeast, it is most often audible at distances up to somewhat over a quarter of a mile. Under especially favorable conditions, however, it has been heard nearly a mile away. The direction of the sound tends to be more confusing to an observer within the woods than to one in the open. Apparently, it echoes to some extent among the tree trunks.

How Produced. Impelled by a certain air of mystery surrounding the performance lecause of the wariness of the hirds. olservers have from the heginning attenpted to explain the method by which the sound is produced. Certain Indian tribes helieved the hirds beat upon a log with their wings and thus called the species the "'arpenter bird" Lahontan" thonglit they struck "one wing against the other". Bartram" pictured them as "clapping their wings: against their sides". a belief shared by Audubon" and Nuttall". Brooke" sugrested "they swell their breasts like a pouting pigeon. and beat with their wings". hut left it ambignous as to whether the wings heat upon the inflated breast or merely the air. An anummous author in American Field suggested that the wings beat upon the inflated lungs. while another writer stated the sound is produced by "inllating an air sal . . striking it with their wings aml forcing the air ont through the mouth". In fact. Maynard even contended it to be primaril! rucal and that "the wings merely aid in producing it . . just as a rouster crows. flapping its wings at the same time". In 1874. however. Brewster" published an acount of a series of careful olservations of a drumming grouse from a blind hot 12 feet away and advanced definitely the conclusion that the sound resulted from the concussion of the wing-beats on the air alone.

So the controsersy went. The "hollow low theory" was early di-prosed by the fact that wrouse frequently drum on lowlders and similar objects. Neither was any apprecialile degree of credence placed in the possibility that air sacs or veral somuls were involved. On the other hand, while considerable belief persisted in the theories of Lahontan and Bartram. the shvious care with which Brewster's olservations had been made and recorded gained wide acceptaner fur his explanation mutil 1905.

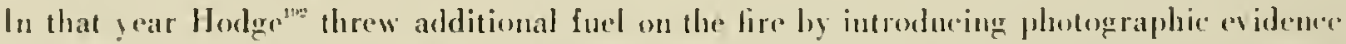
which lye contended showed the sound to be produred lyy "the impart of the stifly held concave" wing on the feather "ushions of the sides". At the same time. Jomes" joined brewster in the belief that the wings berat agrainst mothing but air. 

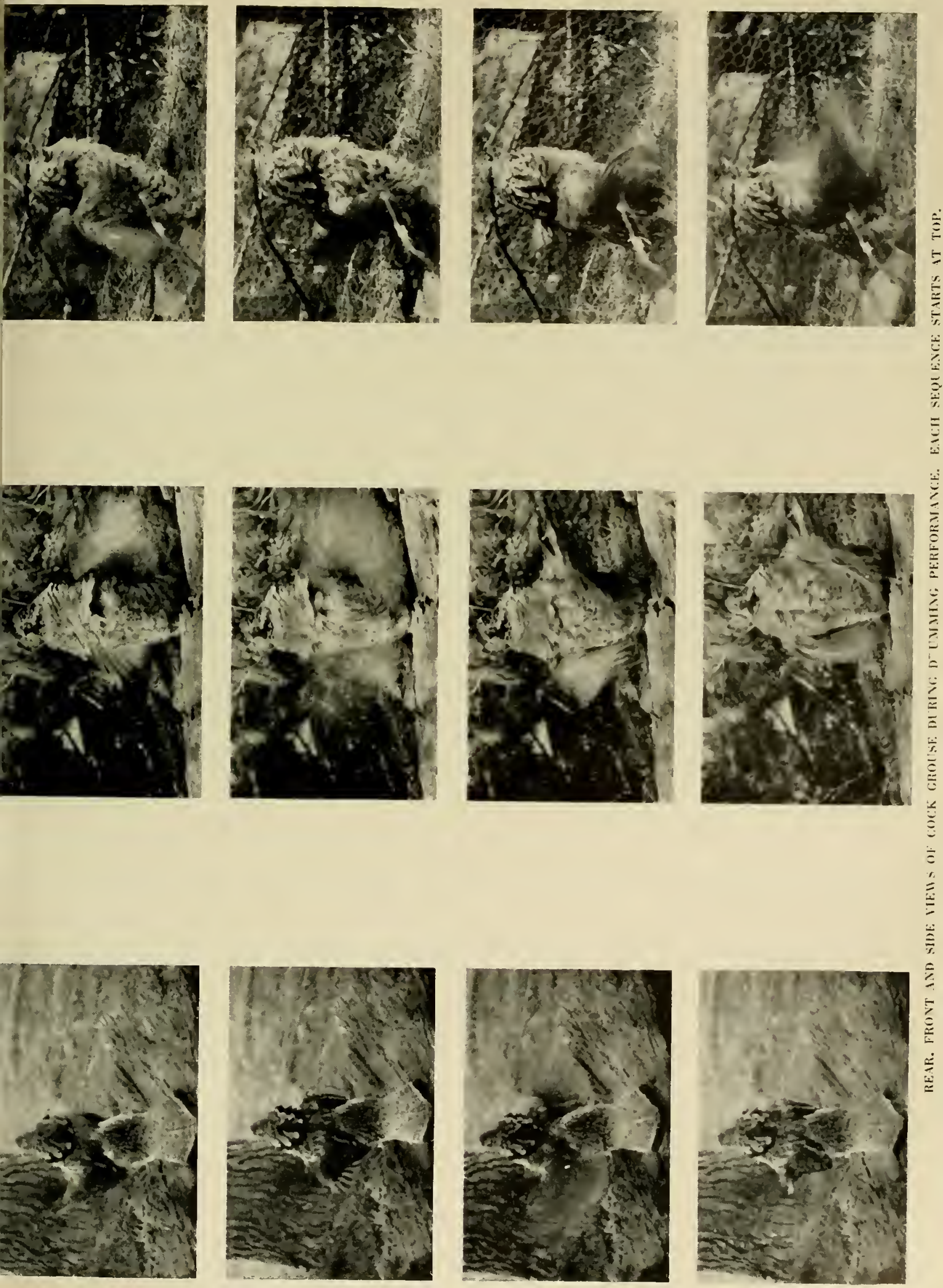
Thus reopened, the debate continued. The next important contribution was that of Vreeland $d^{3 *}$ who. after watching a grouse drum at close range and securing a series of photographs, reached the conclusion that the wings "did actually strike behind the drummer"s back", which was supported by Beck"s who also used the sensitized plate. The latter writer termed the sound "prercussion musie". Then in 1923. Sawyer" rejorted on a study made during the spring of 1921. After watching over a hundred drummings. he liecame convinced that the somind is produced by the wings striking the air alone.

Such was the status of the problem when the senior author began photographing drumming grouse in 1927. three years lefore the Investigation was inaugurated. During that and suc. reeding years, a wealth of material. both in the notebook and on movie fitm, has lieen gathered. In addition in the olservation of wild birds, there has been ahundant opportunity to study individuals in captivity at the Research Center. The data assembled further attest the fundamental correctness of the conchsions of Brewster and Sawyer. as do. also. the excellent motion pictures of $\mathrm{A}$. A. Allen.

With respect to the sound itself. the authors believe that it represents the concussion of the air filling in the vacum ereated by the powerful forward. upward and somewhat inward stroke of the wing followed by its instantaneous reversal of motion. The reaction is somewhat akin to that which produces a clap of thunder or the erack of a whip. In creating a sufficient displacrment of air, the concave nature of the underside of the wing. together with the angle at which it is held. are undoubtedly of great importance.

\section{P'urpose}

An attribute of the male grouse only. drumming is fundamentally a corollary of conrtship and functions to announce the whereabouts of vigorous cocks both to females and to other males. Called "the throhbing heart, as it were, of awakening spring" it is indulged in most commonly during the early brecding season. On the other hand. it has been heard every month of the year and often becomes quite frequent in the early fall. In the spring, it may serve either as an invitation to the female or as a challenge to the world in general. At other seasons. it undoubtrilly represents an expression of rxuherance on the part of an musually. vigorous individual.

\section{The Drumming Season}

Over most of Vew York, the drumming season begins in late March and reaches its height during late April and early May. Al the higher clevations in the nurthem part of the State. the kelledrums commence at week or so later. Observation of grouse in eaptivity at the lieseareh Center reveals that they must learn to drum. Apparently they instinctively know the motions but. even after aepuiring adult phumage. repuire considerable practice to develop the ability to drum with the normal soumel effert. On several occasions young males. which never attempted to drum while in a mixed gronp. have been placed in individual pens with the coming of spring. 'These birds have nsually proceded to give a perfect drumming performance execpt that there was little sound. A bird reposted by Allent took two weeks to learn. Thus, it might low that the stargered dates on which one first notires various wild birds rommenring to drum mat he due. in part. to the goung bircls in the popmlation, although the comparalive viger of varius imdividuals is juobaluly the primary reason.

The predominant drumming periods during the spring are carly morning and late afternown. Beginning usually well hefore daylight, the performance is repeated will remarkable recrularity until sumrios ur somewhat lhereafter. Although at the height of the season inter- 
mittent activity may often be heard throughout the day, it commences with regularity again about an hour before twilight and continues until dark and sometimes later. The frequency of successive drums increases as the height of the season approaches. Grouse have been ob. served to drum regularly for several hours at from 3- to 5-minute intervals. Birds have also been recorded which drummed for periods of half an hour at intervals of less than a minute and on several occasions have been seen to drum a second time with hardly a pause between.

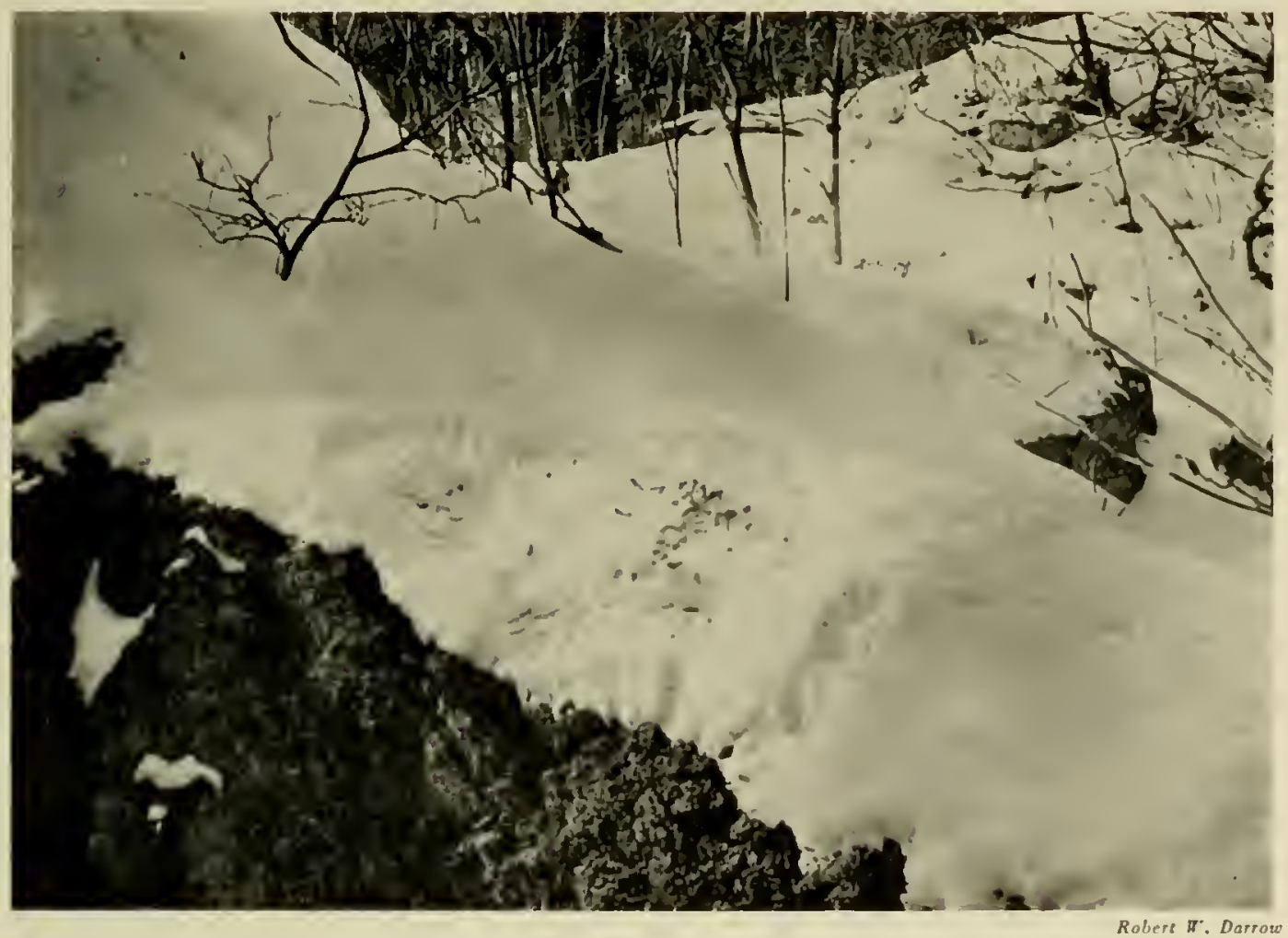

WHERE A GROUSE DRUMMED IN THE SXOW ON A GRANITE LEDGE IN FEBRLARY

During this Investigation, few instances of fall drumming approaching the regularity recorded ly Brewster ${ }^{65}$ have been observed.

\section{The Drumming Log}

For a handstand, a drummer nsually mounts a fallen log. hence the term "drumming log". Most commonly chosen is some old, more or less moss-covered relic of fairly large diameter mouldering on the forest floor. Sometimes an old stump or upturned root is used, but freshly-cut $\operatorname{logs}$ or stumps are seldom favored. In rocky country such as the Adirondacks, boulders and ledges frequently serve this purpose. Birds have also been observed to drum from most any small mound on the forest floor, even stones or bunches of moss no larger than the crown of one's hat. It is probable, however, that in such cases, the bird usually has a more characteristic rostrum elsewhere. since individual males usually have more than one drunming station. Perhaps the most unusual "log" is recorded by Grinnell", who found a bird drunming on the carcass of another bird which had been shot and unrecovered a few 
days before. In captivity, grouse experience no difficulty in drumming on the flat wire floors of their pens.

Little preference as to the location of drumming lows seems to be shown. except that they are usually found in woodland cover and where possible associated with confers. Open or overgrown land types and steep slopes tend to le avoided.

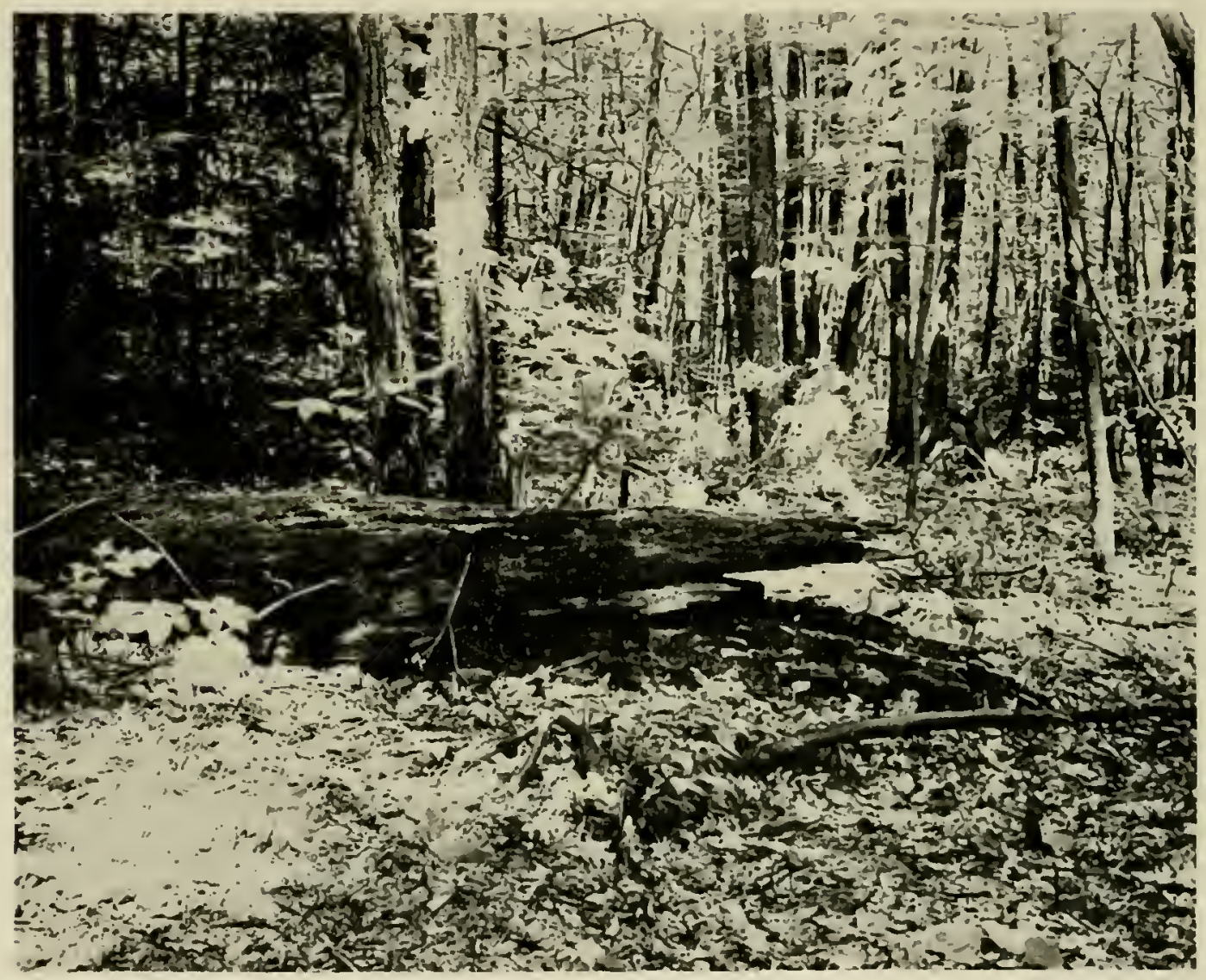

A TYPICAL GIROUSE DRUMMING LOG

During the drumming season. hogs in regular the mat le recognized ly the presence of mumerous fresh droppings on or locide llom. If such droppings are in some wa! obliterated from a series of logs and the sulsedquent accumulation moted at the end of a definite interval. one may secure some indieation of the degree of use of each. This varies with the number of logs per male, the amomut of competition. size of territons. and wher factors. A curious ineident was noted on the Adiromlack area when a hird. whose fatorite logr was located in a swamp, continued to utilize it while it was completcly surroumled hy water from an overflow. ing browk. Nany logs are nsed year after year.

Nember of Logg L'serl. Male gresuse usually establish more than one drumuing ling. In ad. dition to individual differences between males. there is sume indication that the number may tend th vary directly with the degree of eompetition with other males. and insersely with the relative number of females inllueneed. On the wher hand. in several instances. isolated pairs 
have had no known drumming log, although a brood later materialized in the territory. It cannot be assumed, however, that the males of such pairs did not drum, as indistinctive objects are often used for drumming and. if the performance occurred but a comparatively few times, it might go entirely unnoticed. Nevertheless, among hand-raised birds, males which are not separated from the opposite sex seldom drum, although they usually mate successfully.

During the course of the Investigation on the Connecticut Hill area, 1.566 drumming logs have heen noted. In the aggregate, 1,173 male gronse have been present during the same period. Thus, an average of 1.33 recognized logs per male have been utilized during this period. At the same time, in a number of instances, ratios much lower than this have been observed for certain groups of males with no loss of hreeding success among the females involved. For instance. in one covert on the Connecticut Hill area in 1932. a total of 13 males established but two drumming logs. yet nine of the 13 females were known to have nested. On another portion of the same area. in 1934. but one log was found in spite of the presence of three malcs, yet all five females nested. Similarly, in 1939, only one of six males established a log.

Apparently then. mating may often be surcessfully completed without the aid of an established drumming log. although as noted alove. this does not mean that such males did not drum. Conversely, other males have used as high as three and four, or even more logs apiece. In such cases, the relative exuberance of individual males is undoubtedly a factor.

Of the various logs used, however, not all are resorted to regularly. In 1935, a separate record was kept on the Connecticut Hill area of the logs in regular use as against thore uscel only orcasionally. It was found that 155 males used a total of 214 logs. hut only 1.12 regullarly or .92 per male. Thus, it appears that some majes, each year. for one reawn or another. do not drum regularly on a definite log as is the habit of the majority.

\section{Courtship}

Courtship among hirds comprises those actions, performances and displays, employed chiefly ly the male (except in a few species such as the phalaropes). which serve to bring about the pairing of the sexes and ultimate mating. In the ruffed grouse, it consists primarily of strutting and feather display*.

At the same time, largely similar if not identical performances. except for the head-twitching stage $\mathrm{e}^{\wedge}$, are employed throughout the year as one means of maintaining a hird's "socjal rank" + or merely to show off. A modified form of display has also been observed in females attempting to dominate weaker individuals. There is therefore. no clear-cut objective means by which to distinguish courtship activity althongh the feather display associated with it is usually more complete.

Nevertheless, at this season. such exhibitions, together with drumming which is regarded as a corollary: serve to bring the sexes together and undoulitedly. to some extent. to convince the female of the merit of the male. Thus they may be considered to fulfil the function of court. ship even though essentially the same display may be used for other purposes as well. Specifi. cally, they serve this purpose when witnessed ly a female in the proper physiological condition for mating. In other words. they supply the psychological elements needed to complement the physiological. They reach their fullest intensity in the immediate presence of a female in "heat".

* See discussion of merutting. P. 282.

$\triangle$ sere discussion of Hearl-twitehing. P. 283.

Sore Chapter II, P. 63. 
Whether or not a female, having witnessed such a performance, mates with that particular male, is immaterial. In no speeies does courtship guarantee acceptance. Then, too, one must be very cautious in crediting conscious forethought to the activities of any form of wildlife and remember that. among grouse, the male does not seck out an individual female to whom to address his attentions. Furthermore, in a polygamous species, the association of two indivi. duals for mating is short.

To other males. or fegnales not in the proper stage of the reproduction cycle, actions of this kind merely represent a "chip on the shoulder" of the performer.

What seems to be the nearest approach to aetual observation of the courtship of a wild grouse is recorded by Allen ${ }^{50}$. In the course of a study of drumming. this investigator placed a captive female in a wire crate beside a drumming $\log$ in front of the position usually occupied hy the male. Upon coming to the log, the male, without drumming. soon hegan his strutting antics. accompanied by a full plumage display. This was contimed for three-quarters of an hour, both on the $\log$ and $m$ the ground beside the crate. "when he attempted to mate with the fenale . . . though the wire separated them by several inches".

Following this, the male proceeded to drum, apparently as a challenge to any other males which might be in the vicinity.

\section{STRUTtine:}

Strutting and the feather display which accompanies it, has two major functions. First, it is employed throughout the year by individuals of both sexes for purposes of showing off or expressing exuberance and as one means of asserting their self-sufficiency among their fel. lows*. Second, during the hreeding season, it also serves as the courtship of the male ${ }^{\Delta}$. In the former sense, the performance has heen termed the "intinidation display" by Allen". When used to express exuberance or cockiness. the presence of other indis iduals, regardless of sex, appears immaterial.

In its fullest development, as given before a receptive female in the breeding scason, it consists of a display in which the male raises his tail almost perpendieularly. spreading it fan. wise, while at the same time lowering his wings until they drag. Though the crown feathers are not raised, the head is held back and the ruff about the neek is ereeted until it forms an almost complete eircle of iridescent black or brownish feathers. The body position is not un. like that of the strutting turkey gobhler. With slow and measured steps he approaches the oh. jeet of his attentions. occasionally lowering his head and stretching his neck to peck violently several times at the ground or other ohjects hefore him. $A$ slight hiss often accompanies the forward movement. As exeitation increases. the male stands still. though both hiss and move. ment of the head become more pronounced, each aetion being elearly distingnished from the one that follows by a pause. Then the liead is tilted slightly forward and the neck rotated with increasing speed from side to side as thourh pivoted on hody and brak. The sonnd now reminds one of a loeomotive rather rapidly getting under way. Abruptly the motion ceases and, with a prolonged, lond hiss and a dragging of wings. the male completes the action with a short. determined rusls at the female.

Even before a receptive female, there is eonsiderable variation between the actions of different males and, under other circumstanees, a wide range of nindifications i- employed. Especially if no female is cvident. a male often struts up and down his drumming log, either 
before or after drumming. with merely lowered wings and perhaps slightly raised and spread tail. Young birds, particularly in the fall of the year, bluster and show off in a similar manner. frequently accompanied hy a short dash at another individual. Evidence of the same lype

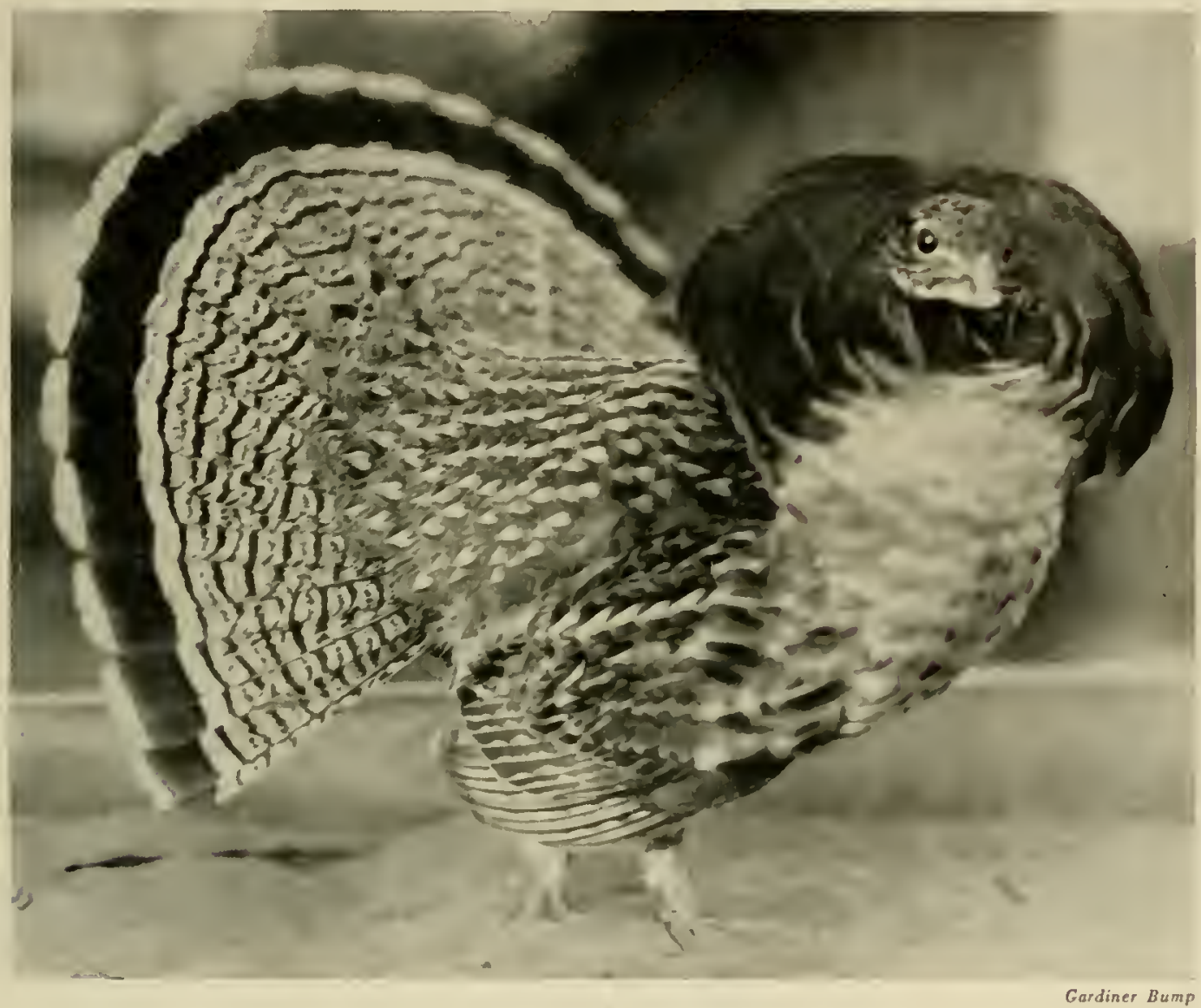

A STRUTTING GROUSE

of reaction may be observed during the winter and particularly in early spring, where snow lingers on the ground, when tracks are often noted flanked on either side by a narrow cut in the snow left by the trailing wings of the bird.

The display of the female is usually much less vigorous than that of the male and seems to be used only for maintaining her social status.

Experience with captive birds, however, has shown that the degree to which a male displays is no criterion as to his quality as a hreeder. Frequently, highly demonstrative individuals prove complete failures, while others which seldom display are often consistently effective.

\section{HEAD-TWITCHING}

As described elsewhere* the male usually becomes quite gentle during the final stage of courtship. Tail down, he follows the female slowly about, pausing when she pauses. At the 
same time he frequently slakes his head and neck slightly from side to side. This action is in no wise violent as is that which aecompanies strutting. liather the head. which is held somewhat hack toward the shoulders, is twitched with a rotating motion as though it hung on an inclined pivot running through the base of the skull.

\section{Relation to Nest}

The Investigation has been unable to discover any relationship between the male and the nesting site of the lemale*. Birds judged to be male grouse have now and then heen flushed near a nest but there is nothing to indicate that such oceurrences are other than eoincidental.

Among birds held in captivity under natural cover eonditions at the Research Center, however, several males have exhibited a tendency to sit on the eggs. One individual actually in'ubated a clutch until it hatched and then undertook to brood the chicks. A similar incident was observed at a farm operated by the American Game Protective Association ${ }^{20}$, and a third has been reported by Allen ${ }^{18}$.

\section{Relation to Broon}

Similarly, it has been impossible to discover any consistent relatinship hetween the male bird and the brood. Nearly every summer, however, there have heen a few occasions when a hird judged to be a male has been flushed very near or even directly with a female and her chicks. Most of these observations have occurred during the first month following hatching and the circumstance has never been recorded twice for the same brood.

In one instance, the second adult elucked and strutted about while the female attempted to lead the intruder away. Several other olsservers have reported similar experiences ${ }^{200}$, ${ }^{18,}$, Loveland ${ }^{200}$ states the male even went so far as to fly at him.

Again, after a brood has been flushed, it has sometimes been noted that an adult, other than the brood female, will fly in and attempt to silence chicks whieh commence to peep. Whether such individuals were male or lemale could not be determined.

It scems doubthu] if oceurrenees of this kind are other than accidental or possiluy, in some eases, representative of unusual individual variation. On the other hand. the second bird may have been another female which had either lost her hrood or merged it with that of the first.

\section{CHARACTERISTIC OF THE FEMALE}

As with her mate, the female also indulges in a number of activitic's ehamateristic only of her sex and they are, likewise, chiefly associated with the reproductive season. Beginning with nesting, they extend through the brood period.

\section{Nestixe, Dates}

With the coming of the breeding season earls spring. most female grouse som undertake to astablish a nest. Little is known of the relationship between this activity and the actual combmencement of (gg laying. In one instance. however. a perfectly formed nest was found April 16 in which the first egg was mot deposited until $A_{\text {pril }} 23$.

First clutehes are most frequently begun in New lork about the cond of the third week in April, except at higher elevations in the Adirondacks where the season is usually about a week later. Nevertheless, the average date often varies somewhat from sear to your. Thus. in 1932 , it was about a week bater than normal and. in 1939) and 1910. lesser variations in the same di. 
rection were also recorded. On the other hand, in 1938. it was several days earlier, resulting in a total difference between 1938 and 1939 of over a week. Although the physiological development of the bird at this season is fundamentally activated by the progressive, daily increase in the amount of light, which is constant each year, the unset of nesting seems to be influenced, alsu, by annual variations in weather conditions and. possibly. the availability of certain foods.

But while the majority of females in a locality commence egg laying within a few days of each other. a normal span of roughly iwo weeks hetween early and late individuals has been noted. In the advanced season of 1938 , a number of clutchcs were recorded which must have been begun hefore April 15. Several similar nests were found in 1941 and 19.12. Conversely, in 1932. many hens. even down state. did not start their first clutch until after May 1. In this connection, there seems to be some tentency for birds, destined to produce large clutches, to start laying alread of the average.

Beyond this, greater individual variations often occur. The earliest date" recorded by the Investigation and, curionsly enough. in the Adirondacks of northern Warren County (N.Y.), was $A$ pril 7 . Since this nest was broken-np before being conpleted, the mumber of egas which would have heen laid remains a question. Nent to this is a record" of April \&. from Dutchess County (N.Y.). for a clutch of 13 egges.

In general. outside the higher Adirondacks, chutches begun after May I usually represent renests.

Outside New York, the nesting season appears to be mmewhat earlier as one goes soutl. Thus, several reports from southern l'enmsy lvania indicate the usmal hatching date to be abont a week earlier than the June 1 average encomtered by the Investigation. In interior $\Lambda$ laska, however, Dice ${ }^{\text {tw1 }}$ found a browd on June 8. And I'reble ${ }^{30 n}$ found females with young on June 15 at Smith Landing on the Mackenzie River.

\section{STRFCTURE (OF THE: \F:ST}

The ruffed grouse is a ground-nesting lird. The nest is a very crude and unpretentious affair. It ean harlly be called a structure, as it is merely a cup-shaped depression formed hy the female to fit her body among the leaves of the forest flow. There is no evidence that any of the components are ever transported to the nest site from a distance. It is lined and the edges built up of materials within reach as she sits in the depression. A few contonr feathers are usually found in the nest. but it is not believed that they are placed there deliberately. Beeause hardwouds are the major component of the shelter ntilized for nesting in New York, leaves of this group alnost invariahly form the nest. A number of instances liase heen noted, however, where evergreen needles predominated. Its formation is cssentially complete before erg laying commences.

With respeet to the aetual size of the nest itself. six typical examples on the Connecticut Hill area were measured. The dimensions of these averaged as follows: diameter. 61, inches: depth, $2 \%$ inehes: thickness (of the walls). '12 inch.

The most frequen loeation for the nest is at the base of a tree or stump while sites under a log. at the edge of a brushpile or at the base of a houlder or rock ledge. are frequent. Characteristically a depression on the forest floor. Smyth" reports one "that was raised about six inches from the ground, heing built in a kind of little pocket formed at the hase of a ten inch tree where several small sprouts grew out to one side". Similar situations have been encountered during the present Investigation. Others have heen found in or on low decaying

\footnotetext{
* Estimated un hasis "l mumher of egge found in rest while female was still laving.
} 
stumps. Sometimes quite unusual sites are chosen. One nest was fomd inside a large stump, the interior of which had rotted out in such a way that entrance was possible through an old axe cut on the side while the top surface was still intact. Several have been found under large

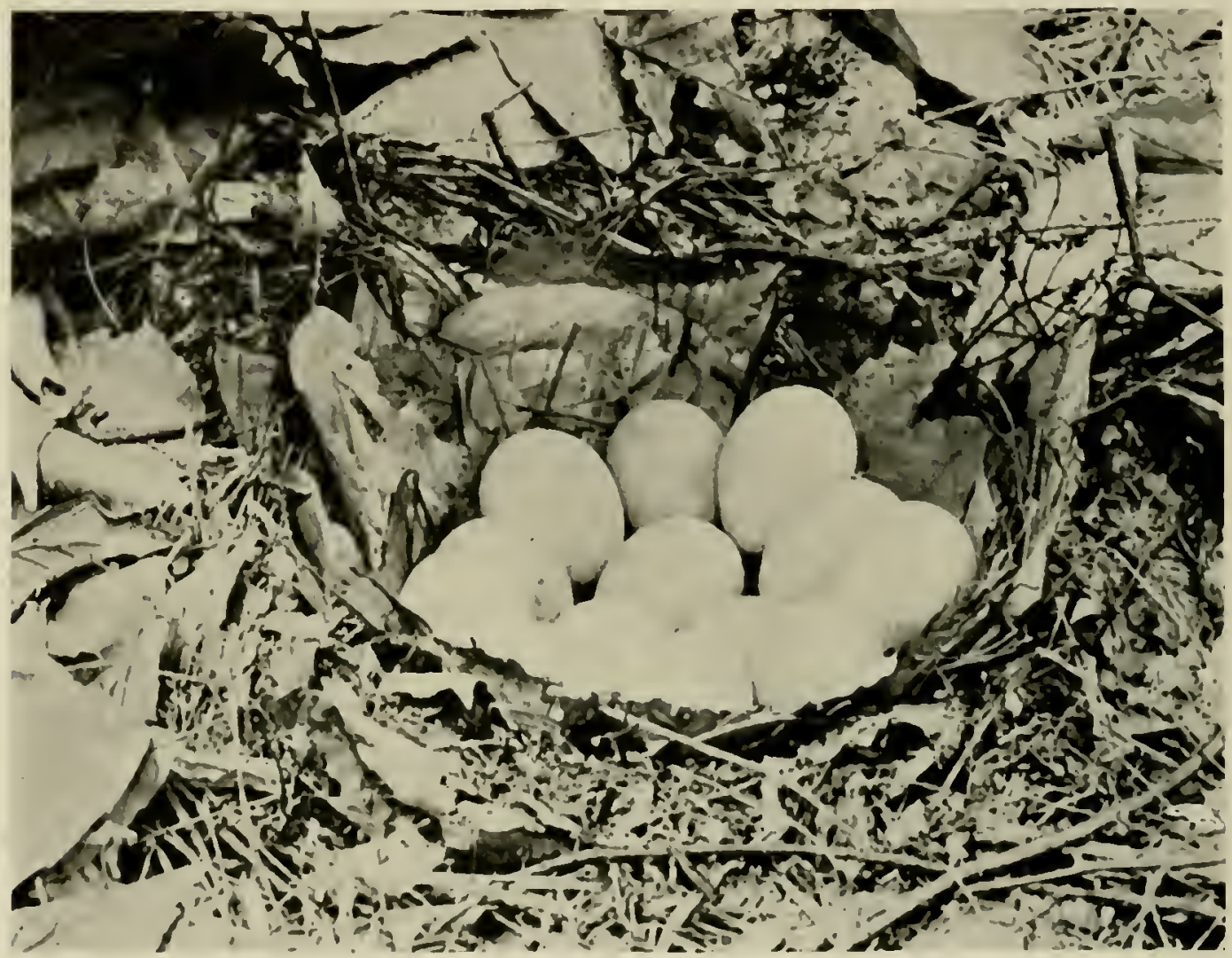

THE NFST OF A RUFFED GROUSE IS MERELY A CUP-SIIAPEI DEPRESSION AMONG THE LFAVE OF TIIE FOREST FLOOR

pieces of bark which formed roofs over them. Nothing, however, has licen observed to support the suggestion of Samuels ${ }^{3 * 0}$ that, if persistently molested, the grouse will utilize the abandoned nest of a crow.

The immerliate site of the nest is often remarkably exposed, the hird apparently relying to a great extent on her protective coloration. Some, however, are in rather thick situations among sprouts. bushes or brush, but, in such eases, usually have an casy avenue of escape.

No instance has been recorded in which the same specific site has heen used more than once.

\section{HantTs DuRing laying and Incunation}

While laying her egrgs, the female grouse spends a minimum amount of time at her nest. Olservations, corroborated by records pertaining to eaptive birds at the lieseareh Center, indieate that, on the average, egg-laying proceeds at the rate of two eggs every three days. Thus. approximately 17 days are consumed in laying an average clutch of $11 \mathrm{cggrs}$. 
Early in the season, comparatively slight disturbances often result in desertion of a nest. On a number of occasions, hirds have been flushed from nests before a single egg had been laid, and, in a few cases, have deserted, apparently as a result of the one contact. The same thing has also occurred with respect to partially complete clutches. But desertion is, in general, infrequent and the great majority of birds persist in their nesting attempt unless the clutch is actually destroyed."

Prior to the beginning of incubation, nesting females flush more easily and at a greater dis. tance from the ohserver than later, although there is a tendency for hirds which have been repeatedly disturbed to he wilder than others in the same stage of the breeding cycle. As the incubation period progresses, she sits increasingly close until, toward the end, one may practically step on her before she will flush.

A number of instances lave come to our attention where hirds bave remained on their nests in spite of logging operations immediately about them. In other cases. road crews. work.

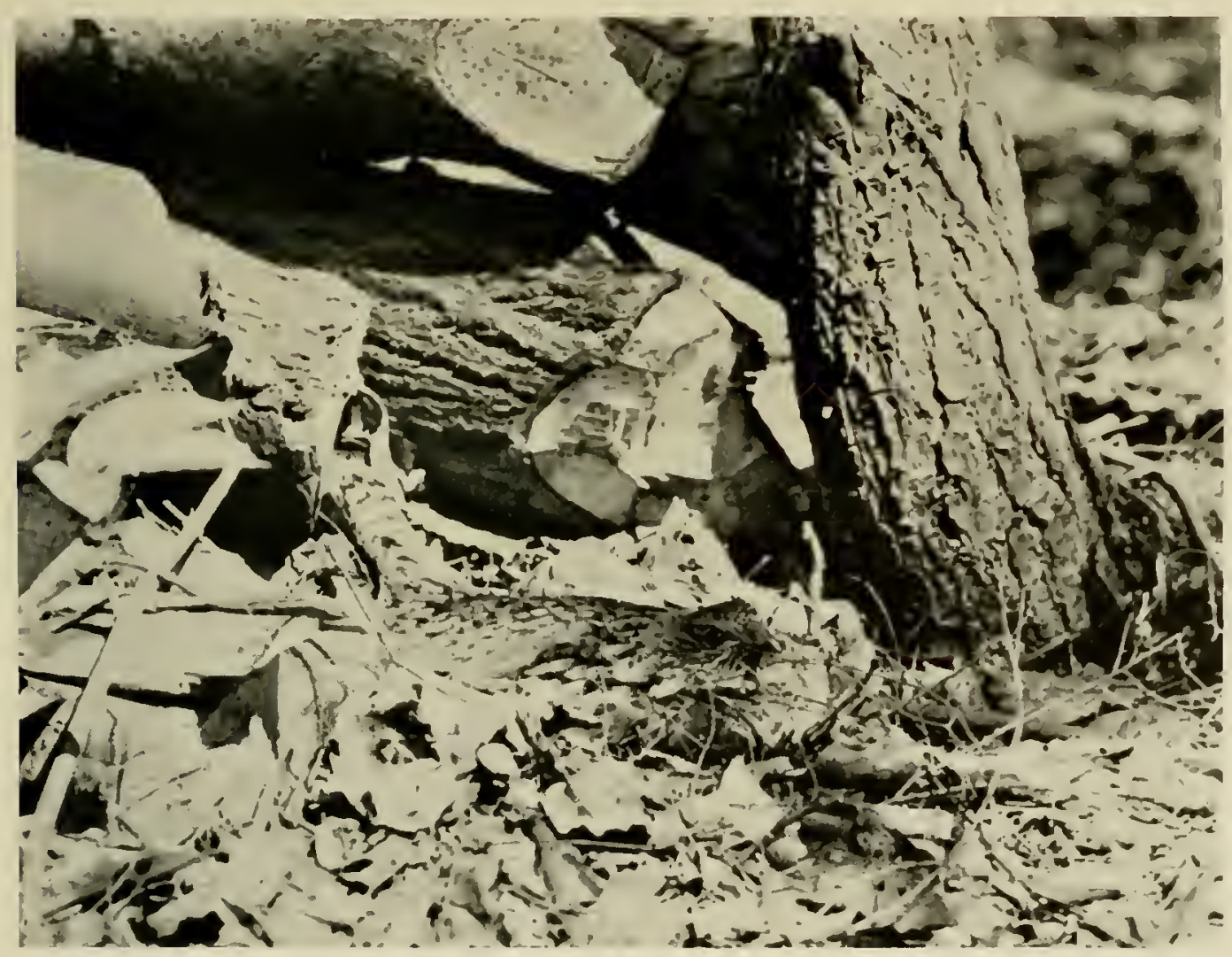

GROUSE WIICII CONTINUED TO SIT ON NEST IN SPITE OF WOOD-CUTTING OPERATION DIRECTLY BESIDE IT

ing within a few feet, have failed to disturb sitting grouse. Perhaps the greatest determination was shown by a bird in Orange County which continued to sit during a forest fire and even allowed a spray of water to be played over her. Similar experiences are reported from 
Pennsylvania", in one of which the bird is said to have fought the flanes with her wings.

A curious activity of the female during this season is related by Allen ${ }^{13}$, who found the approach of nest huilding to be "first indicated by feeble attempts at tossing leaves over her shoulder onto her back as she sits or even as she walks". The same author continues as follows:

"The leaf-throwing continues during the egrg laying period and for several days after inculation starts, so that at first she sits with her hack more or less completely covered. This doubtless accounts for the differences noted in the cuvering of the eggs with leaves amongst wild birds."

No indications have been found that grouse intentionally cover their egros when leaving the nest. The popular belief that they do has apparently originated either from the habit noted above or hecause a bird fhushed from her nest will, now and then. stir up the leaves so that some settle over it.

The attachment of the female for her nest and her fearlessness in attempting to protect it and the subsequent brood from harm represent one of the best recognized habits of the species. Not only does she sit so close that it is occasionally possible to touch her before she will stir, hut when finally flushed she often flies unly a few feet, then tumbles to the ground and attempts to lure the intruder away by feigning severe injury. often accompanied by distressing whines. Pretending to have a broken wing. she half hobbles. half flutters. along the ground. If the in. truder is deceived and follows. she keeps just ahead until a distance of some fifteen to twenty yards has been covered when she suddenly regains her power of flight and departs. Otherwise, she usually remains in the vicinity, fussing and chucking. or she may even attack certain predators as in the case of a black snake as reported in the Pennsylvania Game News ${ }^{14 n}$.

This "brondiness", however. usually develops gradually. primarily during the latter part of the incubation period and does not become pronounced until a few days before the eqgas hatch. But, in a few instances. a tendency in this direction has been noted early in the second week and, jn one case. a slicht attempt to distract the observer was made by a bird which had still to lay the final eggs of a clutch of fourteen.

Incubation in this speries normally requires approximately 2.4 days. varying hetween 23 and 24, a determination which has been amply verified under game farm conditions. In the wild. however. development sometimes takes several days longer, low temperatures or absenee of the female from the nest apparently being the primary factors responsible for differences which oceur.

During this period. the hird mus, of course, sit on her engs most of the time. On the other hand, she must also feed. In order to secure some idea of the daily routine of nesting hirds during this time. two nests on the Connecticut Hill area were watched for several days from tree hilinds during June, 1932, shortly hefore they were due to hatch. These hirds sat continu. ously exeept for infrequent brief periods of almence. presumably to feed. These reesses usu. ally consumed from 20 to 40 minutes. although on one occasion, the hird remained away 110 minutes. Over a period of three days (following which the nest was broken up) the first bird left to feed earh eroning between $5: 30$ and $7: 30$. In addition. she also left for 38 minutes between 4:00 a. m. and 5:00 a. m. wh the third alas. The second bird was also observed for three days. fellowing which the eluteh hatched. The first day was stormy and the female was

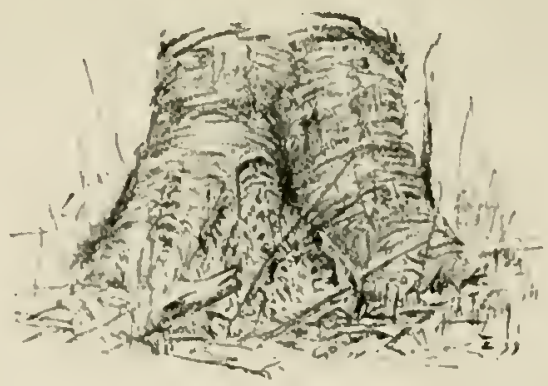


on the nest constantly after observations began at 9:30 a. $\mathrm{m}$. The second day she left at $1: 47$ p. m. for 22 minutes, which was the only absence that day. The next day, however. she was away from 9:50 to $11: 50$ in the forenoon, as well as for two approximately half-hour intervals between 5:00 and 8:00 in the evening.

While on the nest, both of these birds spent most of their time in utter immobility. Occasionally they would change their positions or adjust the eggs. Once one bird picked at objects about the nest, presumably insects. but without moving her body.

When leaving the nest. both birds most often walked a step or iwo and then flew, often somewhat noisily. In returning. the birds invariably walked, although they may have flown to within 15 to 20 yards. A bird. observed by Sinyth ${ }^{245}$, flew to a nearby tree from which she inspected the vicinity before alighting and walking to her nest.

Another characteristic of incubating grouse is the formation of mueh enlarged droppings or "elockers". These are sometimes found in the vicinity of nests in the direction the female habitually travels in leaving.

\section{Nisting, Tolerance}

Customarily a tolerant species, there seems to be little conlliet between nesting grouse and other nesting birds. in New York at least. The romaining gallinaceous species to be found have occupied, in general. different habitats or are so rare that they seldom nest nearby. No evidence of competition between grouse and the many small, woodland birds has been noted.

In localities where woodht and farm environments overlap. however. the pheasant frequently lays eggs in nests of the grouse. But. despite such parasitism, the latter usually proceeds to incubate, often with the result that the pheasant eggs hateh first, thereby sealing the doom of ber own elutch.

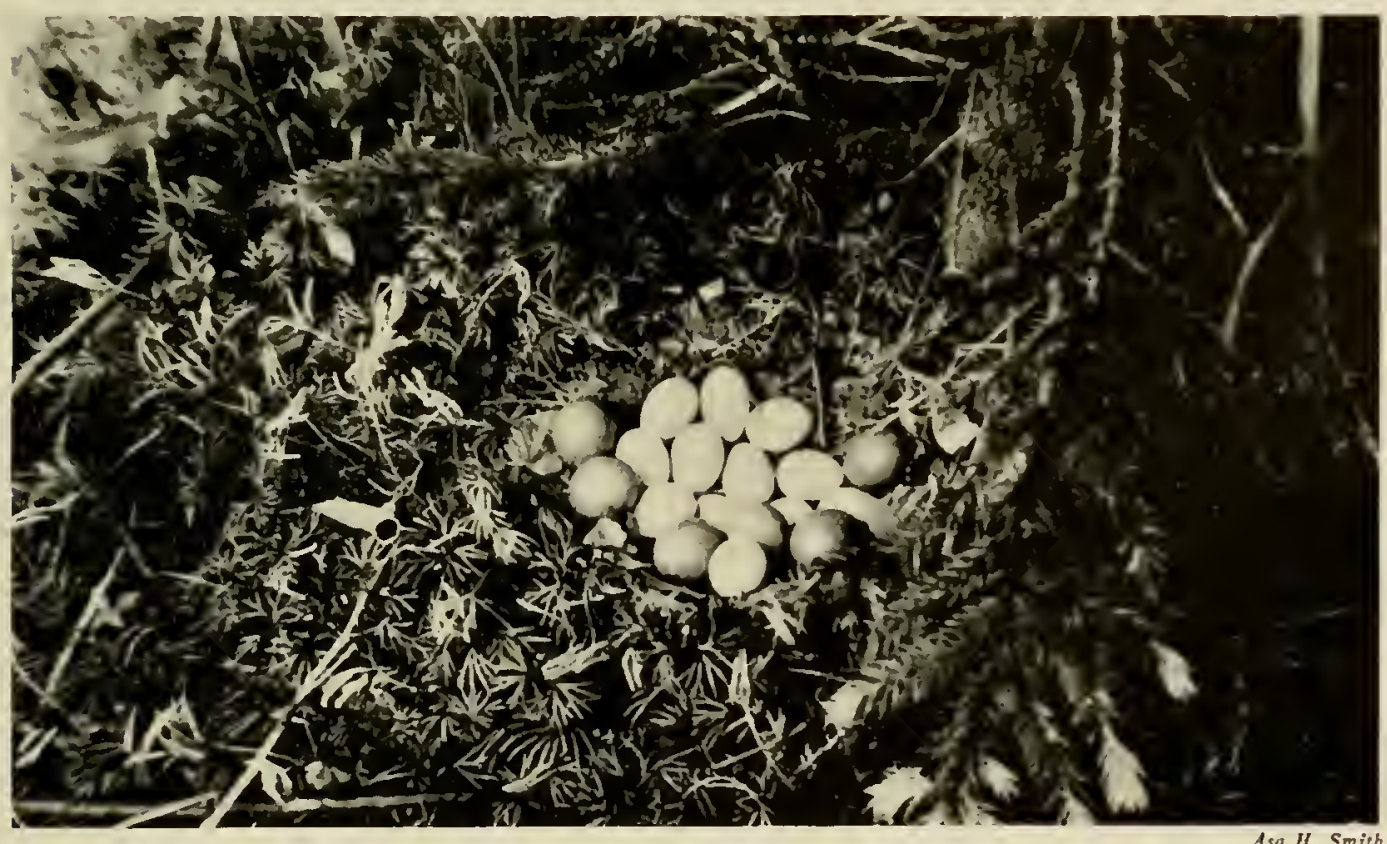

GROLSE NEST CONTAINING SIX PIIEASANT EGCS 
Of 2,016 nests examined from 1930 to 1912,11 contained pheasant eggs in addition to those of the grouse. There seems to be little question, however, that such instances are the result of a parasitic tendency on the part of the pheasants involved rather than competition for the nesting site.

Another report ${ }^{12}$ lells of nests of a grouse and a domestic hen that were but four feet apart. This account also goes on to relate that the grouse nest was broken up, following which the grouse laid several eggs in the hen's nest.

Analysis of the relative proximity of different nesting grouse has revealed some wide variations. The examination of a large number of nests over the last 12 years has shown that female grouse seldom nest within 100 feet of each other and that intervening distances of over 500 feet are the rulc. Neverthelcss, scattered instances of two or more nests quite close together have been recorded. In one, three nests were lound all within 50 to 100 leet of each other. In another. two nests were 50 feet apart, and in a third instance the distance was 75 feet. Furthermore, a number of grouse nests have been found in which there was every indication that wo hens contributed to the clutch present.

It seems probable that nesting grouse exhibit litte. if any, intolerance toward each other. The usual scattered distribution of nests is more likely the result of a lack of need for any greater concentration. In those cases where grouse nests have been found close together, it is possible that both females mated with the same cock.

\section{DESERTION}

Oceasionally, female grouse desert their nests. Such action is usually the result of undue interference with the bird by some outside agency. Rarely is it due to a cessation of the maternal instinct. Desertion from the former cause probably occurs most frequently before any eggs have heen laid. On both the Connecticut Hill and Adirondack study areas, perfectly formed nests have been found in which eggs were never laid, though, in some cases. the female was flushed from the spot. Later, a nest was often found a short distance away in which a full complement of eggs was deposited. In one case, the second nest was directly beside the first. If the provocation is strong enough, however, desertion may oceur at any time, although the probability decreases markedly as incubation progresses.

It is probable that desertion, due to a cessation of the maternal instinct, occurs largely in connection with late renesting birds. One bird incubated until July 5 before giving up. In this case, however, examination of the eggs showed them all to have been infertile.

It is, of course, evident that the death of the femate away from the nest wonld give the inpression of desertion. Thus, in analyzing such records. any error will tend to increase the percentage of frequency. In any case, however, the incidence of desertion", after ecrgs had heen laid, has heen ahmost negligible among the nests examined during this luvestigation.

That the birds will endure a considerable amount of interference, especially during the latter part of the incubation period, without descrting, is evidenced by the experience of the authors in trapping ncsting hirds for marking purposes. Such trapping operations were carried on at the nest site during the last few days prior to hatching. Of 128 females so handled on the Connecticut Hill arca, only cight or 6.2 per cent deserted.

In this connection. one bird, which accidentally broke its wing in a trap, nevertheless returned to its nest, hatched the eggs and successfully reared the resultant brood. Although crip- 
pled during most of the summer, it was finally found to have regained its ability to fly by late August.

\section{Renesting}

Since the latent ability of a female grouse to produce eggs* usually exceeds the number comprising her first clutch, hens, whose initial attempt is broken-up, often try again. Each year, while the great majority of the successful nests in a locality hatch within a few days of one another, a few are incuhated much later and hatch on widely separated dates. Similar evidence is also found in the occurrence of broods which are much younger than the average.

For this purpose, a new site is invariably chosen. And the number of eggs laid is normally less than before, averaging 7.5, although as many as 11 have been recorded.

The probability of a second effort of this kind is greatest when the first clutch is destroyed before it is complete or before inculation has progressed very far. That it may, however. occur considerably later was demonstrated in 1940 when a brood of six chicks, not over three days old, was found July 24. The female of this brood must have begun to lay her final cluteh about June 16. On another occasion. a renest hatched July 1 or 2 . and a third hen incubated until July 5 hefore abandoning a cluteh of infertile eggs.

There is no indication that third attempts are ever made.

\section{LACK OF SECOND Broons}

In the region covered by this Investigation, individual female grouse have but one brond a year. The same is true thronghout the range of the species, so far as is known. Normal first nests hateh in late May or early June and the subsequent hroods regularly remain together until September or October.

The discovery. now and then, of late broods has led to the misconception ly some that second broods were produced. Actually such observations merely represent hirds which renested $^{\Delta}$ after their first clutch of eggs had been destroyed.

\section{REATTION to BroOD}

Bold and timid at once, the gronse is one of the most rourageous of the "motliers of the wild", especially during the early days of the brood period.

\section{Defense of Chicks}

The impulse to protect her hrood from harm becomes stronger and stronger during incubation and reaches its peak at the time the eggs lateh and immediately thereafter. Should she be molested at this time, she may either confront the intruder belligerently or endeavor to lure him away by a ruse. While the chicks or hatching eggs are still in the nest. the female most often resorts to the broken-wing "stunt" in an effort to divert attention from them. Being highly precocial, the chicks leave the nest within a few honrs after hatching. For the next week or ten days. when danger threatens, they immediately take advantage of whatever shelter is at hand and "freeze". On such occasions, for the first three or four days, the female gives a warning call to her brood and at the same time faces the intruder "with hlood in her eye". Rufling ont her feathers and half spreading her wings. she usually utters a loud squeal. apparently to distract his attention. Again she may msh at him. hiss. ing menacingly as she comes. Birds have been known to actually fly into the faces of per-

* See Chapter Vul, p. 360 .

$\triangle$ Sec discussion under Renesting above. 
sons as well as animals. After a moment or two of this. which gives the chicks a chance to hide. the hen retreats. squealing and often feigning injury. If the intruder does not respond. she may return and repeat the performance. She soon flies off. however.

Forbush ${ }^{104}$ reports an unnsual experience in which a grouse actually chased a small boy a short distance across a field.

Nothing has been observed to even suggest that grouse ever carry their chicks in their beaks, as related ly: Wilson ${ }^{4 n}$ or on their backs, as asserted by Smith ${ }^{325}$.

When the chicks are from a week to ten days old. they begin to acquire the powers of flight. At this lime or more often some days earlier. the behavior of the female herins to change. More and more frequently does she fly as soon as the brood is disturbed. Soon, whether she flnshes before. with or after the chicks, depends entirely on rircumstances and by late summer it is often impossible 10 distinguish her from the others.

\section{Daily Activities}

Since incubation is not begun until after the full chutch of eggrs has heen laid. all the chicks hatch within a relatively short period. At this time. only the most imminent danger will cause the female in leave the nest. As the eggs hatch. she broods the chicks until they have thoromohly dried off. Then, when all are ready, she moves several feet to one side, clucking and ralling the while, whereupon the journey of the brool commences. Any ahicks unable to follow are left behind. Only by accident does the brood ever return to the nest site.

Intil the rhicks hegin to assert their independence in late summer. the female shepherds her brosd. Irawing their attention to desirahle food items and kepping a constant wateh for danger. During the first wo or three weeks and weeasionally thereafter she hovers them at night and proteds them during stormy, chilly weather. IT until they have commenced to fly. she also hroods them at intervals through the day. During the latter part of the summer. the family group spends many hours sunning and dusting. mainly during the middle of the day. On such oreasions. the hen is comparatively inaclive while the rhichs plat abuuther.

Experience with hroods held under artifucial conditions indicates that the degree wo which the female "lalks" (1) the chicks as they move along is of major importance with respect to her ability to rontrot and guide them. An interesting observation in this connection is that. when a hrood is disturbed. the female often sems content to mose olf with only two or three rhicks in sprite of what may le happening to the res. Yet. if the whole brond is threatened. she will display comideralle solicitude.

As the season progresses and the ehicks develop. the role of the female als guide and proter. tor heromes less important. By September. the youngsters have hecome essentially adult and. abum the middle of the mouth. the family group wsually berins to break up.

\section{Control of Chicks}

During the early weeks before the wheks have berome strong llicrs. the female som returns after a brood has been flushed. If danger is stilt present. she warns the chicks to remain hidden as well as quiets any that herin to peep. The hrowd may be kept thus conecaled for several hours. The female. meanwhile. cirches aromel or somelines flies to the low branch of at tree. eonthually reprating her warnings 10 the chicks. When she hats satisfoed hereelf that the enast is clear. she calls the dhicks which quickly galter from their hiding places. The following. from the field notes of June 12. 1932. is illustration: 
"Brood 4.III was flushed. The female was chased away to a distance of 200 feet and one of the party concealed himself in a thick white pine about 20 feet from the ground. Within ten minutes, a chick began peeping 30 feet from the base of the pine. Then the fenrale was heard giving an alarm note about 40 feet on the other side of the pine from the chick. The female approached rapidly on the ground. as could be told by following her continuous soft rlucking. Every moment or so between clucks she would give an alarm note. When she was right under the pine in which the ohserver was roncealed, she flew to the limb of another pine alout 10 feet from the ground. For two or three minutes she alternately clueked and warned the chicks. The one chick stopled peeping. When the female was sure no danger was near, she gave a series of low clucks and in two or three minutes alt of the ehicks collected around her. Immediately they moved swiftly off to the east. with the female clucking softly."

That the female is not indispensahle, at least to older broods. has been demonstrated on nunerons occasions by the rhicks moving off individually and collecting themselves. Oftumes. also, older chicks will endeavor to silence wher chicks which start peeping.

\section{Double Broods}

On a number of oecasions doulde brouds lave heen encountered. usually with both fomales present. In most cases. these appear to represent morely chance mertings. The following is from the field notes of June 14. 19:32:

"Two hroods were flushed logether in Section 4. The frmale of one hrood was marked. the female of the other was mot. so that the were easily distinguishable from one another. The females were chased away while two ohservers eoncealed themselves in separate tres alout 30 feet from the ground. In about 15 minutes, a chick began to peep. Sonn another was heard. The chicks of the wo broods hard become all mixed together. but were apparenth very easily separated hy the femates as follows: First the marked female was heard about 100 feet away. She warned the ehicks. then eame up swiftly and pased directly under one of the observers. All of the time she was giving alarm notes. After a few minutes she hegan to call softly. Her own ehicks came from all direetions. some peeping loudl!. and they all moved off quickly to the north. Five minutes after they left. we heard the other female. who seemed more wary than the marked bird. She passed nnder one of the ubservers and low to a low tree. Then she called her chicks together. It was ahout 20 minutes from the time the marked female was flushed until she had collected her lrood and mosed awas. It took the wher female about 30 minutes. There seemed to be no trouble in separating the elinks."

There is some indication, however, that, later in the season. browds may sometimes merge permanently. especially if the female of one has been killed. In other cases, orphaned broods have succeded in maintaining themselves as a unit.

Another interesting olservation involves a female. whose nest was known to have been broken up just before hatching. which was later flushed several times over a period of a montly with a brood of four chicks. The identity of the hen was positive beranse she was marked with colored tail feathers and the chicks were of normal age.

In this comnection, females which have lost their entire brood, especially during the early part of the season, usually continue to act quite broudy for sometime thereafter when fushed.

\section{Guidance}

Juveniles of any animal are. to a considerable degree. dependent on adult guidance in "learning the ropes" of their environment. This is particularly true of precocial species, such as the 
grouse, where the chicks leave the nest within a few hours after hatching. They must be shown suitable sources of food; they must he protected during adverse weather; they must he taught how to avoid the many dangers constantly threatening them. Since the male grouse takes no part in reproduction beyond the mating stage, this task devolves upon the female.

During the period prior to flying. the chicks travel in a loosely-knit group with the female, seldom straying more than ten or 15 feet from her. At this time she maintains a considerable degree of discipline over them by means of a variety of calls and warnings. Many times broods of this age have been observed crossing country roads with the female in the middle of the highway and the chicks strung out in more or less single file from one ditch to the other. Yet among broors held in large natural enclosures the chicks often seemed to lead the hen. spread out fan-wise hefore her.

With respect to feeding, the fenale seems merely to guide them through good feeding territory and, by example. to indicate choice foods. She apparently does not seratch for them: neither does she feed them directly. When danger threatens, she warns the chicks to hide and keeps them quiet until the cause for alarm has passed.

As the chicks become older. they more and more assert their independence, and the degree of guidance from the female diminishes. As her control over them lessens, the group ranges farther and farther afield. Hand in hand with this, an increase occurs in the jurenile mortality rate. which has largely leveled off following its initial precipitousness of the first three weeks. But. by fall. the survivors have acquired the ability to take care of themselves and the female's responsihility has been fulfilled.

\section{CHARACTERISTIC OF THE BROOD}

The chicks, too. even though indulging in activitics common to the adults. exhilit certain distinctive characteristics.

\section{Area Traversed}

From the time of leaving the nest until they lreak up in the fall, broods range to varying degrees in quest of the necessities of life. There is unthing. however, to indicate that juvenile grouse recognize territorial limits in the sense that this term has been applied to the adults. Nevertheless, the area covered undouhtedly reflects the nature of the female's territory as well as her individuality.

It is impractical to attempt to follow grouse broods from day to day. Yet it has been possibe to contact most broods from two to four times a month. during the summer. on the study areas. In this way. a reasonahle estimate of the extent of their wanderings can he made. The identity of individual broods can usually be determined on the basis of location of contact. number of other broods in vicinity, number of rhicks, age of chicks. habitual actions of fomale and artificial markings of female. Unless the female is marked. however. contacts of broods which have traveled unusual distances will often he incorrectly diagnosed.

Brond "territories" estimated in this way have varied considerahly in both size and extent. They have ranged from between five and ten acres in over 100 acres and from relatively conı. pact units to narrow, murh elongater tracts. In 1931. the distance betweon the extreme points visited hy Brood 15.1 was estimated at 3.76 .5 feet. Many whers have reached points over half a mile from where they started. Nevertheless, the majority confine their activities to areas of brtween one-eighth and one-quarter mile in extent. 
The most restricted areas of this kind have been observed on the Adirondack study area. In this section, broods commonly sccupy alder beds and limit their activities to the confines of such cover units to such an extent that they rarely venture beyond their borders until late summer or early fall. For example, throughout each of several summers, two broods occupied a covert of this kind comprising, in all, only about 15 acres, each keeping to its respective end of the tract. On the other hand, many broods were found in the more usual types of cover on this area and ranged over considerably larger areas during the summer.

In the more open type of range of the central and southern portions of the state. of which the Connecticut Hill and Pharsalia study areas are representative, the broods tend to follow the woods edges over much greater areas, although instances of restricted movement have also been noted here. The average, however, is about 40 acres.

Examination of the courses followed by browds, as revealed by successive contacts, demonstrates the significant influence of woods edges. the borders of clearings. slashings, woors roads and the like on the territories chosen. In areas of disconnected coverts, a large proportion of these areas are located about the periphery of the existing woodlots, many extending for considerable distances along the woods edge. hut fenctrating the interior hardly at all. In tracts of continnous forest, however, where openings are comparatively small, the broods, in following their borders, usually remain within more compact limits. This is also true of broods which ehoose the vicinity of small openings within the woudlot of disconnected coverts.

Observations indicate that food is a more important factor than shelter in governing brood movements* although even young broods are often found in cunifer patches. Usually they make their way at once to situations where there is an abundance of low. shrubby vegetation with its accompanying population of insect life. In such sitnations, the sumlight, in addition to heing a necessary element of the conditions imvlved. aids in keeping the chicks warm and in drying them off after a storm. As the season advances. suitable fool continues to become avalable in much the same types of cover. Then, in late July. the raspberries and lilackberries commence to ripen and a noticeable moventent to the brier patches takes place.

There seems to be no tendency for broods to whject to the presence of another lorood on the same area. Many eases of over-lapping routes have been recorded. In fact. as noted elsewhere $\Delta$ two broods have been found lo actually merge and subsegurntly separate again.

That, at times, even quite young bromls will cross appreciable open areas has heen demon. strated on several occasions. For example, me hrood less than two weeks old. the female of which was marked so that identification wats positive. was found to have crossed 600 feet of open field to a separate patch of woods from that in which it nested. This brood later returned to the original covert. Several other similar instances have been noted where broods which hatched in small separated woodlots have traveled to a larger tract and. often, back again. crossing open fields of several hundred feet en route. This. howeser is not a frequent orcurrence.

\section{Hiding:}

The ability of grouse chicks to "vanish hefore one"s eyes", so to speak, has long been commented upon. Contrary, lowever, to popular belief. they do not grasp a leaf in their feet and roll over. Their technique is merely to squat as low as possille and "freeze". In this

* See also Chapters 111 and 16 .

$\Delta$ sec disrusgion under Relation of Female to Broud, p. 29.3.

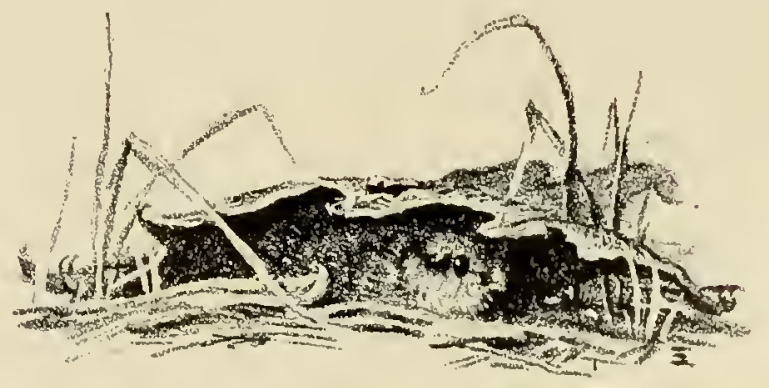


way, they may often be in plain sight and yet be almost invisible, duc to the blending of their plumage with the sunlight and shadow of the forest floor. It is true. however. that they frequently scuttle under a leaf or other protecting object before "freezing".

Although this practice is ehiefly characteristic of chicks before or for a short time after they have learned to $\mathrm{fly}$, it is often utilized later in the season. Furthermore. the same method is employed by older chicks at the point where they settle down after being flushed.

While in hiding, the chicks usually remain silent for upwards of ten to 15 minutes but then frequently become impatient and commence to peep so that the female. which customarily remains in the vicinity. must quiet them with warning calls". Among other chicks. the effect of this sometimes wears off and eontinued peeping oceurs. At such times, chicks have been seen to leave their hiding places and start out by themselves. Isually. however, the danger which caused them 10 go into hiding passes before such a state of unrest is reached. Older chicks. on the other hand, have been known to steal away, silently and unnoticed. under the very nose of an ohserver watching for them.

\section{Roostinc:}

During the first few weeks, the chicks are usually hovered by the female at night. Experience with hroods held in large outdoor pens offering a variety of cover indicated that it may he common practice for hens to hover their chicks in the open rather than within the woods. Broods but slightly over two weeks old, however, have been found roosting in the low hranehes of trees and shruhs. Later. this habit becomes customary: although well advanced broods frequently soost on the ground. usnally in the shetter of a conifer.

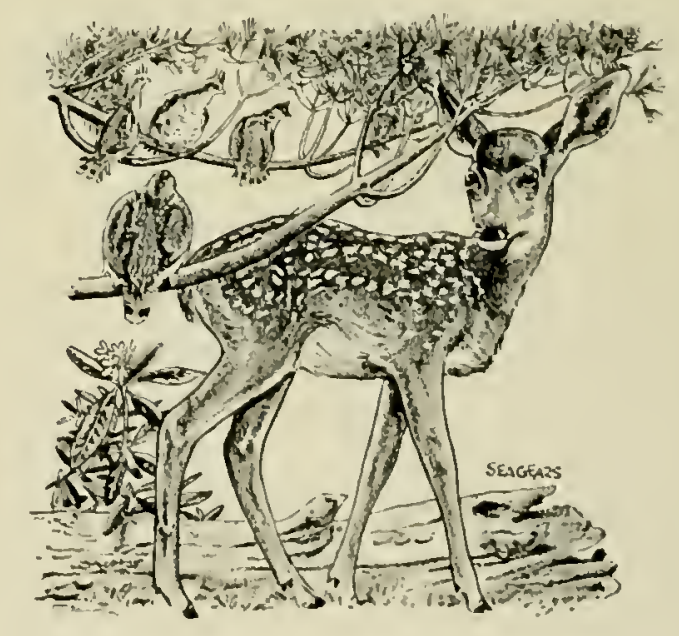

Young broods roost in very closely bunched groups lut as the chicks laneone older and more independent their assoriation beromes progressively looser.

\section{Fefolic: HairTs}

Throughout the brood period. gronse chicks spend nost of their waking hours on the ground. Feeding is their principal activity althongh. for a time after latching. hrooding is frequent and during the latter part of the summer much time is spent dusting.

Wen chapter 11, 8. 99. 
During the first two weeks, insects constitute a large proportion of their food, while later vegetable material is predominant. Young chicks, especially. are a hive of activity, constantly picking anongst the ground litter or chasing insects through the low-growing regetation. In the course of such pursuits. they often flutter off the ground a bit. Older chicks frequently jump eight or ten inches in the air, aided by a wing flap or two. in order to get some particular morsel out of normal reach. They scratch very little with their feet and the hen seldom passes on to a chick a food particle she herself has picked up. She may. however. sometimes call the youngsters to her and encourage them to eat some special delicacy she has found.

As they proceed, the chicks sample everything. both animate and inanimate. Bits of wood and other debris are apparently taken just as readily as a juicy insect. although they are usually dropped again. Invement, however, definitely attracts their attention. This is probably one of the chief reasons why ants are eaten in such large numbers. When a particularly interesting new object is encountered, the chick will stretch its neck. inspect it with one eye and then, turning its head, give it the once over with the other eye.

Activities of this kind are, naturally, very difficult to observe among wild birds. At the Catskill Experimental Station, however. several broods were hatehed and reared by grouse mothers on the ground in large open enclosures affording an abundance of typical cover as well as excellent opportunities for uhservation. These broods usually began their day's adventures shortly after sun-up. Even rainy weather did not long delay the start. For the first week or ten days, before they began to fly, the chicks were brooded at night ly the hen. In the morning, she would get up. the chicks tumbling down from under her wings or emerging from some other retreat. Immediately, she would move off some ten feet and wait while her brood. spreading out fan-wise as they chased hugs and beetles or drank dew from blades of grass. worked up to her. On warm days, upwards of half an hour might be spent in this way, but. when the day was cold or rainy, the chicks often returned to be brooded again after only five minutes. Thus. throughout the day, periods of feeding alternated with periods of brood. ing. Seldom, however, would all chicks be under the hen at one time. individual hirds being continually on the move. As the birds grew older and commenced to fly, they usually roosted at night and brooding became discontinued altogether. For the remainder of the summer. while feeding might be indulged in at any time. it was less common during the midtle of the day which was devoted more to sunning and dusting. Dust baths, however, are often associated with ant-hills and there is every indication that large numbers of ants are picked up on such oceasions.

\section{Dust Bathing}

What has been said under this topic with respect to adults applies equally here as to function, sites chosen and materials utilized. Chicks have been seen dusting when only about two weeks old hut the general onset of this activity is usually a week or so later. From then on, it is common to find dust baths comprising one large depression flanked or surrounded by several smaller ones. where a female and her chicks have had a fanily dusting party.

\section{Gregariousness}

In plotting the travels of individual broods it is not unusual to find that the areas covered by two or, occasionally, three such groups have overlapped. On the other hand. it is unusual 
to find both broods at the same point at the same time, although this situation has been encountered on several occasions. In these instances, both females have usually been present and have subsequently gone their respective ways with their own broods. But in one case, two such broods were again found together the following day, while two others were found together a second time after an interval of two months. It seems probable that such occurrences are largely accidental. Now and then. however, particularly late in the season. a group of orphaned chicks has, apparently, joined another brood permanently.

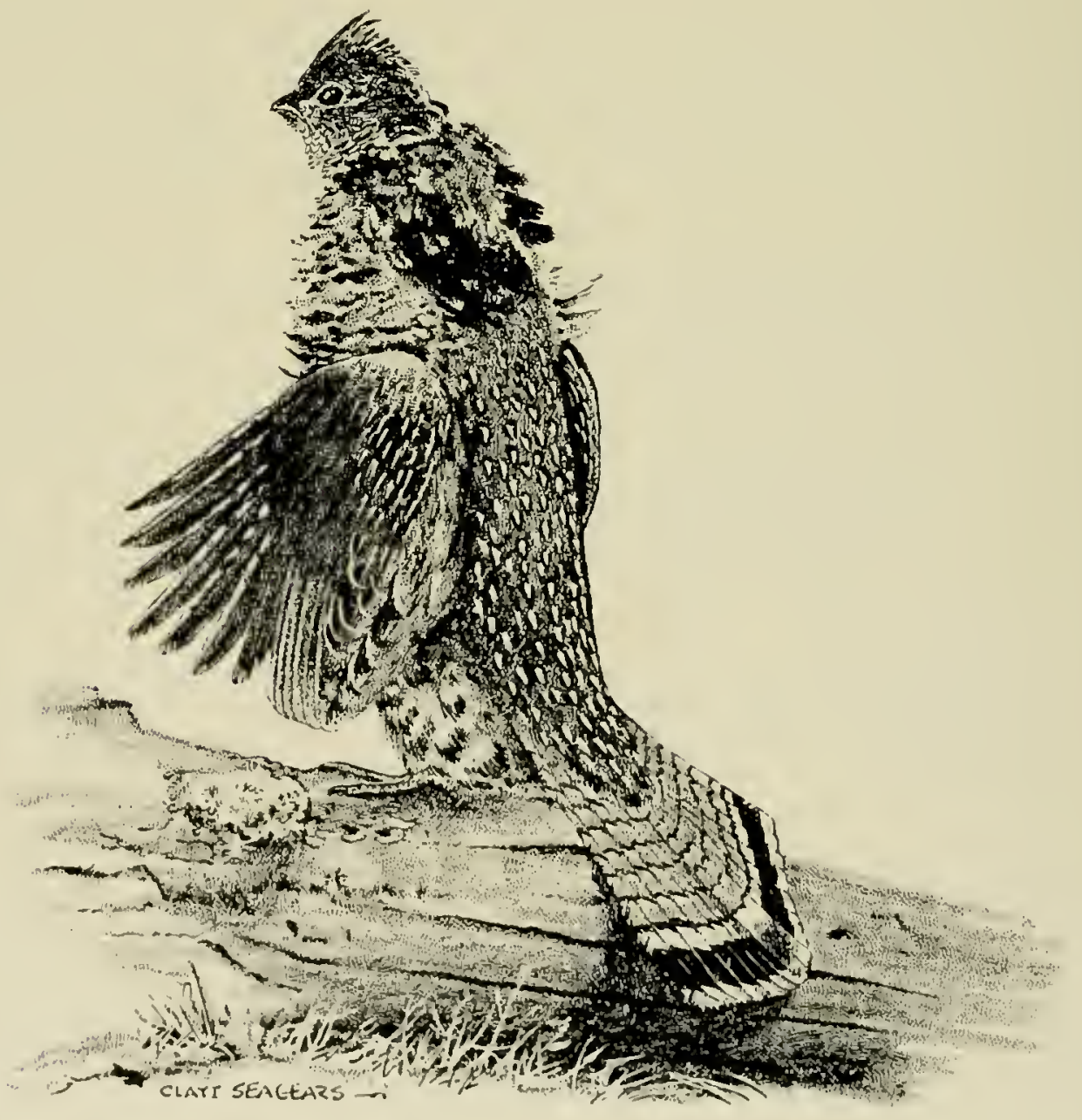




\title{
CHAPTER VI
}

\section{INFLUENCE OF WEATHER}

\author{
by Walter F. Crissey
}

\section{WEATHER AS A DIRECT DECIMATING AGENT}

\section{WEATHER AS AN INDIRECT INFLUENCE}

During the Nest Period-During the Brood P'enod--Durixg the Adelt Period

\section{COVER TYPE USE AS AFFECTED BY WEATHER}

\section{IWEATHER AND FLUCTUATIONS IN GROUSE POPULATIONS}

\section{as}

\section{SUMMARY}

Weather is a basic influence on grouse and other wildlife species through its effect on the emviromment in which they live. (p. 300).

Its effect is largely indireet and specific relationships are therefore diffienth to determine. (p. 300).

Direct losses from weather conditions seem nercligible in New York, but on one occasion a severe cloudburst and flood before the chicks were six weeks old apparenty took a heary toll. (p. 301$)$.

Although the onset of the reproductive season is primarily controlled by the progressivel! increasing length of daylight in the spring, minor variations in nesting dates from year Io year seem related to the average minimum temperature during early April. (p. 303).

There is apparent correlation between temperature and precipitation during the three weeks immediately following hatching and the brood mortality occurring during the latter part of the summer. (p. 303).

The degree of over-winter loss among adult grouse seems to be affected to some extent by the severity of the weather during March. (p. 304).

There appears to be some degree of agreement between the occurrence of low temperatures during March and June and periods of grouse scarcity which have been recorded in the pasi. (p. 306$)$.

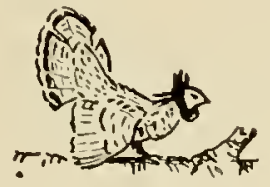


Weather, in its various forms, is one of the basic influences affecting the character of organized life throughout the earth. During the planet's formative stages, precipitation and frost action motivated the forces of exosion which gradually broke down the original rock of the earth's crust enabling primitive plant life to gain a foothold. Rainfall, as well as melting snow and ice, also gave rise to the oceans in which, under warm temperatures, the earliest forms of life developed. Throughout succeeding eons of geologic time, these same forces have been instrumental in establishing the vast array of rock formations and soil types which are fundamental in supporting the vegetation upon which animal life so greatly depends.

Then, too, conditions created by weather have been directly responsible for many of the major changes in life over the earth's surface. Today the distribution of plants and animals, as well as the nature of many of their characteristics. rests to a large extent upon their reactions to conditions controlled by weather. Animals inhabiting these regions, therefore, have become physiologically adapted to certain conditions. When their range reaches an area where the environment is excessively severe, they cease to occur. Similarly, within its normal range. the abundance of a species from year to year may be affected by variations in weather.

Despite its universal significance, however. knowledge of this factor is still quite limited. The science of meteorology has advanced to the stage where short-time weather forecasts can be made with fair accuracy. But prediction of the effect of such conditions upon the growth and abundance of plants and animals is largely speculative.

A major reason why existing knowledge with respeet to wildlife is meager lies in the complexity of the manner in which weather usually exerts its influence. In the first place it comprises a number of components: temperature, prccipitation, sunshine and humidity, to mention a few. But more important are the high variability of these forces, the rapidity with which they fluctuate and the fact that their pattern is constantly changing. Furthermore, the indirect and often delayed nature of their effect on an animal tends to obscure the actual relation. ship.

Another reason involves the applicability of existing weather data to wildlife problems. The standard observations of the Federal Weather Bureau afford an excellent index to the general trend of the various climatic elements. But such records, even those of the nearest individual station, usually differ from the specific conditions experienced on local areas where wildife studics are heing conducted. Therefore, while it is possible, in many cases, to recognize correlations between weather trends and the behavior of animal populations, it is usually much more difficult to determine the mechanism responsible".

Weather. with respect to grouse, has long been considered an important factor affecting its alundance from year to year. Many observers have suggested cold, wet conditions during Vlay or carly June as a primary cause of scarcity the following fall through increased nest and brood lusses. Likewise, "hard" winters have been thought detrimcutal to the aduls. While these conchusions have licen hased largely on conjecture, they are, to some cxtent, corroborated by findings of the Investigation. Similarly, a number of other ways in which weather affects grouse lave been recorded.

Weather. of eourse, can be either favorahle or unfavorable. Ficld observations, however, pertain primarily to its offect on mortality. For this reason, the observations discussed herewith eleal largely with this phase of the sulject.

Apparent correlations have been observed during each of the three life periods. Undoubtedly

* Reararb in experimental physinlugy (nce Chapter 1i) in beginaing to throw some light on these relationahiph. 
many others exist but more detailed study will be required to reveal them. Even with those noted so far, however, it is impossible to establish the exact degree to which they represent cause and effect. Nevertheless, they indicate relationships, a knowledge of which is highly important to an adequate understanding of the pattern of wildlife existence.

\section{WEATHER AS A DIRECT DECIMATING AGENT}

In general, weather appears to he of negligible importance as a direct cause of death among grouse. During the period of egg laying*: snow and freezing temperatures, both potentially destructive, have frequently occurred. In one instance a low of $2 \mathrm{l}^{\circ} \mathrm{F}$. was accompanied by two inches of snow which remained on the ground for four days. Yet no increase in the failure of eggrs to hatch has been associated with such conditions on the areas studied. Prol. ably their location, close to the ground, which did not freeze, was largely responsible. Undoubtedly, however, temperatures much lower than this would kill eggs.

Similarly, losses among grouse chicks, in the experience of the Investigation, have rarely been attributable directly to this factor. Nany times, contacts with the same brood, both before and after cold, rainy periods, have shown no evidence of higher mortality than that oecurring under seemingly more favorable conditions. Deliberate flushing of young broods, under ten days of age, during rain storms has not becn followed by an immediate loss, although in sev. eral instances the chicks were known to have been soaked. That such a wetting can he serious is indicated, however, in that two broods of very young chicks at the Catskill licaring Station lost most of their numbers through failure of the mother grouse to brood them throughont severe thunder storms.

On another occasion weather did appear to have a direct effect. In central New York. in the summer of 1935, a relatively cold. wet June was followed, on July 7 and 8 , by the worst cloud. lurst in the history of the region. On the Connecticut Hill study area, approximately 10 inclies of rain fell in the two days. some 8 inches of it coning the first day. Despite backward conditions during June, no indication of an above average brood mortality had been observed prior to the storm. Y'et, by July 15, losses had jumped to 66.1 per cent. by far the highe-st recorded up to this date. There is little doubt that the July flood, culminating the none too favorable June, was primarily responsible for the excessive mortality. But such storms are extremely rare.

In this connection, on the other hand, in 1937, over 6 inches of rain fell in 24 hours during the latter part of August, resulting in nearly as severe a flood as occurred in 1935. The young birds at this time were approximately 12 wecks old and their adult plumage was essentially complete. No increase in mortality was observed. Thus it would seem that chicks, up to about six weeks of age, are vulnerable to severe rain storms. but that. sometime between then

* A cluteh begun as early as April 7 has been recorded for the Alirondack regioo.
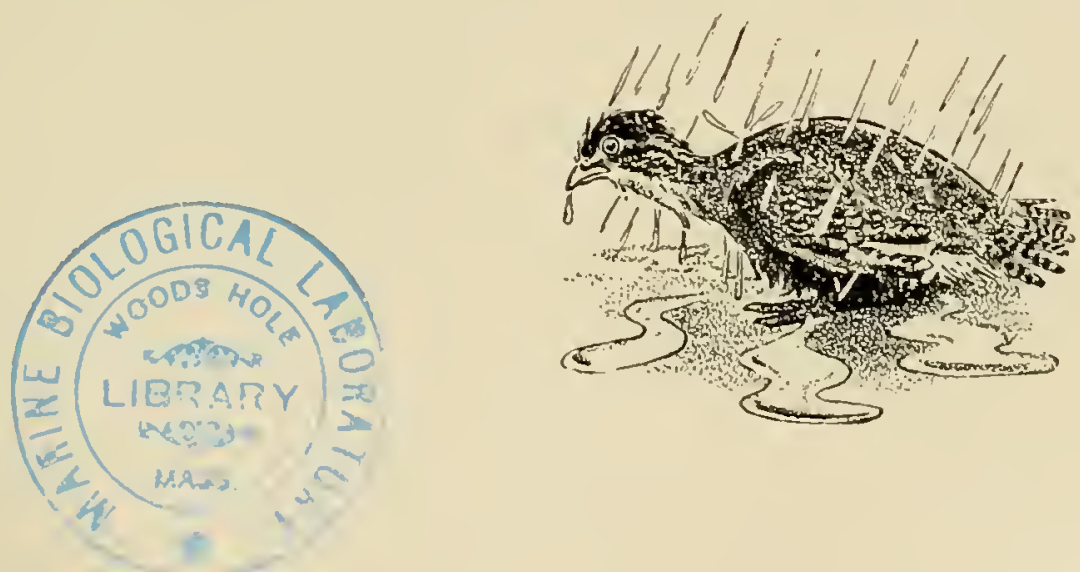
and 12 weeks. they becone able on cope with such tonditions.

With respect to the adults, also, lusses resulting directly from exposure to the elements ap. pear to be of little significance. Even the above mentioned flood had no recognizable effect on this age class. It has been suggested many times that an important cause of winter mortality is the imprisonment and subsequent starvation of suow-soosting birds*. The Investigation did not encounter this condition and has been unable to find a single positive recorl of this kind. This is understandable when one considers that experience during this study has indicated grouse seldom indulge in this habit except when helow freezing temperatures are accompanied by light, fluffy snow. Yet a wet snow is required for crusting. Only when a bird remained in such a roost long enough to allow the surface to become soggy and then freeze, might it be endangered.

On the other hand, there is some evidence that snow-roosting birds are somewhat more vul. nerable to predation.

The possibility that sleet storms result in starvation seems quite remote. The most severe conditions of this kind experienced during the 12 years of the study began on March 17, 1936. Heavy ice-coatings remained on the trees for three days, but no evidence was found to indicate that the grouse had been affected.

\section{W'EATHER AS AN INDIRECT INFLULNCE}

The principal relationships of weather to fluctuations in grouse alundance are of an indirect nature. Physiological studies ${ }^{\Delta}$ have shown that elements, such as temperature and precipitation, definitely affect a bird's vital processes. Often these conditions are adverse but their effect is seldom severe enough to result in immediate death. Rather, by lowering the bird's vilality, they tend to make it more vulneralule to other forces such as predators. disease or the strain of moulting.

Because of the complexity of these interacting inlluences, only data from the most inten. sively worked study area, Connecticut Hill, have proven suitable for analysis. The weather records used here have been largely those of the nearby lthaca (N. Y.) Station. In the following discussion the correlations recognized are grouped according to the three life proriods of a grouse. It must be emphasized again that the degree to which they represent canse and effect has not been completely established.

\section{Durixg, the NFst l'erion}

It is well recognized that the progressive lengthening of daylight during the spring is directly associated in many birds with the enlargement of the reproductive organs and the onset of the breeding season. With grouse, this relationship has been demonstrated ly subjecting experimental birds during the winter at the Research Center to increased duration of light each day by means of artificial illumination ${ }^{i 0}$. These birds produced fertile eggs many weeks before thuse living under natural conditions. There seems little doubt that this is the primary influ. rnce governing the nesting period of grouse.

With only slight differences due to cloudiness, however, the progressive increase in daylight lours is the same one spring at another. If light were the sole influence this would seem to indicate a constant date of nesting each spring. let in actuality. the average date on the Con-

* are Chapter 1, p. 250

$\angle$ Sero Chaptes II, p. 60 . 
necticut Hill area has varied 12 days during the study. Apparently, therefore, other forces alsu are involved.

Analysis of the data, taking into account hours of sunshine. temperature, precipitation and humidity, revealed but one valid relationship. There has been a decided tendency for the average nesting date on Connecticut Hill to advance a few days in seasons when the average minimum temperature during the first 20 days of April was above normal. Conversely, later nesting has accompanied lower temperatures.

Physiologists have long been aware that temperature is a major factor controlling the rate of physiological reactions. When temperature is low. radiation of heat from the body takes place at a greater rate than when it is high and the increased energy required to compensate for this leaves less for the various other body functions. This is undoubtedly the case with grouse. Increasing daylight is probahly the fundamental foree motivating the reproductive cycle, but the rate of advance seems, in some measure. to be controlled by the average minimum temperature just previous to the egg-laying period. Yearly differences in this have ap. parently resulted in the minor variations in nesting date that have been observed.

\section{Duning the Brood Period}

Losses among grouse broods each year are normally high and, as discussed elsewhere", represent one of the major unsolved problems in the ecology of the species. For several reasons the number of dead chicks found by the survey has been too few to sherl much light on the question. Thus it has been necessary 10 depend, to a considerable extent, on eirenmstantial evidence.

In studying the possible influences of weather. certain variations have been fonnd to le regularly associated with inereases or decreases in hrood mortality. These correlations are presented here, not as conclusions, but as information on highly interesting fields for further researeh.

Both temperature and precipitation during the early brood period appear to be important. Yet no connection was observed between weather and early season mortality. Rather it was that of the last half of the summer (July 16-Angust 31) which seemed to be affected. Losses at this time have been constantly higher in those years in which June temperatures ${ }^{\Delta}$ have been below average and. conversely, they have been lower when temperatures have been above aver. age. When the number of days on which .01 inch or more of rain fell during the first three weeks after the average hatching date each year was added to the analysis, the correlation became more significant.

With respeet to precipitation, the number of days on which rain fell seemed to be more important than the total amount. This is logieal in view of the fact that light rains soak the vegetation to much the same extent as heavy ones and the vegetation may remain wet as long after a fall of .02 inch as after a l-inch storm.

Although the variations in hrood mortality have not been large, it is of interest, in view of the degree of relationship, to consider the meehanism which might be involved. Laboratory experiments with gronse and related species, such as poultry, indicate that physiological adjustments to changes in temperature are refleeted by variations in the amount of energy needed for heat production, activity and growth. As the temperature drops, more food is utilized for

\footnotetext{
* See Chapter XII, p. 523 .

A The temperature value useul was what the 1 eather Buteau terms "accumulated temperature". It represents the net deviation of the mean temperature recorded daily for the month from the otandard mean for the oame period.

+ Flood conditions would, of course, be an exception. hut none were experienced by the lnvestigation before mid.summer.
} 
heat production to offset the greater heat loss and less remains for maintenance of body weight and other functions. Loss of heat from the body of a birt is also controlled to some extent by its coat of feathers. Thus, with immature grouse, the early brood period, when the chicks arc less well protected by feathers, would seem to be the most critical.

Similarly, precipitation undoubtedly exerts its influence, in the main, through accelerating loss of body heat. The insulating value of a substance is related to its moisture content. Thus a hird's feathers have much less ability to prevent heat loss when they are wet than when they are dry.

On the other hand, losses which seem to be associated with such conditions, often take place several weeks later. lerhaps cold June weather, especially when accompanied by frequent rainfall, produces a group of chicks which tends to lack the stamina to survive some critical period during the later part of the summer. The moulting of immature feathers and growth of adult plumage, which takes place at this time, represent a severe physiological drain on the bird. It may be that herein lies the answer.

\section{Durivg the Adult Period}

As with broods, it is not intended that the relationships suggested for adults be considered as conclusions with respect to cause and effect. Nevertheless, the degree of correlation is sufficicntly marked to strongly indicate a connection*. Temperature appears to be the primary influence. Interestingly enough, it was not the temperature during the coldest months of the year, January and February, hut that occurring in March which was most closely associated with differences in overwinter mortality among grouse. Low average temperature levels during this month were regularly followed by higher total losses, while the reverse was true when mild weather occurred at this time.

Again, it is probalyly the rate of body heat loss in relation to the energy required to compensate for it which is principally responsible. Throughout mid-winter, it is apparently normal for the energy expended in this way to often exceed that derived from the food caten. Under such circumstances, a bird is forced to draw on its bolily rescrve and it loses weight. This is reflected in the average scasonal weight trend ${ }^{\Delta}$. But. while birds which enter the winter in good condition can withstand its hardships and still cope with moderate weather during Harch. a continuation of low temperatures at this time apparently is "the straw that breaks the camel's back".

The influcnec of precipitation on adult grouse scems of minor importance. Even the severe clondlursts of 1935 and 1937 had no recognizable effect on survival. The hirl's feathers apparently form an effective "raincoat". It is possible, however, that snow, under certain conditions, may even aid grouse in maintaining their body temperature. It is well known that dry, fluffy snow possesses a high insulative value. Thus a bird snow-roustingt under conditions of this kind will undoubtedly use up less encrgy in combating heat loss than onc without such protection. This may explain why grouse are apparcutly capable of remaining in rousts of this sort for considerable periuls without foud.

To sum up this discussion of its indirect influence, weather may le considered primarily as a factor conditioning the susceptibility of grouse to more direct decimating agents through sapping their vitality. Actually, death is usually due to predation or disease.

* - Tatiatscal analvaia has shown them to be hishly eignificant.

$\triangle$ Sre Chapter 11. p. 91.

see Chapler 1. p. 270. 


\section{COVER TYPE USE AS AFFECTED BY IVEATHER}

In grouse management, certain cover types, under various circumstances, are important. If particular types are necessary for survival under adverse weather conditions, then they should form a part of the management plan.

This problem was approached by attempting to determine whether use of any type of cover was more particularly associated with one form of weather than another. Analysis of the locations in which grouse were flushed under different conditions, however, for the nost part, proved inconclusive. Nevertheless. both adults and broods seemed to frequent the heavier types of cover, conifers in particular, to a greater extent during rainy weather, while the more open types, such as second growth hardwoods and wergrown fields, were used more during dry weather.

In general, differences accompanying the change of seasons influence the use made of many types of cover to a considerahle extent. But the issue is confused by the fact that the character of the cover types themselves changes with the seasons due to the growth and loss of leaves from deciduous trees as well as the production of nuts and other fruits. Probahly the most definite relationship with respect to weather occurs during the winter. In the Northeast, areas which lack suffieient coniferous shelter seldom maintain a good gronse population. Other types are necessary to grouse but not particularly from the standpoint of weather".

\section{WEATHER AND FLUCTUA'TIONS IN GROUSE POPULATIONS}

The fact that weather conditions may have an influence on brood and adult survival among the ruffed grouse has been shown in the foregoing portion of this chapter. It has been noted

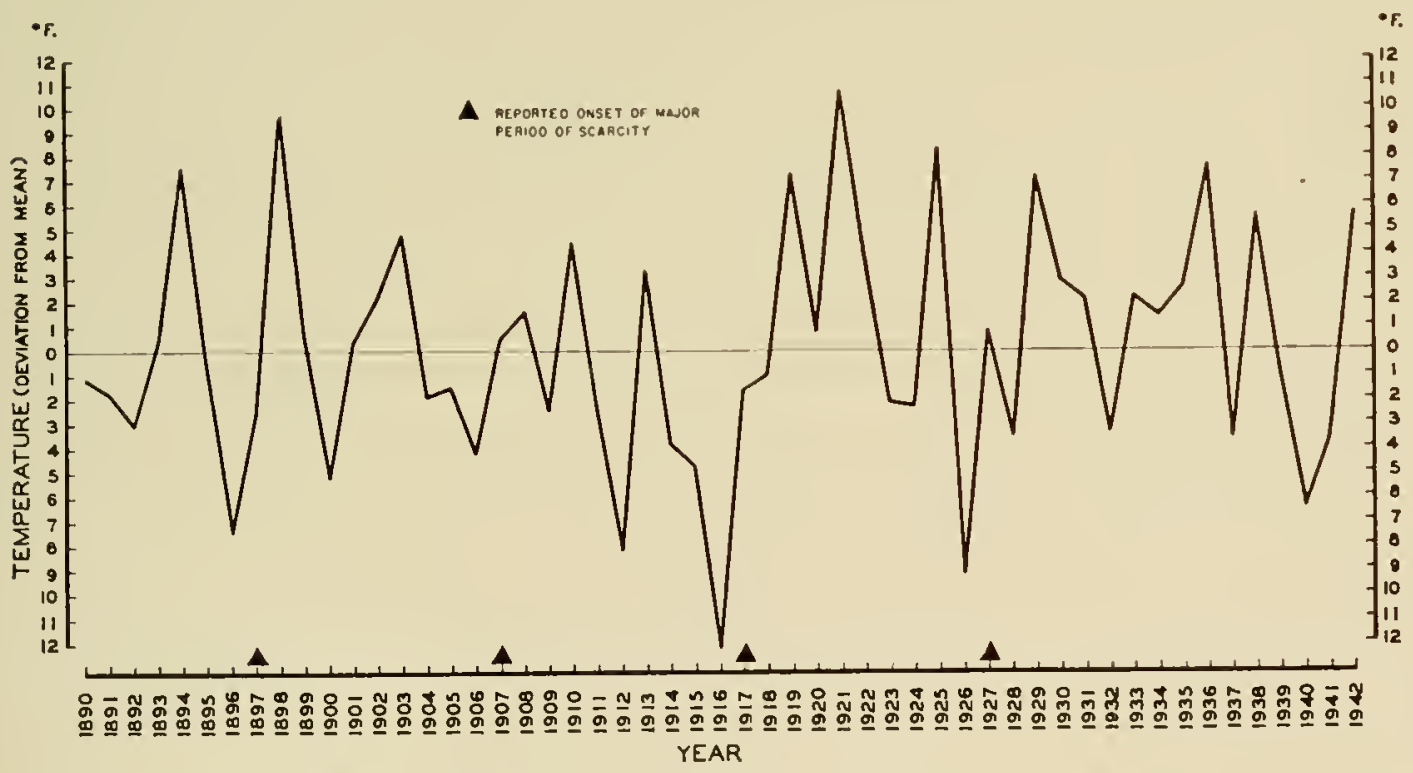

FIGURE 23. RELATIONSHIP OF THE SUM OF TIIE DEVIATIONS FROM THE MEAN OF MARCII AND JUNE TEMPERATURES (U. S. WEATHER BUREAL RECORDS) TO THE REPORTED ONSET OF PERIODS OF GROUSE SCARCITY IN NEW YORK STATE.

* See Chapter 111. p. 161. 
that certain conditions may oceasion severe direct losses while both immature and adult grouse may be affected indirectly by temperature and precipitation. In its 13 years of study, the Inrestigation has had opportunity to olserve the effect of many weather conditions. Nevertheless, even this period is comparatively short in relation to wildlife cycles. Therefore, an attempt has been made to correlate existing information over a longer period. To this end, fluctuations in grouse abundance as recorded for New York by other observers and the records of the Weather Bureau since 1890 were brought together.

If periodic declines in gronse numbers have been directly related to weather conditions, some unusual deviation from normal should lie evident in the records for the years associated with snch lows. Conversely, similar deviations should not have occurred at other times. Experience on the Comnecticut Hill study area, as already presented, indicated temperatures during March and June have been most closely correlated with mortality. Therefore, data for these months* were plotted against the recorded periods of grouse scarcity as show in figure 23.

Some degree of agreement is apparent in this graph between periods of grouse scarcity and years when March and June temperatures were both musually low, although there appcars to have been an unaccountalle lag of a year between the two. In 1906, however, only March was severe. On the other hand. in 1900, in 1912 and again in 1940, similar conditions occurred without a decline in grouse being recorded, although only in 1912 was June below average. Nevertheless, no major decline has been recorded in New York which was not preceded by colder than average weather during one or both of these months. One must bear in mind, too, that this is only one factor affecting grouse abundance and other influences may often outweigh it.

In considering the implieations of this material, it becones obvious that a great deal of data of a much more precise nature will need to be taken before definite conclusions can be reached as to the relationships involsed. Even knowledge gained from physiological studies in the laboratory will be difficult to interpret without more detailed information with respect to the specific conditions under which grouse live in their various habitats.

The standard measurements of the Weather Bureau are taken by means of instruments placed on a platform six fcet above the ground in an open spot. Yet few animals spend much time in such a situation. Rather, they are constantly on the move satisfying the many necessitics of their daily life. In doing this they naturally take advantage of the most favorable sitnations afforded by the environment. Thus the shaded thermometer at a "weather station" may register 20 degrces below zero, but if a grouse occupies a protected nook on a smmy south slope during the day and resorts to a snow-roost at night, it has succeeded, to a considerable cxtent. in minimizing the effect of that temperature.

The problem is complex, to sily the least.

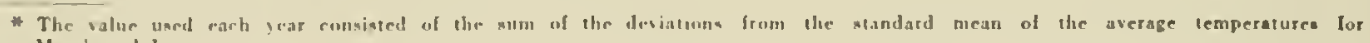
Vlaech and June.

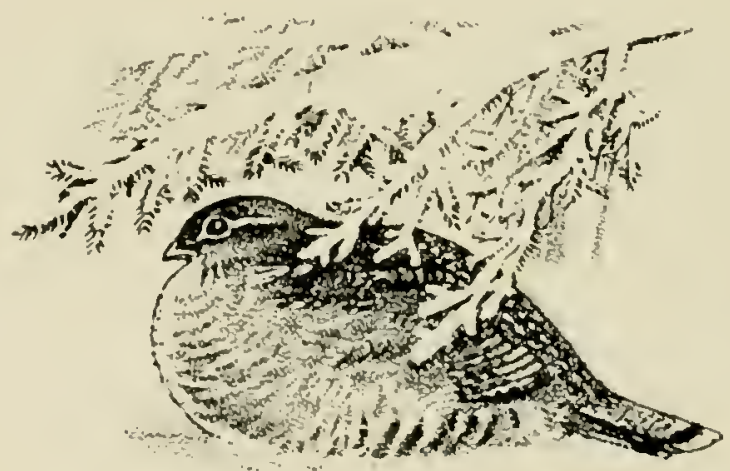




\title{
CHAPTER VII
}

\section{PREDATION}

\author{
By Bobert W. Darrow
}

\section{COMPETING INTERESTS}

\section{ROLE OF PREDATION}

Effect During Each Life Perion - Nest Period - Brood Period - Adult Period I'redator Fluctuations - Buffer Fluctuations - Preditor Pressire - GrousePredator Ratios - Vulagrabihaty - Significance of I'redation

\section{IPPRAISAL OF'THE VARIOUS SPECIES}

Grouse P'redutors of tife Nortieast - Relationshups Dering Each Life Perion Vest Period - Brood Period - Aduh Period - Net Effectiveness Turol choct The Yrar - Food Habits in New York - Fox - Weasel - Skunk - Raecoon - Mink House Cat - Great Horned Owl - Barred Ow] - Snow Owl - Goshawk - Cooper: Hawk - Sharp-shinned Hawk - Red-tailed Hawk - Red-shoullered Hawk - Marsh Hawk - INTERPREDATOR REIATIONSHIPS

THE IROBLEM OF CONTROL

Experiments Conducted - Effect on Predators - Results During Eacil Life Pinsod - Nest Period - Brood Period - Adult leriod - Efffct ox Productivits

\section{as}

SUMMARY

Predation is a fundamental relationship of living organisns functioning, through the removal of surpluses. to keep their numbers within limits compatihle with the hahitat they occupy. (p. 308).

Athough increases in a grouse population cammot be accumulated year after year, predators or no predators. control of foxes and weasels may he useful in producing a greater fall surplus on areas where such a crop will be utilized for sport. (p. 331, 350).

An awerage of approximately 39 per cent of the grouse nests observed by the Investigation have been broken up. mainly by predators. (p. 311).

Foxes, the principal grouse nest predator, have broken np more nests when buffers were scarce than when they were ahundant. (p. 315).

Only about half the usual brood mortality seems attributable to predation. (p. 317). 
Adult losses have averaged slightly over half the fall population each year, some 80 per cent of which. On unhunted areas. succumb to natural enemies. (p. 319).

The number of adults lost has varied directly with the fall population level. (p. 320).

Great horned owls, the major predators of adult grouse over most of New York, have in general taken more grouse as buffers became scarcer. (p. 322).

Resident predators have not fluctuated greatly in abundance on the study areas. (p. 323).

Buffers have exhibited marked fluctuations, some approaching a cyclic pattern. (p. 325).

The degree of activity among foxes, and thus their pressure on grouse. has varied inversely to the abundance of luffers. (p. 328).

Grouse predators include a wide variety of species ranging from tiny shrews to the wolf and great horned owl. (p. 332).

Foxes and weasels are the chief predators during the nest period. (p. 334): Cooper's and sharp-shinned hawks among the chicks, $(p, 336)$ : and the great horned owl and fox among the adults. (p. 337).

In no instance do ruffed grouse constitute the staple food of any predator. (p. 338).

Predator control experiments have been effective in reducing nest losses. but have had less effect on adult mortality and little or none with respect to the chicks. (p. 3.19).

Predator control cannot be depended upon to result in a continued increase among breeding populations of grouse. (p. 350 ).

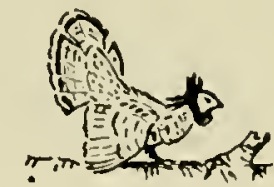

"The large fish eat the small fish:

The small fish eat the water insects:

The water insects eat plants and mud."

So it is with terrestrial and avian species as well. The fox feeds largety on rabbits and nice which in turn live on vegetable material. The Cooper's hawk preys on small hirds which eat insects which subsist on plants or decaying animal matter. Predation is onc of the fundamental rehationships of living organisms.

But because instances are easily olserved and hecause it appears to compete directly for game which they otherwise might utilize. it is one of the most controversial topies of discussion which may arise when sportsmen get together. For example. John Gronsehunter has just returned from a ramble through his favorite covert where he found the remains of a "part. ridge" killed by a fox. His partuer knows of one having heen killed by a horned owl. They are convinced that therein lies the reason for whateror diffeulty they may have experienced in funding grouse during the past lunting season. To them the solution is plain-elininate the predators. The liologist. however. looks beyond this superficial relationship and sees the array of other influences. seldon even suspected hy the sportsman. which would tend to neutralize the intended effect of such a program.

Cause and effect. especially with respect to living organisms, are usually much more com. plicated than they at first appear. In spite of the extensive alteration of conditions oecasioned 
by civilization the multiplicity of interrelationships in any habitat still exists. Thus any lessening of direct decimation of a game species through a reduction of predators would be only one phase of the result. In the long run, the indirect effects might often he of much greater importance. For example, it is possible that. before being checked by some other liniting factor, rodents might increase until they had seriously damaged the suitability of the cover for the game population. Illustrative of the possible ramifications is the situation attributed to a certain part of England where it is said red clover would not grow because the absence of hawks, owls and similar predators permitted field mice to increase to the point where they exterminated the lumble bees. through destroying their combs and nests. thus removing the pollanizing agent of the clover. More pertinent perhaps is the observation of Farrow ${ }^{132}$ that on some English heaths too many rahbits cause the heather to he replaced by grass or bracken. both of which are relatively worthless for Scotch grouse food and cover. There is much more to the problem than meets the eye.

Although the nature of its operation anong wild life populations is not yet fully understood, predation seems, as Errington ${ }^{203}$ has pointed ont. "to be essentially a breproduct of population [surpluses]". It may be a new concept to some readers, but it is nevertheles. necessary to all species that they be prevented from realizing their reproductive potential* Otherwise their abundance would exceed that compatible with their environment.

To one who in an all day tramp has started but one or two grouse or a half dozen rabbits it may be difficult to envision the possibility of over-abundanee. Yet simple arithetic will show that. without some check on their increase. one pair of grouse would produce a population of over 33,000 individuals in only six years.

Losses from predation are largely concerned with such surpluses. But, more important still, Nature's system of checks is quite flexible. If one is removed. others "take over" su that the ultimate result is essentially the same. The effect of the shift. however. may not he immediately apparent. A striking example is the history of the mule deer population in the Kaibal, National Forest in Arizona. Following elimination of their principal predator, the mountain lion, the deer increased until they exhausted their food supply and starva. tion became the limiting factor. Furthermore progressive depletion of the forage ultimately resulted in a lower population than had been maintained hefore the lions were removed. Similarly, following the virtual elimination of its natural enemies, the white-tailed deer is at present overtaxing its winter fond supply over large sections of its eastern range.

It is extremely unlikely that grouse would ever have a comparable effect on their environment. The species seents to have an aversion to densities above a bird to about four acres of cover and tends under such circumstances to disperse to less occupied territory. Although not proven there are indications that on occasion disease may also hecome a controlling influence among excessive populations. Thus a reduction in predators camot be expected to loring about any lasting increase in a grouse population. for instance. except possibly in individual coverts where for some reason predation is holding the species below carrying capacity.

On the other hand, if through predator control an increased fall surplus could be produced, and the hunter be enahled to harvest it, the sport of grouse hunting would be greatly benefited, even though the breeding population remained relatively stable from year to year. Nevertheless, it must constantly be borne in mind that an apparently simple and innocuous action may have startling and unpredictable consequences.

* See Chapter VIll, p. 354. 


\section{COMPETING INTERESTS}

Contemplation of the possibility of predator control for the benefit of game immediately raises a number of issues among those whose interests would be affected. The old adage, "You can't please all the people all the time", applies here as elsewhere. To the sportsman predators represent competitors, but to some orchardists the gronse itself, game bird par excellence, is a predator". To the trapper those which are also fur bearers are a means of livelihood. To the nature lover they are all, game and predator alike, interesting members of the community of the outdoors. To the biologist each species is a unique and irreplaceable $\operatorname{cog}$ in the vast mechanism of the universe. "What is one man's meat is another's poison."

In each faction one finds extremists as well as conservatives. Many so-called sportsmen would welcome the complete elimination of all important predators of their favorite game species. On the other hand there are protectionists who would complacently watch the last grouse fall victin to any predator except the human one. The majority, however, although perhaps less vociferous, are more reasonable, and many have widely overlapping interests.

It is axiomatic that any well founded game management program must take all points of view into consideration. Yet one must realize that their relative importance may vary widely between localities. In the central Adirondacks of New York, for example, fur trap. ping is of greater moment than is bird shooting, while over most other areas of the State the reverse is true. In certain localities the rumning of foxes and raccoons with dogs is a major sport. Similarly the ideal of the protectionist is feasible only in sanctuaries and on private lands.

Morewer, although at first appearing diametrically opposed, the actual conflict between the objectives of the varjous factions is in reality not great when considered with due regard for all sides of the question. Extreme points of view are obviously irreconcilable and. as leopold ${ }^{205}$ says. "biologically unsound and in many cases economically impossille". Yet no reasonably minded person desires the extermination of any native wildlife species, anl only the most selfish will contend that a harvest of the surplus of a wame or fur species is not justified. The principal stumbling-block is the failure to differentiate between the fate of pmpulations and that of individuals.

But the deliberation of sages is merely guesswork unles they have facts upon which to hase their reasoning. Game: managers are no exception. In general. however. existing knowledge has hardly more than peered in at the entrance to the labyrinth of ramifications involved. The following discussion represents what additional light the luvestigation is able to shed on the problem with respect to the ruffed grouse in the Northeast.

\section{ROIF, OF PREDTION}

As has been pointed out, wildlife species must be prevented from realizing their reproductive potentials and predation is one of the major mean by which Yature aceomplishes that purpose. Its hasic function is the reduction of population surpluses. That it represents

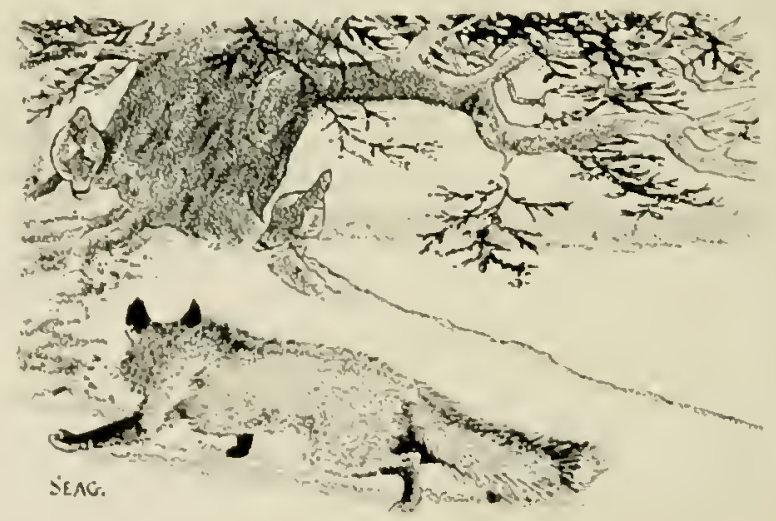


something far more fundamental than mere confliet between individuals was emphasized by Huxley*

"I suppose that most professional biologists think of the relation of carnivores to herbivores, preyer to preyed-upon, almosi wholly in the light of the familiar metaphor of enemies; and of the relation between the two as being in some real way like a battle. The ecologist, however, speedily arrives at the idea of an optimum density of numbers, which is the most advantageous for the animal species to possess. He then goes on to sce by what means the actual density of population is regulated towards the optimum; and finds that in the greal majority of cases the existence of enemies is a biological necessity to the species, ... . To have the right 'enemies', though it can hardly be spoken of as an adaptation, is at least seen to be a biological advantage."

Such is the role played by predation in the ecology of the ruffed grouse. Yel this factor is not a static influence. exacting its "pound of flesh" inexorably year in and year out. Rather its effect in any covert is in a constant state of flux depending on the relative abundance of the grouse and its various predators and buffers. as well as the weather. the amount of hunt. ing done and innumerable other conditions.

\section{Effect Durine Each Life. Period}

Throughout its range the grouse is subject to essentially the same pattern of predation. Beginning with the breeding season the losses may be logically divided into three categories corresponding to the major life periods of the bird. namely. nest, brood and adult.

\section{Nest Period}

Althongh reduction of the possible productivity each season commences with unsucressful breeding in terms of ummated females and infertile eggs, nesting failure represents the first major loss during most years. Since nest survival data could lee recorded without conducling supplementary population censuses, material was gathered throughout the State in addition to the study areas. From 1930 through 19.12 a total of 1.431 nests were examined by the Investigation for which survival figures are comparable ${ }^{\Delta}$. In each case the fate of the nest was noted and for those which had been broken up a diagnosis of the cause responsible was made. Table 35 presents the results with respect to total losses and the proportion attributable to predation. The reliability of the percentages for the years 1930 and 1912 is ques. tionable due to the small number of records.

TAHLE 35. GROUSE NEST MORTALITY HECORDED IN NEW IORK STATE AND PROPORTION TREUITING FROII PIED ITION-19:30-1912

\begin{tabular}{|c|c|c|c|c|c|c|c|c|c|c|c|c|c|c|}
\hline \multirow{2}{*}{ Nest data } & \multicolumn{14}{|c|}{ lirar } \\
\hline & 1930 & 1931 & 19.32 & 1933 & 19.31 & 103.3 & 19.36 & 19.37 & 1938 & 19.39 & 1910 & 1011 & 1912 & Total \\
\hline 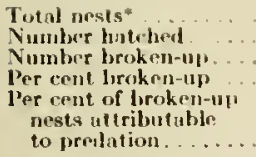 & $\begin{array}{r}1.3 \\
5 \\
8 \\
61.1 \\
62.5\end{array}$ & $\begin{array}{r}206 \\
126 \\
80 \\
38.8\end{array}$ & $\begin{array}{r}211 \\
121 \\
87 \\
+1.2\end{array}$ & $\begin{array}{r}216 \\
125 \\
91 \\
12.1\end{array}$ & $\begin{array}{r}67 \\
11 \\
26 \\
38.8\end{array}$ & $\begin{array}{r}61 \\
34 \\
2.3 \\
36.0\end{array}$ & $\begin{array}{r}71 \\
51 \\
20 \\
27.0\end{array}$ & $\begin{array}{r}52 \\
53 \\
23.6\end{array}$ & $\begin{array}{r}121 \\
36.3 \\
36\end{array}$ & $\begin{array}{r}115 \\
101 \\
41 \\
30.3\end{array}$ & $\begin{array}{r}150 \\
72 \\
78 \\
52.0\end{array}$ & $\begin{array}{r}72 \\
48 \\
21 \\
33.3 \\
100.0\end{array}$ & $\begin{array}{r}23 \\
11 \\
52.2\end{array}$ & $\begin{array}{r}1.131 \\
8.8 \\
553 \\
38.6\end{array}$ \\
\hline
\end{tabular}

* Inclubles only ursts for which sursival data are comparable.

* In Elion, Charles 123

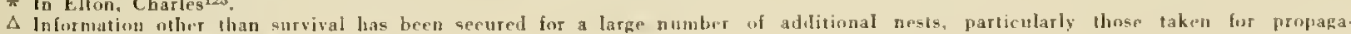
tinn. Thus lables appearing elsewhere in the book, particulaty in Chapter III, involve greater total during some years. 
Over this area during the years studied nest mortality has averaged close to 39 per cent. Prior to 1936 it remained within narrower limits than after that date. The greatest divergence from the mean occurred in 1936, 1937 and 1910. Yet statistical adjustment by analysis of covariance for the number of records involved shows that the proportionate losses for the first two of these years were in reality not as low as the percentages indicate (figure 24), while that of 1939 was even lower. In 1940, however, a very appreciable increase did occur.

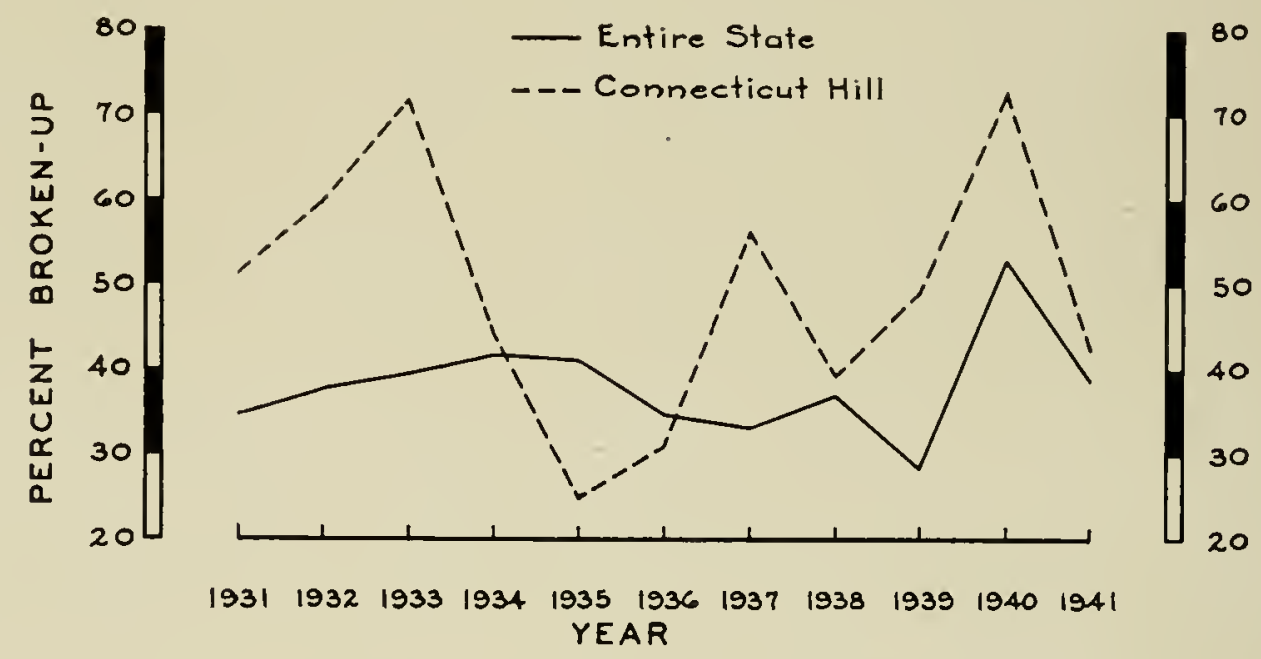

FIGURE 24. IEARLY VARIATIONS IN GROUSF NEST MORTALITY ON CONNECTICUT IILL AREA AS COMPARED WITI ENTIRE STATE-1931-1941

In checking these nests a distinct tendency has been noted for the proportion destroyed to be consistently lower among those in the Adirondack region (table 36 ).

'TABLE: 36. GROUSE NEST MORTALITY IRECORDED IN MOIRONDACK REGION-1931-1912

\begin{tabular}{|c|c|c|c|c|c|c|c|c|c|c|c|c|c|}
\hline \multirow{2}{*}{ Vest datu } & \multicolumn{13}{|c|}{ Year } \\
\hline & 19.31 & 1932 & 193.3 & 1931 & 1935 & 1936 & 1937 & 19.34 & 1930 & 1916 & 1911 & 1012 & Totul \\
\hline Total nests & 11 & 18 & 51 & 5 & $\mathfrak{l}$ & 3 & 1 & 16 & 52 & 55 & 13 & 2 & 291 \\
\hline Per cent brokunsurs. & 21.9 & 22.9 & 37.1 & 40.0 & 0 & 0 & 0 & 18.7 & 1.7 .1 & 21.8 & 7.7 & 0 & 22,7 \\
\hline
\end{tabular}

Comparimon of these figures with those of other workers reveals a considerable lack of similarity, alchough Gross* found nearly 25 per cent of the nests broken up on the Allegheny National Forest in Penusylvania in 1936. King ${ }^{\text {gn }}$ reported nesting lusses of less fhan 3 per cent for an area in Minnesola. Clarke also obarsed very low mortality in Ontario, stating that le found wuly one nest to have been destroyed by a predator. Lacking experience in these loralities it is improsible to correlate such widely divergent dita. In any case it secms crident that the conditions under which these studies were made must be very different from those in New York. 


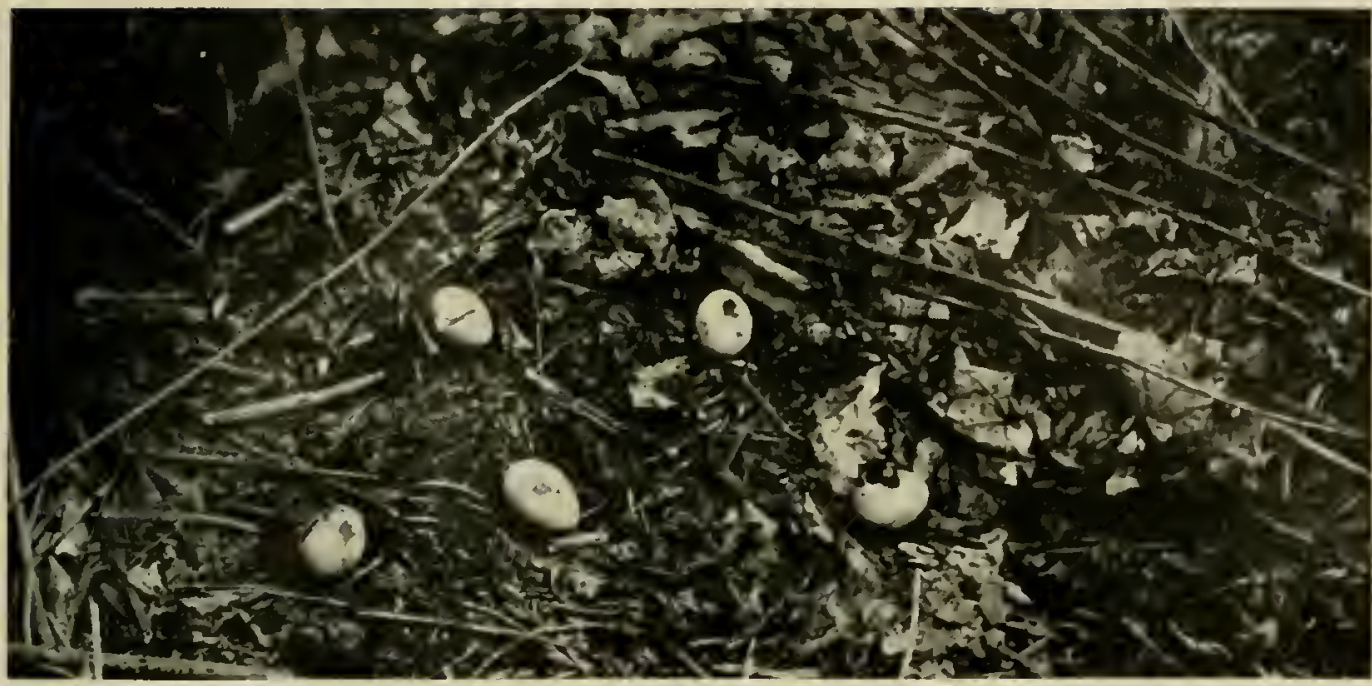

CROISE EGG SHEILS FOUND IN VICINITY OF BROKEN-UP NEST GIVING EVIDENCE, OF IIAVING BEFN EATEN BY A FOX. SHELLS WERE ACTUALIY LEFT MUCH MORE WIDEIY SCATTEREI THAN SIIOWN IN PIIOTO

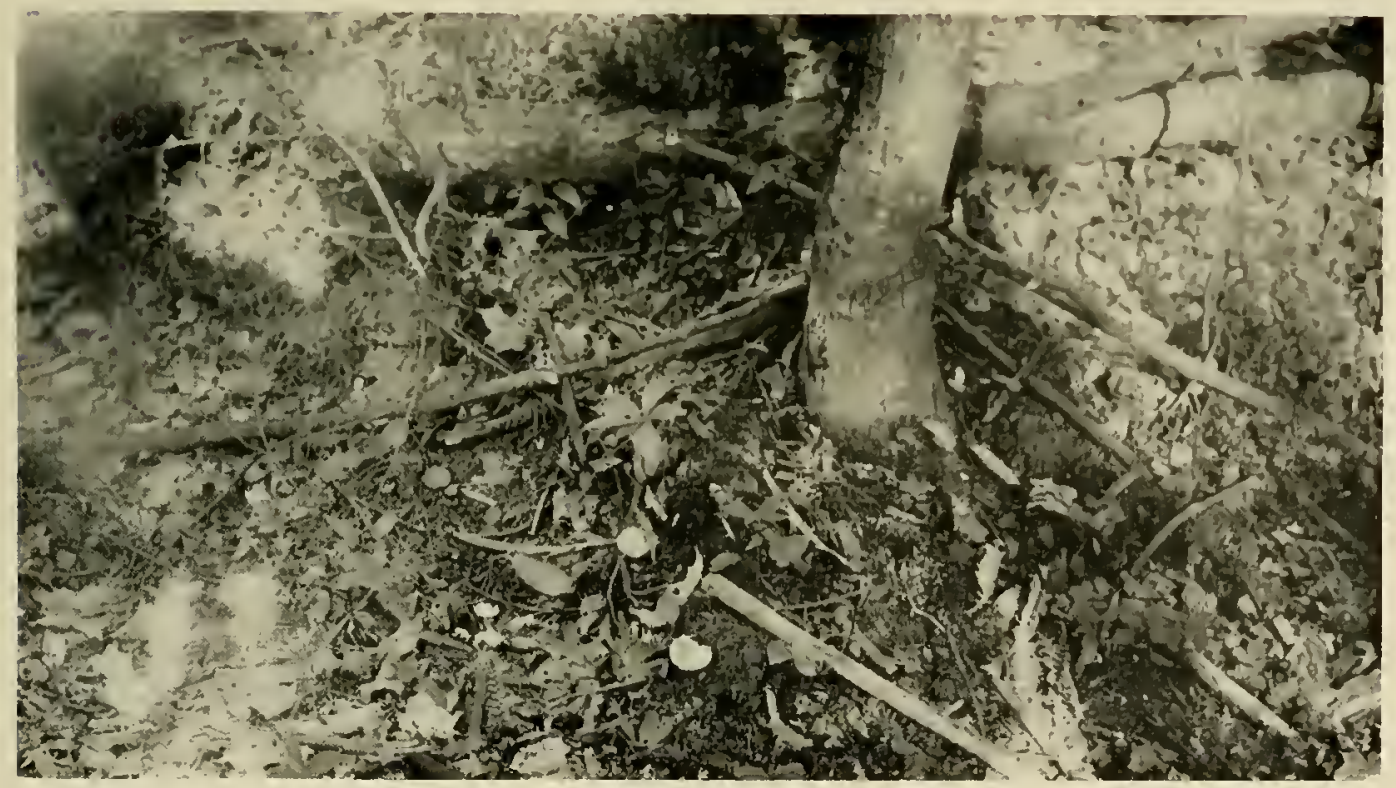

SITE OF BROKEN-UP GROUSE NEST SHOWING FEATHERS OF FEMALE WHICH WAS PROBABLY KILLED BI A GREAT HORNED OWL AND SEVERAL EGG SHELLS GIVNG EVIDENCE OF HAVING BEEN EATEN BY

\section{A RACCOON}

But, while the degree of loss over a region as a whole may average very nearly the same for successive years, local areas often vary more widely. The record for Connecticut Hill is an example (figure 24). During most seasons the number of such local areas ahove average tends to balance those below. Now and then, however, as in 1940 , a majority lean the same way, 
In either case. however. predation has been regularly responsible for nearly 90 per cent of the nests which failed* ${ }^{*}$. Beyond this. predators. particularly the fox ${ }^{4}$, often filch eggs from clutches. the remainder of which hatch successfully. In other words. over 35 per cent of the potential grouse cropt each year over the State (outside extensive forest areas) has thus heen destroyed while still in the egg stage. Within the Adirondacks the latter figure has lieen somewhat lower since total nest losses have heen less. The same is prohably true of extensive tracts of timber in the Catskills although data are lacking.

l'redation of grouse nests may take place at any time from the laying of the first egg to the date of hatching. In general. however. the rate of loss has been greatest toward the end of the incubation period. While experiments with bird dogs have indicated that sitting grouse emit little scent it has been observed that. in many cases. as incubation progresses the eggs become more or less fouled. Under such conditions sufficient scent to attract predators may be given off, especially when the female is away from the nest. Furthermore, there is some evidence that. where a high breeding population exists. certain animals, particularly the fox. often happen on enough nests as the season progresses to associate the flushing of a lird with the possibility of dining on "omelet".

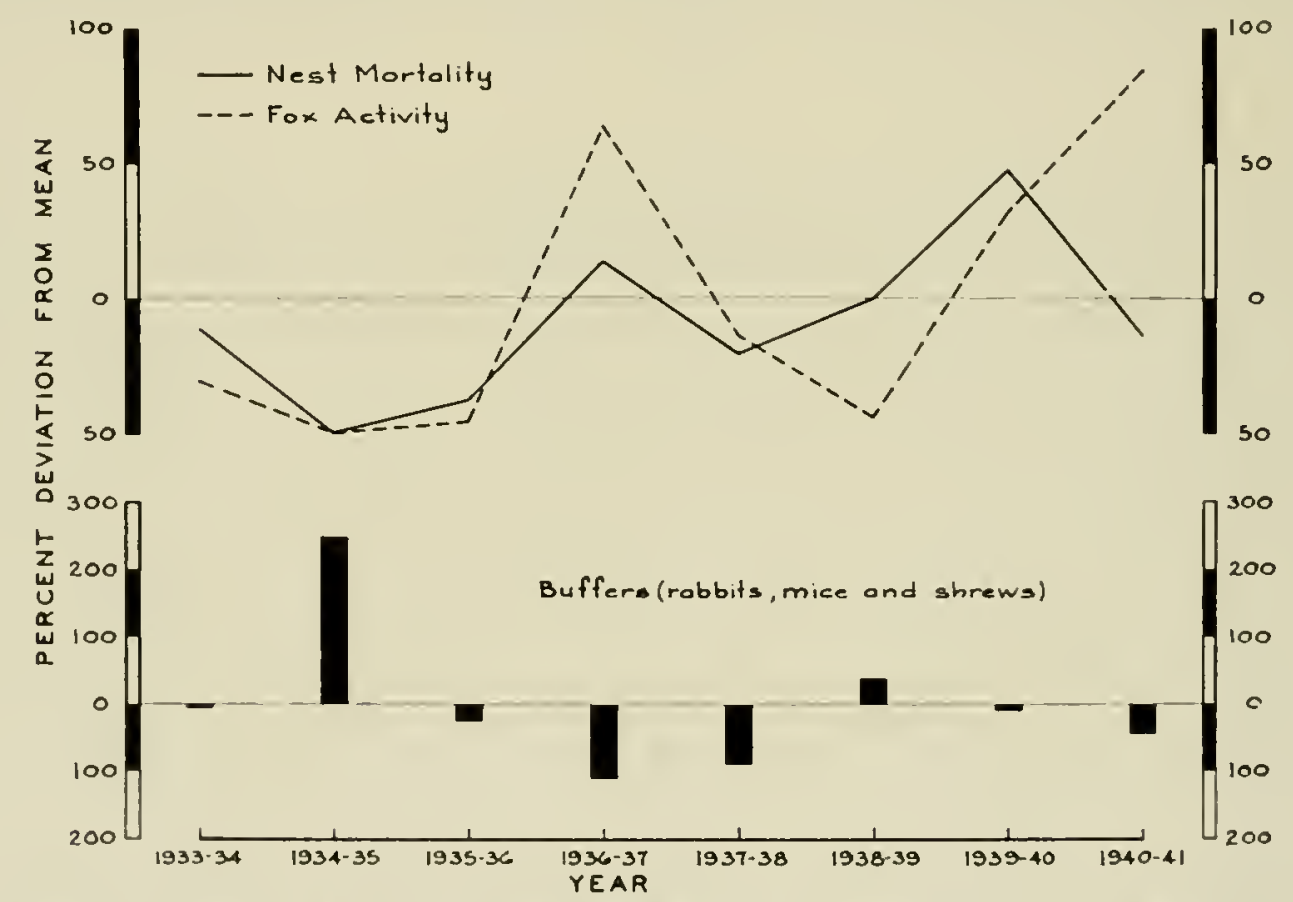

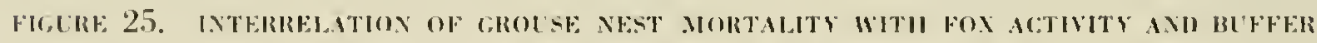
ABUXDAYE - CONXECTCUT HII. . IRE.A - J93.1.1911

Eron though in most years during the perionl studied the average nes mortality for the State has not differed greatly, the fact that it varjes more widely on loeal areas is of interest tu the sportsman and game manager. Since predation is the primary canse of such losses. predatur pressure must vary sinilarly. That it dore vary has heen discused elsewheres.

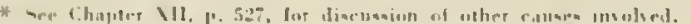

A Either the red fox (J'ulpes fulva) or the gray fux (l pocson cinerenargenteus)

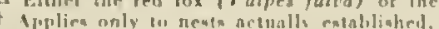

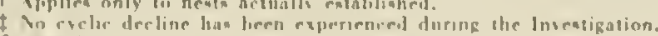

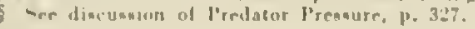


together with data indicating an inverse relationship between the ahundance of small mammals and the degree of aetivity among predators.

In figure 25 is shown the correlation between the degree of activity of foxes from year to year and nest lusses during the eorresponding season on the Conneetieut Hill area. The similarity of the two trends is striking. Apparently they are direetly related, although in 1941 some other influence became controlling. Thus under the conditions studied foxes must be considered to have been a major factor in determining grouse nest failure, and, in turn, the pressure exerted by them has heen greater when small mammals have been scarce than when they have been numerous.

Reference to figure 24 shows a high nest loss on Connecticut Hill in 1933. While comparable data for buffers are not available prior to 193- general records indicate a lower buffer abundance during that year than at any other time except the spring of 1937.

It is not surprising that a substantial proportion of the grouse nests attempted each year should be found by predators and destroyed. A ground nester the female commences to lay during the latter part of April and does not bring off her brood mutil abont June 1. Thus for a period of some six weeks or more the eggs are in comsant danger of diseovery by the numerous animals which would welcome such a change in diet. At this season these species spend considerable time hunting. either to recuperate from winter privations or to supply their growing young of the year. True, the coloration of the female when on her nest blends remarkably with that of the forest floor. But when she is not sitting the eggs are usually more conspicuous, sinee it is only accidentally that leaves tend to "amouflage them".

\section{The Brood Period}

Commencing with the hatching of the eggs, the brood period las been considered to extend through August 33. Unlike nests, however, grouse chicks do not "stay put". Survival records were therefore secured largely from those areas where summer eensus surveys were regu. larly condueted, namely, the Comnectient Hill and Adirondack areas. An average of 12 and 12 broods were studied each season on those traets, respectively. Table 37 presents the percentage mortality ${ }^{\Delta}$ observed each year.

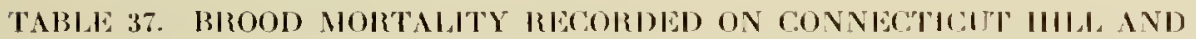
ADIIRONDACK STUDY NREAS-1930-1012

\begin{tabular}{|c|c|c|c|c|c|c|c|c|c|c|c|c|c|c|}
\hline \multirow{2}{*}{ Area } & \multicolumn{14}{|c|}{ lenar } \\
\hline & 1930 & 1931 & 19.32 & 19.3 .1 & 1931 & 1935 & 1936 & 1937 & 1938 & 1030 & $19(0)$ & 1911 & 1912 & Iver. \\
\hline Connecticut Ilill. & $5 . .5$ & 70.0 & 51.8 & 70.7 & 51.1 & 80.8 & 54.2 & 5.5 .9 & 62.1 & (6.3.0 & 57.9 & 59.5 & 75.6 & 0.1 .2 \\
\hline Adirondack.... & $\ldots$ & $\ldots$ & 53.3 & 78.1 & 50.8 & 88.3 & 11.8 & 60.01 & $\because 2.0$ & 57.0 & 57.0 & 61.0 & 5.5 .5 & 00.9 \\
\hline
\end{tabular}

It is evident that losses during this period have been proportionately greater than with respeet to nests. There has also been a remarkable similarity both in trend and degree from year to year on the two widely separated areas. Yet an adequate appraisal of the relative importance of the various factors ${ }^{\dagger}$ involved represents one of the most perplexing problems the luvestigation has encountered.

* See Clapter V, p. 288.

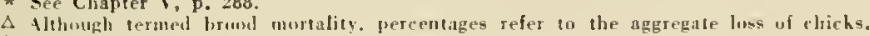

$\dagger$ See Claper X11, p. 528. 
Dead chicks have proven extremely difficult to find. In spite of heary losses during the first few weeks after hatching the most intensive field work has revealed the remains of but very few. Not until nearly the first of August does one begin to encounter tell-tale piles of feathers. This means little, however, for while it is true that many predators devour young chicks whole. it is equally true that the carcasses of individuals of this age which have succumbed to other causes are quickly obliterated by maggots, carrion beetles and similar ageneies. In fact, after only two days, three specimens of this kind which had leen placed on the ground in the woods for olservation could only be identified by the stakes to which they had been fastened. Direct determination of the degree of predation at this season is thus impussible, and it has been necessary to approach the problem indirectly.

Throughout the Investigation the total brood mortality has been measured each summer on the two major study areas. On both, its course has been remarkably similar, averaging slightly aver 60 per cent by the end of August. Analysis of the progressive rate of decline indicates that the eurve drops somewhat more steeply during June than it does thereafter. In fact by July $1 \mathrm{in}$ an average year roughly half of the total brood mortality has already occurred.

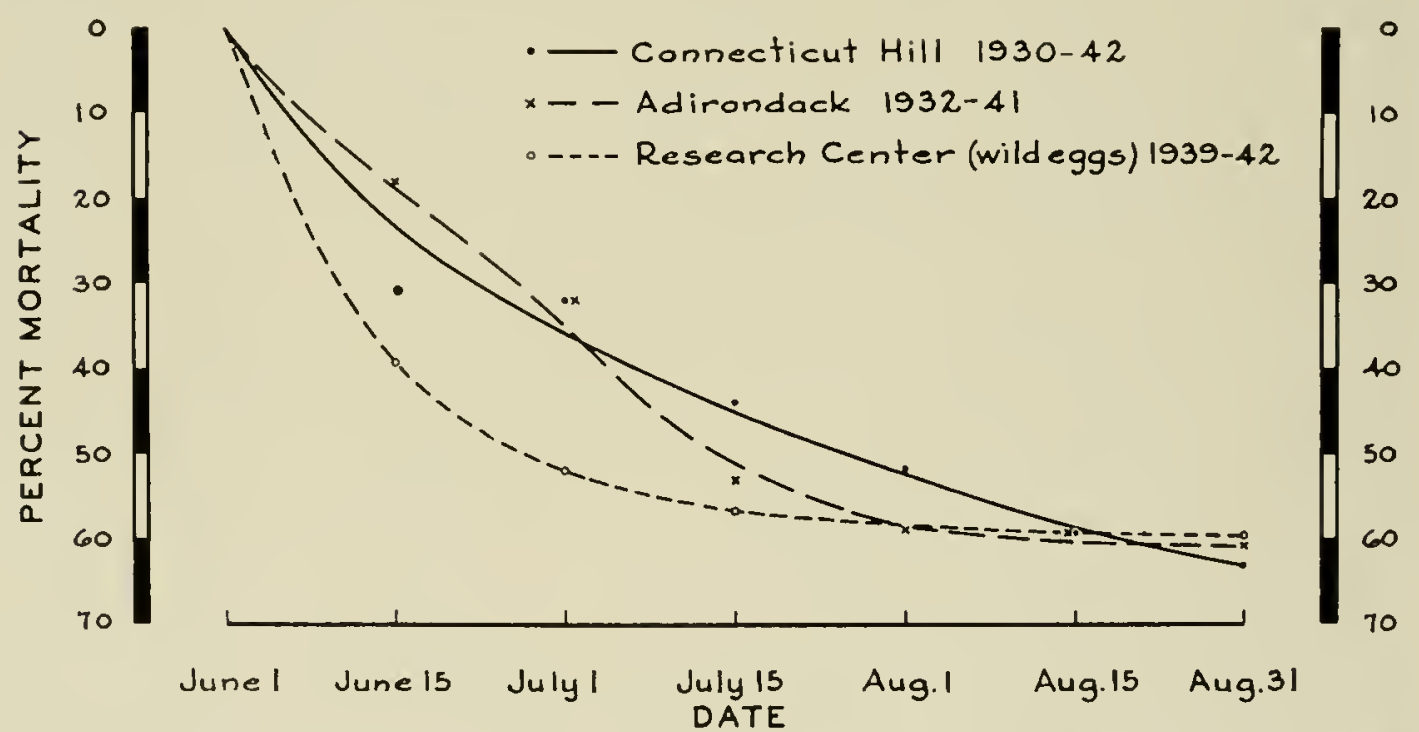

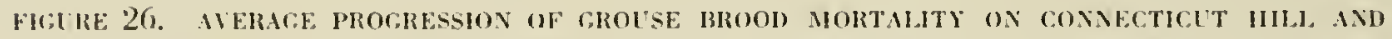
ADIRONDACK AREAS AS COMPAREI WITI THAT OF CIICKS HATCHED FROM WILD EGCS AT TII: RESEARCII CENTER

There seems little doubt that many of these chicks are consumed by predators. Yet experiene with grouse at the Rescarch Center strongly indicates that predation is not the hasic cause of these early season luswes even though in many cases it may he the funal execulioner. A striking parallel has ben oberved among chicks hatehed artificially from wild eggs (figure 26), although here the losses have been somewhat greater. Among the latter, while it likewise remains largely unsolved. the cause is certainly not predation.

This similarly suggests that the chicf ranses of these early losses are peculiar to this age and that predation is secomlary. This conclusion is further suppurted ly the fact that experimental predator control failed to alter the pattern. 
On the other hand, losses experienced during the rest of the summer seem more directly attributable to predator activity. On the game farm mortality after the birds are six weeks old is negligible but in the wild moderate losses continue. The chicks at this time become more and more independent of the female with the result that they probably become more vulnerable to attack. The principal predators at this age, the Cooper's and sharp-shinned hawks (Accipiter cooperi and $A$. velox), were least affected by the control cxperiments. Yet. even here, there is some evidence that variations in the degree of loss during July and August may often be traced to weather conditions*.

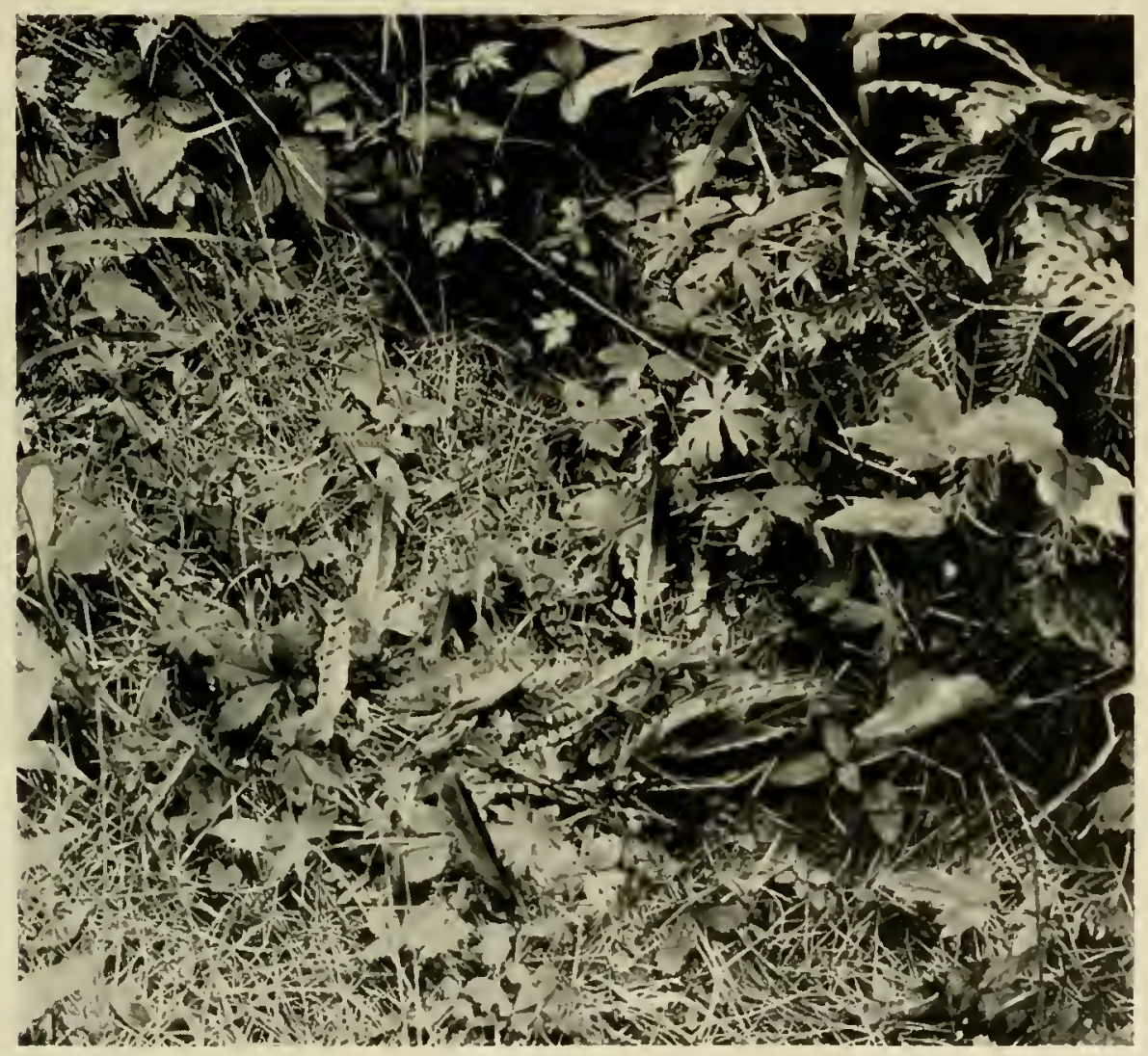

FEATHER REMAINS OF GROUSE CHICK KILIEI BY A IIWK- PROBABLY A SIIARP-SHIN

Considering all the data at hand it appears that upwards of one-third of the chicks hatched, or a little over half of the total lost during the brood period in a normal season. have succumbed as a result of predation. The proportion, of course, varies with circumstances. Furthermore, it represents a greater number of individuals during those years when the hatch was higher. In other words. the more birds present the more frequently they are encountered and caught. Major differences in total losses. however, have apparently heen the result of other inflnences despite the fact that predators may ultimately devour the birds. Thus while this factor is important in determining brood survival it does not seem to have heen paramount, especially with respect to the occasional years of markedly high mortality.

* See Chapter VI. p. 303. 


\section{Adult Period}

Considering birds of the year as adult by September 1 , the fall season ushers in the last of the three life periods. Most broods soon break up, the fall shuffle takes place and then winter sets in. Like their parents, the young birds nust now fend for themselves and "the devil take the hindmost". Between this time and the following April the final culling of the breeding stock takes place.

Again data have had to come from the areas on which seasonal censuses were being con. ducted. In measuring adult mortality two major milestones have been used eaclı year, namely, the breeding season (April), and the following September when the next year's increment comes of age. On Connecticut Hill losses during the former period have averaged 41.6 per cent, while for the full twelve months the mortality has heen 50.2 per cent. On the Adirondack area the figures have been 52.6 per cent and 57.9 per cent respectively. The low proportion taking place during the summer has been consistent on both areas. In table 38 is shown the total mortality each year as well as the size of the initial fall population.

TARLE 38. ADULT MORTALITY RECORDED ON CONNECTICUT IILL AND ADIRONDACK STUDI AREAS-1930-191t*

\begin{tabular}{|c|c|c|c|c|c|c|c|c|c|c|c|c|c|c|}
\hline \multirow{2}{*}{ Area } & \multirow{2}{*}{ Adale grouse data } & \multicolumn{13}{|c|}{ Year } \\
\hline & & 1930 & 1931 & 1932 & 1933 & $193 t$ & 1935 & 1936 & 1937 & 1938 & 1939 & 1910 & 1911 & Aver. \\
\hline $\begin{array}{l}\text { Consrecticut } \\
\text { 1lill }\end{array}$ & $\begin{array}{l}\text { Initial Seqtesuber pmpulation. } \\
\text { Per Cent mortality........ }\end{array}$ & $\begin{array}{r}161 \\
11.3\end{array}$ & $\begin{array}{r}276 \\
28.9\end{array}$ & $\begin{array}{r}16.5 \\
57.6\end{array}$ & $\frac{27.1}{10.5}$ & $\begin{aligned} 120 \\
32.6\end{aligned}$ & $\begin{array}{r}300 \\
52.0\end{array}$ & $\begin{array}{r}311 \\
63.0\end{array}$ & $\begin{array}{l}273 \\
12.8+\end{array}$ & $\begin{array}{r}334 \\
51.2\end{array}$ & $\begin{array}{r}391 \\
58.8\end{array}$ & $\frac{276}{51.6}$ & 300 & $\begin{array}{r}315 \\
50.2\end{array}$ \\
\hline Adirondack & $\begin{array}{l}\text { Initial September polnulation. } \\
\text { Per Ceut mortitity......... }\end{array}$ & & $\begin{array}{r}60 \Delta \\
46.7\end{array}$ & $\begin{array}{r}70 \\
62.9\end{array}$ & $\begin{array}{c}51 \\
43.1+\end{array}$ & $\begin{array}{r}73 \\
78.1\end{array}$ & 30.1 & 71.4 & 54 & 28.6 & 65.7 & $\begin{array}{r}63 \\
60.3\end{array}$ & $\begin{array}{r}5.3 \\
56.6\end{array}$ & $\begin{array}{r}57 \\
57.9\end{array}$ \\
\hline
\end{tabular}

- Year indicated is that of the begiming of each September 1 to August 31 period.

SEtinate made in January 1932 and the refore somewhat below September level.

$\dagger 1$ 1933 on the Adirondack areu and in 1937 on Connecticut IVill, mortalities of 52.9 per cent and 45.8 per cent respectively were recorled by April bot during the ensuing stmmers more hirds moved into the areas than were: lose.

The remains of a large proportion of the adult grouse lost each year have been found and brought in to the laboratory for examination aceompanied by a deseription of the situation in which each was found. They have then been stuclied for evidence as to what the cause of death may have been.

Only about half of the specimens, however, hisve been sufticiently fresh and complete to diagnuse". In fact in 46.8 per cent of those looked over it has heen impossible to form any conclusion at all. Of the balance 94.1 per cent have shown sirns of predation, a proportion which undonbtedly would apply to the others as well. But whether or not this was the initial decimating agent can seldom be determined directly.

One must, therefore, weigh the available evidence witl respect to the other important pos. sible causes of this mortality. Besides predation only two, aceident and discase, warrant consideration. The often suggested relation to birds erippled during the hunting season does not enter here since shooting has been prohibited on these areas.

Regarding the former a few lirds have bem found which had died from injuries sustained in llying into some obstruction. Most of these have oecurred during the fall "crazy llight" season. Yet the majority of the loss does not take place until after mid-winter. It is 
significant, too, that less than half a dozen instances of this kind have been witnessed in upwards of 50,000 grouse flushes observed by the Investigation's field crews. Unless disturbed, these birds seldom resort to reckless bursting flight. The possibility that any large number year after year bring about their own demise by crashing into trees or other obstruc. tions in their environment seems quite remote.

Turning to disease pathological examinations have shown a very low incidence of conditions which might prove fatal to grouse, both on the study areas and elsewhere over the State*. Of 143 specimens collected on Connecticut Hill less than 5 per cent could have been expected to succumb from this cause. Throughout the survey on this area but 20 birds have been found dead, showing symptoms of disease. Unquestionably many other instances occurred but there is little likelihood that this factor has been responsible for more than a very minor part of the overwinter losses recorded during this study.

Thus, by the process of elimination, one must conclude that the great majority of the specimens found each year are attributable to predation as the original decinating agent. although it is implemented in varying degrees by a number of influences affecting the vulnerability of the birds. Unquestionably accidents, disease and other circumstances have taken a small toll-perhaps upwards of 15 per cent. Assuming that these data are representative of the total losses occurring it seems probable that predation may lo considered to have lecn responsible for something over 80 per cent of the amnual mortality among adult grouse, or in the neighborhood of 40 per cent of the fall population on the areas involver. ${ }^{\Delta}$

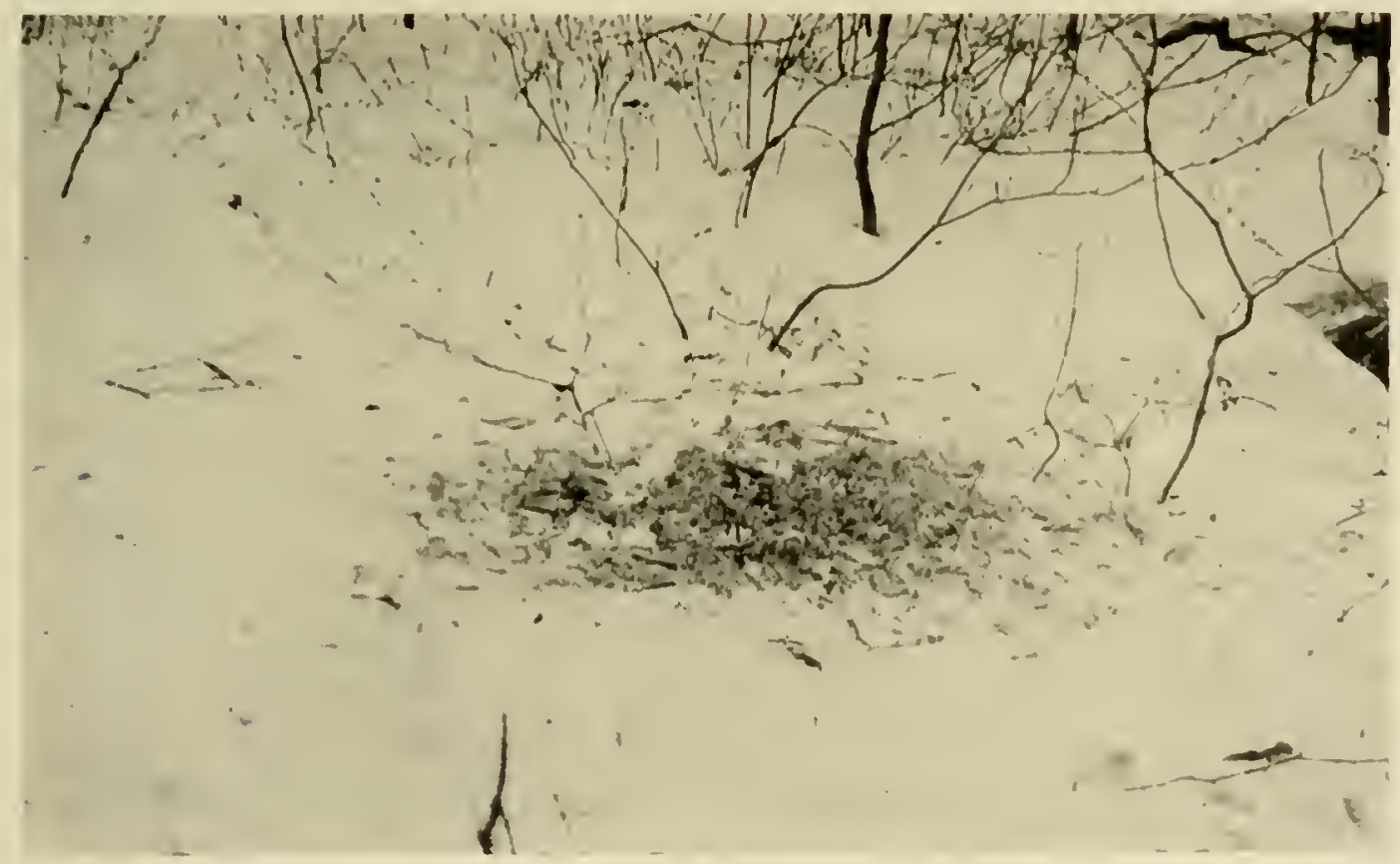

FEATHER REMAINS INDICATING TIIAT AN ADULT GROUSE WAS KILLED BI A HAWK OR OWL

Losses during this period have differed considerably from year to year. Especially note-

* Sire Chapler X, J. 110.

$\triangle$ These areas were not shot over in the lall. 
worthy were the very low mortalities in 1930-31 and 1931.32 when grouse had not yet recoveresl from the scarcity of 1927 and 1928. In general, however, the number of birds killed during the winter has varied directly with the population density of the preceding fall (figure 27). The proportion lost, however, has been less closely correlated".
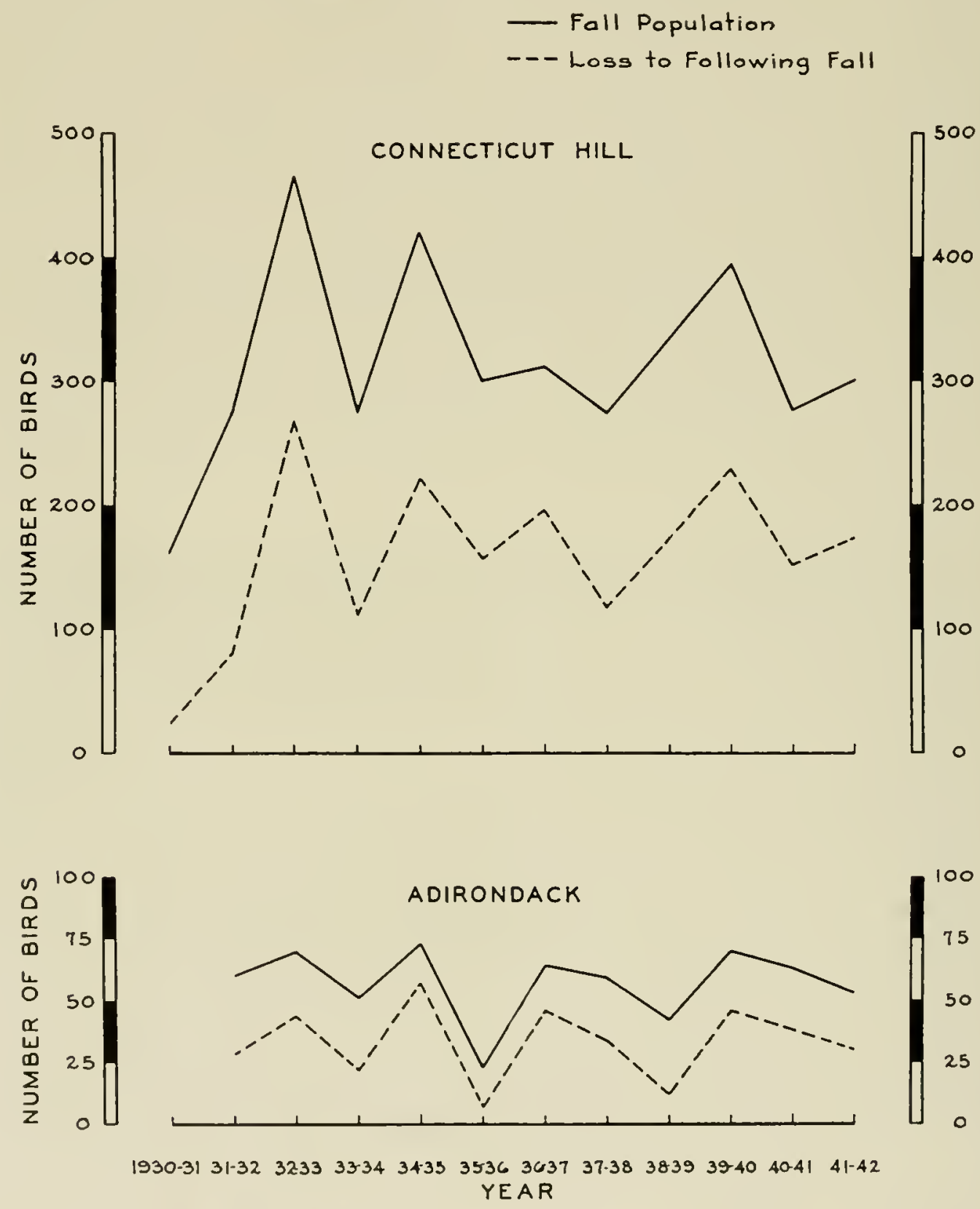

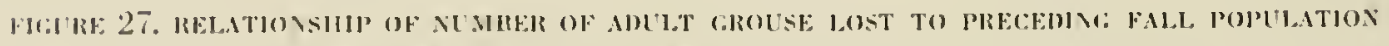
I.ESEL ON CONECTICUT HW.L AND ADHONBICK AREAS - 1930-19.12 
Apparently the relationship between predators and adult grouse is largely an incidental one. No species depends on this game bird for any large proportion of its food. But the greater the number of birds in a covert the more frequently they are encountered and killed.

It is significant that the basic effects of predation should have been so similar on the two study areas in spite of substantial differences in the composition of the predator population. For example, the great horned owl was not observed on the Adirondack area while the goshawk was a regular visitant. Specific data from the latter area are insufficient to draw conelusions as to the comparative relationships of the various species. There is some indication. however, that the fox preys to a greater extent on adult grouse on this area than on Connecticut Hill. ln any case the principle of "ompensatory predation as discussed by Errington ${ }^{131}$ seems to he corrolorated.

At the same time the comparative level of the grouse population is not the only factor affecting the degree of adult mortality. In figure 28 the data have heen statistically adjusted by analysis of covariance to eliminate the effect of the relative abundance of the hirds.
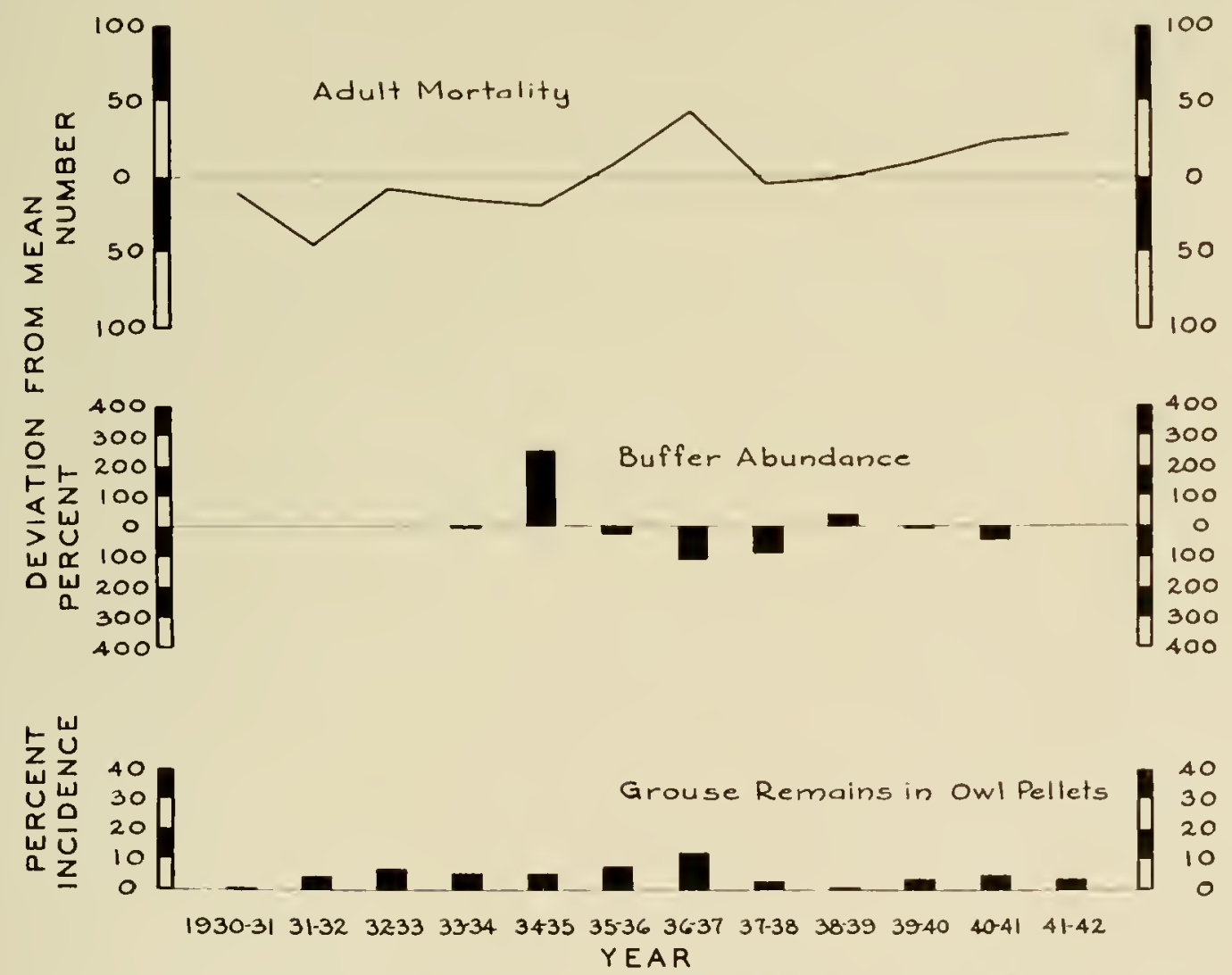

FIGLIRE 28. RELATIONSHIP OF INCIDENCE OF GROLSE REMAIXS IN GREAT HORNED OWL PELLETS TO GROISE ADLLT MORTALITY AXD TO BUFFER ABUNDACE - CONNECTICLT HILL AREA $1930-31$ To 1911.42

Other influences, such as variations in weather and predator pressure have been chiefly responsible for the differences remaining. But just what they are and how they exert themselves is still largely obscure. Attention may he called, however, to certain interesting correlations. 
It scems significant that these forces reached their highest level on Connecticul Hill in 1936-37, when buffer species were at their lowest ebb. Yet the? were most severe in 1934-35 on the Adirondack area where the drop in abundance of hares (Lepus americanus) came earlier than that in cottontails (Sylvilagus floridanus) on the other tract.

On the Connecticut Hill area the great horned owl (Bubo virginianus) has heen a major predator during the adult period. In figure 28 is also graphed the incidence of grouse in the pellets of this owl collected each year. There is a strong similarity between this and the deviation from average of the adjusted degree of overwinter loss.

Shown also is the relative trend in buffer abundance from 1933-34 through 1910-41. It seems significant that in 1936-37. when the greatest increase in overwinter mortality occurred, the frequency of grouse in these pellets should have been the highest of the series and should have been accompanied by the greatest scarcity of buffers recorded. Furthermore, records of the survey give some indication that 1932.33 also witnessed a low level among rabbits and mice. In $1937-38$ while rabbits were still scarce but mice and shrews had increased the incidence dropped but so also did the fall population level and the general overwinter loss. That the pellet representation in 1934-35 was not lower may have resulted from the fact that the grouse population in the fall of 1934 was next to the highest recorded during the study. The data suggest that the abundance of buffers, through its effect on the amount of time predators spend in bunting, exerts an effect on how often they will encounter grouse.

As discussed under another topic fox activity on this area has also fluctuated from year to year inversely to buffer numbers. In this case, while there appears to he a correlation in point of time with variations in overwinter loss, analysis of fox droppings does not substantiate an actual relationship. Table 39 presents the occurrence of grouse in this material.

TABLE 3\%. INCIDINCE OF GROUSE REMAINS IN FOX DROPPING- CONXECTICT HIL, AREA-1930-1911*

\begin{tabular}{|c|c|c|c|c|c|c|c|c|c|c|c|c|}
\hline \multirow{2}{*}{ Imopping data } & \multicolumn{12}{|c|}{ lear } \\
\hline & $19: 30$ & $19: 31$ & $19: 32$ & 14:1:3 & $19: 11$ & 1935 & 1936 & 14:5 & 19:38 & $19: 19$ & 1910 & 1911 \\
\hline 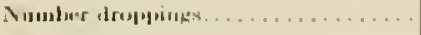 & 2.3 & 31 & 69 & 160 & 136 & 518.3 & 311 & 515 & 6088 & 151 & 100 & 99 \\
\hline Per cent containing porensse. . . . . . . . & 8.11 & 15.1 & 11.5 & 3.7 & $10.1]$ & 1.6 & 1.9 & 1.1 & 1.3 & 1.4 & 1.0 & 1.9 \\
\hline
\end{tabular}

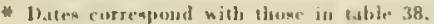

Odtly enough a high representation occurred in 1931-35 when huffers were mest numerous white in 1936-37 the situation was reversed. The increase in the number of seats collected from 1935-36 on was due to a larger area being covered and more stress being laid on lhis phase of the work. The interpretation of this data is not char. Apparently fox predation on adult grromse is much less affected by huffer abmulance than with the great horned owl.

As discussed elsewhere" murtality amonge adult grouse is greatest during the late winter. Since predation seems to be the major decimating agent involved it follows that it is most effective during this eritioal period when envirommental conditions are most severe. buffer foods least avaibable and the grouse at a low physical chb. There has heen no noticeable differcntial lietween the sexes except that the males appear to be sumewhat more rulneralite during the drumming season.

* Ser Chapurer Mll. p. 336. 


\section{Predator Fluctuations}

Someone has said that the only constant quality of life is change. All living organisms continually fluctuate in numbers to a greater or lesser degree. Among wildlife such phenomena have long been recognized. Many obervers have commented on the marked periodic abundance and scarcity of certain hirds and animals. Perhaps the hest-known in North America pertain to the ruffed grouse. the varying hare and the lenming (Lemmus trimucronatus). Among predators behavior of this kind has been reported in a number of speeies, particularly the arctic fox (Alopex lagopus) and the Iynx (Lynx canadensis) ${ }^{334}$.

Such fluctuations appear to be more pronounced among populations inhabiting the boreal and aretic regions than in New York and other temperate sections. The reasons for this are not entirely clear. Undoubtedly the difference in climate is important. One of the principal necessities for sustaining life in any animal is the maintenance of body heat. When foor becomes searce this is more difficult where the average environmental temperature is lower. In the North also the variety of food available to predators especially in the winter is less and. during lows in their cycles. the numbers of small mammals, their staple. drop lower than farther south. These and other less well understood influences enntribute to the marked variations in survival reported. An outstanding example of the response of a predator to its food supply is the relationship hetwen the lynx and the varying hare in Canada ${ }^{2 n}$.

It has been generally believed that these recurrent tides of abundance represent continentwide enditions. Reeent evidence, however, points to a regional pattern. For example Cross" found this to be true for the red fox in Outario, as did Maclulich for the varying hare. It is interesting that the latter concept agrees with the conclusions of the lnvestigation with respect to grouse in the Northeast".

During the Investigation there has not been opportunity to undertake specifir censuses of predator species. Nevertheless data recorded in connection with the regular grouse survev and other field work have afforded a means of appraising their relative abundance from year to year.

The most complete picture pertains to the Connecticut Hill study area. Here, populations of resident species especially. such as fox, weasel (Mustela noveboracensis and $1 /$. cicognanii). skunk (Mephitis mephitis). raccoon (Procyon lotor) and great horned owl. have, in general. remained relatively stable during the years involved ${ }^{\Delta}$. Unquestionably the populations of these predators have varied but the changes have not been great. Certainly nothing approaching the fluctuations reported in Canada has taken place.

The gradual northward spread of the gray fox in southern New York has had little effect on the study area since, as in many grouse coverts of the Northeast, reds predominate. Over its range in this State. however, the great horned ow regularly hecomes snmewhat more numerous during the winter as a result of a southward movenent of wandering individuals from farther north. The degree of this influx seems to have been quite constant from year to year.

Among the migratory hawks. particularly the Buteos. some indication has been noted for their abundance during spring and fall to vary from year to year. The numbers remaining during the summer, however, have been quite stable. Likewise. breeding populations of the Cooper's hawk and sharp-shinned hawk have been very similar each year.

\footnotetext{
* Ser Chapter Xill, p. $56 \%$

$\triangle O$ On those pnrtions of Connecticul Hill where predater rontrol was earried on between 1930 and 1934 the trapping appearel in have little effect on the sbundance of predators except during the season immediately involved. Weasels, however, recuperated more slowly than the others.
} 
Over the State as a whole, although specific data are scarce, there is nothing to indicate that the situation las differed in any important respect. Of course it must be horne in mind that the occurrence of these species is not the same in different localities. Thus the great horned owl is much less common in the Adirondacks than in central New York. Skunks are more mumerous in agricultural sections than in the deep forest. Except for its sonthern border. the gray fox is almost unknown in the Adirondacks. Yet. aside from purely local circumstances. their numbers from year to year have not varied materially.

Apparent fluctuations cluring the past twenty years. suggested by the numbers of various fur-bearers, particularly the red fox, reported taken by license holders, may be traced mainly to the rise and fall of fur prices. There does, however. seem to have been an appreciable reduction in the skunk population during the decade prior to the period of the Investigation. At the same time, as mentioned above, the gray fox has, for the past quarter century, been extending its range through sonthem New York. So also has the opossum (Didelphis virginiana). But in none of these species has anything approaching eyclic behavior been noted.

On the other hand changes in land use have often produced substantial local differences in predator abundance. The adoption of "clean farming" in many of the better arricultural areas has reduced many species. The reversion of sub-marginal land following its abandonment has been adverse to some while favoring others. Similar effects have followed lumbering operations.

Another type of fluctuation results from the temporary invasion of an area from time to time by unusual numbers of predators. With respect to grouse in the Northeast the goshawk (Astur atricapillus) and snowy ow] (Nyctea nyclea) are the principal species in this categry. appearing from the north during the winter.

In New York the gushawk breeds sparingly in the northern Adirondacks and is a regular winter resident of this section in Jimited numbers. But south of the Nohawk River". aside from occasional wanterers. it appears only at irregular intervals, at which times it also becomes more numerous in the northem part of the State. Flights of this kind have been recorded by Deane ${ }^{\text {min }}$ and Fleming ${ }^{142}$ in 1896-97. 1897-98 and 1906-07. According in Fleming. as quoted by Deane. that of $1906-07$ was "not a quater as large" as the one of 1896-97 in southern Ontario. Again in 1916-17 and 1917-18 unusual numbers were olserved", and and more recently in $1926-27$ and $1927-28^{n s}$. Since the latter date no marked influx has oceurred in the State, although Clarke ${ }^{\text {i3 }}$ recorded one for Ontario in 1931-35. On Connecticut Hill. however. a few individuals have heen olserved during several winters, particularly that of 1935-36. An interesting feature of these migrations is that they have nsually involved two sucessive years, the first heing the heariest.

Records of the snowy owl have heen traced by Gross ${ }^{139}$ as far back as the winter of 1876-77. In contrast with the goshawk this species has apprared only one year at a time, although this luas often coincided with an invasion of the other. In ] 911 -12 a moderate influx of these owls was noted in some parts of New York but was not felt on Connecticut Hill.

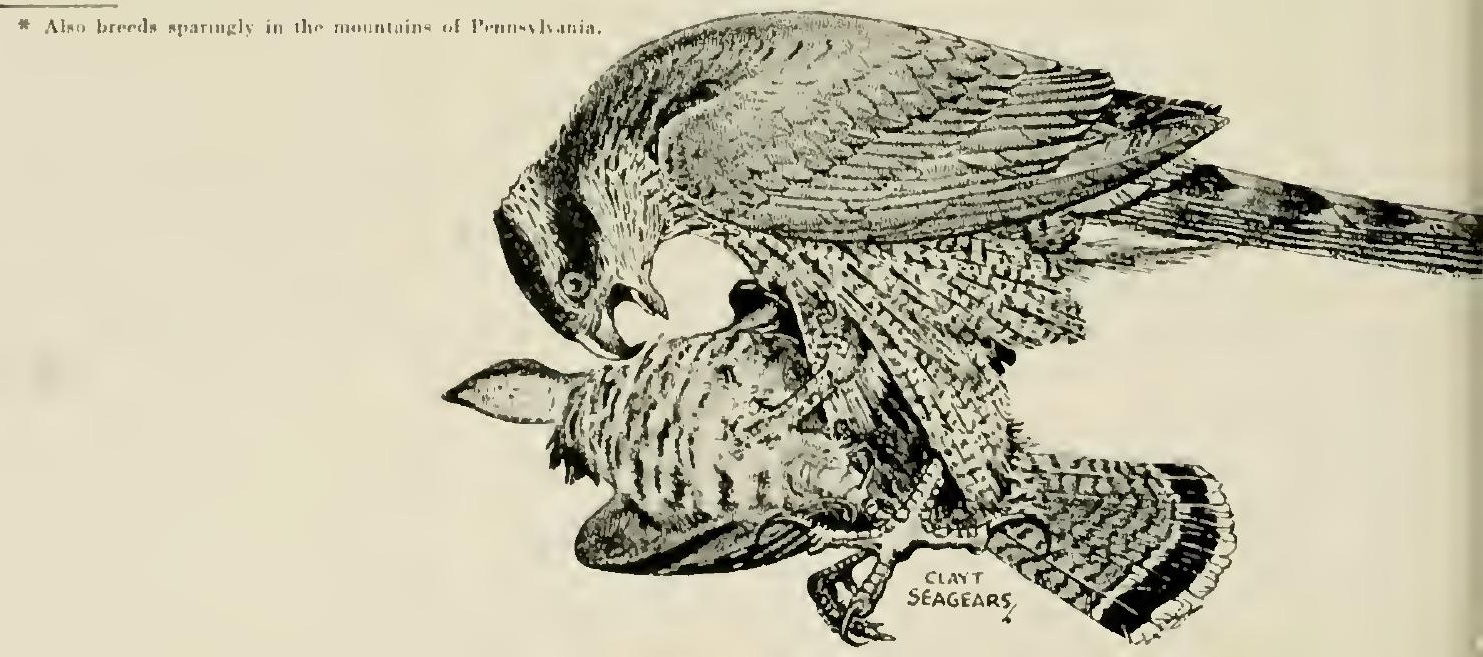




\section{Buffer Fluctuations}

Among game managers the term "buffer" has been applied to those species which serve as the staple foods of predators and thereby lessen the pressure on grouse. In order in serve in such a capacity a species must be present in far greater numbers than the game and be relatively easy to catch. Also. to he most effective it should not compete serionsly with the other. The principal huffers with respect to grouse in the Northeast are the cottontail rabbit, varying hare, squirrels, mice and shrews. Nevertheless, in connection with the Cooper's and sharp-shinned hawks, the many small woodland hirds must also he considered in this category.

Little is known of variations in abundance of these birds, but anong the small mammals. particularly the rodents, fluctuations are well recognized. The pronounced cyclic increases and decreases in populations of the varying hare and certain mice, notahly lemmings. have heen diseussed by a number of anthors ${ }^{12,913}$. As with predators they have heen most violent in Canada and Alaska." Yet their oceurrence has not heen uniform aeruss the continent as some have helieved. In his account Seton states, "A Rabhit year in one part of the country is not necessarily a Rabhit year in another, the condition being beal." Machulich" alo also found that years of peak abundance in hares varied in different districts. Undoubledly the same is true for mice although the pattern has not been worked out and the length of their cycle is much shorter.

In New York the varying hare appears to exhihit an ebb and flow of alundance similar to that displayed farther north but on a much smaller scale. Records indicate an interval of roughly ten years which corresponds with that found in Canada ${ }^{240}$. Aceording to the report. ed take by licensed hunters heginning in 1918 the years 1923 and 1932 marked the end of periods of relative abundance and were followed hy abrupt declines. while the years 1926 and 1936 represented the troughs respectively. The magnitude of the fluctuation. howeser. is much less. During "rahbit years" in Canada both Seton and MacLulich olserved over 3,000 hares per square mile. No such density has ever been recorded here. The distribution of the speeies in this state also is at present limited, heing foumd only in the Adirondacks and a few localities in the Catskills.

Data regarding mice are available for a much shorter period. Yet it is clear that they, and probably shrews 100 , are also suhject to rhythmie increase and decrease in New York and other parts of the Northeast as well as northward. To secure data on this problem the Investigation established a series of half-nile trails on the Connecticut Hill study area in the fall of $1933^{\triangle}$. Duting the following season and each winter thereafter tracks of the various species were tallied along these trails after each fresh snowfall. Since the home ranges of these animals are small this method appears to afford a reliable index of trends in ahundance.

Analyzed statistically the records for mice and shrews indicate a definite cyclic tendency on this area (figure 29). Unfortunately the period covered has not been long enough to more than suggest a three to four year periodicity of the cycle. This, however, corresponds quite closely to the conclusions of Hamilton ${ }^{180}$ and Elton ${ }^{12}$.

That there is probably little harmony in these fluctuations over any considerable area is indicated by comparing the available data for central New York. Thus the Investigation recorded peak populations on Connecticut Hill following the hreeding seasons of 1934 and 1937 , while Hamilton ${ }^{182}$ working near Ithaca, less than 25 miles away. found 1935 to be high. Sim-

\footnotetext{
* This refers only to North American species. In Europe the Norwegian lenming (Lemmus lemmus) is a classical example of this behavior.
}

$\triangle$ See Apperdix, p. 709 
ilarly: Townsend ${ }^{339}$ found mice more numerous near Constantia, N. Y., in 1933 than in 1934. Apparently individual localities are quite independent of one another, although the progressive nature of the cycle is undoubtedly similar in each.

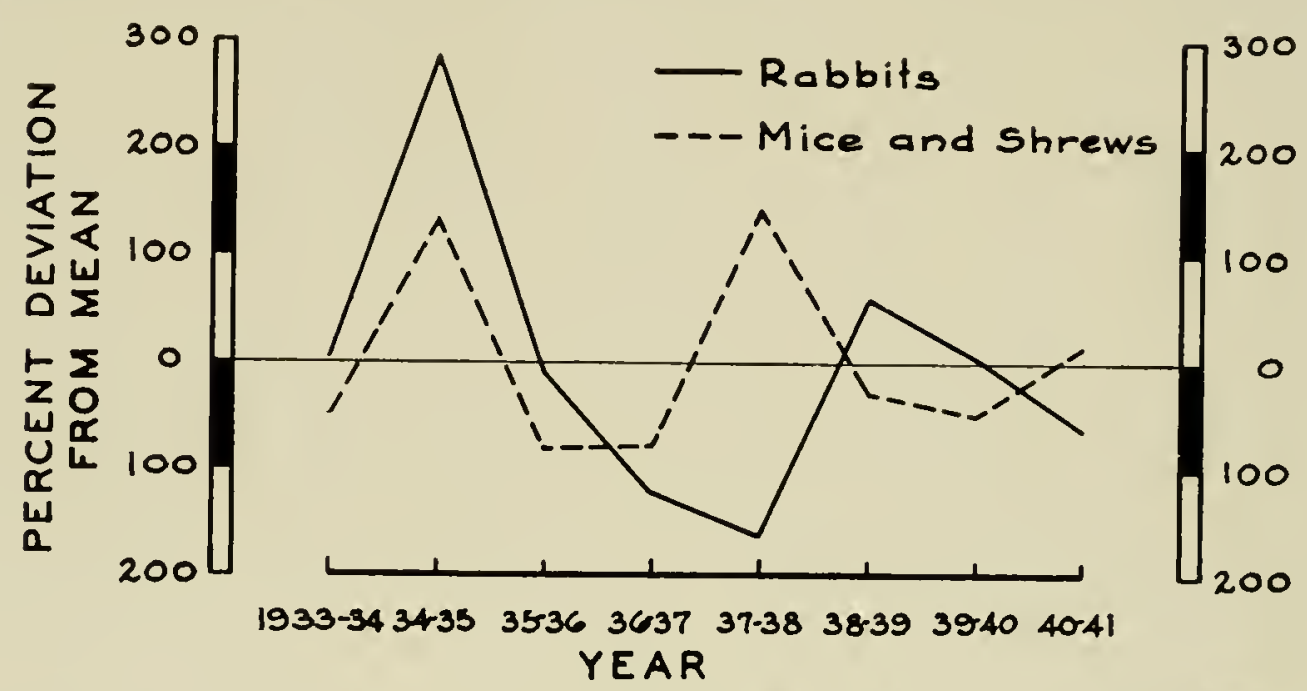

FIGURE, 29. FLLCTUATIONS IN BUFFER POPULATIONS - CONNECTICUT IILL AREA (WINTER)

$-1934-1941$

Cottontail rabbit tracks were commed each winter on Connecticut Hill in the same manner as described for mice. Their analysis is presented graphically in figure 29. The species has varied markedly in alundance between years. Yet the record is too short to warrant conclusions as to cyclic tendencies, since the recovery following the low of 1937-38 did not approach the level of 1934-35. The data also show a lack of conformity hetween its trend and that of mice and shrews.

Further evidence as to the behavior of this rodent in New York is furnished by the reported take of licensed hunters since 191\%. Here again decided changes between years have apparently taken place, but there appears to be no regularity to them. Furthermore. no evidence of cyclic behavior has been reported hy other observers aside from Leopold's suggestion that it may reaet in this manner in certain sections of Wisconsin and other marginal range $e^{2 n}$.

The gray squirrel (Sciurus carolinensis), on the other hand, becones cxcessively numerous during irregular years-exhihiting a curve of the type which Leopold has termed irruptivefollowing which great emigrations take place leaving very few individuals in the original area. According to Seton ${ }^{334}$ outhreaks of this kind recorded during the righteenth and early: nineternth centuries greatly surpassed any which have occurred since.

During the Investigation the fall of 1935 witnessed such an irmption over much of New York and New England. While many eastward movements were noted most of the migration was to the west. Considerable hands of squirrels were observed swimming the Hudson River and Lake Champlain as well as a number of lakes and reservoirs. Large numbers perished in the attempt. On Connecticut Hill the species increased over 300 per cent from the spring of 193t to that of 1935. but had becone very scarce by the time snow afforded tracking conditions in the early winter of the latter year. After a further slight decline in 1936 it has gradually regained a level comparahle with that of 1933. 
Coincident with the grays the red squirrel (Sciurus hudsonicus) population on Connecticut Hill has followed a closely parallel trend. In the Adirondack region also this species reached an abnormally high level of abundance in 1935 following which it fell off sharply.

To sum up it seems evident that in New York buffers fluctuate markedly in numbers, several approaching a cyclic pattern, but that these fuctuations are not harmonious. Furthermore, even during periods of low abundance, an appreciable population remains. particularly since all species seldom hit the hottom together.

\section{Predator Pressere}

One might think that, so long as predator numbers remain relatively constant, their effect on grouse should not change materially. Such is not the case, however. Relationships of this kind are affected by innumerable other circumstances. The abundance of a game bird or animal in comparison with that of its natural enemies and buffers as well as the quality of the protection afforded by its habitat are major influences. In general the more abundant a species is the more often it will be encountered by predators. On the other hand. the smaller the game population the greater the signifieance of individual losses. Yet, as Errington has reported for quail ${ }^{12 z}$, a compensatory influcnce exists in that many prey species appear to become more secure as the number living in a habitat approaches the level where only the ligher quality territories are occupied.

But, even though the numbers of grouse and its predators did not vary appreciahly, the degree of predation would he increased or decreased as a result of a wide variety of other circumstances. As with upland game birds in general. grouse do not represent a staple food of any predatory species. Rather they are taken as the opportunity presents itself although they are preyed upon more heavily as buffers" become scarcer. Then too changing weather conditions continually affect the availability of prey of all kinds.

The number of combinations of such circumstances is endless. Adequate appraisal of their effect on the relative pressure exerted by various predators at different times is. according. ly, difficult. The Investigation has revealed a few of these relationships, particularly with respect to the Connecticut Hill study area.

Throughout the period of survey certain coverts proved consistently superior to others in their ability to support grouse populations over winter. Some tendency has also been noted for snow-roosting birds at times to be more vulnerable to predation. Experimental predator control brought about reductions in nest mortality during the seasons inmediately involved. During the winters in which goshawks appeared grouse kills attributable to them were found but the net effect on overwinter loss was not appreciable ${ }^{\Delta}$.

Differences in the effectiveness of various huffers have also been olserved. Thus squirrels are usually more difficult to secure than most of the others. Deep snow sometimes renders mice and shrews largely unavailable. The residual numbers of varying hares during periods of scarcity are much lower than is the case with respect to cottontails. Predilection among predators scems largely a question of availahility both as to presence and ease of capture. Dislike for potential food species appears to be of minor consequence although there is some indication that shrews are not well-liked by foxes.

That unusual local abundance of grouse may cause a concentration of predator activity was demonstrated when one section of the Connecticut Hill study area attained a density of

* Sce discussion of Buffer Fluctuations, p. 325.

$\Delta$ No pronounced influx of this species was experienced during the Investigation. 
one bird to 2.5 acres in the fall of 1934. In spite of predator control a higher degree of predation ensued than in surrounding coverts. The great horned owl appeared to be most affected. Hamilton ${ }^{178}$ has suggested similar movements of weasels in relation to mice.

Further evidence of the effect of vulnerable excess populations on predator pressure was observed in connection with two liberations of Reeve's pheasants which were followed by the Investigation. In spite of being placed in an apparently suitable habitat these hirds were completely wiped out within a few weeks, primarily ly predation.

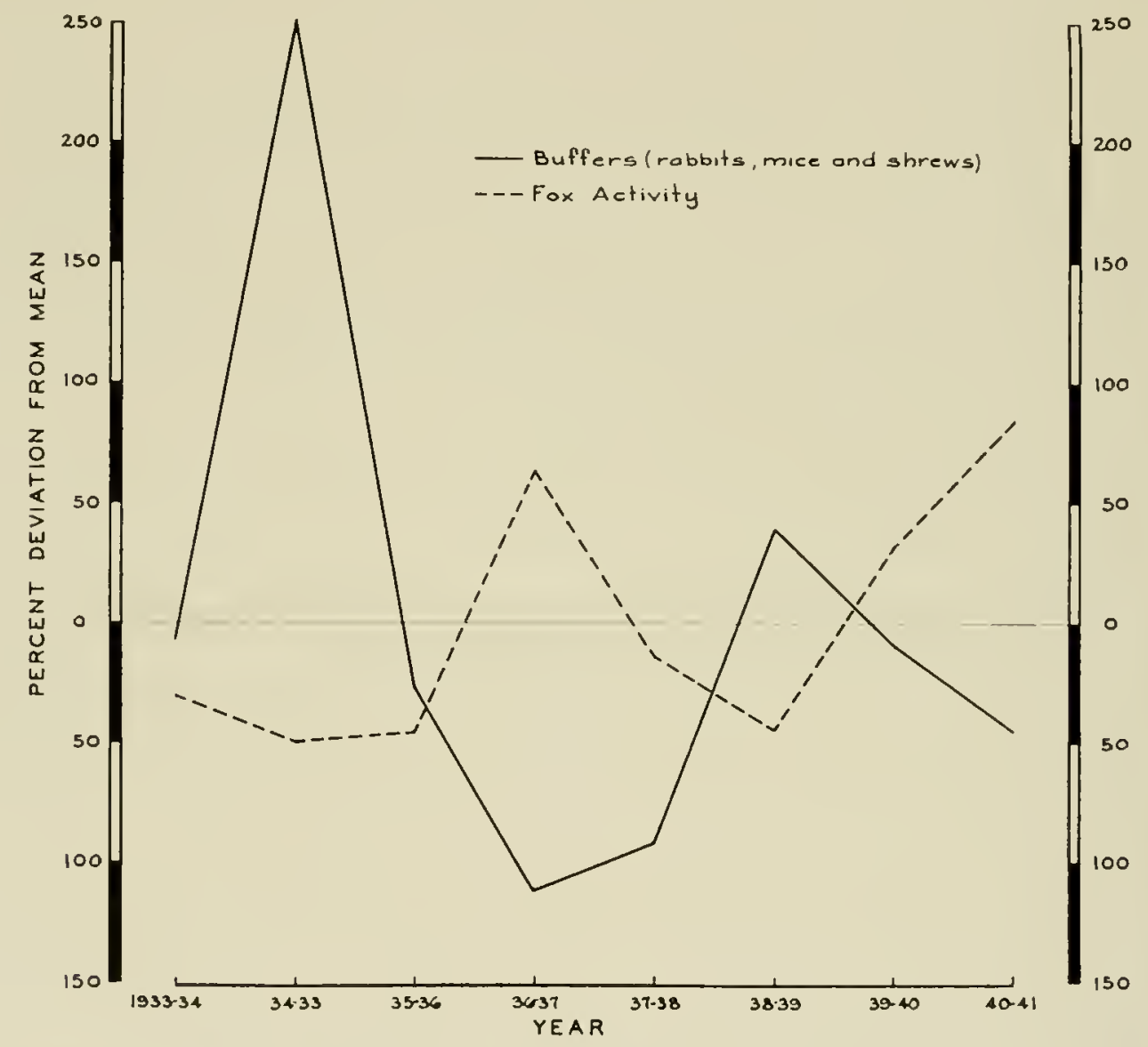

FIGIRE 30. COMPARISON OF FLICTUATIONS IN BUFFER ABUNDANCE AND FOX ACTIVITYCONNECTICUT IILI. AHEA (WINTER) - 1934.1941

But the most important relationship observed has been that between foxes and the small mammals which form their principal food supply. Analysis of the frequency of fox tracks as encountered by survey crews from year to year has shown significant differences ${ }^{\Delta}$. Yet the fox population has appeared relatively stable. Undoubtedly their numbers have fluctuated hut there is nothing to indicate that the abrupt changes noted between suecessive years might be altributed to variations in lrreeding success or in survival. Neither does it seem likely that the increases olserved have resulted from the influx of animals from surrounding territory

- Thir in a woodland apecirs in ith natiur range.

$\triangle$ Data carrelated by analyais of covariance. 
since on such occasions both grouse and buffer populations have been below average. It is, therefore, more probable that the increases in tracks recorded in 1936-37 and 1939.41 were in the main the result of greater activity associated with times of scarcity among small mammals. Figure 30 illustrates this relationship.

Rabbits seem to exert a somewhat greater influence than mice and shrews. Their drop from 1936 to 1937, while the latter remained constant, was accompanied by an increase in the occurrence of fox tracks. Conversely, from 1938 to 1939, despite a sharp decrease in mice and shrews, a greater rise among rabbits was associated with a moderate reduction in fox activity. That mice may nevertheless be important was indicated in 1937-38 when their high abundance apparently offset a severe low in rabbits.

The fact that fewer fox tracks were not recorded in 1934.35 when both small mammal groups as well as grouse were very abundant seems somewhat contradictory. Yet it may lie that a fox will travel about so much at this season regardless.

Another reason for believing that the fox track data represent activity is the fact that the number of droppings picked up by field rrews over the same period has varied inversely.

Undoubtedly the great horned owl and other predators react similarly although the data have not been sufficient for correlation.

With respect to pressure on grouse it follows that the more time a predator spends on the move the more often it will encounter grouse and have opportunitics to prey on them. The situation appears to parallel the old adage, "you won't catch many fish if you don't keep your line wet".

\section{Grouse : Prenator Ratios}

An important part of any study of the role of predation is a knowledge of the complexion and size of the predator population involved in comparison with that of the game. During the Investigation, however, it has not been feasible to undertake actual censuses of these species. Nevertheless, various data have heen recordcd which, supplemented by observations during the regular grouse survey work each year and by the cumulative experience of the authors, make possible a reasonably accurate appraisal of the situation on the areas most intensively studicd.

On Connecticut Hi]l, which is essentially representative of the better grouse coverts of the State south of the Mohawk River, the principal grouse predators were the fox*. weasel. skunk, raccoon, great horned ow], Cooper's hawk and sharp-shinned hawk. With respect to this area predator control experiments carried on during 1931.32 and 1933.34 afford a hasis for a rough estinate of abundance for all except the hawks. The numbers taken per square mile averaged fox-3, weasel-5. skunk-6, raccoon-2 and great horned owl-9.

These data are conservative because no species was eliminated. Furthermore, they primarily represent the fall to spring period. During the season when young are present numbers would usually be higher except in the case of the great horned owl. Here the great majority of the birds trapped apparently were winter visitants. Breeding populations of this owl probably seldom exceeded two pairs per square mile. As pointed out under a previous topic $^{\Delta}$ the numbers of these species have not varied greatly on this area during the years covered.

While occasional Cooper's hawks often remain through the winter the sharp-shinned hawk

* The ratio of red foxes to grav foxes un this area was about 3 to 1.

$\triangle$ Ser discugsion of Predator Fluctuations, p. 323 
almost invariably is absent at this season. In migration these hirds pass through in moderate numbers and a few remain to breed. at which time from one to two pairs per square mile have been observed. Usually the latter species has been more plentiful.

Among the predators of lesser importance to grouse on this area limited numbers of mink (Mustela vison), opossum and barred owls (Strix varia) are present the year around. Now and then wandering house cats are encountered. During the winter goshawks appear irregularly and snowy owls more rarely. The Buteo hawks (red-tailed Buteo borealis, red-shoul. dered B. lineatus, rough-legged B. lagopus s. johannis, and broad-winged B. platypterus) and the marsh hawk (Circus hudsonius) are common in migration and a few breed. Crows (Corvus brachyrhynchos) are moderately numerous particularly in spring.

In correlating these figures with the grouse population winter densities are most comparable. For the years 1931-32 and 1933-34. when the above data for resident predators were obtained. the mean winter density of grouse was 28 per square mile*. The corresponding figure for the total periorl of study was the same although it has varied from 18 to 10 per square mile.

To summarize it may be estimated that the ratio of grouse to their prineipal predators in this area has averaged roughly as follows during the winter ${ }^{\Delta}$ :

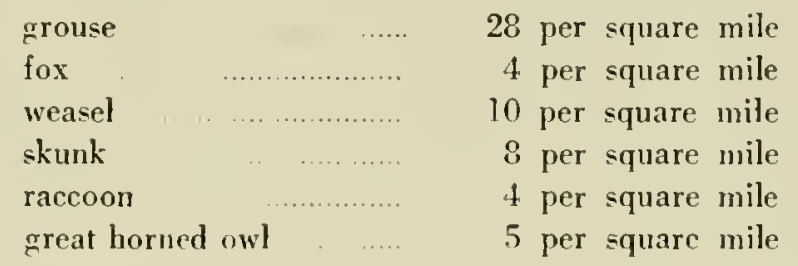

Yet one must remember that these densities were by no means uniform over the tract and that minor changes from year to year have constantly taken place.

Obviously variations in this pattern in other localities over the State are endless but specifie data are largely lacking. Observations on the Adirondack area, however, indicate greater populations of weasels and harred owls: alout the same of foxes and raceons: and smaller numbers of skunks. while great horned owls have not heen observed. Cooper's and sharpshinned lawks are slightly more numerous there during the summer. Goshawks are more frequent and breed sparingly in the region. The most common hawk is the broad-wing which seems 10 he negligible as a grouse predator. Crows are muel less abundant. Occasional bol. cats (Lynx rufus) occur.

Winter grouse densities on this area have averaged 31 hirds per square mile. ranging from 17 to 39 per square mile in diffcrent years. At first glance this appears very similar to conditions on Connecticut Hill. Considering that only about half of the latter area is grouse cover. however. while all of the other falls in this eategory, it beeomes evillent that the actual population density was much lower in the continuous coverts of the northeru region.

\section{VUT.NeRABIIITY}

It is logical to suppose that hirds and animals which are erippled or suffering from diseasc are more easily captured by predators than those in the same habitat which are not so handirapped. In the experience of the Investigation. however, the occurrenee of grouse in such rondition has heen low. In this commertion olservations at the Research Center indicate that

\footnotetext{
* The geonac rover un this asea occupion roughly hall the total nersagr.

$\Delta$ The akunk nnil raccoun bilsernate for rnnaiderable periods at this aramen.

$t$ All foxen on this aren were of the resl eperiem.

$t$ On the arena mont intennively atudied ahoming han not been permitsed.
} 
diseased birds usually retain their vigor up to a very short time prior to death. On the other hand an earlier decline usually takes place in cases of heavy parasitism.

Physical fitness may also be affected by other infuences. It has already been pointed out* that during the early brood period grouse chicks regularly suffer considerable losses from causes mainly other than predation. Undoubtedly the vulnerability of these birds is greatly increased at such times and predators frequently become the ultimate executioners. Then too there is some indication that certain combinations of weather conditions may lower the vi. tality of older chicks and thereby render them more easily caught. Similarly weather may decrease the resistance of adults during the late winter ${ }^{\Delta}$. There has been no indication. however, that starvation is of importance.

Nevertheless, grouse, thoroughly up to par physically, become inore susceptible to predation under some circumstances than others. An outstanding factor influencing such variations is the shelter value of the habitat. The availability of escapc cover is of the utmost importance in enabling birds to elude their natural enemies. Since in any covert there is a limit to the amount of such cover, surplus individuals become increasingly vulnerable as they are forced to occupy less favorable territorics. This was well demonstrated in the instance already men. tioned $d^{\dagger}$ in which one section of Connecticut Hill, after attaining the excessive fall density of a bird to 2.5 acres, still suffered a high loss the following winter.

There is also evidence that during the winter birds of the year are more vulncrable than older individuals, both as a result of inexperience and because the hetter territories tend to be already occupied. At times snow-roosting birds may be more casily capturce by certain predators, but at other times this habit may have just the oppositc effect.

Even under the best conditions the vulnerability of individual grouse is constantly chang. ing as they pursue their daily routine of activity. Among the chicks, particularly during the first few weeks of life, the relative "mothering" ability of the female undoubtedly is of great importance. Similarly, circumstances which cause a chick to peep increasc its chances of being located and caught.

\section{Significance of Predation}

In the introduction to this chapter it has been pointed out that predation serves a very necessary function throughout the organic unirerse in helping to keep the numbers of all species within limits compatible with the environmental niches which they accupy. So it is with respect to grouse. Yet it may scem to the rcader, particularly the sportsman, from the foregoing discussion of its effect in New York that predation is exerting an undne pressure on this gane birl.

A fact uften lost sight of, however, is that adult grouse exhibit an intolerance of population densities above about one bird to four acres even in the best coverts. Like Daniel Boone. who it is said at one time moved farther into the wildcrness when a family settled within some 20 miles of him, these birds tend to avoid crowding beyond that level. In other words, predators or no predators, surpluses over this saturation point may be expected to disperse of their own accord after the birds of the year have "come of age" in the fall.

But most coverts are not of sufficiently high quality for this characteristic to be a regular influence. Yet this merely means that even lower limits are imposed in such cases depending on the nature of the cover. Fall surpluses above this level tend to be eliminated by over-

\footnotetext{
* See discussion of Role of Predation During Brood Period, p. 316

$\Delta$ See Chapter VI, p. 304.

$\uparrow$ See discussion of Predator Pressure, p. 327.

- See Chapter XII, p. 523
} 
winter mortality of which predation has been the chief agent. Moreover, since there is an inberent maximum to the carrying capacity of each covert the elimination of predation would only result in some other factor, possibly disease, sooner or later assuming its role. It cannot be emphasized too strongly that no data so far give any promise that the principle of compound interest can be applied to gronse or similar game populations.

On the other hand predation during the nest and brood periods docs represent a factor limiting the fall abundance which might otherwise occur. Under primeval conditious such a staggering of the total reduction which must takc place is advantageous. Where man's pursuit of the bird for sport-being, as it is, confined to the fall-is important, however, the advantage is less real. But this point of view is valid only where such sporting activities are sufficient to utilize the bulk of any additional surplus it might be possible to produce. Unless so utilized they might better furnish dessert for some predator as eggs or clicks since few would survive to breed.

Another function of predation is that of culling crippled, sick or otherwise defective stock. The Investigation has little direct evidence, however, of the importance of this service. In the first place crippled birds lave not been present on the study areas since no shooting has been allowed. Furthermore, the incidence of disease has been negligible. Then, too, one marked female, in spite of a broken wing was known to have hatched her clutch of eggs and success. fully reared her brood. Nevertheless, such relationships may at times be highly valuable. Some effect of this kind probably occurs during the brood period since a large proportion of the losses at this time appear to result from causes other than predation. It is also likely that the effect of weather on adult mortality suggested in Chapter Vl, jf real, operates through fostering the decimation of the weaker individuals. Certainly there can be little doubt that over the period of its evolution the constant necessity of eluding its natural enemies has been a major influence in developing the very qualities which today make the grouse so prized a game bird.

Finally, in considering its significance one must make a distinction between the fact of predation on individual grouse and the effect of predation on populations of this game bird. Obviously the inevitable reduction of its potential productivity must involve the death of a large number of individuals in one form or another, many by predators. But only under very unusual circumstances does such decimation endanger the maintenance of population levels in accorlance with the carrying capacity of the habitat. Perhaps the greatest obstacle to an understanding of the role of this factor has heen the failure to appreciate this difference.

\section{APIRAISAL OF THE VARIOUS SPECIES}

In addition to an understanding of the role of predation as a factor in the life equation of grouse the game manager must also know what predators occur in his loeality and what their relative importance is. An appraisal of the various specics in Now York has hecn an integral part of this study.

\section{Grolse P'ledatoks of the Nortufast}

At one time or another grouse have probably fallen prey to nearly every carnivorous bird and animal occurring within its range, except those entirely incapalse of attacking it. Beyond this its ecogs are often destroyed by a number of other species.

Anong wild mammals the Investigation has recorded the red fox (I'ulpes fulva), gray fox (lrocyon cinereoargenteus), New York weasel (M/ustela noveboracensis), Bonaparte 
weasel (M. cicognanii), skunk (Mephitis mephitis), raccoon (Procyon lotor), bobcat (Lynx rufus), opossum (Didelphis virginiana), woodchuck (Marmota monax), red squirrel (Sciurus hudsonicus), chipmunk (Tamias striatus), and mice. That other species, inhabiting the Northeast but not encountered in this work, must also be included in this category is indicated by the writings of other observers. Although citing no specific instance Eaton ${ }^{211}$ men. tions the mink (Mustela vison) and marten (Martes americana). Seton ${ }^{334}$ reports the lynx (Lynx canadensis) and fisher (Martes pennanti). The probability that wolves (Canis) take grouse where the two occur together is corroborated by the findings of Skinner ${ }^{32}$ in the West. Recently a case involving the porcupine (Erethizon dorsalum) has been published ${ }^{20}$. Undoubtedly the eastern panther (Felis couguar) formerly included the grouse in its diet, while at the other extreme Allen ${ }^{12}$ has suggested that even shrews may menace young chicks.

Where man's civilization has penetrated, the dog and house cat are added to the list. In this connection Ewbank ${ }^{129}$ makes the interesting statement that in North Carolina razorback hogs destroy grouse nests.

Among the birds have been identified the great horned owl (Bubo virginianus), barred owl (Strix varia), goshawk (Astur atricapillus), Cooper's hawk (Accipter cooperi), sharpshinned hawk (Accipter velox) and crow (Corvus brachyrhynchos). Then too a few instances have been observed in which pheasants (l'hasianus colchicus) have caused nesting failure by laying their eggs in grouse nests. Beyond these, various authors have noted a number of others. Thus Audubon ${ }^{29}$ reported the raven (Corvus corax), Forbush ${ }^{243}$ and Eaton ${ }^{112}$ the duck hawk (Falco peregrinus), McAtee ${ }^{254}$ the red-tailed hawk (Buteo borealis), marsh hawk (Circus hudsonius) and even one instance involving the hroad-winged hawk (Buteo platypterus), Hersey ${ }^{189}$ the red-shouldered hawk (Buteo lineatus), and lipley ${ }^{314}$ the osprey (I'andion haliaetus). Applying only by inference to the eastem race, Patton "as states that grouse in the Black Hills of South Dakota are preyed upon by the Richardson's pigeon hawk (Falco columbarius). Gross ${ }^{721}$ has added two records for the snowy owl (Nyclea nyclea) and Sutton ${ }^{257}$ one for the sereech owl (Otus asio). Undoubtedly several of the rarer species in this region such as the golden eagle (Aquila chrysaetos), gyrfalcons (Falco rusticolus) and the great gray owl (Scotiaptex nebulosa) should also he included lut data are lacking and their significance is negligible.

Finally a number of cases of nest robbing have becn traced to the northern blacksnake (Coluber constrictor).

\section{Relationships During Each Life Period}

The foregoing is a rather imposing array. Yet only a few exert any appreciable influence on grouse populations, especially in sections where the latter are hunted cxtensively for sport. Furthermore, even among those species which are important. some are primarily effective in breaking up nests, others as predators of chicks and so on. The records of the lurestigation indicate these relationships quite clearly for New York*.

To what extent these data may be distorted by instances in which the victim was dead when found by the predator or "on its last legs" is often difficult to judge. Such a relationship certainly does not apply to nests. It probably occurs most frequently among chicks. With respect to adults, as has been discussed ${ }^{\Delta}$. circumstantial evidence by the process of elimination strongly indicates that in the majority of cases predation has been the original decimating agent.

* The basis for diagnosing the species tesponsible lor broken-up nests and birds found dead is described in the Appendix. p. 709.

$\triangle$ See discussion of Role of Predasion During Adult Period, p. 318. 
In interpreting the following data one must bear in mind that, in addition to reflecting the habits of the various predators, the picture is also colored by the distribution and abun. dance of these species. The authors believe that the material presented is representative of the majority of the better grouse range in New York. At the same time it is quite probable that in other sections of the Northeast the situation may be entirely different. In fact in other localities species may be important which are not even mentioned here.

\section{Nest Period}

The degree of predation observed among grouse nests has been discussed under a previous topic $^{*}$. For each nest so destroyed the species responsible was in most cases diagnosed. Table 40 summarizes these data. In this comection it should be pointerl out that it is utterly impossible to secure an acrurate picture of the egg-eating habits of a predator through stomach examination.

'TABIE 10. PROPOITION OF BROKEN-UP GIOUSE NESTS ATTRIBUTED TO VARIOUS PRED ATORS IN DIFFERENT REGIONS OF NEW YORK-1929-1912

\begin{tabular}{|c|c|c|c|c|c|c|c|c|}
\hline \multirow{2}{*}{ Sinevies } & \multicolumn{2}{|c|}{ Adiromlack } & \multicolumn{2}{|c|}{ Cintskill } & \multicolumn{2}{|c|}{ liest of State } & \multicolumn{2}{|c|}{ Total } \\
\hline & Number & Per cent & Number & J'res cent & Numbinet & Jer cent & Niumiber & Por ceut \\
\hline 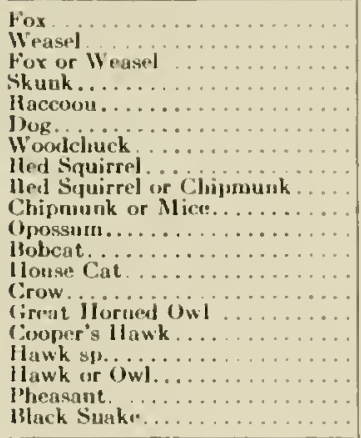 & $\begin{array}{r}20 \\
5 \\
1 \\
1 \\
1 \\
5 \\
1 \\
\cdots \\
\cdots \\
\cdots \\
3 \\
2 \\
\cdots \\
1 \\
1 \\
\cdots\end{array}$ & $\begin{array}{r}13.5 \\
10.9 \\
8.7 \\
8.7 \\
2.2 \\
10.9 \\
2.2 \\
\ldots \\
\ldots \\
\cdots \\
6.5 \\
1.4 \\
2.2 \\
2.2 \\
\ldots\end{array}$ & $\begin{array}{r}37 \\
10 \\
\text { ii } \\
10 \\
5 \\
i \\
\therefore \\
\therefore \\
i \\
1 \\
7 \\
1 \\
\therefore \\
\therefore \\
\therefore \\
\therefore\end{array}$ & $\begin{array}{r}13.5 \\
11.8 \\
11.8 \\
11.8 \\
5.9 \\
1.2 \\
\ldots \ldots \\
\ldots \\
1.2 \\
1.2 \\
8.2 \\
1.2 \\
\ldots \\
2.3 \\
\ldots .\end{array}$ & $\begin{array}{r}113 \\
31 \\
36 \\
15 \\
32 \\
9 \\
8 \\
11 \\
3 \\
2 \\
1 \\
1 \\
11 \\
5 \\
2 \\
1 \\
12 \\
1 \\
2\end{array}$ & $\begin{array}{l}31.1 \\
10.2 \\
10.8 \\
11.2 \\
9.6 \\
2.7 \\
2.4 \\
2.7 \\
0.9 \\
0.6 \\
0.3 \\
0.3 \\
3.3 \\
1.5 \\
0.6 \\
0.3 \\
3.6 \\
1.2 \\
0.6\end{array}$ & $\begin{array}{r}170 \\
10 \\
10 \\
61 \\
1.3 \\
19 \\
9 \\
10 \\
3 \\
2 \\
1 \\
1 \\
2 \\
21 \\
4 \\
2 \\
1 \\
15 \\
1 \\
2\end{array}$ & $\begin{array}{r}36.8 \\
10.6 \\
4.6 \\
13.2 \\
0.3 \\
4.1 \\
1.9 \\
2.2 \\
0.7 \\
0.1 \\
0.2 \\
0.2 \\
0.4 \\
4.5 \\
1.7 \\
0.1 \\
0.2 \\
3.2 \\
0.4 \\
0.4\end{array}$ \\
\hline $\begin{array}{l}\text { Sub-total } \\
\text { J'redator Undeterininable. . . . . . }\end{array}$ & $\begin{array}{l}16 \\
12\end{array}$ & $\begin{aligned} 100.0 \\
\ldots\end{aligned}$ & $\begin{array}{l}85 \\
21\end{array}$ & 100.0 & 53 & $\begin{aligned} 100.0 \\
\cdots\end{aligned}$ & $\begin{array}{r}46.3 \\
88\end{array}$ & 100.0 \\
\hline 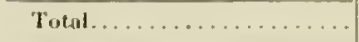 & 58 & $\ldots$ & 106 & $\ldots$ & 387 & $\ldots$ & $551^{*}$ & $\cdots$ \\
\hline
\end{tabular}

* The total number of records yscd in this table differe trom that indicated in table 35 becalase nests not coraparable for aurvival calculations could nevertheless be inciuded here.

There is little question which are the ontstanding predators in the State during this period. Over threc-fourths of all the nests broken-up have been attrihutable to the fox, weasel, skunk and raccoon. Following these, about tied for a poor fifth, are the erow and dog. Noreover their relative importance varies little in the different regions.

By far the most serious is the fox. That this applies to the red species just as much as to the gray has been amply attested by experience on Connecticut Hill where both are present and in the Adirondacks where only the red fox is found. Several times these animals have been observed in the act of breaking up a grouse nest. On one occasion sueh a drama was observed from a tree blind. About dawn one morning a red fox was seen approaching the vieinity of an inculating hird under observation. Finally it flushed her. This individnal 
gave every indication of associating the flushing of a grouse with the possibility of finding a clutch of eggs. After attempting unsuccessfully to catch her it returned and deliberately sniffed the base of one tree after another until it located the nest. In fact seren nests were believed to have been destroyed in one 200 -acre wood lot by this same fox.

Foxes have the habit of taking several eggs from a nest but leaving the remainder. Sometimes they return, sometimes not. In fact, they have been known to leave a few even after the second visit. Losses of this type have been very small.

Next comes the weasel, including both the New York and Bonaparte. Over most of the State the latter is the more common. Although it would appear from the table that the skunk might rank second, analyses of the available evidence indicates otherwise since a large proportion of the records listed as "fox or weasel" in actuality were the work of the latter. In no case did the evidence point to the mink hut this certainly does not suggest that this animal would refrain from plundering a grouse nest if it found one.

Regarding the hawks and owls they of course are not egg-eaters. Yet they now anl then cause nest failure by killing the female bird. Similarly the pheasant sometines lays its eggs in a grouse nest and when they hatch first the deceived hen sets out with the foster brood leaving her own to die.

Occasionally a nest has been found when the eggs had all heen removed and buricd intact nearby, either under the debris of the woods floor or down a hole in the ground. Apparently chipmunks or mice have been responsible. Similar activities of these rodents have been noted by King ${ }^{\text {sis }}$ and Gross*.

\section{Brood Period}

As has heen pointed out analysis of predation among grouse hroods has been a most diffcult prohlcm. Undoubtedly young chicks often fall prey to predators. But they are either devoured "hide, hair and all" or the remains are so quickly obliterated that the most intensive field work has failed to reveal them. A great many are thoroughly sound healthy hirds. On the other hand there is considerable evidence that the bulk of these early losscs is fundamentally the result of something other than predation ${ }^{\Lambda}$.

TABLE H. PREDATORS CONSIDERED RFSONSIBLL FOR DEAD GROUSE CIICKS FOUND ON CONNECTICUT IILL AND ADIRONDACK STUDY ARLIS-1930-1912

\begin{tabular}{|c|c|c|c|c|c|c|}
\hline \multirow{2}{*}{ Species } & \multicolumn{2}{|c|}{ Conureticut llill } & \multicolumn{2}{|c|}{ Adirondack } & \multicolumn{2}{|c|}{ Totul } \\
\hline & Number & ler cent & Numbrr & Per cent & Numbert & Per cent \\
\hline 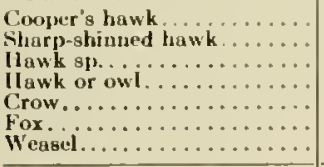 & $\begin{array}{l}1 \\
15 \\
22 \\
1 \\
12 \\
\cdots\end{array}$ & $\begin{array}{r}2.0 \\
29.4 \\
13.1 \\
2.0 \\
23.5 \\
\cdots\end{array}$ & $\begin{array}{l}1 \\
1 \\
6 \\
\cdots \\
4 \\
1 \\
1\end{array}$ & $\begin{array}{r}7.7 \\
76.1 \\
\cdots \\
30.8 \\
\cdots .7\end{array}$ & $\begin{array}{r}1 \\
11 \\
22 \\
1 \\
16 \\
1\end{array}$ & $\begin{array}{r}3.1 \\
1.6 \\
32.8 \\
34.3 \\
1.6 \\
25.0 \\
1.6\end{array}$ \\
\hline Total................ & 51 & 100.0 & 13 & $\ln 0.0$ & of & 100.0 \\
\hline
\end{tabular}

Mortality during the latter two thirds of the summer, however, seems more directly associated with this factor. At this time also remains begin to be found. In table 41 are pre-

* Gross, L. S. Circular Letrer, U. S. Forest Service, Allegheny National Forest, June 15, 1936.

$\triangle$ See discussion of Role of Predation During Brood Period, p. 316. 
sented the diagnoses of the specimens which have been attributcd to predation. Besides these, 21 other specimens were picked up to which no cause of death could be ascribed, but which it is probahle were largely the result of predation.

In spite of the fact that only a small proportion of the chicks which are known to have died were ever found, it seems unlikely that many were taken by predators not included here. Furthermore, on both areas, the situation was similar year after year. It is fair to conclude, therefore, that these records are representative.

The data indicate that the most important species have been certain birds of prey. While, except for a few cases, it has lieen impossible to determine the exact lawk or owl responsible, field experience leaves little doubt that the Cooper's hawk and sharp-shimed hawk are outstanding. Of the specimens referred to "hawk sp." nearly all were found on "killing logs" of these hawks, amid the remains of warblers, thrushes and other woodland birds upon which they regularly feed.

In the group referred to "hawk or owl"-all from Connecticut Hill-the great horned owl undoubtedly entered in. A considerable number of chicks were also taken by the fox, but whether this animal or the owl should rank higher it is impossible to say. As in the case of nests both the red and the gray fox appear equally destructive. The one record of a crow carrying off a young chick appears to have been very unusual.

No definite evidence of predation on grouse chicks by other species has been observed. To be sure it has occurred to a minor degree and under different circumstances might be im. portant. Certainly there can be little question that the gosluawk takes a toll at this season when the two occupy the same habitat. The raccoon, too, will readily kill grouse if given a suitable opjportunity, as was demonstrated at the Research Center when several females and their broods bcing held in natural enclosures were completely wiped out by this animal. The same may be said for the weasel. While losses from house cats liave not been encountered this animal is undoubtedly a factor where it is more frequent in grouse habitats.

On the Connecticut Hill study area in particular the red-tailed hawk, red-shouldered hawk and marsh hawk have been common. Yet no instances of their molesting grouse have been recorded during the Investigation. As their food habits show" their principal diet consists of mice and other forms chiefly found in open land types. Quite probably they occasionally sccure a grousc chick, as for example the red-shouldered hawk examined by Ilcrsey ${ }^{100}$. But in any event one may conclude that the effect of these species on brood survival is negligible. Similarly the broad-winged hawk, although the commonest one on the Adirondack area, was never associated with grouse mortality.

\section{Adult Period}

During the adult period a considerable loss from predation is customary each year. taking place chiefly in late winter and spring. The remains of a much larger proportion of these birds have been subsequently picked up by the Investigation's ficld crews than in the case of chicks. Analysis of this material, while obvionsly far from precisc, nevertlicless affords valuable data on relative predator importance not otherwise oltainable. Of the 1,174 specimens exanined 550 have hecu undeterminable as to cause of death. The proportion of such records, however, has been quite similar throughout the study, both from year to year and seasonally. Those it has been frossible to analyze have, therefore, been considered represcntative. The diagnoses of those ascribed to predation are presented in the following tablc.

\footnotetext{
- Sec discunsion of Fuod Habits in New Sork, D. 3.13.
} 
TABI. 42. PREDATORS CONSIDERED IRESPONSIBLE FOR DEAD ADULT GROUSE EXANIINED BY THE INVESTIGATION-1930-1912

\begin{tabular}{|c|c|c|c|c|c|c|c|c|}
\hline \multirow{2}{*}{ Species } & \multicolumn{2}{|c|}{ Connecticut IJill } & \multicolumn{2}{|c|}{ Adirondack } & \multicolumn{2}{|c|}{ Other Areas } & \multicolumn{2}{|c|}{ Total } \\
\hline & Number & Per eput & Number & Per cent & Number & Per cent & Number & Per ceut \\
\hline 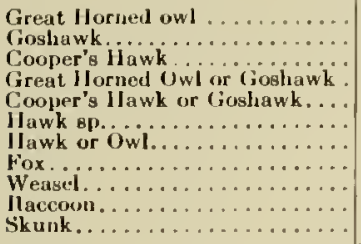 & $\begin{array}{r}58 \\
9 \\
5 \\
1 \\
52 \\
2013 \\
96 \\
15 \\
6 \\
1\end{array}$ & $\begin{array}{r}13.0 \\
2.0 \\
1.1 \\
0.2 \\
11.5 \\
1.5 \\
21.5 \\
3.1 \\
1.1 \\
0.2\end{array}$ & $\begin{array}{l}3 \\
\therefore \\
1 \\
5 \\
6 \\
1 \\
\cdots\end{array}$ & $\begin{array}{r}18.7 \\
\ldots . \\
63 \\
31.2 \\
37.5 \\
6.3 \\
\ldots .\end{array}$ & $\begin{array}{r}22 \\
6 \\
2 \\
i 1 \\
57 \\
2 i \\
2 \\
\cdots\end{array}$ & $\begin{array}{r}17.6 \\
4.8 \\
3.6 \\
3.8 \\
15.6 \\
19.2 \\
1.6 \\
0.8 \\
\cdots\end{array}$ & $\begin{array}{r}80 \\
18 \\
5 \\
3 \\
1 \\
68 \\
260 \\
120 \\
18 \\
7 \\
1\end{array}$ & $\begin{array}{r}13.6 \\
3.1 \\
0.9 \\
0.5 \\
0.2 \\
11.6 \\
11.3 \\
21.5 \\
3.1 \\
1.2 \\
0.2\end{array}$ \\
\hline Total $\ldots \ldots \ldots \ldots \ldots \ldots$ & 416 & 100.0 & 16 & 100.0 & 125 & 100.0 & 587 & 100.0 \\
\hline
\end{tabular}

The predators which have been found responsible for the great majority of this mortality are the great horned owl and fox, both red and gray. In New York the former seems by far the most effective since in actuality it undoubtedly accounted for at least lalf the dead birds which could not be diagnosed heyond "hawk or owl."

On the Adirondack area, however, this owl was not observed during the period of study although this is a purely local condition. It is significant that under these circumstances the total mortality experienced was very similar to that on Connecticut Hill and that it was associated with a greater proportion taken by foxes*, Cooper's hawks and goshawks.

Over the State the Conper's hawk appears to rank next to the fox, followed by the weasel ${ }^{\Delta}$. During an average year this hawk is the more important in New York, aside possibly from certain parts of the Adirondacks, since a few winter regularly throughout the central and southern part of the State. The goshawk. on the other hand, is an irregular winter visitant from the North. While there is ample evidence in published accounts of the destructiveness of this species when it appears in numbers no such invasion has been witnessed during this study. $\Lambda$ few individuals were recorded on Connecticut Hill for the winters from 1933 to 1937 and of the nine kills attributed to it four occurred in 1937. In view of this it is probable that the majority of the records referred only to "hawk sp." were the result of Cooper's hawk activity. The higher proportion of records attribnted to the goshawk under Other Areas (tahle 42 ) is due to the fact that most of this material was collected at Pharsalia where it happened to be present during the winters involved.

Other birds of prey have not been implicated except for the finding of grouse remains in the pellet of a barred owl picked up on the Adirondack area. They, of course. may have taken grouse now and then but there is nothing to indicate that such instances have been more than occasional. In this connection McAtce ${ }^{3 s}$ found grouse in three of 754 red-tailed hawk stomachs, in four of 601 marsh hawks, and in one of 145 broad-winged hawks. Gross ${ }^{100}$ found grouse only once in the many stomachs of the snowy ow $]^{\dagger}$ which he examined.

* Only the red fox is present in this locality.

$\triangle$ No differentiation has been made between the two species, New York and Bunmarte.

$t$ The same author has also reported grouse remains in one pellet of this owl.1:

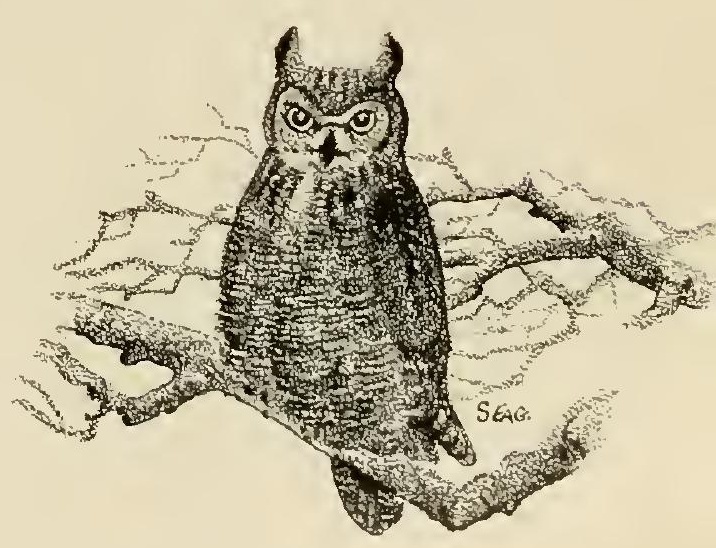


One of the most surprising statements in the literature is that of Townsend ${ }^{\text {sas }}$ in which he reports a crow carrying a full-grown ruffed grouse. Certainly such a feat is rare indeed.

In the experience of the Investigation mammals other than the fox and weascl have been of little consequence to adult grouse. In coverts where stray cats are numerous, however, their depredations may become more frequent. Forbush ${ }^{167}$ reported 46 birds of these species killed by cats but did not state the area or the period of time involved.

As has been discussed previously " the vast majority of the adult mortality each year takes place between fall and the following breeding season. This pattern appears to be primarily associated with the existence of surplus birds in the habitat. It is significant that the seasonal distribution of kills by the various predatory species has followed this very closely.

\section{Net Effectiveness Throughout the Ýear}

From the foregoing data it is evident that the predators most destructive of grouse are not the same with respect to the different life periods. It is, therefore, appropriate to state the conclusions of the Investigation regarding the net effectiveness throughout the year of the more important species.

Over the better grouse coverts of the State the fox is easily outstanding. Not only does it take a considerable number of adults and chicks but it also has been responsible for over a third of all the broken-up nests examined. Second is the great horned owl followed by the Cooper's hawk both of which influence survival during all life periods since they from time to time take nesting females. Next comes the weasel, another species capable of taking grouse the year around but which is most important with respect to nests. These are the paramount grouse predators in New York with the addition of the goshawk when it appears in numbers. Beyond this, in those localities in the Adirondacks where the great horned ow is absent, the latter and the Cooper's hawk take proportionately more.

Regarding the sharp-shinned hawk and skunk it is difficult to say whether the number of ehicks taken by the former outweighs the eggs destroyed ly the latter. The raccoon ranks somewhat lower largely because it is less numerous than the skunk in most sections. Finally may be mentioned the crow and $\operatorname{dog}$.

\section{FOOD Habits IN NEW YORK}

Important as it is to know the effect of a predator on the game species with which one is concerned, an intelligent management program must also take into consideration its other food habits. Only in this way can a well-rounded picture of its place in the cnvironment be secured.

It must be borne in mind that in no instance does a game lird of the Northeast constitute the staple food of any predator. At the same time cren the taking of smath numbers may rep. resent a degrec of predation sufficient to have an important effect on the game population. The two approaches are thus complimentary to each other. Too often this has been lost sight of.

The conclusions of the Investigation with regard to the effect on grouse have been discussed. It remains to summarize bricfly the relative proportions of this and other lypes of food which comprise the usual diet of the more important grouse predators in New York as well as some of those commonly suspeeted of being.

Data of two principal kinds have been collected. First the stomaels of specimens taken in various parts of the State have heen secured from time to time and examined. These have

\footnotetext{
* Sce dincuasion ol Role ol I'redasion Juring Adull J'eriod, p. 318.
} 
been supplemented with respect to the great horned owl and fox by regularly gathering their pellets and droppings on the study areas*.

In compiling the results of the stomach analyses only material from localities situated in grouse territory has been used in order that the data may be as applicable as possible to the prollems of the Investigation. In the Appendix ${ }^{\Delta}$ is shown the seasonal distribution of these specimens. The examinations are summarized in table 43 according to the major types of food, the percentages representing the number of specimens in which the various food categories were found ${ }^{\dagger}$. For purposes of the kind involved in this study the frequency of occurrence method hest facilitates interpretation of relationships to other animal populations. This follows the conclusion of Scott ${ }^{833}$ with respect to fecal analysis.

TABIE 13. JROPORTION OF DIFHEREVT TYPES OF FOOD IN PRIDDTOR STOMACHS EXAMINED RY THE INVESTIGATION-1930-19t2

\begin{tabular}{|c|c|c|c|c|c|c|c|c|c|c|c|c|c|}
\hline \multirow[b]{2}{*}{ Species } & \multicolumn{2}{|c|}{ Number } & \multicolumn{11}{|c|}{ Per cent } \\
\hline & $\begin{array}{l}\text { Exam- } \\
\text { inel }\end{array}$ & Empty & Mablit & Nons:" & Slirew & $\begin{array}{l}\text { Othwir } \\
\text { Mlam- } \\
\text { mala }\end{array}$ & Grouse & $\begin{array}{c}\text { Pheas- } \\
\text { ant }\end{array}$ & $\begin{array}{l}\text { Ponl- } \\
\text { try }\end{array}$ & $\begin{array}{l}\text { Other } \\
\text { Birils }\end{array}$ & Insinets & lerruil & Mise. \\
\hline Red fox. & 134 & $3: 3$ & 31.7 & 11.6 & 1.9) & 8.9 & 3.4 & 0.9 & 8.4 & 7.9 & 4,5 & 11.6 & $10 . n$ \\
\hline Gray fox & 20 & 1 & 13.4 & 261 & 5.3 & 10.5 & $\cdots$ & $\ldots$ & $\ldots$ & 10.5 & 21.1 & 21.1 & 53.0 \\
\hline Wrasel. . & $5 \overrightarrow{4}$ & 18 & 7.7 & $3 n .1$ & 12.8 & 10.3 & & $\ldots$ & $\cdots$ & 2.6 & & & 17.4 \\
\hline Skunk. & 34 & II & $18:=$ & 10.1 & & 6.5 & 5.2 & $\ldots$ & 1.3 & 2.6 & 33.8 & 11.3 & 70.2 \\
\hline Hacconi & 30 & 8 & 22.6 & & 3.2 & 6.5 & 3.0 & $\ldots$ & $\ldots$ & . & 2.3 .8 & 191 & 7.5 \\
\hline Mink......... & 12 & $t$ & & 12.5 & & 37.5 & $\ldots$ & $\ldots$ & $\ldots$ & & & & 62.5 \\
\hline IIouse cat.... & III & 2 & 37.5 & $6,2.5$ & 6.3 & 250 & . . & $\ldots \ldots$ & $\cdots$ & 25.0 & $\ldots$ & & 6.3 \\
\hline Great hormerl suwl & $11 \%$ & 21 & 30.8 & 20.7 & 2.2 & 8. 8 & 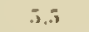 & 11 & 1.1 & 20.1 & 10.9 & & 10.9 \\
\hline Burred owl. ... & 20 & 1 & 6.3 & $37 . .7$ & 37.5 & 6.3 & $\ldots$ & $\ldots$ & . & 25.0 & 18.7 & & 0.3 \\
\hline Sinowy owl & is & 2 & .. & 7.5 .0 & $\ldots$ & & & & . & 25.11 & & & \\
\hline Goshnowk & II & 3 & & 36.1 & $\ldots$ & 9.1 & 4. 1 & 18.2 & $\ldots$ & 36.1 & 18.2 & & 9.1 \\
\hline $\begin{array}{l}\text { Cooper's laswk } \\
\text { Sharp-shintierl }\end{array}$ & 11 & (1) & $1 . \overline{5}$ & 31.4 & . & $\ldots$ & 1.5 & 9.1 & $\ldots$ & 15.5 & 9.1 & . & 18.2 \\
\hline hank..... & 33 & $2: 3$ & 3.3 & 13,3 & & & & & & 83.1 & & & \\
\hline lled-tailovl luark & 76 & 19) & 8.8 & 14.1 & 14,3 & 7.0 & & 1.8 & $\cdots$ & $\overline{1.0}$ & 22.8 & & 31.6 \\
\hline 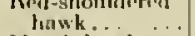 & 15 & 12 & 3.0 & 1.3 .1 & 21.2 & 12.1 & & & & 18.2 & โ5. $\mid$ & . & 15.1 \\
\hline Marsh liawk... & 35 & 14 & 11.3 & 38.1 & . & & . & 11.3 & $\cdots$ & 28.6 & 1.11 & . & $1: 3$ \\
\hline
\end{tabular}

The following comments on these data are considered under each species separately.

Fox

Most of the stomachs were those of red foxes although 20 grays were secured. Supplementing these a total of 4.269 droppings have been examined. Of these 3.054 have come from Connecticut Hill and 719 from other areas in the southern part of the state, while 496 are from the Adirondacks. In the latter material only the red fox is involved, whereas in the other loth species are represented. In table 14 the analyses of these specimens is tabulated in the same way as for stomachs.

There is little to choose between the basic food habits of the two species. It is apparent that rabbits and mice constitute their staple foods throughout the State at all seasons. In the first group the varying hare is paramount in the northern part of the State, while southward it gives way to the cottontail. Among the mice the field mouse is taken most frequently. followed ly the deer mouse. Lesser numbers of the red-backed mouse and other species have

* Tho otomach analyses were made largely by the author although a series of fox materiaI was done by William J. Hamilton. Jr. of Coroell University. Pellet and droppiog examioatioos wore made in part hW the author and in part by John C. Jones, working in collaboration with the Division of Food Habits Resegrell of lhe Federal Fish and 11 ildlife sersire. Thusus smyth and Ralph Palmer also assisted in the latter.

A See Appendix, p. 875 .

A See Appendix, p. 875 .
$t$ ln cach species a number of the stomachs receivel were empty. These were deducted in figuring percentages. 
TABIE 4t. PROPORTION OF DIFFERENT TYPES OF FOOD IN FON DROPPINGS E.I A IINED BY TIIE INVESTIG TTION-1930-1912

\begin{tabular}{|c|c|c|c|c|c|c|c|c|}
\hline \multirow{2}{*}{ Tylue of forol } & \multicolumn{2}{|c|}{ Connecticut itill } & \multicolumn{2}{|c|}{$\begin{array}{l}\text { Other areas } \\
\text { oustsidr. Adirondacks }\end{array}$} & \multicolumn{2}{|c|}{ Adirondacks } & \multicolumn{2}{|c|}{ Total } \\
\hline & Nismluer & lire cint & Number & Per cent & Number & Precent & Number & Per cent \\
\hline 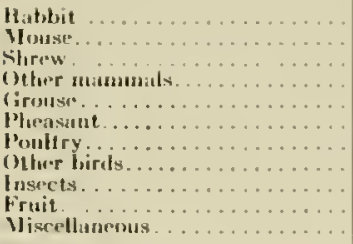 & $\begin{array}{r}1.617 \\
1.323 \\
93 \\
32 \% \\
106 \\
17 \\
175 \\
220 \\
571 \\
901 \\
5.30\end{array}$ & $\begin{array}{r}33.1 \\
13.4 \\
3.2 \\
10.7 \\
3.6 \\
0.6 \\
5.7 \\
7.2 \\
18.7 \\
199.5 \\
17.6\end{array}$ & $\begin{array}{r}331 \\
212 \\
13 \\
31 \\
32 \\
8 \\
51 \\
75 \\
119 \\
968 \\
81\end{array}$ & $\begin{array}{r}16.1 \\
33.6 \\
1.8 \\
11.3 \\
1.5 \\
1.1 \\
10.5 \\
10.1 \\
20.7 \\
37.3 \\
11.3\end{array}$ & $\begin{array}{r}293 \\
1.56 \\
50 \\
66 \\
50 \\
\cdots \\
31 \\
136 \\
173 \\
3.5\end{array}$ & $\begin{array}{l}50.1 \\
31.1 \\
10.1 \\
13.3 \\
10.1 \\
\cdots \\
6.8 \\
27.1 \\
31.1 \\
6.1\end{array}$ & $\begin{array}{r}2.211 \\
1.21 \\
160 \\
172 \\
191 \\
25 \\
229 \\
329 \\
856 \\
1.342 \\
655\end{array}$ & $\begin{array}{r}52.6 \\
40.4 \\
3.8 \\
11.0 \\
1.5 \\
0.6 \\
5.4 \\
1.7 \\
20.0 \\
31.5 \\
15.3\end{array}$ \\
\hline lintal texamined & $3,0,51$ & $\ldots$ & 719 & $\cdots$ & 496 & $\cdots$ & 1,269 & $\cdots$ \\
\hline
\end{tabular}

hcen found. The fox seems to have a definite aversion for shrews, although they have been fully as abundant as the woods mice at least.

Other mammals eaten have been primarily the gray squirrel, red squirrel, chipmunk and woodchuck. Of interest is the occasional occurrence of other predators such as weasel, skunk, raccoon, opossum and house cat.

Analysis of the dropping material brought out a significant correlation during the fall and winter of 1935-36 between the irruptive aloundance of gray squirrels and the frequency with which they were eaten by this animal. The same was true to a lesser degree of red squirrels. There secms to be a tendeney for rabbits to be taken less during the summer than at other seasons and for such species as the squirrels, woodchuck and small birds to be then more.

Grouse make up a comparatively small part of Reynard's diet, although they have been taken more often in the $\Lambda$ dirondacks than elsewherc. Both adults and chicks have been recorded but in only one instance was an egg shell identified. This emphasizes the inadequacy of food habits studies of this kind with respect to rertain types of predation, since foxes have been found to be by far the greatcst destroyers of grouse nests".

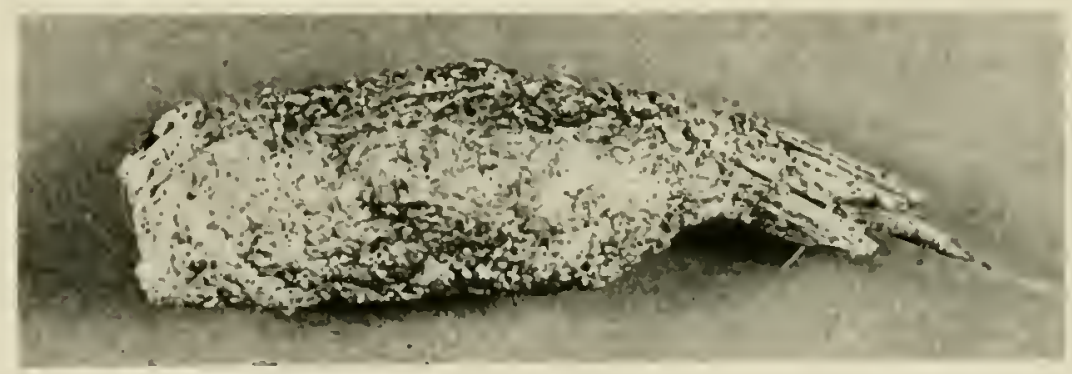

FOX DROPIING CONTAINING GROUSE FEATHER REMAINS

The low incidence of grouse in the diet of this animal as compared with that of small mammals bas also heen shown by a number of other sudies. Hamilon ${ }^{177}$ reported three in 206 red fox stomachs mainly from New York and one in 66 specimens from New Fngland. Similarly English and Bennett in Pennsylvania found it to have been taken ly 3.7 per eent of red foxes ${ }^{120}$ and 3.4. per cent of the grays ${ }^{200}$ which they examined. 


\section{Weasel}

Included in the material examined were stomachs of both the New York and Bonaparte weasels but the number is insufficient to warrant separate treatment. There seems to be very little difference in the foorl hahits of the two species, howeser. Mice were by far the most frequently taken items followed by shrews which occurred more often than rabbits. Grouse remains were not found although the records of the Investigation show this animal to be one of the important predators of this game hirl, particularly during the nesting season.

\section{Skunk}

Although the number of specimens examined has not been large all seasons of the year are well represented in the group. Insects were found more frequently than other types of food. At the same time rablits and mice were taken by over a quarter of the animals and probally constituted a greater bulk. Fruits also were taken in season. Of the 77 stomachs holding food, four (all from the winter and spring) contained grouse remains-a finding which it is difficult to interpret since the skunk has appeared to be only a negligible predator of adult birds. In any case this is not an important source of food. That insects, fruits and small rodents constitute the principal diet of this animal is also evident in the data of Lant $z^{2 n}$ and Hamilton ${ }^{170}$.

\section{Raccoon}

The 'coon too feeds to a large extent on small rodents although considcrable quantities of insects, fruits and grain are consumed when available. Of the 31 stomachs containing food seven held rabbit. Shrews and red squirrels were also taken. Grouse occurred once-a chick taken in August-and other birds not at all. Nice were not found either although Hamil$\operatorname{ton}^{178}$ identified them in 17.4 per cent of the specimens he examined from the State.

\section{Mink}

Only eight of the 12 mink received held fond. In one was found the remains of a mouse and in three muskrat lair while five contained miscellaneous items including a erayfish.

\section{IIouse Cat}

Over three-quarters of the cats examined had fed on small mammals. Mice had been taken most frequently followed by rabbits, shrews and the Norway rat. Also identificd was a weascl. Birds were found in 25 per cent of the material. Grouse, however, were not represented.

\section{Great Ilorned Owl}

In addition to the 115 stomachs of this owl a total of 1,517 pellets have heen gathered from the southern part of the State, primarily Comecticut Hill. The species has not been observed on the Adirondack study area. The analyses of this material are summarized in table 45 in the same manner as the fox droppings were handled.

Like the fox, this species relies chiefly on rablits and mice for its sustenance. The relative importance of the various species is about the same although the wood mice, especially the dcer mouse, rank somewhat higher. Shrews also are more frequently caten.

Among the other mammals red squirrels and chipmunks have been taken oftenest during most years. In 1935-36. however. as with the fox. the greater availability uf gray squirrels was reflected in the ow's diet. But even more interesting was a very much higher incidence of flying squirrels in this year suggesting that they too may have reached a peak of abun- 
TABLF 15. PROPORTION OF DIFFEREXT TYPES OF FOOD IN PEILETS OF THE GIEAT HORNED OWL EXAMINED BS TIIE INVESTIGATION-1930-1912

\begin{tabular}{|c|c|c|c|c|c|c|}
\hline \multirow{2}{*}{ Typo of fiuxl } & \multicolumn{2}{|c|}{ Commedintul Ilill } & \multicolumn{2}{|c|}{ Other Areis } & \multicolumn{2}{|c|}{ Total } \\
\hline & Vinuluer & Prer cont & Dumber & Der cont & Number & Per ceut \\
\hline 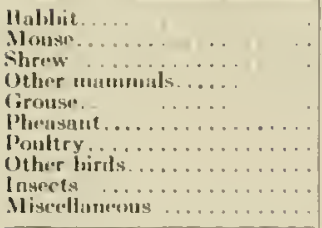 & 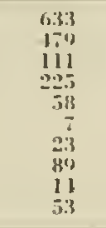 & $\begin{array}{r}10.6 \\
3.6 \\
8.6 \\
17.6 \\
1.5 \\
0.5 \\
1.8 \\
6.9 \\
1.1 \\
1.2\end{array}$ & $\begin{array}{r}111 \\
95 \\
20 \\
00 \\
30 \\
8 \\
\frac{2}{2} \\
0 \\
20 \\
10\end{array}$ & $\begin{array}{l}50.8 \\
31.1 \\
18.3 \\
12.1 \\
3.3 \\
0.8 \\
0.8 \\
3.7 \\
0.8 \\
1.1\end{array}$ & $\begin{array}{l}7: 3 \\
571 \\
131 \\
2.31 \\
66 \\
61 \\
25 \\
18 \\
16 \\
6.3\end{array}$ & $\begin{array}{r}51.2 \\
37.8 \\
8.6 \\
16.7 \\
1.5 \\
0.6 \\
1.6 \\
6.5 \\
1.1 \\
4.2\end{array}$ \\
\hline 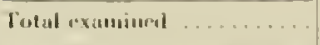 & 1,276 & $\cdots$ & 211 & $\cdots$ & 1.517 & $\cdots$ \\
\hline
\end{tabular}

dance at the same time. A number of skunks were recurded as well as weasels, an opossum. crows, two screech owls, a Cooper's hawk and a sharp-shinned hawk.

Grouse have occurred in only about 5 per cent of the material examined, a proportion very similar to that noted for the fox. Both adults and ehicks have been identified.

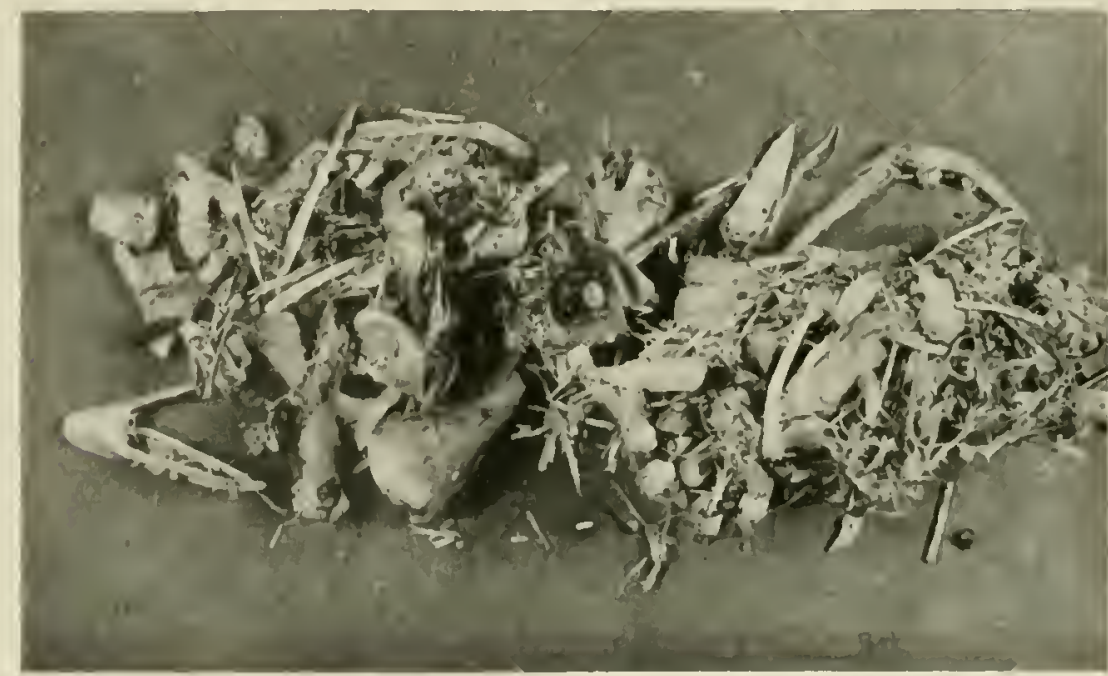

PELIET OF GREAT HORNED OWL SHOWING GROUSE REMAINS AND SUSCEPTIBLITY TO DISINTECRATING OF PELLETS COMIPOSED OF TIIS SORT OF MATERIAL

Small birds were found more frequently in the stomach material than in the pellets. They were tikin more often in summer than at wher seasons. Niscellaneous items have included a considerable number of garter snakes, frogs. salamanders and erayfish.

Analysis of 983 great horned owl stomachs from l'ennsylvanian also slowed grouse to have leen taken only a relatively few times I.I per cent while smalt mammals. mainly rodents, were the principal bill of fare.

\section{Barred Owl}

None of the harret owl stomachs held grouse and its remains have been found in only 
one of the many pellets examined. The principal foods of this owl are mice and shrews, the latter lieing eaten more frequently than by any of the other predators observed. Small birds and insects were also taken to some extent.

Fisher ${ }^{130}$ likewise found small mammals to be the chief food of this owl. although he re. ported that in 100 stomachs poultry and game amounted to 4.5 per cent, mainly "halfgrown fowls which roost among trees and bushes".

\section{Snowy Oul}

The four specimens of this ow enntaining food are too few to indicate much regarding its food habits. Gross ${ }^{100}$, however, has reported the contents of 284 stomaehs. 135 of which were empty. collected in New England during the flight of 1926-2\%. He found over 75 per cent had fed on small mammals, especially the Norway rat. A wide variety of hirds had also been eaten including one grouse.

\section{Goshawk}

Although the number of specimens secured was small. analysis of their contents further demonstrates the tendency of this hawk to prey heavily on birds. Grouse occurred in one of 11 stomachs, pheasants in two and small birds in four, while smalt mammals had been taken by five of the hirds.

Of all the raptors of the Northeast the goshawk comes elosest to meriting the name "partridge hawk". lieporting on 213 examinations Mc Atee states "Grouse. chiefly ruffed grouse. were determined in 31 of the stomachs". He also found hirds of one kind or another in over half of the same group. Similarly in 533 stomachs from l'enus!liania 1.53 or 28.5 per cent contained grouse and many others the remains of smaller lirds, while about half held the remains of small mammals. chiefly rabhits and squirrels ${ }^{2 \pi}$.

\section{Cooper's Ilauk}

Like the goshawk the Cooper"s lawk feeds extensively on other hirds. It preys largely on non-game species herause they are more abundant and more within its capabilities. Yet grouse are taken just as readily whenerer a suitable opportunity presents itself. Mlammals had been eaten ly only a little wer a third of the specimens examined. Its preference for birds has been corrohorated many times ly other workers.

Of interest is the high proportion-nearly half-of the stomachs of this hawk which have been empty. The same is also true of the next specirs, the sharp-shin. It suggests that their rate of digestion may be quite rapid.

\section{Sharp-shimned Ilank}

This hawk preys cron more predominantly on hirds than either of the two preceding. Due 10 its smal! size, however. game species are seldom taken except as chicks. In the speeimens examined by the luvestigation over 80 per cent of its food loas been small birds. the balance being rodents, eliefly mice. NeAtee ${ }^{\text {nst }}$ has reported a small variety of other foods. The records reported by May follow the same pattern.

\section{Red-tailed Hauk}

This hawk, so frequently seen wheeling in broad cireles over field and pasture, is primarily a mouser. Nearly half of those examined had fed on these rodents, mainly the field mouse. while shrews. rahbits and squirrels were also taken in considerahle numbers. 
Over 20 per cent had eaten inseets. Among the other items identified garter snakes have been found in a number of instances.

While no grouse were recorded one specimen contained pheasant remains. NeAtee ${ }^{x-1}$ however, found grouse in three of 754 stomachs and it was also found in two of 193 reeords from Pennsylvania ${ }^{237}$. Yet game birds comprise only a suall proportion of its usual food.

\section{Red-shouldered Hauk}

Although no less a mouser this species-another of the soaring hawk-has taken small birds more frequenty than the red-tail. No game birds of any kind were recorded in the food material examined. One instance of its feeding on grouse has been reported ${ }^{\text {sss }}$. McAtee ${ }^{2 z}$ lias also noted a "strong taste for amphibians and reptiles".

\section{Marsh Hawk}

Beating back and forth over meadow and marsh this harrier hawk feeds mainly on small mammals, mice and rabhits predominating. It does. however. prey to some extent on young pheasants and smaller hirds when they are available. Randall ${ }^{312}$ reports that in l'ennsy-lvania juveniles of many small ground nesting speeies were the most important items of food during June and July. Confining its activities almost entirely to open areas it seldom encounters grouse. Nevertheless, the latter were found in four of 601 stomachs reported by MeAtee ${ }^{\text {sit }}$.

It is evident from these brief resumes that, for the grouse predators of the Northeast as a group, small mammals, mainly rodents, are the staff of life. Only in the "blue-darter" hawks do we find species whose principal diet consists of hirds and anong them only the goshawk customarily takes grouse as an appreciable proportion of its food. At the same time all predators are opportunists and quickly take advantage of variations in prey availability. Thus deviations from the general rule may take place in accordance with local conditions.

\section{Interpredator Reilationsinps}

Predators are usually thought of as spending most of their time harrying and killing the unfortunate species upon which they depend for food. One seldom stops to think that they also prey upon each other. Yet such strife among themselves goes on constantly in any habitat.

The peculiar taste of the great lorned owl for skunks has heen noted many times. Weasels are also taken frequently by this owl and it has alsu heen known (n feed on many of the smaller owls as well as the Cooper's hawk, sharp-shinned lawk and opos. sum. Likewise the fox now and then eatches a weasel. Skunks. racoons and house eats sonetimes fall prey to this animal too. On the other loud. in the Jorth, the lyx is a traditional crueny of the fox. Very often young hawk disappear from the nest long before they are ready to fly. An instance of a red-tailed hank feeding un a freshly killed red. shouldered hawk has also ben reported". To just what extent. however. such halits may serve to limit the numbers of the various species is still a problem for the future.

There is also some indication of a reciprocal relationship letween predator populations. This may be the reason why in certain areas the great horned owl is predominant. while in oflers the barred ow is most numerous. But data of this kind are few and fragmentary. 


\section{THE PROBLEM OF CONTROL}

Early in this chapter it was stated that if, through predator control, the game manager could produce a greater fall surplus of grouse and the hunter be enabled to harvest it better sport would result. Whether or not measures of this kind will have such an effect can only he determined by actual trial in the field. The Investigation has carried on a few experiments of this nature.

\section{Experinents Conducted}

The first series of tests were made on land heing surveyed in connection with the Connecticut llill study area. The tract to be used was divided roughly in half, 1,425 acres of grouse cover to 1.223 acres. Beginning October 1. 1930. an attempt was made to completely eliminate all predators from the former purtion although this goal was never attained. The other portion was used as a check. Nevertheless. between that date and Angust 31. 1932, a total of 557 individuals was taken**

Following this Nature was allowed to take its course for a year. Then between Octuber 1. 1933 and April 30, 1934 elimination of predator was aqain attempted. This time the other portion of the tract was suljected to control since there was a posilility the results obtained previously were unduly intuenced by preculiaritie of the coverts chosen. During this period 195 specimens were removed".

Because the initial experiment had hecn most effectise ju reducing nest losses and because foxes and weasels had heen found the most important nest predators. the selective control of these two species muly was a logical step. This was first undertaken during the winter and spring of 1933-31 on a nearhy area known locally as bull 1lill. The results. however, were inconclusive since even these animals were not sucressfully climinated. Accordingly this selective practice was repeated on a portion (792 acres) of the lest tract on Connecticut Hill from October 1, 1931 to April 30, 1935. During this time 18 red foxes, four gray foxes and two weasels were taken.

Beyond this the fall of 1934 on this area witnesed the highest grouse density recorded by the lnvestigation-an average of a bird to 2.5 acres over a 187 -acre covert. Even though this was a part of the area on which long-tine pupulation trends were being followed it seemed too good an opportunity to pass up. Intensive control of all predators was therefore instituted to determine to what extent such a level of abundance could be main. tained. From Octoher 1, 1934 to April 30, 1935 a tental of 97 predatory birds and mammals were removed from this covert*.

This completed the trials carried out directly the lnvestigation. Throughout all of them the usual grouse survey field work wan carried on at all seasons on both the control and check portions.

In 19.10 a separate project to study this prohlem was established within the Bureau of Game under the provisions of the Federal Pitman-Robertson Wildlife Restoration Act. As a study area. Valcour lsland of 1050 acres, lying about a mile from shore in Lake Champlain, was choscn. A low population of grouse was present here as well as varying hares and cottontail rabbits. Complete elimination of predators was instituted and its effect on grouse and other species followed carefully. 


\section{EFfect on Prenators}

In general control was effective primarily during the season immediately imolied. Of the more imporlant grouse predators only the weasel secmed to recuperate slowly as indicated hy a comparison of the mmbers laken during the successive years 1930-31 and 1931-32*. The lower take of great horned awls the second season means little since most of the winter population of these hirds were visitants from farther north. Likewise the majority of the specimens of migratory hawks were undoubtedly transients and thus would have slight effect on the abundance of such species from year to year. With respect to the Conper's hawk and sharp-shinned lawk their numbers were least affected, even while control was heing earried on.

Another aspert of this question involves the fact that the coverts on Connecticut Hill which were used for these tests were in no way separated from similar surrounding territory. This condition undoubtedly resulted in a certain amount of influx of predators into the test plots as the operations proceeded. Nevertheless most game managers interested in the possibilities of this practice would be confronted by the same situation.

Valcour Island, on the other hand, is more isolated. But hawks and owls trade back and forth from the mainland and even foxes and other mammals can cross to it during the winter on the ice.

\section{Results During, Each Life Period}

In discussing the results of these experiments it secms most logical to consider the data according to the three life periods of the bird as has ben done under previous topics.

\section{Nest Period}

The experiments on Comnecticut Hill prosed effertive in reducing nest hoses as shown by comparing the degree of mortality olserved on the test area with that on the check area (table 46$)$.

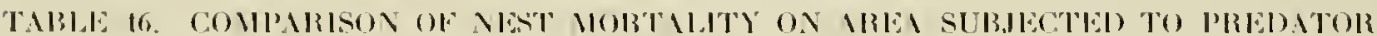
CONTIBOL, AND ON CIIECK ALEA - CONNECTISTT III.I- 19:3t-193.5

\begin{tabular}{|c|c|c|}
\hline \multirow{2}{*}{ Year } & \multicolumn{2}{|c|}{ Por cent mortality } \\
\hline & Conlrobllial ariau & Cherch areu \\
\hline $1931 \ldots \ldots \ldots \ldots \ldots$ & 21.1 & 51.3 \\
\hline 1932. & 30.11 & 72.0 \\
\hline 1931. & 2010 & 10.0 \\
\hline $193.5 *$. & $2: 3,11$ & 37.1 \\
\hline
\end{tabular}

* Confrol limitud to foxn:s and wansols

It is at once apparent that. while the general lesel of mortalit? varied considerahly during these years, the controlled area suffered a matkedly lower loss cach year than the check area. As discusond ilsewhere practically all such loses have heen attrilutable to predators. The difference. therefore, may lie considered a direct result of the predator reduction accomplisherl. Further proof of this effectiveness is the fact that in 1931 the areas used were resersed as to treatment from the arrangement of 1931 and 1932.

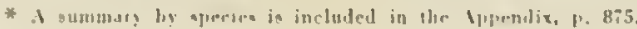


Another highly significant feature is the fact that in 1935 very similar results followed the control of foxes and weasels only, thus verifying the conclusion that they are the paramount nest destroyers in this region.

The one covert where complete elimination of all predators was attempted in 1934-35 had too few nests to merit comparison although none of these were broken up. Similarly the number which have been located on the Valcour Island area have been too small to be indicative. That it has undoubtedly been effective on the latter area may be inferred from the fact that in 1940 only three broods were found (no spring census was made) and in 1941 , after only six months of control work. three bronds resulted from 13 breeders. while in 1942 a spring population estimated at 22 produced 11 broods and 33 breeders produced 13 broods in 1943.

\section{Brood Period}

In contrast with the nest period the predator control carried on had little effect on losses among grouse chicks (table 47). As discussed under another topic" mortality during the brood period seens in large measure due to something other than predation. Beyond this the Cooper's and sharp-shinned hawks were, perhaps, the least well controlled of the important species on Connecticut Hill. Even on the unit where complete control was undertaken during $1934-35$ a brood mortality of 73.9 per cent was recorded.

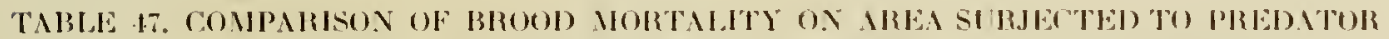

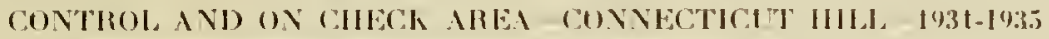

\begin{tabular}{|c|c|c|}
\hline \multirow{2}{*}{ Yinat } & \multicolumn{2}{|c|}{ P'er cernt unortality } \\
\hline & Cinitrulled areas & Clueck are:t \\
\hline $1931 \ldots \ldots \ldots$ & 67.8 & 71.5 \\
\hline $1932 \ldots \ldots \ldots \ldots$ & 33.0 & 51.8 \\
\hline $1931 \ldots \ldots \ldots \ldots \ldots$ & 52.9 & 51.1 \\
\hline $1935 * \ldots$ & 88.1 & 79.7 \\
\hline
\end{tabular}

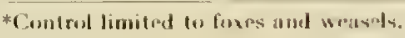

On Valcour lsland the mortality of three loroods in 1910 before any control had been practiced was 74.3 per cent. The next summer afier some eight months of work a loss of only 42.9 per cent was recorded, also based on only three broods. That this cannot be tonstrued as indicative, however, is demonstrated by the fact that in 1942 the proportion was 6.5 .1 per cent in spite of the evident reduction of nesting losses as already noted and in 1943 it was 56.1 per cent.

\section{Adult Period}

Results at this time have been variable. The qreat majority of adult losses take place hetween fall and the following breeding season and predation is an important decimating agent. Yet control of predators has had no consistent effect on the degree of mortality. In fact paradoxical as it may seem. in two of the four years it has been higher on the controlled area than on the check (table 48). Furthermore, the complete control attempted in one covert in 1934-35 failed to prevent a luss of 71.3 per cent. although some of this is attributable to dispersal. 
TABLE 18. COMPMRISOV OF ADILT MORTAITL ON AREA SURJECTED TO PREDATOR CONTROL AND ON CHECK ARE.1-CONVLC'TICUT III,L,-1931-1935

\begin{tabular}{c|c|c}
\hline \multirow{2}{*}{ Yorar } & \multicolumn{2}{c}{ Per cont mortality } \\
\cline { 2 - 3 } & Controlled area & Check area \\
\hline $1930-31 \ldots \ldots$ & 10.9 & 14.5 \\
$1931-32 \ldots \ldots$ & 25.0 & 20.8 \\
$1933-31 * \ldots \ldots$ & 21.9 & 29.2 \\
$1934-35 . \ldots \ldots$ & 55.0 & 18.8 \\
\hline
\end{tabular}

* Diterent method of computation used, sectext.

$\Delta$ Control limited to foxes and weasels.

The figures given in this table represent the differential from September to September of the years indicated. In computing them complete census data have been available except for the fall of 1933 when only a portion of the area was surveyed. It has heen necessary, therefore, to use some other means of evaluating the populations at this time on the two sub. areas. Since the whole tract was surveyed during the winter and spring census estimates were present for May 31. 1934. By adding to these the known mortality in dead hirds actually picked up, conservative figures for the preceding fall have heen secured. While the ratio between these is considered representative it must be remembered that loth are low with respect to the actual degree of loss which took place.

It is interesting to consider these data. If predation is, as it appears to be, the major cause of mortality at this season, then it would seem logical that control of predators should increase survival. Yet the trials conducted have not had such an effect. Certain relationships have been noted. however, which may aceount, in part at least, for the results.

In no instance has the differential hetween losses on the trial and on the check portions lieen great regardless of which was higher. Even in 1933-31. the difference cannot be considered important since. as pointed ont alove, the actual mortality in each case was some 20 per cent more. It is significant, too, that this similarity extends to $1931-35$ when only foxes and weasels were controlled.

On Comnecticut Hill the great horned owl has been the outstanding predator of adult grouse. In 1931-35 it was not affected except in the one covert where cumplete control was undertaken. A possible inference from this is that the operations carried on during the other years were un:ucressful with respect to this species, allowing it to maintain its domination of the situation. That the number of these owls taken may not have areomplished the desired reduce tion involves the fact that the great majority of those present on this area during the winter are transients. Under such conditions replacements would constantly tend to offset the effect of control.

Another influence which may have been involved stems from the fact that the two plots were adjarent as well as being surrounded by grouse coverts. Thus the "spring shuffle"* each rear woull tend to have equalized both populations.

Data from the unit on which a fall density of a gronse to $2 . \overline{\text { ancres of }}$ cover was reached in 1931. indicate several things. In the first place dispersal to surrumding coverts as a result of the lirrl: intolerance of crowding look place immediately. Beyond this, in spite of an intensive attempt to completely eliminate predators indisiduals from adjacent territory quickly 
filled up many of the temporary vacuums created. In consequence a mortality insued even higher than that on the check area where, however, the initial density was less.

With respect to Valcour Island losses in 1940.41 and 1941.42 were 23.5 per cent of 17 birds and 36.4 per cent of 33 birds. These mean little since the population densities were very low. On the Adirondack Area where conditions were comparable except that control has not been practiced a similar density in 1935-36 was followed by a similar degree of mortality. But the population on the Island, which reached 87 in the fall of 1943. suffered a mortality* the following winter of 82.7 per cent returning it to approximately its 1910 level. This occurred in spite of continued predator control.

Thus it appears that predator control, especially on small areas, cannot he expected to maintain fall surpluses.

\section{Effect o. Productivity}

In game management as in other enterprises "the proof of the pudding is the eating". The measure of predator control lies largely in its effect on the resultant survival of grouse.

The experiments conducted have been effective in reducing nest mortality but have not appreciably lowered either lornod or adult losses. Nevertheless, the increased nest survival on the control areas should have produced additional increments to the fall population. Unfortunately, the results are inconclusive regarding this phase of the problem. They do, however, permit certain deductions to be made.

It would seem logical that a comparison of fall population densities would he a suitable index upon which to base conclusions. Yet analysis of the data indicates that this is not the case. The fundamental difficulty lies in the fact that for varjous reasons the reduction in nesting losses accomplished on the controlled area did not consistently result in a higher density of grouse chicks immediately following hatching on this area than on the cherk area (table 49). Thus, since mortality during the brood period, whether high or low. was not particularly altered by predator control, such a comparison is not representative.

TABLE 49. RELATIONSHIW OF DENSITY OF GROUSE BREEDERS TO THIT OF CHICLS AT IIATCIING AND TO TIAT OF TOTAL, POPIIATION IV F.II.L, ON CONTIOLILD AND CIECK ARFAS DURING PRED.TOR (ONTROI. EXIEHIIENTS ON CONNECTICTT HII-1931-1935

\begin{tabular}{|c|c|c|c|c|c|c|}
\hline \multirow{3}{*}{ Year } & \multicolumn{6}{|c|}{ P'opulation density (hirds per 100 acres) } \\
\hline & \multicolumn{3}{|c|}{ Controlled aresa } & \multicolumn{3}{|c|}{ Clieck area } \\
\hline & 13 renders & $\begin{array}{l}\text { Clicks at } \\
\text { hatehing }\end{array}$ & $\begin{array}{l}\text { Total fill } \\
\text { population }\end{array}$ & Hreeders & $\begin{array}{l}\text { Chicks at } \\
\text { hatclitug }\end{array}$ & $\begin{array}{l}\text { Total fall } \\
\text { popmlation }\end{array}$ \\
\hline $1931 \ldots \ldots \ldots$ & 5.0 & 19.6 & 111 & 5.9 & $15 .:$ & 9.8 \\
\hline $1932 * \ldots$ & 8.7 & $22 .+1$ & 19.0 & 3.3 & 22.5 & 18.4 \\
\hline $1934 \Delta \ldots$ & 7.3 & 21.6 & 16.3 & 7.2 & 20.6 & 17.5 \\
\hline $1935 \ldots \ldots \ldots$ & 7.2 & 17.5 & 8.8 & 10.2 & 21.1 & 12.2 \\
\hline
\end{tabular}

*1 H2 acres of controlled area omitted due to extraneous circumstances.

s311 acres of check area omitted diue to extraneous influenees.

The reasons why greater nest șurvival on the test area was not regularly attended by higher 
densities of chicks as compared with the check unit are not entirely clear. $\Lambda$ few. however. may be sugrested. In 1931. for example, the density of the breeding population on the check area was higher than on the other. thereby tending 10 offset the greater nest loss. In 1932 there was some indieation that renesting accomplished a similar result. Again in 1935 grouse were considerably more plentiful in the spring on the check area which may be traced to the lack of effectiveness of control in preventing a high adult mortality on the test plot during the preceding winter.

But even densities at hatching time are not indicative hecause during two of the four years hrood losses were higher on the controlled area than on the check area. In 1931 a relatively larger number of ehicks on the managed tract suffered a lower mortality and produced a greater abundance in the fall. In 1935 the reverse was true on the unit where selective control was practiced. In 1932 and 1934 both June and September densities as well as hrood losses were very nearly the same on both areas.

It will be noted that the greatest apparent effectiveness occurred at a time when the general population level was low and rising. The suggestion has been made that lower brood densities may be suliject to lower losses. While, other things being equal. there may be some truth to this during the same season. it certainly does not apply when different years are involved. For eximple in 1931 and 1935 when the greatest differences in mortality at this time were recorded the higher loss oceurred on the area when the chicks were less numerous. Therefore. une cannot conclude from these data that it is futile to attempt to produce increased fall surpluses among high populations.

Unquestionably. these experiments did not result in a markedly greater alundance of grouse on the areas from which predators were removed in relation to the check areas used. But this does not necessarily mean that they were not effective. Rather. it seems likely that the method of trying to judge such effectiveness by comparing two plots is inatequate for that purpose. On the other hand there is a strong probahility that the resultant fall density on the managed tracts themselves was greater than it would have heen otherwise. Assuming the sane brood mortality would have taken place anyway. the increased nest survival could have no wher result. And, after all. that is what the gane manager is interested in.

Turning to the question of progressively increasing the hreeding population through predator control the data are more clear. Outstanding is the record of the covert which held an average of a grouse to 2.5 acres in the fall of 193-. Incidentally. this high level was reached in spite of a mormal number of predators. On this unit. as well as on others in subsequent years. the grouse soon reduced their own density by dispersing a portion of the surplus ${ }^{\Delta}$ to less well populated surromuding coverts. Followitug this. in spite of efforts to completely control predators. the coincident influx uf these species was sufficient to cause a high overwinter loss just the same. Neither were these practices succesful in the other trials undertaken, particularly that on Valcour Island.

True. if complete elimination of predation were actually accomplished. sursival would at first he greatly increased. That it would last long before loring limited in some other way is highly improbahle. Furhermore. control of such an intensity would seldom. if ever. he feasible. Thus the principal value of this type of managenent seens largely restricted to the reduction of nest mortality and then only on areas where the hunting pressure is great "mough In utilize any additional surpluses ereated. Furthermore, these data indicate that contrul of foxes and weascls abone ean be effective for the latter purpose in habitats sinilar to those studied by the Investigation.

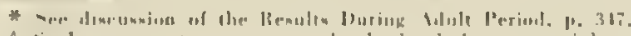

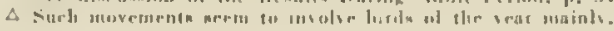




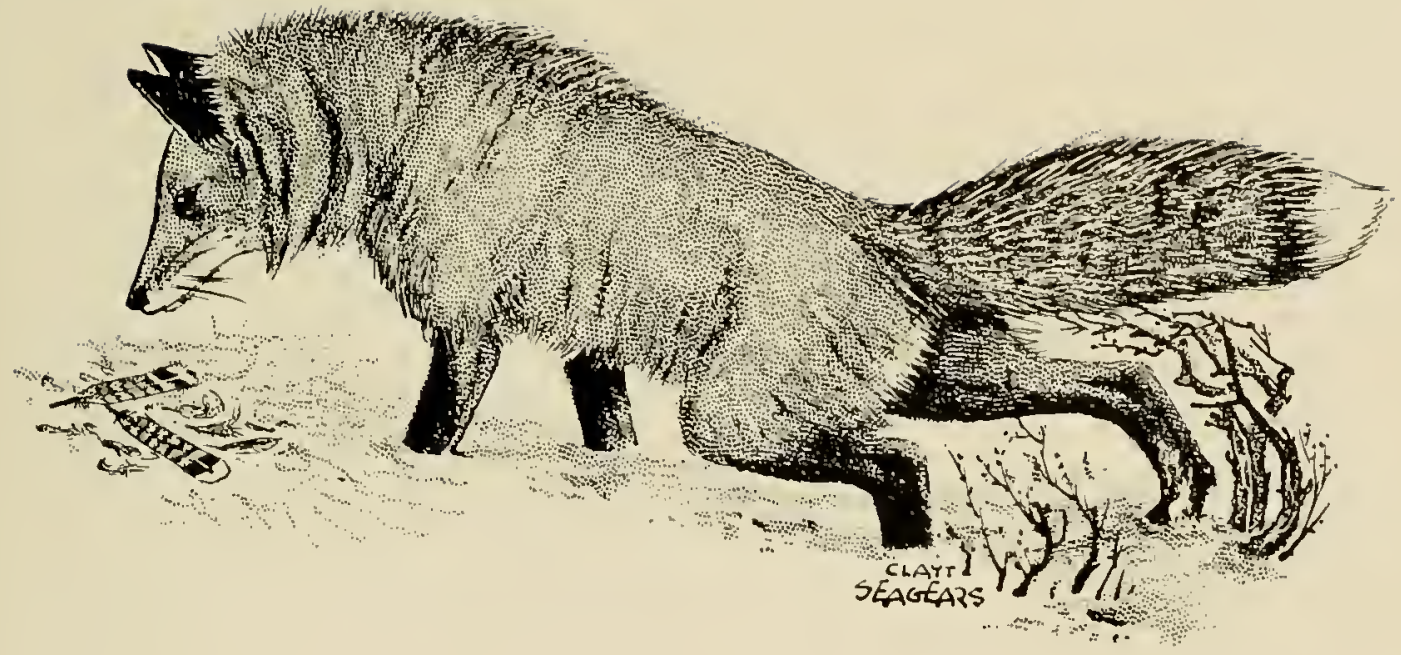





\section{CHAPTER VIII}

\section{REPRODUCTIVE CAPACITY OF THE SPECIES}

By Frank C. Edminster and Walter F. Crissey

REPRODUCTIVE POTENTIAL

EFFECT OF SEX RATIO

PROPORTION OF NON-BREEDING BIRISS

Males - Females

EFFECT OF AGE ON BREEDING

Longenity and Senility

NUMBER OF EGGS IAID

Yearify Variations - Variation in Difteievt Regions of New York

RENESTINC,

Number of Eggs in Renests

FERTIITY OF THE EGGS

VIABHLITY OF THE EGGS

INBREEDING

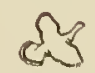

\section{SUMMARY}

Normally, nearly ail female grouse breed each spring. In some years. evidence shows that up to 25 per cent of them may fail to breed in limited localities. Non-breeding by males is unimportant. (p. 359 ).

Both sexes breed the first year when they are about ten months old. (p. 359).

An occasional wild grouse will hreed when five years old or more. In captivity many hreed at this age and a few have reached six years and bred. (p. 359).

No indication of the reproductive capacity of grouse heing affected adversely by variations in sex ratio was observed. Among newly-hatched chicks the proportion of males to females is normally about equal but as summer wanes males tend to predominate among birds of the year (p. 355). 
The arcrage chutch size in furst nests was 11.5 eggs. liluctuations in average clutch size may result from changes in the proportion of old to young hirds in the breeding population. Grouse apparently lay fewer eggs the first year. 1 p. 36011.

Gronse whose nests are destroyed while laying or very early during incuhation are likely to attempt a second nest. hut if their nests are broken up late in incubation. they rarely make another attempt. Since most nest losses occur late in incubation, renests do not ordinarily contribute largely to the increase of hirds. (p. 364 ).

Renests have averaged ahout seven and one-half eggs. No yearly variation of importance has heen observed. (p. 3611.

Egg infertility has varied from one to seven per cent in different years, averaging 2.6 per cent. For renests it has been somewhat higher. averaging 4.3 per cent. This is largely due to occasional renests that are mustly or entirely infertile. (p. 3651 .

Embryo mortality has been consistently low. Only 1.9 per cent of the fertile eggs in first nests and 3.9 per cent of those in renests failed to hatch. The variations in different years have not heen important. (p. 3(15).

Inbreeding probably does not occur to any great extent and when it does. it exerts no observalile detrimental inlluence. (p. 367).

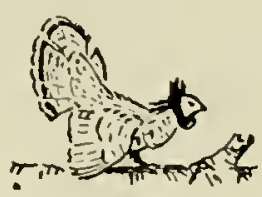

At some perion in the evolution of bird life, the exact time and place of which is lost in the haze of antiquity. a new species developed that might have been recognized as the prototype of the ruffed grouse. From the beginning. its survival and increase were, as with any new species in its formative stages, largely dependent upon its ability to adapt itself to the surroundings and to reproduce in numbers at least sufficient to offset its losses.

Anong the factors controlling the abunlance of any wildife species. the capacity to reproduce is fundimental. The inherent species characteristics that determine this capacity have coolsed from the adjustment of the forces tending to inerease its numbers with those tending to limit them. So long as these forces remain in balance. the speries survives. but if reproduction should fail at any time. the species would he threatened with extinction.

A spereies like the ruffed grouse. that suffers large normal losses each year. must have a relatively high reproductive capacity. The number of exgs lairl and the fertility and hatch. ahility of these eggs must he large enough to proside for a sufficient increment each year to alsorrl, these losses if the pupulation is to remain stahle. The proportion of female hircls that lay egess. as well as that of the males fertilizing them. must likewise he high. Other illrilutes of reproduction are similarly important.

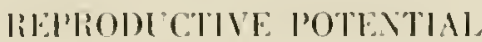

In corder en gise a graphice picture of the potential preductivity of this speries it may be puinted ont that one pair of grouse and their progeny wutd number 33.614 at the end of wnly five yeare if sex ratios were equal. all the females lail the average number of egog

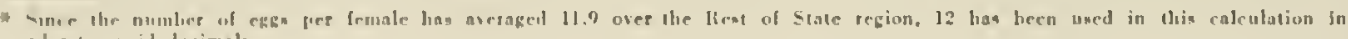
uriler lo anoid decimale. 
and all sources of loss were removed.

In actuality. however, this reproductive potential is progressively diminished by a host of influences which translate it into productivity and populations of mature lirds. These are considered in detail in chapter XIJ. Only the inherent factors of reproduction are covered here.

The subject is opened with a hrief discussion of the sex ratio. While the proportion of males to females is primarily important as a prelude 10 productivity and will he discussed fully under that topic, its inherent tendencies are a factor of reproductive capacity.

\section{EFFECT OF SEX RATIO}

Among newly-hatched grouse chicks the proportion of males to females is normally about equal. Laboratory examinations of 464 grouse chicks under three months old, revealed 51.5 per rent to be males and 48.5 per cent females. In younger age classes the balance was even more perfect.

As the summer wanes there seems to be a consistent tendenry to a slight preponderance of males among the birds of the year. This often results in a few more males than females in the whole population through the fall and winter. Then the lalance changes in the spring as the males suffer a somewhat higher loss as a result of courtship activitics. In later spring and through the summer, the population of females anung the older birds generally exceeds that of the males".

There is no indication in the dala gathered that the capacily for reproduction has at any time been adversely affected by the sex ratio. It is still concrivalyle. however especially in marginal coverts, that the ratio of a scattered population might he so unbalaneed as to prevent sufficient breeding to maintain the population level.

\section{JROPORTION OF NON-BREEIING BIRDS}

The proportion of a population that fails to breed during the spring season lowers the reproductive potential ly that much. Failure to hreed may result from immatmity falthough not in the grouse), physiolngiral difficulties, or lack of contact with hirds uf the other sex.

The cvidence on this factor for each sex wil! loe laken up separately.

\section{MALFS}

Determination of the proportion of male grouse that breed is difficult for it is impossible to obtain enough direct observations. Hence one must rely upon the results of the spring mating season as evidenced by the degree of fertility of the females. This is not entirely satisfactory since it is apparent that. heing promiscuous. even if every female nested and all their eggrs were fertile, it would still be possible that some male grouse failed to mate.

The data indicate that no appreciable failure in lireeding among male birds has occurred. Only three nests of all that have lieen observed have contained complete elutches of infertile eggs. Conceivalily, these could have resulted from lack of contact or from inalility of a male bird to mate. They more likely resulted from physiological deficiencies in the females.

The captive hirds at the New York State Research Center have shown the same evidence of promiscuity that appears to he the hahit in the wilds. Five females placed in a pen with a single male all laid fertile eggos.

* Sies Claptri XII. p. 511.

$\Delta$ Sec Clapter 1, p. $20 \%$. 


$$
1
$$




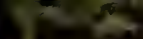

1 纤

(2) 1 os

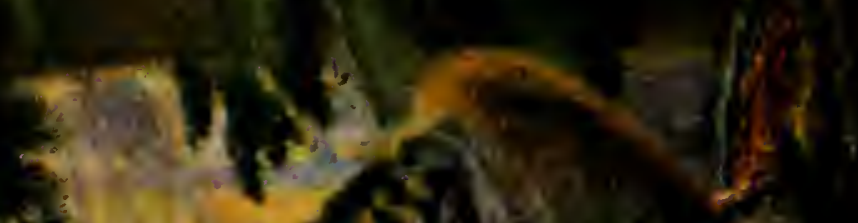

Ninn 2

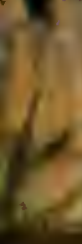
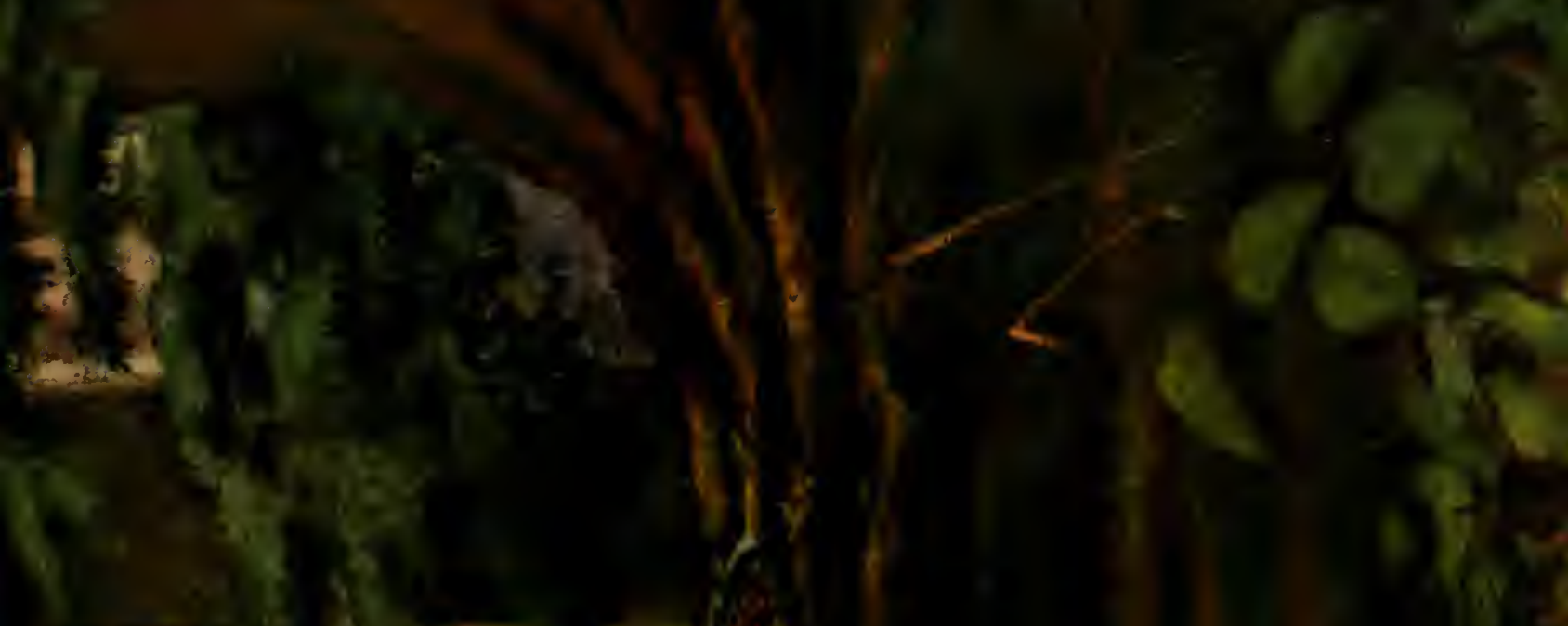
(2) 4942

$$
-13
$$
$\frac{3}{8}$ Q.

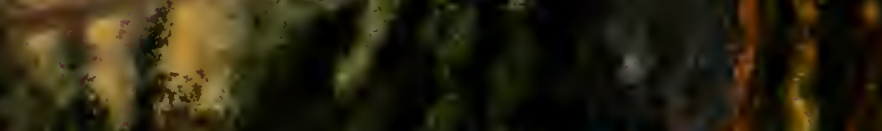

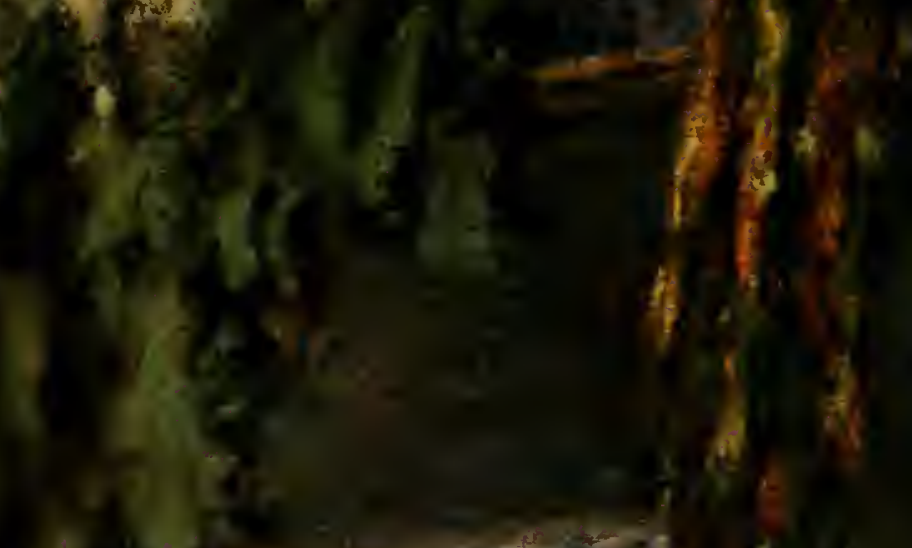



In general there seems to be no hesitation on the part of either sex in accepting a different mate, provided each is in the mating phase of the breeding cycle. If males do occasionally fail to mate, it does not, ordinarily, very seriously affect the number of eggs fertilized.

\section{Females}

Perfect mating is much more important with the females than with males. Every failure means infertile eggs. A small decline in the number of successful grouse nests in some favorite covert may well mean the difference between good and poor hunting the following fall.

Also some females apparently do not attempt to nest and lay eggs. An accurate evaluation of this factor in the field is difficult, even where the population of females is known, due to the diffieulty of locating all of the nests on an area as well as the impossibility of recognizing all instances of renesting. However, a fair estimate of the proportion of females nesting is possible through interpretation of known figures.

The number of unlocated successful nests has been determined Iy sultracting the number of loeated nests from the number of hroods found in the summer. By assuning that the number of unlocated nests that were broken $11 p$ is in the same proportion to the number of located broken-up nests as the corresponding figures for sucessful nests. the number of unlocated nests that were destroyed may be estimated. The total number of nesting females may then be compuled by adding the number of successful and unsucressful nests. after adjustment for the number of renests. Finally, comparison with the known female population gives an estimate of the proportion failing to nest.

The degree of mon-nesting oltained by this method has varied from zero to over 25 per cent of all the females on the Connecticut Hill study area in different yars. the figures for 1933, 1935 and 1936 being especially high. That this is usually a minor factor, however, is evident from the faet that during most of the other ten years studied all known females were accounted for as attempting to nest.

What may have been responsihle for a high incidence of brecding failure when it did occur could not be determined. In a broad way it may loe said that such fenales are probably physiologically upset and unahle to breed properly. At least there is no observation to the contrary. But what the underlying eauses of such variations may be remains an enigma. It has been suggested that. on the study areas, human disturbance of the breeding birds may have been involved, but this influence has not varied greatly from year to year.

Thus, while losses resulting from failure of females $t$, breed may now and then significantly reduce productivity. they are usually one of the host of minor influences on the grouse crop which, by themselves, are relatively unimportant but. which when added together. may measurably affect the hunting season population.

\section{EFFEC'T OF ACE ON BREEDING}

The ruffed grouse is sexually mature early in the first spring following birth. In eaptivity at the Research Center, they have usually bred during the first year. a conclusion likewise confirmed for wild birds by observation. In some vears. every female known to reside on certain areas studied has at least started a nest. Since the whole population would inevitably include some female birds born the preceding year. these eases support the conclusion.

One wild female was known to continue nesting attempts at least through five years. This bird was nest-trapped and leg-banded in 1936. That year she laid ten eggs. The next year 
and again three years later she was likewise caught at her nest. In 1937 her clutch was 13 eggs and in 1940 it was 12. The larger size of her second and, if she nested each interrening year. fifth clutches as compared to the first one observed adds weight to the evidence that the grouse usually lays a smaller clutch on her first attempt than in subsequent years.

At the Research Center there is some indication to show that grouse lay fewer eggs after their fourth year. They seem to luild up to a peak of production when three years old and to fall off slightly thereafter. One 6-year-old bird, which had previously laid larger clutches, dropped to ten eggs in 1940 . However, the wild bird noted in the preceding paragraph still laid a normal sized clutch when at least five years old.

The Investigation does not have evidence to show whether or not the birds continue to lay beyond their sixth year. However, such an advanced hreeding age is unimportant as a factor affecting the reproductive capacity of grouse population. In New York, at least, only a very small proportion live to the ripe old age of six years.

\section{LONGEVITY AND SENILITY}

In 1901. Edgar A. Mearns" wrote: "Mr. Samuel Eldred of Wakefield. R. I.. purchased in December, 1900, a ruffed grouse from Mr. Joshua T. Bradley who stated that the bird was one of several young gronse caught by him in 1883 and marked by clipping off their hind and inner claws. This bird bore evidence of extreme age." And well it might. for if this record were accurate, the bird must have lived to be 17 years old.

More recent literature and the present records of the Investigation indicate that the arerage adult grouse in the wild meets death hefore it is three years old. This is almost invariably a violent death and, therefore, does not indicate the potential longevity of the species. As has heen mentioned, one banded wild grouse attaned an age of at least five years. At the Research Center, 4-year-old birds are fairly numerous, while 5-year-olds are not unusual. Six-year-olds. however, are rare and no bird has yet exceeded this age.

At five or even six years of age, most grouse in captivity still appear vigorous and healthy. Occasionally they exhihit the effect of long confinement by acquiring feather injuries or scalped heads. but the males mate successfully and females lay good clutches nonetheless. Wild birds seldom attain such an age. and hence, one concludes that these is but slight chance that the infirmities characteristic of scnility could appreciably affect grousc populations.

\section{NUMBER OF EGGS IAID}

In considering reproduction. the mumer of eggs that a female hird lays is important. If it were to change apprcciably at any time, the possibilities for the hunting season night well be similarly changed.

The evidence gathered ly the Investigation in New York during the past 11 years. low. ever, does not liring out any apprecialle changes in ege laying proclivitics. On the hasis of 1.473 grouse nests examined between 1931 and 1911, the number of egers found therein has remained relatively constant. The minor fuctuations that have oceurred were not such as to have materially affected the popmlation changes that followed.

Table 50 summarizes these records. It has been divided into parts representing the three areas of the state, as in other portions of the book. with the exreption that the Comecticut Hill data have leen separated from that of the "liest of State". This seemed advisable because of the large number of nests observed on this study area. 
A hen grouse potentially might lay many more eggrs than she actually does. A single bird reared at the Research Center was found to have 177 ova of various sizes in her ovaries, all visible to the naked eye. More than 150 ova have similarly been counted in a wild female taken just prior to the breeding season.

A grouse might thus conceivably lay hundreds of eggs in its lifetime. whereas actually it will lay but a few dozen at most. The maximum number of eggs laid in a single season appears to be about 19. The normal average first clutch is 11.5 , with an average of 7.5 for the renest. in case the first attempt is unsuccessful.

What causes a female grouse to stop laying eggs as the season progresses is not certain. It probably involves some fundamental physiological changes. As has already been mentioned* temperature may have some effect. Likewise, a study of the influence of light, both as to duration and intensity; on the reproductive period of grousc was carried on at the Research Center during 1935 and 1936. In the winter and spring small amounts of light above normal were found to stimulate reproduction; large amounts at first stimulate, then inhihit, this reac$\operatorname{tion}^{03},{ }^{70}$. It is entirely possible that the increasing intensity and the longer hours of daylight which characterize the advance of spring at first encourage, then, within the physiological limits of the birds, delimit the period of reproduction.

Loss of weight has been considered as a poscible faetor in cessation of egg laying. It seems logical that this drain on the hird's system might so cxhanst ler as to cause a condition when egg laying is plysieally no longer possible. The available evidence fails to support this concept, however.

Most of the birds' weight-loss takes place in the late winter. during inculation and in the early brood period. This rate does not apprcciably increase during egcr laying. Furthermore, at the Research Center, both the males. and the females that do not lay. also lose weight. This is also typical of males in the wild ${ }^{\Delta}$.

The very fact that many hirds, after laying a full clutch of eggs. lay another group following destruction of their first elutch, is evidence enough that the bird is not limited at this time

TABLE 50. IVERAGE NUMBER OF LGGS IN FIRS'T NESTS-ENTHE STATE-193t-19th

\begin{tabular}{|c|c|c|c|c|c|c|c|c|c|c|c|c|c|c|c|}
\hline \multirow{3}{*}{ lear } & \multicolumn{12}{|c|}{ Region } & \multirow{2}{*}{\multicolumn{3}{|c|}{ lostal }} \\
\hline & \multicolumn{3}{|c|}{ Adirondacks } & \multicolumn{3}{|c|}{ Catskills } & \multicolumn{3}{|c|}{ Commeticat 1 lill } & \multicolumn{3}{|c|}{ Rest of State } & & & \\
\hline & $\begin{array}{l}\text { Number } \\
\text { clutehes }\end{array}$ & $\begin{array}{l}\text { Total } \\
\text { eggs }\end{array}$ & Average & $\begin{array}{l}\text { Number } \\
\text { clutches }\end{array}$ & $\begin{array}{l}\text { Tutal } \\
\text { eggs }\end{array}$ & Average & $\begin{array}{l}\text { Number } \\
\text { clutebes }\end{array}$ & $\begin{array}{l}\text { lotal } \\
\text { egass }\end{array}$ & Average & $\begin{array}{l}\text { Number } \\
\text { clutches }\end{array}$ & $\begin{array}{l}\text { Total } \\
\text { eqges }\end{array}$ & Average & $\begin{array}{l}\text { Number } \\
\text { clutches }\end{array}$ & $\begin{array}{l}\text { Total } \\
\text { cgags }\end{array}$ & Average \\
\hline 19.31 & 38 & 408 & 10.7 & 30 & 330 & 11.0 & 26 & 29.3 & 11.3 & 72 & 863 & 12.0 & 160 & 1,801 & 11.1 \\
\hline 1932 & 35 & 378 & 111.8 & 27 & 309 & 11.4 & 29 & 3.36 & 11.6 & 90 & 1.019 & 11.6 & 181 & 2,072 & 11.1 \\
\hline 1933 & 38 & 405 & 10.5 & 93 & 1,073 & 11.6 & 28 & 323 & 11.5 & 38 & 1,043 & 11.9 & 217 & 2,814 & 11.5 \\
\hline 1931 & 3 & 35 & 11.7 & 78 & 915 & 11.7 & 31 & $3: 19$ & 111.9 & 35 & 120 & 12.0 & 1.77 & 1,709 & 31.6 \\
\hline 1935 & 1 & 16 & 11.5 & 61 & 663 & 10.9 & 11 & 506 & 11.5 & 12 & 120 & 10.8 & 121 & 1.311 & 11.1 \\
\hline 1936 & 3 & 35 & 11.7 & 13 & 495 & 11.5 & 36 & 119 & 11.6 & 22 & 212 & 11.0 & I01 & 1.191 & 11.5 \\
\hline 19.37 & 1 & 11 & 11.0 & 17 & 207 & 12.2 & 17 & 201 & 12.0 & 39 & 473 & 12.1 & 71 & 895 & 12.1 \\
\hline 19.34 & 18 & 209 & 11.6 & 25 & $28+1$ & 11.4 & $3: 3$ & 396 & 12.0 & 46 & $56 \%$ & 12.3 & 122 & 1.156 & 11.9 \\
\hline 1939 & 11 & 151 & 11.1 & 16 & 200 & 12.5 & 38 & 111 & 10.8 & 41 & 185 & 11.8 & 1.36 & 1,550 & 11.1 \\
\hline 1940 & 1,3 & 472 & 11.0 & 6 & 68 & 11.3 & 19 & 581 & 11.9 & 19) & 227 & 12.0 & 117 & 1,348 & 11.5 \\
\hline 1941 & 12 & 1.31 & 11.2 & 8 & 83 & 11.0 & 28 & 33.3 & 12.0 & 10 & 119 & 11.9 & 58 & $6: 6$ & 11.7 \\
\hline Total & 236 & 2,587 & 11.0 & 401 & $4,6.32$ & 11.5 & 359 & 1.11 .3 & 11.5 & 171 & 5,617 & 11.9 & 1.173 & 16,979 & 11.5 \\
\hline
\end{tabular}

* Sce Chapter I I, p. 303.

$\triangle$ See Chapter 1I, p. 92. 
in its egg laying by physical inahility to continue. On the other hand, the smaller number of eggs laid in renesting attempts does give evidence that the hird may then approach the limits of its physical ahility.

A definite conclusion as to the rause or causes that bring an end to egg laying is not possible with our present knowledge but the evidence points to changes in light intensity as the underlying factor, just as it is the stimulant that slarts the production of eggs earlier in the spring.

\section{YEARLY VARIATIONS}

It has been noted that the changes in the number of eggs laid per female year by year have not been such as to cause material differences in the following autumn populations. An examination of table 50 will reveal. however. that some variation did exist in different years.

Comparing state-wide averages, the extreme variations were between 11.1 eggs in 1935 and 12.1 eggs in 1937. The maximum rhange from one year to another was the inerease from 11.5 eggs in 1936 to 12.1 in 1937.

One might expect greater yearly variations from the reeords of a more restricted area since state-wide averages may tend to reduce irregularities. It is infornative. therefore to examine table 51 wherein the figures have been derived hy regions.

TABIE 51. GHEATEST VABATION IN AVERAGE ANNUA, CLUTCH SIZE (IV EGGS)

\begin{tabular}{|c|c|c|}
\hline Part of state & In H yours & Hetween sucressive yours \\
\hline Arlirundinks.... & 1.2 & $1.2(193.3-34)$ \\
\hline Cinfskills........ & 1.6 & $.8(193+-35)$ \\
\hline Commeticut llill.. & 1.2 & $1.2(1938-39)$ \\
\hline Ilest of Stinta..... & 1.5 & $1.2(1034-35)$ \\
\hline
\end{tabular}

These gross variations are signifieant" hut no consistent trends are discernible to explain them. The Investigation has no evidence to show marked changes from year to year in the egg laying of birds of the same age. Howrur. there seems to be a definite tendency for birds in their first year to lay fewer eggs than older ones. Thus the general average number of eggs would he affected if the proportion of youngsters in the population changed apprecially. This actually is the case ${ }^{\Delta}$ and thus offers a means hy which the observed yearly differences in clutch size may have come ahout. These changes do not, however. seriously affect grouse populations nor explain the great changes that lake place in grouse numbers.

\section{Variation in Different Reglows of New York}

The figures for the ascraye number of engrs per elutch for the difterent portions of the State are given in table 50. The average for the Catskills and for the Comecticut Ilill study area is the same as the state-wide averane. 11.5 eggs. The Adirondack nests averagerl one-half egg lower and those from "Rest of State" four-tenths higher than this. Most of the latter group were taken from the southern tier conuties in range similar to Comnecticut Hill. If these two are lumperl. the average for the discommected covert range is 11.7 eggs per nest. The difference

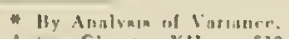

$\angle$ ume Chaveler XII. p. 513. 
between this figure and the general average is of little importance.

The one comparison that seems to hold real significance is that of the Adirondacks with the Rest of the State. The $.7 \mathrm{egg}$ difference. 11.0 to 11.7, between the Adirondack nests and all others in the State, is considerable since it represents 6 per cent of the number of eggs laid. This difference is significant by statistical analysis since the mathematical probability of its being truc is more than the 19 to 1 required.

A possible explanation of the lower egg-laying average of Adirondack grouse may lie in a repressive influence of the environment on the hirds' reproductive ability. For grouse the carrying capacity of the extensive forests in northern New York is far below that of the disconnected coverts through the rest of the state". It is at least a possibility that the level of egg laying might thus be affected.

It is improbable that the physical ability of the female to lay eggs is reduced in the Adirondack environment, even though winter weather conditions are more severe and habitat generally less suitable than farther south. It is more likely that the rapid change of seasons during the breeding period may result in a shortening of the time when grouse have the urge to lay. The late spring causes a delay in nesting of abont a week behind the rest of the State but by the middle of May the seasons have becone equalized. Thus, there may be a seasonal time factor operating to give these northern birds a smaller average elutch size.

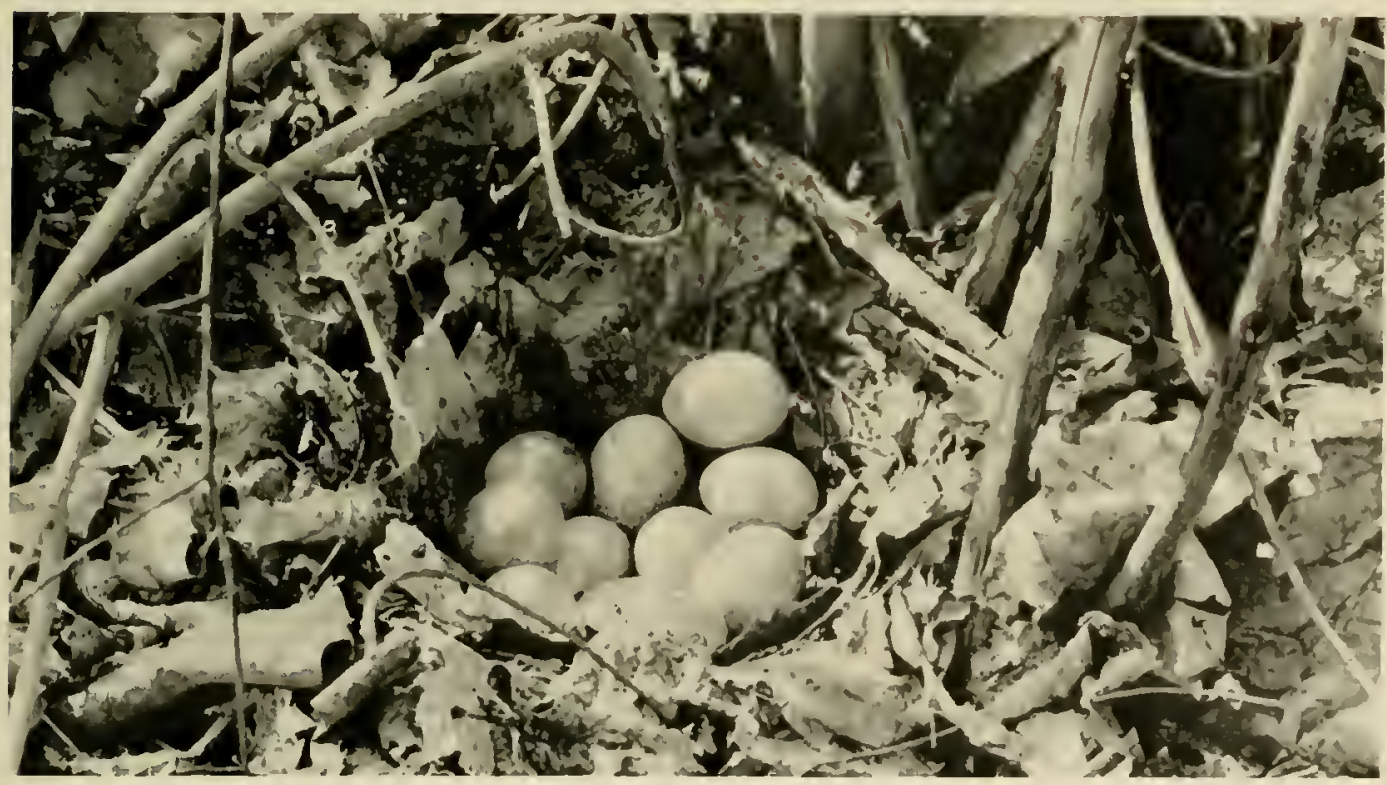

A TVPICA1, CLUTE:H OF GROUSE EGGS

The average number of eggs laid by Catskill grouse lies between that of the Adirondacks and the area of disconnected coverts. Likewise, the character of the Catskill range is intermediate in that the coverts are in rather large blocks, more so than is the case with the disconnected coverts area but not nearly as continuous as the Adirondack forest. There may be significance in these parallek. Summarized. it might be that the carrying capacity of different types of range is an indicator of the average number of eggs the birds will lay. Regional

\footnotetext{
* See Chapter XII, p. 525.
} 
differences in egg laying, while small, exist and probably result from effects of the environment.

\section{RENESTING}

The persistency with which the breeding females of a species of bird will renest-that is, lay another clutch of eggs after one clutch has been destroyed-may well have an important part in determining its population. The mourning dove, for example, makes up for the very small number of eggs laid (only two) by repeatedly renesting over again whenever broken up. The grouse is not so constituted, however. Its ability, or at least its willingness, to try again following an initial failure is very limited.

The time at which the destruction of the first nest occurs seens to be the factor determining whether or not she will renest. If a hen grou*e loses her clutch during the laying period or a very few days thereafter, it is probable that she will continue laying another set in a second nest. In this case the egg-laying period is merely extended.

Once the hen has incubated her eggs for several days, the additional yolks that have formed in the ovary begin to be absorbed. Once this process has started, it becomes a difficult matter for the bird to resume laying. Nests thus destroyed generally meant a broodless female for that year.

This limited probability of rencsting would be less important were it not that most grouse nest destruction by predators occurs during the latter part of the incubation period*. Thus, most destroyed grouse nests are not replaced. On Connecticut Hill, where upwards of 50 nests are lost each spring, it is unusual to find cvidence of more than half a dozen renests. Those that are found correspond consistently with the number of nests destroyed during the laying period.

\section{Number of Eggs in Renests}

'The size of renest clutches has varied widely but has averaged consistently about seven and one-half eggs for all parts of the State, (see table 52). The rather small number of cases observed in any single year makes impossible the finding of any yearly variations that might lave occurred.

TABLE 52. AVERAGE NUMBER OF EGGS IN RENESTS-ENTIRE STATE-1931-L19

\begin{tabular}{|c|c|c|c|c|c|c|c|c|c|c|c|c|c|c|c|}
\hline \multirow{3}{*}{ Yimr } & \multicolumn{12}{|c|}{ Region } & \multirow{2}{*}{\multicolumn{3}{|c|}{ Total }} \\
\hline & \multicolumn{3}{|c|}{ Ardironducks } & \multicolumn{3}{|c|}{ Catskills } & \multicolumn{3}{|c|}{ Comneclicat llill } & \multicolumn{3}{|c|}{ lie'st of State } & & & \\
\hline & $\begin{array}{l}\text { Nurruber } \\
\text { clutchies }\end{array}$ & $\begin{array}{l}\text { Iotul } \\
\text { cokss }\end{array}$ & Average & $\begin{array}{l}\text { Numblxer } \\
\text { clutelues }\end{array}$ & $\begin{array}{l}\text { Tutal } \\
\text { rums }\end{array}$ & Averake & $\begin{array}{l}\text { Number } \\
\text { clutelues }\end{array}$ & $\begin{array}{l}\text { Tutal } \\
\text { rekps }\end{array}$ & Averiage & $\begin{array}{l}\text { Jumber } \\
\text { elntebres }\end{array}$ & $\begin{array}{l}\text { Total } \\
\text { "kess }\end{array}$ & Averisge & $\begin{array}{l}\text { Numin'r } \\
\text { clutehers }\end{array}$ & $\begin{array}{l}\text { lotul } \\
\text { ckoss }\end{array}$ & Averatge \\
\hline 1931 & 5 & 26 & 5.2 & 1 & 28 & 7.0 & 1 & 31 & 8.5 & 6 & 11 & 6.8 & I0) & 129 & 6. -1 \\
\hline 1932 & 5 & 311 & 7.6 & 2 & 10 & 5.0 & $i$ & 27 & $6 .:$ & $1)$ & $6 \div$ & 7.1 & 20 & 1.12 & 71 \\
\hline 1933 & (1) & 6.5 & 7.5 & 6 & 11 & 6.8 & 1 & 3 & 8.11 & 17 & 122 & T.2 & 30 & 216 & 7.2 \\
\hline 14.31 & 11 & 0 & 11 & 2 & 17 & 8.5 & 2 & 12 & 6.0 & 1 & $\pi$ & 7.0 & 5 & 36 & $\because \therefore$ \\
\hline 19.15 & 11 & 0 & 0 & 1 & ห & 8.0 & 1 & 7 & 7.0 & () & 0 & 0 & 2 & 15 & $7 . \overline{3}$ \\
\hline 11336 & 0 & 11 & 11 & I & 1) & 4.11 & $i$ & 7 & 7.0 & 1 & " & 9.0 & 3 & 25 & 8.3 \\
\hline 1437 & 0 & 0 & 1) & 1 & 27 & 9.0 & 3 & 18 & 11.0 & 11 & 11.1 & 18.1 & 20 & 159 & 79 \\
\hline 1938 & 2 & 16 & 8.11 & 0 & 0 & 0 & 1) & 0 & 0 & 3 & 23 & 2.7 & 5 & 39 & 7.8 \\
\hline 1430 & $x$ & 66 & 8.3 & 0 & 0 & 0 & 2 & 15 & 7.5 & 5 & 11 & B.2 & 1.5 & 122 & 8.1 \\
\hline 190 & 11 & 104 & 7.8 & I & B & $6,1)$ & 3 & $2: 3$ & $7 . .3$ & 2 & 17 & 3.5 & 20 & 151 & 6.7 \\
\hline 1911 & 1 & 31 & 8.5 & 3 & 20 & 8.3 & 3 & $2: 3$ & 7.3 & 0 & 0 & 11 & 10 & 82 & 8.2 \\
\hline Totul & 11 & 3.36 & i.6 & 23 & 171 & 7.1 & 21 & 172 & 7.2 & 58 & 111 & 7.6 & $1(1)$ & 1,119 & $\therefore .5$ \\
\hline
\end{tabular}




\section{FERTILITY OF THE EGGS}

When a pair of healthy grouse that are each in breeding condition, mate at necessary intervals, the eggs will be almost all fertile. Infertility may result where the hen bird is physi. cally impaired, where mating is imperfect, or there has been no mating.

The fertility record of the eggs in wild grouse nests observed are summarized in table 53 for those cases where all the eggs could be accounted for*.

TABLE 53. INFERTILITY RATES IN FIRST NESTS AND RENESTS - WNTIRESTATE $-1931-191 t$

\begin{tabular}{|c|c|c|c|c|c|c|c|c|}
\hline \multirow{2}{*}{ Year } & \multicolumn{4}{|c|}{ First nests } & \multicolumn{4}{|c|}{ Renests } \\
\hline & $\begin{array}{l}\text { Number } \\
\text { clutebes }\end{array}$ & $\begin{array}{l}\text { Total } \\
\text { eggas }\end{array}$ & $\begin{array}{l}\text { Numb:r } \\
\text { infertile }\end{array}$ & $\begin{array}{l}\text { Per cent } \\
\text { infertile }\end{array}$ & $\begin{array}{l}\text { Vumber } \\
\text { clutclues }\end{array}$ & $\begin{array}{l}\text { Total } \\
\text { egess }\end{array}$ & $\begin{array}{l}\text { Yumber } \\
\text { infertile }\end{array}$ & $\begin{array}{l}\text { Jer cent } \\
\text { infertily. }\end{array}$ \\
\hline 1931 & 17 & 567 & 17 & 30 & 10 & 75 & 4 & 5.3 \\
\hline 1932 & 61 & 723 & 17 & 2.3 & $\div$ & 50 & 5 & 10.0 \\
\hline 1933 & 81 & 939 & 17 & 1.2 & 1.1 & 99 & 0 & 0.6 \\
\hline 1934 & 25 & 272 & 19) & 7.0 & I & 6 & 1 & 16.7 \\
\hline 1935 & 23 & 263 & 7 & 2.7 & 2 & 15 & 0 & 0.0 \\
\hline 1936 & 28 & 317 & 3 & 1.0 & 1 & i & 2 & 28.6 \\
\hline 1937 & 28 & 336 & 4 & 1.2 & 8 & 62 & 1 & 6.5 \\
\hline 1938 & 68 & 792 & 1. & 1.8 & 2 & 14 & 0 & 0.0 \\
\hline 1939 & 63 & 717 & 20 & 3.1 & 10 & 80 & 2 & 2.5 \\
\hline 1910 & 51 & 597 & 21 & 1.0 & 6 & 47 & 3 & 6.1 \\
\hline 1941 & 31 & 365 & 7 & 1.9 & 5 & 30 & 0 & 0.0 \\
\hline Total & 506 & 5,688 & 151 & 2.6 & 66 & 49.1 & 21 & 1.3 \\
\hline
\end{tabular}

The consistently high fertility rates in both first and renests are remarkable, especially when one considers the complicities of the breeding cyclc. The ycarly variations have been considerable-from one per cent in 1936 to 7 per cent in 1934. No evidence of trends from year to year that might indicate a relationship to population changes are discernible. Likewise, in no year was the frequency high enough to constitute a major threat.

The average rate of infertility for 506 first nests was 2.6 per cent while for 66 renests it was 4.3 per cent. The rate of infertility in renests, while proportionately much higher than for first neste, is still not of any great significance. The 1.6 per cent increase obviously is not a large factor in grouse production but it does indicate a tendency for late breeding to induce more infertility than is normal among first nests.

There is, then, no evidence in this 11 -year record that infertility is a very big factor in determining grouse numbers.

\section{VIABHLITY OF EGGS}

The embryo of a fertile egg is a living organism that may at any time during its development period be subjected to adverse influences and, as a result, may die. Any one or more of several causes may bring death. Among the more common causes may be listed inadequate incubation, an inherited weakness in the germ, or some structural failure in the egg itself. The cause of death in any particular instance cannot be identified except in rare cases.

The records for 462 first and 64 renests for which data are complete are summarized in table 54 .

* Whea the shell remains plus the unhatched eggs failed to equal the hmonn clutch number. the record was not used in the tahles on infertility and embryo mortality of the eggs. Recorde from wild eggs that were collected and placed in incuhatora a tho Research Center were felt to be representative of fertility and are included in the table. 
TABLE 5t. EMBIYO MORTALITY IN FIRST NESTS AND IN RENESTSENTIRE: STATE-1931-19t1

\begin{tabular}{|c|c|c|c|c|c|c|c|c|c|c|}
\hline \multirow[b]{2}{*}{ Year } & \multicolumn{5}{|c|}{ N. I. State except Comnecticut Ilill } & \multicolumn{5}{|c|}{ Contufeticut Hill } \\
\hline & $\begin{array}{l}\text { Number } \\
\text { clutehes }\end{array}$ & $\begin{array}{l}\text { Total } \\
\text { Cogss }\end{array}$ & $\begin{array}{l}\text { Total } \\
\text { fortile } \\
\text { eggy }\end{array}$ & $\begin{array}{c}\text { Number } \\
\text { dead } \\
\text { germs }\end{array}$ & $\begin{array}{l}\text { Per cent } \\
\text { dead } \\
\text { germs* }\end{array}$ & $\begin{array}{l}\text { Number } \\
\text { clutehe's }\end{array}$ & $\begin{array}{l}\text { Total } \\
\text { eggs }\end{array}$ & $\begin{array}{l}\text { Tintal } \\
\text { fertile } \\
\text { eggs }\end{array}$ & $\begin{array}{l}\text { Number } \\
\text { diead } \\
\text { Rernis }\end{array}$ & $\begin{array}{c}\text { Jur cont } \\
\text { deal } \\
\text { germs" }\end{array}$ \\
\hline
\end{tabular}

\begin{tabular}{|c|c|c|c|c|c|c|c|c|c|c|}
\hline \multicolumn{11}{|c|}{ First nests } \\
\hline $\begin{array}{l}1931 \ldots \ldots \ldots \ldots \\
1932 \ldots \ldots \ldots \\
1933 \ldots \ldots \ldots \\
1931 \ldots \ldots \ldots \\
1935 \ldots \ldots \ldots \\
1936 \ldots \ldots \ldots \\
1937 \ldots \ldots \ldots \\
1934 \ldots \ldots \ldots \\
1939 \ldots \ldots \ldots \ldots \\
1940 \ldots \ldots \ldots \ldots \\
1911 \ldots \ldots \ldots \ldots\end{array}$ & $\begin{array}{r}38 \\
52 \\
75 \\
11 \\
2 \\
15 \\
22 \\
37 \\
10 \\
33 \\
13\end{array}$ & $\begin{array}{r}154 \\
619 \\
874 \\
123 \\
21 \\
162 \\
267 \\
418 \\
454 \\
374 \\
151\end{array}$ & $\begin{array}{l}4.10 \\
605 \\
862 \\
115 \\
21 \\
161 \\
265 \\
4.11 \\
411 \\
355 \\
149\end{array}$ & $\begin{array}{r}6 \\
9 \\
5 \\
3 \\
0 \\
3 \\
8 \\
10 \\
0 \\
3 \\
2\end{array}$ & $\begin{array}{l}1.4 \\
1.5 \\
.6 \\
2.6 \\
0.0 \\
1.9 \\
3.0 \\
2.3 \\
0.0 \\
.8 \\
1.3\end{array}$ & $\begin{array}{r}9 \\
9 \\
6 \\
11 \\
21 \\
13 \\
6 \\
15 \\
10 \\
9 \\
12\end{array}$ & $\begin{array}{r}113 \\
104 \\
65 \\
1.14 \\
242 \\
155 \\
69 \\
186 \\
108 \\
111 \\
113\end{array}$ & $\begin{array}{r}110 \\
101 \\
60 \\
138 \\
135 \\
153 \\
67 \\
181 \\
108 \\
107 \\
138\end{array}$ & $\begin{array}{r}11 \\
4 \\
3 \\
10 \\
2 \\
1 \\
2 \\
6 \\
0 \\
4 \\
6\end{array}$ & $\begin{array}{r}10.0 \\
4.0 \\
5.0 \\
7.2 \\
1.5 \\
2.6 \\
3.0 \\
3.3 \\
0.0 \\
3.7 \\
4.3\end{array}$ \\
\hline Tutal ...... & 338 & 3,947 & 3,858 & 49 & 1.3 & 124 & 1.415 & 1,390 & 52 & 3.7 \\
\hline
\end{tabular}

\begin{tabular}{|c|c|c|c|c|c|c|c|c|c|c|}
\hline \multicolumn{11}{|c|}{ Hicuestis } \\
\hline $\begin{array}{l}1931 \ldots \ldots \ldots \ldots \\
1932 \ldots \ldots \ldots \ldots \\
1933 \ldots \ldots \ldots \\
193.1 \ldots \ldots \ldots \\
1935 \ldots \ldots \ldots \\
1936 \ldots \ldots \ldots \\
1937 \ldots \ldots \ldots \ldots \\
1938 \ldots \ldots \ldots \ldots \\
1939 \ldots \ldots \ldots \ldots \\
1910 \ldots \ldots \ldots \ldots \\
1941 \ldots \ldots \ldots \ldots\end{array}$ & $\begin{array}{r}8 \\
7 \\
11 \\
\because 1 \\
\cdots \\
8 \\
2 \\
8 \\
5 \\
2\end{array}$ & $\begin{array}{l}58 \\
50 \\
99 \\
\cdots \\
8 \\
62 \\
14 \\
65 \\
11 \\
17\end{array}$ & $\begin{array}{l}51 \\
45 \\
99 \\
98 \\
98 \\
11 \\
63 \\
38 \\
17\end{array}$ & $\begin{array}{r}2 \\
1 \\
1 \\
0 \\
0 \\
5 \\
1 \\
1 \\
0 \\
0\end{array}$ & $\begin{array}{l}3.5 \\
8.9 \\
1.0 \\
0.0 \\
8.6 \\
1.1 \\
1.6 \\
0.0 \\
0.0\end{array}$ & $\begin{array}{l}2 \\
\cdots \\
i \\
1 \\
1 \\
\cdots \\
2 \\
0 \\
2\end{array}$ & $\begin{array}{r}17 \\
\cdots \\
\cdots \\
7 \\
7 \\
\cdots \\
15 \\
0 \\
11\end{array}$ & $\begin{array}{l}17 \\
\cdots \\
35 \\
7 \\
5 \\
\cdots \\
13 \\
11\end{array}$ & $\begin{array}{l}3 \\
\cdots \\
0 \\
0 \\
\cdots \\
i \\
0\end{array}$ & $\begin{array}{l}17.0 \\
\cdots \\
0.0 \\
0.0 \\
0.0 \\
\cdots \\
6 . \\
0.0\end{array}$ \\
\hline Total....... & 55 & 414 & 390 & 14 & 3.5 & 9 & 66 & 6.3 & $\downarrow$ & 6.4 \\
\hline
\end{tabular}

Calculated in relation w total fertile engs.

Upon examination of the egg viability records for all sections of the State, it was at once apparent that only one group failed to follow the general trend. Connecticut Hill nests had a consistently higher loss and for this reason are listed separately in table 54.

The explanation for this diserepancy in the Connectient Hill nests apparently lies with the Investigation workers and not with the grouse. From the time when first located, these nests were observed once each week until hatched. In spite of special precantions taken, some of the birds were disturbed and flushed several times. This disturbance seems to have resulted in some additional inadequacy of incubation beyond that usually recorded.

On the other hand, most of the nests found over the State were not disturlied after discovery. The final record was made after the hatching date had passed.

Because of this disturbing factor, the state wile dati, exchding Conuecticut Hill, are more typical than the records as a whole. 'This group exhihits a notably narrow range of variation in embryo mortality fron year to year. Anong the first nests these losses ranged from zero in 1939 to 3 per cent in 1937. The 11 -year average loss was 1.3 per cent.

For renests, the upper extreme and average were both greater. The highest loss was 8.9 per cent, occurring in 1932. The number of observations of renests each year was rather low and hence the larger losses observed in the embryos may be somewhat exaggerated. However, the average loss of 3.5 per cent of fertile eggs is derived from quite adequate data and, therefore, some difference appears valid. 
The higher average losses in Connecticut Hill renests compared with all others must be discounted owing to the small number of observations involved.

The differences in average embryo loss in first nests and in renests is considerable, being nearly three times as great in the second nests. However, it is still only an additional 2.2 per cent of all the fertile eggs and does not involve losses of importance.

lt must be concluded, likewise, that all losses from embryonic death are of minor iniportance as compared with many other causes of grouse mortality.

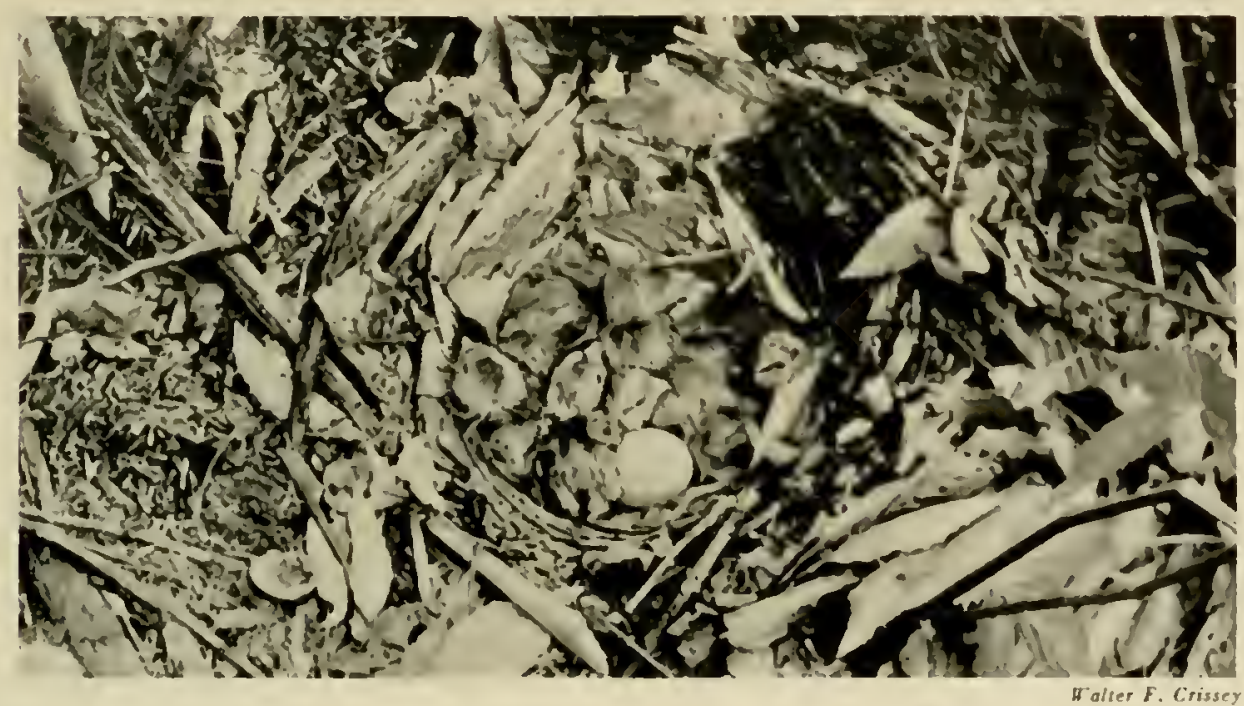

A NEST FULL OF GROUSE CHICKS JUST IIATCIIED (SEVERAL SIIELLS REMOVED BY PIOTOGRAPIIER)

\section{INBREEDING}

A pet bug-i-boo commonly suggested in recent years, as a possible contributing cause of the grouse eycle, is inlreeding. It was first mentioned hy Stoddart ${ }^{204}$ but has since received more and more attention in succeeding years. To many it seemed simple and logical. The sedentary luabits of the bird in times of high populations was thought to result in breeding within families. This, in turn, was said to cause deterioration of the species and sharply reduced numbers.

The concept does not stand up well in the light of numerous pertinent facts.

In the first place, inbreeding is not necessarily detrimental to the offspring. Only when the parents possess serious genetically transmissible defects could inbreeding be a problem. As Leopold ${ }^{3 x 5}$ points out, wild species are of relatively pure strain and the likelihood of serious consequence from inbreeding is much less than in domestic animals where little natural culling takes place.

Inbreeding may operate to a species' benefit as well as detriment. It has proved useful in developing superior strains of some domestic animals.

If it were to injure wild aninal populations, one may assume that it would show up quickly in isolated populations. Here, the opportunity for inbreeding would be greatest. Such miglit be the case where birds were stocked in a lıabitat not previously occupied by 
grouse and where the succeeding generations would all be derived from the stocked birds. Yet the one known case of this kind with grouse attests to the prolificacy and hardiness of large groups resulting from such plantings.

In this instance, 19 grouse were released on Anticosti Island in the Gulf of St. Lawrence. These increased until the species was fairly comnon a few years later. The population has since persisted in the face of a high predator population.

Inbreeding is only likely to occur with birds that are strictly and wholly sedentary. Other. wise, blood strains are continually interchanged. As has already been noted, the grouse is by no means wholly sedentary. The young birds move about considerably prior to their first breeding season. A large proportion of all grouse select a breeding territory different from the place where they were raised.

Since grouse are probably promiscuous in their breeding habits, the opportunity for inbreeding is further reduced.

Thus one must conclude that inbreeding seldom occurs in grouse and that there is no indication of its being detrimental if it does. Thus a ghost is laid.

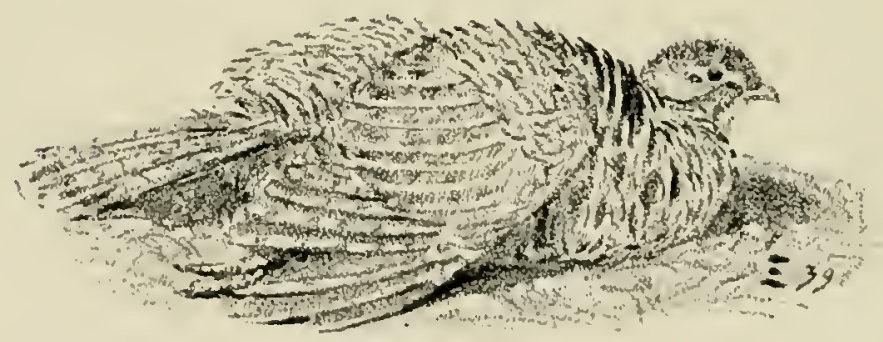




\section{CHAPTER IX \\ INFLUENCE OF MAN}

By Frank C. Edminster

\section{AS A GROUSE HUNTER}

Number and Per Cent Bagged-The Hunter Take-Average Bag, Seasonal and Daily-Crippling Loss-Total Hunter Kill-Success Ratio--Effect on Grouse Abundance of Man's Hunting.

AS A HUNTER AND TRAPPER OF PREDATOLS

Number and Per Cent Taken by Hunting-As a Trapper of Fur Species

\section{AS A FARMER}

Clefaring of Land-Maintenance of Openings - l'asturing of livestock - Other DOMESTIC StOCK

\section{AS A LUMBERMAN}

\section{AS A CONSERVATIONIST}

Laws-Commercialization of the Take - Seasons for Hunting - Bag Linits Metilods of Take-Predator Control-Refuges, Sanctuaries and Land Posting.

\section{EFFECT OF MAN'S AIDS ON GROUSE}

The Axe and Plow-Fire-Automobiles and Highways-Guns, Traps and SnaresGrouse Dogs

\section{¿s}

\section{SUMMARY}

The total hunter kill in New York State was found to approximate 17 per cent of the prehunting season grouse population. This total kill may be divided roughly into five-sixths birds retrieved, or hunter "take", and one-sixth cripples, shot but not retrieved. (p. 373).

The average seasonal bag of grouse per grouse hunter has varied from .95 to 4.9 birds per hunter in New York State. (p. 375).

The daily bag of grouse hunters on check areas was about one-third grouse per actual hunting day of $53 / 4$ hours. Only one in four was found to have taken one or more grouse in the average day's hunt. (p. 375).

The normal success ratio of grouse hunters varied from 7 to 11 per cent of grouse flushed 
that were actually bagged. The average hunter brought to bag about one out of every four birds shot at. (1.378).

The general effect of man's hunting on grouse, as currently practiced, is not detrimental and may even have a positive beneficial effect during years of high populations. (p. 379$)$.

The number of grouse predators killed by hunters in New York is too small to exert an important inlluence on grouse. (p. 380).

The trapping of predatory species for fur, with or without the stimulus uf a bounty, is negligible in its effect on grouse abundance. (p. 382).

Farmers, in the Northeast, are of first importance in determining the condition of grouse habitat. (p. 383).

Land clearing operations, where not too extensive, have improved the productivity of the range; where too extensive, they have exterminated the grouse from large areas of potential range. The maintenance of openings in the form of farm fields carried on by cropping and pasturing is fundamental in preserving a high grouse carrying capacity. (p. 383).

Domestic stock, when pastured in woodland and overgrown areas, serve a useful purpose in maintaining desirable openings but in other instances are destructive to grouse habitat. (p. 384).

Lumbermen have exerted both a favorable and unfavorable influence on the condition of the habitat on which the number of grouse largely depends. (p. 385).

Proper conservation legislation is a prerequisite to good game management. Proper handling of the grouse harvest requires executive authority in the Conservation Department for the proper regulation of seasons, bag limits and other controls of the harvest. (p. 388).

Man's tools have exerted a profound influence upon grouse. Primary anong these are the axe and the plow. Guns, traps and snares were formerly used to take grouse in great numbers. (p. 392).

Automoliles and highways have made distant grouse ranges accessible to the city dweller. On the other hand, the abandonment of many rural highways have made local areas less accessible with the more modern vehicles. (p. 391).

Grouse dogs still play an important part in the day's hunt, although their numbers are less than a few decarles ago. (p. 395).

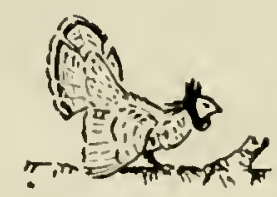

While man's direet effect npon grouse numbers does not often rank him as a limiting factor, still it may he said that. within certain limits, the future of the grouse rests with him. Man not only has a direct influence on grouse numbers through his activities as a humter but also exerts numerous vitally important indirect infuences. He is a many faceted factor.

As a hunter, he not only kills grouse but affects them through killing their enemies. In a still more indirect sense. his activities serve to increase or decrease the primary foods of major grouse enemies, notably some of the rodents, and therehy affect the labits of the preda- 
tory animals themselves.

As a farmer, he cultivates the land and harvests its crops. Through these operations he largely determines the nature of the cover and, hence, the carrying capacity of the land for grouse. In those areas where he does not farm, he often assumes the same role, in so far as grouse are concerned, as a Jumberman.

Probably most significant of all is the gradual evolution of man as a conservationist. In this role he modifies his actions in a deliberate effort at producing more of our renewable resources.

By affecting the numbers of grouse directly and through controlling its habitat, it is clear that he can, within limits, inerease or decrease the numbers of grouse aecording to his will.

\section{AS A GROUSE HUNTER}

The grouse, along with other game species, played an important part in furnishing food for the early settlers of the Northeast. But it was not until the beginning of the nineteenth contury that many written references to grouse hunting were made. Then. it was largely a matter of replenishing the home larder or of supplying the city markets. Wilson ${ }^{400}$ indicates the lack of "sport" in grouse hunting at this time when. speaking of the advantages of a good dog. he says, "the more noise he kecps up seems the more to confuse and stupify them. so that they may be shot down, one hy one, till the whole are killed". In fact. they were such easy prey that traps. snares and deadfalls were in more prevalent use to bag them than guns.

Audubon's ${ }^{20}$ recording of the sale of grouse in the Cincinnati market in 1820 for $121 \%$ cents each indicates that large numbers (in proportion to the demand) must have heen killed. Elliot ${ }^{210}$ relates of one firm that received 1,000 hirds on each Saturday for many wecks in suc. ecssion. Knowing the strict limitations of transportation in that era. it is evident that huge numbers must have been brought to bag.

Market hunting flourished through the greater part of the 1800 s. rising and falling with the abundance of the birds but suceumbing gradually (as a legitimate business) to the restrictions of new laws". Monon ${ }^{37}$ indicates that this "lusiness" died a hard death when he says, "the whole northern country. from Amsterdam to Northville, New York, is infested with pot-shooters who hunt (out of season) for the Saratoga market". Nevertheless, from this period on there was a gradual transition in grouse hunting from "pot-shooting". both legal and illegal, to sport. By the turn of the century the change was about eomplete exrept for a small amount of illegitimate market hunting which continues even today.

One of the few records indicating concretely the quantity of birds killed is given by Forbush $^{100}$ who quotes a Mr. E. F. Staples of Taunton, Massachusetts. This gentleman said that in the early 1880 s about a thousand birds were killed in a season on the 20,000 acres that he ranged. While an estimate is not given for the total number of grouse on the area, he does intimate that they were "real good" years-the last good ones in his estimation up to time of interview (1908). With a density then equal to the peak density of the recent period of abundance, this would have meant about 5,000 grouse and a bag of around 20 per cent.

As the twentieth century progressed. the interest in grouse hunting as a sport increased rapidly and concern over the periodic disappearances of the grouse grew each time they became searee. Volumes were written on the subjeet and over-hunting was one of numerous 
"explanations" prominently mentioned although no one attempted to actually find out what proportion of the grouse actually were taken by hunters. Consequently, among the first assignments of the Investigation was an evaluation of hunting in the field.

\section{Number and Per Cent Bagged}

One measure of the legal harvest of grouse in New York is through the report required of sportsmen by the elerk upon issuing a new license. It is recognized that these reports are not entirely accurate, but the errors are prohably the same one year as another. Hence, allowing for this, they are valuable in indicating trends. These are given in table 55.

TABLE 55. REPORTED KILL OF GROUSE AND AVERAGE SEASONAL BAG PER LICENSED HUNTER IREPORTING IN NEW YORK-1923-1939

\begin{tabular}{|c|c|c|c|c|c|c|}
\hline lear & $\begin{array}{l}\text { Lenglh of } \\
\text { hunting } \\
\text { seasnn }\end{array}$ & $\begin{array}{l}\text { Number of } \\
\text { eromse reported } \\
\text { killed by } \\
\text { licensees }\end{array}$ & $\begin{array}{l}\text { Number of } \\
\text { liceasers* } \\
\text { reporting } \\
\text { game batged }\end{array}$ & $\begin{array}{l}\text { Average oumler } \\
\text { of grouse } \\
\text { bagked } \\
\text { per hunter } \\
\text { reportiag }\end{array}$ & $\begin{array}{c}\text { Average number } \\
\text { of growse } \\
\text { hagged } \\
\text { mer corouse } \\
\text { huntert }\end{array}$ & $\begin{array}{c}\text { Average number } \\
\text { of grouse } \\
\text { per grouse } \\
\text { lunter } \\
\text { per month }\end{array}$ \\
\hline $\begin{array}{l}1923 \ldots \\
1924 \ldots \ldots \ldots \\
1925 \ldots \ldots \ldots \\
1926 \ldots \ldots \ldots \\
1927 \ldots \ldots \ldots \\
1928 \ldots \ldots \ldots \\
1929 \ldots \ldots \ldots \\
1930 \ldots \ldots \\
1931 \ldots \ldots \ldots \\
1932 \ldots \ldots \ldots \\
1933 \ldots \ldots \ldots \\
1931 \ldots \ldots \ldots \\
1935 \ldots \ldots \ldots \\
1936 \ldots \ldots \ldots \\
1937 \ldots \ldots \ldots \ldots \\
1938 \ldots \ldots \ldots \ldots \\
1939 \ldots \ldots \ldots \ldots\end{array}$ & $\begin{array}{l}11 / 2 \text { months } \\
11 / 2 \text { months } \\
11 / 2 \text { months } \\
11 / 2 \text { months } \\
11 / 2 \text { months } \\
\text { no season } \\
\text { mo season } \\
1 / 2 \text { nonths } \\
3 \text { weeks } \\
3 \text { weeks } \\
1 \text { month } \\
1 \text { month } \\
1 \text { month } \\
1 \text { month } \\
1 \text { month } \\
1 \text { month } \\
1 \text { month }\end{array}$ & $\begin{array}{r}131.511 \\
91.797 \\
90.431 \\
118.720 \\
80.680 \\
\ldots \ldots \ldots \\
36,488 \\
40.118 \\
5.815 \\
68,910 \\
84.611 \\
128.301 \\
80.282 \\
91.056 \\
140.851 \\
157.151\end{array}$ & $\begin{array}{l}163,122 \Delta \\
202,661 \mathrm{~J} \\
201,525 \mathrm{~J} \\
180,060 \\
220,920 \\
\ldots \ldots . \\
191,799 \\
163,597 \\
135,980 \\
119,710 \\
156,650 \\
153,379 \\
136,521 \\
147,332 \\
165,811 \\
166,876\end{array}$ & 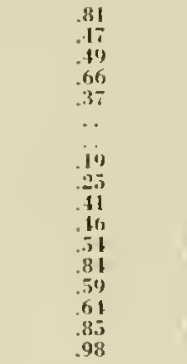 & $\begin{array}{l}1.05 \\
2.35 \\
2.15 \\
3.3 \\
1.85 \\
\ldots .5 \\
\because .5 \\
1.25 \\
2.05 \\
2.3 \\
2.1 \\
1.2 \\
2.95 \\
3.2 \\
1.25 \\
4.9\end{array}$ & $\begin{array}{l}2.7 \\
1.51 \\
1.63 \\
2.2 \\
1.23 \\
\cdots \\
\because 6 . \\
1.67 \\
2.73 \\
2.3 \\
2.7 \\
1.2 \\
2.95 \\
3.2 \\
1.25 \\
4.9\end{array}$ \\
\hline
\end{tabular}

* An average of 61 per cent of nll license holders mike a report, of which 51 per cent (or 33 peer cent of all licensers) report tahing garue.

Only hunting licenses were issued these years, of which it is assumed an average of 61 fues cent repmrterl, as in other yoars in which combination hunting, fishing and irapping lietenses wre issued.

tHased on assimption that 20 per ceot of all New York licensed hunters reporting their gane baje ure prouse lunnters.

\$ Average number of grouse bagkel per grouse hunter when the lemgth of the hunting seasan is correlated to the lasis of 1 month.

In interpreting these figures. certain facts should be noted. The bay limits in all years were three per day and 15 per season. The figures are not weighted to aceonnt for licensees not reporting nor for hunters not licensed. Only part of the liecnsese reporting game bagged were grouse hunters.

When allowanecs are made for these factors. cstimates of the average number of hirdtaken each year by the gronse hunter is approximately the same or slightly lower than experience leads us to expect. While this annual grouse hag per hunter is small, it compares very favorally with that of other species.

The total yearly kill is, no doubt, greater than reported since some licensees do not report. landowners do not need licenses to hunt on their own lands, and some illegal hunting is done. Vo satisfactory method of taking these factors into account is avalable, so any cstimate of the aetual kill is at best only a guess. It js. prolably. at least double that reported.

There are several interesting faets to be gleaned from these figures. In direct eonfirmation of the opinion of many "old-timers". there have heen more grouse in the eurrent peak years than in several deeades. It is very noticeable that the average take per hunter has materially increased, while that for the estimated greuse hunter has nearly doubled. Although these figures meet the general appraisals made on experience alone. those for the later years may be somewhat high sinee, with the increasing numbers of grouse more and more hunters are turning to them for their sport. 
During seasons of few grouse, a larger percentage of the hunters became pheasant minded and did not hunt the partridge. Therefore, our average figure of 20 per cent of all licensees reporting game taken being gronse hunters may be a little high. And. during abundance of these birds, with more gunners taking to the uplands, that arerage may be a trifle low. Even with these allowances, it is still apparent that each sportsman has had a better bag during recent years. All of which means that. during the past ten years in New York. grouse have been more than holding their own in spite of increasing hunting pressure.

\section{The Hunter Take}

Leaving trends. now let us turn to the specific records of the number of grouse bagged. The first field studies to determine the effect of hunting on the grouse population were made by the Investigation during the 1930 and 1931 hunting seasons. Check areas were chosen in Tompkins County in the hilly. south-central portion of the state. For the 1930 study. eight areas were chosen, of which six proved satisfartory. In 1931. twenty-five areas were checked, of which thirleen proved acceptable. Censuses were taken hefore and after the hunting scason and reports were ohtained from the lunters using the areas. Table 50 summarizes the grouse kill records for hoth studies.

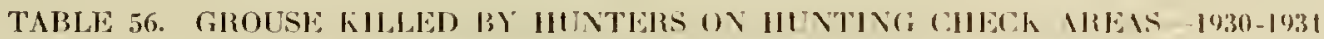

\begin{tabular}{|c|c|c|c|c|}
\hline Yratr & $\begin{array}{l}\text { Number of } \\
\text { reports } \\
\text { receivent }\end{array}$ & $\begin{array}{l}\text { Number of gromse } \\
\text { oul arreas before" } \\
\text { liumliug season }\end{array}$ & $\begin{array}{c}\text { Yumber of } \\
\text { erouse } \\
\text { killed }\end{array}$ & $\begin{array}{l}\text { Per cent } \\
\text { baswered }\end{array}$ \\
\hline 1930 & 20 & 62 & 6 & 9.7 \\
\hline 1931 & 79 & 186 & 20 & 15.6 \\
\hline
\end{tabular}

In 1930, the open scason extended from the first of October until the fifteenth of Novemher. The grouse population was at alont 30 per cent of its peak. The 1931 open season extended from October 26 until November 15 and the grouse population was about 60 per cent of peak abundance. The per cent hagged is lased on all corerts.

In interpreting these figures, it must be recognized that in 1930. when the season was re-opened after two years of closnre. a large share of the hunters did not approve of the open season and refrained from hunting grouse because they believed the hirds were still ton scarce. This reaction is reflected in the low rate of take for that year. In 1931, with a very definite continued increase in the grouse population in spite of the 1930 open hunting season. this fecling was less widespread and the results for this year were probably more nearly. normal.

Another hunting check was made in the fall of 1936 on 1.379 acres of public hunting grounds. In a season extending from October 21 through November 15. hunters bagged 13 grouse. These represented 13.9 per cent of the pre-season grouse population estimate of 94 birds. The highest take on any one of the coverts was 23 per cent. This study simply adds weight to the earlier conclusions. since the results were very nearly the same.

Following the first New York studics. two other similar hunter-check survers were made in the mid-west. While each involves different ecological conditions than New York, both are valuable for comparison.

Saunders* working in Michigan found the hunter take in 1932 to he 6.7 per cent of the September population. This figure is no doult lower than the actual take since the pre-

* Ruhl, 11. D., prersonal letter to the author, 1936. 
season eensus was taken very early.

The bag in $1935^{m a}$ on one area, Pigeon River State Forest, was 17.3 per ecmt while on a second area, Escanaha River Tract, it was 17.4 per cent. But the corresponding figurepercentage of September population-taken on the same area as in 1932 proved to be only 10 per cent. Thus the actual hunter take in 1932 was probably nearly double that indicated. The results correspond remarkably close to those secured in New York.

Trippensee's analysis of threc areas in the Superior National Forest, Minnesota. on which both hunter tallies and before-and-after hunting season censuses* were taken, vary widely as to hunting take. In one area of 1,280 acres the lake was only 9.4 per cent whereas in another of 2,560 acres, it was 38.2 per cent. The average for the 6,400 acres in the three arras was 19.7 per cent. While apparently more variable, these figures are but slightly higher than those of Michigan and New York.

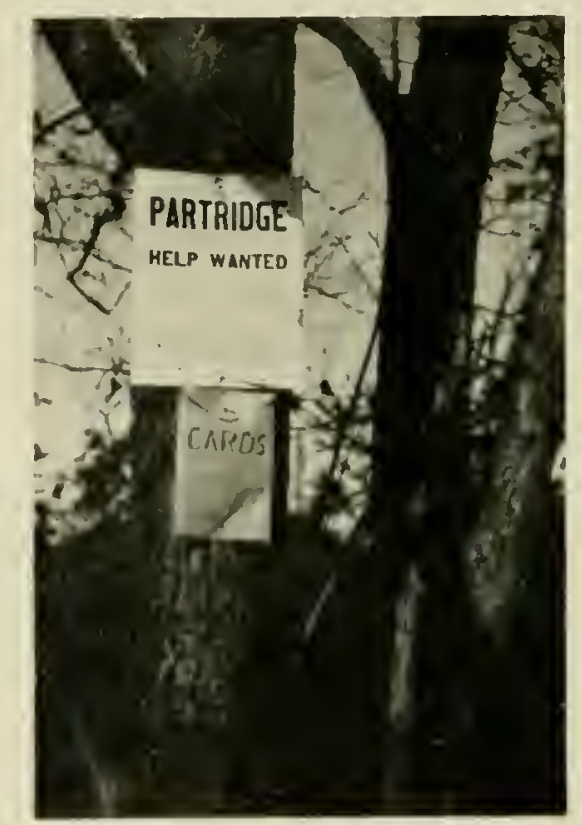

EXPLANATORY POSTERS AND REPORT CARDS WERE TESTED AS A METHOD OF SECURING HUNTER KII.L RECORDS

While not based on direct field studies, another and more extensive mothod of detemining the per cent lagged has been possible througl the correlation of the recorded grouse kill by "ounties ${ }^{\wedge}$ with county game habitat maps (which are completed for a uumber of counties in New York State). In addition to these two soures, it is also necessiry to know the average density of the grouse population for the year in question. This is ohtained from the ficld censuses on the varions gronse survey areas.

From the game habitat map is obained the quantity of grouse cover. The emponents of this totil are weighted according to quality to get the quantity of cover of a quality equivalent (1) that on the survey areas. To this is applied the grouse-per-acre figure from the field

- Cennusen on both the Michlgnn and Minnenota studies werm made by King's aridiren method.

A Taken from the hunter"a reporta obenined upon isaunce of new licenacs. 
survey results to get an estimate of the October grouse population in each county. The number of grouse killed as recorded by the hunter reports is then doubled to take care of such inaccuracies as are described on p. 372. The per cent bagged is then obtained by taking the ratio of grouse reported bagged to the estimated grouse population.

These results are only a general indication of conditions and trends. The arbitrary assignment of cover quality values is obviously open to error, as well as other details of the system. But probably more significant than any of these is the possible error accruing to a faulty distribution of kill reports in relation to residence of the reporters. Thus, it is probable that the per cent bag for counties having large cities is exaggerated due to reports of many hunters who actually went outside the county for their hunting. *

The take in seven counties from 1931 to 1934 ranged from 4 to 28 per cent. llalf of the figures were between 10 and 20 per cent. The extreme range in a single year was 9 per cent. Considering the limitations of this method, the results corrolorate the field studies remarkably well.

\section{Average Bar, Seasoval, ani Dahly}

To those who are on the threshold of becoming gronse hunters. this topic will he a revelation. And to those "old tiners" who may still he smarting from a bad day when they "couldn't get their eye on 'em", it should prove reassuring, for there are many more whose "luck" has been worse. There probably is no other American game bird which presents as difficult a target as does the ruffed grouse, except, of course, in those willerness arcas where the species has not yet hecome man-wary. That such a gamey hird should develop in the space of a century, is a tribute to its adaptahility.

The old journals are replete with records of large daily and seasonal takes. usually by market lunters. Forhush ${ }^{10}$ mentions several case's occurring in Massachusetts. He says, "I can remember when a market hunter going out from the city of Worcester ly train cach day, walking to the covers and returning at night, killed from 10 to 15 lirds daily ... Fjve men of Foxborough suared grousc prior to 1888 and averaged about 100 hirds a week . . Mr. George Howes shot and marketed 398 hirds in one shooting season". Haight "i: relates of two men shooting 998 grouse from the 1.5 h of September. to the following 31st of January, a tolal of 122 hunting days or an average of four birds per man-day. Vot only are the days of the market hunter gone hut so aloo are the days of such legal bagn. Current efforts must necessarily he within hag limits of three a day and 15 a season in New York.

An indication of the average seasonal hag of grouse per hunter in New York may he olstained from the reported kill of licensed sportsmen. These are given in table 55 .

Considering licensed grouse hunters as a whole, the maximum average seasonal hag during this period was approximately five grouse per hunter in the best year. and in the worst year, about one. Leopold records the average bag for all hunters in Wisconsin in 1931 to he .3 bird per hunter for the season. This is somewhat lower than the average for all New York hunters during 1923-1939.

$$
i^{1+\cdots+i}
$$

Information on daily hag has been oltained on the field hunter-check studies in 1930 and 1931. In these two years the data show that it took 19 and 12.6 hours of hunting. respectively, per grouse hagged. The hunting "day" was 5.75 hours in 1930 and 3.4 hour: in 1931. Reduced to an 8 hour day basis. the average daily bag per hunter was .12 grouse per day in 1930 and .63 in 1931. The actual "daily" bag in the short days which were

\footnotetext{
* Reports are assumed to apply to county in which license was taken out.
} 
recorded was .33 in 1930 and .37 in 1931. The bag of .63 grouse per 8 hour day in $1931-$ based only on the efforts of grouse hunters, probably increased slightly with the increase of the birds in succeeding years. However, the check made on Connccticut Hill in 1936 onl! showed a slight increase to .7 grouse per 8 hour day and only .2 grouse for the average hunt. ing "day" of 2.1 hours. However, this low "day" is partly accounted for ly the fact that only the part of the hunters' day that was spent hunting on the check area was counted.

A measure of the distribution, rather than the sizc, of the daily bag may be obtained from the proportion of hunters taking one or more grouse per day. In the 1930 study this was 25.0 per cent; in 1931, 26.9 per cent; and in 1936. only 15.3 per cent. Thus. even restricting our take figures to hunters alone, in fact, to hunters in grouse cover, only a small proportion actually get grouse in any one hunting day.

\section{Crippling Loss}

The number of grouse crippled by hunters but not lrought to bag, being an exceedingly difficult factor to evaluate, has always been the subject of wide differences of opinion. To some olservers it has appeared negligible while to others it loomed even larger than the bag itself. The Investigation has had two opportunities to work on the problem, once in connection with the hunter-check in 1930. 1931, and 1936, and again with the grouse population control experiments in 1933-34, 1934-35 and 1935-36.

An exaggerated version of the crippling loss is obtained by subtracting the hunter "take" from the difference between the pre-season and post-season censuses in a hunter-check survey. This result represents the entire loss of birds during the hunting season except for those brought to bag and includes losses due to predation. disease, and accident as well as from hunter-crippling. It is assumed in these surveys that grouse morement into and away from the check areas is balanced. The results on the hunter-check areas indicate that the whole hunting season loss is approximately double the hunter take. These data are summarized in table 57.

\section{TABLE 5. ANALYSIS OF HUNTING SEASON LOSSES OF GROUSE} IN NEII YORK-1930, 193I AND 1936

\begin{tabular}{|c|c|c|c|}
\hline & \multicolumn{2}{|c|}{$\begin{array}{l}\text { Inmpkins county } \\
\text { lunter clueck areas }\end{array}$} & \multirow{2}{*}{$\begin{array}{l}\text { Inublic } \\
\text { hututiut: } \\
\text { prounds } \\
1036\end{array}$} \\
\hline & 1930 & $19: 11$ & \\
\hline Number of grouse before the humting surason & 62 & 180 & 91 \\
\hline Numler of grouse of ter the luntiag serason... & 51 & 126 & 69 \\
\hline 'Testul lensy of grumse during hunting senson. . . & 11 & 60 & 25 \\
\hline 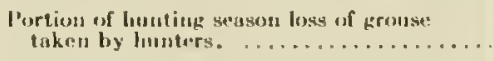 & 6 & 99) & 13 \\
\hline 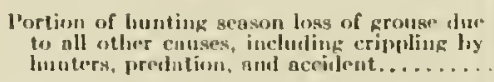 & 5 & 31 & 12 \\
\hline 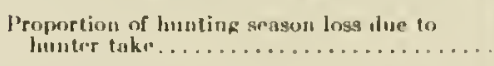 & 51.5 & 48.3 & 52.0 \\
\hline I'roportion of lasu due to all ot hor rumses. . & 15.5 & 51.7 & 18.0 \\
\hline
\end{tabular}

Thus, the lusses dne to all olher causes during the hunting season approximatcly equals the loss due to hunter "take". Saunder's work in Vichigan, which showed a hunter "take" of 6.7 per rent, erives a total Octuber loss (which period is over double the length of the opeu hunting season of 12 days) from all sources as 15.9 per cent of the September popula- 
tion. Covering as it does a period considerably in excess of the hunting season, the 9.1 per cent loss due to causes other than the hunter "take" is roughly comparable to the New York result. Trippensee's figures indicate a considerably different relation between "take" and cripples in Minnesota-his "other losses" amounting to only 21.6 per cent of the hunter "take" for the hunting period.

How much of the 8.1 per cent and 16.7 per cent losses of pre-season populations from these several sources in New York can be attributed to crippling is undeterminable. The censuses on these areas were not sufficiently detailed to evaluate the effects of such factors as predation. These figures do represent, however, the upper limit of possible crippling on these areas.

Beginning in the fall of 1933 , certain portions of the Connecticut Hill survey area were set aside for grouse population-control experiments. This control consisted of collecting every bird possible on these portions the first year and in succeeding years collecting enough to reduce the grouse density to half the normal maximun. Coincident with the collecting of the birds, intensive census work was carried on to check on population changes due to hirds moving into or out of the area. In so doing, it has been possible to get a rcasonably accurate check on lost cripples by careful follow-up searches.

While it would he perfectly possible to determine the percentage of the fall population that were collected, crippled-in-collecting, and died from predation. thesc figures would he meaningless in view of the length of the collecting period involver and the purpose of the work. The crippling therefore has loen worked out only in relation to the "take". Thesc data are summarized in table 58.

These figures represent a minimum estimate of the number of birds crippled but not brought to bag. Included in them are the number of birds knocked down hut lost and that subsequently may recover. It should also be rememlered that the men making the collec. tions on which this table is hased were relatively good grouse shots. Thus the figure representing the number of grouse crippled but not hagged is proliably lower than the average for

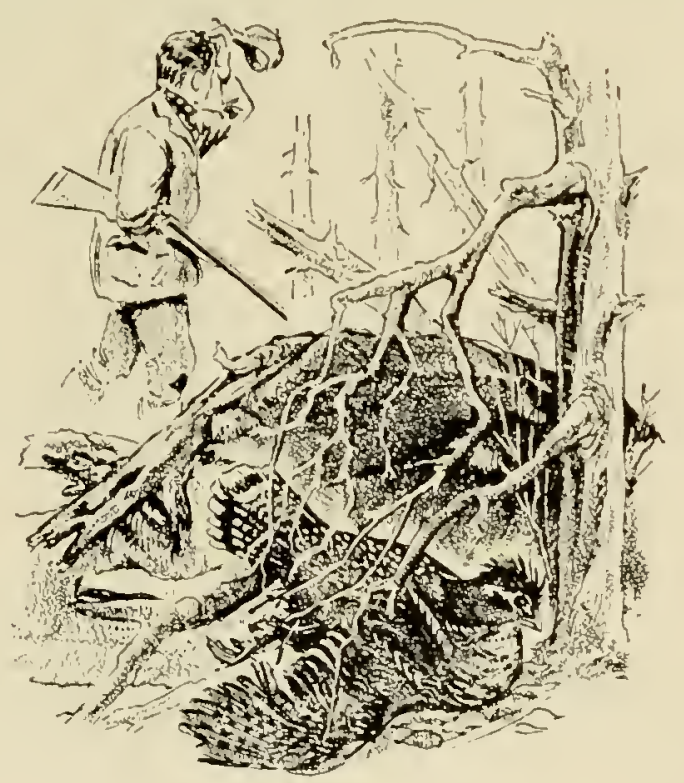


TABLE 58. CRIPPLING LOSS ON POPULATION CONTROL EXPERIMENTCONNECTICUT IILL

\begin{tabular}{c|c|c|c|c}
\hline Year & $\begin{array}{c}\text { Number of } \\
\text { grouse } \\
\text { shot down }\end{array}$ & $\begin{array}{c}\text { Number of } \\
\text { grouse } \\
\text { bagged }\end{array}$ & $\begin{array}{c}\text { Number of } \\
\text { gronse } \\
\text { crippled } \\
\text { but not } \\
\text { bagged }\end{array}$ & $\begin{array}{c}\text { Per cent of } \\
\text { shot birds } \\
\text { that were } \\
\text { rrippled }\end{array}$ \\
\hline $1933-34$ & 31 & 27 & 4 & 12.7 \\
\hline $1934-35$ & 62 & 56 & 6 & 9.4 \\
\hline $1935-36$ & 30 & 26 & 4 & 13.3 \\
\hline Total & 123 & 109 & 14 & 11.4 \\
\hline
\end{tabular}

the state.

Considering the maximum number of birds that might have died following crippling (table 57) and the minimum estimate in the table that follows it, the Investigation believes that the probable loss from hunter crippling is normally ahout $1 / 8$ of the birds shot down, or 2 per cent of the pre-season grouse population.

\section{Total Hunter Kill}

The sum of the hunter take and the loss from erippling gives us the total hunter kill. On the Tompkins County hunter-eheck areas in 1930 the number of birds that disappeared between September 1 and November 30 was 17.0 per cent while in 1931 it totalled 32.3 per cent. This included losses from all causes including hunting. A figure closer to the actual hunting loss is obtained by applying the estimated ratio of cripples as given in the preceding topic to the lag and adding that amount to the six and 29 birds bagged in 1930 and 1931 respectively. Then, in 1930, the estimated total kill was 11.3 per cent of the pre-season population and in 1931 (which is considered as a normal grouse hunting year for the increase phase of the grouse cycle) it was 17.7 per cent. The 1935 public hunting grounds hunter-check showed a total kill of 15.4 per cent. Since these mathematical figures are obviously only approximations of conditions as a whole. we may summarily conclude that the total kill by hunters in New York is about 17 per cent of the pre-hunting season grouse population.

\section{Success Ratio}

Sucees ratio as herein used applies to the ratio of hirds bagged to birds flushed by the individual hunters. The ratio may vary from 0 per rent to 100 per cent but the results oltained on the 1930 and 1931 hunter-checks as summarized in table 59 show that it is more commonly closer to zero.

TIBLE 5\%. SLCCHS RATIO IN GROUSE HUNTIA-TOMPKINS COUNTY AND PIBLIC HINTING GHOUND HUNTIR-CILCK MREAS

\begin{tabular}{|c|c|c|c|}
\hline Year & $\begin{array}{l}\text { Number of } \\
\text { frouse flistied }\end{array}$ & $\begin{array}{l}\text { Nimniber of } \\
\text { Rrouse loagend }\end{array}$ & $\begin{array}{l}\text { Successes ration } \\
\text { (pur cent) }\end{array}$ \\
\hline $19: 10$. & bil & 6 & 8.8 \\
\hline $1+31$ & $39-$ & $=4$ & 7.3 \\
\hline 1938. & $11:$ & 1.3 & 11.1 \\
\hline
\end{tabular}

Thus the suecens ratio in 1930 was 8.8 per cent or one bird hagged to every 11.4 flushed and in 1931 was 7.3 per cent or one bird bagged to every 13.7 flushed. The 1936 check thows the highest ratio of all. 11.1 per cent or one bird bagged for every nine flushed. 
This ratio, being based on total birds flushed, is considerably smaller than the ratio of birds bagged to birds shot at which is the correct test of success in terms of shooting skill. This ratio was nol determined on the 1930 and 1931 check areas but in 1936 it proved to be 27.1 per cent or about one bird hagged for every four shot at.

\section{Effect on Grouse Abundance of Man's Hunting}

Whether the hunters harvest 10 or 20 per cent of the grouse is of importance from the game management point of view, mainly as it affects the continuing abundance of the species. Under ideal conditions, the hunting loss should be the maximum that would leave an optimum breeding stock for the succeeding year. To illustrate. assuming an area with a good grouse population in the fall, there might be two birds of the year for every pair of hreeders existing on the area the previous spring. In such a case, if there were no other sources of mortality from October through the next hreeding season, the hunters could harvest two birds of every four, or 50 per ceat, and still leave the optimum breeding stock. Actually, however, this figure represculs the percentage from which must be deducted the anticipated winter loss due to other causes, in order to get the maximum allowable harvest by liunting.

Examining the record in retrospect, the deductible figure has varied in different years from 11 to 60 per cent (the winter loss on the Connecticut Hill study area). Again assuming a fall population to which the above mentioned 50 per cent is applicable, the theoretical permissible harvest would vary from 39 to 0 per cent of the prehunting season level. But productivity is not constant. On this area it has varied from year to year so that. insteal of 50 per cent, the total allowable overwinter loss with respect to what may he considered an adequate hreeding population has ranged from 17 per cent to 70 per cent. This variability is to a large extent compensated for, however, by the fact that high overwinter losscs have tended to be associated with high fall densities and vice versa.

Fortunately, too, there is substantial evidence which indicates that these figures may run much higher without danger*. The above "deductible figures" are based on an arca where no hunting was allowed. Many of the birds that might have been taken by hunters were lost through other causes. If they had been taken by hunters, it is improbable that in every case other birds would have been lost in their place. One may then fairly conclude that the 17 per cent hunting loss estimated does not endanger the continued alundance of the species in well-stocked coverts.

That modern hunting is seldom an important factor in altering the natural course of grouse abundance is further indicated by the record in New York in recent years. Following two years of closed seasons during the low-abundance period of 1928 and 1929, the season was re-opened in 1930 when the abundance curve had recovered to about 30 per cent of its ultimate peak. Many were the disapproving cries of anxious sportsmen who, having hecome thoroughly alarmed by the "disappearance" of the birds in 1927 , felt that it was not yet safe to allow an open season. But in spite of this and succeeding open seasons, the grouse continued to increase until a high level of abundance was reached, which, in general, has been maintained until the present (1912).

To further indicate the part played by decimation from hunting, it is helpful to examine the relative importance of the various sources of loss by which the potential productivity of a spring grouse population is reduced. The charts included under the discussion of Net

\footnotetext{
* See Chapter XII. D. 538.
} 
Productivity" show graphically the fate befalling an average 1,000 grouse eggs and the cor. responding breeders under the major variations in survival pattern experienced during the Investigation.

In cach case "hunter take" accounts for but a small proportion of the total reduction of the potential 1,000 eggs. In figures 52, 53 and 54 losses prior to the overwinter period are the same and the 17 per cent attributed to hunting represents 38 birds (approximately 33 being hagged and five crippled but lost) comprising only about 4 per cent of the full year mortality. When losses during the spring and summer are greater (figures 55 and 56 ) it becomes even smaller, both numerically and in proportion to the whole. In no instance depicted would climination of shooting alter the population Irend since no more than half of the birds so taken might be expected to survive if no lunting were done. Nevertheless it is obvious that as the season progresses the loss of the same number of individuals becomes of greater import.

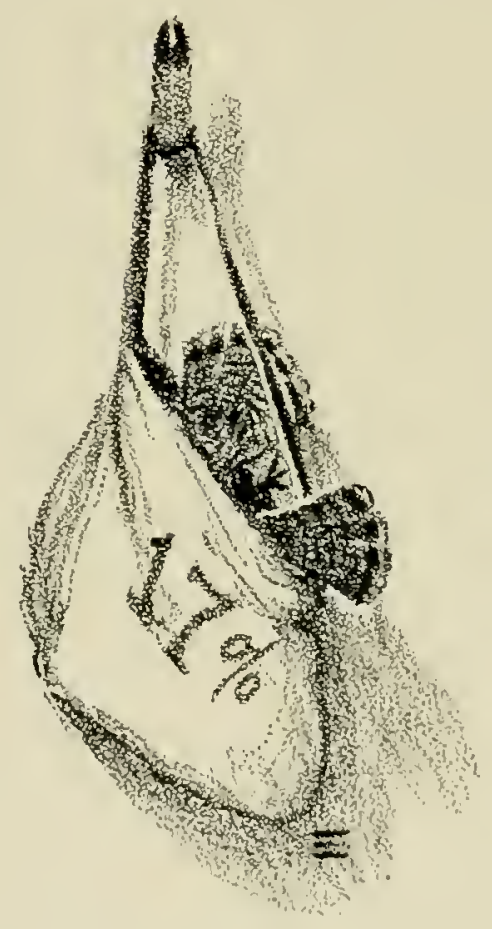

While occasionally an individual covert is adversely affected hy overshooting, it must be concluded that the general effect of hunting for sport as currently practiced on grouse, is not detrimental and may even have a positive heneficial effect during periods of grouse abundance by tending to reduce the opportunity for the agents causing periodic scarcities to becerne effective ${ }^{\Delta}$.

\section{AS A HUNTER AND TRAPPER OF PREDATORS}

The authors approarh this subject with a good deal of trepidation. It is the olject of the

* Sire Chapier XII, D. 5.39.

$\angle$ it mum be recognizel that the discusnion of this topic applics only to the increse and peak phanca of srouse abundance.

$t$ see aluo Chapter VII, D. 316. 
Investigation to substantiate all conclusions with a foundation of observed or demonstrated facts, but man's relations to predators, by its very nature, must be strung together with numerous postulations where facts and figures have not as yet been obtained. Our concern in this instance would be less marked were it not that the subject had already been treated at length by two divergent and highly-opinionated seetions of the public. Statements made in progress reports of the Investigation in past years have in some cases occasioned outeries of varying intensities from both the "leftists" and the "rightists". Being damned by both extremes may possibly be interpreted as back-handed praise. Certainly it has instilled an even greater-than-normal feeling of caution. In all conclusions drawn, man's hunting of predators has been considered purely as it may influence grouse abundance.

\section{Nunber and Per Cent Taken by Hunting}

A reasonably accurate determination of either the numbers or per cent of predators taken by hunters is not easy. In the cases of some of the mammals, the license stub reports required of hunters and trappers in New York give valuable data although most of those reported are trapped rather than taken by hunting *. Only part of the predatory mammals. however. and none of the predatory birds are among the species which are reported to the Conserva. tion Department in this way. Thus, without this statistical help, the prol,lem nust he attacked in broad terms. Written records of sportsmen's club activities, bounty records (in those states which offer bounties), olsservations on hunter-habits and the relative vuluerability of various species to hunting by man must furnish the basis for discussion.

In so far as their potential effect on grouse is concerned, the number of predatory species that need be considered is small. Among the mammals are the red and gray foxes. the \ew York and small brown weasels, and the skunk. Among the birds the great horned owl and Cooper's Hawk are the ones most important in New York, althongh the gosliawk, sharpshinned hawk and crow may at times become troublesome.

The number of predators of any speeies taken by hunters depends not so much on the degree to which it destroys game as upon its vulnerability to man's weapons. That the crow is a mueh-hunted species and also of some importance as a grouse predator is largely acci. dental. That the horned owl is only occasionally taken by hunters, even though it is an'important grouse predator, is mainly due to its seclusive and nocturnal habits. That the red squirrel is seldom important as a grouse predator and yet is commonly shot by hunters is due to the ease with which they are sought out and killed. With notable exceptions, man's hunting of predators has not resulted in their great reduction. Rather, it has forced the varions species to become nore wary and adept at avoiding man. In some cases. largely due to man's improvement of the environment for them, species have actually increased from former num-

* See discussion of Man As a Trapper of Fur Species, P. 382.

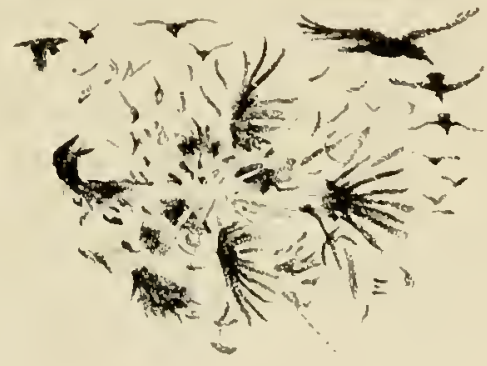


bers in the face of constant hunting.

One must conclude that man, as a hunter of predators, is of little consequence to grouse conservation. Whether it be the normal. haphazard, "catch-as-catch-can" shooting, organized "vermin hunts" or hunting for bounty. the numbers of important gronse predators taken by shooting are small. As for assisting in the mauagement of grouse, sportsmen's efforts as predator hunters are relatively ineffectual.

\section{As a Trapper of Fur Species}

Trapping for fur is an economic enterprise. Returns come in payment for the pelts taken and. in some cases, additional revenue from bounties and from carcasses. Several of the valuable fur-bearing animals are also important grouse predators. Because of the dual role of these species, trappers unintentionally (in contrast to predator hunters) exert an indirect influence on grouse.

Fur bearers in this State which are also important grouse predators are mainly the red fox, gray fox, small brown and New York weasels and skink. The raccoon, while a less important grouse predator, is also trapped in some numbers. The take of all these species, except the weasels, has leen recorded in New York since 1918, along with the reports required of game taken. 'Table 60 summarizes these data begimning in 1926.

TABLE 60. REPORTED TAKE OF CERTAIN PIREDATORY FUR BEARERS IV NEW IORK-1926-1939*

\begin{tabular}{|c|c|c|c|c|}
\hline \multicolumn{5}{|c|}{ Number of Animals Reported Taken by Trappers and Ilunters } \\
\hline Yinar & Ifed for & Gray fox & Skunk & Haceun \\
\hline 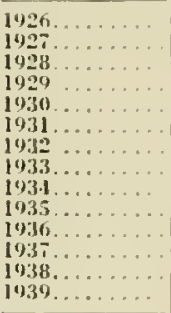 & $\begin{array}{r}18,726 \\
35,658 \\
10,616 \\
10.913 \\
8,611 \\
8,118 \\
7,697 \\
9.278 \\
9.009 \\
11.229 \\
10.593 \\
15,550 \\
19.532 \\
25,852\end{array}$ & $\begin{array}{l}2,402 \\
2,338 \\
2,260 \\
2,7,75 \\
2,6,52 \\
2,806 \\
3,413 \\
3,5,27 \\
4,933 \\
1757 \\
1,217 \\
4,940 \\
5,250 \\
6.975\end{array}$ & $\begin{array}{r}73.618 \\
120.002 \\
72.62 \% \\
71.850 \\
53.511 \\
56.338 \\
41.905 \\
51.063 \\
32.988 \\
3.3 .217 \\
12.660 \\
36,701 \\
33.952 \\
41.170\end{array}$ & $\begin{array}{l}28.750 \\
40.908 \\
27.886 \\
21.230 \\
20,820 \\
18,813 \\
18,686 \\
13,9.39 \\
20,361 \\
23,427 \\
26,921 \\
24,190 \\
25,315 \\
27,159\end{array}$ \\
\hline Averake...... & 14,381 & 3,811 & 51,121 & 21,110 \\
\hline
\end{tabular}

- Ih" recorded take of ollue predatory fur-boarers cont appreciably affection krouse is not includiod here.

Considered from the standpoint of the predators themselves, these data bring out several significant points. With red fox, skunk and raccoon, the take depends mainly on fur prices. It was very high during the hooming fur market of the middle '20s. Then it dropped markedly with the cononic depression of the early '30s following which it has commenced to increase again. No species has shown any indication of a marked decline in number, or, as a corollary, pelt trapping of these spccies scems to take only the surplus population, if that much,

It is apparent that wrdinary fur trapping has not resulted in any widespread reduction of any of these speries. An exception might occur during a prolonged period of high fur price. a circumstance not likely to occur. $\Lambda$ substitute for high fur prices is the granting of a bounty in addition to the return from the pelt. Pennsylvania has attempted control lyy this means but it likewise has failed to control any species except the bobeat. 
Gerstell ${ }^{153}$ eoncluded: "As a predator control measure, the payment of bounties has proven generally inefficient as it has placed under control only one relatively small species popula. tion, while its effect on five others has been negligible". We thus conclude that even with the stimulation of adequate bounties, control of the important ruffed grouse predators is not accomplished in the sense of marked reduction in populations.

Even if populations of fur-bearing predators are not reduced by commercial trapping or trapping for bounty, will not the numbers that actually are taken benefit the ruffed grouse population? In some cases they may. The taking of fox and weasel for fur may lower grouse nest mortality in localities where those predators are severely reduced and thereby inerease the fall surplus*. This sort of trapping, however, is not commonly associated with the better grouse coverts of the state. Furthermore, it is a dubious benefit unless the added surplus is taken by hunting.

Gerstell, speaking of Pennsylvania's experience with the hounty, concludes, "It has been impossible to prove that the operation of the bounty system over a relatively long period of years has improved game conditions. Furthermore, it was shown that the annual amount of money expended for bounty payments was controlled not by the abundance of predators, but principally by climatic and general economie conditions". The trapping of predatory species for fur, with or without the added economic stimulus of a bounty, is negligible in its effect on grouse abundance.

\section{AS A FARMER}

As one delves deeper into the complexities of the grouse problem, he becomes ever more impressed with the role that man plays in affecting the hirds' habitat. Never is this more significant than in his work as a farmer. In the first place, at least in the Northeast, the most productive coverts occur in those portions of the range where the woodlands are broken uy by considerable areas of land in farms. The farmer is responsible for this condition. Secondly, since these lands are privately owned, whatever is done that affects grouse either for good or bad will be done by the farmer.

He clears the land of woods, or keeps it clear. He controls livestock that may inpair or destroy cover values. When he turns lumberman and takes products from the farm wood. land, he is again functioning as a manager of the cover that may or may not support grouse, depending upon how he does his work.

\section{Ciearing of Land}

One of the most generally accepted legends of primeval conditions in the northeastern states is the great abmuance of game in the unbroken wilclerness. Originating in the tales of the early settlers who found adequate supplies of game around their newly-made clearings, it was naturally assumed that this abundance was an attribute of the whole wilderness. Little did these pioneers realize that their very efforts in creating the clearings was largely responsilhe for the local ahundance of grouse. deer, and turkeys which furnished them with a ready supply of fresh meat.

Thus the clearing of the timber to make way for farming was the first game management technique practiced, however unwittingly, by the white man in America. But, as with all good things, too much is no good. The clearing of the land in many regions soon passed the optimum condition for grouse and, in plane of the improvement of the coverts, the needs of farming caused a rapid destruction of the coverts which delimited the available

\footnotetext{
* See Cliapter VIl, p. 346.
} 
grouse range. In those flat, fertile areas of New York which proved to be excellently adapted to farming, the grouse was exterminated and remains so today except for occasional "islands" of wooded swamp or otherwise untillable land.

In the southern-tier counties, which are typical of the better grouse range in New York, the timber on the hill land was generally cleared on from 40 to 60 per cent of the area. It is here that one today can measure the effect of land clearing on grouse. Even when one includes all of the open land in the grouse range, the population density far exceeds that on wilderness areas of unliroken coverts such as the Adirondack mountains. Thus on the Connecticut Hill study area where the brush and woodland cover occupicd about half of the land surface, the grouse density for the range (including all open land) has been from 22 per cent to 88 per cent above that on the Adirondack study area (which is 92 per cent woodland and brush) and has averaged 50 per cent higher during the period of the Investigation.

We must thus credit, at least partially, the farmers' land clearing operations with enabling an increase of one-half in the grouse productivity of the land on this type of range-and of producing that crop on only half the formerly available range. How close this condition lies to the optimum effect of land clearing is not known but it seems probable that a much higher productivity could le secured with from 10 per cent to 25 per cent of land clearedprovided it was well scattered in small units through the range. The arrangement of the open land on the range is more important than the quantity.

\section{Maintenance of Openings}

As just noted, the original clearing of portions of the land exerted a profonnd effect upon its utility as grouse range. The continued farming of these clcared lands has been equally important in maintaining the newly created carrying capacities of the range, some improved and some completely destroyed for grouse. On the intensely farmed lands, the cffect has becn to prevent any potential encroachment of the grouse on the destroyed range. On the half-cleared lands, this maintenance of the openings has made of the farmer a game nanager.

In recent years, the trend toward abandonment of the lands which have proven submarginal to agriculture, has cansed marked improvement of the grouse range. The release from tillage of these fringes of open land has created brushy arcas which add valuable food. producing coverts to the range, increasing both the quantity and quality of the grouse coverts. If this abandonment is not earried too far, if a suftecient quantity of open land is main. tained well-seattered over the range, this improvement will be maintained. But in so far as the abandonment of open land maintenance becomes extensive, that range is destined, in the future, to approach the relatively low grouse productivity of the original wilderness. Only government purchase and management can remedy this condition unless other uses profit. able to private enterprise are developed.

\section{Pasturixc, of Livestock}

As a general proposition, the pasturing of farm livestock in New York is of little importance to gronse. It is fortunate that even where dairying is a major fam industry, the farmers do not practice woodland pasturing extensively in the hetter grousc range. for rarely do we find woodlands heavily pastured even when cattle have access to them.

Woodlots in the intensively farmed areas are commonly pastured to the point of ereating a visible "cattle line". Any gronse range so pastured is rendered almost wholly unproductive of grouse regardless of its other attributes. Fortunately, this occurs mainly on small 
woodlots in areas which are unimportant as grouse range anyway.

The Investigation has not made censuses on comparable pastured and unpastured grouse range and hence can not present specific figures on the effect of livestock pasturing on productivity or carrying capacity. The conclusions reached are based upon general observations, which, however, have been very clear.

It should be noted, in passing, that livestock pasturing: as well as the plow, is a tool of the farmer for maintaining open land. As such, it often assists in maintaining a high grouse population in adjacent coverts made possible by that open land.

Livestock occasionally destroy grouse nest; by trampling, though the luss from such a cause is not of great importance.

\section{Other Donestic Stock}

While the pasturing of livestock is the most important relationship of farm animals to grouse, chickens and other domestic fowl, dogs and cats in some instances may have some significance.

A grouse nest was examined in Delaware County in which a chicken had laid egrgs and caused the grouse to desert. This is not a common occurrence but worthy of passing note. In the summer of 1936 , a grousc brool on the Connecticut Hill study area was flushed from the midst of a group of chickens, all of them having been scratching about in the leaves together. Such contacts of grouse with chickens or other domestic fowt are not uncommon and may provide an occasional means of transmission of disease*. It is clear, too, that even without contact, traversing the same terrain as domestic fowl may possibly lead to disease.

Dogs and cats, especially those allowed to roam at will, often become serions predators. The dog exerts the most effect in nest-destruction while the cat is adept at catching young birds and occasionally adults. The importance of these domestic animals as grouse predators is detailed in Chapter VII.

\section{AS A LUMBERMAN}

When the white man arrived, he found what is now New York covered with a vast forest, broken only by water areas, narshes, cliffs, occasional blow-downs and the scattered clearings of the Indians. Forest cover types merged into one another with a minimum of definite edges, except where such natural forces as wind, firc, insects, discase or decadence had broken the woodland canopy. Undisturbed by civilized man, the forest had achieved a stage

* See Chapter X, p. 415

A By David B. Cook.

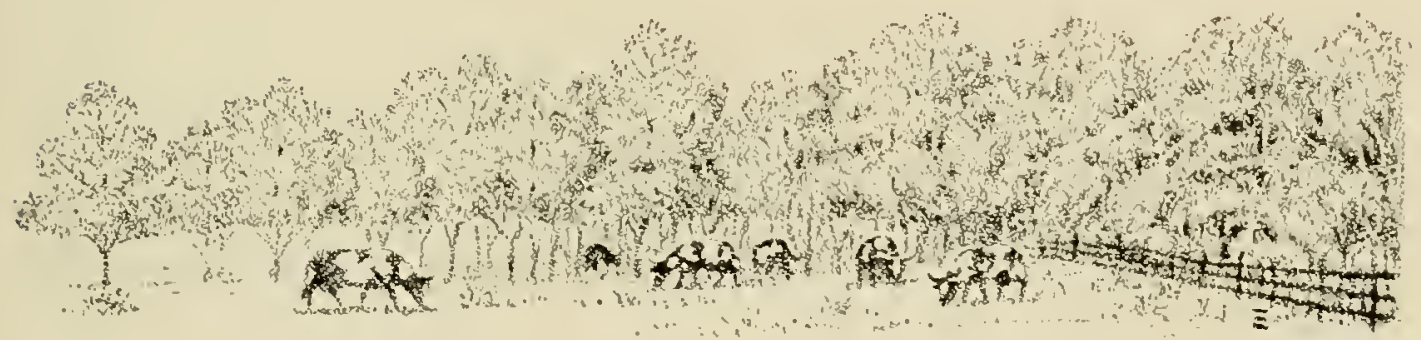


of development approaching the climax. Areas occupied by the earlicr successional stages so necessary to high grouse production were prohably few, small, and scattered.

One of the first products taken from the forest ly the white men were heavy planks, sawed from the choicest white pines. Later they cut oak and other hardwoods, both for their own use and for export. Because of the superabundant supply; these early cuttings were light and highly selective, taking only the largest and choicest trees of certain species. Probably, such operations disturbed the forest very little. Few openings hig enough to serionsly affect the forest composition were made.

As population increased and transportation facilities improved, the forcsts were exploited for a greater quantity and a wider variety of products. Not only choice saw-timber but lower grades of logs and wood were extracted to meet the growing demand. In the Adirondacks, where river driving was the chief means of transport, only softwoods were cut. In the southern tier, tremendous quantities of pine were sawed up and the lumber rafted to market. Untold millions of hemlock trees were stripped of their bark for tanning and left to rot in the woods.

In all but the oldest-inhabited parts of the State, the lumberman and his sawmill kept just ahead of the farmer and his grist mill. Generally, these cuttings were heavy enough to break up the forest canopy. The removal of the bigger trees, with the attendant increase of sunlight and air, the ripping up of the soil in skidding and roadbuilding, and the effects of occasional fires set back the course of forest succession and brought in many light-demanding trees and shrubs which produce grouse food. Thus edges were produced in abundance as each year's cut followed the last.

Later, with decreasing limits of merchantability, the tendency was to clear-cut extensive areas. This was especially true in the Adirondacks, where large bodies of spruce and fir were cut for pulpwood; in the southwestern Catskills, where hardwoods were clear-cut on a short rotation for acid-wood; and in the western part of the southern tier, where timber. lands were stripped for mine props. Elsewhere, the portalle sawmill operators had taken off even the smaller trees.

Such lumbering operations tended to break up the pattern of the forest into a multitude of small blocks of varying age. They stimulated the growth of advance reproduction, nndergrowth and herbs. Especially where fire intervened, the climax forest composition was replaced by woods representing earlier stages in the successional series. Abundant grouse food-producing plants are usually to be found in these. Thus, the rast and uniform arcas of virgin forest were replaced by a patchwork of smail lots of varying age, composition and density.

Such a forest paltern, with its varied and productive flora and its tremendous amount of edges, is ideal for grouse. The now-familiar cover requirements-spring breeding grounds, summer and fall fecling grounds and winter shelter-were arailable everywhere. As fast as new areas of suitable habitat developed, the grouse mored in and occupied it. Though perhaps losing a little territory through fire or too-close cutting, they gained immeasurably in numbers, as is attested ly early records of abundance.

With the disappearance of "inexhaustible" supplies of virgin timber, lumbering is now carried on in smaller mnits. Trees of less size are also in demand. The production of such second-growth, though still largely accidental, does require some care on the part of the landowner. There are taxes to be paid. fires to be kept ont. As the valuc of land and timber 
has increased, so, too, has the intensity of forest management. Silviculture, the deliberate cultivation of the forest, is gradually replacing the old, haphazard methods of exploitation.

Such necessary features of lumbering as roads, skid-trails, rollways and piling-grounds are very useful to grouse. These grow up to tangles of herbs and shrubs, especially briars, which persist despite occasional trampling.

Thus the axe, like the plow, has exerted at times a favorable and again an unfavorable influence on the halitat, on the condition of which, in the long run, the number of grouse largely depends.

\section{AS A CONSERVATIONIST}

In our system of free private enterprise it has taken society a long time to recognize the need for conserving our vital resources. True, from colonial times there have heen a few far-sighted individuals who have warned of the consequences of continued exploitation, but their voices were crying in the wilderness.

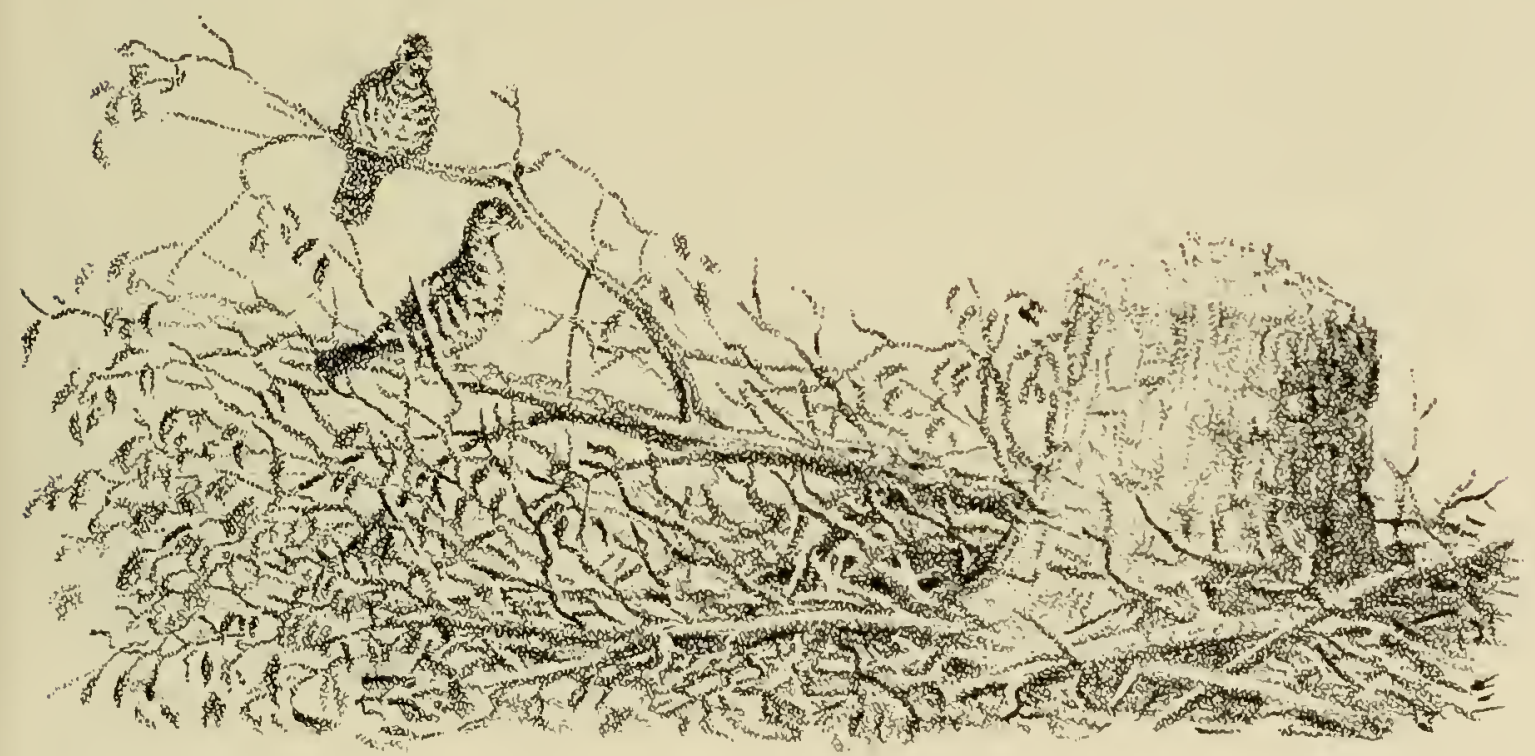

In more recent times these consequences have hecome all too apparent and for many the time for retribution has arrived. The decline of millions of acres of once-productive land. and with it much of its former crop of wildlife. has resulted in the abandonment of vast arcas of farm and forest.

The cuncept of conservation of renewable resources-meaning wise usc-as a practicing credo of man las gained much acceptance in recent years. This trend toward a more per. manent system of land management has not bcen sudden, although its progress has accelerated since the turn of the century. Since the first law restricting the unlimited pursuit of grousc, there has been a gradual evolution of effort toward its conservation.

Man himself has evolved as a conservationist. First believing that the enactment of laws restricting the take of gronse would adequately maintain a satisfactory grouse crop, he has gradually broadened the scope of conservation effort. Today the emphasis revolves around 
the practices of sound land management.

The passage of laws restricting the activity of hunters was not only the first effort at conservation of grouse, but also was a forerunner in the field of cooperative effort in conservaijon. Restocking of coverts. establishment of refuges and bounty payments for destroying predators are later developments of cooperative conservation practice. The basic practices of good land management, however, remain largely a matter of indjvidual concern and their use or their disregard, an individual determination.

The opportunity for the further development of man as a conservationist. especially in the collaborative sense. is great. Why should there not he community cooperation in protecting coverts from fire and grazing; in making plantations for new cover; in the marketing of woods products that will permit more productive woodland managenent methods for both trees and grouse? Therein lies future progress.

Laws

In the early years of the white man's colonization of the northeastern states. the ratio of hunters to grouse was so low that the supply seemed inexlaaustihle. No particular cognizance was taken except the harvesting of them for food. There was no need for protection and no conception of a possible need for cultivation. But as the human population increased and commercial facilities became available, lean years of grouse harvest appeared, likely being years following large losses. Understanding only the loss due to hunting. man turned naturally to a means of checking that loss by controlling hunting, by passing laws restricting the liberties of the individual.

In New York the first law on grouse was passed in 1791. There followed a gradual spread and increase in hunting restrictions. These included the elinination of hunting during certain seasons of the year. the curl on and elimination of market hunting, the prevention of sale. limitations on melhods of take and the imposition of restricted seasons and bag limits. This trend cuhminated in 1928 in New York with the first completely closed season.

It is generally recognized that sane legislation should form the foundation of good game conscrvation. That exjsting legislation is sometimes inadequate should also he recognized as well as the fact that any legislation is only a means to an end and not an end in itself. Legislative machinery is notoriously slow whereas wise grouse management often requires speedy adjustment in existing laws. Proper haudling of the harvest, therefore, requires that the executive game officer of the State be empowered to change regulations relating to seasons and hag limits without resort to legislation. The recent delegation of responsibility hy the New York legislature for the handling of such items within certain limits is a long and produetive step in the right direction.

lack of facilities for adequate enforcement often renders a perfectly proper law practically vidl.

\section{Comareralization of the TAKe}

The nineteenth ecntury saw much development in the marketing of grouse in the big cities of the Northeast. Amazing are the recorded numbers of hirds taken and prices for which they sold*. But. stimulated by the low grouse populations in certain years of the 1870 s and 1880 s and hy the olvious extermination that continued commercialization would hring. conservationists brought about laws which gradually restricted the practice.

- Roworda covering theser are found in Chapeer 1. 5. 8. 
Shortly after the turn of the century, the business was outlawed in very nearly all northeastern states. Because of the control which existed at the consuming end. these laws have been generally very effective. Very few hotels or restaurants are willing to deal in illegal foods. Without a market, the market hunter is doomed.

Thus, while even today this profession still exists in a small way, the laws bringing about its abolition have heen almost wholly successful in New York.

\section{SEasons for Hunting}

Generally speaking. the trend has been uniformly toward shorter and shorter seasons. From the time when no seasonal restrictions existed, the period in which legal hunting could he done in New York was cut from 365 days a year to zero in 1928 and 1929. while more recently it has been about one month to six weeks.

Elliott ${ }^{23}$ says. "The practice of slaughtering the young, even while under the mother's care. ... cannot be ton severely condemned". This view hecame dominant by 1903 when shooting was restricted to the fall of the year. Since 1930. the season has varicd from three to six weeks, taking place between October 1 and November 30 . Except during periods of scarcity, a one-month season is fully justified and, in the considered opinion of the lnvestigation, in peak years a longer season of six to eight weeks would not be too long. The high fall populations of peak years are likely to drop severely anyway and the more that are taken by hunters, up to a certain point, the fewer will die from other causes.

Seasons ean le properly allocated only on the hasis of population status. Olviously, then. they cannot be legislated far in advance. Unless the authority to regulate seasons is delegated to the executive game officer. a moderate scason innst be legislated.

\section{Bag Lints}

Reduction in bag limit in New York has paralleled the shortening of open seasons. The first bag limit. 36 birds per season, was established in 1900. A limit of 4 per day and 20 per season was in effect from 1908 to 1919. During 1920 and 1921. the limit was 2 birds per day and 10 per season. For the past 21 years the limit has been 3 hirds per day and 15 per season except in 1928 and 1929, when there were nn open seasons. laws liniting daily bag limits are reasonably effective as are those limiting legal open seasons. Those who are inclined to take more than the law allows are deterred by a real possibility of apprehension. But seasonal limits are only as effective as the conscience of each hunter dictates. How effective this is we do not presume to know hut there is no question as to the desirability of seasonal bag limits.

Olservations in New York lead us to believe that the current three and 15 bag limit is buth reasonable and justified.

\section{NETHODS OF TAKE}

The literature has been generous with records of the devices and methods that have been used to hag grouse, all of which might well represent a historical pattern of Anerican hunting. In 1812, Wilson ${ }^{400}$, states that they usually are taken by traps in deep snows while Audubon ${ }^{29}$. noted that many were taken with dead falls with a figure-four trigger. Elliott ${ }^{20}$, writing in 1897, records that great numbers were snared by the Indians, and Judd ${ }^{\text {m2 }}$ tells that many market hunters used a little cur dog trained to tree grouse and bark until the gunner approached within range. For this kind of shooting it is required that the head alone be cut 
off. In this connection. Elliott ${ }^{200}$ states further, "If a number have perched on the branches of different trees. the attention of the grouse is cntirely taken up with the antics and noise of the $\operatorname{dog}$... the report of the weapon does not frighten other birds and firing is continued until a number of hirds are tossed upon the ground."

An anonymous writer in Moore's Rural New Yorker, reflecting a change in attitude. writes, "the only sportsmanlike way to bag partridge is with a good dog and gun ... learn to shoot on the wing, and ... despise the trapping of game birds as every true sportsman does." However. Stoddart" in 1918. revealed that unethical practices still continued by stat. ing that shooting from automobiles was one of the causes of grouse scarcity.

The present law in New York State provides that game "shall only be taken . . . with a gun fired at arm's length, without rest, or with a long bow".

Such, briefly, is the chronology of how grouse have been brought to bag. But these few references only give an intimation of the innumerable devices and tricks which have been the stock in trade of grouse hunters in the past, mainly market hunters.

The changes in ethics have been equally important. While laws have restricted the means of taking and good sportsmanship has ruled out unsportsmanlike tricks. the grouse itself has ehanged some of the old methods by changing its own characteristics. Whether or not it is ethical to shoot down a whole covey of grouse from a tree while the cur dog raises a rumpus below is now of small moment for it is not generally possible today because the grouse has adjusted its reaction to the dog.

Even among the current generation of grouse hunters, one hears suggestions of changing grouse liahits. "The birds don't lie to the old setter like they used to do", says an old timer. So today. grouse hunting has hecome more a sport of hunters alone than hunters with bird dogs as it was a decade or two ago. This is partly due to a growing lack of "grouse dogs". most of them now being "spoiled" on pheasants. The ways of our forefathers have changed and the history of the mcthods of taking grouse is a chronology" of grouse hunting.

\section{P'REDstor Coxtrol}

Conservationists have long delated the question of predator control as a means of increas. ing the abundance of game. The American sportsman's loclief in this methot rests to a considerable degree upon its use on the grouse moors of Britain. True, it las undoubtedly been an important factor in producing the high fall populations so frequently encountered there. Few realize, however, the intensity of the management practiced on most of these Scottisl estates where full-time keepers are employed and where the cost of purchase and maintenance is to some extent defrayed by the sale for meat of a large propertion of the birds shot. Referring to American conditions. Lcopold says" "I would point ont. howerer. that stringeut predator control is usually unuecessary save in the upper scale of intensive game management." The same author continues that in gencral in this country suitalue game crops "can best be achieved ly light. local, scasonal and selective handling of the predatorfactor"."

The history of increasing protection for our game birds has leen paralleled 6 a leserer extent by growing restrictions in the taking of predatory speries. There was a time when the expression. "the only good hask is a dead one" excmplificd the universal opinion of sportsmen. To some, this still applies but the light of farts has gradually diwned and in 
New York today the less destructive avian predators are now protected by law. The mammalian predators. with the exception of the foxes, weasels, red squirrels and house cats, are protected except during the prime fur season.

Many of these restrictions, especially those protecting various species of hawks and owls, are largely unenforceable. They depend primarily for effectiveness on cooperation from hunters. which in turn depends upon their "education" for its degree of success.

Any attempt to estimate the indirect effect these laws have on grouse is mere conjecture. It is the opinion of the Investigation that it is small, whether the law protects the predator or not. Grouse mortality in the Northeast is to a considerable extent the immediate result of predation but most of this loss seems destined to occur anyway. The primary values accruing from protection of predators are other than saving game.

\section{Refuges. Sanctuaries and Land Posting}

A study of the value of a refuge as a game producing , unit in comparison with a public hunting area was made on the Pharsalia Game Refuge and Chenango Public Shooting Grounds Area in central New York.

The refuge had been established for a period of five years prior to the beginning of the study. Public shooting grounds had been open to public shooting as private land prior to the study and had been marked as "P'ublic Hunting Grounds" for a year when the study began in the winter of 1935 .

Hunters commonly frequent this region from the nearby cities of Binghamton, Cortland and Norwich as well as from numerous small communities in the vicinity. White no field check on the hunting pressure was made, the area lies in one of the best upland hunting sec. tions of the state. The hunting pressure was at least average on this area. The public hunting ground was hut 3 per cent larger than the refuge. thus the data obtained was essentially comparalle from the quantitative standpoint.

A comparison of the amount and distribution of the types indicated no apparent impor. tunt differences. The cover within each area was essentially independent of surrounding lands. Thus, the two survey areas may he considered for all practical purposes comparable sulpect only to a 3 per cent correction for size.

Threc censuses were made on these areas, all in successive winters, the first being in 1935. The dati on the grouse populations for the refuge and check area are summarized in table 61.

TAB1. 61. HUFFED GROTSE DATA-IHARSALIA REFIGE AND CHENANGO PUBLAC IIUNTING GROUND SURVES-FEBRUARY 193.5-1937

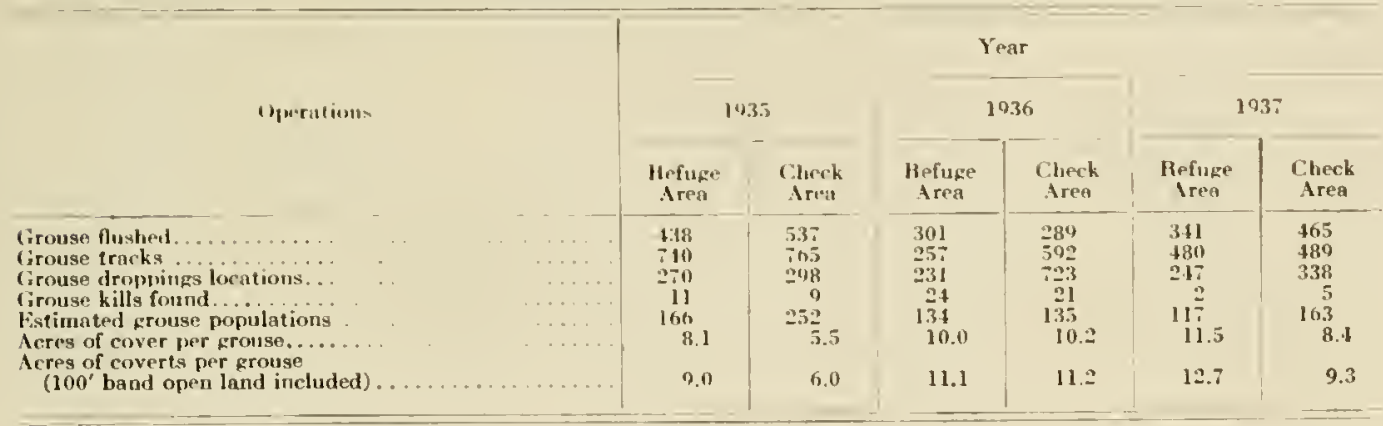


In 1935, the Refuge had only 66 per cent as many grouse as the public shooting area while in 1936 the populations were practically identical. Then in 1937, while the grouse population on the former continued to decrease, that on the latter increased until it carried 39 per cent more hirds than did the Refuge.

While the densities of numbers have essentially the sane ratios as the populations, the 1936 population densities on both areas were considerably lower than those of the previous year. But in 1937 the density of grouse on the Public Shooting Ground showed a marked increase while that on the Refuge continued to decline. The analysis of the effect of the small differences in the areas may serve to explain some of the variations in grouse numbers. but the vital fact still remains that the protection afforded by the Refuge during the period concerned did not serve to enlarge the crop of grouse.

The conclusion seems inevitable that refuges are of little value in maintaining populations of ruffed grouse when hunting pressure is not excessive. Fluctuations continuc regardless of the protected or unprotected status of the coverts.

$\Lambda$ sanctuary is merely an undeveloped refuge. Its value as a means of producing grouse, if different from a refuge. is generally less. Yet we must not overlook the possible value of a refuge or sanctuary for preserving seed stock on areas that have an abnormally high hunting pressure, as on those near large cities. But such areas only function to prevent extermination and not as a means of furnishing hunting on surrounding lands or of increasing the grouse population on the areas themselves.

The practice of land posting by private land owners, if done ohjectively to improve the grouse conditions. is generally unwarranted. Its effect is the same as that of a refuge or sanctuary, depending upon whether the area is utilized and managed or held inviolate. If the object of posting is to keep the hunting privilege for the owner or to prevent trespass, the problem is ontside the province of this discussion.

The explanation of the relative lack of usefuhness of the refuge to grouse appears to be three-fold. Violently cyclic species ran not exceed definitc population levels, nor can they long maintain the maximum levels they do reach. The degree of sedentariness of a species tends to be in inverse ratio to its adaptability to the refuge principle, and grouse are quite sedentary.

The adaptability of a species to management by the refuge principle depends upon the ease with which the species adjusts itself to recognize protected areas. The ruffed grouse is not very adaptable in this respeet, as contrasted with the ducks, for example. Added logether. the facts indicate that the refuge may serve to prevent extermination of some grouse in areas that might he overshot but that it is seldom a primary tool of the grouse manager for increasing the crop.

\section{EFFECT OF MAN'S AIISS ON GROUSE}

The tools of the white man's civilization have excrted a most profound influence upon the wronse since the first colonization of the Northeast. Ironical as it scems, most of these aids have worked both for the benefit and detriment of the species, depending upon how and to what extent used. While man in his various capacities has already been discussed. it seems pertinent at this point to consider further the effects of his implements on grouse. Consid. red sumewhat in their proper chronological sequenee, the more important ones are the axe and plow, types of guns, traps and snares, fire, domestic animals, automobiles and highways. 


\section{The Axe and Plow}

If remaining areas of virgin wilderness may be accepted as comparable with primeval conditions, grouse populations in pre-colonization times attained but relatively sparse densities. Theoretical consideration of the probable status of early grouse populations leads to the same conclusion. The grouse is a species largely dependent upon cover type edges for the attainment of large numbers. Edges must have been scarce in the climax forest, existing only at the border of different climax types, along water courses. hordering burns set by lightning and around Indian clearings. Hence, the carrying capacity of the original range was low compared with the species saturation level.

Grouse heing an "edge" species, the clearing of the land with axe and plow increased the carrying capacity of the range. Woodland borders were created mile upon mile as the embryo empire pushed back the wilderness border. Coverts were broken up and diversified. Except where vast areas of fertile land induced continuous land clearing, the effect was advantageous to the grouse.

The plow followed the axe and to a considerable extent made permanent its ehanges. As a means of maintaining these new margins, the plow has continued to play an important role in preventing the return of the continuous forcst. In many areas, the optimum balance for grouse of open and wooded land was passed and the axe and plow then produced an inmense reduction of availalue grouse range. Thus heing the tools which clcared off the forest and maintained the open land, they have been of first importance both in improving grouse range and in destroying it.

As time went on, the bread hasket of the nation shifted westward and mueh of the land which had been cleared for erops in the Northeast proved unprofitable for firming. This decline of agriculture on submarginal lands has led to considerahle ahandonment. Unless carried so far as to obliterate most open or semi-open spaces. this trent is a distinct advantage to grouse.

The axe must, in the future, be one of the chief took through which the wildlife manager will hold and improve these grouse lands. The plow will also play its part in maintaining the edges so necessary to good grouse range.

\section{FIRE}

Records show that most fires occurring in woodland are man-set, either intentionally or accidentally. Thus the effect of fires upon the grouse is largely the effect of one of man's tools.

With the efficient control now operating throughout most of the Northeast. forest fires are generally eonfined to small areas. They have little effect on the birds directly, although. when occurring in the spring. they may cause appreciahle losses to nests. It seems rather ironic, but small woodland burns may actually improve grouse cover by stimulating growtls of food-hearing trees and shruhs. Phillips ${ }^{503}$ states that the highest concentration of grouse he ever observed was in an area which had been burnel over a few years before.

While small occasional fires may he heneficial to grouse. extensive and repeated burning results in abandonment of the hahitat for many years. In portions of the grouse's former range. notahly in the Ozarks, annual burning for the "improvement" of the range for live. stock, plus overgrazing, has resulted in the externination of the species. 


\section{Automobiles and Higir Ways}

Before the advent of the motor car. grouse hunting was largely confined to an area of a few square miles near home which could be reached on foot, or a few selected coverts not many miles away that were accessihle by a short rail irip or a buggy ride. Today, a day's hunting may involve two hundred or more miles of motoring and hasty inspection of a numher of coverts where the sportsman knows. from his own experience or his guide's, that there are some grouse and that he is likely to find them unless they have been disturbed or taken by other hunters. Modern highways and automobiles have opened distant coverts in the city dweller.

Coincident with the development of these arterial routes in the Northeast, many of the old dirt roads, which proved to be the "back roads" of today, have become abandoned. Areas once served by these roads have become inaccessible to modern cars.

So, two changes have been working in our road systems which tend to counterbalance each other. The hunter's mobility has been increased extensively but has decreased locally. The net effect is difficult to evaluate lut, in itself, has probably had little influence on grouse numbers. Whereas, formerly, hunters stayed "in their own back yards." they now are in someone else's back yard. Except that the total number of hunters has greatly" increased, the back yards are used about as formerly.

Roads and their accompanying poles and wires, affect the grouse in other ways than afford. ing transportation for man. Collision with wires results in some mortality, particularly in the fall "crazy flight" period, and a few birds are killed by automobiles. Roads are openings and, when running adjacent to grouse habitat. may encourage concentrations at the edges. This tendency is enhanced when the road ditches and margins are allowed to grow up to low shruhs and vines. Added to this, the road itself, if of dirt or gravel, provides a source of grit and a place for dust bathing. Whether this is a desirable condition or not depends upon how concentrated the hirds have become and upon whether or not hunters take too great an advantage of such concentrations and overshoot the area. Generally, this is unlikely to happen and roads as openings actually serve a very useful purpose.

\section{Guns, Traps and Snares}

The old-fashioned sportsman paid more attention to the bobwhite, woodeock and heath hen- hirds that lay better to his well trained dogs-than to that erratic bomblicll, the partridge. In those days, the nineteenth century in particular. it was the inarket hunter rather than the sportsman who reaped the largest harvest of grouse. Throughout most of the Northeast, market hunting flourished until late in the century. With few restrictions the birds were taken with guns. traps or snares and brought to market in the cities.

While the gums of this era were not as efficient as are the more motern weapons, they were nevertheless very effective on the relatively "uneducated" grouse of those days. For the sane reason, traps and snares. while less effective on the wary hirds of today, were also very efficient. This market hunting was husiness, not sport. and the tools utilized had to be effi. rient if the business were to he successful.

Improvements in weapons have heen at leas parlially offset by adaptations of the hird itself to this change. Phillips so states: "Technical improvenents in the past forty years we can set aside. for the early hammer guns. in skillful hands. were nearly as effective as the more dainty modern wrapons." The inference will he gathered that possibly the shooter himsell 
has changed. He continues, "jf we compare the average skill of the present day brush shooter with the average of the market shooter fifty years ago, the result would be highly amusing and very disastrous to the pride of the modern edition". Phillips then points out that the great increase in number of hunters in recent years makes the aggregate "as potentially destructive as he of the old school".

Increased protection for the birds and improving coverts combined with the response of the grouse to more intensive hunting by gaining steadily in his ability to steer clear of shot. have balanced the growing popularity of the sport with its improved weapons so that serious depletion from hunting is not likely to occur.

\section{Grouse Dogs*}

There has been an historical sequence in the employment of dogs as grouse hunting aides which must be laid alongside the accounts of other factors affecting grouse to make this report complete. The authors have also had an opportunity to attempt the use of dogs as an aid to game surveying, which has made possible some observations of general interest. Furthermore, to many sportsmen, grouse dogs are inseparably associated with grouse hunting, the perpetuation of which was a prime motive for this Investigation. Hence this special section on grouse dogs.

* By J. Virtor Skift.

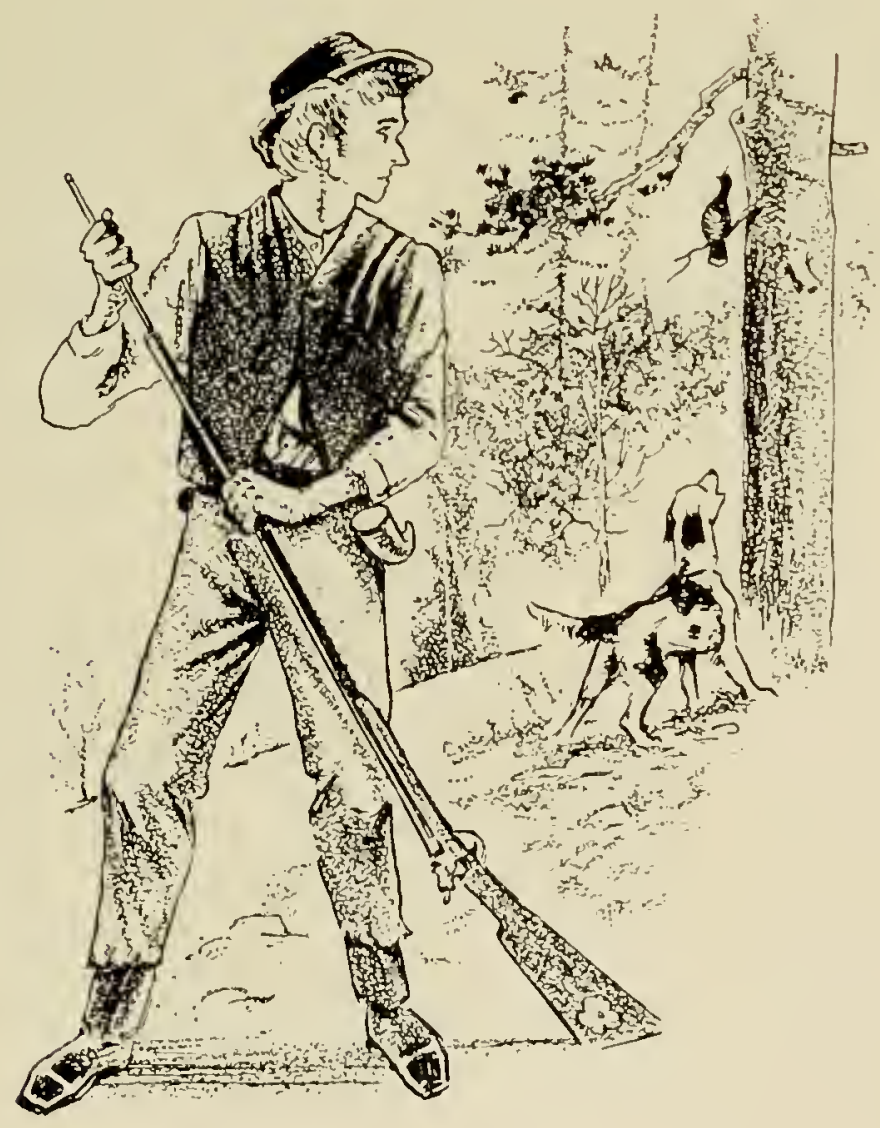


In the early days, probably the first dogs to be used in partridge hunting were of the spaniel type. These were trained to flush grouse into a tree and "bark them up" until the hunter could arrive and shoot them down, onc by one, starting with the lowest to avoid flushing the rest. Alexander Wilson", 18I2, cites the advantage of a "good dog": "the more noise he kecps up, secms the more to confuse and stupify them, so that they may be shot down, one by one, till the whole are killed." In some of the remaining wilderness areas of Maine and Canada, this type of $\mathrm{dog}$ and hunting are still occasionally employed.

As grouse characteristics began to ehange in adaptation to man's influence, this style of hunting became impractical-grouse became too wary of both man and dog. Large forested areas, where it could best be done, gave way, throughout most of New England, to disconnected coverts of small woodlots, brushlots, orchards and hedgerows. Thereupon developed a golden era in the history of grouse hunting over pointing dogs with the setters, notably the Gordon, emerging as the undisputed favorites for many years. If every dog does have its day - this was surely the setter's. Strains of grouse liunting setters were zealously guarded through careful breeding and selection and passed on from father to son. Only those which had a great nose, and could be trained to hunt close-in, were considered. It is probable that even then the patient, painstaking training of a good grouse dog surpassed the education given our finest field trial champions of today. Credit for developing these great dogs must be divided anong the "sports" who hunted for fun, and the market hunters who had to have a dog with which they could deliver the goods day in and day out.

It was this era which produced so many of the great grouse dogs, grouse hunters, grouse hunts and grouse hunting stories, and it was a sad day when old timers began to realize that it was coming to a close, thirty or forty years ago. Various reasons have been cited but four are given most frequently-increased wariness in the bird with accompanying reluctance to "lay to the $\log$ "; the introduction of the pheasant which spoiled many good grouse dogs and grouse hunters; less breeding for the field and more for the bench and trials which resulted in changed canine ideals which were not appreciated in the thick grouse coverts; and periodic declines in grouse which were so severe as to discourage the breeding and ownership of specialized grousc dogs. Probably all four operated in varying degrees in various sections of the Northeast.

Towards the end of this period the English pointer began to take its place in the sun as a grouse hunter. Its relative nerits were argued at great length in sporting publications of that day, even as they still are today. It had one distinct advantage in that it was shorthaired and did not accumulate burrs like the shagry setter. Generally, it was also less timid and less inclined to gun-shyness.

The decline in specialized grouse dogs of the pointing type continued over two or three decales and up until very recent years. The number of grouse hunters actually increased but a greater proportion hunted without dogs or turned again to all-around types such as the corker or springer spaniel. These types could be made to hunt elese and were particularly useful in finding dead or wounded birds. They were also more adaptable to hunting for a mixed big of pheasants, grouse, woodeock or even rabhits and sifuirrels. It has come to be a well recognized fact that few pointing dogs, exept in their old age, can be successfully switched from pheasant hunting to grouse hunting. or vice-versa. It is too much to ask the average dog to range wide and fast over open country for pheasants one day and then to stick to the cover and hunt elose for partridge on the next.

In very recent years, it is possible that we may have entered what will prove to be another 
era in grouse-dog history. Skeet and similar clay bird shooting have produced many splendid wing shots who are turning to partridge as the top gunning bird of the northeast. This, in turn, has revived interest in grouse dogs of all kinds. Along with this development is the happy circumstance that agriculture has long since passed its peak in the northeast and each year finds thousands of acres of cleared land reverting to brush and-grouse cover. History will record the outcome of these two highly significant trends.

To the old line spanjels, setters, and pointers has been added a newcomer-the highly adajtable, all purpose, German shorthaired pointer. Although not fully tested, it gives promise of great things as a cover dog. It is especially tractable, smart and its extra dash of hound blood gives it a great instinct for hunting. However, it is not as stylists as the setter or pointer and its usual dark eolor is a great handicap in close cover where it becomes virtually impossible to hunt without a bell. Its chief advantage seems to be that it is more easily broken and handled by the amateur. Other largely untried breeds may also merit exploration.

Among experienced grouse dog men, those who are able to lay aside strong personal likes and dislikes as to breeds or straius generally agree that, today, the making of a good grouse $\operatorname{dog}$ is more a matter of the individual $\log$ (what he las in him inherently) and the training he receives, than it is a matter of a certain breed or strain. However, breeds and stritins do have some generally well recognized characteristics and it behooves the uninitiated prospective buyer of a grouse dog to ask himself just what it is he wants his dog to be able to do and to keej in mind just where and under what conditions be expects hin to do it. A thongritful consideration of these items will help to indicate the best type or breed for a given job.

As to the broad question- $\operatorname{dog}$ or no $\mathrm{dog}$ - the authors leave that one to the hot stove leagues and pulblications of the sporting world. The authors themselves are divided. If pressed for an answer it would have to be-a good dog, yes; anything less than that, no. The writers have niturally known many gronse hunters and seen nuany alleged grouse dogs in action. All too few of the latter have been properly hred, trained and handled.

The answer to this question also hinges on the type of country to be hunted. In places where a sparse grouse population is under great hunting pressure, a dog is of doubtful value, except perhaps as a retriever. In such situations grouse become so wary lloat dogs are of little value as pointers or funders. They are also of doubtful value in the big woods wil. derness areas. In thick brushy coverts where birds are reasonably plentiful and the hunting pressure moderate, their value is almost unquestioned.

In the early days of the Investigation, the authors attempted the use of grouse logs as an aid to its field work on areas where birds were leing followed closely throughout every season of the year. Tests were made on the Connecticut Hill area with the best grouse dogs locally available. Each dog was handled by his own master.

Somewhat to the surprise of their masters, and to the disappointment of all, even the best of the dogs failed to do any kind of a joh under spring, smmmer and winter conditions. Even in the fall, the fact that dogs have "good" days and "bad" days, made results anything but comparable. In the spring, scenting conditions are so exceptionally poor that it is not unusual to have a good dog pass within a very few feet of a nesting grouse and never detect its presence. In the summer, conditions of heat and rank vegetation quickly exhaust the most stout-hearted and best conditioned dogs, rendering them virtually jnoperative. $l_{n}$ the winter. increased tree roosting and snow roosting take the birds out of the scenting range of dogs; and very deep snow or soft crust, shackle a dog very effectively. 
However, even though dogs cannot be relied upon as a tool for painstaking field work, the authors are, nevertheless, firm in their belief that the individual hunter can learn a great deal about the habits of grouse during the fall season by the close observation of a good grouse dog. Man, as a grouse hunter, is handicapped because he can only see and hear and does not have a nose tuned for bird scent. Thus, most hunters who "walk them up" can only learn by observing and, to a lesser extent, by hearing. This reveals little ahout the hird's movements up to the point it explodes from the ground or a tree. A keen hunter, especially if he raises and trains his own pup, can learn more from his dog than he can teach it.

One of the first and most important lessons has to do with that critical period between the time a bird senses your approach and the moment he actually flushes. It is no accident that a grouse usually flushes from the other side of a piecc of brush, a tree, a stone wall or whatever kind of cover is available. He has maneuvered himself into that position. A pup will often come to a staunch point and hold it expectantly only to have a partridge get up a long ways ahead and, usually, beyond a screen of cover. The pup and his master soon learn that she was pointing where a bird had been when first approached. In the meantime the bird had quietly sneaked ahead until able to fly safely away. As a dog gains in experience, the first point is often momentary, followed by a series of starts and stops along a partridge's trail until the final point is made, indicating that the bird has reached his jumping off place. By fixing one's eyes on a point well ahead of the dog it is often possible to guess where that jumping off place is and then for the hunter to approach from a converging angle in such a way as to disorganize the bird's strategy and force him to jump so that he will offer a fair shot. It is usually a mistake, if the cover is at all heavy, to walk directly ahead of a dog on a line with its nose. To do so means that you are flushing the bird from the angle he expects, thus leaving him master of the situation.

This sort of team play between man and dog is, to many hunters, the most exciting part of grouse hunting and, gradually, both members of the team learn more and more about the tricks a modern partridge has in his bag, all of which adds to the enjoyment of grouse hunting and contributes to the hunter's suecess.

A hunter without a dog can still apply such lessons in a general way. If you are in a covert, where you belicve grouse to be, size it up before you walk through it: try to anticipate the likely places for a hird to run to before flushing; and try to handle yourself and your companions in such a way that you will disorganize the hird and get a fair shot when it flushes. The authors have observed several old time market hunters, indiriduals who always hunt without a dog, who can do this to perfection. They are, in a sense, hird dogs themselves.

Finally, from the conservation point of view. it should be emphasized that many dead and wounded birds left in the field could be recovered by the more general employment of

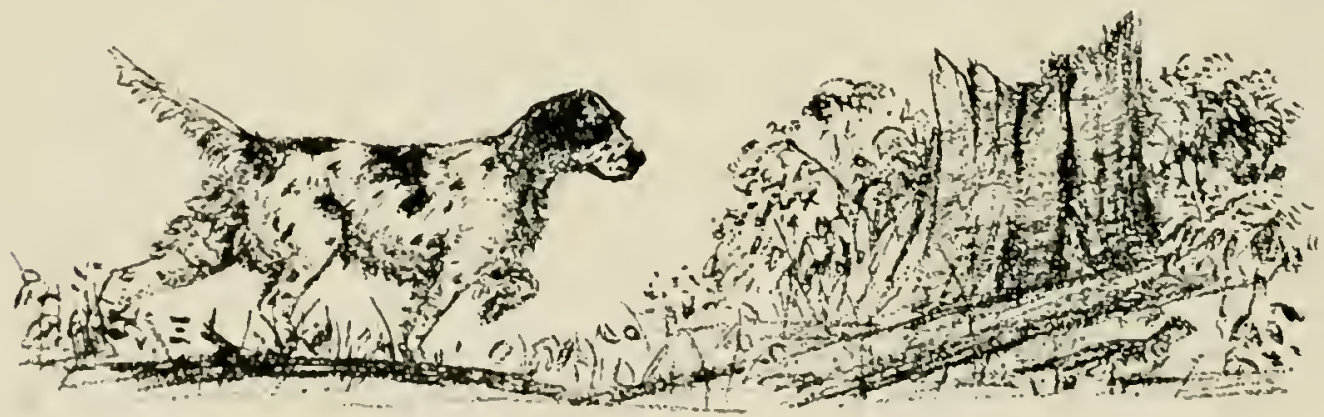




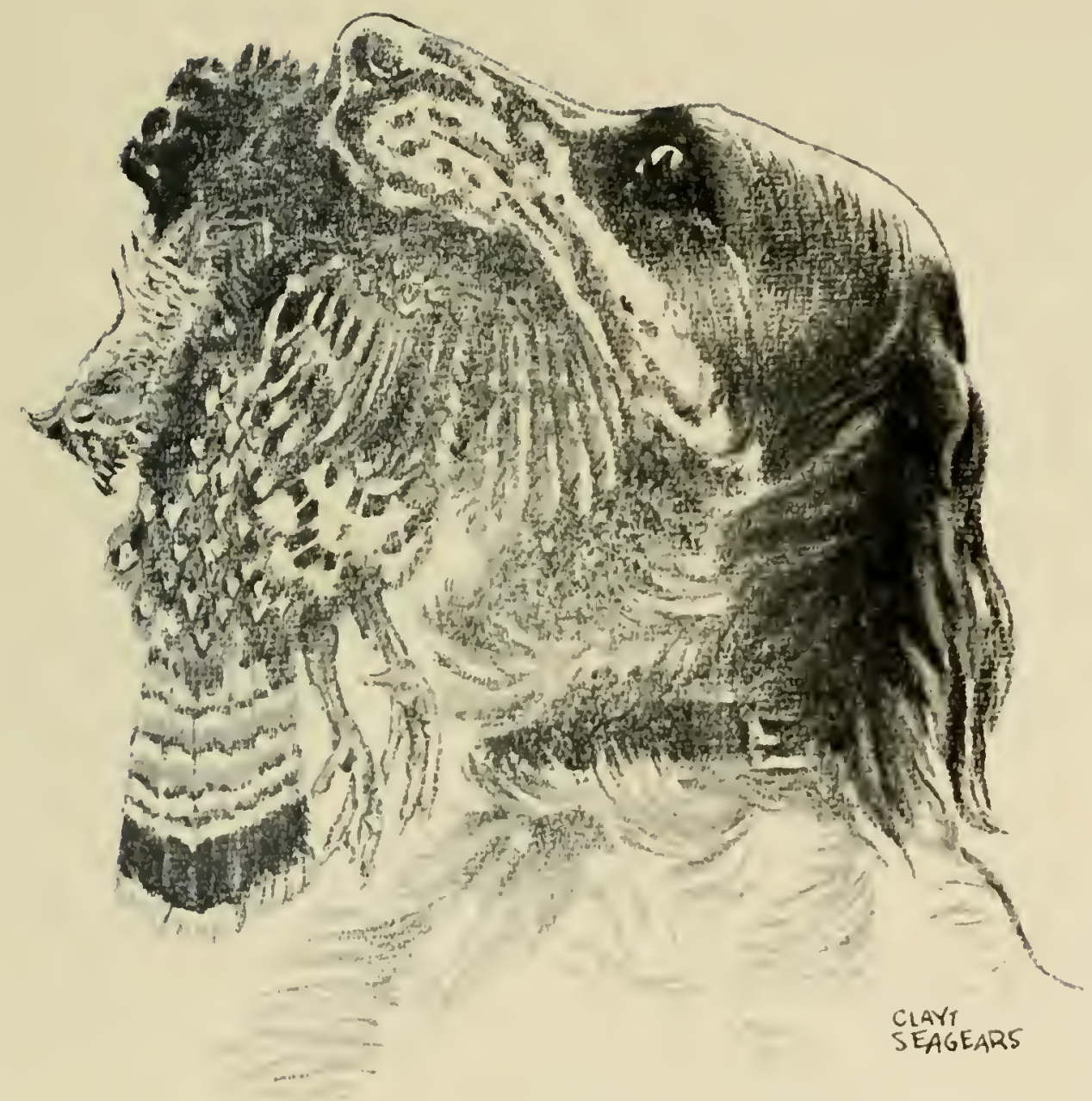


grouse dogs. Even a small spaniel, which is otherwise kept at heel, can very quickly earn his keep by finding a "down bird" or two. Nothing is so disheartening or so contrary to the conservation principle of wise use as to bring down a wily old partridge, only to have to leave him, hecause he cannot be found, to the skunks, crows and mice, instead of giving him his proper place at the head of a festive board.

And then, there is so much to a good grouse dog beyond his utility. One staunch point under a low hemlock, pine or thorn apple, with the sun streaming down through the painted foliage on a crisp October day. makes a picture and provides a thrill which. to use the vernacular, takes the enchanted hunter "right out of this world." And if, perchance, one does his part with his double gun, and his or her canine highness comes trotting proudly back to deliver the prize-one has something to talk and dream about for the rest of his life.

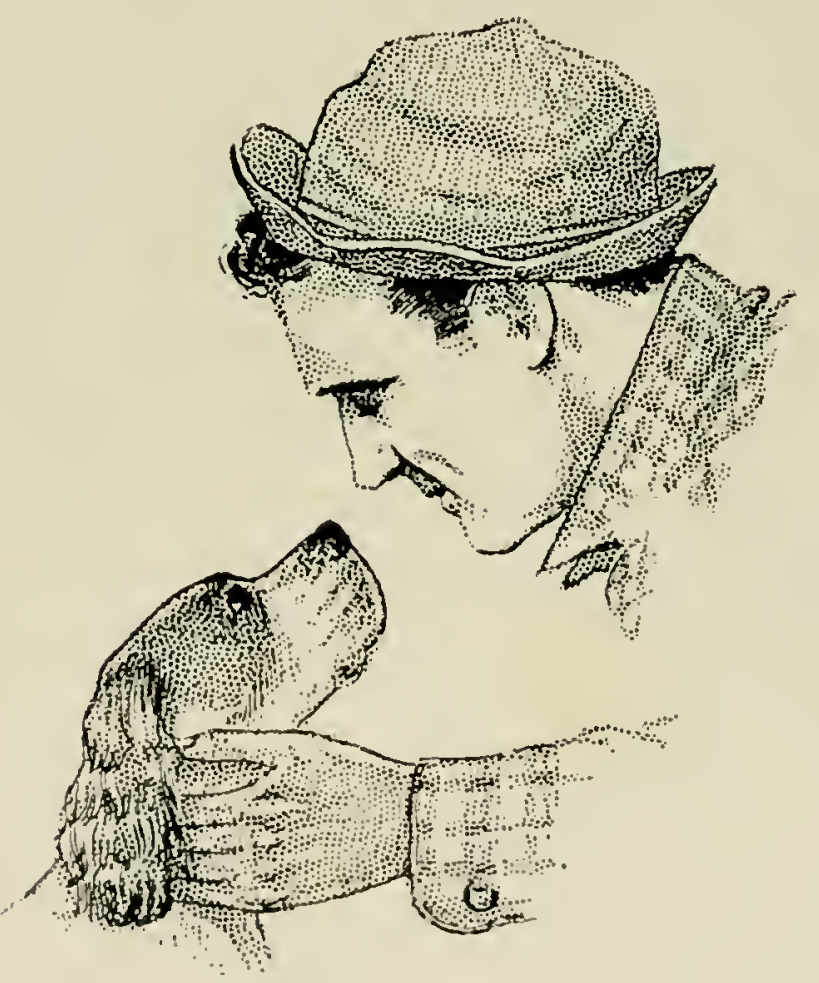




\title{
CHAPTER $\mathrm{X}$
}

\section{PARASITISM AND DISEASE}

\author{
By P. P. Levine and Frans C. Goble
}

\section{DISEASE AND ITS CAUSES}

The So-called "Grouse Disease" - Fa

ical lnjuries - Chemical Poisons - Nutrictors Whicu May Cause Disease - MechanParasites - Filterable Viruses tional Deficiencies - Animal l'arasites - Plint

\section{PARASITISM AND DISEASE IN WILD GROUSE}

Factors Affecting Different Age Classes - Yearly Varlations - Sfasonal. Variations - Regional Distribution - Relation of Other Animal Diseases to Grovse - Poultry Discases in Grouse - Parasites of Other Wild Birds - Diseases of Wild Mammals - Relation of Disease to Pridation

\section{PARASITES OF IVILD GROUSE}

In tile Respiratory Sistem - Gape Worm - In the. Digestive Tract - Crop Worm - Stomach Worm - Gizzard Worm - Large Roundworm - Large Tapeworm - Small Tapeworm - Cecal Worms - Coccidia - Bloon P'Arasites - Microfilaria - External. Parasites - Ticks - Louse Fly - Parasites Not Encountered During the InvesTIGATION

\section{DISEASE IN HAND-REARED GROUSE}

Quall Disease - Blackineal - Tuberculosis - Aspergillosis - Air-Sac Mites Pebosis

THE ROLE OF DISEASE

\section{S \\ SUMMARY}

No evidence has been uncovered pointing to a strong causative relationship between disease and periodic fluctuations in grouse abundance. (p. 442).

No significant variation in the incidence of parasitism and disease occurred from year to year during the period of the Investigation. (p. 413).

No one malady can rightly le termed "the grouse disease". Specific diseases responsible for deaths among grouse in one locality are not found in other parts of the grouse range, while those parasites which have a wide distribution appear largely to be innocuous. (p. 404). 
Grouse found dead in the field may be the victims of mechanical injuries resulting from shooting, being struck by automoliles, or flying into wires, quite as commonly as from disease. (p. 404).

The most frequent cause of death from disease in wild grouse in New York State is the inflammation of the saccular stomach due to infection with a small roundworm parasite, Dispharynx spiralis. This affliction occurs oftener in birds from three to nine months old than in any other age class. Most deaths from this parasitic disease occur during the fall and winter. (p. 411).

The stomach worm, Dispharynx, was not found in grouse collected in the Adirondack Mountains proper and was infrequently encountered on the periphery of this region although the sow bugs which serve as an intermediate host occur in these areas. (p. 420).

The most common parasite encountered was the large intestinal roundworm, Ascaridia bonasae, which occurred in over one-fifth of the adult hirds. No great numbers, however, were found in any one bird and no deleterious effects conld be attributed to its presence. (p. 410).

Some parasites, such as the large intestinal roundworm (Ascaridia), are found throughout the State, while others, the crop worm (Capillaria) for example, are found in limited areas only. (p. 413).

Bird ticks were found to be more abundant in the Adirondack region than in the rest of the State. In that region more birds were infested and more ticks occurred on each parasitized bird than in other regions of the State. (p. 413).

Hand-reared grouse are markedly susceptible to blackhead and "quail disease" (ulcerative enteritis) - the former common to domestic fowl and turkeys. Present grouse propagation methods, however, are effective in keeping these diseases from causing more than occasional losses among hand-reared birds. (p. 435).

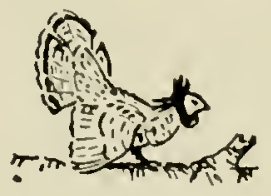

Both the hunter and scientist have become increasingly interested in the hcalth of the grouse. The so-called "Grouse Disease" and cycles have been publicized to the extent that they are generally accepted as facts.

The study of grouse diseascs and their relation to the lluctuating number of the birds in the coverts, as well as the causes and effects of the diseases and how they might he controlled, has been one of the major assignments of the Investigation.

Such research is of particular importance to the sportsman as it sheds light on many of the questions paramount to his interest in the grouse. Each year a number of outdoorsmen discover, for the first time, that their favorite game bird is infected ly various parasites. It comes as rather a shock, so they send them to the State liesearch Center for identification and information. Or they find weak, sick-looking individuals which they fear might have a dread discase. What is the malady, how does it affect their hunting, and what can be done abont it? Every nimrod would like to know because, to him, it is of vital concern.

The rescarch worker studying disease is equally interested in the distribution and relative 
importance of the various diseases to which grouse are subject. The findings here presented are necessarily limited in scope by time and resources. While progress has been made, much is left for future study before all the important questions can be answered.

Realizing the necessity for this research, the Investigation's study of disease was initiated in 1931 and has been continued to date, thus permitting observations over a period of eleven years. During that time, 1,728 adult grouse and 1,119 chicks have been collected for autopsy. The birds were taken from all parts of the State, 50 of the 55 counties outside of New York City and Long Island being represented.

Table 62 illustrates the distribution of the collections by regions and years. The regions here considered, Adirondack, Catskill and Rest of State, are the same as is used in other chapters of the Report (figure 13).

TABLE 62. THE NUMBER OF ADULT GROUSE AND OF GROUSE CHICAS COLLECTED FOR PATIOLOGICAL FAMIINATION BY YLAISS AND REGIONS

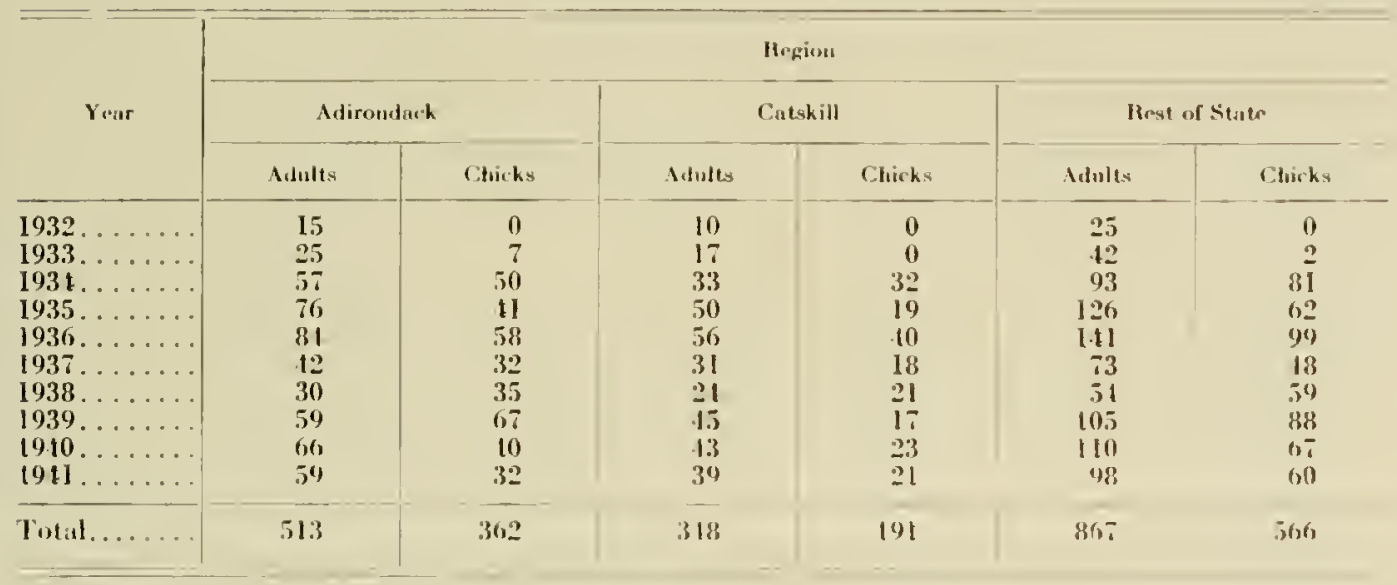

Three separate pathologists examined the material collected during their respective assignments. This fact, together with changes in the methods and techniques employed as experience accumulated, occasionally raise difficulty in evaluating results. Therefore, in carrying out certain comparisons, it was considered advisable to limit analyses to records of antopsies made by the present authors or under their supervision.

\section{DISEASE AND ITS CAUSES}

It is definitely known that most birds and mammals play host to many plant and animal parasites. It is not equally understood, however, that only a few of these rcally damage the animals in which they live. Then they $d o$, it is at their own risk. In effect, these diseaseproducing agents may actually he committing suicide if their activities seriously impair the hosts' well-being. It is erroneous to apply the term "disease" to the presence of parasites which are causing no alteration in the function or structure of their host.

It shonld be borne in mind that disease is not an entity which enters the body from without but is a process of abnormal activity of certain bodily functions in response to an injury. This process may or may not be associated with appreciable changes in hody structure. However. 
much of our knowledge of disease is gained by interpretations of the changes occurring in the various tissues and affected organs.

\section{The So-Called "Grouse Disease"}

In the study of birds whose fluctuations in numbers have so long been observed and speculated upon, it is probably natural that some investigators have had preconceived notions about the relation of disease to these periods of scarcity and abundance.

The concept and term "grouse disease" came into use as early as 1838 in connection with the fluctuating numbers of red grouse in Britain. Naturally, it was applied in America as interest grew in the study of ruffed grouse. Naturalists, sportsmen, and other amateur observers reported as "gronse disease" their discoveries of louse flies, ticks, "abdominal parasites", fowl cholera and tuberculosis. A professor of hacteriology unhesitatingly remarked that the louse fly was probably the carrier of the "germs" of blackhead in grouse. An ornithologist suggested that a small stomach worm might be the cause of "grouse disease" in this country and that the presence of this worm might be associated with the phenomenon known as "crazy. flight".

Investigators of the British Committee of Inquiry on Gronse Disease elaimed that "gronse disease" in England was mainly attributahle to two types of parasitism. One involved a thread-like worm. sometimes occurring in the intestine by the thousands. The other was due to microscopic one-celled animals known as coccidia. These live and reproduce in the cells lining the intestine.

In this country, althongh abont 50 parasites and a number of disease conditions have been olserved in ruffed grouse, none have becn conclusively associated with any widespread decrease in the numbers of these hirds over their entire range.

Some parasites that are known to reach a stage of infection serious enough to cause death in New York have not heen found in Minnesota or even Vermont and New Hampshire. Others, reported as important in Ontario, have not been encountered in New York. Pathological conditions observed in captive grousc are olserved in the wild very infrequently. No disease recorded to date seems. therefore, to make a serious bid for the title of the "grouse disease" in America or to occupy a position comparable to the parasitisms ohserved in British grouse.

\section{Factors Which May Cause Disease}

One of the convenient approaches to the study of diseasc is hased on the natural classification of the factors whose presence may excite pathologiral processes. Some of these may be inherent in the animal itself through inherited traits and tendencies. Others originate in the external environment and, under certain eonditions, become inimicable to the health of the lirct. Part of this latter group are physico-ehemical factors such as methanical injuries. chem. ical poisons and mutritional deficicneies, while part are biological, as represented by animal parasites, plant parasites and filterable viruses. It is necessary to consider each of these in some detail in order to understand their roles in the life and death of gronse.

\section{Mechanical Injuries}

The conditions which result from physical violence to the hodies of the hirds are known as mechanieal injuries or tramma. Some grouse are struck by automobiles and trains. others fly into houses or telephone wires. Shooting and predation also eome in this eategory. 
Although a few cases have been observed in which recovery has heen made from minor injuries, in most cases death ensues sooner or later as a result of the structural and functional changes produced. Occasionally shooting or other trauma will result in the perforation of the intestine without serious injury to blood vessels or other vital organs. Death from peritonitis results sometime later.

Observations on captive birds have shown that even comparatively minor injuries may cause a disinclination to eat and that death from malnutrition may result a week or so following injury. As small an injury as the loss of a toenail may lead to severe bleeding and death. On the other hand, birds so severely scalped that their skulls are laid bare, may recover.

\section{Chemical Poisons}

Contacts with the cluemical poisons which have come to be of importance in connection with other species of wildlife are of rare occurrence in grouse. During this Investigation one gruuse chick, collected for routine examination. presented pathological findings indicative of learl poi. soning. the result of eating and harhoring one small lead pellet in its gizzard. The conditions associated with grouse hunting as well as the halits of the hirds would logically minimize the occurrence of this disorder.

No other instances of either chemical or organic poisrning have heen observed.

That grouse are remarkahly resistant to some of the poisons commonly used in insect or rodent control seens to be indicated by the experiments reported in the chapter on Food Habits (p. 195).

\section{Nutritional Deficiencies}

For the most part, Nature has provided for the adequate nutrition of wildlife in its natural habitat. It is only when hroad natural changes or man's activity disturbs the habitat that diff. culties due to inadequate nutrition are likely to occur.

No evidence of malnutrition has been encountered in wild grouse during the course of the Investigation except in birds which were suffering from merhanical injuries or parasitism which interfered with their normal feeding activities.

On the other hand. at least one abnormality due to inadequate diet has been produced in grouse reared in captivity. This condition, known as perosis, slipped tendon or hig hock disease, has been encountered in young grouse chicks.

\section{Animal Parasites}

The group of organisms most frequently observed ly sportsmen and others interested in grouse are the animal parasites. As the hunter picks up a freshly sluot bird, he may see among the feathers. winged insects with flattened hodies whicl scurry about and soon leave the dead game. If be observes more closely, ticks of various sizes may be apparent, closely attached to the skin.

Later, when he cleans the bird, he may discover thick white worms a couple of inclues long in the body cavity. Or. if the gizzard lining is stripped off preparatory to cooking, thin pink worms may he found lying between the lining and the muscle.

These are the comparatively harmless grouse dwellers that are commonly seen. Other animal parasites live in the blood. some actually within the red blood cells, others in the cells lining the intestine. Still others are small flat worms not readily observed with the naked eye. 


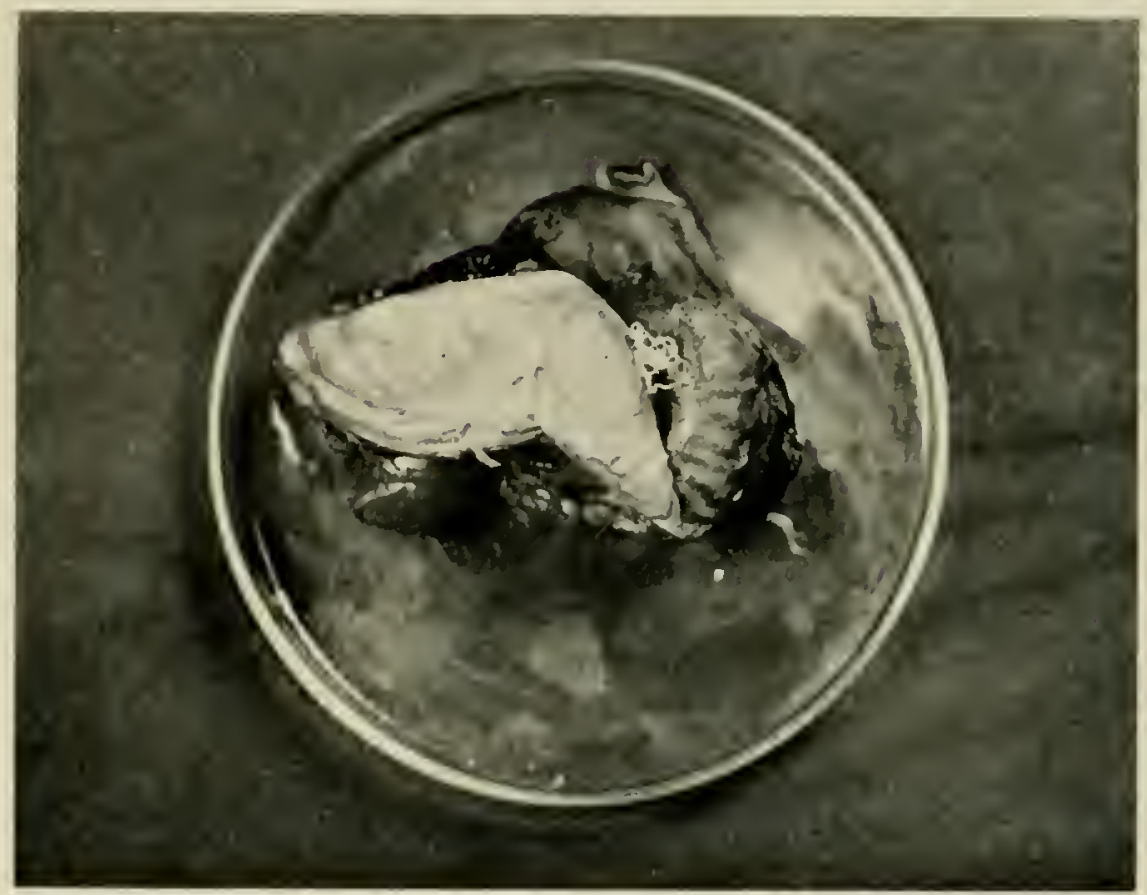

INFESTATION OF THE GIZZARD WORM (Cheilospirura spinosa) UXDER GIZZARD LINING - A RELATIVEL IJARMLESS PARASITE; OF GROUSE

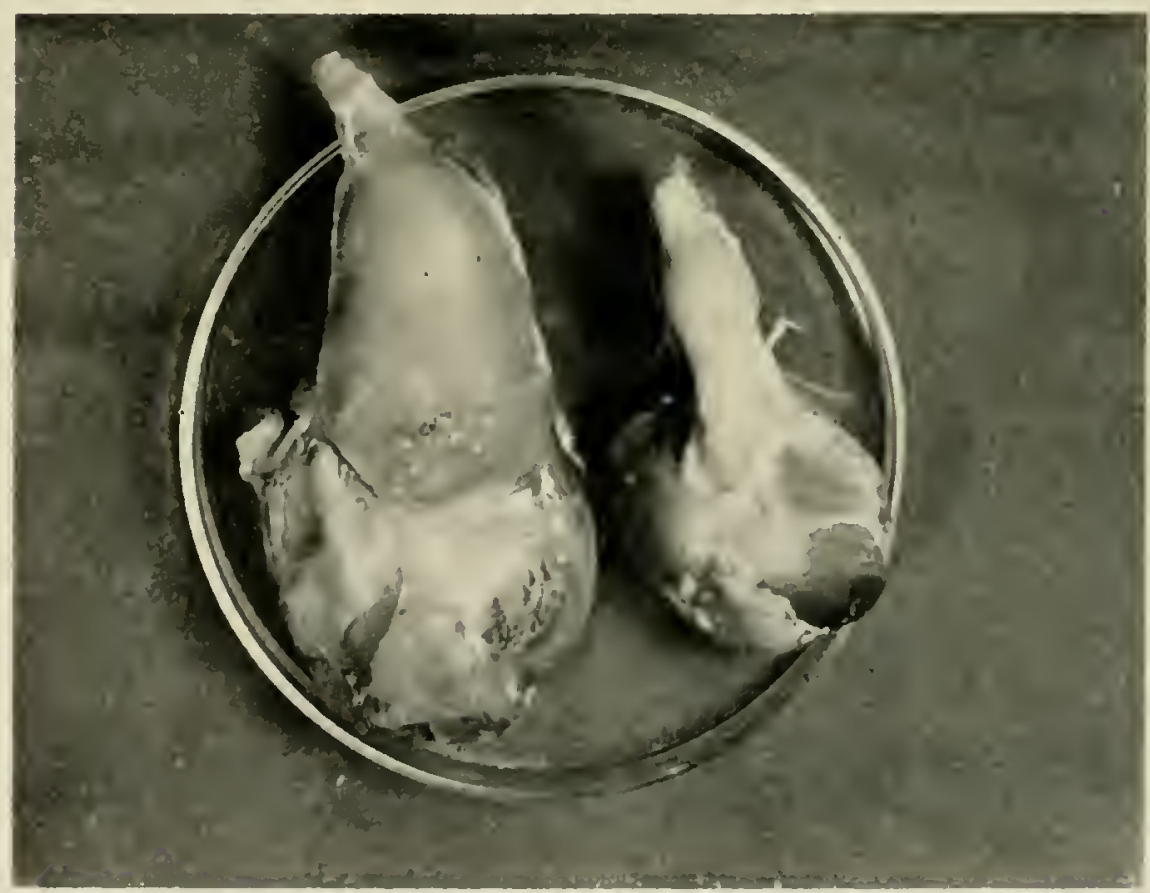

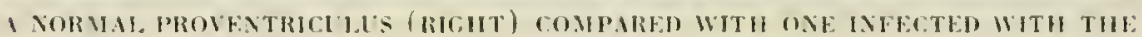

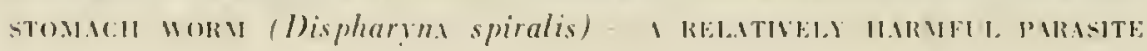
OF CHOLSE. 
Animal parasites may damage their hosts in a number of ways. Tapeworms absorb food from the intestine which might otherwise be utilized by the hird in which they live. Other worms suck blood. Waste products of some parasites are poisonous. In the Investigation of "grouse disease" in Encland it was observed that injuries produced ly parasitic worms provided portals of entry for bacterial infection.

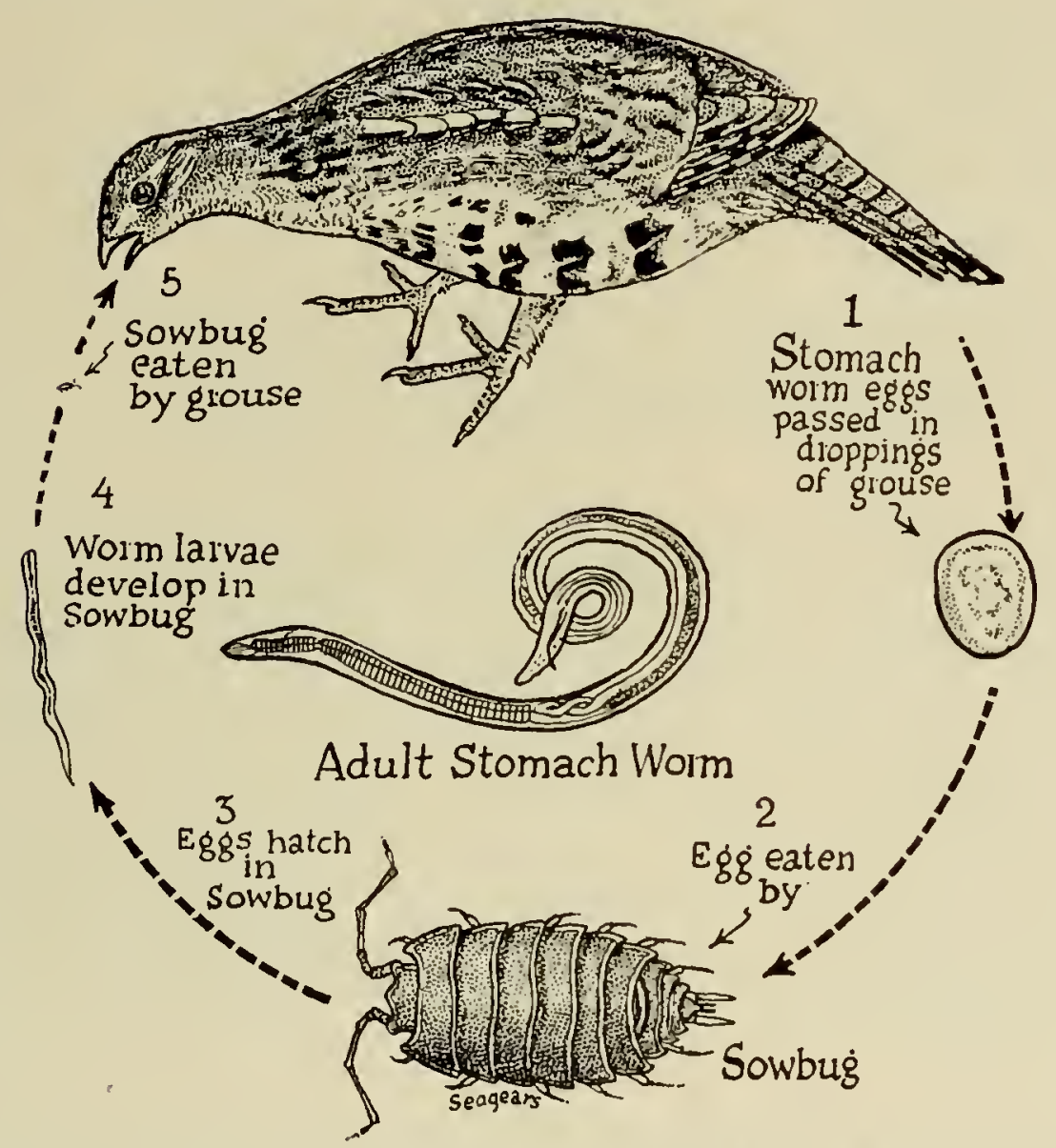

FIGURE 31. TYPICAL LIFE CYCLE OF PARASITE INVOWING INDIRECT MODE OF TLANSMISSION - sтомАси woнм (Dispharynx spiralis)

That the attachment and presence of some parasites may cause extensive tissue destruction and inflammation has been repeatedly demonstrated during the lnvestigation by mumerous cases of infection by the stomach worm (Dispharymx spiralis) of which the following is an example. On December 12.1910. a female grouse abont six months old was found in the field in Chenango Connty. This bird weighed only 292 grams (about 101\% ounces). Postmortem examination revealed that the saccular stomach or proventriculus was enlarged to hetween three and four times its normal size. The cells lining the stomach were being sloughed off and the tissues helow the lining, where numerous stomach worms were found, had been stimulated to excessive growth so that the stomach cavity was nearly filled with a plug of mueus and destroyed stomach tissue. 
Infections with animal parasites are picked up by grousc in various ways. Eggs of the intestinal worm (Ascaridia) and cecal worm (Ileteratis) are passed from the infected birds in the droppings. develop to an infective stage on the ground and are accidently picked up by other hirds while they are feeding. Eggs of some of the other parasites canmot develop to the stage which can infect grouse without first heing taken into the body of some other animal, generally a snail. insect. or other invertebrate. Grouse become infected with the gizzard worm (Cheilospirura) by eating infected grasshoppers. Likewise stomach worms (Dispharynx) become estahlished from feeding on infected pill bugs, while tapeworms are contracted from infected snails. beetles, slugs. ants and flies. Farthworms may he of importance in the transmission of the crop worm (Capillaria) and the gape worm (Sygamus). In these cases it is obvious that the size and number of infections will be influenced by the numbers of the intermediate hosts and the extent to which they are used as food. A typical life eycle is illustrated in figure 31.

Another mode of infection is by the lite of insects. The one-celled animals which canse malaria-like diseases of hirds may be carried by black flies and louse flies. Table 63 presents a list of the animal parasites reported from ruffed grouse.

\section{Planı Parasites.}

The plants which are commonly thought of as parasitic in animals are the hacteria or "germs". These are one-celled organisms, some of which can live in various sitnations outside of animal bodies for long periods and yet under some circumstances cause disease when taken into the hody. Others can live but a short time away from flesh and hlood. These must depend on rather direct contact for their transnission. Still others may be normally found existing harmlessly in some parts of the body but are capable of producing serious effects when some other factor alters the function of the organ in which they dwell.

In domestic hirds bacteria are the cause of many diseases. Some, such as tuherculosis, are occasionally enconntered in hand-reared grouse. However, the plant parasite which has been identified most frequently as a cause of disease in wild grouse is a mold (Aspergillus fumigatus). These microseopic plants are related to the bacteria but have a more complex struclure and reproductive process.

\section{Fillerable Viruses}

The agents causing certain diseases are so small that they can not he observed with ordinary microssopes. One of their eharacteristies is the ability to pass through porcelain filters which arrest the passage of organisms as large as hacteria. Berause of this they are known as filterable viruses.

A discase of horses, corresponding to slecping sickuess in humans, equine encephalomyel. itis, is caused by organisms of this type. This aflliction also attacks humans and has been

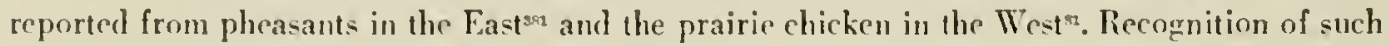
wild reservoirs of diseatse is of great importanee to public heahth authorities in the control of diseases of hmmans and domestic animals.

Bircl pox is an important disease of this gronp which is generally seen in domestic pouttry and game farm hirik. Lut it has also been reported twice from ruffed grouse in New Fingland ${ }^{17}$, ex 
TABLE 63. THE ANIMAL PARASITES OF THE RUFFED GROLSE AND THEIR REPORTED DISTRIBUTION

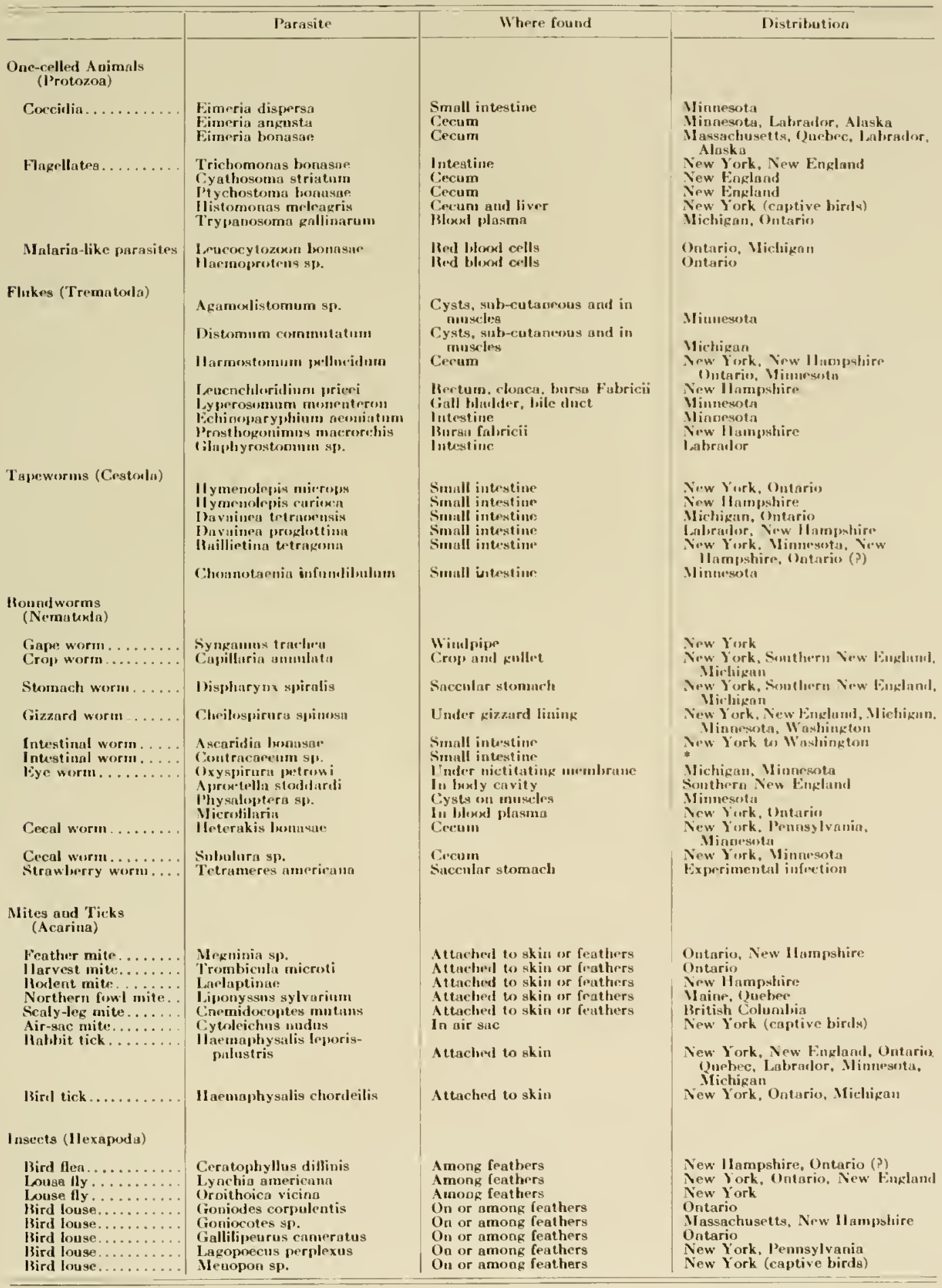

* Listed by Cramino bat no locality given. 


\section{PARASITISM AND DISFASE IN WIID GROUSE}

The fact that all parasites and pathological conditions are not found in all places, at all times and in hirds of all ages. leads to speculation as to the causes which influence the disiribution and effert of varions infections. Here many interesting questions arise: - Is the inci. dence of parasitism in grouse the same in different regions of the State? Does it vary from year 10 year, or from season to season? Do adult birds have the same parasites as the immatures and are they found in the same numbers? What diseases observed in captive birds are found in the wild? Are soil and climatic conditions factors influencing disease?

Wherever the information accummlated during the Investigation appeared reasonably adequate, it has heen analyzed with these problems in mind.

Before the pirture is considered in detail, it is informative to gain an overall impression. Based on the collection of a sulstantial number of wild hirds from each region of the State, for each season and covering a period of ten years, table 64 was compiled showing the relative occurrences of parasites. Examination of this reveals that these are only four internal parasites whose incidence exceels five per cent. It is also apparent that their relative positions differ, depending on whether they occur in adults or chicks.

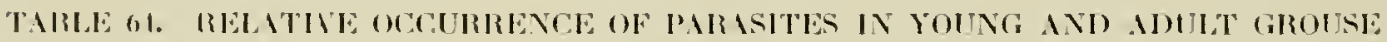
IN NEII YORK -1931-191]

\begin{tabular}{|c|c|c|}
\hline \multirow{3}{*}{ Parasitu. } & \multicolumn{2}{|c|}{ Ige } \\
\hline & Cllicks & Adults \\
\hline & Per antut of inteidnoce & Por etent of incidentive \\
\hline \multicolumn{3}{|l|}{ Inlernal: } \\
\hline Inlestinal worms. & 10.1 & 21.9 \\
\hline Stomnacls worms. & 6.7 & 12.7 \\
\hline Gizkarl worus.. & 2.3 & 7.8 \\
\hline 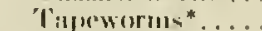 & 19.8 & $\div .0$ \\
\hline levil wormas. & 0.1 & 1.8 \\
\hline Microfilarin.... & $\ldots$ & 1.2 \\
\hline Crop worme. . . & & $1 . t$ \\
\hline Goccidis...... & 10.1 & 0.7 \\
\hline Giape worms... & 0.9 & 0.2 \\
\hline \multicolumn{3}{|l|}{ lixtermal: } \\
\hline Tickss. & 11.8 & 11.6 \\
\hline Iouse flies. & 2.0 & $\therefore .0$ \\
\hline
\end{tabular}

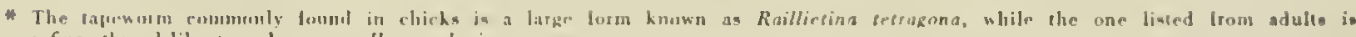

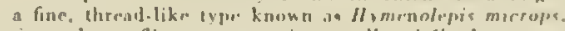

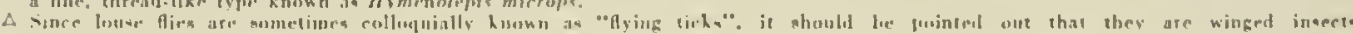
and that the term tick shoubl enly be arghled to the more seilentary, wingless ectuparasitic selatives ul the agiders and miles.

One might conclude from the table that intestinal worms. which werul in such a high percentage of the hirds, are of the greatest importance. Thi- view. however. can not be substanti. atter when the alility of the parasite to produce discase is considered. The intestinal worm

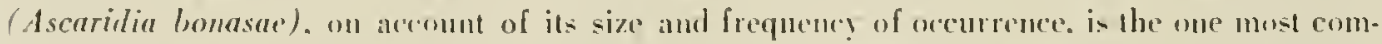
monly olserved hy sportsmen and which they are likely to regard as a serions enemy of gromse. The organism which is. however, most capable of producing disease is the seldom seen stomach worm which arcupies hut fourth place in frequeney of occurrence in chicks and second place in adults. 
It is likewise important to point out that the number of parasites found in any one bird does not necessarily indicate the importance of the infection. since the presence of as many as 78 intestinal roundworms has been noted without evidence of damage to the host. On the other hand, only a few stomach worms may be found in a badly diseased stomach. Table 65 shows the average numbers of parasites per bird of those infected and the maximmm number encountered in any one hased on olservations made during the Invertigation.

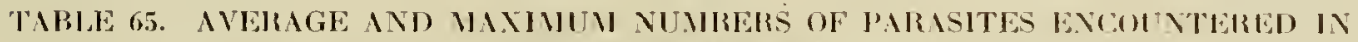
GROLSI: IN NEW IOHK-1931-1911

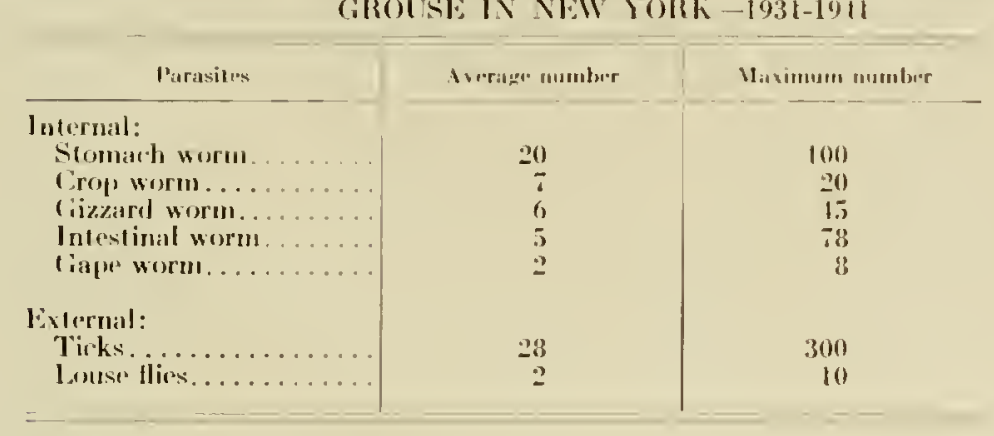

Since this lack of relationship exists between the abundance of parasites and their pathogenicity, a tuhulation of the disease conditions encounlered offer- information of greater significance in the evaluation of the role of these in aders.

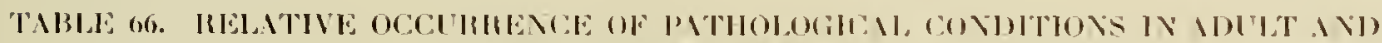

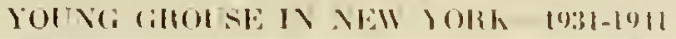

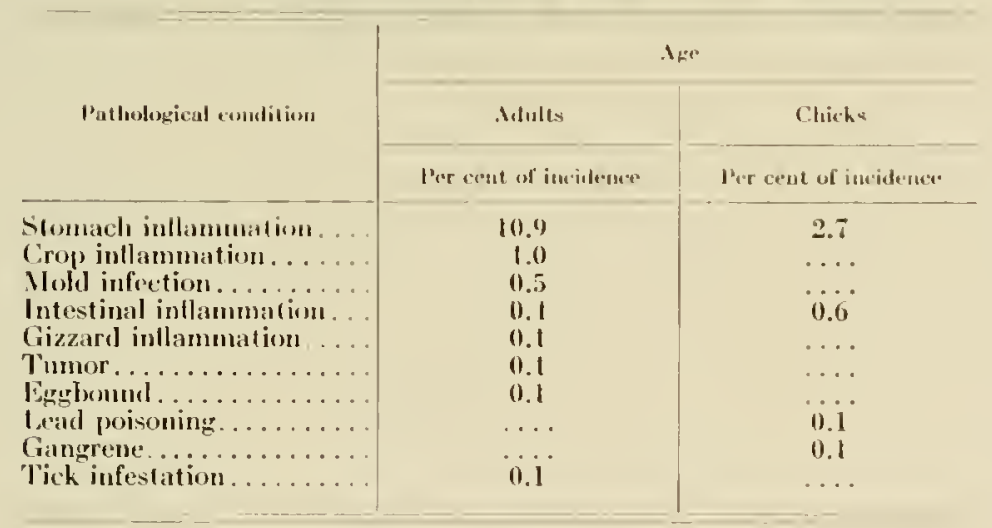

An examination of table 66 reveals the significance of somach worm infection in its true light. since it is apparent that inflammatory reactions due to this helminth lead the list of disease conditions observed. With the exception of one ease of tick infestation. all animal parasitism resulting in death has been attributahle to this small roundworm.

The only other fatal infections olserved were due to aspergillosis. This disease, cauned by the invasion of the body by a mold or fungus organism. was the only malady. which was found 
in both wild and captive grouse. In the former it was encountered only a few times and in widely separated parts of the State.

Inflammation of the crop, intestine and gizzard, associated with infections by crop worms, tapeworms and gizzard worms respectively, were not of a serious nature and no deleterious effects on the well-being of the birds were observed.

Certain variations due to geographical, seasonal and age differences have hecome apparent during the course of the Investigation. These indicated that a table of incidence based on total collections presented information of an extremely general nature. To take but one example, the incidence of the stomach worm (Dispharynx) in all birds over three montlss old is listed at 12.7 per cent. Subsequent analysis revealed that this parasite was almost entirely absent from the Adirondack region, appearing only oceasionally on the periphery. Further examination of the data showed that 29.1 per cent of the birds of the year (from three to nine months old / were infected, but adults taken during the spring and summer had infections in only 8.7 per cent. Accordingly, in order to complete the picture, the variations due to age of the birds, seasons and regional distribution are discussed in the following sections.

\section{Factors Affecting Differfat Age Classes}

That certain organisms commonly parasitize adults while others are more liable to be found in young hosts, has been observed frequently during the course of recent pathological examinations. This phenomenon is clear-cut with reference to certain of the parasites encountered in grouse but is less well defined for others. Incidences of the commoner parasites in the different age classes are shown in table 67.

TABIE 67. INCHANCE OF THE COMMON PARASITES OF GROUSE IN NEW IORK BY AGL: ClASSES 1931-1911

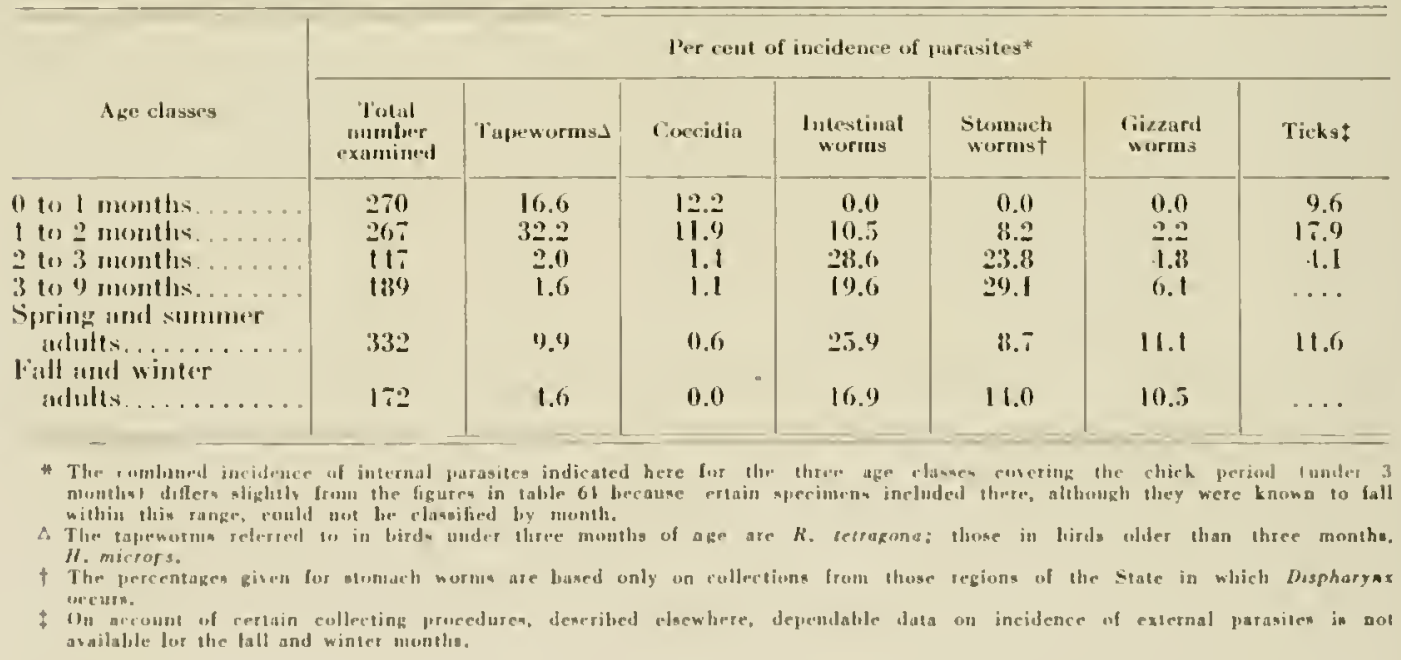

P'arasitism in chicks under two weets of age is relatively infrequent. hut very soon there. ifter tapeworms and coccidia are found. Both of these are relatively abundant in June and July but infrequently found by August. Most of the tapeworms found in these young birds are a large furm (Railliefina letragona) also found in domestic poultry. It is presumed that 
the infection is gained by eating ants, which early in the summer form a large part of the animal food of the chicks. Coccidia, which have a direct life cycle, are obtained by accidental ingestion of the infective stages during feeding. Neither coccidia nor the above tapeworms are found in any appreciable number of adults. Ticks, which occur on about 12 per cent of both chicks and adults during the summer, are most frequent in July.

During July, the three parasites which occur most frequently in adults begin to make their appearance in the chicks. These are the stomach worm (Dispharynx spiralis) gizzard worm (Cheilospirura spinosa) and intestinal worm (Ascaridia bonasae). In the birds of the year during the fall and winter, the stomach worm occupies a prominent position. Although it seems capable of producing lesions equally serious in adults as in young birds, the relative incidences probably indicate its greater importance in the latter.

\section{YEARLY VARIATIONS}

In view of the numerous reports on the cyelical nature of grouse abundance and scarcity, the analysis of the data on parasitism on a yearly basis was regarded as one of the most important phases of the Iuvestigation.

Although, in some instances, superficial inspection of the data seemed to indicatc that yearly variation occurred, this was found to be due largely to changes in the intensity of collecting in localities or scasons in which the parasite might be more or less ahundant than the average.

Since these seasonal and regional effeets had to be removed in treating the material. the incidence of only the numerously occurring parasitcs could be compared from year to year. These analyses were carried out for intestinal roundworms, stomach worms, gizzard worms and tapeworms in adults and for tapeworms, intestinal roundworms. stomach worms and ticks in chicks.

No evidence could be adduced to support the idea that significant changes in the incidence of parasites took place from year to year during the course of the lnvestigation. It must he remembered, however, that no substantial decline in the grouse population occurred during this period.

\section{Seasonal Variations}

The general view that disease and parasitism is more prevalent during the warmer months is borne out by observations on tapeworms and intestinal worms in grousc, but it is not appat rent from the data on stomach worms. No explanation for this difference is suggested hy the data or the facts which are known concerning the parasites and their method of dissemination. The drop in incidence of coccidia from 12 per cent in July chicks to less than two per cent in fall jureniles is probably attributable to age and immunity rather than season since the incidence in summer adults is also very low.

\section{Regional Distribution}

Analysis of the data on parasites taken during the Investigation reveals three salient examples of regional distribution of the parasites observed. A higher incidence of ticks was found in the Adirondack region. In the same region. an exceedingly low incidence of stomach worm was noted. Autopsies revealed no reeords of crop worms outside of the Hudson Valley. With the exception of these three instances, the distribution of the parasites was statewide.

It should be pointed out here that the figures used in comparing the tick popmlations on grouse in the various regions of the State have heen hased only on those specinens taken by 
special collectors during the summer months. These birds were placed in cellophane sacks immediately after shooting so that ticks would not escape in transit. They were found on about 26 per cent of 190 grouse chicks from the Adirondack region and about 6 per cent of 510 from the Catskill region and the rest of the State. The number of ticks on a grouse was also higher in the Adirondacks. averaging 38 there and five in the other regions. The greatest number found on Adirondack birds was 300 while in other regions 26 was the maximum.

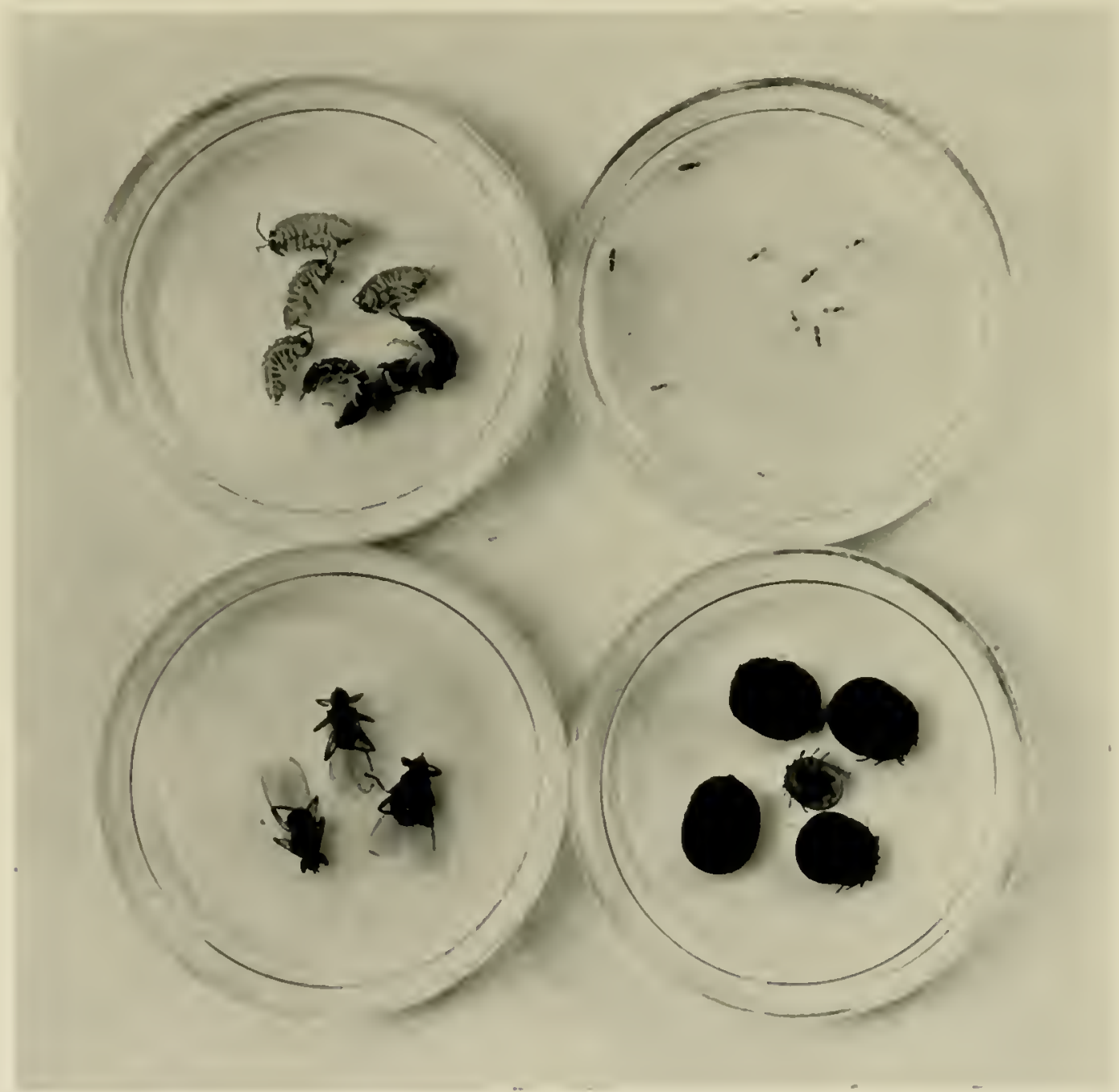

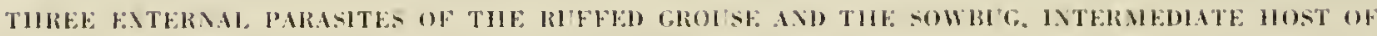
THE STOMACII $110 \mathrm{RM}$ (Dispharm)

Sonlug (Purcellio scaber)

Louse fily (Luchia americana)
Bird louse (lagopoecus perplexus) Bird Tich (llowmaphsolis chordeilis) 
Examination of over 300 Adirondack region grouse which were old enough to show stomach worms, revealed the presence of this parasite in only four cases. All four of these birds were collected on the periphery, two on the northwest boundary adjoining the St. Lawrence valley, and two on the southeast boundary adjoining the Hudson and Lake Champlain watersheds. None was found in the Adirondack interior. It has been reported that infections with this worm are contracted by eating sow bugs. Specimens of the latter (Porcellio scaber) have been found in the crop contents of gronse chicks from this region, so it would appear that it is not the absence of this intermediate host which accounts for the negative findings.

The crop, worm was found only in the counties bordering on the Hudson River. Allen and Gross ${ }^{17}$ repurted it only from New England and Columbia County, New York, while Cram1 reported that the infection of quail with these worms was quite localized. Since this is one of the parasites which has also been reported from poultry, it is of interest to note that it is seldom encountcred in ehickens in New York. Beandette ${ }^{4 t}$ reported only two cases in almost ten thousand autopsies of New Jersey poultry.

\section{Relation of Otheik Aninal. Diseases to Grouse:}

Speculation concenning the relation of other animals to discase and parasitism in grouse wis provoked hy the results of early attempts at hand-rearing. When domestir chickens were used as foster mothers. Reeords of the association of grouse with other wild birds has led to similar conjecture, as has the discovery that they are susceptible to certain diseases which also wecur in mammals.

\section{Poultry Diseases in Grouse}

When altempts were first made to rear ruffed gronse in eaptivity; a number of olservers presented evidence that the birds were commonly afflicted with diseases of domestie fowls. It was thought that their association with chickens might be a factor in "grumse disease". There" is considerable truth in this view when it is applied to artificially propagated birds, since it is probalily posille to transmit the majority of poultry diseases to grouse under exprerimental conditions.

As arly as $1932^{n 2}$ fow cholera was mentioned as a destroyer of ruffed grousc in Illinois but it was not until 1936 that Green and Shillinger ${ }^{\text {sut }}$ reported the actual identifieation of this dis. case in wild grouse. Though air-sac mites were contracted from chickens during the period when artificially propagated grouse were "range reared", this infection has never bren encount. ered iı will birds.

Since the early work on grouse rearing, olservations on certain conditions which were at. tributed to association with poultry have failed to reveal direct comeetions in a number of cases. The large intestinal roundworm of grouse, which was for years reported as Ascaridia lineata. the roundworm of the fowl, has lately been slown to be a distinet species. Ascarilia bonasae, and the cecal worm in the grouse, reported often as Heteratis gallinae or 1 . vesicu. laris by the early workers. has also heen shown to be different (Leterakis bonasae). Infection with the proventricular roundworm (Dispharynx spiralis) is so rare in chickens that it can scarcel be considered a poultry parasite. The tapeworm (Davainea proglottina) has been found in wild grouse in Labrador in localities where no poultry has ever existed, though this worm is generally considered to be a parasite of domestic fowls. Though Allen ${ }^{14}$ recorded white diarrhea in hand-reared grouse chicks, subsequent tests for pullorum disease were negative and this condition was regarded as associated with faulty brooding or nutrition. 


\section{Parasites of Other Wild Birds}

In cousidering the relation of other wild birds to parasitism and disease in grouse, the factors which come to mind are the probabilities of association of grouse with other species and the comparative susceptibilities of the birds. Some observations made during the Investigation will illustrate the situation. The intestinal worms (Ascaridia bonasae), gizzard worms (Cheilospirura spinosa), cecal worms (lleteralis bonasae) and crop worms (Capillaria annulata) found in ruffed grouse in New York have not been found in ring-necked pheasants, Hun. garian partridge or bobwhite quail in this State. Stomach worms (Dispharynx spiralis) which are frequently found in grouse have been occasionally encountered in Hungarian partridge and once identified in a wild bobwhite. Gape worms (Syngamus trachea) are rare in grouse but not uncommon in pheasant chicks in certain areas.

These observations may be taken to indicate that in this State grouse are unimportant factors in the distribution of parasites to other game birds and that the latter are of minor importance in relation to parasites of grouse. The very few cases of aspergillosis which have been reported in ducks have been unrelated to the cases of this disease observed in grouse and in both birds the instances were so few as to be negligible.

Avian tuberculosis has been encountered once in a wild pheasant and once in a crow but was not found in wild gronse during the Investigation, although it has heen observed in captive birds. Gross ${ }^{289}$ reported this disease from grouse in New England. Though gape worms have been reported from about forty species of bircls, the difficulty experienced by Ripple $^{315}$ in infecting chickens with eggs from the gapeworm found in the robin may indicate that wild birds are not as important a factor in the dissemination of this parasite as las heen previously supposed.

Green and Shillinger reported a single case of "quail disease" in a wild grouse in Minnesota, but neither this disease nor blackhead, which ranks with it as a destroyer of grouse in captivity, have been olserved in wild grouse during the Investigation. There seems to be nothing to indicate that these maladies occur in the wild to any extent.

\section{Diseases of IF ild Mammals}

Relatively few diseases are common to both mammals and birds. but it so happens that one of the most serious diseases of game mammals, tularemia. is transmissible to ruffed grouse, sharptailed grouse, quail and sage hens. This disease is found most frequently in cottontails though it also occurs in a number of other mammals. Transmission in the wild is chiefly hy the medium of deerflies and ticks, the most important heing the rabhit tick (I/aemaphysalis leporis-palustris). According to Shillinger and Morley" "Mularcmia as yet has not been found to be the cause of widespread losses anongr game birds."

The potential danger of tularemia in ruffed grmuse in New York State is conditioned considerally by factors concerning relative tick propulations on grouse and collontails and the species of ticks involved. In Minnesota where tularemia has heen reported as naturally oceurring in gane hirds, it is common to find seseral hundred ticks on a grouse. cottuntail or varying hare. while in New York the arerage and the maximum infestations are much lower. Cottontails in

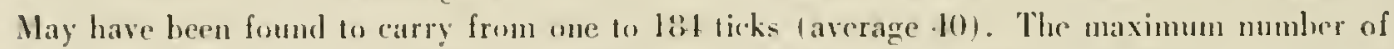
ticks found on gronse in the summer was 300 in the Adirondachs (average 33 ) and 26 in the rest of the State faverage 5). A large percentage of the tick found on grouse in New York are the bied ticks (Il. chordeilis). Up to 87 rabhit ticks have been found on varying hares. 
Although Green and Shillinger ${ }^{101}$ mention only the genus Haemaphysalis with the implication that the rabbit tick is the only one involved with the transmission of tularemia to grouse, Parker, Philip and Davis ${ }^{202}$ present evidence pointing to the probability that the bird tick ( $H$. chordeilis) acted as a vector in an outbreak of this disease on sage grouse.

The rarity of tularemia in New York may be indicated by the fact that, during the decade 1932 through 1941, there were only eight cases of tularemia among persons which could be traced definitely to animals having their origin within the State. Of these, the species impli. cated were as follows: cottontails-4, muskrats-2, fox-1, deerfly-1. In two of the cases where the infection was suspected of having been contracted from cottontails. a collector from the Conservation Department immediately went into the field and trapped or shot all the rabbits which could be contacted in the vicinity in which the original suspect was taken. Blood samples from these were subjected to agglutination tests hy the Department of l'ublic Health and the animals were sent to the Research Center for post-mortem examination. Eighty-seven rabbits were taken from one locality and 27 from the other. In all instances hlood tests and autopsy findings were negative for tularemia.

It seems probable that further observations on the inter-relation of tularemia, wild birds and mamnals, and licks will come from areas where tularemia is more prevalent.

Whether the presence on grouse of certain mites, ordinarity found on small rodents (Laelap. tinae, Trombicula microti), is accidental or significant is a matter for speculation. It has been suggested that rodent mites related to these may be involved in the disscinination of tularemia among meadow mice ${ }^{\text {nog }}$.

\section{Reiation of Disfase: to P'redation}

The relation of predators to the elimination of diseased animals has been the subject of many discussions. During the course of the Investigation, a number of grouse were received which had been killed by predatory mammals or hirds. Of these, 33 were satisfactory for post-mortem examination. In none of these was parasitism or disease present to a degree which suggested that either might be a factor in the susceptibility of the bird to predation. Nineteen cases were completely negative and the parasitism in the others differed neither in incidence nor degree from that found in a nomal population.

We have, however, a number of records of birds which were weakened by a result of stomach worm infection and were readily shot or picked up by dogs. It can be inferred that these diseased grouse would also have been avaitablo to other predators.

\section{PARASITES OF WILD GROUSE}

\section{IN TIE RESPIRATORY SYSTEM}

Gape worms were the only animal parasites encommered in the respiratory tracts of wild ruffed grousc during the Investigation. The occurrence of the fungus infection. aspergitlosis, in both wild and hand-reared birds has already becn mentioned. Discussion of this disorder, which is more likely to be found in captive grouse than in the wild, has been relegated to the section on disease in hand-reared hirds. Air-sac mitcs. also discussed later, were found only in captive grouse in association with poultry.

\section{GaPE Woru (Syngamus trachea)}

Distribution. This parasite is found in most parts of the world. It has been re- 
ported in chickens. bobwhite quail, turkeys, pheasants, peafowl, red grouse, sparrows, thrushes. crows and a number of wher birds as well as in ruffed grouse. It has heen considered as associated with pheasants and domestic birds for so long that it was surprising to find it oecuring in areas in the deep Adirondacks where poultry has never been raised. It has been found in several widely separated localities in New York but its incidence is so low that its ahsence in specimens from other regions is no indication that it is non-existent there.

Description. This worm, sometimes called the "Y" worm, because the male and the female are joined together in the form of a $Y$. is found attached to the mueous nombrane of the windpipe. The worms are l, lood-red in color. The males measure up to 1/ inch long. and the females up to $3 / 4$ inch in length. Cram has given a complete description.

Life Cycle and Dissemination. The eggs are deposited in the windpipe ly the female, are coughed up, swallowed and passed out with the feces. Under optimum conditions of tempera. ture and moisture. development to the infective stage takes place in alout seven days. Infer. tion results when a susceptible bird eats either the embryonated eggs or certain invertebrates. such as earthworms and snails. in which the infeetive larvae are loosely eneysted ${ }^{\text {nases }}$. Within a day after ingestion, the larvae migrate to the lungs. According to Wehro this migration takes place by way of the blood stream. The males and females pair as young adults in the lung and then move up the lonchi to the trachea where attachment iccurs. The woms mature within 17 to 20 days after infection.

The spread and maintenance of this infection in any une species is influenced by the following considerations:

1. Gape worm larvae encysted in earthworms may remain viahle and produce infection for longer than four years as demonstrated by Tay lor ${ }^{304}$.

2. Nany species of small wild hirds are found to be infected with the same speries of worm.

3. In some species of gallinaccous birds there is a definte age resistance to infection. Adult chickens, for instance, are rarely infected, while very young fowl become infected with comparative ease. Turkeys on the other hand retain the infection at all ares. It is inleresting to note that the incidence of gape wom infection in grouse chicks $(0.9$ per(cent) is more than four times the incidence in adults.

It is possible that the extremely low incidence of the infertion in New York grouse is dur to the fact that the exposure to infeetion may he very light and soattered. Gape worm infection in demestic rhickens and lurkeys in this State is seldom encountered by the diagnostic laboratury at the New York State Veterinary Collegere.

Serious reserwirs of infection may exist on pheasant farms. Here the gape worm disease has heen known to take a heary toll of pheasant chicks unless the young birds are raised on soil on which pluasants have not heen previously reared for a period of at least three yours.

Polhogenicity. The ability of gape worms to produce disease in pheasants and domestic poultry is woll known. The blood sucking aclivities of the worm and the merhanical bloek. ing of the windpipe are serjons enough to cause the death of heavily infected birds. In native wild grouse. huwrere the mumber of parasites encountered has never heen more than eiglt fair and in none of these hirds was there evidence of serious injury. The only evilence that S. Irachera can he serions for grouse was observed in 1932. A wild trapped female grouse shipperl to New Jork was found to have died as the result of suffocation ly 35 worms packed in the lower end of the windpipe. This bird was leine used as a herder and was confined in a large pen on ground where no gallinaceous birds had previously been raised. It could not be 
determined whether the bird was infected before or after arrival.

Incidence and Importance. An incidence of 0.2 per cent gapeworm infection in wild adults and an incidence of 0.9 per cent in young chicks would not indicate this parasitism to be of particular importance in grouse populations. even if there were evidence to show that it caused serious lesions.

\section{Jn the Digestive Tract}

It is in the digestive system that the greatest numbers and variety of parasites are found. The roundworms. tapeworms and coccidia which occur there are discussed leekw. They are arranged according to the organs in which they are found, starting with the crop worm and proceeding through a discussion of stomach and gizzard worms to the parasites of the intestine. The relative positions of the various organs is shown in figure 80 .

\section{Crop, Worm (Capillaria amnulata)}

Distribution. This parasite has been reported from grouse in New York. Michigan. soutlem New England, from pheasants in New York, from quail in Virrinia. Turkeys and clickens throughout the Fast and the South, and other gallinaceous hirds in Eurnpe, Brazil and the Philippines are likewise susceptible. In New York. the lirds found to be inferted with this worm were all taken in the Hudson River Valley. It was not found in other parts of the State.

Description. The crop worm is a long, thread-like form that is frequently found imlerdded in the lining of the crop and esophagus of wild grouse. The males meature up to 1 inch long and the females up to $2 \frac{1}{1}$ inches. Though it is fairly long. it is so narrow that it is very difficult to observe.

life Cycle and Dissemination. Wehr ${ }^{300}$ has found that earthworms act as intermediate hosts. Apparently the larvae undergo a period of development in the carthworm before infertion of the avian host ean take place.

Little is known with regard to the spread of this parasite under natural conditions. It is probahle that earthworms harhuring the larvae mal be infortive over kong periods of time. as has been demonstrated with the gape worm. Since the great majurit? of the cases enconntered in grousc were light infections with no noticeable gross changes, it does nut secm likely that conditions for massive infertions of birds exist in areas frequented by gronse.

Pathogenicity. Crop worm infeetion due to C. ammlata has leen found to be pathogenic for many species of lomesticated and wild birds. The literature is well reviewed by Cram ${ }^{\text {sp }}$. Allen and Gross ${ }^{17}$ have described a severe anemia in ruffed grouse when hearily infected. The nature of the lesions produced is quite similar to those found in wher species. There is a marked thickening of the crop lining with an extensive wrinkling of the surface. giving the organ a corrugated or washoard-like appearance. A false membrane is formed on the inside which sloughs off in patches. If the crop is stretched tightly hetween the hands and held up to a strong light. the wavy outline of the parasitcs can be seen in the wall. light infections with this worm in grouse produce a thickening of the crop lining and cause an exudation of mucus.

Incilence and Importance. The incidence of infection in birds of three months or older was slightly more than one per cent. The average number of crop worms found was seven. Most of the loirds having the parasites were only lightly inferted and suffered no marked gross injury. The low incidence and degree of infection and the restricted area in which the para. sitized hirds are found eliminate this disease from serious consideration as an important factor in grouse abundance. 


\section{Proventrieular or Stomach Worm (Dispharynx spiralis)}

Distribution. This parasite occurs in ruffed grouse in New York, New England. Wisconsin and Michigan; in Hungarian partridge in New York, Wisconsin and Michigan; in quail in New York and New Jersey: in turkeys in Maryland; in chickens in Louisiana: in pigeons in Texas: and in guinea fowl in Porto Rico. It has also heen found in sharp-tail grouse and in certain passerine hirds, namely the robin and eat-bird in New Jersey, house sparrow in the District of Columlia and the Carolina wren.

Infection with the stomaeh worm was found to be extrenely rare in the Adirondack region of New York (figure 32). The few cases that were observed were on the periphery of the region although sow lougs, intermediate hosts for these worms. are known to be present in the interior.

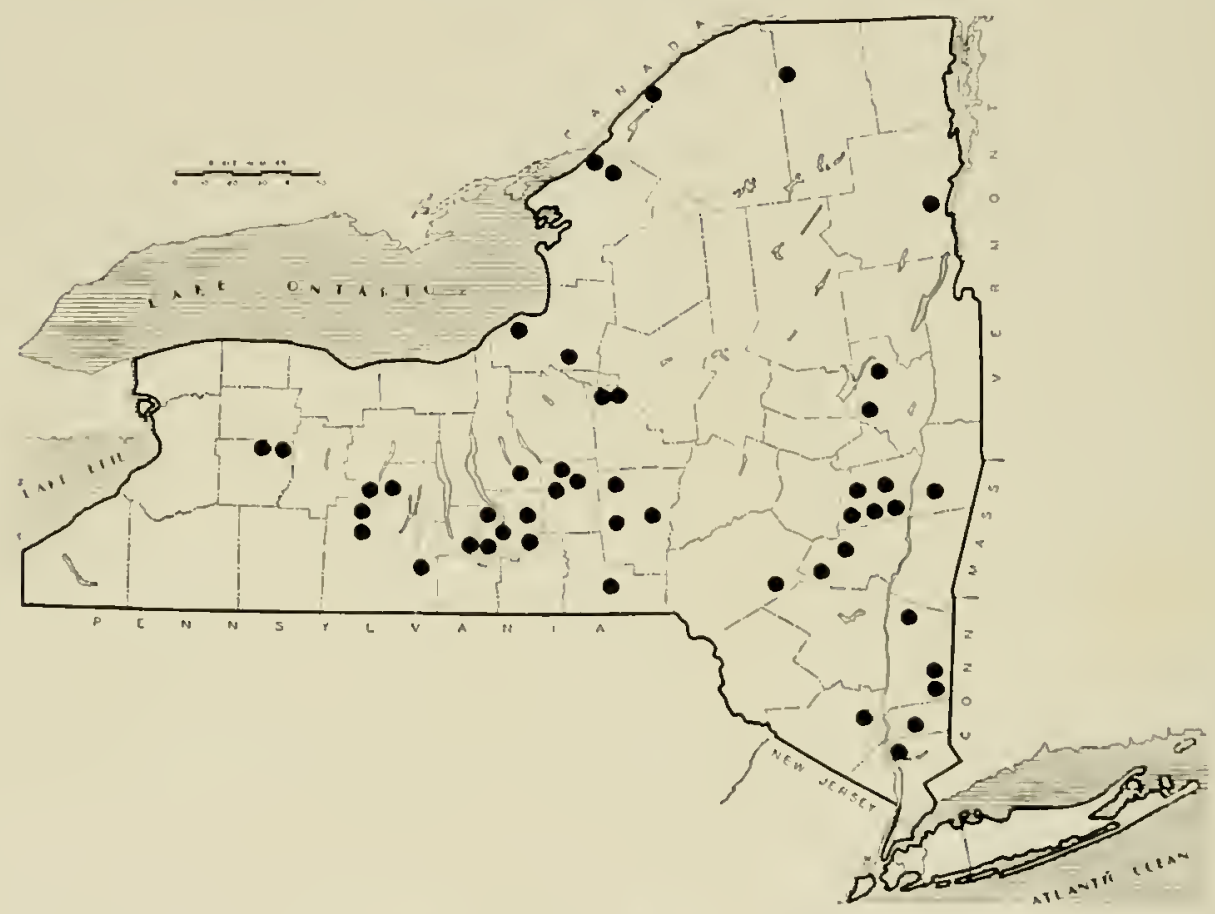

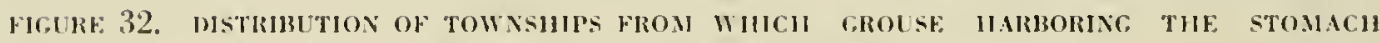
WORM (DispharynX) HAVE HFEA COLLECTED

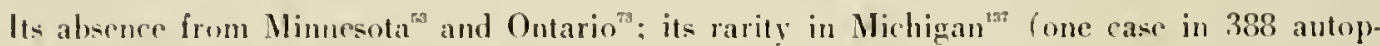
sics) and morthern New York. as well as the scarcity of records of its oceurrence in northern New England. ${ }^{47},{ }^{2 \pi},{ }^{17}$ serem to suggest that its distribution does not extend into the coniferous forest regions or so-called Canadian Zone. The reasons for this are not known.

Description. The stomalh worm. Dispharyns spiralis, is a short, fairly thick. white. coiled nematude (romulworm) that is found deply imbedded in the lining of the preventrieulus (saceular or grandular stonarh). The males are alout 1 ' inch. the females about $3 / s$ inch in linghth.

Life Cycle and Dissemination. The life eycle of this worm was worked out ly Cram ${ }^{\text {mo }}$. It was found that wo species of land erustaceans, the common sow bugs or pill hugs, Porcellio 
scaber and Armadillidium vulgare, arted as intermediate hosts. The eggs laid by the female worms pass out with the feces and are ingested by the sow bugs. After a perind of development of about 26 days, the larvae become infective. When infected sow bugs are eaten by susceptible birds, the larvae are liherated and invade the lining of the stomach. The worms reach maturity in 27 days.

It is not known how long the eggs of this worm remain viable or its larvae live in the intermediate host as a source of infection. It is significant that, in practically every instance, grouse found to have severe lesions or to have died as a result of infection. were encountered during the late fall and early winter. In fact, the incidence of the infection was highest during that time of the year.

Apparently the hirds pick up stomach worms during the summer and fall. The effects of the parasitism are seldom evidenced until the worms have matured.

The smallest hird in which Dispharynx was found was a young male which weighed 144 grams (about 5 oz.) collected on July 27. The carliest record of occurrence was in a young female collected on July 20. That she was in good flesh may be judged from her weight of 292 grams (about $10 \frac{1}{2} \mathrm{az}$. ). at the time of collcetion.

That infections with this worm may he quite localized was illustrated by collections made on Connecticut Hill in 1934. Five birds out of 17 in one covert were inferted while no stomach worms were found in 13 hirds taken in another covert 200 yards away. Fach covert included ahout 250 acres. They were separated by open land.

Pathogenicity. Dispharymx spiralis is probahly the most pathogenir parasile of wild grouse in the more settled parts of the Northeast. Heary infections with this worm result in a severe inflammation of the glandular stomach or proventriculus. This becomes filled with a thick. white, shiny mucus. The proventricular wall becomes tremendously thirkened. sometimes to three and four times its normal size. There is an extensive destruction of the ylandular tissue and of the muscular layers of this organ. This tissue destruction may progress to such an extent that perforation of the glandular stomach may lring on peritonitis.

Tissne necrosis quite often accompanies this parasitism. In many instances the proventriculus, due to destruction of its musculature, becomes quite flaccid and may telescope in its entirety into the gizzard. Cases have been found where healing of the lesions resulted in the production of masses of dense connective tissues resulting in a partial or complete elosure of the organ.

Large numbers of worms may not always he found in spite of extensive tissue damage and sometimes none are encountered. Undonbtedly many of the parasites pass out of the bird with the sloughed off tissue or they may become detached during the time the bird is in a dying state. On the other hand, 100 or inore of the worms have been dissected ont of a single bird. Allen and Gross ${ }^{27}$ have reported as many as $228 \mathrm{in}$ one stomach.

The invasion of the proventriculus by the stomach worm sometimes results in emaciation. weakness and funally death. Hunters occasionally report that birds, later found to be seriously infected, were sluggish in flight or that their dogs. unaided. ran down and caught the birds. This is undoubtedly due to weakness resulting from loss of function of the proventriculus through tissue destruction and plugging of the stomach cavity.

Light infections with this parasite have been encountered where no apparent ill effects on the birds were noticeable. In these cases, however, the parasites were few in number and only a small portion of the proventriculus was involved. 
Athough the stomach worm was found to be the most pathogenic species in ruffed grouse, in no sense should it he imagined that infection is always fatal. Considerable indirect evidence was gathered indieating that hirds may lose their parasites. In a number of instances healed lesions were found in the proventriculus, characterized by extensive scar tissue. Since no worms could be found in these birds, it is safe to interpret these fundings as instances of recovery from the parasitisı.

One case is worth mentioning here since it represented a rather unusual situation. Fifty. three stomach worms were removed from a markedly enlarged proventriculus. Yet the hird. a male, was in excellent condition for it weighed 622 grams (about 22 oz.). It is quite likely that this infection may have been recently acquired and the deleterious effects of the parasitism may not have set in. The extent of the infection and the resistance of the host undoubt. edly play a major role in determining whether or not the parasitism will eventually kill the lird.

With the exception of one serious case of tiek infestation. stomach worm infections were the rause of death of all wild grouse without mechanical injuries that were found dead in the field. The relative infrequency with which dead grouse are pieked up in the field gives this fact even more signifieance.

During the months of Oetober and November, 1933, 11 ruffed grouse were referred to the Investigation by the Commerticut State Board of Fisheries and Game. These birds had heen submitted by hunters and wher interested individuals whose attention harl lieen attracted by their ahnormal hehavior. Seven of this mumer were found to be heavily infected with the proventricular worm. In all probability similar conditions prevail in other areas where this parasile is found.

In no sense, however, should it he assumed that ruffed grouse in all regious suffer from this infection. Altention has been called to Boughton's ${ }^{\text {bs }}$ survey in Minnesota where not a single instance of infertion was eneountered though 560 hirds were autopsied. Again. Mueller's surrey of ruffed grouse in New Hampshire indicated the alsenee of D. spiralis in any of 46 grouse examined. These reeords clearly indicate the danger of altempting to draw conclusions from data collected in restricted aseas.

Incilence and Importance. Aside from being a prime factor in killing birds, stomach worm infection undoubtedly adds indirectly to grouse mortality. Parasitized hirds, especially in the latter statges of the disease. may heome so weakened that their flight is seriously impaired. There is no dould that predators may make short work of many such hirds, if fouml.

Infeetion with stomach worms takes place early in the life of the chirk hut the worms are not apparent until the seeond month when 8.2 per cent of the hirds are infected. The incidener rapidly rises to 29.1 per cent in the three on nine months age eroup and then slumps sharply: to 8.7 per eent in the spring and summer adults.

The high prenentage of infection of the young hirds and the fon perenlige found in those who have surviverl the winter, raises a very pertinent guestion as to the reasons for this rhange of incidence. It is problematical if the parasites are lost during that cold period or whether the inferent hirds deed and only those free of parasitiom lived to be ramined in the spring and summer. The answer depends upon further reseath. If it were found that the stomath worm eaused the death of most of the infected young grouse. Whe larere numbers inwolved would explain one major souree of loss.

Sinee. in the fall and winter adults. the incidenec only rises to 11 per rent. the further 
question to be answered is whether this represents an age immunity or one acquired through recovery from previous infection. The solution will require the infection of young birds held in captivity and the following of the subsequent course of the disease.

The overall incidence of infection in grouse over three months of age was 12.7 per cent. Despite the fact that the stomach worm occurs lalf as often as the intestinal worm during the same time period, the former possesses a much greater potentiality for damage to the lost.

Where it occurs in New York, D. spiralis infection is the most important worm parasite among wild ruffed grouse. The determination of its relative role in grouse population fluctuation is not easy. No significant variation in occurrence from year to year and no relation to cyclic diminution can be demonstrated. During the period of the Investigation. no epizootic phase of the disease has been observed. The scope of this survey can only justify the conclusion that this parasitic infection may be a cause of grouse mortality in certain areas.

\section{Gizzard Worm (Cheilospirura spinosa)}

Distribution. This parasite has been found in ruffed grouse from Michigan, New York, Minnesota, Penusylvania, New Jersey, Wisconsin. and Massachusetts, and in bolwhite quail in Virginia and Tennessee. In New York it has been found to be widely distributed througl. out all the region.

Description. Cheilospirura is a moderately slender piukish worm found beneath the corneus lining of the gizzard. The females measure up to $1 \frac{1}{2}$ inches, the males to $3 / 4$ of an inch in length. Cram gives a complete description ${ }^{\mathrm{s}}$.

Life Cycle and Dissemination. Embryonated eggs, discharged in the feces. are ingested by grasshoppers. The worm larvae migrate from the digestive tracts of these insects and become loosely encysted in their bodies. After 25 days. the infective larvae are developed. When susceptible hirds eat infected grasshoppers, infection results. Maturity of the parasite within the hird is reached in $\mathbf{4 5}$ days.

Cross transmission of the parasite from ruffed grouse to quail was proven experimentally. Aside from the fact that the life cycle of this parasite has been worked out. very few of the factors that determine the spread and pathogenicity of this worm are known. Cram noted that with the gizzard worm infection in chickens (C. hamulosa) a certain proportion of the invading nematodes failed to develop. She suggested the possibility that the health of the individual fowl might play a role in explaining this phenomenon. It is likely that a similar condition exists in grouse thus infected. The earliest date on which Cheilospirura was found in grouse chicks was July 15 when it appeared in a female weighing 221 grams (almost 8 oz.).

Pathogenicity. In experimental transmission experiments. Cram ${ }^{\infty}$ demonstrated the pathogenicity of the gizzard worm for ruffed grouse and quail. Hemorrhage and necrosis of the gizzard lining were noted. these changes being accompanied by flabhiness of the gizzard musculature. Over a period of 84 days, an umutural growth of this organ was produced in one quail with a heavy infection. Fisher ${ }^{137}$ stated that in Michigan. where infection during 1935 and 1936 was over 50 per cent. "Nany of the grouse were so heavily infected with these parasites that part of the lining of the gizzard had been destroyed and there was destruction of the surrounding tissue."

On the other hand, Boughton ${ }^{\text {ns }}$ failed to find serious lesions in infected grouse in Minnesota. 
The heaviest infection olserved during this Investigation was 45 worms, the presence of which 'aused only minor lesions in the gizzard. Whether these parasites would have caused severe damage in time ean only be conjectured.

Incidence and Imporfance. Gizzard worms were found in birds from practically all areas of the State. The incidence of infertion gradually rose from none in grouse chicks less than a month of age to 11.1 per rent infection in the spring and summer adults. The incidence of parasitism with this worm in grouse of three months or over was 7.8 per cent. This figure covers the total number of hirds examined in this survey.

There was no significant difference in the incidence of this parasitism from year to year. Though the pathogenicity of this worm for birds has been demonstrated in certain instances, in the light of observations during the Investigation. gizzard worm infection is considered to be of little consequence in controlling grouse abundance.

\section{Large Roundworm (Ascaridia bonasae)}

Distribution. This parasite has been fonnd in ruffed grouse in Maine, Michigan. Minnesota. Wisconsin, Pennsylvania. Massachusetts, and has been found to he widely distrihuted throughout the three regions in New York. Its distribution in other birds is uncertain. Unti] recently, $A$. bonasae was not distinguished from another form. A. lineata. which is common in poultry and has been reported in various species of game birds.

Description. Ascaridia bonasae is a fairly large. whitish, roundworm commonly found in the small intestine of wild grouse. The males measure up to $13 / \mathrm{s}$ inches long and the females up to 2 inches. A complete description is given by Wehr ${ }^{\mathrm{n} n}$. Quite often these worms are found within the body cavity of grouse that have been shot. for perforation of the intestine permits the parasites to escape.

Life Cycle and Dissemination. Ackert's description of the life cycle of A. lincata of the chicken is summarized helow. It is probable that the life cycle of $A$. Wonasae is quite similar.

In the intestine of the hird. the fermale worms lay eggs which are eliminated with the feces. Under suitable conditions of temperature and moisture. embryonation takes place in from 12 in 16 days. After the hirds take in these embryonated eggs with the feed and water. the young larvae are liberated in the forepart of the small intestine. During the first nine days the larvae live in the intestinal interior. During the following weck. development and growtl proceed within the tissues of the gut. At the end of this time the worms emerge from the intestinal wall and remain in the interior until maturity is reaclod. This oceupies about 50 days.

Ackert and Herrick ${ }^{7}$ and Levine ${ }^{200}$ have noted that in rhickens there is a definite age immunity (n) A. lineata. Furthermore it has also been established that not all of the young worms that cmerge into the inside of the intestine succeed in rstablishing themselves. The viahility of the eggs of $A$. lineatn has also been investigated by Arkert and Cauthen'. and Jevine ${ }^{200}$. In general. Irying and exposure to the sun has a marked lethal effect on the ova. while weathering in the shade tends to greatly prolong the period of survival.

I.evine ${ }^{200}$ showed that the length of time the exrss remain viahle when exposed in the cold de. pends on whether or not they are embryonated. Embryonated ova were destroyed after two weeks of freezing while non-embryonated ova survived a severe New York winter and devel. oped the following spring. It is safe to say that probally all of these factors play a part in infections of wild grouse.

Pathogenicily. The harmful effect of A. lincata infection in young chickens has heen des. 


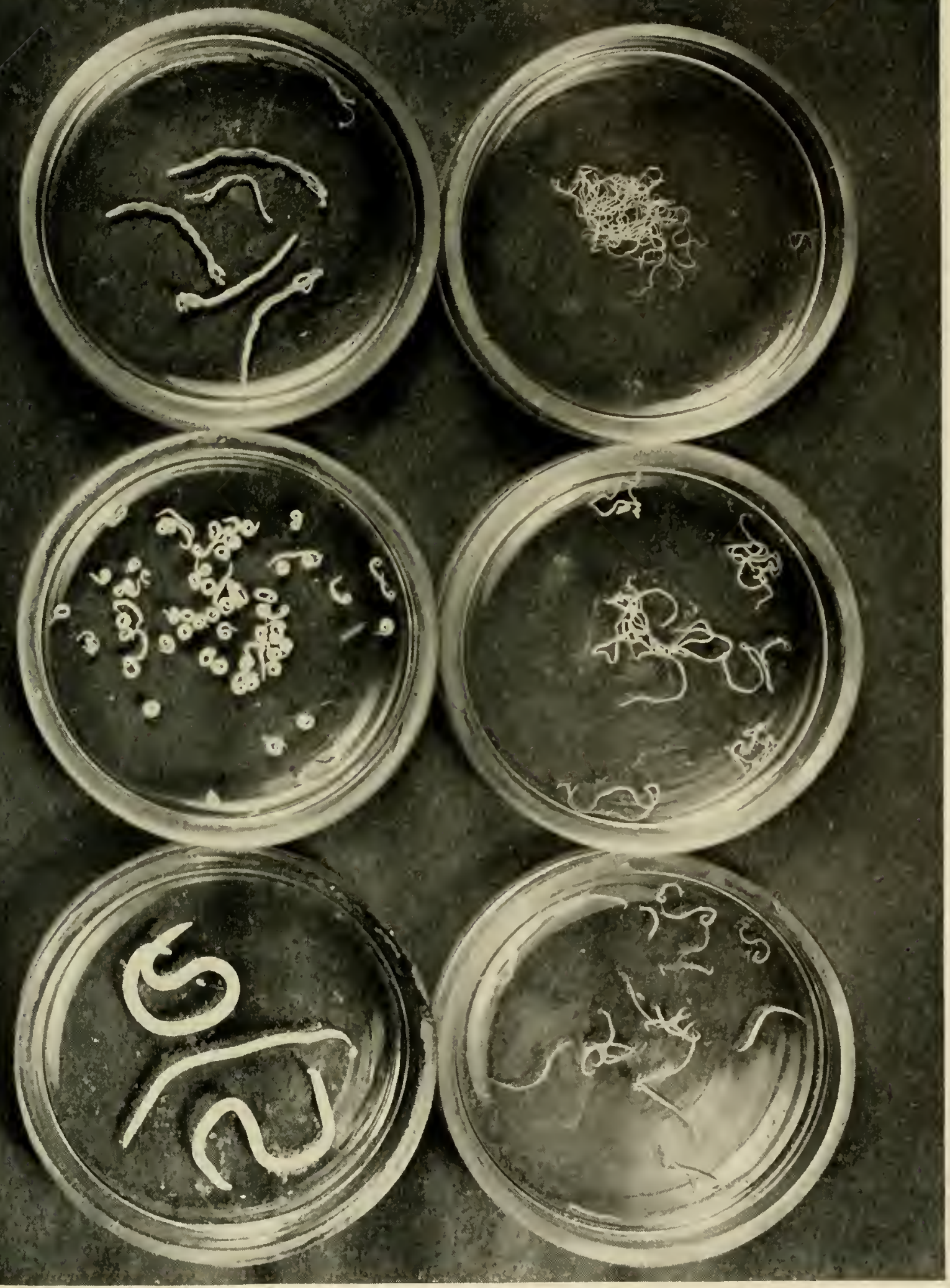

SOME INTERNAL PARASITES OF THE RUFFED GROUSE

Gape W'orm (Syngamus trachea)

Stoniach $\Pi^{\prime \prime}$ arm (Dispharynx spiralis)

Intestinal Worm (Ascaridia bonasae)
Crop $\Pi$ orm (Capillaria annulata)

Gizzard I' orm (Cheilospirura spinosa)

Cecal $\bar{T}$ arm (Heterakis bonasae) 
cribed by Ackert and Herrick. They found that definite symptoms of parasitism and death resulted from heary infections. The greatest injury to the birds took place during the 10 th to 17 th day of the infection when extensive tissue invasion and destruction was occurring.

Although $A$. bonasae in grouse was found more frequently than any other nematode, no in. stances of the pathogenic effects of this worm were observed. The worms were nearly always adult and occurred for the most part in small numbers. five being the average number found.

Incidence and Importance. Grouse chicks pick up the infection when quite young, 10.5 per cent of them becoming infected by the second month after hatching. The following month shows the infection rate more than doubled and from that time on there is a fluctuation in the incidence of infection. A higher percentage of grouse is infected during the summer months and a lower percentage infected during the fall and winter, table 67 . The data available suggests that Ascaridia infection is unimportant from the standpoint of brood mortality.

This large roundworm is one of the most frequently encountered parasites of ruffed grouse in New York State. In its adult stage it feeds on intestinal contents. On account of its size. it is the parasite most often observed and rated as important by amateurs. The number of worms found in each bird is small. In one instance. however, 78 worms were found in the intestine of a male hird. Despite this heavy infection. no deleterions effects were observed. No significant yearly variation in incidence took place during the course of the Investigation.

Insofar as this study is concerned, no cvidence was uncovered which would indicate that infection with $A$. bonasae is a factor in reducing the crouse population in the Northeast.

\section{Large Tapeworm (Raillietina tetragona)}

Distribution. This parasite is found in the small intestine. occasionally in the cccum, of ruffed grouse. chickens. bobwhite quail, turkcys and guinea fowl. It has been reported from Europe and Asia as well as from North and South America. It occurs in all three regions of New York.

Description. These tapeworms may attain a length of 10 inches. They appear as creamy white ribbons about $1 / \mathrm{s}$ of an inch broad, composed of many segments. They possess, as a means of attachinent, four suckers as well as a crown of minute looks.

Life Cycle and Dissemination. The segments farthest from the attached end of the worms contain many eggs. As these scgments become detached from the rest of the parasite and pass out with the droppings. the eggs becone available to various invertelorate animals which serve as intermediate hosts.

A number of organisms have heen reported as the vectors of this common tapeworm of grouse but the nost likely suspect in this area is the ant. Horsfall ${ }^{205}$ reported ants of the genera Tetramorium and Pheidole to he inrolved in this life cyele. While these particular insects have not leen found in the fool analyses by the Investiyation. many of their cluse relatives are taken ly the young chicks.

Since infection with this parasite must follow the cating of some intermediate host, it is mot surprising to find that most of the cases of parasitism with this form oceur in the wild grousc (hicks. whose carly diet contains such high amounts of animal matter. Conversely. in the vege. tarian adult gromse this tapeworm is seldom found and when it dues ocenr it represents the chance ingestion of an infected intermediate hest.

Pathogenicity. Although experimental work with tapcworms (Davainea proglotlina) in poultry ${ }^{231}$ has furnished definite cvidence of the deleterious effects of infections with these par- 
asites on growing chickens. no similar evidence could be adduced from observations on tapeworms in young grouse. In a few cases, excessive mucus production by the intestinal cells was attributed to the presence of the parasites but no more serious changes were observed even in heavy infections. The weights of parasitized birds compared favorably with those not infected but of the same age.

Incidence and Importance. Though the incidence in chicks less than two months old is relatively high, leing 16.6 per cent during the first month and 32.2 per cent in the second, the lack of lesions and the good plysical condition of the infected birds seems to indicate that little harm is caused by the presence of this parasite under natural wild conditions. As the summer progresses the number of chicks infected drops off to 2 per cent in August and there. after it is very seldom found.

\section{Small Tapeworm (IIymenolepis microps)}

Distribution. This parasite is found in the ruffed grouse in New York and Ontario, in the ptarmigan, and in the red grouse, the black grouse and in the capcrcailzic in Europe. It occurs in all three regions of New York.

Description. The tapeworms of this species are found attached ly their head end (scoleces) to the wall of the upper portion of the small intestinc. To the naked eye the parasites appear like long thin filaments. A detailed description is given by Shipley ${ }^{32 n}$. Those found by the Investigation were identified by Jones ${ }^{211}$ whose account is the first record of this worm in ruffed grouse in this country.

Life Cycle and Dissemination. The life cycle of this parasite is unknown. Related tapeworms of the gallinaceous birds reach infectivity in insects, particularly beetles.

Pathogenicity. $\mathrm{ln}_{n}$ one heavy infection with this tapeworm a small blood streaked area in the duodenal mucosa was found where a great many scoleces were imbedded. A catarrhal in. flammation of the npper portion of the small intestine was observed in another case where the infection was severe.

In practically all the other instances, however, the number of tapeworms in any single intestine was relatively few and no gross lesions were observed.

No evidence was nneovered to establish that infection with tapeworms could kill ruffed grouse.

Incidence and Importance. Although this parasite was sometimes encountered in chicks it is regarded as more typical in adults. In juvenile birds from three to nine months old, its incidence was 1.6 per cent. Almost 10 per cent of the spring and summer adults were infected. but less than 5 per cent of the fall and winter adults are thus parasitized. This tapeworm can not be considered of importance as a pathogen in wild grouse on the hasis of any ubservations made during the luvestigation.

\section{Cecal Worms (IIeteratis bonasae)}

Distribution. This roundworm has been found in grouse in all three regions in New York.

It is probable that many of the previous records of cecal worms from grouse, designated as Heterakis gallinae, a common parasite of poultry, may actually represent records of grouse cecal worms. It is therefore almost impossible to establish the distribution of this worm in other hosts and in other regions.

Description. Heterakis bonasae are small white worns measuring about $1 / 2$ inch in length. 
Life Cycle and Dissemination. The life cycle of the closely related cecal worm of chickens has been worked out and is essentially the same as that of the intestinal roundworm, the ascarid. Eggs of the worm pass out in the feces and develop to the infective stage in about seven to twelve days. Upon ingestion, the worm larvae are liberated and quickly find their way to the ceca where development to sexual maturity is completed in 56 days. Undoubtedly the cecal worm of grouse undergoes a very similar development.

Pathogenicity. No evidence of injury to ruffed grouse by cecal worms has been uncurered. Usually the number found are very few.

It is interesting to note that in chickens and turkeys, the cecal worm egg is capable of transmitting blackhead. No case of this disease in wild ruffed grouse has been encountered by the Investigation, though it is occasionally found in grouse reared in captivity*.

Incidence and Importance. The lightness of the infection and the lack of demonstrable damage done by 11 . bonasae make it a comparatively unimportant parasite of grouse. Only 1.8 per cent of grouse over three months of age were found to be infected. Of the chicks, only 0.1 per cent were infected.

\section{Coccidia (Eimeria species)}

Distribution. One species, Eimeria angusta was described from the ceca of ruffed grouse in Labrador and Alaska ${ }^{18}$. It has also been found in the spruce grouse. Another species, Eimeria bonasae was found in the cecum, rarely in the small intestine, of the ruffed grouse in Massachusetts, Labrador, Quebec and Alaska ${ }^{28}$. This form was also encountered in ptarmigan and later in sharp-tailed grouse. A third species, Eimeria dispersa, has been reported from the bobwhite quail, ruffed grouse, domestic fowl, turkey, pheasant and sharptail. The species encountered in New York are probably the Eimeria bonasae and Eimeria dispersa.

Description. Coccidia are microscopic protozoan parasites which, in birds, infect the lining cells of the intestine. The mature forms of this parasite, the oocysts, are spherical or oval cysts with distinct cell walls. Coccidia are distinguished from each other by the size and shape of the oocysts and the number of included sporozoites. Eimeria angusta is an elongate form measuring from 16.5 to 17.5 microns $^{\Delta}$ in width and 27 to 33 microns in length. $E$. bonasae, almost spherical in shape, measures 21 microns in diameter and is found in the caeca and rarely in the small intestine. The oocysts of $E$. dispersa are about $19.8 \times 17.7$ microns.

Life Cycle and Dissemination. Detailed accounts of the life cycle of coccidia are available elsewheres. Very briefly, the life cycle may be outlined as follows. The microscopic oocyst, when discharged with the feces, undergoes internal growth. There develops, within a period of from 24 to 72 hours, four spores, each of which in turn divides into two elongate sporozoites. When the oocysts continining the sporozoites are caten by a hird, the eyst wall is dissolved by digestive enzymes and the sproozoites are liberated. They immediately proced to penetrate the lining cells of the intestine. Now hegins a sequence of events characterized chicfly by the growth of the parasites and their tremendous multiplication at the expense of the intestinal lining cells of the host. The cycle of growth terminates in the development of another crop of oocysts.

Most of the work on avian coccidiosis has been carried ont with donestic chickens. In general the following factors with regard to the spread of coccidiosis would apply to all species of birds:

- Sec dincunaion uf Dismane in Hamd-reared Cround, I. 438.

$\triangle$ A microo is unit of microscopic meaurement which equalo alout $1 / 25,000$ of an isch. 
1. Coccidia infecting one species of host seldom infect another. E. dispersa is an exception to this principle since it has been reported from a number of birds.

2. Oocysts under suitable conditions may survive for a year or more on the ground.

3. In all likelihood, adult birds previously infected may serve as carriers of infection for susceptilsle birds.

4. In some types of infection, there is an age resistance exhibited by the host.

5. The scverity of infection is determined, among other things, by the number and species of the infective stages eaten.

6. Recovery from infection results in a state of immunity in the host. The extent and nature of this immunity and the promptness with which it is brought about depends upon the species of coccidia and the severity of the initial infection.

There is no reason to doubt that these factors operate in the spread of coccidiosis in ruffed grouse. Obviously, until detailed laboratory experimentation and further field observations are done with coccidia of grouse, one may only conjecture on the exact operation of these factors.

Pathogenicity. No instance of severe coccidial infection has becn encountered by the Investigation. For the most part, the presence of coccidia has been detected by the examina. tion of smears from the intestinal inucosa. No attempt has been made to identify the species of oocysts encountered. It is interesting to record that on one occasion during the early attempts to propagate grouse in confinement, fecal examinations* carried out as a part of the routine examination, revealed large numbers of oocysts in the feces. Despite this, the lialfgrown birds showed no symptoms of disease nor was there any clinical evidence that intestinal inflammation was present.

Incidence and Importance. As is evident from table 61 and table $6 \%$, the greatest incidence of coccidia was found in grouse chicks Iess than three months of age. In this group 10.1 per cent of the chicks were found to be affected. On the other hand only 0.7 per cent of the hirds over three months were found infected. A further breakdown of the data indicates that during the first two mouths, the rate of infection remains ahout the same, 12.2 per cent and 11.9 per cent. The incidence of infection in the birds from two months and older takes a sudden drop to 1.4 per cent and decreases still further until no evidence of infection was found in the fall and winter months.

It would seem from this data, that probably a prompt infection of susceptible chicks occurs early in life and that an immunity is quickly built up so that sulsequent exposure results in little, if any, infection. Tyzzer ${ }^{334}$ suggested this during his early work on coccidiosis in game birds. The fact that very young chicks feed largely on food on the ground probably accounts for considerable ingestion of oocysts. As the feeding habits of the birds change and less pick. ing is done from the ground, fewer chances for infection occur.

The relatively low incidence of coccidia and the fact that pathological conditions have not been olscrved in ruffed grouse as a result of coccidial infections. make it obligatory to exclude these parasites from scrions consideration as a factor in grouse mortality.

Though early grouse breeders ${ }^{14}$ reported coccidiosis to be one of the serious problems en. countered in artificial propagation of recent years, the number of cases observed in captive grouse raised at the Research Center has been almost negligible.

* Sugar fotation technique. 


\section{Blood Parasites}

The parasites that have been identified from the blood stream of New York grouse are of only one type, Microfilaria. From Ontario, Clarke ${ }^{72,},{ }^{73}$ has reported two malaria-like parasites, Leucocytozoon and Haemoproteus and a spindle-shaped protozoon, Trypanosoma. The last two have also been identified from grouse in Michigan. Leucocytozoon attacks young grouse with serious consequences, according to reports.

\section{Microfilaria}

Distribution. These blood parasites have been found in grouse in Ontario and New York. Since specific identification could not be made and no adults were found, it is impossible to say whether the same worms exist in other birds.

Description. Microfilaria are microscopic roundworms which occur in the blood. They are presumably the immature stages of tissue dwelling roundworms. These forms have been found in the blood smears of many birds, in which no adult filarial worms have been found.

Life Cycle and Dissemination. The group of parasites to which the microfilaria belong deposit living embryos in the blood streams of their hosts. These are taken up by blood-sucking insects when they feed and are transmitted to other hosts by their bites.

Pathogenicity. So far as is known these parasites do not harm their hosts.

Incidence and Importance. Microfilaria were not found in chicks and occurred in only 1.2 per cent of the adult. There is no reason to believe they are of any importance to grouse.

\section{External Parasites}

In the wild, the external parasites most consistently found on grouse are the ticks and louse flies, although lice and mites are sometimes encountered. As has been noted in table 64, ticks have been found on about 12 per cent of the birds during the summer months while louse flies occur on from 2 to 7 per cent, depending on the age of the birds. It is only during the summer months, when special collectors are in the field, that the freshly shot grousc are placed in wax paper bags immediately on collection. The incidences given above are based on these summer collections, although birds received throughout the year are examined for these parasites and spring and fall occurrences have been recorded.

\section{Ticks (Ilaemaphysalis chordeilis and H. leporis-palustris)}

Distribution. As has been indicated at another point in this chapter, the majority of the ticks identified from grouse during this Investigation, lave been bird ticks (llaemaphysalis chordeilis). Some rabbit ticks (1I. leporis-palustris) have been taken and probahly some numhers of nymphal stages of ticks, which could not be identified to species, belong to the latter group. The bird tick is also resident on other birds across the country, including chickens, turkeys, spruce grouse and songhirds. It has been implicated in the transmission of tularemia among sage hens. The rabhit tick is found on cottontails, varying hares and jackrabbits as well as on a number of other species of mammals and hirds throughout most of North America. Ticks were found on grouse in all three regions in New York but they were more alundant in the Adirondacks than in other parts of the State.

Description. The ticks found on grouse manifest different sizes and shapes depending on their age and state of engorgement. As they suck blood from their hosts they increase in size, the largest being about $3 / 8$ of an inch long and roughly spherical or ovoid. The females are 
larger than males and the color when engorged is a reddish brown. Young and unengorged individuals are much smaller and lighter in color. Identification of ticks to species requires the services of specialists in this line.

Life Itistory and Dissemination. From the ergs of the ticks which are deposited on the ground, small six-legged "seed" ticks hatch. These climb upon vegetation and wait for contact with a suitable host. After attacking themselves thereto and feeding for some time, these larvae drop to the ground and undergo a period of relative inactivity. From this they emerge as 8-legged forms known as nymphs. These forms also must contact a bost on which to feed. Later they too, fall to the ground where a final transformation into adults takes place. The adults become attached to a third host, on which mating takes place. Pregnant females likewise return to the ground to lay their eggs after which they shortly die. Although adult ticks have their preferred hosts, they are sometimes found on a number of species which they do not inhabit commonly. In general, the larrae and nymphs are not as particular as are the adults in the selection of hosts. They may therefore be found on many different animals. This ability to utilize a number of different species is of particular importance $i_{n}$ the maintenance and dissemination of ticks which do not remain on the same animal through all stages, since in dropping to the ground to moult the parasites run a risk of not being able to contact an. other host when the time comes for sulsequent engorgement.

Pathogenicity. Ticks gain their sustenance by sucking blood and during this process may set up considerable inflammation and irritation at the site of their attachment. They are present on hoth chick and adult grouse during the summer.

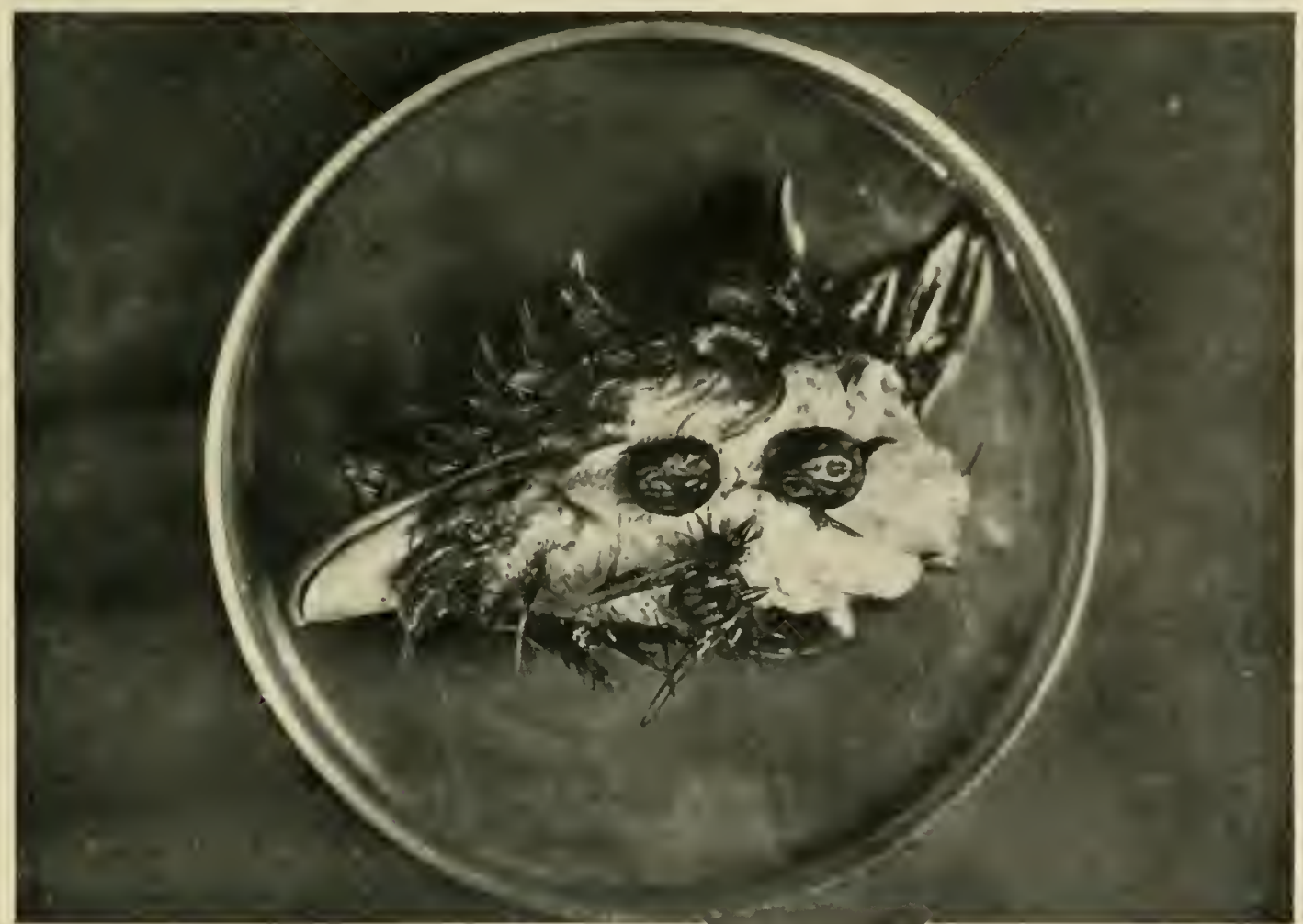

BIRD TICKs (Haemaphysalis chordeilis) ATTACHED TO HEAD AND NECK OF ADULT GROUSE 
In only one case, however, was the death of a bird attributed to these parasites. On June 6, 19:10, an adult female grouse, somewhat emaciated, was fomm near Glens Falls in a dying condition. It was sent to the Research Center and died enroute. Nine adult bird ticks, all fully cngorged, were found attached about the neck close to the head. It was apparent that their presence had caused much irritation. In fact, many feathers had been lost from the region. Complete examination of the bird revealed conditions indicative of starvation. No food or grit had been taken in some time, the gizzard was flably and death was attributed to malnutrition developed as a result of this external parasitism.

The relation of ticks to tularemia in birds and mammals has ben considered elsewhere*

Incidence and Importance. Only during the summer has accurate data been obtained to indicate the incidence of infestation and the number of ticks per bird. Grouse in the Adirondacks were more frequently infested than those in the other regions of the State and each infested bird in that region harbored more ticks than were observed on individual hosts in other regions. The heaviest infestations were observed and the greatest numbers of grouse were found to have ticks during July. These parasites were found in about the same degree each year. No cases were observed in which the number of ticks exceeded 300 , though much heavier infestations lave been reported in the mid-west.

The first record of ticks obtained by the Investigation was that of two from a captured chick, 12-14 days old, during the summer of 1930 and were identified as 11 . choreleilis. The earliest date on which ticks were found on adult grouse during the Investigation was May 4th. Though no accurate connt after the end of August is available, field observations seem to indicate that these parasites are rarely found on grouse as late as the hunting season in October. Adult ticks are readily observed on account of their size. Many amateur observers have therefore considered them to be important causes of grouse decimation. let, evidence of ex. tensive damage has not appeared during the course of the Investigation. This is another case in which the obvious parasites prove to be less important than the inconspicuous ones.

\section{Louse Fly (Lrnchia americana)}

Distrilution. This parasite commonly found on grouse during the warmer months, is also frequently encountered in New York on great horned owls and on marsh. red-tailed, and hroad-winged bawks. In other localities in North America, a mumber of other hawks and owls have also been reported as hosts of this fly.

Description. Though these insects have been called "flying ticks" they are in reality, flies which are adapted to an ectoparasitic existence. They have flattened brownish hodies and long wings which bring their total length to almost 12 inch. Since they quickly leave the body of a dying bird, they are seldom observed unless the freshly shot gromse is immediately lowated and retrieved. Under these conditions, they may be noticed hy the sportsman duringe the hunting season.

Life Cycle and Dissemination. Little is known of the life eycle "f these insects. In flies of this group (l'upipara) the eges are not laid by the female lout are retined within her lody: where they hateh and develop to the state of pupation before they are deposited. It has been suargested that the adults do not survive the winter in temperate regions. If this is the case, reinfestation of non-migratory birds must take place each spring when the migratory hosts return. Certain is it that they have not been encountered in the spring earlier than Mareh 26.

Pathogenicily: No deleterious effects lave been observed as a result of infestation with these

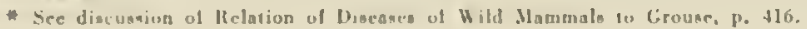


external parasites. Related flies (Lynchia hirsuta) and (Lynchia fusca) have been shown to be vectors of malaria-like diseases of California valley quail ${ }_{2}^{358}{ }^{167}$. Another form, Pseudolynchia canariensis, serves as the intermediate host of a related blood parasite of pigeons ${ }^{32}$. Although Clarke ${ }^{74}$ has reported a Haemoproteus infection in grouse and suggested the louse fly as the possible vector, no conclusive evidence exists to confirm this view.

Incidence and Importance. The low incidence of this parasite and the little trouble which it apparently causes, seem to indicate that this organism is of no great importance in limiting grouse abundance.

\section{Parasites Not Encountered During the Investigation}

During the course of investigations on grouse carried on in other parts of the country, a number of parasites have been recorded which have not been encountered in New York or which appeared so infrequently as to make evaluation of their role impossible.

Important among these is a parasite of the red-blood cclls of grouse, (Leucocytozoon bonasae), first noted in Ontario and since found in Michigan and Naine. It is presumably transmitted by the bite of the black-fly (Simulium venustum). Clarke in studying Canadian grouse, considered it "significantly associated with the cyclic diminution" in numbers. O'Roke, who has made a study of the malaria-like disease of ducks ${ }^{250}$ caused by Leucocytozoon anatis, also regarded this grouse parasite to be pathogenic in young lirds ${ }^{2 m}$, though he did not study it during a period when die-off was apparent.

During the Investigation, blood smears from 781 grouse were examined for the presence of this parasite. Of these, 214 were not taken during the summer months and therefore might not be expected to show the parasite. Of the smears taken during the summer, 106 were from adult birds and 461 were from chicks. None of the smears examined revealed the presence of the parasite.

In addition to the blood smears, livers, in which certain stages of Leucocytozoon are found, were saved for miscroscopic study. Of the 195 livers exanined, 117 were from chicks and 78 were from birds over three months old collected in October and Novenber. These likewise were negative. The blood smears and livers from birds taken in many parts of the State, though the majority of the specimens came from Essex and Lewis Connties in the Adirondacks, Tompkins County in the Southern Tier and from southern Albany County at the northern edge of the Catskills.

A related one-celled animal (IIaemoproteus sp.) which inhabits the red blood cells of ruffed grouse was found in Ontario by $\mathrm{Clarke}^{73}$ in the summer of 1935. Nothing is known of its effect on grouse. A parasite of the same genus is transmitted to California valley quail by louse flies ${ }^{2 \times 9}$ and it has been suggested that the same process may occur in ruffed grouse. Still another protozoan (Trypanosoma) which lives in the fluid portion of the blood but not in the blood cells, has been reported from ruffed grouse in Michigan ${ }^{351}$ and Ontario ${ }^{73}$ but no disease condition is attributed to its presence.

Certain one-celled intestinal parasites lıave been described from New England grouse, though they apparently are associated with no conditions harmful to the bird. These organisms move by means of whip-like structures and are commonly known as flagellates (Trichomonas bonasae) ${ }^{300}$, (Cyathosoma striatum), (Ptychostoma bonasae) ${ }^{375}$. Shillinger and Morley ${ }^{337}$ have reported that similar organisms, resembling Trichomonas gallinarum, have been observed to cause a highly fatal disease of young quail and grouse. 
Several specics of flatworms known as flukes, have been reported from scattered localities throughout the range of the grouse. One (I/armostomum pellucidum) was originally found in the cecum of a rohin ${ }^{302}$ but has been encountered in ruffed grouse in Minnesota ${ }^{63}$, New York, New Hampshire ${ }^{271}$, and possibly Ontario ${ }^{73}$. Another very minute worm (Leucochloridium pricei) first found in the rectum of an Alaka spruce grouse was recently found in ruffed grouse in New Hampsire ${ }^{2 \pi 1}$. Neither of the above parasites appear to damage the birds. Probably both species are obtained by cating certain land snails.

Other intestinal flukes reported for ruffed grousc are Glaphyrostomum from Labrador ${ }^{\text {"1 }}$ and a spiny-mouthed form (Echinoparyphium aconiatum) from Ninnesota ${ }^{*}$. The tatter was first described from the lapwing ${ }^{102}$ in Europe and is probably accidental in grouse. Sone of this group of flatworms occur in other organs. Lyperosomum monenteron, which was described from the livers of rohins, bluebirds and kingbirds ${ }^{310}$, has been found in grouse in Minnesota. In the muscles of grouse in that State, immature flukes ${ }^{53}$, Agamodistomum sp., have been encountered. Prosthogonimus macrorchis, the oviduct fluke of poultry and pheasants, has been reported from the bursa Fabricii of grouse in New Hampshire ${ }^{m-1}$.

A tapeworm (Davainea proglottina) which is generally considered to be a parasite of chickens and turkeys has been found in ruffed grouse in Labrador ${ }^{11}$ and New Hampshire ${ }^{2 i 1}$. The fact that no pouttry existed in the former region where this worm occurs poses an interesting question. Is it typical of chickens and transmissible to grouse or is the wild bird the normal host?

Two other poultry tapeworms have also been reported from grouse (Choanotaenia infundibulum and Hymenolepis carioca). These were found in Ninnesota ${ }^{63}$ and New Hampshire ${ }^{8 / 1}$, respectively, the identification of the latter being tentative. Davainea tetraoensis, a tapeworm known atso in the capercailzie in Switzerland, has been encountered in ruffed grouse in Michigan ${ }^{351}$ and Ontario ${ }^{73}$.

In the mid-west ${ }^{* 3}$, 1ai a roundworm parasite (Oxyspirura petrowi) occurs under the nictitating membrane of the eye of grouse occasionally causing considerable inflammation. An intestinal roundworm (Contracaecum) has been listed as a parasite of grouse lut is probably an accidental oceurrence because worms of this genus are generally found in fish-eating birds and mammats. The strawberry worm (Tetrameres americana) whose common name is suggested by the almost spherical, blood-red form of the female. is found in the glandular stomach of chickens and bolwhite guail and has heen experimentally transmitted to grouse, pigeon and domestic duck by feeding certain species of infected grasshoppers ${ }^{(0)}$. There is nothing to indicate that it is a natural grousc parasite or that it is of importance in the witd. Nematode cysts, (Physaloptera) found in the muscles of grouse in Hinnesotas are undoubtedly. accidental and innocnous.

Rovlent mites (Laclaptinae) have leen reported from grouse in New Hampshireso and harvest mites (Trombicula microti) from Ontario' white in both these localities feather mites lave also been found ${ }^{33}$, 20 .

In the summer of 1932. a female grouse was flushed from her nest in Otsego County, New York, revealing the presence of hundreds of mites within the nest and envering the eggs. Un. fortunately there were no facilities for their collection and they were. therefore, not made available for identification. The parasites of this group, however, are thought to cause but little if any trouble among grouse.

The northern fowl mite, (Liponyssus sylviarum) on the other hand, has heen reported to 
have caused the death of captive hirds in Maine ${ }^{50}$ while the scaly-leg mite (Cnemidocoptes mutans) which burrows under the scales of the legs, may cause severe inflammation and lameness. Both species are ordinarily poultry parasites. The latter also occurs in pheasants and was recently reported from ruffed grouse in British Columbia ${ }^{\text {so }}$

Among the insect parasites occurring occasionally on grouse are bird fleas (Ceratophyllus

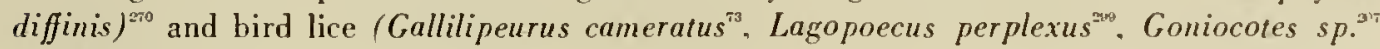
and Menopon sp.).

Although the above list may seem long and formidable, in actuality grouse probably do not harbor more parasites than do most other game birds. As has been pointed out, in most cases, large numbers of any given species do not appear in individual birds. It is sel. dom that one bird harhors more than a half dozen different parasitic forms. It is also important to recall how few of the organisms mentioned during preceding sections have been demonstrated to have disease producing proclivities. The fear that the numbers of grouse in the coverts are seriously affected by their internal and external inhahitants has not yet been substantiated.

\section{DISEASE IN IIAND.REARED GROUSE}

Early experience in the hand-rcaring of grouse demonstrated that discouraging losses re. sulted from disease". The maladies observed nust commonly were blackhead (cnterohepatitis), stomach worm infection, ulcerative enteritis ("quail disease") and coccidiosis.

The presence of these affictions was probably due partly to the fact that the hirds were raised on the ground or in some form of litter rather than on wire, partly that they were usnally in contact with poultry, directly or indirectly. In some cases, indirect connection with other game hirds, particularly quail. may have heen responsible.

Knowledge concerning the means of transmission and spread of parasites and disease has grown. Practical methods of prevention and control based on this knowledge. have been adopted. The use of hens as foster mothers for young grouse has heen abandoned. Rearing of birds on the ground is now considered to le not only unnecessary but dangcrous. These steps have led from a disheartening period of pionecring to the present phase in artificial propagation when infectious disease is less of a problem than certain aspects of incubation, brooding and nutrition.

An understanding of the methods used in hand-rearing grouse at the Research Center as described in Chapter XI, Artificial Propagation of Gronsc. shonld logically precede the consideration of the disease conditions encountered in captive grouse. Described in a nutshellthe eggs are artificially incubated and the newly hatched chicks are transferred to battery brooders with wire floors. At the end of ten days they are placed on wire in a colony house where they remain until they are 6 weeks old, at which time they are transferred to outdoor pens again equipped with wire floors. The nearest poultry are one-half mile away and the only other birds kept at the Research Center are waterfowl and pheasants.

The sanitary precautions which are an inherent part of the propagation program eliminate worm parasitism entirely and reduce even highly contagious diseases, such as ulcerative enteritis and blackhead, to a few cases a year. while tmberculosis, aspergillosis and coccidiosis are so rare as to hardly require consideration. The use of wire-bottomed pens to prevent contamination of food and water with droppings is the procedure to which this control is largely attributable. 
It has been pointed out that. during recent years, none of the pathological conditions encountered in the wild* have occurred in grouse hand-reared at the Research Center, and none of the diseases which occasionally appear in captive grouse ${ }^{*}$ have been found in wild birds. It has heen observed that the infestations with bird lice, when they do occur, are heavier in the captive birds than in the wild ones. The lice involved. however, are not the same species. The ones which oceur on the hand-reared birds have pheasants as their ordinary hosts. The heavier infestations are undoubtedly due to the lack of dusting facilities in the eages.

In the following sections, the important specifie diseases of ruffed grouse in captivity are discussed. Three of these, "quail disease". blackhead and tuberculosis, make their primary invasions in the digestive tract, though other organs may later he affected. Two, aspergillosis and air-sae mites, are typically disorders of the respiratory tract and its appendages. One is a nutritional disorder which affects the leg joints.

It should be indicated that certain other pathological conditions appear in hand-reared grouse, though $n$ o specific disease-producing organism is held to he responsible for their occurrence. For instance, congestion of the lungs or pneumonia, which is observed in young chicks, generally follows exposure to over-heating or chilling. This may result from inadequate brooding facilities. There is also a condition in which urates, substances ordinarily eliminated by the urinary system, are retained within the body and precipitate in the kid. neys. liver and heart. Since this disorder can be produced experimentally by altering the diet or environment, it is difficult to identify its cause.

In the following sections, detailed descriptions of symptoms of the various diseases have been omitted because of their undependability in the diagnosis of disease. Sick birds usually tend to present the same appearance and behavior when afflicted with any of a variety of disorders. Positive identification of pathological conditions is best made by post-mortem examination of birds which died of disease or birds seleeted from pens where infection is sus. pected.

The several diseases which afflict hand-reared grouse may now be taken under specifie consideration.

\section{"Quail Disease" or Ulcerative enteritis}

Cause. The causative agent of this infection is still in doubt. Morley and Wetmore isolated an organism which they helieved to be the eause and named it Corynebacterium perdicium. Recently Bass ${ }^{\text {s7 }}$ reported that the true cansative agent was an anaerobic organism. Neither of these claims have heen confirmed by Durant and Doll who were unahle to determine the eause of this disease.

Vuture of the Disease. The malady may be described as an acute contaginus discase that attacks the cera and intestine of quail, grouse, chukars and turkeys. Outhreaks in the two former speries have occurred only in artificially propagated lirds although Green and Slillinger ${ }^{122}$ in Ninnesota have reported finding ulcerative enteritis in a wild grouse. Postmortem lesions may be entirely lacking, especially in hirds that die at the heginning of an cpizuntie. Later. the dead hirds are found to have small hemorrhages on the surfaces of the internal organs and extreme congestion of the intestinal and caeca mucosa. In more advanced (asses. discrete romud white necrotic areas 2 or $3 \mathrm{~mm}$. in diameter are easily visihle through the intertinal wall. On the mucosal surfare. these white areas are found to consist of raised

\footnotetext{
- With but ore rxerption, napergilluvia.
} 
nodules which later break down in the center to form ulcers. These ulcers increase in size and in many instances coalesce to produce large areas of dead intestinal lining. In most of the fatal cases in grouse, perforation of the intestine by one or more of these ulcers occurs with resulting peritonitis.

Of the other organs, the liver is most often affected. Occasionally small, white, necrotic foci are scattered throughout. More often the liver is covered with a translucent gelatinous exudate. In a few instances, where hirds survived for two weeks or longer. the liver contained round, white caseous nodules resembling, somewhat. the lesions of tuberculosis.

Dissemination. In a severe outhreak of ulcerative enteritis in grouse. reported liy Levine ${ }^{2 s}$. it was shown that the disease could be easily transmitted to quail hy feeding them feces or intestinal lesions of diseased grouse. The hirds usually appeared unwell four days after infection and death usually followed from one to two days later. Houseflies, after having been allowed to feed on infective matcrial, also transmitted ulcerative enteritis to susceptible quail. The flies undoubtedly acted as mechanical carriers of the causative agent.

Practically all outbreaks of this disease, within recent years. have been reported in artifi. cially reared hirds which. of necessity, were closely confincd and relatively crowded. Inder those conditions, fecal contamination of feed and water is relatively easy. thereby facilitating rapid spread of the disease.

Most often the origin of an outbreak is rather difficult to tracc. In one instance a clue as to the sourre of infection in grouse was uncovered when it was found that an ingredient of the ration was heing prepared in a lahoratory where heavy losses anong quail from ulcerative enteritis were occurring. On other occasions. contamination with chicken feces was suspected but no definite evidence could be found.

The possibility that there may he carriers of disease among quail and grouse slould not be overlooked. Undouhtedly, future investigational work will clear up the many questions about ulcerative enteritis which are still unanswered at present.

Control. Once an outbreak of ulecrative enteritis has started. steps should he taken to have hirds removed from the flock at the first manifestations of disease. These lirds slould le isolated and placed in quarantine. Every attempt shonld be made to get the non-affected birds on wire, if possible.

It should he emphasized that control of flies should he an integral part of the sanitary precautions observed in combatting an outbreak of ulccrative enteritis. Screening with gauze or other netting may be as important as all the other procedures combined in limiting its spread. In a number of instances the immediate screening of suspected pens on positive diagnosis of "quail disease" has halted the spread of the infection without resorting to the costly and difficult procedure of isolating susperts from the flock by moving them to scparate quarters.

Necdless to say, all ordinary sanitary precautions should be rigidly enforced. Attendants should be warned against tracking of the infection from one pen to another. It is very de. sirable to have separate workers tend the different groups of pens, so that the men who feed and water the isolated and suspected hirds do not come into contact with the healthy grouse.

Carcasses of victims of the disease should he incinerated or deeply buried and should never be accessible to flies. Control of rats and mice is desirable.

Thongh rearing birds on wire has largely eliminated losses from this disease in later years. from time to time sporadic cases occur. These are readily brought under control. The source 
of these outbreaks is usually unknown but obscrvations on chronic infections of ulcerative enteritis suggest that all cases do not terminate fatally and that carriers exist.

\section{Blackhead or Enterohepatitis (caused by Histomonas meleagridis)}

Cause. Tyzzer ${ }^{5 \% 0}$ demonstrated that the causative agent of blackhead or enterohepatitis was not an amoeba hut a flagellate protozoan which he named Histomonas meleagridis. Cultures of this organism. when fed to turkey poults or when injected into the cloaca, produced typical lesions of the disease.

Nature of the Disease. Blackhead is a disease affecting the ceca and liver of turkeys, chickens, grouse, quail. and other gallinaceous birds. Grouse are among the more susceptible birds. The primary sites of infection are the ceca. The walls of either one or both of these become tremendously thickened due to invasion by the parasites of the mucosal and muscular layers. The surface epithelium becomes necrotic and eroded. A typical cheesy core adhering firmly to the cecal wall is generally found. It is believed that spread of the parasites to the liver takes place by way of the blood stream. Here the lesions take the form of depressed shallow ulcers similar to those found in turkeys. In cases where the disease has run an acute course. the liver may be covered with white necrotic foei several millimeters in diameter.

Dissemination. The researches of Tyzzer and others have demonstrated that the causative organism, when climinated with the feces, is highly infections. Furthermore, it has been proven that chickens may act as carriers of IIstomonas meleagridis without heing affected therely. The organisms are also slued by birds that are suffering from the initial stages of the disease. An inportant contrihution to onr knowledge of the transmission of enterohepatitis was made by Graybill and Smith ${ }^{100}$ and Tyzzer, who found that feeding embryonated cecal worm cggs to turkeys resulted in blackhead infection. Although the evidence supporting this manner of transmission is sound. no one has as yet demonstrated the presence of the protozoan within the ceral worm egg. Furthermore, it is recognized that blackhead can also loc found in turkeys not parasitized with cecal worms.

The disease occurs in both young and old grouse and at times may affect entire pens with the rapidity of an acute contagious infection. Outbreaks of enterohepatitis have occurred in pens of artificially reared young grouse that had been on wire screen floor from the day they were hatehed. Some of these birds succumbed to the infection in spite of all precautions that were taken to prevent access to droppings and to prevent fecal contamination of the feed and water. It goes without saying that these hirds were free from all worm parasites.

A number of inestigators have found that infection with blackhead can resule from exposure to ground that had not been ocrupied by gallinaccous hirds for over a year. However, a resistant form of the causative organism has not heen found as yet. It is diffeult to reconcile these apparently contradietory faets. Nuch more nects to loe learned about the transmission of this disease.

Control. The primary requisite in both prevention and control of hlackhead is the maintenane of the hirds on wire. This practiere. together with the elimination of poultry from farms on which sllsceptible hirds are raised. results in a reduction of losses from this disease to a very low level.

There may. howerer. les outhreaks at times. enen muler these conditions. Strict sanitation and removal of suspeeled hirds may hring the disease under control before it affects any numbers. In rertain instances, the administration of a milk llush" has seemed to stem the 
tide of the outbreak. Unfortunately, in the cases observed to date, the treatment was by necessity given to all the birds and no control group was left untreated as a check on the normal course of the disease. In view of information desired in the selective breeding program, it was considered inadvisable to risk loss of part of the exposed group if they could be saved by the treatment. Similar therapy has been reported to be of value in treating blackhead in turkeys ${ }^{\star}$.

It should be reiterated that blackhead is no large problem when birds are kept on wire and good sanitation is practised. Its devastating effects will soon be apparent if attempts are made to maintain grouse in jens on the ground.

\section{Tuberculosis (Caused by Mycobacterium avium)}

Cause. A bacterial organism, Mycobacterium avium, is the causative agent of avian tuberculosis, which was recognized as a disease of chickens as early as 1868 and was reported from pheasants and ducks in 1872. The disease has been reported from many species of birds including sparrows, crows, hawks and owls. Among captive birds, the gallinaccous and pigeon groups scem to be the most susceptible.

Nature of the Discase. Tuberculosis in birds is a contagious disease which pursues a chronic course. It is characterized by the production of nodular lesions, known as tubercles. These are grayish yellow or white and of firm consistency. varying in size from that of a pin point to over an inch in diameter, the larger ones licing more irregular in shape. The organs most frequently affected are the intestines, liver and spleen, which may become considerably enlarged as a result of the infection. Other organs which are often involved are the lungs and bone marrow.

Development of the disease takes place slowly over a number of months. In some cases. a couple of years may elapse before death ensues. It is therefore almost always found in older birds. As the malady progresses, the birds generally suffer a loss of weight and appetite.

Tuberculosis has occurred very rarely and only in isolated cases among the captive grouse at the Rescarch Centcr. Less than one case a year has heen observed and all the affeeted lirds were over two years old.

Dissemination. The presence of the tulercle hacilli in the feces of infected birds is probahly the most important factor in the spread of the disease. Earthworms and fly larvac which have fed on the carcasses of dead tuberculons poultry, have been suggested as disseminating agents, hut exposure to these vectors is not likcly to occur in modern grouse rearing.

Control. Ingestion of the organisms by other lirds is effectively eliminated in grouse propagation by keeping the birds on wire.

\section{Aspergillosis (Caused by Aspergillus fumigatus)}

Cause. A mold or fungus organism is the causative agent of the condition known as aspergillosis, pulmonary mycosis or brooder pneumonia. The mold and its spores occur in moldy grain, straw or other plant material and are inhaled by birds which contact these products.

Nature of the Disease. The spores which are taken in by exposed birds find their way to the lungs and air sacs where they germinate and give rise to mold colonies varying in size from those which are barely visible to the naked eye to some over one quarter of an inch in

$\triangle$ Service Bulletin No. 30, Larro Milling Co., pp 1.5 (undated). 
diameter. The reaction of the tissues to these invaders results in the formation of firm nodules which are usually fomd in or on the lungs but may oceur in many parts of the body wherever the air sacs exteml. The hirds uswally become emaciated hefore death.

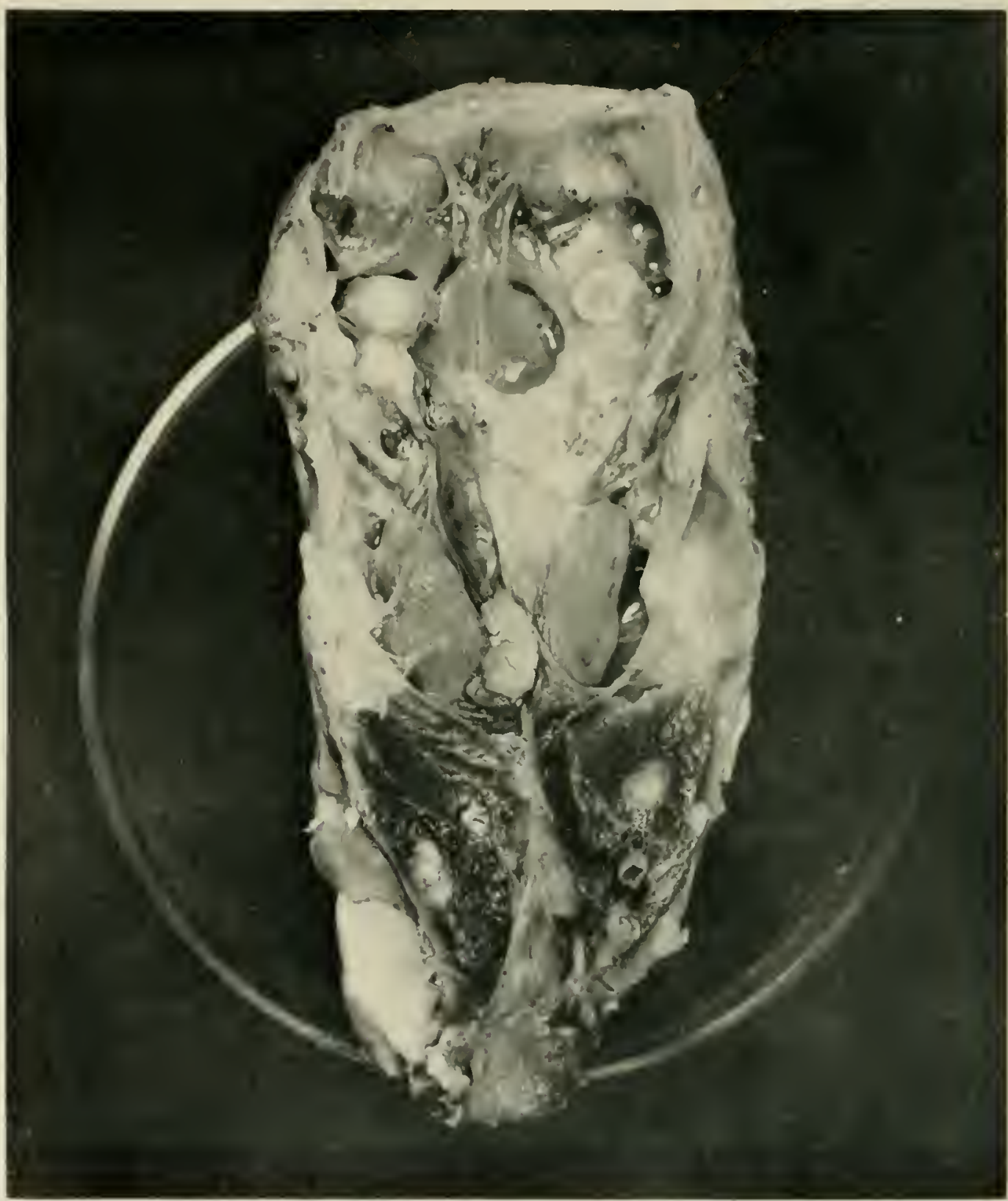

LESOMS OF ASPERHLOSIS IN LUXG AND KUNEY OF MULT GROUSE 
When the disease occurs in young poultry, during the brooding period. it has an acute course for death eommonly occurs within a few days after exposure. This rapidly fatal form of the malady is extremely rare in grouse. Most cases which have been observed at the Center have been chronic and eonfined to adult birds. Aspergillosis is a decidedly infrequent finding in grouse autopsies.

Dissemination. Dark and damp conditions either in the bird's quarters or in places of grain storage are conducive to the development and maintenance of the mold.

Control. Procedures which foster dry, clean, uncrowded housing of birds and feed should he employed.

\section{Air Sac Mites (Cytoleichus nudus)}

Cause. The air sac mites are very small spider-like animals, found in the air saes and less often in the bronchioles. lungs, trachea and even in the hollow bones of grouse and other game birds. chickens and pigeons. The parasites appear as tiny yellowish-white spots. The males measure $450 \times 300$ microns and the females $500-600 \times 400$ microns.

Nature of the Disease. Light infections of these mites produced no gross pathologic changes. If the birds had just been killed or had just died, the tiny mites could be detected by their slow movement over the air sae membranes. In heavier infections the membranes became much thicker than normal and tended to become more opaque. In a few severe cases, purumonic areas in the lungs with catarrhal exudate in the brombii and lower trachea were found. Large numbers of eggs and adult mites were seen in wet preparations of mucus taken from these places.

Very few hand-reared gronse succumbed to this infection.

Dissemination. Little is known about its life eycle or natural method of transmission from one host to the next. The females lay eggs which contain larval mites rearly to liatch.

In the cases encountered in artificially reared grouse, infection was believed to have been acquired from chickens which, in the early days of the lnvestigation, were used for hatrhing grouse eggs.

Control. Discontinuance of the use of chickens as foster mothers and prompt isolation of all grouse that appeared dumpy served to eliminate this infection.

\section{Slipped Tendon. Hock Disease or Perosis}

Canse. Work by Wilgus and co-workers ${ }^{398}$ in 1937 and confirmed since then ly many others, indicates that the basic canse for this nutritional disease is a lack of manganese in the ration.

Nature of the Disease. This disease, fairly common in domestic poultry. is characterized by the shifting either to one side or the other of the large Achilles tendon as it passes over the hock joint. There results a curving of the shanks and a twisting of the leg out of the normal position. The birds not only become lame but in many instances are obliged to hobble along with the hock dragging along the ground. Only a small number of grouse chicks succumbed to this condition although it always seemed that the largest and fastest growing chicks were most likely to come down with perosis. The disease has not been observed among adults.

Control. Prevention of this condition is effective when sufficient manganese is present in the ration. Domestic pouhry require 50 parts of manganese per million. 


\section{THE ROLE OF DISEASE}

It can be seen from the preceding pages that the relation of parasitism to disease and disease to the life of the ruffed grouse is difficult to evaluate. Many of the parasites do not produce disease and those which do are not widely distributed throughout the range of the bird.

Though it has long been asserted as a generality that the limits of game populations are probably set by disease ${ }^{\approx 0}$, clear cut examples of this are not easy to find. It seems logical to assume that transmission from animal to animal takes place more readily as the population increases. Furthermore, even though the increase of virulence of certain disease producing organisms by rapid passage through susceptible hosts is demonstrable, the actual occurrence of these phenomena in nature is not often observed. Under conditions obtaining in human populations and in concentrations of domestic animals, these processes may be followed, but to explain density fluctuations in wildlife on this basis, without more definite information than that available to date, seems inadvisable.

Whether disease reaches dangerous levels in natural grouse coverts is a matter for speculation. The question is by no means solved by pointing to the absence of other factors to which "die offs" can be attributed. The difficulties encountered in studying the role of disease in wild animals foster the temptation to make broad generalizations the basis for interpreting problems which must he approached from a factual standpoint if sound conclusions are to be drawn.

The possibility that local variations in abundance may occur and the fact that complete information on relative abundance cannot be obtained for all of the areas from which hirds are collected, further handicaps interpretation of autopsy findings in terms of the relation of pathological conditions to the grouse population.

An additional matter for conjecture is the suggestion that, since, during periods of abundance, transmission of disease is probably facilitated, increased hunting pressure during such times would be of benefit in reducing the population to a "safe" level. As a corollary to this is the attitude that certain of the birds shot in fall might well die of disease or other causes during the winter, if they were not so harvested.

Proper evaluation of these questions should also be based on sound olservations on the actual rate and mode of increase of disease during increases in abundance and on the relation of the haphazard sample taken in fall hunting to the normal and diseased sectors of the bird population.

The fact that disease does occur and on occasion accounts for deaths of both wild and captive grouse, necessitates its recognition as one of the factors limiting abundance. In this sense, it can no more be removed from consideration than can weather, predators and the other items which in one way or another influence the lives of grouse individuals and groups.

Observation on pathological conditions during a period of over ten years, however, has revealed no disease of epizontic proportions which would account for a sudden and widespread disappearance of ruffed grouse. 


\section{CHAPTER XI}

\section{ARTIFICIAL PROPAGATION}

By Gardiner Bump

\section{ORIENTATION}

Background and Difficulties-Methons of Raising Grouse-J'rogress to DateRESULTS

\section{THE STARTING POINT}

Eggs from Wild Nests-Collecting and Transporting Grouse Eggs - Wil.d-Trapped BIRDS

\section{THE NATURAL COVER METHOD OF RAISING GROUSE}

Penning Birds and Providing Shielter - Feeding - Protection from PredatorsDANGER Fron Disease-Vitality

\section{THE INCUBATOR-BROODER METHOD OF RAISING GROUSE}

Caring for the Breeding Stock-Overwintering Grouse Breeders-pens and penningfoods and feeding techniques-handling the spring shufple-weight and physical wcll-heing - The Spring Period-selection of brceding stock-brecding pens and equipment-penning and care of breeders-feeding breeding birds-mating and egg fertility-egg production and collection-controlling disease-The Summer and Fall Period-moulting and recuperation-The Incubation of Grouse Eggs-Grouse Mothers-Foster Mothersconstruction of hatching coop and nest-care of eggs--The lncubator Mcthod-location of the incubator-1ype and care-incubator operation-measuring incubation progressselting and care of eggs-hatching and transfer of chicks-BRoOding of THE CHICKs Brooders and Brooder Houses-Brooder Operation-Care of the Chicks-Feed and Feeding Techniques-Feather Picking and Camnibalism-Reducing the Danger from Disease and Predation-Rearing of the Young Birns-Rearing Fields and Units-Pens and Penning-Feed and Feeding Techniques-Diseasc Prevention and Control-Care During Rearing-The Period of Social Adjustment.

\section{PRACTICABILITY OF ARTIFICIAL GROUSE PRODUCTION}

Production Equations-Factors Limiting Production - Biological Limitations Scarcity of Obtainable Breeding Stock or Eggs-Lack of Trained Manpower-Cost 


\section{GROUSE LIBERATIONS}

Trassportation for Liberation-Method of Liberatiox-Marking for Identificatiox-Wiat Determines Survival-Source and Experience-Age-Physical Condition - Ability of Liberated Birds to Survive.

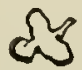

\section{SUMMARY}

Ruffed grouse can be reared and maintained in fairly substantial numbers in captivity. A total of 1,999 grouse have been raised to liberation age by the Investigation at the Research Center 10 date. (p. 450).

Birds, for liberation at eight weeks. can be produced, using the methods and equipment here described, at a cost of from $\$ 4.00$ to $\$ 8.00$ each. With additional research this cost can be reduced somewhat. (p. 502).

Among the important factors restricting production of lower-cost hirds are biological limitations, a lack of trained manpower and the need for specialized equipment. (p. 499 ).

Some biological limitations. while probably not insurmountable. are extremely difficult and time-consuming to master. Outstanding among these is the average production of but 18 to 20 eggs per breeder per year in raptivity and the diffieulties encountered in consistently rearing more than 30 to 50 per cent of the grouse chicks. The overcoming of strong dominant and subordinate complexes in the bird represents another difficulty. (p. 500).

A start has been made in overcoming many of these lijological obstacles through selective breeding. This must be continued over many years. however, before one can expect thus to mitigate these difficulties. (p. 446. 463).

Other liological limitations snch as the susceptibility of the lird to disease in captivity and the effect of the pronounced mating cycle have becn largely overcome. Likewise. neither the artificial incubation of grouse eggs nor the maintenance of a brood stork throughout the year now present serious problems. (p. 4161 .

In inaugurating a grouse breeding experiment it is locter to start with eggs collected in the wild than with adult wild lireeders. (p. 452).

Wild nests can best be located by cnlisting the cooperation of others in reporting them. (1). 451$).$

liggs from wild nests should be eolleeted and transported as elose to the pipping date as pos. sible. (p. 152 ).

Of the two methods of rasing grouse. the one on the ground in large enclosures under nat. ural cover conditions, the other on wire in pens. only the latter is practical. (p. 457).

Commercial foods ran be utilized snccessully in fecling grouse in captivity. (p. 489).

Disease necel not he a serioms cause of loss in the artificial propagation of grouse. (p. 416 ).

Gronse can be reared at least to the eleventh generation on wire without apparent physical impairment. 'p. 457 .

Healthy birds probahly capable of taking care of themselves when liberated at eight weeks 
can be produced ly this method. Artificially raised adult grouse represent poor stock for liberation hecause of their tendency to remain unwar! of man. (p. $507.50 \% 1$.

The artificial production of grouse either to restock depleted coverts or to provide "hirds for the gun " is at present seldom justified except where cost is not an important factor. where research ends are to he served. or where birds are needed to reintroduce the species into a farorable habitat from which they have been extirpated. (p. 502 ).

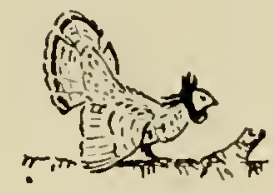

We are gradually learning that there is no royal road to wildlife abundance. Vol even the liberation of thousands of artificially reared crame hirds can quaranter a crood crop.

There was a time. not far hack. when great emphasis wa- placed m the artificial propagation of game birds. Then came a rhange. With game management emphasizing other practices. many widlife technicians today do not realize the potential balue of this artivity as one of their practical production tools.

There is and will continue (o) be, a place to use artificially propagated game hinds until we have learned how to mantain a wild seed stock year after year at a level somenhere near the carrying capacity of our coserts. The Sentch grouse in Fingland has heen managed sueressfull! for 300 years. lout much tou little is known of our grouse to permit such intonsive handling. Decades must clape and mucls good scientific work he completed hefore we can look forward to a like result with most of our gane speries. In the meantime. natural forese, aided by man, will occasionally reduce some species to a proint where atrificial restocking may prove the quickest and surest. if not the only way. to rescore an arlequate seed stock. In a pinch, it might he the means of saving a species from extinction.

Grouse are still dillieult and (ostly to raise in captirit! by comprarison with pheasants and quail. For this reason the artificial production of gronse either to restock depleted corcerts or as "hirds for the gun" is at present seldom justified exeept where cont is not an important factor. where research cuds are to be served. or where birds are necded to reintronluce the species into a favoralse habitat from which they have been extirpated.

\section{ORIENTATION}

Before proceeding with a detailed description of how to raise grouse in captivity it is well to consider hriefly the picture in general terms. Ihat are the major problems one must fare? What choice is there as to propagation metheds? What progress has heen made to date in raising grouse in captivity? Let us then get first at hirl s-eye view of the situation.

\section{BACKGROLYI AND DIFFiculties}

One has but to turn to the first chapter of the look to see how clearly the game enthusiast of resteryear visualized the productive potentialities that lay in artificial propragation. That they were seldom realized with grouse is due perlaps to the biolog! of the species rather than the men who tried tirelessly to raise these birds lis adapting the methords that had proved so successful with pheasants and quail. 
Thuse who raised some grouse, and there have been many, found them to be tame and rather easy to manage. Though normally not a social species, at the New York Research Center they can be kept congenially a part of the year in flocks of up to 300 individuals. In cap. tivity, at least, grouse are polygamous. The eggs are not too difficult to hateh in incubators. Once the chicks have passed the month-old mark, they are as easy to raise as quail.

But there are substantial difficulties to be overcome before mass production is economically feasible.

For instance, physiologically, most female grouse do not seem to be gaited to lay the large numbers of eggs normally produced by the species which have been successfully raised in captivity. It is the occasional bird which lays more than 30 eggs that holds forth the promise of developing a high producing strain by selcetive breeding.

The diffeulty of synchronizing the mating period of the sexes and the tendency of the male to viciously dominate the female during much of the breeding period are frequent causes for trouble. An even more puzzling problem is presented by the chicks, many of which have a discouraging way of dying in the first month without any thus far detectable reason. Here again careful selection of the breeding stock to correct this difficulty may prove the solution.

None of these troubles appear to be insurmountable. Eight years of selective breeding at the Research Center direeted at increasing egg production, fertility, livability and social balance, have shown some eneouraging though many conflicting results. As every breeder knows this period is far too short to change even one characteristic when so many factors are involved. Quite frankly, a way of eliminating the early losses among young birds has not yet been found. That it may ultimately be accomplished is indicated by an oceasional season during which 50 to 80 per cent of the birds hatched were raised to maturity.

Some may be surprised that the much publicized susceptibility of grouse to disease is not included as a primary diffienlty. In the light of today's experience, this factor is no more difficult to control in propagating grouse than in quail. In fact, unless intelligently handled, more birds nay be lost, particularly in spring and fall, through the desire of some individual hirds, usually males, to dominate their penmates. This tendency may be referred to as the "dominance complex". It may cause fighting and chasing, sometimes resulting in severe injuries to the subordinate birds, and it may also seriously impair the breeding potential of many of them. Unlike the primary difficulties listed above, these last two have been satisfactorily overcome.

There has been one other substantial bar to progress, a characteristic not of the hirds but of those who would raise them. Until recently, artificial propagation has been largely an enpirical procedure. Here success depended upon the fortuitous blending of native intuition with a knowledge of the "secrets" of the trade. In many instances these have been well guarded.

Although, when properly equipped, it is today no trick to raise these birds from eggrs collected in the wild, little progress is likely to result from so doing, for every conceivable angle of this procedure has been thoroughly explored. It is lime indeed for the enthusiastie grouse

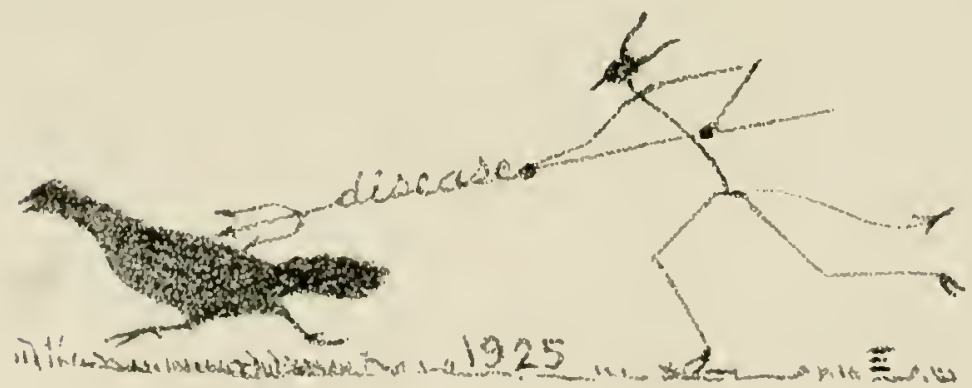


experimentor to realize that the problem may not be solved by adopting a new type of hover or by adding wintergreen to the diet. In fact, little useful purpose beyond encouraging public hopes and interest is likely to be served by continuing such rule-of-thumb experiments.

Large-scale production of grouse in captivity apparently depends upon the ability of grouse breeders to produce, by selective breeding, a strain of birds which will lay a large number of fertile eggs which will, when hatched, produce chicks that can be reared to maturity without undue effort or loss. Perhaps a hundred individuals have raised a few grouse in captivity, but each has been unable to translate early successes on a small scale into continuous large-scale production.

\section{Metiods of Raising Grouse}

There are but two main systems of raising grouse in captivity, the natural cover and the incubation brooder methods. Under the first, the birds are maintained on the ground in large covered pens under semi-natural conditions. In contrast with this, birds that are hatched in incubators, reared and held on wire and closely penned are said to be handled by the incubator-brooder method. Many combinations of these have been tried.

The merits and drawbacks of each method are described later in some detail by way of presenting the whole picture, although the factor of disease has made the raising of grouse on the ground at best a precarious proposition.

\section{Progress to Date}

This phase of the Investigation was largely an outgrowth of the pioneering experiments of Dr. A. A. Allen at Cornell", although Hodge, Merrill, and Torrey had demonstrated previously that grouse could be raised from wild eggs". However, little progress had been made in overcoming many of the difficulties standing in the way of mass production. While trying modifications of the old and accepted methods for ten years, Allen realized that his first limitation lay in the susceptibility of grouse to certain diseases. He then made two pivotal advances. First he abandoned disease-carrying hens as foster mothers in favor of the then none too reliable artificial hovers. Secondly he developed a method of raising and wintering grouse on wire.

* See story of early grouse rearing experiments in Chapter I.

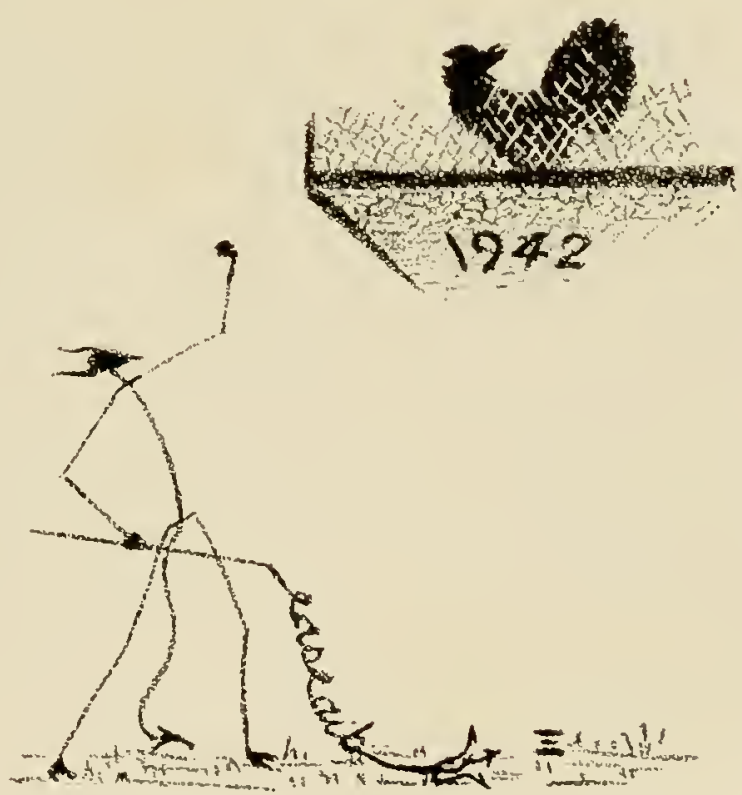


The comparative frestom from diease thus gained provided the first reat opportunity for fuding practical method of raising the chichs. maintaining them as breeders and studing the protilen of securing a large number of fertile eggos.

The problem was attached on wo fronts. The Insesigation established in 1931 a small field station in the western Catskills near the village of Harrard. There, as a result of the confusion of methods emploved ly those then raising gronse. man of the earlier techniyues were reebecked. The major effort was concentrated. howeser. on developing and lesting new ideas for rearing grouse on wire in small artifuially heated hrooders.

Coimeidental with the work at this station. funds and enpipment were prosided Dr. Allen by the Investigation so that he might continte his own long-time and promising experiments at Ithaca".

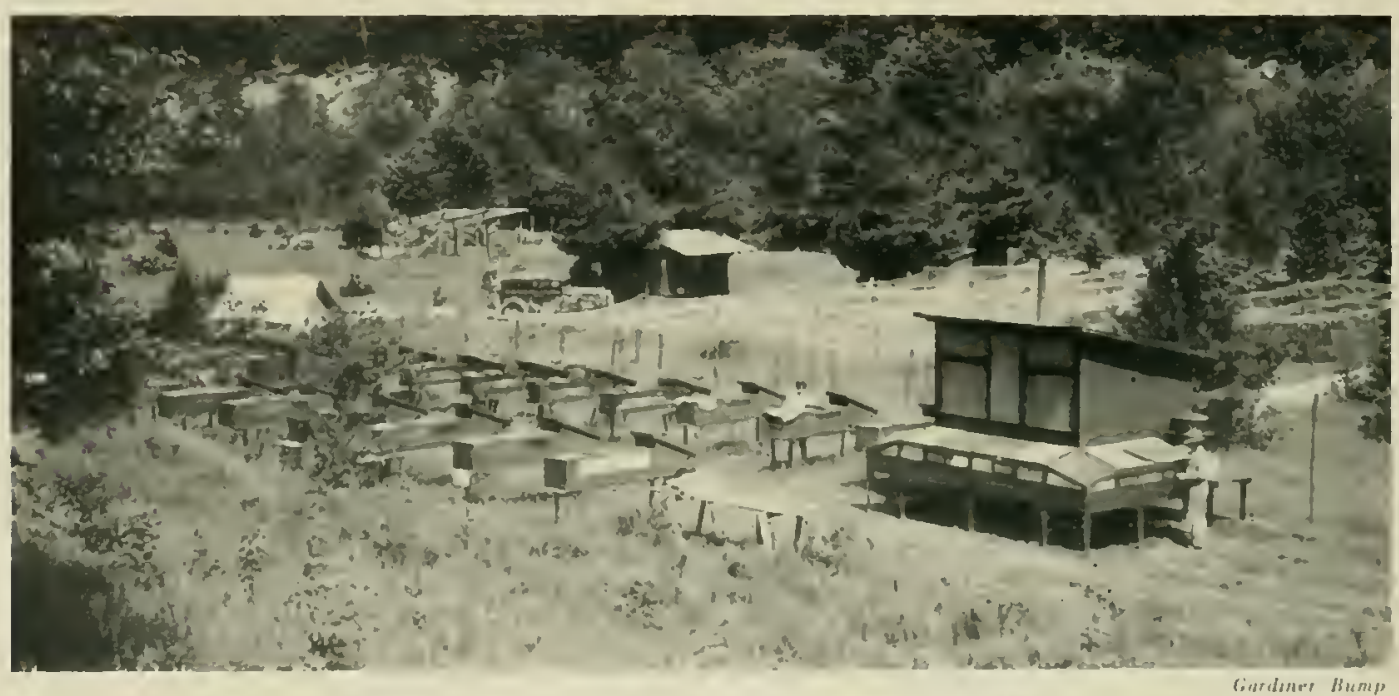

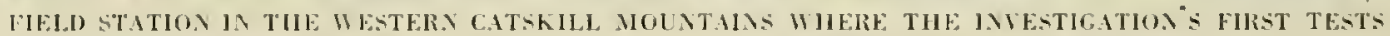
1) FEARIAG GROLSF I NDER SEMI-NATERAL CONDITIONS. AS WELL AS IN BROODELS. WERE

(CIIRIEI) OUT

By 1933 interes in seientific game production had increaned to the point where an Experi.

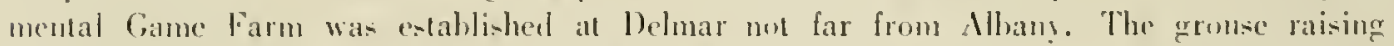
project. as une of the Department: major experimental actisitics. accordingly was transferted (1) the new station. bientuatly this mil became the hub of the game researet pre-

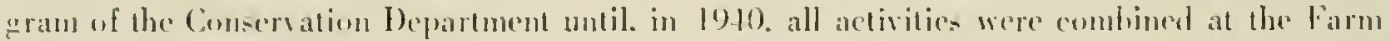
to form a liesiarch Conter. There grouse propagation became but one of the man! projecis.

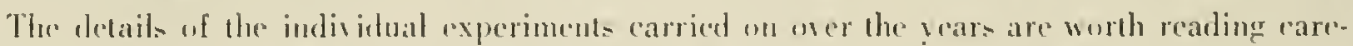
fulls if one is interested in rasing grouse. I smmman of these has areordingly hern

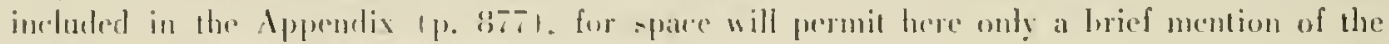
more productice projecto and results.

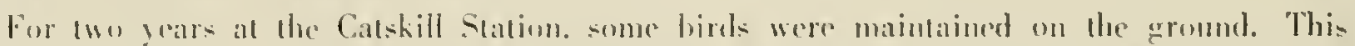

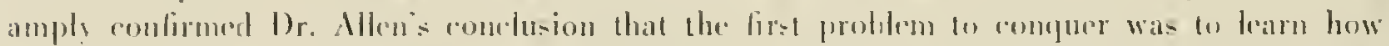
(1) contrul discates. A real wart had been mate hu rearing and raming grouse on wime. 
The slogan then coined, "Never let their feet touch the ground." proved valid at least to the extent of preventing epizootics of blackhead among old and young alike.

Real strides were made in learning how to render impotent other limiting factors. The years from 1931 through 1937 were largely spent in learning how to raise and maintain healthy grouse on commercially obtainable feeds and in lesting out a host of promising incubation, brooding, breeding and disease prevention practices.

The artificial inculation of grouse eggs presented few serious prollems although extensive tests both at the Research Center and at Cornell wese conducted to determine the proper lechnique.

Precedent was shattered by sulstituting for the time-honored chick diet of hard-buled eggs. clabber, and fly larvae or ant egg, an easily purchased game bird feerl to which was added white fishmeal and milk, liver and lirewers yeast all carefully drierl. Sulsequently. equally satisfactory results were secured by utilizing a commcreial turkey ma-b supplemented by grains and green food.

Brooding, too, was much simplified. The small hovers and wire runs wed in 19:31 were soon superseded by a large, all-pmrpose pen with an entosed electrically heated hwver in une corner. Since this was not altogether satisfactory. it was soon abantoned in fallor of colculy brooder houses. Several types and sizes were lested. As samting units. hattery lirouders adapted for grouse were developed to facilitate raising the bircts churing the first 12 elays following hatching.

The inventive genius of hover manufacturers was then at its best and day-old grmuse chicks: were carefully exposed to all commonly used types sizes and shapes of horers with equal impartiality. A low, rectangular box-type "still air" hower proved mont ataptable though the difference between it and others was not great.

Birds were brooled in groups of from six to orer 100 with hest results olitained from small groups of not over 25.

It has always been common practice to shift the !oung hirds at alont six weeks frum brooders to rearing pens. Of thess. nany sizes and designs were tried out and the minimum requirements for rearing and "aring for young hinds. while thus confuned. were determined.

The opinion that adult grouse should he overwintered. full-winged in large pens muder natural cover conditions, has leen helel by man! who have attempted to rear this hird. This method was given an extensive trial over a two-year period. Some trouble with disease was experienced but losses from predation. accident and escape were prohibitive. Nor were more eggs produced by this group than by their elose-penned companions.

Other pens. including those of the all-purpose $1 !$ pe. so constructed as to facilitate holding the breeders in large groups on wire, were also given thorongh tests. Eventually an efficient overwintering pen, accommodating up to 300 hreeders. was constructed. Because the lirds could fly back and forth it was appropriately named the "flying pen."

Throughout all the years much effort was concentrated on the difficult prollem of securing large numbers of fertile eggs. Breeders. breeding pens. combinations of breeding birds, food and care. all play a part in this problem.

It was detemined early that wild birds when reduced to captivity were usually por 
breeders by comparison with hand-raised grouse, although the former did lay some eggs while penned under semi-natural conditions at the Catskill Station. Even the number of fertile eggs laid by the birds raised in captivity was found to vary widely.

In an effort to locate the reason for this, a study of penning conditions was undertaken. It was found that birds placed on the ground under semi-wild condition did no better than those on wire. The all-purpose pens previously nentioned proved quite acceptable to breeding birds. Much smaller pens were tricd, but difficulties increased, resulting in a higher ratio of infertile eggs. To save steps, in 1937 a multiple-unit breeding pen was constructed, which, with few modifications, has proven quite satisfacto

Looking towards the solution of the same problem, many combinations of breeding birds were tried out. Grouse are polygamous in captivity. Combinations of one male with up to five females in a pen have proven moderately satisfactory, although best results have been obtained by penning the birds in pairs early in Marel. Also, females were pemned alone, fertile eggs being secured by introducing selected males which were in the mating cycle. Success proved, however, to depend largely upon the experience and capabilities of the attendant and so this latter practice, as a standard procedure was discontinued.

After thoroughly testing several combinations of foods, a breeding mash and a grain mixture commercially produced for game birds were selected for feeding breeders.

Begun in a small way in 1933, the planned selection of breeders for high egg production, fertility and for livability in the resultant chicks was made a major project in 1936. Since then all three items have shown a slow and irregular but encouraging trend upwards.

Disease has caused the termination of many a grouse experiment, though, contrary to general belief, grouse probably are no more susceptible to it than are bobwhite quail. It was learned early that to confine young grouse, even on fresli ground, was to invite trouble from disease. Some old as well as young birds died from hlacklsead or from ulcerative enteritis (quail disease) in the large covered pens at the Catskill Station even though great care was taken to avoid bringing in these ailments and no ponltry had previously occupied the site. Both thesc diseases likewise caused considerable loss during the early experiments even when the grouse, old and young, were held on wire.

Chemical preparations reputed to be disease-inhibiting when placed in food or water, were found to have little, if any, heneficial effect. Nor did "rubber glove" sanitation prove cffective in curbing epizootics of ulcerative enteritis and blackhead in the pens. Eventually, simple and satisfactory methods of prevention and control were worked out.

\section{Results}

To some who may, in a few nimutes, read this summary of 12 ycars of experiment and glance at tables 179 to 183 in the Appendix, the story will not be complete without realizing that exeellent breeling birds have been produced whose forebears, to the eleventh generation, have never touched their feet to earth. Nor have they been fed on aught save commercially prepared foods, interspersed with lcaves of apple, dricd alfalfa or needles of pine or hemlock to furnish the requisite ronghage. During the course of these experiments a total of 1,999 birds lias been raised to maturity. Of this group 191 have been utilized in liberation experiments. From the rest, year after year, have been sclected superior breeders from which must crentually come a strain of birds psychologically and physically adapted to withstand the limitations and respond to the artificial stimulations of eaptivity. 


\section{THE STARTING POINT}

Irrespective of whether natural cover or more artificial propagation methods are to be employed, the question most frequently asked by those who would breed grouse is, "How can a start be obtained?" Hand-raised stock is still scarcely obtainable at any price, thus limiting one to the securing of eggs from wild nests or from wild-trapped breeders.

\section{Eggs from Wild Nests}

Early experimentors. with few exceptions, started with the collection of a clutch or two of eggs from the wild. Nests were usually discovered by accident, for, unless one is skilled in the art, they are difficult to find. The Investigation, however, saved time by requesting the cooperation of game protectors, forest rangers and interested sportsmen. Advertisements in local papers inserted periodically for sevral years were responsible for the reporting of over 370 nests to the Investigation for purposes of study or of collecting the eggs.

Difficulties with adverse public opinion may be overcome if the experimental naturc of the project is carefully publicized in the region from which the eggs are to be collected.

\section{Collecting and Transporting Grouse Eggs}

The nest location, when found, should be carefully marked to avoid subsequent confusion in refinding it though the immediate surroundings should not be disturbed lest predators thereby be attracted. It is not necessary to gather unincubated clutches for, if carefully: handled, grouse eggs may be transported several hundred miles with no apparent ill effect even dnring the early stages of incubation when they are most sensitive to change. This may be completed with least likelihond of loss, however, just before hatching. Most of the eggs collected hy the Investigation in the sonthern part of New York were transported hetween May 20-25.

For scveral years great care was exercised in collecting wild exgs and in transporting them overland or by plane over distances up to 200 miles. Upon collection they werc placed in a pail half-filled with lukewarm grain and carried thus from nest site to a waiting car. Therc they were transferred to a well insulated five.gallon kettle. in the bottom of which heated grain had been placed. Over this wcre sct a series of beaverboard trays in which the eggs were placed between layers of cotton hatting. A thermometer was inserted in each layer of eggs. This was consulted as often as nccessary to make certain that the tempera. ture did not rise above $100^{\circ} \mathrm{F}$. or drop below $80^{\circ} \mathrm{F}$. The container, open at the top except for a loose fitting beaverboard cover. was set on the car cushion or, if the road was unusu. ally rough, suspended by springs above the floor not far from the heater.

By closing the car windows and turning on the heater, temperatures satisfactory to the eggs, if not to the driver, were maintained almost indefinitely. Later, heater and egg con. tainer were boxed in, thus permitting the car windows to be left open. At the height of egg collecting, several containers were sometimes delivered to a nearby airport from which they were flown to the Research Center by the Department's airplane. 
Amos unifomly the corges spemed to arrive in excellent condition. Eventually. however, it was discovered that. if they were gathered within a period of three or four days prior to hatching. no apjarent harm resulted from transporting them in an unheated container earried on the front seat of the car. At this late period incubation has apparently progressed to a point where suffeient internal heating is generated to allow the egces to resist conoling for

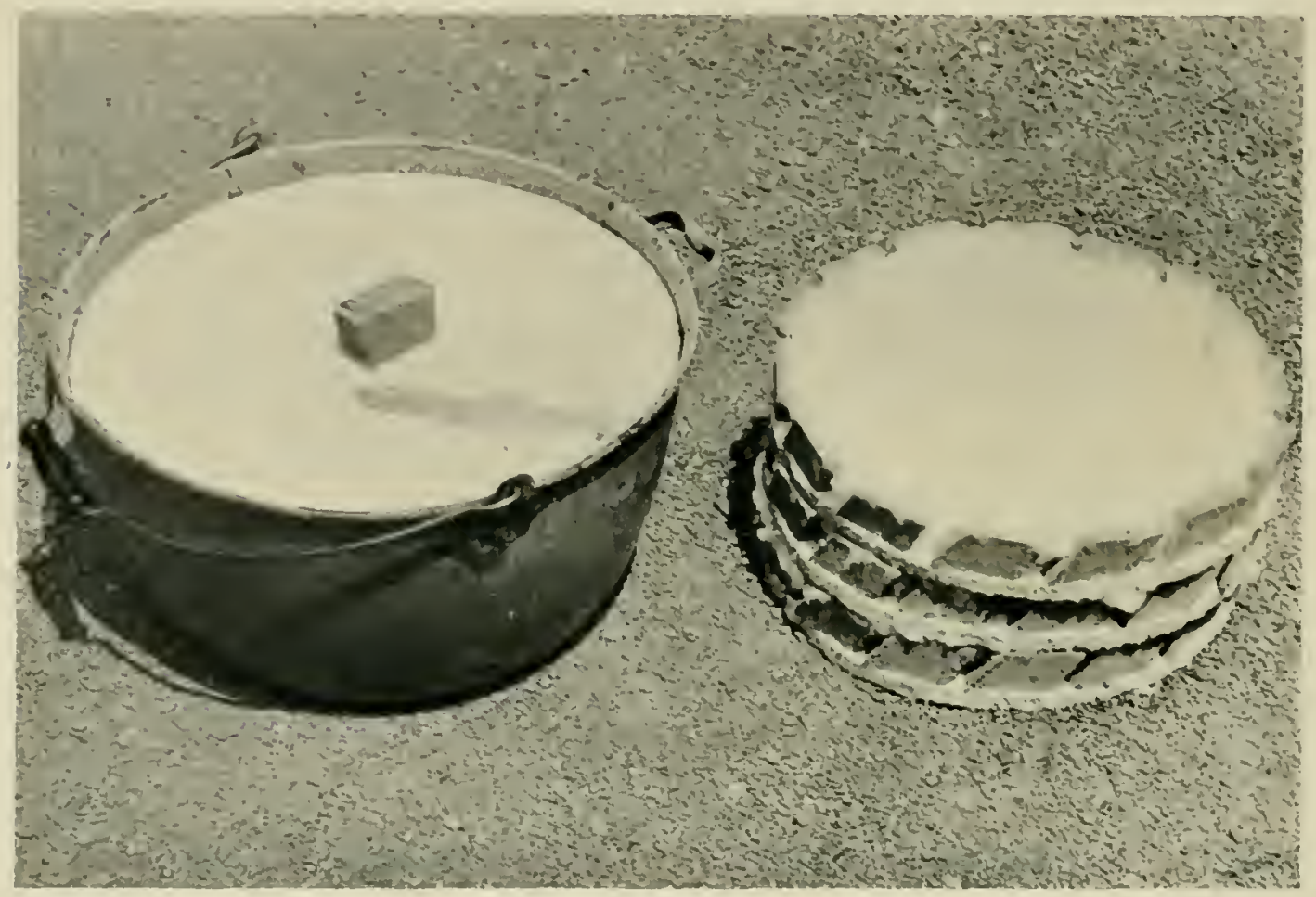

II TUIS KETTLE, IXCLBATED GROLSE EGCS, BLRIED BETWEEX LAYERS OF COTTOX, WERE, CIRRIED SLCCESSFUJY OYER DISTAMES IP TO 200 MHLFS

periogls of six to 12 hours. In fact. one eluteh, cold ujon collection and thought to be dead. was plaved on saturdas noon in a refrigerator at a temperalure not far abose freezing. On the following Monda! morning the chutch was removed for examination. The first egg to les upenerl revealed a lise mbryo. The remaining seven eggs were immediately placed in an inculator and soreral ehicks subeeguentl were latched. Aone lived for long. howerer. for an! unusual strain placed upun the cmlurgo uswally is reflected in lowered hatchability of the egg and in a poorer livabiity in the chick.

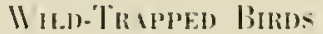

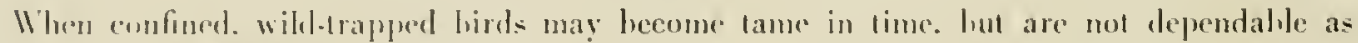

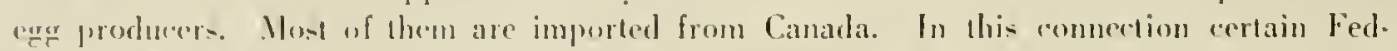
ral and state permit- encringr importation and pessession are ustatly required.

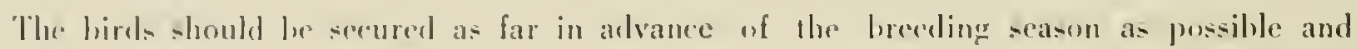

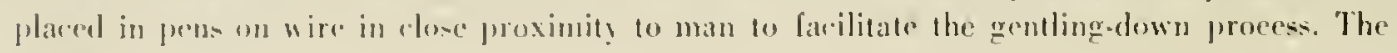


"all-purpose" pen hereafter described is quite adaptalle to this purpose. To prevent injury the birds may he wing-clipped. To inhihit constant raseling up and down along the sides of the pen. called "walking of the wire" it is wise to cover the outside of the pen with burlap or other material for a distance of a foot above the floor. The feeding equipment may he plared in one corner under a shelter. If a few evergreen boughs are placed at one end the hirds will spend the areater proportion of their time in the ewrer thus provided.

To avoid difficultiss in adjustment at the hreeding period it is well to place the birds in Ireeding pens as soon as they are received. although spring mas till be some months away. This should lie done not later than the first of March in the latitude of Vew York State. Among 15 wild-trapped hirds placed mostly in pairs in emi-natural cuclosmres cluring early April 1931. no mating was observed. The following year ton wild-trapped females. similarl! ronfined in Decemher, laid a total of 41 eggs. 26 of which were fertile.

Though from one to five fromales may be placed with a single male. it is olu iou-ly desirable (1) mantain a pair to a pen so that the progen! of each hird can be recognized and a program of selective lireeding started withont lose of time. I -mall nest hox prosided with a

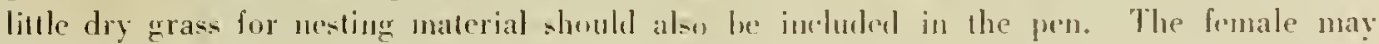
retire into this if chased hy lier mate. The ergers. laid there or at random on the wire. ma! lee removed when desired witlout afferting toti: roger probluction.

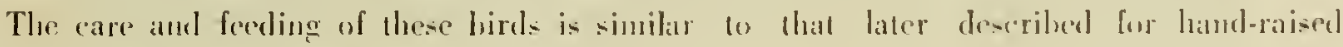
breeders proned at lhe same seasish of the yeatr.

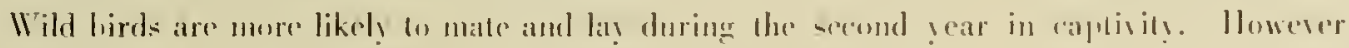
a certain proportion will alwa!s remain lame lut unprobluctice.

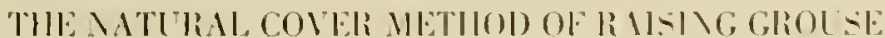

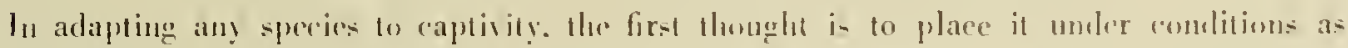
nearly similar w it native lahitat as possible. It is small wonder that Clark" in 1899. put four wild partrielges. collected in the fall. in a circular enclosure 10 feet in diammer with

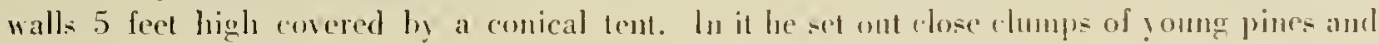
firs and covered the ground with dry forest heares. One of the hirds subequently nesterl and laid 18 eggs.

Others. too. had the same idea. It will be rememlered* that. to provide his loreeders with natural wintering habitat. Hodge $e^{\text {nos }}$ some 30 years later completely corered a large - ipruce tree with poultry netling in the front yard of his lanme. Two of the hirds placed therein were snagged by cats throngh the inch-mesh wire of the entosure and died of their wounds. The rest were poisoned. The American Gane Protective Amociation. in 1912. salulished a grouse farm on Cape Cod. and Torres ${ }^{3 n}$ luilt there a wintering and breeding pen of fisls netting resembling a cirrus tent. This was placed so as to enclose a heary growth of young pines. But disease and predation forced the ahandonment of the idea after a year"s trial. On the other hand. in Manitoba, Bendich ${ }^{40}$ for years sold grouse said to hase been reared from eggs laid hy wild hirds held captive in a large enclesure.

Between 1919 and 1929 Dr. Allen ${ }^{\text {Tt }}$ repeatedly tried to raise young birds in pens entaining natural cover. Breeders. too. were thus confined. but few escaped the ravages of "enteritis". predators and unfarorable weather conditions.

Still not satisfied. the Investigation. in 1931, huilt a series of covered pens enclosing several 
acres of excellent grouse cover. This was composed of pine, hemlock, laurel and hardwoods. Every effort was made to keep the pens disease-free. No poultry had ever previously occupied the site and none was permitted close by. Yet, of the birds liberated therein. disease and predators took a heavy toll. Nor was egg production. fertility or the general condition of these birds as good as has been obtained with grouse held on wire.

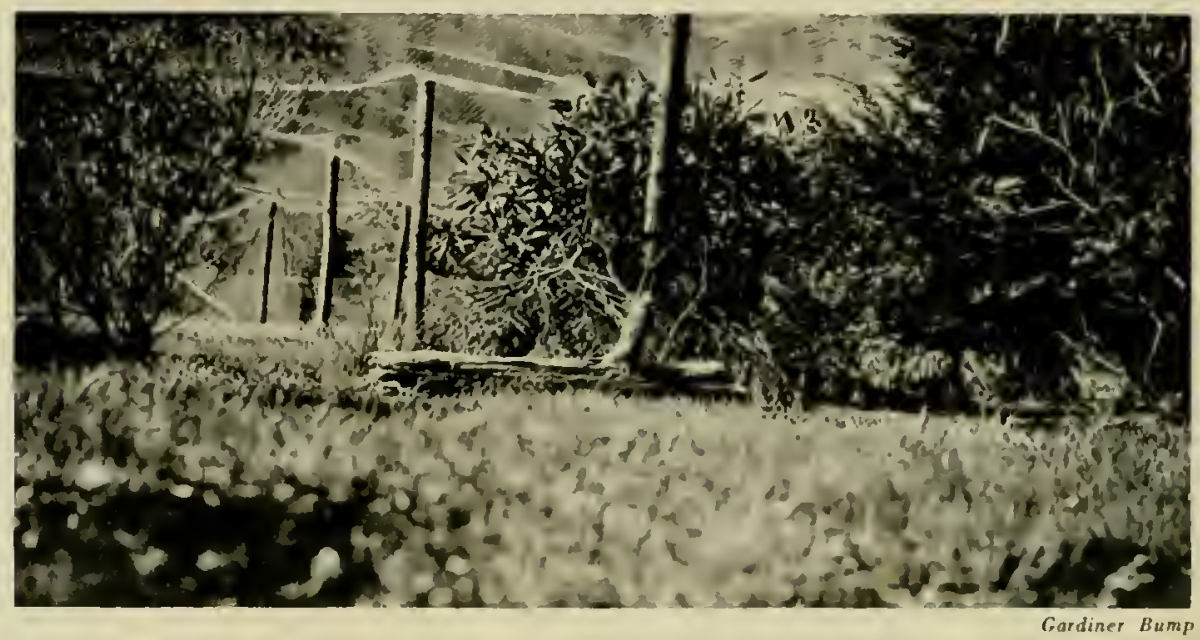

TIIE INTERIOR OF A PEN USED TO RAISE GROUSE BY THE SEMI-NATURAL METIOD

AT TIE CATSKILL STATION

The first year 15 wild grouse were secured early in April through the courtesy of Mr. R. W. Tufts of Nova Scotia. Two died in transit and ten were paired on the ground in 9 foot $\times 12$ foot segments of the pens described ahove. The remaining three, together with two locally trapped birds, were liberated in the rest of the enclosure, totaling an acre and a half. Only one female nested, laying but four eggs, all of which were infertile. $\Lambda$ single hird. handraised the year before and confined in another pen witl a wild-trapped male. laid 25 eggs. Only three of these proved to be fertile.

The second year, ten wild-trapped grouse, placed in these pens in December and January, laid 41 eggs, 65 per cent of which were fertile. A similar number of hand-reared females provided real encouragement by producing 165 egrs. 68 per cent of which were fertile.

An indication that the gronnd possessed no unusually stimulating powers which could not likewise be brought to bear on hirds held on wire came from Ithaca where Dr. Allen was experimenting with thus raising grousc. From one group of his breeders held on wire, 96 per cent of the eggs produced. proved to be fertile. Likewise. at the Researel Center females have since laid up to 36 eggs each in a single year although their feet had never touched the ground.

With the above picture in mind, one may wonder why, on succeeding pages, the natural cover method of raising grouse is descrihed at all. Though the difficulties inherent in it have engendered in the author a firm belief that no large number of grouse can he raised by this method over a period of years. a description is included for the sake of completeness and for those who are willing to chance the risks in this method. Furthermore. there are game breeders who still recommend it. 


\section{Pennivg Birds and Providing Shelter}

A concensus of opinion dictates the choice of a well drained, fairly open site for all pens. The size of the wintering enclosure must of course vary with the number of birds to be held therein. From the standpoint of preventing disease there is no safe minimum, for a few birds liberated on an acre of ground are still likely to become infected. At the Catskill Experimental Station about 40 adults were wintered in a pen 54 feet $x 75$ feet $x 8$ leet without encountering serious losses. Subsequent experience, however, indicated clearly that one should expect an increase in mortality caused by blackhead after holding the grouse on the ground.

Such a wintering pen should contain considerable natural shelter. Jeffries ${ }^{208}$ claims that the proportion of shaded to sunlit ground is important and recommends that 60 to 75 per cent of the area is shaded. Sunlight may, however, be a strong aid in controlling disease. For this reason, at the Catskill Station the wintering and breeding area was left but one-quarter shaded. In this portion the birds tended to gather, and a wire floor was constructed over that part of the ground to reduce the danger of infection.

The pen should be constructed of sturdy material and covered with l-inch poultry netting strongly supported to withstand winter snowfall and to discourage predators. At the Catskill Station, where 2-inch mesh was used, in one night a great horned owl beheaded five grouse. Frightened by the air raid, they had persisted in attempting to fly through the top of the pen until beheaded.

To prevent the breeders from "walking the wire", boards or hurlap ahout 12 inclses high may be placed on edge along the side walls next to the ground.

In February or early March the breeders may be placed, preferably in pairs, in small enclosures. The "all-purpose" pen (fignre 37) is ideal for this purpose. By covering the windward end of the pen, shelter against inclement weather for adults and chicks alike, can be secured. In the spring, breeding females need small hidcaways where they may seck pro. tection from the malc. In fact, if the female is to incubate ber own eggs. the males should be removed from the pens when the clutch is completed.

Many suggestions detajled later in the chapter will he found applicable to the care on the

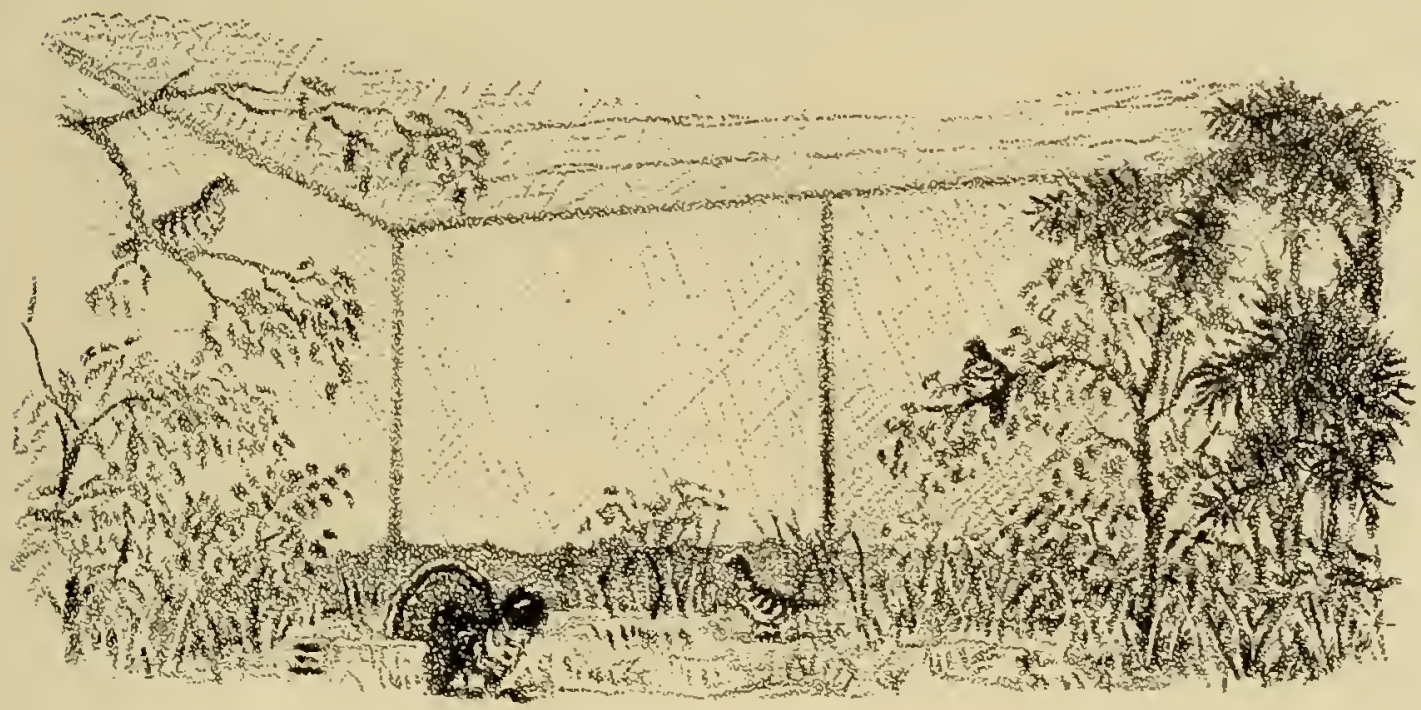


ground of old and young alike. For instance the incuhation of the eggs collected from the penned birds is fully described in a separate seetion devoted to this sulject (p. 473).

If one is also determined to try raising the young grouse in contact with the soil. the pens should he small enough to be moved easily to a fresh site at frequent intervals. Of course they should be kept scrupulously clean. One of the "all-purpose" pens placed on the ground contains plenty of room for a single brood.

Particular care must be taken to chink all crannies where the pen meets the rround for the hirds are adept at squeezing through small openings. In faet. when first hatched, they have no difficulty in slipping through inch-mesh poultry netting. so that 3 -inch mesh must be used.

\section{FEeding}

The literature is rich in feeding suggestions, many of which are impractical because the material recommended is not easily available. Ant eggos. loee larvae. maggots and mealworms are interesting examples. At the Catskill Station several tons of beef lungs were consigned to the "maggoteria" every year. The lungs were divided. placed in milk pans and exposed to the sun. Later the pans were placed in a beetle-proof cage until the larvae. now fully grown. migrated over the edge into other pans containing bran. Here they quickly eleaned them. selves and were ready for use.

There was always the danger of botulism with this method. Accordingly. in 1931. a graduate student at Cornell was commissioned to develop a method of producing large mumbers of fly larvae that feed on plants. A year later, however, satisfactory suhstitutes for fly larvae wore discovered and both the practice and the experiment were discontinued.

Alhough there is still some controversy among grouse breeders concerning whether hest results may be obtained by feeding natural food. the difficulty of ohtaining it in large quantities has dictated the use of the feeding formulas and techniques later described for hirds held on wire.

\section{Protection from l'remators}

Birds held on the ground are notaloly exposed to atticks hy predators. In late August 1933. at the Research Center. 40 wing-clipped hreeders were placed in an open pen several acres in extent. The enclosure was located near the middle of a meadow and was at least 750 feet from any woolland. Yet the first night a great horned owl. later trapped on its kill, deeapitated six individuals. A somewhat similar ease has previously been mentioned. On another oceasion young grouse. winerelipped and placed in a pen similarly situated. were promptly killed. The evidene pointed to a Cooper's lawk as the responsible predator.

Birds on the gromel are also sureptible to attack ly rats. eats. weasels and dogs. On one ofeasion two dogs fored the cutrance to a pen at the Research Center, killing l.t nearly grown birds. Raceous are also weasionally destructive. A grouse hen with her brool. placed in a wooded enclusure. was destroyed three nights later ly a coon whose sulsequent depredations were effectively checked hy placing an electrie fence along the top wire of the pen.

The best protection is to huild the pons tightly. rovering them with small mesh wire and to plaes tunnel traps at frequent intervals along the ontside houndaries for weasels and rats. These may lue screened with two-inch poultry netting to prevent the entrance of escaped birds. 


\section{Danger from Disease}

Disease difficulties have caused the termination of many a grouse experiment, though, contrary to general belief, grouse are probably no more susceptible to this trouble than are bobwhite quail. As previously mentioned, to place grouse on the ground in confinement is to invite disease. To keep this to a minimum, feed and water should be placed on wirecovered frames and the surplus frequently removed. Any accumulations of droppings, par. ticularly under shelters, should be regularly cleaned out. A wire bottom built to fit each breeding or rearing pen is a wise precaution against a possible outbreak of disease. Pens and lirds should be placed thereon at the first sign of trouble.

Though the records contain a few instances where hroods of qrouse were reared more or less successfully with bantam hens, as Dr. Allen aptly put it, "One might almost believe the successful grouse hreeder should not eat poultry even on Sunday". so susceptible are the birds to several of the more widely spread chicken ailments.

Nor are fresh ground and seclusion guarantees against disease. As already mentioned, birds both young and old died from llackhead or from ulcerative enteritis (quail disease) in the large covered pens at the Catskill Station. even though great care was taken to avoid contamination and no poultry had previously occupied the site. Another year, at the Research Center, 75 hreeders, all raised on wire, were divided among 15 pens placed on fresh ground. Extreme care was taken not to introduce disease, yet 16 of these birds died from hlackhead before the breeding experiments were concluded. These experiences. verified hy those of other breeders. point inescapably to the conclusion that no large number of grouse can be raised or carried in captivity in contact with the ground without sooner or later suffering a high loss of hirds from disease.

\section{Vitality}

The question is often raised as to the vitality of generations of gronse raised on wire in comparison with those reared and held on the ground. The situation is, in fact purely academic, for few if any hreeders have been able to avoid the pitfalls long enough to bring captive grouse beyond the second generation on the ground. Neither do wild birds offer a valid comparison. In contrast, grouse have been raised and maintained on wire at the Research Center to the eleventh gencration without experiencing any of the much feared degeneration of stock.

\section{THE INCUBATOR-BROODER METIIOD OF RAISING GROUSE}

Six thousand years ago an inventive Egyption moleled in mud and baked in the sunlight a queer structure for the purpose of hatching out the eggs of the half-wild fow that frequented his dooryard. Perhaps his friends langhed at the contrivance but it worked and eventually better ones were built. Thus out of an interest in the harnessing of nature's forces to man's ends was born the artificial nethod of propagating the birds of field and forest.

At first game breeders were much prejudiced against applying artificial methods to the raising of game birds. But the comparative freedom from the destructive forces of weather. predation and disease thus afforded has forced an increasing number to adopt then during the past 25 years. Early results left much to be desired but refinements in methods and techniques followed rapidly after the discovery that the new way was markedly less expensive than the old. 
With a species as susceptible to disease as is the ruffed grouse or the bobwhite quail, the choice seems not to lie between rearing methods. Rather it is dependent on how far one can go in applying artificial techniques. Generally speaking. quail and grouse are alike in that each can adapt itself rather successfully 10 meet most of the limitations of heing kept on wire.

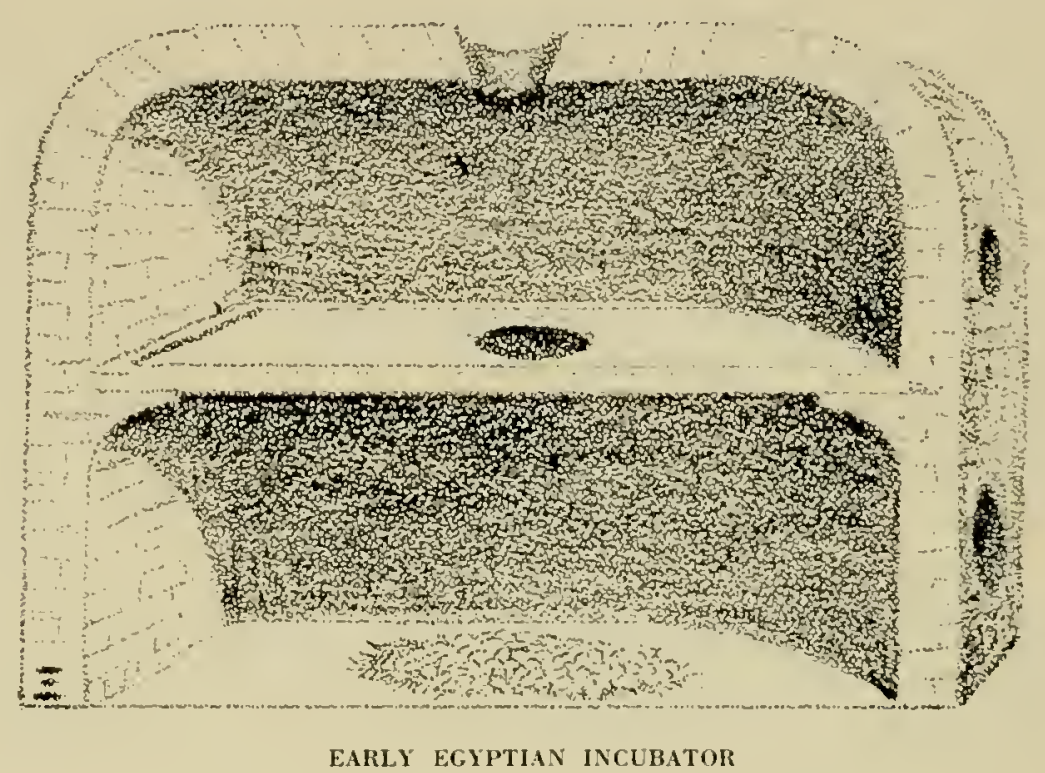

$A$ glance at table 68 will indicate that the differences which make game farm production of quail much more succesful than grouse propagation exist chiefly in the differential in egg production and in the rearing success with the young birds.

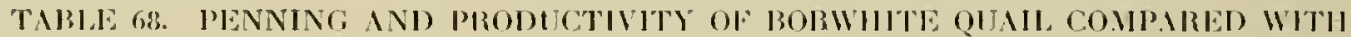
RIVFED GBOISE IN C.PTIVITY

\begin{tabular}{|c|c|c|}
\hline Penuitus or productivity & Quail & Crouse \\
\hline Wrethorl of mennilug breeders. & P'uirs & Jairs \\
\hline Size of prus netedrol . . . . . . . & $f^{\prime} \times B^{\prime} \times z^{\prime}$ & $6^{\prime} \times 8^{\prime} \times 3^{\prime}-8^{\prime} \times 10^{\prime} \times 3^{\prime}$ \\
\hline Normal are produclion........ & $50-80$ & $15-25$ \\
\hline Normul verk fırtility.......... & $35-110 \%$ & $65-80 \%$ \\
\hline Normul hatedubilify. ..... & $90 \%$ & $70-80 \%$ \\
\hline Normal livabilify............ & $75.130 \%$ & $30-50 \%$ \\
\hline Normal overwinloring loswres. . & $12 \%$ & $15 \%$ \\
\hline
\end{tabular}

To those who would raise grouse by the incubator-brooder method, a detailed consideration of the methods rmployed and the attendant results should be of interest. In presenting this picture, each natural unit of operation, such as breeding. brooding or rearing, together with its attendant problems and practices, such as feeding and preventing disease, has been himblled as a suhject romplete in itself. Only by so doing can one secure a well integrated idea of the way in which cach period or problem can be handled. 


\section{Caring for the Breeding Stock}

One key to the successful production of any game species is the quality of the breeding stock* With grouse this is all-important, for the gradual increase in the number of fertile eggs laid per female through selective breeding is a prerequisite to large-scale production.

Once secured, there are three problem periods to be considered in handling grouse breeders. Least attention is usually given to the over-wintering of the breeders. This is a mistake for it is then that the number of eggs to le produced the following season is largely determined. Most attention is paid to the spring period when the breeders are actually mating and laying their eggs. Likewise, there is a tendency to forget the adults again while they are moulting and recuperating during the succeeding summer and fall.

\section{Over-Wintering Grouse Breeders}

Pens and Penning. By the first of October the lirds of the year hccome restless in their rearing pens. Adult breeders have completed their moult and are ready to he moved into winter quarters. Although it is advisable to separate the males from the females, larger numbers of birds can be held together throughout the winter than at any other time.

Adult grouse are not particularly disturbed by normal rains, snow or sleet. On sub-zero

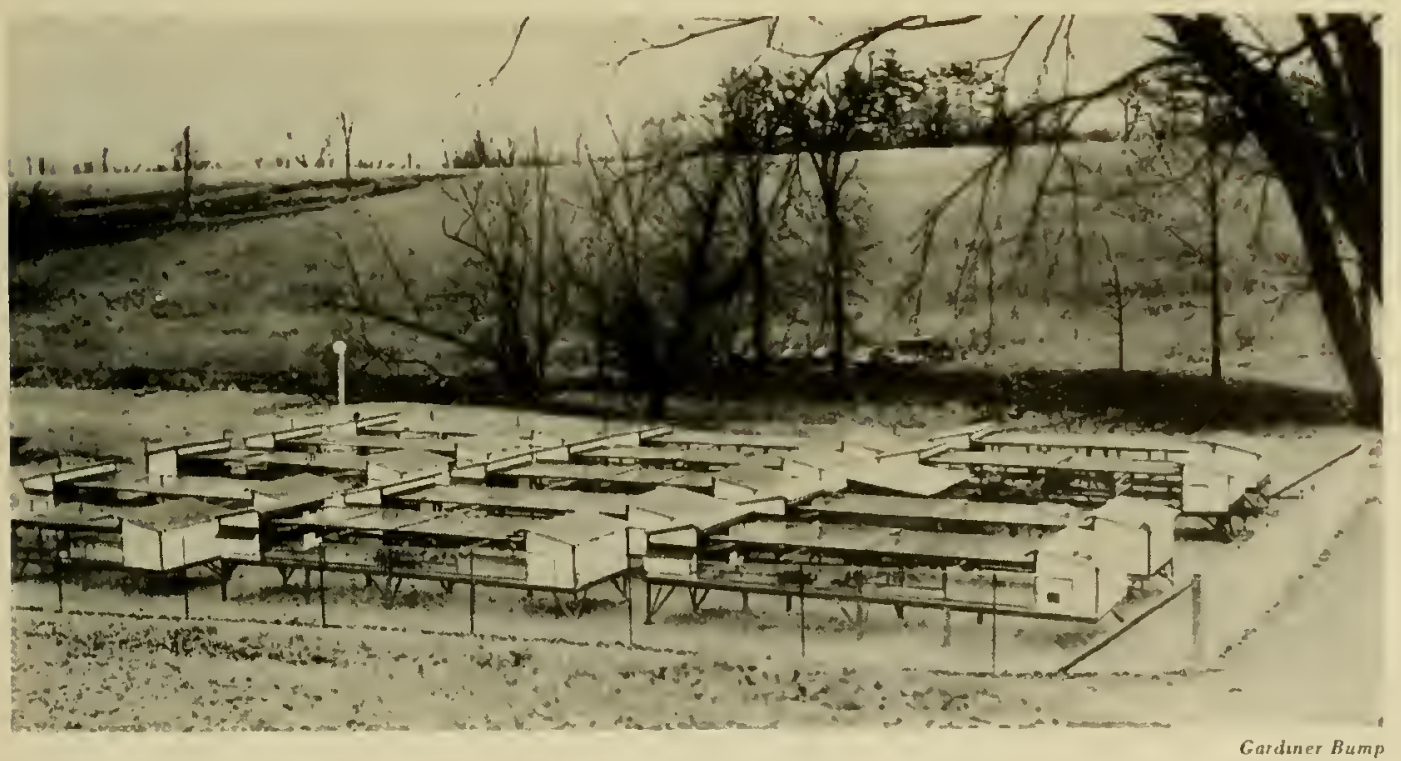

W INTERING YARDS AT THE RESEARCH CENTER CONTAINING ALL-PURPOSE PENS PLACED END TO END

days their movements are restricted somewhat but they do not appear to be uncomfort. able. The one item of weather which they dislike particularly is wind. Windy days are nervous days for grouse botl penned and in the wild.

At the Research Center, two all-purpose pens placed end to end, making a single enclosure 8 feet $\times 32$ feet $\times 3$ feet with a shelter at either end, easily house up to 20 breeders. Eight birds can be fairly successfully maintained over winter in half this space, though the work of caring for a smaller group would, of course, be doubled. To provide perches and places

* For methods of obtaining breeding stock, see p. 451. 

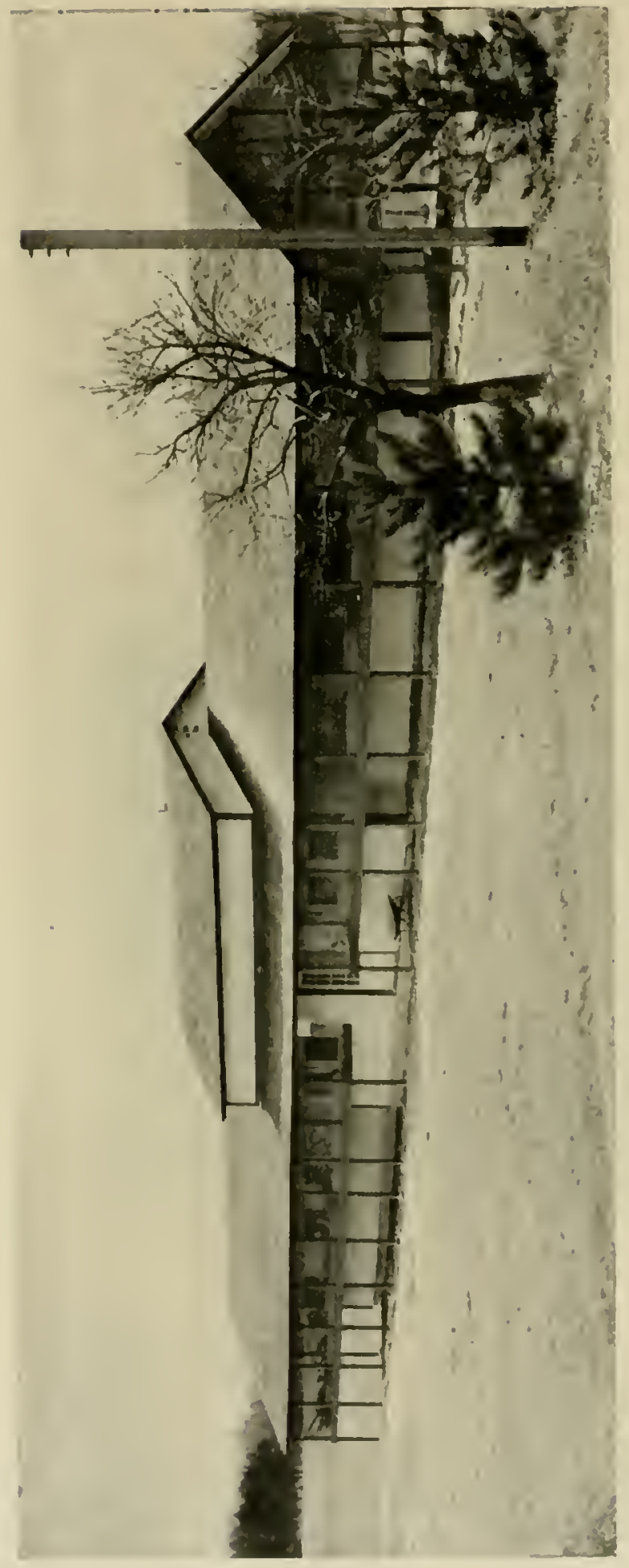

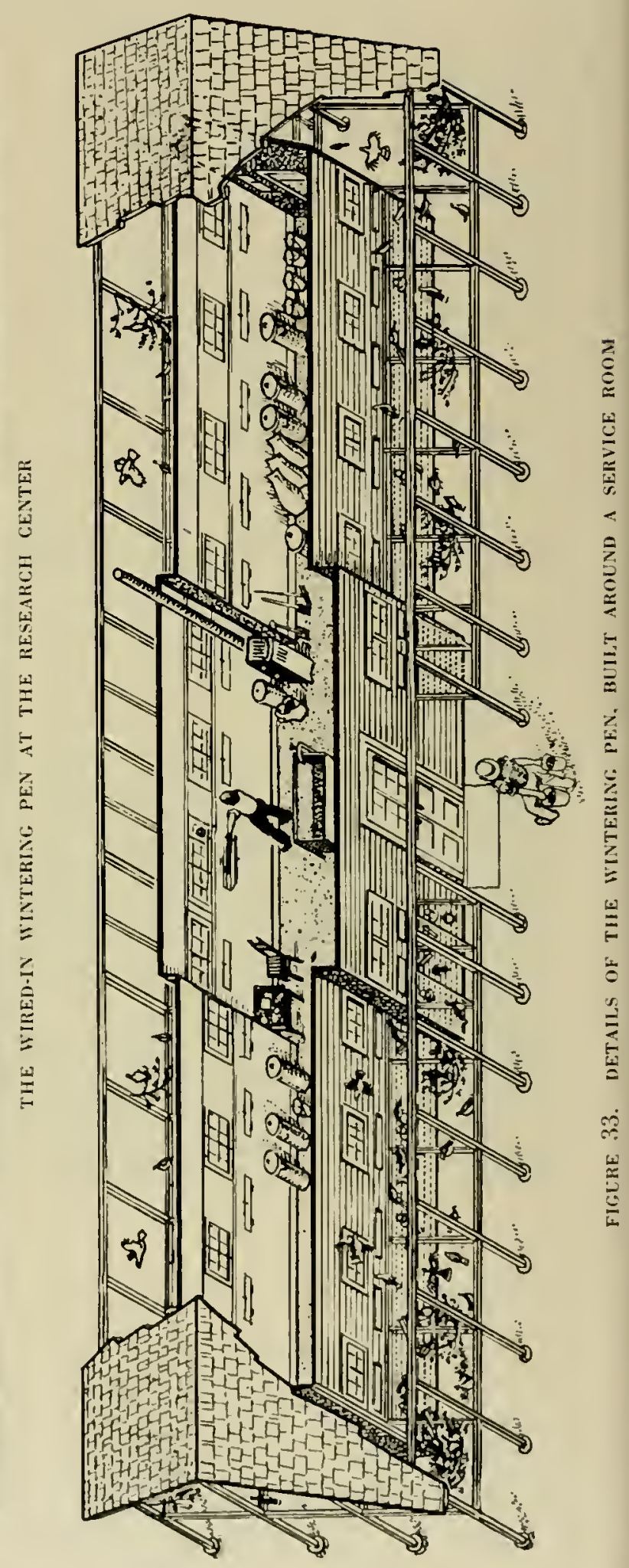




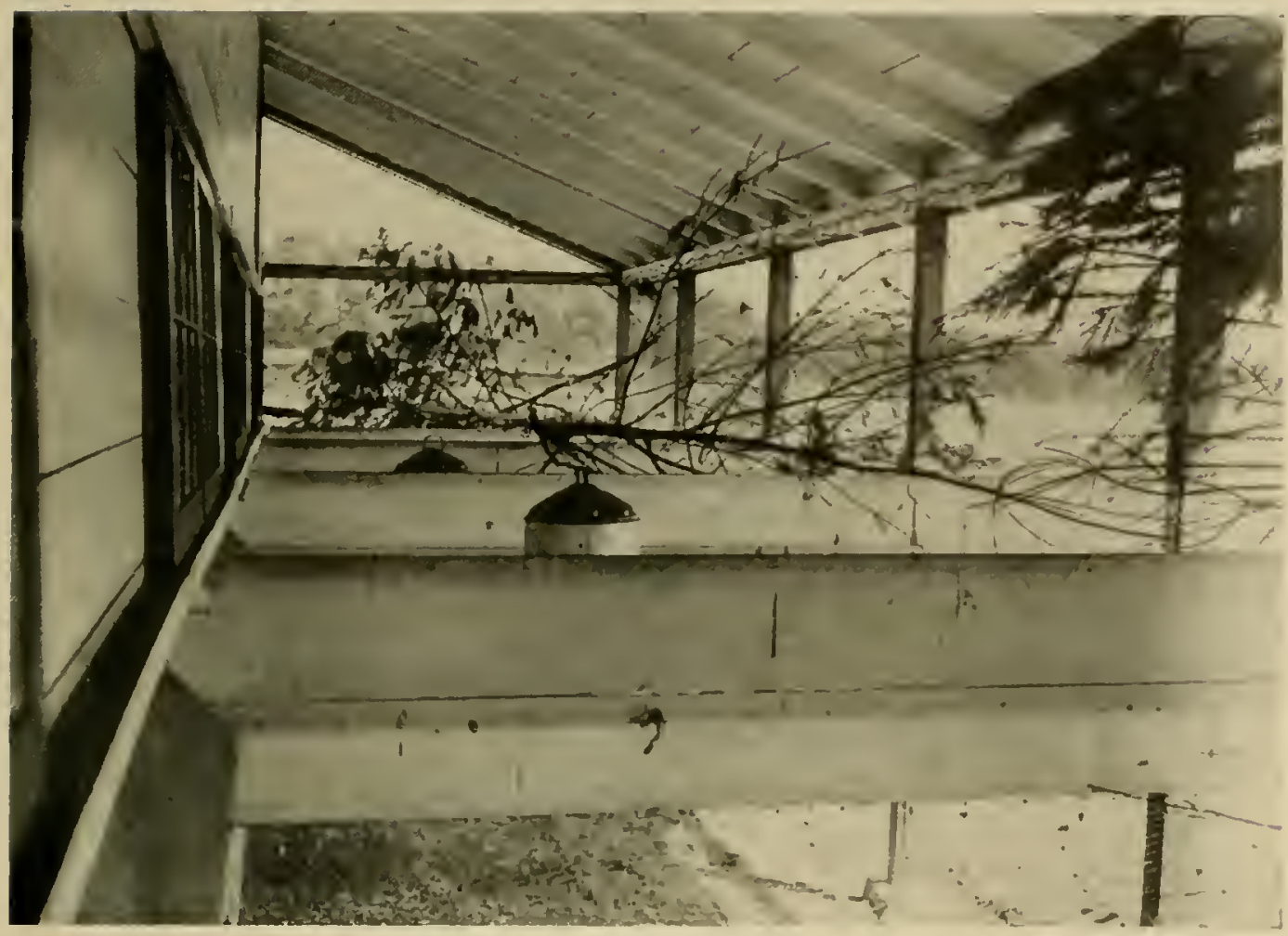

TIIE WINTERING PEN IS DIVIDED INTO SECTIONS B) LOW IBOAROS TO DISCOLRAGE THE, BIRDS FROM CHASING ONE ANOTIIER

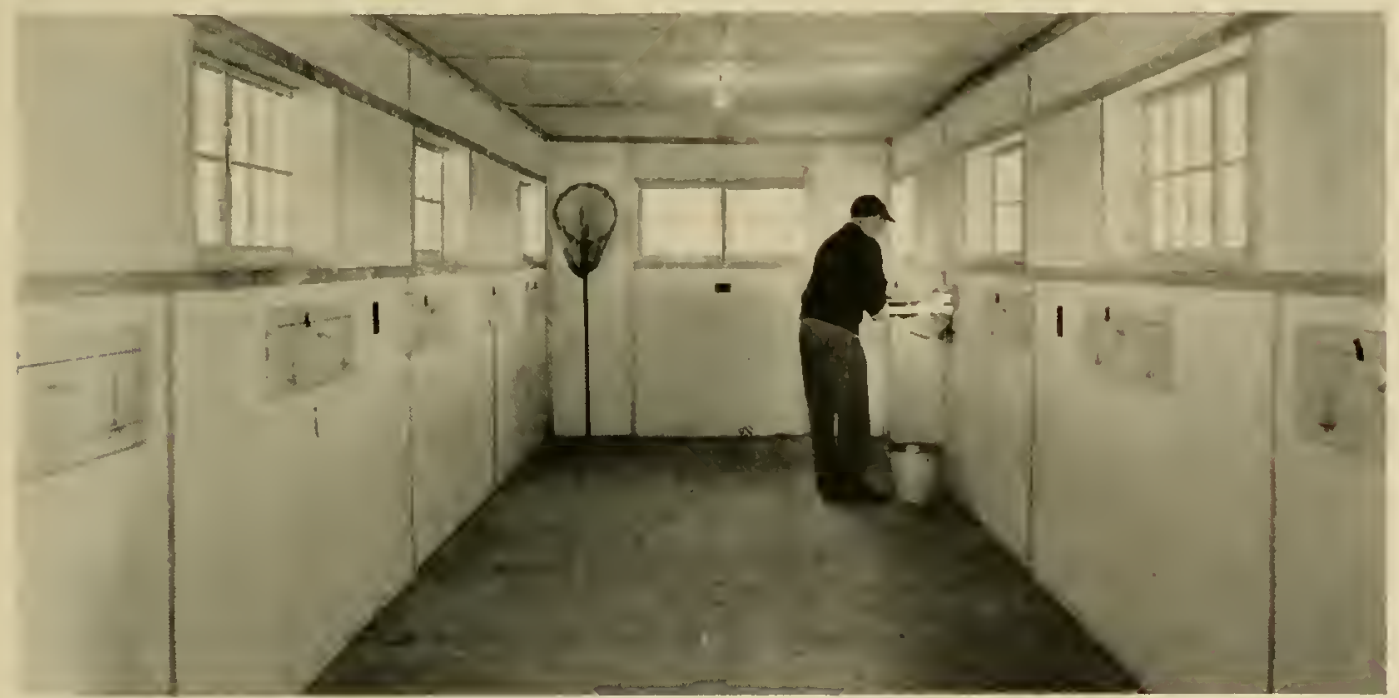

TIE SERVICE ROOM IS CONSTRUCTED WITH SIIDING WINDOWS AND DOORS THAT OPEN INWARDS TO FACILITATE CATCHING, FEEDING AND IVATERING THE BIRDS OUTSIDE 
of escape needed by all save the dominant bird in each pen, two or three small pines or hemlacks may be cut and stacked butt up in a convenient corner. Allen found that a series of boards each 10 inches high and placed on edge and crosswise at 4 -foot intervals helped to maintain the established pen society by permitting the setting up of several territories therein over which individual birds might exercise dominance. This materially increases the chances that each bird in the pen will find among the several communities thus established, one or another into which it can fit.

To many this may seem like drawing a fine distinction, for the birds, of course, do not always keep to the particular section of the pen where they find their companions and surroundings most congenial. Nevertheless, when chased, their own part of the pen offers a haven into which a combative outsider is often loath to continue pursuit.

The matter of dominance, as discussed in Chapter 11 , is of considerable importance, for each year adults of both sexes are lost as breeders through being harried by more aggressive birds as to acquire an inferiority complex. Some birds are killed outright in the process and many are severely scalped in attempting to escape. The size of the over-wintering loss depends largely on maintaining the social balance in the pens. Of course there will also be an occasional death from accident or from chronic diseases such as tuberculosis, blackhead or ulcerative enteritis.

A wired-in wintering pen 25 feet $\times 110$ feet built around a service room (figure 33 ) and designed to hold 300 full-winged grouse comfortably, was put in operation at the Research Center in 1937. Here each bird has a relatively large choice of companions and of communities. Heavy cotton netting is stretched along the sides to ease the impact if a flying bird should misjudge distances. Most grouse quickly learn to alight before reaching the netting. The daily flights up and down the pen seem to furnish a good conditioning routine.

Foods and Feeding Techniques. The food, 10o, during the overwintering period is important, for the young birds have just completed the strain of growing up and the adults the stress of moulting. Each must build up resistance and reproductive capacity for the breed. ing season to come. Nor is it necessary to resort to special foods augmented by a variety of the items wild grouse normally eonsume at this time of year. The composition of the feeding formula currently (19.2) in use at the Research Center is indicated in figure 4.1. All of these may be purchased at reasonable prices from many commercial feed concerns.

Mash, in pelleted form, and grain are fed in low, reel-type troughs placed so as to be protected from the weather.

In the wintering pen at the Center all feeding and servicing, as well as the carching of the birds, is carried on from the central service room ly means of feed shelves and sliding windows. Water is provided by automatic fountains of one-gallon capacity set on thermostatically controlled electric plates to prevent freezing.

In the smaller pens where electricity is not available, carthenware dishes. set slightly ahove the level of the wire, will suffice. These must be filled daily and cleaned frequenty.

'The lengthening days of early March bring with them increased activity and plysiological preparation for the breeding season. The birds, whose consmption of corn in winter will vary with the temperature, now pay little attention to this grain. Since weight is a factor in egg production, it is wise to tempt their appetites further by setting hefore them a variety of cereals. A moist mixture eontaining three parts of laying mash to one part of cereals and the sulstitution of letuce heads for dried alfalfa, assist in accomplishing this purpose. These 
changes should be made at least a week before the birds are placed in the breeding pens, thus reducing somewhat the confusion incident to the change.

Although the ration here suggested seems to meet the needs of the birds rather well, it is desirable to provide them with supplemental foods, such as apples. and alfalfa hay, in a rack. These serve to keep the birds occupied and accordingly better satisfied with their quarters.

It is interesting to note that some difficulty may be experienced in inducing grouse to eat an unfamiliar food such as beechnuts or buds, even though it may be a staple diet of their wild cousins.

Handling the Spring Shuffle. As spring approaches one may notice a gradual increasing unrest among the captive birds. The males strut with increasing frequency on the warmer, quieter days. In the wild this restiveness marks the hegimning of the spring shuffle. Its counterpart in the wintering pen calls for close attention to the dominant hirds, for they are most likely to scalp or kill their inferiority-complexed companions at this time. It may be necessary to segregate many of the more active males until the hirds are placed in the breeding pens. Such separation is undesirable if it can be avoided for these males must reestablish their social position in the flock when they are returned*.

In the latitude of Albany it is wise to pair off the birds ahout the first of March, utilizing the suggestions for the selection of breeding stock as described later.

Weight and Physical Well-being. In grouse, as in most other lirds. weight is a fair indication of physical well-heing. Chronically diseased individuals often may he discovered if the birds are periodically weighed and the results checked with table 69.

TABLE 69. AVERAGE WEIGIITS IN GRA IS OF HAND-REARED GROLSE: A'T THE RESEARCH CENTER DURING CIRTAIN JIRIODS

\begin{tabular}{|c|c|c|c|c|}
\hline \multirow{3}{*}{ Periost } & \multicolumn{4}{|c|}{ Age and Sex } \\
\hline & \multicolumn{2}{|c|}{ Over one year old } & \multicolumn{2}{|c|}{ birits of the year } \\
\hline & Male & Fromeale: & Male & Female \\
\hline Nov. 1.5tl. & 6.25 .6 & 565.3 & $59: 3.8$ & 513.5 \\
\hline Mareh $15 \mathrm{th} \ldots$ & 500.2 & 578.9 & 580.1 & 516.7 \\
\hline Juno $15 \mathrm{th} \ldots \ldots \ldots$ & 60)8.0 & 502.3 & 551.6 & 512.6 \\
\hline
\end{tabular}

\section{The Spring Period}

Selection of the Breeding Stock. The success of artificial grouse propagation lies to no small extent in the quality and condition of the breeding stock, for this is the foundation upon which the year's work is built. The qualities inherent in these birds, coupled with proper care and attention, are reflected in egg production and hatchability and in the subsequent brooding and rearing success.

Results clearly indicate the need of a selective breeding program in order to develop a strain of grouse possessing as many desirahle characteristics as possible. Space does not permit more than a brief resume of the breeding plan followed at the Research Center. While most persons interested in improving their own strain of grouse may want to develop their own plan, this synopsis might be useful as a guide. The program is designed to encourage 
the establishing of groups or families of grouse capable of high egg production, hatchability and livability.

The method of establishing these fanilies is an important consideration. Berinning in 1935 all females were classified into four groups depending upon whether they laid in cxcess of 25 eggs in a single season, from 20 to 24 , from 15 to 19 , or below 15 . In each of these groups the females were further rated according to the percentage of their eggs which were fertile, the percentage which hatched and the number of chicks which subsequently survived. Each male was rated on the basis of his parents' and his own performance records and on his ability to get along with his penmates.

All these items were carefully considered in mating the birds each year. As a result, family groups, containing the cliaracteristics desired, were built up. Birds from these groups are the foundation of the breeding stock.

Progeny testing or analyzing the performance of the offspring of each pair of birds, has disclosed errors in previous matings and provided clnes for correction.

While the selective lreeding plan has not been in effect long enough to disclose any far reaching results, it is evident that such a program may go far towards answering many problems. Progress has been necessarily slow since it is difficult to l,ring through an adequate number of the progeny owing to the high mortality during the hrooding period.

It is essential in such a program to maintain a complete record (figures 34 to 36 ) of pedigree and performance covering the history of every bird. This hegins with the breeders, both male and female and includes the past performance covering egg production. fertility, hatchability and livability, not only of the individual bird but also of its brothers, sisters and ancestors.

There is another factor which should be considered. In addition to choosing birds from families with outstanding performance records, it is also desirable to select for type and temperament so as to retain the wild characteristics. Size. weight, structure and general body conformations are other important considerations. It would seem a good practice to maintain the average for wild hirds. For example, it would probalsly he unwise to attempt to improve upon nature to the extent of producing a strain of grouse all weighing two pounds or over.

The birds retained for breclers should le alert and thrifty in appearance, with the funda. mental characteristics of a wild bird. Those with any physical alnormalities such as long or short necks and legs as well as those heavier or lighter in weight than normal might hetter he disearded.

After the breeders have leen solerted and a decision made in regand to the matings. they are placed in the hreeding pens.

Breeding I'ens and Equipment. To date there seems to have been no gronse hreeding pen developed which has been areppled as standard. There are. however, certain prerequisites which might well he considered. When dealing with large numbers of hirds it is important to construct and arrange the pens so they may be ansily sorviced. Likewise. Hore which are largely solfecleaning and combenient to heep free of deloris and to disinfect are. of rourse. preferable. Adequate floor space for the normal activity of the hirds is essential to gencral health and well-heing. While the gronse appreciate some slelter from the elements, it is desirable to admit sunlight to a portion of the pen. To prevent annoyance loy the male, par- 


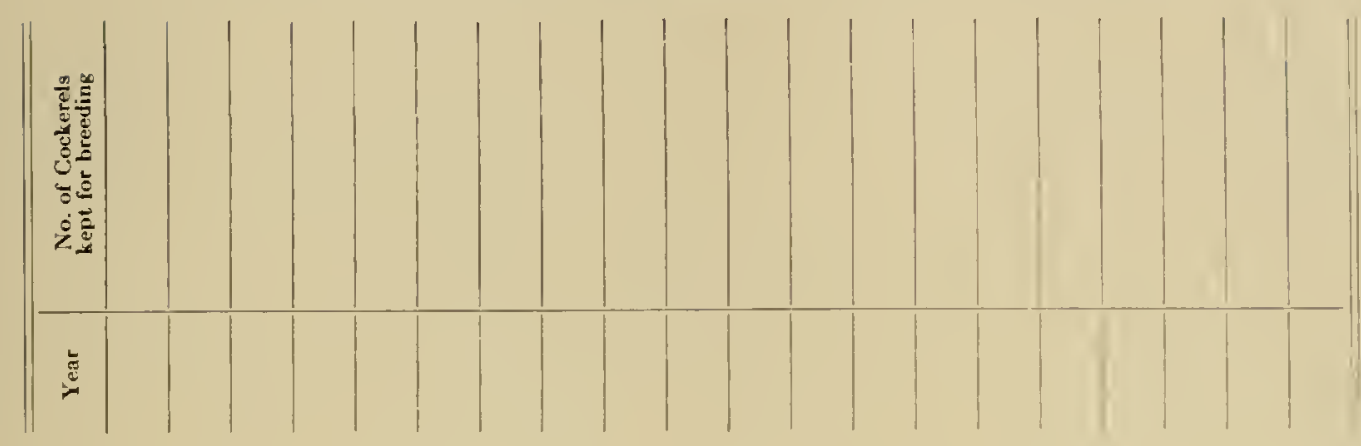



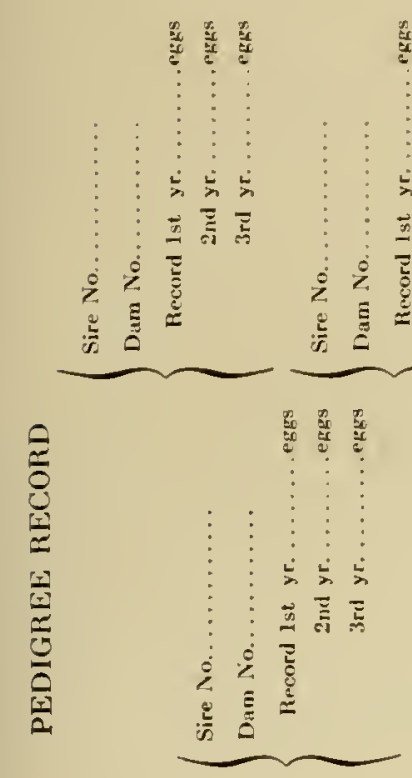

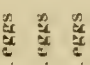

ty

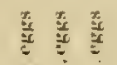

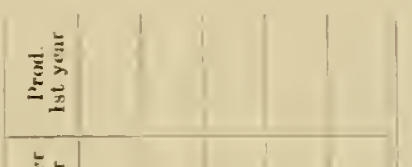

离

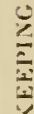

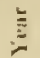

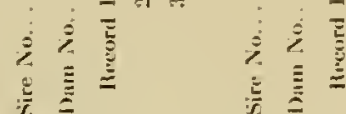

焉恶

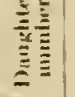

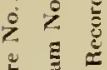

至

$\therefore$

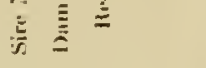

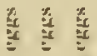

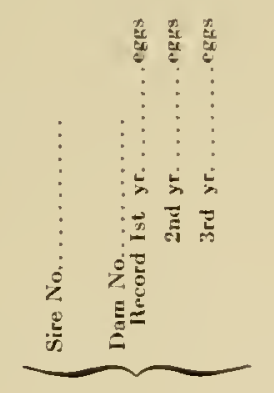

$\dot{\Delta}$

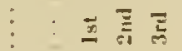

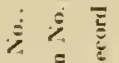

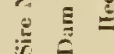

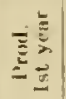

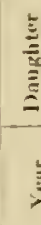
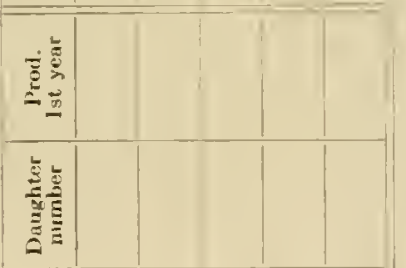

E

का

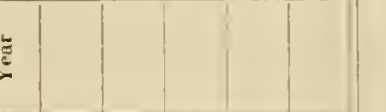

苞

OGICAL

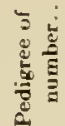

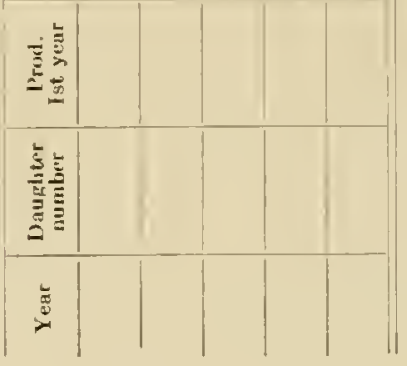


INDIVIDUAI, MALI: RECORI)

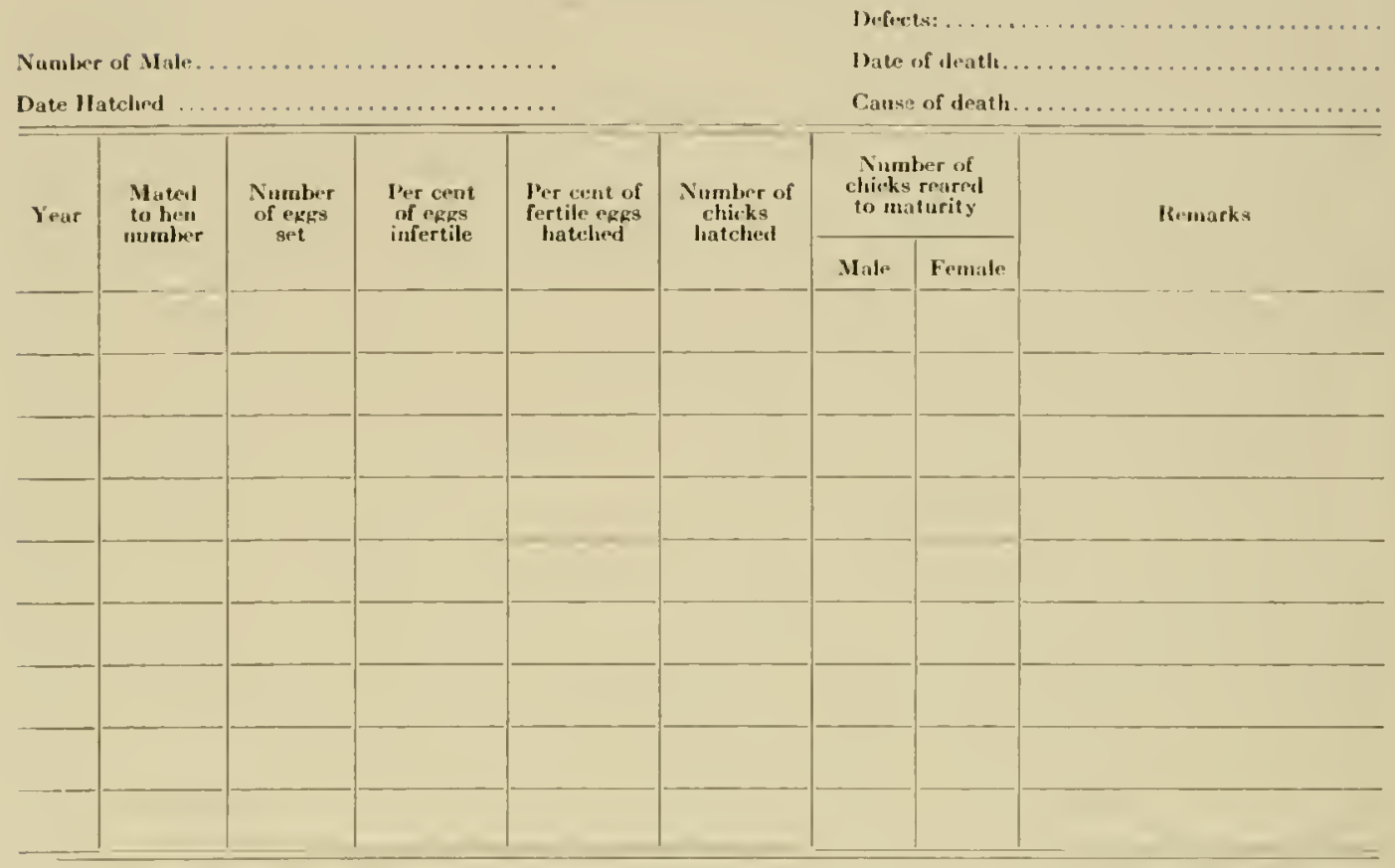

FICURE 35. FORM USED FOR KEEPING RECORDS OF INDIVIDUAL MALE BIRDS

\section{INDIVIDUAL, IIEN RECOIRD}

Number of IIen

I) inte Ilatusturl

\begin{tabular}{|c|c|c|c|c|}
\hline Vear & I'en & Production & $\begin{array}{l}\text { Date of } \\
\text { Ist efir }\end{array}$ & $\begin{array}{l}\text { Date of } \\
\text { last eght }\end{array}$ \\
\hline & & & & \\
\hline & & & & \\
\hline & & & & \\
\hline & & $-1-1=$ & & \\
\hline & & & & \\
\hline
\end{tabular}

Bureets:

Date of ileut

Ciuse of oteatl

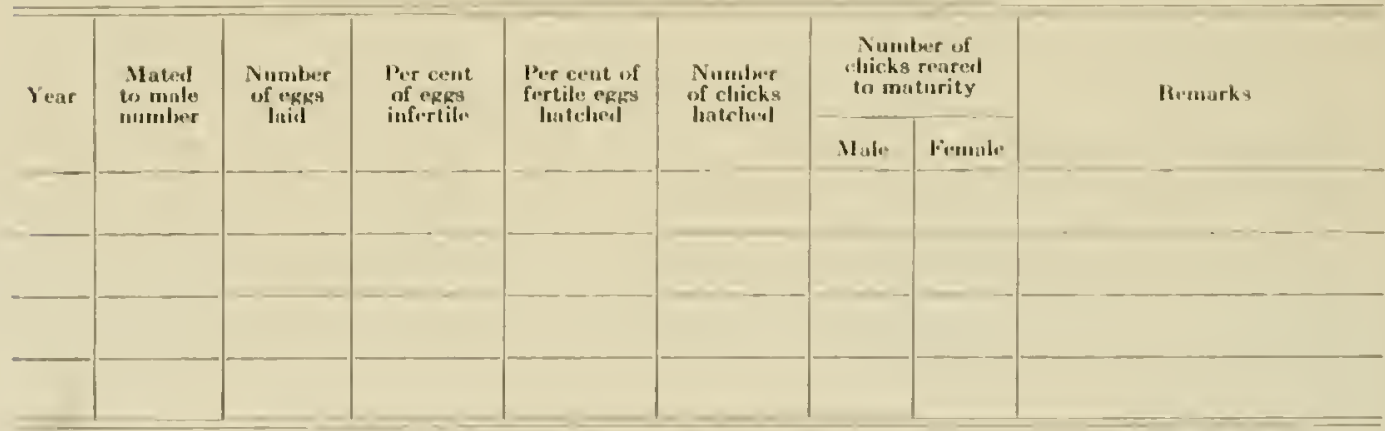

FICULE. 36. FORM USII, FOR KEEPING IECOKIS OF INDIVIUUAL FEMALE BIRDS 
ticularly during the breeding season. protective cover should be provided for the female.

It it sometimes difficult to incorporate all of these factors into a single pen without running into considerable expense. The number of birds that are to be accommodated will, in large measure. determine the basic design and arrangement. Only by trial and error will the type best suited to a particular purpose he developed.

Many sizes of pens, mostly of the coop and run type, have been tested experimentally at the Research Center. The 8 feet $\mathrm{x} 16$ feet $\mathrm{x}$ feet all-purpose pen (figure 37) proved quite satisfactory when polyganous matings were being tested but was found to be larger than necessary when the hirds were mated in pairs. A pen measuring 8 feet $\mathrm{x} 12$ feet $\times 3$ feet was accordingly designed to accommodate such a grouping. This met nost of the requirements and was used as the basis for the development of less expensive, permanent, multiple-unit breed. ing pens.

It was later found that the floor area for a pair of birds could be reduced further if certain modifications were incorporated. With this in mind four such pens were constructed and cach subdivided to accommodate 12 pairs of brceding lirds. The over-all dimensions are 8 feet $\times 72$ feet. The pen is built on posts with the floor $2 \frac{1}{2}$ feet above the ground. The individual unit housing each pair of birds is 6 feet in width by 8 feet in length and 3 feet in height. One side of the pen is enclosed and roofed, making a coop shelter measuring 2 feet $\mathrm{x} 6$ feet in each individual breeding compartment. The rest of the pen is enclosed with $3 / 4$-inch mesh poultry netting, the sides and top leeing 20 gauge. The floor under both coop and run is two gauges heavier. Each run is separated from the next by a removahle partition which slides upon a 12 -inch baseboard. Each coop portion is separated by a linged door.

All partitions may be removed at the end of the lorecling season, allowing the birds more freedom. The males may be segregated in one half and the females in the other.

Feeding equipment, after many trials, was selected from anong the several types manu. factured for game birds. For a pair of grouse, two low 12 -inch metal feeders are satisfactory, one for grain, the other for mash. Water is fumished in the multiple-unit pens through automatic fountains while, in the other pens, clay water dishes 4 inches in diameter and $I$ inch deep are used. The same type of dish may be used for feeding wet mash.

Feeding and watering equipment and a removable, open-type nest hox are sheltered in the coop and serviced through doors conveniently located. The nest box, 12 inches square and 6 inches high, is lined with grass. This must be replenished at intervals since the birds will consume most of it.

It is interesting to note that the built-in nest boxes in the all-purpose pen did not seem to meet the full requirements of the birds. These boxes were totally enclosed, the birds entering through an opening in the side. The females seemed more contented when the open-type nest box was used. This appears logical since the wild grouse. which nests on the ground, normally selects a site which is open from above.

Penning and Care of Breeders. After the pens at the Center have been thoroughly cleaned and disinfected and are ready for occupancy, the breeders are transferred to them. One pair is placed in each individual unit. Fresh evergreens are placed in the corners of the run to give the birds seclusion.

With the coming of spring, there are certain social readjustments to be made by the birds. 
The males will be seen more frequently in their courtship display. At the Center the birds are moved into the breeding pens early. usually by the first of Mareh. This encourages harmony anong the penned pairs and results in an increase in the number of fertile eggs produced. To allow the confusion incident to the change to take place at the hegining of the mating period is to run an unnecessary risk.

One must watch the birds clusely up to the time mating occurs. If the pair do not get along well during this time. a high degree of infertility may result.

Grouse are extrenely sensitive to any changes during the breeding season. These may reduce egg production and fertility. At the Center all birds are attended regularly and punctually by the same attendant. A definite routine of feeding, watering and collection of eggs at the same hour each day is followed. Strangers should be kept away from the hirds. It is a good idea to discourage all visitors during the laying season.

To whistle, eall and talk to the birds helps to establish a certain, almost intimate, acquaintance. But they should not be handled except when absolutely necessary lest they become unduly wild.

With the advent of warm weather. disease once more hecomes a potential problem. It is usually less prevalent if the pens are kept sanitary, the feed elean and the water fresh**

Feeding Breeding Birds. There has been much progress during the past welve years in developing suitahle feeding rations for game birds. From carefully guarded ganekeepers' formulas containing seeret and mysterious ingredients, the ration has at last emerged as a series of standard commercial products prepared for game birds.

Grouse feeds are still largely in the empirical stage of development. In selecting one, it is wise to choose a ration witl a wide variety of ingredients so that as many as possible of the nutritive requirements of the hirds may be met. There is an insufficient number of birds currently arailable to permit the carrying on of thorongh. scientific tests covering these requirements. Ninerals and vitamins are extremely important in the feed to secure maximum production and at the same time maintain body weight and normal metabolism.

In fact. the guality of the egg and the resultant chick depends to a large extent upon the quality of the feed given to the breeders.

It is not only essential to supply a balanced ration but the feed must also be in a form which will he readily accepted by the birds. With grouse it has heen found that a mash pelletel in the proper size is preferred to the regular. finely ground product.

The feet used at the Center is a commercial product designed for game hirds. Basically it consists of pelleted mash and a misture of grains $\Delta$. These are presented in separate hoppers. Granite or other insoluble grit is added at the rate of four pounds per hundred pounds of mash or grain. In order to stimulate the appetite of the birds while they are in production, a hopper of a mixture made up of two parts mash and one part of grains. moistened with water to a crumbly consistency. is provided once each morning.

In the grain mixture a variety is desirable. The one which has proved most satisfaetory is a commercial mixture for pheasant and quail, containing kafir corn. wheat. oats. milo and clipped barley as well as smaller sends. Anong the latter. millet and certain other seeds are seldum eaten. Yollow corn is not sought often hy grouse during the mild spring and hot sumuer weather.

* Sirr alan dincusnion p. 1:2.

$\triangle$ Sec Feede and Feeding scincdule, Figute 11, p. 180 


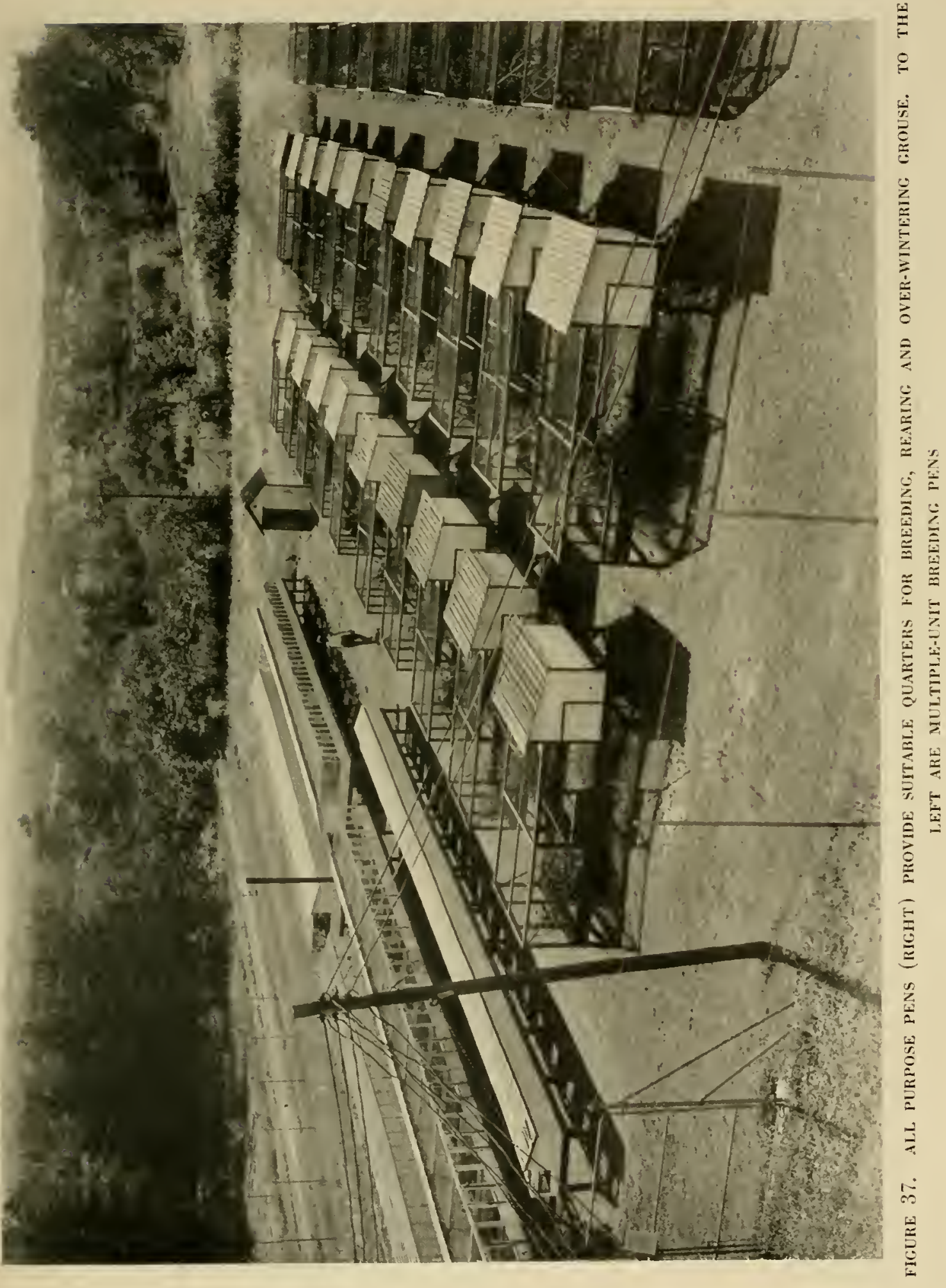


Since the grouse is largely a plant feeder, it follows that an abundance of succulent greens is in order during this scason to satisfy their particular requirements. Lettuce is taken greedily by the birds. This may be supplemented with alfalfa hay, thus providing desired bulk in the diet. Apples, too, are relished at this time of the year.

Birds show an individuality in their feeding habits. It is, therefore, desirable to offer pelleted mash, grains and greens in separate hoppers so that each bird will have an opportu. nity to select the particular feed it prefers. This will eliminate much of the "billing-out" of feed, thereby reducing waste and the accumulation of moldy feed under the pens.

Quite frequently attempts are made to force egg production by increasing the protein content of the feed. But extreme care should be exercised in changing the protein-carbohydrate balance in the ration of low producing birds. Usually egg production will cease and the birds will go into a moult when the amount of protein is increased too rapidly.

It is interesting to note that the birds consume very little pelleted mash during the cold winter months, subsisting rather on mixed grains. With the coming of spring the pellets are taken in increasing amounts. After the breeding season gets under way. more pelleted mash than grain is consumed.

The amount and kind of feed a bird takes is apt to be a reliable indicator of its productive capacity. Hence a female that consumes more than an average amount of pelleted mash can usually be depended upon to be a good producer.

Mating and Egg Fertility. One of the more serious obstacles which retarded early progress in the artificial propagation of grouse was the difficulty of securing satisfactory egg fertility. Allen ${ }^{15}$ in 1934, described a mating cycle in the male. Working with small numbers of birds, he secured excellent fertility by introducing males in the mating phase of the reproductive cycle with females also ready to mate. Later observations have modified some of Allen's conclusions although his method is still used on occasion.

Low fertility has been largely overcome by the application of a few simple techniques adopted as a result of inany carefully controlled tests. By close olservation one may learn to recognize certain actions in male or female which indicate the bird's willinguess to mate. By applying this knowledge judieionsly, it is possible to do much to increase the fertility of the eggs produced. Previously mentioned is the necessity for establishing the hirds in their breeding pens at an carly date.

At the Research Center the hirds usually indicate an inclination to mate in an average season about the middle of March. If one is not familiar with the actions of a male during this period a stuffed bird mounted in a squatting position may he placed in the pen. If the male is inclined to mate he may immediatcly. or after a short display. attempt to do so with the diummy.

As has been previously discussed", there are four distinct series of reactions in the male brought about by physiological and psychological changes during the breeding period. Since these follow a rather regular pattern in most males, there may he occasions when the mating periods of the male and female do not coincide. But it does not follow that these manifestations appear in all nale birds. For example, in 1938 a number of females were mated to a single male over a period of 21 days. The inatings orcurred in 3- $t 0$. 5-day intervals on April 20, 23, 26, 29, May 4, 7, and 11. Similarly, another male mated on April 22, 27, May 3 and 7. While these may be exceptions to the rule, it is generally believed that more of the males

- Seo Chapler 11. p. 69. 
could be made to respond in a similar manner if desired.

The normal mating period of the hen seems to be about four days. It ordinarily occurs from three days to a week before the first egg is laid. During this time there is a characteristic action among many of the unmated females which it is well to learn to recognize. They squat, half open their wings at their sides and at the same time stretch their heads forward. Often this squatting may be prompted by extending the arm and hand over the bird. On sucls occasions she will show no indication of fear. Quite frequently if such a female is held in the mating position, the male in the same pen will approach and promptly effect a mating. If this does not occur, it is usually necessary to hold the female for a male in the mating cycle introduced from another pen.

Care must be exercised to prevent promiscuous matings since a male selected at random may not possess the characteristics required for improving the strain. For instance, it would be inadvisalsle to mate an exceptionally good female with an inferior male lest the selective breeding program be seriously retarded. It is far better to take a chance that a male having the proper characteristics will be found before the female passes through the mating period. It is well to remember that, after the bird begins to lay, it is often rather difficult to secure a mating which will produce fertile egrgs.

One mating is usually sufficien to insure fertility in a sulstantial number of eggs, often 12 to 16.

Females are watched carefully for actions indicating a desire to mate again two or three weeks after a mating or when eight to 12 eggs have been laid. If, for example, a female were to lay but eight eggs for her first clutch, another mating is sometimes neccssary to secure even fair fertility in any additional eggs that slıc may lay.

In the Appendix (table 181) the effect of various sex ratios and arrancements of breeding pens on grouse egg production have heen tabulated.

Egg Production and Collection. While individual grouse at the Center have laid as early as April 4 and as late as June 25. the hulk of the eggs are collected between April 21 and May 20. The peak usually comes carly in the latter month. While most hirds will average one egg every other day. the better producers usually may be identified hy a higher rate of production. A clear picture of this may be secured by glancing at the table in the Appendix

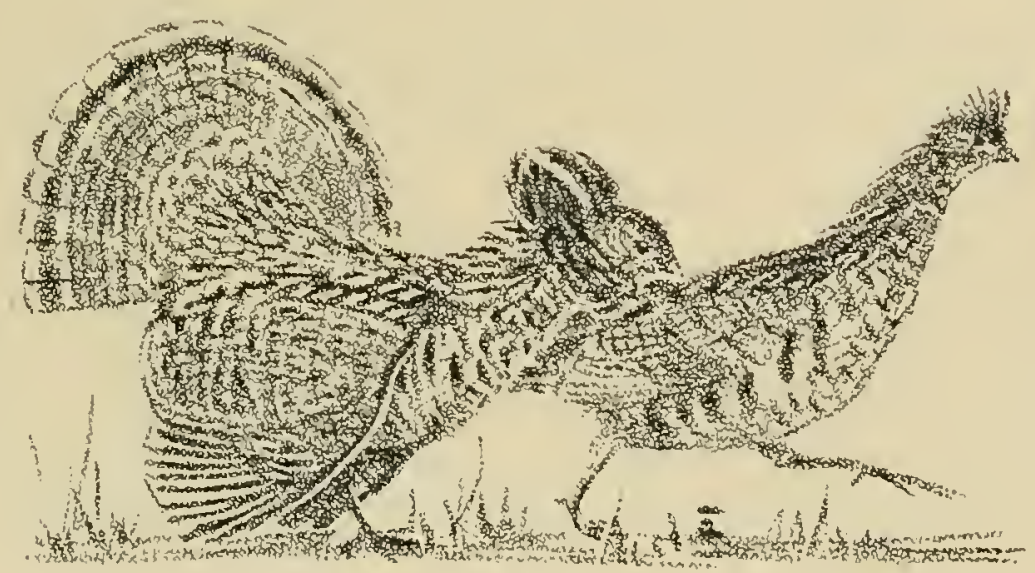


p. 878. illustrative of the spread of yearly egg production at the Center.

Farly writers often nentioned the necessity of removing eggs of wild hirds with the aid of a long-handled sponn lest the mother desert her nest. Subsequent expcrience indicates the story to be without foundation, either in the wild or in captivity.

The pen number and date may he marked in pencil on the large end of the egg to facili. tate identification. An accurate record showing the date on which each egr is laid should he maintained for each pen.

At the Center the eggs are collected and set cvery four days. The frequent settings allow opportunity to check fertility. Collecting every fourth day does not disturb the hirds ton often.

Controlling Disease. All the work incident to selecting the breeders and their subsequent care is of no avail if a rigorous program of sanitation is not maintained. Disease prevention is far more important than disease control.

Blackhead has proved to he the most persistent disease. Each year it has been responsihle for the loss of a few females either during or subsequent to the breeding season. To prevent such losses, all hirds which show symptoms of the disease or which have heen exposed. should he eliminated from the flock. This mle also applies to adults having ulcerative enteritis or other chronic diseases.

During the past seven years no serious outbreak of blackhead has occurred at the Center. This has been due largely to the continuous application of a few simple control measures. They are:

1. Maintenance of strict sanitation in the pens.

2. Discouragement of flies and other carriers of disease by treating droppings under the pens.

3. Prompt disposition of all dead birds.

1. Consistent removal of feed and other waste materials. which might sour and attract flies. from under or near the pens.

5. Mowing of grass under and adjacent to pens to eliminate dampness and discourage the presence of grasshoppers and other insects which might he carriers of discase.

6. Prompt examination of all dearl birds to determine the canse of death.

7. Immediatc application of treatment and control measures as soon as the disease is reeognized.

Among grouse reared on the ground, disease is still a factor causing almost prohibitive lusses. But when hreeders are properly cared for and raised on wire. there need be little fear of serious losses.

\section{The Summer and Fall Period}

Voulting and Recuperntion. It is in the period following the loreeding season that the adults are likcly to receive least attention, for the energics of the wane farm personnel are then directed to the hatching of the eggs and the rearing of the chicks. Nevertheless, care is essential for, shortly after egg laying ceases, the females are at or ucar their lowest weight of the year and the period of the moult is just ahead. To provide the nutrients needed to build the hirds hack to health. the laving ration should be continued until the middle of August. 
Then it is usually safe to shift to the winter maintenance ration previously detailed. Green food is still relished. It is regularly supplied at the Center through the medium of small apple limbs with leaves attached. Bunches of red or of alsike clover may also be made available, although they wilt quickly. Water is, of course, necessary though the daily consumption of it does not seem to vary much during hot weather.

During this period the males lose their pugnaciousness and may be grouped together in wintering units if desired. At the Center, both sexes are left in their breeding pens throughout the summer and early fall as a precaution against the spread of disease. particularly blackhead and ulcerative enteritis. The fenales, at low ehb in early summer seem to be especially susceptihle to the former and the loss of an occasional hird from this cause, eren on wire, is to be expected. Although the adults of both sexes are equally resistant to ulcerative enteritis, chronic infections may eause the death of a few birds, especially during August and September. Infected pens should be fly-pronfed with cheesecloth as soon as the presence of the disease is recognized. It is not necessary to remove the pen from close proximity to others, though the birds therein should be fed and eared for. if possible, ly an attendant who does not have contact with the rest of the grouse. With the advent of cold weather, usually by October 15, the danger of disease is largely passed.

Grouse in captivity are apt to moult more irregularly than do wild hircls. Smoother feather development will result if a dusting box containing elean sand is included in the equipment of the pen. This is advisahle only if the groups maintained together are small. Removal of the sand, of course. is in order at the first sign of disease.

Throughout the warm weather some shade is a desirable feature over part of every pen.

Care should be used that moldy feed and dehris. including droppings. are frequently removed. A good coating of slaked lime on the ground heneath the pens will assist in discouraging a concentration of disease-carrying flies.

There is no set date at which the birds should be transferced to their wintering pens. In fact, most would remain quite happy in their breeding pens throughout the winter. It is the increased lahor involved and the difficulty of kecping all avennes of escape closed that dictate the change.

One must remember to transfer all the birds at once. To drop in one bird after the rest have hecome settled is 10 make of it a hird without a territory and thus a likely misfit in the community of the pen.

It is well to weigh the hirds while they are being transferred and to set aside for observation any that seem to be abnormally light when compared with weight-given in talse 69. As the weather becomes colder and activity among penned birds hecomes progressively less it is then often possible to return any recorcred suspect to the main foek without causing serious complications.

\section{The Incubation of Grouse Eggs}

To one who is familiar with their rather uniform texture and moderately thin shells, there would seen to be hut little difficulty in suecessfully incubating grouse eggs artificially. Such in fact is the case. though considerably more care and attention is required than with the eggs of quail and chukars if they are set in an incubator. Some still utilize the time-honored method of using a captive grouse or a bantam hen to hatch a clutch of grouse egogs. Where small numbers of eggs are involved and under proper conditions it may prove fairly satisfactory. 


\section{Grouse Mothers}

Wild grouse are extremely constant in the incubation of their eggs but amid the distractions of captivity it is seldom wise to allow the female grouse this privilege. In fact, when the eggs are removed from the nest at 4-day intervals, many hirds never become broody. Even when the eggs are left in the nest. by no neans all of the females may be depended upon to incubate them.

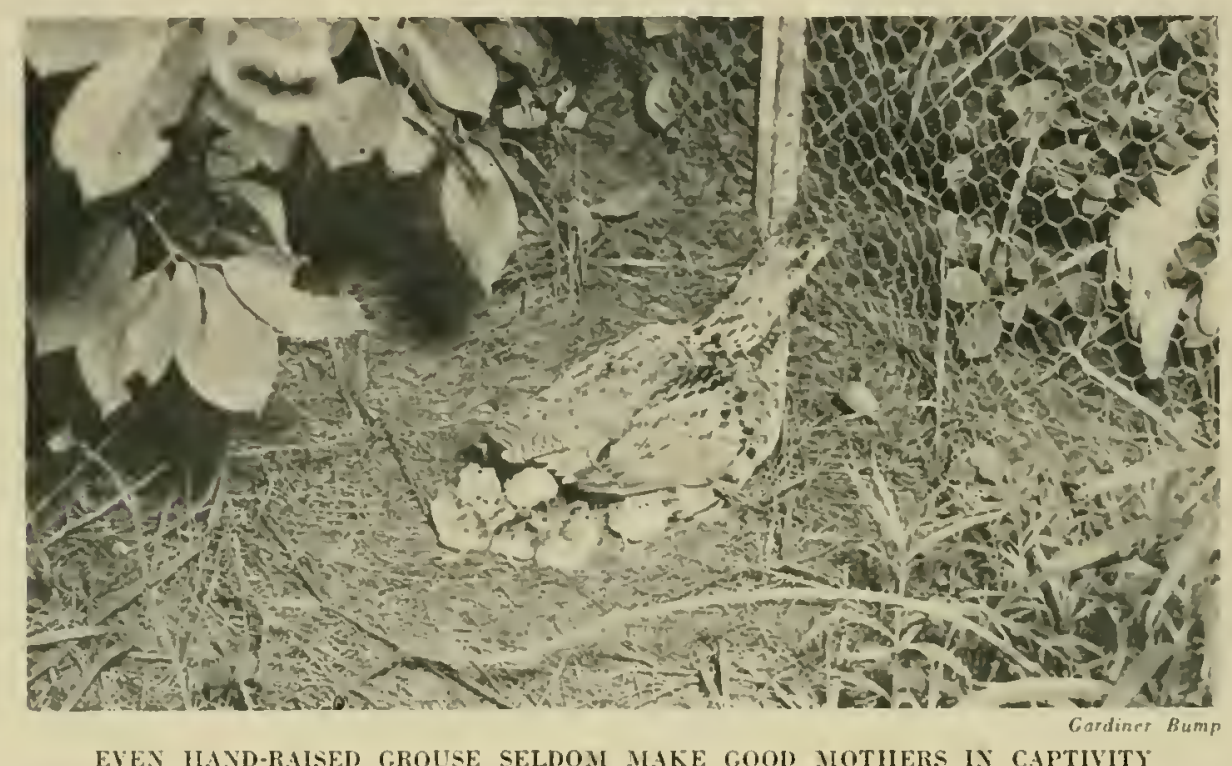

When such is desired, it is best to confune a pair. early in March, in a fairly large predator. proof enclosure on the ground. To avoid ehasing. the male may be removed shortly after the first egg has heen laid. The female should he disturhed as little as possible lest she become nervous. Shortly after hatehing. mother and brood may be moved to a rearing pen on wire to avoid accidents and infection.

\section{Foster Mothers}

Because incubaturs were uncertain and has readily available, all early breeders of grouse at one time or another used foster mothers to inculate eggs collected from wild nests. Preference for this purpose was given to silkies. cochins and seabrights. Should this practice be followed source from which these may he seeured should be loeated well in advance of the date of egg collection. The ever-present danger of disease when using hens may he mitigited somewhat if hantams raised on wire are available. Grouse eggs should he transferred from the wild to the foster mothers nest just before they hatch. This date, for first uests in New York, will usually fall between May 26 and June 3. though it is of course somewhat later in the higher Adironlacks.

Since the broody hen may best be moved at night, while egess are collected by daylight. it is wise to set her on a dummy nest a day or two before hes serviees are required. Occa. sionally hens refuse to accept a new nest. The presence of an cxtra lorody lontam is there. fore a wise precantion. 
Particular care should be taken to see that the birds are free of lice or mites which might infect the grouse chicks upon hatching. It is common practice to dust the bantams thoroughly with pure pyrethrum powder several times well in advance of the hatch.

The hen should be fed and watered each day at a point a little to one side of the nest. Unless the weather is warm and the eggs well along towards hatching, the time off the nest for feeding should not exceed ten to 15 minutes.

Construction of Hatching Coop and Nest. A hatching coop to enclose nest and broody bantam may he improvised from material at hand. Good ventilation and the ability to close the coop securely at night to keep out predators are prerequisites. At the Catskill Station, where most eggs were hatched by bantams, simple pens two feet square, built in series with removable tops but without bottoms, proved reasonably satisfactory. One may also use the ordinary pheasant hatching coops for this purpose.

The nest may be built inside a wooden frame 12 inches square and about 4 inches decp. The earth should he hollowed slightly and danpened before being lined lightly with dry grass.

Care of Eggs. Cleanliness in and about the nest is a small item lut important. Clean eggs hatch better. Chicks, soon after they are dry, start picking at their surroundings. Dirty conditions foster disease. Soiled eggs may be cleaned off with a damp cloth, taking carc not to use much water.

During a prolonged dry spell, the eggs occasionally should be sprinkled lightly with lukewarm water while the ben is feeding.

Grouse eggs under outdoor conditions normally hatch in about $231 \% 2$ days, usually pipping from six to 12 hours before hatching. At this time it is wise to build up the nest frame with boards six inches high to prevent the chicks from straying.

As the liatch progresses, leaving the egg shells in the nest helps to prevent the hen from sitting too heavily on the delicate new arrivals. Though the hen should not be unduly disturbed during hatching, one may transfer groups of chicks to a pre-heated brooder, as soon as they are dry. To leave them in the nest longer is to run unnecessary risk from trampling. Furthermore, most hens are carriers of such discases as coccidiosis or blackhead, to which young grouse are extremely susceptible. Occasionally, too, a liantam, disappointed at the hatch, may destroy the entire brood with a few sharp pecks.

Great care should be exercised to avoid chilling while conveying the chicks to the brooder. The hover under which they are to be placed should be regulated and pre-heated and all else made ready to receive the birds before they are transferred.

The hen never should be allowed to hover the newly hatched chicks for any length of time. Any attempt to rear the young grouse with a bantam foster mother is almost foredoomed to failure. Unnecessary risks result from intermingling the very occasional bird, thus raised, with other grouse, for it is a likely carrier of disease.

\section{The Incubator Method}

In the light of yesteryear's experiences with bantams, by far the most satisfactory way of hatching any quantity of grouse eggs is with an incubator, skillfully operated. But grouse eggs are so valuable that this method should be used only by an individual well versed in incubation techniques. 
Anyone wishing to experiment with or to raise grouse in numbers will make better progress loy undergoing a year's training in incubator operations or by employing and watching a skilled operator. The operation is not too difficult for, although grouse egg incubation requires certain techniques all its own, in general it is handled much as are other game birds' eggs.

This is very important because poor incubation is one of the cardinal reasons for the loss of many grouse chicks from two to five days after hatching. The probability of chicks surviving after hatching varies, in general, directly with the percentage of fertile eggs hatched.

At the Research Center, the average of the fertile eggs hatched has been 72 per cent with a high for one season of $871 / 2$ per cent. This is encouraging as it compares very favorably with the hatchability of the eggs of other game birds which have, through the years, been fully adapted to artificial propagation.

Location of the Incubator. To assure good hatches there are certain factors to be taken into consideration. One of these is the proper location of the incubator. Successful operation requires a room well ventilated but not subject to sudden marked changes in temperature or humidity. Windows should be located so that the incubators will not he subjected to direct drafts or sunlight. Room temperature between 60 and 70 degrees are a distinct aid to efficient incubator operation. About the same degree of humidity is desirable. Concrete floors belp to make the room rat-proof and easier to keep clean.

Type and Care. As with people, each incubator has its own peculiarities and limitations. Of the two types tested at the Center, still and agitated air, the former is preferred because it is simpler and easier to control and the chicks hateh better. Since large numbers of eggs are seldom involved, a small "still air" sectional machine, electrically controlled, has given satisfaction since 1934. A single section handles up to $180 \mathrm{eggs}$ in turning trays made for pheasants. At the Center two of these sections are used for hatching, and four for incubation.

Pedigree hatching trays are necessary to permit the wing banding and identification of each chick for the selective breeding program.

An incubator is only as good as its temperature control. Failures of this important mechanism are doubly costly. Reliable thermostats and thermometers are therefore a sound investment. At the beginning of each breeding season the former should he checked for leaks and the latter for accuracy.

The incubators always should be kept scrupulously clean and should be disinfected at the end of each season. To give time for necessary adjustments, the machine should be leveled, put in operation and carefully checked for at least 72 hours before the first grouse egrg are set.

Incubator Operation. There are several ways of determining how best to operate an incuhator. In the absence of previous experience one must be gruided by the manufacturer's instructions. Later, knowledge horn of past results pruves the best mentor. In the early days of the Jnvestigation few grouse eggs had ever been incubated artificially. Nothing was known of the adaptability of any of the commercial incubators for such a purpose. Dr. A. L. Romanolf, Professor of Experinental Embryology at Cornell had. however. sucesefully hatched grouse eggs for some of Dr. Allen's experiments. Because of the widespread application of this technique to the propagation of game birds, beginning in 1932 and continuing for five years, Dr. Romanoff ${ }^{2 n}$ carried ont a study of game birel incubation reguirements. This was based on the three important physical factors of incubation-temperature, humidity and 
air movement. During the study the basic requirements for artificially incubating pheasant and quail eggs were determined and those for grouse eggs were outlined as a result of experiments with some 350 eggs.

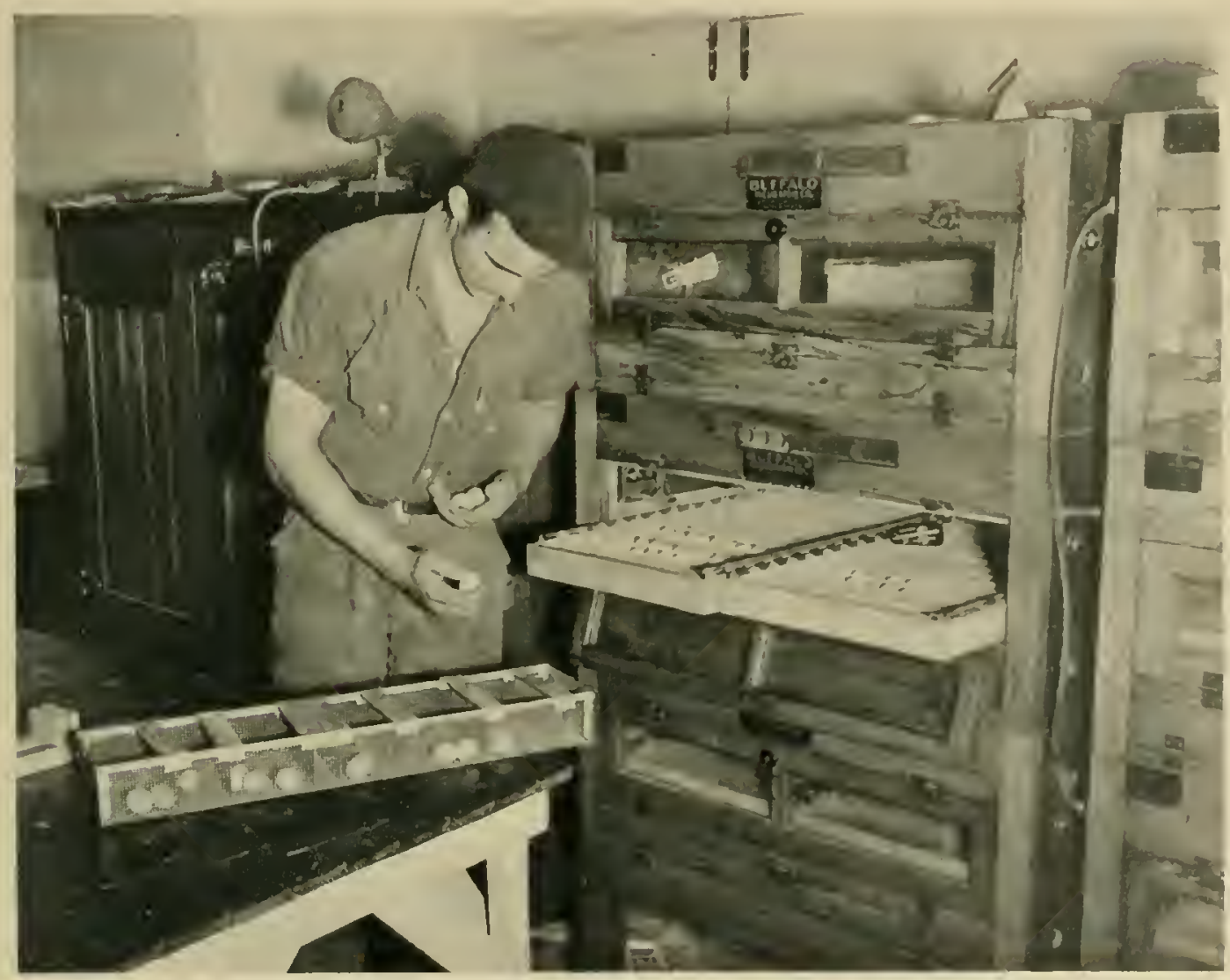

"STILL AIR" INGUBATOR WITI TURNING TRAYS TO HOLD INCUBATING EGGS AND PEIMFREF TIATS INTO WHCII THE EGGS ARE SIIFTED BEFORE IIATCHINO

Beginning in 1933, a series of tests covering incubators and incubator conditions were also carried out at the Research Center where incubator techniques were set up, carefully checked and modified as appeared desirable. Laboratory recommendations, rcsulting from the Cornell experiments, were also tested on large numbers of grouse eggs under praclical condilions. Thus was secured the background for the recommendations detailed later.

The studies carried out to date indicate that grouse eggs may be incubated and hatched more successfully in properly constructed still-air incubators than in agitated-air machines. No unusual situations or difficulties were encountered in securing successful hatches of eggs in the former type. In general the operation of the machine is not materially different from that employed with pheasants or quail.

The conditions recommended in table 70 will serve as a guide for the operation of the incubator. 
TABLE: 70. SUGGRSTID CONDITIONS ROH TIIE INCURATION OF GROUSE EGGS

\begin{tabular}{|c|c|c|c|c|c|c|}
\hline \multirow{3}{*}{ luculuatiug conditions } & \multicolumn{6}{|c|}{ Types of inculators } \\
\hline & \multicolumn{3}{|c|}{$\begin{array}{c}\text { Still-air } \\
\text { (hot-air or hut-water) }\end{array}$} & \multicolumn{3}{|c|}{$\begin{array}{l}\text { Afoituted-air } \\
\text { (with separate hatcher) }\end{array}$} \\
\hline & Int wiok & $2 n d-3 r d$ weth & Fron 20th day & Ist week & Ind werk un & From zoth day \\
\hline lingurature... & $10.3^{\circ} \mathrm{F}$ & $103^{\circ} \mathrm{F}$ & $103^{\circ} \mathrm{F}$ & $991 / 2{ }^{\circ} \mathrm{F}$ & $9011_{2} \circ \mathrm{F}$ & (9) $1,2^{\circ} \mathrm{F}$ \\
\hline Ilumidity $\left\{\begin{array}{l}\text { relativis } \\
\text { wet bull } \ldots \ldots \ldots\end{array}\right.$ & $\begin{array}{l}100-65 \% \\
\ldots \ldots\end{array}$ & $60-65 \%$ & $\begin{array}{l}60-65 \% \\
\cdots\end{array}$ & $\begin{aligned} 60-63 \% & \\
37-88^{\circ} & \end{aligned}$ & $\begin{array}{l}0.0-6.5 \% \\
8 \mathrm{i}-338 \%\end{array}$ & $\begin{array}{l}60-6.5 \% \\
87-83^{\circ} \%\end{array}$ \\
\hline Ventilatiun....... & 1, ори & $1,2-\frac{3}{4}$ वुला1 & unuch redurend & small & mexterate & laregl \\
\hline Turuing of ektits ..... . . . . & 3 to 1 timss & 3 to + times & none & 3 to 1 times & Ito \& timss & none \\
\hline
\end{tabular}

In connection with the ahove table there are certain qualifications to bear in mind. Because of different rates of air movement in various makes of still-air type incubators the average reading of temperature may vary from $102^{\circ} \mathrm{F}$. to $104^{\circ} \mathrm{F}$. The references given above are for a room temperature of $60^{\circ} \mathrm{F}$. If the room temperature is low, for example $40^{\circ} \mathrm{F}$, the incuhator temperature should read about $1 / 2{ }^{\circ} \mathrm{F}$. higher; and, if the room temperature is high, for example $80^{\circ} \mathrm{F}$, the incubator temperature should read about $1 / 2{ }^{\circ} \mathrm{F}$. lower throughout. This is to compensate for the current of warmer air entering through the ventilators.

The bulb of the thermometer normally is placed about two inches from the egg tray level. The temperature should be higher when the bulb is more than two inches above the tray level and it should be lower when the bulb is elevated less than two inches.

Because it is important to secure the exact temperature, it often is desirable to take a read. ing on clinical thermometers, the one placed on the floor of the cgg tray, the other level with the top of the egg. The optimum temperature for grouse egg incubation is $991 / 2{ }^{\circ} \mathbf{F}$. at a point one-half to two-thirds above the bottom of the egg. It is a good practice thus to check the incubating temperature at the beginning of each successive hatch for, as the season advances, the temperature of the incubator room likewise usually increases.

Unless onc is skilled in still-air incubator operation, it perhaps is safest to open the ventilators a quarter during the first week, one-half the second week and three-quarters from the 15th to the 20th day. After that the ventilation should be reducel markedly. Such suggeslions of necessity are general and subject to modifications as experience dircets.

Whenever an increase in humidity is desirable, particularly at hatching time, all moisture pans should be filled to allow as great an area as possible for craporation. Otherwise, they should lie kept partially covered or left dry according to the humidity in the room and the condition of the eggs as indicated by the last recorded per ccut of weight loss or by the moisture gauge. It is well to remember, too, that excessively evaporated or old eggs require a higher humidity than do unevaporated or fresh cggs.

Measuring Incubation Progress. As proficiency is attained, a need is sensed for more definite methods of determining the progress of the hatch. Two techniques are helpful-peri. olic candling of the "regs in orter to check on the progress of development and the cheching of weight losses to determine the rate of evaporation of moisture from the eggs. When one becones skillful in interpreting these indices, they will provide many a cue for modifications of the suggestions heretofore mentioned. For instance, too rapid development of the embryo indicates that the inculator is being run at too high a temperature. This must be lowered until the normal schedule of development is resumed, else dead germs and poor hatches are 
likely to result. If the eggs have not lost sufficient moisture at a given point in incubation, it is necessary to reduce the humidity and increase the ventilation to permit more rapid dry. ing through the shells. In the still-air incubators temperature also is affected by ventilation changes and, thereafter, must be readjusted.

Although the shell of the grouse egg is almost as thick as a pheasant's, averaging $0.21 \mathrm{~mm}$. it has less pigment and is less opaque. It is wise to candle all newly set eggs on the third day. As pointed out before, those that are infertile may then be identified although not removed and arrangements made immediately to place a different male in the lreeding pen in which the eggs were laid.

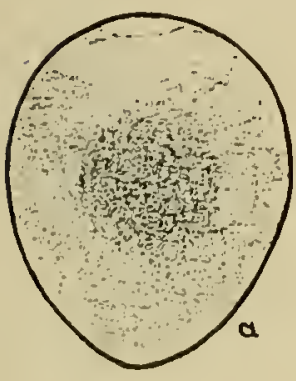

Fresh egg

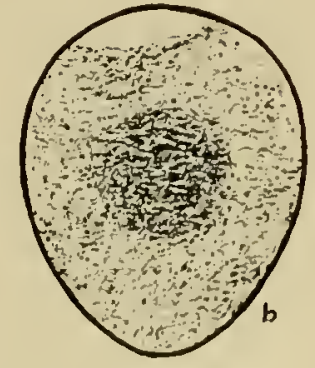

Injertile egg. 5th day

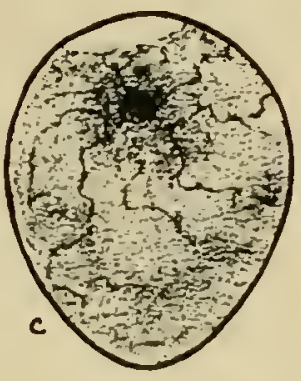

Fertile egg, sth day

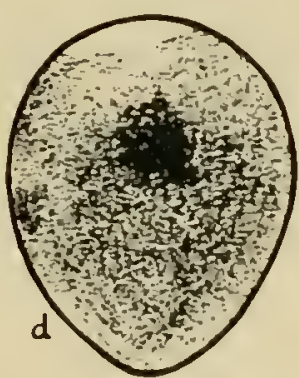

Dead germ after th day

FICURE 33. APPEARANCE, INIER TIIE CAMIIIMG IAMP. OF FERTIIE AND INFFRTII.F

EGCS DETING. INCUBATION

A little experience, aided by a careful study of figure 38 will assist the heginner to detect the clear eggs which are infertile. As incubation progresses a live embryo may be identified under the candling lamp as a dark floating spot from which blood vessels radiate. Under normal development, by the 12 th day the blood ressels have adranced until they meet at the small end of the egg. Just prior to hatching, the egg will be opaque except for the area occupied by the air cell. Once one has become skilled in recognizing these changes, it is helpful to candle the eggs on the 12 th day and again on the 21 st day, just hefore shifting them to the hatching compartment.

The practice of checking weight losses to determine moisture content is also distinctly helpful, for unless a chick hatches clean it is apt to die or be weaker than the rest. Careful experiments at the Center have indieated that grouse eggs hateh best when about 13 per cent of their weight is lost in the first 21 days of incubation.

The following is a simple formula for determining the percentage of weight loss at hatehing time provided the existing rate of moisture loss is maintained.

$$
\begin{aligned}
\frac{\mathrm{WL}}{\mathrm{WE}} \times \frac{1}{\mathrm{D}} \times 100 & =\text { Percentage loss in weight projected to hatching time } \\
\mathrm{WL} & =\text { Weight loss at the time of weighing } \\
\mathrm{WE} & =\mathbb{W e i g h t} \text { of eggs at time of setting } \\
\mathrm{I} & =\text { Ineubation period (231/2 days for grouse) } \\
\mathrm{D} & =\text { Number of days eggs have been incubated at the time of weighing }
\end{aligned}
$$


'The figures needed to apply this formula nay be easily sccured. By weighing the empty tray and the tray with eggs on it at the time of setling and by subtracting the former from the latter, the weight of the eggs at setting time is determined. The weight loss at any subsequent point in incubation may be found by similarly finding the weight of the eggs at the desired time and subtracting it from the weight at the time of setting.

Many factors, among them temperature, ventilation and outside atmospheric changes, influence the regulation of humidity. Obviously, even though a humidity curve such as the one illustrated may represent the optimum, a successful hatch of grouse eggs will not occur unless the other factors are also properly balanced. The correct weight loss, hypothetically, would be represented by a straight line. However. owing to the influence of these other factors. such a line rarely exists. In order to visualize the rate of moisture loss, figure 39 may be helpful since this weight curve represents the moisture loss in a setting of grouse eggs of which 87 per cent hatched.

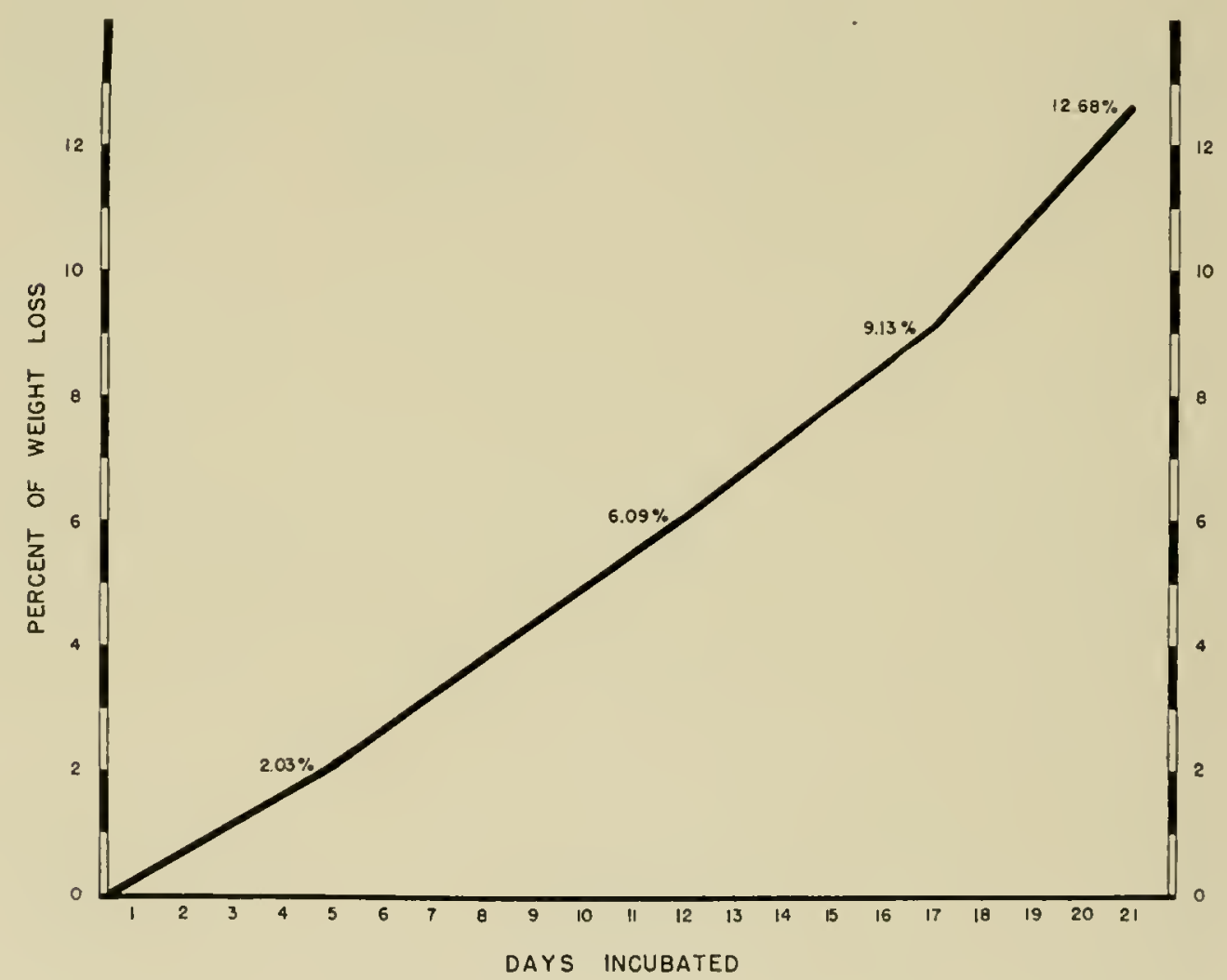

FICURE 39. PROCRESSIVE MOISTURE LOSS DURING INCUBATION OF GROUSE EGG

Since the early removal of infertile eggs or those with dead germs would complicate the com. putation of weight loss, they are left in the trays until such determinations are complete.

Seving and Care of Eggs. While it is hest to set the eggs within a few hours after they are collected, they may be stored withont undue risk in trays, preferably at temperatures between $40^{\circ} \mathrm{F}$. and $50^{\circ} \mathrm{F}$.. since incubation commences at ahout $60^{\circ} \mathrm{F}$. To keep the germ spot or hastoderm from sticking to the shell, the eggs should be turned at least once a day. A tray 
with an automatic turning device, as commonly used for pheasant eggs, is satisfactory for this purpose. Because of probable deterioration, it is not advisable to hold the eggs longer than ten days before setting. Those from wild nests, if they are already partly incubated, obviously should be placed in the machine at once.

Dirty eggs should be scraped with a penknife or wiped with a damp cloth before storing or setting, for washing destroys shell cuticle. Misshapen eggs, as well as those with badly cracked shells, should be culled out. Those with minor cracks will sometimes hatch if the injured area is covered with shellac.

Eggs in the incubator tray should never be placed with the small or pointed end up lest one encourage embryonic deformities.

The normal incubation period for grouse eggs is $23 \frac{1}{2}$ days. Occasionally, because of undue heat, a few may hatch in 23 days. In the wild, if the weather is cold, the hatching date may be deferred until the 25 th or even the 26 th day.

The wild grouse mother may leave her nest on warm days for several hours at a time. But at the Research Center care is taken to avoid chilling of the eggs during incubation except when required in carrying out candling or weighing procedures.

Hatching and Transfer of Chicks. When the developing chick breaks into the air cell, usually alout the 22 nd day of incuhation, it is time to shift the eggs into the hatching compartment of the inculuator. A separate scction is utilized for this purpose. The cogs from each female are placed in individnal compartments or wire baskets called pedigree cases so that the identity of each chick will not be lost.

There are several successful ways of handling the eggs at hatching time. At the Center, as soon as the first egg pips, the ventilation is reduced to conserve humidity and the moisture pans are often filled with lukewarm water. If the chicks pip the shells but have difficulty in getting out because of a toughened egg membrane, they may be sprinkled with tepid water.
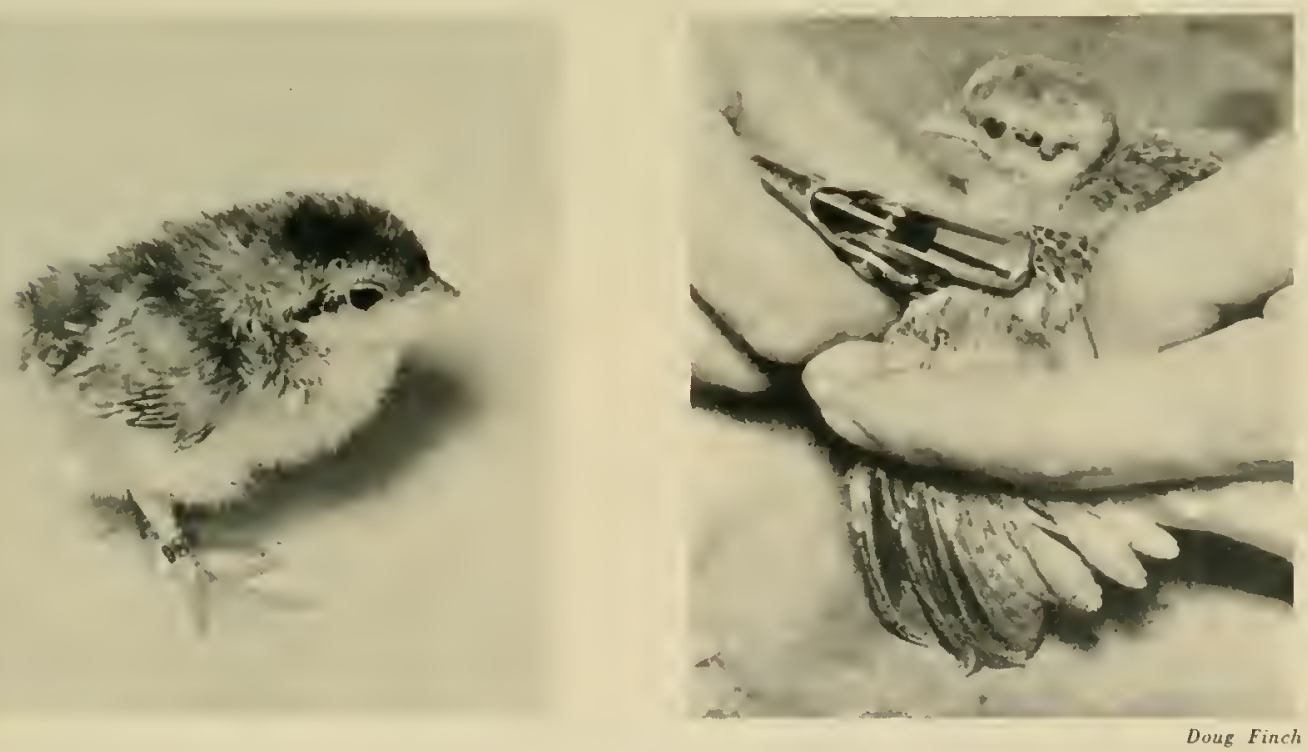

CHICKS MAY BE IDENTIFIED BY ATTACIING A BAND TO LEG OR WING BEFORE TRANSFERRING THEM FROM THE PEDIGREE HATCHING TRAY TO THE BROODER 
Do not open the incubator more than is necessary during this period.

If egg development and inculsation conditions are right, the hatcl should be complete within 18 hours of the time the first egg is pipped.

The new arrivals do not require food or water until they have been transferred to the brooder for, like the camel's lump, nature has provided the chick with a large unabsorbed yolk in which much of the food for the first two or three days is stored. When the chicks are completely dry they may be weighed, wing-banded and placed in a small clean box, the bottom of which has been covered by a suft material, such as cloth. If the weather is cold, the box may be warmed and wrapped in a blanket to make certain that the chicks do not become chilled in transit to the brooder.

\section{Brooding of THE CHICKS}

In any extensive wildlife research project, one or two baffling problems are to be found which common sense tells us can be solved but which may elude the best efforts of the research worker for many years. So it is with the low rate of survival during the brooding period. The largest loss experienced in raising grouse still occurs before the chicks are four weeks old.

The problem is puzzling, for chicks held under apparently identical conditions and fed the same ration may thrive or die without apparent reason. To all appearances the same conditions that encourage the survival of 60 per cent of the chicks started one year will result in but half that number pulling through the next. Many of the dead birds seem to be in good physical condition and without evidence of disease.

Following the lead of earlier experimentors, the Investigation carried out exhaustive tests of brooders and brooder houses, of hover operation and of all the various other items so important in the care of ehicks. Feeds and feeding techniques were repeatedly checked and changed with the aid and advice of collaborators skilled in the solution of nutritional difficulties. For two years Dr. L. C. Norris of the New York State College of Agrieulture carried out reconnaissance studies of nutritional requirements of grouse chicks for the Investigation. Great progress has been marle in reducing certain recognizable sources of loss, sucl as failure of the chicks to start feeding promptly, lung inflammation brought about by chilling and nutritional disorders due to improper feed. Other difficulties, notably feather picking and cannibalism and the danger from disease were also among those to which sat. isfactory answers were secured. But the underlying combination of causes of this early mortality remains the largest unsolved and disconcerting mystery in the field of artificial grouse propagation today.

A dozen new methods have given high promise the first year in which they were tried. chly to prove stulbornly unreliahle in succeeding trials. liemembering that in the wild the normal mother gronse loses up to 30 per cent of her lirood during the first two wecks after hatching, it has even been suggested that grouse may possess a lethal gene similar to that recognized in some strains of poultry.

It is axiomatic in brooding grouse chicks that the chances of success tend to he inversely: proportional to the number of birds cared for. Oftumes a single hrood is raiserd with the loss of only onc or two individuals.

The answer, as far as is known today, lies in unremitting care and attention to the details incident to feeding and brooding the chicks. Visitors at the Center have sometimes de- 
scribed this situation as "fussing with the birds." Yet it is true that even at this early age, each chick exhibits an individuality all its own. Game breeders, used to raising pheasants and quail en masse, may shake their heads at the thought of paying separate attention to the individual requirements thus discovered. But to one intent on raising grouse, nevertheless, it will pay big dividends in terms of chiek survival. The more one works with grouse the clearer one realizes the necessity of paying attention to such minute details if one is to divert the forces of untrammeled Nature to serve Man's ends. Later it may not be necessary, for

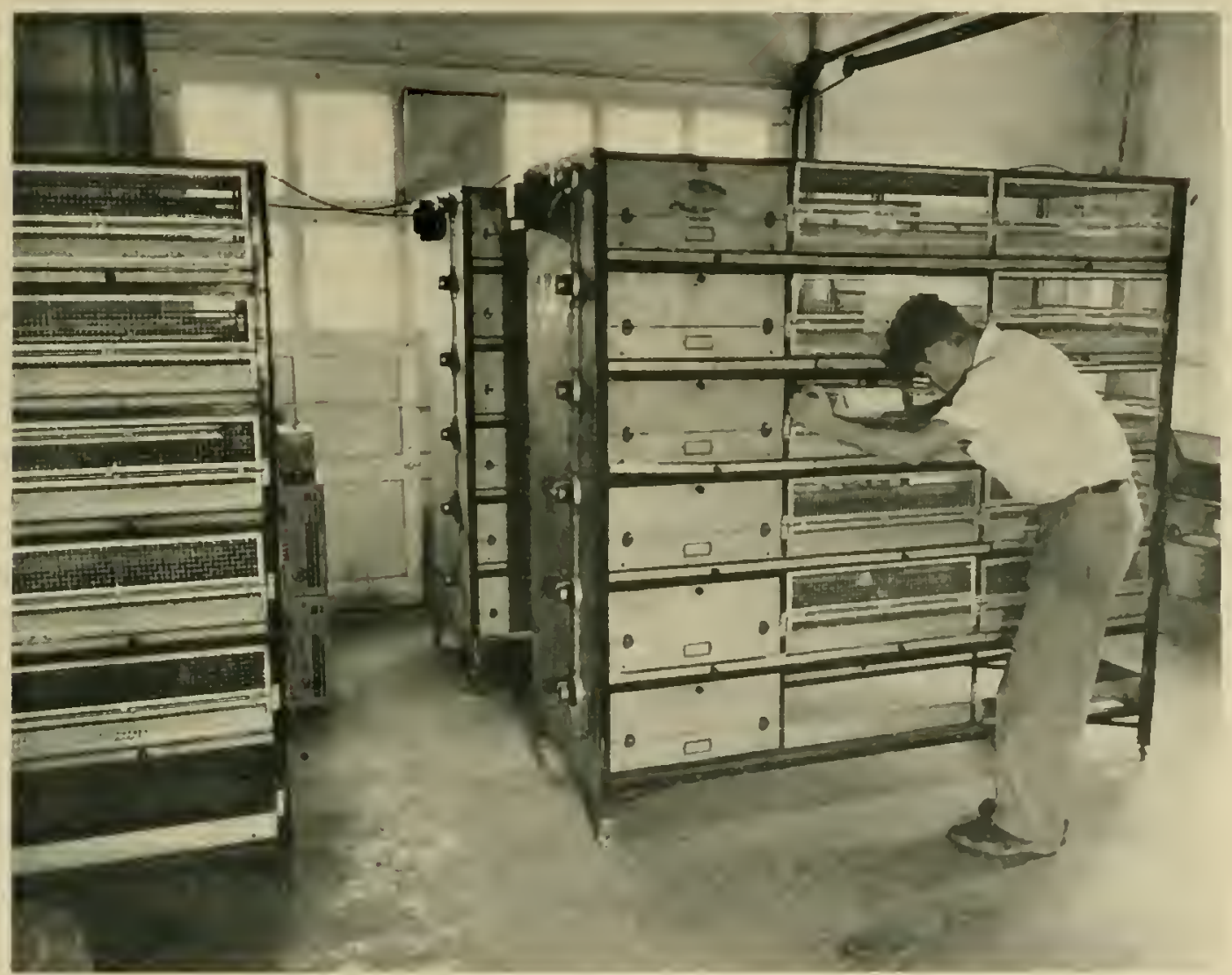

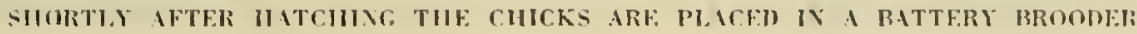

selective hreeding slould produce a strain of gruuse that can be raised in eaptivity, with proper care and without prohibitive carly losses.

Bccause of the obvious importance of the problems already mentioned, it slould le lelpful to treat each in some detail.

\section{Brooders and Brooder Houses}

Is probably every gane breader knows, the type of brooder or brooder lonse inlluencethe method of caring for the chicks as well as the feeding techniques. The reversc also is true. Therefore the design of the housing facilities and equipment should be such that all of the aetin ities incident to the handling of the birds will be expedited. 


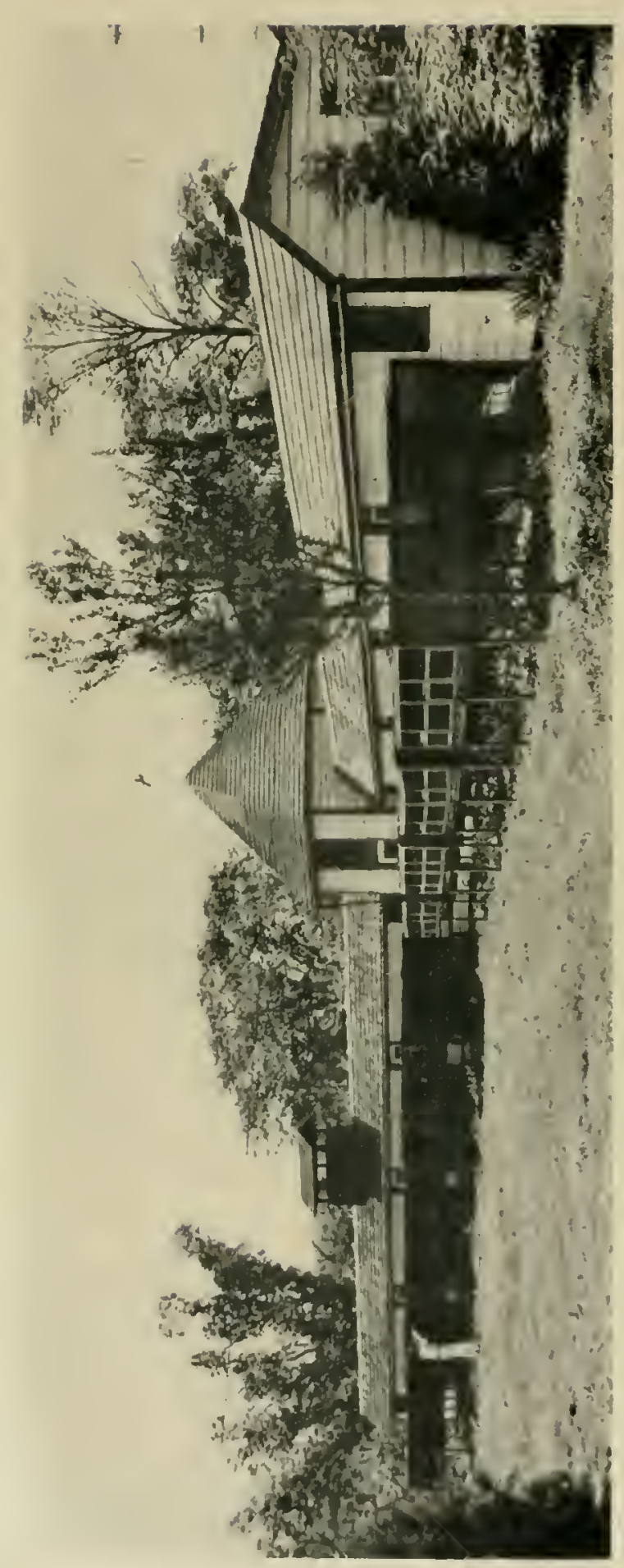

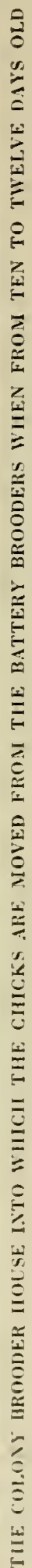

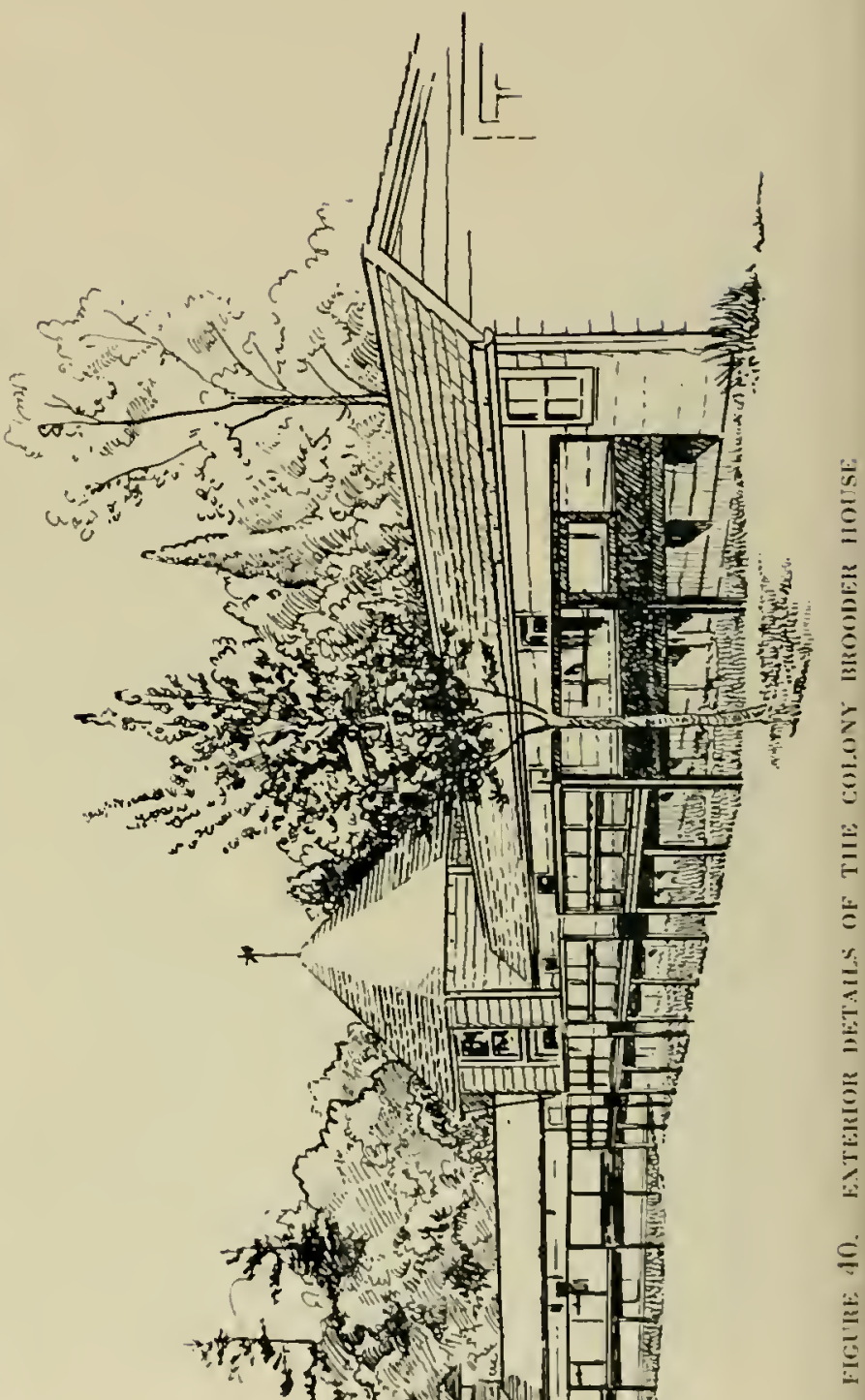


A decade ago it still was generally believed that nothing short of a broody hen could be trusted with the care of newly hatched grouse chicks. However, when a foster mother was used, the many failures largely due to the disease indicated a need for a mechanical-type brooder that could be kept clean.

All the early types tested proved tricky and often unreliable. In spite of this, encouraging results often were secured. Allen gives a graphic picture of this situation in his "Ten Years Experiments in the Rearing of Ruffed Grouse in Captivity"'.

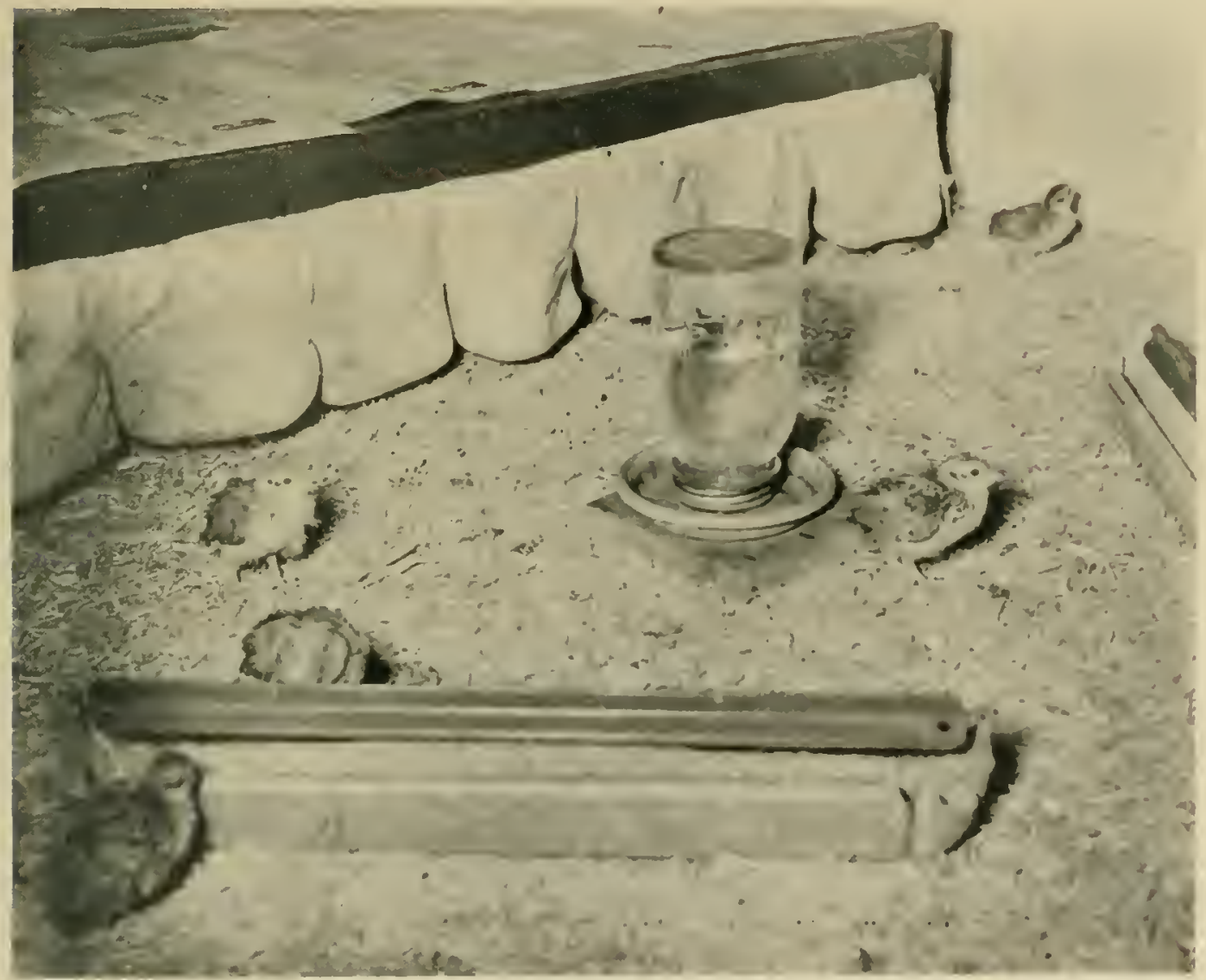

A FLAT-TOPPED. BOX TYPE IIOVER WAS FOUND MOST SATISFACTORY FOR BROODING YOUNG GROUSE

IV THE COLONY BROODER HOLSE

During the early years it was quite natural that attempts should be made to adapt the Coleman type brooder, so successful with quail. At the Catskill Station 20 of these with their kerosene heaters provided enough work to keep the operator husy day and night. Some idea of the difficulties encomntered is indicated when seven of these units caught fire and three were destroyed in one season. Herculean efforts were required to raise 46 grouse from the 189 which were started.

The struggle required to maintain reasonably constant temperatures even with the best equipment soon prompted the search for a more efficient type of brooder. Considerable prog- 
ress was made by installing a small insulated brooding compartment in one section of the allpurpose pens already developed by the Investigation. In 1933 they were equipped with electrically heated hovers of sufficient size to accommodate 25 to 30 newly hatehed chicks. Wirc floors above removahle pans to catch droppings reduced the chore of cleaning to the minimum.

Other types were tried out in an attempt to find units that would accommodate still larger numbers of chicks. A circular brooder house, similar to that commonly used for domestic fowl and equipped with a standard 56.inch circular electric hover providing several heat zones, was tested. Several trials, utilizing from 50 to 200 ehicks, were run with this unit. The results in all cases were extremely discouraging.

It appeared that the proportion of losses mounted as the number of birds hrooded together was increased. This also seemed to hold true in other types of units that were used. Not only was it impossible to give the birds the close attention which they received in small units but lluctuations in temperatures appeared to be an imporlant factor resulting in high mortality.

With these experiences in mind, a colony house was designed to overcome as many of the difficultics as possible. This unit. 12 feet $\times 100$ feet $\times 10$ feet, accommodates 16 individual pens. These are elevated so that the floor of the pens are waisthigh for convenience in handling and to raise the chicks above floor drafts. The basal area of each pen is 40 square feet. An alleyway at the rear, as well as one between each set of two pens, facilitates the servicing and care of the hirds. To exclude disease-carrying flies. fine mesh sereening encloses the sides and sliding doors of each pen. An outside wire-floored rum. also screened, approximately equal in length and width to the interior pen but only two feet high. provides fresh air, sumlight and additional space for exercise for the growing chicks. To facilitate frequent removal of the droppings, tough, waxed wrapping paper fed from rolls is stretched beneath the wire floors of the run and above the floor screen. The exterior of this colony house is shown in figure 40 .

All the widely recommended hovers. including feather brooders, contact hovers. radiant agi. lated air types and others. were tested*. Nonc seemed to give the close control that young grouse chicks apparently require. Thus it was that a standard hattery-lype hrooder was util. ized to house the chicks for the first ten days to two weeks.

After many tests. the most satisfactory brooder developed utilizes a heated compartment. enclosed on three sides. witl a heavy denim curtain separating it from the run. This run is enclosed with tight-fitting removable wire mesh doors which are hinged at the hottom. With this arrangement there is no (pportunity for lively young chicks to squecze through openings or to hop out while the unit is heing serviced. For easy cleaning. the whole ean be disasscm. bled by removing the sides, floors and dropping pans.

The hattery hrooders are placed in a concretc-floored room with large windows affording an alundance of light. Room Iemperatures are thermostalically controlled to remain as nearly as possilule at $70^{\circ} \mathrm{F}$. during the early spring. This serves fo redue temperature fluctuations in the batteries themselves.

\section{Brooder Operation}

To maintain conditions ideal for the growth and devehopment of the chicks. much mu-1 be left to the judgment of the atteudaut. Brooding failures usually are due either to faulty epuipment such as enterols which permit a wide temperalure variation or to drafts. For this 
reason it is wise to check thermostats to make certain that they are functioning properly and to test their wafers for any leaks before chicks are placed in the brooders. If the battery is new it should he thoroughly scrubbed with a strong soap solution to remove the protective grease film which is applied at the factory. Batteries previously used should also be cleaned and disinfected.

At the Research Center the temperature in the heated compartment is adjusted to $95^{\circ} \mathrm{F}$. with the thermometer suspended so that the bulb is even with the backs of the chicks. This may then be reduced at the rate of ahout five degrees per week depending somewhat upon outside conditions. Thus, when the weather is warm. it may be lowered more rapidly. The actions of the chicks are, of course, the best criterion. If they crowd together and stretch their heads toward the source of the heat, it is usually an indication that they are too cool. If this condition is not quickly remedied, chilling may bring on diarrhea and lung congestion. On the other hand, if they stand hunched with wings drooping weakly. the temperature probably is too high. Such a condition not only may lower the vitality of the birds but also may stunt growth and provoke nutritional disorders.

\section{Care of the Chicks}

As soon as the chicks are dried off in the incubator, they should be banded immediately and removed to the battery brooder. Here all should be in readiness for the ensuing critical period. Eighteen to 20 chicks arc placed in each section which. incidentally. has a capacity for 100 chicks of domestic fowl. Here they are confined to the heated compartment of the battery for the first two days, after which they are permitted to venture into a portion of the unheated run for brief intervals.

Travel is limited by an adjustable partition in the runway. At first the chicks are allowed only about a foot of space until they become accustomed to the source of beat. An attractionlight burning in the heated compartment helps guide them to its warmth. The partition may he moved farther out from day to day until finally the chicks have access to the entirc run. Since some chicks are slow to learn it is well to make frequent inspections to see that none becomes stranded in the run and chilled. As soon as all have identified the source of heat they may be left to come and go at will.

The chicks remain in the battery for a period of ahout 12 days and are then transferred to the colony brooder house. There they are brooded under a flat-topped box-type hover with a heating unit at the rear so arranged to provide a constant circulation of warm air. A curtain over the front edge helps to maintain an adequate temperature. By the time the chicks are moved to this unit, a brooding temperature of $35^{\circ} \mathrm{F}$. to $90^{\circ} \mathrm{F}$. is optimum.

A maximum of 30 chicks are placed in each unit of the colony house. Again. they must be confined close to the hover for the first few days until they have become thoroughly acquainted with the new source of heat. Then they may be allowed the full range of the interior pen, and the run as well. in warm weather.

Though at one lime the birds were placed directly on a wire floor which formed the pen bottom, this was soon found to he unnecessary as a disease preventive measure. Furthermore, it encouraged drafts. Litter, either sugar cane pulp or softwood shavings, accordingly is spread over the floor to a depth of about two inches.

When it is desired to start the newly hatched chicks in this unit instead of in the battery brooder, the operation of the hox-type hover is similar to that dcscribed for the battery. To 
prevent the baby chicks from eating the litter, it is covered with unbleached muslin sheeting for the first few days. Extreme care must be exercised to eliminate any openings into which they may crawl. A movable partition at least 12 inches high is set up in front of the hover and shifted back day by day, as in the batteries. Care should be exercised to make certain that the chicks do not crowd and pile up at night.

If the weather is favorable, the young chicks started in the colony house may be given access to the outside run for increasing periods beginning with the end of the first week. The 12-day-old chicks brought in from the battery may be allowed in the run as soon as they hecome accustomed to their new home. Here they walk on $1 / 2$-inch wire mesh floors. One should guard against sudden summer thunder storms and make certain that all chicks are under shelter before the rain begins.

At three wecks of age low roosts are provided which the birds will use at night if the weather is warm. It is desirable to induce roosting as early as possible. Heat under the hover may be discontinued at the end of the fourth week if weather permits, but the attraction light should remain on at night so that those birds which have not yet learned to roost will not pile up in the corner of the pen.

\section{Feed and Feeding Techniques}

The feeding equipment necessary for the newly.hatched chicks includes paper towels, a low 10 -inch metal hopper and a pint mason jar-type water fountain-the latter filled with stones to prevent the clicks from getting in and drowning. Following exhaustive tests, a commercial pelleted game hird feed containing 30 per cent protein was found hest on which to start the chicks. At first some of the pellcts are pulverized and placed in the hopper. Over this a small amount of clean sharp sand or grit is sprinkled. Another portion, likewise pulverized, is slightly moistcned with water and mixed with finely chopped lettuce. Then it is sprinkled on damp paper towels as also may be some of the dry feed. Towels and hopper are then placed under or immediately in front of the hover.

It is not unusual for individuals or groups of birds to refuse to eat. This may be caused by withlolding food too long after hatching. Sometimcs such birds may be induced to eat by fastening to the sides of the pen several wet towels sprinkled with particles of moist mash. The fced thus placed at about the level of their heads, may be taken accidentally but it serves the purpose since, once started, the birds usually continue to eat. Occasionally, fine charcoal. hils of lettuce or finely chopped soft strawberries sprinkled over the mash also will serve as starters.

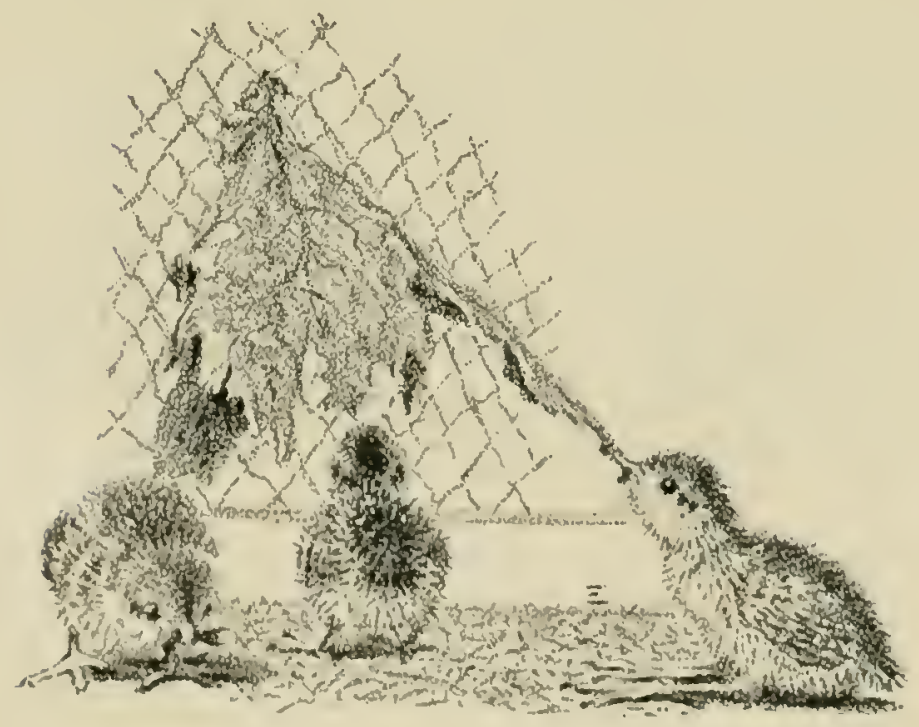


After the birds have begun to eat regularly, paper plates may be substituted for the fowels. These should be filled with mash to which four per cent insoluble grit has been added. Grit at the same rate should be added to all feed, the size of the grit being increased with the age of the birds.

Chopped lettuce should be freshly supplied each day. A paper towel or plate which can be thrown away when soiled makes a good tray for this purpose. A leaf hung here and there in the brooder after the fifth day will be eagerly picked at by the chicks. As soon as they are taking the leaves readily, the chopped lettuce may be discontinued. At three to four weeks of age, tender apple leaves are substituted for the lettnce at the Research Center. The birds eat these greedily. From that time on through the brooding and rearing period apple leaves appear adequately to fulfill the green feed requirements.

It is wise to warm the drinking water for the first few days. After that time it may be taken directly from the cold water tap, although lukewarm water will be more rapidly accepted. As the weather becomes hot, cool water is preferred by the birds. It should be changed at least once daily. oftener if it hecomes dirty.

Complete feeds and feeding schedules for all ages and seasons of the year are set forth in simplified form in figure 41.

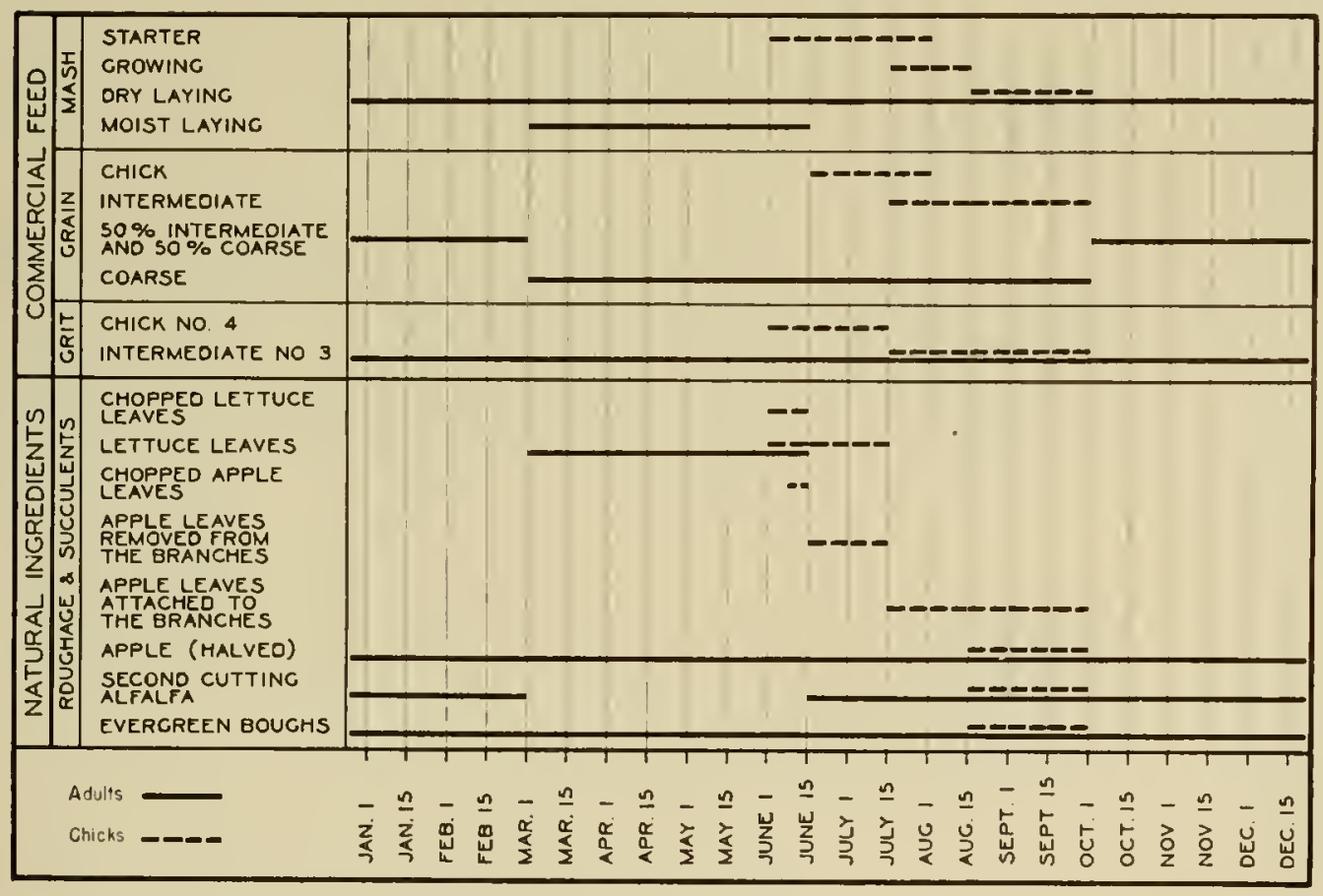

FIGURE 41. FEEDING SCHEDULE FOR YOUNG AND FOR ADULT GROUSE

\section{Comments}

1. Chicks are introduced to starter mash that is placed on wet suspended towels and sprinkled on dry towels on the floor.

2. After three days, low six-inch hoppers are introduced. 
3. Chick grit No. 4 is mixed at the rate of four pounds per 100 pounds of mash and grain.

4. After two weeks, chick grain is fed at the rate of ten pounds per 100 pounds of mash and increased by a like amount weekly for four weeks.

5. After ten days, the starter mash is fed only in hoppers.

6. After seven weeks, a separate hopper is provided for grain and for inash.

7. Chopped lettuce is fed the first ten days.

8. Chopped apple leaves are fed from 6 th to 9 th day only.

9. For the purpose of this chart, the hatehing date is set at June I; the birds are consid. ered as adults after October 1.

\section{Feather Picking and Cannibalism}

Those used to handling quail and pheasants wil] be impressed by the fact that the vicious habits of grouse are negligible by comparison. Such common ones as toe picking and feather pulling have not been important diffieulties at the Research Center during the 12-rlay period the chicks arc in the battery brooder. Likewise, it seldom occurs after they are transferred to the colony house if the light is subdued.

The one period when feather picking is most likely to he annoying is in late summer or early fall when the tail feathers of the juveniles have been moulted and those of the adults are just appearing. It often is necessary to segregate a few of the worst picked birds until new feathers arc well started.

Oceasionally chicks are picked at the hase of the upper mandible. at the end of a toe or around the vent. If the offending hirds are isolated for a few days the difficulty usually. ceases after which they may be returned to the pen. When picking does occur, it may be serious, for grousc. like the mountain quail of the West, succumb rather easily to sueh mishaps. The loss of blood from an injury as slight as a picked toe often will result in death. Simi. larly, a pulled toenail which may have been caught in the wire floor, often proves fatal. Whether this is due directly to loss of blood, to shock or to some other factor. has not been determined. It is well, therefore. to eare promptly for such dificulties.

Sevcral factors tend to cncourage picking and camnibalism. Excessively high or low temperatures as well as lack of feed or water may induce these vices. It is therefore adrisable. in addition to keeping an abundance of feed and water before the birds, to supply some form of attractive green food to keep them busy. The rare severe onthreak may be checked hy keeping the birds in a darkened brooder unit.

\section{Reducing the Danger from Disease and Predation}

Grouse chicks. like quail. are susceptihle to most poultry diseases though a few are not common to the latter. It is important to keep disease preventive practices constantly in mind. Battery brooders slonld be thoroughly eleaned. scrubbed and disinfected before a new lot of ehicks is started. The same applies to each wnit of the colony house which has licen previously occupied. Attendants responsible for the eare of the adult grouse or of other species should. if possible, keep away from the battery brooder room as well as from other luilding or units where ehieks are heing reared. At the Center. as an added precaution, a mat soaked in disinfectant is placed hefore each outside door so that sloc soles ean be dis. infected. 
All feed for the young grouse should be separated from other feed. Likewise, there should be no exchange of feeding equipment or accessories unless they are adequately sterilized.

Doors and windows in the battery brooder room and in the colony house are best fitted with tight screens to prevent the entrance of flies. The outside run, used in connection with the colony house, also should be screened.

Control of mice and rats is important. The latter occasionally kill chicks. The former are not predators but their raiding of feed hoppers might possibly aid in spreading disease. Then, too, the unmistakable signs of mouse travels are left for the young chicks to pick up.

\section{Reaking of The Young Birds}

As soon as the young grouse can do without artificial heat during cool nights, usually between the fifth and sixth week, they may be transferred to the more spacious rearing pens. The brooding unit, while providing sufficient space for chicks, is costly to build if one makes it large enough to furnish the space desired from this time forward.

At the onset of summer, birds are more likely to pick feathers or become cannibalistic. These, in fact, are the most likely causes of loss during this otherwise quiet growing period. Contrary to common belief this trouble may result as much from over-crowding or from failure to keep the birds occupied, as from inadequate feed.

Since grouse seldom develop a strong desire to dominate their penmates until the early fall they can be re-grouped in any desired combination in the rearing pens. During this adolescent period it is normal for the birds in the close social entity of the brood to devote most of their time to the business of growing up. In fact, at no other period, except when they are in the wintering pens, do the birds require less attention.

The summer is, however, not without its dangers unless the requirements characteristic of it are properly understood. The type of rearing unit, the feed, the discase precautions and the recognition of the danger signals heralding the onset of unrest and aggressivencss in the young birds must all be considered if the rearing period is to pass without untoward difficulties.

\section{Rearing Fields and Units}

The ideal field, in which to place rearing pens, is a level, well drained site protected from strong winds and partially shaded. A properly situated apple orchard provides an excellent combination, for the trees may be judiciously trimmed all summer and the leafy branches placed in the pen to furnish satisfactory inexpensive roughage. Woodland glades have not proven satisfactory locations because of the number of grouse predators frequenting such locations and the difficulties of finding an occasional escaped hird in the surrounding undergrowth.

The field need not be large, for the rearing uitits can be left permanently in the same location. To deter roving dogs, eats, rats and skunks and to keep curious visitors at a safe distance, the area may be surrounded by a 6 -foot poultry netting fence. The lower third should be $3 / 4$-inch mesh galvanized wire with the bottom anchored firmly in the soil to lessen access by rats. A few tunnel traps, properly screened with 2-inch poultry netting to discourage entrance by escaped young birds, placed along the outside of the fence will catch many predators while they are following the fence. 
In spite of the preponderance of cvidence against it, so attractive was the idea of raising the hirds on the ground in large covered units containing natural cover, that three such structures were tried out during two rearing seasons at the Catskill Experimental Station. Athough the birds were fed and watered on wire screens and the pens were kept meticulously clean to inhibit the onset of disease. severe outhreaks of ulcerative enteritis, coccidiosis and blackhead were encountered. Rats and weasels eluded every safeguard to take toll of the

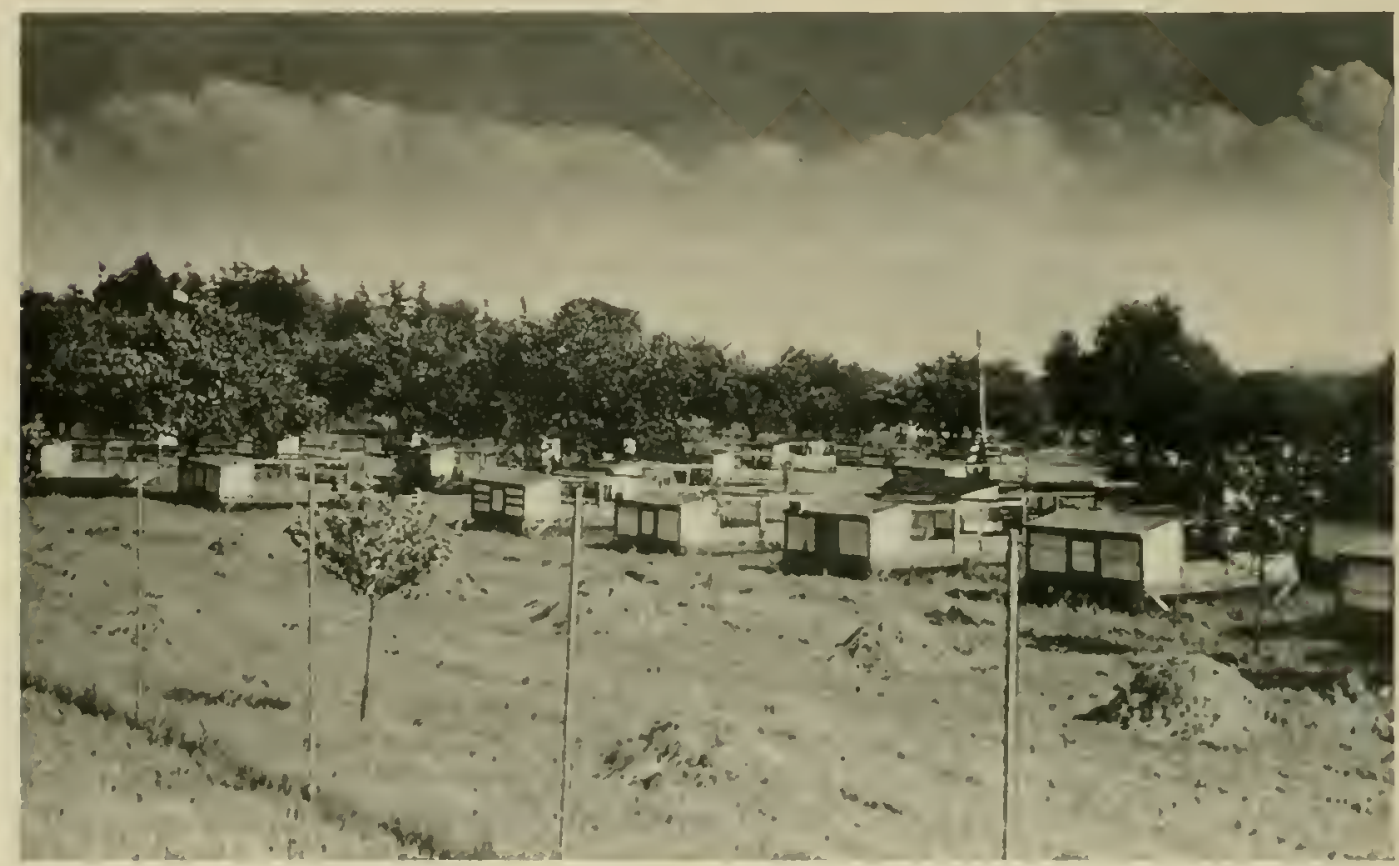

ALL-PURPOSE PENS, SCATTERED OVER TIE, REARING HLLD, MAKE IDEAL UNITS IX WIICIS TO RAISE TIIE YOUNG GROUSE TRANSFERRED FROM TIIE COLONY JROODER HOUSE

young birds and great hormed owls beheaded a number that, in fright, persisted in attempting to fly through the top of the enclosure. This type of housing accordingly was abandoned in favor of much smaller units.

\section{l'ens and Penning}

The prime requisites of a good rearing pen are spacionsness and accessibility. It should of eourse have a wire floor raised from the ground a distance sufficient to allow free access underneath for eleaning. It is desirable to provide a permanent shelter against unusual wind and rain at one cul. Needed also are several roosts to which the lirds may retire at night or take refuge when chased. To prevent "walking the wire," a 10-inch hasehoart may be placed along all sides. The rest of the sides, top and base should be covered with smonth, galvanized $3 / 4$-inch poultry netting.

Two types and four sizes of rearing pens were cxperimentally tested at the Center. Birds were raised to maturity in the colony hrooder house, in 8 feet $x 16$ fect $\times 3$ feet all-purpose pens and in units 8 feet $\times 12$ feet $\times 3$ feet and 4 fect $\times 8$ feet $\times 3$ feet of similar design. 
The colony brooder units proved not too satisfactory because of the large proportion of enclosed house in comparison with the small run. It was found that the requirements of the older birds were best met by providing a minimum of 12 square feet of floor space per bird, in contrast with but four square feet needed by the younger chicks. As the birds grew older the periodic cleaning required in the brooder houses also was time consuming.

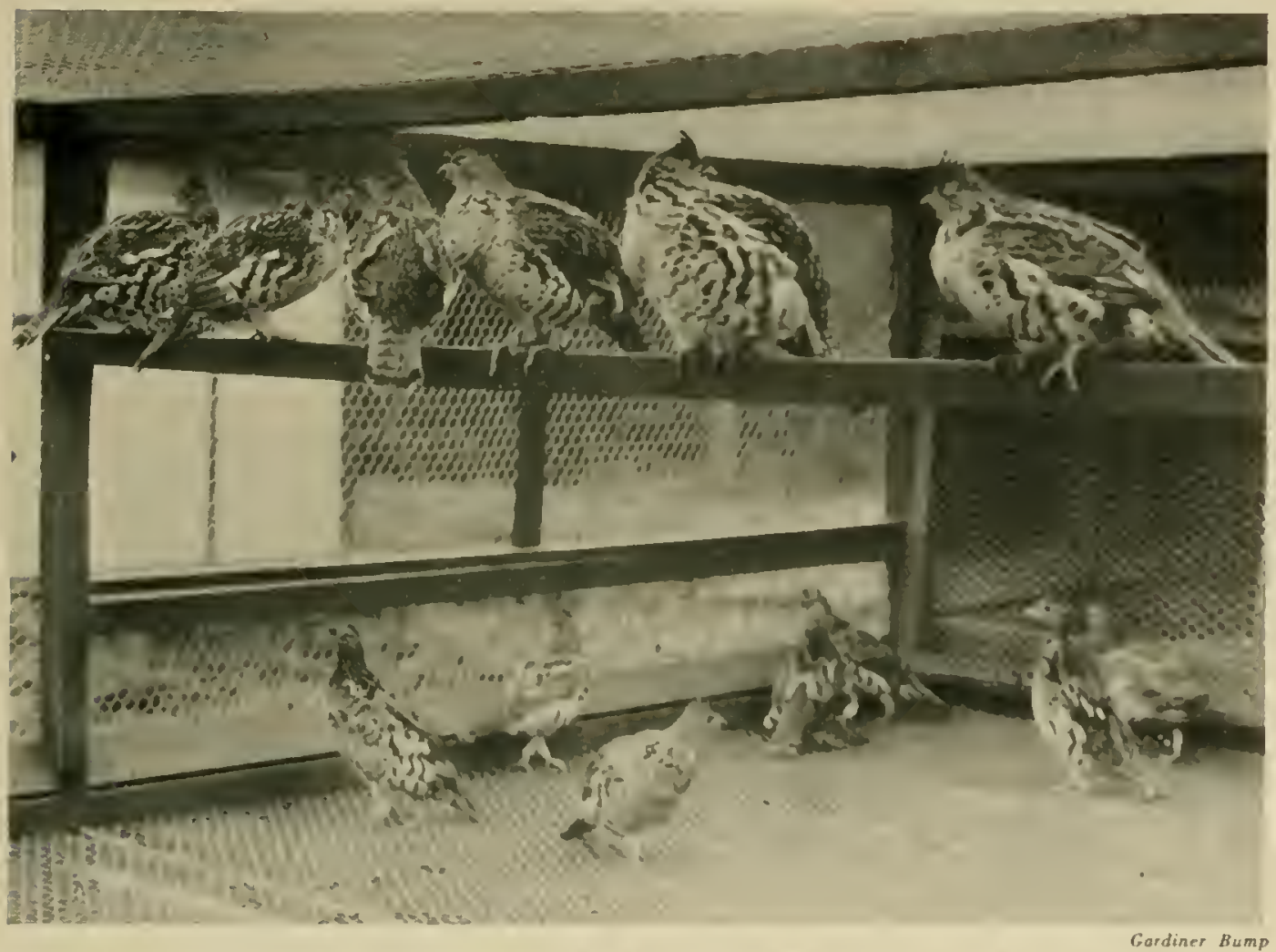

BIRDS MAY BE KEPT IN TIIE ALL-PURPOSE PENS IN THE REARING FIELD UNTIL WELL INTO THE FALL

Of the three field rearing pens tried, only the smallest proved too limited in space. Under normal conditions, eight birds may he safely reared in the 8 feet $x 12$ feet $\times 3$ feet unit, and ten to twelve in the larger one. If the pens are joined end to end and the intervening wire panels removed. still greater freedom of movenent is provided, while maintaining the mobility of each unit.

To provide shelter and to keep the birds busy, it is wise to lay small evergreens, butt up, in one corner of each pen.

Rearing pens may be placed in rows at 8 -foot intervals. A greater space between each pen sometimes facilitates the control of certain diseases but increases the time necessary to service each unit.

\section{Feed and Feeding Techniques}

The shifting of the birds from the brooder to the rearing field entails more than merely a change of pens. The moult from juvenile to adult plumage has already begun. 
In the wild the young birds are paying less attention to insects and more to the leaves, seeds and fruits which largely make up the diet of adult grouse at this period. Likewise in the pens one finds an increasing tendency to eat more grain, in proportion to mash. The actual change in feed at this time is, however, not so much in composition as in size. The more coarsely-pelleted growing mash is substituted for starting mash, the intermediate-sized grains for the finer ehick grains and intermediate grit for the smaller size previonsly used, as indicated in figure 4.1 .

By now the birds are also quite able to secure roughage by stripping apple leaves from the limbs. Lettuce may aceordingly be eliminated and whole branches of apple or other edible leaves placed in the pen. Beginning with the seventh week the hirds will make increasing use of apples cut in half and impaled on nails. Bunches of clover or alfalfa, tied together and hung up or placed in a feeding raek from which they may be pulled as needed, are also relished, though they wilt and pack down easily. These, together with needles from the evergreen bouglis placed in a corner of the pen as shelter, not only offer the desired bulk to the diet, but also serve to keep the birds occupied.

All substitutions and changes shonld be carried out gradually over a period of a week to cushion the shock possibly attendant upon sudden shifts in diet.

To one who is raising grouse for the first time there comes an almost overpowering desire to add wild delicacies such as berries and insects to the standard diet here recommended. Yet sowbugs, for example, are known to be an intermediate host for the stomach worm (Dispharnyx) and grasshoppers may carry the gizzard worm (Cheilospirura). After yielding to this temptation for three years the Investigation diseontinued the practice without any apparent adverse effect upon either the physieal developinent, feather growth or the rate of survival among the growing birds.

Little change in feeding or watering equipment is necessary at this time. Separate troughtype feeders for mash, for grain and for grit may be used, or the last two items may be mixed together. Small containers which require filling several times a week are preferahle to the large hopper-type feeders. In the summer moist feed should not be allowed to remain long in the feeders lest mold develop.

Nor is it difficult to supply the birds with water, reasonably fresh and cool. Feeling that the mason jar type of water fountain might encourage the spread of disease, a simple arrangement eausing drops of water to form slowly at the ends of short glass tubes protruding into each pen, was developed in 1931. But while the birds enjoyed picking at the drops thus formed, the device required considerable servicing and was not easy to handle. Nor did it apparently exert any influence ou the incidence of disease; so it was alandoned.

\section{Disease Prevention and Control}

During the summer and early fall. properly reared young grouse present such pictures of health as to lull the inexperienced breeder into a false sense of security. Early accounts contain innumerable records of entire groups being wiped out at this time, usually by the ever mysterious "grouse disease." The prevention and control of the diseases known to affect grouse during this period are today however, so well understood as to furnish little cause for anxiety, providing a few important preeautions are followed.

Each pen should be thoroughly cleaned with disinfectant or firegumed in the fall in preparation for the following season. All grass and debris under the pens should be removed or 
burned. During the rearing season, flies. which may carry ulcerative enteritis, can be dis. couraged by the prompt removal of waste feed and the covering of the ground under each pen with a thin coat of hydrated lime once every two weeks.

The price of freedom from most diseases is the maintenance of clean conditions within as well as about each pen. All feeding and watering equipment should, therefore, be disinfected at least twice a week and any accumulation of droppings either on the wire floor or on the conifers used as shelter should be promptly removed. As a precautionary measure it is wise to continue limitations on visitors and to place a folded feed bag in a pan of disinfectant so that all who enter the rearing field may step on it. It is, of course, hazardous to allow poultry or those caring for it, access to the immediate vicinity of the rearing field.

In spite of every precaution, the two most serious epizootic diseases known to affect grouse in captivity, ulcerative enteritis and blackhead, occasionally may appear at this time. Until Dr. P. P. Levine, working for the Investigation, demonstrated in 1933 that the former might be carried by Aies, even the most exacting precautions failed to check its spread. In 1932, 96 out of 196 hirds were lost during September from such an outhreak. Each day, after this disease appeared all pens were disinfected, all feed dishes hoiled and all feeding done by attendants wearing rubber gloves. These were dipped in disinfectant after servicing each individual pen. Yet the disease spread. During a similar epizootic the following year, all birds occupying supposedly uninfected pens were moved to a hastily fenced rearing field a quarter of a mile away where carefully disinfected pens were placed 100 feet apart. Even though a new attendant, who kept scrupulously clear of the old rearing field, was assigned to care for these birds, many subsequently were infected and died of this highly contagious disease.

In 1934, however, it was demonstrated at the Research Center that by fly-proofing each pen with cheesecloth or muslin at the outset of the epizootic and by carrying out all the precau. tions normally associated with the control of an extraordinarily infectious organism, the disease usually could be confined to the unit in which it originated. To make ccrtain of control, uninfected pens may likewise lie screened, although this practice was discontinued as unnec. essary at the Research Center.

The key to effective control of ulcerative enteritis* is the prompt recognition of its presence. The very swiftness of the onset provides one of the liest indications. Infected birds seldom appear sick more than 24 hours before death occurs. The unexpected loss of several young grouse from the same pen in a single night without apparent cause should always be a danger signal to he followed by the immediate screening of the pen against flies. At this time a prompt examination of dead birds by an experienced pathologist may not always reveal ulcerative enteritis, for the characteristic lesions in the small intestine often do not appear in excessive numbers until the epizootic is well under way. Dead birds should never be kept within the rearing field.

The only other serious disease likely to be encountered is blackhead. Birds reared in cap. tivity on the ground are most apt to acquire it, although even on wire a few are mysteriously affected each year. In the latter situation, isolating the birds from the infected pen into groups of two or three is usually sufficient to check it from spreading ${ }^{\Delta}$. Grouse thus infected may appear to be sick for several days since its progress in birds of eight to twelve weeks of age is not usually as rapid as is that of ulcerative enteritis.

* See Chapter X, p. 437 for description and full control measures.

$\triangle$ See Chapter X, p. 438. 
Very occasionally when accessible moldy feed has been allowed to accumulate, a fungus disease, Aspergillosis, may be the cause of death.

Properly guarded against, one seldom has much to fear from any of these diseases at this period. Yet more of the early attempts to raise grouse artificially ended in failure through these causes than from all other difficulties combined-and just when favorable results seemed assured.

\section{Care during Rearing}

Constant attention to small items is the price of success during this comparatively meventful period. It is wise to check conditions in the rearing fields several times daily. Rats are apt to congregate here because of the presence of waste feed beneath the pens. Tunnel traps properly screened are usually effective. Occasionally cyanide gas may have to be introduced into holes and closed runways to secure effective control.

There have been several instances at the Center of raccoons amputating the legs of young birds. The feet were caught and pulled through the wire floor of the pen. By placing a single-strand electric fence outside of and close to the top of the rearing field fence these animals usually ean be excluded.

Dogs, cats and visitors, if allowed about the rearing field, may frighten the lirds, causing head injuries. Though such scalping may be severe, the wounds usually heal. Hore important is the likelihood that the balanced social relationship so important in a pen may be upset by the scarred birds becoming increasingly nervous until a permanent inferiority complex eventually is acquired. Such birds should be liberated for they seldom make good breeders.

Birds quickly learn to know their attendants and to be reassured by familiar sounds when frightened. The practice of occasionally whistling or talking while working in the vicinity may also be used to quiet them during the periods of fright.

Tame birds make the best breeders and reduce maintenance difficultics to a minimum at other scasons of the year. Considerable fear of man may be induced in young birds selected for liberation by freguent catching and handling or by placing a wild bird in the pen just previous to release.

\section{The Period of Social Adjustment}

The first cool days of early fall may bring into sharp relief the ever-present problem of social adjustment. Wild broods are then starting their fall shuffle or "crazy flight." The young males, previously seldom more aggressive than their sisters, now liegin to display and to attempt to dominate their fellow penmates. Nlthough fighting for supremacy may begin as early as the tenth weck, the cliasing and bullying of less aggressive hirds is now apt to reach

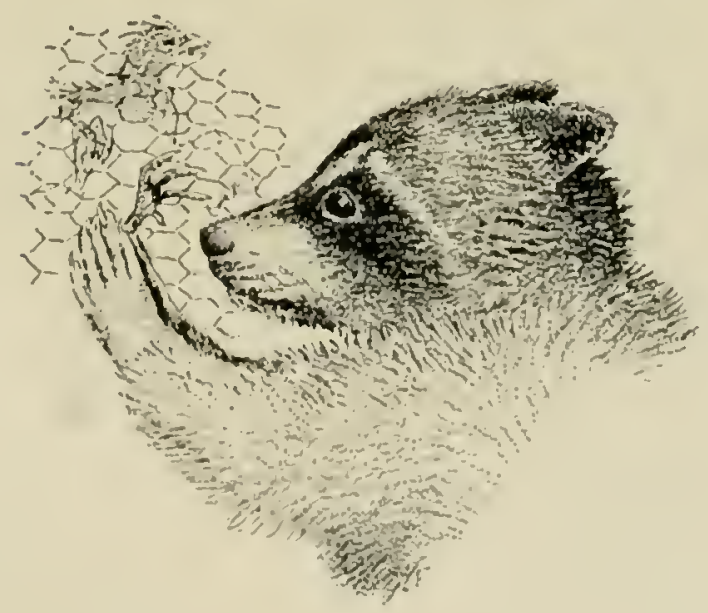


a critical stage completely upsetting the social balance. The weaker individuals, bullied into attempts to escape, may be forced to spend most of their time on pen roosts or in the shelter of the pines placed in the pens for this purpose. Failing to reach such haven, they are occasionally severely sealped either by flying against the wire or by being viciously head-picked.

As soon as trouble begins, the coniferous cover in the pen should be increased. Low corner roosts to which birds attempting to escape may fly, are also effective. By dividing the pen into several sections set apart by 10-inch base-boards placed on edge, the territory of the aggressive individual may be limited considerably, thus also assisting in reducing chasing.

Occasionally the situation may be solved by segregating especially vicious birds for several days or by placing them in other pens where their dominant attitude tends to be neutralized by the resultant difficulties of establishing themselves in a new territory already occupied by strangers.

Exposed to the proper brooding and rearing conditions, little difficulty should be experienced with feather picking or cannibalism until the fall moult when the juvenile tail feathers are lost and the adult rectrices first make their appearance. Encouraged by the nervousness characteristic of the season. these, as well as the upper tail coverts, are often so severely picked as to cause considcrable temporary injury. The prompt removal of loth the offending and the injured bird for a period of a few days has already been suggested. To leave them apart for a longer period is, however, to run the risk of increasing difficulties in adjusting themselves to their companions upon their return.

Young grouse, to be kept as brecding stock, may be overwintered" in their rearing pens. particularly if two of these can be placed end to end to provide adequate flying space. Less labor and chance of accident are involved, however, if the grouse are brought together in large groups. A separate structure has proven most satisfactory at the Center for this purpose. Birds may be concentrated in winter quarters at any time after the first heavy frosts of fall have reduced the danger of a serious outbreak of ulcerative enteritis. In fact. provided quarters are larger, less trouble during the adjustment period will be experienced if this is done.

\section{PRACTICABILITY OF ARTIFICIAL GROUSE PRODUCTION}

Few will read this chapter without realizing that there are still several major difficulties to be overcome before the average game breeder can produce grouse in substantial numbers at a price within the reach of most individuals interested in restocking their coverts. A little time, however, may well be spent in analyzing production possibilities and limitations.

The science of artificial grouse propagation is still too immature to permit an adequate evaluation of eventual possibilities. Sufficient progress has been made, however, to indicate that grouse properly handled in captivity will more than reproduce their numbers year by year. In 1940, at the Research Center, 65 hand-raised breeders laid 851 eggs, from which 502 youngsters were hatched. Of these 224, were reared to maturity (September 1). All but 37 of the latter were placed in breeding pens the following spring.

It should be recognized that it has not as yet been found possible to maintain this pace each year. The care of the breeders, the incubation of the eggs and the rearing of the young all represent specialized problems, the successful handling of which requires experts with initiative, enthusiasm for the work, a flair for details and what is colloquially known as "grouse sense". Given all these, one still encounters "breaks", the reasons for which are not 
always clear, that strongly influence production one way or the other. Nor should it not be forgotten that the results in terms of birds produced are usually better with sinall numbers than with mass production.

The picture at the Research Center was further complicated because it was necessary each spring to use part of the available breeding stock for one or another of the several experiments then underway. If uninterrupted attention could be given to the production of grouse for liberation, it now seems possible to rear from two to five birds to eight weeks of age for every female placed in the breeding pens.

\section{Production Equations}

For the reasons just indicated, it has not yet been possible to base a grouse production schedule on the record established at the Center. Each season some progress has been made experimentally in reducing the effect of the items which limit production. With such a stubborn problem, however, 13 years are still insufficient to learn to recognize and control all of the limiting factors.

But those who would breed grouse artificially are naturally anxious to secure some basis for determining a logical production schedule. For such, the best guide at present seems to be the results obtained from experiments that have proved most successful after repeated trial. Given the proper conditions and supervision, it would seem quite possible to equal or to exceed the production indices here set up.

TABLE 71. INDICLS OF PIRODUCTION

\begin{tabular}{|c|c|c|c|}
\hline Factors & Symbol & $\begin{array}{l}\text { Normal } \\
\text { range }\end{array}$ & $\begin{array}{l}\text { Best } \\
\text { recorit }\end{array}$ \\
\hline 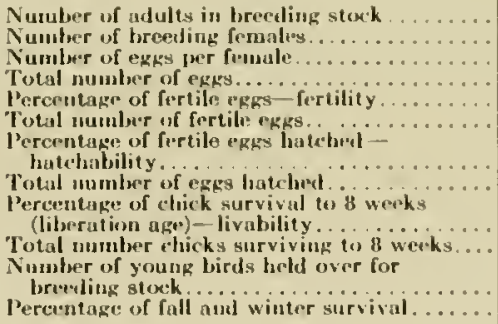 & $\begin{array}{l}\text { A } \\
\text { II } \\
\text { E } \\
\text { E } \\
\text { F } \\
\text { F } \\
\text { bi } \\
\text { II } \\
\text { L } \\
\text { L } \\
\text { C } \\
\text { S }\end{array}$ & $\begin{array}{l}12 \ldots \\
12-18 \\
25-80 \% \\
\ldots \ldots \\
70-80 \% \\
\ldots \ldots \\
30-50 \% \\
\ldots \ldots \ldots \\
80-31 \% \%\end{array}$ & $\begin{array}{l}3 \ldots \\
36 \\
83 \% \\
\cdots \cdots \\
87.5 \% \\
81,2 \% \\
\cdots \cdots \\
8 \% \%\end{array}$ \\
\hline
\end{tabular}

Using these factors, which are based on results at the Rescarch Center, estimated production of chicks and of next season's brceders may he quickly figured or a clieck on progress to date at any period during the season, may be oltained. The optimist will use the highest figures, the pessinist the lowest. while the hopeful individual will, no doubt, take the averages for cach factor. Computations are in simple multiplications. For example:

Number of females (B) $x$ Number of eggs per female (e) = Total number of eggs (E).

Total number of eggs (E) $x$ Per cent of fertility (f) $=$ Number of fertile eggs (F).

Using the symbols, the equations are as follows:

$$
\begin{aligned}
& \mathrm{F}=\mathrm{B} \mathrm{C} \\
& \text { F Bef or Ef } \\
& \text { II Befli or Fh } \\
& \mathrm{I}=\mathrm{I} \text { eflil or } \mathrm{HI} \\
& A(\text { next season })=(\lambda+\text { C } S
\end{aligned}
$$


In terms of chicks ( 8 weeks old) per laying female, substituting the actual figures for symbols, one may obtain the following estimates secured by applying the formulae

$$
\begin{aligned}
\mathrm{L} & =\mathrm{B} \text { e } \mathrm{f} \mathrm{h} \mathrm{t} \\
\text { Optimistic } & \mathrm{L}=\mathrm{B} \times 18 \times .80 \times .80 \times .50 \\
\mathrm{~L} & =\mathrm{B} \times 5.76 \\
\mathrm{~L} & =\text { Number of breeding females } \times 5.76 \text { chicks per female } \\
\text { Pessimistic } \mathrm{L} & =\mathrm{B} \times 12 \times .65 \times .70 \times .30 \\
\mathrm{~L} & =\mathrm{B} \times 1.64 \\
\mathrm{~L} & =\text { Number of breeding females } \times 1.64 \text { chicks per female } \\
\text { Average } \quad \mathrm{L} & =\mathrm{B} \times 15 \times .725 \times .75 \times 40 \\
\mathrm{~L} & =\mathrm{B} \times 3.26 \\
\mathrm{~L} & =\text { Number of hreeding females } \times 3.26 \text { chicks per female }
\end{aligned}
$$

In listing items such as production indices and equations, it is difficult to avoid the implication that those who would breed artificially may confidently expect to maintain such a pro. duction schedule year by year. In actuality, it should be remembered that the field is still far too young to justify any such expectation.

Conversely, by adopting, in general, the methods and techniques previously descrihed and by paying strict attention to the business at hand. it is fair to assmme that a skillful breeder, about every other year, may equal or occasionally exceed the estimates of mass production given here.

It is, of course, mnderstood that considerable time must first be spent in luilding up a breeding stock properly selected for egg production. fertility. livability of resultant chicks and adaptability to the conditions of captivity. The smaller the number of breeders and chicks, the better the record is likely to be.

There is one other point not to be overlooked. The number of young grousc reared during the current experiments las varied from a low of less than one bird per hen to a high of 7.5 for the best year's average. The differential is in part tracealle to the various experiments carried on, to improvements in the brood stock, the feed and the methods of handling the birds. Year by year, however, it was the individuals responsible for incubating the cggs, rearing the young birds and caring for the breeders on which success, in no small measure, depended. Inexperience, even in one job, was inevitably reflected by a seriously lowered production. As indicated later. exceptionally well trained and competent men deeply interested in the problem are a prime requisite to success.

\section{Factors Limiting Production}

A difficulty understood is a difficulty half overcome. Thus it becomes particularly pertinent to consider the major known factors that limit the production of large numbers of grouse in captivity. Many of these are biological. Others revolve around the scarcity of breeding stock or eggs, the lack of trained manpower, the cost involved in setting up the necessary plant and the carrying out of the techniques of production.

\section{Biological Limitations}

Many of the limitations within the birds themselves already have been discussed.

The inherent capacity of grouse to adapt themselves to the requirements of captivity in 
response to proper managenent is one of the most important items controlling production. Nor are these as yet clearly defined, for each improvement in rearing technique, as developed, increases the ability to raise more and more birds. Also such jtems as their comparatively limited egg production and their intolerance of each other, during certain periods of the year, due to the dominance complex, jnvoke unusual restrictions on the grouse breeder seldom encountered in raising pheasants or quail.

On the degree to which man can learn how to stimulate the full reproductive capacity of grouse in captivity rests, in no small measure, the ultimate chances of success. Among the stimulating techniques adopted to date, some have proven satisfactory answers to the problems they were intended to solve. with others considerable progress remains to be made. In this latter group lje three objectives which must be realized before ultimate success can be attained. They are:

1. An increase in the number of eggs produced per female during the breeding season.

2. An increase in egg fertility and hatchability, particularly during the latter portion of the laying period.

3. A much higher average survival rate among chicks from five to 25 days old.

Indications are that the first of these problems may eventually be solved by selectively breeding for high egg production, which is apparently an inherited characteristic. A total of 170 ova have been recognized in a single female at the start of the breeding season. On the other hand, though an individual bird at the Research Center has laid 36 eggs in a single year, the normal is but 15 to 20. Another key to this situation might be food. Examining this possibility, however, we find the grouse in captivity, irrespective of the number of eggs laid, lose very nearly the same weight during the breeding season as do their wild cousins. Likewise, the threshhold of reproductive exhaustion seems to lie between 500 and 515 grams for both groups. It is a fact that high producers eat more although losing ahout the same weight as low producers. The average weight at the beginning of the breeding season of the ten grouse laying the most eggs at the Center in 1942 was 556 grams in comparison with 552 grams for the ten poorest producers. The average weight of the respective groups slortly after the last egg was laid was 513 and 515 grams. Though exact records of food consumption during the interval were not kept, the attendant conservatively estimated that one-third more food was eaten by the higher producing group.

The problem, then, may be one of building up a strain of birds which produce more eggs because they are physiologically capahle of maintaining production weights on game farm diets throughout most of the lireeding season. Further progress in adapting these foods to the nutritive requirements of the hird probably is dependent upon fundamental advances in the field of bird nutrition.

The second problem, that of securing fertile eggs, is largely traceable to the peculiar psychological hehavior of the grouse during the mating period. This bas already been described".

The difficulties here are several. In the close confuncment of a pen the male may so frighten the female by his pugnacious. dominating tactics that mating may not occur. Due to this harrassment, her weight may decline abnormally, thus lowering egg yield. A second limitation involves those males in which the reproductive cycle appears to be of such short duration that the period during which the female will accept the male does not fall within it. If the male is vigorous, one service is usually good for a clutch of eggs. However, the female that

* See Chapier 11. p. 65. 
lays an unusually large number is likely to have difficulty in finding a male still in his reproductive cycle when a second mating is necessary.

It now seems that these limitations may best be attacked by selectively breeding to produce vigorous though not strongly dominant birds which exhibit relatively long breeding cycles. The presence of escape cover in the pen for the female when chased is, of course, an important corollary.

The situations mentioned above may be mitigated to some extent by the care and skill of the game breeder. This applies also to the third problem, that of reducing loss of young chicks in the brooders. By penning the grouse in small groups as is customary in battery brooders, or in units of not over 25 or 30 birds to a larger hover and by giving then close attention, one may reduce the losses considerably. Still they remain high. The answer again lies in part in selective breeding. for there are certain families in which survival is comparatively high.

Here, too, a part of the difficulty may rest with the feed, althongh extensive experiments, as described*, have not as yet located it.

The younger birds also appear to be extremely susceptible to chilling. This is a forerunner to diarrhea, lung congestion and death.

While the above evidences of hiological limitations are both a tax on and a challenge to Man's resourcefulness, there is still no clear indication that they cannot he satisfactorily over. come, providing that the end justifies the means.

\section{Scarcity of Obtainable Breeding Stock or Fggs}

So few grouse have heen raised in captivity that it is almost imperative for one to secure eggs or breeders fron the wild. This is not easy, for in most states and provinces it is illegal to collect them. Thus limited, most experimenters have found further progress blocked by their inability to raise more than a few hirds from the clutch or two of eggs that accidentally have come to hand. In past years an interested sportsman's club or a conservation commis. sion occasionally assisted in the collection of eggs or birds, but the numbers were seldom sufficient to make up for the losses inevitable in pioneer work. Under such discouraging conditions it is no wonder that few individuals carried their experiments heyond the recon. naissance stage.

In passing, one might suggest that, where grouse are widespread and abundant, no biologically sound reason exists for depriving qualified research men. interested in game breeding, from securing a seed stock of grouse from the wild. Considering that. out of every hundred grouse eggs laid in New York during an average year, only about 12 to 15 of the birds hatched survive to breed, the few thus diverted wonld never be noticed in terms of birds in the coverts by even the most ardent sportsman.

\section{Lack of Trained Manpower}

The success of any experiment is usually dependent upon the number of trained, experienced and interested minds whose attention can be concentrated on the problem at hand. With the present situation this is particularly true, for the nature of the grouse is such that the usual game propagation methods are not always applicable.

\footnotetext{
* See Appendix, p. 880 .
} 
Much previous experimentation has heen carried on largely by rule of thumb. Fundamentally; one should have a sound knowledge of genetics to carry out properly selective breeding: of nutrition, 10 attack intelligently the food problem; and of hird physiology and psychology, to handle the problems arising during the mating season. Men thus qualified rarely are attracted to the game breeding field.

The rearing of grouse also suffers from a lack of manpower of a different category. Even such secondary johs as feeding and caring for breeders and young birds inust be done by unusually keen-eyed and intelligent individuals, capable of detecting details which, if unnoticed. might cause failure in one or more of the project's intricate parts. The Investigation once lost a bird because thoughtless workmen failed to pick up a roofing nail dropped in completing a pen; another hird died from swallowing a cigarette butt carelessly tossed aside by an attendant. Failure to recognize and segregate dominant and vicious males has resulted in funding their subordinate companions severely scalped on many occasions. It is difficult to find individuals who. once the novelty of the work has worn off, will day after day attend to the innumerable details incident to keeping a grouse rearing project up to par. The work is much more exacting than is that of raising pheasants, quail or ducks.

Failure to follow through on the required details is often the greatest source of lost birds.

Cost

The last limiting factor to he discussed is the cost. for it is largely dependent upon the sucress with which the difficulties previously mentioned are overcome. The possibility of obtain. ing a large number of grouse over which the cost can be spread is strictly limited ly the comparatively small group of eggs produced by each breeding bird. Though this number is being increased ly sclective loreeding at the Research Center, progress is slow and. therefore, expensive.

At the Catskill Experimental Station and during the early days at the Research Center when every hird produced was involved in one or more experiments, costs up to $\$ 15$ per adult raised were to be expected. With the incorporation of the results from fruitful research in the techniques followed at the Center, the cost dropped accordingly. Today it will run hetween $\$ .5$ and $\$ 8$ a hird.

But the field is still so new that the size of the yearly crop is as yet uncertain. Therefore, no lireeder should undertake to raise grouse on a large scale without being financially prepared to meet the inevitable lean years.

\section{SIGNIFICANCE OF ARTIFICIAL PROPAGATION}

No discussion of grouse rearing wonld be complete without questioning its real value. The answer of course depends upon the purposes to be served by the birds thus propagated.

If the species were in danger of extermination, there would he suffeient justification alone in the rearing and maintenance of grouse in captivity without assistance from periodic introductions of egrgs or hirds from the wild. It is possible that the eastern heath hen might have heen saved if the secrets of its artificial propagation had been known.

We lack such justification for ruffed grouse propagation-for the species is at present in

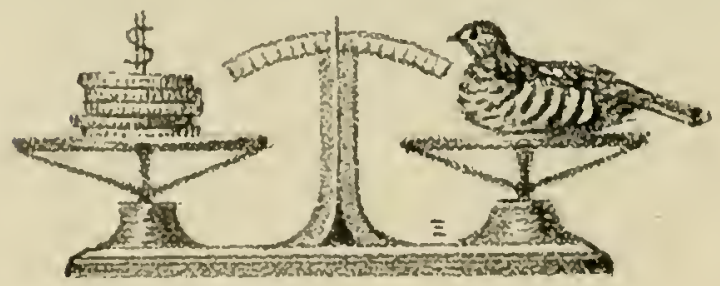


no danger of extermination over most of its range except at the fringes. There still exist many areas where grouse were once known but to which they are now strangers. Whatever the cause of their disappearance may have been, it is always possible that the situation may have righted itself. Environments change with time. Such limiting influences as over-shooting and destruction of the hahitat through fire or grazing may he modified through conserva. tion education and agricultural adjustment to produce, once again, conditions favorable for grouse.

The species is in reality much more sedentary than is generally realized. For this reason, unless a habitat from which grouse have been eliminated is adjacent to well populated coverts. the return of this game bird is apt to be a matter of many years. Where such coverts are isolated, successful reintroduction is dependent upon the liheration of new stork. This must either be trapped in the wild or reared artificially.

As has heen pointed out. few wild-trapped hirds are available for purchase and those only at prices ranging from $\$ 10$ to $\$ 25$ or more a pair. However. there is seldom a valid reason for not trapping grousc from sections where they are abundant but litte hunted to be used for restocking depleted coverts elsewhere. The controlling factor here is the reluctance of most sportsmen to seeing any birds trapped from their localities.

If a strain of grouse could he produced in captivity which eould be raised in sulstantial numbers at a reasonable cost. and which was sufficicntly adaptahle to survive and breed. once liberated, this problem might he solved. This was one of our most important objectives. But the biological limitations of the bird. as already discussed. scem to be such that there is little likelihood that they can be modified except by an exhaustive program of selective hreeding encompassing many years. For all practical purposes, therefore, one must conchide that. for the present. at least, the raising of grouse in captivity for restocking purposes offer: little promise of producing sufficient hirds at a cost reasonable enough to make it a practical proposition.

But on the broad fromt there is much more to be gained than this end alone. Some of these considerations are so little recognized that they might well lo listed:

1. Reasonahle assurance that errouse can be maintained in captivity if they are thesentened with extermination in their natural enviromment.

2. liecognition of some of the lass obious life history facts through asometation with grouse in captivity.

3. Opportunity for studying the bird's physiolegical and psychological reactions to the enviromment in which it is placed.

1. Availability of a much needed supply of experimental grouse with which to carry on studies of the fundanental reactions of the bird to various emironments.

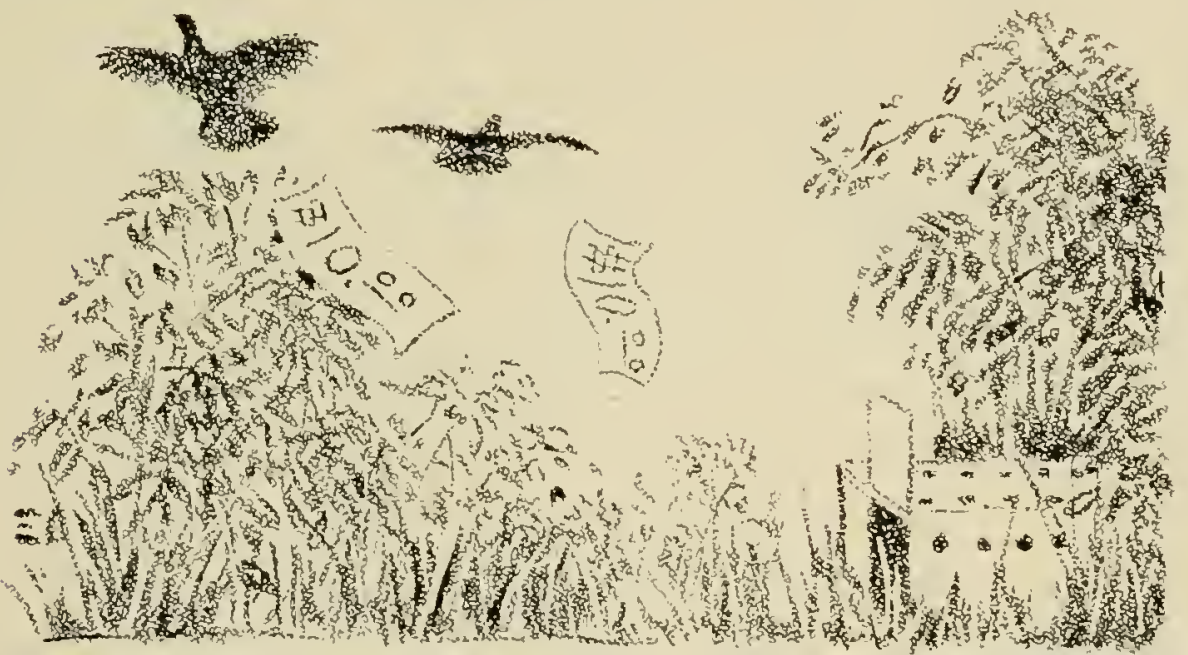


There is, for instance, some indication that there exists an important relationship hetween the weight of grouse in the early winter and the livahility of the chicks hatched the following spring. Such a relationship may perhans be hest measured by a careful physiological study where all factors can be controlled. For such a study. captivityraised hirds must be utilized, for no method is known whereh wild-trapped hirds ean he handled in captivity without producing serious physiologieal disturbances.

Likewise. though one may determine grouse food preferences and composition from field studies and chemical analyses, it is not yet possible to translate these in terms of the nutritive value derived except by feeding various items to captive grouse and measur. ing the results.

\section{GROUSE LIBERATIONS}

The prime reason behind most efforts to raise wild game in captivity is the thought that it may some day lead to the production of a brood stock for liheration. The "increase in liberation" idea at times has worked well with some species such as heaver. decr. pheasant. quail and Hungarian partridge, though only where the hahitat was suitable. Here, when the natural brood is short. artificial restocking may give just the boost necessary to speed recovery.

The urge to produce grouse for this purpose was the spark that kindled most of the early grouse raising experiments. Only in the last decade have a few sportsmen. administrators and research men realized the added advisability of producing the hird artificially for study pur. poses.

In reality ton few grouse. either trapped in the wild or raised by man. have hecn liberated in depleted coverts to date to test adequately the effectiveness of increasing the seed stock by this method. True. one nay remember that 19 survivors of the liberation on Anticosti Island in 1911 hecame the nueleus of an occasionally plentiful supply of grouse todav; that, of fire marked. hand-raised hirds liberated in the fall of 1931 on a part of New York State's Connectieut Hill gronse study area, two were killed hy predators. two survived the winter and one vanished. Most of the early introductions. however, disappeared or were alsorbed by the resident population so that no real reend of results were ever ohtained.

\section{Transportation fOR IjBFration}

No diffeulty has ever heen encountered in transporting either adult or young grouse raised in captivity. In the carly davs of the Investigation the hirds were carried five to a pillowease on the hack seat of a ear. Iater. shipping crates with wire bottoms and individual compartments for each hird were constructed. Most reently up to ten adults have heen placed in standard pheasant shipping erates for transportation by express.

Whatever the method. it is hest to exclude all save a little light from the shipping compart. ment to discourage feather picking. Burlap may he used to cover any portion of the cage made of wire except the floor.

If the hirds are to he en route less than a day. they will feed or drink very little, so it is not necessary to make provision for either. Grouse from Vura Suntia and Vanitoba plared in the eompartmented erates described above and given heechnuts or wrain and green food. such as cabhage or halved apples. were received in perfect shape at the Catskill Experimental Station. Water was provided in a small tin cup. This. though securely fastened to one corner, should he removable to farilitate cleaning.

Where such distances are involved, it is best on ship the hirds in a wire-hottomed crate to aveid fouling the floor and soiling the feathers. Where more than one hird to a compart. 
ment is shipped, one encounters the possible danger of spreading disease and parasites, particularly if the floor becomes dirty. Then, too, water spills through the wire floor, thus eliminating further fouling.

At present, most birds for liberation are obtained in Canada. Importation permits must be procured from the Federal Fish and Wildlife Service for those brought across the border

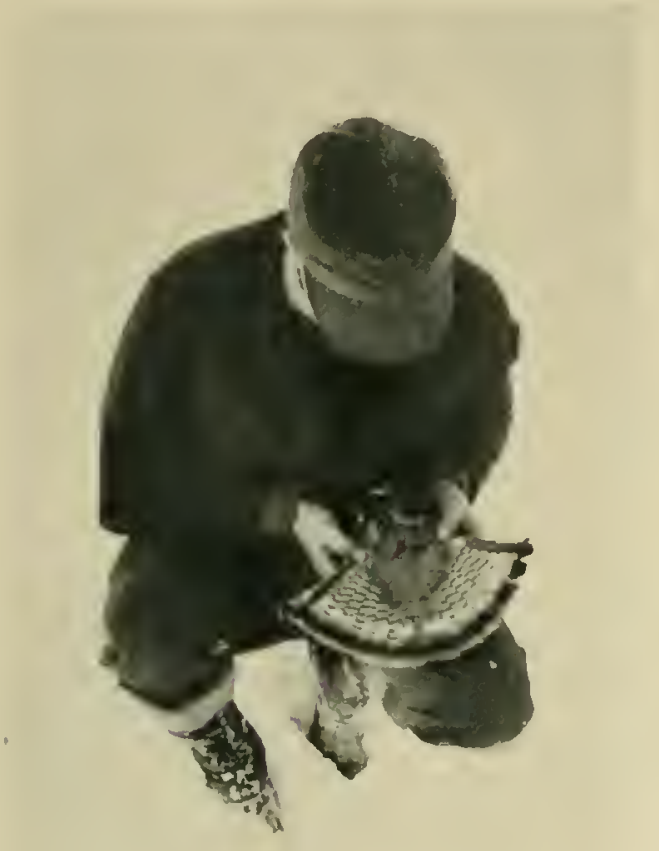

II HITE OR ORANGE-COLORED CHICKEY FEATHELS, WIRED FAST TO THE TAL FEATH. ERS OF TIL GROISE BEFORE LIBERATION. AU IN CIIECKING ON SUBSEQIFET MOTEMENTS

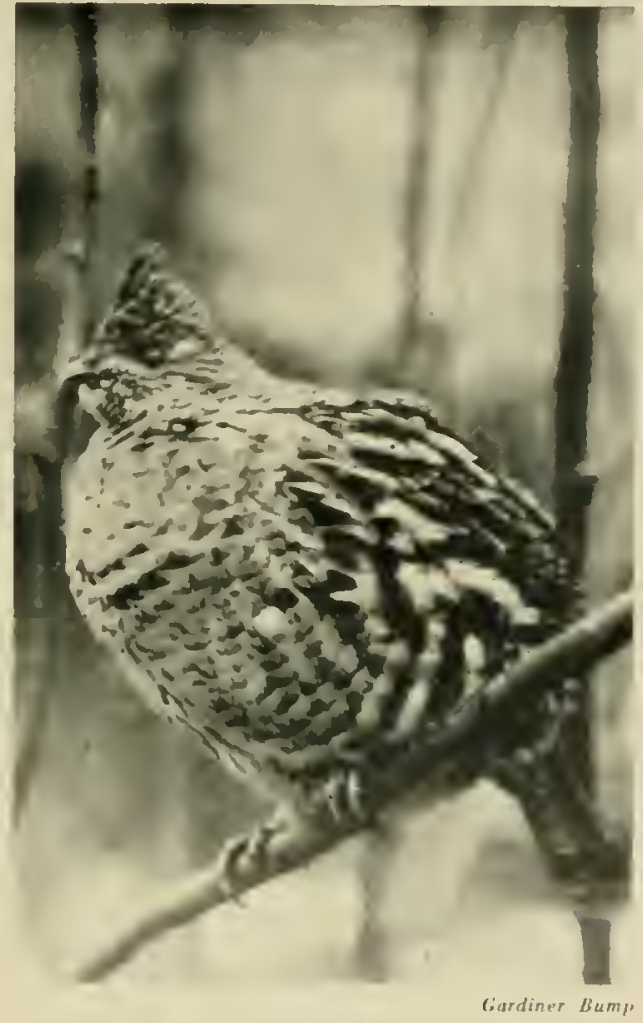

I.IBERATHI GROLSE SOON AIMUT THEMSELYES TO WILD CONDTIO.NS ALTHOLGII SOME NEVER LERAIN TILIR FEAR OH MAT SO CHARACTFRISIIC OF THEIR WIIN COISIVS

into the United States. To avoid unnecessary delays it is wisc to forward these permits either in the shipper or to the point of importation.

\section{Netion of Liberation}

Although there is a thrill in the sight. no game bird shoult be encouraged to fly from the point of liberation. If possible. the container should he placed where food and shelter are abundant and the lirds allowed to wander out at leisure. Even wilh hand-raised hirds it is mot at all necessary to place feed in the immediate vicinity, for once in the covert they seem instinctively to sample buds. leaves and insects. A few released grouse may linger in the vicinity for up to a week, particularly if the feer to which they are accustomed is placed close by. There is no evidence. lowever. that such artificial feeding tends to encourage any 
large number of birds to settle in the immediate locality.

Once liberated, most grouse will wander until they find suitable sections of the covert not currently occupied lyy others and then set up their own territory. They seldom seem to wander far for the rest of their lives. A number of birds thus liberated and later weighed several times were found to have lost from ten to 50 grams before adapting themselves to wild foods. Providing they are in proper condition, however, this loss is seldom serjous.

Care must be used to make certain that hand-raised birds can fly we!l. All troken primaries should be pulled out to allow for their prompt replacement.

\section{MARKING FOR IDENTIFICATION}

It is best 10 release only banded birds unless there are no native grouse present. Size $\# 9$ aluninum leg bands are seldom lost if placed on birds over six weeks of age. Aluminum wing bands carefully attached to the inner webb in the bend where the humerus, the radius and the ulna meet, are also quite satisfactory when subsequent sight records of occurrence are not required. Where the hirds are to be followed, tail marking ${ }^{*}$ with brightly colored chicken feathers is also recommended as a distinct aid to future identification. But they are, of course. lost when the old rectrices are molted. not later than the following July or August.

\section{Witat Deternines Survival}

Assuming that grouse are placed in suitahle habitats, certain other considerations exercise a strong, though often little recognized. influence upon their subsequent survival. Notable among these are the source and experience of the hirds. their age and their physical condition upon liberation. Success in dodging enemies, in finding food and shelter, in nesting and in raising a brood depends largely upon these puints. Of course the inherent adaptahility of the bird to new surroundings is also important.

\section{Source and Experience}

The first of these points, the source and experience of hirds destined for liberation, is often difficult to control. Few hirds arr for sale and there are many who would huy them. It is almost axiomatic that the success of any colonizing effort depends in part upon the degres of similarity hetween the new habitat and the one from which the birds were taken. Thonsands of dollars have been wasted in introducing southern quail into northem areas to which they were little adapted. Even though grouse may he a more versatile speries in this re. spect. the chances of survival in a new hahitat are closely tied in with their previous experiences.

It is for this reason that hand-raised adults secn to encounter consideralule difficulty in making good when liberated. Once they have grown up in association with man. many H Sir Aluendix. B. 71:.

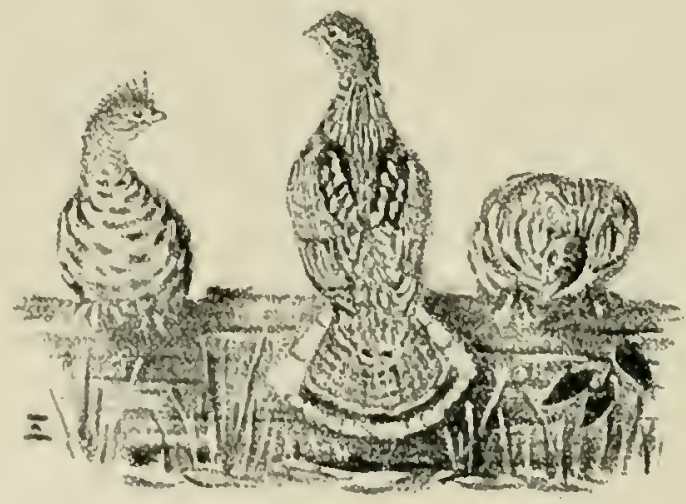


seem not to acquire a strong fear of hin, even after sume time spent in their native coverts. Breeding birds escaping from the Research Center are occasionally picked up in the yards or gardens of the surrounding farms. One such bird traveled three miles during a period of several weeks, only to be caught quietly feeding in a greenhouse. Another, liberated on the Hyde Park estate of President Franklin D. Roosevelt, was killed in Poughkeepsie six miles away.

Of the marked birds subsequently contacted from among the 191 hand-raised grouse, not necessary for propagation experiments and therefore available for liberation, about onequarter never established a fear of man, one-half would flush at distances of from 25 to 50 feet when approached and the remainder compared well in wildness to native birds on the liberation area.

With wild-trapped stock the situation obviously is somewhat different. Unless they are kept for a month or more in constant contact with people, they usually remain wild both in captivity and when released. Only adults are trapped for restocking, for the younger birds from six to ten weeks of age are usually quite difficult to catch. Where the lirds are heavily hunted and therefore difficult to approach, as in the Northeast, the luvestigation found it practicable to trap birds for banding only on the nest or in the late fall or winter*. For this reason restocking with grouse in the younger age classes has seldom been attempted.

Age

The tameness of artificially-raised adults mitigates against their utilization for liberation. Young birds, however, are much more adaptable than are the adults. In restocking a covert, the age of the birds liberated often exercises a measurable effect on the results attained. Host game birds raised in captivity seem to adapt themselves lest to a new environment at a relatively early age. Experience to date indicates this may also be true of young gronse.

There are no published records to indicate that any number of young grouse six to eight weeks of age have ever been released. At the Center, in order to secure the proper records of survival to be utilized as one criterion in the selection of the following years' grouse breeders, all young birds, except escapees, have heen carried through to October before those to be liberated were chosen.

Though few records are available to support the theory, it was olserved that those birds accidentally liberated from the rearing pens in August usually went native quickly. Few of these birds were subsequently recaptured. Some were recognized months later by their colored leg bands.

The indications are, then, that the best age at which to liberate captivity-raised grouse, is when they are eight to ten weeks old. Older birds are more likely to seek the habitations of man unless they are liberated at a considcrable distance therefrom.

\section{Physical Conditions}

Another common cause for the failure of liberated birds to survive is poor physical condilion at the time of release. In 1931 the Investigation received a shipment of 34 Canadian birds, only 18 of which were in fit shape for liberation. That this situation is not unusual is indicated by many similar reports such as one from Martha's Vineyard where many of the birds received were described as "sick if not dead." Those released were never heard of again. Or. the other hand, two shipments from Nova Scotia arrived in excellent shape.

* See Appendix, p. 716. 
Distance, msatisfactory shipping crates inviting injury and discase, and delays in transit sometimes due to importation difficulties all play their part. The condition under which the birds are held prior to shipment is also a factor. Unless all these considerations are propcrly met, survival may be markedly lessened from the start.

\section{Ability of Liberated Birdo to Survive}

In Chapter I (table 2, pr. 18) one furds a record of sone 2,300 grouse that have been lil. erated over the years, largely by sportsmen. These for the most part were wild-trapped birds. Yet a glance indicates that the number of valid returns covering the results obtained from this restocking effort is discouragingly small. In part this follows from the general failure to mark liberated birds in order to insure their subsequent identification. Likewise, only a few releases have ever becn intensively followed to determine survival. Grouse, like pheasants and quail, even though plainly marked and faithfully followed are most difficult to find again following liberation. The only other basis on which results may be judged are the records of introduction that succeeded or were failures.

The outstanding record of achievement already mentioned is the liberation of grouse on Anticosti Island in the Gulf of St. Lawrence. Most other releases have been into coverts where native birds were also present, thus making the attendant degree of success difficult to determine. Liberations are also being made and carefully followed in Ohio and Mlissouri but are not yel old enough to produce indicative results.

l'erhaps the most intensively controlled releases to date have been those made by the Investigation. Over the past 13 years, 191 land-reared and 76 wild-trapped gronse have been liberated. These were made on areas where regular field surveys were being carried on by Irained crews. In addition to banding, some of the birds were marked with brilliantly dyed chicken feathers wired or cemented to the tail feathers to facilitate subsequent identification.

With the exception of 13 reared by Dr. Allen, the hand-raiserl birds came from the Research Center. Unavoidably, they were chosen from the surplus that remained after the breeding stock and birds for various experiments had been selecter. Therefore, they might not be expected to do as well as birds turned out in the pink of condition. Nevertheless, of 81. released on the Pharsalia Game Refuge in 1938, 40 were sulsequently contacterl. One of these was four miles from the point of liberation. A marked female was found with a brood of seven chicks 78 days after release. The remains of 17 were found, though in most cases the cause of death was difficult to determine.

In Deember 1932, on the sane refuge, 29 marked, wild-trapped birds werc released. At least 12 were still resident there the following April. In fact, four females nested and reared broods of young. Both of the above records are conservative as it is probalile that some were not recognized beeause of the loss of identifying feathers. The latter hirds wandered widely. one traveling three and a half miles in seven days while another was found six miles from the point of liberation a few months later. Others undoubtedly survived lut. having jour. neyed off the survey area, were not contacted again.

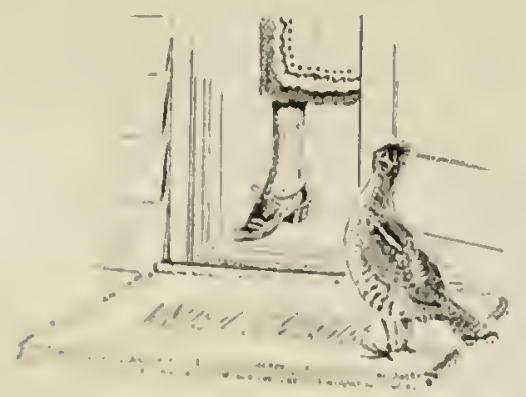


Already mentioned are the five hand-reared and five wild-trapped birds released in the fall of 1931. Two from each group were later found dead. Three of the wild and two of the hand-reared grouse survived at least until the following July. One was unaccounted for.

One hand-raised grouse released on the Pharsalia Refuge nested the secund year following liberation. This is worthy of note as the only record of this occurrence.

Of the ten additional releases, all of which were carefully followed, the results were not radically different from those described above.

In summary, of the 276 grouse liberated by the Investigation, 9.1 per cent were positively known to be alive a month or more after release. Though additional birds unquestionably. survived, it is informative here to remember that Stoddard ${ }^{3: 3}$ found the hunter return from 2,516 imported Mexican quail, 680 native trapped and 211 hand-reared bobwhites to be but 6.3 per cent. Likewise, of 1,794 young male pheasants banded and released on New York State Landowner-Sportsman controlled hunting areas in 1941, only 362, or 20.1 per cent, were brought to bag during the subsequent hunting season.

In addition to the above records of liberations made by the Investigation, there is a report. previously mentioned (Chapter 1, p. 191, of a release of ten males and seven females on Protection Island, Oregon, in 1939. The birds were followed closely and, although one produced a brood the year fullowing liberation, they gradually decreased until but one remained in 1942. Hawks and owls apparently preyed heavily upon them and, while they became quite wary, they remain, ". . too trusting of mankind ...", and ". . have not been able to withstand conditions on the island with success."

In view of the above, there seems little room for sound conclusions based on present records of survival of liberated birds. We know that some birds will survive and a few, at least, will nest and raise broods. But it is yet to be determined whether or not hand-raised grouse, liberated into favorable habitats, can establish thenselves or boost materially the num. bers of a depleted resident population.

The general similarity of the results obtained from the release of hand-reared versus wild. trapped birds is interesting lout not especially significant lecause of the small numbers involved. This is also true of the relationship loctween grouse, quail and pheasant contact rec. ords following liberation.

Additional stocking then of first-class birds, particularly of the younger age groups, as previously suggested, on suitable areas must he carefully checked before one can adequately evaluate the possibilities of establishing or increasing grouse populations by restocking either with wild or with hand-raised birds. This is still a problem challenging to both wildlife manager and the grouse-conscious sportsman.

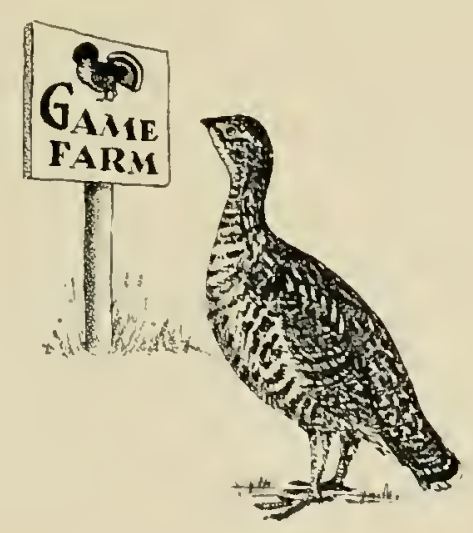




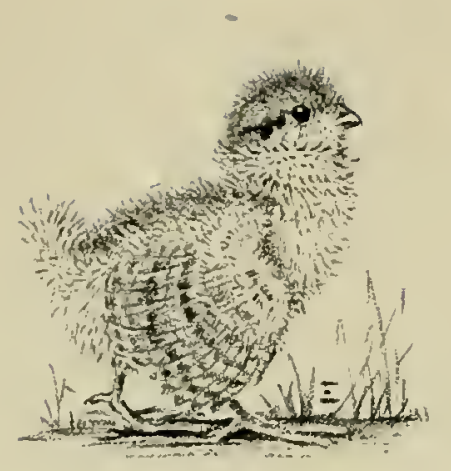




\section{CHAPTER XII}

\section{PRODUCTIVITY OF GROUSE POPULATIONS}

By Robert W. Darrow

\section{POPULATION CHARACTERISTICS}

Composition - According to Age - Sex Ratios - Grouse, Densities - Nest Densities - Brood Densities - Adult Densities - Situration l'onnt - Rate of Spreal - CarRYing Capacity

\section{PRONUCTIVITY OF POPULATIONS}

Breeding, Success - Survival Durixg Eich Life Peiriod - Nest Period - Brood Period - Adult Period - Net Pronucturtty - Ijafe Equatioxs

THE BIOLOGICAL BAIANCE SHEET

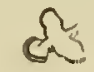

\section{SUMIMARY}

In the same way that individual grouse exhibit certain peculiaritics of hehavior so also do grouse populations have characteristic resctions fo various influences and circumstances. (p. 513).

Grouse productivity is the result of a continual tug-of-war hetwcen the forces tending to increase the population and those tending to reduce it. $1 \% 551$ ).

The factors of increase include primarily the various components of the reproductive potential of the species. Factors such as shelter. food and weather fall in this category only insofar as they are favorable. ( 1.551$)$.

Decimating factors include predation, disease, hunting and accillents. (p. 551 ).

When one limiting factor (such as predation) is eliminated, others tend to take its place. (p. 552).

It is probably the cumulative effect of a number of small factors becoming active at the same time, rather than any one of them alone, that nust often causes marked variations in grouse populations. (p. 551 ).

Relative productivity from year to year tends to vary inversely with the density of the breeding population. (p. 540).

When a fall grouse population numbers at least twice the corresponding breeding population it may be considered to represent a good crop. (1. 539). 
The sex latio has anesaged nearly even during the luvestigation hut a temlency has been noterl for a regnlar seasonal variation to take plare. (p. 511).

$\Lambda$ verage survival rates olserved have been approximately 61 per cent for ne-ts, 40 per cent for chicks and I6 per cent among adults on areas where no hunting recurred. (p. 525, $527,531)$.

A considerable proportion of the hunting losses usually experienced appear to be deduetible from the overwinter mortality which would otherwise take place. (p. 538).

Individual coverts vary in their ability to support grouse populations over winter, depending basically on the quality of the cover. This concept has been termed carrying capacity. (p. 522).

Densities of population tend to be higher in discomnected "woodlot" coverts than on wilderness range. (p. 520).

Adults tend to avoid crowding above an average of one bird to four acres of grouse cover even in the hest habitats. (p. 521).

Grouse tend quite rapidly to move into a covert whose population has been depleted out of proportion to those surrounding it. (p. 522).

Over a period of years productivity oscillates first to one side and then to the other of "dead center". (p. 516).

Management may bring about a rise in the average population level but, once it has reached the improved plane, the tendency toward equilibrium will again assert itself. (p. 516).

Real abundance, like real seareity, is an abnormal situation, to eorreet which Nature is constantly striving for a balance. (p. 553).

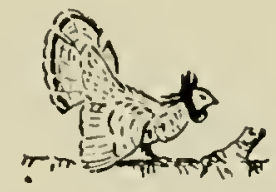

The potential productivity of most organisms is very high. As an entomologist has pointed out, a single pair of plant lice and its offspring eould produce enough progeny in 12 years to cover completely the surface of the earth if all the various causes of mortality were removerl. Grouse differ only in degree*.

But in actuality unimpeded increase is seldom, if ever, approached. From its first appearance each speeies lias faced constant conllict with a more or less adverse environnent. Is a result it has lecomie adapted to a distinct biological niche, entailing innumerable interrelationships with other species and influences. In this way its produetivity has been eontrolled. As stated by Yappen

"We may perhaps regard the organisms, hoth plants and animals, occupying any given hahitat as woven into a complex hut unstable weh of life. The character of the web mas change as new organisms appear un the seene and old ones disappear during the phases of succession, hut the weh itself remains."

The mechanism of regulation, however, is highly complex and is only beginning to be understood.

One of the carly attempts to explain it was that of Malthus ${ }^{2 a}$ who eame to the conclusion that penpulations are directly controlled ly competition for food and that they always increase to the

* sece Chapiter IIII, p. 35.1. 
limit of sustenance. Inspired by this principle. Darwin hased on it his theory of natural

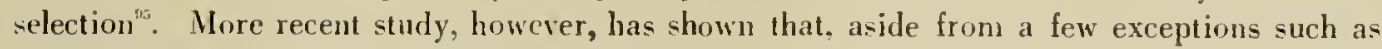
deer which, in the absence of predators. have overbrowsed their winter range in certain localities, lack of food is seldom a limiting factor. As pointed ont by McAtee ${ }^{256}$, only rarely is the solution so simple as Malthus supposed.

Rather a host of interdependencies, both direct and indirect, are involved. Outstanding among them are those associated with the factors of shelter. food, weather, and predation. Less obvious are such influences as mating success, fertility and physiological resistance. Their combined interaction tends, on a long-term basis, to maintain the numbers of wildife species in a state of equilibrium compatible with the biological niches to which they are adapted.

In preceding chapters the various factors affecting grouse abundance have been considered individually. It is proposed to discuss here their combined effect on populations of this game bird as observed during this study.

\section{POPULATION CHARACTERISTICS}

As discussed in the chapter dealing with general habits, individual grouse exhibit certain peculiarities of adaptation and behavior. In the same way grouse populations also have a typical pattern of composition as well as characteristic reactions to varions influences and cir. cumstances. A knowledge of these is of the utmost importance to the game manager because in many respects they govern the extent to which management practices may he effective.

\section{Composition}

A fundamental factor in determining the productivity of any species is the agre- and sexcomposition of the population. This is particularly true for those which, unlike the grouse. do not breed their first year, but it is still of potential inportance with these birds.

\section{According to Age}

In New York the great majority of grouse chicks hatch during the last week of May or the first week of June. These young birds have been considered adult by September and are capable of breeding the following spring. Therefore, populations of this species are made up entirely of mature individuals except during the summer.

At hatehing time the chicks have always considerably outnumbered the adults, the actual degree varying with breeding success and nest survival. On Connecticut Hill they have averaged 2.6 times as many, while on the Adirondack area the proportion has been $3.1: 1$, reflecting the usually lower nest mortality on this type of range. One should not assume, however, that a degree of nesting failure sullicient to cause a reversal of this situation may not have occurred elsewhere or may not be experienced on the study areas at some future time.

As the brood period progresses the preponderance of chicks diminishes until by the end of August the young birds usually but little exceed the adults in number. On Conmecticut Hill the proportion* at this time has averaged $1.0: 1$, ranging from 1.6:1 in a year of high productivity (1934) to 0.4:1 following a season of brood failure (1933). On the northern tract the average was 1.4:1 and the extremes 3.0:1 in 1936 and $0.4: 1$ in 1935.

Data have not been sufficient to permit an analysis of age groups above the one-year level, although there is considerable evidence that among wild populations few grouse live more than three years ${ }^{\Delta}$.

* Figures represent number of clicks fur each adult.

$\triangle$ See Chapter V1II, p. 360. 


\section{Sex Ratios}

Among newly-hatched grouse the proportion of males to females has been very nearly equal. At the Research Center this has been true both for chicks derived from wild eggs and for hand-reared stock.

During the course of the Investigation the sex of birds encountered in the field has been judged so far as possible. But, as many a grouse hunter knows, there is no one sure way to tell males from females on such occasions." Nevertheless certain criteria are arailable, particularly in the spring. At this season especially and, to a lesser degree at other tines, male grouse, when flushed, tend to rise rapirlly from the ground while females tend to fly low for some distance. The sex of drumming and nesting lirrls is, of course, obvious. During the summer, too, most females are readily identified by the presence of a brood or by their broody actions.

Summer data. laking into consideration also drumming and nesting information gathered dnring the spring, afford a reasonably accurate estimate of sex ratios at the heginning of the fall period. Data for the Connecticut Hill area are shown in table 72 . In compiling this table, birds recorded as "sex unknown" have been omitted.

\section{TABLl: 72. SUMIER SEX RATIOS OF ADULT GROUSE AS INDICATED BY POPULATION ESTIIATES-CONNECTICUT IILL AREA*} - IUGUST 31, 1930-1912

\begin{tabular}{|c|c|c|c|c|c|}
\hline leur & $\begin{array}{l}\text { Number } \\
\text { of males }\end{array}$ & $\begin{array}{l}\text { Number } \\
\text { of females }\end{array}$ & $\begin{array}{l}\text { Total } \\
\text { sexed }\end{array}$ & $\begin{array}{l}\text { Per cent } \\
\text { male }\end{array}$ & $\begin{array}{l}\text { Per cent } \\
\text { femule }\end{array}$ \\
\hline $\begin{array}{l}1930 \ldots \\
1931 \ldots \\
1932 \ldots \\
1933 \ldots \\
193 . \ldots \\
1935 \ldots \\
1936 \ldots \\
193 . \ldots \\
1938 \ldots \\
1934 \ldots \\
19.40 \ldots \\
19.11 \ldots \\
1912 \ldots \\
\end{array}$ & $\begin{array}{r}19 \\
50 \\
00 \\
26 \\
105 \\
120 \\
100 \\
52 \\
72 \\
56 \\
90 \\
63 \\
72\end{array}$ & $\begin{array}{r}36 \\
75 \\
105 \\
33 \\
107 \\
112 \\
121 \\
93 \\
115 \\
156 \\
115 \\
112 \\
91\end{array}$ & $\begin{array}{r}55 \\
156 \\
20.1 \\
59 \\
212 \\
262 \\
221 \\
145 \\
187 \\
210 \\
211 \\
175 \\
166\end{array}$ & $\begin{array}{l}34.5 \\
50.6 \\
18.5 \\
41.1 \\
49.5 \\
45.8 \\
45.2 \\
35.0 \\
38.5 \\
26.7 \\
16.3 \\
36.0 \\
43.4\end{array}$ & $\begin{array}{l}65.5 \\
49.4 \\
51.5 \\
55.9 \\
50.5 \\
51.2 \\
5.1 .8 \\
61.1 \\
61.5 \\
73.3 \\
53.7 \\
61.0 \\
56.6\end{array}$ \\
\hline Total.... & 962 & $1,30.6$ & 2,266 & 12.5 & 57.5 \\
\hline
\end{tabular}

- Fipures apply to entire area censused each year and. therefore. in many cases exced thou for the portion of the area used in iracing ropulation fluctuations.

The average ratio of 12.5 males to 57.5 females indieates that the summer grouse population on the Connecticut Hill area during the years covered contained more females than males. At the same time ratios as low as 31 males to 65 females (approximately). and as high as 49 males to 51 females. indicate that the relationship is far from constant.

On the other hand. surveys conducted on the smaller Adirondack area failed to indicate a consistent predominance of females in the summer population (table 73).

Because spring surveys on the Alirondack area were primarily designed to provide breeding population estinates, detailed drumming and nesting information was not recorded. Therefore, aside from females with hroods, it was necessary to judge largely ly flight chararteristies when the hirds were flushed. The number of individuals was low and the results as noted are inconsistent. Whether these data are of sufficient weight to invalidate the idea 
that the number of females exceeds the number of males in a normal summer population is a question. In all probability they are not.

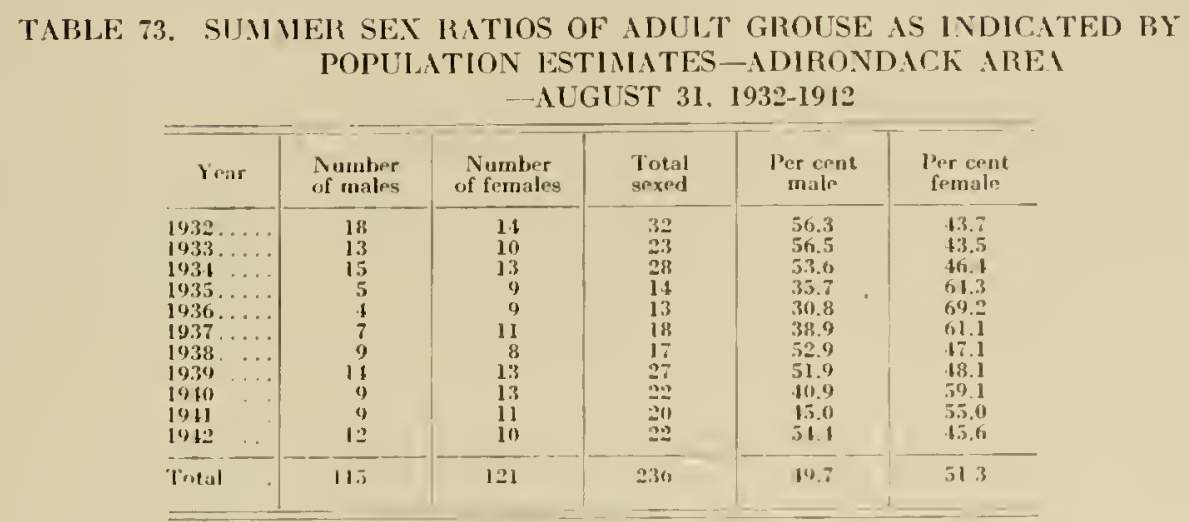

Supplemental data on this subject are available from the records of grouse that have been shol in connection with discase studies, popmlation control and other special problems. There is reason to believe, however, that much of these data is subject to errors which tend in accumulate rather than to compensate for each other. Thus. the use of a cylinder bore gum by several collectors over a period of years may have had more effect upon the sex ratio of the hirds shot than did any variations which may have actually existed in the wild. Giving a wide shot pattern at close range, but with little capacity to kill at longer distances. its use resulted in a tendency to take the more closely lying females with somewhat more regularity than males rising at a greater distance. Therefore. instances in which the entire grousc population, or nearly so. of a covert was taken are al hetter hasis from which to draw conclusions.

In table 74 are summarizd data representing the cullection of practically the entire grouse population on a tract comprising three compartments totalling 1.526 arres atjacent to the Connecticut llill study area hetween 1934 and 3936. num compartment being covered each year.

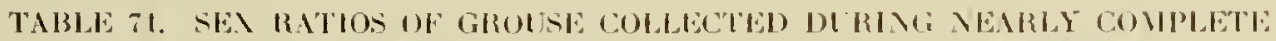
EIIMIINTION OF POPULATION ON TR ICT IDJ ICENT TO CONNECTICIT IIIL,OCTOBEI-IIRCH, 1931-1936

\begin{tabular}{|c|c|c|c|c|c|}
\hline Yrar & $\begin{array}{l}\text { Number } \\
\text { of tuales }\end{array}$ & $\begin{array}{l}\text { Vumbir } \\
\text { of females }\end{array}$ & "Tolal* & $\begin{array}{l}\text { Per cent } \\
\text { male }\end{array}$ & $\begin{array}{l}\text { Per resut } \\
\text { femalo }\end{array}$ \\
\hline $\begin{array}{l}1934 \ldots \\
1935 \\
10,36 .\end{array}$ & $\begin{array}{l}15 \\
31 \\
20\end{array}$ & $\begin{array}{r}9 \\
23 \\
18\end{array}$ & $\begin{array}{l}21 \\
57 \\
313\end{array}$ & $\begin{array}{l}62.5 \\
50.6 \\
.32 .6\end{array}$ & $\begin{array}{l}37.5 \\
10.1 \\
47.4\end{array}$ \\
\hline Total & 109 & 30 & 114 & 58.0 & 42.0 \\
\hline
\end{tabular}

* Dora nut indude hirde so badly shot.up that sex determination was imposaible.

To the extent that the tract on which the collections were made is representative of Connecticut Hill as a whole, one may assume from these data that males exceeded females in numbers during the fall and winter on the basic study area also, but that there seemed to be a trend during the years involved toward a better balanced ratio. 
It wonld thus appear that the sex ratio among adults at the end of the summer, in which females predominated. shifted to one having a majority of males between that time and early winter. Further, the fact that there has leen no indication of hens suffering heavier decimation during the fall than cocks suggests that males outnumbered females among the maturing hirds of the year.

Analysis of collections of young grouse from August through December since 1938* further indicates this possibility (tahle 75). It is recognized that these data are subject to sampling errors through selective shnoting as noted above. although to a lesser degree because similarity in the habits of birds of this age is probably greater than anong older birds. Nevertheless the differences are sufficiently consistent to he noteworthy and statistically sound as demonstrated by analysis of variance. But the reasons for unbalanced sex ratios among naturing grouse are still obscure.

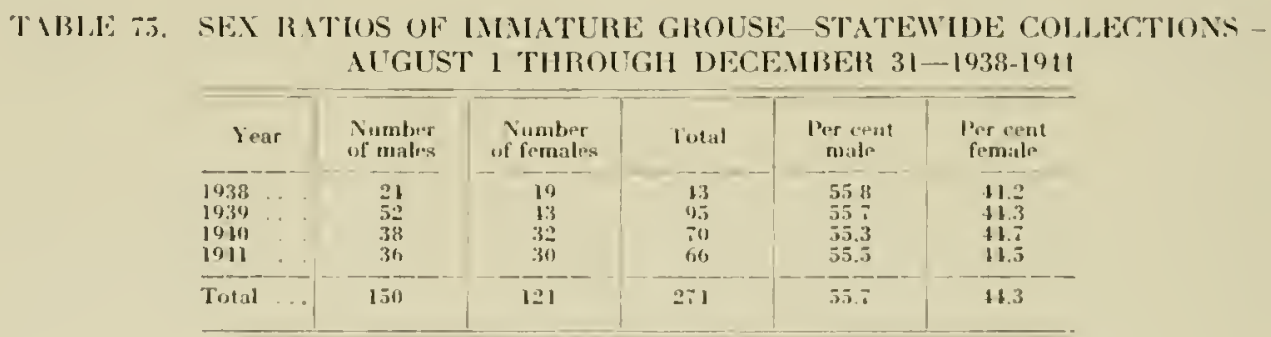

If the trend so far suggested is real. then some influence must bring about another shift in the sex ratio from more males in winter to more females in summer. Such a factor scems to be a differential mortality in spring through which the rocks suffer more heavily. Of the 47 . dead grouse (which were sexahle) found on the Connceticut Hill area throughout the Investigation and judged to have died from January througl May. 59.5 per cent were males. That this is quite likely associated with the breeding behavior of the curks. especially drumming. is indicated by the fact that their mortality eurve reaches its peak in April while that of their mates drops off following a high in llarchs.

These data. therefore. indicate the existence of a basic tendency for the sex ratio of wild grouse populations to become unhalanced in the spring through a disproportionate mortality among males, following which the balance is swung the other way hy preponderance of this sex among the maturing young in the fall. Normally the ratio is most nearly even at some time in late winter or early spring.

It is likely. however, that this fundamental pattern is often modified hy various circum. stances. For example. in a sason of failure in the chick crop. the number of maturing males might not he sufficient to offset the summer surplus of females. Then the ultimate effect would he an augmented proportion of breeding females the following spring tending to compensate for the previous year"s low productivity. On the other hand. the greater the proportion of maturing younc in the fall. and henes the number of extra males added. the more the resultant ratio would favor that sex.

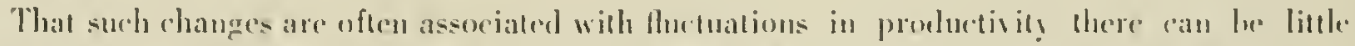
douln, lout it has been impossille from the data at hand le determine just how strong the

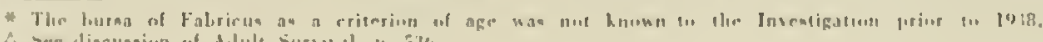

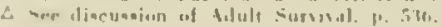


relationship may become. In any case, there seems small likelihood that, in rears of increasing or high abundance. variations in sex ratio exert a controlling effect on grouse populations. Throughout the 13 years of the Investigation the proportion of breeding females on the areas under observation has at no time heen serjously reduced. Nevertheless, one must bear in mind that a major perind of grouse scarnity has not been experienced during this study.

\section{Grouse Densities}

Of interest also, to the sportsmen as well as the game manager. are the grouse population levels which may be attained in various coverts. It is often next to impossible to appraise adequately estimates of game abundance hecause they are not expressed in relation to some definite standard of measurement. What one observer may judge a plentiful supply of birds. another, with different experience, may consider only noderate. The data of the Investigation are, therefore, expressed in terms of the acreage involved.

The ratio of population to covert area is the density of population. In tracts of extensive forest, of which the Adirondack area is representative, the halitable range is usually the same as the total land surface. In disconnected coverts. which constitute most of the more heavily hunted grouse range in the Northeast, this is not true as only a part of the intervening fields is appreciahly used by these hirds. As explained in Chapter III. qrouse cover in such localities has been considered to const iute all woodland and lorush plus a 100 -foot belt of the. adjacent open land. This strip. on Connectirut Hill. amounts to about 29 per cent of all of this type present.

\section{Nest Densities}

As discussed in Chapter $\mathrm{V}$, instances have often heen ohserved where several grouse nested in quite close proximity to one another. But. in dealing with population behavior, coverts must he considered in their entirety. It has never heen possillle. lowever. to locate all the nests on the study areas. On the other hand. it is helieved that nearly all the females present in the spring have nested during most years*. although this proportion sepms in have heen somewhat low on Connecticut Hill in 1935 and 1936. Therefore. the number of this sex present during the breeling season represents a generally close approximation of nest density (table 76).

It is apparent that nests are normally more numerous within the disconnected tracts of grouse cover making up "woodlot" range than in extensive forest areas. This, of course, is also true of the average abundance of grouse. Nevertheless. wide variations are common in loth regions.

With respect to individual coverts, the highest densities witnessed by the Investigation occurred on certain units of Connecticut Hill in 1935, even though the breeding population for the whole area was only the second highest observed. Just what levels were reached cannot he determined precisely, however. because no means has heen devised for accurately judging the number of females failing to nest. The available evidence suggests that this proportion may have been above average in that year. $I_{n}$ any event at least seven or more nests per 100 acres occurred on two units of 155 and 166 acres respectively, the number on the latter perhaps having been nine or ten as the density of breeding females was 11.5. On another unit of 131 acres, the corresponding figmre was at least nine. During the same season several similar coverts held only three nests per 100 acres. At the other extreme a 230-acre 
covert had only two nests in 1930. while in later years densities of less than wo per 100 acres have not been uncommon on this area.

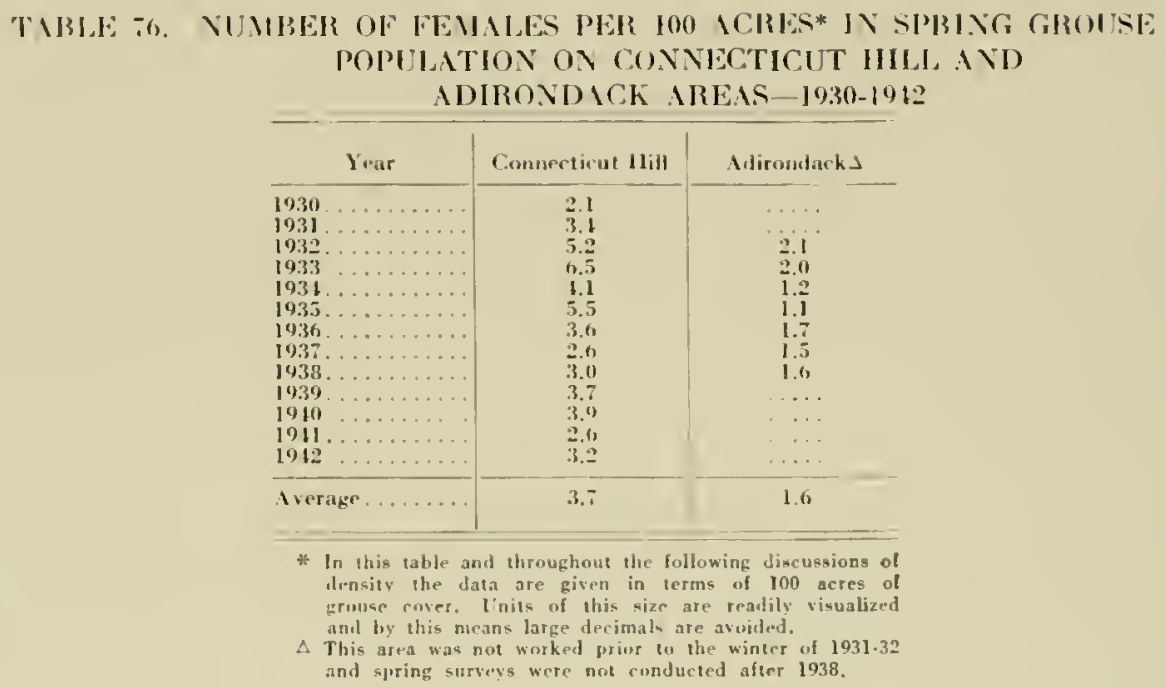

\section{Brood Densities}

Grouse brond densities have been computed directly hecause complete censuses have been made each summer on the Connecticut Hill and Adirondack study areas (table 77 ).

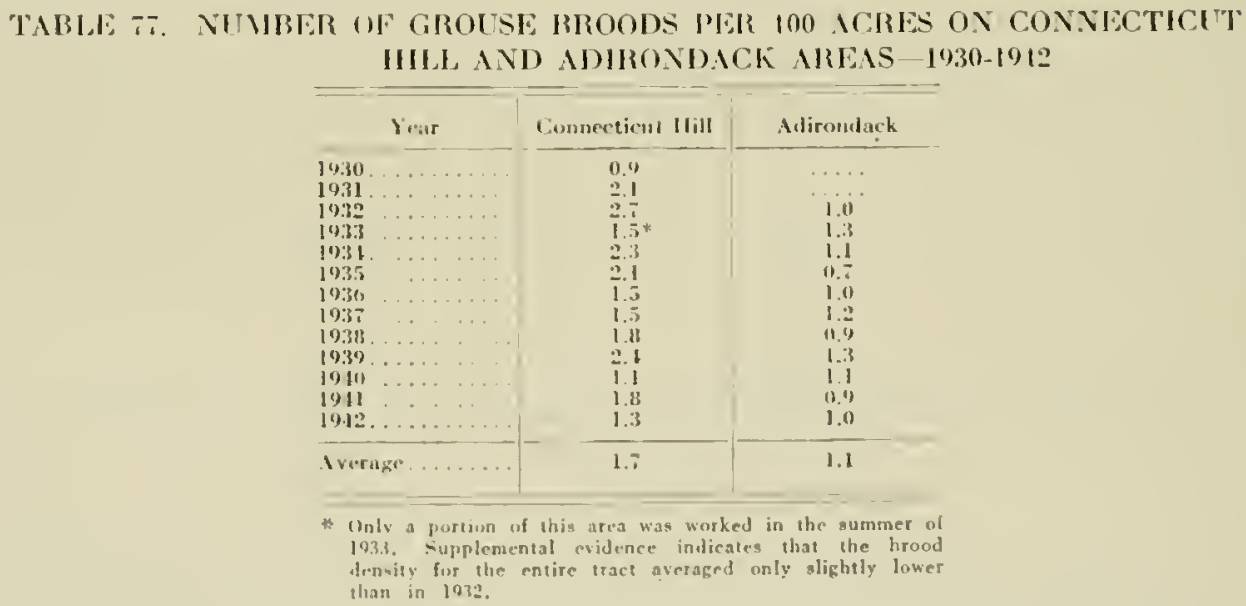

As with the abmdance of the species at all seasons. hrods have usually ben markedly less frequent in the forest hahitat of the northern area. Similarly their numbers have fluetuated less from year to year on that tract. On three accasions. however, their density on Comecticut IJill has dropped within the ranoe of that on the Adirondack area. heing just the same in 19.10.

lndividual coverts have often exhilited higher, as well as lower. densities than any appearing in the averages for the area as a whole. Thum as man! as 4.3 hroods per 100 acres have been found on one tract of 183 acres while similar unit. have hela only wne in a number of instances and in 1930 none at all were oberved on che of 231 acre- 
Brood density depends on the number of nests established, their mortality and the degree of renesting*. When nest losses are high, renesting may become quite important. This was apparently the case in several years when the number of family groups found during the sum. mer was greater than otherwise would have been possible in view of the breeding population and the nesting losses observed. On the other hand. there is at times a low abundance of broods in spite of bigh nest survival, as in 1935 when the data suggest that the degree of breeding failure may have been ahove average.

\section{Adult Densities}

The abundance of adult grouse is of especial significance at two times each year-the breeding season and the hunting season. In table 78 are presented the densities attained dur. ing the Investigation over the Connecticut Hill and Adirondack areas.

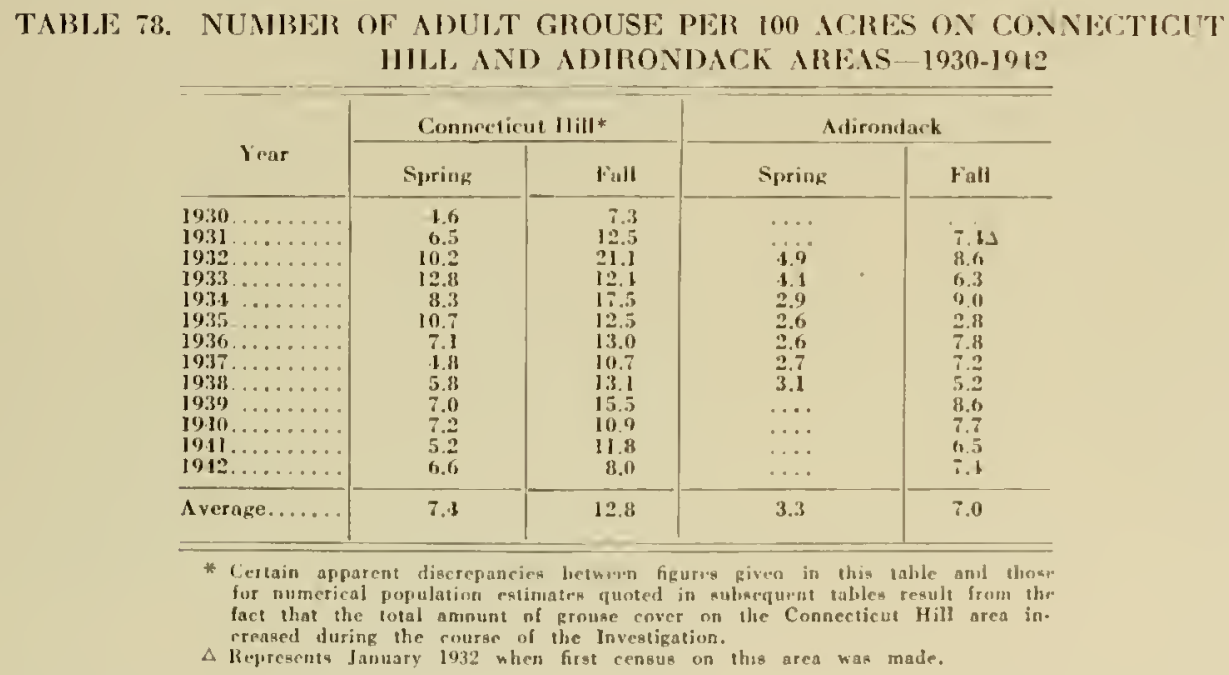

Population estimates during the hminting season have not been made regularly. Sufficient work has been done at this season, however, to demonstrate that losses between September 1 and mid-October in general are minor. Therefore, data for the end of the brood period (August 31) when the young hirds become adult have been considered representative.

Comparison of the two areas shows that grouse have been consistently more numerous over the woodlot range of Connecticut Hill. Beyond this. individual coverts have reached still higher levels. Thus in 1935 the breeding population on a 166 -acre unil was 22.3 birds per 100 acres while in other instances densities exceeding 15 birds have been recorded. Similarly in the fall a maximum of 38.8 on the same scale occured over $] 87$ acres at the end of the brood period in 1934. On another mit the figure was 31.5 in 1932 and a number of cases above 20 have been noted. It should he pointed out. however, that these very high densities have invariably been lowered through dispersion to surrounding less well stocked coverts, largely prior to the hunting season. But such population equalization has had no observable effect on the arerage density for the area as a whole.

As would be expected the minimum densities noted were associated with the generally low 
grouse abundance of 1930 . These were 1.8 and 2.7 for spring and fall respectively.

On the Adirondack area the birds have occupied certain portions of the tract to a much greater degree than others*. For this reason the density over several hundred acres has been regularly somewhat higher than the average figures listed in the tahle. Likewise, throughout this type of range one will encounter pockets where grouse abundance closely approaches that of more diversified coverts.

In the same way preference is often exhibited for particularly favorable situations in the smaller coverts of the woodlot type. Especially in the fall the hunter will frequently encounter concentrations within limited areas far exceeding anything attained over a range unit as a whole.

Yet. even over larger tracts, abundance greater than observed during this study is indicated by accounts of others. Thus $\mathrm{King}^{213}$ has reported a bird to 3.8 acres in the fall $(55.5$ per 100 acres). In a letter to the authors Rowan ${ }^{\Delta}$ tells of a party of four hunters who, in the fall of 1941 , killed more than 2.000 grouse in one week while operating from a single camp some 70 miles northwest of Edmonton. Alberta. But what is perhaps the most remarkahle statement is that of Mershon ${ }^{201}$ who relates that in 1891 two hunters fushed 2,000 grouse in one day near Hentock, Michigan.

In addition to the two principal study areas a number of others have been censused at various times. These, although essentially similar in character to Connecticut Hill afford data from other sections of the State. The longest record is that of the Catskill area in southern Albany County where surveys were conducted in March of the years 1931.1941 except for 1936. Densities of adult grouse there averaged 6.7 per 100 acres and ranged from 2.5 in 1931 to 10.3 in 1933. Densities for the late winter season (February-March) for six years between 1931 and 1938 on the Pharsalia Game Refuge in Chenango County averaged 7.3

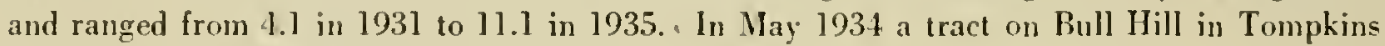
County held 5.2 hirds on the same scale.

Supplemental information has also been obtained for range of more extensive character through the collahoration of technicians cmployed liy the Resettlement Administration on two areas located on the fringe of the western Adirondacks and on one area in the western Catskills. Adult densities on these ranged from 1.8 to 4.7 in the spring and from 5.2 to 10.6 in the fall.

Summarizing. the better grouse range of the woodlot type in the State may produce hunting scason populations of upwards of 20 hirds per 100 acres in individual coverts, although the average has heen about 12 . Yet even in years of generally high numbers, instances of scarcity are not uncommon. Alundance is usually lower over intermediate and wilderness range although local concentrations arc often cncomntered.

Most of the population censuses in recent years outside of New York have heen in Michigan and Minnesota. Hallitat conditions in these regions are so different from those here that the results are not strietly comparahle. Nevertheless a number deserve mention. It should he noted that all of them employed the "gridiron methol" developed by King which is entirely different from the "complate strip" method used in the New York Investigation.

Based on a survey of two square miles of a township in the l'igcon River Statc Forest, Mich-

* Ser Chapier 111. p. 173.

$\Delta$ Rowan, W. I'rolmaor of Znology, Univernily ol Alberta. 
igan, in 1933, Ruhl* estimated 3,444 grouse in the township, or nearly 15 birds per 100 acres (September). He states that the population on this area "during the 1933 season seemed to be high although the number was less than observed during the 1932 season." For the same area in Septemher 1932 Fisher $^{197}$ gives an estimated 191 grouse per section (sq. mi.) or 29.9 per 100 acres as well as 250 per section or 36.4 per 100 acres on a tract in Munuscong State Park (Mich.) in November 1934.

In Minnesota, Trippensee ${ }^{37 z}$ gave 269 birds as the pre-hunting season (October) population of four sections of the Superior National Forest in 1934, or 10.5 birds per 100 acres, and 316 as the population of an area of the same size in the Chippewa National Forest, or a den. sity of 12.3 .

King $^{213}$ states that the maximum hreeding season population observed near Cliquot, Minnesota, was a bird per four acres or 25 per 100 acres. The highest spring ahundance recorded by Fisher $^{137}$ was 15.4 per 100 acres in April 1933 on the Munuscong Park tract.

\section{Saturation Point}

From time immemorial hunters and others interested in wildlife have dreamed of game abundance far in excess of any it has been their fortune actually to encounter. Thus fancifully populated were the "happy hunting grounds" of the American Indian. Today's sportsmen are no less given to wishful thinking. One of the principal measures of the worth of a game management program is its effectiveness in increasing the density of such species as well as reducing the frequency and severity of periods of scarcity.

Yet one must not expect the impossible. Regardless of how the habitat may he improved or the impact of decimating agencies relieved, populations will not increase alove certain levels except sporadically. These levels and the ultimate limiting factors vary with the species. Deer, for instance, and other animals and birds which are highly gregarious may become very abundant hefore some environmental condition halts the advance. The ruffed grouse. on the other hand, appears to exhibit an intolerance of crowding above an average of about one bird to four acres even in the best coverts. This has heen termed the saturation point of the species and is a property of the bird itself apart from the quality of its environment.

Evidence of this characteristic lies in the fact that, when greater densities occur. dispersion of excess individuals to surrounding territory tends to take place immediately. The influ. ence, however, does not apply to birds of the year until after they have reached adulthood. Thus it seldom manifests itself except in the fall. While crowding almost invariably occurs within a brood group at the end of the summer. its numbers are usually accommodated within the same covert. But. when the covert as a whole is overpopulated, wider movements ensue.

During the Investigation, behavior of this kind has been observed on several occasions. Outstanding was the 187-acre covert which held 38.8 grouse per 100 acres as of August 31, 1931. Censuses later that fall showed its population to have dropped to 21.8 while those of adjacent units gained. Similarly in 1939 the density on a plot of 131 acres decreased from 29.5 to 20.6 while those of others nearby increased.

That the birds will tolerate as many as 25 per 100 acres (approximately) was demonstrated when a portion of the Connecticut Hill area held a breeding population of 22.3 in 1935. King ${ }^{213}$ has reported the same conclusion for an area in Minnesota.

\footnotetext{
* Ruhl, H. D. personal letter to the authors July 2, 1936.
} 


\section{Rate of Spread}

Yet exceeding the saturation point is not the only cause of birds shifting from one covert to another. It is a basic axiom that "nature abhors a vacuum." Thus grouse spread from well-populated to unoccupied or poorly stocked territory unless for some reason the latter is definitely unsuitable. Because even adjacent coverts seldom follow the same trend in their population fluctuations such differences in relative abundance occur frequently. Accordingly; movements tending to equalize the distribution of the hirds are continually taking place. But, because the net changes in population are usually small, it is difficult to follow them in detail.

Although adjustments of this kind may oceur at any time they are mainly associated with the fall and early spring seasons. In fact the terms "fall shuffle" and "spring sluuffle" respeclively have been used to describe them." In general hirds of the year are chiefly involved.

The best indication obtained by the Investigation concerning the rate of spread into depleted habitats came in connection with a series of population control studies on land adjoining the Conmecticut Hill study area. During the winter of 1933-34, 34 gronse were collected from coverts totalling 681 acres of grouse cover, reducing the number present to four birds by April. One month later 12 others had moved in and by the end of August further novements had increased the number of adults to 29 , a gain of 25 in five months.

The following winter. similar collecting was done in another covert of 572 acres. By Mareh I there were 13 grouse left. During the ensuing month 13 more were taken but the population in early April was estimated at 17. Two additional hirds were shot on April 7 and two others were lost to natural enemies during the spring redueing the number left to $13 \mathrm{by}$ the end of May. Apparently none had moved in since Mareh. By Angust 31 the estimated adult population had risen to 21 , representing a total influx of at least 25 birds in six months.

In 1935-36, the population of a third tract of 273 aeres was reduced from 22 birds in October to two in March. But in the interim, 24 lirds had been taken. Thus four birds, in addition to those present at the start. must have moved in during the late fall and winter. Five more moved in by the middle of April, one more in May and one more in the summer.

As the collecting carried on in these experiments was not hegun until after the period of the "fall shuffle", these records demonstrate that appreciable shifts to restock depleted coverts may oceur in March and carly April and show that summer movements also take place. The consistency of the results on all three units indicates that such movements are customary and that any unoccupied territory in good grouse range will be quickly found hy roving birds except possibly during times of widespread scarcity. The distance from which these inflowing hirds liad cone is not known although in most instances they at least had to negotiate stretelies of open land from a hundred yards to a quarter mile wide. That such distances are no barrier to grouse has been noted in the discussion of molility ${ }^{\Delta}$. It is probahle that many of the hirds had traveled much farther than simply across the open land extending to the next covert.

\section{Carrifer Capacity}

The ability of game range to support wi]dlife is limited. Like any container it can be filled only so full. Surpluses spill over and must find accommodation elsewhere or he elim.

* vere Chander 1. p. 255.

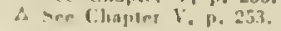


inated in some other way. Game managers have used the term carrying capacity to denote this limitation.

Carrying capacity is a property of the environment and accordingly differs in various habitats. Basically the determining factors are food and shelter, as is most clearly seen among the hoofed manmals which exhibit no apparent psychological intolerance of crowding. With respect to grouse it is associated primarily with shelter values, no indication of food scarcity having been ohserved*. Furthermore. its effect is ultimately limited by the saturation point of the species ${ }^{\triangle}$ although few of the coverts surveyed in this study have evidenced such high quality. Whatever the variations, however, any area of range has a fundamental capability of supporting only a certain number of birds.

The most significant measurement of this relationship is the number of individuals remaining after the critical period each year. For the ruffed grouse in the Northeast this falls at the end of the winter season. Other things heing equal, the population of a given area should, in theory, return to about the same level each spring regardless of the extent to which the density of the preceding fall may have exceeded it.

But, although this concept seems fundamentally sound. the number of grouse recorded from year to year at this time on the areas studied by the Investigation has not been constant. Rather they have fluctuated considerably as shown in table 79.

'TABLE 79. RELATIVE SECURITY OF FALA, GROUSE POPULATIONS ON CONYECTEAT HILL AND ADIRONDACK AREAS-1930-t9H

\begin{tabular}{|c|c|c|c|c|}
\hline \multirow{3}{*}{ Year* } & \multicolumn{4}{|c|}{ Fistimated population } \\
\hline & \multicolumn{2}{|c|}{ Consecticut IIIll } & \multicolumn{2}{|c|}{ Adiroudack } \\
\hline & Strptember & April & September & Aprils \\
\hline $\begin{array}{l}1930 \ldots \ldots \ldots \\
1931 \ldots \ldots \ldots \\
1932 \ldots \ldots \ldots \\
1933 \ldots \ldots \ldots \\
1934 \ldots \ldots \ldots \\
1935 \ldots \ldots \ldots \\
1936 \ldots \ldots \ldots \\
1937 \ldots \ldots \ldots \\
1938 \ldots \ldots \ldots \\
1939 \ldots \ldots \ldots \\
1910 \ldots \ldots \ldots \\
1911 \ldots \ldots \ldots \ldots\end{array}$ & $\begin{array}{l}161 \\
276 \\
165 \\
271 \\
420 \\
300 \\
311 \\
273 \\
331 \\
391 \\
276 \\
300\end{array}$ & $\begin{array}{l}112 \\
225 \\
283 \\
199 \\
256 \\
170 \\
123 \\
118 \\
177 \\
181 \\
132 \\
167\end{array}$ & $\begin{array}{l}\cdots \\
70 \\
51 \\
73 \\
23 \\
6.1 \\
59 \\
42 \\
70 \\
63 \\
53\end{array}$ & $\begin{array}{l}\cdots \ldots \\
36 \\
2.1 \\
21 \\
21 \\
22 \\
25 \\
(35) \\
(28) \\
(29) \\
(27)\end{array}$ \\
\hline
\end{tabular}

* Reptesentr fall of each overwinter period.

$\triangle$ Figures in parenthesis computed from number of adults remaining the following september on hasis of average summer losses for precediog years since no epring census was niade on this area atter 1938.

Considering the average of the two highest survivals on Conneclicut Hill as an index, the carrying capacity of this area must be at least 270 . This level was associated with the high fall densities of 1932 and 1934. Yet in 1931, 1933, 1937 and 1940 populations exceeding it only slightly suffered substantial mortality. On the other hand, the low number present in 1930 lost few birds.

The less densely populated Adirondack area at first glance appears to have maintained a more stable level, especially from 1933 to 1936. But the residual number of grouse during these years cannot be considered to represent carrying capacity as nearly twice that many have

\footnotetext{
* See Chapter IV, n. 229.

$\Delta$ see discussion of Saturation Puint, P. 521.
} 
survived on other occasjons. Furthermore, analysis of these figures on the basis of their percentage deviation from the mean (figure 42) shows the variability on the two areas to have been quite similar.

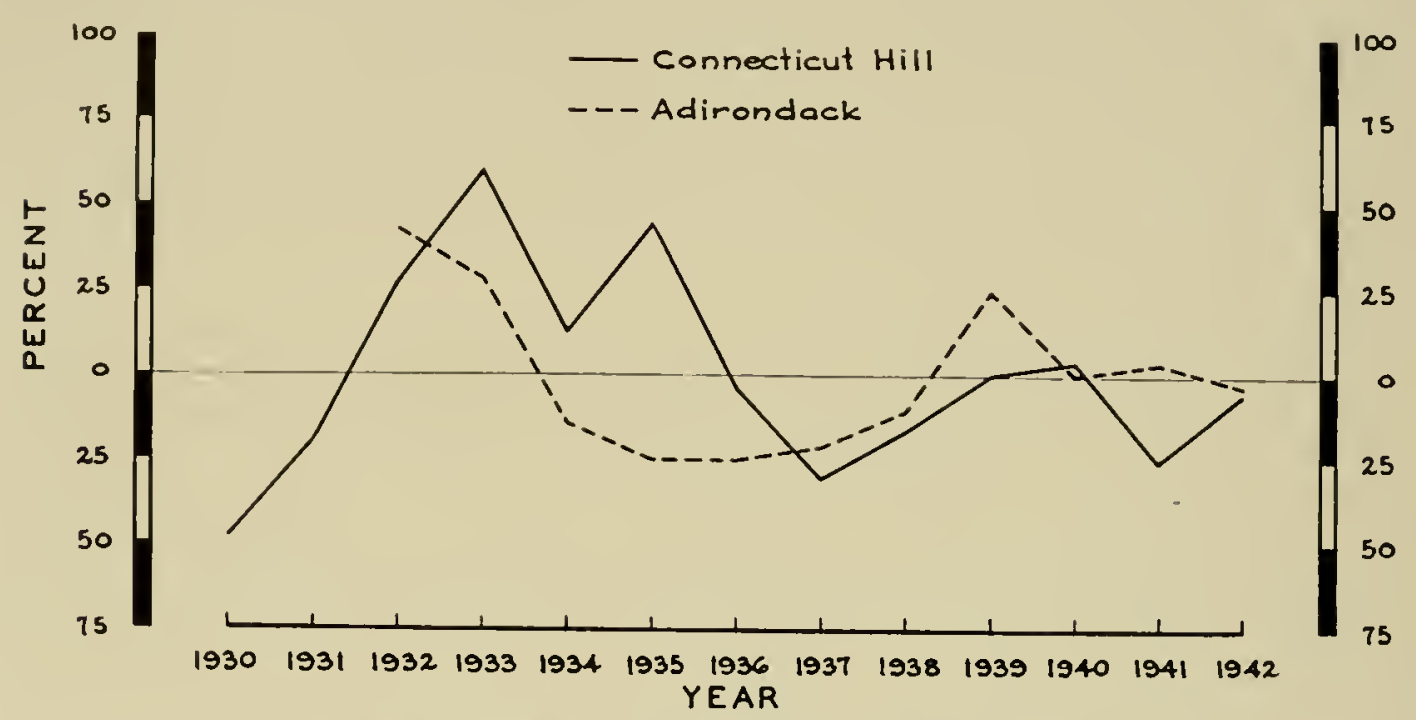

FIGURE 42. DEVIATION FROM MEAN OF SPRING POPULATIONS GN CONNECTICUT IHIL AND ADIRONDACK AREAS-1930-1942

Apparently other factors such as weather and predation have varied sufficiently in their effect 10 overbalance the influence of carrying capacity to a greater or lesser degree each year.

A much greater degrec of definiteness has been reported by Errington ${ }^{120}$ with respect to marginal grouse range in cerlain north-central states. His data, covering seven years, indicate a relatively stable survival of about 18 birds on five square miles of such range in Wisconsin. In the same paper he also records data taken by $\mathbb{W}$. J. Breckenridge showing a ralher definite level of from eight to ten birds on a square mile tract in Minnesota over a H-year period. Thus it may be that grousc on marginal range do exhibit a considerable uniformity of survival. Scattered observations in connection with pheasant studies in New York have shown one or two grouse usually prescut in isolated woodlots of 50 to 60 acres. But in the better grouse hahitats of the Northeast the data consistently refute it.

Nevertheless some idea of the relative quality of different coverts is afforded ly the spring densitics recorded. For the Connecticut Hill area as a whole. the residual population at this time reached 10.7 lirds per 100 acres in 1935 and on the hasis of sample data exceeded 12 in 1933. A possibly more representative figure would be the average of the highest level for each of the component units regardless of the year in which it occurred. or 12.7. Among these units one held an estimated 22.3 hirds per 100 acres in 1935 hut this was believed to he to a considerable cxtent the result of influx from surrounding territory during late winter rather than survival of the hirds actually present in the fall. Aside from this instance the greatest number of grousc succesfully wintered by such a habitat was 19.9 per 100 acres in the same year. On the other hand other nearby everts have never been able to support cren ten hirds on the same scale. 
The situation on the Catskill and Pharsalia study areas has been quite similar to that on Connecticut Hill, the highest spring densities for the entire tracts being 10.3 and 11.1 birds per 100 acres respectively.

The maximum noted on the Adirondack area, however, was 4.9 again indicating that the carrying capacity of wilderness range is lower than that of more diversified territory.

\section{PRODUCTIVITY OF POPULATIONS}

Productivity may be defined as the relationship between a wildlife population and the breeding stock which produced it. Usually it is considered to apply from one breeding scason to the next. The game manager, however, is also interested in the production of as great a fall surplus as possible. But whatever standard is used. the number of birds present at any time is the resultant of the inherent reproductive capacity of the species modified by a wide variety of delimiting conditions, environmental influences, and decinating agencies.

The reproductive capacity of the species has already bcen consilered". The other major influences have also been taken up separately. It remains to discuss their combined cffect on grouse populations as observed during the Investigation. The first source of loss to the potential productivity of such a population is failure to breed.

\section{Breeding; Success}

As has been discussed in Chapter VIII (p. 355) non-breeding has been a diffecult factor to evaluate. Nevertheless there has been no indication that such a condition anong unale grouse has been important. Among females, too, it appears to have been of negligible significance during most years. In the seasons of 1933, 1935 and 1936, however, on the Connecticut Hill study area less than 75 per cent of the females appear to have nested. Yet what influence or combination of influences may have brought about these variations is as yet unknown.

Beyond this point the principal yardstick of productivity is survival.

\section{Survival During Eacil life Period}

Survival is best measured according to the three life periods of the bird. The data presented here pertain chiefly to observations on the Connecticut Hill and Adirondack study areas. They are believed to be essentially representative of New York and similar sections of the Northeast. Elsewhere over the range of the species, however, entirely different conditions may exist.

\section{Nest Period}

As discussed in Chapter VII (p. 312), nest losses of about 39 per cent have been experienced over the State during this study. Survival, therefore, has averaged approximately 61 per cent, the degree varying more widely on individual areas (figure 24). Regarding the Connecticut Hill data, however, there is some indication that the mortality among nests under observation has been slightly higher than among those not located. But while the actual survival over this tract as a whole may have been somewhat greater than shown in the graph the variations from year to year are still representative.

Studies of certain other species, notably the ring-necked pheasant ${ }^{120}$, have revealed that a consideralle proportion of the total nest mortality suffered each season is usually compensated for by the renesting of hirds whose initial attempts were broken up. In the experience

\footnotetext{
* See Chapter IIII.
} 
of the Investigation this has been of little significance with respect to the productivity of ruffed grouse populations. Fenales that have more than just commenced incubation seldom undertake to renest, while for those that do the average clutch size is smaller and the degree of jufertility higher than among first nests*. Moreover, the great majority of the unsuccessful nests recorded had been destroyed during the latter part of the incubation period. Further evidence that renesting has not lieen important is the fact that the nest losses observed largely account for the differential between the number of females in the breeding population and the number of broods ultimately materializing in the area. Therefore this influence has not been considered strong enough to warrant separate recognition in the life equations presented later in this chapter.
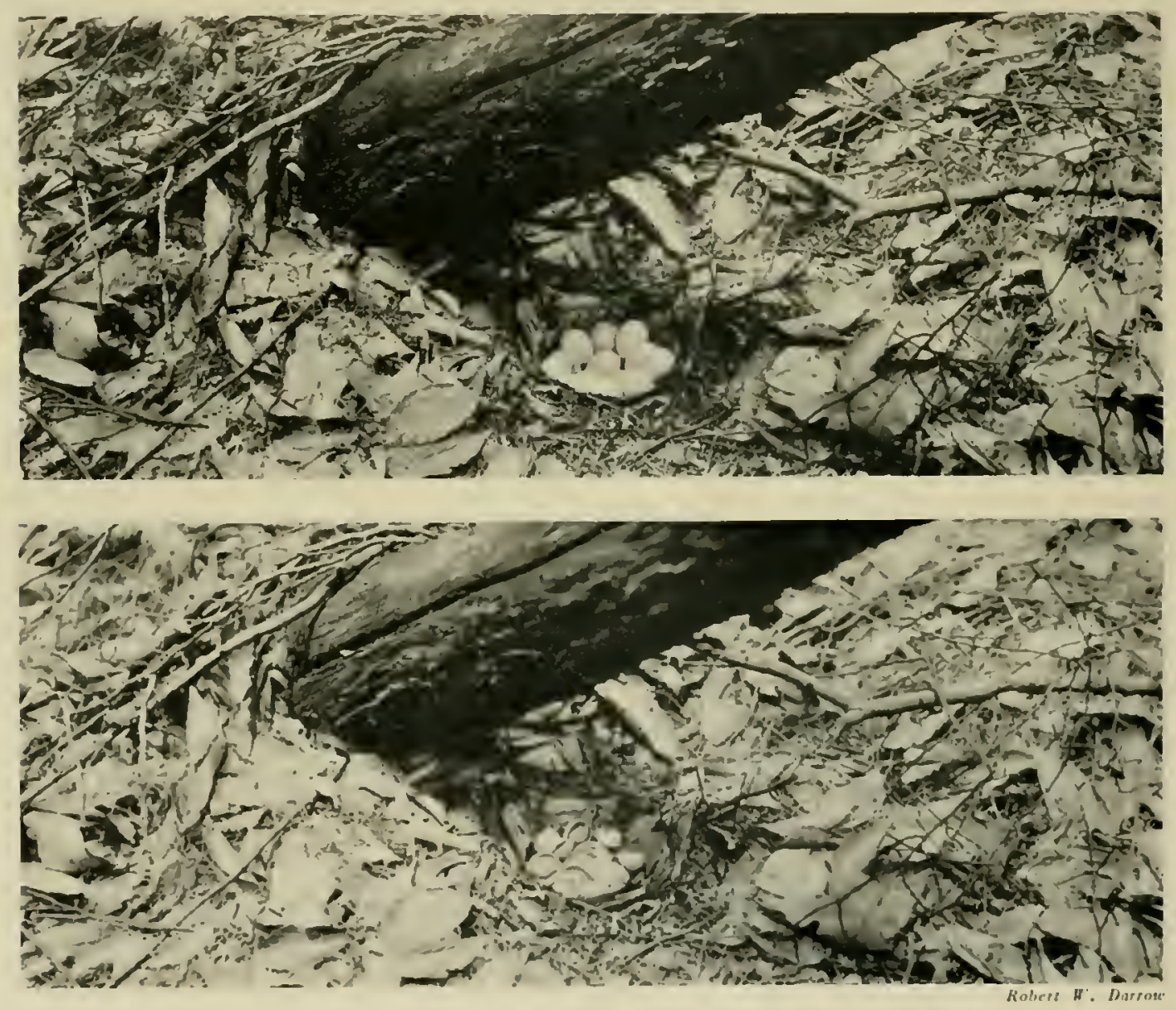

A SUCCESSFLL GROLSE NEST BEIORE ANI AFTEL HATCHINC.

The principal cause of nest mortality has consistently heen predation. A number of other sources of loss have lieen recorded lout altogether they lave accounted for only about one out of ten broken-up nests. or four out of 100 clutehes laid. The instanees of this kind which hase heen observed are listed in table 80.

In addition (o lusses resulting directly from ner-l destruction. productivity is also reduced - Sare chapter VIII, p. 301. 
during this period by the occurrence of infertile eggs and embryos which do not survive in chutches the remainder of which hatch successfully. These have been of minor importance in the experience of the Investigation." So also have been the eggs now and then filched by foxes and other predators.

TABLE 80. PROPORTION OF BROKEN-UP GROUSE NESTS OBSEIRVD DURING THE INVESTIGATION ATTRJBUTED TO VARJOUS CAISES 1930-1912

\begin{tabular}{|c|c|c|}
\hline Cause & Vumlerer & Prercent \\
\hline 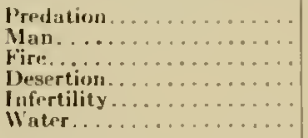 & $\begin{array}{r}551 \\
10 \\
13 \\
12 \\
3 \\
2\end{array}$ & $\begin{array}{r}88.8 \\
6.1 \\
2.1 \\
1.9 \\
0.5 \\
0.3\end{array}$ \\
\hline $\begin{array}{l}\text { Sub-tutal . . . . . . . } \\
\text { Canse undeterminatsle... }\end{array}$ & $\begin{array}{r}621 \\
27\end{array}$ & 100.0 \\
\hline Total ................. & $618 *$ & $\ldots \ldots$ \\
\hline
\end{tabular}

* A greater number ol broken-up nests were olsserved than were comparahle for correlatioa with the number known to have hatchel as shown in tahle 35.

Except for the occasional "drowning" of a nest, weather has had no recognizable effect on nesting success, although certain conditions may facilitate discovery ly predators.

\section{Brood Period}

By late August, broods comprising more than a hen and four chicks have been uncommon and those with fewer chicks frequent. Average survival, however, has varied appreciably between years (table 81), although the mean for the period covered on hoth the Connecticut Hill and Adirondack study areas has averaged slightly less than 40 per cent.

TABLE 81. BROOD SURVIVAL, RECORDED ON CONNECTICUT HHL AND ADIRONDACK SII D) AREAS-1930-1912

\begin{tabular}{|c|c|c|c|c|c|c|c|c|c|c|c|c|c|c|c|}
\hline \multirow{2}{*}{ Area } & \multirow{2}{*}{$\begin{array}{c}\text { Hrood survival } \\
\text { data }\end{array}$} & \multicolumn{14}{|c|}{ licar } \\
\hline & & $19: 30$ & 1931 & 1932 & 19.33 & 19.31 & 19.35 & 1936 & $19.3 \%$ & 1938 & 19.39 & 1910 & 1911 & 1912 & $\begin{array}{l}\text { Aver- } \\
\text { age }\end{array}$ \\
\hline \multirow{2}{*}{$\begin{array}{c}\text { Connecticut } \\
\text { Ilill }\end{array}$} & $\begin{array}{l}\text { Number clicks } \\
\text { liatched....... }\end{array}$ & 200 & 161 & 596 & 330 & 529 & 527 & 365 & 358 & 171 & 625 & 264 & 431 & 3.39 & 423 \\
\hline & Per cent survival... & 42.5 & 30.0 & 1.5 .2 & $2: 3.3$ & 48.6 & 19.2 & +5.8 & 41.1 & $3: .6$ & 37.0 & 12.1 & 40.5 & 221 & 30.8 \\
\hline \multirow{2}{*}{ Adirondack } & $\begin{array}{l}\text { Number chicks } \\
\text { hatched }{ }^{*} \ldots\end{array}$ & & & 163 & 139 & 120 & 60 & 110 & 110 & 100 & 142 & 100 & 100 & $13 \%$ & 116 \\
\hline & Per cent survival. & . & . & 41.7 & 21.5 & 19.2 & 11.7 & 58.2 & $\$ 0.0$ & 28.0 & 13.0 & 13.0 & 36.0 & 41.5 & 39.1 \\
\hline
\end{tabular}

*These figures in some cases are larger than those: given elsewhere with res]ect to [nopulation trends because survival datu were of ten secured on broods oceupying territory adjoining the area proper.

It has also shown a strong similarity in trend in the two localities. This is especially noteworthy in view of the distance between them and the fact that the general abundance of grouse on the two has been very different. Furthermore, adjustment of the data for each area by analysis of covariance for differences in the number of chicks hatched each year indicates

* See Cbapter vill. p. 365. 
that variations in the net effect of the forces responsible have paralleled each other quite closcly (figure 43 ).

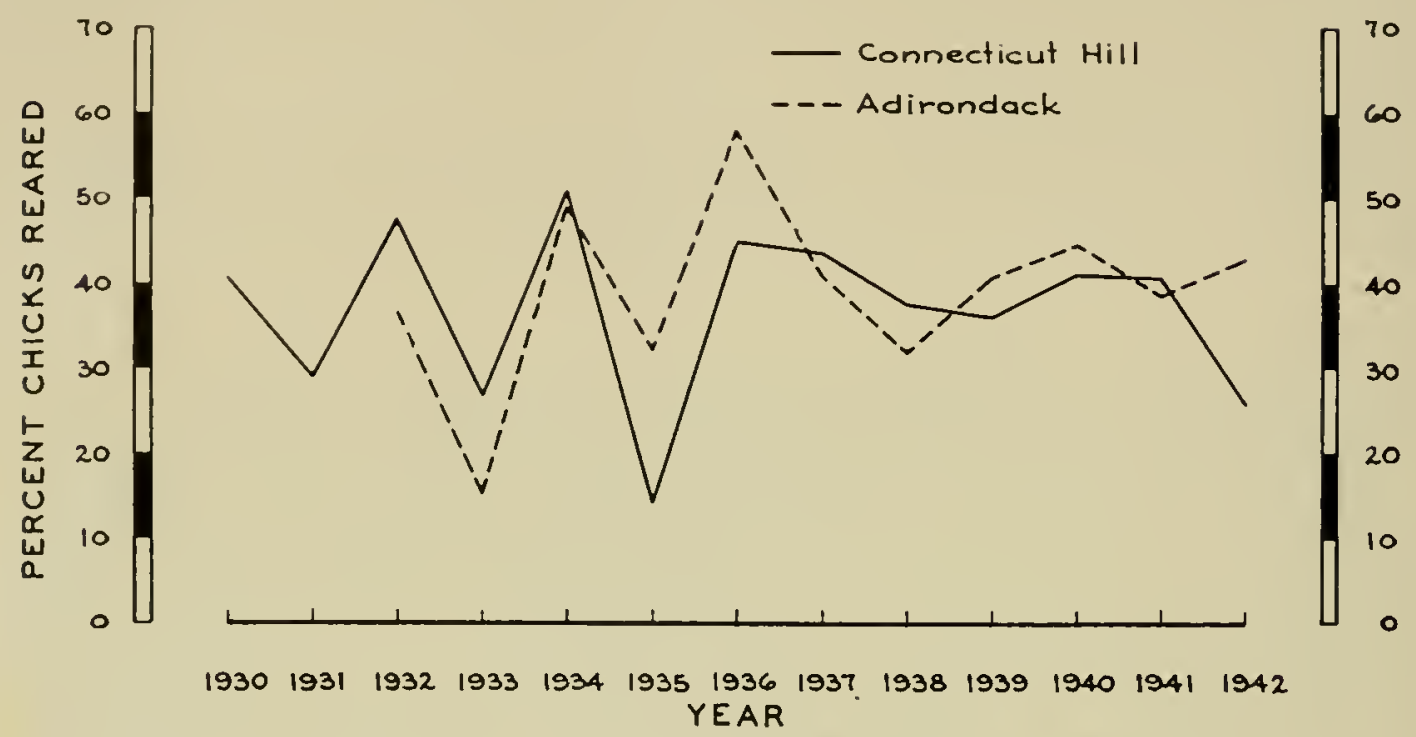

FIGURE 43. CROLSE BROOD SURVIVAL RECORDED OX CONNECTICUT IILL AND ADIRONDACK AREAS $-1930-1942$

The primary causes of losses at this age, however, are still a major problem. Predation secms to be responsible for roughly half the mortality in average seasons. Few specific data have been obtained to account for the remainder. As noted in Chapter VII (p. 316). a sul). stantial parallel has heen observed between the early decline among grouse chicks hatched and reared artificially at the liesearch Center and that among wild broods. But even here the closest diagnosis which has been possible so far is the ambiguous term "nutritional deficiency" which scems actually to refer to some physiological disturbance as sufficient food is always availahle to these hirds. Also studies of the foods eaten by wild chicks have indicated a superabundance. Another influence is weather but its significance has not been determined. althongh there can be little doubt that the cloudburst in central New York in early July. 1935. directly increased the mortality of wrouse chicks. Furthermore it scems most likely that the markedly lower survival experienced in some years may fundamentally be the result of some combination of these other factors rather than of preatation. There is no evidence, however, that disease has beem important.

Anong the relatively few chicks found dead nn the study areas, no cause of teath other than predation has bern mied. although in 2.1 .7 per cent of the cases no diagnosis at all could he made. Elsewhere fatalities resulting from highway and miscellaneous accidents have now and then been observed.

It has been suggested that. as the number of chicks hatched pre unit of area decreases, the corresponding proportion maturing tends to increase. The data. however, do not support such a conclusion as slown in table 32 , in which the records for the Comecticut Ilill and Adirondack areas were gronped according to the relative abundance of chicks at the beginning of the brood period. In fact on the northern tract, better survival was associated with the higher 

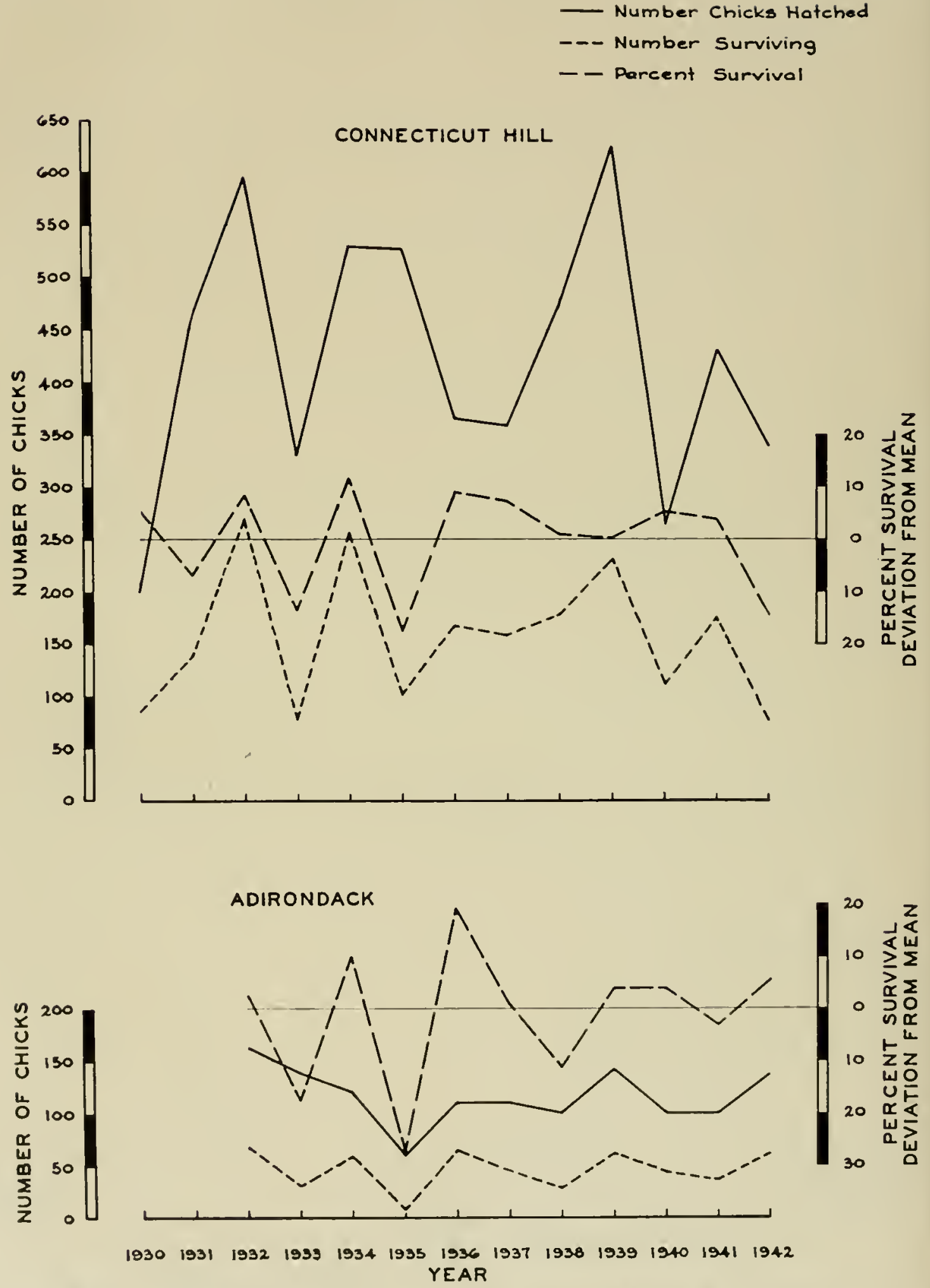

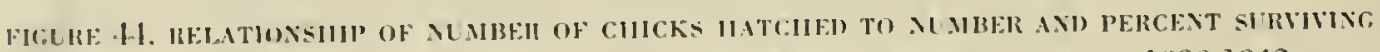

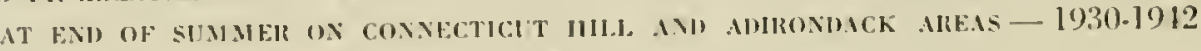


TABLE 83. REIATIONSHIP OF DENSITY OF BREEDING POPULATIONS TO SURVIVAL DURING TIIE BROOD PERIOD ON CONNECTICUT IILL A ND ADIRONDACK STUDY AREAS-1930-1912

\begin{tabular}{|c|c|c|c|c|c|c|c|c|}
\hline \multirow[b]{2}{*}{ Group* } & \multicolumn{4}{|c|}{ Confrecticut llill } & \multicolumn{4}{|c|}{ Adirondack } \\
\hline & $\begin{array}{l}\text { Avrrage } \\
\text { density of } \\
\text { breeders per } \\
100 \text { acres }\end{array}$ & $\begin{array}{l}\text { Average } \\
\text { number of } \\
\text { chicks } \\
\text { hatched }\end{array}$ & $\begin{array}{l}\text { Yearly } \\
\text { variation } \\
\text { io cliveks } \\
\text { hatched }\end{array}$ & $\begin{array}{l}\text { Per cent } \\
\text { survivals }\end{array}$ & $\begin{array}{l}\text { Average } \\
\text { derisity of } \\
\text { breeders imer } \\
100 \text { acres }\end{array}$ & $\begin{array}{l}\text { Average } \\
\text { number of } \\
\text { chicks } \\
\text { hatched }\end{array}$ & $\begin{array}{l}\text { Vearly } \\
\text { yariation } \\
\text { nu chicks } \\
\text { hitched }\end{array}$ & $\begin{array}{l}\text { Per cent } \\
\text { survival }\end{array}$ \\
\hline $1 \ldots \ldots \ldots$ & 5.2 & 366 & $200-171$ & 40.7 & 2.8 & 62 & $60-100$ & 50.0 \\
\hline $11 \ldots$. & 7.2 & 131 & $364-625$ & 37.9 & 1.7 & 81 & $83-109$ & 38.3 \\
\hline $111 \ldots \ldots$ & 10.6 & 181 & $330-596$ & 30.8 & $\ldots$ & .. & $\ldots$ & $\ldots$ \\
\hline
\end{tabular}

* Group 1-years having a Lreeding population density, on Connecticut libll of undre 6 per 100 acres, on the Adirondack area

of under 4 .

Group III-vears on Connerticut Hill with dengitics over In.

$\triangle$ Analysis by chisquare shows that on Connecticut llill Group Il was very close to the total arerage while Groups I and II: หere signifirantly different.

\section{Adult Period}

In appraising adult survival, September 1 each year has lieen taken as a starting point because this is the lime the young of the year are considered to "come of age". By the same date the following year slightly less than half have been left as an average, most of the loss having taken place prior to the breeding season (tal)le 81 ). On Connecticut Hill, however, a much higher survival followed the low fall populations of 1930 and 1931. A similar relationship was observed on the Adirondack areal in 1935-36.

TABIE 81. ADI I'T SI RVIVAL RECORDED ON COVVECTICI T IHI. AVD ADIIOVDACK STITDY AREAS-1930-t911*

\begin{tabular}{|c|c|c|c|c|c|c|c|c|c|c|c|c|c|c|}
\hline \multirow{2}{*}{ Area } & \multirow{2}{*}{ Adult survival data } & \multicolumn{13}{|c|}{ Yinit } \\
\hline & & 1930 & 1931 & 1432 & $14: 33$ & 10.31 & $14: 5$ & 1936 & 14:3? & 19.38 & $10: 30$ & 1110 & 1911 & $\int_{1100^{\circ}}^{A v e r}$ \\
\hline \multirow{2}{*}{$\begin{array}{l}\text { Comnectient } \\
\text { tlill }\end{array}$} & $\begin{array}{l}\text { Initial septemler } \\
\text { popmation ... }\end{array}$ & 16.1 & 276 & 16.5 & 271 & 120 & 300 & 311 & 273 & 3.31 & 341 & 276 & 300 & 315 \\
\hline & 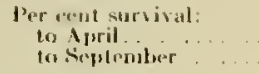 & 88.2 & $\frac{81.5}{71.1}$ & $\begin{array}{l}60.9 \\
12.1\end{array}$ & 50.5 & $\begin{array}{l}61.0 \\
17.1\end{array}$ & $\begin{array}{l}5 \mathrm{~h} .7 \\
18.0\end{array}$ & $\begin{array}{l}39.5 \\
37.0\end{array}$ & 51.2 & $\begin{array}{l}5.3 .11 \\
18.8\end{array}$ & $\begin{array}{l}16.2 \\
11.2\end{array}$ & $\begin{array}{l}1.8 \\
15.3\end{array}$ & $\begin{array}{l}35.7 \\
12.3\end{array}$ & $\left\{\begin{array}{l}58.1 \\
119.8\end{array}\right.$ \\
\hline \multirow[b]{2}{*}{ Adirondnck } & $\begin{array}{l}\text { Initial sipgtember } \\
\text { popmlation......... }\end{array}$ & & $600 t$ & 70 & 51 & 73 & 2.3 & 01 & 50 & 12 & 70 & 63 & 53 & 5: \\
\hline & $\begin{array}{l}\text { Per cent survival: } \\
\text { to April } \$ \text { to September. . . . } \\
\text { to }\end{array}$ & $\begin{array}{l}\cdots \\
\cdots\end{array}$ & $\begin{array}{l}66.7 \\
53.3\end{array}$ & $\begin{array}{l}51.1 \\
37.1\end{array}$ & $\begin{array}{l}1-.1 \\
56,9 \Delta\end{array}$ & $\begin{array}{l}28.4 \\
21.9\end{array}$ & $\begin{array}{l}91.3 \\
69.6\end{array}$ & $\begin{array}{l}34.4 \\
28.1\end{array}$ & $\begin{array}{l}42.4 \\
12.1\end{array}$ & 71.4 & 31.3 & 39.7 & 13.1 & $\begin{array}{l}17.1 \\
12.1\end{array}$ \\
\hline
\end{tabular}

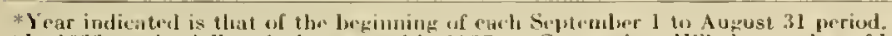

$\Delta$ In 19:33 on the Alirondinek arem and in 1937 on Conmelicut llill the number of birds moting into the aren during the summer inceded the inubire lost.

trislimate made in Jumury 1932 und therefore somewhit bolow siptember level.

tSpring ceususes wre lliscontinum! on this area after 1938.

As has been discussed in Chapter VII. some 80 per cent of the losses during this period have been attributable to predation, the remainder resulting largely from accident and disease. Just what the relative importance of these minor causes has been. however, is difficult to judge because few of the dead grouse located during the survey have been found in a thoroughly fresh condition that would permit recognition of disease. On the other hand, field experience indicates that accidents are infrequent and the collection of specimens for pathological examination has revealed a very low incidence of disease. At the same time one must re- 
member that the effectiveness of all these decimating agents is affected in varying degrees by a number of factors such as cover quality, weather and buffer alundance. The basic data of the Investigation are not influenced by the factor of hunting since this has been prohibited on the prinary study areas. Neither has there heen any evidence of starvation observed.

The following table summarizes the analyses of the dead grouse picked up. Some of the specimens charged to predation very likely died of other causes but the available evidence gives no reason to believe that the proportion of such instances has ever exceeded the difference between the figures listed below and the 15-odd per cent estimated to cover such losses*.

TABIE: 85. PROPORTION OF DEAD GROUSE FOUND ON VARIOUS STUDY AREAS ATTRIBUTED TO VARIOUS CAUSES-1930-1912

\begin{tabular}{|c|c|c|c|c|c|c|c|c|}
\hline \multirow{2}{*}{ Causes } & \multicolumn{2}{|c|}{ Consecticnt Ilill } & \multicolumn{2}{|c|}{ Adirondack } & \multicolumn{2}{|c|}{ Other areas } & \multicolumn{2}{|c|}{ Total } \\
\hline & Number & I'er cent & Number & Per cent & Number & l'er cent & Number & Per cent \\
\hline $\begin{array}{l}\text { l'redation . . . . . . . . } \\
\text { Accident. . . . . . . . . } \\
\text { Disease. . . . }\end{array}$ & $\begin{array}{l}116 \\
17 \\
20\end{array}$ & $\begin{array}{r}92.3 \\
3.5 \\
4.2\end{array}$ & $\begin{array}{l}16 \\
\cdots \\
\cdots\end{array}$ & $\begin{array}{l}100.0 \\
\cdots \\
\cdots\end{array}$ & $\begin{array}{l}125 \\
\cdots \\
\cdots\end{array}$ & $\begin{array}{l}100.0 \\
\cdots\end{array}$ & $\begin{array}{r}587 \\
17 \\
20\end{array}$ & $\begin{array}{r}94.1 \\
2.5 \\
3.2\end{array}$ \\
\hline $\begin{array}{l}\text { Sulb-total . . . . . . } \\
\text { Cause undetrminable . }\end{array}$ & $\begin{array}{l}183 \\
1.50\end{array}$ & $\begin{array}{l}100.0 \\
\cdots\end{array}$ & $\begin{array}{l}16 \\
11\end{array}$ & $\begin{array}{l}100.0 \\
\cdots\end{array}$ & $\begin{array}{r}125 \\
86\end{array}$ & $\begin{array}{l}100.0 \\
\cdots\end{array}$ & $\begin{array}{l}621 \\
550 \\
\end{array}$ & $\begin{array}{l}100.0 \\
\ldots \\
\end{array}$ \\
\hline Total ............. & 933 & $\ldots \ldots$ & 30 & $\ldots \ldots$ & 211 & $\cdots \cdots$ & $11: 4$ & $\ldots \ldots$ \\
\hline
\end{tabular}

On the various study areas, causes other than predation were identified only on Connecticut Hill. The instances of accidental death are all attributable, so far as is known, to collisions with trees. fences and sometimes buildings. Also they have occurred chiefly during the fall and, in most cases, appear to have heen associated with the so-called "crazy flight". Losses resulting from crippling by hunters have not been a factor on the areas from which this material was collected, although on heavily shot tracts they undoubtedly enter in ${ }^{\Delta}$. Incidental records from elsewhere over the State have also involved a number of other types of accident. Along improved highways hirds are often struck hy automobiles. Females have been found burned to death on their nests following forest fires. And. now and then, a grouse has been caught in a fox trap. The disease relationships olserved are discussed in Chapter $\mathbf{X}$.

The number of adults surviving from year to year has been only slightly correlated with diffcrences in the level of the preceding fall population (figure 45).

On the other hand, the number of adults lost each winter has horne a marked relationship (1) fall abundance. As discussed elsewheret. other conditions being similar, the more numerous grouse are the more frequently they will be encountered and killed hy predators. The data for each year on the two main study areas are comparcel in figure 16 . In both cases, as the fall population has risen, so also has the mortality.

Yet the proportion lost has been less related (figure 1.7) similar, the degree of change las licen less and exceptions more frequent. The correlation has been stronger on the Adirondack area than on Connecticul Hill.

At the same time. when the data were analyzed on the lasis of average values after the

* See Chaprer III, 0. 319.

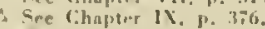

t tee rhapier lii. 1i. 321

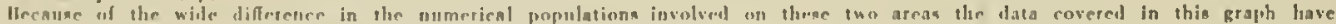
been reduced in pereentage devintion from the man. 


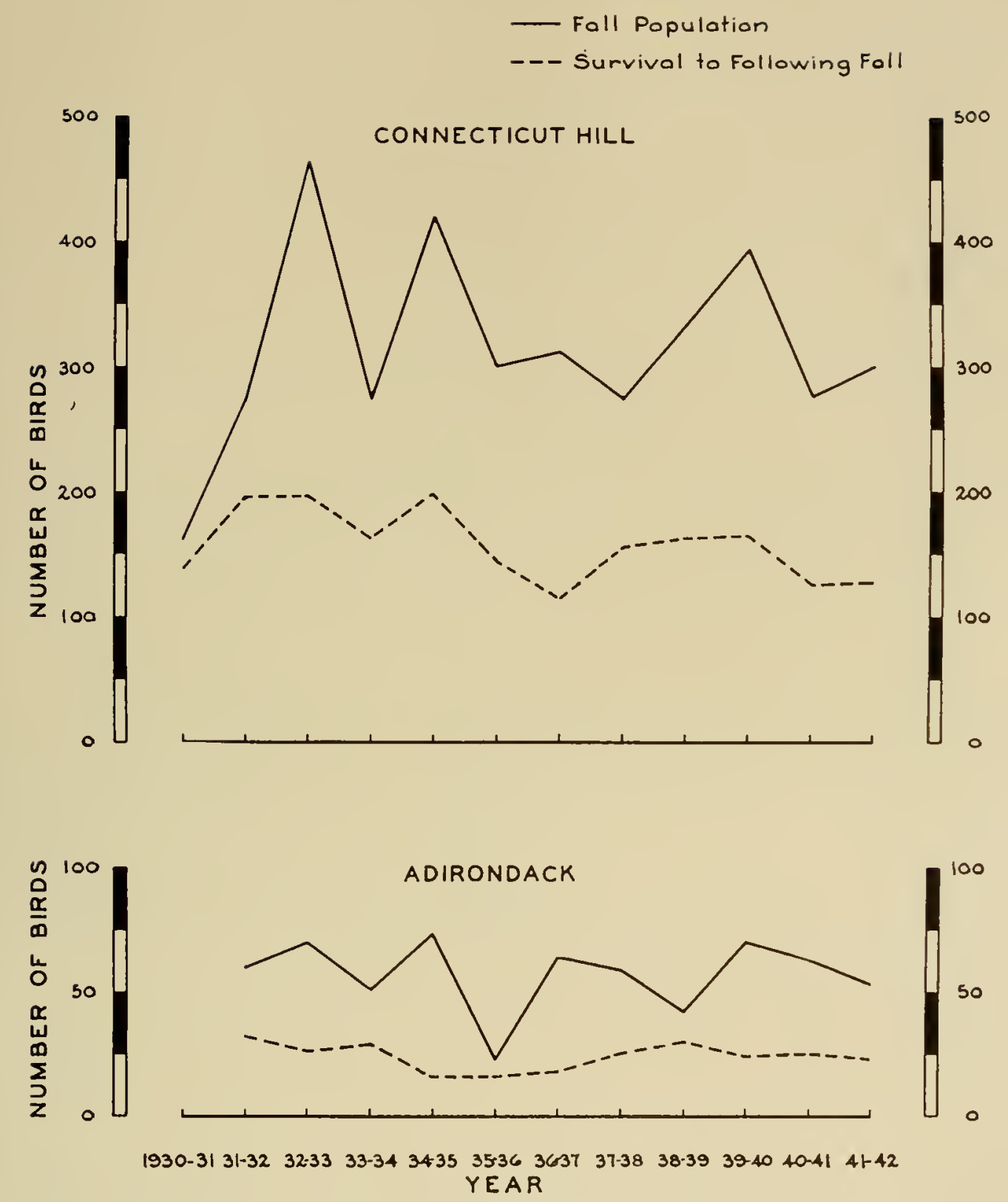

FIGURE 45. RELATIONSHIP OF ADULT SURYIVAL TO FALL POPULATION LEVEL ON CONNECTICUT HILL ANI ADIRONDACK AREAS - 1930-1942

records had been grouped according to the density at the beginning of the period each year, further evidence of a fundamental relationship of this kind was revealed (table 86 ). Again it was more pronounced on the northern area.

It is on this basic tendency for the proportion of mortality to vary with the fall population level that the concept of carrying capacity* depends. That the figures have in many instances

* See diseussion of Carrying Capacity, p. 522. 


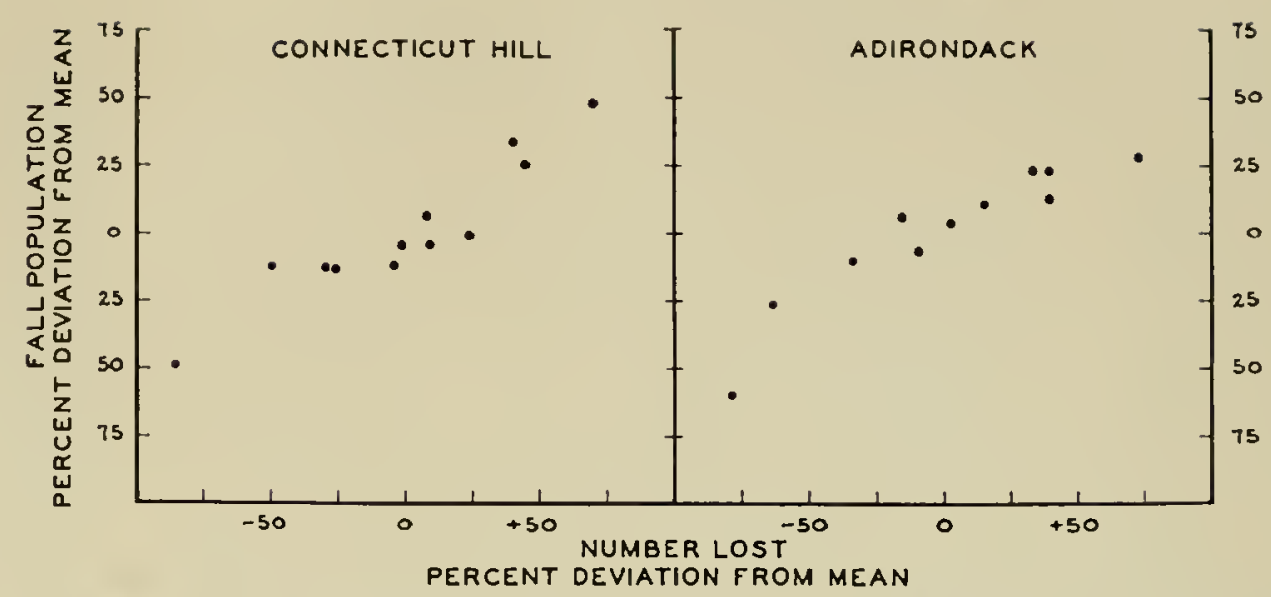

FigURE 46. RELATIONSHIP OF FALL, POPULATION LEVEL TO NUMBER OF ADULTS LOST ON CONNECTICUT IIILL AND ADIRONDACK AREAS - 1930-31 TO 1941-42

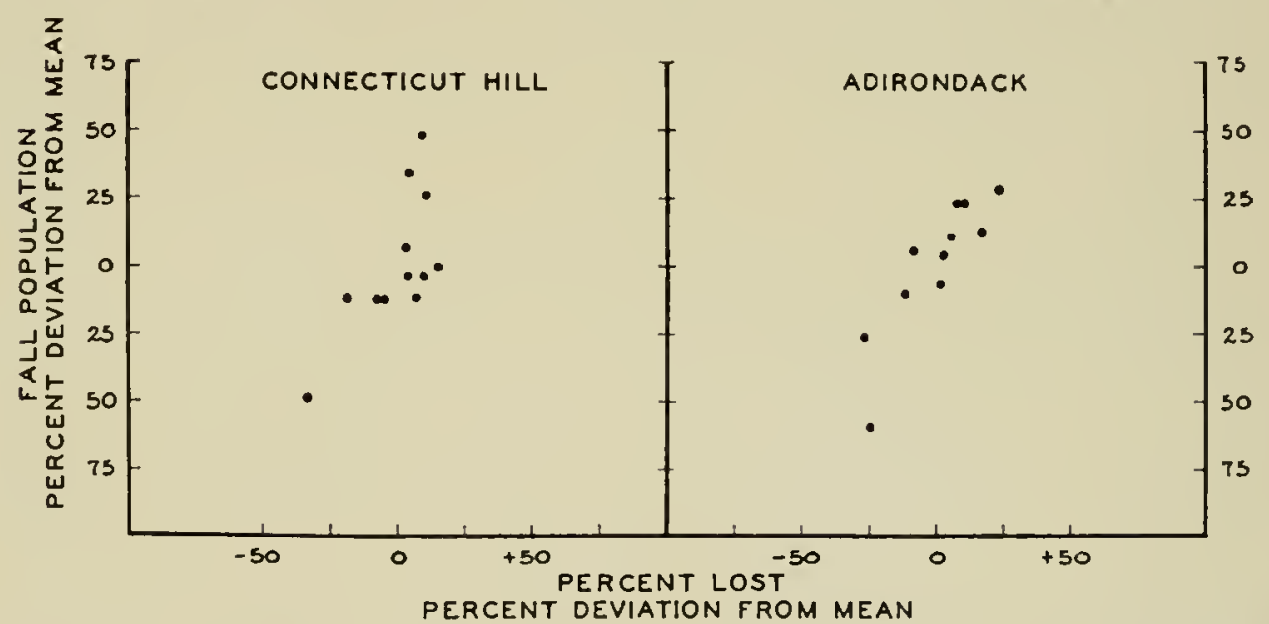

FIGURE 47. RELATIONSHIP OF FALI, POPULATION LEVEL TO PROPORTION OF ADULTS LOST ON CONNECTCUT IIIL. AND ADIRONDACK AREAS - 1930-31 TO 19.11-12

failed to eonform to snch a pattern may be traced to the fact that mortality is conditioned by a number of highly variable cnvironmental forees in addition to the more stable ones of range quality. The relative number of birds surviving to breed in any year appears to be determined to a large extent by the particular complex prevailing at the time. Thus. on the areas studied by the Investigation, the relatively constant number of adult hirds which the shelter and food conditions should enalle to survive each spring has been modified from year to year by the varying effect of these fores. especially weather and the availability of huffers.

Fluctuations in the fall population level have been directly correlated with the relative number of maturing chicks each season. On Connecticut llill the ratio of adults to these birds of the year has averaged $1: 1.0$. but has ranged all the way from 1:1.6 to 1:0.1. On the Adironlack area the average has been $1: 1.4$, while the extremes have been $1: 3.0$ and $1: 0.4$ respeetively. It has been suggested that the younger birds might be more vulnerable and aecordingly represent an important factor in the above inverse relationship. 
TABLE 86. RELATIONSIIP OF DENSITY OF FAIL GROUSE POPULATIONS TO SUIBSEQUINT SURVIVAL ON CONNECTICUT HILL AND ADIRONDACK STUDY AREAS-1930-19.12

\begin{tabular}{|c|c|c|c|c|c|c|c|c|}
\hline \multirow[b]{2}{*}{ Groupt } & \multicolumn{4}{|c|}{ Conaecticut 11 ill } & \multicolumn{4}{|c|}{ Adirondack } \\
\hline & $\begin{array}{c}\text { Average } \\
\text { fall } \\
\text { populition }\end{array}$ & $\begin{array}{l}\text { 1)ensity } \\
\text { pir } 100 \\
\text { acres }\end{array}$ & $\begin{array}{c}\text { Average } \\
\text { number of } \\
\text { birds } \\
\text { surviving }\end{array}$ & $\begin{array}{l}\text { Per ceut } \\
\text { survival }\end{array}$ & $\begin{array}{c}\text { Average } \\
\text { fall } \\
\text { population }\end{array}$ & $\begin{array}{c}\text { Density } \\
\text { per } 100 \\
\text { acrea }\end{array}$ & $\begin{array}{c}\text { Average } \\
\text { number of } \\
\text { lireds } \\
\text { surviving }\end{array}$ & $\begin{array}{l}\text { Per cent } \\
\text { survival }\end{array}$ \\
\hline $1 \ldots \ldots$ & 253 & 10.5 & 137 & 54.2 & 46 & 5.6 & 25 & 54.3 \\
\hline 11. & 2,0 & 12.1 & 155 & 52.2 & 68 & 8.3 & 22 & 32.3 \\
\hline $111 \ldots$ & 426 & 17.7 & 187 & 43.9 & $\ldots$ & $\ldots$ & $\ldots$ & $\ldots$ \\
\hline
\end{tabular}

$\dagger$ Group J-years having a fall population deosity. on Connecticut Hill of ander 12 per 100 acres, on the Adirondack area of uoder 7.5 .

Gronp 1I-years having densities between 12 and 15 , and over 7.5 respectively.

Group III-years on Connerticul llill with densities over 15.

In figure 4.8 the composition of the fall population has been graphed in relation to the subsequent mortality. It is evident from this that the trend in numlier of adult birds lost each year has paralleled to a remarkable degrce that of the number of young birds present in the fall. Probably it is the lirds of the year whieh absorl, the bulk of the overwinter loss. It may be, however, that sometimes these young birds usurp the territories of older individuals, forcing them into poorer situations whicre they become more vulnerable.

On the other hand, it does not follow that the size of the annual increment is more than a general index to the proportion of the total population destined to survive. In 1935-36 on Connecticut Hill, for example, the latter was practically idcntical with that of the previous year (talle 84) in spite of a drastic change in the ratio of young to old birds. $A$ similar situation occurred in 1940-41. On the Adirondack area there is more indication of such a relationship. This suggests that some fundanental principle of the sort may exist but that its effect is often obscured by other influences.

In order to dctermine tlic cxtent to which these variations in survival liave been due to causes other than the varying levels and composition of the fall population, the data were correlated statistically to remove the effect of those factors. The adjusted relationships" are presented in figure 49. It is interesting that these other forces affecting alult survival exerted less pressure in 1931-32 on the Connecticut Hill area than during the preceding year when the population level was lower. It is also noteworthy that on the Adirondack area in 1935.36, in spite of the apparently high degrce of security of the very low fall population (table 84) this analysis indicates that the relative weight of the liniting fores was next to the highest recorded on this tract.

Since predation has been shown to loe the prinary decimating agent responsible during this period, the graph reflects mainly differences in predator pressure as well as in the vulnerability of the birds. The reasons for these variations are many. Some may be traced to fnctuations in the abundance of the predators themselves. In general, however, a number of environmental influences acting as catalists are involved. The comparative quality of the particular coverts which lold the bulk of the hirds in a given year is highly important. Units which produce well during the breeding and rearing seasons may have comparatively low wintering value. The weather is another factor capalle of affecting vulnerability. Buffers, too, may exert a substantial control through their effect on predator activity as dis-

\footnotetext{
* Lata correlated by regression teclunique.
} 
Foll Population- $1 \mathrm{~mm}$.

- - Fall Papulation-Adult

- Totol Loss to Following Fall

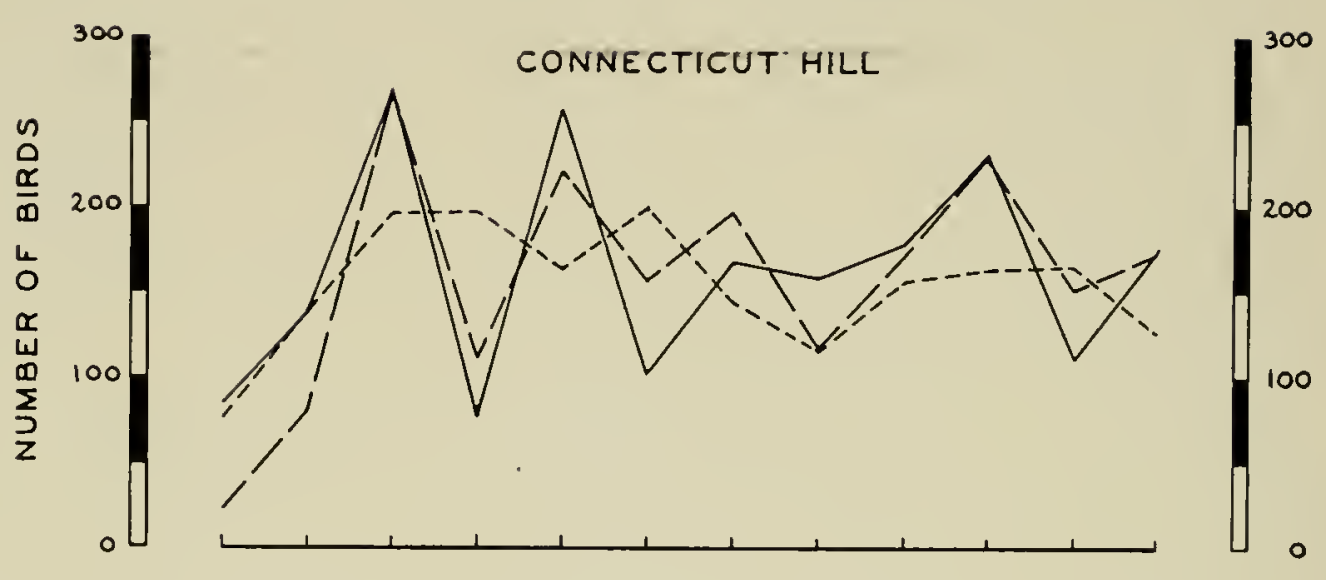

$\begin{array}{ll}n & 100 \\ 0 & \\ \alpha & \\ 0 & \\ u & \\ 0 & 50 \\ \alpha & \\ \omega & \\ 0 & \\ \vdots & \\ z & 0\end{array}$

ADIRONDACK

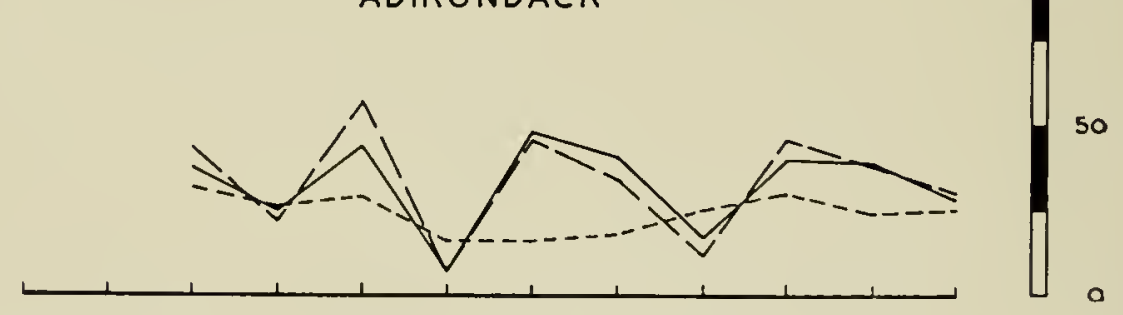

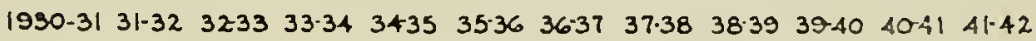

YEAR

FIGURE 18. ADLLT MORTALTY (SEPTEMHER TO SFPTEMHER) IN RELATION TO THE COMPOSITJON OF THE FALL POPULATIOA ON CONNECTICUT HHLL AND ADIRONDACK AKRAS - 1930-31 TO 19.11-12

cussed in Chapter VII. But just how these and many others interact in relation to their resultant effect on adult survival remains as a problem for future study.

Adult mortality each year has taken place largely between fall and the following loreeding season although losses have continued to be high among the males during April. Losses dur. ing the summer bave consistently heen light. Furthermore, within the former period they have reached their peak during February and March although appreciable losses among males have continued during the drumming season in April. With respect to the majority of the dead grouse pieked up on the survey areas it has been possiblo to estimate quite closely the time of death. These data are plotted in figure $50^{*}$. No important variations hetween years have licen noted.

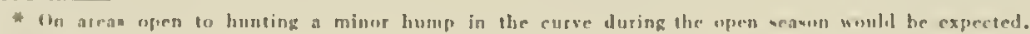




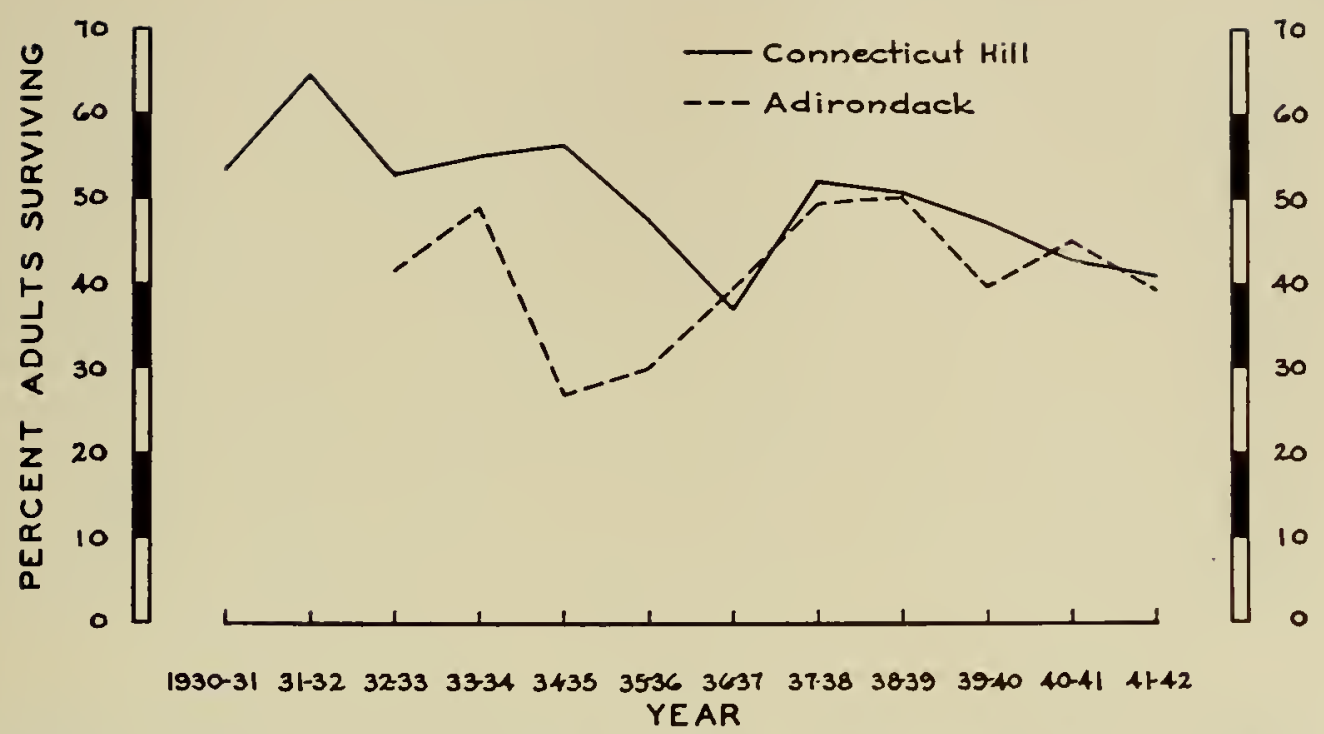

FIGURE 49. RELATIVE SURVIVAL AMONG ADULT GROUSF AD.ILSTED TO TIIE MEAN SIZE AND AGE COMPOSITION OF THE FALL POPUlation ON CONNECTICLT IILL, AND ADIRONDACK AREAS $1930-31$ To 1911.42

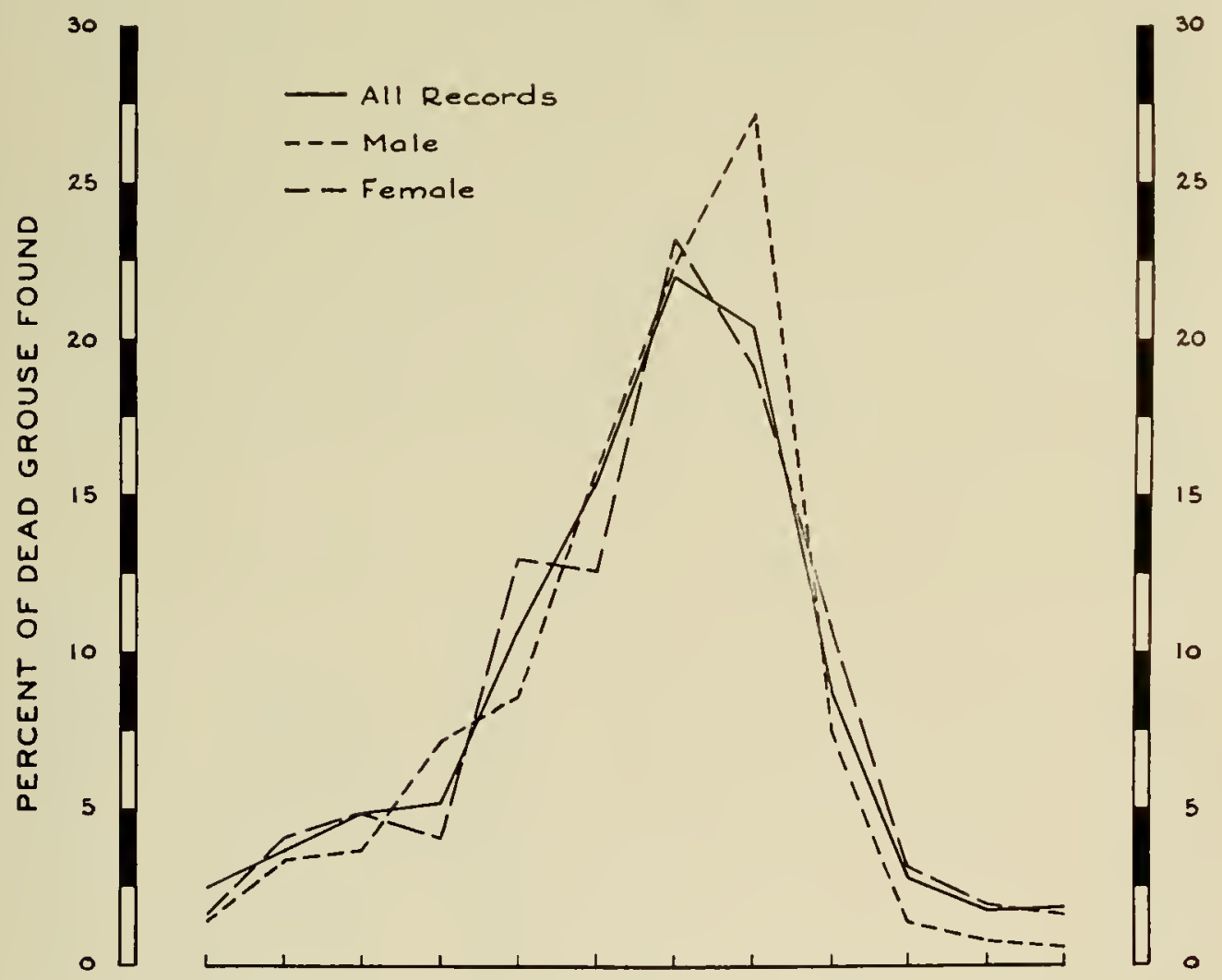

Sept. Oct. Nav. Dec. Jan. Feb. Mar. Apr. May June July Aug.
MONTH

FIGURE 50. SEASONAL DISTRIBUTION OF DEAD GROUSE FOUND ON CONNECTICUT HILL AREA 1930-1942 
The foregoing data refer to conditions under which no hunting was pernitted. Yet the sportsman and game manager are more concerned with areas open to shooting. Therefore, what is the effect of such sport on adult survival?

Some indication of this relationship was procured when members of the Investigation purposely reduced by hunting the grouse population of a 681 -acre covert adjacent to the Con. necticut Hill study area. Between October and March 1934-35, 19.5 per cent of the birds present in the fall were so taken. By April a total overwinter loss of 45.2 per cent was recorded as compared with 39.1 per cent for the tract where shooting was prohibited. The following year 10.5 per cent of the fall population was shot, in addition to which a limited amount of public hunting brought the total reduction from this source to about 20 per cent. The ensu. ing winter mortality was 55.8 per cent compared with 43.4 per cent on the check area. In 1935-36 after a take for sport of 13.4 per cent the corresponding mortality figures were 65.8 per cent and 60.5 per cent respectively. In no instance did the difference between total losses on the two plots approach the proportion taken by hunting. It must be borne in mind, how. ever, that the experimental unit was not large and that some birds very likely moved in from nearby coverts.

Further evidence that moderate hunting seldom seriously affects productivity resulted from the three-year study of a game refuge in comparison with a public hunting ground". The two were apparently comparable as to cover and any difference in the predator population favored smaller numbers on the refuge due to some control by the caretaker. During the period the number of grouse on the refuge declined steadily. At the same time their abundance nn the other tract, although decreasing the second year, rose the following season in spite of an average hunting pressure.

Final appraisal of this question must await the opportunity to undertake more specific experiments on areas of suffieient extent largely to remove the influence of influx from sur. rounding territory. Nevertheless, the conclusion may be tentatively drawn that on areas open to hunting in the fall approximately half the lirds so taken would not survive to breed anyway. Since studies have shown that during the past decade the average proportion of the fall grouse population taken by hunting has heen 17 per cent ${ }^{\Delta}$ it follows that only ahout 8 per cent would be deducted from the adult survival which would otherwise occur. One must remember, however. that these data have not covered a perind of general decline in grouse abundance.

* See Chapter 1.,. 10.301

$\triangle$ Sec Chaptur IX. p. 378 .

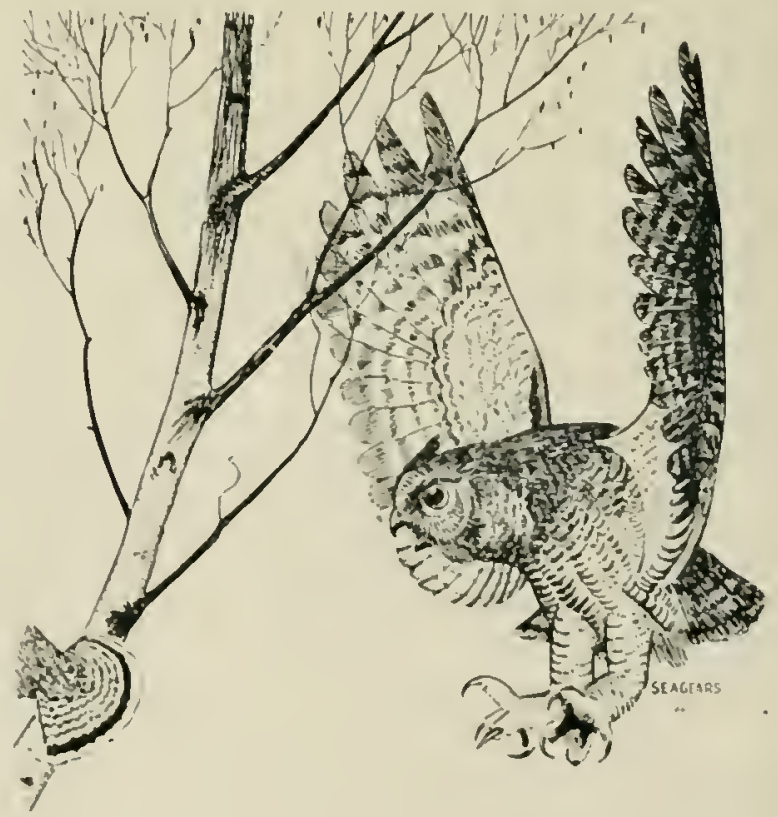




\section{Net Productiviti}

The degree of survival observed during each life period from year to year has been discussed. Yet the actual number of grouse which a hunter may find in a covert in the fall depends on the net success of the whole breeding and rearing season. Likewise the size of succeeding breeding populations rests on the progressive survival throughout the year. The records of the Investigation for the areas studied afford some idea of how this net productivity may vary.

Considering first the hunting season, table 87 presents the ratio of the April to the Septem. her* populations observed on the two principal study areas.

\section{TABLE 87. PRODUCTION RATIO OF GROUSE BREEDING POPULATIONS ON CONNECTICUT IILL AND ADIRONDACK STUDY AREIS IS OF SEPTE.MIBER $1-1930-1912$}

\begin{tabular}{|c|c|c|c|c|c|c|}
\hline \multirow{3}{*}{ Year } & \multicolumn{3}{|c|}{ Connecticut Hill } & \multicolumn{3}{|c|}{ Adirondack } \\
\hline & \multicolumn{2}{|c|}{ Number of birds } & \multirow{2}{*}{$\begin{array}{l}\text { Production } \\
\text { ratio }\end{array}$} & \multicolumn{2}{|c|}{ Number of birdy } & \multirow{2}{*}{$\begin{array}{l}\text { Production } \\
\text { ratio }\end{array}$} \\
\hline & A pril & Seplomber & & April* & September & \\
\hline $\begin{array}{l}1930 \ldots \ldots \ldots \\
1931 \ldots \ldots \ldots \\
1932 \ldots \ldots \ldots \\
1933 \ldots \ldots \ldots \\
1934 \ldots \ldots \ldots \\
1935 \ldots \ldots \ldots \\
1936 \ldots \ldots \ldots \\
1937 \ldots \ldots \ldots \\
1938 \ldots \ldots \ldots \\
1939 \ldots \ldots \ldots \\
1940 \ldots \ldots \ldots \\
1941 \ldots \ldots \ldots \\
1912 \ldots \ldots \ldots \\
\end{array}$ & $\begin{array}{l}92 \\
142 \\
225 \\
283 \\
199 \\
256 \\
170 \\
123 \\
118 \\
177 \\
18.1 \\
132 \\
167\end{array}$ & $\begin{array}{l}161 \\
276 \\
465 \\
274 \\
420 \\
300 \\
311 \\
273 \\
334 \\
39.3 \\
276 \\
300 \\
203\end{array}$ & $\begin{array}{l}1.75 \\
1.91 \\
2.06 \\
0.96 \\
2.11 \\
1.17 \\
1.82 \\
2.21 \\
2.25 \\
2.22 \\
1.50 \\
2.27 \\
1.21\end{array}$ & $\begin{array}{l}40 \\
36 \\
2.1 \\
21 \\
21 \\
22 \\
25 \\
(35) \\
(28) \\
(29) \\
(27)\end{array}$ & $\begin{array}{l}70 \\
51 \\
73 \\
23 \\
61 \\
59 \\
12 \\
70 \\
63 \\
53 \\
60\end{array}$ & $\begin{array}{l}1.75 \\
1.41 \\
3.01 \\
1.09 \\
3.04 \\
2.68 \\
1.68 \\
2.00 \\
2.25 \\
1.82 \\
2.22\end{array}$ \\
\hline A verage......... & $17 \%$ & 307 & 1.73 & 28 & 57 & 2.0 .3 \\
\hline
\end{tabular}

* Figures in pareothesig computed from number ol adulis remaining in september on basis of average summer Jonses for pre. ceding years since na afring census was made on this area aiter 1938.

On both a considerable range of productivity has been observed. In one instance on each area, 1933 on Connecticut Hill and 1935 on the northern tract, the populations barely held their own. On other occasions they more than doubled themselves. In fact, on the Adirondack area the ratio twice reached 3.04, although in 1934 the proportion was actually a little lower since several birds were known to have moved in from surrounding territory during the summer. On the basis of this record anything over 2.0 may he considered to represent a good crop.

The reasons for low productivity have been different on different occasions. In 1933 on Connecticut Hill unusually high losses throughout the breeding. nesting and rearing periods resulted in a net decrease by September. In 1935 on the same area, in spite of a low nest mortality, what the authors believe to have been a high degree of breeding failure ${ }^{\Delta}$ coupled with low brood survival, resulted in an increase of only 1.17. In 1910 nest mortality alone was controlling, and in 1942 brood nortality. On the Adirondack area very high brood losses were responsible for the poor crops in 1933 and 1935.

Of interest is the fact that the lower densities characteristic of the latter area have exhibited a somewhat higher average production ratio. Beyond this, correlation of the data for each

\# No indication has been noted of more thap very minor mortality between September and tbe usual open season.
$\Delta$ See Chapter V111, p. 359 . 
area reveals a distinct tendeney for greater relative increases to be associated with lower breeding populations*.

To examine further the effect of abundance the records for each area were grouped according to the density of the breeding population (table 88). This method too shows an inverse relationship ${ }^{4}$ between the numler of birds in the spring and productivity ly the following fall. But just what interaction of factors may be involved is not elear. Certain features of the data may, however, be mentioned.

\section{TABLE 88. RELATIONSHIP OF DENSITY OF BREEDING POIUIATIONS TO PIRODUCTION RATIO ON CONNECTICUT IIILL AND ADHRONDACK STUDY AREAS-1930-1912}

\begin{tabular}{|c|c|c|c|c|c|c|c|c|}
\hline \multirow[b]{2}{*}{ Groul $\Delta$} & \multicolumn{4}{|c|}{ Connecticut Ilill } & \multicolumn{4}{|c|}{ Adirondack* } \\
\hline & $\begin{array}{l}\text { Average } \\
\text { breeding } \\
\text { population }\end{array}$ & $\begin{array}{l}\text { Density } \\
\text { per } 100 \\
\text { acres }\end{array}$ & $\begin{array}{c}\text { Average } \\
\text { fall } \\
\text { population }\end{array}$ & $\begin{array}{l}\text { 'roduction } \\
\text { ratio }\end{array}$ & $\begin{array}{l}\text { Average } \\
\text { breeding } \\
\text { population }\end{array}$ & $\begin{array}{l}\text { Deasity } \\
\text { ber } 100 \\
\text { acres }\end{array}$ & $\begin{array}{c}\text { Average } \\
\text { [all } \\
\text { population }\end{array}$ & $\begin{array}{l}\text { Production } \\
\text { ratio }\end{array}$ \\
\hline $1 \ldots \ldots \ldots$ & 124 & 5.2 & 267 & 2.15 & 23 & 2.8 & 52 & 2.26 \\
\hline $11 \ldots \ldots$ & 173 & 7.2 & 313 & 1.81 & 38 & I. .7 & 61 & 1.61 \\
\hline $111 \ldots \ldots \ldots$ & 255 & 10.6 & 316 & 1.36 & $\ldots$ & $\ldots$ & $\ldots$ & $\ldots$ \\
\hline
\end{tabular}

* Does not cuver years after 1938 when spring censuses were not made.

$\triangle$ Acrurding los same grougs as nsed in iable 83.

In the first place, the proportion of the loss in potential produetivity as of September 1 which occurred during the lreeding and nesling season has averaged 69.5 per cent on Connecticut Hill and 50.6 per cent on the Adirondack area as against 30.5 per eent and 49.4 per cent respectively for the brood period. On the former area loss of productivity up to this print, therefore, has been due more to breeding and nesting failure than it has to brood mortality, while on the northern traet the two have had nearly equal weight.

To analyze this relationship still further these ratios were broken down (table 89) accord. ing to the same groupings of breeder density considered in table 83 .

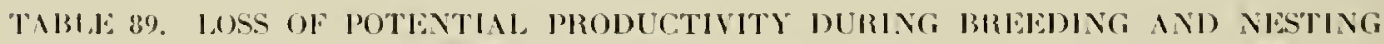
SIEASON COMHAREL WITIJ THAT DLIRING BROOD PEIRIOD ON CONVICTICUT HIJI, ANI) ADIRONDACK STUDI NIEAS-I930-1912

\begin{tabular}{|c|c|c|c|c|}
\hline \multirow{2}{*}{ Giгмиц* } & \multicolumn{2}{|c|}{ Connecticut Hill } & \multicolumn{2}{|c|}{ Adirondack } \\
\hline & $\begin{array}{l}\text { Brreding amd } \\
\text { nesting seusos! }\end{array}$ & Hrotal imriod & $\begin{array}{l}\text { Hrmeling and } \\
\text { mesting sevison }\end{array}$ & 13rood period \\
\hline $\begin{array}{l}11 \ldots \ldots \ldots \\
\text { III } \ldots \ldots \ldots\end{array}$ & $\begin{array}{l}66.1 \\
68.1 \\
73.1\end{array}$ & $\begin{array}{l}33.9 \\
.11 .9 \\
26.6\end{array}$ & $\begin{array}{l}53.8 \\
48.6 \\
\ldots\end{array}$ & $\begin{array}{l}46.2 \\
51.1 \\
\ldots . .\end{array}$ \\
\hline
\end{tabular}

It is noteworthy that on Connecticul Hill as the density of the spring population increased so also did the proportion of the loss in prodnctivity which took place during the breeding

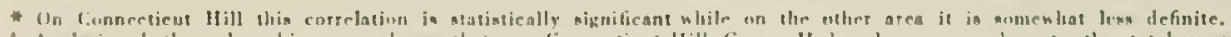

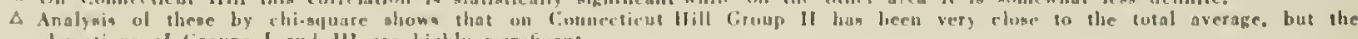
drviatiuns of liroups I and IIt are highly mignalicant. 
and nesting season. This occurred in spite of the fact that, as shown in table 83, the actual degree of brood mortality recorded also increased as the breeding population rose. On the Adirondack area, however, there was no valid difference*

Considering these observations in the light of the fact that the trend in the production ratio has been inverse to that in the number of breeders (table 88) certain inferences may be drawn. On the Connecticut Hill area, with its generally higher population level, losses prior to the brood period appear to have been the stronger influence with respect to the greater average reduction in productivity observed to be associated with higher densities among the breeders. On the Adirondack area, however, even though the net productivity declined as total losses increased with higher densities, the relative imporlance of the breeding and nesting season as compared with the hrood period did not change materially. At the same time, because the percentage of brood mortality itself has been very similar from year to year on the two areas, the fact that it has represented a greater proportion of the total loss of productivity on this area suggests that the higher nest survival usually experienced in the Adirondack region may have been largely responsible for the greater average production ratios recorded.

Since the relationship of density to productivity may be of major importance in grouse management special efforts were made to evaluate it. After virtually eliminating the birds over 681 acres of coverts adjacent to the Connecticut Hill study area during the winter of 1933-34, the population unit was deliberately reduced during each of the succeeding three winters well below what appeared to be its carrying capacity. The data for 1935. 1936 and 1937 are compared in table 90, that for the first year not being comparable hecause of the rapid influx of birds from surrounding territury.

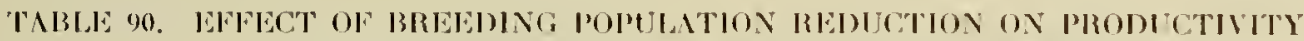

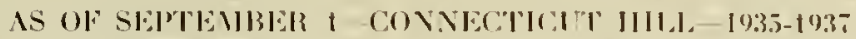

\begin{tabular}{|c|c|c|c|c|}
\hline \multirow{2}{*}{ Year } & \multicolumn{2}{|c|}{ Controlled arra } & \multicolumn{2}{|c|}{ Chrek arma } \\
\hline & $\begin{array}{l}\text { Numbler } \\
\text { breweders }\end{array}$ & $\begin{array}{l}\text { Proslaclion } \\
\text { ratios }\end{array}$ & 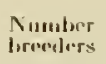 & $\begin{array}{c}\text { Promlustion } \\
\text { ratio }\end{array}$ \\
\hline $10.35 \ldots \ldots \ldots$ & 15 & 1.91 & 250 & 1.17 \\
\hline $1936 \ldots$ & 38 & 2.16 & 170 & 1.82 \\
\hline $193 \%$. & 28 & 2.29 & 123 & 2.21 \\
\hline
\end{tabular}

Several aspects of this record are of considerable interest. Each year the prodnction ratio was greater on the controlled unit than on the basic study area. Furthermore. it increased from season to season as the number of breeders was reduced lower and lower. Yet it in. creased on the clieck area also until in 1937 the differential between the two was negligible. This, too, was accompanied by a progressive decline in the spring population. In view of the fact that the two productivity rates came closer and closer together each year it is noteworthy that the actual density of breeding birds on the two units followed a similar pattern in spite of their both decreasing.

Further analysis of the records reveals another significant fact. The scason of greatest difference in relative increase, 1935. also winnessed heavy brood losses, apparently as a re-

* Data were analyzed by chi-square.

A Sce discussion of Rate of spread, p. 522. 
sult of the July flood. The average number of chicks per brood maturing, however, was similar on both plots. On the other liand the percentage of females rearing broods on the controlled unit was nearly donble that on the unmanaged area (table 91). The same relationship prevailed the following two years, though less strong. These data indicate that, during the same year when envirommental conditions were uniform over both unis, the greater proluctivity associated with lower de:ssities of the spring population was largely a result of more suceessful breeding and nesting rather than of greater survival among the chicks.

\section{'TABLE 9I. EFFECT OF BTEEDING POPULATION HEDUCTION ON I'LA CENT OF FEMALES REARING BROOUS AND AVERAGE NUMBER OF CHCKS PER BROOD MATURING-CONNECTICUT IIILL-1935-1937}

\begin{tabular}{|c|c|c|c|c|}
\hline \multirow{2}{*}{ lear } & \multicolumn{2}{|c|}{ Controlled area } & \multicolumn{2}{|c|}{ Chrek area } \\
\hline & $\begin{array}{l}\text { Per cent of } \\
\text { females } \\
\text { rearimg bromds }\end{array}$ & $\begin{array}{c}\text { A verage: } \\
\text { mumber of } \\
\text { chicks thaturiug }\end{array}$ & $\begin{array}{l}\text { Per cent of } \\
\text { fominles } \\
\text { rearing lirouds }\end{array}$ & $\begin{array}{l}\text { Averige } \\
\text { uumber of } \\
\text { chichs maturim }\end{array}$ \\
\hline $1935 \ldots \ldots \ldots$ & 69.5 & 2.8 & 38.9 & 2.0 \\
\hline $1936 \ldots . . .$. & 47.6 & 4.7 & 40.2 & 4.8 \\
\hline $1937 \ldots \ldots \ldots$ & 68.7 & 3.7 & 56.7 & 4.2 \\
\hline
\end{tabular}

At the same time, however, it has so happened, as shown in talle 83. that survival anong the chicks on the study areas over the full period of the Investigation has varied inversely with the density of the breeding population. Yet the extent to which this represents cause and effect is not clear. In any event, on Connecticut Hill, it apparently was the weaker influence, on the average, in reducing the productivity of high spring populations, although this does not seem to have been the case on the Adirondack area.

With respect to the relative roles of breeding failure and nest mortality, lack of sufficiently precise data makes appraisal difficult". On Connecticut Hill there seems little donbt that in 1933 both were high. In 1935 and 1936 the former seems to have been high and the latter low, while in 1940 the reverse was the case. In 1912, the other year of especiall! low productivity, both were average but brood mortality was high. On the $A$ dirondack area both have been consistently low.

To sum up, it appears that in the letter grouse coverts of New York, supporting as they do higher densities, the increment of young birds little more than equals the number of breed. ers even in years of good productivity. In the more sparsely inhahited Adirondack eorerts. on the other hand, it has averaged nearly half again as great. Now and then, however, the forces limiting productivity result in virtual failure of this erop. lieyond this, the relative in. crease on a given area tends to vary inversely with the density of the breeling population.

Tuming to the net productivity experienced from one breding season to the next, the reeords of the lnvestigation for the two principal study areas are presented in talle 92. Here. too, marhed variations between years have been noted. On Connertient 1 lill 1930 and 1931 were years of recovery following the perind of scarcity in the late "20. and accordingly were as. sociated with the highest ratios recorded. During suceedling years moderate gains alternated with substantial Insses. The trend on the Adiromdack area los shown a similar pattern, al- 
though here the population was already relatively high when work was begun in 1932 and no nct gain was experienced until 1936. Considering the entire period covered on each tract, the grouse population has just maintained itself. In fact, in spite of a greater average produetion ratio on the northern area as of the end of the summer, there has heen no signifieant difference in the corresponding values by the following spring.

TABLE 92. PRODUCTION RATIO OF GROUSE BREEDING POPULATIONS ON CONNECTICUT HILL AND ADIRONDACK STUDY AREIS IS OF THE FOLLOWING BREEDING SEASON-1930-1942

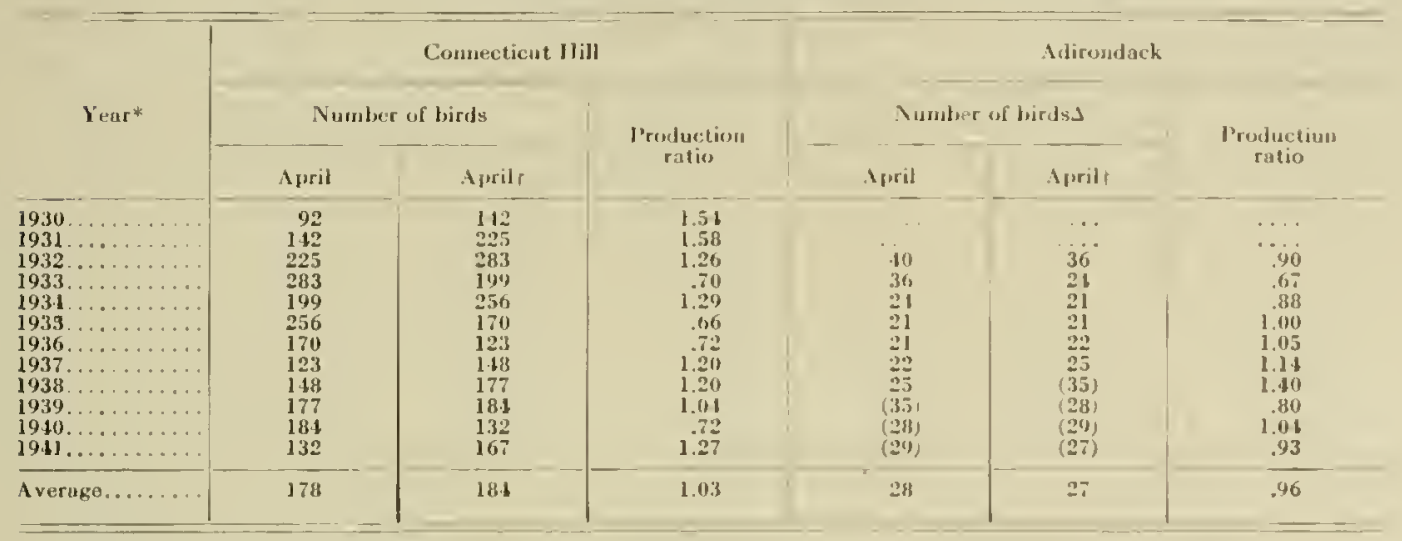

* Year stated is that of the beginning of each period (i.e. 1930=1930-31)

$\triangle$ Seo footnote (*) of table 87 .

t April nI the folluwing year in each case.

On the Pharsalia area the average over six years hetwcen 1931 and 19.10 was 1.03 and for eight years on the Catskill area during the same interval it was 1.05 . On the latter the ratio recorded in 1931.32 (3.27) was the highest observed throughout the study.

In general the trend in the two production ratios (tables 87 and 92) has shown considerable similarity over the period of study on both the Comecticut IIIll and Adirondack areas, be. ing stronger on the former. Oloviously the value for the full year must be less than that for only a part of that lime. But when the two are examined with respect to the relationship of specific values little correlation remains. It may be mentioned, howerer, that in no instance did a net loss of breeders on Conneeticut Hill follow a production ratio in Septemher exceeding 2.0 .

With respcet to the three life periods the distribution of the total loss of reproductive potential has differed somewhat on the two main study areas (table 93).

As has been pointed out productivity at the end of the brood period has averaged somewhat lower on Connecticut Hill than on the other area chiefly as a result of higher breeding and nesting losses. Accordingly; the role of overwinter mortality has been proportionately greater on the Adirondack traet.

The data for individual years, however, have often varied considerably from the above pattern. For example in 1930 and 1931, when the grouse population was low and increasing on Connectieut Hill, less than 10 per cen' of the total loss of potential occurred during the overwinter period. Similar values were associated with the low fall productivity experienced in 1933 and 1935. On the Adirondack area the proportion lost during this season rose to 46.0 
per cent in 1934 as a result of a very high fall population and a severe scarcity of buffers. Then following the nearly complete lack of a crop of young birds in 1935 it fell to 2.0 per cent.

That the per cent of mortality based on the number of individuals entering a given life period is frequently a poor indication of the relative weight of the losses during that period with respect to the total reduction of potential each year must be borne in mind. For instance. in 1936, 76.7 per cent of the chicks hatched on Connecticut Hill failed to survive until fall. Yet because of unusually high losses during the breeding and nesting season this represented only 18.1 per cent of the total drop in potential.

TABLE 93. AVERAGE ANNUAL, LOSS OF RET'RODICTIE POTENTIA ASSOCIATED WITH EACH LIFE PELIOD ON CONNECTRCUT HILL AND ADIRONDACK AREAS $-1930-1912$

\begin{tabular}{c|c|c}
\hline \multirow{2}{*}{ Life l'eriod } & \multicolumn{2}{|c}{ Percentage of total loss } \\
\cline { 2 - 3 } & Conneticut Hill & Atlirondack* \\
\hline Breeding and nesting & 60.9 & 38.5 \\
Brood............ & 26.6 & 39.6 \\
Adult............ & 12.5 & 21.9 \\
\hline
\end{tabular}

* Includes unly period through winter of 1937.38 .

Using the breeding population each year as a starting point the data have been tabulated for the Connecticut Hill and Adirondack areas*. The relations..sps of greatest interest to the sportsman and game manager are illustrated graphically in figure 51.

As has been pointed out ${ }^{\Delta}$ the basic attributes of reproduction-sex ratio. breeding, and the number, fertility and viability of eggs-have remained quite constant. Thus the potential number of chicks each year has leen closely correlated with the breeding population. But beyond this point the varying vicissitudes of the nest, brood and adult periods have resulted in pronounced fluctuations in productivity.

On Connccticut Hill the breeding population gained steadily from 1930 through the spring of 1933 in spite of increasing overwinter morlality. Then, as a result of unusually high losses throughout the breeding, nesting and rearing seasons. a net loss had taken place by the fall of the latter year which was reflected the following spring. Productivity was slightly above average in 1934. however. and next to the highest September population observed was recurded. But brood losses the following summer were abnomal due to the flood in early July and another failure in the crop of young occurred which, although the ensuing winter mortality was average, resulted in the sccond net reduction in brecding stock. A further reduction in 1936-37 was associated with the highest overwinter mortality noted. This was correlated with a marked scarcity anong luffer species. After this the population gained steadily until the spring of 19.10 when a high rate of loss during the nesting period brought about a fourth set-back. Nevertheless, recovery again commenced in 19.12. although a hight brood mortality lirought the September population to a level very little above that of the spring.

On the Adirondack area the number of grouse was comparatively high when work was * Sec Apretidix, p. B8:2.

A sere Chapler Vili. 
PRODUCTIVITY OF POPULATIONS
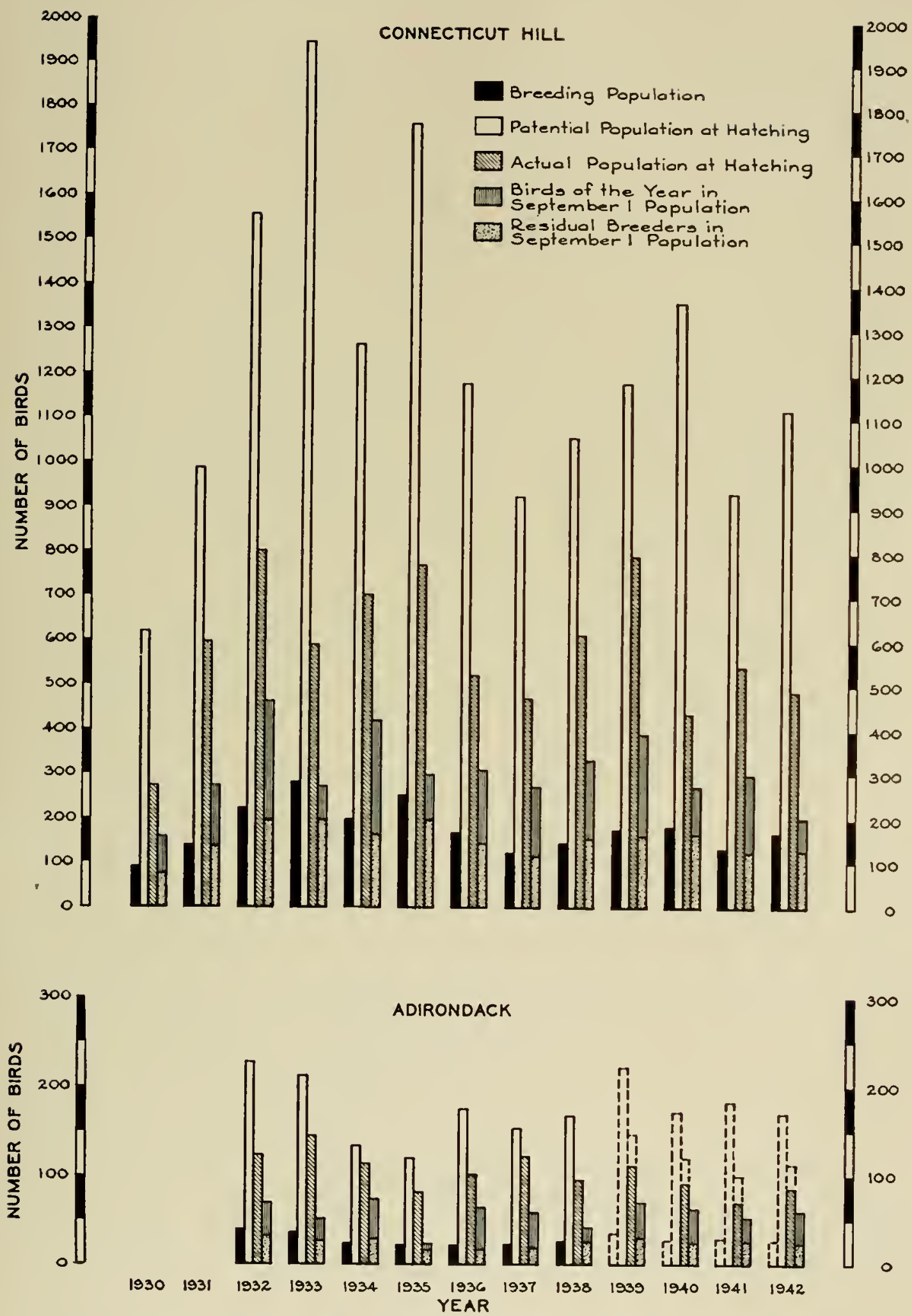

FIGURE 51. GROUSE POPULATION FLUCTUATIONS RECORDED FRONI YEAR TO YEAR DURING TIIE INVESTIGATION ON THE CONNECTICUT HILL AND ADIRONDACK STUDY AREAS - 1930-1942 
begun in 1932 and for three years the breeding pupmlation experienced net losses. From 1935 to 1936 it just maintained itself and then gained slightly during the next two years. After 1938 spring surveys were discontinued but datit from summer work each season indicate that a still greater gain oceurred in 1939 followed ly a minor decline to a level which ap. parently varied little in 1941 and 19.12. Of particular interest are the years 1934-35 and 1935-36. As a result of above average survival throughout the breeling, nesting and rearing seasons the fall population of 193. was the highest recorded. But during the ensuing winter the availability of buffers reached its lowest ebb and winter mortality rose to 71.2 per cent. Following this, excessive losses among the chicks in 1935 had reduced productivity to almost zero by September. Yet with huffere still low winter mortality dropped to 8.7 per cent.

These observations lead to the conclusion that, in hahitats of the Northeast in which substantial changes in the character of the environment do not occur, breeding populations of this species tend in the long run to fluctuate about a level of abundance determined chiefly by the quality of the coverts involved. Net productivity from year to year oscillates above and below this level. Manipulation by management of certain environmental elements, especially shelter composition and arrangement, may raise the carrying capacity of the range. But, once the birds have reached the inproved plane, the tendency toward equilibrium may be expected to assert itself again. It must be pointed out, however, that the luvestigation has had no epportunity to study conditions during a period of decline and scarcity.

\section{Life EQuations}

It is obvious that no population can continue to increase for very long without becoming over-abundant, nor can it continue to decrease without disappearing. Thus the game manager must strive for a balance between the two as well as to maintain a level of abundance as close as possible to the carrying capacity of the range. Further, he must so manipulate the enviromment that the greatest possible proportion of the inevitable losses each year result from hunting for sport rather than from other causes.

The net productivity of any population may be expressed by the equation:

$$
\mathrm{BP}+\mathrm{MY}-\mathrm{AL}=\mathrm{B}^{\prime} \mathrm{P}^{\prime}
$$

in which $\mathrm{BP}=$ initial breeding population, $\mathrm{MY}$ - maturing young, $\mathrm{AL}=$ adult losses and $\mathrm{B}^{\prime} \mathrm{P}^{\prime}=$ breeding population the following year. In a stable situation the annual increment equals the aduh losses. When the number of birds increases the former exceeds the other and when it decreases the reverse is true.

As an aid in roughly appraising what may be taking place on an area an attempt has been made to summarize graphically the data illustrative of increasing. sable and decreasing pro. ductivity (figures 52 to 56 ). These diagrams, however. lo not represent exact records for sperifie years. Rather they constitute composite pictures of hasic patterns which have heen observed to be associated with the respective results*. Obviously innumerable other combina. tions of circumstances conld have the same effect. But in the experience of the Investigation these have occurred most frequently.

In each case the initial breeding population (17.1) is that which, under an even sex ratio and at the average rate of 11.5 eggs per female, would produce 1,000 eggs if breeding were complete. The progressive reduction of this potential inerement is then shown in the lefthand circle while the wher deals with the fate of the breeders themselves. Together the survivors compriec the population the following spring.

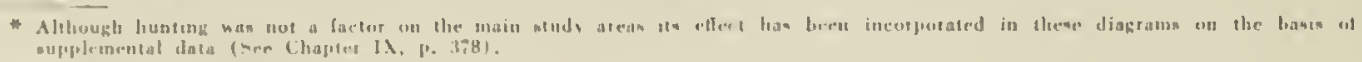


Whether this net productivity is high or low has been primarily a consequence of the degree of mortality to nests, broods, or adults during the overwinter period. Considering first circumstances under which a net gain in the number of breeders would result figure 52 is representative. Survival during both nest and brood periods is good while overwinter mor.

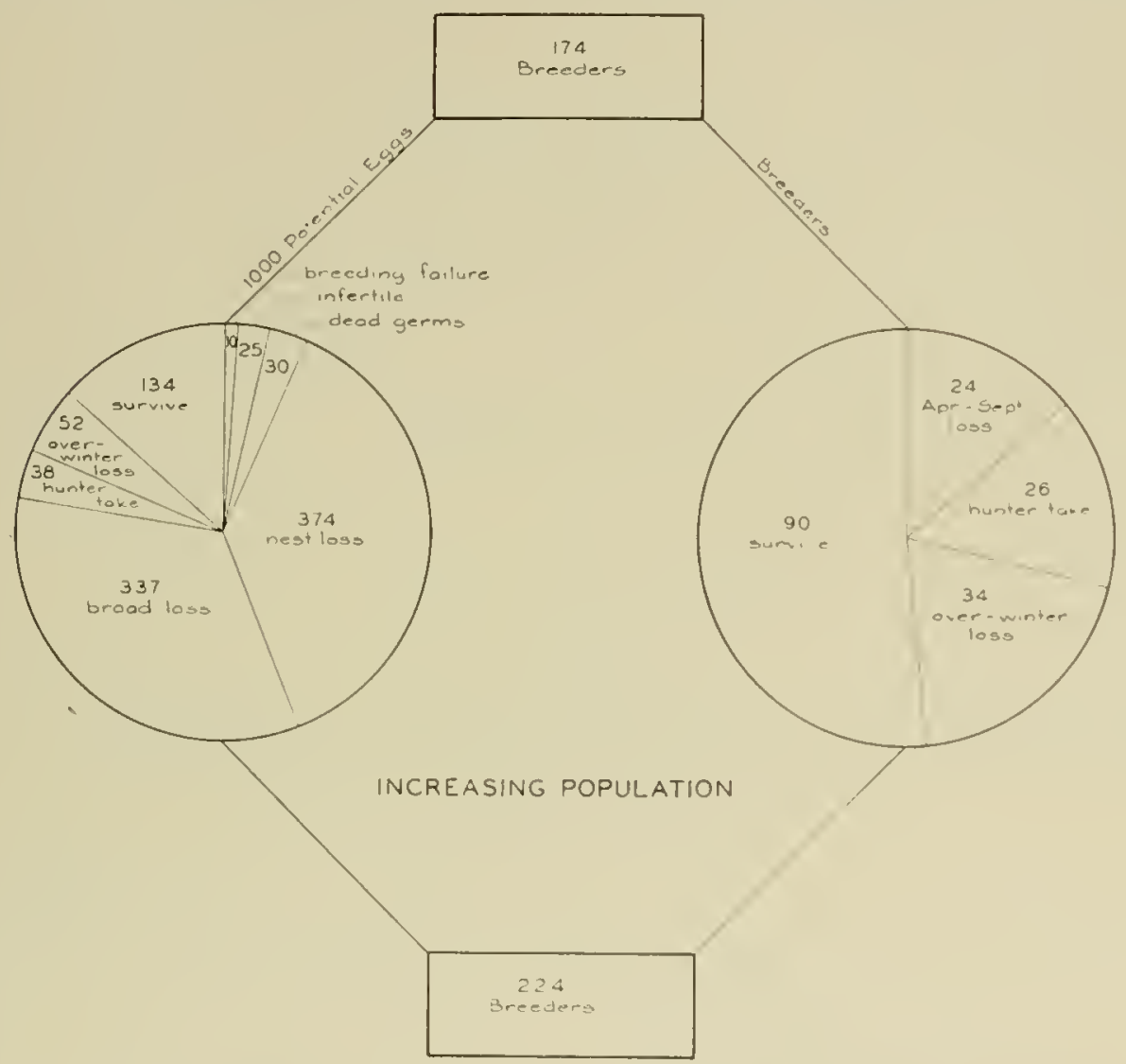

FIGURE 52. MERACE LIFE EQUATION OF INCREASIAG GROLAE POPLLITIOI

tality is below average. The latter is the difference hetween this situation and the one in figure 53 depicting a stable condition and is usually associated with populations well below the carrying capacity of their habitat. By the same token when adult losses increase appreciably a net reduction may follow as in figure 54. That either nest or brood failure can also be the cause of occasional set-hacks is shown in figures 55 and $56^{*}$.

Other losses, with one exception, have not been observed to vary sufficiently to exert any appreciable influence. The exception is non-breeding among the females, which apparently approached 25 per cent on Connecticut Hill in 1933. 1935 and 1936. Since, however, the evidence of this is indirect, more specific appraisal of its role must await further study.

With respect to the effect of hunting, studies ${ }^{\Delta}$ have slown that in the better grouse coverts of New York about 17 per cent of the hirds present in the fall are usually taken. Of this pro.

* The reader should bear in mind that there is no evidence as yet to correlate those situations depicting net losses with any

cyclic tendency which may exist.
See Chapter IX. p. 378 . 


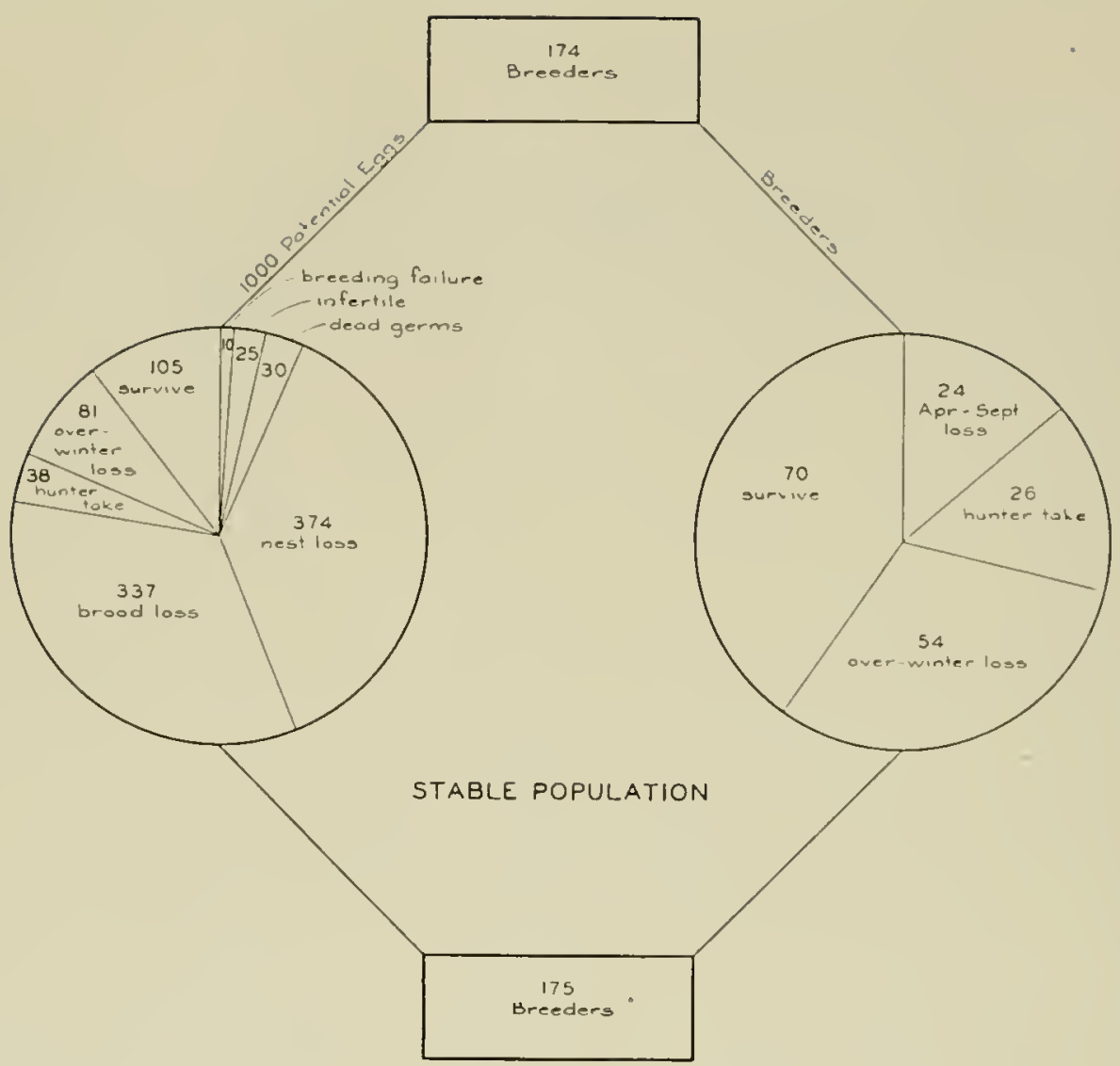

FIGUIE 53. AVERAGE LIFE EQUATION OF STABLF, GROUSE POPULATION

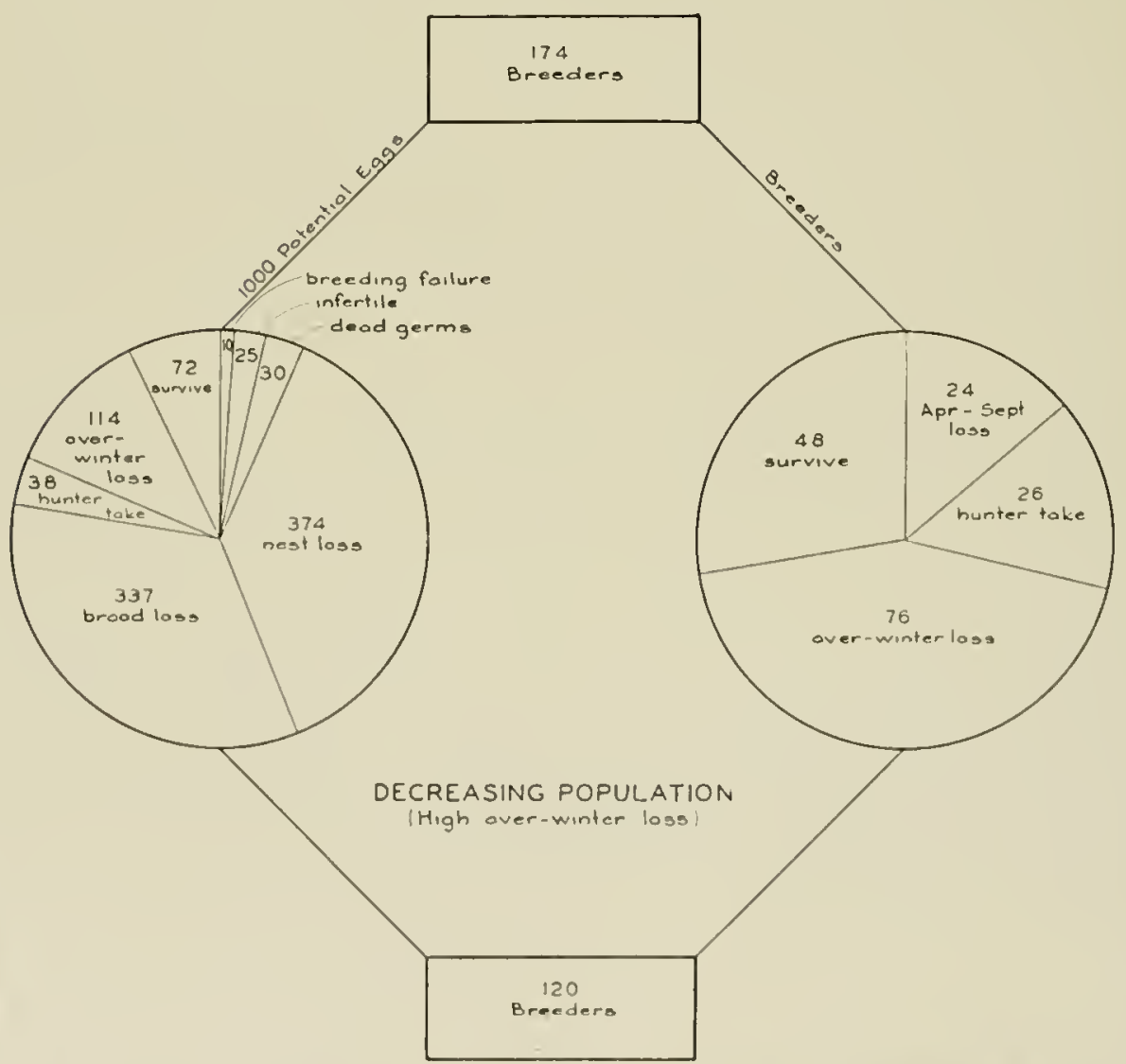

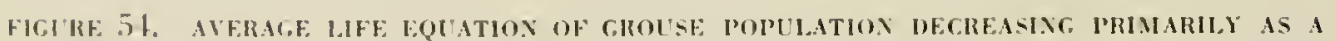
RESLLT OF HICH OVFRWINTER MORTALITY 


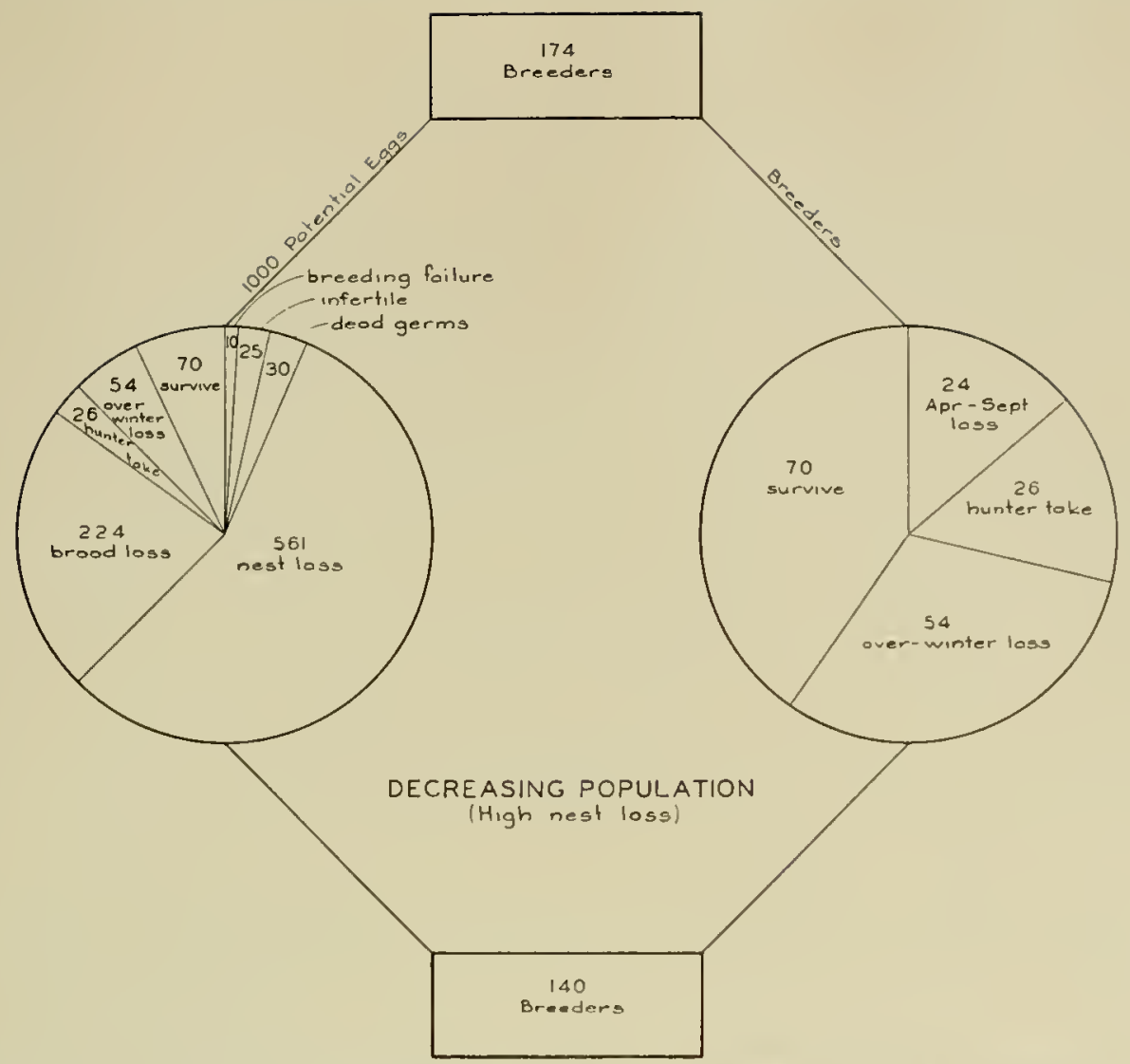

FIGURF, 55. ALERACE HIFE EQUATION OF GROLSE POPULATIOA DECREASIMG PRIMARILY AS A RESLLT OF HIGH NEST MORTALITY

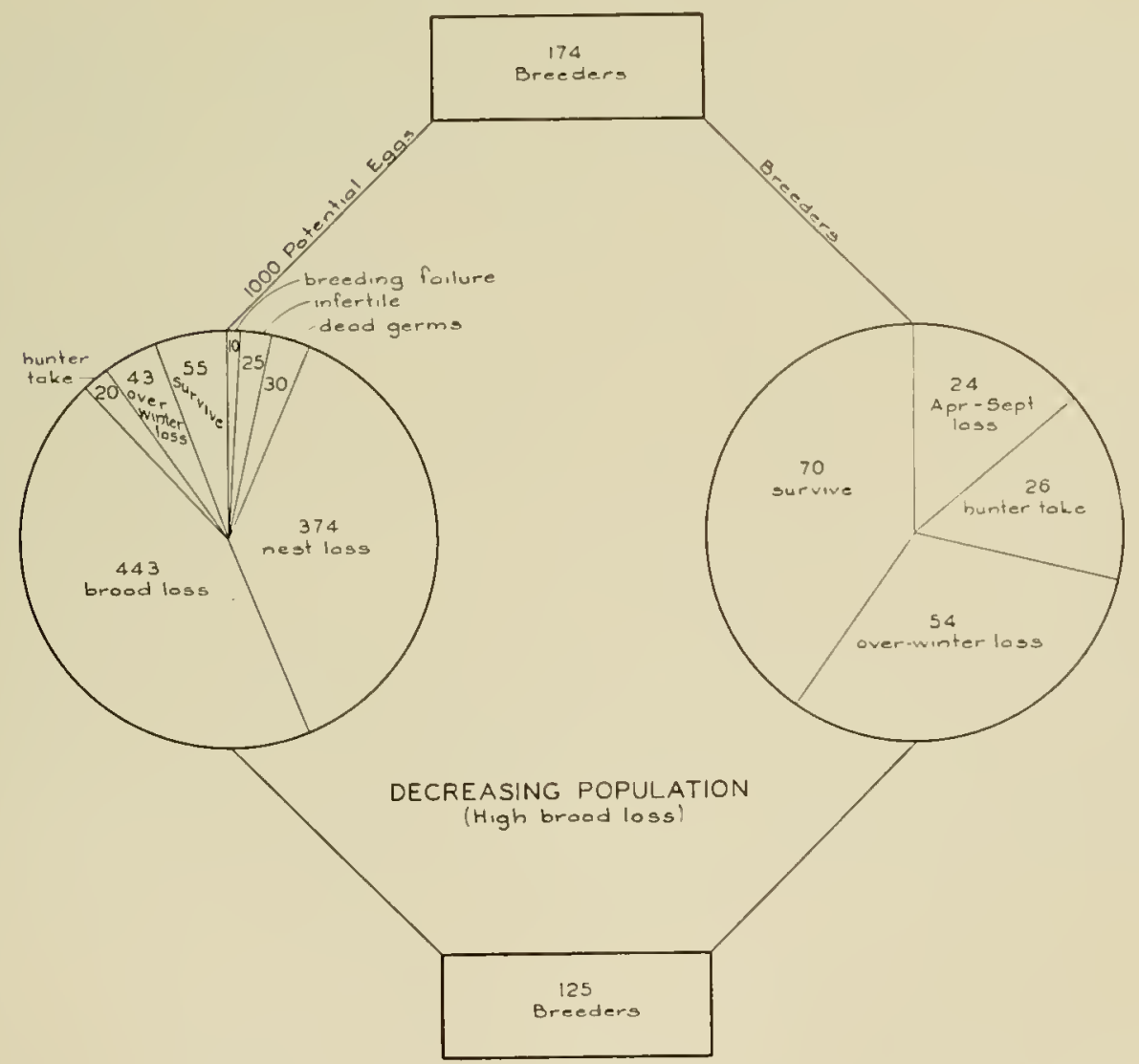

FIGURE 56. AVERAGE LJFE EQUATION OF GROUSE POPULATION DECREASING PRIMARILY AS A 
portion, as discussed earlicr in this chapter (p. 538), observations indicate that about half, or 9 per cent. represents a loss which would occur anyway. Therefore, in the diagrams the lunter take is shown in full while 9 per cent has been deducted from the overwinter mortality as derived from the study area data. The data indicate that this degree of hunting is seldom a decisive factor. Even under the situations represented by figures 55 and 56 its elimination would still fail to prevent a net loss of breeding stock.

On the other hand. as populations approach scarcity in an area the importance of hunting increases and may become limiting. Under such circumstances a low degree of productivity by the end of the lrood period would he the cue for reducing hunting pressure. But while the general population level remains high even failure of the increment of young birds does not necessarily mean that shooting should be curtailed. For example, while the September production ratio on the Connecticut Hill area in 1933 was only 0.96 , it followed the highest breeding population recorded and the actual fall density was greater than those of 1937 and 1940 when the production ratios of lower breeding populations were 2.21 and 1.50 respcctively. There seems little doubt that in all three of these years the birds could have withstood average hunting without endangering the prospect of a good crop the following season.

The possibility that a greater harvest might on occasion lic permitted, withort impairing the brecding potential, depends on the size of the fall crop. The foregoing equation may he modified to indicate the latter by restricting the term $\mathrm{AL}$ (adult losses) to cover only the period from April to the beginning of the hunting season. But practical interpretation of estimates at this time depends on a knowledge of the portion constituting a surplus. Means of evaluating this point are discussed in the section of this report dealing with management* .

\section{THE BIOIOGIC U, BULACE SHEET}

In preceding chapters the obersations of the Investigation with respect to the major faclors controlling grouse abundance have been discussed individually. In the present chapter the data relating In survival, productivity rates. and life equations have also heen considered. It seems logical at this time to undertake a hrief summary of the host of interactions among the various competing influences involved.

The situation may he likened to a picturc puzzle composed of a great variety of pieces. sume large. some small, with a few still hiding unrecognized in the box. The title of the picture is "The Grouse Crop." On the skill and accuracy with which the preces can lee fitted tugether depends the solution. lint the game is made more difficult and interesting because Nature has provided an infuite variety of basie patterns, constituting grouse cover on which the pieces. like semi-transparent overlays, may be fitted together. For each such pattern the pieces combine a little differently so that. in reality. each one represents a puzzle in itself.

Standing at om: elluw in this game are many players, both amateur and professional. rach convineed that the solution of the various puzales recpuires a different arrangemest of the pieres (such as shelter. food. predation ur diseasc). Cuiling rules as to the soundness of (onclusions regarding relationshipe must lie developed through experience and study. It is the intent of this book to define and explain as many of these rules as the authom have enure to know during the lnvestigation.

* Sire Chapter Xill, 5. 674.
6. Jiv Cardines liums. 
But here the analogy ends, for no puzzle-maker ever found a way of creating a problem as complex as this one. Reduced to its simplest terms, life for the grouse is a constant tug-ofwar between the factors that increase and those that shrink its ranks. On the one hand is the inherent capacity of the bird to reproduce and to adapt itself to its surroundings. This, as one will remember, may be broken down into such components as the sex ratio, the number of eggs, their hatchability, the livability of the chicks and the physiology and psychology of the species. On the other hand are first, delimiting conditions, principally range quality in terms of food and shelter, and, second, the forces which tend to decimate the grouse crop. such as predation, disease, weather, hunting and accidents. Food is not listed in the latter group since in good grouse coverts it seems to he available in adequate amounts (though possibly not always in sufficient variety) to meet the basic nutritive requirements of the bird. At least no partridge has been found dead as a result of lack of food.

Whether or not grouse may be expected to occupy an area depends on the character of the range. If the minimum essentials of food and shelter are lacking the species will not thrive regardless of other factors. In the following discussion it will he assumed that these conditions are not seriously delimiting.

Within narrow limits the factors that tend to increase the grouse crop seem to exert a steady pull. It is, then, the comparative strength or weakness of the influences working in the opposite direction that delermines productivity. When these influences are weak, the grouse crop may prosper up to the point of saturation. When they are strong. it declines.

Within hroad limits one may discem a general pattern of relationships. In a low popula. tion the birds tend to occupy the most favorable coverts where they have the best food. shelter and protection from adverse influences. Survival. particularly during the overwinter period, is high. But as the population increases the birds are forced to spread out into labitats where, because food and shelter are farther apart. they are more exposed to their cnemies. More hunters take to the field. predator pressure may increase. and disease, with more birds to work on. has a better chance to spread. Those individuals in the poorer habitats are. likewise, more subject to accident. In other words. in itself. an increase in the numbers of grouse develops a greater resistance on the part of the enviroment to further expansion. Soon a point is reached where this resistance becomes so strong that the reproductive capacity of the bird cannot keep pace and further increase becomes impossible. Yet at any time the pressure of adverse influences may loring ahout a decline in ahundance.

But the situation is not as simple as it might seem. Collectively. the forces involved are only as strong as the sum of their individual plus and minus values. Thus. if buffers are plentiful and the grouse not overly abundant. a net gain in the crop may he attained al. though predators may be numerous. On the other hand, even though natural enemies are scarce. a severe rain just at haching time may spell death to so many chicks that no fall surplus can be produced. A single event such as this, however. is only occasionally sufficient to turn the tide. In the main it is the cumulative effect of a number of factors rather than any one of them that causes signifieant rariations in survival.

The ultimate degree to which grouse alundance may lre affected depends on the severit! and duration of the forces involved. Yet these are relative, constantly conditioned by the end. less variety of circumstances. For instance, when grouse are scarce. a hunting pressure that may mean little to them when they are abundant. may be the drag that prevents their increasc. On the other hand. excessive populations appear nore susceptible to disease. 
While there can be little douht that predators are the chief executioners of grouse, except during the early brood period. this game bird can be considered little more than a delicacy or dessert to most of them. At the same time a host of other influences are responsible for fluctuations in the vulnerability of the birds. The effect of shelter quality has been noted as has also that of the density of the grouse population. Weather, too, can be favorable or unfavorable. Another highly important factor is the availahility of huffers. Usually more numerous and easier to catch. they constitute the staple diet of predators as long as the supply lasts, even though grouse may also be plentiful. But let the buffers decrease substantially and the fox, weasel. great-Horned owl and goshawk, harder put to keep from starving, make more frequent and more determined efforts to capture grouse. Thus an epizootic, decimating the ranks of rabbits and mice, may indirectly exercise a strong influence on partridge abundance even though predator populations remain essentially unchanged.

That predators are more likely to catch hirds slowed down by disease there can be little douht. Though such cases do not appear to be as common as is generally supposed, the removal of afflicted hirds from the coverts obviously is beneficial in inhibiting a further spread. In America. the usual restrictions on hunting are still so fixed as to discourage the taking of a large part of the crop when appreciable surpluses occur. Thus, during the more productive years. disease may actually he encouraged hy leaving an over-abundance of birds in the field. To the extent that predation serves to whittle down this excess, it may help to maintain a goodly number of birds. So clearly is this situation recognized in Great Britain. where pred. ators are scarce, that gamekeepers each rear spend considerable time in "shooting down" the population of Scotch grnuse, left at the end of the hunting season, to a level where out. breaks of disease are unlikely and the carrying capacity of the moors is not excceded.

Furthermore. reduction of a decimating agent is no guarantee of a corresponding in. crease among the grouse. Compensatory adjustments soon tend to take its place. For example. unless applied to a large area. the effects of predator control are rapidly offset by the influx of individuals from surrounding territory. Similarly. as was observed on one study unit, if only certain species such as foxes and weasels are removed the depredations of others such as skunks and crows increase. On Valcour Island (N.Y.). where this relationship was also studied. after the elimination of all the usually more important predators. the propor. tion of nesting loss attributahle to red squirrels increased.

Even if some combination of circunstances should allow an cxcessive densit? of hirds to luild up in the fall. heavy overwinter mortality may usually be expected to ensue unless the majority of the surplus is taken by hunting. It seems probable. too, that the occurrence of high concentrations may often set the stage for scrious outhreaks of disepase. Nature is constantly trying to halance her books.

Onc cannot cxamine this picture without becoming conscious of its tremendous complexity. There is little solace in it either for the sentimentalist who would stop all hunting or for the sportsman who thinks an abundance of hirds can be assured through predator control. for the data clearly show that Nature's grouse budget can never be increased for long by either means. Certain factors. such as weather. accident and the productivity of the hird, are beyond human control. Over others. such as hunting. discase. predation. huffer ahundance. food and shelter. the game manager may exercisc varying deerres of regulation. But grousc populations are dynamic. never stable. Experience indicates that their fluctuations are not rasily predictable. so that mcasures taken to alleviate scarcity or maintain abundance are often too little and too late. 



\title{
CHAPTER XIII
}

\section{FLUCTUATIONS IN GROUSE ABUNDANCE}

\author{
By Ronert W. Darrow
}

\section{OCCURRENCL}

\section{CHARACTERISTICS}

Amplitude - Rate of Change - Duration of Abunimance and Scarcity - PeriodiCITY - SINCHRONISM

\section{CAUSES}

Relative Significance of Losses During Different life Periods - Contibutory Influences - Predation - Disease - Solar Activity - Weather - Population Density

\section{CYCLES}

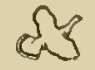

\section{SUMMARY}

Grouse fluctuate in abundance in all parts of their range. In addition to the constant oscillation of local populations more widespread fluctuations have been reported at periodic intervals. (p. 556).

With respect to regional areas there has been a tendency for major declines in abundance to recur at intervals of eight to ten years since 1900 at least. (p. 563).

Such periods of decline have most frequently occupicd two to three years: those of recov. ery three to four years. (p. 560).

Periods of general abundance sufficient to afford good hunting have usually lasted three or four years, although longer terms have been experienced. (p.561).

Major declines in grouse abundance during the years covered have not taken place simultaneously over its range. nor have recurrent declines followed a regular sequence loetween regions. (p. 567).

Pronounced fluctuations at irregular, shorter intervals, often in direct opposition to the gen. eral trend, have been characteristic of local populations. (p. 568).

Periodic synchronization of the trends of a preponderance of the component local popula. tions of a region seems responsible for the recurrence of general abundance or scarcity. (p. 571). 
Failure of the annual increment of young birds appears to be the key to such fluetuations. (p. 571).

It is not known what may be the underlying eause of synchronism anong such losses. Of the suggested hypotheses, a weather relationship of some kind seems most likely to be con. (rolling. (p. 576).

Arother contributory influence is population density although the nature of its effect is not clear. (p. 576).

The concept of eyclic behavior is tenable with respeet to the fluctuations of grouse abun. dance only if their variability and the uncertainty of prediction are recognized. (p. 579 ).

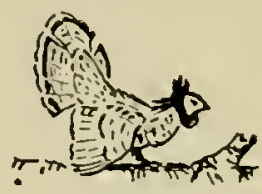

That wildlife populations are subject to fluctuations in abundance has long been recognized. History is full of accounts of plagues of rodents and insects. With respect to game, as Wing ${ }^{400}$ has said, in times of plenty "the beknighted savage bowed down in pious supplication and tendered offerings to the Gods and Spirits". During periods of scarcity, however, primitive peoples as well as the pioneers of more eivilized races have often had to shift their hunting grounds or be faced with starvation. The, writings of the early explorers and historians record innumerable instances of this kind. Sportsmen, 10o, although seldom dependent on such species for the necessities of life, have become alarmed when numbers of their favorite game dropped to low levels and have voiced their concern in contemporary sporting journals.

But until comparatively recent years such fluctuations were principally of local concern and were regarded as haphazard in oceurrence. About the heginning of the present century, however, olservers began to realize that in many instances they had recurred in certain species with considerable regularity. Perhaps the outstanding examples were the Norwegian lemming (Lemmus lemmus) in Europe and the varying hare or snowshoe rabbit (Lepus americamus) in North America. Among the first to call attention to the phenomenon were MaeFarlane ${ }^{229}$, Seton ${ }^{323}$ and Jewitt ${ }^{\text {tam }}$ who nsed records of the number of hare and other fur-bearer pelts handled by the Hudsun's Bay Company to illustrate it. Since then Elton ${ }^{120}{ }^{12}$, Leopold ${ }^{2 x}$ and others have demonstrated fuctuations of nore or less regular periodicity in these and a variety of other species over the earth.

It has heen pointed out in the preceding chapter that grouse populations are in a constant state of oscillation above and below an average which is correlated will the quality of the coverts involved. Beyond this, apparently nore pronounced fuctuations at periodic intervals lave been reported. The recurrence, during the past half century, of several quite widespread conditions of scareity las led to the snggestion that this hehavior might follow a regular pattern. It scems appropriate, therefore, to review the evidence briefly and to discuss how the data of the present lusestigation relate 10 the problem.

\section{OCCURRENCE}

Many early accounts apparenty refer to the occurrence of periods of ahundance or searcity among ruffed grouse populations. Lut the data are seattered and fragmentary unti] the latter part of the ninetently century. It is interesting to note, however. that as early as 1721 , the 
species reached such a low level in the vicinity of Quebec that the provincial governor issued a decree prohibiting its being shot ${ }^{323}$. Later Nuttall ${ }^{2-1}$, although believing that the birds had migrated, made this interesting observation with reference to November 1831 "in the present season, in travelling nearly to the extremity of New Hampshire, not a single bird of the species was now to be seen," although he states they had been "so unusually abundant, previously to that period, as to sell in the market of Boston as low as $12 \frac{1}{2}$ cents apiece." Another in. stance is the statement of an old market hunter that a companion. catering to the Saratoga Hotel (Saratoga Springs, N. Y.), had extreme difficulty in finding birds shortly after the Civil War.

More data are available for the years after about 1880 , mainly in the form of observations published in various sporting periodicals and in the reports of State Game Commissions. In the more settled sections of the East many such accounts actually referred to the elimination of grouse as a result of man's occupation of the land. Mlost of these records, however, apply' to localities where no serious impairment of the range had taken place. Several compilations of this material have been made.

Based on statements in the literature augmented by personal correspondence and inter-

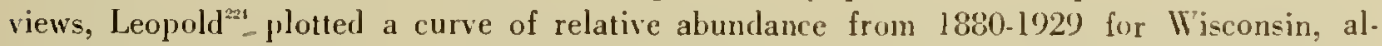
though prior to 1892 it is rather indefinite. The same author also summarized similar data for the north-central states from 1898-1929". Michigan records were summed up briefly by Tubbs $^{372}$ while Clarke ${ }^{73}$ gathered information for Ontario covering 1873-1935 and for other parts of Canada for various periods between 1893 and 193.5. For New York and the nortl. eastem region in general Bump ${ }^{50}$ presented a preliminary analysis of the trend of grouse abundance covering 1880-1935, though here again the records for the early years are scanty.

In considering these compilations one must bear in mind that they represent nercly esti. mates of the average grouse alundance over the region involved from year to ycar on the basis of the material available to the authors. Conflicting reports for different localities in a region in the same year have been frequent. Thus if additional observers had reported the average might have been shifted somewhat. Furthemore the available source material is largely expressed in broad terms so that the comparative degree of change between abun. dance and scarcity cannot be interpreted precisely. As Leopold ${ }^{m 5}$ comments regarding his graph. "The vertical ordinate has no numerical validity, the curve simply comnecting the most frequent of five grades of abundance reported as obtaining during each year."

Nevertheless these records have clearly indicated an alternation of abundance and scarcit!. for the period covered, with respect to the general status of the grouse populations of the regions involved. Presumably the same holds true throughout the present range of the species except, perhaps. in enviromment so marginal that the hirds never hecome numerous. Furthermore, since this behavior has been olserved among populations situated in remote localities where the environment is still in a primitive condition (Gross ${ }^{171}$ and others), it may be as. sumed that it has been a characteristic of the species from time immemorial. On the other hand Leopold has suggested that the optimum portion of the original range of the species lay in the agricultural belt and that fluctuations were less prominent there $e^{224}$. Unfortunately it is impossible now to test this hypothesis.

More recently several studies, each extending over a period of years on the same area, have been conducted. The first of these was the record kept by Criddle ${ }^{\text {ns }}$ from 1895 to 1929 at Aweme, Manitola. Similarly King ${ }^{\text {g13 }}$ reported the trend of fall abundance at Cloquet. Minnesota, from 1931 to 1933. In Michigan, Fisher ${ }^{137}$ conducted anuual censuses on five areas. the 
longest series extending from 1932 to 1936 although estimates for the l'igeon River tract were continued through 1940 by the Michigan Conservation Deparment." Finally that of this In. restigation has covered 1930-1942 and 1931-1912 on its Connecticut Hill and Adirondack study areas respectively, the records of which have been already presented. ${ }^{\triangle}$ These data also demonstrate the constant fluctuation of grouse abundance.

\section{CHARACTERISTICS}

In order to pursue further an appraisal of these fluctuations the major features of those which have been recorded may be examined. The territory considered has been limited mainly to the range of the grouse east of Manitoba and the Dakotas, and from Pennsylvania north. In this area environmental conditions are most nearly similar to those of New York.

\section{AMPLITUDE}

While it is evident that grouse populations have repeatedly fluctuated from abundance to scarcity and back again it is less clear just what has constituted abundance and scarcity at different times. Only recently have studies in a few localities furnished estimates of density. in terms of birds per unit of area. Nost of the evidence is of a nuch less precise nature. As has been pointed out the assumption of similar values for the two extremes in various graphs which have been published covering the past half century has been purely arbitrary and with. out numerical validity. There is no assurance that successive "highs" and "lows" have involved similar densities. Another complication arises from the fact that the season during which grouse hunting has been legal has changed considerably over the years. Throughont the "90s the usual opening date was sometime in September. Undoubtedly such early hunting colored many accounts, of abundance at least, disproportionately in comparison with present experience during the open season. Nevertheless there can be no doubt that the differential has often been great.

$\Lambda$ few accounts, however, suggest densities which have been involved. Thus in 1881 a writer in Forest and Stream ${ }^{\circ}$ described grouse as plentiful in Franklin County (N. Y.) and stated that one man bought over 2,000 for the market. Another olverver reported seeing more than 150 grouse in a day near Lowell, Michigan in $1887^{\text {*3. }}$. In 1899 a correspondent at Smithville Flats, N. Y. ${ }^{125}$ commenting on partridge being "more numerous . . than they have been in a dozen years," noted putting up 50-100 in a day"s hunt in September. Again in 1906, just before the general scarcity reported the following year, an item from Chenango County (N. Y.) ${ }^{189}$ reported flushing $40-50$ birds a day and commented that they were "more common than last year." Leopold ${ }^{22}$ has recorded a number of statements by market hunters and others indicating high levels of abundance in the north-central states on many occasions during the late nineteenth century.

Turning to scarcity, three early records have already been mentioned ${ }^{\dagger}$. Similarly a report from southwestern Ontario in $1883^{1}$ stated that not a single individual was seen in a whole day's tramp where two years before grouse had been plentiful. Later Carpenter ${ }^{\text {wo }}$ related that he found only two grouse in the vicinity of Moosehead Lake. Maine from September 27 to Octoher 10, 1887. An even greater dearth of these birds in northern Maine was noted in 1899 hy IIardy" who saw only one partridge in traveling "150 miles by canoe and half as far hy foot" during the early fall. Another observer ${ }^{107}$ stated that he found from two to eleven grouse near Woodhaven, N. Y. in 1917 where in former years 25 would lave been found. In Pine

* Rulil. II. D. permanal letter to the authora December 12, 1911.

A Sece Chajuer Xil. p. 53y.

$\uparrow$ See discumion of Occurrence, p. 550 
County, Minnesota in 1929 King* reported less than lwo grouse per 100 acres.

Recent studies, however, are begiming to furnisl a knowledge of what the range of fluctuation may be on the same area. Thus $\mathrm{King}^{213}$, although reporting a density of 55.2 per 100 acres on an 1,800-acre tract in Minnesota in the fall of 1933, concluded that an average area of four square miles in the same region would have dropped from about 38 to three birds per 100 acres from 1933 to 1936. In Michigan, Fisher ${ }^{137}$ recorded decreases in density on the same scale of from 25.6 to 4.7 (1932.1935 on Pigeon River tract of 2,520 acres), 36.4 to 10.3 (1932-1934 on Munuscong Park tract of 2.044 acres) and 24.1 to 2.8 (1933-1937 ${ }^{\Delta}$ on Houghton Lake tract of 2.574 acres).

With respect to the present Investigation it seems evident that the population on the Connecticut Hill study area in the fall of 1928 was below five per 100 acres. From this point it rose to 21.1 in 1932 and fell to 8.0 in 19.12 with several pronounced intermediate fluctua. tions as shown in figure 58. On the Adirondack area the extremes were 9.0 in 1934 and 2.8 in 1935.

That densities experienced during recent years have bcen comparable to what has been considered abundance on many occasions in the past is evidenced by the fact that when the grouse population on Connecticut Hill has reached or exceeded about 15 per 100 acres, it has not been difficult for two men working the more likely coverts to flush more than 100 birds in a day.

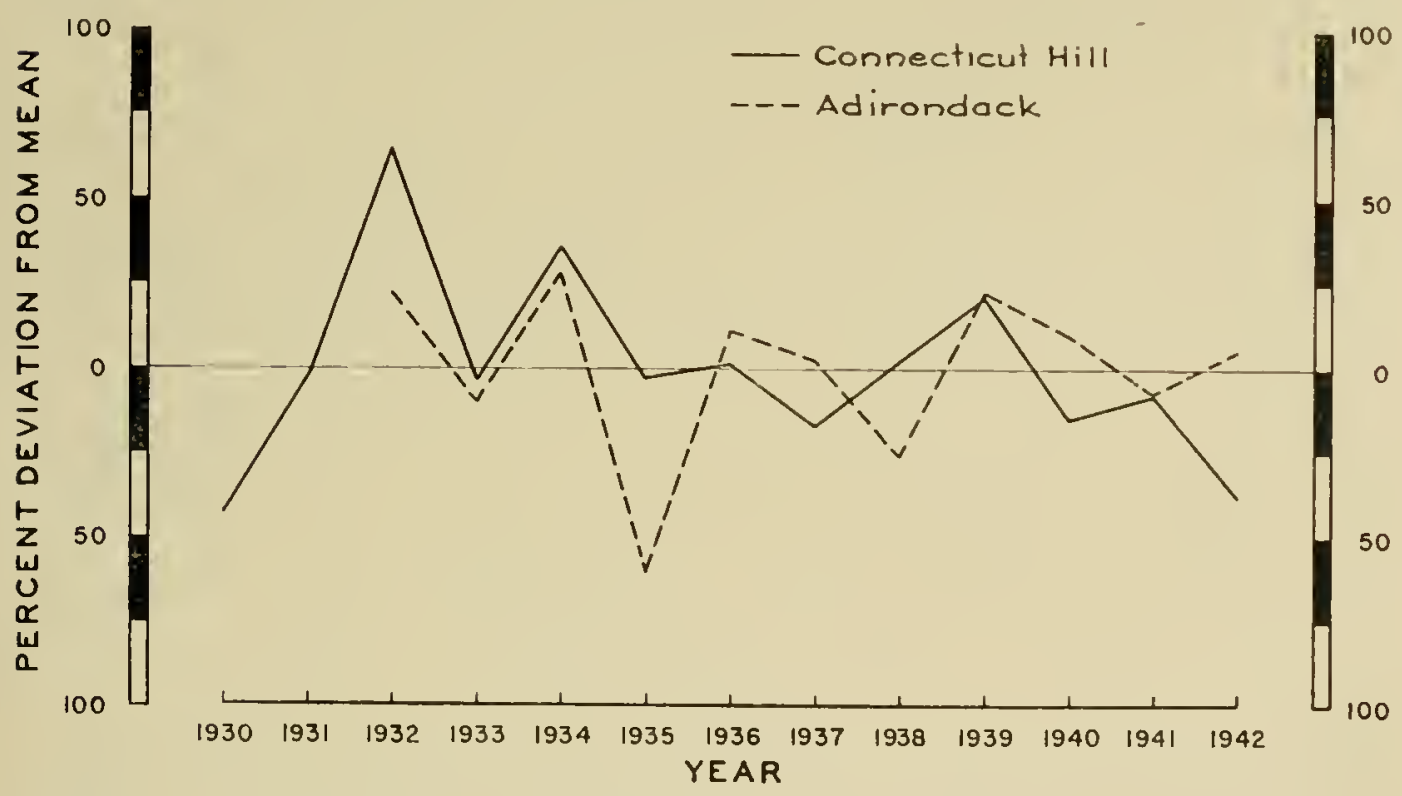

Figure 57. RELATIVE DEgreEs of fluctuation OF FALL CROUSE population deNsities oN CONNECTICUT HILL AND ADIRONDACK AREAS - 1930-1942

In this connection it is interesting to note that, while the densities involved on the Adirondack area have been much less than those for Connecticut Hill, the relative degree of fluctuation has been quite similar in both localities (figure 57).

* In Leopold 224 .

$\triangle 1937$ population estimate supplied by Michigan Conservation Dept 


\section{Rate of Change}

Of interest atso is the rapility with which grouse abundance may change to scarcity and vice versa. Considering first areas of regional size. several representative records of declin. ing abundance may be cited. In New York, for example, the last great decline brought the grouse population to a low level in 1927 or four years after its high point in 1923, although it is important to note that most of the change took place during the years 1926 and $1927^{59}$. Similarly the previous low ebb in this State was reached in $1917^{154}$ four years after the abundance of 1913, though the birds were still at a high level in 1914. Here again most of the decrease took place during the last two years of the period. On the other hand the marked scarcity of 1907 followed a high level of abundance in $1906^{4+1}$. A similar pattern was observed over most of the Northeast, except that longer periods were involved in New York (1914-17 and 1924-27) and Penusylvania (1914-17 and 1924-28) than elsewhere during those decades.

In Ontario Clarke" concluded that "such diminutions have occurred . . in the following years: 1933-4 (and 1935 presumed); 1924-5; 1914-6; 1904-5-6". Two or three year periods of decline were reported from the Lake States between 1914 and 1917, the greatest decrease being experienced in 1916 and 1917. In the following decade the years 1924 to 1926 marked downward trends in Michigan and Wisconsin with the sharpest fall occurring in the last two years of the period. In Minnesota, however, an abrupt drop in abundance took place in 1924. Then in 1934 and 1935 grouse populations throughout all three states fell abruptly to a low level after reaching high densities in 1932 or 1933*. Similarly the Lake States experienced major declines within one or two years after the high level of 1942.

Turning to the rate of recovery grouse reached a peak of abundance in Ncw York in $1935^{\Delta}$, six years after the scarcity of 1927.29 , although a high level had been attained by 1934 and in many localities the birds had become numerous by 1932. By 1921 the birds were reported ${ }^{270}$ to have generally recovered from the fow point of 1917 although they did not reach their peak until 1923, and $1912^{239}$ marked the end of the depression begun in 1907. The trend at this time seems to have followed a similar course over most of the New England area.

Clarke's interpretation of material from Ontario indicates that recovery most often occnpied four or five years but he apparently included the last year of the low period. With respect to Wisconsin ${ }^{157}$, the population had regained a high level by 1921 or 1922 following the low of 1916-17. In Michigan ${ }^{372}$, ${ }^{137}$ grousc had becone numcrous by 1931, four years after the trend started up in 192\%. More recently (19.10) populatious thronghout the Lake States grencrally again hecame abundant after the scarcity of 1934-36.

One may conclude, therefore, that regional trends have usually imolicd several years and that the period of deerease has averaged shorter than that of recovery, although both have exhibited considerahle variation. The most frequent intervals of decline have been two to three years in length, with the sharpest drop taking place during the last year or two. Recovery, on the other hand, has usually hecn more gradual, three or four years being the most frequent intervals.

But a recrional population is merely the composite of a host of local populations which may or may not follow similar patterns of Ructuation. A knowledge of these local variations is thus of importance also. hut unfortunatedy rerords of this kind are few.

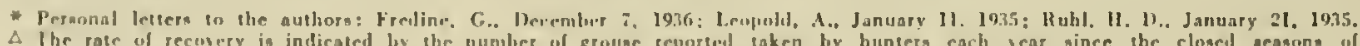

The rate of recosery is indicated by the number of groume segortend taken by hunters each wear sinee the elosed aeason of

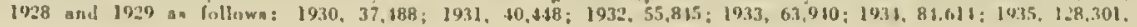


Grouse abundance on the study areas used in this Investigation has exhibited both gradual and abrupt rates of change (figure 58). On Connecticut Hill the fall population, after the low point of 1928, climbed steadily upward until a high level of abundance was reached in 1932. Then in 1933 a sharp set-back took place but was followed by an inmediate recovery the next year. This was suceeded by a 3-year decline and a $2 \cdot y e a r$ recovery ending in 1939. Since that date the trend has been downward, sharp losses taking place in 1940 and 1942 . It must be pointed out, however, that the low points reached in 1933. 1937 and 1940 repre. sented only about half the differential between the levels of 1928 and 1932. Not until 1942, three years after the high density of 1939 , did the population again approach real scarcity.

On the Adirondack area the population did not exhibit any sustained decline during the Investigation. Rather it reversed its trend almost annually. Nevertheless it is noteworthy that the year of greatest scarcity (1935) followed immediately after that of greatest abundance* and was sueceeded by recovery to a high level the next year.

In Michigan, Fisher's data ${ }^{137}$ show a generally gradual rate of decline in grouse abundance on the areas he studied between 1932 and 1936, although in 1933 the population of his Area IV dropped much more sharply than those of the other study tracts while that of his Area IlI did not begin to decline until 1934. King, however, working in Minnesota interpreted his data as indicating a progressive increase from scarcity to ahundance covering seven years followed by a 3.year decline to scarcity again ${ }^{21.3}$.

Thus it is evident that local populations also have failed to exhihit a uniform rate of change with respect to their fluctuations in alundance. Moreover, although often following a trend roughly in harmony with that of the surrounding region. they have also been sul. ject more frequently to rather abrupt intermediate fluctuations.

\section{Dltation of ABUNdance and Scarcity}

The foregoing discussion has dealt with the rate of change between high and low levels of abundance. Of interest also is how long periods of abundance and scarcity have lasted. On each occasion, although some one year witnessed the highest or lowest average density reached, there have usually been several years during which the general status of grouse abundance has been either good or poor.

The duration of suel periods has been from two to four years in most instances. By far the most frequent period of scareity has been three years. Such periods, of course, include the last year of decline and also the initial year or so of recovery. With respect to general abundance sufficient to afford good hunting. three and four year periods have predominated. Here again an overlap occurs since the first year of abundance corresponds to the last year of recovery. That they may last longer, however. was slown by the 1924-28 scarcity in Minnesota and by the good years of 1939-4t in Vermont and New Hampshire. Furthermore, in ease of a minor depression. like that experienced in New York in 1936-37, grouse may be generally numerous throughout such a region for as many as thirteen years or more ${ }^{\Delta}$.

\section{Periodicity}

As evidenee of the recurrent nature of these fluctuations aceumulated, sportsmen and naturalists alike become interested in their degree of regularity. One of the earliest observers to sug. gest a fairly constant interval was Hatch. whom Forbush" quotes as saying "that there is an

\footnotetext{
* As mentioned elsewhere there is some indication that the density in the fall of 2931 may have been as high or higher than that in 1934 but specific data are lacking.

$\triangle$ The current period in New losk lugan about 1932 and. lisregarding the minor depression of 1936-37, had not abated in 1944.
} 
unusual scincity of the birds about once in eight years, and that this has occurred three times in his experience of thirty years"." In 1918 Burnham" conclucled that. in recent years, sliortages of grouse had recurred at about 10-year interials. Liut it was the scarcity of 1926 . 29 that really stimulated study of this phase of the problem, although a sharp loss of productivity in 1924, especially in parts of the Northeast, had resulted in the formation by the American Game l'rotective Association of a Grouse Investigation Committee and its subsidiary the New England Grouse Investigation Committee. Since that time a number of workers have conpiled information indicating, for their respective regions, what the trend of grouse abundance has been. The principal accounts of this kind are those of Leopold ${ }^{24}$, Clarke ${ }^{73}$, Bump ${ }^{60}$,

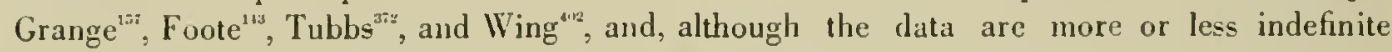
prior to the turn of the century, they do reveal that a major decline and recovery took place throughout nost of the range of the species during eacli decade between 1900 and 1940 .

These regional accounts together with supplemental data, both coutemporary and more recent, derived from State and Provincial reports, personal correspondence with State and Provincial officials, wildlife journals, and sporting periodicals furnish a background against which to interpret the data of the present Investigation. In assembling this material, however, it has been found that different statements for the same region often fail to agree regarding specific years. For this reason it has been difficult to determine in some instances just when the high and low points of grouse ahundance were reached, although the occurrence of scarcity can be plotted more definitely because it has always caused greater concern. Another feature is the fact that fluctuations have seldom followed a smooth curve. Rather than rising and falling steadily between 1-year peaks and troughs, the trend of abundance has exhibited high and low levels which have usually lasted from two to four years and which have themselves often leen characterized by considerable variation. Nevertheless the data can be correlated sufficicntly to permit defining within narrow limits the intervals which have occurred in recent years between periods of abundance and of scarcity (figure 59).

In New York the records leave no doult that grouse abundance over most of the State reached a low ebb in $1907^{\text {sas }}, 1917^{340}$ and $1927^{39}$. Morevver there is a general agreement in these dates throughout the Northeast, although the decline of the late '20s apparently took place a year or two earlier in New England ${ }^{171}$ and the Maritime Provinces ${ }^{\text {is }}$, and a year later in Pennsylvania". There is also evidence of less severe reductions in $1903^{100}$ and $1924^{30}$ and some indication is to be found of scarcity during the late "90s. Onitting these ninor "lows", however, there has been a remarkalle regularity in the spacing of the other periods at intervals of nine to ten years.

But since the low period which began in 1927 no comparable widespread scarcity has occurred in New York although there was a minor depression in 1936-37, apparently sinilar 10 those of 1903 and 1924. Yet more pronounced declines in grouse alundance were re.

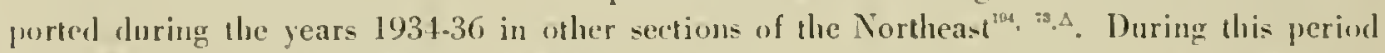
all of New lingland and eastern Canada were affected. In fact, in 1936 the open scason in Massachuselts was curtailed on this account ${ }^{2 n}$. Where these declines occurred they followed the preceding lows by intervals of eight to ten years. Mureover, the same was true of the minor depression of 1936 in New York.

Summarizing his data for Ontario, Clarke recognized diminutions among ruffed grouse during the years "1933-1. (and 1935 presumed): 1921-5: 1914.6: 1901-5-6; 189 1.5: 1863-1.5: 1874." indicating an average period of "leetween nine and ten years".

- Stateniesir madr en 1908.

$\Delta$ Peraonal enerrapotadence with State and Provinrial officiale. 
More recently grouse in Pennsylvania. Maine and much of eastern Canada variously dropped to low levels of abundance in 1943 or 1944* although in Ontario the decline of 1943 was minor. Again the intervals involved were of eight to ten years in length. In New York. Connecticut, Massachusetts, Vermont, and New Hampshire there has still (1914) been no significant general decrease in the present decade. It may be noted, however, that in these states 1944 was only the eighth year since the last depression although, as has already been pointed out, the latter was not marked in New York.

In the Lake States (Minnesota, Wisconsin and Michigan), these fluctuations have exhibited an even greater degree of regularity. There. considering only records since 1900 . a condition of general scarcity was reached in the years 1907-08. 1916-17. 1924-26. 1931-35. and 1943-14 (figure 59). The intesval involved has varied from eight to ten years with nine the most frequent ${ }^{\wedge}$. The fact that so lighls a degree of periodicity has now been recorded for four successive lows in this territory seems especially significant.

The intervals which have elapsed hetween recurrent times of high abundance are not sn clear as those between lows. The records are frequently indefinite as to just when the grouse populations of different regions reached a high level following the various perinds of scarcity. The same is true, although to a lesser degree. with respect to peak numbers. A hetter criterion. in view of the available data. seems to be the last year of high ahundance preceding a major decline.

In New York, according to Conservation Department records and other data. 1906, 1911. and 1923 seem to have heen such years. So was 1935. although it was followed by only a minor depression. Thus, in this State, three intervals of eight. nine and twelve vears, respec. tively. have been experienced sine 1000 . In the fall of 191\% eight vars after 1935. the gronse population over the State as a whole was still at a high level.

Elsewhere in the northeastern United States and eastern Canada intervala of eight to ten years have predominated. In much of the East. however. 12-year periods occurred hetween 1923 and 1935. In Pennsylvania this was followed by nue of seven rears associated with the minor low of 1936-37 after which the population fell off tharply in 1943. In Yew Bruns. wick a short-lived decline occurred in 1940 but the hirts were again numerous in 1912 hefore the scarcity of 1943. Throughont most of this region the records cover four perinds since the beginning of the century. hut in sonthern New England, as in New York. nnly three are involved. although grouse numbers have recently hern at a high level for several years.

As in the case of scarcity a remarkalle degree of regularity bas existed in the Lake States throughout four successive periods with respect to the recurrence of grouse abundance. The interval has varied from eight to ton years in length. nine years heing the most frequent.

These data thus lead to the conclusion that the general abundance of grouse over the major regions of its range in eastern Canada and the northeastern and north-central United States has, during the present century at least. exhihited recurrent furtuations between high and Jow levels. the intervals between which have varied from eight to ten years in the case of lows and from seven to twelve years in the case of highs: that in hoth cases nine years has been the most frequent ${ }^{\dagger}$ : Jut that. in spite of these narrow limits. there is no eridence of a precise neriodicity.

\footnotetext{
* Personal corncanondence with Siate and Provincial oflicials. ten in elesen years between peaks of abundance and two intervals, one of twelve years and one of nioe years between troughs. giving "an average perjud of a fraction over ten yearg". But he lumped the several species of grouse together while the data

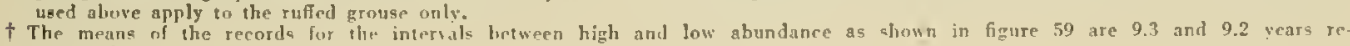
spectively.
} 
One must realize, however, the distinction between the above and the interval between the end of one period of general abundance or scarcity and the beginning of the next. The record indicates that in the case of abundance this interval has most frequently been from four to seven years in length while in the case of scarcity it has most often been six or seven years. But this does not mean that there was any need for four to seven year closed seasons. Abundance is used here to denote a quite uniformly high population level. while enough birds to justify hunting have usually been present nver longer periods with a corresponding shortening of the intervals of acute shortage to which closed seasons would apply.

So far the discussion of this topic has dealt with the trend of general abundance over areas of regional size. In most years, however, different localities in the same region have exhibited conditions diametrically opposed to each other as well as various intermediate gradations. This raises the question of to what extent the same individual localities have been mvolved in successive manifestations of this phenomenon.

Unfortunately, few specific data based on actual censuses of the same area have been recorded covering a period of years sufficient for such analysis. Criddle's graph ${ }^{\text {s }}$ indicates a fairly regular periodicity of close to ten years but the area involved comprised less than 50 acres with a correspondingly small number of birds and only the portion from 1914 to 1929 was based on numerical census figures. Furthernore, the latter are spring records and therefore not entirely comparable with fall data. In Michigan grouse population censuses on the Pigeon River tract of 2,520 acres, begun by Fisher in $1932^{137}$ and continued until 1910 by the Conservation Department, showed a steady decline from a high level in 1932 to relative scarcity in 1935 followed by a gradual increase to moderate abundance in 1940. The only other record long enough to he considered is that of this Investigation.

In figure 58 have been plotted the fall population estimates for the two principal areas studied. The data for 1930.42 on the Connecticut Hill area and for 1932-42 on the Adiron. dack area (approximately 2.200 acres and 816 acres respectivel!). represent actual censuses conducted by the lnvestigation. The approximate trends for several years before and after these dates have also been indicated on the hasis of other information.

These records reveal that the fall population levels on these areas hase fluctuated widely from year to year rather than following a steady course. That the trough of $1936-37$ on the Connecticut Hill tract was minor is evidenced by the fact that the populations of 1927-28-29 are known to have becn below that of 1930. Furthermore alundance on this area in 1933 dropped to a level comparable to that of 1937 hut immediately recovered the next year. Although intensive field work became imposible after 1912. the limited data available clearly indicate that the trend continued to decline at least through 1911 so that gromse numbers quite probably fell to the 1930 level if not lower.

On the Adirondack area initial work in January. 1932. indicated that the fall population of 1931 was comparable with, if not higher than. any recorded later. The most severe decline ocrurred in 1935 but was of only one vear's duration. Since 1936 grouse ahundance remained generally high throughout the survey and supplemental information shows it was still high in 1941.

In figure 5i, smoothed enrses" have been superinposed on the actual data in order to indicate the general trend which has taken place. These, too, show the trough in 1936.37 on Conneeticut llill to have heen minor and that it was not until 194. that the population again

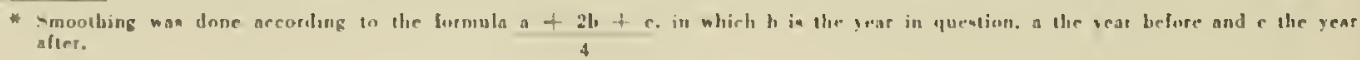




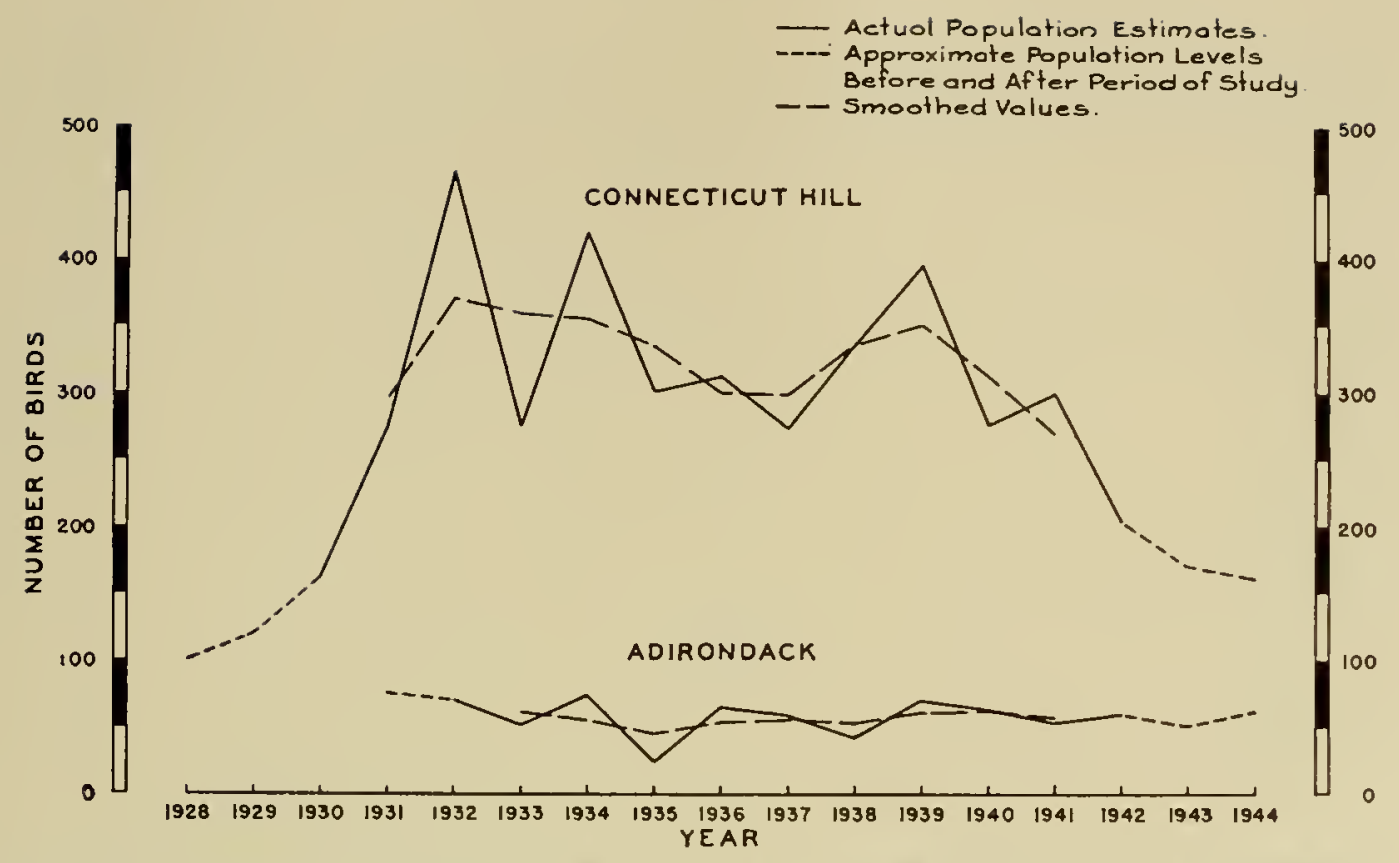

FIGURE 58. TREND OF FALL POPULATION LEVEl.S ON THE CONNECTIClT HILI. AND ADIRONDACK AREAS WITH SMOOTHFI) VALUES SUPERIMPOSEI

reached a low ebb comparable with that of the late '20s. The interval between these major depressions would thus be at least 17 years. Nevertheless it is significant to note that the minor depression of 1936-37. which cane at a time when much of New England was experiencing a scarcity of grouse, occurred nine ycars after the low of 1927.28 and eight ycars before the scarcity of 1944 on this area. On the Adirondack arca there was a moderate depression in 1935 but it is not known when the previous scarcity took place.

\section{SrnchronisM}

The data prescnted so far show clearly that grouse populations have characteristically ex. hibited an alternation of abundance and scarcity. Furthermore, the records indicate that, at least since 1900, these fluctuations with respect to the average number of grousc over regional areas have recurred with considerable regularity although their periodicity has not been precise. In general, during this time, a high level of abundance followed by a decline to scarcity has occurred in each decade. The specific years insolved. however, have differed between regions.

The record for the north-central and northeastern United States and Canada, as well as it has been possible to interpret it from availahle information*, is illustrated in figure 59 . The range divisions considered have been states and provinces because the principal sources of data have been official reports and other records in terms of such units. In two instances (Massachusetts-Connecticut and Vermont-New Hampshire) states have been grouped becausc of their similarity and rclativcly small size. In these cases the records for certain years con.

\footnotetext{
* The dala upon which this chart is based lave beca compiled principally from official reports of the several states and provinces as well as from personal letters to the authors from conservation officials in these areas. Use has also heen made of the writ. ings of varinus research workers who lave studied the problem. But comments in the literature of purely local conditinns have usually been too fow and seattered to be of much value for this purpose.
} 
flict somewhat necessitating interpretation as to the average status of grouse abundance. Ontario, on the other hand, has been divided into three parts according to Clarke ${ }^{73}$ whose data have been used for the years through 1934. Admittedly a closer alinement with ecological boundaries would be desirable but the data have not been adequate for such treatment.

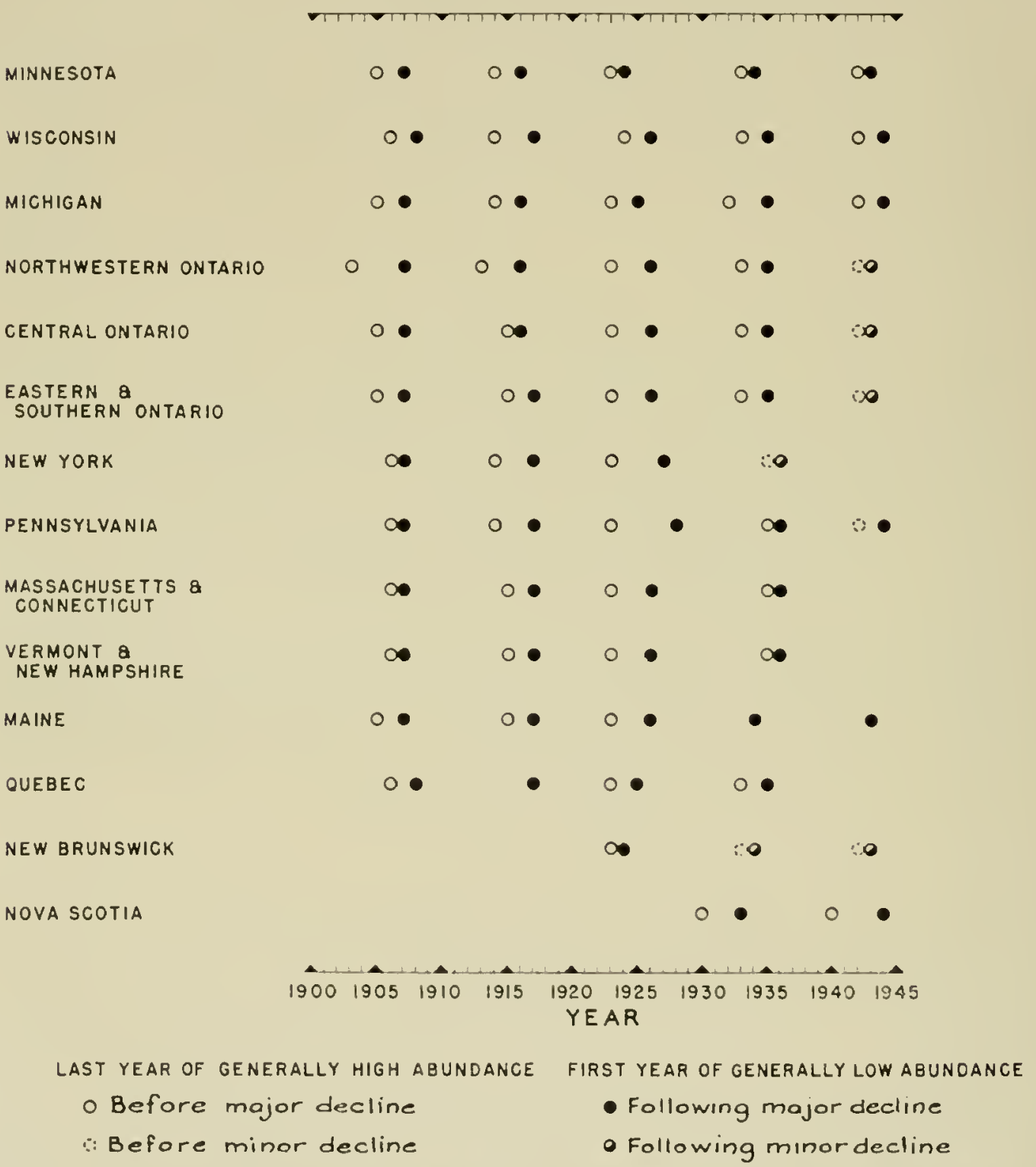

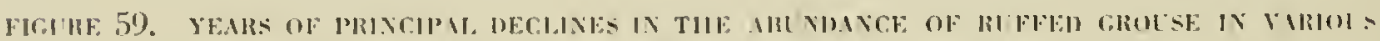

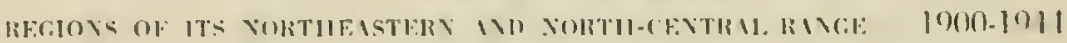

Two indices have ben used in this ehart. First, at hals been mentioned before. the oceurrence of scarcity seems to have aroused the most enneern and thus affords the best eriterion of the fluctuations which have taken place. For the purpuse of this disenssion the year plotted 
in each case has been that during the fall of which the grouse population first reached a significantly low level even though the absolute bottom of the trough may have been a year or two later. Not only is it often difficult to determine which season was lowest but the year in which scarcity was first reached must have been more closely associated with the conditions which were responsible.

The second index is that of the last year of real abundance preceding each major decline in each region. Here. too, the year plotted is not necessarily the one during which the fall grouse population was at its maximum. Rather it marks the end of each period of generally high abundance and, in conjunction with the year when the following low ehb was reached, further delineates the primary interval of decline.

It is evident from this chart that the major declines in grouse abundance during the years covered have not taken place simultaneously over its range. Records indicate that the nearest approach to uniformity probahly occurred in 1907. although in 1917 also grouse populations over a large proportion of this range were reported to have reached a low level at the same time. But in the latter inslance there was wide variation in the year when the decline commenced. Since then the pattern has been more irregular, exhibiting the greatest degree of variability during the decade between 1920 and 1930. when. paradoxically: the initial year of decline scems to have been quite uniform.

Even closely allied regions such as Minnesota and Wisconsin have not usually been affected simultaneously. Yet considerable similarity is shown in the records for Minnesota, Michigan and northwestern and central Ontario. In New York the declines of 1907 and 1917 coincided with similar fluctuations in Pennsylvania and New England, lut subsequent years have shown a lack of harmony in this territory. Apparently the populations of rarious regions tend to react independently of one another.

Similar conchusions have been stated regarding the population behavior of other species. NacLulich"10 after intensive study of the snowshoc hare in Ontario demonstrated that "the last year of great abundance. which is the year in which the decrease began" varied from 1932 to 1935 in different districls. I,ikewise Cross" after studying the red fox (I'ulpes fulra) in Ontario found. with respect to different regions of the province, that "there were wide variations as to the years in which the maximum numbers occured. the years in which the minimum numbers ocenred and in the intervals between these years".

On the other hand, it has been suggested that the onset of grouse scarcity. while not at any time simultaneous over the range. might nevertheless follow a similar course from region to region in recurrent instances. The records are conflicting in this respect. however. Clarke's data for Canada in the $30 \mathrm{~s}^{73}$ exhilit a trend heginning in the northeastern and northwestern districts at ahout the same time and progressively converging southwestward and southeastward respectively. A pattern of this kind during that decade is further indicated by the fact that conditions in Maine and the Lake States ronghly coincided with those of Quebec and Ontario while the decline in New York. Pennsylvania and southern New England took place still later. Figure 59 also indicates that the pattern was generally similar in the previous decade. But no such progression is apparent in the records prior to 1920 . Neither does it seen to be true of the current situation although this has not yet run its course. In this connection it may be mentioned that in Nova Scolia the recent period of grouse abundance seems to have ended earlier than elsewhere even though this was not similarly true of the time when the population reached a significantly low level. Thus the available evidence does not support the idea that recurrent declines follow a regular sequence between regions. Yet in 
spite of this lack of harmony throughout the range of the species in the onset of major declines in abundance, in most instances there have been a year or two during which grouse have been generally scarce.

To analyze the problem further it may he pointed out that the average status of grouse abundance throughout a regional unit of range represents the sum of conditions on the many local areas involved. Moreover, while it is obvious that if the average abundance over a region fluctuates the populations of individual areas must also fluctuate, it does not follow that they all exhibit the same pattern. That in actuality they have not done so is evident from the records in the literature. In these accounts one finds all degrees of variation from agreement to direct opposition within the same region at the same time.

As Bump" commented "it is a rare year in which there does not occur some apparently reliable report indicating both abundance and marked scarcity in the same part of this range". Leopold ${ }^{223}$ in assembling data relative to the onset of the decline of the ' 20 s in $W$ isconsin, found "a completely irregular incidence, such as moths would make in invading a carpet". Similarly Green and Shillinger ${ }^{193}$ observed that populations "may become abundant at the same time and die off at the same lime in widely separated areas, whereas in two closely adjacent areas an abundant population may develop in the one while animals* are dying off in the other". In correlating the available information for Ontario and other provinces in Canada. Clarke ${ }^{\text {;3 }}$ found "local differences of at least three years in the time at which diminution begins". The same author, in descrihing his method of summarizing questionnaire information ${ }^{\Delta}$ indicates that reports of both alundance and scarcity were received from the same region during most years. Gross ${ }^{171}$ recorded a parallel situation for New England. In 1937 Connccticut ${ }^{\infty}$ reported "islands of abundance in a fairly general scarcity". A great many other accounts also attest the fact that such disparity among local grouse populations has been of frequent occurrence.

During the most recent period of severe grouse slortare in New York (1927-23) Allen ${ }^{13}$ reported that the birds were "still apparently in normal numbers" in a few places in the central and northeastern parts of the State. In fact the population of nne compartment of the Connecticut Ilill study area is known to have been high in 1928. Likewise Woodruff ${ }^{\text {ma }}$ quoted a State game protector to the effect that in Allegany County (N. Y.) in 1907. when grouse in the Northeast generally were at a very low level, "Partridge seem to he more numerous than last year-fifty birds seen a day".

During the present Investigation the grouse populations of the two principal study areas have followed similar courses during some years and at other times have been divergent (figvre 58)t. In 1931. while the Connecticut Hill area was still recovering from the scarcity of a few years before, the number of hirds on the Adirondack area was at as ligh or higher a level as at any time after that. From 1932 to 1939 both areas exhilited generally similar trends although the low point rcached on the northern tract in 1935 was relatively much lower than the depression of 1936-37 on Connecticut Hill. Since 1939 the trend on the latter area has been steadily downward while this has not been the case on the other. In this connection it may he noted that the minor trongh on Connecticut Hill in 1936-37 coincided with the status of grouse reported at that time for New York as a whole and the Northeast in general.

Fisher's data for Michiyan ${ }^{\text {san }}$ afford another example of a lack of synchronism hecause, al-

* The term animal wan used hre as applying to hoth the grounr and varyang hare.

4. "The exeran of the percentage zeporting "abundant' over thome repurtiug "ucarce' was the figure uaed in plotting the graphs."

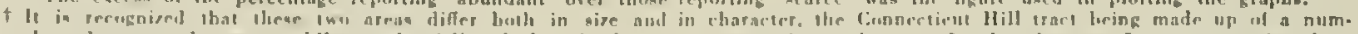

ber of neparated cosmis while on tho Adirondack unit the grouse enver in continunus. In the abance of more extensise data.

howeser, their enmparison scems warrasted. 
though they corroborate a general shift throughout the north-central region from high to low numbers between 1932 and 1935 followed by gradual recovery. they show that individual areas were often at variance with one another. For example, in 1933 when populations on the Pigeon River and Munuscong Park tracts were found to have decreased sharply over the preceding fall, that of the Houghton Lake area more than doubled. Two years later abundance on Munuscong Park took a marked upturn while it continued to decline at Pigeon River although previously the two areas had paralleled one another.

These and many other records serve to demonstrate that ultimate understanding of the part synchronism plays in the fluctuation of grouse abundance must rest on a knowledge of what happens on the smaller units of range. The data of this Investigation for its Connecticut Hill study area offer a clue to the nature of this relationship even though no condition of severe scarcity was experienced.
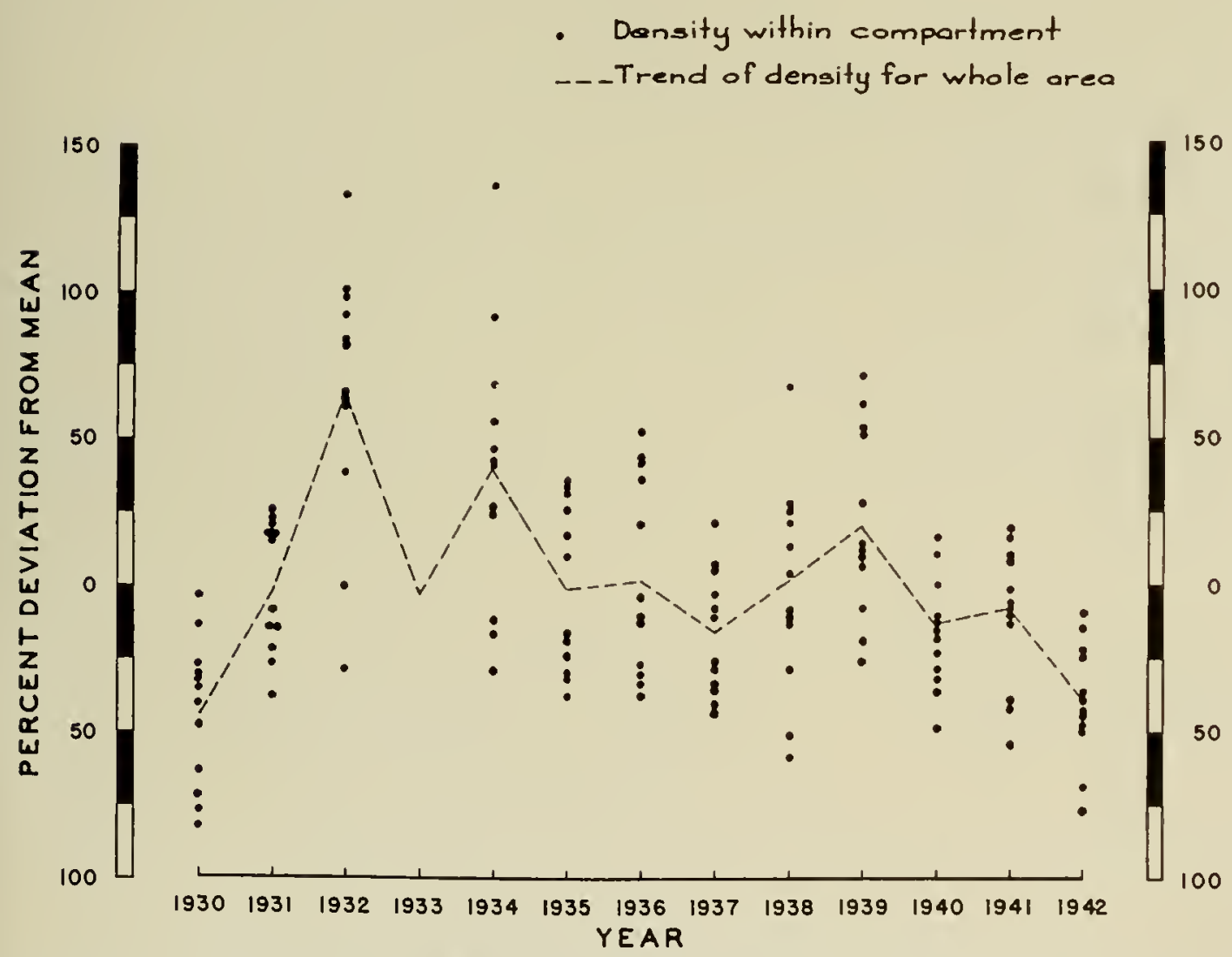

FIGURE 60. RELATIONSHIP OF TREND IN THE AVERAGE DENSITY OF THE FALL GROLSE POPULATION ON THE CONNECTICUT HILL AREA TO THE DENSITIES WITHIN THE VARIOUS COMPARTMENTS COMPRISING THE AREA

As has becn discussed elsewlere* this area is not a continuous mit of grouse habitat but comprises a group of woodlot coverts more or less separated from each other by open land. The basic portion. which has becn used for appraising the population trend of the area as a whole, has been divided into twelve compartments of 130 to 300 acres each largely 
conforming to these individual coverts. The grouse populations of these compartments behaved quite independently of one another and seasonal estimates of numbers were made for each. The sum of these constituted the estimate for the whole area.

In figure 60 the fall population density on each of these compartments has been plotted year by year in terms of its percentage deviation from the mean for that compartment together with the trend of that for the area as a whole. It is significant that there was a wide spread in the degree of deviation among the different units each year and that each fall some units were at a low level although the specific ones varied constantly. It is also significant, with respect to those compartments which were low in various years, that the degree of deviation from the mean was often as great when the aggregate population level was high as when it was low. In fact in 1942, when the population as a whole fell to the lowest point since the first year of the study*, all but two compartments were within the same range of deviation that had been observed during other years. The difference lay in the fact that in 1942 a greater pro. portion of all the units were "below the line". Similarly years of abundance were those in which the coverts producing an above-average number of birds outweighed the ones below average, hut nevertheless each year witnessed some units below average.

It is important, too, to realize that the relative rank of the different compartments, as shown in figure 60 , constantly varied from year to year. To give some idea of the lack of unison obscrved a composite graph of the individual trends has been prepared (figure 61).

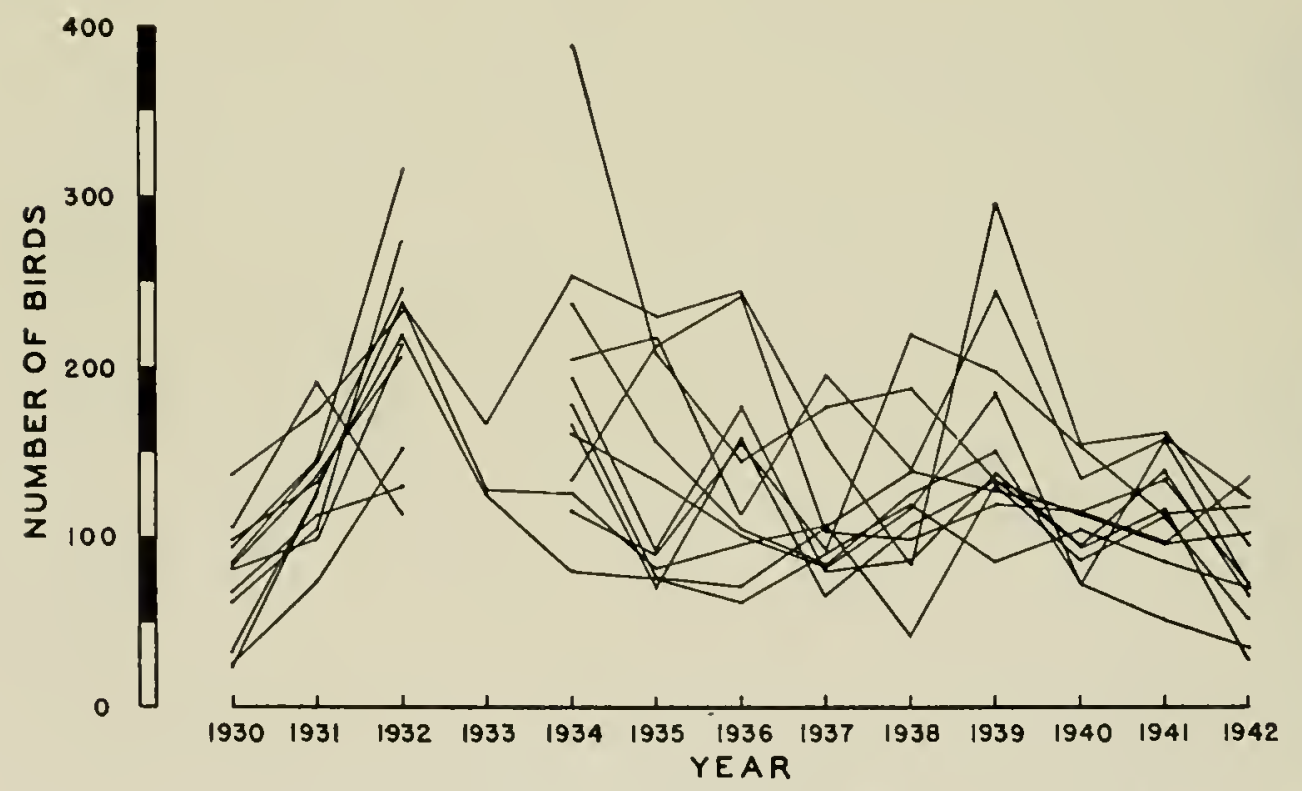

FIGURE 6I. TRENIS OF FALI, GROUSE, POPUIATION DENSITIES FOR TIE VARIOLS COMIPAT. MENTS OF TIE CONXECTICUT III.L AREA - 1930-19.12

These dista, althouph cosering only a comparatively slort period of time with respect to the behavior of wildlife populations, seem to demonstrate that the ahundance of grouse in individual coverts is constantly fuctuating and that. even during seasons when the birds are plentiful over a tract as a whole. many such coverts are normally below average. It secms prob-

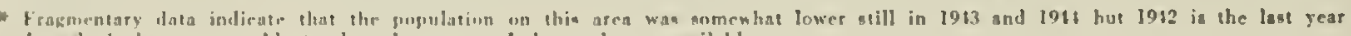
for which rlata comparable to the other years of the study are asalable. 
able that a similar relationship exists with respect to the status of grouse abundance through. out any range area. The data also suggest that conditions of general scarcity which occur from time to time over wider areas may be primarily a consequence of some combination of factors causing a loss of productivity over a preponderance of the component coverts, but that the actual populations of many of these coverts may often fall little lower than they do in other years.

Synchronism, with respect to the status of grouse abundance over any range area, thus seems to have been greatest during recurrent major troughs, but to have occurred a year or so later than many parts of the area initially reached a low level. Considerable lack of syn. chronism has been characteristic of the early stages of most declines. The term "spotty" has been applied to conditions of this kind when grouse are still plentiful in many localities but noticeably scarce in others. Lack of synchronism has also been frequent during times of generally high abundance.

\section{CAUSES}

The reproductive potential of a species constantly tends to increase its numbers. The potential productivity of the ruffed grouse is greatly in excess of that which ean actually be realized hecause the range will accommodate only about so many. For this reason low popu. lations tend to rise, but those already at a peak have little opportunity to increase and tend to fall back. A wide variety of jnfluences operate as limiting factors. Most of these vary from year to year, and even from season to season, causing grouse populations to fluctuate continually in numbers. Morcover, radical changes in the environment may cause local scarcity at any time.

The observations of this lnvestigation as to the manner in which these influences have affected grouse productivity on the areas studied have heen discussed in the preceding chap)ter. These data have shown that differences in the degree of survival during one or more life periods rather than changes in the reproductive potential of the birds are the chicf reasons for the population changes recorded. It is probable that this is typical of the behavior of such populations.

It has also been shown that, in addition to the constant but irregular fluctuation of local populations, there have been recurrent periods of general abundance and of general scarcity over greater areas. It has been shown, too, that these periods. particularly those of scarcity, have recurred at intervals of eight to ten years in many parts of the species' north-central and northeastern range during the time since 1900. Furthermore, data have been presented which suggest that such longer-term fluctuations in the average abundance of grouse over extensive areas may be primarily a result of the recurrent synchronization of a preponde. rance of the local populations at low average levels, althongh at such times many of the com. ponent units exhibit densities little, if any, lower than are often reached in other years.

In other words it seems cvident that the immediate causes of these major fluctuations in general abundance lie among the same agencies which limit survival on local areas regardless of to what extent they may be governed by more deep-seated influences.

\section{Relative Significance of Losses During Different Life Periods}

The data increasingly point to the success or failure of the ammual increment of young as the key to the problem. As already discussed under Net Productivity", this has been the most frequent cause of low fall populations on the Investigation's study areas although just when 
the loss occurred has varied on different occasions. On Connecticut Hill losses during the breeding and nesting season have averaged proportionately greater than those during the brood period. In 1940 high nest mortality caused a sharp drop in the fall population level. On the other hand. in those years when failure of the crop was most severe $(1933,1935$ and 1942), unusually high brood mortality always occurred. On the Adirondack area very high brood losses were responsille for the poor crops in 1933 and 1935. Although breeding fail. ure apparently oceured its significance is not clear. Unfortunately there was no opportunity to observe conditions associated with a real scarcity throughout the State.

Evidence that failure of the annual inerement has frequently been the chief cause of major declines in the general abundance of grouse is also found in the observations of others. Among the first to report this were Woodruff ${ }^{\text {ses }}$ and Forbush ${ }^{145}$ with reference to the scarcity of 1907. As a result of his investigations in New York, Woodruff noted that "with only one exception the observers state that all or nearly all the birds shot in 1907 were old birds, and most of them cocks. Scarcely any young birds of the year were seen." The same author also quotes similar reports from Connecticut. Massachusetts and Michigan. Speaking of New England, Forbush stated "I had been much in the field during the spring and summer of 1907 , and had noted that very few young birds were reared in the region with which I was familiar." Also applying to the 1907 decline the following statement appeared in the Annual Report of the Pennsylvania Game Commission" "Game birds have not been as plentiful during the last season as heretofore, notwithstanding the promised increase because of the many birds left over the year before."

Regarding the dechine of the following decade Minnesota stated" "In 1915 all hunters reported finding few coveys of young birds and the few found were small. Wuch the same condition prevailed in 1916." Similarly Pennsylvania"s Annual Report for $1916^{m+m}$ commented that most of the grouse killed in the fall were old hirds.

Again in the next decade an official report for Hinnesota contains the following state. ment. "During ... 1923. the increase in partrilge. or ruffed grouse. in many districts of the state was almost unbelievable, these birds abounding in great numbers in suitable localities. So far as it has been possible to ascertain the hirds wintered well during the winter of 1923 and 192.1 hut for some unaccountable reason at the close of the nesting season in 1924 the decrease in numbers of these hirds was so enormous that the closing of the normal shooting season was being seriously considered." In northern Michigan, too, a large crop was said to have hatched in 1924 hut most of the young died before the hunting seasun ${ }^{115}$. Similarly Brewster" called attention to "the woll known fact that every now and then almost no young grouse arrive at maturity in Now England during seasons when very many are suecesfully hatched". McDonald ${ }^{25}$, speaking of castern Canada, reported a great abundance in the spring of 1921 and a good hatch but few at the end of the summer and alsu com. mented "In fifty years with the grouse I find that they change in numbers greatly and always in the summer".

After his study of fluctuations in Canada, with particular reference to Ontario from 1932 to 1935. Clarke ${ }^{\text {?3 }}$ staterl that his field studies at the time of the diminution showed that the dying-off was the result of a condition "affecting chiefly young grouse and taking place lluring the summer". With respert to 1936 Massachusetts reported" "linffed gronse had a good hreeding season, and the young and old birds alike eame through the summer. hut by the time the season opened their numbers were bally depleted-so much so that. in order to protect the brood stock. it appeared to be the best policy to close the scason." 
More recently Gordon" stated with reference to poor hunting in 1944 in Pennsylvania, "It is believed that the two bad hatching seasons in succession, 1943 and 1944, are largely responsible". In New Brunswick a good stock of birds at the end of the 1942 season and a good hatch in 1943 were reported lout in the fall of the latter year grouse were scarce and few birds of the year were lound ${ }^{2 \pi 7}$.

That failure of the crop of young in a season can have a pronounced effect on grouse abundance is evident when one considers the proportion of immature birds in an average fall population. As has been shown ${ }^{\Delta}$ the Investigation's data indicate that the increment of young surviving by September does not greatly exceed the number of breeders even in a year of good productivity. Therefore. if this increment should not materialize, the abundance of grouse in the fall would be only about half what it would have been had productivity been average. Such a loss would also be felt the following year as a result of reduced breed. ing stock.

If, however, a similar failure of the increment should occur for two years in succession grouse abundance would drop to a very low level. Average adult mortality coupled with little or no replenishment of young would result in the population the first fall being roughly half that of the preeeding year and in a further recluction approaching the same proportions by the second fall. But about this time another factor would enter in, nanely; the average life span of the species in the wild. As has been discussed elsewhere ${ }^{\dagger}$ it seems likely that few grouse live to he four years old. Following a season of average productivity only about onc. quarter of the grouse present in the hunting season are more than two years old. Yet, in addition to greatly reducing overall alundance, failure of the increment for two successive years would also change the age composition of the remaining population to one in which nearly all the birds were more than two years old and close to half more than three years old. It seems probable that losses among these older hirds would he somcwhat accelerated and thus still further deplete the ranks.

Although the evidence points strongly to loss of productivity in terms of hirds of the year as the primary manifestation of the forces responsille for the major leclines in grouse abundance that have been recorded, adult mortality (apart from that associated with longevity) seems to have been a contributory factor in a number of instances. But the data do not support the conclusion that it may have heen controlling. As was demonstrated on the Con. necticnt Hill study area in 1936-37 above average overwinter losses can result in decreased abundance the following fall. Shonld such losses occur in conjunction with the scason during which the ensuing increment failed also, they would act to increase the severity of the resultant scarcity. This seems to have been what happened in $1906-0 \overline{7}$. for example, when a record flight of gushawks imaded the north-central and northeastern states.

But the question remains as to what have been the principal causes of crop failures, especially brood mortality, and what has effected a sufficient degree of sychronism among them to result in periods of general grouse scarcity over wide areas recurring with the degree of regularity that has been reported. Neither of these problems has been solved. Nevertheless certain facts may he cited.

\section{Contributori Influences}

Over the years, periods of grouse scarcity have been attributed to a wide variety of causes

* Gordun. S.. pressonal lifter to the anthors, Februsry 23, 1915.

$\triangle$ See Chapter Xil, p. 542 .

$\dagger$ Sce Chapier VIII, j. 360 
as noted in Chapter I, the great majority being of an essentially local nature. A few theories have been advanced, however, to explain more extensive fluctuations.

\section{Predation}

In one of the first hypotheses suggested. Bumliam ${ }^{\infty 0}$ related unusual invasions of goshawks (Astur atricapillus) during the winters of 1906-(07 and 1916-17 to disappearances of the varying hare and reasoned that, with their staple food gone, goshawks and other predators preyed more heavily on grouse and were responsible for their periodic depletion. Subsequent records. however, have shown that this correlation has not been corroborated. For example Clarke ${ }^{\text {73 }}$ reported "A goshawk migration is recognized to have occurred in Ontario in the winter of 1934-35. Reference to the map of the areas of dying-off for 1934 shows that. for the most part, dying-off has preceded this migration." Similarly, Leopold ${ }^{204}$ although speaking of Wisconsin, summed up the situation generally when he wrote "it would appear . . that invasions are much too local and infrequent to account for the periodic Statewide decimation in ruffed grouse, although goshawks doubless accentuate the shortages where and when they oceur." Furthermore such flights take place in winter whereas the data indieate that recurrent periods of general grouse scarcity have resulted mainly from breeding and rearing lusses. Therefore, incursions of migratory predalurs may he eliminated as a primary cause of grouse fluctuations of this kind although they undoubtedly are contributory on occasion. Neither is there evidence that ehanges in the abundance or food supply of resident predators have been responsible.

\section{Disease}

Another possible cause is disease. The idea of some scourge periodically sweeping through the ranks of the grouse has been an easily visualized explanation. For many years the common leelief was that one disease, the so-called "Grouse Disease," was responsihle for the periorlic diminution of grouse abundance. So far, however. no such ailment has been found to fit the circumstances.

Although some condition of this kind had been mentioned ly a number of writers and IVoodruff had included it among the three principal reasons he listed for the searcity of 1907 , its relationship to grouse abundance was first really sludied hy Alten ${ }^{17}$ and Gross ${ }^{173}$ whose investigations were given impetus by the searcity of 1921-27. Other studies of this kind have heen carried on by Green and Shillinger ${ }^{*}$ and Clarke $^{73}$ as well as by this Investigation. Grouse have been found to he subject to a great variety of diseases and parasites. Outstanding among them as decimaling agents of wild grouse are the stomach worm (Dispharynx), unlaremia and a blood parasite (Lencocylozoon). The last of these in partieular was found to be associated primarily with mortality amone chicks. Yet none of these maladies has been fonnd widely distributed throughout grouse range. while those parasites which have a wide distribution appear largely to be innowous ${ }^{\Delta}$. On the ofler hand, the fact that there is still so little known of the paramoun causes of loroml mortality leaves the possibility that some impurtan but as yed unrecugnized disease exists.

But assuming that some condition of this kind were found. a mechanism capable of syuchronizing its irruption over larere areas and at the same time allowing for extensive local bariations would remain to be discovered. Clarke has sngesesed what might take place if lecucocylozoon were the principal cause invoted. Biut the presence of leucocylozoon has

* Ser varioun papers by Green and Slillineer.

$\Delta$ Sire Clajuet X. p. \$2. 
not been demonstrated in connection with grouse fluctuations outside Ontario. Nevertheless, whatever may be the underlying cause of widespread diminutions in grouse abundance it seems probable that it is usually accompanied by lowered vitality among the young. If this is true, the stage would be set for disease to add momentum to the decline even though the specific organism involved might be different in various regions.

\section{Solar Activity}

As students continued to ponder the geographic extent of recurrent major fluctuations in grouse abundance as well as their seemingly high degree of harmony they began to look for some all-pervading force as the cause. About this time interest was stimulated in the possibility that variations in solar activity might be correlated with such behavior in wildlife pop. ulations. Using sunspots as an index a relationship between solar activity and terrestrial life, presumably through the medium of rainfall, had been suggested in data on rates of tree growth ${ }^{100}$. DeLury ${ }^{07}$ and later $\mathrm{Wing}^{4 / 1}$ reported fluctuations in hird migration dates which appeared to correspond more or less to changes in the number of sunspots. Elton ${ }^{20}$ interpreted records representing the trends in abundance of several species of hircls and mammals, notably varying hare and $\mathrm{ly} x$, as following palterns sufficiently close to the 11.2 year periodicity of sunspots to indicate a connection. Here seemed to be the answer-a force capable of eausing the continent-wide sweep helieved to characterize grouse declines.

But it has become evident that such a relationship, if it exists at all, is nol as simple as at first envisioned. As brought out at the Matamek Conference most North American species, for which the availahle data indicate some regularity in the intervals between recurrent fluctuations, have exhibited periodicities of less than ten years which do not correlate with that of sunspots*. MacLulich" ${ }^{2+1}$ later demonstrated this quite conclusively for the varying hare and byx (Lynx canadensis). Similarly the records for ruffed grouse. to the extent that they represent periodicity. have exhibited an average interval of $9+$ years which cannot be directly assuciated with the sunspot interval of 11.2 years ${ }^{4}$. Furthermore the data of this lnvestigation and other recent studics, as well as more critical analysis of older records, have shown far less uniformity in the fluctuations of the component populations of a region than was once thought to be the case.

Nevertheless no one can deny that the sun is the original source of energy upon which the existence of life on the earth depends. Clanges in the amount of effective solar energy reaching the earth, although relatively small, are known to take place. Moreover, sunspots are but one manifestation of these changes. Some force not yet recognized may be involved. But, however that may be, there seems little doubt that, if any connection does exist, the motivating mechanism with respect to synchronizing fluetuations in grouse abundance must opcrate quite indirectly and he subject to considerable variation.

Several intermediate factors which might function in this way have been suggested. One possihility is that the virulence of disease organisms might vary with changes in solar aetivity; another that the vilamin content of food or some other nutritional factor might be affected; still another that some influence associated with climatic or weather conditions might be responsible. Yet little evidence has so far been presented for the first two and even the degree of relationship between weather trends and changes in solar activity is still being debated ${ }^{\pi 7},{ }^{70},{ }^{3 \pi 0}$, as?

* Leopold"2s has shown a lack of agreement also for the red grouse in Great Britain.

$\triangle$ Grange ${ }^{158}$, using $\mathbb{W}^{-}$isconsin data, has suggested a method of weighting sunspot figures in order to correlate them with grause abundance but it does not provide for differeoces such as have occurred between varjous regions. 


\section{II' ealher}

Regardless, however, of what governs it, or to what extent it may or may not be related to the forecs represented by sunspot changes, the evidence is becoming increasingly strong that weather is a primary factor in governing variations in grouse abundance. Data from the Connecticut Hill study area indicate that both temperature and precipitation are important. Other elements of weather are undoubtedly insolved also. Despite its evident significance, however, a great deal still needs to be explained regarding the specific ways in which weather functions in affecting grouse productivity.

With respect to major fluctuations, the data discussed in Chapter VI" with respect to the relationship between March and June temperature trends in New York and recurrent grouse scarcity in this State reveal some agreement in point of time. Furthermore, temperature records for other grouse states exhibit similar degrees of agreement. Perhaps this was coincidence for exceptions also occurred. Certainly the channels through which it may have exerted its affect are not clear. Then, too, temperature is only one element in the complex of factors, even with respect to weather, operating in any instance. All of them vary in intensity and no one of them is likely to be the lest index at all times. Nevertheless. the possibility of a connection warrants serious consideration.

To speculate regarding the modus operandi of such a relationship is hazardous. One possibility, though, is indicated by obscrvations during this Investigation. In view of the fact that the evidence points most strongly to failure of the increment of young as the key to grouse scarcity of this kind, weather may function through some physiological effeet in which the weather conditions involsed would not cause direct decimation but rather would set the stage for subsequent losses. It must be emphasized that this is mainly conjecture. A suggestion of something of this kind, however, is found in the data from the Connecticut Hill study area $^{\triangle}$ which indicate a corrclation lecteen temperature and precipitation during the three weeks immediately following hatching and the brood mortality occurring during the latter part of the summer. In this connection, too, may be cited the observation that a lack of sharp lemperature changes from day to night may inhibit the maling of sheep and lhus result in failure of the lamb crop ${ }^{3 n}$.

If weather should prose to be a significant factor in recurrently synchronizing grouse scarcity throughout large areas. the fact that, in spite of general conditions, it varies greatly from place to place lecause of such influences as irregular topography and shifting storm tracks would help to explain the disparities between localities which have been so frequently recorded. But how much fire there may be under al] this smoke must await further research.

\section{Population Densily}

Another piece which must esentually he fitted into the puzzle pertains to the role of population density in relation lo fluctuations in gronse abundance. As was discussed in the chapter dealing with productivity a tendency was noted during the Investigation for high breeding populations to be less productive. relatively. than low ones and for this lo result from a lower increment of young leeing producedt. Horeoser, on the Connecticut llill study area those compartments which exhibited relatively high densities at limes when the general average wals low were often those which. for one reason or another. had heen low the preceding year.

\footnotetext{
* Sor ligure 13.30 .305$.

A. Sere Chaping i I. J., 303.

$\uparrow$ See Chaner Nil, 1 . 510.
} 
While no severe scarcity was experienced during the investigation, this, nevertheless, suggests that the immediate causes of such shortages may be effective primarily with respect to high breeding population densities. It also suggests that they will result in general scarcity mainly when they occur in conjunction with a preponderantly high level of abundance among the component local populations of an area. If this should prove to be the case it would help to explain why abnormal weather, such as that of 1912 for example*, was not associated with a pronounced low in grouse abundance ${ }^{\Lambda}$. In other words it may be that density is a necessary catalyst.

Other observers have reported similar experiences. After stating that although apparently scarce early in the season, gronse in most localities turned up later. a Connecticut report ${ }^{\text {to }}$ continued "However, in places where birds had been very numerous in the previous year. they appeared to be very scarce in 1924." A news release of the Wisconsin Conservation Department in October 1933 stated regarding mortality in certain northern countics in the fall of that year " $\mathrm{U}_{p}$ to the present time it has afferterl ruffed grouse principally, and on areas where the birds were most plentiful." Commenting on a general slump of more than 50 per cent throughout most counties of both peninsulas of Michigan in the fall of 1931 as compared with 1933 Ruhl ${ }^{\dagger}$ stated "In other counties. . . , characterized by scattered coverts which are heavily hunted, grouse were almost unanimonsly reported to be more abundant than in the autumn of 1933." Similarly, in speaking of the deeline in Minnesota in 19.12 and 1943 Blair ${ }^{\ddagger}$ reported that it "apparently was not as effective in the arcas where birds were most hunted as it was in the places off the heaten trails where less huntiug was done." It may be, therefore, that reduction of high population densities through hunting for sport, regulated in accordance with actual productivity from year to year. can serve to lessen the severity of recurrent scarcity.

In this comnection it is possible that the lack of marked fluctuation in numbers reported by Leopokl $l^{\prime=4}$ for the remaining grouse habitats of the Middle Ifest during recent years, and which he suggested might indicate that the species did not originall! exhihit such behavior in that part of its range, is not an inherent characteristic lut rather a result of the fact that the birds no longer attain high densities in that region.

It is evident from the foregoing that. while the record concerning major fluctuations in grouse abundance suggests a considerable degrce of regularity in their recurrence, there is still a great deal to be explained regarding the mechanism involved. If anything is certain it is that the interaction of several factors is usually responsible. Nevertheless, the data pre. sented secm to narrow the problem to some extent. They indicate that the key lies among the forces which cause failure of the annual increment of young. but that a preponderantly high level of abundance among the component unit populations involved may he a necessary prerequisite to the synchronization of the effect of these forces. They also indicate that the rate and degree of decline are closely related to the relative size of the increment compared with the breeding population and to the average life span of the species. Further they suggest some of the factors which may implement these relationships and point to weather as of prinary importance among them. The remainder of the solution must await further research.

\footnotetext{
* See figure 23, D. 305 .

$\triangle$ Assuming that the temperature finctor cited also proves significant.

$\dagger$ Ruhl, II. D., personal letter to the authors, January 21, 1935 .

f. Mair, F. 1)., personal lether to the authors, February 28, 19.15.
} 


\section{CYCLES}

No discussion of fluctuations in wildlife abundance would be complete without including the concept of cycles. Ever since observers began to realize that the intervals between successive periods of abundance and scarcity of many species had exhibited a tendency toward regularity, the idea of their recurring in cycles has appealed to scicntist and sportsman alike. It has appealed particularly to those interested in gane because it suggests the possibility that the future course of abundance can be predicted. For this reason it is important to "look at the record," especially with reference to grouse, to see how strongly existing data support this hypothesis.

The concept of cyclic behavior is not new. Since the beginnings of time the cycle of night and day, and the annual cycle of the seasons have been recognized. During the past two centuries, however, cycles have been ascribed to a great many other things. Probably the best established, aside from the movements of various celestial bodies, is that of the changes in the sun represented by sunspots. Closely associated with this are the variations in terrestrial magnetism, while less well correlated are fluctuations in ultra-violet radiation from the sun and climatic changes". But cycles have atso been described in such things as. the price of common stock, building activity, the production of pig iron and death rates from various diseases ${ }^{2 w 0}$. With respect to wildlife, abundance data have been interpreted as indicating cyclic behavior among a varicty of species chiefly in the northern hemisphere. Among them, in addition to the ruffed grouse, may be mentioned mice and lemmings ${ }^{1,1}$, ${ }^{124}$, varying hare and lyn $\mathrm{x}^{210}$, the arctic fox (Alopex lagopus) ${ }^{126}$, the red grouse (Lagopus scolicus) in the British Isles ${ }^{220}$ and the Atlantic salmon (Salmo salar) ${ }^{213}$.

A significant feature about these fluctuations, however, is the variety of periodicities represented. For example, the ruffed grouse seems to have exhibited an average interval between peaks and troughs of slightly more than nine years". MacLulich" ${ }^{210}$ concluded that those of the varying hare and lynx were both 9.7 years and Elton ${ }^{1 m}$ found approximately the same periodicity in the records of the Hudson's Bay Company for the muskrat (Fiber zibelhicus), red fox. marten (Marles americana), wolf (Canis) and mink (Mustela vison). An interval of between nine and ten years has heen reported also for the Atlantic samon ${ }^{\text {sin }}$. On the other hand, mice, lemmings (mainly Lemmus trimucronalus) and the arctic fox have followed ayear trends in North America and Europe ${ }^{124}$ " ${ }^{21}$. That of the red gronse in Britain has av. eraced 6.5 ycars $^{2 n}$, while its cousin, the willow grouse or rype (Lagopus lagopus) of Scandinavia, has shown a pattern of three to four years ${ }^{12}$. The sunspot cycle has a mean of 11.2 years, while agricultural productivity in the United States, which would scem to reflect climatic changes, has shown a 18.6 year fluctuations ${ }^{\text {mos }}$.

But, irrespective of the periodicity involved, none of these trends has exhibited a precise recurrence of its successive peaks and troughs. The degree of variability in this respect has differed considerably hetween spccies. in man! case being quite wide. The intervals seem to have been most nearly constant among the mice and lemmings as well as the arctic fox. Other species have varied to a greater extent. Fur the ruffed grouse from seven to twelve years have elapsed loetween "lughs" in different instances and from eight to eleven years between "fows". This frequency has ranged from eight to eleven years for the varying hare and from eight to welve years for the lynx. In the case of the red grouse in Britain it has varied from four to eight years. But even the recorded lluctuations in smspots have slown a variable recurrence of from scien to seventern years.

* Sce dincuraion al l'erimdicity. p. 503. 
All this raises the question of just what the term "cycle" should be considered to mean. In discussing the characteristics of cycles in connection with weather phenomena Marvin ${ }^{248}$ wrote:

"Mere recurrences of natural phenomena without reference to the time interval between recurrences do not necessarily constitute crcles. To be cyclic there must be svstematic recurrence ... If. as some claim, the variations observed in length and amplitude of the cycle-such, for example, as the differing lengths and intensities of the sunspot cycle - are not of an accidental character but are controlled by law. then the proponent of such a view must not only prove the reality of the climatic cycle he claims, but the nature and reality of the systematic fluctuations in length and iniensity nust be fully set forth ... Proof of cycles by verification of predictions is the ultimate criterion, but its utilization is obviously beset with difficulties. If climatic features are the composite of the operation of several cyclical effects then past features must he capahle of synthetic reproduction from cyclical elements, thus affording pronf of the cycles."

The same analysis could be applied equally well to the use of the term with respect to the fluctuations in abundance of grouse and other wildlife. If a definition such as the alove were adhered to, grouse and many other species could not be classed as cyclic on the basis of existing data.

On the other hand, the fluctuations of grouse, for example, have shown a distinct tendency. toward rhythmic behavior. especially in certain regions. Furthermore, if arcurate quantita. tive data were available, the degrce of variability might he found to have heen even less. In view of the absence of such data the possibility remains that the trend has followed a systematic pattern and, to prove or disprowe it, highly accurate records will have to be kept for some time to come. The data marshalled by Elton ${ }^{236}$ with respect to mice, lemmings and foxes afford some idea of what is needed for such a purpose.

Likewise, correlation or lack of correlation with the fluctuations of other species or events will require long series of data in cach case. This was shown by MacLulich ${ }^{210}$ who found that the relatively accurate records for the varying liare in Canada for the 87 years from 1847 to 1934 were insufficient in demonstrate their lack of correlation with the sunspot trend although this could he proven through the use of similar records for the lynx extend. ing over 174 years (1751-1925). But it must be emplasized that mere correlation of the periodicities of two trends. even though quite perfect, does not mean they are related with respect to cause and effect. For instance, mice near Ithaca, New York were found to exhibit a cycle in harmony with that of Presidential elections ${ }^{100}$. Some link connecting the two must be identified.

For the present. however. the element of variability cannot be plotted in advance. The next "high" or "low" may occur a year or two before or after that representing the average interval. Amplitude also may vary. as happened in New York in 1936-37, so that a segment of the cycle is largely obliterated. Furthermore. local populations have often been out of step with the general average and the relative status of such populations is subject to change at any time in response to changes in the local environment.

With these limitations in mind. continued application of the cyclic concept to grouse may be warranted. But predictions regarding the prospects for fall abundance in any particular year cannot be made with any degree of exactitude on the basis of data assembled to date. Rather such prospects, for the time being at least. must be judged during the same season on the basis of a knowledge of the spring population level and of the degree of breeding and rearing success.

* Principally those of the Hudson's Bay Company. 


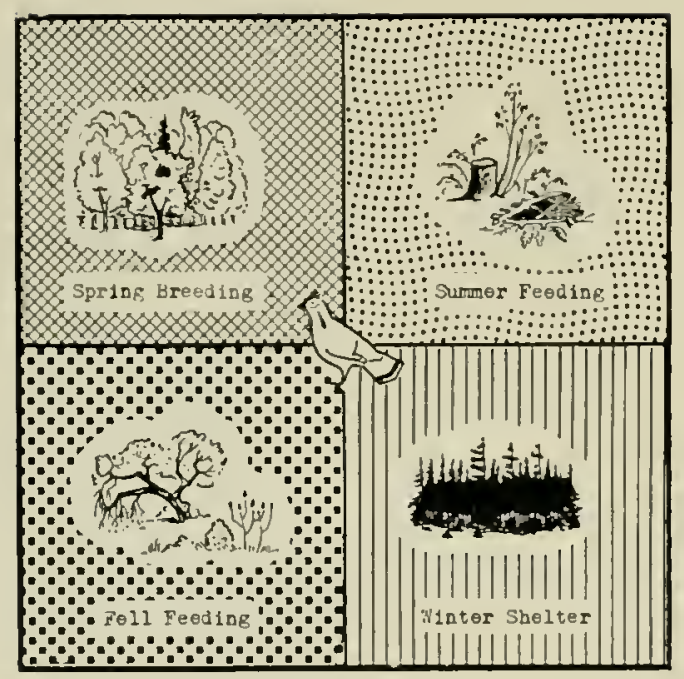

A

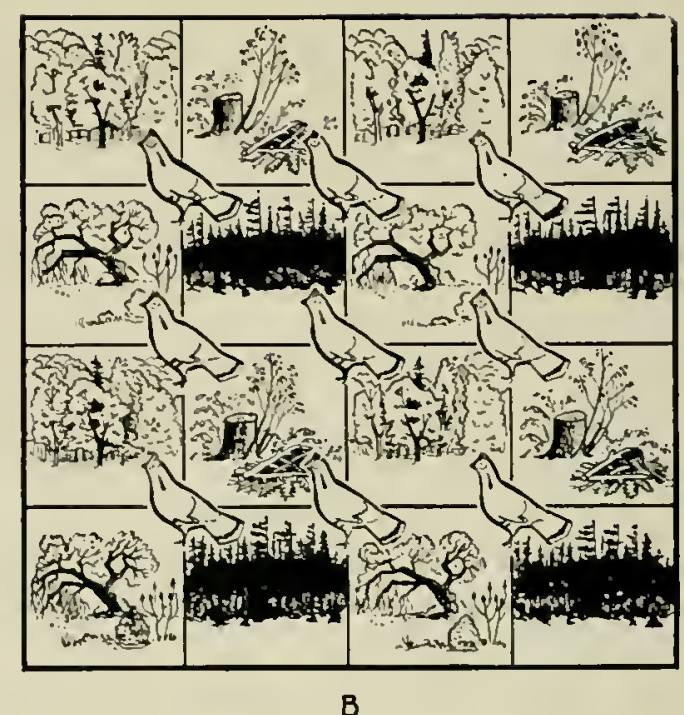

B

Nucleus of Grouse Habitat 


\section{PART III}

Managing the Grouse Chop 



\title{
GROUSE MANAGEMENT
}

\author{
By GARDINER Bump
}

Game management is the process of putting together known facts to produce, maintain and use the game crop.

The days when this had to be done largely "ly guess and by gosh" are gradually becoming a menory. In their place, for species after species, research is beginning to supply a blueprint; management to translate. and implement this to produce the desired results.

The Investigation, therefore. has sought to marshal the pertinent facts ahout the ruffed grouse which could be used as a sound basis for grouse managcment throughout the State.

In New York, on the Conservation Department rests the responsibility for fixing, each year. the hunting regulations for grouse. In addition it is called upon to manage some cight! thousand acres of game lands. most of which represent gromse cover. It also altempts to make some provision for game management on approximately half a million acres of submarginal farm land bought for reforestation purposes and on which grouse and other species of game represent a valuahle, secondary crop.

At the same time there are millions of acces of grouse cover in private ownership. Moreover, an ever-increasing proportion of this is finding its way into the hands of people who place a high value on recreational opportunities which such lands can provide. These people seek. and are entitled to have, advice in the development of their land to improve and main. tain a gane as well as a forest crop. New lork is now. and probably always will he. primarily, a forest and woodlot game state. Among the small game species. none is so highly: prized as the rufferl grouse. Conseguently. its cucouragement. hy apply ing appropriate measures on State or private lands. is highly desirable.

Nanagement, to usc the vernacular, is the "pay-off" on the investment in research. Inevitably, this pay-off will come in instalments over the years. There are a number of reasons for this. First, it would be presumptuons for the authors to assume that they have found out everything worth knowing about grouse and have completely mined the accumulated data for every conceivable productive application. Secondly. while many of the findings have been translated into practical suggestions which have been field-tested. sufficient time has not elapsed to permit full evaluation of all the results. Application. too. is dependent upon interest in the problem which bids fair to grow with the years.

In the preceding chapters on research the authors have made every attempt to meet scien. tific standards to the liest of their ability. In the ensuing chapters. in attempting to translate the findings and the personal experience gained into management suggestions, this will not always be possible. Here. in order to make the most complete contribution. it is often neces. sary to state the case as we now see it. In doing this it is understood that. in the light of future experience, modifications are inevitable. 
To encuurage a broad understanding of the problem and still present in workable sequence the specific steps by which a grouse crop may be encourayed, the management material has been organized as follows:

1. A brief account of the experimental grouse management work already undertaken on State game lands.

2. A resume of the ten factors affecting the abundance of grouse by way of showing which may be utilized and how in producing more grouse.

3. A discussion of what may lie done on a broad scale to encourage grouse over the State as a whole (Chapler $\mathrm{XIV}$ ).

4. A detailed, step by step, analysis of how to design productive grouse coverts and sel up long-range nuanagement plans therefor (Chapter XV).

5. A discussion of how this may best be carried out hy improving and maintaining grouse cover (Chapter XVll.

6. A consideration of other ways of maintaining the grouse crop (Chapter XVII).

7. A discussion as to how best to coordinate the work of various Federal. State and local agencies with private enterprise in carrying out grouse management projects (Chapter XVIII).

\section{Expermental Management Projects}

The hases for the management suggestions have heen the present factual study of grouse life history and requirements and the experience and observations of the authors in applying the principles here learned to State game management lands over a ten-year period".

As a part of the lesting progran. the composition and type arrangement of the cover on each manaqement area were surveyed in the ficld. then placed on large seale maps. The viswal presentation facilitated an analysis of cover conditions forming the basis for sulsequent improvement projects. as well as for long range management plans. These were drawn up in considerable detail.

The improvement work fell largely into two categories. establishment of cover and its mainlenance. Under the first. open lands were planted to conifers and hardwood species, so arranged as to produce ultimately a substantial timler erop meanwhile providing excellent food and shelter for grouse. Around many of these, shrub horders, utilizing such species as (hornapples. dogwoods, vilurnums, apples and evergreens, were set out in clumps (with due 'regard to future hunting possibilities.) In the cutire program about 2,000,000 evergreens and ، 100,000 lroad-leaved trees and slirubs were set out.

Overgrown land improvement projects centered mainly about the problem of maintaining the status quo. This was done by employing eutting. poisoning. and infrequently, hurning to arrest the normal surcession and eliminate undesirable species. Occasionally conifers were planted in such areas to provide needed shelter.

In wooded areas. the composition and arrangement of cover were altered by judirious thinnings and b! selective lumbering of merchantable trees. Where forest cover was extensive and unbroken. small areas were clear-cut. in rotation. to provide necessary summer and fall feeding groumds and therely increase materially the earrying capacity for grouse of such cover. In all. about 100 of these were estahlished.

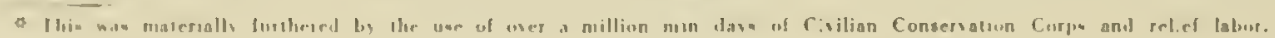


But trees and shrubs, like constructive ideas, lake time to grow. Some results of these cultural practices may, therefore, not be fully evident for some years. To bridge this gap. the Investigation also noted the effect, on cover, of eutting, planting, burning and grazing carried on at some previous date in many coverts and under a variety of site conditions.

\section{Fittixg the Factors Controlling Abundance into the Mayagenent Picture}

Before considering the management suggestions that follow, it might be helpful to analyze objectively the factual blueprint research has produced. Its overall design embodies the ten factors that, collectively, determine grouse abundance*. Three of these. the physiology. the reproductive capacity, and the general habits representing the basic characteristics of the species are but little subject to man's control. Yet all are adversely afferted by insuffiejent food and shelter which we. within limits, can influence. Another. wealher, while in itself uncontrollable. can also have its adverse effects mitigated by assisting Nature to provide the proper environmental setup.

Disease, so far as can now be determined, is of particular importance only when grouse have heen allowed to overpopulate their hahitat. A part of the treatment lies in adjusting the yearly harvest so as 10 leave in the coverts, breeders suffieient to produre a satisfactory crop for the following year and no more. This only ran be done if the reaponsihle puhlir ageney (in the case of New York State. the Conservation Department) has the power to establish the proper seasons, the technically trainer men to deternine what they should be. the protectors to enforce them and the backing of an interested and an informed publie. In addition to this, food and shelter again are important, for a favorable composition and arrangement of cover produce healthier birds and tend to distribute them throughunt sn as to make disease less likely to reach epidemic proportions.

Predation is more complicated. When grouse are few, cvery lird taken hy predaturs, as well as by any other cause, may well represent a significant loss. If the reverse is true, a considerable number of birds may fall prey to predators without seriously afferting the general level of abundance.

Normal yearly losses from predators, as recorded by the lnvestigation, liave averaged about 40 per cent of the aclults. Yet the climination of such destructive species would not result in saving. for the sportsman, nost of these birds unless they were killed in lheir first fall.

Of all those that prey on grouse, only the goshawk makes grouse a significant part of its diet. The others catch a hird or break up a nest occasionally. but their main reliance for food is on plants or on other animals. The abundance of these "buffer species." then also influences the part predators play in limiting the numbers of grouse.

It is neither possible nor desirable to eliminate all grouse predators from the coverts. On the other hand. in New York State, if the numbers of great-horned owls, foxes and weasels, where they are overly abundant. could economically be controlled, the harvestable surplus of birds would probably le increased. But such control is not practical over large areas.

Since losses from predation adversely influence the total grouse population much less in productive than in poor coverts, liabitat improvement assumes increased importance. At the same time it seems probable that, on small areas to be managed for intensive shooting, the control of the principal nest predators would result in a greater fall crop of grouse. This would be worthwhile, however, only if the additional birds were harvested for sport.

\footnotetext{
* These are phrsiulugv, reproductive capacity, genteral habits, foou, shelter. weather, predation, disease, man, artificial propags
tion.
} 
Of all the factors, man, today, probably leaves the strongest impress on the grouse. But his interests are so diverse. his activities so complex and the results so varjed as to make generalizations exceedingly difficult.

As a sportsman. his annual kill. when a shootalle surplus exists, lakes for sport a substantial proportion of the crop which otherwise would be lost to predation or would disperse. Furthermore, where the hirds are very abundant. hunting may function advantageously by reducing the population density before discase has had a rhance to become important. Conversely, in a period of grouse scarcity. hunting may slow down recovery by subtracting from the population many birds that might better be left to breed. There is. though. some evidence to indicate that the annual kill. during periods of substantial decline or increase, affects the trend of abundance much less than is generally believed.

As a trapper (and hunter as well) man tends to reduce the abundance of predators. particularly if they are present in considerable numbers.

Nuch more important, lowever, are the farmer and the lumberman, for they create, conIrol the development of or destroy the habitat itself. Plow. cow and axe determine the size of the grouse crop in New York State over a period of years to a far greater extent than do trap and gun. Today's best grouse coverts largely result from the abandonment of poor farms and from small wooklcutting operations. To subtract these influences from the picture would be to sacrifice, after a period of years. the variety of vegetation and the interspersion of cover without which grouse can never hecome really plentiful. It follows. then. that those who wish more grouse must, in the long run, encourage such activitics or be prepared to pay the cost of the cultural operations neressary to maintain similar conditions.

Here is where man's role as a conservationist enters in. No longer is it sufficient merely to regulate hunting pressure. One must also learn to produce and maintain environments in which grouse will thrive. To accomplish this requires organized effort on the part of a public informed on the problem and on the benefits to be derived from solving it.

A closely related factor is the practicahility of restoching depleted coverts with handraised birds. These are. at best. costly to raise and difficult to produce in any mumbers. Nor is there. $t$ date, any indication that. with properly constituted coserts. it is necessary unless the seed stock of birds has licen completely diminated.

Throughout this section the emphasis on providing the proper food and shelter is inescap. able. Arcordingly in the management section. emphasis has heen placed on how to design and manage grouse coverts and on how to maintain the crop of hirds. The broad picture is ontlined in the first chapter with intensive management heing liscussed in the surceeding pages. The final chapter deals with courdinating and utilizing the forees that largel! mus he relied upon to carry out the work.

Coordination of all of the above mentioned forces should result. over a period of years. in maintaining a fopulation level that will provide a large shootalle surplus duringr most vears. It may ameliorate lut will not prevent. however, yearly fluctuations in grouse alumdance in any individual covert. Our goal. then. should be to huild up and maintain as many. high-produring everts as pusilble so thit in any one year there will always be an alumdances of these carrying a slootalile surplus.

Thus reads the formula for many a memoralile day afield. 


\section{CHAPTER XIV}

\section{MANAGING GROUSE AREAS}

By GaRdNER liUMP

\section{WHY MANAGEMENT IS NECESSARY}

\section{INTENSIVE VERSUS INCIDENTAL COVER MANAGEMENT}

THE GOAL - IDEAL COVERTS

For Grouse - For Nesting - For Bruods - For Adults - For the Grouse Huxten

OVERALL COVER CONDITIONS, TRENDS AND NEEUS IN NEW YORK STATE

Tue Adirondack Region - The Catskills - The Rest of the State

\section{SOME PRACTICES HARMFUL TO GROUSE}

\section{THE ROLE OF THE STATE}

Annual Responsibilities - Yearly Inventory - Regulation of Hunting - Loxg-tera Projects - Research - Service to the Landowner - Acquisition and Development of Grouse Lands - Maintaining Junting Grounds-Stimulating Grouse Production on Private Lands - Stimulating Interest and Understanding - Emphasis on Fundamental Conservation Programs

\section{as}

\section{SUMMARY}

With constantly increasing hunting pressure on grouse, either the hunter must harvest less or he must see that more and better coverts are produced. (p. 587).

Intensive cover management for grouse alone can seldom be justified on a large scale (p. 587 ).

The management of woodlands for grouse may be combined with the production of other forest products so successfully as to make the real question one of individual interest rather than of opportunity or economics. ( $p .587$ ).

To better define the goal - the establishment of as many productive halitats as possille ideal coverts for nesting, for broods and for adults are described. (p. 589, 593).

It is perfectly possible to produce coverts providing excellent conditions both for the grouse and for the hunter. Edges, small slashings and openings. properly arranged. are the major prerequisiles. (p. 594). 
Ovcrall cover conditions, Ircnds and needs in a heavily-forested region (the Adirondacks), a forest and farm area (the Catskills) and in a farm and woodlot section (Rest of the State) are described. (p. 596).

Long-time maintenance of good cover is, in large mea-ure, dependent on moderate though widespread lumbering, grazing of overgrown lands and stable farming communities. The wide adoption of better forest and soil conscrvation practices is of definite concern to the sportsman as a practical means to this end. Other suggestions as to how sportsnen anl oller conscrvationists may assist are presented. (p. 598).

Practices detrimental to grouse cover include clean farming, heavy grazing of woodlands, uncontrolled burning: and too much or too little lumbering. (p. 599).

Lcadership in planning and in carrying out broad projects of benefit to grouse must come from the State. (1, 601).

On the State rests the responsibility for deciding on yearly lunting regulations in accordance with the picture provided by an annual census of grouse abundance and conditions. (p. 602).

To assure future grouse crops, the demand for which is constantly increasing, the State must also vigorously prosecute cerlain long term projects. Included among these are managenent research, application of the facts thus found, maintenance of lunting opporlunities, encouragement of landowners to produce better coverts and the stimulation of an active interest in grouse problems. (p. 602).

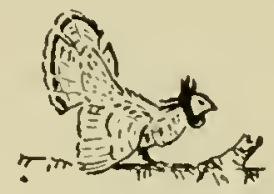

Broadly speaking, those interested in improving conditions for grouse fall into one of two groups. There are the individuals and organizations who are active in supporting any pro. gram for the betterment of the bird, but scldon have the opportunity for earrying on any: actual management work. There is a second gronp, equally interested but who also own or control grouse coverts and who wish specific guidance in making conditions therein as nearly perfect as possible. This chapter is written with the first group in mind. The others will find it informative as a background for the more specific pattern of cover improvement contained in succeding chapters.

Perhaps the general picture may hest be presented by anticipating broad questions. the answers to which will help to hetter define the path to be trod in hettering conditions for this grand game hird. Why is mangement necessary? How intensive slould it he? What are we aiming at in torms of an ideal cutert for grouse and for the lumber? In general, what actisities are likely in result in improved coverts and. therefore. should be encouraged? What practies are likely to he harmful? What part can the State play in improving condilims for grense? Iat us consider these. hriefly, to avoid confusion. but in tetail suffieient to stimulate lhunghtful consideration.

\section{IHW MANAGEMENT IS NECESSARY}

It is axionatic that the gronser is a prodect of the emvironment in which it lives. Left to her uwn devices. Nature only here and there produces a combination of conditions sufficiently 
favorahle to result in a bumper crop of grouse. Yet the number of sportsmen wishing to harvest this crop is constantly increasing. The alternatives are clear. Either the hunter harvests less or he must give Nature a helping hand by encouraging her to produce more and better coverts. Though of less importance, the local control of the more destructive predators $^{*}$, and a complete harvest of the surplus of grouse each year, will also help to maintain the supply. But, fundamentally, grouse populations are a reflection of covert quality and abundance.

The surest way to have more grouse, then, is to improve the coverts and increase their number. This requires management.

\section{INTENSIVE VERSUS INCIDENTAL COVER MANAGEMENT}

Considering the State as a whole, grouse are but one of several desirable crops, to the production of which wooded areas are adaptable. Each crop has its own set of requirements which parallel or conflict at points with those of the others. To fully meet these for any one usually entails an expense greater than the value of that particular crop. On the broad front, therefore, it follows that any management practices favoring grouse must he extensive in character, and dovetailed wherever possible to meet the needs of as many other crops as possible. Furthermore they must be modified to some extent where serious conflicts arise.

When one considers the individual covert, however, the decision must be made at the outset as to whether grouse is to be the primary crop or merely an important subsidiary product to be skillfully encouraged as opportunity arises. In many cases, the latter will be the case for few have as yet developed grouse shooting preserves where the sport is so superior as to encourage the expenditure of substantial funds for grouse improvement alone. In fact. the management of woodlands for grouse often may be combined with the production of other forest products so surcessfully as to make the real question one of individual interest rather than of opportunity or economics.

For instance, in New York State, grouse require a mixture of hardwood and coniferous cover. To enconrage such a combination is likewise good forest practice. Grousc nced brushy edges, overgrown lands or small slashings to provide summer and fall feeding grounds. Scattered through most woodlands are areas, which because of poor sitc conditions or the character of the present stand, are of little value for the production of timber. With a little thought and effort many of these can be made or maintained so as to meet grouse needs. Here it should be clearly understood that such areas must be scattered through the woodland in such a way as to make a large number of good habitats meeting all the predominant requirements of grouse, rather than concentrated in a few locations. In general, if one is willing to devole from 10 to 20 per cent of the total wooded areas to this end, fair to good grouse crops may be had, with very little sacrifice of forest products. In the Northeast where, at present. only a small fraction of our forest lands are producing at anywhere near capacity, there is, therefore, little economic justification for not including grouse production among the principal ends to be encouraged on managed woodlands.

$\mathrm{It}$ is well to point ont that in developing a woodland for grouse many subsidiary ends, each desirable in itself, are attained. Both bank and sheet crosion are controlled, stream flows are regulated, floods made less severe, fire made easier to control. Soil fertility is improved to a greater degree when the forest cover is varied than when it is composed of but

* No practical method of predator control, applicable on a state wilfe basis, is koown. 
one or two species. In the same wa! insect damage to trees normally is more severe where the stand is relatively pure. Recreational opportunities are increased, not alone because more wildlife is present, but also in accordance with the principle that variety is the spice of life.

Yet there are an increasing number of organizations and individuals who wish to make the production of a grouse crop a primary end in itself. While, as a matter of economics, this is seldom feasible, in terms of total enjoyment per dollar expended there is much to recommend it. l'erhajs a happy medium might be attained were one to devote 25 to 30 per cent of the covert to fully meeting grouse needs and the rest to pruducing other forest crops on a self-sustaining basis. This in general is the background against which succeed. ing chapters dealing with the intensive development of grouse areas have been written.

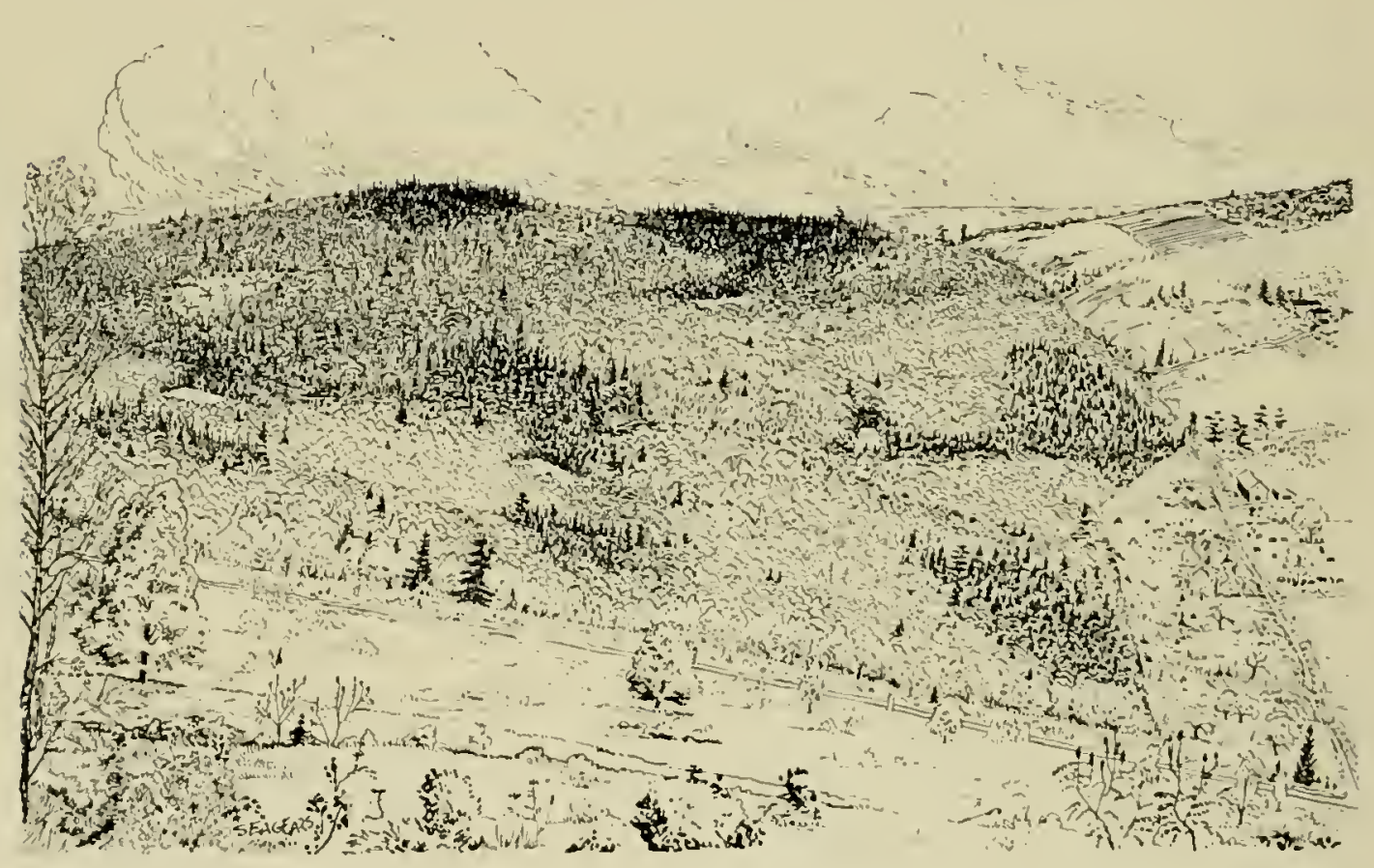

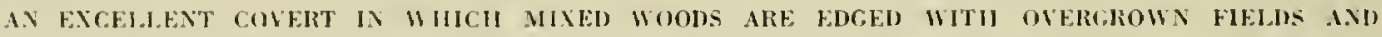
HROKEN, HEIE: ANI TILAF. BY SMAL, SLASIINGS AND ABANDOAEI LANDS. SUCH A COVEHT MAY IROVIUE LARGE CIOPS OF BOTII GIOLSE AVD TIMBER, IF SKILLFELLY MINTAINEI

\section{THE GOAL - IDFAI, COVFIRS}

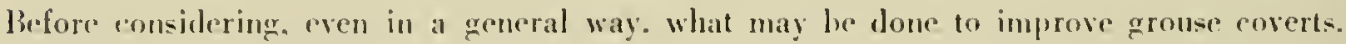
naturally whe mus hase a clear pieture of the product desired. What, then. are the characteristies of an ideal covert?

Grouse cover must serve the needs of the hirds during the nesting. the brood and the adult periods. Siner the production of a harvestable erop is the goal of most game managers, at. tention must alse be given a covert"s "huntahility." to coin a term. But first. what con. ditions are ideal for the bird? 


\section{For Grouse}

\section{For Nesting}

Typical nesting cover exhibits a more definile pattern than one might imagine. The sites chosen are usially favorable. not only for that purpose but also for the youngsters which, when hatched, will need to travel but a short distance to find food and shelter. For New York State the picture shapes up as follows:-

Basic Palterns. Second-growth woodlands intersected by woods' roads and bordered by overgrown fields, old pastures, young slashings or patches of popple. hirch or alder provide ideal nesting sites. Should a part of the woods be made up of mature trees, it would make but little difference for a considerable proportion of the broods spend the first few days, after hatching, in such a location.

If, here and there throughout the second-growth wondlands. a few trees have been cut. perhaps to furnish the winter's wood supply and thus encourage small islands of bricrs and other open land vegetation, the area is doubly attractive. Some hirds will choose such sites and thereby be somewhat safer from predators than as though their nests were located in the more open hardwoods.

Composition. Hardwoods are preferred as nesting cores although the particular specie: seem not to matter. While few nests are found in coniferous stands it is immaterial whether or not an occasional evergreen is present in the vicinity of the nests.

Undergrowth Densily. Little attention nceds be paid to providing protected ncst sites for the majority of the hirds choose a rather open spot arainst the hase of a tree or stump for this purpose.

Slope. The nesting cover might equally well he located on a steep slope, a gentle incline or on flat lands for nests are equally apt to be located on any of these.

Extent. The nesting cover need not be extensive, for nests are commonly placed within 100 feet of an edge. Woods' roads or open trails within the forest seem equally attractive in this respect.

\section{For Broods}

Optimum brood cover in New York State is characterized hy its youth and its diversity. It is the early stages of woodland succession. in which are found fresh herbacents growth in considerable profusion, that are attractive.

Here, then, are the most common brood cover patterns and characteristics:-

\section{Basic Patterns}

1. Second-growth woodlands surrounded ly broad bands of woods' edge type vegetation preferably fairly open in character.

2. Second-growth woodlands interspersed with substantial amounts of overgrown lands, ald shrub-dotted pastures, brushy corners or brier patches.

3. Moist alder runs, separated by hardwood slopes inclined to he dry in summer.

4. Small slashings, still in the hrier, herb and small sprout stage, scattered through second-growth woods.

5. Selectively-lumbered hardwood stands in which the openings thus created are filled 


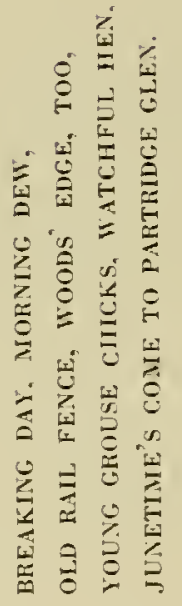




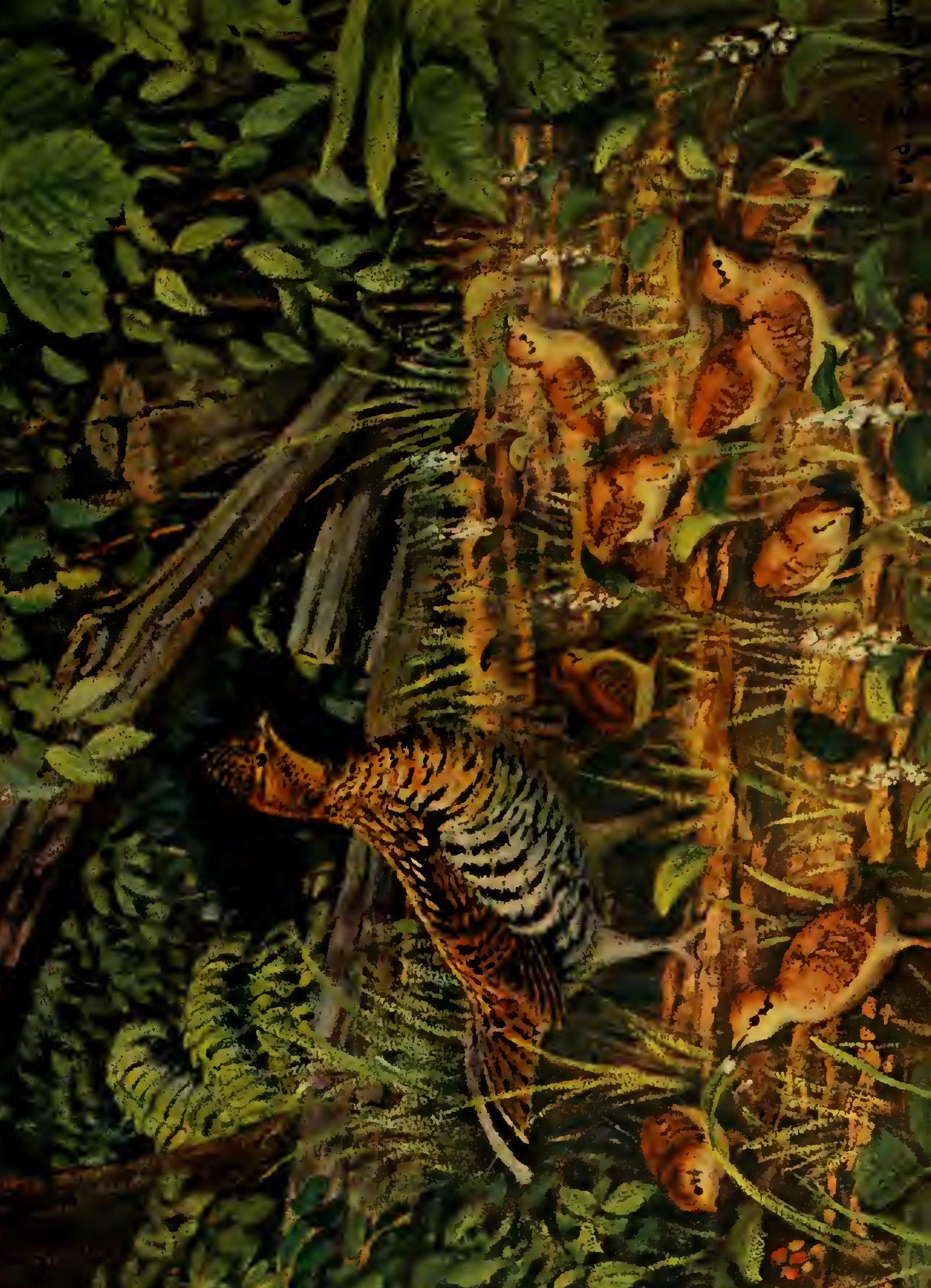



with regetation characteristic of recently cul-over areas, though usually somewhat less varied and abundant. Grassy spots are seldom much used.

Composition. The greater the variety of the vegetation. the better. Conifers are not important and predominantly coniferous woods are but seldom utilized.

Density. Woodlands rather open or of medium density are considerably used, especially about the edges. Overgrown lands and slashings, which are preferred, may be densely rege. tated if rather open spots are scattered throughout.

Undergrouth. Variety here is likewisc important. Small hardwoods. shrubs. herry lushes and lush herbs are preferahle.

Slope. Steep slopes are avoided.

Water. Open water, such as a stream. is not a necessary component of brond cover since dew, succulent vegetation and moisture-filled fruits meet brood needs in this respect. Indirectly. moist spots, because they encourage a profusion of herhaceous vegetation and insect life. are quite attractive to broods.

\section{For Adulls}

The hallmarks of quality in cover for adult grouse are variely in composition and a high degree of interspersion of the eover types. Woodlands. particularly if they contain some conifers, are the backbone of a covert although brood enver. brushy patches and cut-over areas are much used. particularly in summer and throughout the early fall. To meet vearround needs the ideal covert should include the following:-

Basic patterns. 'Pyjical cover cumsists of patches of second-errowth or mature conifers scattered through a stand of mixed hardwoots and conifers. edged ly second-growth hard. wouds" ahutting osergrown land ir cut-over areas.

For the sake of clarity. Int us further subdivide this intu the following seasumal palterms:

Spring - Second-growth hardwords adjacent to coniferous elumps or to mixed hardwouds and conifers.

Summer-Slashings. spot-lumbered woodlands and mature or second-growth hardwoods. Conifers are not desired.

Fall -Broad bands of rather open woods' edges. overgrown lands ur slashings adjacent to a mixed woods of hardwoods and conifers.

Winter - Coniferous patches scaltered through second-growth hardwoods or mature hard. woods and conifers.

Composition. Pine. hemlock. spruce, halsam and white cedar all provide excellent shelter. In mature stands. an understory of mixed coniferous and hardwod reproduction is desirable.

A substantial part of the hardwoods present should be species producing food for grouse. Birches. poplars and cherries are excellent in this respect. Beechnut mast. when available. is eagerly songht after. Small beech groves or wide-spreading old trees scattered throughout the wodland make for more attractive cover.

Density. Except as heretofore indicated. the density of the woodland cover seems not to be directly of prime importance. Clumps of conifers are perhaps. most used when of med-

* Important prinarily for nesting coler and should not be extensive. 
ium density although the relatively very dense cover, typical of many reforested areas, may be much frequenied for a few hundred feet in from the edges. Hardwood stands of medium density are most satisfactory.

Undergrowth. The important point here is to have a variety of undergrowth available beneath the crown cover. The density is of less moment though extensive patches of thick undergrowth are not particularly productive while contributing materially to the difficulties of the hunt. Large areas covered with grass or rank herbs such as goldenrod or asters are usually avoided.

Slope. Neither slope aspect or degree are particularly important insofar as adult grouse are concemed.

Water. As with broods, a stream or other open water is not a necessary component of ideal adult grouse cover.

The above represents a broad pattern towards which one may direct his efforts. But. though the basis lies in an analysis of 19,619 adult grouse flushes, 1.515 brood contacts and 1,270 nest locations, it is unquestionably possible to deviate from it to some extent and still produce many grouse.

\section{For the Grouse Hunter}

A much more controversial subject is the planning of a covert to provide not alone favorable conditions for the birds but for those who would hunt them as vell. Here the authors have but little to go on ${ }^{*}$ save their own experience as enthusiastic and persistent grouse hunters. and those of other experienced sportsmen who have generously contributed their ideas on the subject.

Naturally the first specification for an ideal hunting cover is that there be at least a fair concentration of grouse. This varies in most coverts with hoth the year and the season. One may expect but will not find a good crop every year even in the best of coverts. To be reasonably assured of good hunting opportunities, one must. therefore, have a number of excellent coverts from which to select those with currently high populations for hunting.

Even where birds are usually ahundant. every hunter knows of some coverts which are seldom hunted hecause the birds do not "fly right" when flusherl. What he usually means by this is that fool and shelter are so intermingled that, though many birds may he flushed. they seldom remain in sight long enough to provide even a sporting cliance for a shot. It is perfectly possible to have highly productive coverts which also offer excellent hunting oppor. tunities.

With respect to the hunter, in the Northeast, at least, an ideal covert is one which contains a number of edges in which the birds are apt to be found feeding, especially during the early part of the lunting season before the leaves have fallen. No gronse enthusiast need he told of the attractiveness in October of hedgerows, old pastures and overgrown lands, especially if they adjoin a woudland of mixed lardwoods and conifers. Woods' roads lush with rlover, also. then, are much frequented. Later, the hirds may be expected to concentrate more in the wouded areas, particularly if evergreens are present.

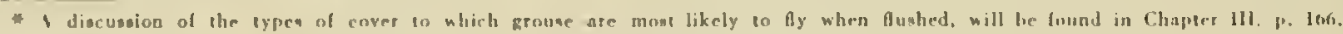
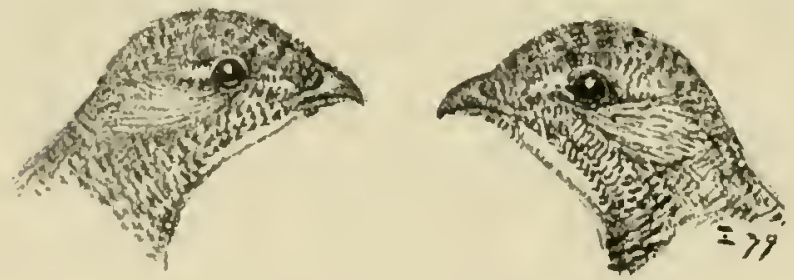
Another favorite feeding spot throughout the fall and early winter is the cut-over land or slashing. Small slashings scattered throughout the interior of a covert, especially if bordered by conifers on at least one side, provide a likely place in which to find birds when they are not feeding in the overgrown lands.

It is desirable also to have the covert bisected or at least deeply indented with one or more narrow openings across which some birds are likely to fly when flushed from the adjacent cover.

Favorite hunting coverts usually provide these conditions in abundance. But there are also other considerations. Thick cover seldom adds to the enjoyment of the hunt. nor do steep slopes. For the former reason, slightly grazed woods and overgrown lands often furnish the best lunting possibilities. Dense, extensive blocks of conifers or large tracts of hard. woods without evergreens are equally undesirable. Here the cover is either too thick to shoot or too poor to attract many birds.

For hunting, an ideal "edge" in New York State may be made up of clumps of trees and shrubs, including thornapples, apples, viburnums, dogwoods, cherry and evergreens growing in a relatively open setting though immediately adjacent to a rather open mixed woodland. Here a dog works well, and the hirds, once flushed and lieading for the wooks usually must cross one or two small openings, thus providing superlatively good shooting opportunities.

The size of the cover types that make up a covert is also important, in that extensive areas of overgrown land or of mixed hardwoods and conifers tend to scatter the hirds more and to make then difficult to follow once flushed.

These points are illustrated in figure 62 where the eover has been so organized as to provide not only excellent conditions for gronse but for the hunter as well.

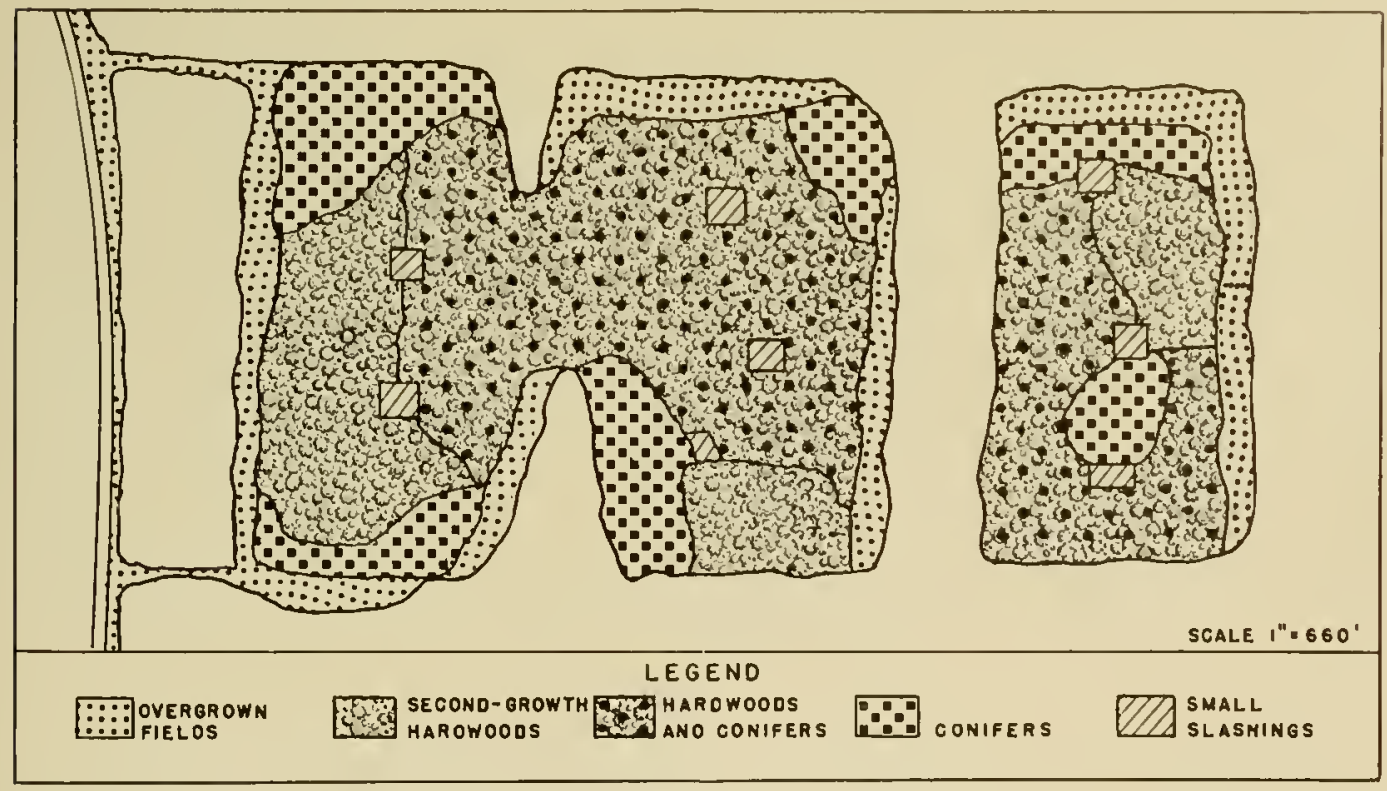

FIGURE 62. ONE OF MANY POSSIBIE ARRANGEMENTS OF COVER TYPES WITHIN A COVERT WHICII SHOULD PROVIDE EXCEPTIONAL CONDITIONS FOR BOTH BIRD AND HUNTER 


\section{OVERALI COVER CONDITIONS. TRENDS AND NEEDS IN NEIN YORK STATE}

Considering the State as a whole, grouse eover is made up of a vast assortment of individual coverts. The extent to which these, individually and collectively, fall in with the patterns heretofore descrilsed. largely determines our grouse crop over the years. The inprovement of individual coverts speeifically for grouse is important. But there are also broad influences and activities at work which, though often not recognized as seriously affecting the quality of the grouse range as a whole, yet exert a substantial influenee upon it. Likewise. there are certain characteristies of the land and the nse man makes of it which must he taken into consideration. To better picture these, let us outline the situation and needs in a heavily forested region (the Adirondacks), a forest and farm area (the Catskills) and a farm and woodlot section (the rest of the State).

\section{The Adrondack Regiox*}

Grouse cover in the Adirondack region is characterized by extensive. often unbroken forest areas. Only the larger valleys are farmed. Most of the region lies within the Adirondack Forest Preserve of which 36 per cent (2.171.538 acres) is in State ownership. On this no improvement activities for either forest or game are permissible. for under the constitution of the State it must be kept as "wild forest land forever." This provision effectively prevents exploitation of the timber resources. It prohihits not alone lumbering, but also any hetterment of the existing cover for timber or willife production. As the forest grows and matures. it tends to become more even-aged and less hroken up ly openings, thus making conditious for grouse relatively unfarorable.

Interspersed with State-owned lands are private holdings. These are generally extensive. Vany are in the hands of alsentee owners. Periodieally: most such lands are eut over in large blocks for lumber or pulp.

As a result, exrept about the periphery or in the vicinity of farmlands. conditions are generally not particularly favorable for grouse and large concentrations are seldom to be found.

Such conditions. quite frankly. place marked limitations on what may be done to improse the grouse crop. Any activity which tends to diversify and break up the extensive forest areas into smalles hloeks is. for the hirds. a move in the right direction. The application of sound forest improvement and lumbering practices to private lands. and the loeation of more small wood-using industries within the ddirondacks would materially advance this oljective.

Those interested in grouse in this region would also do woll to encourage. wherever possihle, farming and pasturing since overgrown lands and attractive wods" edges are largely byproducts of these activities.

More intensive development, cxeept on a small seale, is searcely practical unless gromse hecome an inportant sulsidiary crop worthy of attention in its own riorlt as a part of the recrational opportunities for which this section of the State is famous.

\section{THE: Catśn,L, Recios}

In the Catskill region, with its farms and valleys. pastured slopes and rooded uplands, the situation is quite different. 'Thongl much of the area lies within the Catskill Forest l'reserve. State ownerohip is much less extensive. Voderate pasturing. coupled with a large number

\footnotetext{
* I general deweripenen of rach semion is to be found beginuing on p. 111.
} 
of usually small lumbering operations, has tended to diversify the cover and maintain productive edges to a much greater extent than in the Adirondacks. These, coupled with the progressive abandonment of the poorer or less well situated farms, has resulted in the estab. lishment of much fine grouse cover. Conifers are generally less abundant than in the Adirondacks, however, and good winter shelter. particularly in the more extensively forested parts, is often lacking.

In this region, as in the Adirondacks, the maintenance of a good grouse erop over the years is intimately tied up with the adoption of good forest and soil conservation practices and the continued encouragement of small lumbering and farming operations. Where grazing is heavy, cattle should be fenced out of the woodlands. Fencerows should be eneouraged and stream banks, gulleys and steep slopes allowed to revegetate naturally without interference by grazing. The planting of small blocks of conifers in old fields and pastures is another activity worthy of considerable encouragement.

\section{The Rest of State Region}

Except for the Lake Plains. the Lower Hudson Valley and Long Island, the rest of the State is characterized by well-farmed valleys lying hetween poor uplands. Here one finds the largest areas of good grouse coverts in the State, for much of the land. unce cleared. has been worked to exhanstion and abandoned. Overgrown ficlds, old pastures, long forgotten or perhaps still moderately pastured. seeding in to apple. hawthorne, pine and cherry, are the rule. Many woodlots, too often and intensively lumbered over for their own good. provide an abundance of summer and fall feeding grounds, though the preference for softwoods has resulted in the elimination of much desirable winter shelter.

Between lowland and upland. such a wide diversity of conditions exist that this region may well be subdivided into farmed lands and largely abandoned nplands. On the former, conditions are not unlike those described for the Catskill region. In general the farmer. with cattle and axe, is maintaining a fair amount of orergrown land. hedgerows and pastures. Wood. lots are lumbered upon oceasion to provide for the normal needs of the farm. Small timber sales are common.

Here the grouse hunter has a definite, though often unrealized, stake in any program which directly or indireetly helps to maintain farming activities on such lands. Over the years. the price of milk and wool unquestionably will exert a stronger influence on grouse than will the limit of the hunting season. for eow and sheep are still the most effective instruments for slowing down the natural reversion of pastures to forest. $I_{n}$ like manner, to encourage the wide adoption of better farming and forest standards and practices, calculated to improve soil and forest conditions, is to lelp provide a practical, though indirect means of maintaining present coverts for the future.

On the abandoned uplands. the siluation is quite different. Cover diversifieation. so important to gronse. is here a fact. Open fields are heing rapidly swallowed up by woods as brusls lots become second growth forests in a surprisingly short period of years. Large tracts are heing reforested with conifers, either privately or hy the State.

The problem, here. is low lest to maintain the diversity of forest and overgrown cover since lout little of the land is pastured and lumbering is sporadic for necessity, born of poverty. lhoroughly denuded the woodlands of merehantable timber before abandonment.

To sharpen up the picture. let's be more specifie as to what will have to he done under each 
of the conditions described above, to maintain gronse cover.

On the farm lands. to help hold hack the forest and maintain about it that fringe of overgrown fields so important to grouse. one might well encourage the following activities:

1. Those programs which help the farmer to maintain his cconomic positions. Included in these are those of the Soil Conservation Districts, the State Forest Practice Act. the farm extension program of the State College of Agrieulture and the interest in rural electrification.

2. Dairying and the moderate pasturing of sheep as an indirect means of maintaining the overgrown pasture.

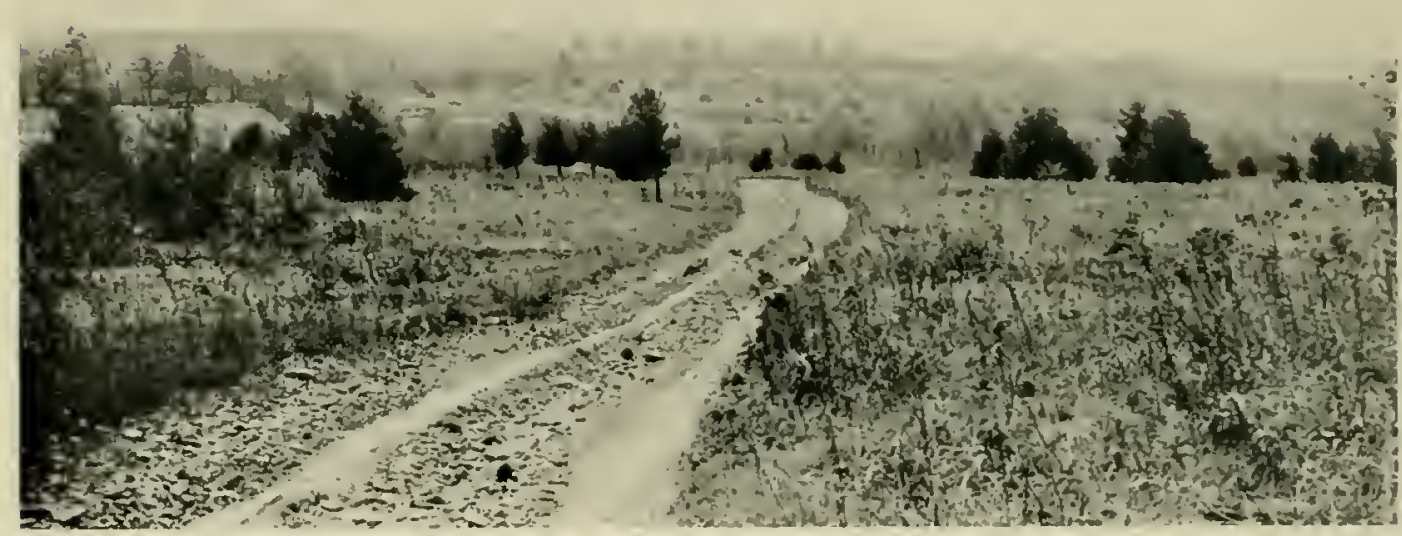

TYPICAI, ABANDONED IPLAND

On the abandoned uplands. to maintain an indispensable diversity of woodland cover. a more active interest must be developed in projects such as:--

1. The wide acceptance of forest standards as set up under the State Forest l'ractice Act.

2. The selective cutling of wondlots.

3. More local wood-using industries.

4. The frucing out of cattle from woodlots.

5. So managing wodlands as to stimulate coniferous reproduction in predominantly hardwood stands.

6. The encouragement of a wide baut of roods' edges about woodlands.

7. A program of reforestation of idle lande providing for:-

(a) The planting of conifers in small horks.

(b) Variety in the species to be planted.

(e) The erentual development of stands composed of hardwoods as well as softwoods.

(d) The leaving of wide bordess between blocks and of frequent openings within 
them which are allowed to grow up to trees and shrubs producing food for wildlife.

While the importance of maintaining good grouse habitats and increasing their numbers cannot he overemphasized, the picture would not be complete without reiterating the desir. ability of continuing other types of activities. Chief among these are:-

1. The wise regulation of hunting so that surplus populations may be harvested or hunting pressure reduced in accordance with the situation.

2. The hunting and trapping of the more destructive predators. particularly those which break up grouse nests.

3. The stimulation of an intelligent, vigorous interest in conservation in general and in grouse in particular.

To accomplish some of these objectives will require a re-orientation in thinking and activities, even among those who have the best interests of the grousc at heart. It is human nature to live for the present. This being here. wise heads will look to the future and direct today's programs into channels which will produce more grouse tomorrow.

\section{SONE PRACTICLS HARMFUI, TO GROUSE,}

Many an activity of bencfit to grouse. when carried on in moderation. may have the opposite effect if pushed to extremes. Wildlife. because of its more or less specialized reguirements for survival, has suffered particularly from the exploitation, beyond reasonahle bounds. of such ideas as the draining of swamps and clean farming* It is. therefore. worth considering for a moment some practices that may adversely affect the grouse. All lend to standardize rather than to diversify covert vegetation.

Among them should be mentioned the followitg:-

1. Clean farming

2. Heavy grazing of woodlands

3. Uncontrolled burning of woodland and overgrown fields

4. Large lumbering operations within individual forest tracts

5. The prothibition of lumbering

6. The complete reforestation with conifers of large contiguous areas

7. The maintenance of relatively pure stands of any species of tree. shrub or herbaceous growth

The undesirable aftereffects of the first three are too widely recognized to necd further emphasis. With respect to lumbering. too little or too much. concentrated in any one area, is apt to encourage uniformity in cover. A slashing half a mile across will be used largely along its edges. The removal of all the merchantable conifers from a woodht, seldom leaves conditions as attractive as they were even though herries follow the axe. Acid-wond cuttings are particularly damagring in this respect because of the frequency with which whole hillsides are reduced to briers and sprouts. Wherc. however, as in parts of the western Catskills. the trees are removed in long. narrow strips. each separated by second-growth woodland. the situation is reversed and more favorable conditions are the result. 
Conversely, the policy of sparing the axe and letting Nature take her course is certain in the long rum to produce forests replete with cover furnishing winter shelter but sadly deficient in summer and fall feeding grounds not alone for grouse. but for many other species of wildlife as well.

In principle the situation may be much the same where conifers are planted in large blocks, unbroken by brushy openings. hedgerows or hardwoods. Only along the edges will sueh plots be much used by grouse. On the other hand, properly thimed and opened up to encourage a mixed stand of hardwoods and conifers rather than a dense. lightless evergreen mass. a plantation can he quite attractive to grouse. By leaving strips, along hedgerows, old apple orchards. thornapple clumps. swales and similar cover furnishing food for grouse. umplanted much ean be done to provide vegetative variety. Most plantations lack this from the time the tree crowns meet until opened up aqain ly thinning or lumbering operations.

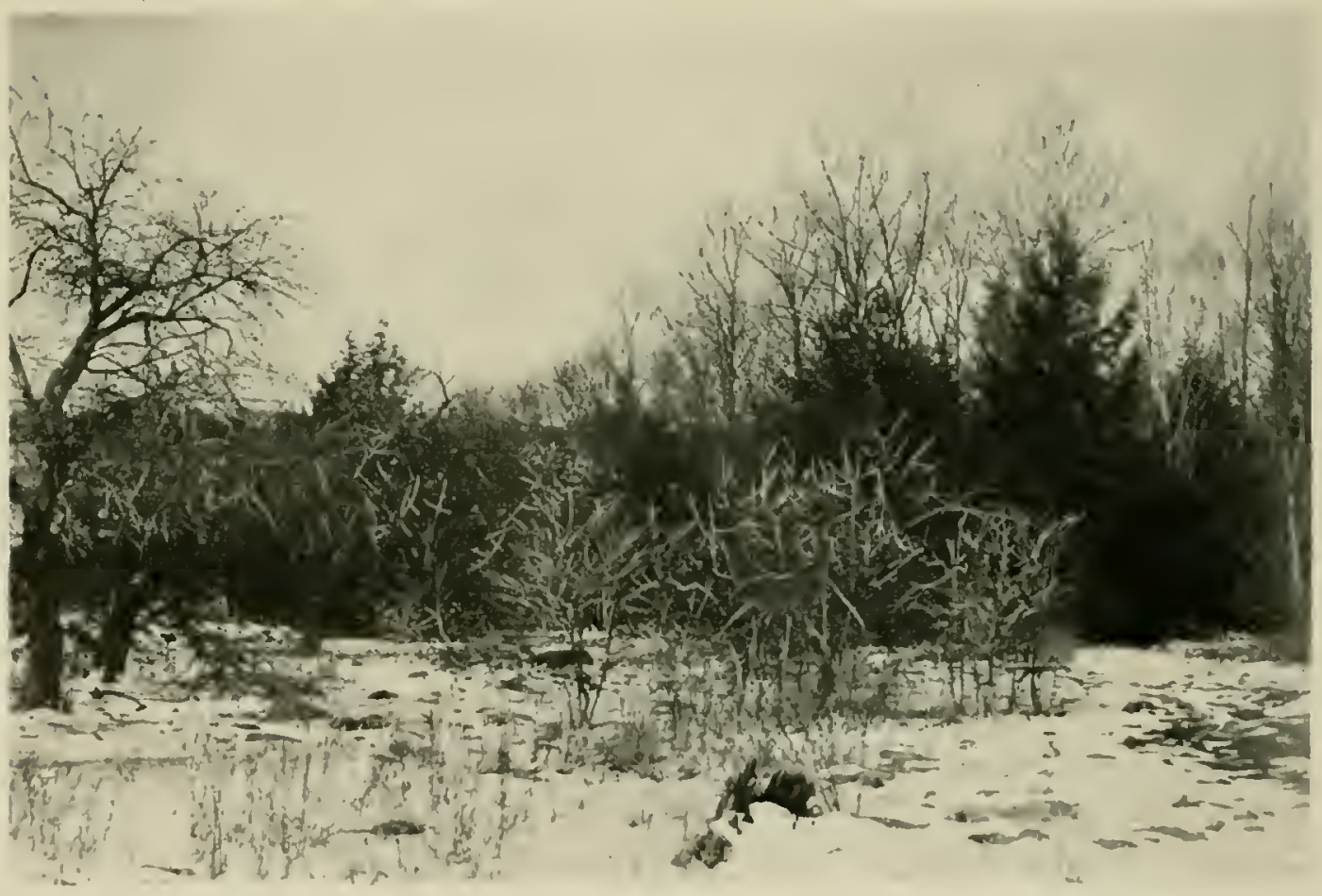

AV IUYAL EDG: SUCII AS THIS IS OF MOIE VALLE FOR WHIHIFE THAX IS A SITE ON IIIICH TO PI.ANT EVERGREENS

In considering reforestation one must remember that it is an activity anmed primarily at resuring idle. run down acres to a productive status. For this purpose there are sound reasons for planting conifers in close rows. So long as this practice is followed, there will he periods in which the trees are growing uj, when grouse will he found largely along the edges. muless openings are provided within. Once the crop trees lecome merchantable and cutting

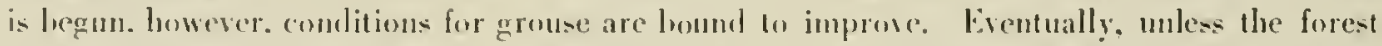
is clear-eut and replanted again to conifers. dhe composition mal be expected to approach that of the surrounding wondlands. The sugegestions, given in the preceding paragraph simply tend to hasten this day. 
With regard to the last mentioned harmful practice, fortunately, one seldom finds conditions in the Northeast so uniform as to stimulate large areas composed almost exclusively of one or two tree species. Where these do occur, either naturally or as a result of some activity controlled by man, grouse usnally are notable by their absence.

Common sense and scientific fact are combining to counsel moderation with all of these practices. They are their own worst enemies, in that when vigorously carried out they tend to so far destroy the balance of Nature as, ultimatcly, to build up a strong resistance to the very things they seek to accomplish. To combat them it is necessary first clearly to establish cause and effect by pertinent research, and secondly, to discourage the practice by emphasizing the undesirable results. Only by such a program, even though it cover a span of years, can many of these harmful practices be combatted.

\section{THE ROLE OF THE STATE}

Grouse, like other wildlife, are the property of all the people. Individuals and organiza. tions, therefore, rightfully look to the State for leadership in planning and carrying out any overall projects in behalf of the bird.

Here the State is confronted with a difficulty of long standing. Naturally, concern for and interest in the bird's welfare breeds many a suggestion as to what should be donc. The halls of the hot-stove leaguers resound with well-intentioned, vigorous debatc. Come hunting season, the State's Conservation Department is deluged with suggestions, complaints, demands, constructive ideas and crackpot impressions. Bedeviled by such a deluge it is small wonder that many state game administrators are apt to overlook the broad picture in trying to satisfy the immediate demand. In this respect New York is fortunate in that the pertinent facts are already at hand as a guide for constructivc action.

What, then, ought we to expect of the State by way of practical assistance in producing more grouse? The suggestions that follow fall broadly into two divisions. The first concerns responsibilities of an annual nature, the carrying out of which inmediately affect both grouse and hunter. The sccond group are long-time comprehensive prujects calculated to produce a steady improvement in conditions for the hird over a period of years.

Annual responsibilities include:-

1. A yearly inventory of conditions and abundance.

2. The regulation of hunting.

Long-term projects encompass:-

1. Research into the life history * and management of grouse.

2. Application of the facts thus found.

3. Acquisition and development of public lands on which grouse represent one of the major crops to be encouraged.

4. Maintenance of adequate hunting opportunities.

5. Encouragement of private landowners to produce more and better grouse coverts.

6. Stimulation of an interest in and a knowledge of grouse prohlems, and their solution.

7. Sustained efforts on fundamental game. soil and forest conservation programs.

To carry out any one of these is a job in itself. Attendance to all of them, even over a

* Practically complete for New York. 
period of years. requires an organization and funds leyond the reach of many states, particularly since some problems are more pressing than others. New York is among the fortunate in that the interes, the funds, and the technical assistance prerequisite to attacking all of these simultaneously have alrearly been put to work on these problems. With a background of experience thus gained, let us see what part a state can play in improving conditions for grouse.

\section{Yearly Inventory}

\section{AnNual Responsibilities}

Every husiness takes a periodic inventory of stock and conditions. Faced with a species that fluctuates widely in abundance and an ever-increasing hunting pressure, this, for grouse, is an absolute prerequisite to any intelligent adjustment of season, bag and take limits, to supply and demand. It may he secured in several ways. These are described in Chapter XVII beginning on p. 675 .

\section{Regulation of Hunting}

Hunting, with grouse, is not the bete noir it is generally supposed to be, but, where surpluses exist or populations are scarce, the necessity for reasonable control is clearly recognized. So also is the State's responsibility for making its regulations a reflection of the condition of the grouse crop. Withont a good annual census this is impossible. Since the fall crop is dependent, not alone upon the number of birds in the winter coverts, but also upon nesting and brood success throughout the succeeding spring and summer, it is obvious that such an inventory cannot lie completed before late summer. For this reason a state legis. lature, in session the previous winter. cannot possibly have the facts at band with which to intelligently establish open seasons and bag limitations on the daily take. Realizing this. New York has wisely placed the responsibility for setting such regulations on the Conservation Commissioner who is in the best possible position to decide on the yearly restrictions in accordance with conditions. The law transferring this responsibility requires that the regulations be promulgated not later than September 15 , and wide publicity is given 10 them thereafter. In this way alone can the season be made to best serve buth the grouse and the hunter. As the needs of the situation are more elearly understood. other states are gradually adopting a similar course.

\section{long-term Projects}

\section{Research}

Facts are the fabric out of which any pattern of succesful management is woven. But rescarch is at hest a slow and costly undertaking. with results seldom directly transhatahle into dollars. l'ublic agencies, largely federal and state, therefore must accept the lions share of the work of carrying out factual explorations. Where funds are insufficient to meet state needs in this respect. there still exists the opportunity for collaborative work with a miversity. A fow thousand dollars thus spent ma bring sulstantial returns. The Investigation is an example of what ma! he acemplished by culisting assistance from many quar. ters. In some cases it will he possible to addant hasie studies carried on elsewhere to local conditions.

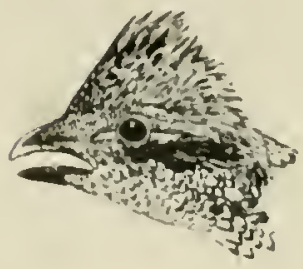


In all but a few states the necessity of employing men technically trained for such work is recognized. Often, they may serve a dual purpose by acting as consultants on wildlife problems in addition to carrying out their researeh.

\section{Service to the Landowner}

Facts are largely valuable in proportion to their use. Realizing this, the Conservation Dejartment has divided New York State into eight game management districts. In each a trained technieian is available 10 advise on grouse and other wildlife problems. But assisting landowners and answering questions is only a part of their assignment. They are also responsible for purchasing State game lands, planning productive developments thereon, and seeing that they are carried out. If the State is to fulfill its responsibility in these respects, some such an organization is a prime prerequisite.

\section{Acquisition and Development of Crouse Lands}

In New York State it is no longer considered necessary to acquire public lands to serve as refuges for grouse. Emphasis instear is placed on providing pullic lunting grounds and

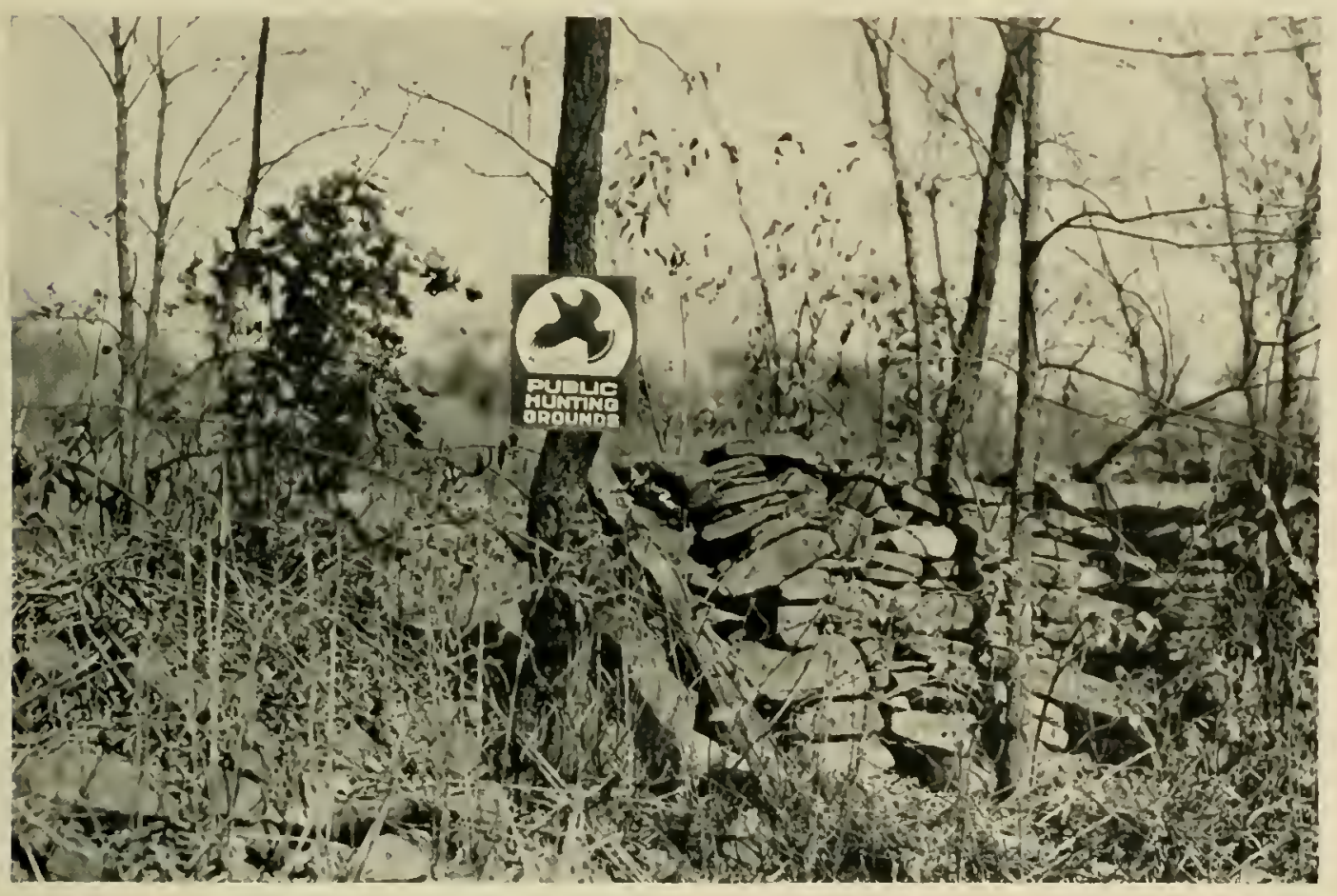

NEW YORK STATE"S GAME MANAGEMENT AREAS ARE DEVELOPEO ON TIE MULTIPLE USE PRINCIPLE

on managing the cover thereon so as to produce as ncarly maximum crops as possible. On public lands where grouse are not the majur crop it is usually possible to make conditions more favorable for them by suggesting. to those in charge, practices and improvements which may be carried out incidental to the major development of the area. Nuch can be done in this manner to encourage hetter grouse liahitats on statc lands where recreation or forestry are the main considerations. 


\section{Maintaining Hunting Grounds}

In New York, where there is at least one grouse hunter for every 50 acres of grouse cover, it is obvious that the State can never be expected to own sufficient public hunting grounds to supply adequate hunting lands. Only in the vicinity of the larger centers of population, therefore, is the State justified in purchasing and developing any substantial areas primarily for this purpose. Even this is dependent upon the availability of low-cost lands and their subsequent management to provide recreation and a forest as well as a wildife erop. This does not preclude the desirability, however, of acquiring large areas of abandoned land in other parts of the State for such purposes. The principle of State purchase and restoration of such lands to productive use is a sound one. Properly directed, such a project cannot but substantially increase the amount of land open to public hunting.

Because the ruffed grouse is seldom found in heavily farmed areas, less cover is posted against grouse hunting than is true with many other species. Where posting becomes scrious, the State should consider remedial measures. In this connection the establishment of landowner-sportsman cooperatives, such as have been developed to meet similar situations in pheasant areas, might he tried out providing the grouse are sufficiently numerous to warrant the expense.

\section{Stimulating Grouse Production on Private Lands}

Though obviousty desirable, few states have made even a start in stimulating private landowners to produce more grouse. Yet, until ways of doing this are worked out, the State can exert but litte influence on the majority of grouse covers lying within its borders. The district manager setup already mentioned stands ready to advise and help those landowners who have the interest of the bird at heart. To reach the others, it will be necessary to provide some other quid pro quo to stimulate constructive action.

\section{Stimulating Interest and Understanding}

Another contribution of the State lies in stimulating an interest in and an understanding of the grouse problem. Books such as this, articles, talks, discussions and movies all help. So also does the formation, with State encouragement, of local conservation clubs. Only by starting an educational program with the youngsters in the schools, however, can we, in the long run, get across the story of the value and problems of wildlife in general, and of grouse in particular. The school lecture program of New York's newly created Division of Conservation Education represents a long step in the right direction.

\section{Emphasis on Fundamental Conservation I'rograns}

By now it is elear that whatever helps conservation in general, sooner or later is likely also to benefit grouse. Basic farm and forest, soil and wildlife conservation projects should be vigorously supported after making certain that adequate consideration is given therein to improving game conditions.

Reading this chapter, it may seem to some that any effort they can make to hetter grouse conditions must be so small as to make it unimportant. Nothing conld he further from the truth. Granting the enthusiasm of the authors for their task. the material for this book conld never have been develnped without the help and hacking of thousands of grouse-conscious individuals. Oaks grow from acorns. Inherent in the germination of every seed of interest and activity lies the probability of making conditions better for this grand game hird. 


\section{CHAPTER XV \\ DESIGNING GROUSE COVERTS AND SETTING UP MANAGEMENT PLANS*}

By Gardiner Bump

\section{THE ESSENTIALS OF GOOD COVER DESIGN}

lntegration With Other Uses

\section{COVER ORGANIZATION}

Planting Design for Open land - Overgrown land Design - Woodland Design Clear-cut Units - Forest Stand and Gane Cover Improvement

\section{PLANNING COVER IMPROVEMENT}

Estarlishing Management Orjectives-Detehmining Current Coner Conditions-The Cover Survey-Cover Type Mapping-Axalyzixg the Covert in Terms of Grouse Needs-Recognizing Cover Deficiencies-Locating Hunting Areas and Seed Stock Refuges

\section{ORGANIZING THE OTHER FORCES OF PRODUCTION}

Predation - Disease - Control of tile Harvest - Dispersion of the Birds Some Generally Unproductive Practices - Providing Artificial Food and Shelter Restocking

\section{SETTING UP MANAGEMENT PLANS}

Basis - Organization of the Plan - Background-Objectives-Division of the Management Area - Covert Surveys - Analysis of Cover Conditions -- Dcrelopment and Maintenance Plans - Regulation of the Harvest - Coordination with Other Lses Protection and Other Special Problems - Appendix.

$$
\text { os }
$$

\section{SUMMARY}

Nature produces the plants and animals that make up the environment in which the grouse lives. Left to her own devices, the quality of the coverts produced, influenced as it is by a variety of conditions, may be good or poor. It is perfectly practical, however, for the sportsman, landowner or wildlife manager to plan and carry out changes in these to the end that better coverts will result. These improvements should be made in ac-

* The word "covert" is here used to represent the vegetative cover and physiographic features within a more or less distinct unit, separated Irom other units by some easily recognized leatures such as open lands, roads or water. A covert may contain one or nany grouse lahitats plus some relatively unproductive areas. 
cordance with a definite plan. Such planning is here called "design." (p. 607).

A elear understanding of the essentials of good cover design will be of material assistance in determining what changes are desirable and how they may best he made. (p. 607$)$.

The basic component of grouse coverts is the cover type. Both fundamental and incidental needs of the grouse are satisfied, lut in varying degrees, according to season by these types. In planning cover improvements, the purpose each serves must be kept constantly in mind. (p. 608).

The arrangement of cover types in large measure controls the productiveness of the individual habitat as well as the number of habitats to be found in the covert. (p. 609$)$.

The possible combinations of cover types that collectively make up a grouse luabitat are legion. Ten of the simpler, most common ones are diagrammed and analyzed by way of illustrating their value for grouse. (p. 610).

Since the greater the number of good habitats in a covert, the larger the number of grouse likely to live there, the arrangement of cover types to produce the maximum number of habitats practical is discussed and diagrammed. (p. 612-613).

It is quite practical to produce subsidiary crops such as forest products and recreational op)portunities, as well as to assist in controlling soil erosion and halancing water runofl. along with the encouragement of a good crop of grouse. Consideration should therefore be given to the integration of these other uses in planning gronse habitats. (p. 615).

l'roductive patterns for open lands (p. 616). overgrown lands (p. 618), woodlands (p. 620) and (lear-cut units (p. 62H) are here outlined, to give an idea of the changes which one may undertake by way of making these types more adequately fulfill the critical require. ments of the grouse.

A survey of existing conditions and influences, both plant and animal. that may affect gronse. is a step prerequisite to the organization of appropriate development plans. The intensity with which this should be carried out is dependent upon the extent of the improvements contemplated. (p.626).

A cover type map is an almost indispensable aid in effectively analyzing the covert in terms of grouse needs, in planning improsements, and in keeping a record of progress. (p. 626$)$.

With a gool covert survey and cover type map it is easy to reeognize existing cover deficiencies and to locate areas lest suited for development as hunting grounds or refuge units. (1). 627).

It is sometimes nceessary also to control. to some extent. the other forces influencing productiun such as predation, disease and hunting. and to restock depleted areas. Each of these must be considered in any well orelered plan. (p. 629).

Management plans for developing and maintaining a grouse area should be set up to include certain definite oljectives. Since the items which should be included in such a plan have not, as !et, hecn standardized. a sugerested organization of these is here described. (p. $632)$.

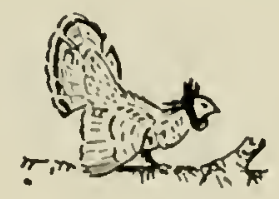


The preceding chapter painted with a broadbrush the picture of what may be done and what to avoid in improving conditions for grouse. In this chapter are pencil-pointed the specific procedures and practices by which covert conditions and needs may be analyzed and the forces controlling production marshalled in accordance with a pre-determined plan of management. Succeeding chapters offers suggestions as to how cover and crop, predators and buffer species, may be so handled as to maintain continued productivity.

These are presented in considerable detail to provide as broad a basis as possible for those interested in the intensive development of grouse coverts under the variety of conditions characteristic of the birl's extensive range.

No one realizes more clearly than the authors that grouse management is scarcely out of its swaddling clothes. Under such conditions the procedures here suggested must not be accepted as the only or perhaps even the best ones likely to accomplish the desired results. They are suggestions to be modified as experience directs rather than cut and dried practices. But they are tried and workahle. As such they represent a concrete starting point for those who would venture into the relatively uncharted field of making two grouse live tomorrow where but one exists today.

How then does one go about analyzing and organizing grouse coverts according to a busi. nesslike plan? Architects and land-use experts call such planning "design", though wildlife managers have not yet widely adopted the term. The architert plans a structure to meet a given use; the manager designs a game covert to produce game and other crops. Woods, fields and fence corners, rather than steel, lumber and stone, are the materials with which one must work but the fundamental steps are the same. In either case satisfactory results are dependent on good designt.

\section{THE ESSENTIALS OF GOOI) COVER DESIGN}

The principles of cover makeup are presented in Chapter III. Covert and type size and shape, composition and arrangement are discussed on pages 111 to 113 . The role played ly the latter points is so decisive as 10 warrant a separate section. found on pages 168 to 170 . The plant species, important as food, are detailed in Chapter IV and the makenp of ideal coverts lias just been pictured in the previous chapter.

While these discussions provide the background for understanding effective cover organiza. tion, a few points may well be amplified. The first of these concerns the role each cover type plays in fulfilling grouse cover needs.

Grouse are adaptable birds. No one of the many types of cover, that make up their habitat, fails to provide some food and shelter at one or another season of the year. Since much of this is, however, incidental, table 94 has been prepared to illustrate the principal requirements fulfilled by each type.

Lest confusion arise between this and statements made in Chapter III, one must have elearly in mind that this analysis is hased not as much on the use made of each type as on the extent to which they meet the major food and shelter requisites at the time in which they are important. For example, patches of conifers are most frequented during eight of the twelve months of the year. Yet only in providing winter shelter do they supply a prime need, not also adequately filled by one or more other types. Thus. in winter they are of primary im. portance. As another case to point, in spring many adults frequent mature woodlands where available. Yet several other types are also largely used for feeding and resting. But the basic 


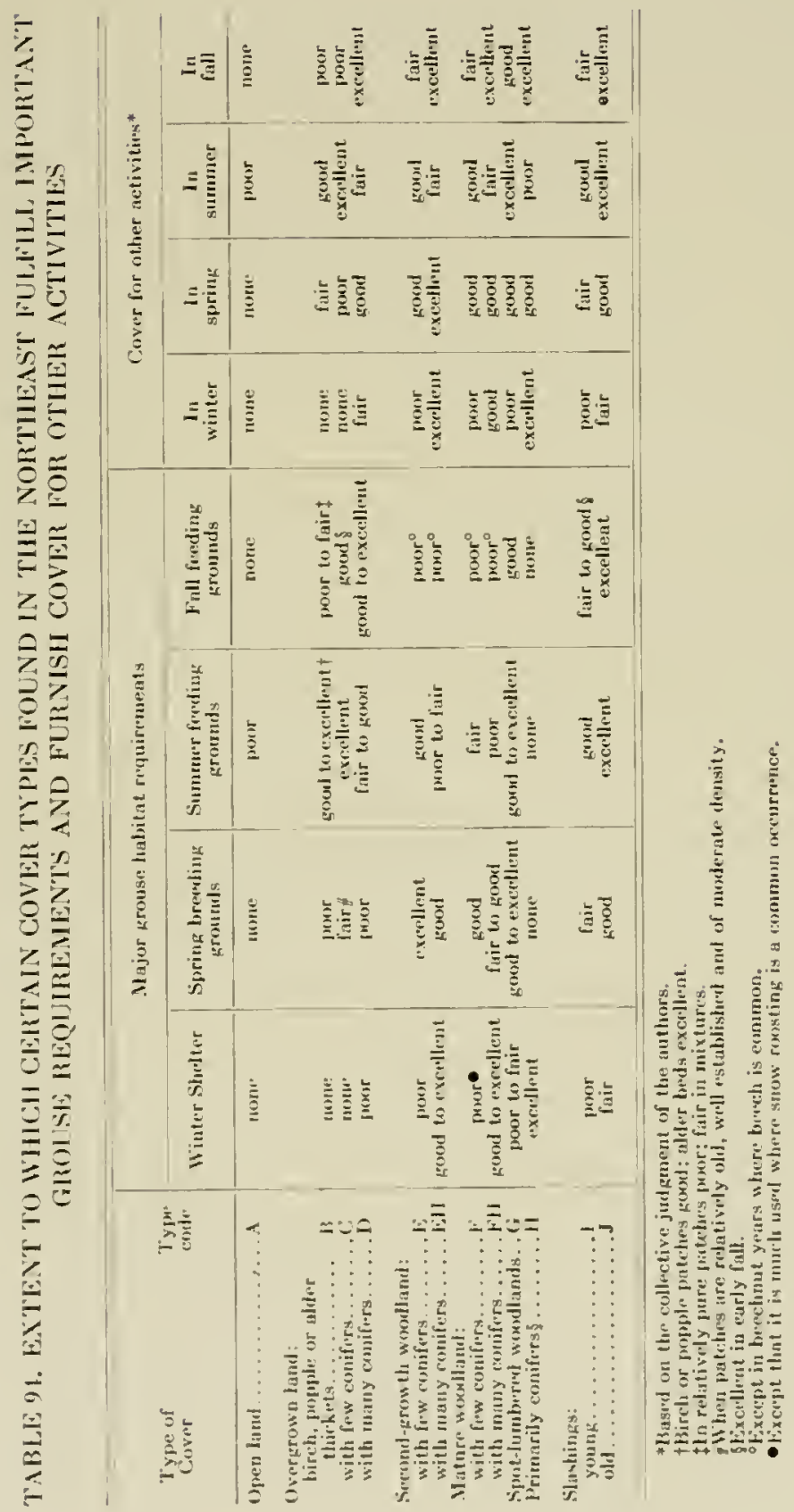


spring activity is reproduction. For nesting, female grouse prefer second-growth hardwoods. Thus, at this season, this type occupies a position of special importance although, in actuality, it is less used for other purposes than are mature hardwoods. In other words, many types may provide food and shelter for the incidental activities of life but only a few seem adequately to meet the major seasonal needs that must be provided for if the bird population is to thrive.

A second point, always in need of emphasis, is the importance of proper cover arrangement. A thousand-acre tract of dense woodland usually attracts but few birds except along the edges where it adjoins overgrown fields or slashings. Broken up into smaller cover units, an area of the same size will be used to a much greater degree. Likewise, hedgerows intersecting open fields may furnish excellent fall food but will seldom be used by grouse unless the other components that collectively make up good grouse cover are close hy.

The arrangement of cover types in large measurc controls the productiveness of the individual habitat as well as the number of habitats to be found in the covert. Let us consider each of these points separately.

To visualize the part cover arrangement plays in producing the individual habitat ten of the simpler combinations. commonly found in the Northeast. are reproduced in Figure 63. Alongside each is an analysis of the extent to which the combination meets the four hasic grouse requirements as well as the prohable result in terms of gronse habitat.

In presenting these. it is of rourse recognized that any one component, such as "overgrown lands" may in actuality be made up of one or of several of the types that collectively represent this group. For example. alder runs. birch thickets. overgrown pastures. with or without conifers, all represent overgrown lands. While all of these provide summer and fall feeding grounds for grouse, some are much more productive than others in this respect. as indicated in table 9l. Thus the number of lirds to he found in any ne combination may vary somewhat depending upon the type of overgrown lands present. The same is true of the other designations.

Let us look into each of these combinations for a moment. for they may well give us a clur why some woodlands harbor many birds. others hut few. Here. too, is a tip-off as to what to try for in redesigning a covert. The figures are, for elarity's sake. diagrammatic but it is easy to find their counterpart on the ground.

The first, where only one trpe is present, cannot possihly maintain a resident population of grouse with two exceptions. Where, in spot-lumbered woodlands. conifers are present to furnish winter shelter, good cover is available. and patches of berries and herbs provide summer and fall feed, one may often find birds throughout the year. Much the same situation exists in open, uneven-aged stands of mixed hardwoods and conifers.

The second combination. that of hardwoods surrounded by overgrown lands, is poor hecause winter shetter is lacking. There conifers are to be found intermixed with the hardwoods (combination 3). this deficiency may well be eliminated and good grouse populations often result.

Where. however. a central block of woodlands composed largely or entirely of conifers. is surrounded by overgrown lands or hardwoods (combination 4). a new consideration enters in, that of winter feed. All woodland types. save pure conifers, usually contain a sufficient proportion of hardwood species furnishing buds and mast so as to make food in winter normally ahundant. Here, however. there is a deficiency in winter feed. This forces the hirds 
FIGURE 63. AN ANALYSIS OF THE PRODUCTIVENESS OF SOME OF TILE MORE USLAL COMBINATIONS OF COVER THAT MAKE UP GROLSE HABITAT IN NEW YORK STATE

L'sual Habitat Combinations
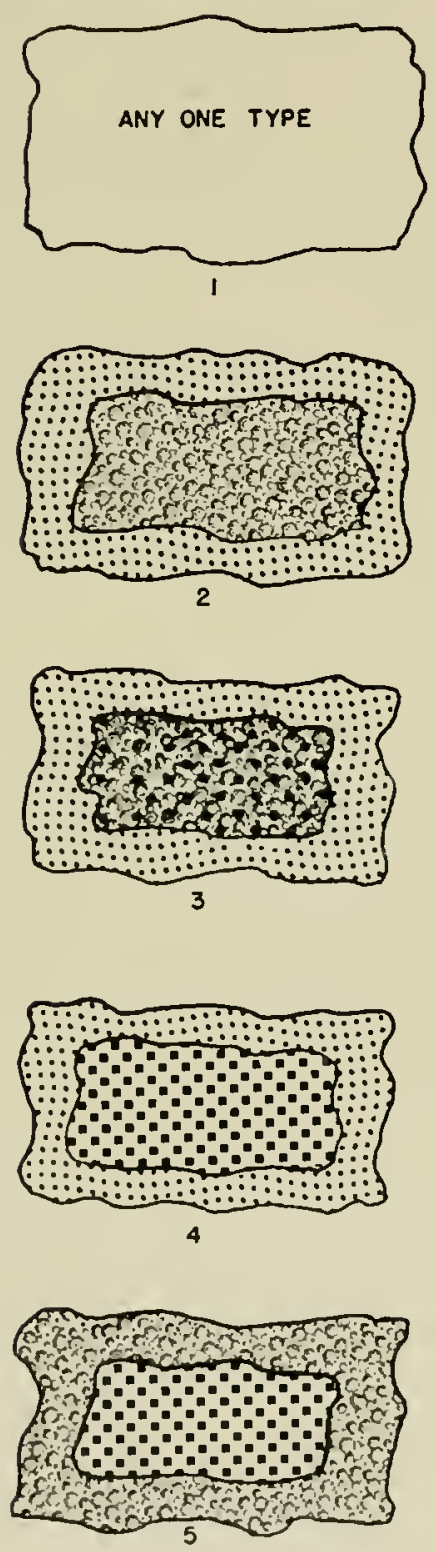

Analysis*

Only one or two of the primary habitat requirements met. ${ }^{4}$

No grouse present.

Winter shelter

- poor

Spring breeding grounds

- excellent

Summer feeding grounds

- good to excellent

Fall feeding grounds

- fairt to $\operatorname{good}^{\dagger}$
Winter shelter

Spring loreeding grounds

Summer feeding grounds

Fall feeding grounds $-\operatorname{good}$

- good

- good to excellent

- fair to goodt

Fair to good habitat for grouse

Winter shelter

Spring breeding grounds Summer feeding grounds

Fall feeding grounds

Fair habitat for grouse

Winter shelter

Spring breeding grounds Summer feeding ground: Fall feeding grounds

P'onr loabitat for grouses
- excellent

- fairt to good

- good to excellent

- fair to grood
- excellent

- excellent

- fair to good

-powr

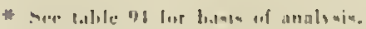

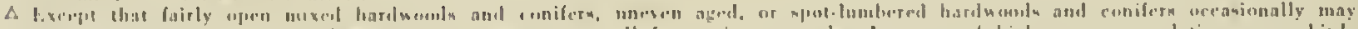

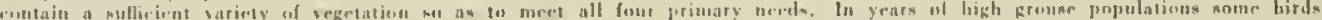

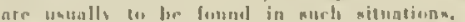

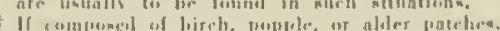

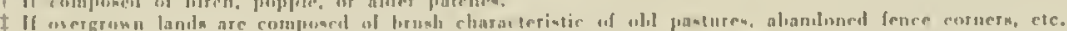

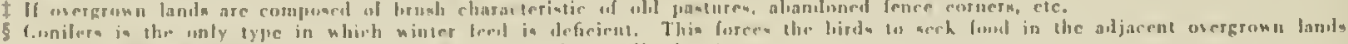

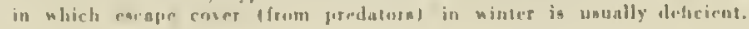




\section{Usual Habitat Combinations (Continued)}
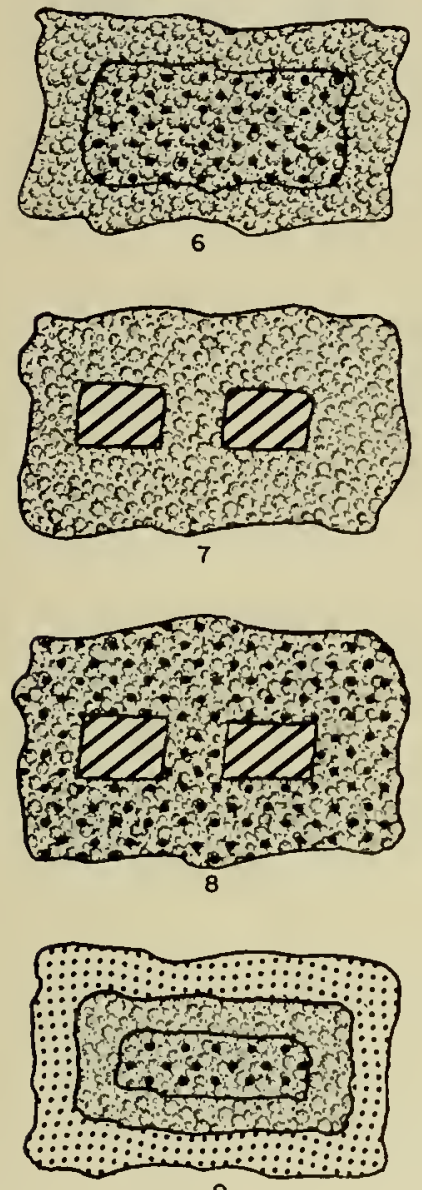

9

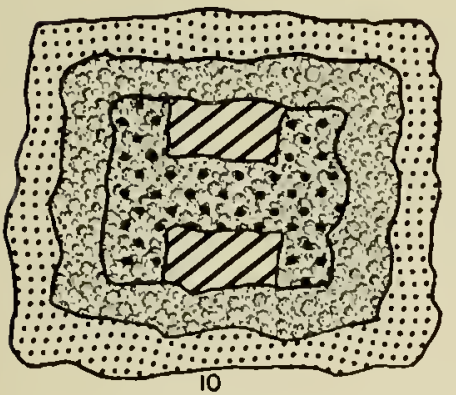

.
Winter shelter

Spring breeding grounds Summer feeding grounds Fall feeding grounds

Fair babitat for grouse

Winter shelter

Spring breeding grounds Summer feeding grounds Fall feeding gromnds
Analysis

$-\operatorname{good}$

- excellent

$-\operatorname{good}$

- poor

Poor to fair hal,itat for grouse

Winter shelter

Spring breding grounds Summer feeding grounds Fall fceding grounds

Good halitat for grouse

IVinter slielter

Spring loreeding grounds Summer feeding grounds Fall feeding orounds

Good habitat for grousc

Winter shelter

Spring breeding grounds Summer feeding grounds Fall feeding grounds Excellent habitat for grouse
- poor to fair

- excellent

- good to excellent - good to excellent [rood to exceillent

- good

- goos to excellent

- good to excellent
- excellent

- good to excellent

- good to excellent

— fair 10 good ${ }^{\ddagger}$
-. excellent

_ good to excellent

- good to excellent

- good to excellent

KEY TO FIGURE 63

$\square$ OPEN LAND
$\square::: 3$ OVERGROWN LAND HAROWOODS a CONIFERS
HIST HARDWOODS CONIFERS


to seek buds and herries in the adjacent overgrown lands. Here escape cover from predators is often deficient in winter. This is one of the reasons why from 10 to 20 per cent of a predominantly conferous plantation may well be planted or left to grow up to food-producing broad-leaved species. The more such hardwoods can he scattered through the plantation. the better are the conditions for grouse.

Another common grouping (6) is to have conifers surrounded by hardwoods. Conditions here are likewise unfavorable for grouse because of a lack of productive summer and fall feeding grounds.

The same may be said of hardwoods hordering mixed hardwoods and conifers (combinalion 7) since no provision for variety in summer and fall feeding grounds. as represented by slashings and overgrown lands, is made.

The above cover groupings are often associated with regions where the land is being, or was once, farmed. In the more heavily wooded regions of the State. few grouse are commonly to be found except where man or nature has made substantial breaks in the forest cover. Such situations often result from lumbering or from land clearance followed by moderate pasturing. Where the cut-over areas or slashings are surrounded by hardwoods (combination 7), adequate winter shelter is lacking in the latter lype and is provided but moderately in the slashings. The result. in terms of birds is, accordingly, disappointing. On the other hand, where the cover surrounding the slashing is composed of mixed hardwoors and conifers. as in combination 8 , this deficiency is eliminated. Providing a slashing is old enough to furnish excellent summer and fall feeding grounds, the result is usually a rather productive habitat.

Perhaps the best combination fairly frequently encountered is where mature hardwoods and conifers are to be found adjacent to second-growth. Which is in turn adjacent to a belt of overgrown fields (combination 9). Open up the cover a bit more by making a few small slashings in the hardwoods and conifers and the habitat becomes as nearly perfect as arrangement of cover types can make it. This is illustrated in combination 10.

From the above it is evident that type arrangement. as well as composition. plays a decisive role in determining the number of grouse an indivilual halitat can produce. It is equally true that the greater the number of good habitats in a covert. the larger the number of grouse likely to live there. Conversely it is perfectly possible to have an adequate amount of each cover type present in a given covert and still produce but few grouse. This prineiple is illustrated in figure 6.t where both areas contain the same amount of each important cover type. Yet only in " $B$ ", where all types are within short distance of each other. does more than one really productive grouse halitat exist. Here, though the total amount of each type is the same as in " $A$ ", they are so arranged as to furnish many more units of complete bircl or brood cover within the same area.

To transkate this theoretical conception into a practical situation as it might exist on the ground, let us glance at covert 1 of figure 6.5. Here the only really desiralle habitats for grouse occur at the point where hardwoods, slashings and mixed woodlands meet and along the dashed line between the lather two types. One would expect to find but few gronse in a covert so composed. By way of illustrating the opposite situation. covert 2 contains ahout the same anount of each ly pe hut so arranged as to provide not one but cleven productive hahitat spots (identified ly cireles) as well as seven particularly desirable edges. The normal level of abundance in this rovent would exceed that in covert 1. in most years. many fold. 


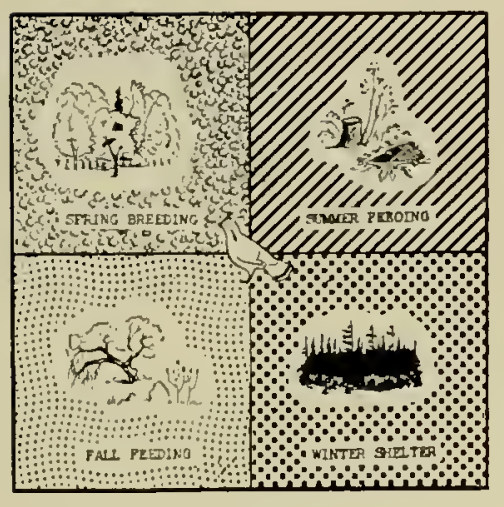

A

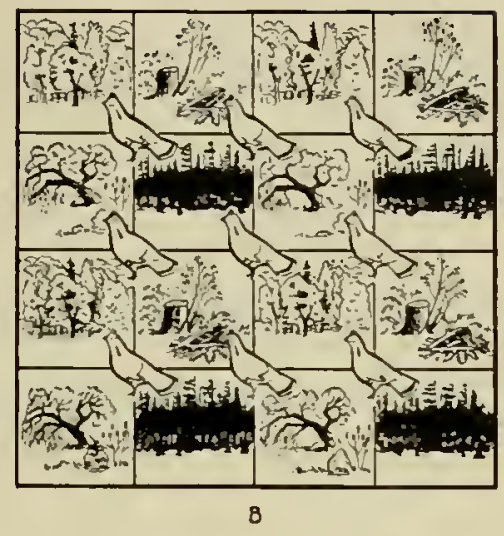

Nucleus of Grouse Hobifat

FIGURE 61. THEORETICAL MISTRIBUTION OF THE SIME AMOUNT OF CRITICAI, GROUSE, COVER TYPES TO ILLISTRATE THF IMPORTAYE OF PROPEL ARRANGEMENT
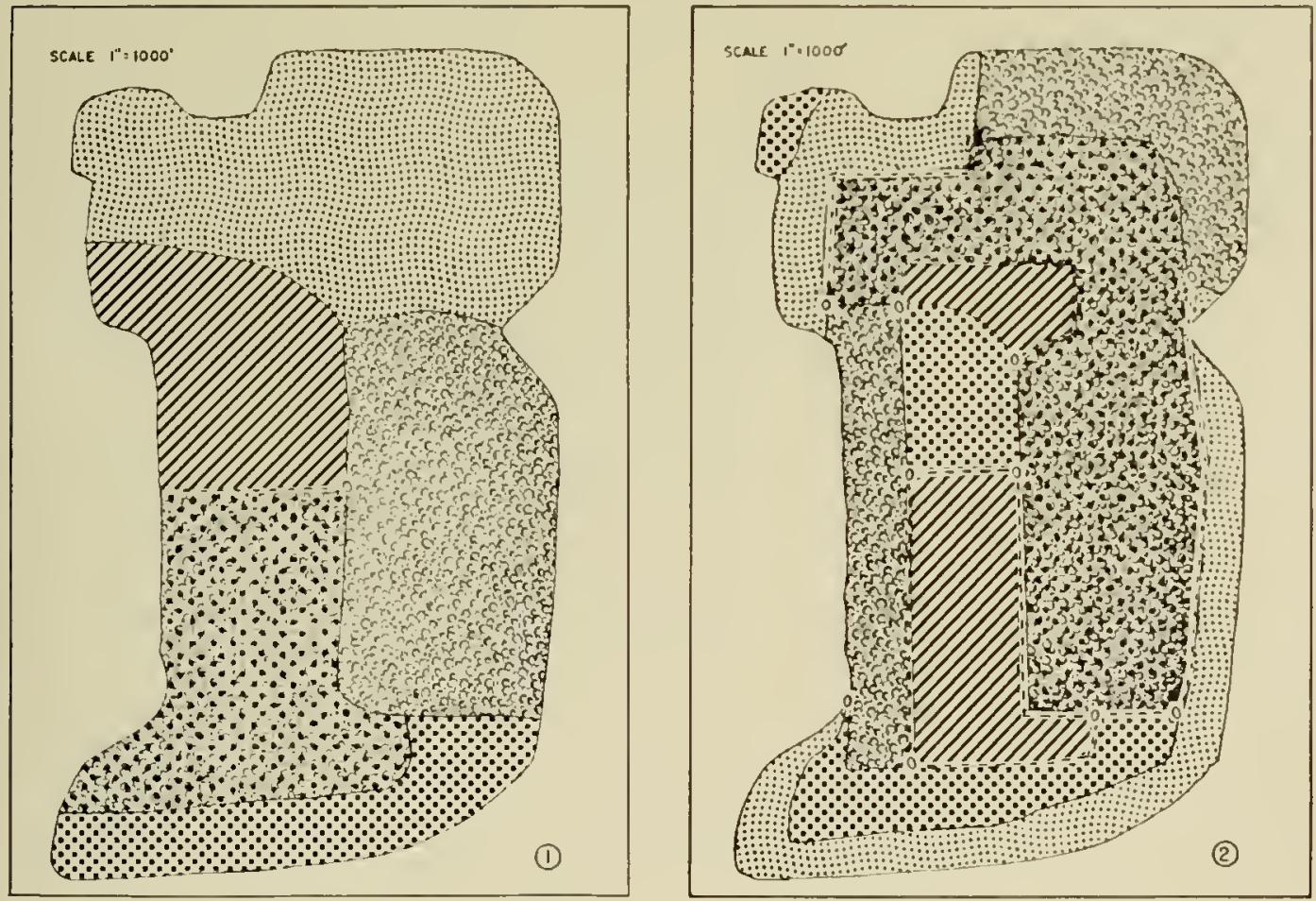

KEY TO FIGURE 65

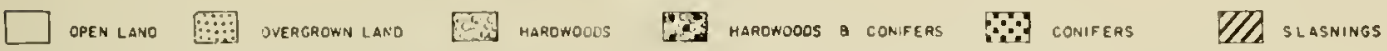
FIGURE 65. A PRACTICAL ILLUSTRATION OF THE EFFECT OF COVER TYPE ARRANGEMENT IN DETERMINING THE NUMBER OF GROUSE IIABITATS IN A COVERT 
In studying the combinations ilhstrated ahove, it is of course realized that trees and shrubs, unlike lumber. cannot easily be moved about and put in place to quickly translate a desirable pattern into reality. Much can be done, however, to alter the existing arrangement of cover types in any covert for the better over a period of years, if the principles and ends are well understood.

Another major point, entering into good cover design, is the actual composition of each type that collectively comprise the covert. While this has been described in detail in Chapter IIl. it is well to emphasize here that grousc cover is not static by nature. Thus the makeup of a type is constantly changing. Take, for example, a clear-cut area. An eight year old slashing may furnish excellent, a two year cutting but fair, summer feeding grounds depend. ing upon whether the growth is open or dense and the food-producing species are ahundant or scarce.

Inherently, however. slashings have the capacity to produce good summer food. Primarily they serve this purpose. Secondarily, they may also afford considerable fall food. As the character of a cut-over area progresses from herbs and herries to predominantly sprout growth, it becomes progressively less attractive to grouse. If growth continues unchecked by cutting, sncceeding years will see such a unit change completely in type from a slashing to second-growth forest. Though it still will he frequented to some extent by broods in summer, its main function then will be to provide spring breeding grounds and next. some winter shelter if conifers are present.

Other types, notahly overgrown fields, also may change rapidly in composition. Allowance for this should be made in designing and maintaining coverts.

A frual major point, not to be overlooked, is the effect type size and shape may have on covert productivity. The size of a cover type determines the amount of space inside an area while its shape controls the amount of edge enclosing that space as well as the greatest distance at which any point within it is situated from the edge. Thus a square or a circle has less edge than a long, narrow strip or one irregularly shaped.

Since edges may he an important component of good game cover. it is wise to encourage the longest possible outline while retaining sufficicut depth. Just how far one may go in this direction will depend a great deal on the physical condition of the site and the uses to be served.

While coniferous reforestation may furnish admirable winter shelter, much of it is wasted, so far as grouse are concerned, if it is deep. Only a strip along the periphery approximately 200 feet wide is likely to he much used.

The normal degree of use in most types of cover tends to be inversely proportional to the distance from the edge. $A$ small slashing may attract many hirls. $A$ s the distance across the cover type increases beyont the minimum necds. utilization per unit of area decreases because the birds have more from which to ehoose. They may oceasionally travel deeper into cut-over areas or hrushlatuds, at times groing half a mile or more from their usual haunts. More than 80 pere ent of the grouse nests recorded have leeen localded within 200 feet of a woods' road. Irail, clear-eut area, "vergrown fickl or other upening.

The ideal situation is to have cach cover component just hig emongh to satisfy the needs of the birds. Small components. well shaped, are much more productive per acre of area than are larger ones, poorly shaped. 
The needs of the birds change with the lime of year. their age and the quality of the food or shelter produced by each individual situation. Even considering ideal cover, it is not possible to say just what the minimum size of each type should be.

The pattern recommended by the Investigation for planting open fields eventually to form excellent grouse cover is illustrated in figure 67. The distances suggested are probably ample and in the absence of more directive experience. may also be considered safe.

\section{InTEgRation With OTHER Uses}

Another component of good design, though not necessarily of good grouse coverts, is the coordination of management recommendations with other uses for which grouse habitats may be suited. Among these are the production of forest crops, the development of recreational opportunities other than hunting, the control of sheet and stream bank erosion and the regu. lation of stream fow hy revegetation of areas characterized by quick run-off.

If multiple use is desired. it is inevitahle that the specialized improvensent practires associated with one or another of these uses he modified so as not to interfere scriously with the main object of building gond grouse habitat. The first decision to be made is to establish the order of importance of the crops to be encouraged.

In the Northeast. and in many other sections as well. it is quite possible. by an intelligent integration of the needs of both forest and wildlife management. to plan and carry out cover improvement so that a large crop of grouse may be produced together with a crop of forest products almost as large as though that were the prime consideration. For instance, it is wise to plan. where possible. to develop woolland types providing winter sleter and spring breeding grounds where soil and moisture conditions are conducive to good forest growth and where the trees therefrom may eventually be harvested without undue difficulty.

Effective erosion control may be accomplished by planting stream banks. gullies or steep slopes to trees and shrubs that furnish fall feeding opportunitics for grouse. However. other similar units should be developed on less difficult terrain to provide good fall hunting grounds.

The methods of accomplishing this synthesis of interests are discussed in some detail in the next chapter. That good habitat design can be built armund the prineiple of multiple use should not be forgotten.

\section{COVER ORGANIZATION}

Having considered the pertinent principles of cover design as well as their integration with other land uses, one is now ready to consider their application in properly designing a covert.

Most coverts contain open land. overgrown land and forested areas within their borders. One is accordingly faced with the problem of so handling these as to produce the maximum numbers of desirable grouse hahitats. Open lands may be left to seed in naturally or the process may be guided and hastened by artificial plantings, sn arranged as eventually to form good cover. Likewise, overgrown lands and forested areas may be maintained or im. proved by a variety of means as discussed in the succeeding chapter. For best results, such practices shonld be carried out according to a preconceived plan.

Previous to the Investigation few. if any patterns for ruffed grouse coverts had been worked out. The present suggestions are based on a study of the composition, size and arrangement of types in outstandingly productive grouse habitats, supplemented by experience in producing them. 
Some of the designs here suggested were first tried on the Connecticut Hill area in 1932 and since then have been widely adopted as productive covert patterns for grouse and other woodland game on the State's various game management areas. Where sufficient time has elapsed to produce the required conditions, the results appear to have been satisfactory.

\section{Planting Design for Open Land}

It is not generally realized that a considerable proportion of tomorrow's game coverts are being artificially planted today. Nor is the statement wholly accurate for, in many cases, reforestation is still carried out with little or no thought given to encouraging a crop of wildlife as well as of timber. Yet with slight modifications of the practices usually employed such could be the case. In fact many examples of integration of practices designed to produce both crops may be found on State-owned game management and reforestation areas in New York. As early as 1934 foresters and gane managers drew up and adopted a set of regulations governing the reforestation of idle acres calculated ultimately to accomplish this end. The suggestions here presented place a bit more emphasis on eventually producing good grouse as well as forest cover than do the ones referred to above since they are for use on an area where wildlife is the major crop to be encouraged.

Usually the minimum needs of grouse can be satisfied by providing a patch of secondgrowth hardwoods for spring breeding grounds togelher with scattered low conifers or their equivalent for winter shelter. This, in turn, must be edged with such pioneer trees and shrubs as cherry, popple, briers and dogwood to provide summer and fall feeding grounds for broods and adults. Under favorable conditions, suitable year-round environment may be furnished

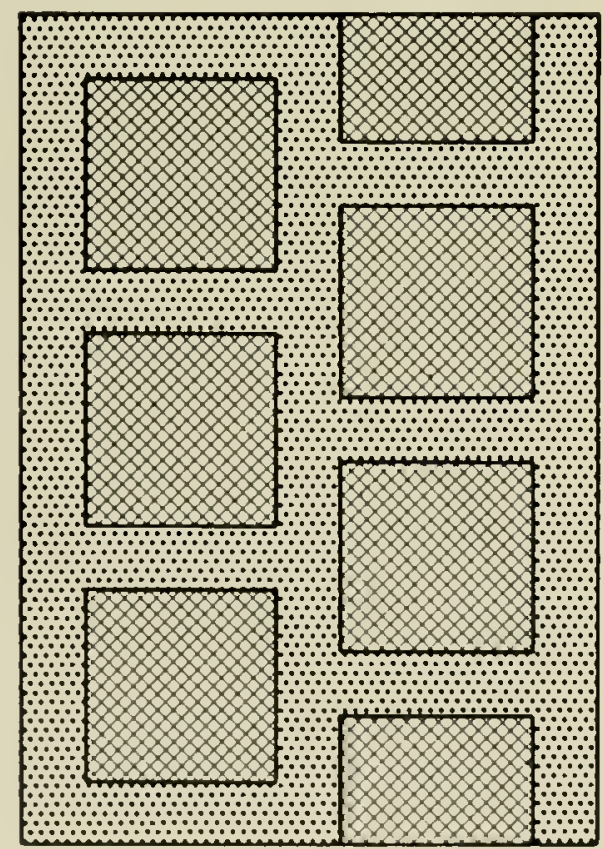

A THEORETICAL

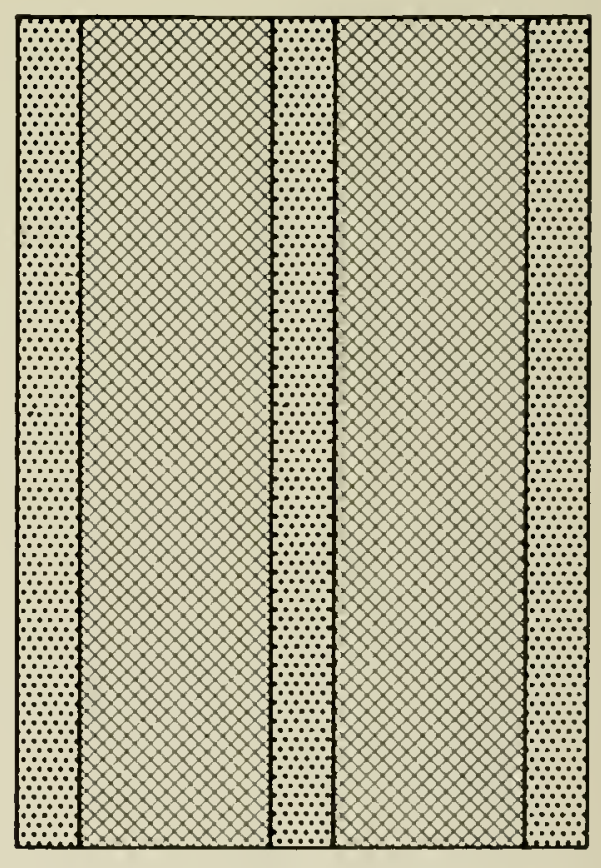

B PRACTICAL
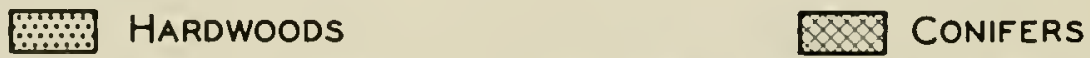

FIGURE 6G. SIMPLEST BESIG FOR PIANTING OPEN IAND TO JROVHE SOME GROUSE COVER 


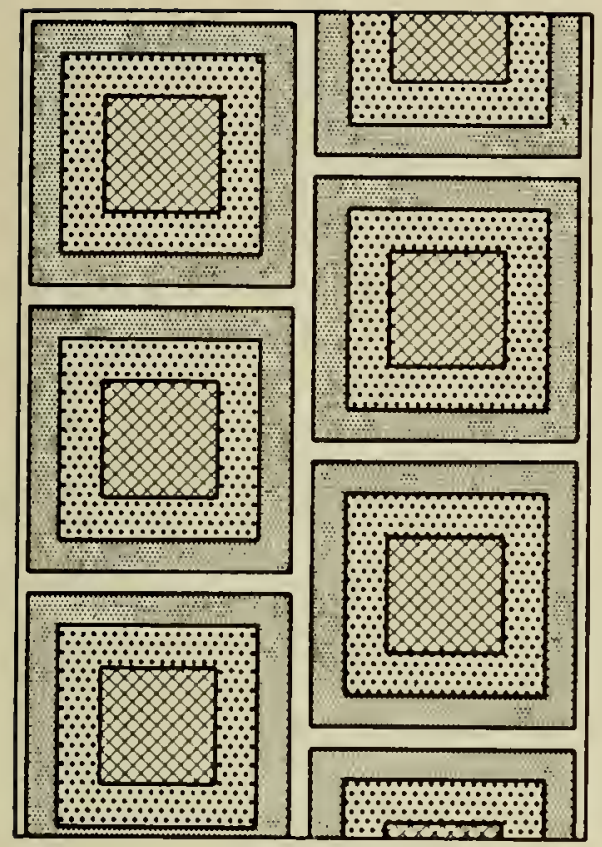

A THEORETICAL

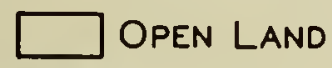

SHRUBS

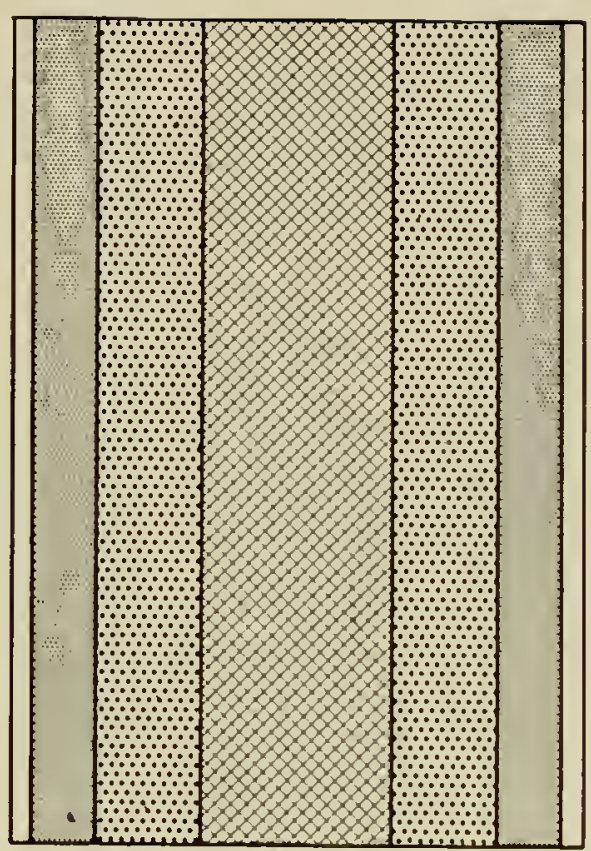

B PRACTICAL

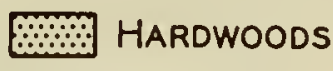

CONIFERS

FIGURE 67. MORE PRODUCTIVE DESIGN FOR PIANTIN, OPEN LAND TO PROVIDE GOOD GROUSE COVER

by just two types of cover-mixed woods and overgrown lands. The simplest design, then, which might be followed in planting open land to provide these combinations, would be a series of units as shown in " $A$ " of figure 66 . Because of planting costs, though, it might better be organized as shown in "B".

In the most productive coverts analyzed, an advantage scems to accrue when winter shelter and spring breeding grounds are separate and when summer and fall feeding grounds are, likewise, represented by different types. In New York the best winter shelter is furnished by conifers, a block of which is accordingly included in suggesting the design of a theoretically productive grouse habitat (figure 67).

A narrow strip of open grassland, from 30 to 50 feet wide, may well separate each group of habitats. The Investigation has been unable to demonstrate any positive value accruing from such strips, yet those coverts which grouse use the most usually contain such openings. These strips can be made into good firebreaks.

The best summer feeding grounds over most New York grouse range are clear-cut areas or slashings from three to ten years old. Obviously this type camot be utilized in designing grouse habitats arising from lands to be planted. Unless woodlands, in which small clearcut units may be established. are found adjacent to open fields, it is still necessary to combine summer and fall feeding grounds in the form of edge development.

With the right species properly arranged in strips across open fields (" $B$ " of figure 67), a 
combination may be secured which should produce not only a good crop of grouse hut also of other forest products.

As regards the size of each type to be planted. no minimum dimensions have been determined. The area required is, in part, dependent upon the composition of the type some years after planting. Naturally this, in turn, is influenced by many local factors. To avoid difficulty the dimensions of each type suggested bere are considered to be sufficient assurance against possible inadequacies.

The open land development pattern commonly used in New York provides for winter shetter by utilizing a central strip of conifers from 300 to 500 feet in width and of any desired length. Here the trees may well be planted $8 \times 8$ feet apart, so that a crop of forest products may result. However, if grouse are the sole consideration, the spacing might better be further apart unless the site is poor. This is less expensive, results in a bushier tree and tends to encourage a more desirable mixture of conifers and hardwoods by giving the latter more open space in which to establish themsetves naturally. This band may be flanked on either side lyy strips from 200 to 300 feet wide in which conifers and hardwoods are planted in irreg. ular clumps to furnish spring breeding grounds. When such an area can be placed close to existing woodlands, it may be practical to plant only the conifers, leaving the hardwoods to seed in by natural means.

To allow for fall feeding grounds it is suggested that a strip from 50 to 100 feet wide he left. Over this, at irregular intervals, may be planted small elumps of conifers edged with broad-leaved trees and shrubs that normally produce attractive food at this season of the year.

Theoretically these strips might well be placed as indicated in figure 67 , although, in actuality, there is no value to the geometrical regularity of the design. In fact, a scalloper outline is desirable. Full advantage should be taken of any food species already present. Hedgerows, woods' edges and stream borders, where attractive plants normally occur, make ideal units around which to organize a fall feeding strip. The small, open strip previously mentioned may then be left before repeating, in reverse, this planting design.

\section{OverGrown Land Design}

In New York State, Nature is a past master at producing brushy spots altractive to grouse in summer and early fall. Most of these result from the abandomment of once-cleared fields, pastures, or from hedgerows. Some predominant characteristics which nake them desirable are:-

1. A variety of trees and shrubs, many of which furnish feed as well as shelter for brood and adult alike. $A$ scattering of snch species as apple, thornapple, cherry, witd grape, viluurnum and dogwoud, thronghout overgrown lands materially increases their usefuhess not alone to gronse but to many other forms of wildlife as well.

2. The replacement of grass, asters or goldenrod by other ground cover more characteristic of a woods" edge environment.

3. In general, a rather open stand of trees and shrubs atthough the presence of oceasional small, dense thickets of shrubs seems not to be detrimental.

4. Few, rather than many, conifers.

Every gronse hunter pictures, from his own experience, the necessary composition of orergrown areas for it is there that hirds are most likely to be found in the early part of the 
hunting season. Little space need, therefore, be devoted to describing them.

In the Northeast, perhaps the most common situation involves the development of grouse cover from an area of abandoned farmlands and woodlots. The former are usually more or less overgrown. Thus is provided an existing pattern on which to build. Figure 68 illustrates such a development. Advantage should be taken of food and shelter already present whenever possible rather than to attempt the relatively expensive procedure of artificially producing it.

Overgrown fields usually furnish good fall feed. If they are large, the parts most strategically located and productive of fruits should be maintained as fall feeding grounds. The

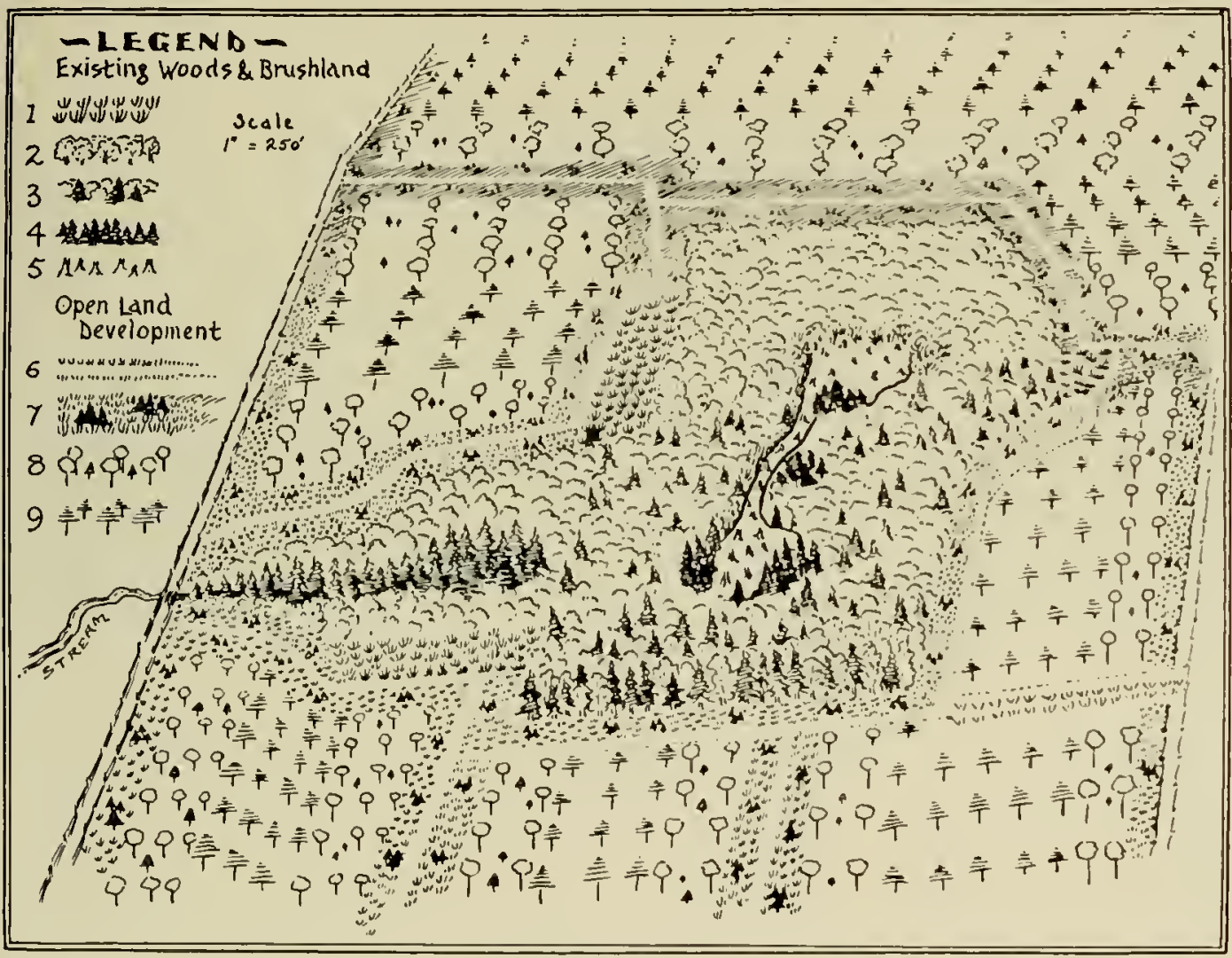

FIGURE 68. GROUSE HABITAT DEVELOPNENT ON SUBMARGINAL LAND

\section{Explonation}

Existing woods and brushland

(1) Overgrown fields

(2) Ilardwoods

(3) Ilardwoods and conifers

(4) Conifers

(5) Cut-over areas
Open land developnent

(6) Open land-not to be planted

(7) Overgrown edges - to be planted to food producing shrubs and trees with occasional clumps af conifers. It may also be left to seed in naturally on the len side of the woods ar hedgerows.

(8) Hardwoods and conifers-to be plonted or left to seed in naturally according to the situation.

(9) Conifers-to be planted with mixture of coniferous species 
rest will naturally grow up into spring breeding grounds. One of the toughest problems is to prevent this transition from taking place where productive fall feeding areas are already well established. This may be accomplished by periodically removing the taller saplings that threaten to choke out the other trees, shrubs and ground vegetation on which the birds rely for food. A method of poisoning the less desirable species, to prevent sprouting, is described in the succeeding chapter." Clearing with an axe is expensive since, normally, but little use can be made of the cuttings.

Moderate grazing by cattle tends to hold back the natural development of brushy areas into forest although patches of unproductive grass may be encouraged therely. Where overgrown fiekls are pastured adjacent woodlands should be fenced off.

Even in case maintenance of the necessary amount of overgrown land proves to be too costly, it is always wise to release from competition any particularly desirable food producers such as apples, thornapples or clumps of dogwoods or viburnums that may be present.

Conversely, where trees or shrubs of the right species are scarce, as in an abandoned meadow bordering a woods, it may be justifiable to introduce suitable species by planting if they do not appear to be seeding in naturally. This, also, is discussed in the next chapter.

\section{Woodland Design}

With but few cxceptions, not too much can be done to improve the forested parts of a covert except over a period of years. By selective logging of parts of a woodland, small openings with their attendant shrubs and ground cover may quickly be created. A thinning of crooked or diseased species of low value to game or as timber will, likewise, open up a thick patch of woods. Skillfully planned and carried out, such practices generally tend to improve both food and shelter for grouse. However, care should be used not to encourage too dense an undergrowth as the birds are more partial to a woodland with moderate undercover. Where grass is likely to be encouraged by heavy cutting, this should be avoided. Even light grazing, except where undergrowth is dense, is definitely detrimental.

In planning woodland improvement, conifers, either scattered through the woods or localized in clumps here and there, are particularly to be encouraged since they furnish escape cover and winter shelter. The only exception to this is where second-growth hardwoods, in the vicinity of openings, are available for use as spring nesting grounds.

Where winter shelter is desired but not present, it is usually best to plan for coniferous plantings in adjacent fields and in small openings in the woods. Underplanting, unless the crown cover is open, is seldom successful for both root and crown competition in woodlands are usually severe.

It is wise to encourage woods' roads and small openings within the forest cover. Conversely, extensive areas composed largely of a few species are seldom productive of grouse and should be gradually diversified by selective lumbering or by thinning the stand unless the crown cover is already sparse.

In gencral, uncven-aged stands are preferable since a greater varicty of trees. shrubs and ground cover is likely to be encouraged thereby.

Lastly, it should not lie forgotten that, while woodlands are the backbone of gronse cover.

* Promiang experinuent: uning newly develuped plant hormoner and tranalocating poioons to eliminate undesirable trece aod ahrubs are al present being carried out. 
there is seldom a good reason why they cannot be so managed as to produce, also, periodic crops of pulpwood. mine props, acid wood, cordwood or timber. Thus one may help to defray the costs of the improvements here described and of forest stand improvement practices as well. Specific suggestions as to how both objectives may be met are given further on in this chapter.

\section{Clear-cut Units}

In extensive forest areas where summer and fall food or winter shelter are deficient, one practical way of improving the situation is to cut a few small slashings here and there. These units may often be worked into the covert design so as to fulfill more than one objective. One small slashing may furnish first a supply of wood and later a rich source of food. Where winter shelter for grouse is notably deficient, the tangle of briers. sprouts and vines

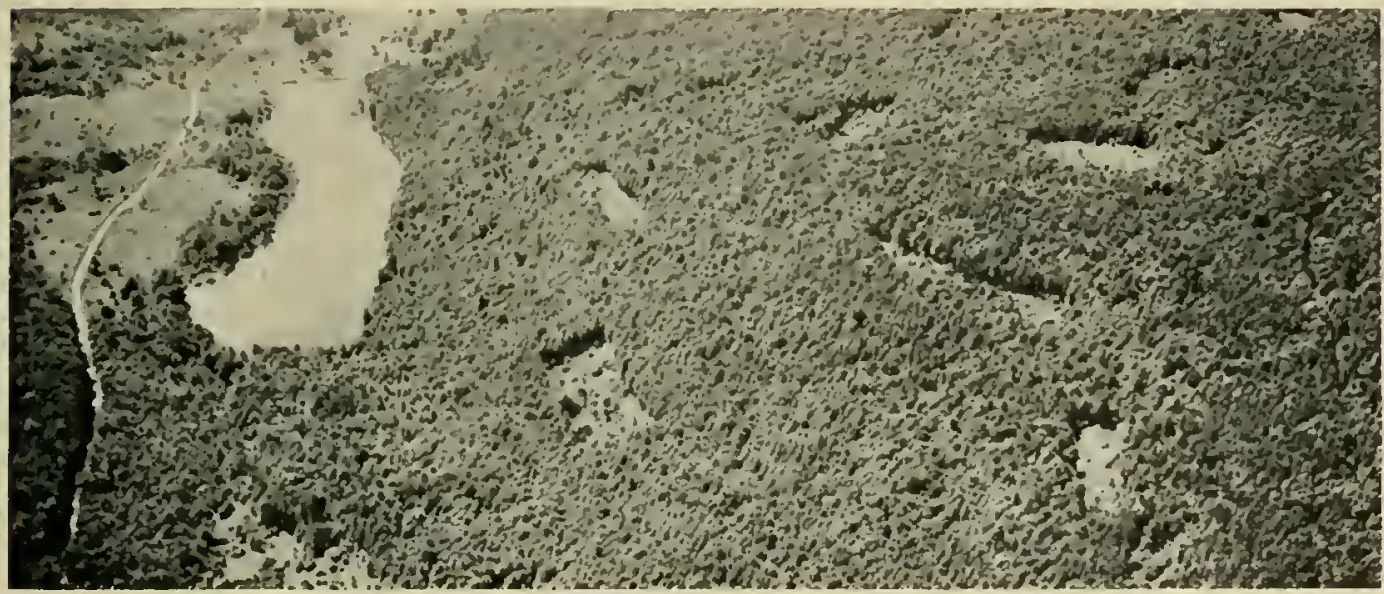

AN OCCASIONAL SMALL, SLASHING MAKES EXTENSIVE WOODLANDS MORE ATTRACTIVE TO GROUSE

which often springs up on cut-over lands may provide a quick though temporary substitute for the conifers and broad-leaved evergreens that normally meet this need.

In planning such areas, the possibility of disposing of the wood may often determine whether the unit is to be re-cut at the end of ten to fifteen years to preserve the characteristic slashing vegetation or whether it will be cut in rotation with several similar units. The latter practice is desirable where a market for the smaller sizes of wood is available.

Units to be cut in rotation are usually laid out close by one another so as to provide food and shelter year after year. In figure 69 the three divisions of slashing $S 1$ would be cut in rotation, while S 2 and S 3 would be recut as soon as sprout growth drove out herbs and berries.

Repetition of cutting at intervals over the same unit can be continned as long as grass and sedges do not replace the normal herb and shrub cover.

The suggestions here outlined covering the character, size, shape, location and rotation of clear-cut units are still too tentative to be called rules. In connection with the multiple purposes to be served ly the area as a whole and the individual characteristics of the slashing 
site and of the inmediately surronnding woodlands. the following points are worth considering:-

\section{Number and Size}

1. It is seldom necessary to devote more than 10 per cent of the total woodland area to clear-cut units.

2. A large mmber of small, clear-cut units is preferable to a few large ones.

3. To save maintenance costs, both number and size of units cut shonld be reduced to the minimum necessary to provide adequate food and cover distribution.

\section{Shape}

1. Since edges are desirable, wherever practical, clear-cul units should be linear (strip slashings) rather than square or circular in design.

2. Scalloped boundaries may be used to avoid cutting desirable trees and to increase edges.

3. Strip slashings should be bent from a straight line wherever an advantage is to be gained, except where there is a likelihood of their being used as sight lines to facili. tate the taking of a game census when desired.

\section{Location}

1. It is desirable to locate clear-cut areas from 1200 to 1600 feet apart or from other food patches.

2. For esthetic reasons, clear-cuttings should be located where they will not interfere with the landscape value of the woodland. None should be placed elose to a muchtraveled road.

3. Where possible, they should be established to contact and lie between the maximum number and variety of woodland cover types.

4. Sites to be clear-cut should be chosen, when practicable, where the second.growth or mature timber is of minor potential value.

5. To disconrage erosion, they slould occupy flat or gentle slopes as against steep oncs.

6. Clear-cut units lying along, rather than across, the contonrs are preferable.

7. loorer, raher than richer soils, should be favored in locating slashings.

8. Sites containing both danp and dry situations should be chosen where available.

9. It is wise to locate strip slashings with relation to possible use as lines of communica. tion or as fire lines in eabe of need.

Culling Cycle

1. In New York slashings are usually in need of recutting every ten to fifteen years if shrub and herb vegelation is to be maintained. The time elapsing between ruts varies with the fertility and moisture eonditions of the site. The moister, richer lands have the shorter culting cycle.

2. Where single muits are part of a group to be cut in rotation, the ummber of units present and the length of time necessary in produce salable wood must also be considered in setting the cutting cycle. 


\section{Forest Stand and Gáne Cover Improvement}

For the sake of clarity, many of the suggestions made so far have been presented as though grouse were the most important crop to be considered. In most cases there is much to be gained by cropping not only the game but the forest as well. This is the principle of maximum or multiple land use.

In creating environments favorable to the production of both forest and game crops, it should be remembered that cach has certain basic requirements. Each crop prospers according to the degree to which these are met. An important difference arises, however, from the fact that the forest itself is the crop whereas wildlife merely occupies the woodland as a habitat. Thus when the wildlife manager, to better grouse conditions, suggests alterations in the forest cover, he may, in effect, be asking the forester to destroy or forego a small part of his crop that game may prosper. It is equally logical that wildlife be controlled when, as with deer, it seriously damages forest reprodnction.

Failure to realize these simple truths has led to the building up of antagonisms, fargely unwarranted, to management suggestions promulgated ly either group and to a tendency to discount the importance in the minds of each of the nccessity of mecting those requirements considered basic ly the other fellow. The first step. therefore, in integrating the production of forest and game crops, is to develop a knowledgc of and appreciation for the point of view and requirements of cach. Once this is done, the problem is half solved.

It is desirable, before management plans are made, to establish the order of importance of the varions uses to which a given area is to be put. On this decision depends the degree to which any of the suggestions presented here may be applied.

If it is decided to give equal emphasis to timber and to wildlife production, conflicts in management practices may often be avoided if portions of the woodlands particularly suited to the production of a forest crop are set aside for this primary purpose. Established plantations or patches of woodlands of high commercial value are examples of this point. Likewise, throughout the area, an adequate amount of certain cover types may be set aside as of primary importance for grouse production. Among these are overgrown fields, fencerows, orchards, scattered clumps of conifers, and snall slashings or other openings in the forest cover.

Having located each of these primary-use units. the practices necessary to produce the main crops thereon then may be carried out, together with such other cultural activities as may assist in the production of the subsidiary crop. Such an arrangement, clearly understood and sympathetically carried out, will help to avoid many of the difficulties characteristic of forest and game cooperatives.

One of the more difficult decisions to be reached, before any cutting is done, is to define crop trees, wolf trees that crowd out more desirable individuals, and weed species. For New York, crop trces, from the point of view of grouse, are such food-producers as cherry, birch, beech, thornapple and the hornbeams, and such shelter-producing species as hemlock, pine and spruce. Some of these also represent forest crop trees. A conflict of interests is most likely to occur in deciding which are weed species. The classification of these is dependent upon use which, in turn, is based on whether or not better species are present. Thus. where species furnishing excellent grouse food and shelter are abundant, the kinds normally less at. tractive may be considered weeds unless they are particularly valuable for other purposes such as for lumber. Were the better species absent, however, the latter would then become crop 
trees. On the other hand, to the forester, thornapples and hornbeams are unimportant; popple, birch and beech are of particular value largely where a local market for such species exists. The degree to which any species fits into a particular situation, then. must determine whether it is to be classified as a crop or weed tree.

The designation of individual trees as wolf trees depends upon their classification as a crop or a weed species and upon the extent to which they are crowding out more desirable trees or shrubs. A maple over-topping a thornapple may be considered a wolf tree if the latter species is scarce and a grouse crop is particularly desired. Conversely, if thomapples are abundant and the maple of good shape and important for firewoor, timber or for seed, it would be inadvisable to eut it simply to release the tree beneath. A veteran bech overtopping other species nore used for timber may, nevertheless, be kept to produce beechnuts for grouse. But if it is one of many scattered throughout the forest, it might well be sacrificed in the interests of better timber production.

Where the main crop to be benefited by a woods operation is forest products, it is clearer il one refers to the improvement work as forest stand improvement. When the principal crop is grouse, it is often termed game-cover improvement.

Figure 69 illustrates a tract, some of which was originally open land, organized primarily for grouse production but adapted to growing a subsidiary timber crop.

It will be apparent that good cover organization is a more complex problem than is gen. erally realized. Those who have the interest, time and means to carry out management prac. tices, whether for grouse alone or in combination with other forest products, may be able to make use of many of these suggestions. Others, with lesser means, can still obtain good results by meeting the basic requirements of composition, size and dispersion within the habitat, even though many desirable refinements are not possible.

\section{PLANNING COVER IMPROVEMENTS}

With the foregoing picture of cover essentials and organization in mind, there are three steps necessary before one can produce a blueprint for cover improvement. First, the objectives of management must be decided upon. Then current cover conditions must be determined. These done, one is then ready to analyze the situation in terms of how well it fulfills grouse needs.

\section{Establishing Management ObJectives}

The possibilities of multiple use of grouse areas as well as the intcgration of forest stand and game cover have already been presented. Obviously the first move is to decide on the crops to be encouraged. One thinks naturally of firewood and lumber, of places for camping and hiking, of preventing soil erosion and of regulating stream flow as some of the forest attributes which may be combined with the primary oljective of encouraging a grouse crop. Other gamc species, such as the elusive deer or the lowly collontail, may be welcome likewise. Development plans must be modified accordingly.

\section{Detemuning; Cunkent Cover Conditions}

The objectives once outhined, the next step is to take careful stock of present covert conditions. The detail with which such an inventory is undertaken depends, naturally, upon the intensity of the contemplated development. This rataloguing of existing conditions as they affect grouse may he termed the cover survey. If real progress is to be made it is at the same time most helpful to prepare a cover type map from which one can more easily see 


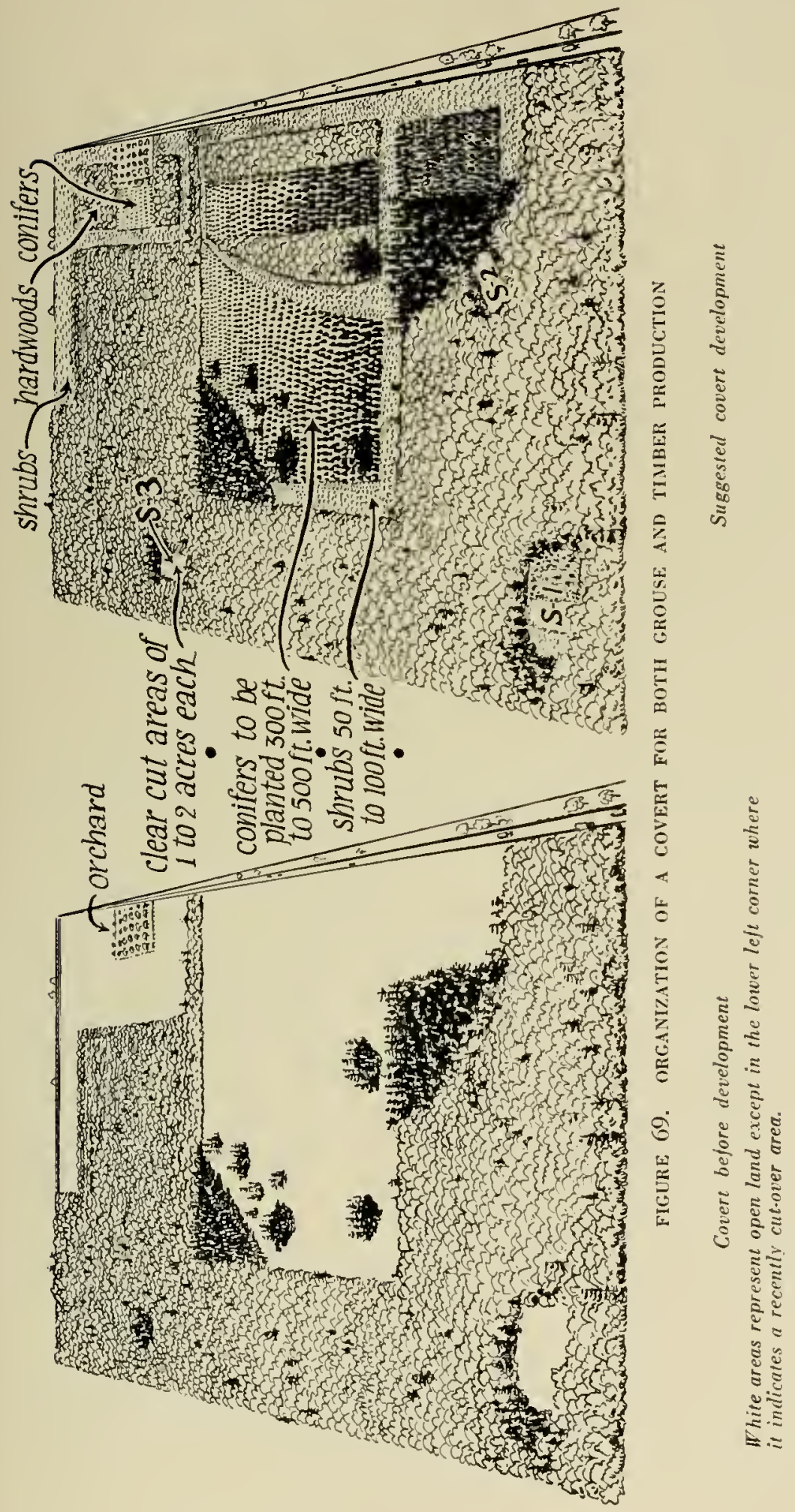


the cover improvements that need to be carried out. Later it will form the basis for devel. oping a covert management plan should one so desire.

\section{The Cover Survey}

Through an inventory of the current situation one seeks to learn the distribution of plants producing food and shelter and the various combinations (called cover types) in which they occur. Annther purpose is to find out whether these types are so arranged as to produce few or many desirable grouse territories. Incidentally one may gain some idea of the wild. life relationships existing between game, predator and huffer species and the hunter.

The degree of precision to which the analysis should be carricd depends upon the purpose to be served. If one is merely interested in periodic changes in cover and in the abundance of grouse on a given area, a hrief reconnaissance will suffice. If time and effort are to be expended on improving habitat conditions. a broad biophysical survey. covering many or all of the items listed below, is desirable. If one is not certain as to the degree of use to he made of a cover survey, it is wise to secure the maximun amount of information which time and funds will permit.

Among the items one may wish to consider are:-

1. The distribution and character of the physiographic fcatures of the area-topography, soils, water conditions and climate.

2. The distribution, size, composition and density of cover types (crown cover, undergrowth and ground cover)."

3. The degrce to which each type fulfills seasonal grouse requirements. particularly; as regards food and shelter.

4. The distribution and relative abundance of grouse predators and buffer species.

\section{Cover Type Mapping}

One effective way of securing much of this information is to make a cover-lype map of each rovert. ${ }^{\triangle}$ Such a map conveys graphically much useful information. With it one may visualize the arrangement of cover and thus more asily plot the rhanges which need to be made therein. Also, the close inspection which such work necessitates naturally draws attention to many details otherwise likely to he overlooked. The field notes may lie expanded to eover as many otler points. in addition to those here listed. as seems desirable.

It is wise to make up the type map reasonahly accurate. Where substantial improwements are planned, it is almost essential. Suitahle mapping practices. in general. follow those described in standard texts on forest management. The techuique developed by the lnvestigation is described in the Appendixt. The scale should he the smallest that will clearly show the requisite details. The Investigation's survey arcas were mapped on a scale of one inch to 10 chains $(660 \mathrm{fect})$. This was found not only to meet the alwove requirement lut to facilitate easy acreage computations.

Wherever it is possible to serure a good hase map. such as lhose pullisherl by the United States feolugical Survey. the sertions covering the area umler cousideratiun and locating promineut existing landmarks (roads, watercourses, houses and hills) may he cularged to

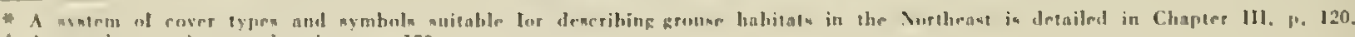

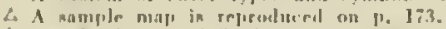

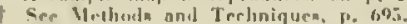


provide the necessary space for indicating cover and olher details. It is usually possible to secure aerial photographs which, properly interpreted, will also provide the line of demarcation between the major variations in cover, as well as picture graphically the general layout.

If printed lightly these may also be used to advantage as a hasis on which to project plans for covert development.

Even though these are available, a strip survey or at least a reconnaissance is still neces. sary to determine cover type composition and density, and to secure the incidental data on other items already mentioned as desirable.

Usually, however, cover type boundaries are best secured by establishing base lines from which, by means of compass and pace, a series of survey lines are run across the area at intervals sufficiently frequent so as 10 allow such details as changes in cover type or density occurring between the lines. to be sketched in. The compass direction of each course is en. tered on a rough field map, as are the distances along each course at which the features noted occur.

It is, of course. necessary to determine the cover types to he recognized hefore mapping is actually started. In New York all grouse cover has been divided into twelve major types". These, singly or in comhination, furnish the four items-winter shelter. spring breeding grounds, summer feeding grounds and fall feeding grounds-one or another of whieh is most likely to be deficient in otherwise good grouse hahitat.

As the survey progresses. it is helpful to transpose the field notes to the final map and the accompanying descriptive record at frequent intervals. Details from soil. topographical or aerial surveys may then be incorporated. Once one becomes reasonably proficient, from 100 to 150 acres can be mapped in a day depending upon the number of details noted. the amount of open land and the complexity of the cover.

\section{Analyzing; the Covert in Terms of Grouse Needs}

The field reconnaissance, with or without a map. completed and the notes on cover. game and predator conditions brought together, the next step is to analyze the data to trace out present conditions and to fund just what measures are reguired to bring the covert up to full productive capacity. The luvestigation firmly helieves this to he in large part a matter of improving the cover and of controlling the harvest so that the surplus but not the seed stock shall be taken annually. The overall aspects of control. including seasons and hag limits, are discussed in Chapter XVII, p. 673. leaving the location and designing of seed stock refuges for discussion here. Likewise the role and suppression of predators. diseases and other factors are considered in the same chapter, since they represent control measures rather than covert design.

\section{Recognizing Cover Deficiencies}

The problem in determining cover deficiencies is to visualize the cover actually existent, to decide whether or not it provides an adequate number of spots where winter shelter, spring breeding grounds and summer and fall feeling grounds adjoin or lie close to one another and to redesign the covert to accomplish this end where such is not already the case. It is worth reiterating here that the number of grouse a covert can support is dependent largely on the frequency with which these ideal locations occur. One has but to turn to figure 64

\footnotetext{
* See Chapter 111. p. 120.
} 
on page 613 to see how basic is this point.

If one has merely cruised a covert it may prove difficult to remember where all these spots occur and, of more importance, where they are not. The types often are found in an array so confusing as to make it more practical to locate them from the cover-type map. Here, if each type is colored differently, the size, shape and relation one to another may be seen at a glance and plans laid to correct the deficiencies utilizing the methods discussed in the following chapter.

It is not so simple to evaluate composition from a map. However. since cover types are classified according to their composition. one may obtain a general idea of the makeup of each type from the map. For example, young slashings are distinguished from older slashings by defining them as different cover types. The former are usually full of herbs and berries while, in the latter, hardwood sprouts commonly predominate.

For a more exact idea of the individual cover type composition, one must refer to field notes unless cover type symbols are used to include this information on the map. Suitable symbols indicating density and the degree of food and shetter value are described in the Appendix under Methods and Techniques".

The deficiencies to be guarded against fall logically into two classes. These are the size. shape and arrangement of cover, and the composition of the individual types. Both are discussed in detail in Chapter III, the first on p. 111 to 113 , the second on p. 112 to 113. By comparing the points there raised with the actual situation in the field desirable changes in the design of any covert hecome apparent.

The following will give an idea of how cover-lype maps may be used to help recognize cover deficiencies. It is easy to see from a map where he the open areas that may he planted to extend the habitat. Where woodlands are concerned, deficiencies are not as easy to identify. Many such areas, at least in the Northeast. afford ample winter shelter or spring breeding grounds but are often lacking in summer and fall food. To gain a general idea of where the latter may be inadequate, those zones containing suitable food for these seasons and within easy reach of the birds may first be outlined rouglily on the map. This may he done by drawing lines from 600 to 800 feet around and parallel to the edges of existing feeding grounds.

The rest of the woodlands outside these lines constitutes a zone in which summer and fall feeding grounds are inadequately represented. To remedy this defect, the location of clearcut units or slashings may be plotted inside the inadequate zone from 1200 to 1600 feet apart and of a similar distance from existing feeding grounds. Thus roughly located. the clear-cut units may be placed more exactly in accordance with the points heretofore mentioned. ${ }^{\wedge}$

It is less difficult to determine where winter shelter or spring breeding grounds should he located. If necessary, the same technique may he applied. The zone of adernuey is probably about the same for the first. hut for the second it is represented by a strip seldom more than 200 feet wide along woods' roads, field borders, small openings in the woods or similar edges.

No mention has licen made of what to do with open lands such as fields or meadows. These may lie left to seed in naturally, or, more profitably, may be planted to provide both a game

- Sire T. 698.

$\triangle$ See 11. 62\%. 
and a timber crop at some future date. Detailed suggestions covering this point have been presented.

The need for and the positions of adequate food and cover areas thus having been determined, the problem of locating refuge and shooting units still remains to be considered to make the blueprint for improvement complete.

\section{Locating IIunting Areas and Seed Stock Refuges}

High grouse populations are seldom maintained for long in coverts where the surplus is not harvested by hunting. The role and control of the hunter is discussed in Chapter XVII. p. 678 to 679 .

Well-planned grouse management areas should be laid out so as to facilitate the harvest of the grouse crop. Not that the hunter is given all the breaks-the hirds see to that for grouse are famous shot-dodgers. Cover types may, therefore, be arranged occasionally so as to provide many possible shooting opportunities before the birds reach the comparative safety of thick cover. This possesses the double advantage of helping to prevent surplus crops from going unharvested and allowing the less skillful hunter a better opportunity to share in the birds taken, thus spreading the enjoyment over a larger group.

Specific suggestions for setting up areas for hunting gronse, are detailed in Chapter XIV 011 p. 594 to 596 .

As regards seed-stock refuges, they are of little value where hunting is strictly regulated as on a preserve. Likewisc, where dense stands of conifers or hardwoods present a considerable proportion of impenetrable thickets. no artificially cstahlished seed stock refuges are necessary as the birds soon learn to make good use of these as escape cover.

On the other hand, where grouse coverts are likely to be subjected to heary and long. continued hunting pressure. or where they are presently so poor as to support but fow hirds. an occasional small refuge unit, strategically placcd. provides some assurance that a fair number of breeders will remain in the coverts at the conclusion of the season. The proper locations for these nay be determined hy examining the cover-type map in conjunction with field observations. Fall feeding grounds, together with adjacent thick cover, make excellent refuge units. It is desirahle to set up the refuge in the nidst of good grouse cover so as to provide an abundance of favorable locations nearby for the birds to occupy in the event such coverts are overshot.

Assuming a refuge is desirable, the most appropriate size is from 25 to 100 acres. So long as the boundaries are clearly marked, the better the fall feeding and escape cover contained therein, the smaller the unit should be. Not over me-fourth of the total acreage of any covert need normally he used for this purpose.

The determination of size and location must be based to a considerable extent upon expediency. Easily recognized boundaries should be used wherever possible. Woodland borders, roads and other natural features serve this purpose excellently. By so doing, trespass thereon, as well as the cost of establishment and maintenance will be cut to the minimum.

\section{ORGANIZING THE OTHER FORCES OF PRODUCTION}

While the main emplasis, heretofore, has rightly bcen placed on designing the best possible food and shelter combinations, it would be in error to assume that these alone are important. The role played by each of the other forces controlling grouse abundance has been described

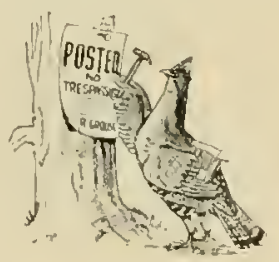


in detail in preceding chapters. A practical analysis of just how cach fits into the scheme of grouse existence may be found in the introduction to the Management section of the book." One cannot read these without realizing that, while each affects the grouse crop in its own way, few are susceptille to direct control. Indirectly, by building better cover and by controlling the harvest, the effect of those factors which encourage increase can be strengthened; those limiting grouse numbers may be made less destructive. Beyond this, as a practical proposition, there is not a great deal that can be done to help the bird except at prohibitive cost and effort.

In considering the possibilities, one remembers the losses from predation and disease, overshooting and dispersion, and is apt to wonder if some control measures for these might not he incorporated in any plan for managing grouse coverts. Such items as the providing of artificial food and shelter and restocking depleted coverts are also occasionally adrocated. Let us, then. see to what extent these fit into the overall design.

\section{Predation}

Predation, as a force, may work both for and against more grouse, as already described. When grouse are abundant, forcing some to occupy poorer habitats, these birds are naturally more likely to be canght by predators. One of the best ways to aroid such losses is to improve habitat quality. Most important in this connection is the arrangement of feeding and escape areas adjacent to each other.

Predator control is one of several activities collectively responsible for maintaining large grouse populations in Seotland and England, where the red grouse is produced in almost unbelievalble numbers. It is used hand in hand with the control of certain diseases. ${ }^{\Delta}$ the building up of excellent cover. and the complete harvesting of the surplus each year. Though millions have heen spent nn predator control in this country. no similar result has ever been achieved.

Where predators are not overly abundant. it is doubtful if their control can he justified. True, over small areas, particularly if they are isolated, it is perfectly possible to remove most of the resident ground and winged predators hy trapping and hunting. But the cost over a large territory is prolibitive and the results. as previously described. are by no means as favorable as has been generally pictured. For are hountics a practical way of holding grouse predator numbers in clieck.

Cover improvement over large areas supplemented by trapping or shooting of species particularly destructive to grouse. such as goshawks, great horned owls. foxes and weasels.

* Sare p. 580

A Mainly strongvinsis, not foumd in rufferl grouse.

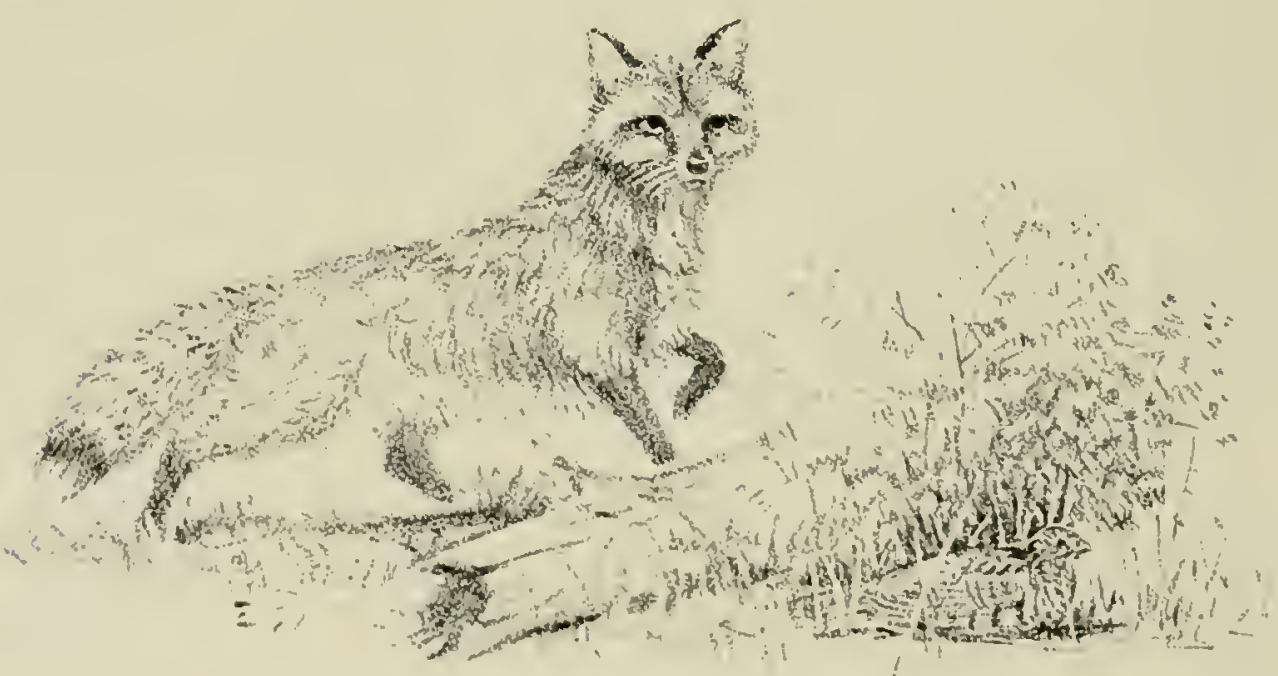


when abnormally abundant in a particular locality, are the only practical methods by which losses from this factor may be controlled. For the latter the cooperation of local trappers may well be solicited.

\section{DISEASE}

It has been popularly supposed that little could be done to aid in the control of grouse diseases. Insofar as individual diseases go, this is correct. There are at least three general ways, however, of reducing the incidence and therefore the power of grouse diseases in general. The first is to create as many grouse territories as possible within a covert, thus tending to prevent large concentrations of population. The second is to formulate a plan for reducing these concentrations, should they occur, by harvesting the surplus through lengthening the shooting season. With grouse, it is impractical to redistribute the birds by attempting to trap the surplus. The last is to see that predators are not reduced in num. bers to a point where they cannot he rlepended on to harvest any surplus not taken by hunters.

Though the Investigation knows of $n 0$ exact proof, it is also a generally accepted principle that the hetter the cover the stronger the bird and the less likety it is to become weakened and fall prey to disease.

\section{Control of the Harvest}

In designing a gronse area it is important that provision be made for adequate control of the harvest. Even with careful planning and control of hunting, grouse numbers will vary considerably from year to year. Therefore an estimate of the season's crop is neccssary.* It is advisable to incorporate in the management plan some means whereby the season may be shortened from the normal period or closed altogether if the birds prove to be unusually scarce. Conversely, if they are found to be overly abundant it is equally desirable that the season be lengthened so as to allow for the harvesting of the unusual surplus rather than leaving it to he removed ly disease and predation.

\section{DISPERSION OF THE BIRDS}

Grouse are. ly habit, relatively asocial birds. This means that in, periods of abundance. many of the young birds may be expected. in fall, to seek out the less populated coverts. By so arranging the cover as to provide more and better halitats in each covert. this tendency may be minimized except in years of peak populations.

* Methods of censusing are plesented on p. 676 .

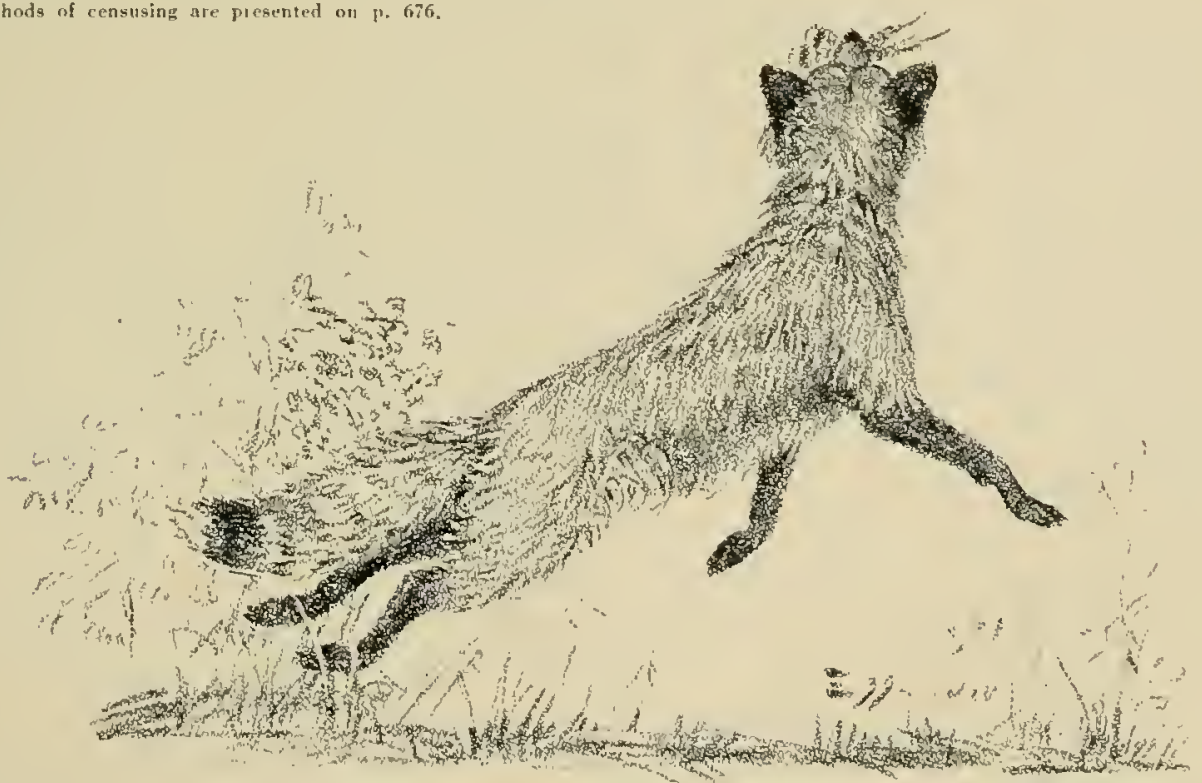




\section{Some Generally Unproductive Practices}

Two ideas, commonly expressed, have but little place in the plans for managing grouse coverts, except under unusual circumstances. So that time and money may be better em. ployed, they are mentioned here.

\section{Providing Artificial Food and Shelter}

Natural food and shelter result from proper cover, as heretofore discussed. Occasionally. one may be tempted to provide these items artificially either through setting up winter feeding stations or by building escape covers such as brush piles. Neither of these has proven necessary or particularly useful when tried out by the Investigation.

\section{Restocking}

As a productive technique, restocking has been, for the most part. poorly planned and badly carried ont. That it has its place, as described in Chapter XVII", is unquestioned.

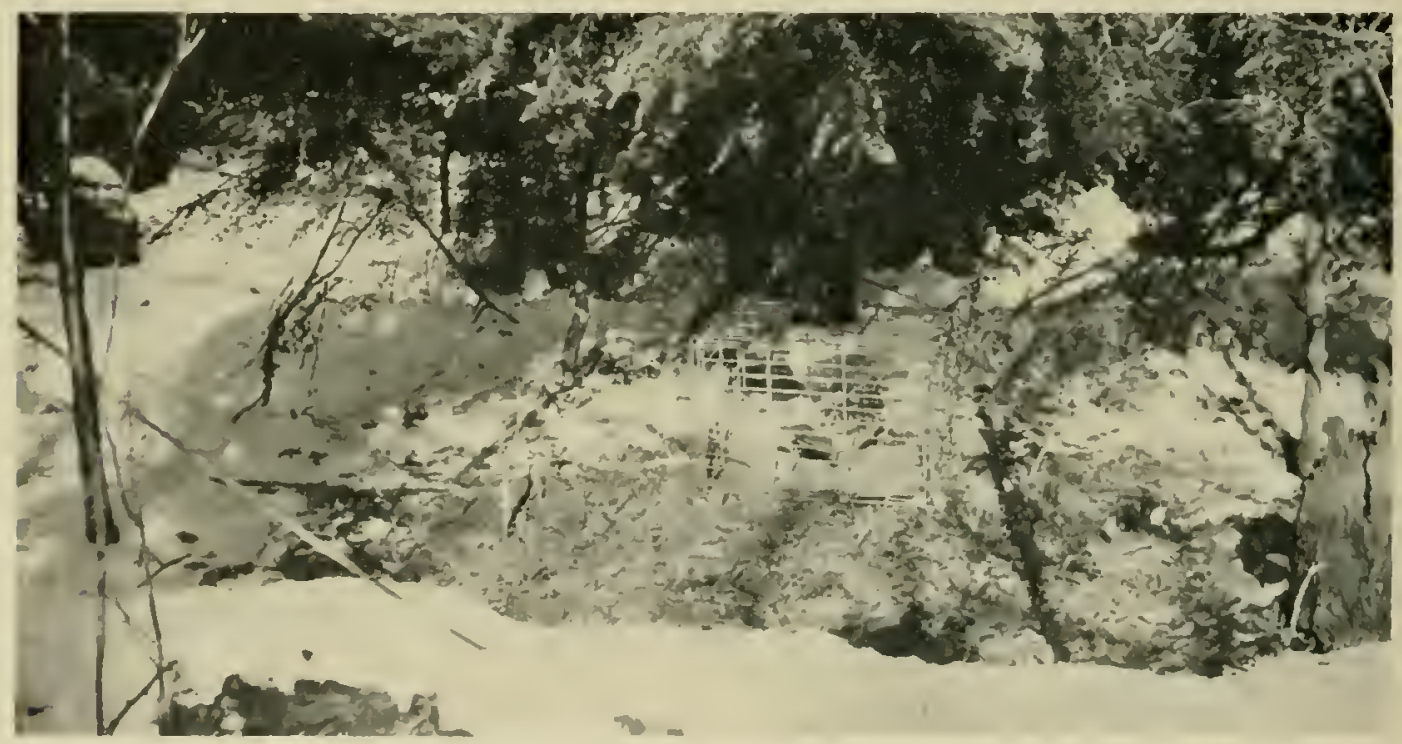

WINTER FEEDING STATIONS ATTRACT ONIY AN OCCASIONAL BIRO

But as a means of quickly increasing the possible fall harvest of birds, it is altogether too costly and uncertain to warrant inclusion in any management plan.

\section{SETTING UP MANAGEMENT PLANS}

There is an air of assurance alout the title to this section which may be misleading. It seems to imply that the science of producing and perpetuating a grouse crop is sufficiently cut and dricd to allow plans complete in every detail to be drawn up, much as an architect does for a house and with much the same certainty of satiwfaction ower the results, once they are carried ont.

Surli an impression is naturally wide of the mark. The results of the present study, even - See p. 67:. 
though interpreted against a background of past and of contemporary research in all pertinent wildlife fields, can only point the way. The grouse crop on a managed area is still dependent on a skillful direction of the natural forces of production about which our knowledge is fragmentary and over which we can exercise, at best, but imperfect control.

Why, then, set up formal development plans at all? Why not plant and cut wbere conrenience and individual notion dictates? For the same reason that foresters bave busied themselves designing forest management plans for the past 40 years in America and over 200 years in Europe. They provide an orderly outline of prescnt conditions and of what should be done, in the light of our present knowledge, to improve then if the grouse crop is to be increased. They represent a point of departure for our efforts and, if properly carried out, a chance to measure progress against the standard of conditions before covert improvements were inaugurated. They help to focus our attention on objectives and details alike. They provide an orderly sequence and a time schcdulc, as well, for the activities to be carried out.

It is with these thoughts and reservations in mind that the setting up of management plans is here briefly considered. The suggestions offered arc a long way from being complete. But then, how many have ever seen a perfect forest working plan?

\section{BASIS}

There are a few prime considerations to be kcpt in mind in building up a grouse management plan. Some have already been mentioned but will hear repeating.

Conmon sense dictates that such plans be formulated only where the continuity of ownership and funds, required for development and maintenance, are reasonably assured. They are primarily of use on large estates, or on land in public ownership which is to be developed for refuges and public lunting grounds. But there is no good reason why the owner of a small piece of grouse cover may not find it productive fun to develop and carry out grouse management plans.

Other items, too, have to be kept in mind. Any plan mus be subject to frequent revision as research uncovers facts applicable thereto. Coverts are suliject 1 11 unlooked-for mishaps resulting from wind, fire, insects and sinilar causes which nay force changes in design and operation. Nor must we forget that, in the present state of the art, the best laid plans can only be tentative and subject to revision if the desired results are not fortheoming.

The prime yardstick, of course, is the production of a large harvestable grouse crop. The effort would scarcely be justified unless a sustained yield were also approached.

\section{Organization of the Plan}

Few reasonably definite and complete game managennent plans have ever been drawn up either for grousc or for any other species. Yet within the limitations previously expressed, more should be. Toward this end the following suggested organization, patterned in some respects after forest working plans but particularly adlapted to meet the requirements of a grouse area, may be helpful.

\section{Background}

Under this heading may be described such items as location, size, history, ownership, houndaries and physiographic features such as soil, topography and climate in general for the entire area. 


\section{Objectives}

The purpose to be fulfilled hy the manigement arca slould be clearly defined in the management plan. The various possibilities which might be considered under this heading have previously been discussed in this chapter.

\section{Division of the Management Area}

To facilitate the development of an area it should be divided systematically into units. No set terminology for these has as yet been established by common usage. The names used by the Investigation when developing the experimental management units fall logically into divisions based on area and use. The entire gronse area to be managed under one working plan may lec called the management area. A major division of this, usually comprising a main hunting and development unit, might be called a block. A smaller division, separated by natural houndaries such as open fields or roads and containing a number of complete grouse habitats, might be termed a covert. Habitat may be used to represent the gronping of all the cover types and conditions necessary for the existence of a single group of grouse or a brood. The habitat is composed of cover types. They are the individual vegetative com. ponents of the habitat, so identified because each is made up of an association of plants sufficiently distinctive to be recognized as fulfilling, at least in part, one or another of the food or cover requirements of grouse.

Depending upon the size and intensity of development of the management area, use will be found for several or all of the terms here suggested. For the sake of clarity, a map, on which each unit is outlined, named and identified by number or letter, might well be in. cluded under this heading.

\section{Covert Surveys}

The next section to be included is the survey of conditions in each of the coverts which collectively comprise the management area. The cover type maps, if they have been prepared, should also be placed here. It is helpful, if this section is further subdivided, to include separately all references to items other than cover. This allows onc to picture quickly the situation as regards predator conditions, distrihution and alundance of grouse and ofher game or buffer species.

\section{Analysis of Cover Conditions}

The covert survey provides a picture of current conditions. An analysis of these to show where changes are in order, is the purpose served by this section. All maps illustrative of cover deficiencies should be included.

\section{Development and Maintenance Plans}

Plans for maintaining or improving existing conditions, lased on an analysis of the nceds indicated by the covert survey, must be laid. These should include the organization of planting plans for open fields; cover improvement schedules for maintaining or altering overorown or woodland types; for laying out and setting up cutting instructions to establish and maintain clear-cut areas; and for inter-planting to introlure desirable species, where such are needed. into openings within a type.

Plans for predator control (if necessary); for refuge lucation and development; for hunt- 
ing arcas; and for restorking, if nceded, must also he provided.

Scattejed throughout the management plan, such details are likely to escape notice. It is helpful, therefore, if they are brought together perhaps as an "operational schedule" at the end of this section.

\section{Regulation of the Harvest}

It is suggested that hunting regulations be detailed in a separate section. Within the framework of applicable state game laws, it is often desirable to add special regulations controlling hunting or other uses to which the area may be put.

If the best possible shooting is to be had, some method of securing an anuual estimate of populations of game, buffer and predatory species must lse worked out." Likewise it is necessary to set up a system for determining the proportions that may safely be harvested. ${ }^{\Delta}$ Provision for setting up and enforcing open seasons, bag limits and any special hunting restrictions must be made with sufficient flexibility to allow a quick change, even in the midst of the hunting season, if occasion demands.

\section{Coordination with Other Uses}

If the area is heing managed to serve other objectives as well as the production of grouse, special surveys may be necessary to provide a hasis for working such activities into the management plans. The production of forest products, of recreational opportunities, the control of soil erosion and the lessening of flood damage are some of the likely subsidiary uses to be considered.

\section{Protection and Other Special Problems}

Protection from unwanted fire and trespassers, as well as from occasionally serious inscet or disease onthreaks, may need to le considered.

Here also is the place to outline plans for restocking coverts from which grouse have disappeared lecause of a combination of conditions, al some past time unfavorable, but subsequently improved to a point where the bird now should be able to maintain itself, once reintroduced.

\section{Appendix}

In building a management plan there are always a number of small but important details such as forms to be used, lists of erpuipment and supplies needed, methorls and techniques to he employed and miscellaneous data often of more or less general application. To avojd the confusion incident upon including these in the main part of the management plan, it is hetter to place them in an appendix.

Individual situations will suggest other considerations and interests to be included. Though the broad divisions of a management plan can be sketched with some assurance of applicability, many of the details to be considered must grow out of a personal knowledge of the conditions inherent in the individual working unit. After all, grouse production is largely a problem of skillful direction of envirommental forces, the interplay of which varies with each individual locality.

* See suggestions on p. 708.
$\Delta$ Discussed on p. 676. 


$$
4
$$




\title{
CHAPTER XVI
}

\section{IMPROVING AND MAINTAINING GROUSE COVERTS}

\author{
By Gardiner Bump and Fravk C. Edminster
}

\section{ALTERING EXISTING COVER}

Methods Avallable-Cutting-Girdling-l'uisoning Grazing-Fire-Prodicixc aNd Maintaining Productive Cover-Fall Feeding Grounds-Spring Breeding GroundsWinter Shelter-Summer Feeding Grounds - ConRelatiox of Grouse Cover lmproveaent Work with Other Forest Practices - Furest Stand Improvement Work-Control of Forest Insects and Diseases.

\section{DEVELOPING FOOD AND SHELTER BY PIANTING}

Basic Principles Controlling Plantinc- Determining Cover Establishment Methods to be Used-Securing and Caring for l'lanting Stuck-I'lanting Methods-Coxifer PLANTincs-Hardwood Tree l'lantings-Sirub Border l'laitixgs-Herbaceous l'lantings

PROTECTING THE EXISTING COVER

Fine, Its l'revention, Control and Use-Control of Domestic Lavestock-ConTROL OF DEER BROWSING

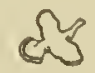

\section{SUMIMARY}

Good grouse cover may be produced or maintained in three ways; by altering the existing cover, by planting new cover, and hy protecting the existing habitat from destructive forces. (p. 639, 645, 664).

The surest way of encouraging large grouse populations is to take full advantage of the existing cover by improving it. (p. 639).

There are five methods by which existing cover may he changed.

Cutting may be used where the timler products are valuable and the ensuing hardwood sprout growth is desired. (p. 640).

Girdling may be resorted to where trees have little commercial value and it is desired to inhibit sprouting. (p. 640).

Poisoning, with certain species, offers a method even more effective than girdling in inhibiting spront growth. Under some circumstances it is the least expensive of all these methods for eliminating undesirable tree or shrub growth. (p. 640). 


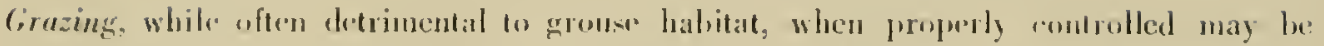

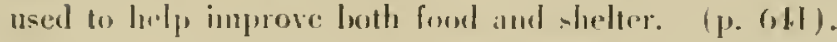

fire is useful in thimning out gronse cover and selting back the succession. It is potentially the most dangerous method of all, however, and the cost of control may therefore be high unless expertly handled. (p. 642).

Covert conditions vary with the site and with the past history of the cover. In producing better grouse habitats, it is up to the individual to ehoose the method best suited to each situation. The adaptation of each methor to the production of better fall feeding grounds, spring breeding grounds. winter shelter and summer feeding grounds is therefore de. scribed in some detail. (1).612).

Where desired there are a number of ways in which game cover improvement work may be correlated with other forcst practices to produce a forest as well as a grouse crop. Where these are combined it is important to select a timber crop, the encouragenent and harvesting of which will result in larger grouse populations. (p. 650).

Forest stand improvement work may be carried out to encourage both timber and game production by adapting the practices here described. (p. 651, 77万).

The control of destructive forest insects and diseases, as currently practiced in New York State, is seldom detrimental either to grouse cover or to the hird itself. (p. 65.1).

The basic principles controlling food and shelter plantings for grousc must be clearly understood and closely followed if satisfactory results are to he ohtained. Many of the most desirable trees and shruhs are not commonly used in reforestation work and are not particularly easy to cstablish. (p. 654).

The moisture, tolerance to shade and fertility requirements of 32 specics adaptable for planting in the Northeast are given in tahle 97. (p. 655).

Generally speaking, hardwood planting stock must be large, with a good root system and carefully planted, preferably ly the "center hole" technique to give it the best chance for survival. (p. 660).

Direct seeding of nut and mast species is practical only when rodents, such as squirrels and mice, are not numerous or can be controlled. (p. 661 ).

Conifers seldom develop with sufficient rapidity to provide good grouse cover when planted under woodtand cover. (p. 660$)$.

Ilardwoods usually require a more fertile soil for successful establishment by artificial planting than do conifers. (p. 661 ).

Shruhs and herbaceous cover can best be cstablished by creating the right conditions and ly necasionally assisting natural sceding by judicious planting. (p.601). White clover, where the soit is neutral or atkaline. may well be encouraged. (p. 664).

Better grouse halitats usually result from protecting the cover from fire and grazing though. under certaiu circumstances, each may be useful in opening up to luxurious cover types or in maintaining openings or brushy cover. (p. 665).

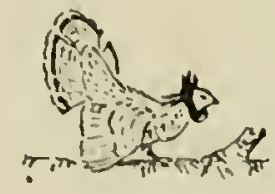


It is one thing to lay the plans to create and improwe grouse habitats and quite another to put them into operation. The best set up plans, he the'y complicated or simple, are of little use unless practical inethods of carrying them out arc available. This chapter, then, deals primarily with the ways of improving and maintaining grouse cover.

It is not possible to suggest improvement techniques that will fit every situation. Some methods, such as those employed in planting open fields to conffers or to certain hardwoods. have been well developed through years of use. Others, for example those designed to encourage clumps of food-producing shrubs along wouds borders, are as yet scarcely out of the experimental stagc. The problem is further complicated in that such methods must often be modified to meet individual situations. Here is a condition which places unusual empha. sis on the training, experience and ingenuity of those who are to do the actual work of developing grouse coverts.

In planning, one thinks largely of low to make existing conditions better. In carrying out the plans, the practical question of maintenance also demands considerable attention. One has to remember that most grouse cover is constantly changing. Thus nature establishes first one cover type after another, jn orderly fashion. until no further change takes place. Fortunately, as previously indicated, these types follow a definite successional pattern. On grouse lands, open fields or grasslands gradually give way to overgrown fields or brushlands, which in turn grow up into second-growth woodlands and eventually becone nature forest. Thus is provided the background against which all grouse management practices must be carried out.

The covert management plans may require that existing cover types be maintained, or that they be altered in order to provide adequate food and shelter in the most productive arrangement. To do this one must control succession. It may be set hack by removing undesired species or speeded up by means of artificial plantings. There is also the prublem of maintaining existing types in their present status by retarding or arresting succession.

In doing this one is simply trying to bring food and shelter into a more productive balance by changing the composition and arrangement of the cover. In general, the methods by which these ends are accomplished fall into three groups: altering the existing cover, planting new cover, and protection of the existing habitat from forces such as fire and grazing.

\section{ALTERING EXISTING COVER*}

In building up grouse areas, too little attention has usually been paid to the possibilities of securing the desired result by changing the existing cover. The idea of planting the right species in the right place so that Nature may lose no time is producing the right habitat, somehow has a much stronger appeal to most of us than does the less spectacular proposition of encouraging changes in the existing vegetation. It is only through experience that one learns of the substantial difficulties lying in the path of establishing good cover by planting. Then the desirability of making the most of the existing corer is fully appreciated. Planting has its place, as we shall presently sce, but where possible, working with the regetation already present is by far the surer and quicker way of producing a larger grouse crop.

\section{Methods Available}

Every grouse hunter probably remembers parts of his favorite coverts that, in his mind,

* By Gardiner Bump. 
are ideal for grouse and others that are not. In the latter case the difficulty can usually be ascribed to poor composition, to an over-densc cover, or to the size, shape or general arrangement of the types. The cure involves changing the cover. To accomplish this, any one or a combination of five methods may be utilized. They are cutting, girdling, poisoning, grazing and fire.

\section{Cutting}

The usual method of harvesting timber products or of eliminating unwanted trees, is to cut them. There grouse cover improvement can be dovetailed with forest operations, this practice should be followed because of the necessity of salvaging the timber which is left uncut in applying any of the other methods. Cutting is the most expensive, as well as the most certain, of all the possibilities here suggested. However, that many hardwood stumps sprout, following the cutting of the tree, is often a drawback especially in maintenance work.

\section{Girdling}

With species that sprout, girdling ofttimes provides a useful process for ehecking sucker growth. Care must be exercised to thoroughly separate the hark by a wide cut. Individual trees often take several years to die even though well girdled. In loth this and the next method, the trees are left standing, thus providing a likely source of future difficulty.

\section{Poisoning}

Developed some years ago, this practice has been given extensive trials in improving cover on New York game management areas. The idea is to make a wide band of cuts through the bark overlapping cach other and encircling the trusk. Into these is injected a poison that will kill the tree or shrub and inhihit subsequent sprouting.

Sodium chlorate, sudium arsenite, heavy diesel oil, and other plant poisons developed for control work at Cornell University and by the U. S. Forest Service, are used. Though, in the earlier tests, the cuts were made with an axe, it proved more convenient to adopt a poisoning tool made of hollow pipc, capped at one end and ground to a cutting edge at the other. The hiquid is placed within the pipe and, through a valve at the lower end, is fed to the cutting edge each time the tool is vigorously jabbed into the bark of the tree to be killed. The poison is allowed 10 run into the wound thus formed, thereby putting it in direct contact with the cambium layer which carries the sap.

Sodium arsenitc was found to he the most effective of the poisons lested. Its major advan. tage lies in its eomparative cheapuess and its tendency to inhibit sprouting to a greater degree than does girdling. 'The success of the treatment depends upon the time of year. the species. and the rclative vigor of the individual tree. The following table indicates the degree of susceptibility of the specics tcsted.

TABIE 95. BEIATVE SUSCEPTHBITT OF VARIOUS TRIES

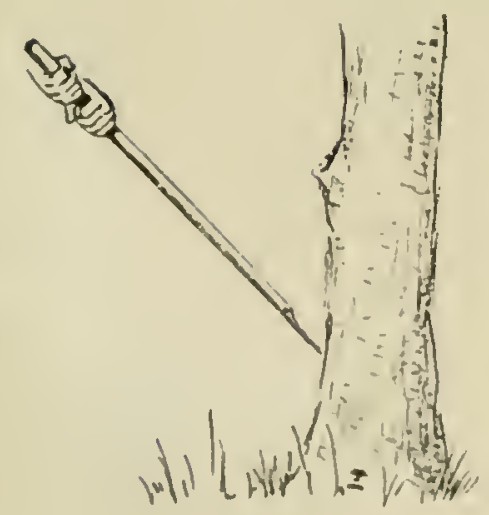

AND SHIUUBS TO IP()ISO.VING WTII SODIUM MISI:NITI:

\begin{tabular}{|c|c|c|}
\hline Suscepetilip" & Intermediate & Ilassiscunt \\
\hline 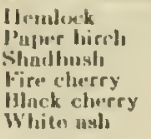 & $\begin{array}{l}\text { Aspen } \\
\text { Yellow birch } \\
\text { bioch } \\
\text { liad oak }\end{array}$ & $\begin{array}{l}\text { Ciray birch } \\
\text { seft majle } \\
\text { ilard majule }\end{array}$ \\
\hline
\end{tabular}


The disadvantages are that it has been used successfully only on certain species, and then only in the late summer and early fall. When tried in the spring and early summer the compound has been known to attract and poison deer which have heen killed by the arsenite. As with many newly developed techniques, the results are apt to be uncertain. The solution is also potentially dangerous to handle and the poisoning tool awkward to use. Recently; a poisoning axe has been developed and used suceessfully in the South but there is still much room for improvement.

Recently a series of translocating poisons. of which " $2,4 \mathrm{D}$ " is a well known example, have been developerl. Thile potentially extremely useful in corer control, they are as yet too new to have been thoroughly tested for effect on many trees and shrubs. In New York State the District Wildlife Managers are familiar with test results as available and may well be consulted before cover control measures are decided upon.

\section{Grazing}

Woodland grazing is usually lighly detrimental to grouse. When long continued, it reduces the variety of the plant life present. Grass is encouraged. Undergrowth and the lower branches of the trees are closely trimmed. In a heavily pastured covert, food and shelter for grouse are usually so deficient as to make it impossible for the hird to survive for long. The parklike look of grazed woods and the "qrousy nook" so dear to sportsman and lird lovers alike never go together.

There are times, however. when grazing. under New York State conditions. may prove beneficial particularby with overgrown lands. Moderate grazing, long continued, tends to reduce hardwoods in favor of conifers and may result in jroducing patches of pure soft. wood cover, as well as in lringing in a few desirahle frod plants such as chover and apples. Some plants. not palatable to cattle lut of consiclerable importance to grouse. as thorn.

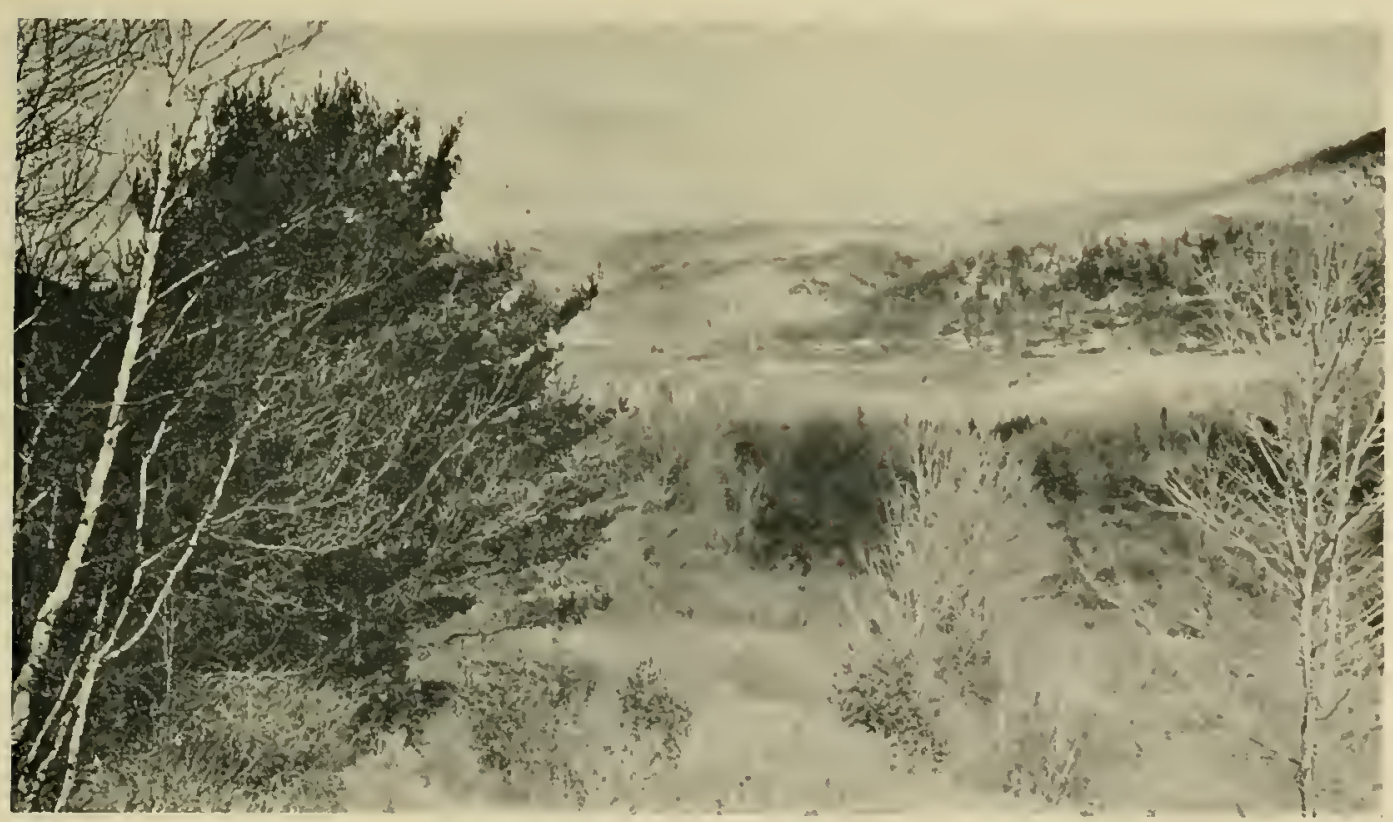

IN BACK PASTURES, MANY A "GROUSY NOOK" IS MAINTAINED BY MODERATE GRAZING 
apples and blackberries, will often thrive where competing vegetation is removed by grazing. Back pastures, where lightly grazed, have produced many a spot locally famous for the concentration of partridges found there in the early fall. Tangles of thick growing species or of dense underbruslı may be opened up by light grazing. Even in some woodlands, restricting or stopping grazing. after allowing it 10 thin out the understory, will often help establish new growth beneficial to grouse.

As with fire, the secret of successful use of this method lies in knowing when and how to control it so as to bring about the desired result. Where conditions permit its use. moderate grazing is one of the cheapest ways of retarding succession and of reopening overgrown fields where the vegetation threatens to beeome too dense to well serve grouse needs.

Fire

Expertly handled, fire, too, will thin out the vegetation and set back the succession. Otherwise it is likely to cause altogether too much damage, both to soil and to the food and shelter to warrant its use. Nevertheless. it should not be ruled out of consideration as a method of altering existing cover. Where proper controls are possible. light burning represents a reasonahly inexpensive and effective way of temporarily eliminating a patch of undesirable species in an overgrown field or of removing undesirable undergrowth in a woodland. As a method of maintaining small summer feeding units, its possibilities have long been overlooked. principally hecause of the difficulties of keeping it under control and of the complex public relations involved. Some pertinent effects are discussed shortly; others are noted in Chapter IV*.

In setting back the succession of plants and trees to an earlier stage. the choice of method is. of course. dependent upon the results desired and the individual situation 10 which it is to be applied. Here. again, experience is the best teacher.

\section{Proncing an Mastaxing Prome cthe Covio}

The ways of changing existing eover. to produce better conditions for grouse, remain the same over the entire range of the hird. Their application is a problem to be skillfully worked out, for it may differ even within a region. On the basis of experience in New York, a few suggestions for developing and maintaining the types that fulfill one or another of the four major grouse cover requirements may prove helpful.

\section{Fall Feeding Grounds}

The cover types that serve primarily as fall feeding grounds have their origin largely in fields or pastures, once cleared but allowed to seed in with sliruh and tree species. Slashings or openings caused hy windfalls also serve this purpose to a considerable extent. Usually. such areas contain a large proportion of wind-sown species such as aspen and birch, and of those whose seeds have heen rarried into the fields by hirds or mammals. Included in this latler group are cherries, thornapples. dogwoods and vilurnums together with an occasional sprinkling of apples if the land was onre pastured. Pine or spruce, loo, here find conditions favorable for germination and will often lecone established if seed trees are located to wind. ward.

The ideal arrangement of trees and shruls in a fall feeding ground is a scattering or clump. ing of such species interspersed with patehes of low herl growth including elover and herries. 


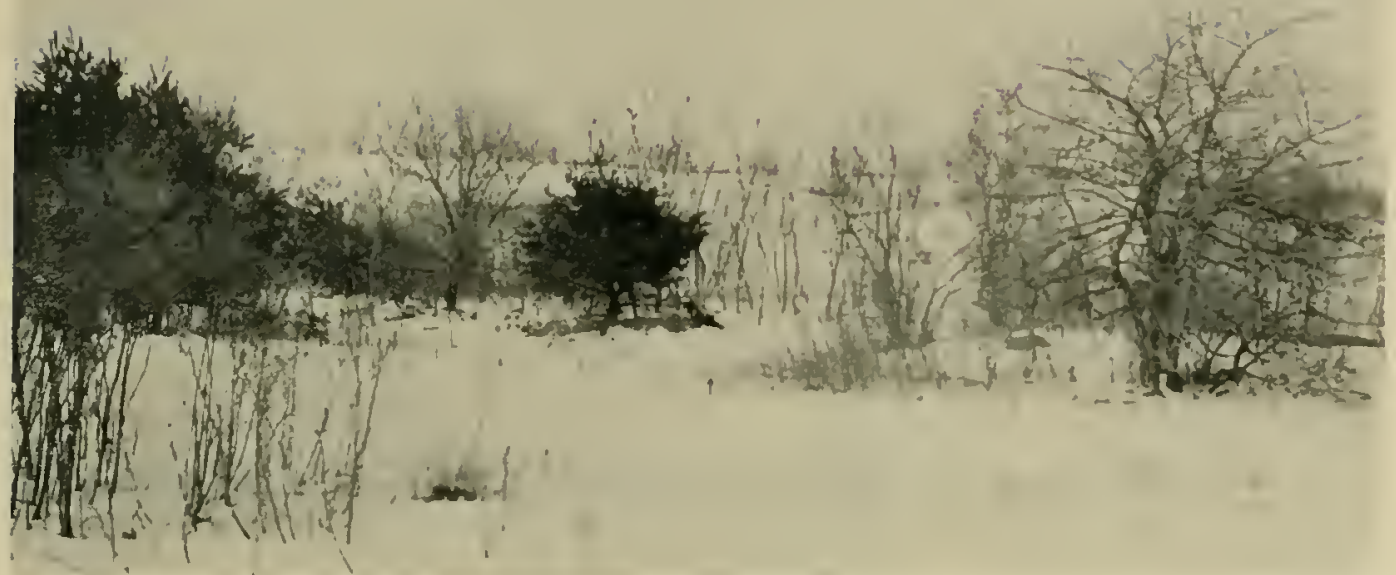

Gordiner bump IN TIE EARLY STAGES, SMALL PATCHES OF FAII. FEEDING, GROUNDS MAY IE MAINTAINED RATIER EASILY

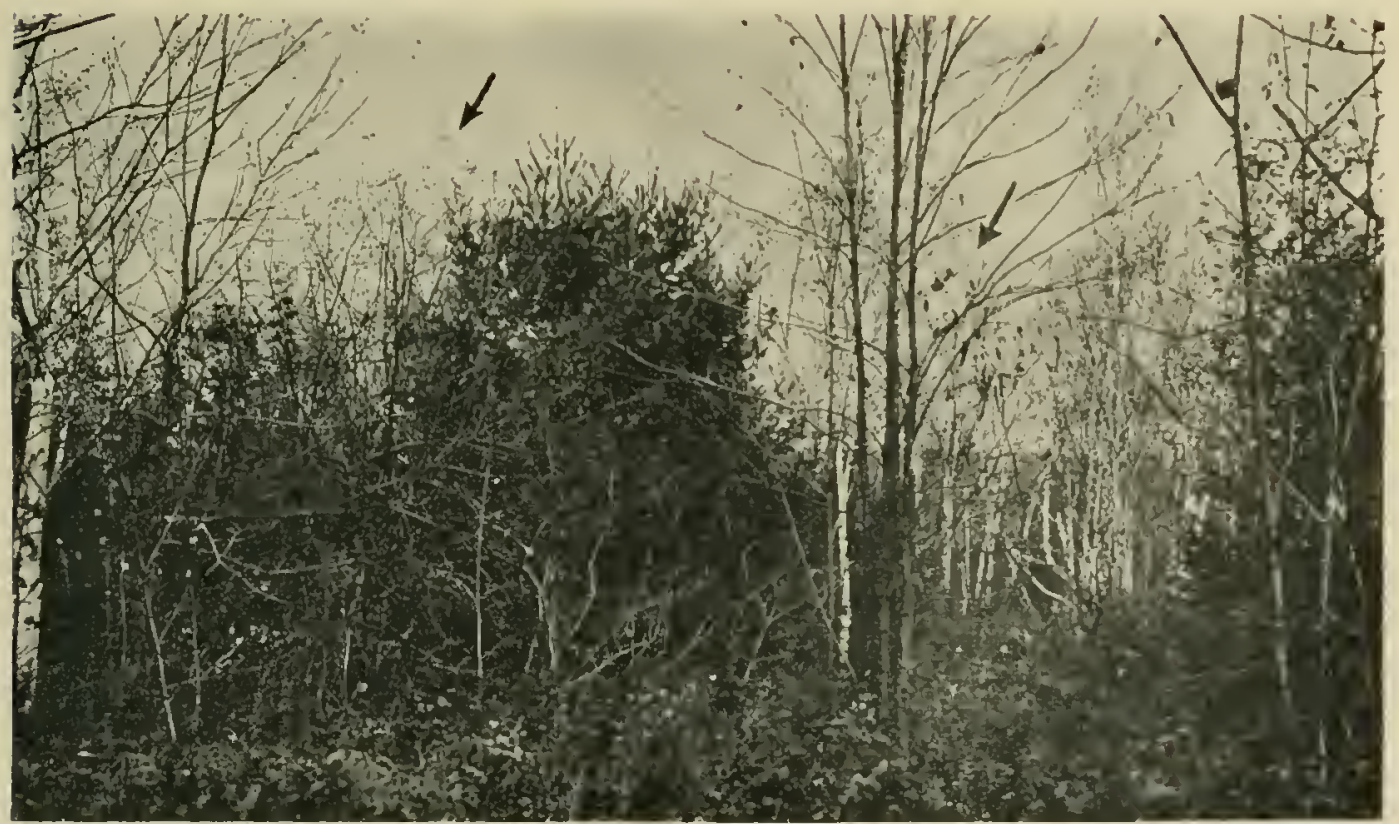

WIJEN ALLOWED TO GROW UP. CONSIDERABLE CUTTING IS NECESSARY TO RELEASE FOOD SPECIES FROM TIE COMPETITION OF THEIR TALLER NEIGHBORS. WITHOUT TIIS HELP, APPLE AND SUMACII (INDICATED BY ARROWS) WILL SNON BE CHOKED OLT 
Improvement practices, therefore, consist of periudic release to free the best developed trees and shruh clumps fumishing good fall food from the competition of their more vigorous but less desiralule neighburs. Apples and thornapples, for instance, may be over-topped by trees which normally grow taller. A few strokes of the axe or poisoning tool may lelp to keep many of the former in fruiting condition for years. It is also productive to trim up old apple trees. relics of the past, hut oftimes capahle of producing sought after huds and fruit for many years. if given a little care. It is wise to have a backlog of such projects against the time when other activities are slack.

Limited grazing is also an aid in maintaining the fairly open character of the types making up fall feeding grounds. Too much pasturing. however, tends to make islands of the tree and shrub clumps ly maintaining close-cropped grasslands between them.

Where fall feeding grounds are in imminent danger of growing into second-growth woodlands, a more extensive culting, girdling or poisoning of the larger and less desirable trees may be necessary if the type is to be perjetuated. In fact, of all the types making up grouse cover. none presents a more difficult maintenance problem than do overwrown lands. Nor is the problem made easicr lyy the fart that one must be alle to recognize a great variety of valuable slurubs in addition to the usual tree species with which any competent woodsman is familiar.

In heavily wooded areas, where fall feeding grounds are not present, the development of clear-cut units has proven valuable, since sone sjecies furnishing good fall food will always be found there. The method of developing these is described later in this section.

\section{Spring Breeding Grounds}

Grouse have been known to nest in every type of cover from slurub-dotled fields to the center of a small patch of dense forest. Most, however, prefer open woodlands where the undergrowth is not too thick. The presence of conifers in the immediate vicinity apparently makes little difference. Most birds choose a site within a hundred feet of an opening. such as a woods' edge. a piece of cut-over land, a woods road or a windfall, where snceulent vegetation will provide food and shelter for the prospective hrood. Any second-growth or mature woodland, if it is not too thick. nor comprosed mainly of conifers, may furnish acceptable spring breeding grounds. Even fall fceding grounds are occasionally used.

The characteristics described here and in greater detail in Chapter III* are seldom difficult to find in grouse coverts lhroughout the Northeast. The common practice of utilizing farm woodlots for light pasturine, for fumishing the winter's supply of wood and for an occasional crop of timber for farm use or for sale. has, in general, provided ideal grouse nesting cover.

In extensive forest lands. action by insects and disease often results in setting up somewhat similar open conditions. Where the forest has not been lumbered or burned over for a long time, the stand may sometimes he so thick as to make it desirable to selertively lumber small areas or 10 cut deformed trees, here and there, tw open up the crown eover.

The most desirable conditions seem to result when the forest canopy is not allowed to occupy more than 60 w 80 per cent of the available space orerhead. This allows suffieient light w filter through to encomrare a not-tonedense undergrowth.

\footnotetext{
- See page 126.
} 


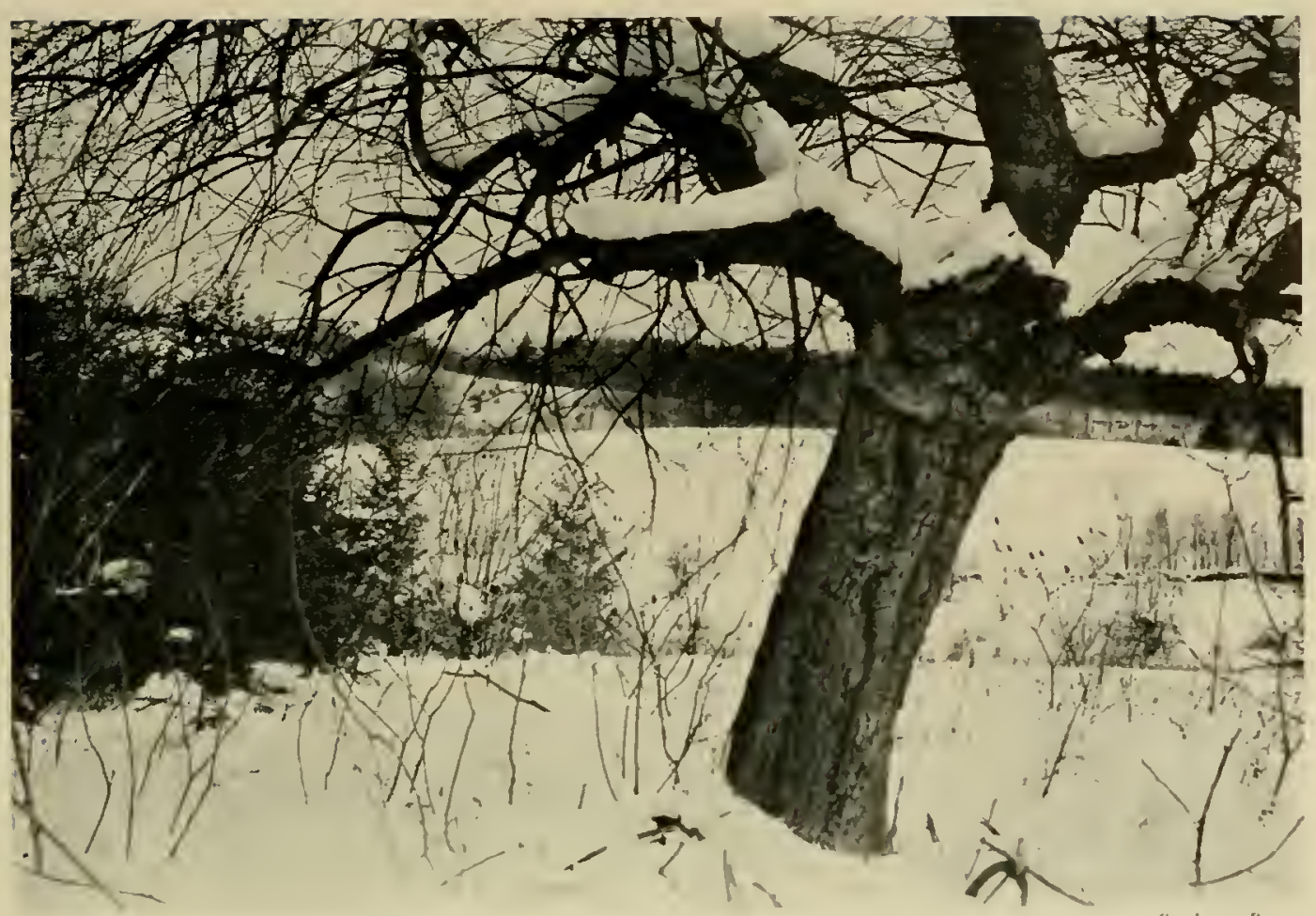

FORTLNATE IS THE COLERT IIICH SLPPORTS A SCATTERIXC, OF APPLE. TREES ALONO, ITS EDCES

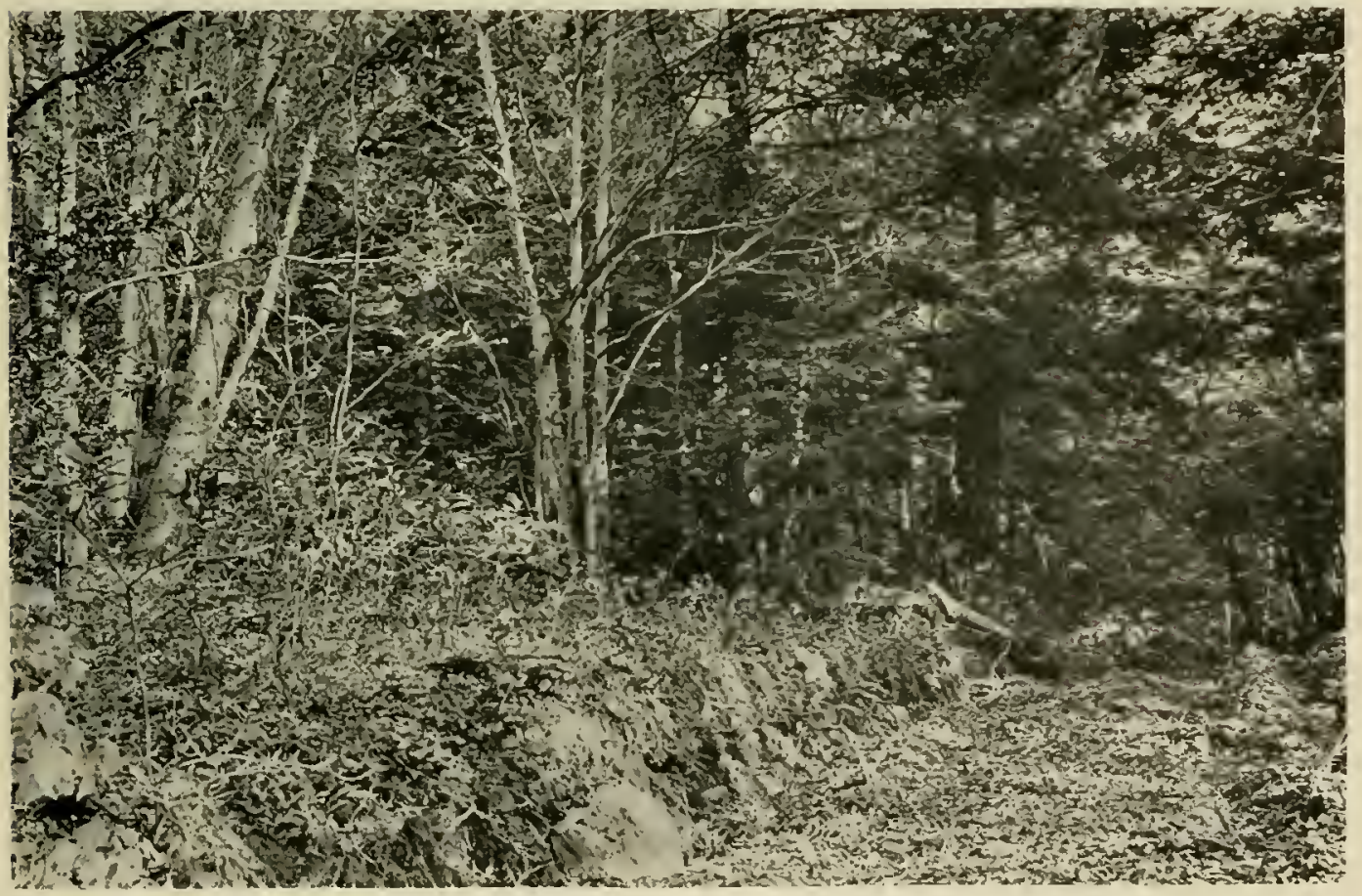

A BRLSHED-OLT WOODS' ROAD IS ATTRACTIE ALIKE TO NESTING BIRDS. BROODS A.TD ADLLT: 
Occasionally one will be faced with cut-over lands which have grown up into a dense jungle of large sprouts. In accordance with good forcst and game practice, these may well be thinned out especially if other nesting cover adjacent to openings or woods' roads are not available.

In carrying out such cultural operations, it is wise to give preference to trees furnishing food and shelter as well as to those worth saving as timber producers. An excellent, though temporary combination of spring breeding grounds and summer feeding units may often he established, in the Northeast. by cutting out an occasional, usually overmature. widespreading "wolf" tree. This encourages the light-loving herbs and berries to take over the forest floor which, otherwise, is too often bare. Where den-loving wildlife, such as squirrels and raccoon, are desired, hollow trees may be girdled and left in place. Woods roads also help to hreak up the forest cover and provide small openings along which partridges prefer to nest.

\section{W'inter Shelter}

Unless a woodland is heavily grazed or recently burned. adequate shelter for grouse is usually present except in winter. At that time clumps of conifers or. in their absence, thick groups of evergreen shrubs such as mountain laurcl. may provide congregating plaees for the

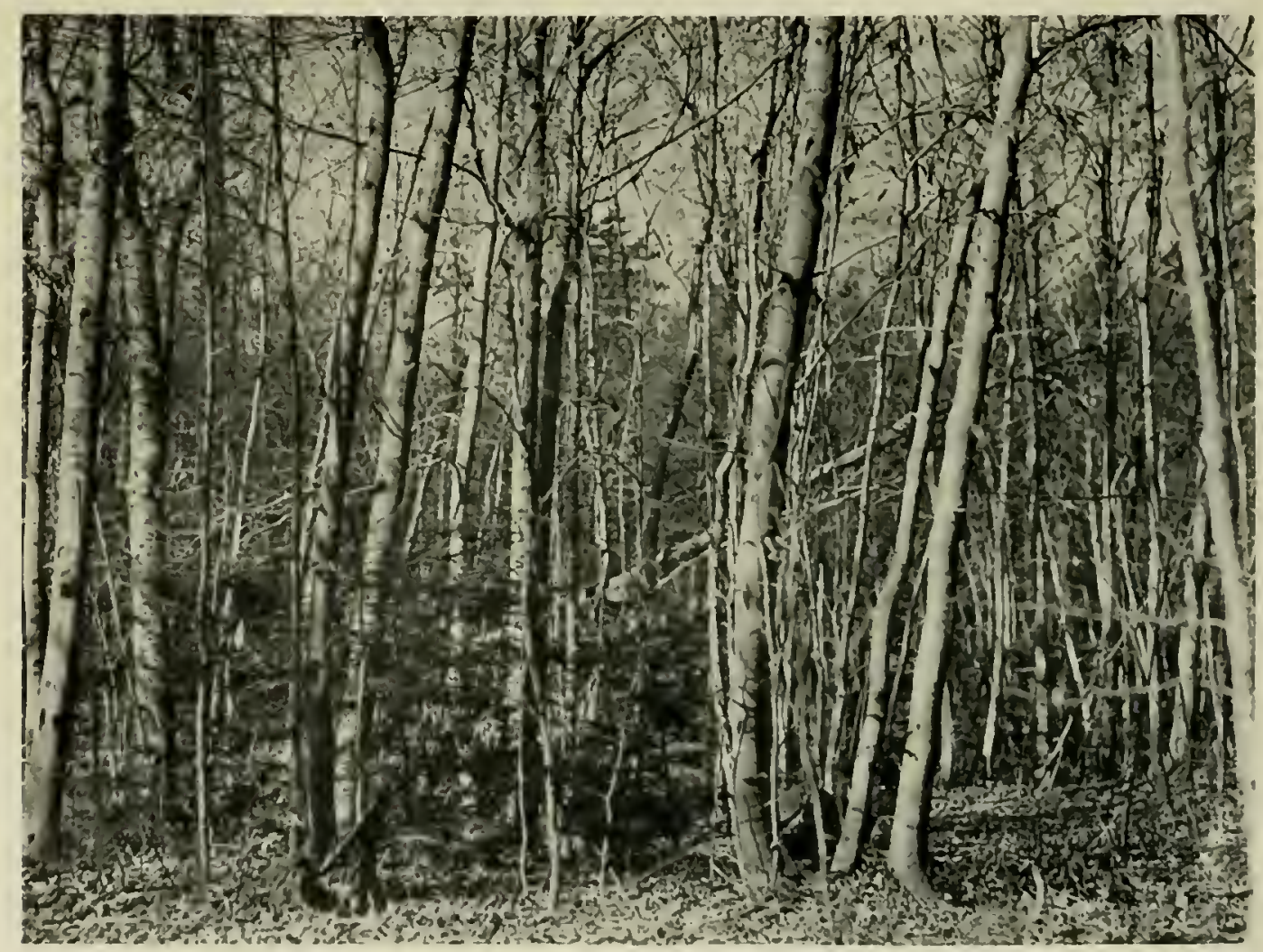

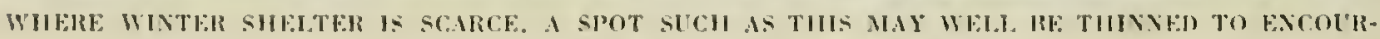

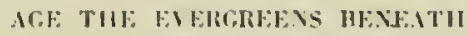

birls. Il ithont llese, at leas in the Northeast, grouse are apt to experience serions difficulty in avoiding predators while keeping comfortable. When conditions allow. they will resort to snow roosting as a sulstitute but here, also, lloes are liahle 10 attack. llardwood 
covers and fall feeding grounds, bereft of such evergreen shelter, unless unusually dense, seldom attract many birds in New York while snow covers the ground.

Where conifers occur naturally in clumps or blocks seattered through the woodland, little need be done except to maintain them and encourage their reproduction. The occasional opening up of the forest canopy will allow young evergreens more light. Where conifers are not present, a fairly acceptable substitute may result from establishing a scattered serjes of clear-cut units, each occupying from one to two acres. The tangles of sprout hardwoods, vines and berries which grow up following cutting may be depended upon 10 provide some shelter until the crown cover closes.

The interplanting of conffers to provide winter shelter is discussed in the section on Conifer Plantings.

\section{Summer Feeding Grounds}

No other summer feed approaches the omnipresent raspberries and blackberries in popularity. This may help to explain why so many grouse, old and young, spend much of July, August and September in the cut-over lands and along the feeding grounds that streteh out from the woods' edges. Windfalls and selective lumbering, also, often let in sufficient light to encourage small islands of these berries amil the comparative bareness of the surrounding floor. Thus is produced a typical summer feeding ground pattern rich in herbs. shrubs. leares and berries that produce food and shelter in endless profusion.

The genesis and development of the overgrown field or woods edge type has just been discussed. Of the three major types producing summer cover. this. while always popular. is, however, least sought out.

More attractive are the recently spot-humbered woodlands. the result of cutting individual trees, or elumps. here and there. Wind, disease or insects. Wy attacking now and then a spot or a species, throughout the forest often prorluce much the same result.

At the top of the list, howerer. at this season stand the small cutenver areas or slashings. This is natural for if one studies such situations he will fund there the greatest variety of food-bearing species and the most hirds.

The name "cut-over" indicates the way in which such summer feeding grounds usually originate. The farmer. intent upon securing wood for farm use. and the lumberman, by removing small blocks of salable conifers and hardwoods. may each be doing the grouse hunter a real service. Again, the same result may originate through natural agencies. sueh as fire. insects or disease. Unless controlled. however. the area affected is usually far larger than necessary and is seldom properly siluated.

It is probable that in extensive woollands a few summer feeding ground units will need to be opened up. Suggestions concerniug their location. size. number and rotation have heen discussed in the previous chapter. Here we are concerned with the actual process of estahlishment.

There are at least three ways of accomplishing this. One may estahlish what is colloquially known as a jungle slashing by cutting the trees and letting them lie where they fall or by lopping off only the larger limbs from the trunk. Or the undesirable trees may be girdled or poisoned and left standing. Either practice is apt to create a fire hazard over a small area and should he used only where the cost. as indicated in table 96. must be kept as low as possible and the potential logs or cordwood are not worth removing. Though the appearance 
of a small unit. thus treated. is nol prepossessing. light-Joving vegelation som takes orer the site and the grouse find litle difficuly in making full use of il.

Where inexpensive labor is avalable or wood is salable. the trees ma! he cut. the logs sold and the brush piled on widely-spread large limbs laid on the wround. Such brush piles

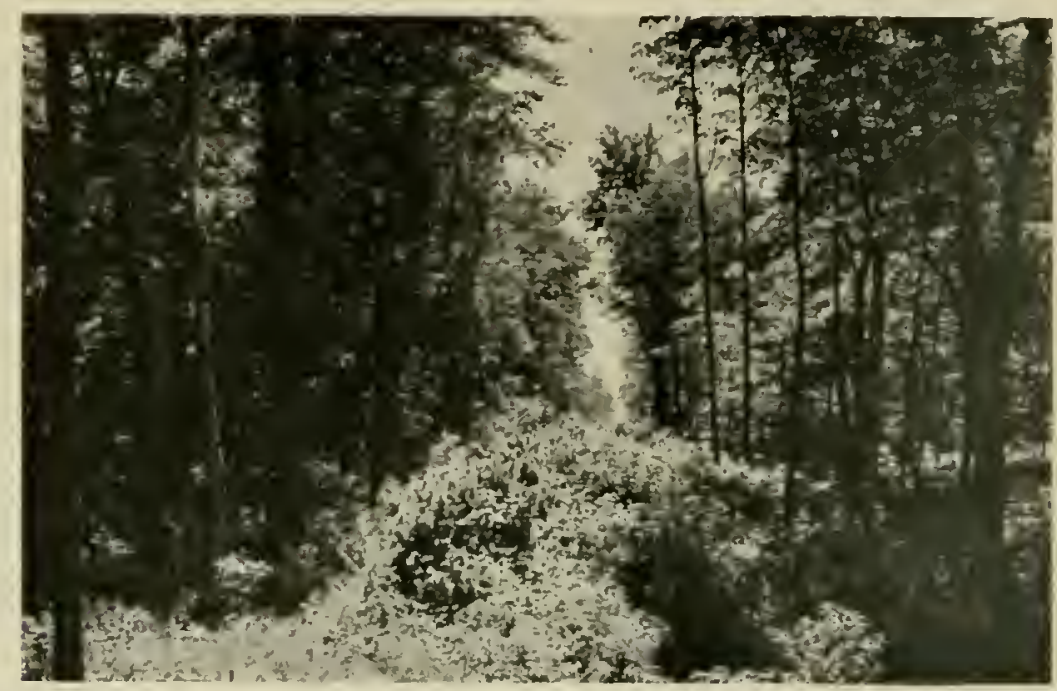

SLASH LANES, FROM 30 TO 50 FEET WIDE PROVIDE EXCELI.EXT SIMMER FEEDYF; CROUNHS FOR BROODS AVD FALL, FEFDING AREAS FOR WILTS

furnish some immediate cuser which. althengh grouse are nol particularly partial to the thelser thus provided, wher wildtife will use. By piling and burning the surplus brush. one may enourage the sceding in of desirable spectes sulh as pin thrors and aspen that follow fire.

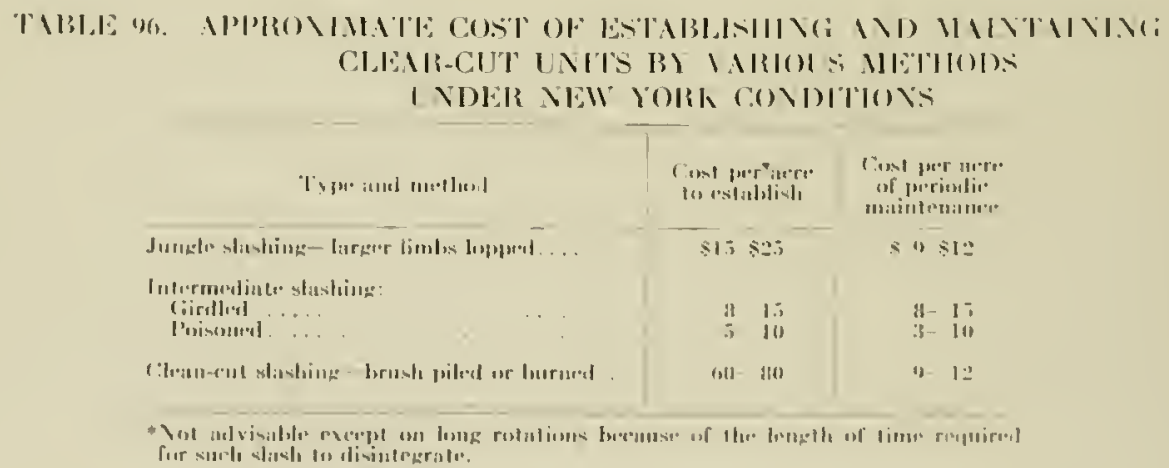

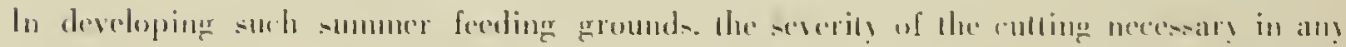

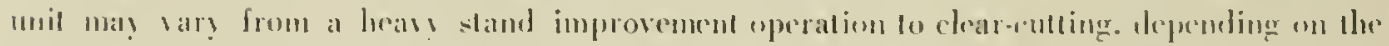

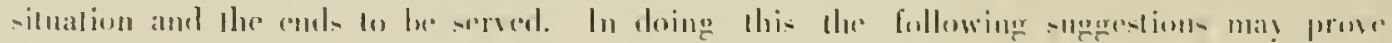
liclpful:

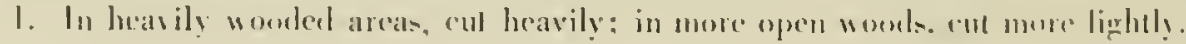


2. If trees producing good food or correr occur in the area to be cut over. leave a few for seed. feed and shelter. Whern winter cover is defieient. do not cut or prune conifers.

3. In establishing a clear-cut unit in a coniferous forest, leave a few hardwoors; in a hardwood forest leave conifers if they are present.

4. On rich moist sites, leave fewer trees than on dry sterile sites.

5. Leave a few mast producers. particularly "wolf" trees. such as large heeches, so lung as they do not provirle shade sufficient to prevent maintenance of a satisfactory understory of food- and shelter-producing herbs and shrubs.

6. Where practical. one or two clean strips. at least six feet wide. are desirahle through a cut-over unit to provide easier access.

7. Remove merchantable logs and cordwool from each unit as cut.

8. Cul stumps as low as praclical.

9. If a small number of young trees is 10 be left, faror species producing mast. "oncr. palatahle luds and leaves. Do not rorourage future stands compused almon exclusisely of one or two speries. I'reserve such shruhs as dogwoods, vihurnum and witch-hazel.

The problem of maintaining the herb and herry association in a culouer arean mus alse receive some attention. As indicated in Chapter III. under Yen York conditions desirable foot is anly to be fount in such spots as long as the crown cower. formed ly the surceeting vegetation, remains upen. Few conifers, native to the Northeast pver sprout from the stump. Units lwated where everorens were abundant. and not too taluable. therefore prises the advantage of low initial mantenance eos. On the other hand. many broad-leaverl specie sprout prolifieally. Where the trees to be remowed are motly hardwonds. girdling or poison.

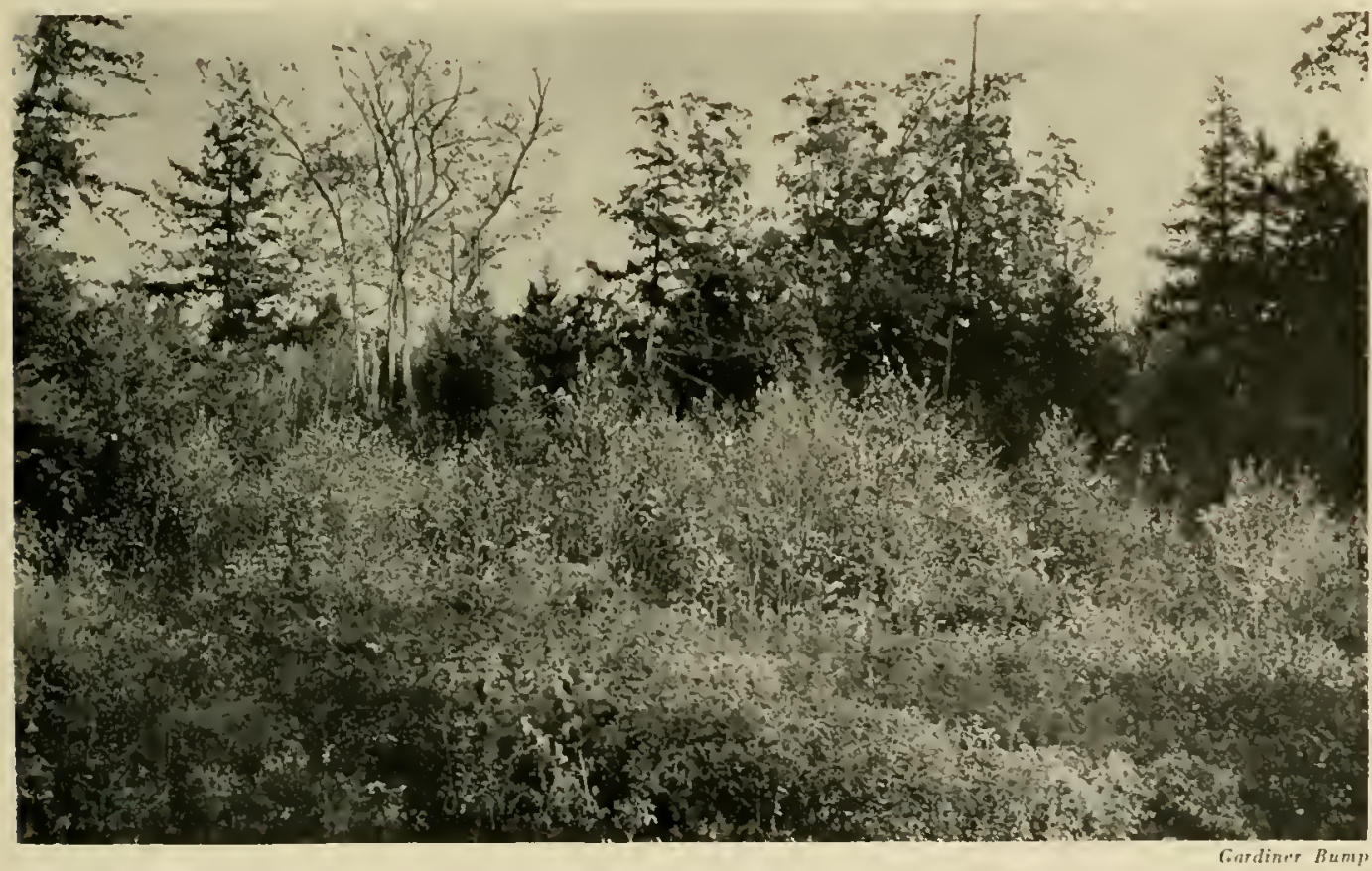

IN IDEAL, SMALI, SLASHING. CLEAX CUT. IRRFGULAR IN OUTLINE AND WITH EVERGRENS NEARB 
ing may sulstantially rotanl crown elesure hy inhibiting suckering.

British gamekeepers have fong used controlled burning as a means of assuring a fresh growth of heather $m$ grouse mors. With adequate safeguards, the same principle may be applied to keep open our own small, cut-over units in much the same way as a railroad bums the brush from its right of way or a farmer may burn over a field. The fire must, however, he kept on the surface lest the soil be harmed or two many desirable food species be killed and grass encouraged to take their place. The exceedingly dry periods, when fire is likely to get out of control, as well as the months of Ma! and June, when grouse are nesting or the broods are small, obviously should be avoided.

Where grass is likely to follow repeated removal of the forest cover, a rotation of units to be used as summer feeding grounds is called for. Other reasons for this practice have been discussed in the preceding chapter.

\section{Correlation of Grouse Cover Improvement Work with Other Forest Practices}

In carrying out management, some conflicts in desirable forest and wildlife practices are unavoidable, but the concessions, which must be made to encourage the production of several crops concurrently, are seldom as serious as is generally supposed.

In developing the covert, full advantage should be taken of forest management operations such as thinning, improvement cuttings and the harvesting of wood products. In terms of dollars and cents intensive cover development for grouse alone is apt to be a costly undertaking. Combined with other forest improvement work, it can often be made to pay its share of the total expense.

Briefly, the steps by which this may be accomplished are the following:

1. Determine what other products can he produced.

2. Find out for which of these a profitable market exists.

3. With the above in mind. seleet the other crops with due regard to their effect on grouse.

4. Enlist technical assistance, where available, in determining how hest to encourage and when to harvest each crop.

5. Carry out forest stand and game cover improvement practices when labor costs are low.

Since grouse coverts are largely wooded, one thinks naturally of lumber, pulpwood. acid wood, ties and firewood, as the possible subsidiary crops. The local market demand for these is not always easy to deternine. Sofwoods of sufficient size to produce lumber are nsually: salable. The demand for hardwoods is less easily predictable. With the development of new processes, an increasing number of pulp mills are purchasing hoth hardwoods and suftwoods cut in standard cordwood lengths and with a diameter limil as low as four inches. Some mills accept only peeled bolts, others can use the woul with the hark left on. In Now York State the market for acid wood is limited largely to the western Catskills. Ties are always in denand though contact must usually be made with the distriet purchasing agent of the railroads in the vicinity to find out just what is salable. Likewise there exists in most communities a market for fuelwood, although in limited quantities.

Naturally the periodic harvesting of any of these crops will alter the halitat for grouse to some extent. On a long-tine hasis lumber production is guite compatible with the maintenance of high grouse populations providing the hasic requirements of the hird are met. The 
following are a few general suggestims whirl may lof lp in this respect.

1. Where practical. woodlands should be managed on a sustained yield hasis. This implies that the cutting is to be spread wer a numlier of ycars, preferably by a periodic lumbering off of crop trees.

2. The areas to be cut in any one operation should be kept as small as practicable.

3. Avoid encouraging stands composed of but one or two species.

4. Where possible, maintain mixed stands composed of hardwoods and conifers rather than a pure stand of either.

5. Leave sufficient conifers, preferably in clumps, well scattered throughout the woodlands, to furnish escape cover and winter shelter for the birds.

6. Encourage uneven-, rather than even-aged, stands.

7. Follow the practice of periodic selective cutting of crop trees rather than clear-cutting large areas.

8. Always keep the basic cover requirements of grouse in mind. Carry out the timber harvest so as to increase rather than decrease the number of good grouse habitats.

The management of a covert to produce pulpwood as the main timber crop is likely to have serious repercussions on the grouse population unless the cut-over areas are fairly small and are well scattered. This is seldom considered to be practical. On the other hand, where a market is present for pulp, there exists a golden opportunity to make thimings, cut in connection with the maintenance of overgrown lands and woodlands, return a profit. On New York's game lands several thousand acres of woodlands have lieen thinned in accor.

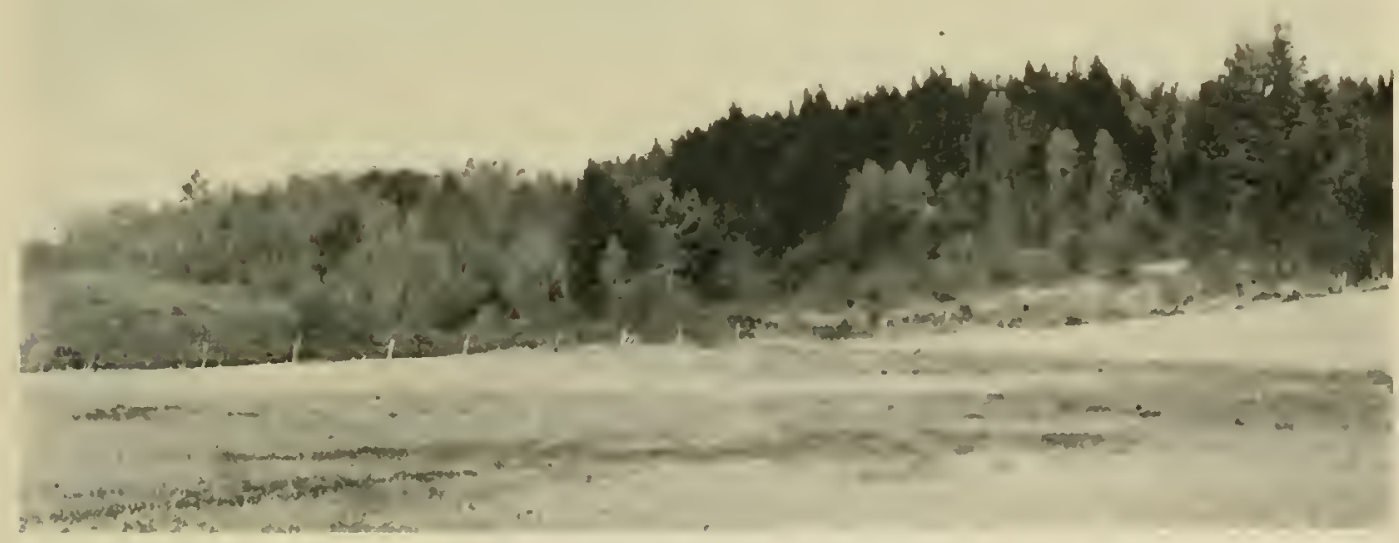

A COMBINATION SICH AS THIS OFFERS A CHALLENGING OPPORTUNITY TO PROLLCE LARGE CROPS OF BOTH GROUSE AND TIMBER

dance with good forest and game management practices. the wood thus cut being transported up to 80 miles to pulp mills for sale at a price sufficient to cover the cost of the entire operation.

Nuch the sane situation exists as regards acid wood as a crop to be cut from grouse cov- 
crts. Il here cultiug can be worked into the gremeral plan fore desclopment and maintenance of grouse coner all is well-liut this is seldom the case.

Perhaps the most salisfaclur! situation acurs when it is possible to combine fuelwood and grouse as joint crops. Here it is seldom neressary $l$ cut large areas at one time and the operations ma! usually be so scattered as 10 make them fit excellently into the game cover improvement prowram.

It is seldom necessary to make the funal dccision. either as regards the erop to be encouraged or the cultural praetices to lie carried out. alone.

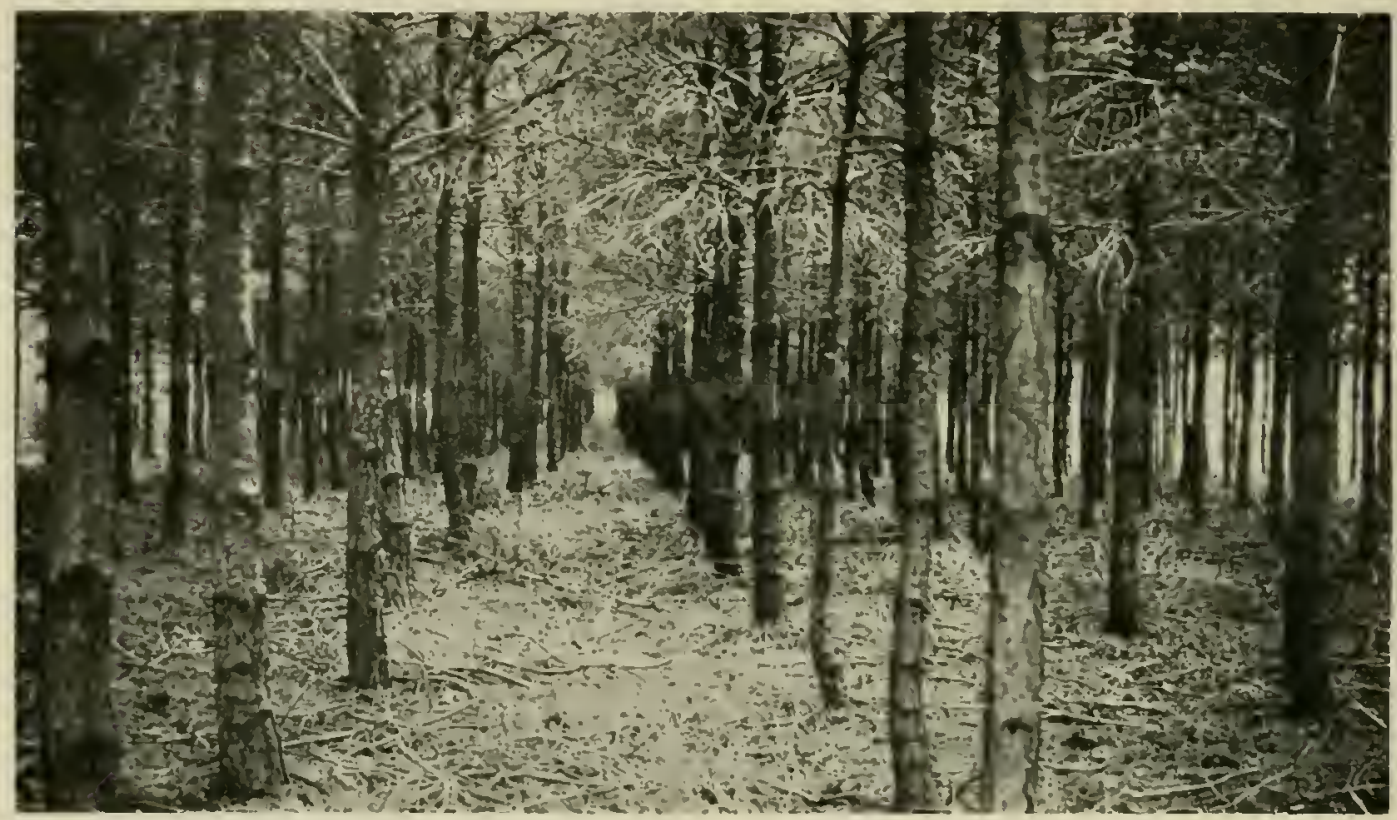

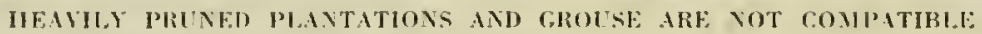

If a landowner is in need of technical aswistance in managing his woodland. there are ser. cral service groups to which he ma! turn. In many states there is the Extension Service of the State Colleges of Agriculture and Forestr! with their attendant specialists in forest and farm woollot impresement. Likewise mam states are dis ided up inte Soil Conservation Districts. the persomel of which know how to halane the equities between forestry and wildlife. In Vew Furk there are Farm Furesters. District Foresters and District Wildlife Managers. The last two are consantly chgaged in managing State lands on a multiple-1ase basis. A part of theje job is to eneourage and an-ist landewners lo produce timber and game crops on a smstained gedd basis. In some counties there are aleo Farm Foresters who specialize in assisting prisate owners of forest lands. A disconsion of covert problems with ant of them is likely to prose highly prolitable.

\section{Forest Stand Improvement Irork}

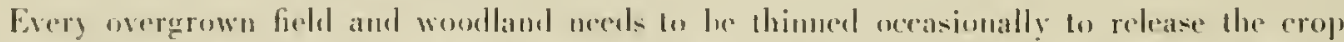
trees from undur comprtition. stimulate their growth and mantain a desirable composition and arrangement of the eover. 
The word "desirable" here comoles trees and shrubs furnishing food and shelter for wildlife as well as those that provide forest products. In England. such thimings are commonly employed to maintain the open character of the young stand so desirable for game production. The same practice, applied in New York. can often be made to encurage much summer and fall feed for grouse, and to develop excellent winter shelter and spring breeding grounds as well.

How best to carry this out to serve the needs of both forest and grame has accurdingly been carefully considered. The brief guide. currently in use on the State game management areas, is reproduced on p. 777 to p. 782 in the Appendix.

The pruning of softwoods is one practice which it is well to use sparingly on grouse areas. Where conifers are abundant. as in a plantation. the lower limbs on possibly 150) crop trees per acre can be cut without seriously impairing the shelter value of the stand as a whole. Where this is carried to the point where the stand hecoms open beneath the rown cover. one finds grouse notably alısent.

In carrying out forest stand improvement operatiuns orer a large area, it is soldom neressary or desirable to open up the woodland to sucts an extent that parklike conditions result. Where heavy cuttings are needed to ereate the proper composition. it is snergrated that the? be spread over a number of years, thus enconraging letter tree form and lengthening the period in which ahundant summer food is availahle. If the existing wowlland cover is of little value, it may be considered a nurse crop and be so handled as lo encourage the reproduetion of the morc valuable species.

As the woolland becomes older. good fores pratice calls for the continued removal of deal or defective trees, as well as for the further relcase of those that are to provide the final timber crop. llere forest stand improwencent practices can be carriesl ont in a mamer 6) encourage willlife by so opening up the forest ranop! as to maintain heneath it a fairly abundant undergrowth. On New York gane areas this has been accomplisherl by culting enough trees so that the remaining crowns accupy from 50 to 60 per cent of the available space. Even if the stand is of inferior quality, to open up the fores conce further may cncourage crosion. stimulate grass henealh, and forfeit the advantage of a canopy sheltering the reproduction so desirable if one is to maintain a sustained timber yield. On the other hand. to leave ton many trees is to encourage a relatively bare forest floor acceptable. perhaps, to grouse as a nesting area. hut deficient in summer and fall foud as well as in desirable young growth.

As the forest matures, the method of harvesting the limber may likewise increase or decrease the productivity of the area for grouse. The selective removal of crop trees creates small openings thereby maintaining sufficient shelter and food for the lirds. Rielatively clear cutting even to a diameter limit of six to eight inches. wer large areas. on the other hand, is usually detrimental by creating a super-ahundance of summer feeding area. To prevent this, scattered small slashings are always more desirable, where practical. than is a single large lumbering operation. By giving some thought to the maintenance. on each acre. of half a dozen trees providing food and shelter and by encouraging their reseeding and growth. the game-producing attributes of the stand may be maintained. By skillful culting, it is often possible. over a period of years, to secure an even better distribution of species which colleclively will produce a forest and encourage a grouse crop.

Other ways of increasing the crop of wildlife and of forest products will suggest them- 
selves to the skilful forest manager interested in obtaining a maximum harvest from his lands. Those mentioned here have been fouml practical in New York. It is recognized, of course. What in wher regions it will be neessary to adipt such practices as fit local conditions and enviromments. But if une is sufficiently interested, there is little doubt that it can be done.

\section{Control of Forest Insects and Diseases}

The measures currently in use in New York for controlling forest insects and diseases do not seem to affect grouse much one way or the other. True, weeviled white pines are apt to provide better shelter for hirds than do straight, fast-growing trees but the difference is seldom sufficiently pronounced so as to make it inadvisable to carry out control measures on young trees. Terminal shoots, infected by the white pine weevil, may usually be recognized by the witting of the terminal leaders. Control consists of cutting the shoot below the hole during the month of July and burning them.

The eradication of gooseberries and currants, either wild or cultivated, from within the covert, to prevent the spread of the white pine blister rust is important in those areas where this destructive disease is prevalent.

Much concerm has recently been expressed over the possible harmful effects on bird life of spraying woodlands with a weak solution of DDT to control insects such as the gipsy moth, the spruce bud worm and the pine saw-fly. While young grouse feed to a considerable extent, on insects during the first ten days following hatehing, where cuncentrations of one pound per acre have been sprayed from an airplanc, no harm 10 grouse, old or young, has been noted. The indications are, however, that larger applications may prove dangerous.

\section{DEVELOPING FOOD AND SHELTER BY PLANTING*}

In many cases, the habitat may be improved by planting additional shelter and food producing cover types. How this can be done will he detemined by the existing conditions on the area. The methods to be used on open fields will differ from those needed for cover already estallished, while varying deficiencies within that cover will call for particular planting techniques to improve them.

\section{Basic Principles Controlling Planting}

In general, at least portions of the improvement must be accomplished lyy planting seeds or seedlings. There are certain hasic principles that should he followed. They are:

1. Determinc the proper estahlishment method required.

2. Test for the most important soil factors, such as its fertilit level and moisture character. Site requirements for trees and shrubs. recommended for planting in New York, are given in table 97.

3. Select species suitalile to the climate, light and shade, and soil conditions. These are shown in table 97.

1. Secure suitable seed and planting stock.

5. Care properly for planting stock.

6. lise the proper planting methods.

- Hy Erank C. Adumuter. 


\section{Determining Cover Establishment Mrohods to he I'sed}

The methods by which the cover types should lo established are the first consideration. The character of the soil is the major limiting fartor. The simplest and cheapest way, providing it works out satisfactorily is to let nature take her own course through the orderly process of plant succession, while the most difficult and expensive one is to set out earh woody plant. In some instances, there are intermediate stages that may be employed whereby one can avoid complete planting of the area by assisting the establishment of desired types ly cultural operations that promote the growth of certain species and groups of plants, while retarding unproductive ones.

TABII: 97. USES OF TRELS, SIIRUISS AND VINES FOR JLANTATIONS. AND THEIR SITE REQUIREMENTS

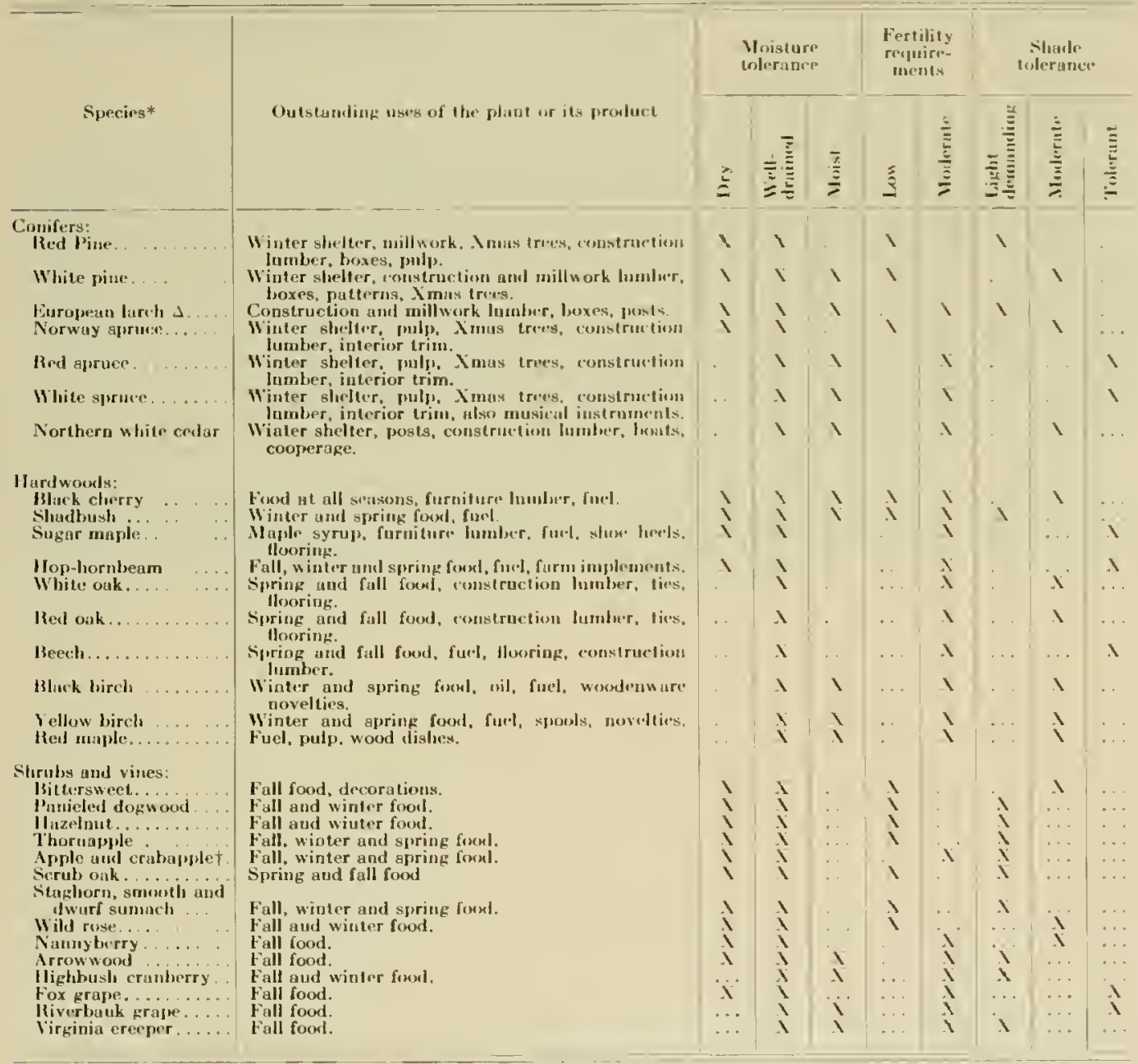

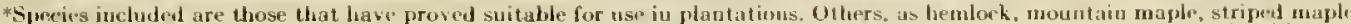
rel-berried elder and maple-leaved viburnum hive not been generally suecessul in dield plantings. Some such as blarkberries pin clurery and hlueberry are established more onsily by colinral practices.

$\Delta$ Lareh. while a confer, is sot evergreen but sheds its needlos in the auturoo.

The apples aud crabupples are not aetually shruba, hut ure trees. llowever, they are part of the fall ficding trounds assuciation and not the hardwood woodland. 


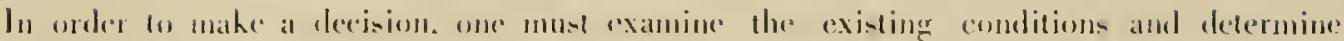
"hat the probabilitics are for sucess by the arious methods. Naturally, those selected will vary arcording to the lype of halitat desired on ang given location. Thus. if the design ealls for fall feeding grounds. one must eonsider the possibility of ohtaining the desirable shrub rover.

If scedlings of the required species will estahlish themselves by natural seeding and at the same lime not produce to many unwanted competing types. the site will probably develop satisfactorily b! itself.

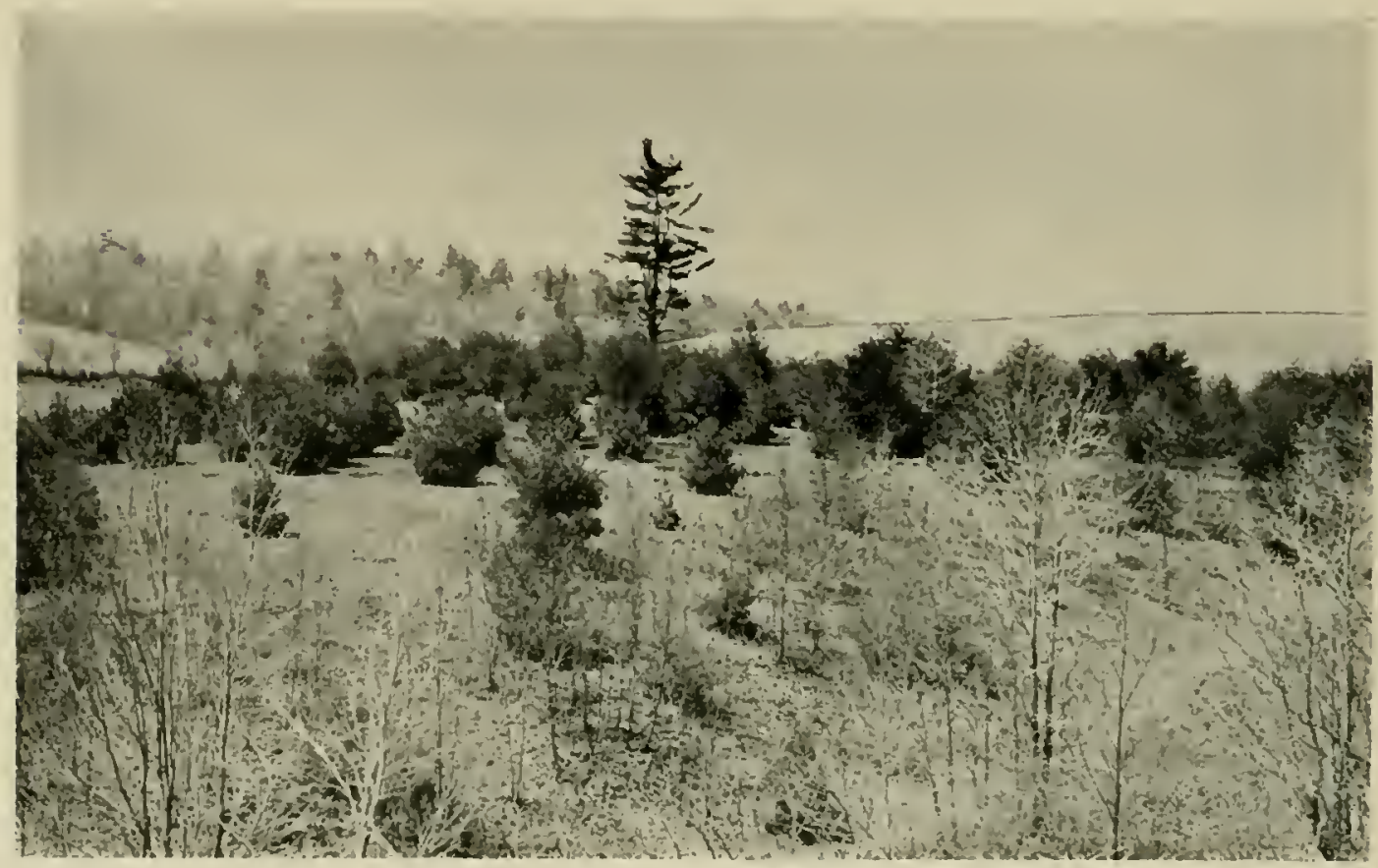

WIEKE TIL: PROPER SEEO TREES ARE PRESENT NATURE MAY OFTEN BE, DEPENIEO IPOY TO REETABISH SATISFACTOH WOOM COYH

When the eover needed on a partienlar location is winter shelter. then whe must tetermine whether or not there are adeguate soed trees of desirable conifers close enough so that natural sediner may he depended npon. If the probability of natural sceding is poor. then ennifers must he artifieially stated. rither by sowing seed on exposed mineral soil or by direct plante ing.

The eatulishment of hardwered areas. ower most of the Northeast. generally results through the natural growing-up of such speries. Which crowed out less igerous typese. The number and arrangenent of the desirel trees will not. in all eases. Ine satisfactory. Where this natural plant sucression will not proside for an adepuate mixture lo furnish gomel spring nesting grounds cover, then at leas partial plantings shenlal be made.

Where the habitat alreads exists. the metheds to he used will depend upeot what ehanges and improvements ate needed to preduce the reguired halitat. Some of these methods bave 
already been discussed under the section on altering the existing eover, wherein the making of openings and clearings is described. These may be used for interplantings and estab. lishing herbaceous cover types.

\section{Securing and Caring for Planling Slock}

Planting stock for extensive revegetation work must, necessarily; he rather low in price in order to make the operation econmically feasible. At the present time. state and federal nurseries produce a good many of the species recommended for the different types of plant. ings and make them available to the pullic. in various ways, at a reasonable cost. The production of state nurseries is predominanty of coniferous species. thus making available the material for the greatest portion of plantation work.

It is often possible to obtain suitahe planting stock frum private nureeris. Material known as "lining-out stuch" in commercial nurseries is often purchasable al a reasonable cost. Generally speaking. a desirable lardwoud seedling of one or two years nursery growth is from six to fifteen inches high and wilh a root sistem nearly as large.

Care in selection of ronifer sock for use in interior plantings is ver! important. The stock should be large and thrift!. For the species recommented. a four-year old unrsery grown plant is usually best. Foresters call them "2.2 plants" 10 indicate that they have been grown in a seed bed lwo years and in a transplant beel an additional two years.

Planting stock should be carried in a pail part! filled with water so that the roots are not permitted to dry out. Portions of it that can not he placed in the ground immediately upon removal from the mursery, should be heeled-in in a damp. shady. Well-drained spot. To do this, a trench is dug deep cuough to acommodate the root systems. about a foot wide and long enough to take care of the material at hand. The bundles of seedlings are loos. cned and laid with the roots in the trench and covered froml with soil. The plants are kept moist by wetting and covering will hurlap. Thes should he remosed from the heel-in lied only as needed for immediate planting.

Some wildlife managers may wish to propagate their onn seedlings. This is an immense subject by itself which cannol he covered here. There are numerous texts on the suliject and a wealth of experience. in buth public and private nurseries. is available. Host of the infurmation from these sources. at least in so far as it concerns reforestation nee, is contfined to the eonifers and a rery few hardwood trees.

For those who desire to propagate plants for grouse habitat. particularly the shruls and hardwood trees. the specifie data needed is summarized in table $186^{*}$. Most of this material was recorded through the comrtesy of the Soil Conservation Service and with the assistance of Robert B. Thornton. formerly Chief of the Nursery Division of the Dortheast Region.

\section{Planting Methods}

In placing seedlings in the gromul. considerable care should be taken in urder to assure good survival and growth. In most soils. the best planting method is that known as the center hole teehnique. By using a mattock or other similar tool, at least a square foot of the sod cover is removed and a hole dug in the middle of this "sealp" deep enough and wide mough w accommodate the seedling without cramping its roots. The seedling is held in the center of the hole with the root collar at the ground line level and the soil is then placed firml around the root and tamped down at the top, nstlally with the foot.

\footnotetext{
* See Apprendix. p. 883.
} 
Direct seeding of nut species is arranged as though the seedlings were being planted. Sod scalps are first made. Then two nuts are buried in the center of the spot about wice as deep as the diameter of the seed. Rolents cause considerable loss to plantations of acorns and muts. For this reason, plantings shonld be kejt away from the edges of existing woodlands in so far as possible. Greater success will be attained when these plantings are made in years when squirrels and mice are not excessively alundant. No satisfactory material has yet leen developed to repel rodents from either muts or seedlings.

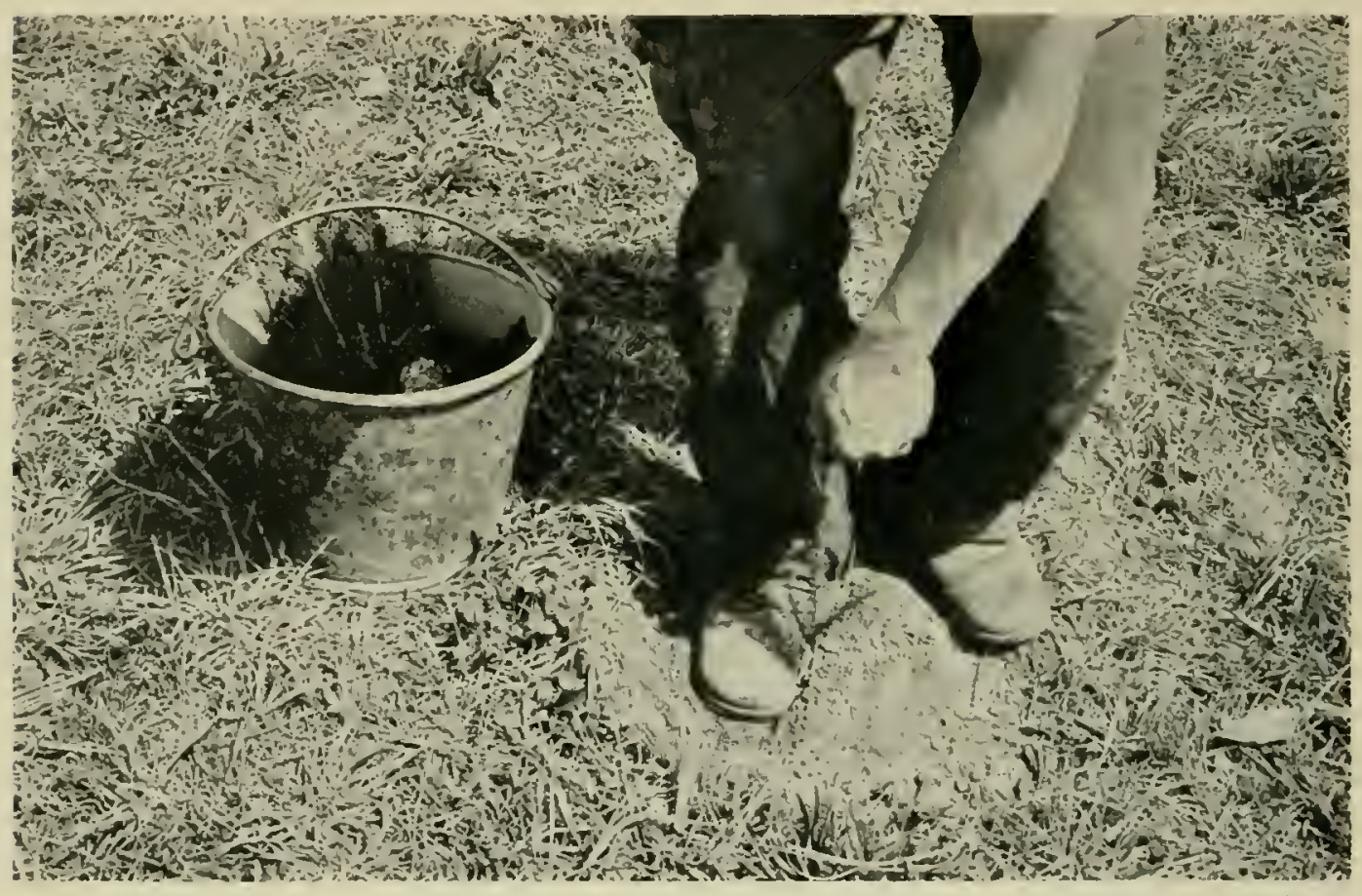

PLANTING SPRUCE BY TIE CENTFR HOLE, TECINIQLE.

Serds may be planted directly into newly plowed furrows. Is a precaution against unnecessary soil lons, the furrows should be plowed on level lines. that is. crosswise to the slope. For large shrub and tree species, the furrows should lo about six feet apart and for small shrulss, about four feet.

For herhaceous cover. the seding maly be done by simply disking with the usual farm disking-harrow in order 40 prepare a good seed bed.

The germination of conifer seed is stinulated by exposing the mineral soil by plouechingr the furrows. When seel trees are present, natural seroling in the furrows will usually suffice but, if not. then seds of the desired speeies mily be planted in them. This practice is still in the experimental stare and will require a greal deal more study before the forehuical details required to ohtain successful growth can he predicted witl am! aecuraey.

The possibilities of mablishiner hardwowd ly similar direct seding methods are even less well known today. Coptain types of hardwood shrubs ean he grown ly dirret seeding on 
seed heds prepared in a manner similar to that for herbaceous cover. None of the shrubs that are of particular use to the grouse are among those that can be established with assurance.

\section{Conifer Plantings}

Most of the conifers are adapted to growing in soils that are acid and low in fertility. Like most plants, however, they will do better in more fertile soils. Therefore, since the hardwood trees and shrubs are more demanding in this regard. it is a good plan to depend

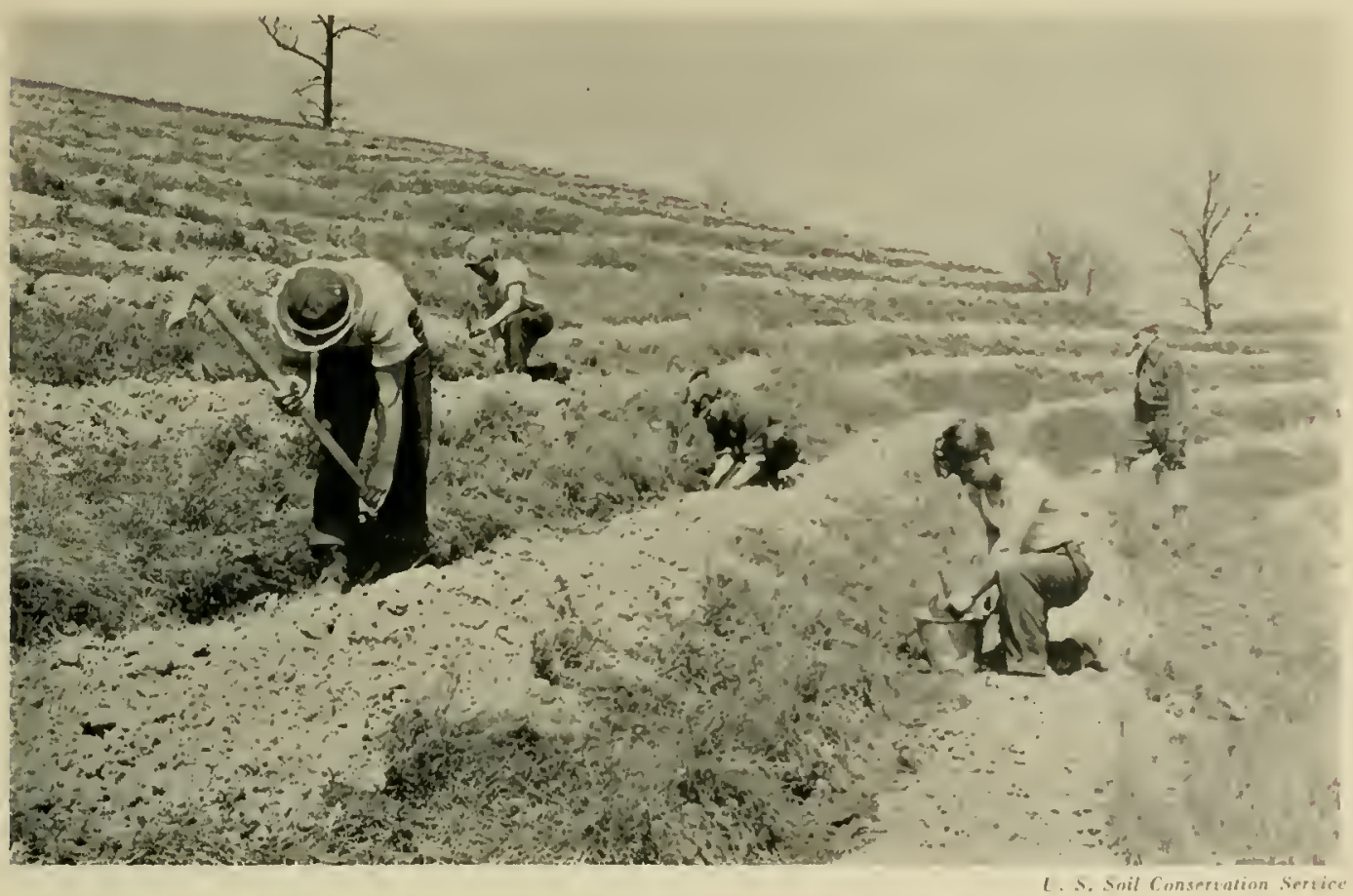

MOST HARDWOON TREES AND SHRUBS RESPOND BEST WHEN PLANTED DIRECTIX INTO VEWLY PLOWEII FURROWS

upon the conifers for revegetating the pourer sites. One must not expect the most vigorous growth under these conditions.

The species of conifers best suited for winter shelter are hemlock, white pine. red spruce. white spruce. black spruce. Norway spruce, red pine, and northem white cedar. It is unfortunate that hemlock is difficult to produce in murseries for reforestation use and is nol dependable in field plantations. Under most circumstances, the wildlife manager will depend upon the red. white and Norway spruce, white and red pines and notthern white cedar. for the greater portion of his winter cover. Another desirable conifer in the mixture is European larch. While not an evergreen, this tree protides a necessary element in the winter sleelter composition ly developing a useful herbaceous ground eover. often lacking with many other conifers.

If other species of pines, spruces or firs are availalle and valuable for their woorl products. they may be included in the mixture. In all plantings for winter shelter. it is advantageous to 
use a mixture of several species rather than planting in hlocks of a single variety. The species arrangement may he either as a random selection from pail mixtures or in continuous rows of each kind.

Where the development of winter shelter. in hardwood stands deficient in conifers. is required. it is often necessary to interplant. Within the woodland. this should be done in ex. isting open glades wherever possible. or openings should be made to provide the necessary sunlight for adequate gruwh. This may be accomplished when harvesting the wour or by

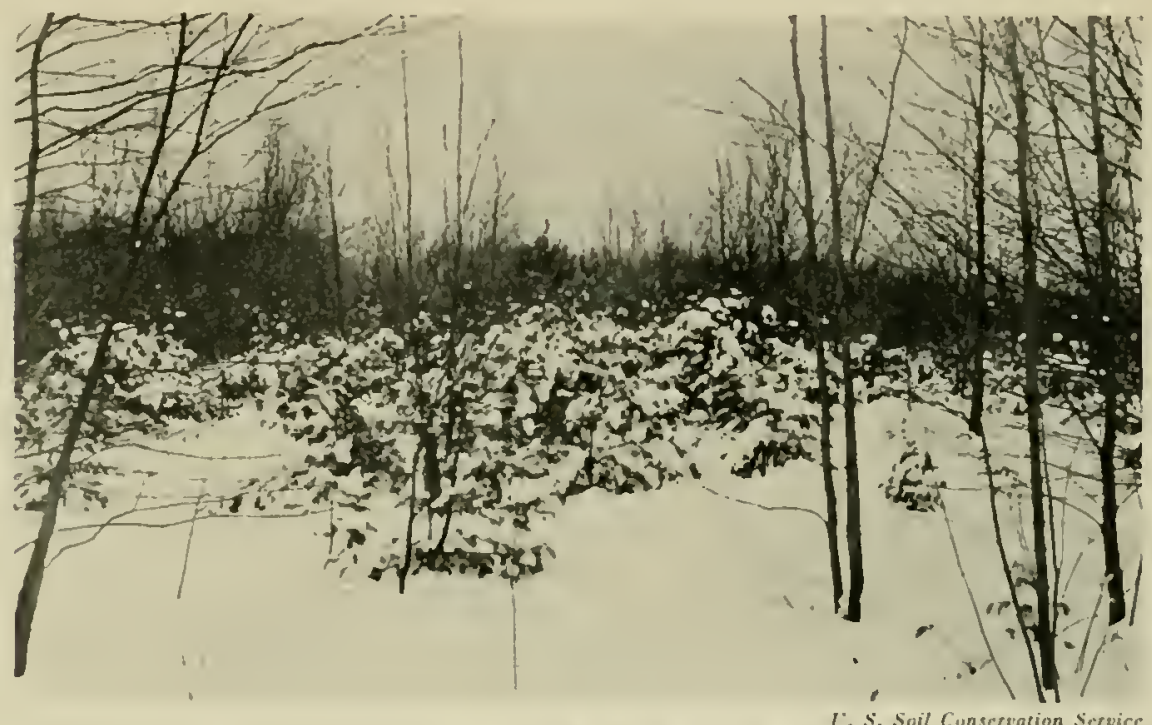

WUITE PINE, WTERPLANTED IN AX OPFNING IN SECOND-GROWTH HARDWOODS.

IIERF, PROYIDES MICH NEEOEU WINTER SHELTER FOR GROISF:

silvieulural thimningrs. ats previnusl! discussed."

In eover thus opened. there still may he considerable shade and. therefore. shade-tolerant species. such as white or red suruce. are recommented. If the cruwn canupy is sufficiently: "pen. so that the site is not more than half sladed. then white pine. Vorway spruce and northern white redar ma! also be used successfully.

Cutlings of hardwoods on sites intended for interplantings will generally result in considerahle sprouts and stumple. These vigorous shouts are likely tu result in exressive competition and strading for the mewly-planted secdlings. Inder these conditions. it is suggested that the stumps of the cut trees be puisoned ${ }^{4}$ in order to insure adequate sunlight for the rapid establishment of the exerereen trees.

Sparing for interplantinge nust he judged on the conditions at cach bocation. Ordinaril!. the tsual six to right foot plantation spacing may low used. Where the openings are small

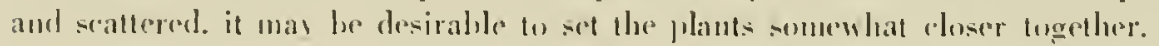

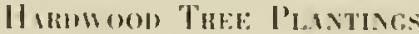

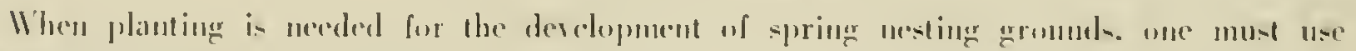


considerable care in the selection of the sites. Hardwood trees usually require a more fertile soil for successful establishment than do the conifers. It is fortunate, however, that, in most portions of the Northeast, natural plant succession will develop some hardwood tree species. In most cases it is only necessary, therefore. to plant a portion of the area to attain a better balanced hardwood stand. This provides an opportunity to select the best ground for setting out the trees where artificial planting is needed.

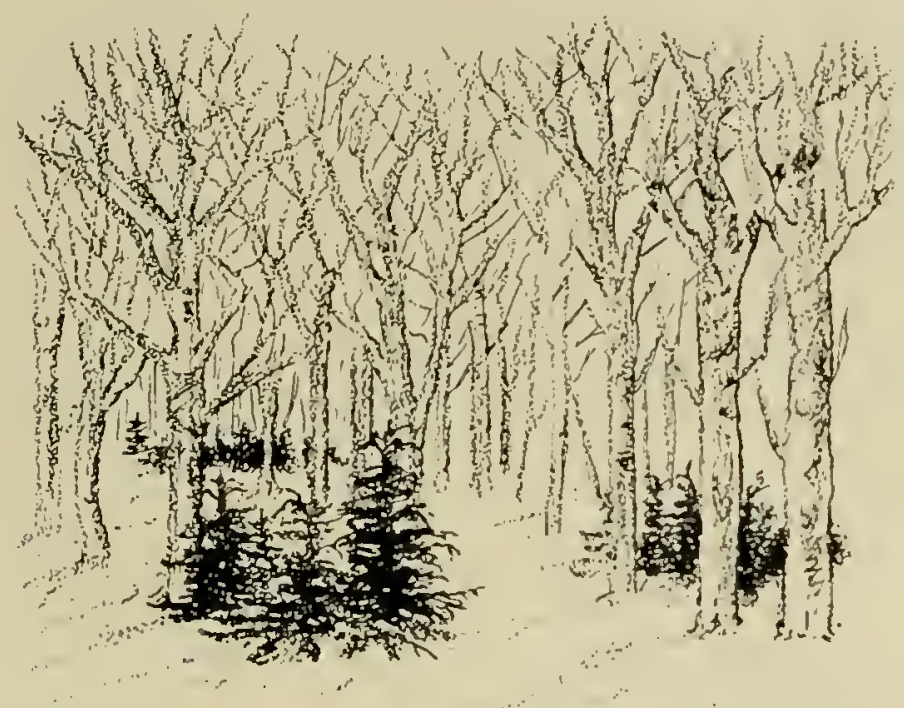

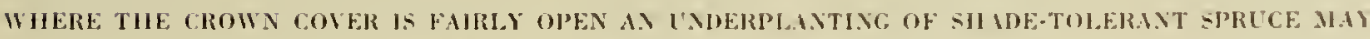
ILSO FERNISI WIXTER SIELTF.T

A mixure of speries is just as necessary in hardwowl plantings as wirh the conifers. Those listed in table $186^{*}$ have been selected hecause of their particular alue to spring nesting grounds. Others, such as the walnuts. hickories and chestnuts. while not of particular importance to grouse as a source of food. are of significance to a number of wildlife species. These large seeded trees. as well as the oaks. ma! be estahlished hy planting the nuts instead of the scedling trees.

There are a number of other species of hardwood trees that are suitable to plant but which are not of special use to the grouse. However, one may wish to add some of these to the mixture for their value as wood products. Among these are tulip poplar. white ash and basswood.

\section{Shrub Borner Plintings}

As presinsly mentioned. summer and fall feeding grounds usuall! are best combined in a single strip. In most instances. such a strip is a horder of the cover. A minimum width of about 25 feet is needed in order to maintain this plant type. The width may be increased np to approximately 100 feet or until it constitutes 30 to 15 per cent of the hahitat are: where this cover is particularly needed. 
Plantings of the large shrubs and small fruit-hearing trees should be made next to the woodland trees. The spacing between the scedlings for this portion of the border is recommended to be 6 feet. The small and medium sized bushes may be placed in the outer portion of the border and next to the open land. Here the spacing may well he cut to 4 to 5 feet hetween rows and plants. By utilizing the lower growing shrubs on the outside and the higher ones next to the trees, a sloping border will develop which provides the greatest protection for the woodland and the best conditions for fruit production.

The economical establishment of the summer and fall feeding grounds demands that the wildlife manager, wherever possible, should take full advantage of the opportunities for assisting nature as a substitute for direct planting. A portion of the strip may be lightly burned over, in scattered spots, with the expectation that desirable species for summer feeding grounds will establish themselves naturally. Blneherries, raspberries and blackberries, pin cherry and popple all respond well to this treatment and furnish valuable summer and fall foods. Strict control must be maintained since indiscriminate use of fire is very destructive.

For the rest of the border, partial planting is often necessary in order to permit the shrubs to become fully established, or dominant, before tree species can get a start. The proportion to be planted will depend upon the need for additional shrubs, both as to the kind and num. ber of them.

Since the purpose of the shrub borler is to furnish summer and fall feeding grounds. the types chosen for planting should he those which will furnish plenty of required food for these seasous. A majority of the shrubs and small trees that will do this are also suitable for planting. They are listed in table 97 together with the most essential site characteristics of each. Arranged according to their lype of growth, they are:

Low shrubs and vines

Bittersweet

Virginia creeper

Wild rose

Fox grape

Riverhank grape

Dwarf sumach
Medium high shrubs

Panicled dogwood

Hazehnt

Scrub oak

Arrowwood

Highbush cranberry

Multiflora rose
Tall shrubs and small trees

Thornapple

Apple and crabapple

Staghorn and smooth sumach

Nannyberry

Some of these species are not among the most important grouse foods. Bittersweet. Virgrinia creeper and arrowwood. for example, do not rank high as grouse food in New York. However, they are inchuded because they do furnish a desirable part of the composition of summer and fall feeding grounds.

It is a good policy to plant at least four species in each shrub strip. One or two kinds from each of the three height groups may be selected and the species arranged in rows so that there will he four or more rows in the entire horder.

As the summer and fall feeding ground develops, a number of tree species will usually seed in naturally among the shrubs. If these are permitted to grow, they will eventually dis. place the shrub lorder and enmert it into a spring nesting grounds type of cover. To prevent this, these trecs should be climinated periodically by atting or poisoning. This may be done when the adjacent woodland or tree cover is being weeded or thinned. By su arranging the operation, hittle additional effort will be required to maintain the shrul, association. 


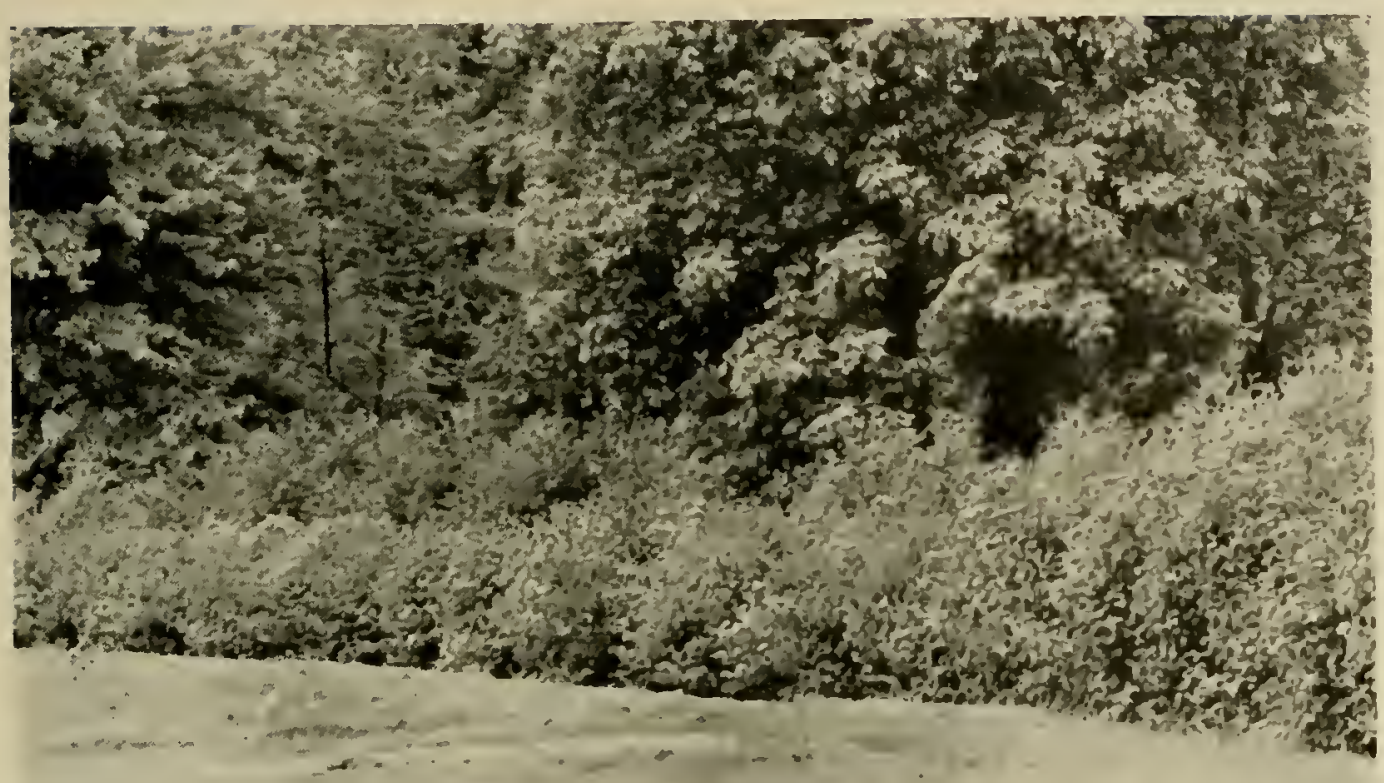

AN EXCELLENT PLANTED SHRUB BORDER

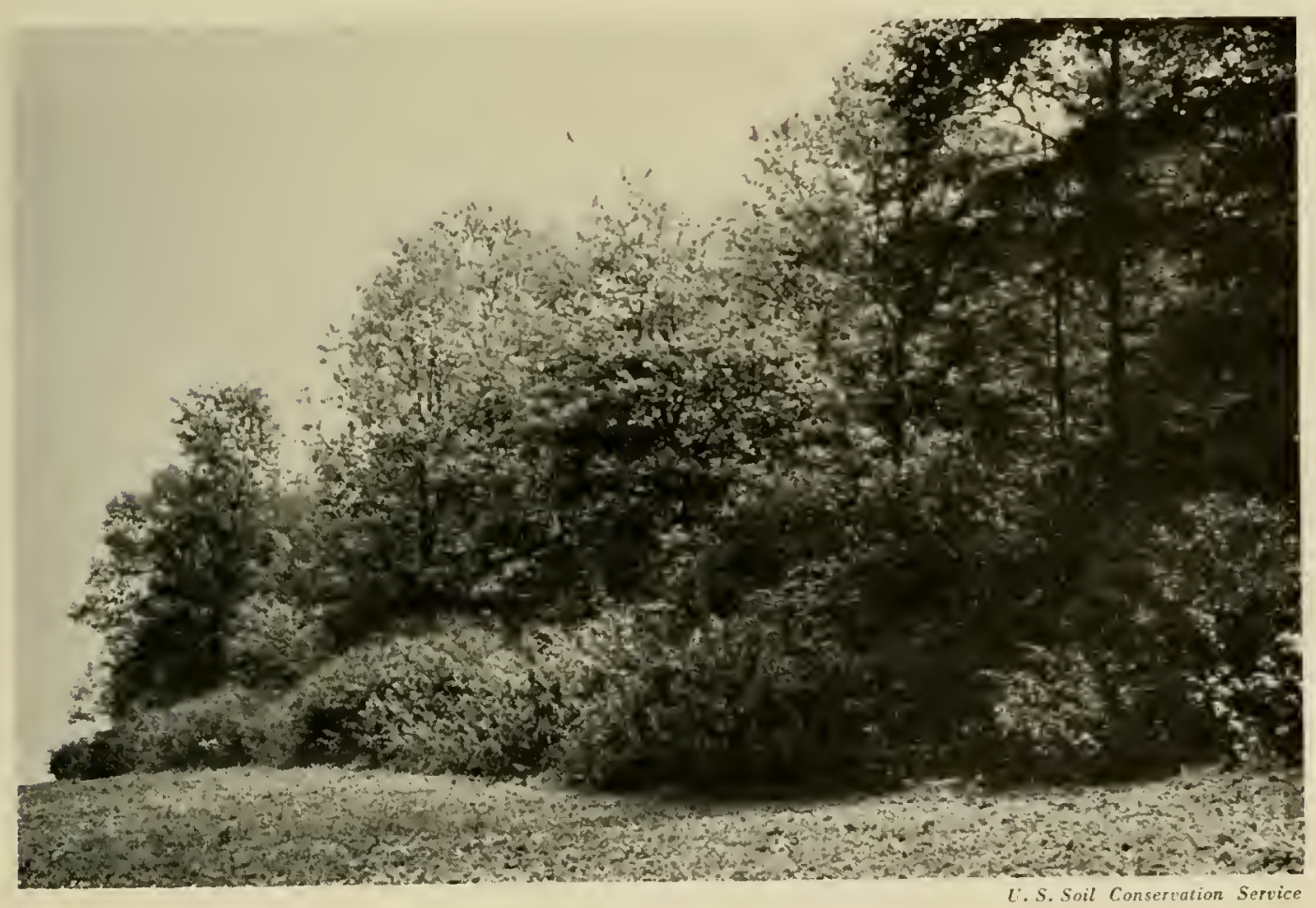
THIS SHRUB BORDER RESULTED FRON CUTTING A BAND 20 FEET WDE ALONG THE EDGE OF THE: WOODS 


\section{Herbaceous Plantings}

In evaluating the coser requirments of grouse* it was apparent that edges often were of particular significaner. They come where openings meet existing woodlands. Many of these. particularly fickl edges and woods roads, provide an opportunity for the development of additional grouse foods and useful ground cover through the establishment of herbaccous plants.

One of the best treatments is to seed wild white clover. Seeding is recommended at the rate of four pounds of seed per acre or about one pound for each one-quarter nile of eight feet wide strip of roadway. Clover should only be established in soils having a neutral or alkaline lime content. If the $\mathrm{pH}$ of the soil (relative acid-alkaline) tests acid, it will be necessary to add lime in sufficient quantities to at least make it neutral in order to obtain a successful crop.

When an herbaceous field edge or roadway already contains a desirable type of vegetation, including important grouse foods. it can usually be maintained by an occasional mowing or disking.

\section{PROTECTING THE EXISTING COVER}

One of the important aspects of maintaining ruffed grouse habitats is the protection of the existing cover values. At the same time, this also may be used to accomplish habitat improvements. Generally; it is amed at controlling five destructive infuences: fire, domestic livestork. decr. insects and disease organisms. The control of the last wo groups. insofar as is practical. is carried out as a part of the woodland improvement operations and was ar. cordingly mentioned previously ${ }^{\Delta}$. Particular attention is often needed. however. to prevent and control woodland fires. to exclude domestic lisestuck and to control deer.

\section{Fire Its Prevextios. Control aNo Use}

Incontrolled fires in the woodland are a menace to the ruffed grouse. The problem of preventing and controlling them in New York and. in fact. over most of the Northeast. has been gradually reduced. in recent sears. by the increasing efficiency of organized fire control services. Except as fire may he, in some measure. a useful tool in disposing of slash. in creating small. light ground lourns to promote the germination of rertain desirable plants. or in arresting plant succession ${ }^{\dagger}$. lhe prevention of woods hurning and efficient eontrol of fires. that are acridentally started. is recommended.

In extensive fores arras. where the problem of accidental fires is mos critical. the conflagrations are ordinarily the result of carelessness on the part of recreationists. The prob$1 \mathrm{em}$ is most diffeult during the spring and fall at which times there is a dearth of rainfall roupled with an aceumulation of dry litter on the gromud. During season of drought. the problem sometimes becomes so acute that the forest preserve areas have to be closed. tempo. rarily. 10 general public use. The only solution to the prevention of these fires is more and more edueation of the public to the proper use of fire and the avoidane of its abuse.

The organization of fire-fighting servies in extensire forest lands is generally wetl developed where grouse habitits are inportant enough to warrant management. Such forest fires ats do get ont of eoutrul are ordinarily put out before larere areas are burned. Vew York State has a very reficient sisten of roads and trails. lowkouts. radio and telephone equipment.

- virer Chapler IJl.

A ser plage 6ist.

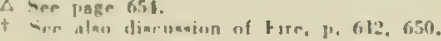


and other fire-fighting and reporting facilities. Owners of forest lands should be fully acquainted with the fire control arrangements in their vicinity and should always be in a position to cooperate with the authorities in whatever manner is needed.

ln those portions of New York grouse range where fires are common. the problem is quite different. Here most of the fires are started as a result of the deliberate burning of fields or hedgerows. These occasionally eseape and invade adjacent woodland areas, the edges of which are often the best grouse habitat. Although these fires are seldom extensive, the danger for grouse is considerable, especially since the facilities for fire control are not ordinarily as thorough. On the other hand, it is usually possible, without undue delay, to get together equipment and manpower for putting out fires in small scattered woodlands.

The prohlem of eliminating this type of fre is also largely one of education of the farm population. The burning of fields and hedgerows is unwarranted under almost all cireumstances and rarely produces the results that the operator desires.

Particular care should always be taken to see that any legitimate fires are thoroughly extinguished before leaving, especially in dry weather and on windy days. Fire in the woodland, like many another of man's tools, may be either good or bad. depending upon how. when and where it is used. The general principle of prevention and control of fire in the woods does not, in any way, depreciate the value of fire when properly used for legitimate purposes, such as eamp fires or in eonncction with improvement of habitat. In all instances, the utmost care should be used to prevent fires from getting out of eontrol.

\section{CONTROL OF DOMEsTiC livestock}

Farm livestock, particularly cattle, are oftimes allowed to range through the farm wond. lands. Usually, the owner believes that wonl pasture furnishes enough forage to make this

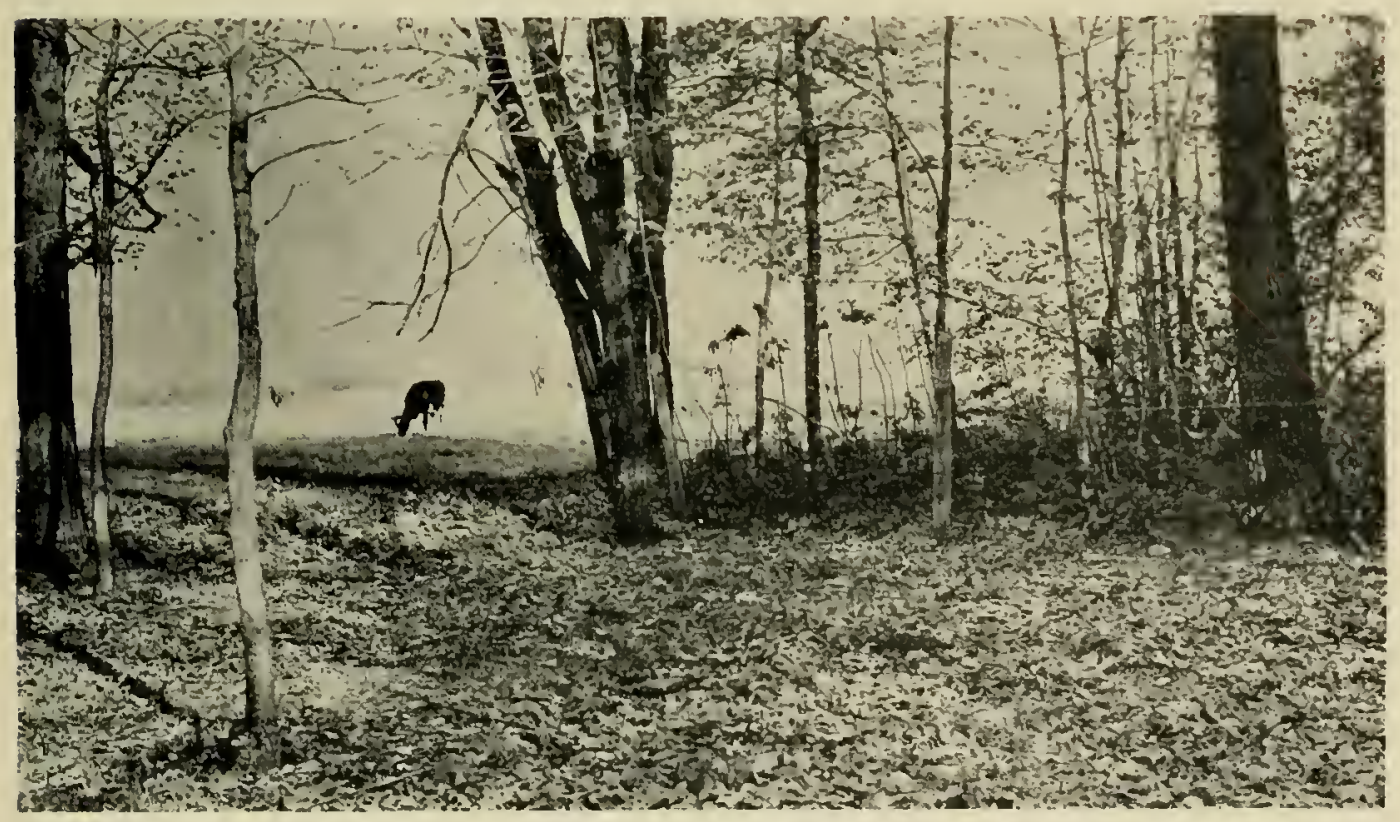

L.S. Soil Consertation Service

TILRE IS A SHARP CONTRAST IN UNDERGROWTII DENSITI AND DIVERSITY RETWEEN HEAVILY PASTURED WOODLANDS AND THOSE FRON WHIC CATTLF HAVE BEEN EXCLUDED 
practice worth while. However, in all cases where evaluations have been made, it has been shown that it is not profitable. The amount of forage is ordinarily small and of inferior quality and the excessive exercise required of the aninals to secure it often results in a loss of meat or milk production. The fact that many farm woodlands are at consideralle distances from the luildings and are on steep slopes, adds weight to this conclusion.

The practice of pasturing livestock in the woodland can have a very detrimental effect upon the plant association. How serious this will be depends upon the intensity of the pasturing and, to some degree, upon the type of animals involved. Sheep and goats are more destruc. tive of the ground cover than are cattle.

The tendency is toward the gradual elinination of the herhaceous and woody ground cover and understory and the tramping down and compaction of the woodland soil. If the intensity of grazing is such as to prevent the regeneration of the understory plants, the end result is a decadent woodland composed of older trees with a park-like floor. In this condition, it is neither good woodland nor good pasture. If the practice is long continued the woodland will vanish.

Heavily pastured woodland loses a large part of its value as cover for grouse. Nol only are many of the desirable plants eliminated from the woodland floor, but those that remain are usually less accessible than in a normal woods. This affects both the shelter and food conditions for grouse. The tendency is to leave adequate shelter only high above the ground where it is least useful to the birds. The effect on food is generally the elimination of a large number of important herbaceous and shrubby food species.

But the effect of pasturing on the grouse habitat is not entirely on the red side of the ledger. Grazing does tend to result in the introduction of cerlain plants desirable for food. Clover, for example, will ofttimes le found in woodland openings as a result of the activity of domestic livestock. Likewise, many plants are resistant to the effects of grazing and tend to become more prevalent in the woodland understory as their competitors are eliminated. lncluded in this group are such shrubs as thornapples and blackberries, where there is adequate sunlight present.

The solution to this problem is simple: merely fence the livestock into their proper pastures. Ilowever, it should not be forgotten that occasional light grazing may be beneficial. If it were not for the eash outlay required for woodland feneing it would not be difficult to persuade most famers to do it. However, they often are not certain that the cost will be offset by the advantages gained. When one considers the improvement to the livestuck. the increase in wood products and the henelits to grouse and other wildife, the economic balance is definitely in favor of protection.

\section{Conthol of DeER Browsine}

In most cases, the over-lirowsing of the woodland understory is the result of grazine by domestir lisestork. However. in some areas, the white-tailed deer has lirought almut sulstantially the sime results. The solution to this problem is entirely different than that ereated hy domestic livestock. Provision of adequate upen shootingr seasons and hag limits, coupled with enough lunters, to reduce the density of the deer popmlation below the earrying capacity of the range is all that is required. The State should have adequate discretion. ary power to insure enough hunting of either sex as may he required in order to prevent the destruction of valuable woodland cover. 


\title{
CHAPTER XVII
}

\section{THE MAINTENANCE OF A GROUSE CROP}

\author{
By Gardiner Bump, Robert W. Darrow and Frank C. Edimster
}

\section{CONTROL OF ASSOCIATED ORGANISMS}

Control of Predators - Control of Buffers-Control of Disease

\section{RESTOCKING DEPLETED COVERTS}

When to Restock-How to Restock

\section{REGULATION OF THE GROUSE HARVEST}

Measuring the Harvestable Crop-Determining Grouse Populations-The Proportion of the Crop Available for Harvest by Hunting-Regulation of Hunting.

\section{$\Omega$}

\section{SUMMARY}

Most grouse coverts will furnish a sustained yield provided a suitable seed stock is maintained. The number which may be harvested safely varies from year to year aecording to the size of the fall surplus. (1. 6088$)$.

While no serious disease eondition in grouse has been encountercd by the Investigation, harvesting the surplus population cach fall by hunting is a practical means of guarding against it. (p. 671$)$.

Selective predator control may be useful on small areas managed for intensive hunting, mainly in reducing nesting losses. (p. o( 8$)$.

The predators of primary concern to the grouse manager in New York are the fox. weasel and great horned owl. (1).669).

Restocking of grouse will be justified only where habitat conditions are suitable and for one reason or another an adequate seed stock is not present. (p. 672).

A rough, lut useful, method of estimating the fall population in local eoverts is to count the number of broods in late August and correlate this with the average number of birds in each. (p. 676).

Knowing the fall population density and something of the comparative quality of an area one can judge approximately the proportion which can be safely harvested. (p. 677).

Refuges as a means of modifying the take are recommended only when hunting pressure is excessively high. (p. 679).

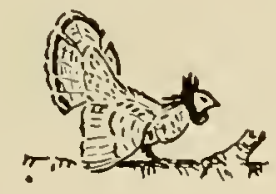


lunportant as is the nature of the cover and its arrangement. even the most carefully dereloped habitat is mo guarantee of snstained grouse production. Unavoidably subject to Nature's vagarico, the species will continue to have its ups and downs. The number which may he harrested safely will. therefore, vary from year to year according to the size of the fall surplus. Nerertheless, most grouse coverts will furnish shooting during most years provided a suitahle seed stock is maintained.

To insure an arlequate number of breeders, as well as to mitigate losses in general, one must consider a variety of factors in addition to the design of the coverts themselves. Restriction of hunting ly man las long been a basic practice. Only recently, however, have we come to realize that, at limes, an inerease in hunting may be equally valuable. Control of preda. tors and disease, as well as restocking, when employed properly. may also he helpful to the game manager.

\section{CONTROL, OF ASSOCIATED ORGANISHS*}

The activities of associated organisms, from horned owl to lacillus, are a constant influence affecting gronse abundance either directly or indirectly. Suitable control of such forms may therefore be a useful management tool.

\section{Control of Predators}

Whether or not to undertake the control of predators on a grouse production unit must be decided for each area individually. The purpose for which it is being managed must be considered. as well as its size and the nature of the wildlife populations present.

As has been pointed out in preceding chapters ${ }^{\Delta}$, the reduction of predators is by no means the simple solution to the problem of creating grouse abundance that it is sometimes pictured. Horeover, it will not be effective if the quality of the habitat is not sufficient to support additional hirds. And one shonld remember that. in the Northeast at least, a population density anong aclult grouse of about one 10 four acres is all that the social tolerance of the birds themselves will permit cven in optimum coverts. Furthermore, the cost of such a program will usually limit its feasibility to eomparatively small areas or club properties.

On extensive tracts. therefore, management funds would generally be spent to much better alvantage in habitat improvement. The same is true with regard to refuges, sanctuarics and other units where little or no lunting is done although individual predators may occasionally become unduly destructive and need to he eliminated.

On the other hand, predatur control may at times be employed to advantare on units handled primarily for the purpose of hunting. Unusual numbers of certain predatory species sometimes oceur and need to be reduced. Again, winter inlluxes of such species as the great horned owl and goshawk may need to le disoipated. But. in the main. comtrol measures will be found uscful chiclly in lowering nesting losses as a means of increasing the amual increment which. in turn, detemines the harrestable surplus. At the same time. it should be emphasized that. in the final analysis the quality of the habitat is the cornerstone of game alundance and that neitleer predator control nor restocking nor similar practices will take its place.

Even where predator control secms a wise procedure, complete climination of such species over any appreciable area shunld he aroided. Their relationship to gronse is but a small part of their function in the animal community as a whole.

* Hy Lubert W. Darrum

\& See Chapter VII, D. 350, and Chapler IX. p. 390 
If, however, a program of this hind seens justified, one should first acquire some idea of the specics of predaturs with which he is dealing and the numbers of each. For mammals. this can hest be done in the winter when snow affords suitable tracking conditions. For predatory birds, the breeding season, which in the case of the horned owl may commence as early as February, is probably the best time. Such an inventory will enable one to formulate a plan for the most effective use of his cfforts as well as to judge when such operations can logically be suspended.

In New York the predators of primary concern to the grouse manager are the fox, weasel and great horned owl. The two mammals are the outstanding nest robbers, while the other is the most successful predator of the grouse themselves. All these are permanent residents of the region.

Other spccies may, of course, present prublems now and then. Raccoms, skunks, opos. sums, crows and even woodchurks, will eat eggs when they find then. Temporary overabundance of goshawks may accompany winter invasions from the north from time to tine. Cooper's and sharp-shimed hawks destroy many grousc chicks. By and large, however, thesc species are of much less consequence thin those noted in the preceding paragraph.

In view of this, selcetive control, directed at the particular species involved on the individual area under consideration, is recommended. It is olvious. therefore, that such work should be carried ont only hy qualified persons. Noreover. the species with which one is most conecrned are also the more shy and elusive ones. The services of a first class fox trapper are highly desirable. While the amateur can attain considerable suecess in taking predatory birds, the trapping of the manumals. cspecially the fox. requircs considerably more knowledge and skill. Ability to distinguish the different hanks and owls is also important.

With respect to mothods, each 1rapper has his own pet sets and scents for the furbearers and other mammals. ln regard to the taking of predatory hirels. however, a few words may not be amiss. For the horned owl, pole-trapping is the most effective practice. At the sanc time, it is indiscriminate and, unless employed with considerable discretion, will destroy many desirable birds. To reduce this difficulty to a minimum. it should be carried on only during the winter and traps located where other birds are least likely to be caught. $A$ better method, whenever possible, is that of shouting.

Among the other avian species, the wouds-frequenting "blue darter" hawks (Cooper's. shapp-shinned and goshawk) are the oncs most often troublesome. For these, shooting resident hirds during the brceding season is ly far the most effective practice. Goshawks may have to be hunted during the winter, also.

There are available a number of designs for live-traps which permit the release, unharmed. of individuals taken unintentionally. Also various devices can he used to make traps more or less sclective through adjusting the pan or trigger in such a way lhat a certain weight or force is necessary to spring it. Their use is desirable wherever they can be employed effectively.

Trapping may he continued the ycar around, if necessary, for species on which there is no closed scason but it is helter, whenever possible, to confine the taking of furbearers to seasons when the pelt is prime. Similarly, with respect 10 birds, operations should be reduced to a minimum or suspended completely during the periods in spring and fall when migratory sprecies are passing through, sinec the majority of such transients have little effect on any particular local area. 


\section{Controi, of Buffres}

Another factor in the maintenance of grouse populations involves the presence of sufficient numbers of buffer species to provide an adequate reservoir of staple foods for the predators present. An ample supply of these will serve as a guard against excessive predation. Foxes. for example, have been found to travel more extensively and to spend more time hunting when rablits and mice were scarce. At such times their chances of encountering grouse are increased. At the same time, an overabundance of these buffer species may at. tract undue numbers of predators. One must also hear in mind the danger that tow man! buffers, which are mainly rodents, may damage essential regetation. Just what population densities among these species are most desirable and how to determine them are still largely problems for the future.

In New York; the principal representatives of this group are the cottontail rabhit. rarying hare. red squirrel. chipmunk and the various mice. shrews and moles. Strictly speaking. with respect to grouse, any other food of a predator is a buffer and, in the case of Cooper's and sharp-shinned havks, the many small woodland birds they prey upon must be considered in this category. The present discussion. however. will be limited to the mammal forms.

A number of methods of reducing rodent populations have been developed ${ }^{33:}$. chiefly in connection with various branches of agriculture. In addition to trapping they principally inrolve certain poisons in a form which disintegrates and becomes harmless if not consumed almost immediately". With respect to field mice. the elimination of grass might also be helpful.

But in most cases the grouse manager will be concerned with maintaining the abundance of buffers rather than decreasing them. Present knowledge of how to do this, is limited. Nevertheless a few suggestions can be made. Any appreciable cleaning-up of the underbrush, rotting logs and forest-floor debris tends 10 make conditions less farorable for them. The presence of slashings and other openings, as recommended for cover management, creates a more productive environment than woodland alone for rabbits and field mice which are prolably the most important buffers in New York. Although brushpiles are short lived they have proven somewhat effective as shelter for rablits. Woodchucks, through providing burrows, are an aid. For mice, it is possible that cutting grass and leaving it in cocks or wind. rows would help these rodents 10 winter.

So little experimental work, however, has been done on buffer control that one must, in the main, rely on his own ingenuity as he goes along.

* For the Nurtheast the U. F. Fish and Wildble service hita develoged a phosphorus compround which, when mixed with cubed apple, has proven very effecive.

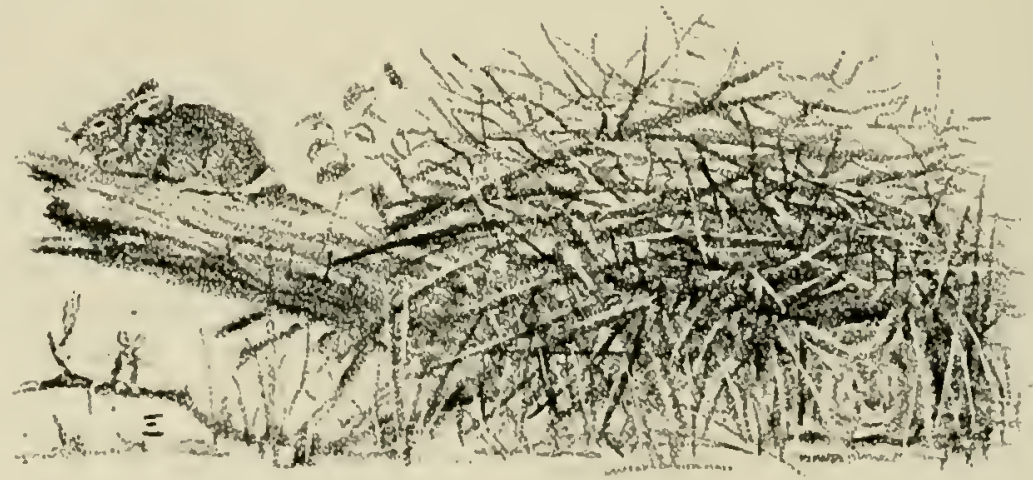




\section{Control of Disease}

From the data at hand the grouse manager will seldom, if ever, be faced with a serious dis. ease problem. So far nothing even approaching an epizootic has been encountered in New York birds. On the other hand, there has been no opportunity to study a period of pronounced cyclic decline in abundance.

Thus, the possibility should not be ignored. In the first place, disease is the result of influences or conditions to which the bird is subjected. These underlying causes may be mechanical, chemical, nutritional or parasitic. Since medication or other treatment of wild populations is practically impossible, control measures must be directed toward removing the cause.

Few definite recommendations can be made with respect to grouse because the conditions necessary for experiments of this kind have seldom occurred during the Investigation. It may, however, be of interest to consider some of the measures which have becn used effectively in connection with other species. For example, botulism, a condition in which waterfowl are poisoned by the waste products of certain bacteria. has been controlled by changing the water level and by the establishment of certain plants which destroy the bacteria. Again, eradication of hoof-and-mouth disease among California deer was accomplished by actually eliminating these animals from the affected region. In Wyoming, the incidence of necrotic stomatitis, a serious bacterial disease among elk, was lowered by removal of certain grasses from the range. In Britain, losses among the Scotch grouse from coccidiosis and certain worm parasitism have been reduced by burning the moors and draining low damp areas. lhus expos. ing the eggs and other immature stages of the organisms to the direct drying and irradiating effects of the sun.

In cases where an intermediate host is involved in the life cycle of a parasite, it is sonetimes possible to break the chain of transmission by destroging this link. Some of the fluke diseases of domestic animals can he controlled by poisoning the suails in which the early stages of these flatworms develop.

If it shonld ever become necessary to combat an established discase condition among ruffed grouse, effective procedures will undoubtedly follow some such coursc as the ahove.

But "an ounce of prevention is worth a pound of cure". Although normally latent. organ. isms capable of giving rise to an epizootic are ever present. They need only favorahle conditions to "light the fuse".

While definite experimental evidence is lacking with respect to grouse there is every prol, ability of a direct corrclation between such outbreaks and population density. The source of diseases of this kind is not to be found in "unwholesome vapours" hut in some other indi. vidual which has become infected. Thus the more frequent the contact of such individuals with their neighbors the greater the opportunity for spreading the ailment. This principle is easily demonstrated in the case of stock held on game farms. It is also believed to be a para. mount factor in connection with the violent fluctuations of the snowshoe rabbit and many mice. In managing the grouse moors of Scotland it is regarded as sufficiently important that, if the owner and his guests do not take enough birds, the keeper subsequently reduces them to the desired level. Furthermore. the rapid transmission possible among a population at times of high density often steps up the virulence of the causative organism.

Dissipation of excessive concentrations is a means of guarding against such consequences. Therefore, harvesting the surplus each fall, by hunting, is a practical management measure. 


\section{RRATOCKING DEPLETEO HABITATS*}

Much of the problem of restorking depleted habitats las leen thoroughly discussed in the chapter on artificial propagation. ${ }^{\Delta}$ The hope that grouse might be raised like pheasants or quail for restocking purposes has been the compelling force behind most grouse propagation attempts. The reasuns for past failures are detailed there, as well as cautions for securing stock for liberation. Those who have read this account will remember that young birds seven to nine weeks of age are preferred to adults for restocking; that wild birds in good condition, captured in habitats similar to the one in which the! are to be released, probably have a better chance of survival than do artificially raised birds, though the latter have been successfully used. The value of repeated liherations; even in a good hahitat, was also stressed. Though most attempts to date have failed of their purpose, that docs not necessarily mean that satisfactory results eannot be secured from liberated hirds when the reasons for past failures are thoroughly understood and the proper corrective measures are applied. Certain additional considerations will. therefore, be discussed here.

\section{WheN to Restock}

Much misunderstanding has arisen coneerning the purpose of restocking. Outstanding among the inlluences popularly supposed to he responsible for grouse scarcity is the specter of inbreeding. Yet the luvestigation has not been able to unearth the slightest reason to justify: this theory. So far as can be determined, no willlife species has ever suffered from this cause and geneticists tell us that the possibility is extremely unlikely.

The second reason commonly given for restocking is to increase the shootalle surplus. Usually a fair crop of lirels is known to exist lut additional birds are added in the lope that the increase will be manifold and the shootahle surplus materially enlarged. llere, too, there is some vague idea that a "change of bloud" will revitalize the birds in the coverts thus stocked. Again there scems nu value to the assertion except that, if the coverts are not already fully stocked, the birds may simply add numbers to the population. But, as the resident popula. tion approaches the carrying eapacity of the habitat, the probability that recently liberated individuals will mose to less thickly settled coverts slould not be overlonked.

When, then, is restocking justified on the l,asis of profitalse return? Briefly the uccasions mal he summed up as follows:

1. When a hahitat, originally suited to grouse, has heen destroged by fire or by mans: varied activities and has sulsecpuently improved to a point where it again appears adequate for grouse.

2. When grouse have been eliminated from suitalble labitats, presumally ly predators, dis. ease or ly overhunting and the cause is thonght to be under eontrol.

3. When. over a fairly large area, grouse are almost noncxistent and recover! to a normal population level is unusually slow and this lag is not explainable hy habitat inadeguacy or wher eiremustance's.

But, even under there conditions. isolation from a secd soch which might wherwise spreacl to it is alse a necessary prerequisite.

When grouse are fairly abundant, the momal dispersion of the hirds from woll to poorly suched coverts is such that few farmathe ones alose hy will remain seriously underpopulated

- Hi Cardiner Humy

A Sre thapter Xil. p. 501 
for long. Naturally. as the distance between coverts increases, the likelihood of restocking them by dispersion decreases. While little indicative information is available, it seems doubtful that much natural iransfer of population is likely to occur when the distance exceeds four or five miles.

Such natural movement may obviate the expenditure of effort and money involved in a restocking program. Individual circumstances may occasionally arise. however. which will justify this expenditure.

\section{How to Restock}

Providing the conditions outlined at the beginning of this section are met. and one takes due care to avoid the causes of the many previous failures, successful restocking should not be too difficult an undertaking. The hirds should be liberated in the best habitat possible in groups of not less than 20 to 25 . It is important to repeat the liberation annually for at least three to four vears to permit the birds to receive additions to their numbers to make up for a normal loss ineident to their establishment.

The best period for liheration is helieved to be in the summer or early fall. which corre. sponds to the time when arlificially propagated hirds seven to nine weeks of age could be secured. Wild hirds are more easily trapped in the wintertime and are. therefore, usually liberated as adults. Since they lose weight ronsistently letwcen early January and midl. March it would seem wise to liberate them either as early in the winter as possible or in April. Unless they are in poor condition at the time appointed for liberation they should not be kept in eaptivity any longer than is alsolutely necessary lest they lose additional weight.

Young hand-raised birds may be fod at the point of liberation though their wild-trapped brethren will pay but little attention to such efforts. The carriers from which they are liberated should be placed so as to make it diffeult for the lirds to fly upon emergence. Thi- will encourage the birds to remain as long as possihle in the immediate vicinity of the liberation point.

\section{LEGLTATION OF THE GROL'SE HARVEST*}

Regulation of the larvest itself in accordance with the relative aloundance of the species from year to year represents the concluding phase of a management program. In America the taking of non-migratory game is governed by whatever linitations the various state legislatures see fit to lay down in their gane laws each year. Within the limits thus establisherl. however, it may become desirable for the administrator as well as the individual game manager to make additional adjustments to fit particular situations. Thus. if the grouse crop should fail on a managed area. it would he logical to set up on it further restrictions than pro. vided liy the current state-wide laws.

The regulations adopted should be directed towarl maintaining a sustained yield. Neither two many nor too few of the species should be harvesterl. This means that in years of plenty the rrop should be adequately utilized. whereis. in years of scarcity the grouse should rereive suffeient protection to provide the greatest possible hunting epportunity and at the same time insure the preservation of a sufficient breeding stork. A reliable means of measuring the crop. or shootable surplus. is therefore a primary requisite to attaining this goal. 


\section{Measlring the Harvestable Crop"}

If the maintenance of a seed stock were the only motive for measuring the grousc crop it might be debatalle whether the results would be worth the effort. One could easily "take what the gods send along", shooting hirds when they are abundant and passing them ly when but few can be found. But the preservation of a seed stuck is not the sole reason. Only by knowing their size can ahove-average crops be utilized to the best advantage. And conversely, such knowledge cnables an administrator to make necessary allowances for a year of poor productivity to prevent an unwarranted open season from cutting into the brood stock. Furthermorc, in addition to the huntable surplus, a record of population trends from year to year is also important in evaluating the results of past regulations. And. perhaps most significant of alt on managed areas. the measurement of the gronse crop is the yardstick by which the productivity of habitat improvements may be appraised.
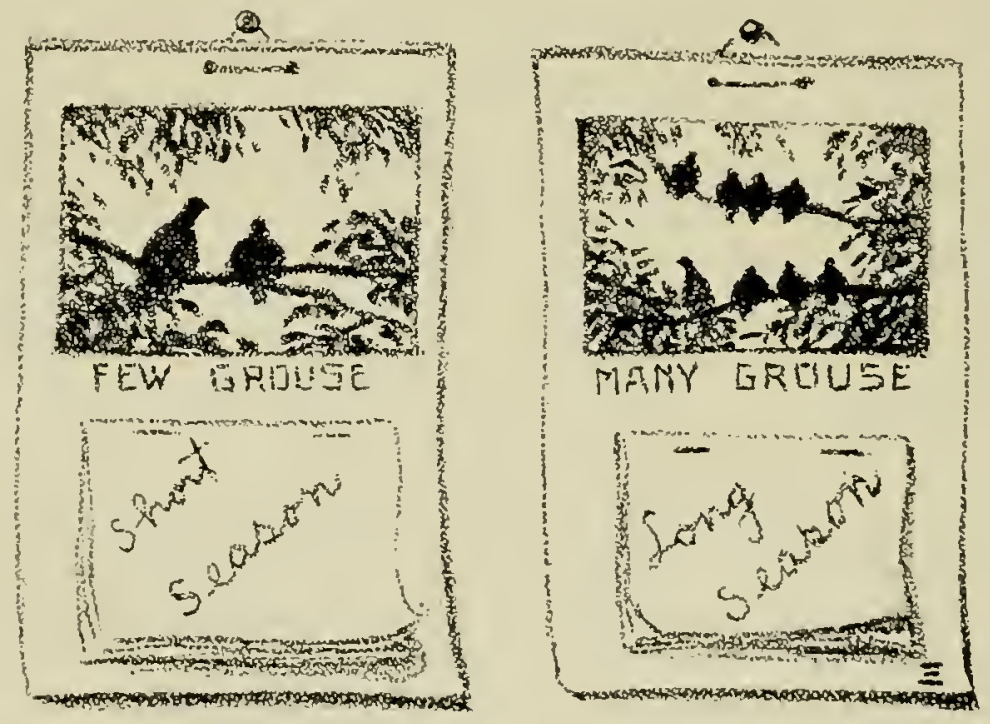

But it is seldom an easy job to determinc, with even fair accuracy, the harvestahle crop of any game specics. Leopold" singied out the ruffed grouse as "conspicuonsly difficult to cent. sus ly ordinary methods". The aduits do not covey like quail or form packs as do prairie chicken. In the fastnesses of their range, where they are little hunted, they are easily trapped. But where they have come to know hunters their wariness and trickiness is legendary.

During the fall and spring, the most significant census periods, many hirds frequent heavy cover in which, while often heard, they are seldom secn. Nor are the sex ratios casy lo ascertain liceause the birds look so mueh alike. White they are not migratory and exhibit no cxtended seasonal movements, they are molile over fairly large territorics. thus seattering the individuals widely enough to make funding them often diffieult. To complicate matters further they are predictably mureliable as to their decision to fly at onc's approach or to lie elose.

Furthermore, adjacent coverts of comparalle quality. even thugh exhibiting similar trends in abundance, are usually at different relative population levels in any one ycar. One covert 
may be teeming with birds, another at or near a low point. All these characteristies combine to make a census notably difficult.

Yet the picture is not all dark, otherwise the Investigation could have learned little of the characteristics of grouse populations. The birds are sedentary in that the adults seem to establish certain territories. When caught near the edge of these they tend to turn back. The fact that individuals or groups of birds are usually scattered makes it easier to avoid duplication once the extent of their territories has been learned. Furthermore the males establish drumming logs which they use regularly in the spring. Likewise, the females nest for the most part in predictable portions of their habitat though their numbers cannot be counted at this time lyy such an index as the elocker droppings (enlarged droppings from nesting birds) of the red grouse of Scotland which commonly leaves them at the same place each day along watercourses.

\section{Determining Grouse Populations}

Reports of interested observers, game protectors and other field workers have commonly formed the basis of abundance estimates preceding the fall hunting season. If ruffed grouse were as predictal,le in their increase as Scotch grouse we, like the British. might rather estimate the fall crop from the number of brceding birds in the spring. But there are more accurate ways of arriving at such an inventory, although none of the gronse census methods so far developed is without serious drawliacks.

The birds are generally too widespread to make practical the expensive direct count practice* used by the Investigation on its study areas. True. such complete censuses are quite workable for small areas providing funds. trained manpower and direction are available. On large tracts the time required, as well as the costs, is prohihitive.

The next most accurate procedure is to estahlish a series of sample plots in representative grouse habitats to he measured yearly by the complete census method. This presupposes that the coverts selected have been surveyed in advance and are normally found in carry large numbers of birds. The difficulty here lies in the number of such sample plots which must be covered to give a balanced picture. On a 5.000-acre area. for instance, at least at dozen would probably be necessary. This would make the number prohibitive if a county or a state were involved.

Because only highly productive areas are chosen, this method will yield a figure far in excess of the actual population. Used as an indicator of abundance trends, however. it is apparently fairly relialle.

King $^{378}$ developed a somewhat different application of the sample plot method for Minnesota conditions by dividing the area to be censused into 40 -acre blocks the houndaries of which are followed in making the survey. Figuring the average grouse flushing distance from those recorded each day the proportion of the total area covered is computed by nultiplying Iwice this distance by the length of line covered each time the survey is carried out. The amount of each type of cover over the entire area is established by a type survey. The strips are "walked" at intervals and a record kept of the number of grouse flushed within each type. By comparing the number of hirds flushed per unit of each type within the strips to the total of each on the area. an estimate of the total birds to be found in each type may be secured. These added together give an estimate of tolal area population.

* See Appendir, p. 699. 
This method is useful where a considerable uniformity of cover exists and populations are relatively high, hut otherwise the probable error is too great. It is not suitable to the well mixed coverts characteristic of the principal gronse territory in New York. Its weakness lies in the fact that in this kind of cover such a system of strips seldom intersects enough well populated habitats in provide a number of flushes sufficient to avoid large errors in compulation. And to include a larger proportion would require an undue amount of labor sine carh strip must be worked at least three times 10 secure a reasonably accurate estimate of the birds accupying it.

Relative abundance from year to year hut not total numbers can often les estimated after the hunting season by requiring that kill records he kept. An example of these covering 17 years for New York is found in Chapter IX. p. 372. Though many hunters do not report their take accurately. the proportion of error remains relatively constant thus providing rea. sonably accurate trends. The largest defects here are that such information is not arailable in time to be useful during the season in question. and that a good kill one year is no guarantec of the presence of many birds in the coverts the following fall. The length of open seasons. as well as the number of man days in the field. must also be taken into considera. tion.

Other indices of production such as hrood and nest counts are occasionally useful where considerable trained lalor is available and birds are to be found in sufficient numbers. In using the results as indices. however. a correction for the loss occurring hetween the census and the harrest period is necessary. a diffeult job since this figure may rary widely between years.

Fnough has been sail to make it apparent that no one census method applicable to all conditions is to be found.

Where a research problem ropuires an accurate determination of breeding and of earh fall populations and the necessary expenditure is justified. the complete census based on three cloesely spaced coveraces of an area has proven satisfactory.

Probalsl the most practical method of judging the general prospects for the hunting season in lecal coserts is through a late August lowed count. Enough time must be spent to cover the area thoroughly, particularly young growth and "edges". Better results will he oltained if two or more individuals work together. The mumber of broeds found. together "itl the arcrage number of hirds in each. will indicate the general population level. One must remember. however. that mus hrouls will have broken-up and the hirds lecome seattered ly the lime the hunting season opens. Furthermore. they will seldom be found in the same places. Nevertheless, if such a practice is continued sier a preriod of years in the same area. informalion secured in this mamer should provide a vahable index.

Ouer more extensive areas one munt le content with estimated abundance. For lhis a combination of a large number of random ol ervations, backed up ly a brood count in late summer or early fall on an adequate number of representalise simples of ordinaril! wellpopulated habiats will usually laty the hasis for arriving at an inder suffeiently good to judge the harreablile erop.

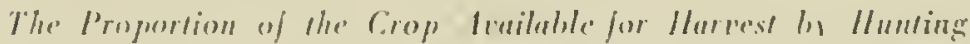

If all grouse habitats were fully socked, the entire inctement each gear. satse only that

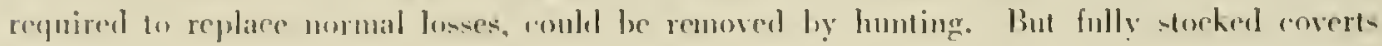


neither occur frequently nor do they usually maintain themselves as such for long. at least in the Northeast. The proportion available for harvest, then, is normally something less than the total increment. Theoretically, as the density approaches the maximum number of birds a covert will hold, an increased proportion of the birds may he harvested.

But in actual practice the carrying capacity for many habitats is so low that, even when well stocked ( $f(r)$ such coverts), few or no birds may be taken by man without running the risk of reducing the total population to a point where maintenance of the seed stock is endangered. Just where this point lies has not been accurately determined. It is certainly dangerous, however, to reduce the numbers over a sizeable area below one bird to 30 acres of grouse habitat.

If it were possible to determine accurately the carrying capacity of individual grouse coverts, as well as the degree to which the fall population approached or exceeded that figure, one could then closely estimate the number of grousc available for harvest by the hunter and still leave a reasonable seed stock. But the ability of an area to support grouse changes, even from year to year, with the weather, with predator-huffer relationships, and with cover succession. Furthermore, the cost of detailed censuscs is prohibitive except on relativcly small areas.

Thus a more practical, if less exact. method is here suggested. Its hasis lies in part on

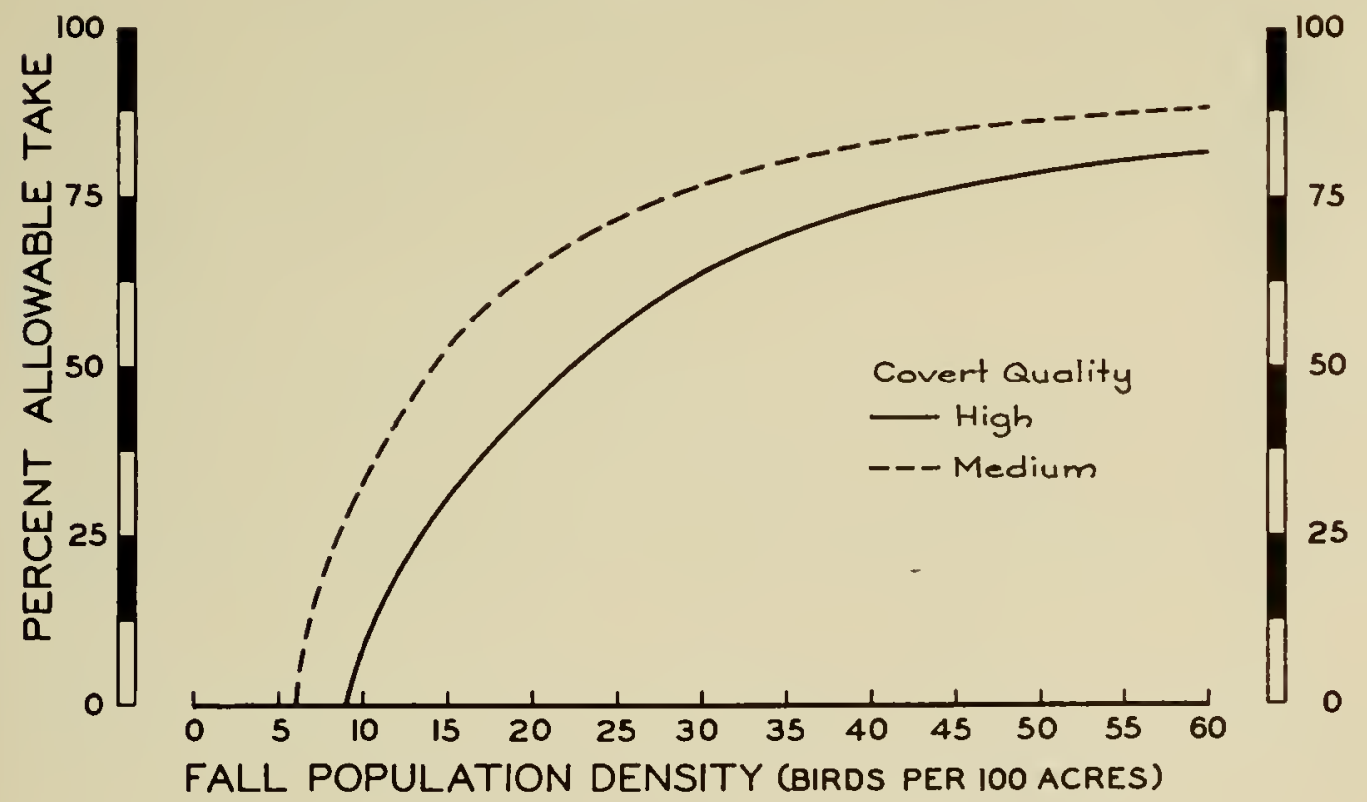

FIGURE 70. APPROXIMATE MAXIMUM ALLOWABLE HARIEST BY HUNTING ACCORDING TO DENSITY OF FALL POPLLATION

measurements of grouse productivity* made during the Investigation, in part on that indefinable product of experience called "grouse sense". In utilizing data from the study areas it las been necessary to make certain assumptions and judgments. The accompanying chart must. therefore be regarded as the best interpretation the authors have been able to make 
covering their observations to date. Nevertheless, it is conservative and should serve as a valuable guide to the interested game manager.

This sliding seale of allowable take. as shown in figure 70 , requires for its application only an estimate of the total fall population in relation to the size of the area involved (birds per 100 acres) and an appraisal of the general quality of the coverts on the area. Only dala for high and medium quality coverts have been used, however, since it seems unlikely. that intensive management of poorer areas for grouse will often be undertaken.

Under this yield tahle, when grousc are abundant or scarce, the take may be correspondingly large or small. For instance. from a 2.000-acre tract of high quality coverts supporting a fall population of ten grouse to 100 acres or 200 birds in all. 9 per cent or 18 birds might be taker. Were the population twice as high $(20$ to 100 acres $)$ the allowalle harvest would approach 50 per cent.

One may wonder why it is recommended that hunting be suspended on a good area when the birds are still more plentiful than on a medium area where a take is permitted. But. if a fall popnlation on any area were reduced to the lowest point from which it might he expected to recover, one could expect little or no harvestable surplus the following year. The levels below which hunting is not recommended, therefore, represent populations which should, with average natural losses, produce enough birds the following fall to insure an adequate breeding stock. This level is lower for coverts of medium quality since the overwintering ability of such areas is somewhat less than for better habitats. Of course, the latter conld safely be rednced just as low or lower. But to do so would result in reducing the general population level they are capable of supporting. One must also remember that. even though a smaller proportion of the population has been taken when hunting is suspended on the good area. the artual mumber of linds harvested is usually greater.

\section{likgulathon of HINTw:}

Hore exact regulation of the number of hirds taken by hunting than can be accomplished ly executive action through selting open seasons and bag limits will rarely be warranted over large areas. On local units under intensive management. however. it may sometimes he desirable to limit the kill to a predetermined number hased on the known harvestable surplus at the heginning of the hunting season*. The ncet for supplementary control on a managed area implies a very high hunting pressure which, operating freely. might endanger the maintenance of an adequate brood stock.

The simplest way of accomplishing this aim is to restrict the number of hunters or the size of their take or both. In order to carry out such limitations one must lave complete eontrol of trespass on the area. The land must he posted within the legal requirements of the state law and must he patrolled to prevent poaching. Some system of ehecking hunters in and out of the area is also needed in order that records of the harvest can he maintained. When these records show that the allowalle take has heen atlained. hunting of grome should be sinpped for the year.

The point may be raised that, over an area. certain good coverts. being in the productive phase of their cycle. are well storked while whers. equally good, are hut sparsely occupicd and should therefore not be lunted as intensively. Theoretically this is truc. But in prac. tire over large areas it $i$. of course, quite impossible to limit the intensity of the hunting on 
an individual covert. Nor is it necessary. Many birds of the year do not establish territorjes until after the hunting season and must be depended upon to fill in the gaps where huntertake may cut too heavily into the seed stock in individual coverts. This is not impractical for the youngsters will range widely during both the fall and spring shuffles in search of situations to their liking. Furthermore, hunted grouse rapidly hecome wilder. Under such conditions, the birds of the year may be expected to seek less heavily hunted coverts, thus making, as old grouse hunters know. an excessive harvest unlikely except in the most favor. able situations on small areas.

An indirect means of regulating the effect of heavy hunting pressure is ly insuring an adequate seed stock through the medium of well distributed refuges.

Theoretically, if the grouse on an area were equally distributed and half of the area was in refuges, while hunting was permitted on the other half. then at least 50 per cent of the population would remain after the hunting season. Actually. however, the distribution of hirds will seldom be constant enougl to make this true. Furthermore. the elimination of hunting on the refuge does not insure that a high mortality of qrouse will not nceur from other causes. One must also recugnize that. pren if no grouse were lost from the refuges, it does not follow that the birds on these units wuld restock the hunted area as desired. Another factor limiting the feasibility of this metlow in the cost of estahlishment and patrol. Nevertheless, on areas of excessively high hunting prensure where adequate natural protective cover is scarce. refuge units may be established for the benefit of hoth grouse aud other game species.

Yet one should not forget that regulation of the harsest. like all the other management principles presented in this book. must depend in the fnal analysis on the skill and understanding of the one responsible for its planning and supervision.

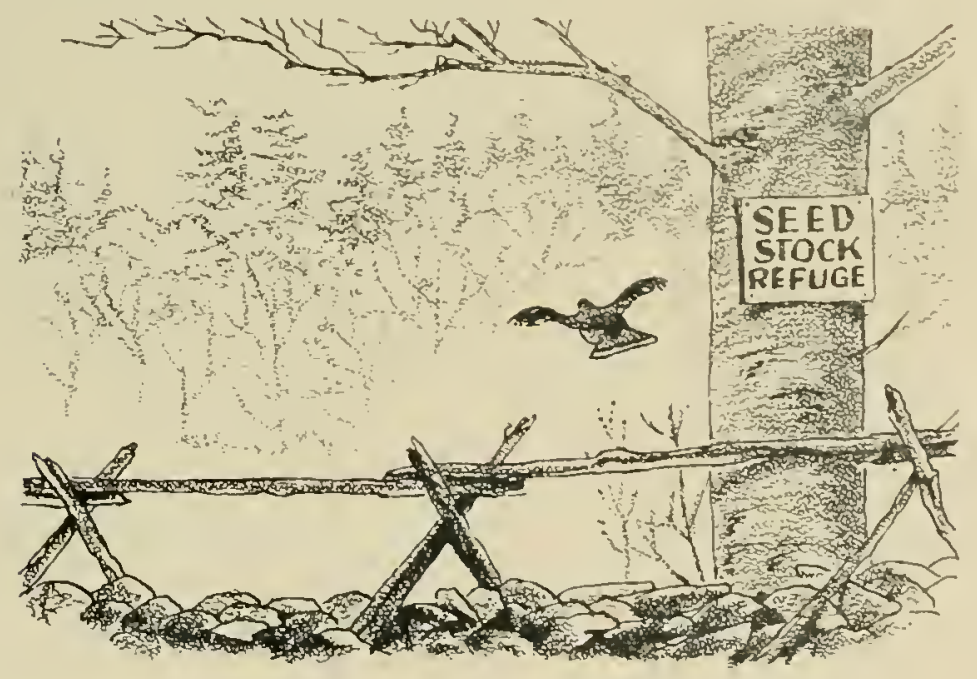





\title{
CHAPTER XVIII
}

\section{COORDINATING GROUSE PRODUCTION WITH OTHER PRIMARY LAND USES}

By Frank C. Edminster

\author{
FITTING GROUSE NEEDS INTO MANAGEMENT OF PUBLIC LANDS
}

Gane Lanins - Public Forests - Parks and Forest Preserves

COORDINATING GROUSE PRODUCTION WITH PRIVATE LAND MANAGEMENT

Lands Ownen by Individuals - Lands Owned by Corporations - Soll Congervation Districts - Forest Districts - Sourcrs of Tecinical, Aid

THE FUTURE

\section{S \\ SUMMARY}

The type of ownership. as well as the primary use of the land, is an important factor in coordinating grouse management with other land use practices. (p. 682 ).

On public lands in grouse range, where primary land use is for game. it is merely a question of halancing the requirements of the various species. 1p. $6 \$ 21$.

Areas not in grouse range but mainly adapted to waterfowl and farm game specjes will offer little opportunity for practical grouse production. (p. 6833 ).

The largest public areas are forests, in which are often found real opportunities for coordinating grouse production with the primary use, timber production. (p. (883).

Inblic interest is best serverl by producing both timber and game crops with a fair regard for each. (p.683).

The degree of correlation to be sought between grouse management and wood production is a matter of policy and is administrative in nature. (p. 6.83).

In portions of a park, managcment of its woodlands may well incorporate measures advantageous to grouse. (p. 681 ).

The forest preserve type of park, in the Northeast, is all grouse range and is capable of great - improvement. (p. 684).

National Parks present essemtially the same prollems for grouse management as do forest preserves. (1.685).

Coordinating grouse production on privately owned lands is vastly different than on public lands; a public agency has a responsibility to the people not felt by private owners. (p. 685). 
Interesting landowners in practiding erronse management on their lands is primarily a matter of eclueatiur. (p. 685).

On corporate lands, grouse mandement mily best he realized through desirable practices for timber, livestock or crop production as well as for grouse. (p. 686).

Catering to the hunting fraternity builds goodwill for corporate owners of large land areas. (1). 686).

Soil Conservation Districts and Forest Districts offer an opportunity for landowners to carry ont soil, water, forest, and wildlife conservation in a coordinated program with the aid of state and federal conservation agencies. (p. 686).

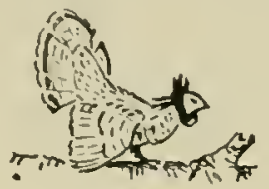

The ruffed grouse is but one of the useful game species produced in most woodlands. Likewise, game, as a group, is lut one of several important natural resources that are derived from the land. It is evident that the degree to which grouse needs may be worked into the handling of an area will depend, to a large extent, upon the primary uses of the land and the ways in which these uses conflict with grouse interests.

Since the grouse is a resource of impertance to the public at large, its development is of great social importance as well as of interest to landowners. Thus, the type of ownership as well as the primary land use is an important factor in coorlinating grouse management with other land use practices.

\section{FITTING GROUSE NEEDS INTO MANAGEHENT OF PUBLIC LANDS}

P'ublic lands are of many sorts. acquired for a wide variely of purposes. The Federal Government owns land in vast acreages for national forests, and in small areas for light. houses, national parks and monuments, prisons, customs humses, and waterfowl refuges, which are just a few of the hundreds of types of use of land ownerl by the United States. Similarly; the State acpures land for many purposes. some of them paralleling feleral uses. Forests, penitentiaries, parks, lighways, eanals and game lands are a few examples. Among the smaller units of erovernment. the counly is must likely to own lands extensively. However, other govermmental units such as townships and conservation districts many also have lands of various sorts under their control.

A large proportion of these pullie lants will not contain inportant grouse coverts. Offselting this. those that do include gronse halitats are usually among the more extensive linldings. Of greatest importance are game lands. public forests and parks.

\section{GAME J JANDS}

There slould he little diffieulty in meting grouse cover requirements on most game lands. Where the primary land use is for game, it is merely a quention of halan ing the requirements of the various species. The eonfliets are less likely to be common or serious than on other lands. Within this limitation anything the grouse needs may he provided, limited. of enurse. lyy the restrictions of economie feasibility.

In the Northeant. the grame and fur animals mus commonly found on grouse range are cot. 
tontail rablit, white-taited deer, gray squirrel, woodcock, varying hare, raccoon, mourning dove (a game lird only in the south), black duck, beaver, red and gray foxes, New York and small lowwn weases, skunk, muskrat and mink. In some places the pheasant overlaps the fringes of grouse range. Only the first six are usually of enough widespread importance to seriously affect land management problems.

In their lroad aspects, the needs of rabbits, deer, squirrels, woodcock, hares and 'coons are much the same as for grouse. They occupy, in part at least, the same habitats and their corer needs are similar in many respects. Clear-cut plots that are good for grouse are likewise useful to rabbits and deer. Spring nesting grounds are good gray squirrel cover. with due regard for denning facilities. Winter shelter for grouse will serve the same purposc for deer, hares and cottontails. In most ways the one pattern of land use fits the group to a surprising degree.

In minor details there must be adjustments, some of which may affect the grouse. If beaver are stocked they may destroy valuable fall and winter food in popple groves. The beaver may also furnish desirable openings by flooding and killing small areas of woodland. These and similar interests must be reconciled in the overall plan. Generally. the broadening of the resource base, as by the addition of heaver, will be warranted for the development of more favorable conditions for native species, eren though it may mean a fow less grouse.

On game lands not in grouse range, or in marginal grouse range, the land use pattern may well be unsuited to the species. Arcas mainly arlapted to waterfowl and farm game species will offer little opportunity for practical grouse production. Here there is no problem of coordination insofar as grouse are concerned.

\section{Public Fonests}

The largest public land areas are in this category. Here one often finds real opportunities for coordinating grouse production with the primary use of timber production. This comes about not only because of the extent of these areas but because much of this land is in regions where grouse can be produced in significant numbers. Management of public forests has given but little recognition to the development of secondary crops. such as game and recreation, until very recent years. Nuch more progress can be made in this direction.

Coordination of grouse requirements with tumber growing implies that some modifications in the plans for developing wood products are needed in order to produce on the same land a reasonable crop of grouse. It also implies that the public interest will best be server by producing the two crops with fair regard for each, rather than concentrating on the one alone. This decision is fundamental.

The technical methods of correlating grouse management with wood production have already been fully covered. ${ }^{*}$ The prohlem here is one of policy, and is administrative in nature. It is apparent that the varions modifications of forestry practice neederl in favor an increase in grouse will only be realized if it is the policy of the agency handling the lands to include these provisions in their various plans and operations.

As an example, the planting policy of the New York Conservation Department Division of Lands and Forests on State reforestation areas may be cited. In the early years of the acquisition and development of suhmarginal farm lands for State forests, it was the standard practice to plant all open fields solidly to trees-excepting, of course. lanes needed for fire 
lines. Since these areas were also "Public Hunting Grounds", this policy was of great concern to many sportsmen. As a result of many conferences between interested foresters and game managers the policy was changed to further both interests. Among the screral revisions was one to provide that a chain width (66 feet) be left unplanted on each side of all roads and fencerows. Thus a network of hardwood cover was assured through the new coniferous areas since most natural reproduction would be of that type. Also it provided an opportunity for shrub borders to be planted or open edges maintained in accordance with the grouse or other game needs of the area.

The important thing to emphasize here is not only that an adjustment in favor of grouse was made but that it was only possible by adjusting the policies of the agency. It is in the top office that the coordination of grouse production with forestry must originate for public forests.

\section{Parks and Forest Preserves}

There are two types of state parks in New York and they differ from each other markedly. One is the typical reservation of a unique spot for recreational use, such as bathing beaches, beautiful ravines, picnic groves and the like. In the second class are extensive forest areas that include great opportunities for recreation. The Adirondack and Catskill Forest Preserves and the Allegany State Park are examples of the latter. Their management differs from that of a public forest in that they are not managed for the production of wood products. In fact, in the Adirondack and Catskill parks, the State Constitution expressly forbids the harrest of live trees, which includes a large share of practical forestry, as well as those game management practices involving improvement of the environment by controlling the vegeta. tive cover by cutting.

The ordinary state parks are areas of concentrated human activity and hence it has been necessary to prohibit hunting. Even where grouse range exists in a park, this obviously limits the opportunity for correlating grouse production. since the normal objective of pro. duction is harvest by hunting. The cause is not wholly lost. however, for the grouse is also a first class asset to a park just from the natural history point of view. If a park area can support grouse for people to see, the usefulness of the park for recreation is thereby enhanced.

Exccpt within the highly developed (and often artificialized) portions of a park. the management of park woodlands may well incorporate measures advantageous to grouse. When a woodland horder is being landscaped, it can well become a useful shrul, border (fall feeding ground) for grouse hy a judicious selection of shrub species. When a nature trail is being constructed, it maty well provide desirable openings for the grouse.

These methous should be worked into the development plan for the area with deliherate consideration of the desired oljectives. The maintenance problems must likewise be cared for by specifie practices to he followed in the operation of the park.

The forest preserve type of park presents a greater opportunity for producing grouse than parks of the kind just mentioned. In the Northeast, it is all grouse range. usually with a rather low carrying eapacit? hut capahle of great improvement. On the other hand. most grouse managenent in such preserves in New York State is impossible uwing to the legal limitations on use of the areas. Most of the forest preserve parks are open to hunting. however. 
In wooded land. tree cutting is essential for the development and maintenance of grouse cuver values. With cutting of live trees explicitly prohibited, grouse management, in fact most game and timber management, is exceedingly limited in scope and the opportunity for multiple-use of the land is small.

The wilderness areas of our National Parks present essentially the same problem in so far as grouse are concerned as do the forest preserves. The objective being to maintain primitive conditions as nearly as pussible, one cannot expect large grouse populations. Some National Parks offer more opportunity for coordinating grouse production with recreation. especially large forested areas. Here the problem is similar to that of public forests, excepting those portions that are intensively developed and where hunting is not allowed.

Most other types of parks, city- and county-owned arcas primarily, are small and are usually not suited to producing grousc. Generally they are situated where grouse have long since been excluded by civilization.

\section{COORDINATING GROUSE PRODUCTION WITH PRIVATE LAND MANAGEMENT}

The problem of working grouse improvement measures into the handling of private lands is vastly different than it is with public lands. With pullic lands, each agency may handle large areas and, once adequate policies and procedures are established, they become widely effective. A public agency has a responsibility to the general pullic that is not felt by the private owner. Furthermore, a public agency such as a Fish and Game Commission has a specific responsibility to the sportsmen.

\section{LANDS OWNFD BY INDIVIDUALS}

Today there is very little in our civil laws that requires private land owners to use conservation practices. Each man is King on his own land and he can do about as he wishes, with a few exceptions. He cannot always, in the Northeast at lcast, burn his woods at will. He must keep his livestock on his own land. He may have to accept certain measures in the pub. lic interest, such as the elimination of gooseberries and currants for blister rust control. But even therc, he doesnit have to do it himself.

Many of the acts he may commit on his land may be detrinental to grouse. Some may le destructive to his neighbor, or to the general public interest. But except where specific personal damages, not caused by "an act of God". can he proved to have resulted from his negligence, there is no recourse for either his ncighbor or the public. He can graze the woodland, clear-cut it with destructive lumbering practices and otherwise eliminate grouse cover values and no one can say him nay.

Socially-minded pcople will agree this is not as it should be. Some day there may come to pass a change whereby conservation ordinances will prevent such destruction. But until there are greater limitations in the use of land and its resources by the individual, gronse and other game production will be either accidental or the result of personal interest.

The development of the interest of the landowner in grouse production to the end that he will practice grouse management on his lands is primarily a matter of education. If he is interested in hunting, he may be a willing student. If he just likes to have grouse around he may likewise do many things in their favor. If he has no special interest in having more birds. the only way that heneficial practices can be coordinated into his operations is by indirection. He may benefit grouse through means aimed at some other objective. 
When livestock are fenced wet of a woedland as a measure in aninal husbandry, grouse may be benefitted just as much its though it were done deliberatcly for their interests. Shrul, borders that are planted (or developed ly cutting) and maintained for woodland protection, for crop field protection, or simply for their beaty may be just as useful to grouse as though they were planned for them. By edncating farmers and woodland owners to good land management practices, much improvement of grouse cover may be accomplished.

\section{Lands OWned bY CoRporations}

Private land has been discussed as a problem of individual wn nership. Much of this land tuday, especially large forest lands, is owned by corporations or other similar groups. Here one eannot appeal very strongly to personal interests for the land to them is an impersonal matter. Things which arc not good business. that is, ccononically profitable. are not likely to demand their attention. Since grouse are a somewhat undependable crop at best, and in any case are owned by the Statc and may not be commercialized, grouse manarement in itself has not to date been considered a profitable enterprise.

Altaining grouse production on corporate lands may best be developed through practices that are desirable for cither timber, livestock or crop production as well as for grouse. Over and above this group of agricultural and forestry opcrations, some modifications in favor of grouse may be promoted through the public spiritedness of the organization. More and more companies are realizing the value of good public relations and those operating large land areas shonld certainly find adequate reason for catering to the hunting fraternity.

\section{Soll Conservation Districts}

The history of conservation endearors on private lands shows clearly the need of technical assistance on the ground if owners are to becone practicing conservationists. The common educational methods are not enough. Formal schooling, written anticles, bulletins and books, public demonstrations, radio talks, and the like, invaluable as they are, have not succeeded in stemming the tide of destruction of our natural resonrces-the land and its products. Ad. ditional assistance to private owners has becn provided in a number of ways in recent years. The furnishing of tree planting stock for reforestation is a good example. These seedlings are grown by statc nurseries and sold to the public for a very nominal fee to enconrage proper use of lands not suited to growing farm field crops. Farm foresters and district ganc managers provide technical arlvice tailored to the specific needs of each property so that the planting stuck may be must effectively used.

The growth of the national soil conservation program has helped to clarify some of the principles that are cssential for successful conscrvation work on private lands. Four of the cardinal points are: 11) conservation planning should be based on an aceurate physical inventory of the land. liy mapping the area according to its inherent capabilities, the proper use can he determined; (2) the varions seiences must be coordinated to produce best results. As an example, the needs for growing wood products and wildlife in the same woodland require the harmonious fitting together of the sciences of forestry and wildlife management; (3) the complete land ownership enterprise should be planued as a unit. All parts of a farm are interrelated as portions of a singke husiness. Only ly planning the entire farm at once can the proper land use and needed ronservation practices be assured: (1) relations among private lanlowners and conservation agencies mus be democratic.

This principle of a democratic approach to the conservation jol, on private lands de- 
sirves special attention. Fortunately, it has receiverl a lot of thought in the past decade. lı 1937 a number of states passed laws cnabling the estallishment of a new political subdivision called the Suil Conservation District. Now all 48 states have such a law. They vary somewhat in their specific provisions but all lave the same objective - to permit landowners to obtain help on conservation problems in an efficient, democratic way. New York's law was passed in 1940 .

The philosophy of the soil conservation district is to apply grass-roots democracy to conservation work. In the beginning, the stimulus for the creation of a conservation district in any area comes from the people. Through pelition, or by personal appearances before the county board of supervisors, they make known their desires. After adequate consideration by public hearings, the county supervisors decide liy rote whether the county shall become a soil conservation district. (In many states. a farmalle referendum ly hallot by the landowners is required).

During the period when interest in such a conservation district is developing, the Extension Service of the State College of Agriculture takes the leadership in a program of information and education. Later, after the district is created. this educational program is continued to encourage landowners to scek aid in conservation work. The directors of the district are appointed from among progressive. local farmers. They begin the work of the newlyformed district by developing a program setting forth the conditions that make conservation work urgent and the objectives of the district. Then a work plan is prepared to set forth the methods by which the district will operate, including the types of help that will be provided by the different cooperating aqencies. Experls from these agencies are orlinarily called in for advice in preparing these ducmments. When the organization is thus completed. the men, matcrials and equipment facilities are ready for husiness. Landowners may apply to the Directors for on-the-farm assistance in the plannine and extablishment of a complete conservation plan.

It makes little difference what conservation problcms an individual land owner has; they all fit into a sound plan for soil conservation. Thus, grouse management practices go hand in hand with the control of gully crosion, contour strip-cropping, and field drainage. The owner applies for ajd to the directors of the soil conservation district in which he lives. The facilities of the district, made availahle through its cooperating local, state and federal agencies. are applied to his farm on a voluntary hasis. A conservation survey provides the needed physical inventory. Based on this survey, and on the economic needs of the farm business, a complete farm conservation plan is developed by a planning technician. This service is generally made available to the district hy the U. S. Soil Conservation Service which is especially set up to carry out this function. Spccial senvices to implement the woodland and wildife phases of the conservation plan may be rendered ly techuicians from the forestry and game divisions of the State Conservation Department. Thus, the available conservation services are funneled to the landowner through the facilitating soil conservation district.

\section{Forest Districts}

A recent development that should become of great importance in grouse management in New York was the enactment in 1946 of the Forest Practice Standards Act. Its purpose is to provide a voluntary, cooperative program whereby over-cutting of woodlands may be avoided, forest product industries stabilized. and sound forestry encouraged. It provides for the establishment of forest districts, district forest practice loards to determine standards needed 
in forest practices, and a state forest practice board to review district forest practice standards and promote the welfare of these forest districts. The chairman of each soil conservation district within the forest district is antomatically an ex-officio member of the forest practice board to assure integration of the soil conservation district program with the forest practice standards developed for the area.

The State has been divided into 15 forest districts. Each has its own board consisting of three members from each county included who are appointed by the chairmen of the respective county boards of supervisors. Only one of these three may be chosen from the county boarl of supervisors. At least two must be resident woolland owners. The state board is made up of the chaimen of the 15 district boards plus ex-officio members, without vote, from several state agencies.

These district hoards determine the forest practice standards necessary for their districts. $\Lambda$ fter adoption, these standards are promoted by the district on a voluntary basis. However, woodland owners who desire the technical forestry services furnisheel by the district must agree to abide by these standards as a condition to the furnishing of the aid.

It is anticipated that these standards will he fairly simple and will have as their basis the control of fire and grazing and the marking of harvest trees by a forester prior to lumbering. This would assure adequate protection of these woodlands and the use of a cutting plan that would assure future productivity of wood products. These sorts of standarels fit well into the needs of grouse management. It is conceivable that the practice standards might go even further in areas of good grouse range and inclute more detailed cutting practices that would he definitely aimed at improving grouse cover. But that is still iu the future. We must wait and see how it develojs.

The significance of the soil conservation and forest district developments lies in the fact that they are symbols of a new conservation era. They are touls of society, developed to make conservation of these resoures a reality through a denocratic system. They represent substantial progress toward genuine working cooperation between the various interests concened. They facilitate the inclusion of gronse matnagement to any desired degree.

By the same token in other situations also it will be only through sincere. mutually coopcrative effort. both in planning and in action. that effective coordination ean be achieved. lake of such team work will result either in ineffectiveness or wasteful duplication. "Ding" Darling once said that ten thousand wild horses free on the range couldnit pull a rubbertired baby carriage. But harness these to pull logether and they can move "montains".

\section{SuRCES OF TrCHNical $A$ II}

The need for technieal assistance in comrdinating gronse management with other land nses has been moted. In New York the distriet game managers of the Conservation Department epresent the primary souree of such aid. Advice on special problems is av alibale from wildlife research personnel. distriet foresters and fores terhnicians of the same Deparment. and from the Extension Serviere of the State Colleare of Nerriculture. In eonnection with soil conervalion distriets in particular the U. S. Soil Conservation Servie is important. Valuable information can also be ohtinned from the U. S. Fish and Willlife Service. The fact that such assistaner is avalable. however. will result in no benefit to grouse or other wildlife unless it is actually put to use on the hand. 
THE FUTURE

The opportunities for integrating grouse management with other land use interests have been discussed earlier in this chapter. Similar possilbilities exist for other forms of wildlife. Means of implementing such coordination are being developed. It is up to us to make them work. The alternatives do not make a pretty picture. Either we manage our soils, timber and wildlife on a sustained yield basis through volnutary methods in a democracy. or we waste them to the point where we become a second-rate "have-not" nation, or we force restrictions on their use by government control, autocracy. conmunism. or whatever else you may wish to call it. Which will we choose? 


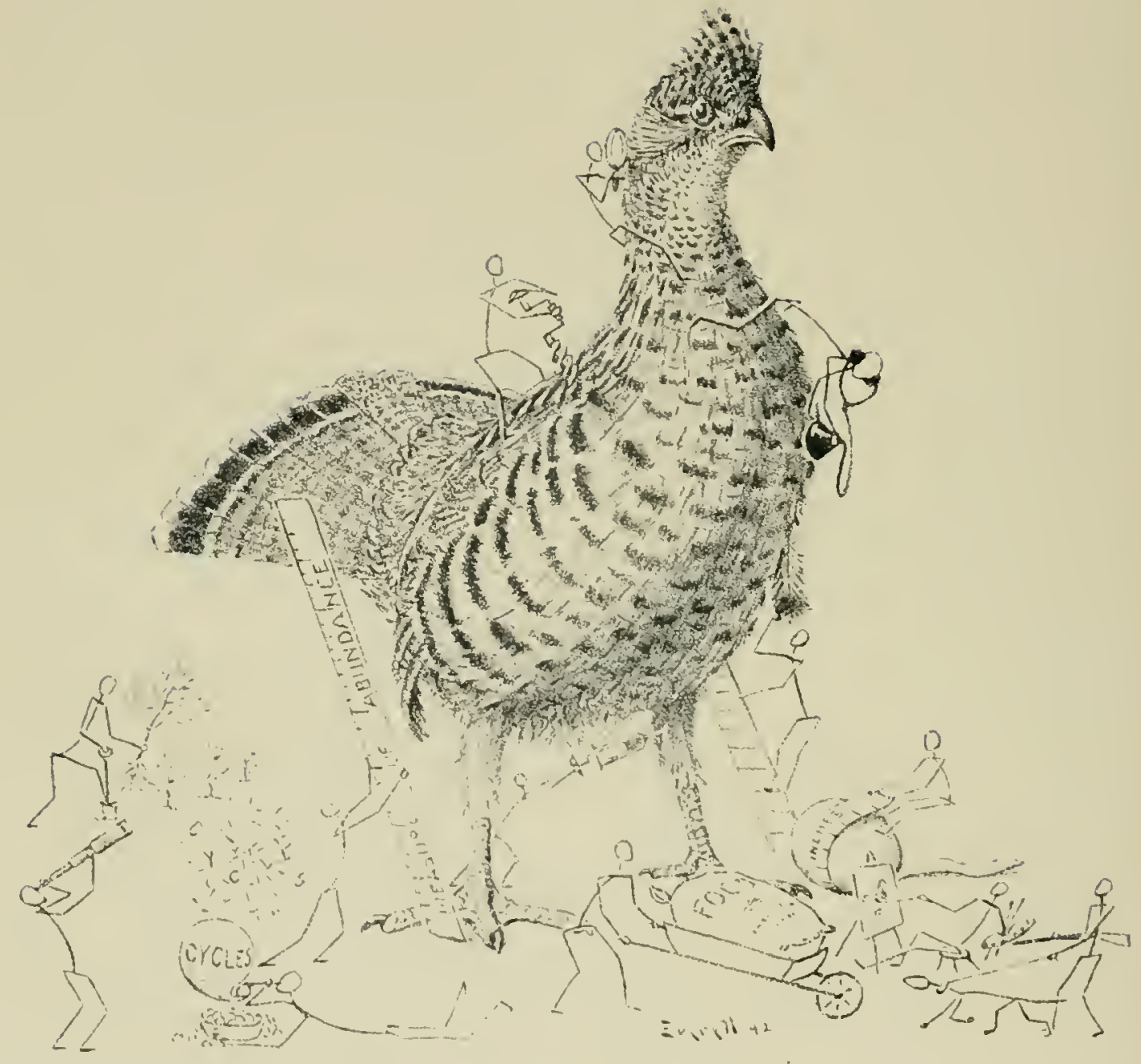




\section{IN MEMORIAM}

As we idly finger the pages of this book, our work seemingly done, we realize with a guilty start that, in the very last sentences we have left the poor grouse fluttering in the dubious care of the communists. Surely, this is no fitting end for such a gallant friend, the source of years of research, work and fun. It is our desire. as well as our duly. to make the parting fit the honor we owc him.

The Investigation has been cxlensive. We liave gonc back over twenty-five thousand years to dig him up. We've played with him among the Indians and pioneers: slaughtered him with sticks and guns, and trapped and sold him to greedy markets. We've invaded and destroyed his home and designed new mansions for him: sampled his food and preprared new menus: robbed his nests. arlupted his bahies and nursed them for hetter or for worse. We've tried to propagate and manage him. practiced cugenies on hin, psychoanalyzed him. probed his insides, studied his diseases and rejosed his parasites. We've consorted with his enemies. we've swapped stories and spun yarns about him.

We've thrilled to his quick wit and tricky flight; stood spellhound listening to his drumming and watching his love antics. We've discovered he's a healthy specimen and lost most of our preconceived notions about eycles and the grouse diseasc and pet fallacies of what causes the fluctuations in his abundance. IJe's still a mystery. still mpredictable and. because of our research, a higger, broader prollem than ever before.

With it all, we love him for what he has leen in the past, what he is in the present and what we hope he will be in the future. He may have thrown us for many a technical loss. he is a stuhborn sulject, lut science refuses in be discouraged-the work will go on.

No report or lrook will ever write finis to a scientifie subject as complex as is the grouse. Keen minds will continue to delve ever decper into this fascinating riddle. To them, and to you, oh reader, who has waded with us through this labyrinth, our deepest sympathicsand to the ruffed grousc our humblest regards.

THE AUthors. 



\section{PART IV}

APPENDIX 



\section{METHODS AND TECHNIQUES}

By Walter F. Crissey

\section{ORGANIZATION OF THE INVESTIGATION}

GENERAL METHODS

Selection of Study Areas - Mapping - P'ersonnel - Securing Orbervations Recording Observations

\section{SPECIAL TECHNIQUES}

Determining Shelter Relationships - Deterninisg Foon Relationships - Determining Weatiler Relationsilips - Determining Preidator and Buffer Relationsinips - Predator Abundance and Activity - Buffer Alundance - Food Halits of Predators Predators Responsible for Grouse Kills and Nest Destruction-Determining Fffect of Hunting - Determining Disease: Relationships - Estimating Grouse Popula. tions - Trapping and Marking, Grovse- Determining, Sax ani Age

\section{USE OF BIOMETRICAI, ANAL,YSIS}

Significance - Cini-Square - Analysis of Variance - Regrfission and Coririation

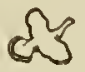

The success of any project is greatly influenced by the methods and terhniques employed. At the heginning of the Investigation there was a lack of standard means for carrying on sueh work since most of the pionering. upon which eflicient methods were eventually based, had only just begun. It was natural, therefore, that the process of standardizing methods, weeding out unsatisfactory techniques and the production of usalble knowledge should have gone hand in hand during the course of the study.

Both sportsmen and wildlife research workers are naturally interested in knowing how the records were collected and analyzed as well as what conelusions were drawn from them.

To that end. it is the purpose of this section to discuss briefly the organization of the Investigation and, in more detail. the methods which were newly developed or adapted from existing wildlife researeh techniques.

\section{ORGANIZATION OF THE INVESTIGATION}

The Ruffed Grouse Investigation was the direct result of the great searcity of grouse in New York State in 1927-28. At the request of a special committee of alarmed sportsmen* funds were provided by the 1928-29 Legislature for a thorough study to determine and evaInate as many as possible of the eauses underlying the varying abundance of ruffed grouse 
and, if possible. to find and develop means of producing and maintaining high grouse populations.

The Investigation was organized and has been directed throughout by the senior author Gardiner Bump. Field work hegan in March 1930 and was carried on continuously until September 1912. Artificial propagation studies and laboratory investigations of disease and parasitism were expanded with the estahlishment of the New York State Game Research Center in 1933. The analysis of data secured was completed in 1943 as was the first draft of this report. Publication was, however. delayed until 19.17 by the war.

The first step was to outline the problem and plan the work so as to secure the maximum information available. The work was organized around the following ten major factors which affect the production of grouse:
1. Physiology
4. General Habits
2. Shelter
5. Weather
3. Food
6. Predators

7. Parasitism and Diseasc

8. Man

9. Reproductive Capacity

10. Artificial Propagation (Replacement of seed stock)

These were in turn subdivided into 253 potential problems. The work was conducted and summarized largely around this original nutline.

Study areas were selected and tentative survey methods chosen 10 collect as much data as possible. As the information aceumulated. the important problems hecame more clearly defined. Techniques were checked and altered. where inadequate, to insure evidence that better represented the existing conditions and could he analyzed for valid conclusions.

As the study progressed and expanded it became evirlent that no one person could le responsible for all the specialized details. The responsibility for carrying on most of the field work was aceordingly divided hetween the two junion authors Robert $\mathbb{T}$. Darrow and Frank C. Edminster. Jr. The latter left the Investigation in 1937 and was replaced $h$ Walter F. Crissey. The following specialists were engaged either to direct work on specialized problems or to collaborate wilh the authors in their solution: food habits. John C. Jones: parasitism and disease, Dr. P. P. Lcrine and Dr. Frans C. Colule: artificial propagation. Dr. A. A. Allen. Farl R. Holm and Janet W. Bump; physiology. Dr. Wm. II. Long; embryology. Dr. Alexis L. Romanoff: pterylngraphy. John E. Trainer: anatomy. Dr. Divid E. Davis: hiometrical analysis of data. Dr. Mason Lawrenee and Dr. C. Mr.C. Mottley: and hiblingraphy. Dr. Mary Thornton and Nhert G. Hall.

\section{GENERAI, METHODS}

In setting up the Investigation there were certain general ennsiderations which preceded the actual work on specific problems. They included selection and mapping of representative study areas. chonsing of personnel. as well as deciding on the methods to be used in secur. ing and recording data.

\section{SFi.feTtoN of StITPY Areas}

Considering the State as a whole. three major regions were recognized on the lasis of habitat differences. The Adirondacks are distinct in comprisine extensive forest areas of a largely coniferons climax type and having a more severe winter climate: the Catskills arc a rugged region consisting of a heavily forested muclens suppurling a more predominantly hartwood cover. surcounded ly a zone where consideralle aqrieultural decelopment has taken place: the "Rest of the State". typified by the central aud Southern Tier plateatr. is character- 
ized by disconnected woodlots, primarily hardwood in composition. Accordingly, four primary study units*, one each in the Adirondacks and Catskills and two (the Connecticut Hill and Pharsalia areas) in the plateau region, were selected in order to facilitate recognition of any differences in relationships which might exist. Also, from time to time, special problems have been studied in other areas. The following important itenis were among those considered in choosing these areas:

1. Representativeness - whether typieal of the region in which situated

2. Size-sufficient to yield adequate data

3. Control-public ownership if possible

The major study area, Connecticut Hill, is located in the plateau section of southwestern Tompkins County, overlapping slightly into Schuyler County. The basic portion comprises some 2,200 acres of grouse cover with many intervening tracts of open land. Formerly an agricultural distriet, the farms have heen largely abandoned during the past 30 years. In consequence, the fields surrounding the woodlots are becoming overgrown with bushes and small trees. The woodlands exhibit a high degree of diversification and, in spite of having been extensively cut over for many years, contain a considerable admixture of conifers, chiefly hemlock. The topography is shown in figure $7 I$, and the relationship of wonded and overgrown land to open land in figure 72 . The cover type composition of a typical compartment is illustrated in figure $14($ p. 171$)$.

The Pharsalia area of some 2.100 acres lies in northcentral Chenango County along the divide between the Chenango and Otselic valleys. It is quite similar to Connecticut Hill but the woodlands are somewhat more extensive and contain a number of wooded swamps.

The Catskill area of some 850 acres is situated along the northern margin of the Catskill Region in southern Alhany County. Its woodlands are also broken up by intervening fields, but the latter are relatively less overgrown hecause most of the farms in the vicinity are still operated.

The Adirondack area is a forest tract of slightly over 800 aeres lying in an upland valley on the eastern slope of the Jay Mountain ridge in northeastern Essex County. A few small clearings along a road which partially bounds the area constitute the only open land present. Likewise the only overgrown land is found in conjunction with these clearings. The cover is mixed second-growth timber, conifers being chiefly spruce and balsam. The area also contains two large alder beds. The topugraphy of this area is shown in figure 71 and its cover type composition in figure 15 (p. 173).

\section{MAPPING}

The construction of adequate maps of the study areas eonstituted the next step preliminary to conducting freld surveys.

Starting from an existing base, details were usually filled in hy the "pace and compass" method although "tape and compass" lines were often used for greater accuracy. United States Geological Survey maps formed the base maps in 1930. but revisions and additions were made from acrial photographs as they becane available.

The degree of detail was controlled by the requirements of the research to be conducted. Where mere reconnaissance surveys were adequate, details were only roughly drawn in. Where the actual beation and amount of each cover type were desired they were mapped

\footnotetext{
* See figure 13, p. 111.
} 

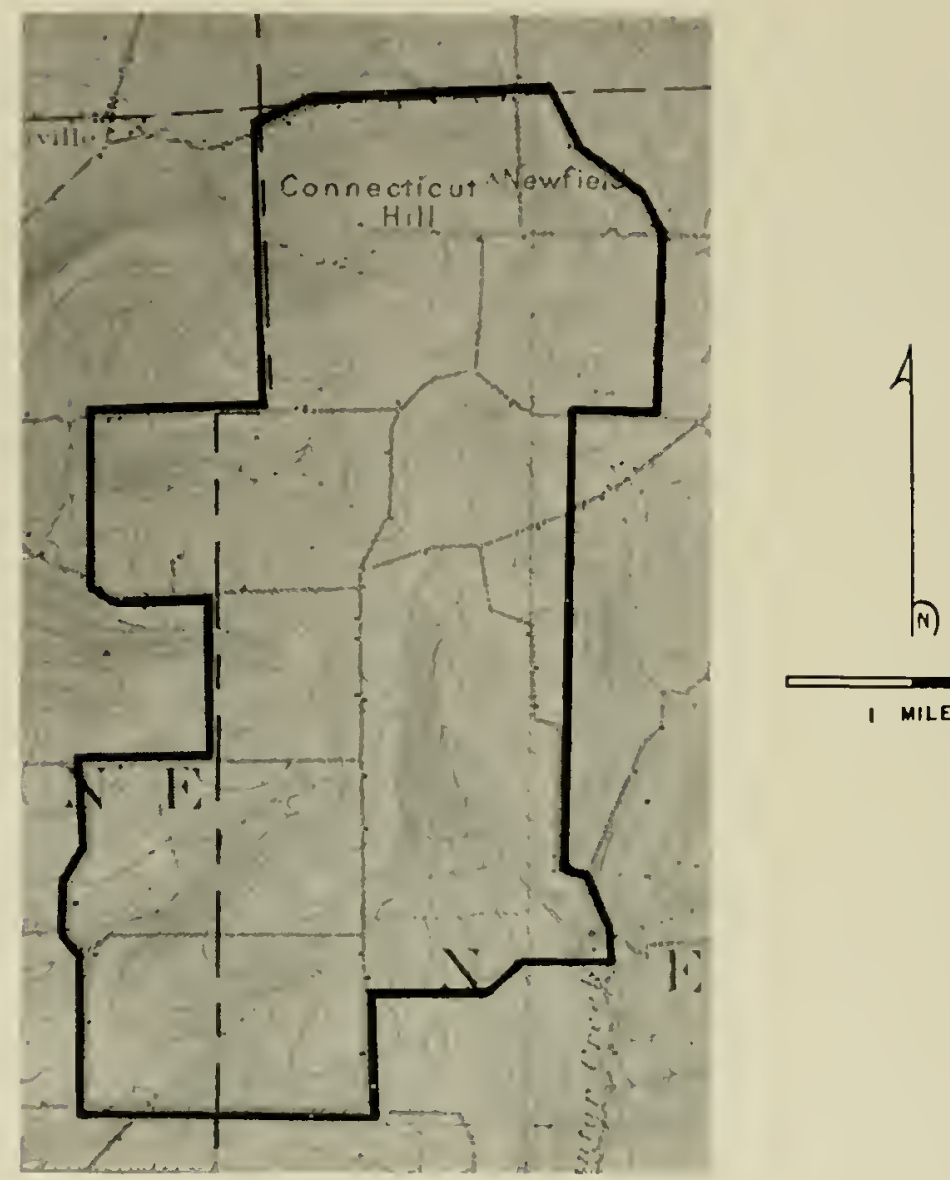

CONNECTCUT MLL STUDY AREA

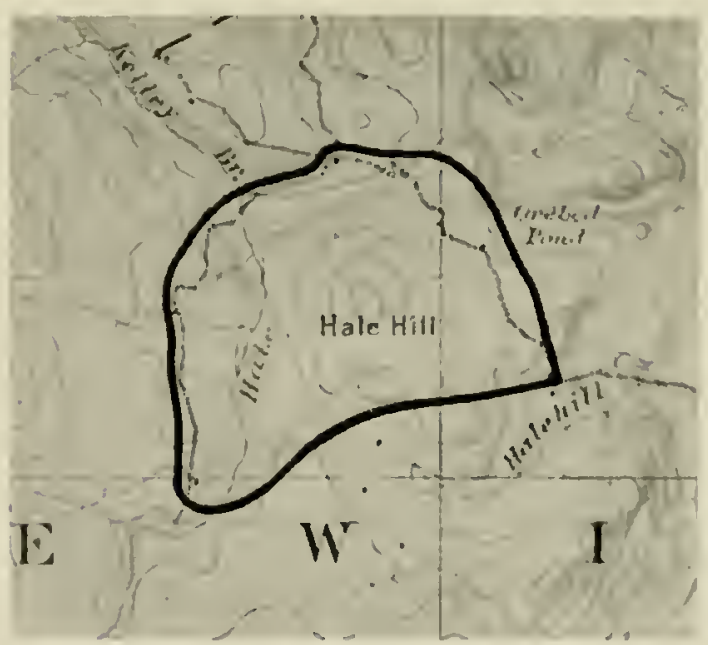

ADIROKOACK STUOY AREA

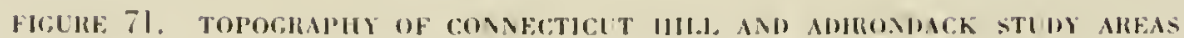




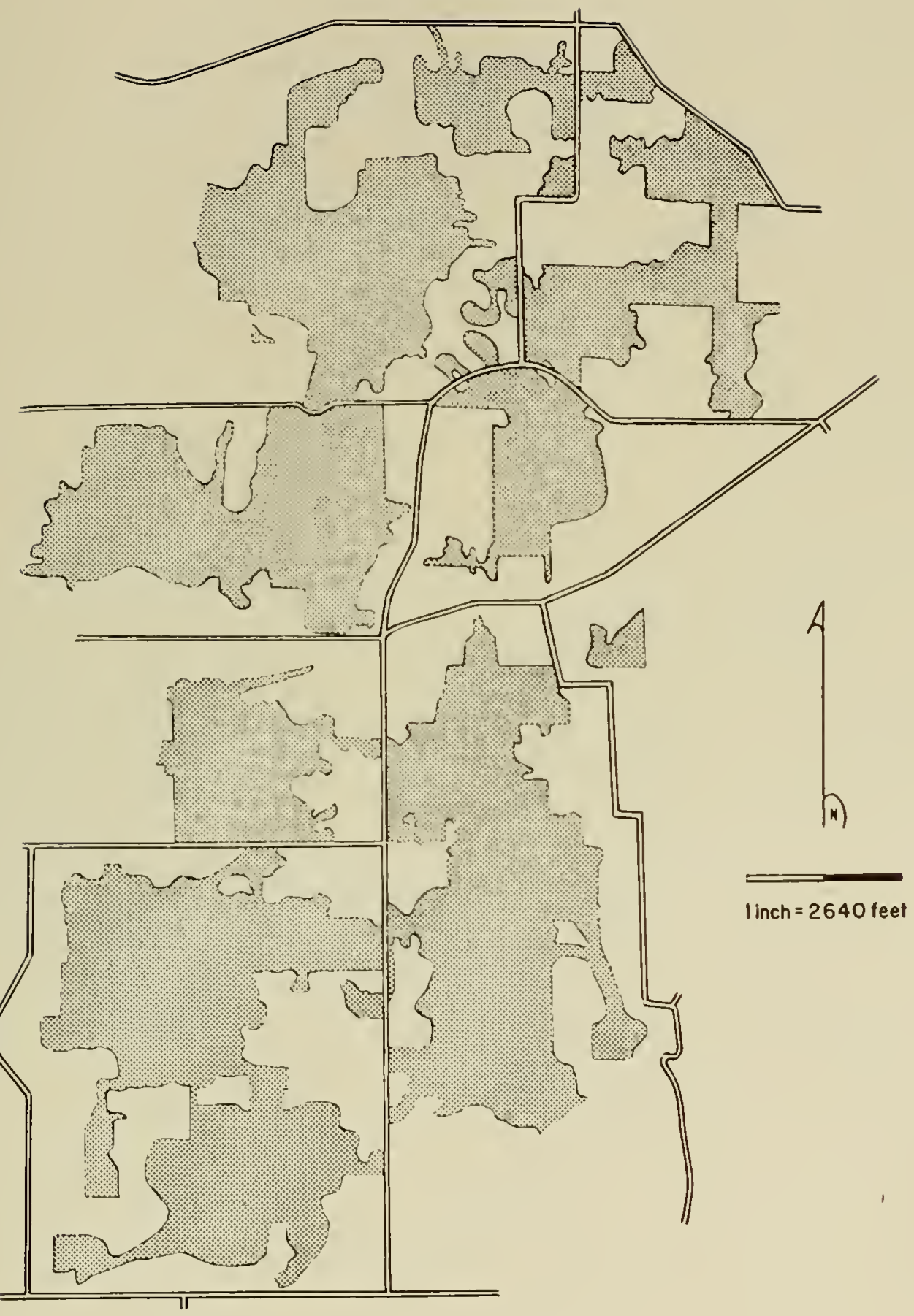

\section{Wooded a Overgown Land}

FIGURE 72. RELATIONSIIIP OF WOODED AND OVERGROWN LAND TO OPEN LAND ON CONNECTICUT HILL 
with greater care and accuracy. In the beginning it was thought sufficient to map specific cover units down to one acre in extent. Further work indicated, however, that units much less than an acre in extent influence the distribution of grouse, and the areas were accordingly remapped showing cover types to one-tenth of an acre.

Since records were desired, not only of the type of cover but also of such items as food and shelter and cover density, a fractional system of combining symbols deseriling these items was developed". That is, the cover type designation ${ }^{\wedge}$ was shown as the numerator with numerals representing cover density, food conditions and shelter value, in that order, as the denominator.

Cover density for each type was indicated by a classification rumning from 1 to 10,1 representing minimum and 10 maximum density. Thus an open grassy area, providing the grass was tall and thick, was given a density rating of 9 or 10 . A woodland, on the other hand, might be classed as 3 or 4 , if the crown cover were relatively open.

Food conditions for grouse, the second in the series of three symbols making up the denominator of the fraction, were indicated by numerals from 1 to 5. The following differen. tiations were recognized:

1. Poor during all seasons

2. Adequate or abundant during seasons when lype was used by grouse

3. Fairly adequate during all seasons

4. Adequate throughout all seasons

5. Abundant throughout all seasons

The analysis of shelter value was symbolized by the numerals 1 to 6 , again interpreted from the point of view of the grouse.

1. Adequate shelter absent

2. Adequate shelter scarce

3. Shelter conditions superior to 2 , but not yet adequate throughout all seasons of the year

4. Adequate

5. Abundant

6. Doninant to the exclusion of most food speeies.

In extensive units of a single type, the fractional symbol representing existing conditions of food, shelter and density was written in the proper location as the lood. shelter or density in that particular portion of the type changed.

As an example of the usc of the above system, a fairly dense piece of second growth woodland composed of beech, hirch, hop-hornheam, maple and a few scattered hembek (food fairly adequate all seasons and shelter adequate) would he described as follows: $\frac{E}{8.3 .3} \cdot A$ 20-year-old pine plantation. on the other hand, wonld probably be designated as $\frac{11}{10.1-6}$ while an overgrown linshy field might be $\frac{c}{4-2 \cdot 1}$.

To facilitate the recording of data. the study areas after leing mapped were divided into

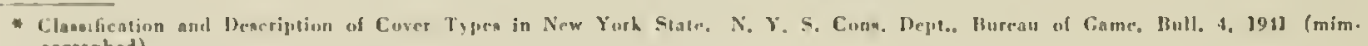
cographed).

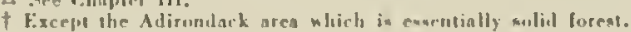


compartments of a size that could be conveniently covered in one day by a small crew of men. The compartments varied from 130 to 300 acres of woodland and as far as possible each was surrounded by open land. Some blocks of woodland were too large and blazed lines had to suffice as boundaries. These sub-units of the larger areas were mimeographed for field and office use.

The division into compartments also aided in the analysis of data by providing a means of obtaining sampling-variations. Observations regarding a single item were repeated for each compartment and the consistency or degree of sampling error could be measured for each year. For example, grouse flushes in relation to cover type when analyzed by comparments within years, yielded a much better picture of the consistency of the grouse cover type use relationship.

Compartment maps were made to a scale of 660 feet to the inch. These were mimeographed in outline form on $81 / 2$ by 14 -inch paper with proper titles.

lin addition to field and office use, the more detailed maps were employed in many prob. lems dealing with the extent and interspersion of various cover types.

\section{PERSONNEL}

Great care was taken in selecting field men. To this end graduate or undergraduate collene students with training in wildlife managenent or in elosely related fields suclı as forestry, botany or zoology, wcre employed where practical.

The field forces were made up of the authors together with leaders and assistants. The authors supervised the work on entire study areas, while crews consisting of a leader and his assistants were responsible for the various compartunents within an area. The leaders, chosen for their experience or ability, recorded the data. The conscientiousness of the leader was an important item affecting the results, since the assistants were mainly olservers. It was found that less care was needed in selecting the latter group. Relatively untraincd men could be initiatcd, in a short time, into the more or less standardized method of covering the compart. ments and observiug data. College students. older hoys from Scout gronps, CCC boys, W'A men and local residents have, at different times been used as assistants.

In connection with the work of analyzing the field records. draftsmen, bihliographers, stenographers and elerks were employed. To some extent this force consisted of hand-picked labor from WPA and student NYA programs, thus reducing costs.

A survey of this kind cannot he carried out by field men alone. Therefore. special field and laboratory work, requiring technically trained men, was handled by ornithologists, mammalogists, entomologists, botanists, foresters, engineers, nutritionists, hiochemists, physicists. statisticians, trappers, food hahits investigators, physiologists and pathologists.

\section{Securing Observations}

The scope of the problems confronting the Investigation was very wide. Therefore a complete (100 per cent) coverage of each study area by the strip method was used to yield the most satisfactory data pertaining to the greatest number of the proposed prohlems.

To carry out this method crews consisting of leaders, each with from one to four assistants, according to the size of their compartments. were used. The men walked abreast at a given distance apart, thus covering the unit in strips. back and forth from one edge to the other. The end men acted as guides utilizing land marks or a compass to maintain a reasonably straight line. Since cover utilized by the birds in relation to time of day constituted one of 
the problems, the working pattern of a compartment was changed on successive days.

The intensity of work varied with the ohjectives and the season. During the fall and winter, when the woods were relatively open, a distance of 60 to 80 feet between men proved satis. faetory. Distances of 30 to 50 feet were used for spring population estimates and summer

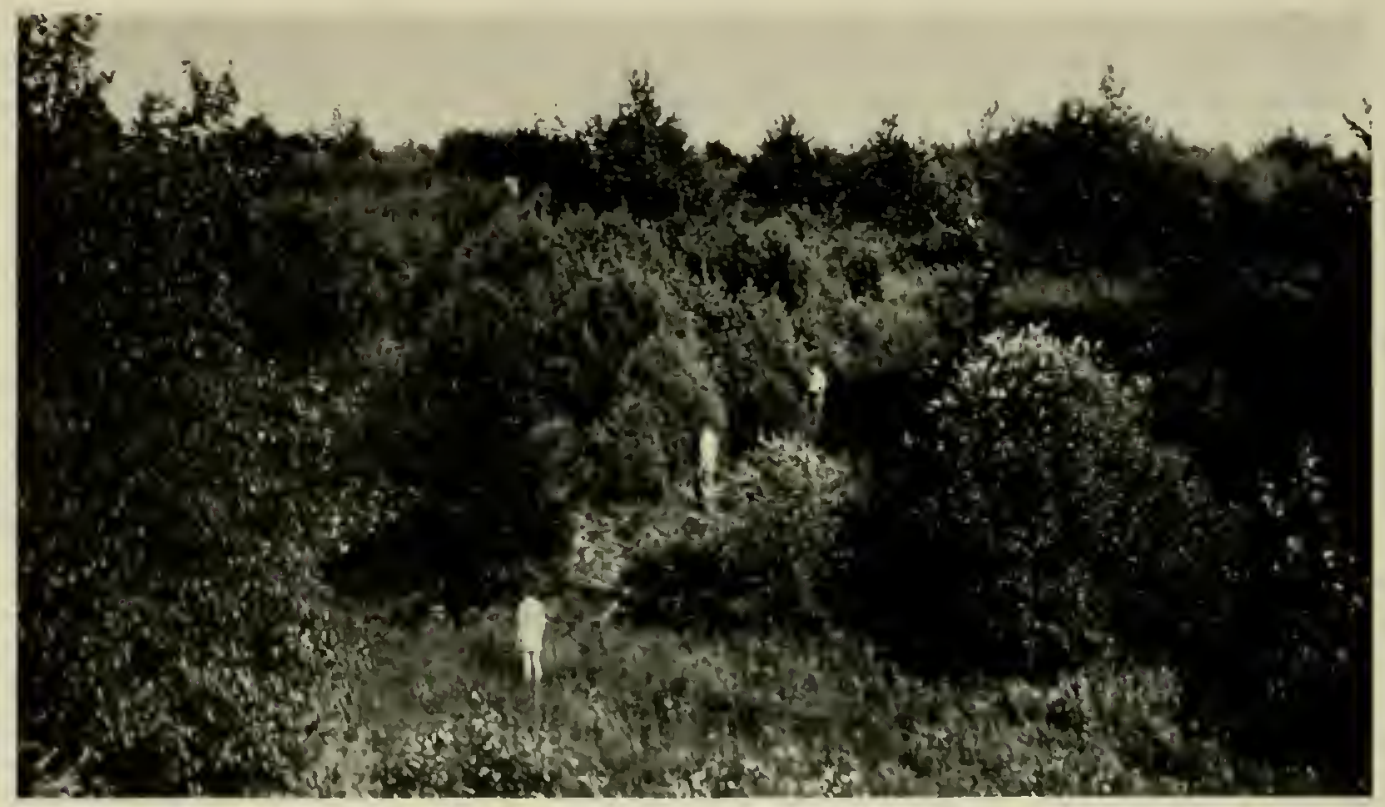

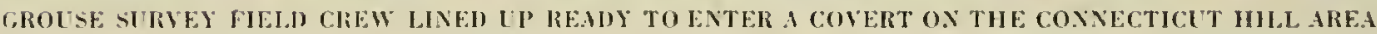

brood studies, while a reduction to 20 feet hetween men was necessary hefore most of the grouse nests conld be loeated. On the average, a crew of two men working 50 feet apart was able to cover about 150 acres per 8-hour diy.

During the first two years of survey. dogs were used by some of the crews. It hecame apparent, however, that they often eatsed confusion and tended to introduce varialoles that were harel to account for. Their use was, therefore, discontinued in favor of the more easily standardized crew of assistants.

\section{Reconoing Orserrvations}

At the outset it was recognized that only by standardizing the method of securing and recording information could its signifieance be accurately appraised. Continuity of the method by which notes were taken was of prime importance in determining yearly trents in relationships. If the method were changed and the effect not recognized, a fluctuation in sone faetor pertaining 10 a problem would have seemed to exist when. in actuality. it did not.

Standardization was therefore the keynote followed in all note-taking. Since many individuals were involved in the field work, the first step wis to design uniform reeord sheets around the more important or complicated problems. New compartment leaders were trained and given explicit written instructions on how to record observations. Notes were frequenty. clecked for continuty of handling. 
Note-taking was also designed in such a way as to eliminate, to the greatest possible extent, personal judgment on the part of the compartment leaders. When a personal interpretation, such as the determination of a nest predator, was necessary, the leader referred the matter to the director of the survey. Thus the handling of such decisions rested with a relatively few persons. The compartment crews were used mainly to collect the data and not to interpret them.

Records were taken in such a manner that a daily numerical summary of the basic material could be kept. The information used in reducing data to a common basis, such as weather and man hours, was carefully recorded on each set of notes. Daily notes were then combined into seasonal totals, reduced to a comparable basis with other seasons or years and then analyzed.

The amount and character of the information gathered was so closely determined by the organization of the data sheets that they are included here. It should be noted that cocle spaces are provided on each sheet to facilitate the mechanical tabulation of the data (figures 73 to 76$)$.

\section{SPECIAL TECHNIQUES}

Gathering evidence pertinent to the specific problems involved, often required special techniques. Those used in collecting data to evaluate relationships of shelter, food, weather, disease or predator and buffer species to grouse, all differed from each other in many respects.

\section{Determining Shelter Relationships}

A man usually sees a forest in terms of firewood or lumber whereas it is important to a grouse in terms of its food and shelter value. The first step. therefore. was to subdivide grouse habitats into types according to their food and shelter value to the grouse. Since many individuals were to record shelter data, the subdivisions formulated were reduced to letter symbols*, descrilhed in brief form and mimeographed for use on a reference sheet.

A grouse uses a wide variety of cover types, perhaps more of one than another. When a survey crew flushed a bird, a record was made of the cover it was in. However there was no indication of the relationship of any one such llush location to the cover requirements of the particular bird involved or the species as a whole. In other words. data regarding the preference of various cover types was extremely variable in nature and immense numbers of records were necessary before any real understanding of the relative degree of use or of the underlying reasons therefor could he obtained.

A satisfactory number of records was built up by filling out a data sheet each time an adult or a brood of grouse was flushed during the entire period of survey. Over 19,000 adult and 1,500 brood flushes were thus recorded by 1937 when their tabulation was undertaken. In order to handle this data efficiently. provisions were made for mechanical coding and sorting. Each individual item on the data sheets was given a descriptive code number and these were punched on code cards. After a specific problem was set up, it was possible to run the cards through a mechanical "sorter" and thus obtain the totals of the items desired.

Shelter relationships were analyzed around the statistical principle of deviation from the random or "no choice" $\Delta$ distribution of the bird. Thus an establishment of the pattern in

\footnotetext{
* Sec Chapter 111.

$\triangle$ If a grouse exercises no choice of the type of cover it uses. flushes should be evenly distributed thruughout the area and flushes within a single type would occur in proportiun to the extent ut that type.
} 
Weather: (encircle correct condition)

a. warm, normal, cold

b. sumy, cloudy, rainy, snowing

c. strong wind, gusty, still

Ground: llry, damp, wel,......"snow.
GlKOUSE: FI,LSHISD

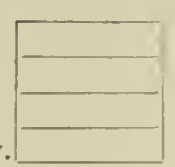

Sirial number.......

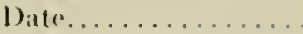

Survey..............

Compartment ........

Nanes.

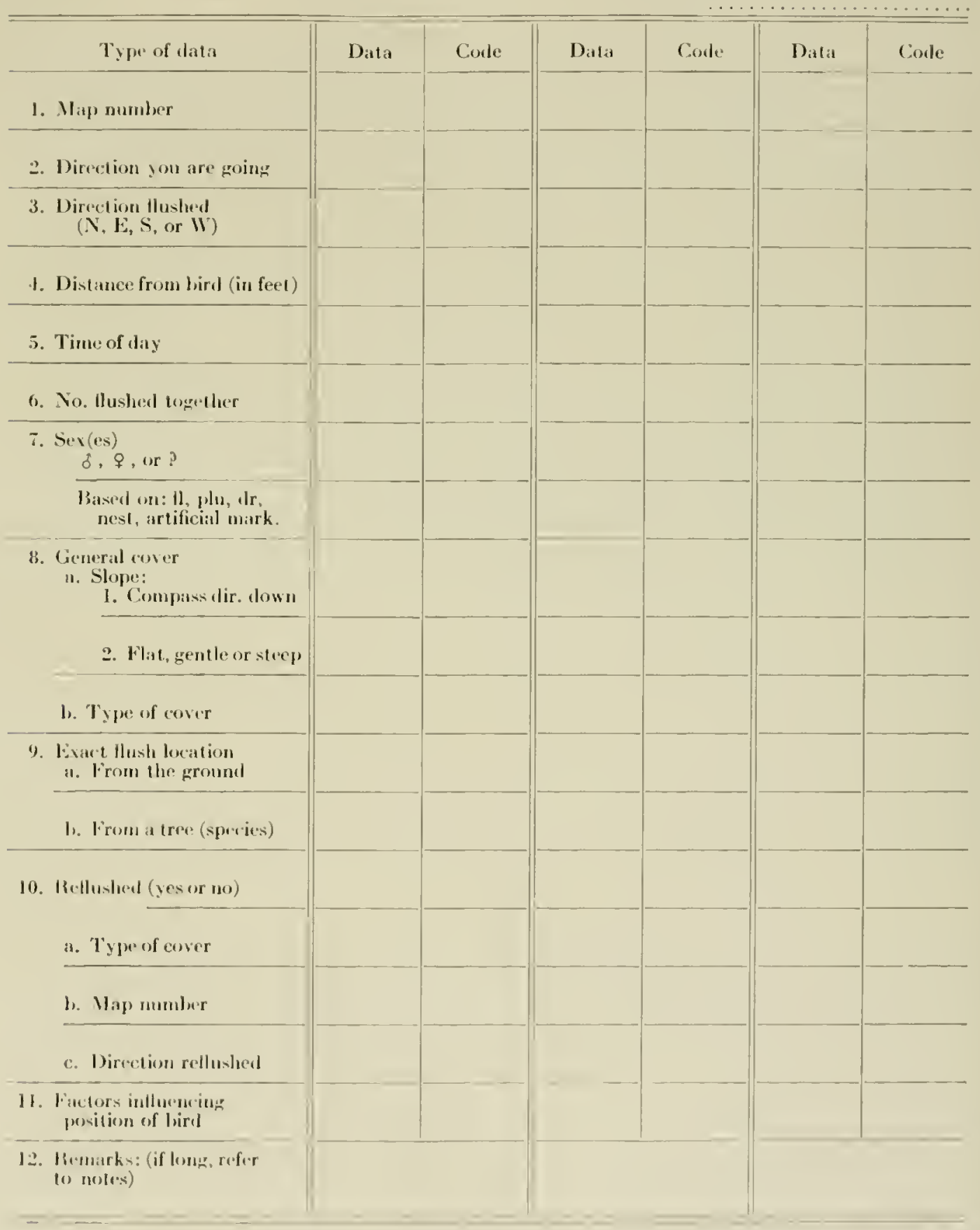

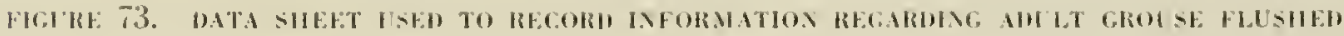




\section{GROUSE NEST}

County

Locality

Year.
Serial number

Survey.

Compartment

Name.

1. Map No

2. Nest Nu.

3. Date found

4. No. eggs: a. When found

b. Total cluteh

5. First nest or renest

6. Finale flusherl: yes, no. a. Dist. from olserver.

fi.

b. Direction llushed ............. c. Distance $\mid$;own ............ ft.

d. Birl feigned injury: yes, no.

7. Numbur of enlarged droppings found

a. Dist. from nest. ...........ft; ;. Dirertion from uest..

c. Downhill, tevel, uphill from nest..............

8. Nearest dr. Ior: DI, No.

: Dist.

ft.; Direct. from nest.

9. Distance from: woodsroad or trail, mulblic rond

fi.

10. Gromeral comlitions prevaling in nest vicinity:

a. Slope: Direction (downhill)

Degree: llat, gentle, sterp. . . . . . . . .

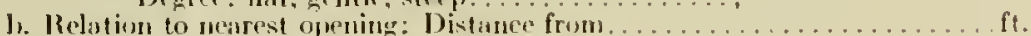

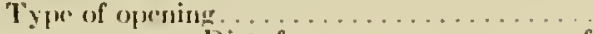

c. Norest slashing: Size. ......... neres: Dist from . . . . . . . . ft.

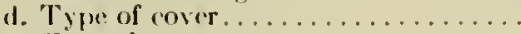

e. Ground eover type..............

f. Judergrewtli: Type..............

Speries. . . . .

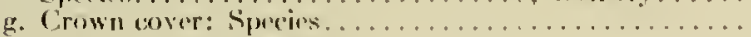

$$
\text { 1)risily. }
$$

11. Specific site of nest:

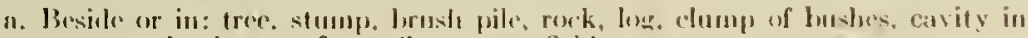

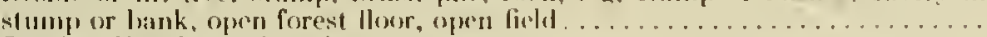

b. Surceices (if at hisse of tree).

c. Diamentr I foot from groming if at hase of tree)

I. Exposure (elirection it faees).

\&. Distane from nearest conifors. . . . . . . . .

f. Density immoliate situation: in open spot, in theket. . . . . . . . . . .

.

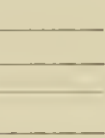




\section{GIROUSI: BROOD FLUSIHED}

Weather: (encircle correct contition)

a. waru, normal, coll.

h. sunny, cloudy, rainy, snowing..

('. strong wind, gusty, still......

Fround: dry, damp, wet...."snow
Serial number

Date.

Survey.

Compariment

Name.

Brood number.

1. Min No.

2. lime of day

3. Contact No....

J. Distance from: a. Female

b. Nearest chick

5. Amount of time spent with lrood minutes.

6. Direction you are going

7. Direction: is. Female llusherl

I. Chicks fluslıed

8. General (ewer from which flushed (answer a, b, c and d):

a. Slepe: 1. Compass dircetion don

1). Distance from opening

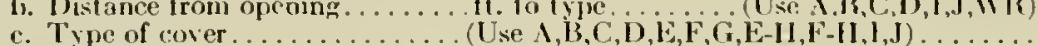

d. Distance from crown (ower (if llushed in open)

9. Immediately surrounding (cover (within 100 feet of llush):

a. Crown cover ( $\%$ of types represented)

h. Indergrowth: 1. Type............ 2. Density...........

c. Ground cover: 1. Type........... 2. Density.

10. Fxact cover from which llushed (within 10 feet of flush point):

a. From 1 be ground......... (yes or no). Answer 1 or 2 and 3.

1. Close to trees or shrubis; (a) Species......... (b) Height

2. In the apen (at least 10 feet from trees or slirubs):

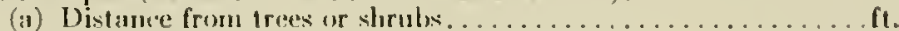

(l) Sprecies of trees or shruls. . . . . . . . . . . . . . . . .

3. Fiact rescription of species of eover at point of ilusli:

(a) Crown cover: species........... density

(h) Undergrowth: specir.............. density

b. From a tree: species....... ; tree height .......ft.; lird height...ff.

11. Male gromse flusbed neirliy....... (yes or no); distanee from hromb.

12. Condition of lireosl:

a. Number of clicks: 1. seen. . . . . . . . 2. hearul, not seen . . . . . . .

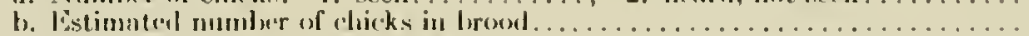

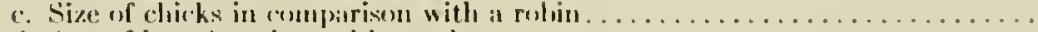

1. Age of brood, estimated in weeks.

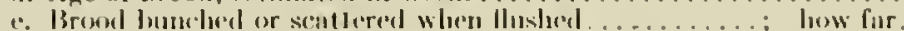

f. Desclopment of plumbate.

13. Behavior and mosements of fimate, of broot and of men on survey .........

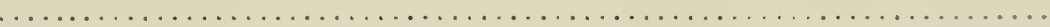

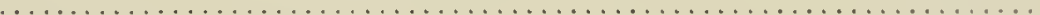

11. Ilentity of broul based in:

15. Probalile influerucing facters:

a. Regarding pesition of brood:

2. .

I. Hegarding behavior of brond: 1

2. .

c. Ihegarding mothods of discovery and hambling: 1

; 2.

16. Quality of broml contact as 10 number of elicks...

17. Markings of frmale: a. Artilicinlly markerl or nut

1. If markiel, give color

$\therefore$ Color plasise of fomale..

$(10 x$, no or $?)$

1B. IR:marks: (if long, give reference to position in noles). 


\section{DEAD GROUSE FOUND}

Orjginal Kill.

Serial numlıer.

Date...

Survey.

Other Partis.

Compartment

Name.

1. Map numler.

2. Adult or click

3. Sex

1. Color phases.

5. Fiedd datia:

i. Cover: 1. In an open arcil ( 1 or 1 ) or woodsroad

Jistance from woods or brushland.

ft.

2. In cover.

type

Distance from open area $(\mathbf{A}$ or $\mathbf{l})$ or woodsuad ..............ft.

Type of open area or wooksrond.

b. Number of points where remains were found, their size and distance apurt . . . . . . . .

c. On, under or near what found

d. l'redator sign fonnd with kill.

p. Were any portions of the thrd fomd "in situ"?

f. Age of remains (in days, weeks, or months)

6. Jaborutory data:

a. Quantity of remuins found:

Bones:

Feathers: tail..........; wing..........; contour

b. Evidence found on finthers:

e. Evidence found on lounes:

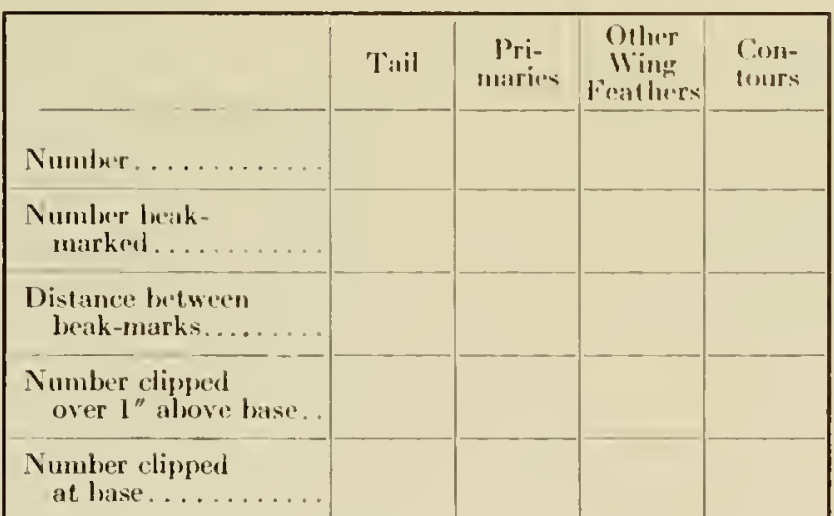

7. Cause of death

8. Quality of evidener:

1. Eacillent, good, fair

b. Bused on .

9. Hemurks:

FIGIRE 76. DATA SHEET USED TO RECORD INFORMATION REGARDING DEAL GROUSE FOUND 
which flushes would oceur in relation to the various cover types. if grouse exercised no choice of them, was a necessary preliminary step.

For the purpose of the Investigation. the "no choice" pattern. with one exception, was set up on the basis of the amount of each type present. Three of the sludy areas were located in a habitat type characterized ly abandoned farms. so the woodland. though sizeable, was surrounded by open fields. Since these are not used by grouse except along the edges bordering the woods, an arbitrary limit of 100 feet from existing wood or brushland was taken as the extent of open land that should be included in figuring the amount of each type present. It was also ohvious that the habit of frequenting the edges, rather than the centers of large blocks of cover. excluded olher areas from the birds' usc. Therefore. a measure of the amount of each type available was better than the total amount for determining the pattern of occurrence which would be associated with no choice regarding cover type. No practical melhod existed, however, for evaluating availability.

The reliability of the information was checked by two mellods. If 20 per cent of an area was composed of a certain type of cover and 25 per cent of the flushes during a period oceurred in that type, the validity of the difference was determined by the statistical method of chi-square*. More detailed prohlems, such as those dealing with difference in cover type usage hetween areas, seasons or years, were cherked by analysis of variance.

\section{Determinix, Foon Rfi.ationships}

The items of food upon which the grouse sulsists were determined by an cxamination of the gizzard and erop. The birds collected during the course of the Investigation were taken by various means and by a variety of individuals. Satisfactory sampling of the grousc population has depended on the cooperation of sportsmen. naturalists, game protectors. special collectors and the publie in general. An attempt was made to maintain a uniform flow of birds to the lieseareh Center in order that continuous information ly regions during all seasons throughout the period of study. with a gond representation of louth sexes and different age groups would be provided.

Through the cooperation of the alowe-mentioned groups. hirds have heen receired which were found dead in the ficld. hit by automobiles and Irains, those which have flown into louses or wires, and others killed hy predators as woll as a considerable number taken during the regular open season. The hackbone of the continuous sudy. however. was formed by collections made ly shooting specified numbers of hirds from designaded areas at pre. seribed times. For this purpose. speeial collectors were hired as needed. Certain game protectors were also assigned to the joll. The standard mothods of procedure as developed and deseribed ${ }^{\text {aro }}$ by the Section of Fond Hahits of the U. S. Fish and Wildlife Service. Were followed in making the analyses. Food ilems diffeult to identify were referred to specialists.

Simple but important refinements in the method of determining the average volume of each food item, as ohained from a number of analyses. were adopted. Previously. the volumetric percentage of a single item in the total diet has been figured ly first finding its percentage in each individual bird. then averaging these to secure the percentages for all birds. This procedure is, of course. mathematically unsound. For cxample, one bird may eat only two bechnuts. representing 100 per cent. While in another, the same number makes up only 10 per eent of the volume. Averaging these. four beechnute become 5.5 per cent of the total volume. Oliviously this is not truc.

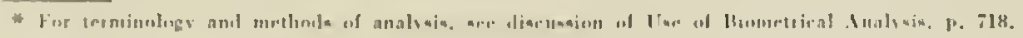


By the new method the volume of all food items in the specimens examined is added together and then the actual percentage of each is computed. It is as though all the items from all the birds were dumped together and then each kind of food separated and the percentage of its volume in relation to the whole computed. On this basis, the four beechnuts now equal but 18.18 per cent of the total volume eaten by the two birds. By using this system. a given amount of a single item has the same relationship in all instances.

As will be seen hy the accompanying table, the differences tend to cancel out where large numbers of examinations are involved. But even with 1,093 grouse analyses, the differences with some food species, figured by both methods were substantial. On the basis of use, four of the species classed among the first 15 by the old method were replaced under the new method of computation. Lastly, the "volume" method is quite as easy as the old one.

TABLE 98. COMPAIISON OF TILE "AVERAGING PERCENTAGES" AND "AVERAGING VOLUME" METIODS OF SUMMARIZING GROUSE FOODS

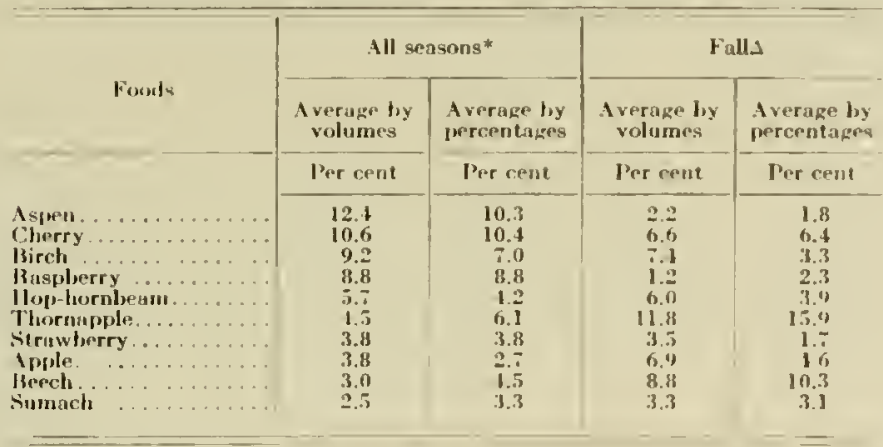

* Based on 1,093 lirds.

Jlsasel on 308 birils.

It was not always practical, however, to take advantage of the greater accuracy permitted by the use of volumes. For example, the amonnt of food eaten ly a 3-week-old chick is many times greater than the capacity of a chick less than a week in age. Obviously, one nust expect an increase in capacity as the bird matures. Since it is impractical to collect, each day, sufficient specimens representative of each successive stage of growth. it becomes necessary to consider larger groupings with the less desirable. but none the less unavoidable, difference in capacity. For this reason the discussion of the juvenile diet is based upon areraged percentages, otherwise the quantity of food eaten the last half of June would so far outweigh that of the first half as to cause the former to lose all significance.

\section{Deternining Weather Relatjonships}

It has been contended in the literature that adverse weather has been related to some periods of grouse scarcity that have occurred. The weather. however, was not described in other than general terms, such as long hard winters or cold wet springs. The task of specifically relating the various weather constituents to ruffed gronse was therefore attempted along two lines.

One series of problems was attacked with data from daily records of temperature, wind. humidity and precipitation (snow and rain) taken at the Ithaca station of the U. S. Weather Bureau, 15 miles from the study area at Connecticut Hill. Supplemental information was also secured from readings taken from time to time on the area itself. The minor uncon- 
formities noted between the two seem largely attributable to a difference in altitude of 1.500 feet.

Each time an immature or adult grouse was contacted. the field leaders recorded the weather information for a second series of problems. These observations were in general terms* temperature being noted, for example, as warm. normal or cold. In this case the basis of comparison was the average conditions for the particular time of year involved.

Realizing that the influence of weather was the result of the inter-relation of the various constituents. appropriate statistical methods were utilized in evaluating these interactions. The relationship of grouse mortality rates to such items as temperature and rain. was determined by means of multiple regression ${ }^{4}$. The results indicated. for example, the effect of precipitation on grouse mortality. with the effect of temperature also taken into consideration.

The weather conditions. as recorded in general terms by the field leaders. were utilized in determining the relation between this factor and the use of various cover types. Such records. when summarized by seasons and analyzed hy chi-square made it possible to judge whether the use of various types of cover tended to vary according to changes in weather as recognized hy the field leader

\section{Deternining, Predator and Buffer Relatronships}

Determination of the importance of predators and huffers as influences affecting grouse abundance was one of the most difficult problems facing the Investigation. In attempting to establish the true relationships, data were accumulated regarding predator abundance. buffer abundance. food hahits of predators and predators responsible for grouse found dead and nest destruction.

\section{Predator Abundance and Activity}

Practical methods of estimating actual predator populations were not known and did not heeme availahte during the course of the Investigation. Adequate methods of determining trends in activity. however. were devised for the more important ground predators in 1933. These methods contered around the idea of utilizing fluctuations in the number of predator tracks as an index of activity. The idea of activity is emphasized since it appears that the fox, for example. produces tracks in relation to its food supply. Similar populations of foxes produced many more tracks when food was scarce than when it was plentiful. Thus it is prohahle that a general increase or decrease in tracks. throughout a period of years. may be an indicator of fox numbers. while variations from year to year more nearly represent activity.

Predator activity trends were obtained during the winter period when a tracking snow was present. The various tracks were recorded on the daily notes in a preseribed manner. Since the amount of field work varied between years. it was necessary to reduce each year"s data to a comparable base through the use of a slatistical tool. multiple regression. Utilizing only. those days when a tracking snow fone inch or more) was on the ground and taking into areount the mumber of man hours per section and the number of times the section was covered. thre number uf tracks recorded was adjusted to a base common for both type and amount of effort. Thus accurate searly fuctuations in the abmolance of predator traeks were estal. lished.

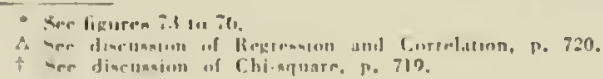




\section{Buffer Abundance}

Rahhits, mire, and to some extent, squirrels. are the prineiple huffer species with respect to grouse. When these foods become scarce. predators are forced to turn to other sources and grouse suffer accordingly. Thus fluctuations in the abundance of buffers are of importance in evaluating the effect on grouse of changing numbers or activity of predators.

It was found that rablit. squirrel. niouse and shrew Iracks were ton numerous to he accurately recorded by the regular survey crews. Accordingly. a controlled Iracking system. hased on trail counts, was organized.

Trails, each one-half mile in length. were laid out through representative cover types on a study area*, carc heing laken that the locations chosen would change as little as possihle in cover relationships during the course of study. Each I rail was marked in such a manner that an identical path could he followed during each working and in subsequent years.

Tracks were observed and counted along these trails in a controlled manner. Approximately 24 bours after a fresh snow. the trails were traversed by a single man and alwa! in the same order. In practice. a day was judged fo be suitable if it had slopped snowing the previous day betwen the hours of $10 \mathrm{a} . \mathrm{m}$. and $1 \mathrm{~m} . \mathrm{m}$. The character of weather during the time since snowing ceased was recorded. logether with the character of the snow. All tracks which crossed or touched the trail made by the ohservers" feet were emunted as individual tracks. If an anjmal walked directly along the trail, it was counted as a single track. hut if it deviated from the trail by more than one foot and then returned to the trail. it was counted a second time. This was done to eliminate the personal element to the greatest possihte extent.

The trails were covered as many times during the winter period as the above-mentioned snow conditions occurred. However. an attempt was made to cover the set of trails at least four times each year.

Trail track count data was analyzed by the methorl of eovariance by adjusting the number of tracks recorded for the mumber of limes worked. Individual trails were nsed for reperition.

\section{Food llabits of Predators}

In order that the true importane of predators be understood. a picture of the seasonal and yearly changes in their normal food was necessar!. This was ohtained through the analysis of stomach specimens from the State as a whole as well as droppingrs and pellets collected hy the regular survey personnel on the study areas during all seasons over the entire period of the Investigation. Collections of the latter type were often large. with such items as fox droppings (scats) sometimes running to folo specimens for a single seasoll. When examined and summarized. yearly and seasonal changes in the oceurrenee of items eaten were revealed. Correlations were also made with known fluctuations in the abutulance of some of the more important foods, such as rabhits and mice.

This material was examined hy the laboratory persomnel conducting the foud habits studies.

\section{I'redators Responsible for Grouse Kills and Nest Destruction ${ }^{\Delta}$}

An accurate knowledge of the predators responsible for the observed mortality of grouse during the stages of their development is alsu of importanee. Early in the Investigation.

\footnotetext{
* Eigh such trails were used on the Connecticus Hill ares.
}

$\triangle$ By R. W. Darrow. 
preliminary experiments were run at the Research Center to fund a method by which the signs left where hirds were killed or nests broken up could furnish a lasis for recognizing the predator responsible.

Observations of penned wild animals checked ly an occasional experience in the field when predators were surprised in the act of breaking up a nest, formed the basis for the following key. One must remember, however. a key of this kind must he confined largely to typical examples while in practice one frequently encounters situations where the evidence is conflicting. This is particularly true with respect to eggs destroyed toward the end of the incubation period. In such cases. the different indications must be weighed against each other as well as against circumstantial information such as the presence of tracks or hair. Also. the relative prohability of the various suspected species finding the nest location must be considered. Beyond this. nne may record the quality of the evidence by rating the diagnosis as excellent. good or fair.

Furthermore, the key deals only with the characteristics of wild predators, except that the dog and house cat are included. and also applies only to species found in New York. It assumes that nests destroyed as a result of such causes as fire. flood or the actirities of man will he recognized by the investigator from other sources.

Key for Dią̧nosing Predators Responsible fur Breaking up Grouse Nests

A. All or most of clutch intact in nest

1. All eggs in nest. cold

Female probahly killed*

2. Threc or four eggs missing: remainder usually still heing incubated

Foxes frequently filch a few eggs at a time from a nest. Crows and red squirrels unay do the same thing. Furthermore. any species which carries the eggs: away from the ncat may be interrupted and thus leave this result ${ }^{\wedge}$

B. Nest empty of eggs or slicll remains but structure not disturbed

1. Remains of individual eggs left at points from 1 to 75 feet from nest in different directions

a. Shell usually retaining its general spherical form

(1) Shell irregularly opened at nne sille: frequently found on stumps

(a) Punctures usually conforming to shape of crow's bill. frequently with smaller nutward punctures opposite

Crow

(h) Opening not having punctured appearance: two portions of shell sometimes separated: yolk or oller egg contents nccasionally found smeared on tree trunk: all eggs seldom taken

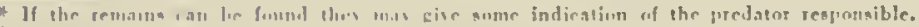

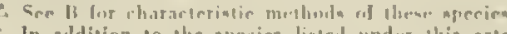

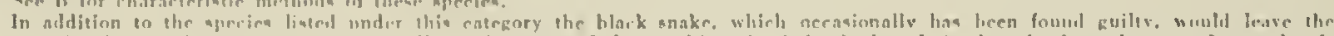

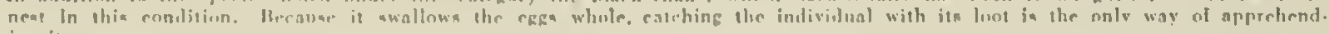
ing it. 
(2) Slıell having a large "bite" taken from one side about midway between the ends and extending from one-lalf to three-quarters the way around; opening sometimes smaller but inward punctures made by the canine teeth can usually be found in the opposite side

Red Fox, Gray Fox

b. Shell not retaining shape, one-half or more usually eaten away along the long axis; edge of remaining portion very finely chewed but the fragments largely held together by the membrane; shell remains frequently left under a $\log$, projecting root or similar shelter, often several at the same place

Weasel ${ }^{*}$, Mink Mice $^{\Delta}$

2. Whole eggs buried in runways under or near nest Skunk

C. Shell remains in or close beside nest, latter often torm apart

1. Nest torn apart, completely crushed eggshells mixed with the debris

2. Nest intact or very slightly disturbed

a. Shell remains usually retaining much of their spherical shape, one end bitten off, most frequently the smaller one; if broken to a greater extent the fragments neither held together by membrane nor mixed with debris

Raccoon

b. Shell remains well crushed

(1) Remains, much chewed but fragments held together by membrane, largely in nest, latter not disturbed

Bolscat, House Cat

(2) Remains largely absent, but sinall bits of shell usually scattered in and beside nest

Dog, Opossum, Woodehuck ${ }^{\dagger}$

* Ejiher Mustela nocaboracensis ur M. cicognanii.

$\triangle$ Except that they may have brom involved in some of the few instances of this kind, the lnvestigation has found no esidelle that chipmunks disturb, grouse newts.

$\div$ Little differntiation is possible betwcen these specica except un a circunstantial basis. Dogs nore frequently faw up the nest but there is consilerabl, variation between breeds as nell as individuals.

The majority of broken-up nests were examined only ly the authors throughout the $l_{n}$ vestigation in order to climinate the personal element to the greatest extent. Their reports, together with all the evidence that could be gathered was in turn checked by one individual to reduce further the possibility of error.

The same author also decided which predator, if any, was responsihle for each grouse found dead. The field evidence was noted on an appropriate data sheet. The feathers, bones or other remains were placed in a hag. The specimen and the sheet were then checked in light of the results of experiments as well as field experience.

Unfortnnately, judging the predators or cause responsihle for adult grouse kills does not lend itself to being summarized in key form since circumstantial evidence is involved. and space does not permit the detailed discussion which would otherwise be necessary. 


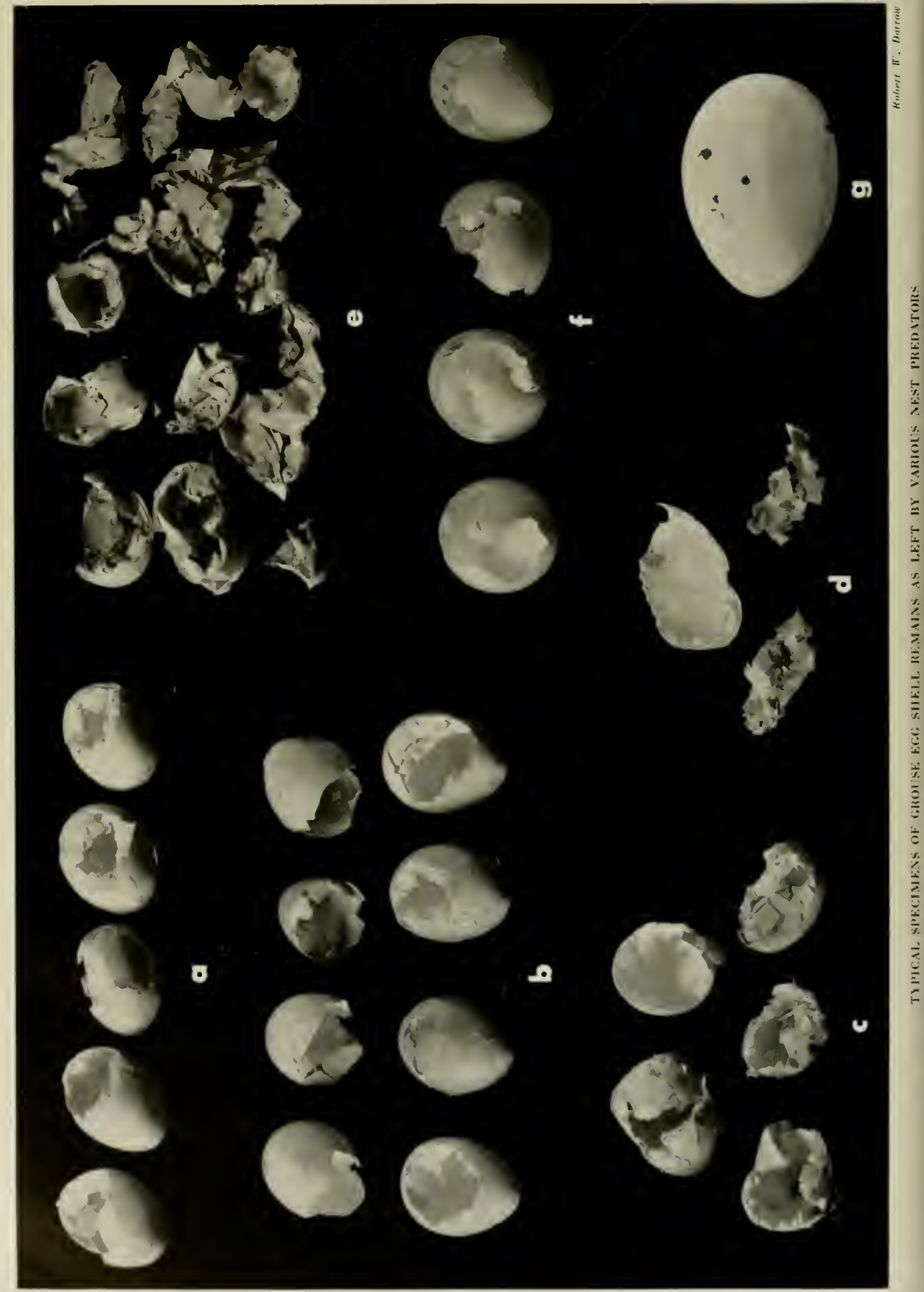




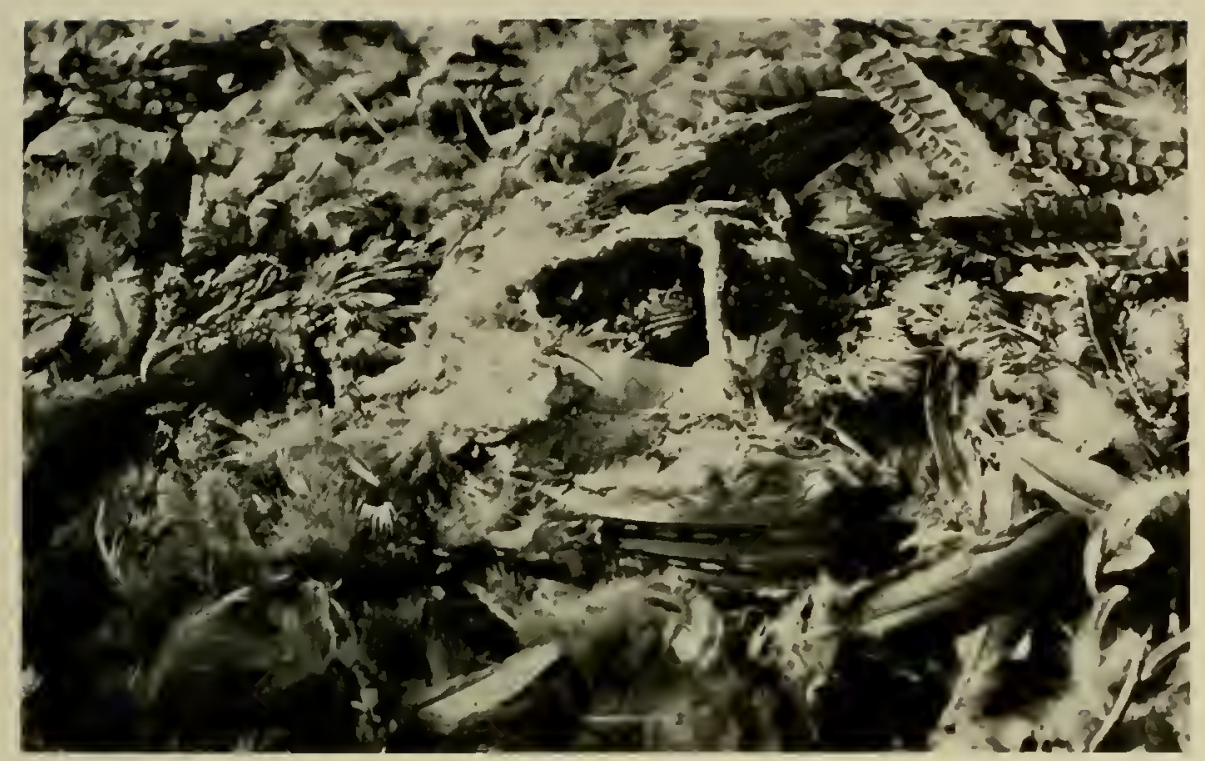

REMAINS OF ADULT GROUSE KILLED BY AN ACCEPITRINE HAWK (I'ROBABLY COOP. ER'S) SHOWING IIEAD STILL ATTACHED TO CARCASS, FEMUR PICKEN CIAAN BUT NOT FRACTLRED, AND GIZTARD UNEATEN *

\section{Detemalining Effect of Huntixg}

The proportion of hirds taken by the gun and its effect on grouse populations has always been a debatable subject. To collect evidence on this a hunting check was cstablished and used in 1930, 1931, and again in 1936. On the first trial the areas under observation were posted with signs asking the hunters' cooperation and giving instructions. Shellacked envelopes containing printed postal carcls were nailed beneath the posters. The hunters were asked to fill in and return the questionnaires to the Investigatıon.

The following year, instead of postal cards, blank spaces for names and addresses were left on the posters. Personal visits to obtain information were then made to those who cooperated.

Both of the above methods were dropped when it became apparent that children or unthinking sportsmen did not cooperate lut destroyed or defaced the envelopes or posters.

In 1936, with the aid of C.C. labor, a method of checking hunters in and ont of an area

EXPLANATION OF PLATE ON OPPOSITE PAGE.

a. Red fox - showing characteristic manner of biting into egg from side but not crushing it greatly.

b. Raccoon-characteristically bites into end of egg (upper row) but sometimes quite similor to fox (lower row).

c. Slunt - showing high degree to which shells are crushed.

1. I' easel - showing typical fine chewing of edge of shell along longitudinal axis.

e. Mink - similur to wcosel but somewhat coarser.

t. Crow - showing "pcclied" nature of holes in shell.

g. Crow - showing outword pipping on opposite side. 
by establishing check stations was used. $\Lambda$ form sheet was filled out for each man and any grouse taken were examined.

The questions asked by each method were identical. They concenied the number of grouse flushed, number shot at, number killed, weight and sex of those taken, number of hunters in the party, number of dogs, if any, number of hours hunted, other game taken, and the probable number of birds crippled.

\section{Determining Disease Relationships}

The birds collected* were utilized for both food habits studies and pathological examination. Most specimens were shipped to the Research Center by express, refrigerated by one of two methods during the warmer months. Birds taken during June, July and August were placed in wax paper bags immediately on collection to retain whatever external parasites might be present. These specimens were shipped with dry ice, when it was available, or in wooden boxes containing wet ice and sawdust.

In some cases, blood smears were made by the collectors in the field. When the collector was within driving distance of the Research Center the smears were made at the end of the day of collecting. Those of birds collected by persons not in a position to make them or to bring the specimens to the laboratory, were made on arrival. They were not taken from all birds. The distribution of birds from which blood smears were made is discussed in the chap. ter on disease.

Many other grouse, supposedly diseased, and some viscera were sent in by sportsmen and game protectors.

Examination of the birds involved the systematic search of all organs for parasites and pathological conditions. Standard methods of collection and preservation of parasites were used. A search for coccidiosis was made by the smear method rather than by the flotation of oocysts. This also revealed the presence of microscopic tapeworms. Identification of parasites was checked from time to time by workers at the U. S. Bureau of Animal Industry.

Routine procedure included recording the weight, sex and age of all birds. The crops and gizzard contents were weighed and preserved for food habits examination.

\section{Estinating Grouse Populations}

The determination of the densities of grouse per unit of area was a necessary part of the solution of many problems. As mentioned previously, a complete coverage of each study area was necessary not only for grouse population estimates but also for other purposes. $A$ method for determining their number was, therefore, evolved from the data gathered by this system.

It hecame evident that a single working of an area did not yield contacts with all of the hirds present. Previous information, plus data gathered during the first year of the Investigation, however, indicated a characteristic of the bird which aided in the development of an estimation system. Adult grouse, particularly during the spring period, exhibit territorial tendencies. It was found that by working the area three or preferably four times, over a sliort period, the territories of individuals or groups of individuals could be plotted with fair accuracy and that the chances of completely missing a bird during all of the workings was slight. The population of a compartment was, lherefore, a summation of its occupied territories and the population of a study area was the sum of the compartments.

* See dincusniun ol Determining Food Relationalupn. p. 706. 
To illustrate the method, a brief description of its application with respect to estimating a spring breeding population, is given. It is assumed that as a basis for the estimate, the compartments comprising the area were worked four times, at weekly intervals, during the month of April. Data from the daily notes regarding flushes, drumming logs, droppings and kills are then plotted on individual outline maps. Each working is indicated separately by recording the information in different colored inks. As a further aid, flushes are plotted by sex as judged in the field, using the conventional symbols $\hat{o}$ and $q$ for male and female respectively while those of unknown sex are indicated by $\uparrow$. All three symbols are drawn so that their points indicate the direction of flush as recorded on the data sheets. The difficulty of judging sex under field conditions "has been insofar as possible allowed for*

Having prepared the "flush map", it is then analyzed for possible reflushes that were not recognized as such in the field. This has been done by utilizing location, sex data, distance from supposed original flush, whether flushed from ground or tree, direction flushed, elapsed time and color phase (if recorded). These reflushes must be discounted. Territories are then plotted on the basis of the contact locations plus information from drumming logs and droppings. Individuals that are judged to have been contacted on successive days usually may be separated from individuals that were flushed but once during the period on the basis of location due to the territorial habits during the spring period. Sex distribution has been estimated on the basis of drumming $\operatorname{logs}$, subsequent nest and brood information from late spring and summer records, and from the estimation of sex at the time of flush.

Familiarity with the area has been a distinct advantage in making population estimates. Topography and cover often influence the destination of a bird once it is flushed, and a knowledge of these items aids in the elimination of possible reflushes. In this connection, it has been the practice for two persons to cstimate the population individually and then to arrive at a funal estimate by compromise.

The application of any system for determining populations completely hides the inherent variability of the original data and prevents checking the reliability of the estimate statistically. Realizing the existence of a possible error, the Investigation attempted to check the system used in the following manner.

Based on the assumption that the number of grouse flushed per unit of effort would vary directly with the population, if other conditions wcre equal, the daily flushes by sections, recorded on the Connecticut Hill area during April over a ten-year period were statistically analyzed by multiple covariance. Effort (man hours). wind (miles per hour), and rain (inches) were used as the items affecting the number of flushes recorded. As might be expected, both rain and wind caused a field crew to record fewer flushes per unit of effort. When the number of flushes was adjusted for the yearly variations that occurred, the resulting trend in flushes was analyzed by regression against the estinated population. The relation was found to be satisfactory and the conclusion was reached that the estimation system largely eliminated the variations that might have been eaused by adverse weather when the data were recorded. Therefore, if it is valid to assume that the number of flushes recorded per unit of effort, adjusted for wind and rain. is representative of the population, the estimates, with only a small degree of error, may be considered to represent a true picture of the changing population of grouse.

During the summer season the system has worked nearly as well, since adult territories in general remained the same and means of distinguishing the various broods have usually been

* See Chapter II. 
available. During the fall and winter. howeser, territories have been most difficult to recognize. At this season considerable movement by the hirds has taken place and estimates have often had to be based primarily on the hest one out of three or four workings, supplemented hy in. formation from the others. These estinates were usually somewhat lower than the actual population since there was no way of determining whether a bird. flushed during one working, was missed during a previous or subsequent working.

\section{Trappixg and Marking Grouse}

The need for specific information regarding the daily and seasonal range of grouse indicated the desirability of marking as many birds as possible and in such a way that they conld he easily recognized when contacted in the field.

The first problem was to trap the hirds. Two methods were tried out, one during the winter and the other during the spring nesting season.
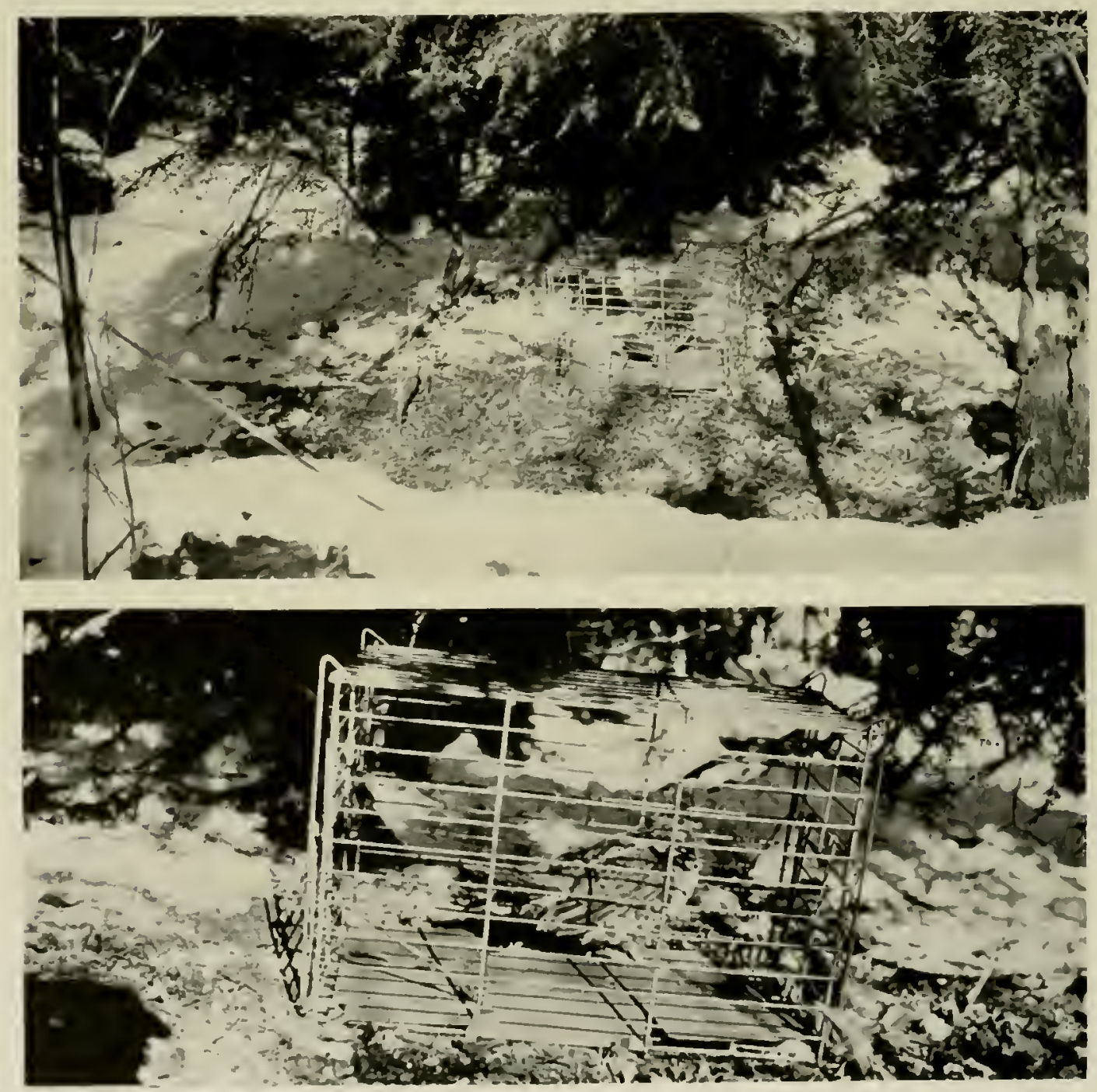

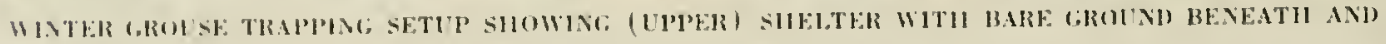

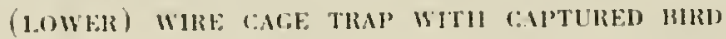


to be the most easily identified colors. White leghlorn chickin feathers were nsed. Colors were obtained by using the following commercial dyes:

$$
\begin{aligned}
& \text { Yellow - Wool Yellow - Extra Concentrated } \\
& \text { Orange - Wool Orange - } 2 \text { G Crystais } \\
& \text { Pink - Croceine Scarlet MO O. }
\end{aligned}
$$

The marking feathers were easily visible and usually remained until the tail feathers were moulted during late August.

All birds were weighed and aluminum leg bands put on before release. Blood smears were taken, in a number of cases, from a vein in the wing.

\section{Determining Sex and AgE}

Insofar as laboratory techniques were possible, sex was determined by dissection and examination of the internal organs*. External appearance and behavior have also been used as discussed elsewhere ${ }^{\Delta}$.

No means of determining age beyond one year is known. In order to distinguish birds of the year from adults of more than one year the presence or absence of the bursa Fabricii afforded the best criterion. This is a sacular structure which opens into the cloaca. It is pres-
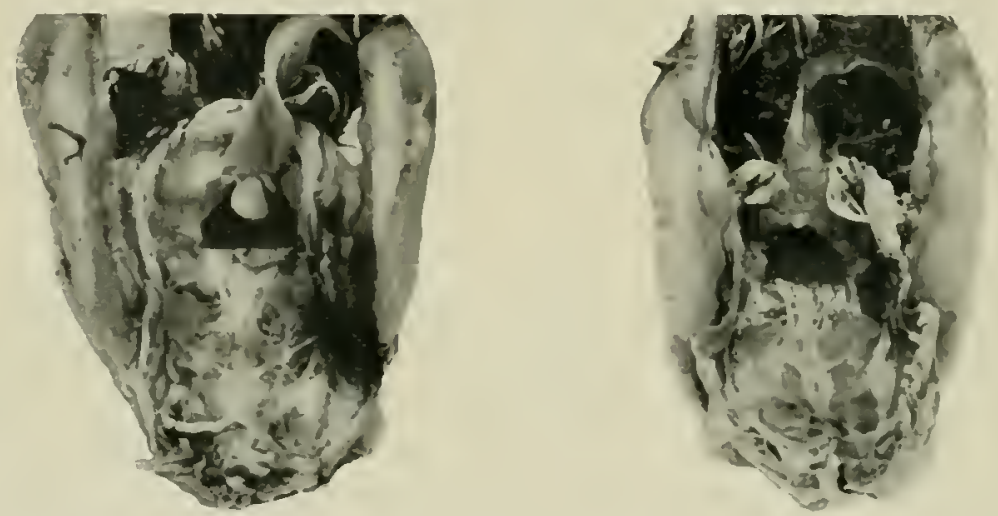

IREA PORTION OF BODY CAYITY OF A BIRI) OF TIIE YEAR (LEFT) SHOWING IBURSA AS COMPAREI) WITI TIIAT OF AN OLDER BIRD

ent in young birds but is ahsent in adults. Its use as an index of age in game birds was pointed out ly Gower ${ }^{150}$. Experience has indicated that in grouse the bursa may be relied upon to separate birds of the year from adults lhrough February and that a certain number of birds may show bursae during March and April, though its ahsence during these months does not necessarily mean that a specimen is not a lird of the year. Another feature which has also been used is the character of the first (wo primaries. since the juvenile feathers are not moulted until the late winter of a birl's first yeart.

\section{[SE OF BIOMETIRICAI, ANAI,YSIS}

Throughout this book references have been made to the use of biometrical methods in the analysis of data. When the luvestigation was organized in 1930 advanced statistieal techniques

* Sere Anatuens. 11. \$ 10.

† See Chapier 11. p. 84. 
were not in general use in wildlife research. As the work progressed every effort was made to subject each problem to the most thorough and critical analysis possible. At the same time methods were being developed whereby the significance of biological data could be judged more precisely. As applicable techniques of this kind became available the Investigation has used them.

The results have added weight to the conclusions drawn. Substantiation has been given to many relationships already recognized while new ones have been disclosed and some, apparently valid by inspection. but found not to be statistically significant, have been discarded.

The wildlife biologist. of necessity. must often work with samples of unknown quantities. whether they be grouse populations, cover composition. food availability or weather. A fundamental characteristic of such samples is variability, i. e. repeated measurements of the same thing seldom yield the same value. The greater the variability, the greater the number of measurements that must be taken before a summation of the information will not be unduly affected by an additional measurement that might, by chance, be either very low or very high. Statistical methods have afforded a means of taking this aspect of the data into account in analysing the records of the Investigation.

Of paramount importance has heen the fact that hiometrical analysis provides objective criteria for evaluating the significance of relationships in terms of probability. In other words. they make it possible to determine the degrec to which a correlation may have occurred by chance rather than from cause and effect.

\section{SigNificaNice.}

To denote the degree to which chance may be involved three terms are used. namely, not significant, significant, and highly significant. These terms define three limits of probability. Not significant indicates that the relationship would be expected to occur more frequently than once out of 20 times by chance alone; signifieant that it would occur not more than once out of 20 times by chance: highly significant that it would oeeur hy chance not more than once out of 100 times.

The mathematical basis of statistics is not important (1) the avernge field worker, but may be found in standard text books ${ }^{32,}$, 238, 230 . However, a brief discussion of the methods used in analysing the data of the Investigation seems worthwhile.

\section{Cini-Square}

The chi-square test is designed to compare observed with expected or lypothetical values and to determine the significance of departures therefrom. With sex ratios* for example. an expected ratio of 50 males to 50 females was assumed and the magnitude and consistency of the recorded deviations from this ratio controlled the degree to which such differences might he considered real. Chi-square was also used in evaluating cover type use. Here. however, the detcrmination of the "expected" values from which departures could be measured constituted a preliminary problem ${ }^{\Delta}$.

\section{ANALYSIS OF VARIANCE}

When data are taken in such a manner that the variability of a single factor can be segregated into component parts, cach traceable to an independent source. then the technique known as analysis of variance may be used to test the significance of each. In preparing this re-

* See Chapier vili.

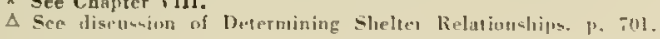


port it was especially uscful in untangling the effects of years. seasons. sex and agc. For example. a series of weights of grouse collected over scveral years from all seasons would moan little until analysed by this method. When the variability due to each of these influences was separated from that of the whole it became possible to judge the significance of each.

\section{Regression and Correlation}

In many wildlife research problems knowledge of the relationship or association betwecn two or more factors is important. Regression and correlation are methods of analysis which provide means of expressing the degree of relationship between such factors. They summar. ize. in mathematical terms, information usually presented by graphs and visually appraised. Mathematical evaluation has the advantage of leading to tests of significance.

One of the most important uses made of regression analysis by the Investigation was in the statistical adjustment of data. For example. variations in the degree of overwinter mortality recorded among grouse on the study areas over a scries of years required such adjustment with respect to fluctuations in the preceding fall population level to oltain comparahle yearly trends. Similarly, records of the number of fox tracks olserved were corrected for differences in the amount of effort spent in the field from year to year.

Simple regression. when cxtended by measuring more than wo factors coincidentally. gives rise to a form of analysis termed "multiple regression". When several groups of such data are handled together the analysis of variance is combined with either simple or nultiple regression in what is known as "analysis of covariance". This method was. for instance. used to correlate records of wind. rain. man-hours and grouse flushes on the various compartments of the Connecticut Hill area for a series of years*.

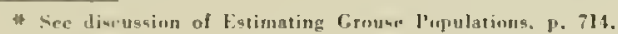




\title{
THE ANATOMY OF THE RUFFED GROUSE*
}

\author{
By David E. Davis
}

The ruffed grouse is a member of the family Tetraonidae and. like other Galliformes, has a generalized structure, as shown by the presence of two carotid arteries and a gall bladder. and the absence of a penis. The intestines are looped in a primitive manner within the body cavity. There is no hemipterygoid bone. The palate is schizognathous. However. the parasphenoid rostrum (basisphenoid rostrum) has specialized knobs for the articulation of the pterygoids which are not homologous with the hasipteryoid processes.

A notable specialization is a cutaneous muscle lying beneath each tract of ruff feathers. This muscle is about two centimeters long by one centimeter wide at the base and is somewhat triangular with the apex pointed ventro-anteriorly. The feather follicle extends into the muscle, and the contraction causes the rachis to rise away from the neck. Edcreworth ${ }^{113}$ states that M. cucnllaris is not developed in birds and its functions are taken over hy M. craniocervicalis. The ruff muscles are prohably a derivative of M. cranio-cervicalis.

\section{ThF, SKELEToN}

Skull. The skull is illustrated in figure $7 t$ a.e. The premaxillary bones are concave downward and pointed anteriorly to form the top of the beak while posteriorly they terminate in three prongs. The nasal processes are dorsal and pass between the nasal hones as far lark as the frontals. The maxillary process on each side passes lackward along the border of the jaw to form part of the jugal arch. The palatine processes extend on the surface of the palate to join the palatine bones on each side.

The maxillary bones lie posterior to the premaxillary bones and each has two processes. The palatine process lies along the palatine bone and the jugal process forms most of the jugal arch.

The nasal hones are broad and are sutured to the fruntals. Each has two anterior processes. The premaxillary process is a thin pointod sliser which lies along the external side of the nasal process of the premaxilla. there being an open slit between the two. The maxillary process extends downward to join the maxillary lone. The external nares are holorhinal. formed by the premaxillaries in front and the nasals behind. The nasals are sutured to the frontals in such a manner that a forward extension of the frontal lies under the nasals but is not fused with them.

The frontal, comprising the surface of the skull in the interorbital region, is concave upward and somewhat narrowed. Behind this lies the parietal. a thick spongy bone which makes up the hinder part of the top surface and extends down to the supraoccipital bone to form most of the posterior aspect of the skull. The latter lies directly above the foramen magnum. These bones of the top and hack of the skull are paired during early development lut in the mature bird are so completely ossified that neither the sutures between the parts nor hetween

\footnotetext{
* Tbe stuly upon which this account is based was undertaken by Dr. Duvis in collohoratinn with the Xew York State Con. servation Department and under the auspices of the Museum of Comparative Zoologv. Caral,ridge. Mass. The anthor Katherine Nilson who assisted in the preparation of the drawings. Acknowledgment is also due to the late John C. Phillips for sperimens utilized in dissection.
} 
the different bones can be identified.

The posterior aspect of the skull is sub-circular. The foramen magnum, bounded by the occipital bones, is round except on the ventral border where the occipital condyle protrudes. On each side of the foramen are two small foramina for the lyypoglossal nerve. The glossophyaryngeal, vagus and accessory nerves pass out through a more lateral foramen on each side. At the lower lateral margin of the posterior aspect lies the otic region formed by the coalescence of the three otic bones. Just at the edge of this area is a fossa into which passes the internal carotid artery and from which pass out the vena capita lateralis and the palatine branch of the facial nerve.

The orbit occupies most of the lateral aspect of the skull. Anteriorly. it is bounded by the prefrontal (lacrimal) which is a scale-like bone extending from the frontal-to which, however, it is not ankylosed-part way to the jugal arch. The interorbital septum has a small centrally placed fenestra. The posterior wall of the orbit is formed largely by the orbitosphenoid and the pleurosphenoid ("alisphenoid"), and is bounded by the postorbital process of the frontal. This process is fused distally with the zygomatic process of the squamosal bone to produce a sharply pointed forward extension which is serrate on its ventral horder. The temporal muscles pass through the canal formed by the partial fusing of these two processes. The squamosal, comprising much of the lateral wall of the brain case as well as a portion of the orbit, is fused anteriorly to the pleurosphenoid, dorsally to the frontal, dorsoposteriorly to the parietals, and posteriorly to the exoccipitals. There is an otic process of the squamosal which protrudes over the otic region. The olfactory tract lies along the underside of the roof of the orbit and has a large opening into the brain case. The optic foramen, through which passes the optic nerve, is large. The oculomotor, trochlear, the profundus branch of the trigeminal. and the abducens nerves pass out through separate foramina. In the pleurosphenoid and below the zygomatic process is the foramen ovale for the maxillary and mandibular branches of the trigeminal nerve.

The otic region lies within a deep fossa. its posterior border being formed by the parotic process of the exoccipital and its anterior horder by the pleurosphenoid. The anterior part of the fossa is a reticulum through which the Eustachian tube passes downward from the in. ternal ear to the mouth. In the sidewall of this tympanic cavity is the fenestra ovale, an ohvious opening in which lies the columella. The facial nerve docs not come out on to the surface of the skull but, with the vena capita lateralis. passes through a bony canal just superior to the fenestra nvale. This canal opcus to the cxterior just medial to the position of the internal carotid artery in the fossa on the posterior aspect of the skull. The semi-circular canals are not imbedded in solid bone but lie in a spongework. Air enters this area through the Eustachian tuhe and reaches the parietals and other skull bones through pneumatic openings.

The palate is perfectly schizognathons. The pterygoid extends from the quadrate to the rostrum of the parasphenoicl. where it articulates with the palatine. This latter hone, on each side, extends anteriorly" wide at first. and then narrowing to join the palatal processes of the premaxilla, while its posterior cxternal angle is completely rounded off. The maxillo. palatines pass dorsad of the palatine and are directed posteriorly and medially. The rostrum of the parasplenoid is thick and stroner. The prevomer ("voner") consists of a pair of carti. lagenous slivers just anterior to the rostrum. The bisipteryguid processes are represented hy two facets on the parasphenoid rustum. The parasphenoid has two pairs of openings in it: anterior part. The medial pair is for the Eustachian tubes and the more lateral ones for the internal carotid arteries. The hasis cranii is rounded and hulging. 

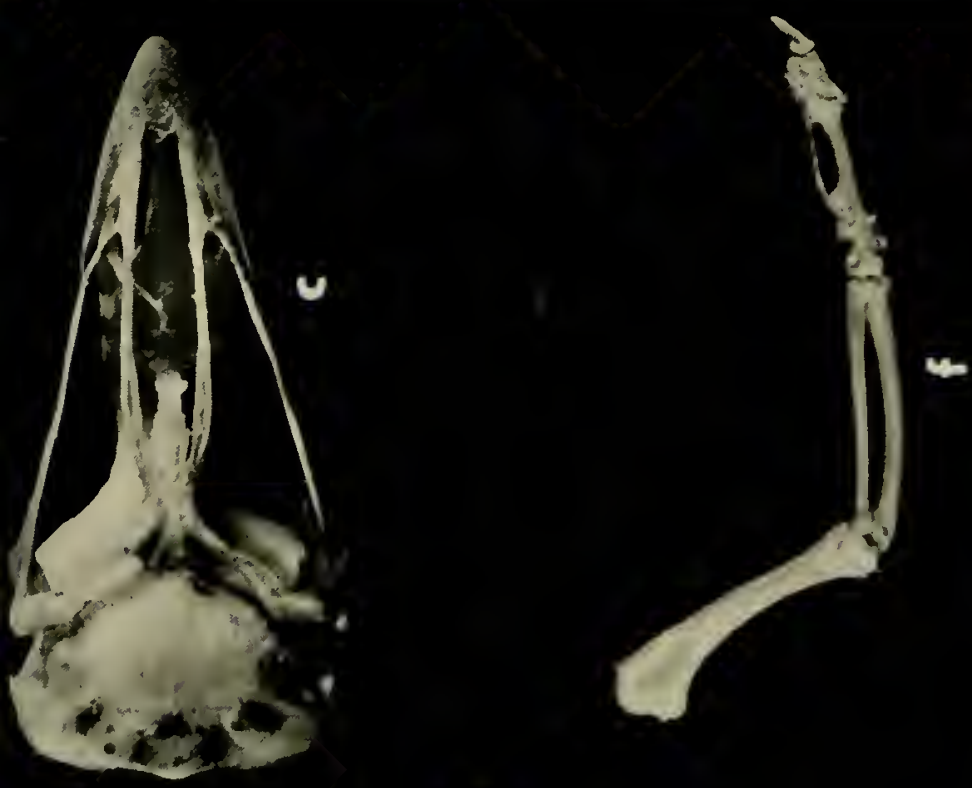
The quadrate bone consists of three processes. The otic process has one condyle. as in most primitive birds, and articulates with the squamosal. thus forming the main articulation of the jaw. The orbital process protrudes into the posterior recrion of the orbit. The ventral process is divided into two parts. one of which articulates with the lower jaw and the quadrato-jugal arch, while the other is more medial and articulates with the pterygoid.

The external aspect of the lower jaw is formed from the dentary. angular and surangular. The dentary forms the most anterior part and extends posteriorly to the fenestra between the surangular and the angular, and on the lower edge passes beyond the fenestra for some distance. The surangular meets the quadrate. From it there are two processes: the internal articular process extends into the orbit for a little distance: the retroarticular process curves upward around the posterior part of the quadrate. The latter is a long process on which is inserted M. depressor mandibulae. On the internal aspect of the jaw, the splenial bone is discernible. covering the inner side as far posteriorly as the fenestra. The other elements of the lower jaw are completely fused to the angular and surangular.

In general, the skull of Bonasa is much lighter than that of other members of the Tetraonidac. The skull of Lagopus is proportionally shorter, Jroader and higher, and has no slit between the nasals and the nasal process of the premaxilla. Centrocercus has a highly arched bill and low frontal region. The nasals are as in Lagopus. The prevomer ossifies, although it is very small. The mandibular fenestra is slit-like. Tympanuchus has a large prefrontal bone, a long postorbital process and the prevomer is ossified.

Vertebral Column. There are fifteen separate cervical vertelnae. including the athas and the axis. The atlas. which bears the head by means of a socket into which fits the occipital condyle. is a ring-shaped bone possessing postzygapophyses and an articulation on its lower posterior surface for the odontuid process of the axis, upon which the whole revolves. The postzygapophyses of the axis form a wide flange of bone. The next wo vertebrae have this flange of bone penetrated by a fenestra. as in Gallus. The following six vertebrac are elongated and have the remunt of a rilh fused to the diapophysis and directed posteriorly. Their postzygapophyses are long and thin, bearing their articular facets at the tip. The next five vertebrac are shorter and stouter. The seond (axis). third and fourth vertebrac each possess a sharp. kecl-like hypapophysis. On the fifth. the hypapophysis is a small narrow process. In these characters Bonasa differs from Gallus in which the hypophyses are long and sharp.". The last four cervicals each have an anteriorly directed hypapophysis, but the sixth to eleventh vertelorae inchusive lack hypapophyses. The leminal cervical vertehra possesses a romparatively short. thin. cervical rib which is articulated with hoth the centrum and the dia. pophysis hut which does not reach the sternum. The transwerse foramen is progressively larger till, in the last cervical vertebra. it is lacking.

There are fise thoracie vertebrae of which the first fur are fuset. Dorsally. there is a ridge formed from their fused neural spines. The lips of the first three hypapophyses are fused. thus forming two fenestrae on the ventral side. The tip of the middle hypapophysis is expanded to form a small plate. as in Tympanucluss. In Gallus. the first fenestra is smaller. The tips of the transierse processes are connected and the foramina thus formed are partly filled ly a thin film of lone. The articulation for the bead of the rib is clearly visible

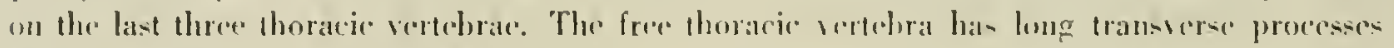
and an arlicular facet fur the sorenth rib.

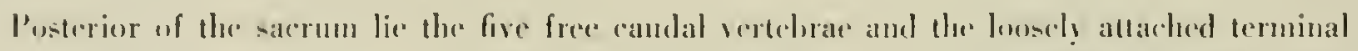
pyenstyle which is sharply pointed and protrudes slightly upward. Each vertebra has a trans- 
verse process and a short thick neural spine. According to Shufeldt ${ }^{30}$. Gallus and Pedioecetes have six free caudal vertehrae. Tympanuchus has five.

Ribs. The rib arrangement of Bonasa is typical of the Tetraonidae. There are seven pairs of ribs, including one borne on the last (fifteenth) cervical vertebra and one borne on the first thoracic vertebra. neither of which reach the sternum. The cervical pair are short slivers of bone, while each of the second pair is longer and possesses an uncinate process. The next four are composed of two parts: the dorsal. which articulates hy its head with the centrum of the vertebra and by its tuberculum with the diapophysis: and the ventral. which articulates with the sternum. All possess an uncinate process loosely joined to the dorsal part. The two parts form a $V$ with the apex directed posteriorly. The seventh and last rib arises from the first vertebra of the synsacrum, but also (as noted above) articulates with a facet on the fifth thoracic vertelira. It also is composed of two parts. The ventral part does not reach the sternum and neither does it have an uncinate process. In Trmpamuchus this sternal rib unites with the sixth rib.

Sternum. The sternum (figure $77 \mathrm{~d}$ ) possesses the forked lateral xiphoid processes. characteristic of the Galliformes, with the thin medial branch extending nearly as far posteriorly: as the tip of the sternum. In the median line. at the upper end. lies the manubrium which has a perforation in line with the coracoid groove. The anterior manubrial process is widely separated from the manubrium proper. The ribs attach to the edge of the sternum hetween the external lateral process and the manubrial process. There is a wider gap between the second and third than between the olhers. In Bonasa, the stermum is narrow and rounded posteriorly in dorso-ventral aspect. In Lagopus, it is square posteriorly and the lateral processes are wider at the tip and shorter than the stermun. These characters are still more pronounced in Centrocercus.

Pectoral Girdle. The pectoral girdle (figure $\bar{i}$ e) is composed of the furcula. coracoids and scapulae. The furcula or wishbone is a forked bone. the head of each memler of which articulates with the hear of the coracoid. At its free ventral tip it forms a high thin plate. the candal border of which is curved gently and not pninted. This plate is low in Lagopus and Tympanuchus. The furrula is $\mathrm{V}$-shaped in Bonase. but is I-shaped in Centrocercus.

The coracoid is a stoul puemualie bone. the head of which is hooked medially to form the canal for the tenton on M. supracoracoidens. Laterally. the head is cupped for articulation with the head of the hmmerus. Below the head, on the dorso-medial side. is a facet for articulation with the scapula. This is a wide flat facet and is directed olliquely to the length of the lone. Posteriorly the coracoid hroadens to articulate will the sternum. On its dorsal surface is a large irregular hole for the entrance of air ducts. The base of the coracoid is triangular in outline and. on its medial side. is inserted into the coracoid groove of the sternum. The lateral border is at right angles on the axis of the hody and lies above the base of the anterior manubrial process.

The scapula is a thin pneumatic bone extending as far back as the sacrum. In Centrocercus, it is straight with a rounded and enlarged tip. It possesses a lateral tubercle below its head which articulates with a corresponding facet on the coracoid. The head forms the medial border of the tendon canal. although it does not completely close it.

IIng. The wing (figure 7if) has three major divisions. The proximal comprises the humerus: the medial, the uha and radius: and the distal. the land or manus. The humerus. the ulna and the manus are all of the same length.

The humerus is the only pneumatic bone in the group. Its proximal end is large and flat- 
tened in the sagittal plane and hears several tuberosities, the most anterior of which is large and forms the articulation with the coracoid. Dorsally; there is a crest, the crista lateralis. which also protrudes laterally and which serves for the attachment of M. pectoralis thoracicus. Ventrally: there is the tuherculum mediale which contains on its posterior aspect a large foramen for the entrance of the air duct. The distal end turns a hit laterally and possesses two condyles.

In the medial division of the wing. the ulna and radius lie roughly parallel. The ulna is concave internally and has, on its external aspect. about eight slight tuberosities indicating the points of attachment of the secondaries. The radius is a straight terete hone, slightly outcurved distally. and articulates with the more dorsal of the condyles of the humerus.

The outer division of the wing consists of those bones distal to the ulna and radius. Digit I is small and its metacarpal is a small block of bone fused to metacarpal II. Digit II is the longest and consists of two phalanges. Its metacarpal is well developed and possesses the characteristic Galline process about one-third the length from the proximal end which is a somewhat flattened spur-like extension. protruding outward over the third metacarpal. Digit IIl has only one phalanx which is. however, free. Its metacarpal is thin and is fused at both ends to the metacarpal of II. producing a long fenestra.

Pelvic Girdle and Synsacrum. The synsacrum (figure $7 \mathrm{ig}$ ) is composed of fourteen fused vertebrac. the first of which is really of thoracic origin and hears a jointed floating rib. The first four have their transverse processes fused with the ilium. The last six vertehrae have a thin sheet of hone connecting them with each other and with their transverse processes. As in other grouse and in Callus. the transwerse process of the tenth vertehra is markedly larger than that of the others and there is a perforation hetween it and the roof of the sac. rum. The ilium is a large pneumatic home attached to the vertebral column. mainly by the transverse processes of the vertebrae hut also by a thin plate of bone from the internal horder of the iliac fossa to the fused spinal processes of the first four vertebrae. The concavity forms the whole preacetabular portion of the ilium. The postacetabular portion is flat and is fused laterally with the ischium and extends as a cornice over the region of fusion. Tympanuchus has an extreme development of the ilial cornice so that it empletely covers the ischium. The ischiadic foramen. located immediately behind the acctabulum, is large and somewhat pointed posteriorly. The obturator foramen is located between the pubis and ischium. The ischium is sharply pointed posteriorly. The pubis is slender and is attached for ahout one-half of its length to the ischium. Posteriorly, it protrudes beyond the ischium and then is directed medially. It is much smaller than in Gallus. In Tympanuchus. the transverse processes of the sacral vertehrae are wider, as seen from the under surface. and the anterior portion of the ilium is much broader than in Bonasa.

Leg. The head of the femur (figure $7 \mathrm{Th}_{\mathrm{h}}$ ) is a round knob projecting nearly at right angles to the shaft and fitting into the acetahulum of the pelvis. Opposite this is a prominent shoul. der, the trochanter, which extends as a short ridge. parallel to the shaft. on the internal edge of which are several perforations for the passage of pneumatic ducts. The shaft is not straight but is slightly convex forward. The distal part is composed of two condyles. the external of which has a small fossa in its anterior aspect.

The patella is a well developed sesamoid hone. lying on the anterior surface of the knee joint. The tibia is a long straight hone. the proximal end of which is considerably expanded and terminates in a broad transverse surface with raised edges, which is indented for the articulation of the condyles of the femur. On the anterior aspect of the proximal end is the cuemial 
crest, parallel to the shaft. There is also anotlier crest laterally. On the anterior aspect of the distal end is a bony bridge through which passes the tendon of $M$. extensor digitorum communis. Just lateral to this is a small tubercle. The articular surface of this end of the tibia is distinctly pullcy-like with the groove more pronounced anteriorly.

The fibula is a long slender bone lying along the outer side of the tibia for nearly twothirds of its length and finally joining with it at its tip. Just below the head, it is fused with the tibia for a distance of about $15 \mathrm{~mm}$. where a ridge forms to meet it. Its head is enlarged and articulates with the fossa of the external condyle of the femur, but the shaft narrows quickly and tapers to a point distally.

The tarso-metatarsus is grooved on its upper surface for the passage of tendons. At its proximal end there is a small tubercle just internal to the groove to which the tendon of the M. tibialis anticus attaches. On the lower surface at this end, there are two short flanges of bone parallel to the shaft forming a passageway for the flexor tendons. Both Lagopus and Tympanuchus have the medial one of these two flanges extending nearly to the distal cnd of the tarso-metatarsus. The distal end of the tarso-metatarsus consists of three knobs, of which only the middle (that of digit III) is a trochlea with two condyles. Between the tips of the two projections, corresponding to digits III and IV, is a foramen with a distinct gruove running up to it. The phalanges are all essentially similar. Except for the basal phalanges, the proximal end of each has a facet with double indentations for the articulation of the two distal condyles of the preceding member. The accessory metatarsal (hearing digit !. the hind toc) articulates with a facet on the ventro-medial aspect of the tarso-metatarsus.

In comparison with the other members of the Tetraonidae, it is seen that Bonasa is the lightest built. Most of the differences, however, are merely of degree. Bonasa has a higher pelvis than the others. The large posterior iliac comice of $T_{y} m p a n u c h u s$ is characteristic of that group. The other variations are slight. It scenis of interest that there is greater variation between the genera in the pelvis and the vertebral column than in the bones of the extremities.

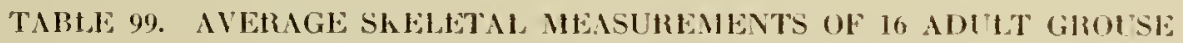

\begin{tabular}{|c|c|}
\hline Part & Average Measurement \\
\hline 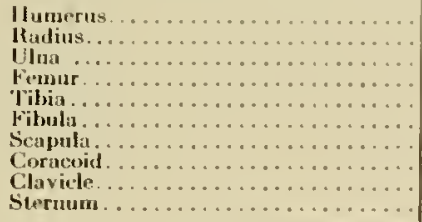 & $\begin{array}{l}5.3 \mathrm{~mm} . \\
47 \\
48 \\
59 \\
79 \\
52 \\
58 \\
15 \\
53 \\
91\end{array}$ \\
\hline
\end{tabular}

\section{The Nusculature*}

Leg. Garrod ${ }^{158}$ developed a leg muscle formula for use in classification in which A represents the presence of M. candofemoralis; B, M. psoas; $\mathrm{X}, \mathbf{M}$. flexor cruris lateralis: and $\mathrm{Y}, \mathbf{M}$. femorocruralis. The same author also considered the presence of $M$. ambiens and the vinculum between M. flexor longus digiti I and M. flexor profundus, but he did not represent either of these by the use of a letter. Hudson ${ }^{201}$ has added the letters Am (ambiens), V (vinculum), C (M. iliacus, pars medius), and D (M. piriformis). In Bonasa all these ele. 
ments are present and thus the formula is $A B C D \Lambda \backslash A m \backslash$. This formula obtains in Pedioeceles $^{312}$ and has been found by the writer in Colinus and Gallus.

In the following discussion of the myology of the hind limb, the terminology of Howell ${ }^{\text {s. }}$ lias been used strictly for the hip and thigh. For the shank and foot, the terminology of Gadow has been followed cxcept in these details: (1) the term "Nl. flexor profundus s. perforatus" is shortened to "M. flexor profundus"; and (2) the word "hallucis" is replaced by "digit I". The arrangement of these muscles is illustrated in figure 78 .

In Bonasa 11. extensor iliotibialis anterior is the most anterior of the superficial nuscles of the thigh. It arises from the anterior part of the raised border of the ilim and passes down over the M. gluteus profundus and the external border of the ilium, forming the anterior edge of the thigh and passing on to the mesial side. Its fascia fuses with those of the M. extensor iliotibialis lateralis and the $\mathrm{M}$. vastus medialis to insert on the crest of the tibia.

M. extensor iliotibialis lateralis is a large muscle covering the external aspect of the thigh, except the anterior and posterior borders. It arises from the internal margin of the ilium both pre and post acetabular, thus covering the whole postacetabular ridge. It is a very thin muscle with the portion behind the femur being thicker. Its fascia extends over the M. gluteus profundus. Distally, the fascia merges with that of $\mathrm{M}$. vastus lateralis, thus forming an aponeurosis which covers the entire anterior aspect of the knee. Gadow ${ }^{250}$ considers this muscle as divided into three parts but these are very poorly defined in Bonasa. The insertion passes under the topmost part of the origin of the pars externa of M. gastrocnemius and on to the patella.

N. gluteus profundus originates from the supcro-internal margin of the preacetabular moiety of the ilium and the concave surface of the bone external to it. It lies immediately beneath the aponeurosis of M. extensor iliotibialis lateralis and the proximal portion of M. extensor iliotibialis anterior. The fibers insert ly a broad tendon on the head of the femur proximal to the insertion of M. iliacus, pars medius. This muscle is relativcly large in Colinus.

M. iliacus, pars anterior is a small musele which is only slightly covercd by the preceding. It originates along the external border of the acetalular fossa and also from the last rib. The insertion is just distal to the insertion of $\mathrm{M}$. ghtens profundus and is formed by a hroad tendon. In Colinus, the origin is almost entirely from the ventral surface of M. gluteus pro. fundus.

M. iliacus, pars medins originates on the external horder of the ilimm about one-half the distance from the acetabulum to the origin of M. iliacus. pars anterior. The insertion is between the insertions of the above muscles. The helly of this muscle is completely covered by M. gluteus profundus.

M. vastus lateralis underlies M. extensor iliotibialis lateralis. It originates along the antero. external portion of the fenur just distal to the insertion of the M. iliacus, pars anterior. Its fascia is, as mentioned ahove, fused with that of $\mathrm{Ml}$. extensor iliotihialis latcralis. These pass wer the tip of the femur and insert on the patclla. In Gallus, the origin overlics the insertion of M. iliacus, pars anterior. In Colimus, the origin is even more proximal, partly covering the insertion of $\mathrm{M}$. iliacus. pars medius and the muscle is divided into two parts. Pars media originates from the proximal one-third of the anterior aspeet of the femur. Its fascia fuses distally with that of II. extensor iliotihialis lateralis and inserts on the patcha. Pars externa is on the external aspect of the femur. In Bonasa, pars media is not distinctly separated from pars externa. 
THE ANATOMY OF THE RUFFED GROUSE

729

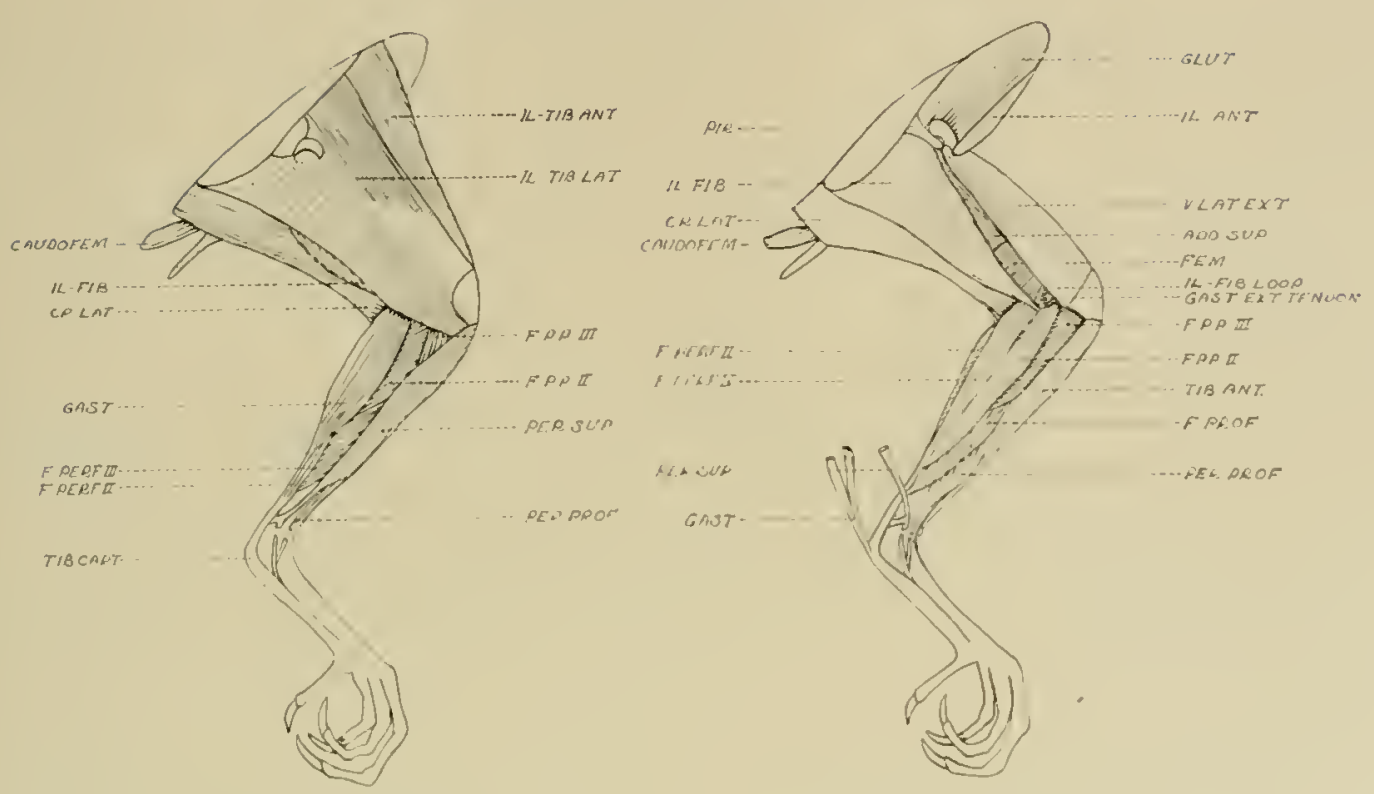

Superficial muscles

Superficial muscles removed

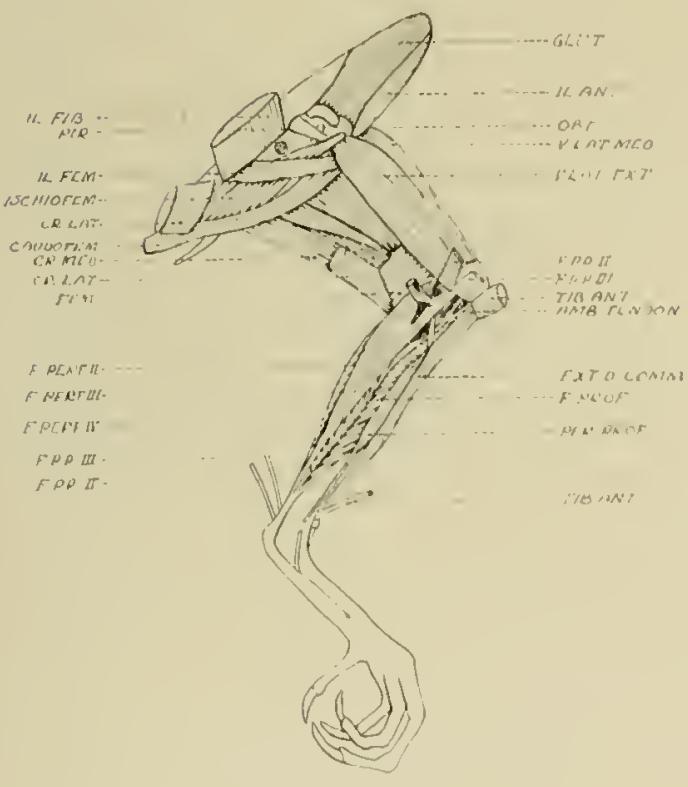

Deep muscles

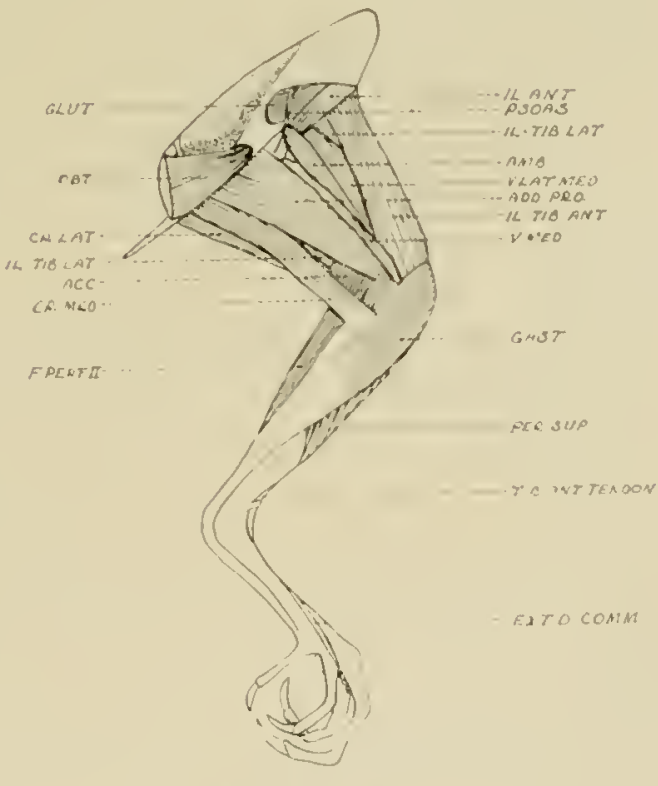

Medial muscles

Figure $78^{*}$. Leg musculature. Lateral view $(x \quad 0.43$ )

* For explanation of abbreviations. save [1. 710. 
M. vastus medialis extends along the internal aspect of the femur. It is wider at the distal end and there passes over the inner edge of the mesial condyle to insert on the crest of the tibia. The origin is along the fenur, beginning abuut $5 \mathrm{~mm}$. distal of the head. In Gallus, the origin is at the head and is fleshy.

M. piriformis is a small triangular muscle originating on the ilium immediately alove the acetabulum. The tendon passes over the insertion of the tendon of M. obturator and inserts on the femur just posterior to the insertion of the tendon of M. gluteus profundus. In Gallus, this muscle is relatively large.

M. psoas is a slender muscle originating from the lateral border of the ilium anterior to the prepubis. There is a small knob at this point. The insertion is on the inesial aspect of the femur between the head and the insertion of $\mathrm{M}$. vastus medialis.

M. ambiens is a small muscle and is visible only from the medial side. The origin is on the ventral face of the prepubis. Its tendon passes over the condyles of the femur and then laterally and obliquely through the fascia of $\mathrm{M}$. vastus lateralis and down to join M. flexor perforatus. The distal portion of $\mathrm{M}$. extensoriliotibialis lateralis internus covers much of the tendon.

M. extensor iliofibularis is a triangular muscle which originates along the postacetabular ridge of the ilium and is situated below the pars posterior of $\mathbf{M}$. extensor iliotibialis lateralis and anterior to M. flexor cruris lateralis. The fibers converge distally and pass posterior to the knee joint, to form the tendon. A wide and thin division of the tendon extends down onto the fascia of pars externa of M. gastrocnemius. In Gallus, this slip passes mesially, entering the pars externa and also has a slip to M. flexor perforans digiti IV pars media. The inain tendon passes through a fibrous loop and then downward to insert on a tubercle of the fibula. The inner part of the loop is attached to the anterior border of the femur just proximal to the external condyle. The outer and shorter end of the loop merges with the tendinous origin of the external head of M. flexor perforans digiti IV and then passes to the lateral crest of the tibia. In Colinus, the origin docs not extend as far anteriorly, and does not cover any of the head of the femur.

M. flexor cruris lateralis is typically developed. It arises from the posterior lorder of the ilium and the fascia of the caudal muscles. Its fibers pass obliquely to insen distally along the tendinous raphe which forms the posterior margin of M. femorocruralis. From this area a broad tendon extends to the fascia of pars interna of $\mathbf{M l}$. gastrocnemius. M. femorocruralis has its fibers parallel to the tibia, passing from the tendinous raphe, as a broad muscle, up to the femur, to insert along the distal one-third on the lateral border. One portion passes mesiad to the insertion of $\mathrm{M}$. flexor perforans digiti IV and then inserts in the cavity between the two condyles. In Gallus, these fibers merge on the distal border with M. gastrocnemius. In Colinus, N. femorocruralis is relatively very wide, inserting along one-half of the femur.

M. flexor ischiofemoralis arises in the concavity of the ischim and passes as a loroad, thin nuscle forward. It forms a wide tendon which inserts on the external aspect of the femur just below the trochanter.

M. flexor cruris medialis originates from the onter edge of the ischium, at the point where the pubis and ischium fuse. The muscle is riblon-like and passes below M. flexor cruris lateralis to terminate mesial to the tendinous riphe of the latter, in a fascia which merges with that of the pars interna of M. gastrocnemius. A broad tendinous fascia, common to M. flexor 
cruris medialis and M. flexor cruris lateralis, passes internal to the pars interna of M. gastrocnemius and passes over M. plantaris and then inserts on the tibia, just distal to the mesial condyle. In Colinus, M. flexor cruris medialis is relatively small.

M. caudofenoralis inserts along the external aspect of the shaft of the femur below M. vastus lateralis. As a thin curved band of parallel fibers. it passes over the ischium from its origin on the caudal vertebrae.

M. flexor iliofemoralis arises beneath the rim of the postacetabular portion of the ilium, posterior to the ischiadic foramen. It passes obliquely to insert with 11 . caudofemoralis. In Gallus M. flexor iliofemoralis differs greatly. It has two bellies, connected by a fascia. The medial belly inserts on the posterior border of the obturator foramen.

M. obturator arises from the entire ventral surface of the ilium. It is broad at the posterior part and then narrows as it passes anteriurly. Its fibers join to form the tendon which passes through the obturator foramen and inserts on the outer aspect of the femur opposite to the insertion of M. extensor iliotibialis lateralis. In Gallus and Colinus, this muscle is large and extends up onto the ventral surface of the ilium.

Mm. accessorii $\mathrm{m}$. obturatus. This group of inuscles has only one small representative in Bonasa and Gallus. It stretches from the fossa letween the obturator foramen and the acetabular foramen to the trochanter of the femur and inserts with the previous muscle.

M. adductor superficialis originates along the pulis just posterior to the oluturator foramen. It passes as a band of fibers parallel to the femur to insert on the femur, posterior to the insertion of M. Jemorocruralis and also in the fossa between the condyles.

M. adductor profundus lies immediately mesial to the 11 . adductor superficialis. Its pubic portion is parly formed from an aponeurosis which is attached to the pars externa. The insertion is along the distal two-thirds of the femur, lut mainly in the condylar fussa.

M. gastrocnemius is the large muscle covering most of the pusterior and internal aspects of the lower leg. It is composed of three parts. The pars externa has its origin on the outer condyle of the femur. The outer part of the tendinous loop for the M. extensor iliofibularis also originates at this point. This is proximal to the insertion of M. extensor iliotibialis lateralis and M. vastus lateralis. This part is fairly long and thin and is distinct from the two other parts. The pars media arises from the inner surface of the inner condyle of the femur. It is small and soon fuses with the rest of the muscle. The tendon formed by M. flexor cruris lateralis and M. flexor cruris medialis fuses with it and passes through to insert on the internal aspect of the tibia. M. femorocruralis is not connected with the pars nedia in Bonasa as it is in Colinus. The pars interna takes its origin from the imer rim of the tibial summit and the faseia of M. extensor iliotibialis anterior. This is the largest division of the muscle. The tendon (tendo Achillis) is formed from the tendons of the pars externa and the pars interna (the tendon of pars media has fused more proximally). It passes over the tarsal joint in a groove of the tibial cartilage and inserts on the tarso-metatarsus just distal of the proximal head. The tendon is perforate for the other tendons which pass over the back of the joint, thus inserting in two parts. Part of the tendon continnes along the ventral surface of the tarso-metatarsus and inserts in the region of the accessory metatarsal.

M. plantaris is a small muscle lying just under the pars interna of M. gastrocnemius and originating on the internal crest of the tibia. Its tendon inserts on the tibial cartilage. The fascia of M. flexor cruris medialis passes over (ntesiad) its belly to insert on the inner edge of the tibia. 
II. peroneus superficialis is a broad thin mus.le which covers the anterior aspect of the tibia. lis origin is on the cnemial crest of the tibia. The tendon passes along the exterolateral aspect and divides just proximal to the tihial condyles. The larger branch passes over to the posterior side and inserts on the under surface of the tibial cartilage just external to the insertion of the tendon of M. plantaris. The other branch continues along the lateral aspect. passing under a tendinous bridge, past the joint and inserts on the tendon of $M$. flexor perforatus digiti III. In Gallus, there is no bridge. Colinus has a slight one.

M. peroneus profundus originates along the anterior aspect of the fibula and the lateral frart of the tibia. It is attached to these bones for its entire length. The tendon is formed ahout a centimeter above the joint and passes under a tendinous bridge and over the lateral side of the joint and inserts on the summit of the tarso-metatarsus. The tendon widens out into a strap-like band as it passes over the joint.

11. popliteus is situated on the posterior side of the fibula and tibia just below the heads. It is the most deeply placed muscle. The origin is on the fibula and the insertion is on the adjacent area of the tibia.

The origin of M. tibialis anticus is undemeath that of M. peroneus superficialis from the pro- and ecto-cnemial crests of the tibia. There is no femoral head in Bonasa. The tendon passes under an oblique fibro-cartilage bridge and over the anterior surface of the tibial condyles, to insert on a tubercle just below the head of the tarso-metatarsus. The tendon becomes wider and cartilaginous as it passes over the tibial cartilage.

M. extensor digitorum communis originates from the procnemial crest of the tibia, mesiad to the M. tibialis anticus, and passes along the anterior aspect of the tibia. The external erlge is flattened out and closely appressed to the tihia. The tendon passes under a bony bridge just proximal to the tibial condyles. Just above and mesial to the tubercle for the insertion of the M. tibialis anticus on the tarso-mctatarsus the tendon passes through a fibrous liridge. About midway along the anterior surface of the tarso-metatarsus, the tendon divides into two branches, the extemal one soon bifurcating again. The internal branch divides at the hase of digit 11 , one half going to digit II and the other half inserting on the hasal phalanx of digit 1. Each branch passes 10 the dorsal aspect of the toe and divides to form the tendons for each phalanx.

M. flcxor perforatus is the principal flexor of the toes. In Bonasa, as in most birds, it is divided into three parts whose bellies are connected together but have distinct tendons. The origin is lyy a strong tendon from the intercondylar fossa, a tendinous slip from the external portion of the sling of M. extensor iliofibularis, and a strong tendon from the ectocnemial crest which receives the tendon of M. ambiens. The insertion is on the phalanges and is perforated for the passage of the other tendons to the phalanges.

In Colinus, this muscle is split into its components quite distinctly. The origrin of cach part is separate from the others. M. perforatus digiti IV has two places of origin, one passing un the external and one passing on the internal side of the tendon of M. extensor iliofilunlaris.

M. flexor perforatus digiti $\mathrm{IV}$ is the most superficial of the group and is triangular and thin. The origin is from the interendylar region (mesial to the tendon of M. extensor iliofibularis) and. also, from a fascia which extends up onto the external part of the sling for the tendon of M. extensor iliofihularis. Thus this origin is lateral to that tendon. The intercondylar origin is independent of the tendinous origin of M. flexor perforatus digiti II 
and M. flexor perforatus digiti III. The tendon passes through the tibial cartilage to the basal phalanx of digit IV. The flexion of the second and third phalanges of digit $I V$ is accomplished by tendons which have split off from the tendon of M. flexor perforatus digiti IV after it has passed the basal phalanx.

M. flexor perforatus digiti $\mathbf{H}$ l is divided intu two parts. The smaller originates from the strong tendon connected with that of M. ambieus and is thus connected with M. flexor perforatus digiti IV. The larger division originates from the tendon in the intercondylar region. The tendons of the two divisions join after passing through the tibial cartilage and then receive the tendon of $M$. peroneus superficialis. A vinculum joins the tendons of this muscle and M. flexor perforans et perforatus digiti III just proximal to the toes. The insertion is on the basal phalanx only. Gadow ${ }^{150}$ mentions great variation in this muscle. In Gallus, there is no division into two parts. In Colinus, this muscle is divided into two distinct parts and is not fused with M. flexor perforatus digiti IV.

M. flexor perforatus digiti II may be considered "1 originate as the tendon from the intercondylar region. This muscle is most mesial and separates from the main body to form its tendon. This passes through the tibial cartilage and extends to the basal phalanx of digit II. $\mathrm{f}_{\mathrm{n}}$ Gallus it is separated from the main lonly mly at short distance before it forms its tendon.

The flexion of the second phalanx of digits II and III is performed by the M. flexor perforans et perforatus group. The tendon passes through the perforation of the tendon of M. flexor perforatus at its insertion on the basal phalanx and inserts on the second phalanx. This insertion is perforated for the passige of the tendon of M. flexor profundus.

M. flexor perforans et perforatus digit II is a superficial muscle arising from the fascia (immediately proximal to the external part of the loop for 11 . extensor iliofibularis) covering the lateral condyle of the femur, anterior to the pars externa of $\mathrm{M}$. crastrocnemius. It is a small, thin, but wide muscle which soon forms its tendon. This passes through the tihial cartilage to insert on digit II. In Gallus. it differs greatly. Its middle portion (which is mainly fascia in Bonasa) has disappeared. leaving an anterior and a posterior head. The anterior division, however, has a small helly, distal to the main part of M. flexor perfurans et perforatus digiti $I$, which is attached to the pusterior head by a slender strip of fascia. The Iwo tendons fuse at once.

M. flexor perforans et perfuratus digiti III is a large musele lying immediately anterior to and partly under the above muscle. It arises, in part, from the fibula hut nuainly from the fascia, immediately anterior to the origin of M. flexor perforans et perforatus digiti II. Its tendon passes through the tibial cartilage to its insertion. In Callus, this muscle is relatively short.

I. flexor profundus is the deepest of all the muscles at the back of the tibia. It arises along the proximal two-thirds of the tibia and along the fibula. The origin is not double as Hudson $^{3 n}$ found it in Pedioeceles. The tendon passes over the tarsal joint, deepest in the tilial cartilage, and along the under surface of the tarso-metatarsus. It is connected by the vineulum with the tendon of M. flexor longus digiti I. Beyond this point it trifurcates. one tendon going to each of the three anterior toes to insert on the penultimate and ungual phalanx.

M. flexor longus digiti $l$ is a small muscle arising from the posterior aspect of the femur between the condyles, just distal to the origin of M. llexor perforatus digiti $\mathrm{N}$. and mesial to the tendon of M. extensor ilioflexorius. It soon forms its tendon which passes down through the tibial cartilage and then mesially across the tarso-metatarsus to digit $f$. It passes external 
(1) the tendon of M. flexor profundus and is connected (1) that tendon by the vinculum. The tendon perforates the tendon of 11. flexor brevis digiti 1 to insert on the ungual phalanx.

M. extensor hevis digiti I originates from the head of the tarso-metatarsus on the dorsal side and the adjoining part of the bone. This is a small muscle whose tendon passes mesially to the accessory metatarsus to insert on the basal phalanx.

M. extensor brevis digiti III is small and lies on the distal one-fuurth of the anterior surfice of the tarso-metatarsus. The tendon inserts on the basal phalanx. The origin is more extensive in Gallus and the muscle is larger. There is only one short extensor of digit III. Hudson ${ }^{301}$ points out that this is true of all Neognathae examined. The term "brevis" seems preferable to "proprius".

M. extensor brevis digiti $I V$ originates at the proximal end of the anterior surface of the tarso-metatarsus. The tendon soon forms and passes through a foramen of the metatarsus to insert on the ventro-medial surface of the basal phalanx.

M. flexor brevis digiti I originates at the proximal end of the posterior surface of the tarsometatarsus. The muscle is on the ventral internal side. There are two distinct, though small, heads whose tendons soon fuse. The muscle is bounded internally by the ridge of bone on the ventral surface of the tarso-metatarsus. Its tendon passes on the ventral surface to insert on the basal phalasx. The tendon is perforated at its insertion for the passage of the tendon of M. flexor longus digiti I. In Callus, there is no ridge of bone.

II. flexor brevis digiti II was not found.

11. adductor digiti 11 is absent as in Pedioecetes ${ }^{201}$.

M. adductor digiti IV was not found.

M. adductor digiti II is a very small muscle on the internal distal one-fourth of the anterior surface of the tarso-metatarsus. Its slender tendon inserts on the hasal phalanx. It is well developed in Gallus.

M. alductor digiti IV mateles the position of M. flexor brevis digiti I, lying on the exterual edge of the ventral surface. The tendon passes to the lateral side of the proximal end of the basal phalanx, where it is inserted.

Movement of Leg. The manner in which movement of the leg is accomplished may be briefly described as follows. The ruffed grouse possesses all the leg muscles which are pres. ent in hirds except for certain ones associated with the digits. This indicates a great freedom of motion and a lack of specialization for any particular direction of movement. Each joint las great flexibility. It has been pointed out that in the grouse-like birds, the muscles for rotation and toe movement are, in comparison with other birds, powerfully developed. This is correlated with pecking and seratehing.

The rotation of the femur in the acotabulum is performed primarily by Mn. iliacus, grluteus profundus, ohturator, and flexor ischio-femoralis. M. piriformis is a weak abductor as is M. psuas which also tends to flex the femur on the pelvis. Forward movement of the femur is produced by M. extensor iliotilialis anterior and. to some extent, by the anterior part of M. extensor iliotibialis lateralis. The hackward movement and flexion of the fenur is performed hy .ll. adductor superficialis primarily, lut assisted by M. caudofemoralis and I. flexor cruris lateralis. MI. vastus medialis rotates the tilia inward.

The flexion of the lihia on the femur is perfurmed hy $\mathbf{M}$. flexor cruris medialis and $M$. flexwr cruris lateralis. The extension of the tibia is caused ly M. vastus lateralis. The tarso- 
metatarsus is flexed on the tibia by M. tibialis anticus and extended by M. gastrocnemius and M. peroneus superficialis. M. plantaris is a weak extensor of the tarso-metatarsus. M. peroneus brevis abducts the tarso-metatarsus. The fibula and tibia are drawn together by M. popliteus.

M. extensor digitorum communis is assisted in the extension of the fore toes by M. extensor brevis digiti II and M. extensor brevis digiti IV. Digit I (hind toe) is extended ly M. extensor brevis digiti I. The muscles for the flexion of the toes are numerous. M. flexor perforatus has a separate tendon to each of the fore toes. M. ambiens acts on digit II through the connection of its tendon with M. flexor perforatus digiti II. M. flexor perforans et perforatus digiti II and M. flexor perforans et perforatus digiti III act to flex the more distal phalanges. M. peroneus superficialis acts on digit III since its tendon attaches to the tendon of M. flexor perforans et perforatus digiti III. In addition, M. flexor profundus has a hranch to each of the fore toes. Digit I is flexed by M. flexor longus digiti I. There is a M. flexor hrevis for digit I. Digit II has a small abductor and adductor and digit IV has an abductor. The presence of a vinculum between M. flexor profundus and M. flexor longus digiti 1 and alsu between M. flexor perforatus digiti III and M. flexor perforans et perforatus digiti III tends to result in unity of action for the toes.

W'ing. The following are brief descriptions of the important muscles" of the wing (figure 79.)

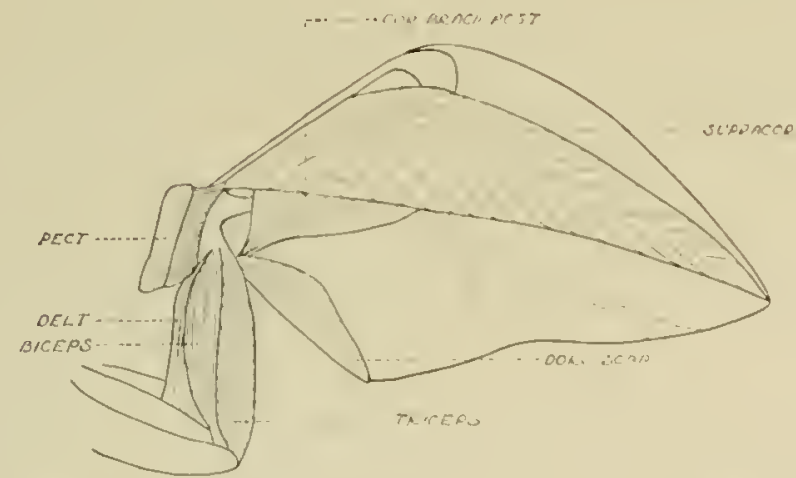

FIGURE $79^{\triangle}$. WING MISCULATLRE. LATERAI VIEW OF DEEP MLSCLES ( 0.43 )

M. rhomboideus superficialis originates on the last cervical vertebra and along the crests of the first three thoracic vertebrae. The muscle extends as a wide hand to the scapula and also extends forward to insert on the dorsal part of the clavicle.

M. rhomboideus profundus underlies M. rhomboideus superficialis. Its origin is from the neural crests of the last cervical vertelora and all five thoracic vertebrae. The insertion is on the dorsal border of the scapula just under that of M. rhomboideus superficialis.

M. pectoralis superficialis is divided into three parts. M. pectoralis thoracicus originates along the ventral part of the sternum, the membrana stemo-coraco-clavicularis and clavicle. and inserts on the lateral crest of the humerus. This is the great flexor of the wing. M. pectoralis propatagialis is a poorly defined slip which has a small extension to the propatagial ligament. M. pectoralis abdominis extends just under the skin from the pubis to the lateral

* Terminulogv acrurding to Huwell. A. B. $1(m)$
$\triangle$ For explanation of ahbreviations. see p. 
crest of the humerus. Its function is movement of the skin.

M. supracoracoideus is the great elevator of the wing. The muscle lies under the M. pectoralis thoracicus and originates from the sternum, membrana coraco-clavicularis, and the coracoid. and its tendon passes through the foramen triosseum to insert on the lateral tubercle ol the humerus.

M. coracobrachialis anterior is a small muscle stretching between the tip of the coracoid and the ventral surface of the proximal head of the humerus. It lies under the tendon of M. supracoracoideus.

M. coracobrachialis posterior lies under the dorsal part of M. pectoralis superficialis. It originates along the coracoid and the anterior lateral process of the sternum and inserts by a tendon on the ventro-external border of the humerus.

M. hiceps is the strong flexor of the ulna on the humerus. It originates from the strong fascia covering the head of the humerus and the head of the coracoid and extends along the rentro-lateral horder of the humerus to insert on the una a short distance distal of the head. 1 slip. M. biceps propatagialis. extends to the propatagium.

M. brachialis is a small muscle which connects the proximal portion of the ulna with the distal head of the humerus. It lies medial to the insertion of M. biceps.

M. latissinus dorsi is divided into two parts. Pars anterior originates from the neural ridge of the first thoracic vertehra and passes orer M. rhomboideus superficialis to insert on the medial border of the humerus. It passes ventral to M. deltoideus and M. triceps. The pars posterior originates from the spines of the sacral and thoracic vertebrae and joins the pars anterior where it passes to the humerus.

M. deltnideus propatagialis arises from the dorsal and anterior tip of the clavicle and passes to the fascia covering the muscles of the ulna and radius. It soon forms its tendon. which is wide. and merges with that of M. hiceps propatagialis. This tendon divides into a longus portion which extends to the distal area of the ulna and a brevis portion which attaches more hasally.

M. deltoideus longus originates from the tip of the claticle and the adjoining area of the scapula. It passes posteriorly to insert on the proximal half of the medial surface of the humerus. It is entirely fleshy.

M. deltoidens brevis is a small musele which comects the tip of the clavicle to the anterior face of the humerus. It lies dorsal to the tendon of M. supracoracoideus.

I. dorsalis scapulac is the large muscle which originates along the lateral horder of the entire posteglenoid region of the scapula and whose fibers converge to form a strong tendon. This tendon inserts on the proximal end of the humerns at the precessus medialis humeri.

11. proseapuhhumeralis is small and partly covered hy the preceding muscle. It originates on the anterior portion of the lateral horder of the scapula and inserts on the humerus at the origin of $\mathrm{M}$. triceps.

II. suhcoracoideus arises in three parts which join to insert on the medial head of the humerus. Caput coracoidem is a large. division originating on the internal surface of the curacoid. Capul sapulare internum arises un the internal face of the seapula and the raput s'atpulatre exsermum arioes on the external fite. 'This last head is small.

W. triceps is the ereat extensor of the uhua and radius. It is divided into three heads. Caput 
scapulare is the largest and originates from the internal basal part of the humerus and the adjoining faciae, and passes fleshy along the humerus between the M. deltoides major and the body. Furbringer ${ }^{13}$ classifies the origin of this head into four types. Bonasa belongs to type 3- "proximale humerale Ankerung". Caput coracoideum consists of a long tendon which originates by a branched tendon from the M. coracobrachialis posterior and M. proscapulo. humeralis, and passes along the ventral surface of the wing to end in a small muscle which expands the secondaries. Caput humerale originates on the dorso-medial surface of the humerus and passes along the medial surface to insert on the olecranon of the ulna. This head is attached to the humerus for its entire length.

\section{Specialized Strlctlres and Systems}

Syrinx. The syrinx is formed by modification of the junction of the trachea and bronchi. and thus is of the tracheo-bronchial type. The last six tracheal rings are reduced in size but are not vestigial and are complete rings. In the sub-order. Galli, each tracheal ring is fused on the dorsal side and thus does not leave a drum-like area ${ }^{350}$. The penultimate ring is somewhat enlarged ventrally to form a small posteriorly directed protrusion and dorsally it is fused with the dorsal plate of the pessulus. The ultimate tracheal ring is fused with the ventral plate of the pessulus but is incomplete dorsally. The first bronchial semi-ring is not attached to the plate of the pessulus but is suspended by the memlirana tympaniformis externa. It: dorsal end is free and expanded. The second bronchial ring is attached to the ventral plate of the pessulus and is wider than the first ring. The pessulus is rod-like in form and extends dorso- anteriorly. Its ends are cxpanded to form a dorsal and a ventral plate.

The nembrana tympaniformis externa forms the lateral wall of the syrinx. The memhrana trmpaniformis interna stretches between the ends of the bronchial scmi-rings. The bronchidesmus is a memlurane stretched hetween the membrana internae of the hronchi. Triangular pieces of cartilage are included within the membrane.

There are two sets of muscles which move the trachea and syrinx. The 11 . trachealis set is composed of one muscle, extendine along the tracliea as far posteriorly as the sixth (last) tracheal ring. Its function is contraction of the trachea. The N. sternotrachealis set is composed of one muscle on each side of the syrinx. The insertion of each member extend. from the penultimate trachael ring anteriorly along the dorso-lateral border of the trachea for about two centimeters. A slip extends posteriorly to cover the dorsal plate of the pessulus. The origin is on the outer lateral process of the stermum.

Digestive Tract. This is illustrated in figure 80 . The mouth cavity contains the thich muscular tongue, which is hroad. slont and triangular in shape. On the floor and roof of the mouth are mmerous short. harlened spines pointing posteriorly. There is a definite row of these surrounding the entrance to the pharynx. The nesophagus is a simple tube extending to the crop. Although Tuttle mentions rudimentary vocal sacs. there is no indication of an extension of the oesophagus related to the production of rocal sound as in Tympanuchus ${ }^{270}$.

The crop is a large spherical diverticulum of the oesophagus lying between the divisions of the furculum on the upper part of the breast. mainly on the left side. Its opening to the oesophagus has approximately the same diameter as the oesophagus itself. Gallinaceous hirds have a true crop. which is a diverticulum of the oesophlagus. rather than a "false crop" formed ly the expansion of the oesophagus as found in certain hawks. From the crop. the oesophagus extends as a short tuhe to the sentriculus. 


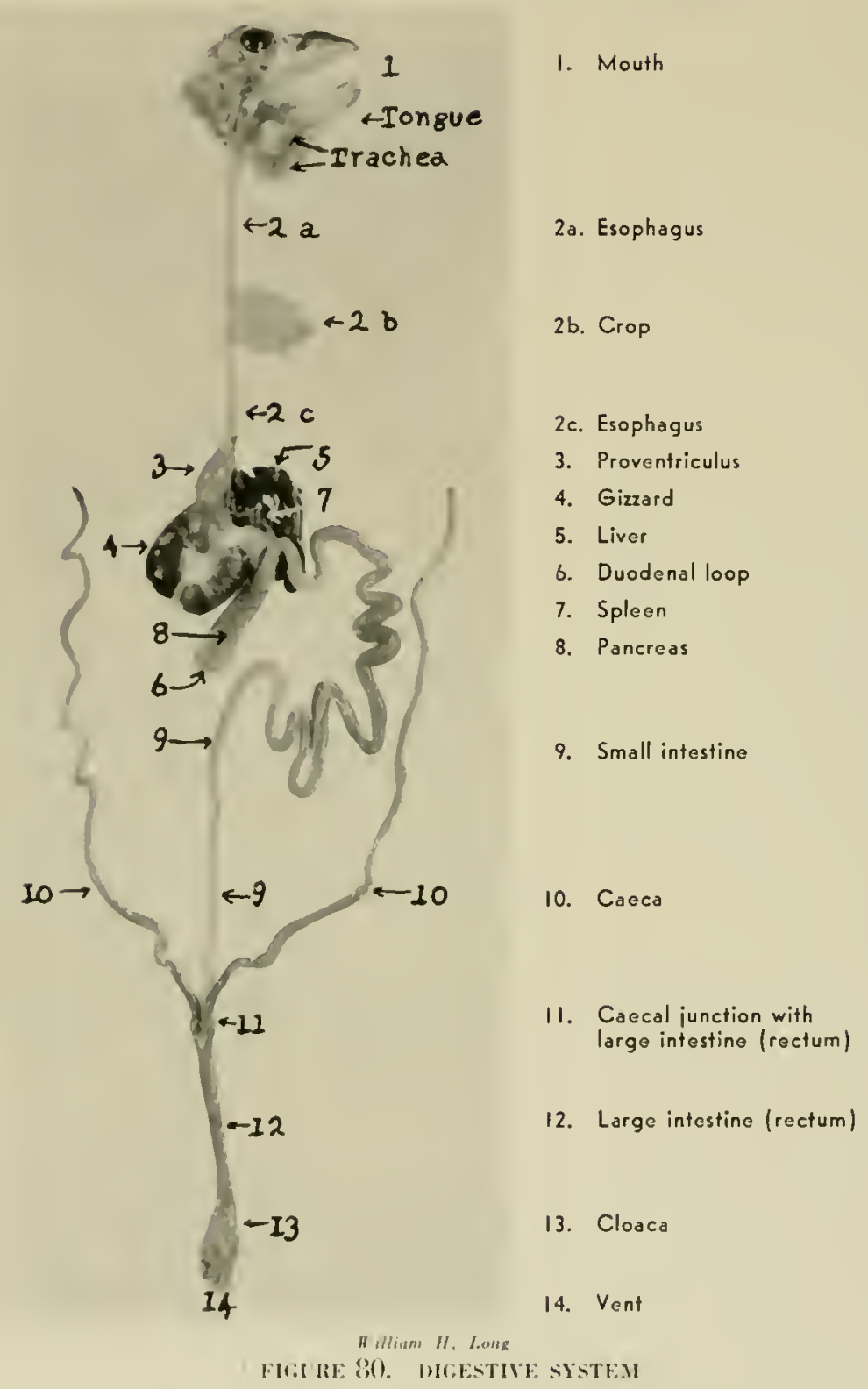

The latter is divided into an anterior glandular portion (proventriculus) and a posterior grinding portion (gizzard). with a narrow istlmus separating them. Gallinaceons birds belong to the lype in whith the proventrieulus is separated from the gizand by a section which is non-glandular internally ${ }^{20 *}$. Theme lirds have the ventriculus highly specialized, for feeding on regetal material. by the great development of the mosenlar portion and the tongh thick inner linintr.

The dundenum extends from lloc dursal and anterior part of the gizard and then forms a longitulinal lewp. The panereas lies betweren the arms of this loop. The entranee of the franereatie duets marh the beginning of the small intestinc. This passes immediately dorsad 
and then forms several loops, the last one extending ventrad and at right angles to the axis of the body. It then passes dorsad and anteriorly to join the large intestine. The two caeca diverge at this point and form a series of coils at right angles to the body axis, posterior of the gizzard. The small and large intestines are of equal diameter. There is considerable variation in the details of the arrangement of these structures. The Galli are grouped among the birds with long cacca as opposed to the types in which they are small or functionless ${ }^{3 \pi n}$.

The large intestine (figure 81 ) is the shortest section of the gut. It lies just under the roof of the visceral cavity and is divided into three parts. coprodeum. urodeum and proctodenm ${ }^{2 m}$.

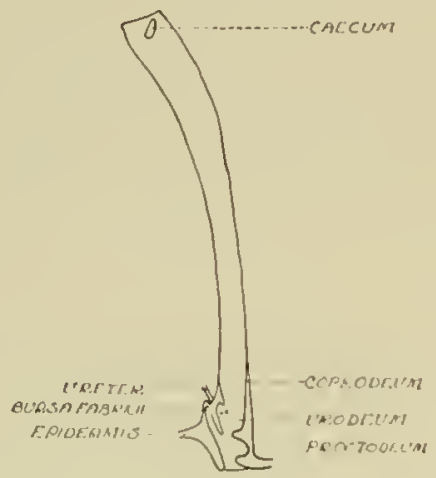

FigURE 8I. LONGITUDHNA SECTION OF IARGE INTESTINE $(\times 0.21)$

The coprodeum extends from the eaeca to the small flap which separates it from the urodeum. The latter is a slort section, bounded posteriorly by a flap. It receives the ureters as well as the oviduct or the vasa deferentia. The proctodeum is the terminal section. On its dorsal side is a diverticulnm, the bursa Fabricii*. The external opening is smaller than the cavity of the proctodeum.

TABLE 100. AVERAGE MEASUREMENTS OF DIGESTIE TR ACT OF 16 MDITT GROUSE

\begin{tabular}{|c|c|}
\hline l'art & Avrrase Mlosasurement \\
\hline 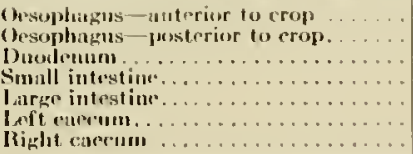 & $\begin{array}{r}11.5 \mathrm{~mm} . \\
5.3 \\
112 \\
79.3 \\
9.5 \\
320 \\
32.3\end{array}$ \\
\hline
\end{tabular}

Urogenital System. The urogenital system is extremely uniform throughout the Class Aves and is composed of the sex organs and their ducts. and the excretory organs. The kidneys are paired structures lying ventral to the sacrum and dorsal to the aorta and its large branches. the ischiadic arteries. Each kidney is lobed and sends the excretory products to the cloaca through the ureter.

* This is a sac-like pouch which is present in hirds of the year up to an age of abuut nine noonths. It is therefore the

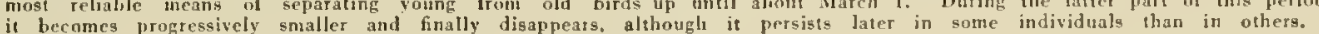


In the male, the testes are oval bodies lying ventral to the anterior part of the kidneys. In the breeding condition they are much enlarged. The epididymis is a mass of fine tubes connecting the testis with the ductus deferens which enters the cloaca just ventral to the entrance of the ureter. The sperm pass from the testis through the epididymis and ductus deferens to the cloaca.

In the female. the sex organs consist of the ovary and the oviduct. Normally, only those on the left side develop. The ovary is in the same position as the testis and resembles a bunch of grapes in appearance. The egg is extruded from the ovary into the infundibulum of the oviduct. The chalaza is produced here. while the egg white is formed in the tuhe region, and the shell and color are added in the uterus. These regions are poorly defined and cannot be distinguished in the non-breeding condition.

Ahnormal conditions of the gonads are not infrequent. An ovotestis may develop or, under certain conditions, the ovary may atrophy on the left and then the right gonad develop into a testis. Such abnormalities often have remarkahle effects on the plumage and other seenndary sex characters.

\section{EXILANATION OF ABBREVIATIONS IISED IN FIGURES 78 \& 79}

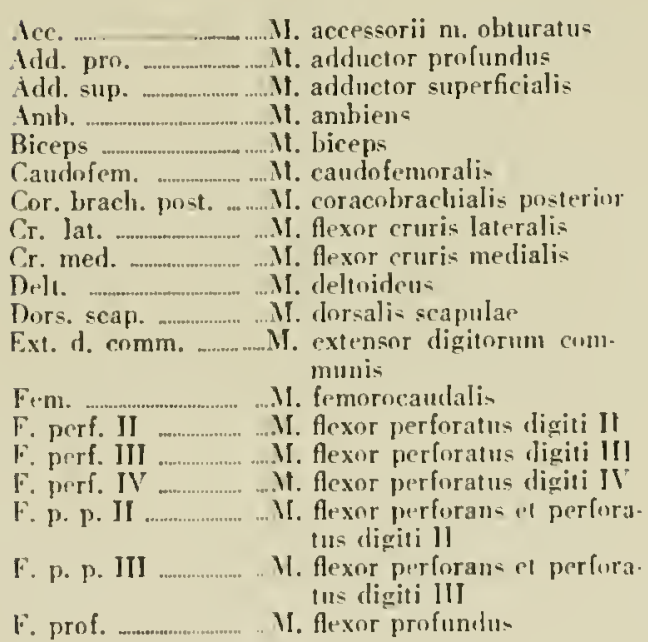

Gast. …....................... gastrocnemius

Gast. ext. ........................ gastrocnemius, pars externa

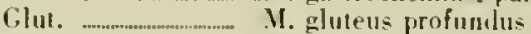

11. ant. ….................... iliacus. pars anterior

11. fem. .............................. flexor iliofemoralis

II. fih. ...................................... extensor iliofibulari

11. tib. ant. -.................. extensor ilotibialis anterior

Il. tib. lat. ……........... extensor iliotibialis laterali

l-chiofem. ............ flexor ischiofenoralis

Obt. ................ oliturator

Pect. ….................... pertoralis superficiali-

Per. prof. ................. peroneus profundus

Per. sup. …...... peroneus superficialis

Pir. ........................ piriformis

Psoas _..................... pioas

Supracor. ...................... supracoracoilens

Tih. ant. M. tilialis anticus

Tib. cart. ................. Tibial carılage

Triceps _.................... triceps

r. lat. ext. V.............. Vantus lateralis, par exterua

I. lat. med. …......... vastus lateralis. pars mediu-

I. med. M. va-tus medius 


\title{
THE PTERYLOGRAPHY OF THE RUFFED GROUSE*
}

\author{
By John E. Trainer
}

The pterylography of a bird concerns the arrangement of the feathers on its body. Among the different kinds of birds there is considerable variation in this characteristic, a feature used extensively in studying the relationships of the various groups. Among gallinaceous birds there is great similarity of arrangement and among the grouse alone it is even more uniform although there are minor differences. In almost all kinds of hirds the feathers grow in dis. tinct tracts rather than indiscriminately over the surface of the body. The intervening areas of hare skin, termed spaces. are covered by feathers situated in these tracts. There follows a description of the various tracts and spaces (figure 82 ). together with a discussion of the lypes and mmbers of feathers. their variations. and a description of the "suowshoes".

\section{The Tracts}

The tracts in which the feathers are organized are hilaterally symmetrical. Within them the feathers are generally arranged in two series of rows. one at an angle to the other. The pattern is readily seen on a plucked hird although in this study it was found that greater accuracy resulted when the feathers were clipped.

Capital. Included in this tract is the entire head region with the exception of the area between the lower jaws. Within it there are a number of small unfeathered spaces which are generally covered by feathers above and in front of them. On the top of the head one series of rows radiates in all directions from the occipital region while the other makes up a set of concentric eircles. Both gradually unite with the spinal tract posteriorly. On the side of the head one series is more or less horizontal and the wher vertical. In the recrion of the eye and ear the rows are more numerous and their feathers are highly modified. In the loral region and the forward part of the malar the feathers project nearly perpendicular to the skin, although their tips curve larkward. Over the rost of the head the feathers geverally: point backward at their hase.

The crest originates in the region between the forward part of the eyes and is made up of about fourteen enlarged feathers. Usually two are especially long. The crest of the female is only slightly smaller than that of the make.

Spinal. This covers the upper surface of the body from the capital tract to the caudal. It is divided into the cervical, interscapular, and posterior regions. The same general plan of feather arrangement is present throughout. the major series of rows sloping posteriorly away from the middle line. The secondary set of rows is not as evident. particularly in the cervical and interscapular regions. In the former. the feathers intermingle with those from the under side of the neck closing off the lateral cervical space. The feathers increase in length posteriorly. The interscapular recion is narrow because of the adjacent space which is apparently needed for freedom of wing movements. The posterior region resembles an inverted wide-hottom vase and encloses a large portion of the spinal space in the middle

\footnotetext{
* The study upan which this account is based was rarried out hy Mr. Trainer in connertion will mreting the require. menta for a Master of Sciente degrce at Cornell Univernity.
} 
line. The thick. long. aftershafted feathers in the interscapular and posterior regions provide excellent protection.

Oil Gland. This tract is small. consisting of eight small feathers arranged in a circle surrounding the apex of the oil gland.

Caudal. The caudal tract is made up of the large rectrices, their coverts. and the feathers surrounding the anus. The rectrices make up the tail proper. although the middle pair has been crowded out of line dorsally. Usually ejghteen are found. but deviations from this number are not particularly rare. Birds having twenty are usually large males while those with sixteen are usually females. The number is not associated with age since twenty have been found in young hirds. Neither is it a subspecific character.

Protecting the bases of the large tail feathers on the upper side are the upper-tail coverts. These lic in a single row and usually comprise eight pairs, occasionally nine. They scparate two rows of small. down-like feathers.

At the base of the tail. underneath. are the under-tail coverts consisting of about five rows. Those of the first row (nearest body) are very small. The second. third, fourth and fifth rows contain much larger feathers. but gradually decrease in size in that order. A space occupies the middle line.

The anus is surrounded ly small tuft-like feathers.

Ventral. The entire ventral surface of the hody. from the lower jaw to the anal region. is included in this tract. In the majority of birds it continues posteriorly over the breast and
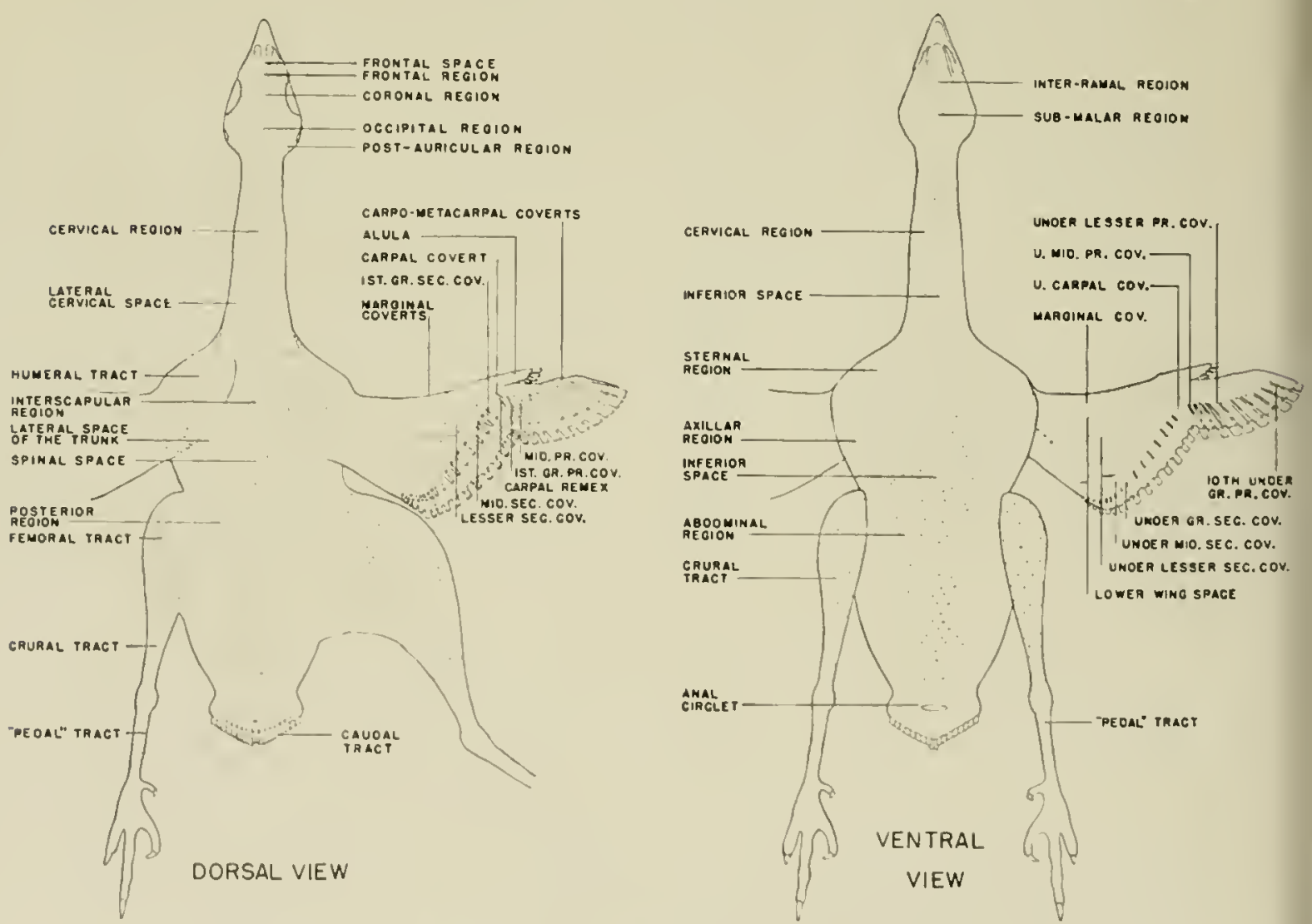

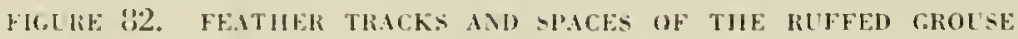


sends a lateral branch loward the wing but in the ruffed grouse. as with most other gallinaceous birds, the main portion seems to extend laterally. This lateral branch is divided into the sternal and axillar regions. The middle portion, also highly developed and well separated from the lateral branch, is the abdominal region. The remaining portions of the tract comprise the inter-ramal, sub-malar and cervical regions.

The inter-ramal region bears feathers which are erect or nearly so. At the edges they bend outward, mixing with those of the malar region, thus covering the sub-malar space on the lower jaw. The sub-malar region is not well marked off from the inter-ramal and bears similar feathers except for a gradual increase in size.

The cervical region which extends to the base of the neck encloses the inferior cervical space on the middle line. The ruff consists of about five rows near the midpoint of the neck in which the feathers are more numerous and nuch larger. They are unique in their silky, truncate tips, often with iridescence. The male differs from the female in the grreater number of feathers making up the ruff and usually in their greater length.

The feathers of the sternal and axillar regions protect the larger portions of the ventral surface, primarily because they are much longer than those of the aldominal region. The latter, while well separated from the other two. is poorly defined on the sides where the lateral space of the trunk is more or less obliterated by small feathers. Thus it is. in a sense. continuous with the tract of the leg. In life, however, the small feathers proluably have very little effect. In the illustration they are represented hy the smaller marks. A gradual in. crease in size posteriorly is well marked. Likewise, and possibly associated with decreased protection from the sternal and axillar regions. there is a great increase in the proportion of downy parts in the feathers of the posterion portion.

Ilumeral. This lears the scapular feathers which cover the adjacent spaces as well as the bases of the feathers of the spinal tract.

Alar. Including all the feathers of the wing with the exception of thuse in the humeral region, this tract is most important from a taxommic standpoint and is also interesting. due to the fact that in many cases feathers can he recognized as individnals and are quite constant among related birds. Romghly. it is made up of the large flight feathers. the eoverts and the alula feathers. The flight feathers or remiges consist of the primaries attached to the "hand", the sccondaries attached to the forearm and a single carpal remex hetween the wo. The coverts are regular rows of smaller feathers in a shingle-like arrangement protecting the bases of the remiges as well as of the other coverts. They become progressively smaller toward the forward part of the wing. The alnla might be compared with the human thumb although it actually is the remnant of a second finger.

The relative lengths of the remiges produce a short wide wing suitable for the well-known short bursts of rapid flight characteristic of this bird. Among the ten primaries the suventh and eighth are longest and the first is shortest, counting from the imnermost.

The secondaries are more or less variable in number. Usually there are sixteen or seventeen, although. lecause the innermost are relatively small, only about fifteen are actuall! functional as flight feathers. These smaller remiges are not allached to the forearm hut in the elbow region and are thus often referred to as tertiaries. Even though the first or outermost secondary is reduced, a gap in the wing does not oceur becanse it overlajs the adjacent primary. The remaining secondaries are all nearly equal in size.

The greater primary coverts, like the primaries, number ten. They lie between the latter, 
each distal to the one it covers, the last or cuternust being very much reduced. Fhe middle primary coverts are attached near the inner ends of the flight feathers. those of the first two heing absent and the remaining ones all small. The lesser primary coverts consist of four or five small feathers associated with the outer remiges. The small size of these midldle and lesser coverts is probably linked with the covering of this area by the alula feathers.

The greater secondary coverts have their origin proximal to the secondaries, the number of which they usually exceed by one. All have a distal overlaj). The first nine are sinilar in size, the tenth to the twelfth are larger, but from the twelfth un they again decrease. The middle secondary coverts are not distinguishalle from the lesser coverts except by their origin. Usually they are two less than the number of greater coverts, with the deficiency at the inner end. The lesser coverts of the uppes surface of the wing may le divided into two groups, a set of three rows which functionally belong to the secondary covert series and a number of other rows further forward which simply serve to cover that area of the skin and are included in the term lesser coverts for lack of a better term.

The marginal coverts are short, stiff feathers attached to the forward edge of the wing. In the region of the hand their counterparts are the carpo-metacarpal coverts.

On the under side of the wing none of the coverts are as large as their counterparts on the upper side. The greater primary coverts in this area are about equal in length except for the outer five which gradually decrease. The single middle covert is associated with the first primary. The under lesser coverts are situated in a single curved row.

The greater secondary coverts on the under surface lie proximal to the bases of the sec. ondaries and cover their bases. They are longer in the region of the elbow. The under middle secondary coverts are reduced in the ruffed grouse to the extent that they are not exposed but covered by the first row of lesser coverts. Associated with this is the fact that they are not pigmented except at the tips. The lesser coverts, like those of the upper surface. are of two groups. The rear group consists of two rows closely associated with a third and separated from the other by a space. Among the inner lesser coverts are the large axillary feathers.

On the under side of the wing an interesting condition exists in the greater and middle coverts of both the primaries and sccondaries. These feathers are inverted, with the surface of the feather, normally lying against the skin, lese exposed. This is evidenced by the greater amount of pigment on the hidden surface and the presence of the aftershaft on the exposed surface. Similarly, they curve outward instead of inward. Thus, the morphological dividing line between the upper and lower surface of the wing is between the uniddle and lesser coverts of the under side.

The carpal remex is a greatly reduced llight feather of the wrist which has apparently been crowded out in the hending of the wing. It measures only about an inch in length and is generally weak. An upper and lower covert. similarly reduced, are also present.

The alula or bastard wing carries four large feathers and a number of coverts. The large series tapers ahruptly with the largest outer one reaching to the tips of the greater primary coverts. The alula coverts are continums with and resemble the marginal coverts and the (arpo-metacarpal coverts.

femoral. This is very well developed in the ruffed grouse, extending wer most of the lateral surface of the thigh. Its general shape is triangular with the apes at the anterior end. From this point the rows radiate posteriorly while several additional rows occur in 
the posterior region. Another set of rows curves up toward the back. Besides covering the thigh, the feathers aid in protecting the side of the abdomen by extending backward to the tail coverts.

Crural. This tract covers the tibio-tarsus and may be divided into internal and external regions, both of which are similar to and continuous with the femoral tract. The rows are not very definite. The feathers are sparse and present a peculiar appearance, more like fur than feathers. They are possibly of a type which is less subject to wear than the ordinary flat, stiff kind. The feathers of the tarso-metatarsus, although a direct continuation of those of the femoral region, are sometimes considered to make up a separate pedal tract. They are most prominent in the more northern suhspecies".

\section{THE SPaces}

As already mentioned, around and between the feather tracts are areas of bare skin called spaces. Although devoid of feather growth ${ }^{\Delta}$ they arc, in life, covered by the feathers adjacent to them. Like the tracts, their arrangement is similar on both sides of the body. The following have been recognized.

Capital. Several areas of this kind are found on the head. The large temporal space is above and in front of the ear. It is covered by feathers on either side and in front. Above the eye is the superciliary space into which folds the upper eyelid. A similar but smaller space is found on the lower eyelid. Ordinarily these two spaces are not covered by feathers. The rictal space extends over the rear part of the fower jaw bone on either side. In the middle of the forehead is the frontal space.

Lateral Cervical. This space hegins about nidway in the front of the neck and extends to a point parallel to the humeral tract. Together the portions on either side of the median line occupy about one-third of the circumference of the neck. In life the area is well cor'ered by feathers from the ventral and dorsal cervical tracts. Its function has bcen considered to be to provide a space for the shoulders when the neck is folded. Probably another function is to facilitate greater flexibility of the skin since, in wher reginns of the neck, the skin is noticeably stiffened by the feather bases.

Lateral Spaces of the Trunk. These include all the various spaces of the hody surround. ing the wings and legs. A few small downy feathers are found scattered throughout. They facilitate freedon of movement and accommodation for the folded wing and bent leg.

Spinal and Inferior Spaces. These occur along the middle lines of the upper and lower surfaces of the body. Both are relatively small in the ruffed grouse, particularly the spinal space which is quite inconspicuous except at its anterior end. One function of the inferior space is, apparently, to provide a smooth body contour, not only by hiding the projecting breastbone hut also by concealing the folded neck.

Upper and Lower Wing Spaces. Rather indefinite in shape on the upper surface of the wing, the space is the general area outside of the humeral tract which bears a reduced number of small feathers. On the lower wing surface there are several small spaces on either side of the axillary feathers, one of which can be traced out to the hand. both seem to facilitate folding the wing.

Crural. Separating the femoral tract from the rest of the plumage. the crural space appears in most birds as a naked ring or the upper region of the tibia. In the ruffed grouse

* Ser Cliapter 11. p. 47.

$\triangle$ Other studies have shown that many of thes. spaces regularly become cusered with doun during the winter. (p. 81 ). 
it is relatively small and. on the inner surface, is entirely missing. while on the outer side it is continuous with the lateral space of the trunk.

The functions of the spaces have been described above when quite definitely accepted. Some, however, are without any definitely known function. For several of these, possible explanations present themselves. For example, certain spaces of the head and the inferior space occur on protruding lones. It is generally conceded that these spaces provide a smooth contour lint possibly the bones pressing against the skin hinder an adequate blood supply. Again it is probable that a number, such as the spinal space, facilitate increased efficiency through allowing greater centralization of the blood vessels supplying the feather tracts.

The Brood Spot. This might also be considered as a space. In order to incubate the usual clutch of eggs, practically the whole under surface of the body is plucked of feathers. All feathers, regardless of size, are removed except, apparently, the hair feathers. The area plucked roughly includes the last four rows of the sternal and axillar regions and extends from there almost to the anus. Often the forward edge is irregular. On the legs. all of the area which could come in contact with the eggs is plucked.

\section{THE FEATHERS}

The feathers of any bird comprise a variety of types modified for divers purposes and differing widely between species. Those found in the ruffed grouse are described, as well as what little is known concerning total number and variations with sex and season.

Types. The feathers which make up the downy coat of the newly hatched chick are referred 10 as neossoptiles, leing characterized by the presence of pigment and the alssence of a slaft. They range in length from 2 to $14 \mathrm{~mm}$. With certain exceptions, the neossoptiles are followed by the juvenile plumage. a fact which has led to the application of the term mesoptiles to the latter. In addition to their maner of devclopment, a weaker. lacier appearance and pale coloration also distinguish the mesoptiles from the typical feathers or teleoptiles of the adult.

Filoplumes are the so-called hairs. actually highly modified feathers. They are distributed generally over the body and can be readily identificd growing from the elevations of the skin surrounding the bases of the ordinary feathers.

Plumulae, or true down feathers. are charaterized by the absence of both a central shaft and pigment. They are, strictly speaking. entirely lacking in the ruffed grouse although a number of small semiplumes have the superficial appearance of plumulac. Such feathers are found in the various spaces and among the coverts of the wings and tail.

The typical feathers are the teleoptiles comprising the rectrices. remiges, their coverts, and the general contour feathers. Basically, each consists of an inner, fluffy purtion for warmth and an outer flat, stiff jortion, hut variations range from the almost completely pennacous rectrices and remiges to the almost completely downy feathers found anterior to the anus.

Many of the highly modified teleoptiles are functional although some are probahly only vestigial. Those of the eyclids serve as small pychashes. The feathers of the luft on the oil gland are without a central shaft and are greatly weakened. The auriculars covering the ear openings are specially adapted for the purpose of protecting the ear without interfering with hearing to any extent, the stiff shaft hearing very few harbs.

Completely downy teleoptiles are quite mumerous and are frequently reforred to as scmiplumes. Unlike the truc down feathers, they possess a central shaft. Scldom are they exposed 
to the surface. They range in size from the large ones found in the lateral portions of the abdominal tract to the small tufts resembling true down.

The ruffed grouse is well known for its large aftershafts. This is a second shaft bearing most of the typical feather parts and attached near the base of the main shaft. Thus the feather is more or less double. In this species it is found on all of the semiplumes and the teleoptiles, except the rectrices and functional remiges. In the highly modified feathers and some of the coverts. it often cannol be distinguished. In all cascs it is entirely plumulaceous or downy and coloring occurs only at the tip. Usually the aftershaft is one-half to three-quarters the length of the main shaft.

Numbers. The feathers of a female ruffed grouse* were counted as they were plucked. The resuits are shown in table 101. The figurcs. however. represent only the number of teleoptiles and semiplumes present. It is to be noted also that in some cases the divisinns between the regions of the tracts of necessity had to be arhitrary.

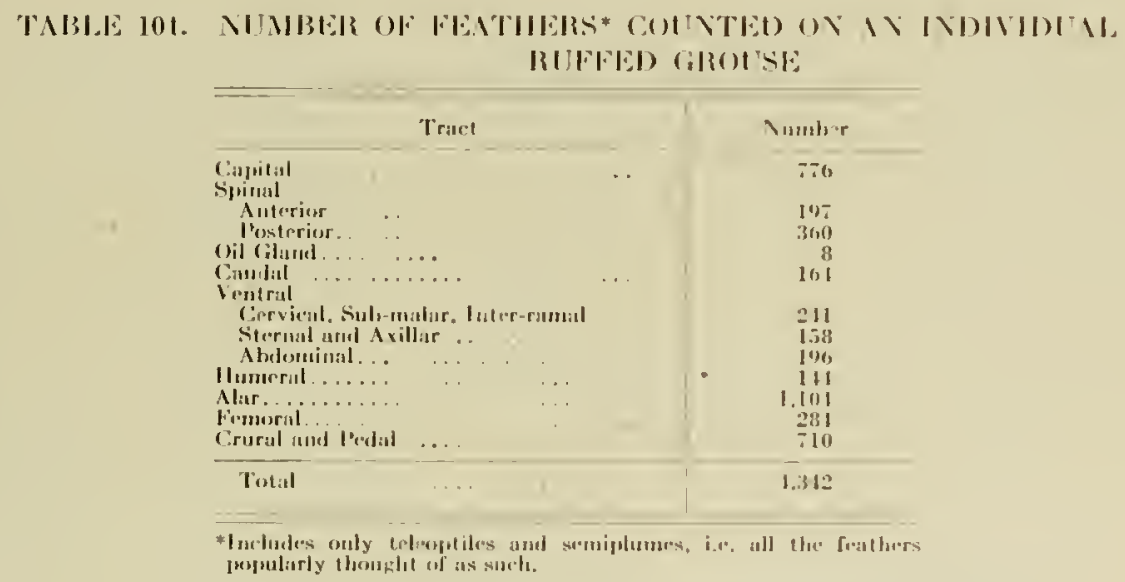

Sexual variations in the number of feathers are minor. For instance. in the cervical region the tolal number is essentially constant. although a greater number are modified to make up the rulf in the male. Similarly, the occasional hird with more than eighteen tail feathers is more frequently a male. In many other birds, Wetmorc has found small differences betwcen the sexes in the total number of feathers and probably the same is true of this species hut little significance can be attached to such variations. In fact they are probably more closely associated with size than with sex.

Scasonal variations in the total number of feathers have not been studied in the ruffed grouse, athough Wetmore has found rariation of this kind in a number of other species. particularly among the small perching birds. Following the normal fall mouh, most of the feathers are immediately replaced but others do not grow until the approach of winter. Similarly. during the spring. as the temperature increases, the number is gradually decreased by shedding. a loss which is not replaced until the normal mont or later.

Plumage $W^{\prime}$ ear. Plumage wear is not readily evident until several month after the com. pletion of the mout in September. the first sign appearing in the throat region. The gradual fading and soiling of the plumage is not very evident until winter. It is most pronounced in

\footnotetext{
* Taken near lthaca, N. Y., April 27, 1937, neiglt 539.7 gm.
} 
the abdominal region where the white turns 10 a songy gran and in the lighter regions of the head. But occasionally the plumage is remarkably clean at the end of the summer when the next monle takes place. Envirommental conditions vary sn widely, howeser. that this wear may differ considerably lictween localities.

Age l'ariations. Age variations are primarily associated with growth. At hatching, the chick is covered with down. Within the first day, the llight feathers of the juvenile plumage begin 10 grow and within three or four weeks the bod! is fairly well protected hy the jurenile feathers. With the possilble exception of the remiges, which begin to grow almost immediately after hatching. it is believed that all the juvenile feathers are preceded by down. The distribution of the down is the same as that of the later plumages with the exception of the changes due to body growtl. In the down plumage and juvenile plumage the spaces are, for the most part, evident but are smaller in proportion. Concomitant with the growth of the hody: the juvenile plumage presents a gradual spreading sut of the tracts and spaces.

Snoushoes. The "snowshoes". so called, of the ruffed grouse are a unigue temporary growth along the sides of the toes, acquired during the fall and shed the following spring. As the name indicates, they increase the surface of the feet (from two to three times) and thereby reduce sinking into the snow. They are included under the heading of feathers since they are derived from the skin and are moulted regularly. They consist of a series of small cuticular rods which, in New York State birds, average ahout $2 \mathrm{~mm}$ in length** Growth normally hegins ahout the middle of September and continues for alout three weeks. They are usually lost between the latter half of April and the third week of May. although the shedding may begin as early as March. The rods are shed by hreaking off at their bases in an irregular order, but, more often. first at the hase of the toes.

* Utualsan has reported thrke to be somewhat lunger in certisin more nurthern and western sulispecies.

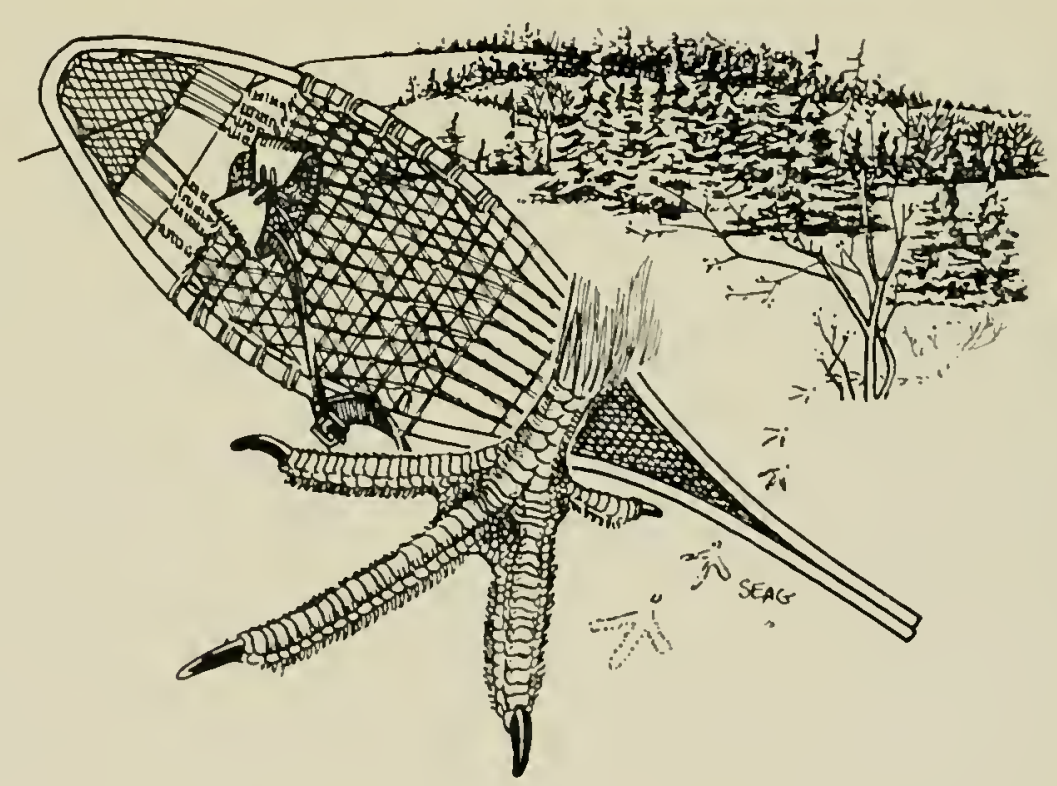




\title{
PHYSIOLOGICAL STUDIES OF THE RUFFED GROUSE*
}

\author{
By Wilíam H. Loxs,
}

Commenting on some of the causes for variation in the behavior and distribution of wild animals living under natural conditions, Charles Elton, the well-known English ecologisı, states $^{123}$ :

"most animals are, in practice, limited in their direct distribution by their habits and reactions, the latter being so adjusted that they choose places to live in which are suitable to their particular plyssiological requirements... every animal has a certain range of external conditions in which it can live successfully, ultimate limits of the environ. ment are set by its physiological make-up. if these limits are reached the animal will die."

A knowledge of the physiological limits of tolerance and susceptibility to normal and abnormal influenecs is an important objective in wildlife research. Yet the physiology and physiological needs of wild animals, particularly upland game birds, are practically unknown. Therefore, a study of the interaction of vital processes and envirommental conditions. as well as of the role which specific factors or combinations of factors such as temperature. food and water play in regulating the distribution and behavior of a species, is valuable as a supplenent to ecological investigation.

Through direct or indirect effect on the internal vital processes and external physical reactions of an animal, variations in air temperature, air movement, radiation, evaporation, humidity and light govern to a large extent the daily and scasonal activity of the animal in its nat. ural habitat. When unfavorahle conditions exist. physiological resistance and mortality inerease. On the other hand, when favorable living conditions are maintainerl. both mortality and physiological resistance decrease, with the result that wild game species have a hetter opportunity to survive, reproduce, and increase in number.

An individual bird is not an entity isolated from the habitat. Rather, there is a continual exchange of energy between it and the enviromment. The habitat. in the form of regetative. cover and its by-products (food. minerals. water) furnishes the potential energy. The hird. through processes of internal metaloulism. absorbs and assimilates the energy. the waste material (carbon dioxide, water, heat, ete.) heing returned to the environment. If the halitat does not furnish an adequate supply of potential energy to meet daily requirements for maintenance of physical activity and vital processes, and sufficient protection against adverse weather conditions and animals of prey, then the inherited ability of the bird to support bodily functions at normal levels is weakened and survival time is shortened. W'hen there exists a condition of stable physiological equilibrium with the habitat. the hird will he ener. getic and better ahle to resist unfavorable change.

When we know more exactly low much of the behavior of a game species is hased on the interaction between vital processes and envirommental conditions and how each physical factor or combination of factors regulates internal and external activities, including the ntilization of food and water, then the game manager will be far letter equipped to handle important wildlife problems.

\footnotetext{
* The studies npma which this paper is hased were conducted by the author in the Physiologinal IIihlife Research Lahora. pory located at Comeli University, Jthaca. New York, and established jointly by the New York State Conservation Department.

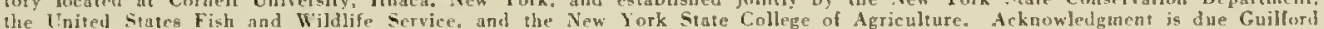
$\mathrm{K}$. Woodward for precise. conscientious ani untiring assistance rendered throughout these investigations.
} 
The ideal situation for moanring plysiological responses of animals in relation to specifie environmental conditions would he lo conduct an investigation outdoors under natural conditions. Such a procedure would he most diflicult. if not impossible. Wild animals are. therefore taken into the laboratury where thes an be letter controlled and where the various phases of their physiolegy can be investigated in orderl! sequence under hoth constant and changing conditions. In this way it is possilule to detemine the degree of adjustment required to compensate for various changes in the enviromment.

The present sudy of the ruffed crouse was conducted in a calorimeter cabinet designed by the author and constructed at the laboratory. The gross dimensins of the callinet are 15 feet long. 10 feet wide, and 10 feet high with a wall thickness of 10 inches. It contains three separate compartments in each of which physical factors may he held constant automatically or varied independently. Means are provided for accurate control of air temperature. light. humidity and air movennent. The temperature ean be varied over a range from $-40^{\circ} \mathrm{F}$. 10 wer $150^{\circ} \mathrm{F}$. with an insignificant differential. Facilities have also been installed for simulating rainfall through spraying the birds with either warm or cold water at different air temperatures. One of the compartments was used for preliminary physiological adaptation of birds to specific envirommental conditions. The others atcommodated an entire respiration apparatus for measuring beat production as well as other equipment and instruments. If desirable. however, each of the latter compartments can be used as a calorimeter chamber for measmring the gaseous metabolism of either large or small animals.

Weights were taken. in the main. on a balance with accuracy to within one gram. In certain studies. however, weighings were made on an analytical balance accurate to one milligram. Weighings were secured at definite times during the moming from 8:00 to 10:00, during the afternoon from 4:00 to 6:00. and frequently at midnight or other hours.

Muscular movements of the body (cage activity) with respect to amount and intensity at different environmental conditions and nutritional levels were recorded graphically by means of tambuns, ink-writing pens, ant an electrically rotated kymograph drum. Cage activity was reproduced hy means of the recording pens writing antomatically on standard cross. section paper $26 \times 100$ inches long scaled in millimeters.

Records of body temperature were secured by means of calibrated mercury or electric thermocouple thermometers. A preliminary experiment revealed that a hody temperature com. fraralle to that of the gizard could be secured ly inserting is thermometer at least 2 inches intu the rectum of a grouse.

The breathing rate was detcrmined ly counting respiratory movements as visually ohserved on varions portions of the external body surface or hy placing the bird in a cage and oltaining a graphe recurdiner of the respiratury movement by means of the kymograph.

Records of heart beal were secured ly using a sensitive stethoseope and symehronizing the sound with "hand-tappinge" a pemoil point on moving paper or the pressing of an automatic clectric counter.

Various special terhniques were derised by the author to meet specifie needs as the work procereded.

In planning the studies to lie conducted amphasis was placed on seruring information prer. taining to the general physiological characteristies of the speries which might have a bearing on management practices as well as to securing basic data" prerequisite to conducting more

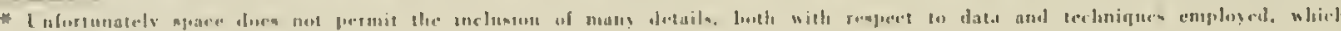

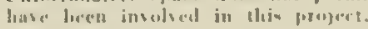


elaborate physiologic investigation on grouse. Therefore, attention was directed chiefy to those physiological activities which are intimately associated with the production and maintenanee of body heat, namely, body temperature, breathing and heart rate; ingestion and digestion of food and water; and change in body weight.

Experimental birds were supplied from hand-raised stock at the Research Center. At the laboratory. when not on experiment. they were held in a temperature-regulated room under natural lighting and were fed the usual ration employed at the Center. One must bear in mind. however, that there are undoubtedly some differences hetween the reactions of such birds and those of wild grouse.

\section{Determination of Body Temperature and Respiration Rate}

Experiment 1 dealt with the determination of the average londy temperature and respiration rate of adult grouse under conditions of normal cage activity. Cumulative data from ten hirds were secured on consecutive days for several weeks under identical envirommental conditions. The results are presented in table 102.

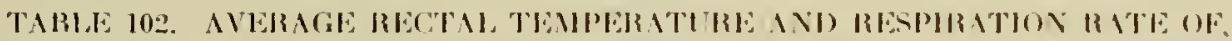
AI)ITT GR(OISE:

\begin{tabular}{|c|c|c|c|c|c|c|c|c|}
\hline \multirow{2}{*}{$\begin{array}{l}\text { Numbers of } \\
\text { liress }\end{array}$} & \multirow{2}{*}{ Sex } & \multirow{2}{*}{$\underset{\text { Air }}{\text { Amprafure }}$} & \multirow{2}{*}{$\begin{array}{l}\text { 'Tiure } \\
\text { of diıy }\end{array}$} & \multirow{2}{*}{$\begin{array}{l}\text { Numbler of } \\
\text { rolstervations }\end{array}$} & \multicolumn{2}{|c|}{ Hactal femperillure: } & \multicolumn{2}{|c|}{ Mrspiration per minul" } \\
\hline & & & & & Averaline & $\begin{array}{l}\text { Sitamdard } \\
\text { error }\end{array}$ & Averize & $\begin{array}{c}\text { Siandalard } \\
\text { errose }\end{array}$ \\
\hline $\begin{array}{l}5 \\
5\end{array}$ & $\begin{array}{l}\text { In:ile: } \\
\text { forinaslo: }\end{array}$ & $6.5^{\circ} \mathrm{F}$ & $\begin{array}{l}\text { mornimp } \\
\text { mornink }\end{array}$ & $\begin{array}{l}12: 3 \\
103: 3\end{array}$ & $\begin{array}{l}10-2,2010 \\
10(1,20)\end{array}$ & $\begin{array}{l}0.0 .35 \\
0.0 .50\end{array}$ & $\begin{array}{l}61,5 \\
58,2\end{array}$ & $\begin{array}{l}0.871 \\
10.91,9\end{array}$ \\
\hline $\begin{array}{l}5 \\
5\end{array}$ & $\begin{array}{l}\text { manlas } \\
\text { J"entandis }\end{array}$ & 6.5 & $\begin{array}{l}\text { uflermoun } \\
\text { ufleruosul }\end{array}$ & i⿱ & $\begin{array}{l}107.05 \\
10 \div .76\end{array}$ & $\begin{array}{l}0.0199 \\
0.018\end{array}$ & $\begin{array}{l}67.1 \\
34.13\end{array}$ & $\begin{array}{l}1.1 .10 \\
1300\end{array}$ \\
\hline $\begin{array}{l}5 \\
5\end{array}$ & $\begin{array}{l}\operatorname{mix} x d \\
\text { mixed }\end{array}$ & $\begin{array}{l}80-11.5 \\
80-16.5\end{array}$ & $\begin{array}{l}\text { mornine } \\
\text { ufternusus }\end{array}$ & 611 & $\begin{array}{l}1018.21 \\
1013.12\end{array}$ & $\begin{array}{l}0.199 \\
0.1 .5 .3\end{array}$ & $\begin{array}{l}31.60 \\
\div 1.0\end{array}$ & $\begin{array}{l}3.110 \\
1.610\end{array}$ \\
\hline
\end{tabular}

*Normal cano un livily.

Comparison of the average rectal temperature and respiration rate indicales some significant biological differences between sexes. The morning temperature and respiration rate of the male grouse were higher than those of the fomales. In the afternoon respiration rate was higher for the males but both sexes were quite similar as to temperature.

There was a consistent rise among individuals of the same sex between average moruing and afternoon temperatures, indicating that the higher afternom level represents a real physiological difference. $\Lambda$ similar relationship was also nuted between rectal temperalure averages secured at $65^{\circ} \mathrm{F}$. and $85^{\circ} \mathrm{F}$. In this case statistical evaluation of the data indicates a direct effect of air temperature itself upon metabolic processes.

\section{Diurnal Trend in Body Temperature}

Experiment 2 was undertaken to estahlish the diurnal trend in body temperature. Two groups of birds were used, each comprising five male and five female grouse. Rectal temperatures were taken for each group at regular 3-hour intervals for two separate 24-hour periods beginning in one rase at $8: 30 \mathrm{a} . \mathrm{m}$. . in the other at 10:00 a.m. This procedure permitted plotting the data at intervals of 1 liz hurs. With one exception (the factor of light) both groups werc subjected to comparable conditions of environmental temperature. activity and food. With respect to light. Group A was exposed to an additional hour of illumination at night. 
The results, summarized in figures 83 and 84, elearly show the existence of a diurnat variation in rectal temperature. indicating a similar trend in hody temperature. Highest

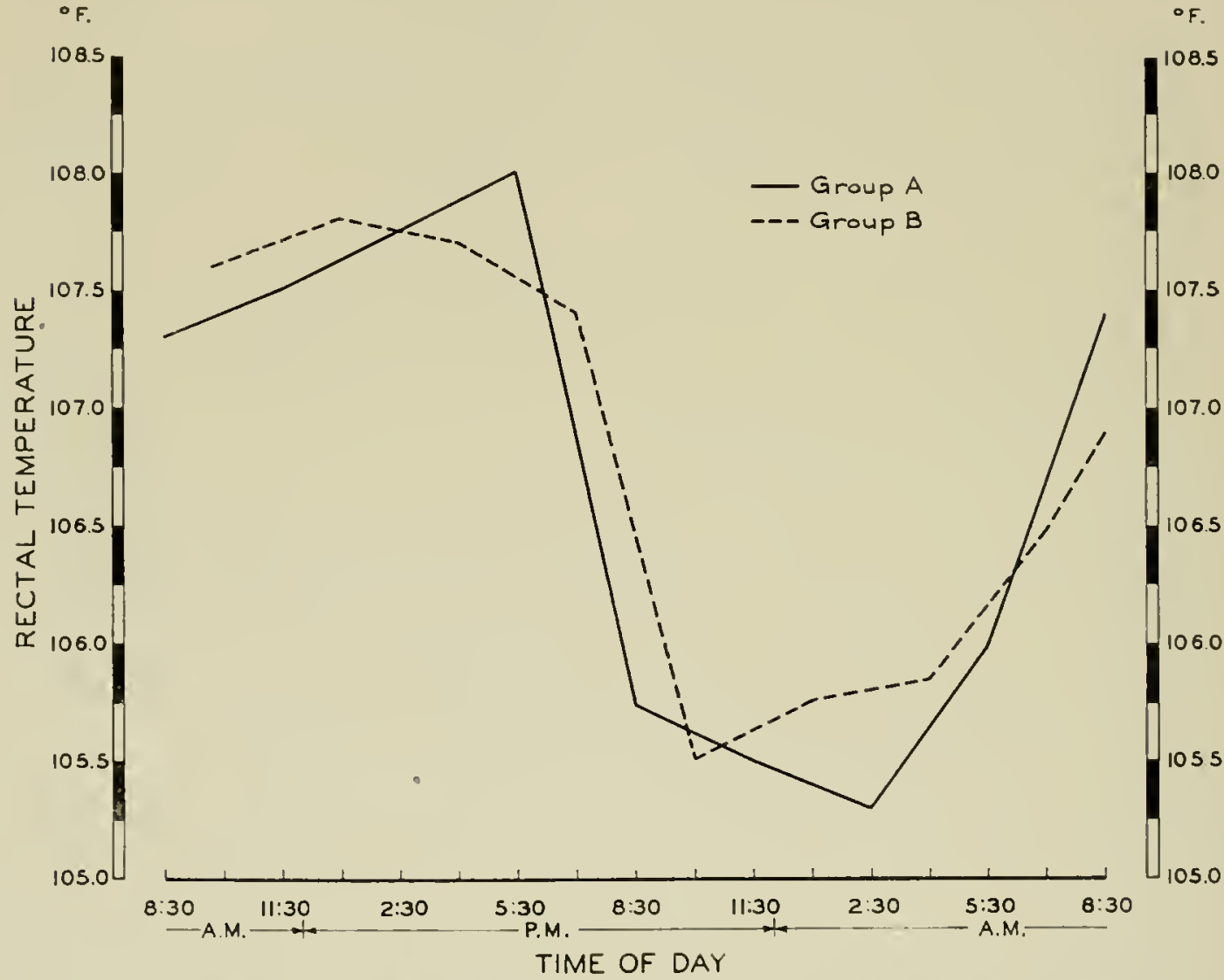

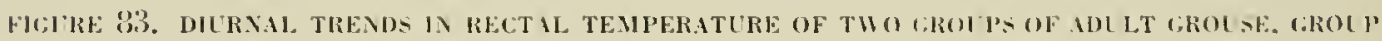

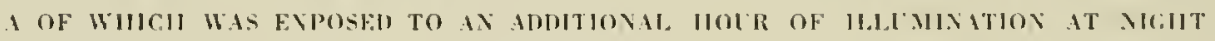

temperatures were reached between $2: 30$ and $5: 30$ p.m., and lowest hetween $11: 30$ p.m. and $2: 30 \mathrm{am}$. The average difference hetween the highest and lowes temperatures during the 2 -hour period, was:

For males: $2.69^{\circ} \mathrm{F} \pm 0.257^{\circ} \quad 1=$ landard error

For females: $2.29^{\circ} \mathrm{F} \pm 0.139$ Islandard errur

With reference to the effect of light on the diumal curve. the peak in lond temperature reached at 5:30 p.m. for Group $A$ seems to have hren due chiefly to evtra activity and freding allowed them during the additional hour of light.

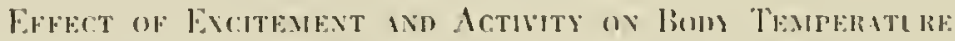

lixperiment 3 was designed to measure the effert of emotional exeitement and muscular acelivity on rectal temperature and rate of breathing. Four female and two mate hirds, in a state of arlive digestion. were used. They were removed from the age one al a lime for body temperature and respiration recordiners. Fach was then put inte another rage and 


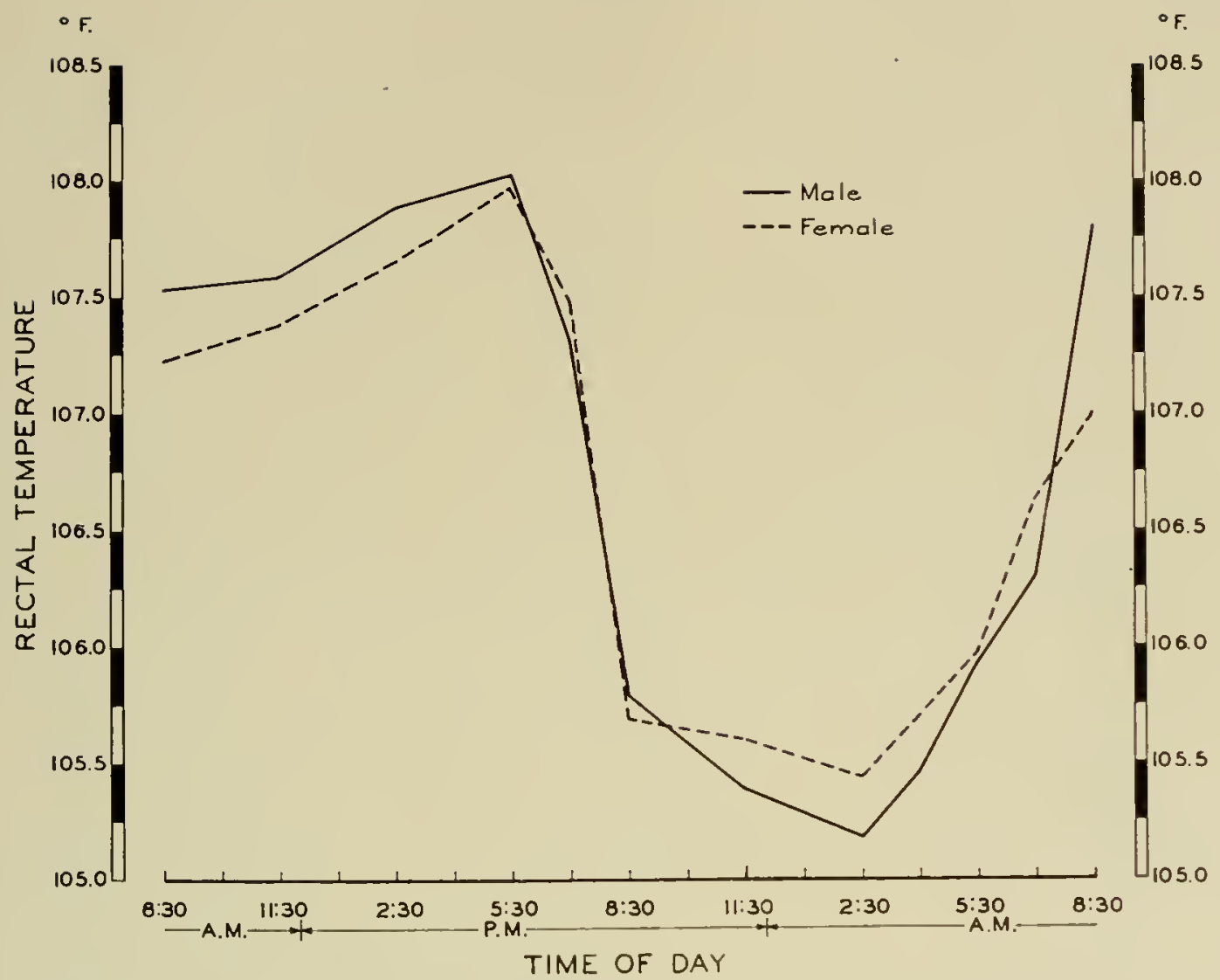

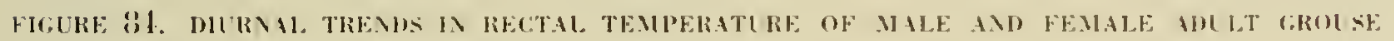

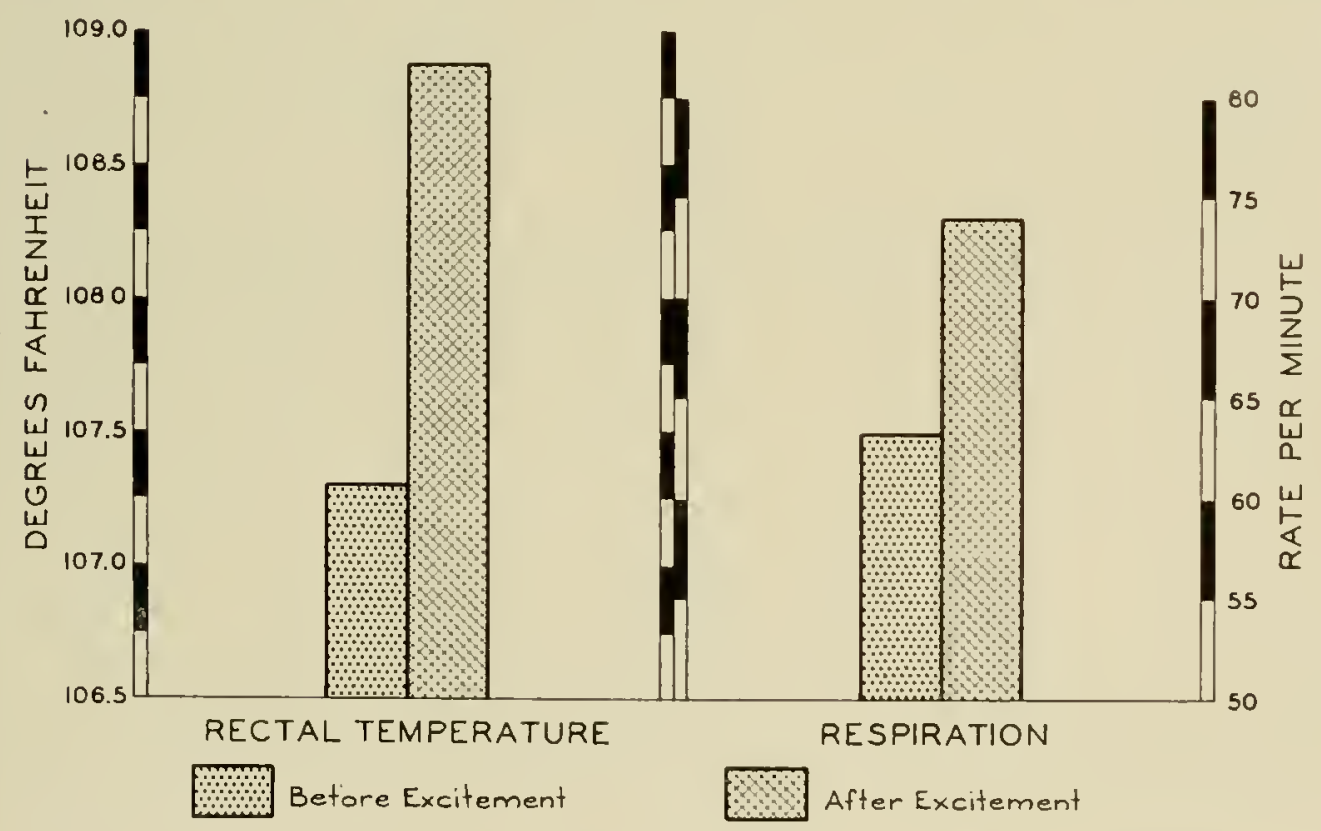

HOURE 35. EFFECT OF EXCITENENT ON RECTAL TEMPERATI RE AND RESPIRATIOS RATE OF ADLTT GROLSE 
forced to run and move ahout for ten minutes. after which temperature and respiration were acrain recorded. The results of this test are slown in figure 8.5. They indicate a significant increase in hoth respiration rate and hody temperature following ten minutes of activity.

\section{Effect of lianfale, on Mastexayce of Bom Temperatloe}

Experiment 4 inwolved a study of the effect of rainfall under various conditions of air temperature and air movement on the bird"s abilit! to maintin its body temperature. Two groups (A and C) of five grouse each. and one (B) of six. were used. All were in a condition of active digestion during the tests. Rainfall was simulated in the experimental cabinet by spraying water on the hirds. Air movement was slow. Specific conditions for each group were as follows:

Group A--Exposed to Air Temperature $40^{\circ} \mathrm{F}$; Humidity, $60 \%$; Water Temperature $44^{\circ} \mathrm{F}$. Group B-Exposed to Air Temperature 65 $\mathrm{F}$; Humidity, $30^{\circ} ;$; Water Temperature $44^{\circ} \mathrm{F}$. Group C-Exposed to Air Temperature $30^{\circ} \mathrm{F}$; Humidity. $35 \%$ : Water Temperature $62^{\circ} \mathrm{F}$.

The results are shown in figure 36 . It is 10 be noted that in each ease a sharp drop in body temperature occurred during the half hour immediately after the birds were wet. This

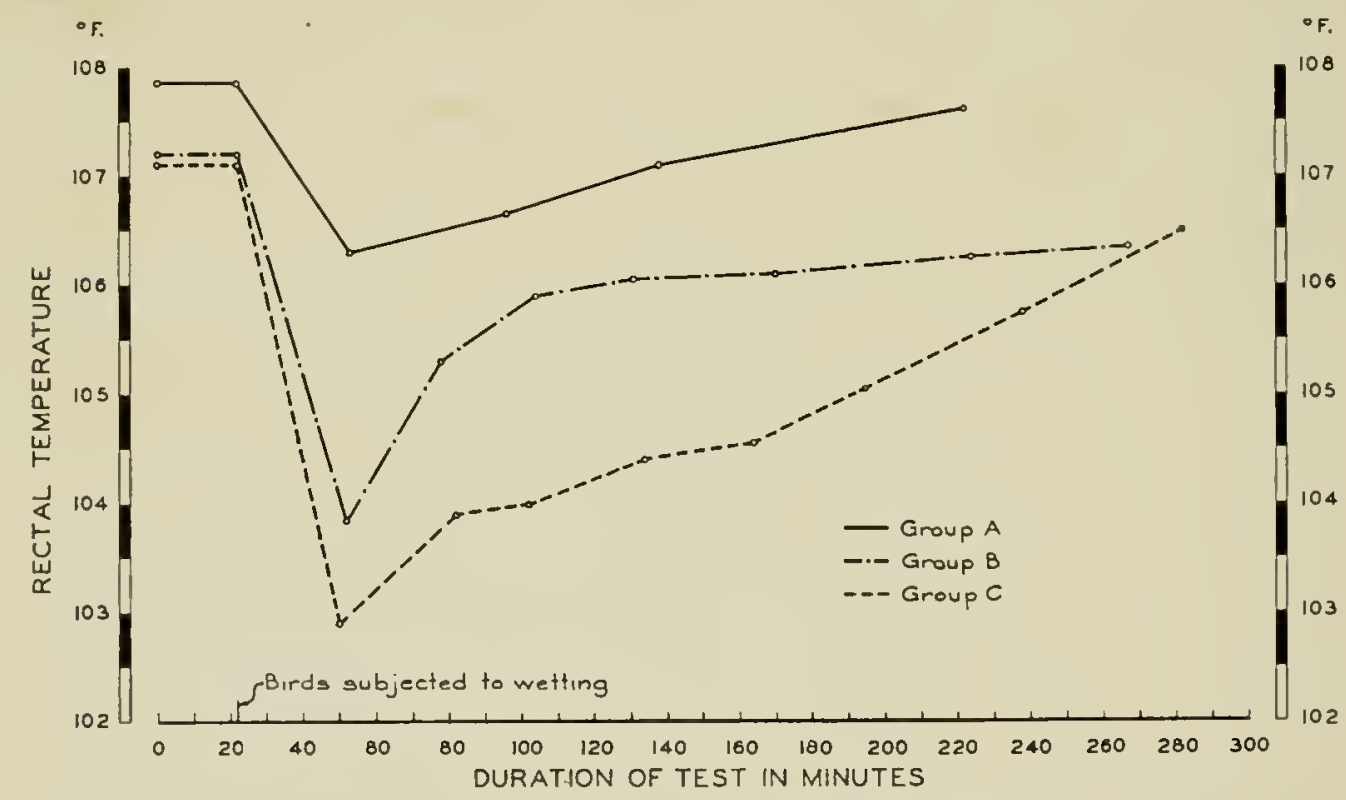

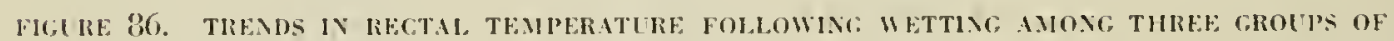

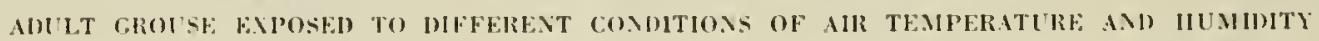

was mos serere aul recovry was slowest amoner Group $A$. which were exposed to a water temperature of $11^{\circ} \mathrm{F}$. at an air temperature of $10^{\circ} \mathrm{F}$. Wien at an air temperature of $80^{\circ} \mathrm{F}$. wetting ransed a marked and rapid fall in hody temperature (Group C). The data clearly: show that wetling the lody with water is a factor of considerahle physiolocical importance in itself. The combination of luw air temperature and wetting with water was still more effective since the rate of clrop in body scmperature was faster and rate of recoser! slower. linder eonditions such as those to which Groups $A$ and B were subjected. comtimed exposure without good bodily protection would eause death. 
In another part of the experiment five apparently healthy grouse were subjected to similar rainfall at an air temperature of $62^{\circ} \mathrm{F}$. and an air movement of 15 miles per hour. Figure 87 shows that only two of the test birds (Nos. 8 and 29) withstond this treatment and sur.

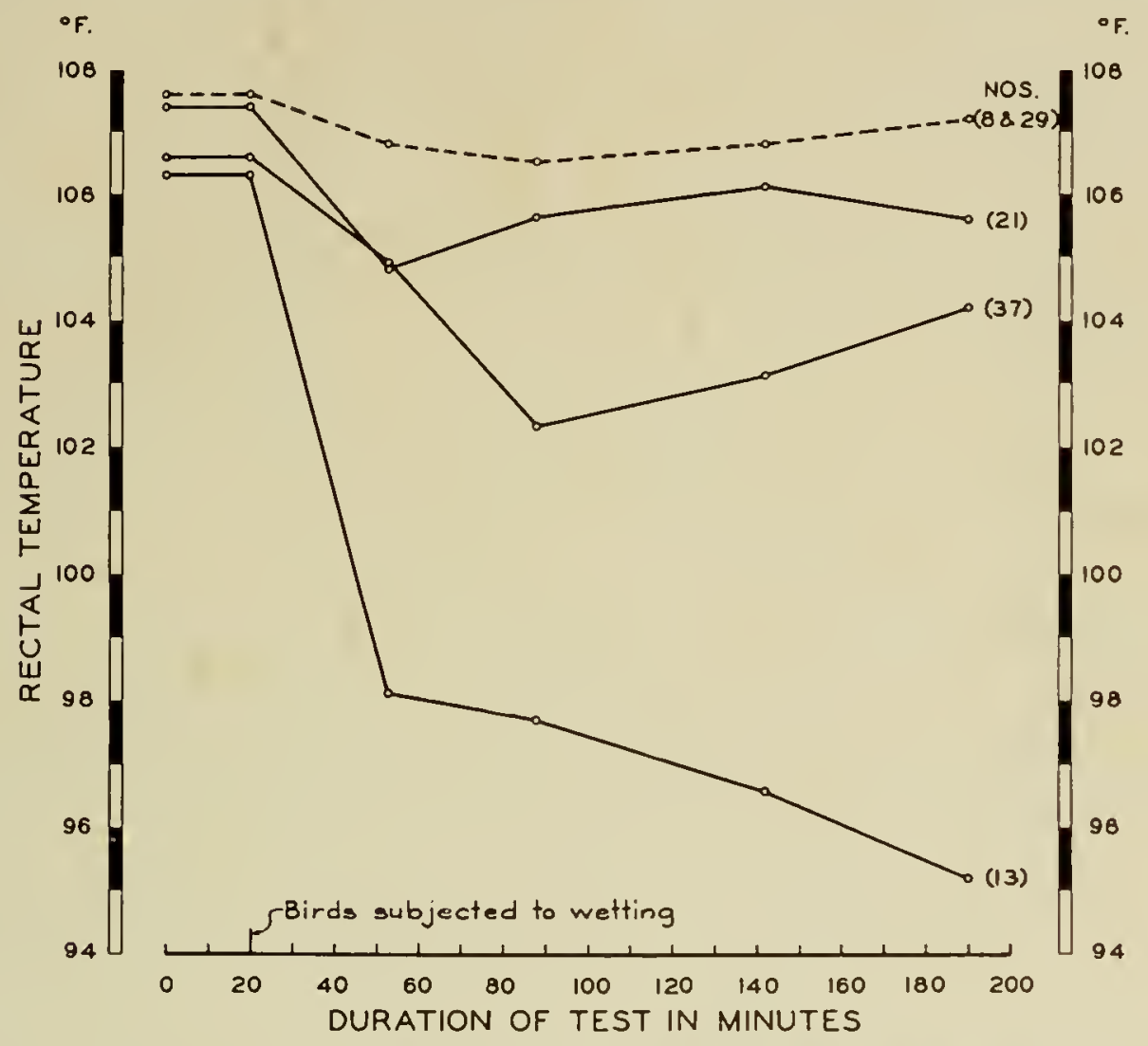

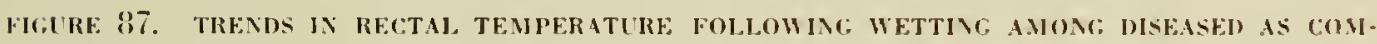
PAREl WITI HEALTIY ADULT GROUSE

vived, whereas grouse $\mathrm{N}$ o. 13 dicd within four hours after the completion of the test. its body temperature falling to a very low level. Grouse No. 37 died two days after the test and grouse No. 21, three days after its completion. Postmortem examinations indicated that all three of these hirds were suffering from enteric disease", although prior to the test they appeared healthy. These data indicate that pathological conditions such as enteritis or intestinal gout when latent or inactive in the body of a grouse can be activated by a drop in body temperature as a result of wetting the lody with water of chilling temperature.

\section{Heart Activity as an Index of Vitality}

Experiment 5 consisted of a series of tests to determine the significance of heart activity as an index of vitality. To hegin with. a general study was undertaken of the relationship hetween hody temperature, respiration and heart rate in relation to activity. inactivity and emotional excitement. Grouse in different groups were held inactive from 11 in to $2 \%$ hours. 
Previous to testing some of the hirds had been living at $65^{\circ} \mathrm{F}$. and $80^{\circ} \mathrm{F}$. Some were meas. ured immediately after ingesting food. others a few hours after eating and still others after fasting from 100 to 148 hours.

After the birds had been held inaetive for the time specified, they were subjected to a short period of activity. following which measurements were again recorded to determine the influence of this type of activity and excitement upon physiologic factors. The resultant data are presented in table 103.

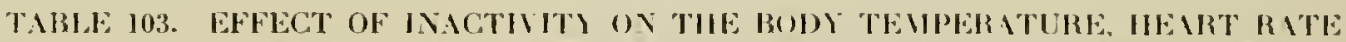
IND RESPIRATION OF BOTH FELDING I VD FASTIG GAOUSE

\begin{tabular}{|c|c|c|c|c|c|c|c|c|}
\hline \multirow{2}{*}{ Condition of lirds } & \multirow{2}{*}{$\begin{array}{l}\text { Number } \\
\text { of hirds }\end{array}$} & \multirow{2}{*}{$\begin{array}{c}\text { Air } \\
\text { temperature }\end{array}$} & \multirow{2}{*}{$\begin{array}{l}\text { Time of } \\
\text { inactivity }\end{array}$} & \multicolumn{5}{|c|}{ Weasurements recorded } \\
\hline & & & & At start & $\begin{array}{l}\text { After } \\
\text { inaelivity }\end{array}$ & Drop & $\begin{array}{l}\text { After } \\
\text { excilement }\end{array}$ & Misi" \\
\hline & & & & \multicolumn{5}{|c|}{ Hectal temperalure } \\
\hline $\begin{array}{l}\text { Average soon after eating...... } \\
\text { Fasting } 100 \text { to } 148 \text { hours ..... } \\
\text { Normally feeding. . . . . . . }\end{array}$ & $\left\{\begin{array}{r}6 \\
6 \\
13 \\
6\end{array}\right.$ & $\begin{array}{l}6.5 \% \mathrm{~F} \\
6.5 \\
6.5 \\
80\end{array}$ & $\begin{array}{l}2 \frac{1}{1 / 2} \text { hrs. } \\
1-5 / 6 \\
11 / 2 \\
2=2\end{array}$ & $\begin{array}{l}108.20 \mathrm{~F} \\
106.9 \\
107.7 \\
108.4\end{array}$ & $\begin{array}{l}106.1^{\circ} \mathrm{F} . \\
105.8 \\
106.6 \\
106.2 \\
\text { Respirati }\end{array}$ & $\begin{array}{l}2.1^{\circ} \mathrm{F} \\
1.1 \\
1.1 \\
2.2 \\
\text { rato }\end{array}$ & $\begin{array}{l}107.0^{\circ} \mathrm{F} \text {. } \\
106.8 \\
107.3 \\
107.3 \\
\end{array}$ & $\begin{array}{l}0.9^{\circ} \mathrm{F} \\
1.0 \\
0.7 \\
1.1\end{array}$ \\
\hline $\begin{array}{l}\text { Tverage soon after putint } \ldots . . \\
\text { Fusting } 100 \text { to } 148 \text { hours } \ldots . . \\
\text { Normnlly feeding . . . }\end{array}$ & $\left\{\begin{array}{r}0 \\
6 \\
13 \\
3\end{array}\right.$ & $\begin{array}{l}6.5 \\
6.5 \\
6.5 \\
80\end{array}$ & $\begin{array}{l}21 / 2 \\
1-5 / n \\
11 / 2 \\
2 \cdot 3 \\
-2 / 3\end{array}$ & $\begin{array}{l}73 \\
55 \\
61 \\
75\end{array}$ & $\begin{array}{l}51 \\
16 \\
16 \\
51 \\
\text { Heart }\end{array}$ & $\begin{array}{l}2 \frac{3}{4} \\
18 \\
21 \\
\text { te- }\end{array}$ & $\begin{array}{r}79 \\
61 \\
6 \% \\
78\end{array}$ & $\begin{array}{l}2: 3 \\
1.3 \\
21 \\
21\end{array}$ \\
\hline $\begin{array}{l}\text { Iverage son ufter eatiug. . . . . } \\
\text { Fasting } 100 \text { to } 118 \text { hours...... }\end{array}$ & 6 & 6.5 & $\begin{array}{l}21 / 2 \\
1-5 / 6\end{array}$ & $\begin{array}{l}333 \\
310\end{array}$ & $\frac{280}{2: 17}$ & 73 & $\begin{array}{l}314 \\
3.31\end{array}$ & 97 \\
\hline
\end{tabular}

Both inactivity and excitement lad a significant effect upon heart rate and body temperature. This rapid physiologic adjustment to changing onvironmental conditions demonstrates considerable labilit! in heart beat in which the great increase from the minimum level of repose to the level of emotional exeitement is particularly noteworthy. especially for fasting grouse.

Because of indivilual variation in the frequemey. duration and intensity of active periods. it was not practical to plot the average trends for the various facturs for all grouse used $j_{n}$ this experiment. To do this would definitely mask the true effect of repose on metabolic ac. tivity. However, the physiologic reaction of two grouse to repose has heen plotted at fourminute olservational intervals (figure 88). These records are representative of ten other individuals.

There was a considerablereduction in rate of hreathing and heart heat and in body tem. perature as these grouse became more and more inactive. Of the two hirds used. the female exhilited a greater rate of reduction in the intensity of the three plusiologieal activities. The metabolic intensity of the male remained higher and required a longer time to reach a basal level at about the 216 th minute than the female whose basal level was reached at about the 168th minute of stucly. Slight movements of the external body (indicated ly $\lambda$ in figure ais) resulted in a small increase in the several physiologit" attivities.

Of interest are the observations. designated $l y \theta$ at various points in the figure. that a slieclut rise in hody temperature preesded a drop of exreater ilegree. This phenomenon was noted fre- 
quently throughout the tests. It apparently is not a result of visible muscular activity for the birds were quiet when the change occurred. More probably it is caused by cellular variations in heat production and the subsequent flow and distribution of heat throughout all parts of the body.

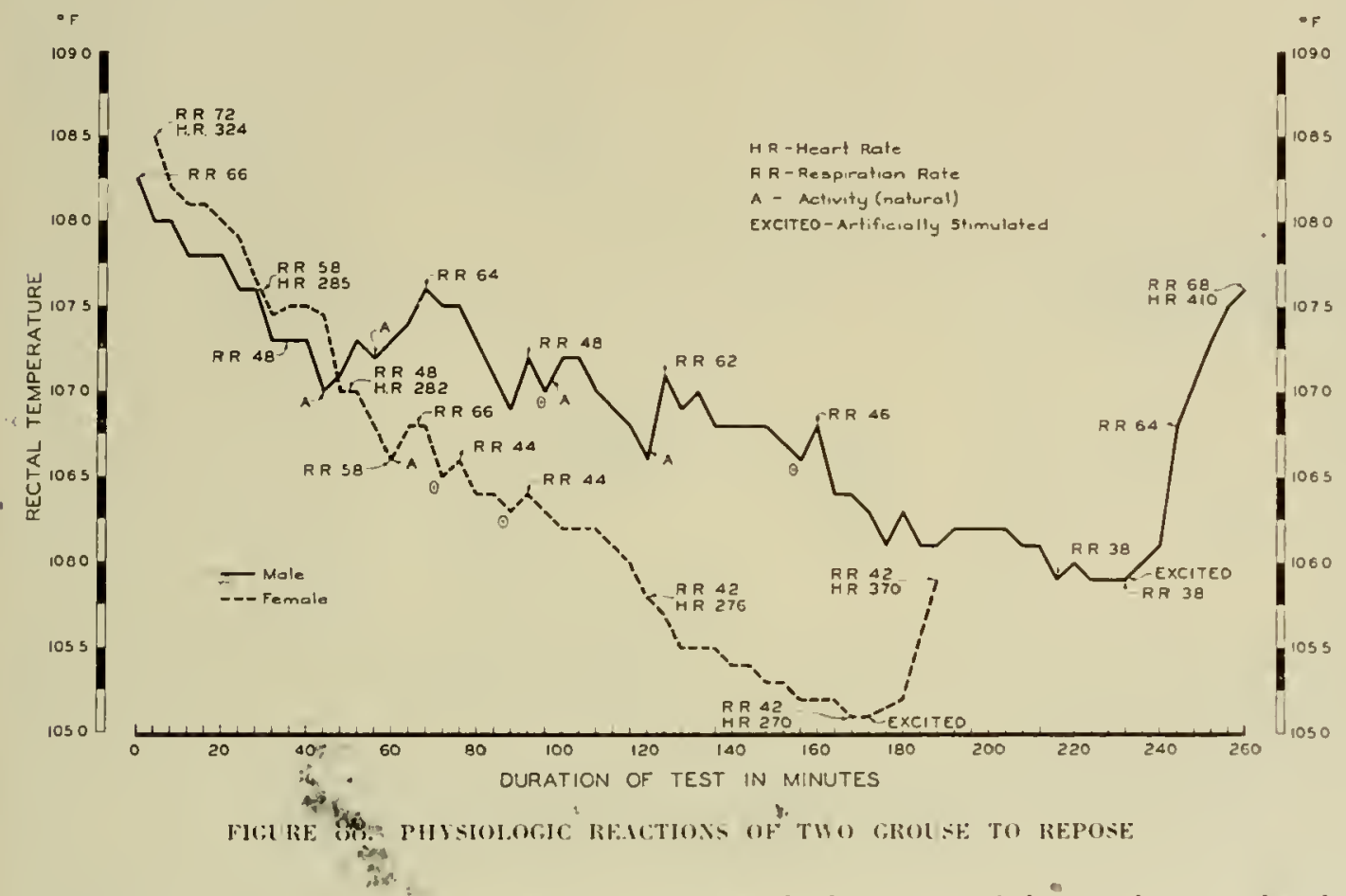

The rate of metalulic activity was more rapid at the heginning of the test. hut as a lasal condition was approached the rate decreased. When final basal levels were reached hoth of the grouse (representative of ten individuals) wre removed from the "hulding hoard" (figure 89) and excited emotionally and muscriarly. The result of this stimulation was quickly reflected by pronounced increases in body temperature. respiration and heart rate. These results again clearly demonstrate the intimate relationship between envirommental conditions and physiological phenomena.

Next the rate of heart heat was estahlishecl for both feeding and fastingr grouse at difforent air temperatures. In these tests the heart rate was classified under three headings. that is. (1) the standard rate of the inactive bird held for study immediately after remosial from its cage; (2) the standard quiet rate of the inactire hird held quietly for some time after recording rate $\mathrm{No} .1$; and (3) the excited rate resulting from muscular stimulation. The air temperature indicated is that to which the birds were aceustomed to living hefore testing.

The results for feeding hirds are presented in table 104 . Throughout these tests the heart rate of birds with food was higher at $40^{\circ} \mathrm{F}$. than at $65^{\circ} \mathrm{F}$.

Immediately upon remoral from the cage. female grouse exhihited a faster heart rate than males at both $65^{\circ} \mathrm{F}$. and $40^{\circ} \mathrm{F}$. As indicated by the standard deviation the range of variahility among both sexes was considerable. In all olservations the lowest range for females was approximately equivalent to the highest range for males. Likewise. after the birds had had an opportunity to quiet down. the same relationships existed. 


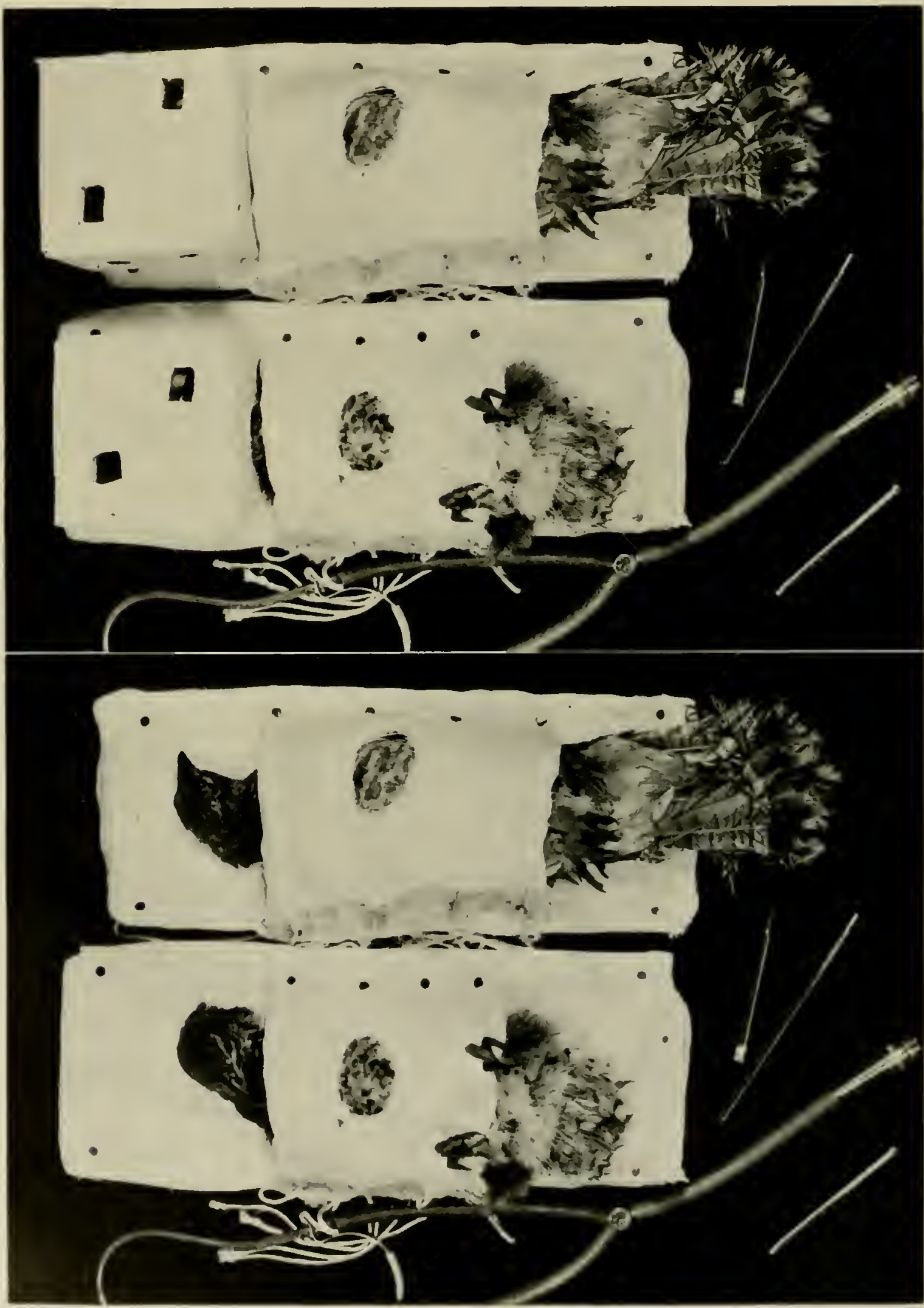

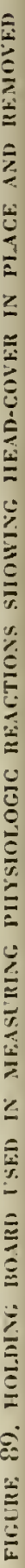


Data recorded when the birds were excited showed no apprecialle difference between the sexes. The extreme variability of the heart rate under these conditions. however. might easily mask the difference indicated in inactive and quiet birds.

TABLE t0t. IIEART RATES OF ADULT GROUSE IIIING*AT TWO AIR TEMPERATURES WITI RESPECT TO DIFFERF.NT DEGIFES OF ACTIVIT

\begin{tabular}{|c|c|c|c|c|c|}
\hline \multirow[b]{2}{*}{$\begin{array}{c}\text { Vumber of } \\
\text { Jirds }\end{array}$} & \multirow[b]{2}{*}{ Sin $x$} & \multirow[b]{2}{*}{$\underset{\text { temperature }}{\text { tir }}$} & \multicolumn{3}{|c|}{ Measurements recorded } \\
\hline & & & Average & $\begin{array}{l}\text { Standard } \\
\text { deviation }\end{array}$ & $\begin{array}{l}\text { Staudard } \\
\text { prrot }\end{array}$ \\
\hline & & & \multicolumn{3}{|c|}{ Standard inactive rute } \\
\hline $\begin{array}{l}2.1 \\
18 \\
316 \\
18\end{array}$ & $\begin{array}{l}\text { nuale } \\
\text { male } \\
\text { female } \\
\text { female }\end{array}$ & $\begin{array}{l}65^{\circ} \mathrm{F} . \\
10 \\
65 \\
10\end{array}$ & $\begin{array}{l}3116.5 \\
321.6 \\
366.5 \\
379.1\end{array}$ & $\begin{array}{l}36.3 \\
36.2 \\
25.4 \\
31.6\end{array}$ & $\begin{array}{r}2.6 \\
12.5 \\
1.3 \\
10.6\end{array}$ \\
\hline & & & \multicolumn{3}{|c|}{ 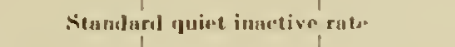 } \\
\hline $\begin{array}{l}21 \\
11 \\
36 \\
18\end{array}$ & $\begin{array}{l}\text { male } \\
\text { male } \\
\text { female } \\
\text { female }\end{array}$ & $\begin{array}{l}6.5 \\
50 \\
6.1 \\
10\end{array}$ & $\begin{array}{l}295.3 \\
308.5 \\
358.5 \\
36.6\end{array}$ & $\begin{array}{l}32.5 \\
31.6 \\
25.6 \\
27.4\end{array}$ & $\begin{array}{r}12.3 \\
15.5 \\
12.5\end{array}$ \\
\hline & & & \multicolumn{3}{|c|}{ Stundard excitaed rute } \\
\hline $\begin{array}{l}2.1 \\
18 \\
16 \\
18\end{array}$ & $\begin{array}{c}\text { male } \\
\text { mule } \\
\text { female } \\
\text { female }\end{array}$ & $\begin{array}{l}6.5 \\
10 \\
6.5 \\
10\end{array}$ & $\begin{array}{l}386.6 \\
391.3 \\
3194.3 \\
116.2\end{array}$ & $\begin{array}{l}36.1 \\
33.8 \\
12.2 \\
33 .\end{array}$ & $\begin{array}{r}13.4 \\
15.1 \\
3.9 \\
15.0\end{array}$ \\
\hline
\end{tabular}

* Normal cage life.

$\Delta$ Composed of 288 individual records. tlleats per minuto.

When the data for quiet and excited birds are compared a tremendous and almost instan. taneous increase in heart beat under stress of excitement is evident.

To determine the influence of food on the rate of the various physiological activities the birds were subjected to fasting for 100 hours and then tested (table 105).

TABIE 105. AVEKAGE STANDARD QUIET IHEART IRATE OF INACTIV ADITT GROUSE 100 HOURS AFTEIR WTHDKAWA, OF FOOD

\begin{tabular}{|c|c|c|c|c|c|}
\hline $\begin{array}{l}\text { Numbure } \\
\text { birtis }\end{array}$ & Sex & $\begin{array}{c}\text { Air } \\
\text { tomperture }\end{array}$ & $\begin{array}{l}\text { Average } \\
\text { lieart rata }\end{array}$ & $\begin{array}{l}\text { Standard } \\
\text { deviations }\end{array}$ & $\begin{array}{l}\text { Situludaril } \\
\text { error }\end{array}$ \\
\hline $\begin{array}{l}y \\
y \\
y \\
9\end{array}$ & $\begin{array}{l}\text { Uale } \\
\text { Wale } \\
\text { Femule } \\
\text { Femali }\end{array}$ & $\begin{array}{l}65^{\circ} \mathrm{r} . \\
10 \\
65 \\
111\end{array}$ & $\begin{array}{l}295.6 \\
282.0 \\
308.0 \\
291.0\end{array}$ & $\begin{array}{l}21.9 \\
25.3 \\
1.3 .0 \\
20.0\end{array}$ & $\begin{array}{r}8.4 \\
8.4 \\
13.5 \\
7.1\end{array}$ \\
\hline
\end{tabular}

There was no significant difference between male and female heart rates after fasting 100 hours. At this stage of fasting the destruction of cellular tissue and fat deposits was progressing rapidly, the bird probably having utilized most of its reserve supply of liver and muscle glycogen. Practically all of a grouse's energy for maintenance of vital processes is derived from the combustion of body fat after fasting only 36 to 48 hours. Thus the true sex difference in heart rate is masked by the catabolic activities being carried on at an accelerated rate in the body. It should also be noted that, in addition to being considerably. slower and showing less variability, the heart rate of fasting birds was lower at $40^{\circ} \mathrm{F}$. than at $65^{\circ} \mathrm{F}$. It is apparent that cardiac action is affected by fasting in similar plysiologic ways 
as body temperature and rate of hreathing. The great irregularity of heat action and the vital capacity of the heart to compensate for adverse envirommental change, is indieated by the standard deviation with respect to the variability of the rate of heart beat.

In these tests of grouse the number of heart beats per minute (sexes combined) averaged 342.6 and 350.5 at $65^{\circ} \mathrm{F}$. and $40^{\circ} \mathrm{F}$. respectively for hirds on lood. and 301.8 and 288.0 respectively for fasting individuals.

Statistical methods described by Baten ${ }^{36}$ for calculating data were used to measure the vital relationship between the physiologic variables where $\mathrm{x}=$ heart rate per minute: $\mathrm{y}=$ hody temperature; and $z=$ respiration rate per minute. By this means the significance of the relationship and the amount of dependence each variable has upon one or more of the others ean he demonstrated.

Calculations of the various coefficients ${ }^{34 ;}$, sa for both feeding and fasting grouse are presented in tables 106 and 107.

TAIBLE 106. CAICIJATION OF AMOUNT OF DEPENDENCE BETWEEN PHYSIOLOGICAI. REACTIONS OF FELDING ADULT GROUSE*

\begin{tabular}{|c|c|c|c|c|c|}
\hline Haction & $\begin{array}{l}\text { Nouber of } \\
\text { observations }\end{array}$ & $\begin{array}{l}\text { Averases } \\
\text { rate: }\end{array}$ & $\begin{array}{l}\text { Staudiard } \\
\text { error }\end{array}$ & & $\begin{array}{l}\text { Correlation } \\
\text { coeflicient }\end{array}$ \\
\hline $\begin{array}{l}\text { Heart rate } \quad(x) \\
\text { Hody temperature }(y)\end{array} \ldots \ldots \ldots$ & $\frac{27}{27}$ & $10 \div .1^{\circ} \mathrm{r}$ & 3.2 & Hxy & $=+n .58 \pm 0.13$ \\
\hline $\begin{array}{ll}\text { Jloart rate } & (x) \ldots \ldots \ldots \\
\text { Respiration rat: } & (z) \ldots \ldots\end{array}$ & $\frac{27}{27}$ & $\begin{array}{l}301.2 \\
39.4\end{array}$ & $\begin{array}{l}5.2 \\
1.9\end{array}$ & $R \times z$ & $=+0.18 \pm 0.108$ \\
\hline $\begin{array}{l}\text { Wody temperature (y) } \ldots \ldots \ldots \\
\text { llespiration rate: (z) . . . . . . . }\end{array}$ & $\frac{27}{27}$ & $\begin{array}{l}107.1^{\circ} \mathrm{F} \\
59 . \mathrm{H}^{\circ}\end{array}$ & 0.2 & Ilyz & $=+0.68 \pm 0.151$ \\
\hline
\end{tabular}

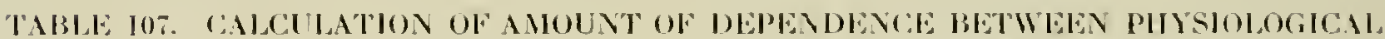
REACTIONS OF FASTING AIJLT (IROUSE*

\begin{tabular}{|c|c|c|c|c|}
\hline Ilenction & $\begin{array}{l}\text { Number of } \\
\text { observations }\end{array}$ & $\begin{array}{l}\text { Average } \\
\text { rate }\end{array}$ & $\begin{array}{l}\text { Staudiard } \\
\text { error }\end{array}$ & $\begin{array}{l}\text { Correlation } \\
\text { coellicient }\end{array}$ \\
\hline $\begin{array}{l}\text { Mrourt rute } \quad(x) \ldots \ldots \ldots \ldots \\
\text { Borly tromperature(y) } \ldots \ldots \ldots \ldots\end{array}$ & $\begin{array}{l}18 \\
18\end{array}$ & $\frac{261.1}{106.3^{\circ} \mathrm{F}}$ & $\begin{array}{r}11.41 \\
0.3\end{array}$ & $11 x y=+0.60 \pm 0.160$ \\
\hline $\begin{array}{l}\text { Iheart rate } \\
\text { Jiespirulion rato }(\mathbf{x}) \ldots \ldots \ldots \ldots\end{array}$ & $\begin{array}{l}18 \\
18\end{array}$ & $\begin{array}{r}261.4 \\
13.0\end{array}$ & 11.8 & $R_{x z}=+0.72 \pm 0.120$ \\
\hline 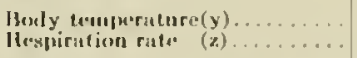 & $\begin{array}{l}\text { I8 } \\
\text { I8 }\end{array}$ & $\begin{array}{l}106.3^{\circ} \mathrm{F} \\
48.0\end{array}$ & 0.3 & $\mathrm{Ryz}=+0.11 \pm 0.208$ \\
\hline
\end{tabular}

Comparison of the differences between averages for the three physiologie reactions for both fasting and feeding birds indicates the following t-values of signifieance:

2.63 - Ileart rate

2.07 - Bedy temperature

3.59 - Respiration ralc

These data support our hiologieal understanding of the intimate interplay of these physiologric fartors. Sinee the coeffeients are all positive and highly significant. either when related individually fo each other or when all are related fogether it may be stated that a higher beart rate is intimately related to a ligher body temperature. Thus when hody temperature increases 
or decreases, both rate of heart and breathing are accelerated or retarded. Because of the great degree of interdependence anong these physiologic variables* it may be safely concluded that rate of heart beat per minute and body temperature are fundamentally significant as in. dices of the level of vitality. Respiration rate per minute is a factor of less importance as an index of metabolisn, especially for the type of experiment described here. Under other experimental circumstances, for example where an excessice change in body temperature oc. curred, there might be pronounced changes in rate of breathing.

\section{Resistance to Starvation}

Experiment 6 was devised for measuring the resistance of ruffed grouse to starvation using rectal temperature and respiration rate as indices.

First, all food except water was withdrawn over a 10-day period from 12 grouse. six of which (Group A) were held at $65^{\circ} \mathrm{F}$. and six (Group B) at $40^{\circ} \mathrm{F}$. throughout the test. Records of rectal temperature and respiration were taken three times daily-morning, afternoon and midnight. A summation of the data for each of these time intervals is presented in table 10 is.

TABLE 108. EFFECT (IF STARVATEN WITH WITER AVAILABLE UPOT TIE RECTAL, TEMPERATURE OF ADUIT GROUSE:

\begin{tabular}{|c|c|c|c|c|c|c|}
\hline \multirow[b]{2}{*}{ tiromit } & \multirow{2}{*}{$\begin{array}{l}\text { Number } \\
\text { of birds }\end{array}$} & \multirow[b]{2}{*}{$\sin x$} & \multirow[b]{2}{*}{ Time of day } & \multicolumn{3}{|c|}{ Hectal homperalure } \\
\hline & & & & Averabe & $\begin{array}{l}\text { Suandurd } \\
\text { deviation }\end{array}$ & $\begin{array}{l}\text { Stuudiarel } \\
\text { error }\end{array}$ \\
\hline \multirow[t]{2}{*}{ (irous $A$, al air temperature $6.5^{\circ} \mathrm{s}$. } & 3 & mule & $\begin{array}{l}\text { morning } \\
\text { ufternovon } \\
\text { niduight }\end{array}$ & $\begin{array}{l}106.37^{\circ} \mathrm{F} . \\
106.25 \\
103.51\end{array}$ & $\begin{array}{l}0.352 \\
0.110 \\
0.303\end{array}$ & $\begin{array}{l}0.117 \\
0.137 \\
0.117\end{array}$ \\
\hline & $\mathbf{x}$ & f'mal: & $\begin{array}{l}\text { morming } \\
\text { afternuxin } \\
\text { miduight }\end{array}$ & $\begin{array}{l}106.56 \\
106.50 \\
103.56\end{array}$ & $\begin{array}{l}0.128 \\
0.131 \\
0.789\end{array}$ & $\begin{array}{l}0.01: 1 \\
0.1 .15 \\
0,2019\end{array}$ \\
\hline \multirow[t]{2}{*}{ Group 13 , at air temperature $10^{\circ} \mathrm{f}$. } & 3 & mule & $\begin{array}{l}\text { morning } \\
\text { ufternoon } \\
\text { midnight }\end{array}$ & $\begin{array}{l}105.53 \\
106.17 \\
101.96\end{array}$ & $\begin{array}{l}0.182 \\
0.265 \\
0.830\end{array}$ & $\begin{array}{l}0.161 \\
0.0838 \\
0.3310\end{array}$ \\
\hline & 3 & fomal:: & $\begin{array}{l}\text { moruiug } \\
\text { ufternom } \\
\text { midnight }\end{array}$ & $\begin{array}{l}106.04 \\
105.86 \\
103.90\end{array}$ & $\begin{array}{l}1.111 \\
1.180 \\
0.316\end{array}$ & $\begin{array}{l}0.300 \\
0.106 \\
0.120\end{array}$ \\
\hline
\end{tabular}

Of interest to the game manager is the greater drop in the level of rectal temperature for fasting birds at midnight compared with that of well-fed birds at the same hour (Experiment 2. figures 83 and 84 ). During the night there is a natural rhythmical lowering of metabolic activity and external physical movement. Also between midnight and dawn under outdoor conditions the lowest air temperatures usually occur. As the air becomes colder. however. the metabolic rate would tend to increase in order to prevent a drop in hody tenperature. Under such conditions a fasting bird would have greater difficulty in preventing an excessive reduction of body temperature than would a well-fed bird.

The difference between the averages of data obtained at $40^{\circ} \mathrm{F}$. and $65^{\circ} \mathrm{F}$. shows that there was a high physiological correlation between body temperature and environmental temperature at these levels. The smaller standard error for females at $65^{\circ} \mathrm{F}$. indicates less variability in their temperature than in that of males at the same air temperature. At $40^{\circ} \mathrm{F}$. the degree of variability apparently was not significant between the sexes. 
The average trend of rectal temperature during the periot of the test is plotted in figure 90 . It shows greater variability among the hirds living at $65^{\circ} \mathrm{F}$. (Group A). Also the hirds in this group maintained their temperalure at a higher level than did those in Group B which were subject to greater loss of body heat by radiation at $40^{\circ} \mathrm{F}$. than at $65^{\circ} \mathrm{F}$. It is probable that a difference of 20 degrees in air temperature would have a more pronounced effect upon the metabolism of fasting grouse than upon that of well-fed grouse.

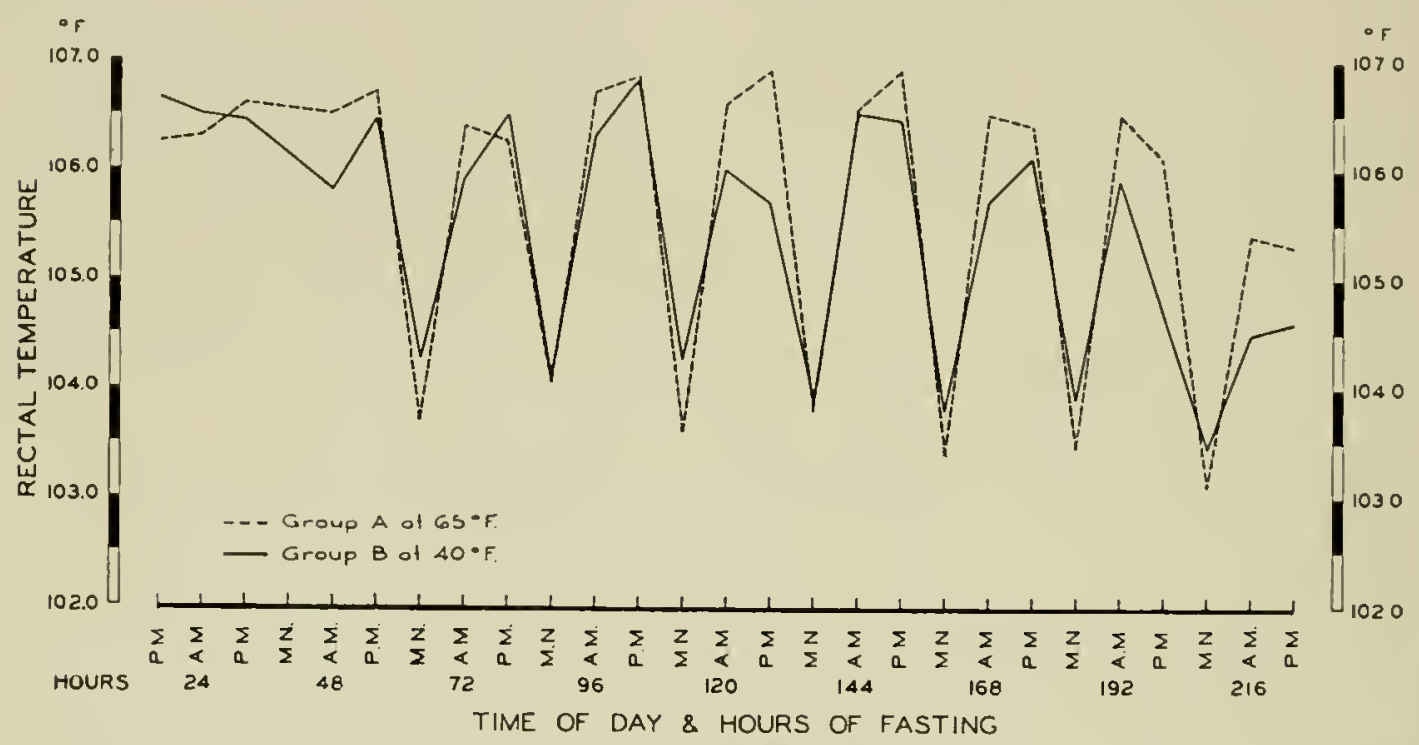

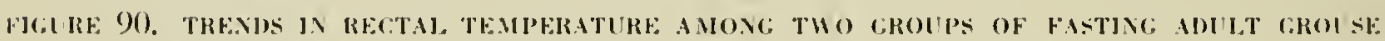
IIELJ) AT IIFFERENT IIR TEMPERATLRES

The respiration rates recorded for these birds are summarized in tahle 109. When com. pared with the data secured for well-fed birds in Experiment l. Lable 102, they show that fasting lowered this rate in loth sexes. Also shown is a distinct difference in this reaction at $40^{\circ} \mathrm{F}$. and at $65^{\circ} \mathrm{F}$. similar to the trend in rectal temperature. Furthermore, the difference between the sexes at $40^{\circ} \mathrm{F}$. namely 13 respirations per minnte higher for female, is statistically significant.

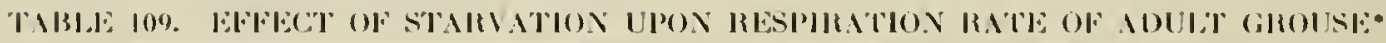

\begin{tabular}{|c|c|c|c|c|c|}
\hline \multirow[b]{2}{*}{ Periesl } & \multirow[b]{2}{*}{ Sir } & \multirow{2}{*}{$\underset{\operatorname{dir}}{\text { tamperture }}$} & \multicolumn{3}{|c|}{ Pteypiralion ral. } \\
\hline & & & Avernge: & $\begin{array}{l}\text { Sinndari } \\
\text { Jeviation }\end{array}$ & $\begin{array}{c}\text { Sitamilaril } \\
\text { errer }\end{array}$ \\
\hline 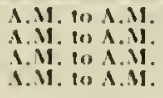 & 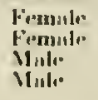 & $\begin{array}{l}65^{\circ} \mathrm{F} \\
10 \\
65 \\
10\end{array}$ & $\begin{array}{l}5.3 .03 \\
17.51 \\
56.31 \\
60.14\end{array}$ & $\begin{array}{l}1.08 \\
5.79 \\
3.90 \\
1.30\end{array}$ & $\begin{array}{l}1.07 \\
2.07 \\
1.10 \\
1.10\end{array}$ \\
\hline
\end{tabular}

As a second part of this experiment. six additional grouse (Group C) were held at $6.5^{\circ} \mathrm{F}$. with neither food nor drinking water available for 81 . hours. The average rectal temperatures and respiration rates of these birds are presented in talle 110 . During the period of study half the birds died. Sinee this group was tested under identical environmental condi- 
tions with the other two, except for the absence of drinking water. it would appear that such water, or a suitable substitute, is a daily physiological need of grouse.

TABLE 110. EFFECT OF STARVATION WITIOUT WATER IPON TIE RECTAI. TEMPERATURE AND RESPIRATION BITE OF ADULT GROUSE*

\begin{tabular}{|c|c|c|c|c|c|}
\hline \multirow{2}{*}{$\begin{array}{c}\text { Nuruber of } \\
\text { birals }\end{array}$} & \multirow{2}{*}{$S \cdot x$} & \multirow{2}{*}{$\begin{array}{l}\text { Timm of } \\
\text { dany }\end{array}$} & \multicolumn{3}{|c|}{ Vrasurements recordenl } \\
\hline & & & Averumer & $\begin{array}{l}\text { Slandard } \\
\text { deviation }\end{array}$ & $\begin{array}{l}\text { Sitandaral } \\
\text { perrour }\end{array}$ \\
\hline & & & \multicolumn{3}{|c|}{ liretal trapmerature } \\
\hline 3 & Malu. & $\begin{array}{l}\text { Mornjige } \\
\text { Arternoxin }\end{array}$ & $\begin{array}{l}107.19^{\circ} \mathrm{F} \\
106.9^{\circ}\end{array}$ & $\begin{array}{l}0.829 \\
0.8 .0\end{array}$ & $\begin{array}{l}0.575 \\
11.135\end{array}$ \\
\hline$: 1$ & Femul. & $\begin{array}{l}\text { Morning } \\
\text { Afternicele }\end{array}$ & $\begin{array}{l}106.71 \\
106.18\end{array}$ & $\begin{array}{l}0.896 \\
0.464\end{array}$ & $\begin{array}{l}10.118 \\
11.233\end{array}$ \\
\hline 3 & $M a l \cdot$ & $\begin{array}{l}\text { Morniug } \\
\text { Afterusen }\end{array}$ & $\begin{array}{l}62.5 \\
56.3\end{array}$ & $\begin{array}{l}\text { spiratiun ri } \\
6.0: \\
1.15\end{array}$ & $\begin{array}{l}3.17 \\
2.118\end{array}$ \\
\hline$x$ & F'енйl. & $\begin{array}{l}\text { Vorning } \\
\text { Afternoou }\end{array}$ & $\begin{array}{l}57.01 \\
39.3\end{array}$ & $\begin{array}{l}3.3 .3 \\
3.16\end{array}$ & $\begin{array}{l}2.60 \\
1.38\end{array}$ \\
\hline
\end{tabular}

*Group C, al air temperature $65^{\circ} \mathrm{F}$.

The influence of length of fasting, time of day, and absence of drinking water upon the temperature-regulating mechanism is presented in figure 91. The female grouse in Group C showed least resislance to fasting, as indicated by the trend of their temperature, especiall! at midday. After the 48 th hour of fasting without water neither the males nor females were

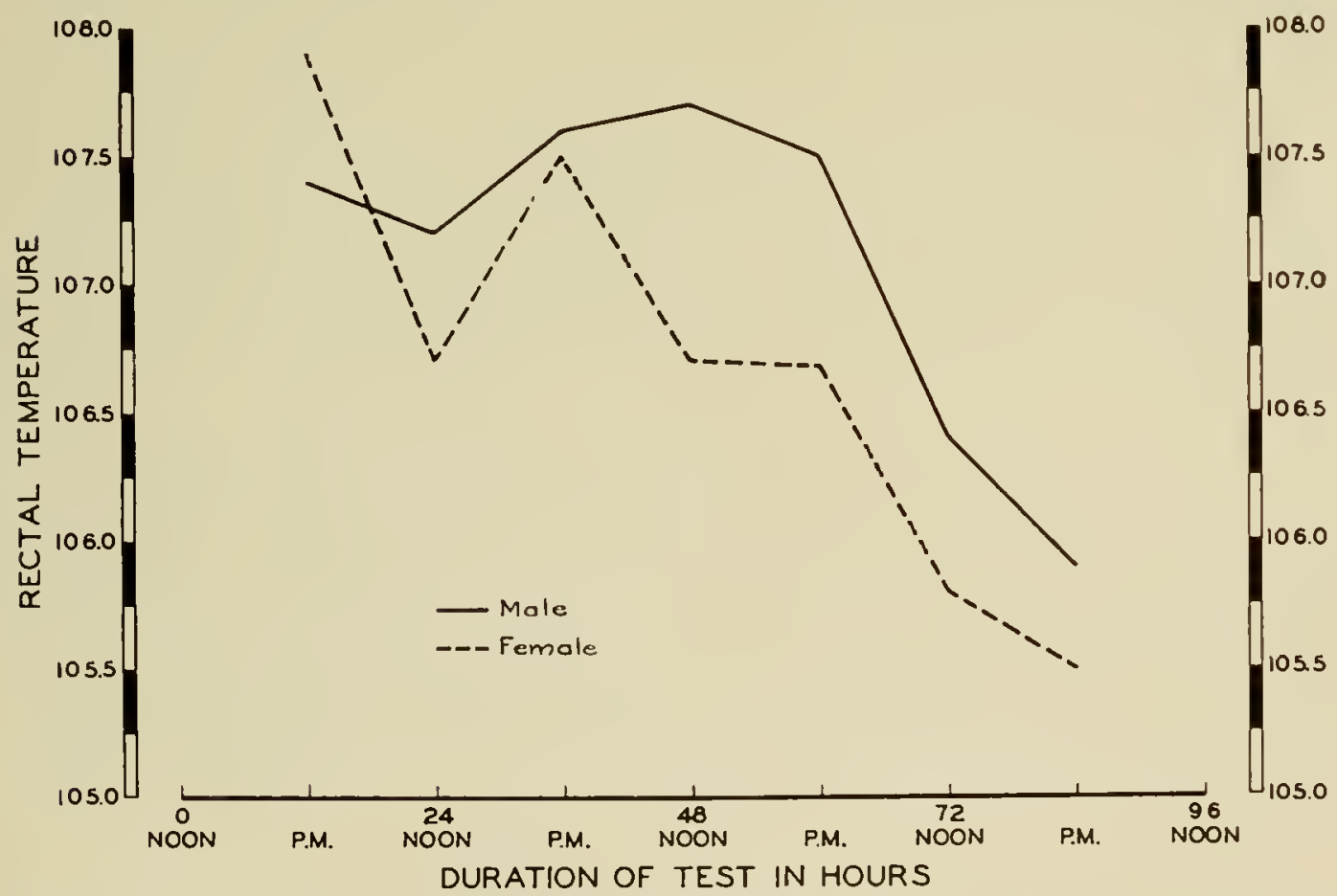

FIGLRE, 91. TRENDS IN RECTAL TEMPERATURE AMONG MALE AND FEMALE ADLLT GROLSE FASTING, WITHOIT DRINKING WATER 
able to increase their metabolism sullicienty to prevent a breakiown of their temperatureregulating mechanism. In this particular instance there was a signifurant difference between the averages of body temperature for males and females, beginning at the 3 oth hour of fasting.

In table IIl the body temperatures of Groups $A$ and $C$ are compared with those of normally feeding birds. The rectal temperature of Group $\mathrm{C}$ birds at the 8 th hour of fasting averaged higher for both sexes than for Group A hut lower than for individuals that were not subjected to fasting during these tests. The experimental data from this group demonstrate the effect of both active digestion and starvation upon body temperature. Variability in rectal temperature, as indicated by the magnitude of the standard error. was least for the control birds and most for those individuals fasting without water.

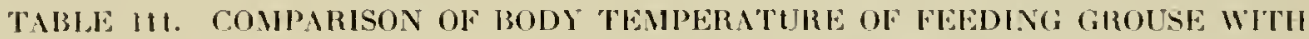
THAT OF GROUSL: AFTEIR FASTIVG 81 HOI'RS 130TH

WITH AND WITIOUT WA'TEI?

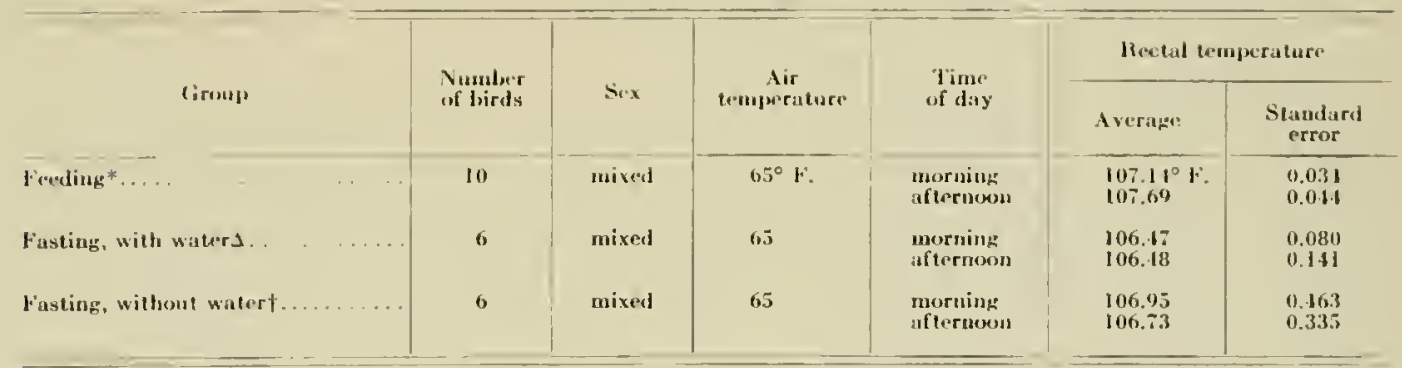

* Average cinge artivity.

$\lambda$ Group A.

triroup C.

When fasting without water, grouse apparently are subjected to rapid dehydration of body tissues. The dryjng-uj process is of such magnitude as to cause a definite increase in mortality. The data from all groups of birds in these tests clearly indicate that grouse have definite daily need for water to satisfy particular physiologic functions. Due to limited data the actual cause of carly death of grouse fasting without water is not clearly understood at this time.

\section{EFFECT of Fasting on BODY WeIGHT}

Experiment 7 was supplementary to the preceding study and inwolved data taken coineidentally from the same groups of hirds. Its purpose was to study the elfort of fasting (hoth with and without water) upon hody weight.

By suhjecting the hirds to fastiner conditions the resultant data furnished a fundamental hase-line of minimum vital needs for maintenunce of the various physologic functions. By superimpuxing upon the hase-line of minimum needs the effect of such factors as muscular artivity. digestion of food. and air temperature, the maximum physiologic needs for main. taining sital functions at normal kevels will be reveated.

The 18 hirds were suljected to prolonged fasting as follows:

Gromp $1-6$ grouse at $6.5 \% \%$, without food hut with water.

Group B-6 grouse at $10^{\circ} \%$... without food hut with water

Group C-6 grouse at $65^{\circ} \mathrm{F}$., withoul food or water 
In each group. the sexes were evenly divided. The results of the total perind of fast are recorded in table 112.

The ability to withstand fasting does not seem to be entirely dependent upon nor strictly proportional to brody size (weight) alone. Temperature factors appear to have been highly significant in the case of the three female grouse which lost approximately 31 per cent of their weight after fasting 189 hours at $40^{\circ} \mathrm{F}$.

The trend of daily weight change for individual fasting grouse in all groups is shown in figure 92. Figure 93 shows the percentage of weight loss. The slopes of these curves are interesting in several respects. They indicate that (1) the daily ingestion of water prolonged life and sustained body weight; (2) grouse of lower weight suffered a more rapid loss in weight*; (3) heavier grouse had a tendency to maintain a more constant weight loss: and (4) percentage losses in weight were more or less proportional to the hour of fasting.

Sixty-seven per cent of the grouse in Group C, on test without food or water at $65^{\circ} \mathrm{F}$., died, on the average, at the 88th hour of fast, with an average loss of 16.5 per cent of the initial weight. When lhis weight loss for Group C is compared with the arerage percentage loss for Groups $A$ and $B$ at the same hour of fast, it was revealed that the latter had lost only 11.7 per cent of their initial weight. This small difference is highl! significant since the 83th hour of fasting with water represents only 10 per cent of the total period of fasting to which they were exposed. Undoubtedly this greater degree of resistance to fasting was due to the ingestion of water by those hirds that were allowed it during the test.

The average distribution in weight loss per 24 hours showed the rate to be considerably less during the daytime than during the night. the greatest loss occurring from midnight to 8:00 to $9: 00$ a.m.

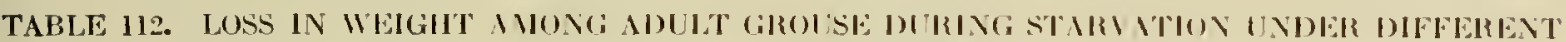
C.NDITIONS

\begin{tabular}{|c|c|c|c|c|c|c|c|c|c|c|}
\hline ('тони) & $\begin{array}{l}\text { Numbler } \\
\text { of lijerls }\end{array}$ & Sex & $\begin{array}{l}\text { Air } \\
\text { temperature }\end{array}$ & $\begin{array}{l}\text { Percent } \\
\text { lomiclity }\end{array}$ & $\begin{array}{l}\text { Iuitial } \\
\text { wright }\end{array}$ & $\begin{array}{l}\text { Finial } \\
\text { wriglit }\end{array}$ & $\begin{array}{l}\text { I"rerent } \\
\text { wright loss }\end{array}$ & $\begin{array}{l}\text { Lenptli } \\
\text { of fast }\end{array}$ & $\begin{array}{l}\text { lime } \\
\text { per hour }\end{array}$ & Mortality \\
\hline $\begin{array}{l}\text { Fasling, with waler. } \\
\text { (Iron, A) }\end{array}$ & 3 & $\begin{array}{l}\text { male } \\
\text { femalo. }\end{array}$ & $6.3^{\circ} \mathrm{F}$ & $\begin{array}{l}30 \\
30\end{array}$ & $\begin{array}{l}61: 3.3 \mathrm{kmt} \\
533.3\end{array}$ & $168.7 \mathrm{~km}$ & $\begin{array}{l}2: 3.6 \\
2=2.4\end{array}$ & $\frac{231.7 \mathrm{hrs}}{232.0}$ & $\begin{array}{l}0.02 \\
0.53 \\
\mathrm{~km} .\end{array}$ & 2 \\
\hline $\begin{array}{l}\text { Fusting, with water. } \\
\text { (Cironj, l3) }\end{array}$ & $\begin{array}{l}3 \\
3\end{array}$ & $\begin{array}{l}\text { male } \\
\text { femalo }\end{array}$ & $\begin{array}{l}\text { III } \\
\text { III }\end{array}$ & 6.3 & 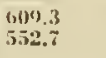 & $\begin{array}{l}173.0 \\
132.0\end{array}$ & $\frac{22.1}{30.1}$ & $\frac{272.0}{189.3}$ & $\begin{array}{l}0.58 \\
0.911\end{array}$ & 1 \\
\hline $\begin{array}{l}\text { Fasting, without water. } \\
\text { (Group C) }\end{array}$ & 3 & $\begin{array}{l}\text { male } \\
\text { feroule }\end{array}$ & 6.5 & 30 & $\begin{array}{l}621 . \overline{1} \\
515.3\end{array}$ & $\begin{array}{l}.111 .3 \\
137.0\end{array}$ & $\begin{array}{l}16.5 \\
15.2\end{array}$ & $\begin{array}{l}90.0 \\
92.11\end{array}$ & $\begin{array}{l}1.17 \\
0.86\end{array}$ & $\begin{array}{l}3 \\
1\end{array}$ \\
\hline
\end{tabular}

The grouse subjected to fasting without drinking water available lost orer twice as much weight during the day as those that fasted with water available. It would be expected that considerable luss in weight would be temporarily compensated for by the ingestion of large quantities of water. The weight-sustaining properties of water are clearly indicaterl by these data.

The influence of water as a factor in sustaining life and retarding loss in body weight is slown in figure 9l. When these data are compared to data presented in table 112, it is 
obvious that Group 13 females suffered the largest percentage weight loss and consumed on the average less water per hour than all other birds. Furthermore those individuals con. suming the least amount of water suffered the greatest loss in body weight.

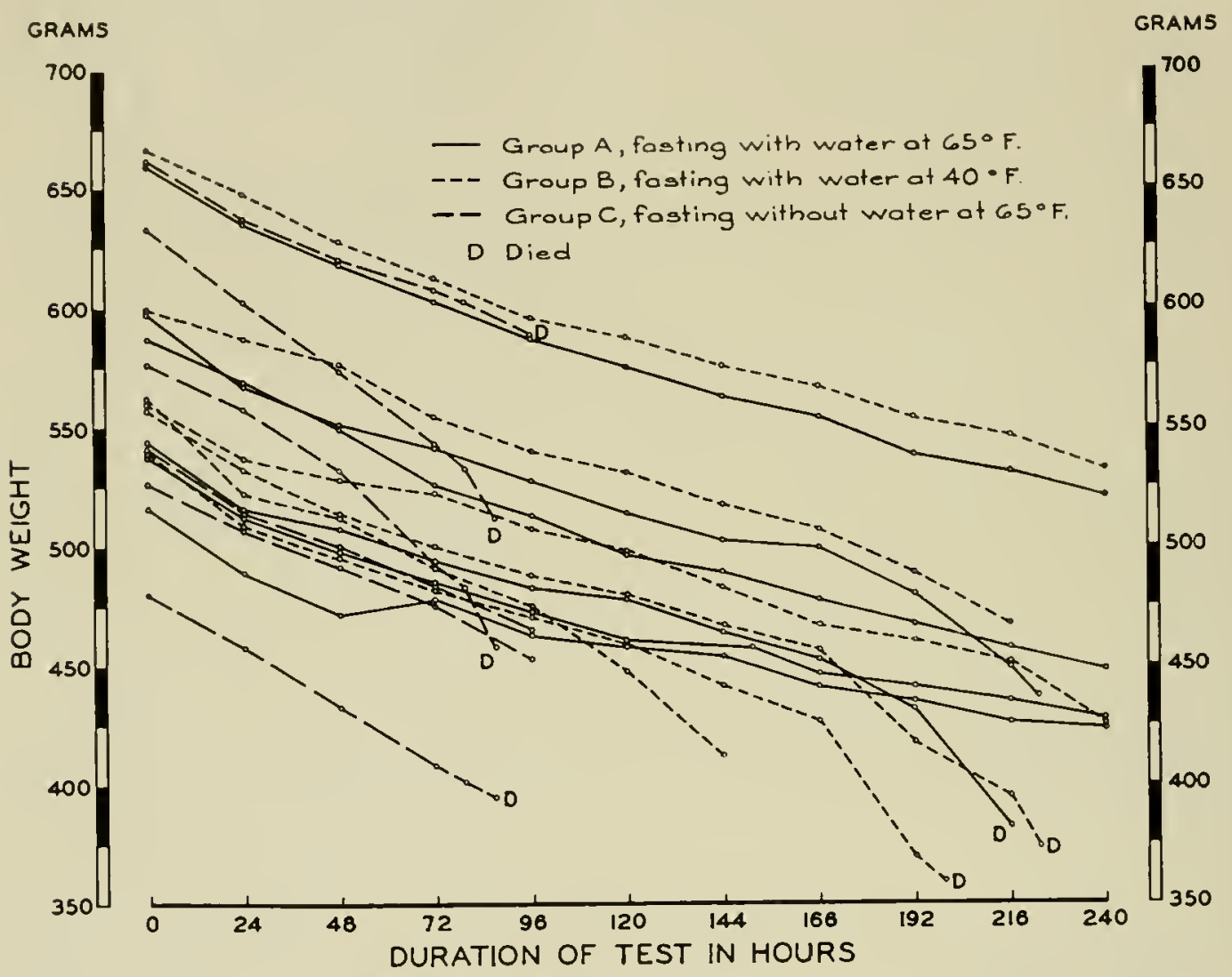

FI:URF, 92. TRENIS OF 2J-HOUR CIANGES IN BODY WEIGITT OF ADULT GROISE DURING, PROLONGED FSSTING, WITH AND WITHOUT WATER

Analysis of data from 16 observations on the relationship between water consumption and change in body weight were calculated statistically as follows:
Predicting equation:
$Y=103.25-1.083 .3 \mathrm{x}$
Correlation roefficiont:
lixy $=-0.05 \pm 0.151$ (standard error)

Since the value of the correlation coefficient is both high and negative it indicates that with an increase in the amonnt of watcr consumed there is a derrease in the amount of weight loss.

\section{l.kigtil of Time for Foon to Digest}

Experiment 8 involved a determination of the length of time required for food to digest and pass through the alimentary canal under different conditions of air temperature. Beyond this, comparisms were made between fasting birds and others whose feeding had not been interrupted. A smalt gelatin capsule containing solid food particles and a small quamity of specially prepared powdered scarlet dye was inserterl into the crop. The rate of digestion was calculated as the time elapsing between feeding the capsule and the first appearance of 


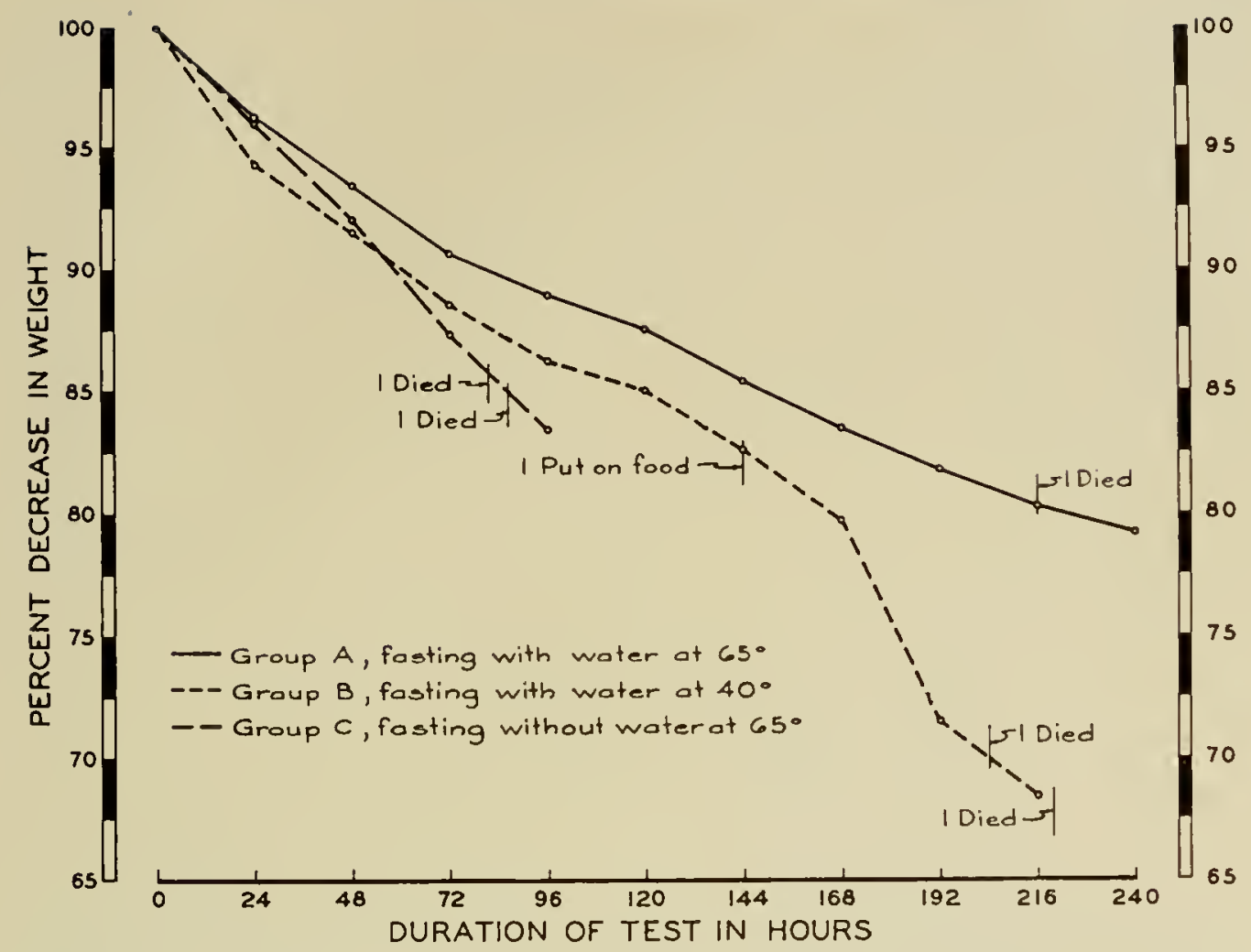

FICURE 93. TRENDS OF PERCENTACE I.OSS IN BOHY WEIGIIT OF WULT (:RO) SE, MERING PROLONGEI FASTIN; WITI WM WITIOOT WATER

the dye in voided exereta. A sunmation of the data secured is presented in tables 113 and 114.

It is apparent that rate of digestion is influenced by both air temperature and composition of food. At the lower air temperatures digestive activity was appreciably slower. In this connection it is to be noted that the rate of activity of the various digestive enzymes is retarded at lower air temperature, but just how this phenomenon is related to a slower rate of digestion is not clear for the hody temperature was not materially affected at the experimental air temperature, as shown in tables 113,114 and 115.

When the data are interpreted statistically (table 115). it is of considerable interest to note

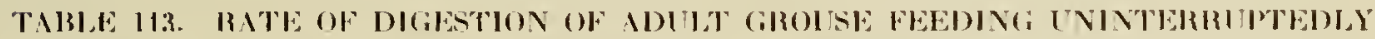

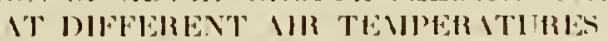

\begin{tabular}{|c|c|c|c|c|c|c|}
\hline \multirow{2}{*}{$\begin{array}{l}\text { Numblu.r } \\
\text { of hirrls }\end{array}$} & \multirow{2}{*}{$S \cdot x$} & \multirow{2}{*}{$\underset{\text { tempralure }}{\text { Air }}$} & \multirow{2}{*}{$\begin{array}{l}\text { lerer renut } \\
\text { lumindity }\end{array}$} & \multirow{2}{*}{ Rution* } & \multicolumn{2}{|c|}{ Hate of dizestion } \\
\hline & & & & & Average & Variution \\
\hline $\begin{array}{l}1 \\
1 \\
1 \\
8 \\
1 \\
6 \\
1\end{array}$ & $\begin{array}{l}\text { mixed } \\
\text { femule } \\
\text { male } \\
\text { mixed } \\
\text { male } \\
\text { mixed } \\
\text { mixed }\end{array}$ & $\begin{array}{l}80^{\circ} \mathrm{k} \\
811 \\
811 \\
6.5 \\
6.5 \\
32 \\
11\end{array}$ & $\begin{array}{l}37 \\
11 \\
11 \\
30 \\
21 \\
63 \\
00\end{array}$ & $\begin{array}{l}\text { serutch grain und mush } \\
\text { mash } \\
\text { seratch gruiu } \\
\text { scratch grain and musl } \\
\text { scratch grain } \\
\text { serntch grain und mash } \\
\text { serulch grain and mash }\end{array}$ & $\begin{array}{l}67 \mathrm{~min} . \\
107 \\
110 \\
134 \\
145 \\
239 \\
212\end{array}$ & $\begin{array}{l}55-79 \mathrm{~min} \\
105-110 \\
130-150 \\
130-160 \\
335-155 \\
190-288 \\
172-310\end{array}$ \\
\hline
\end{tabular}

*All diets inchaded ulfulfa, apple and wuter. 
the finding of a neigative coefficient for hirds actively digesting food and a positive coefficient for fasting birds. The values of both coeffieients are biologrically very high and demonstrate a strong relationship befween air temperature and digestive activity.

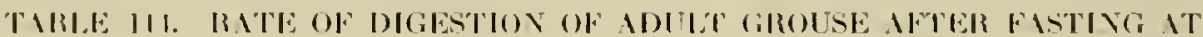
DIFEERENT AIR TEMTERTTURES

\begin{tabular}{|c|c|c|c|c|c|c|}
\hline \multirow{2}{*}{$\begin{array}{l}\text { Number } \\
\text { of birds }\end{array}$} & \multirow{2}{*}{$\sin x$} & \multirow{2}{*}{$\begin{array}{c}\text { Air } \\
\text { temperature }\end{array}$} & \multirow{2}{*}{$\begin{array}{l}\text { ler ccral } \\
\text { lumidity }\end{array}$} & \multirow{2}{*}{ Iength of fast } & \multicolumn{2}{|c|}{ Rate of dipestion } \\
\hline & & & & & Average & Variation \\
\hline $\begin{array}{l}1 \\
1 \\
1 \\
1 \\
1 \\
1\end{array}$ & $\begin{array}{l}\text { mixed } \\
\text { mixed } \\
\text { mixed } \\
\text { mixed } \\
\text { mixed } \\
\text { mixed }\end{array}$ & $\begin{array}{l}8.20 \mathrm{~F} . \\
6.5 \\
6.3 \\
6.5 \\
40 \\
10\end{array}$ & $\begin{array}{l}18 \\
30 \\
30 \\
30 \\
60 \\
60\end{array}$ & $\begin{array}{c}12-15 \mathrm{hrs} . \\
12-1.3 \\
78 \\
190 \\
78 \\
102\end{array}$ & $\begin{array}{l}75 \text { min. } \\
90 \\
116 \\
18.3 \\
102 \\
111\end{array}$ & $\begin{array}{l}60-90 \text { min. } \\
60-115 \\
112-120 \\
165-200 \\
85-120 \\
100-125\end{array}$ \\
\hline
\end{tabular}

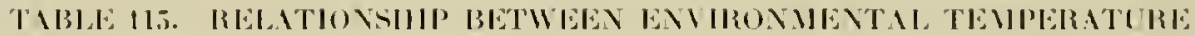
AND DIGESTIVE ACTIVITY

\begin{tabular}{|c|c|c|c|c|}
\hline $\begin{array}{l}\text { Numbuar of } \\
\text { cotoservations }\end{array}$ & $\begin{array}{l}\text { Plane of } \\
\text { tultrition }\end{array}$ & $\operatorname{lir}_{\text {tomprature }}$ & & $\begin{array}{l}\text { Correlation } \\
\text { roellicient }\end{array}$ \\
\hline 23 & foeding & $.30-86^{\circ} \mathrm{F}$ & Itry & $=-0.8 .3 \pm 0.0603$ \\
\hline 10 & fastimg $78-100$ lars. & $10-6.5$ & nxy & $=+0.63 \pm 0.161$ \\
\hline
\end{tabular}

Physiolngically the high negative correlation coeffeient is interpreted to mean that when environmental temperature decreases the lengh of time required for food to pass through the alimentary canal increases. Under these conditions metabolism rould be stimulated by (o)ld but food substances would be retained longer in digestive processes in order to exhanst and absorb all of the possible available nutriments. At high air temperatures the reserse would be the case for actively feeding birds.

The high pusitive coellicient is of considerable physologie interest. It suggests that exposing a fasting grouse to lowering envirommental temperature decreases the length of time required for food to digest and be voided as exereta. Greater oxidation of cellular tissue (at from is 10100 hours of fasting. essentially a fat metaloblisml to eombat cold apparently stimulates metabolism consideral)l. At higher air temperature the rate of digestion of fasting birds would also increase.

These two observations on digestive activily in relation to air tamperature are of considerahle importance in evaluating the prohahility of survival of game species during winter months, especially during hours of darkness. liegardless of the temperature effert. the rate of passage of digestible sulsances through the alimentary canal of the fasting hird was considrralily faster than for the fecting birt.

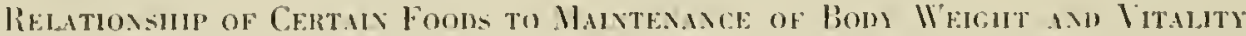

Experiment 9 insolsed the relationship of certain foud rations to the maintenance of hods

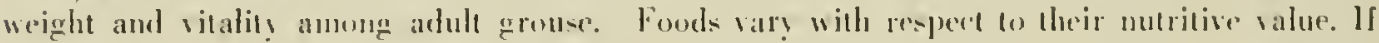
at change acturs in the compusition of the food ralion. or in the amount of foed consumed daily. there may follow apprerialle changess in body heal production. in composition of bod! tissues and in hody weight. When catabolic processes the breaking down and destruetion of 
body substances) exceed anabolic processes (assimilative reaction involving the building up of body substances) in body eells, the maintenance of vital functions is interfered with. On the other hand, anabolic activities equaling or exceeding catabolic activities result in a stable physiological balance of vital processes. Thus when an animal neither loses nor gains weight, the body is in a condition of nutritive equilibrium. The adjustment between the two phases of total metabolism in the body is essential for the continuation and maintenance of life at normal levels.

Foods are utilized in the body through a process of oxidation or burning in which heat is one of the principal products. Since the basic food ingredients (protein, fats and carboliyIrates) differ in their heat producing values ${ }^{19,}$ and food substances are made up of various combinations of these ingredients, it is necessary to use some standard unit of comparison. The most convenient unit of this kind is the large calorie*.

Correcting for the part of each substance lost in digestion the physiological fuel values of the basic ingredients are:

1 gram of carbohydrate

1 grain of fat

4.0 calories

I gram of protein

9.0 calories

4.0 calories

On this hasis. the foods used in this experinent compare as follows:

1 gram of mash furnished 3.23 calories. or 1 pound. about 1467 calories

1 gram of grain furnished 2.78 calories, or 1 pound. about 1261 calories

1 gram of alfalfa furnished 0.70 calories. or 1 pound. about 317 calories

1 gram of apple furnished 0.61 calories. or 1 puund. about 290 calorie-

The total nutritive value of earh food substance is not entirely included in its calorific value, for the vitamins, water, and minerals contaned therein are not direct sources of heat energy. 'These last elements ${ }^{2 \pi n}$. lowerer. are vitall! lenefreial as contributing materials necessary for normal growth. reproduction. hatchability. maintenance of other vital functions, and cure and prevention of disease. The water content of the different sulstances composing the ration ranged from $5 \mathrm{to} 15$ per cent for grain and mash. 80 to 85 per cent for apple, and alout 70 per cent for alfalfa. Neither does the total eatorific salue include the arldition of me pint of cod liver oil to each 100 pounds of grain.

The untritional requirements of gronse were studied by measuring the daily food and water consunption of 16 apparently healthy birds. nine for a period of 33 days at an air tenperature of $65^{\circ} \mathrm{F}$. and seven for 13 days at $35^{\circ} \mathrm{F}$. They were fed ad libium on a ration of mash. grain, alfalfa and apple. the calorifie values of which are deseribed abose. Water was available at all times. The amount of food and water consumed as well as changes in body weight were recorded simultaneously each morning and evening at regular hours duriug the periods of study. The results are presented in table 116.

Of the nine birds held at $65^{\circ} \mathrm{F}$.. five (Group A) either maintained or increased their lody weight. whereas four (Group B) lost weight on the amomt of food eaten. Approach to a normal caloric intake is demonstrated for the birds in Group A. It is improbable. how. ever. that actively feeding grouse would have to produce additional hody heat to combat an air temperature of $65^{\circ} \mathrm{F}$. Therefore. the caloric value of the ingested food in excess of daily physiological needs permitted a storage of organic substances in the body and the birds gained in weight. On the other hand. the amount of food consumed ly Group B hirds was 
not sufficient to maintain body weight. although why they did not eat more is not clear.

It is to be noted from previous experiments that increased muscular activity greatly raises the metabolic rate. In confinement. however. muscular activity is markedly reduced as rom. pared witl birds whose movements are not greatly restricted. Within a certain range of air temperature the metabolism of gallinaceous birds is unaffected by air temperature itself. but either below or above this range it is accelerated to maximum levels.

Of the grouse living at $85^{\circ} \mathrm{F}$. two (Group C) gained weight, while five (Group D) lost. Because less body heat is required as the environmental temperature rises, physiological demands should be satisfied ly lower food consumption (ealorie values being equal) under such conditions. Yet it is apparent that the caloric intake of the birds in Group D was inadequate for vital needs. On the other hand. Group $\mathrm{C}$ hirds consumed relatively larger amounts of food than was necessary physiologically at an air temperature of $85^{\circ} \mathrm{F}$. These two hirds were able to gain even more, proportionally. than Group $A$, although consuming no more than Group B which could not maintain weight at $65^{\circ} \mathrm{F}$.

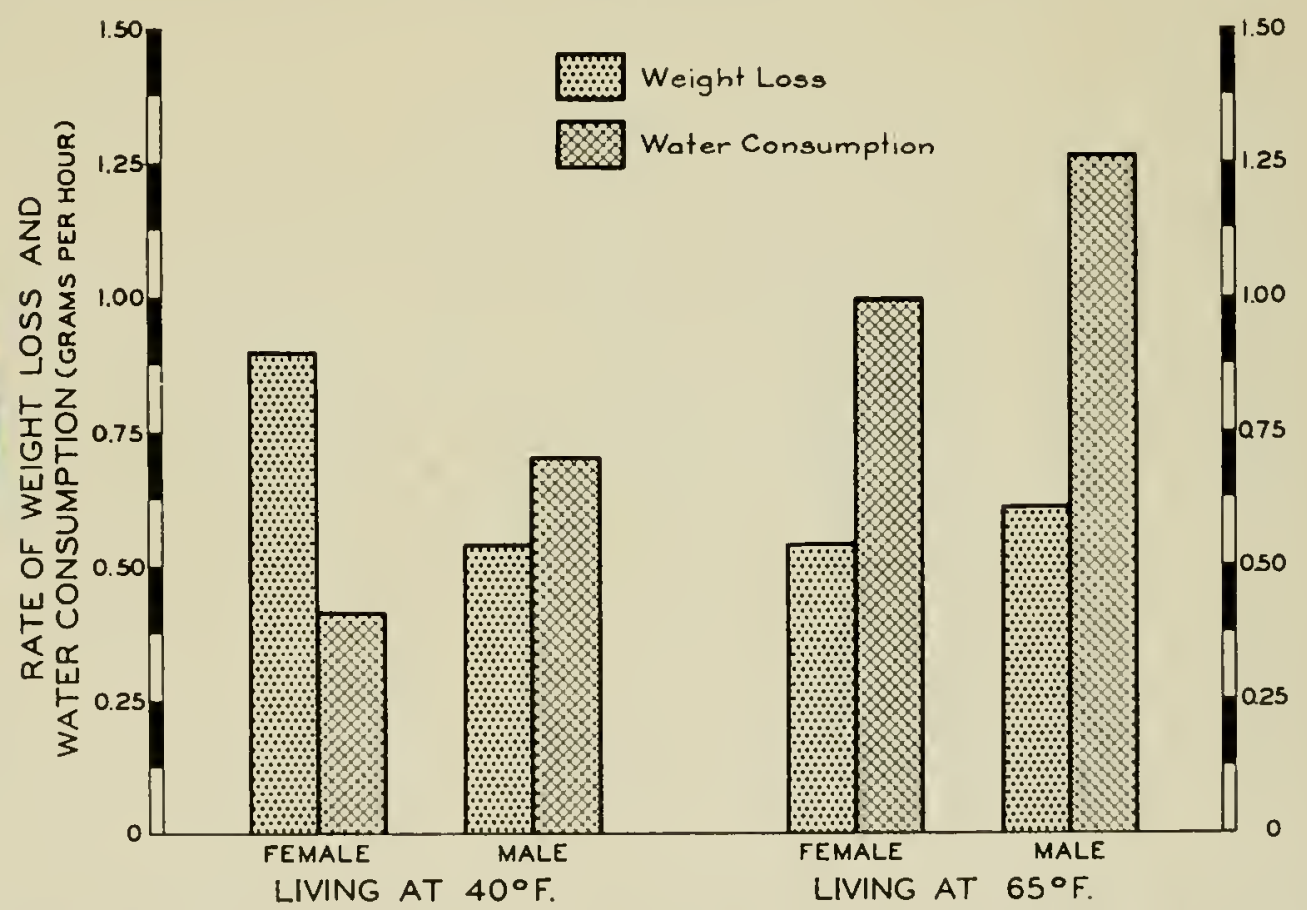

FIGLRE 91. RELATIONSIIP BETWEEN BOH WFIGHT 1.OSS MND WATER CONSLMPTIOS OF .MH I.T CROESE: HCRING PROLGNGFII FASTING IT TWO AIR TEMPERATIRES

A possible explanation for variations in weight and food consumption is that a temperature of $85^{\circ} \mathrm{F}$. is physiologically unfavorable during winter months for confined grouse in full plumage and while in a condition of active digestion. Under these conditions two of the hirds manifested polypnea (an exaggerated rate of breathing or panting) which is a chief physical means for cooling the lody ly the vaporization of water from the lungs and air sacs.

Another phase of the experiment was designed to study the effect of the ingestion of food upon grouse in a physiolngical state of undermutrition. Ten birds which had survived the 

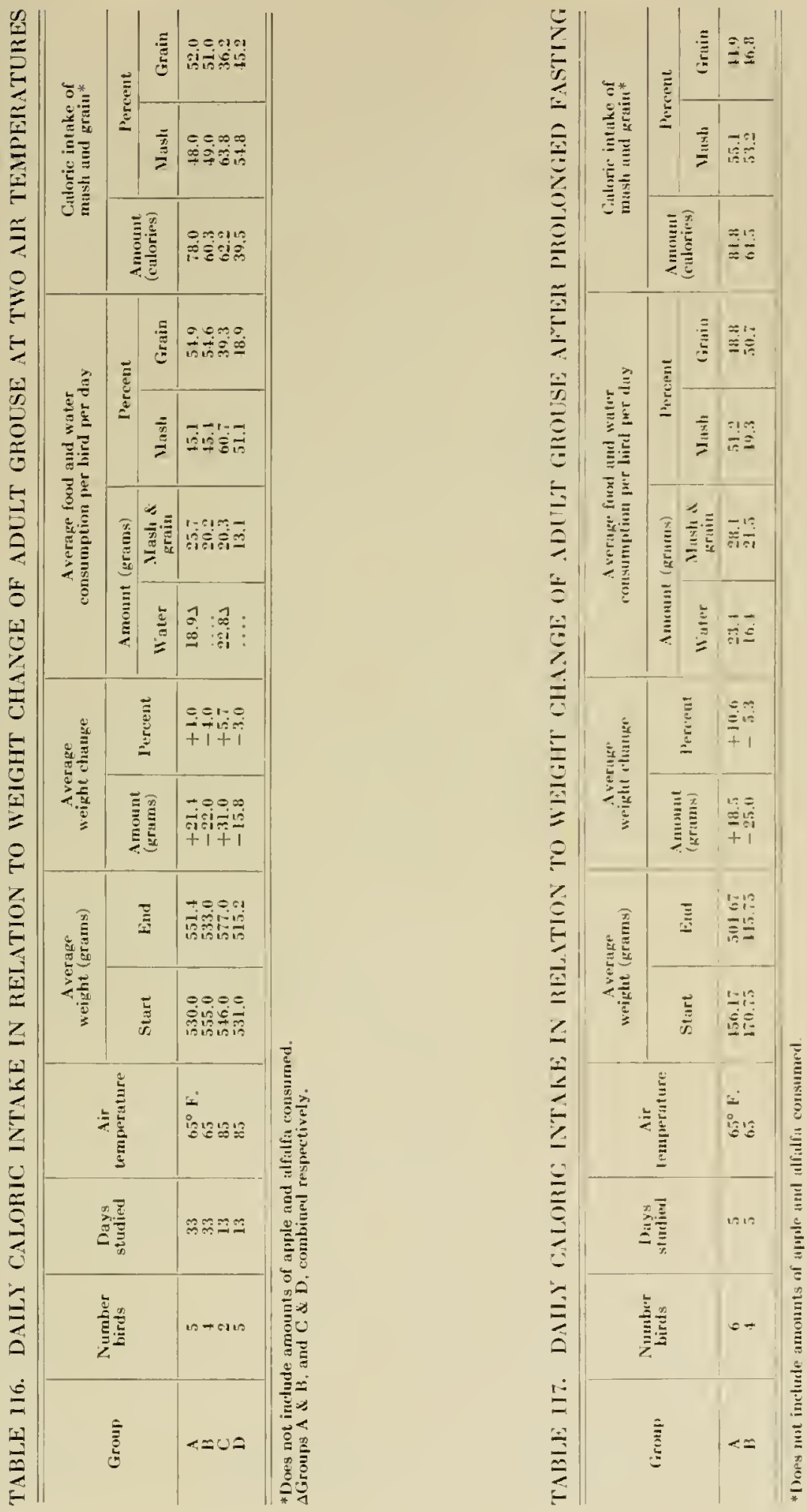
prolonged fast previously described (Experiment 7) were given the same rations as above and were studied similarly for five days at an air temperature of $65^{\circ} \mathrm{F}$. The observational data are recorded in tahle 117. This study immediately followed ten consecutive days of living without food during which all the birds lost weight. Despite the daily ingestion of fond during the 5-day period, four birds (Group B) continued to lose weight. The remaining six, however, gained. 'The average trends in body weight during lise periods of fasting and recovery are shown in figure 94 . It will he noted that the caloric value of the food eaten per day by the birds in Group B was considerably below that of Group A. Also, the former group averaged heavier at the beginning of the fasting period. but lost a somewhat greater proportion of their initial weight before again being given food.

As shown in figure 95, Group $A$ was again weighed at the end of 13 days. The rate of recovery was about three times faster during the first five days than during the remaining eight. At the end of this period these birds. after losing about 19 per cent of their initial weight while fasting had recovered only 65 per cent of the loss and therefore were still about 6 per cent below their initial weight.

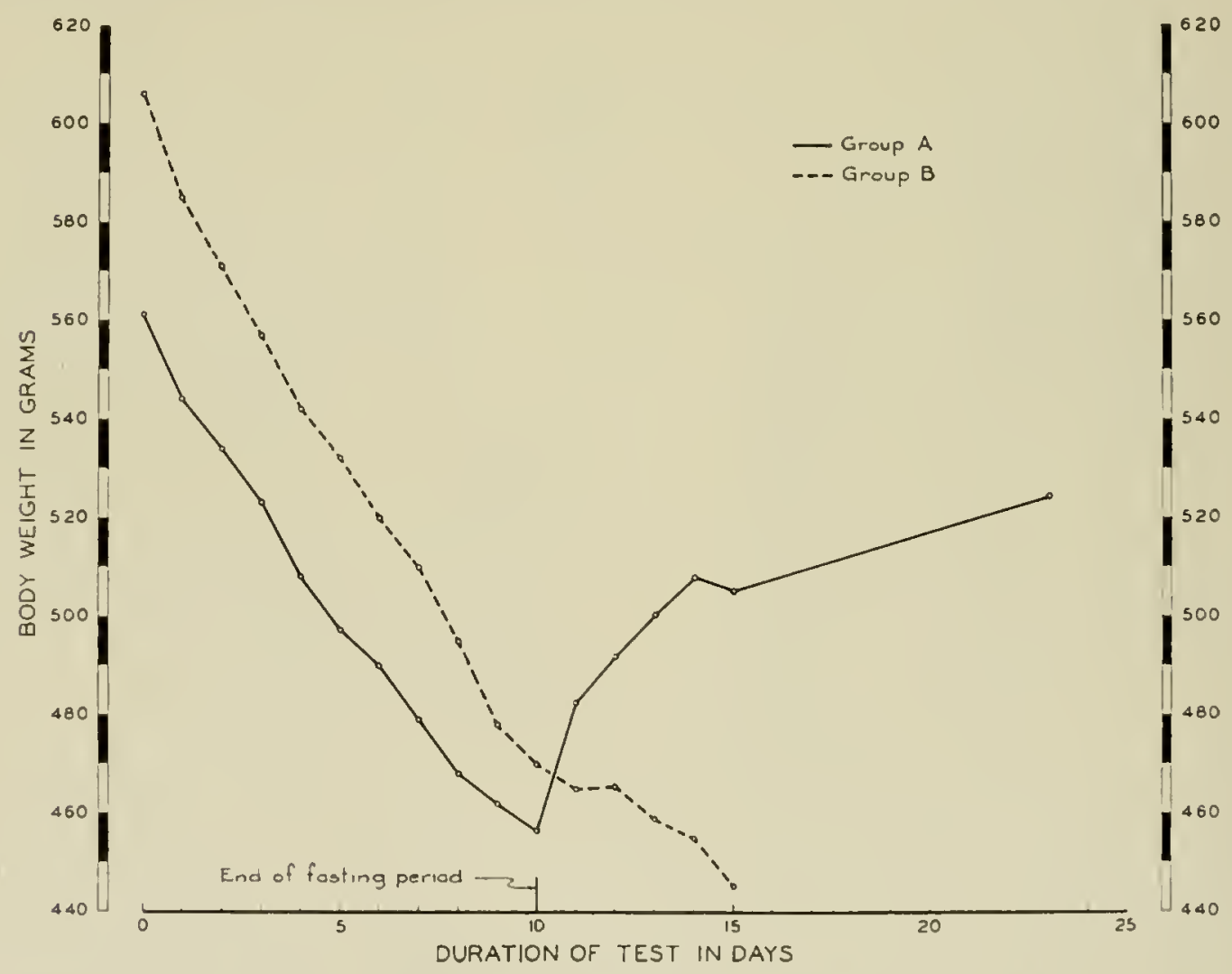

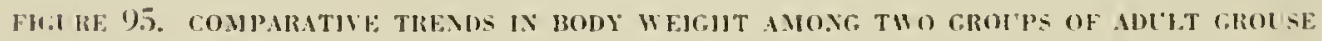

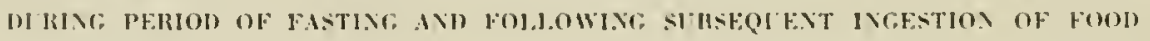

The consistent gain of certain birds was due chiefty to a larger daily food and water intake. Such hirds would recover their nitrogen balance quicker after fasting than ones which ate less fond. Furthermore. the more protein eaten the more rapid the replacenent of 
body tissue which had been destroyed as a result of fasting. The importance of the water relationship in maintenance of hody weight has been presented in a preceding experiment.

An interesting observation is that even among birds showing a steady net gain some weight was lost each night when no food was eaten.

In table 118 are listed the calculated amounts (in calories) of the foods used which should have satisfied the physiological needs of the birds studied under the environmental conditions specified. The caloric intake determined at $65^{\circ} \mathrm{F}$. and at $85^{\circ} \mathrm{F}$. should maintain body weight within the limits of normal 24-hour fluctuations; and at $65^{\circ} \mathrm{F}$. should maintain (1) an average body temperature of $107.3^{\circ} \mathrm{F}$. plus or minus the limits marked by diurnal range: (2) an average respiration rate of alout 63 per minute; and (3) an average heart rate between 300 and 385 beats per minute or an average rate of 342.6 beats per minute.

TABLE 118. CALCIJATEI) DAIS CAIORIC INTAKE OF FOOD NELIELO BY ADUTT GROUSE TO MANTAIN WEIGITT ANU VIGOR*

\begin{tabular}{|c|c|c|c|c|c|c|}
\hline \multirow{2}{*}{ Air tempralure } & \multicolumn{5}{|c|}{ Average daily foxd and waler conanmption per lirel (grams) } & \multirow{2}{*}{$\begin{array}{c}\text { Waily raloric intink } \\
\text { fwre lird }\end{array}$} \\
\hline & Wentrer & Mash & Grain & Apula & Alfilfa & \\
\hline $0.5^{\circ} \mathrm{F}$ & 22,6 & 111.6 & 12.7 & 29.7 & 11.9 .3 & 90.8 \\
\hline $80.133^{\circ}$ & 26.11 & $\{3.8\}$ & 7.9 & 20.7 & 1.08 & $6,1.8$ \\
\hline$-\frac{1}{2}$ & & $-\ldots$ & & & & \\
\hline
\end{tabular}

*Applies only to the birds used in these studies nad the condilions under which "xperiments were combluctent.

According to the data, approximately 3.6 calories (liolngical value) are required to produce one gram of body substance containing 0.40 calories at $65^{\circ} \mathrm{F}$. Nlthough the data are slightly inadequate for predicting the caloric value per gram substance relationship at higher air tenperatures. it may be estimated with a fair degree of accuracy that about 2.0 calories are required to produce one gram of hody substance containing 0.50 calories at $8.5^{\circ} \mathrm{F}$. 



\section{AVAILABLE INSECT FOOD FOR GROUSE CHICKS*}

Grouse chicks. for the first few weeks of their existence, are largely dependent upon insects and closely related forms of animal life as a source of food. Since their welfare is thus concerned with the availability and abundance of this kind of food. population studies of insects and their allies were undertaken. To this end samplings were carried out in each of the various types of cover that make up grouse halitat and under varying weather conditions from June 2 to July 1, 1936 on the Connecticut Hill area and from June 9 to July 11, 1936 on the Adirondack study area. These were repeated on the former area from June 1 to July $1,1937$.

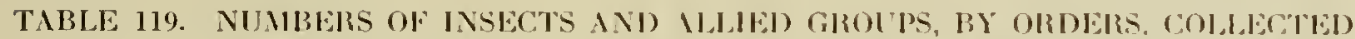

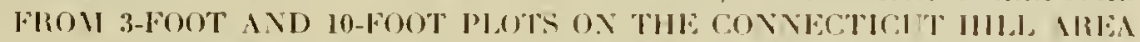

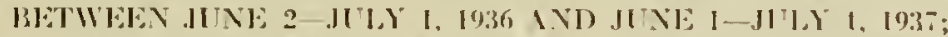

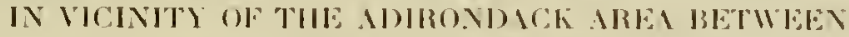
IINE: $9-J[1,11,1936$

\begin{tabular}{|c|c|c|c|c|c|c|}
\hline \multirow{4}{*}{ Order } & \multicolumn{6}{|c|}{ Area } \\
\hline & \multicolumn{2}{|c|}{ Adirondack } & \multicolumn{4}{|c|}{ Connfoticut Hill } \\
\hline & \multicolumn{2}{|c|}{$19: 36$} & \multicolumn{2}{|c|}{1936} & \multicolumn{2}{|c|}{1037} \\
\hline & $\begin{array}{l}\text { Swrfoping } \\
\text { lo-fout } \\
\text { splutare pilute }\end{array}$ & $\begin{array}{c}\text { Intmpive } \\
\text { 3-fowt } \\
\text { squario phots }\end{array}$ & $\begin{array}{l}\text { Swesping } \\
\text { li)-font } \\
\text { spuare pulote }\end{array}$ & $\begin{array}{c}\text { Intonsive } \\
\text { b-fownt } \\
\text { siguare dolsts }\end{array}$ & 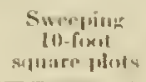 & $\begin{array}{l}\text { Intensive } \\
\text { 3-fomit } \\
\text { splnitre fluts }\end{array}$ \\
\hline 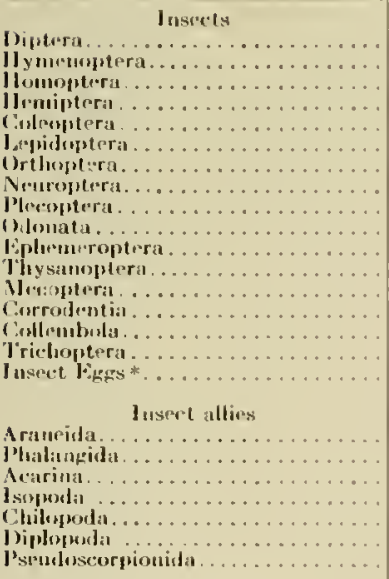 & $\begin{array}{r}36.3 \\
171 \\
648 \\
285 \\
217 \\
1.31 \\
54 \\
3 \\
0 \\
0 \\
0 \\
0 \\
6 \\
1 \\
3 \\
0 \\
0\end{array}$ & $\begin{array}{r}11 \\
361 \\
138 \\
106 \\
175 \\
36 \\
23 \\
10 \\
1 \\
0 \\
0 \\
11 \\
1 \\
1 \\
8 \\
11 \\
0\end{array}$ & $\begin{array}{r}2.211 \\
628 \\
491 \\
181 \\
315 \\
136 \\
11 \\
12 \\
2 \\
6 \\
1 \\
70 \\
5 \\
12 \\
8 \\
0 \\
0 \\
\\
175 \\
7 \\
1 \\
11 \\
0 \\
0 \\
11\end{array}$ & $\begin{array}{r}528 \\
701 \\
160 \\
153 \\
175 \\
62 \\
11 \\
22 \\
0 \\
0 \\
0 \\
17 \\
0 \\
11 \\
645 \\
0 \\
0\end{array}$ & 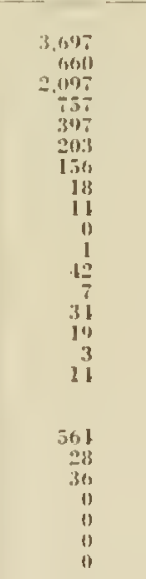 & 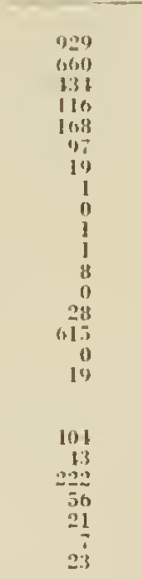 \\
\hline Tintul. . . . . . . . . . . . & 2.227 & 1,821 & 5,383 & 3.119 & 8.75 & 3.872 \\
\hline
\end{tabular}

* Not an order but included for complewness.

Sample plots of two sizes were used to test the populations. A 3-foot area was subjected to an intensive collecting, in which all specimens on the ground, on low vegetation and under loose debris were picked up, and a 10 -foot square within which the insects and their related 
forms were gathered ly repeated sweepings with a net. Fonr or more plots of each kind were laid out in each of the 12 cover types. In all, samplings were taken from 110 plots on Connecticut Hill and from 54 on the Adirondack area.

The numbers of insects and allied forms of each wder that were collected are shown in table 119.

The estimated population of insects on Connecticut Hill in June, 1936 was 280,000 per acre, while that of the Adirondack area was 326,000 per acre. In June, 1937 there were 334,000 per acre on the former area. The three most prominent orders of insects were the flies (Diptera), the ants, lees and wasps, ete. (Hymenoptera) and the aphids, leaf-hoppers. etr. (Homoptera). Spiders (Araneida) were likewise abundant. The eight orders that supply the bulk of the animal food eaten by grouse chicks were similarly the eight found most numerous in this study.

Collections made during rainy weather averaged about one fourth less than those made on dry days. Both very hot and very cold days produced noticeahly fewer insects than when the temperatures were normal. It is noteworthy that in 1936 the marked deficiency in rainfall tended to lower considerably the insect population. Their numbers decreased during rainy weather, lut required normal precipitalion to attain optimum proportions. The year following, 1937, was characterized by a much higher rainfall, and the study for that year resulted in a much higher take of insects, as ean be seen in the precelling table. Although there was little change in the relative positions of the varjous orders. in most instances the individuals present were much more numerous.

Insects proved to be far more abundant in the open and overgrown, or brishland, types of cover, as well as along woods edges, than they were in the woodlands. Heavy pure coniferous stands showed the least abundance as would he expected, having less than half the lowest number found in the mixed woods type and less than one quarter of that characteristic of the overgrown land. The average number of insects and allies per plot in the different cover types on eacl of the areas is shown in tahle 120.

TIBIE 120. THE AVEBAGE NTIIBER OF INSECTS AND ALIIES COILLCELD FROM 3fOOT AND 10 FOOT PLOTS IN DIFFERENT TYPES OF COYLIR ON THE

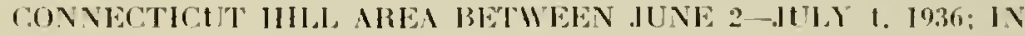
ICINTTY OF THE ADIRONDACK AREA BETIFEEN JUN" JIT I1, 1936

\begin{tabular}{|c|c|c|c|c|c|}
\hline \multirow{3}{*}{$\begin{array}{l}\text { 'I'yim: } \\
\text { of } \\
\text { eover }\end{array}$} & \multirow{3}{*}{$\begin{array}{l}\text { Tyju: } \\
\text { comle" }\end{array}$} & \multicolumn{4}{|c|}{ Area } \\
\hline & & \multicolumn{2}{|c|}{ Adiroudach } & \multicolumn{2}{|c|}{ Counceticut llill } \\
\hline & & $\begin{array}{l}\text { Swerping } \\
10 \text {-foot } \\
\text { square folots }\end{array}$ & $\begin{array}{l}\text { Iuterusive: } \\
\text { 3-fout } \\
\text { square plots }\end{array}$ & $\begin{array}{l}\text { simerpinf } \\
\text { I0)-f(x)t } \\
\text { syture plutes }\end{array}$ & 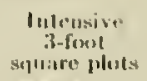 \\
\hline 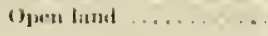 & $A$ & 157 & $11:$ & 170 & $10 \% 3$ \\
\hline (tverperuwn land.. & $\left\{\begin{array}{l}13 \\
1 \\
1\end{array}\right)$ & $\begin{array}{r}108 \\
106 \\
20\end{array}$ & $\begin{array}{l}37 \\
3 i 5\end{array}$ & $\begin{array}{l}156 \\
112 \\
131\end{array}$ & $\begin{array}{l}5.2 \\
311 \\
413\end{array}$ \\
\hline Wisullurud....... & $\left\{\begin{array}{l}1: \\
1: 11 \\
1 \\
1: 11 \\
1: \\
11\end{array}\right.$ & $\begin{array}{l}33 \\
28 \\
10 \\
311 \\
111 \\
\ldots\end{array}$ & $\begin{array}{l}51 \\
11 \\
61 \\
67 \\
52 \\
17\end{array}$ & $\begin{array}{l}67 \\
\div 3 \\
51 \\
51 \\
30\end{array}$ & $\begin{array}{l}56 \\
36 \\
36 \\
56 \\
= \\
213\end{array}$ \\
\hline Slashings. . . . . . . . . . & $\left\{\begin{array}{l}1 \\
\mathrm{~J}\end{array}\right.$ & il & 15 & $\begin{array}{l}10 \% \\
108\end{array}$ & $\begin{array}{l}15 \\
11\end{array}$ \\
\hline
\end{tabular}

- Not sumplat on the Connecticut Ilill arem Sivot manplual on the Adirondack srea. 


\title{
FOREST STAND IMPROVEMENT WORK IN WOODLANDS IN WHICH A COMBINATION OF FOREST AND GAME CROPS IS DESIRED*
}

\author{
By Gardiner Bump
}

Whenever the multiple purpose of producing sizeable crops of timber and of game are to be served within the same wooded area. it is incritalle that many specialized forest stand improvement practices, usually considered desirable by foresters or game technicians, must bc markedly modified. The first decision still remains the determination of the erops to be cncouraged. The forester may be interested in producing posts, ties, cordwood, pulpwood or saw logs-the wildlife technician, remembering his choice is limited to woodlot and forcst game, may think of grouse, squirrels, ralshits, varying hares, decr and bear.

The control of woodland plant succession to encourage the production of onc or more of the forest and game crops mentioned above is little understood. Foresters aim to improve stand composition, quality, density and origin by carrying on cultural practices particularl! weedings, improvement cuttings and thinnings. Wildlife technicians seek to so manipulate composition, quality, density, origin and arrangement as to producc adequate food and rover relationships for the species which it is desired to encourage. The addition of arrangement is important.

Recognition of the character of the various woodlands must precede proper management. The principal components are: crop trees, wolf trees, weeds. trainers, whips and under. growth. Classification of forest individuals or species into these groups depends largely on use. A massive, though decrepit, beech may represent a wolf tree to the forester and a crop tree to the wildlife technician by providing both mast and den hollows (food and shelter). White ash may be a weed or a crop tree depending upon the use to be made of it. Elm is seldom the latter. The important criterion is use.

\section{Determination of Use}

The principal use to which a given area of woodland is to be put is usually determined when it is acquirel. Recently the principle of "multiple use" of land under either puhlie or private ownorship has been much discussed. Over large areas devoted primarily to forest or to game production there exist, ofttimes, excellent opportunities to encourage a subsidiary or secondary crop of either forest products or game which should not be overlooked. In the past it has been considered satisfactory to attempt developments which encourage such a subsidiary crop on the same area and in conjunction with those designed to further the primary use. Carried to extremes, this has, however. led to considerable confusion and conflict of development practices. It is therefore suggested that, as a result of type reconnaissance. it should be possible to divide an area up into primary and secondary use units. The primary

* Originally issued in mimeographed form as Circular No. 3 by the Burean ol Game of the New York State Conservation Depart. ment as a guide Ior Forest Stand Improvement Work on State Game Managemeat Areas. 
use unit might normally include the majority of the total area and encompass all save those individual spots which because of cover, topography, composition or location are particu. larly adaptable to secondary use crops.

The following suggestions are offered by way of defining more clearly the characteristics of each unit:

\section{Primarily jorest units}

1. Plantations

2. Stants of relatively pure hardwood or confers where game food and/or shelter is markedly deficient.

3. Extensive areas of mixed hardwoods and conifers where the crop trees are approaching marketability and are of the more valuable species.

\section{Primarily game units}

1. Uneven-aged stands of mixed hardwoods and coniferous species attractive to game and possessing an abundance of "edges" or brushy openings.

2. Overgrown areas which have seeded in mainly to a combination of food-and of shelterproducing species such as apple and pime.

3. Old orchards, fencerows, and road borders, where substantial stands of food species, attractive to game, exist.

4. Stands of mixed hardwoods and conifers where such border on areas of practically pure hardwoods.

5. \arrow stream lottoms and banks where the species are particularly valualle to willlife.

6. Small slashings or burns occurring in forest stands in which other openings and desirable nuderbrush and ground cover are deficient.

Depending upon the local market for forest products. the game specics to lee encouraged and individual site cover conditions. additions or modification of the above are. of course, in order.

Once the primary units have been delimited, emphasis in development should be placed on each depending on whether the primary use is for forestry or for fish and game. In this connection the following suggestions may serve as a guide.

\section{Order of Forest Siand Improvement Operations}

A priority of forest stand improvement operations is suggested as follows:

A. In units where the dominant use is to produce game

I. In stands deficient in qame shelter, increase the latter by:

a. Liheration of suppressed conifers

b. Creation of small slashings

2. In stands deficient in foods, increase the latter by:

a. Creation of small slashings. especially near coniferous chumps

b. Libreration of food-producing tree and shrub species 
3. Elimination of trees that are diseased. of poor form or of species of little value for game or forestry wherever thes are retarding the development of more desirable speties

4. Harvesting merthantable timber

B. In units in which the dominant use is to produce forest products

1. Improvement of composition by weeding in young stands. both natural and planted

2. Thinning in even-agcd stands of pole size

3. Elimination of trees that are diseased, of poor form or of species having little value for timber or wildlife

4. Harsesting merchantable timber

\section{Cutting Policy}

A. As regards composition

1. On any given site, in accorlance with the relative importance of the two major objectives, favor the following species:

a. For forest products
1. White pine
2. lied pine
¡. Hard maple
3. Hemlock
8. Black cherry
4. Spruce
9. Hickory
5. Oaks
10. Black licust
6. White ash
11. Bassworol
12. Bcech

b. For game shelter
1. Hemlock
5. White Coctar
2. Spruce
6. Mountain laurel
3. Pine
7. Yew
4. Balsam
8. Common Juniper

9. Den trees beech, maple, basswoud. etc.

c. For ganc food

1. Fruit tree species such as apple and pear

2. Mast producers such as bech. hazelnuts and oak

3. Nut producers. such as hickory. Walnut and butternut

4. Pulpy fruit producers such as cherry. mountain ash. shadbush, hawthornc, viburnum, dogwood, mulberry, elderberry and blueberry

5. Budded species such as birches. hop hormbeam, and popple

6. Browse spccics such as cedar. hemlock, yellow birch, red maple, striped maple. witch hobble and yew (Taxus)

2. In all cuttings regardless of purpose, at least 5-10 indisiduals of each of two or more species from the secondary use group should he loft per acre when found growing naturally, and. where possible, in addition to conifers. Wherever they occur in sufficient numbers, several ironwood (Ostrya) should be left per acre.

3. In managing the hemlock-hardwond association. it is necessary to secure hemlock reproduction before the final cutting is male. If the stands are even-aged, a 
shelterwool antting. or if mneventagad, a group solertion routing should be used to encourage hemluck reproduction.

B. As regards density

1. Maintain a erown cover density of from 50 to 70 per cent

2. Except when trees are removed because of a seriously diseased condition, cut lising trees only to release desired individuals, to improve growing or seeding conditions, or decrease the density or overstocking of future food, shelter or crop trees.

3. Where present crown cover is of little value, consider maintaining it as a nursery under which more valuable species may seed in.

4. Wherever trees are hollow, have extensive limb cavities or are well on their way to producing such, leave them uncut up to a total of two such trees per acre.

C. As regards origin

1. If there is a choice between single-stemmed trees from seedling origin or sprouts the former should be chosen for crop trees. Whether thinned or not, sprouts are often in danger of being infected with heart rot.

D. As regards arrangement

1. In general, favor a mixed stand in which conifers occur in clumps, if possible.

2. When forestry is the dominant use. forest stand improvement might aim to pro. duce even-aged stands; when game is dominant uneven-aged stands slould be encouraged.

3. Wherever practicable, leave a sprinkling of several food-or shelter-producing species, including shrubs, rather than a large number of a single species.

\section{Jlarking rules}

1. Mark in a distinctive manner all trees to be removed.

2. Mark few trees smaller than three inches in diameter, for eutting.

3. Mark "wolf" trees for removal where felling of such trees is possible without damaging the adjacent stand except where wolf trees of preferred species are necessary to provide mast and den cover or to supply seed in stands deficient in that species.

4. Nark out woods' roads for removal of wood products so as to afford the least amount of damage to the remaining stand, and to chcourage food and/or cover where needed.

5. In sprout elumps, mark to free the one or two stems which are more or less inde. pendent of the remainder of the clump and which give promise of developing into merchantable stems.

6. Nark most "whips" for removal unless they are of a particularly desirable species which is locally not common. In such cases they should be released from compe. tition.

Culting and removal of wood products

1. Remove all deal trees except den trees for squirrels and coons. 
2. Cut only marhed irees.

3. In cutting over the area, remove the larger trees lirst so that if, in felling, any unmarked trees are so injured as to necessitate their removal, the area affected ean be re-marked to adjust for the trees so damaged.

4. Lop and scatter all brush less than four inches in diameter. Cut such material so that it will lie close to the ground thus facilitating decay. or pile and burn it.

5. Where timber is of prime importance, prune coniferous crop trees listed under this group when of pole size, to seventeen feet in height so as to produce one clear log. In game units, pruning should not be carried out to a point where the shelter value of the stand is impaired.

6. Remove all wire fences from the interior of any woodland to prevent injury to game and to forest users.

7. To prevent injury to young growth, girdle those wolf trees which are not desired for game or lumber, but which should be elininated. Beech. basswood and other species which naturally tend to form hollows should be girdled.

8. Trees should be poisoned rather than cut or girdled where sprouts are particu. larly undesirable.

\section{Fire hazard reduction}

1. Plan fire hazard reduction work to cover first those areas which have been recently lumbered and where a large amount of slash, debris and damaged trees remain. These constitute a serious fire menace particularly where they are adjacent to mucls-traveled roads.

2. Salvage all usable material from dead and dying trees when compatible with the uses to which the area is to be put.

3. Slashing debris which cannot be salvaged should be piled or scattered. Slash may he burned in small piles whenever it is thought neccssary to reduce the forest fire hazard along strips adjacent to highways, or where the aesthetic values are important. In this case particular eare should be exercised to prevent damage to desirahle advance growth. Where rabbits are to be encouraged such brush should he piled rather than scattered or burned.

4. Construct fire hreaks only where extrenc hazard warrants. Forest roads well lrnshed out will ordinarily serve this purpose. Where forest plantations and extensive natural coniferous stands are adjacent to railroads. main lighways. pienic grounds or olher recreational developments, the construction of artificial fire lireaks is usually warranted.

\section{Definitions}

Forest Stand Improvement is here used to include all operations aimed at improving the composition and quality, establishing desirable densities and correcting undesirable situations arising from poor origin or arrangement by altering the component parts of any woodland.

Origin of a Stand refers to the method by which the individual trees or shrubs making up a stand have heen reproduced. These include seeds, sprouts and root suckers. 
Stand Arangement refers to the relative position of individual trees and or shrubs or of Irees as they occur in making up the stand.

Crop Trees or Shrubs include those individuals of sueh species. form. condition and productive capacity that are best adapted to the production of the desired crop.

W'olf Trees or Shrubs include those individuals occupying more space than their silvieultural or game value warrants and therehy curtailing more potentially productive neighbors.

ITeed Trees or Shrubs are those which have little or no value when considered with rela. tion to the dominant use of the area.

Trainers are the subordinate trees in the stand which have fallen behind the crop trees and weeds and form an understory of weak and slender individuals. They aid in the production of rlean boles.

W'hips are tall, slenter trees. even in height with the crop trees but too weak and narrowcrowned to make desirable erop trees. In their whipping action caused hy wind they injure the crowns of the erop trees.

Improvement Cultings are cuttings made to improve the composition (varicty and number of individuals of a species) and quality of the stand by removal of inferior trees.

Thimnings (Crown Thimning) require the removal of trees in the main eanopy in order to give the selected crop trees room for crown expansion.

Undergrouth includes all woody plants under the crown canopy.

Stand Composition refers to the numbers of each species of trees and. in some cases. shrubs which make up a given stand.

Stand Density refers to number of trees and. in some cases, shruls per acre.

Shelerwood culting refers to the gradual removal of the mature crup in an even-agch stand by a series of cuttings. From $10-15$ years usually intervene from the first cutting and the removal of the last of the crop.

Selection Cutling refers to the culting of trees as they mature hore and there in an mevenaged stand.

Girdling refers to the method of killing a tree by severing the cambium layer. Girdling should be accomplished hy two downward strokes three inches apart. at about waist high of the chopper, removing chips in a continuous line around the tree.

Poisoning refers to the method of killing a tree by injecting a poison solution in cuts made in the trunk of the tree. A land of multiple axe cuts is made aromol the tree close to the ground and the poison solution injected here, preferably with the Comell poisoning tool. 

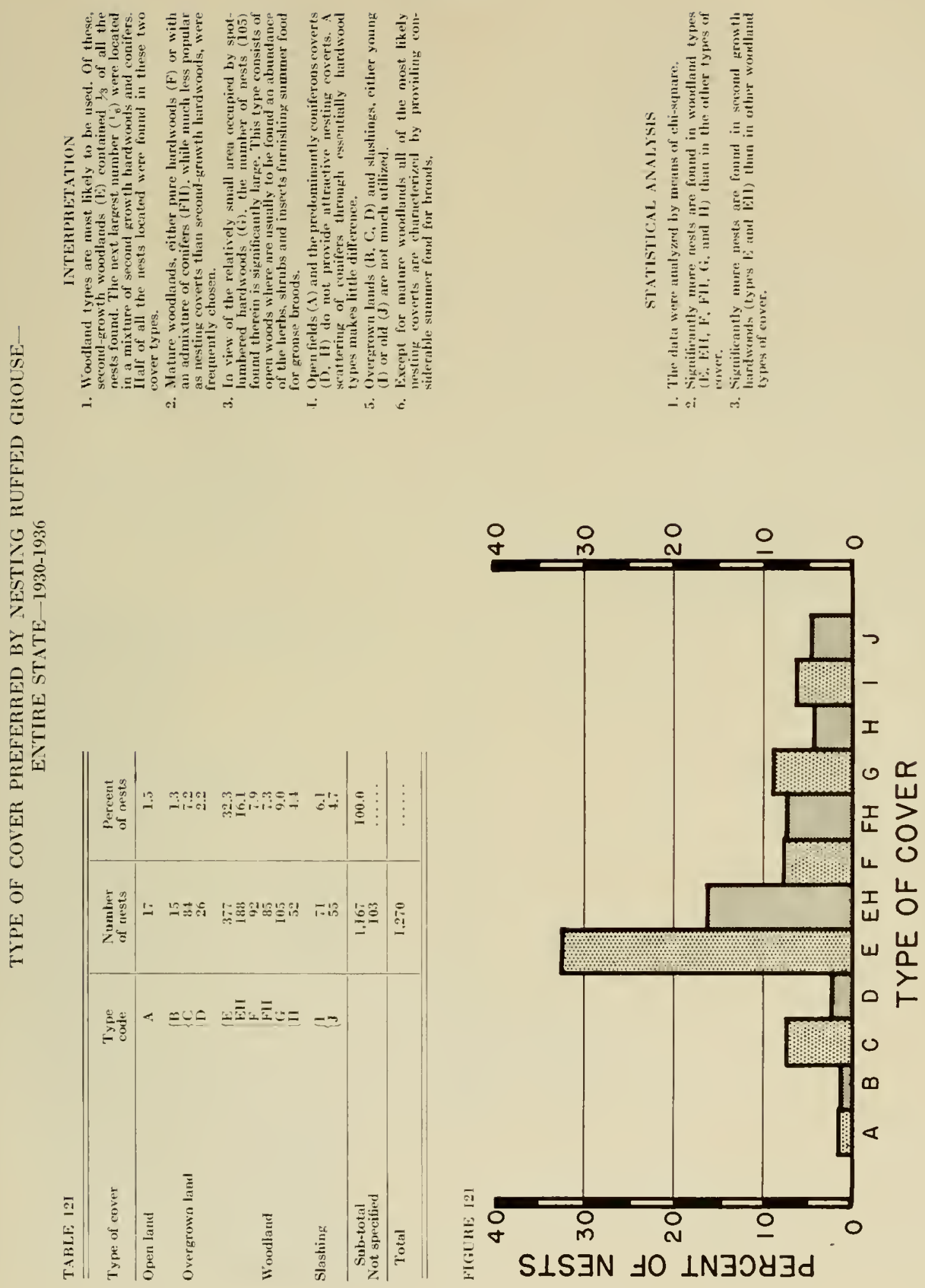


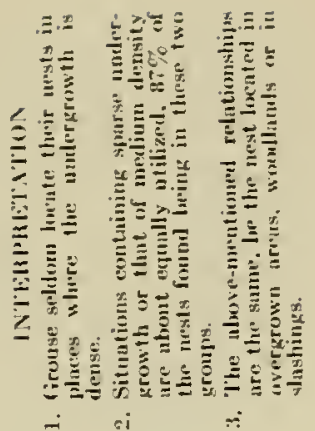

?.

蒙宅

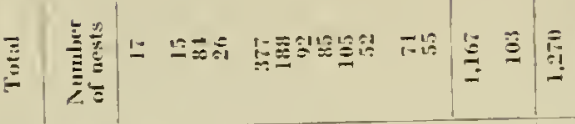

$\vec{r}_{2}$

כ)

$=$

5

?

2

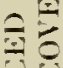

$y$

言

$=$

$\underline{-}$

5

0

政

-

年



$\div$

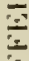

ב

$\simeq$

立

$\vdots$

$\equiv$

$\vdots$

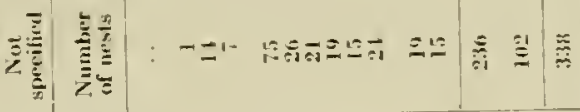

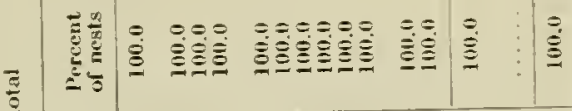

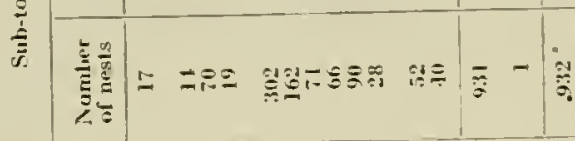

\begin{tabular}{|c|c|c|c|c|}
\hline$\frac{1}{4}$ & 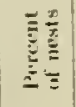 & 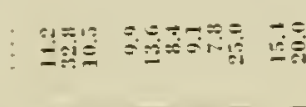 & $\stackrel{=}{2}$ & $=$ \\
\hline
\end{tabular}

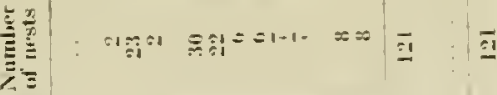

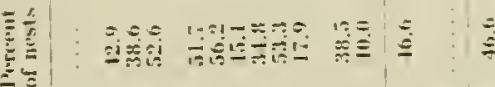

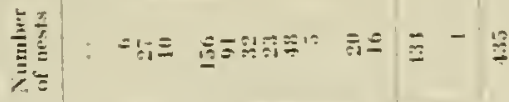

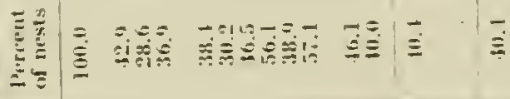

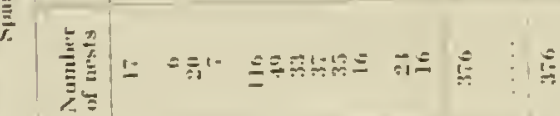

-

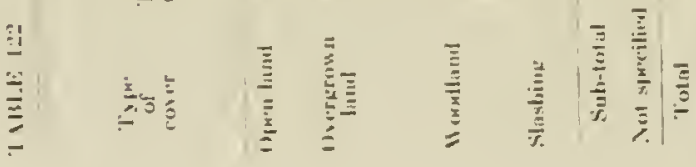

产
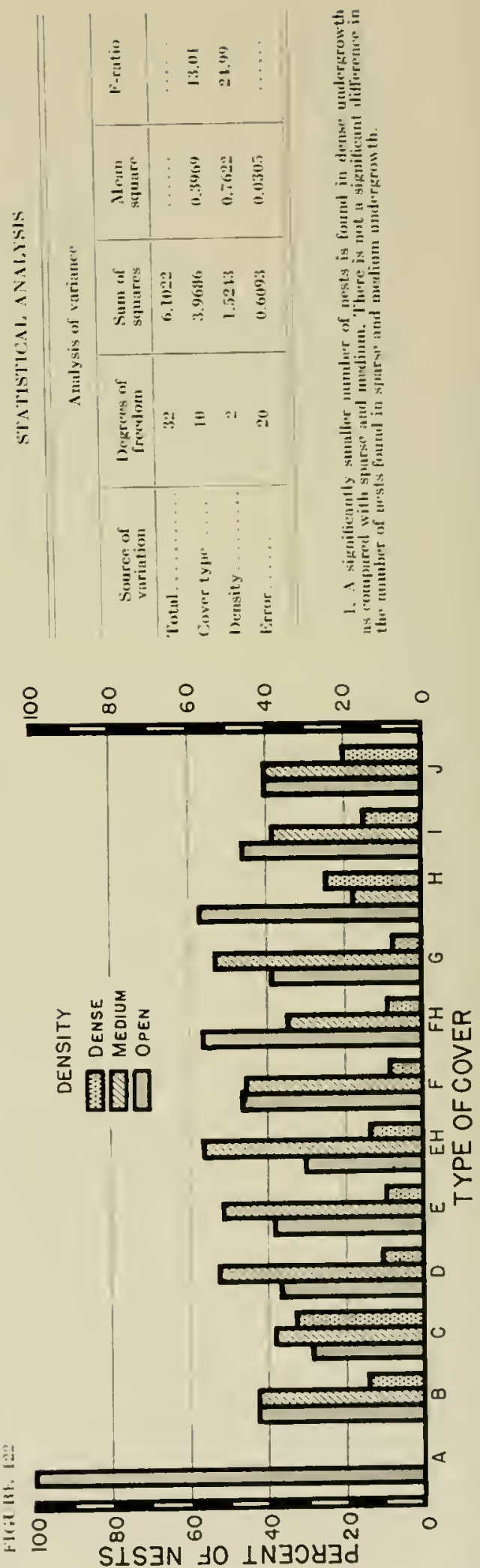


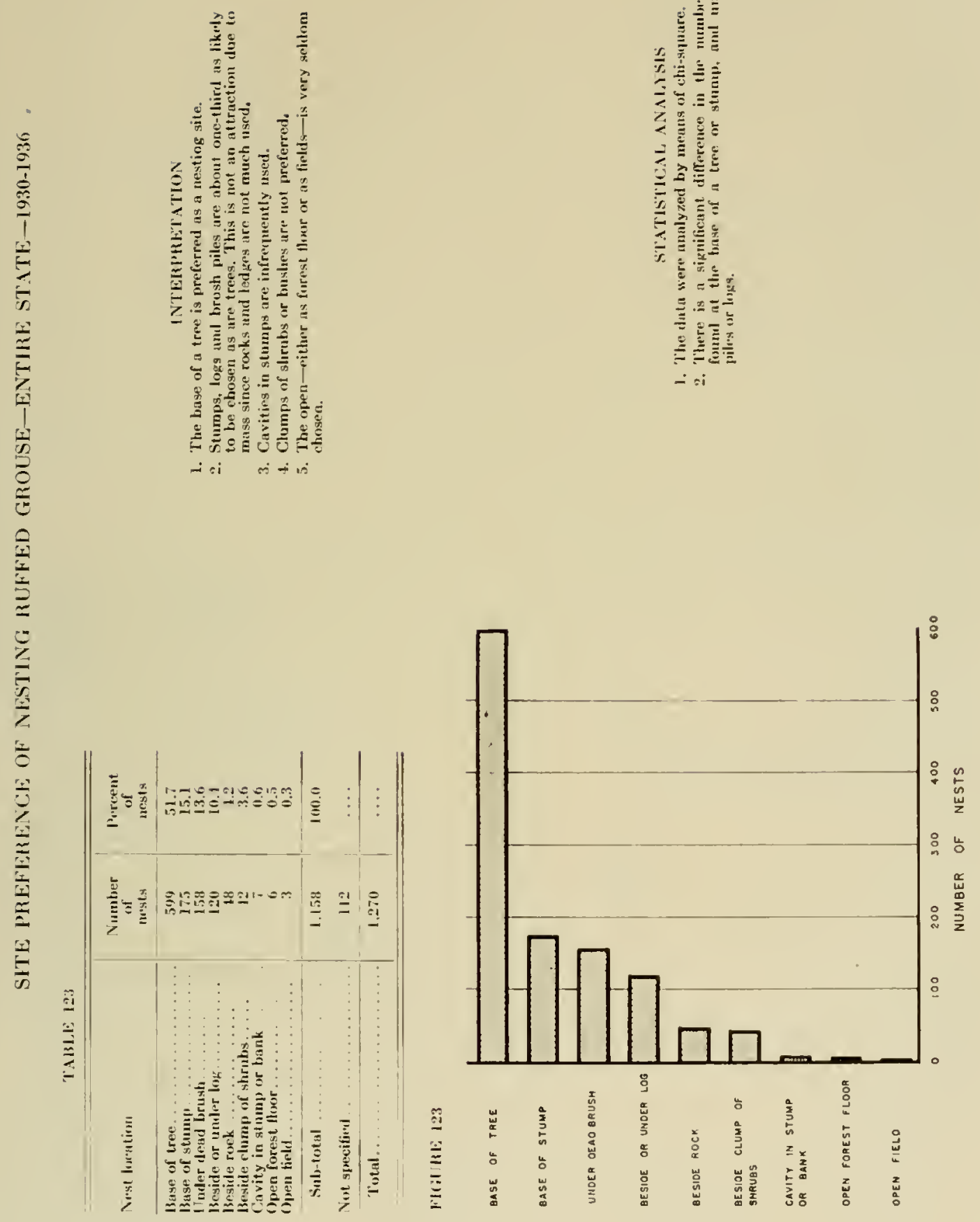



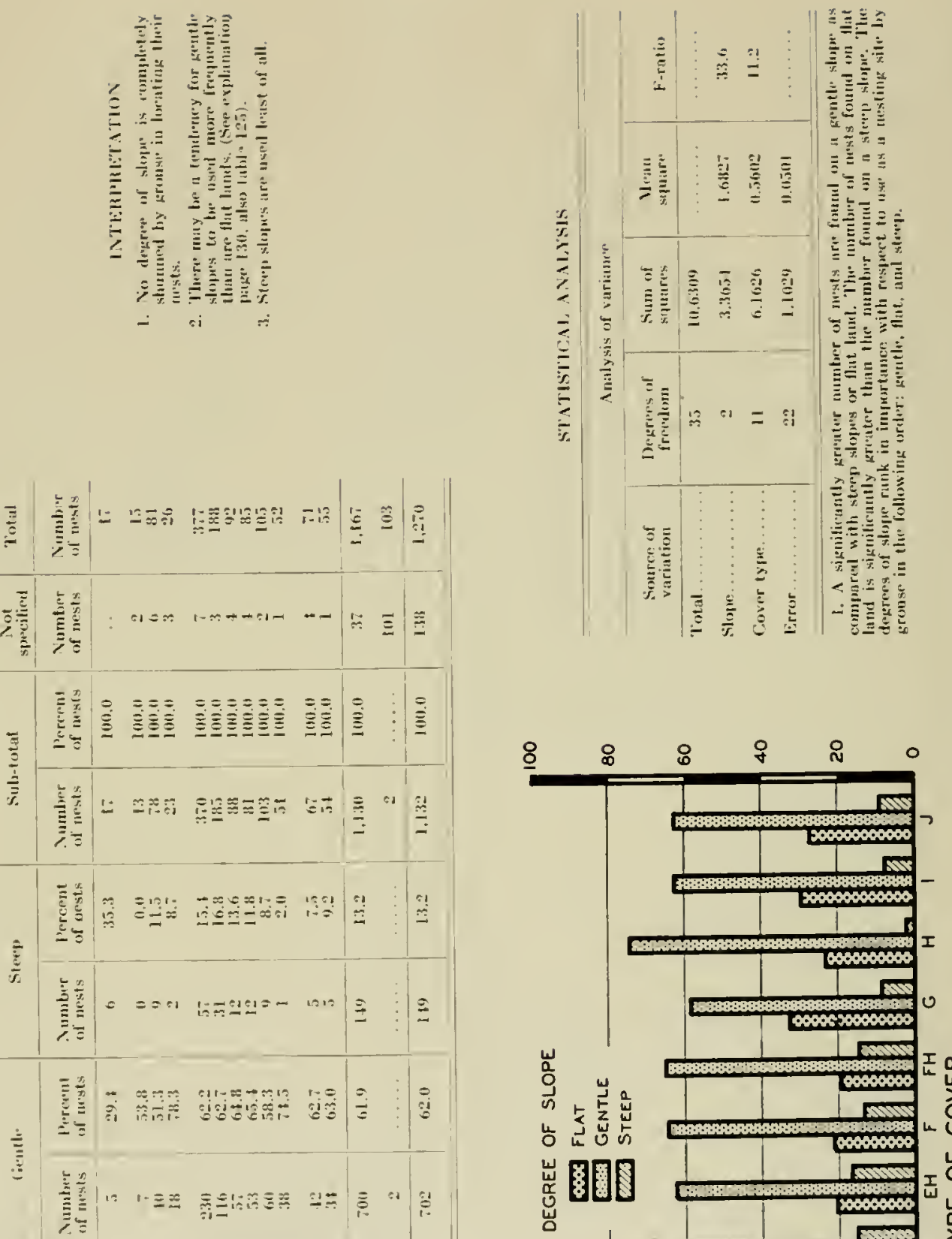

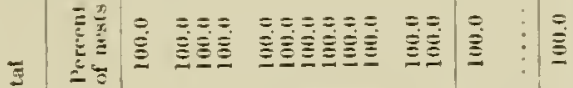

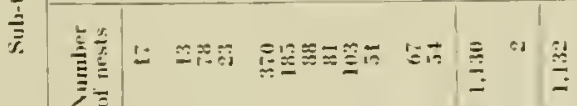

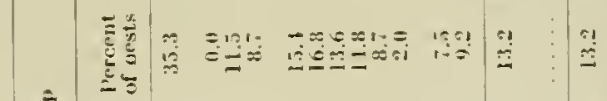

辛商

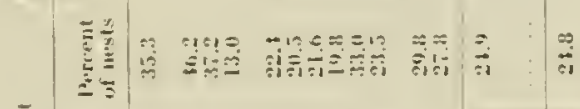

$\overline{\underline{z}}$

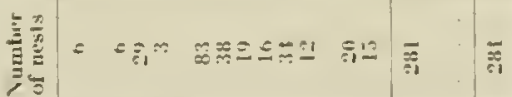

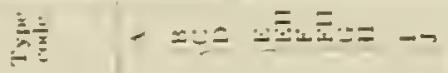

II

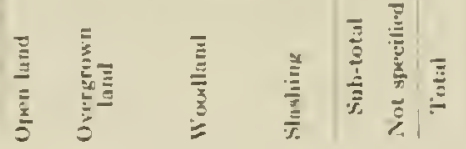

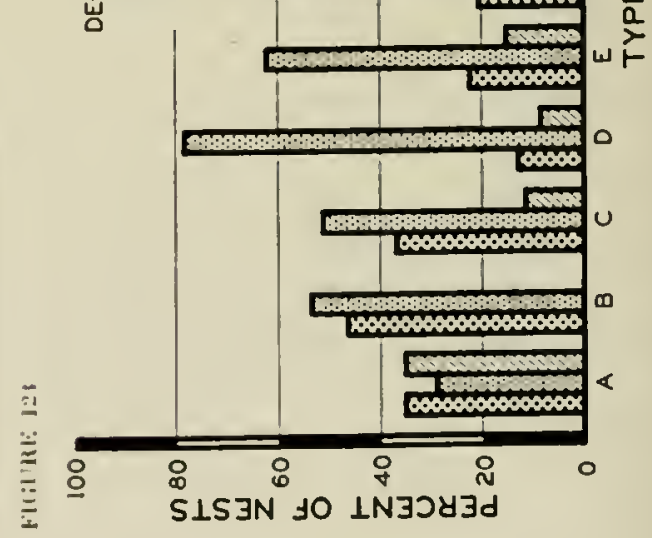




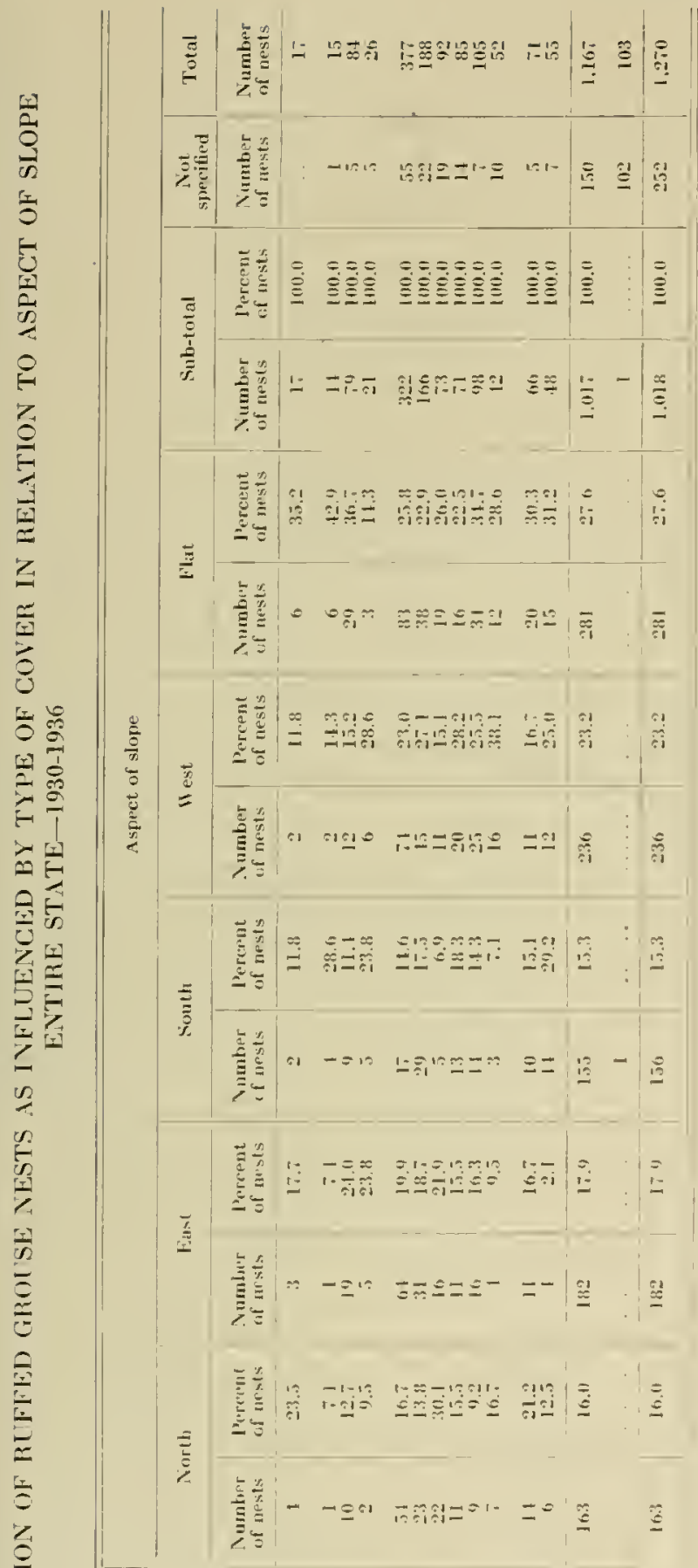

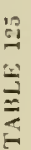

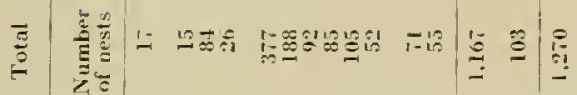

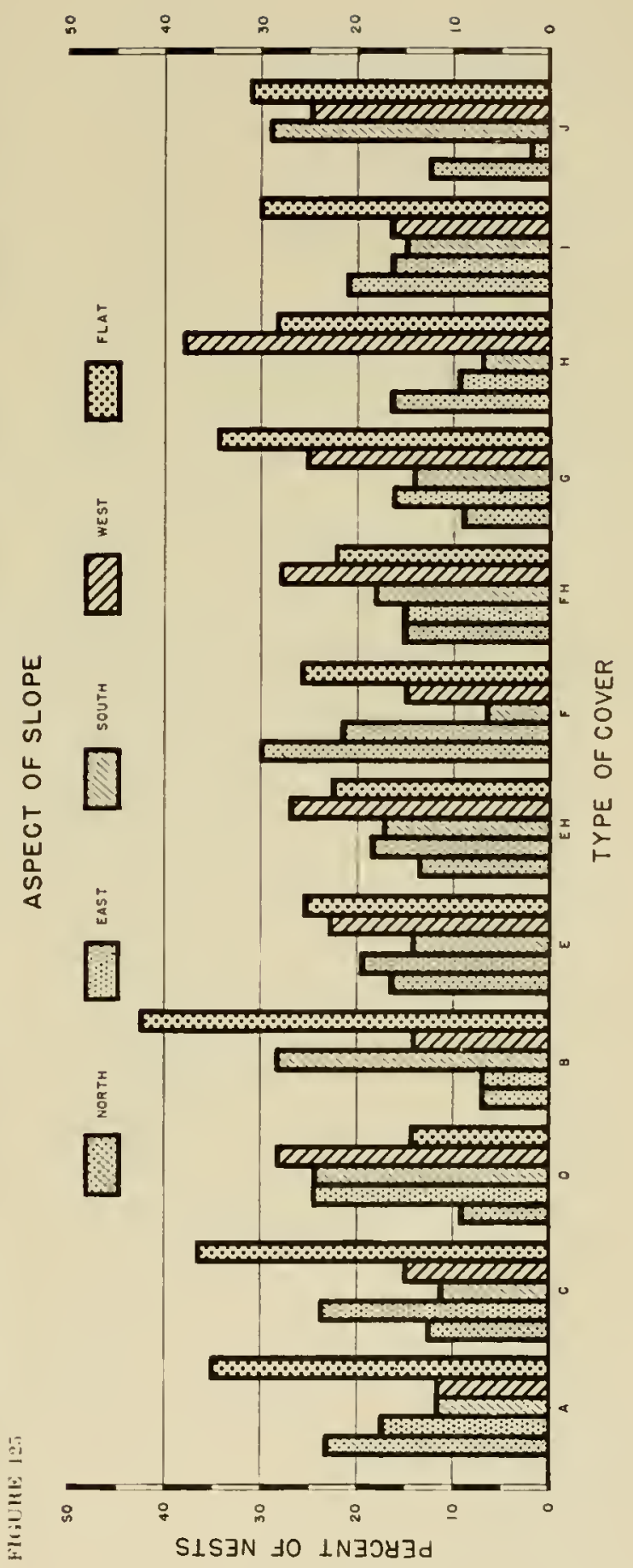



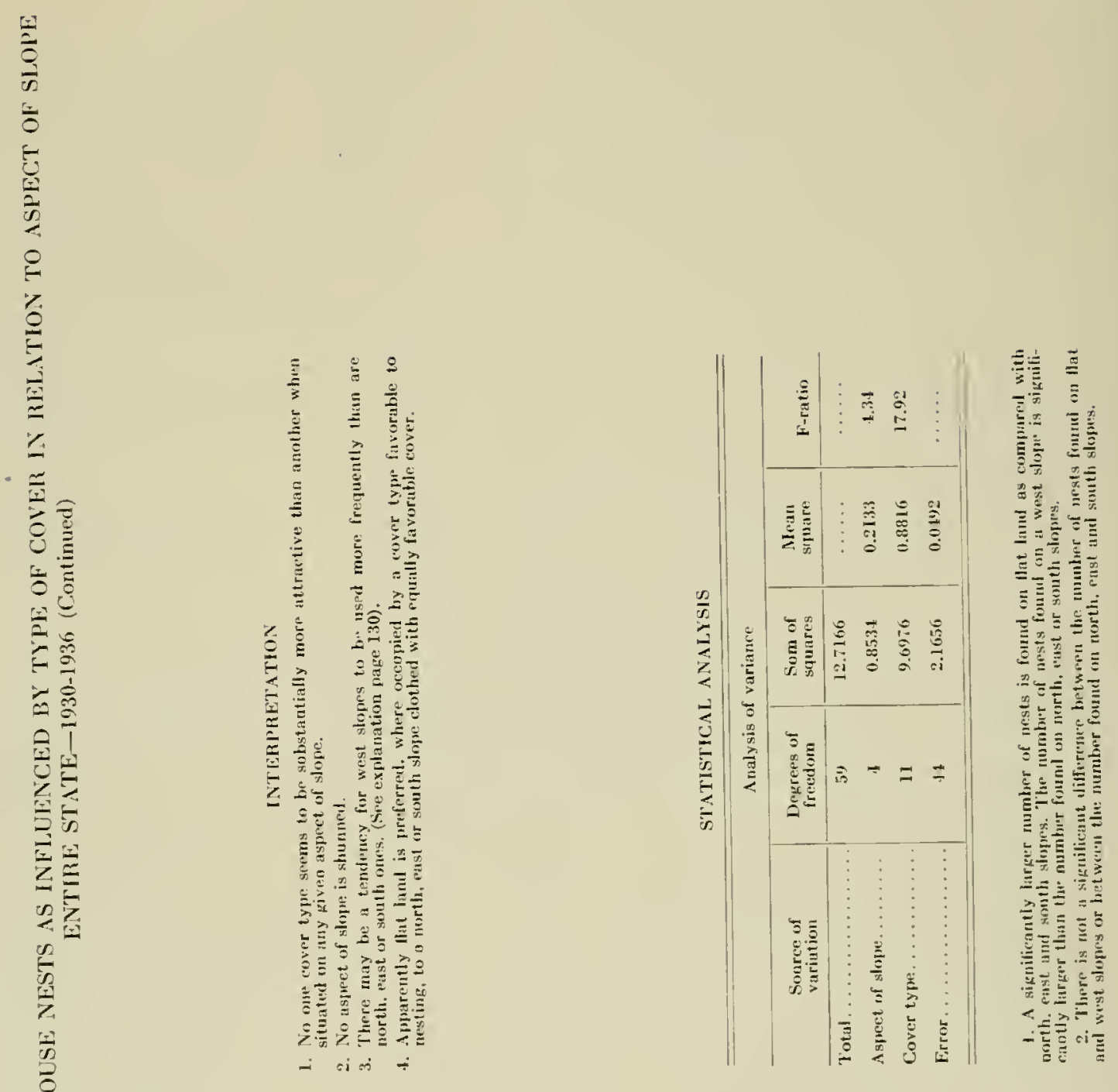

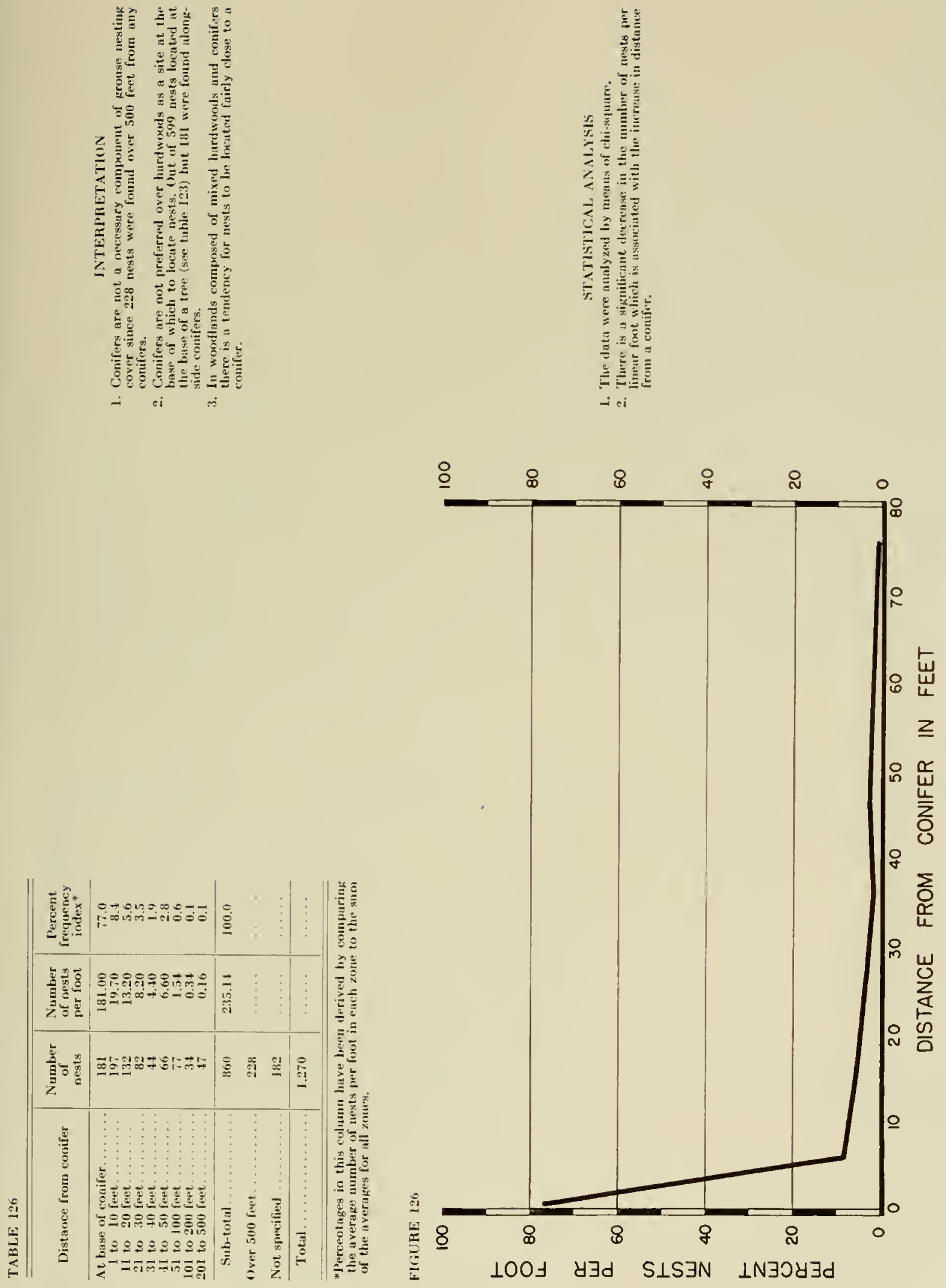

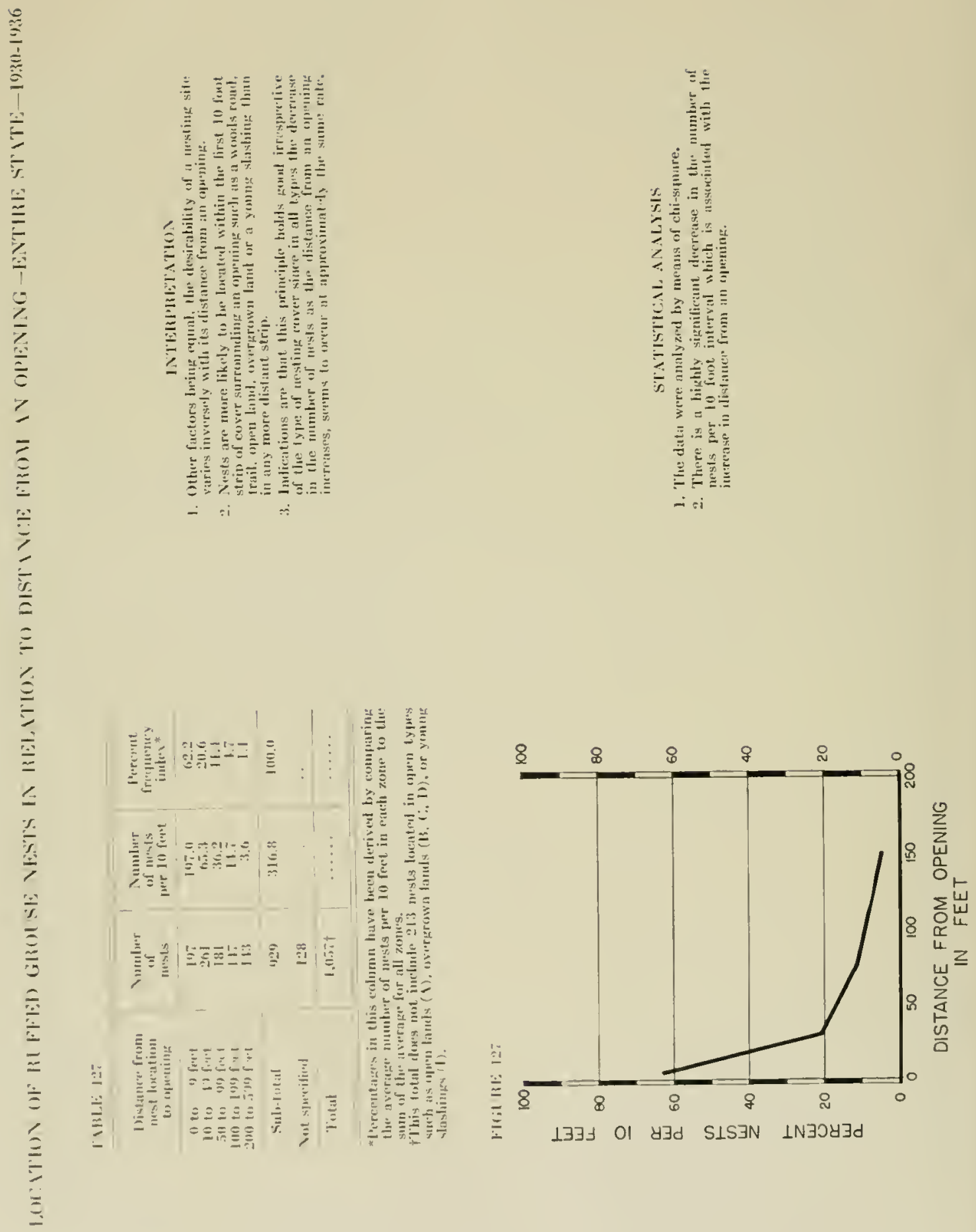


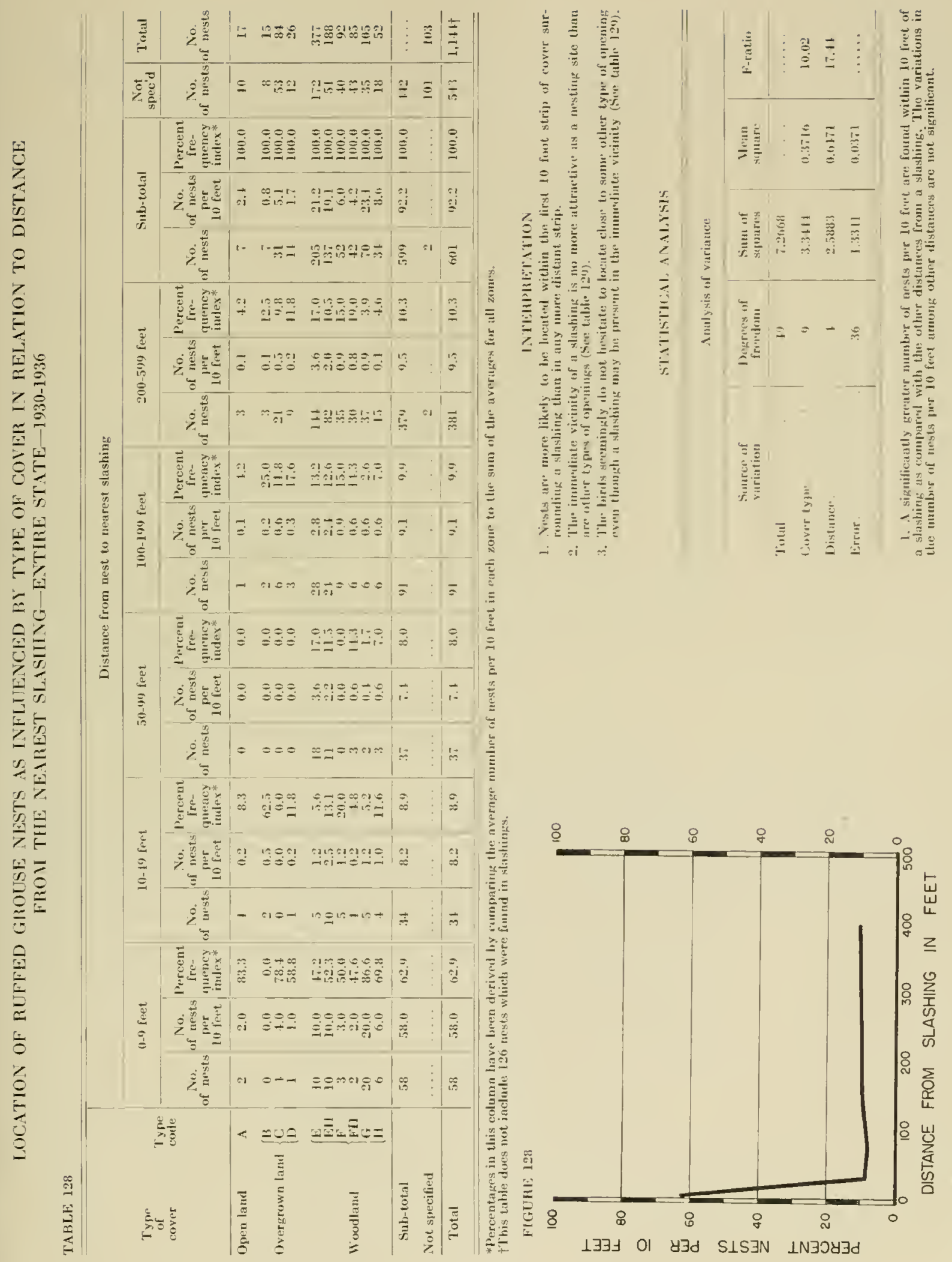




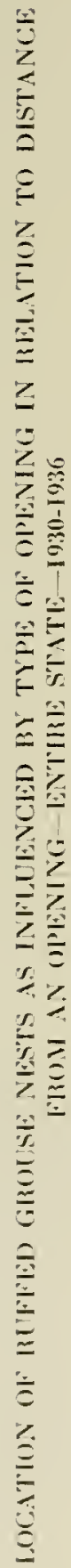

\begin{tabular}{|c|c|c|c|c|c|}
\hline & 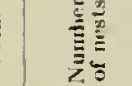 & 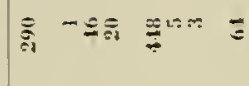 & 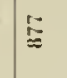 & 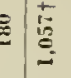 & \\
\hline & $\bar{z}$ & & - & ปั & \\
\hline & & 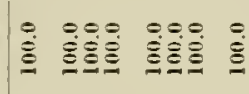 & $\stackrel{\theta}{\theta}$ & 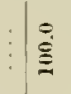 & \\
\hline & 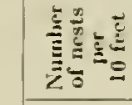 & $\vec{\beta}=0$ & $\overline{\dot{D}}$ & $\frac{2}{\bar{m}}$ & 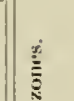 \\
\hline & & 章一年 & 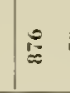 & t. & \\
\hline & & 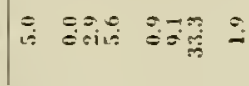 & $=$ & 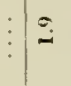 & \\
\hline & 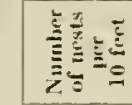 & 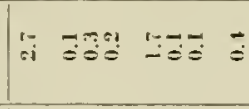 & $: \square$ & : & 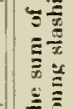 \\
\hline & & 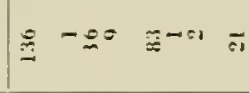 & $\mid \stackrel{\Delta}{G}$ & 7) & \\
\hline & & 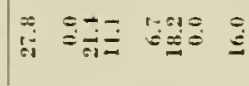 & $=$ & $\stackrel{\vec{\Xi}}{ }$ & \\
\hline & & 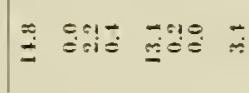 & $=$ & 号 & \\
\hline & & $\overrightarrow{10}=0.15-0$ & 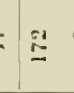 & $=\overrightarrow{\underline{\mathbf{\Xi}}}$ & 知 \\
\hline & & 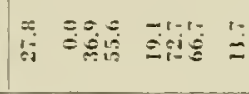 & $\sum_{10}^{3}$ & $\stackrel{10}{91}$ & \\
\hline & & 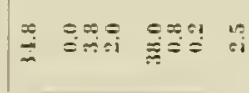 & $\bar{i}$ & 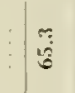 & \\
\hline & 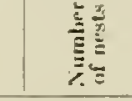 & 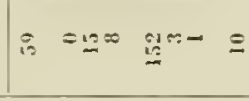 & $=\frac{x}{c 1}$ & $\bar{E} \overline{\hat{a}}$ & \\
\hline & & 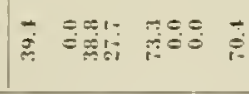 & $\stackrel{0}{0}$ & "i & \\
\hline & 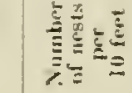 & 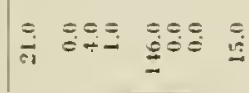 & 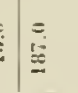 & 客 & 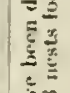 \\
\hline & 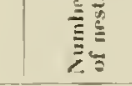 & $\overline{{ }_{11}}=-\bar{E}=0$ & 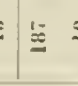 & $E$ & \\
\hline & $=$ & 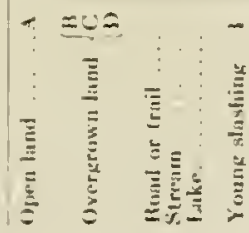 & & 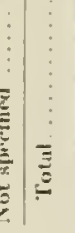 & $\mid$ \\
\hline
\end{tabular}


$\mathcal{F}$

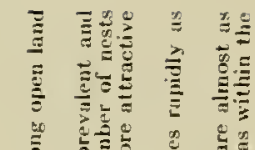

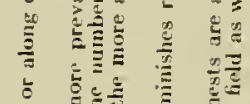

告

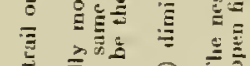

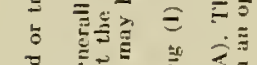

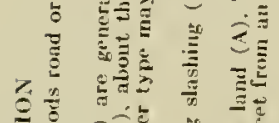

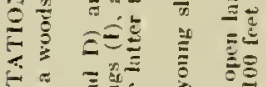

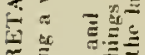

$\div \equiv$

ㄴํำ

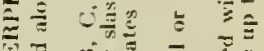

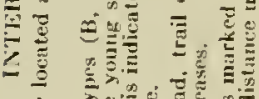

¿

t5

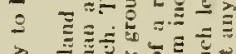

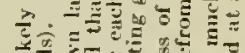

舟

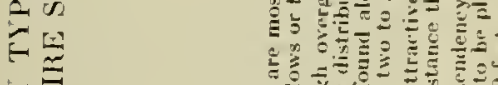

$\approx$

0

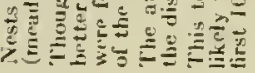

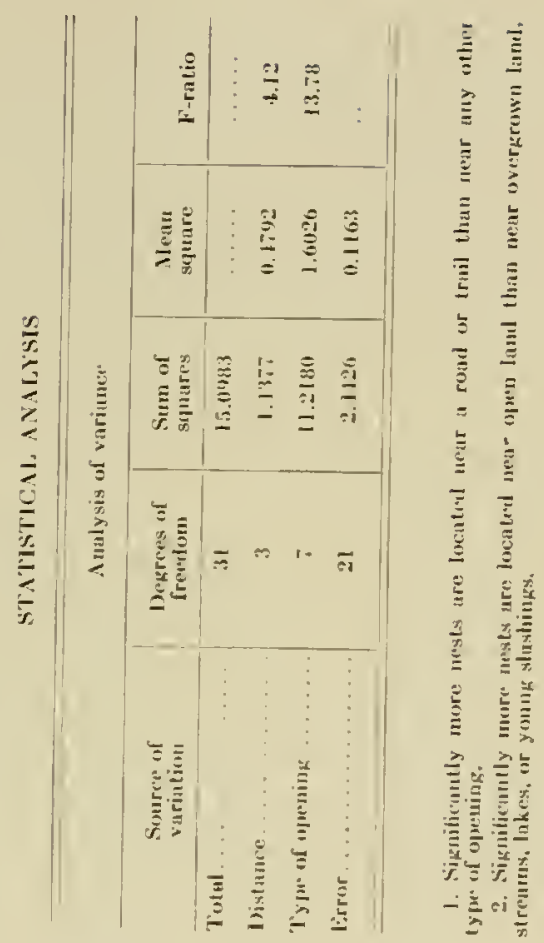

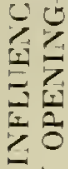

는

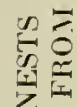

帘

范

5

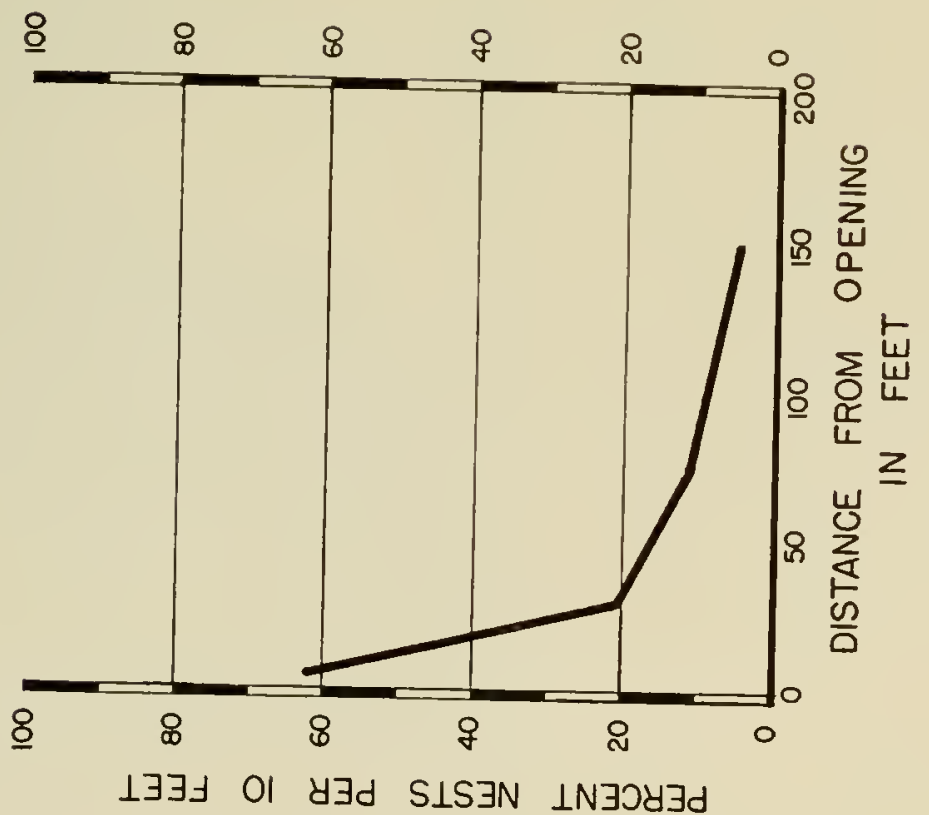




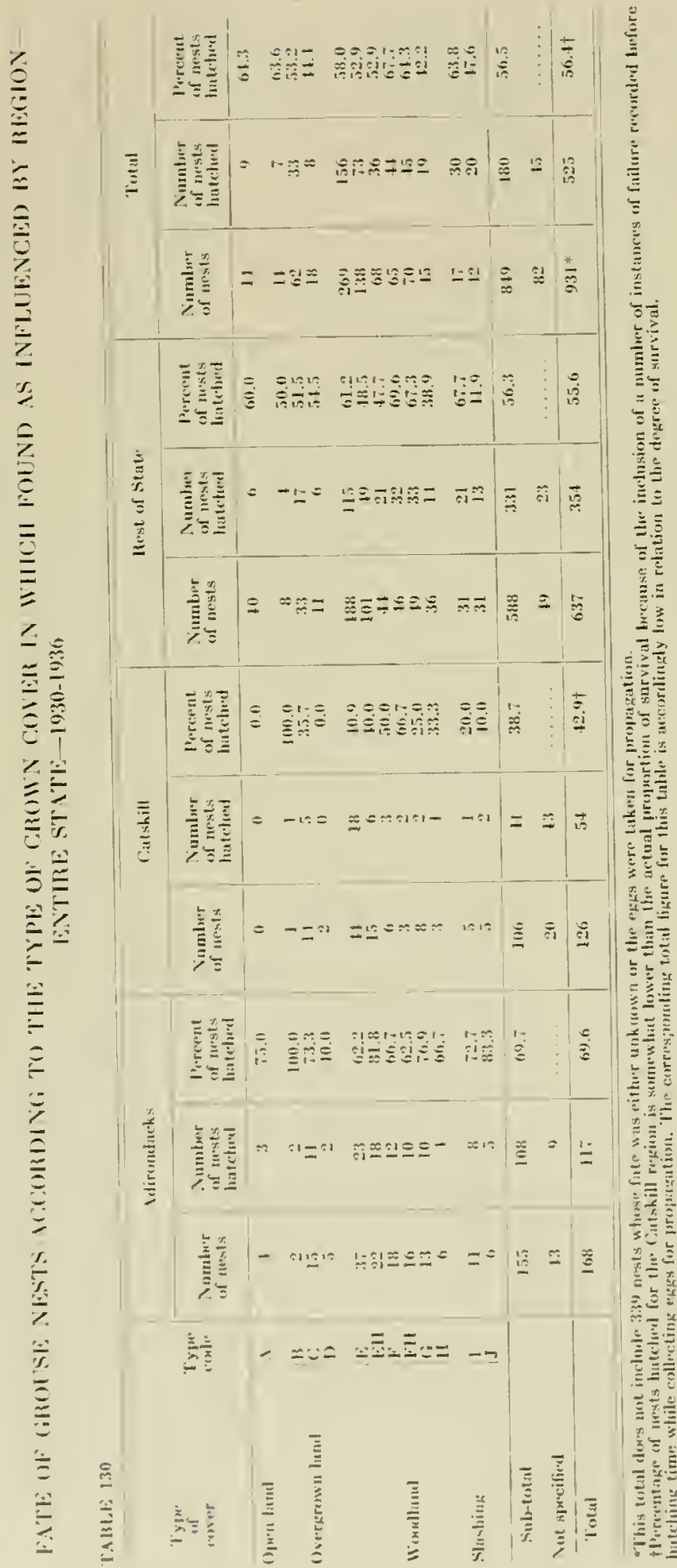

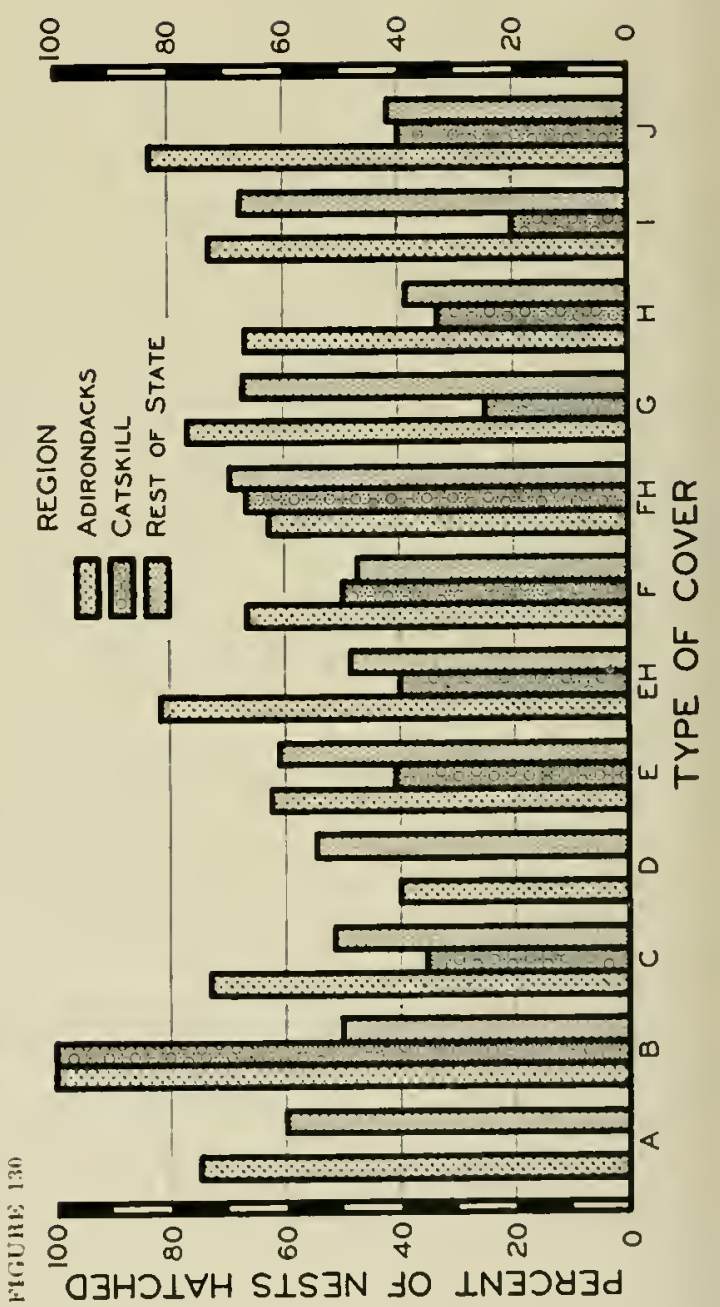




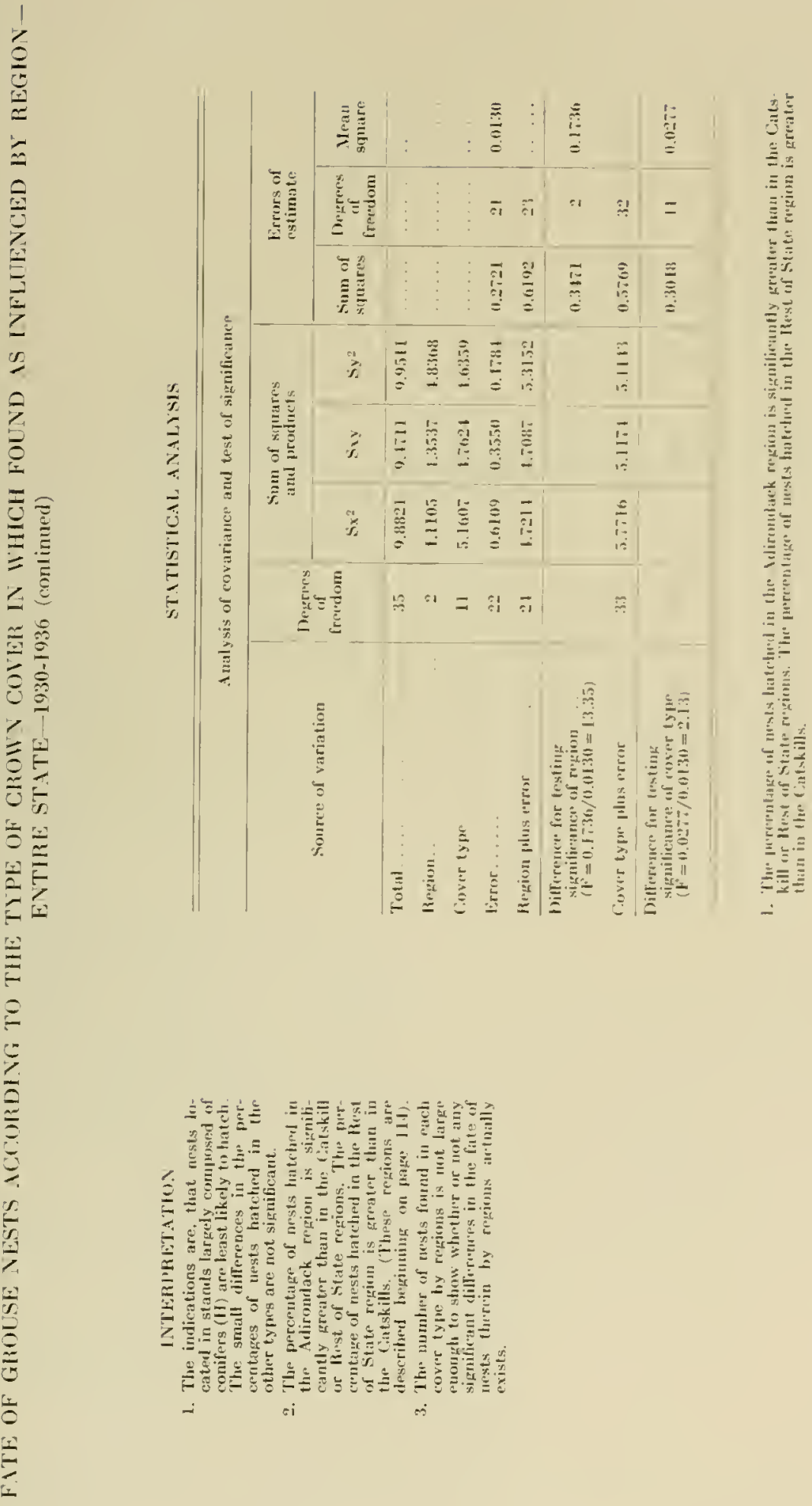




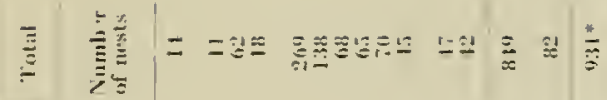

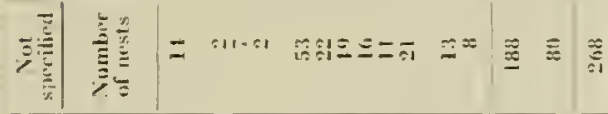

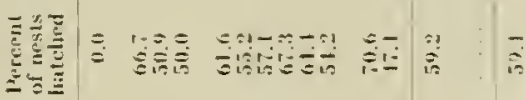

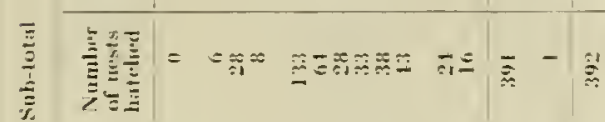

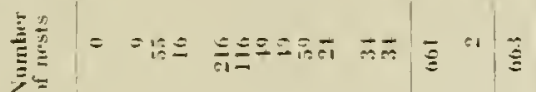

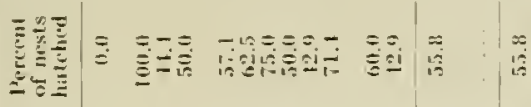

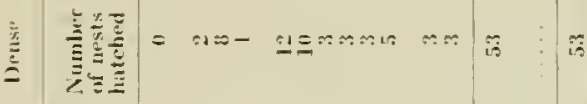

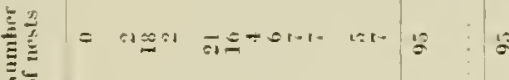

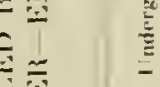

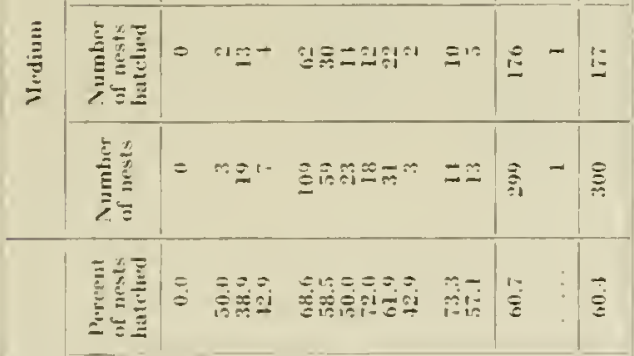

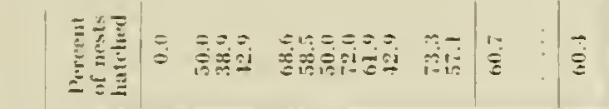

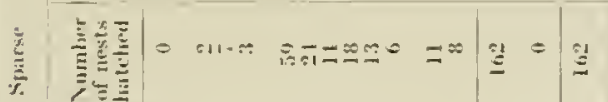
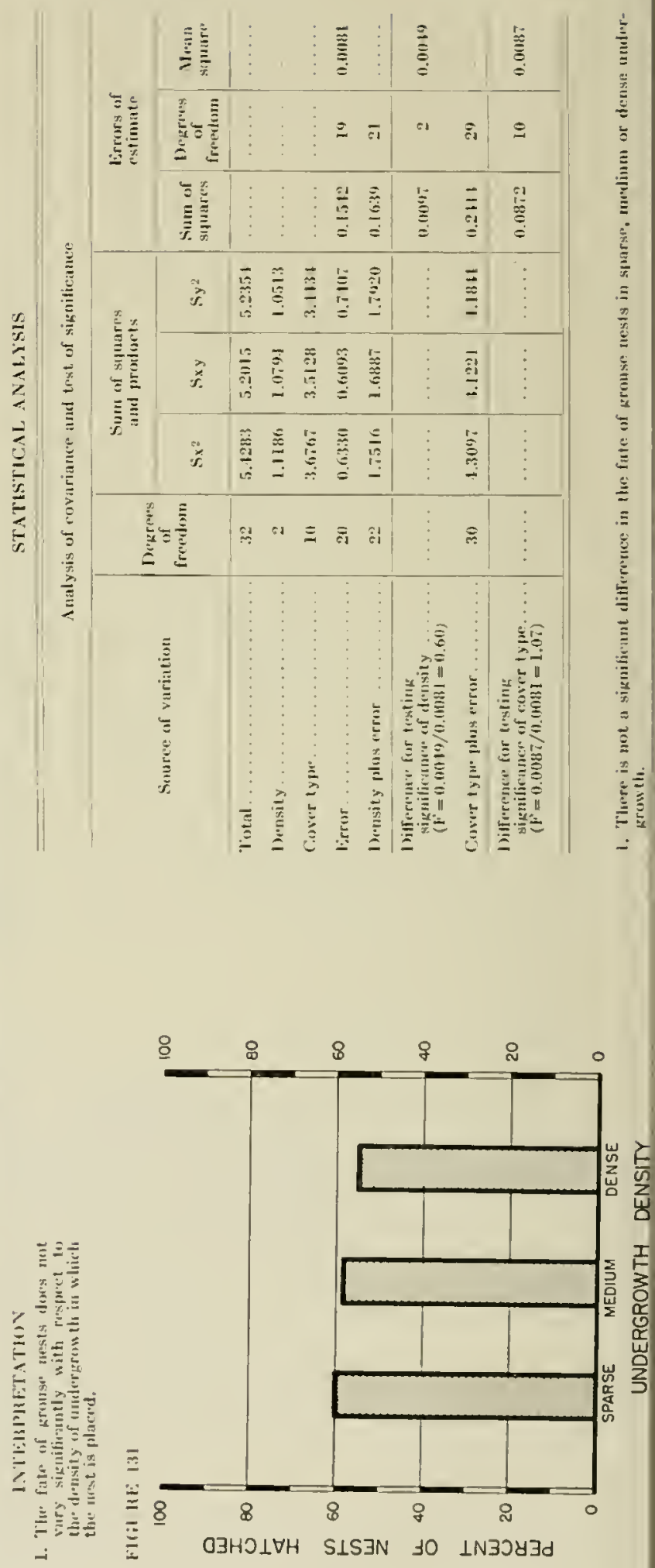


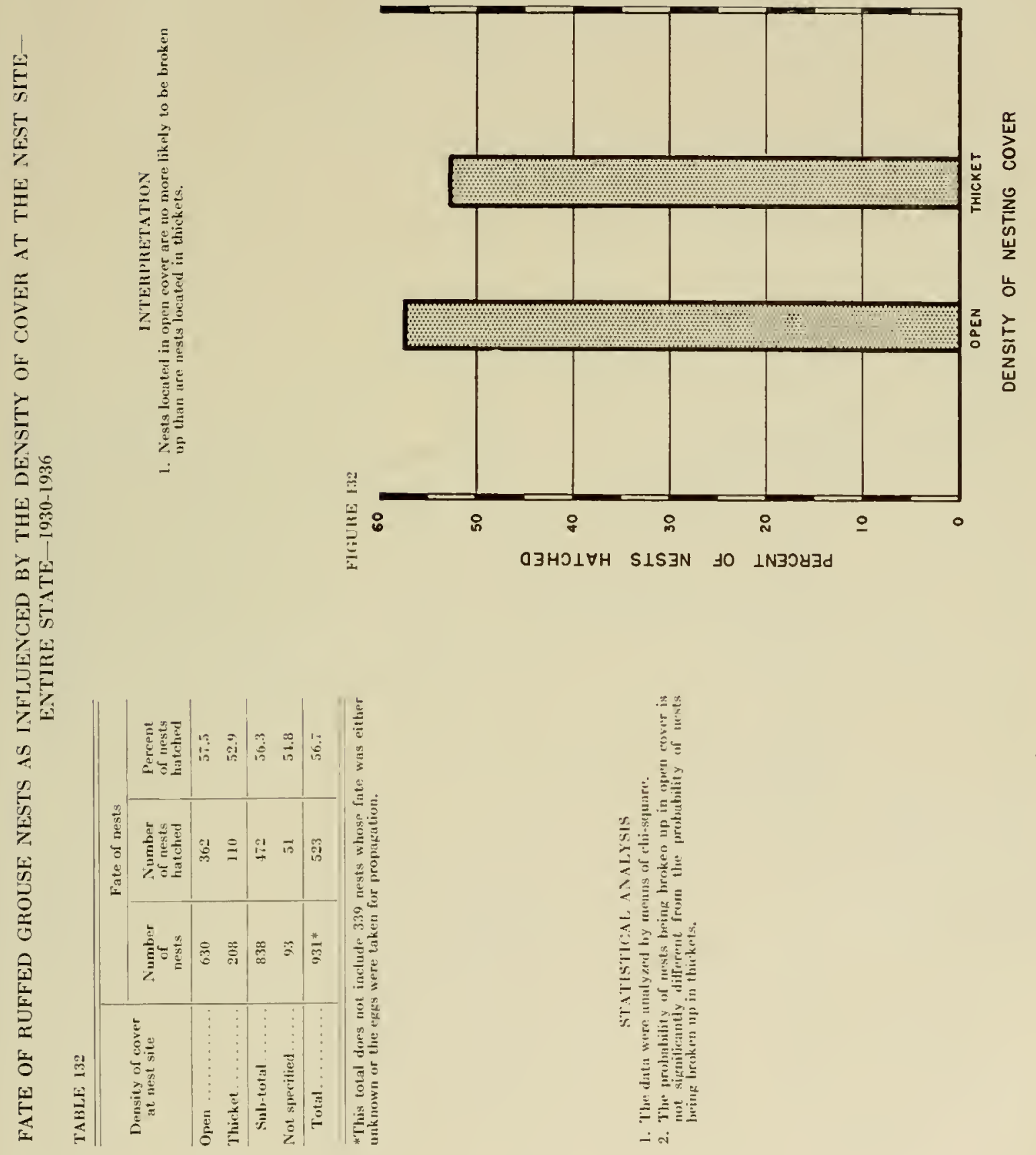



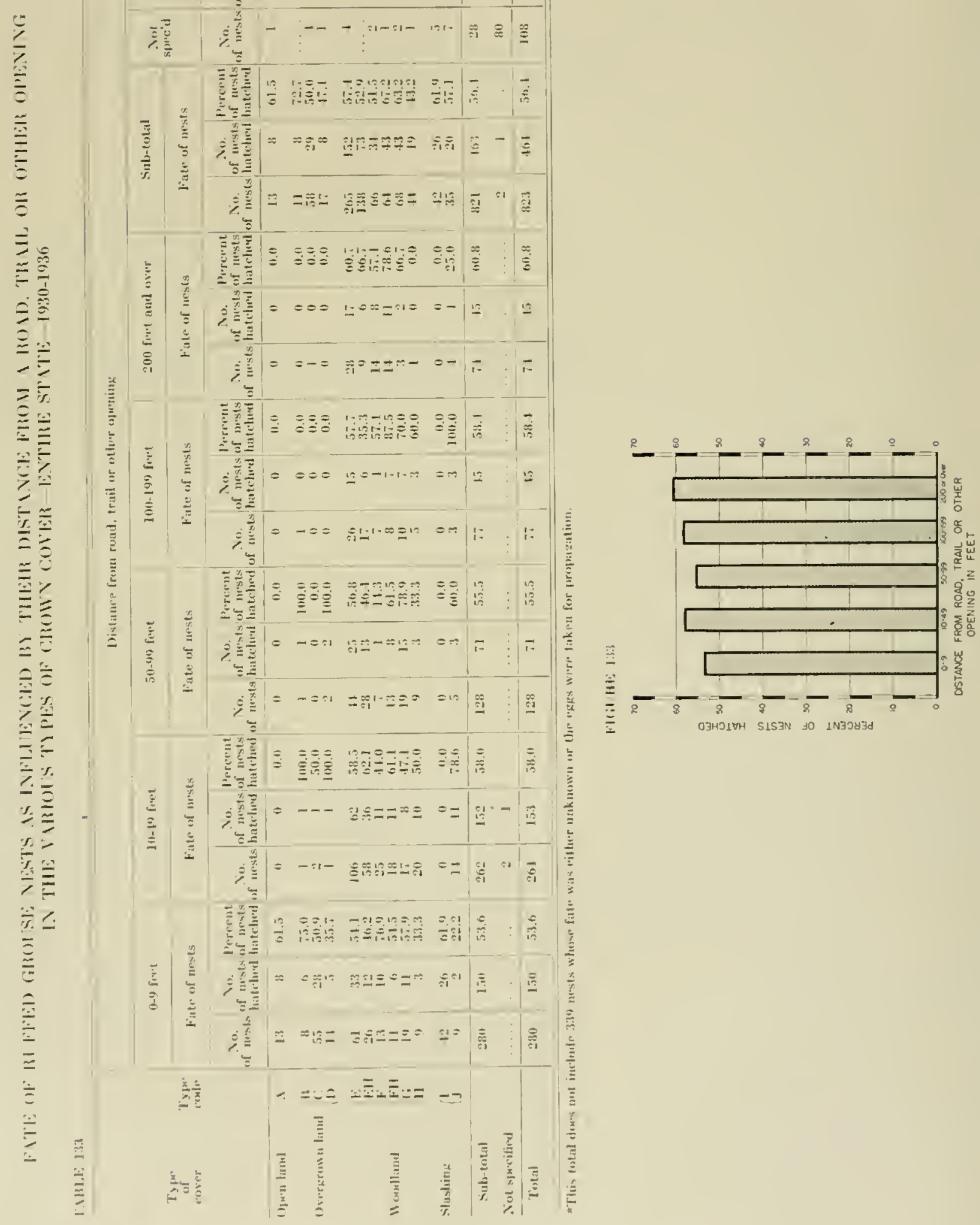


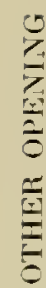

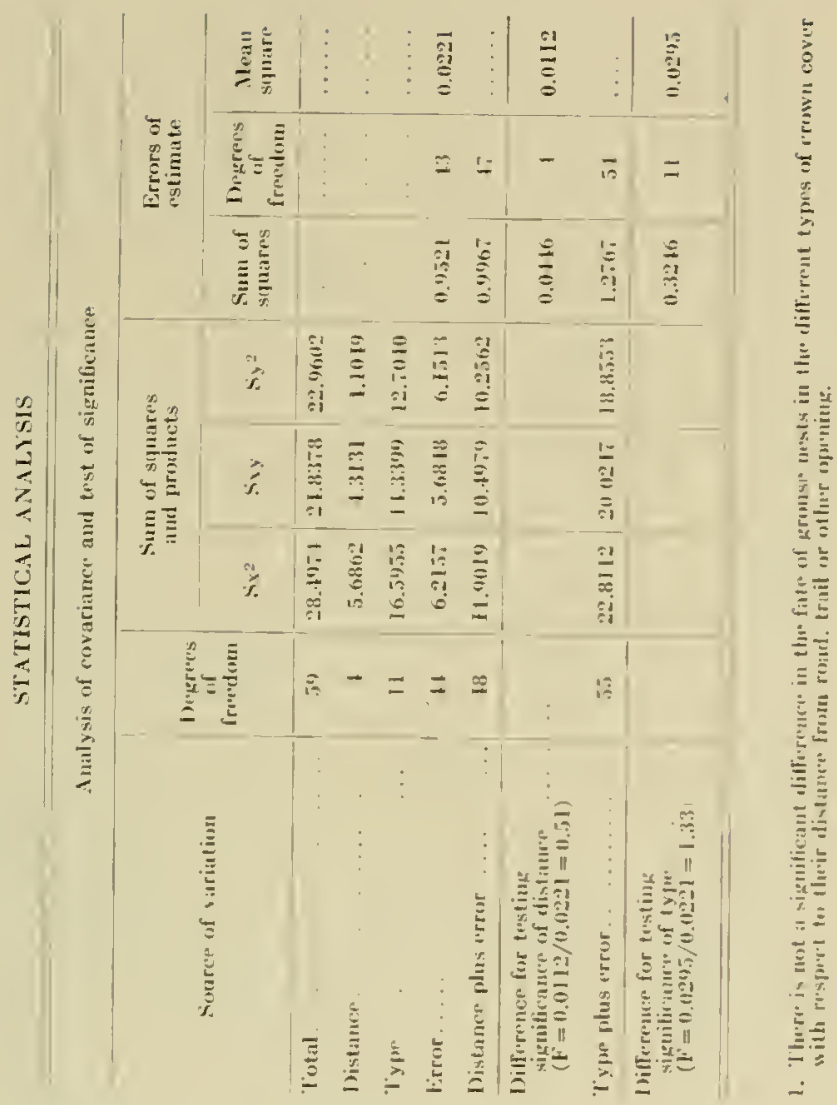

等

言

$=$
0

罂

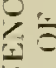

$=$

들

S.

告

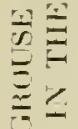

ב

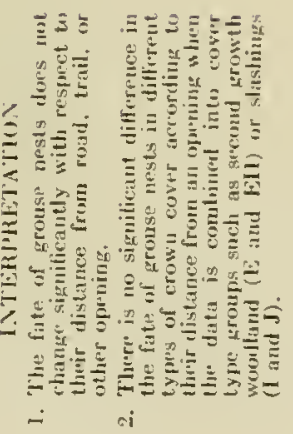



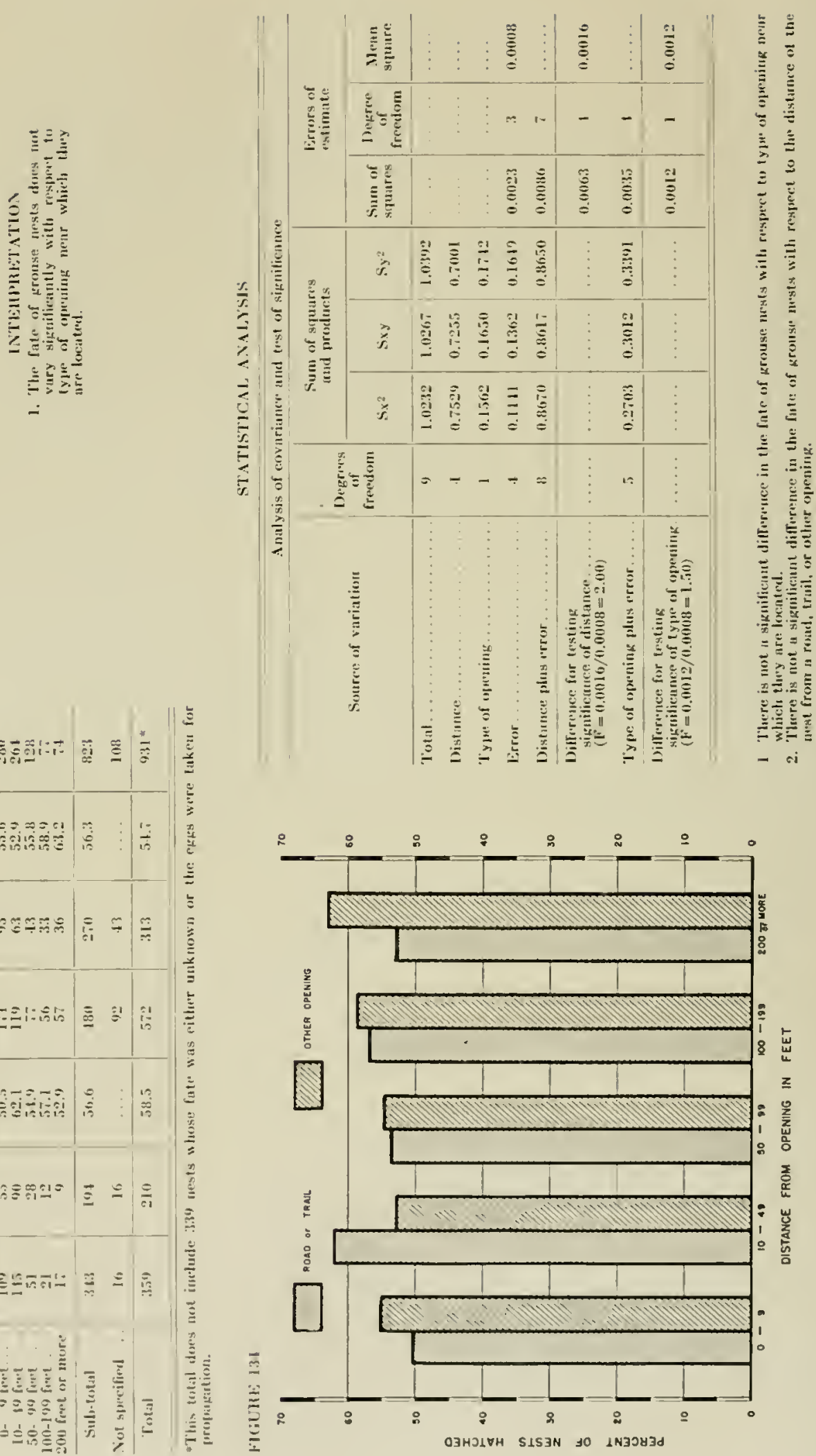


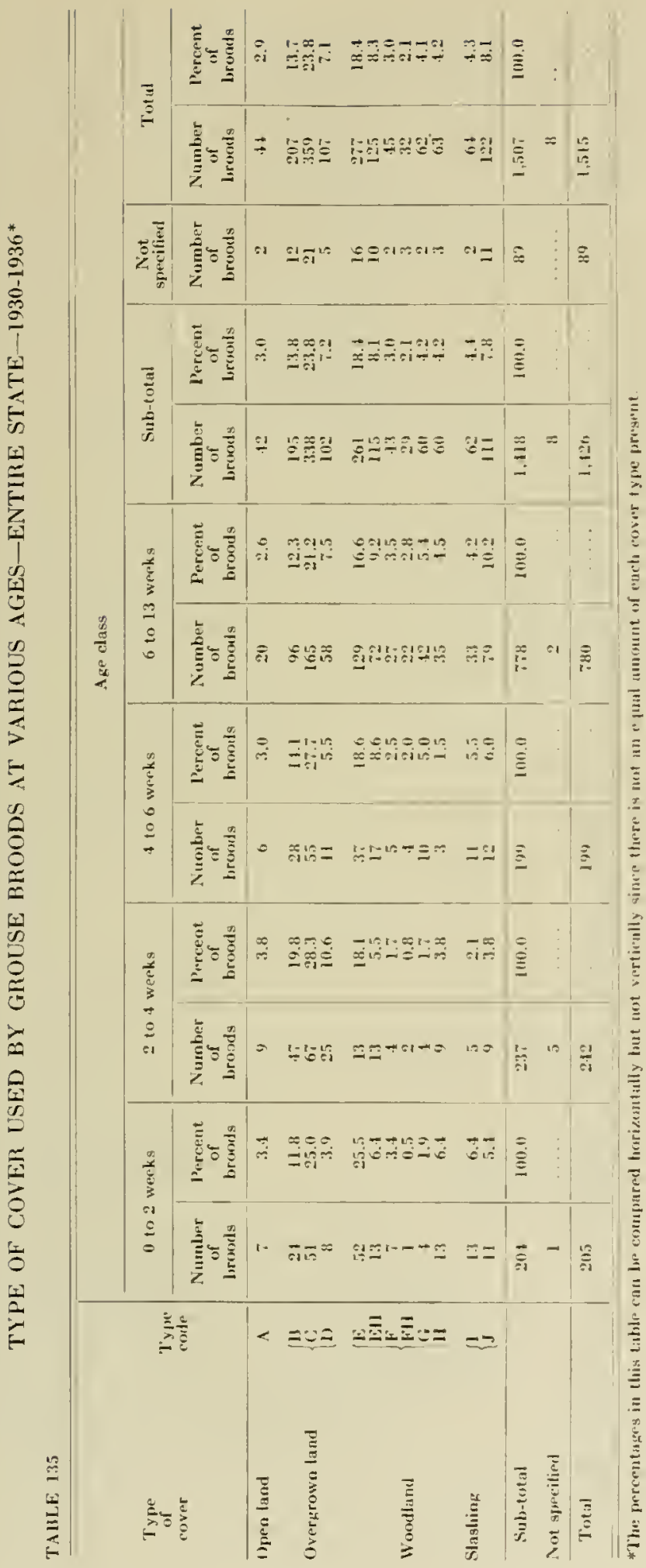
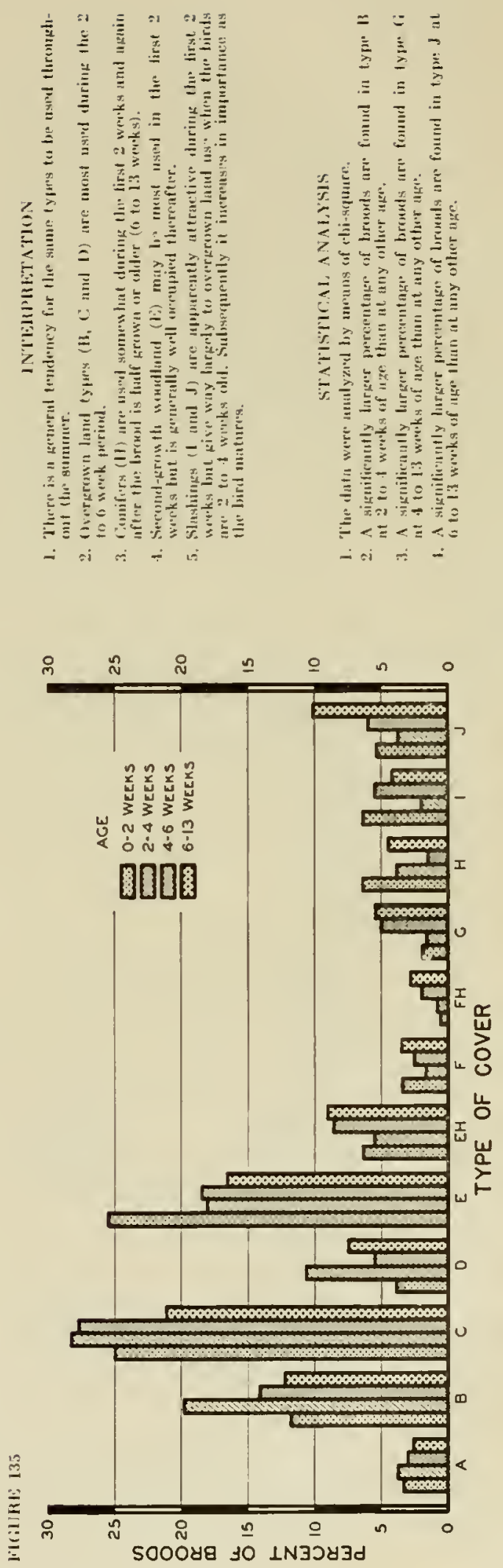


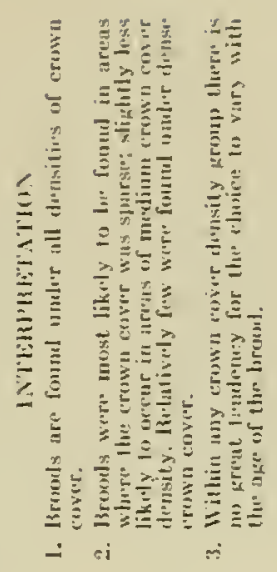

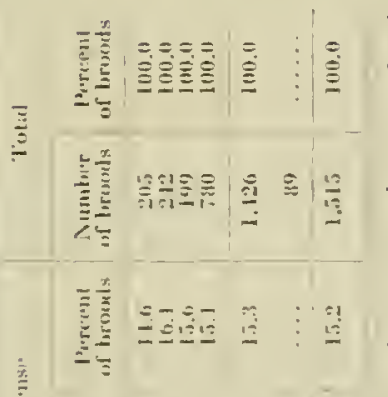

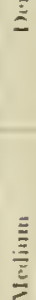

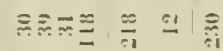

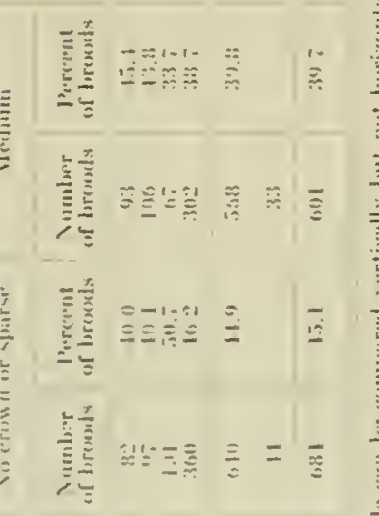

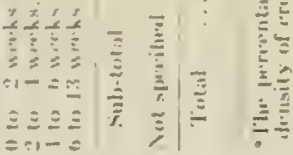
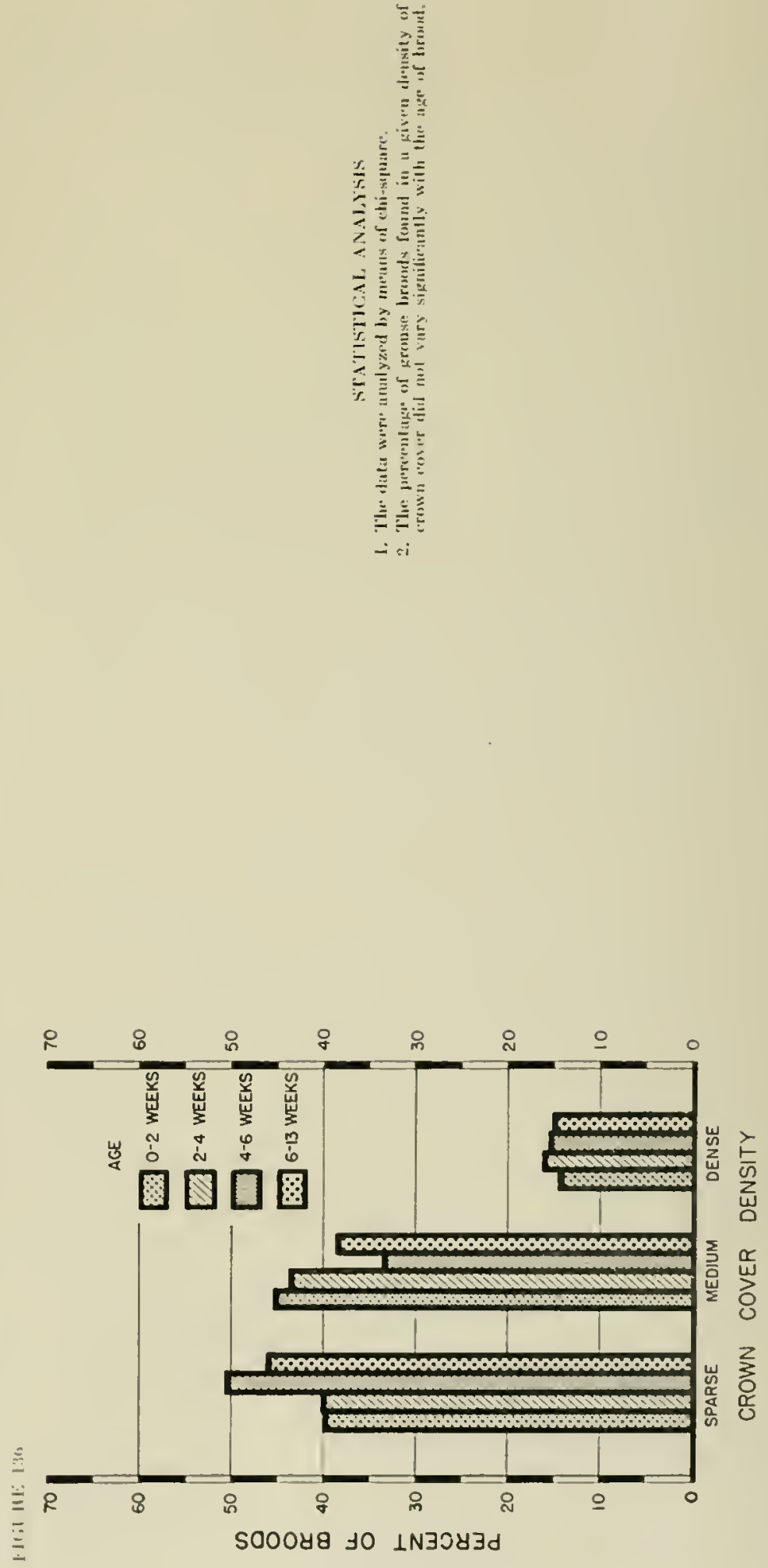


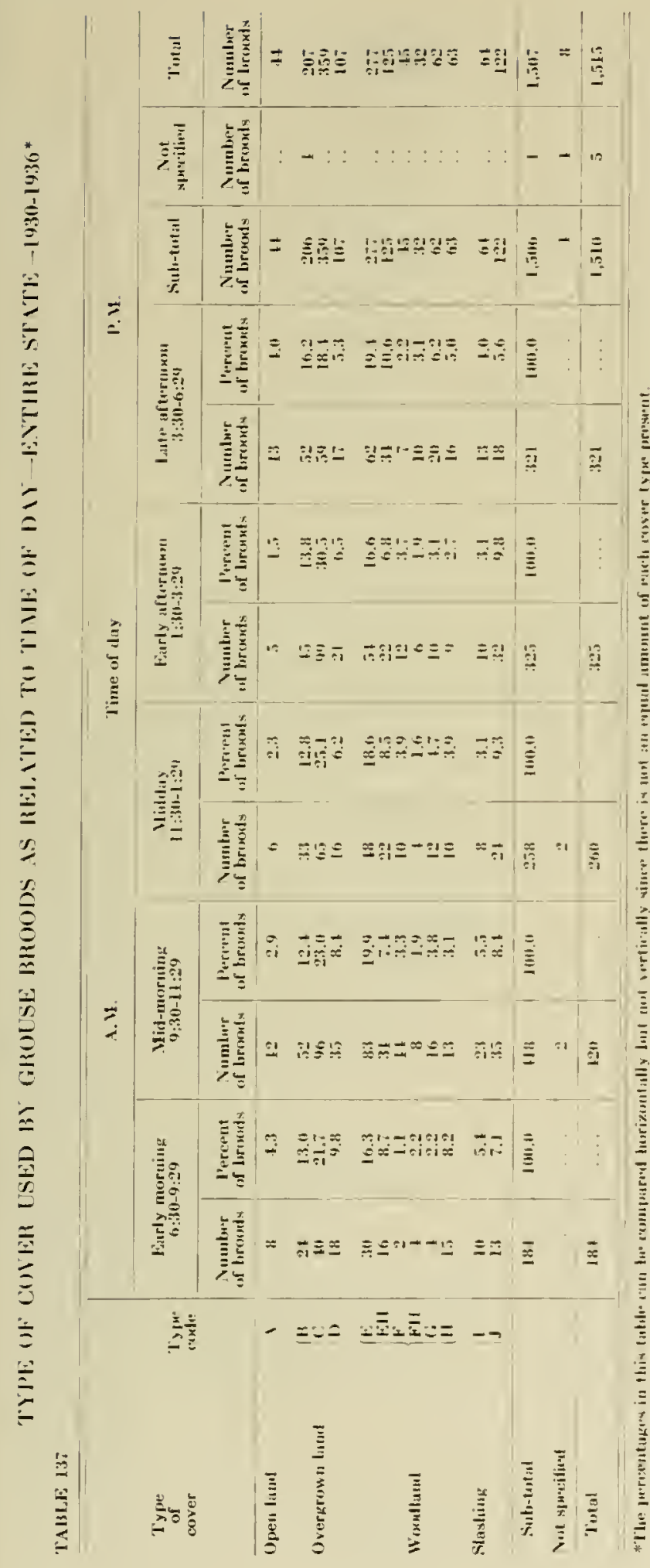

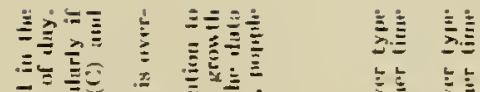

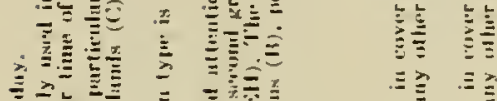

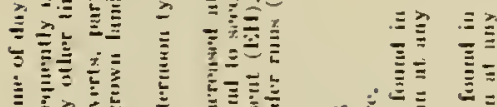

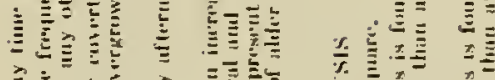

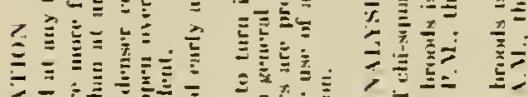

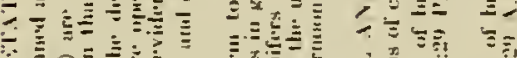

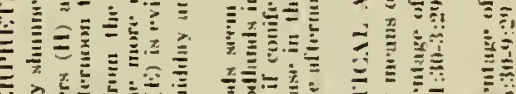

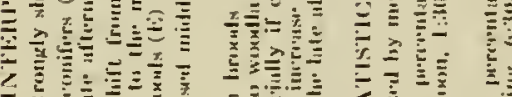

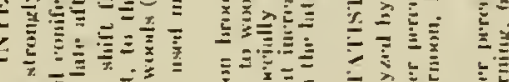

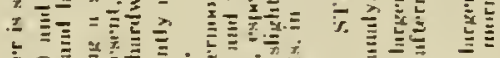

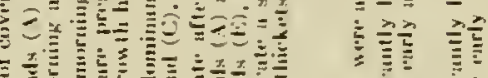

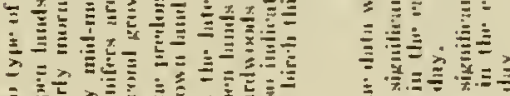

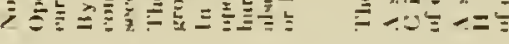
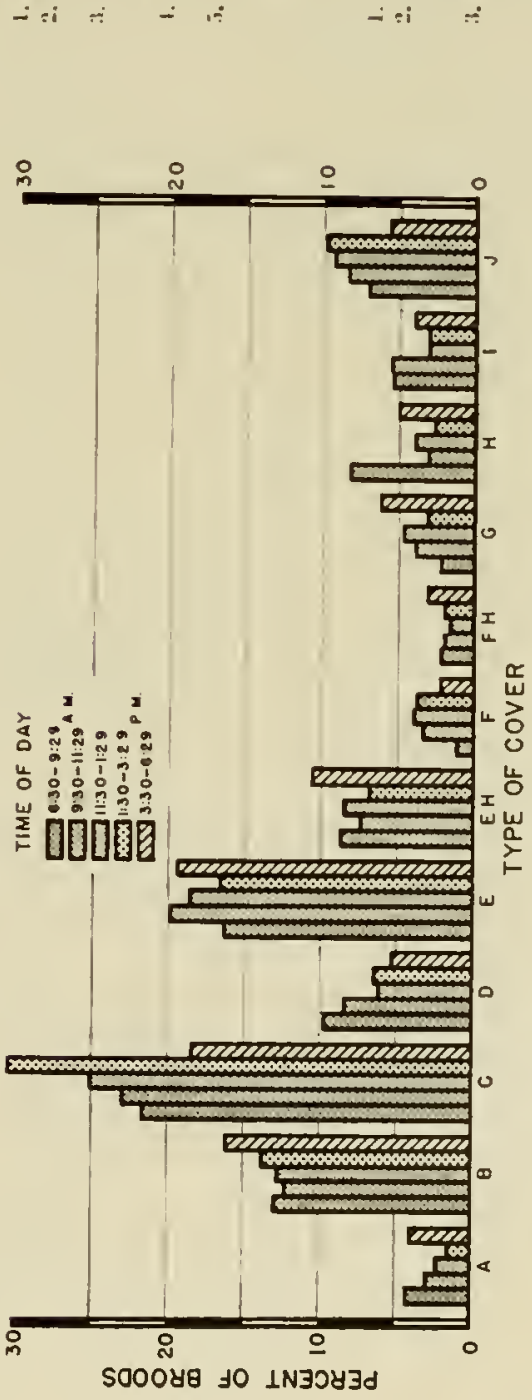


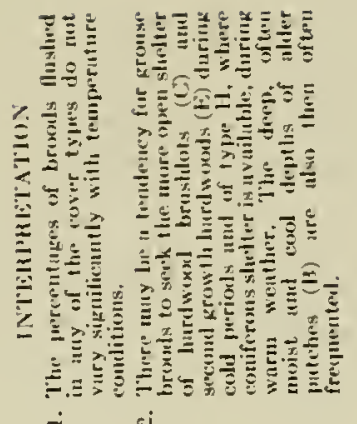

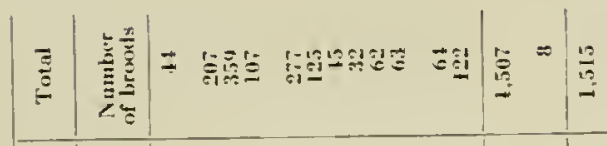

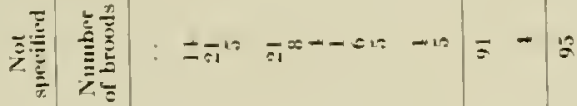

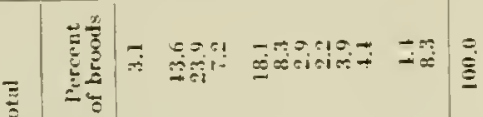

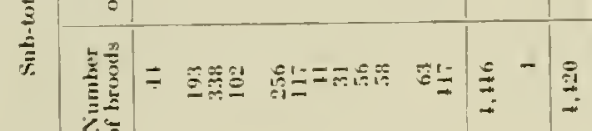
竞

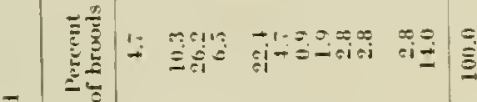
בֶ

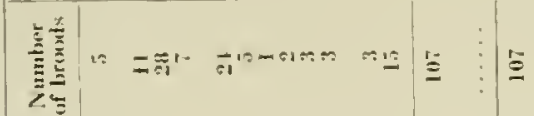

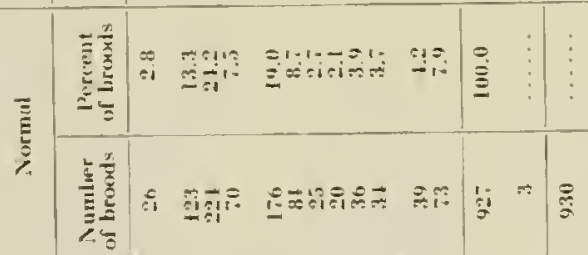

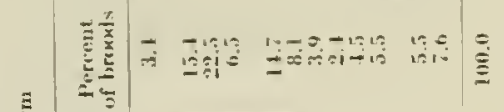
$\stackrel{E}{\equiv}$

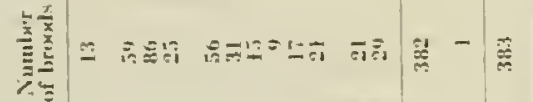

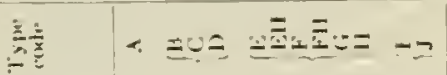

$\stackrel{\infty}{-\infty}$

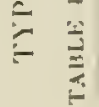
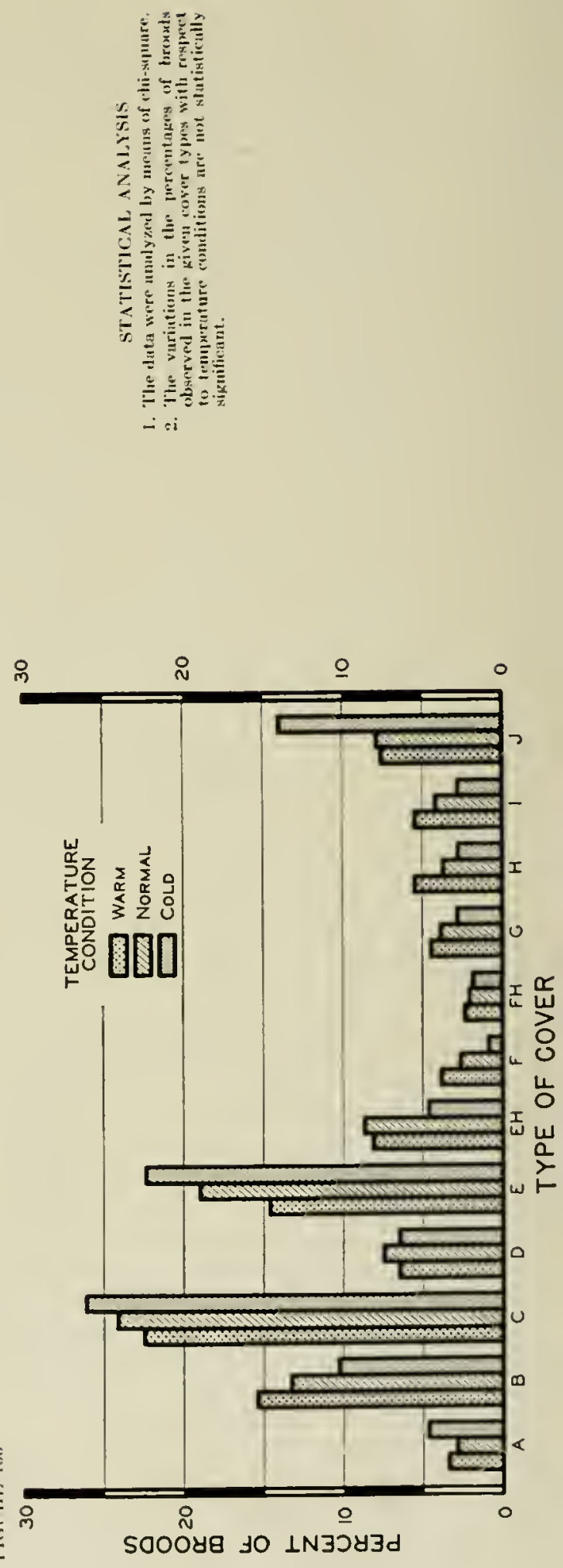

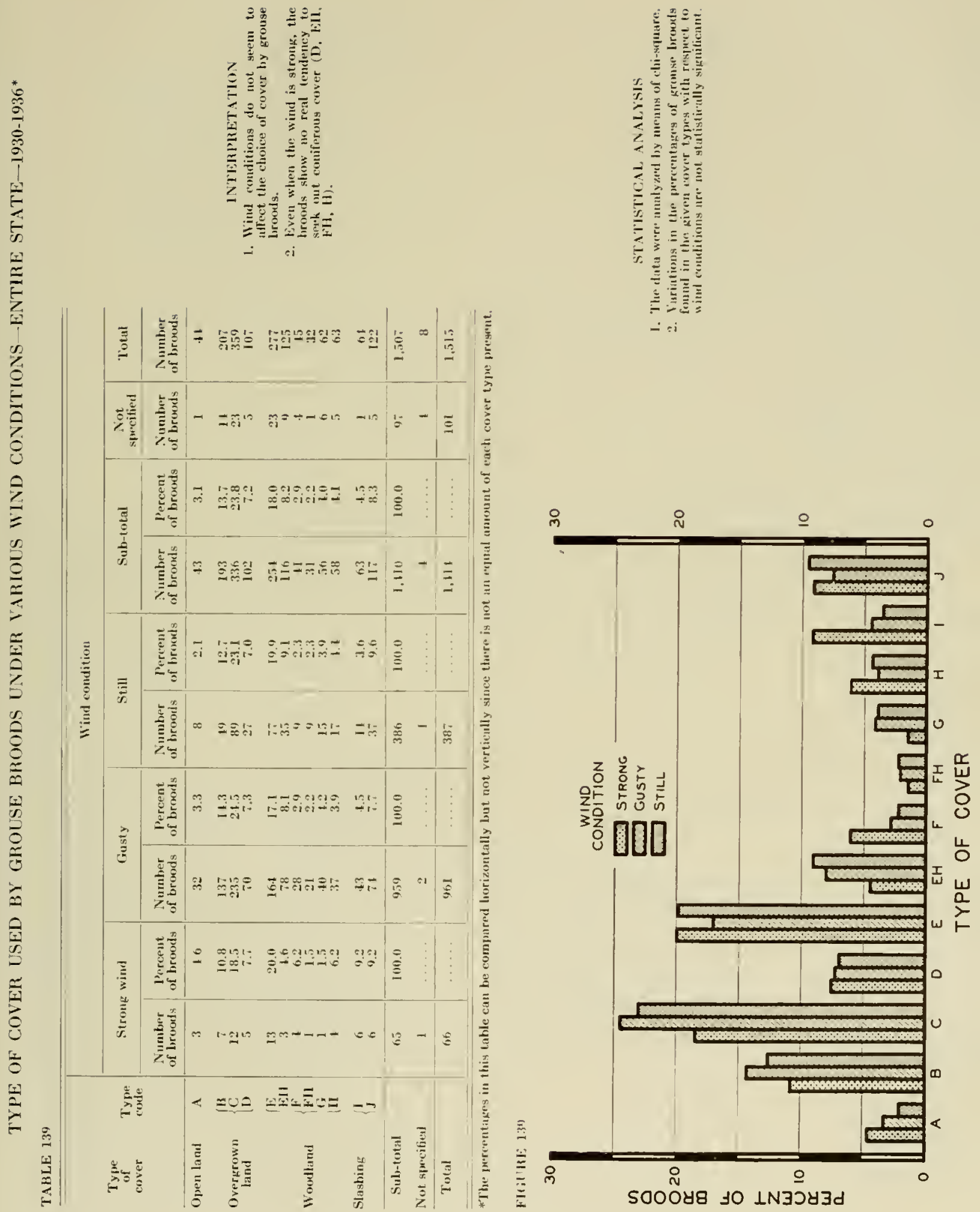

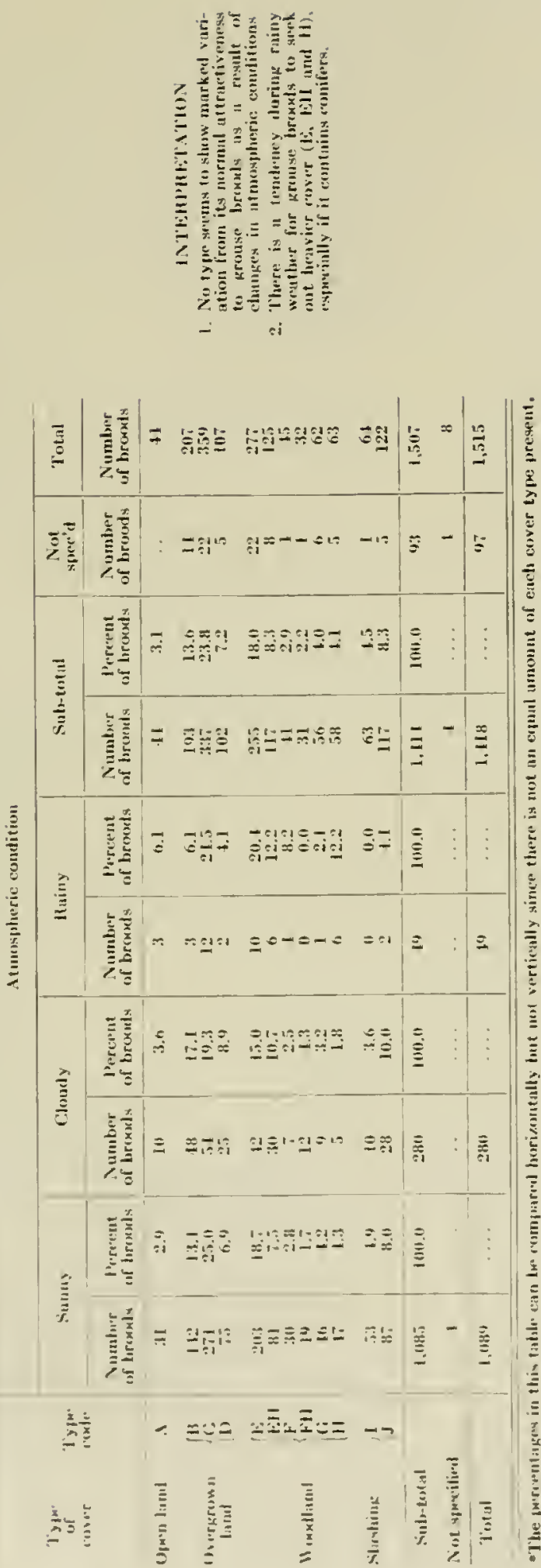
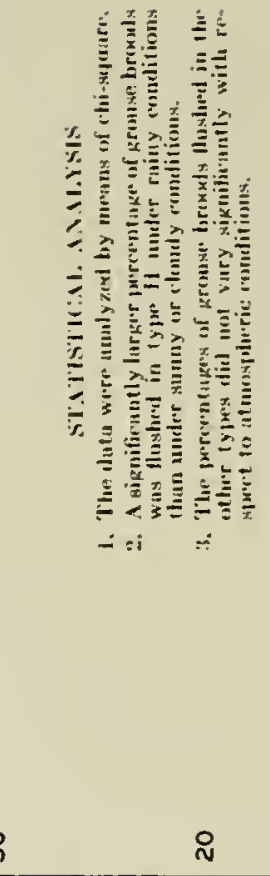

으
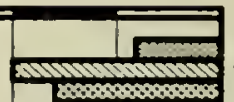

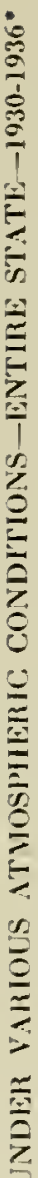

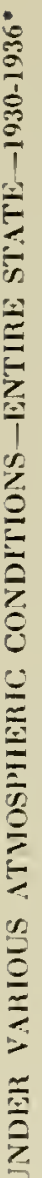

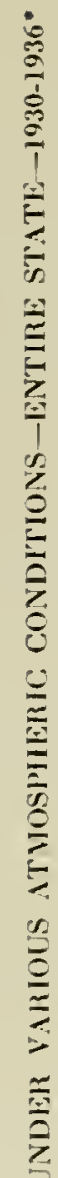
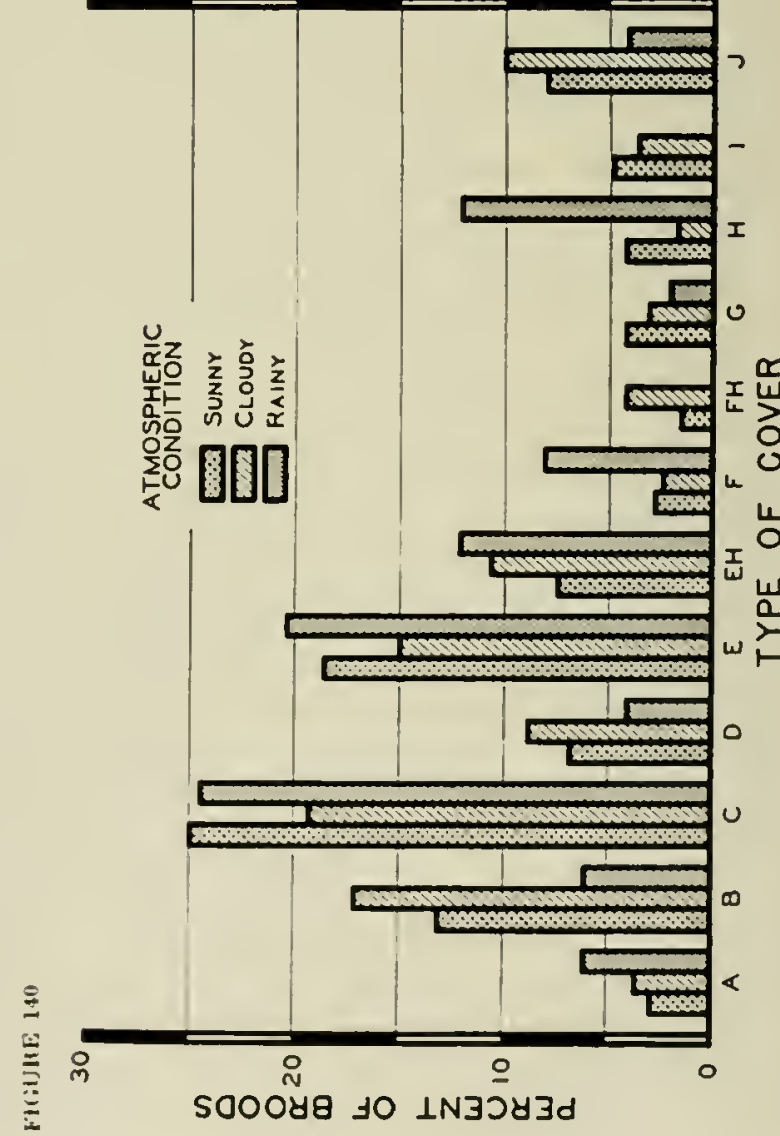


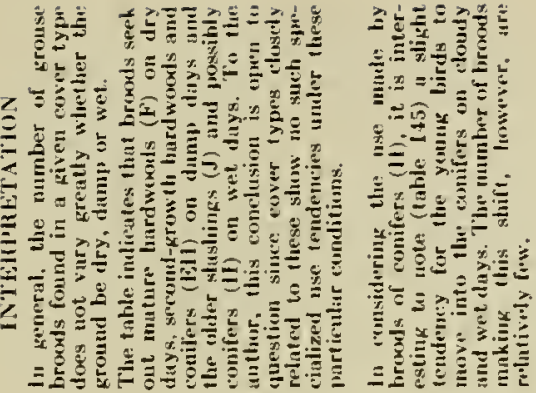

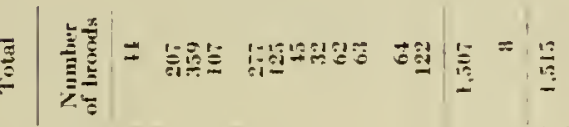

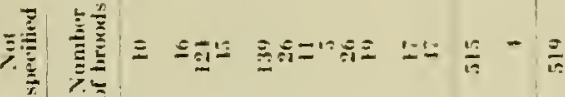

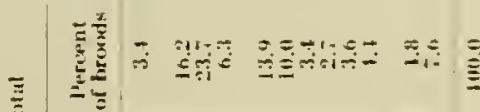

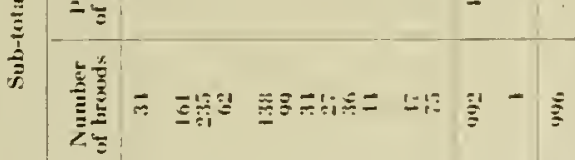

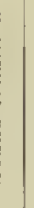

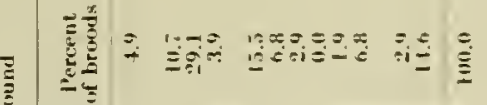
政

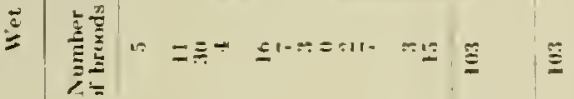

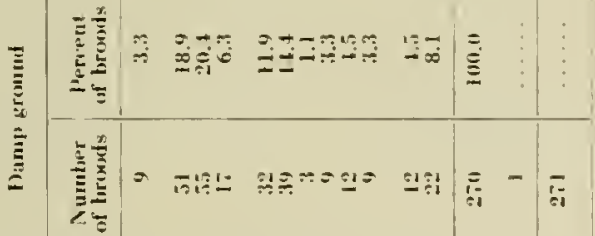

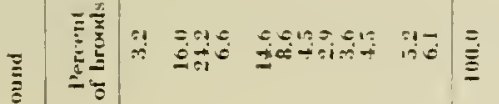
部

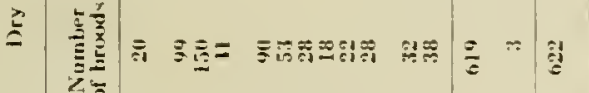
言产

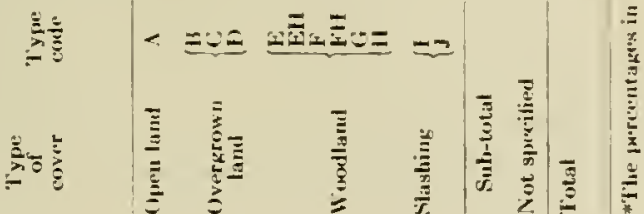
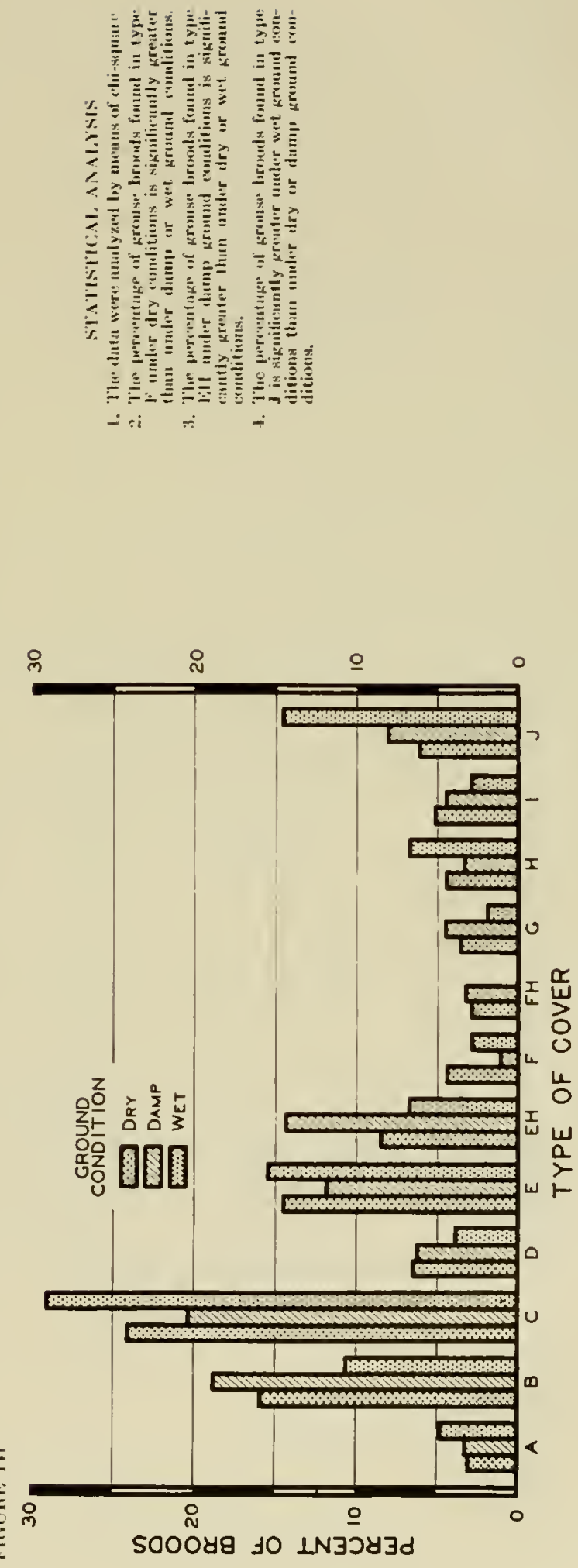


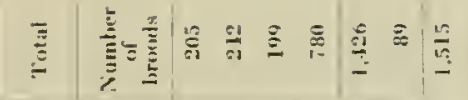

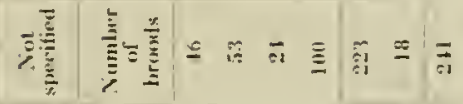

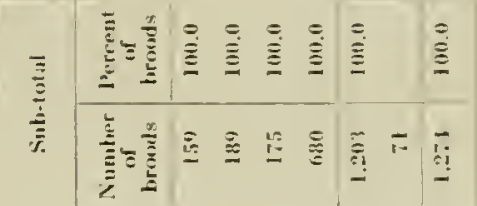

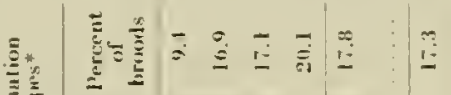

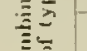

$\bar{z}$

||

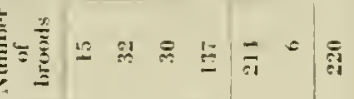

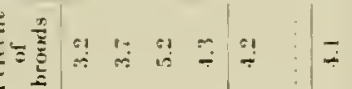

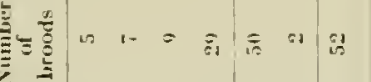

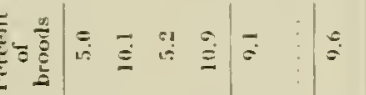

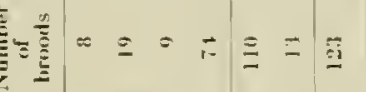

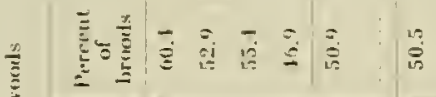

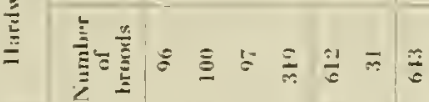

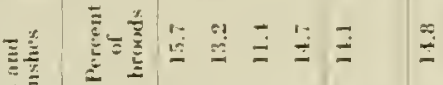

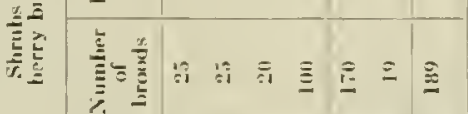

告|

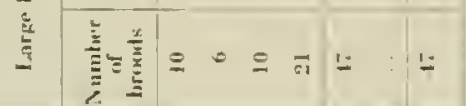
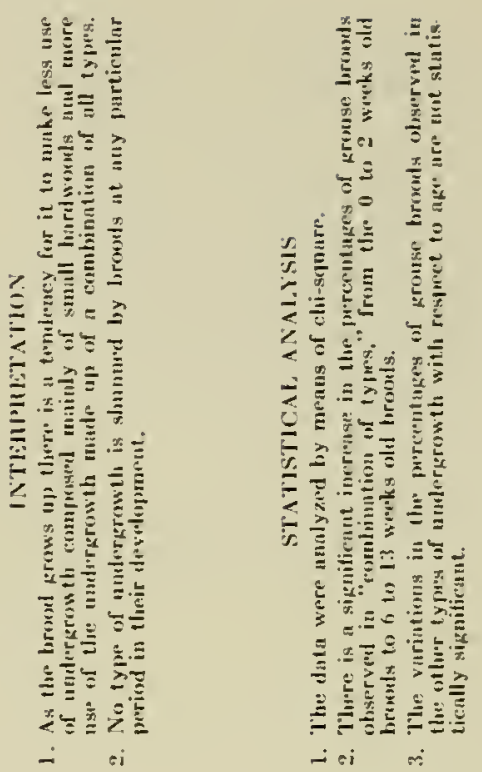

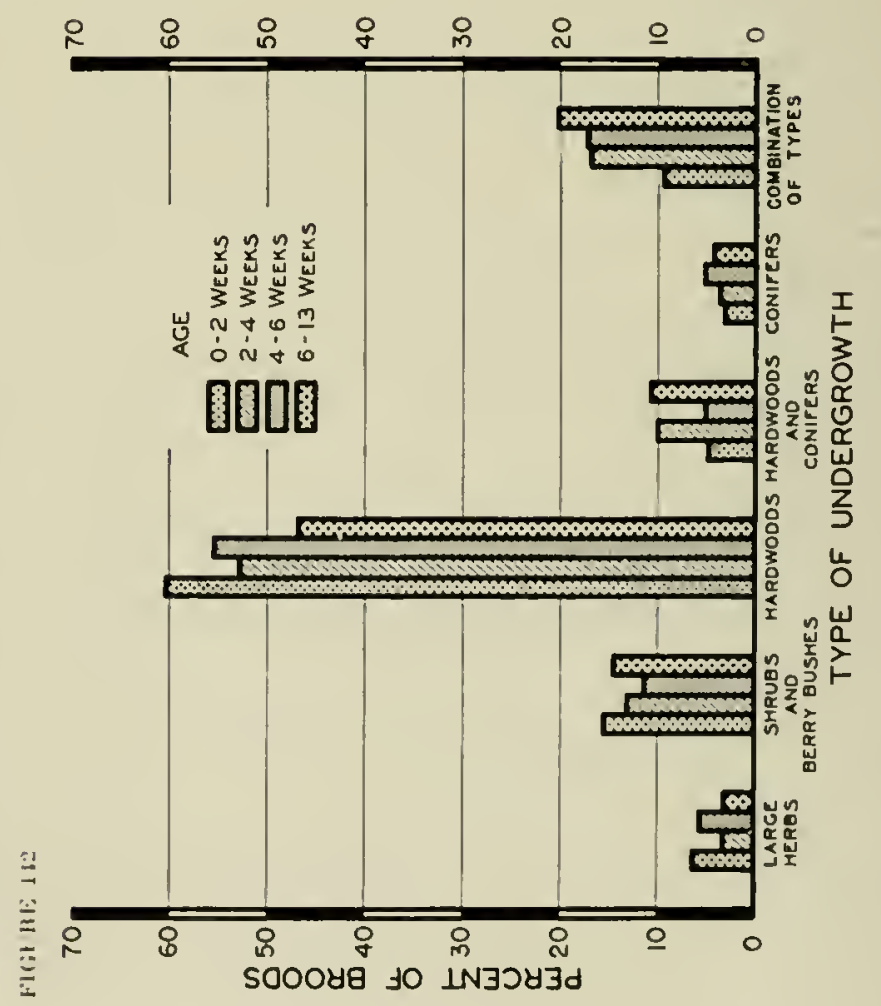




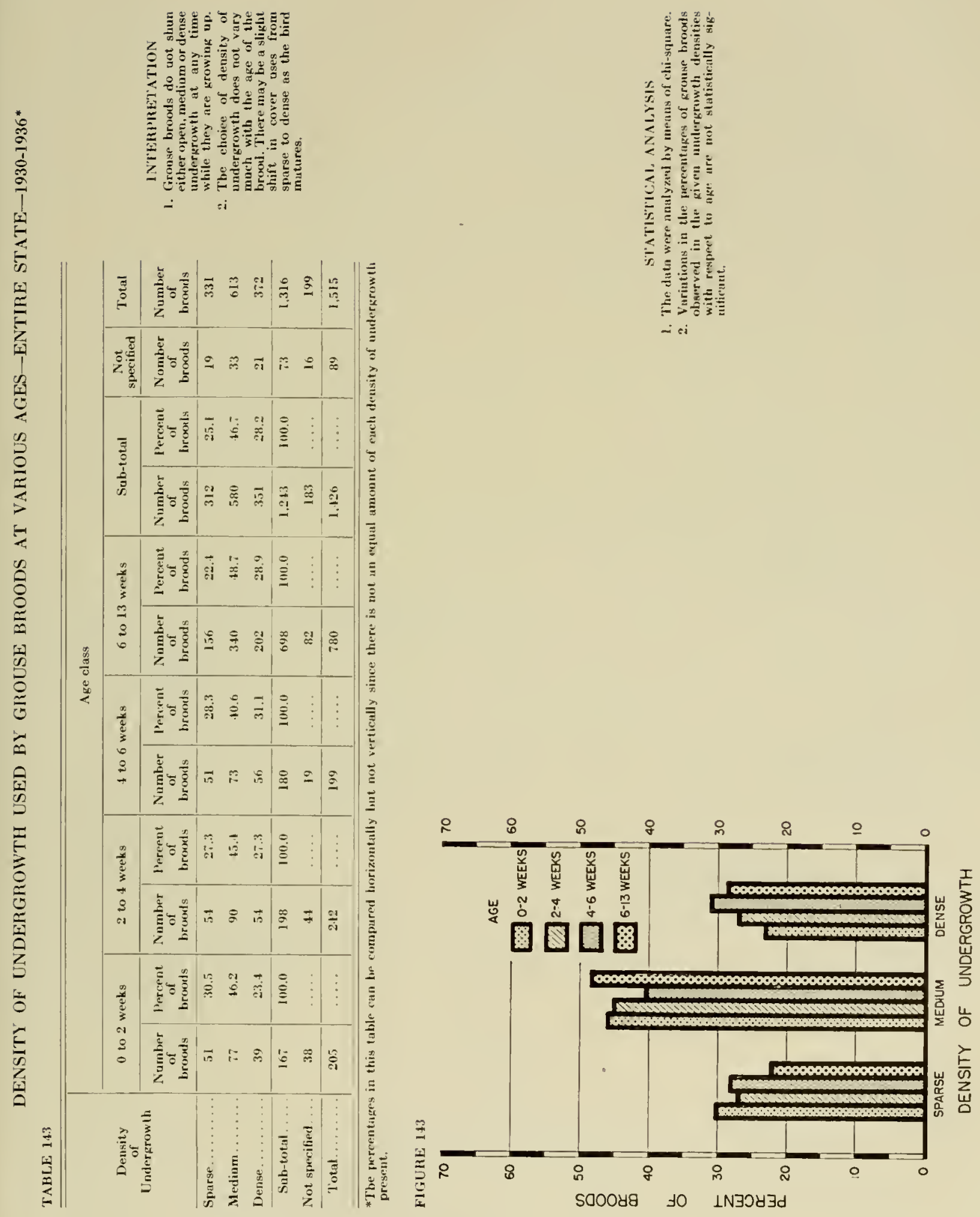



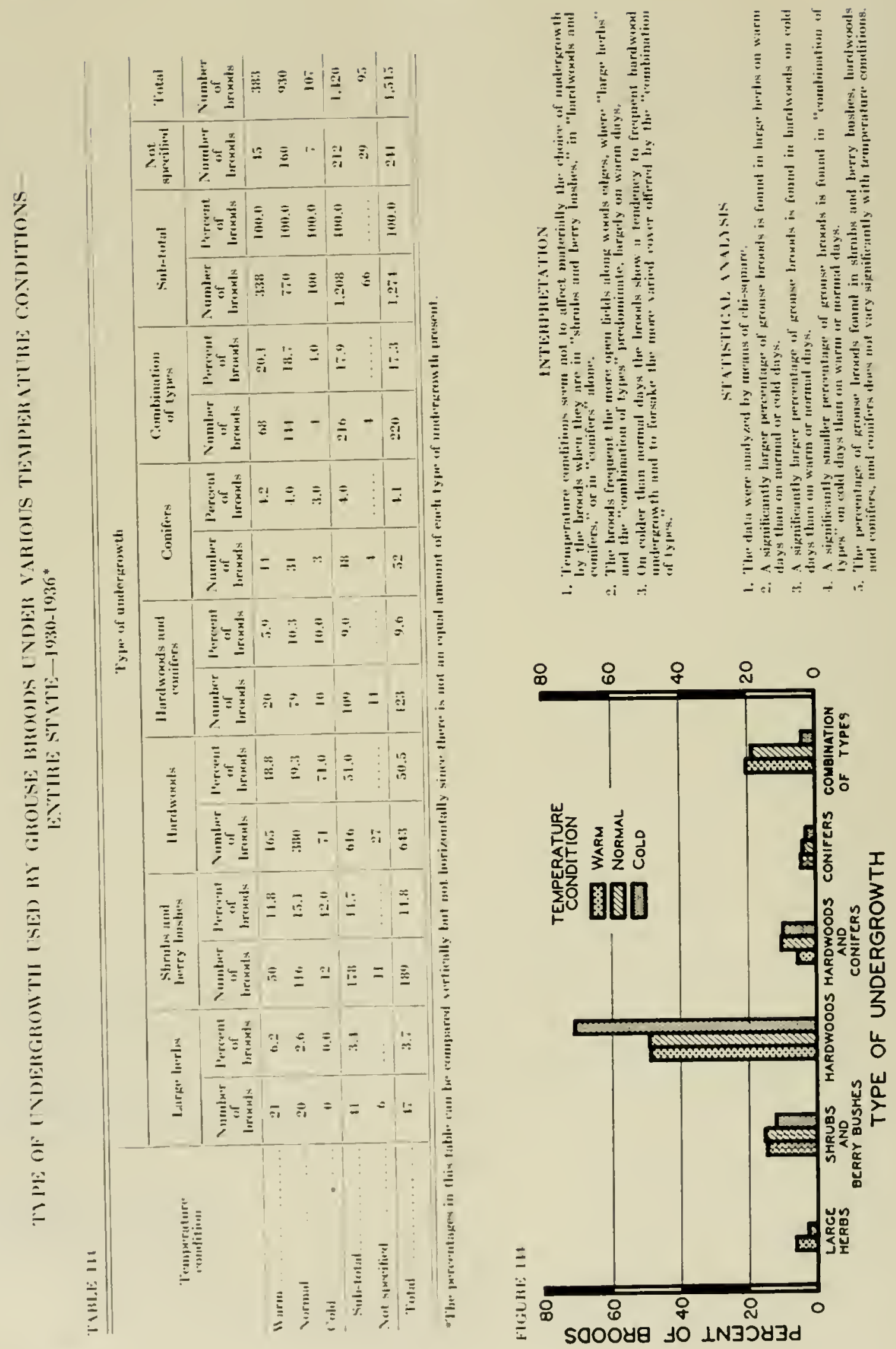
$\frac{1}{2}$

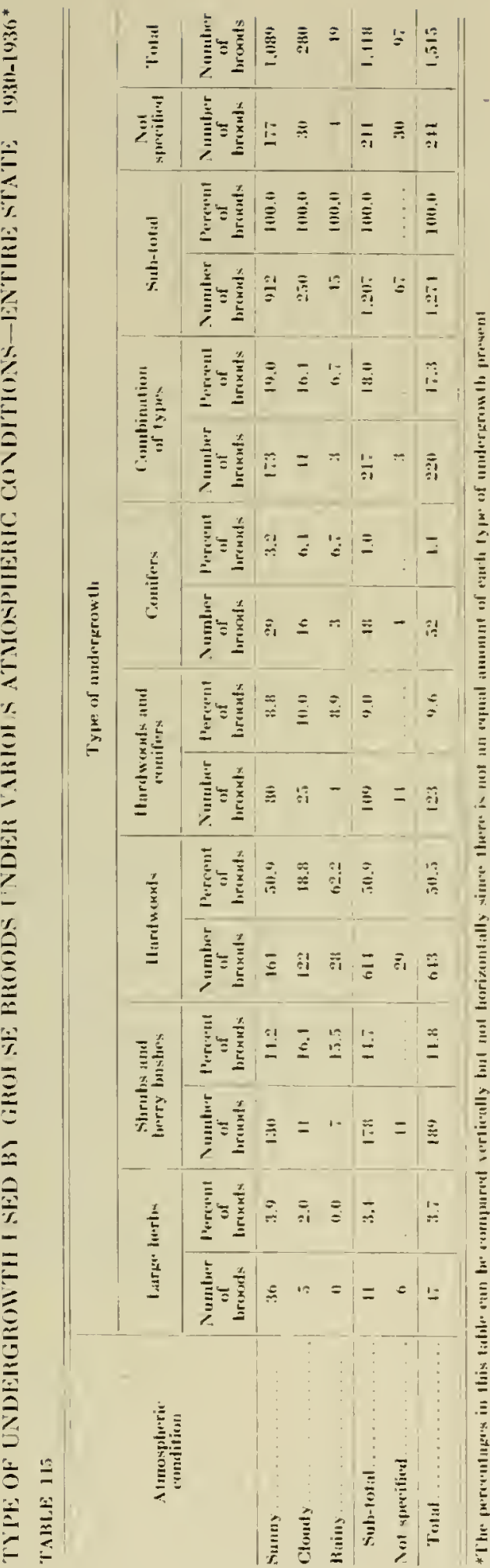
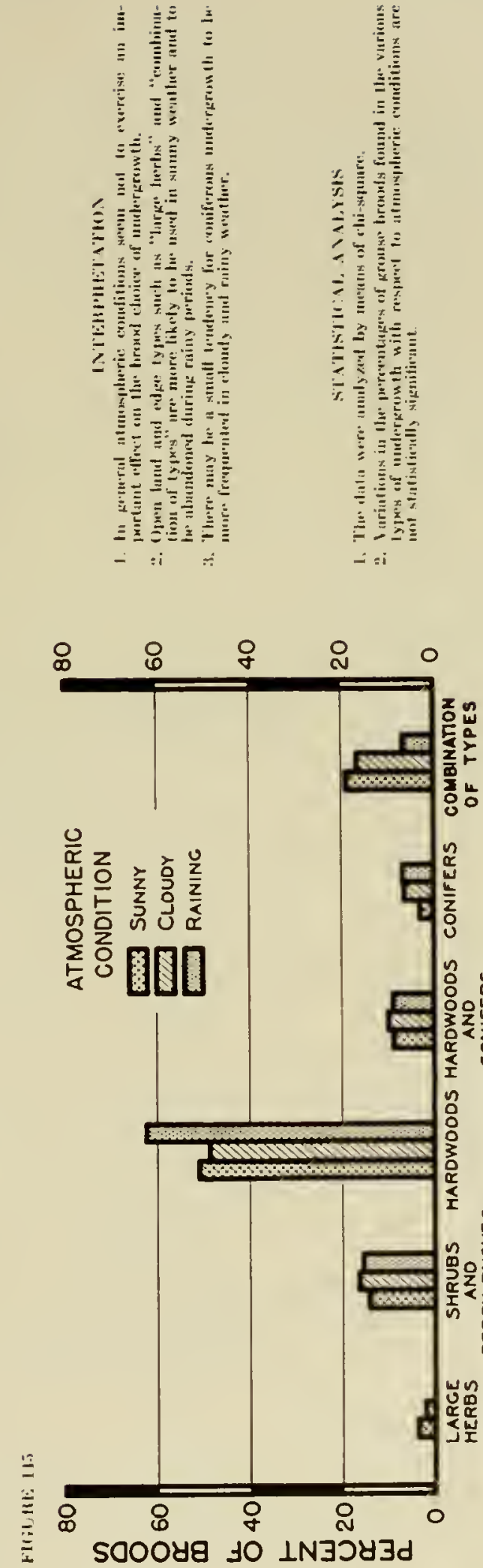

$I$
5
3
0
0
0
0
0
$w$
0
$\frac{1}{2}$ แั 0

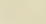
n 

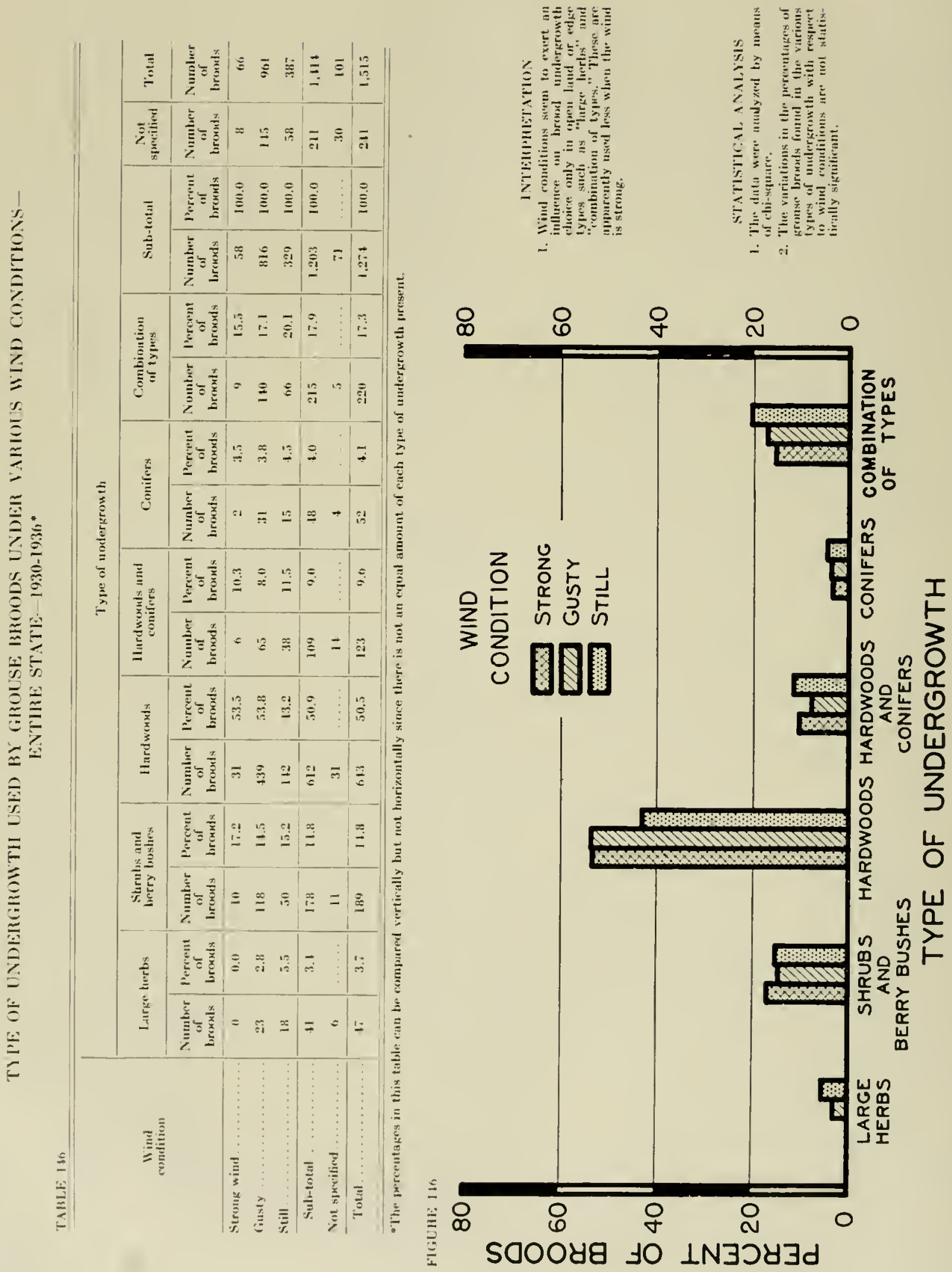


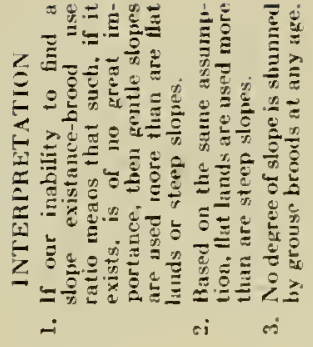

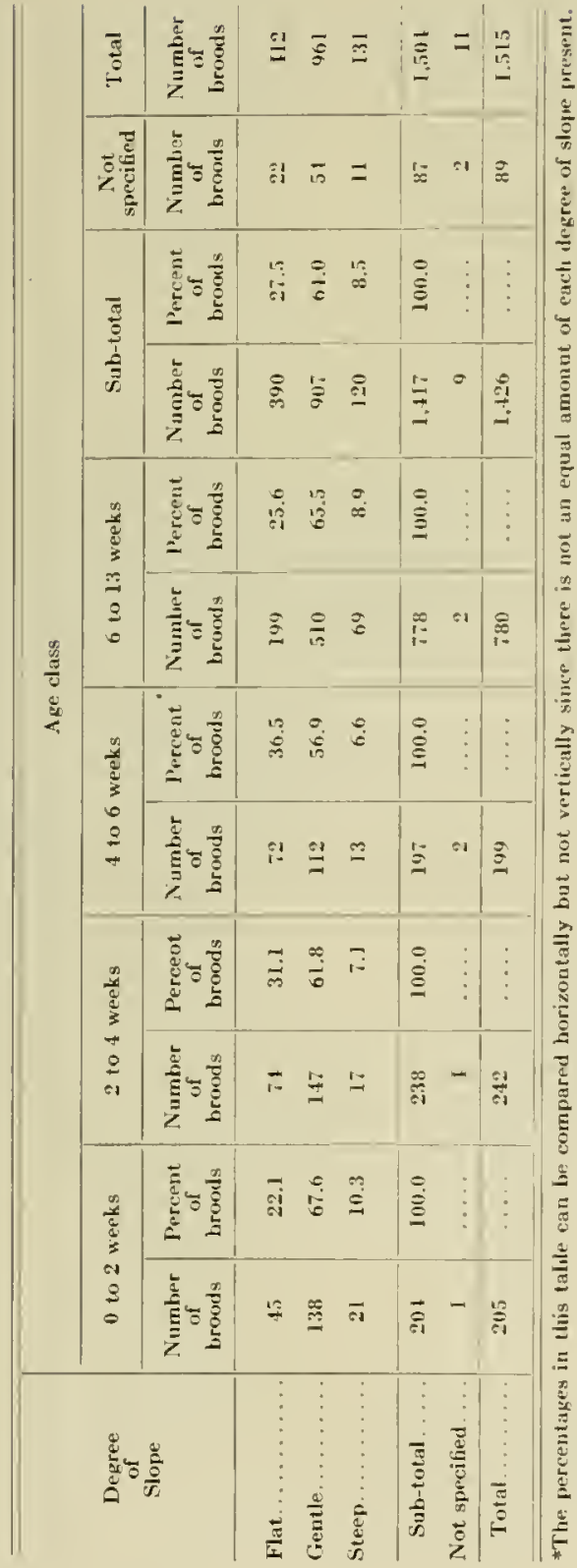
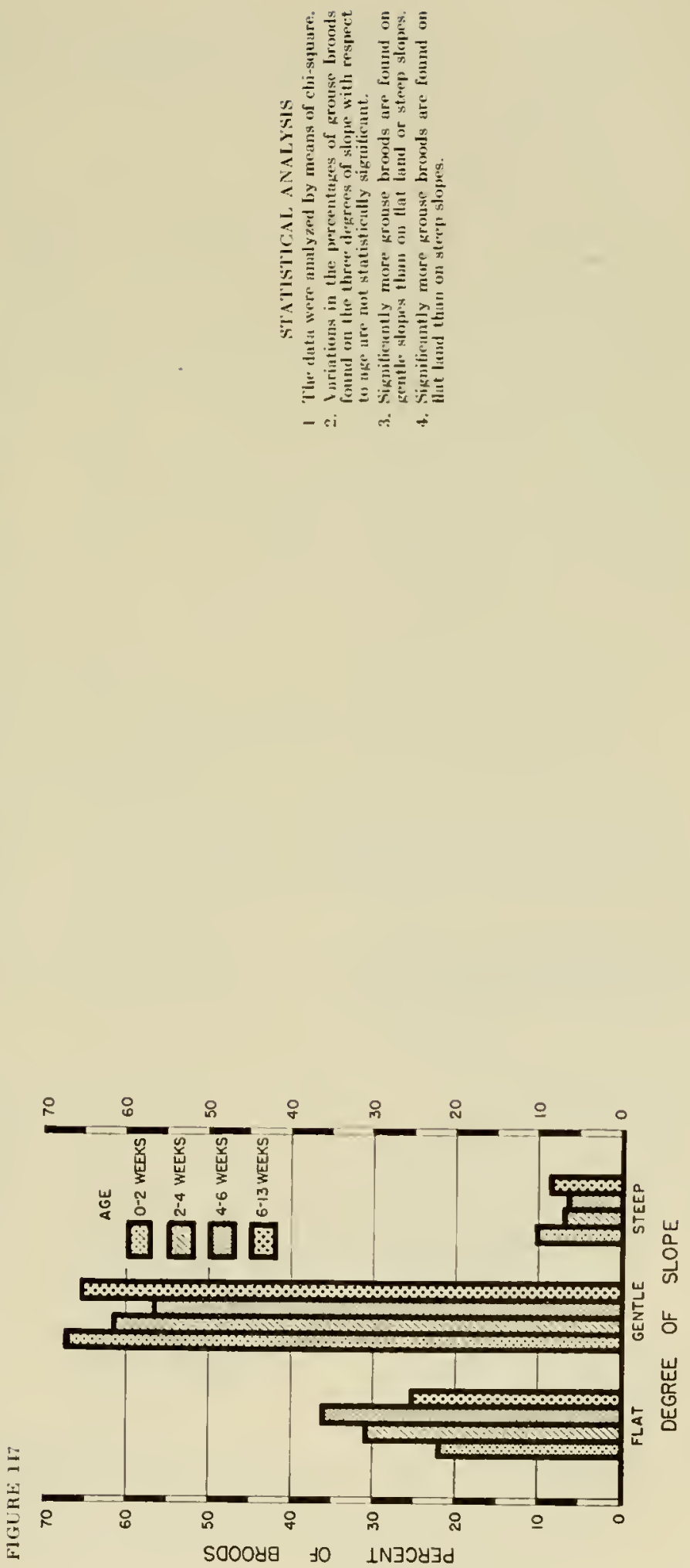

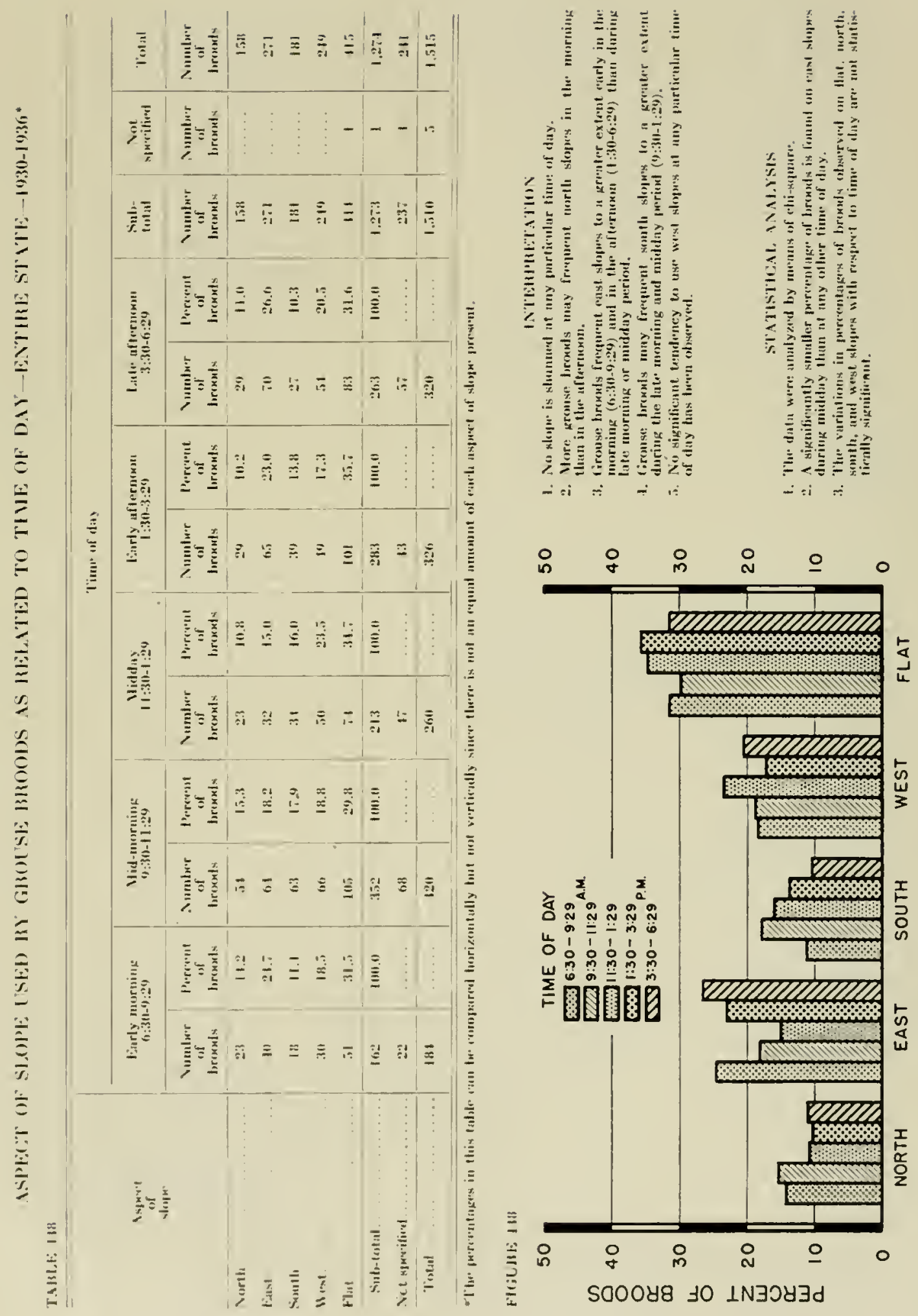

닝
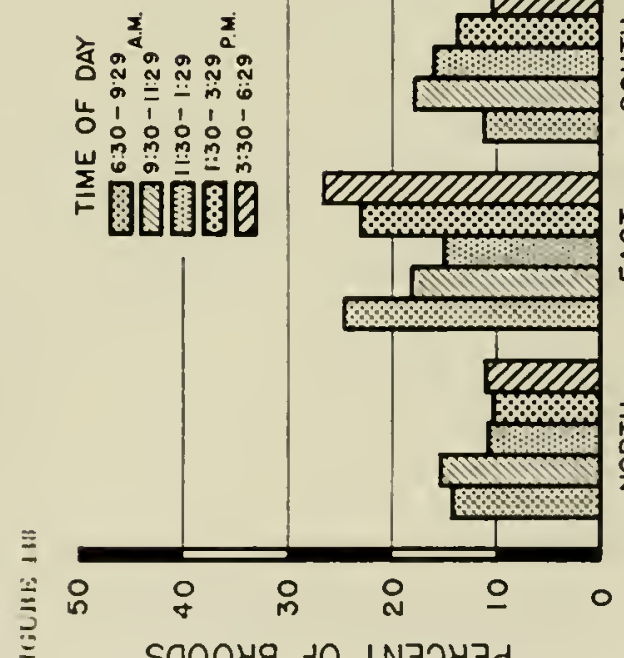

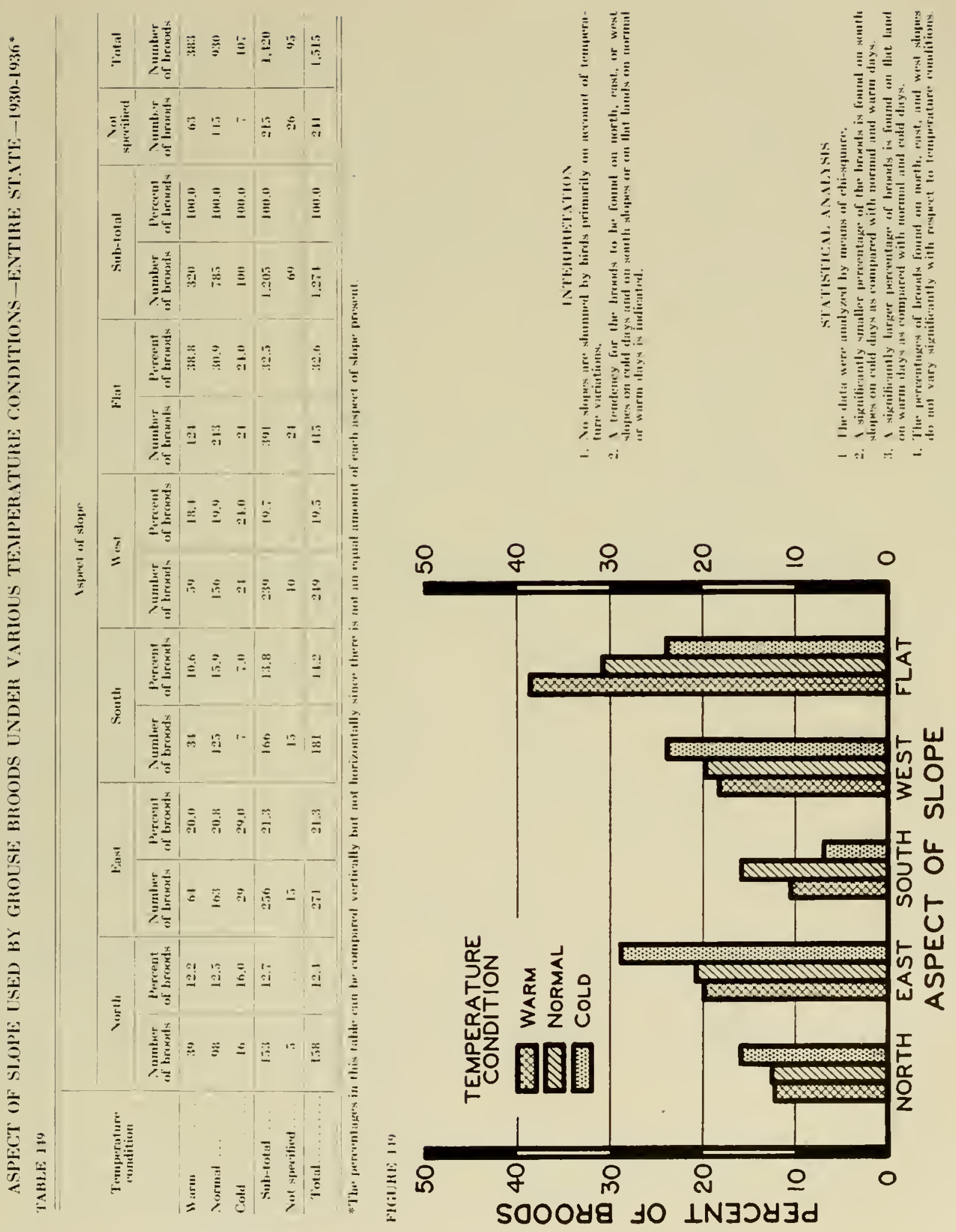

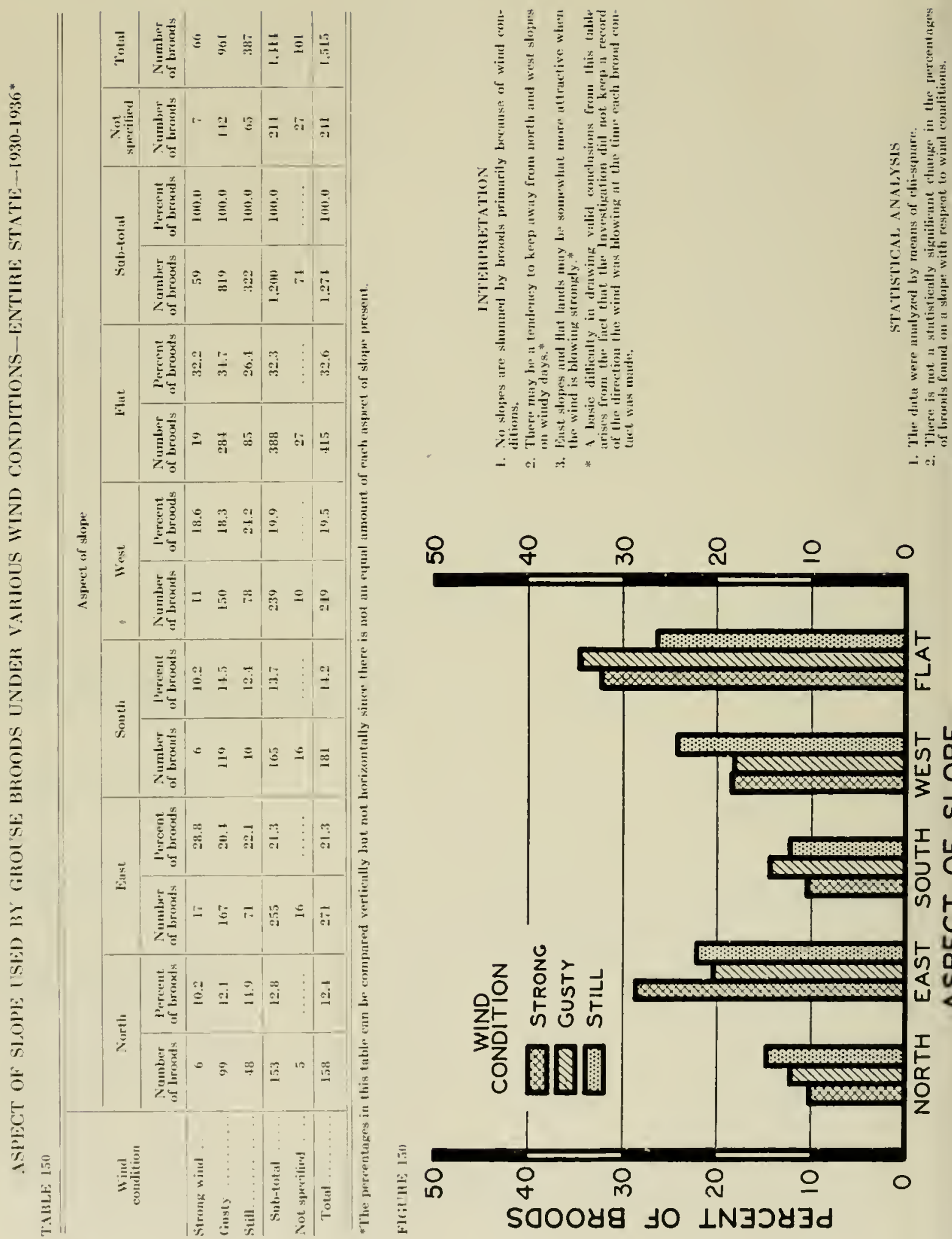

ถ

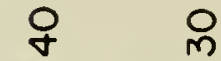

음

오으

o

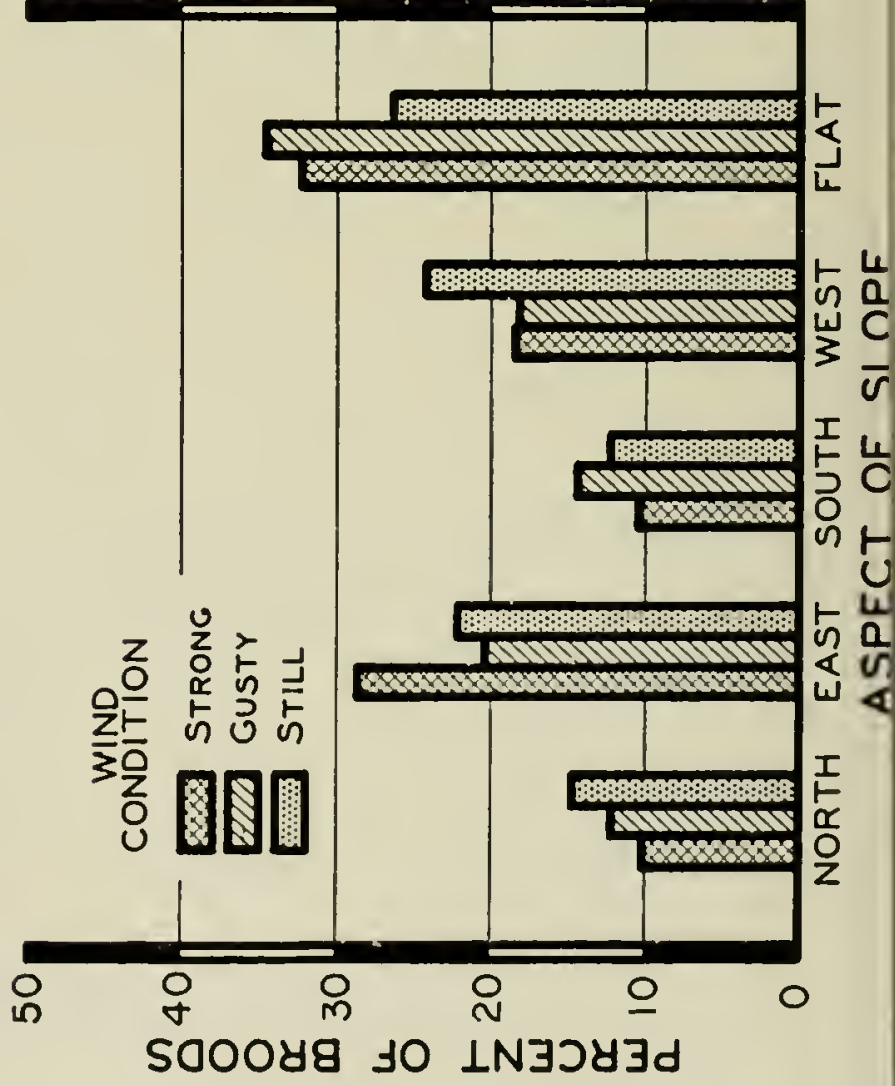



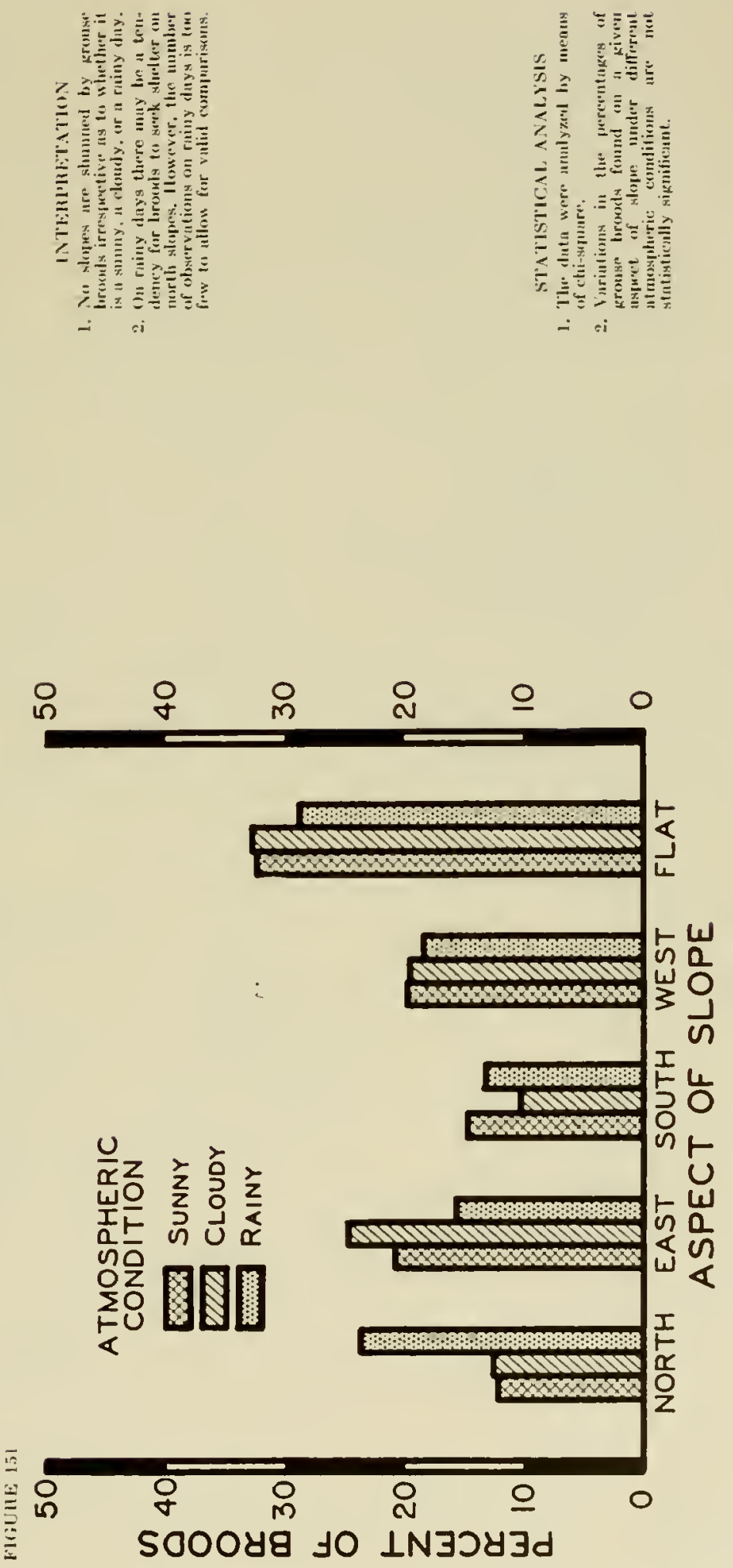


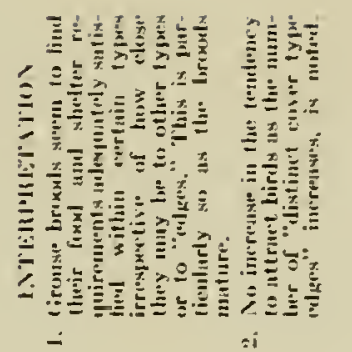

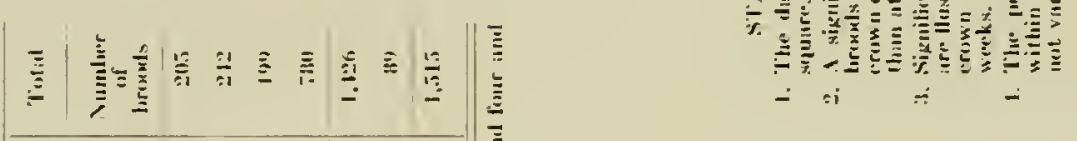

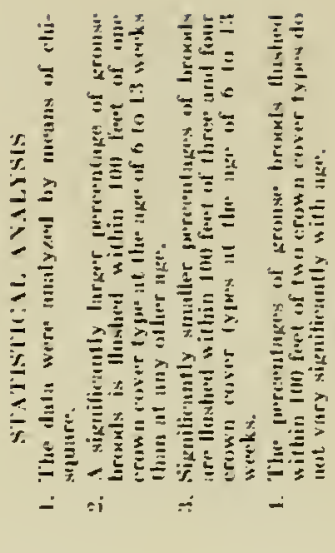

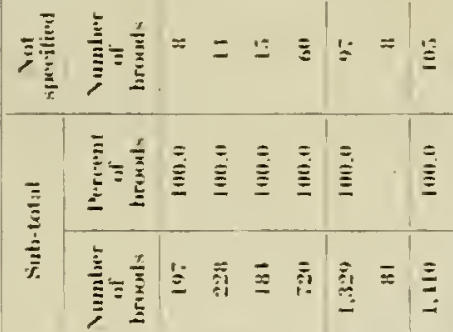

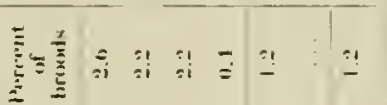

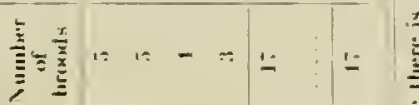

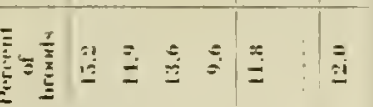

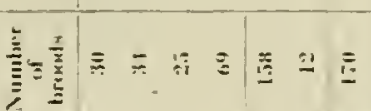

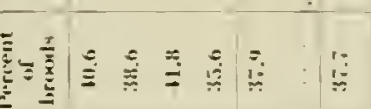

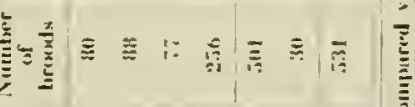

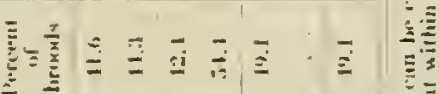

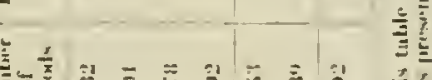

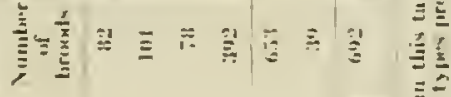
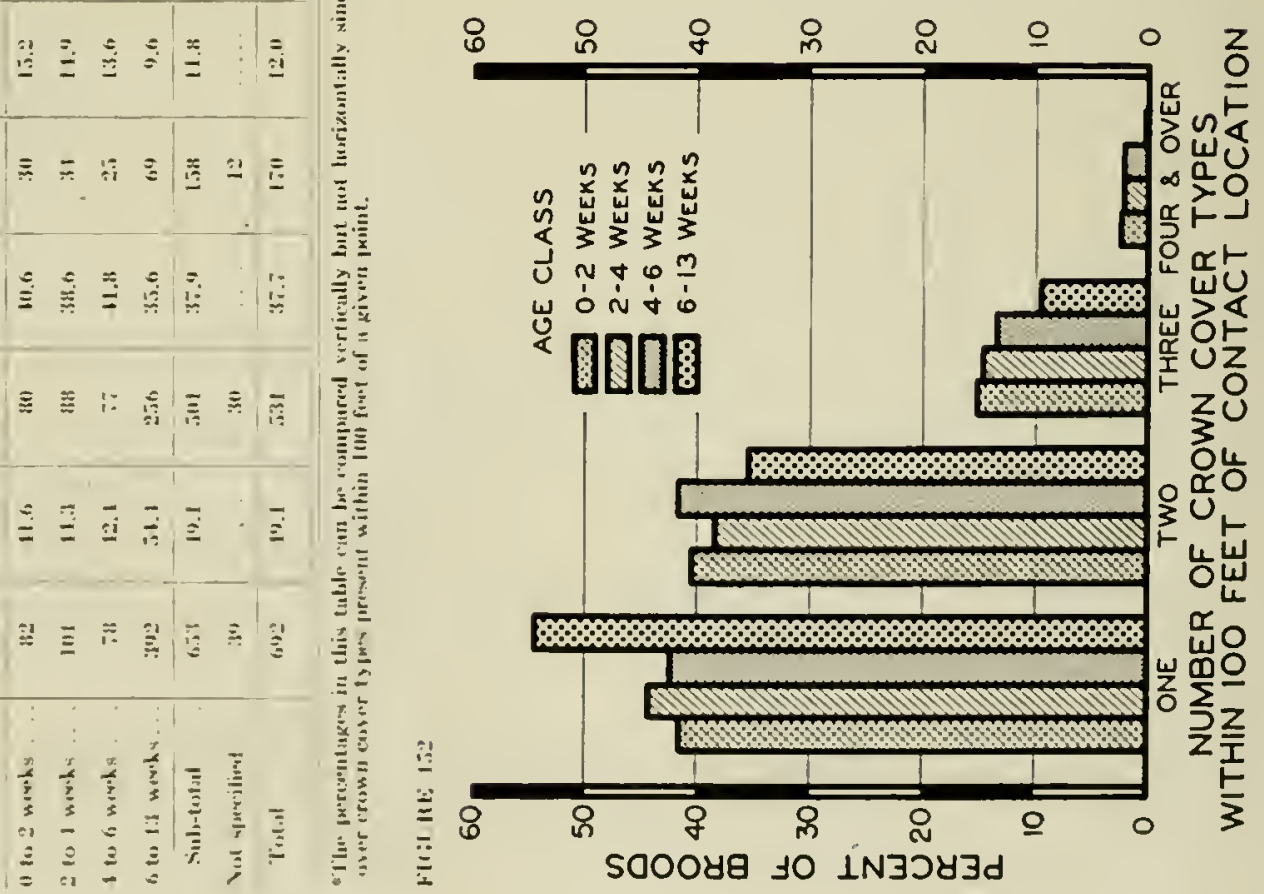


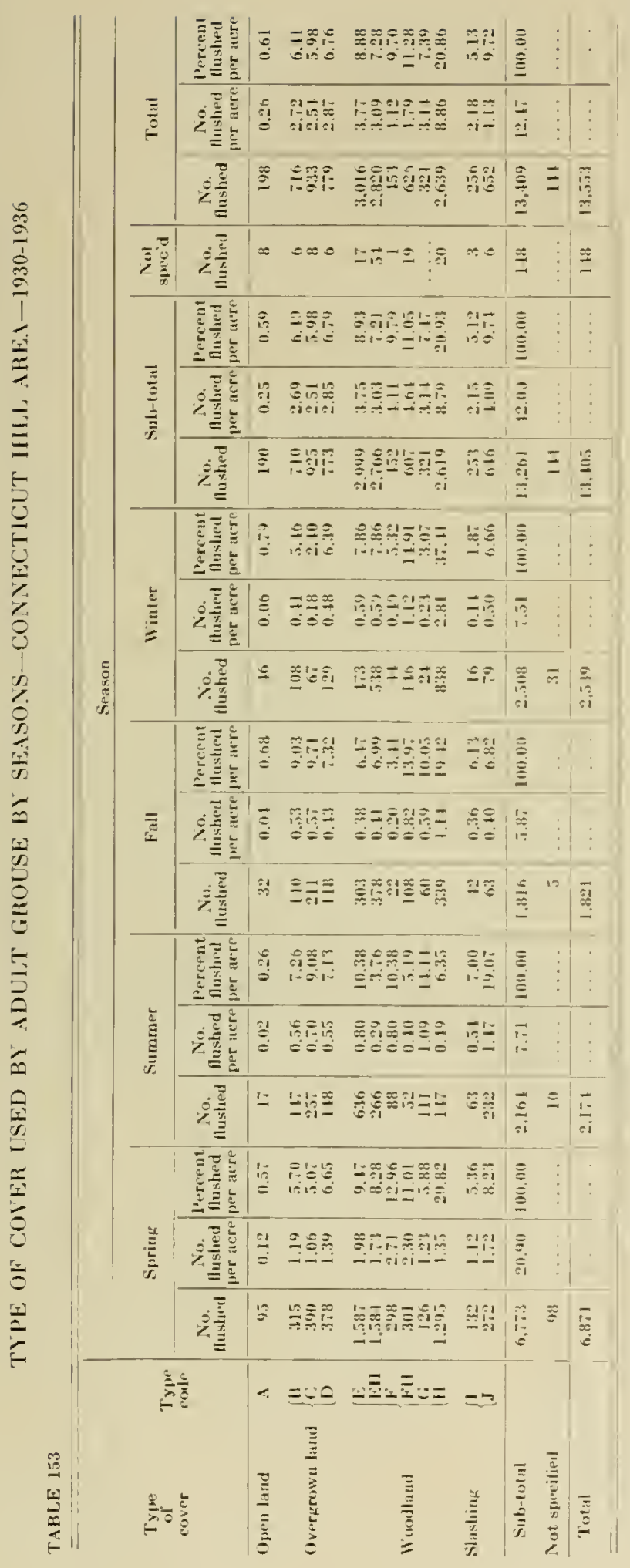

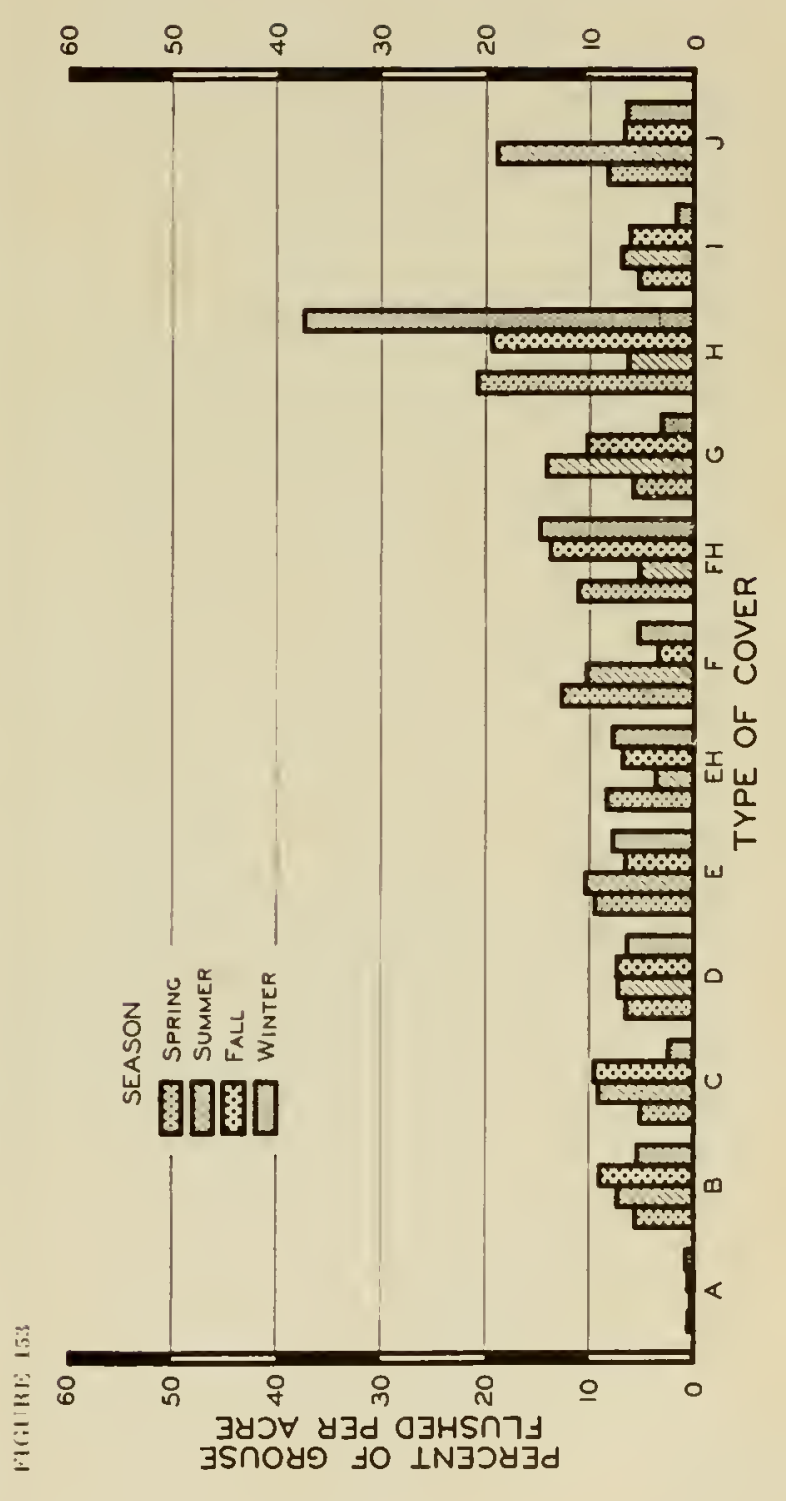




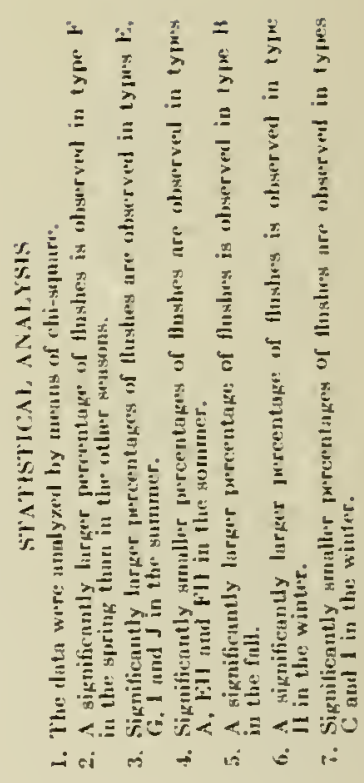




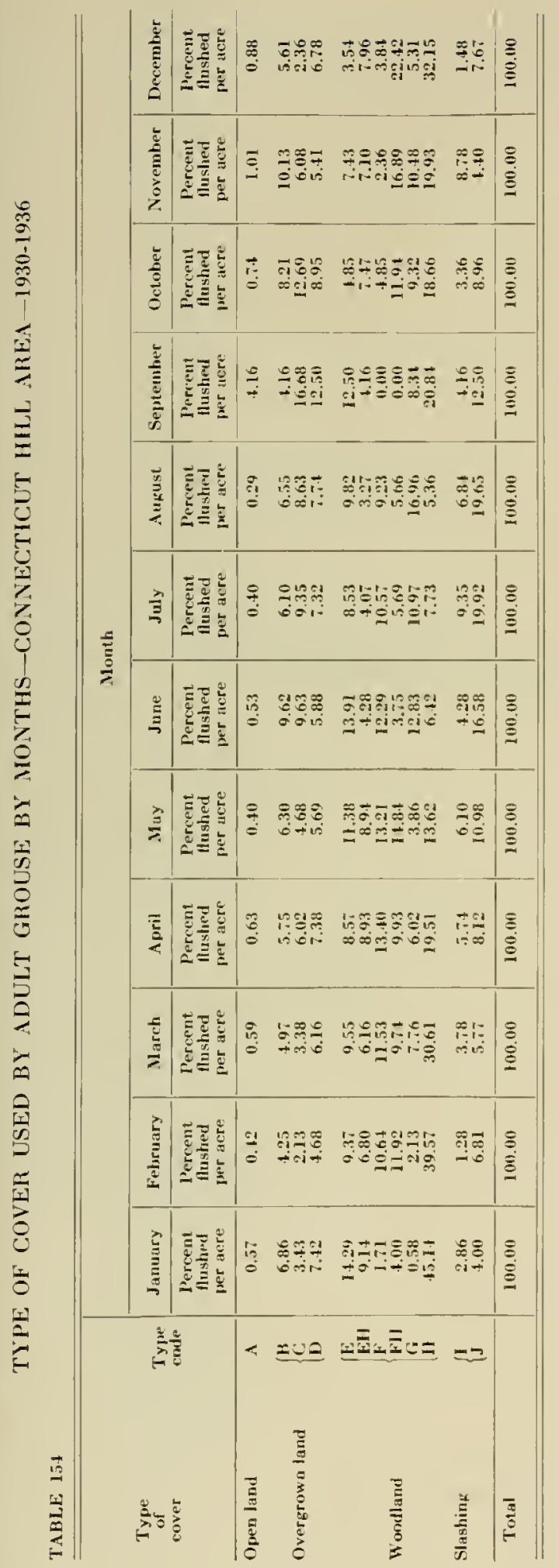

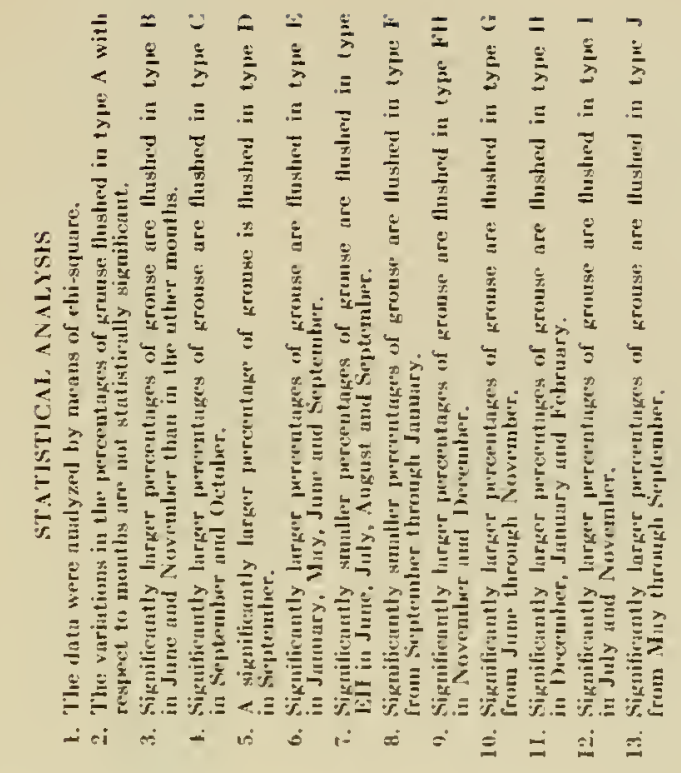

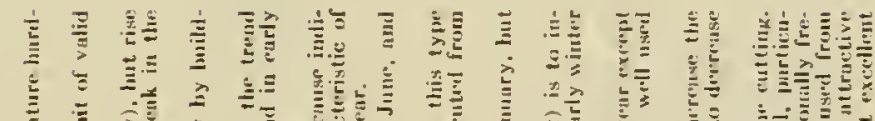

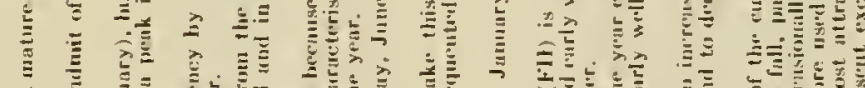

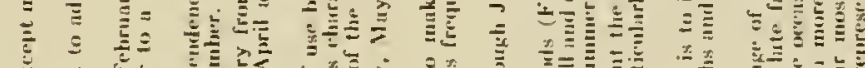

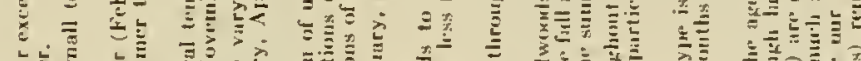

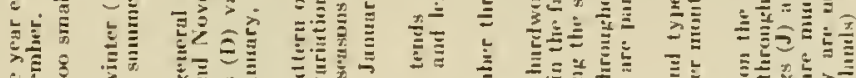

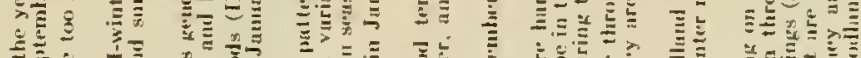

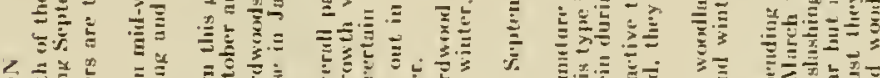

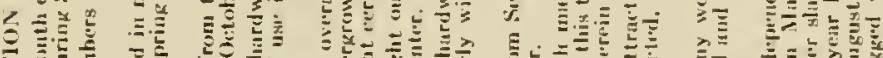

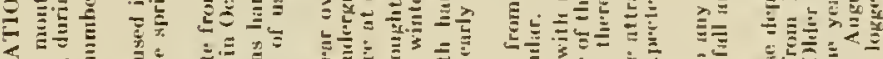

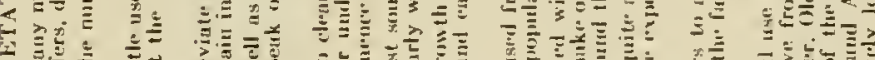

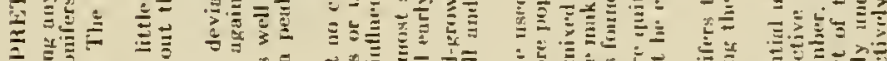

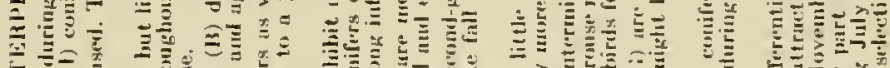

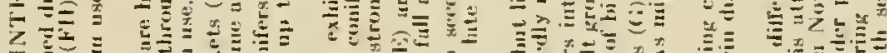

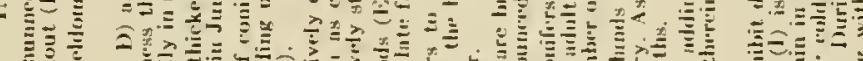

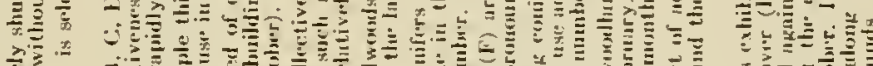

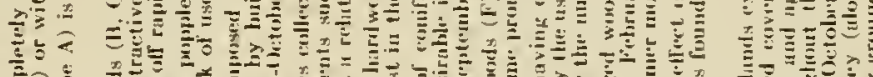

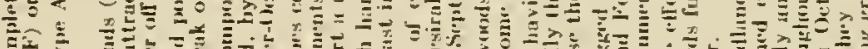

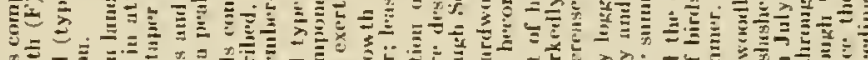

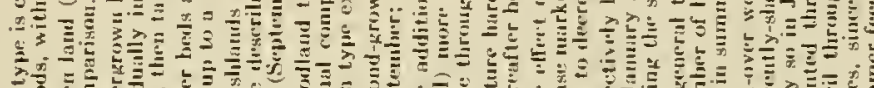

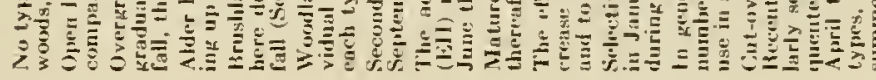




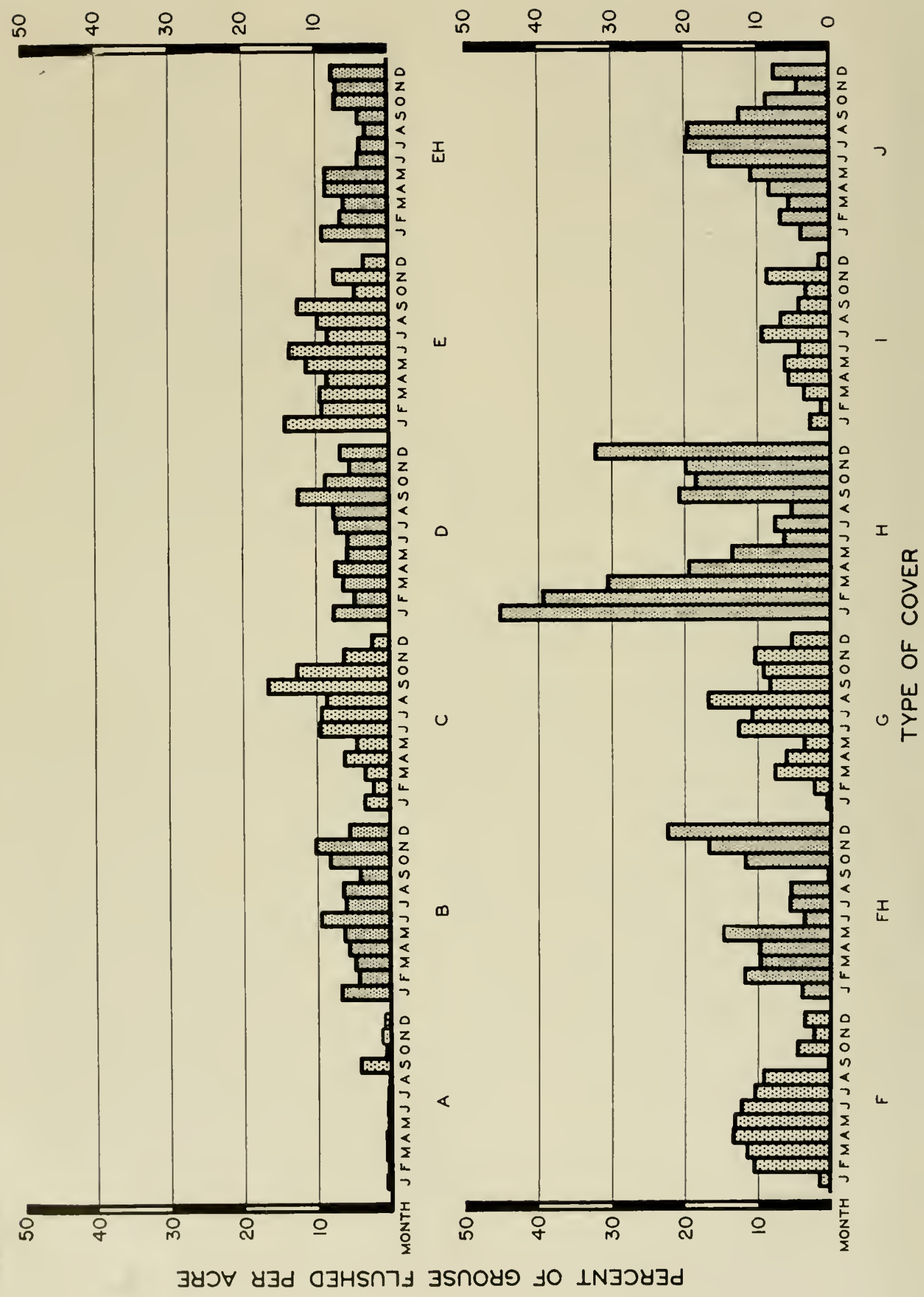



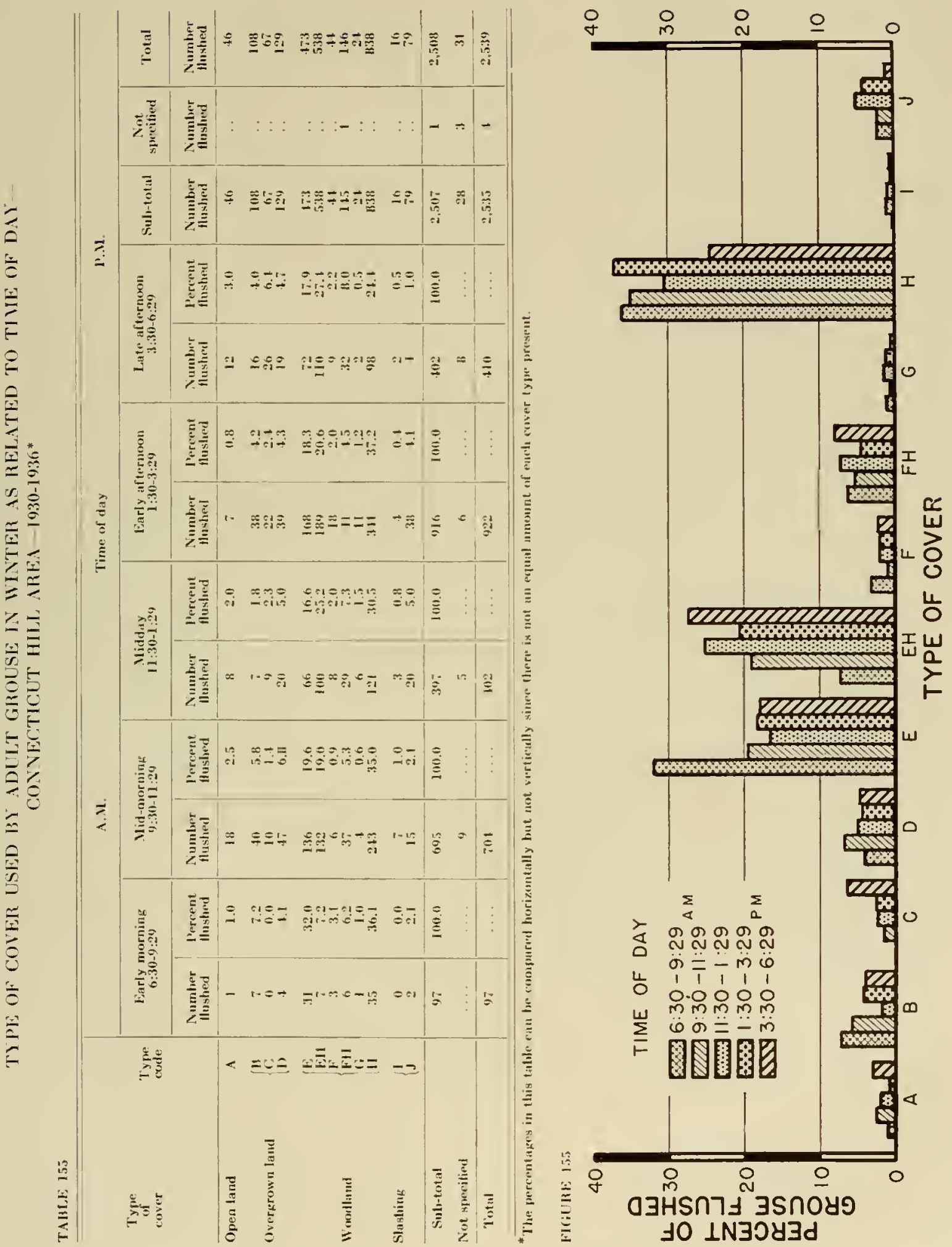

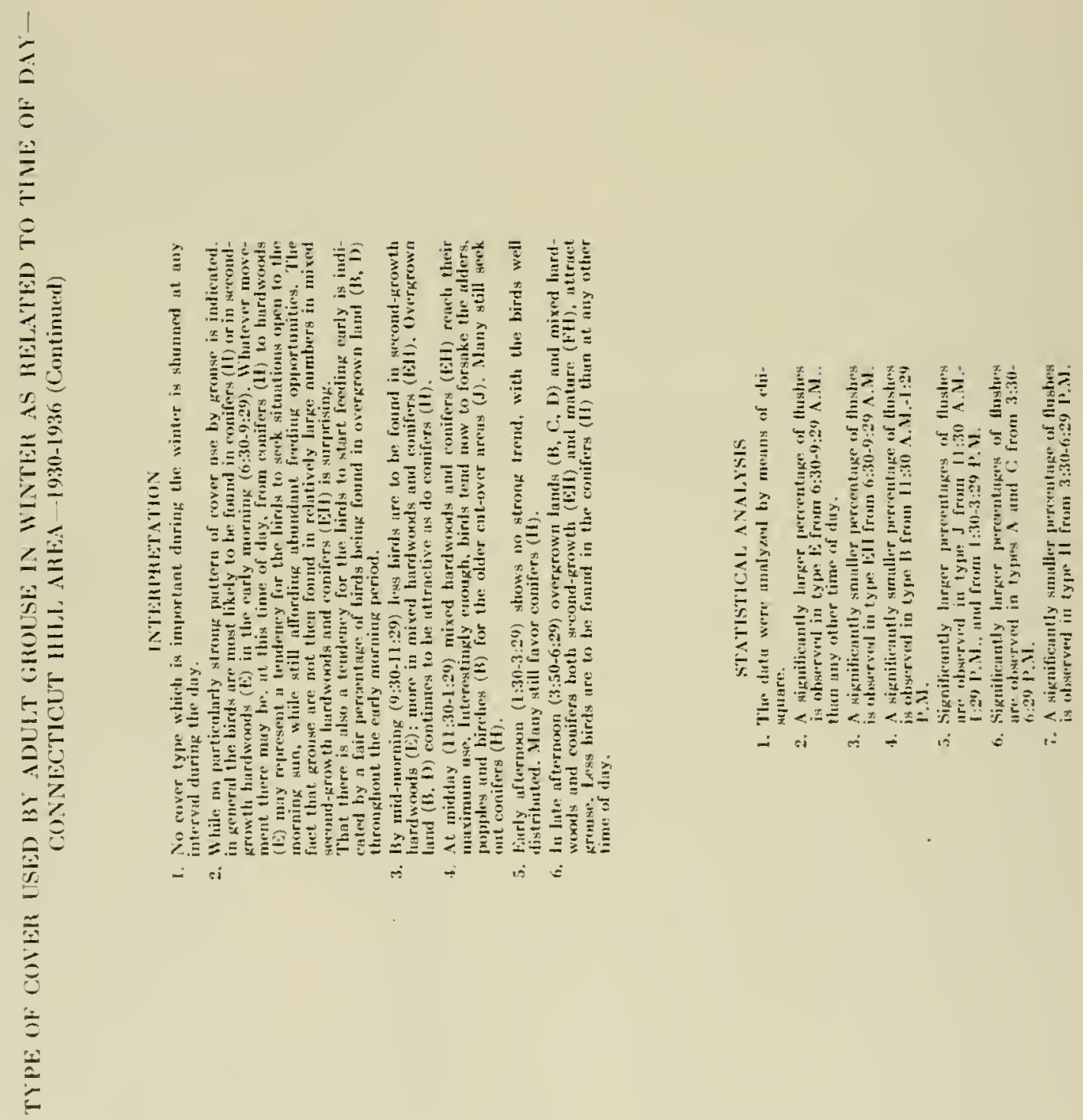


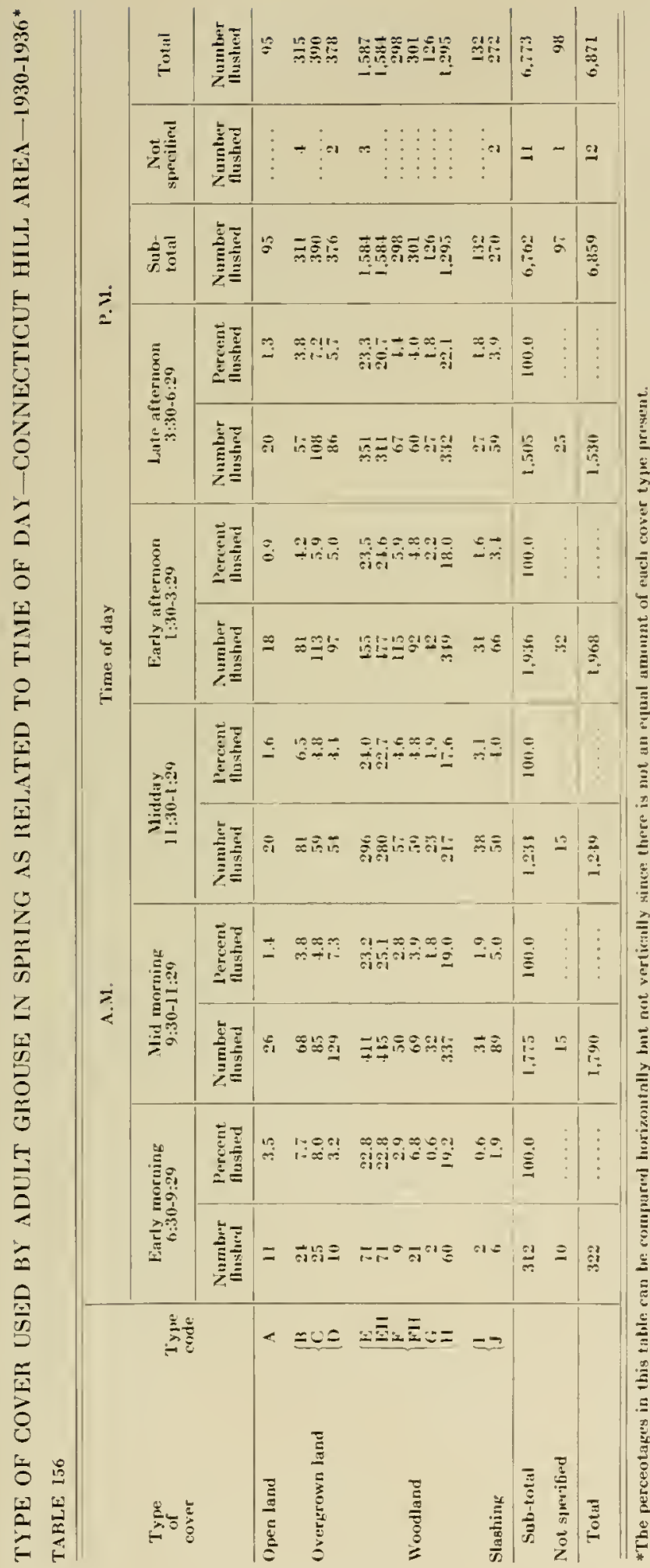

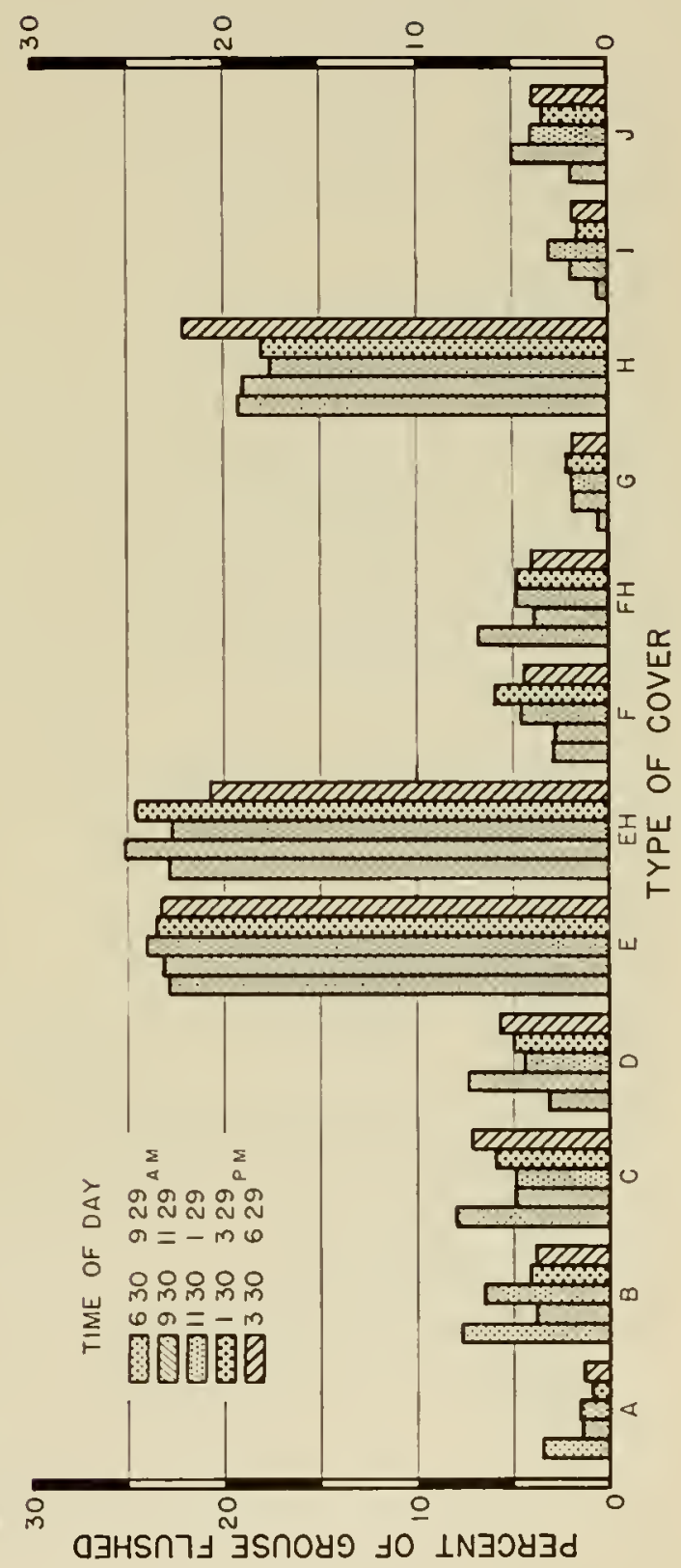




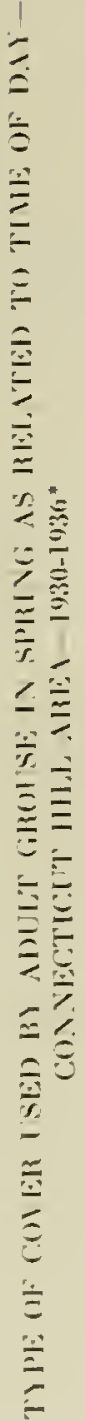

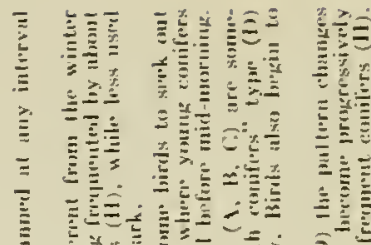

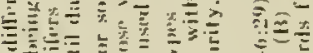
2 2.

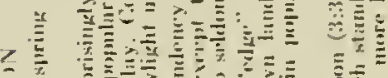

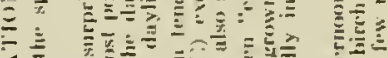
-

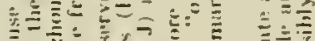

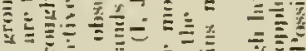

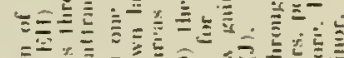

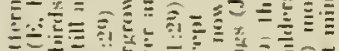

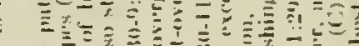
气

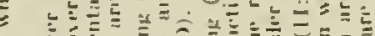

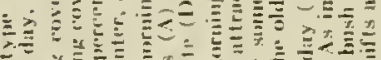

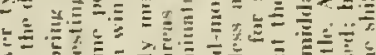

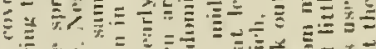

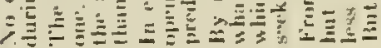

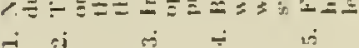

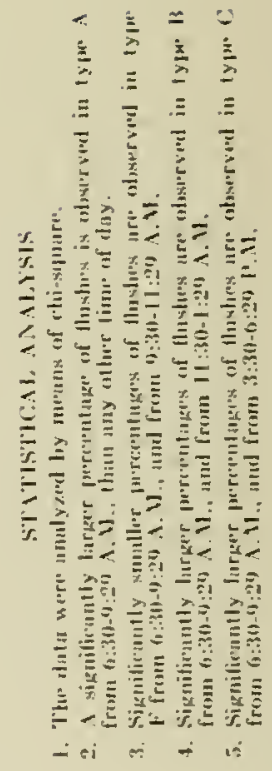



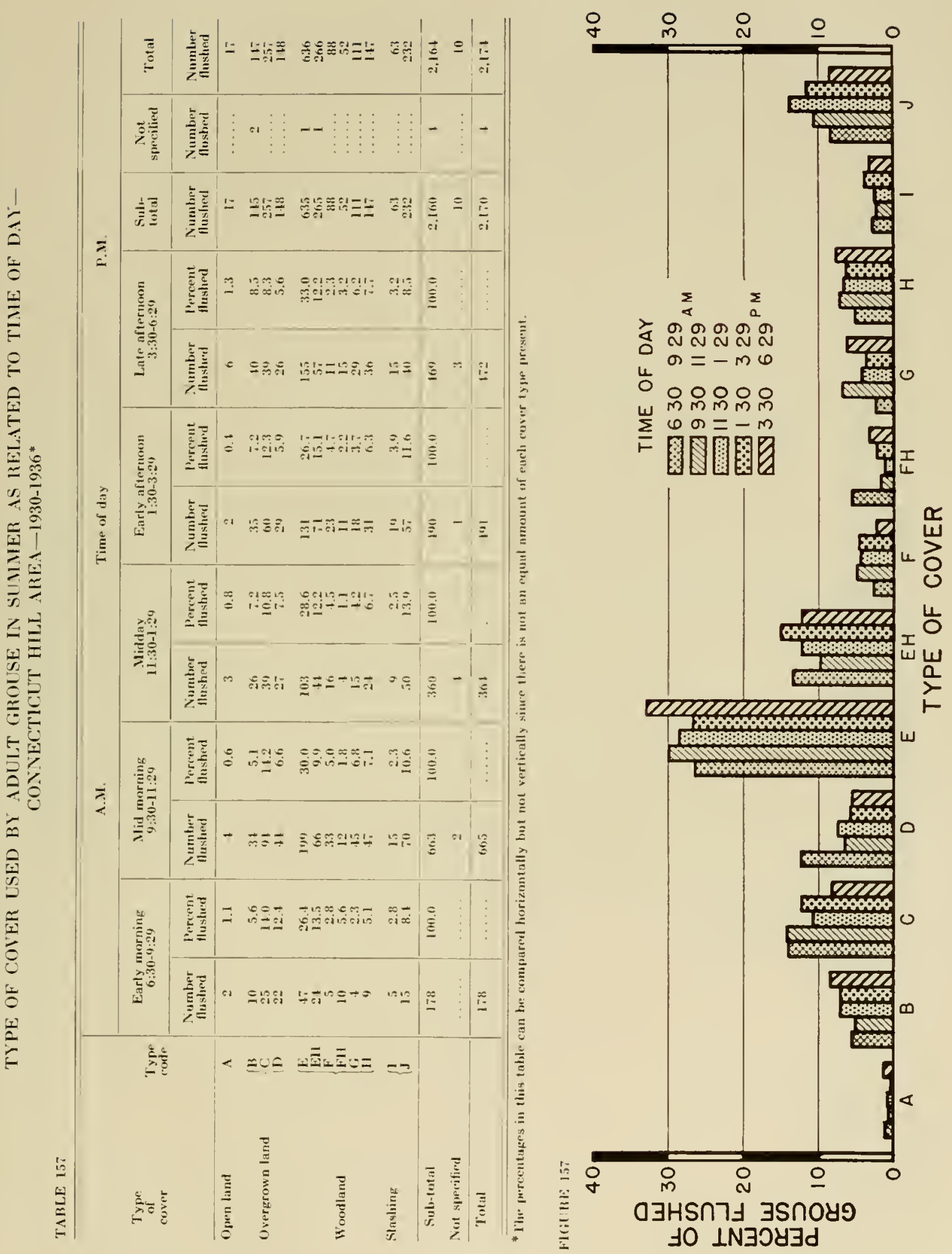

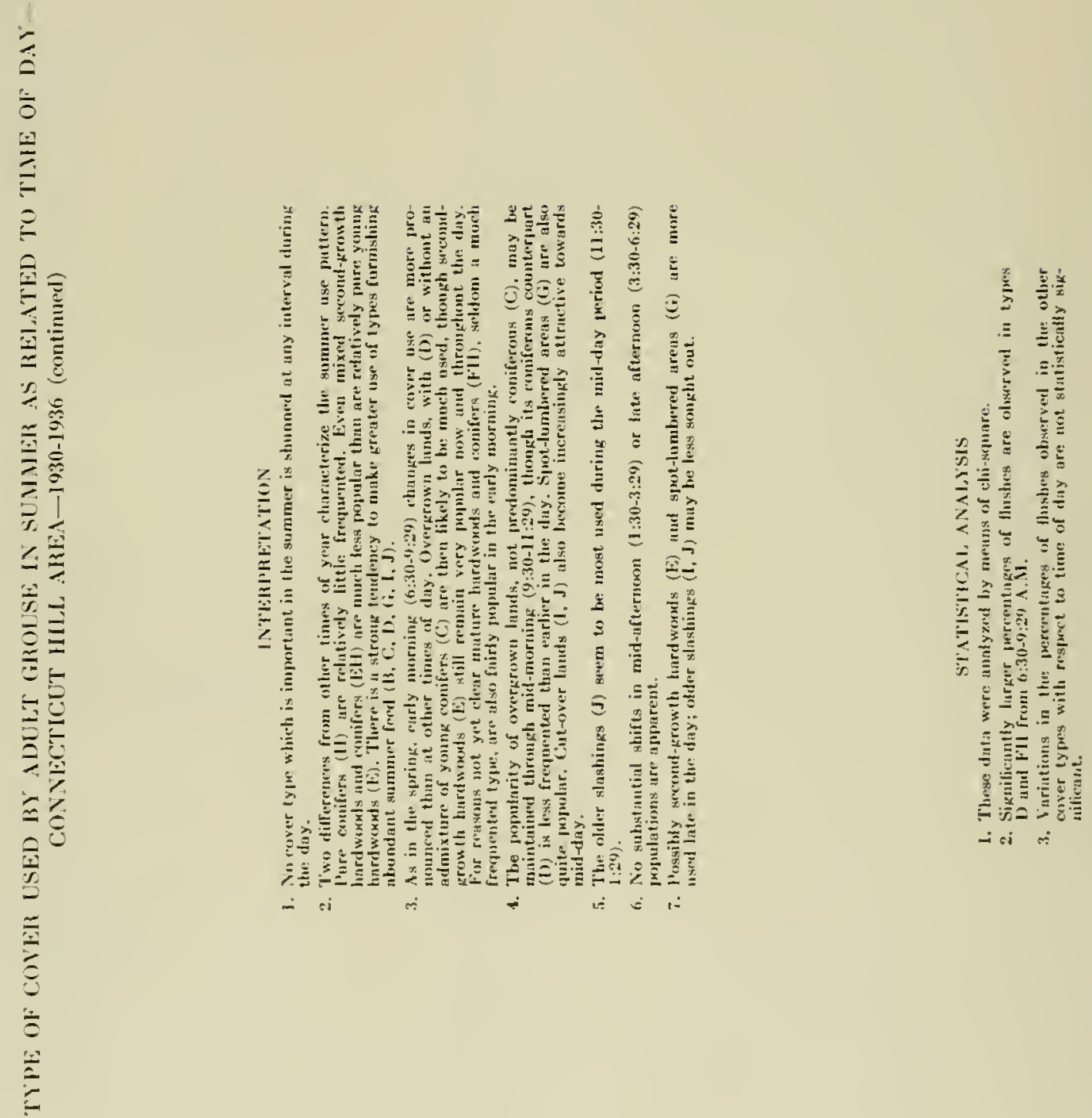


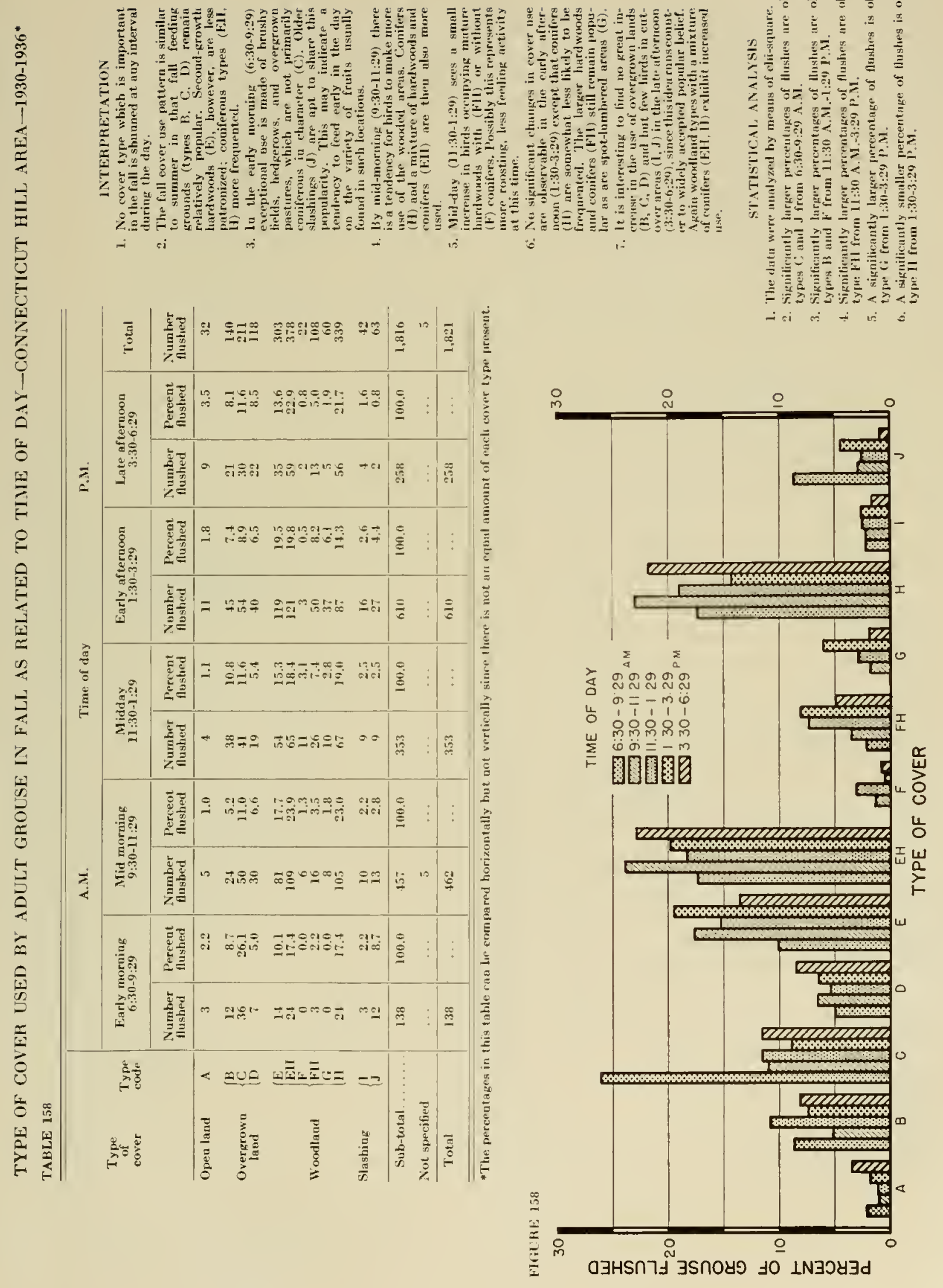



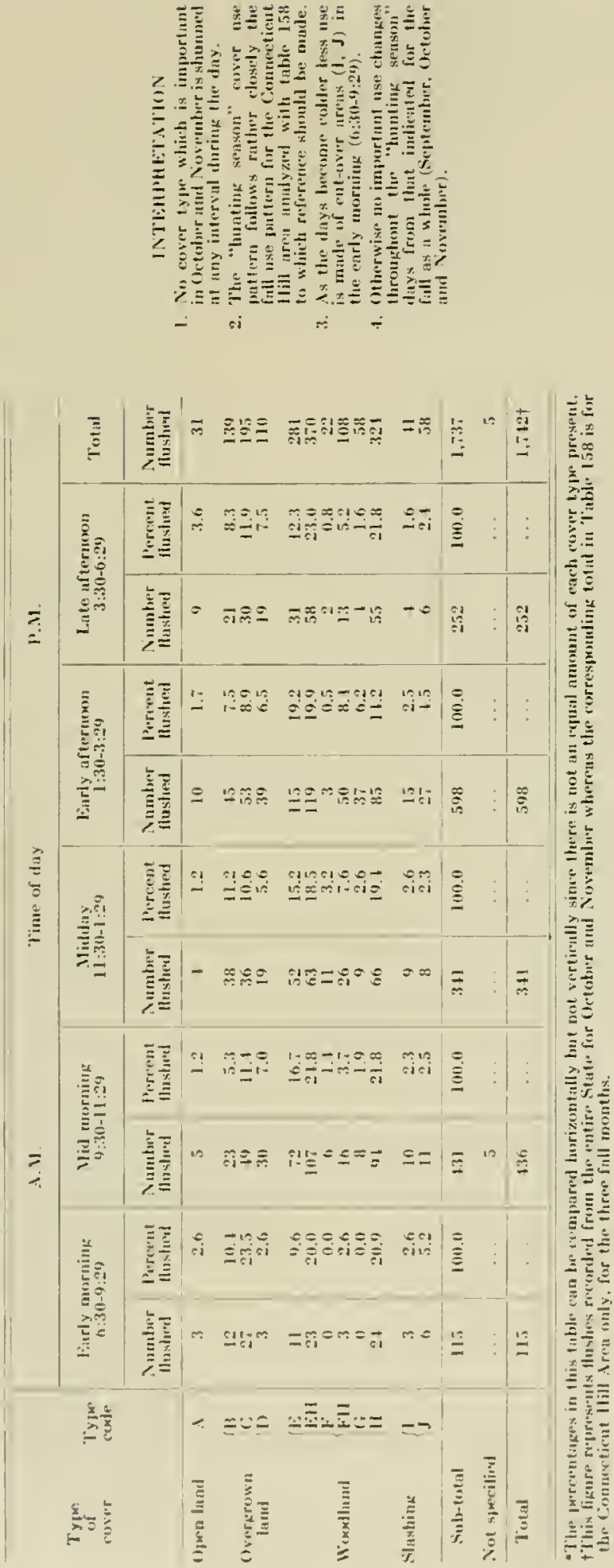

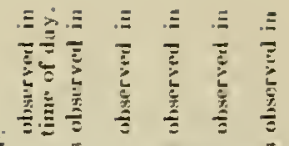

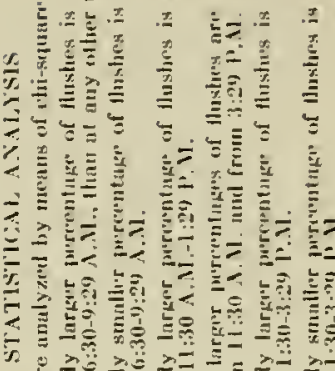

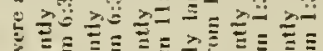

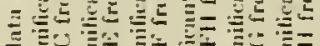

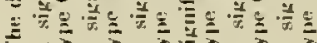

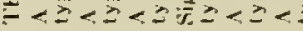

$\therefore \therefore \div \therefore<1:$

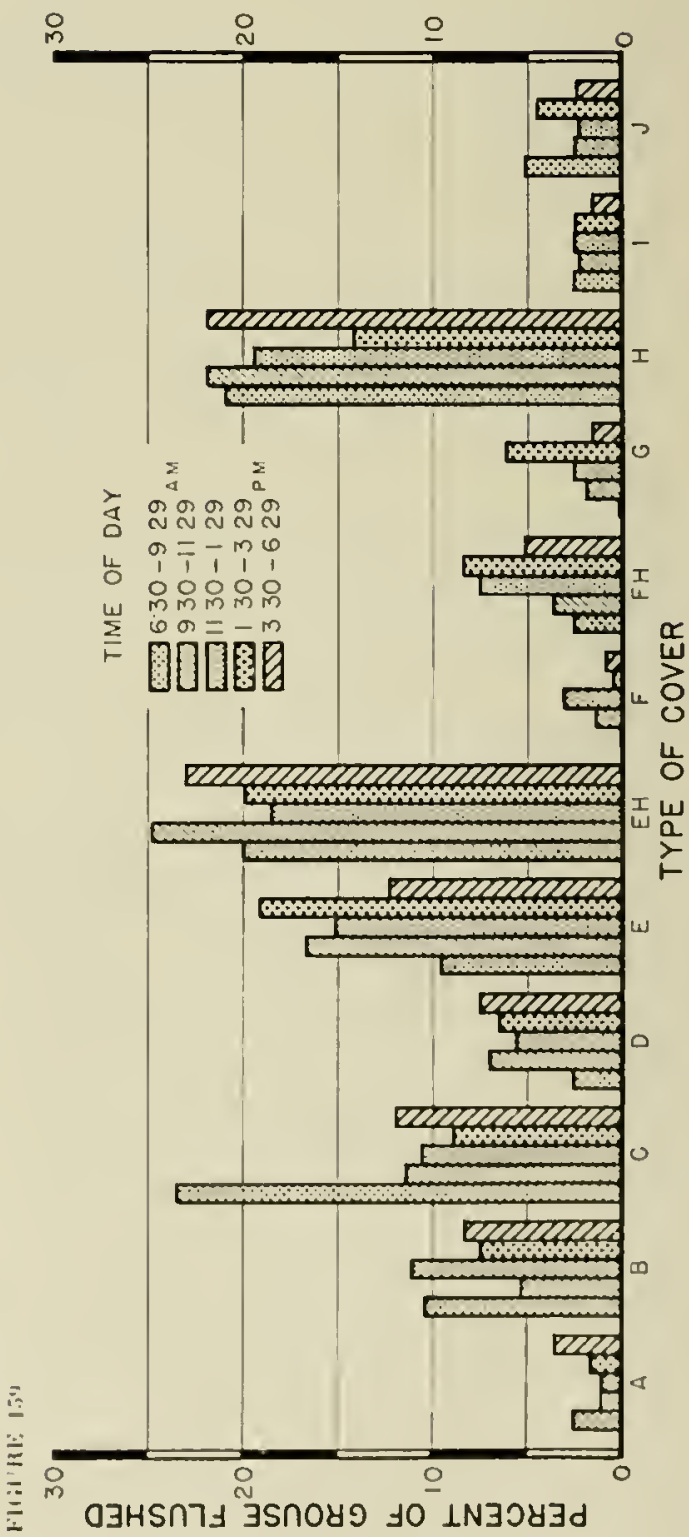



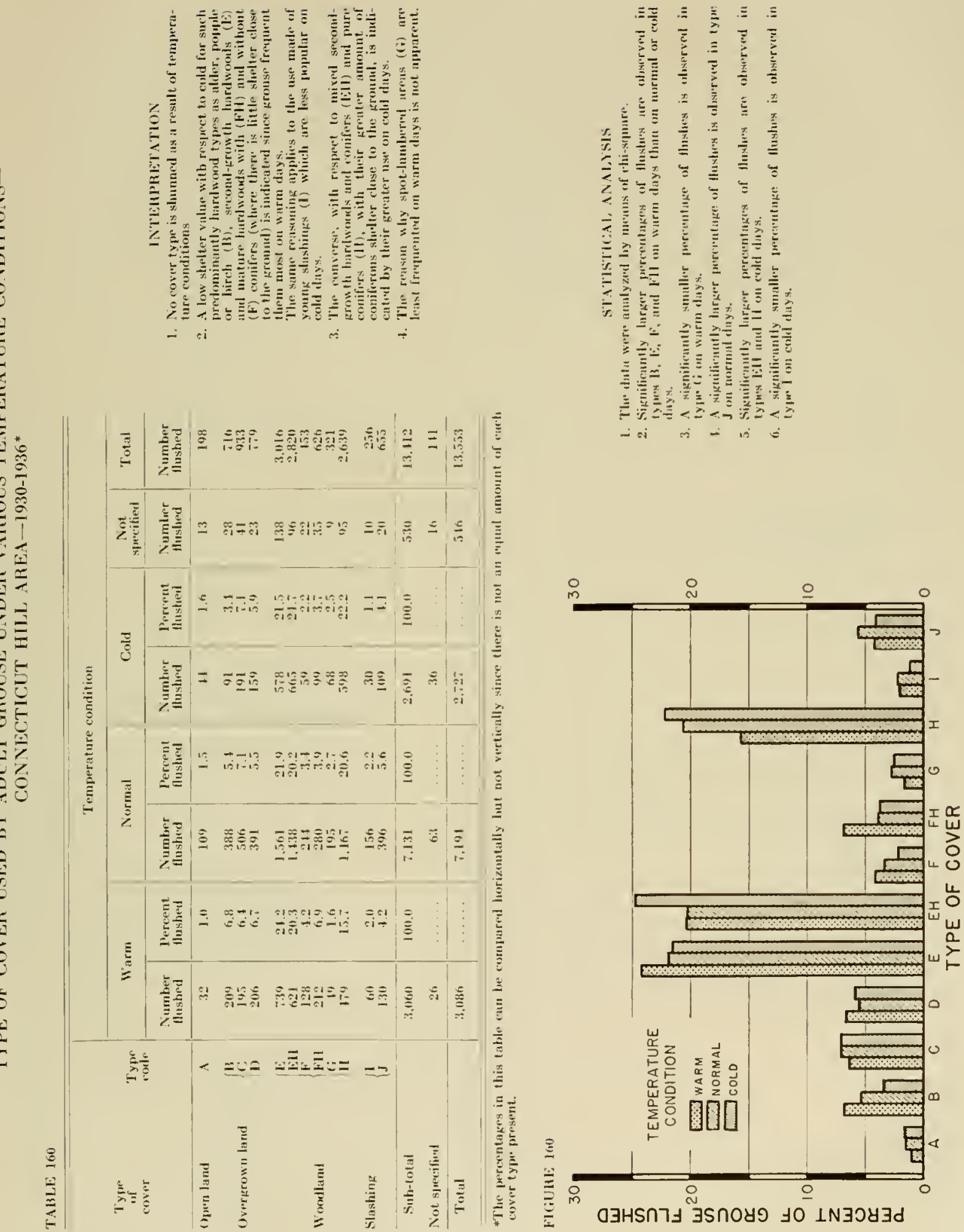

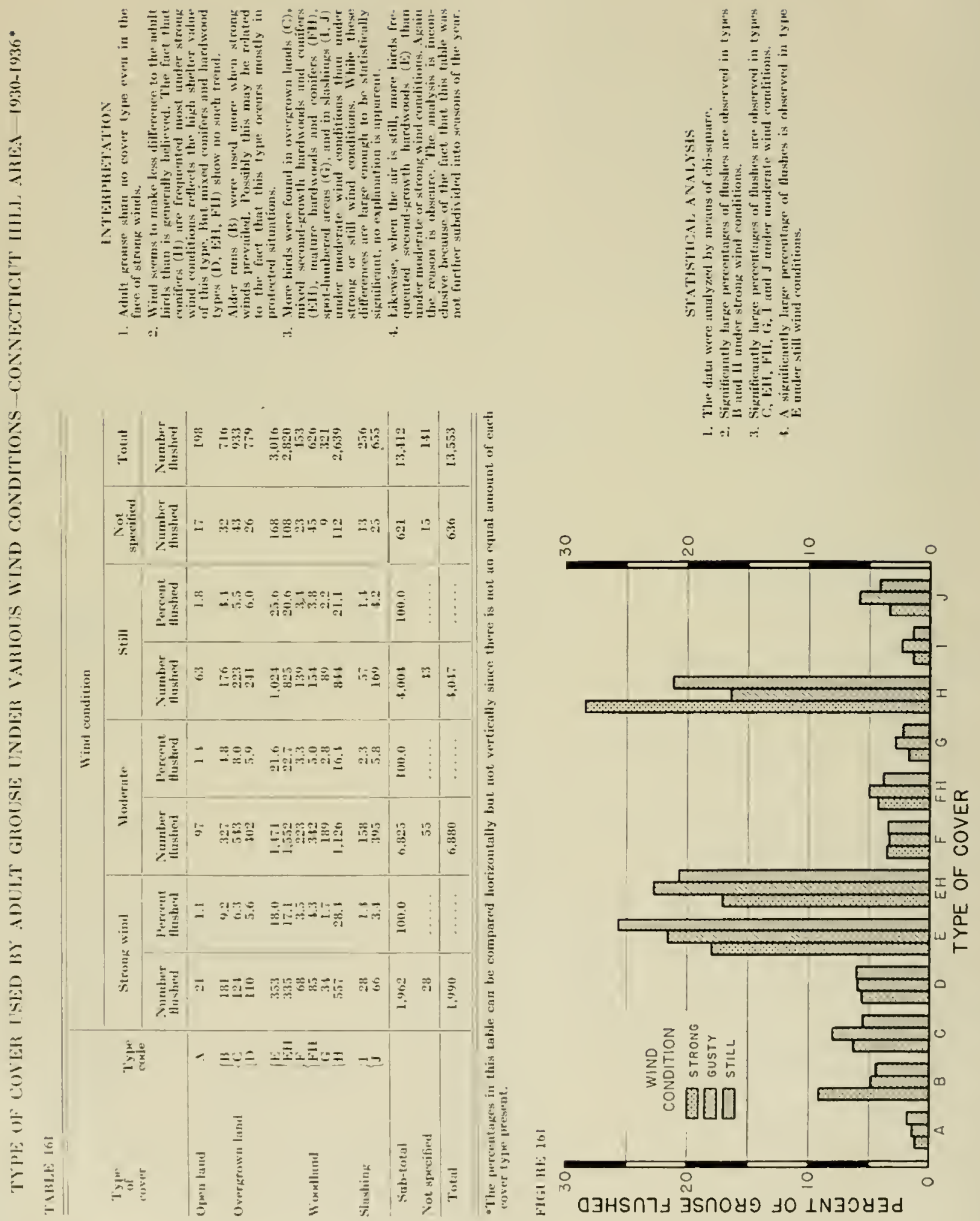


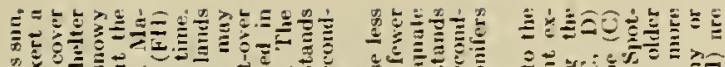

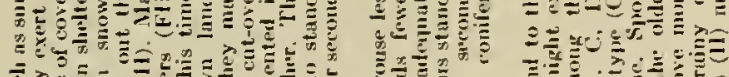

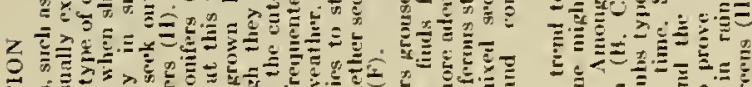
等 40

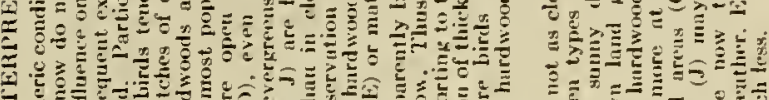

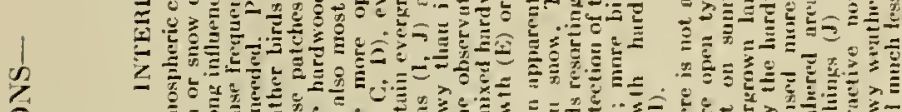
思

8

正

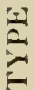

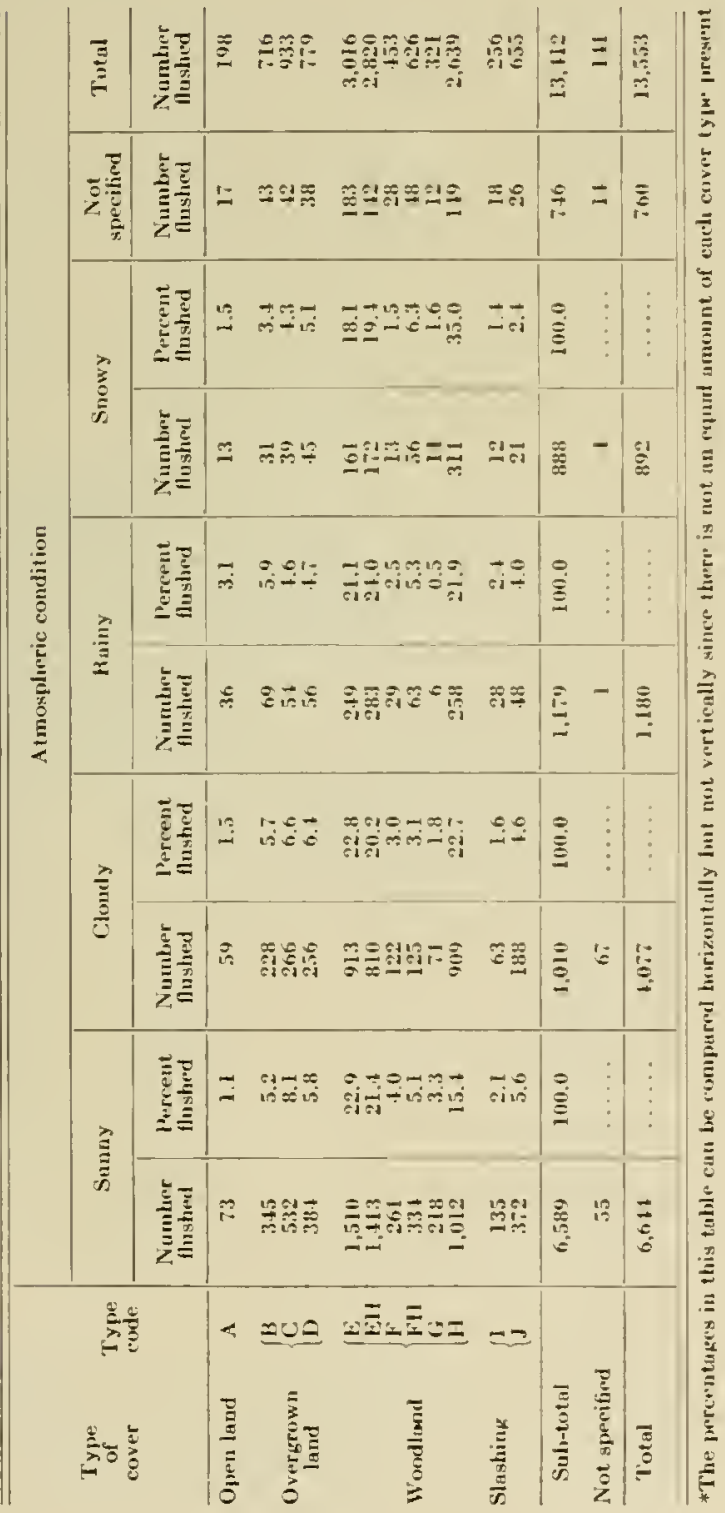
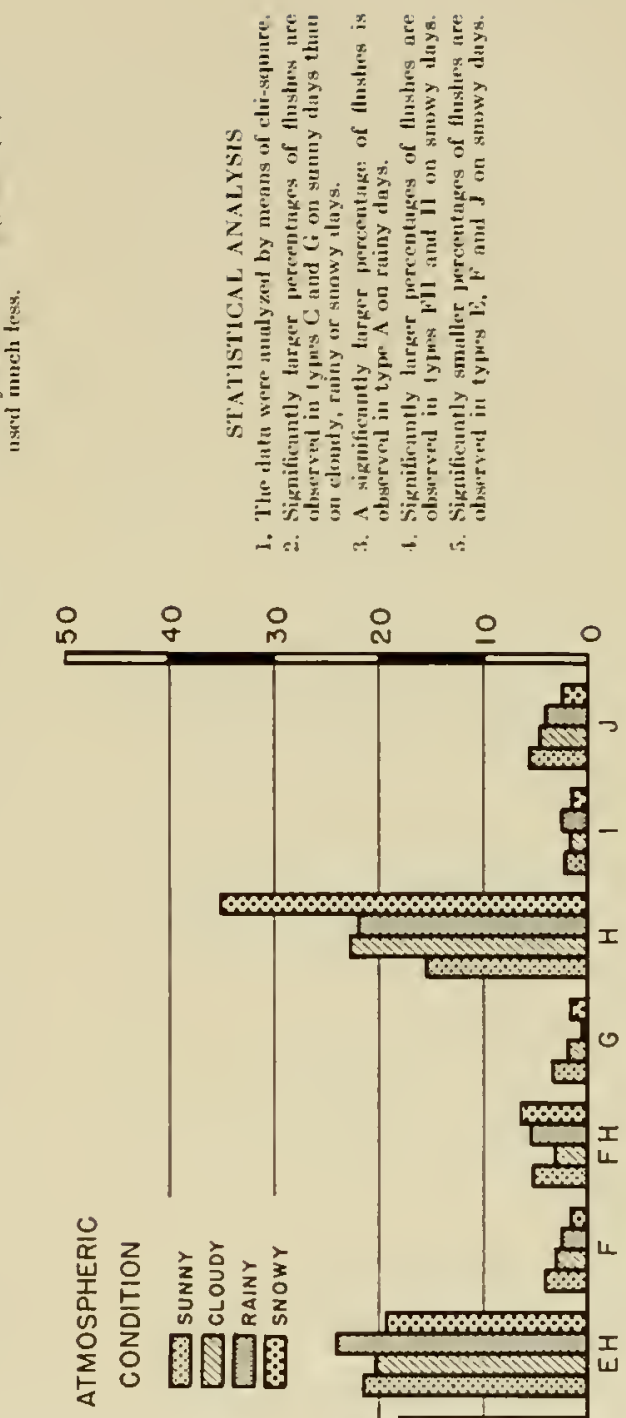

요

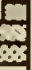

ㄴ.
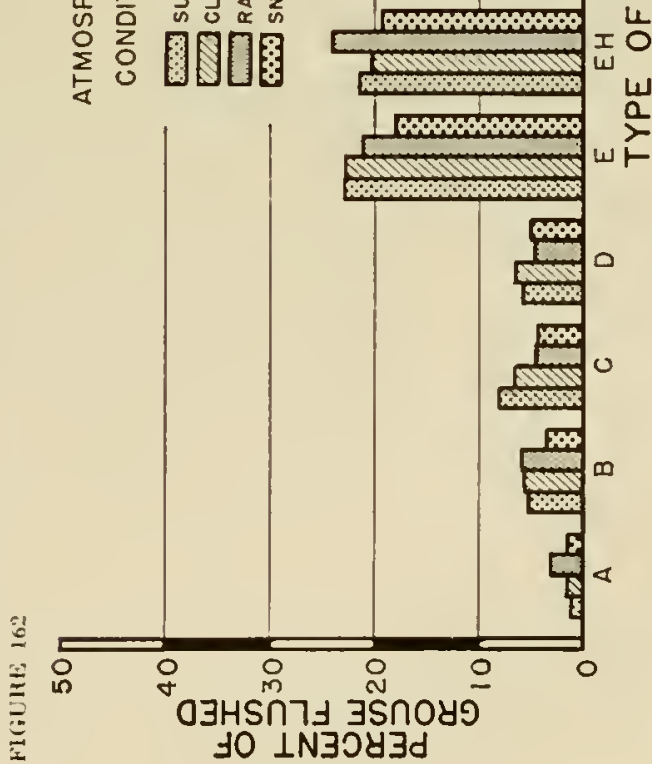

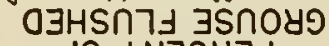
IO $\perp$ N $3043 d$ 


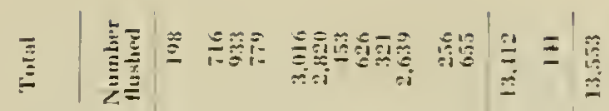

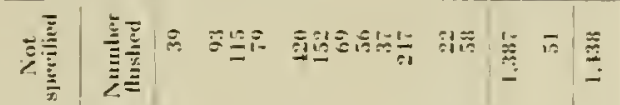

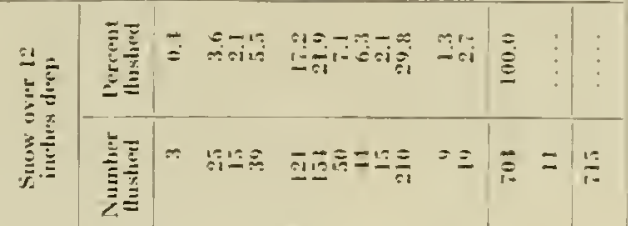

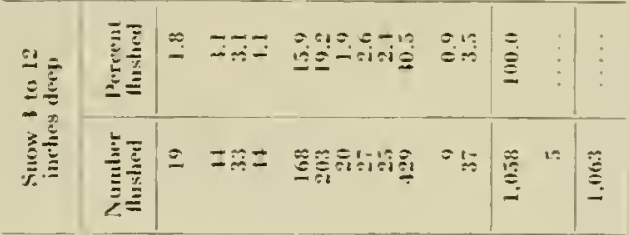

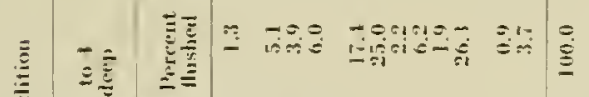
竞

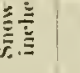

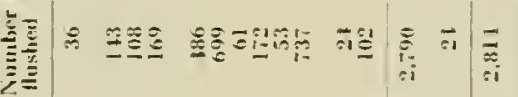

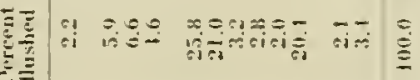

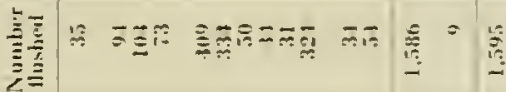

i

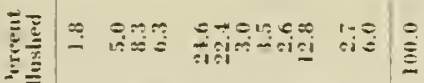

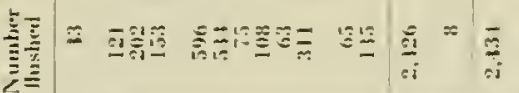

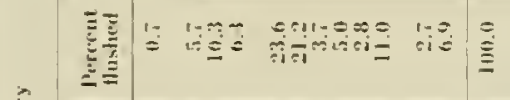

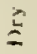

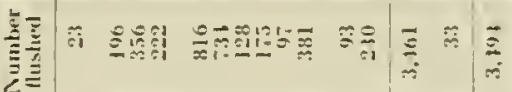

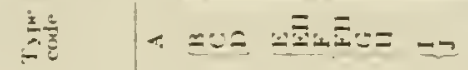

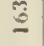

产

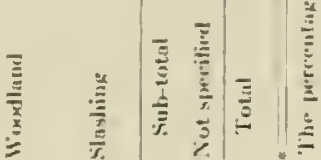

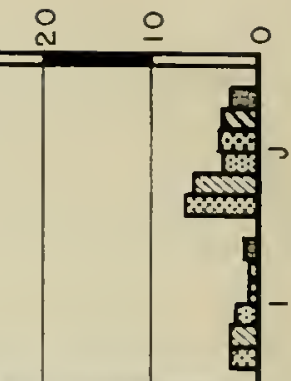
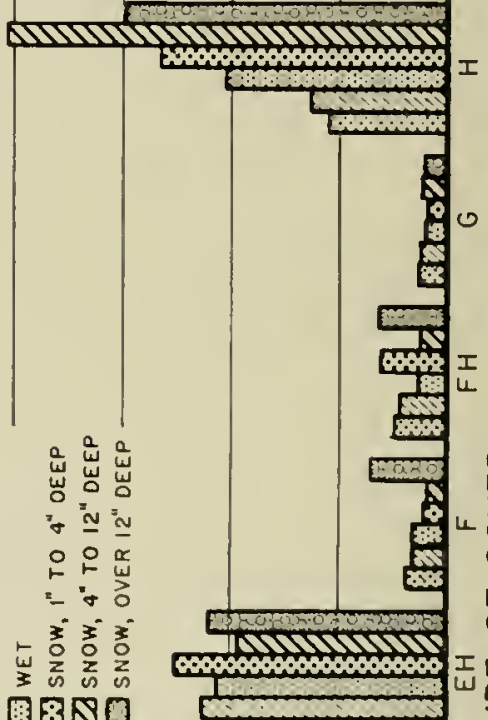

를

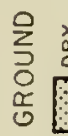

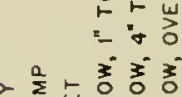
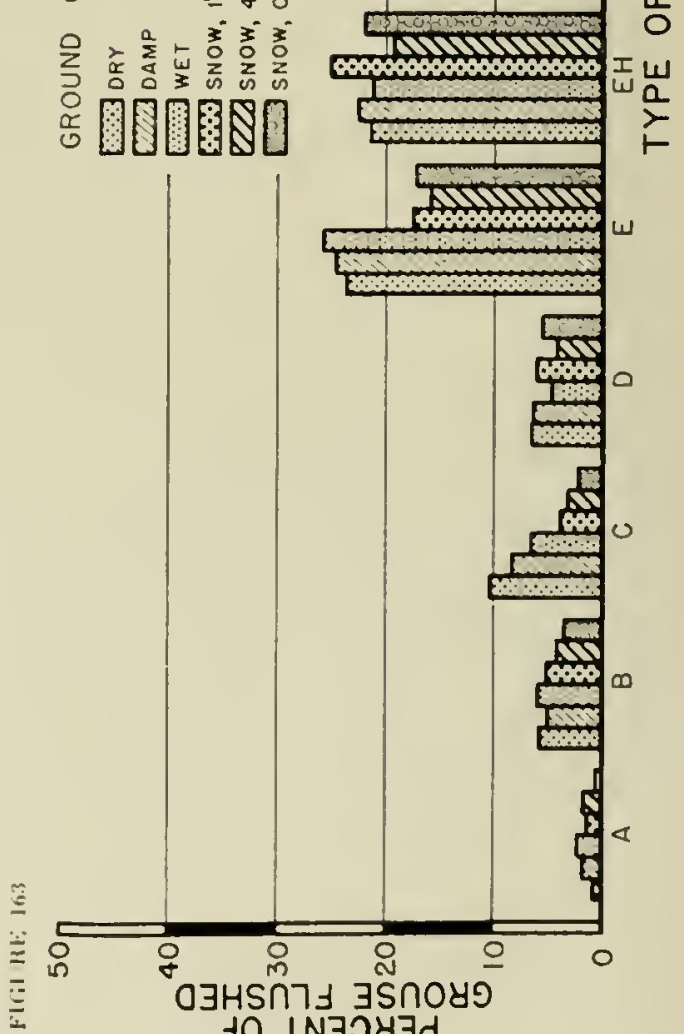

둥

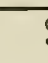

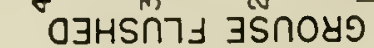
to $\perp$ N $\exists$ Y $\exists d$ 


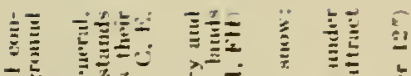

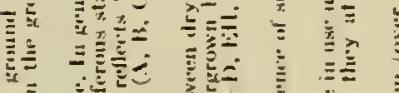

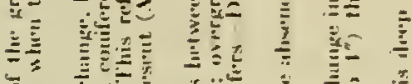

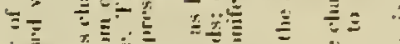

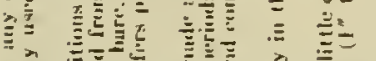

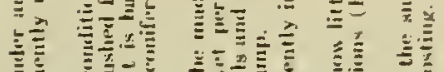

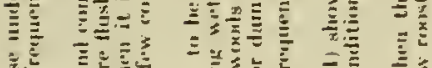

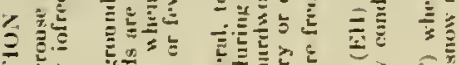

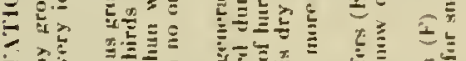

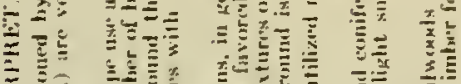

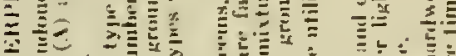

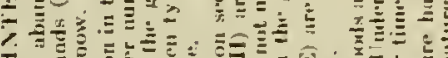

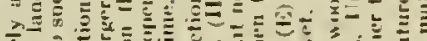

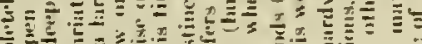

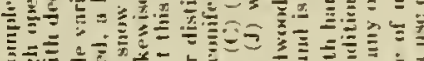

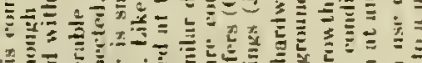

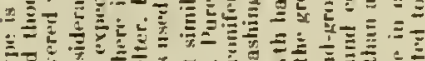

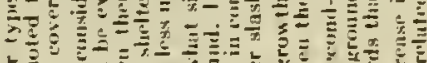

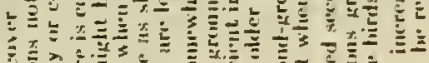

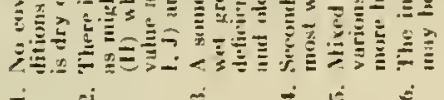

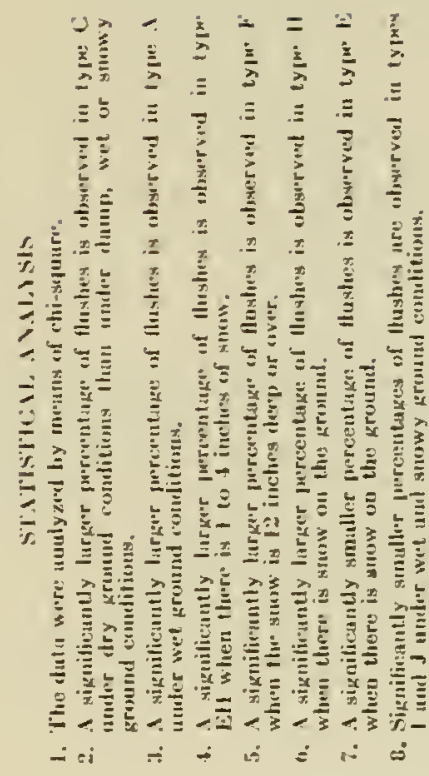




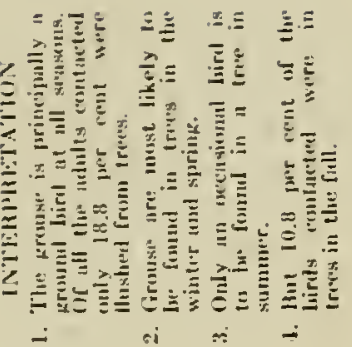

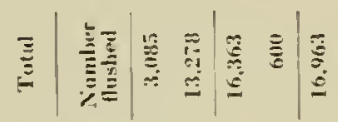

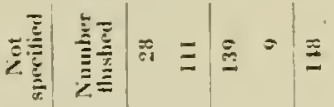

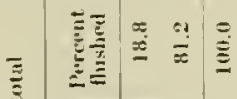

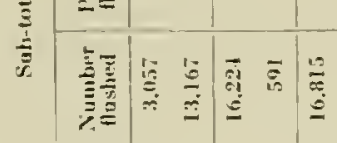

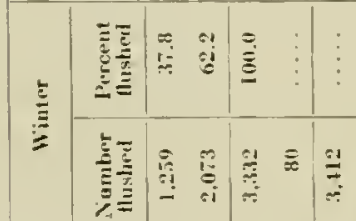
.

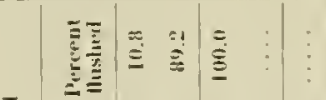$$
\overline{\underline{\underline{P}}}
$$$$
\overline{\bar{E}}
$$

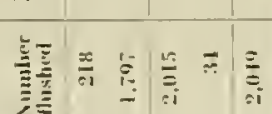
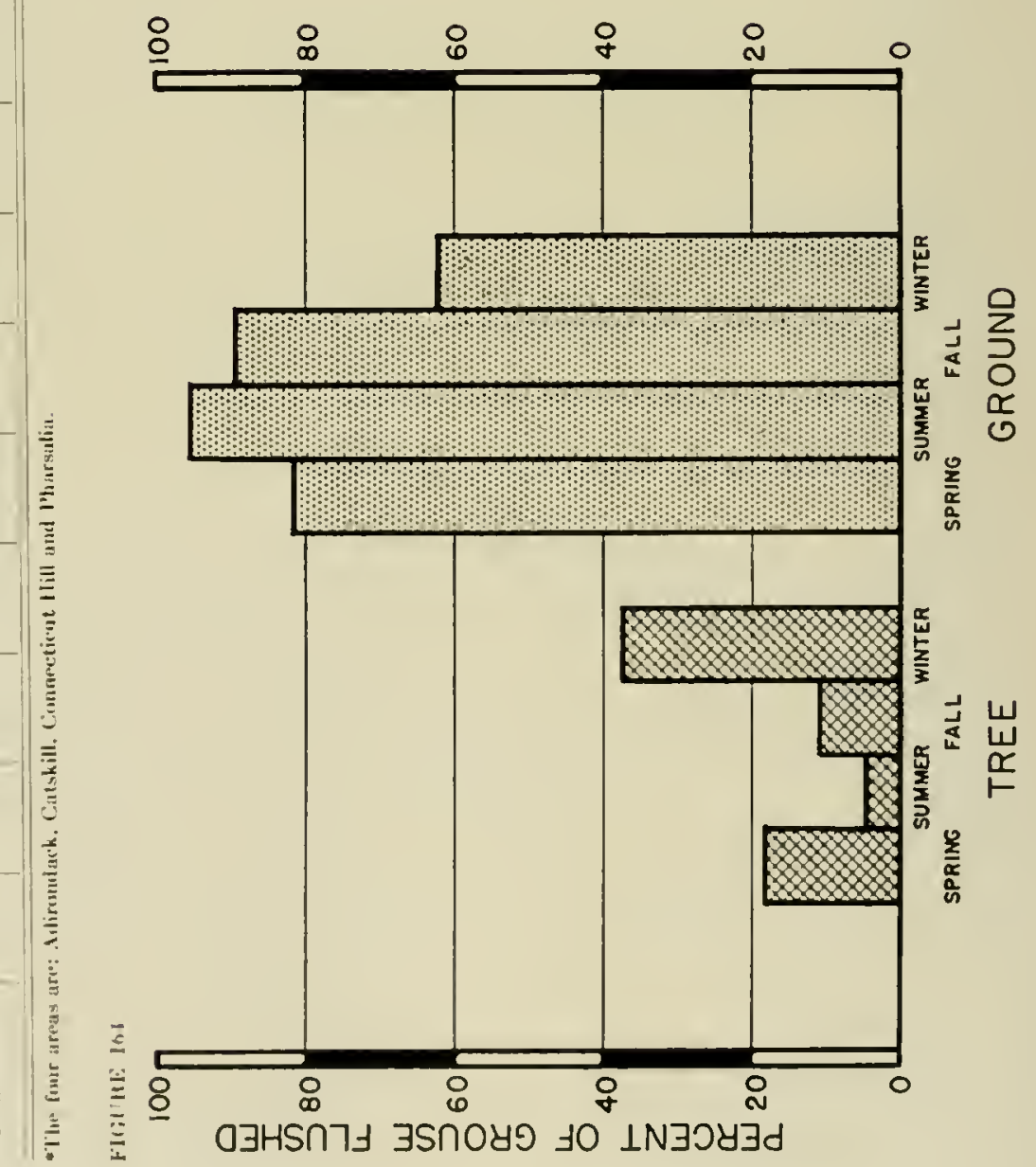


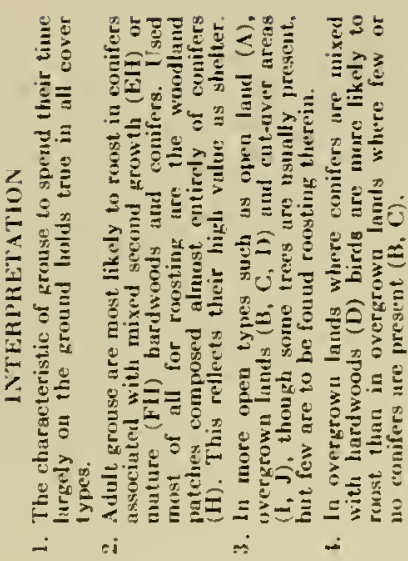

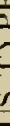

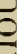

|

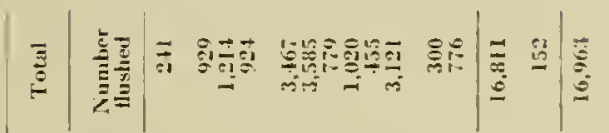

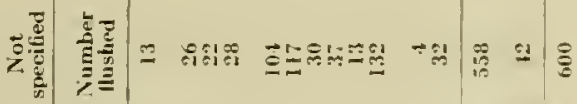

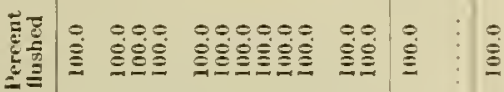

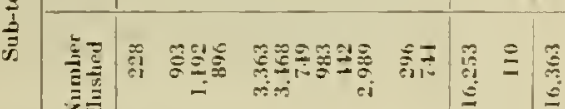

|

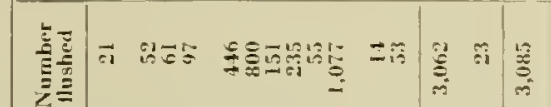

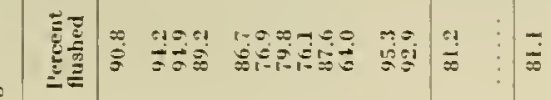

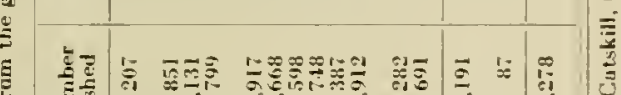

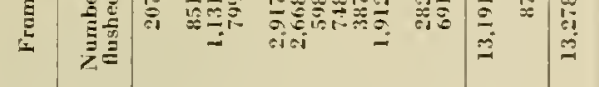

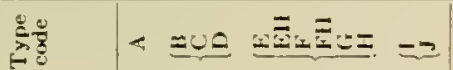

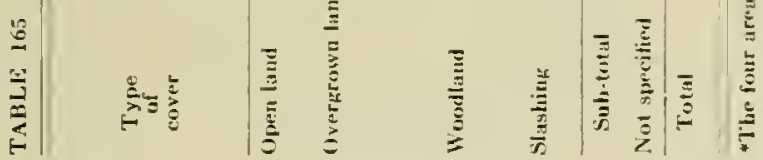
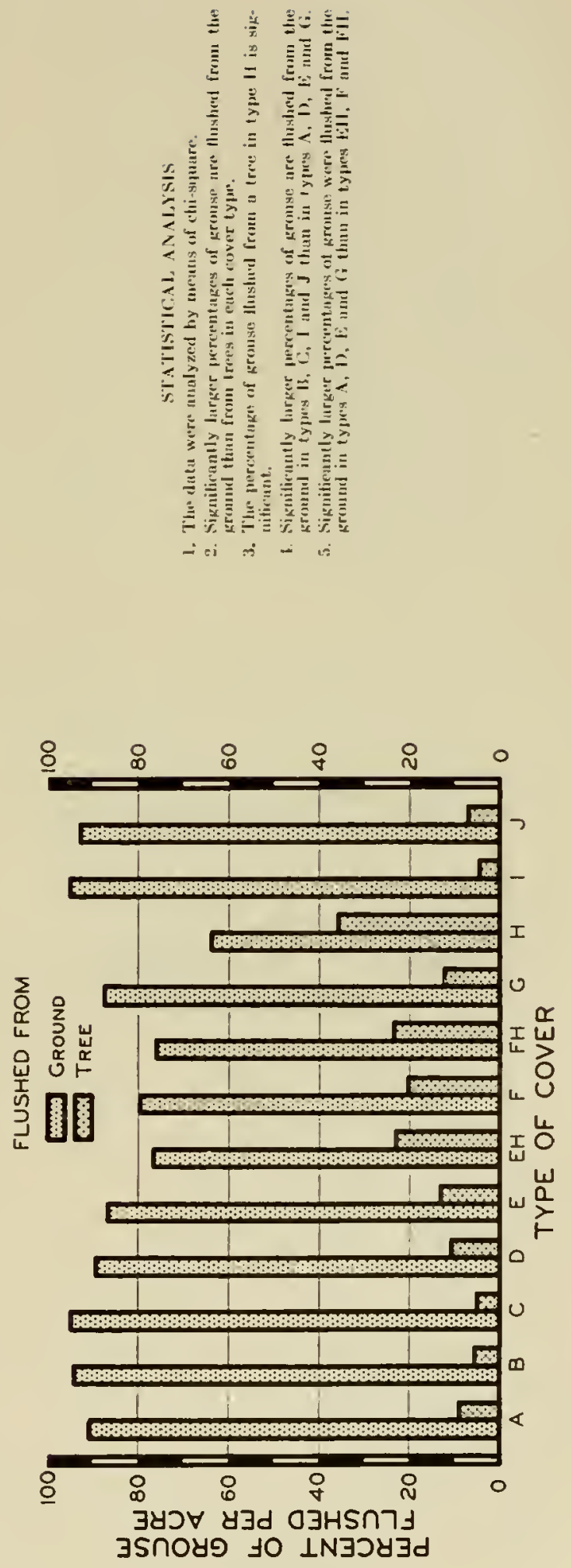

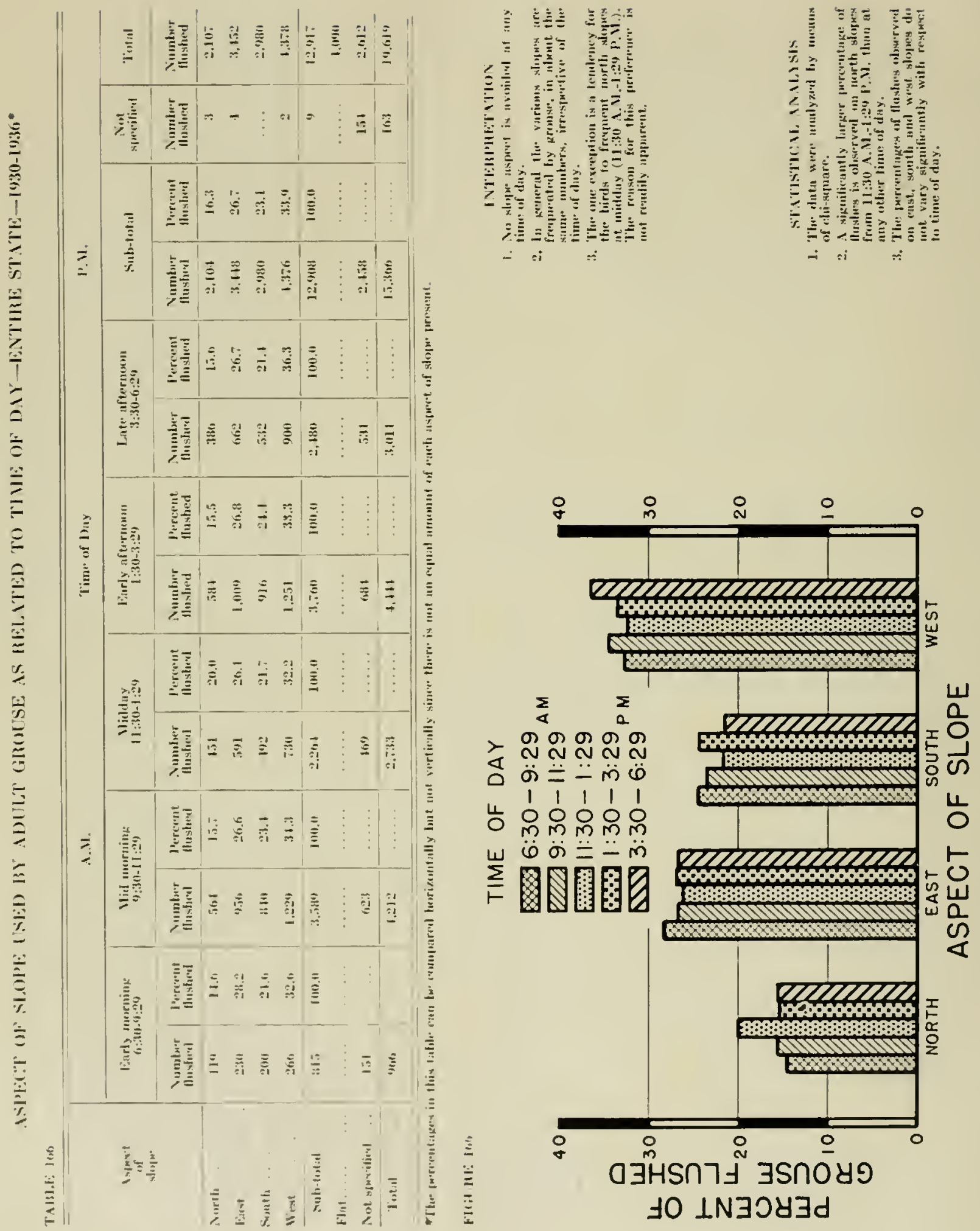


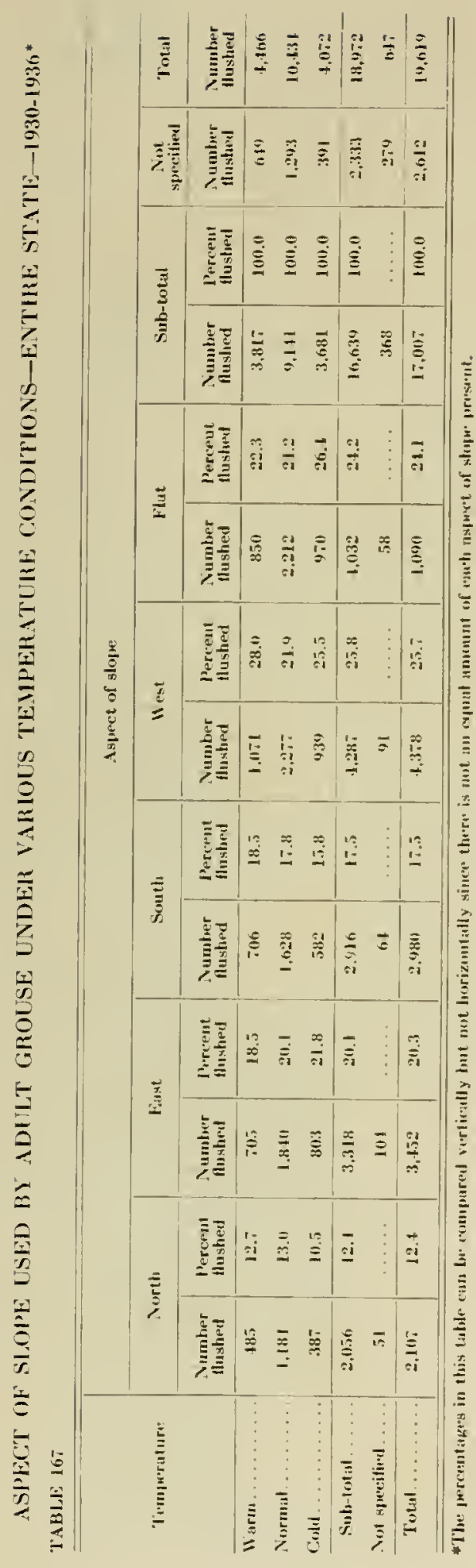

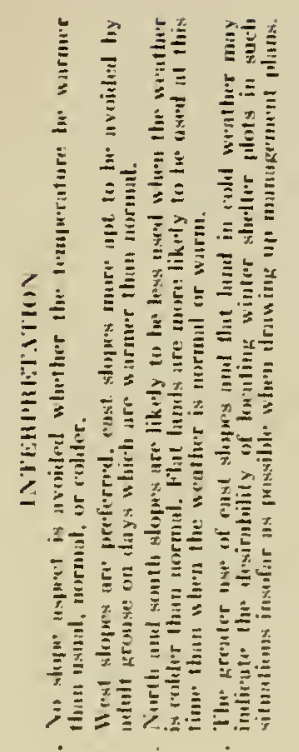
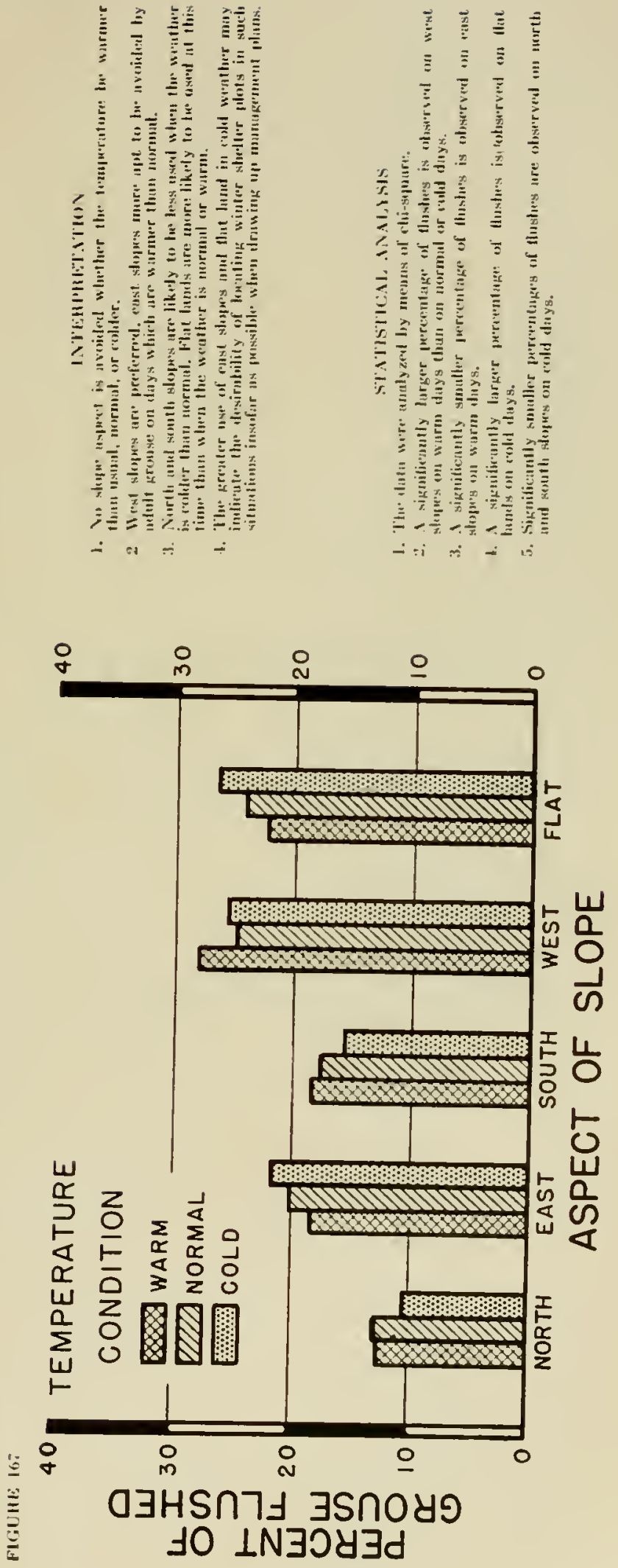

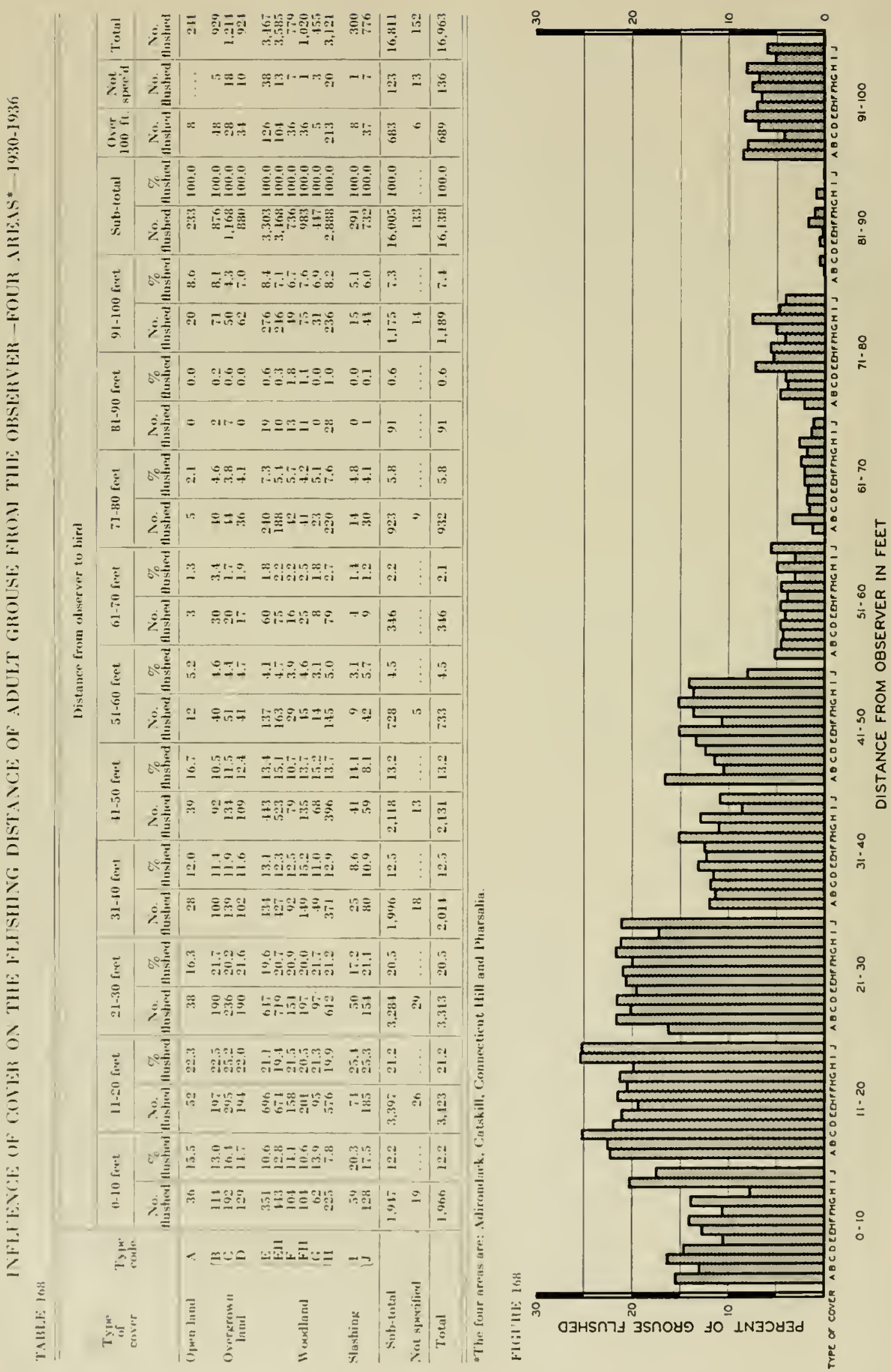


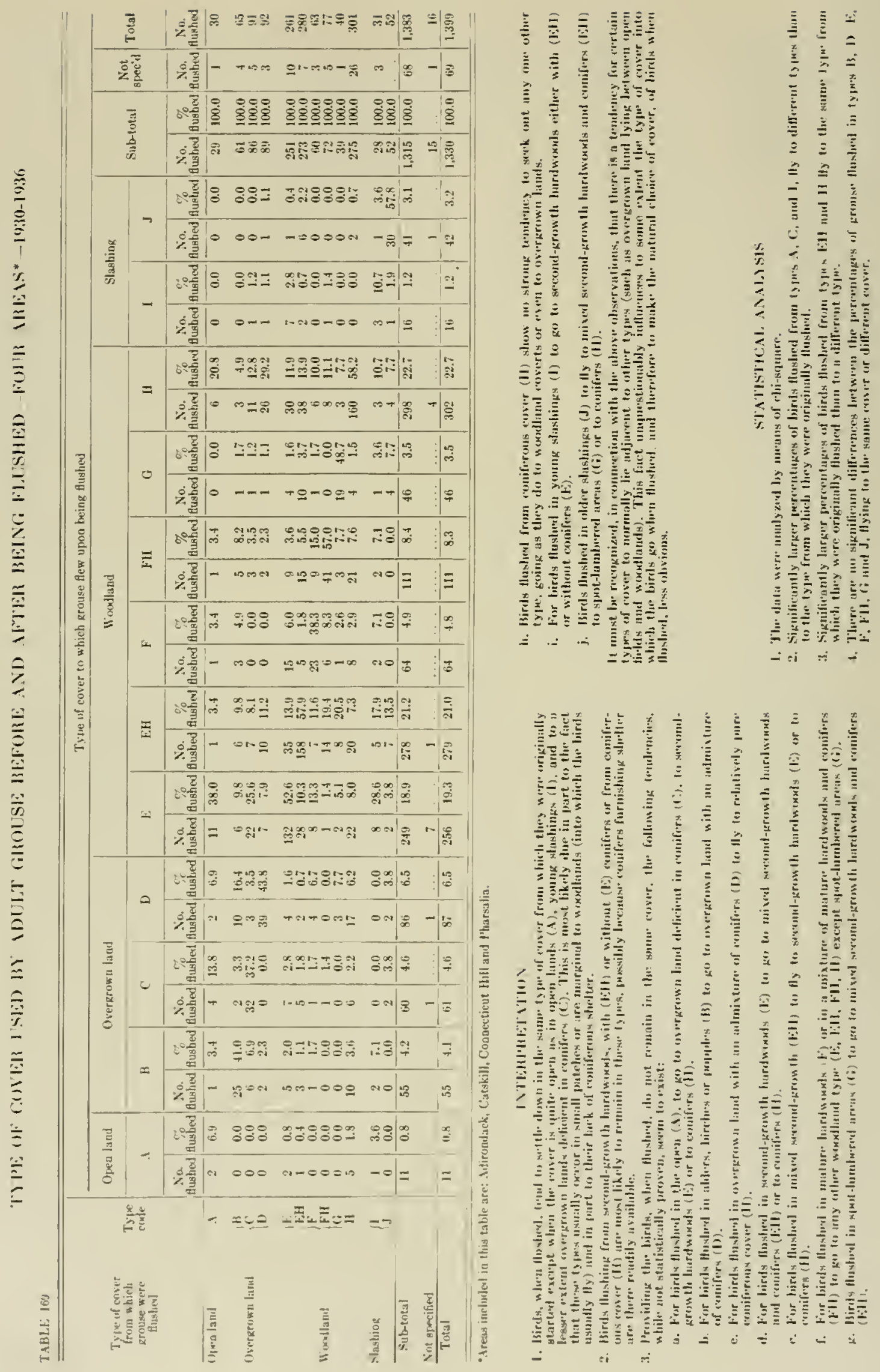



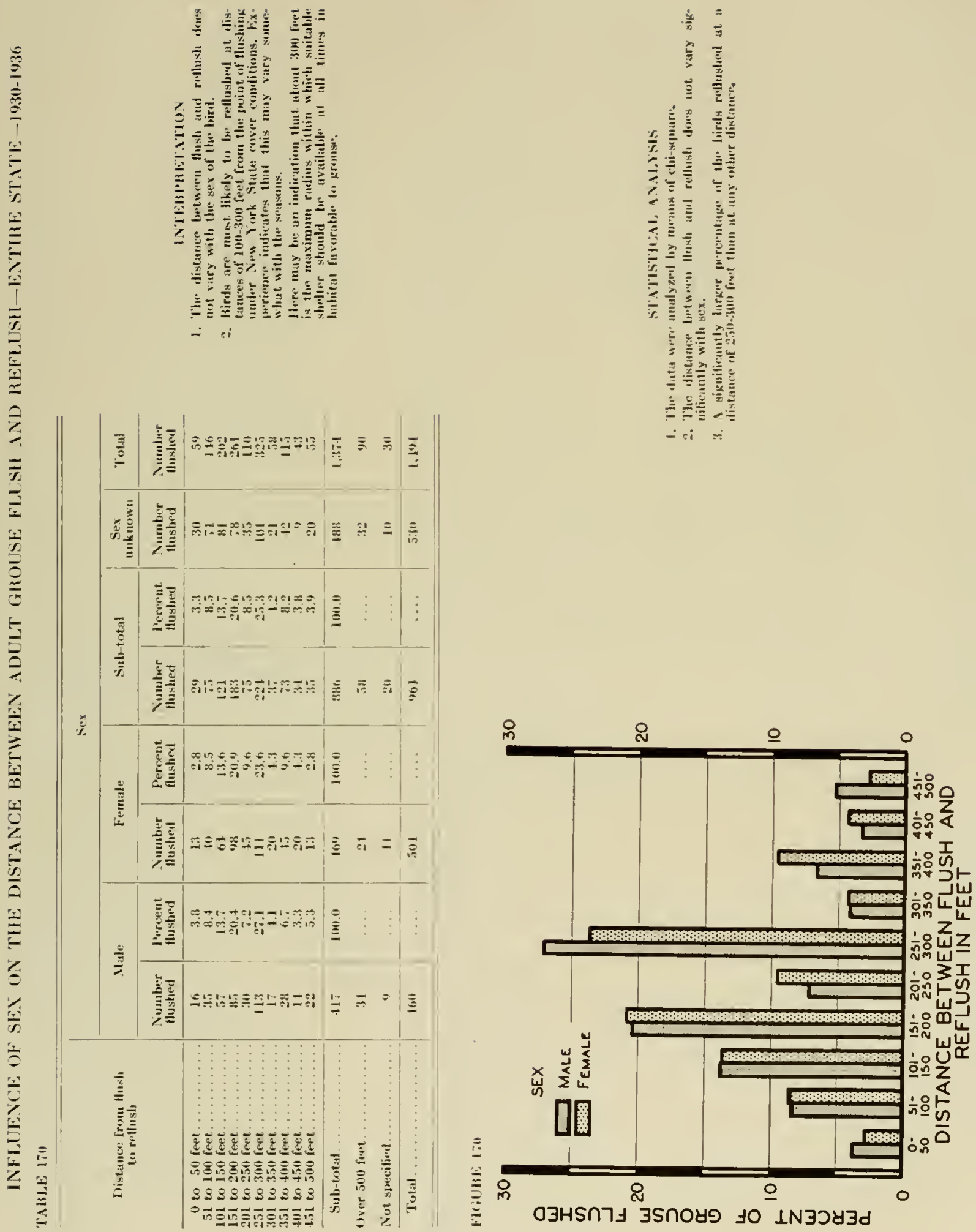

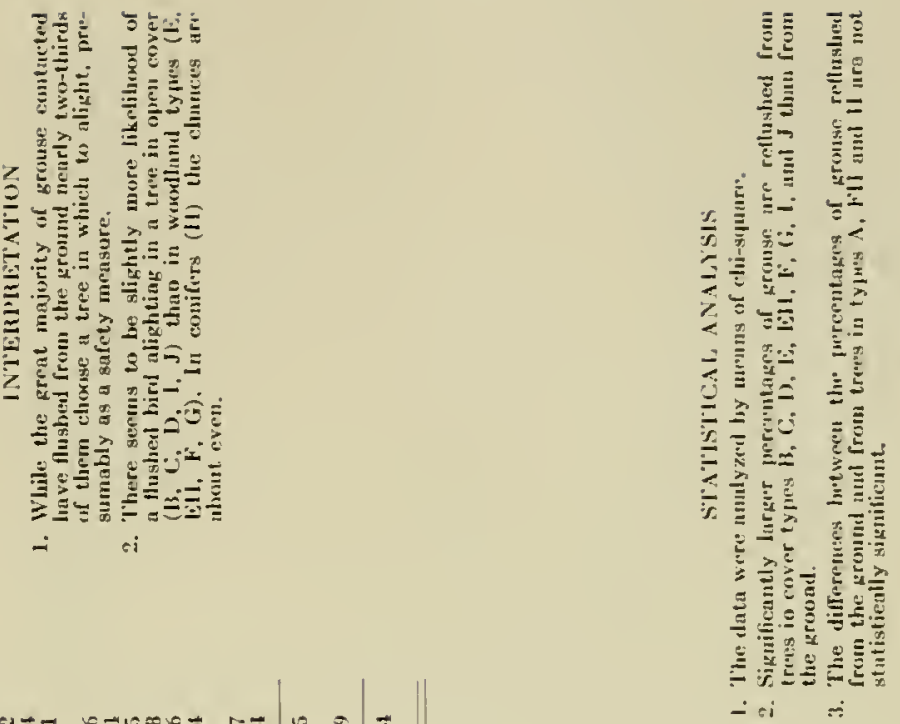

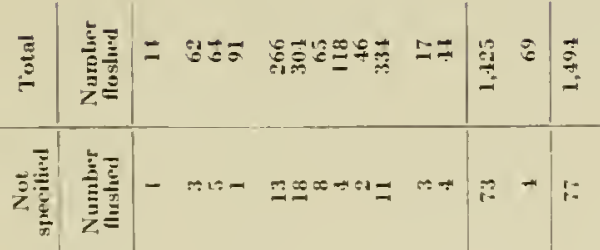

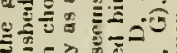

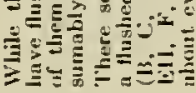

oi

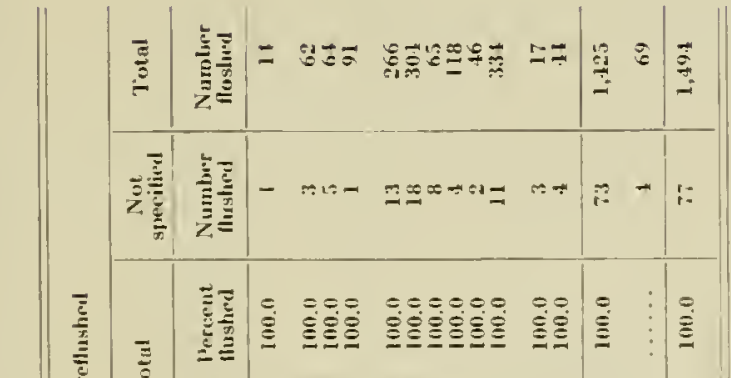

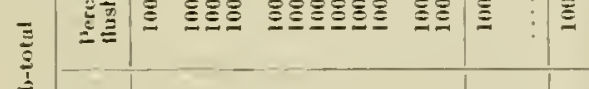

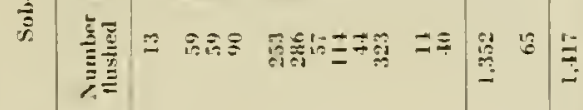

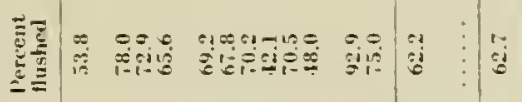

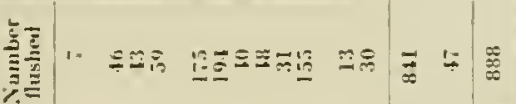

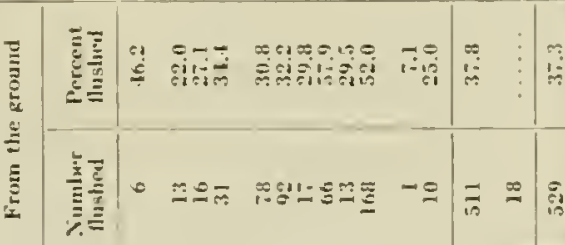

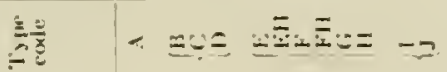

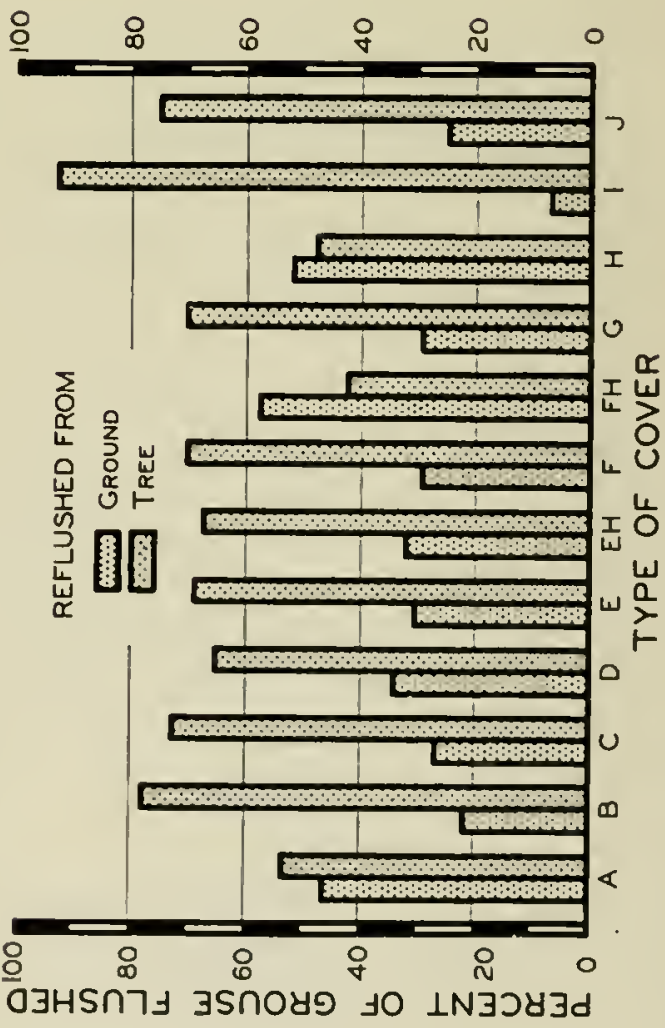




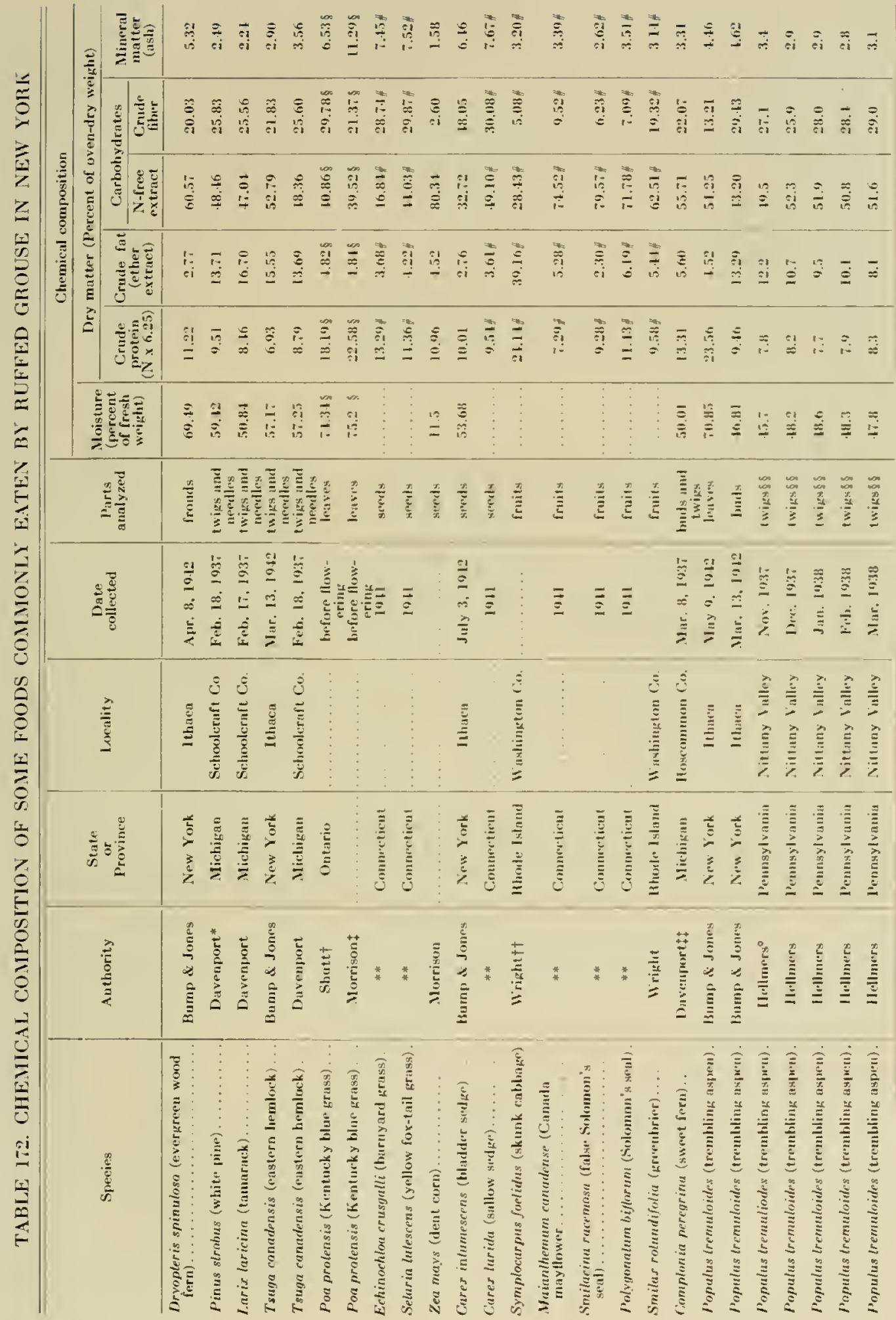




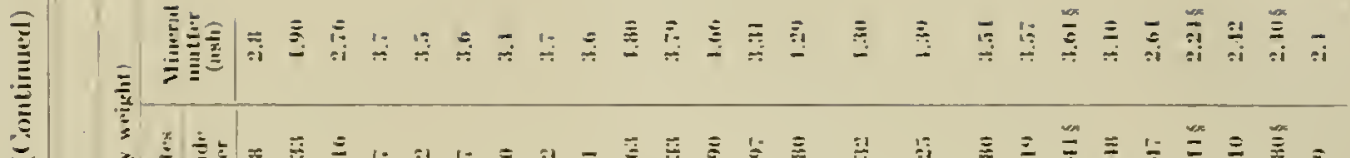

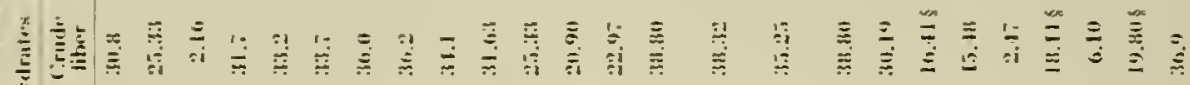

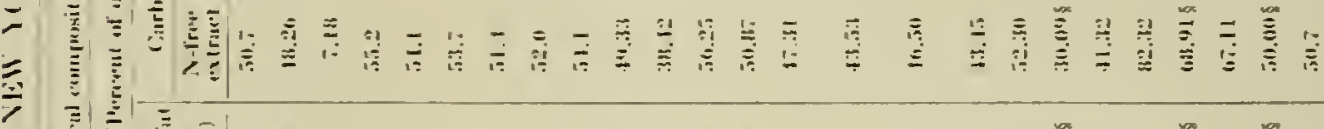

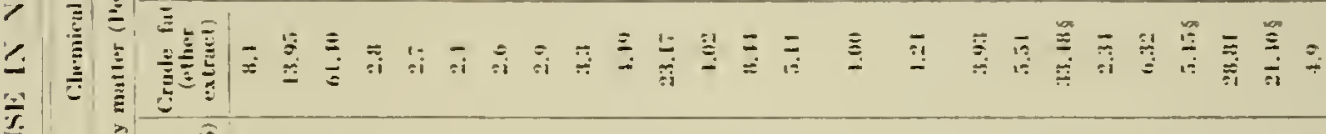

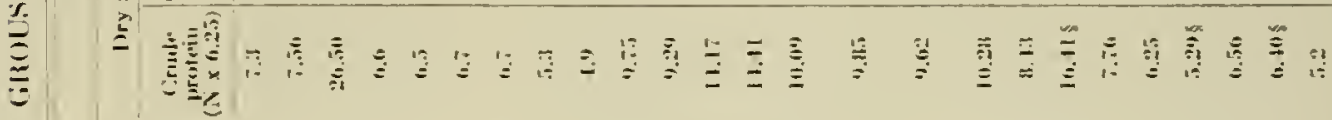

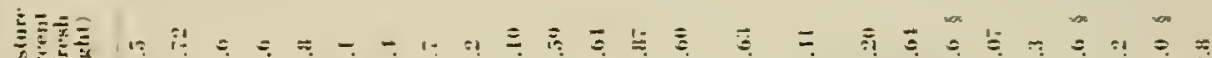

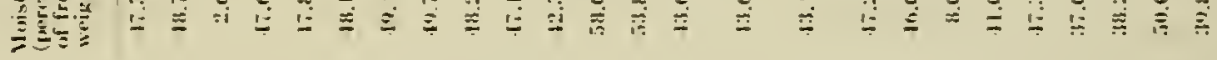

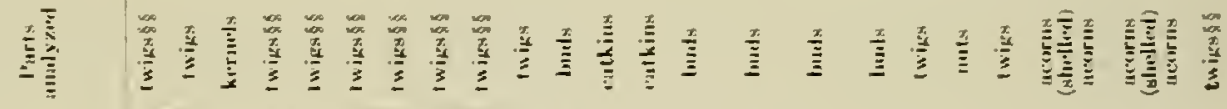

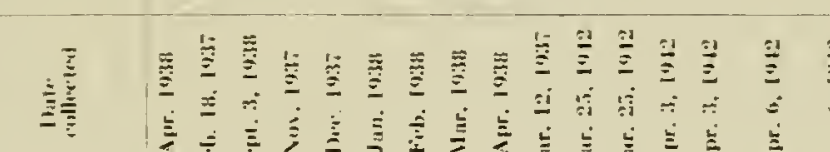

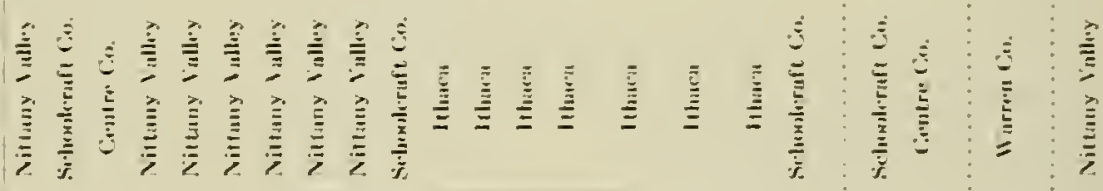

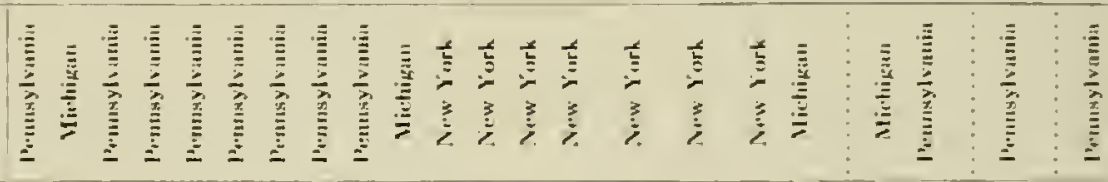

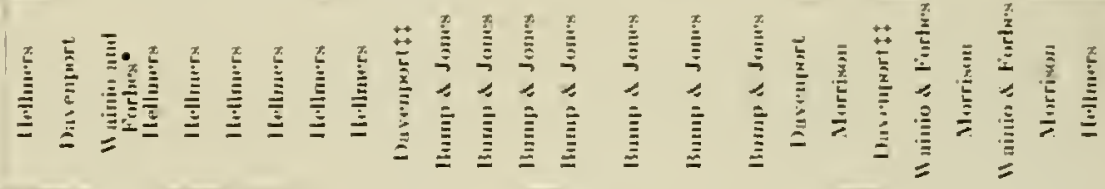

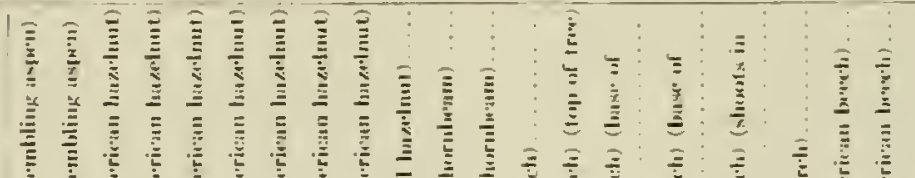

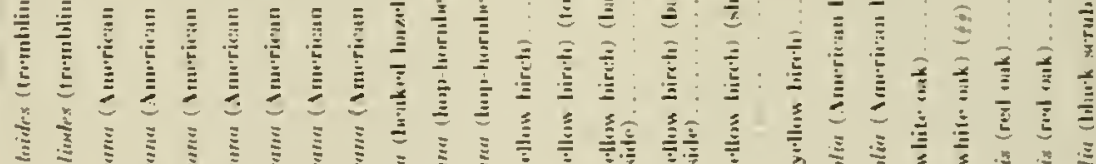
i!

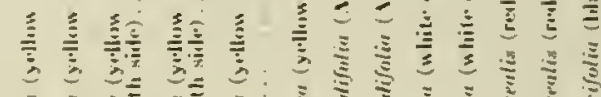
产

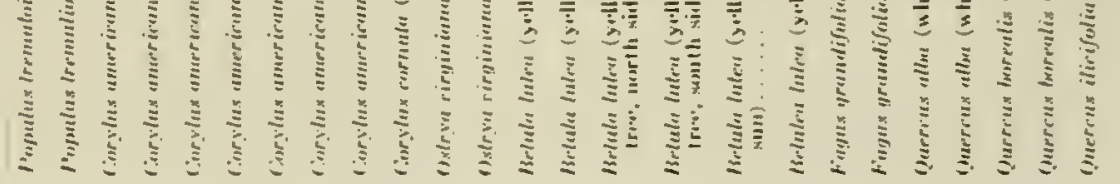




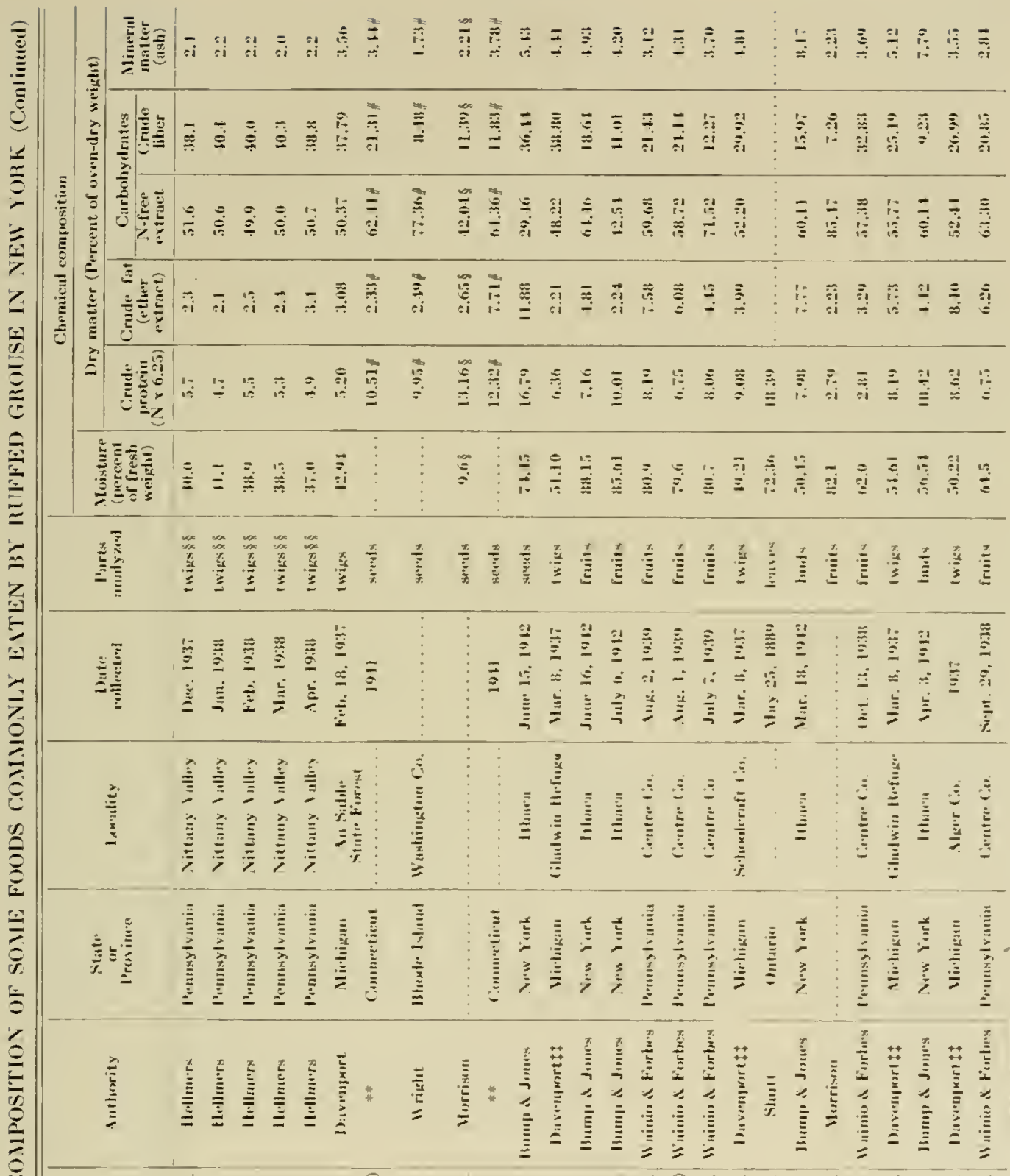

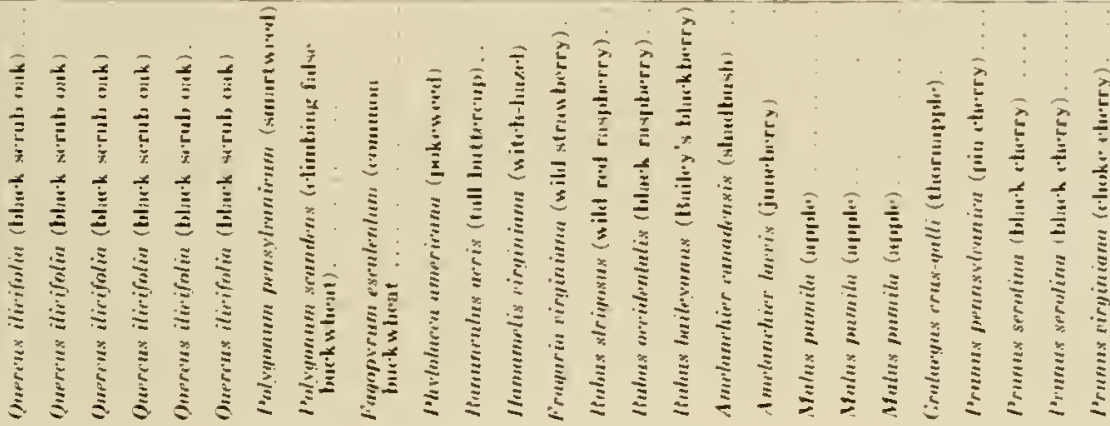


$\cong$

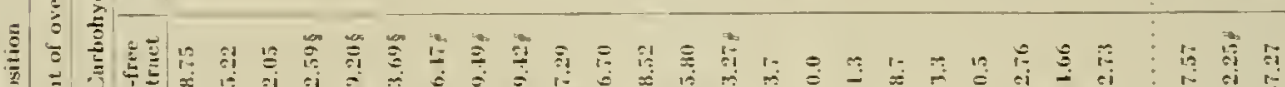

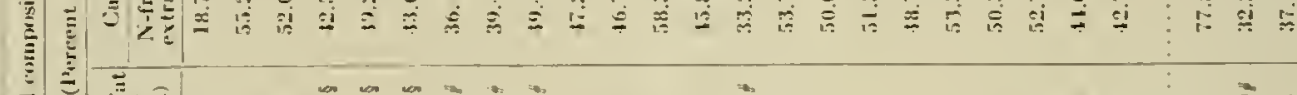

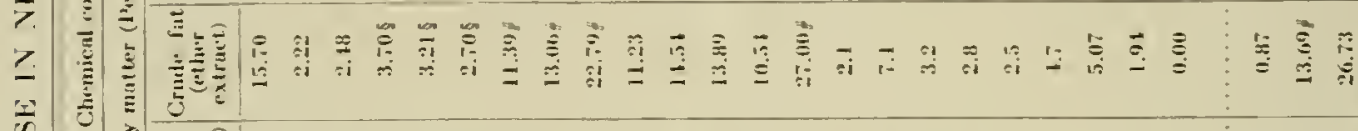

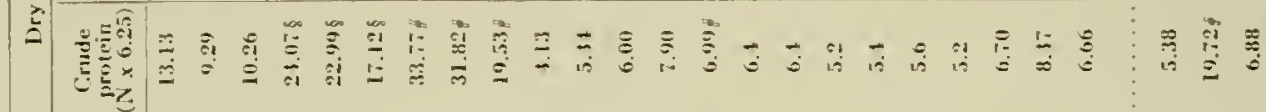

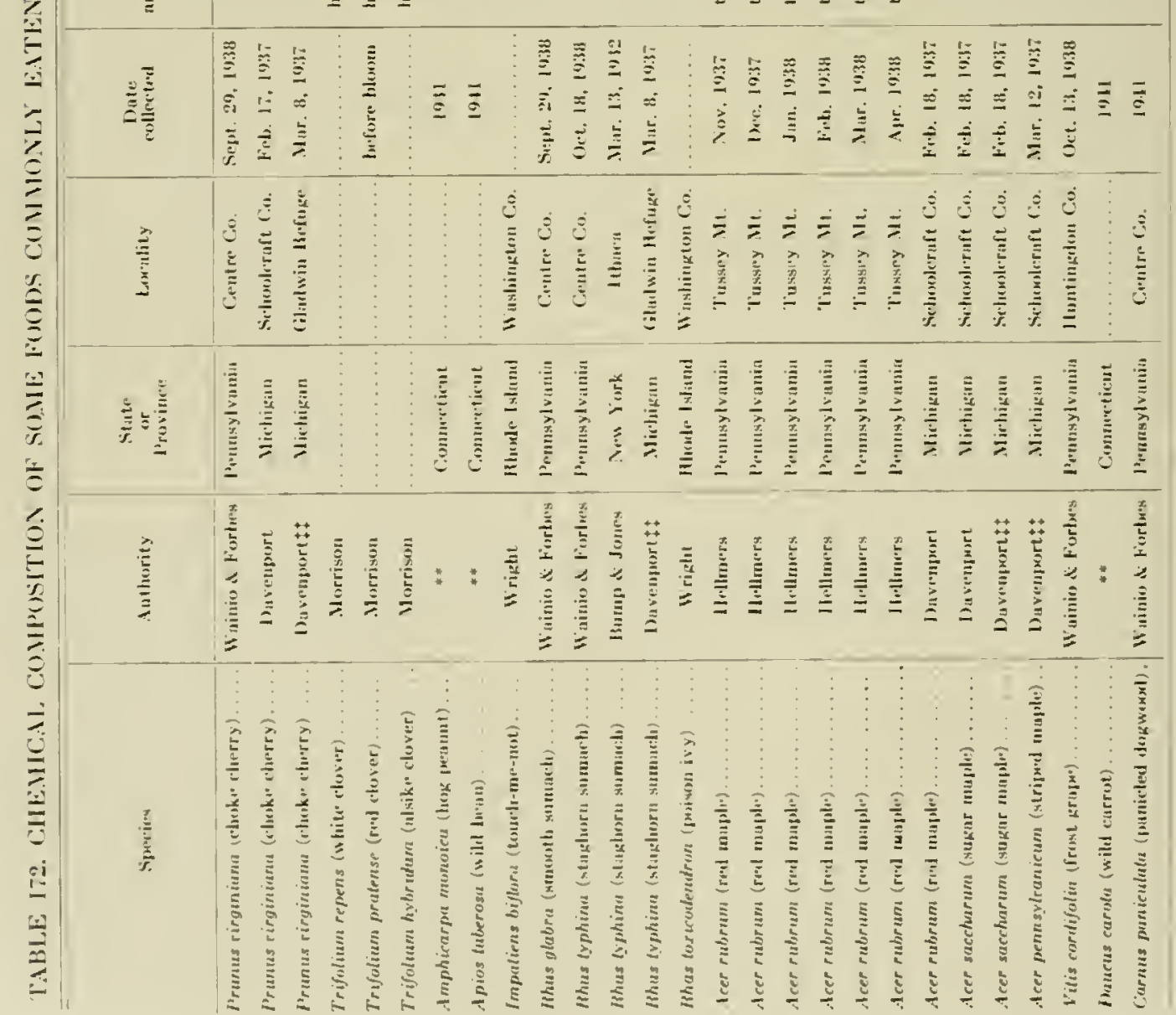

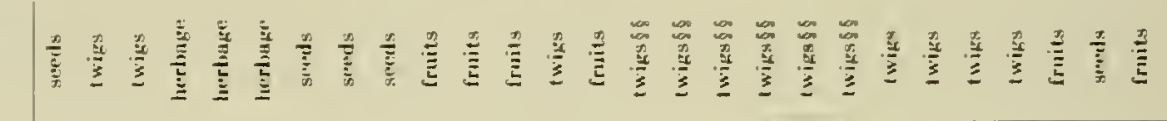

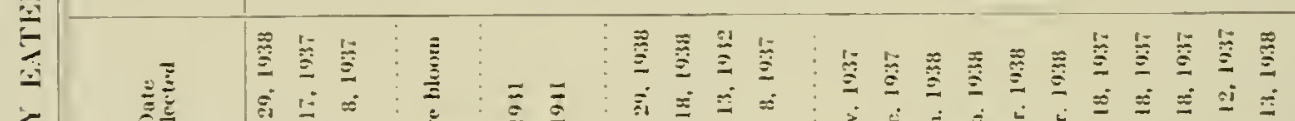




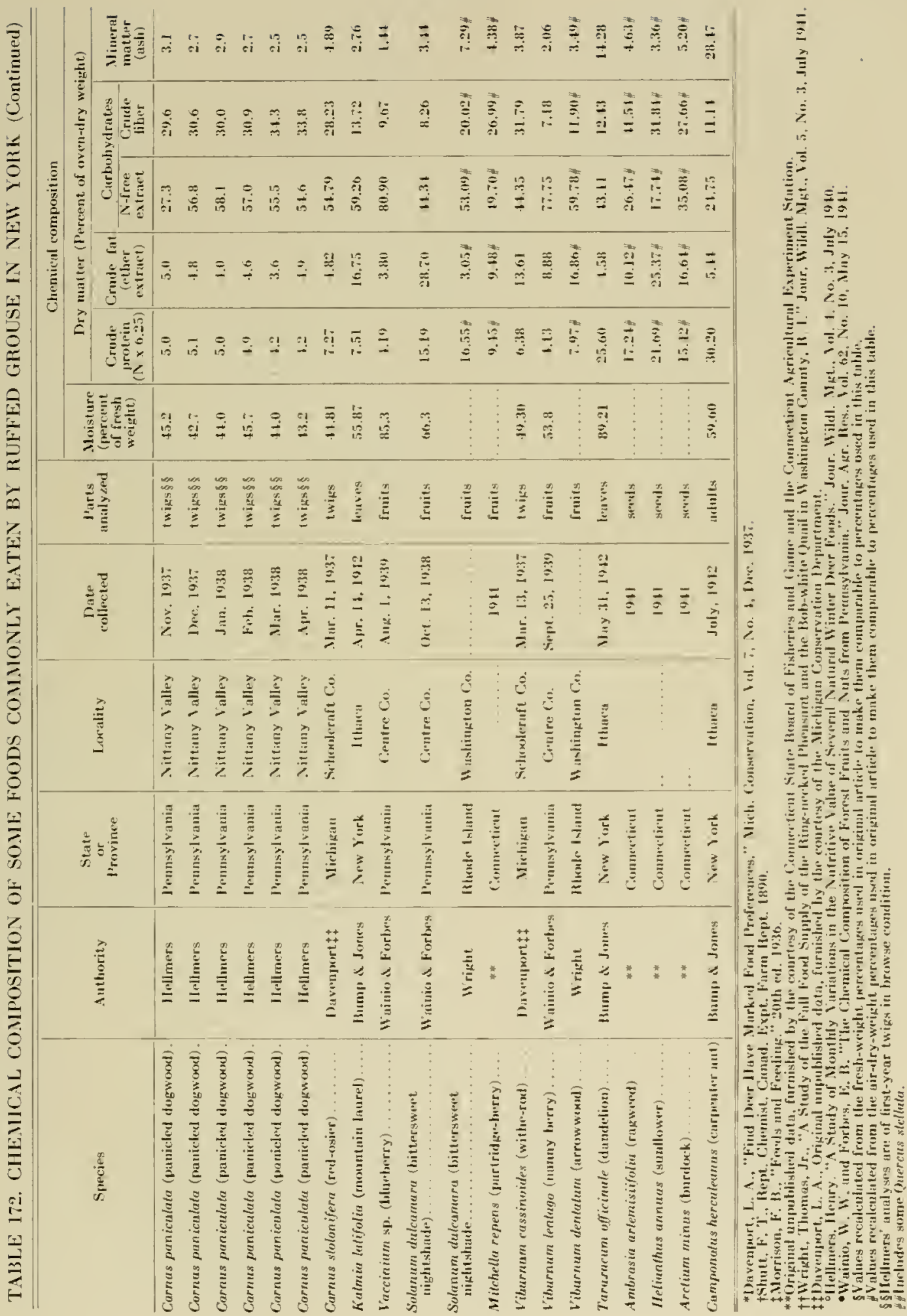




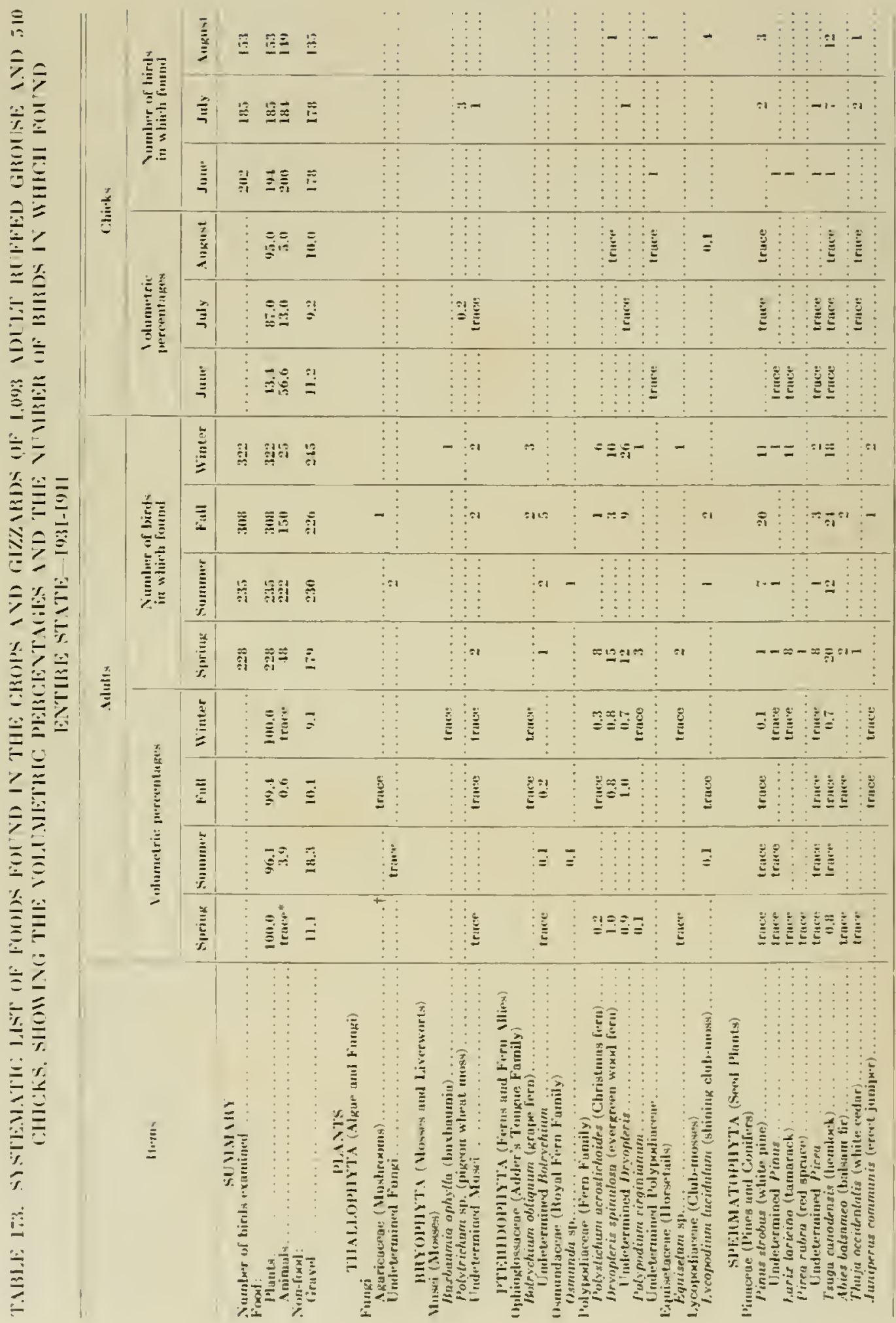




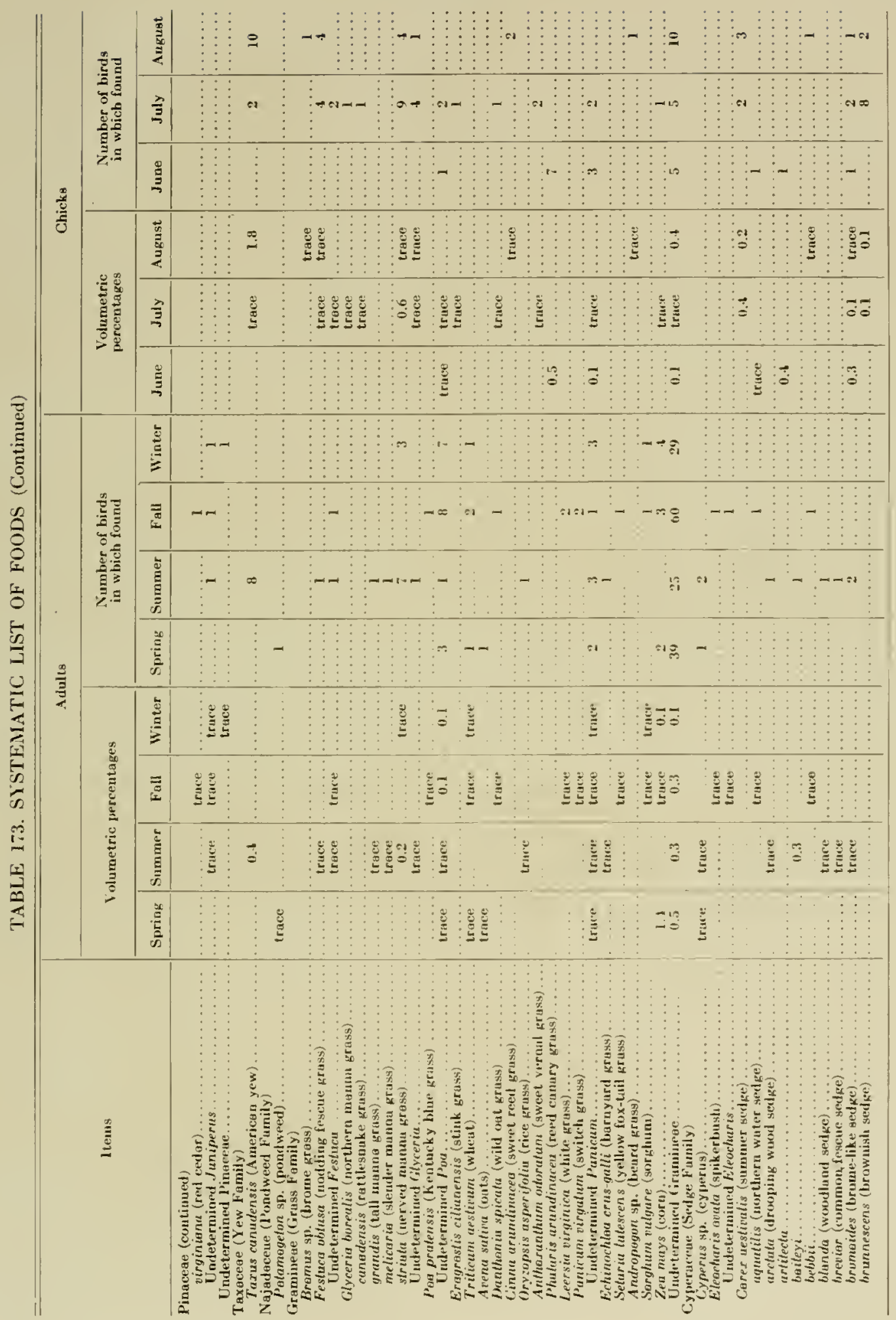




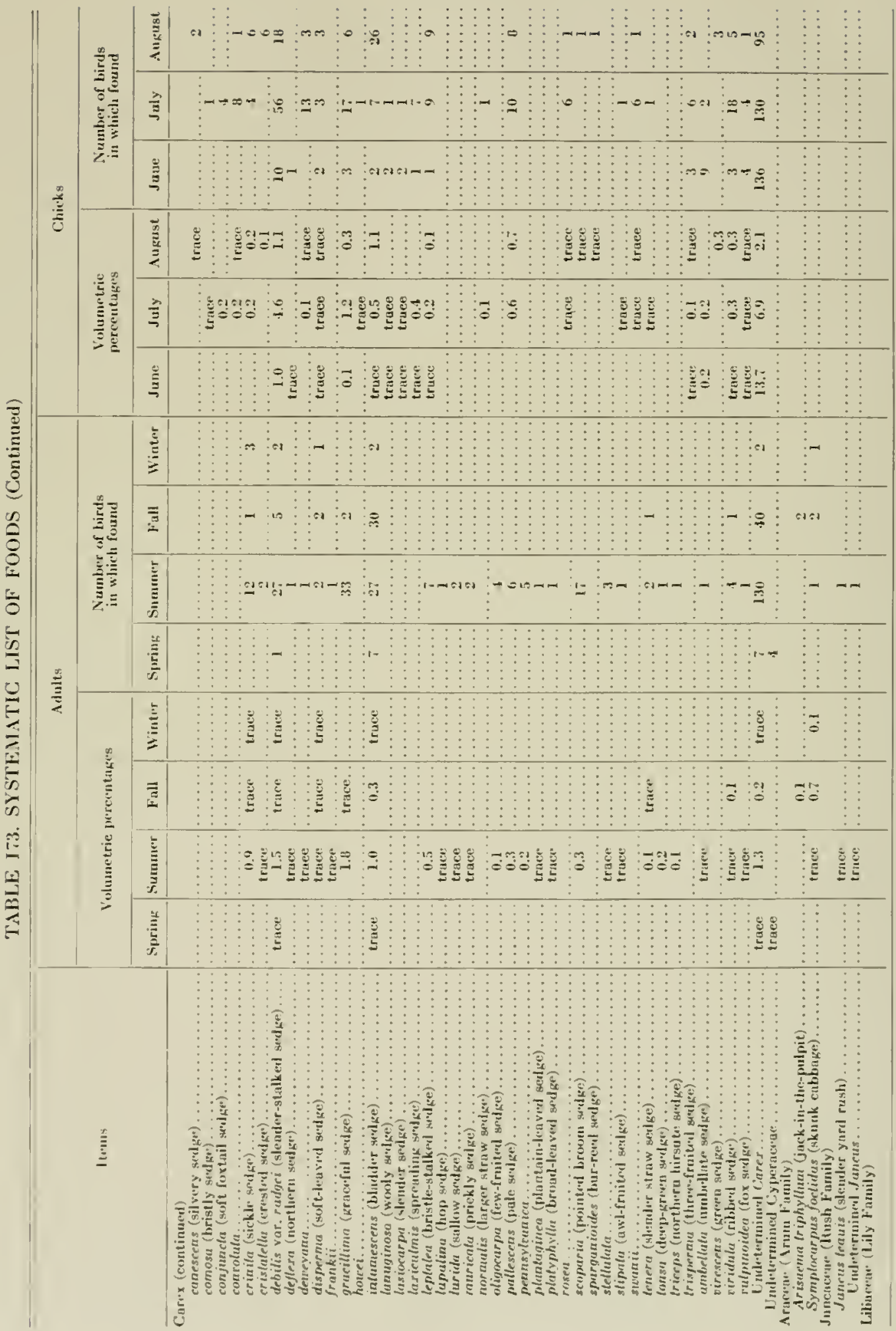




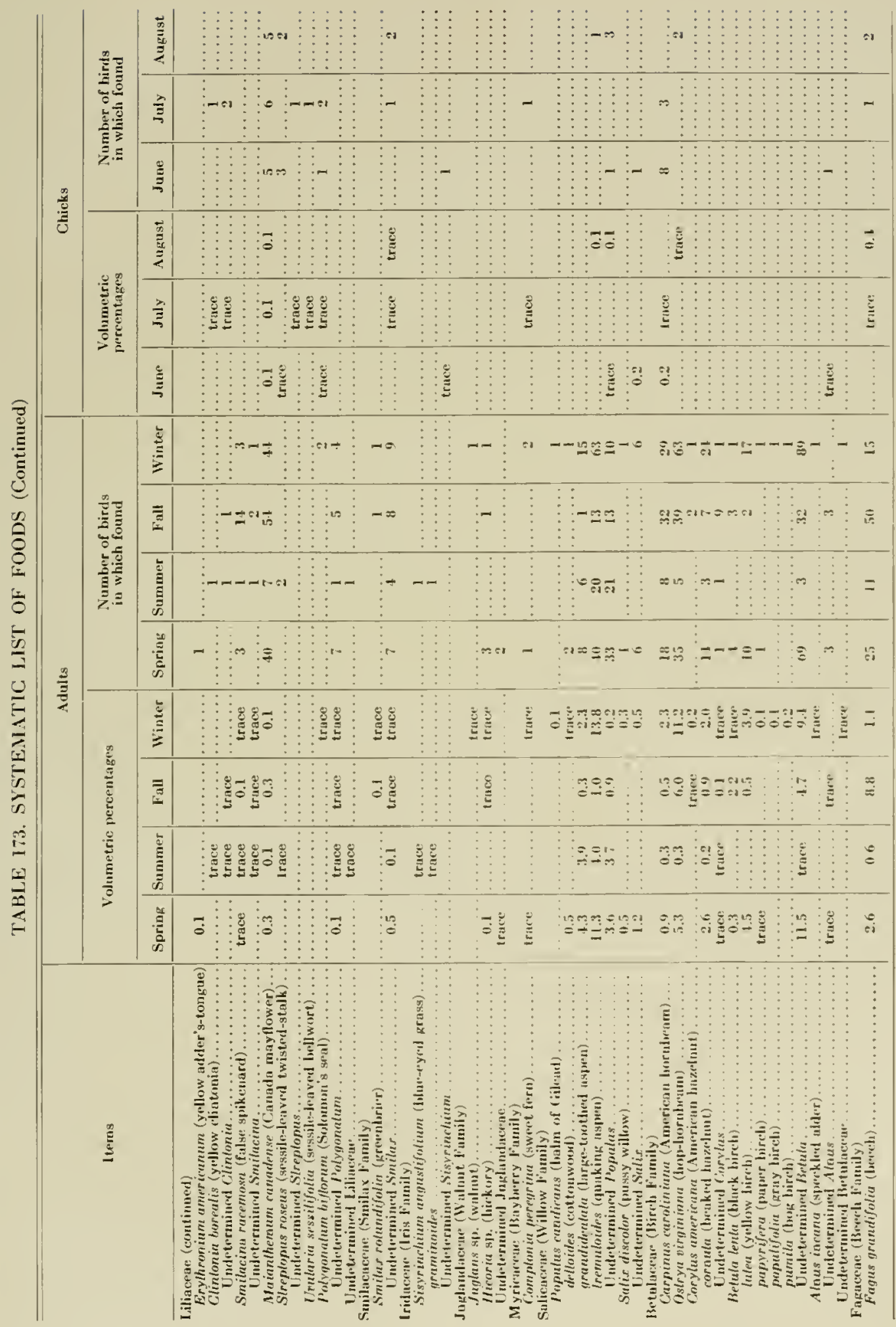




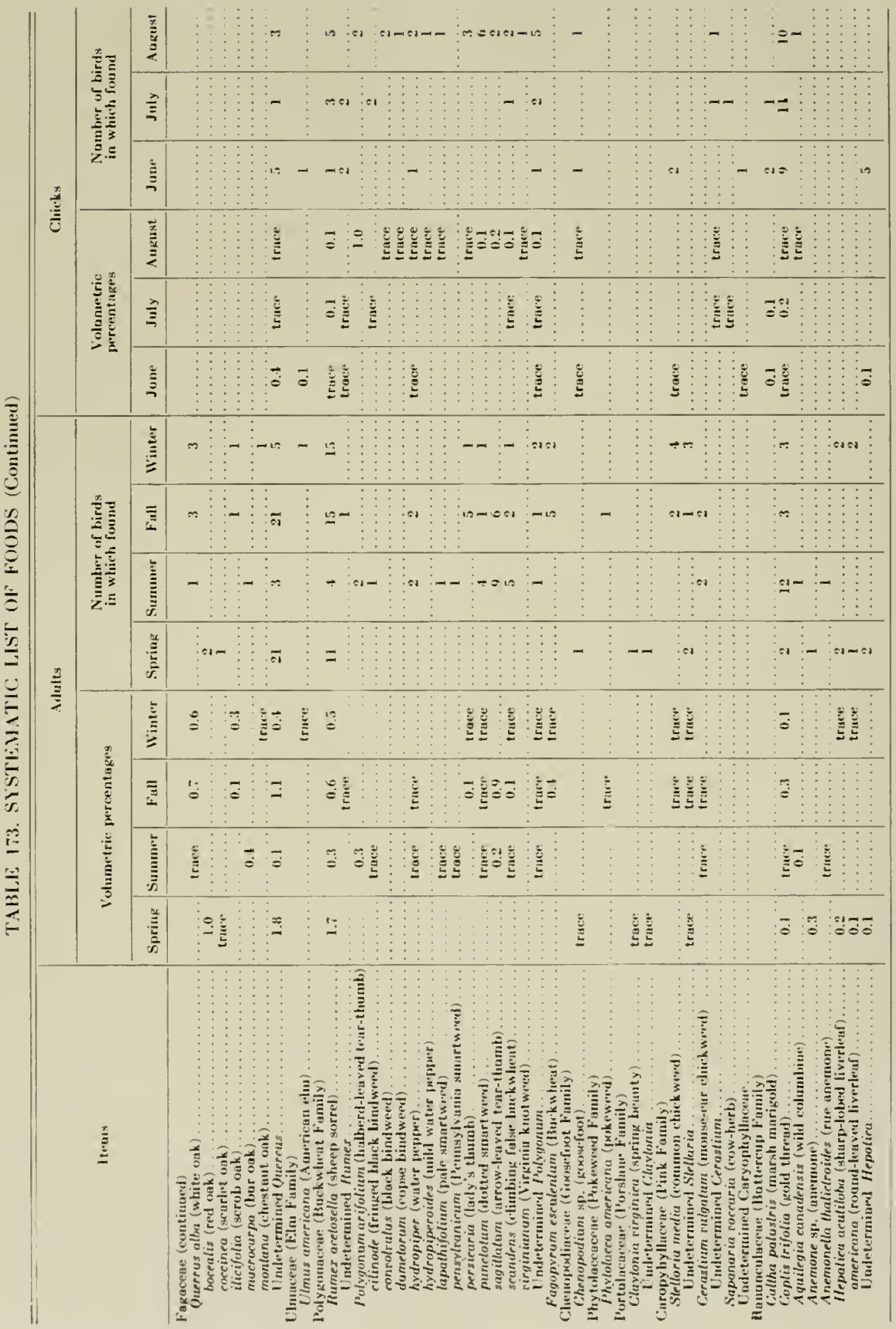




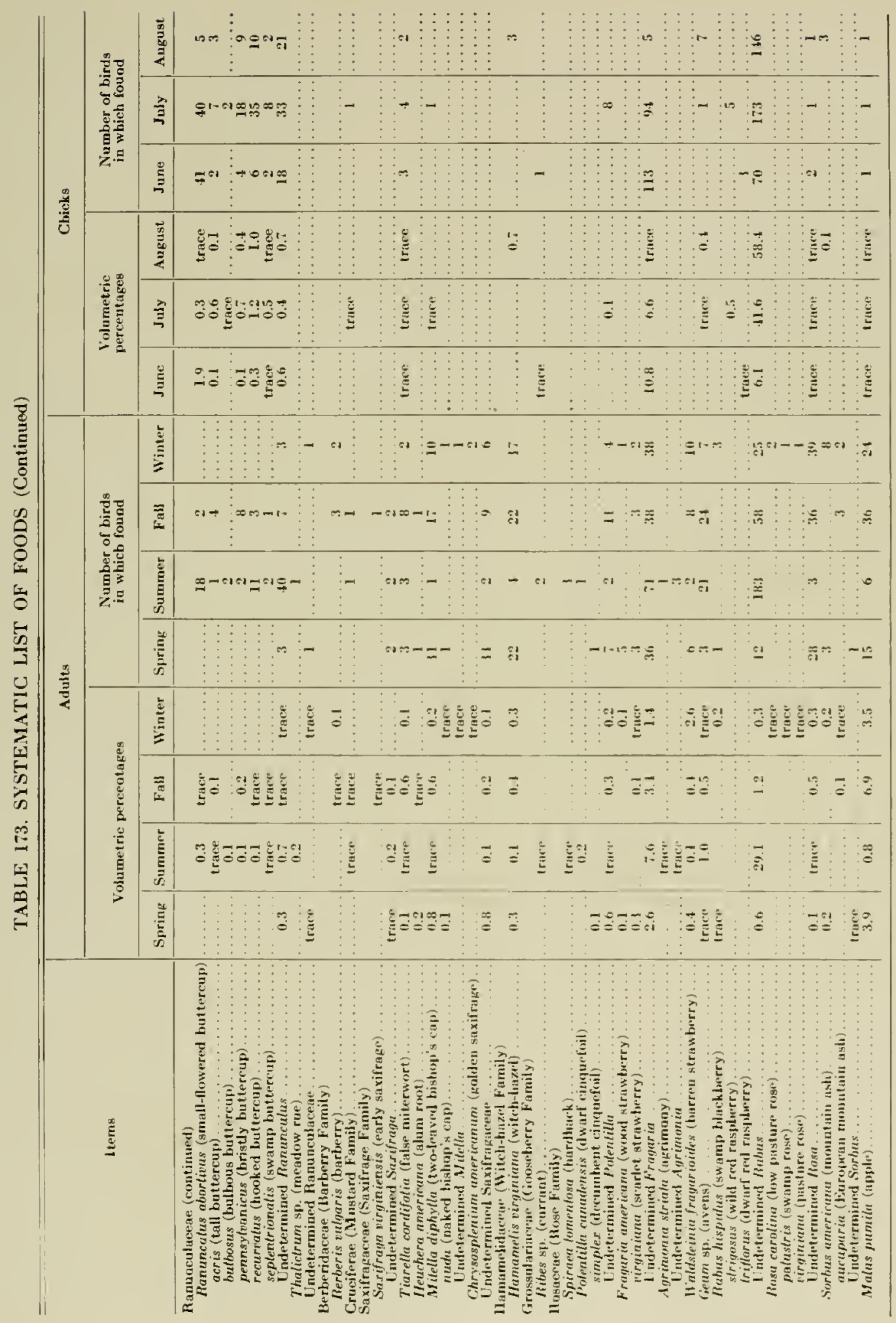




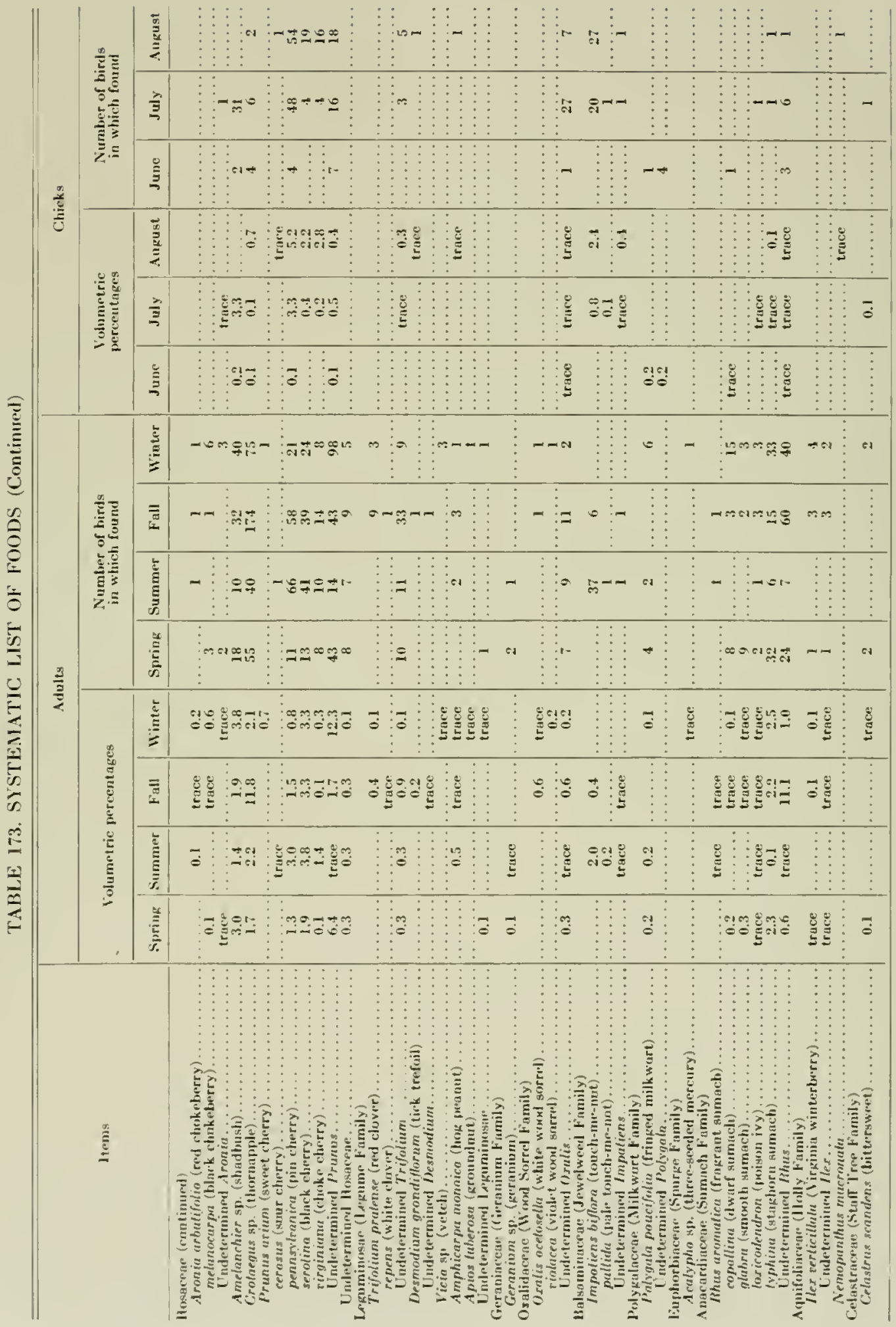




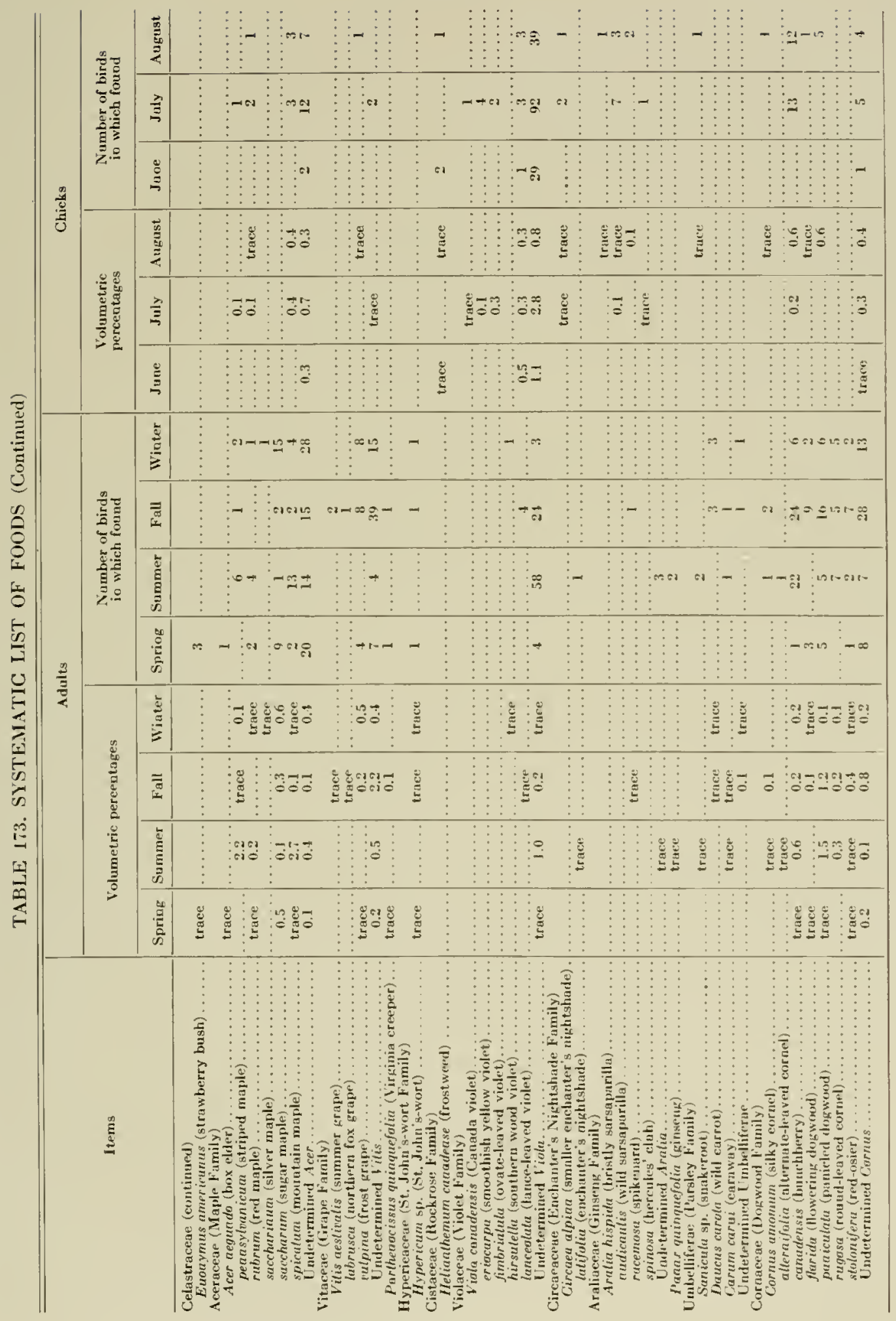




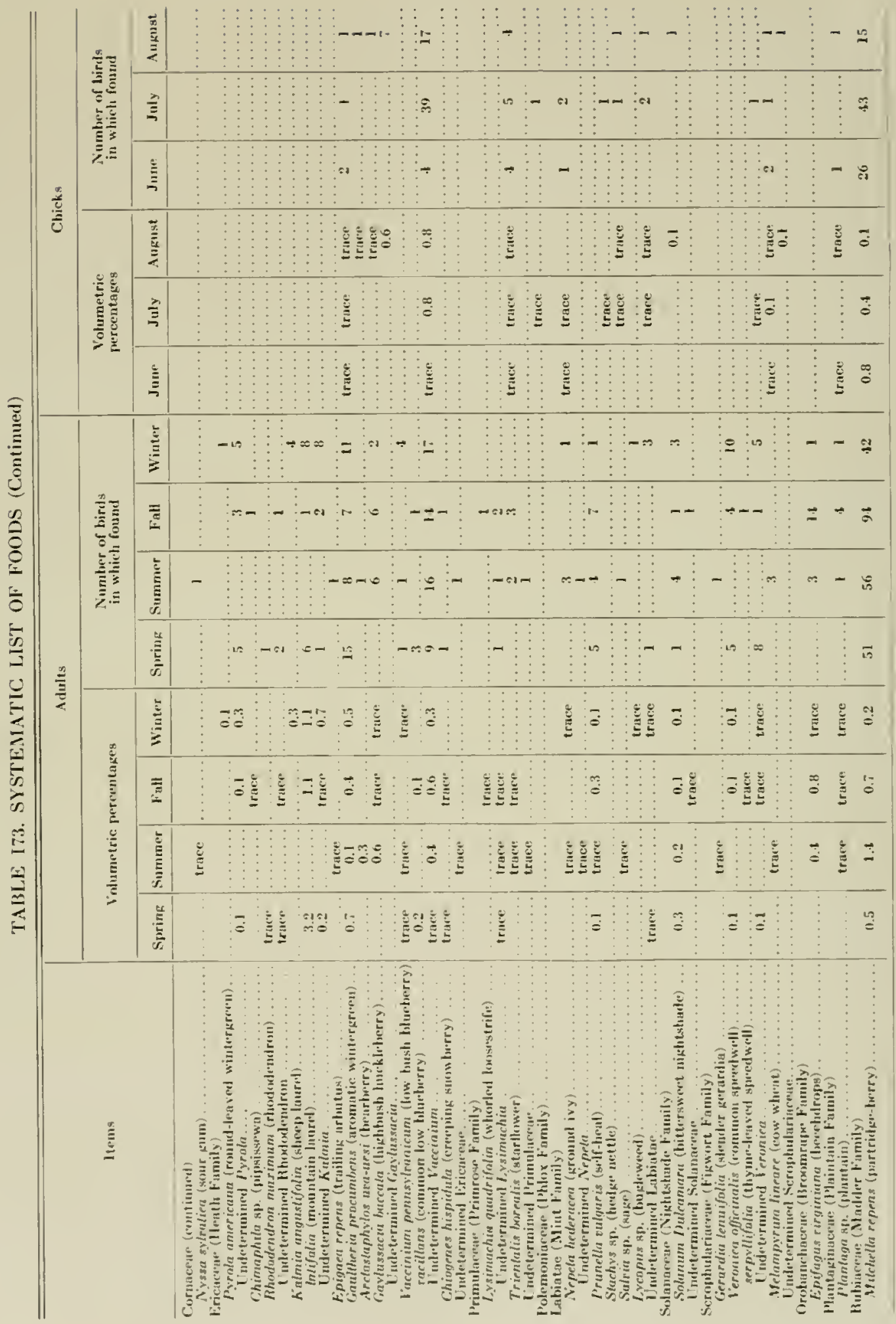




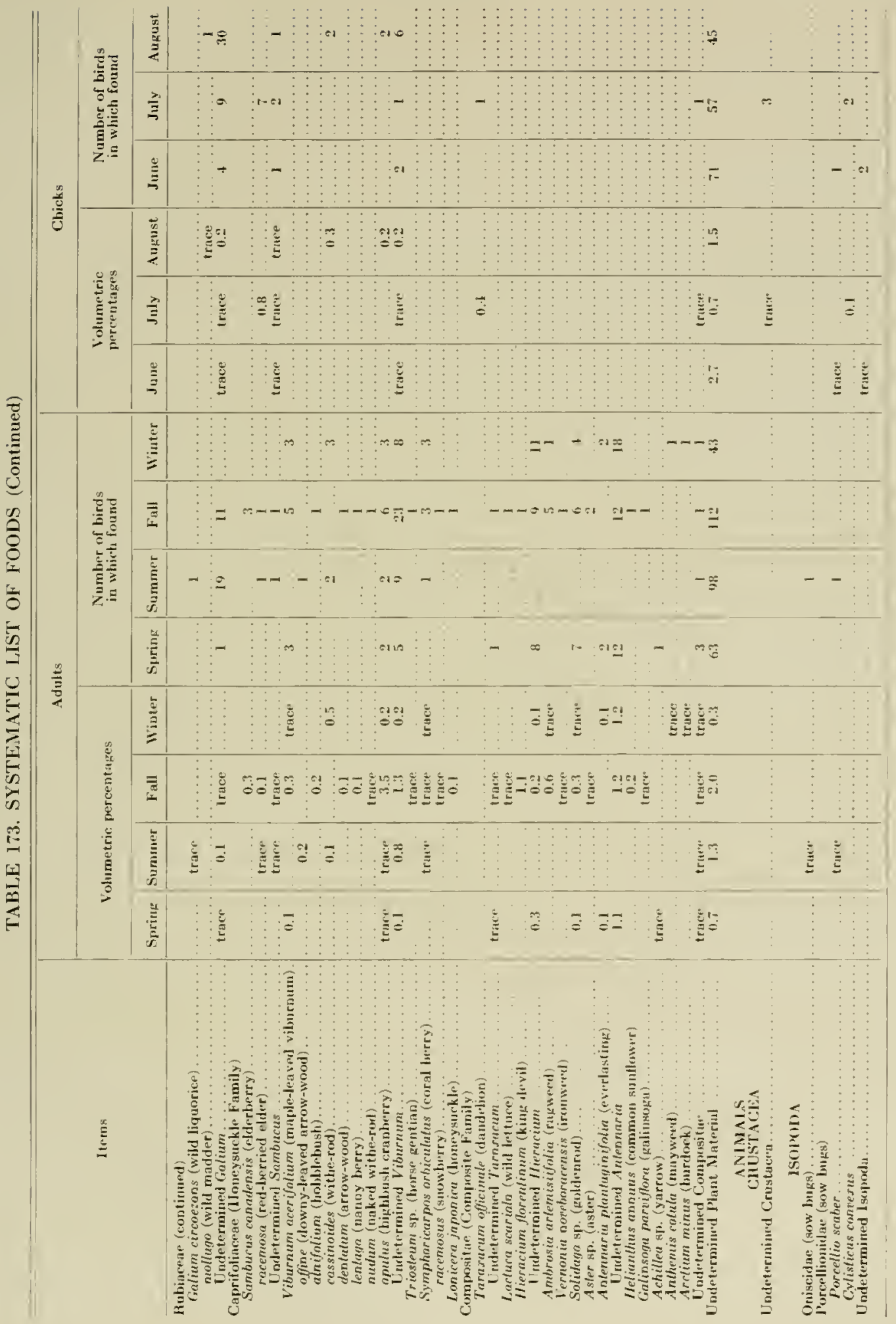




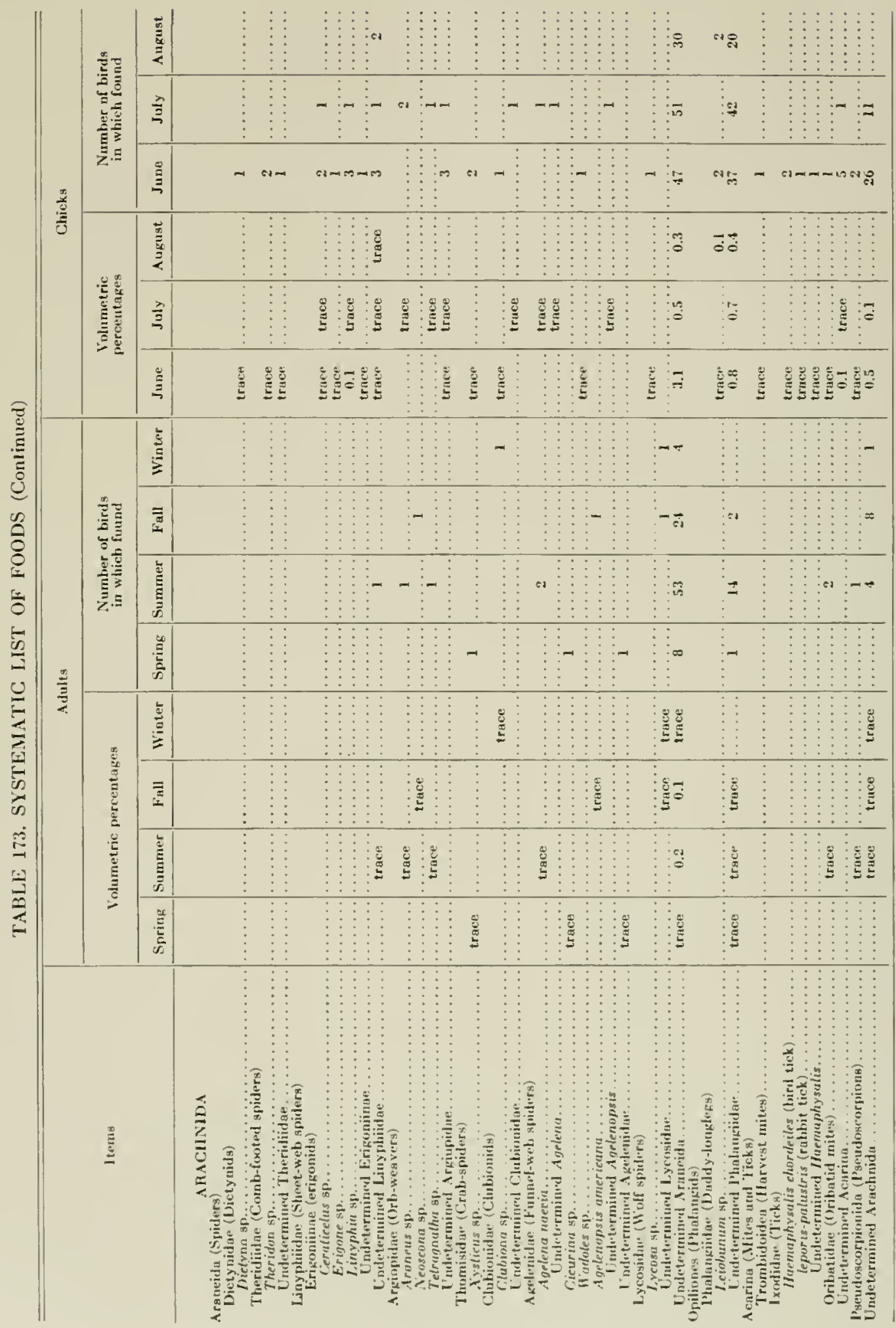




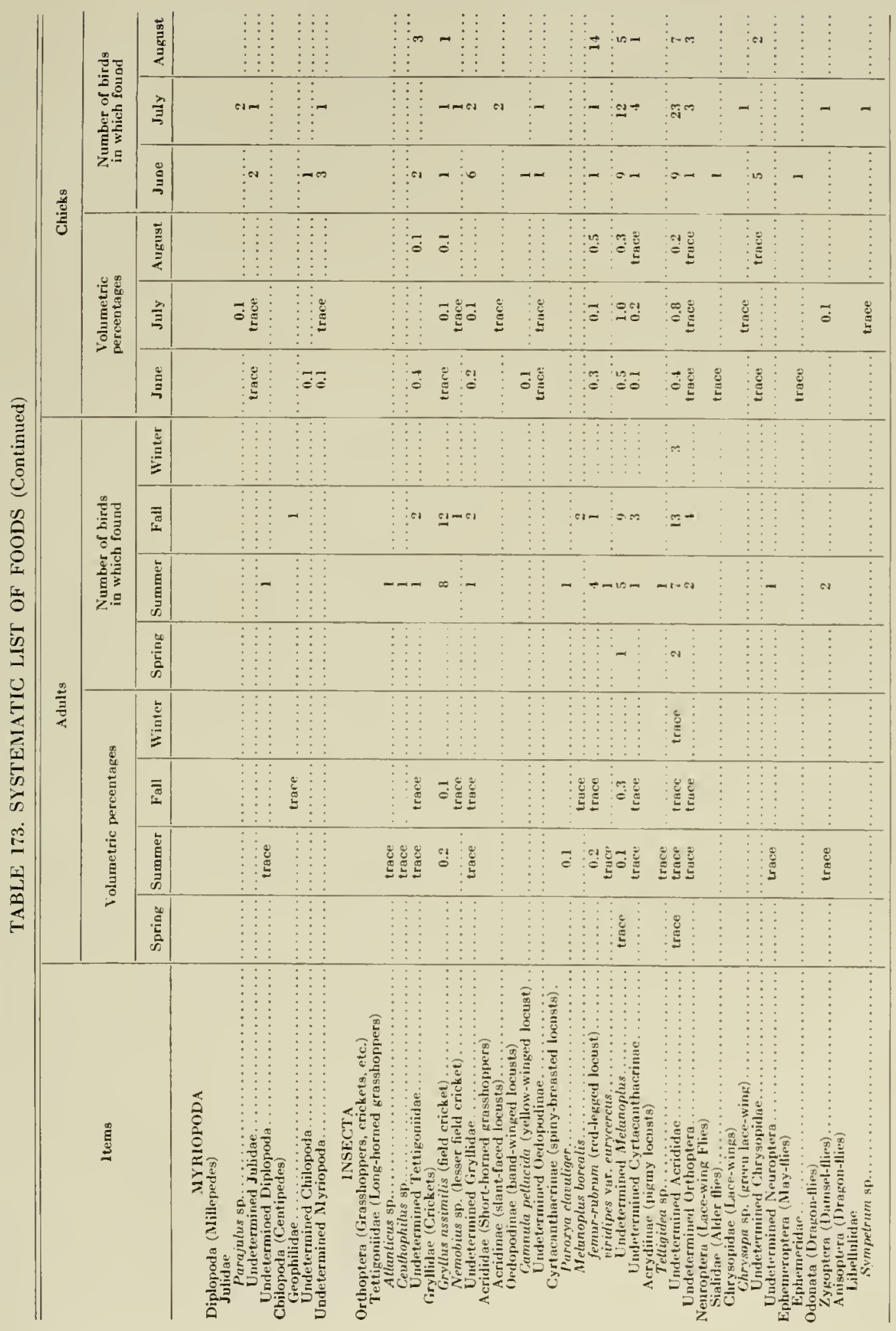




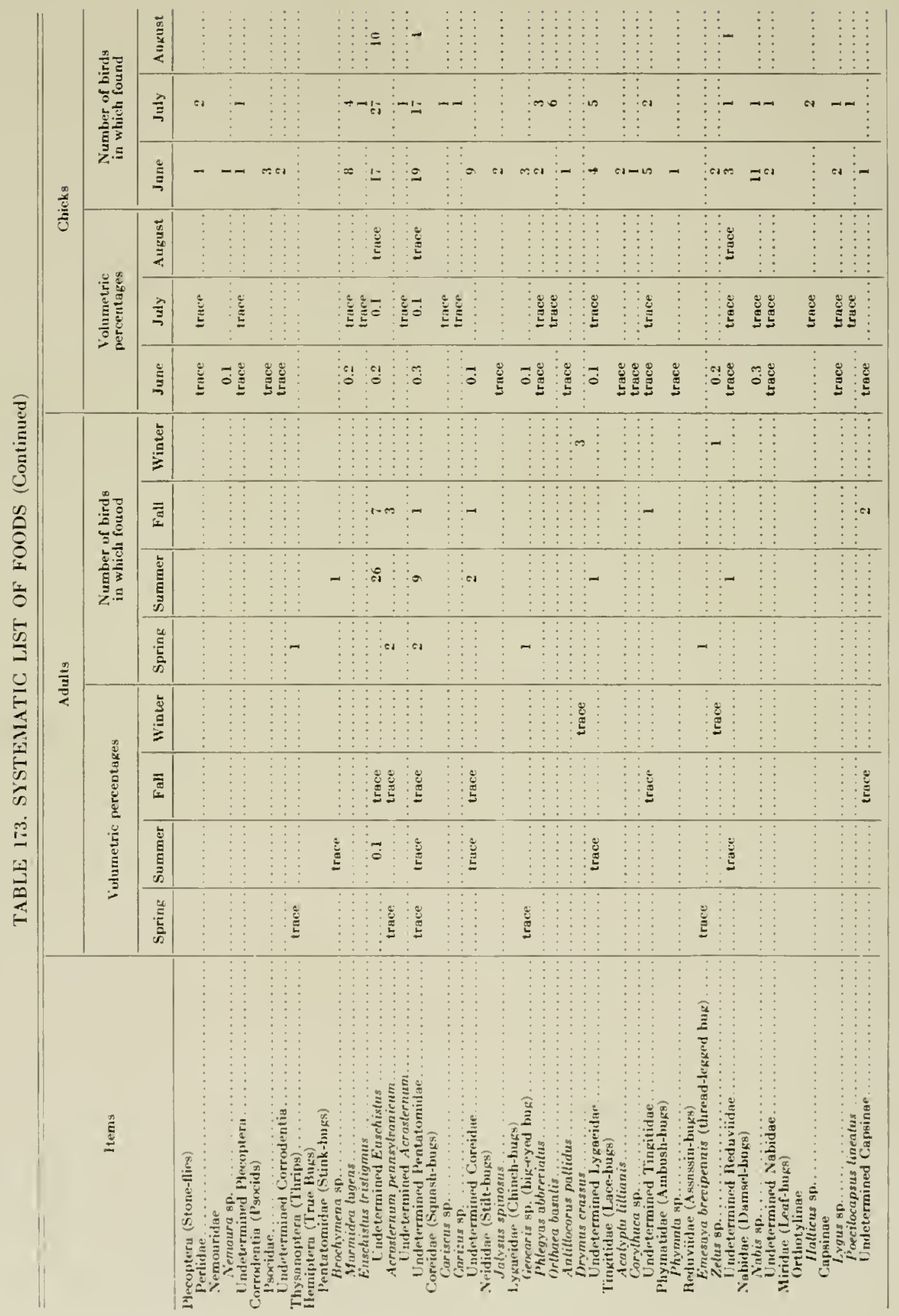




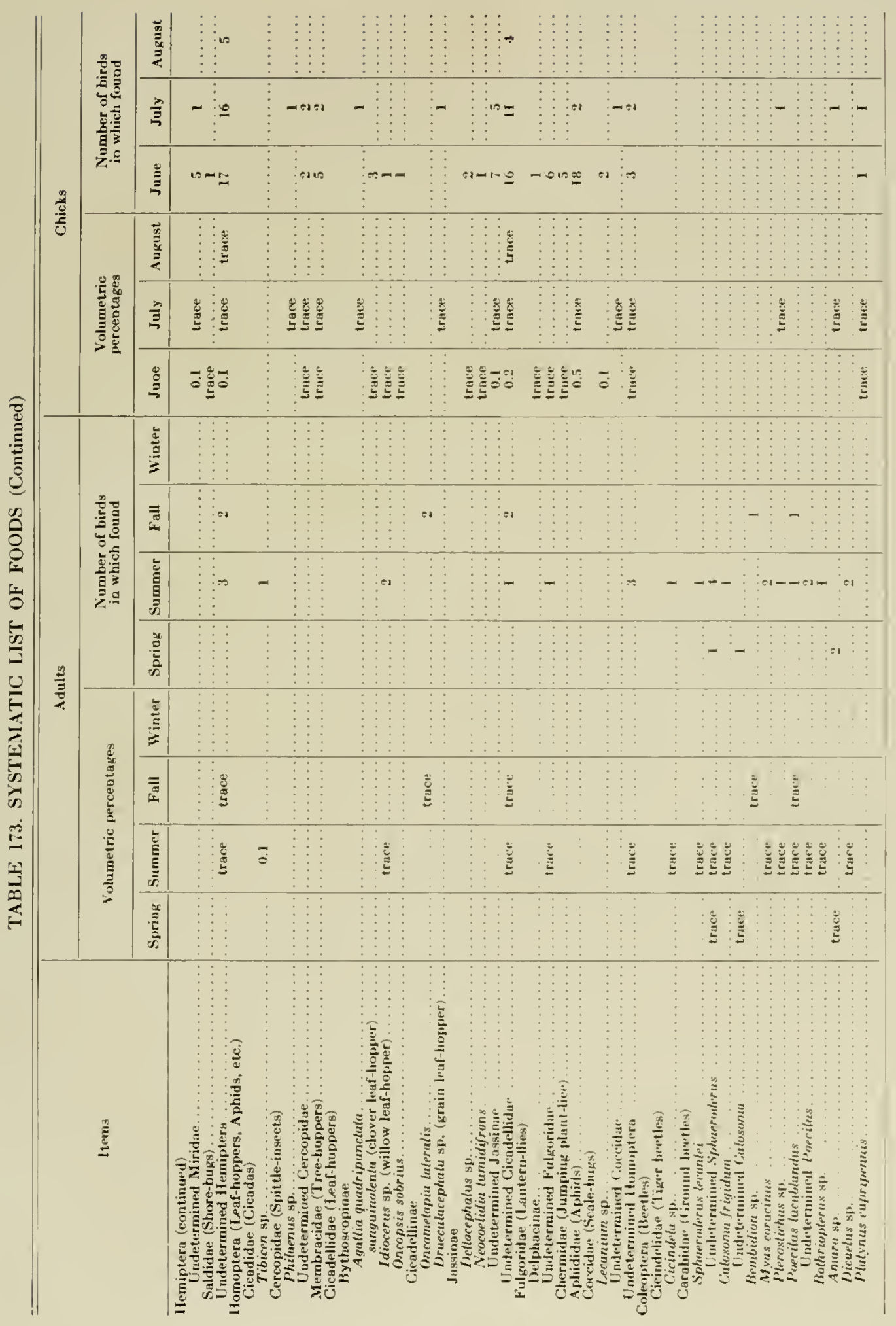




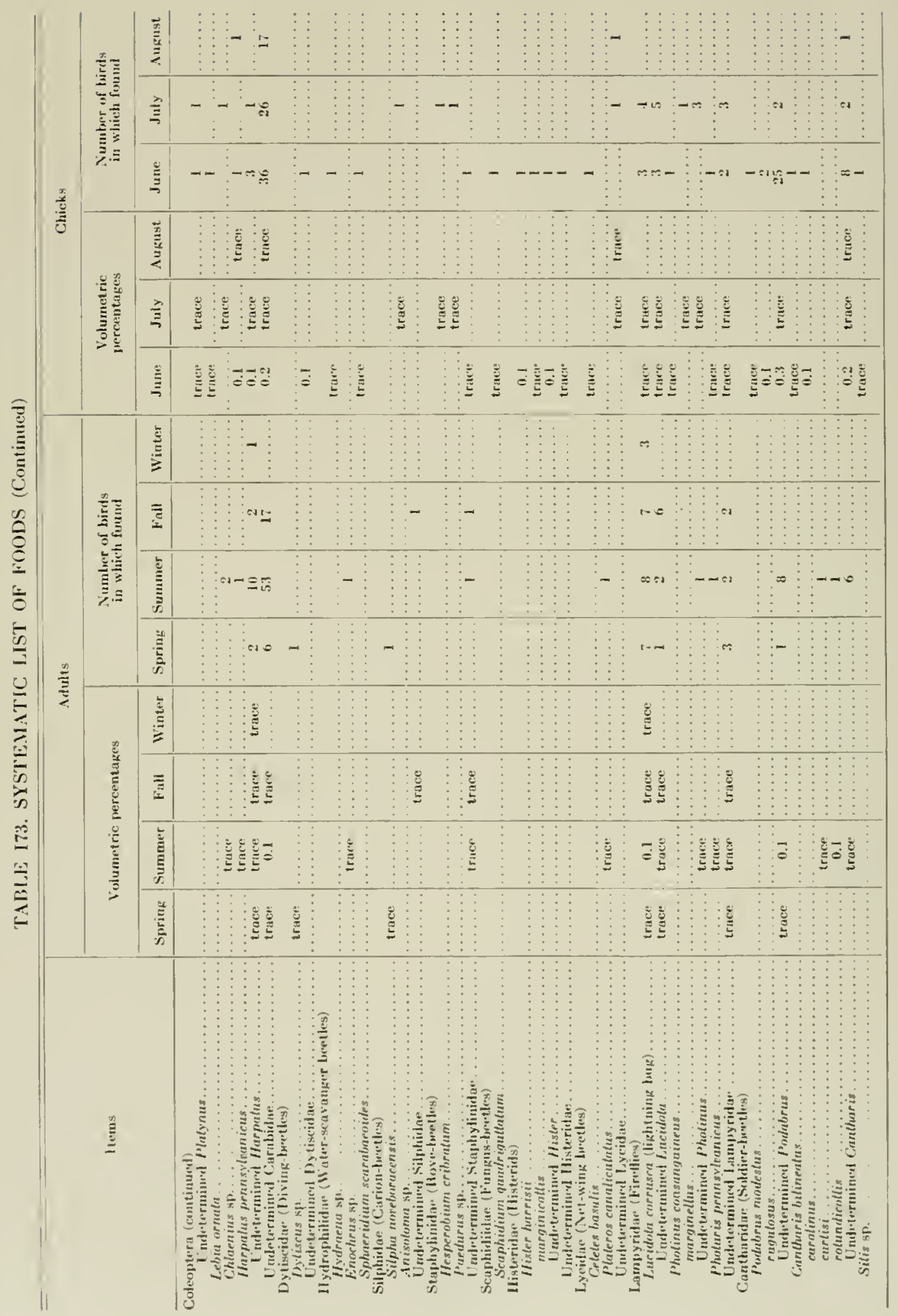




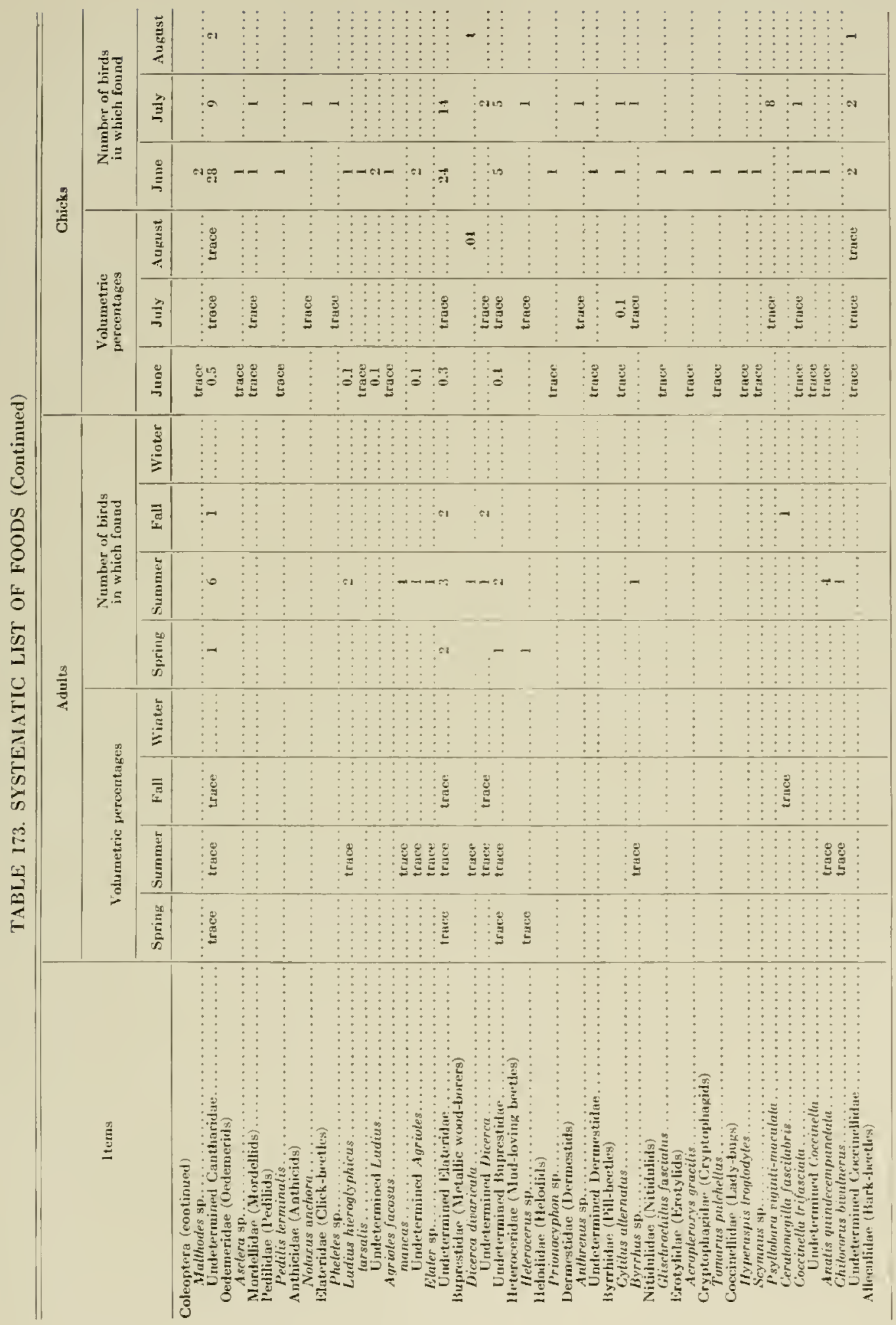




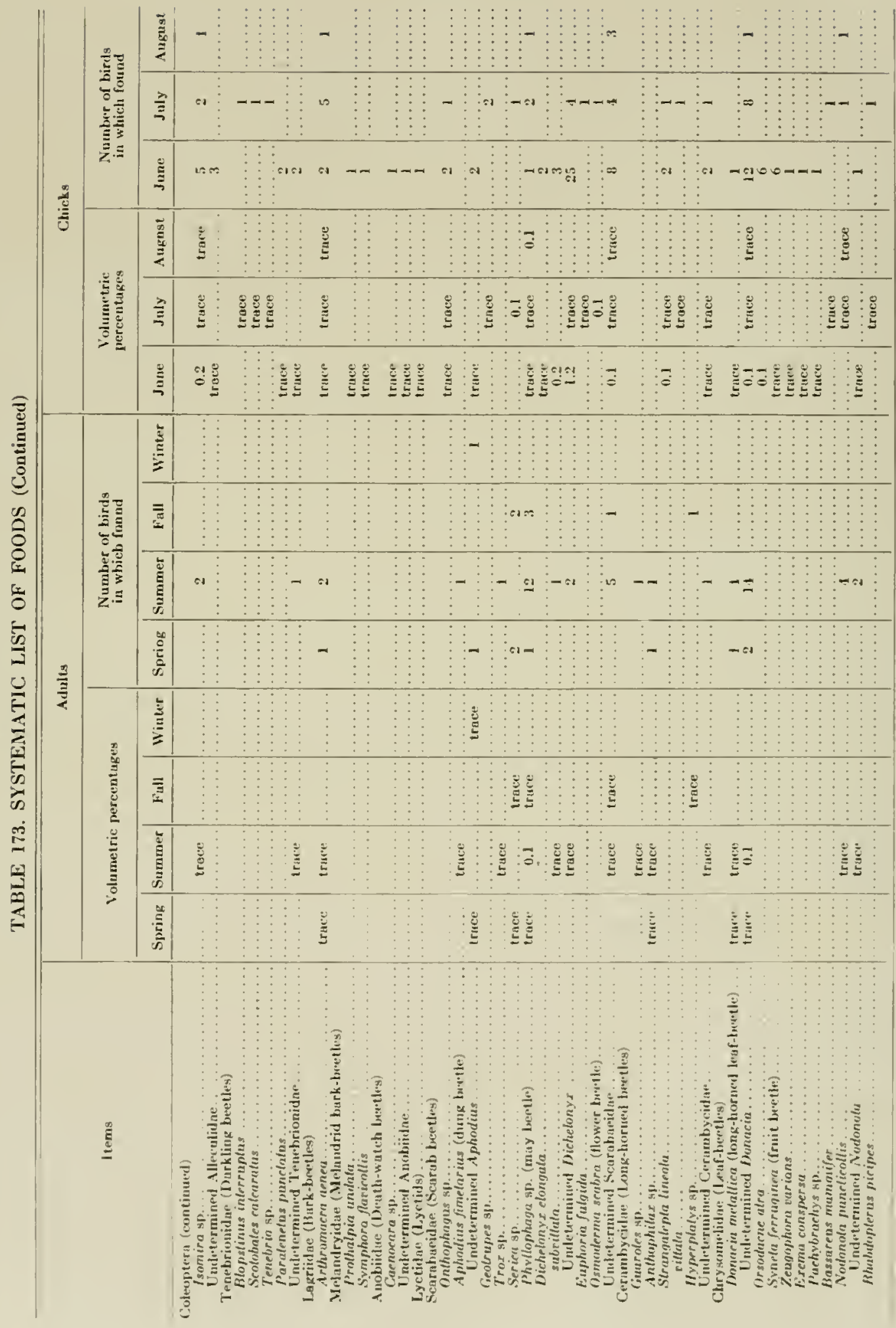




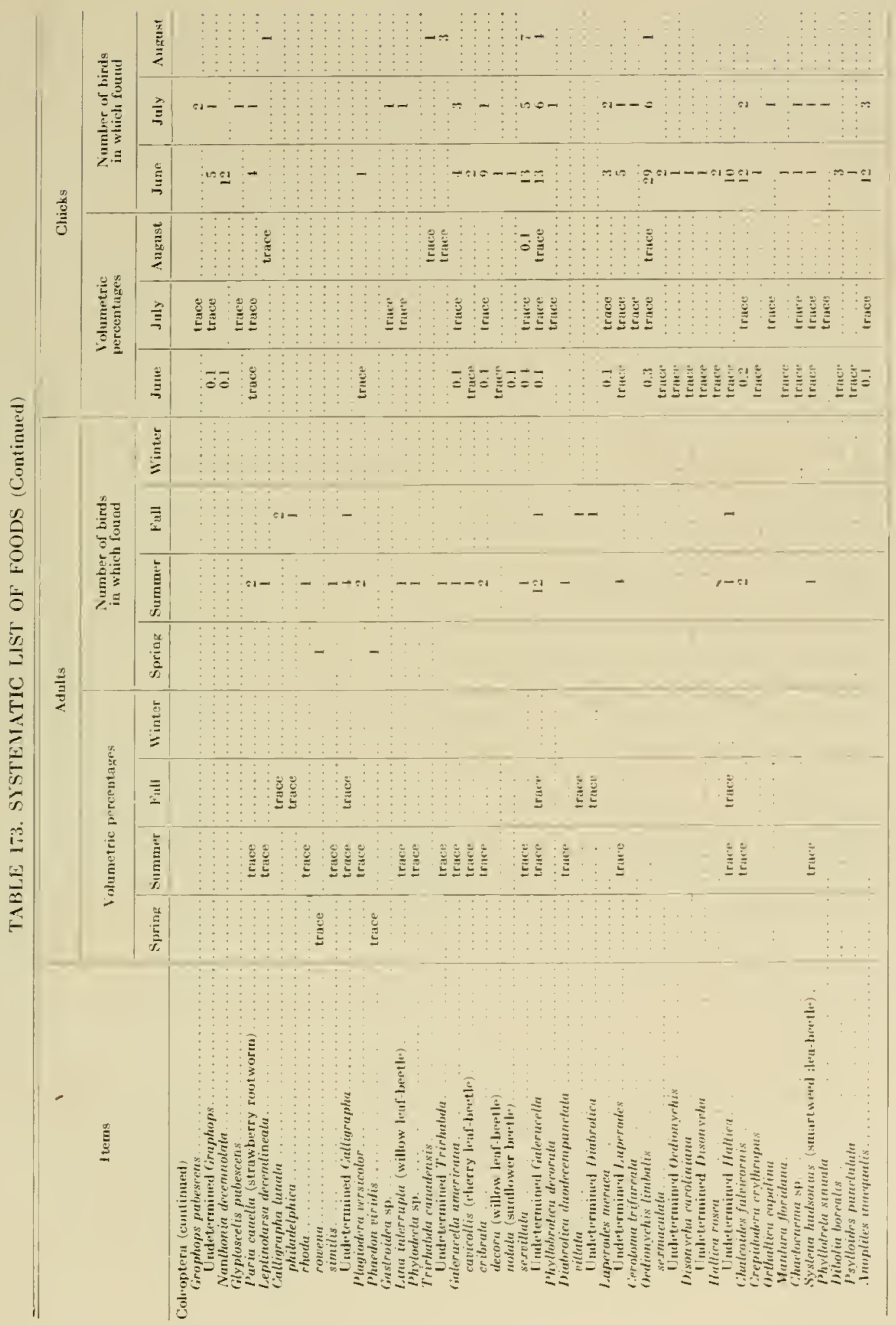




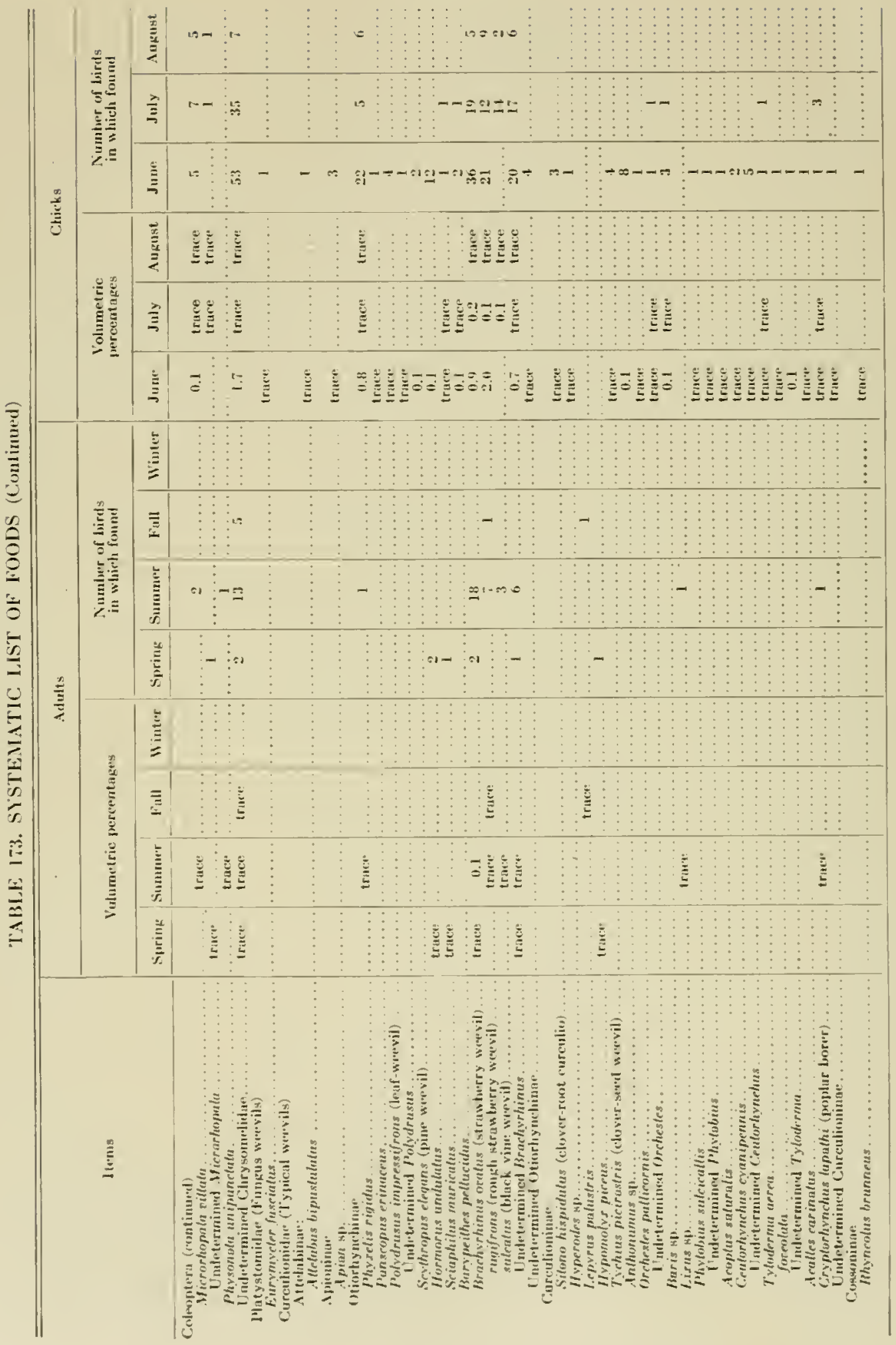




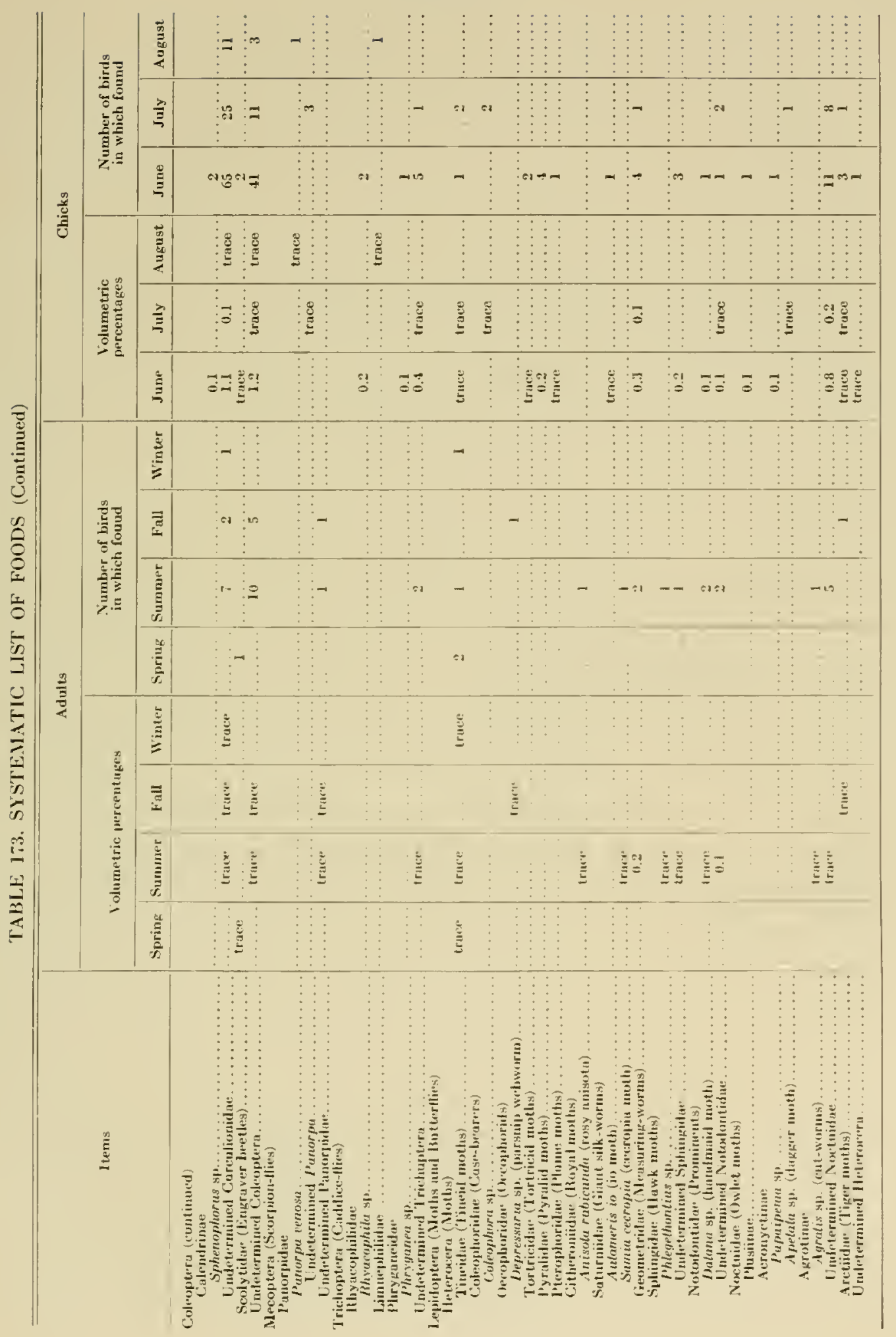




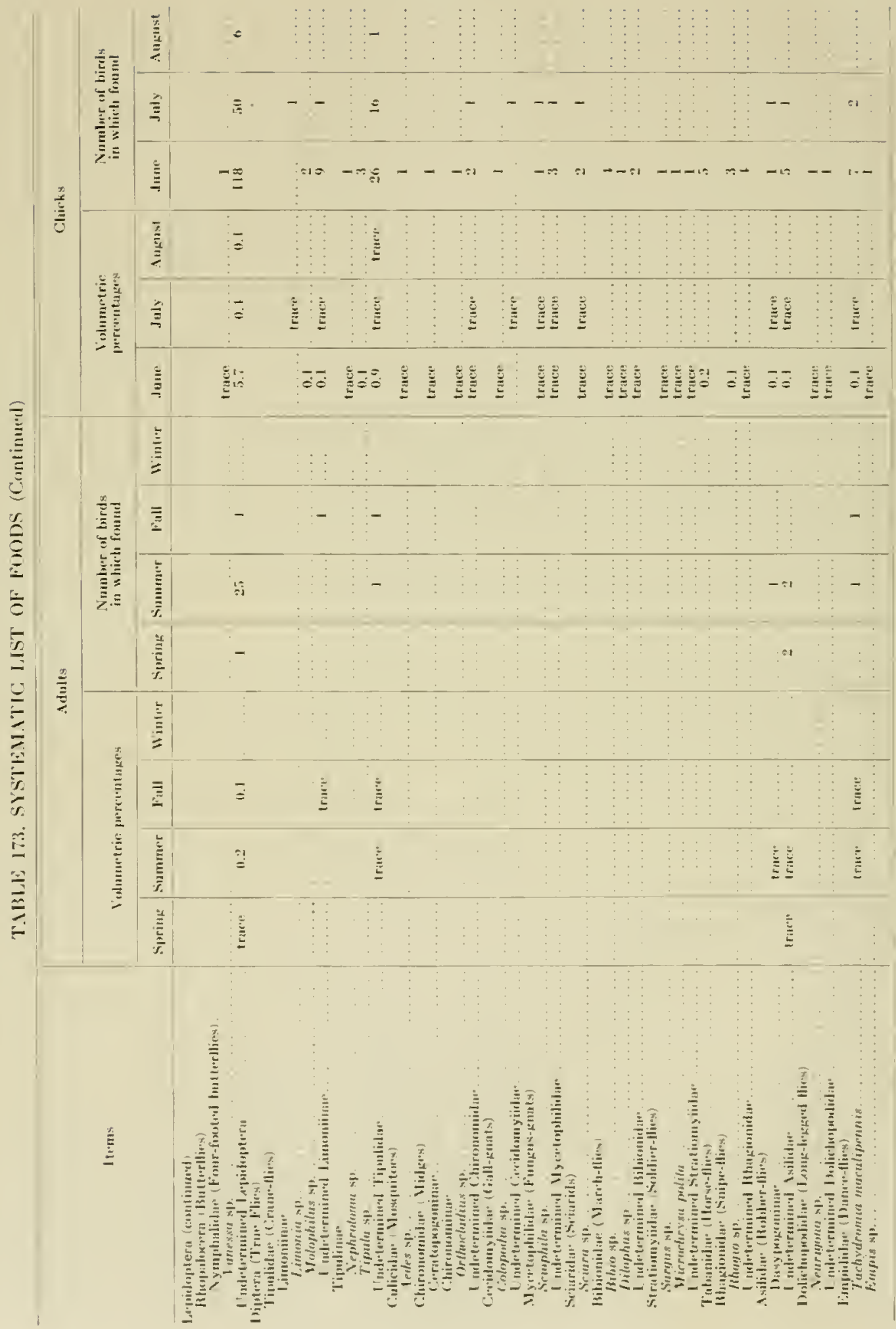




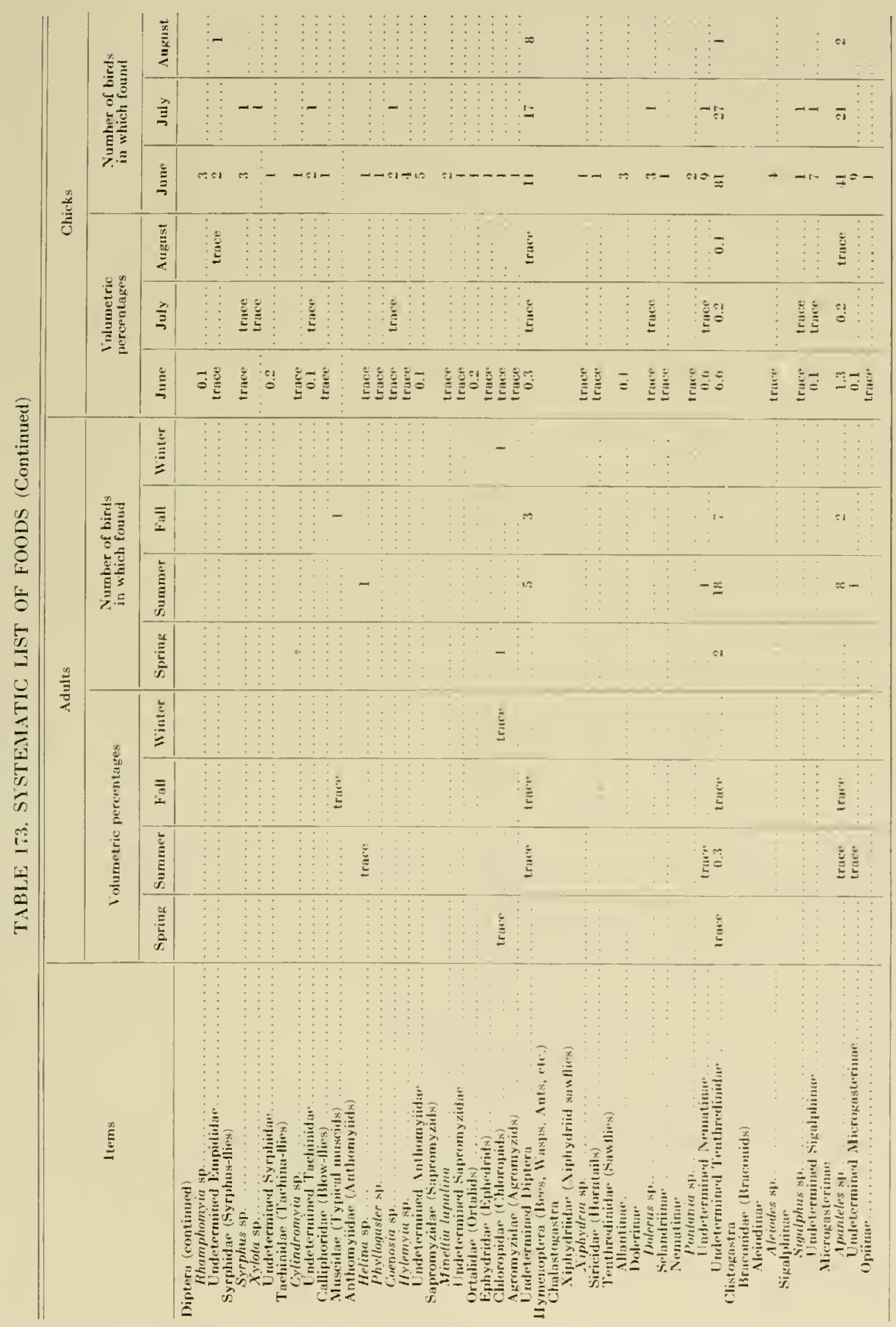




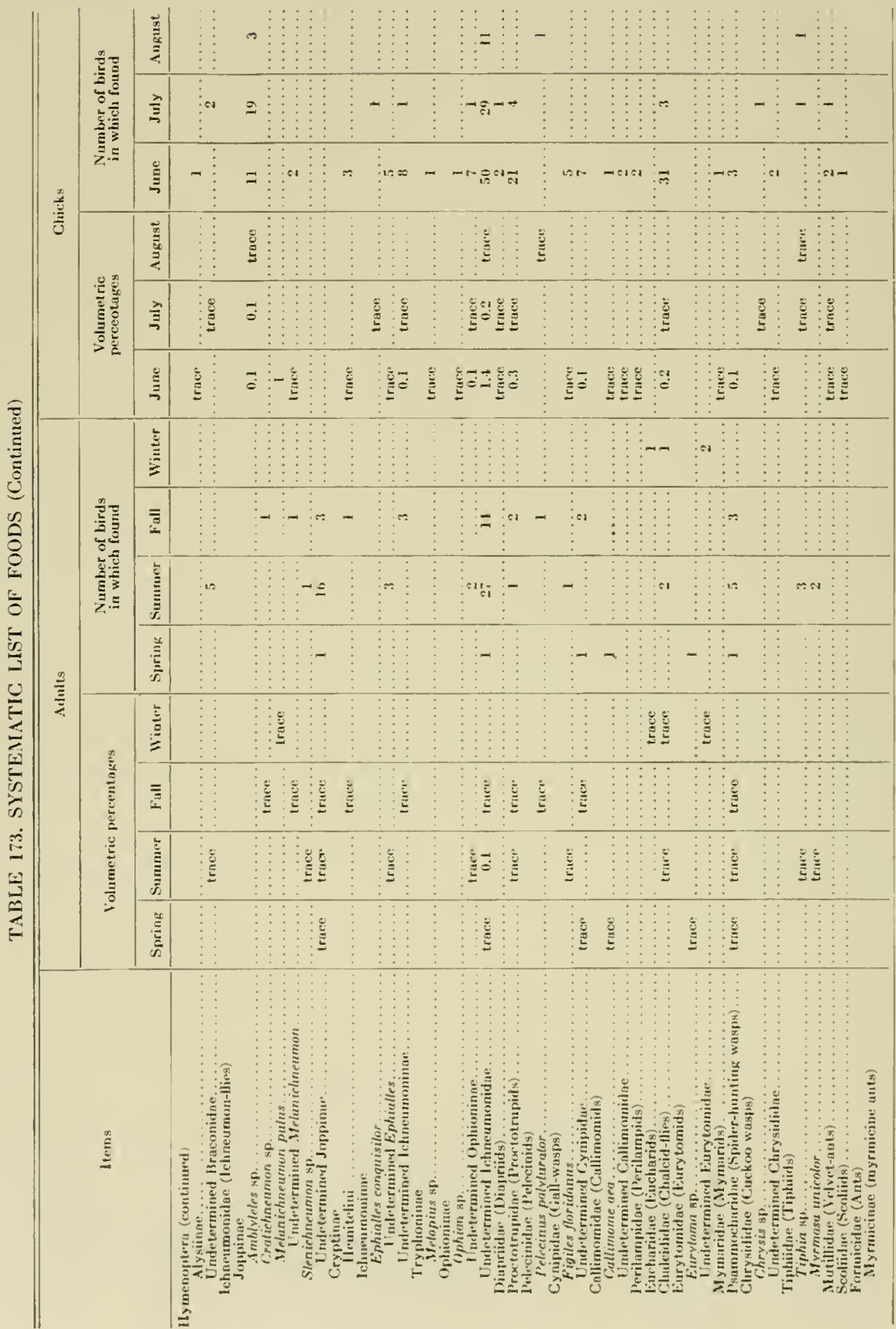




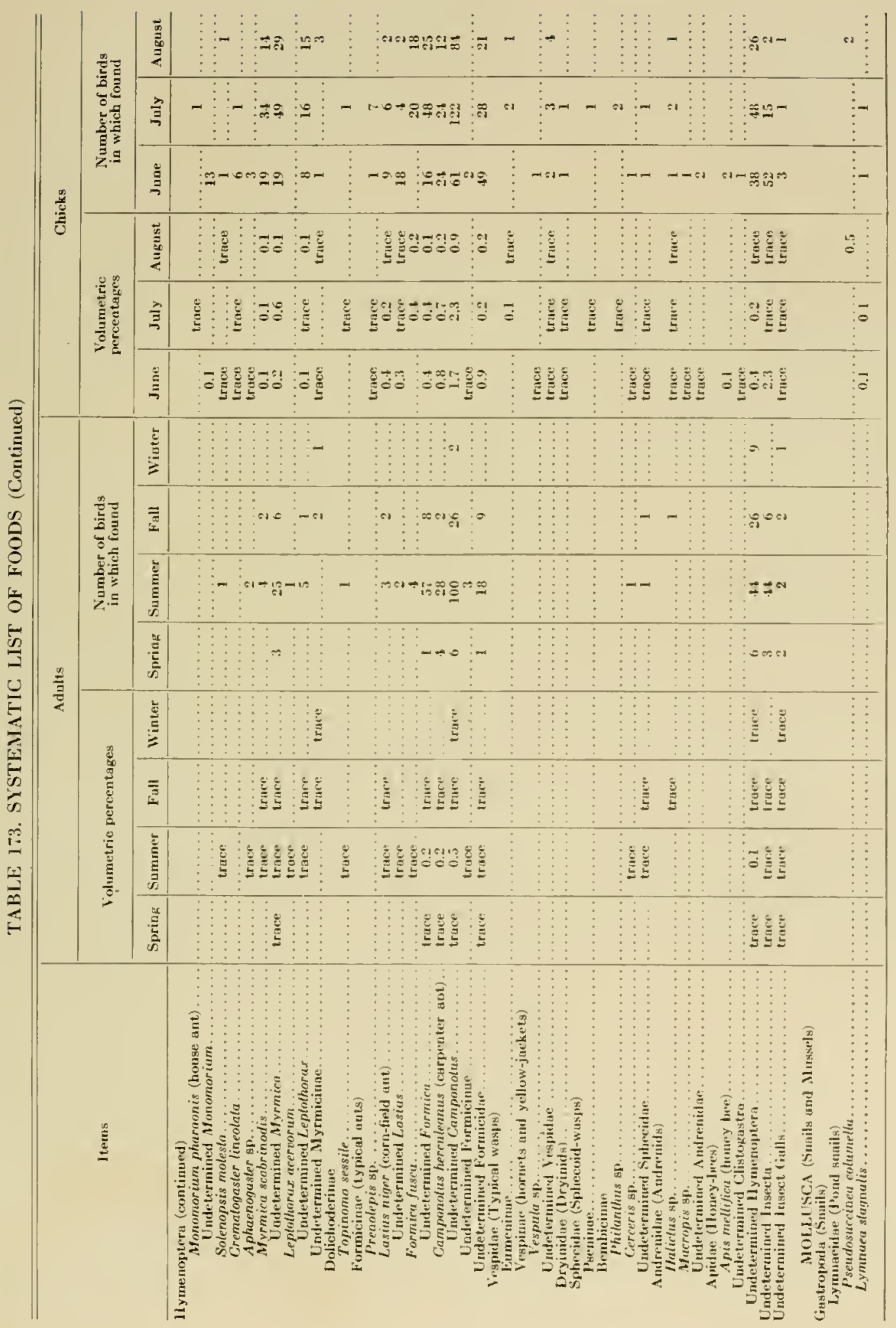




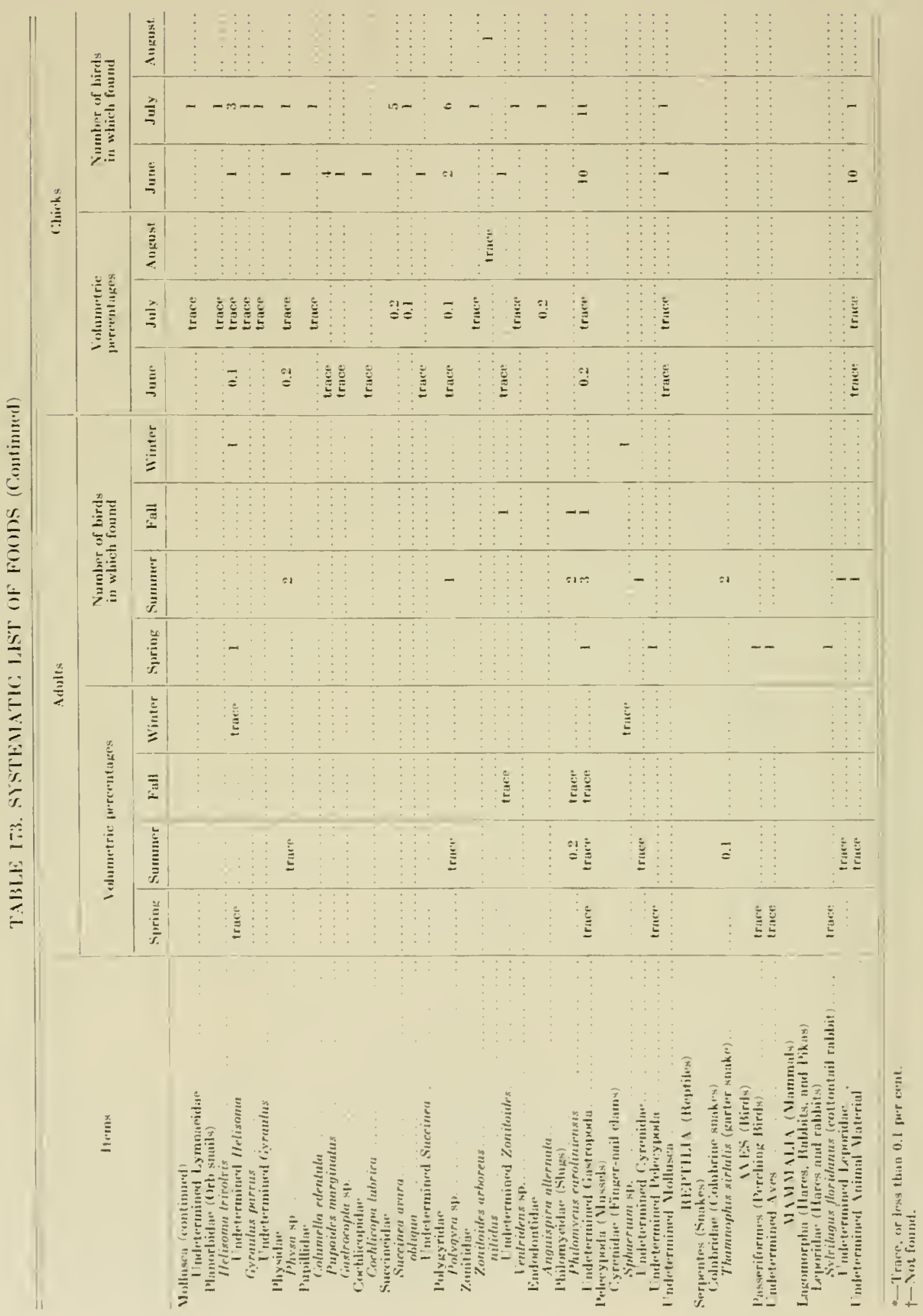


'TABLE 171. SEASONAL DISTRIBLTION OF PIEDATOR STOMACH SPICIMENS FAAMINED

\begin{tabular}{|c|c|c|c|c|c|c|c|c|c|c|c|c|c|}
\hline & Jan. & Feb. & Mar. & April & May & June & Joly & Ang. & Sept. & Oct. & Nov. & Dec. & Total \\
\hline Great horned owl............ & I4 & 3 & 12 & 16 & 21 & 3 & 5 & 2 & & 11 & 11 & 11 & 115 \\
\hline 13arred owl ................ & 3 & .. & 1 & 5 & 6 & 1 & . & 1 & 1 & 1 & & 1 & 20 \\
\hline Snowy owl $\ldots \ldots \ldots \ldots \ldots \ldots$ & 3 & & & 3 & & & . & & & & & & 6 \\
\hline Groshawk. . & 1 & 1 & 1 & 2 & 2 & 1 & & 2 & 2 & i & i & .. & 14 \\
\hline Cooper's lawk. & 1 & 2 & 1 & 4 & 3 & 3 & 5 & 15 & 6 & & i & . & 41 \\
\hline Sharp-shimued hawk......... & . & . & & 10 & 8 & 2 & 3 & 4 & 12 & 13 & i & & 53 \\
\hline Hed-tailed hawk ............ & . & 1 & 1 & 23 & 19 & 9 & 3 & I & 2 & 6 & 1 & 4 & 76 \\
\hline Bred-shoullered hawk ....... & . . & . & 4 & 17 & 1.3 & $\geq$ & & & 5 & 3 & & 1 & 45 \\
\hline 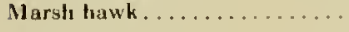 & . & $\cdots$ & . & 4 & 7 & 5 & 5 & $\tau$ & 1 & 2 & 1 & & 35 \\
\hline$\ldots \ldots \ldots \ldots$ & 39 & 5 & 1 & 2 & 5 & I & 1 & s & I & 28 & 31 & 6 & $13 !$ \\
\hline 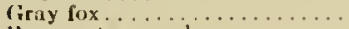 & 8 & & $\div$ & 1 & 1 & 1 & $\therefore$ & 1 & . & 2 & . & 4 & 20 \\
\hline Honaparte weasel. . . . . . . . . & 1 & 6 & 2 & 5 & 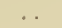 & 3 & . & 3 & & l & & 4 & 25 \\
\hline New York weusel ............ & 3 & 2 & 1 & $\cdots$ & .. & 1 & . & & $\cdots$ & & 2 & 3 & 12 \\
\hline Weasel sp................. & 2 & 1 & 1 & $\cdots$ & . & 1 & & I & .. & 1 & 3 & 10 & 20 \\
\hline Mink . . . . . . . . . & 3 & 4 & 2 & $\therefore$ & & & 1 & & $\cdots$ & & I & 1 & 12 \\
\hline 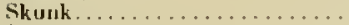 & 12 & 1.3 & 14 & 5 & 3 & 5 & 1 & 9 & 2 & 6 & 11 & i & 88 \\
\hline 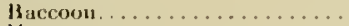 & 3 & I & 1 & 3 & 12 & 2 & 5 & 7 & 1 & & 1 & 3 & 39 \\
\hline Itouse cat............... & 2 & . & 1 & 1 & 2 & . & 1 & 2 & 3 & 3 & & & 18 \\
\hline
\end{tabular}

TABLE 175. NI MBEIS OF VARIOIS PREDATORS TAKED DI RING CONTROL EXPERIMENTS ON CON VECTICUT IIII, ARlil-1930-1935

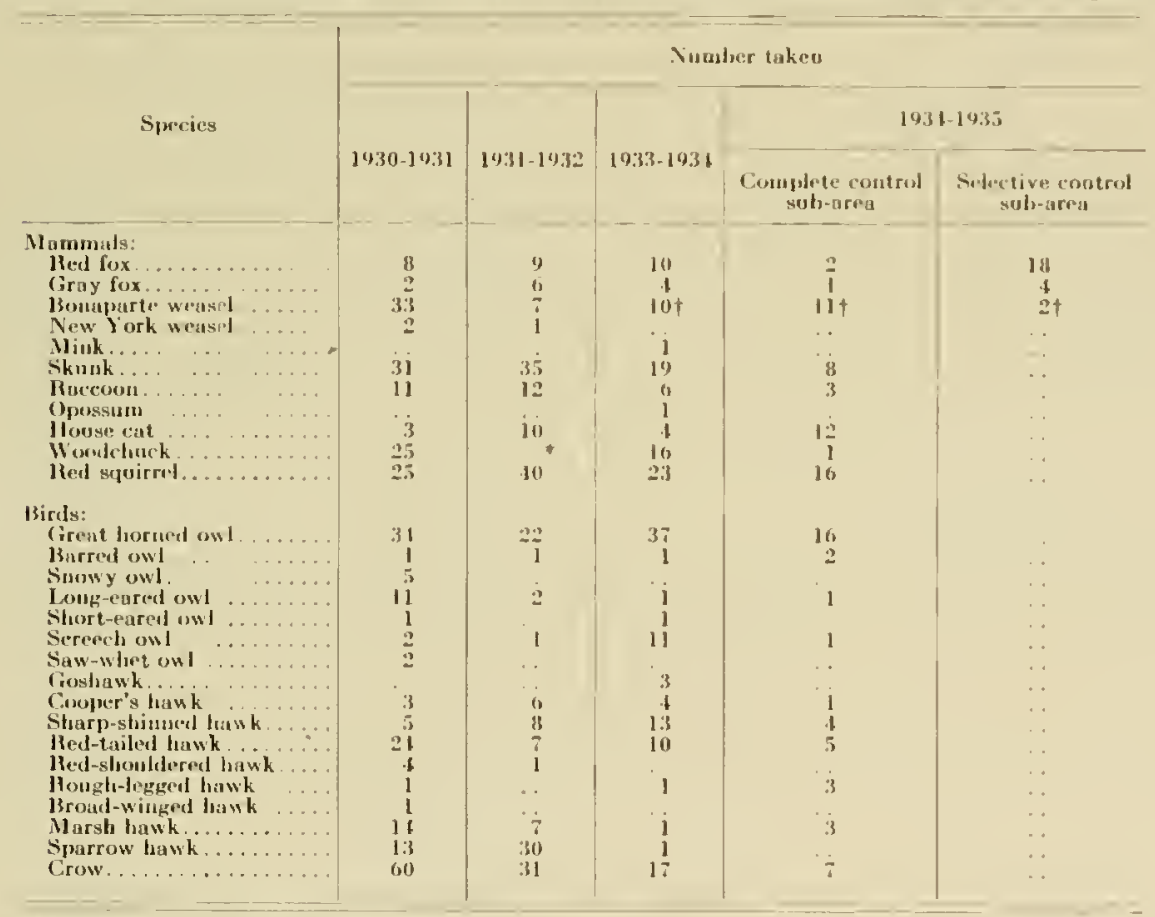

* Vot trapned in 1031-19\$2

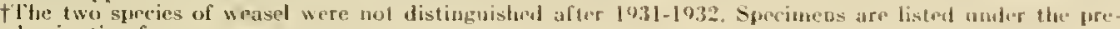
ioniuatiag form. 
"TAHLE 176. QI AITY OH EVIDEVCL ASCHIBED 'TO DIAGNOSES OF BROKEN-UI' GROUSE NESTS FOIND BY TIEE INVESTIGATION AND ATTRHBL"ILD 'TO PIREDATION 1929-1912

\begin{tabular}{|c|c|c|c|c|}
\hline \multirow{2}{*}{ Species } & \multicolumn{3}{|c|}{ Quality of rvidener } & \multirow{2}{*}{ Total } \\
\hline & lincellent & Good & Fair & \\
\hline 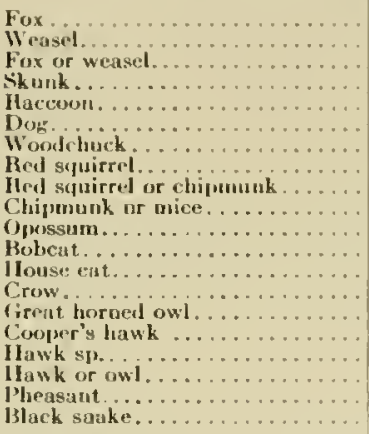 & $\begin{array}{r}40 \\
17 \\
28 \\
25 \\
2 \\
2 \\
2 \\
1 \\
2 \\
\cdots \\
10 \\
6 \\
1 \\
11 \\
1 \\
1\end{array}$ & $\begin{array}{r}74 \\
17 \\
19 \\
16 \\
11 \\
2 \\
3 \\
\cdots \\
\because \\
1 \\
0 \\
6 \\
2 \\
i \\
2 \\
1\end{array}$ & $\begin{array}{l}56 \\
15 \\
10 \\
20 \\
22 \\
6 \\
7 \\
5 \\
2 \\
1 \\
1 \\
2 \\
5 \\
1 \\
3 \\
2 \\
\cdots\end{array}$ & $\begin{array}{r}170 \\
49 \\
40 \\
61 \\
11 \\
19 \\
9 \\
10 \\
3 \\
2 \\
1 \\
1 \\
1 \\
2 \\
21 \\
8 \\
2 \\
1 \\
15 \\
1 \\
2\end{array}$ \\
\hline 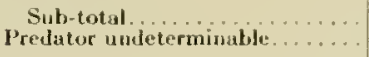 & 12.1 & $\begin{array}{c}155 \\
\ldots\end{array}$ & $\begin{array}{c}181 \\
\ldots\end{array}$ & $\begin{array}{r}16.3 \\
88\end{array}$ \\
\hline 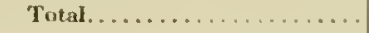 & $\ldots$ & . & $\ldots$ & $55 I^{*}$ \\
\hline
\end{tabular}
*The total number of records used ia this talle differs from that indicated in
table 35 because nests not comparable for survival calculations could nevertheless be included here.

TABLE 177. QU ALITY OF EVIDINCE ASCIRIBED TO DIAGNOSISS OF DEAD GIROUSE CHICKS FOUND BY TIHE INVESTIGATION AND ATTRIBUTED TO PIREDATION $-1930-1912$

\begin{tabular}{|c|c|c|c|c|}
\hline \multirow{2}{*}{ Species } & \multicolumn{3}{|c|}{ Quality of evideoce - } & \multirow{2}{*}{ Totu } \\
\hline & Excelleat & Good & Fuir & \\
\hline 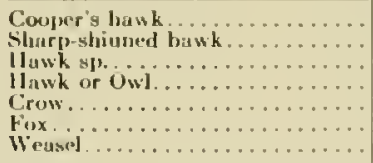 & $\begin{array}{l}2 \\
1 \\
7 \\
6 \\
1 \\
3 \\
\cdots\end{array}$ & $\begin{array}{c}\cdots \\
9 \\
7 \\
3 \\
3\end{array}$ & $\begin{array}{r}\cdots \\
9 \\
10 \\
1\end{array}$ & $\begin{array}{r}2 \\
1 \\
21 \\
20 \\
1 \\
10 \\
1\end{array}$ \\
\hline 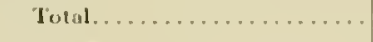 & 20 & 19 & 25 & 61 \\
\hline
\end{tabular}

TABIE 178. QI ALITY OF EIDENCE ASCRIBEO TO IIAGNOSES OF DIED ADULT GIROUSE

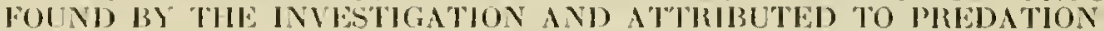
$-1930-1912$

\begin{tabular}{|c|c|c|c|c|}
\hline \multirow{2}{*}{ Sprecies } & \multicolumn{3}{|c|}{ Quality of evirlesece } & \multirow{2}{*}{ Tulal } \\
\hline & lixedleut & (3om? & Fuir & \\
\hline 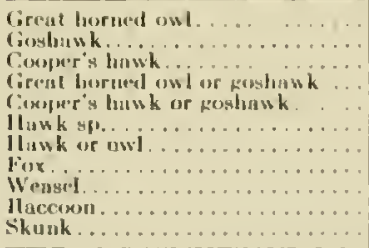 & $\begin{array}{c}11 \\
11 \\
2 \\
\cdots \\
17 \\
35 \\
11 \\
3 \\
1\end{array}$ & $\begin{array}{r}21 \\
6 \\
1 \\
1 \\
26 \\
98 \\
25 \\
5 \\
1 \\
\cdots\end{array}$ & $\begin{array}{r}55 \\
1 \\
2 \\
2 \\
1 \\
125 \\
127 \\
10 \\
10 \\
0 \\
\cdots\end{array}$ & $\begin{array}{r}180 \\
18 \\
5 \\
3 \\
1 \\
68 \\
260 \\
126 \\
18 \\
7 \\
1\end{array}$ \\
\hline 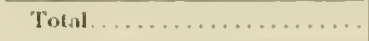 & 81 & 18.1 & 122 & 587 \\
\hline
\end{tabular}


TABLE 179. RUFFED GROUSE ARTIFICIAL, PROPAGATION EXPERIMENTS YEAR BY YEAR

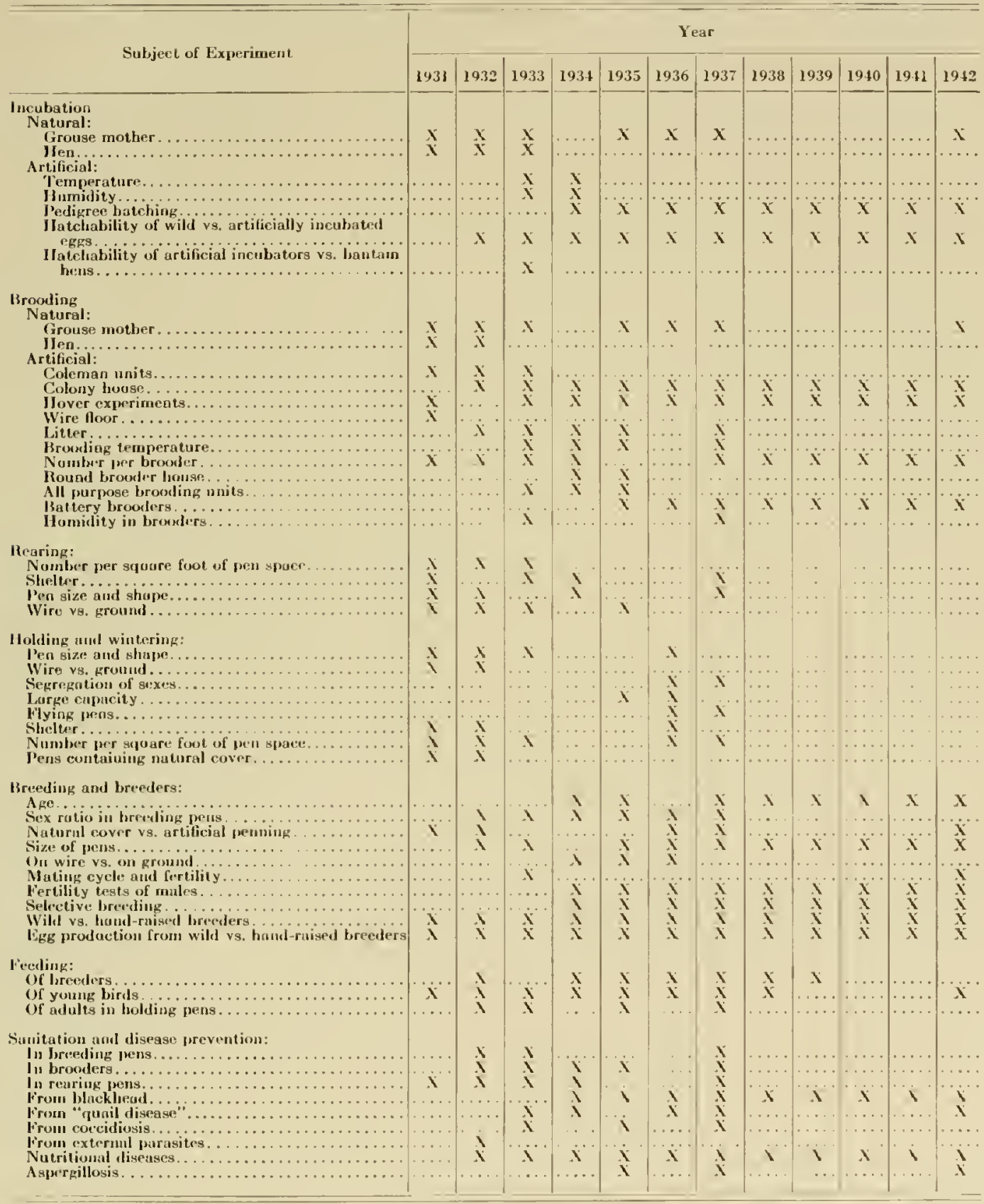



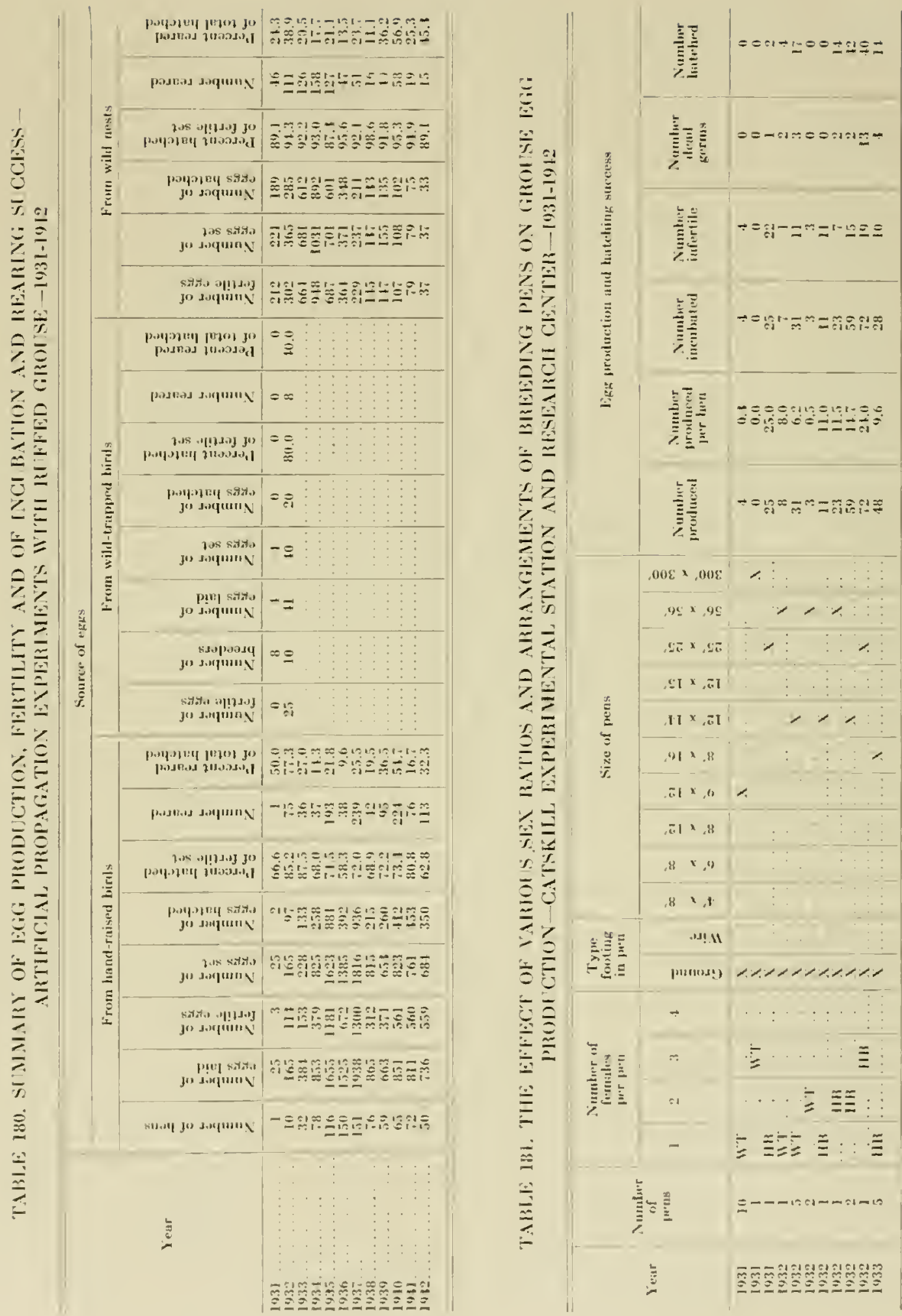


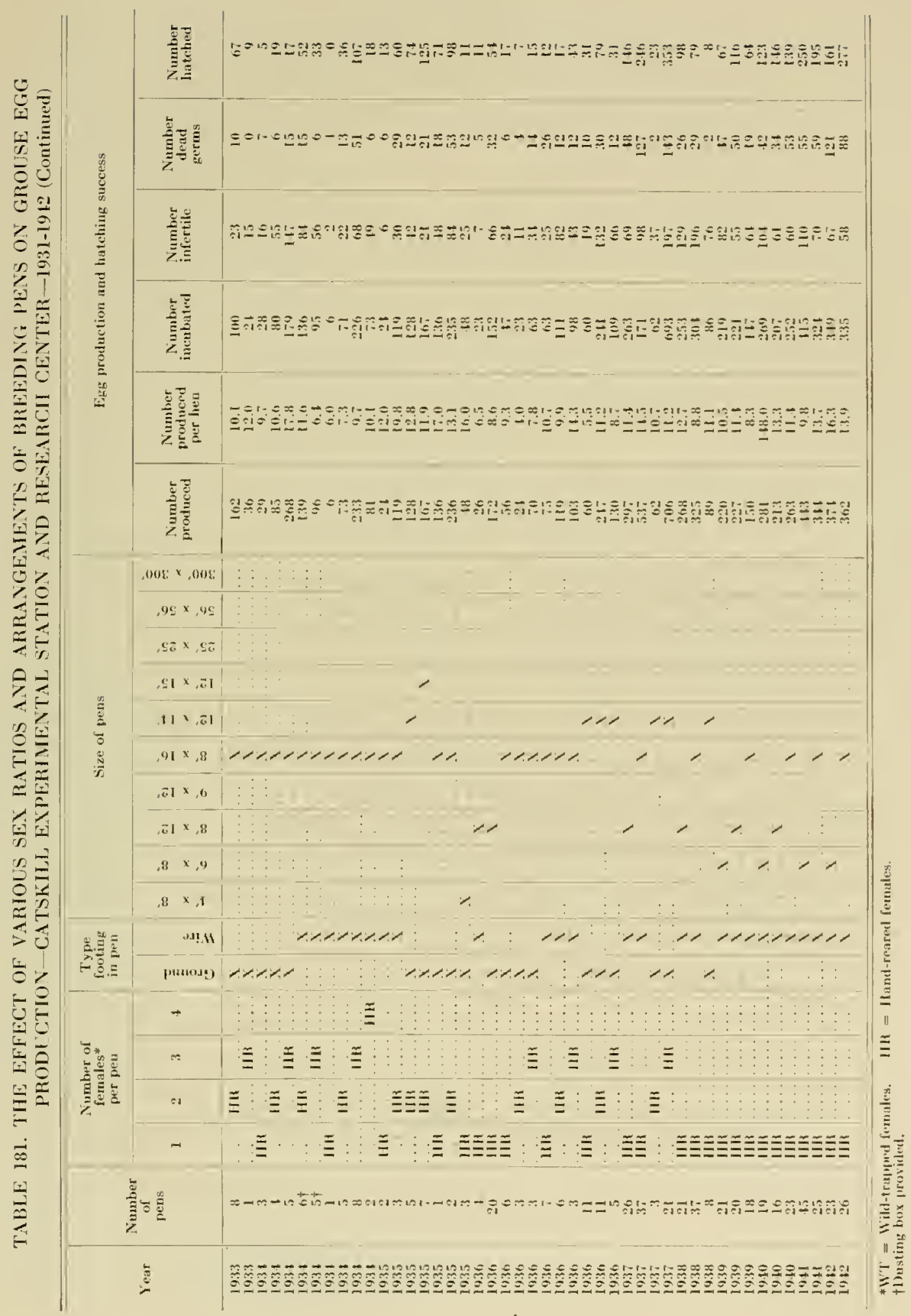




\begin{tabular}{|c|c|}
\hline 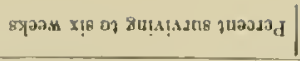 & 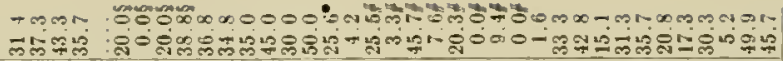 \\
\hline 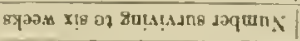 & 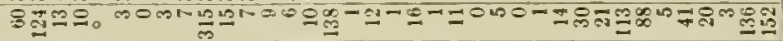 \\
\hline 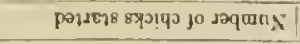 & 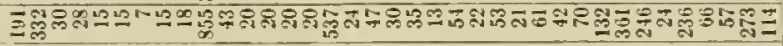 \\
\hline 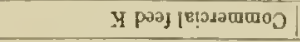 & $\vdots \vdots \vdots \vdots \vdots \vdots \vdots \vdots \vdots \vdots \vdots-$ \\
\hline 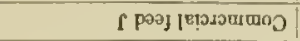 & $\vdots \vdots \vdots \vdots \vdots \vdots \vdots \vdots \vdots \vdots \vdots \vdots \vdots \vdots \vdots \vdots \vdots$ n \\
\hline 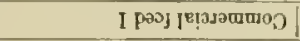 & $\vdots \vdots \vdots \vdots \vdots$ \\
\hline 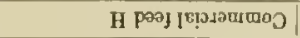 & $\vdots$ irs \\
\hline 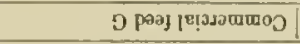 & 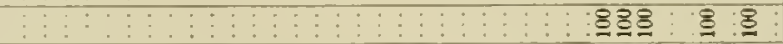 \\
\hline 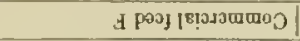 & $\vdots \vdots \vdots \vdots \div$ \\
\hline 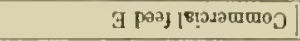 & $\vdots \vdots$ \\
\hline 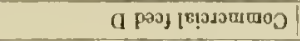 & $\vdots \vdots$ \\
\hline 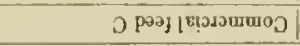 & 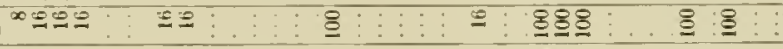 \\
\hline 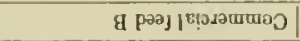 & $\vdots \vdots \vdots$ \\
\hline .V реал & $\vdots \vdots \vdots \vdots \vdots \vdots: \Omega \underline{8}$ \\
\hline puะs da ทุม & 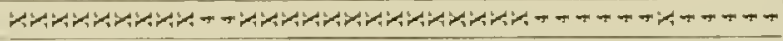 \\
\hline دथุв. 11 & 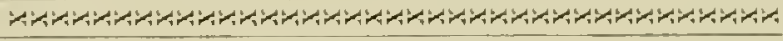 \\
\hline 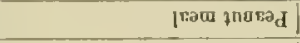 & im \\
\hline кәчм рәч) & $\vdots \vdots$ \\
\hline 28Ea 5 8, & 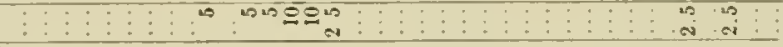 \\
\hline 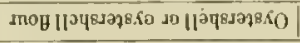 & $\vdots-ー-\infty-\infty-ー \vdots \vdots \vdots \vdots \vdots \vdots \vdots \vdots \vdots$ \\
\hline 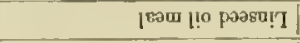 & $\therefore \vdots \vdots$ \\
\hline IIs : & $\ln ^{2}$ \\
\hline desos 1ะo $W$ & $\vdots$ \\
\hline 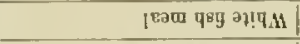 & $\Xi=$ \\
\hline 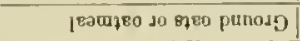 & 122 \\
\hline วвачม рนกอมอ & 2 \\
\hline แฺฺระอ & $\stackrel{2}{-2}$ \\
\hline 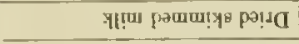 & $\vdots \vdots \cong \Omega$ \\
\hline บะมุ วвач.11 & $\therefore 200$ \\
\hline 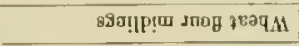 & 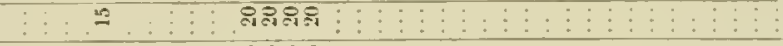 \\
\hline 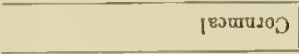 & คดลี : : \\
\hline 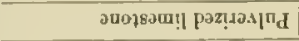 & $\vdots \vdots$ Nerere $\vdots \vdots \vdots \vdots \vdots \vdots \vdots \vdots \vdots \vdots \vdots \vdots$ \\
\hline [80328प0 & $-ー-\infty x^{23}$ \\
\hline 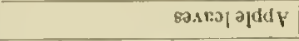 & 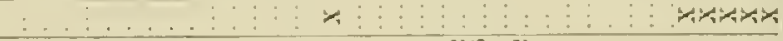 \\
\hline 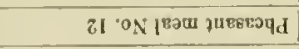 & QQ909 $209 \vdots \vdots \vdots$ \\
\hline 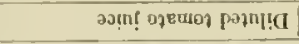 & Frr $\vdots \vdots \vdots \vdots \vdots \vdots \vdots \vdots \vdots$ \\
\hline 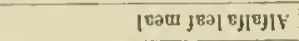 & 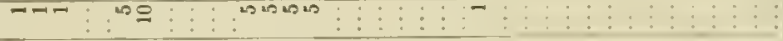 \\
\hline 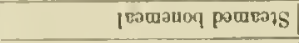 & 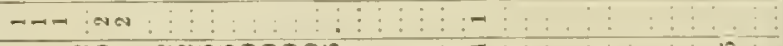 \\
\hline 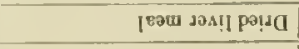 & 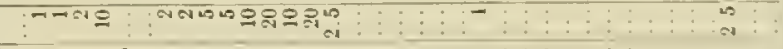 \\
\hline $1 ! 0$ dəa!l1800 & 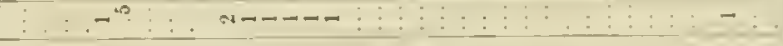 \\
\hline 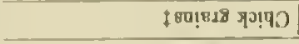 & 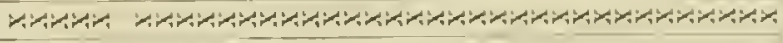 \\
\hline 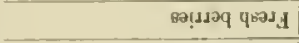 & - \\
\hline 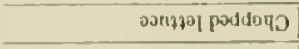 & 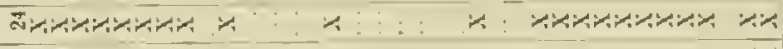 \\
\hline มा10 pod & $: \quad \because \%: \%$ \\
\hline 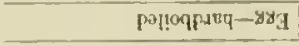 & $\therefore \quad \therefore \because \geq 2 \cong$ \\
\hline 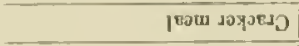 & $\cdot \vdots \vdots \vdots: \simeq 2$ \\
\hline 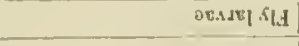 & 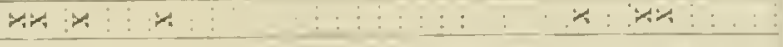 \\
\hline 党 & 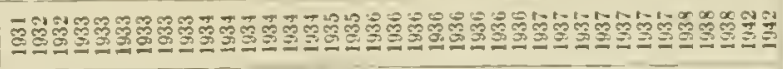 \\
\hline 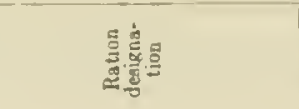 & - \\
\hline
\end{tabular}

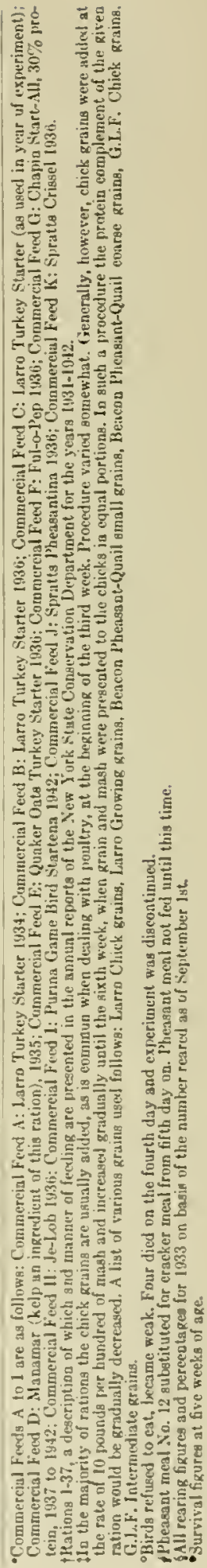




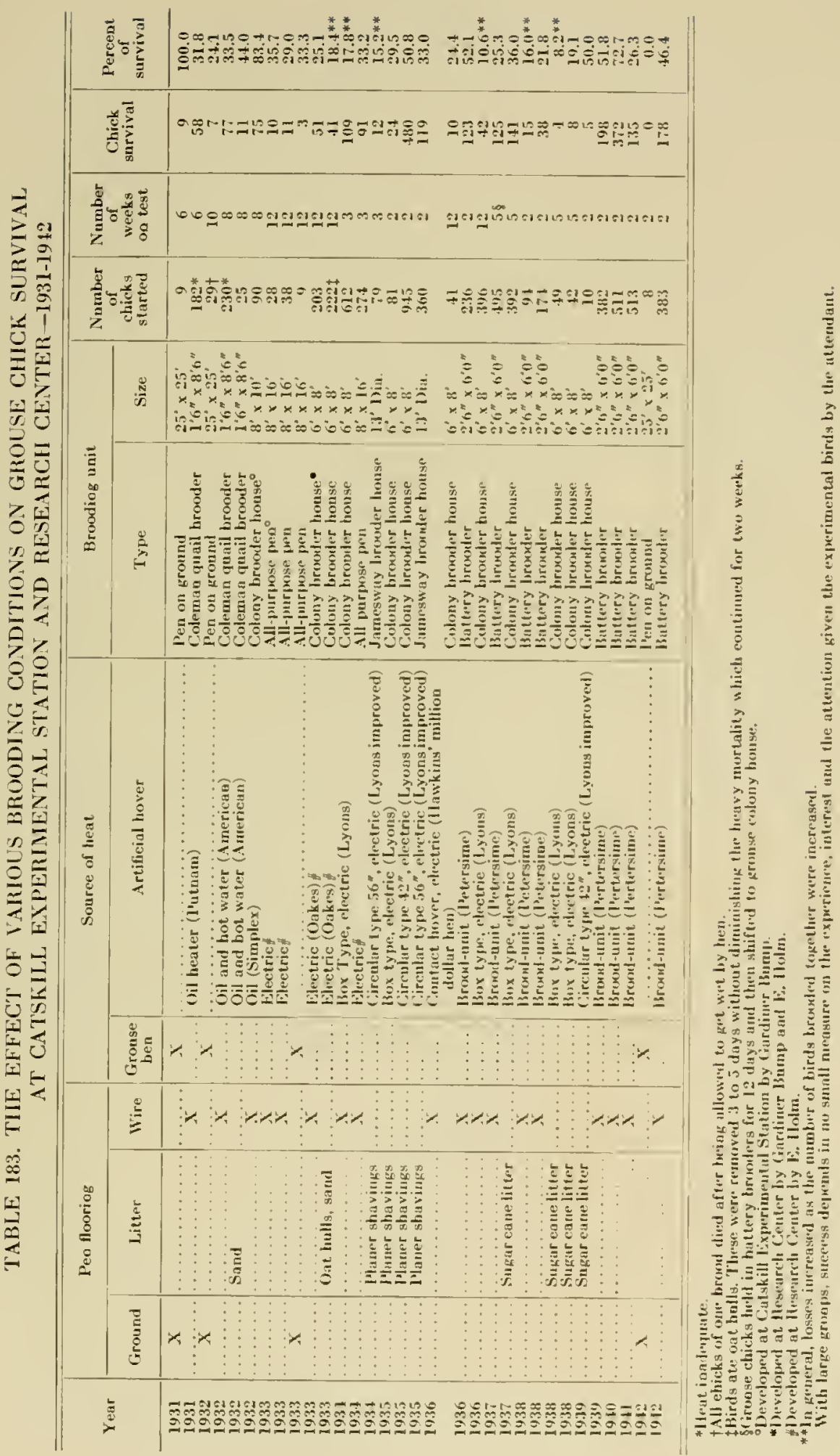




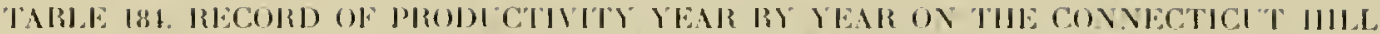
AND ADIRONDACK STI DI ARIAT-1930-1912

\begin{tabular}{|c|c|c|c|c|c|c|c|c|}
\hline Yeir & $\begin{array}{l}\text { Iircraling } \\
\text { inipulation }\end{array}$ & $\begin{array}{l}\text { Arlolts } \\
\text { irrosent } \\
\text { II ay } 31\end{array}$ & $\begin{array}{l}\text { Potential } \\
\text { rlucks }\end{array}$ & $\begin{array}{l}\text { Cliveks } \\
\text { J bitrlored }\end{array}$ & $\begin{array}{l}\text { Chicks sur- } \\
\text { viving to } \\
\text { supteruber }\end{array}$ & $\begin{array}{l}\text { Adults sur- } \\
\text { viving to } \\
\text { siptumber } 1\end{array}$ & $\begin{array}{l}\text { Septrmber } 1 \\
\text { fropulation }\end{array}$ & $\begin{array}{l}\text { Orerwinter } \\
\text { loss }\end{array}$ \\
\hline \multicolumn{9}{|c|}{ Comsuetirut llill } \\
\hline 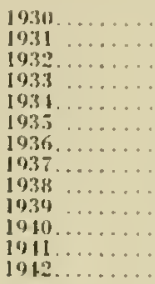 & $\begin{array}{l}122 \\
112 \\
225 \\
283 \\
109 \\
250 \\
170 \\
123 \\
118 \\
127 \\
181 \\
139 \\
167\end{array}$ & $\begin{array}{l}75 \\
135 \\
2013 \\
261 \\
176 \\
215 \\
154 \\
115 \\
112 \\
167 \\
171 \\
113 \\
119\end{array}$ & $\begin{array}{l}5: 99 \\
818 \\
1331 \\
1668 \\
10643 \\
1508 \\
1004 \\
801 \\
1012 \\
1001 \\
1178 \\
1301 \\
1053\end{array}$ & $\begin{array}{l}2010 \\
161 \\
5121 \\
3311 \\
509 \\
527 \\
365 \\
158 \\
171 \\
102 \\
201 \\
131 \\
3.39\end{array}$ & $\begin{array}{l}35 \\
138 \\
249 \\
73 \\
257 \\
1111 \\
167 \\
1.38 \\
178 \\
231 \\
111 \\
175 \\
76\end{array}$ & 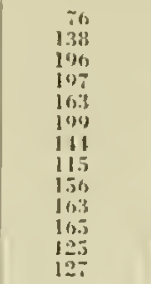 & $\begin{array}{l}161 \\
276 \\
16.5 \\
271 \\
120 \\
3110 \\
311 \\
273 \\
331 \\
3111 \\
276 \\
300 \\
2113\end{array}$ & $\begin{array}{r}19 \\
51 \\
182 \\
75 \\
161 \\
130 \\
188 \\
125 \\
157 \\
310 \\
111 \\
133 \\
\ldots \ldots \ldots\end{array}$ \\
\hline \multicolumn{9}{|c|}{ Adiroublack } \\
\hline $\begin{array}{l}1932 \ldots \ldots \ldots \\
1933 \ldots \ldots \ldots \\
1931 \ldots \ldots \ldots \\
1933 \ldots \ldots \\
1936 \ldots \ldots \\
1937 \ldots \ldots \ldots \\
1938 \ldots \ldots \ldots \\
1939 \ldots \ldots \ldots \\
1910 \ldots \ldots \ldots \\
1911 \ldots \ldots \ldots \\
1912 \ldots \ldots \ldots\end{array}$ & $\begin{array}{l}10 \\
36 \\
21 \\
21 \\
21 \\
22 \\
25 \\
(3.5) \dagger \\
(28) \\
(29) \\
(27)\end{array}$ & 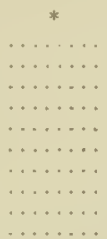 & $\begin{array}{l}187 \\
176 \\
110 \\
09 \\
151 \\
132 \\
1113 \\
(187) \dagger \\
(1113) \\
(151) \\
(14: 3)\end{array}$ & $\begin{array}{r}83 \\
109 \\
190 \\
60 \\
80 \\
100 \\
70 \\
110 \\
92 \\
70 \\
86\end{array}$ & $\begin{array}{l}38 \\
23 \\
11 \\
18 \\
11 \\
17 \\
10 \\
30 \\
213 \\
37\end{array}$ & $\begin{array}{l}32 \\
26 \\
39 \\
16 \\
16 \\
18 \\
25 \\
30 \\
21 \\
25 \\
25\end{array}$ & $\begin{array}{l}70 \\
51 \\
73 \\
23 \\
61 \\
31 \\
12 \\
10 \\
603 \\
5313 \\
60\end{array}$ & $\begin{array}{l}31 \\
27 \\
52 \\
2 \\
12 \\
31 \\
(2)+ \\
(12) \\
(31) \\
(26) \\
\ldots \ldots\end{array}$ \\
\hline
\end{tabular}

* Spring surveys on the Adirmdark area were mot carried on during the later part of bay and, therefore, did aot permit a lay

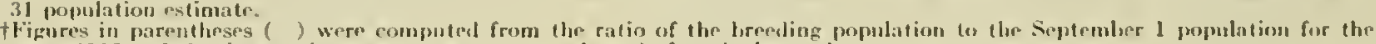
years 1932 to 1933 siner sprion surveys wore bot combetwd after the latter date.

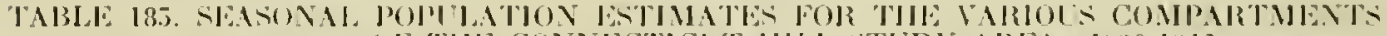

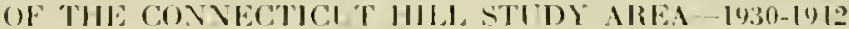

\begin{tabular}{|c|c|c|c|c|c|c|c|c|c|c|c|c|}
\hline Compartment & 19.30 & $19: 31$ & 1932 & $19383 *$ & $19: 31$ & 1935 & 1936 & 1937 & 1938 & 1939 & 1910 & 1911 \\
\hline
\end{tabular}

Spring (April)

\begin{tabular}{|c|c|c|c|c|c|c|c|c|c|c|c|c|c|}
\hline 1. & 11 & 18 & 27 & 25 & 17 & 21 & 11 & 7 & 17 & $=1$ & 24 & 17 & $\because$ \\
\hline & 6 & 2.2 & 31 & 38 & 28 & 21 & 19) & 18 & 11 & 21 & 25 & 12 & 2.3 \\
\hline $3 \pi$ & 6 & 10 & 10 & 18 & 26 & 311 & 19 & 1.3 & 1.5 & 17 & 18 & 11 & 11 \\
\hline 35 & 6 & 13 & 17 & $\ldots$ & 15 & 11 & 11 & 3 & $\overline{0}$ & 8 & 8 & c & \\
\hline 1 & 7 & 10 & 17 & $\ldots$ & 20 & $\therefore 6$ & 11 & 10 & 12 & 12 & 13 & 11 & 9 \\
\hline 5. & 1 & 7 & "1 & $\ldots$ & 10 & 12 & ") & 6 & 12 & 13 & ") & 8 & 8 \\
\hline 6 & $?$ & 8 & 14) & $\ldots$ & 13 & 16 & 10 & 10 & 1) & 16 & 4) & 1) & 9 \\
\hline & 11 & $14 t$ & 26 & $\ldots$ & 16 & 37 & $\because 1$ & 11 & 12 & 12 & 17 & 11 & 21 \\
\hline 8 & 8 & it & 8 & & 10 & 20 & 1.7 & 10 & 16 & 1.5 & 17 & 1:1 & 12 \\
\hline 9 & 5 & [0] & 25 & 22 & 8 & 18 & $1 . \overline{7}$ & 10 & 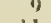 & 11 & 13 & $1 "$ & 8 \\
\hline 11 & 5 & ") & 12 & 20 & 13 & 20 & 12 & 1) & 11 & 10 & 12 & 10 & $?$ \\
\hline 15 & 11 & 12 & 15 & & 11 & 1.5 & 11 & $1: 3$ & 11 & 18 & 11 & 12 & 16 \\
\hline rotal & 92 & 112 & 225 & 28.3 & $1(x)$ & 256 & 1.01 & 12.3 & 118 & $1: 7$ & 181 & 132 & $16:$ \\
\hline
\end{tabular}

Finll (Neptemlere

\begin{tabular}{|c|c|c|c|c|c|c|c|c|c|c|c|c|c|}
\hline$!$ & 27 & 36 & 60 & 31 & 27 & $2 h$ & 21 & 38 & 50 & in & 11 & 18 & 263 \\
\hline 3 & 22 & 27 & 58 & . & $5 i$ & $\approx 2$ & 17 & 211 & 32 & III & 20 & 12 & 20 \\
\hline II! & III & $1 i$ & 1.3 & $\ldots$ & 73 & 319 & $=7$ & 33 & 35 & 27 & 21 & 18 & 19 \\
\hline 3is. & I11 & 17 & 24 & $\ldots$ & 25 & 12 & 23 & 11 & $1: 1$ & I" & 13 & 16 & 1 \\
\hline 1 & ["] & 21 & 32 & $\ldots$ & 37 & 21 & 16 & 11 & 21 & 28 & 12 & 26 & 12 \\
\hline 3. & $h$ & 16 & 13 & . . & 11 & 18 & 1.4 & $\because 2$ & 29) & 21 & 25 & 21 & 17 \\
\hline (1). & 11 & 23 & 3.5 & $\ldots$ & 21 & 21 & 18 & 16 & 21 & $3 n$ & 11 & 10 & 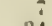 \\
\hline 7 & 15 & 93 & 50 & $\ldots$ & 22 & 1.3 & 111 & 18 & 3.5 & 21 & 20 & 18 & 21 \\
\hline 8 & 13 & 7 & (16) & & 273 & 3.7 & 18 & 182 & $2: 1$ & (1) & $2: 2$ & 20 & 20 \\
\hline ") & $i$ & 27 & 50 & 27 & 25 & 16. & i0 & 23 & " & 28 & 14 & $\div 1$ & 11 \\
\hline 11 & i & 16 & 311 & 21 & 33 & in & 32 & $\therefore 1$ & 1.1 & III & $\because 1$ & 2.3 & 15 \\
\hline 1.5 & 11 & 23 & 27 & & 21 & 11) & 33 & $\because 2$ & 52 & I: & $3 n$ & 27 & 28 \\
\hline listal & 101 & $2 \pi 1$ & 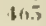 & $2 \because i$ & $\approx 0$ & 300 & 311 & 273 & 334 & 301 & 206 & 300 & 203 \\
\hline
\end{tabular}

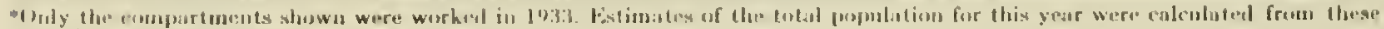
samples and rilatid data. 


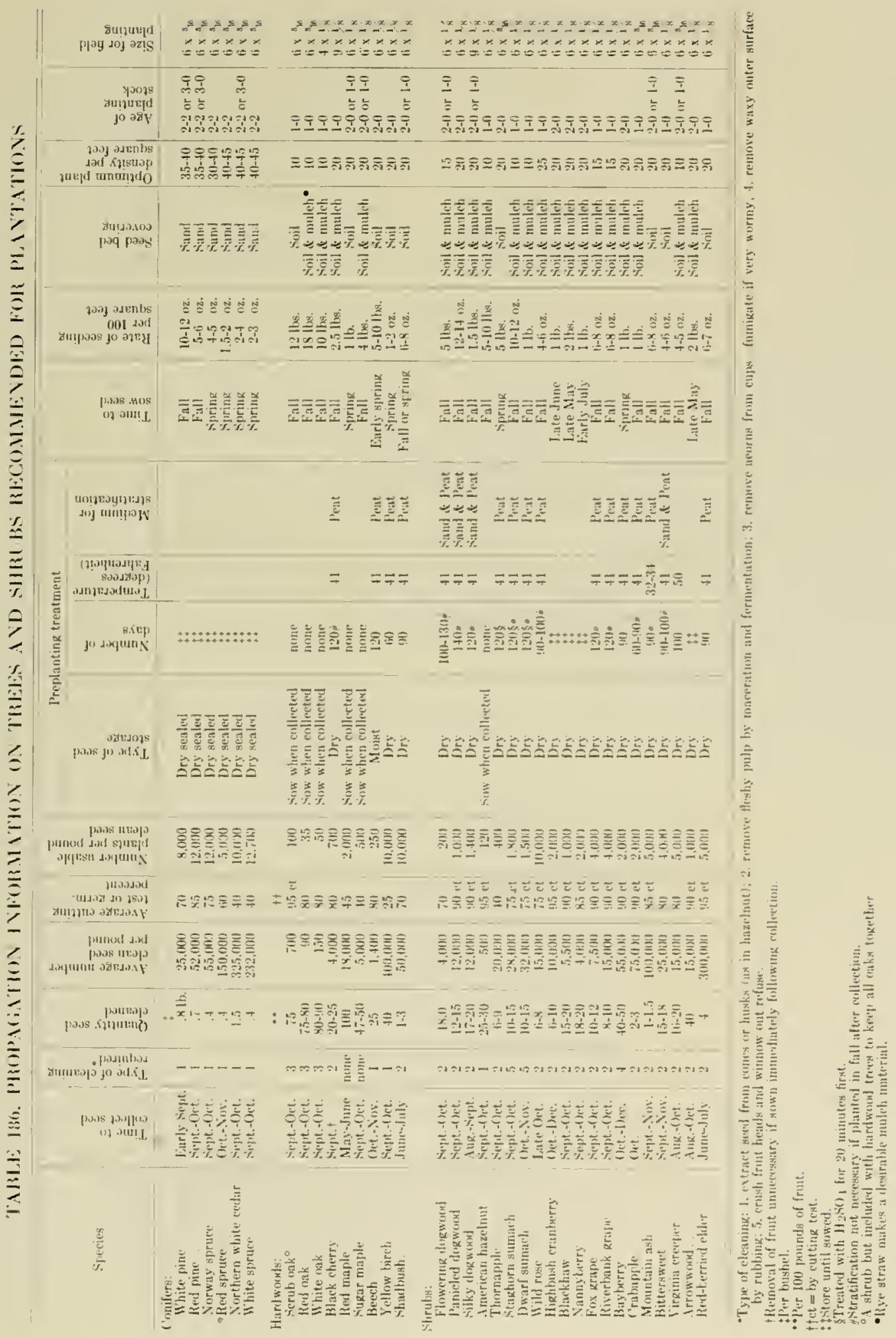





\section{LITERATURE CITED}

1. A.G.C. 1883. The Fluetuating Grouse Supply. Forest and Stream 21 (10) : 185.

2. Аввотт, C. C. 1895. The Birds About Us. J. B. Lippincoll Co., Phila.

3. Arrott, Cunton G. 1918. "Biddy". The Conservationist 1 (8) : 115.

4.

1920. Billy and the Steel Mule. The Conservationist 3 (10): 155.157.

5. Aскент, J. E. 1931. The Morphology and Life History of the Fowt Nematode Ascaridia lineata (Schneider). Parasitology 23 (3) : 360-379.

6. Aскент, J. E. and G. E. Cauthen. 1931. Viability of the Eggs of the Fowl Nematode Ascaridio lineata (Schneider) Exposed to Natural Climatic Factors. Jour. Parasitology 18 (2) : 113.

7. Ackert, J. E. and C. A. Hzrrick. 1928. Effects of the Nematode Ascaridia lineata (Schneider) on Growing Chickens. Jour. Parasitology 15 (1) : 1.13.

8. Adams, W. S. and S. B. Nicholsux. 1933. Symposium on Climatic Cyeles. Proe. Nat. Acad. Sciences 19 (3) : $371-375$.

9. "Adrian Ondack". 1881. Deer and Partridg". Forest and Stream 17 (18) : 348.

10. Alouch, J. W' and Il. Futkdusy. 1913. A Revision of the Rufferl Grouse. Condor 45 (3) : 83.103.

11. Aldee, W. C. 1938. The Soejal Life of Animals. W. W. Norton \& Co.. New York.

12. Alles, A. A. 1927. The Autobiograply of a Mother Gronse. Bird Lore 29 (6) : 414.416.

13.

1928. Diseases of the Ruffud Grome. American Game 17 (2) : 29.

14.

1929. Ten Years' Experiment= in Rearing Ruffert Cromse in Captivity. Trans. American Game Conferenc $16: 3.21$.

15. 1934. Sex Rhythm in the Rufferl Crums. (Bonasa umbellus) (Linn.) and other Birds. Ank 51 (2) : 180.199.

16. 1934. Breeding Season Buthaviour ol the Ruffed Crunse. Trans. American Game Conference $20: 311-322$.

17. Allein, A. A. and A. O. Gross. 1926. Ruffed Groune Inve-tigation, 1925.26. American Game 15 (4) : 81-84.

18. Altev, E. A. 1934. Eimeria angusta sp. nov. and Ëimeriu bonasue sp. nov. From Grousc With a

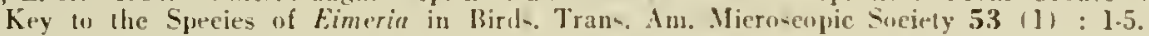

19. Altex, V. C. 1936. Ruffed Grouse Shmoting. Came Breeder and Sportoman 40 (10): 216.217.

20. American Ornithologists" Union. 1931. Check List "f North American Birds, Fourth Edition.

21. Anonymoss. 1856. Pheasant, or Partrigge. Mowre's Rural New Jorker 7 (18) : 385.

22. Anonymonk. 1875. Trapping Rulled Grouse, Forest and Stream 5 (16) : 213.

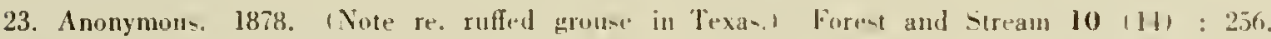

24. Anonymous. 1897. Amending the Game law of New lorh. American Finde 47 (12) : 267.

25. Anonymous. 1915. P'roblem of Ruffed (iroune Brecoling a Diffenlt One. Bull. American Came Protective Assn. 3 (3) : 5-6.

26. Anonymons. 1933. Porcupine Eats Grnune Eiggs. Penustrania Game News 4 (3) : 5

27. Anonymous. 1934. Cronse Fights Fire. Pennsyliania Ciame News 5 (4): 7.

28. Audurox, Joнs J. 1831. Onnithological Biography. Adam Black, Edinburgh.

29.

1856. The Birds of America. Y. G. Audubon, New York.

30. Banty, II. II. 19.41. An Undescribed Rare of Eantern Ruffed Grouse. Bailey Museum and Library of Natural llistory Bull. $14: 1$.

31. Band, S. F., T. M. Brewer and Ronert Romu.y. 187t. A History of North Amprican Birds 3. Litule, Brown \& Co., Boston.

32. Bamo, S. F., J. CAssis and G. N. L.twmenck. 1858. General Repurt Lipun 'llue Zoulugy of The Several Pacific Railroad Rontes, Birds-in U. S. War Dept. Report of Explorations and survey in 1853-56. Serial No. 799. 33rd Congres 2nd Session, House Exee. Does. 11 : (9).

33. Bangs, Outrani. 1912. A New Subspecies of the Ruffed Grouse. Auk 29 (3):378.379.

34. Barger, E. 11. and L. E. C.rrd. 1938. Diseases and Parasites of Poultry. Lea \& Tobiger, Phila.

35. Bartlett, Мотt L. 1924. Ruffed Groune and Fruit Trees. Am. Game I'rolective A-n. Bull. 13 (1) : 19 


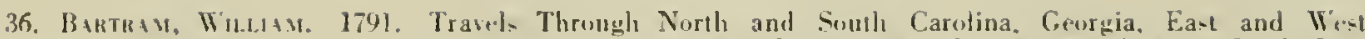

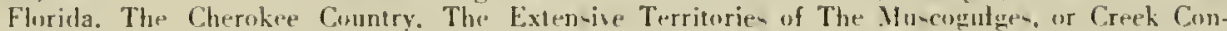
feeleracy and "The Country of The Chactaws, James \& Johnoon. London.

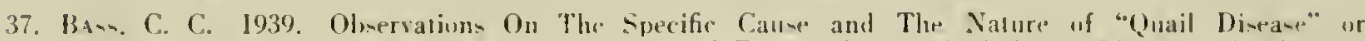
lilceratis. Entritis in Quail. Proc. Soc, of Exp. Biology and Nedicine 12 121:377-380.

38. Batex, IV. D. 1938. Elementary Mathematical Stati-tice. John Wiley \& Sonc, New York.

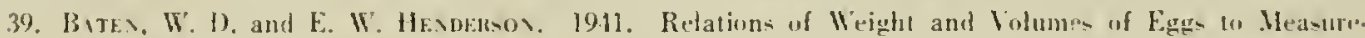
ments of Longr and Slont Axp. Puuliry Science 22 (6) : 556-564.

10. Barses. Eusast II. 1918. A Ruffed Grouse A. A Huasess. An. Game Prutectise Amn. Bull. T (3): 6-7.

1]. Beatdet7e, F, R. 1931. Ilint- Tis Pultrymen. N. J. Agr. Exp. Sta. 19 (6) : 2

42. Beck. Ilekbki1 11. 1922. Aeolian and Percusoion Bird Music. Auk 39 (3): 429.430.

43. Berker, E. R. 1931. Coccilia and Coccidionis of Dume-licated, Game and Laboratory Animats and Man. Collegiate Press. Ancs.

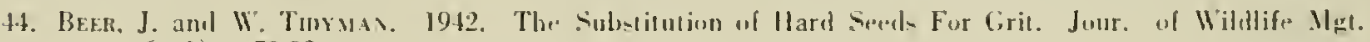
6 (1) : 70.82

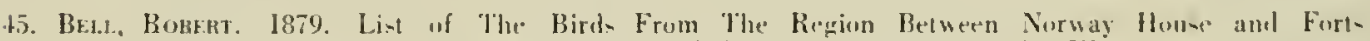
Churdill and lork. Geological Survey of Canada 1878.79. Appendix V1.

46. Brisbrк, D. H. 1922. Breeding Grouse. Crame Breeder 21 (6) : 163.

17. Bespme, Chanles, 1892. Life llisuries of North American Birds Wilh special Reference lo Their Brtesling Ilabits and Eggs. L. S. National Musum Special Bultetin 1.

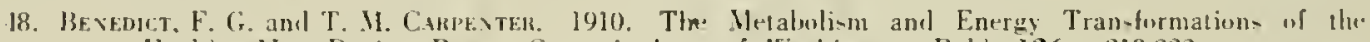
Healthy Man During Rert. Carnegie Inst. of Wasthington. Pubt. 126: 218-222.

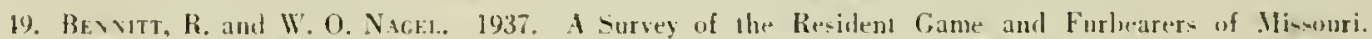
I'niv. of lliswuri studies-1 Quarterly of Research 12 121: 10-41.

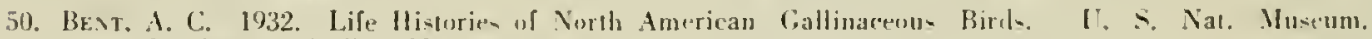
Smillumian Bull. 162.

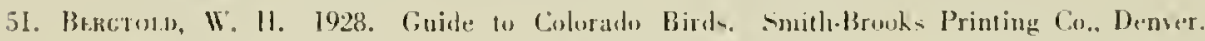

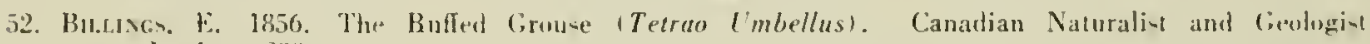
$1111: 289$

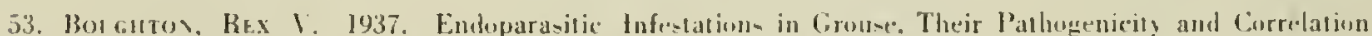
With Meteoro-lopographical Condition. Lniv, of Minnesola Agr. Exp. Sta. Fech. Bull. 121.

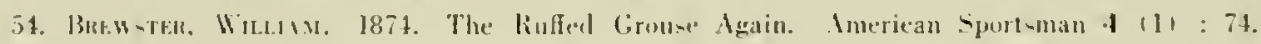

5.5 .

1925. The Birdo of the Lahe I mbarng Reginn of Vaine. Butl. Muarum of Cistup. Zamlogy, Harsard $66121: 276.305$.

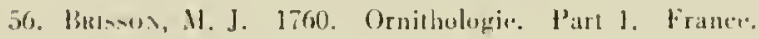

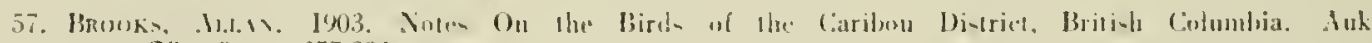
20 (3) : 277.231.

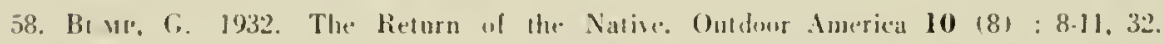

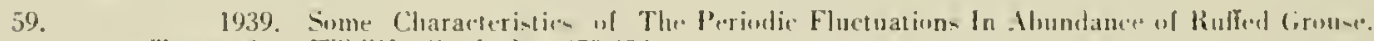
Tran-. Im. Witllife Conf. I : 478.181.

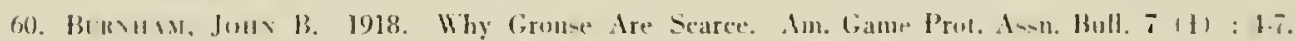

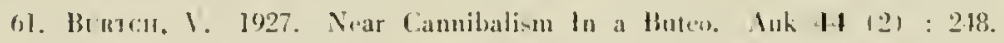

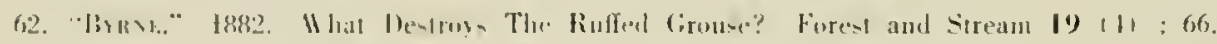

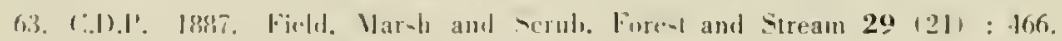

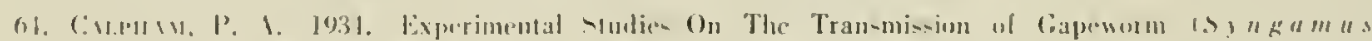

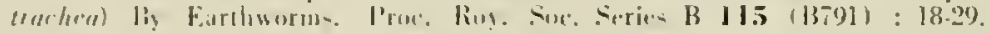

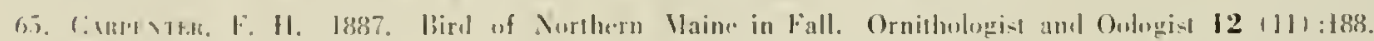

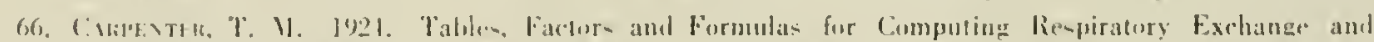

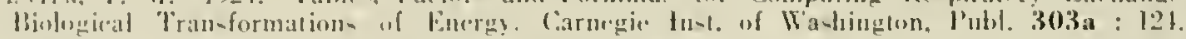

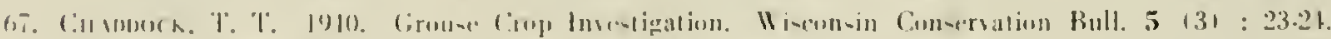

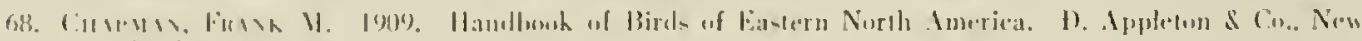
Jurk.

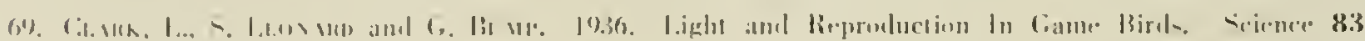
$(21,21): 268$. 
70. $85(2205): 339-340$.

1937. Light and The sexual Cycle of Game Birds. Science

71. Cl.akK, M. W. 1879. Domesticaled Ruffed (;rulise. Furet and Stream 12 117) : 326.

72. CuAkKe, C. Il. D. 1935. Blond Parasites of Ruffed Crouse (Bonasa umbellus) and spruce Grouse (Canachites canadeasis) With Description of Leurorytozon bonasae n. : r. Canadian Juur. of Research 12 (5) : $646-650$.

73.

1936. Fluctuations In Numbers of Ruffed Grouas Bonass umbellus (Linne), With special Reference to Ontario. Univ. of Toronto Studies Biol. Series Bull, 41.

71. 1938. Organioms of a Malarial Type in Rufted Groume IWitl a Description of the Schizogony of Leucocytazoon bonasue. Jour. of Wildlife Hanagement 2 (3) : 146.150.

75.

1940. A Biological Investigation of The Thelon Game Sanctuary. Nat. Museum of Canada, Dept. of Mines and Resources Bull. 96.

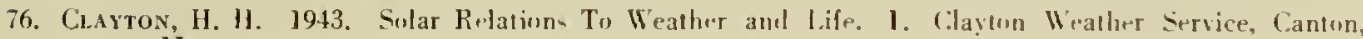
(Mass.).

77. Cuements, F. E. and V. E. Shelford. 1939. Bin-Ecolony. John ITiley \& Sons, New York.

78. Covoren, H. B. 1935. A New Race of Ruffed Groune From Vancouser 1-lanul. Condor 37 (4) : 204-206.

79. Connfcturt, 1924. Biennial Report of the Stato Boaril of Fisheries and Came. 1922-21:67.68.

80 .

1938. Biennial Report of the State Burarl of Fisheries and Game, 1936-38: 18.

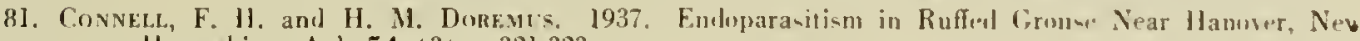
llampshire. Auk $54(3): 321.323$.

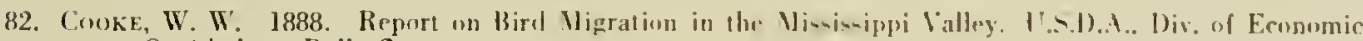
Ornithology Bull. 2.

83. Cooper, J. G. 1870. The Fauna of California and lis Geographioal Dintribution. I'ruc, California Academy uf Science $4: 61.81$.

81. Cottan, Cinnexce. 1935. Economic Ornithology and the Correlation uf Lahoratury and Findl Wethol-. Wildlife Research and Management leallet 13S-30. Imimergrapherl).

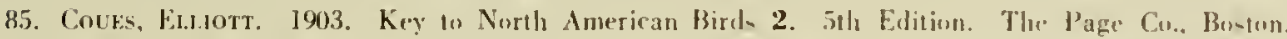

86. Cowan, IAN M. 1910. Two Apparently Fatal Grouse Dikeases. Jour. of Willlife Management 4 (3) $: 311.312$.

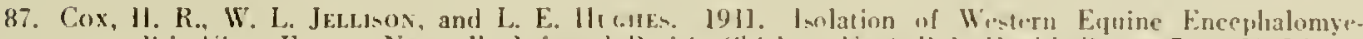

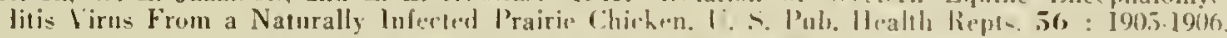

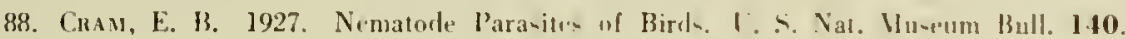

89. 1928. Nematodes of l'athological significance Fumml in Sume Economically Important Birds in North America. U.S.I).A. Tech. 13ull. 19.

90. 1931. Developmental Stages of Some Nemalonde of Hw Spiruroidea l'arasites in Poul. try and Game Birds. U.S.D.A. Tirh. Bull. 227.

91. 1931. A Comparison of Iutcrual l'araniles of kiuffed Groume of Labrador witl Thume of Ruffed Grouse of the (Inited Stales. Jour. Paranitolugy 18 11) : 18.

92.

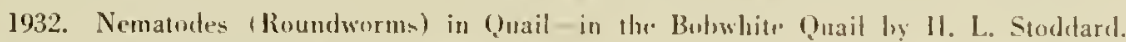

93. Cunde: Nomuas. 1930. Some Natural Factors Governing the Fluctuations of Cromse in .llanitoba. Canactian Field Naturalist $441.11: 77.78,80$.

91. Crons, E. C. 1940. Periodic Fluctuations in Numbers of the Red Fox in Ontario. Jumr. Nammalngy 21 (3) : 291-306.

95. Darwin, Cuarles. 1869. The Origin of Species. J. Murray, Londun.

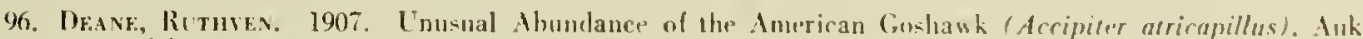
$24(2)$ : 182.186.

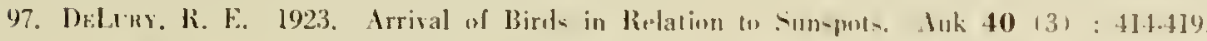

98. 1930. Sunspots in Relation to Fluctuations in Crawhopper and Girmse at iseme. Manitoha. Canadias Field Naturali-1 44 (5) : 120.

99. Droxs, Nicholas. 1908. Description and Natural History of the Coasts uf Nurth America. Champlain Society Publications 2 : 391.

100. Dlwey, E. R. 19.2. Putting Cycles to Work in Science and Indusiry (multilithed). Foundation for the Sturly of Cycles. New York.

101. DiCE, LeE R. 1920. Interior Alaska. Condor 22 (5) : 179.

102. Dietz. E. 1909. Die Echinosomiden der Vugel. Zoul. Inz. 34 (6): $180-192$. 
103. Dilli, J. G. (CApt.). 1920. The Effect of Forest Fires on Game. Am. Gane Prot. Assn. Bull. 9 (3) : $5-7$

104. "Don1." 1890. $\Lambda$ Grouse Cumbat. Furest and Stream 35 (15) : 286.

105. Douglas, David. 1833. Observations on Some Species of the Genera Tetrau and Urtyx, Natives of North America. Trans, of Linnaean Society of Londun 16 (1) : 137, 148.

106. Duuclass, A. E. 1928. Climatic Cycles and Tree-Growth. Carnegie Inst. of Washington Publ. 289 (2) : 1.166.

107. Dunsinc, W. J. 1918. The Scarcity of Ruffed Grouse. American Field 89 (6) : 131.

108. Dlmant, A. J., and E. R. Doll. 1941. Ulcerative Enteritis in Quail. Univ. of Missuuri Agr. Exp. Sta. Res. Bul. $325: 5,7$.

109. Dwicht, J., JR. 1900. The Moult of Nurtl Anerican Tetraunidae (Quails, J'artrilges and Grouse) Auk $17(1,2)$ : 34-51, 143.166.

110. E. S. K. 1884. Massachusetts Game Pruspects. Forest and Stream 22 (12) : 227.

111. Eaton, Elon Howard. 1910. Birds of New Yurk. N. Y. S. Museum Memoir 12 (1).

112.

1926. Game Enemies. Game Breeder 28 (4) : 127.

113. Edgenorth, F. H. 1935. Cranial Nerves of Vertebrates. Cambridge Univ. Press, Englant.

114. Edror. 1874. [Comments Following Article "Grouse and Woodcock."] Forest and Stream 2 (2) : 22.

115. Editor. 1925. Interesting Grouse News. American Field 104 (4I) : 404.

116. Eowards, George W. 1754. On the Pheasant of Pennsylvania, and the Otis Minor. Philosophical Trans. Roy. Soc. of Londun 10 (63) : $450-452$.

117. 1758. Gleanings of Natural History 5. Londun.

118. Eifric, C. W. G. 1910. Stomach Contents of Some Canadian Birds. Ottawa Naturalist 24 (1) : 18.

119. Elliott, Daniel G. 1864. The Game Birds of the United States. U.S.D.A. Annual Report : $363-364$.

1897. The Gallinaceous Game Birds of North America. Suckling \& Co., London.

121. Elciotr, RoBert. 1906. Extracts From the Diary of the Late Rohert Elliott. Ottawa Naturalist 20 (6) : $120-126$.

122. Elton, Charles. 1924. Periodic Fluctuations in the Numbers of Animals: Their Cause and Effects. Br. Jour. Exp. Biol, 2 : 119-163.

123. 1927. Animal Ecolory. MacMillen Co., New York.

124. 1942. Voles, Mice and Lemmings. Clarendon Press, Oxford.

125. English, P. F., and L. J. Bennetr. 1942. Food Habits of the Gray Fox in Pennsylvania. Penna. Game News 12 (12): 10.22

126.

12 (11): 6-7, 22-23.

19.12. Red Fox Food Ilahits in Pennsylvania. Penna. Game News

127. Errincton, P. L. 1934. VuInerability of Bohwhite Populations to Predation. Ecology 15 (2) : 110 127.

128.

1937. What Is the Meaning of Predation? Smithsonian Inst. Anmual Report, 1936 : 243-252.

1937. W'inter Carrying Capacity of Marpinal Ruffed Grouse Enviromment in North. central United States. Canadian Field Naturalist 51 (3) : 31-34.

19.12. On the Analyses of Productivity in lopulations of IIigher Vertehrates. Jour. Wildlife Management $6(2): 165 \cdot 181$.

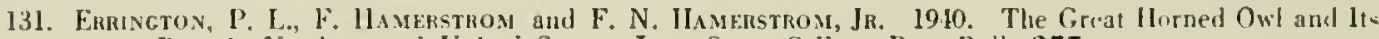
Prey in North-central United States. Iowa State College Res. Bull. 27.

132. Ewbank, Ennest L. 1907. The Ruffed Grouse Scarcity. Forest and Strean 69 (24) : 936.

133. Funow, E. 1'. 1925. Plant Life on East Anglican Heaths. Cambridge Univ. Press., England.

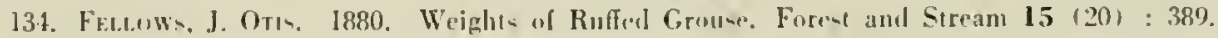

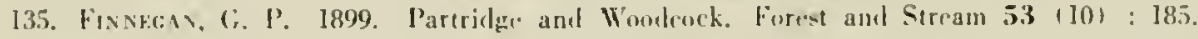

136. Fisнer, A. K. 190\%. llawks and Owls From the Standpoint of the Farmer. U.S.D.A. Biul. Surves Circ. 61.

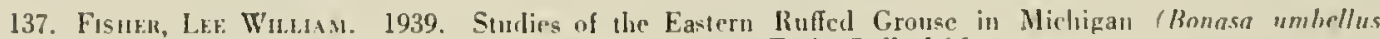
umbellus). Michigan State Coll. Agr. Exp. Sta. Tech. Bull. 166.

138. Fuıtr. R. . 1937. The Design of Experiments. Oliver \& Boyd, London.

19.11. Statictical Methots for Resarch Workers. Oliver \& Buvil, Inndun. 
140. Fisher, William H. I895. Notes on the Ruffed Grouse. Oologist 12 (12) : 173.175.

141. Fiske, Jessie G. 1932. Some Poisonous Plants of New Jersey. N. J. Agr. Exp. Sta. Circ. 261.

142. Fleming, James 11. 1907. Birds of Toronto, Canada. Part II Land Birds. Auk 24 (1) : 71.

143. Foote, L. E. 1944. Ifistory of Wild Game in Vermunt. Vermont Fish and Game Serv. Bull., PirtmanRobertson Series 11.

144. Forbush, Edward Howe. 1904. The Decrease of Certain Birds, and Its Causes With Suggestions for Bird Protection. Annual Rept. Nassachusetts State Bd. of Agriculture 52 : 429-543.

145. riculture.

1907. Useful Birds and Their Protection. Massachusetts State Bd. of Ag-

146. 1912. A History of the Game Birds, Wildfowl and Shore Birds of Massachusetts and Adjacent States. Mass. State Bd. of Agriculture.

147. 1915. Facts About Cats. Bird Lore 17 (2) : 165.

148.

1927. Birds of Nassachusetts and Other New England States 2. Mass. Dept. Agrieulture.

149. FurBringer, Max. 1902. Zur vergleichenden Anatomie des Brustschulterapparates und der Schultermuskeln. V. Teil. Vogel Jenaischien Zeit. fur Naturwiss., Band 36.

150. Gadow, IIans. 1891. V'ogel In Bronn's Klassen und Ordnungen des Thier-Reichs. Leipzig.

151. Garrod, A. H. 1874. On Certain Muscles of the Thigh of Birds and on Their Value in Classification. Proc. Zoo. Soc. 44 : 111.

152. Gauman, E. 1935. Der Staffhausholt der Buche (Fagus sylvatica L.) im Laufe (ines Johre's. Berichte der Schweizerischen Botaniscien Gesellschaft, Band 44.

153. Gerstell, Richard. 1936. Pennsylvania’s Field Game Investigations. Trans. An. Wildlife Conference I: 365.370 .

154. Girard, Georce L. 1937. Life Ilistory, Hahits, and Food of the Sage Grouse. Univ. Wyoming Publ. 3 (1).

155. Giraud, J. P. 1844. The Birds of Long Island. Wiley \& Putnam, New York.

156. Gower, W. Carl. 1939. The Use of the Bursa of Fabricus as an Indication of Age in Came Birds. Trans. North Ameriean Wildlife Conf. 4 : 126.430.

157. Grange, Wallace. 1936. Some Obrervations on the Ruffed Grouse in Wisconsin. Wilson Bulletin 48 (2) : 104.110.

158.

1941. Report of Grouse Management Research l'roject. Wisconsin Wildlife Res. Quart. Prog. Rept. 1 (2) : 10.

159. Gray, George Robert. 1840. A List of the Genera of Birds. London.

160. Grayblu., H. W., and T. J. Smitu. 1920. Production of Fatal Blackhead in Turkeys by Feeding Em. bryonated Eggs of Heterakis popillosa. Jour. Exp. Medicine 31 (5): 647.655.

161. Green, Robert G. and J. E. Shillinger. 1932. A Natural Infection of Sharp-tail Grouse and the Ruffed Grouse hy Pasteurella tularense. I'roc. Suciety of Exp. Biolugy and Mredicine 30 (3) : 284-287.

162.

163. port, Octoher. (mimeographed) Univ, of Minnesta Wildife Diseace

1934. Progt'ss Report of Wildlife Disease Studies for 1933.

Trans. American Game Conf. $20: 288 \cdot 297$.

164.

1936. Progress Report of Wildlife Disease Studies for 1935 Trans. North Ameriean Wildlife Conf. 1 : 469.471.

165. Grinnell, Georee B. 1910. American Game Bird Shooting. Furest \& Striam Puib. Co.. New York.

166. Grinnell, J. 1916. A New Ruffed Grouse From the Yukon Valley. Condor 18 (4) : 166.

167. Gross, A. O. 1925. Diseases of the Ruffed Grouse. Science, n. s. 62 (I594) : 55.56.

168.

1925. Disease of the Ruffed Grouse. Auk 42 (3) : 423-431.

169.

1928. Progress Report of the New England Ruffed Grouse Investigation Committee. Mass. Fish and Game Assoc.

170. 1928. The Heath IIen. Boston Soc. Nat. IIist. Memoir. 6 (4) : 491-588.

171.

1930. Annual Report of the New England Ruffed Grouse Investigation. Proc. New Eng. land Game Conf.

1931. Snowy Owl Migration, 1930-31. Auk 48 (4) : 501-511. 
174. Halght, Arstix D. 1934. The Biography of a sipurlsman. Fielil and Sircam 39 (5): 62.

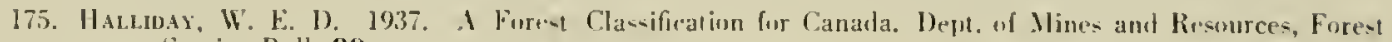
Servier Bull. 89.

176. Hasultox, W. J., Jr. 1933. The Weanls of New York. American Millanil Naturalist 14 (4): $300-3] 4$.

177. Manmalogy 16 111: 16.21 .

178. $36(3): 131.140$.

1936. The Fund and Breeding Jlatits of the Rateonn. Ohin Jour. of Scrence

179. : $240-21 \%$.

180. 1936. Seasnal Fousl of Skunk- in New York. Jour. of Vlammology 17 131

181. 1937. The Biolugy of Mirrotine Cycles. Jour. Amr. Res. 54 (10) : 779-790. m.ll [nis. Exp. Sta. Nemuir 237.

182. HanuY, Nanly. 1899. Maine Partridge. Fore: and Stream 53 (12) : 333.

183. 1905. An Old Cork l'artridge in Charge of a Brond. Furest and Stream 6.5 (2) : 27. 184. Hathan, F. 1908. Grome in Chunango Comnty. Fores and Stream 71 (17): 656.

185. Hel.ter, Y. G. 1938. The Clumieal Composition of Oklahmma Rainfall. Okla. Igri. Exp. Sta. Tect. Bull. 1.

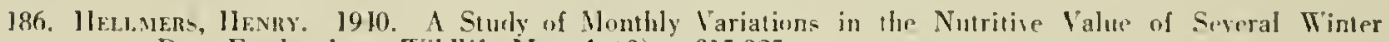
Deer Fomlis. Junt. Nildife IIgt. 4 (3): 315-325.

187. HzRms, W. B., and C. G. Kadvin, 1937. The Louse Fly, Lynchia fusca. Parasite of the Ow]. Bubo virginimnus parificus, a New Vectur uf Malaria of the Califurnia Valley (auall. Jour. Para-i. lology $2.3(3): 296297$.

188. Hersey, F. SEYMoth. 1923. A Nesting Red-shoultlered llawk's IJearty Weal. Auk 40 (4): 693.

189. Hfanick, B. D. 1935. Groune are "Scrappy" in Butler County. Pinna. Game News 6 (1): 15.

190. Hewtт, C. C. 192]. The Conwervation of the Wildlife of Canada. Chas. Seriluner's Sons. Nin Yurk.

191. Ilugivos, F. L. 1630. New England's Plantatiou. New England Sur.. New lurk (1930).

192. Jlodef. C. F. 1905. The Drumming Grouse. Country Caltnrlar 1 (7) : 610.611.

193. 1906. Nursery Fond of the liuffed Grome. Country Life ln Amrica 9 (6) : 746.748.

191. 1loulavb, R. P. 1937. Disease Or Vernin? Field and Stream 4 l (9) : 1,.

195. Horsfal. M. W. 1938. Olservations on the Life Ilintory of Raillinting fechimobothrida and of $R$. tetragona. Jour. Parasilnligy 24 (5) : 109-121.

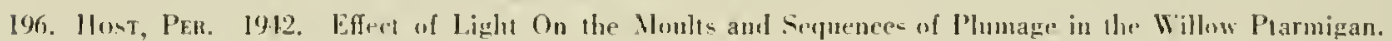
Aık $59(3): 388-403$.

197. Jlow und, II. E. 1920. Territury In Bird Life. E. P. Dultun \& Co.. New York.

198. 1929. An Jutroduction to the Study of Bird Behavior. Cambriclge Lnis. Press. Eng. land.

199. Jlowkit., A. B. 1937. Morphegenesis of the Shoulder Arebitecture: Ares. Auk 54 (3) : 364.375.

200. 1938. Mureles of thr. Avain llip and Thigh. Auk 5.5 1]) : 71-88.

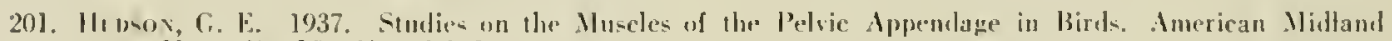
Naturatict 18 (1): 1-]08.

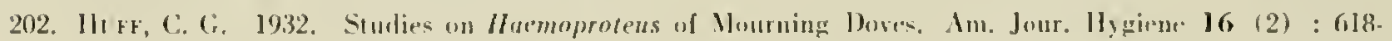
623.

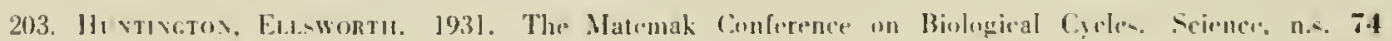
$119111: 229.235$.

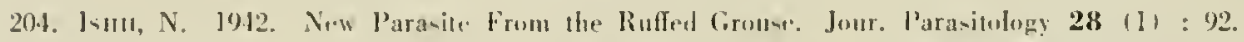

205. J. S. 11. 1886. [Comments on Junting Seann Prospects]. Forent and siream 27 (1) :6.

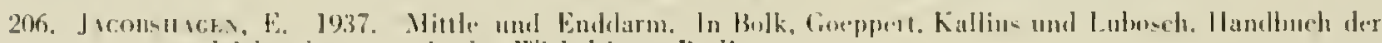

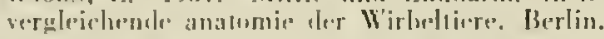

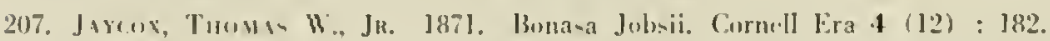

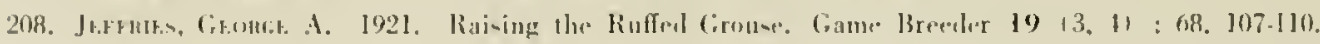


209. Johnson, E. L. 1924. Relation uf Shrep to Climate. Jour. Agr. Re-earch 29 (10) : 491-500.

210. Jones, Lynds. 1905. The Drumming of the Ruffed Grouse. Wilson Bull, 17 (3) : 94-96.

211. Joves, M. F. 1935. The Cestodr. Hymenolepis microps (Hymenolepididap) in Ruffed Croum (Ronasa umbellus). Proc. Iletm. Snc, of Wahington 2.

212. Judd, Srlvester D. 1905. The Grouse and Kridl Turkeys of the United States and Their Fconomic Value. U.S.D.A. Biol. Survey Bull. 24.

213. King, Ralph T. 1937. Ruffed Grouse Management. Jour. Forestry 35 (6) : 523-532.

214.

1938. Ruffed Grouse Management in Minnesota. Game Breeder and Sportaman 42 $(7,8): 104,112,113 ; 120,121,131$.

215. Kingit, Ora W. 1908. The Birds of Mlaine. Chas. H. Glass \& Co., Bangor.

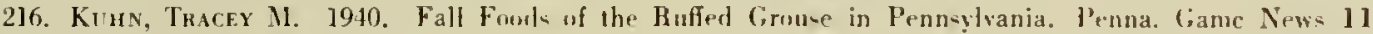
(10): $4,5,31$

217. Lahonton, Loulo A., Barov de. 1703. New Voyages to North America 1. Jondon.

218. Lantz, D. E. 1914. Economic Value of North American Skunke. U.S.D.A. Farmers Bu!1. 587.

219. Lawrexce, B. 11. 1935. A Big Ruffed Crouse. Field and Stream 40 (3): 73.

220. LEE, K. F. 1928. "Birds" and "Biddies". Forest and Stream 98 112) : 748.

221. Lef, W. C. 1898. [Grouse Seawn in Manitola.] American Field 49 118): 351.

222. Lehman, Valcke W. 191]. Atwater's l'rairie Chicken, I- Life History anel Management. I. S. Dept. Interior, Fish and Wildtife Service, North American Fauna 57.

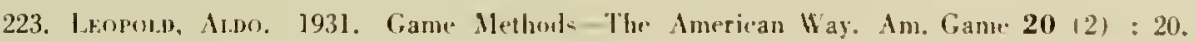

224.

1931. Report On a Game Survey of the North Central State. Spmrting Irme am Ammunition Manufacturers" Inst., Madionl.

225. 1933. Game Management. Chas. Seribuer's Sums. Nien lork.

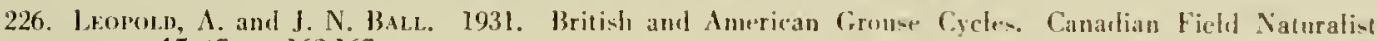
45 (7) : 162-]67.

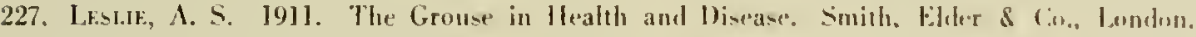

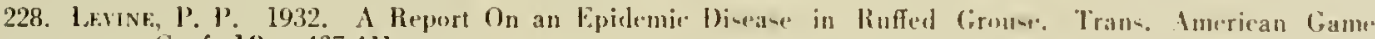
Conf. $19: 437.411$.

229.

1936. The Treatment of $A$ seariasis in Chicken- Cornetl Vel. 26 121: 120.12\%.

230.

1937. The V'iability of the Ova of Ascaridia lineata When Fexpmed w Varion Envirununental Conditions. Jour. Parasitology 23 (4) : 368.375.

231.

1938. The Effect of Infertion With Marainea proglontina On the Weights of Growing Chickens. Jour, Parasitology 2.1 (6) : 550.551.

232. Lingenfelten, W. P. 1899. Fame and Shoting. American Field 52 (2:) : 123.

233. Linnatis, Carr. lox. 1766. Systrma Naturae 1 12, l2ih codicion.

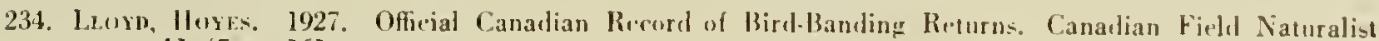
41 (7): 161.

235. Loonts, Leverett: M. 1890. Ohservations on Some of the Summer Birde of the Hountain Portions of Pickens County, South Carolina, Auk 7 (1): 36 .

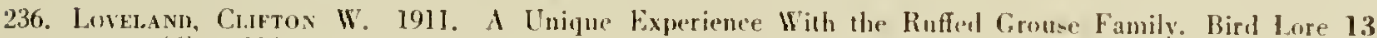
(6) : 304

237. Luttrinfer, L. A. 1935. Nawks-What They Eat. Nature Magazine 26 (3) : 173.175, 177.

238. MacFarlane, R. 1905. Mammalo of the North-west Territory. Proc. [I. S. Nat. Murum 28 (]105) : 673.764 .

239. MacGregor, Artuor E. et al. 1911. Summary of Grouse Crop and Gizzaril Analyos for 1940. Ninw Hampshire Fish and Game Dept. Tirh. Cire. 9.

240. Haclibicir, D. A. 1937. Fluctuations in the Numbers of the Varying Hare (Lepus americanus.) ('nis. of Toronts Studies, Biol. Serie's 43.

241. Macoun, John and Janzs, 1909. Catalog of Canadian Birda. Goy. Printing Bur., Ottawa.

242. Marlicar, Donald. 1918. Practical Grouse Preserving. Am. Game Prot. Aasn. Bull. 7 (2) : 7.9.

243. Maltuls, T. R. 1817. An Essay on the Principle of Population. J. Murray, London.

244. Marble, D. R. 1934. Relation of Juvenal Plumage to Growth and Sexual Haturity, Punftry Science $13: 195.201$. 
215. 1930. The Moulting Factor in Judging Fowls For Egg Prochetion. Cornell Univ. Agr. Exp. Sia. Bull. 503.

216. Makvin, C. F, 1929. Characteriatice of Cyclen. Reports of Conferences on Cyeles. Carnegie Inst. of Washington. Supplemental Pul., I : 11.12.

247. Massacuusetts. 1900. Annual Report of Conmissioners on Inland Fisherim and Gane: 37.43.

1906. Annual Report of Commissioners on Inland Fish and Game: 162-167.

249.

1936. Annual Report of the Division of Fisheries and Game : 16.

250. Matukws, F. Scuurler. 1921. Field Book of Wild Birds and Their Music. G. P. Putnamis Sons, New York.

251. MaY, J. B. 1935. The Hawks of North America. Nat. Assoe. Audubon Soe., New York.

252. Maler, Alfked M. 1883. Sport With Gun and Rod in Ameriean Woods and Waters. The Century Co., New York.

253. Maynard, Charles J. 1881. The Birds of Eastern Nortl America. C. J. Maynaril \& Co., Newtonville (Mass.).

254. MCATEE, W. L. 1935. Food llabits of Common llawks. U.S.D.A. Circ. 370.

255. 1936. The Malthusian Principle In Nature. Scientific Monthly 42 : 4\$1-456.

256. McAtke, W. L. and F. E. L. BeAl. 1924. Sone Conmon Game, Aquatic, and Rapacious Birds In Relation to Man. U.S.D.A. Farmers Bull. 497.

257. McDonald, D. 1935. Some Notes on the Habits of the Ruffed Grouse, Bonasa umbellus. Canadian Field Naturalist $49(7):$ : 18.

258. McDowell, Robert. 1940. The Great Horned Owl. Penna. Game News 11 (8) : 10, $11,29$.

259. McIntosi, A. 1932. Some New Species of Trematode Worms of the Genus Leucochloridium Carus, Parasitic in Birds From Northern Michigan, With a Key and Notes on Other Species of the Genus. Jour. J'arasitology 19 (I) : 32.53.

260. Mearns, Edgar A. 1901. Winter Birds of LakeWorden, Washington County, Rhode Island. Notes on Rhode Island Ornithology 2 (1) : 3.

261. Mershon, William B. 1923. Recollections of My Fifty Years Hunting and Fishing. The Stratford CQ., Boston.

262. Micuigas. 1936. Bienuial Report, Dept. of Conservation (for 1935.36) : 203-206.

263. 1910. Biennial Report, Dept. of Conservation (for 1939-40) : 241.

264. Mut..Al, J. G. 1909. Natural History of British Game Bircls, Longmans, Green \& Co., London.

265. Minnesota. 1916. Biennial Report, State Game and Fish Commissioner (for period ending July 31 , 1916) : 26.

266. 1924. Biennial Report, State Game and Fish Commissioner (for period ending June 30 , 1924) : 37.38 .

267. "Monon". 1875. Shooting Out of Season. Forest and Stream 5 (2) : 24.

268. Montey, L. C. and P. W. WetMont. 1936. The Etiology of Ulcerative Enteritis in Upland Game Birds. Science $84(2177): 272.273$.

269. Morton, Tuonas. 1637. New English Canaan. Prince Soc.. Boston (1883).

270. Muellki, J. F. 1910. Parasitism and Disease in New llampslije Ruffed Grouse Bonasa umbellus Linnaeus. New Hampshire Fish and Game Dept., unpublished report.

271. 1941. Some Parasites Newly Recorded for the Ruffed Gronse, Bonasa umbellus, in the United States. Proc. Helm. Soc. of Washington 8 (1) : 14-15.

272. "NatuиA". 1887. A Swimning Ruffed Grouse. Forest and Stream 29 (24) : 163.

273. "Natural Histom". 1878. Mabits of Ruffed Grouse. Forest and Stream 10 (15) : 27.1.

274. Nfison, A. L., T. E. Clark and W. W. Bati.y. 1938. Early Wintur Finol of Ruffed Grouse on George" Washington National Forest. U.S.D.A. Circ. 50.1.

275. Nas.sox, kiwano W. 1887. Report Upon Natural History Collections Made in Alaska Between 1877 and 1881 . U. S. Army Signal Service, Aretic Series 1II. Serial No. 2349, 49th Congress Ist Session. Senate Misc. Boes. 8 (156).

276. Nistizk, Ras.'p B. 1939. Fcedling Requiremonts of Gallinaceous Upland Game Birds. U. S. Dept. of Agri. Yrarbook: 893.924 .

277. New Buusswick. 1944. Annual Report, Dept. of Lands and Mines (for 1913) : 12.

278. New Yonk. 1913. Annual Report, Conservation Commission (for 1912) : 131. 
280. New York State Conservation Depsrtizest. 1941. Classification and Description of Cover Types in New York State. Bureau of Game Circular 4.

281. Newton, Alfred. 1896. A Dictionary of Birds. Adam \& Chas. Black, Londun.

282. Nicholson, S. B. 1943. Influence of Sunspots on Weather. Science, n.s. 97 (2510): 10 in supplement.

283. Nokks, J. P. 1866. Ruffed Grouse. Country Gentleman 28 (712) : 162.

284. Nuttall, THOmas. 1832. A Manual of the Ornithology of the United States and of Canada. I1illiarl \& Brown, Cambridge.

285. O. O. S. 1891. Ruffed Grouse in Confinement. Forest and Stream 36 (21) : 411.

286. OnD, G. 1815. Nurth American Zoolugy-in Guthrie's Geography, 2nd American Edition. Jolnnson \& Warner, Phila.

287. Onde-l'owlets, N. A. 1933. Furestry and Sport. Scottish Forestry Jour. 47 93-107.

288. O'RoKe, E. C. 1930. The Morplology, Transmission, and Life llislory of llaemoproteus lophortyx O'Ruke, a Blood Parasite of the California Valley Quail. Univ, of Calif. Publications in Zoology 36 (1).

289. Bull. 4.

1934. A Malaria-Like Disease of Ducks. Univ. of Mlich. Scls. of Furestry and Cons.

290.

1940. A Field Study of Leucocytozoon bonasae Clarke, in Jusenile: Ruffed Grouse, Bonasa umbellus. Jour. of l'arasitology $26(6): 14$.

291. Palser, T. S. 1912. Chronology and Index of the Mor. Important Events in Ancrican Gane Protection 1776-1911. U.S.D.A. Biol. Surrey Bull. 41.

292. Paliker, R. R., C. B. Puilip and G. E. Davis. 1932. Tularemia: Oecurrence in the Sage llen. U.S. Pub. Health Repts. 47 (9) : 479.487.

293. Patton, F. A. 1923. Nesting of the Richardsm l'igeon llawk. Oolugist 40 (9): 147.

294. "Penn." 1886. Woodcock and Grouse. Forest and Stream 27 (15) : 286.

295. Pennsylvania. 1908. Annual Repori Game Commissioners (for 1907) : 6 .

296. 1917. Annual Report, Board of Gane Commissionters (for 1916) : 4

297. P'kirnkopf, E. und J. Lenner. 1937. Vurderdarm. In Bulk, Gueppert, Kallius, und Lubosch, 1landbuch der vergleichende anatomie der IVirbedtiere. Berlin.

298. Perry, J. C. 1928. Tularemia Anong Meadow Mice (Microlus californicus aestuarinus) in California. U. S. Pub. Il calth Repts. 43 (5) : 260-263.

299. Peters, Ilarold S. 1936. A List of the External Parasites From Birds of the Eastern Part of the United States. Bird Banding 7 (1) : 14.

300. l'Eteks, J. L. 1934. Clieck List of Birds of the W'orld 2. Harvard Univ. Press, Cambridge.

301. Purlups, Joun C. 1926. An Investigation of the Periodic Fluctuation in the Numbers of Ruffed Grouse. Science, n.s. 63 (1621): 92.93.

302. Tech. Bull. 61.

1928. Wild Birds Introduced or Transplanted in Nortl Anerica. U. S. D. A.

303.

1937. Man's Influence on Grouse l'opulatious. Cusmos l'ress, Cambridge.

304. "Picus". 1888. Drumming of the Ruffed Grouse. Ameriean Field 29 (10) : 223.

305. P'IPeR, S. E. 1909. The Nevada Mlouse Plague of 1907-08. U. S. Dept. Agric. Farmers Bul. 352.

306. P'telka, Frank A. 1941. Distribution of Birds in Relation to Major Biotic Cunmunities. American Midland Naturalist 25 (1) : 123-124.

307. Polderboer, Emmett B. 1912. Seasonal Food Preference Trends of Eastern Ruffed Grouse in lowa as Shown By Dropping Analysis. Iowa St. Jour. Se. 66 (3) : 331-335.

308. Poole, Eart L. 1938. Weights and Wing Areas In North Ameriean Birds. Auk 55 (3) : 511.517.

309. Preble, E. A. 1908. A Biologieal Investigation of the Athabasca-Mackenzie Region. North American Fauna 27.

310. Price, E. W. and A. Mclntosit, 1935. A New Trematode, Leperosomum monenteron, n. sp. IDi. crocoeliidael From a Rohin. Proe. Ilelm. Soc. of $\mathbb{W}$ ash. 2 11) : 63-61.

311. Radi, M. H. and D. C. Warren. 1938. Studies on the Physiology and Inheritance of Feathering in the Growing Chick. Jour. Agr. Res. 56 (9) : 679.705.

312. Randal, P. E. 1940. Seasonal Food Ilabits of the Marsh Hawk in Pennsylvania. Wilson Bull. 52 (3) : 165-172. 


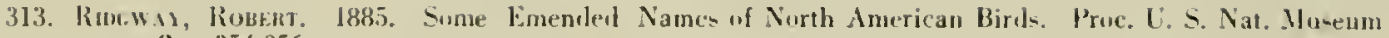
$8: 351.356$

314. Iilptr., Ozмkк, 1939. Ilawh Episudes. American Field 132 1331: 171.

315. Rullt., R. C. 19H1. Studies on the Gapeworn Syngamus trachea (Hontagu 1811, in Rubin- and Chickenu. Jonur. Parasitology 27 (5) : 369-37t.

316. Robrits. THomA- S. 1932. The Birds of Minnesta. Univo of Minnesuta Mress, Minneapolis.

317. Ruviযof, A. L. 1931. Why Sume Eggs Do Not Hatch. Cornetl Univ, Agr. Bull. 205.

318. 1934. Stuly of Artificial Incubation of Game Birels. Cornelt Univ. Agr. Exp. Sta. Bull. 616.

319. 1938. Study uf Artificial Incubation of Game Birels. Cornelt Univ. Agr. Exp. sta. Bull. 687.

320. 57.63.

1939. From the Egg to the Chick. Cornett Univ, Rural Sch. Leaflet 33 (1) :

321. Romanofk, A. L., G. Bump and E. R. IIn.31. 1939. Artificial Incubation of Upland Game Birds' Egg. Came Breeter and Sportsman 43 (3): $34-35$

322. Romaxoff, A. L. L. L. Switu and R. A. SrLlwan, 1938. Bio-chemistry and Bio-physics of the Developing llen's Eggs. Cornell Univ. Agr. Exp. Sta. Memoir 216.

323. Bon-. Bervarn R. 1862. List of the Mammals. Birds, and Eggs Otherved in thr Mackenzie's River District. With Notices. Canadian Naturalist and Geologist 7 (2) : 149

321. Rutuedge, Akcumbi.f). 1933. Cronse of the Cloudlands. Field and Stream 37 (11):30, 31, 66, 67.

325. S.. T. B. (Sumtu). 1877. The Ruffed Grouse-A Query. Furest and Strean 9 15): 85-86.

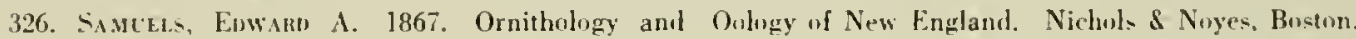

327. Sindrs, Eowry, 1901. The Ruffed Grouse and lts Shooting. Outing 39 (1) : 3.9.

328. "SAviwllat1", 1885. Drumming of the Ruffed Grouse. Forest and Stream 24 (14) : 268.

329. Suvprk, A. A. 1921. Distributional List of Birels of Montana. Couper Ornithological Club of Calif. Pacific Coast Avifauna 14

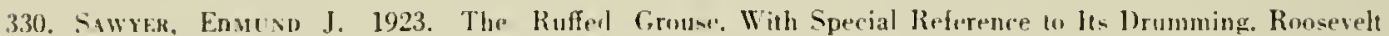
Wildlif. Bull. 1 (3).

331. Sinutvkesstix, R. 1932. Weight of Game Birds. Field and Stream 36 (1) : 71.

332. Sclater, Willan L. 1912. A Jlistury of the Bird of Culoradu: Witherby \& Cu., lundon.

333. Scort, T. G. 1911. Methods and Computation in Fecal Analysis W'ith Reference to the Red Fox. lowa State Coll. Junr. Seitence 15: 279.285.

334. SETox, E. T. 1928. Lives of Came Animals. Moubleday, Doran \& Cu., New Yurk.

335. Seto., E. T. and E. A. Prek1... 1911. Arctir Prairies. Chas, Scribner's Sons, New York.

336. SHFinb. Ensks E. 1937. A Partridge Conservation Measure uf li2l in Quebec Pruvince. Hunting anel Fishing in Canala 3 (9) : 20.

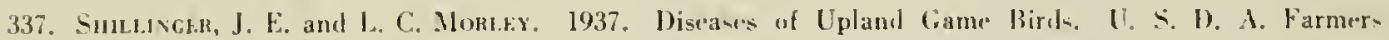
Bull. 1781 .

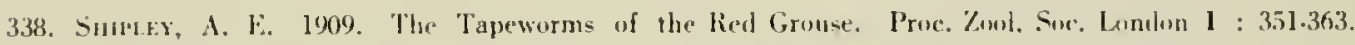

339. Sнont, Emast 11. 1895. A Family of Bonasa umbellus. Oologist 12 17): 111.115.

3.0. Surffidt, R. W. 1909. Osteology of Birds. New Vurk State Museun Bull. 130.

1913. Review of the Fossil Fauna of the Desert liegion of Oregon with a De. wription of Additional Material Collected There. Bull. An. Mus. Nat. Hist. 32 17) : 123-178.

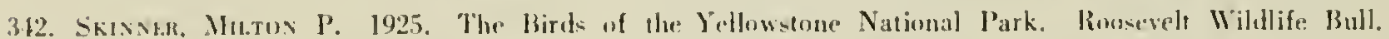
3 (1).

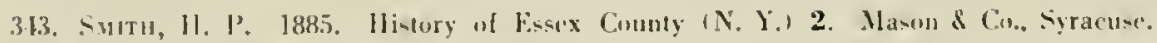

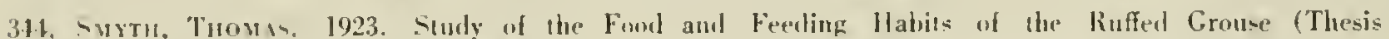

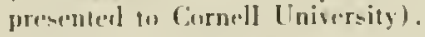

345. l'niversity).

316. 1925. Studies in life History uf the Ruffed Grouse (Thesis presented on Cornell $13: 62.67$.

1939. Sexual Dimorphiom in Ronasa umbellus. Prue. Penna. Acal, of Science

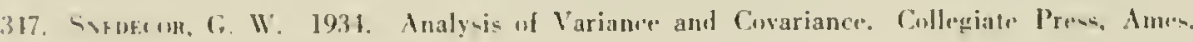


348.

319. SPILLER. B. L.

1940. Statistical Methods. Collegiate Press. Amen.

350 .

1935. Gronse Feathers, Derrydale Pres, New York.

1936. Ruffed Gronse for Supper. Field and Siream 61 (7) : 30-31.

35I. Stafieti, H. J. and A. Kotlan. 1925. Report of Investigations on an Alleged Epizontic of Ruffed Grouse in Michigan. Jour. Am. Vet. Med. Assn. New Series 20 (67) : 260.267.

352. Stephers, J. F. 1819. In Shaw General Zuslogy or Sysematic Natural Hi-lory 1] 11'art 21. London.

353. Stondann, 11. L. 1932. The Bobwhite Quail. Chas. Scribner's Son-, New York.

354. Stoddart, A. M. 1918. Rufferl Grount in New York State. N. Y. State Conservation Commision.

355. Stresemann, Erwix. 1927. Aven. In Kukrnthal und Krumbach, Handbuch der Zoologie : 188.

356. "Sus Q Hannau". 1890. Weight uf Grumse. Furest and Stream $33(26): 515$.

357. Sutton, George. It. 1927. Ruffed Croun. Captured By a Screedı Owl. Wilmn Bulletin 39 (3) : 171.

358. Came 17 (5): 75 .

1928. Notes on the Status of the Ruffed Gremes in Peumblvania. American

359. Swansox, W. and J. Riciandsox, 1831. Fauna Bureali-America, or the Zoulugy of the Northern Parts of Britisll America 2. J. Mlurray, Lomdon.

360. Taxabe, M. 1926. Morploulogica? Surlies on Trichomonan. Jour. of Para-itology 12 131: 120.130,

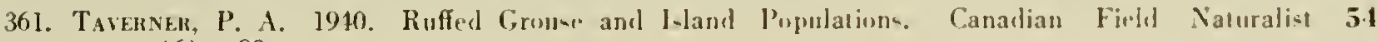
(6) : 90

362. "TAxidermist". 1883. Capturing Grouse Nive. Forend and Stream 20 1101: 189.

363. TaYuon, E. L. 1935. Syngamus trachea. The Langevity of the Infective Lartar in the Lartiwnrm. Slurs and Snails As Intermediate Howts. Jour. Comp. Pathology and Theraputice 48 (2) : 119. 156.

364.

1938. An Exten-ion to the Kuonu longesily of Capeworm Infection in Eartiworms and Snails. Vet. Jour. $94(8,9): 327 \cdot 328$.

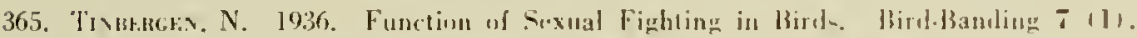

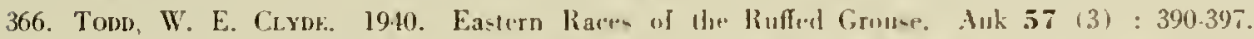

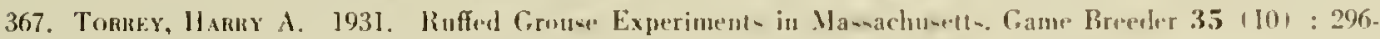
$297,313.315$.

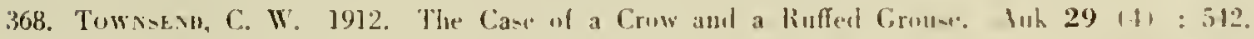

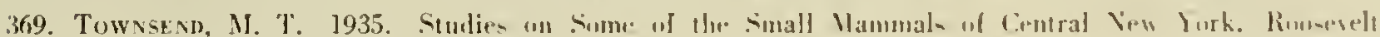
Wilcllife Sta. Annalo 4 (1).

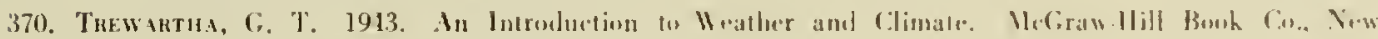
York.

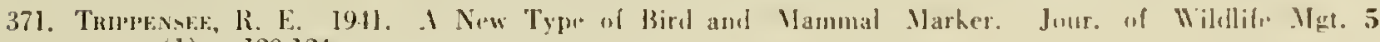
(1) : $120-121$.

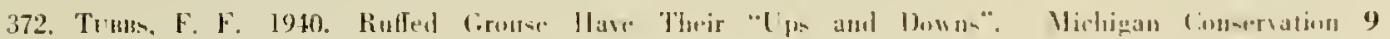
(12) : $2-10$.

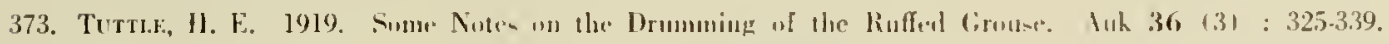

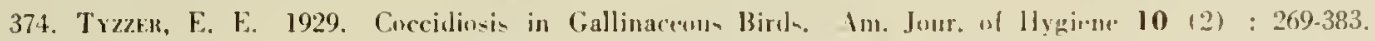

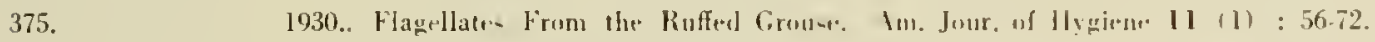

376. 1934. Studies on Histomoniasis or "IBlackbead" Infrotinn In the Chicken ant the Turkey. Proc. An. Acarl. Arts anil Sci. 69 (15): 189.261.

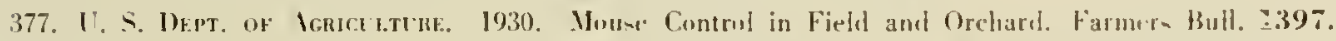

378.

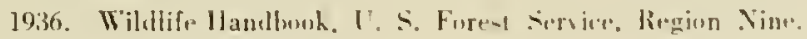

379 .

1938. Outline of Procedure for Recurding l)ata Oheaimed in stomach Examinations. Bureau Birl. Survey Bi-1515

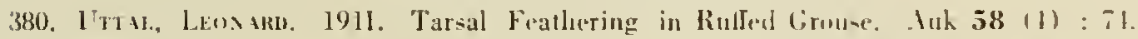

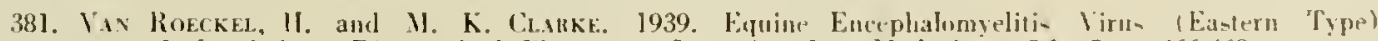
Imlated from Ring-nteked Pheasant. Jour. An. Iet. Met. A-n. 94 (5) : $166-468$.

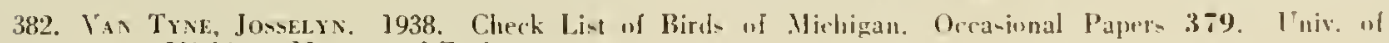
Mlivigan Mhoum of Zomlues. 
383. Vreeland. Freperick K. 1918. Ilow A Ruffed Grouse Drums. Am. Game Prot. Assn. Bull. 7 (1) : 12.14

384. Wamo. W. W. and E. 13. Forkes. 1941. The Chemical Composition of Forest Fruits and Nuts From Pennsylvania. Jour. Agri. Res. 62 (10): 627.635.

385. Warren, B. 11. 1890. Report on the Birds of Pennsylvania, Ilarrisburg.

386. Warrex, D. C. and C. D. Gordos. 1935. The Sequence of Appearance. Mult and Replacement of the Juvenile Remiges of Some Domestic Birrts. Jour. Agri. Res. 51 (5) : 459-470

387. Wayse, Artma T. 1910. Birds of South Carolina. Daggelt Print. Co., Charleston.

388. Wren, C. M. and Ned Dearbors. 1903. Birls in Their Relation to Man. J. B. Lippincott Co., Mhila.

389. W'atr, E. E. 1926. Eartlworms as Transmitters of Capillaria annulata, the "Crop.Worm" of Chickens. N. Am. Vet. 17 (8) : 8-20.

390. 1937. Observations on the Deselnpment of the Puultry Gapeworm Syngamus trachea. Trans. Am. Micr. Soc. 56 (1) : 72-78.

391. 1940. A New Intestinal Round-worm From the Ruffed Grouse in the United States. Jour. of Parasitology 26 (5) : 373-375.

392. Wraray, H. J. 1928. The Trematode Genus Hormostomum. Trans. Am. Micr. Snc. 47 (1) : 68.81.

393. Wetmore, Alexander. 1937. Obervations on the Birds of West Virginia. Proc. U. S. Nat. Museud $84(3021): 401.441$.

394. Misc. Coll. 99 (4).

1940. A Check-List of the Fossil Birds of Norll, Anterica. Smithsonian

395. Wuite, F. B. 1929. Birds and Motor Cars. Auk 46 (3) : 399.

396. Wurtentan, F. E. 1934. The Effect of Arsenic, as Used in Poisoning Grashoppers. Upon Birds. Okla. Agri. and Nech. Coll. Agr. Exp. Sta. Bull. 218.

397. W'rut, H. M. 1930. Pheasant Management Studies In Michigan. Trans. An. Game Conf. 17 : 222.

398. Wh.ces, 1I. S., JR., L. C. Norkis and G. F. IIEuser. 1937. The Role of Manganese and Certain Othre Trace Elements In the Prevention ol Perosis. Jour. of Nutr. $14: 155-167$.

399. Willett, GFoncf. 1914. Birds of Sitka and Vicinity. Condor 16 (2) : 89.

400. Wilson. Alexander. 1812. American Omitholngy. Bradford \& Inskeep, Phila.

401. Wrase, L. W'. 1934. Cycles of Migration. Wilon Bull. 46 (3) : 150.156.

402. 1935. Wildlife Cycles in Relation to the Sun. Tranc. Am. Game Conf. $21: 345-363$.

403. 1937. Wildife and Cycles. American Forest 43 (10): $512-513$.

401. Wompifr, E. Seruour. 1908. The Ruffed Grouse, A Stuly of the Causes For lis Scarcity in 1907. Annual Rept., N. Y. State Forest, Fislı and Game Commission. (for 1907) : 159-178.

205. YAPr, R. 11. 1922. The Concept of Ilahitat, lour. Focology $10: 1$. 


\section{INDEX}

Abboti, C. C. 3,260

abantoned lands, importance aod encouragement of 597

ahundance, grouse (see also fluctuations)

early records 2, 6, 11, 53, 558, 560. 562

factors governing (see also factura) ?

reduction of 55 ?

relative $53,55,557,559,676$

Acarina 109,775

accidents (see mechasical injtary)

tccipiter cooperi 317,333

Accipiler velax 317,333

Acer $198,20.1$

Acer pennsylvanicum 201,818

teer rubrum 204. 848

tcer saccharum 201. 848

lcer spicalum 20

Aceraceae 204

Ackert, J. F. 124, 426

aconitic acid 195

scorn 188, 202,215,22,

action, sex differences $41,45,165,167,810,813$

Allasns, C. C. 32

Waptability in ehanging moirmment $27 \%$

Addy, C. E. 31

Adirondack Furest Preserve (X.X.) 596. 681

Adirondack Mountains (N.Y.) 3, 36, 5i. 5\%, 57, 95, 381, 386

Adirondack region (N.Y.)

absence of atomacl wurm reriulw from 115

characteristics of $111,217,211,596,691$

cover management in 596

Adrondack study area (N.Y.). dearription 695. 499

adult cover

basic patterns 593

basic patterns 593

composition

density 59.30

monthly and seatunal preferene', 153,819

relation to roosting hat
relation to slope 591

relation to slope 591
relation to time of day 159 . 823

rulation to watcr 591

relation to weather 161, 831

relative importance: of tyjees 15

types ehosen 152, 156,819

undergrow: (h, 591

use during lunting season lou, 8:34

adult mortalicy (sep also survival during adult furitwl) :118

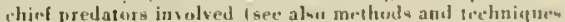

$308,322,337,318,669$

uffect of pretaifur control 308, :128, 317

iffect of pretafur control 308, 328.317

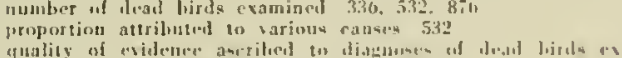

quality of evie

amined 876
mestigation 308,318

erordid Juring lusestigation
selation to accidents $318.5 \% 1$

iclation to accidents 318,531

wation in fall pupulatiun density $308,320,331,338,5: 3,5.3$

$534,5.35,5.52$

wation to maturing elieh in fall population 535, 536. 514

r.lation to variations in buller alundauce $322.532,535$, 51:. 516. 5.52

relation to variationa in predatos preasure $321,53.5,552$

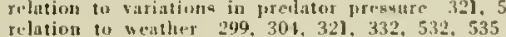

rution to weather $299,301,321,332,532,535$
role of preation $308,319,322,332,333,317,531,532,543$

role of prealation $308,319,322,332,333$,
scusonal variation $322,336,338,53 \%, 537$

aftershaft 59,747

1 ginudistomum 409,131

breeding 359

how to judge 84,718

longevity 360

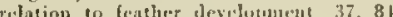

The

age componition of joputations 51.1

$5,536.537 .51$

sienificance in fluetuations in abundance 571,57

agricultural productivity, cyele in 578

agriculture (see farming)

terimonio 193

airplane, use in transporting eggs 1.5

air-suc mitm 404, 115. 117. 1:60

air-sac mite infoling

cause ill

dissemination 115,111

nature 411

Nubama 236

Jlakka $36,48,52,53,51,110,236,285,325,409,428,131$

Altany County of; $199,-313,+33,520,69.3$

Alberti $[8,20,47,48,53$

Alberti I8, 20,47

albunen :it alder $212,235,244$

alder Leds, importance in Adirondarh region 110

Aldrich, J. W. 18

Alger County (Mich.) 817

alimentary trart I see anatomy)

alkaloids, toxic 19

allantoi: 74.76

tllegany County (N.) 568

Alegary Mountains 53.21

Allegany State Park (N.Y.) 68

Allegheny National Foresi (Pa.) 3l:

tllen, A r xi, xxxvi, 15, 22, 21, 27, 29, 30, 32, 58, 183

$187,210,256,26-2-4,2-5,278,282,281,288,333,415,119$

$121.0,153,151,457,162,176,508,568,57 t, 691$

Illen, G. Y, Xxxvi, 72

tlinus 212

llopex lagopus 323,578

tmbrasia artemisiifolia $206,8 \mathrm{k}$

imolanchier 198. 200

Imrlanchier canodensis $B$ th

tmelanchier laevis 817

American Game Conference 12, 24, 32, 33

American Ganue Protective Ansoriation ruxi, 12.22, 25, 29, 30. 15.3, 562

1.

Imphicarpo monoica 818

Amefrralam (N,Y.) 37

amyedalin 195

Inacardiacear 203

anatomy 58,721

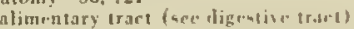

comparion of various generd of Tetraunidar 58.721. 725. 726 , 727,728

digeslive traet 58.737

distinctive claaracteristic 58

movenaent is $\mathrm{log} 731$

movento

muaculature of wing 3.5

muaculature of wing 58 '

theletal meanurements 727

kicletris $i 21$

structure of lieg 7.26

atructure of jerlic pirdle and - sumatrmm 726

structure ent rilon izs

atructure of shill ist

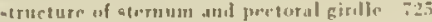

utrueture af strinx $58,-337$

etructure ul vertetural coluren at

tructure of nimg -igs

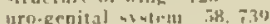

aulrumelestuxin 193, 12.

aismonte 208

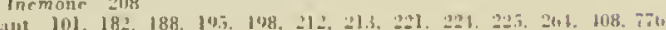

dint 101, 182., 188. 19.5. 108. 212. 21.3. 23.

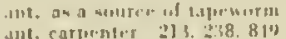

ant. corntielil 2]\}

ant, nound 21:

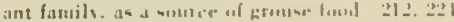

trempariis 198, ,

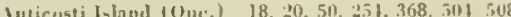

Thlicte $=7$

Jpins tuberosis 818

Vpuslachian Wountaine 18, 51, 53. 51. 217

trile 148, 198, 144, 205, 204, 211, 215, 216, 218, 219.220, 221.

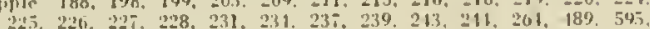
12., $6162,-70 \%, 817$

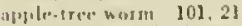

iproceclitis studdardi bile

tequida rhrysortos 33.3

Aracharida 198, 21.3

Iranuil. 775 .

lrctium 19.1

Irisium munus gli)

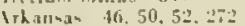

tsmadillidium unigare 121

army worm 101

fronio 200

atrangenumt of cover faee interspe-1sim

arron nout $203,204,635,602,819,883$

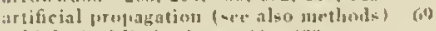

liolegical limisations $\$ 160.490$

compatisen of "qual athd gremer 1.58

(i) 50 :

dificultirs 110,500

discases encountered 116. 118. 15-, 190

curly atsonuts $21,47,153$

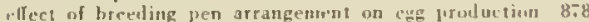

-fiect uf brumbling ronditiuns on rhirk survival $8 B 1$

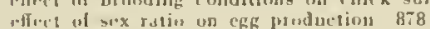

. Hect of neather 450

ogg production at Research Cinter $8: 8$ 


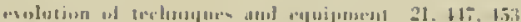

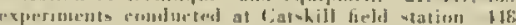

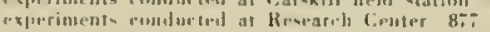
facluse Jimiting proslurtion 116, 500

fertility of rege frum Jirita belli on gramenl bis

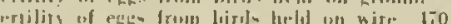

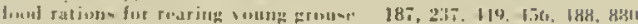
hislors of $21,11$.

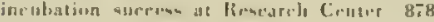

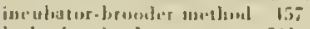

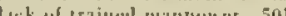

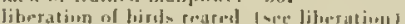
Illating bejtas iur bi

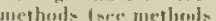

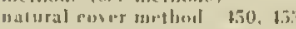

"hlaining breedling - tow $h$ 501

practirabilits 114, 150. 19?

[1riv]dtion 156. [11]

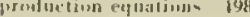

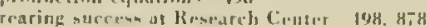

rewulis 150

-rustity of ubtainablr stmeh 501

ienifieancition

$502+10$

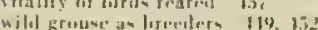

lociridier $98,102,4198$

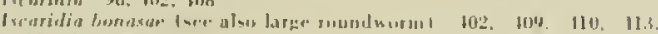
115. $116,121.12$

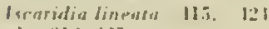

an 212.223

a-h, menuntain 88.

1-h, whit: 610

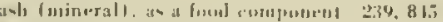

Inia 1206

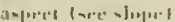

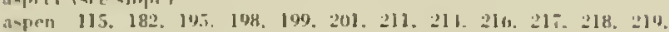

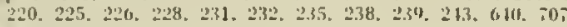

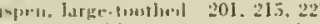

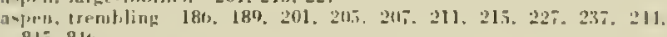

815.816

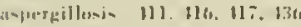

- julse $\quad 1.39$

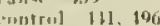

dishemination 111

malture 131

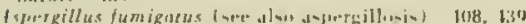

I-pinuall, T, II

a*pirin je5

$\lim 201.220$

tseet 301

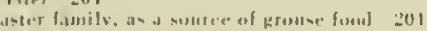

Astur atrirapillus $321.333,571$

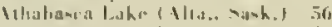

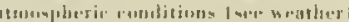

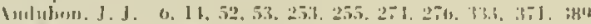

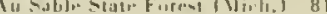

inturumbijle fore man a nits

(1) 19. 19.3. 200

IVim. II. H. II

Inivilu. (VI.ju, 55-

re ture manis ailat

Ifaled 20 ?

"alıw.k. 1.. I1

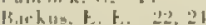

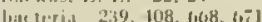

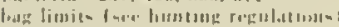

Pailon. H, H. 18

Builin. IT. UI. 18:

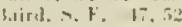

Itall, J. i. 30

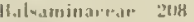

II.1ng- 0., 18. 1\%, 18

Jiarta, I. 28, 30

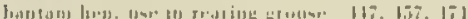

Hirtur. 11. 6, xroi

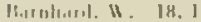

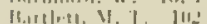

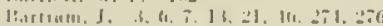

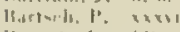

$1: 31+4,1,1,1,16$

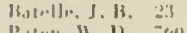

Pistin. W. H.

Iborl. 1. I. I. 10

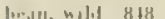

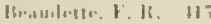

the the o.

lion h. 1. 2., 2:月

Juelot

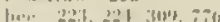

1

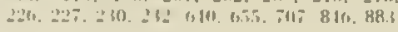

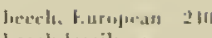

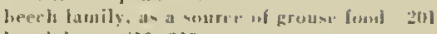

luevelutrous 210,218

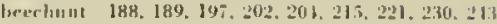

Hurruation in erup 202

unantitim cumatument 201

Hirer, J. 31, 203

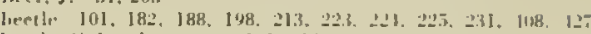

luectle. Ciolugarlo fuitaso 101.212

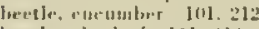

lwowle, rlum leaf 101. 2]:

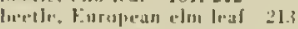

betetle. grapu vine leaf li1

bremle. frusum! 213, 2:2

fientle, Jraf 212,221

lowetle, Vas 101, 213

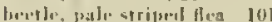

lunetle, siarible 221

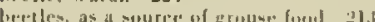

hehavier, displas of deminalere $37.61 .203,28$

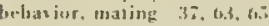

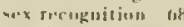

sex risthe

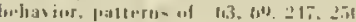

Bril]. K. 5:

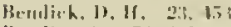

Rembire. 1.. -2.201

B.Mnelt, I.. J. 314

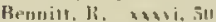

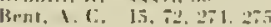

lieguart, J. 1.. revi

Rergen (N.Y. S:

Beretwili, II. H. So

firlulis 148, 200

Befula lentis 20 ]

Picrula luted 200, 811

Berula popuritern 200

Brisulariar 200

Bezils.k. 11, 31

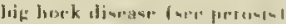

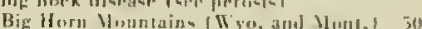

Rilling, F, t, 24,0

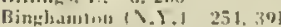

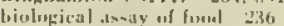

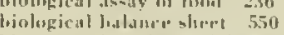

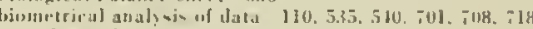
analysis of soriance ilo

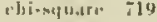

regstession and rerselutian $5335,708,720$

*ignifirane" 719

lifirli 56. 115. 18:2, 148, 200, 215, 216, 217, 218, 214, 220, . $2=21,231,235,70-$

birch, black 201, 21.5, 23, 22, 235, 6.5

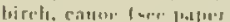

bisch. gray 2025,610

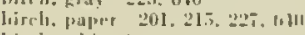

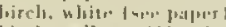

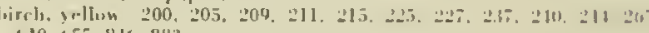
$610,055,8 \mathrm{~W}_{1}, 89.3$

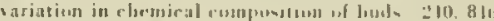

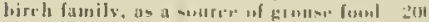

biril-por. 204

Bist J off 52

liisliup. J. . 31 31

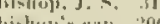

Hili

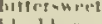

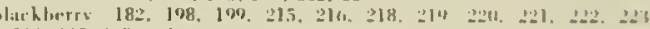
$2=1,225,2327,231,213,6,3$

hathluess. Hajles : 81

lol.tikhiril jo1,

blorkrosh 2, b. 2:

[.] arkel, 108, t. B.

l. Jarkhat 883

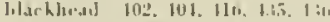

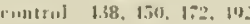

liowsunation 1:88, 1.5.5

nature $1: 18$

13late II)

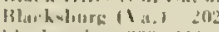

blachanahr itik, I31. givi

Illair, f, 11, 57?

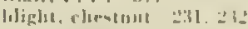

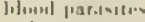

Amarription 130

Ijatribution 1.11

m(3)

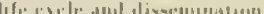

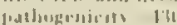

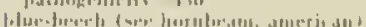

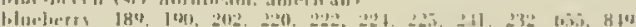

buelovers. low buali gez

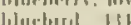

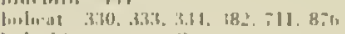

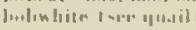


hody temperature (see also physiological studies) 62

Bonaso 46, 724, 725, 726, 727, 728, 730, 732, 733, 73i

Bonasa ceres 40

Bonasa. characters of 46

Bonnsa jobsit 4 i

Bonasa nmbellus brunnescens 48

Bonasa umbellus helmer 48

Ponasa umbellus sabini 47, 48, 52, 53, 72,23

Banasa umbellus thayeri 47,48

Bonasa umbellus togata $39,47,48,53,261$

Bonasa umbellus umbelloides $47,48,53,197,210$

Bonasa umbellus umbellus $38,39,47,48,53$

Bonasa umbellus yukonensis 47, 4h, 19,

Bonosio major Canadensis 17

banosus 46

boter, poplas 101, 212

Boston (Mass.) B, 557

botulism 671

Boudoin College 33

Boughtoo, R. V. 42:3, 12.3

bounties, oo grouse $11,37,102$. 18

bounties, on predators $381,382,383,388$

Rrarlyrhintes rugitrons 213

brackea 309

Brackett, E. A. 23

Brackett, M. W. $x \times \pi \mathrm{V}$

Bradbury. H. M. 243

Bradley. J. T. 360

Bradshaw, F. 15

Brazil 419

Breckentidge. W. J. 526

breeding (sec also mating habits)

realiness for 69.267

relation to age 353,359

brecding failure (sce slso non-brceding) $311,353,355,539,543$

breeding season 265

trrecding stock, salc of 10.

brecding success (sce productivity)

Brewar T M 52

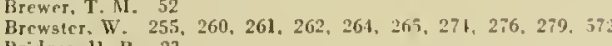

Bridges, H1. P. 23

Brisson, Columbia $31,47,50,52,53,51,703,109,83.5$

British Columbia Provincial Alusem 31

British Commitice of Inquiry on Grounc Dinedure nit

British Isles 103, 101, 578

Bronx County (N.Y.) 56

breasd cover 138

basic patterns 589

basposition 593

Comprosition

deflect of density of crown cover 161,802

effect of density of crown cover 161,802

influcnce of slope 148,593,813

influence of slope $148,593,813$

influences aflecting choice 138.
relation to age of brood 111

relation to age of brood 141

relalius to ground conditinns

relation to water 59

relition to weather $112,117,305,801,810,815$

rilative importance of tyror 139.801

types uf rown cover chosen 139.801

types of undererowth shosen is 6,808

unulurewth 593

bront mortaliey (sec alou survival during brood period 31.3 causcs rcsponsilule 528

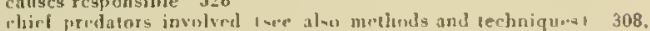
335,385

"imparison with artifically reared stock 316,528

efirt inf preilator critrul $308,316,31$

number of dead birds examined 335

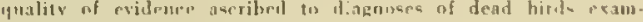
ined 876

rreorled during lnvestigation 315

imlation to weather $299,303,317,528$

re

mine of rredation

broods (sce also chicks)

area traversed $2.18,29$

double 293

habits of 291

Brooke, Mr. 13, 274, 27

bronmrape Ianily 210

Brown Sand Hills $(\mathrm{T}$ (x.) 5

Rrunest. E. L. 33

Brutswick (Me.) 36

Bubo virginianus 3 mo 333

buckhrush 203, 20.

buckwhest 210,212,230,233

luckwheat, common $\mathrm{As}$ ?

liuckwheat, common

bockwheat family, as a source of grouse food 306

huckwheat family, as
hudliting $37,103,18$ ? buffers, (see aloo methods of management)

Auctuations io abuodance (see also metbods and techniques)

$308,322,325,556,567$

nrincipal species of the Northeast 325

relation of Buctuations to fox activity 308,322

Telatioo of fluctuations to predation $307,308,315,322,552$

bug 213,221

bug. plant 101, 212

hups. true 213

building activity. cycle in 578

345.520

Bump. C. $1,15,22,24,30,34,35,63,90,100,105,181,183$, $220.413,550,557,568,581,585,605,637,667,671,694,845$, 816, 847. 848, 819

Bump. J. 22, 24, 30.694

hunchberry (sec dogwood)

Burckmyer, E. K. x $x \times v i, 33$

lurdock 193,849

Burnham, J. B. xxxi, xxxvi, 15, 27, 30, 32, 95, 26b, 562, 57

bursa Fabricii $81,90,94,256,434,516,718,739$

Bursen, E.. H. 1

Bucea 323, 330

Butea borealis 330,333

Buteo logopus s. johannis 330

Buteo lincatus 330,333

Butea platypterus 330,333

huttercup, 208, 218, 222, 223, 224, 231

buttercup, tall 817

buticreup family, ah a source of grousc fond 208

butter0y 213

calcium, a fond component 239

raleium oxalote 19

California $2,36,16,272,433,671$

ralls 99

Camden (So. Cor.) 52

Camponous hrpeuleanis 213,810

Canachutes canedensis 210

Canada $4,8,18,30,36,48,52,53,54,56,108,241,323,325$. $3196,505,557,562,56,3,565,567,568,572,579$

Canandaigua (N.Y.) 208

Canss 333,5 i8

canker.wnrm I01, 212

Cope Crut (Mass.) $\quad 453$

Cope Mrndocino (Calil.) 47

rapercailzic $25,427,43$

Capullaria 402,108

Capillaria annulato (sec also crofiworm) 109, 116, 119, 125

Cappitol District Game Beluge (X.Y.) 18

Caprifoliaccos $20-1$

Carabihlar 21:

Carbohylrale, a lood componch1 236, 238, 239, 210

Carex J198. 203

Carex crinieg 203

Capex delitis rar, rudseri 203,222

Copex pracillima 222

Capex incime"scens 203,222,815

Carex lupida $8: 5$

Carex viridula 22

Caribno Mountams (Br. Col.) 5.3

Carnegic lnmeitute of Washington 25

Carpinler. F. H. 5.58

Corperbtr. R. C; 102

Carpinus 398, 201

corrot, will 103,818

carrying $309,332,393,512,522,546,672,677$

criteris $\$ 23$

definition $5: 3$

ohservations is others 52

aliurs rccordeal by Investigation $5 \geq 3$

varialiality 521

Cortier, J. 46

Coriwright. 16, W: , xxvi

Cancade kangr st

cat. house 14, $25,330,333,331,336,338,339,310,311,344,385$. $391,456,496,711,875,876$

catbiral 120

caterpillar 101, 182, 195, 212, 22.8, 231

caterpillar, forestetent 232

Catskill Expreriment Station (N.). 297, 301, 418, 45. 115,185 492, $502,50 t$

C.atskill Format Prosers (X.Y.) 596.68.4

Cotskill Mountains (X.Y.) 56, 5i, 115, 386. $\$ 18,590$

Catskill region (N.Y.)

haracieristics of $115,217,596,698$

cuver nonagement in $\mathbf{5 9 6}$

Catskill study area (N.Y.), description 695

cottle (sce livesturk)

Coulophrllum thalictroides 195

causes of fuctuations in grouse ahundance (see also productivity) 571

gencral $511,571,573$

relatinn to age composition of population 573

rrlalion to disease $309,401,574,575$

relation to pogulation density $556,576,577$ 
relation ta predation sit

selation to solar activity $5 i 5$

relatiun (1) weather $556,575,576,577$

role of adult nortality $\$ 18$

irnificance of smecess or tailure of anuual increment of yuune

$534,556,571.572,573,57:$

Cauthen. C. E, 121

cave, Cumberland (Md.) 2. 16.272

cave, Frankstiown (Pa.) 1,46.272

cave, Putter Creck (Calif.) 2,46,272

Cayuga County (X.Y.) 19

recal worms

description $115,125,127$

distribution $109,416,427$

incidence and importance $\$ 10,4: 8$

life cycle and dissemination 108,128

lathogenicity 128

cedar, white $655,660,883$

Cedar Lake (Tex.)

Celastrus scandens 198

cellulose, a food component 239

census of grouse populations (sce methods and irehniefues)

Centre County (Pa.) 816

Centrocercus 721, 725

Ceratophyllus Jiffinis 409,135

Crsinda $400^{\circ}$

Chudluik. T. T . 183,208, $112,2.20$

Chamberlain, W.J. $x \times x \times$ i

Chapman, F. B. 30

Cham F if 38

characteristics (sce anatomy, (axonomy)

Chateaugay IX.Y.) 202

Cheslospiruris 108, 194

Cheilospirura hamulosa 123

Cheilospirura spinosa (see alsugizast worm) 106, 109, 113, 116. 123. 125

chemical cumprasition of grouse foods 815

chenical poisun selation 10 disease 401,105

Chemung Rives (N.Y.) \$7. 10,95, 222, 407, 520,558, 695

Cbrnango Comnty (N.Y.) 10,95, $222,407,520$.

Cheoango public shooting grom

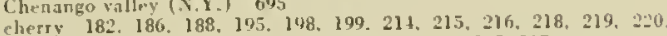

221, 223, 221, 225, 231. 235, 237, 238, 239, 211, 595, 707

clerrv chuhe 191, 207, 211, 215, 226, 227, 230, 817, 818

herry, uin 11\%, jon. $199,20 \%, 215,221,222,225,226,227,228$ 232. 610.615 .817

cherry, wild biack $199,205,215,225,227,228,610,655,817,883$

chestinut 188. 202

Chestnut 188. 202

chicken taee foul

rhieken fuec
chirks 218

aliblity tw hide 295

calls 90

disat hathing 297

feeding halits 221. 20

greguriumsurese 29

growith and dinclopment 78

rousting 296

Childs and Walcott V'reserse (Conn.) 27

Cliilopoda $7 i 5$

chipmunk 28, 333, 331, 335, 310,311, 670, $111,8: 6$

Chipuewa Yutional Forese (Minn.) 521

chi.square (sere linmetrical analysis)

chisquare (sire linmetrical an

chitin. a feres counponent 239

Choanotienio infundibulum 409, 13.4

chukelerertiv 200

Chrominelidac 213

Cincinnati (0.) 8, 3il

Circus hudsonius 330, 333

Cisil WI ar 557

Cisilian Conacrvatisun Corus xavi

lam, finerer-nail 192

Clare (Mieh.) 19

Cisak, G. $11,17,21,22,21,153$

Clask, Ml. 11, 21, 22,

(:latk, 1. E. 31. 18:

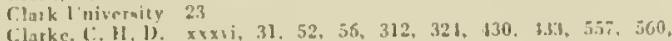

$562,560,54,568,5,2,571$

classifuration 16

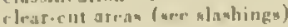

- Iraring of land 383

clatum tue rouse alumlaner. 116, 370, 384, 393

cleatinge, influruer uf settlers" 383

cleating infurier of

- - Jimate (nece nritlier)

climax flowa of Comsuretirnt

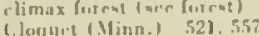

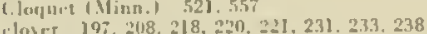

r. lowr 19\%. $208.218 .2 \%$

rlines, alaike 208,818

cliner, real 208, 309. 818

Fluser, whise 208, 601. 818 cućcidis 104. 109.419

veseripuion 128

distribution $\$ 28$

inciderec and imprortance $110,412,429$

life cycle and dissenuination 113,428

pathogenicity 439

curcidinsis 35, 192, 6il

Cuffin. M. Ii. 22

eohosh 195

Coleman, II, B. 22,2

Coleoptera 198. 213, 223, 221, 77

Culinson. P. 46

Colinus $728.730,731,732,733$

Collembola its

Colony of Niew link $x \times x$

color attraction 187

color phasea 18. 57

Colorado t7. 50. 53. 51

Coluber consirictar 333

Columbia Countr (V.Y.) 12,415

Culumbia River 47

commercialization of grouse (see exploitation; markef hunting) Cumpositae 201

cumporitien (sec cover type; habitat)

Comptonia peregrina 815

coniferous fulantation, use by grouse 1 i.t, 230

conilers

impertance as an relement of grouse lobitat 132. 110, 156, 163. $776,789,801,819,821$

in 3 ucrec on nest location 132,789

influence un use of brood coner in

truning of 649.653

Conarcticut 18, 22, 21, 27, 30, 3I, 563, 565, 36t. 568, 53.., 5:-. $845,817,818,819$

Connecticut Agricultural Fxperimant station 819

Connecticut Hill Gane Refuge IXY.) 18, 19. 214. 241

Connectic ut Hill study area (N.Y.). descriptiot 695, 690.69-

Connecticut State Bont of Fisheries and Came 23, 12.2. 819

Conover. H. B. 47,18

cunservation (sce alsel bunting, regulation of )

evolution of nucthuls $38^{-}$

Irgislation $x \times x i, 370,388,6 \pi$

"nceans "wise use" 387

ivelatur exntrol $390,6.30 .607 .668$

refuges. sunrtuaries and land posting 388, 391.629.667

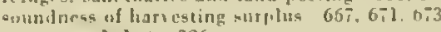

Cenafantial ( \.).1 326

Consracuecum 109, 434

Cook. $11.13,385$

Couke, W. W. 52

Cooper. J. G. S2

Coptis irifolio 208

Coptis tritolio $208,220,230,233,845$

"orn 2t0, 212.

cornel, r(warf face derwood, bunchberry)

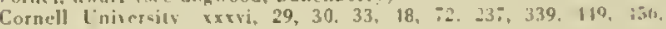
$176,610,711,219$

Cornus 198, 200

Comus cumadensis 200

Cornus paniculapa 206, 818,849

Cornut rugosa 200

Comiss stolonifern 819

corpuratinu lunds (nece prisate lands)

cosrulation of laia (ace liometricul analy aial

Corriganville (Md.) 2

Correulentia $:-5$

Cursen, G. 11.15

Cortland (X.i.) 39$]$

Copus broith whinchos 330,333

Con us corax 33.3

Corplus 198, 201

Corvilus umeracana 810

(orilus cotnuta 8to

Cottnm. C. $x \times x+1$

cottuntal thee rablitit

cottonworm 10

Cours, E. 1:

courtship 206, 26:, 281

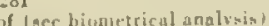

cover (aece also shirlter)

als lyais of mermal runer combinations 609

chatalurintice of fuoductive 110

concrts so and sliave 111

prelerners of groute 152

recentlltun of Jeficiencies 628

icending and couditions 698

relatson to stil 100

cuver requurburnta (see alko mauagement) 121

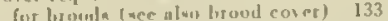

for fill fuidiug (ace alao adult cover I 153, 160, 230

for fill fine (ue alen neating cover) 1.97

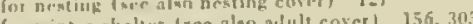

for winter wheltit (wre J J

ines tive. thue secompuzed 120, 111, 698 
curer types

arrangensent 112.168,609

characteristics 120,14

composition 112,614

function in filling habitat requirements 110.607

influence of size and shape 111. 609, 612

interspersion (see also intersperaion) 113.609

mapping of 626,698

of open land 120,226

of overgrown Jand 120, 226

of slaklings 120,125

of slakhings 120,125

"if woodlands 120,123

relatim to food sipply 326

relation to nest survival 135

succession of 118

rover use, field data rccordel by lnvestigation 701

roverts, designing of ( $\mathrm{sec}$ also management)

clear-eut units 621

essentials 607

foreat atand and game cuver imurovemes) $623,650,777$

open land 616

uvelgrown land 618

wertown land

588

(1)icrls, illeal 588

in adults 593

for luntiog 591

for huntiog 59.1

firz nesting 589

eoverts, pattern of 60

Cowan. I. McT. 31

rrahapple $655,662,883$

Cram, E, 13, xxxvi, 33, 109, 115, 118, 119, 120, 12:

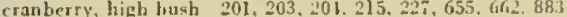

Cirmtitegus 198, 200

(iraturepus crus galli 8.17

crayfish $3.11,3.22$

crazy flight $248,253,255,258,318,401,532$

cricket 188, 213

cricket, fiel, 213

Crildle. N. 211, 557, 561

rippling lose 376

f.rigurs: W. F. 30, 98, 299, 353,693,691

rrip, gromar as a 58

crup, part of digestive tract iis:

crou cuntents, average whime 186

rrop infammition 111,112

repp worm $\$ 19$

Iescription 419,125

distribution $402,109,113,115,116.119$

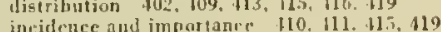

incidence and importaner

pathugenicity 412,419

liruss, E, C. 323, 56

1' 80 15, $330,333,331,335,336,337,338,381,116,418,439$, 552. $(1,6), 710.875,876$

'rusn encer (sec neuting coser, brool cover, adult cover)

1.ultivatiun (sec farming)

Curruliunialase 213

cuttiug at timber or brush

its a manitement 600

the ming

relatiun to bool supaly 233

relation to thot

11t-uorm 101.212

(1athosome striatum 409,433

cieles (see alsa fluetuntions) $402,5 i 8$

applicalility of icm in graust. 556

jhenomena to which term las been ascibel 5 i

jrestirtion 579

recurde of 12,16

studies uf 13,17

sugeresed cases 17, 20

sugented rumedics 30.31

variable periodicitics of Aluctuations recorded 578

Civeralcie 203

Cyperas 192

Cipress Llilis (Sask.) 18,50

(rolcichus nudus (sce also air.sac mites) 109. I1

Iaddy fong-Jegs 213

Daknta $50,5.58$

lamane to orchards $11,102,187$

daudelion $220,238,213,819$

Danswille (Me, 21

Danswille (Ne), 21

Darling, J. N. $6680,35,16,18,53,24 \bar{i}, 307,511,555,667,1668$. Tarrow, $R$.

Darwin, C, 513

lata (see olso methods and terhrignes

analysis of (see biometrical analisis)

form slifets used $702,703,70.1,705$

recoriled in field 126,700

represmativencss 126
Daucus carola 193. 848

Davainea terrooensis 409,434

Davainea proplatring $409,415,426,434$

Dasenport. L. A. $845,816,847,848,819$

Davis, D. E. $58,694,721$

Davis. G. E. 11:

dead falls 389

Deane, R. 324

Dearborn, X. 203, 206

death rate. human 578 .

decrease in grouse abundan

leer $239,513,521,849$

radication of hoof and mouth disease in $6-i$

relation to grousc mabatemeot 660

leer, nule 309.691

deer, white-tailed $309.383,682$

leer-flies, as a source of infection of tularemia 116, H:

Deer Run Refuge (Ma.) 19

Du Garmo, H. R. 31

Delaware County (X.Y.) 19,20.206. 213, 261.385

Dethi (X.Y.) 20

Deslinger. Dr. 21

De.lmar (X.Y.) 19, 181, 118

De.Lury, R, E $185,281,5=5$

denaity of

imethord it recorrling ilt

af adulta 519.525

withourds 518

uf f:maliw in wpring 517,518

uf newts 517

relation to flut tuations in abutudince $350,511,532,533,5,31$

535. 539. $510,511,542,514,576$

relatiun to net productisity 331,32

saturation point 331,5$) 2.521$

Denye 8,3

Ir prosits, [']cistornte 16, 2792

deweringiun of erouth

firat 3,36 . 16

geriral 36,38

ecr difterences 36,39

d. -gertion (sce nesting)

Desmentum 208

develepument of rence $6.39,65$

ilevelupiment of growar it

itrw, as a sourer if water 213

diarrlies, whice 115

Ui.e. L. R. 28.5

dirlyromatiom 36, 78,57

Jidelphis urginiang $3: 1333$

iliwet, of grenuas 196

Hiets. . . . 31

bighy (X.S.) 4:

Jipelive trant

frillin. D. J. 1.3

(s) numirk. C., 2

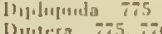

Diplera 785 , ith

diecosrry af apecies 36, 36

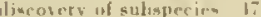

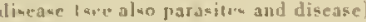

an a cause of mortalits. 31 ?

a* a combributury factur in flurguaresns of grounc abundance $309.111,571$

lanut and munth in lene fort

studien of 30,31

dispases of wilu inammals. relation to giouse 116

dispersal. lall (ace alsn i rutzy flight) 255.522

Dispharint to8. 112. 111. 5il

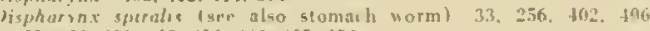
$107,109,+13,115,416,420,425,191$ diapling

as a liart of wourtulip 281,282

ittimislation bo 28 ?

relation to stecist uthet 61.268

divtance buenern succesuisc flushes of grousc 167,813

distume beturean unccruaive nests of marked [e-male grousc 250

distance grousc flush from oliserver

influence of cobre 105.810

influence of $x$ ind 162

rillushes $166.8 \mathrm{~J} 2$

Distomum commutatum tog

distrilution af

relation to ansilalile water 243

relation to food 229

listribution of sprence (sect also rattge)

effect of man's at tivities 50,5 f

general 36,53

in Yow York 30. 56

in northern Cianarla 52.56

in the Rockies $18,50,51$

(1) vrious islauls 50.254

tistrict forest practice hoard 687,688

distriet game manater 686,688

Dintrice of Columltia 120 
diversificatlon of caver 596

dog (sec also grouse dogs) $15,333,334,338,3 \% 1.385,389,390$, $156,496,711,876$

dugwood 198, 204, 206, 207, 209, 215, 218, 219, 220, 222, 221. $231,231,595$

dogwooul, bunchberry 206,215, 225,227, 231

dogwood, fowering 883

dogwood, panicled 206, 215, 227. 655, 662,848,819,883

dogwaad. red osier 215, 819

dogwood, round leaved 206

dogwood, silky 215, 883

dogwand family, as a sururce of gruuse food 200

Doll. E. R. 130

domestic animals, effect on grouse $384,385,392$

donieatic fowl (sec fow $)$

dominance (sro social order)

Douglas, D. 47

dove, mourning 683

down $36,79,7.16,748$

drumming $66.218,266,27$

d.seriplion 27.

bow produced 248,276

purpose 278

вและก 248.278

druaning $\log 279$

number per male 280

relation to nest 266

role during breeding sesson 266,267

variations ohserved 279

Dryapteris 198

Dryopteris marginalis 206

Dryopleris spinulasa 206.845

duck $101,103,392,416,433,131$

duck, black 212. 683

Durant, A. J. 4.36

Durvea. 1. IB. vxxv

dust bathing 271,39 .

Dutrlima finunty (N.Y.) 285

Juight, J., Jr. T8

eagle. golden 333

earthworm 439

as a suurce of cropworm infectioe 408, 419

a a seurce of gapeworm infection 408,418

Fast Sandwich Ganie Farm (Mass.) 27

Faton, F. I1. 235, 333

Echinachloa crusgalli 915

Eclunoparyphium aconialum 400.434

economic imporsanee of arouse 37, 100

conl vilue $100,235,371$

number taken by hunters 10
orchart damage $37,102.187$

"rehark damage $37,102.187$

relation to agriculiure 101,212

sialo of brecting atnck
aporting value 103,371

sporting value 103. 371

edges (ace alao interapersion) 393
iflers on adult grnuse distribution 171

rflect on hroml diatrihution 172

importane of emniferous plantations 17

value ul jio

variation in importance 173

Elseworth, F, 11, 721

E.dmineter, F. C. $30.353,369,637,667,673,681,691$

Eidmonton (Alia.) 520

Edwarils, G. 3, 6, 11, 14, 21, 36, 46, 17, 274, 270

egghund. a pathologic condition is

egg-lnying

habita of Junnle during 286

rate of 286

relation to semperature 303

lime of $26.5,281$

eges

color 37,71

develoriment of 73

tertilisy (ace reproductive capacity

hatchability (are reproductive capacito

numlur (see number of raga)

number (Nee number of rggs)

shapis $37,-1$

shaper 72

Fimeria (ace alan corcirlia) $\$ 28$

Fimerig angusin 409. 428

Fimeras bonasa 104,428

Fimeria dispersal 109,428

Finararn. A. S. 20

Elateridae 213

- Meler, red-berrieal 201, 222, 655, 883

eleferbersy 201

t.Jired, $S .360$

E.Inocharis 10:

rlk 671

L.11ictl. 1), G. 235, 261, 371, 389, 390

(im 212

i.linira (N.Y.) 201.201

Flton, C. 3il, 325, 55\%, 575, 578, 579, 719 entaryology 72

annual changes 75

ehemical composition of rhick 37,70

development ul embryo 76

hatchability of eggs 72,365

livability of chicks 73

mortality 76,366

physico-chemieal properties is

structure of ege and embryo 73

encruhalonyelitis, equine 408

Endsley, 11. S. 14

Finglond 2, 3, 103, 264. 309, 406, 630, 650. 653

Englislı, P. F, 310

enterohepatitis (see also blackbead) 435,438

F.phemeroptera 775

Epilagus lirginiana 210

equisetin 195

Ericaceae 202

Erishizan darsarum 333

rrosion conirol 58\%, 615

Errington. P. L. 30, 309. 321, 327, 521

Escanaha River (Mich.) 374

Eskime 4

Essex (N.Y.) $26 !$

Easex County (X.Y.) 95. 221, 433. 69.-

ellier extract, a foon component 238

euonymin 195

Europe 251. 419, 126, 427, 131, 556, 578

Euschistus 213

$\begin{array}{lll}\text { Everett. F. } 39 & 39\end{array}$

Ewbank. E. 1. 3.37

Experimcntal Game Farm (N.Y.) in

explaitation of grouse 8, 398

Extension Sarvice 687,688

exposure (see also slope)

rolation to nest location 130,787

eyr worm 109

factors of abundance (see also productivity; management) 311 . 513.694

food $181,229,58$

habits 21 ?

man 369.581

parasitism and disrnse 401,583

physiology 60 , : 19

predation 307 . 593

propagation, artificial 413,58

reproductive capacity 353

slifler 105. 581

weather 299

Faparrac 201

Fogopyrum esculeneum 817

Fagus 2098, 20

Fagus grandifoliz 201, g16

Fagus stivatice 210

Falco columbarius 333

Falra peregrinus 333

Falco rusficolus 3.3

fall ferding frounds 153.155, 160, 230,642, 801, 829

fall shufile (sce dispretsal)

farming

effert of abandonturnt of submarginal land 116. $226233,381$. 597.618

eflert on frotuse frod supply 116, 233

relatiou to frumse aluundance 370,383

Farrow, E, P 309

fat. a fond consponctl 236, 23i, 238, 815

[anthers (ave alsu pteryjograpby)

lusction 78

growih and replacement $37.85,71$;

Linds 50.3 it

intult $37.78,717$

number $36,60,76$

surersion 78

feather spaces 59, 7.t1, 715

fearher tracts 59.211

Jeeding hatits $37,218,261$

amout of food easen 189

caution in arcepting new fonts 186

influence of w ratlur 186.26 .5

of ailults 197. 201

of chick 187, 221

periuds 186, 265

freding peculiarities

budliting 37, 103, 187

effect of eolnr. Iexture, size 187

Felis couguar 3.33

Frllows, J. 0. 95

female grouse (arer almu nesting

rutrul of rhicks 202

thefrae of rhich 3218,201

Jer तe of rich 398

Guidaner of clisk 218,293

lialite 281

proportion meating 359.517 
fern. $1806,228,239,213$

ferr. Christmas 206

fero, evergreen wood $198,218,220.225,227,231,237,239,243$. 244,815

fern, polypody 206

f

fern family, as a source of grense ferend 206

Ferris 14

feriblity (see alsu reproductive caparity) $36.5,513$

Filber zibethicus 578

fiber, a food compunent 237. 239.815

Field, G. W. 15, 26, 30

field data recorded (see alas data; methols and teclinialuss)

regarding adults 702

regarding broods 701

regarding nesis 03

fighting 218,268

relation to breeding lehasin 67,269

relation to mainsenarre of sucial order 61. 268

filoplume 59,716

filterable virus 404,408

fir, balsam 115,386

Gre (sce also man's ajils) 1

as a cause of nest mortality 527,532

eflect in furest succession 231, 39?, 612

effect on grousc food plants 228, 232, 39.

effect on grouse food supuly 228, 2.32

role in management $51.594,612,650,661$

fislier 333

Fisher, A. K, 194, 343

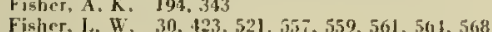

fish hawk (sice osprey)

flagellates 109,133

Flanigan. L. J.

flatwornis 23.4

flator, of grouse as fond 191, 235

flea, bird 409,435

Fleming. J.H. 32 !

flies 408, 437, 139, 495, 776

fliglat. crazy 218

flight distances $50,16 i, 26,253$

flight, manner of $25 \%$

flight speed! 2 : 25 ?

Flint. P. 14

fluctuations in abundane. Ispe aluo furetuutious in general grouse

abundancel

among buffers $325,556,567,576,578,579$

among predators $323,567,571,578,579$

among wildlife in general $323,556,575,578$

vuriety of periodicites 578

fluctuations in general grusure ahuodance (are also cycles: popula. tion trends) 323

anulitud. 5.58

calses (see causes of flurluationa)

characteristive 558

changrel of 58.3

duration of abundance and wearcily $5.55,54,54$

iscurrente $6,7,11,12,555,556,511$

periodicity $55.5,561.5 \% 1$

rate uf change $555,5 t, 0$

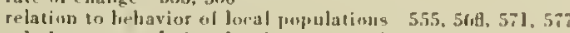

relation to pounlation deusity (see prouluctivity, net

sequence lietuedu reginus 5.5.5. 56?

shachrouism 5.55, 565.571

years of princifual decline 11900.141560

flukes $109,434,6: 1$

flushing distanre (sep diataure grouae fluali (rom ubarver)

fy larvae, rajging 156

fy larvae, rajing 456
fuamflower $206,220,227$

fuamflower $206,220,227$
Folleti, R, F, $19,23,26$

foud conditiuns, recorling 60

fool habits of grouse (afe alus fewing habits 181

competition with onlues sperien $2: 31$

materials studied 181

methorls of study 18: 181, 706

relation to other facturs of albumbuce $211,511,513$

seasonal differences 18:2, 21 I

stiudies if $30,31,183$

food of grouse

amount eaten 189

chemical composition 237 , g15

chuice in relation to nutritive value 239,210

effect of epening uj the wowilaul 231

effect on grouse distritution (laral) 182, 229

general availability 182, 227.229, 528, 775

items often considesul jujurius 19:

migcellaneous itctus 189, 192

monthly variations in food of chirks 221

nutritive salue 237

of young grouse 18:2.21. 115

other vertehrates tohen 188,102

principal chick foods 221

regional differences in New York 217.227

relation of food composition to snlar activity 212

relation of food comprosition to weatber 212 relation to cycles 211

relation to lrealth of the bird 235

relation to weight of the bird 37.211

apasnal differences $182,21 \%, 22 \%$

types caten $19^{-}$

variation throughout range of grouse 18:2, 220

variations in eomposition 237

variety of choice 182.191. 198

yearly differences 182,218

firod plants

distribution in New Yosk 227

eflect in lumbering on 233

habitat requirements 225,22

relation tis cosses ly Jus 227. 231

relation in fortat aucression 223.2

food requirements (see also physiolugiral mulies) 37, 181

fewi shestages 182, 185, 2299,523,532

food value of erinuse 100

pussibility of prisonous effres 19

relation of faviut to diet 191,235

foods. animal (sece aloo vasious orders, fonilies and wperies)

Isce Appendix. p. 859. for rmiplete lins af all -precien found to

have bren maten) $182,198,212$

amaun consumeil by individual liris : 21

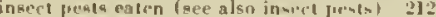

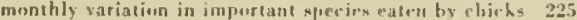

relative importaner 198

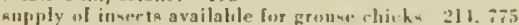

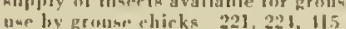

uur by gerbis" hirks 21,221

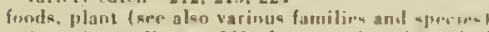

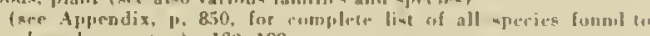

liave ticen eateril) 18:2,198

amount ronatumed by individual hirits $18 \% .180$

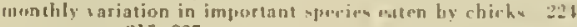

parts maten 213,227

regismal sariation in New busk of the tr-n now impurtant groups 21 i

arasunal distribution of the tell mom imprortant groups 215

seasnal uxe of various sprecien 211. 2ü

apecien most fremuents laken 198

variety caten 198

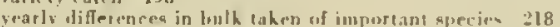

Foote. I. $56^{\circ}$

Forbre, E. B. 202, 896, 81\%, 818, 819

Furbu, A. 101

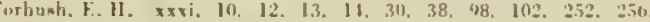

260, 262, 261, 269, 270, 292, 333, 338, 371, 37, 561, $71=$

Fordham, S. 22, 21, 30

forest, climax 53, 112, 386, 393, (3)

forest. sub-itimax 53.51

forent dintricts 68 , 1188

forest managument foif grone" $387,587,509$

Forest Pracije Ant 5 g日

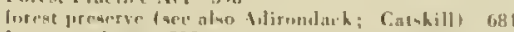

[orest prindures 580

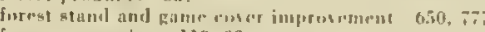

forest auccerasion 118, 386

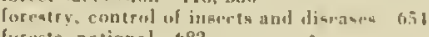

feresto, national 082

foreata, state ti82, 683

formir aritl 195

Formica 213

Fenmicidae 213

Fort Reliance iN, A. Terr. $\quad 52,54$

Fortynijle (Y, T".) di

fossil record $36,16,272$

fowl. dmancutie $239,213,108,112,115,116,118,114,120,123$. 121. 126, 127, 428, 130,131

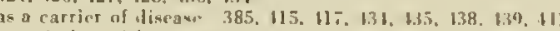

association with groun 2 (28. 290,383

firwl. Ruinea 120, 4:6

fowleliolera mi, 115

Fins. A, xrxui

fux (aee also varione speciral 11. 313, 321, 323, 329, 330, 3.39

350. 391, $11 ;, 55 \%, 630,607$, at,

us a predator during adule periesl $308,32 \%, 33-, 338,348,8 \% 0$

as a predater during neat perial 30:, $308,311,331,31 \%, 52-$ a

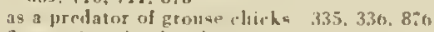

fluctuationa in abundance 328.565 .570

food habits $30 \mathrm{f}, 327,339,310,311,312,311,700$

relation of variations in fox antivity to tulult mortality 322

relation of varintima in fur artivity (1) huffer ahundance 308 ,

322. 328. 670, 708

relation of variations in for actisitu to neat nortalite $31=$

fox. arrtic $32,3,578$

fox. gray 311, 324, $320,332,336,337,339,381,392,683,711,875$

fox. red $314,323,326.329,332,336,331,339,381,382,578$ $683.711 .8 \% 5$

Foxborough 1Mass, 1 10,375

Fragaria 186. 198, 199

Fragaria tirginiana $81^{-}$

France 3

Franklin County (X.Y.) 19. 358 
Fraser River (Br, Col.) 53

Froxinus 212

Frederick, K. T. $x \times x \times$ j

Fredericks, W. 2

Fredine. C. S60

Friedmann.

fruit, oecurrence in ficediles foxed analesis $339,310,311$

fungus, as a cause of liaceace to

lus-trapping 382

Furbringer, H. 73 T

Gadow. II. 728, 733

Gnlerucella 213

Galium 208

Galliformes $46,721,725$

Gallitipeurus cameratus 409, 131

Gollus 721, 725, 726, 728, 730, 731, 732, 733, 731

game landa. related (6 grouse management Gat

gangrene $\$ 11$

description 418, 425

distribution 409, 116, 317, 118

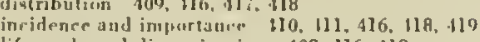

life cyele and diancmination $108,416,418$

frashogenicity 418

Ciarrod, A. 11. 727

Gaston, H. E. xxxv

Gastropoda 198,213

Goultheris procumbens 203

Gauman. F.. 210

Crumansacis 202, 22.

general balits (see habits)

geoeric characters 46

Cenesee County (N.Y.) 57

Genesee River (N.Y.) 5 ?

George, A. E. 22, 24

George Washington Natiunal Forest (Va.) 31, 183

Cecorgia 36. 47, 110

Ferry. R. 19.20.22. 21

Gerstell. R. 383

Grum 193. 200

Coiblus, J.T. $\times \times \times 4$

Cirani, C. L. 243, 254

girdling of trees, as a management tool 6,10

gimard contents, average volume 186

gizzard inflamation 411,41 ?

gizzard worm 406, 419

description 423,425

distribution 409, 413, 416, 423

incidener and importance $410,411,412,413,121$

life cyele and dissemination 408, 323,191

patbengenicity 412,423

Cladwin keluge (.Mich.) 817, 818

Glaphyrastomum 409, 4.34

Glaphyrastomum $409,43$.

glucoside (amygialin)

fisecria 208

Clvcerio striato 208

Cinlile, F. F. 401, 69

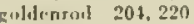

Lithlithreal 208

Goníacoles 409.435

roniodes corpulentis

(iordon, $5,78,573$

gushawk (ate loawk)

gentrawk (siec loaw

lishan, G. H. 22

gratio, as a groitse fond 189, 191, 210, 212

Ciramineac 208

Cirand Manan Island (.X.lB.) 50.251

(irange. W'. 562.575

Lrape 19R. 206, 218, 220, 259

grnpe, fur $6.55,662,883$

grape, from! 206, 227, 230, 848

craje, riverbank $655,66^{\circ}, 83_{3}$

crape family, as a sinurce of grouse furd $: 06$

erasy 208, 226, 231, 233, 234

glasm, hatnvard 815

gidam, batnvard 81

RHans, lilur 208. B

crans, monna 208

Rrans, reed canasy 208
graks, yellow fox-taif 845

grasa family, as a source of grouse foud 208

forasshoppers 101, $18 \%, 134$

as a source of gizzard wirm infection 108

an a soure of grouse food 108, 212, 213,221

rlfere of cating fwitumeuts $1 \%$

gravel conaumption 192

Grav, f., 1R. 46

Corav, ... K. 46

geraving (ace also liventock

a* a monagement tonl 620,611

fireat Hritain $104,401,552,575,578$

l.reat bliting $18,50,53$
Great Slave Lahe (Y. R. Terr.) 52, 50

Green. R. G. 15, $30,415,436,417,136,568$, 5i

(ireen Bay (Wis.) is, 20

Green Ray (twis, 18,20

greenbrier 210, 220, 221, 8 :

gregariousness, among adults 218. 23.5. 2.11

gregariousnek, among adults 218 .

Grionell, C. B. 11, 212, 261, 265, 279

Grinnell, J. 47

grit (sec gravel consumption)

(irnsa, A. (1). xxтvi, 15, 30, 33, 183, 220, 256, 321, 333, 337, 3.13, 115. $116,419,121,557,568,57$.

Gruse, 1.. $5.312,335$

ground comditions

relation to cover closen by adulis 162.836

relnsion su cours chusen hy broods 1.41, 807

grouse (sec also lieath hen ond prairie chichen) 101

grouse, black 16, 427

grouse, red (Sicstch grouse) 46. 91, 103, 251, 309, 101, 118, 127.

$552,578,671.675$

grouse, ruffed

as a game crap 587

linubty on 11, 102, 187

classed au vernin 11,102

common names $2,6,27$

factors of aliugulance (sep factura)

fuctuations (see fluetuations)

occurrence in predator food allalvsis $339,340,311,312,313$. 341

productivity (see iruductivity)

raoge 48

scientific classificatiun 16

studies of 30,31

grouse, sage $46,243,416,417.230$

grouse, sharp-tailed $46,232,416,120,+28$

gronse, spruce $46,53,210,273,428,130,131$

grouse. willow 578

"grouse discasc" (sre parasitism and iliscasce)

grouse doge $390,391,395$

frouse lusestigation Committee 12, 32, 31, 562

prouse : predalor ratius 329

gronell 77

Gryllus assimilis 213

gum, suur 206

Euns (see man's airl?

Cumer A B. хxหs

balitat (see also terrilory)

definition 631

important romplouents 111

ivefersed it

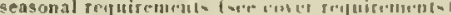

varicty acceptable 53

lhabitat manaremert

designing portuctive cutur (at):

desiralsle conuresitiun 589

for fall foculing erciund 230.018 . 61

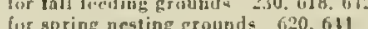

fir spring neating groubre 6i20, 611

fur winfer shelter 6:0.616

function of variens conot upm the

liarmful pratices 590

improving and maiulding 596 , th?

survey and analysi4 b.21

loahitat regions in New York II

luahits, Eeneral $30,11 \%$

of hoth sexes $163,168.251$

if the trool 298

of the female 38 !

of the remale 28

llaemaphysalis (sce alau ticks I II

Iloemophysalis chosdeilis t0?, 114. 116, 11:, 1.30, 411

II cemaphysalis leparis.palustris 409, 11 h. 4.30

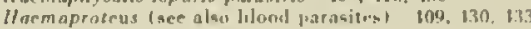

Haight, A. 10,375

lanir-feachers 36

II 11. A. C. 699

Hall, $C, \mathrm{~L}, 17$

II alpin. J. L. Xrr

Hamamelis riscininan 208, 81 -

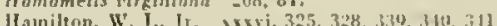

Homilton County (X.Y.) 30 s

hordback (ace bormbesm)

Hardy, 1\%. 201, 558

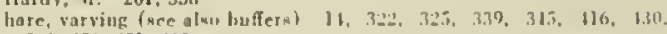
$568,670,671,683$

furtuotions in ahumlance 323, 325, 327. 536. 54. 5it, 5\%, 578.579

IIarmastamum pellacidum 109. 131

Inneney Boain (O)e.) 48

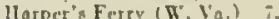

II art, D. 23.21

llart, D. 23,21 . 418

Harvard Mealical Schonl 3,3

Harvard [nisereits 3] 
Hatch, J. Y. 561

hat hing dates, average 513

hawk (sec also varinus species) $14,309,331,335,337,3 \%, 391$, $132,439,876$

food habits 336

hawk, hroad-winged $330,333,336,337,432,875$

liawk. Cooper's 15, 308, 323, 325, 329, 333, 33t. 338, 339, 312, $313,341,346,347,381,669,670,875,876$

as a predator of adult grouse $337,456,713,876$

as a predatur of grouse clicks $308,317,335,336,669,876$

lawk, dilck 333

jawk, goshawk $14,262,321,330,333,336,338,339,313,381$. $552,630,668,6129,875$

as a contributory factor in grouse fluctuations 571

as a predator of aduit gronse $327,337,876$

feriodic influxes from the North $324,574,669$

hawk, gytfalcon 333

hawk, marsh $330,333,336,337,339,341,432,875$

liawk, pigeon 333

hawk, red-shouldered 15, 330,333, 336, 339, 311, 875

hawk, red-tailed 15, 330,333,336,337,339,313,311, 132, 87

liawk, rough-legged 330,875

hawk, sliarp-shinned $323,325,329,333,338,339,312,313,311$.

$346,317,381,669,670,875$

as a freilatur of grous thicks 308, 317. 335. 3361. 669. 876

lan $k$, sparrow 87

hawkwerd 190, 201, 218

lawthorn (see thomapple)

hazelnut $198,201,211,218,655,662$

hazelnut, american $215,816,88$ ?

hazelnut, beaked 215,816

liead-I witching 283

heart rate (see also physialogiral studice) 37,62

heatl family, an a source of grous font 203

heath hen $25,46,391,502$

lieatlier 309

licinrich, C. $x \times x$ vi

Velianthus annums 8.19

Heller, V. C. 244

He\}lmers, 11, 239, 8.15, 816,817, 818,819

Hejlners, $11,239,815,816,817,8$
Henipleta $198,213,223,221,775$

llentork (Mjicli.) 520

hrmilock 115, 210, 228, 238, 386, 610,655, 81

Henry VIII 2

Ilenry House (Alia.) 47

Ilepatica 208

Herkimer County (N.Y.) 11

Hermann, F. J, xxxvi

Jerrick, C. A. 121, 126

Herrick, C. A. 121,126

llersey, F. S. 408

Uleterukis bonasoe (sec also cecal worms) $109, \quad 115,416,425,127$

Ule perahis gallisue 415,427

Heterakis qesiculnris 115

IIewitt. C. G. 556

Hexapoia 409

llieracium 201

lighways (sec man's uida)

Jistomonas mirleagris (sce alsen blakkhead) 100,138

lonck disease

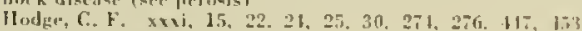

ling, razorliack 333

ling, razorliack 333. . R. 212,2 , $30,77,69$

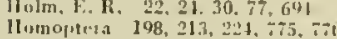

honeysuckle family. as a sourre of Etensa fomi 201

llonkway, W. E. 12

low. Hornbeam (sec homleart. hop)

lownluean, american $198,201,211,215,218,237$

linulueam, hop 182, 186. 190, 198, 201, 205, 209, 211, 211, 215

$216,217,218,219,220,225,227,237,238,241,655,707,816$

borucd nowl (sen owi)

Ilomelisville (N.Y.) 95

herse-tail 195

llorsfall, M. W. 426

Hosley, N. H1. 31

Hoat, l'. 78

Houtution. $\mathbb{K}, 11,22,21$

Hutehenn I.uhe i Mirh.) 559, 569

Housc, 11. D, xxw

louse rat (ace cat)

llnward. H. F. 251

Haward. II, C. xxy

Howell, A. B. 728,735

Hower, 6. 10. 375

Hoy (Si.ot.) 253

Hoy (s.ot.) 251 , 220, 221, 2125. 231

liucklebers 202. 220, 22

Hudson. G. F. F.
Hudsom. Henty 16

Hudsom. Henty 46
Hudson lay 47, 52,110

Hudson River 326

Iudson villey (X.Y.) 36.5\%, 225. 413, 115. 119.50

Hudsnir's liay Company 556,578

hunting, organization of coverts for 591, 630

hunting of grouse (see alsu conservatiun)

t management measure $370,380,552,57 \%$. 667 671, 19:3 rrippling loss 376

effect oo grouse abundance $370,373,379,511,512,532,538$. $547,550,551$

for sport 103, 37

for the market $101,371,558$

methods 3 iा, 389

number and per cent bagged $369,372,376,378$

regulation of (see also honting regulations) 557, 602, 478

seasonal and daily bags $104,369,375$

success ratio $369,372,375,376,378$

use of dogs 395

hunting of predators (see also predatur enntrol) 381

effect on grouse abundance 382,383

effect on predator abundance $381,38^{\circ}$

number aod per ceot taken 381,382

hunting regulations

bag limits $370,372,389$

elimination of market hunting $17,388.389$

laws $17,370,388,55 \%, 602$

limitations on methods 389

time and duration of spasnn $370,372,373.387$

huoting seasun, cover preferted 160. 8:9

Huntinzdon County $|\mathrm{Pa}| \mathrm{I} 818$

Huntington, D. W. 15

II uxley, J. 3] I

hybrids 248,268

Hydo J'ark (X.Y.) $19.50=$

livdrorvanic acid 195

Mrdrorvanic acied $195,109,131$

Himrnolepis microps (see also sinall tapimarm) 109. 11:2. 1:4

llusurners 198. 212.223. 221.

ichucumon.flice 213, gat

lelineumonidae 213

Jdaho 3I. 48

llex verticillala 210

Illinoir 50, 51, 191, 25.5, 11.

Impatiens fillora 208

impotted anck. liluration of fape smalu hate)

inhreding 1.5. 367.672

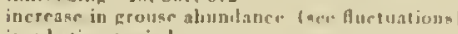

itreubation puriod

tralita of female ifuring 280

length uf $73,288,475$

Indian, Aureican 2. 1, 5. 11. 16, 385, 380, 39s

Indian Trail Reluge (M/o.) 19

Indiang 50,53,51,255

inacct, scale 213

insert reca, representerl in fout collewions 213

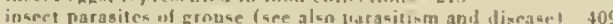

insert prata enter 101, 212

insert plagues 550

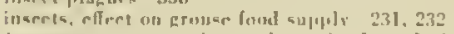

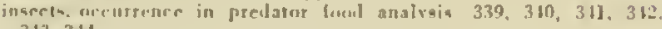
313,311

inarets ratern lis groujace (sec alen animal fouds)

alundaner in diflerent ene trpes 790

numbers coliecterl un study plocs 211 . 75

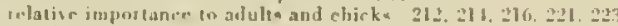

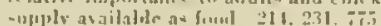

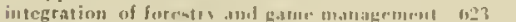

interliterdine 208

interplomitis 600

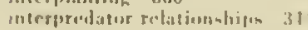

interspersicon, sule of $113,164,604,818$

iutestinal inflammation 411. 412

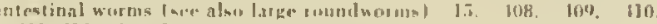

$111.412,113,1] 6,125$

intimidation dinglav 66,282

imvetigatiens mastling

$30,50,18.3 .188$

Inwa Agriemli

ironwond tare heprolowinheram

alıam. R. I1. 23

(-hii. N. 3i

ise Roval (Nich.) 50,25

lospoda 775

haca (X.Y.) 183, I99, 203, 213, 239, 255, 302, 325, 579, 7.17,

$815,816,81 \%, 818.819$

Jthaca Came Fasm (V.Y.) 18

ivv, grommil 195

ivy, prison 191. 195. 203

Jackann, H. H. 15

Jacohson. K. A. 31

Jacekel, H. F.. Ir. 21

Jay Mountain (Y.Y.
Jefterson County (A.Y.

Jeffries, G. A, 16, 22, 24, 27, 30

jewel-weed $207,208,215,218,222,243$

jawel-wred. prate 215

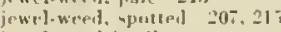

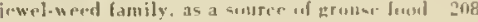

Jut, II K. 22,28 
Juhnunก, K, A. 30

Junes, J, C. 181, 183, 220,339, 694, 845, 816, 812, 818,819 Jurtew. L., $=26$

Junes, M. C., xxxbi

tunes. II. F. 127 .

Jinid,

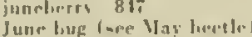

Kaibal, Sitiuetal Forest (Aric.) 309

A almiu 198,203

Kislmies nneustrlolis 203

Kalmies larifolia $186,189,103,203,819$

Kanage 50

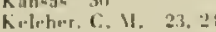

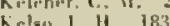

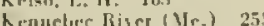

henuelue Riser (Ve.) 255

henturky 50, 51, 102, 255 $211,312,335,371,520,521,55,55 \%$

Kine. R.

kinglitirl 131

Kinge County (X.Y.) 56

Kingetien $1 \mathrm{X}, \mathrm{Y}, \mathrm{I}$ \&

kinnry, A, B, F, 14

Krishi. $O, W, 72$

Kulhn. T. Y. 183. 220

Kiser, A. R, 23

la Pintre Howar (V. W. Ters.) 52.50

laliradior $17,56,109,115,128,131$

l.adil. C. F. xirr, rervi

l.arlaptinar $109,417,43$

logoperecus perplexus $109.111,1.35$

l.agopus $721,725,72$

t.akopus lagopus $5: 8$

lacopus scoficus 578

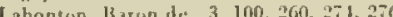

laing. II. M. 15

Lake Champlain (X.Y, and VI.) 3, 326. 31.5. 115

lake Suluetiut 50. 25 i

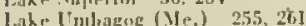

labil elearing (sere cloaring of lamil

1.an1z, D. F.. 311

lapising 1.31

lareh 1$]$

larch. Furopwan 655

larix lmicina 815

Lasius niger 213

l.1181 193, 195. 198. 203. 205. 210. 218. 235

lux,4, murustain $186,189,193,203,215,218,22 \%, 23-, 238,211$. 8.19

liatrrl. sherey, 20 ?

lautel projurning 193

l.awrenco, W: Ii, 6,96

lawy fare romservatien ; hunting regulations)

I.anver, C, A. rrvi, rrvi, 3

lend aruenute 106

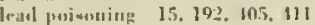

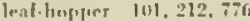

1.n.enipte. F.. L. 23, 21

I.res. HeKar Colliger 23. 21

l.effingueti. D. J. $30,3,3$

lare (uere anafomit

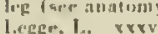

l.egge. l.. rurv

I."cuminosae 208

I. iman, R, in

l.c.limann, V. W", 213

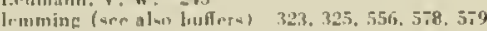

l. $\mathrm{mmm}$ limmas $325,5.36$

L.rmmus ermacronurus 32.3. $5: 8$

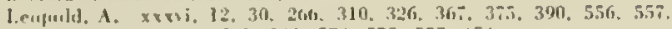
$58,559,360,562,563,568,5 i t, 575,57 \pi$, his

l.rpilifugera $108,213,223,2: 21,75$

lepus americanus 3:2, 5 in

l.murarhloridius prirei 104. 131

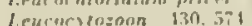

lemerveruzoun anutis 133

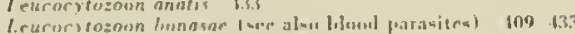

1.evine, 1., 1', 101, 128, 137., 295. 696

limis, II. F. Vxxis

lemin, V. 17

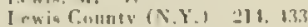

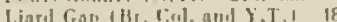

Liblue. T) 1

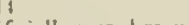

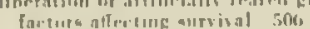

fasturs atterstre a

lumping s0.7, ilf

metlisul rof liturration s01. $6: 3$

atrival rercurderl 18, 5n8

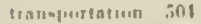

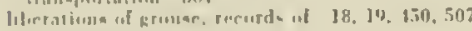

litirars

Amrriran Vuarum of Jatural lliatory rrwi
Comell C'nisersity $\times x \times v$

New Yorh fin xirsi

Now Jouk Sitato xxxi

lier (ser louse)

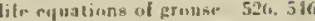

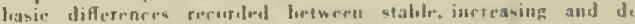

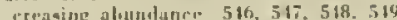

effect ul spert bunting 5.38, 566. 550

lignin, a limed rumpunent 239

Liliaceae 210

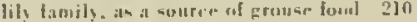

linnactse, Ciarl sut $3,4,46,17$

Liponssus solvarium 109.131

liverleat 208

livertert tape alor farming ! 15, 239

effert of prysturitag $370,389,393,597,620$

relation to griblse misnagement 596, 620,611

1.lny.1. 11. 258

locess, hlark 208

forstun (F.ng.) 36. 46

lone Pise llilln (Mont.t 50

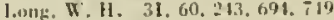

Long Island (XY.) 48, 50,57, 2.25, 232, 597

langevity 360

I.nomis, L. . U. 197. 210

Lotuisiana $1: 20$

linime bivd $809,414,130,135,8130$

foilser plant 21

levar fly 201, 208, 130

Arereriptim 114.832

distrilutiun 109.132

in iulence and inportance $110.111,133$

lifu ryele antl disseminationt 132

pathofenicity 432

L.rwell (Vlich.) 558

lumbering 380

divelupment in New Yusk 386

effect un grumse fousl plants 386

flect on grouse furul supply 617

flect on gresuse habitat 370, 386, 506, 6.7.

linther Preserse (X:Y, 18

l.uteringer. I. A.. Jr. 15

l. menasia rolumella 21.

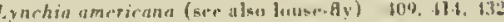

linghis fusca $\$ 33$

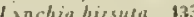

Jonx, Candu 15, 323, 333, 3.14, 5-5, 578, 5-9

fivis canodinsis $323,333,575$

(1) $12,54 / 45,330,333$

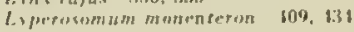

Var]lomald, A. ruri, txry, 3

YacFariane, R. 55 h

Vac.Gergor 1. F, 31. 18 ?

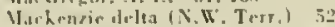

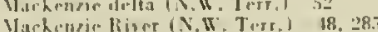

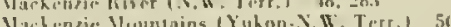

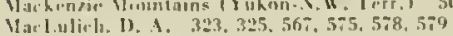

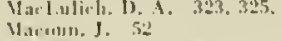

Jar \iear, 1), 22, 24, 28, 30

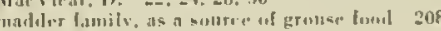

macjier $19 \%$

Wrianthemum canadense 210.815

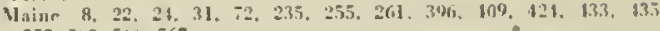
$5.58,56,3,5016,563$

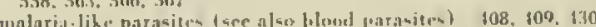

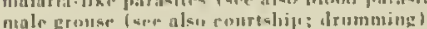
hithite 231

Telution to bronal 28.28

telation t" nem 218 , 28

Valihua, T, K. 512

Vulthusian prine igule. 513

Vlulus 198,199

Vlilus pumila g:

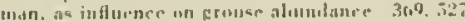

as a comactsationint $371,38 \%$

7. a former $116,370,37,383,59=$

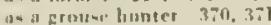

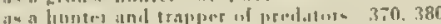

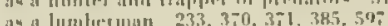

as

(14)

atsier un 10 in

Afreigning crestus romerta 607

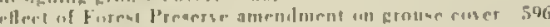

of wert ut lumbering $5 \%$

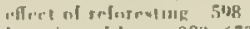

fulurtion w thw . 388, 673

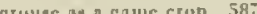

erume mane land 30\%, 50\%, 685

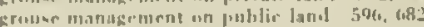

harminl protirm 509

juleal inescre (ace courrel

imgroving and maintaining crouser balitat 23.3. 5 th 
integration with other land use $588,598,615,623,650$ intersive vs, incidental 58 \% maintenance of a grouse erup 590.66; managemeat plans 632

al cuverts for hunling 594.629 organizing the forces of preduction 629 regulation of hemting $602-60$

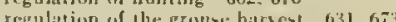
regulation if the grouse harbent 631.67 selition to seril consirvation 587,597 sole of the state fsec state significance and polentialities 581,586 studies of 30,582

summary of pertinent research 583

mandrake 195

nunganese, a fuod component 239, 111

Manitau lstand (Wis.) 19

Manituba $23,453,501,558$

Manlius School (N.Y, 30

Mauruss, F, N $22,28,30$

man's aids, effect on grouse ahundane $23.3,370,392$ automoliter and highways 15,390, 392, 391 automotriles and highwa axe and

grouse dugs 39.

guns, trap's and smares 15,39

methods of laking grouse 8 ,

marle $115,198,201,215,218,219,222,221,225,233$

maple, munse (sep usaple, striped)

maple, meuntain $201,207,215,220,225,227,6.5$

maple, red 201, 215, 227, 640, 655, 848, 883

maple, striped 201, 215, 225, 227, 655, 818

malle, sllgar $190,204,228,232,610,655,818,883$

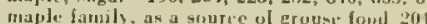

maple-1rete nurm 101, 21:2

maps, used by Investigation 69

Marble, D. K. 78

Maritime f'rovinces 50 :

market lawnting 11.388, 39

methode $8,371,375,389$

numbers taker $8,371,375,558$

outlanerd $17,388,389$

marhet price 8, 101, 371, 557

anaking grous. (reve metlinds and techusigues)

Vumafu monax 333

Marshall W. 22, 2.

marten 333,578

Martes americuna 333,578

Uurtes pennunti 333

Mathas Viscyart (Masw.) 18, 50, 507

Martin, A. M. 3

llarvin, C, F, 579

Maryland 2, 13, 18, 23, 21, 36, 16, $22,272,278,420$

Maryland Consersation Diplartaient 23. 25

Massachusetts 10, 12, 17, 22, 30, 102, 187, 201, 375, 409. 123, 121, $1 \geq 8,562,563,56,5,566,572$

Massachaketh Agrirultural College 30

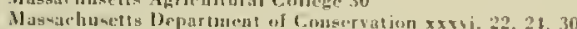

Massitehuselt Fish and Gam. Jivinion 18. 30

Massarhumpte Fish and Ciante Protectise Amenciatien xroj, 30 mast 20:

Mlatameh eonference 575

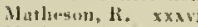

Vathe's, F. S. 235

utatint habits $67,248,265,28:$

May, J, 13, 3.13

may-apple (sie mandrake)

mayflower, Canada 8.5

Maynard, C. J. 10, 18, 102, 260, 270

MeAter, W. L., xxavi, 101, 333, 337, 313,316, 513

Me. Carthy, D, f, 2:

M. Curmack. J, T. $\times x \times$.

Medunald, D. 57

HcLean, G. I". 22, 24

Ul. Namara, L. C. 23

McVicar, A. J. 2

inealworm 189

Urarns, E. A. 360

measurements 98

mechanical in jury

as a cause of mortality $102,511,528,531,532$

relation to diseave 104

Mecoptera 775

Melani,hy, G. E. $2: 2$

zurianigm 58

Melenoplus femur.rulerum 21 :

Utnopron 409.4.35

Vephitis mephitis 323,333.

Verili, A, $22,21,20,30,417$

IIryalion, $10,16,10,3: 3,5 \times 0$

mereytiles 59, 716

newabolism 7.49

me?hods and rechnigures llsed by Investigation 693

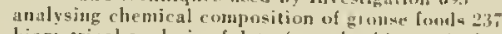

hionetrical analysis of data (see also hivatetrical andygisl 718 determining buffer abundace 709

determining disease relationships ilt

determioing effect of hunting 713

determiniog fund selationshijs 184,706

determining predator abundanee and activity 708

delermiaing predator fnod habis 709

determiniag predaurs renponsible for grouse kills and nest

destruction -09

determaing sex and age 511,718

determining shetter relationships i 01

determining neather selationships 707

estimating grouse porfulations (eensus i1

tnaking and recording field obmervatuns 6\%9, 70u

mapping stud, arean 6,05

organication 693

principle of randum distribution 701

recording ohersations $699,702,703,701,705$

secusing obsarvations 699

sulection of perbunnel 699

belection of utudy areas 69

trapping and marking grouse 507, i16

methorly of altering exinting corer 639

rutting 234.610

fire $2=28,232,612,650,661$

girslling ob

krazing 233.611

indirect 590

puisuruing to 10

meshorla of artifirial propagation (are ialon artuficial proplagation)

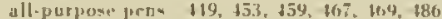

broider infepation 186

liraeders and bromder hrunes 119. 18:

lirroding on chich 4119,182

care of breeding slow'h 159

carr of chicha at hatehing tinse 181

caro of clije he following hatrhiag 18

care of eges during ineulation 175

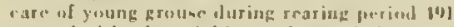

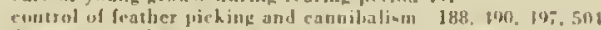

diverame control 135, 137, 138, 13\%, 111, 116, 117, 157. 17.2. (40), 191

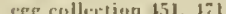

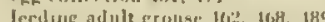

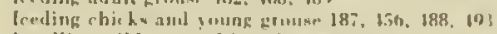

landling nild-rajplied lirewlers 111,152

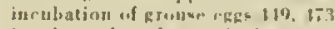

incubater firmenler metlind 1.5

incubators and their worsation $1: 5$

natural cuver method 150, 153

abuiming frutile rege 1:0

averninterine hirmbere 150

yens and perning $110,153,155,159,64,192$

prollevioun ftom prealatora $15.5,190$

jereviaisn of vifleres 156

rearing fired in

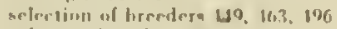

arlection lirecting Mo.?

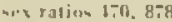

irangurtation of eggo 1.5$]$

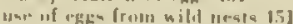

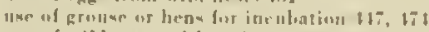

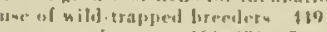

nater reppirrments 1612. 182, 189, 191, 501

weight as an inder of heralth $26,3.500$

nertimed of managernent

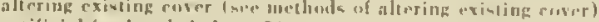

artifirial foml and showerr 632

clear-rut unita trer slanhingat

control of buffers tion

comtrol of deer 660

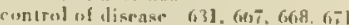

comtrul of lismatok 388, 6il. Gets

control of man (ane alss humbing) 629). (331. 658

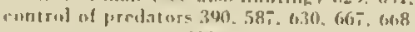

cwer arzangement 609

coserer draizo $60_{t}^{-}$

covet survey and anali-is the

caver type maspling dize

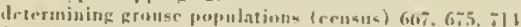

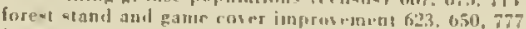

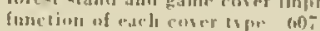

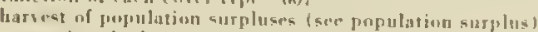

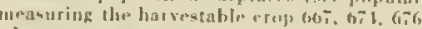

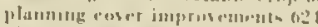

ulanting (sre platring!

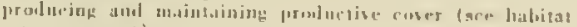
matuagemtat)

prostertang evinting habitat bot

resturking (sen resturhing

rol. of firr 232, 393, o12, b.50, ofot

mele of refuzes 391,630 60 60

sotling up management plans is's?

treatment of upron land 610

trpilthent of wrrgrown lant 618

trittuent of slashings 621 
treaturent of woovltand 620

use of chruiral joisens $660,6.51$

methorls of taking grumae (sire man's aids

methylc visine 195

Michigan $8,10,19,23,30,33,53,51,197,208,373,371,376,109$ $419.120,123,424,133,431,520,557,559,560,561,563$

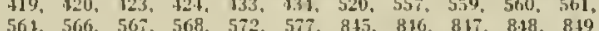
Ylichigan Conservation 1), Xlichigan

Microfilaria (sec also blowil parasites) 409. 110, 120

Middletown I. N.Y.

migration $11,11,218,25 \%$, 67 ใ

Millais, J, C. 251

Miller, J. I'. 30

mineral matter, a food component 236, 237, 239, 116. 81.

Mingan Inlands (Que.) 50

mink 15, 330, 333, 339, 341, 578, 683, 711, 875

Vinnesuta $30,53,211,312,371,3,7,404,109,116,420,122,123,421$ $43.4,436,520,521,521,559,560,561,563,566,567,572$ 577. 675

Minnesota Conservation Mepartment vหrsi

Vississipui 52.53

\issnuri 19,50,508

Uismouri Conservation Conmisaium J"

Viechellat terpens 198, 208, 810

mite $409,410,11 \%, 130$

mile, air-sac (nce air-sac mite)

IIritr. feather 409,434

milr, harsest 409,434

mite, nurthern fowl 409. 13

mite, rodent $109,41 \mathrm{i}, 43$

mite, Bcaly. Ing 409,435

Yitello diphylla 206

mitsewort 22 ?

mobility 252

Vuhawk River (N, Y.) 36, 5i, 321, 329

moisture, a fored coniponeme $23 \pi, 24$ !

moisture content of various fomd species 211,815

nold. as a cause of ulikrase $.408,111,439$

mole 670

$110 \cos 371$

Mintana $30,50,53$

Montreal $\left(\mathrm{Ont}_{n}\right)$ 47

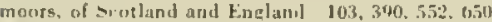

Mroschead Lake (Me.) 558

Morenthau, 1I, xxxy

Morloy, L. C. $116.133,136$

U11risoll, F, B. 815, 816,817, 818,819

Morrison, J. F. xтrvi

.1lorse, .11, 31

morality (yee alsu adule, hrool, nest mentality: anrvival cumpensatury $511,525,552$

Morten. T. 3, 26io

Horus 210

IIIoth 198, 212,213, 223; 22,

inth, Eypsy 15

muth, In 22 b

Muttley, (:. McC. xxrvi, 691

moult $37,78,7+7$

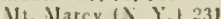

Mit. Pinnacle (Sn. Car.) 210

meumitin licm (sece panther

monse (4ee alsu variont specity; buffers) 11, 188, 308, 325. 327,

$328,329,333,334,335,339,310,311,312,313,34,670,109$. 711,876

molus", Juer 188, 339, 311

mouse, field or meadow 309, 339, 313, 117, 670

monse, red. backed 339

Mousley, H. 15

Mllellor, J. F. 422

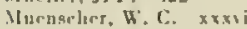

mulluery 197,210

multiple us: 615, 623,6.50, 738

Munro, J. A. $x \times x$ vi

Vunuscung Park (Mich.) 521. 5.5., 5u"

monselra (are allatums:

Vuacow (Sask.) 258

Miacum of Comparative Koulogy (IIarsarel 17, Fil

Muscusu of Vertchate Zonhogy (Calif,) b7

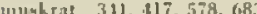

Musecla cicopnanit $323,3,3,3$, il

Wustela cicoknanit 323,313, ill

Wusterin noveboracris is $32,3,32$

Yicobacterium atiun (n" nlk (ubereulamin) 1,30

llipmiea 213

Nagei, W. (1), 50

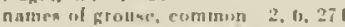

namey of groure, sinitihe if. if

nannjlicriy $650,662,81 \%, 88$.

Vantucket lsland (M

natal down 79.718

Jatehez (Misa.) 52

Virhraka 50 necrutic stomatitis, lisesse of clk

G-1

Ciclson, A. 1.. 31, 183, 220

Nelson, F. WT. 52, 197

Nelson River (Man,) 52,56

Nematoda 409

meosangule $59,59,716$

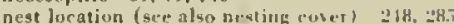

eflect of openinfs 132, 131, 790, 71

eflect of openings 132,131 .

influence of conifers 1.32. 784

relation to drumuing his 266

relation to exposure 130. 286.78 ;

relation to slenpi 130.786

sites jircletred 130, 285, 785

narst mortality (wee also survival during nest perionl) 311

chief predahrs in olved $307,308,315,331,360,315,31 \%, 385$.

Filect of predator control $308,327,346,667$

number of nests oberived $290,311,527,876$

nimber of nests observed $290,311,527,876$

quality of evidener aseribed to diagmesis of brukeo-up Jienta es $8=6$

recorded by ollice observers 312

recorded during Investigation 135, 307, 311, 525

relation to variations in huffer abundance $307,31:$

srlation to variatiens in predatur presentre 311

relation to weather 301

role of predation $307,311,520$

nest structure 28

nest survival (see alsu survival during neat puriual।

effect of crown cosir 135, 791

effect of distance from opering 136, 998

effect of thickets is operer 136,797

effect of undirgrowith iensity 135,700

nesting ( see also nest location)

number of Dests observel 127,290

occurrence of desertion $287,290,527$

accurrence of renesting 248, 291, 361

parasitism by pheasant 273.290

proportion of fenales nextint 359,517

season 248, 28

tolcrance of other nesting grouse mul

nesting coser (see also nesi location)

hasic pattern 589

composition 589

extent 589

importance of umilergrsim th density $128,589,781$

influme of slope 58

tupes chosen 127,783

net productivity (sec productivity)

Veuroptera 715

Vevadia $50,52,5.6,196$

Virw Brurswick $563,506,573$

Neweontc, A. 22, 23

Neweontc, A. $11,30,53,51,183,220,221,23 \%, 310,313,396,408$

$409,415,416,419,420,-133,560,562,56,56 \%, 568,57$

Vew England Grouse Investigation Comultie 33,56 ?

Virufuumiland 50,251

New Hampshite 11, 13, 18, 22, 29, 30, 102, 18.1, 293, 104, J19 $122,431,557,501,563,565,560$

Sew Hanasbire Fish and Game Commiwiul 30

Vow Hampahire Furest Service 18, 30

New Jersey $3,23,260,415,420,1,3$

Viw Jersey Brand of Fisla and Game Commisainners i2

Vinw Yexico 309

Vew York - 11, 13, 18, 22, 20, 30, 53, 54, 56, 215,21-, 220, 221 $222,225,226,228,229,231,232,231,235,236,239,211,212$ 211, 245, 265, 208, 273, 278, 285, 310, 312, 323, 321, 3:5, 326

$331,333,337,338,310,369,372,373,37 \%, 375,376,377,379$

381, 382, 384, 385, 388, 389, 390, 391, 101, 109, 415, 116, 417

$119,120,123,421,126,427,428,430,132,433,436,513,520$ $521,525,55 \%, 560,561,56 \%, 563,566,56 \%, 668,57 \%, 519,589$ $676,681,815,816,817,818,819$

New Yurk, prosille of 17

Irn York lity $\%, 10,1 \%, 50,20$

Jen lork foumt, (v,Y) 50

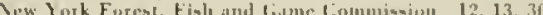

low lork State Cullege of A

Thu York state cine 181, $117,563,601,683,687,688,721,717$

(1)

New Yurk State Departmant of l'ublie llealıl, at

Jow Yurk State Lameislature 388

Vew link state leterinary Cullege 31. 118

techerunn. $r$, 23

Jicotine sulfuhate 190

tightshatr, bittersuret Ju1, 19.5, 210,819

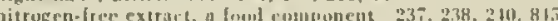

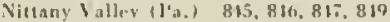

Ninble 18

non-breeling 353, 355, 5.25, 51-

Vuria, I. C 185, 237, 238, 231\%, 182

Vurll America $38,426,430,132,5.41,5-8$

Vorth Carolina $23,24,333$

Sorthrille (N.Y.) 371 
Norwich (N.Y.) 391

Nova Scotia $3,18,33,47,454,504,507,566,567$ number of eggs, hand-reared grouse 454 number of eggs, wild grouse $71,354,360$ io first nests 354,361

in renests $291,354,364,526$

regional variations io New York 362

yearly variations 362

aumber of grouse in Vew York, estimatesl 101

number of grouse killed by hunting

crippling loss 376

ptoportion taken 373,378

reported kill in New York $37 \%$

seasonal and daily bags 10,369, 375

succesa ratio $369,372,375,376,378$

nutrition (zee food of grouse; physiological atulies) nutritional deficiency

rclation to brood mortality 528

relation to disease $401,405,415$

nutritive requisements 238, 239

mutritive value of food, as a contributory inturste in flucturuma

in grouse abundance 241,575

Nuttall. T. 9, 11, 13, 14, 260, 276, 557

Nyctea nyclea $32,4,333$

Nyssa syluatica 206

oak $198,202,215,218,220,221,221$

oak, black 202, 215

oak, bur 202

oak, pin 202

oak, pin $202,205,215,610,655,8.46,883$

aak, scarlet 190,202

oak, scarlet 190,202

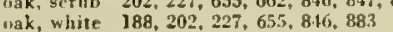

"ak, white 188, 202, 227, $655,816,883$
rak fanjily, as a source of grunge food 201

rak fanjily, as
ast 210,212

Odonata 775

nestrus 67,267

Ohio $17,19,23,24,30,50,53,54,255,508$

Obio Conacrvation Departinest 19, 20, 23, 21

Ohio River 255

Ohio Wildlife Research Unit 30

Okjahoms 52

Oklahoma 52
Oneida County (N.Y.) 111

Oneida County (N.Y.) 116 $324,404,104,920,127,430,133,131$

$557,558,560,562,563,566,567,568,572,531,815,017$

()otario Plain (N.Y.) 36

upenings, cover

effect on nest survival 136,798

influence on nest location $132,137.790,792$

man-made 234. 176

relation to food supply 231,776

significance in pronse habitat $132,170,59$

open lanul (see also rover)

planting design for 616

planting design for $616,819,821$
use ly aduits $152,156,819$

use liv aduits $152,156$.
use by brooda 110.801

use by hrooda 198, 801

use for nesting 128,783
.

Orage Couniy (N.Y.) 287

prclaard damage by grouse 102,187

IIrd, G, it

Oregon 18

Oregon Wildlife Reuearsh Unit 19, 20, 509

Ornithoira vicuna 409

Orobanchaceae 210
O'Roke, E. C. 433

Orthoptera 198, 212, 223, 775

Osborne, L. xxxy

osprey 333

Ostryo virginiana 180, 201. 8.16

Oswego County (N.Y.) 210

Otsego Cunnty (N.Y.) 131

Otselic valtey (N.Y.) (,D.S

Ott, F. 23, 24

Utus osin 333

Ouachita Mountains (A,k.) 50, 52

overgrown land (sec alars cuver

design 618

maintenance 6.1

maintenance $611,155,819,821$

use hy adults $152,155,819$

use by hoods 110,801

owl (sce various species) 14, 309, 331, 335, 337, 391, 432, 139, 876

owl, barred $330,333.337,339,342,34,875$

owl, great gray 333

owl great horned $308,313,321,323,321,329,330,333,334,336$ $338,339,341,311,346,381,432,552,630,667,668,66 \%, 875$, 876

as a predator of atlult grouse $27,300,322,328,337,348,455$.

frequency of grouse in pellets in selation 10 buffer abundance $32: 2$

ow], long-eared 675 owl, saw whet 875

owl, screech $57,333,312.875$

owl, abort-eared 875

owl, saowy 330, 333. 337, 339, $313,87.5$

periodic influxes from the Porth 321

oxalic acid 19.5

Oxolis $195,2 \mathbf{I 0}$

1)xyspirura petrouti 199. 134

Orark Mountains (Ark.-Uro) $\quad$ \&. 50, 393

Palmer, K. 339

P'andion holinetus 333

planther 309.333

paraly sis, relation of vitamins to 239

parasites, animal (see also various spories) 10

manner of infirrtion 408

numbers encounteres per hird 411, 41 t, 416, 418, 421, 421, 426, 132

trpional distrilututon 401, 409. 412. 113. 415, 416. 574, 5is

regional distrilsutisn $401.409 .412,133$

relation to dise 35 e 403,408

relative oceusrence in New York 110, 115, 130

srasonal variations 112,413

species Inund in grouse. 409

yearly variations 413

marasites, plant 40.1, 108

prirasitiam and discase 101, 110.691

animal parasites of grouse (sre alsis prasasiles) 405

disease in hond-reared grouse 102, 108, 415, 116. 417, 420. 129. $435,446,450$

xternal parasites $410,411,430,453$

"xternal parosites 410. 411, 4.30. 4.3 67

"grouse discase", so-called $401,402,401,415,551$

interas] parasites 410,411

macthods of study 403,718

tusber of specimens autopsied $103,115,133$

parasites not eucountered during Investigation 43:

parasites of the digestive tract 119,436

parasites of the rrapiratory systen 417,436

plant parasitr's of grouse 408

relation of dismase (a) predation (ace also predation) 417,552

relation to grouse of diseases of other apecies $385,408,115,135$. 136, 138, 139

culaiun

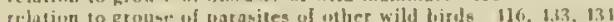

relation to managunirnt $442,631,67$

relation to securrence of patholngical conditiont 411 . 112

role of discase $412,511,531,532,551$

significance of anmach form infertion $33,402,411,121,57$

l'ardec. A. xxxvi

Parker, R. R. xxsi, 30 11 .

lisrk

national 692 o85

Ielated to grousc manatirancnt 68

state 682

Parthenocissus quinquelolio 208

partrilge, clsukas 130

partridge. Ilungorian 103, 416, 420

partridge, name of ruffed grouse

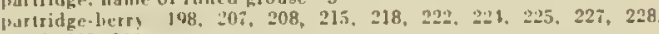
$231,235,819$

lartridge Run Catue Management Area (X.Y.) 19

frasturing (see livesturk)

pathology (are parasitisul and discase)

buttern for idcol grouse covert 588

Iatton. F, A. 333

linace iliver (Alta.) ha

pualuwl (pravock) 46.418

meanut, hog 818

pectural girdle (are andtomy)

Polinecetes 725. $-28,733,73 !$

Peel Jiver (Yukoul.N.W. Terr.) 52, 56

jielvic girdle (sre anatumy)

Pronsylvania $1,4,7,11,13,18,22,24,31,36,46,53,183$ $221,222,239,272,274,285,288,312,321,310,342,383,311$ $38,283,409,123,121,558,560,562,563,566,567,573,815$ $48,837,818,811$

H.unaylvania Game Commission xxxi 18. 24.572

Pennsylvania Wildlife Researeh Unit 31

Perdicidae 40

peritonitis 405

Peroniscus 188

nerosis 405,436

cause 411

control 239, 111

nature 411

mests (see insect rests caten)

Peters, J, L. 33

Phalangida $7 \%$

Phaloris arundinacea 208

l'harsalia (N.Y.) 18, 19

P'harsalia Game Refuge (X.Y.) 18,391, 508, 520

I'luarsalia study area (N.Y.), deseription 695

Phosianas colchicas 333 
Plyeasan, Rervers 273,328

pheasut, ring-necked 15, 16, 73, 7., 103, 212, 229. 235, 236, 266. 33.3, 331, 339, 310, 313, 31.3, 311, 3-3, 390, $108,116,118,119$ 128, $436,435,436,5 * 5,683,819$

coriutrence with gromser 21,273

og laying in groump nestw 2:3,290, 333. 335. 8:6

interlerresling with groume 268

theidole 1:26

l'hiladelphis (l'a.) $7,8,198$

Fbilip, C.J1, 117

"hilipuine lolands 419

lhillipus , C x

lhillivis, Mi. F 775

whaphoris, a [ausd somplunens 239

Phollophnga 213

libualopiera 109, 13

l'hysulugical Lahuratury (N.Y.) 719

physolegical studies 799

ludy temperature 75$]$

chaice of iruhling for study 750

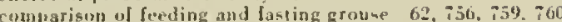

liural trend in body temerature 751

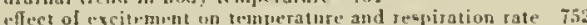

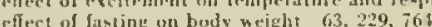

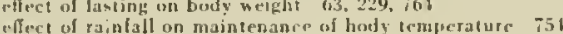

fifect of raintall on main

heart artivity as an index of vitality 755

methenls of ntuily 750.758

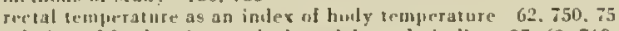

sulation of foot rations to lunly wejght and vitality 37,63 , T68

resistaner of gruse tu stamation 62, 229, 761

respriratioti sate 62,751

vignificance 60

time required for ford to digent 63,766

water reuvirements $6 \pm, 239,761,763,765,750$

physiologey (swe also physiologiral studies) 36, 60, 513

Phyralacea americana 817

pigeren 120. 1:33, 134,439

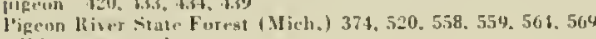

pill buts lare wumlugel

(iime 115. 210.38f

liifte, jacl 56

pine, red 655, 883

pine, red $65.883,855,815,883$

pine. White $270,655,845,883$

Pinus Strolius 210.815

lipier. S. E. 196

l'itrika, F, A. 53

Pittmat-Rohertsen fretjects rovarling guruse

Connerticut 31

New Il amushire 31

Vicw Yurb 3.15

(Ohiv 31

Virmont 31

Virmont 31

lirginia 31

(1) anring (1) develoul groume habiats

lata regarling furujnuthation of stock 88.3

interplanting 600

planting devign for open lames 616

Jlantiug methods 0.57

reinirrments of sarious planta tos

seruring and earing for =leuck b3

specien in une 555

IVlues of ulantinues 65 "

19nderplanting 620,601

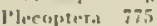

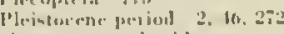

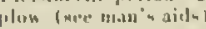

plumage

aduli $78,81,7.66$

develogment $33,79.81,718$

function 78

jumenile $28,811,016$

natal $78,79,7$ i6

r.lution t1 age 81.78

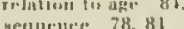

plumblace 59.79 .76

13.

Poa 208

Poa promensis 815

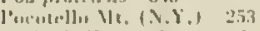

Pudophsiliam parlestum lys

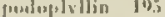

cusimen in 101, 203,918

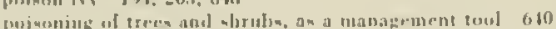

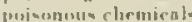

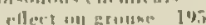

Here in managrament $610,11.5$

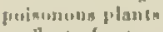

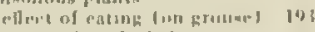

propertien of $10 ;$

(40)

luhinewrel 817
Polderbur. F., B. 183. 188

polychrouatim 36,57

inl) gamy 2 เด, 266,150

Porlygunarear 206

Poligonsitum biflorum 815

Polygonum pennsolennicum

Poligonum seandens 81 -

Pulypodiaceae 206

Polvpodium tirginionum 200

Polystichum aerastichoides 200

[iuristwerel 19:

P'upe Cesunty (HII,) 50

gitenlar free alsis asmon 188

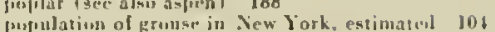

poprolation surplus

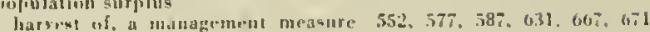
$6 \rightarrow 3$

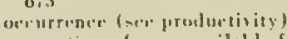

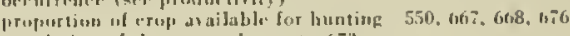

regulation of the gronse harvest 6.3

relation to fredation $309,328,330,332,338$

ponulation trends (see alsu life equations) $51: 513$

perienlicits ton local areas 561

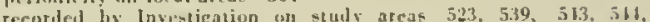
$545,561,505,569,570,882$

recurileal by wher oliservers on lacal arean $35 \%, 558,559$

reginal (sec fluctuatiens)

4ruchrunium on lueal areas 55.5, 55\%, 568, 569, 570.67\%

pupulations. characteristics (are alsu arimes tupirs ab listed

helow) 511,513

ige complosition 513

carrving eapacity 512,52

derinity $510^{2} 517$

ratc of spread 512,520

rate of spredd $512,522,512,521$

qe. $\times$ ratio 512,514

Populus 198

Populus gruadidentato 20

Populas temuloides 180. 189. 201.815.81h

Porcellio sculiep 41 1, 115,420

poreupine 11, 333

P'urcupine liver (Alsk.-Yukon) 5:

Porto Ricis filo

fosting of land 391. 392, 648

posting al land 192

Paughkerpase (N.Y.) 10,507

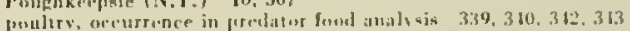

poultsy liseases, relatien to grume 408, 113, 115. 117,175

prairic clickens 263, 408, 67

Prithle, F. A. 285

precipitation

relation to adult mortality 30

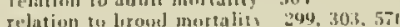

relution to trese grisuth $5 i 5$

predation 307

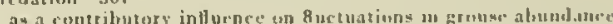
57.1

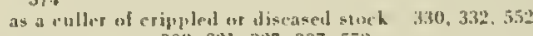

rumpensatiry $30 \%, 321,32 \%, 337.552$

completing interests 310

(1) fiet during allult periou 308, 319

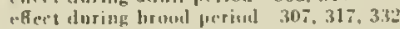

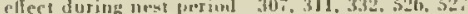

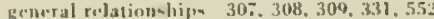

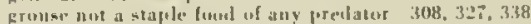

in hnenere of suluerability $32 \%$. 330,552

relution in carrying caparity $5: 1$

rele of $310,511,513,551$

riqnibeance of $\quad 309,331,338$

unler artificial perpagatien iss

promlatur control 315

etfert on gronep promluctisits 308. 350

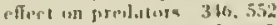

cxperimetits conturesed 345

number uf prealit tors tahen 329, 3 k. 875

Miln

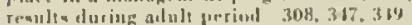

revile durige broml periml $308,317,3$ ge

reanle during hew perenl $307,308,327,315,316,319$

selective $331,315,350,552.667$. n(t)

prelator presante 327

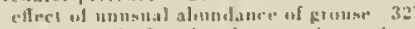

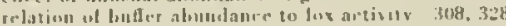

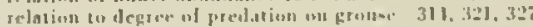

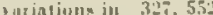

preilaturs

drusition ulartsed $3: 9,334$

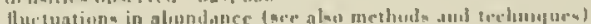
308,329

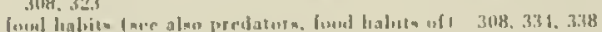

arrilime : problates ration 320

interpledator telationaligis 31 : 
numbers taken during contrul experiments $329,8: 5$

principal species in New Yusk 329, 338, 668

relative importance ol varions specins during adult period 308. 337.338 .669

relative importance of varions specim during lirond period 308 . 335,338

relative importance of various species during nent pierind 30 .

$334,378,669$

suecies uf the Northeast (see aloo various species) 308,332

variations in distribution in Now York $321,330,33 \bar{s}, 31.4$

predators. food hebits of (see also vurious species) 338

nethods of siudy 338.709

arethods of study 3as. Tomachs pxantined $8: 5$

seasunal distritution of

presidential elections $5 \pi$

prices, of grouse (see market price)

printary feathers 60,713

Priuce Edward Island 50.251

private isods, relation in grouse management 68.3

Procyon lotor 323,333

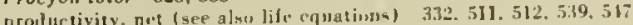

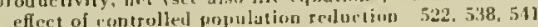

eflect of rentroliet poplulation res

occurrence of staploses 5.39 .550
priduction ratiog (April) 512,513

prouluction ratios (April) 512, 513

production ratios (September) 511. 539

reasons for low proluctivity observed $539,511,512$
relation to density of breeding jopulation $350,511,539,510,511$.

relation to runge qualaty $512.522,535,596,551.55 \%, 6088$

relation to range quals of

$539,510,541,512,513,514,516,517,518,514,571$

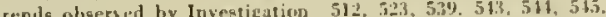
trends
882

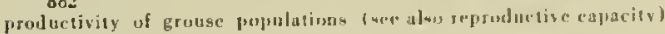
511.525

brceding suecess $35,3,513,517,525$

lefinition of term 525

interrelationships invelum! $511,512,513,528,532,535,511,516$. $550,551,552,55.3$

life equations (sce life copations)

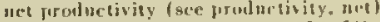

uportunity for monageant 51\%, 521, 516, 5.x. 57

potential 309, 51:2, 5.5.5

surplus (sce population surplus)

surplus (see population surplus)

promiseuity $288,266.267,355,318$

irepgatiotion (sce artificial propragation)

Prosthogonimus mocrorchis $109,1.31$

Protection Islaral (Ore.) 19.20.50

lirotein

a luod roniponent 236. 237.815

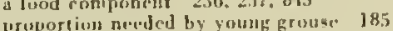

pirctizena 109

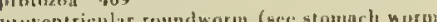

Pruventririlas fontind 180, 198, 199

Prunas peths)lanicum 917

Pranas serofina 8.17

Prunus virginiana 817.818

Pacudolyachia canariensis 133

Partudeacuspionida 775

Pesyeliolugy 63,217

puarmican (are also grouse, sel, grunar, willum) 16. 12\%, 128

pererlieraphy $59,78,7.71$

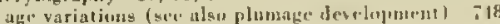

liroul spot 7.16

feather spareg $59,311,715$

fenther tracts 59.711

numbes of feathers $36,60,71 \%$

plumage wear it7

"gnowslives" 711, 748

types of featlies $59,7.16$

Ptychostuma bonasae 109. 133

Public hunting frounds 391,68

public lands, iutegrating gususc manarement ous 682

Pupet sound (Wask.1 18

pullur un discease 115

pulmonary mycusis (ace aspergillusis

J'upiparia 432

insaey's lot's 198.20

Putuan Counl: (N.Y.) 18

Pyrola 203

qunil 46, $73,71,229,235,267,327,415,416,419,120,475,136$ $437,+38,674$

quail, bubulise $16,267,327,391,416,118,123,126,128,431,811$ (1)ail. valley 433

"थाแแil discase" 102. $116,435,436$

cause 130

cuntrul $13 \bar{T}, 450,172,192,495$

dissemination 137

stature 136

Qurliec 17, 33, 57, 56, 409, 128, 55i, 566, 567

Queen Clarlute lslande (Br Col, 5

Qneers County (X.Y.) 50
Quercus 198, 202

Quercus allia 202.816

Quercus borealis 202,816

Quercus coccina 202

Quercus ilicifolin 202, 816,81i

Quercus macrocarpa 202

Ouepcus padustris 202

Quercus stellata $8+9$

Oupercus seelueina

rabbit (sere alsu buffers) 14. 308, 309, 322, 329, 339, 310, 311.

312 $343,311,552,709$

ralit ruttontail 192, 322. 325. 339. 310, 315, 430, 670, 68:

as a surue uf eularenia infertion 416,417

fluctuations in abusulance 326,327

rahbit. jack 430

rablit, snownhore quep sarying hare)

raccurn $15,313,323,329,330,333,331,334,337,338,334,311$

311. 311, 382. 1.56, 196, 689. 68.3, $711,875,870$

Ruli. W. H, 78

Rac. T. 22, 24

raginced 206,810

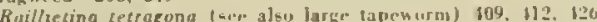

rails, as a sutuce of drinking water 243

rainfall (wo precipitation; weather)

rambalcr. psemerser ol mineral matter is 211

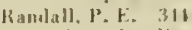

range (seco altou diatrilumtion) $36,18,49$

dinlifinl recurds 52

uns varimes imlants 50,251

Jrensent 18, i"

agimitive $18,-19$

shrinhage uf 50. 51

spesadic occustence. 52, 56

Kanunculaceae 208

Ranunculus 208

Rununculus acris $81 \%$

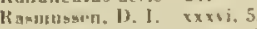

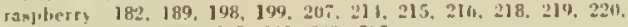

$221,222,223,221,225,227,213,707$

cantutuerrs, hlack 81

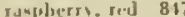

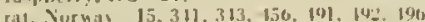

ratc uf apreal of prouse pepulatioun 512,5:2

raven 333

Raหลin, C.. 1.. 22, 21

raxorbach isee hing)

fiet Kiver (X.Y.) 201

sefluabies

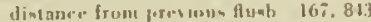

riclasien to cover type 100,81:

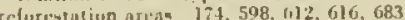

re[upe, mational watrifisu]

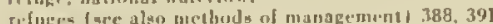

catablialiment 20

relation tos frouke abundance 391

acel sluck 603,629

alue of $20,607,679$

regions of Sen Yusk, deseription 113,596,691

A.lirundack 111,596, 691

Ciuthill 115, 506, 69

rest of sitate 116.597,691

linine 1,15

relatise abundane of grouse 5.3. 55, 6:6

renesting 218, 291, 351, 361, 519,525

reperted hill uf trenge in ten York 37

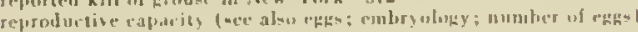
$30,35,3,531$

effreet uf age 354

frrtilits of egge $351,345,151,52 \%, 527$

intreceding 351,367

lerngeis and acrilits 300

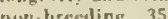

nember of coge laid 351, 360,5060

repesting $351,361,519,5 \% 5$

rer ratio $35,3,355$

s.r ratio $35.3,355$, 35 ,

reprobluctive perential 309. 351. 311, 512, 511, 515, 53.3, 511

requirmentw of grouse I sce factors of abundancel

rersearch, value of $581,601,602$

Regrarcli Centrg (N.Y.) rxtii, 19, 181, 118, 162, 177, 198, 50:2, 508,

691

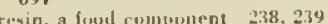

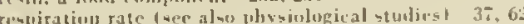

respiratury sostem (see also anatumy?

enpiratary system

rel of tate region I.X.Y.1. characteristics of 110, 59:,691

coser mullagezuent in $59^{\circ}$

irstocking 50. 388

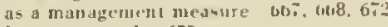

huw to restock 673

when so sestork 632,672

Therde lalund $815,817,818,819$ 
Rhodudendron nudiflorum 203

Rhus [08, 203

Rhus glabra 818

Rhus liphino 186, 203, 818

riba (see anatomy)

lich, W. H. 11

llichardson. J. 6

Richmond County (N.Y.) 56

rickets 212

Ridgway, II, 15, 47, 52

Riley, P. M. II,

Ripley, O. 333

Rijple, R. C. 416

Roherts, T, $5,15,38$

tohin $416,120,131$

Rubinia psiudo-acacia 208

Roreliester (N.Y.) 12

Rocky Mountains $17,18,50,52,53,51$

rodents 556

control in 670

Rogers, 11. \%, 23, 28, 1:6

liomatult, A. 1. $72,95,176,691$

Rousescle, F. 1). 50:

roosting habits 269

in snow $163,248,264,270,302$

celsticut to cuses 163, 168, 269, 836, 811

Rosarrae 199

Rascrumun (.nuzty (Mich.) 845

rose $193,220,655,662,883$

rose, nutitiflora 662

ruse family, as a source of gruuse fund 199

lloss, B. 11. 52

Koss, 1R. K.

Roth, E, 23

roundwitz: $409,419,420,430,431$

round worm, large 428

destripting $115,424,425$

distribution $402,409,413,416,421$

incislente and inportance $402,410,411,112,113.120$

lile rycle and dissemiaation 424

pathogrnicity 111, 421

roundwurti, proventriculat (see stomach worm)

Ronatl, II. Axxvi, 5:0

Ruhiaceate 208

Rubus 198,199

Rubus buileyanus 847

Rubus vecidentalis 81 ?

Rubus strigusus 817

Kully Minulaing (Xins.) 50.5:

гиा $721,713,717$

Rubl, 11, L) 23, 373, 521, 558,560, 577

Rumex 198. 206

Rumex acceaselln 195, 206

Rumex actraselin 195

liutledge. A. 253

rype 578

sacearide, a foul componest 238

a.lge hen (sec grouse)

A. Lawtence. Gulf of 368

1. Lawrence County (N.Y.) 190

St. Lawrace River 47,415

St. ['aul's I-land 50

St. Steplicus iN.R.) 8

salaunader 36 ?

Salicaceac 201

salicylic acid 19

Salix 201

Silix discolvt 201

Salno a alu 578

Salmo safur 578 . 58

samng, Athantis

Snmbacus candersis 20

Simbucus suermasn 201

Samuels, F.,A. 286

mant tuarias 391

banilys, 5.235

saratoga (N.) 371, 55\%

Sarano 1101012 ,

Saskatowan 18, $18,50,51,258$

Saskatriewin

Siassofras varufolium 212

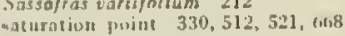

-aunilers, $6,13,373,37$

ata-fy $101,212,213,223,224,232$

aw.fly, Iarcli 23 ?

sawrer, E., J. 27!, 278

Siverfragu 2016

axilragaserar: 206

a vilrace 206

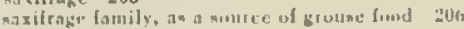

Scandanaris 578

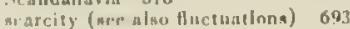

early records $\times x \times 1,11,5.58,560,562.566 .3$

remedics that have hecn proposed 17, 20

surveys and suggested eauses of 12

Srhoharie Cuunty (N.Y.) 201

- chuoleraft County (Mich.) 845, 816, 81- 818,81 ,

- luuyles County (N.Y.) 695

Sciurus caralinensis 320

Sciurus hudsanicus 327,333

Sclater, II. L. 50

Scotiaprex nebulosa 333

featland $103,251,630,67$

Seote, T, C. 339

Scuilder, B. A. 15

Seamuns, R. 31

staconal activities 250

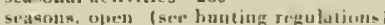

sccond brouds, liack of 248,291

second nests (see renesting)

secondary feathers 60,71 .

scilge 188, 198, 203, 207, 218, 219, 221, 222, 223, 224, 225, 226 227,231

sedge, hladiler 203, $215,222,815$

setlge. bristle-stalked 215

sidge, graceful 215, 222

sedge. Greeo 222

sedge, pale 215

sedge, sallow 8.4.

sedge, sirkle 215

sidge, slender-stalked 203, 215, 212'2

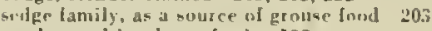

sirds, used in place of grit 192

sclective cutting 614, 651

scuiplumes 59

seruility 360

service herry (see sliadbush)

Setaria lutescens 845

ston, E. T. $256,325,326,333,536$ $\operatorname{sex}$

influenre on flight behavior 105, 167, 81 .?

recognition of $39,167,51 \%, 718$

si. r ratio $15,267,514$

among newly hatclied chieks $353,355,511$

of adult specincos collected during winter 515

of immature specimens collected 516

sergonal trend $353,355,512,516$

summer trlationshi] on sturly area 355. 511

sex rhytism 68,267

shadhush 190, 198, 200, 205, 209, 210, 211, 215, 218, 219, 220. $222,224,225,227,610,655,817,883$

sisefter (see also cover; tables 121 to 17 in Appendix) 30,105 . 511,513

relation to carrying eapacity 523,5 . 1

slielter selationships, deternining 701

sheler value if cover, recording 698

Slierburae State Game Farm (N.Y.) a

Sherman. I. 13. 22

shillinger, J. k. .115, 116, $117,133,136,568,57$.

shinleaf 203

Shipley, A, E. 1:-

shooting, spring and summer it

slirew (ace also buffers) $308,322,325,327,329,333,339,310$,

$341,312,313,670,709$

shrubs (sce tretes and shunbs)

Gludeldi, R. II. 10,725

ilute, F. $1 \%$. $86,812,819$

vibley, C. L. 21

Simulium tenuslum 433

sines, H. J. 2.

Sitka (Alsk.) 5

size 37,98

skeletal nueasurements 72

skeletal struretute 721 , 723

xhifl, J, B. $x \times x 6,262,34, \bar{x}$

shinuer, Ml. I'. 333

skull (ace anatomy)

shumk 11, 323, 321, 329, 330, 3:13, 336, 337, 338, 339, 340, 311 .

$312,311,381,382,552,669,682, \pi 11,875,876$

shunk eabluge 210,815

s.oshinga (sece alsa caser; upunings)

lesign of 621

influence on nest lucation 136, 79

place in a manageinent pirgram $176,61 \%$

use hy aclulis 152, 155, 819, 821

11sc hy broals 110.801

480 for nestiug $128,131,783$

value of cleas-cut oreas $176,233,665,750$

wlipped tendon (uee perosis)

slupe

relatien en neat luratiou 1:30, :80

114 hy adults in relution (1) tane of day 161, Bis

149. by adules in relation "1" neather 161,839

unt hy hrouds in elatiun to ace 118,813 
use by broods in relation to time of day 149,814 use by broods in relation to westher 149,815 slug 408

smartweed 191, 222, 847

Smilacina recemosa 845

Smilax 210

Smilax roundifolis 8.15

Smith, R. G. 2.3

Smith, T. B. 29

smith, T. J. 438

Smith Landing (N.W. Ters.) 285

Smithville Flats (N.Y.) 558

Sinyth, T, 30, 3.3, 98, J83, 191, 201, 203, 255, 269, 285, 339

soail 434,67 I

as a source of gapcworm infection 418

as a source of frouse food $192,198,213,221,223,221$

as a source of tapeworm infection 408

snail, pond 211

snake 15

snake, garter $192,342,34$

snake, green 188,192

Snake River Plains (Idaho) 48

snares (see man's aids)

snsting grouse 14,252

snow (see also precipitation: wrather)

as source of drinking water $2 \%$

snow roosting $163,218,302$

snowberry 201

"snowslioes" 18, 63, 218, 269, 270

Snyder, L. L. $x \times x$ i

social order $37,63,268$

among hand-reared grolne $116,162,191,496$

velation to rex 6.1

gignificance in wild 65

sndium ararnitc, use in poisoning trecs and shrulus 6,10

soil

effect on mineral content of plants 234

relation to cover and liahitat 169

soil eonservation district 596, 686, 687, 681

solanine 195

Solanum Dulcamura 191, 210,819

solar netivity ( $\mathrm{sec}$ alsu cycles)

as a contributory infuence in flumbutions in grouse aloumanter 28 a con 575

relation to other natural phenumene 5-5

relation to weather facturs affrecting food 212, 585

solarization 242

Solidago 20

Solomon's seal 815

Solomoo's aed, faloe 8.15

Solomon's Beal, iwo-leaved 220

Soper, J. D, $x \times x \times$

sorrel 235

surrel, shcep $195,198,206,220$

sorrel, wood $195,210,218$

sorrel, wood 206

tionth America 426

Simutls Carolina 52, 197, 210

Soutli Carver (Mass.) 26

Sisuth Dakota 50,333

Cinthern New York Fish and Gane Associution 18

soutleen Tics section (N.Y.) $56,104,116,69$

suwlung 114

यs a source of atonuch wolm infection $10 \%, 108,115,120,191$ sparrow 418,439

sparrow, houge 420

speedriell $] 90$

STersy, C, C. 33

Splaerium 192

spiders $198,212,213,221,223,221.110,770$

spike-rusl] 192

spiller, 13. 1., 230, $25.5,200$

spoare, J. W. 12

Sporting Arms and Ammunition Manulacturer's Instume 3t) spinting value of gause $20,103,371$

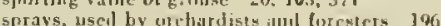

spring nesting grounds $127,153,360,61,783,825$

spring shooting 10

spring shufle $218,256,348$

spruce $115,210,235,386$

spruce, black 50

spruce, Norway 655, 883

spruce, red 655,883

proce, white 655,883

squirrel (sec also various specieg) $15,325,327,313,709$

Auctuations in sbundance 320

Auctuations in slu

squirrel, gray $57,326,310,341,683$

squirrel, red $327,333,331.310,311,381.391 .559,670,710,875$. 876

Staked Plaina (Tex.) 52

siaples, E. F. 10,14,3i

starch, a food compooent 238 starvation, effect of (see physiolugical studies)

State, role of in grouse management 601

acquigition and development of grouse lands 603

annual inventory 602

maintenance of huoting grounds 601

regulation of hunting 602

research 602

service to lsndowners 603

Staten lsland (N.Y.) 18

statistical analysis of data (see biometrical smalysis)

itephens, J. F. 40

strrnum (see anatomy)

Sirwart. R. 31

stink-bug 195, 213,221

stock, cnmmon 578

Stodiaril. H, L, 267,509

Stodilart. A. M. xxxi, 15. 1\%, 30.367

atnmach inflavmation 411

atoriach worm 401,406, 419,435, 57 t

deseription 420,425

slistribution 402,409, 112, 413,415,416, 120

incidence and importanee 402, 410,411, 412, 413, 115, 116 , 417,422

life cycle and dissemination 407, 408,411,420. 49

pathogeniejty $407,411,421$

stratagems of alarmed grouse 262

stranberty 186, 189, 190, 198, 199, 205, 207, 209, 215, 216, 218 219, 220,221, 222, 223, 221, 225, 226, 227, 231, 233, 707

strawherry, harren 198, 200, 211,215, 218, 220

atrawbers: wild 817

atsawberzy worm 409.431

Strix raria 330,333

strongileajs 630

strutting 282

os a part of rourtahip 6.5, 28:

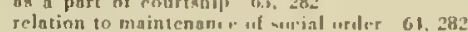

atrychrine 196

atudy areas uard hy lusmaligation, deacriptions

Adirondack $695,69 \%$

Catskil\} 695

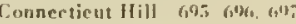

Phassalja 69.5

Sturgis 18

allbclimax format furm (ingant)

enbaperica

characters 18

Jasaification 17

lincovery it

distribution $47,17.53$

Subulura 209

uecriaion, lorest

after elcar-cutting 17

effect of fire on 612

relation to grousc food plants 231

Iole of 118

Euerulence, as a source of water 24 ?

- nigar, a lood compnnent 238

sullivan County (N.Y.I 213

alluach 196, 198, 199, 215, 216, 217, 218, 219, 220, 225, 2226, 238 239. 21.3, 707

4umarl, dwast 215,227, $655,662,88: 3$

411marls, smootl $211,215,227,655,662,818$

sumarl, staphom 186, 190,203, 205, 209, 215, $227,237,230$

$243,241,655,662,818,883$

sumach family, as a somrec of grouse fond 203

summer boarders is

sllmer ferding grounds 139, 152, 15.5, 230, 617, 801, 819, 8:7

sunflnwer 819

sunlight, as a weather factor affecting food composition 212

sinmpots (sec colar artivity)

cuperior National Forist (.1tinu.) 3:1. 521

surplus (see population aurplus)

anrvess (see alao methouls and technivics

of others regarding grouse $12,30,32$

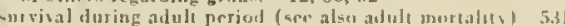

annual records for the stuly arcas 531

arrage degree recorded 512, 531

ilfect of sport hunting $512,5.32,5.38,517,5.50$

influeneing factors $532,53 i$

relation to age composition of fall population $535,536,537,545$

Jelation to earrying capacity $\mathbf{5} 35$

Jclation to density of fall population $532,533,531,535,54$

scrsonal treod 536,537

varions causce of mortality $308,391,531,535$

survival liuring brood period (see also lirond mortiliul 527

annual records lor the study areas $5: 2 i$

average degree recorded 512,527

relation to density ol breedine pinulation 5:9, 531, 51:

rclation to number of chicks hatehed 528, 5.30

various catses of mortality $307,308,528$

survival during nest perjod (sce also Ban murtality) 523

avernge degree tecorded 512,525 
uffect of renneming 526

variuns canters of murtulity $307,308,526,527$

suequeliania Riser 57, 251

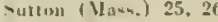

suttum, (r., 31. 15, 25:1, 3.33

Swainvtr. II: 6

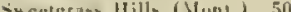

thismmille. Ly grouse 252

Sylrilagus Horulenus 322

Simphericarpus 204

Symplocurpus foetidus 210.815

Singumus 108

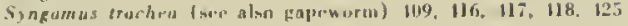

syearsum ther natom?

Syracuse (X.1.) 12

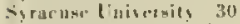

syrinx (utr. anatomy)

Tyatema vaturae ab

Tinitur, (:. 1!, 18

tumarack 56,815

tamuness 260.262

Tumuas seriotus 333

tastinin, o fout rimpunent 202, 238

tap?

tapeworm. Jatge

description 126

distribution 113.426

incidentr anl impurtastre 410, 112. 113. 427

life cyele atul dissemination .126

pathegenirity 112,42:

tapewirm, small

diecrietion 128

distribution 113, 1227

incidente and importaner $110,112,413,427$

life ryele and disamination i27

prathrogenicity 112,427

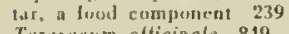

Turasucum officinale 819

Talumien (31a-9, 371

tavine 195

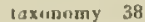

Tuxus candedensis 19.1

Tay lur, k. I.. 118

Treal. 11. A. $x \times x y$
torteoputiles 59,746

temperature, air (are also physurligiral studies; neather)

relutinu to ansalt mortabity 301

relativa 10 brection in sheron 570

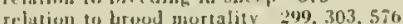

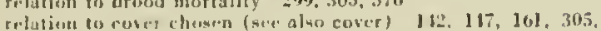
retutiett tos

rellation to akning dater 2y9, 303

relation to plant monposition 212

relationt Lo furulation fluctuations 299, 305

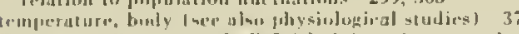

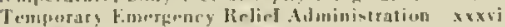

Troncesse 3t, 4t, 52, 272, 12:3

Tentherdinidenc 213

erregtrial macuetiom 578

trritusy (sec alsu hobitat) 218, 25

application of term 25 -

at alulte in breceling seasun 257,368

of broods 291

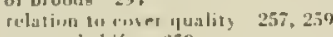

scasinal hilfu 259

sice 258,273

y equ arumind 257,506

retromueces americana 10, 131

Tetramurium 1:6

Tetroo iis

retrao lusriz 47

Terous subins it

Teture gegusus 17

letrue ! mbellendes it

Trernes Lmbrllus 10

Tetruntidas $40,721,721,725,72$

Te:sas 5:. 1:00

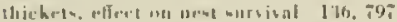

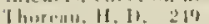

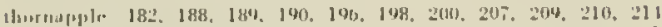

$215,21 \%, 218,21 \%, 220,221,222,225,220,227,288,230,231$.

231, 251\%, 50\%, 655, $11,2,707,817,883$

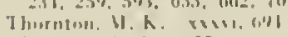

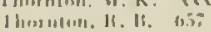

themale 118

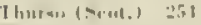

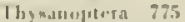

Courrlla cordilotia 200

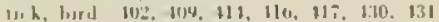

1urk, tablit $10 \%, 130$

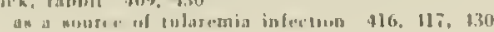

tiche 101. 109, 1.30

dracription 430.431

distribution 109, 11.3, 130

distribution 109 . 11.2. 130 130, 111, $413,111,132$

life.

life rgele and dinue

Prathogrnivits 1.31

1 jermder ogga 1.1 .1 .13

timber frimluction $587,546,610,650,653.683 .685$ lime of Jay

relation (1) riner elusen $112,159,803,823$

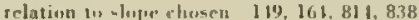

Tindil. W. E. C. 18

tolerance of atber mpecires 273

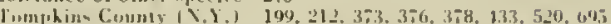

Turrev. H. A. 22. 21. 26. 2- 30, 11- 1.5

Torres. J. 1. $2: 2$

touch-ment 208

Ton nacrud. C., R, 20, 338

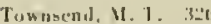

Traincr, J, F. 31, 54, (4)1, - I

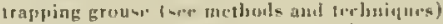

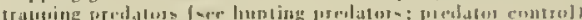

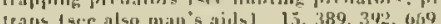

Triutunan, $11,13,23: 21$

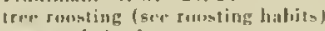

Irwen snd shrubs

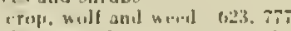

dala regardiag firugutectien fus planting purpusen 88.7

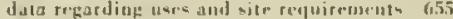

Ircluil. tirk 208

Tremellenl, t(10)

Trichomonus berlusue 1049,173

Trichomonos gulliustum 133

Triclumiera $7 \mathrm{is}$

Trifolium hibrilum 208, 818

Trifolium putensm 208. 818

Trifolium rejurns 208, 818

Trippenser, K, F., 23, 31. 371, 37., 521

Trombiculumirroti $109,117,131$

Tropenosama 1:30, 1:3:

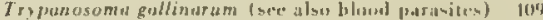

Trugn cunadersis 210.815

Tublis. F. F, 557, 962

ruluerculemin 101, 108, 416,130

cullac 439

control $1: 69$

dimaninatiun 439

nature 439

Ellarrmia $116,417,430,581$

tutues 111

turhey 10, 101, 273, 383, $418,119,120,426,128,130,138,136$,

138

Turrill. 1), 2:2, 21

Tuswe, Mt. (1). 818

Tuswe) Mt. Mra. M

limplanachus $16,721.725 .720 .725 .735$

ine lewalitive 10,17

wpe specimen, of ppecies $3,46,45,29$

"1pe sperimens, of subspecies t5

types of cemet (sece cover)

liger, 1., t. $13,124,138$

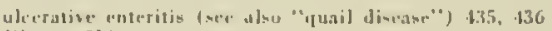

C Im 43 S1:

ulera-ushet adiation $5 \% 8$

undergrouts

impurtanice as bresud coser 180,808

impertance as nealuse comer 12k, 78

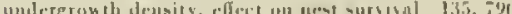

inderplanting 020,061

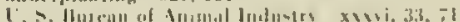

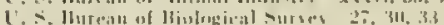

1. Expesimemal rur Fan 30

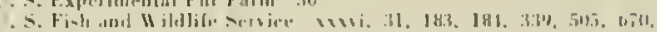
:06, i10

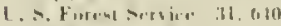

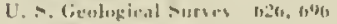

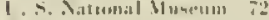

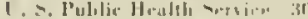

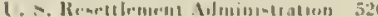

I. S sil Cinner.

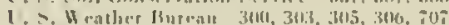

I niveraity of Alloeita $5: 11$

1 nim-ind of 11 aim 31

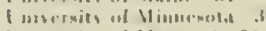

Inisesate of Vlaveruri in

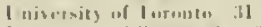

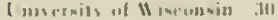

urates Pith

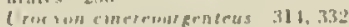

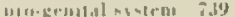

uruahioul 125 
Utab 36,54

Uital, L. 48,718

Vaccinium 202, 22+, 8.19

'асстинm pennsvlennicum 202

Yalcour lsland (N.Y.) 345.316, 317. 350, 552

value of erruse (see erourmic imfurtanes: market pricel

bancouver (Wash.) 47

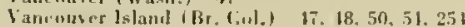

Van Cleve, II. 253

Ian Neme 1. 15

variauce analysis of fore bicumerrical analy sis)

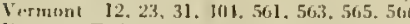

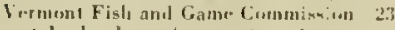

verteliral columu faece duatomy)

viability of eggs fsee riprinluetive raprarity)

vihurnum 198. 201. 206. 209. 215. 218, 219.220, 221, 231, 234.

595

vilurnum. majele lrasial 190, 203, 201, 215. 655

V'iburnum 198, 14t.

Vibusnum acerfolium 20:3, 204

Viburnum cassinodes 203, 201. 819

Viburnum dentatum 202, 203. 201.810

ibhurnum lentago 819

Vilsurnum opulas 201, 203, 201

Virulacear 210

virlet $210,218,221,222,223,221$

Virginia $22,24,31.51,183.220,221,12:$

lirginia rreejer 208, $655,662,88$ :

Virginia Polytorhuic lustitute 3]

virus, biletahle 108

Vitaceac 206

sitamin (sec also nutritional routcult of fersul) if

importance in tir.l 2:34)

effect of sunlight on :212

ritis 198, 206

Iieis rordifolius 818

Vitis vulpina 206

vative 98

lircelani. F. K. 27., 278

vilnerahility $333 ., 531$. 5.35, 5.5:

Fulpes fulur $311,332,567$

W'ainit, W, W. 2012,816,817,818, 889

Wiakrificld (R.i.) 360

Wakthehl, s. W. 50

Walcut, F. . . vxxi, vkMi, 21, 21, 2-, 28, 32

Naldsecinia jos, 200

walhing, lis grustact $25 \%$

walhing, liy grouser 252
Warcluans (Mlats.) is

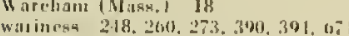

Wartuese 218.260.

Narren Comsiv (N.), 28

Harren fistents (I: $: 1$, \& 81 ,

II awhingtin] 18, 19, 30, 31, 17, 18, 100

II ashingtun, 11.1: \&

Wiahingten tiumas (1R. I) $815,817,818,810$

Washington Ialand (Win) 20

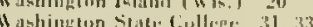

waspo 108, 212.123, 776

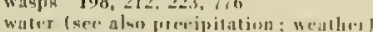

aq a cause of utest mortalits 5 ? $^{2}$

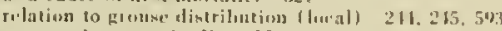

waler requirentats in diet 183, 21:

elfert of defitioney 21 :

sources 243

Watertown (N.Y.1 31

Niyne, A. T. 52

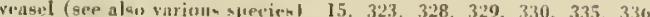
338, 334, 310, 311, 312, 311, 316, 350, 391, 552, 630, $\left(160^{-}, 6164\right)$ 875

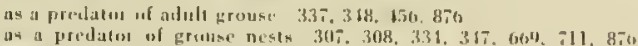

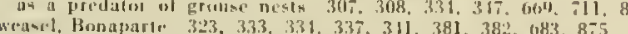

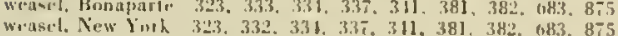

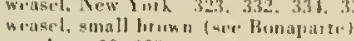

whither 30,290

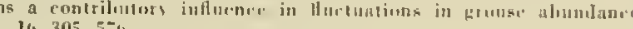

lir, 305.55

as a direvl levimating angut 2yn 301

as an indilect influx.luce $290,30 \%$

cyrars in 5 ing

effere on grusur fout -upuly 231, 23:2

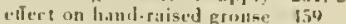

influence on fueling geriods 186.297

matsence

relation lw rarsying caparity S2s

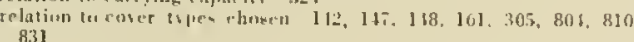

relation to food cumpusition 24

selatiun to mortality $299,301,303,306,317,321,527,528,332$ 5.35

relation to fropulation trends (locall 300, 301, 528. 541 5t: $5: 1$

relatien to furouluctirity 511. 51.3. 551.552

relation to slense use. 164

Wiect. C. M. 203. 206

weevil 21:2. 213.22!

neevil, black vine 101. 21:

neevil, rlover row lol

neevil. strawbury 101.212.213

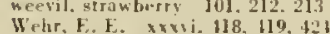

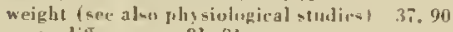

age differences 91.91

rritical hase 37.95 , 96

danger zune 15.5 .96

extrimes 95

fartora afiecting $3 \bar{s}$, go

Irose during wgg laying 361

normal sariatisu 91

iff hand-rained growise 163

relumal differenres on

5. Tation to hralth 37,95

seanual [r.mi] 9]

sex differences 91, ys:

binnifieance

yearly differeneen of

Wistihester Cominty (N.Y.) 18, 19. 37

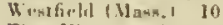

Weat Virginia 23

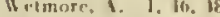

He.mure ji: 136

what 210.212

th hite. $J$, 212

White Nomatainm (.).J1.) 5

White Pine Mountain (X.1) 50.5

Whitelieal. F. F. 8, 190

whertleluery 23:

Hight, H. M. 2tot

willuw 195, 201,21

nillow: prusey 201

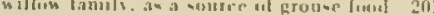

Bilpus, II. . III

Hilenn. A. 6, 7, 191, 235, 259, 260, 292, 371, 38\%, 390

II ilum, h, $\rightarrow 1$

wind fare wrather!

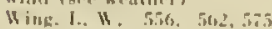

wing fore anat om th

wintes shelter $153,154,636,837$

winterberry 210

wintergreen $203,218,220,225,23$

wir..witm 21

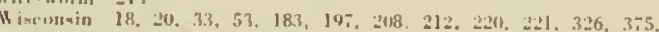

60. 123, 121, 521, 557, 560, 56.1, 560, 567, 568, 57, 575

Nincts)

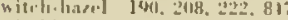

wierlihulple 231

withr. rust 203, 2011. 21.5, 22\%, 810

weil $308,333,5 \pi 8$

II usu, F, W. 22, 21

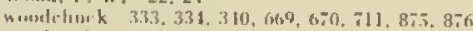

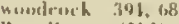

Hunllaven (N.Y.) $\quad 5.58$

womdlands tace also mether)

derign bico

liae by anlults 152.819.82

115e liv broust 190.811

lav for neatiun $128,-83$

แแน

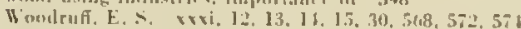

Hendwaril. $\mathrm{A}$. K. TH

Worccoter \{ Vass, , 21,375

Wurk. Progreas Aleninintratiun tros

Wright. T. 845, $817,818.810$

Wruming 30, 53, 6i

Yale shomel of $\mathrm{F}$ orrater 3

Yalu. R. H. 51 t:

Yeatter. R, 1: Sil

yew 191, 195, 22:2, 224

whlh anc :1. 76

luth Faturi (\$1at.) 5\%. 5f

Yukmo Tesrifury 47. 58,235

Yukn valles $1 ., 18,50$

Zen muss 85 






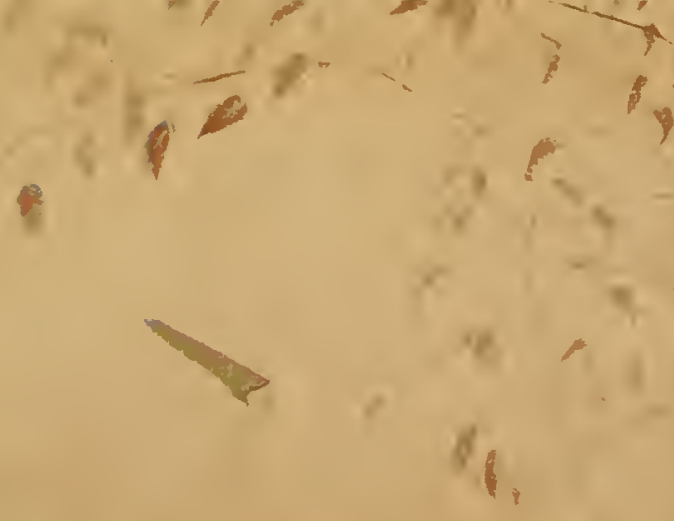

,

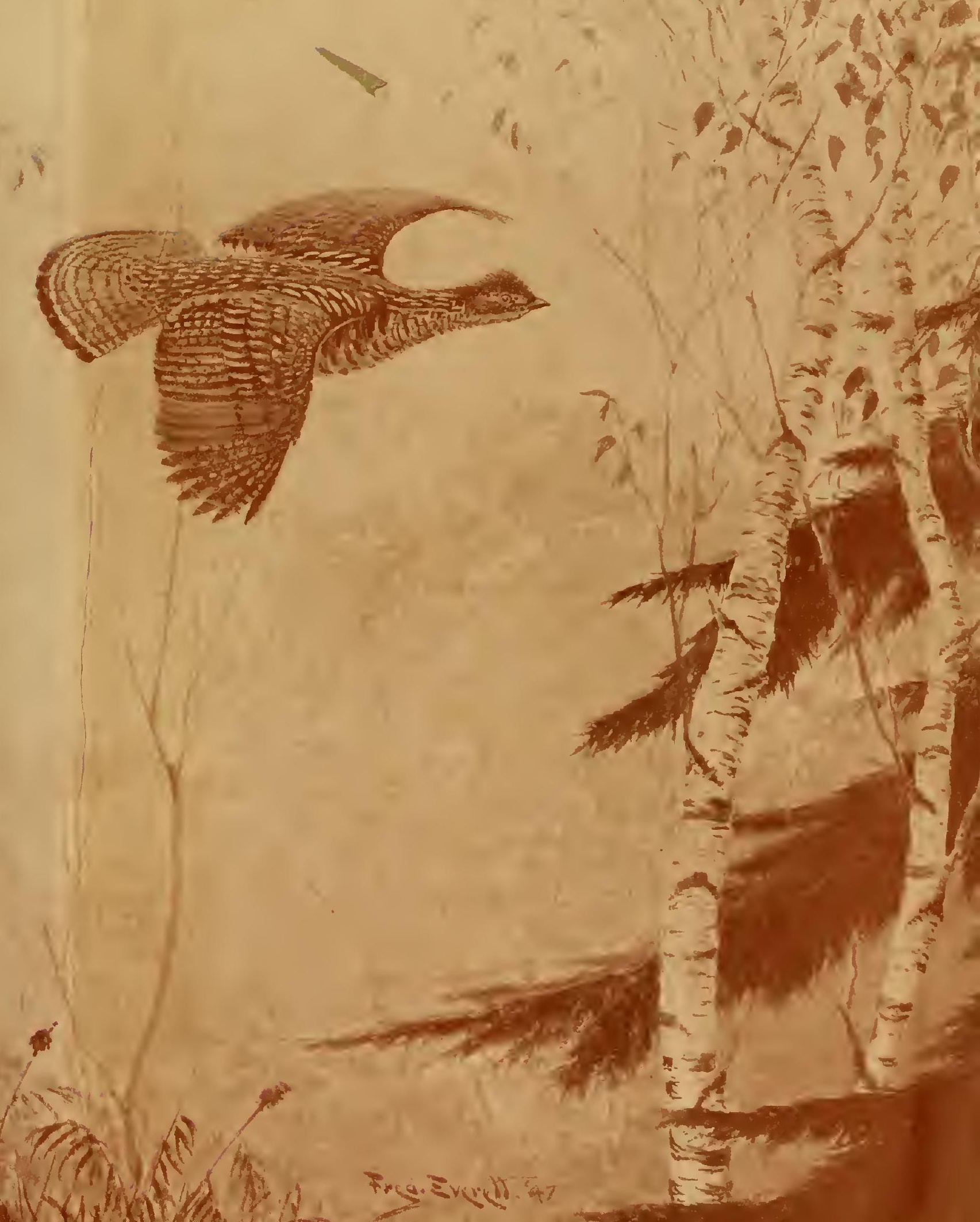

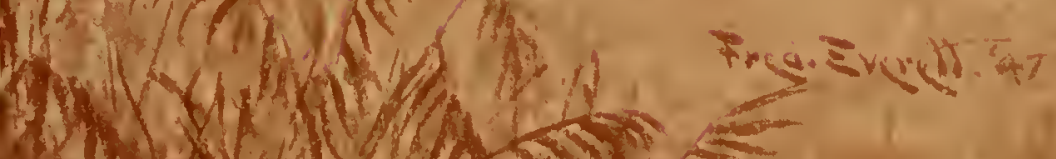
M) Wans andrant 
